US Army Corps

of Engineers $S_{\overparen{B}}$

Engineer Research and

Development Center

\title{
Analysis and Comparison of Documented
} Seepage and Sand Boil Events on the Lower Mississippi River from 1937 to 2011

Volume 1: Main text

Joseph B. Dunbar, Amber L. Ensign, Nalini Torres,

August 2018

and Maureen K. Corcoran

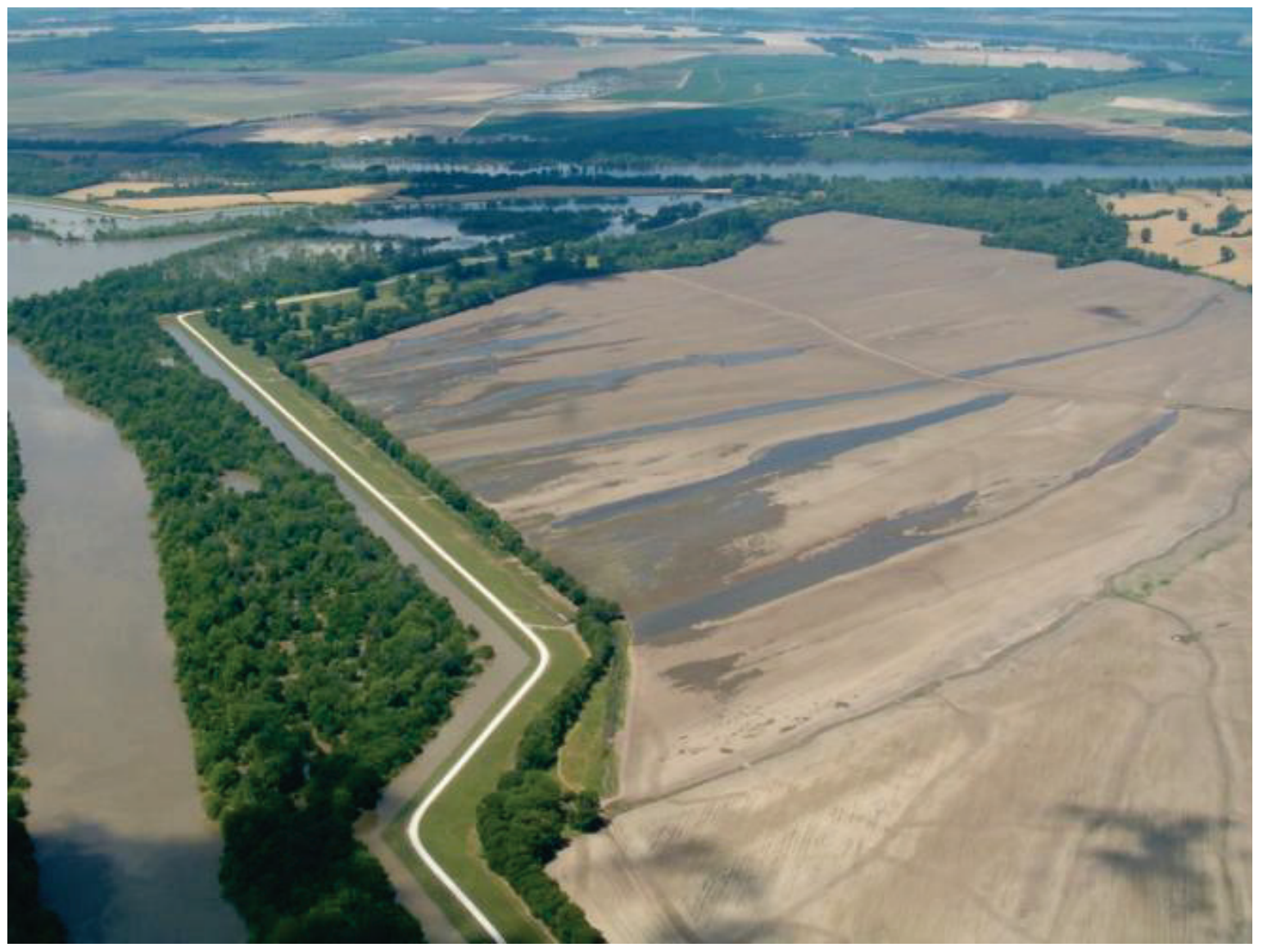


The U.S. Army Engineer Research and Development Center (ERDC) solves the nation's toughest engineering and environmental challenges. ERDC develops innovative solutions in civil and military engineering, geospatial sciences, water resources, and environmental sciences for the Army, the Department of Defense, civilian agencies, and our nation's public good. Find out more at www.erdc.usace.army.mil.

To search for other technical reports published by ERDC, visit the ERDC online library at http://acwc.sdp.sirsi.net/client/default. 


\section{Analysis and Comparison of Documented Seepage and Sand Boil Events on the Lower Mississippi River from 1937 to 2011}

Volume 1: Main text

Joseph B. Dunbar, Amber L. Ensign, Nalini Torres, and Maureen K. Corcoran

Geotechnical and Structures Laboratory

U.S. Army Engineer Research and Development Center 3909 Halls Ferry Road

Vicksburg, MS 39180-6199

Report 1 of a series

Approved for public release; distribution is unlimited.

Prepared for U.S. Army Corps of Engineers

Washington, DC 20314-1000

Under Project Number J8D2HJ 


\section{Abstract}

The following study examines the occurrence of seepage incidents and sand boils observed and documented during the 2011 Mississippi River Flood in the Lower Mississippi River Valley (LMV) within the boundaries of the U.S. Army Corps of Engineers (USACE), Mississippi Valley Division (MVD), Vicksburg District. This study examines the occurrence of sand boils in relationship to the underlying floodplain geology and identifies locations where large sand boils occurred. Large sand boil areas will be the focus for additional detailed study to better understand the mechanics of underseepage and internal erosion in USACE flood-control levees. Seepage and sand boil incidents documented during the 2011 Flood are presented in this report on geologic base maps and pre-flood imagery to compile a record of their occurrence and identify geologic relationships, as well as spatial patterns associated with the underlying fluvial landforms. A review of levee evolution within the LMV is summarized here along with past research studies of seepage involving major historic floods and their control.

DISCLAIMER: The contents of this report are not to be used for advertising, publication, or promotional purposes. Citation of trade names does not constitute an official endorsement or approval of the use of such commercial products. All product names and trademarks cited are the property of their respective owners. The findings of this report are not to be construed as an official Department of the Army position unless so designated by other authorized documents. 


\section{Contents}

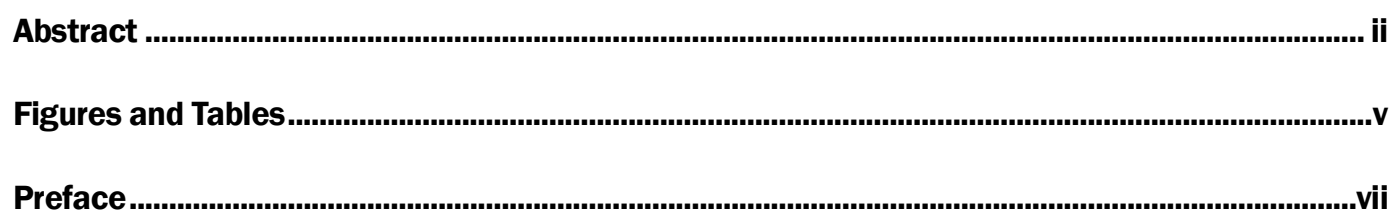

Unit Conversion Factors .............................................................................................................. vili

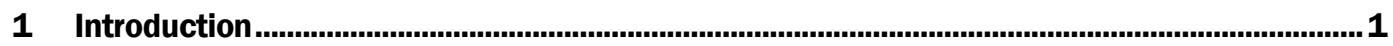

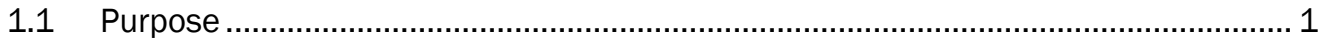

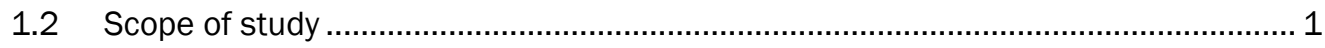

1.3 Vicksburg District study area .................................................................... 4

1.3.1 Previous seepage and sand boil studies ............................................................ 4

1.3.2 Seepage and sand boil incident data - A historic perspective ............................... 5

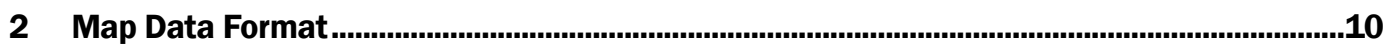

2.1 Seepage and sand boil data ..................................................................... 10

2.2 Map presentation methods and format ........................................................... 11

2.3 Classification of seepage and severity of sand boils......................................... 12

3 History of Seepage and Levee Engineering in the Alluvial Valley ...........................................14

3.1 Geology of underseepage ............................................................................ 14

3.2 Standard levee section ...................................................................................... 17

3.3 Construction of seepage berms............................................................................. 19

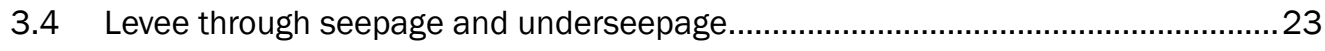

42011 Vicksburg District Seepage and Sand Boil Incidents ...............................................26

4.1 Seepage and sand boil incident data................................................................ 26

4.2 Relationship between sand boils and depositional environment...........................27

4.3 Occurrence of high priority and large sand boils ...................................................33

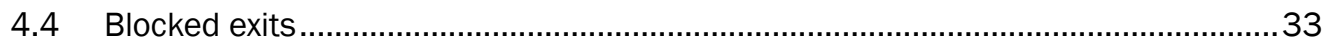

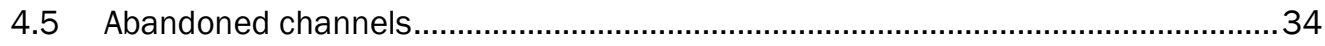

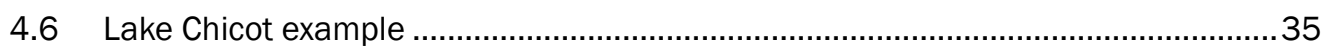

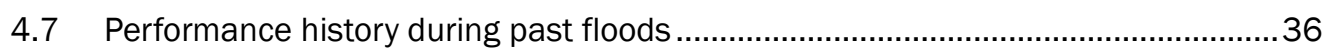

4.8 Chronic seepage and sand boil areas ................................................................ 40

4.9 Leland Chute-Lake Chicot ..................................................................................... 48

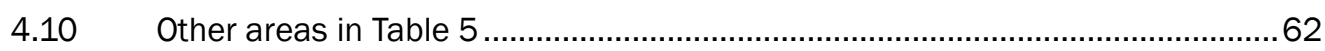

Seepage control measures ............................................................................ 62

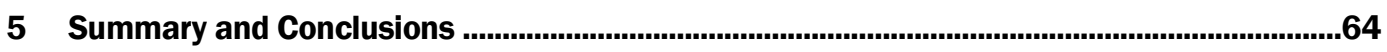

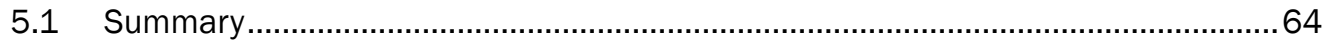

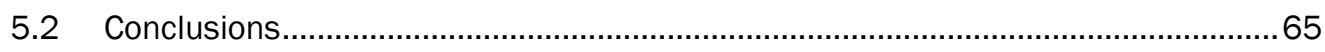

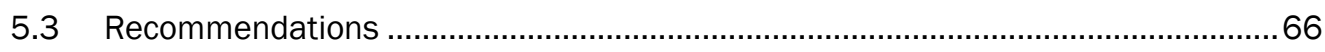

References .........................................................................................................................................68 


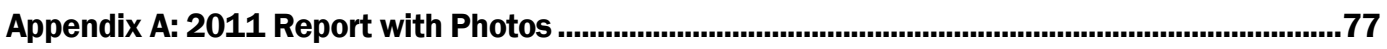

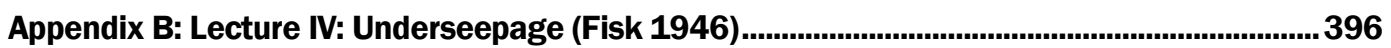

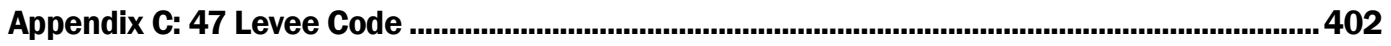

Appendix D: 1929 Vicksburg District Levee Handbook ...........................................................443

Report Documentation Page 


\section{Figures and Tables}

\section{Figures}

Figure 1. Index map to 15 -min quadrangles.

Figure 2. Greenville levee front showing 2011 seepage and sand boil incidents. Levee stationing is according to National Levee Database (NLD) designation.

Figure 3. Greenville and Winterville front levee showing seepage and sand boil occurrence during the 1973 flood (USACE 1973a). WES geologic map base underlies the 1973 flood incidents.

Figure 4. Greenville front levee showing performance data from the 1937 flood and underseepage control measures in 1948 (WES 1948). Solid blue line corresponds to presence of a berm or drainage wells. Sand boil and seepage information are noted where solid red line is heavy underseepage area and dashed red line is light to moderate underseepage area.

Figure 5. Generalized cross section showing point bar geology beneath a levee in the LMV and seepage flow in the underlying alluvial aquifer (Mansur et al. 1956). The concept of exit gradient $i_{0}$ behind the levee is expressed as the ratio of $h_{0} / z$, where $h_{0}$ is the excessive pressure or head under the blanket, and $z$ is the blanket thickness. The concept of exit gradient is central to blanket theory and forms the basis for seepage control measures involving berms and relief wells behind levees. A complete description presentation of blanket theory is presented in Mansur et al. (1956) and Appendix B in USACE (2000).

Figure 6. Abrupt changes in the top stratum from change in the depositional environment can concentrate underseepage in the aquifer and promote formation of sand boils. The figure shows concentration of seepage and development of sand boils adjacent to finegrained point bar swales (Mansur et al. 1956). Open borrow pits into the aquifer shorten the seepage path and increase hydraulic gradients across the levee.

Figure 7. Evolution of the standard levee section in the LMV (Moore 1972).

Figure 8. 1928 levee section in the Vicksburg Engineer District. Note the slope on the landside levee toe to control the seepage during prolonged flooding. Class of levee based on type of soils in the embankment. See Appendix D for specifications and complete details of the 1928 standard levee profile.

Figure 9. Example of seepage berm construction. Photograph of the east bank of the main-line MR\&T levee, between river mile 451 to 447, near Vicksburg, MS, showing the levee right-of-way and past remediation efforts for underseepage. This section of the levee was built between 1922 and 1926 to the 1914 profile, upgraded to the 1928 profile after the 1927 flood, and subsequently modified because of seepage-related issues with 150-ft and 300-ft-wide berms following the 1973 flood (USACE 1973a).

Figure 10. Through seepage (green triangle) and sand boil (red asterisk) incidents between river miles 447 to 451 (see Appendix A, page 146 for description).

Figure 11. 2011 Sand boil distribution by depositional environment.

Figure 12. Distribution of 1973 sand boils based on depositional environment.

Figure 13. Distribution of 1937 sand boils based on depositional environment. Point bar incidents are separated into their respective meander belt ages (Hpm1 to 3) on right side of graph.

Figure 14. Channel cutoffs between Memphis, TN, and Angola, LA, between 1929 and 1942 (Winkley 1977). Thirteen cutoffs occurred in the Vicksburg District.

Figure 15a. Francis 1937. 
Figure 15b. Francis 1973

Figure 15c. Francis 2011.

Figure 16a. Leland Chute-Lake Chicot area, cumulative 1922 to 1945 flood performance data. Lower photograph of large bagged sand boil during the 1922 flood is located in the upper loop of the Lake Chicot abandoned channel, along the south side of the old channel. The sharp bend in the levee just upstream of the upper arm of Lake Chicot predates the 1879-1880 hydrographic survey of Mississippi River and corresponds to the local levee right-of-way at this time (chart 40, 1879-1880 survey of the Mississippi River). Solid blue line corresponds to presence of a berm or drainage wells. Sand boil and seepage information are noted where solid red line is heavy underseepage area and dashed red line is light to moderate underseepage area.

Figure 16b. Leland Chute-Lake Chicot area during 1973 flood. Boils and seepage use the traffic light analogy with red (large/high), orange (moderate), and green (low/small). Blue line corresponds to seepage berms present during the 1973 flood.

Figure 16c. Leland Chute-Lake Chicot area during the 2011 floods...............................................51

Figure 17a. Greenville area 1937 flood (WES 1948)........................................................................53

Figure 17b. Greenville area 1973 flood (USACE 1973a)..............................................................54

Figure 17c. Greenville area 2011 flood. ........................................................................................55

Figure $17 d$. Location of the LaGrange crevasse in the lower Greenville levee reach (WES 1948). The crevasse occurred on 27 March 1903 and was 3,875 ft long (from House Document No. 798 on report to U.S. Congress 1931). The cause for the crevasse was assumed to be underseepage (WES 1948). Large sand boil occurred in 1929 flood (see last paragraph ) and represents a case for hydraulic fracturing of the blanket, and levee underseepage causing piping and backward erosion leading to a large cavity under the levee, and eventual collapse of the levee foundation into the void. The collapse preventing breaching of the levee.

Figure 18a. Seepage and sand boils from the 1937 flood (WES 1948). Note the amount of seepage berm present in 1948 (denoted by the solid blue line).

Figure 18b. Seepage and sand boil data from the 1973 flood (USACE 1973a). Note the amount of seepage berm present in 1973 (solid blue line).

Figure 18c. Seepage and sand boil data from the 2011 flood. See Figure $17 d$ for seepage berm extent.

\section{Tables}

Table 1. 1928 standard levee profile (Moore 1972; USACE 1929)...................................................18

Table 2. 1947 standard levee profile (Moore 1972; MRC 1947) ........................................................18

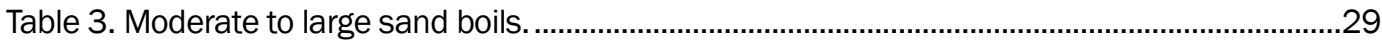

Table 4. Comparison of point sand boil data based on size-severity across major floods in

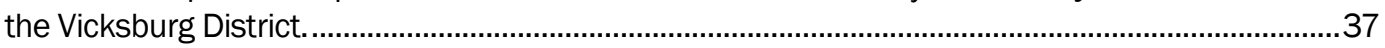

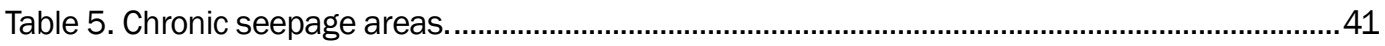




\section{Preface}

This study of the 2011 Mississippi River flood was conducted under the Infrastructure Technology Program, Flood and Coastal Storm Damage Reduction Program (FCSDR), in the research focus area for Improving Flood Risk Management and Water Control Infrastructure Resiliency and Reliability (WCIRR). Dr. Julie D. Rosati, U.S. Army Engineer Research and Development Center (ERDC), Technical Director, Coastal and Hydraulics Laboratory (CHL) was the Program Manager for FCSDR.

This study was conducted by personnel of the Geotechnical and Structures Laboratory (GSL). Dr. Michael Sharp, Technical Director, and Dr. Maureen K. Corcoran, Associate Technical Director, provided general supervision for this study. Dr. Joseph B. Dunbar, Geotechnical Engineering and Geosciences Branch (GEGB) of the Geosciences and Structures Division (GSD), was the principal investigator for this study of levee seepage and sand boil occurrence in the Vicksburg Engineer District during the 2011 flood. At the time of publication, Mr. Chris Price was Acting Chief, GEGB; Mr. James L. Davis was Chief, GSD. The Deputy Director of ERDC-GSL was Dr. William P. Grogan and the Director was Mr. Bart P. Durst.

COL Ivan P. Beckman was the Commander of ERDC, and Dr. David W. Pittman was the Director. 


\section{Unit Conversion Factors}

\begin{tabular}{|c|c|c|}
\hline Multiply & By & To Obtain \\
\hline acres & $4,046.873$ & square meters \\
\hline cubic feet $\left(\mathrm{ft}^{3}\right)$ & 0.02831685 & cubic meters \\
\hline cubic inches (in. ${ }^{3}$ ) & 1.6387064 E-05 & cubic meters \\
\hline cubic yards (cu yd) & 0.7645549 & cubic meters \\
\hline degrees Fahrenheit $\left({ }^{\circ} \mathrm{F}\right)$ or (deg F) & $(F-32) / 1.8$ & degrees Celsius \\
\hline feet (ft) & 0.3048 & meters \\
\hline gallons (US liquid) (gal) & 3.785412 E-03 & cubic meters \\
\hline inches (in.) & 0.0254 & meters \\
\hline miles (nautical) & 1,852 & meters \\
\hline miles (US statute) & $1,609.347$ & meters \\
\hline pounds (mass) (lb) & 0.45359237 & kilograms \\
\hline pounds (mass) per square yard (lb/yd²) & 0.542492 & kilograms per square meter \\
\hline square feet $\left(\mathrm{ft}^{2}\right)$ & 0.09290304 & square meters \\
\hline square miles & $2.589998 \mathrm{E}+06$ & square meters \\
\hline square yards $\left(\mathrm{yd}^{2}\right)$ & 0.8361274 & square meters \\
\hline tons $(2,000$ pounds, mass $)$ & 907.1847 & kilograms \\
\hline yards (yd) & 0.9144 & meters \\
\hline
\end{tabular}




\section{Introduction}

\subsection{Purpose}

The Flood of 2011 ranks as one of the major Mississippi River floods of record (Camillo 2012). For the first time in the history of the Mississippi River and Tributary Project (MR\&T), three diversion structures were active simultaneously: Birds Point-New Madrid Floodway in Missouri, Morganza Floodway near Baton Rouge, LA, and the Bonne Carrie Spillway upstream of New Orleans, LA. However, water levels were well below the design flood elevations which the levees were built to withstand. Levees are the backbone of the MR\&T project and protect the vast expanse of the developed alluvial valley from periodic overflows of the Mississippi River (Camillo 2012). Seepage and sand boil data from this historic flood provide an important source of information to evaluate levee performance, validate engineering design, and identify important geologic and engineering parameters leading to the development of sand boils.

This study involves review and analysis of the seepage and sand boils observed and documented during the Mississippi River Flood of 2011 in the Lower Mississippi River Valley (LMV) within the boundaries of the U.S. Army Corps of Engineers (USACE), Mississippi Valley Division (MVD), Vicksburg District. This study examines the occurrence of sand boils in relationship to the underlying floodplain geology and identifies locations where large sand boils occurred. Areas where large boils occurred will be the focus for additional detailed study and will be documented in a separate report of investigations. Seepage and sand boil incidents recorded during the 2011 flood are presented on geologic base maps and pre-flood imagery. The purpose was to compile a map based record of their occurrence and to identify geologic relationships and spatial patterns. Seepage and sand boils presented on base maps, herein, were recorded, described, and flood fought during the 2011 flood in order to protect the levee system from underseepage and internal erosion type failures.

\subsection{Scope of study}

This study presents seepage and sand boil incidents recorded by the Vicksburg District on U.S. Geological Survey (USGS) 15-min (scale 1:62500) quadrangle maps. An index to the 15 -min maps containing the mainline Mississippi River levees within the Vicksburg District is presented in Figure 1. 
Figure 1. Index map to 15-min quadrangles.

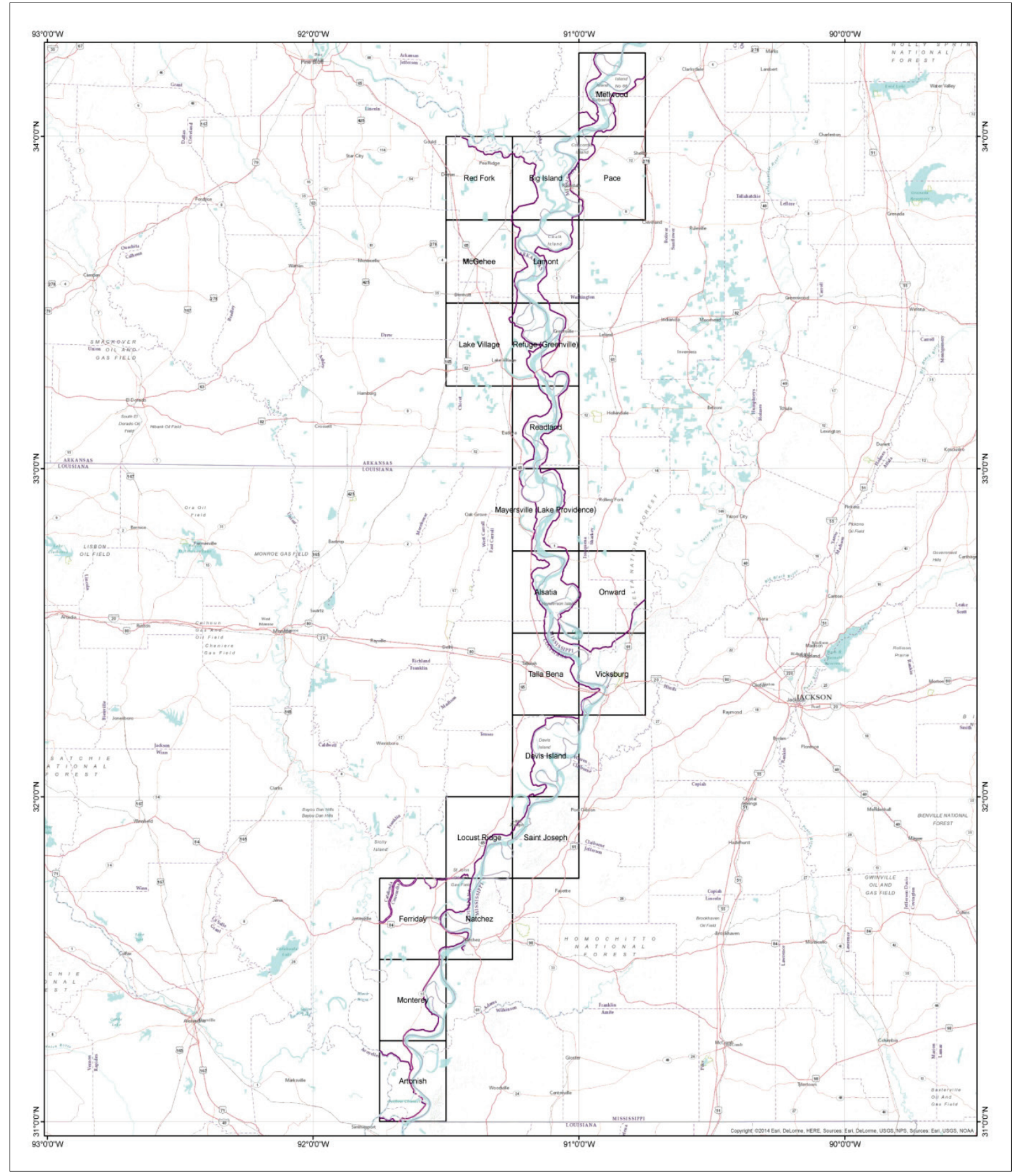

Data are presented on both geologic (Volume II) and photographic (Volume III) base maps for better understanding of the spatial patterns and geological distribution of these incidents. The design of the current day flood protection system in the LMV is a legacy of historic levee performance, involving large magnitude floods and the development of 
engineering counter measures to protect the integrity of the levee system from these floods.

Major geologic and engineering studies performed during the past 75 years are described here for background information and for better understanding of the history and evolution of design of the current day flood protection system. These studies defined the geologic setting within the alluvial valley and helped in the development of an effective seepage control policy to protect the levees from underseepage and internal erosion failures. The levee design and construction, the alluvial geologic setting, and the types and pattern of seepage incidents observed during the 2011 flood are directly interconnected. Thus, a map-based presentation of the Flood of 2011 data using geologic base maps and pre-flood imagery was intended to permit visual comparison of these data.

Presentation of the 2011 flood incidents on pre-flood photographic base maps was intended to facilitate the identification of past flood protection measures that have been constructed for underseepage control. Construction of both riverside and landside seepage berms in the LMV has been an ongoing response to seepage incidents identified during major flood events since the Flood of 1937 (U.S. Army Engineer Waterways Experiment Station (WES) 1948; Mansur et al. 1956; USACE 1973a). Presentation of the 2011 incident data on pre-flood photographic base maps permits visual examination of sand boil locations in terms of the levee right-of-way, and comparison to the presence of any seepage berms that may have been constructed in the past.

Relief well locations are not shown on the enclosed maps in Volumes II and III. This coverage would be an easy addition because these data are typically located using geospatial coordinates and can be easily displayed in a geographic information system (GIS) on a map coverage. Relief wells were first used in the Vicksburg District beginning in the mid-1990s and have become an important component for remediation against severe underseepage (Mendrop 2014)*.

\footnotetext{
* Mendrop, C. 2014. Personal communication. Geotechnical Branch Chief, U.S. Army Engineer, Vicksburg District.
} 


\subsection{Vicksburg District study area}

Mississippi River levees within the boundaries of the Vicksburg District are located on twenty-one, 15-min USGS topographic base map quadrangles in Arkansas, Louisiana, and Mississippi (Figure 1). The District's area of responsibility extends from river mile 306 above the head of passes (AHP), near the vicinity of Angola, LA to river mile 632 AHP, near Clarksdale, MS. Beginning at the upstream limit and moving downstream, levees flank both sides of the Mississippi River to the vicinity of Vicksburg, MS. South of Vicksburg, the flood protection levee exists only on the west bank (Louisiana side) of the Mississippi River, where it prevents flood waters from spilling onto its former floodplain. The reach of the Mississippi River between Vicksburg, MS, and Angola, LA, is bounded on its eastern side by steep upland bluffs which expose Tertiary (65 to 2 million years) marine sediments and Pleistocene (2 million to 10,000 years) terrace deposits (Saucier 1994). Terrace deposits are sediments deposited on past floodplains of the Mississippi River, its tributaries, and coastal plain deposits that are elevated with respect to the present day floodplain and Gulf of Mexico shoreline. The levee system within the Vicksburg District was built on Holocene $(<10,000$ years old) alluvial sediments.

\subsubsection{Previous seepage and sand boil studies}

The map scale and format adopted for this study follows previously documented seepage and sand boil incidents from historic floods (USACE 1973a; WES 1948). WES (1948) shows seepage and sand boil locations on topographic base maps at the 15 -min scale $(1: 62,500)$ from the Mississippi River Flood of 1937, the Mississippi River Flood of 1944 , and other incidents (past crevasses and levee breaks) from historic (1927 and earlier) floods in the lower valley. Dunbar et al. (2015) provides general background information on the history of this map folio.

USACE (1973a) is a 15-min geologic base map of seepage and sand boil incidents from the Mississippi RiverFlood of 1973 in the Vicksburg District. The history of this publication in terms of the authors involved and the specific purposes for production of this map folio is unknown. This map product was likely intended for planning and addition of new seepage berms in the Vicksburg District because of the seepage performance data observed during the 1973 flood. 
Both of the map folios described here have been digitally reproduced as part of this work effort and added to the library holdings at the U.S. Army Engineer Research and Development Center (ERDC) (WES 1948; USACE 1973a) to permit wider dissemination of historic information and for research purposes into underseepage and internal erosion. Neither of these publications ever received widespread circulation and were likely limited to only a few internal (USACE) copies. The sole surviving copy of (WES 1948) was part of the personal library holdings of C. I. Mansur. This folio was discovered while the author was scanning the historic map collection belonging to the Mississippi River Commission (MRC), MVD (USACE 1975). Mansur was the lead author on WES Technical Memorandum No. 3424 (Mansur et al. 1956). This study along with other research conducted in the LMV for the President, MRC, is further described in this report for background purposes for understanding of levee engineering in the MR\&T project. The lessons that were learned from MRC-funded research in the LMV would later be incorporated into the USACE engineering manual for levee design and construction (USACE 2000).

\subsubsection{Seepage and sand boil incident data - A historic perspective}

High-water surveillance and inspection of the levee system is an important part of levee safety for effectively controlling major floods in the LMV. Mapbased portrayal of historic seepage and sand boil data permits effective early surveillance during flood events as well as long-term examination and identification of levee reaches where chronic seepage and sand boil issues exist. Cyclic flood events can have a cumulative impact on the levee system and a historical perspective is an important component to identify these impacts. Furthermore, display of incident data on base maps documents the locations where close monitoring is needed for future generations, especially for those infrequent events involving large magnitude floods. Thus, historic performance maps are an especially important tool for surveillance and flood-fight personnel, especially for large magnitude floods with recurrence intervals greater than 25 to 30 years.

A map-based presentation showing large historic flood events permits an easy way to compare and evaluate the current levee performance as compared to historic performance across multiple flood events. Figures 2 through 4 serve as an example of this type of critical review. This series of illustrations is from the Greenville and Winterville, MS, levee fronts and show historic seepage and sand boil data from the 2011, 1973, and 1937 floods, respectively. These illustrations identify historic changes that have 
occurred in this area, including shortening the course of the river in the Greenville area by the cutoff program during the 1930s, levee setbacks to the levee right-of-way, and the presence of persistent seepage and sand boil activity in the reach north of Greenville during three major flood events. This reach is adjacent to the old course of the Mississippi River labeled as Batchelor Bend. This bend was cut from the active river in 1935 as part of the cutoff program following the Mississippi River Flood of 1927 to reduce flood stages by shortening the course of the river. During the Mississippi River Flood of 2011, a large boil was present at the edge of the seepage berm and required remediation of the boil and seepage berm extent. This set of illustrations indicates large sand boils have been problematic for this area according to the historic performance data presented.

The purpose for presenting the Greenville area example in Figures 2 through 4 was to highlight the nature of historic performance data presented in Volumes II and III. These data are not isolated incidents, but rather a culmination of incidents and changes to the levee system over multiple floods. Incidents are normally associated with multiple flood events and can be chronic in nature. Oftentimes they are caused by both natural and man-made imperfections in the blanket or other geologic factors. This study is intended to identify locations of the major sand boil areas during the 2011 flood and define geologic trends in their occurrence. Selected large sand boil areas will be the focus of site specific investigations that are documented in separate reports. Those investigations will involve the examination of detailed geologic and engineering data to better understand underseepage and internal erosion parameters in levees. 
Figure 2. Greenville levee front showing 2011 seepage and sand boil incidents. Levee stationing is according to National Levee Database (NLD) designation.

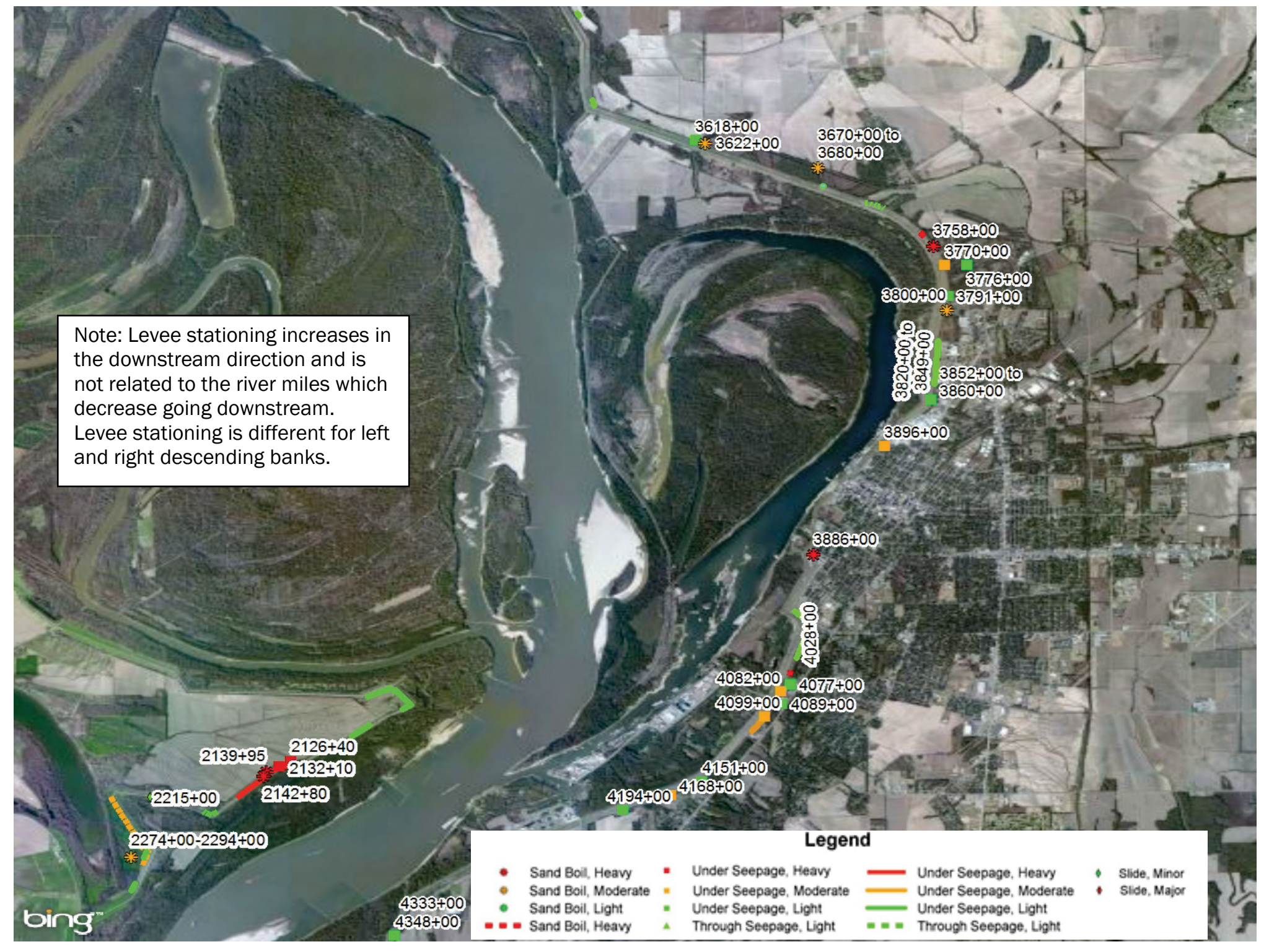


Figure 3. Greenville and Winterville front levee showing seepage and sand boil occurrence during the 1973 flood (USACE 1973a). WES geologic map base underlies the 1973 flood incidents.

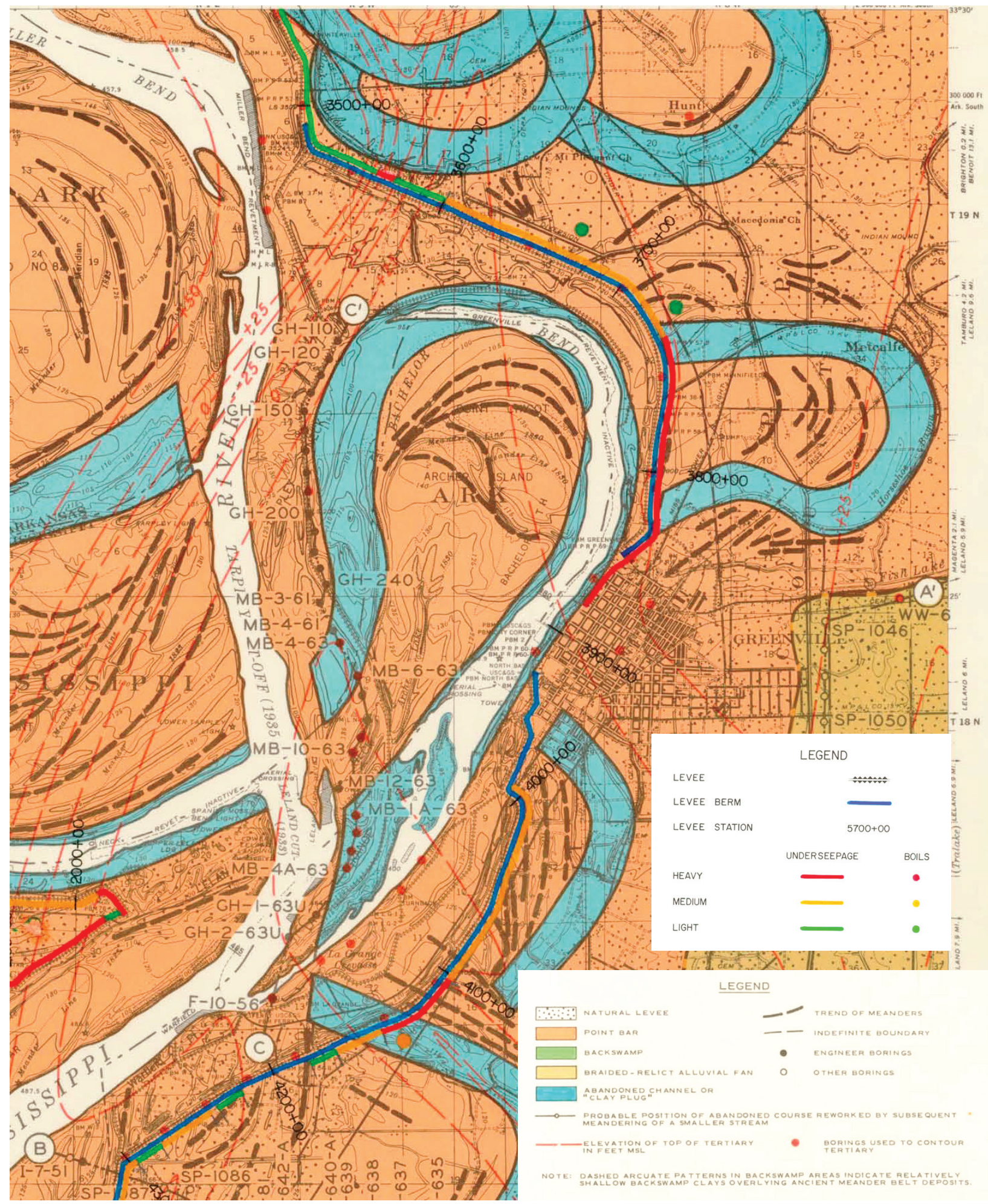


Figure 4. Greenville front levee showing performance data from the 1937 flood and underseepage control measures in 1948 (WES 1948). Solid blue line corresponds to presence of a berm or drainage wells. Sand boil and seepage information are noted where solid red line is heavy underseepage area and dashed red line is light to moderate underseepage area.

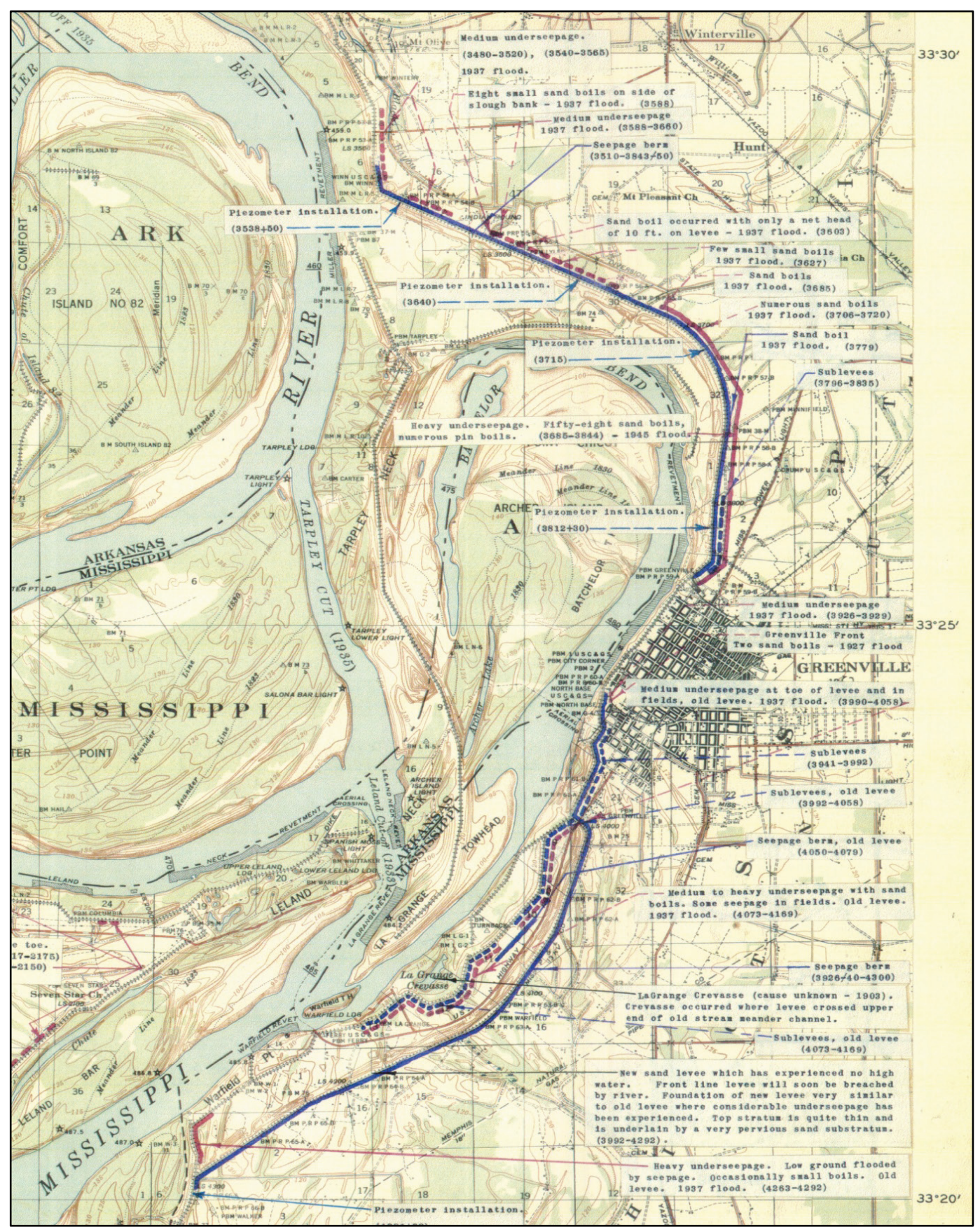




\section{Map Data Format}

\subsection{Seepage and sand boil data}

The source of seepage and sand boil data used in this report is from the 2011 high-water levee inspection by the Vicksburg District (USACE 2011). Three separate inspection teams were formed from the Geotechnical and the Levee and Drainage branches in the Vicksburg District. The main-line Mississippi River Levee (MRL) was subdivided into reaches and inspections were made by the respective teams walking or riding allterrain vehicles (ATVs) along the toe of the levee in the different reaches during the course of the 2011 flood (USACE 2011). The inspection teams prepared notes regarding scour, current, seepage, sand boils, slides, and other noteworthy observations. Additionally, Android smartphones were used by the inspection teams to collect data and send these data to the Vicksburg District Freeboard website for assessment by emergency operations personnel. The Android smartphone application used to collect these data in real-time was the Mobile Information Collection Application (MICA), which uses global position system (GPS) technology.

The MICA application was developed by ERDC's Information Technology Laboratory (ITL) to capture levee distress in real-time and transmit this information to command and control centers for priority ranking used in flood fighting. Records of levee distress include GPS location, observed performance information, and photographs from each incident. The unfiltered MICA data often contain multiple reporting of the same sand boil by different observers. Multiple sand boil and seepage incidents for each location were evaluated, prioritized, and filtered for the final data presentation by USACE flood-fight officials to eliminate multiple listings in the Mississippi River Flood of 2011 Report. Consequently, seepage and sand boil incidents presented here were derived from the USACE (2011) highwater inspection report, rather than directly from the MICA database because of the multiple listings of incidents in the unfiltered MICA database.

The USACE (2011) incident report was used in this study for the display of seepage and sand boil incidents on the base maps presented here. The 2011 flood report is directly comparable to past seepage reports from the 1937 and 1973 floods as previously described. These earlier reports are the official record of incidents that were observed during these major flood 
events (WES 1948; USACE 1973a, 1974). Seepage and sand boil incidents presented in this report generally follow the same basic map presentation format that was used to display the 1937 and 1973 incidents (WES 1948; USACE 1973a). The Greenville area in Figures 2 through 4 are examples of the three reporting formats used.

\subsection{Map presentation methods and format}

The MRL was subdivided into river reaches based on levee stationing identified by USACE (2011). Tabular inspection data from each river reach in this comprehensive report (Appendix A) were converted to a digital format by importing the data contained in the paper tables into a Microsoft Excel spreadsheet. These data were then manually edited in Microsoft Excel during this study to format the data for visual display using GIS software. These edited records were then imported into Environmental Systems Research Institute (ESRI)'s ArcGIS software using the geographic coordinates reported for each incident.

This list of records was next screened to extract only the seepage and sand boil incidents. Records involving current and scour were not imported because these records are generally not applicable to this study. Records of levee slides were included where seepage conditions were noted to have occurred. Seepage and sand boil records were imported into the ArcGIS software as either points or lines, depending on the nature of the coordinates used in the record and the geographic coordinates that were reported. For presentation purposes, the line data used to identify landside seepage were edited to conform to the levee footprint using the beginning and end (From and To) coordinates in the reported record. Seepage lines were next edited and shaped to conform to the levee right-of-way for display purposes in order to match the "From and To" extent observed by the inspection teams for each seepage record that was recorded. This type of editing was necessary to prevent seepage lines from crossing the levee where abrupt changes in the levee alignment occurred, and to be consistent with previous reporting of this data onto maps (WES 1948; USACE 1973a).

Depiction of sand boil data on the accompanying maps is presented as both point and line (arcs) feature types, because the incident data were reported as being in both types of incident format. A single large boil (point feature) and multiple boils along a specific levee reach (line feature) may be shown concurrently, because the incident data may present both types of feature classes for the conditions that were observed and reported 
during the 2011 flood (USACE 2011). Consequently, the two types of feature classes may contain incidents in common with the larger boils being identified as a separate point feature class.

Seepage and sand boil data from the 2011 flood are presented on 15-min (1:62,500 scale) geologic base maps (Volume II) and photographic base maps (Volume III). Photographic coverage was provided by Bing's online digital service to ArcView. Geologic data used for the base maps were derived from the legacy LMV Engineering Geology Mapping data set (see Imvmapping@erdc.usace.army.mil). Geologic mapping was conducted at the 15-min scale on topographic base maps by WES geologists for the MRC between 1957 and mid-1990s for USACE districts within the LMV (examples are Kolb 1949, 1975; Kolb et al. 1968; Kolb and Van Lopik 1958; May et al. 1984; Saucier et al. 1964, 1967, 1969; 1994; Smith et al. 1986, Smith and Russ 1974; Smith and Saucier 1971). This body of geological work in the LMV will be described herein as the WES geological mapping program.

Incidents shown on the geology and photographic base maps in Volumes II and III are labeled with their National Levee Database (NLD) stationing to permit comparison to the incident tables. The NLD stationing was used for labeling purposes and permits referencing of the incident displayed on the maps to their original source data. An example subset map from the Greenville, MS, levee front was presented in Figure 2, showing the 2011 seepage and sand boil data reported for this area. Presented in Figure 2 are point data containing sand boils and point observations of seepage condition, as well as linear (vector or polyline data) where seepage conditions extend along a continuous levee reach. Thus, both point and vector data were used to denote incidents during the 2011 flood.

\subsection{Classification of seepage and severity of sand boils}

An underlying goal for presentation of the incident data was to accurately convey the severity of the seepage and sand boils identified from the data tables. In some instances, it was necessary to interpret the reported data for classification purposes. Background data are presented here on the classification scheme that was used for interpretation of records that were not clearly classified. The severity of seepage is normally classified as being light, moderate, and heavy; while sand boils are typically considered as being small, moderate, or large in their aerial extent. This basic classification scheme is analogous to a traffic light, involving green, amber, and red, corresponding to small or light, moderate, and heavy or large, 
respectively. Sand boils are typically classified according to their size and by the volume of water that is flowing (Cunny 1987).

Areas experiencing heavy seepage will generally display numerous pin boils (small pipe openings without sand cones) and/or small sand boils with sand cones behind the levee (Cunny 1987). Moderate seepage involves running water at and beyond the levee toe, while light seepage corresponds to wet areas at and beyond the levee toe. Mansur et al. (1956) classified heavy seepage as more than 10 gal per min (gpm) per $100 \mathrm{ft}$ of levee, medium seepage as between 5 and $10 \mathrm{gpm}$ per $100 \mathrm{ft}$ of levee, and light as less than $5 \mathrm{gpm}$ (Kolb 1975).

Classification of seepage quantity and sand boils by size can be a subjective interpretation and may vary between different observers. Large sand boils are ordinarily classified as being large when the throat is greater than $12 \mathrm{in}$. in diameter, medium boils when the throat diameter is between 6 to 12 in. in diameter, and small when the boils are less than 6 in. in diameter. The occurrence of multiple sand boils can lead to areas with heavy seepage. Thus, every effort was made in this study to present the data with this general framework in mind. 


\section{History of Seepage and Levee Engineering in the Alluvial Valley}

\subsection{Geology of underseepage}

Seepage and sand boils occur at the landside levee toe because of the high artesian pressure produced in the alluvial aquifer by confining flood waters between artificial levees (Figures 5 and 6). A meandering river system, such as the lower Mississippi River, by its inherent nature of channel migration and overbank flooding, is composed of a fine-grained top stratum, or blanket, and an underlying coarse-grained substratum (Figures 5 and 6). Because of channel migration and lateral accretion of coarse sediment in the channel as point bars, the substratum is formed and is composed of sand and fine gravel. A composite geologic map of the Yazoo Basin is presented as Plate 1 and shows the large number of abandoned channels that have formed within the past 10,000 years as the Mississippi River has migrated across its floodplain to its present day position. The Mississippi River has created distinct river courses forming meander belts that are composed of point bar deposits.

During high-water flooding, increased hydraulic pressure in the alluvial aquifer can fracture and heave the top stratum or blanket at the levee toe because of the artesian pressure acting at the base of the blanket, and produce seepage and sand boil conditions through cracks and other natural defects in the blanket. Entry points for aquifer recharge occur in the river channel, abandoned channels, and in riverside borrow pits that extend through the top stratum near the levee toe during flooding (Figures 5 and 6). Contributing factors that have been identified for seepage and sand boil formation are the underlying geology, namely the depositional environment (primarily point bar but can include natural levee, abandoned channel, or abandoned courses (multiple linked abandoned channels) see Volume II for examples), blanket thickness, blocked seepage exits, or any type of natural and man-made defect in the blanket (Figure 6). 


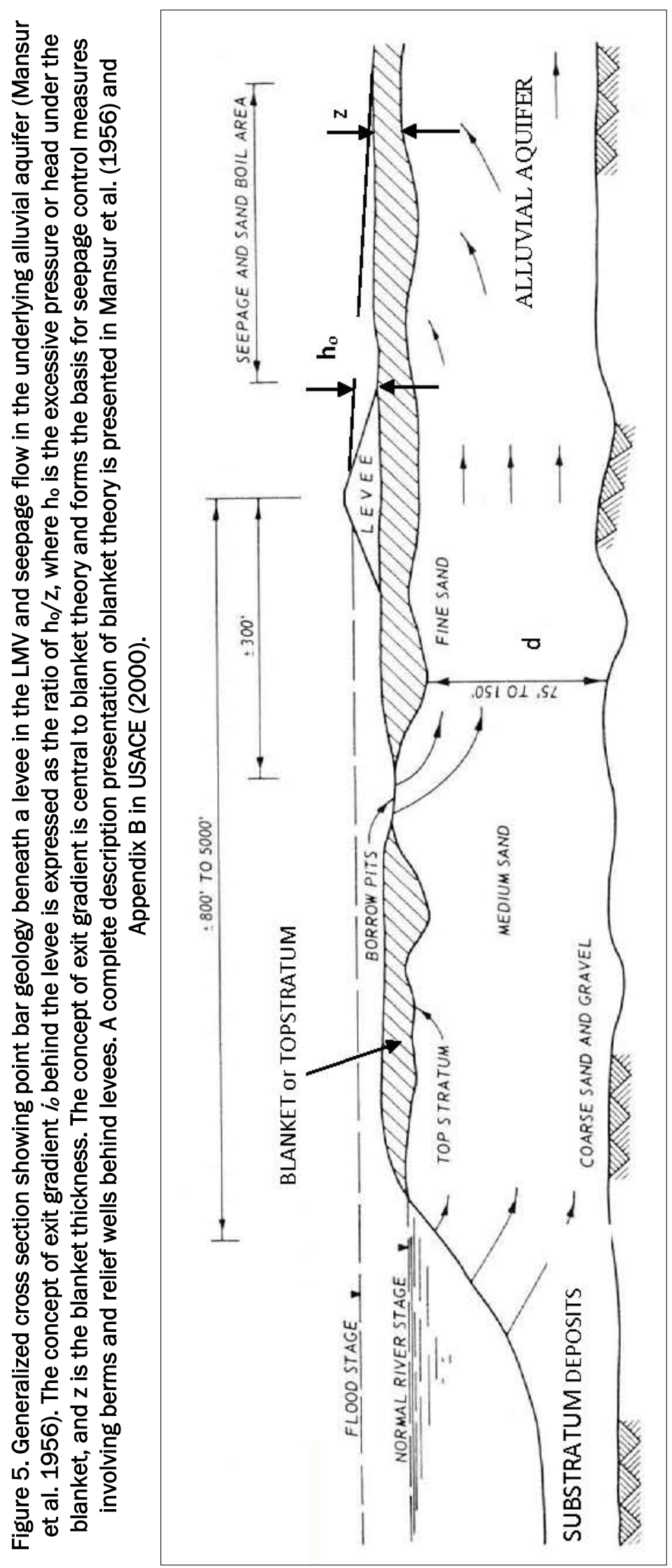


Figure 6. Abrupt changes in the top stratum from change in the depositional environment can concentrate underseepage in the aquifer and promote formation of sand boils. The figure shows concentration of seepage and development of sand boils adjacent to fine-grained point bar swales (Mansur et al. 1956). Open borrow pits into the aquifer shorten the seepage path and increase hydraulic gradients across the levee.

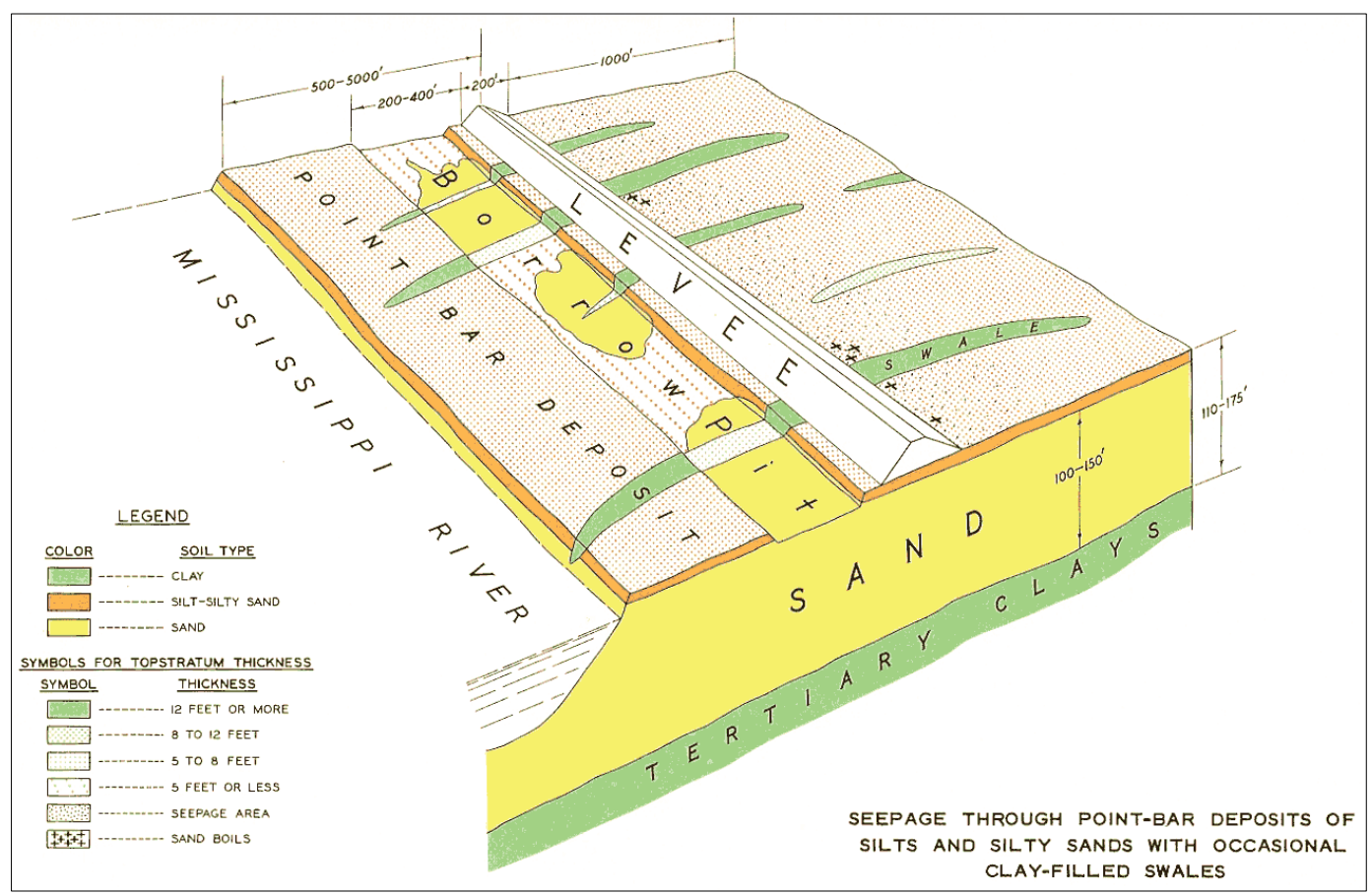

Blocked seepage exits typically involve an abrupt change in the floodplain geology (i.e., change in depositional environment) and associated change (reduction) in hydraulic conductivity of the soils within the depositional environment or due to levee orientation (Fisk 1944, 1946; Mansur et al. 1956). Recognized defects in the blanket include thin zones, point bar ridges, desiccation cracks, tree roots, man-made features, such as a utility or fence poles, boreholes, seismic shot points, activities of burrowing animals, or any combination of these different factors either individually or in combination.

Geologic investigations into underseepage problems involved case history studies by the Vicksburg District (USACE 1939 and 1941) and the MRC between 1941 and 1946 by Dr. H.N. Fisk, professor of geology at Louisiana State University (LSU), and his staff of graduate student geologists. This research was conducted because of severe seepage and sand boil incidents observed during the Mississippi River Flood of 1937 within the LMV levee system. Results of these different geologic case history studies would later be incorporated into the work by Mansur et al. (1956). A description of the underseepage mechanism in the lower Mississippi River alluvial valley and 
problems involving levee engineering is presented in Appendix B (Fisk 1946). Presentation of the underseepage mechanism in Appendix B is from a lecture series given by Dr. Fisk to engineers from the Lower Mississippi River Valley Division Headquarters, WES, U.S. Army Engineer Districts Memphis, Vicksburg, and New Orleans. The clarity and brevity of this presentation concerning the underseepage mechanism bears inclusion here for further reading and to facilitate wider dissemination of basic geologic concepts that were identified nearly 75 years ago.

Figure 6 from Mansur et al. (1956) is often referenced to show seepage and sand boil relationships involving foundation geology and levee orientation and was derived from illustrations presented in Appendix B from the various case history studies by the geologic staff supporting Dr. Fisk. The series of illustrations in Appendix B identify locations used for study of the geology in relationship to known seepage problem sites in WES (1941b) and Mansur et al. (1956). This brief summary of underseepage principals, along with the information presented in Appendix B, will facilitate better understanding of the underseepage mechanism, causes of sand boil formation, and the incidents observed during the 2011 flood (see Volumes II and III).

\subsection{Standard levee section}

MRC (1947) has been the basis for current day levee design and construction in the LMV for the MR\&T project (Appendix C). Lessons learned from geologic study of levee underseepage during the 1940s by Dr. Fisk and his team were incorporated by the MRC into the 1947 Levee Code (MRC 1947). The basic geometry of the standard levee section in the code specifies crest width, riverside, and landside slopes to control levee through seepage from long duration floods that were common on the lower Mississippi River (see Figure 7 and slope data in Tables 1 and 2). The design of the standard levee section in the 1947 Levee Code has been an evolutionary process. This evolution was due in part to closure of natural outlets within the Mississippi River's floodplain, the corresponding increase in river stage by reducing overflow areas (Camillo 2012), and because of poor performance in terms of seepage and sand boil incidents following major historic flood events on the lower Mississippi River. A copy of the 1947 Levee Code and associated amendments are presented in Appendix $\mathrm{C}$ for reference purposes and to provide wider distribution of legacy documents involving the MR\&T levee system. 
Figure 7. Evolution of the standard levee section in the LMV (Moore 1972).

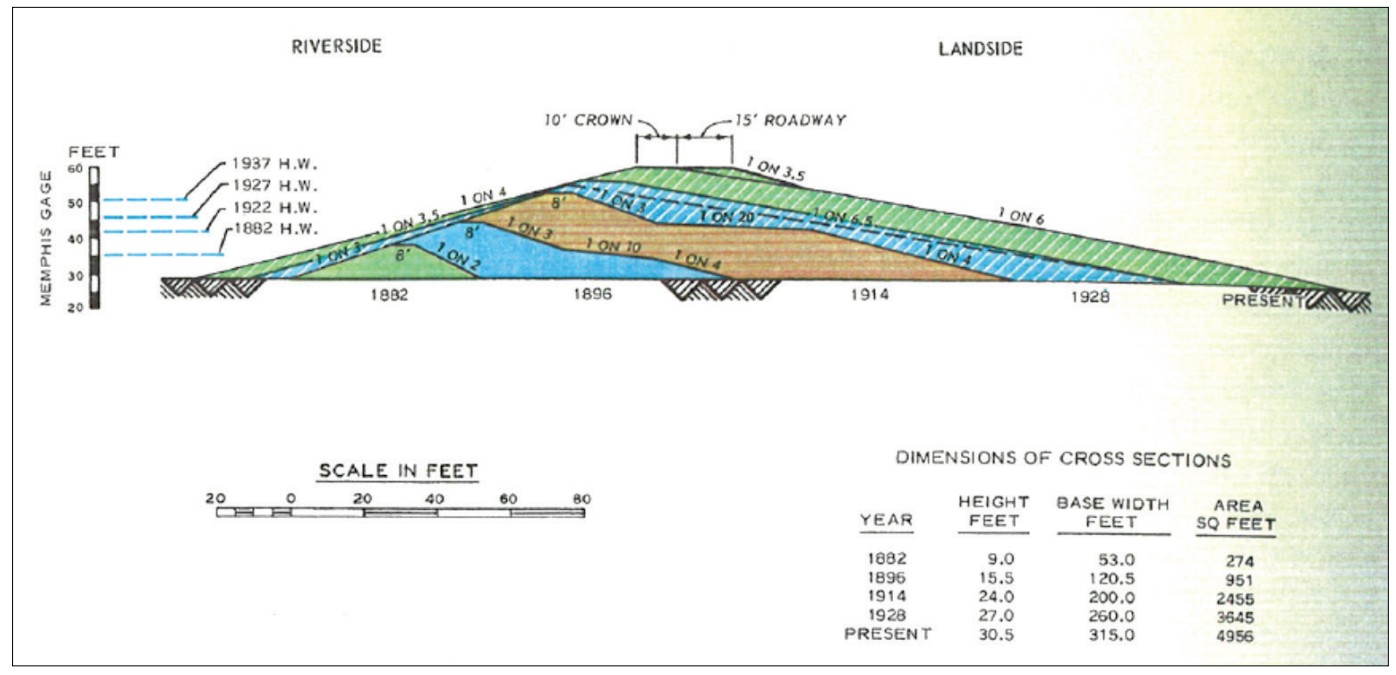

Following the Great Mississippi River Flood of 1927, levees in the LMV were rebuilt to the 1928 standard levee section. Specific details of the 1928 profile in the Vicksburg District and construction details are described in Appendix D. The 1928 profile was completed in the Vicksburg District by the time of the Mississippi River Flood of 1937 (USACE 1941a and 1941b). The 1928 section was originally based on material type (Figure 8 and Table 1), which was later revised to a compaction specification by the 1947 Levee Code (Figure 7 and Table 2).

Table 1. 1928 standard levee profile (Moore 1972; USACE 1929).

\begin{tabular}{|l|l|l|l|l|}
\hline Section & $\begin{array}{l}\text { Crown } \\
\text { Width, } \mathrm{ft}\end{array}$ & Riverside Slope & $\begin{array}{l}\text { Landside Slope to Contain } \\
\text { Seepage Line of: }\end{array}$ & Predominating Material \\
\hline A & 10 & 1 on 3 & 1 on 6 & 75 percent or more buckshot (clay) \\
\hline B & 10 & 1 on $3-1 / 2$ & 1 on $6-1 / 2$ & Loam \\
\hline C & 12 & 1 on 5 & 1 on 8 & 75 percent or more sand \\
\hline
\end{tabular}

${ }^{1}$ Seepage line was assumed to spring from riverside slope, $1 \mathrm{ft}$ below crown of levee.

Table 2. 1947 standard levee profile (Moore 1972; MRC 1947).

\begin{tabular}{|l|l|l|l|}
\hline Section Type & Riverside Slope & Crown Width, $\mathrm{ft}$ & Landside Slope \\
\hline 1 & 1 on $3-1 / 2$ & 10 & 1 on $4-1 / 2$ \\
\hline $2^{1}$ & 1 on 4 & 10 & 1 on $5-1 / 2$ \\
\hline $2^{2}$ & 1 on 4 & 10 & 1 on 6 \\
\hline 3 & 1 on $4-1 / 2$ & 10 & 1 on $6-1 / 2$ \\
\hline
\end{tabular}

${ }^{1}$ Less than $25 \mathrm{ft}$ in height

2 Twenty-five feet or more in height. 
Figure 8. 1928 levee section in the Vicksburg Engineer District. Note the slope on the landside levee toe to control the seepage during prolonged flooding. Class of levee based on type of soils in the embankment. See Appendix D for specifications and complete details of the 1928 standard levee profile.

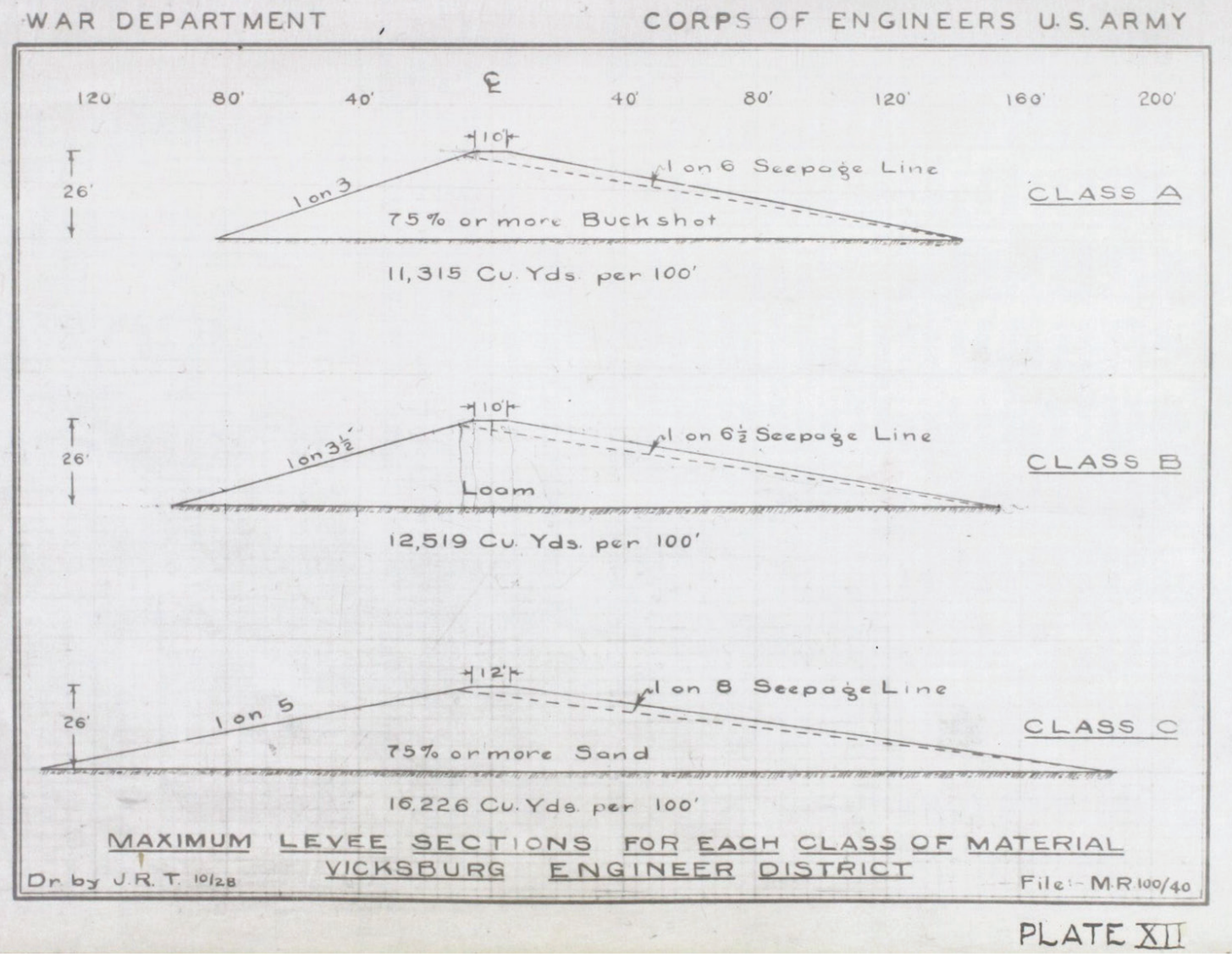

The 1947 Levee Code also described the need for geologic studies to support levee engineering design. Levee design in the Vicksburg District was modified again following the Mississippi River Flood of 1973 because of flow line issues and channel aggradation in some reaches within the Vicksburg District limits. Consequently, the levees are being raised an additional 3 to $5 \mathrm{ft}$ and widened accordingly due to freeboard considerations caused by channel sedimentation issues. Raising the crest elevation of the levee system in the Vicksburg District to meet the 1973 flow line standards is an ongoing process and continues today.

\subsection{Construction of seepage berms}

Historic levee construction in the LMV should be considered when examining the 2011 incident data. The basic levee prism that was specified by the MRC for the lower Mississippi River was built to accommodate a design flood event. It has subsequently been modified from the 1928 and 1947 profiles by seepage-related issues due to large historic flood events. 
Seepage modifications typically have involved the addition of landside seepage berms between 150 and $300 \mathrm{ft}$ in width, and, more recently (post1990), use of relief wells in the Vicksburg District.

Additionally, riverside berms were built as well to fill deep borrow pits that extended into the substratum deposits (Figure 6), construction of riverside buttress berms for areas experiencing frequent shallow slough slides due to high plasticity clays, and where historic oxbows intersect the levee alignment. As an example of seepage berm modifications, Figure 9 shows a section of the MR\&T levee alignment downstream of the Eagle Lake area where the main-line levee ties into the Yazoo backwater levee leading to Steele Bayou. This section of levee has experienced several seepage-related issues in the recent past and subsequent modifications. These modifications are further described in the following paragraphs to help facilitate understanding of performance-related seepage control measures.

Figure 9. Example of seepage berm construction. Photograph of the east bank of the main-line MR\&T levee, between river mile 451 to 447, near Vicksburg, MS, showing the levee right-of-way and past remediation efforts for underseepage. This section of the levee was built between 1922 and 1926 to the 1914 profile, upgraded to the 1928 profile after the $1927 \mathrm{flood}$, and subsequently modified because of seepage-related issues with 150-ft and 300-ft-wide berms following the 1973 flood (USACE 1973a).

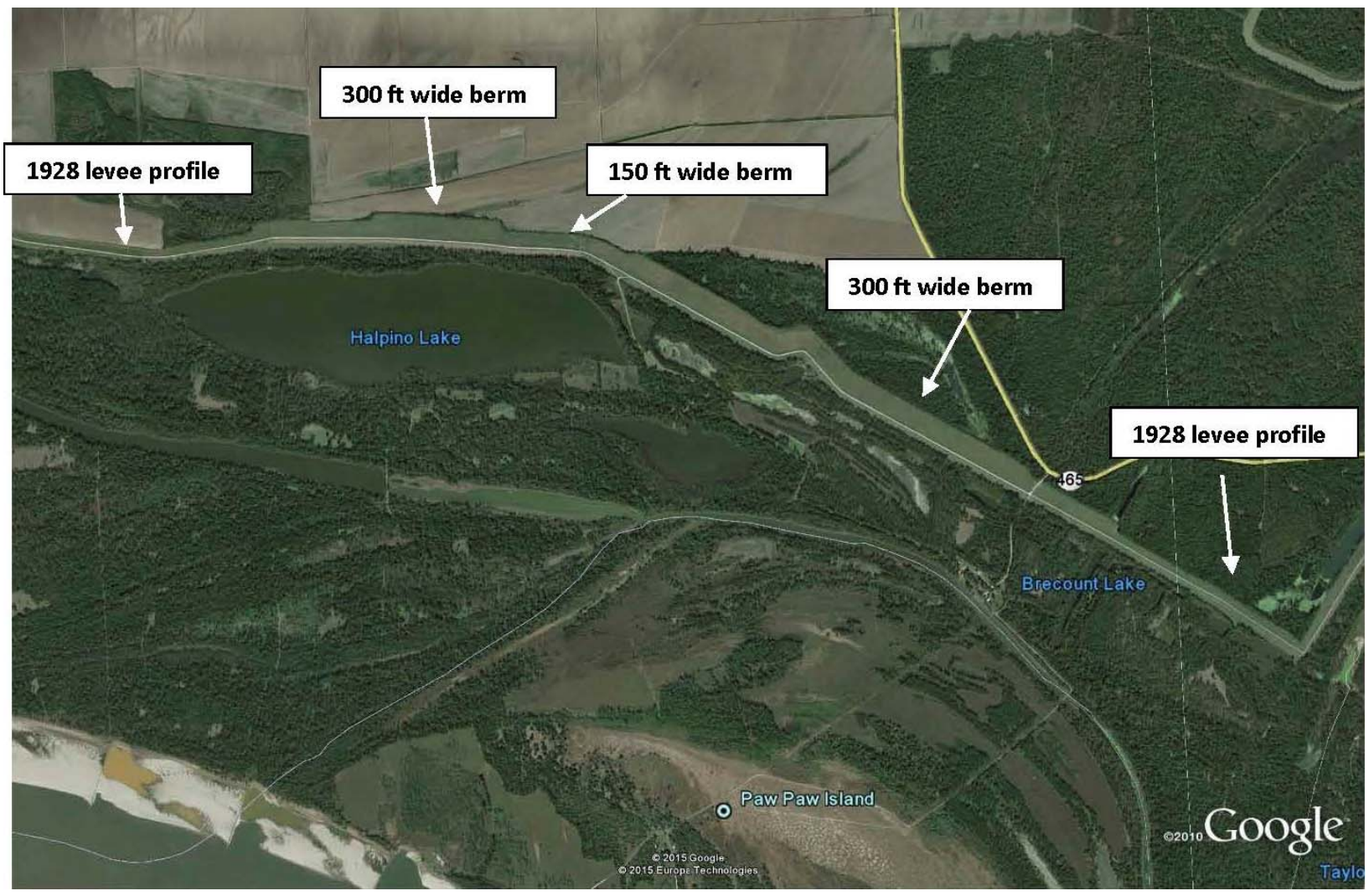


The Eagle Lake levee was built between 1922 and 1926 to the 1914 standard levee profile (Figure 7) as the New Brunswick levee extension, upgraded to the 1928 standard profile following the 1927 flood (USACE 1929, 1941a, 1941b) and subsequently modified again because of seepage-related issues following the 1973 flood. The intent for this particular example in Figure 8 is to draw attention to various changes that have occurred with the original levee design profile and geometry when examining 2011 seepage incidents along the levee right-of-way (Figure 9). Multiple levee modifications have occurred within this reach because of past performance incidents. The example shown in Figure 9 identifies one "moderately high-energy boil with a 12-in. throat, flowing approximately 75 to 100 gpm" at the toe of the 300-ft seepage berm at the location shown (see description in Appendix A, page 146, sta 9180+oo NLD). The large boil at this location was likely not an isolated incident because of the presence of several different widths and lengths of seepage berms that were constructed following the 1973 flood. The absence of a berm in the Figure 9 example is oftentimes based on the presence of a thick blanket at the levee toe due to a clay-filled swale, clayfilled abandoned channel, or presence of backswamp deposits.

The basis for seepage berm construction is centered on the concept of exit gradient ( $\mathrm{i}_{\mathrm{o}}$ ) at the landside levee toe, where exit gradient is the ratio between the excessive head beneath the blanket $\left(h_{0}\right)$ and the blanket thickness (z), where $i_{o}=h_{o} / z$ (see Figure 5 ). This excessive head can be viewed as the water level that would naturally occur in a piezometer installed at the landside toe of the levee during a flood event. A 300-ftwide seepage berm is built where the exit gradient at the levee toe is $>0.75$, while a 150 -ft-wide berm is built where the gradient is between 0.5 and 0.75 . Less than 0.5 , a berm is not required. Criteria for berm design are presented in USACE (2000).

Another component has direct bearing on the development of sand boil incidents at sta $9180+00 \mathrm{NLD}$, which involves land use changes: the post1973 construction of a water-control structure at Muddy Bayou and the construction of the Yazoo Basin backwater levee protection system. The latter includes the control structure at Steele Bayou and levees to protect the lower delta region from backwater flooding from the Mississippi River. Further explanation is warranted to fully understand the contribution of man-made activities to the development of sand boil and seepage issues at this location. 
The Muddy Bayou control structure currently regulates backwater seepage flow into Eagle Lake (see Plate 21, Volume III). Muddy Bayou was a natural outlet channel for interior drainage into Eagle Lake that is derived from the Yazoo Basin (drainage basin along the east bank of the MR\&T levees between Memphis and Vicksburg, see Plate 1). This bayou was formed when Eagle Lake was an active bend of the Mississippi River prior to 1867 . Presently, the Muddy Bayou water-control structure serves to regulate the flow of backwater drainage (seepage and rainfall) into Eagle Lake, MS. The control structure was built in part to prevent agricultural drainage affecting water quality in Eagle Lake.

A short distance downstream and east of the Muddy Bayou control structure is the Steele Bayou control structure. Gates at the Steele Bayou control structure are normally closed when the Mississippi River is in flood stage to prevent rising flood water from entering into the lower parts of the Yazoo Basin and flooding the lower delta region. However, closing the gates at Steele Bayou traps rainwater and seepage flow during flooding, which collects behind the levee system until the flood stages on the Mississippi River are low enough to open the gates and permit this trapped water to drain into the Mississippi River.

Prior to construction of the Muddy Bayou and Steel Bayou control structures, and the Yazoo Basin backwater levee protection system, a tailwater would collect in the lower parts of the Yazoo Basin as the Yazoo River would back up when the Mississippi River was in flood stage, and would flood low-lying areas in the vicinity of Eagle Lake, especially during moderate to large flood events. This overflow would form a tailwater in the low-lying areas, and effectively reduce the hydraulic gradients that now form behind the levee in this area. Incident data from both the 1937 and 1973 floods do not show any sand boil activity in this area, which is attributed to the natural backwater flooding into this area prior to the control structures and Yazoo Basin backwater protection levees being built. Standing water behind the levee in this area would have masked this condition and/or prevented it from occurring because of the tailwater that reduced the hydraulic gradients (WES 1948; USACE 1973a). In summary, the Eagle Lake example illustrates how historic levee construction and land use modifications can have a direct bearing on current day seepage and sand boil performance. 


\subsection{Levee through seepage and underseepage}

The Eagle Lake area identified two incidents as being through seepage in nature instead of underseepage. The 2011 seepage data contain a limited number of through seepage incidents (Figure 10). An important distinction is made on the map presentation of the 2011 incidents in terms of levee through seepage and underseepage incidents. The first being seepage through the levee embankment, while the latter being the movement of water horizontally in the substratum deposits or alluvial aquifer. A separate symbol was used to identify each type of event.

Figure 10. Through seepage (green triangle) and sand boil (red asterisk) incidents between river miles 447 to 451 (see Appendix A, page 146 for description).

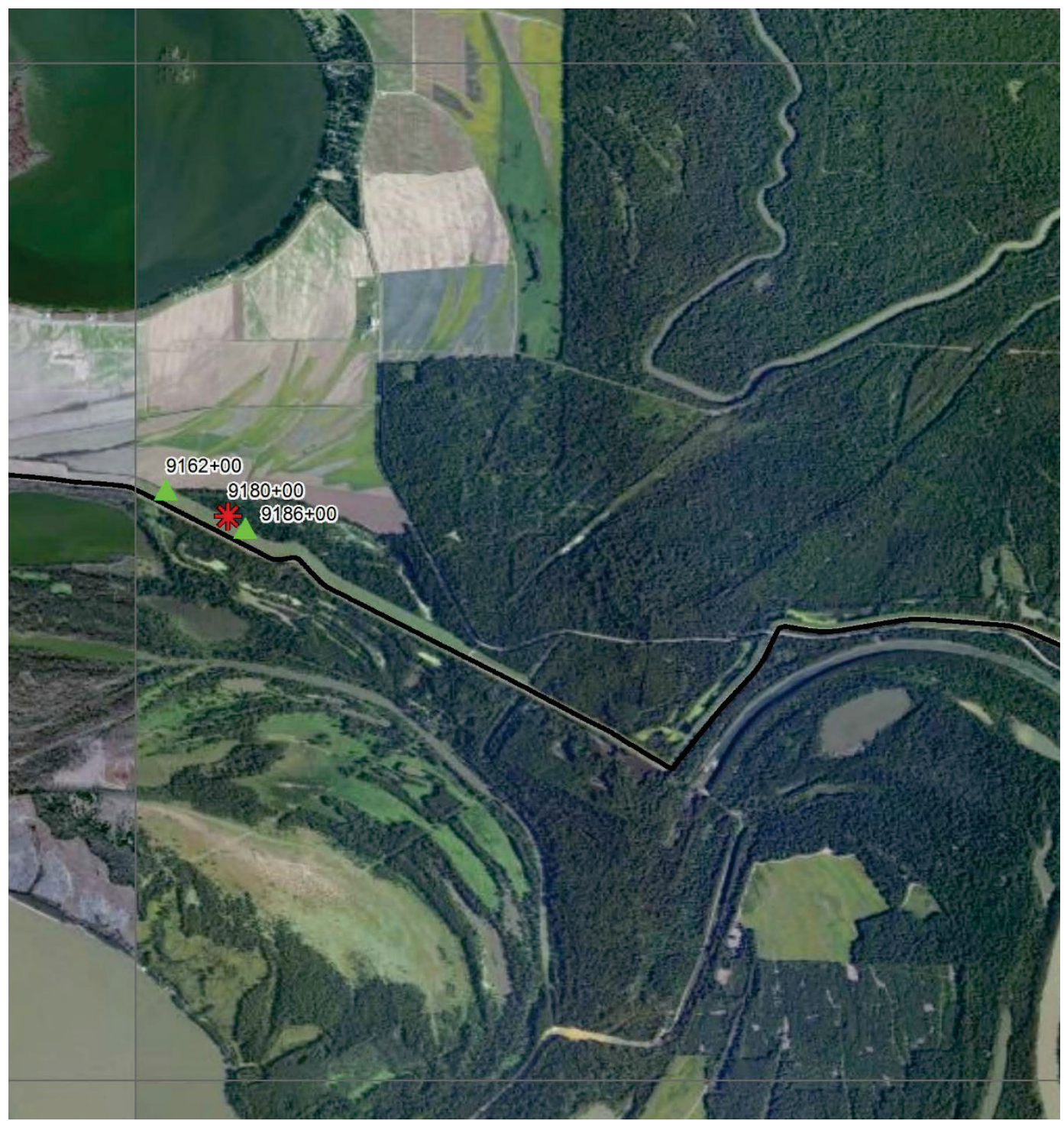


Additional context is briefly presented on MRC history involving through seepage events on the lower Mississippi River and its relevance to presentation of incidents observed during the 2011 flood. The MRC sponsored extensive research between 1929 and 1941 into levee through seepage on the lower Mississippi River. Some of the early research involved evaluation of the banquette section that was the design standard for the 1914 profile (Figure 7) against the benefits of the 1928 trapezoidal section that was ultimately adopted by the MRC as being the final form of the standard section (Long 1930). Results of these different studies ultimately determined that the fundamental problems that were observed with levee performance and seepage on the lower Mississippi River were primarily due to underseepage in the deep alluvial aquifer instead of levee through seepage (USACE 1941a, 1941b; WES 1931a, 1931b, 1936, 1938, 1939, 1941a, 1941b, 1945). Directly related to this early research effort was the underlying design of the standard levee section previously described (Figures 7 and 8). The poor performance of the 1928 levee section on the lower Mississippi River during the 1937 flood in terms of seepage and sand boils would lead the MRC to sponsor numerous long-term studies to better understand and effectively control the effects of underseepage (Mansur et al. 1956; Moore 1972; USACE 1939; 1941a, 1941b; WES 1938, 1939, 1941a, 1941b, 1945). The needs for underseepage research by USACE following the 1937 flood are further described in United States (1939) and WES (1945).

The 1928 levee section was designed for long-duration floods that were common in the LMV, and the underlying design slopes were intended to control through seepage conditions. The $1 \mathrm{~V}: 5.5$ to $6 \mathrm{H}$ back slopes were gained from long practical experience with Mississippi River floods in controlling levee through seepage (Figure 8). As previously described, the 1928 profile would later be modified in terminology by the 1947 Levee Code. Thus, the basic levee design in both the 1928 and 1947 sections specified a wide levee embankment section to effectively control through seepage conditions due to long duration floods (Figures 7 and 8). Nearly 90 percent of the all the levees built in the Vicksburg District were classified as clay levees (B levees in the 1928 profile, or Type II levees in the 1947 Code), which were typically not prone to through seepage issues (Moore 1972). The material spec identified by the 1928 profile was changed to a compaction spec by the 1947 Code with Type II levees corresponding to a moderate degree of compaction at the soils natural moisture content. 
In terms of the presentation of the 2011 flood incidents, any observations where through seepage conditions were observed (and identified) were classified separately from underseepage-related incidents on the maps in Volumes II and III to identify areas where through seepage conditions were reported. Generally, most 2011 through seepage reports involve minor incidents associated with berms. However, one through-underseepage incident stands out involving a levee slide, which will be discussed in more detail in the next section of this report. 


\section{Vicksburg District Seepage and Sand Boil Incidents}

\subsection{Seepage and sand boil incident data}

The portion of the Mississippi River in the Vicksburg District is flanked by levees divided into 12 reaches, with 6 reaches each along the left descending (east) and right descending (west) banks. The 2011 flood data contains 518 incident descriptions of seepage and sand boils that were subdivided for display purposes into points (total of 192 incidents) and polylines (total of 326 ). In terms of their map presentation and organization for this study, moderate-to large-sized sand cones/boils were generally reported individually as point features, while seepage extent behind the levee and/or locations with smaller sand boils and pin boils along a levee reach were presented as polyline (arc) features.

Incidents involving surface scour, current flow, relief well descriptions, the presence of sloughs, low spots, or other observations not directly involving seepage and sand boils incidents were not included for display. Slides involving the levee were also presented on the seepage maps as this type of incident often involves a seepage component. Incidents that did not have a latitude and longitude coordinate associated with the recorded observation were not included on the enclosed maps.

Polyline (arc) seepage data contains 326 recorded incidents and these were classified as sand boils (30 incidents), through seepage ( 9 incidents), underseepage (286 incidents), and a single incident involving a combination of a sand boil, through seepage, and slide (i.e., Albemarle slide at sta $8218 \mathrm{NLD}, 8170$ field). Seepage incidents, as previously described, were displayed using the traffic light analogy, classified as light (green), medium or moderate (orange) and heavy (red). Presentation of polyline sand boil-related incidents may overlap with individual point reporting of larger sand boils. This condition is unavoidable due to the reporting nature of the incidents where this dual reporting convention was observed.

Some incident descriptions were classified by the observers as being in a range from light to moderate or moderate to heavy. Incidents characterized by a classification range were included in the higher classification bracket for display purposes. Thus, light to moderate and moderate to heavy were mapped as being moderate and heavy, respectively. The distribution of the 
remaining 286 polyline underseepage incidents described in the 2011 flood report are as follows: heavy (14 incidents), moderate to heavy (13 incidents), moderate (25 incidents), light to moderate (36 incidents), and light (198 incidents). The vast majority of seepage data described in USACE (2011) are in the low to moderate category. The main focus of this study are those incidents reported as being in the large and heavy (red) category.

Point data were similarly classified, and involved 192 incidents composed of sand boils (74 incidents), slides ( 4 incidents), through seepage (11 incidents), and underseepage (88 incidents), underseepage with pin boils (15 incidents). Only 15 point type sand boils were classified as being heavy, large, or high-energy in nature, and 12 polyline areas were similarly classified. Thus, the combined 27 incidents of sand boils were reviewed for their description of condition, determination of overall severity, and for duplication of point and polyline features. A final list of 25 incidents was compiled from this data set, and these incidents are presented in Table 3 according to their NLD stationing. The summary table presents local name, incident description, associated quadrangle map where the incident occurs (for reference to Volumes II and III), and depositional environment associated with each incident. Information on the depositional environment was derived from the WES geological maps (Volume III).

\subsection{Relationship between sand boils and depositional environment}

Attention first focuses on all the 191 incidents of sand boil occurrence in the Vicksburg District during the 2011 flood involving small to large boils. As shown by Figure 11, this distribution is consistent with the earlier reporting by Mansur et al. (1956) and WES (1941b), which examined only a limited distribution of sites. Relationships between seepage occurrence and landform (depositional environment) was based on detailed site investigations of problem sites in these earlier studies and was concluded without the benefit of the comprehensive geologic mapping program by WES within the alluvial valley.

The majority of sand boil incidents identified in the Vicksburg District in Figure 11 correspond to the point bar environment (68.25 percent). The remaining number of incidents are associated with abandoned channels (23.5 percent), backswamp (6.25 percent), and outwash plain (2 percent) deposits. Included in Figure 11 is the distribution of point bar incidents in relationship to meander belt designation. Not surprising, the overwhelming majority of point bar incidents (121 incidents) are associated with the more 
recent meander belt 1 deposits, which are less than 3,000 years old (Saucier 1994). Incidents involving meander belt 2 (2,700 to 4,800 years old) comprise eight incidents, and one incident was associated with a tributary stream.

Rather surprising, however, are the large number of incidents (45 incidents, 23.5 percent) that are associated with abandoned channel settings. Previous reports of sand boil occurrence and relationship to depositional environment identified the point bar deposits as being the primary landform (Kolb 1975; Mansur et al. 1956). The high frequency of abandoned channel incidents relates to the types of pervious sediments contained within this environment, their often lower surface elevation, the nature of the channel filling-avulsion process, and the underlying principles behind artesian pressure distribution in the alluvial aquifer. An example is described in a subsequent section using the Lake Chicot, AR, area as an illustration of fundamental principals involved. However, before examining the abandoned channel setting in more detail, further discussion of the major sand boil incidents involved during the Mississippi River Flood of 2011 are described. 
Table 3. Moderate to large sand boils. (Note: These sand boils are highlighted in yellow in Appendix A.)

\begin{tabular}{|c|c|c|c|c|c|c|c|c|c|c|c|c|}
\hline Name 1 & Name 2 & $\begin{array}{l}\text { NLD } \\
\text { Station }\end{array}$ & $\begin{array}{l}\text { Field } \\
\text { Station }\end{array}$ & Type & Condition & Remarks & Latitude & Longitude & Quad & $\begin{array}{l}\text { Page No. } \\
\text { Append A }\end{array}$ & Photos & Environment \\
\hline Francis & $\begin{array}{c}\text { Lower Francis (TM } \\
\text { 3-424) }\end{array}$ & 151 & $151+00$ & $\begin{array}{l}\text { Sand } \\
\text { Boil }\end{array}$ & High & $\begin{array}{l}\text { A large, high-energy sand boil (photo 4, Appendix A) was identified moving } \\
\text { significant quantities of silt and fine sand material at the toe of a } 200-\mathrm{ft} \\
\text { seepage berm. The boil was bagged by the Levee Board with prison labor for } \\
\text { initial containment and subsequently sandbag ring was encircled by a larger } \\
\text { earthen berm. A filter of sand and stone was constructed over the boil throat } \\
\text { to filter fines and dissipate energy. Stabilization took } 4 \text { days of } 24 \text {-hr/day } \\
\text { effort (photos } 5 \text { to } 7 \text { ). Flow from boil was estimated at } 300 \text { gal/min. Boil had } \\
\text { potential to cause backward erosion and piping and lead to loss of berm and } \\
\text { foundation material. Two more sand boils were found } 100 \text { to } 150 \mathrm{ft} \text { from } \\
\text { berm toe (photos } 8 \text { to } 10 \text { ). These boils were moderate energy and move } \\
\text { approximately } 5 \text { to } 7 \text { cu yd of material. Boils were bagged by local prisoners. } \\
\text { Heavy seepage and numerous pin boils were noted and monitored 2,000 ft } \\
\text { either side. }\end{array}$ & 34.0862604 & -90.8652468 & Mellwood & A3 & $4-10$ & PB \\
\hline Winterville & $\begin{array}{c}\text { Greenville } \\
\text { Front } \\
\text { Levee }\end{array}$ & $\begin{array}{c}3744 \text { to } \\
3750\end{array}$ & 3710 to 3720 & $\begin{array}{c}\text { Sand } \\
\text { Boil }\end{array}$ & Heavy & $\begin{array}{l}\text { Winterville sand boil site - A large, high-energy sand boil approximately } 30 \mathrm{ft} \\
\text { from the toe of } 200-\text {-ft seepage berm near levee Sta. } 3720 \text {. The boil was } \\
\text { estimated to be flowing approximately } 300 \text { to } 350 \text { gpm and was moving } \\
\text { significant quantities of silt and fine sand (approximately } 100 \text { cu yd). Boil was } \\
\text { bagged by levee board with prison labor and a small earthen levee was } \\
\text { constructed by local contractor. A filter sand and stone was constructed over } \\
\text { the boil throat to filter fines and dissipate energy. Four additional medium } \\
\text { sized boils were identified within } 250 \mathrm{ft} \text { of the berm toe that required either a } \\
\text { small sandbag ring or a } 30 \text {-gal drum for stabilization. Boils are located } \\
\text { between levee sta } 3710 \text { and } 7320 \text {. }\end{array}$ & 33.4552370 & -91.0497397 & Refuge & A47 & 31-42 & PB \\
\hline $\begin{array}{l}\text { Lake } \\
\text { Ferguson }\end{array}$ & $\begin{array}{l}\text { Greenville Front } \\
\text { Levee }\end{array}$ & $\begin{array}{l}4065 \text { to } \\
4072\end{array}$ & 4031 to 4030 & $\begin{array}{l}\text { Sand } \\
\text { Boil }\end{array}$ & Heavy & $\begin{array}{l}\text { Multiple moderate to high-energy sand boils were identified moving large } \\
\text { quantities of fine sand in two separate areas on the east side of the railroad } \\
\text { tracks approximately } 400 \mathrm{ft} \text { from the levee toe. There is no seepage berm in } \\
\text { this area. Heavy seepage, numerous pin boils and saturated, soft ground was } \\
\text { identified in and around the boil areas. One area is on the power line right-of- } \\
\text { way and the other is in the woods approximately } 30 \text { yd to the southeast. } \\
\text { During the initial site visit, there were numerous small boils identified in the } \\
\text { wooded area. The throats on these boils ranged from } 3 \text { to } 6 \text { in in diameter } \\
\text { and several yards ( } 5 \text { to } 8 \text { cu yd) of material had been transported over a } \\
1,000-s q \text { ft area; however, most of these boils were producing clear water. } \\
\text { Some of the larger boils were later stabilized with } 30 \text {-gal drums placed over } \\
\text { the throats of the boils. There were approximately three high flowing sand } \\
\text { boils identified in a low spot along the power line. These boils were flowing } \\
\text { approximately } 100-200 \text { gpm each, and were transporting a significant } \\
\text { quantity of fine sand and clay/silt balls. More than } 15 \text { to } 20 \text { yd of material } \\
\text { had already been transported from the boils and material was still being } \\
\text { moved. Throat diameter of the boils ranged from } 12 \text { to } 18 \text { in. Levee board } \\
\text { work crews and inmates addressed these boils by building a sandbag } \\
\text { containment ring which had to be raised at a later date to increase the head } \\
\text { over the boils. }\end{array}$ & 33.3781530 & -91.0742310 & Refuge & A47 & 65-73 & PB \\
\hline $\begin{array}{l}\text { Lake } \\
\text { Ferguson }\end{array}$ & $\begin{array}{l}\text { Greenville Front } \\
\text { Levee }\end{array}$ & 3886 & $3852+00$ & $\begin{array}{l}\text { Sand } \\
\text { Boil }\end{array}$ & $\begin{array}{c}\text { Moderate/ } \\
\text { High }\end{array}$ & $\begin{array}{l}\text { Active sand boil identified on the edge of seepage berm approximately } 75 \text { yd } \\
\text { from the railroad tracks near levee sta } 3952 \text {. Area is under } 6 \text { to } 10 \text { in. of } \\
\text { seepage water. Sand boil has a } 12 \text {-in. throat and has formed a cone that is } \\
\text { approximately } 12 \text { in. high. Boil is flowing approximately } 50 \mathrm{gpm} \text { and continues } \\
\text { to transport moderate quantities of silt/fine sand. }\end{array}$ & 33.3994421 & -91.0701666 & Refuge & A48 & 61-62 & AC \\
\hline $\begin{array}{l}\text { Leland } \\
\text { Chute }\end{array}$ & Leland Chute & $2139+95$ & $2135+35$ & $\begin{array}{l}\text { Sand } \\
\text { Boil }\end{array}$ & Heavy & Bagged boil in ditch & 33.3601000 & -91.1632000 & Refuge & A180 & $33-37$ & PB \\
\hline
\end{tabular}




\begin{tabular}{|c|c|c|c|c|c|c|c|c|c|c|c|c|}
\hline Name 1 & Name 2 & $\begin{array}{l}\text { NLD } \\
\text { Station }\end{array}$ & $\begin{array}{l}\text { Field } \\
\text { Station }\end{array}$ & Type & Condition & Remarks & Latitude & Longitude & Quad & $\begin{array}{l}\text { Page No. } \\
\text { Append A }\end{array}$ & Photos & Environment \\
\hline $\begin{array}{l}\text { Leland } \\
\text { Chute }\end{array}$ & Leland Chute & $2142+80$ & $2138+20$ & $\begin{array}{c}\text { Sand } \\
\text { Boil }\end{array}$ & Heavy & Bagged boil in ditch & 33.3594000 & -91.1637000 & Refuge & A180 & $38-43$ & PB \\
\hline Lake Chicot & Lake Chicot & $\begin{array}{c}2309+50 \\
\text { to } \\
2544+90\end{array}$ & $\begin{array}{l}2305+60 \text { to } \\
2541+20\end{array}$ & $\begin{array}{c}\text { Sand } \\
\text { Boil }\end{array}$ & $\begin{array}{l}\text { Heavy/ } \\
\text { Large }\end{array}$ & $\begin{array}{l}\text { Lake Chicot - The site is historically an area with large boils. A large, high- } \\
\text { energy sand boil was located on the edge of a dredged channel at the south } \\
\text { end of Lake Chicot. There were multiple sandbag rings placed around the } \\
\text { boil. The throat would move and bypass the sandbag rings. A dike was } \\
\text { eventually constructed across the channel. Moderate seepage was exiting the } \\
\text { lake bank } 30 \mathrm{ft} \text { above the water surface. Several other medium to large, } \\
\text { moderate energy boils were located along the lake bank. These boils were } \\
\text { also ringed with sandbags. The boil closest to the levee was approximately } \\
400 \mathrm{ft} \text { from the toe of a } 300 \text {-ft seepage berm. This boil has repeatedly moved } \\
\text { significant quantities of material during previous high-water events and } \\
\text { exhibits some potential to develop pipes that may migrate towards the } \\
\text { berm/levee. Boils were identified up to 2,000 ft from the levee toe. }\end{array}$ & 33.2905000 & -91.10037 & Refuge & A180 & & AC-PB \\
\hline Fish Bayou & Lake Chicot & $2544+20$ & $2540+90$ & $\begin{array}{c}\text { Sand } \\
\text { Boil }\end{array}$ & Heavy & $\begin{array}{l}\text { Area known as Fish Bayou located approximately } 500 \mathrm{ft} \text { from berm toe at the } \\
\text { downstream end of Lake Chicot. }\end{array}$ & 33.2881300 & -91.1713600 & Refuge & A180 & 80-88 & PB \\
\hline $\begin{array}{c}\text { Lake } \\
\text { Washington } \\
\text { Area }\end{array}$ & $\begin{array}{c}\text { Washington/ } \\
\text { Issaquena } \\
\text { Counties }\end{array}$ & 6048 & $6025+00$ & $\begin{array}{c}\text { Sand } \\
\text { Boil }\end{array}$ & $\begin{array}{l}\text { Moderate } \\
\text { to Heavy }\end{array}$ & $\begin{array}{l}\text { Five or six small, active sand boils with 4- to } 5 \text {-in. throats were identified } \\
\text { along the toe of the seepage berm near levee sta } 6020 \text {. Boils were flowing } \\
\text { approximately } 20 \text { to } 30 \text { gpm and transporting fine sand producing cones } 2 \text { to } \\
3 \mathrm{ft} \text { in diameter. Area being monitored by levee board. Some of the boils } \\
\text { ringed by plastic drums. }\end{array}$ & 33.0143355 & -91.1355288 & Readland & A76 & $\mid 16-17$ & PB \\
\hline Longwood & River Mile 520 & 5400 & $5368+00$ & $\begin{array}{c}\text { Sand } \\
\text { Boil }\end{array}$ & $\begin{array}{l}\text { Moderate- } \\
\text { Large }\end{array}$ & $\begin{array}{l}\text { On July } 7,2011 \text {, landowner called and reported a "hole" out in his field. Levee } \\
\text { board took photos and measured hole to be } 2 \mathrm{ft} \text { deep with } 4 \text {-ft diam. There } \\
\text { was evidence of very fine sand material in the buckshot bean field. The boil } \\
\text { was located } 780 \mathrm{ft} \text { from levee center line. }\end{array}$ & 33.1438800 & -91.0719000 & Readland & A76 & |63-64 & PB \\
\hline $\begin{array}{c}\text { Lake } \\
\text { Washington } \\
\text { Area }\end{array}$ & River Mile 516 & $\begin{array}{l}5640+00 \\
\text { to } \\
5651+00\end{array}$ & $\begin{array}{l}5608+00 \text { to } \\
5619+00\end{array}$ & $\begin{array}{c}\text { Sand } \\
\text { Boil }\end{array}$ & $\begin{array}{l}\text { Heavy/ } \\
\text { Large }\end{array}$ & $\begin{array}{l}\text { Multiple large sand boils in this area. There are multiple boils in drainage } \\
\text { ditch just off toe of berm. Also, there are multiple boils on both sides of the } \\
\text { drainage ditch. Three of the boils occur right at the toe of the berm. Most of } \\
\text { these were bagged and were no longer moving material. Throat sizes range } \\
\text { from a couple inches to greater than } 6 \text { in. Sandbag ring constructed around a } \\
30 \text {-ft x } 10 \text {-ft sinkhole that formed in field. Plywood wall constructed around } \\
\text { boil also. Seepage is also exiting in the berm crown }\end{array}$ & 33.1054852 & -91.1294727 & Readland & A78 & \begin{tabular}{|l|}
$78-87$ \\
\end{tabular} & PB \\
\hline $\begin{array}{l}\text { Lake } \\
\text { Washington } \\
\text { Area }\end{array}$ & $\begin{array}{l}\text { Washington/ } \\
\text { Issaquena } \\
\text { Counties }\end{array}$ & $\begin{array}{l}6051 \text { to } \\
6057\end{array}$ & 6030 to 6035 & $\begin{array}{c}\text { Sand } \\
\text { Boil }\end{array}$ & $\begin{array}{l}\text { Moderate } \\
\text { to Heavy }\end{array}$ & $\begin{array}{l}\text { Three to five sand boils and large area of widespread moderate seepage } \\
\text { along the toe of the seepage berm near levee sta } 6030 \text {. Seepage extends } \\
\text { approximately } 1 / 4 \text {-mile out into field. Two sand boils were ringed with } 30-\text {-gal } \\
\text { plastic drums. Two or three boils were identified near the drums. Boils were } \\
\text { transporting fine sand and clay/silt balls. Numerous pin boils and moderate } \\
\text { seepage in bean field near sta } 6035 \text {. Most boils are transporting a small } \\
\text { quantity of material and are under } 2 \text { or } 3 \text { in. of water. }\end{array}$ & 33.0121588 & -91.1374451 & Readland & A107 & $\mid 18-22$ & PB \\
\hline $\begin{array}{l}\text { Lake } \\
\text { Washington } \\
\text { Area }\end{array}$ & $\begin{array}{l}\text { Clarence Hall } \\
\text { Road Site }\end{array}$ & $\begin{array}{l}6074 \text { to } \\
6050\end{array}$ & 6051 to 6070 & $\begin{array}{c}\text { Sand } \\
\text { Boil }\end{array}$ & Heavy & $\begin{array}{l}\text { Numerous, medium to large sand boils }(25+\text { ) approximately } 10 \text { to } 30 \mathrm{ft} \mathrm{from} \\
\text { the toe of the seepage berm between levee sta } 6050 \text { and } 6070 \text {. Levee board } \\
\text { was onsite placing drums, galvanized culverts, and sandbags over and } \\
\text { around boils. Entire area is under } 1 \text { to } 3 \mathrm{ft} \text { of seepage water from boils. } \\
\text { Several boils are high-energy producing } 50 \text { to } 100 \mathrm{gpm} \text {. }\end{array}$ & 33.0121588 & -91.1374451 & Readland & A107 & 23-30 & PB \\
\hline Moon Chute & Moon Chute & $2544+90$ & $3273+00$ & $\begin{array}{c}\text { Sand } \\
\text { Boil }\end{array}$ & Heavy & $\begin{array}{l}\text { Sand boil in ditch } 200 \mathrm{ft} \text { from berm toe with } 6 \text {-in. pipe. Moved about } 2 \mathrm{yd} \text { of } \\
\text { material. Additional pin boils in ditch with clear flow }\end{array}$ & 33.1582000 & -91.1795000 & Readland & A292 & 104 & PB \\
\hline
\end{tabular}




\begin{tabular}{|c|c|c|c|c|c|c|c|c|c|c|c|c|}
\hline Name 1 & Name 2 & \begin{tabular}{|l|} 
NLD \\
Station
\end{tabular} & \begin{tabular}{|l|} 
Field \\
Station
\end{tabular} & Type & Condition & Remarks & Latitude & Longitude & Quad & $\begin{array}{l}\text { Page No. } \\
\text { Append A }\end{array}$ & Photos & Environment \\
\hline $\begin{array}{c}\text { Lake } \\
\text { Washington } \\
\text { Area }\end{array}$ & $\begin{array}{l}\text { Near St Paul } \\
\text { Church }\end{array}$ & 6285 & $6265+00$ & $\begin{array}{c}\text { Sand } \\
\text { Boil }\end{array}$ & Heavy & $\begin{array}{l}\text { Several (4 to 6) large, high-energy sand boils under } 3 \text { to } 4 \mathrm{ft} \mathrm{of} \mathrm{water} \mathrm{in} \mathrm{a} \\
\text { drainage ditch in the bean field approximately } 200 \mathrm{ft} \text { north of Elwood Road } \\
\text { near levee sta } 6265 \text {. Two other boils have caused the banks of the ditch to } \\
\text { cave. Boils are transporting small quantities of silt/fine sand. Area was } \\
\text { flagged during inspection. }\end{array}$ & 32.9994266 & -91.1072870 & $\begin{array}{l}\text { Mayersville - } \\
\text { Lake } \\
\text { Providence }\end{array}$ & A108 & 51-52 & PB \\
\hline $\begin{array}{l}\text { Ben } \\
\text { Lomand } \\
\text { Road }\end{array}$ & Carlisle Lake & 7067 & $7100+00$ & $\begin{array}{c}\text { Sand } \\
\text { Boil }\end{array}$ & Heavy & $\begin{array}{l}\text { Multiple, high-energy, sand boils approximately } 10 \text { to } 50 \mathrm{ft} \text { from the seepage } \\
\text { berm toe near levee sta } 7100 \text {. Boils were flowing } 20 \text { to } 50 \mathrm{gpm} \text { and } \\
\text { transporting moderate quantities of fine sand ( } 2 \text { to } 5 \mathrm{cu} \text { yd each). Throat } \\
\text { diameters for the boils generally ranged from } 2 \text { to } 10 \text { in. Some of the boils } \\
\text { were ringed with culverts. }\end{array}$ & 32.8317126 & -91.1031782 & $\begin{array}{l}\text { Mayersville - } \\
\text { Lake } \\
\text { Providence }\end{array}$ & A109 & 95-99 & PB \\
\hline $\begin{array}{l}\text { Ben } \\
\text { Lomand } \\
\text { Road }\end{array}$ & $\begin{array}{c}\text { Lake Washington } \\
\text { Area }\end{array}$ & $\begin{array}{l}7195 \text { to } \\
7210\end{array}$ & $7120+00$ & $\begin{array}{c}\text { Sand } \\
\text { Boil }\end{array}$ & Heavy & $\begin{array}{l}\text { Ben Lomand road site - Several medium to large sand boils were identified } \\
\text { moving moderate quantities of fine sand and silt in a drainage ditch along the } \\
\text { toe of the seepage berm and in an open area east of the ditch. All of the sand } \\
\text { boils were within } 10 \text { to } 20 \mathrm{ft} \text { of the seepage berm toe. Water berm was } \\
\text { created over most of the sand boils in the ditch by the levee board by } \\
\text { constructing dikes on the upstream and downstream sides of the sand boils. } \\
\text { Also, at least three of the sand boils in the ditch were ringed with galvanized } \\
\text { culverts. As a result of the dikes and culverts, most of the boils in the ditch } \\
\text { were covered with at least } 3 \text { to } 4 \mathrm{ft} \text { of water. Also, there were several medium } \\
\text { boils identified in the edge of a field on the east side of the ditch that were } \\
\text { ringed with culverts by the levee board and eventually two sandbag rings were } \\
\text { constructed around the area to increase the head and slow the movement of } \\
\text { material. Most of the boils were flowing approximately } 50 \text { to } 100 \text { gal/min } \\
\text { each, and continued to by remedial action by the levee board transport a } \\
\text { significant quantity of material until the area was stabilized. }\end{array}$ & 32.8013736 & -91.1219469 & $\begin{array}{l}\text { Mayersville - } \\
\text { Lake } \\
\text { Providence }\end{array}$ & A110 & $\begin{array}{l}100- \\
118\end{array}$ & PB \\
\hline Buck Chute & Eagle Lake & $\begin{array}{l}8749 \text { to } \\
8764\end{array}$ & $\begin{array}{l}110+00 \text { to } \\
131+00\end{array}$ & $\begin{array}{c}\text { Sand } \\
\text { Boil }\end{array}$ & Heavy & $\begin{array}{l}\text { Buck Chute - Stabilization berm constructed at Buck Chute. Water Control } \\
\text { Plan for Eagle Lake, A significant boil developed about } 5 \mathrm{ft} \text { west of relief well } \\
\text { BC-2-98. Stabilization berm constructed and was completed in early May } \\
2011 \text { to control seepage and sand boils. A deviation in the water control plan } \\
\text { for Eagle Lake was enacted to minimize seepage pressures through the levee. } \\
\text { Water level in Eagle Lake was raised to } 89.8 \mathrm{ft} \text {. }\end{array}$ & 32.5348209 & -91.0780773 & Alsatia & A146 & 74-91 & $A C$ \\
\hline $\begin{array}{c}\text { Tara } \\
\text { Hunting } \\
\text { Camp }\end{array}$ & Eagle Lake & $\begin{array}{l}8847 \text { to } \\
8964\end{array}$ & $\begin{array}{c}210+00 \text { to } \\
327+00\end{array}$ & $\begin{array}{c}\text { Sand } \\
\text { Boil }\end{array}$ & $\begin{array}{l}\text { Heavy/ } \\
\text { Large }\end{array}$ & $\begin{array}{l}\text { Moderate to heavy underseepage, numerous active, medium sized sand boils } \\
\text { and pin boils were observed within } 50 \mathrm{ft} \text { of the levee toe between Brunswick } \\
\text { Extension Levee (BEL) sta } 210+00 \text { and } 327+00 \text { near and around Tara } \\
\text { Hunting Camp. Two to three, large, high-energy sand boils with } 12 \text { - to } 16-\text { in. } \\
\text { throats were identified between Sta. } 210 \text { and } 220 \text { that flowed } 100+\text { gal/min } \\
\text { and transported } 5+\text { cu yd of fine sand/silt before and during remedial action. } \\
\text { These boils were located between } 10 \text { and } 20 \mathrm{ft} \text { from the toe of the eveee. One } \\
\text { boil, located near sta } 212+00 \text { BEL was ringed with sandbags by the levee } \\
\text { board. The other boils were eventually stabilized with drums placed over the } \\
\text { throats of the boils. A large water berm, several feet in depth, was created by } \\
\text { the underseepage in this area and the bermed area was investigated by boat } \\
\text { on } 5 / 23 / 11 \text {. During this investigation, over } 30 \text { sand boils were identified } \\
\text { under the surface of the water berm in the general area of levee sta } 260 \text {. }\end{array}$ & 32.4986254 & -91.0754191 & Alsatia & A147 & $95-109$ & PB \\
\hline
\end{tabular}




\begin{tabular}{|c|c|c|c|c|c|c|c|c|c|c|c|c|}
\hline Name 1 & Name 2 & $\begin{array}{l}\text { NLD } \\
\text { Station }\end{array}$ & $\begin{array}{l}\text { Field } \\
\text { Station }\end{array}$ & Type & Condition & Remarks & Latitude & Longitude & Quad & $\begin{array}{l}\text { Page No. } \\
\text { Append A }\end{array}$ & Photos & Environment \\
\hline Albemarle & $\begin{array}{l}\text { Albermarle } \\
\text { Slide/Boil }\end{array}$ & 8218 & 8170 & $\begin{array}{l}\text { Sand } \\
\text { Boil- } \\
\text { Slide }\end{array}$ & Heavy & $\begin{array}{l}\text { Five medium-sized, high-energy sand boils along the toe of the levee near 16- } \\
37 \text { levee sta } 8170 \text { (no berm). A large, landside, slide developed immediately } \\
\text { downstream from the boils. A stone ring was placed around the sand boils } \\
\text { and a filter of sand was placed over the throats of the boils. The levee board } \\
\text { worked throughout the night to stabilize the boil. The stabilization of the slide } \\
\text { began the following day with Corps hired labor forces. An additional slide } \\
\text { developed during the second night immediately upstream from the sand } \\
\text { boils. Both slides were accompanied with and possibly the result of heavy } \\
\text { seepage exiting at the slide face and on the slope below. Hired labor } \\
\text { continued daytime stabilization of the slide by placing crushed limestone at } \\
\text { the toe and sand on the lower end of the slide to provide additional weight } \\
\text { and drainage. The slides were present in the lower } 1 / 3 \text { of the levee } \\
\text { embankment and were relatively shallow in depth. A small slide near the } \\
\text { levee toe formed immediately above the sand boils on the third day that } \\
\text { connected the two larger slides. The hired labor forces maintained daytime } \\
\text { activities on the site for approximately } 14 \text { days to stabilize both the slides and } \\
\text { the boils. There were approximately } 6,000 \text { tons of limestone (\#t } 57 \text { stone) and } \\
11,000 \text { tons of sands placed on the site to stabilize the slope. The boils at } \\
\text { the levee toe and the embankment instability could have progressed to loss } \\
\text { of levee foundation material and/or significant loss of the net levee section. }\end{array}$ & 32.6282974 & -90.9990409 & Onward & A145 & $16-37$ & AC-PB \\
\hline $\begin{array}{l}\text { Tara } \\
\text { Hunting } \\
\text { Camp }\end{array}$ & Eagle Lake & 9180 & $542+00$ & $\begin{array}{c}\text { Sand } \\
\text { Boil }\end{array}$ & Heavy & $\begin{array}{l}\text { Moderately high-energy sand boil with a 12-in. throat along the toe of the } \\
\text { seepage berm near levee sta } 542 \text { (BEL). Boil has transported about } 3 \text { cu yd } \\
\text { of silt/fine sand and is flowing approximately } 75 \text { to } 100 \mathrm{gpm} \text {. Boil was flagged } \\
\text { for the levee board. }\end{array}$ & 32.4628870 & -90.9924057 & Vicksburg & A147 & 117 & PB \\
\hline Oakwood & $\begin{array}{l}\text { Near Villa Clara } \\
\text { Church }\end{array}$ & 6178 & 6183 & $\begin{array}{c}\text { Sand } \\
\text { Boil }\end{array}$ & Large & $\begin{array}{l}\text { Inspected May } 28,2011 \text {. Reported by night crew approximately } 4 \text { miles south } \\
\text { of St Joe, LA. Boil is located } 950 \mathrm{ft} \text { landside for top of levee at sta } 6185+75 \\
\text { downstream of culvert in ditch. This large, high-energy boil has produced } \\
\text { possibly over } 100 \text { yd of material. Ditch at this location is about } 1 \mathrm{ft} \text { teeep and } \\
\text { there is material above water level. Within a } 2 \text {-hr period the boil increased } \\
\text { from } 4 \text { - to } 6 \text {-ft- diam with a } 13 \text {-ft-diam sand cone. Outside perimeter of the } \\
\text { sand cone is approximately } 60 \mathrm{ft} \text { in diameter with some material flowing } \\
\text { downstream. This area has a } 100-\mathrm{ft} \text {-diam sunken cracked area along the } \\
\text { upstream and east-west side of ditch. The boil throat is at least } 18 \mathrm{ft} \text { in } \\
\text { depth. Majority of material appears to be a silty sand with some clay particles } \\
\text { inside hole. Clay does not appear to be foundation material. On May } 29 \text {, the } \\
\text { levee board placed two sandbag dams across the ditch one on each side. } \\
\text { There was about } 4 \mathrm{ft} \text { of water over the boil. }\end{array}$ & 31.8831611 & -91.2736138 & Locust Ridge & A287 & $22-24$ & PB \\
\hline Oakwood & $\begin{array}{l}\text { Near Villa Clara } \\
\text { Church }\end{array}$ & $6178+50$ & $6183+50$ & $\begin{array}{c}\text { Sand } \\
\text { Boil }\end{array}$ & Heavy & $\begin{array}{l}\text { Large high-energy boil inspected on June 1, 2011. Seventy-five feet NNW of } \\
\text { above boil. }\end{array}$ & 31.8833440 & -91.2737270 & Locust Ridge & A287 & & PB \\
\hline Lake Bruin & $\begin{array}{l}\text { Lake Bruin/ } \\
\text { Melancon Camp }\end{array}$ & 5659 & $5663+00$ & $\begin{array}{c}\text { Sand } \\
\text { Boil }\end{array}$ & Heavy & $\begin{array}{l}\text { Large boils at Melancon Camp. - They have moved material from behind } \\
\text { seawall. Most are located in the lake and cannot be measured. Some small } \\
\text { ones along the bank. Seven boils in Lake Bruin, which have produced } 10 \text { yd } \\
\text { of silty sand, range in size from } 2 \text { to } 5 \text {-ft diam. }\end{array}$ & 31.9880299 & -91.1863609 & St Joseph & A285 & $1-6$ & PB \\
\hline Lake Bruin & $\begin{array}{l}\text { Lake Bruin/ } \\
\text { Melancon Camp }\end{array}$ & 5706 & $5710+00$ & $\begin{array}{c}\text { Sand } \\
\text { Boil }\end{array}$ & Large & $\begin{array}{l}\text { Large boils in Botany Bay Ditch. - Boils have been sandbagged and ditch has } \\
\text { been bagged to allow higher head over boils. Both have moved large amount } \\
\text { of material. Approximately } 450 \mathrm{ft} \text { from the levee toe. }\end{array}$ & 31.9762521 & -91.1891261 & St Joseph & A285 & $7-10$ & PB \\
\hline
\end{tabular}


Figure 11. 2011 Sand boil distribution by depositional environment.

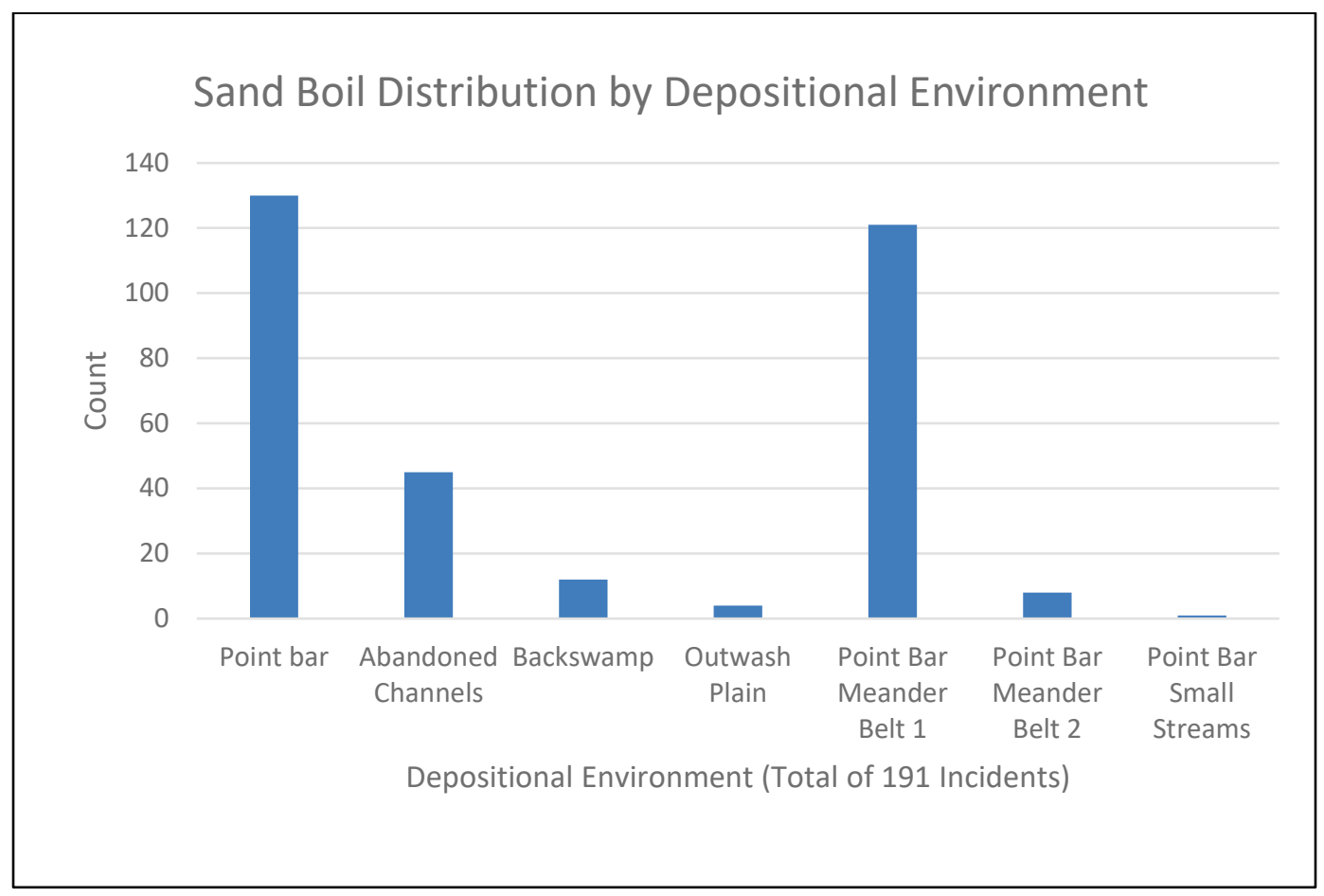

\subsection{Occurrence of high priority and large sand boils}

High priority and/or large sand boil incidents during the 2011 flood in the Vicksburg District are identified in Table 3. These incidents number 25 in total. The vast majority of these incidents are associated with point bar (PB) deposits, followed by two incidents associated with abandoned channels (AC), and two incidents occurring at the boundary between the point bar and the abandoned channel environment. Incidents involving abandoned channel settings are expected to occur because of their lower ground elevation (contributing to higher gradients), presence of aquifer sands near surface, and/or oftentimes a thin top stratum (blanket) present, especially involving historic abandoned oxbows.

\subsection{Blocked exits}

Incidents occurring at the boundary between two environments are considered to be representative of a blocked exit type setting (Figure 6). An abrupt change in the hydraulic conductivity of the seepage pathway occurs at these locations within the alluvial aquifer. The seepage model shown by Figure 6 from Mansur et al. (1956) is representative of a blocked exit because of the presence of fine-grained swale deposits. A swale corresponds to fine-grained filling of slough deposits that separate the 
sand ridges (lateral bars) in the point bar environment. Presentation of the blocked exit condition is also shown in Appendix B, see Figure B2 (Fisk 1945). Illustrations in Appendix B identify other conditions favorable for seepage and sand boil formation behind levees involving blocked exit conditions. Ridge and swale or meander scroll topography are diagnostic features of the point bar environment and are believed to be a major contributor to a blocked exit condition (Fisk 1946; Mansur et al. 1956). At the local landform scale, the blocked exit condition is more representative of sand boil incidents involving point bar deposits, because of the abrupt change in horizontal conductivity in the aquifer and the higher pressure concentrations at these locations.

\subsection{Abandoned channels}

The large number of incidents of sand boils associated with abandoned channel settings is likely a function of their lower surface elevation and the shallow daylighting of aquifer sands in these settings. This condition is especially apt to occur where oxbow lakes are relatively young in terms of their separation from the main river. Another contributing factor to the high number of incidents is the thickness of the blanket (top stratum) in the oxbow channel. The blanket is more apt to be thin or absent near the arms of the avulsion point, especially in abandoned channels that are less than 100 years old. Depth to the underlying aquifer sands varies with the distance from the neck cutoff (avulsion) location. Typically, both the upper and lower arms of abandoned channels contain pervious sand deposits, which are deposited fairly shortly after separation from the main channel. Following separation, the oxbow then receives only fine-grained sediment from overbank deposition during the annual flooding cycle as a direct connection to the oxbow is blocked by coarse channel fill at the separation point. The lake-filling process can vary from as little as 100 years to as much as 1,500 years, depending on sediment supply (Gagliano and Howard 1984).

Oxbow lakes that have been separated from the main channel less than 200 to 300 years ago are apt to have a relatively thin blanket near their upper and lower ends, and contain shallow aquifer sands in the subsurface. This combination of blanket thickness and shallow depth to aquifer sands, combined with their much lower surface elevation, makes these locations favorable for sand boil occurrence behind levees. Incidents associated with this landform were fairly common during the 2011 flood at Lake Chicot, AR, Lake Providence, LA, and Eagle Lake, MS, (Table 3). 


\subsection{Lake Chicot example}

Sand boil incidents during the 2011 flood at Lake Chicot are described here in more detail to highlight basic relationships described and identified by the incident distribution in terms of depositional setting, topography, floodplain soils, lower surface elevation, and general proximity to the river. The character and extent of sediment filling within an abandoned channel loop at different points along its length are shown by Plate 2. This example was originally presented by Fisk (1947) as part of a study on the effects of fine-grained deposits on river migration. The series of channel cross sections in Plate 2 show the nature and thickness of channel-fill deposits along various points in the old river channel as well as the changes in channel bathymetry (elevation in feet mean sea level) that was present in 1947. Because of the levee system blocking introduction of new sediment into the lake, it is unlikely that the 1947 bathymetry has significantly changed over the past 68 years.

The series of cross sections through the Lake Chicot channel show the coarse nature of the channel-fill deposits in the vicinity of the neck cutoff, which become progressively finer grained in texture in the interior parts of the abandoned channel. However, the presence of backwater drainage into the oxbow lake can locally affect the texture of the channel fill deposits as shown by the occurrence of shallow sands in cross section D-D' in Plate 2. At this location, a tributary stream intersects the old channel and is introducing sand into the channel.

The 1947 surface topography has been overlain on a current photograph of the Lake Chicot area in Plate 3. This example clearly shows the extent of active river channel migration that has occurred in this reach since 1947, prior to hardening the present course of the river with revetment and control dikes. Separation of Lake Chicot from the main channel occurred prior to the 1700 and is in the lacustrine stage of the filling cycle (Gagliano and Howard 1984). Overlain on Plate 3 are the locations of the recorded sand boil and seepage incidents from the 2011 flood (see also Table 3 and Appendix A). The association of sand boil incidents at the upper and lower arms of the old oxbow is clearly evident from this example. Aquifer sands are fairly shallow as shown by the boring data in Plate 2 .

The relationship between landform topography and sand boil occurrence is shown in Plate 4 with the addition of the 2006 Light Detection and Ranging (LiDAR) data along the levee corridor from the Lake Chicot area. The 
importance of local topographic features involving depositional environments is further highlighted by the 2006 LiDAR data. The relationship between the ridge and swale topography that is characteristic of the point bar landform and the occurrence of sand boils is identified by Plate 4 .

Local topography has been accented by using hill-shading techniques in Plate 4 to show the relief that is present. Large to moderate sized sand boils were located at the edge of the old channel or at the nearby point bar ridges, where aquifer sands daylight at the surface. The intervening swales are typically fine-grained and promote a blocked exit condition locally. The presence of a drainage ditch at the landside toe of the levee between stations 2124 to 2161 (north eastern reach of Plate 4) probably intersected point bar sand ridges, where the shallow aquifer sands daylight in the bottom of the drainage ditch and help create a seepage pathway for these boils to develop.

In summary, incidents associated with abandoned channel settings and point bar deposits were not isolated cases during the 2011 flood. These incidents are fairly representative of a class of alluvial depositional environment where local topography, soil type, blanket thickness, depth to aquifer sands, surface elevation, presence of blocked exits, and other kinds of local defects unique to each location occur. A major goal of the WES geologic mapping program in the LMV was to characterize the soils composing the various depositional environments and their distribution across the floodplain (Kolb et al. 1968; Saucier 1994, 1967, 1964). This characterization identified basic relationships that exist between depositional environment and sediment texture based on energy flow within these environments.

\subsection{Performance history during past floods}

Major floods as previously described occurred in 1937, 1973, and 2011 in the LMV. Incidents of sand boil occurrence during the 2011 flood have been described in the preceding sections and their relationship to the underlying geology in terms of environments of deposition have been explored. Sand boil incidents from the 1937 and 1973 floods are similarly evaluated and summarized in this section and are compared to the 2011 data, especially as it relates to reaches that have experienced chronic sand boil and seepage issues. Table 4 presents a general summary of historic sand boil point data, size/severity distribution of known incidents for the three largest floods of record in the Vicksburg District, using the historic 
maps of sand boil and seepage incidents from these floods (WES 1948; USACE 1973a and 1973b).

The vast majority of sand boil incidents are typically small to moderate in size and severity. Large and/or severe sand boils correspond to about one quarter of all the incidents observed.

Table 4. Comparison of point sand boil data based on size-severity across major floods in the Vicksburg District.

\begin{tabular}{|l|l|l|l|l|}
\hline Flood Event & $\begin{array}{l}\text { Small } \\
\text { No. and (\%) }\end{array}$ & $\begin{array}{l}\text { Moderate } \\
\text { No. and (\%) }\end{array}$ & $\begin{array}{l}\text { Large } \\
\text { No. and (\%) }\end{array}$ & Total Incidents \\
\hline 1937 & $96(65)$ & $27(18)$ & $24(16)$ & 147 \\
\hline 1973 & $52(55)$ & $9(10)$ & $33(35)$ & 94 \\
\hline 2011 & $37(50)$ & $22(29)$ & $15(20)$ & 74 \\
\hline General Average & $56.7 \%$ & $19.3 \%$ & $24 \%$ & - \\
\hline
\end{tabular}

Figures 12 and 13 present the distribution of sand boil incidents for the 1973 and 1937 floods, respectively, according to the underlying depositional environment. Point bar deposits in Figures 12 and 13 for the 1973 and 1937 floods are shown both cumulatively and classified according to their meander belt age using Saucier's (1994) chronology. General trends in terms of landform distribution are similar across the three major floods as one would expect. Point bar deposits account for nearly 75 percent of the total incidents, abandoned channels represent about 20 percent, and the remaining 5 percent are a combination of other environments, abandoned course, outwash plain and backswamp.

These other environments were associated primarily with the 1937 flood data and involved a channel that was subsequently modified by cutoffs to shorten the course of the river (Figure 14). Approximately 151.9 miles of the Mississippi River in the central part of the alluvial valley were removed through a series of 16 cutoffs across major meander loops in the river between 1929 and 1943 (Winkley 1977, Figure 14). The purpose for the cutoffs was to quickly route flood flow through the central alluvial valley, thereby lowering flood stages. Twelve of the 16 cutoffs occurred within the Vicksburg District area. The success of the cutoff program in reducing flood stage eliminated the need for a planned Boeuf-Tensas floodway across Louisiana (Camillo 2012). The distribution of incidents involving depositional environments in Table 4 likely includes a modified channel and levee right-of-way after 1942 when the last of the cutoffs were completed. 
Figure 12. Distribution of 1973 sand boils based on depositional environment.

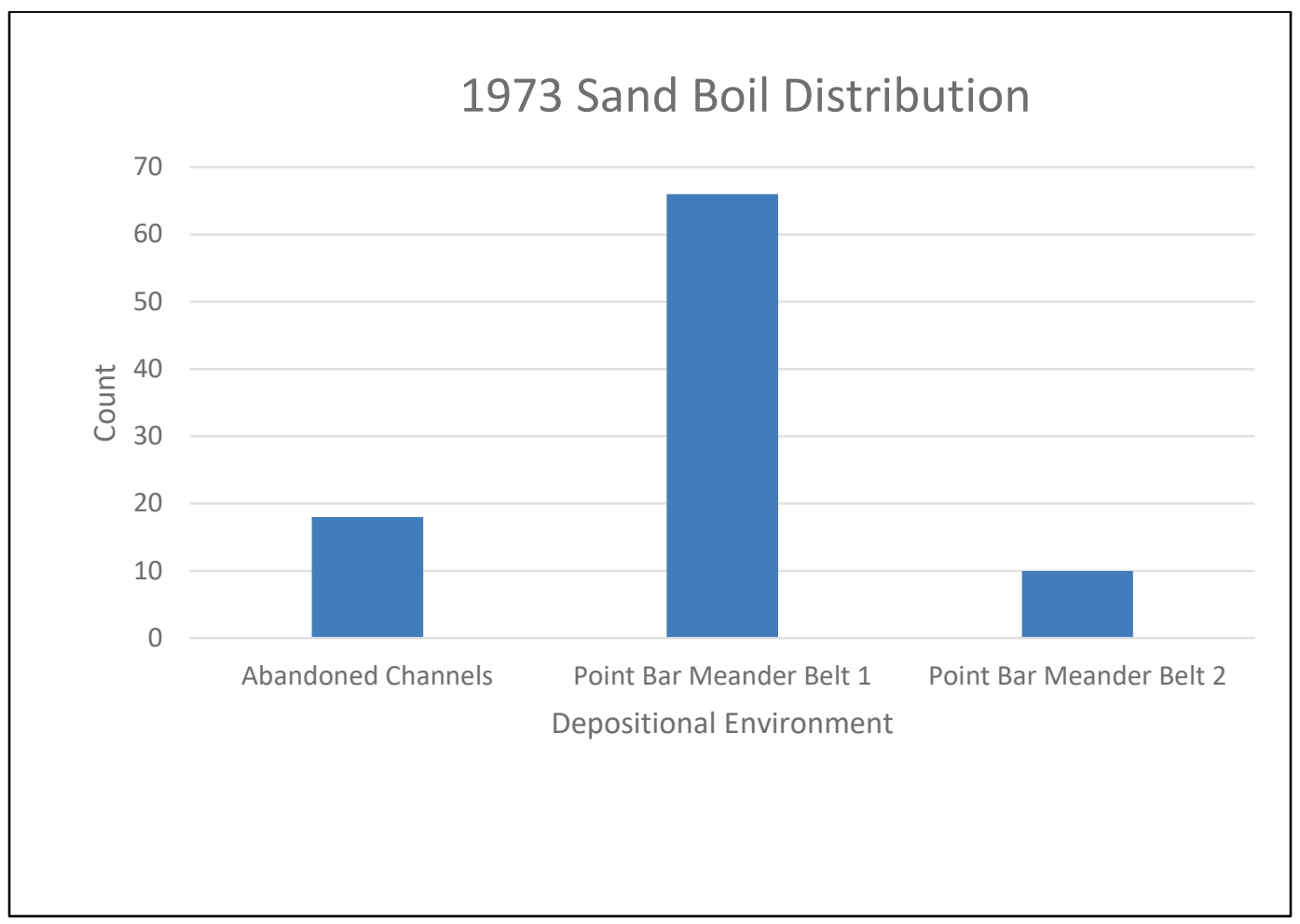

Figure 13. Distribution of 1937 sand boils based on depositional environment. Point bar incidents are separated into their respective meander belt ages (Hpm1 to 3 ) on right side of graph.

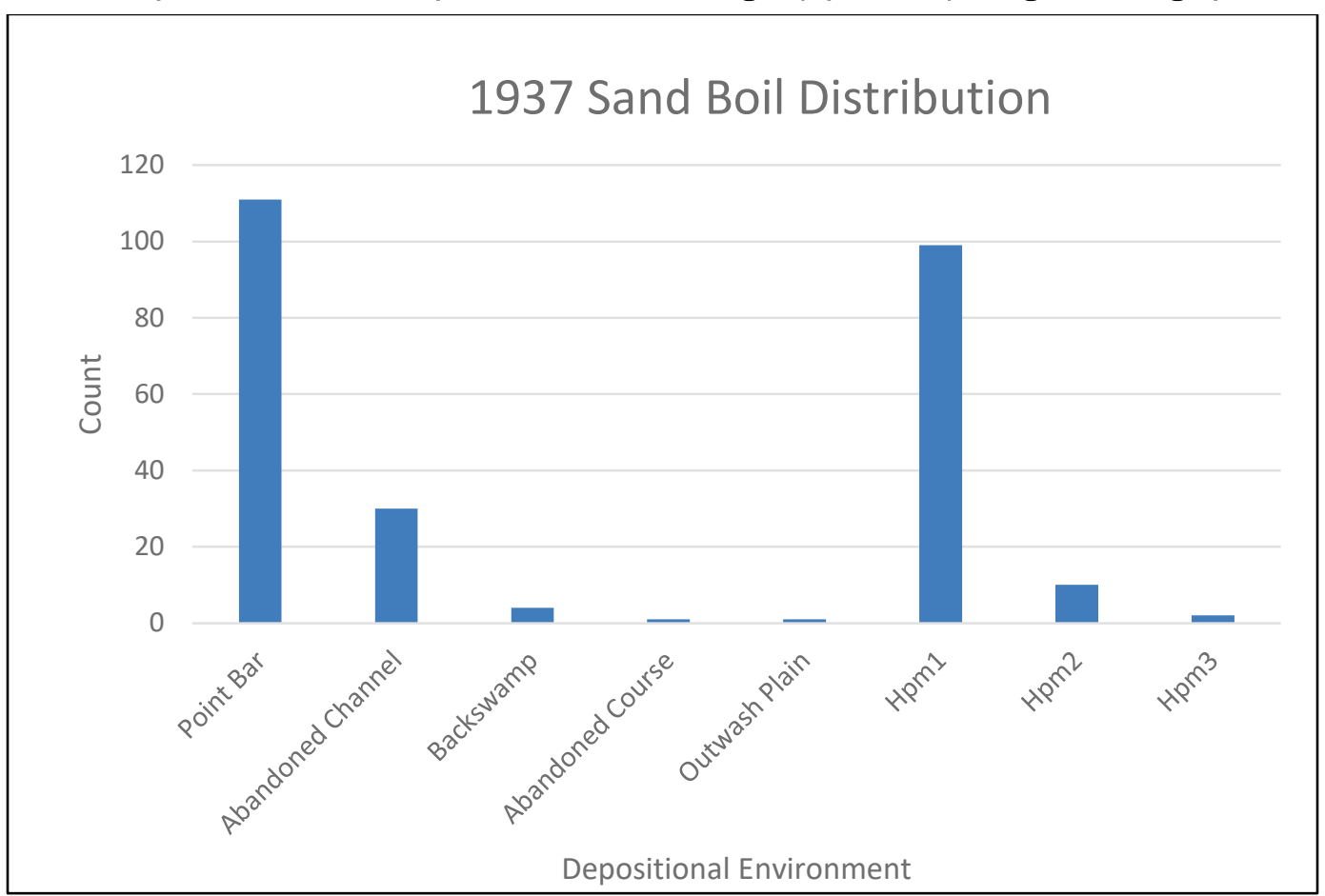




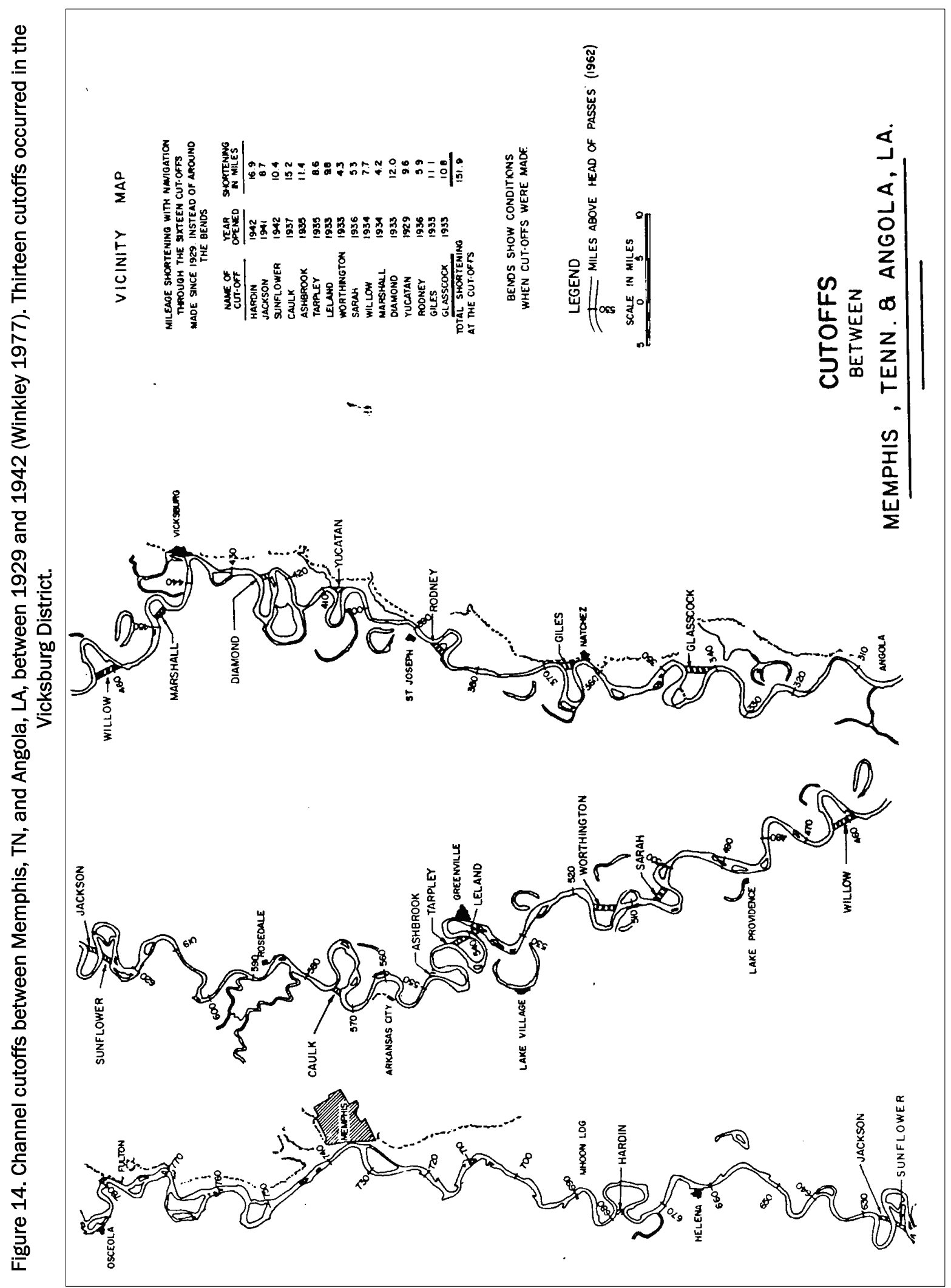




\subsection{Chronic seepage and sand boil areas}

A list of the significant seepage and sand boil areas during the 2011 flood was presented in Table 3. This listing was compared to the seepage and sand boil maps from the 1937 and 1973 floods to determine whether any of these locations have experienced chronic performance issues. This comparison of historic locations is presented as Table 5 and identifies four principal areas, Francis, Leland Chute-Lake Chicot, Greenville, and a reach of the Lake Washington area that has experienced performance issues across each of the three major flood events. These four locations are examined in more detail in this section.

Francis, MS. Seepage and sand boils for Francis, MS, are shown in Figures 15a through 15c for the 1937, 1973 and 2011 floods, respectively. A levee setback occurred at this location as shown by Figure 15a (WES 1948, Plate 17). The exact date of the setback is unknown. Although the lower Francis new levee section had no observed performance issues in 1937, it is included here because of later chronic seepage and sand boil issues occurring during the 1973 and 2011 floods as shown by the respective maps in Figures 15b and 15c. Additionally, this reach is included here because it was one of the initial study sites for underseepage examined in WES (1941b) and Mansur et al. (1956). The area shown in Figure 15a was designated as the lower Francis by Mansur et al. (1956). This same designation will be continued here for discussion purposes. As shown in Figure 15a, a sublevee was fronting the current day levee when the 1939 topographic base map was produced.

Large boils were present at lower Francis during both the 1973 and 2011 floods. A large boil occurred at lower Francis at sta 151+oo, at the edge of the seepage berm (see Tables 3 and 5 for index to photographs in Appendix A for this large boil). As shown by the geology map (Figure 15b, also see Mellwood Quadrangles in Volumes II and III), the boil area is located near the boundary between the point bar and abandoned channel deposits. This continued seepage and sand boil occurrence is likely due to a blocked exit condition caused by the presence of the abandoned channel. The abrupt change in hydraulic conductivity within the aquifer sands by the presence of the fine-grained abandoned channel deposits has likely resulted in excessive seepage at point bar ridges and/or hydraulic fracturing of the thin blanket from buildup of pore pressures in the underlying aquifer beneath the blanket. 
Table 5. Chronic seepage areas.

\begin{tabular}{|c|c|c|c|c|c|c|c|c|c|c|c|c|c|c|}
\hline Name1 & Name2 & \begin{tabular}{|l|} 
1937_Flood \\
\end{tabular} & 1973_Flood & NLD_Stat & Field_Sta & Type & Condition & Remarks & Lat & Long & Quad & Page & Photos & Environment \\
\hline Francis & $\begin{array}{l}\text { Lower Francis } \\
\text { (TM 3-424) }\end{array}$ & no & yes & 151 & $151+00$ & $\begin{array}{c}\text { Sand } \\
\text { Boil }\end{array}$ & High & $\begin{array}{l}\text { A large, high-energy sand boil (photo } 4 \text { ) was identified moving significant } \\
\text { quantities of silt and fine sand material at the toe of a } 200 \text {-ft seepage } \\
\text { berm. The boil was bagged by the Levee Board with prison labor for initial } \\
\text { containment and subsequently sandbag ring was encircled by a larger } \\
\text { earthen berm. A fitter of sand and stone was constructed over the boil } \\
\text { throat to filter fines and dissipate energy. Stabilization took } 4 \text { days of } \\
24 \text {-hr/day effort (photos } 5 \text { to } 7 \text { ). Flow from boil was estimated at } \\
300 \text { gal/min. Boil had potential to cause backward erosion and piping and } \\
\text { lead to loss of berm and foundation material. Two more sand boils were } \\
\text { found } 100 \text { to } 150 \mathrm{ft} \text { from berm toe (photos } 8 \text { to } 10 \text { ). These boils were } \\
\text { moderate energy and move approximately } 5 \text { to } 7 \text { cu yd of material. Boils } \\
\text { were bagged by local prisoners. Heavy seepage and numerous pin boils } \\
\text { were noted and monitored 2,000 ft either side. }\end{array}$ & 34.08626 & -90.865247 & Mellwood & A3 & $4-10$ & PB \\
\hline Winterville & $\begin{array}{l}\text { Greenville } \\
\text { Front Levee }\end{array}$ & yes & yes & $\begin{array}{c}3744 \text { to } \\
3750\end{array}$ & $\begin{array}{c}3710 \text { to } \\
3720\end{array}$ & $\begin{array}{l}\text { Sand } \\
\text { Boil }\end{array}$ & Heavy & $\begin{array}{l}\text { Winterville sand boil site - A large, high-energy sand boil approximately } \\
30 \mathrm{ft} \text { from the toe of } 200-\mathrm{ft} \text { seepage berm near levee sta } 3720 \text {. The boil } \\
\text { was estimated to be flowing approximately } 300 \text { to } 350 \text { gpm and was } \\
\text { moving significant quantities of silt and fine sand (approximately } \\
100 \text { cu yd). Boil was bagged by levee board with prison labor and a small } \\
\text { earthen levee was constructed by local contractor. A filter sand and stone } \\
\text { was constructed over the boil throat to filter fines and dissipate energy. } \\
\text { Four additional medium-sized boils were identified within } 250 \mathrm{ft} \text { of the } \\
\text { berm toe that required either a small sandbag ring or a } 30 \text {-gal drum for } \\
\text { stabilization. Boils are located between levee sta } 3710 \text { and } 7320 \text {. }\end{array}$ & 33.455237 & -91.04974 & Refuge & A48 & 31-42 & PB \\
\hline $\begin{array}{c}\text { Lake } \\
\text { Ferguson }\end{array}$ & $\begin{array}{c}\text { Greenville } \\
\text { Front Levee }\end{array}$ & yes & no & 3886 & $3852+00$ & $\begin{array}{c}\text { Sand } \\
\text { Boil }\end{array}$ & $\begin{array}{c}\text { Moderate/ } \\
\text { High }\end{array}$ & $\begin{array}{l}\text { Active sand boil identified on the edge of seepage berm approximately } \\
75 \text { yd from the railroad tracks near levee sta } 3952 \text {. Area is under } 6 \text { to } \\
10 \text { in. of seepage water. Sand boil has a } 12 \text {-in. throat and has formed a } \\
\text { cone that is approximately } 12 \text { in. high. Boil is flowing approximately } \\
50 \text { gpm and continues to transport moderate quantities of silt/fine } \\
\text { sand. }\end{array}$ & 33.399442 & -91.070167 & Refuge & A48 & 61-62 & $A C$ \\
\hline $\begin{array}{c}\text { Lake } \\
\text { Ferguson }\end{array}$ & $\begin{array}{l}\text { Greenville } \\
\text { Front Levee }\end{array}$ & no & no & $\begin{array}{c}4065 \text { to } \\
4072\end{array}$ & $\begin{array}{c}4031 \text { to } \\
4030\end{array}$ & $\begin{array}{c}\text { Sand } \\
\text { Boil }\end{array}$ & Heavy & $\begin{array}{l}\text { Multiple moderate to high-energy sand boils were identified moving large } \\
\text { quantities of fine sand in two separate areas on the east side of the } \\
\text { railroad tracks approximately } 400 \mathrm{ft} \text { from the levee toe. There is no } \\
\text { seepage berm in this area. Heavy seepage, numerous pin boils and } \\
\text { saturated, soft ground was identified in and around the boil areas. One } \\
\text { area is on the power line right-of-way and the other is in the woods } \\
\text { approximately } 30 \text { yd to the southeast. During the initial site visit, there } \\
\text { were numerous small boils identified in the wooded area. The throats on } \\
\text { these boils ranged from } 3 \text { to } 6 \text { in. in diameter and several yards s } 5 \text { to } \\
8 \text { cu yd) of material had been transported over a } 1,000 \text { sq ft area; } \\
\text { however, most of these boils were producing clear water. Some of the } \\
\text { larger boils were later stabilized with } 30 \text {-gal drums placed over the } \\
\text { throats of the boils. There were approximately three high-flowing sand } \\
\text { boils identified in a low spot along the power line. These boils were } \\
\text { flowing approximately } 100 \text { to } 200 \text { gpm each, and were transporting a } \\
\text { significant quantity of fine sand and clay/silt balls. Over } 15 \text { to } 20 \text { yd of } \\
\text { material had already been transported from the boils and material was } \\
\text { still being moved. Throat diameter of the boils ranged from } 12 \text { to } 18 \text { in. } \\
\text { Levee board work crews and inmates addressed these boils by building a } \\
\text { sandbag containment ring which had to be raised at a later date to } \\
\text { increase the head over the boils. }\end{array}$ & 33.378153 & -91.074231 & Refuge & A48 & 65-73 & PB \\
\hline
\end{tabular}




\begin{tabular}{|c|c|c|c|c|c|c|c|c|c|c|c|c|c|c|}
\hline Name1 & Name2 & 1937_Flood & 1973_Flood & NLD_Stat & Field_Sta & Type & Condition & Remarks & Lat & Long & Quad & Page & Photos & Environment \\
\hline $\begin{array}{l}\text { Leland } \\
\text { Chute }\end{array}$ & Leland Chute & yes & yes & $2139+95$ & $2135+35$ & $\begin{array}{c}\text { Sand } \\
\text { Boil }\end{array}$ & Heavy & Bagged boil in ditch & 33.3601 & -91.1632 & Refuge & A180 & 33-37 & PB \\
\hline $\begin{array}{l}\text { Leland } \\
\text { Chute }\end{array}$ & Leland Chute & yes & yes & $2142+80$ & $2138+20$ & $\begin{array}{c}\text { Sand } \\
\text { Boil }\end{array}$ & Heavy & Bagged boil in ditch & 33.3594 & -91.1637 & Refuge & A180 & $38-43$ & PB \\
\hline Lake Chicot & Lake Chicot & yes & yes & $\begin{array}{c}2309+50 \\
\text { to } \\
2544+90\end{array}$ & $\begin{array}{c}2305+60 \\
\text { to } \\
2541+20\end{array}$ & $\begin{array}{c}\text { Sand } \\
\text { Boil }\end{array}$ & $\begin{array}{l}\text { Heavy/ } \\
\text { Large }\end{array}$ & $\begin{array}{l}\text { Lake Chicot - The site is historically an area with large boils. A large, } \\
\text { high-energy sand boil was located on the edge of a dredged channel at } \\
\text { the south end of Lake Chicot. There were multiple sandbag rings } \\
\text { placed around the boil. The throat would move and bypass the sandbag } \\
\text { rings. A dike was eventually constructed across the channel. Moderate } \\
\text { seepage was exiting the lake bank } 30 \mathrm{ft} \text { above the water surface. } \\
\text { Several other medium to large, moderate energy boils were located } \\
\text { along the lake bank. These boils were also ringed with sandbags. The } \\
\text { boil losest to the levee was approximately } 400 \mathrm{ft} \text { from the too of a } \\
300-\mathrm{ft} \text { seepage berm. This boil has repeatedly moved significant } \\
\text { quantities of material during previous high-water events and exhibits } \\
\text { some potential to develop pipes that may migrate towards the } \\
\text { berm/levee. Boils were identified up to 2,000 ft from the levee toe. }\end{array}$ & 33.2879 & -91.1691 & Refuge & A180 & & AC-PB \\
\hline Fish Bayou & Lake Chicot & yes & yes & $2544+20$ & $2540+90$ & $\begin{array}{c}\text { Sand } \\
\text { Boil }\end{array}$ & Heavy & $\begin{array}{l}\text { Area known as Fish Bayou located approximately } 500 \mathrm{ft} \text { from berm toe } \\
\text { at the downstream end of Lake Chicot. }\end{array}$ & 33.28813 & -91.17136 & Refuge & A180 & $80-88$ & PB \\
\hline $\begin{array}{l}\text { Lake } \\
\text { Washington } \\
\quad \text { Area }\end{array}$ & $\begin{array}{l}\text { Washington/ } \\
\text { Issaquena } \\
\text { Counties }\end{array}$ & no & no & 6048 & $6025+00$ & $\begin{array}{c}\text { Sand } \\
\text { Boil }\end{array}$ & $\begin{array}{l}\text { Moderate to } \\
\text { Heavy }\end{array}$ & $\begin{array}{l}\text { Five or six small, active sand boils with 4- to } 5 \text {-in. throats were } \\
\text { identified along the toe of the seepage berm near levee sta } 6020 \text {. Boils } \\
\text { were flowing approximately } 20 \text { to } 30 \mathrm{gpm} \text { and transporting fine sand } \\
\text { producing cones } 2 \text { to } 3 \mathrm{ft} \text { in diameter. Area being monitored by levee } \\
\text { board. Some of the boils ringed by plastic drums. }\end{array}$ & 33.014336 & -91.135529 & Readland & A76 & $16-17$ & PB \\
\hline Longwood & $\begin{array}{l}\text { River Mile } \\
520\end{array}$ & yes & no & 5400 & $5368+00$ & $\begin{array}{c}\text { Sand } \\
\text { Boil }\end{array}$ & $\begin{array}{l}\text { Moderate- } \\
\text { Large }\end{array}$ & $\begin{array}{l}\text { On July } 7,2011 \text {, landowner called and reported a "hole" out in his field. } \\
\text { Levee board took photos and measured hole to be } 2 \mathrm{ft} \text { deep with } 4 \mathrm{ft} \\
\text { diameter. There was evidence of very fine sand material in the } \\
\text { buckshot bean field. The boil was located } 780 \mathrm{ft} \text { from levee center line. }\end{array}$ & 33.14388 & -91.0719 & Readland & A76 & 63-64 & PB \\
\hline $\begin{array}{l}\text { Lake } \\
\text { Washington } \\
\quad \text { Area }\end{array}$ & $\begin{array}{l}\text { River Mile } \\
516\end{array}$ & yes & yes & $\left|\begin{array}{c}5640+00 \\
\text { to } \\
5651+00\end{array}\right|$ & $\begin{array}{c}5608+00 \\
\text { to } \\
5619+00\end{array}$ & $\begin{array}{c}\text { Sand } \\
\text { Boil }\end{array}$ & $\begin{array}{l}\text { Heavy/ } \\
\text { Large }\end{array}$ & $\begin{array}{l}\text { Multiple large sand boils in this area. There are multiple boils in } \\
\text { drainage ditch just off toe of berm. Also, there are multiple boils on } \\
\text { both sides of the drainage ditch. Three of the boils occur right at the } \\
\text { toe of the berm. Most of these were bagged and were no longer moving } \\
\text { material. Throat sizes range from a couple inches to greater than } 6 \text { in. } \\
\text { Sandbag ring constructed around a } 30 \text {-ft x } 1 \text { 1-ft sinkhole that formed in } \\
\text { field. Plywood wall constructed around boil also. Seepage is also exiting } \\
\text { in the berm crown. }\end{array}$ & 33.105485 & -91.129473 & Readland & A78 & 78-87 & PB \\
\hline $\begin{array}{l}\text { Lake } \\
\text { Washington } \\
\quad \text { Area }\end{array}$ & $\begin{array}{l}\text { Washington/ } \\
\text { Issaquena } \\
\text { Counties }\end{array}$ & no & no & $\begin{array}{l}6051 \text { to } \\
6057\end{array}$ & $\begin{array}{c}6030 \text { to } \\
6035\end{array}$ & $\begin{array}{c}\text { Sand } \\
\text { Boil }\end{array}$ & $\begin{array}{c}\text { Moderate to } \\
\text { Heavy }\end{array}$ & $\begin{array}{l}\text { Three to five sand boils and large area of widespread moderate } \\
\text { seepage along the too of the seepage berm near levee sta } 6030 \text {. } \\
\text { Seepage extends approximately } 1 / 4 \text { mile out into field. Two sand boils } \\
\text { were ringed with } 30 \text {-gal plastic drums. Two or three boils were } \\
\text { identified near the drums. Boils were transporting fine sand and } \\
\text { clay/silt ballls. Numerous pin boils and moderate seepage in bean field } \\
\text { near sta } 6035 \text {. Most boils are transporting a small quantity of material } \\
\text { and are under } 2 \text { or } 3 \text { in. of water. }\end{array}$ & 33.012159 & -91.137445 & Readland & A107 & $18-22$ & PB \\
\hline $\begin{array}{c}\text { Lake } \\
\text { Washington } \\
\text { Area }\end{array}$ & $\begin{array}{l}\text { Clarence Hall } \\
\text { Road Site }\end{array}$ & no & no & $\begin{array}{l}6074 \text { to } \\
6050\end{array}$ & $\begin{array}{l}6051 \text { to } \\
6070\end{array}$ & $\begin{array}{c}\text { Sand } \\
\text { Boil }\end{array}$ & Heavy & $\begin{array}{l}\text { Numerous, medium to large sand boils ( } 25+) \text { approximately } 10 \text { to } 30 \mathrm{ft} \\
\text { from the toe of the seepage berm between levee sta } 6050 \text { and } 6070 \text {. } \\
\text { Levee board was onsite placing drums, galvanized culverts, and } \\
\text { sandbags over and around boils. Entire area is under } 1 \text { to } 3 \mathrm{ft} \text { of } \\
\text { seepage water from boils. Several boils are high-energy producing } 50 \text { to } \\
100 \text { gpm. }\end{array}$ & 33.012159 & -91.137445 & Readland & A107 & $23-30$ & PB \\
\hline
\end{tabular}




\begin{tabular}{|c|c|c|c|c|c|c|c|c|c|c|c|c|c|c|}
\hline Name1 & Name2 & 1937_Flood & 1973_Flood & NLD_Stat & Field_Sta & Type & Condition & Remarks & Lat & Long & Quad & Page & Photos & Environment \\
\hline $\begin{array}{l}\text { Moon } \\
\text { Chute }\end{array}$ & Moon Chute & no & yes & $2544+90$ & $3273+00$ & $\begin{array}{c}\text { Sand } \\
\text { Boil }\end{array}$ & Heavy & $\begin{array}{l}\text { Sand boil in ditch } 200 \mathrm{ft} \text { from berm toe with 6-in. pipe. Moved about } \\
2 \text { yd of material. Additional pin boils in ditch with clear flow. }\end{array}$ & 33.1582 & -91.1795 & Readland & A292 & 104 & PB \\
\hline $\begin{array}{c}\text { Lake } \\
\text { Washington } \\
\text { Area }\end{array}$ & $\begin{array}{l}\text { Near St Paul } \\
\text { Church }\end{array}$ & no & no & 6285 & $6265+00$ & $\begin{array}{c}\text { Sand } \\
\text { Boil }\end{array}$ & Heavy & $\begin{array}{l}\text { Several (4 to 6) large, high-energy sand boils under } 3 \text { to } 4 \mathrm{ft} \text { of water in } \\
\text { a drainage ditch in the bean field approximately } 200 \mathrm{ft} \text { north of Elwood } \\
\text { Road near levee Sta. } 6265 \text {. Two other boils have caused the banks of } \\
\text { the ditch to cave. Boils are transporting small quantities of silt/fine } \\
\text { sand. Area was flagged during inspection. }\end{array}$ & 32.999427 & -91.107287 & \begin{tabular}{|l} 
Mayersville - \\
Lake \\
Providence
\end{tabular} & A108 & 51-52 & PB \\
\hline $\begin{array}{l}\text { Ben } \\
\text { Lomand } \\
\text { Road }\end{array}$ & Carlisle Lake & no & no & 7067 & $7100+00$ & $\begin{array}{c}\text { Sand } \\
\text { Boil }\end{array}$ & Heavy & $\begin{array}{l}\text { Multiple, high-energy, sand boils approximately } 10 \text { to } 50 \mathrm{ft} \text { from the } \\
\text { seepage berm toe near levee sta } 7100 \text {. Boils were flowing } 20 \text { to } \\
50 \mathrm{gpm} \text { and transporting moderate quantities of fine sand ( } 2 \text { to } 5 \mathrm{cu} \text { yd } \\
\text { each). Throat diameters for the boils generally ranged from } 2 \text { to } 10 \mathrm{in} \text {. } \\
\text { Some of the boils were ringed with culverts. }\end{array}$ & 32.831713 & -91.103178 & $\begin{array}{l}\text { Mayersville - } \\
\text { Lake } \\
\text { Providence }\end{array}$ & A109 & 95-99 & PB \\
\hline Albemar & $\begin{array}{l}\text { Albermarle } \\
\text { Slide/Boil }\end{array}$ & no & no & 8218 & 8170 & $\begin{array}{l}\text { Sand } \\
\text { Boil- } \\
\text { Slide }\end{array}$ & Heavy & $\begin{array}{l}\text { Five medium-sized, high-energy sand boils along the toe of the levee } \\
\text { near } 16-37 \text { levee sta } 8170 \text { (no berm). A large, landside, slide } \\
\text { developed immediately downstream from the boils. A stone ring was } \\
\text { placed around the sand boils and a filter of sand was placed over the } \\
\text { throats of the boils. The levee board worked throughout the night to } \\
\text { stabilize the boil. The stabilization of the slide began the following day } \\
\text { with Corps-hired labor forces. An additional slide developed during the } \\
\text { second night immediately upstream from the sand boils. Both slides } \\
\text { were accompanied with and possibly the result of heavy seepage } \\
\text { exiting at the slide face and on the slope below. Hired labor continued } \\
\text { daytime stabilization of the slide by placing crushed limestone at the } \\
\text { toe and sand on the lower end of the slide to provide additional weight } \\
\text { and drainage. The slides were present in the lower } 1 / 3 \text { of the levee } \\
\text { embankment and were relatively shallow in depth. A small slide near } \\
\text { the levee toe formed immediately above the sand boils on the third day } \\
\text { that connected the two larger slides. The hired labor forces maintained } \\
\text { daytime activities on the site for approximately } 14 \text { days to stabilize both } \\
\text { the slides and the boils. There were approximately } 6,000 \text { tons of } \\
\text { limestone (\#57 stone) and } 11,000 \text { tons of sands placed on the site to } \\
\text { stabilize the slope. The boils at the levee toe and the embankment } \\
\text { instability could have progressed to loss of levee foundation material } \\
\text { and/or significant loss of the net levee section. }\end{array}$ & 32.628297 & -90.999041 & Onward & A145 & $\mid 16-37$ & AC-PB \\
\hline $\begin{array}{l}\text { Ben } \\
\text { Lomand } \\
\text { Road }\end{array}$ & $\begin{array}{l}\text { Lake } \\
\text { Washington } \\
\text { Area }\end{array}$ & yes & yes & $\begin{array}{l}7195 \text { to } \\
7210\end{array}$ & $7120+00$ & $\begin{array}{c}\text { Sand } \\
\text { Boil }\end{array}$ & Heavy & $\begin{array}{l}\text { Ben Lomand road site - Several medium to large sand boils were } \\
\text { identified moving moderate quantities of fine sand and silt in a } \\
\text { drainage ditch along the toe of the seepage berm and in an open area } \\
\text { east of the ditch. All of the sand boils were within } 10 \text { to } 20 \mathrm{ft} \text { of the } \\
\text { seepage berm toe. Water berm was created over most of the sand boils } \\
\text { in the ditch by the levee board by constructing dikes on the upstream } \\
\text { and downstream sides of the sand boils. Also, at least three of the } \\
\text { sand boils in the ditch were ringed with galvanized culverts. As a result } \\
\text { of the dikes and culverts, most of the boils in the ditch were covered } \\
\text { with at least } 3 \text { to } 4 \mathrm{ft} \text { of water. Also, there were several medium boils } \\
\text { identified in the edge of a field on the east side of the ditch that were } \\
\text { ringed with culverts by the levee board and eventually two sandbag } \\
\text { rings were constructed around the area to increase the head and slow } \\
\text { the movement of material. Most of the boils were flowing approximately } \\
50 \text { to } 100 \text { gal/min each, and continued to by remedial action by the } \\
\text { levee board transport a significant quantity of material until the area } \\
\text { was stabilized. }\end{array}$ & 32.801374 & -91.121947 & $\begin{array}{l}\text { Mayersville - } \\
\text { Lake } \\
\text { Providence }\end{array}$ & A110 & $\begin{array}{l}100- \\
118\end{array}$ & PB \\
\hline
\end{tabular}




\begin{tabular}{|c|c|c|c|c|c|c|c|c|c|c|c|c|c|c|}
\hline Name1 & Name2 & 1937_Flood & |1973_Flood & NLD_Stat & Field_Sta & Type & Condition & Remarks & Lat & Long & Quad & Page & Photos & Environment \\
\hline Buck Chute & Eagle Lake & no & no & $\begin{array}{c}8749 \text { to } \\
8764\end{array}$ & $\begin{array}{c}110+00 \\
\text { to } \\
131+00\end{array}$ & $\begin{array}{c}\text { Sand } \\
\text { Boil }\end{array}$ & Heavy & $\begin{array}{l}\text { Buck Chute - Stabilization berm constructed at Buck Chute. Water } \\
\text { Control Plan for Eagle Lake, A significant boil developed about } 5 \mathrm{ft} \text { west } \\
\text { of relief well BC-2-98. Stabilization berm constructed and was } \\
\text { completed in early May } 2011 \text { to control seepage and sand boils. A } \\
\text { deviation in the water control plan for Eagle Lake was enacted to } \\
\text { minimize seepage pressures through the levee. Water level in Eagle } \\
\text { Lake was raised to } 89.8 \mathrm{ft} \text {. }\end{array}$ & 32.534821 & -91.078077 & Alsatia & A147 & 74-91 & $A C$ \\
\hline $\begin{array}{l}\text { Tara } \\
\text { Hunting } \\
\text { Camp }\end{array}$ & Eagle Lake & no & no & $\begin{array}{c}8847 \\
\text { to8964 }\end{array}$ & $\begin{array}{c}210+00 \\
\text { to } \\
327+00\end{array}$ & $\begin{array}{c}\text { Sand } \\
\text { Boil }\end{array}$ & $\begin{array}{l}\text { Heavy/ } \\
\text { Large }\end{array}$ & $\begin{array}{l}\text { Moderate to heavy underseepage, numerous active, medium sized } \\
\text { sand boils and pin boils were observed within } 50 \mathrm{ft} \text { of the levee toe } \\
\text { between Brunswick Extension Levee (BEL) sta } 210+00 \text { and } 327+00 \\
\text { near and around Tara Hunting Camp. Two to three, large, high-energy } \\
\text { sand boils with } 12 \text { - to } 16-i n \text {. throats were identified between sta } 210 \\
\text { and } 220 \text { that flowed } 100+\text { gal/min and transported } 5+\text { cu yd of fine } \\
\text { sand/silt before and during remedial action. These boils were located } \\
\text { between } 10 \text { and } 20 \mathrm{ft} \text { from the toe of the levee. One boil, located near } \\
\text { sta } 212+00 \mathrm{BEL} \text { was ringed with sandbags by the levee board. The } \\
\text { other boils were eventually stabilized with drums placed over the } \\
\text { throats of the boils. A large water berm, several feet in depth, was } \\
\text { created by the underseepage in this area and the bermed area was } \\
\text { investigated by boat on } 5 / 23 / 11 \text {. During this investigation, more than } \\
30 \text { sand boils were identified under the surface of the water berm in } \\
\text { the general area of levee sta } 260 \text {. }\end{array}$ & 32.498625 & -91.075419 & Alsatia & A147 & $\begin{array}{l}95- \\
109\end{array}$ & PB \\
\hline $\begin{array}{l}\text { Tara } \\
\text { Hunting } \\
\text { Camp }\end{array}$ & Eagle Lake & no & no & 9180 & $542+00$ & $\begin{array}{c}\text { Sand } \\
\text { Boil }\end{array}$ & Heavy & $\begin{array}{l}\text { Moderately high-energy sand boil with a 12-in. throat along the toe of } \\
\text { the seepage berm near levee sta } 542 \text { (BEL). Boil has transported about } \\
3 \text { cu yd of silt/fine sand and is flowing approximately } 75 \text { to } 100 \mathrm{gpm} . \\
\text { Boil was flagged for the levee board. }\end{array}$ & 32.462887 & -90.992406 & Vicksburg & A147 & 117 & PB \\
\hline Oakwoo & $\begin{array}{l}\text { Near Villa } \\
\text { Clara Church }\end{array}$ & no & no & 6178 & 6183 & $\begin{array}{c}\text { Sand } \\
\text { Boil }\end{array}$ & Large & \begin{tabular}{|l|} 
Inspected May 28,2011 . Reported by night crew approximately 4 miles \\
south of St Joe, LA. Boil is located $950 \mathrm{ft}$ landside for top of levee at \\
sta $6185+75$ downstream of culvert in ditch. This large, high-energy \\
boil has produced possibly more than 100 yd of material. Ditch at this \\
location is about $10 \mathrm{ft}$ deep and there is material above water level. \\
Within 2 -hr period the boil increased from $4 \mathrm{ft}$ to $6 \mathrm{ft}$ in diameter with a \\
$13-\mathrm{ft}-\mathrm{diam}$ sand cone. Outside perimeter of the sand cone is \\
approximately $60 \mathrm{ft}$ in diameter with some material flowing \\
downstream. This area has a 100 -ft-diam sunken cracked area along \\
the upstream and east-west side of ditch. The boil throat is at least \\
$18 \mathrm{ft}$ in depth. Majority of material appears to be a silty sand with some \\
clay particles inside hole. Clay does not appear to be foundation \\
material. On May 29 , the levee board placed two sandabag dams across \\
the ditch one on each side. There were about $4 \mathrm{ft}$ of water over the boil.
\end{tabular} & 31.883161 & -91.273614 & Locus Ridge & A287 & $22-24$ & PB \\
\hline Oakwood & $\begin{array}{c}\text { Near Villa } \\
\text { Clara Church }\end{array}$ & no & no & $6178+50$ & $6183+50$ & $\begin{array}{c}\text { Sand } \\
\text { Boil }\end{array}$ & Heavy & $\begin{array}{l}\text { Large high-energy boil inspected on June 1, 2011. Seventy-five feet } \\
\text { NNW of above boil. }\end{array}$ & 31.883344 & -91.273727 & Locust Ridge & A287 & & PB \\
\hline Lake Bruin & $\begin{array}{l}\text { Lake Bruin/ } \\
\text { Melancon } \\
\text { Camp }\end{array}$ & no & no & 5659 & $5663+00$ & $\begin{array}{c}\text { Sand } \\
\text { Boil }\end{array}$ & Heavy & $\begin{array}{l}\text { Large boils at Melancon Camp - They have moved material from behind } \\
\text { seawall. Most are located in the lake and cannot be measured. Some } \\
\text { small ones along the bank. Seven boils in Lake Bruin which have } \\
\text { produced } 10 \text { yd of silty sand range in size from } 2 \text { to } 5 \mathrm{ft} \text { diam. }\end{array}$ & 31.98803 & -91.186361 & St Joseph & A286 & $1-6$ & PB \\
\hline Lake Bruin & $\begin{array}{l}\text { Lake Bruin/ } \\
\text { Melancon } \\
\text { Camp }\end{array}$ & no & yes & 5706 & $5710+00$ & $\begin{array}{c}\text { Sand } \\
\text { Boil }\end{array}$ & Large & $\begin{array}{l}\text { Large boils in Botany Bay Ditch - Boils have been sandbagged and ditch } \\
\text { has been bagged to allow higher head over boils. Both have moved } \\
\text { large amount of material. Approximately } 450 \mathrm{ft} \text { from the levee toe. }\end{array}$ & 31.976252 & -91.189126 & St Joseph & A286 & $7-10$ & PB \\
\hline
\end{tabular}


Figure 15a. Francis 1937.

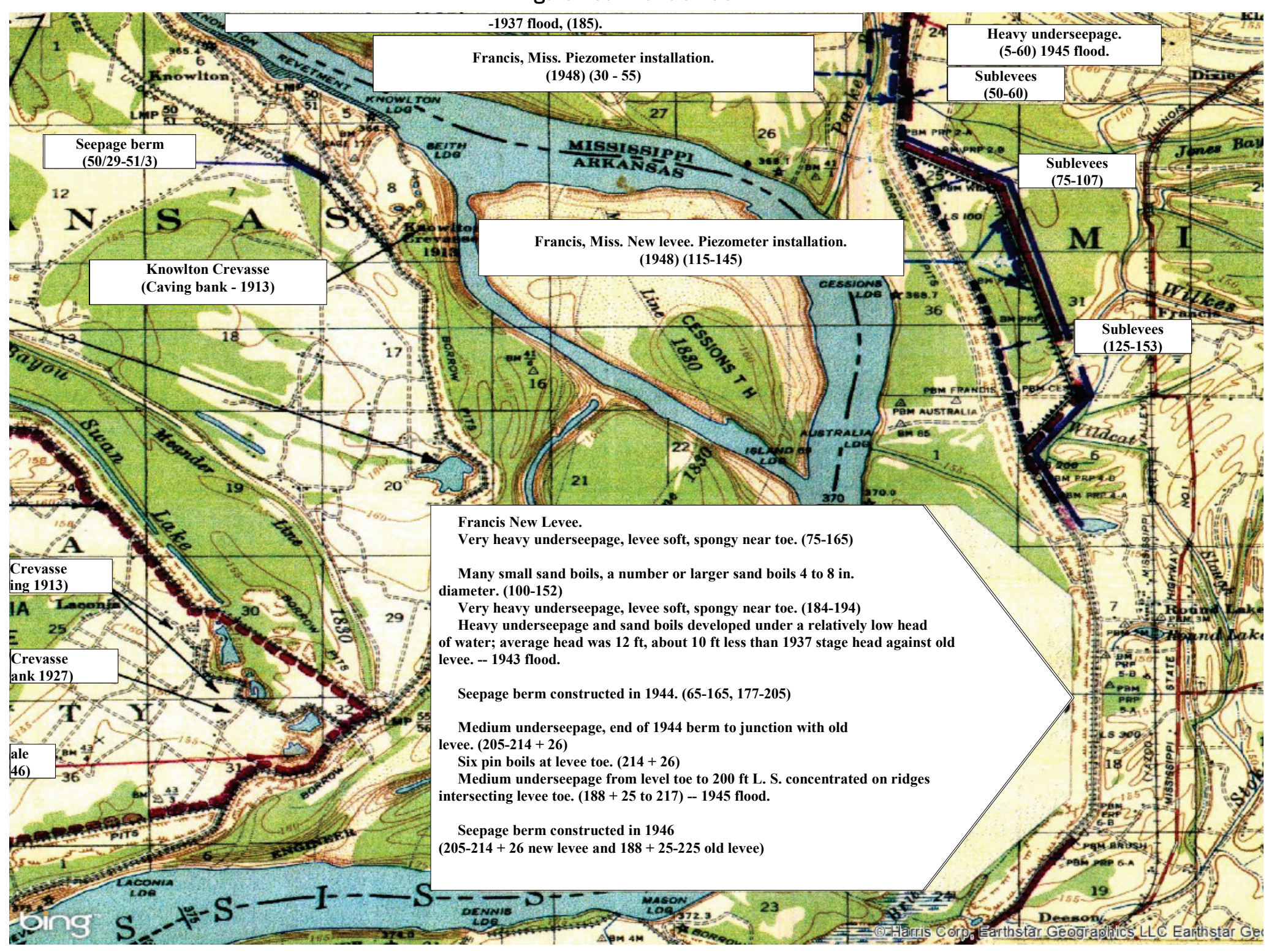


Figure 15b. Francis 1973.

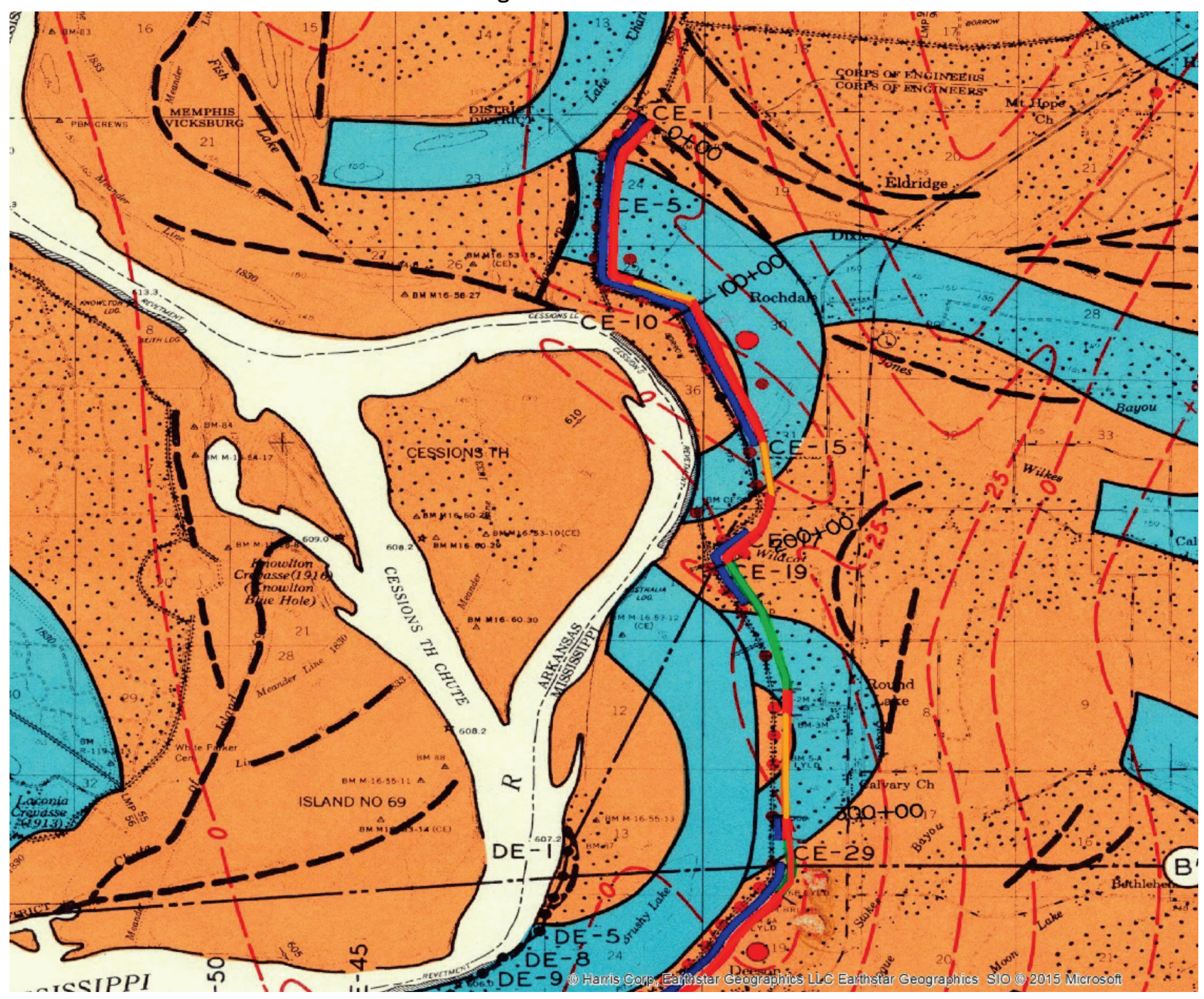


15c. Francis 2011.

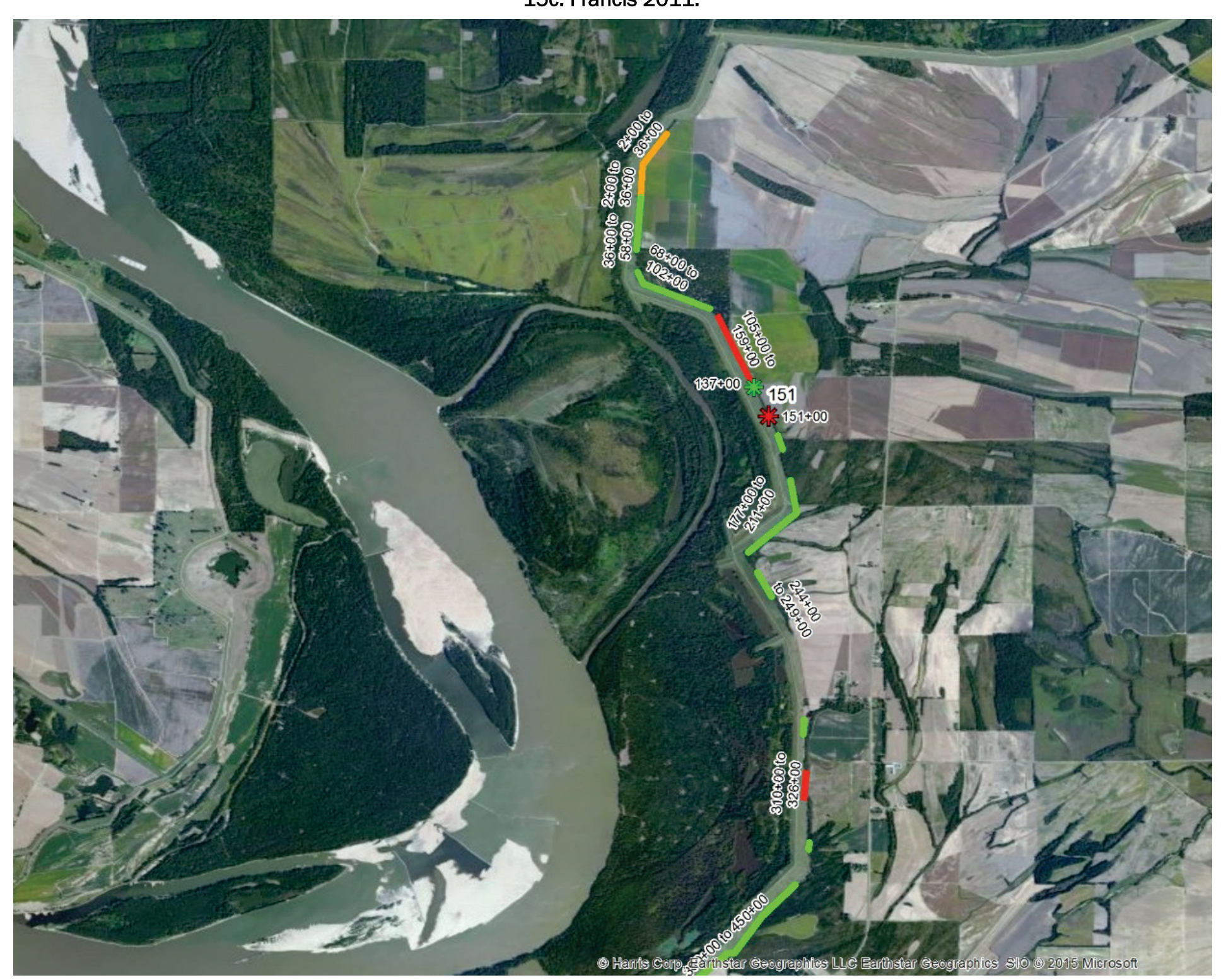




\subsection{Leland Chute-Lake Chicot}

Seepage and sand boil occurrences for the Leland Chute-Lake Chicot area are shown in Figures 16a through 16c for the 1937, 1973 and 2011 floods, respectively. The geology and stratigraphy of the Lake Chicot abandoned channel area was previously described (Plates 2 through 4) using boring data from Fisk (1947) to characterize the nature of abandoned channel deposits. As shown by the series of flood maps in Figures 16a to 16c, low lying areas within and adjacent to the arms of the Lake Chicot abandoned channel are prone to sand boil activity. Using boring information previously described from the Lake Chicot area (see section C-C', Plate 2), aquifer sands are identified as being relatively shallow adjacent to the channel margins. This condition is likely enhanced by smaller drainage channels that occupied the oxbow before a levee was built across the old channel during historic times, which has prevented high water from flowing into the old lake during the annual flooding cycle. The photograph from the 1922 flood at Vancluse, AR (bottom of Figure 16a), looking at the large sand boil behind the levee and the view upstream at the steamboat in the background, shows the general conditions and relief present in the old channel where the levee crosses the upstream arm at this location.

During the 1973 and 2011 floods, moderate to large sand boil activity occurred within both the upper and lower arms of Lake Chicot as shown by Figures 16b and 16c (boil photographs in Appendix A, see page A179 for index to photographs of the boils). Further upstream in the Leland Chute area, persistent sand boil activity has occurred. This occurrence is associated with the point bar ridge and swale topography and the presence of a landside drainage ditch, which has exposed these sands as previously described. The front cover of this report shows an aerial photography taken during the 2011 flood of the Leland Chute area with the upper arm of Lake Chicot in the background. The "V"-shape of the levee immediately upstream of the upper arm of Lake Chicot suggests a past crevasse at this location. The USACE hydrographic survey of 1879-1880 identifies the presence of a local levee with this same orientation, and there is no record of a historic crevasse at Vancluse between during the period 1770 and 1930 (U.S. Congress 1931). 
Figure 16a. Leland Chute-Lake Chicot area, cumulative 1922 to 1945 flood performance data. Lower photograph of large bagged sand boil during the 1922 flood is located in the upper loop of the Lake Chicot abandoned channel, along the south side of the old channel. The sharp bend in the levee just upstream of the upper arm of Lake Chicot predates the 1879-1880 hydrographic survey of Mississippi River and corresponds to the local levee right-of-way at this time (chart 40, 1879-1880 survey of the Mississippi River). Solid blue line corresponds to presence of a berm or drainage wells. Sand boil and seepage information are noted where solid red line is heavy underseepage area and dashed red line is light to moderate underseepage area.
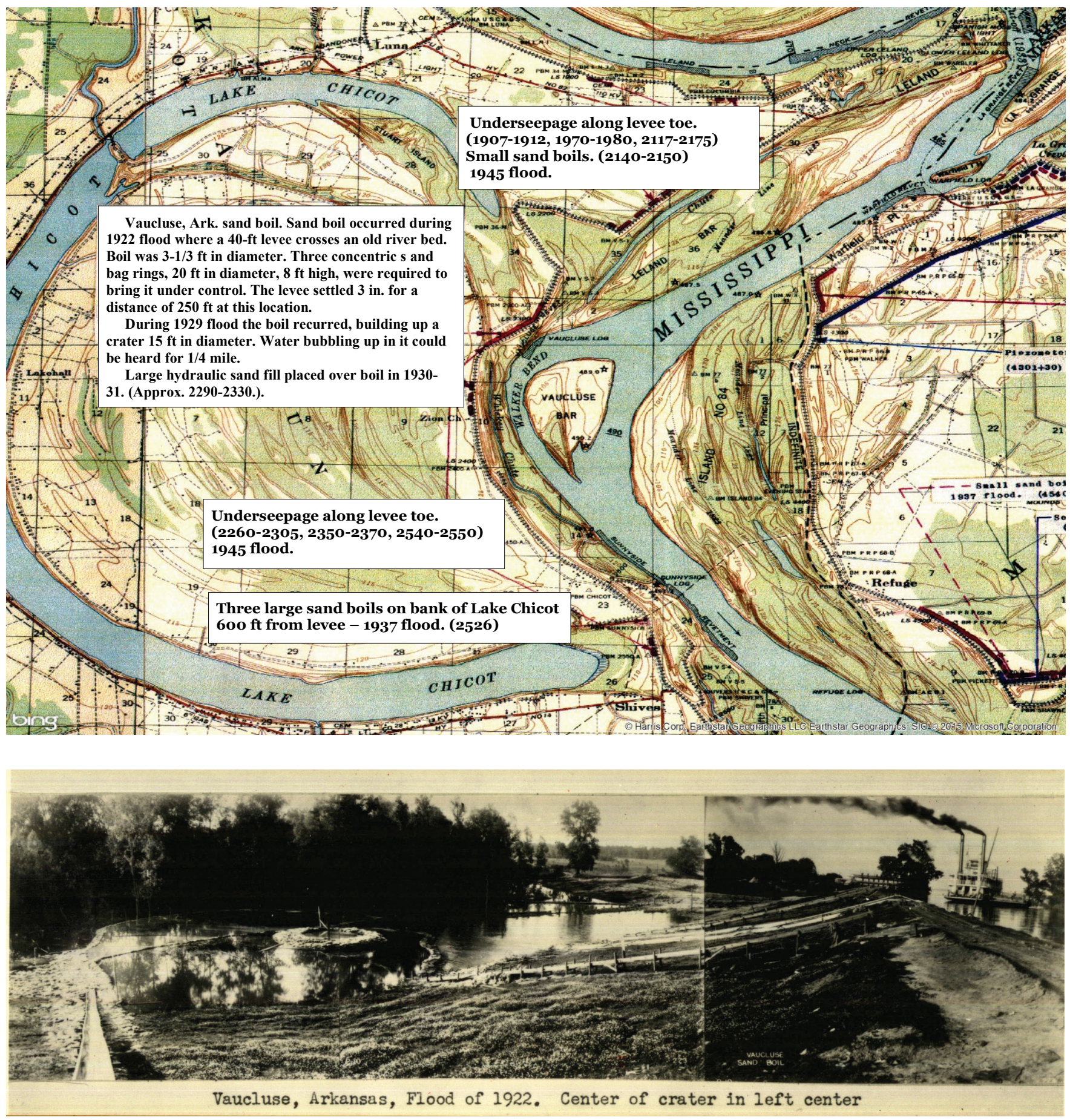


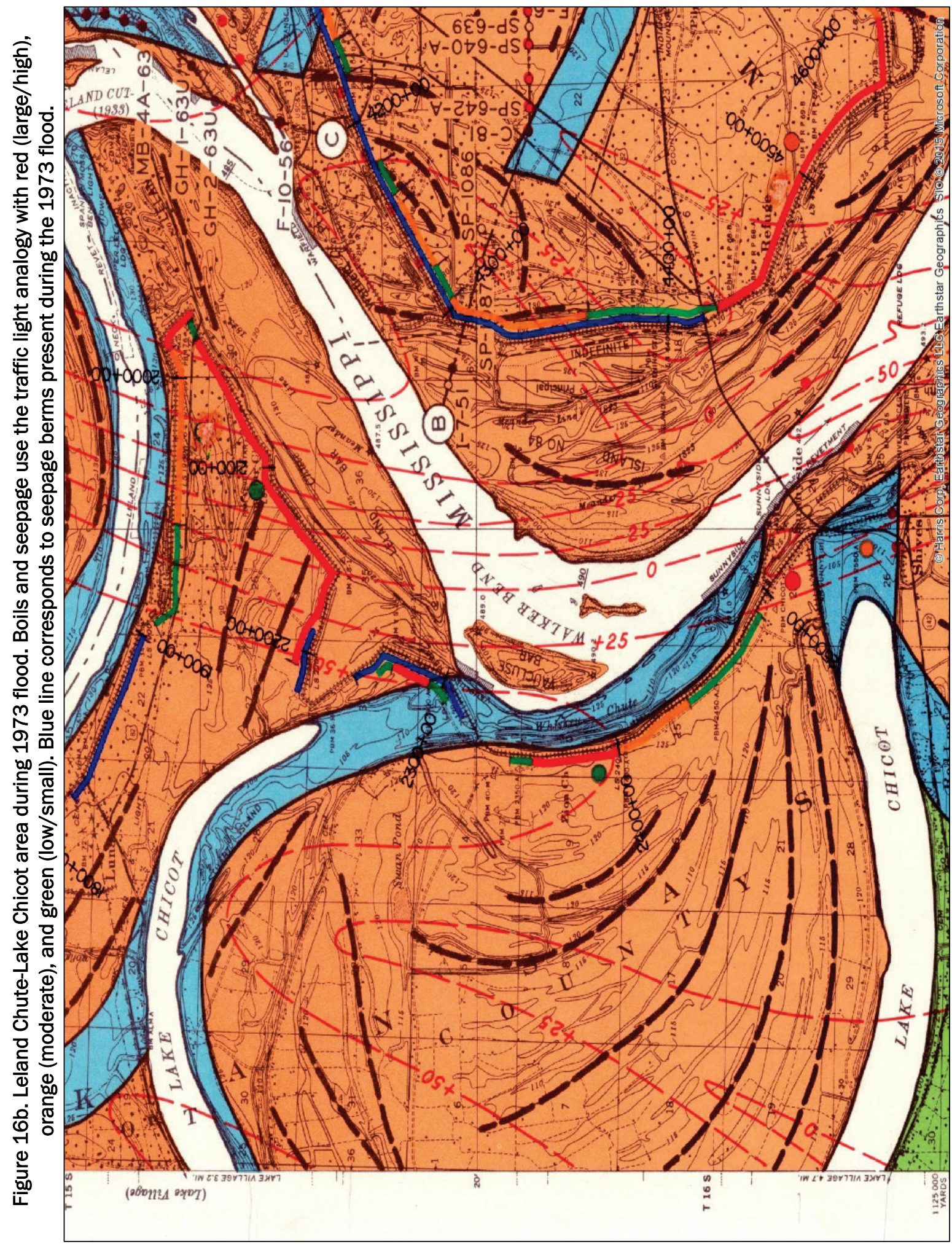




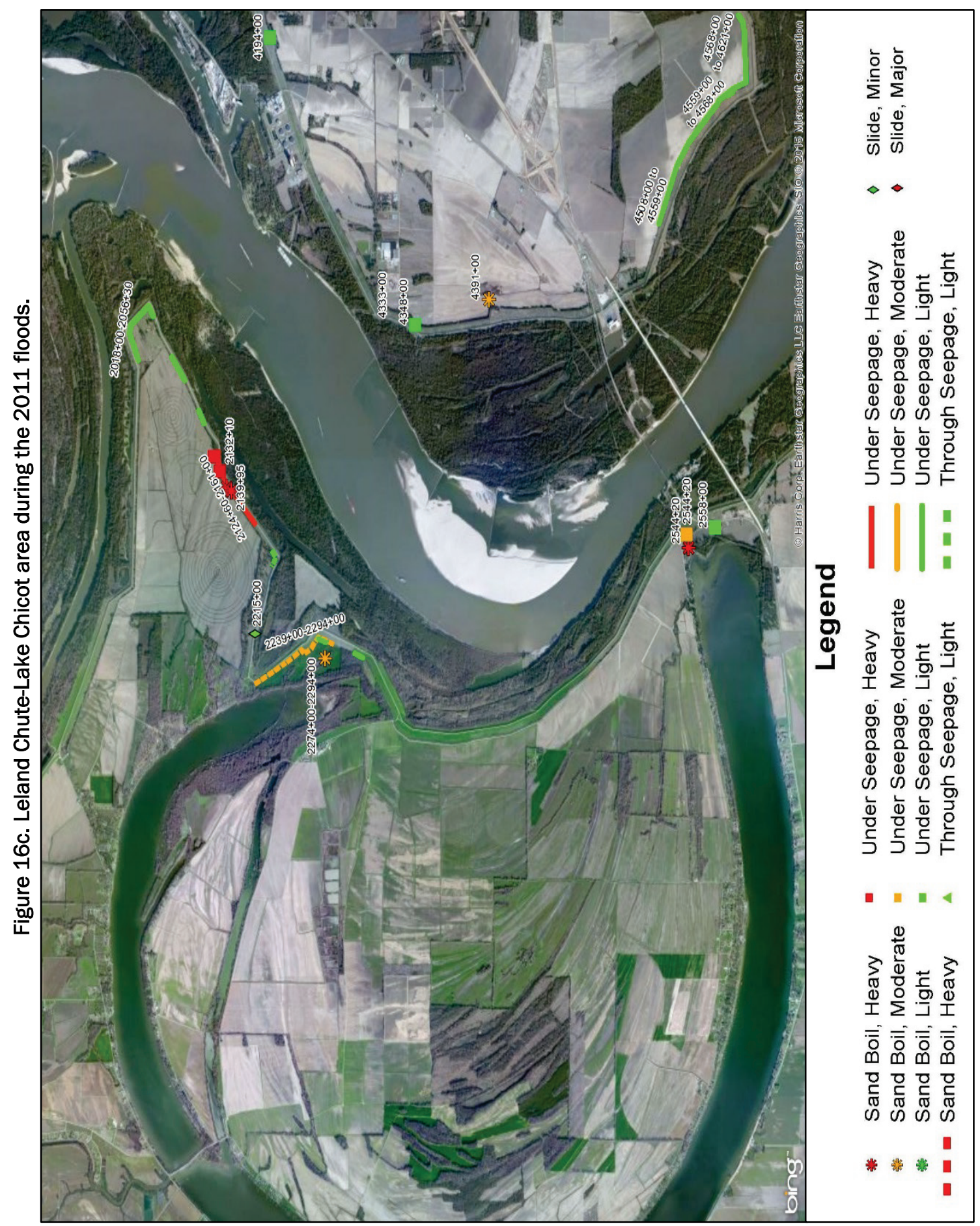


Greenville-Winterville. Seepage and sand boil occurrences for the Greenville-Winterville area were previously shown in Figures 2 through 4 for the 2011, 1973, and 1937 floods, respectively (note chronology is reversed from the above two areas). This reach was previously used to serve as an example for the importance of conducting a historic comparison of past performance data across major flood events. No detailed discussion was performed during this earlier presentation. This area will be examined in more detail in this section. For consistency of presentation and discussion of flood order, the Greenville-Winterville area is presented as Figures 17a through $17 \mathrm{c}$.

For purposes of this discussion, the Winterville levee reach occurs north of Greenville and the Greenville levee front area extends downstream from Greenville in the areas shown by Figures 17 a through $17 \mathrm{c}$. Chronic sand boil activity has occurred during each major flood event in this area as shown by Figures 17a through 17c. During the 2011 flood, a major sand boil occurred at the edge of the seepage berm in the Winterville reach. This boil required emergency repairs to control loss of foundation soils (Figure 17c). This entire area has had a seepage berm in place since the 1937 flood as shown by the blue line in Figure 17a. Small to moderate sand boil activity occurred during the 1973 flood and heavy seepage was present, especially adjacent to abandoned channels as shown by Figure $17 \mathrm{~b}$. Similarly, moderate to large sand boil activity was present during the 2011 flood as shown by Figure $17 \mathrm{c}$.

An investigation of the Winterville sand boil was performed by Stephens (2014). The investigation involved a backhoe excavation into the boil to expose features of the boil and characterize the underlying stratigraphy and cone-penetrometer tests (CPT) to determine blanket properties. This investigation identified localized defects (i.e., surface depression, tree roots), forming a roof, and thin spots in the blanket (i.e., due to ridge and swale topography from CPT data). Excavation of the boil area identified small clay balls in the boil throat and evidence of turbulence from the character of the clay balls and orientation of mixed sands in the excavation. 
Figure 17a. Greenville area 1937 flood (WES 1948).

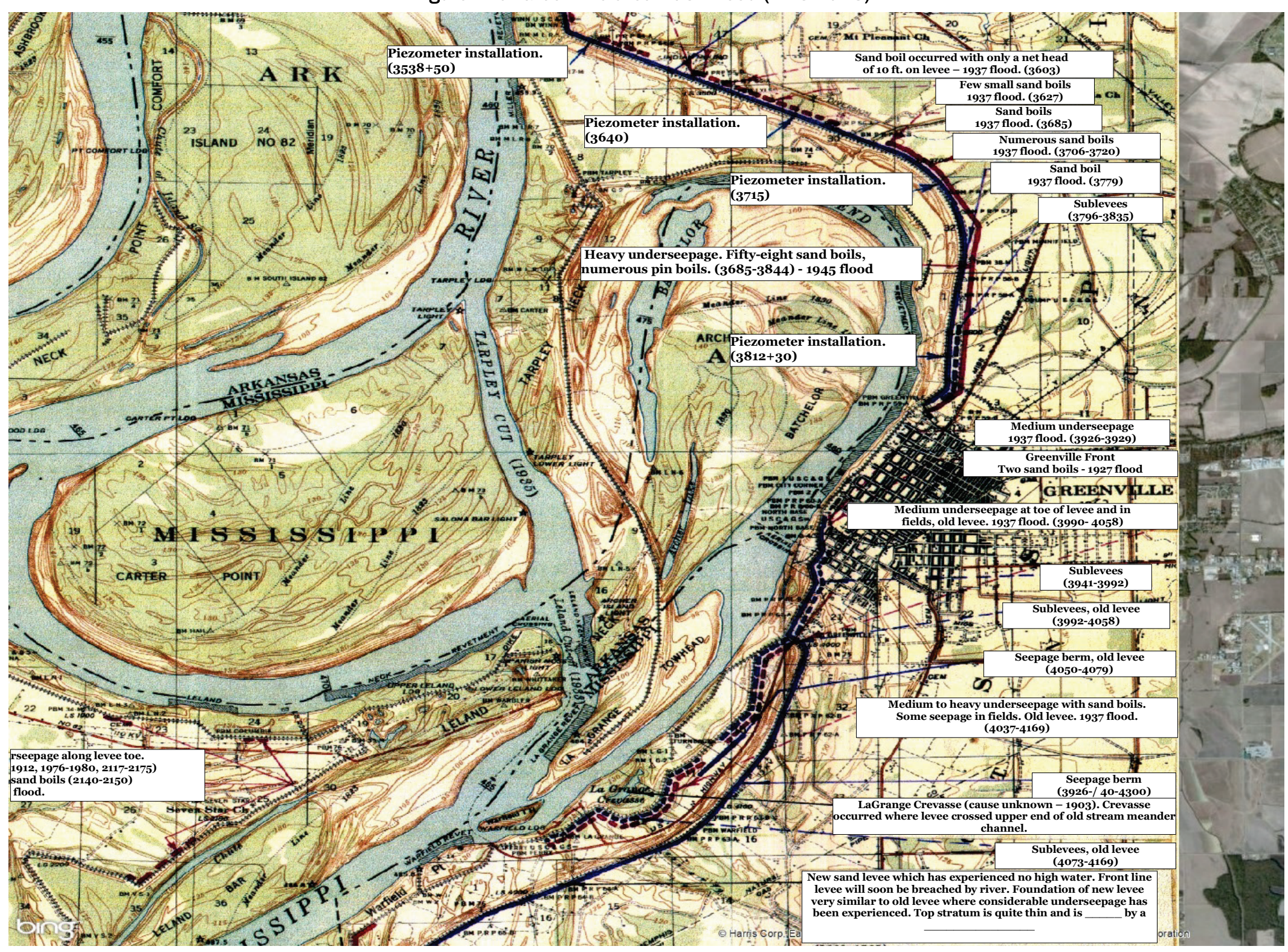


Figure 17b. Greenville area 1973 flood (USACE 1973a).

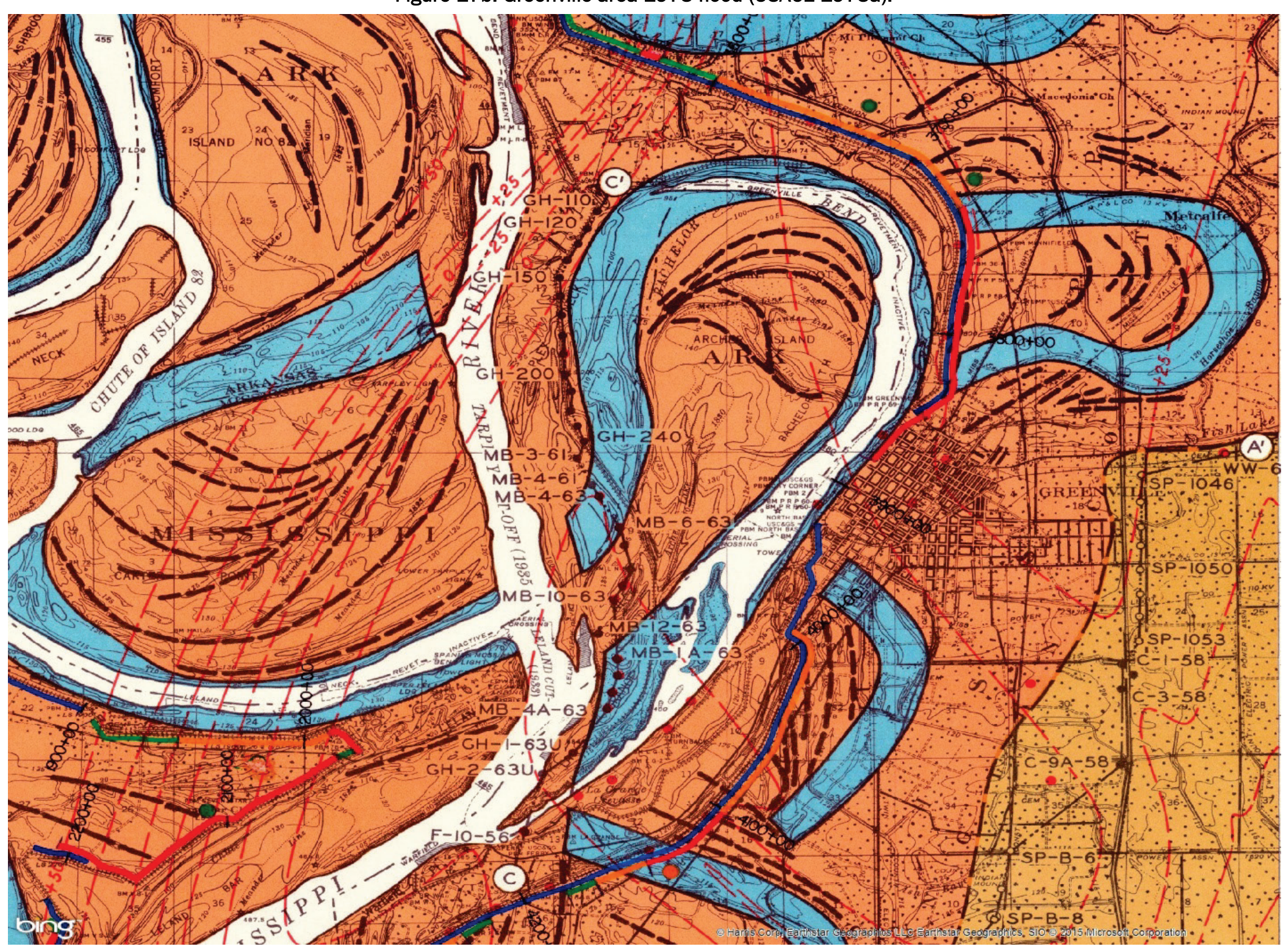


Figure 17c. Greenville area 2011 flood.

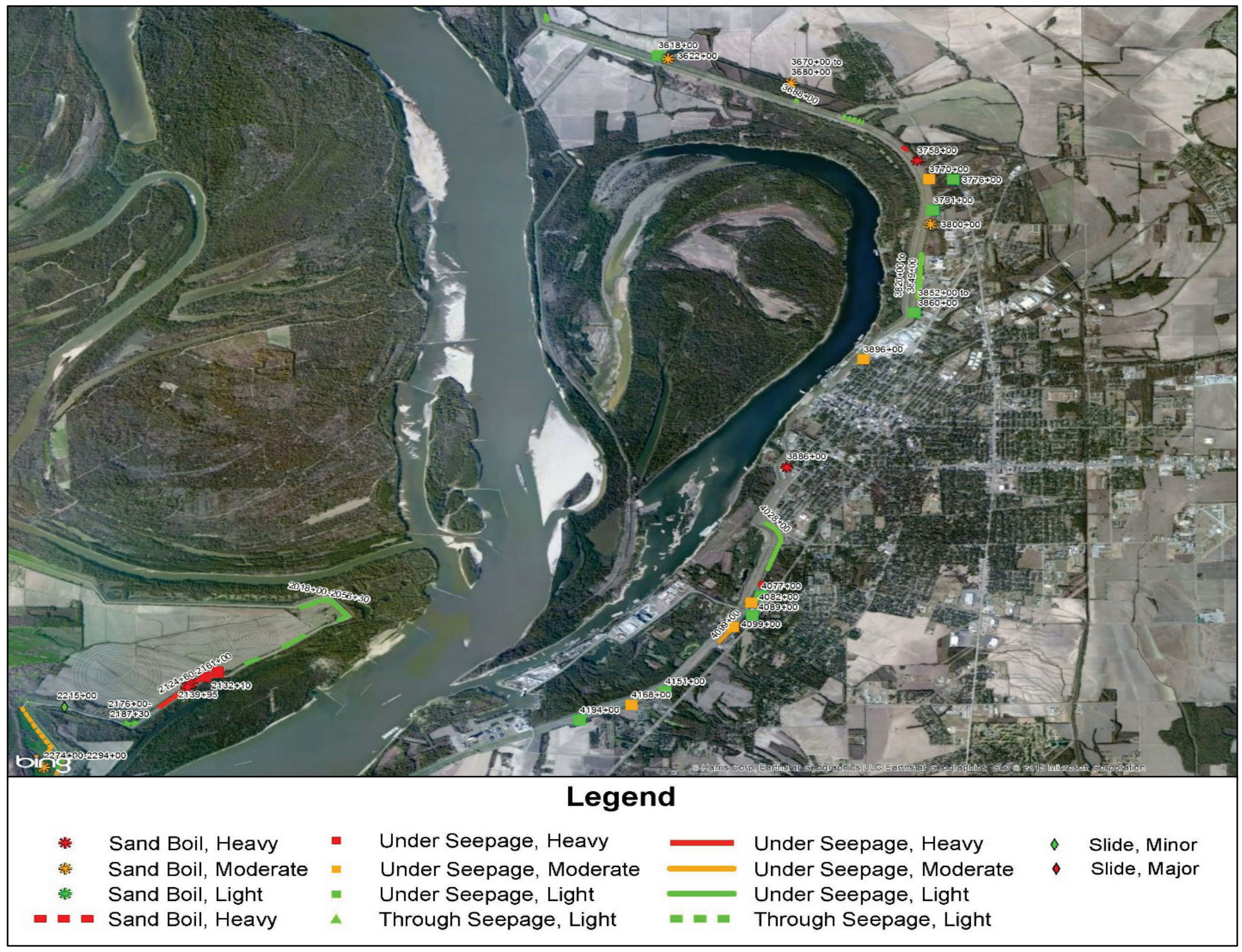


An interesting historic account of seepage and piping during the 1929 flood occurs in the vicinity of the La Grange crevasse, which is located south of Greenville (Figure 17d), near levee sta 4100+oo. The crevasse occurred on 27 March 1903 and was 3,875 ft long (U.S. Congress 1931). The exact cause of the crevasse was unknown (U.S. Congress 1931), but was assumed to be from underseepage (WES 1948). The description of the large sand boil during the 1929 flood at this area in Figure $17 \mathrm{~d}$ points to a case for hydraulic fracturing of the thin blanket due to excessive hydrostatic pressure in the aquifer sands, leading to piping of foundation sands, formation of a large cavity beneath the levee, and eventual collapse of the levee foundation into the void. The levee collapse into the void prevented complete breaching and another catastrophic failure at this location. Noteworthy details of this incident are contained in the description in Figure 17d.

This 1929 case serves to highlight the susceptibility and hazards of abandoned channel settings for presence of sand boil activity. Interestingly, the new levee that was constructed during the 1930 s as a setback contains a seepage berm as shown by the presence of the blue line in Figure $17 \mathrm{~d}$. This levee setback and seepage berm would have been built to the 1928 levee profile standards that were adopted by the MRC following the Great Mississippi River Flood of 1927 (Figure 8). Characteristics of this levee profile were previously described in Chapter 3 of this report. What is interesting about this particular example is the heavy seepage that was present during the 1973 flood in the vicinity of the La Grange crevasse (Figure 17b) and moderate seepage that was present during the 2011 flood (Figure 17c). What is unknown about this example are the additional seepage control measures that may have been added because of performancerelated issues at this location after each flood event. The geologic map in Figure 3 identifies the presence of an abandoned channel and major ridge and swale topography landside of the levee in the vicinity of the La Grange crevasse area where past issues have occurred. The previous discussion does not address any relief wells that may exist at this location. 
Figure 17d. Location of the LaGrange crevasse in the lower Greenville levee reach (WES 1948). The crevasse occurred on 27 March 1903 and was 3,875 ft long (from House Document No. 798 on report to U.S. Congress 1931). The cause for the crevasse was assumed to be underseepage (WES 1948). Large sand boil occurred in

1929 flood (see last paragraph ) and represents a case for hydraulic fracturing of the blanket, and levee underseepage causing piping and backward erosion leading to a large cavity under the levee, and eventual collapse of the levee foundation into the void. The collapse preventing breaching of the levee.

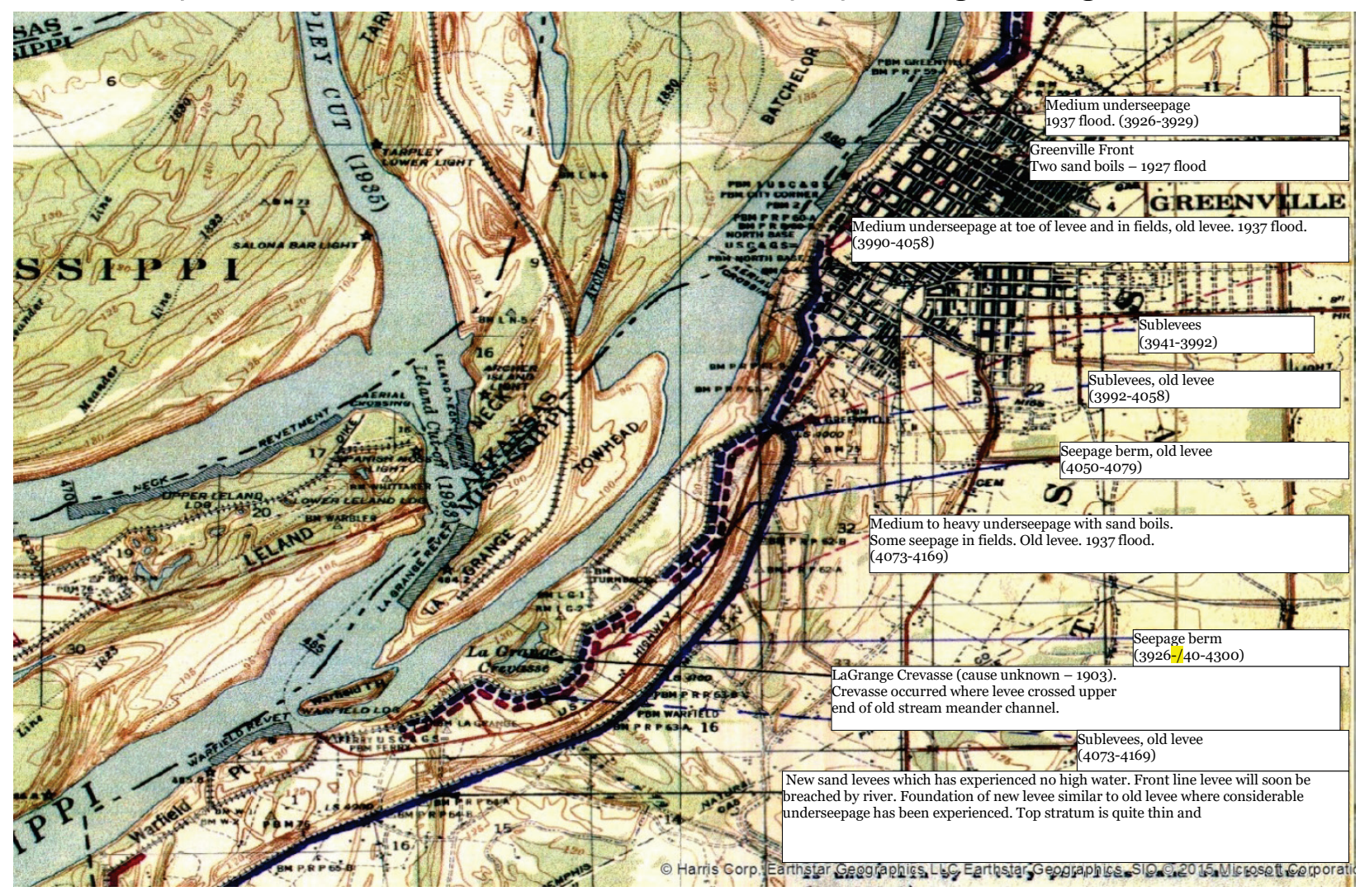

Greenville sand boil (1929). LaGrange crevasse occurred 3 miles south of Greenville. Cause of crevasse is listed as unknown but probably was caused by underseepage. Crevasse resulted in deposit of a thick stratum of coarse sand in a roughly semicircular area behind the levee. Crevasse closed by a setback loop protected by sublevees.

Upper end of loop relocated in 1913 across crevasse sand. Sand was excavated to original ground surface and put in a landside (L.S.) berm for new levee. Berm appears to have been of considerable effect in controlling underseepage. Near junction of 1903 and 1913 setbacks, levee for $300 \mathrm{ft}$ was protected neither by berms nor sublevees. Foundation consists of 5 to $7 \mathrm{ft}$ relatively impervious material underlain by sand.

In 1929 with the Greenville gage above $50 \mathrm{ft}$ for 21 days, partial failure of the levee occurred. Hydrostatic head in the pervious substratum blew up the surface soil at the L.S. toe over an area $4 \mathrm{ft}$ by $7 \mathrm{ft}$, followed by a settlement $30 \mathrm{ft}$ wide entirely across the levee. This settlement of the levee, which consisted of sandy soil and which was unable to support itself above the flowing stream, cut off the foundation cavity, thereby stopping the flow of water and saving the levee.

Lake Washington area. Seepage and sand boil occurrences for the Lake Washington area are shown in Figures 18a through 18c for the 1937, 1973, and 2011 floods, respectively. The levee through this reach was set back and reconfigured when the Worthington Cutoff was dredged across Matthews Bend in 1933. The Lake Washington area levee right-of-way 
would have been redesigned because of the cutoff through this area and would have been built to the new 1928 profile standards prior to the 1937 flood. The extent of seepage berm construction in this reach in 1937 is shown by Figures 17a. Identified on Figure $17 \mathrm{c}$ is a current image of this same area with seepage berm construction during the 2011 flood. Remnants of the 1928 profile are still in place, and these reaches correspond to where older, clay filled, abandoned channel deposits intersect the levee as shown by geology map in Figure 17b. For the most part, this area has a $300-\mathrm{ft}$-wide seepage berm in place.

Despite the additional seepage berm measures that were adopted following the 1973 flood (Figure 17b), two noteworthy boils were identified behind the levee during the 2011 flood in the Longwood area at sta 5400 and at sta 5651 at Worthington Point (Table 5). The addition of a continuous seepage berm in this area highlights the chronic nature of the underseepage problem through this reach. The presence of a thin blanket in younger point bar deposits and numerous older (clay filled) abandoned channels behind the levee through this reach are major contributing factors to performance issues. Additionally, another contributing factor to this chronic performance is the narrow flood corridor that was established when the point bar neck sands were dredged to create the Worthington point cutoff. The new channel would have scoured deeply into these aquifer sands as the oxbow diminished in channel capacity to carry the flow. As shown by Figure 17a, the presence of channel sands is shown at relatively shallow elevation (depths). Thus, the hydraulic gradient is relatively high across the levee profile through this reach because of the close proximity of the new channel to the levee. 
Figure 18a. Seepage and sand boils from the 1937 flood (WES 1948). Note the amount of seepage berm present in 1948 (denoted by the solid blue line).

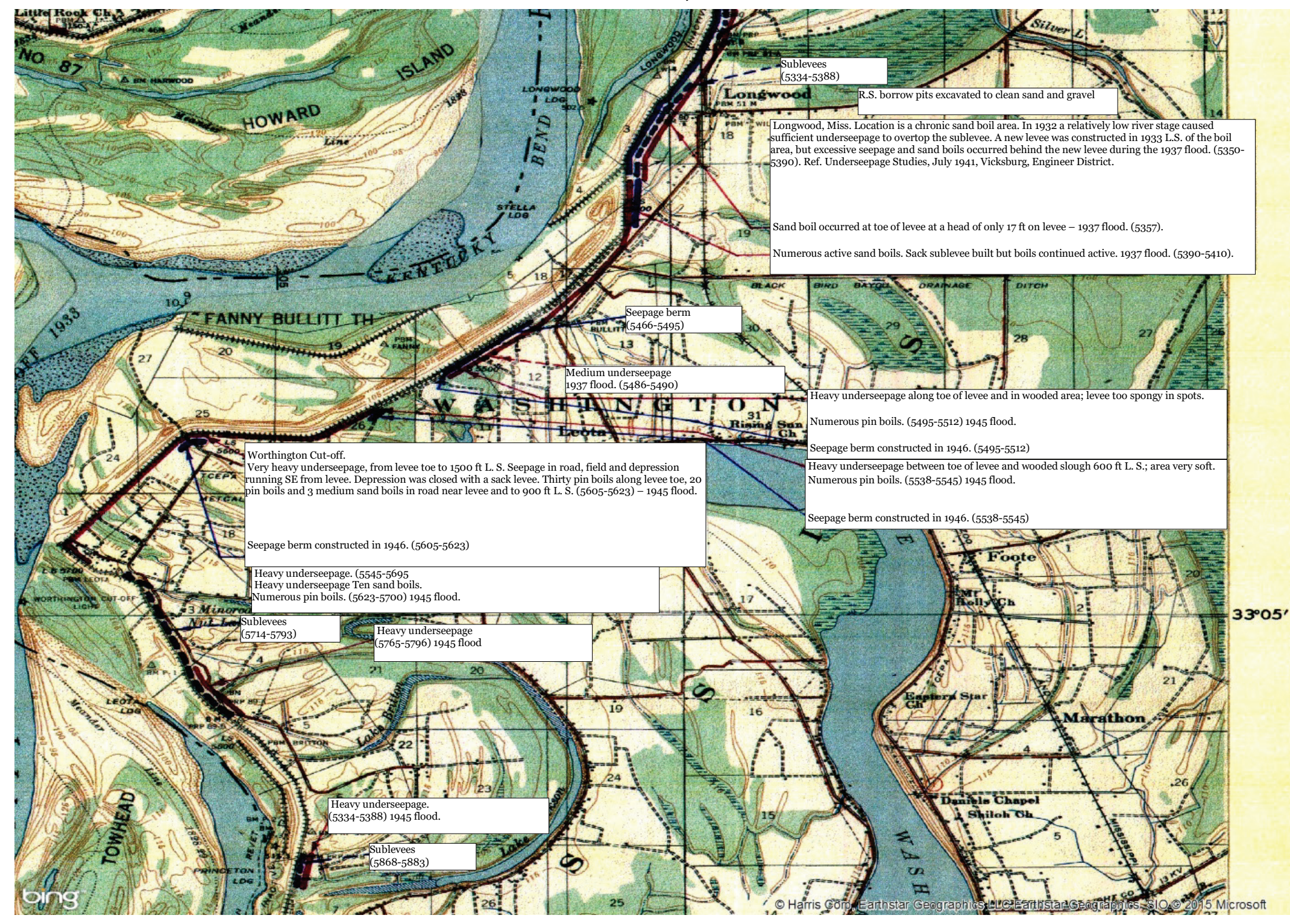


Figure 18b. Seepage and sand boil data from the 1973 flood (USACE 1973a). Note the amount of seepage berm present in 1973 (solid blue line).

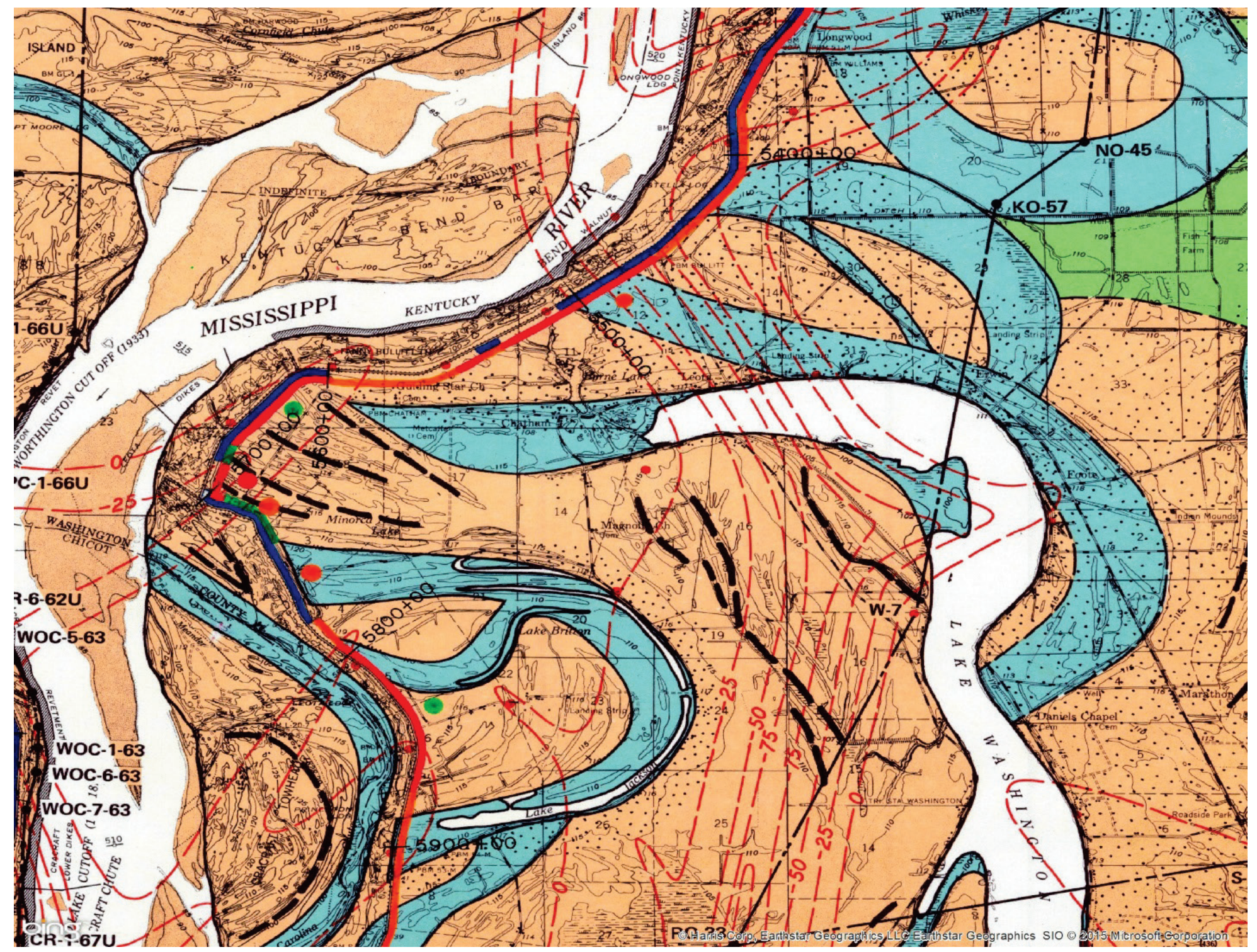


Figure 18c. Seepage and sand boil data from the 2011 flood. See Figure $17 \mathrm{~d}$ for seepage berm extent.

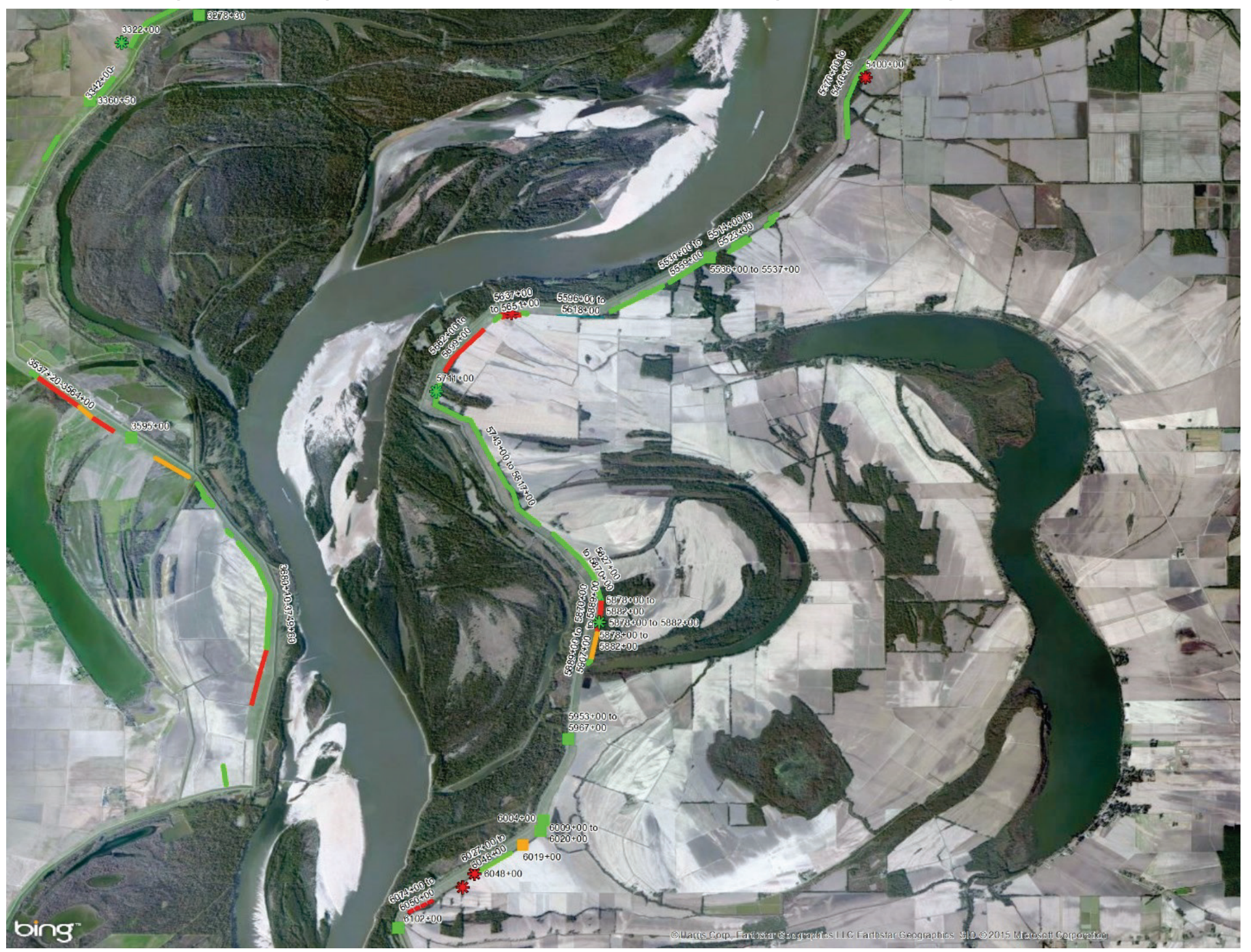




\subsection{Other areas in Table 5}

Other areas in Table 5 that have experienced performance issues in recent times are the Albemarle slide and the lower Eagle Lake area as previously described. The Albemarle area (sta 8170) is an interesting case because of the slide that occurred during the 2011 flood, where underseepage was attributed to the partial levee failure. However, this reach has been known for slough slides where the riverside slope has experienced minor slides because of high plasticity $\mathrm{CH}$ soils from the former river channel. A shallow riverside slide had occurred at this same location two years prior to the 2011 flood. Thus, it is uncertain as to whether levee through seepage had contributed to this slide. Emergency repairs to stabilize the levee and rebuild following the 2011 flood did not permit a forensic investigation of a through seepage mechanism as being a contributing factor.

As noted in Chapter 3, the Eagle Lake area prior to 1973 would collect backwater drainage behind the levee through Muddy Bayou and Steele Bayou. The Muddy Bayou and Steele Bayou control structures were built following the 1973 flood and were designed to prevent extensive backwater flooding into the Buck Chute area (southern arm of Eagle Lake) and the Tara Wildlife Hunting Camp areas. This reach of levee is known as the New Brunswick Extension with Eagle Lake, Forest Home, and Halpino Lake Enlargements (Figure 9). Sand boils started becoming a significant seepage issue in the early 1990 and were problematic during the 2008 and 2009 floods. Performance issues prior to the 1973 flood were not noted for this area. Thus, this reach during the past 20 years has been the focus of extensive seepage control measures following the 2011 flood. Detailed geologic and geophysical studies of the Buck Chute and Terra levee reaches are described by Martin et al. (2016) and Strange et al. (2016).

\subsection{Seepage control measures}

Seepage control measures mainly involve seepage berms, relief wells (not examined in this study), drainage ditches, and a combination of these methods. Identified on the WES (1948) and USACE (1973a) flood performance maps were seepage berm locations. These locations were digitized in ArcView to obtain the total length of berm construction for the two-time periods (1948 and 1973). Additionally, Bing photography was used to map the addition of new berms that have been constructed after 1973 . The total extent of main-line Mississippi River levees in the Vicksburg District is approximately 524 miles for perspective purposes. In 1948, there 
were 62 miles (12 percent of total length) of seepage berms that had been constructed in the Vicksburg District. In 1973, there was an additional 95 miles of seepage berms that had been built between 1948 and 1973, corresponding to 157 total miles (30 percent of total length). An additional 231 miles of berms were constructed following the 1973 flood, for a combined length of 387 miles (74 percent of total length). These values do not differentiate between berm type or width (150- or 300-ft-wide berms). The increasing extent of berms has generally reduced the severity of seepage based on the areas that had previously experienced heavy seepage. 


\section{Summary and Conclusions}

\subsection{Summary}

The backbone of the MR\&T flood protection system involves levees to prevent periodic overflow of the developed alluvial valley by the Mississippi River. Incidents of sand boil and seepage activity recorded during the Mississippi River Flood of 2011 by the Vicksburg District were overlain onto photographic and geologic base maps for this study to evaluate the distribution of incidents in terms of the underlying depositional environment and historic land use changes. The presentation of the 2011 flood incidents of seepage and sand boil incidents onto photographic and geologic base maps follows similar depictions of performance data from the 1937 and 1973 floods (WES 1948; USACE 1973b). This study reviews historic levee construction activities by the USACE following the Great Mississippi River Flood of 1927 and past studies to evaluate levee underseepage and their control. From the distribution of incidents involving three major floods of record in the Vicksburg District between 1937 and 2011, areas where chronic sand boil and seepage activity occur are identified and reviewed as to geologic controls and underlying changes in levee design to remediate these areas. Geologic data from the alluvial valley were obtained from the legacy WES geologic mapping program conducted for the MRC between the late-1940s and the mid-1990s (see Imvmapping.erdc.usace.army.mil).

Important to understanding the performance of the MR\&T levee system during large flood events is the underlying design principals and changes that have occurred to the levee system since the modern day system was established with the completion of the 1928 levee profile by the time of the Mississippi River Flood of 1937. In addition, the reach of the Mississippi River in the Vicksburg District encompasses 15 of the 16 meander cutoffs that were constructed between 1929 and 1942, effectively shortening the course of the river by 135 miles and resulting in significant changes to the levee corridor. MRC legacy documents and noteworthy studies involving levee seepage issues are incorporated into this investigation where applicable. Included in this report are appendices containing the 1947 Levee Code and the 1928 Design and Construction standards used by the Vicksburg District to rebuild the levee system from the 1914 profile to the 1928 profile following the 1927 flood. The goal for including this information here was to consolidate this information into a single source 
for those seeking additional information. These type of studies are the corporate history regarding the levee system which become less consolidated with the passage of time, personnel changes in the USACE organization, and transfer of responsibility to the next generation of engineers tasked with maintaining the flood protection system. The current levee system has evolved and will continue to evolve in the future because of the dynamic nature of the river, the demands imposed on the system during each major flood event, and future changes in land use.

Levee boards are responsible for the day to day operation and normal maintenance of the main-line levees and these boards were in operation prior to the passage of the Flood Control Act of 1928, which authorized the MR\&T Project. Most of the levees that were in place in 1927 were typically private levees that were under the jurisdiction of the local levee boards. USACE presence in the lower valley prior to 1928 was primarily related to maintaining navigation, mapping the navigable waterways, and regulating levee construction along navigable waterways. Today, the levee system is a shared partnership between the USACE Districts and the local levee boards which are responsible for their maintenance and management.

\subsection{Conclusions}

Sixty-eight percent of the seepage and sand boil incidents identified during the 2011 flood are associated with recent point bar deposits, which are less than 3,000 years old. This distribution is consistent with earlier studies of sand boil and landform relationships (Mansur et al. 1956; Kolb 1975). Blocked exit conditions were the most favorable locations for sand boil occurrence, involving ridge (lateral bars) and swale (clay filling slough between lateral bars) topography and at the boundaries between point bar and abandoned channels. Levee orientation in relationship to depositional features has an important bearing on the concentration of seepage behind the levee, especially where the levee creates a closed basin condition with the underlying alluvial aquifer and less permeable depositional environments that intersect the levee.

The next highest concentration of sand boils occurs in the abandoned channel, with approximately 23.5 percent of all the observed incidents during the 2011 flood being in oxbow settings. Incidents involving abandoned channels are typically associated with meander loops that are relatively young in terms of their abandonment from the main channel and are in the early stages of their natural filling cycle. Most incidents 
during the 2011 flood were located in close proximity to the cutoff, where the fine-grained blanket is relatively thin and the alluvial substratum or aquifer sands occur at shallow depths. Lake Chicot, Lake Providence, and Eagle Lake are examples where this condition was common during the 2011 flood.

Twenty-five significant boil areas were identified from the recorded 2011 flood incident data. Four areas of chronic sand boil occurrence were identified from this listing based on performance incidents occurring at these locations during the three major floods of record, 1937, 1973, and 2011 floods. These areas correspond to the Francis, Leland Chute-Lake Chicot, Winterville-Greenville Levee Front, and Lake Washington reaches. Seepage berms have been typically constructed following the major floods at these locations as evidenced by historic performance maps from the 1937, 1973 and 2011 floods (WES 1948; USACE 1973a). These maps identify the presence of seepage berms that have been developed in response to poor performance during flooding.

Approximately 15 percent of all the sand boil incidents recorded during the 2011 flood involved large/high-energy sand boils. Historically, large boils account for between 15 to 24 percent of the total incidents during large floods. The majority of seepage areas during the 2011 flood were in the low to moderate category. Areas of high seepage were generally less than the 1973 flood extent because of the addition of new seepage berms and the increasing use of relief wells in seepage prone areas since the mid-199os. The efficacy of relief wells and their impact to the overall levee system in terms of controlling seepage were not considered by this study. Approximately 387 miles of seepage berms have been added to the mainline levee system in the Vicksburg District since the 1928 profile was adopted as the standard profile following the 1927 flood.

\subsection{Recommendations}

The following recommendations are made for conducting research of problem levee reaches.

1. Continue long-term historic assessment study of the Memphis and New Orleans Districts.

2. Conduct focused studies of chronic problem sites to determine specific properties about each site. These studies should involve a detailed geological site characterization, evaluation of existing boring data, 
topography, and other physical parameters to fully understand the specific engineering and hydraulic factors at play.

3. Major sand boils should be excavated to obtain detailed information on boil characteristics and properties (namely the blanket and ejecta soils, seepage pathways, their size and extent, type of aquifer soils).

4. Sand boil ejecta should be routinely collected and grain-size data obtained to determine the depth and the stratigraphic horizon from which the foundation material is being removed.

5. A detailed checklist of sand boil properties should be collected from all large boils in future flood events.

6. Geophysical methods should be incorporated into a study of chronic problem sites to image between the available boring data to help resolve blanket characteristics and properties.

7. Finally, conduct a study of long-term impacts from multiple flood events and levee performance. Do chronic seepage problems cause subsurface erosion and degradation that leads to more severe problems with time? Selected study sites should be targets for this chronic condition and assessment of levee performance data conducted in relation to seepage control measures. 


\section{References}

Camillo, C. A. 2012. Divine providence, The 2011 flood in the Mississippi River and tributaries project. U.S. Army Corps of Engineers. Vicksburg, MS: Mississippi River Commission.

Cunny, R. W. 1987. Inspection and control of levee underseepage during flood fights. Technical Report REMR-GT-5. Vicksburg, MS: U.S. Army Engineer Waterways Experiment Station.

Dunbar, J. B., M. K. Corcoran, and N. D. Vroman. 2015. The legacy of the 1948 underseepage and crevasse maps, lower Mississippi river levees. Technical Note, Vicksburg, MS: U.S. Army Engineer Research and Development Center.

Fisk, H. N. 1944. Geological investigation of the alluvial valley of the Lower Mississippi River. Vicksburg, MS: Mississippi River Commission.

Fisk, H. N. 1946. Underseepage and faulting (Lecture IV), Results of geological investigations of the alluvial valley of the Lower Mississippi River, Lectures III and IV, Application of geological studies. Lectures presented to Engineers of the Mississippi River Commission, Waterways Experiment Station, and Memphis, Vicksburg, and New Orleans Districts as part of training program developed by the Training Sections. Vicksburg, MS: Mississippi River Commission.

Fisk, H. N. 1947. Fine-grained alluvial deposits and their effects on Mississippi River activity, MRC-WES-2000-2-48. In Two Volumes. Vicksburg, MS: U.S. Army Engineer Waterways Experiment Station.

Gagliano, S. M., and P. C. Howard. 1984. The neck cutoff oxbow lake cycle along the Lower Mississippi River. In: River Meandering Conference Proceedings, Rivers 83. New Orleans, LA.

Kolb, C. R. 1949. The entrenched valley of the Lower Red River. Technical Memorandum No. 3-298. Vicksburg, MS: U.S. Army Engineer Waterways Experiment Station.

Kolb, C. R. 1975. Geologic control of sand boils along Mississippi River levees. Miscellaneous Paper S-75-22. Vicksburg, MS: U.S. Army Engineer Waterways Experiment Station.

Kolb, C. R., W. B. Steinriede, E. L. Krinitzsky, R. T. Saucier, P. R. Mabrey, F. L. Smith, and A. R. Fleetwood. 1968. Geological investigation of the Yazoo Basin, lower Mississippi Valley. Technical Report No. 3-480. Vicksburg, MS: U.S. Army Engineer Waterways Experiment Station.

Kolb, C. R., and J. R. Van Lopkik. 1958. Geology of the Mississippi River deltaic plain, southeastern Louisiana. Technical Report No. 3-483. Vicksburg, MS: U.S. Army Engineer Waterways Experiment Station.

Long, H. T. 1930. Preliminary report on investigation of seepage in levees. Vicksburg, MS: U.S. Army Engineer Waterways Experiment Station. 
Mansur, C. I., R. I. Kaufman, and J. R. Schultz. 1956. Investigation of underseepage and its control, Lower Mississippi River levees. Technical Memorandum No. 3-424. Vicksburg, MS: U.S. Army Engineer Waterways Experiment Station.

Martin S. M., J. B. Dunbar, M. K. Corcoran, and D. Schmitz. 2016. Geologic controls of levee underseepage at Buck Chute, MS. Vicksburg, MS: U.S. Army Engineer Research and Development Center.

May, J. R., L. D. Britsch, J. B. Dunbar, J. P. Rodriguez, and L. B. Wlosinski. 1984. Geological investigation of the Mississippi River deltaic plain. Technical Report GL-84-15. Vicksburg, MS: U.S. Army Engineer Waterways Experiment Station.

Mississippi River Commission (MRC). 1947. Code for the utilization of soils data for levees. Vicksburg, MS: Mississippi River Commission.

Moore, N. R. 1972. Improvement of the lower Mississippi River and tributaries. Vicksburg, MS: Mississippi River Commission.

Saucier, R. T. 1964. Geological investigation of the St. Francis Basin. Technical Report No. 3-659. Vicksburg, MS: U.S. Army Engineer Waterways Experiment Station.

Saucier, R. T. 1967. Geological investigation of the Boeuf-Tensas Basin. Technical Report No. 3-757. Vicksburg, MS: U.S. Army Engineer Waterways Experiment Station.

Saucier, R. T. 1969. Geological investigation of the Mississippi River area: Artonish to Donaldsonvnille, LA. Technical Report No. 3-757. Vicksburg, MS: U.S. Army Engineer Waterways Experiment Station.

Saucier, R. T. 1994. Geomorphology and quaternary geologic history of the Lower Mississippi Valley. Vicksburg, MS: Mississippi River Commission.

Smith, F. L. and D. P. Russ. 1974. Geological investigation of the Lower Red RiverAtchafalaya Basin area, Lower Mississippi Valley. Technical Report No. S-74-5. Vicksburg, MS: U.S. Army Engineer Waterways Experiment Station.

Smith, F. L. and R. T. Saucier. 1971. Geological investigation of the western lowlands area. Technical Report No. S-71-5. Vicksburg, MS: U.S. Army Engineer Waterways Experiment Station.

Stephens, I. J. 2014. Field Investigation of a sand boil developed during the Mississippi River Flood of 2011. Proceedings of the $31^{\text {st }}$ annual conference. San Diego, CA: American Society of Dam Safety Officials.

Strange, R. C., M. K. Corcoran, J. B. Dunbar, and D. Schmitz. 2016. The influences of geologic depositional environments on sand boil development, Tara Wildlife Lodge area in Mississippi. Vicksburg, MS: U.S. Army Engineer Research and Development Center.

United States. 1939. Proceedings of the Soils and Foundation Conference of the U.S. Engineer Department, June 17-21, 1938, Boston, MA, Corps of Engineers, U.S. Army. 
U.S. Army Corps of Engineers (USACE). 1929. Standard instructions for levee inspectors for use in Vicksburg Engineer District. Vicksburg, MS: U.S. Army Engineer District, Vicksburg.

U.S. Army Corps of Engineers (USACE). 1939. Mississippi River levees underseepage studies, Black Bayou Levee, East Bank in Mississippi, 44O M.B.C. Vicksburg, MS: U.S. Army Engineer District.

U.S. Army Corps of Engineers (USACE). 1941a. Mississippi River levee underseepage. Vicksburg, MS: U.S. Army Engineer District, Vicksburg.

U.S. Army Corps of Engineers (USACE). 1941b. Seepage and foundation studies. Map at 1:125,000 scale, E-MR-49. Vicksburg, MS: U.S. Army Engineer District, Vicksburg.

U.S. Army Corps of Engineers (USACE). 1973a. Underseepage and boil occurrence, data related to geologic conditions. Vicksburg, MS: U.S. Army Engineer District, Vicksburg.

U.S. Army Corps of Engineers (USACE). 1973b. Mississippi River and tributaries. Postflood report 1973. Vicksburg, MS: Department of the Army, Corps of Engineers, Lower Mississippi Valley Division.

U.S. Army Corps of Engineers (USACE). 1974. Report of 1973 high water inspection of levees, U.S. Army Engineer District, Vicksburg, Lower Mississippi Valley Division, Volumes 1 through 3. Vicksburg, MS: Department of the Army, Corps of Engineers, Lower Mississippi Valley Division.

U.S. Army Corps of Engineers (USACE). 1975. Master index: Upper and lower Mississippi River surveys for period 1879-8o to 1928 and some historic maps prior to this period, Vol. I-III. Vicksburg, MS: Mississippi River Commission.

U.S. Army Corps of Engineers (USACE). 2000. Design and construction of levees. EM-1110-2-1913. Washington, DC: Department of Army.

U.S. Army Corps of Engineers (USACE). 2011. Report of 2011 high water levee inspection, U.S. Army Engineer, Vicksburg District. Vicksburg, MS: Department of the Army, Corps of Engineers, Lower Mississippi Valley Division.

U.S. Congress. 1931. Control of floods in the alluvial valley of the Lower Mississippi River, table No. 24, table of crevasses on the Mississippi River below Cairo, Ill. House Document No. 798, $71^{\text {st }}$ Congress, 8d Session. Washington, DC: U.S. Government Printing Office.

U.S. Army Engineer Research and Development Center. 2016. Lower and Middle Mississippi Valley engineering geology mapping program. Vicksburg, MS: U.S. Army Engineer Research and Development Center. Imvmapping@erdc.usace.army.mil

U.S. Army Engineer Waterways Experiment Station (WES). 1931a. Experiment to determine the comparative stability of a sluiced levee and a dry fill levee. Vicksburg, MS: U.S. Army Engineer Waterways Experiment Station. 
U.S. Army Engineer Waterways Experiment Station (WES). 1931b. The effect of impervious walls in levees. TM-8-2. Vicksburg, MS: U.S. Army Engineer Waterways Experiment Station.

U.S. Army Engineer Waterways Experiment Station (WES). 1936. The efficacy of bentonite in reducing seepage through and under levees. TM-135-1. Vicksburg, MS: U.S. Army Engineer Waterways Experiment Station.

U.S. Army Engineer Waterways Experiment Station (WES). 1938. The efficacy of sublevees and berms in the control of seepage. TM-101-1. Vicksburg, MS: U.S. Army Engineer Waterways Experiment Station.

U.S. Army Engineer Waterways Experiment Station (WES). 1939. The efficacy of systems of drainage wells. TM-151-1. Vicksburg, MS: U.S. Army Engineer Waterways Experiment Station.

U.S. Army Engineer Waterways Experiment Station (WES). 1941a. Seepage model of Greenville Front levee. Technical Memorandum No. 182-1. Vicksburg, MS: U.S. Army Engineer Waterways Experiment Station.

U.S. Army Engineer Waterways Experiment Station (WES). 1941b. Investigation of underseepage, Lower Mississippi River levees. Technical Memorandum No. 184-1. Vicksburg, MS: U.S. Army Engineer Waterways Experiment Station.

U.S. Army Engineer Waterways Experiment Station (WES). 1945. Conference on Control of Underseepage, Cincinnati, Ohio. 13-14 June 1944. Vicksburg, MS: U.S. Army Engineer Waterways Experiment Station.

U.S. Army Engineer Waterways Experiment Station (WES). 1948. Underseepage and crevasse data, Lower Mississippi River levees for 1937 and 1945 high waters, Lower Mississippi Valley Division, Cairo, Illinois to New Orleans, Louisiana. Vicksburg, MS: U.S. Army Engineer Waterways Experiment Station.

Winkley, B. R. 1977. Man-made cutoffs on the Lower Mississippi River, conception, construction, and river response, potamology investigations. Report 300-2. Vicksburg, MS: U.S. Army Engineer District, Vicksburg. 

Plate 1. Alluvial geology map of the Yazoo Basin (Saucier and Kolb 1967). Generalized geologic profile extends from Memphis to vicinity of Vicksburg and shows the top stratum and substratum deposits in relationship to the longitudinal profile.

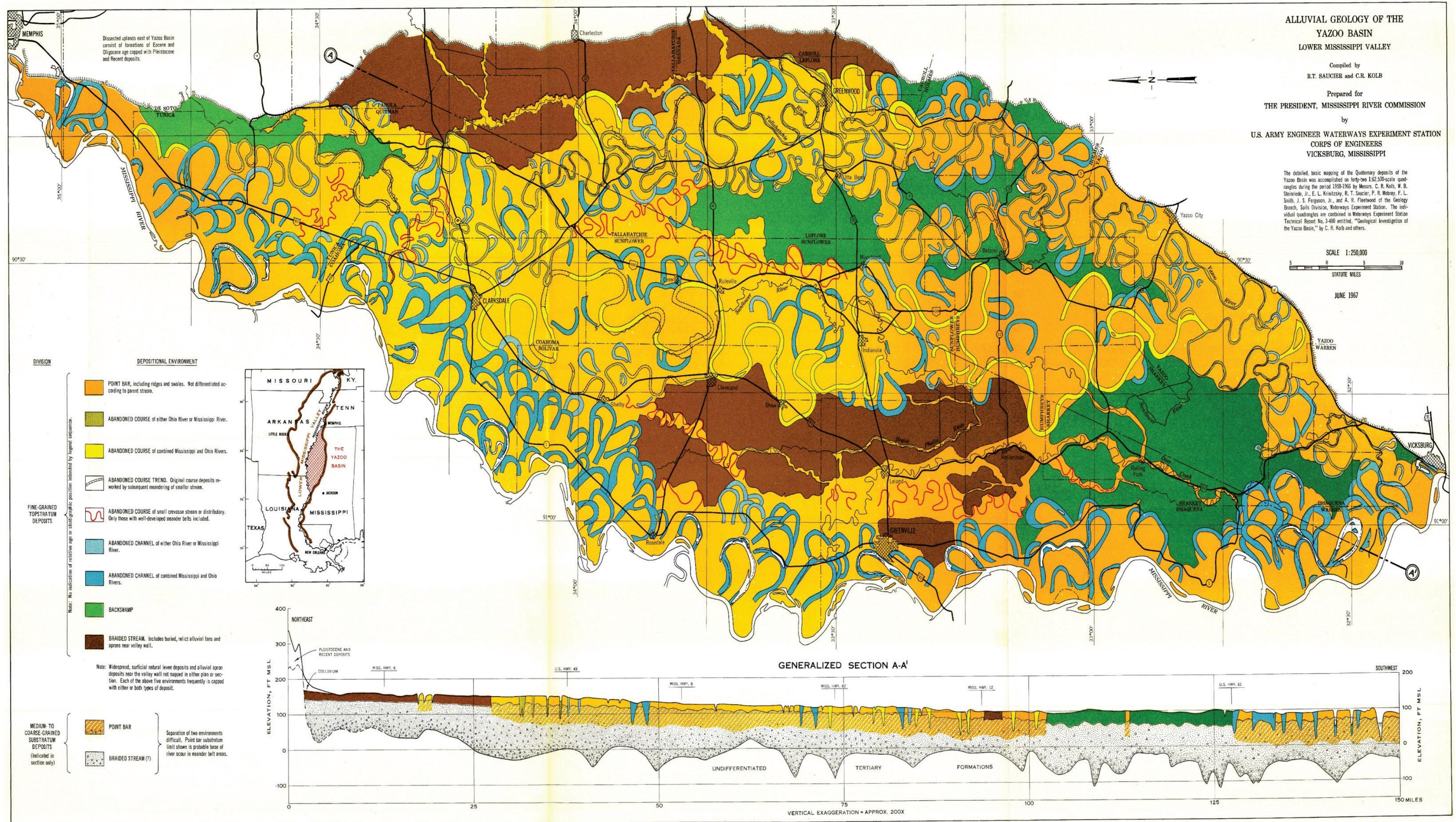


Plate 2. Character of abandoned channel filling at various locations along the Lake Chicot oxbow (Fisk 1947). This area was the site of numerous sand boil incidents during the 2011 flood.

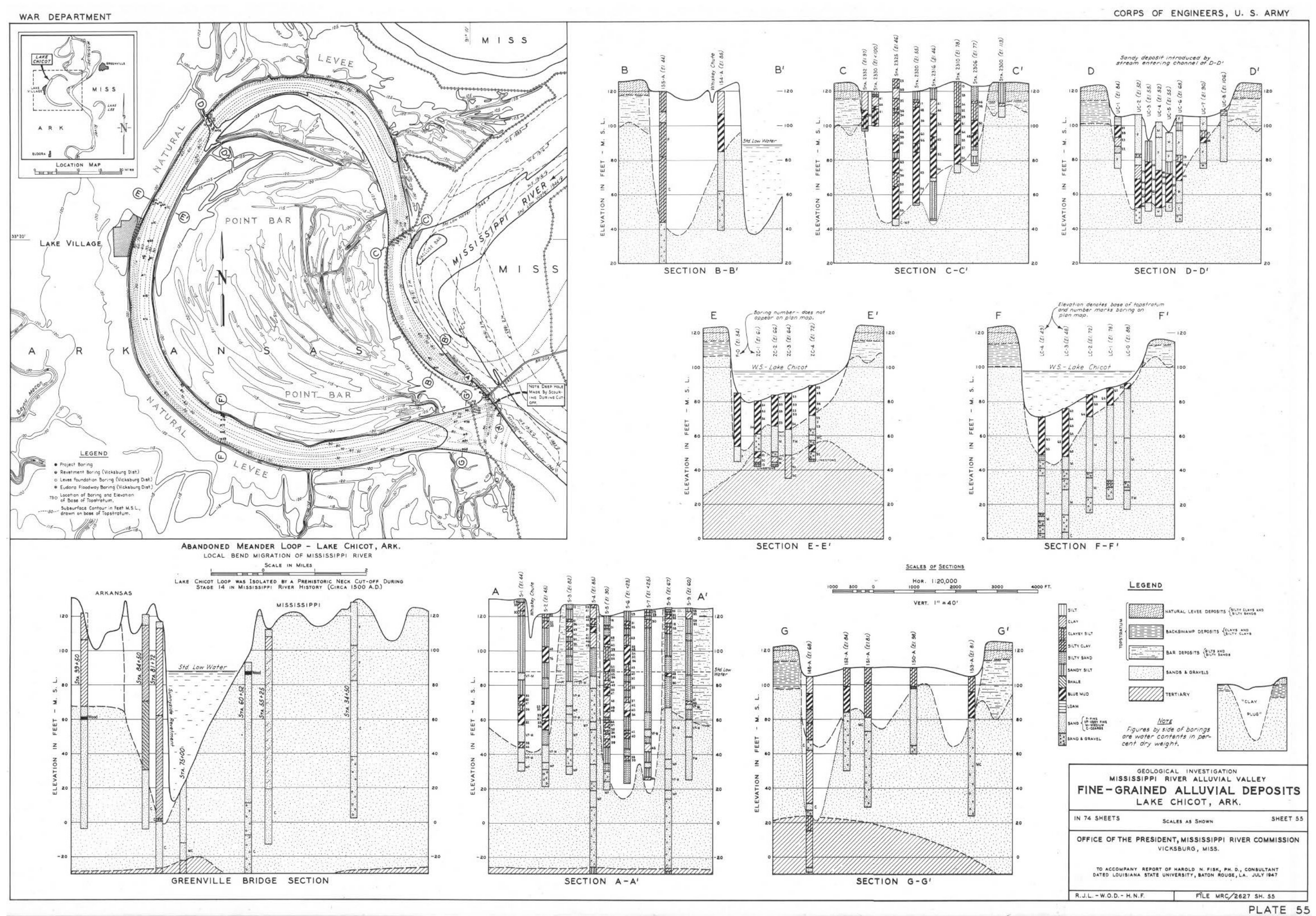


Plate 3. Lake Chicot, AR.

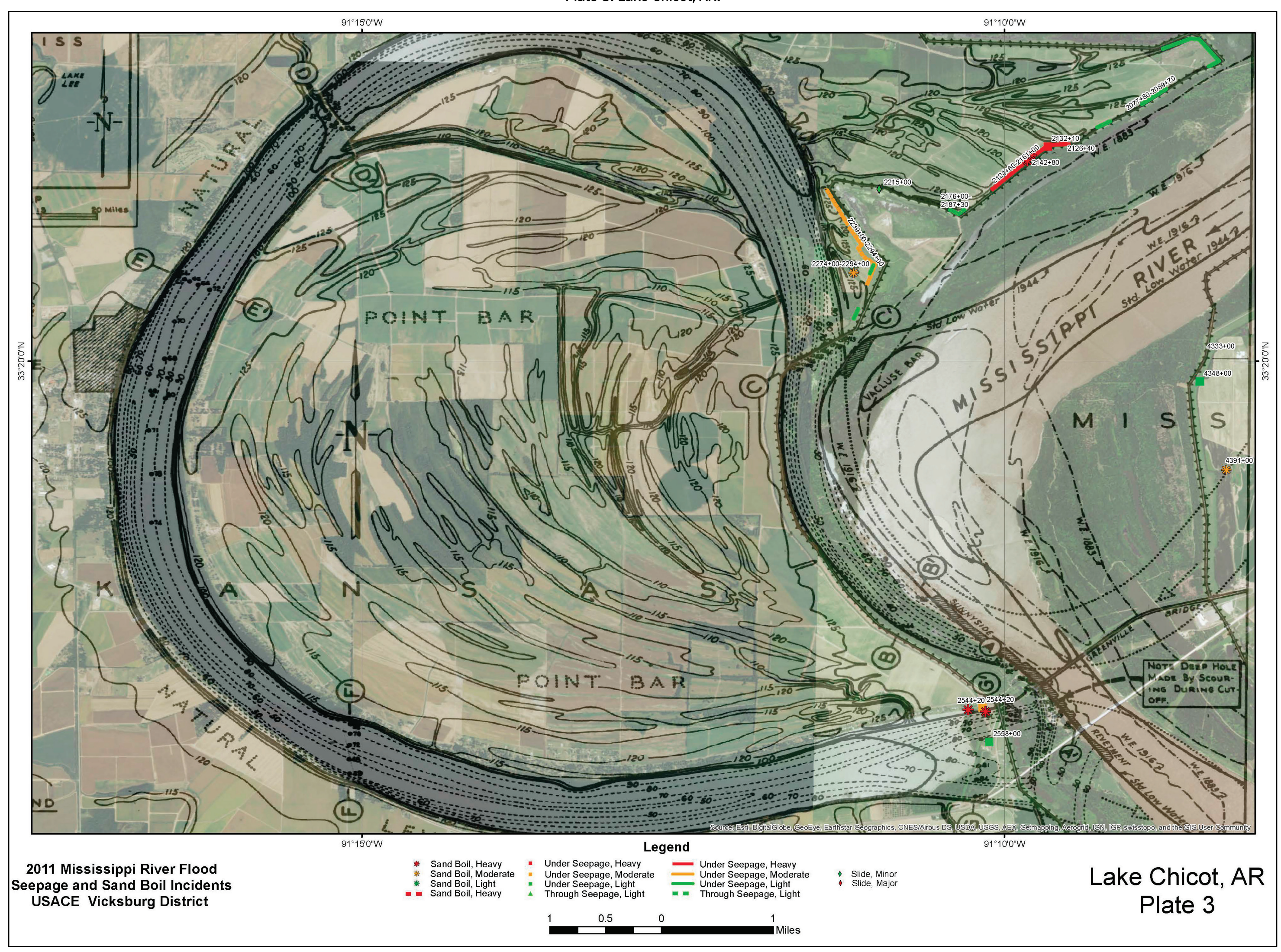


Plate 4. Lake Chicot, AR, 2006 LiDAR data.

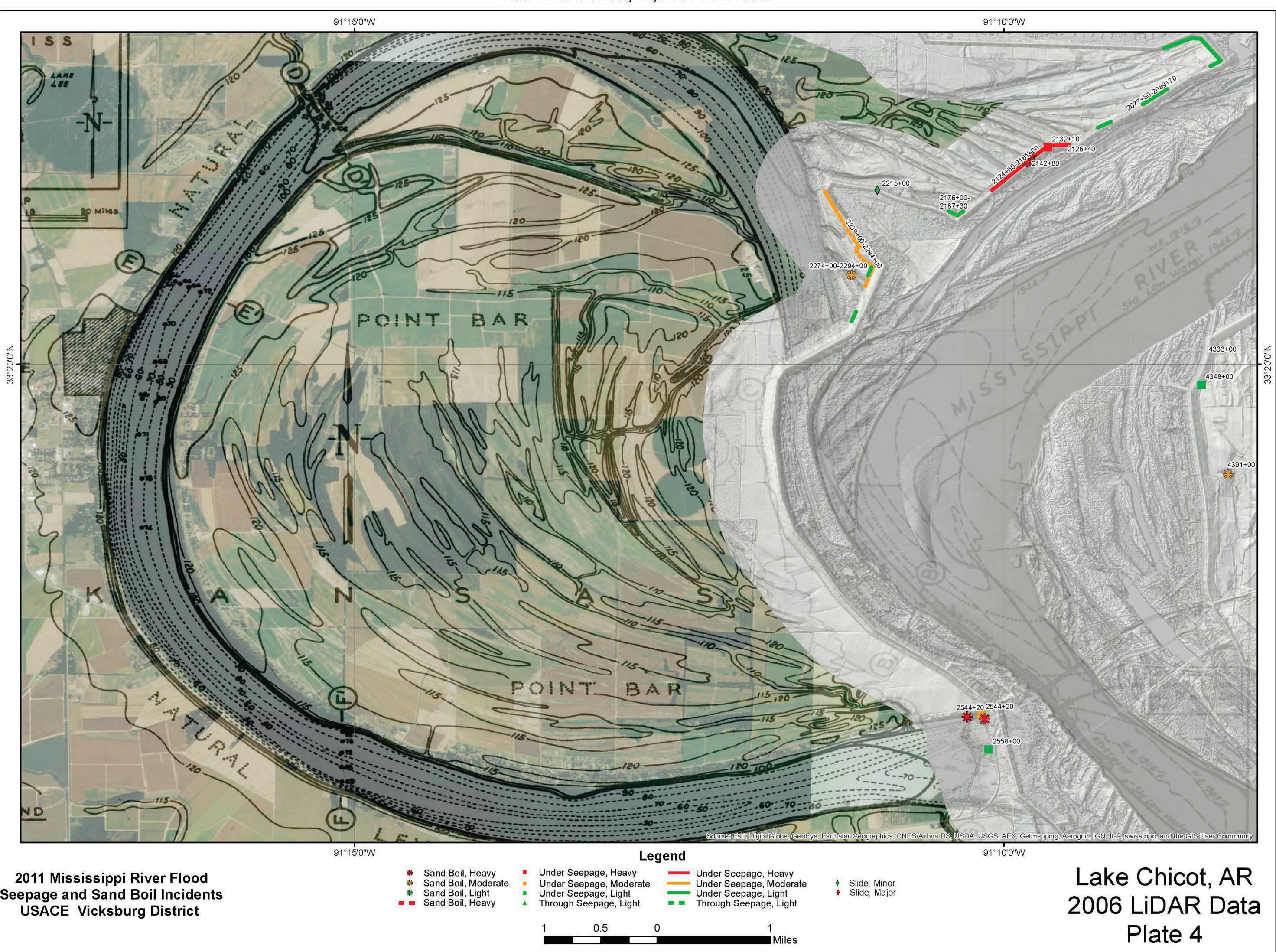




\section{Appendix A: 2011 Report with Photos}


Appendix A: 2011 Flood Report - Incident Data

US Army Corps of Engineers, Vicksburg District

August 2011 


\section{EAST BANK MISSISSIPPI RIVER LEVEE STATION 0+00 TO 1500+00}


LEVEE SECTOR: District Line to Rosedale

DATE: May 16-18, 2011

TEAM MEMBERS: Heather Sibley, Lance Gullett and Justin Jones

\begin{tabular}{|c|c|c|c|c|c|c|c|c|c|}
\hline \multicolumn{2}{|c|}{ START } & \multicolumn{2}{|c|}{ END } & \multirow{2}{*}{$\begin{array}{l}\text { STATION } \\
\text { NLD }\end{array}$} & \multirow{2}{*}{$\begin{array}{c}\text { STATION } \\
\text { FIELD MARKER }\end{array}$} & \multirow[t]{2}{*}{ TYPE } & \multirow[t]{2}{*}{ EXTENT } & \multirow[t]{2}{*}{ REMARKS } & \multirow[t]{2}{*}{ РНОТО } \\
\hline Latitude & Longitude & Latitude & Longitude & & & & & & \\
\hline-- & -- & -- & -- & $0+00$ to $5+00$ & $0+00$ to $5+00$ & Current & Moderate & Moderate Current just out from the toe of the levee. & \\
\hline 34.11147204 & 90.87997861 & 34.10548407 & 90.88043276 & $\begin{array}{l}36+00 \text { to } \\
58+00\end{array}$ & $\begin{array}{l}36+00 \text { to } \\
58+00\end{array}$ & Under Seepage & Light & $\begin{array}{l}\text { Seepage transitions to light seepage. Not flowing and no boils found. Extends } \\
\text { from the levee toe out } 200 \mathrm{ft} \text {. }\end{array}$ & \\
\hline 34.10291772 & 90.88032166 & 34.09872932 & 90.87199129 & $\begin{array}{l}68+00 \text { to } \\
102+00\end{array}$ & $\begin{array}{l}68+00 \text { to } \\
102+00\end{array}$ & Under Seepage & Light & $\begin{array}{l}\text { Light seepage. Begins at the toe and extends out. Cannot determine full limits } \\
\text { of seepage. }\end{array}$ & \\
\hline 34.09800244 & 90.8711749 & 34.08962979 & 90.86691213 & $\begin{array}{l}105+00 \text { to } \\
159+00\end{array}$ & $\begin{array}{l}105+00 \text { to } \\
159+00\end{array}$ & \begin{tabular}{|l} 
Under \\
Seepage/Pin \\
Boils
\end{tabular} & Heavy & $\begin{array}{l}\text { Heavy Seepage. Numerous pin boils in field. Two areas with very light } \\
\text { seepage exiting just up the slope from the toe of the berm. Extends from the } \\
\text { toe out } 1000 \mathrm{ft} \text {. }\end{array}$ & 2 \\
\hline 34.08962979 & 90.86691213 & -- & -- & $137+00$ & $137+00$ & Sand Boil & & $\begin{array}{l}\text { Small Boil throat less than } 3 \text { inches. Has been bagged. Moving very small } \\
\text { amount of material. Located approximately } 25 \mathrm{ft} \text { from the toe. }\end{array}$ & 3 \\
\hline 34.08578056 & 90.86633889 & -- & - & $151+00$ & $151+00$ & Sand Boil & & $\begin{array}{l}\text { A large, high energy sand boil (photo 4) was identified moving significant } \\
\text { quantities of silt and fine sand material at the toe of a } 200 \text { foot seepage berm. } \\
\text { The boil was bagged by the Levee Board with prison labor for initial } \\
\text { containment and subsequently the sandbag ring was encircled by a larger } \\
\text { earthen berm constructed by Corps hired labor forces. A filter of sand and } \\
\text { stone was constructed over the boil throat to filter fines and dissipate energy. } \\
\text { The stabilization of the boil took } 4 \text { days of } 24 \mathrm{hr} / \text { day effort (photos 5-7). Flow } \\
\text { from the boil was estimated at approximately } 300 \text { gals/min. This boil } \\
\text { appeared to have the potential to result in backward erosion and piping that } \\
\text { could eventually lead to loss of berm and levee foundation material. Two } \\
\text { additional sand boils were identified approximately } 100-150 \text { feet from the } \\
\text { berm toe (photos } 8-10 \text { ). These boils were classified as moderate energy } \\
\text { levels and moved approximately } 5-7 \text { cubic yards of material. These boils were } \\
\text { also bagged by the local prisoners. Heavy seepage and numerous pin boils } \\
\text { were noted and monitored along the slope and toe of the berm upstream and } \\
\text { downstream of these boils for a reach of approximately } 2,000 \text { feet. Area } \\
\text { known as Francis. }\end{array}$ & $4-10$ \\
\hline 34.08413458 & 90.8641464 & 34.08248059 & 90.86361787 & $\begin{array}{l}158+00 \text { to } \\
166+00\end{array}$ & $\begin{array}{l}158+00 \text { to } \\
166+00\end{array}$ & Under Seepage & Light & $\begin{array}{l}\text { Seepage is light and ends just before the end of the seepage berm. From the } \\
\text { end of the berm on the North to the start of the berm on the South, there is a } \\
\text { small amount of seepage where berm ends. }\end{array}$ & \\
\hline 34.068335 & 90.86654317 & 34.06554717 & 90.86485715 & $\begin{array}{l}226+00 \text { to } \\
237+00\end{array}$ & $\begin{array}{l}202+00 \text { to } \\
213+00\end{array}$ & Under Seepage & |Light & Light to very light seepage beyond berm toe. & \\
\hline
\end{tabular}




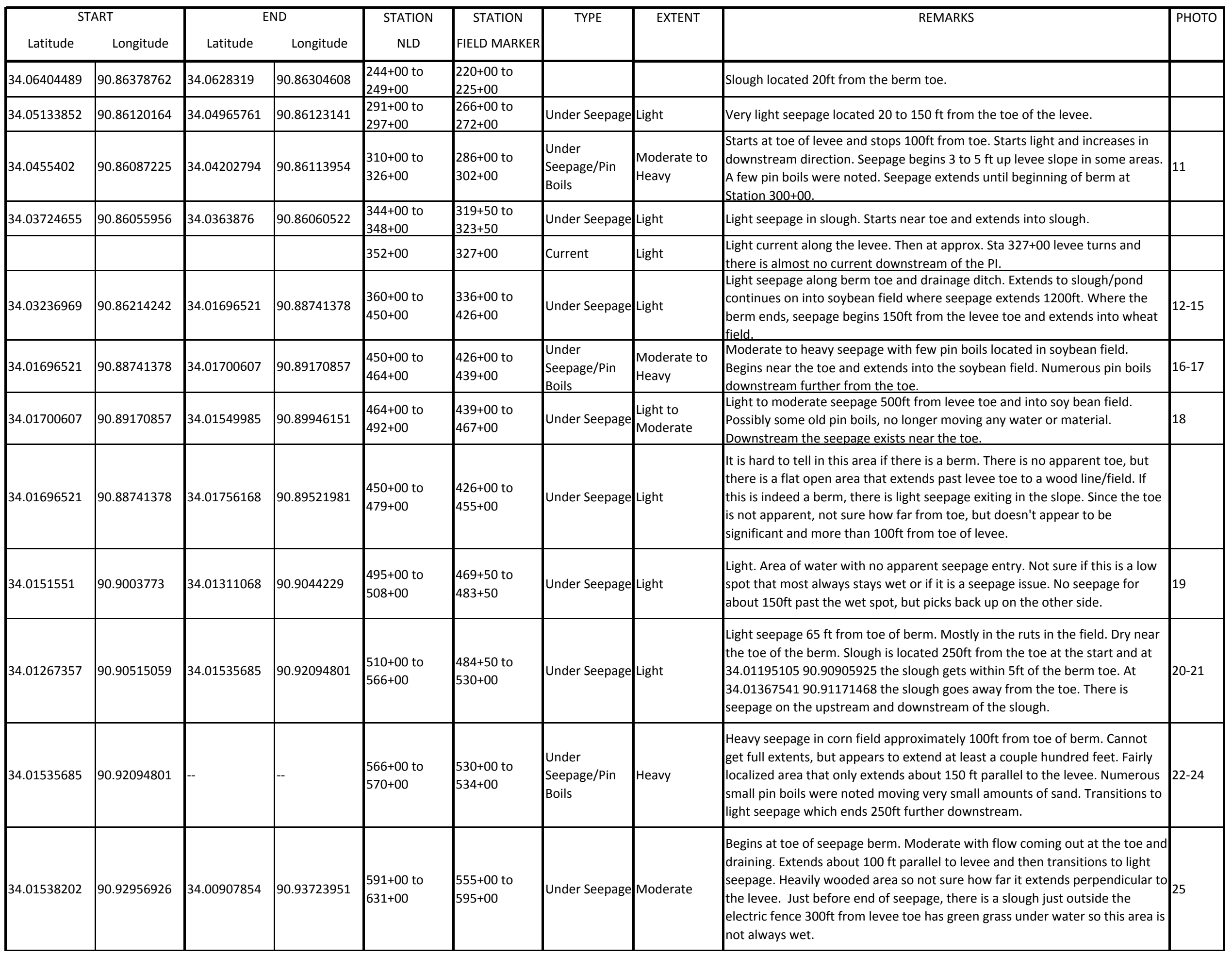




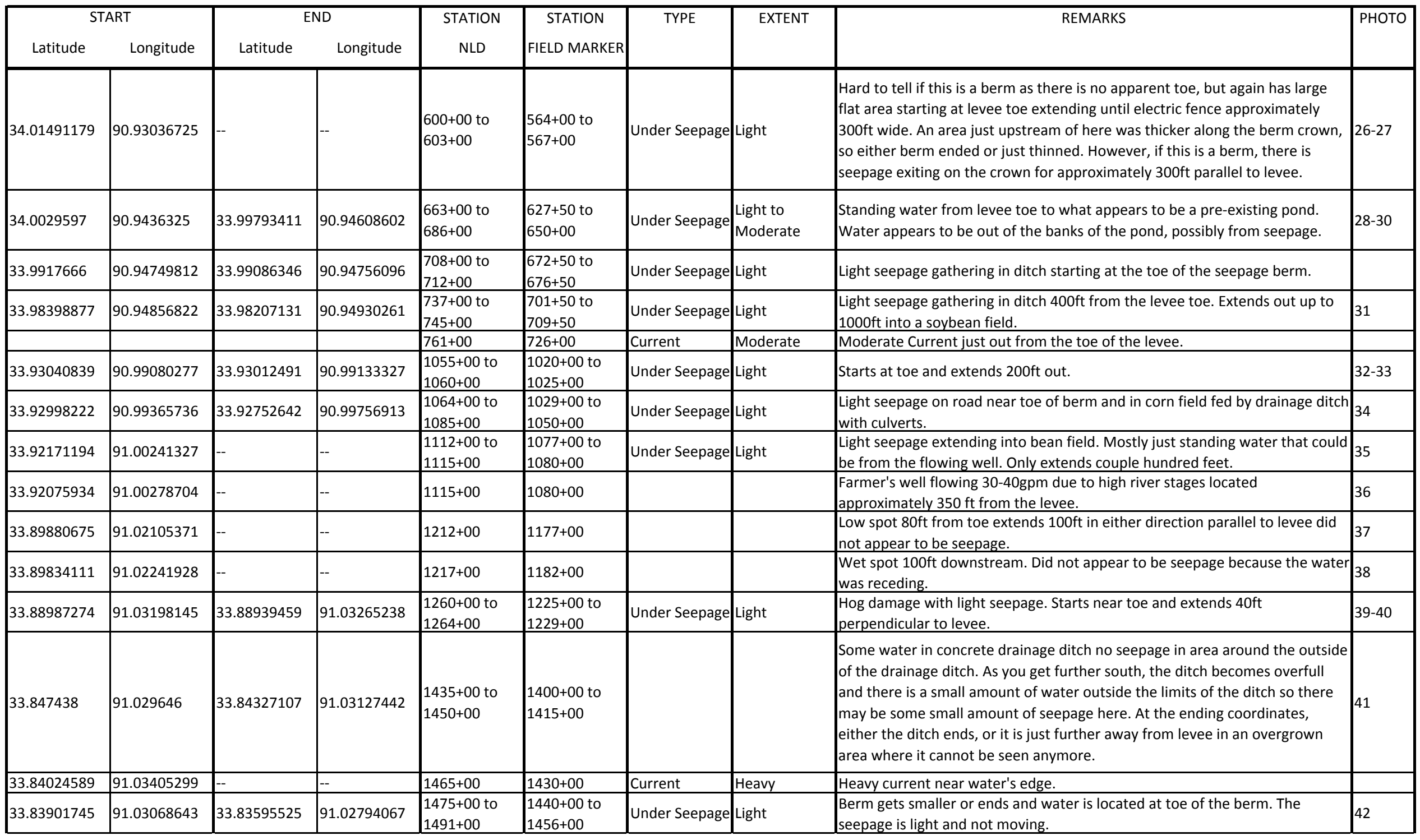




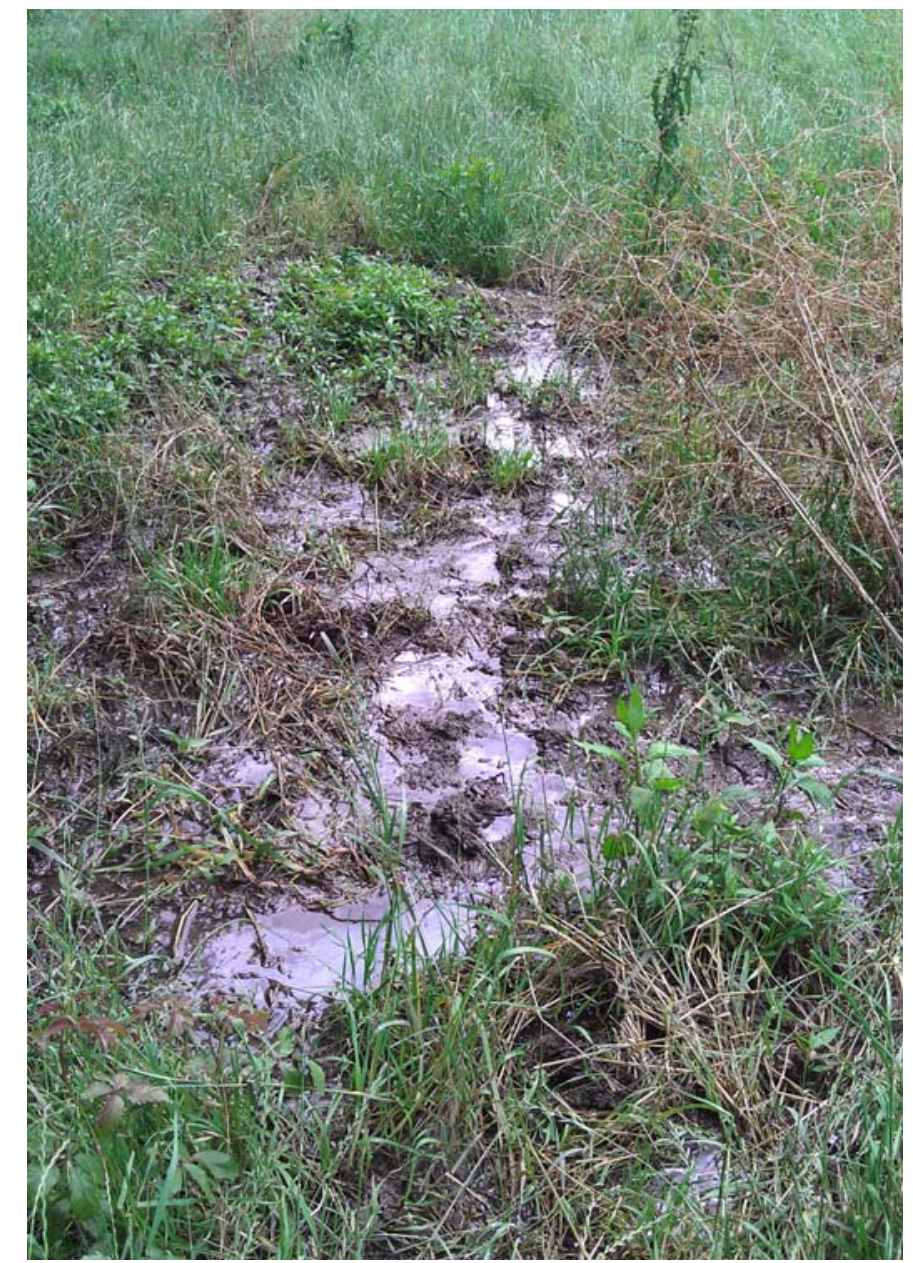

1

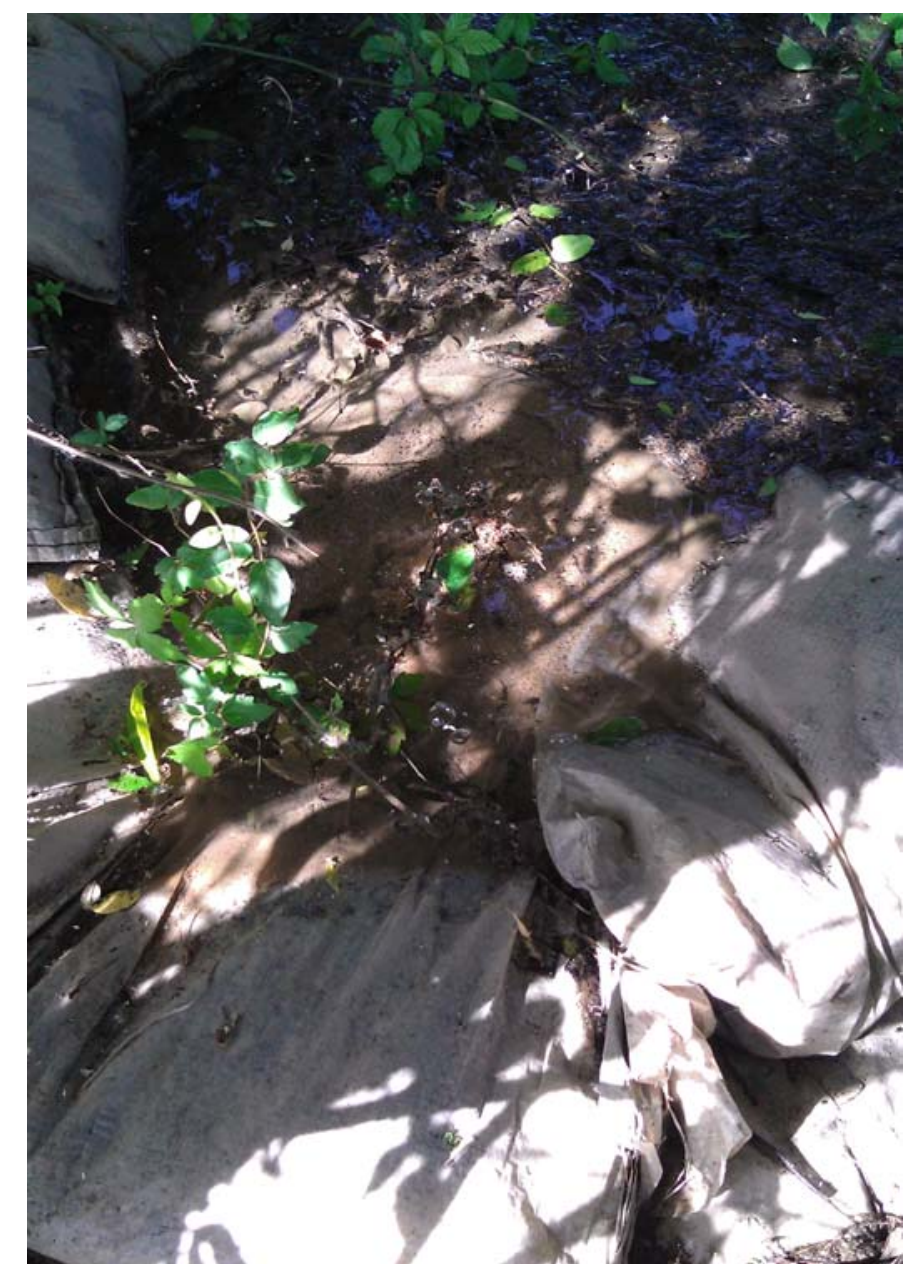

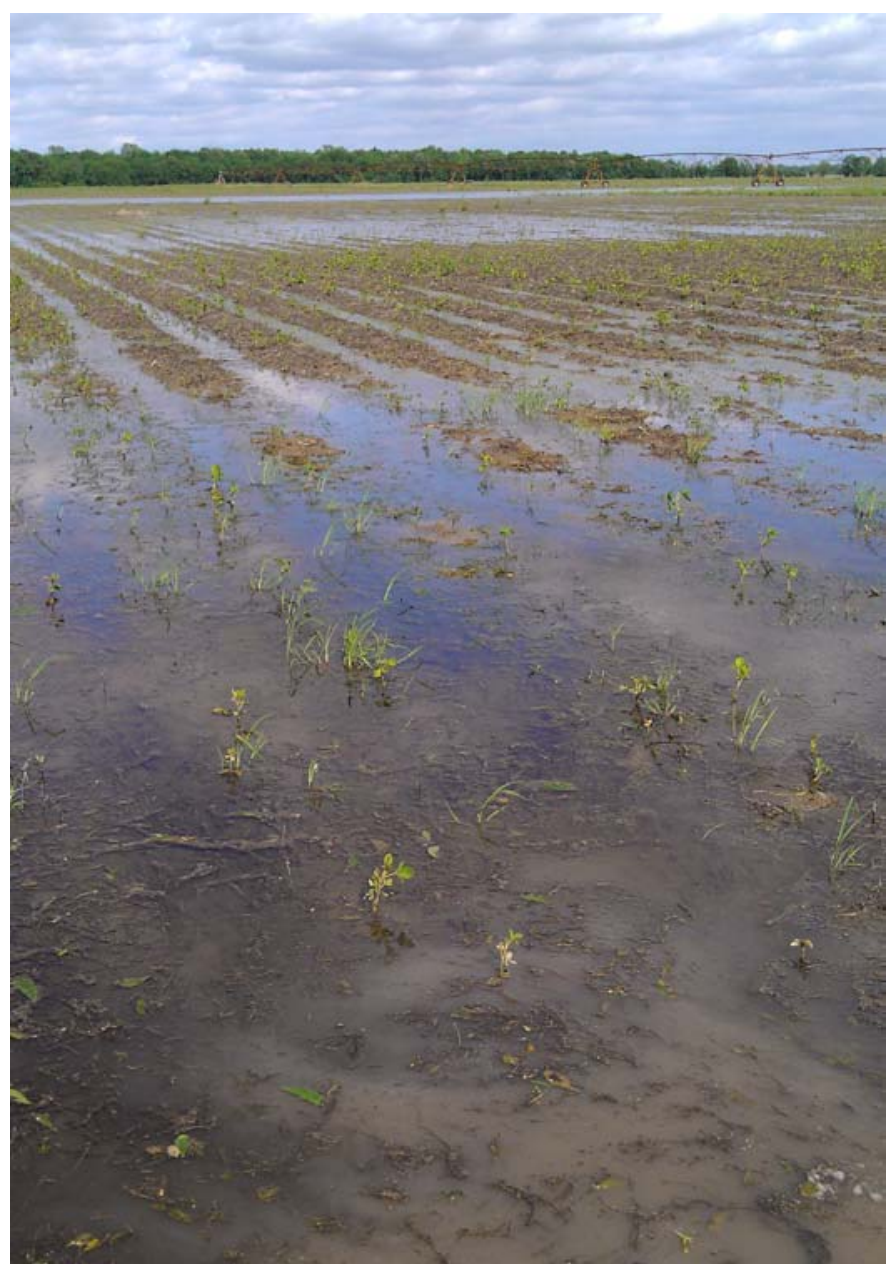

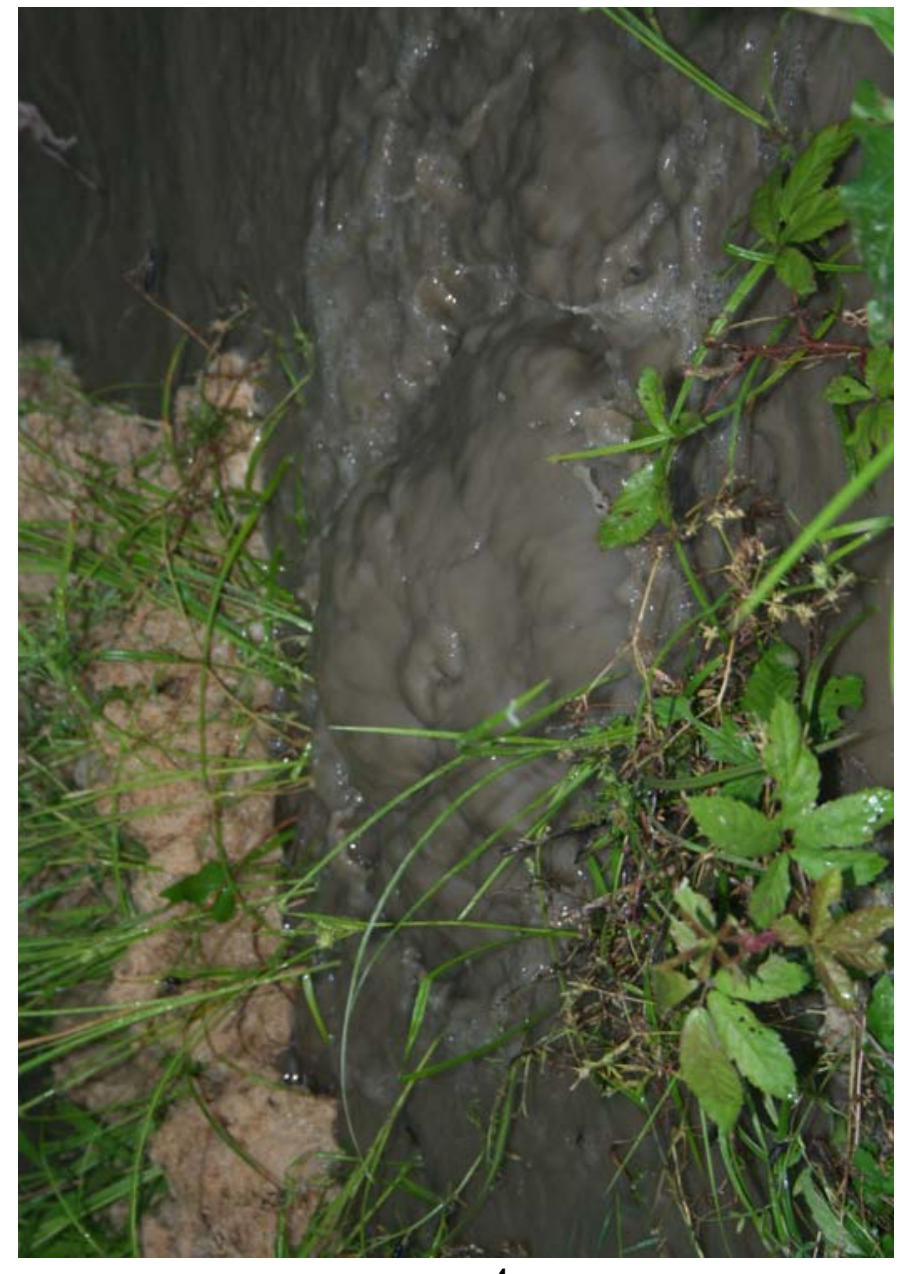




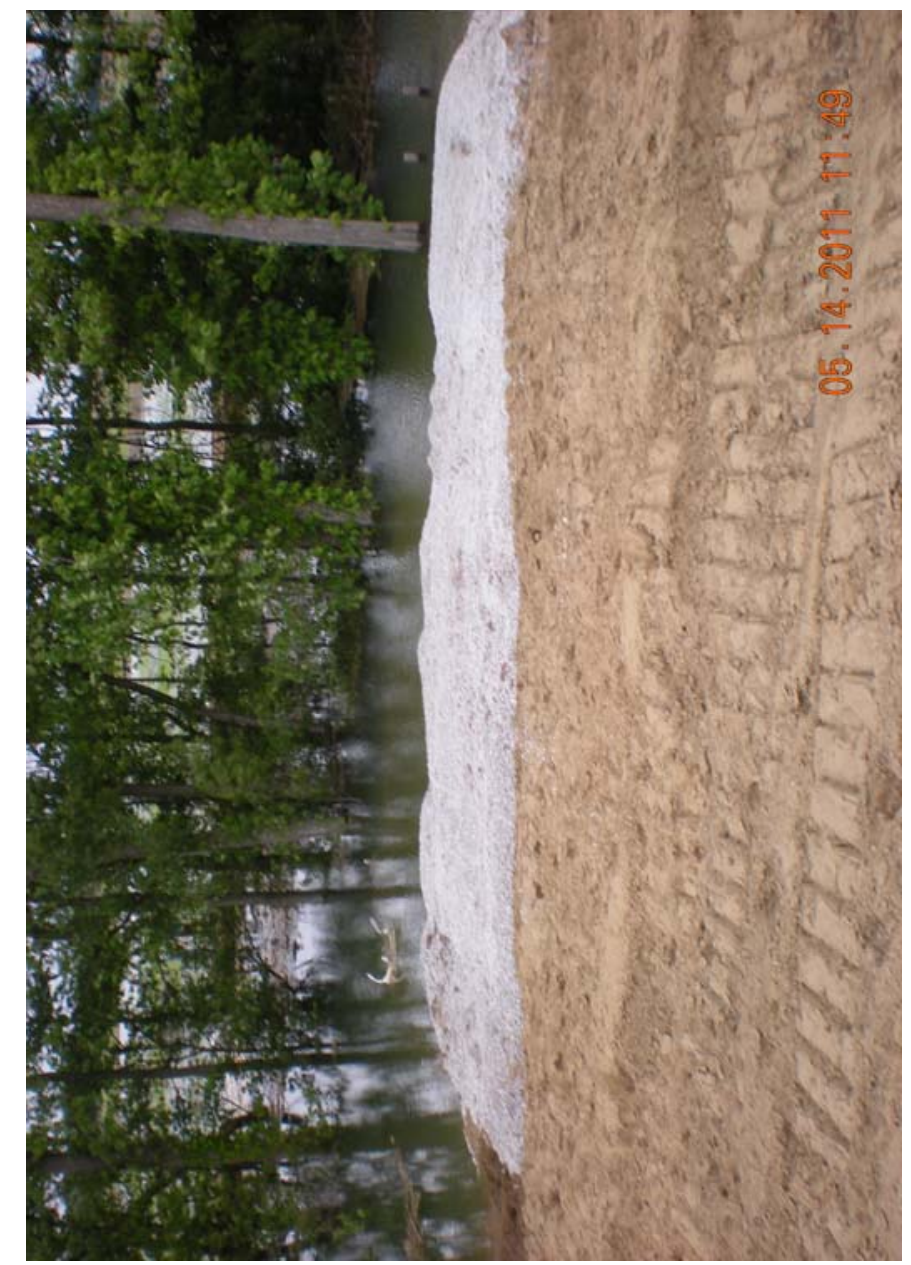

5

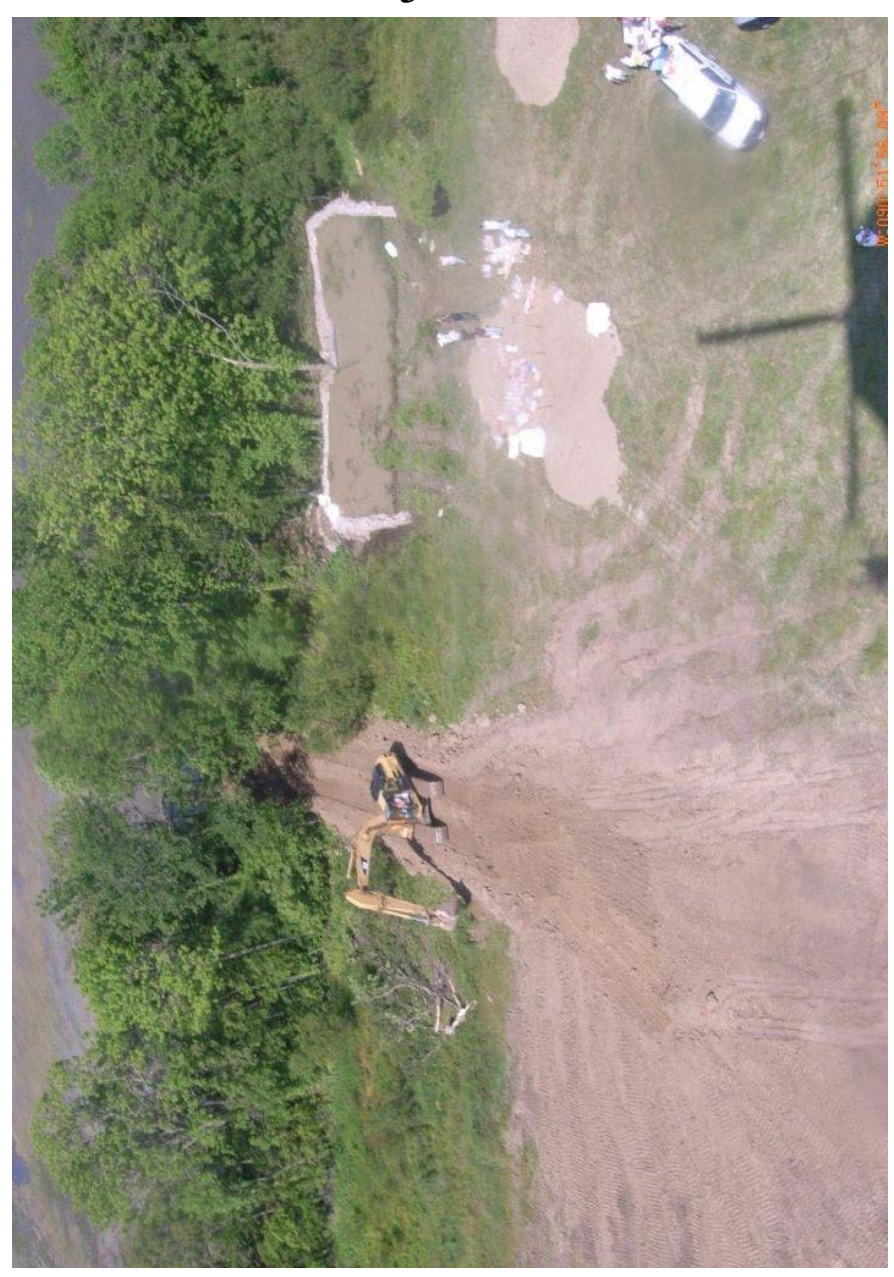

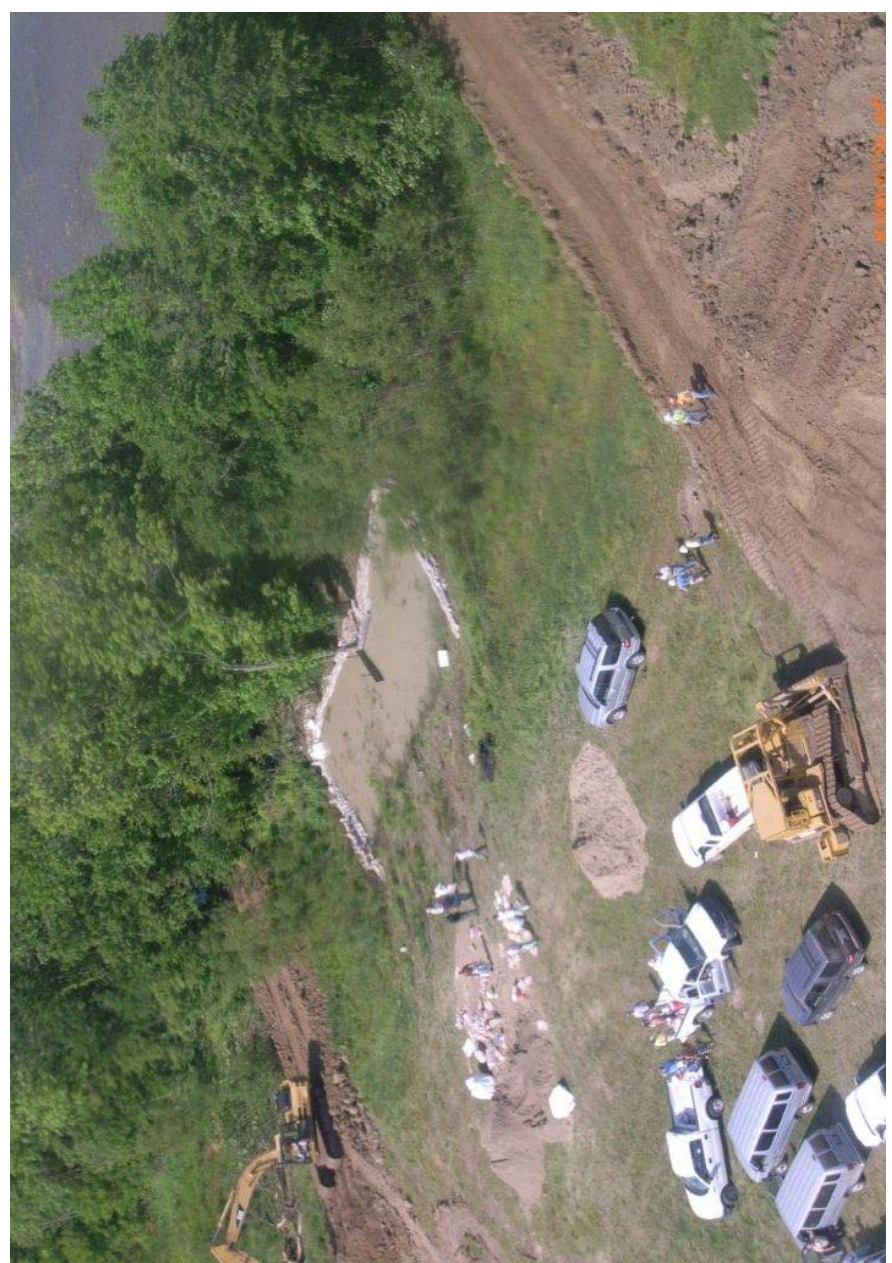

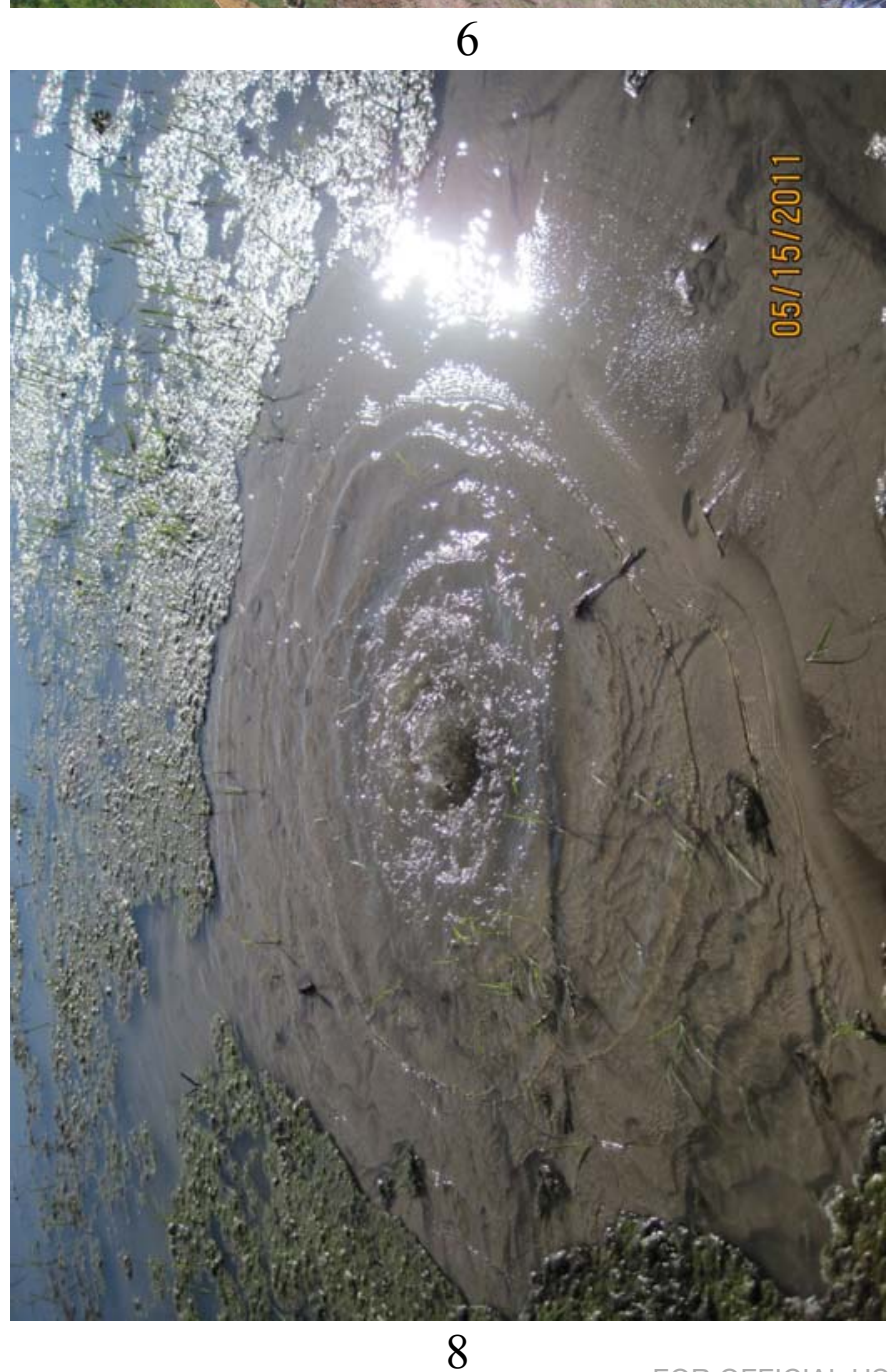

FOR OFFICIAL USE ONLY 


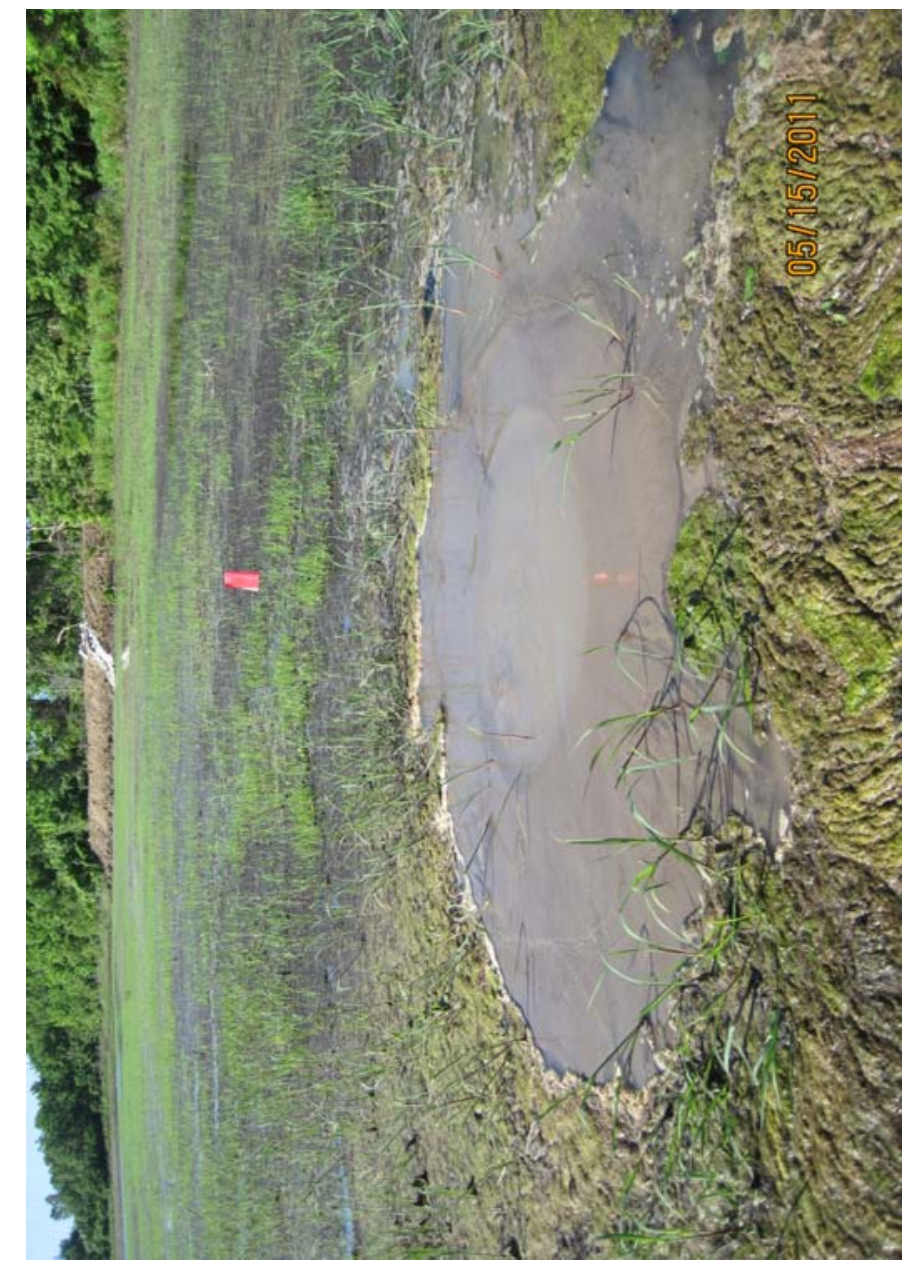

9

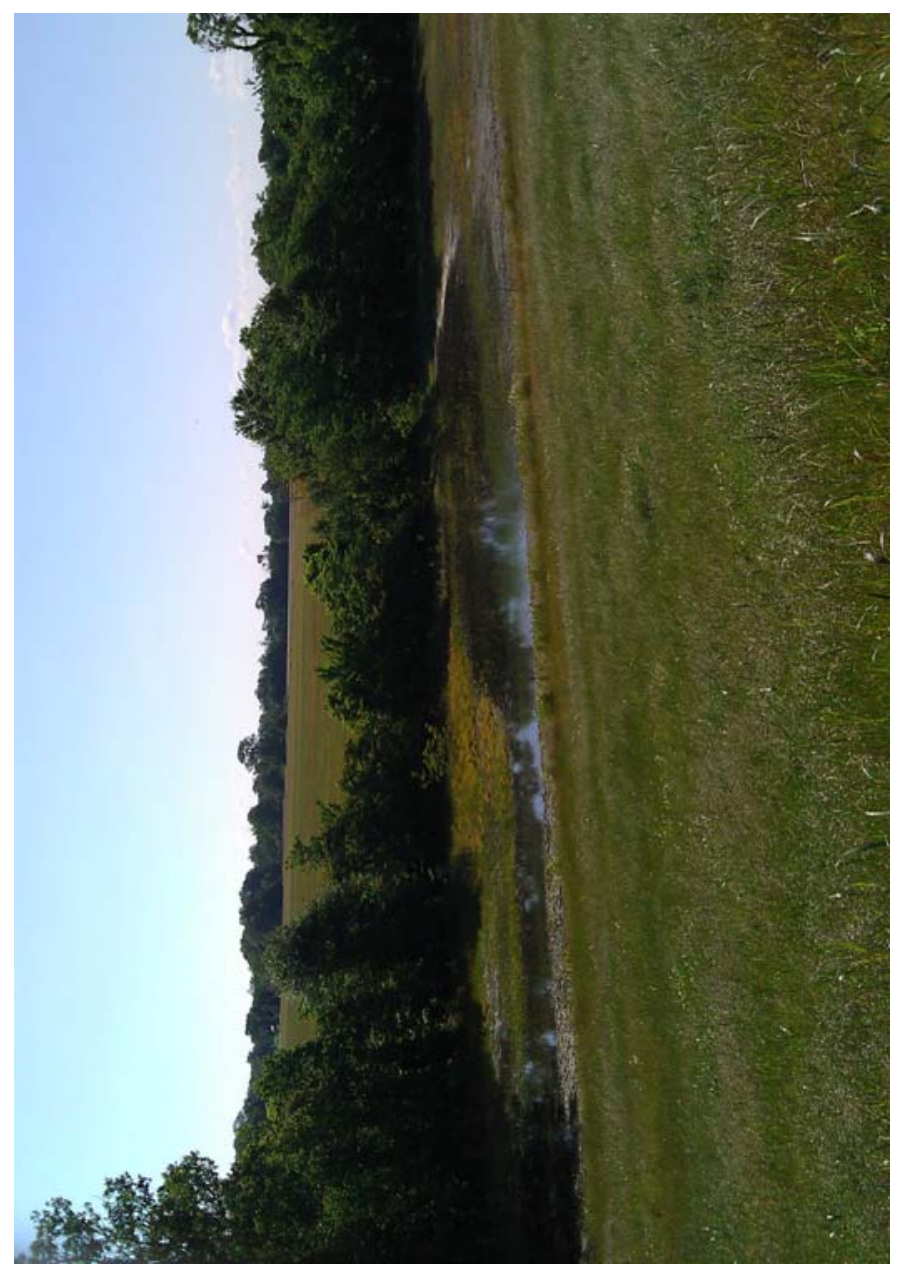

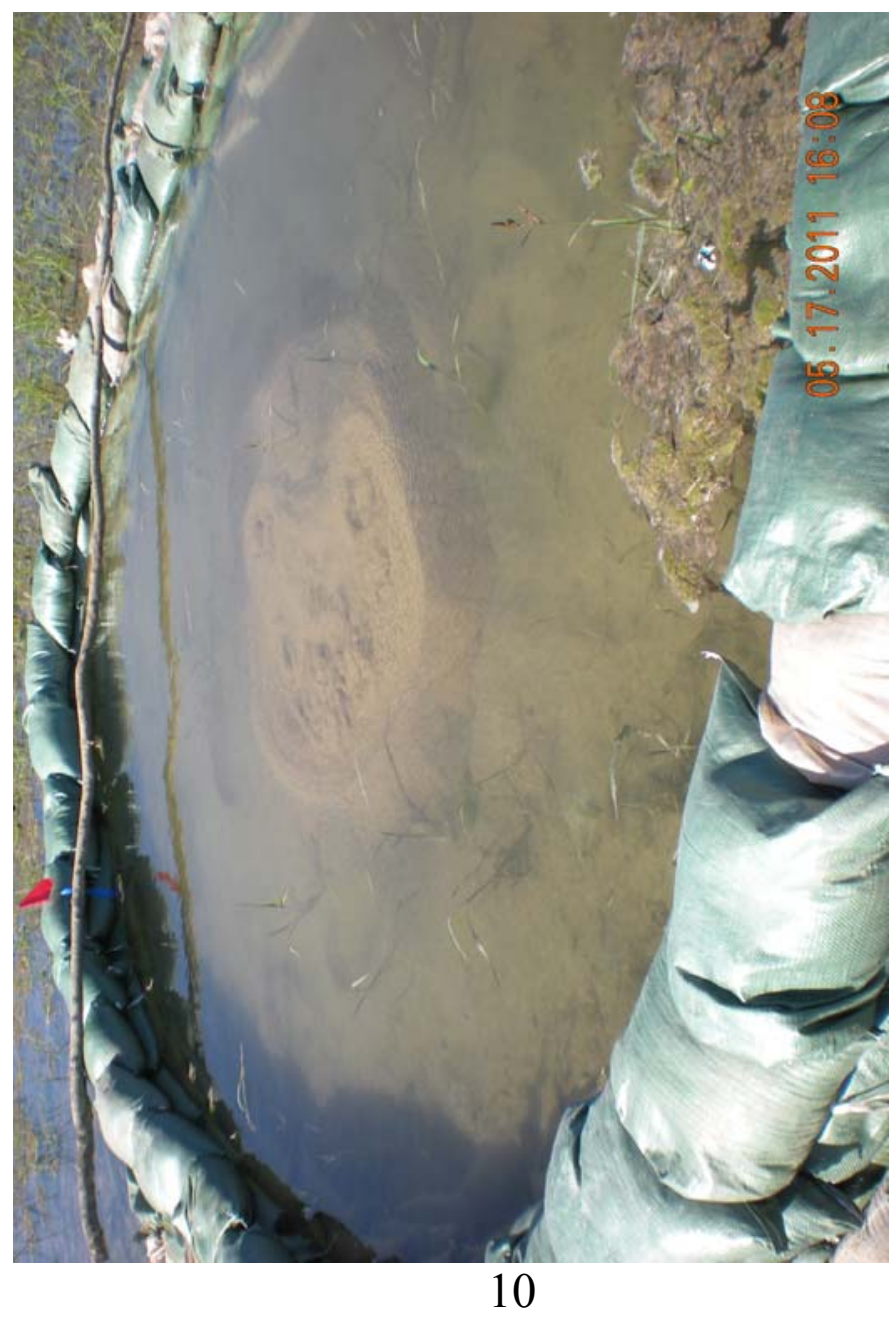

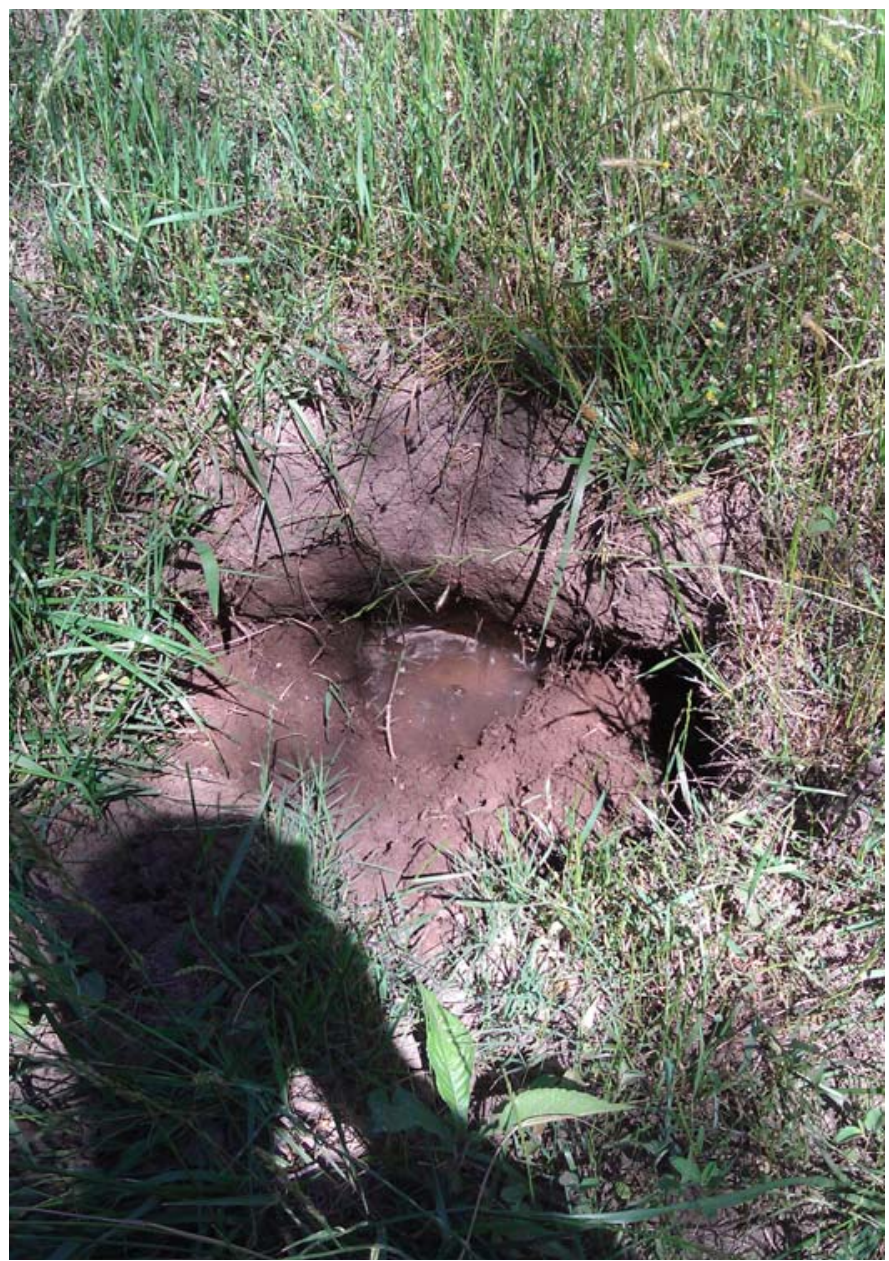




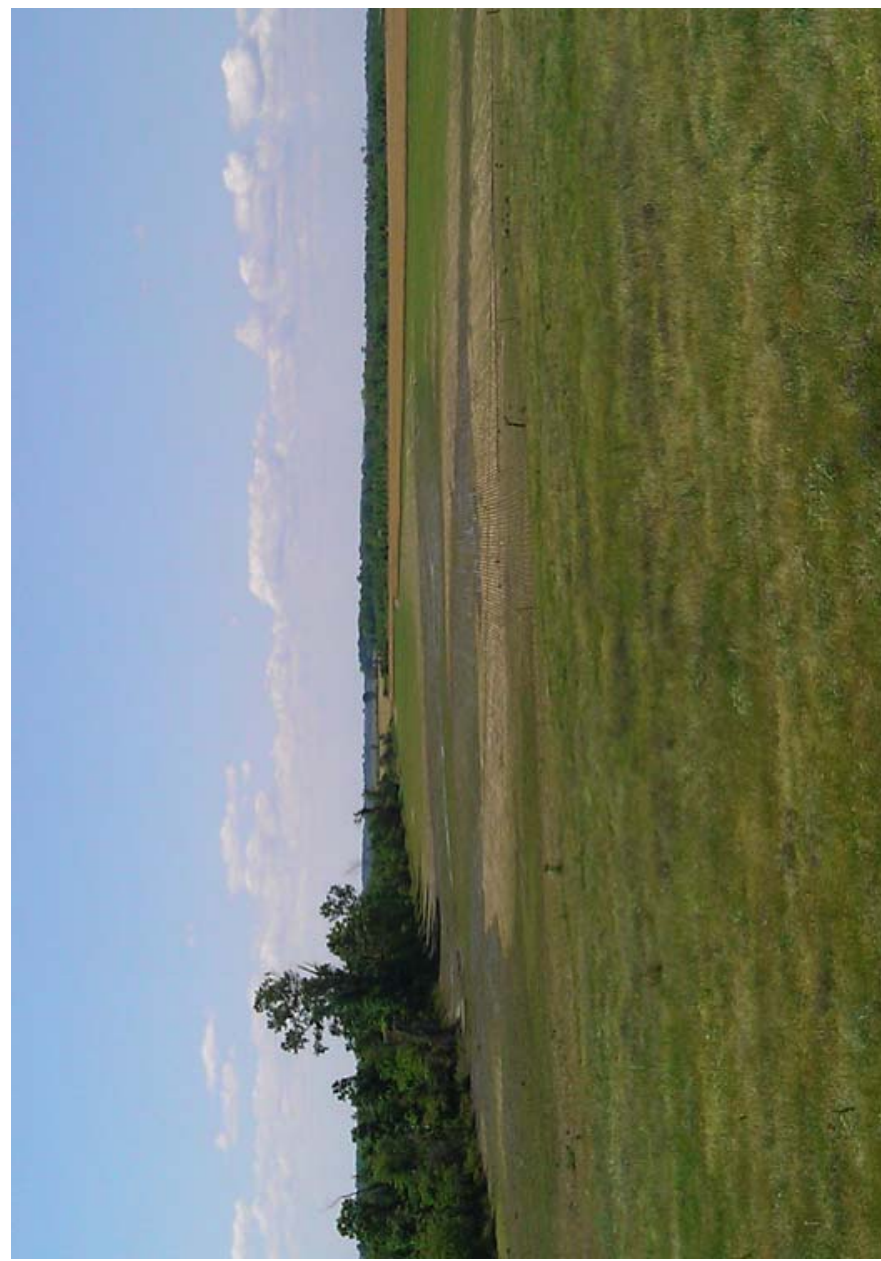

13

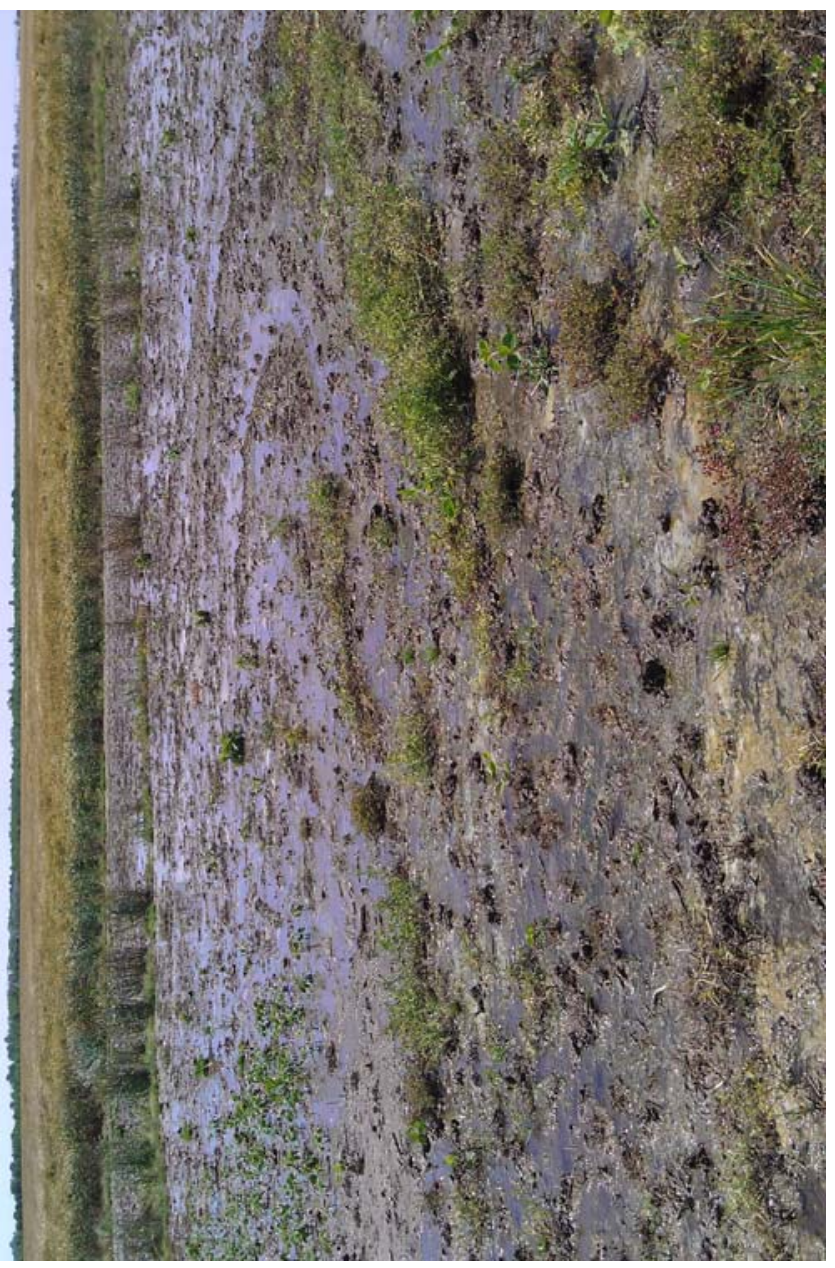

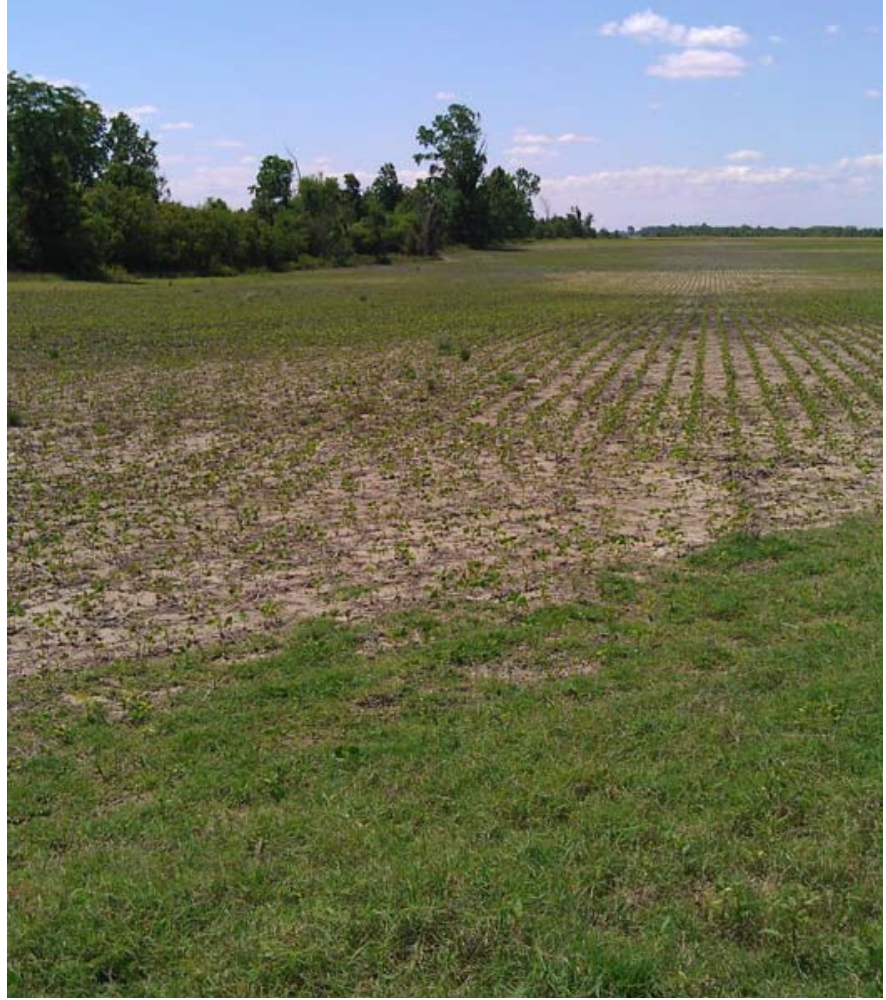

14

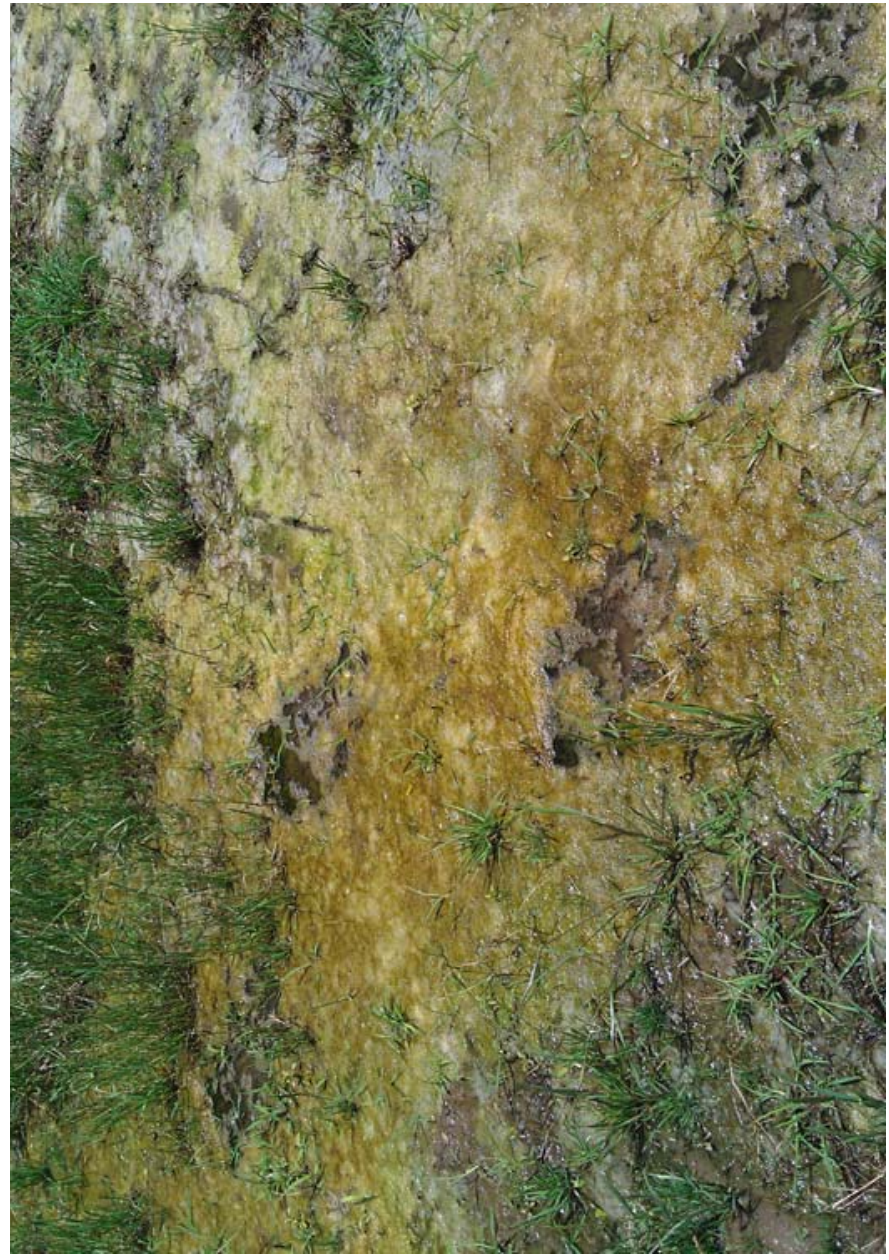




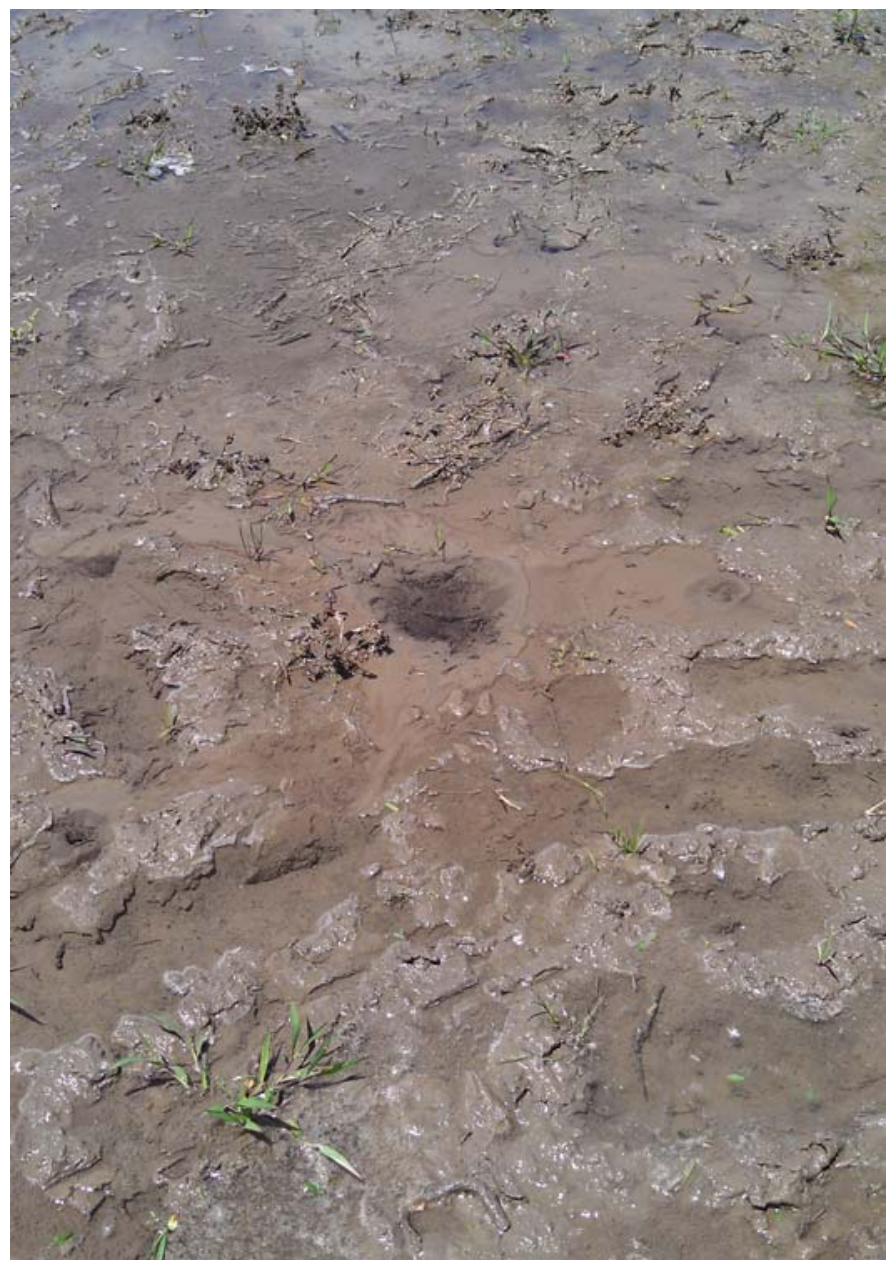

17

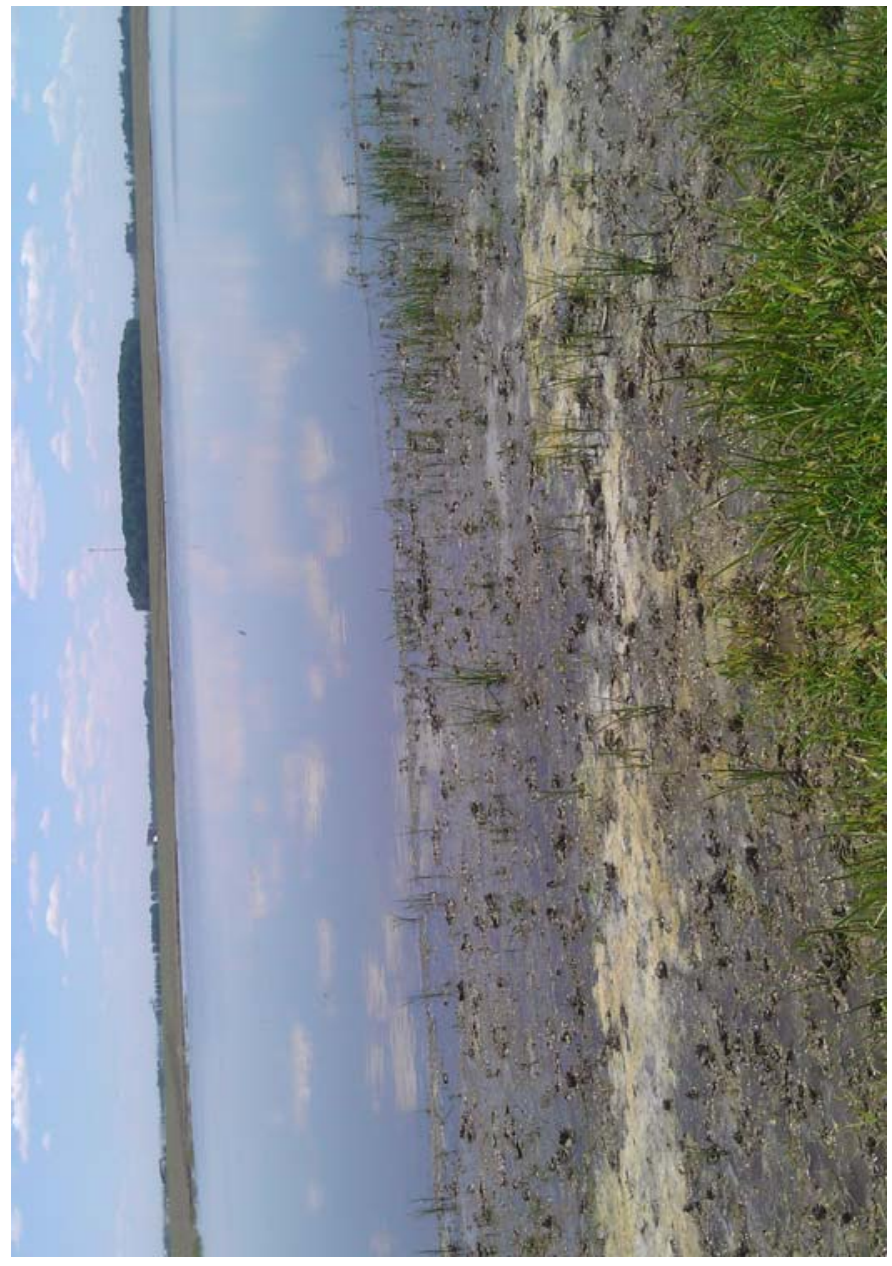

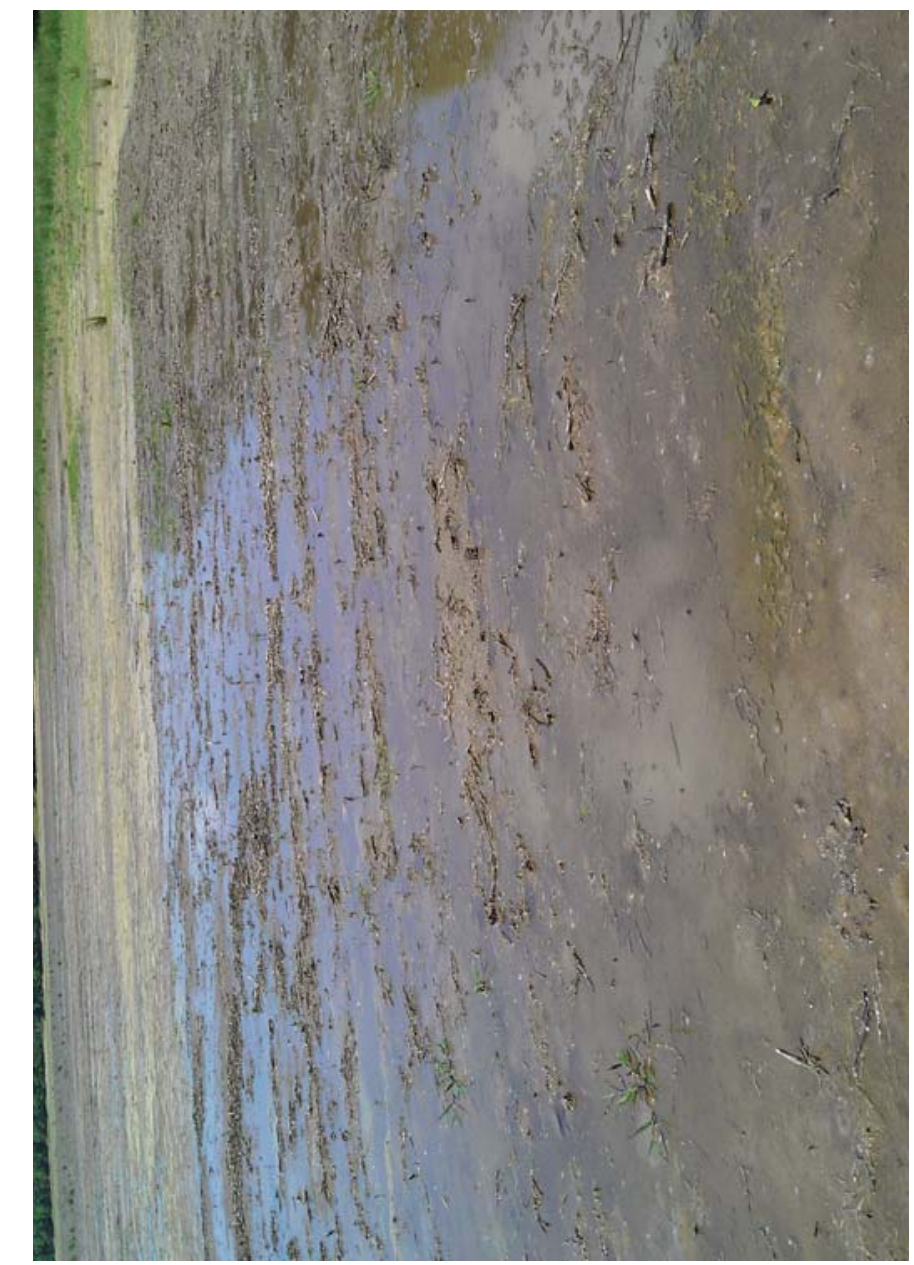

18

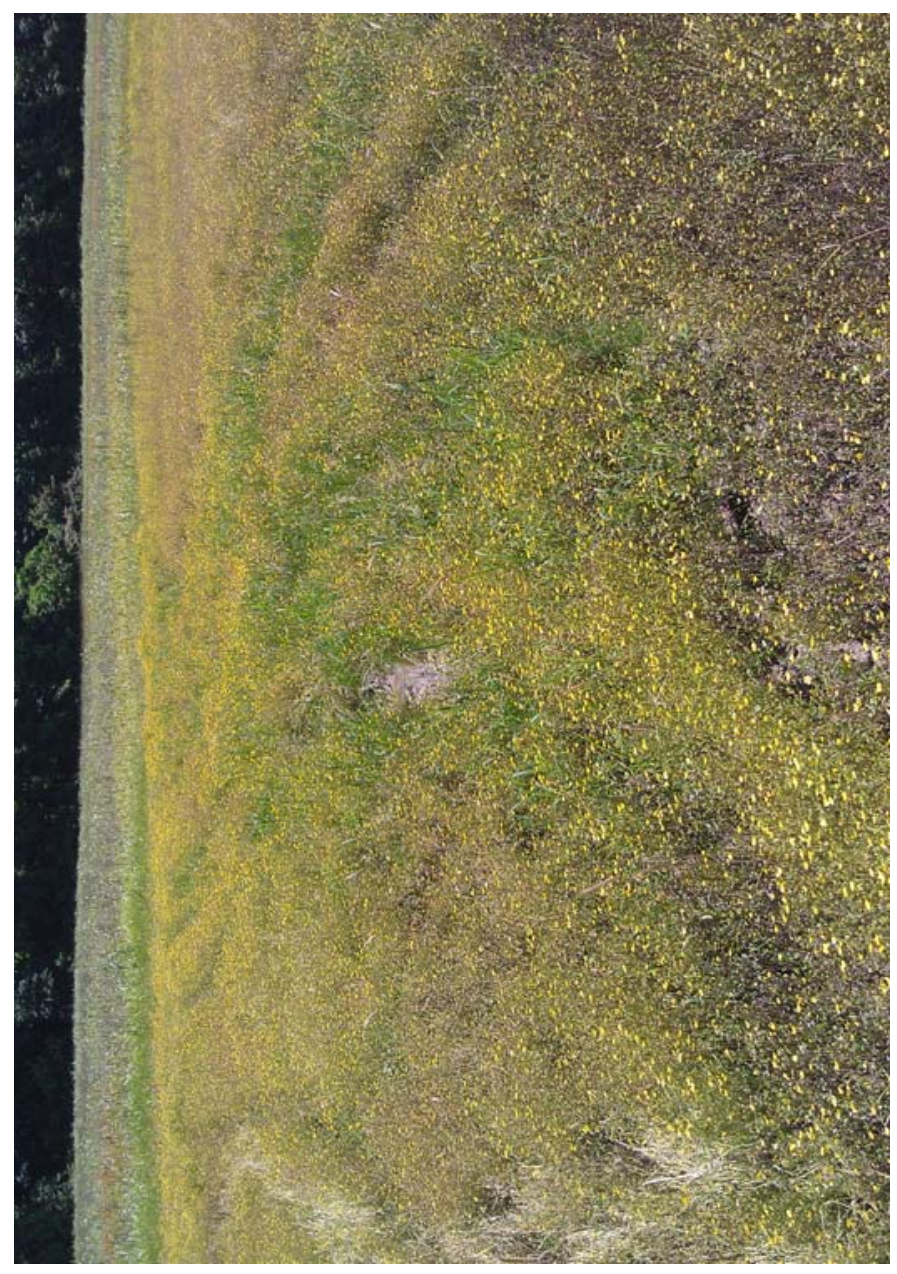




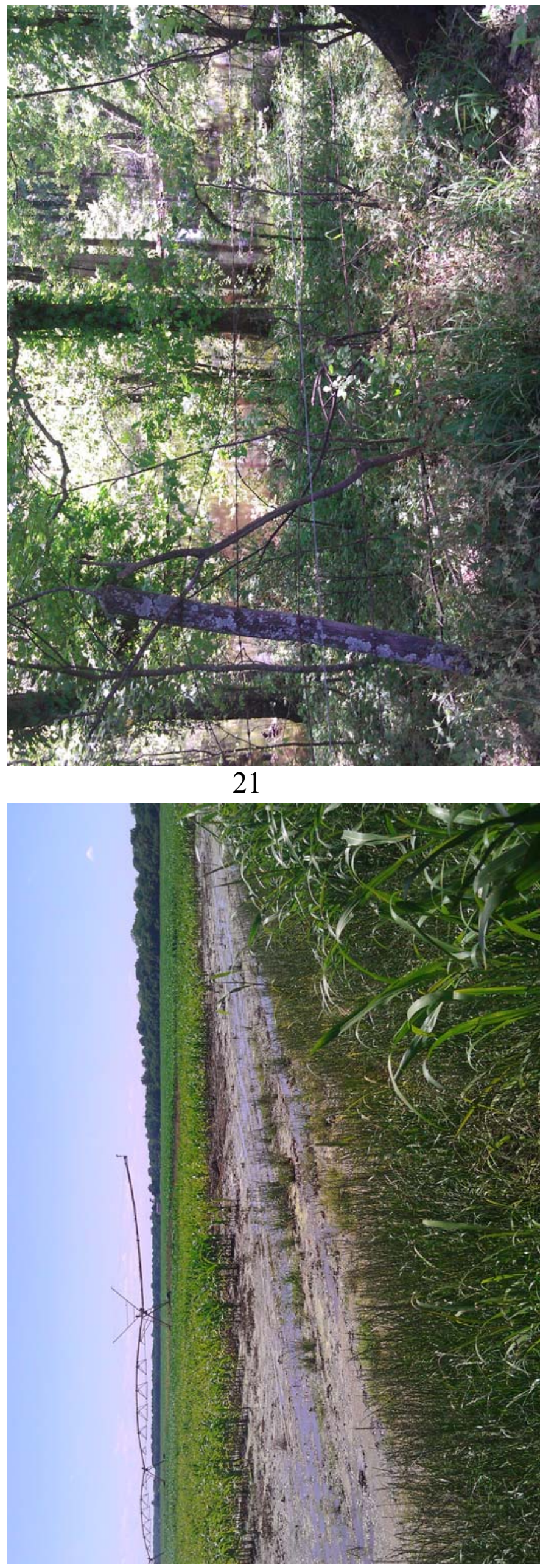

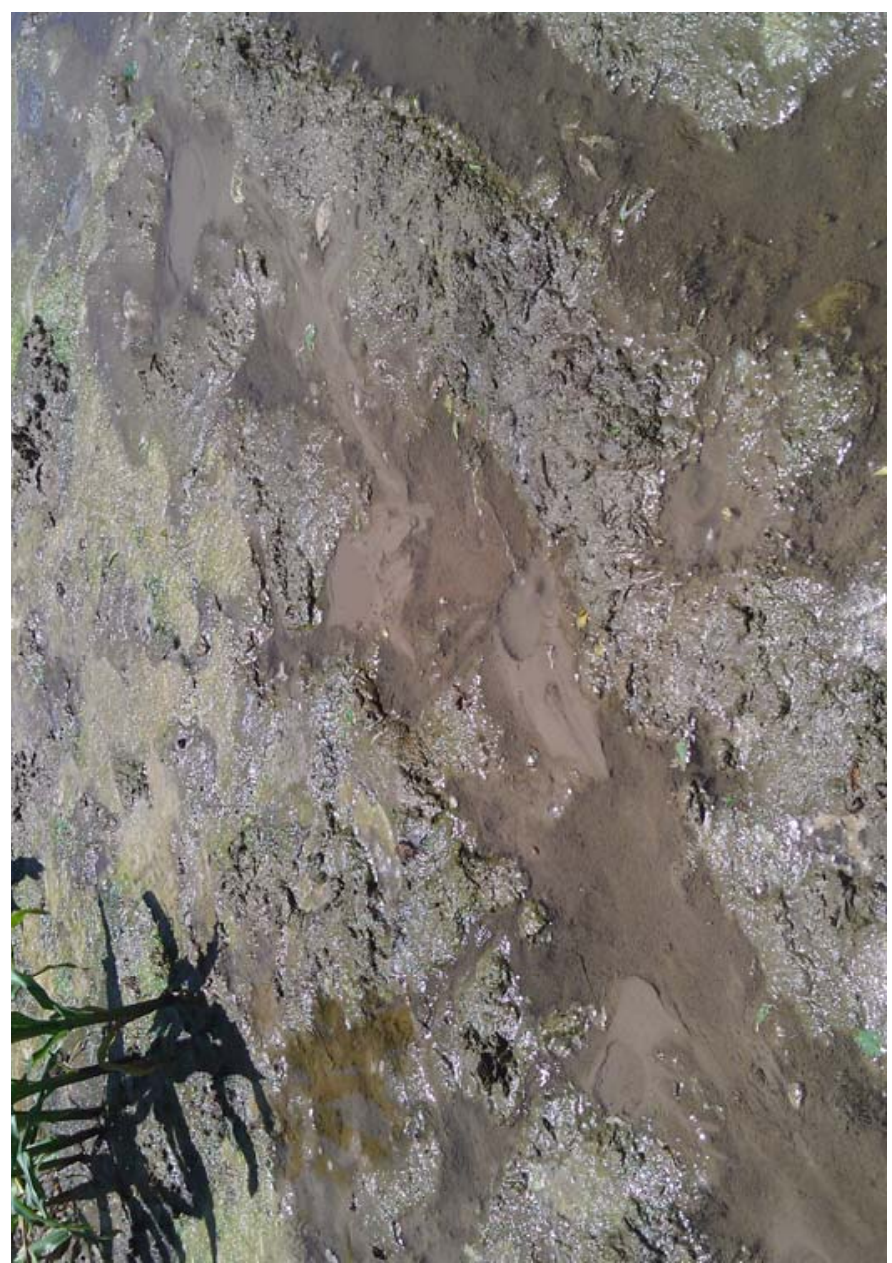

22

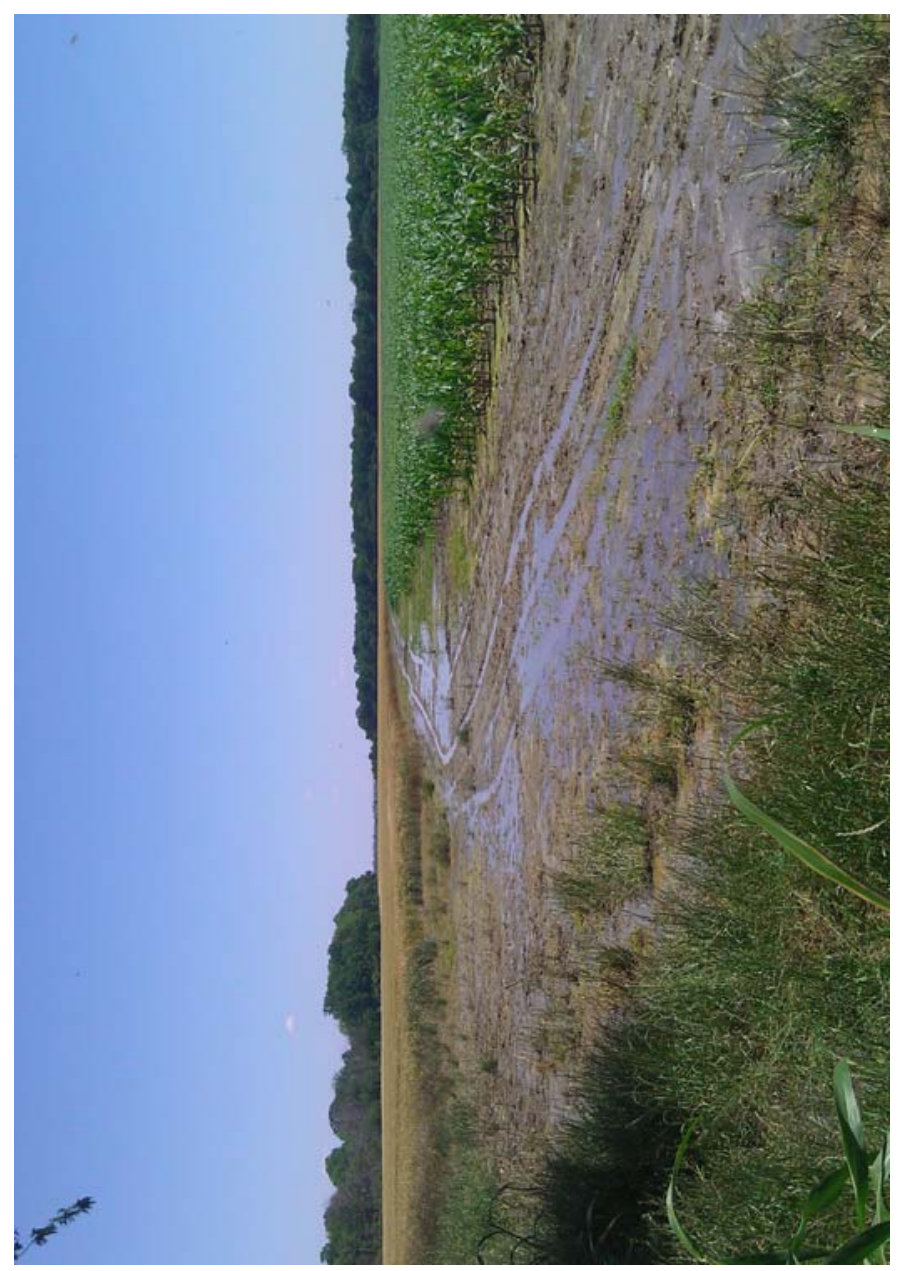




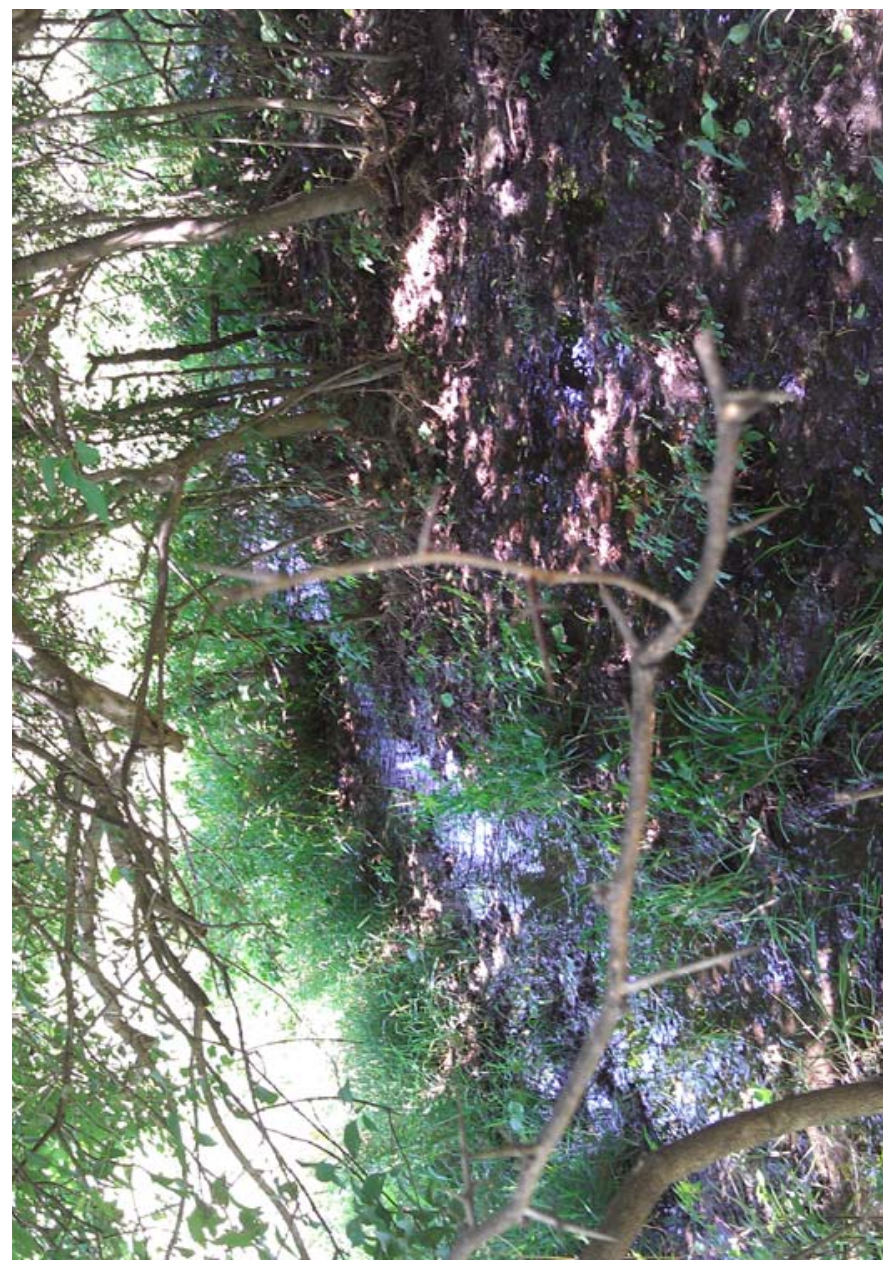

25

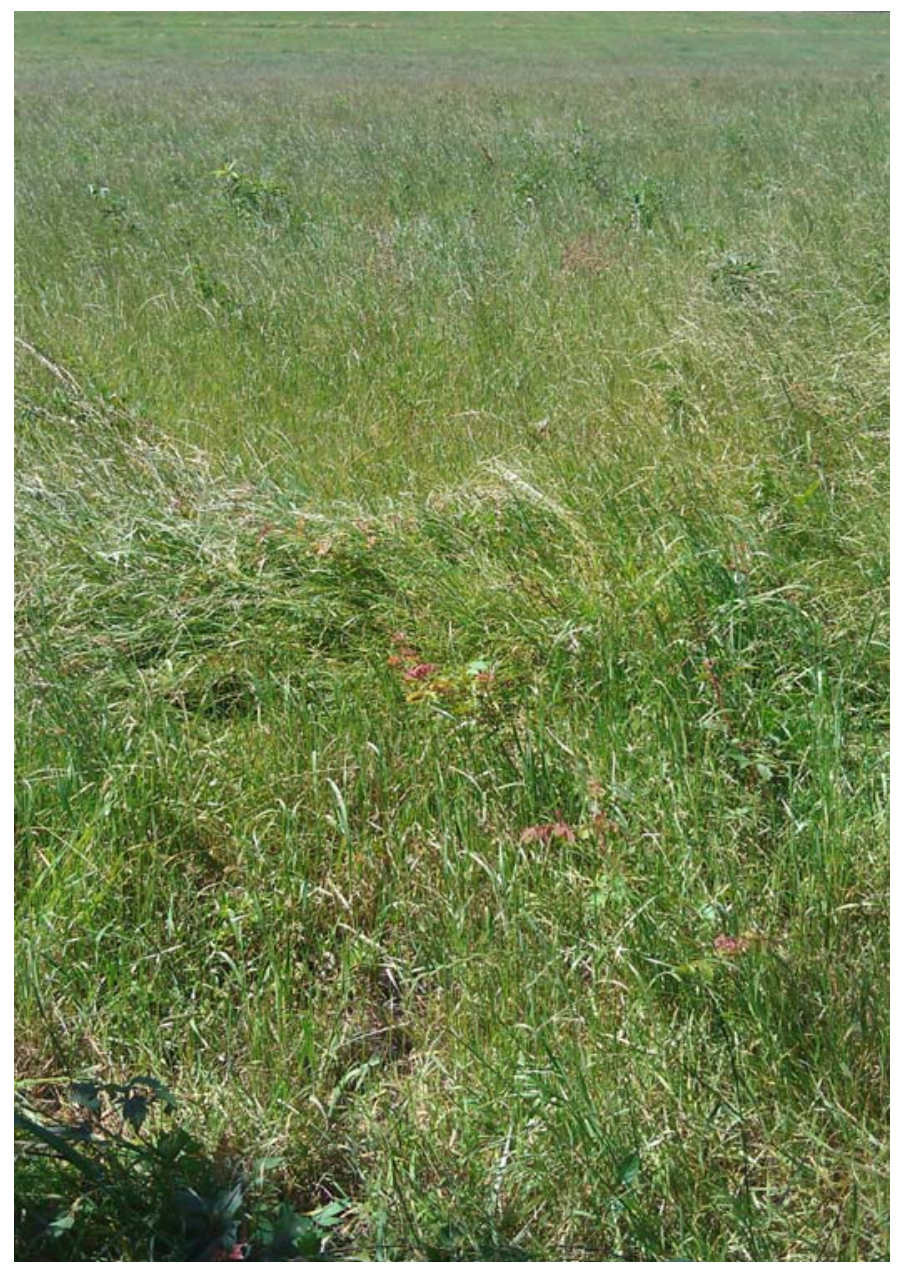




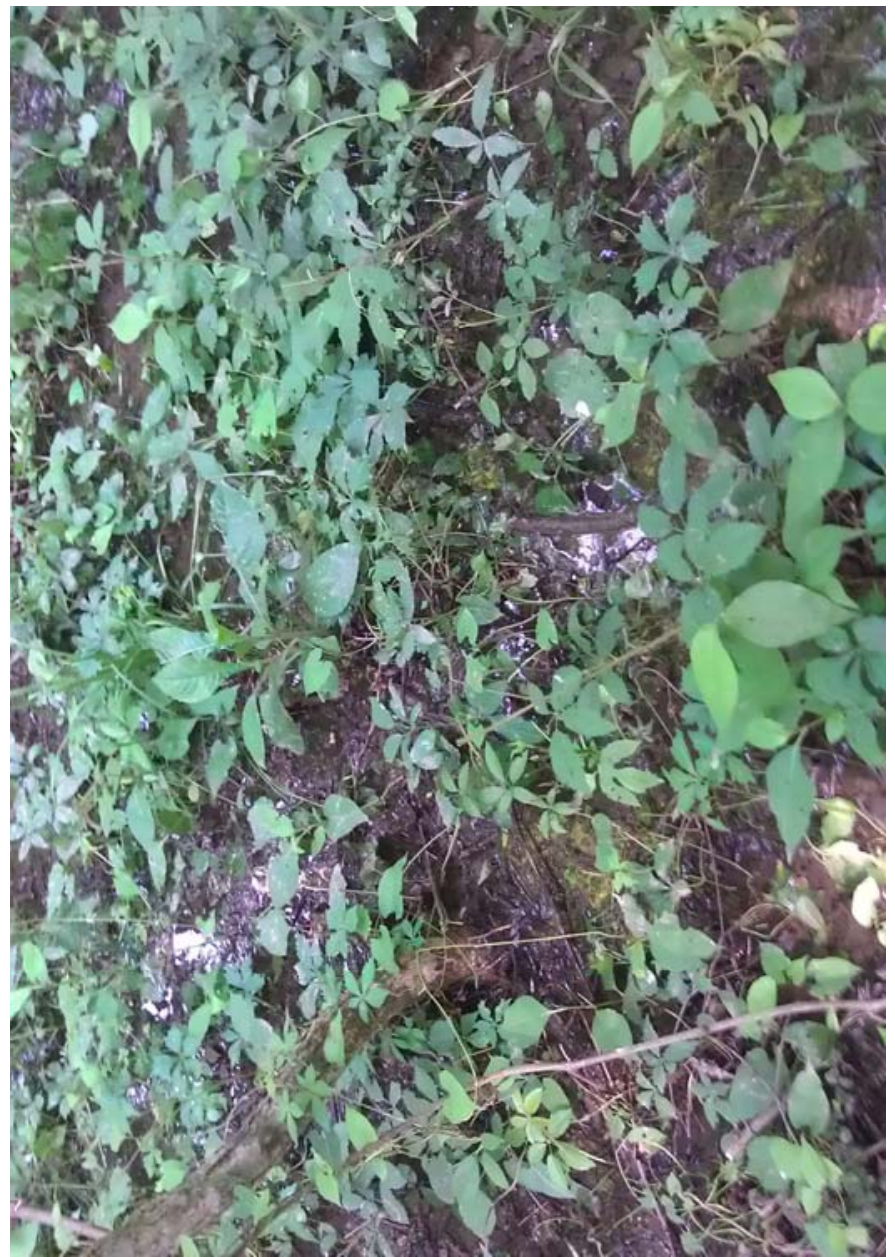

29

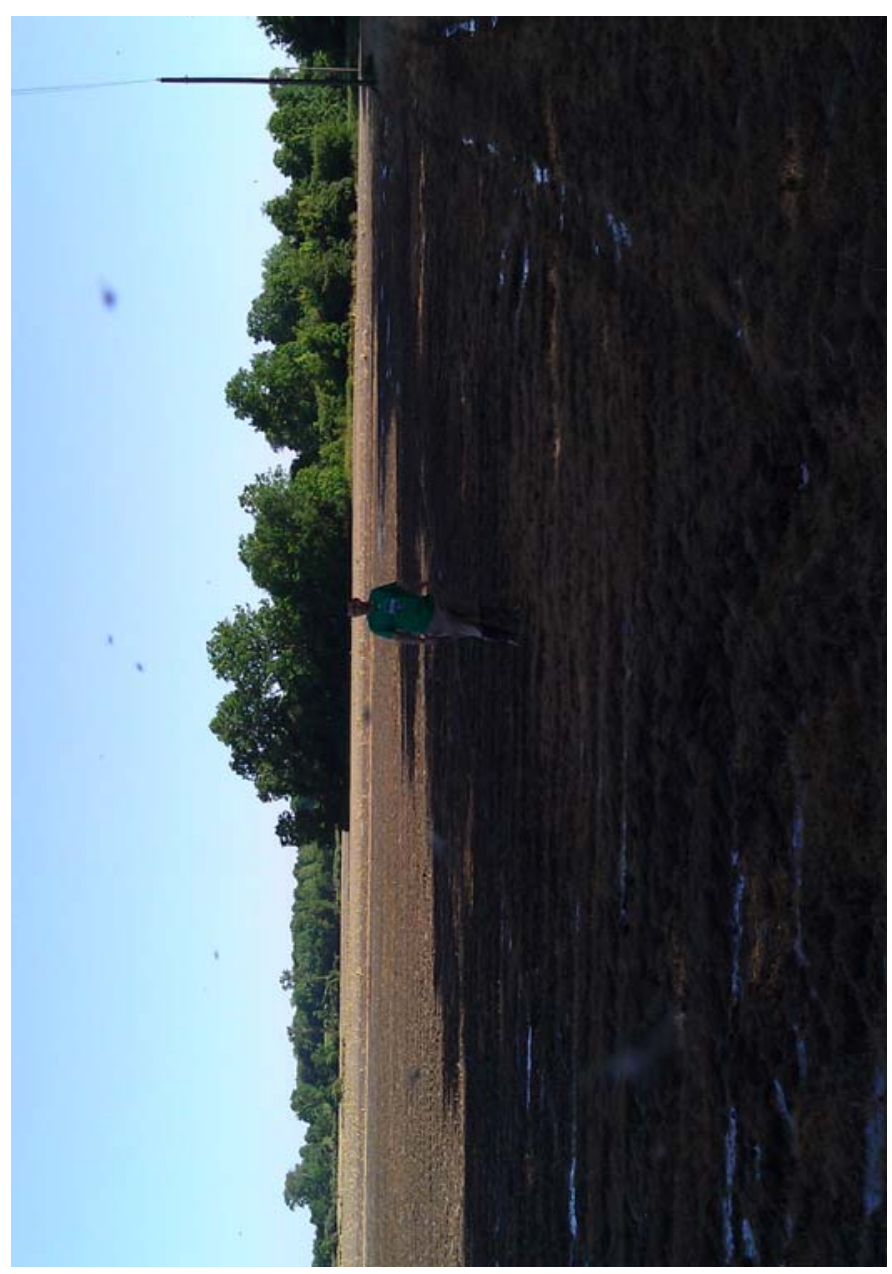

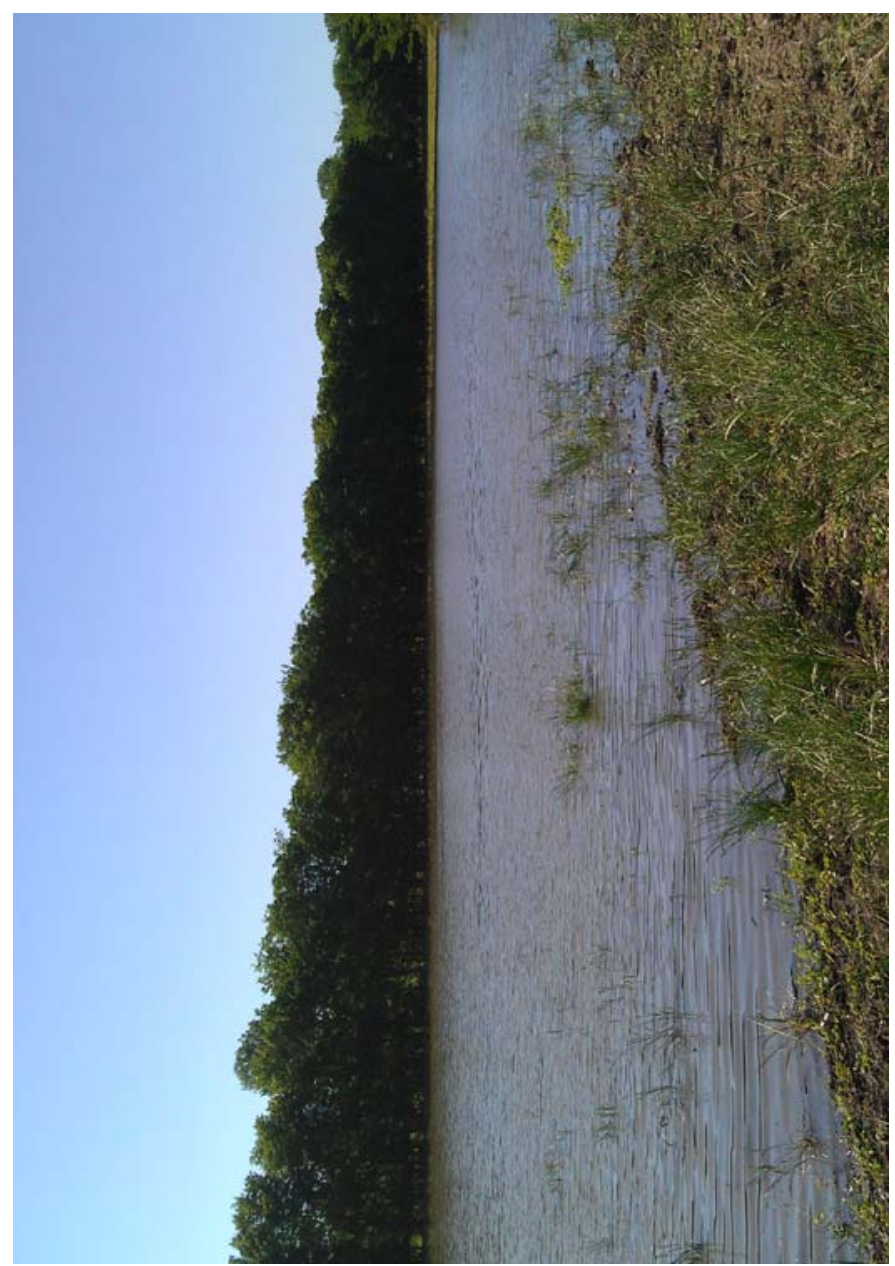

30

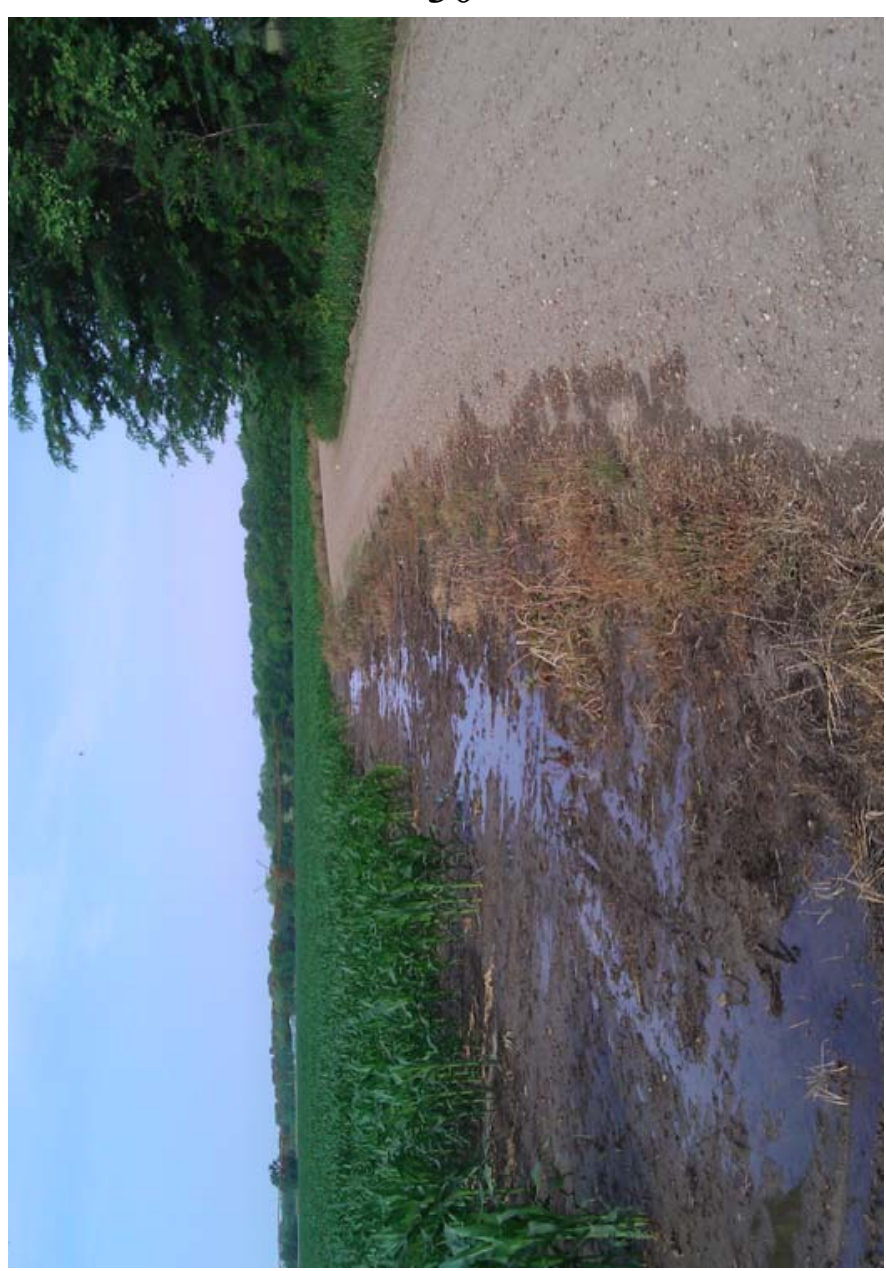




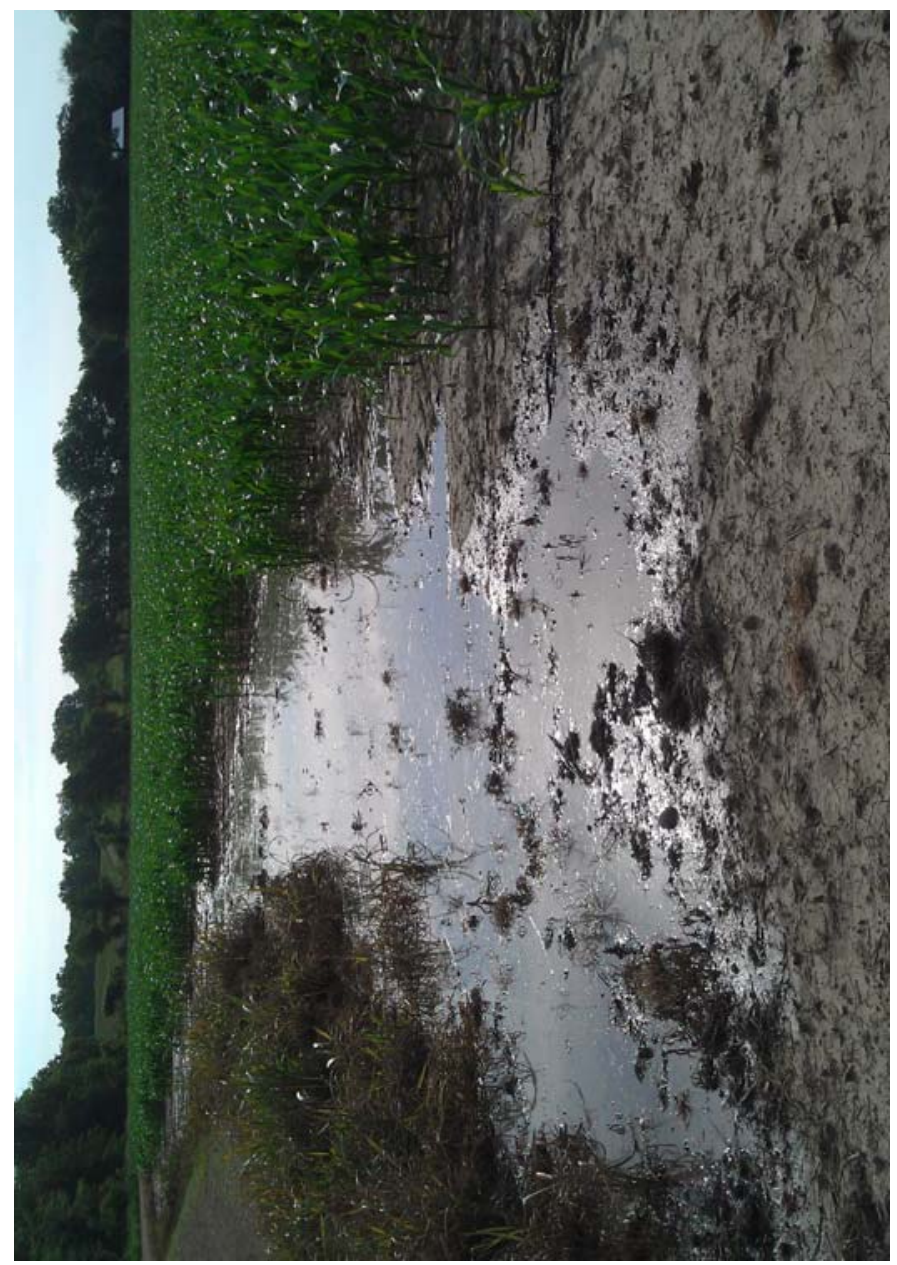

33

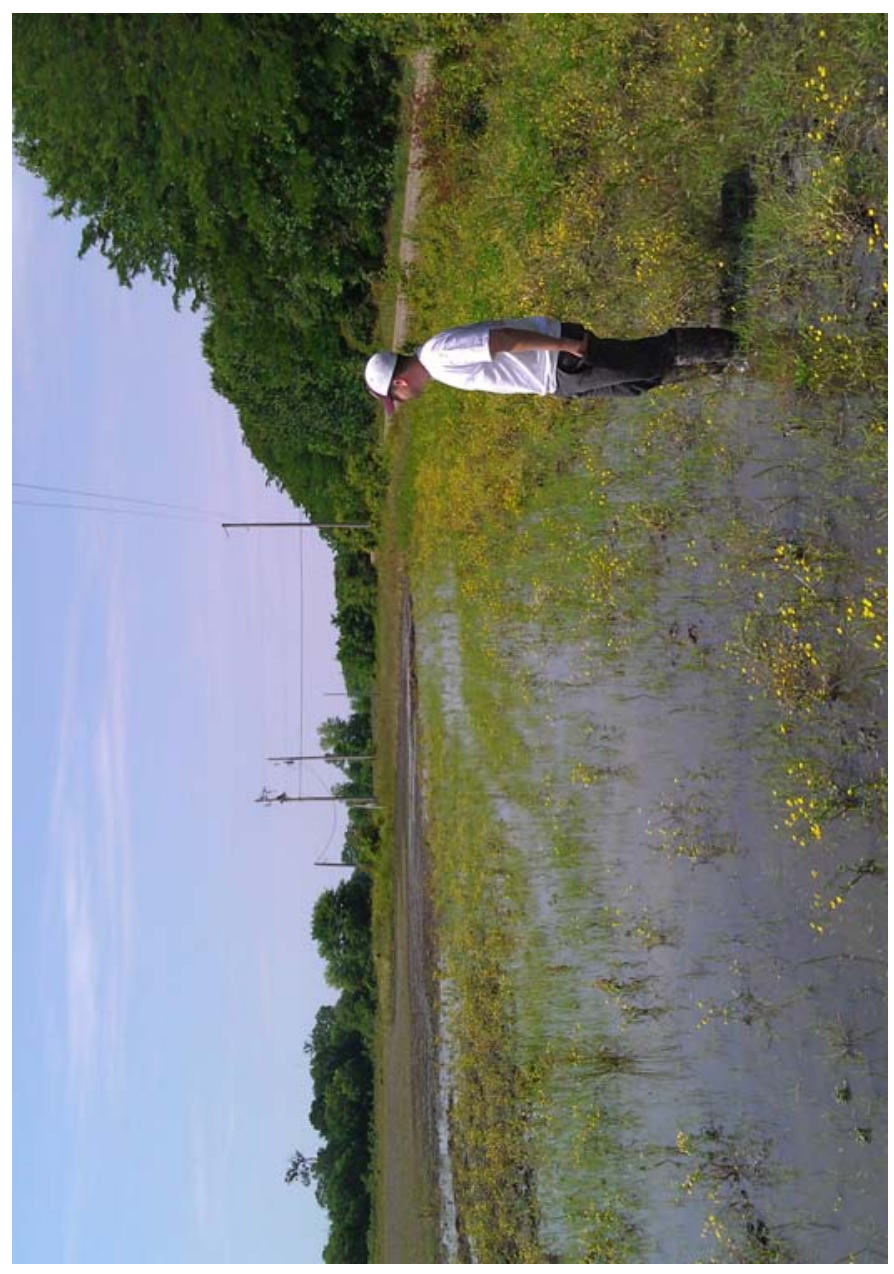

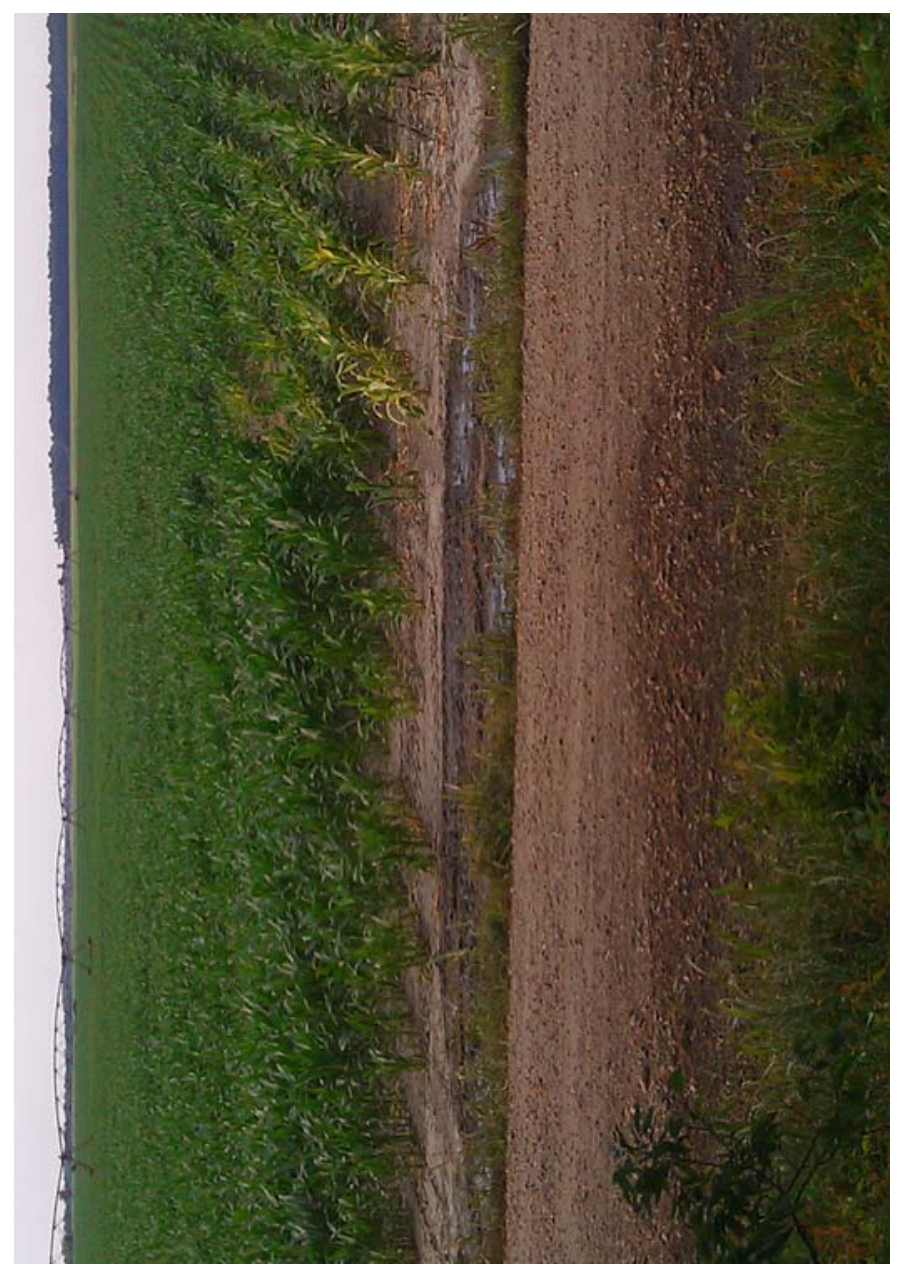

34

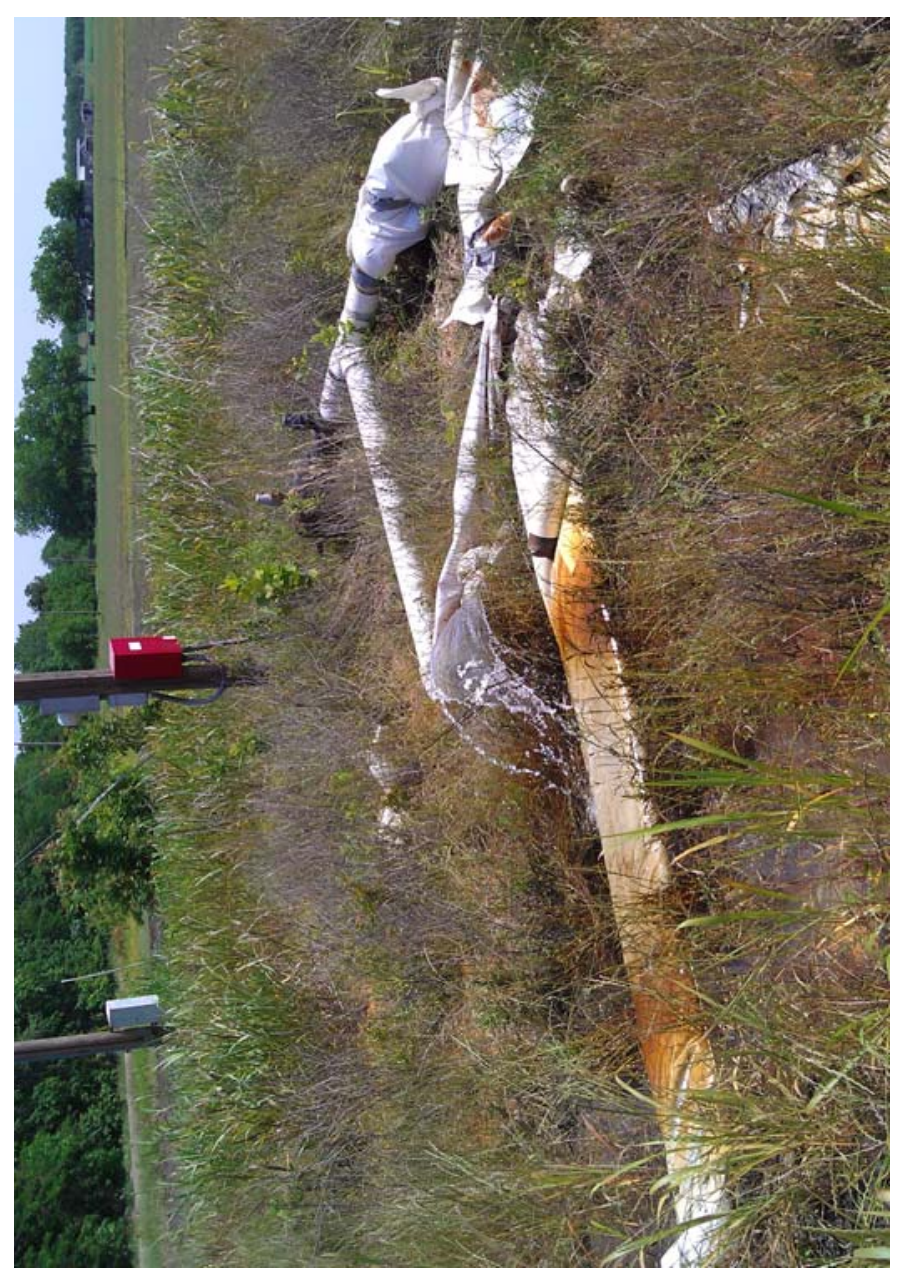



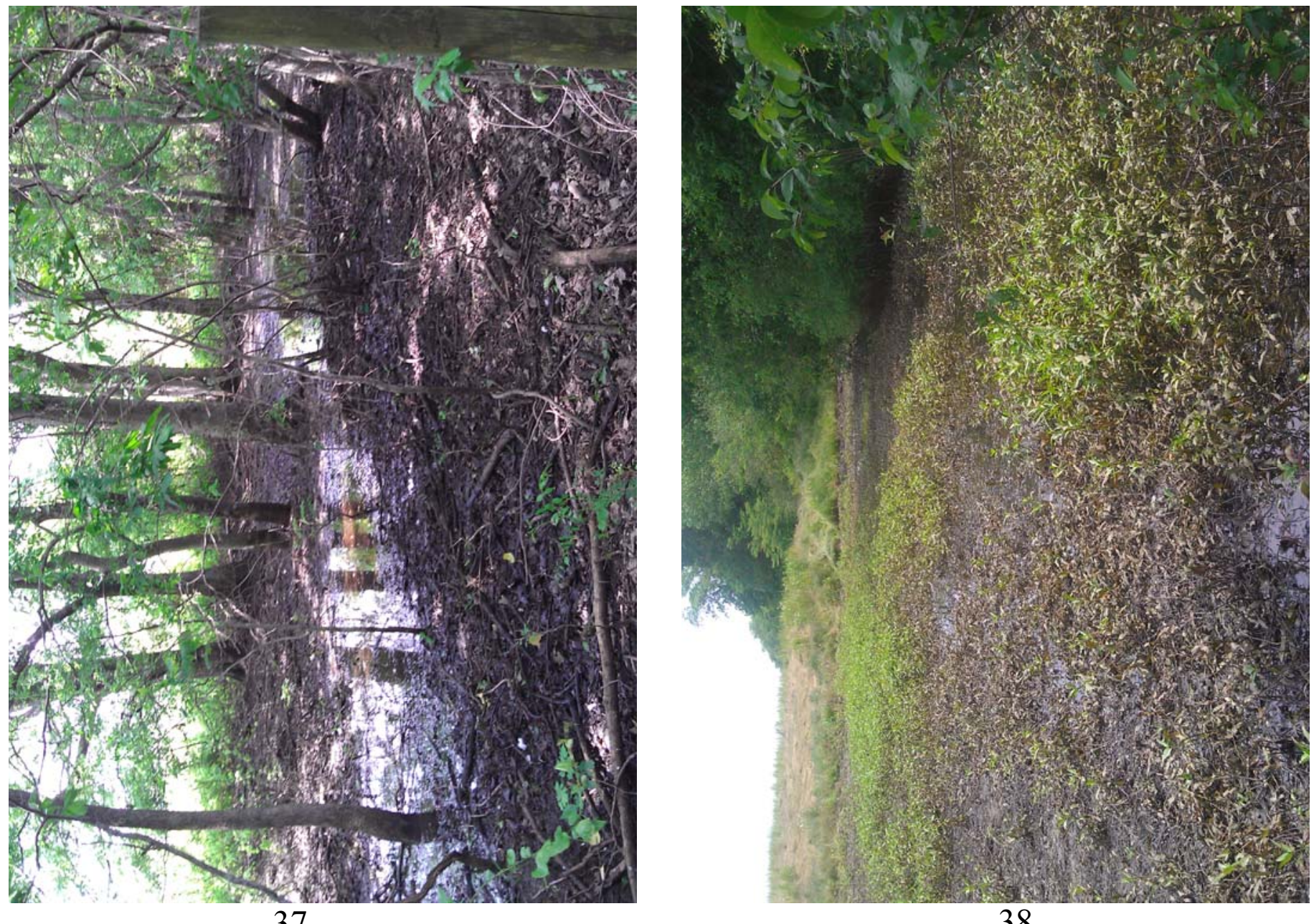

37
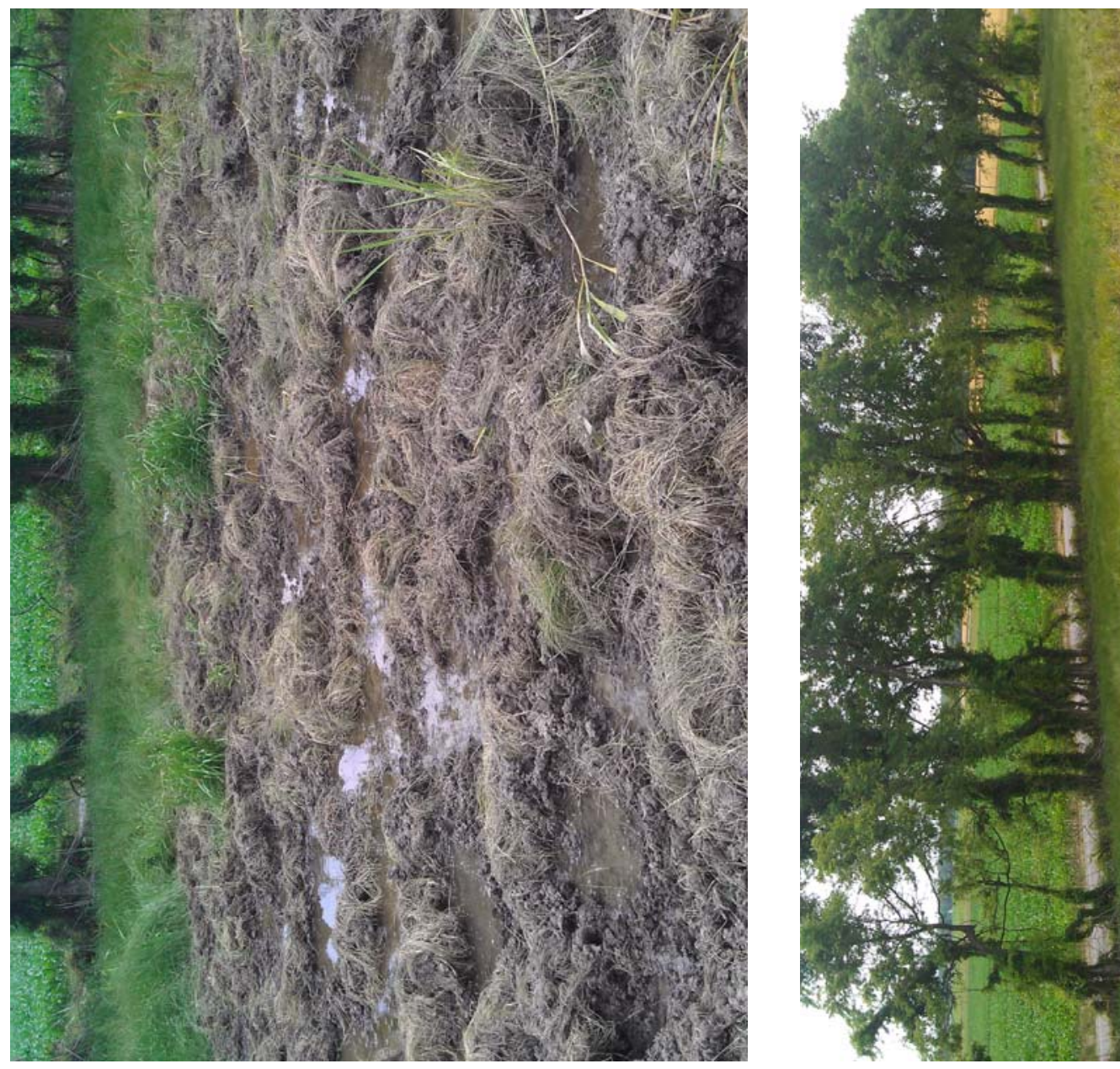


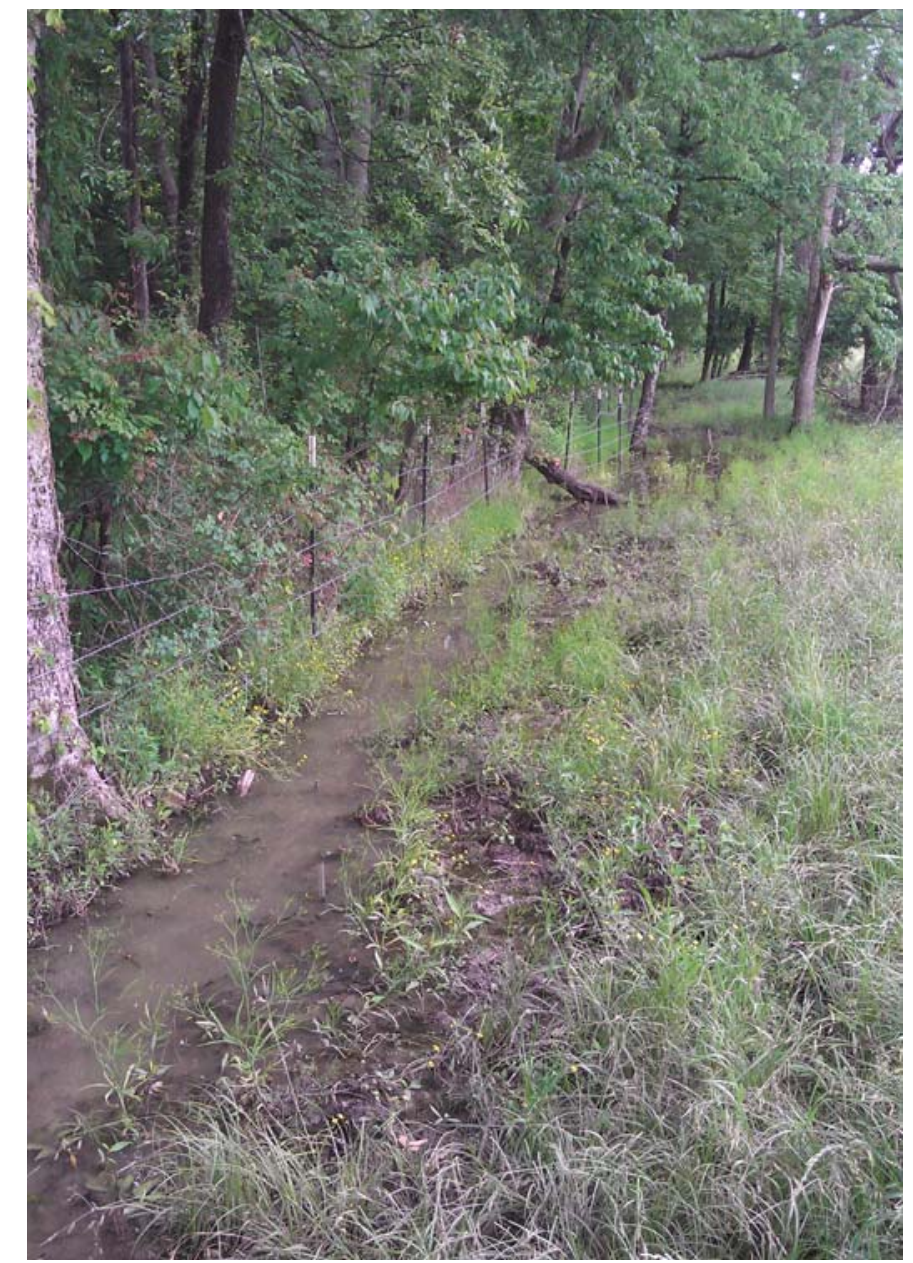

41

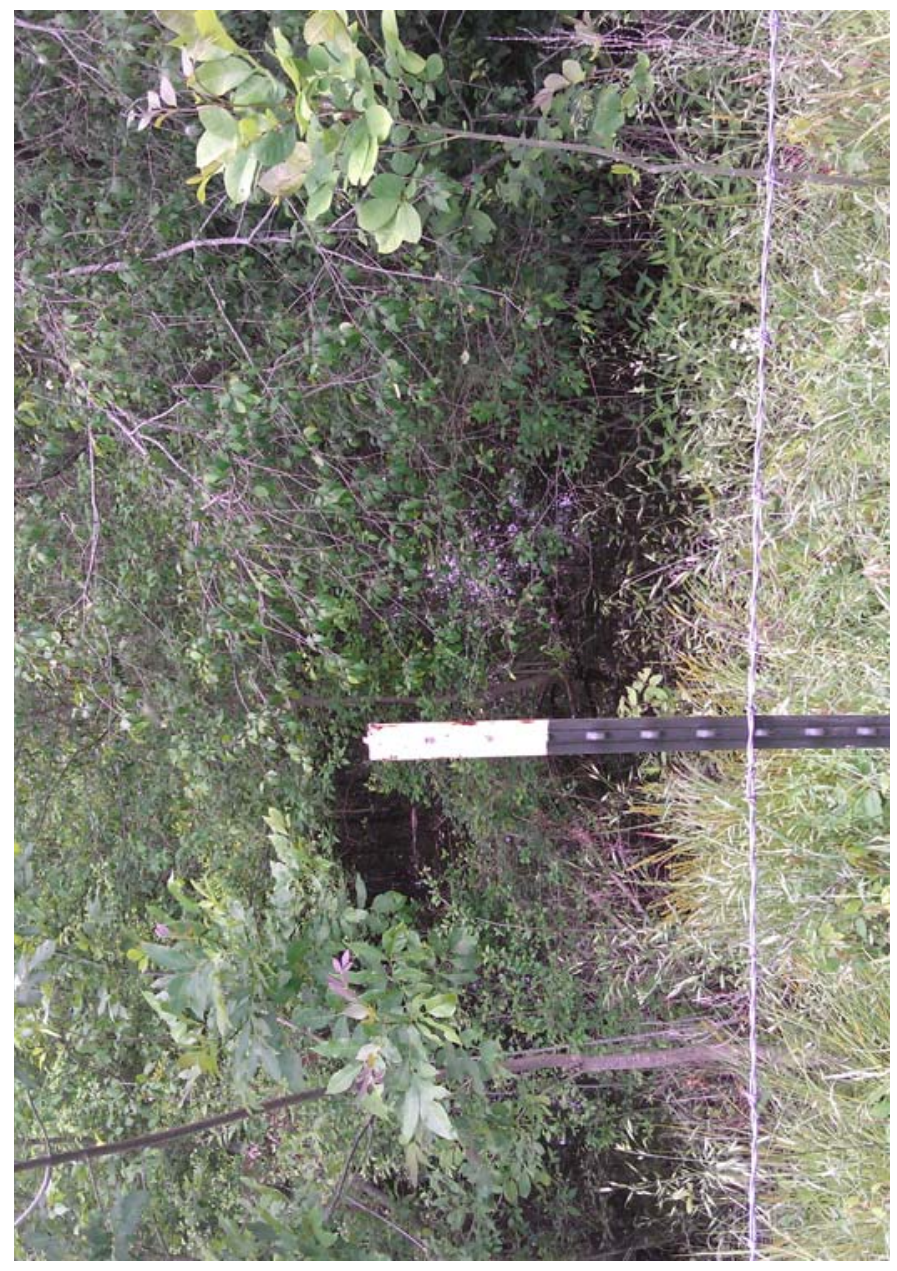

42 


\section{STATION 1500+00 TO 3000+00}


LEVEE SECTOR: Rosedale to Lake Bolivar

DATE: May 18, 2011

TEAM MEMBERS: James Sims, Dustin Herr, Ryan Reeves, Jim Hearn

\begin{tabular}{|c|c|c|c|c|c|c|c|c|c|}
\hline \multicolumn{2}{|c|}{ START } & \multicolumn{2}{|c|}{ END } & STATION & STATION & TYPE & EXTENT & REMARKS & PHOTO \\
\hline Latitude & Longitude & Latitude & Longitude & NLD & FIELD MARKER & & & & \\
\hline 33.81886831 & 91.00144065 & 33.81886831 & 91.00144065 & $1594+00$ & $1559+00$ & Under Seepage & Light & $\begin{array}{l}\text { Light under seepage approximately } 75 \text { to } 100 \text { feet from the toe of the } \\
\text { levee. No pin boils were observed. Seepage area is approximately } 50 \\
\text { feet wide and } 75 \text { feet long. Surrounding area is saturated. }\end{array}$ & 1 \\
\hline 33.81764188 & 90.99924689 & 33.81338905 & 90.99537994 & $1618+00$ & $\begin{array}{l}1565+00 \text { to } \\
1581+00\end{array}$ & Under Seepage & Light & $\begin{array}{l}\text { Widespread light under seepage starting at the toe of the seepage berm } \\
\text { and extending approximately } 250 \text { to } 300 \text { feet into the woods (photo 2). } \\
\text { Light seepage and standing water was observed within a ring } \\
\text { levee off the toe of the berm. }\end{array}$ & $2-3$ \\
\hline 33.81338905 & 90.99537994 & 33.81228052 & 90.99295616 & $1633+00$ & $\begin{array}{l}1581+00 \text { to } \\
1599+00\end{array}$ & Under Seepage & Light & $\begin{array}{l}\text { Light seepage and standing water within an old ring levee } \\
\text { approximately } 100 \text { feet from the toe of the berm. Area is approximately } \\
100 \text { feet wide and } 500 \text { feet long. }\end{array}$ & 4-5 \\
\hline 33.80178504 & 90.98387623 & 33.79962 & 90.98482 & $\begin{array}{l}1682+00 \text { to } \\
1690+00\end{array}$ & $\begin{array}{l}1648+00 \text { to } \\
1655+00\end{array}$ & Under Seepage & Light & $\begin{array}{l}\text { Light seepage between the toe of the berm and a small toe levee } \\
\text { near the woods approximately } 50 \text { feet wide and } 500 \text { feet long. } \\
\text { Seepage also identified in the woods behind the toe levee which } \\
\text { extends approximately } 200 \text { feet through the woods and into an } \\
\text { adjacent corn field. }\end{array}$ & $6-8$ \\
\hline 33.80178504 & 90.98387623 & 33.79962 & 90.98482 & $\begin{array}{l}1682+00 \text { to } \\
1690+00\end{array}$ & $\begin{array}{l}1648+00 \text { to } \\
1655+00\end{array}$ & Under Seepage & Light & $\begin{array}{l}\text { Light seepage between the toe of the berm and a small toe levee } \\
\text { near the woods approximately } 75 \text { feet wide and } 500 \text { - } 600 \text { feet long. } \\
\text { Seepage also identified in the woods behind the toe levee which } \\
\text { extends approximately } 200 \text { feet through the woods and into an } \\
\text { adjacent corn field. }\end{array}$ & 9 \\
\hline 33.79824034 & 90.98367397 & 33.79548 & 90.98508 & $\begin{array}{l}1693+00 \text { to } \\
1705+00\end{array}$ & $\begin{array}{l}1659+00 \text { to } \\
1670+00\end{array}$ & Under Seepage & Light & $\begin{array}{l}\text { Light seepage between the toe of the berm and a small toe levee } \\
\text { near the woods approximately } 75 \text { feet wide and } 300 \text { feet long. (Site is } \\
\text { between Levee Sta. } 1659 \text { and } 1670 \text { ). }\end{array}$ & 10 \\
\hline 33.75839541 & 91.02122709 & 33.75839541 & 91.02122709 & $1905+00$ & $1870+00$ & Under Seepage & Very Light & $\begin{array}{l}\text { Very light seepage approximately } 30 \text { to } 40 \text { feet from the toe of } \\
\text { the seepage berm. Damp area with some standing water } \\
\text { approximately } 50 \text { feet wide and } 75 \text { feet long. }\end{array}$ & 11 \\
\hline 33.75672498 & 91.02373737 & 33.75672498 & 91.02373737 & $1918+00$ & $1882+00$ & Under Seepage & Very Light & $\begin{array}{l}\text { Very light seepage in edge of corn field approximately } 75 \text { yds. } \\
\text { from levee toe. Area is approximately } 20 \text { feet wide and } 50 \text { feet } \\
\text { in length. Seepage berm cannot be identified. }\end{array}$ & 12 \\
\hline 33.75288298 & 91.02396933 & 33.74701487 & 91.02315479 & $\begin{array}{l}1934+00 \text { to } \\
1955+00\end{array}$ & $\begin{array}{l}1900+00 \text { to } \\
1920+00\end{array}$ & Under Seepage & Light & $\begin{array}{l}\text { Light seepage from the toe of the berm extending out } 150 \text { feet } \\
\text { between Levee Sta. } 1900 \text { and } 1920 . \text { Seepage extends though the field } \\
\text { and into the woods and inot an old slough starting near Levee Sta. } 1910 .\end{array}$ & $13-15$ \\
\hline 33.74517483 & 91.02399651 & 33.74517483 & 91.02399651 & $1962+00$ & $1935+00$ & Under Seepage & Light & $\begin{array}{l}\text { Widespread light seepage in the woods approximately } 30 \text { feet from } \\
\text { the toe of the berm, possibly into an old slough or lake. }\end{array}$ & \\
\hline 33.74298177 & 91.02399655 & 33.72534 & 91.02121 & $\begin{array}{l}1969+00 \text { to } \\
2035+00\end{array}$ & $\begin{array}{l}1940+00 \text { to } \\
2000+00\end{array}$ & Under Seepage & Light & $\begin{array}{l}\text { Light seepage along a ditch approximately } 50 \text { feet from the toe of the } \\
\text { berm. }\end{array}$ & $16-17$ \\
\hline 33.72328212 & 91.02148339 & 33.72328212 & 91.02148339 & $2043+00$ & $2008+00$ & Under Seepage & Light & $\begin{array}{l}\text { Light seepage in along ditch draining into a small pond or crevasse } \\
\text { approximately } 150 \text { yards from levee toe near Levee Sta. } 2008 .\end{array}$ & 18 \\
\hline
\end{tabular}




\begin{tabular}{|c|c|c|c|c|c|c|c|c|c|}
\hline \multicolumn{2}{|c|}{ START } & \multicolumn{2}{|c|}{ END } & \multirow{2}{*}{$\begin{array}{l}\text { STATION } \\
\text { NLD }\end{array}$} & \multirow{2}{*}{$\frac{\text { STATION }}{\text { FIELD MARKER }}$} & \multirow[t]{2}{*}{ TYPE } & \multirow[t]{2}{*}{ EXTENT } & \multirow[t]{2}{*}{ REMARKS } & \multirow[t]{2}{*}{ PHOTO } \\
\hline Latitude & Longitude & Latitude & Longitude & & & & & & \\
\hline 33.69927545 & 91.0286645 & 33.69927545 & 91.0286645 & $2142+00$ & $2110+00$ & Under Seepage & Light & $\begin{array}{l}\text { Light seepage from the toe of the berm extending out in a corn field } \\
\text { approximately } 300 \text { feet near Levee Sta. } 2110 \text {. Seepage area is } 300 \\
\text { to } 400 \text { feet in length. }\end{array}$ & $19-21$ \\
\hline 33.69574044 & 91.02625476 & 33.69574044 & 91.02625476 & $2158+00$ & $2123+00$ & Under Seepage & Light & $\begin{array}{l}\text { Possible light seepage or wet area identified in the woods approximately } \\
500 \text { feet from the toe of the levee at Levee Sta. 2123. Surrounding area } \\
\text { is dry. }\end{array}$ & 22 \\
\hline 33.69351302 & \begin{tabular}{|l|}
91.02504064 \\
\end{tabular} & 33.69253 & 91.0246 & $\begin{array}{l}2166+00 \text { to } \\
2168+00\end{array}$ & $\begin{array}{l}2131+00 \text { to } \\
2134+00\end{array}$ & Under Seepage & Light & $\begin{array}{l}\text { Light seepage in the woods approximately } 400 \text { feet from the levee } \\
\text { toe. }\end{array}$ & 23 \\
\hline 33.68879273 & 91.02409858 & 33.68879273 & 91.02409858 & $2182+00$ & $2148+00$ & Under Seepage & Light & $\begin{array}{l}\text { Light seepage in a low spot inside a ring levee off the toe of the berm } \\
\text { near Levee Sta. } 2148 \text { approximately } 600 \text { feet from the toe of the } \\
\text { levee. }\end{array}$ & 24 \\
\hline 33.68673 & 91.02417 & 33.68675929 & 91.02417334 & $\begin{array}{l}2189+00 \text { to } \\
2191+00\end{array}$ & $\begin{array}{l}2152+00 \text { to } \\
2158+00\end{array}$ & Under Seepage & Light & $\begin{array}{l}\text { Light seepage in a low spot inside a ring levee off the toe of the seepage } \\
\text { berm approximately } 500 \text { feet from the levee toe. Extends from Levee } \\
\text { Sta. } 2152 \text { to near Levee Sta. } 2158 .\end{array}$ & $25-26$ \\
\hline 33.67567552 & 91.0258355 & 33.67567552 & 91.0258355 & $2229+00$ & $2194+00$ & Under Seepage & Light & $\begin{array}{l}\text { Light seepage approximately } 300 \text { feet from levee toe at Levee Sta. } 2194 . \\
\text { Extends out approximately } 100 \text { feet and widens to } 300 \text { feet near } \\
\text { near Ingersol Road. }\end{array}$ & $27-28$ \\
\hline 33.67325 & 91.02718 & 33.67325 & 91.02718 & $2238+00$ & $2203+00$ & Sand Boil & Moderate & $\begin{array}{l}\text { Medium seepage/pin boils in a pasture and along Ingersol Road } \\
\text { near Levee Sta. } 2203 . \text { Approximately } 200 \text { feet from the toe of the levee. }\end{array}$ & $29-30$ \\
\hline 33.67325 & 91.02718 & 33.6665 & 91.03417 & $\begin{array}{l}2238+00 \text { to } \\
2277+00\end{array}$ & $\begin{array}{l}2203+00 \text { to } \\
2240+00\end{array}$ & Through Seepage & Light & $\begin{array}{l}\text { Light seepage on top of the seepage berm approximately } 50 \text { to } 100 \text { feet } \\
\text { from the woods between Levee Sta. } 2203 \text { and } 2240 \text {. Seepage is } \\
\text { approximately } 50 \text { to } 75 \text { feet wide. Cannot distingush berm at Sta. 2222; } \\
\text { however, seepage can be seen in ditch in the woods. }\end{array}$ & 31 \\
\hline 33.66667408 & 91.03375951 & 33.66667408 & 91.03375951 & $2267+00$ & $2231+00$ & Sand Boil & Moderate & $\begin{array}{l}\text { Sand boil under } 1.5 \text { to } 2.0 \text { feet of water in wooded area approximately } \\
350 \text { to } 400 \text { feet from the toe of the levee near Sta. } 2231 . \text { Boil has made } \\
\text { approximately } 1-2 \text { cubic yards of fine sand and has a } 12-18 \text { inch throat. } \\
\text { Numerous (10-15) pin boils in the same area. Seepage water was also } \\
\text { observed on top of the seepage berm approximately } 200 \text { feet from the } \\
\text { berm toe. }\end{array}$ & \\
\hline 33.66493961 & 9103856805 & 33.66296 & 91.04516 & $\begin{array}{l}2285+00 \text { to } \\
2304+00\end{array}$ & $\begin{array}{l}2250+00 \text { to } \\
2270+00\end{array}$ & Under Seepage & Light & $\begin{array}{l}\text { Light seepage on top of the seepage berm near Sta. } 2250 \text {. Area is } 50 \text { to } \\
75 \text { feet long and } 75 \text { feet wide and approximately } 300 \text { feet from the } \\
\text { levee toe. Seepage extends off the berm toe and into the woods } \\
\text { between Sta. } 2250 \text { and } 2270 .\end{array}$ & $32-33$ \\
\hline 33.66228704 & 91.05173309 & 33.66228704 & 91.05173309 & $2325+00$ & $2290+00$ & Under Seepage & Light & $\begin{array}{l}\text { Light seepage in wooded area just off the toe of the berm at Sta. } 2290 . \\
\text { Standing water is clear. }\end{array}$ & 34 \\
\hline 33.66183394 & 91.0527781 & 33.66184 & 91.05306 & $\begin{array}{l}2328+00 \text { to } \\
2330+00\end{array}$ & $\begin{array}{l}2293+00 \text { to } \\
2295+00\end{array}$ & Under Seepage & Light to Moderate & $\begin{array}{l}\text { Light to moderate seepage along access road and in surrounding area } \\
\text { between Sta. } 2293 \text { and } 2295 \text { (Little Man's Landing Entrance). Seepage } \\
\text { area is approximately } 500 \text { feet from the levee toe. Two to five small } \\
\text { pin boils observed near abandoned house. Seepage water is clear. }\end{array}$ & $35-39$ \\
\hline 33.661561 & 91.052689 & 33.661561 & 91.052689 & $2330+00$ & $2295+00$ & Sand Boil & Moderate & $\begin{array}{l}\text { Small sand boil located in driveway in front of a house on Little Man's } \\
\text { Landing Road at Levee Sta. 2295. Sand boil has a 4-5 inch troat and is } \\
\text { not transporting material. }\end{array}$ & \\
\hline 33.65844141 & 91.06250651 & 33.65844141 & 91.06250651 & $2363+00$ & $2330+00$ & Under Seepage & Light & $\begin{array}{l}\text { Light seepage in a field approximately } 400 \text { feet from levee toe near Sta. } \\
500 \\
\text { feet long and } 150 \text { to } 200 \text { feet wide. }\end{array}$ & 40 \\
\hline
\end{tabular}




\begin{tabular}{|c|c|c|c|c|c|c|c|c|c|}
\hline \multicolumn{2}{|c|}{ START } & \multicolumn{2}{|c|}{ END } & \multirow{2}{*}{$\begin{array}{l}\text { STATION } \\
\text { NLD }\end{array}$} & \multirow{2}{*}{$\frac{\text { STATION }}{\text { FIELD MARKER }}$} & \multirow[t]{2}{*}{ TYPE } & \multirow[t]{2}{*}{ EXTENT } & \multirow[t]{2}{*}{ REMARKS } & \multirow[t]{2}{*}{ PHOTO } \\
\hline Latitude & Longitude & Latitude & Longitude & & & & & & \\
\hline 33.65627142 & 91.07000784 & 33.6530074 & 91.07840416 & $\begin{array}{l}2388+00 \text { to } \\
2417+00\end{array}$ & $\begin{array}{l}2355+00 \text { to } \\
2382+00\end{array}$ & Under Seepage & Light & $\begin{array}{l}\text { Light seepage in corn field between Levee Sta. } 2355 \text { and } 2382 \text { on south } \\
\text { side of Bolivar Road. Seepage seepage extends out in field } 200 \text { to } 400+ \\
\text { feet. Seepage confined to ditch near Sta. } 2370 \text {. }\end{array}$ & $41-44$ \\
\hline 33.65214 & 91.08445 & 33.65214 & 91.08445 & $2438+00$ & $2409+00$ & Through Seepage & Light & $\begin{array}{l}\text { Light through seepage on top of the seepage berm near Levee Sta. } 2409 . \\
\text { Seepage area is approximately } 30 \text { yards long and } 30 \text { yards wide and is } \\
\text { located approximately } 20 \text { yards from the seepage berm toe. }\end{array}$ & 45 \\
\hline 33.65252397 & 91.0886489 & 33.65339 & 91.09421 & $\begin{array}{l}2444+00 \text { to } \\
2461+00\end{array}$ & $\begin{array}{l}2410+00 \text { to } \\
2428+00\end{array}$ & Through Seepage & Moderate & $\begin{array}{l}\text { Numerous pin boils ( } 20 \text { to } 30 \text { ) and moderate seepage in corn field near } \\
\text { levee Sta. } 2410 \text {. Very little material transported by pin boils extending } \\
50 \text { to } 75 \text { yards into corn field. Light seepage extends out into the corn } \\
\text { field between Levee Sta. } 2410 \text { and } 2428 \text {. }\end{array}$ & $46-48$ \\
\hline 33.66258614 & 91.12074863 & 33.66258614 & 91.12074863 & $\begin{array}{l}2554+00 \text { to } \\
2560+00\end{array}$ & $\begin{array}{l}2520+00 \text { to } \\
2530+00\end{array}$ & Under Seepage & Light & $\begin{array}{l}\text { Light seepage in ditch and in field approximately } 300 \text { feet from the toe of } \\
\text { the levee. Area extends from } 100 \text { to } 500 \text { feet out from the toe of the } \\
\text { levee. Possible source of some of this seepage may be a flowing irrigation } \\
\text { well observed near Levee Sta. } 2530 .\end{array}$ & $49-53$ \\
\hline 33.66257434 & 91.13414106 & 33.66600 & 91.14644 & $\begin{array}{l}2585+00 \text { to } \\
2634+00\end{array}$ & $\begin{array}{l}2551+00 \text { to } \\
2600+00\end{array}$ & Under Seepage & Light & $\begin{array}{l}\text { Light seepage observed approximately } 200 \text { feet from the toe of the levee } \\
\text { extending out for a distance of } 1000 \text { feet + near Levee Sta. } 2551 \text {. Seepage } \\
\text { berm starts near Levee Sta. } 2551+40 \text {. Light seepage } 20 \text { feet off the toe } \\
\text { of the seepage berm extending down stream for approximately } 2000 \\
\text { feet. Moderate seepage with several sand boils in a corn field located } \\
\text { near Levee Sta. } 2600 .\end{array}$ & $54-60$ \\
\hline 33.6687078 & 91.15117997 & 33.66412 & 91.15781 & $\begin{array}{l}2650+00 \text { to } \\
2690+00\end{array}$ & $\begin{array}{l}2618+00 \text { to } \\
2660+00\end{array}$ & Under Seepage & Light & $\begin{array}{l}\text { Light seepage in a low spot 20-30 feet from the toe of the seepage } \\
\text { berm near Levee Sta. 2618. Ring levee holding water at toe of the berm } \\
\text { begins near Sta. } 2620 \text { and ends near Sta. } 2650 \text {. Clear, standing, water. }\end{array}$ & $61-65$ \\
\hline 33.66173826 & 91.15997205 & 33.66173826 & 91.15997205 & $2695+00$ & $2661+00$ & Under Seepage & Very Light & $\begin{array}{l}\text { Very light seepage in low area approximately } 150 \text { yards from the toe } \\
\text { of the levee. Seepage berm existance cannot be determined. }\end{array}$ & 66 \\
\hline 33.66072878 & 91.16072878 & 33.66072878 & 91.16072878 & $2700+00$ & $2668+00$ & Under Seepage & Very Light & $\begin{array}{l}\text { Very light seepage along fence approximately } 20 \text { feet from the toe of the } \\
\text { seepage berm. Seepage is approximately } 150 \text { feet yards wide and } 100 \\
\text { feet long near Levee Sta. } 2668 .\end{array}$ & 67 \\
\hline 33.65864364 & 91.16244547 & 33.65864364 & 91.16244547 & $2708+00$ & $2675+00$ & Under Seepage & Very Light & $\begin{array}{l}\text { Very light seepage in a low spot and ditch approximately } 20 \text { feet from the } \\
\text { toe of the seepage berm near Levee Sta. } 2675 \text {. }\end{array}$ & $68-70$ \\
\hline 33.65436177 & 91.16517513 & 33.65137 & 91.15979 & $\begin{array}{l}2726+00 \text { to } \\
2753+00\end{array}$ & $\begin{array}{l}2690+00 \text { to } \\
2720+00\end{array}$ & Under Seepage & Light & $\begin{array}{l}\text { Light seepage along the toe of the seepage berm that extends out } \\
\text { approximately } 150 \text { feet between Levee Sta. } 2680 \text { and } 2720 .\end{array}$ & $71-73$ \\
\hline 33.65093776 & 91.15853697 & 33.65093776 & 91.15853697 & $2758+00$ & $2722+00$ & Under Seepage & Light & $\begin{array}{l}\text { Light seepage in low spot approximately } 150 \text { feet from the toe of the } \\
\text { levee near Sta. } 2722 . \text { No seepage berm identified. Seepage water is } \\
\text { clear. }\end{array}$ & $74-75$ \\
\hline 33.64847838 & 91.15403412 & 33.64783 & 91.15335 & $\begin{array}{l}2773+00 \text { to } \\
2775+00\end{array}$ & $\begin{array}{l}2740+00 \text { to } \\
2743+00\end{array}$ & Under Seepage & Very Light & $\begin{array}{l}\text { Light seepage approximately } 200 \text { feet from the levee toe near Levee } \\
\text { Sta. } 2740 \text { extending out into field. Seepage extends approximately } \\
250 \text { to } 500 \text { feet out. Light wet spots in field approximately } 100 \text { feet from } \\
\text { the levee toe between Levee Sta. } 2741 \text { and } 2742 \text {. Another larger spot was } \\
\text { observed near Sta. } 2743 . \text { Spots are } 150 \text { to } 200 \text { feet wide and } \\
\text { approximately } 300 \text { feet long. }\end{array}$ & $76-77$ \\
\hline 33.64302513 & 91.14801013 & 33.64278 & 91.14376 & $\begin{array}{l}2802+00 \text { to } \\
2816+00\end{array}$ & $\begin{array}{l}2765+00 \text { to } \\
2785+00\end{array}$ & Under Seepage & Light & $\begin{array}{l}\text { Light clear seepage inside several ring levees at the berm toe between } \\
\text { Levee Sta. } 2765 \text { and } 2785 . \text { Light seepage also in the field behind the ring } \\
\text { levees approximately } 100 \text { feet from the ring levees extending out } 300 \text { to } \\
400 \text { feet. }\end{array}$ & $78-81$ \\
\hline
\end{tabular}




\begin{tabular}{|c|c|c|c|c|c|c|c|c|c|}
\hline \multicolumn{2}{|c|}{ START } & \multicolumn{2}{|c|}{ END } & STATION & STATION & TYPE & EXTENT & REMARKS & \begin{tabular}{|l|} 
PHOTO \\
\end{tabular} \\
\hline Latitude & Longitude & Latitude & Longitude & NLD & FIELD MARKER & & & & \\
\hline 33.62187814 & 91.12089806 & 33.62057 & 91.11994 & $\begin{array}{l}2737+00 \text { to } \\
2944+00\end{array}$ & $\begin{array}{l}2902+00 \text { to } \\
2908+00\end{array}$ & Under Seepage & Light & $\begin{array}{l}\text { Light seepage in the woods approximately } 30 \text { feet from the toe of the } \\
\text { seepage berm between Levee Sta. } 2910 \text { and } 2920 \text {. Seepage extends } \\
\text { approximately } 150 \text { feet into the woods. }\end{array}$ & \begin{tabular}{|l|}
$85-86$ \\
\end{tabular} \\
\hline 33.61980862 & 91.11899542 & 33.61255 & 91.12078 & $\begin{array}{l}2945+00 \text { to } \\
2973+00\end{array}$ & \begin{tabular}{|l|}
$2910+00$ to \\
$2940+00$
\end{tabular} & Under Seepage & Light & $\begin{array}{l}\text { Light seepage and standing water off the toe of the seepage berm } \\
\text { and in the woods between Levee Sta. } 2910 \text { and } 2940 .\end{array}$ & $87-89$ \\
\hline 33.60806 & 91.12198 & 33.60806 & 91.12198 & $2992+00$ & $2955+00$ & Under Seepage & Light & $\begin{array}{l}\text { Access road leading to levee ramp (27 Break Road) before chain crossing } \\
\text { has light seepage with pumping gravel near Levee Sta. } 2955 \text {. }\end{array}$ & \begin{tabular}{|l|}
$91-93$ \\
\end{tabular} \\
\hline
\end{tabular}



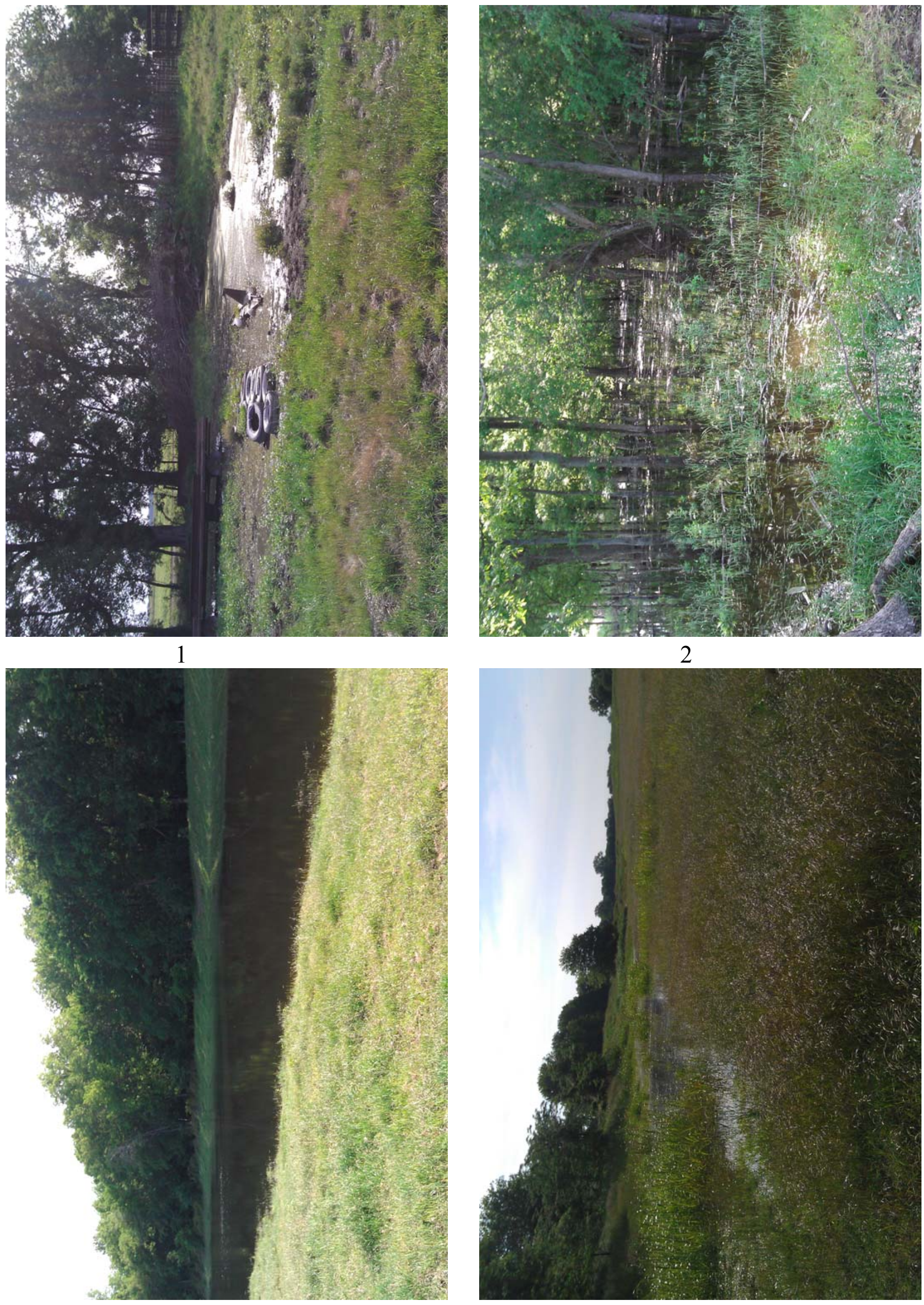


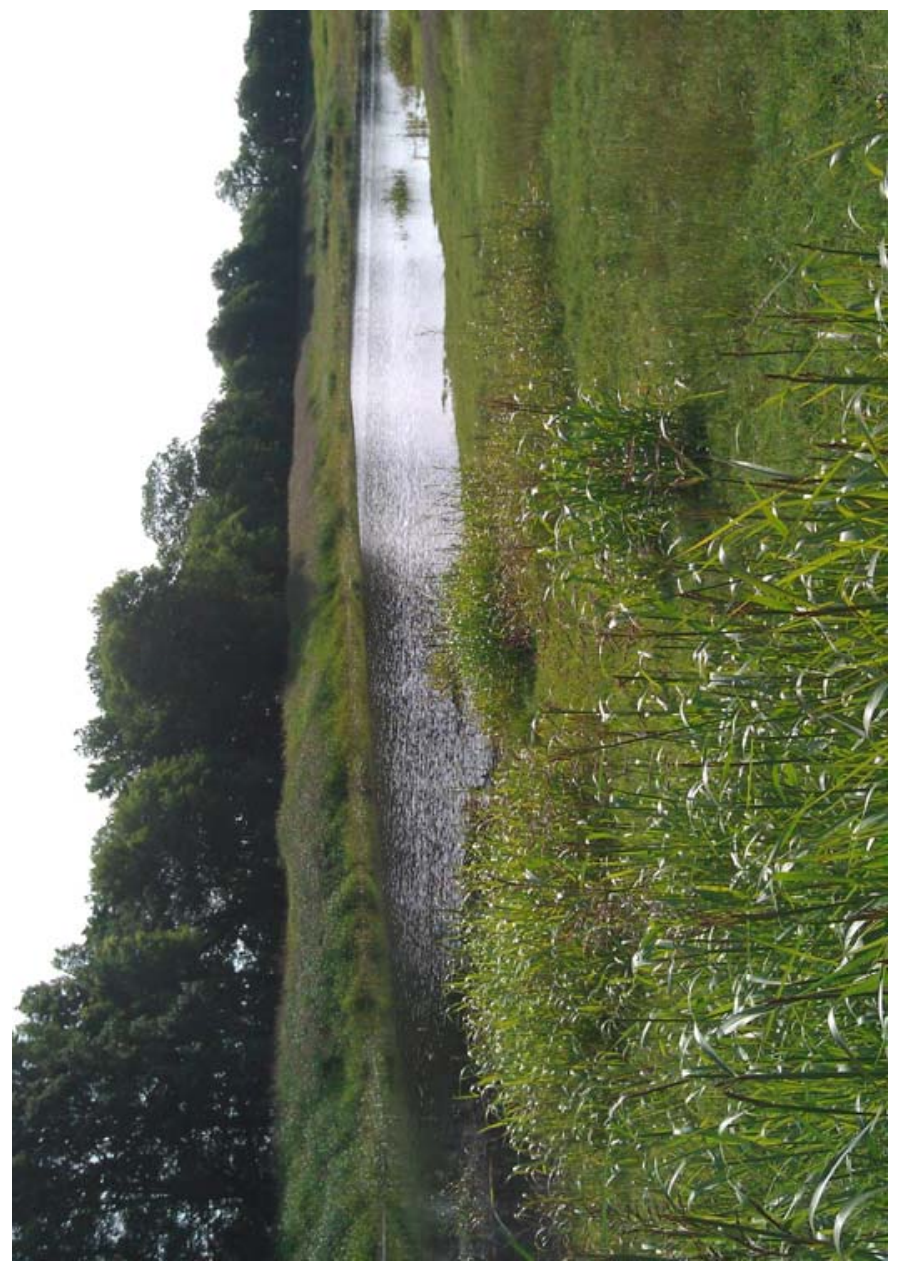

5

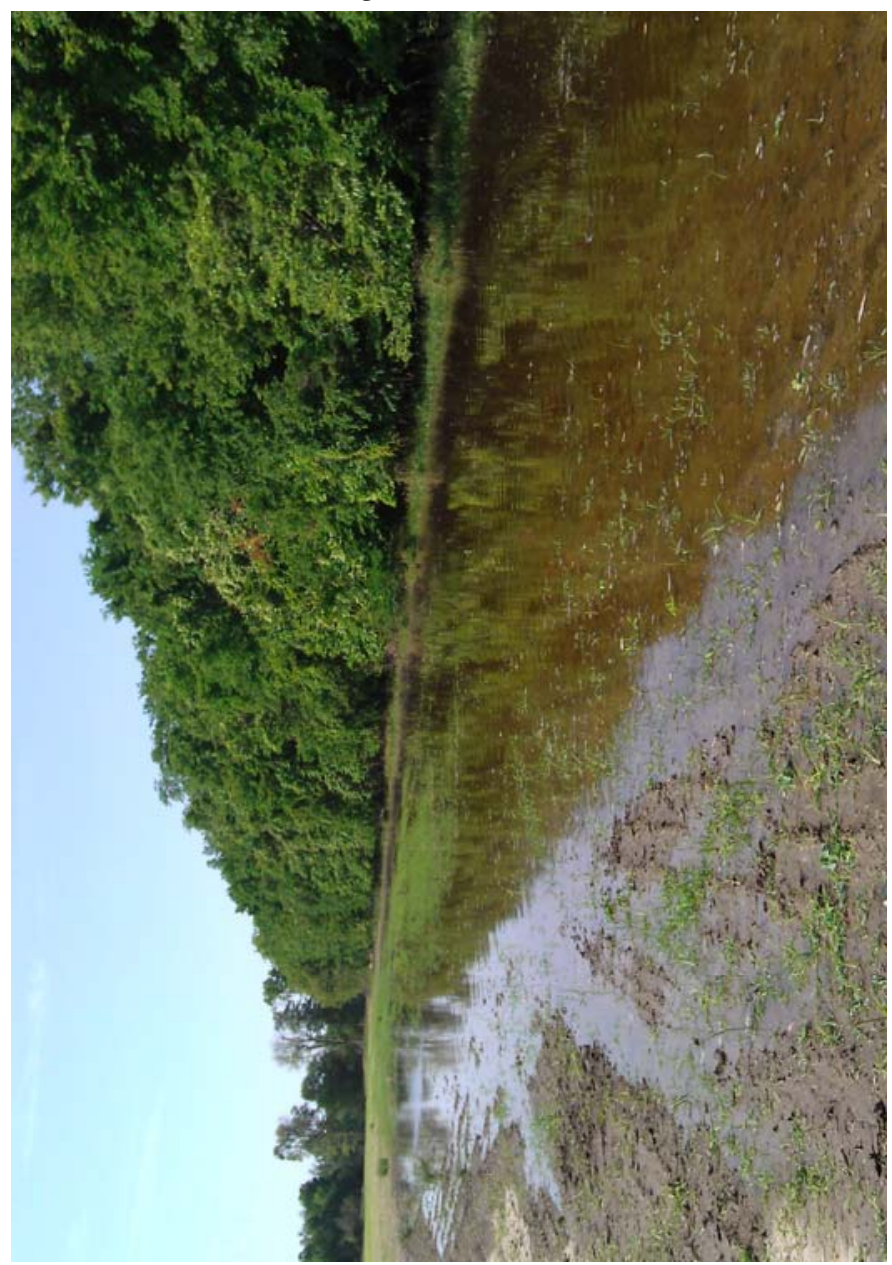

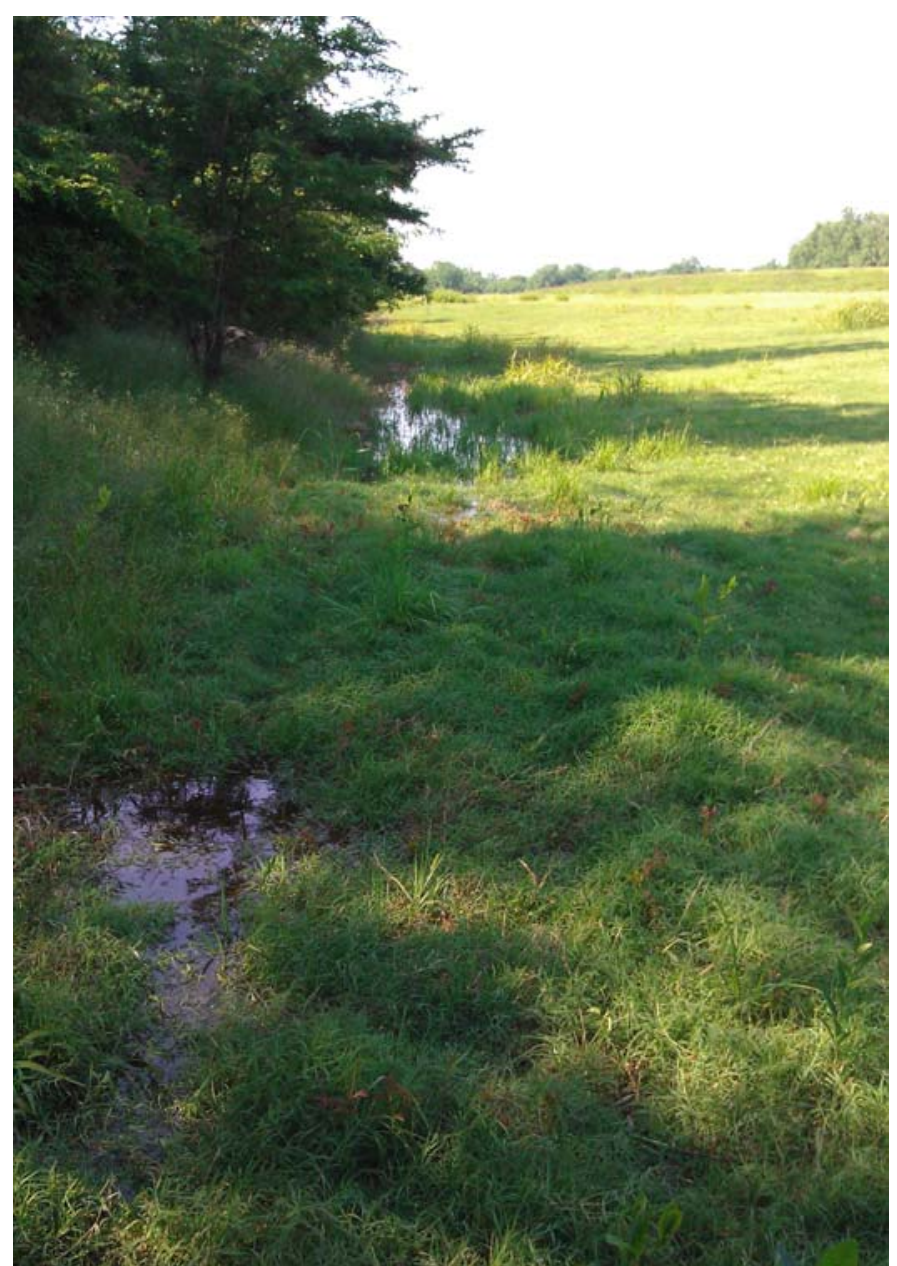

6

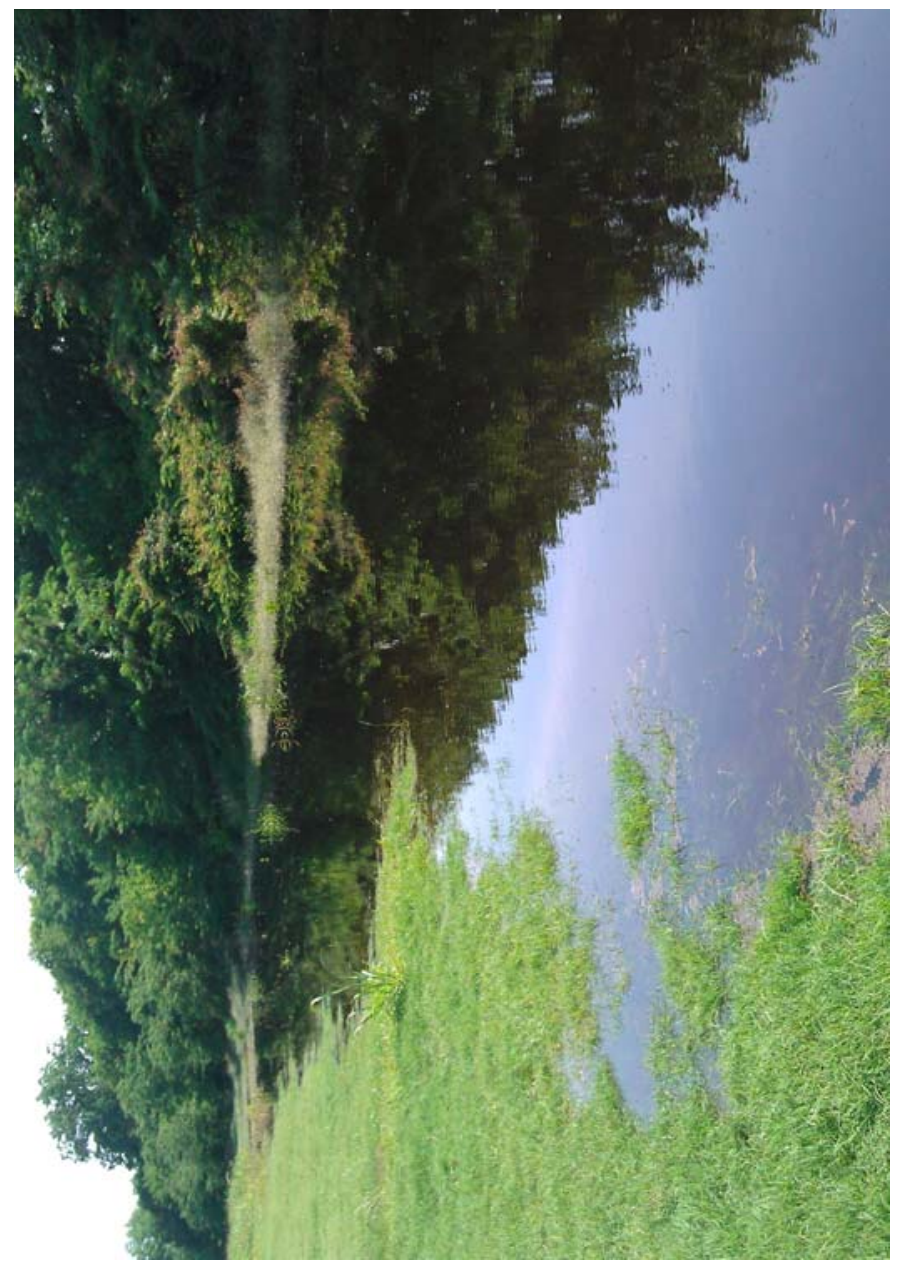




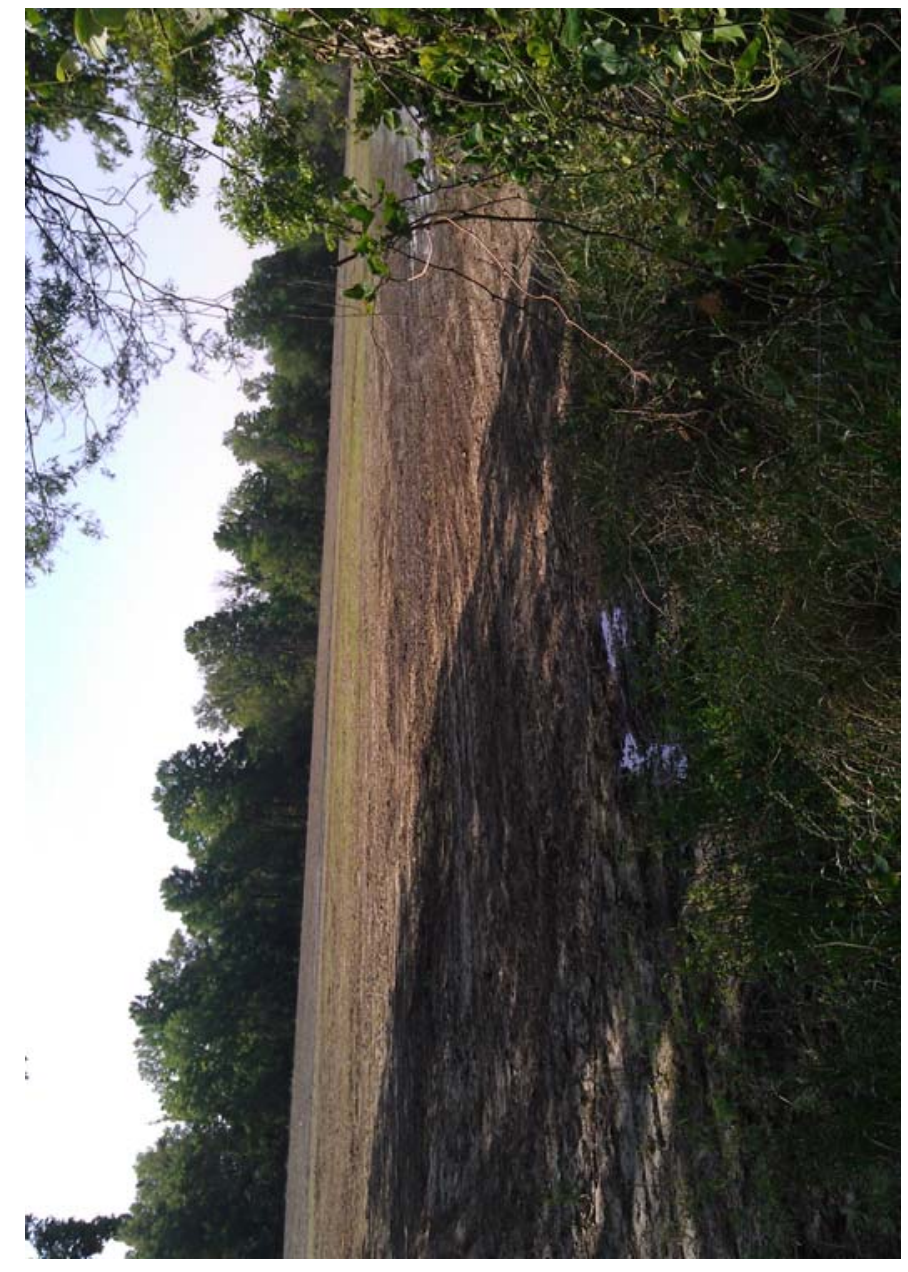

9

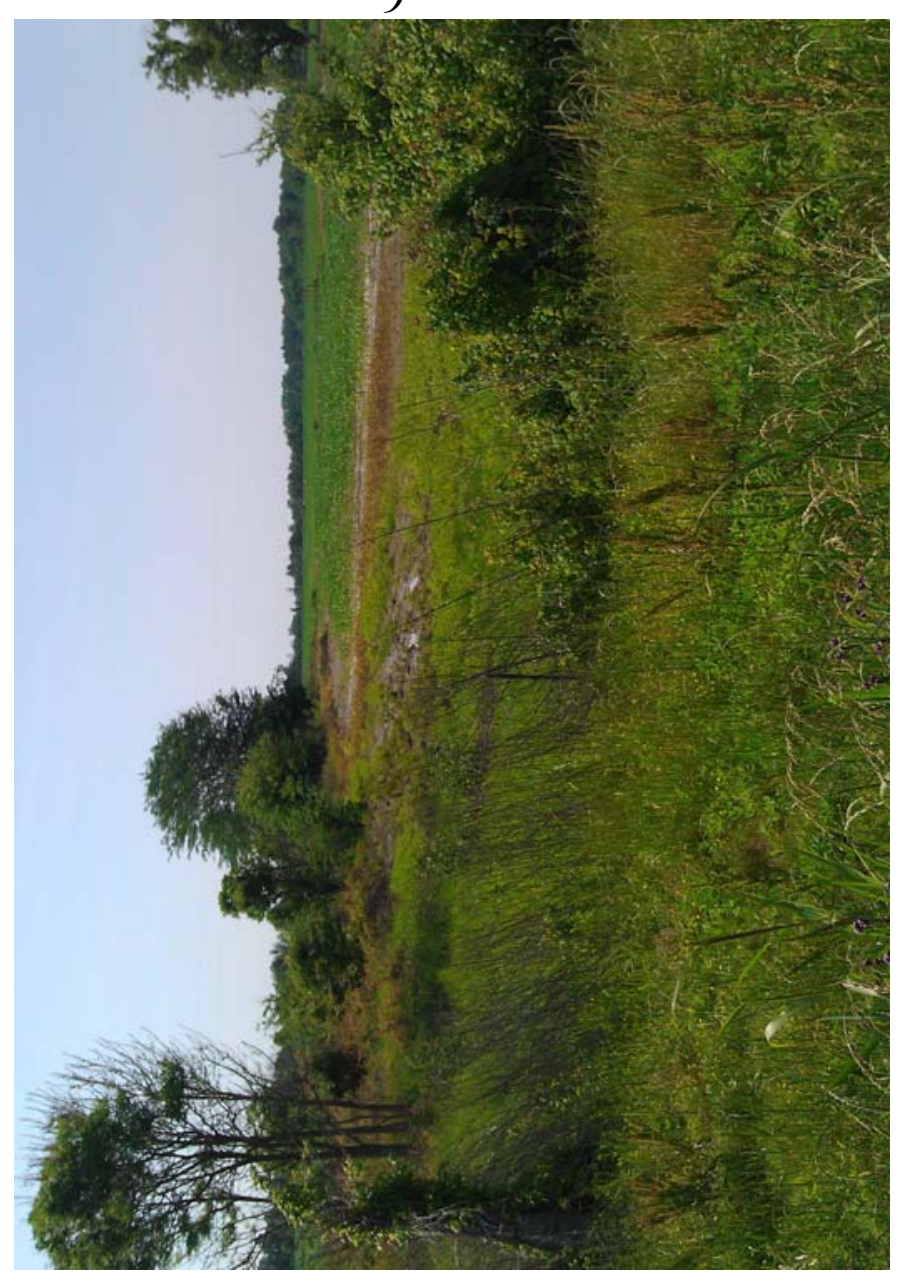

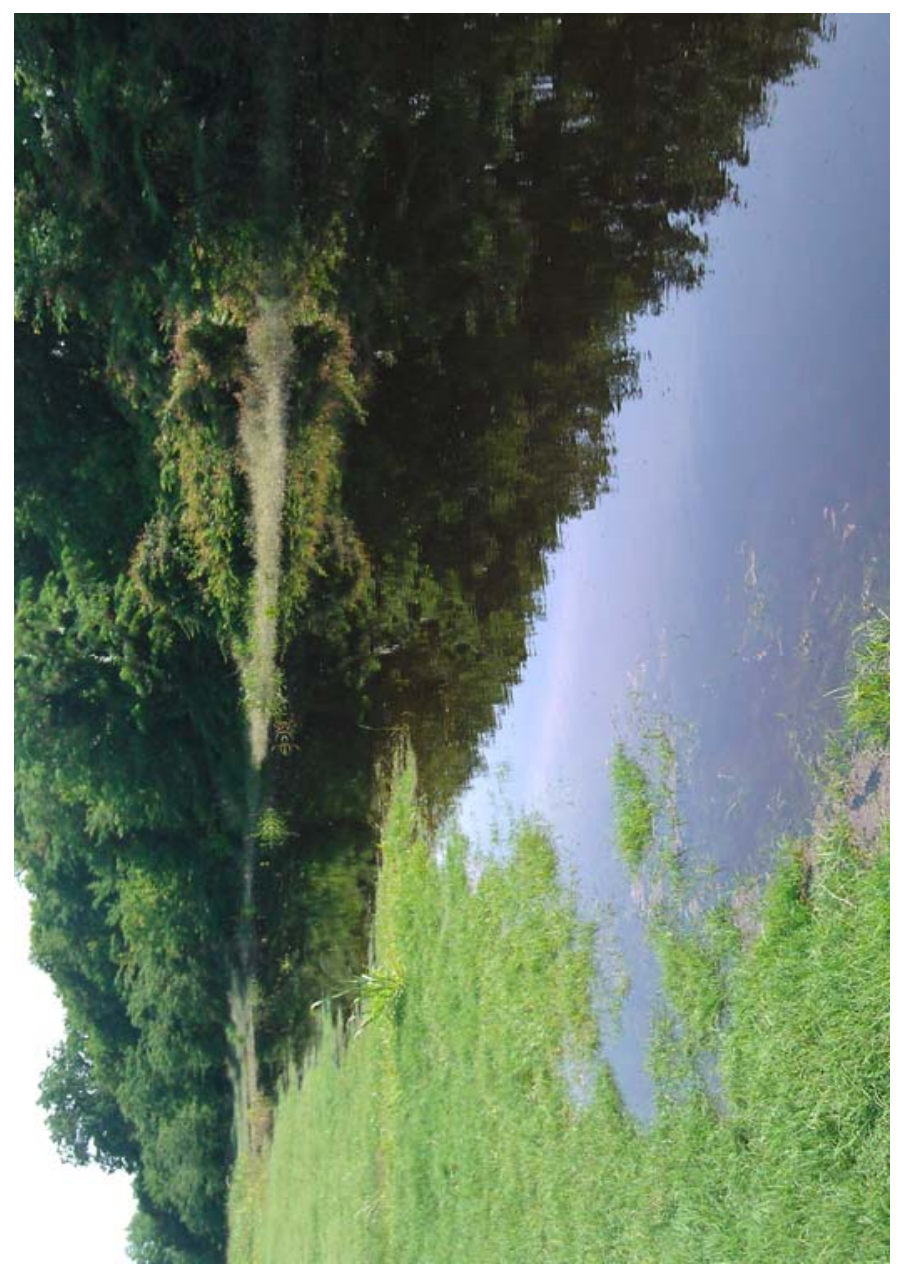

10

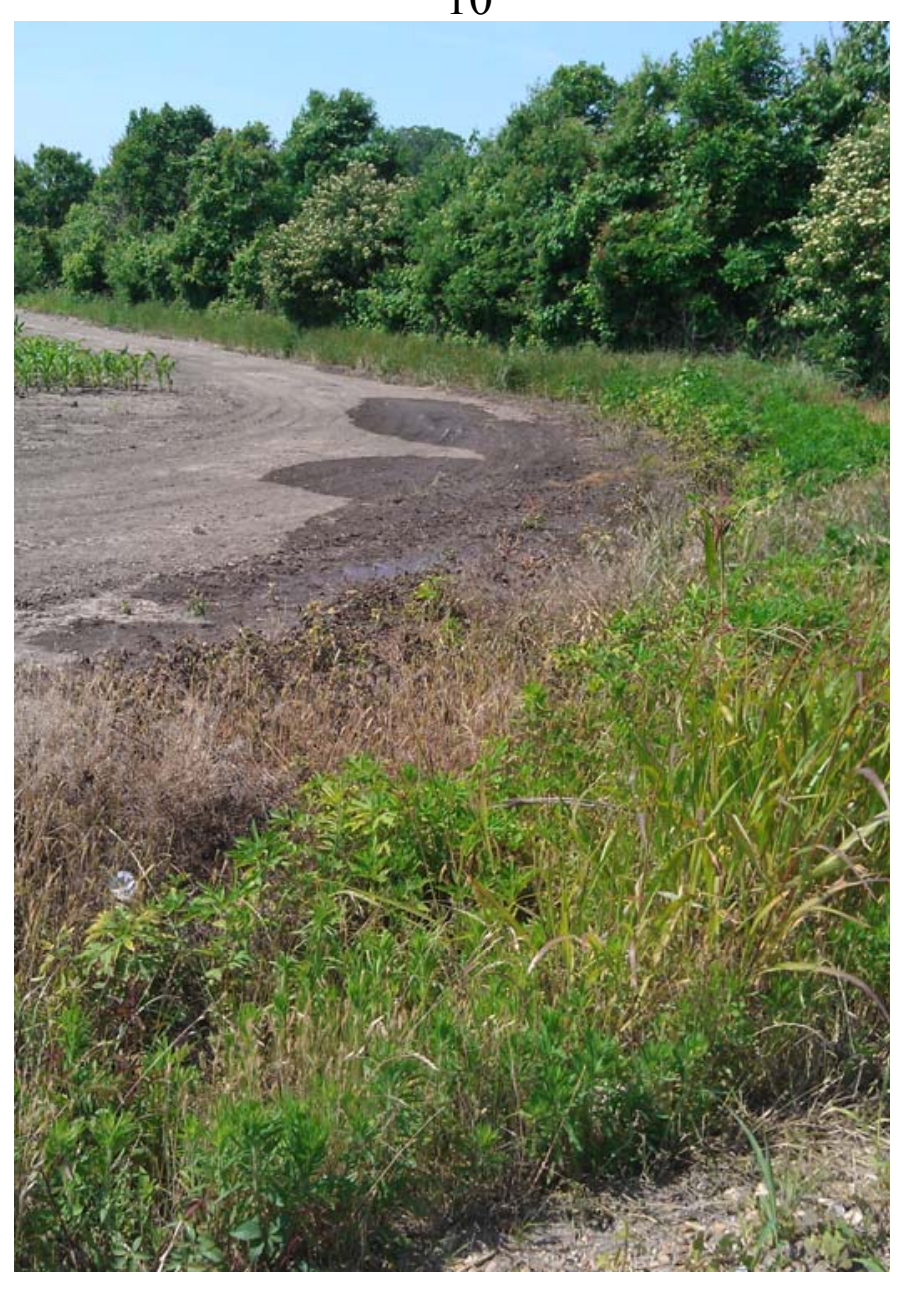




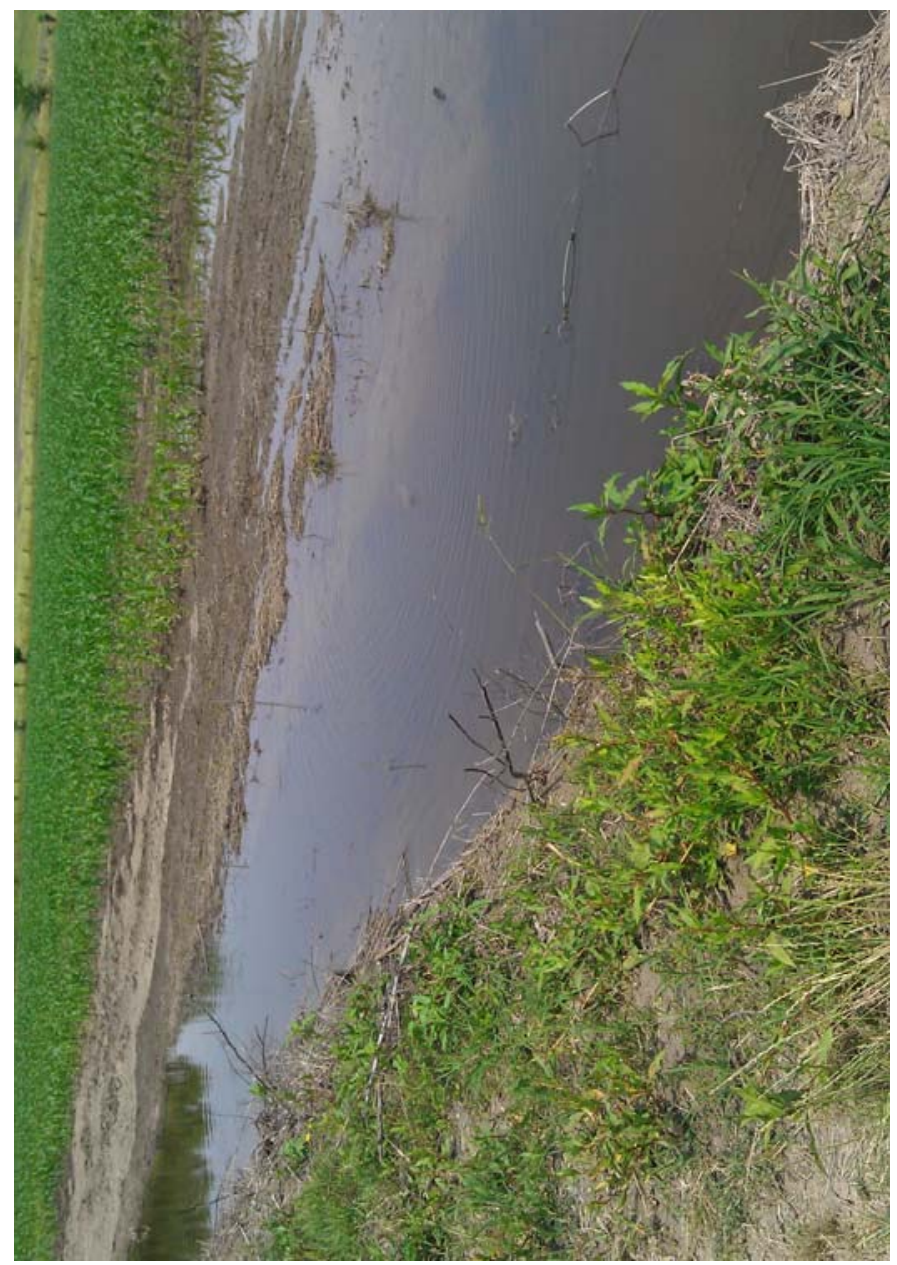

\section{3}

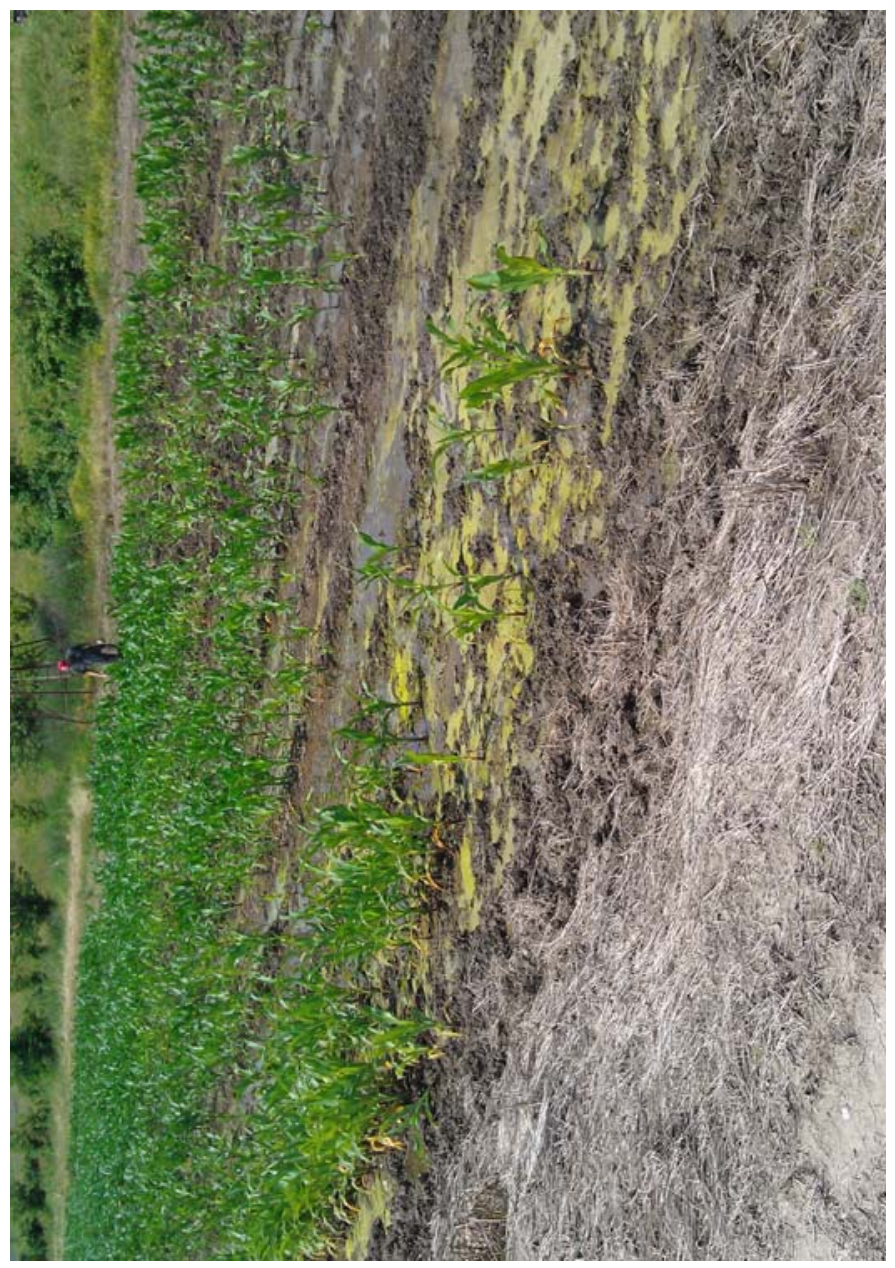

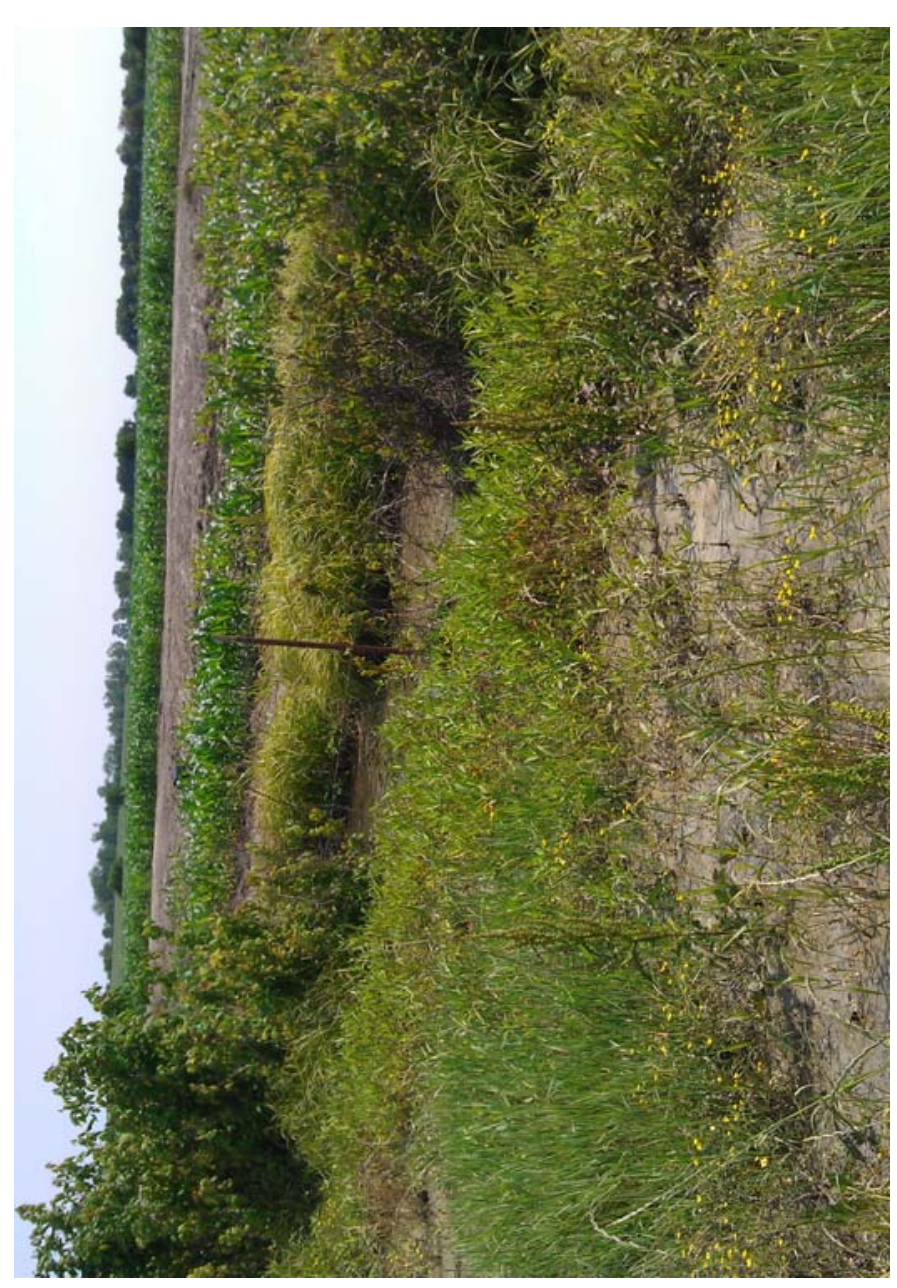

14

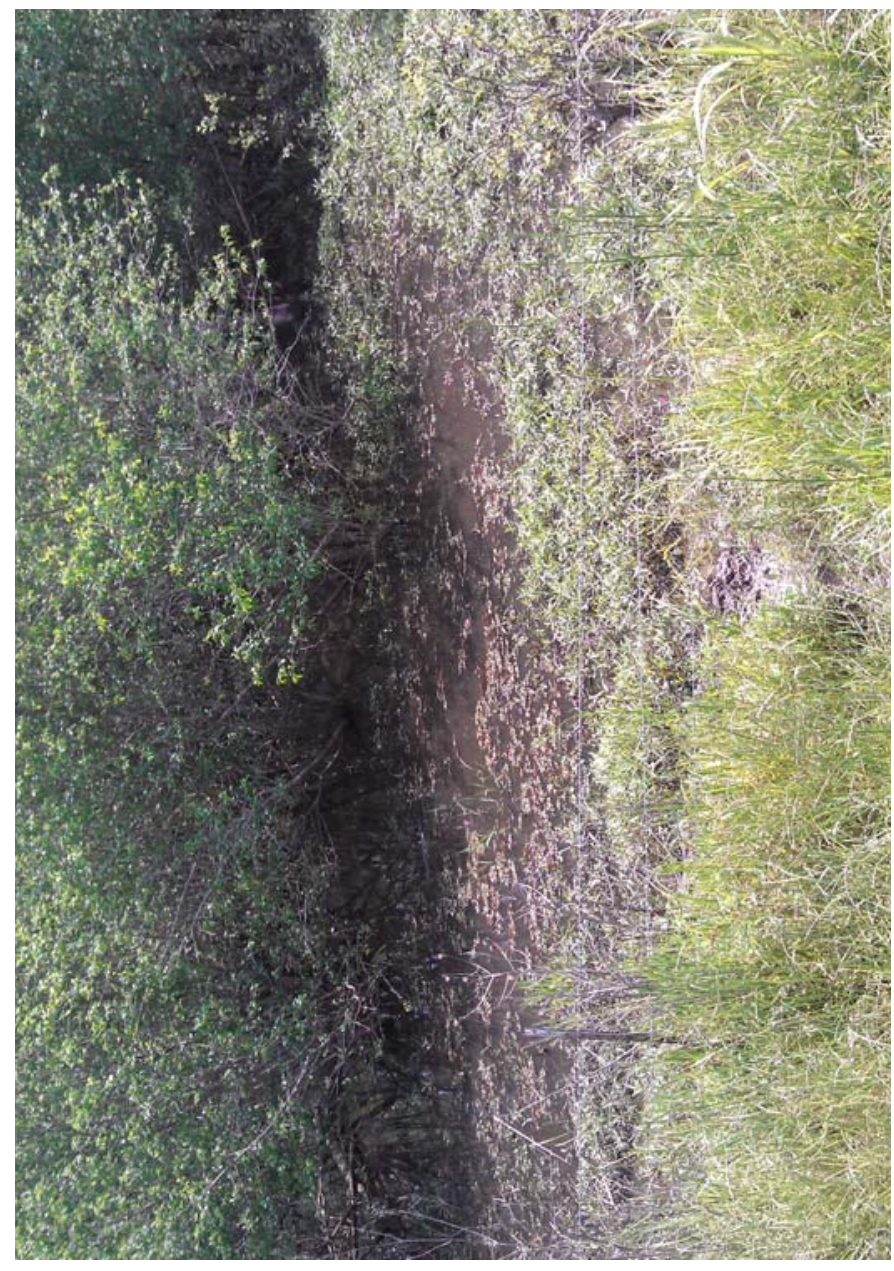

16 

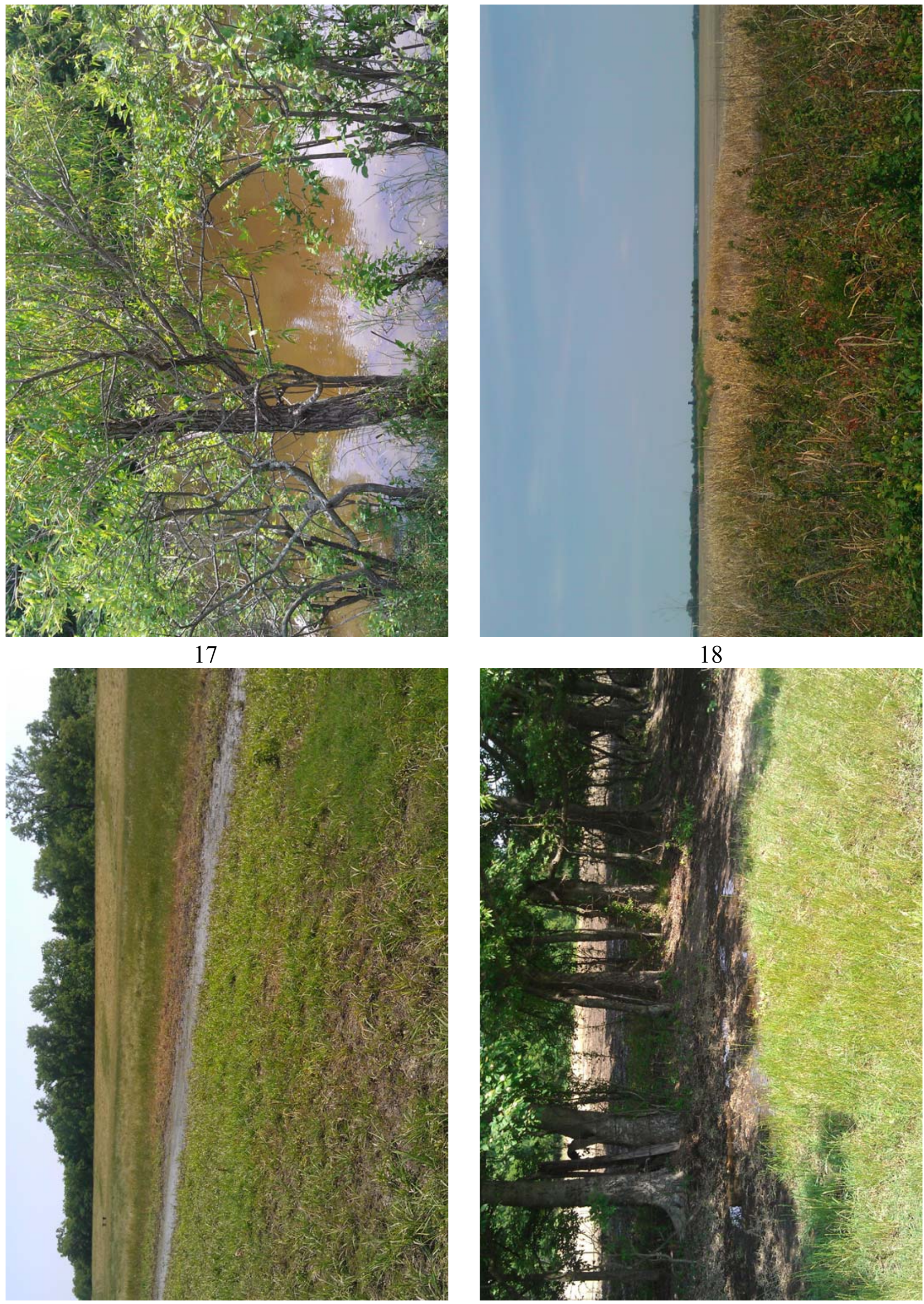


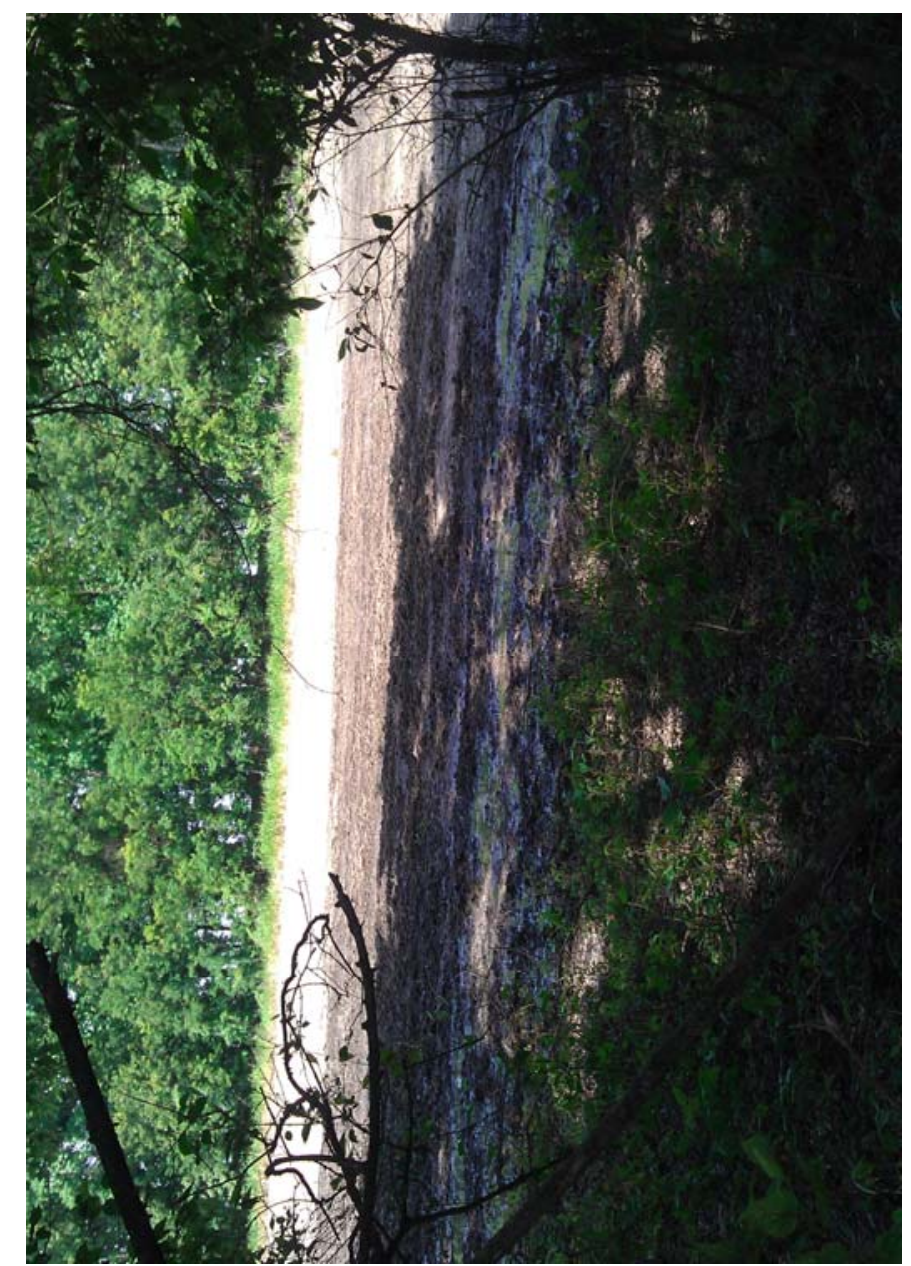

21

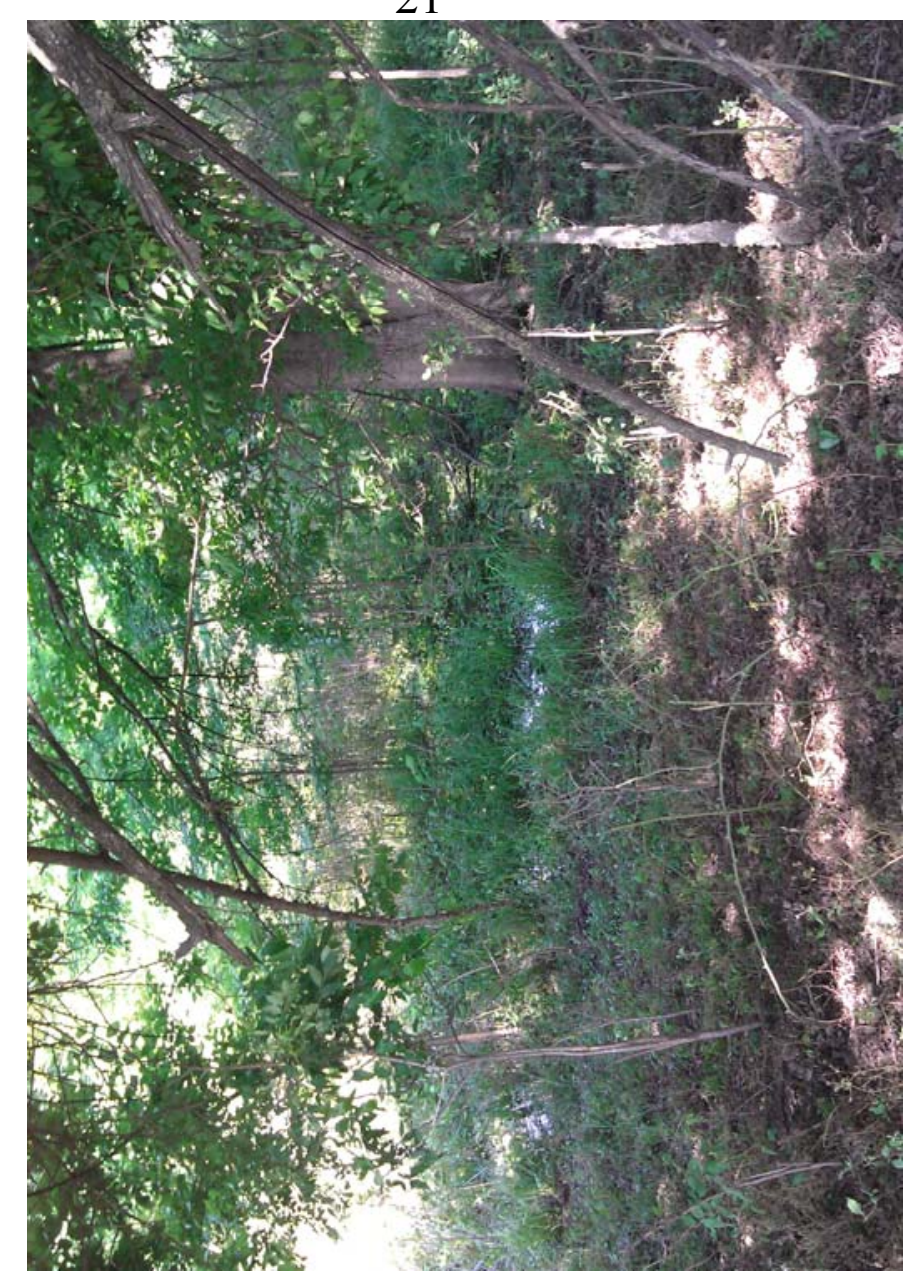

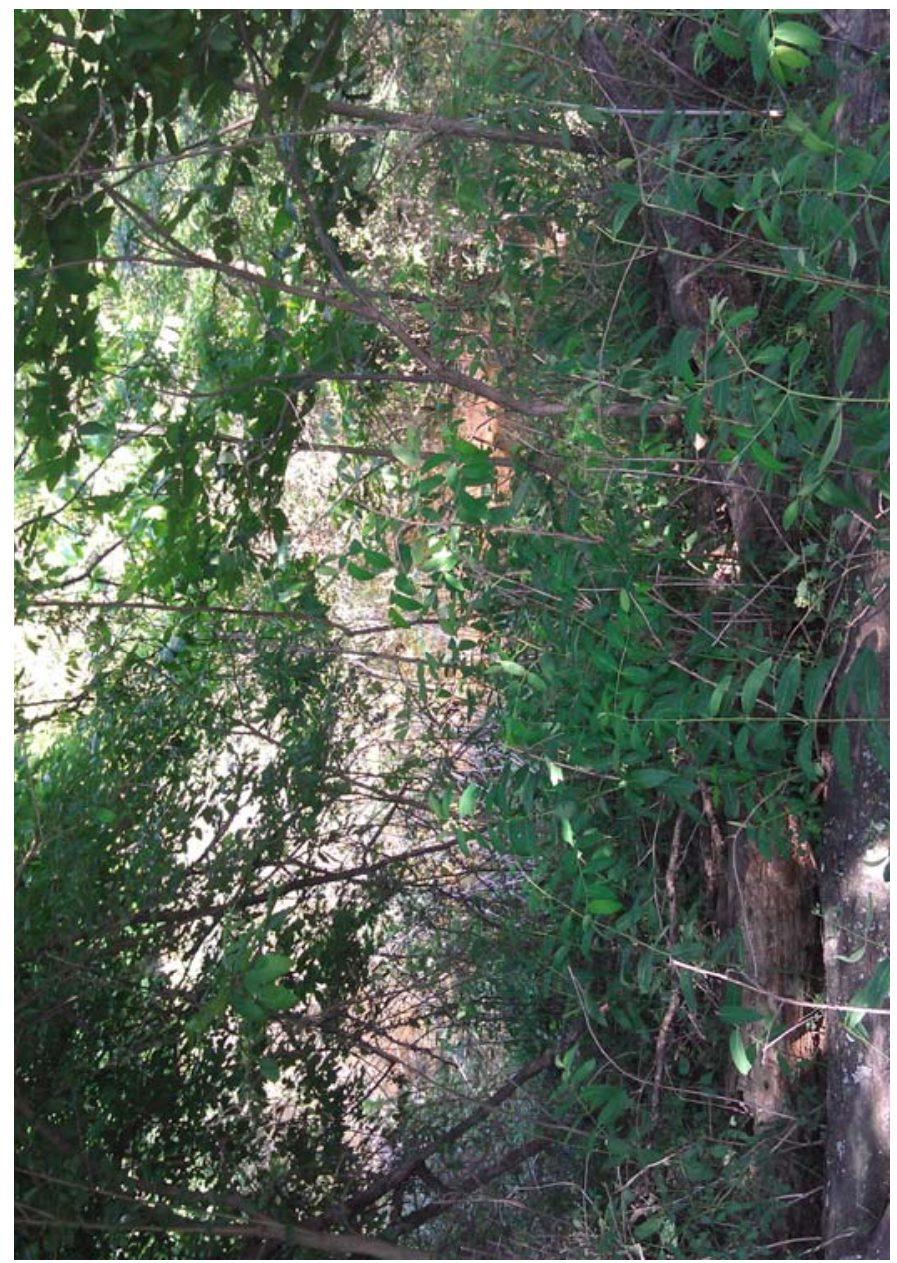

22

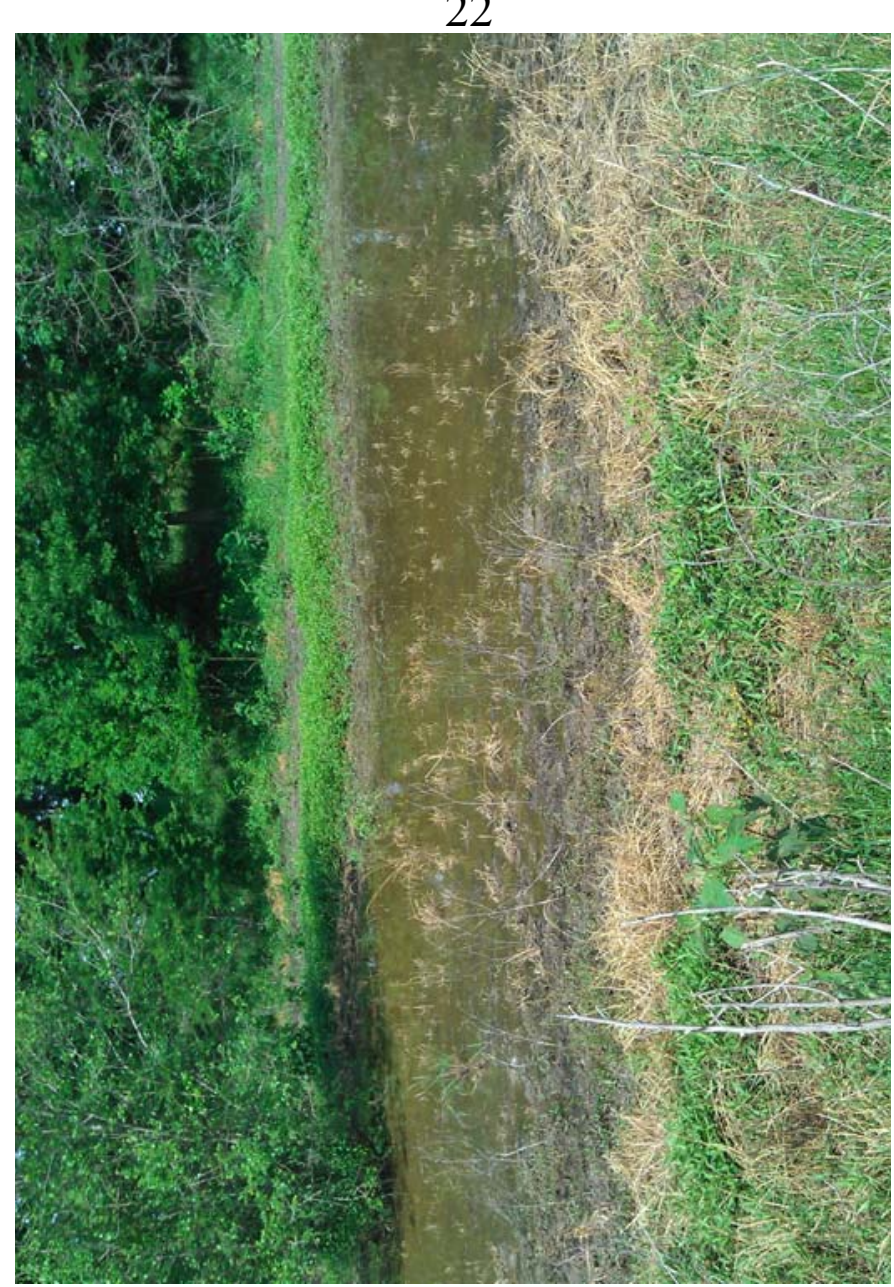




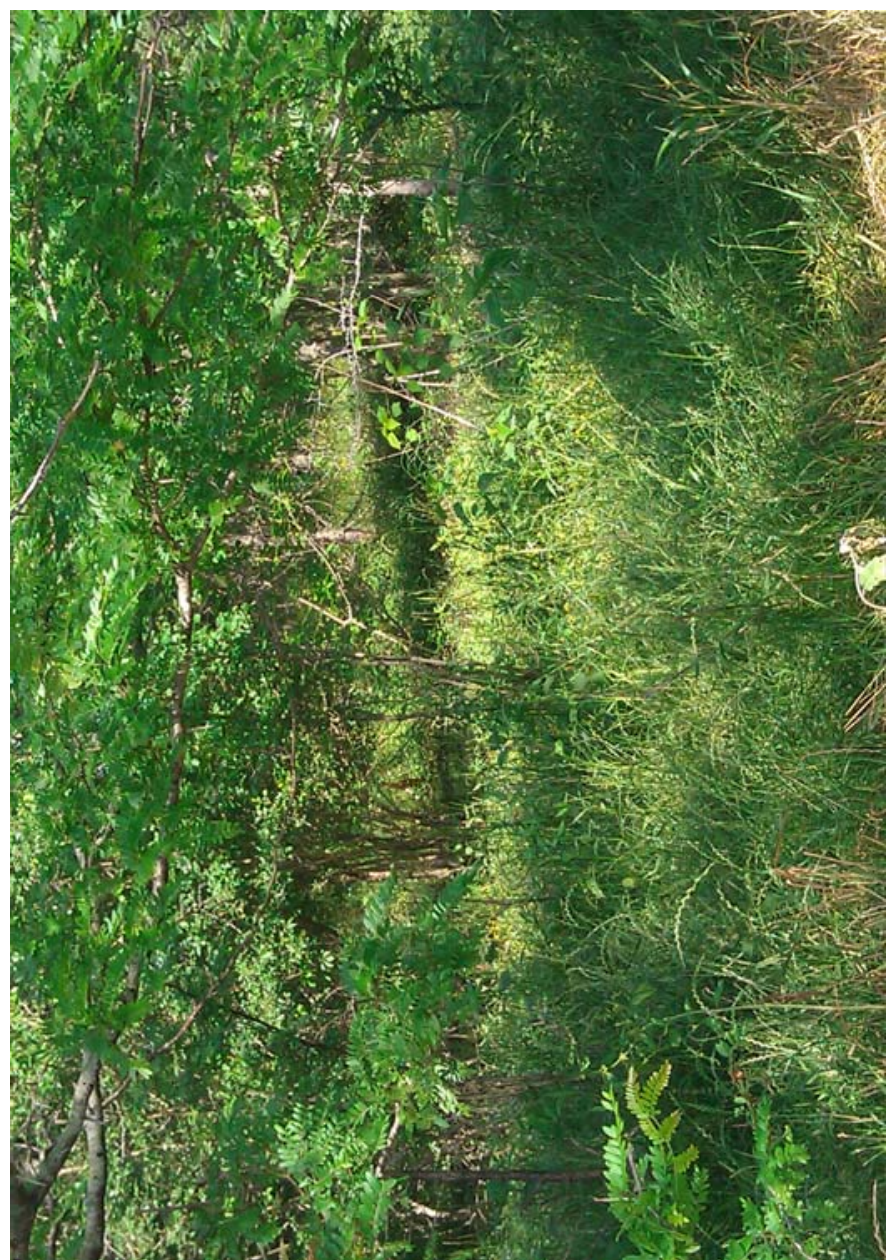

25

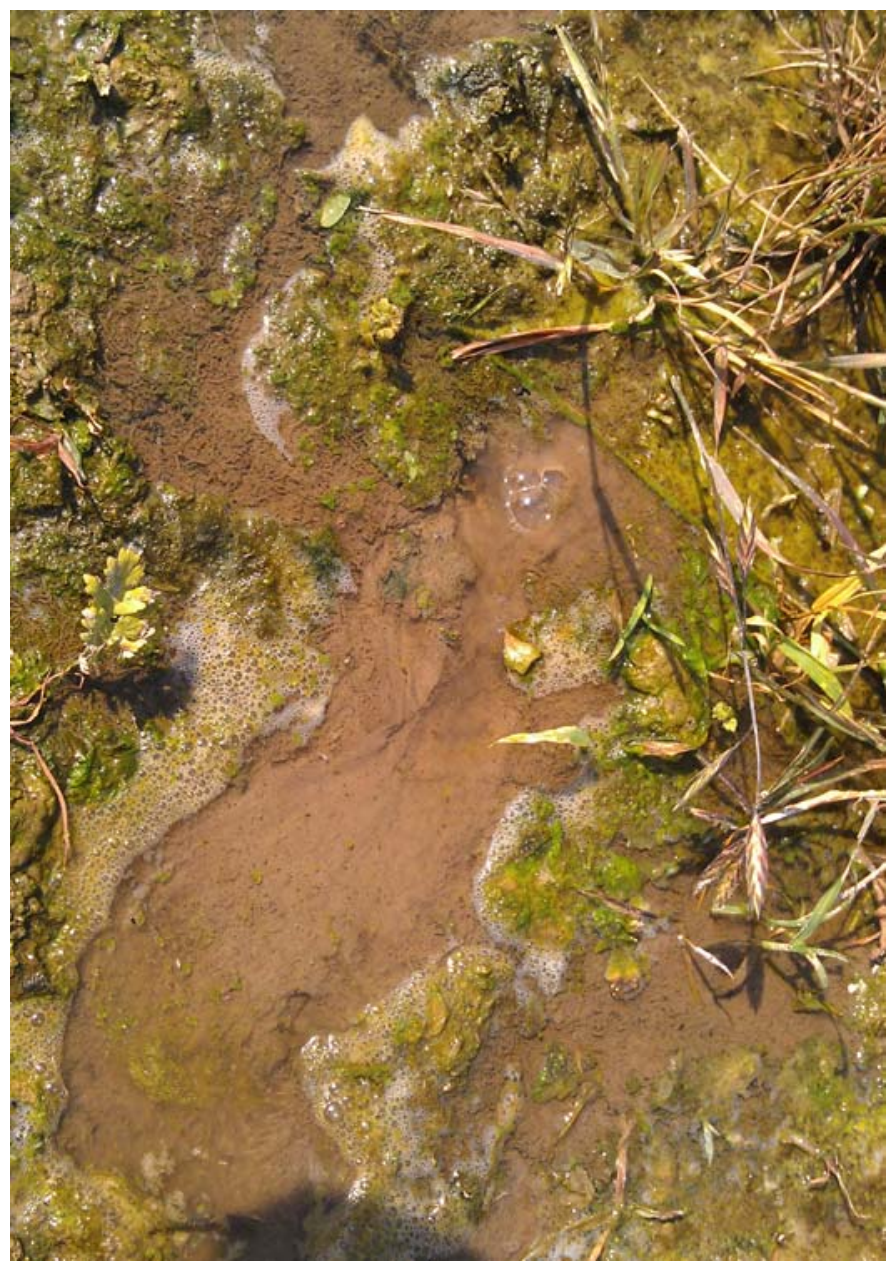

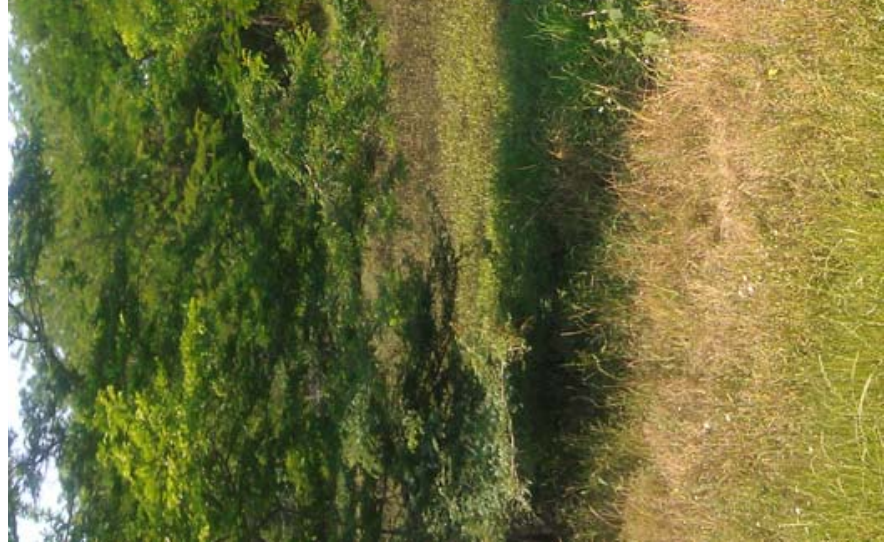

26

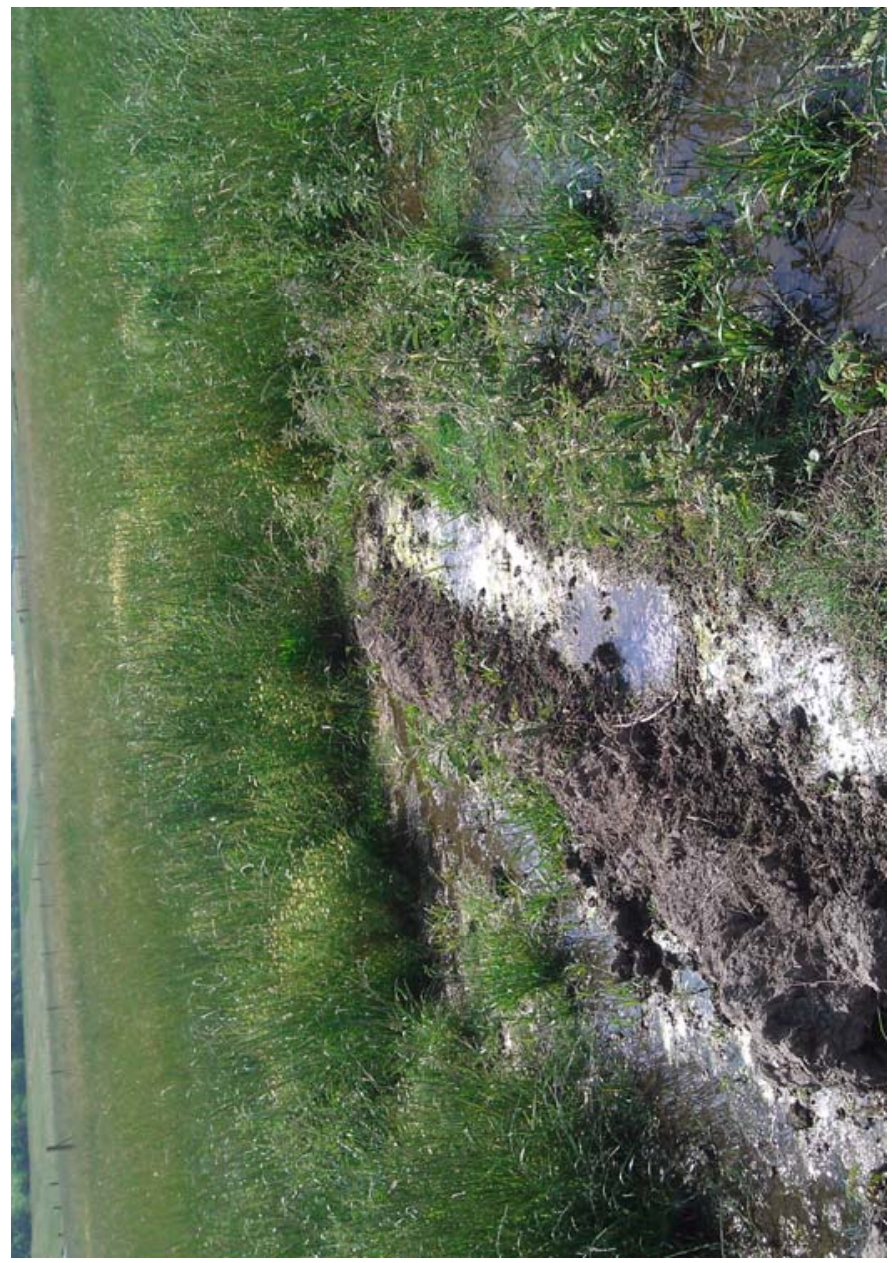




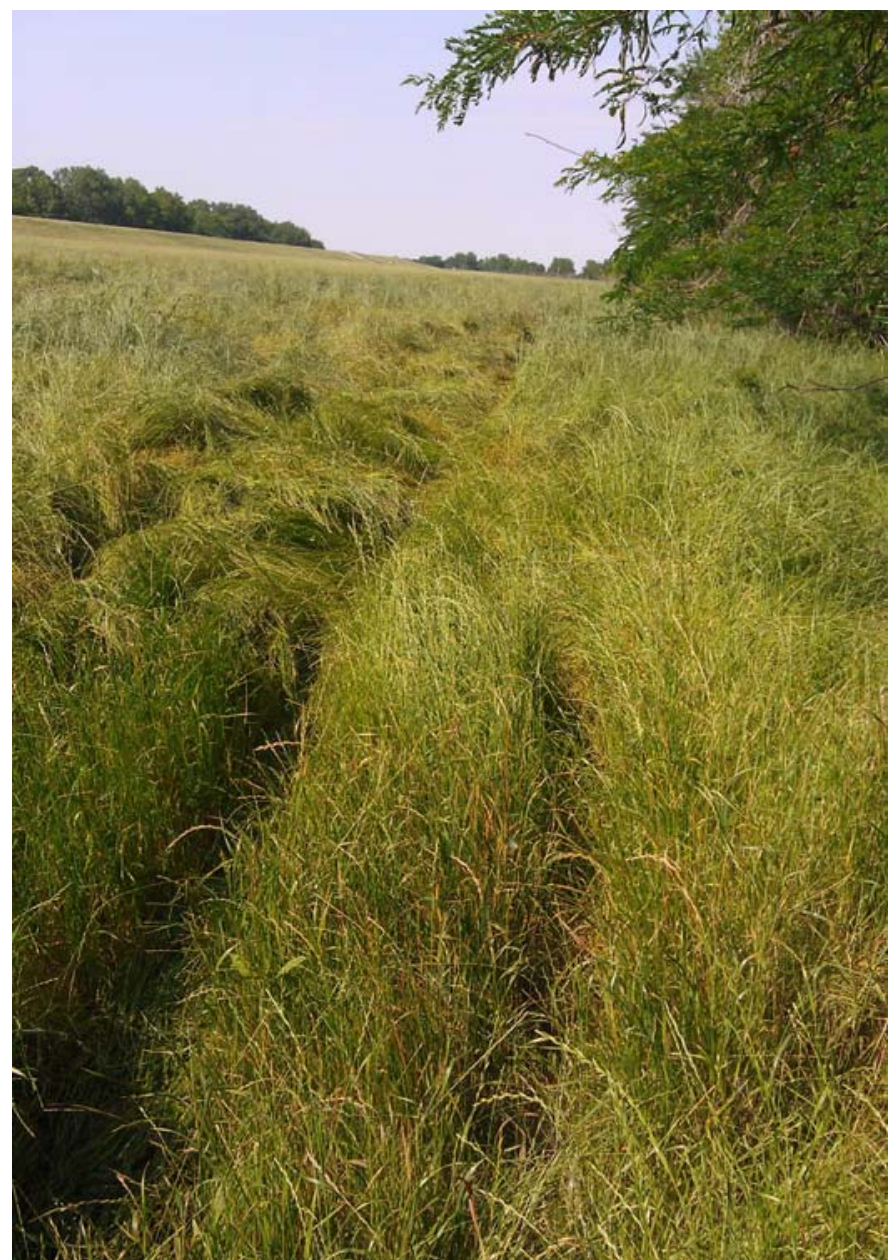

29

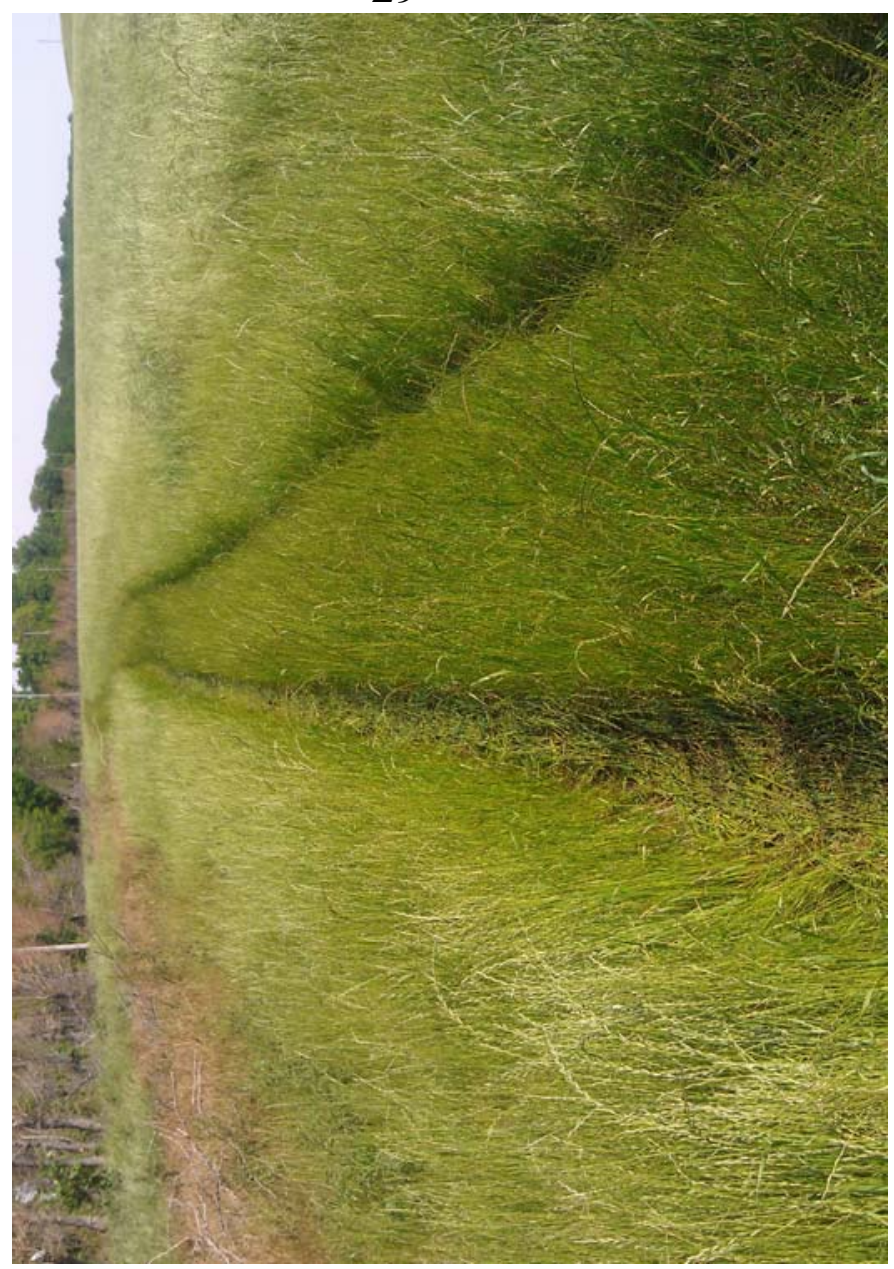

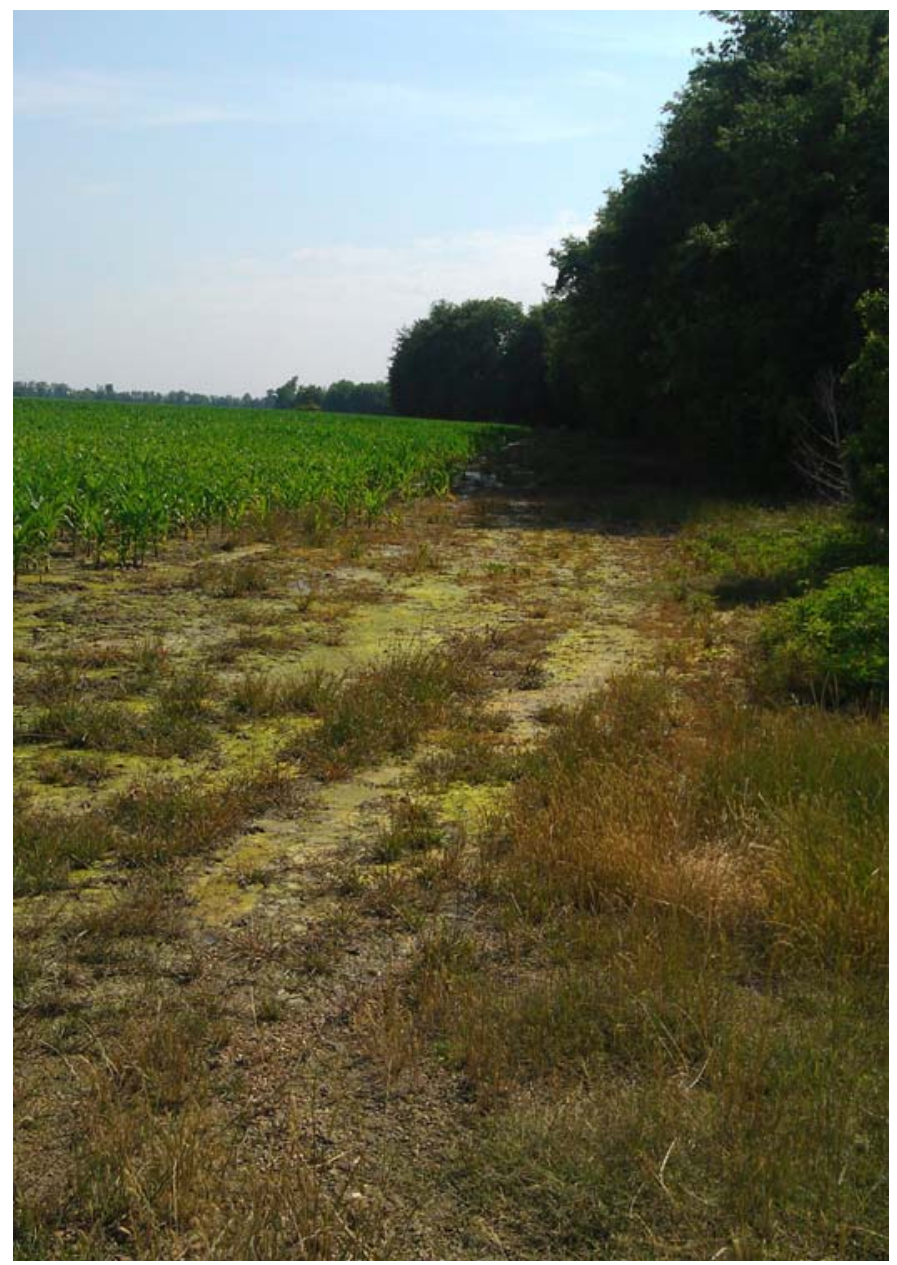

30

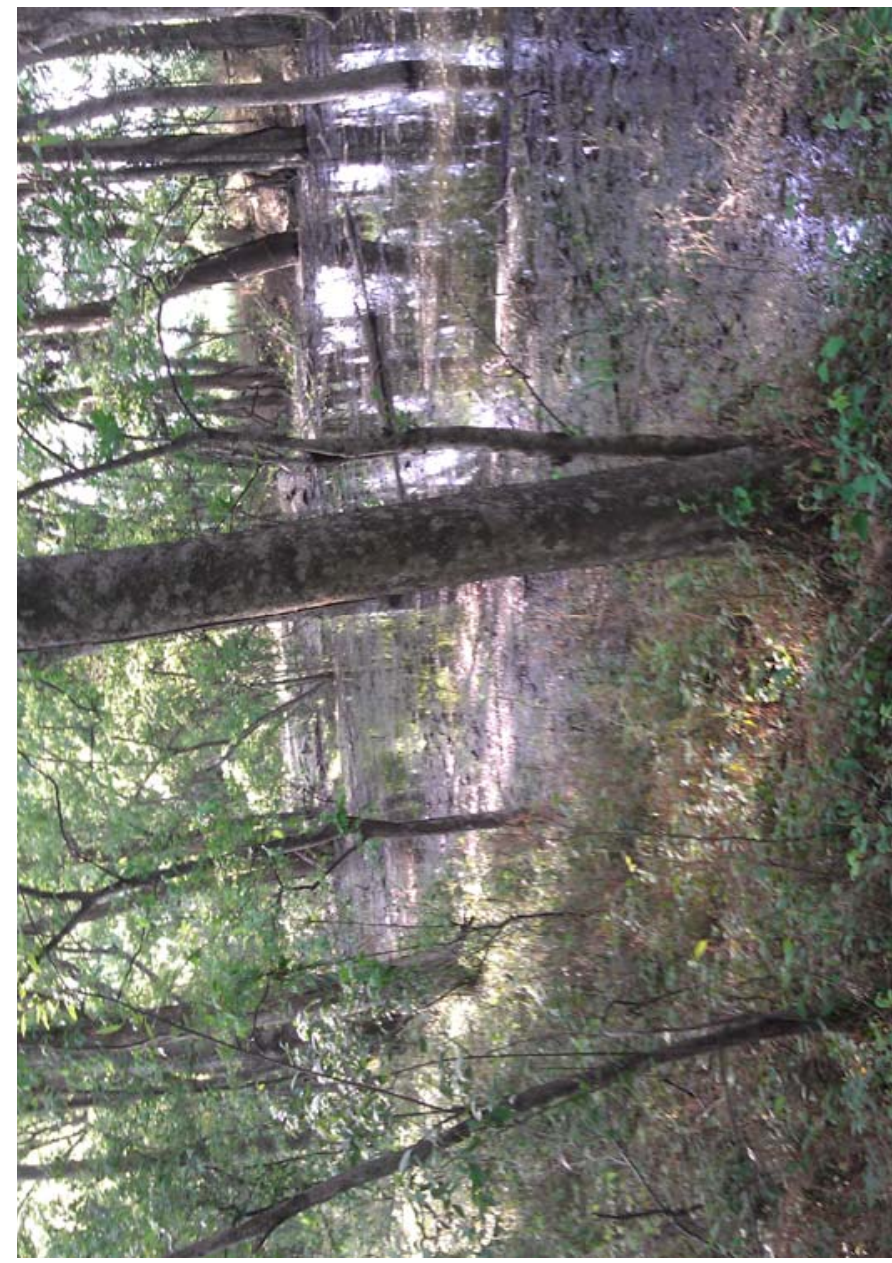




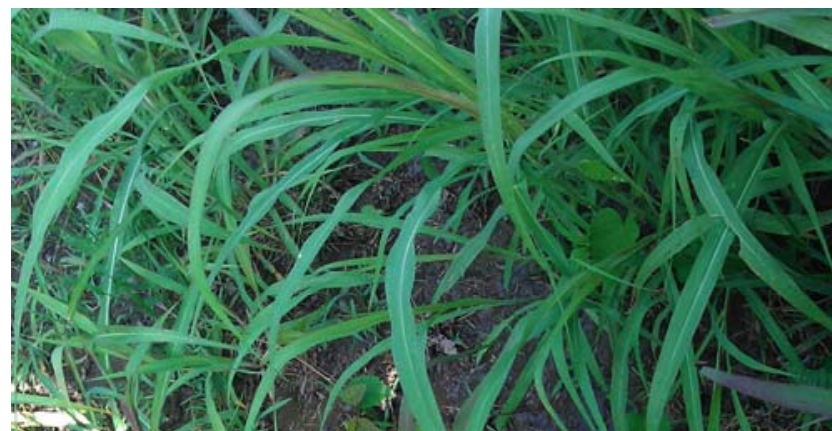

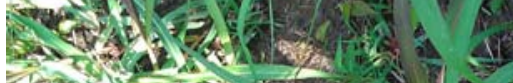
- cols
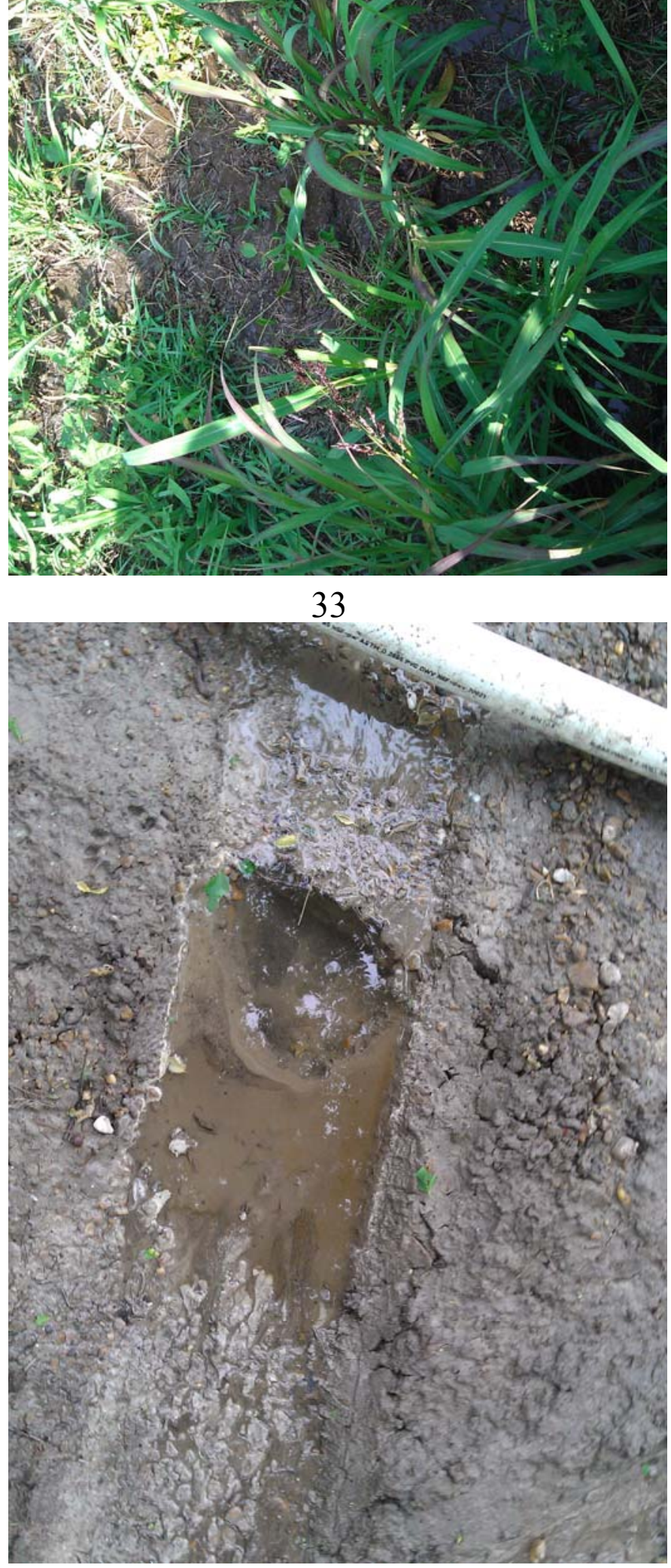

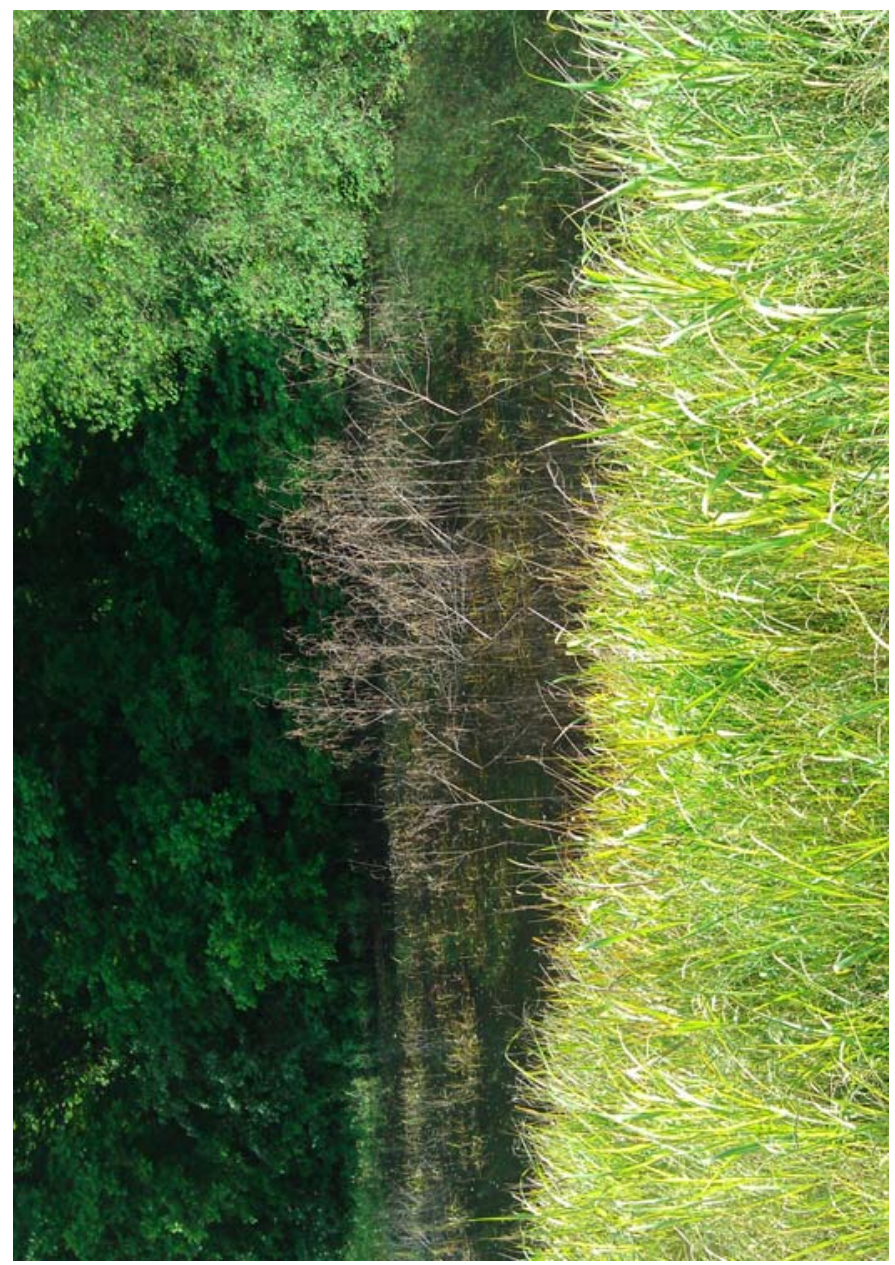

34

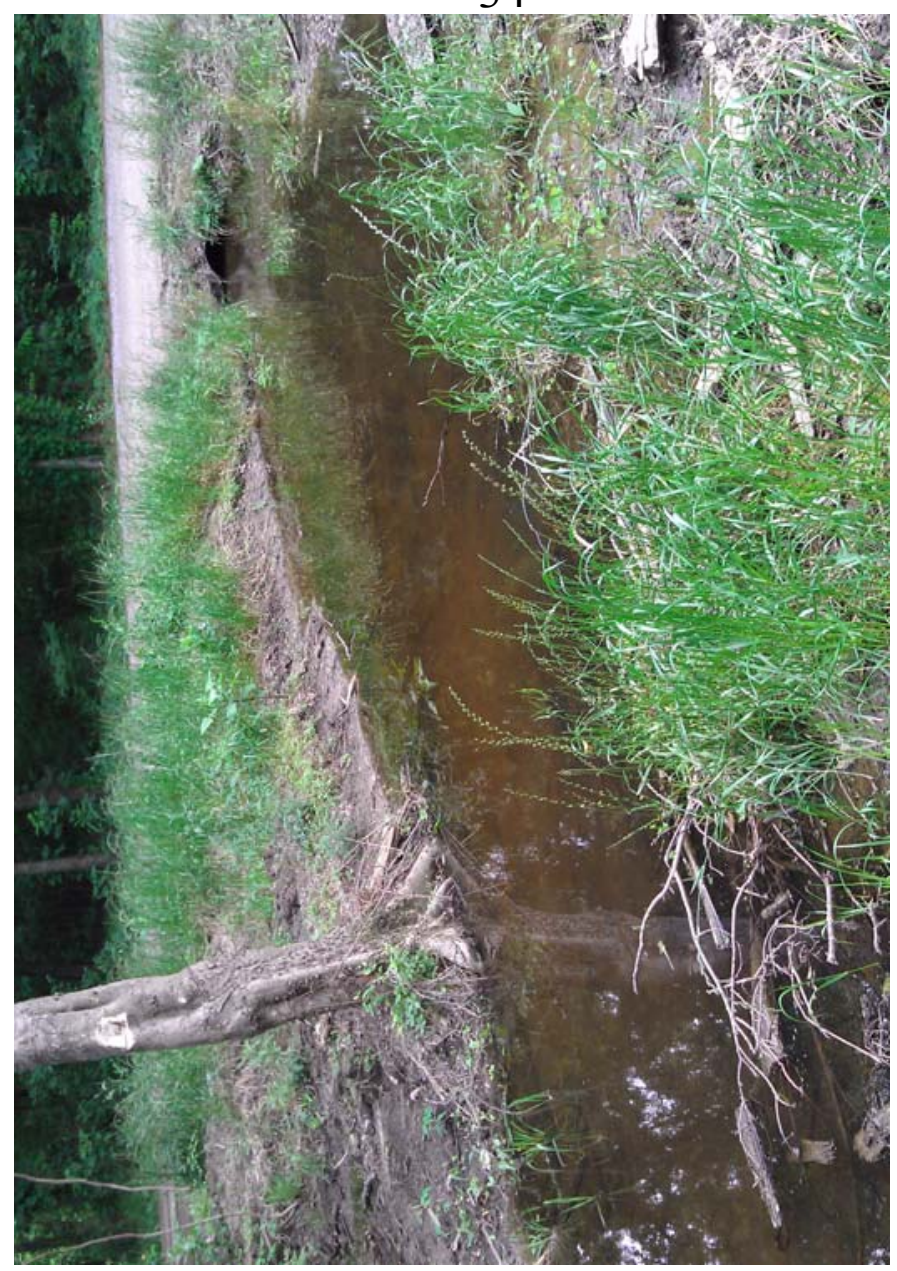




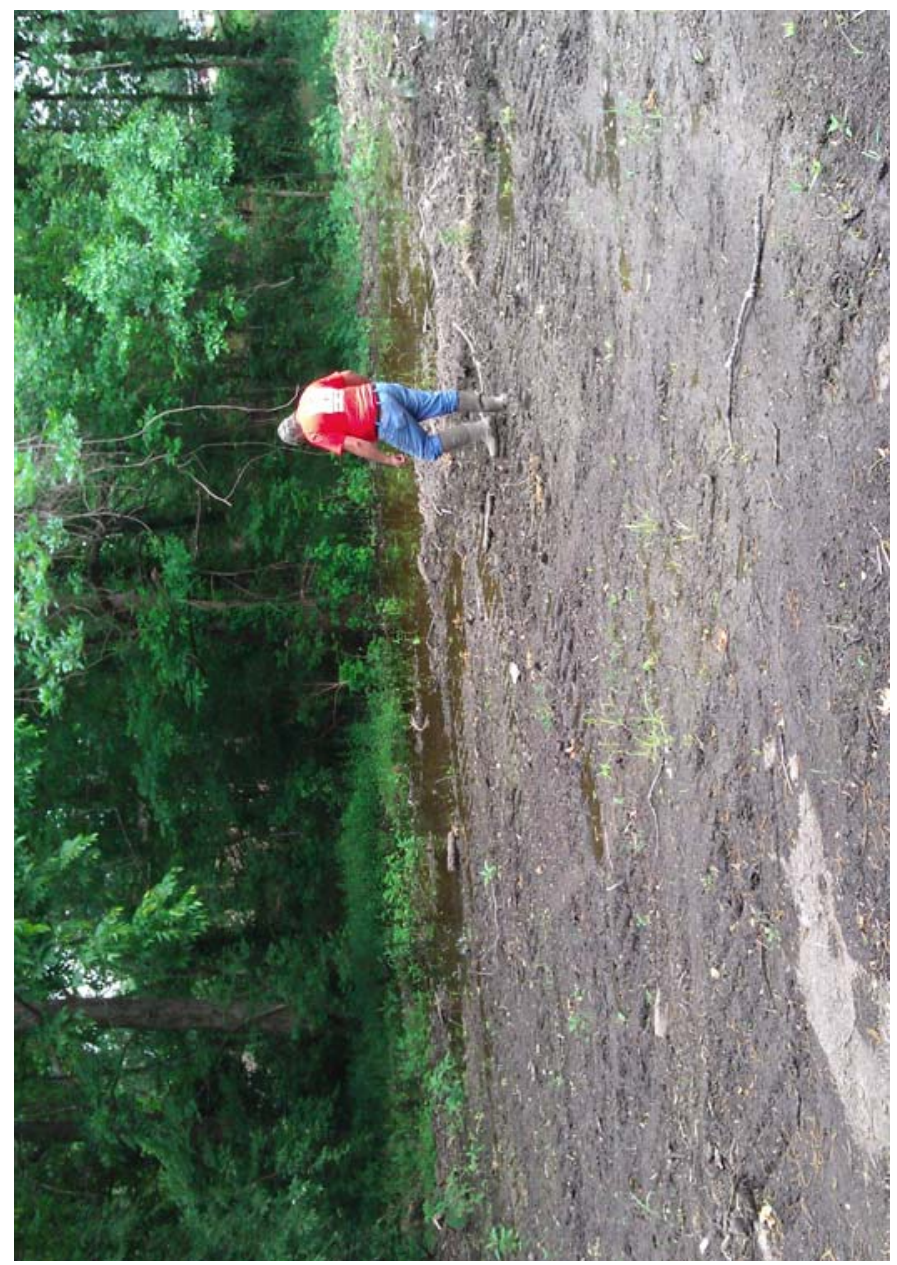

\section{7}

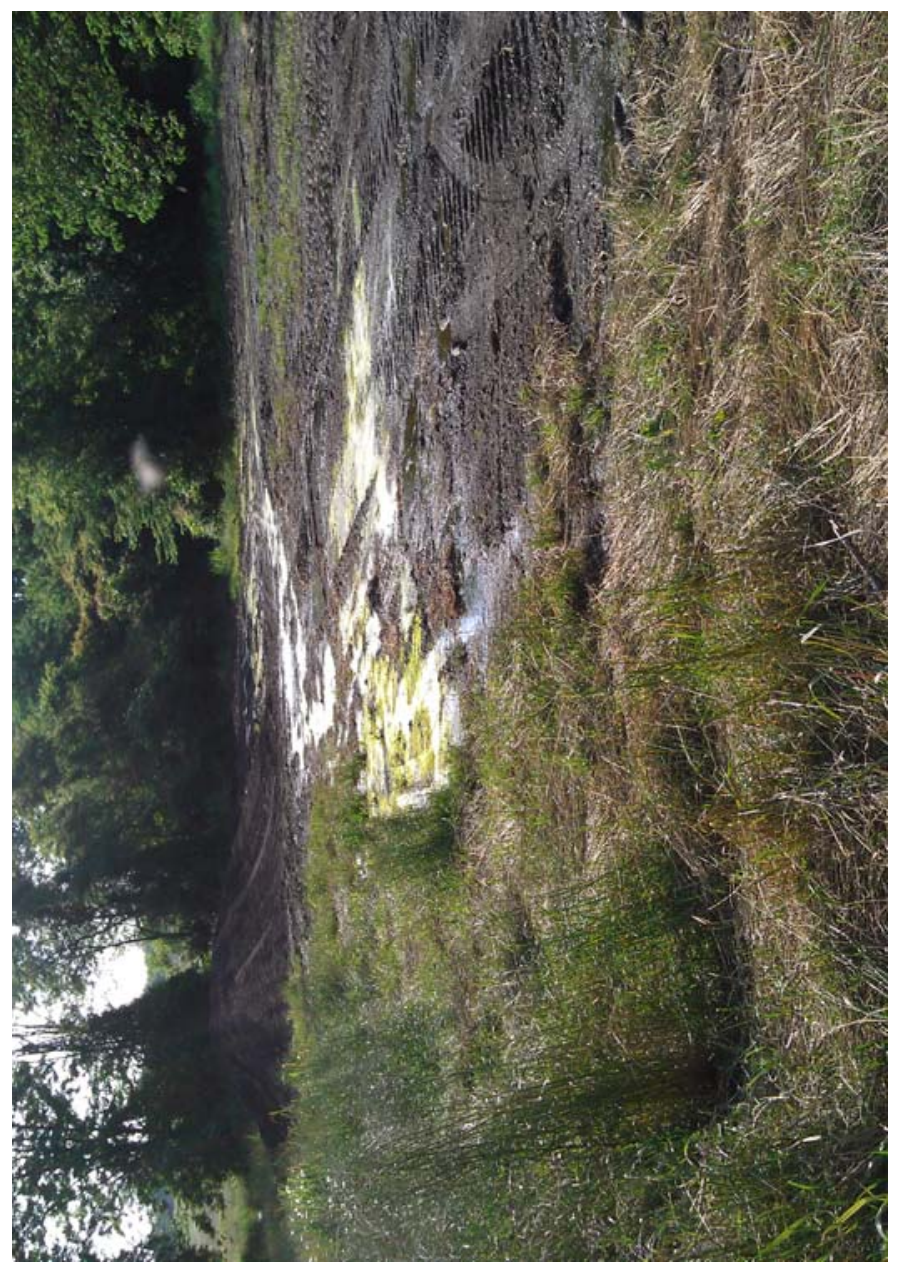

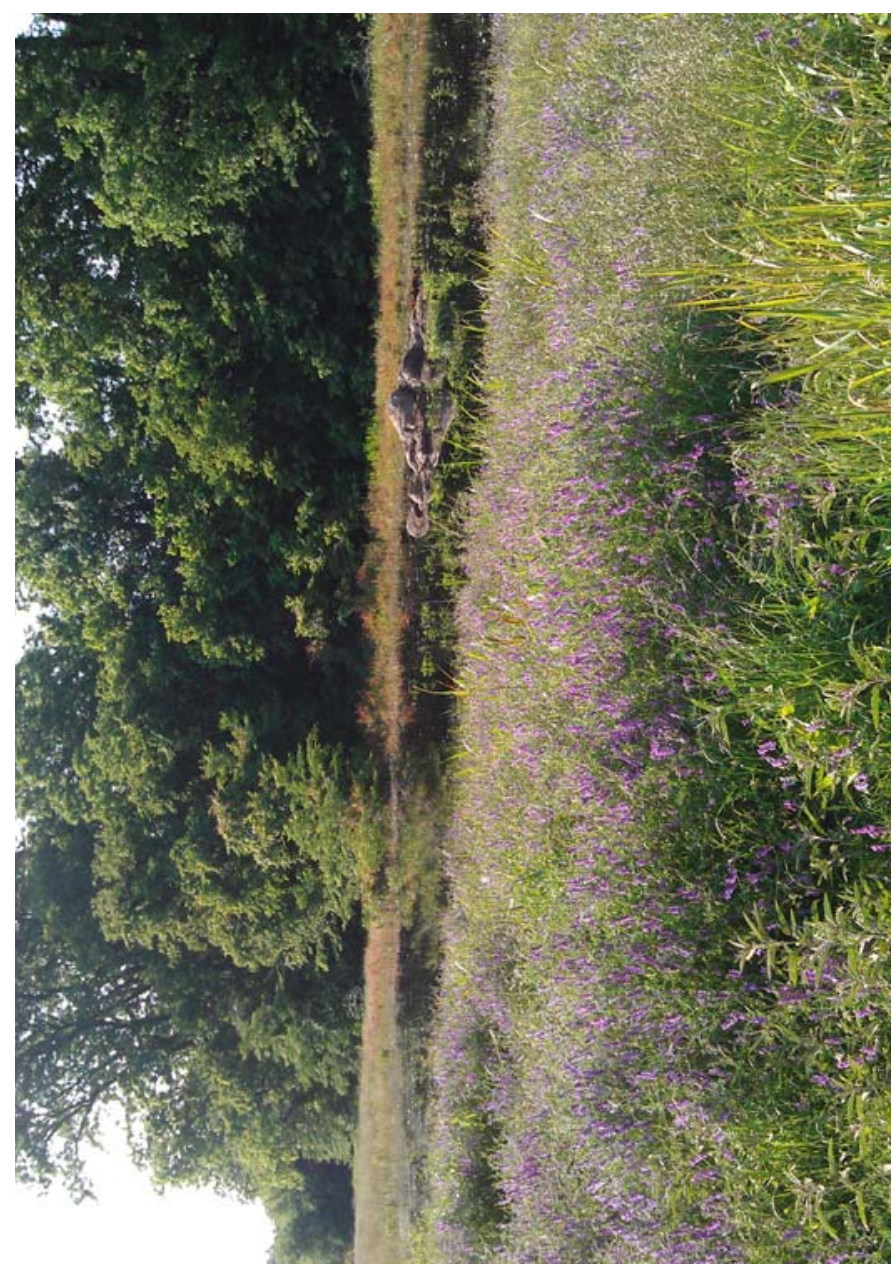

38

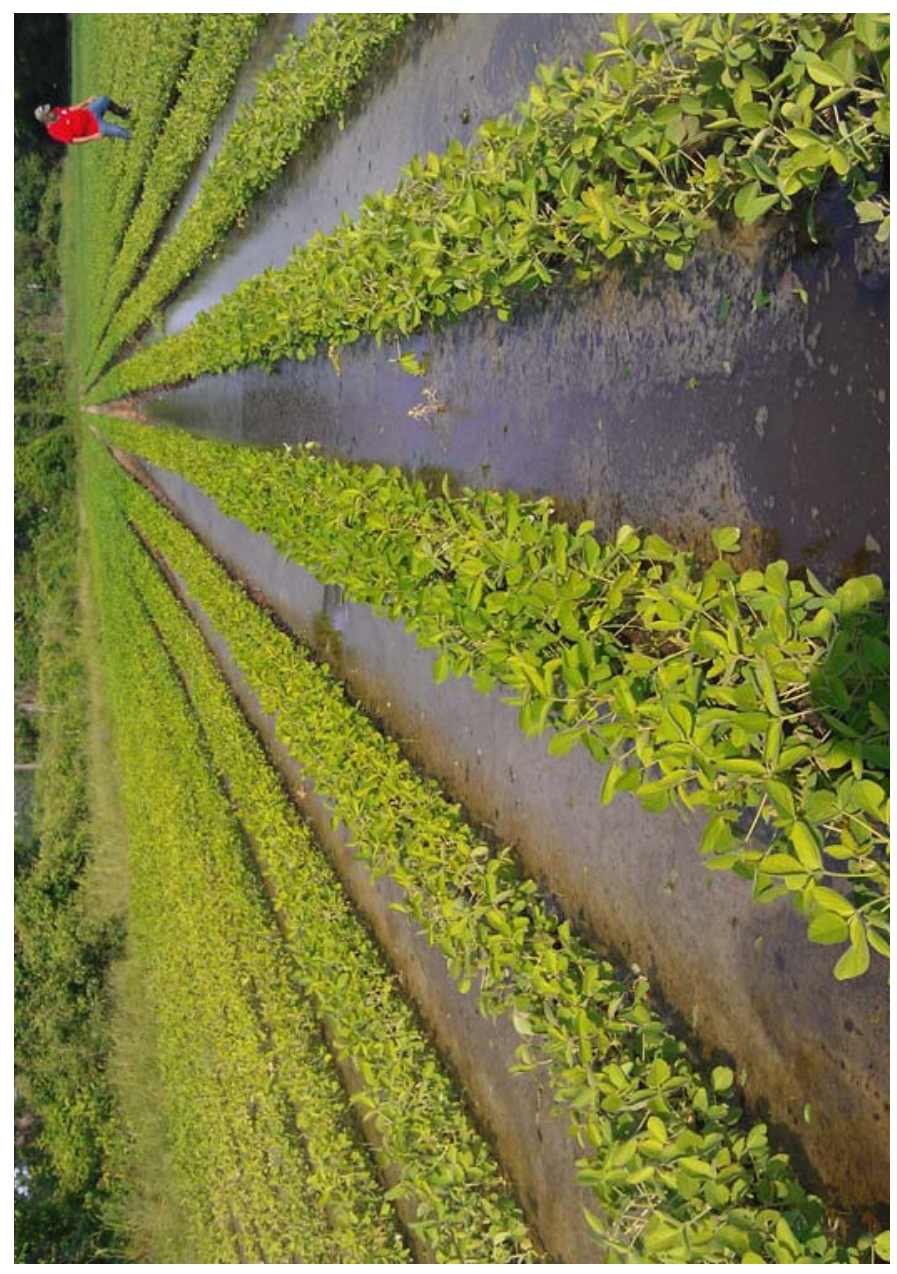



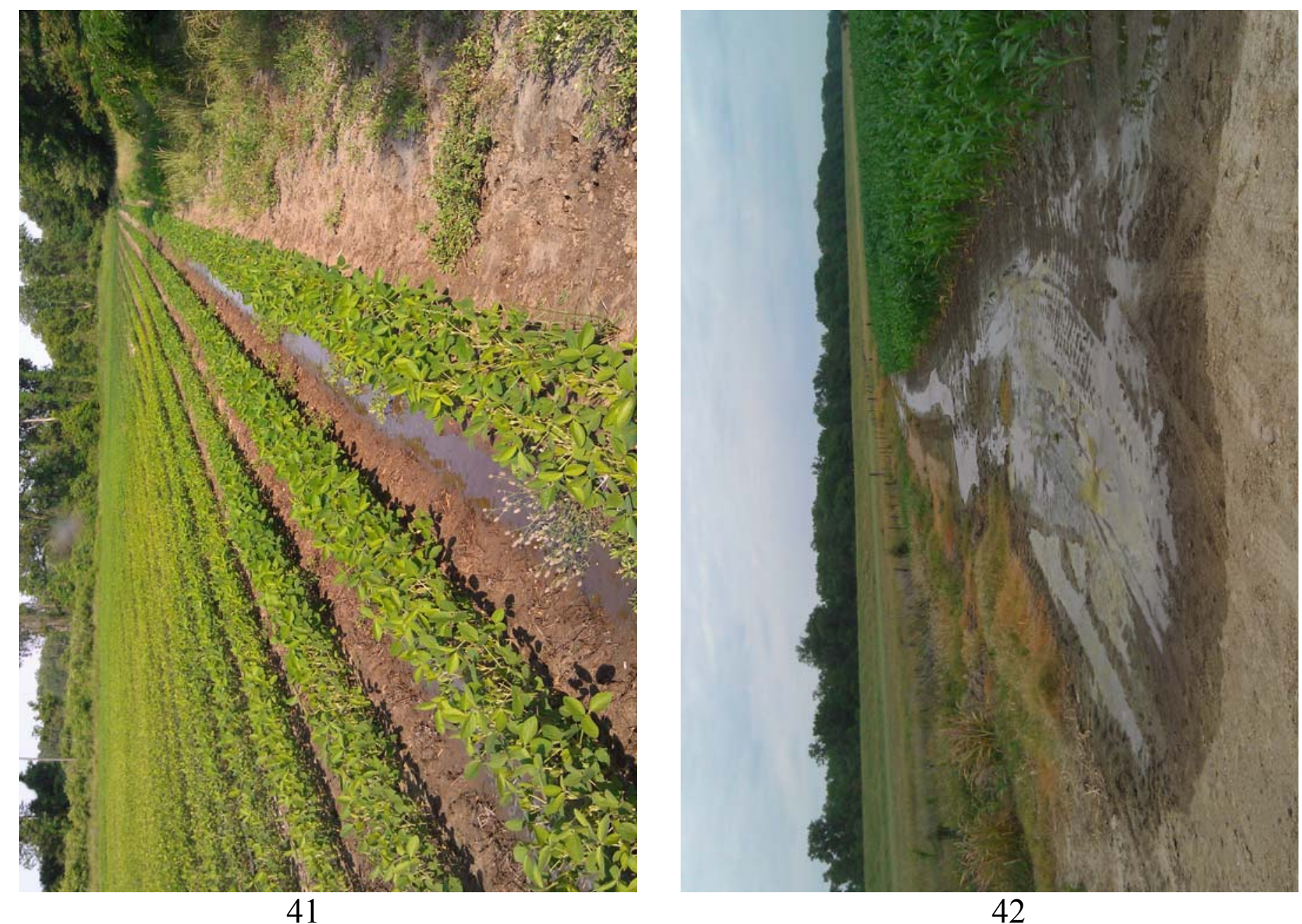

42

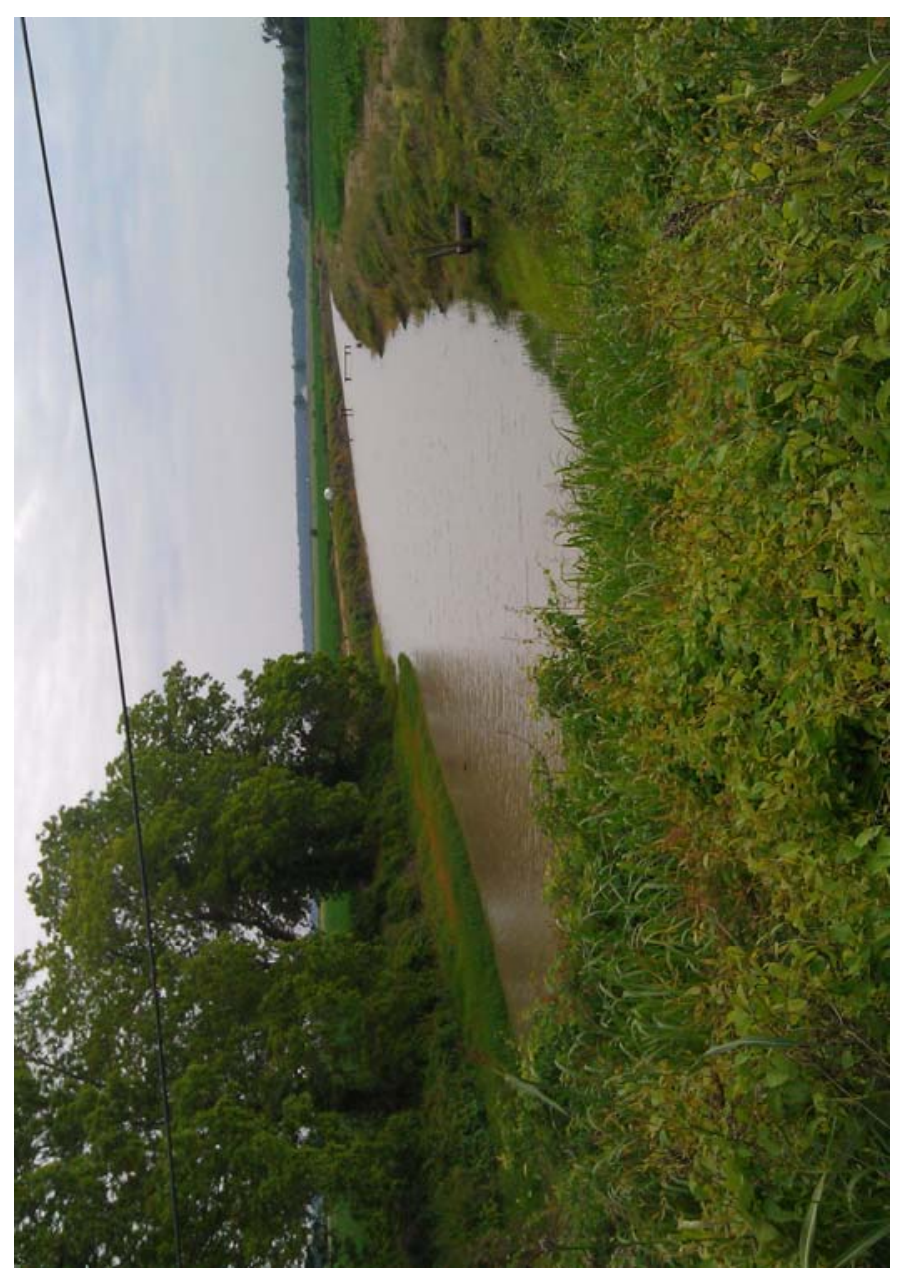




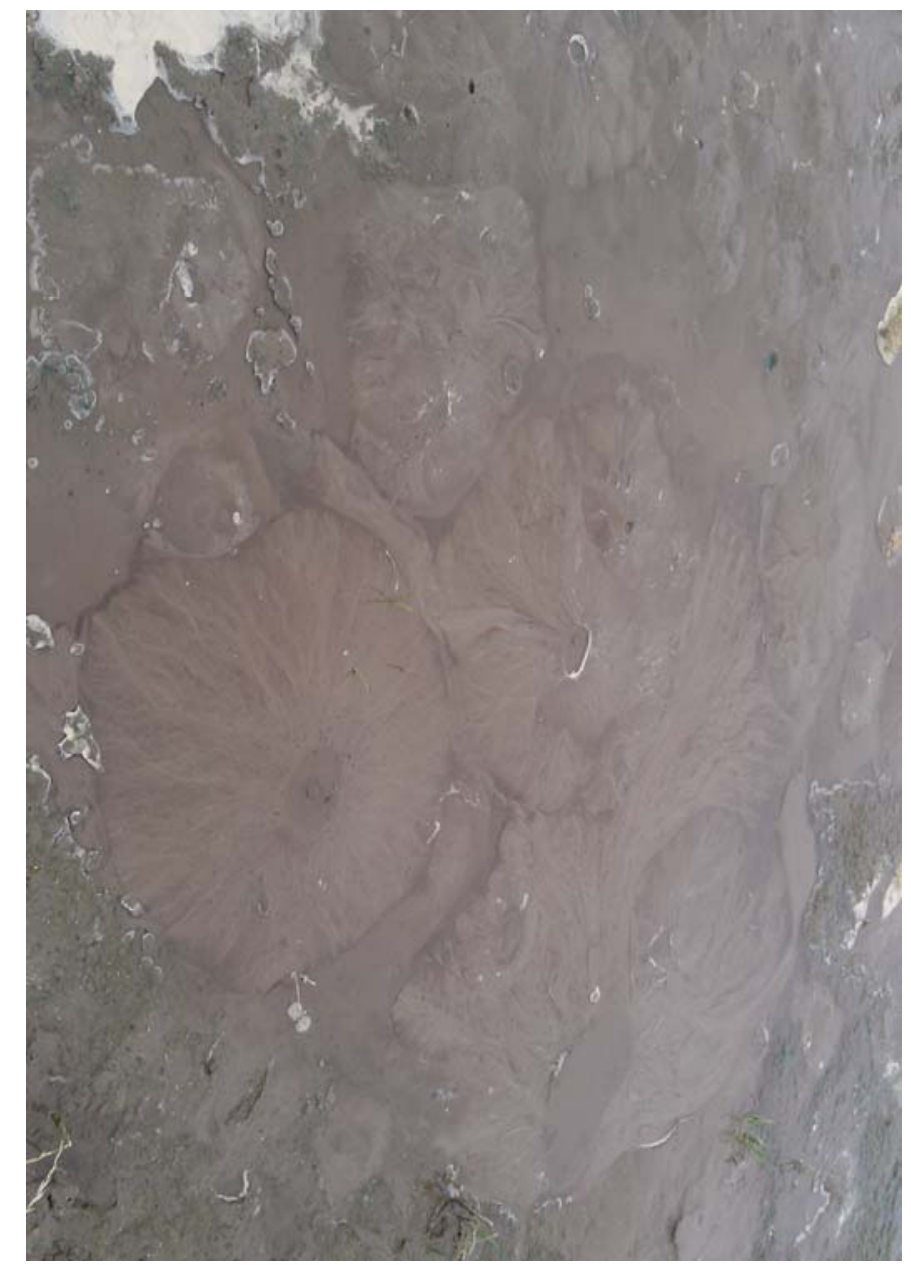

45

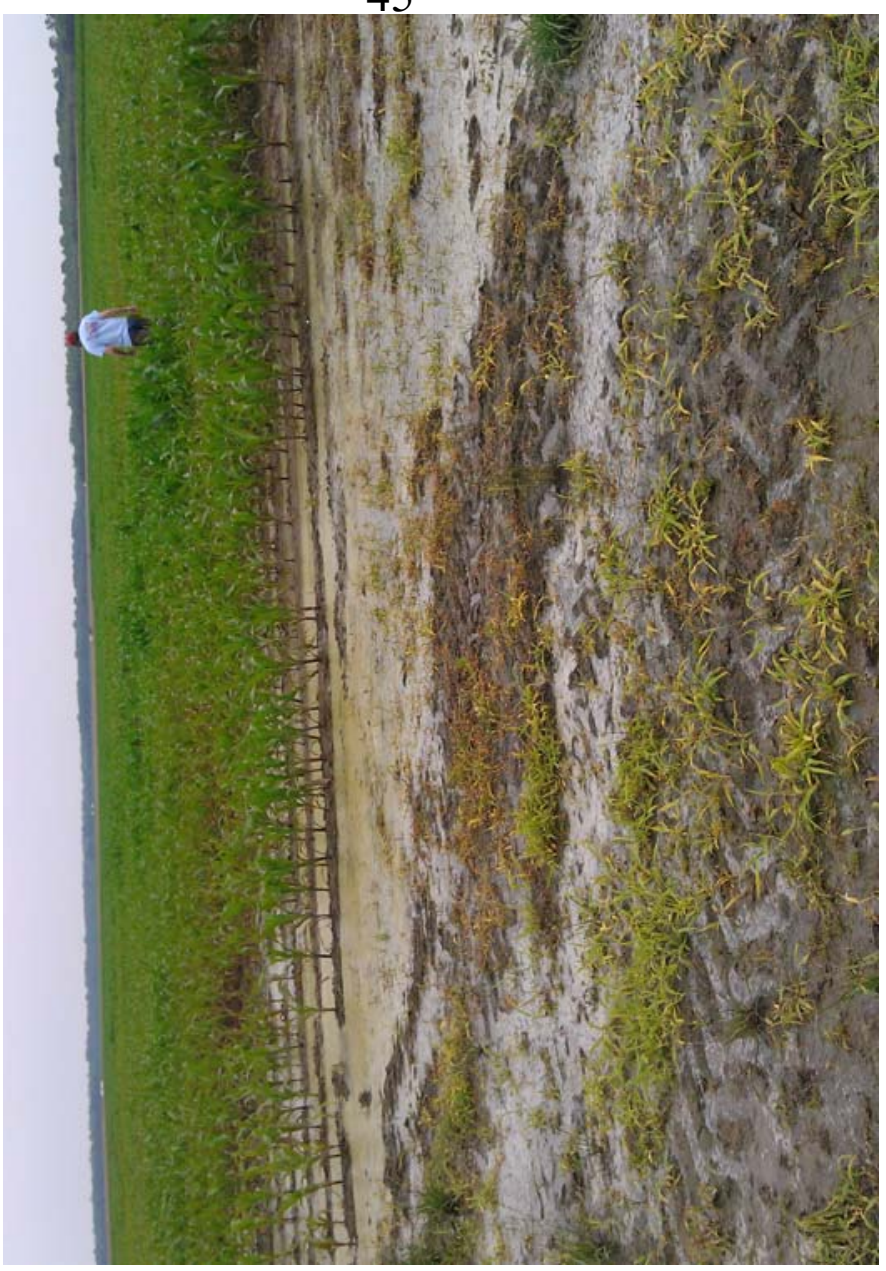

47

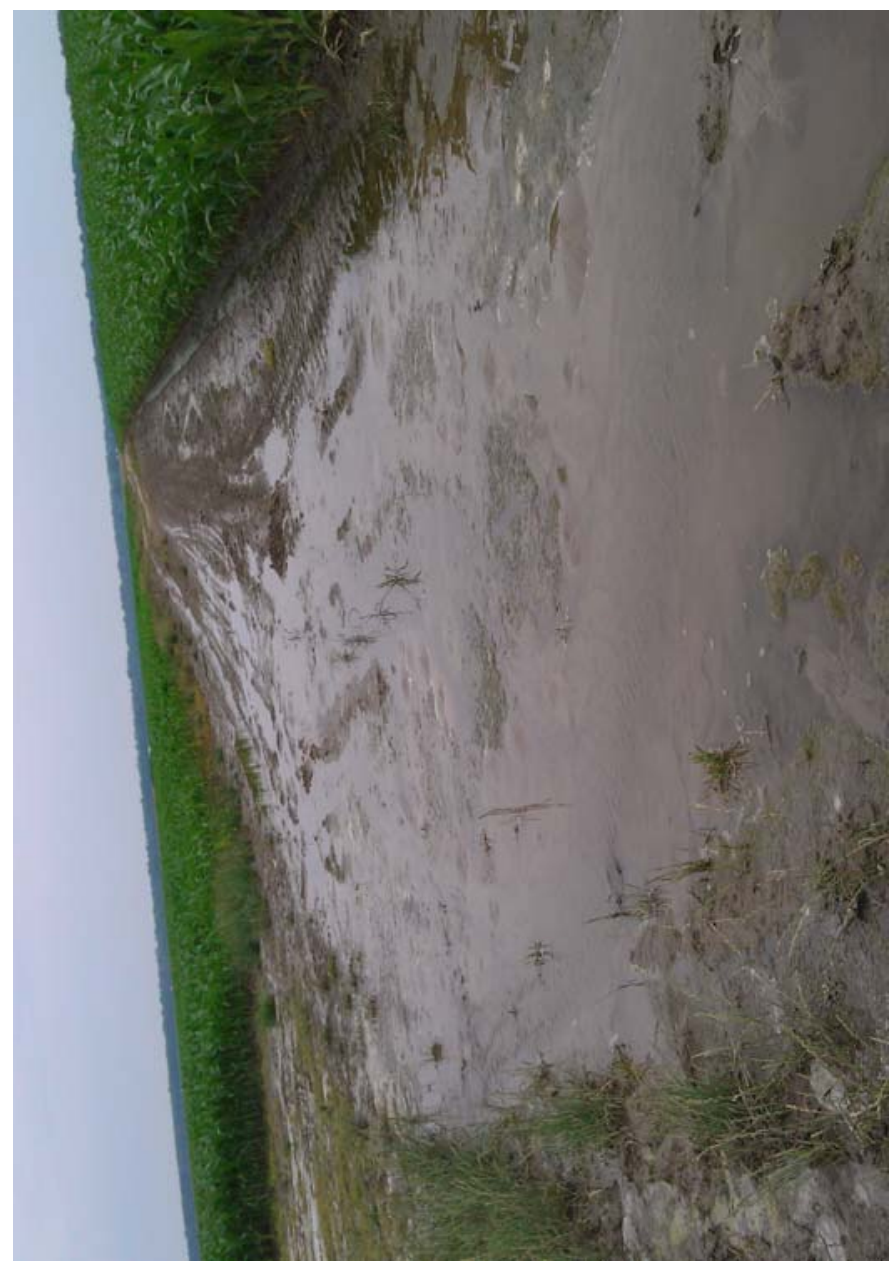

46

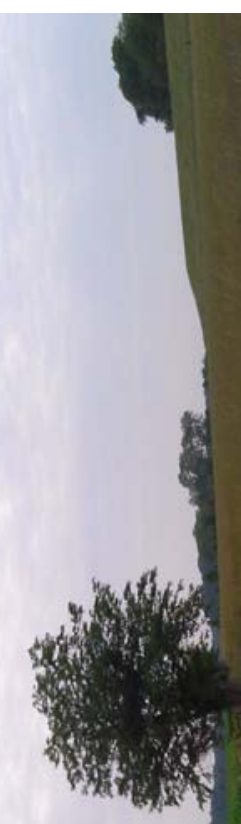




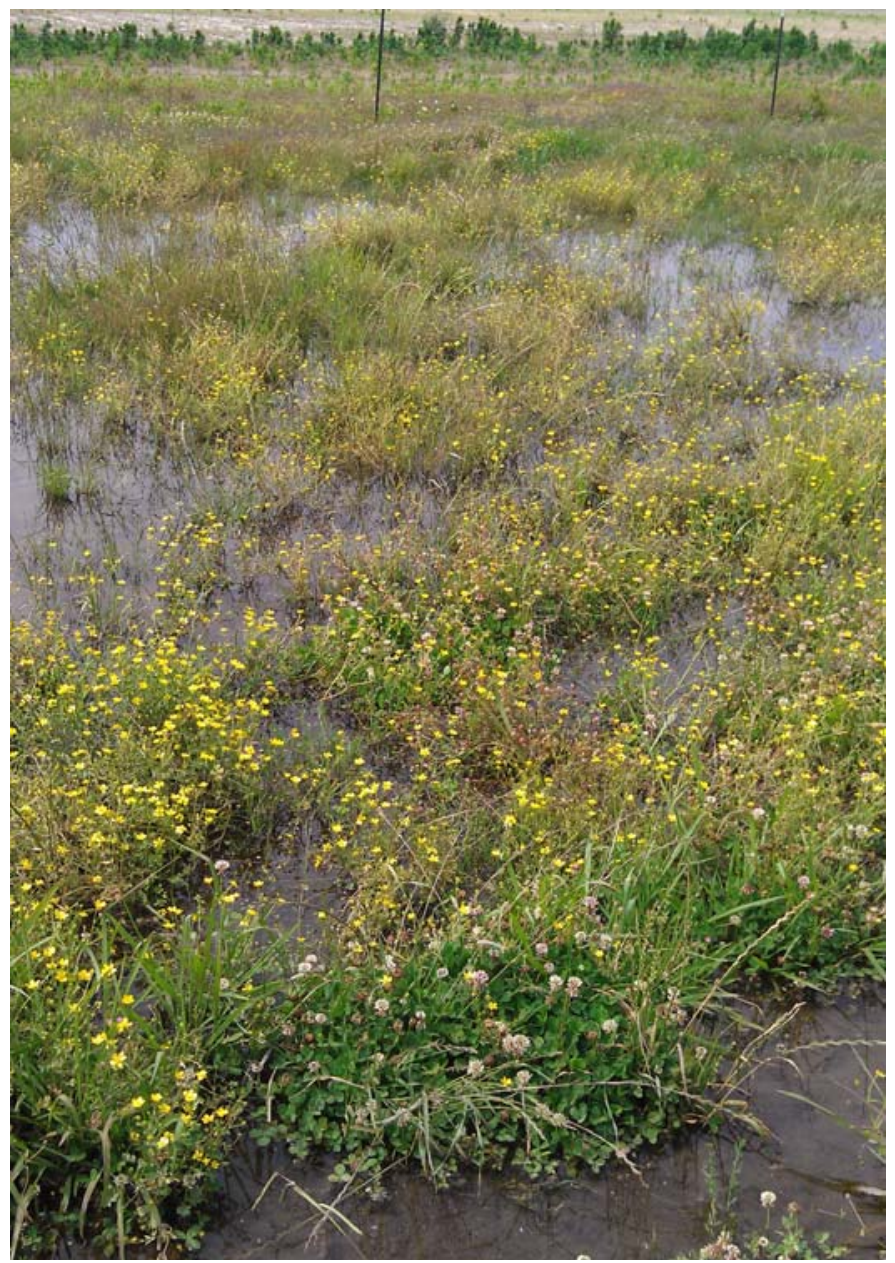

49

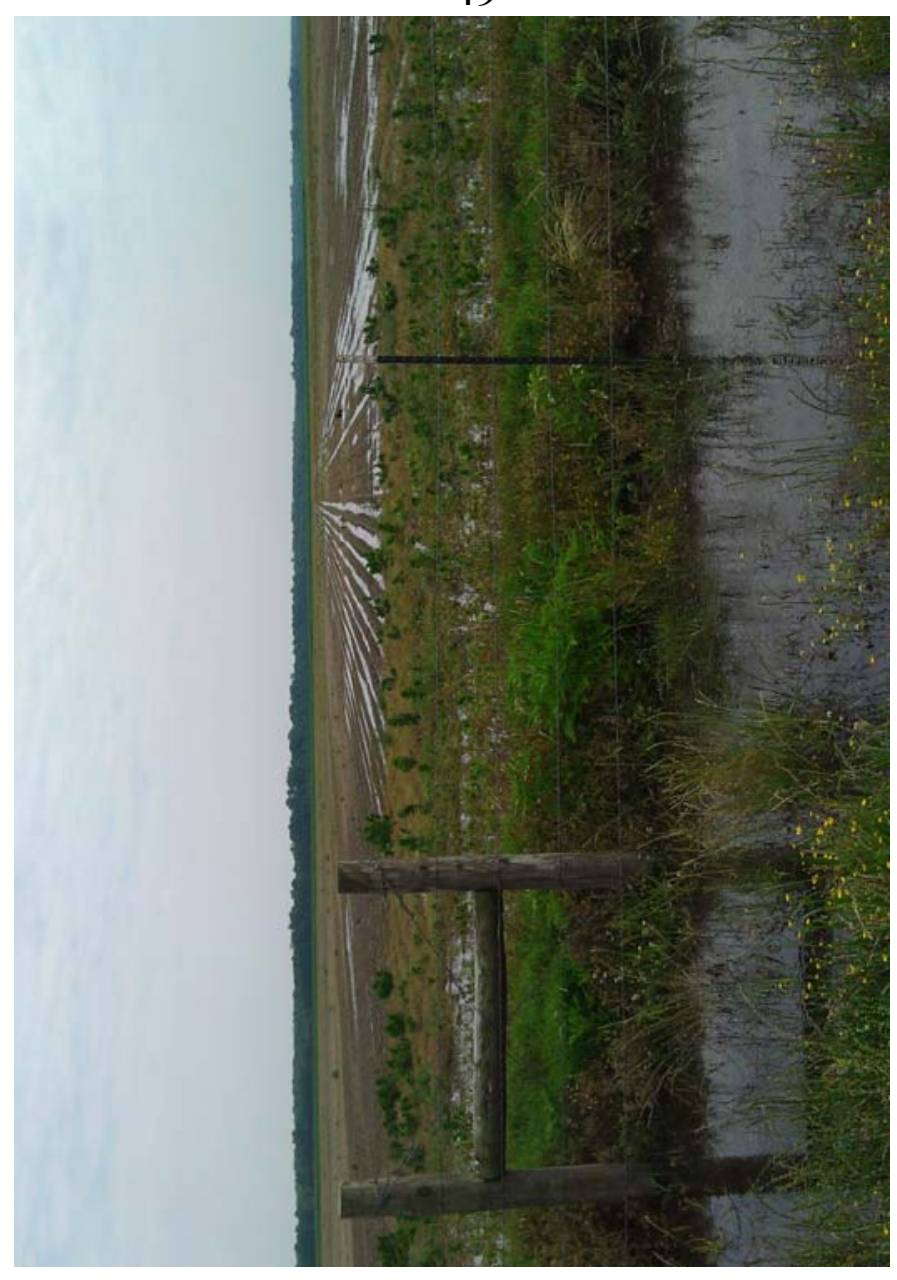

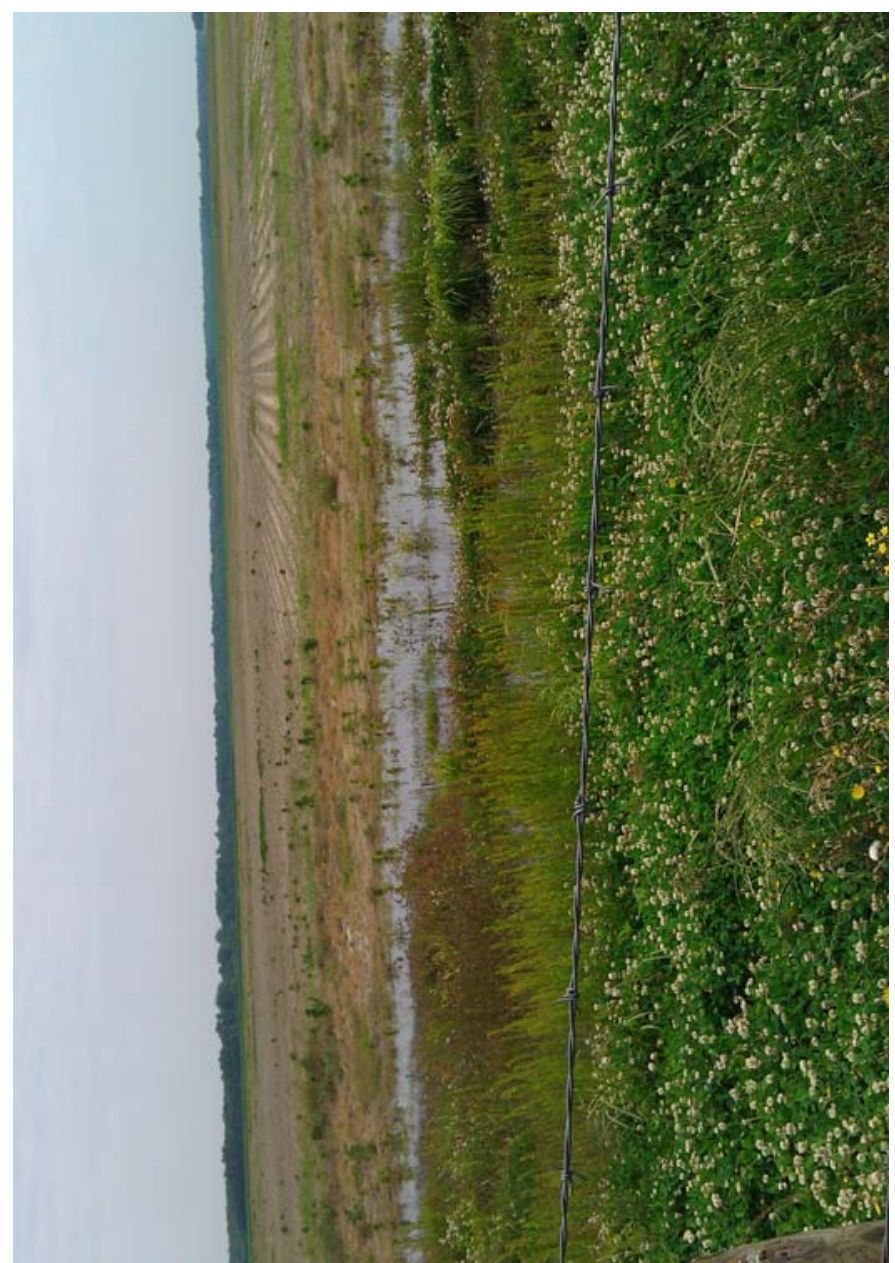

50

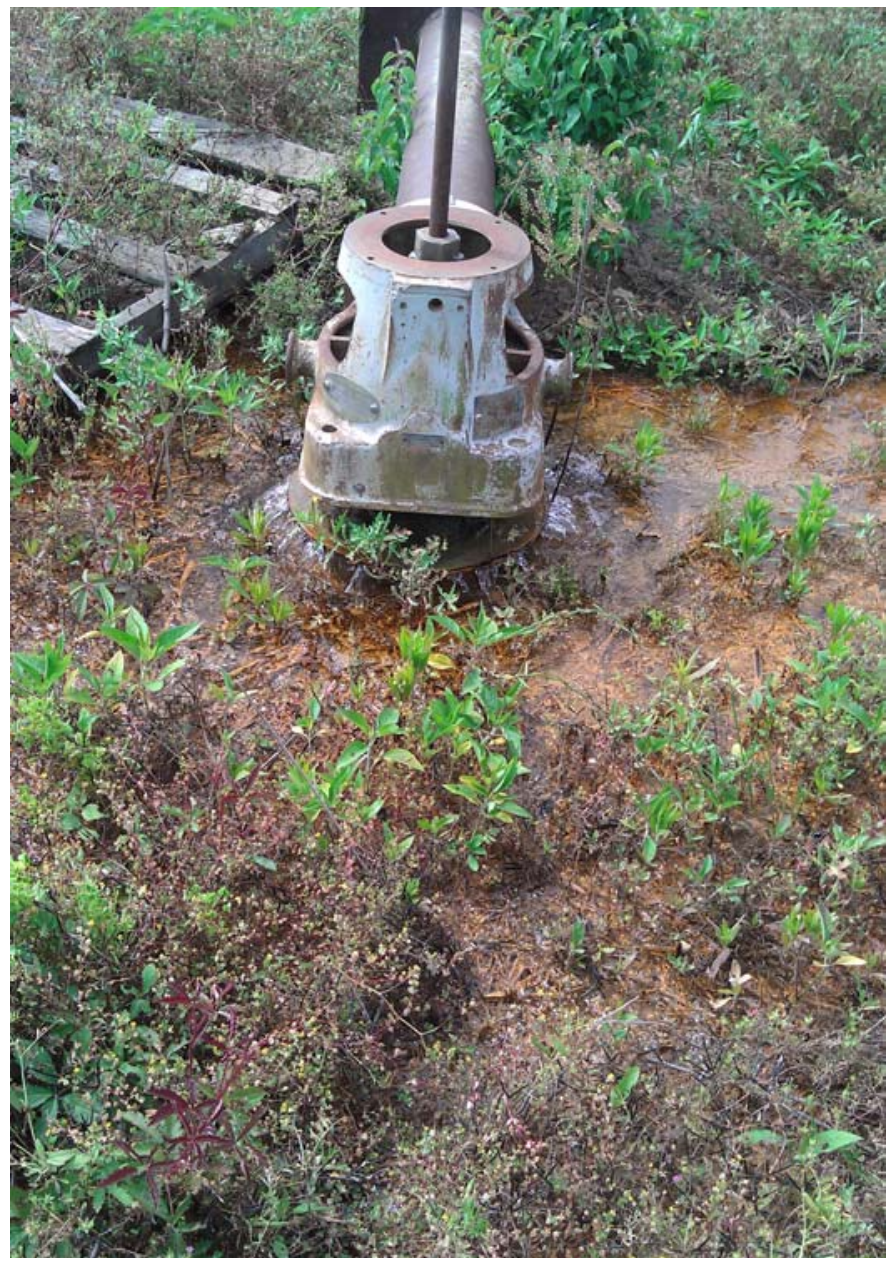

52 


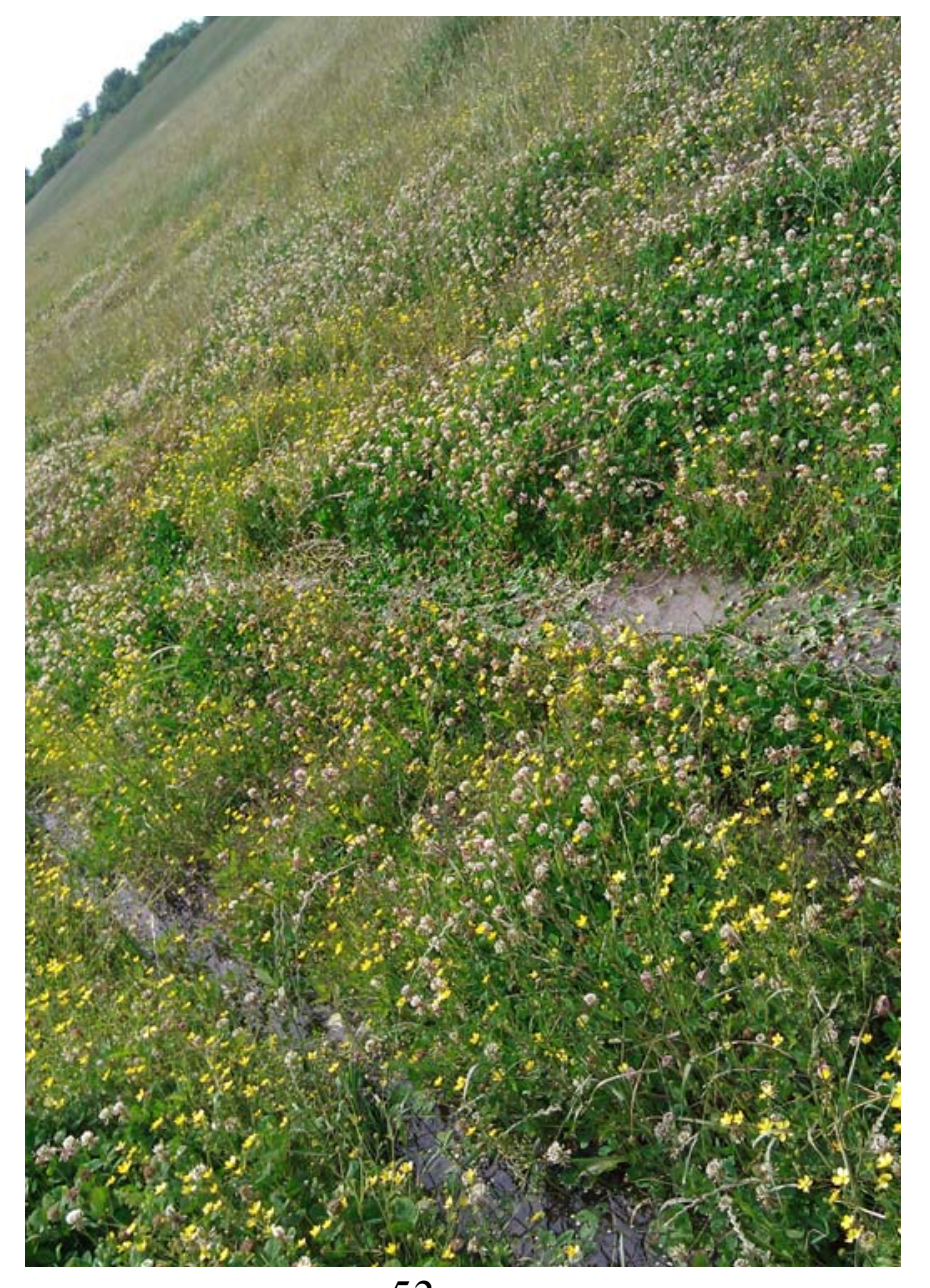

\section{3}
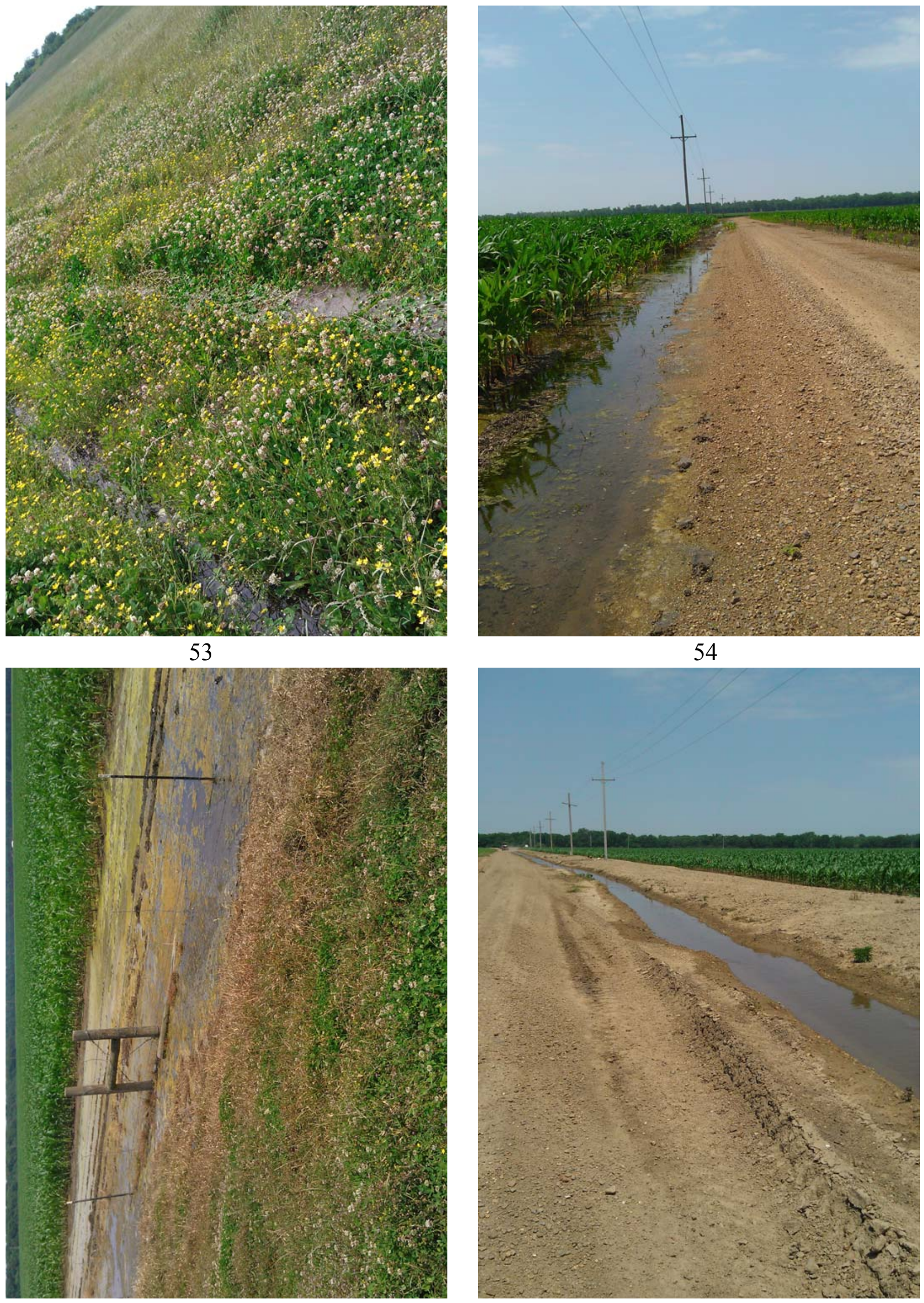

54

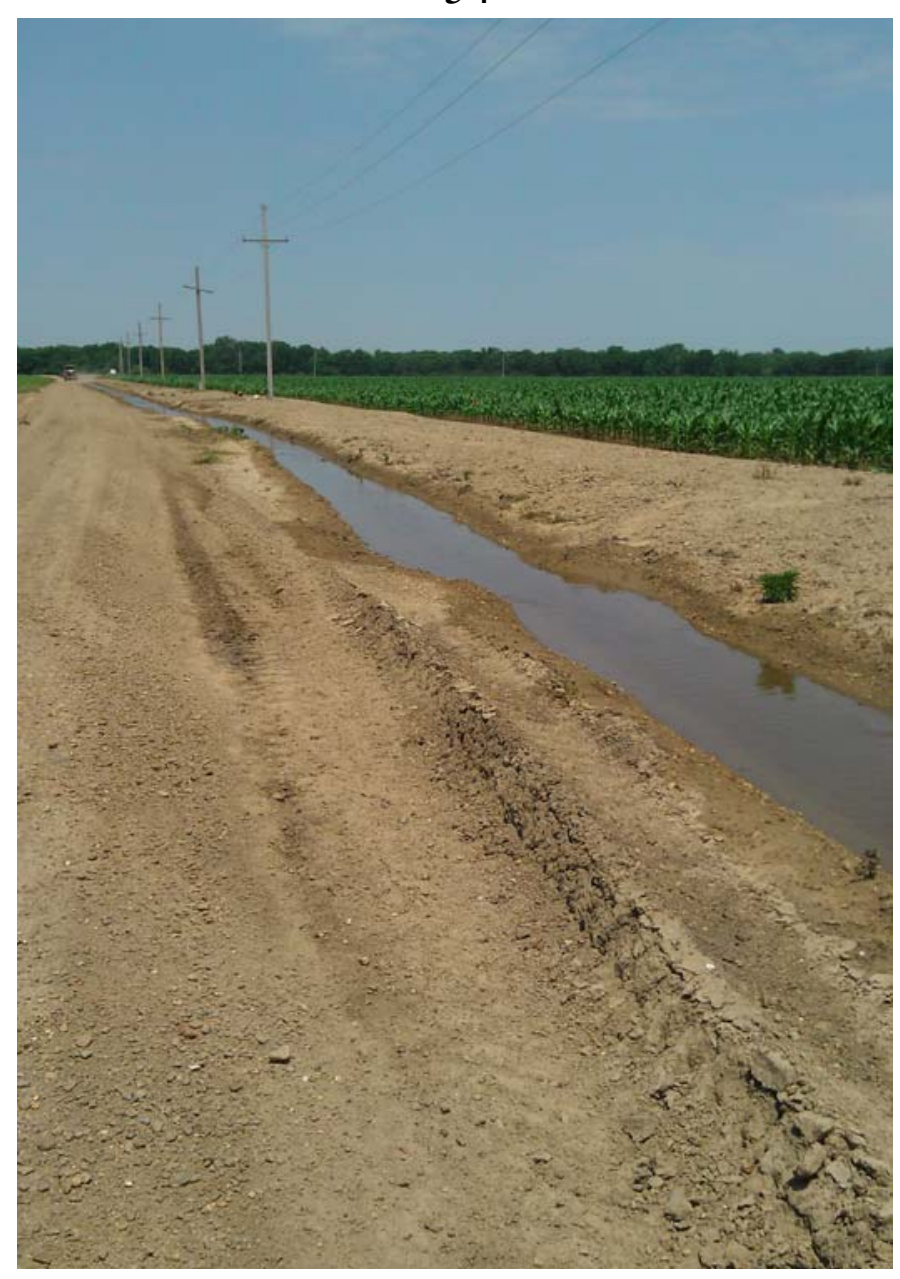




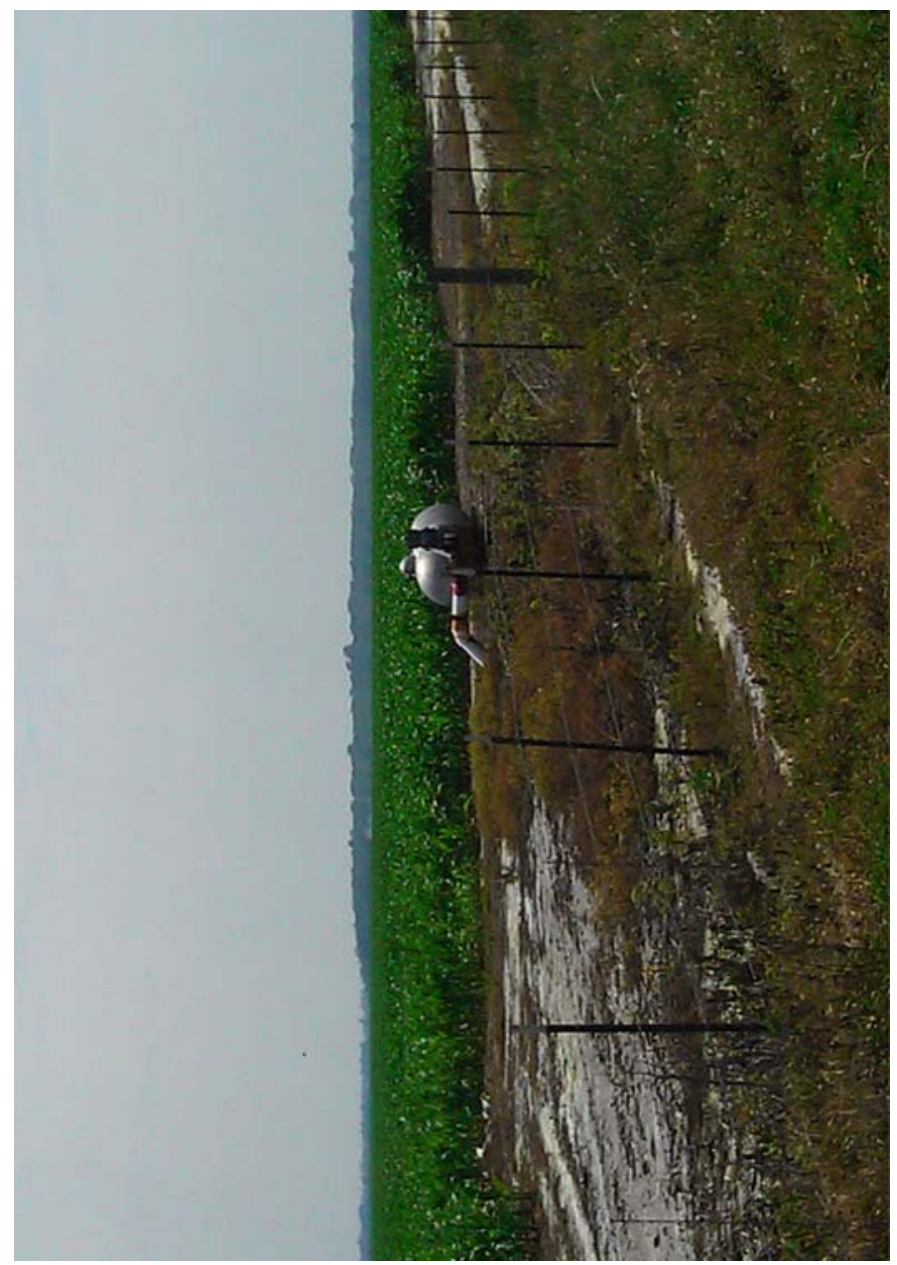

57

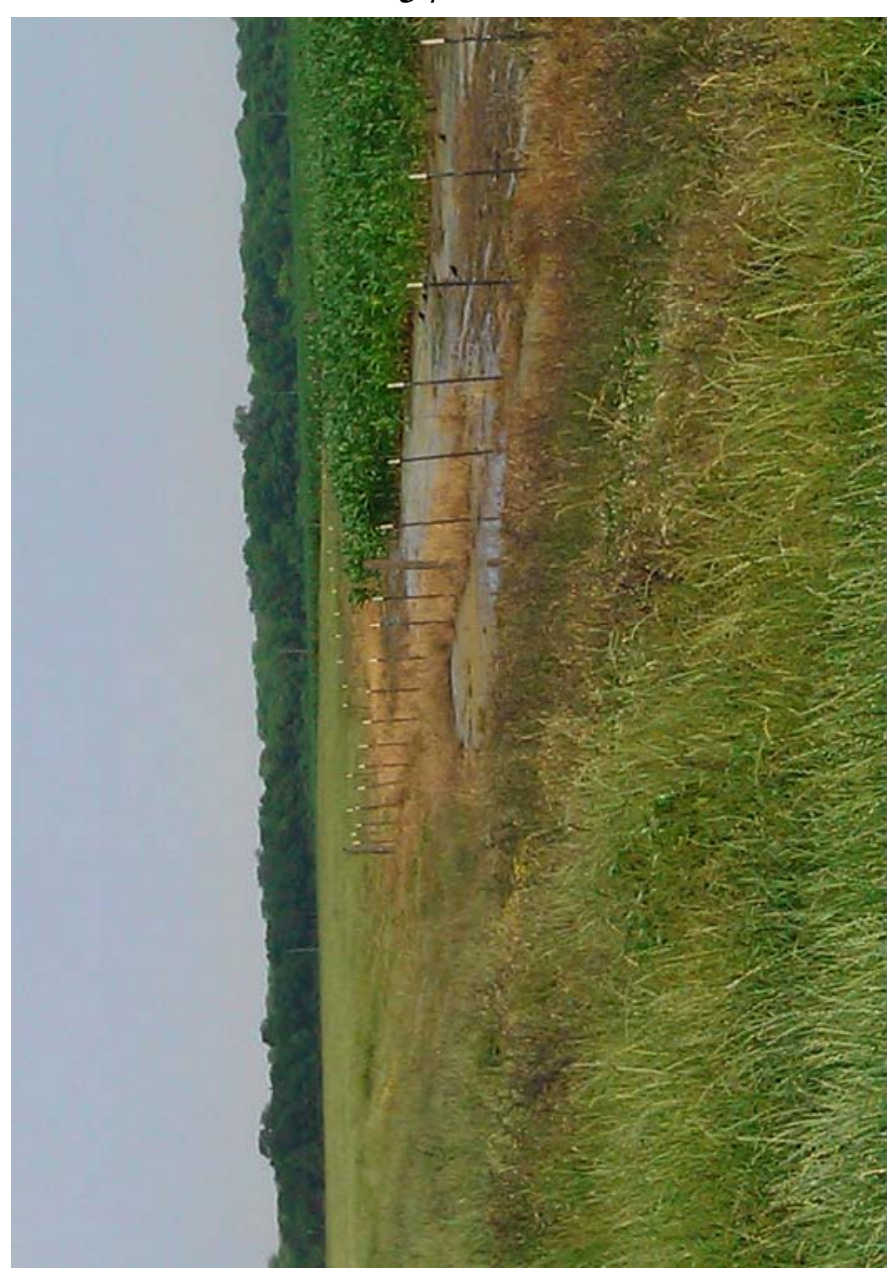

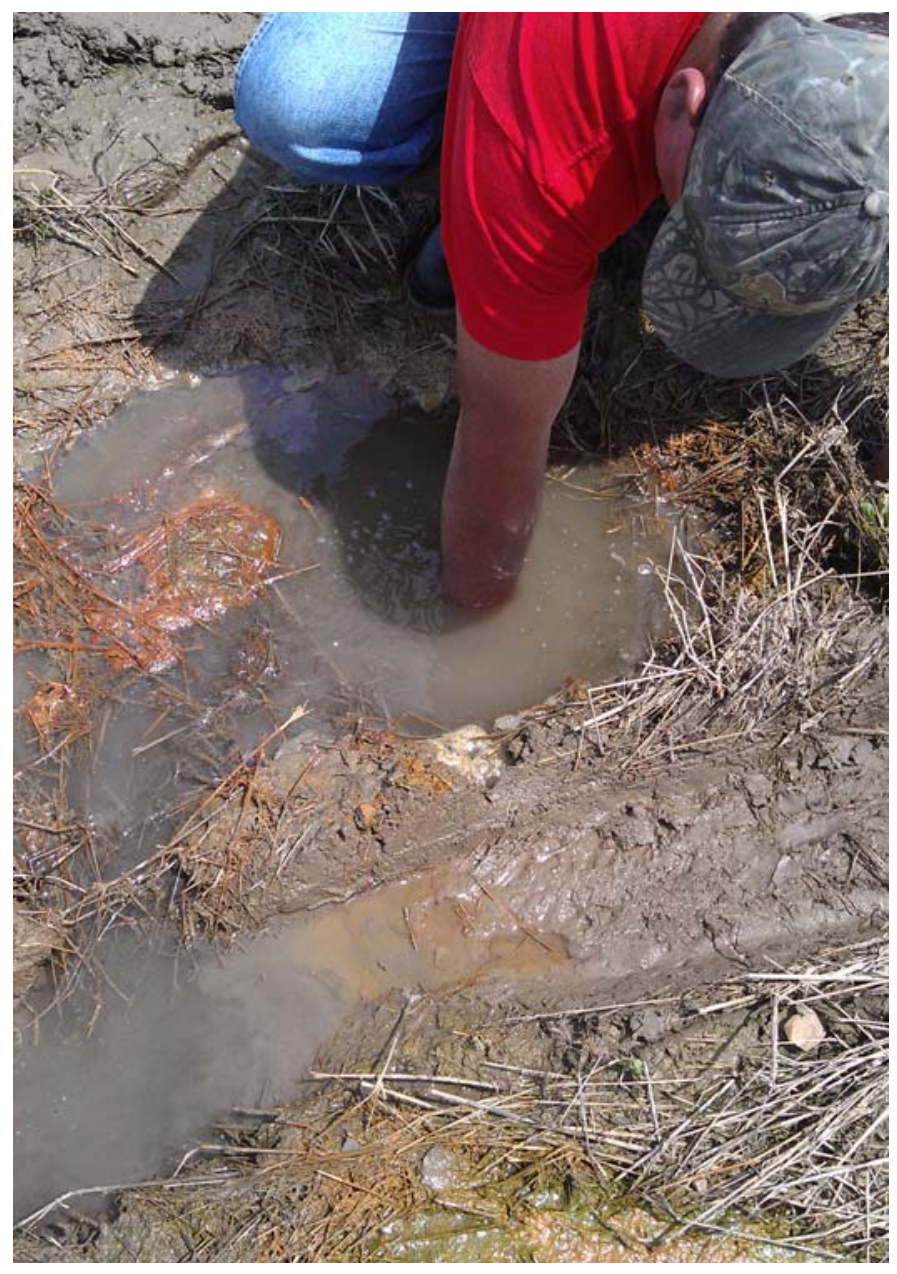

58

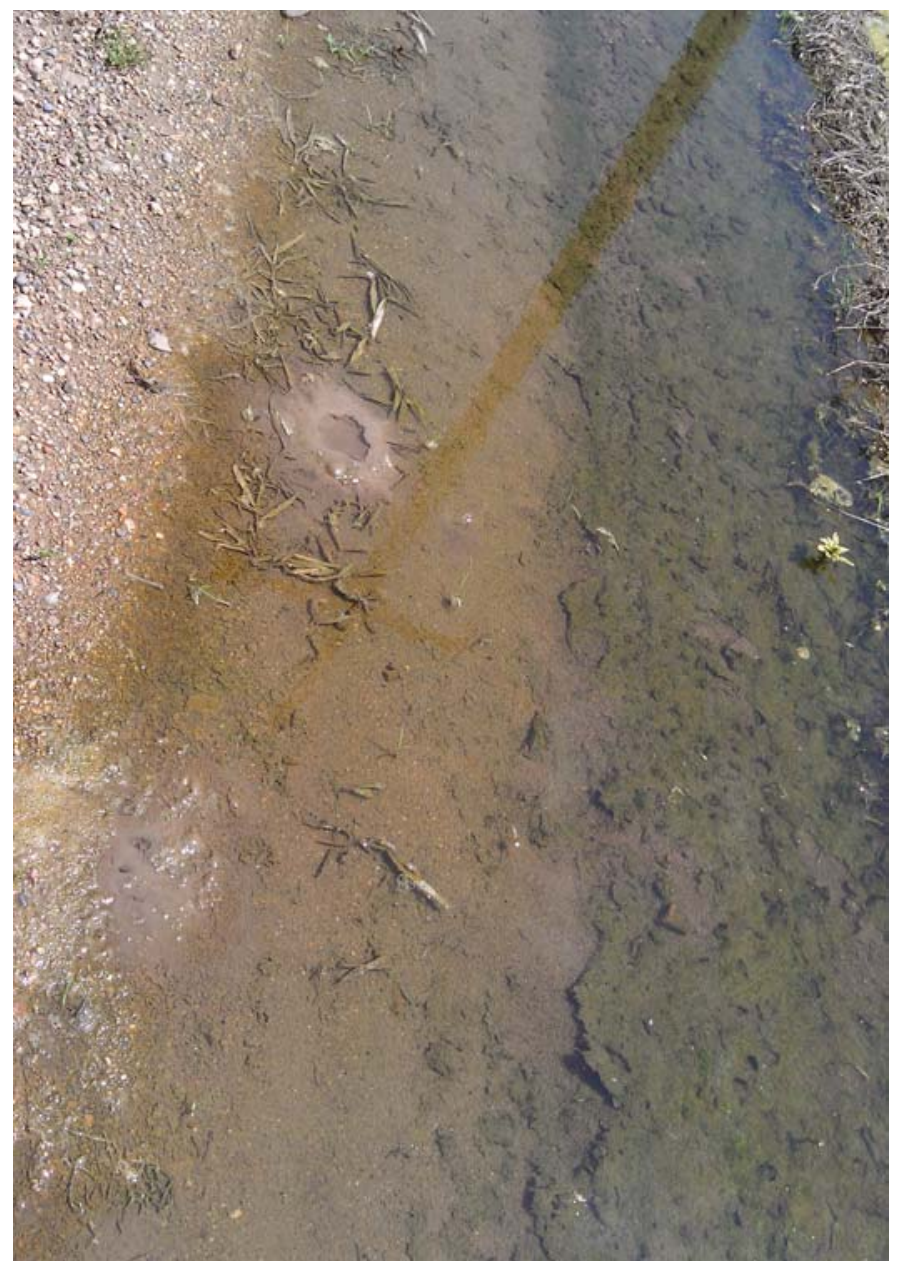




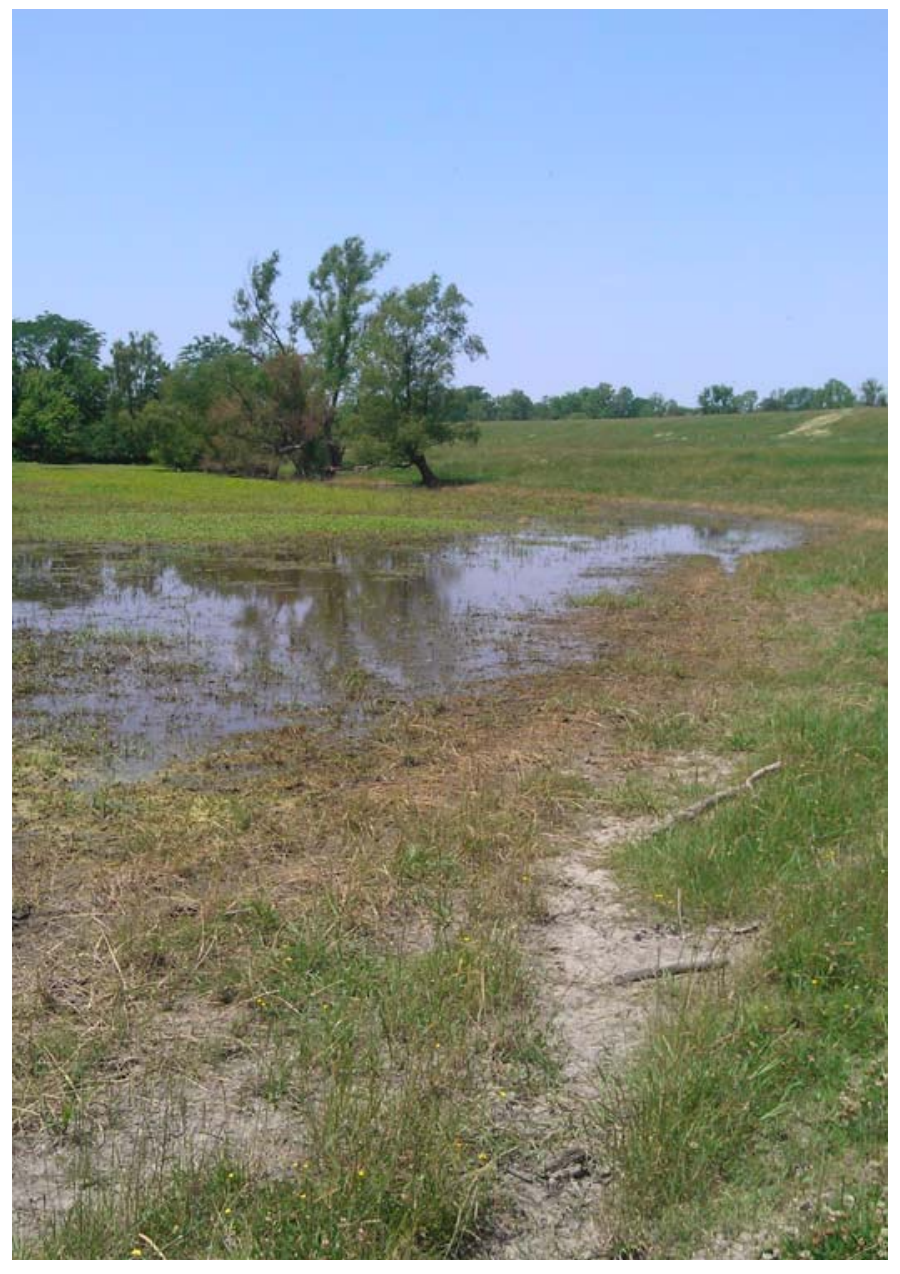

61

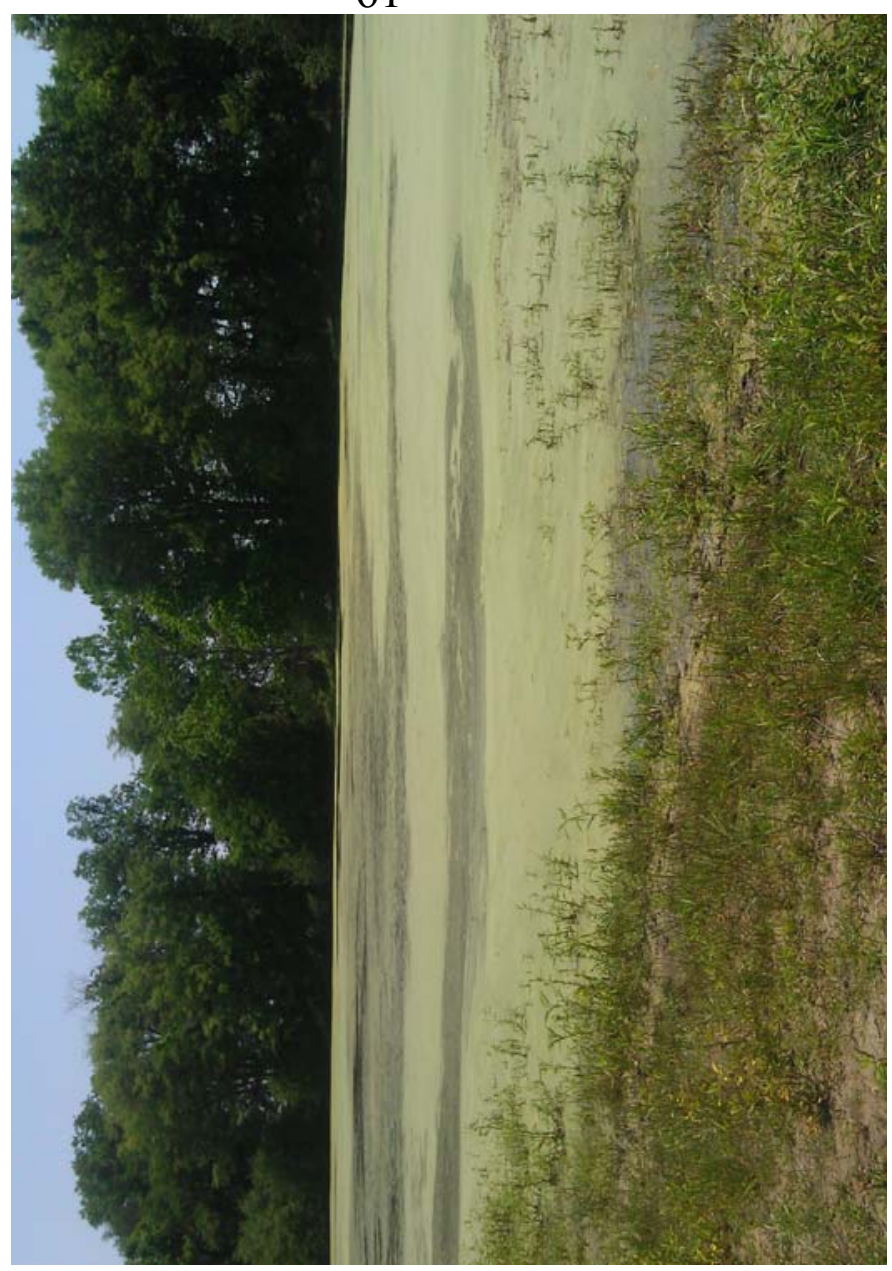

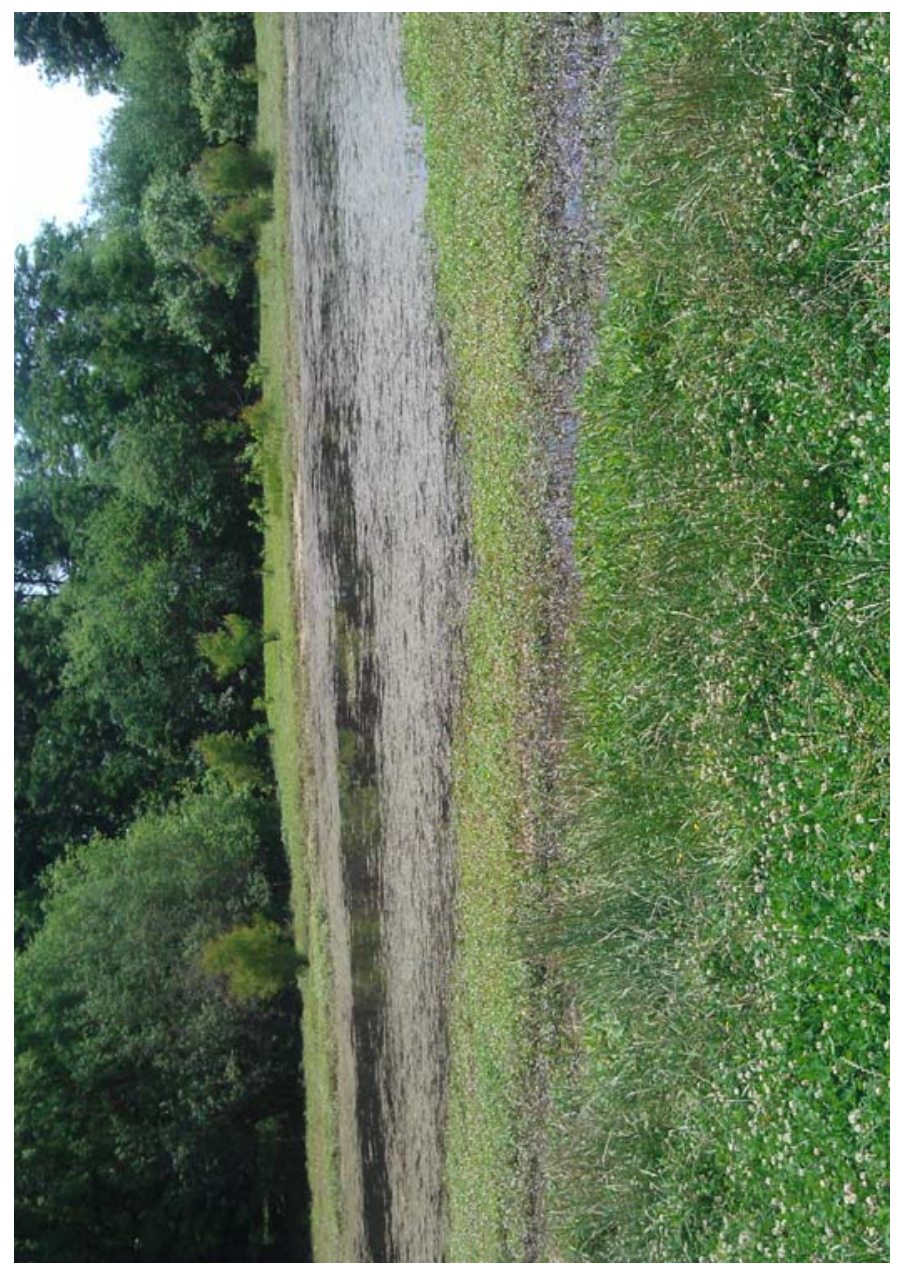

62

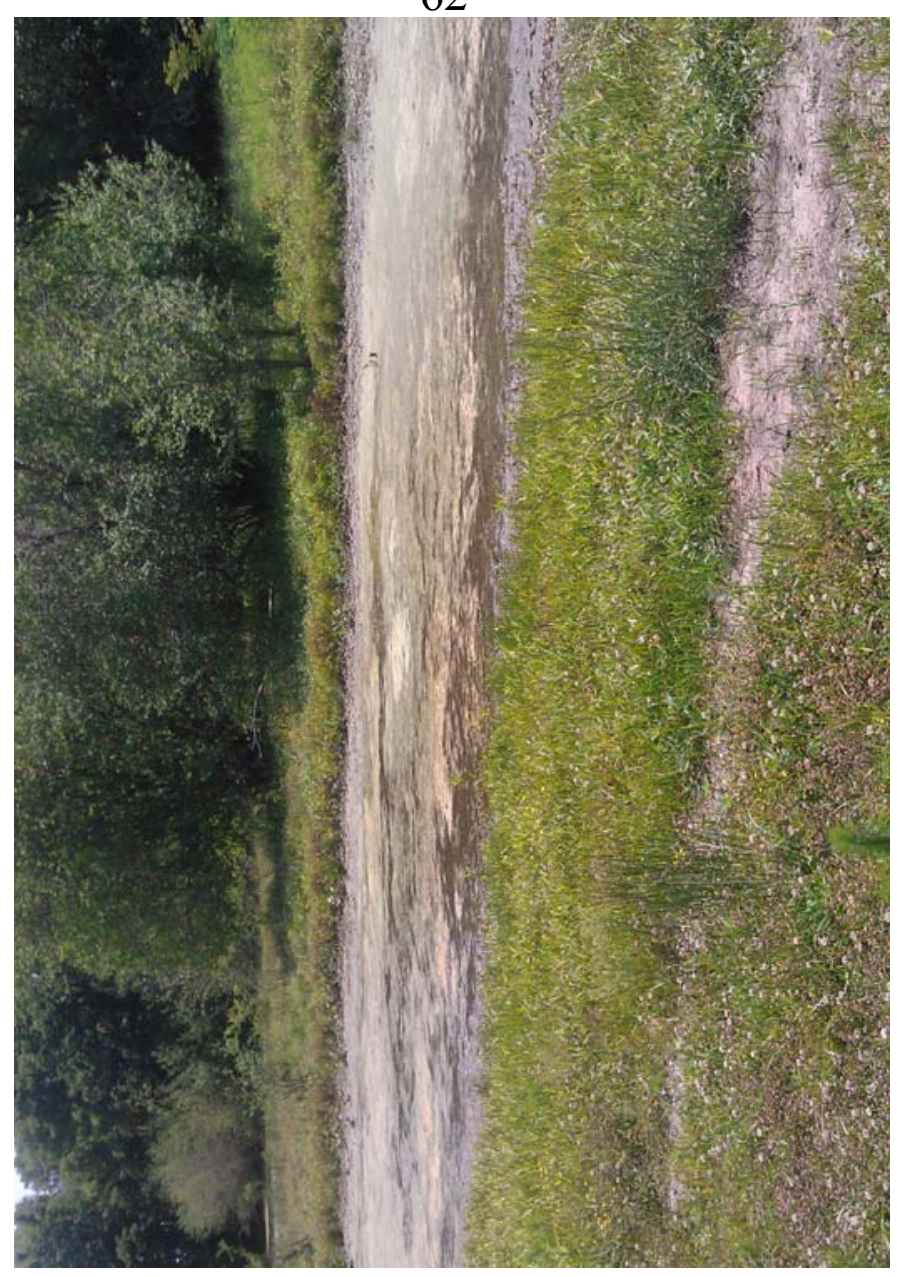




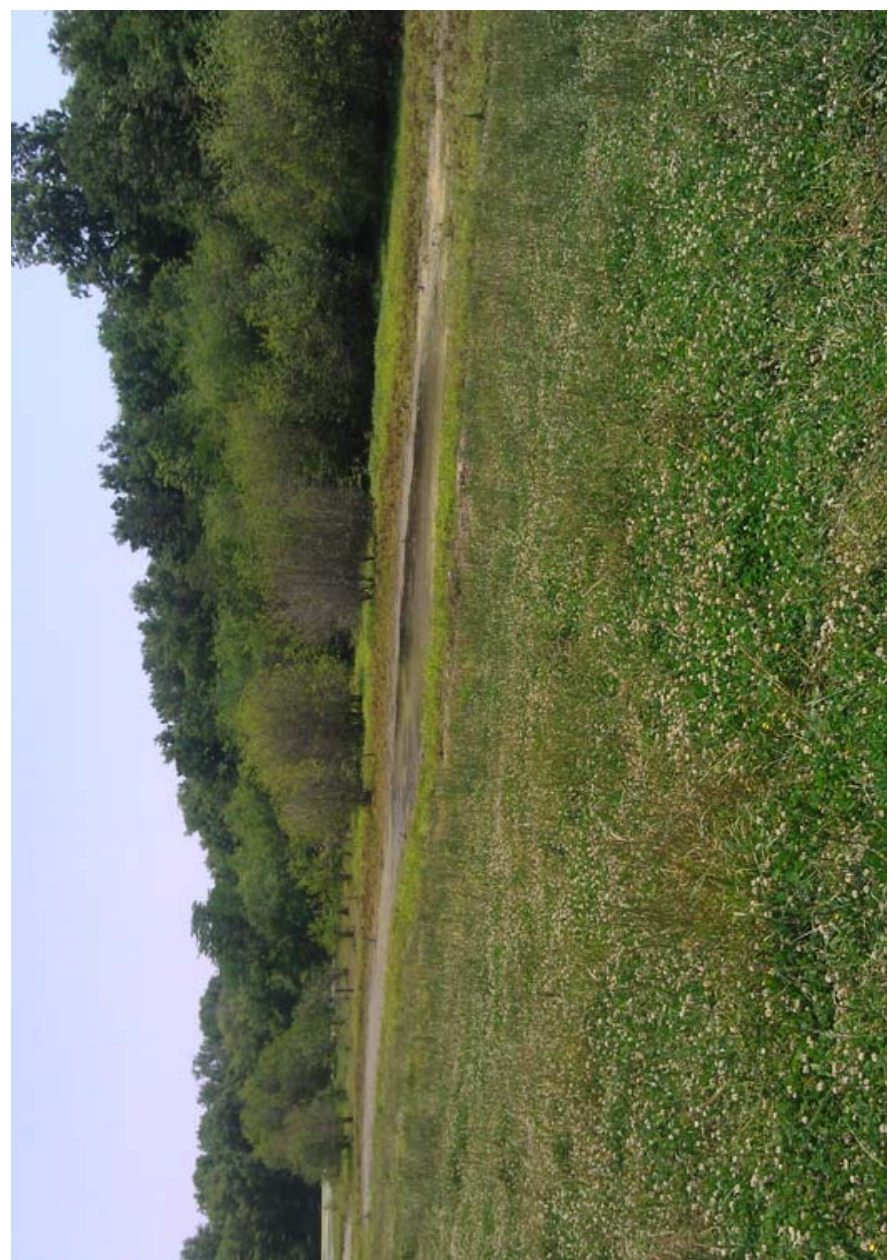

65

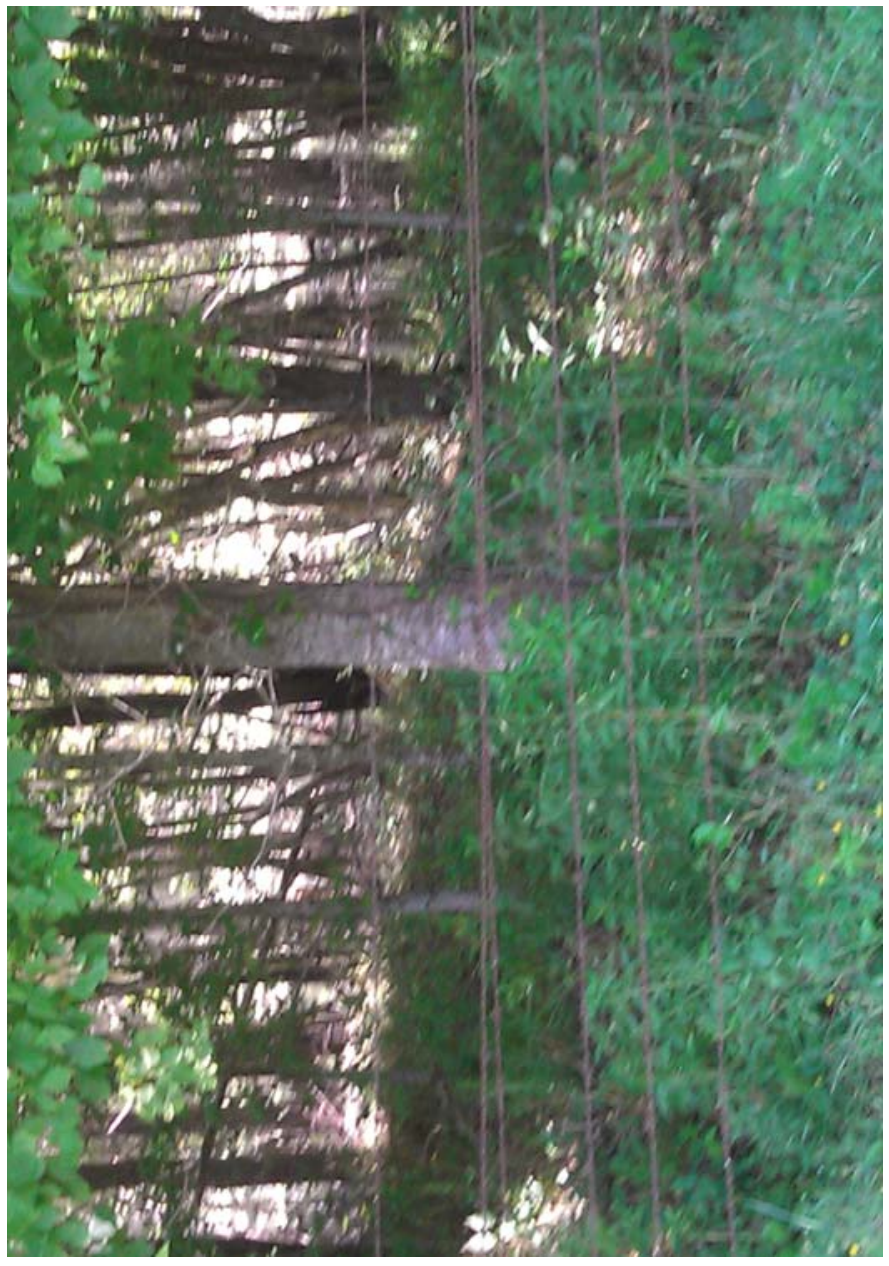

67

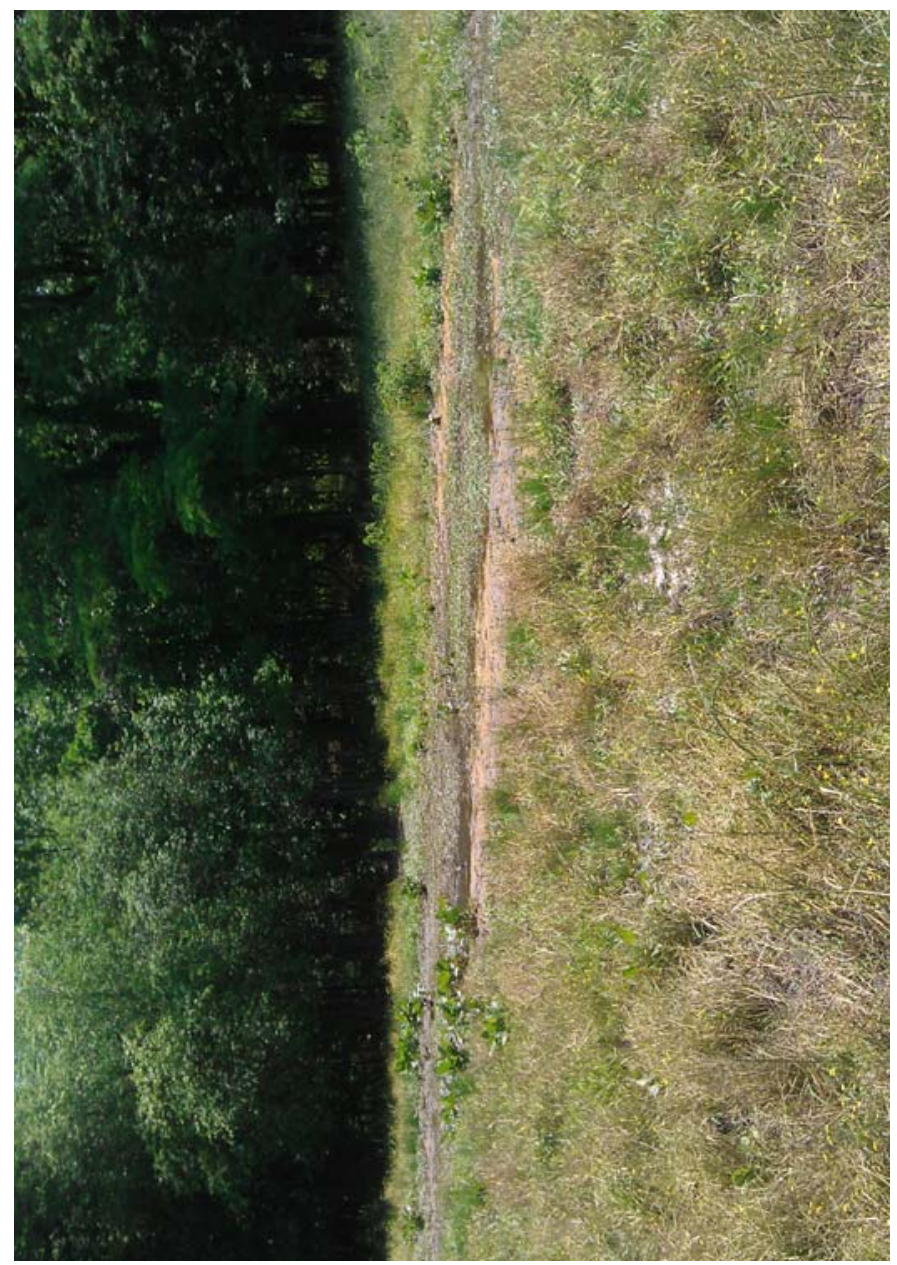

66

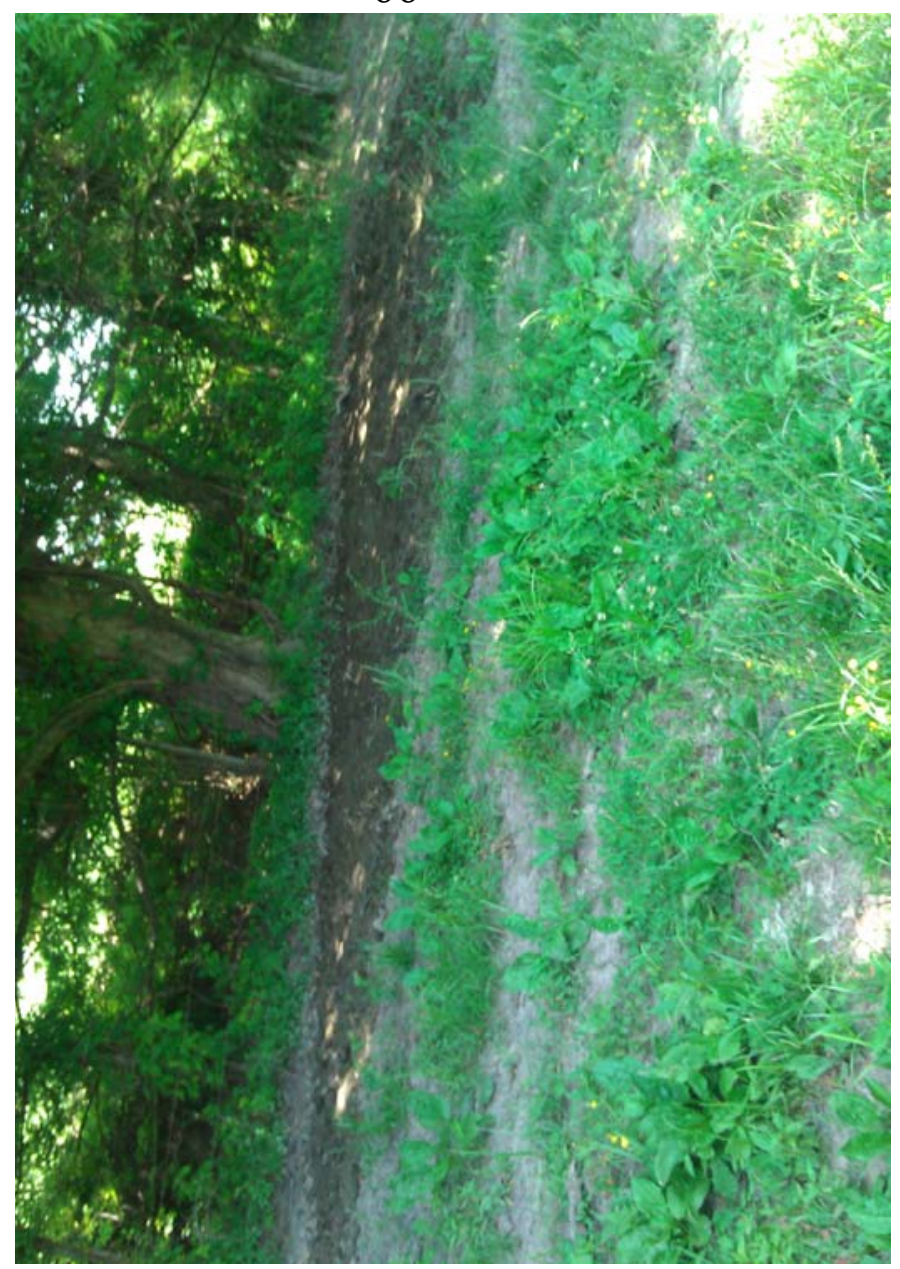




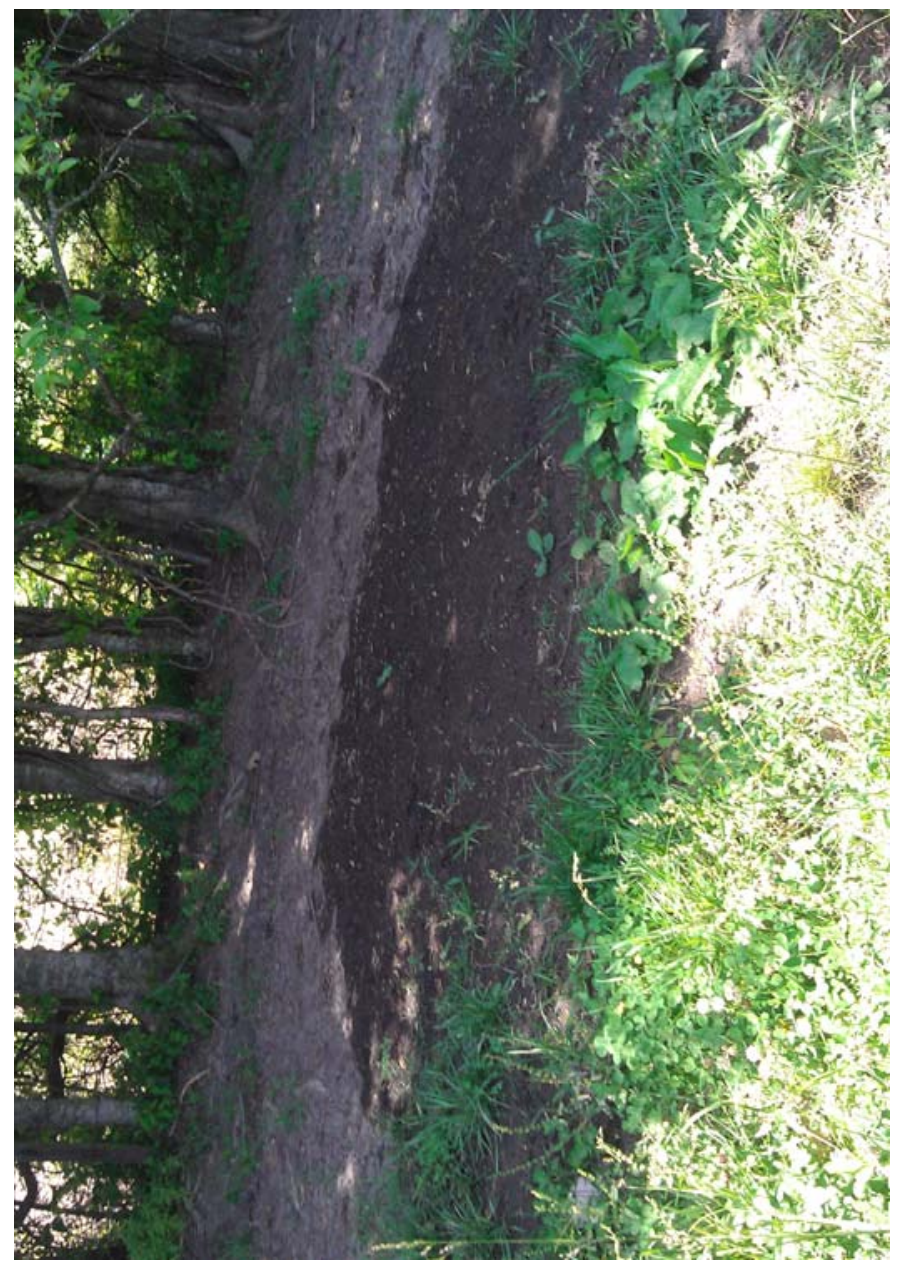

69

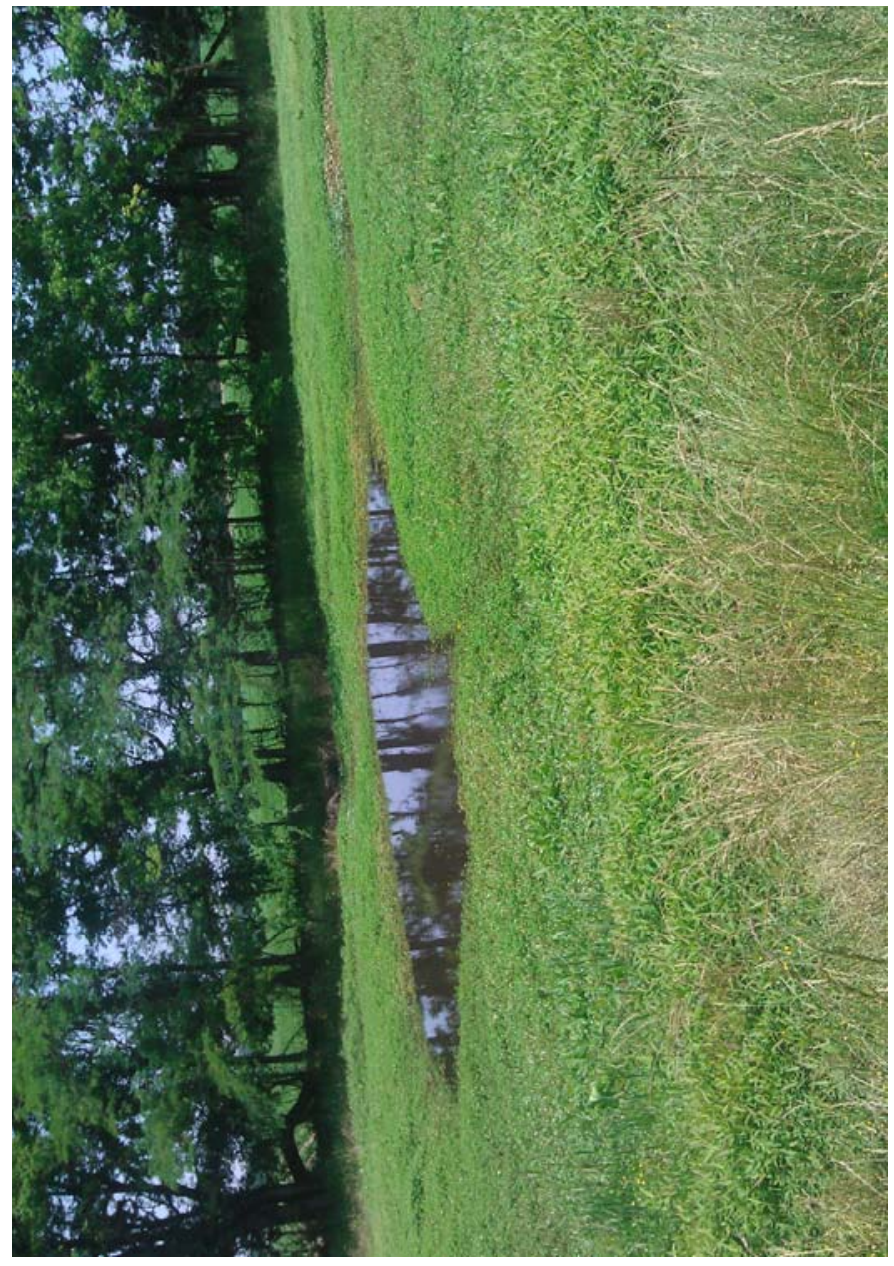

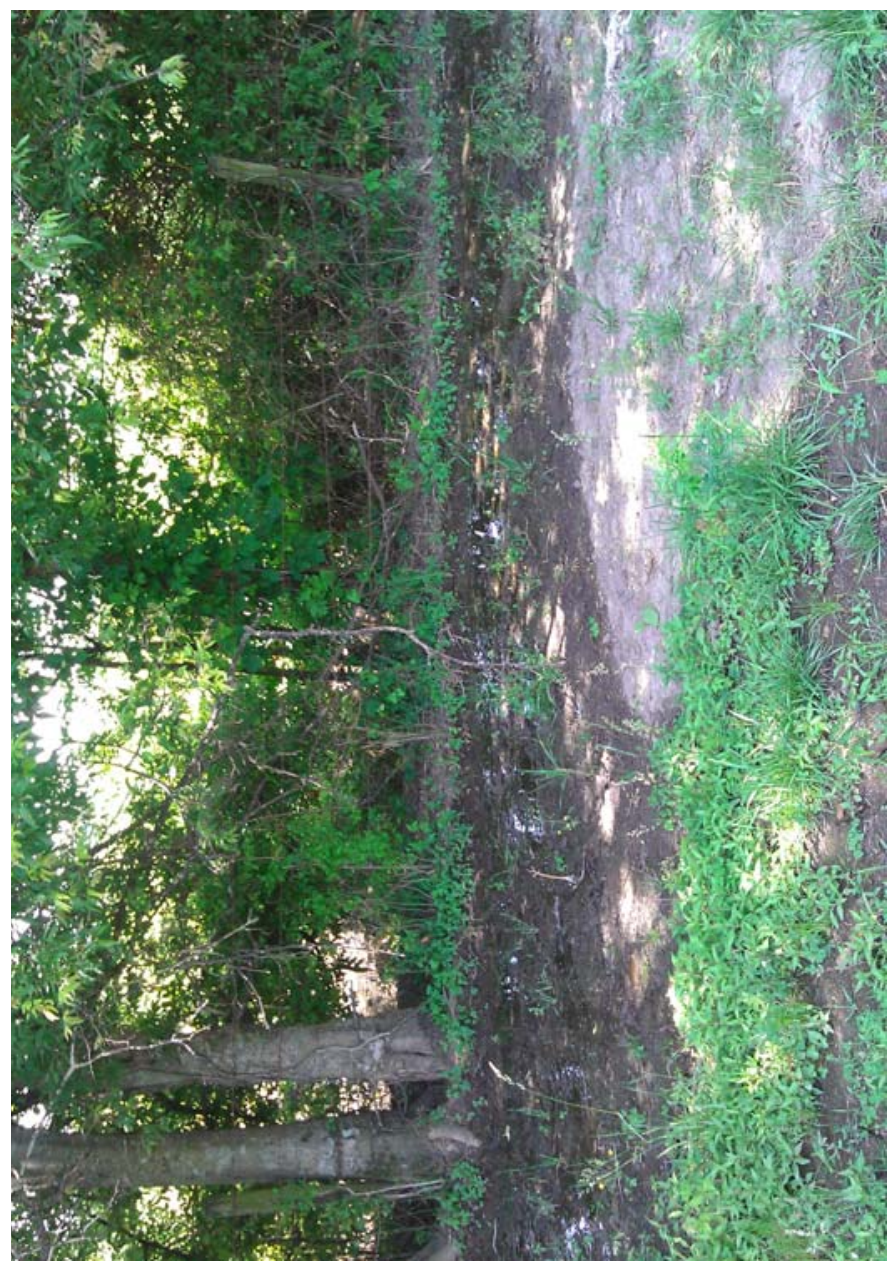

70

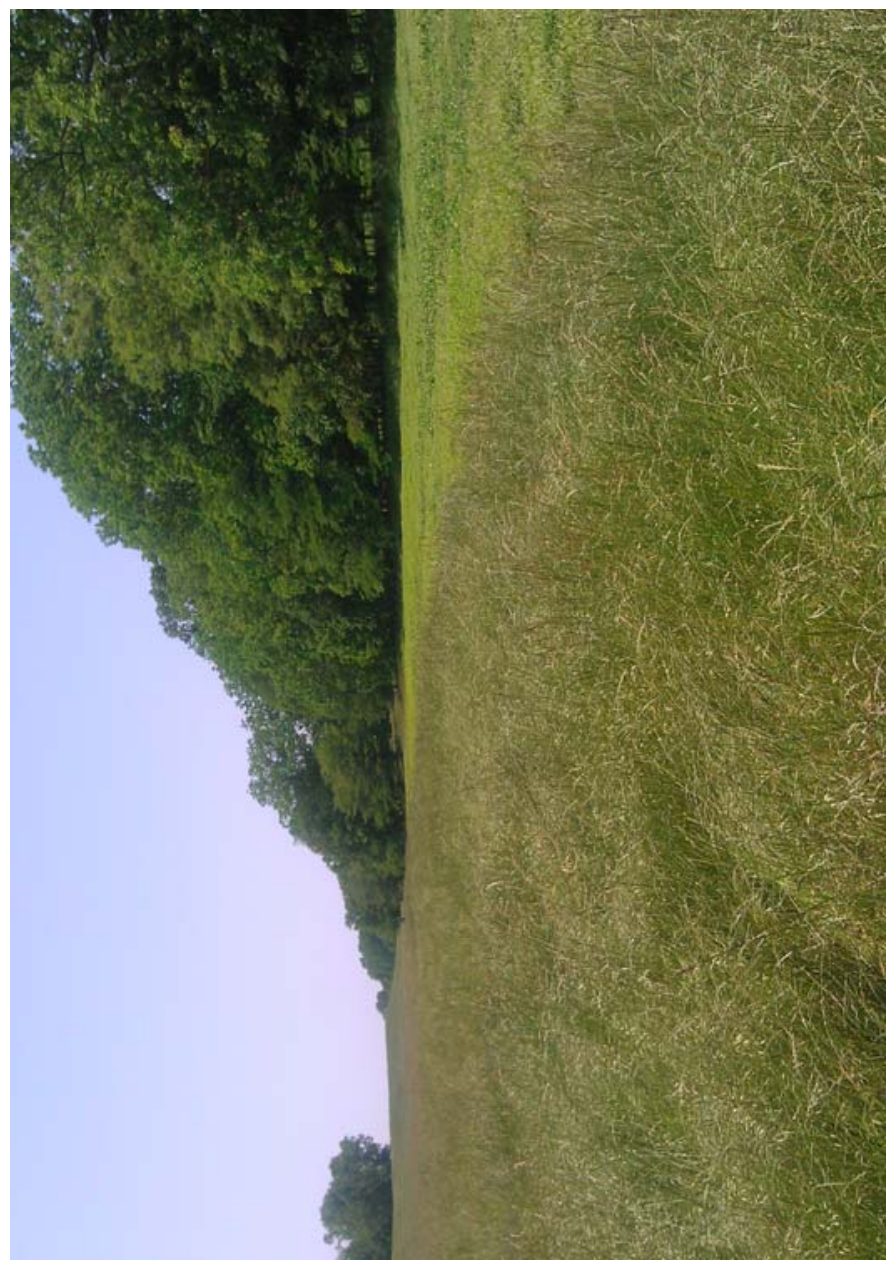




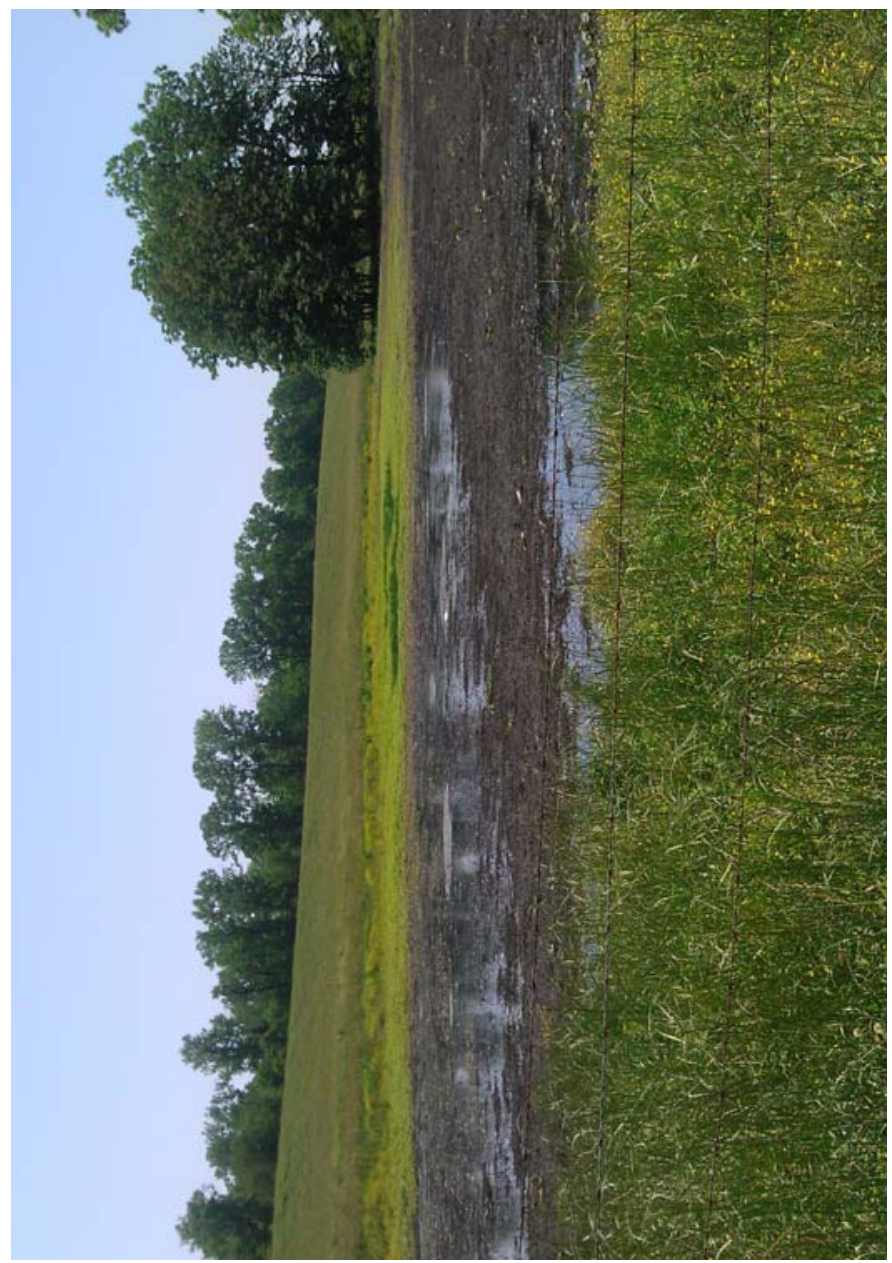

73

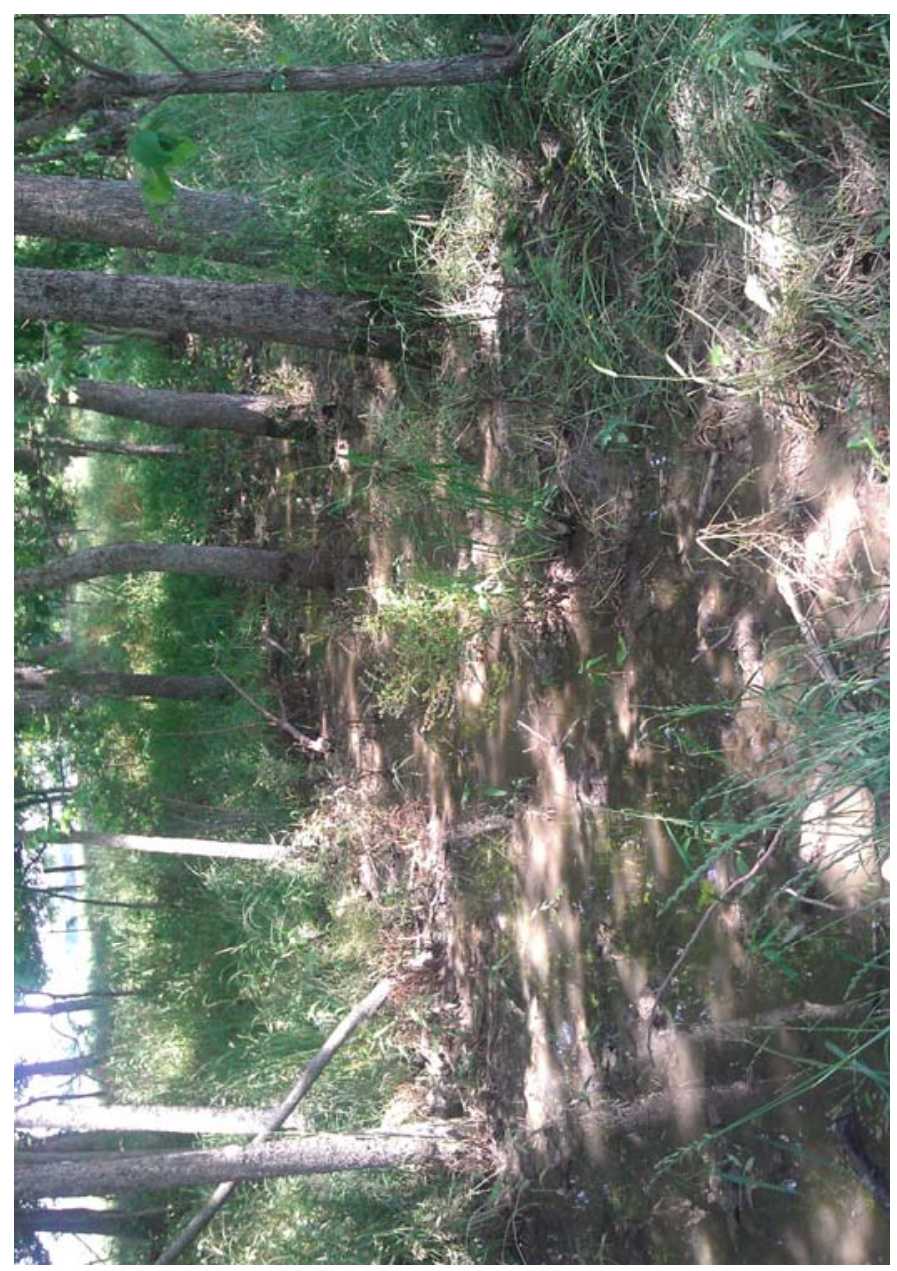

75

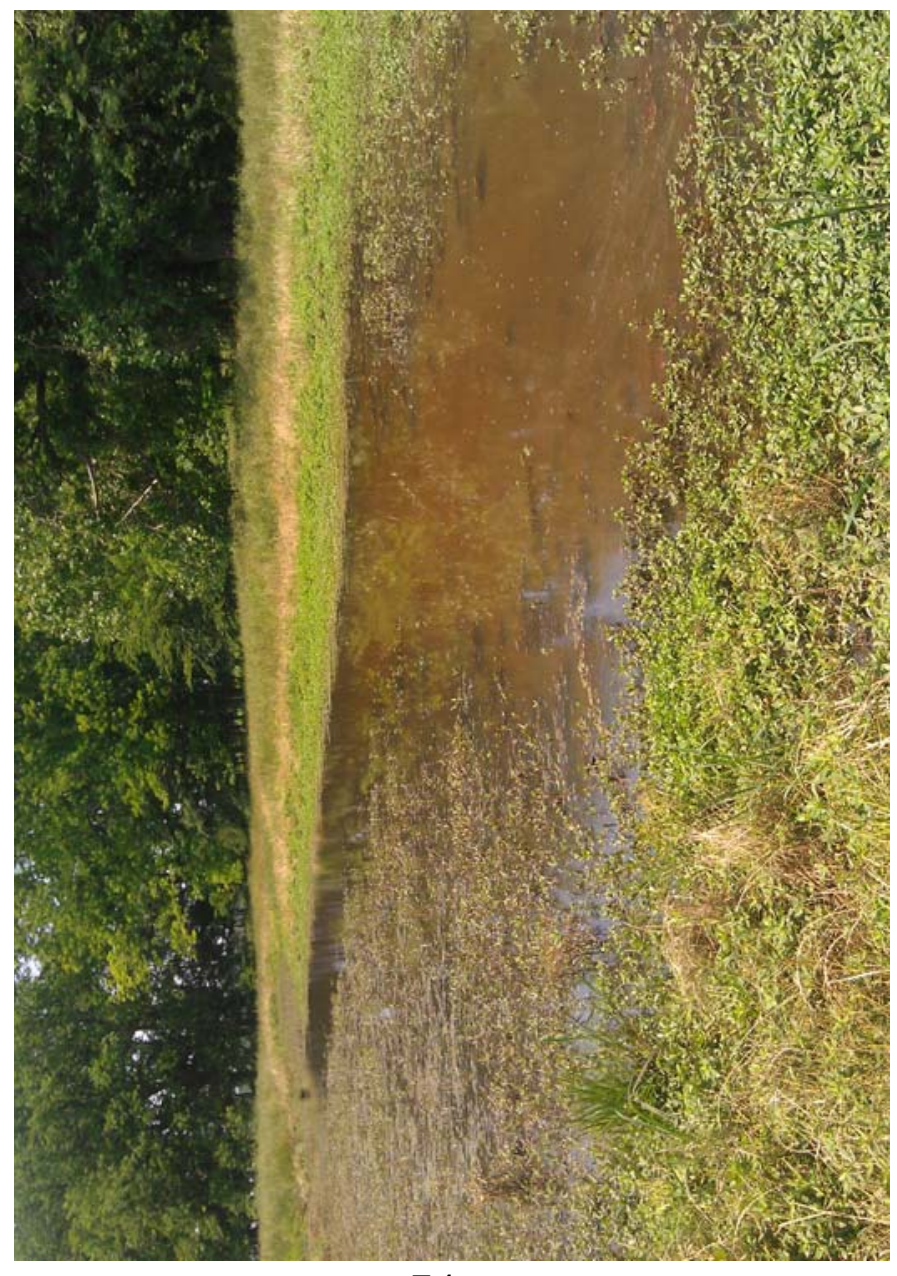

74

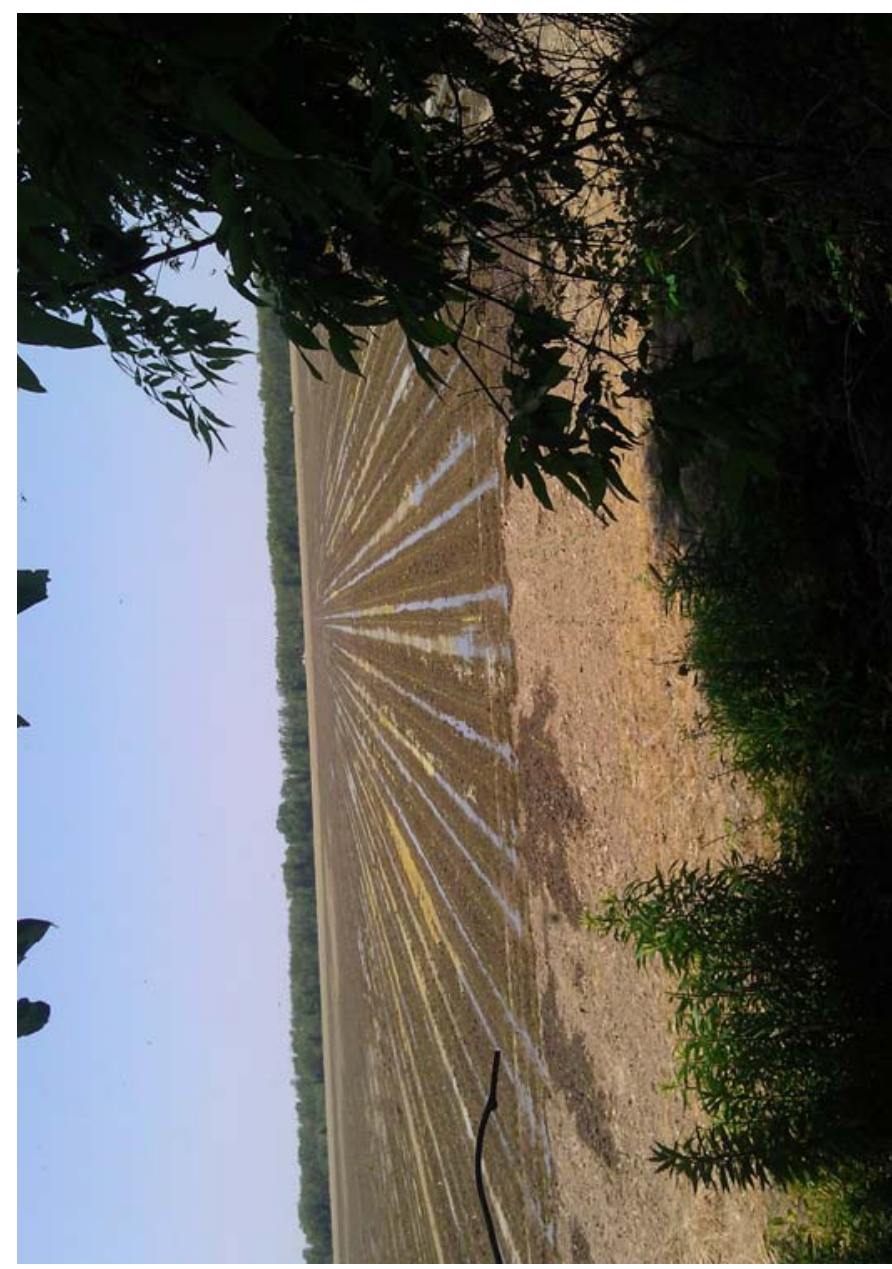




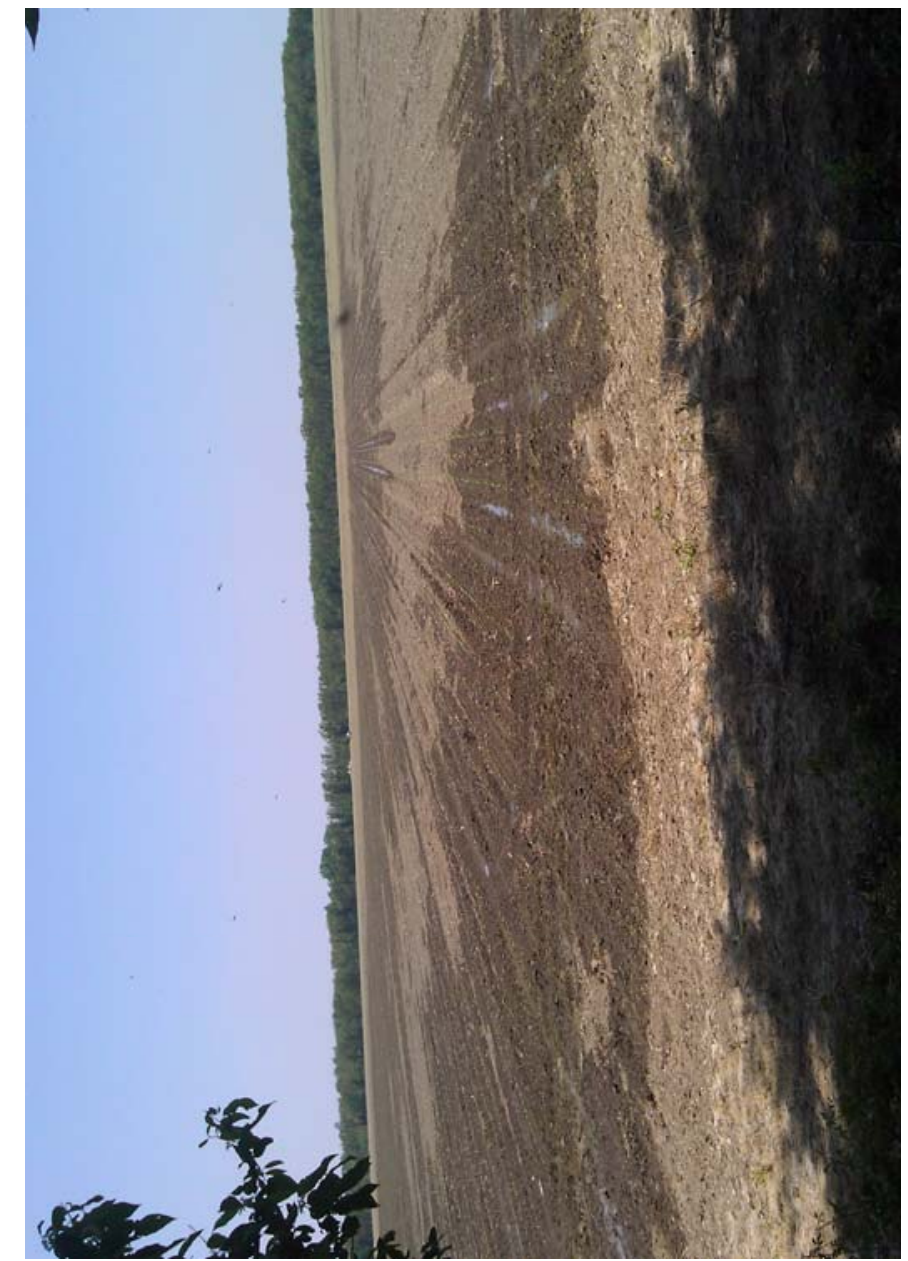

77

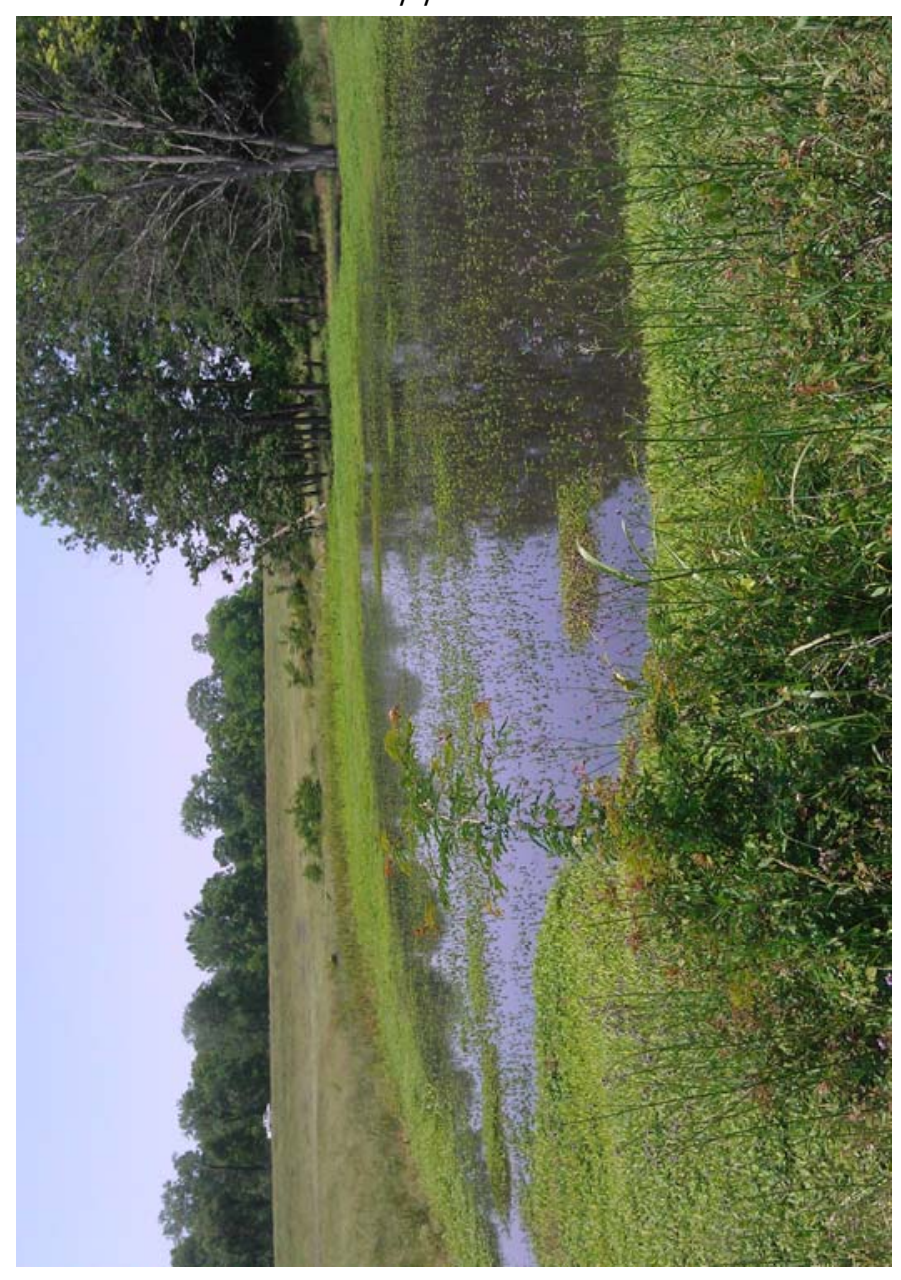




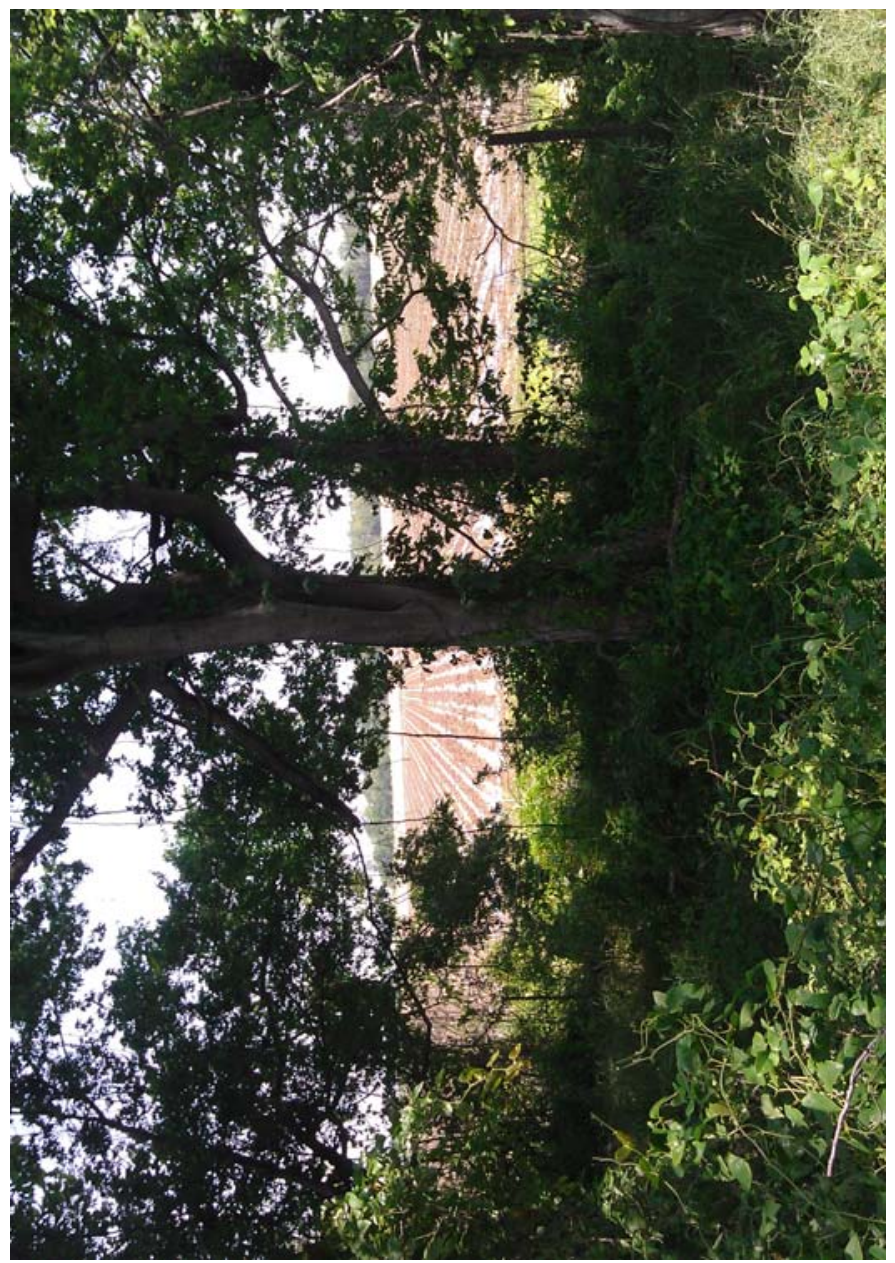

81

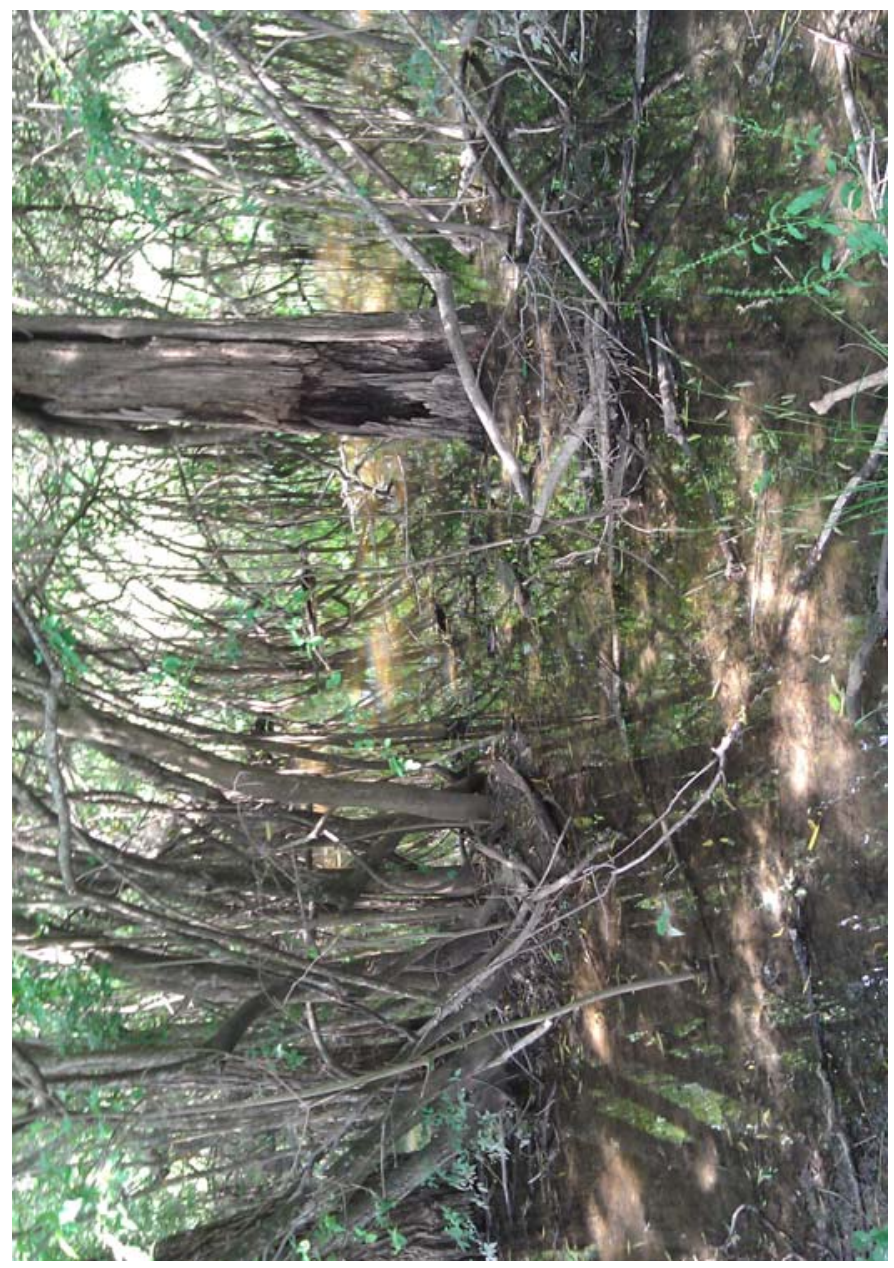

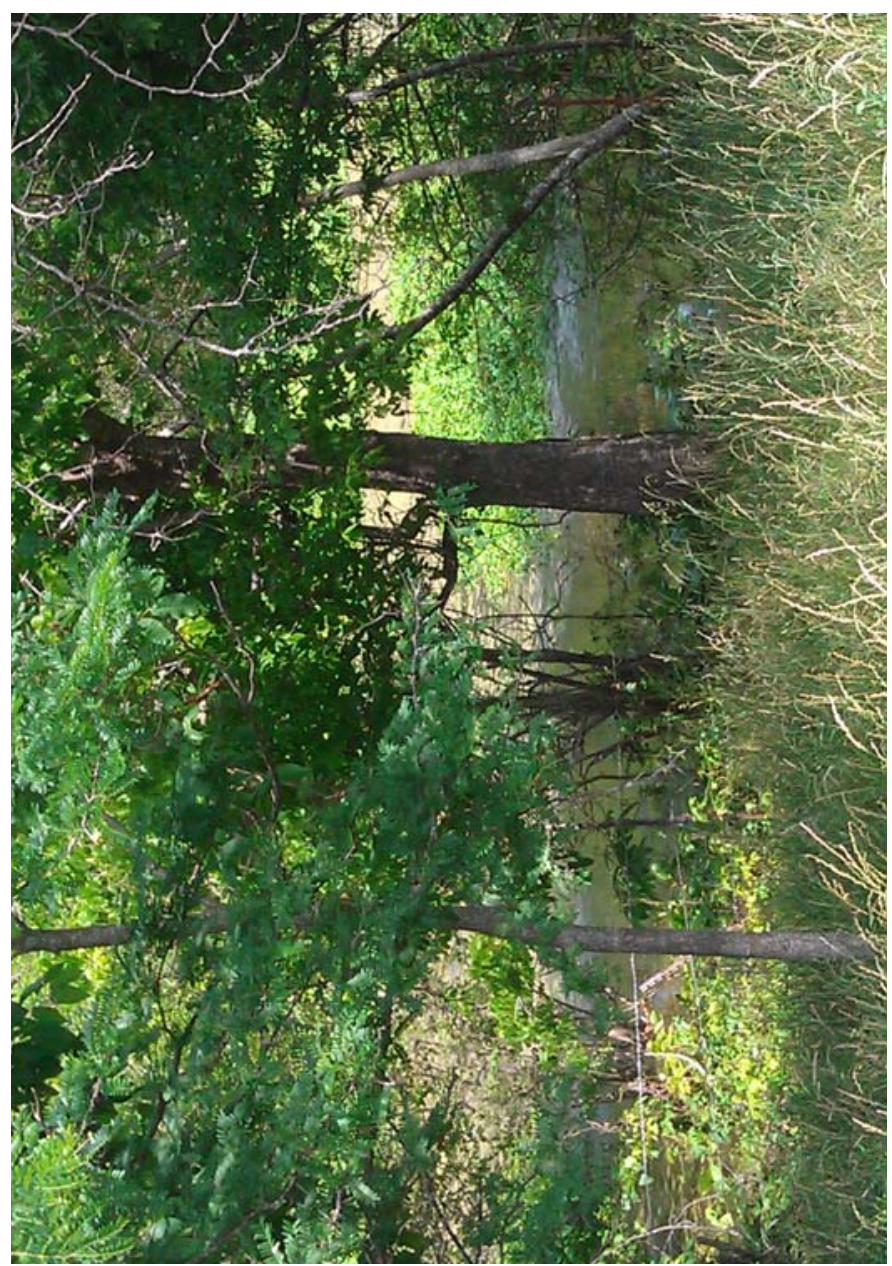

82

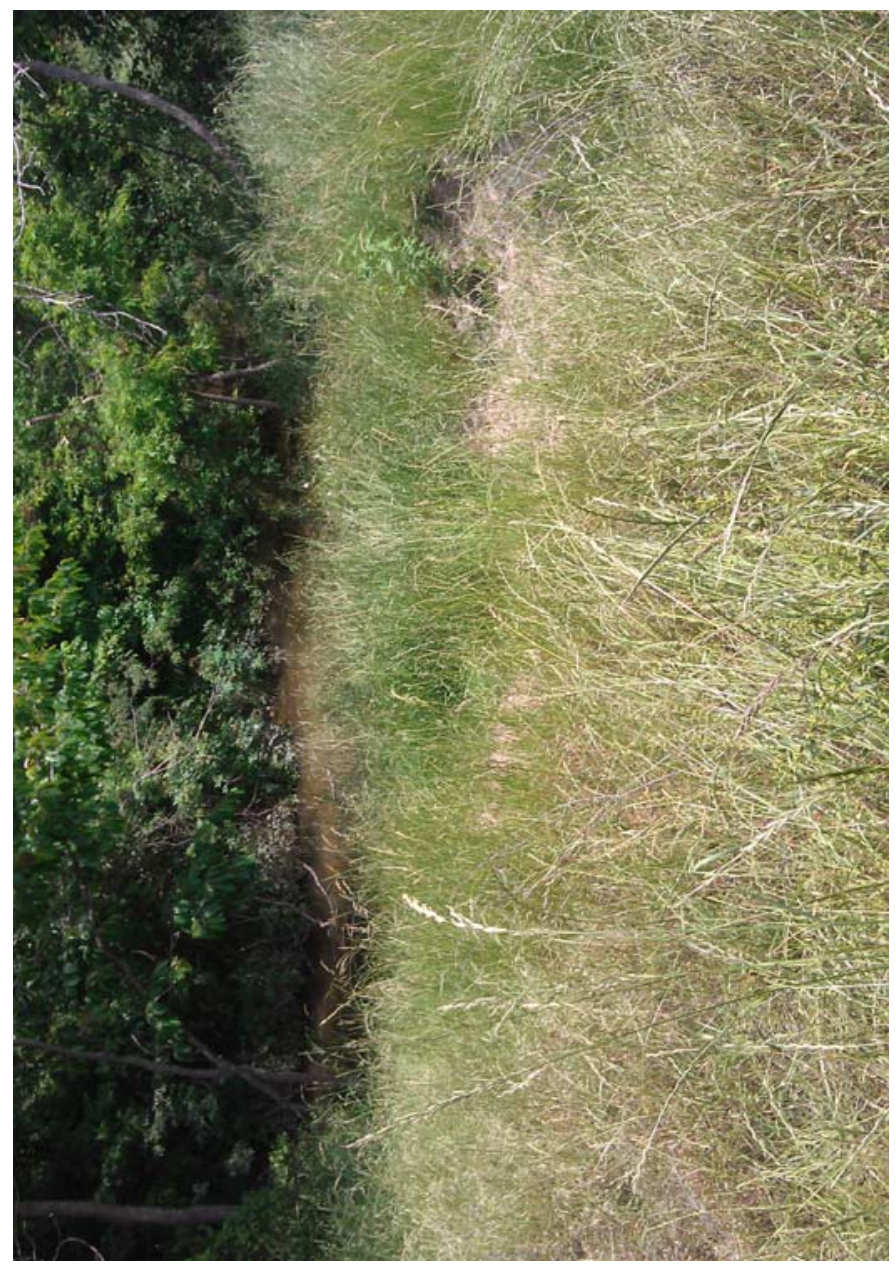




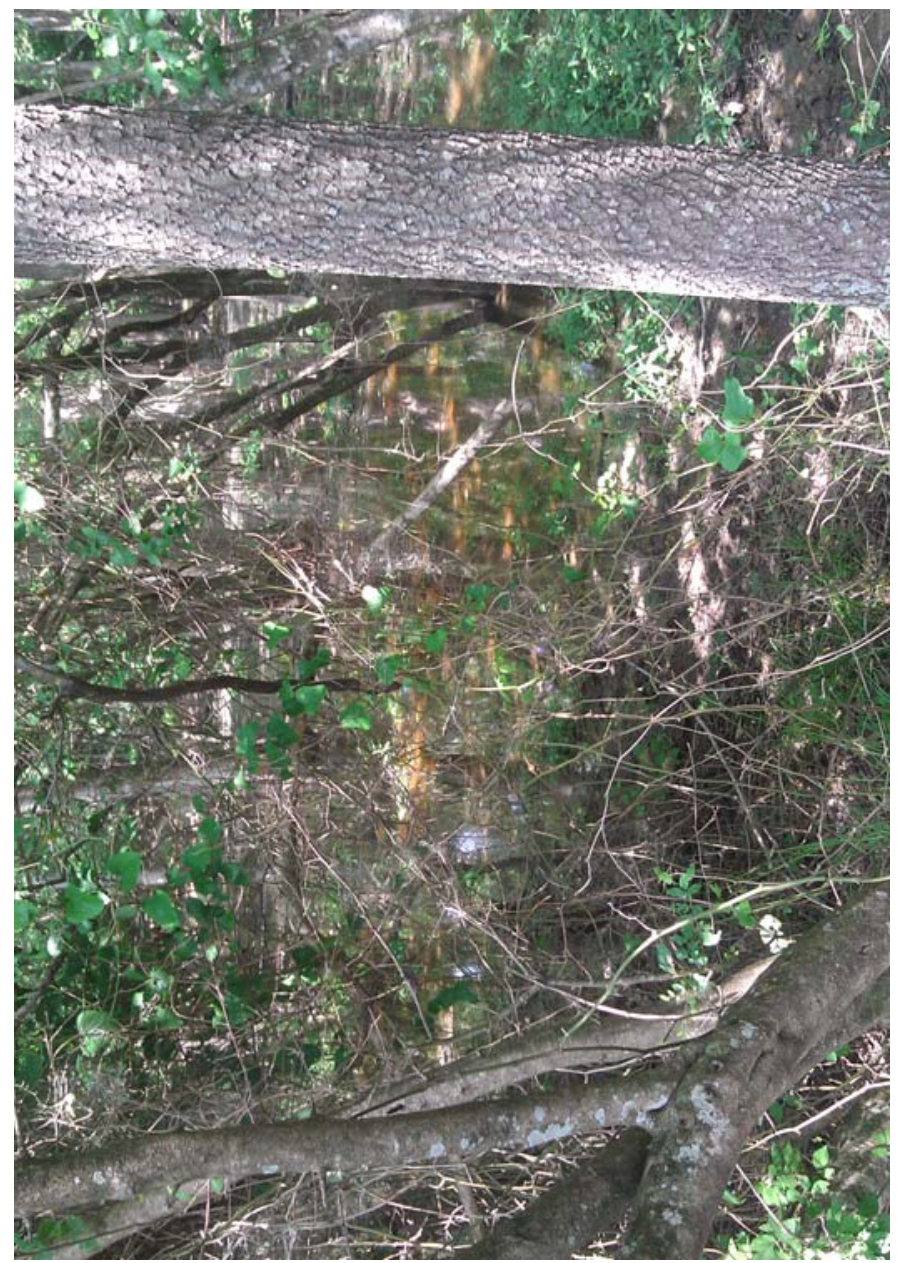

85

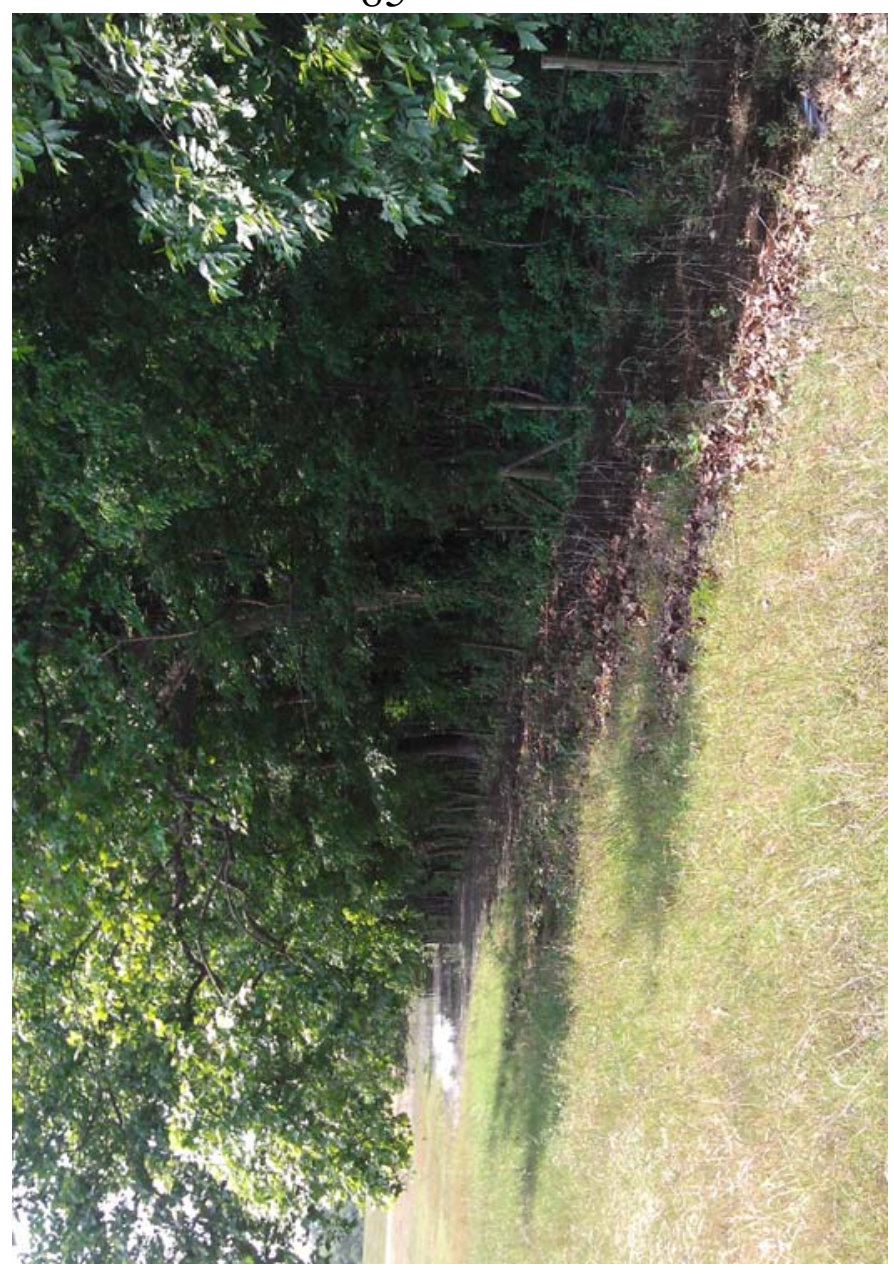

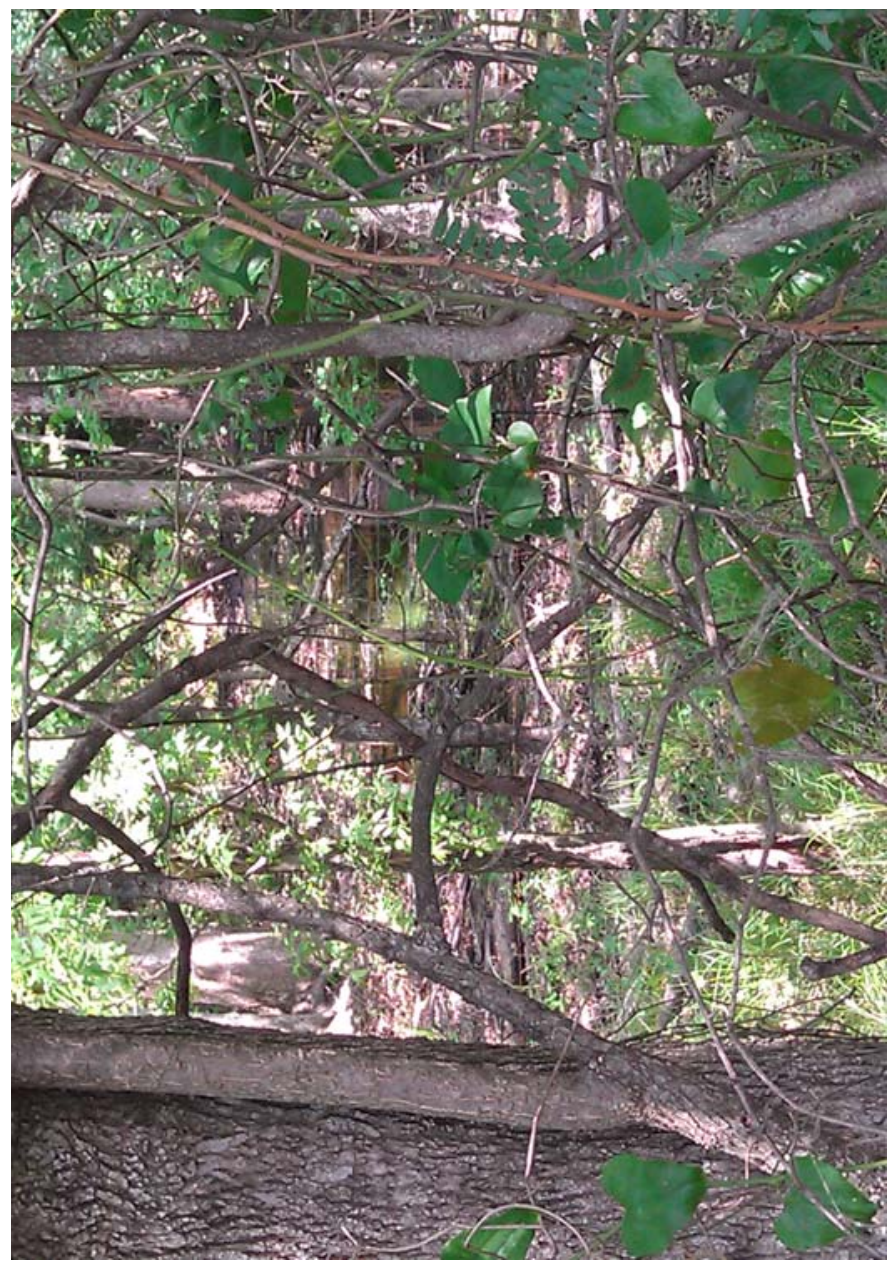

\section{6}

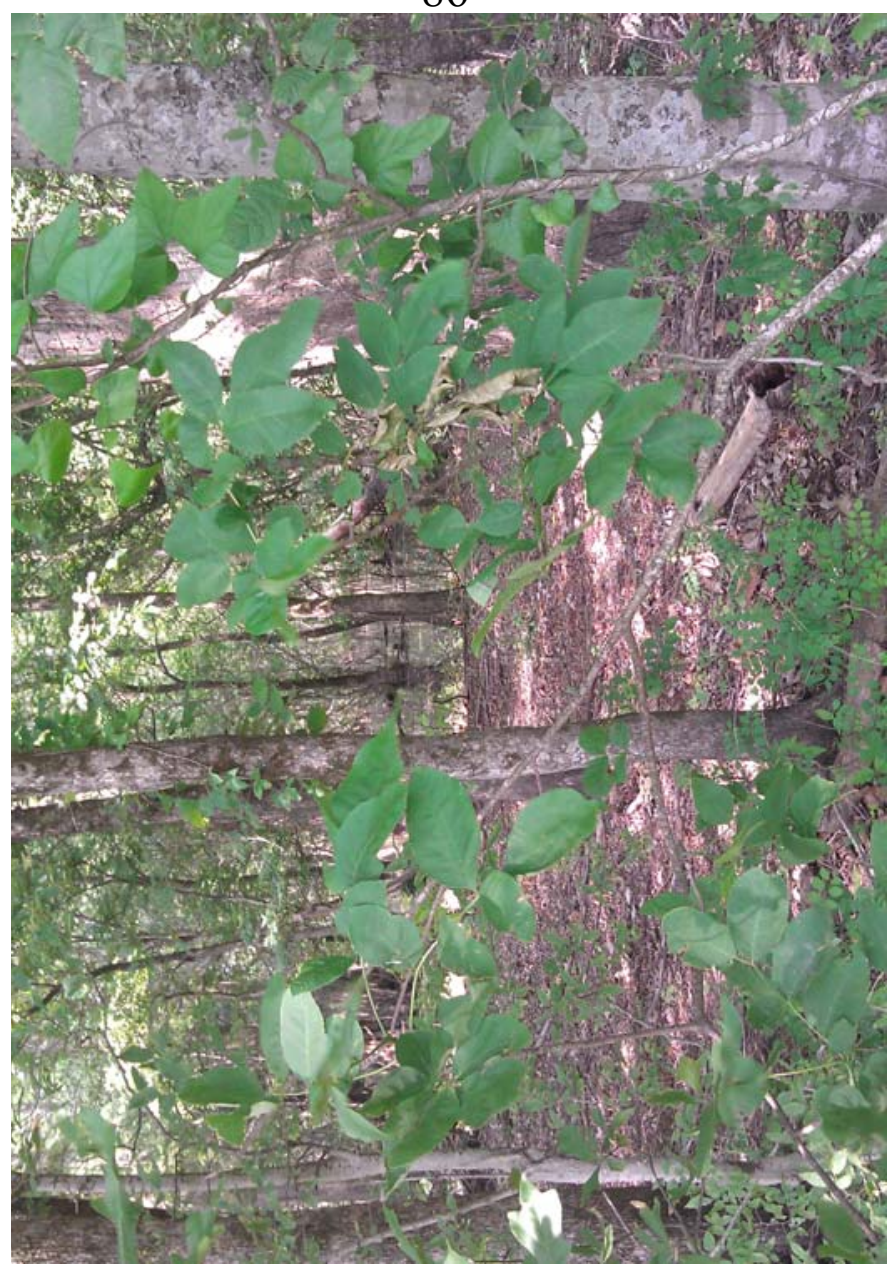




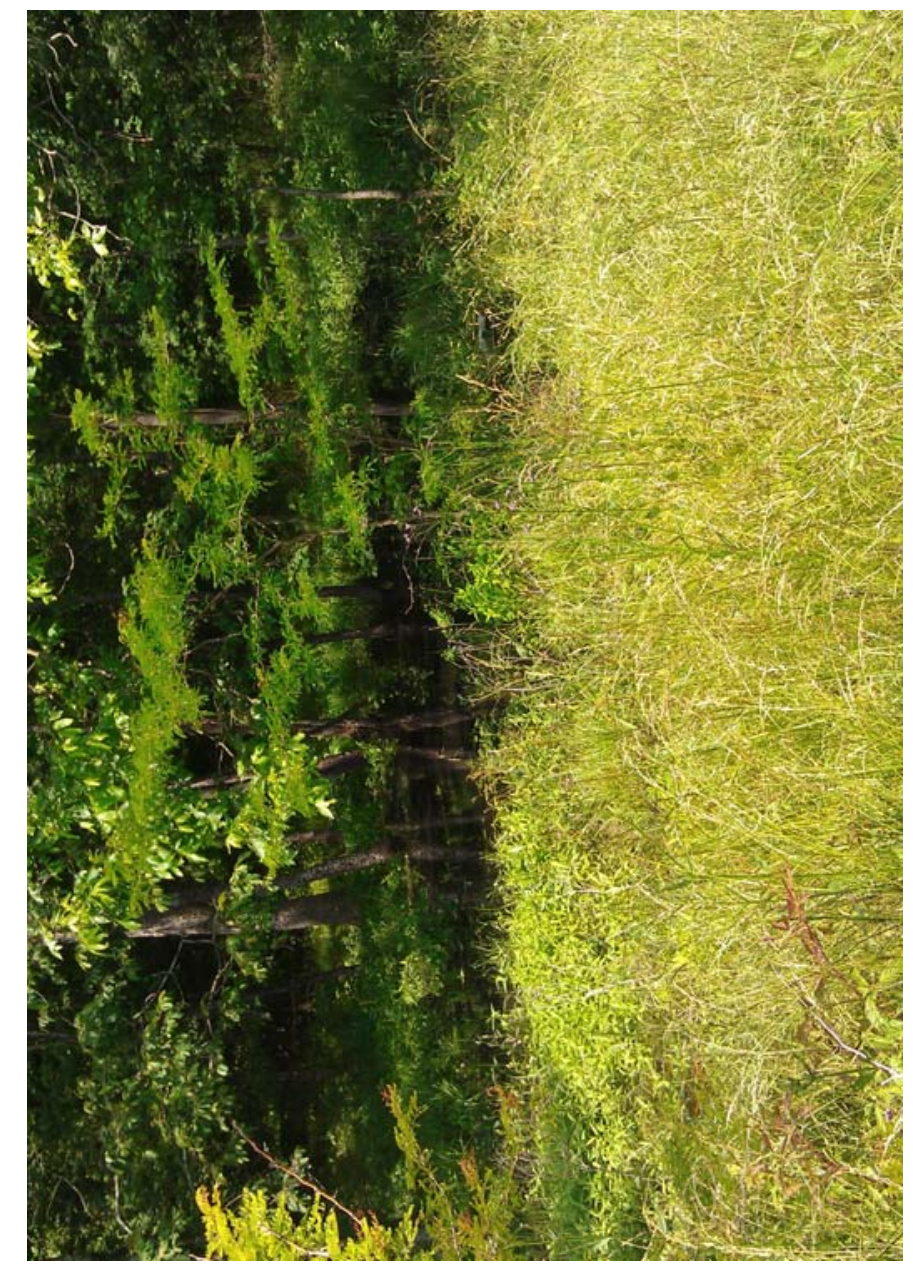

89

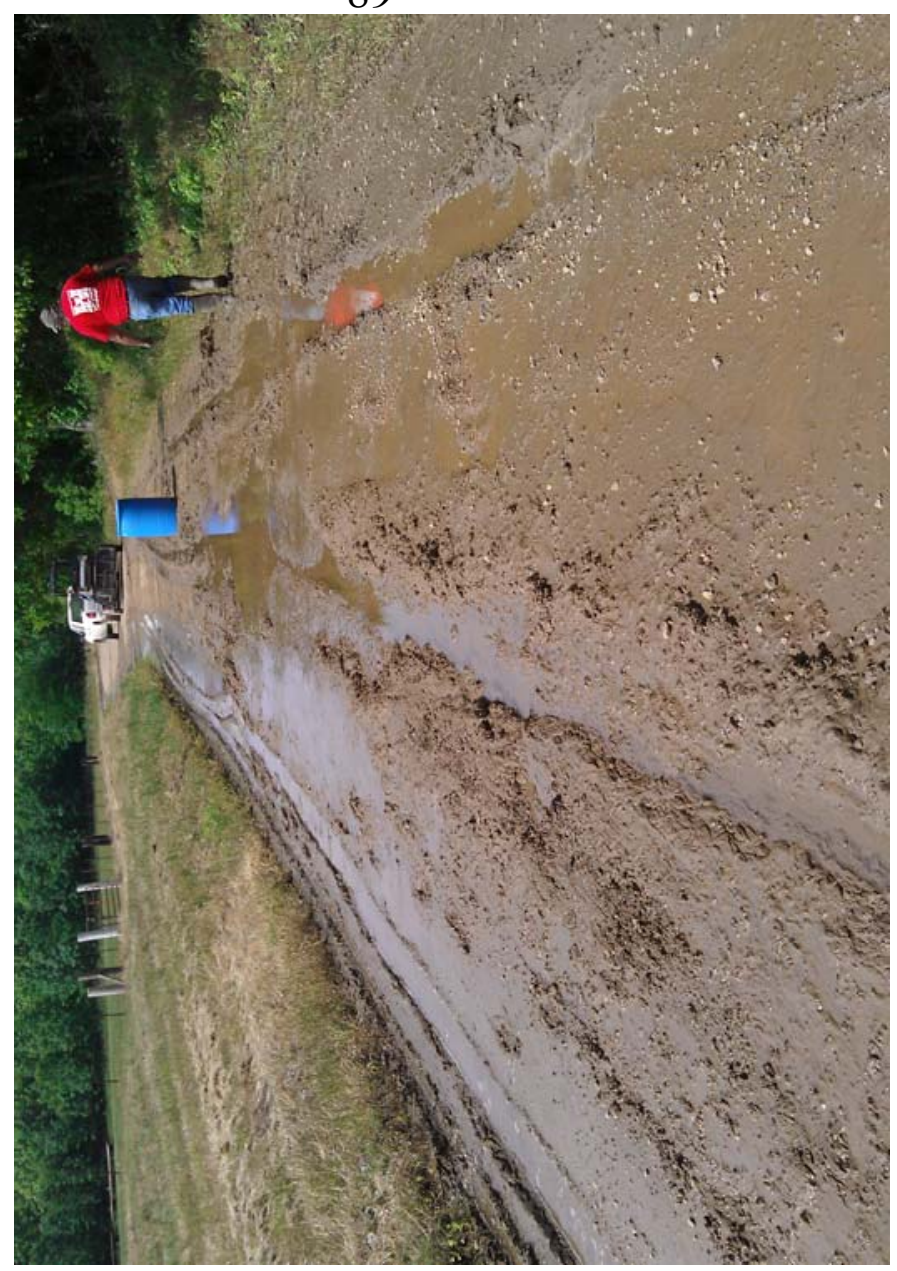

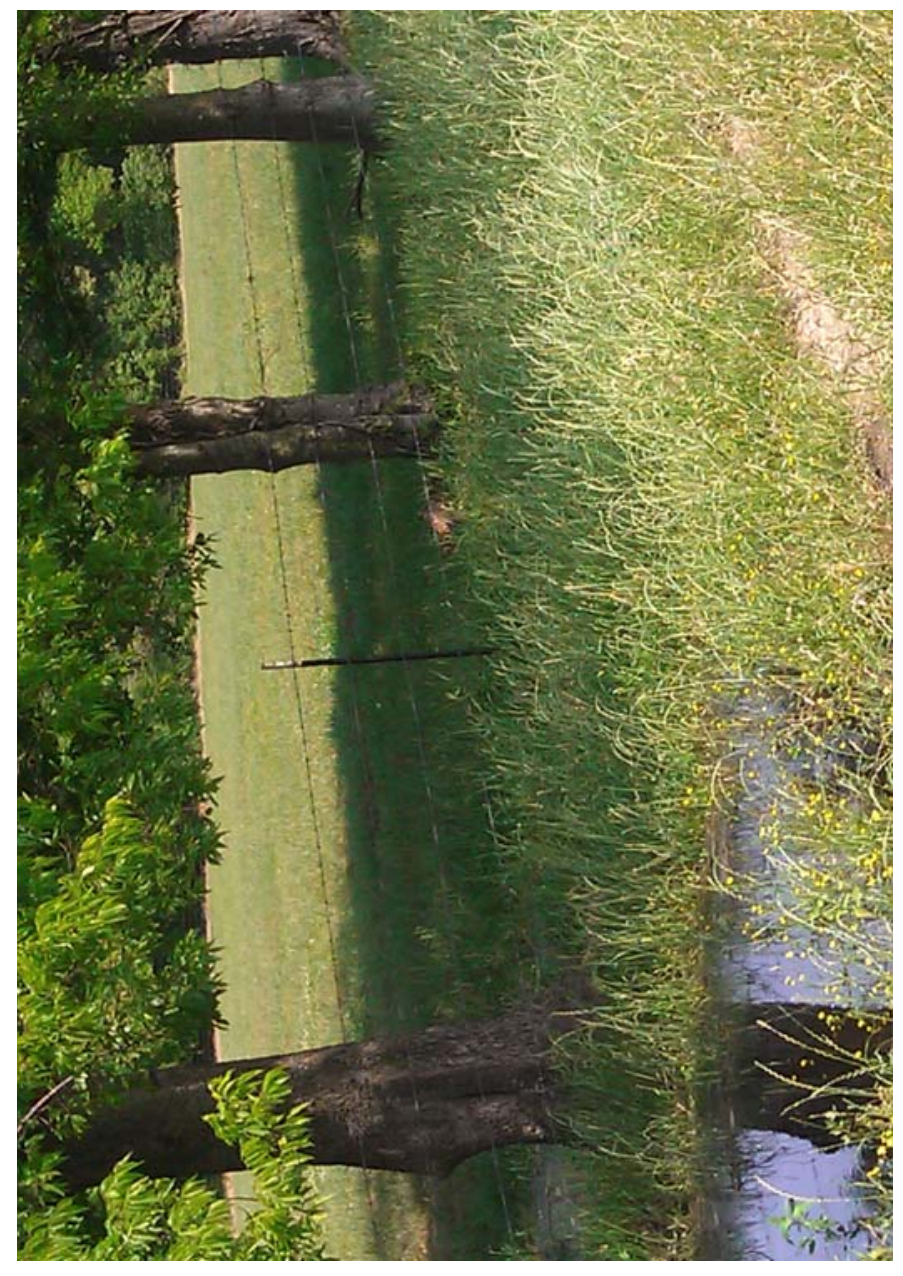

90

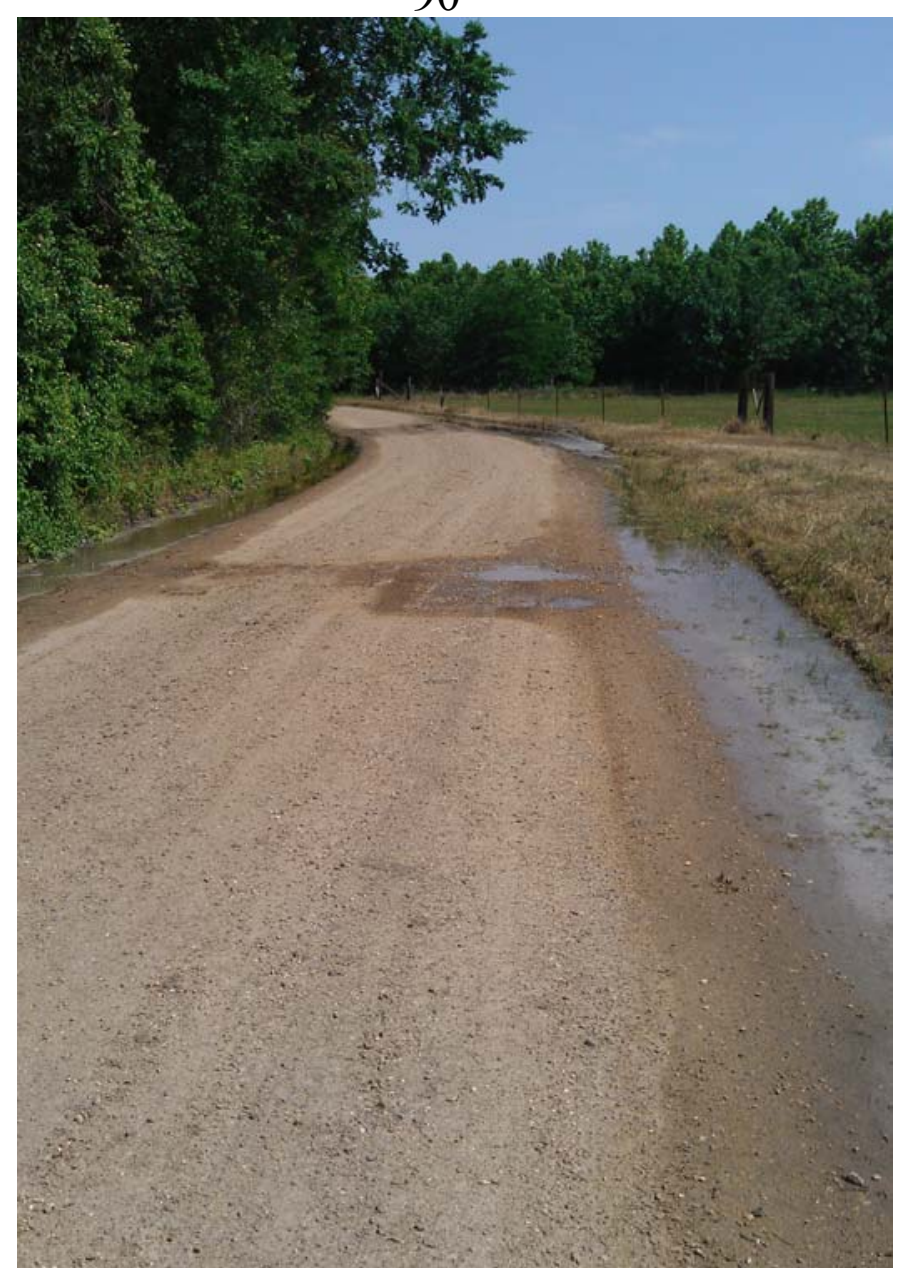




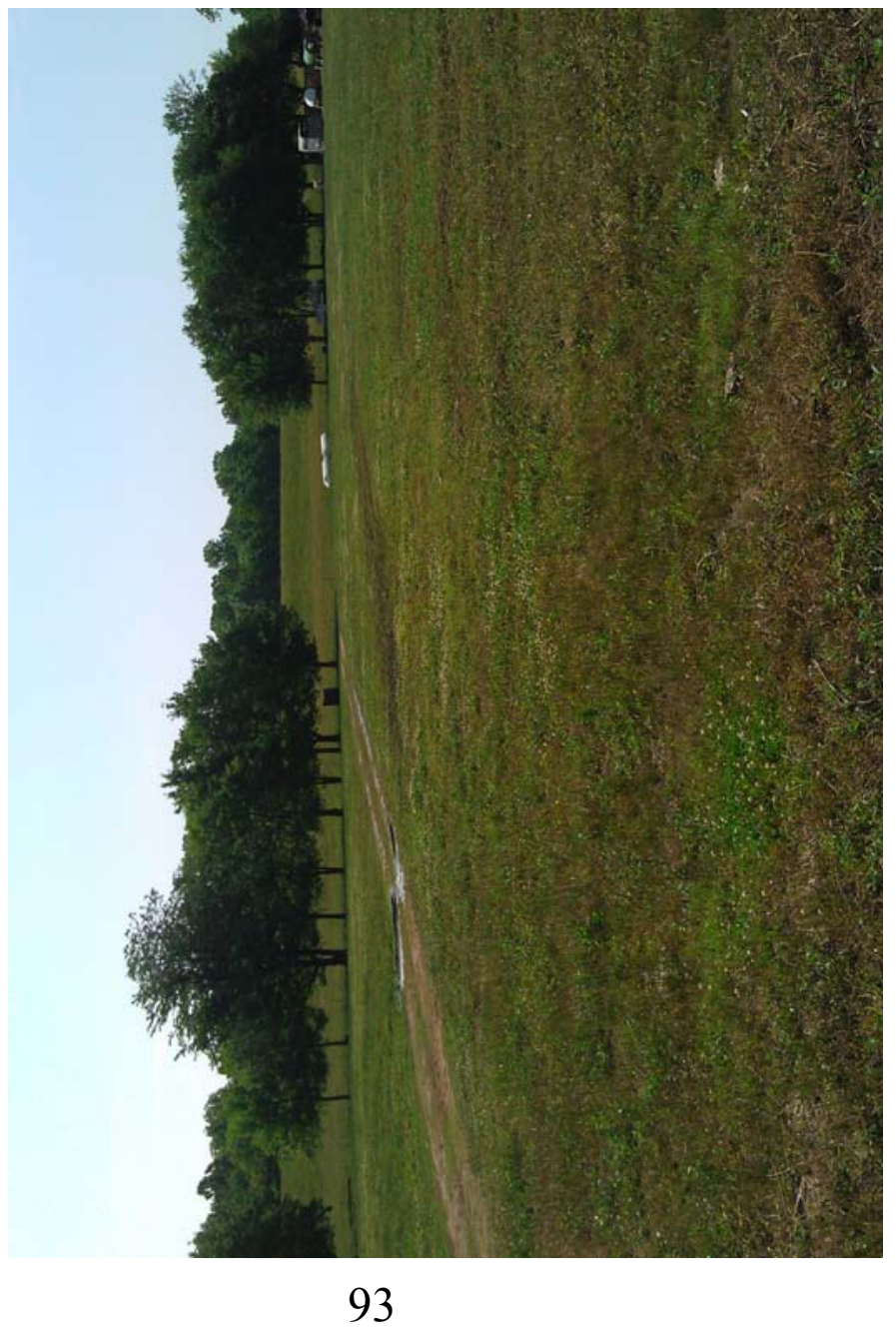

FOR OFFICIAL USE ONLY 
STATION 3000+00 TO 4500+00 
LEVEE SECTOR: Lake Bolivar to Highway 82

DATE: May 16, 2011

TEAM MEMBERS: James Sims, Dustin Herr, Ryan Reeves, Jim Hearn

\begin{tabular}{|c|c|c|c|c|c|c|c|c|c|}
\hline \multicolumn{2}{|c|}{ START } & \multicolumn{2}{|c|}{ END } & \multirow{2}{*}{$\begin{array}{l}\text { STATION } \\
\text { NLD }\end{array}$} & \multirow{2}{*}{$\begin{array}{l}\text { STATION } \\
\text { FIELD MARKER }\end{array}$} & \multirow[t]{2}{*}{ TYPE } & \multirow[t]{2}{*}{ EXTENT } & \multirow[t]{2}{*}{ REMARKS } & \multirow{2}{*}{$\begin{array}{l}\text { PHOTO } \\
\text { LINKS }\end{array}$} \\
\hline Latitude & \begin{tabular}{|l|} 
Longitude \\
\end{tabular} & \begin{tabular}{|l|} 
Latitude \\
\end{tabular} & Longitude & & & & & & \\
\hline 33.58603026 & 91.12101992 & 33.58603026 & 91.12101992 & $3072+00$ & $3040+00$ & Slide & Light & $\begin{array}{l}\text { Possible slide or levee damaged by cattle approximately } 10 \text { feet up from } \\
\text { the toe of the levee near Sta. } 3040 .\end{array}$ & 1 \\
\hline 33.57750377 & 91.12755206 & 33.57750377 & 91.12755206 & $3108+00$ & $3075+00$ & Under Seepage & Light & $\begin{array}{l}\text { Light seepage in low area } 150 \text { yards from the levee toe near Sta. } 3075 . \\
\text { Area is approximately } 10 \text { yards wide. }\end{array}$ & 2 \\
\hline 33.57288961 & 91.13396492 & 33.57195 & 91.13556 & $\begin{array}{l}3133+00 \text { to } \\
3136+00\end{array}$ & $\begin{array}{l}3100+00 \text { to } \\
3108+00\end{array}$ & Under Seepage & Light & $\begin{array}{l}\text { Light seepage in field approximately } 150 \text { yards from the toe of the levee } \\
\text { between Sta. } 3100 \text { and } 3108 \text {. Area is approximately } 100 \text { yards wide and } \\
200 \text { yards long. }\end{array}$ & $3-4$ \\
\hline 33.56972699 & 91.13833917 & 33.56972699 & 91.13833917 & $3157+00$ & $3125+00$ & Under Seepage & Light & $\begin{array}{l}\text { Widespread light seepage approximately } 100 \text { yards from the toe of the } \\
\text { levee extending into the woods and field for approximately } 100 \text { to } 20 \mathrm{C} \\
\text { yards. Clear water noted seeping from around a piezometer near the } \\
\text { wood line near Sta. } 3125 .\end{array}$ & 5 \\
\hline 33.56273076 & 91.14501628 & 33.56539038 & 91.14271368 & $\begin{array}{l}3172+00 \text { to } \\
3192+00\end{array}$ & $\begin{array}{l}3140+00 \text { to } \\
3160+00\end{array}$ & Through Seepage & Light & $\begin{array}{l}\text { Widespread seepage on top of the seepage berm from approximately } \\
\text { levee sta. } 3140 \text { to } 3160 . \text { Seepage is approximately } 100 \text { feet wide and } \\
\text { extends up from the toe of the berm. }\end{array}$ & 6 \\
\hline 33.56071579 & 91.14773982 & 33.56071579 & 91.14773982 & $3196+00$ & $3162+00$ & Under Seepage & Light & $\begin{array}{l}\text { Widespread seepage and standing water within an earthen ring leve } \epsilon \\
\text { near levee Sta. } 3162 \text {. Seepage begins approximately } 35 \text { yards from the } \\
\text { levee toe and extends approximately } 100 \text { yards into wooded area. Ring } \\
\text { levee is overtopped on the northeast corner. A sand boil with a 6-inch } \\
\text { throat was identified in the ponded area. Boil was stable. }\end{array}$ & $7-10$ \\
\hline 33.5604 & 91.14803 & 33.55987 & 91.14882 & $\begin{array}{l}3197+00 \text { to } \\
3201+00\end{array}$ & $\begin{array}{l}3163+00 \text { to } \\
3170+00\end{array}$ & Through Seepage & Light & $\begin{array}{l}\text { Light seepage on top of the seepage berm from near levee Sta. } 3163 \text { to } \\
\text { Sta. } 3170 .\end{array}$ & \\
\hline 33.54508094 & 91.1511177 & 33.54508094 & 91.1511177 & $3278+00$ & $3245+00$ & Under Seepage & Light & $\begin{array}{l}\text { Light seepage from the berm toe extending out approximately } 50 \text { yards } \\
\text { near levee Sta. } 3245 . \text { Seepage extends downstream from approximately } \\
100 \text { yards. }\end{array}$ & 11 \\
\hline 33.53888418 & 91.15161226 & 33.53888418 & 91.15161226 & $3285+00$ & $3251+00$ & Under Seepage & Light & $\begin{array}{l}\text { Light seepage in a low area approximately } 150 \text { yards from the toe of the } \\
\text { levee near Sta. } 3251 \text {. Seepage berm cannot be identified. }\end{array}$ & 12 \\
\hline 33.5371533 & 91.15131648 & 33.52690206 & 91.14132887 & $\begin{array}{l}3291+00 \text { to } \\
3348+00\end{array}$ & $\begin{array}{l}3260+00 \text { to } \\
3312+00\end{array}$ & Under Seepage & Light & $\begin{array}{l}\text { Light seepage in drainage ditch along the toe of the seepage berm } \\
\text { extending from levee sta. } 3260 \text { to } 3312 \text {. }\end{array}$ & 13 \\
\hline 33.52151822 & 91.13672269 & 33.52151822 & 91.13672269 & $3371+00$ & $3339+00$ & Under Seepage & Light & $\begin{array}{l}\text { Light seepage along a cattle path off the seepage berm toe near levee } \\
\text { Sta. 3339. Seepage extends upstream approximately } 150 \text { yards. }\end{array}$ & $14-17$ \\
\hline 33.49741 & 91.11043 & 33.4969265 & 91.11014706 & $\begin{array}{l}3493+00 \text { to } \\
3496+00\end{array}$ & $\begin{array}{l}3460+00 \text { to } \\
3463+00\end{array}$ & Under Seepage & Light & $\begin{array}{l}\text { Light seepage approximately } 50 \text { yards from the levee toe between levee } \\
\text { Sta. } 3460 \text { and } 3463 \text {. Seepage is approximately } 50 \text { to } 100 \text { feet wide. }\end{array}$ & 18 \\
\hline 33.48164 & 91.10782 & 33.48083803 & 91.10758151 & $\begin{array}{l}3551+00 \text { to } \\
3554+00\end{array}$ & $\begin{array}{l}3519+00 \text { to } \\
3521+00\end{array}$ & Under Seepage & Light & $\begin{array}{l}\text { Light seepage appoximately } 20 \text { yards for the toe of the seepage berm } \\
\text { between levee Sta. } 3519 \text { and } 3521 \text {. Seepage is approximately } 150 \text { yards } \\
\text { wide. }\end{array}$ & 19 \\
\hline 33.47434 & 91.09022 & 33.47434 & 91.09022 & $3618+00$ & $3585+00$ & Under Seepage & Light & $\begin{array}{l}\text { Light seepage approximately } 25 \text { yards from the toe of the seepage berm } \\
\text { in a wheat field near levee station } 3585 \text {. Seepage area is approximately } \\
50 \text { yards long and } 25 \text { yards wide. }\end{array}$ & $20-21$ \\
\hline 33.47376433 & 91.08870023 & 33.47376433 & 91.08870023 & $3622+00$ & $3590+00$ & Sand Boil & moderate & $\begin{array}{l}\text { Small sand boil with } 2 \text { to } 3 \text { inch throat under water in the edge of an olc } \\
\text { slough approximately } 50 \text { yards from the seepage berm toe near levee } \\
\text { Sta. } 3590 \text {. Sand boil has been flagged and is flowing clear water at } \\
\text { a rate of less than } 20 \mathrm{gpm} \text {. }\end{array}$ & 22 \\
\hline 33.46619 & 91.06873 & 33.46612896 & 91.06861329 & $3688+00$ & $3655+00$ & Under Seepage & Light & $\begin{array}{l}\text { Light seepage along the toe of the seepage berm near levee Sta. } 3655 \text {. } \\
\text { Seepage extends approximately } 75 \text { yards upstream and is approximately } \\
20 \text { to } 30 \text { feet wide. }\end{array}$ & 23 \\
\hline
\end{tabular}




\begin{tabular}{|c|c|c|c|c|c|c|c|c|c|}
\hline \multicolumn{2}{|c|}{ START } & \multicolumn{2}{|c|}{ END } & \multirow{2}{*}{$\begin{array}{l}\text { STATION } \\
\text { NLD }\end{array}$} & \multirow{2}{*}{$\begin{array}{c}\text { STATION } \\
\text { FIELD MARKER }\end{array}$} & \multirow[t]{2}{*}{ TYPE } & \multirow[t]{2}{*}{ EXTENT } & \multirow[t]{2}{*}{ REMARKS } & \multirow{2}{*}{$\begin{array}{l}\text { PHOTO } \\
\text { LINKS } \\
\end{array}$} \\
\hline Latitude & Longitude & Latitude & Longitude & & & & & & \\
\hline 33.46929403 & 91.06947247 & 33.46929403 & 91.06947247 & $\begin{array}{l}3670+00 \text { to } \\
3680+00\end{array}$ & $\begin{array}{l}3640+00 \text { to } \\
3660+00\end{array}$ & Sand Boil & Moderate & $\begin{array}{l}\text { Multiple sand boils within canal at Black Bayou. Sand boils have been } \\
\text { stabilized by the levee board with the installation of an earthen dam } \\
\text { and galvanized culvert in the canal. Flow through the culvert was } \\
\text { estimated to be } 200 \text { to } 300 \mathrm{gpm} \text {. Sand boils in the canal are } \\
\text { approximately } 1200 \text { feet from the toe of the levee. (Site is located } \\
\text { off North Lake Ferguson Road between Levee Sta. } 3640 \text { and 3660). }\end{array}$ & $24-28$ \\
\hline 33.46317 & 91.06138 & 33.46217026 & 91.05817124 & $\begin{array}{l}3712+00 \text { to } \\
3725+00\end{array}$ & $\begin{array}{l}3680+00 \text { to } \\
3691+00\end{array}$ & Through Seepage & Light & $\begin{array}{l}\text { Light through seepage on top of seepage berm from levee Sta. } 3680 \\
\text { to } 3691 . \text { Seepage is approximately } 50 \text { to } 100 \text { yards wide on the berm. }\end{array}$ & $29-30$ \\
\hline 33.45778773 & 91.05204931 & 33.4569 & 91.05114 & $\begin{array}{l}3744+00 \text { to } \\
3750+00\end{array}$ & $\begin{array}{l}3710+00 \text { to } \\
3720+00\end{array}$ & Sand Boil & Heavy & $\begin{array}{l}\text { Winterville Sand Boil Site - - A large, high energy sand boil approximately } \\
\text { thirty feet from the toe of } 200 \text { foot seepage berm near levee Sta. } 3720 \text {. } \\
\text { The boil was estimated to be flowing approximately } 300-350 \mathrm{gpm} \text {. } \\
\text { and was moving significant quantities of silt and fine sand (approximately } \\
100 \text { cubic yards). The boil was bagged by the Levee Board with prison } \\
\text { labor and a small earthen levee was constructed by a local contractor. } \\
\text { A filter of sand and stone was constructed over the boil throat to filter } \\
\text { fines and dissipate energy. Four additional medium sized boils were } \\
\text { identified within } 250 \text { feet of the berm toe that required either a small } \\
\text { sand bag ring or a } 30 \text {-gallon drum for stabilization. Boils are located } \\
\text { between Levee Sta. } 3710 \text { and 3720). }\end{array}$ & $31-42$ \\
\hline 33.45523702 & 91.04973971 & 33.45523702 & 91.04973971 & $3758+00$ & $3725+00$ & Sand Boil & Moderate-Heavy & $\begin{array}{l}\text { Light seepage and two small sand boils that were ringed with } 30 \text {. } \\
\text { gallon drums by the levee board near levee Sta. } 3725 \text {. The sand boils } \\
\text { were stable and flowing approximately } 30-50 \text { gpm of clear water. } \\
\text { The boils and seepage area extends from the toe of the seepage berm } \\
\text { and is approximately } 200 \text { yards wide. }\end{array}$ & $43-45$ \\
\hline 33.45183974 & 91.04785526 & 33.45183974 & 91.04785526 & $3770+00$ & $3738+00$ & Under Seepage/Pin Boils & Moderate & $\begin{array}{l}\text { Moderate seepage with five pin boils with } 1 \text { to } 2 \text { inch throats near leve } \\
\text { Sta. } 3740 \text {. Area is within } 25 \text { feet of the toe of the seepage berm. }\end{array}$ & $46-47$ \\
\hline 33.45177212 & 91.04406652 & 33.45177212 & 91.04406652 & $3776+00$ & $3741+00$ & Under Seepage & Light & $\begin{array}{l}\text { Light seepage in ditches and in residential area along Highway } 1 \text { neal } \\
\text { Lake Fergusson. Seepage is located near Levee Sta. } 3741 \text { and is } \\
\text { approximately } 800 \text { feet from the toe of the levee. }\end{array}$ & $48-51$ \\
\hline 33.44615703 & 91.04725582 & 33.44615703 & 91.04725582 & $3791+00$ & $3759+00$ & Under Seepage & Light & $\begin{array}{l}\text { Light seepage in a field along along the toe of the seepage berm near } \\
\text { levee Sta. } 3759 . \text { Water in the field is approximately } 8 \text { inches deep. }\end{array}$ & $52-53$ \\
\hline 33.44273663 & 91.0495045 & 33.44273663 & 91.0495045 & $3800+00$ & $3765+00$ & Sand Boil & Moderate & $\begin{array}{l}\text { Sand boil and light to moderate seepage at the intersection of Abbot Road } \\
\text { and Barnes Landing near levee Sta. } 3765 . \text { Sand boil is ringed with a } 30 \text { - } \\
\text { gallon plastic drum and is flowing approximately } 30 \mathrm{gpm} \text {. Light tc } \\
\text { moderate seepage was observed along ditch and in residential area. } \\
\text { Light through seepage on top of the seepage berm near levee Sta. } 377 C \\
\text { extending from the toe of the levee to the toe of the berm and approx. } \\
200 \text { yards upstream. }\end{array}$ & $54-56$ \\
\hline 33.43817539 & 91.04912592 & 33.43039867 & 91.04962619 & $\begin{array}{l}3820+00 \text { to } \\
3849+00\end{array}$ & $\begin{array}{l}3788+00 \text { to } \\
3816+00\end{array}$ & Under Seepage/Pin Boils & Light to Moderate & $\begin{array}{l}\text { Light to moderate seepage from the toe of the seepage berm extending } \\
\text { out approximately } 40 \text { to } 60 \text { yards between levee Sta. } 3788 \text { and } 3816 \text {. } \\
\text { Several small pin boils under } 3 \text { to } 6 \text { inches of water along stretch that } \\
\text { are moving small quantities of silt and very fine sand. }\end{array}$ & $57-59$ \\
\hline 33.42750527 & 91.05013354 & 33.42750527 & 91.05013354 & $\begin{array}{l}3852+00 \text { to } \\
3860+00\end{array}$ & $\begin{array}{l}3820+00 \text { to } \\
3829+00\end{array}$ & Under Seepage & Light & $\begin{array}{l}\text { Light seepage along the toe of the seepage berm between levee Sta. } \\
3820 \text { and } 3829 . \text { Seepage is approximately } 100 \text { yards long and } 20 \text { yards } \\
\text { wide and is held in by a ring levee off the toe of the berm. }\end{array}$ & 60 \\
\hline 33.39944213 & 91.0701666 & 33.39944213 & 91.0701666 & $3886+00$ & $3852+00$ & Sand Boil & Moderate/Heavy & $\begin{array}{l}\text { Active sand boil identified on the edge of seepage berm approximately } \\
75 \text { yards from the railroad tracks near levee Sta. } 3952 \text {. Area is under } 6 \\
\text { to } 10 \text { inches of seepage water. Sand boil has a } 12 \text {-inch throat and have } \\
\text { formed a cone that is approximately } 12 \text {-inches high. Boil is flowing } \\
\text { approximately } 50 \mathrm{gpm} \text { and continues to transport moderate quantities } \\
\text { of silt/fine sand. }\end{array}$ & $61-62$ \\
\hline
\end{tabular}




\begin{tabular}{|c|c|c|c|c|c|c|c|c|c|}
\hline \multicolumn{2}{|c|}{ START } & \multicolumn{2}{|c|}{ END } & \multirow{2}{*}{$\begin{array}{l}\text { STATION } \\
\text { NLD }\end{array}$} & \multirow{2}{*}{$\begin{array}{c}\text { STATION } \\
\text { FIELD MARKER } \\
\end{array}$} & \multirow[t]{2}{*}{ TYPE } & \multirow[t]{2}{*}{ EXTENT } & \multirow[t]{2}{*}{ REMARKS } & \multirow{2}{*}{$\begin{array}{r}\text { PHOTO } \\
\text { LINKS } \\
\end{array}$} \\
\hline Latitude & Longitude & Latitude & Longitude & & & & & & \\
\hline 33.419069 & 91.058111 & 33.419069 & 91.058111 & $3896+00$ & $3863+00$ & Under Seepage/Pin Boils & Moderate & $\begin{array}{l}\text { Three or four pin boils and moderate seepage at the intersection of Hunt } \\
\text { and Court Streets in Greenville. Site is near Levee Sta. } 3863 \text {. }\end{array}$ & \\
\hline 33.38902229 & 91.07378533 & 33.38089 & 91.07314 & $4028+00$ & $3995+00$ & Under Seepage & Light & $\begin{array}{l}\text { Light seepage along power line on both sides of the railroad tracks near } \\
\text { levee Sta. } 3995 \text {. Seepage is approximately } 50 \text { feet wide and extends } \\
\text { downstream approximately } 300-500 \text { yards. }\end{array}$ & 63-64 \\
\hline 33.37860781 & 91.07400535 & 33.37758257 & 91.074514 & $\begin{array}{l}4065+00 \text { to } \\
4072+00\end{array}$ & $\begin{array}{l}4031+00 \text { to } \\
4040+00\end{array}$ & Sand Boil & Heavy & $\begin{array}{l}\text { Multiple moderate to high energy sand boils were identified moving large } \\
\text { quantities of fine sand in two separate areas on the east side of the } \\
\text { railroad tracks approximately } 400 \text { feet from the levee toe. There is no } \\
\text { seepage berm in this area. Heavy seepage, numerous pin boils and } \\
\text { saturated, soft ground was identified in and around the boil areas. One } \\
\text { area is on the power line right-of -way and the other is in the woods } \\
\text { approximately } 30 \text { yards to the southeast. During the initial site visit, } \\
\text { there were numerous small boils identified in the wooded area. The } \\
\text { throats on these boils ranged from } 3 \text { to } 6 \text { inches in diameter and } \\
\text { several yards ( } 5 \text { to } 8 \text { cyds.) of material had been transported over a } 1000 \\
1000 \text { square foot area; however, most of these boils were producing clear } \\
\text { water. Some of the larger boils were later stabilized with } 30 \text {-gallon drums } \\
\text { drums placed over the throats of the boils. There were appproximately } \\
\text { approximately three high flowing sand boils identified in a low spot } \\
\text { along the power line. These boils were flowing approximately } 100-200 \\
\text { gpm each, and were transporting a significant quantity of fine sand and } \\
\text { clay/silt balls. Over } 15 \text { to } 20 \text { yards of material had already been } \\
\text { transported from the boils and material was still being moved. } \\
\text { Throat diameter of the boils ranged from } 12 \text { to } 18 \text { inches. Levee } \\
\text { board work crews and inmates addressed these boils by building a sand } \\
\text { bag containment ring which had to be raised at a later date to increase } \\
\text { the head over the boils. }\end{array}$ & $65-73$ \\
\hline 33.375919 & 91.074039 & 33.375919 & 91.074039 & $4077+00$ & $4045+00$ & Under Seepage & Light & Light, clear seepage behind Buckshot Marine near levee Sta. 4045. & \\
\hline 33.374711 & 91.075681 & 33.374711 & 91.075681 & $4082+00$ & $4049+00$ & Under Seepage & Moderate & Moderate seepage around an apartment complex near levee Sta. 4049. & \\
\hline 33.372481 & 91.075511 & 33.372481 & 91.075511 & $4089+00$ & $4055+00$ & Under Seepage & Light & Light to moderate seepage at Delta Steel Sales Lot near levee Sta. 4055. & \\
\hline 33.37025 & 91.07851 & 33.37025 & 91.07851 & $4099+00$ & $4066+00$ & Under Seepage/Pin Boils & Moderate & $\begin{array}{l}\text { Moderate seepage/saturated soil on top of seepage berm with } 5 \text { to } 10 \text {, } \\
\text { pin boils near levee Sta. } 4066 \text {. Pin boils have transported small } \\
\text { quantities of silt, but currently are producing clear water. Area is } \\
\text { approximately } 30 \text { yards wide and } 50 \text { yards long. }\end{array}$ & \\
\hline 33.37025 & 91.07851 & 33.36764216 & 91.0807224 & $\begin{array}{l}4099+00 \text { to } \\
4110+00\end{array}$ & $\begin{array}{l}4066+00 \text { to } \\
4078+00\end{array}$ & Under Seepage & Light & $\begin{array}{l}\text { Light seepage around businesses and along Harbor Front Road between } \\
\text { levee Sta. } 4066 \text { and } 4078 \text {. Seepage begins approximately } 15 \text { yards from } \\
\text { the toe of the seepage berm and extends out approximate } 50 \text { to } 100 \\
\text { yards. }\end{array}$ & 74-79 \\
\hline 33.35850925 & 91.08910007 & 33.35850925 & 91.08910007 & $4151+00$ & $4119+00$ & Under Seepage & Light & $\begin{array}{l}\text { Very light seepage in wooded area approximately } 20 \text { yards from the } \\
\text { railroad tracks off the toe of the seepage berm near levee Sta. } 4119 . \\
\text { Seepage drains into an old slough approximately } 30 \text { yards from the to€ } \\
\text { of the seepage berm. }\end{array}$ & 80 \\
\hline 33.35610669 & 91.09436779 & 33.35610669 & 91.09436779 & $4168+00$ & $4135+00$ & Under Seepage/Pin Boils & Moderate & $\begin{array}{l}\text { Moderate seepage with numerous small pin boils near levee Sta. } 4135 \text {. } \\
\text { Area is approx. } 75 \text { yards wide and extends downstream approximately } \\
100 \text { yards. Pin boils are flowing clear water. }\end{array}$ & $81-84$ \\
\hline 33.35333521 & 91.10247586 & 33.35333521 & 91.10247586 & $4194+00$ & $4161+00$ & Under Seepage & Light & $\begin{array}{l}\text { Four areas of light seepage approximately } 20 \text { yards from the railroad } \\
\text { tracks in the edge of a pasture near levee Sta. } 4161 . \text { Each area is } \\
\text { approximately } 25 \text { feet wide and } 50 \text { feet long and is inactive. }\end{array}$ & $85-87$ \\
\hline 33.334781 & 91.140339 & 33.334781 & 91.140339 & $4333+00$ & $4300+00$ & Heavy Current/Scour & Moderate & High current observed along riverside berm near levee Sta. 4300. & \\
\hline
\end{tabular}




\begin{tabular}{|c|c|c|c|c|c|c|c|c|c|}
\hline \multicolumn{2}{|c|}{ START } & \multirow{2}{*}{\multicolumn{2}{|c|}{ END }} & \multirow{2}{*}{$\begin{array}{l}\text { STATION } \\
\text { NLD } \\
\end{array}$} & \multirow{2}{*}{$\begin{array}{c}\text { STATION } \\
\text { FIELD MARKER } \\
\end{array}$} & \multirow[t]{2}{*}{ TYPE } & \multirow[t]{2}{*}{ EXTENT } & \multirow[t]{2}{*}{ REMARKS } & \multirow{2}{*}{$\begin{array}{l}\text { PHOTO } \\
\text { LINKS }\end{array}$} \\
\hline Latitude & Longitude & & \begin{tabular}{|l} 
Longitude \\
\end{tabular} & & & & & & \\
\hline 33.33068647 & 91.1412728 & 33.33068647 & $91.141272 \varepsilon$ & $4348+00$ & $4315+00$ & Under Seepage & Light & $\begin{array}{l}\text { Light seepage from under the seepage berm near levee Sta. } 4315 \text {. Area } \\
\text { is approximately } 25 \text { feet long and } 50 \text { feet wide. }\end{array}$ & 88 \\
\hline 33.319239 & 91.137919 & 33.319239 & $91.13791 \mathrm{c}$ & $4391+00$ & $4359+00$ & Sand Boil & Moderate & $\begin{array}{l}\text { Multiple sand boils with } 2 \text { to } 4 \text {-inch throats located in a slough area under } \\
\text { approximately } 3 \text { to } 4 \text {-feet of water near levee Sta. } 4359 \text {. Flow from boils } \\
\text { is light and moving small quantities of silt/fine sand. }\end{array}$ & \\
\hline
\end{tabular}



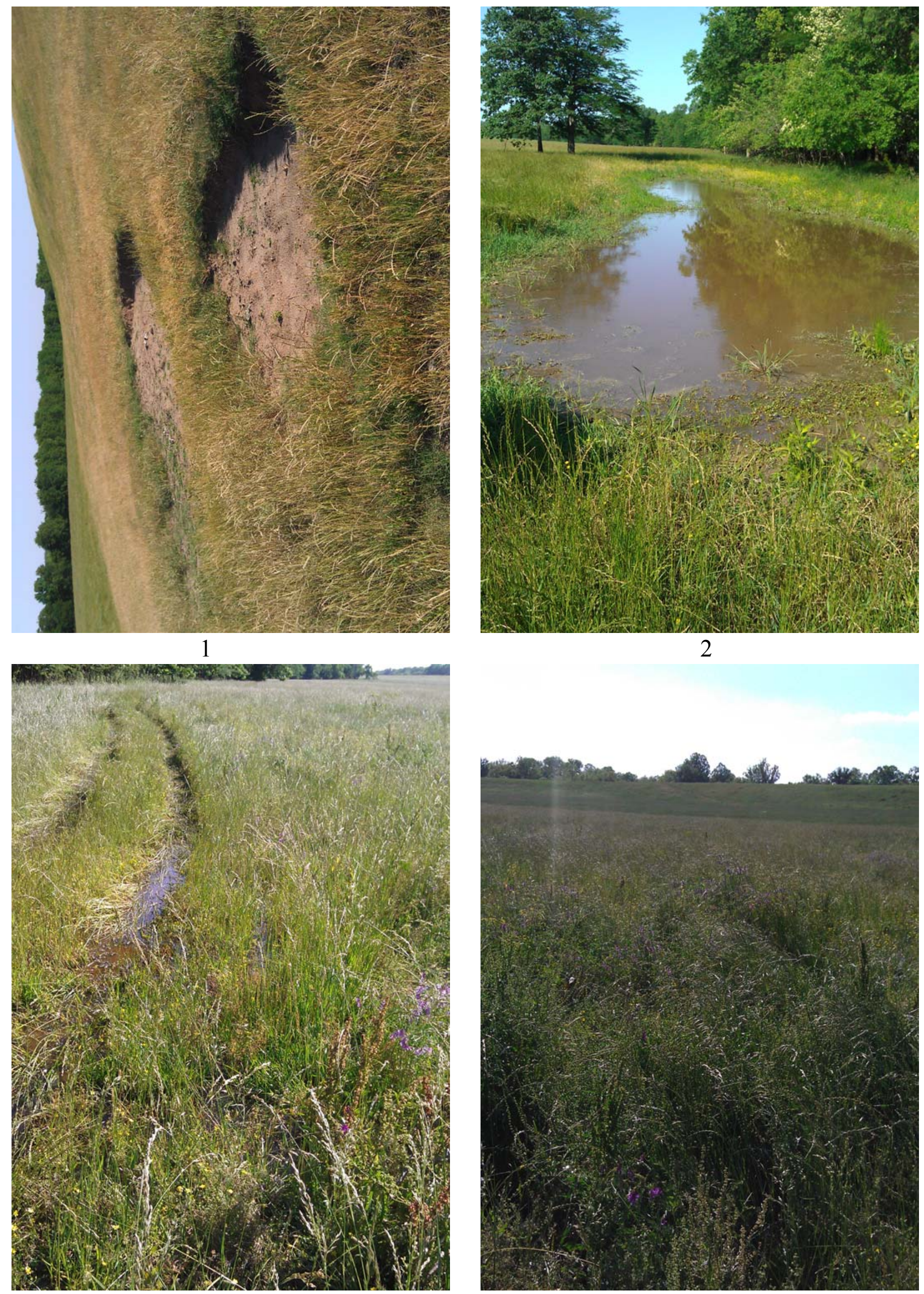


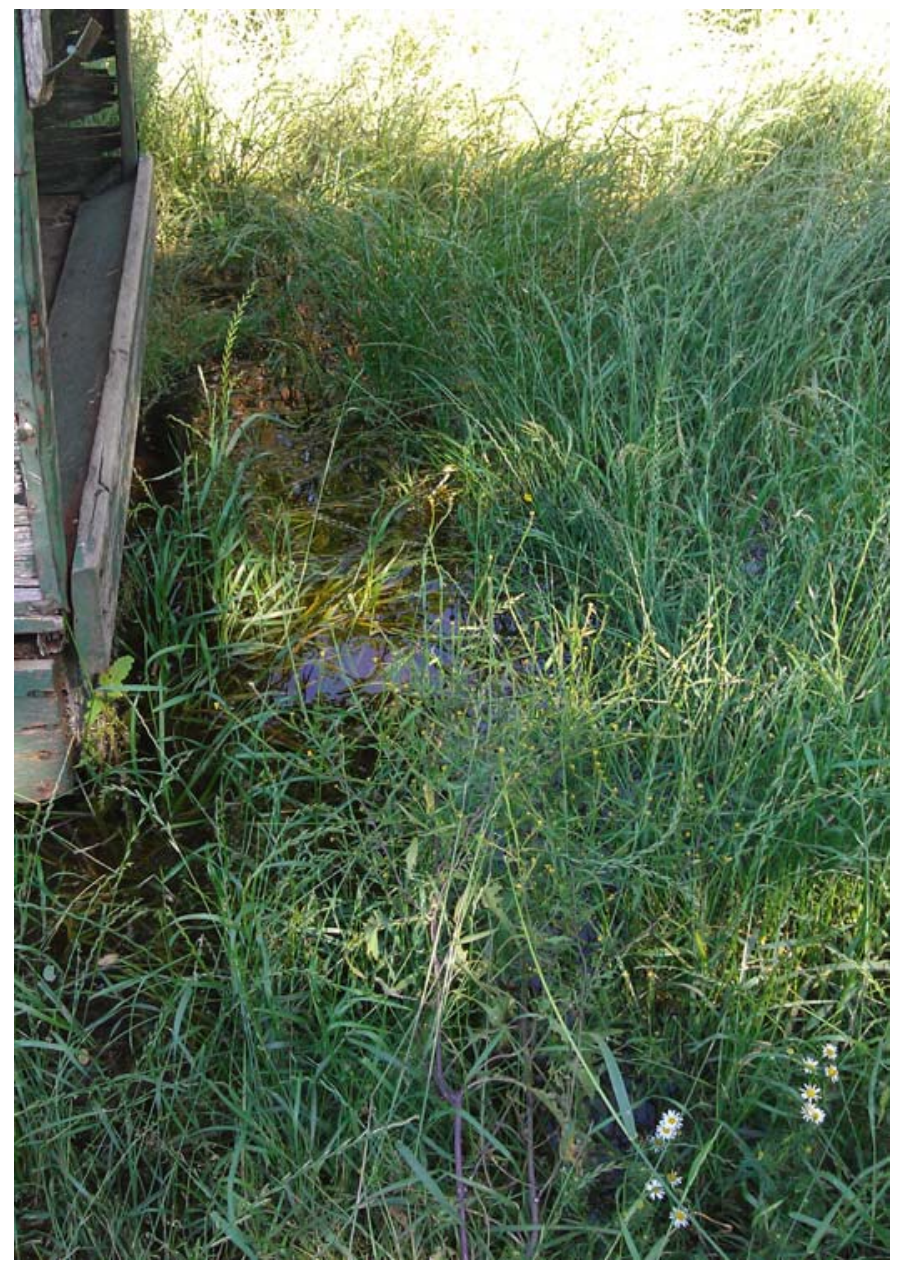

5

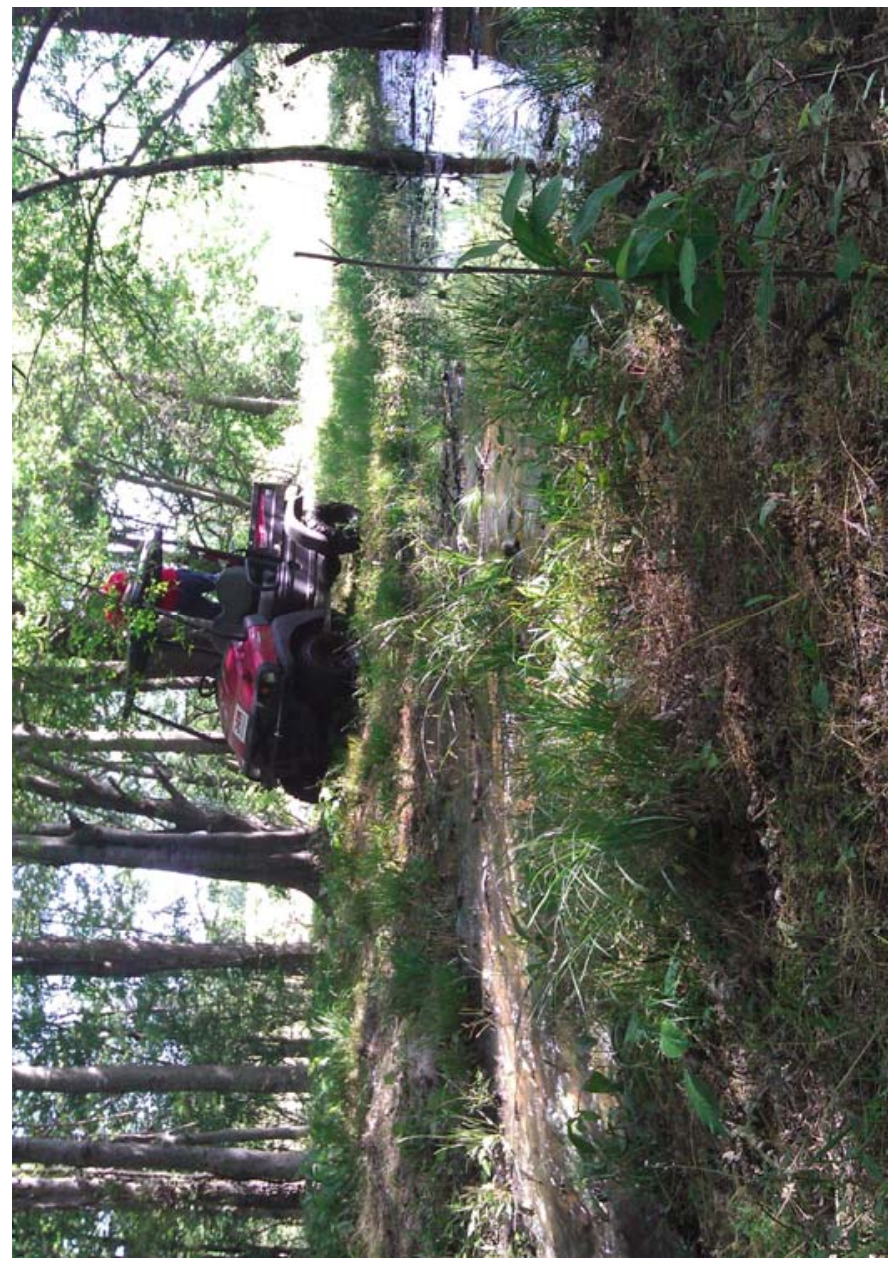

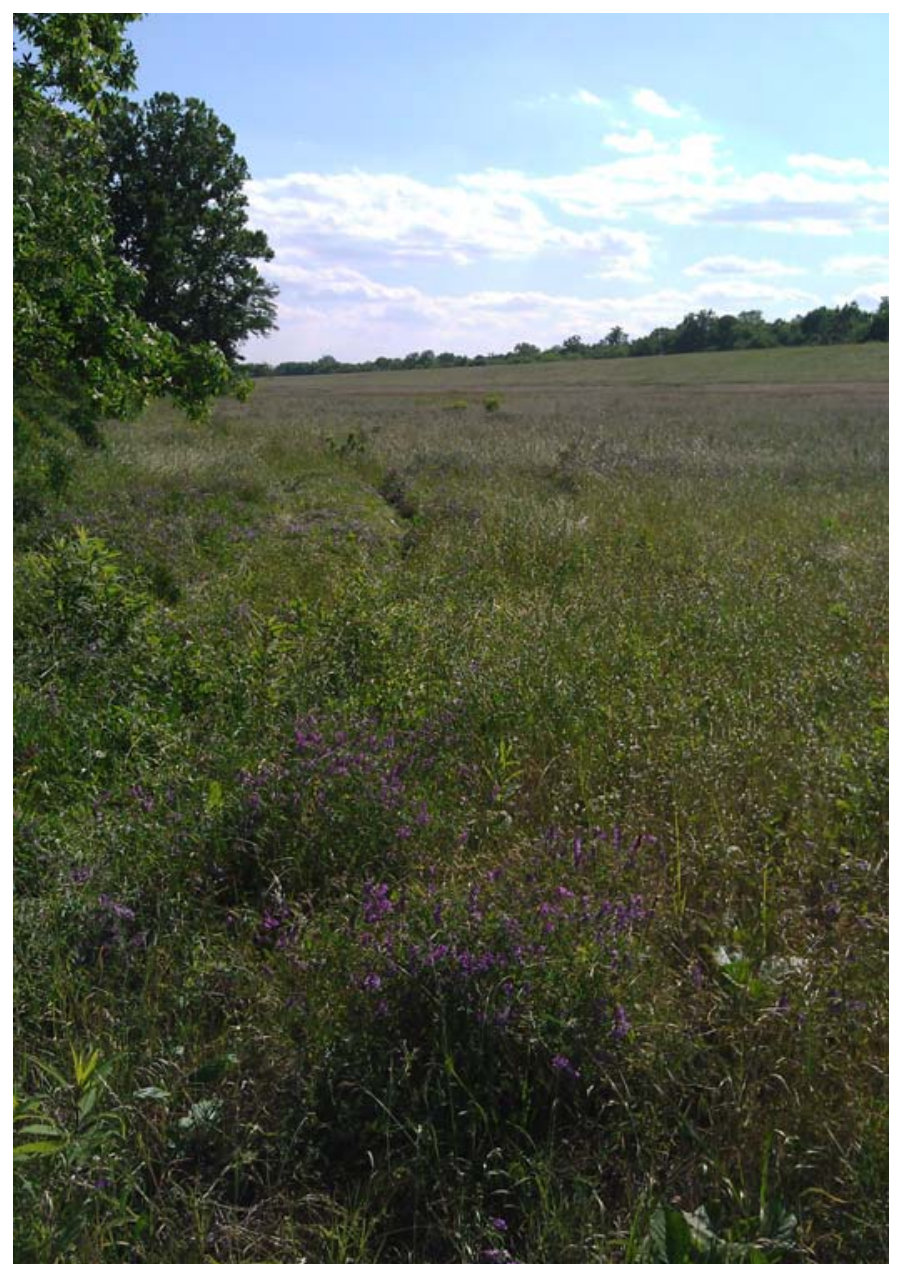

6

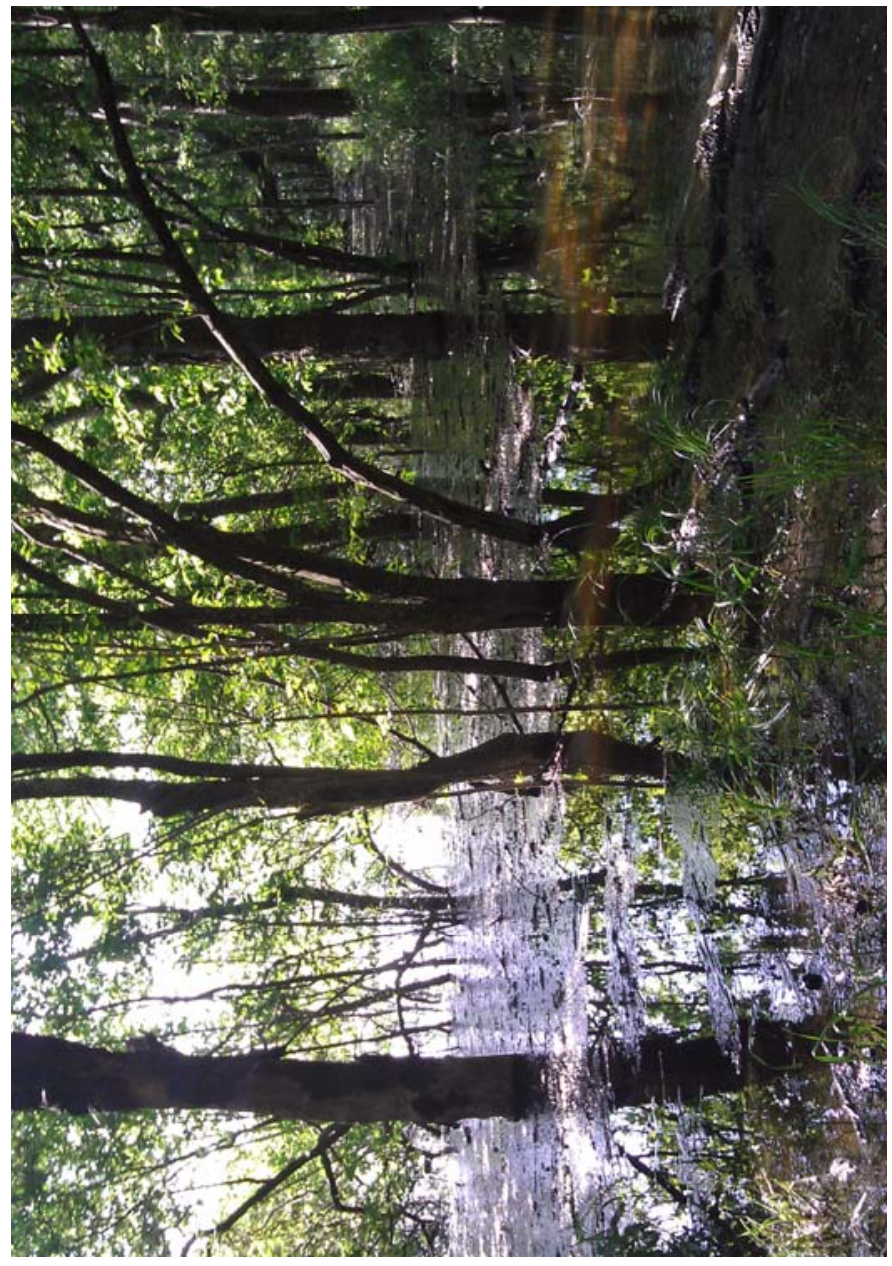




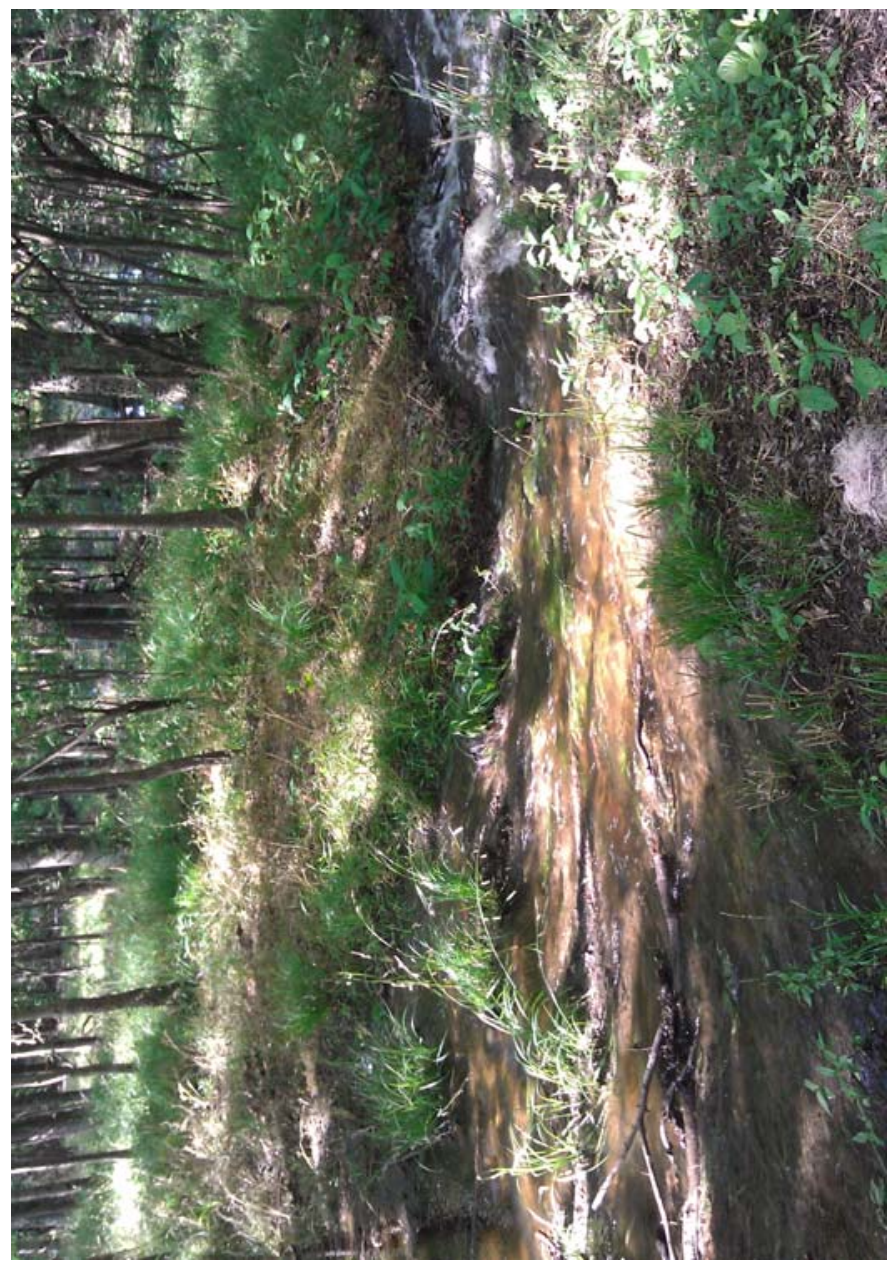

9

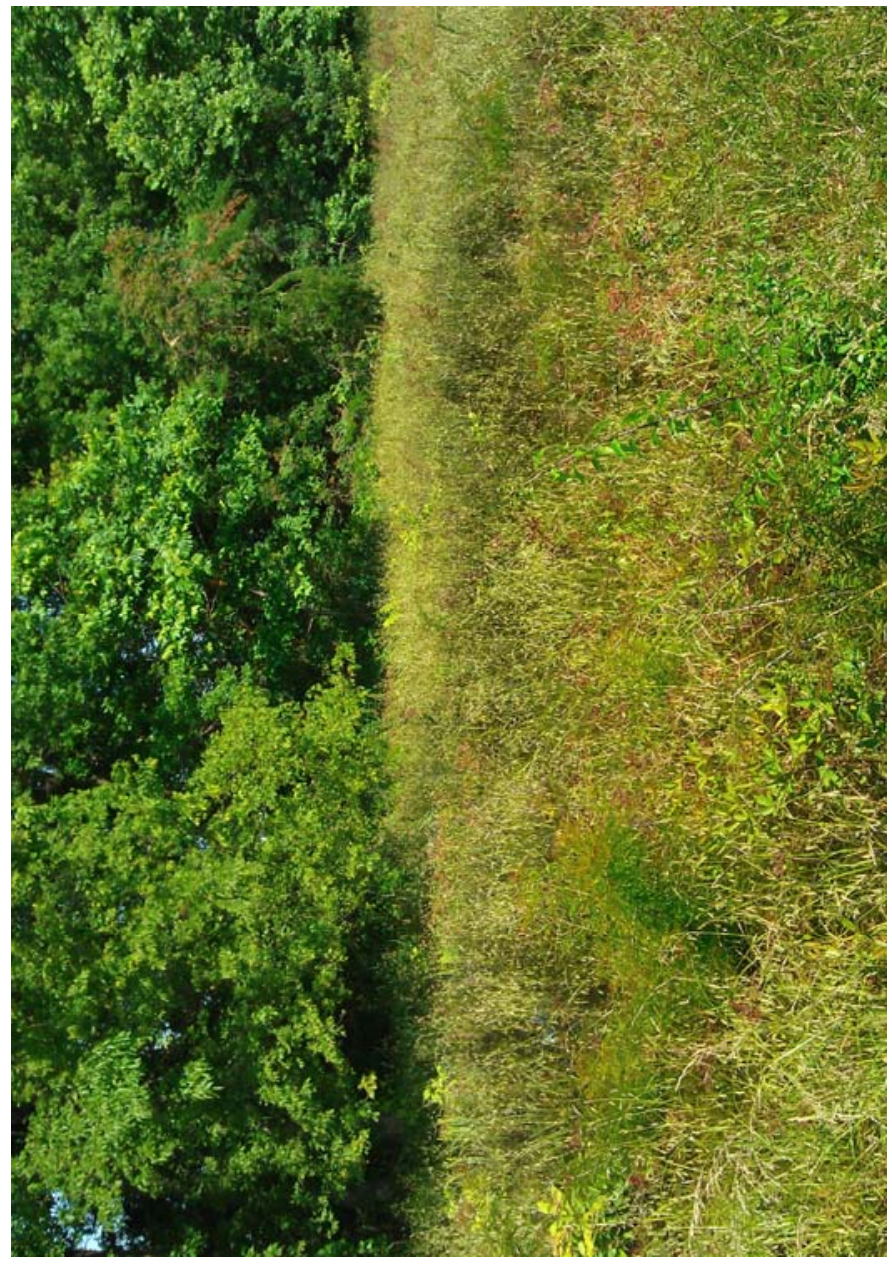

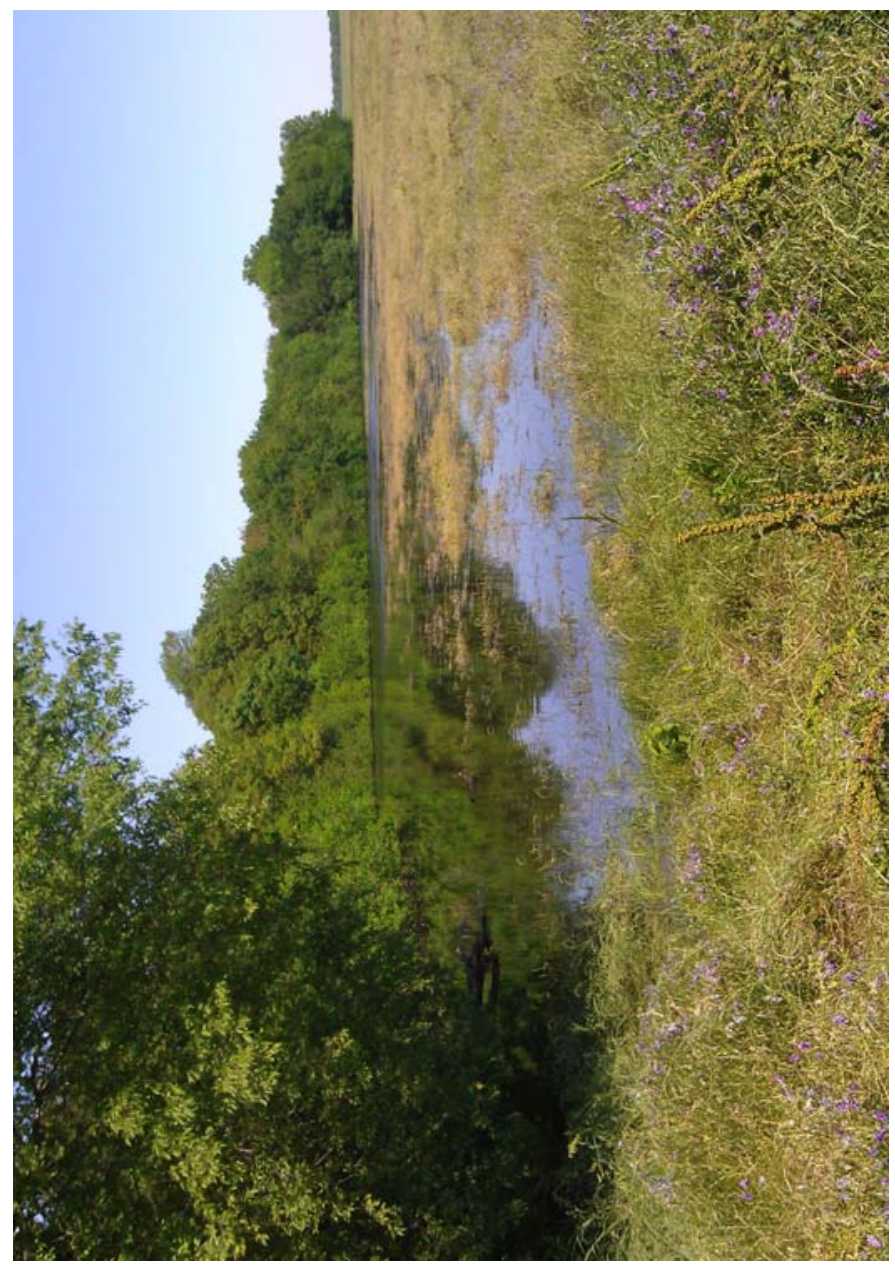

10

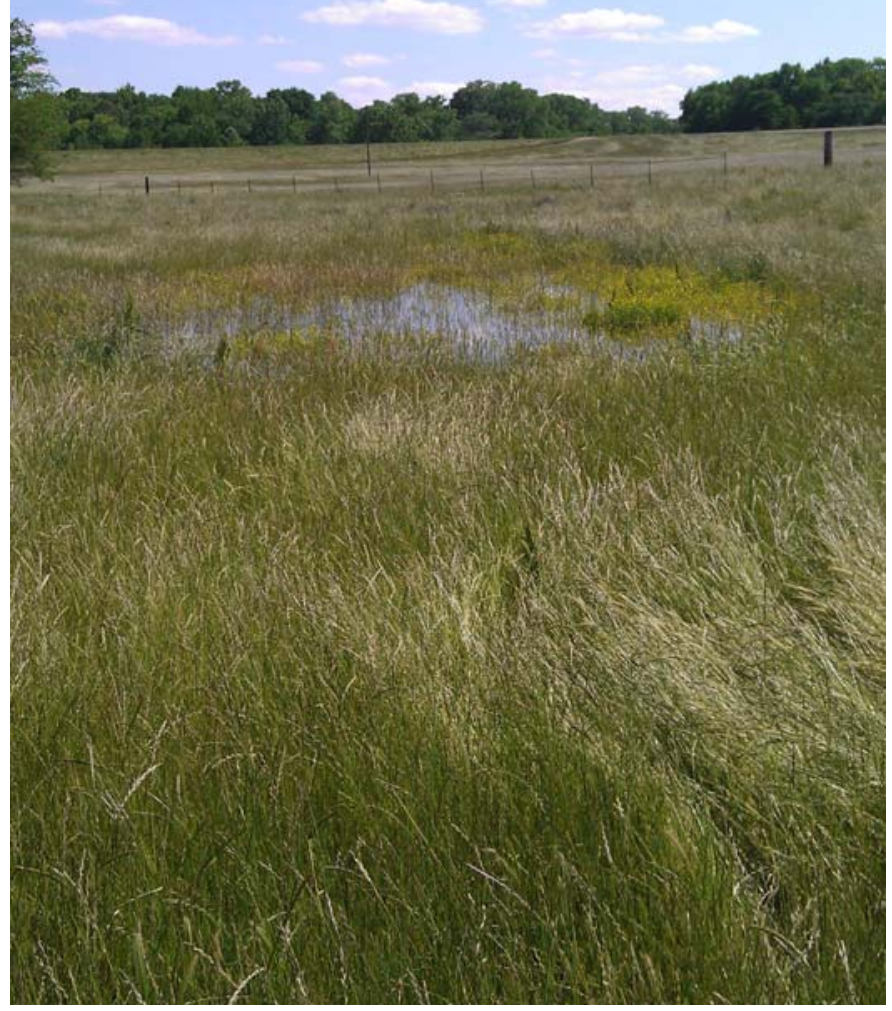




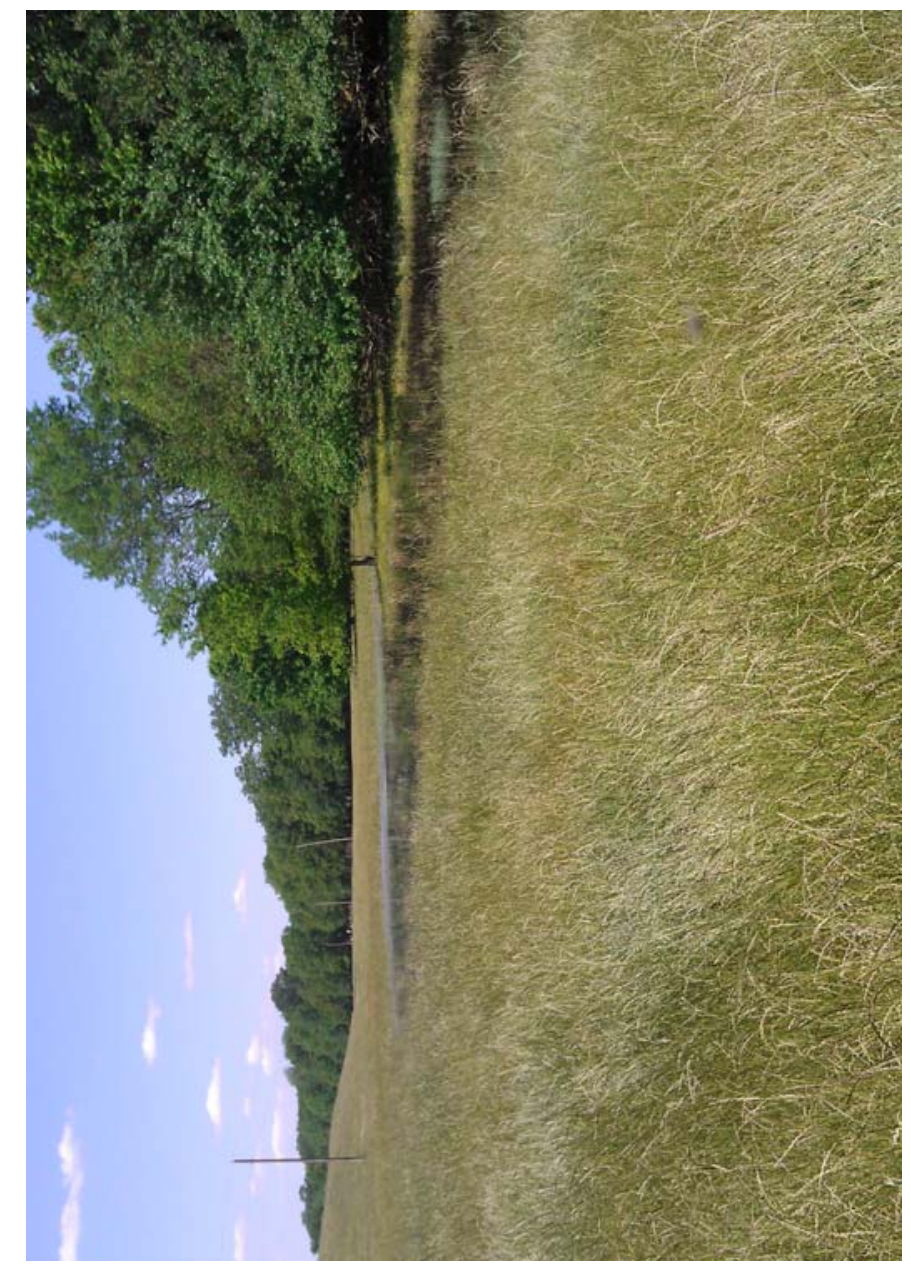

13

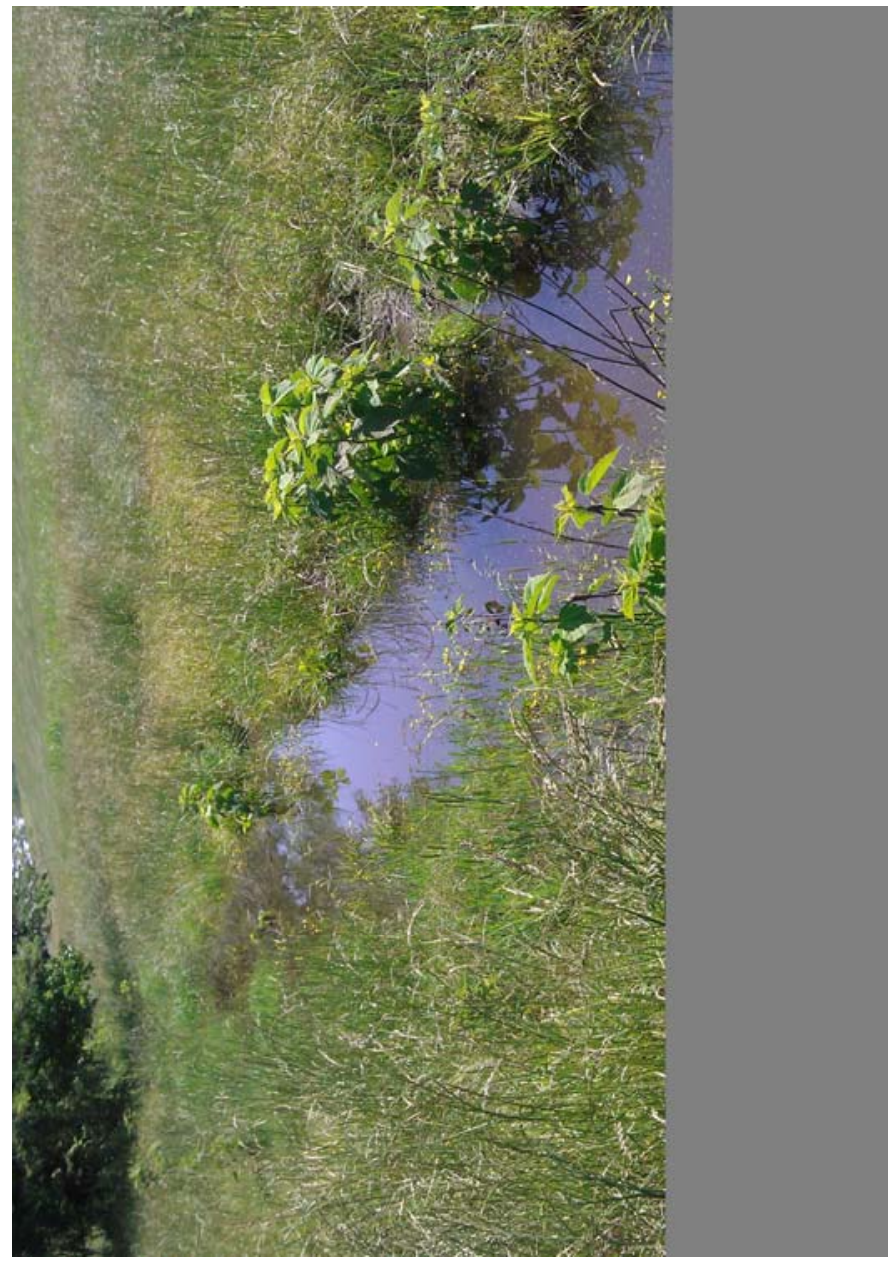

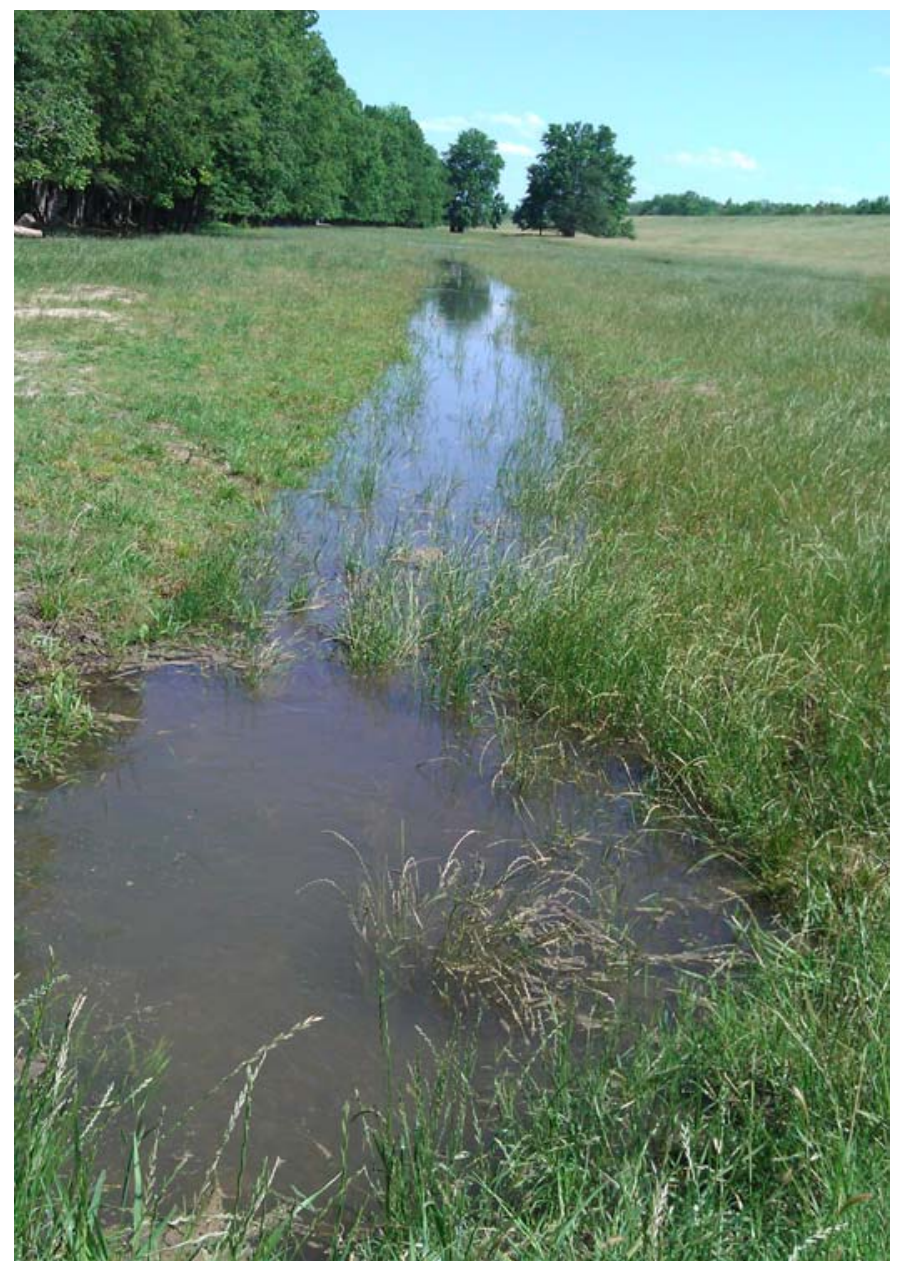

14

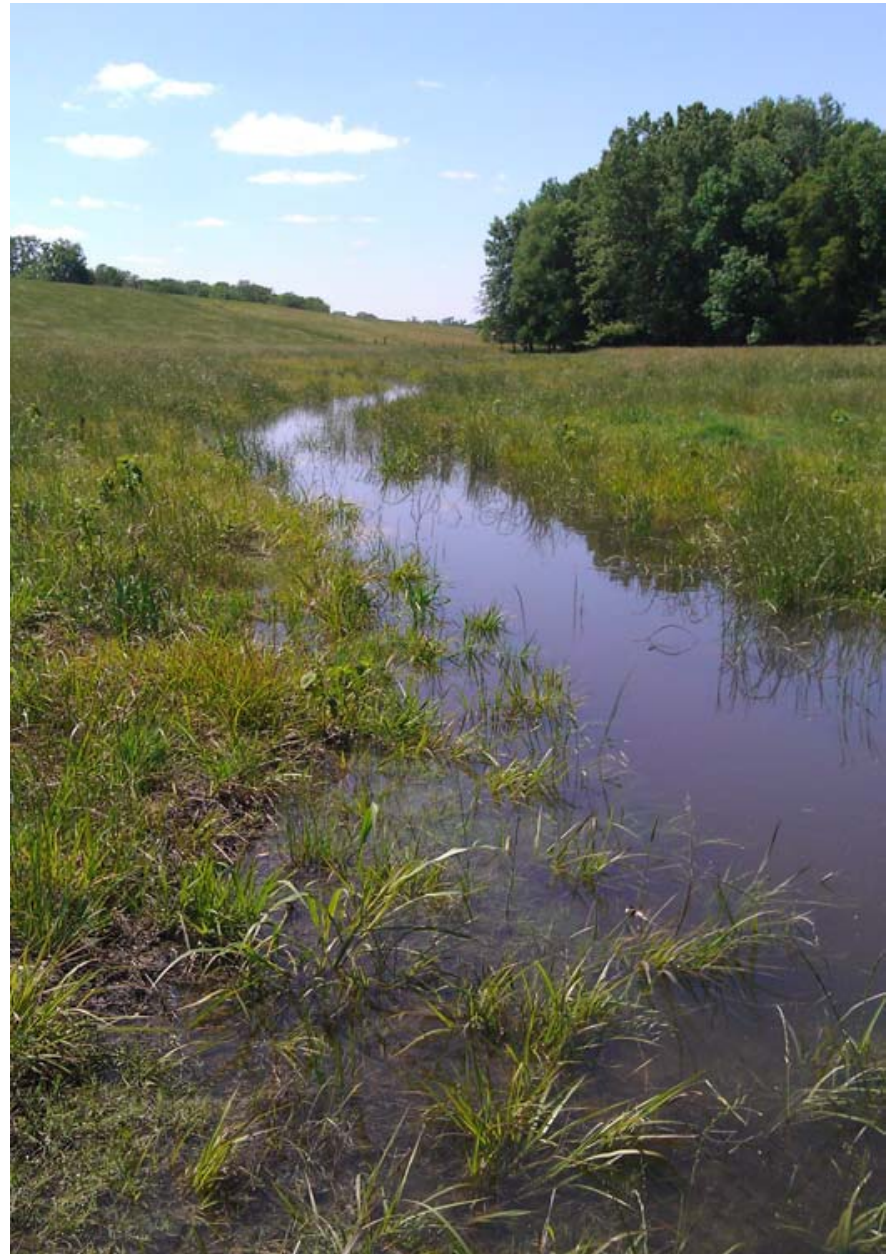




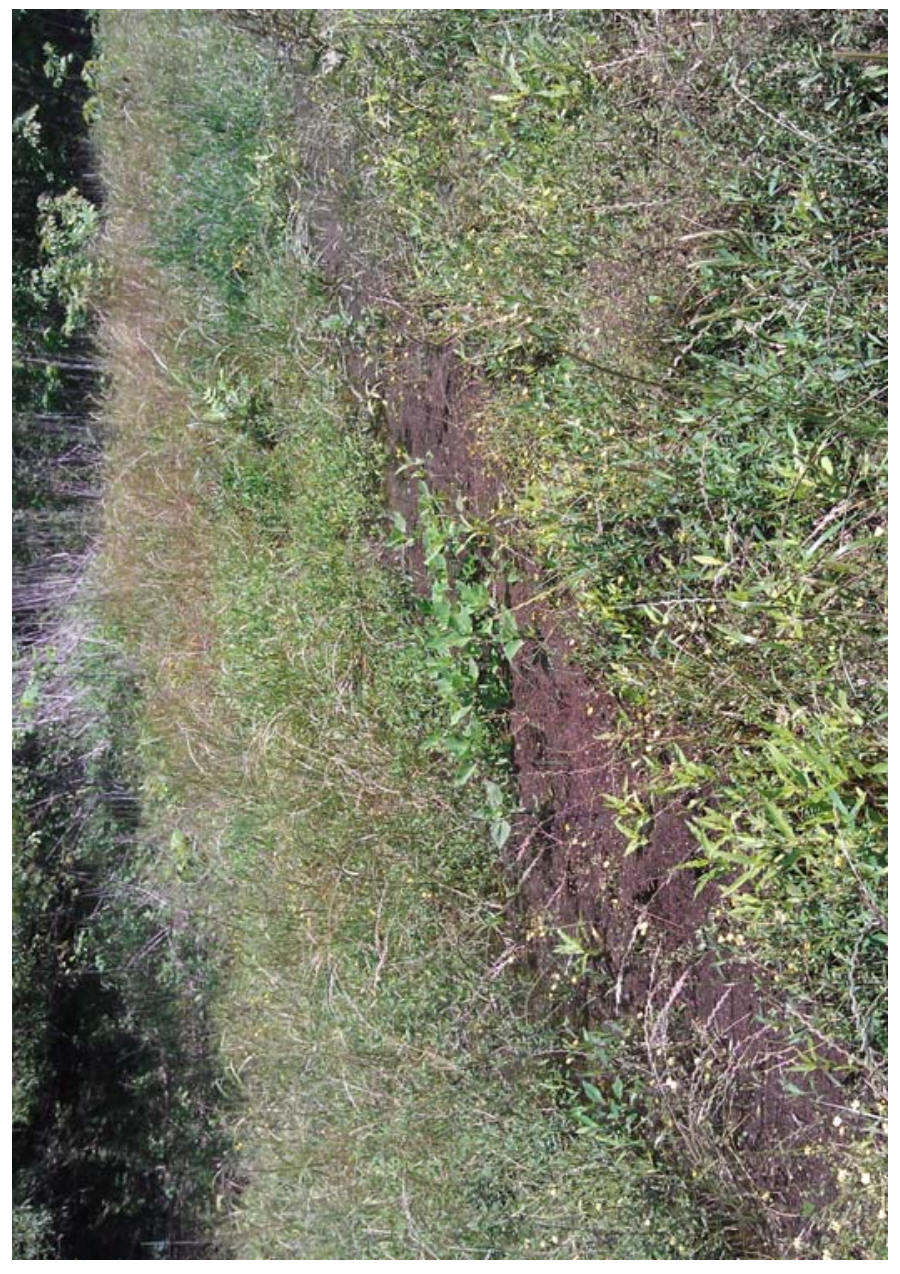

17

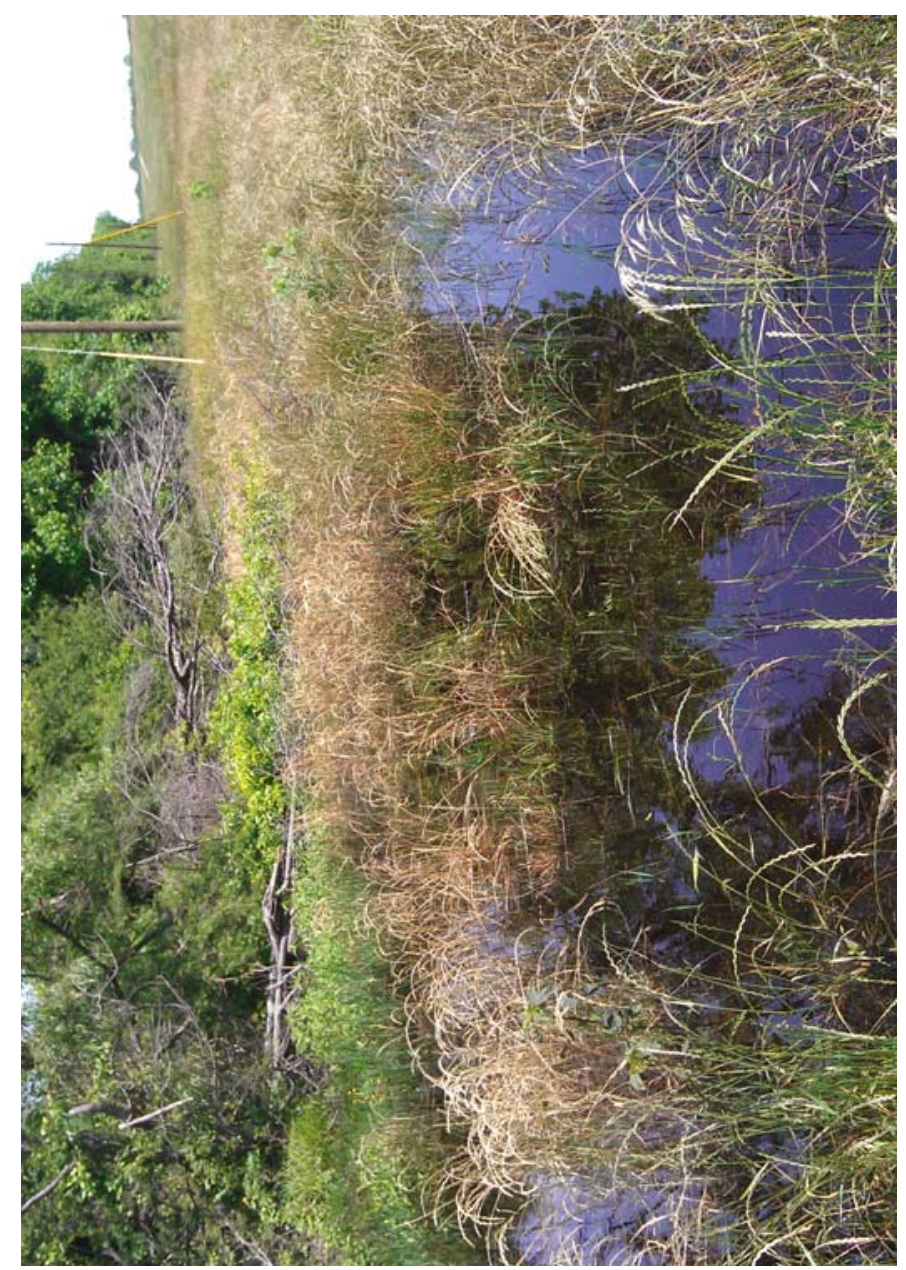

18

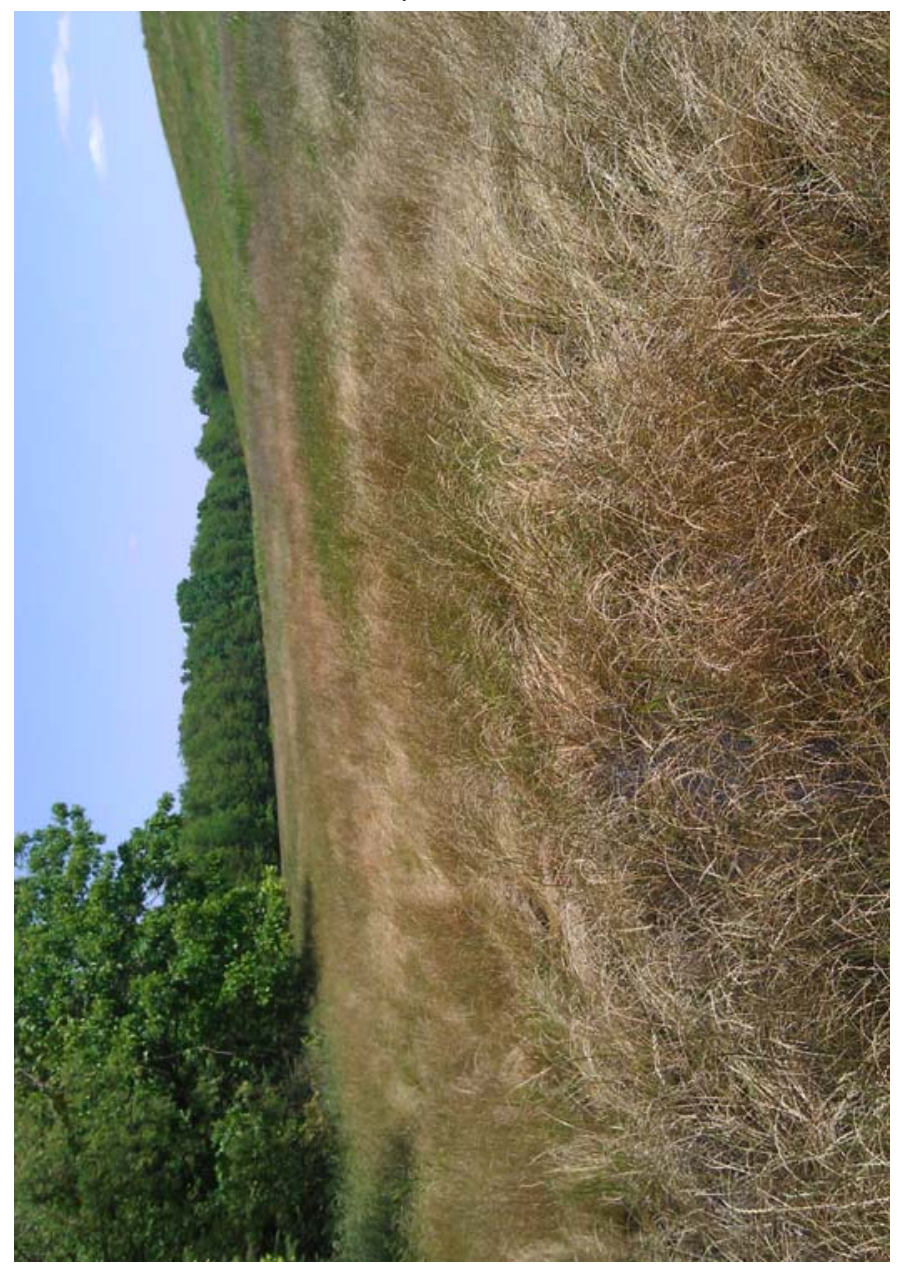




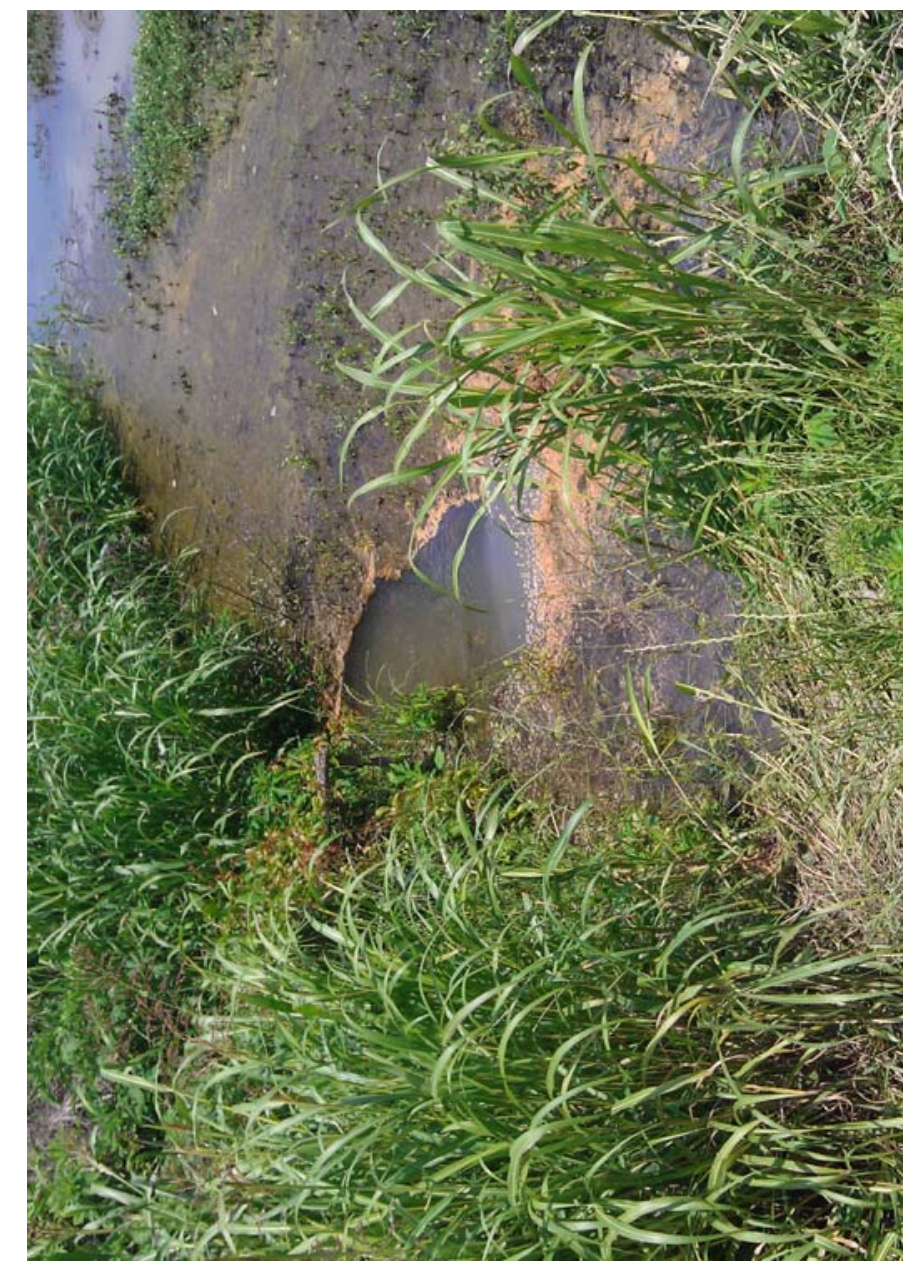

21

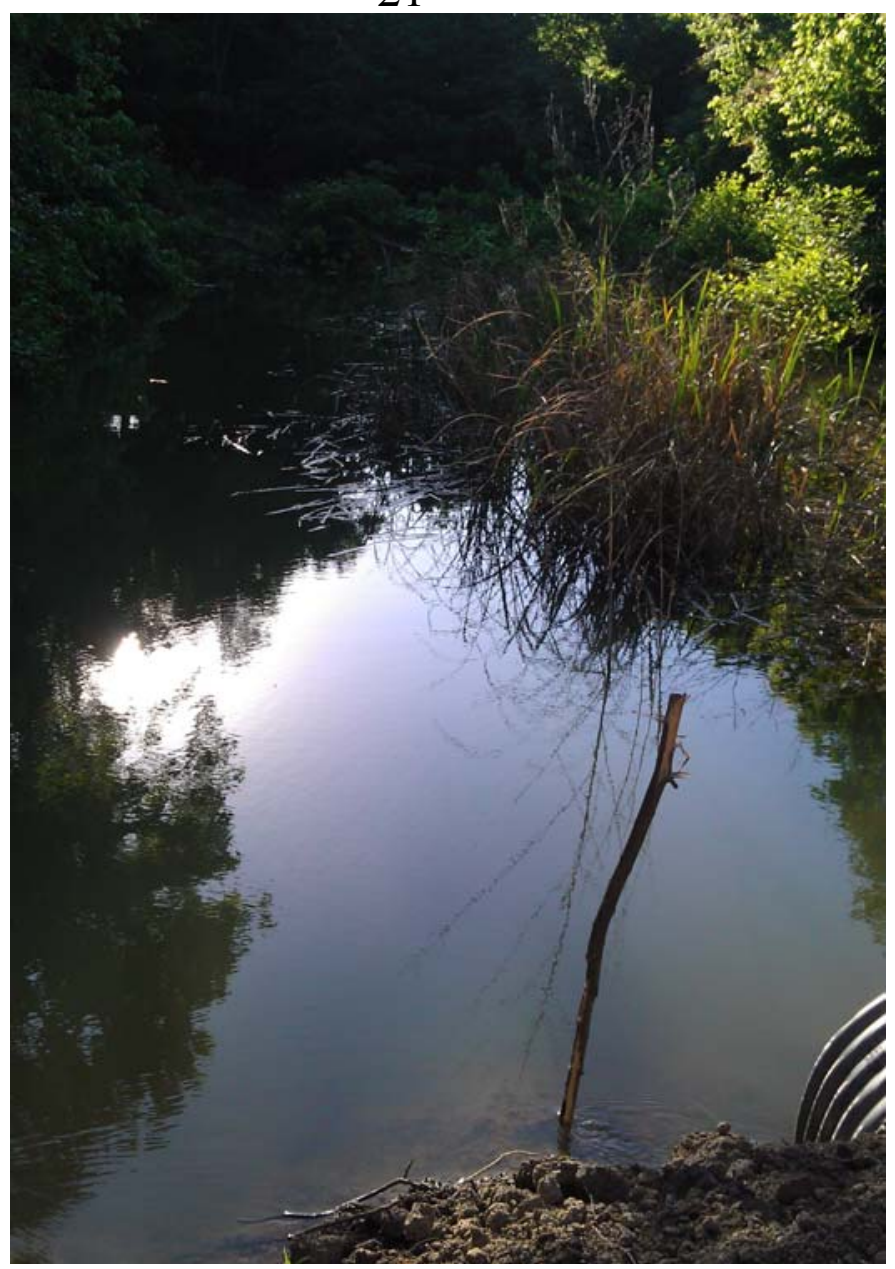

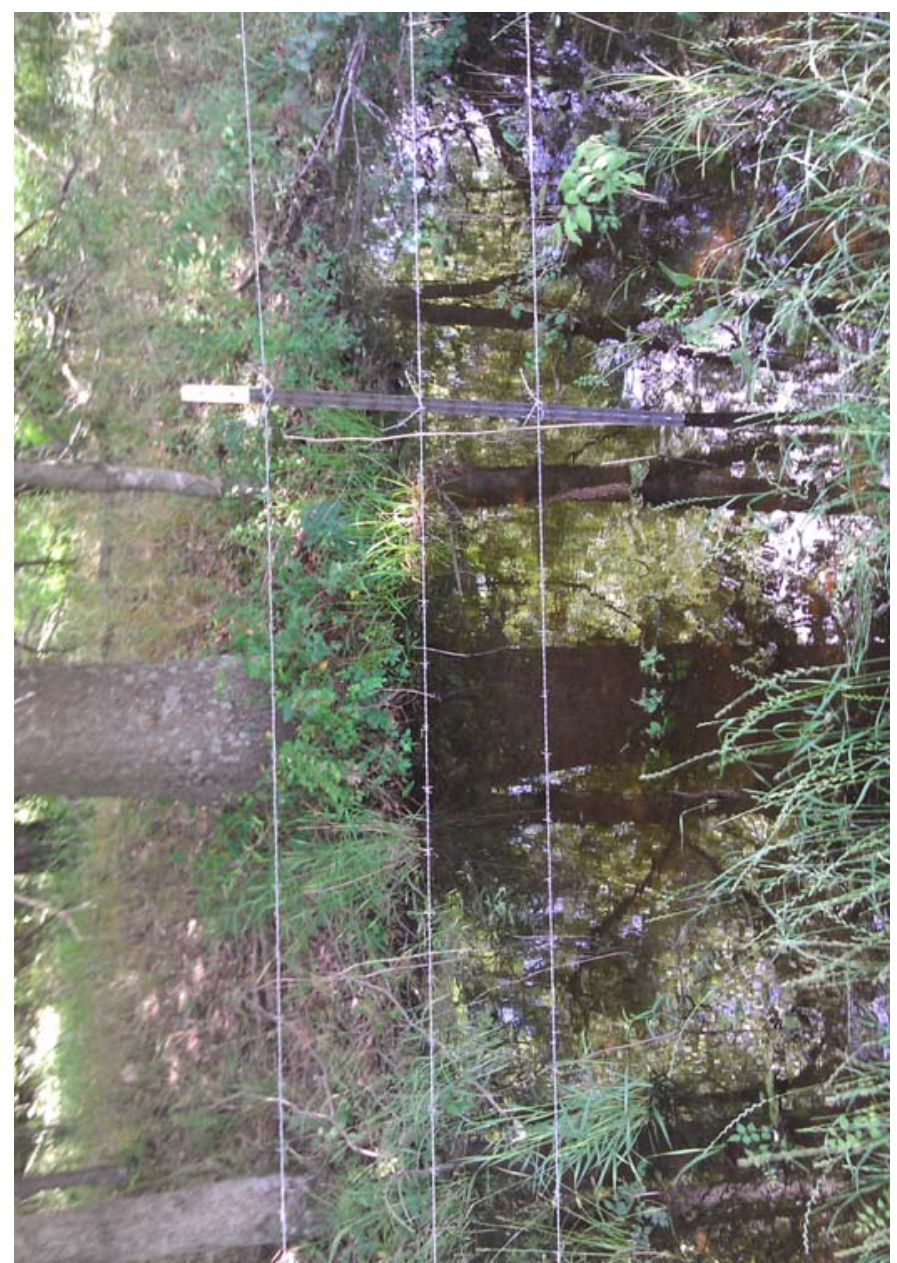

22

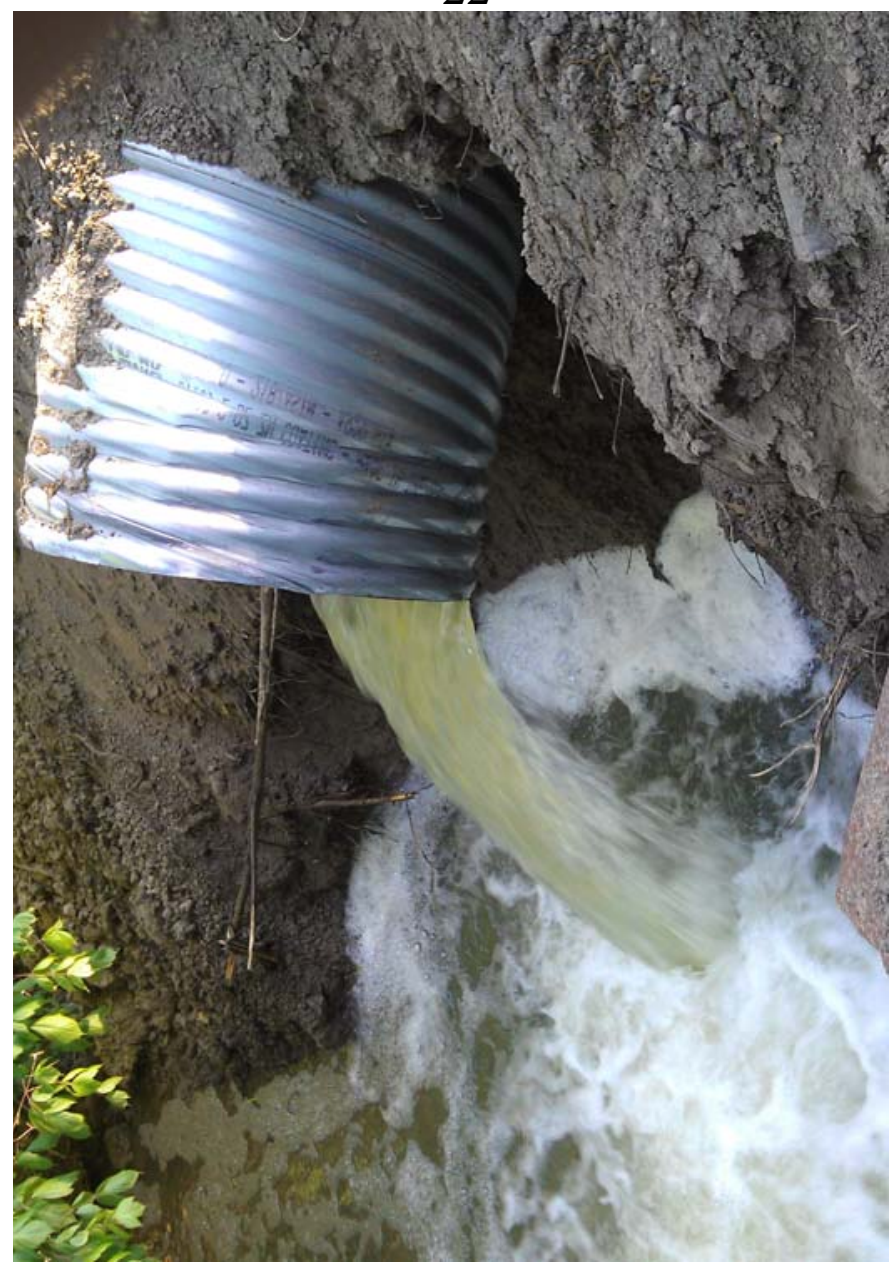




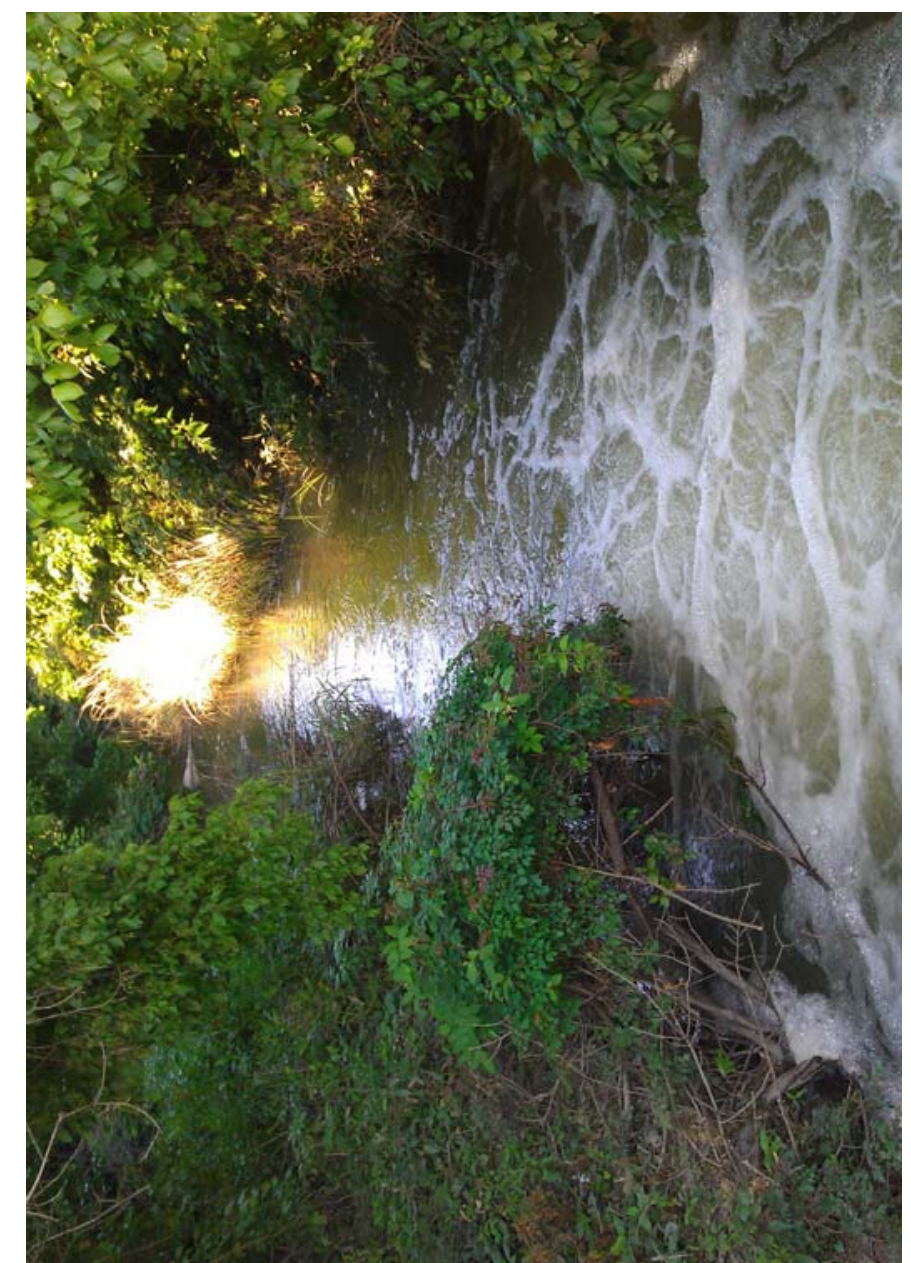

25

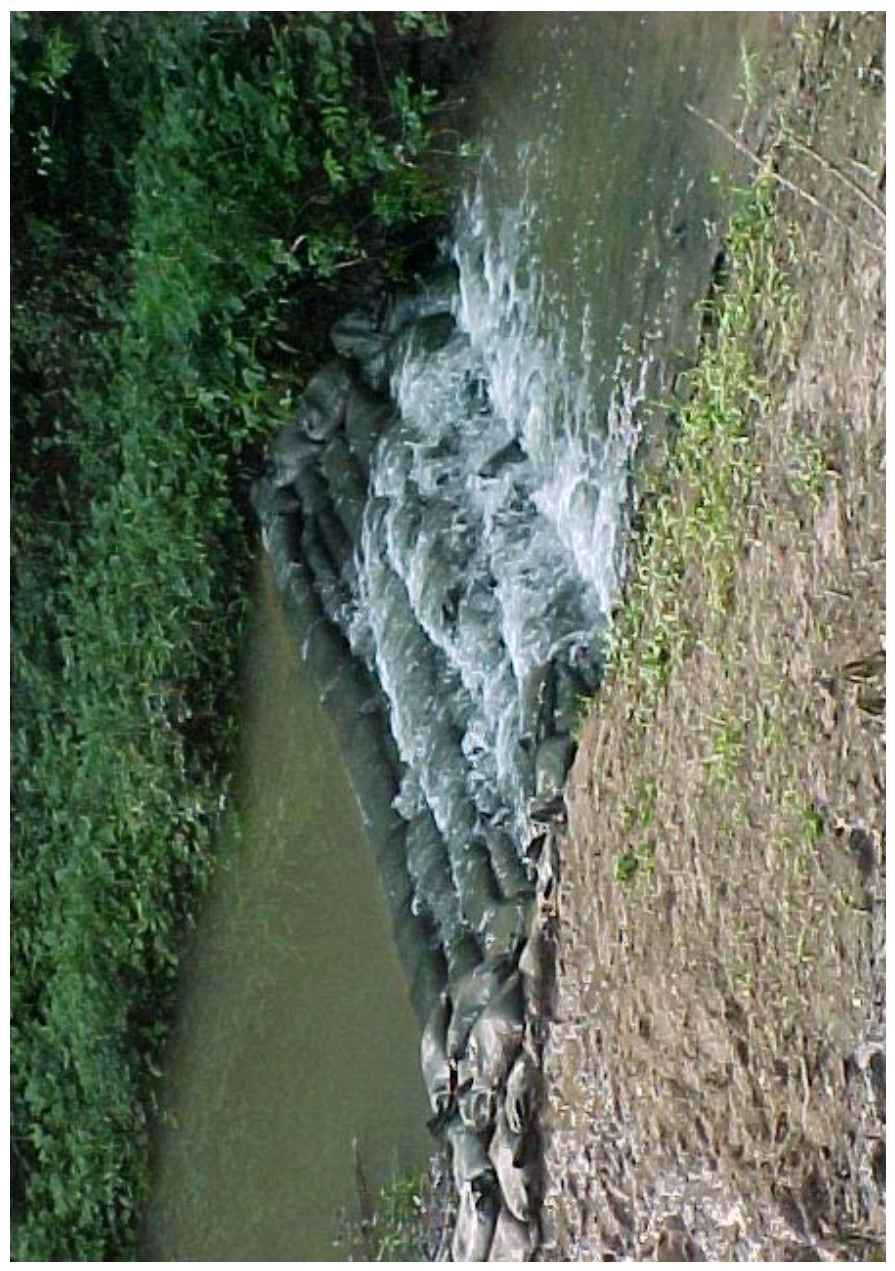

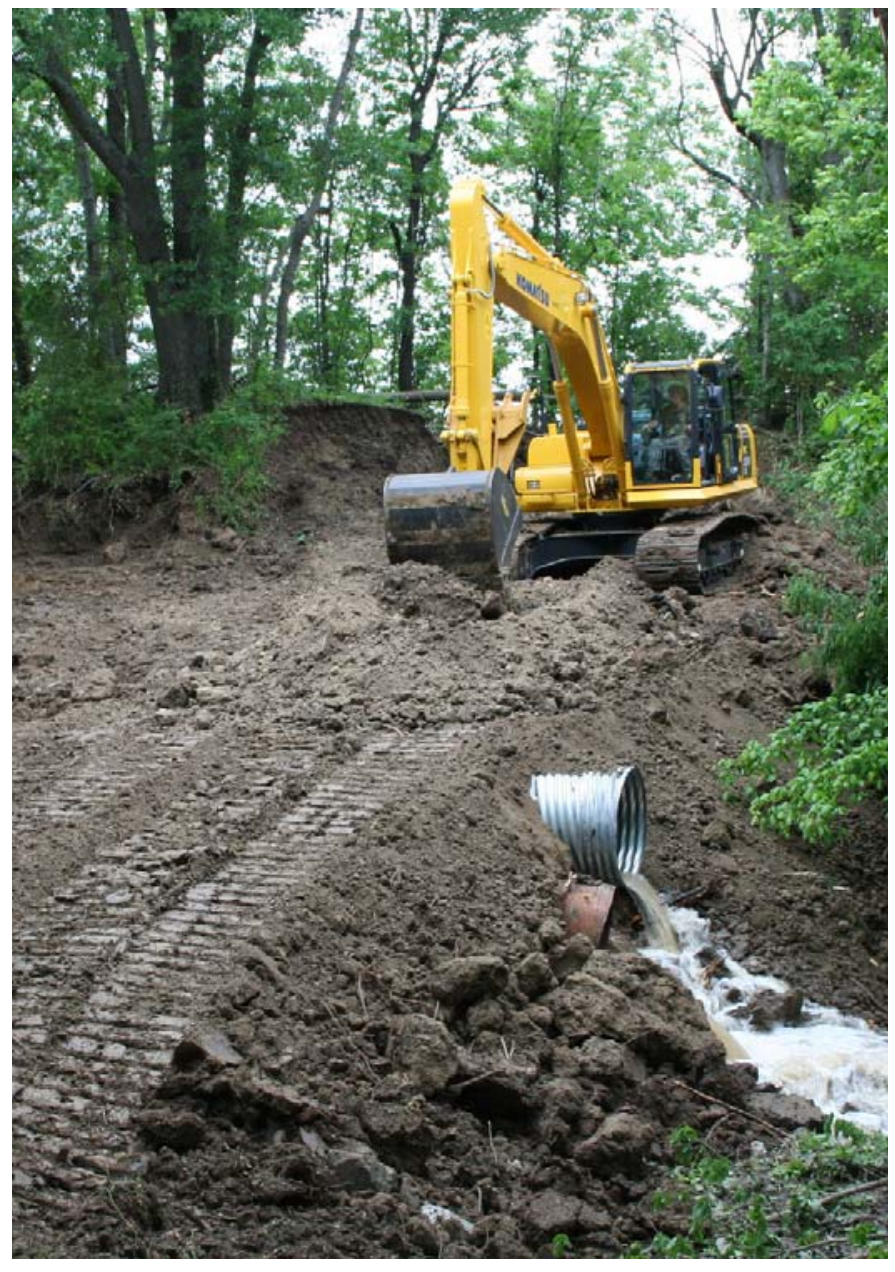

26

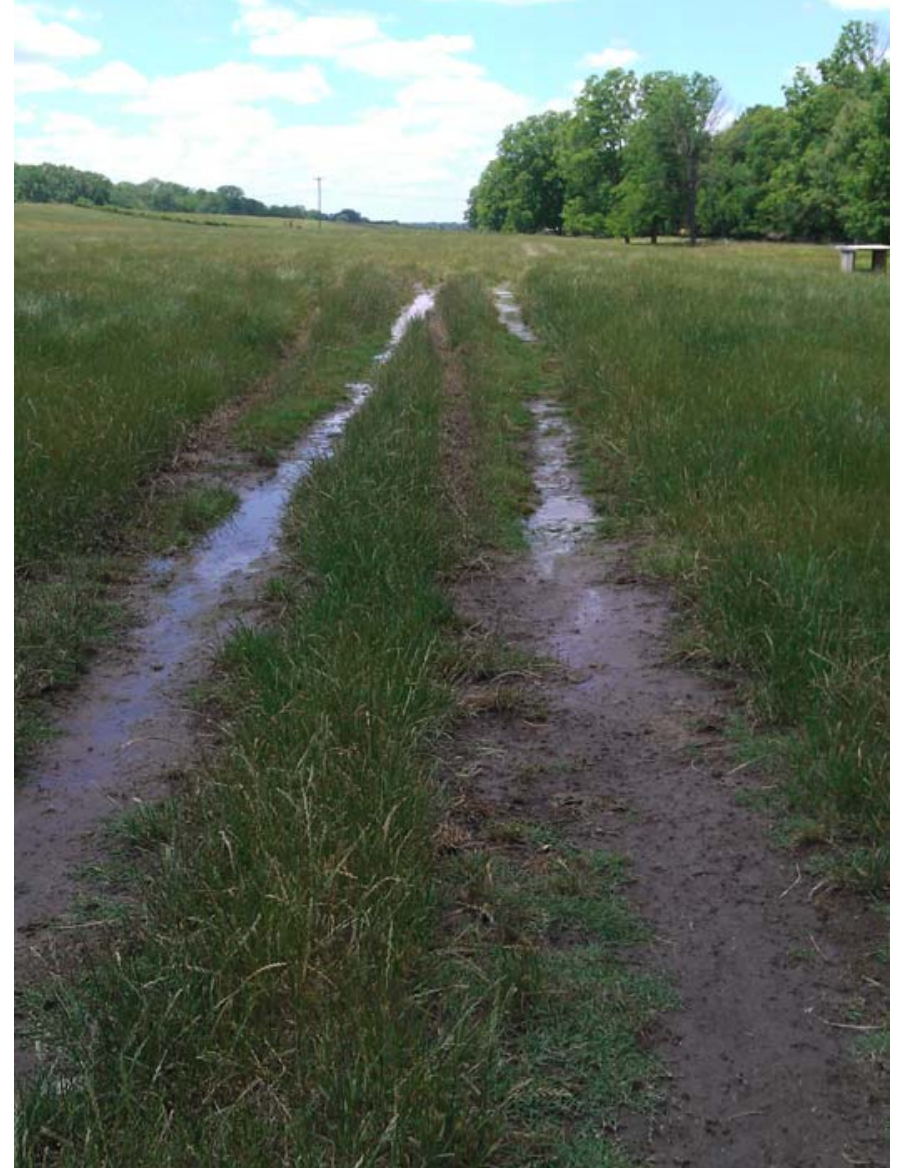




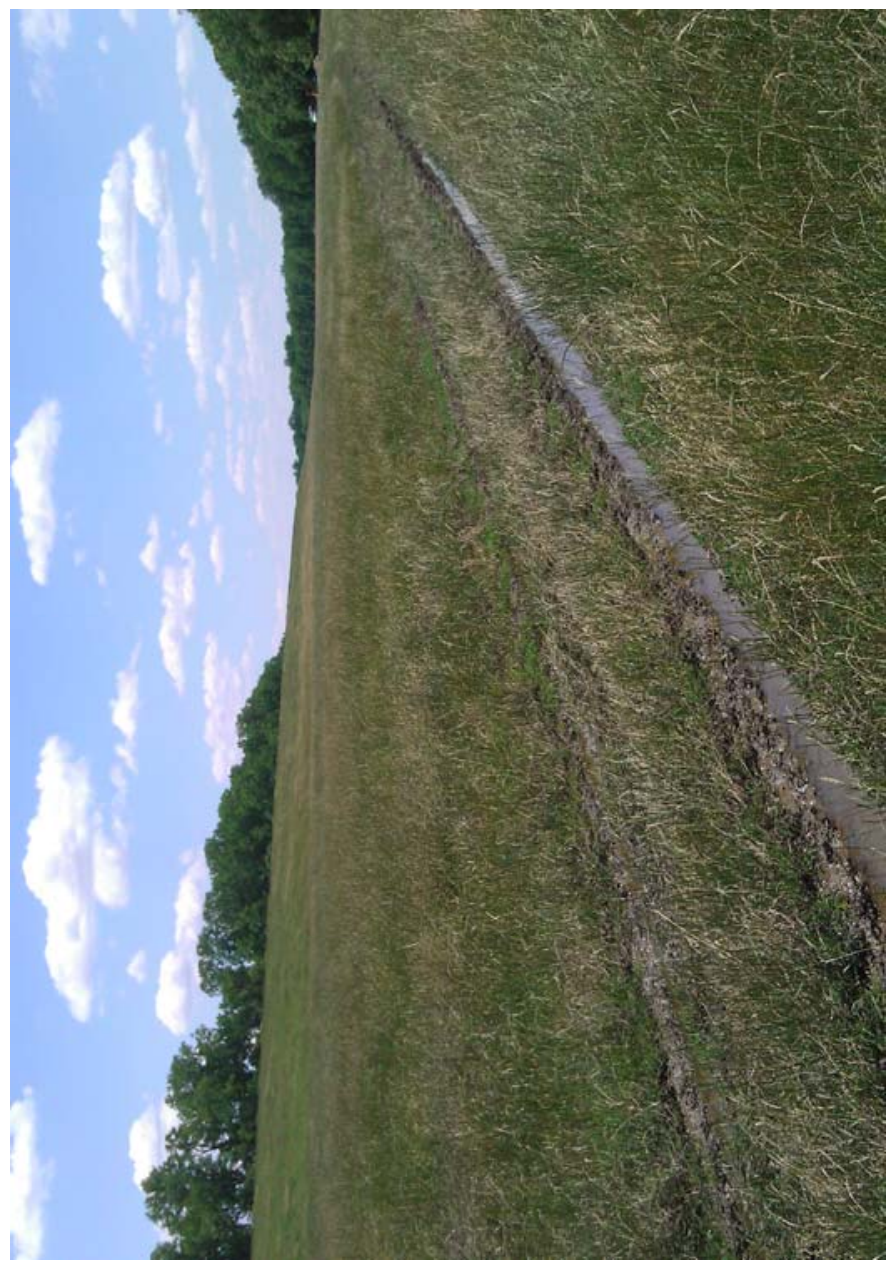

29

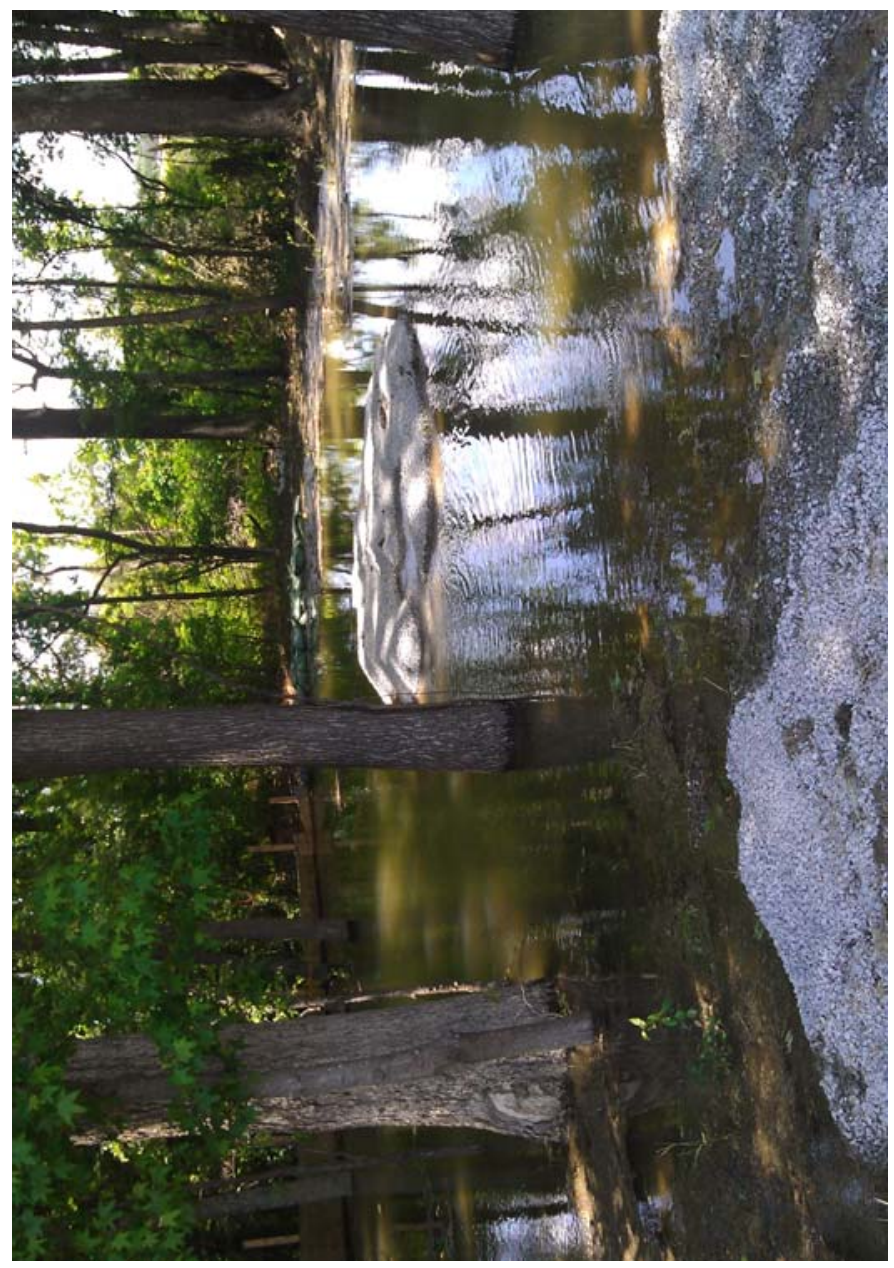

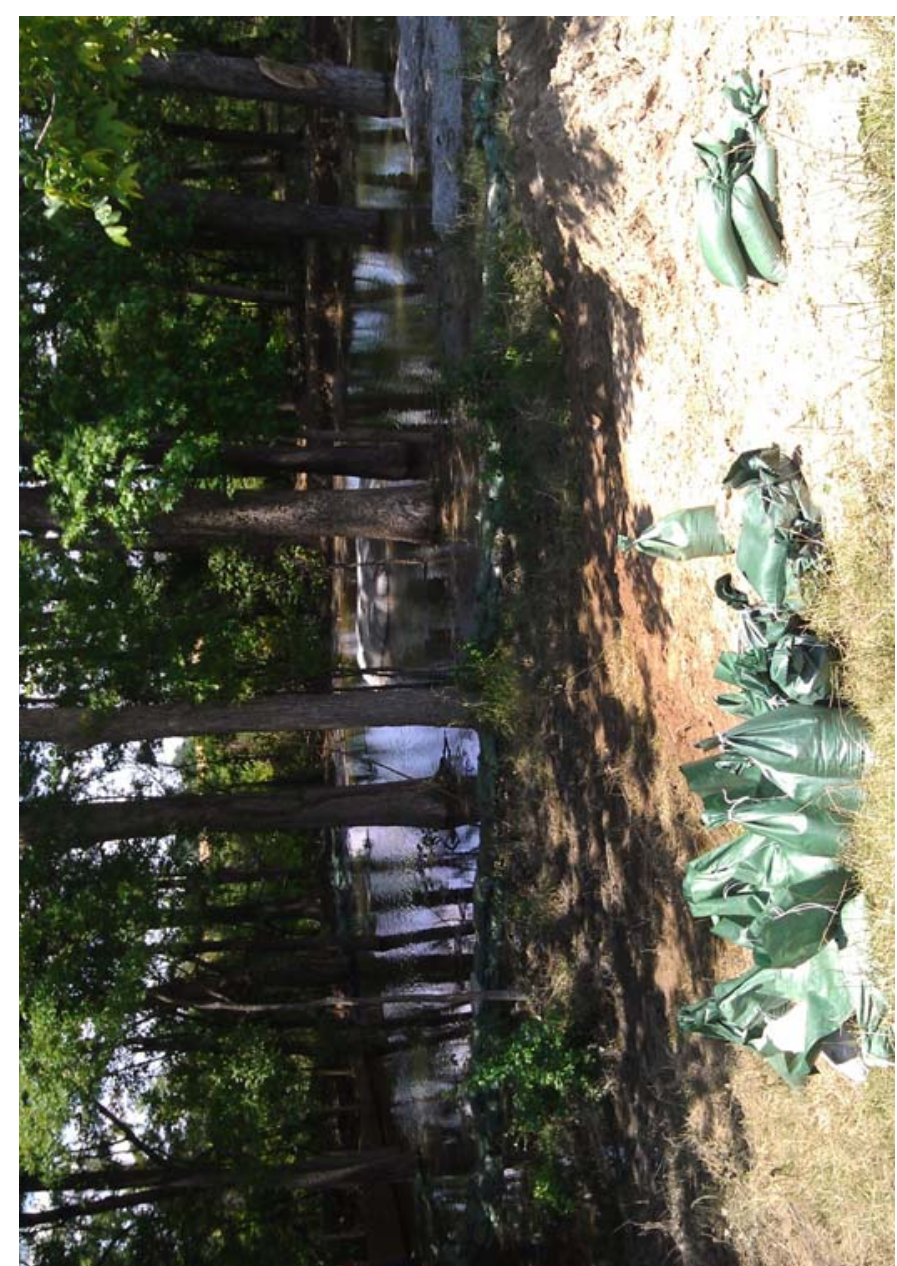

30

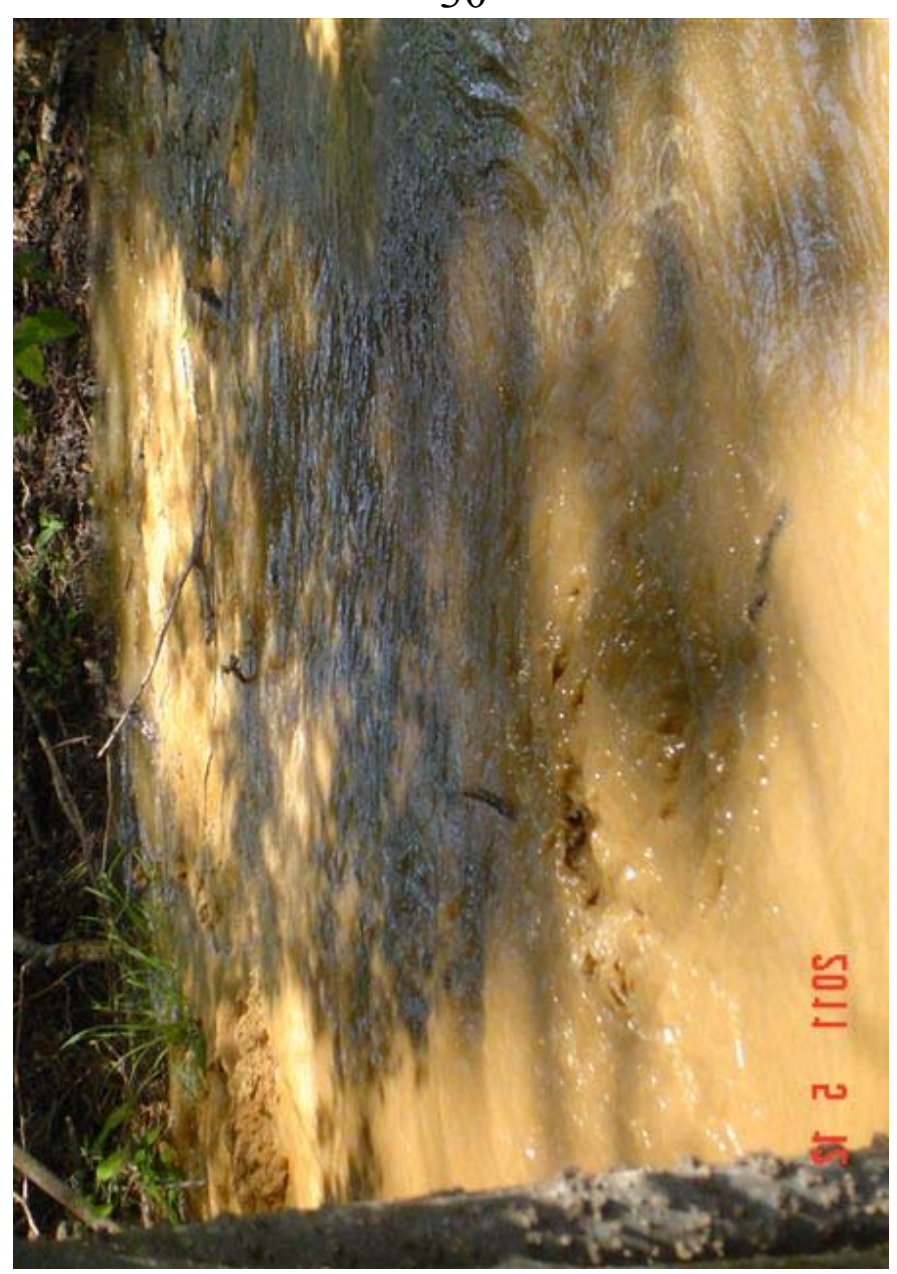




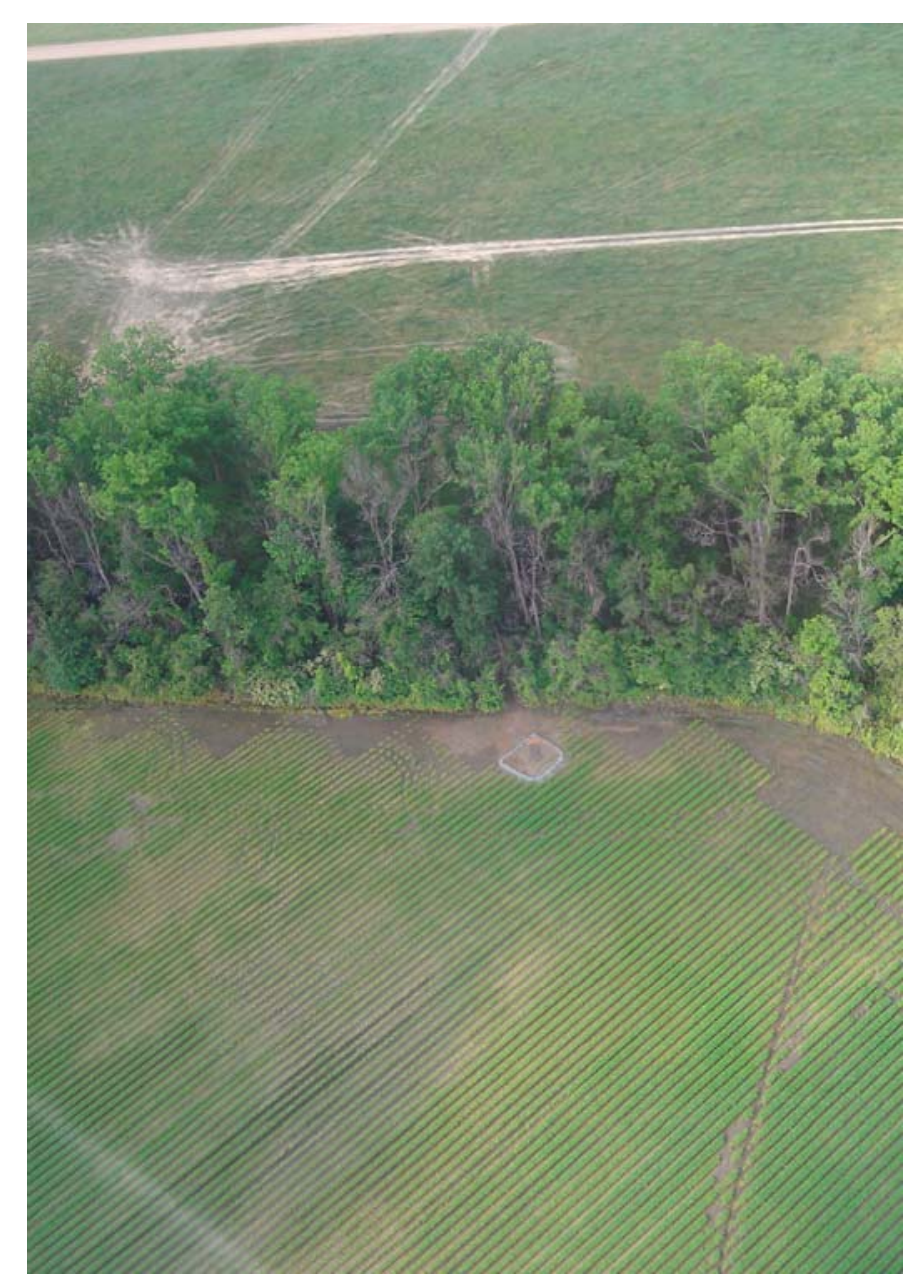

33

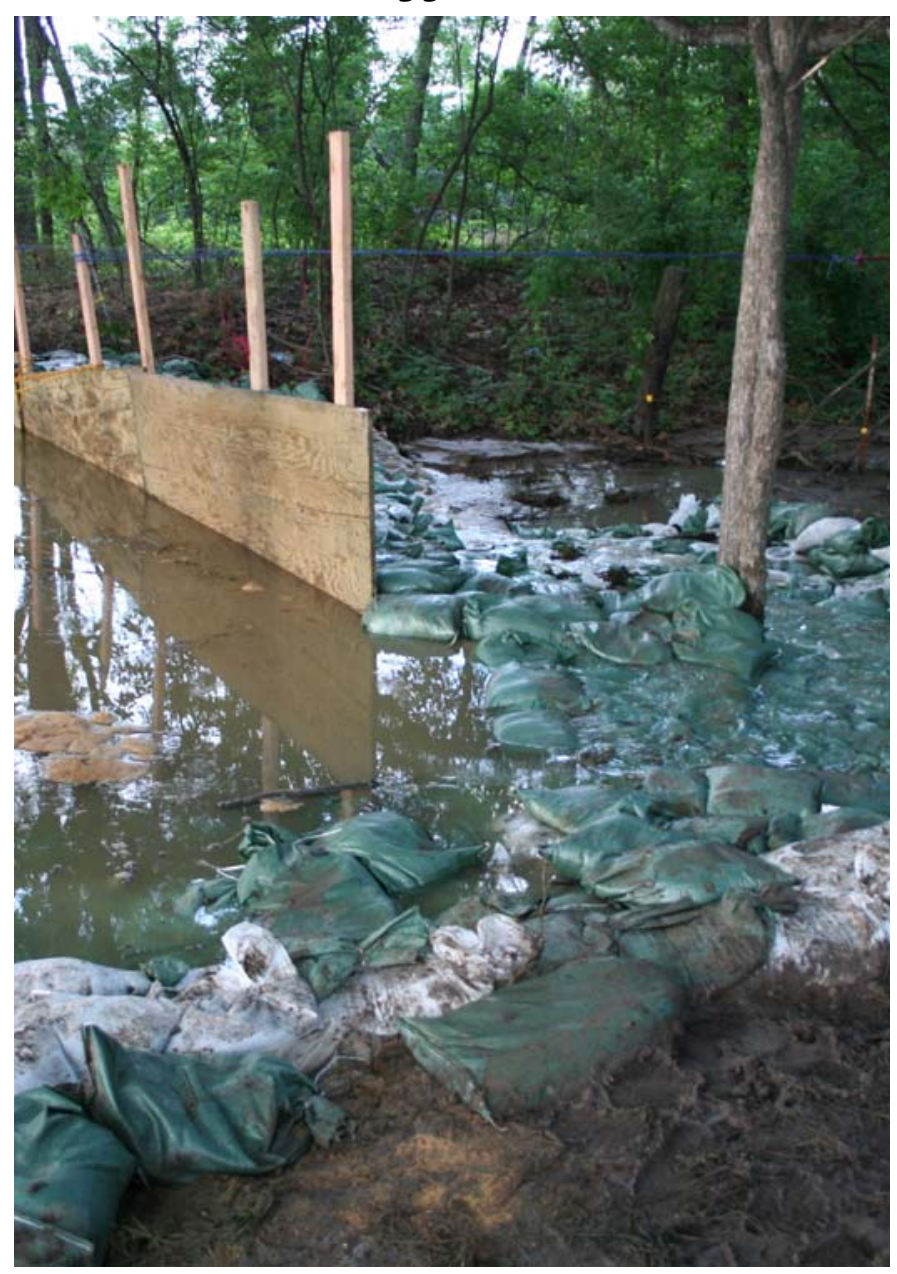

\section{4}

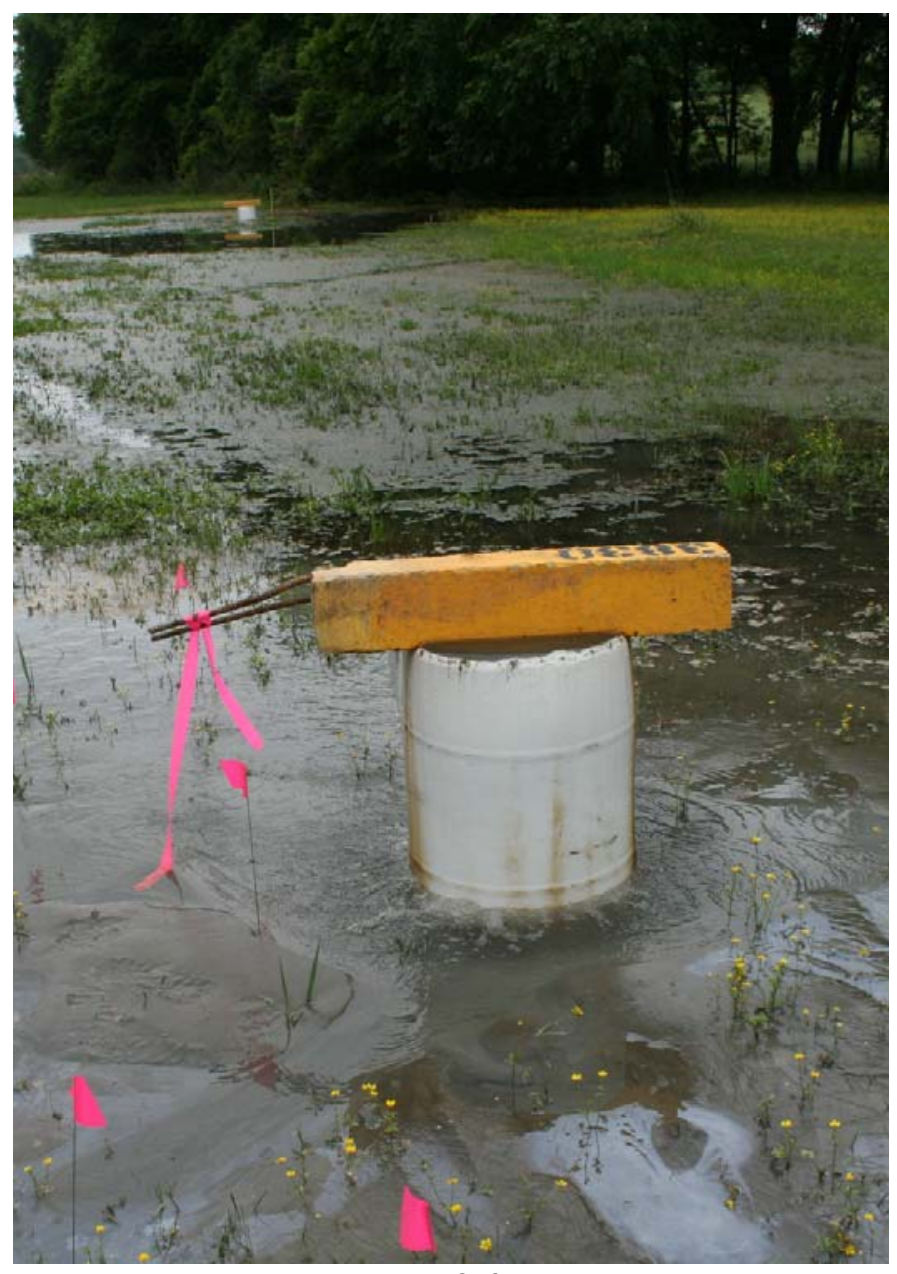




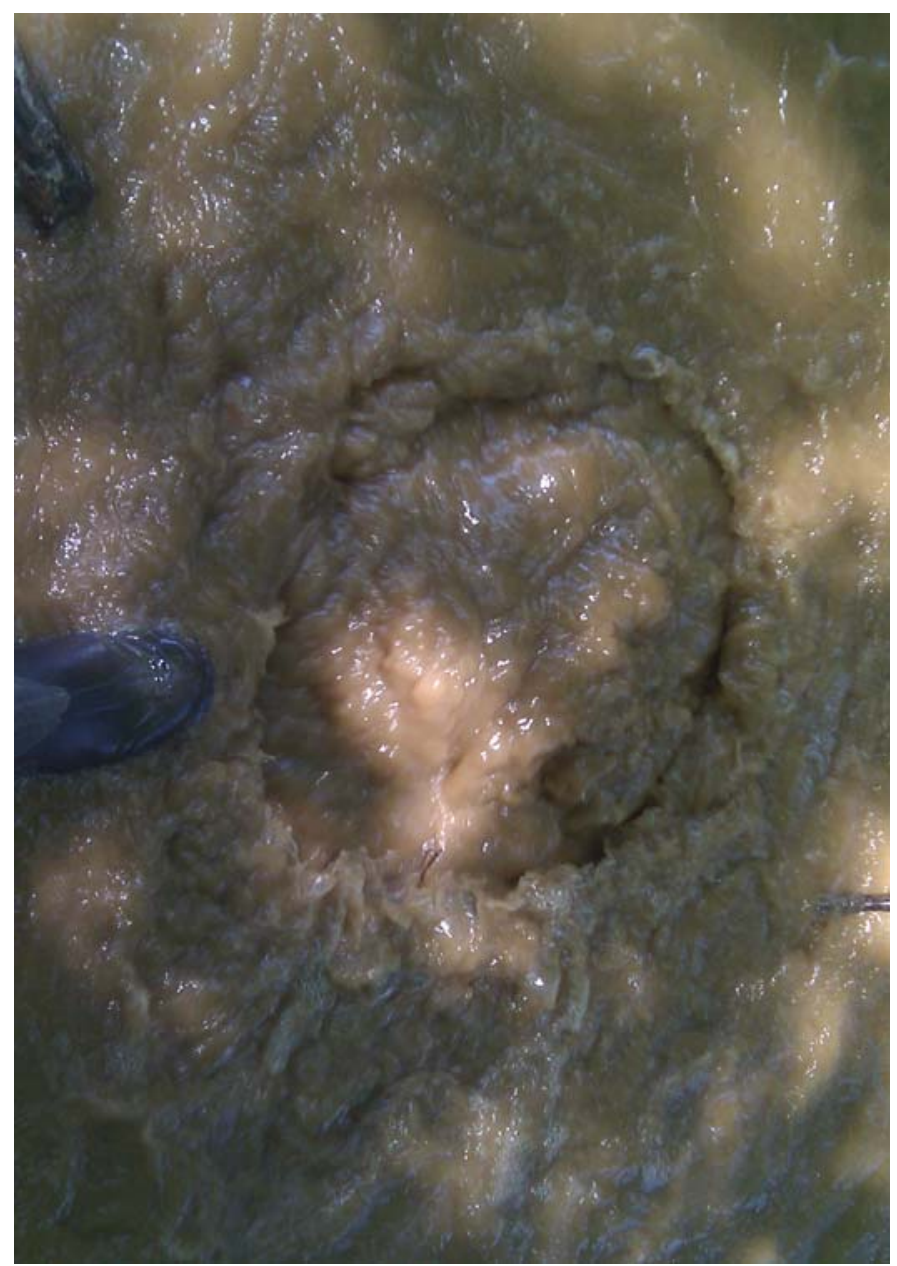

37

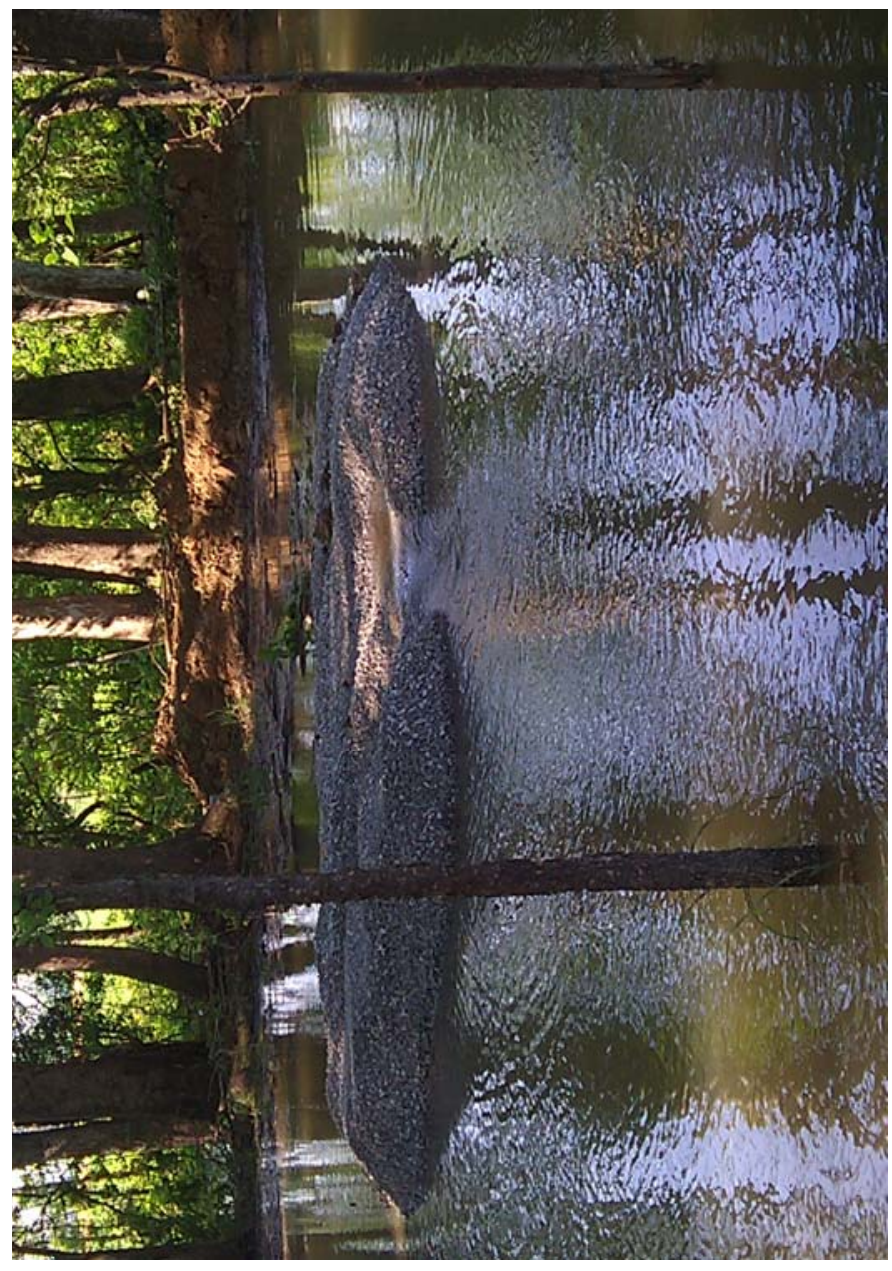

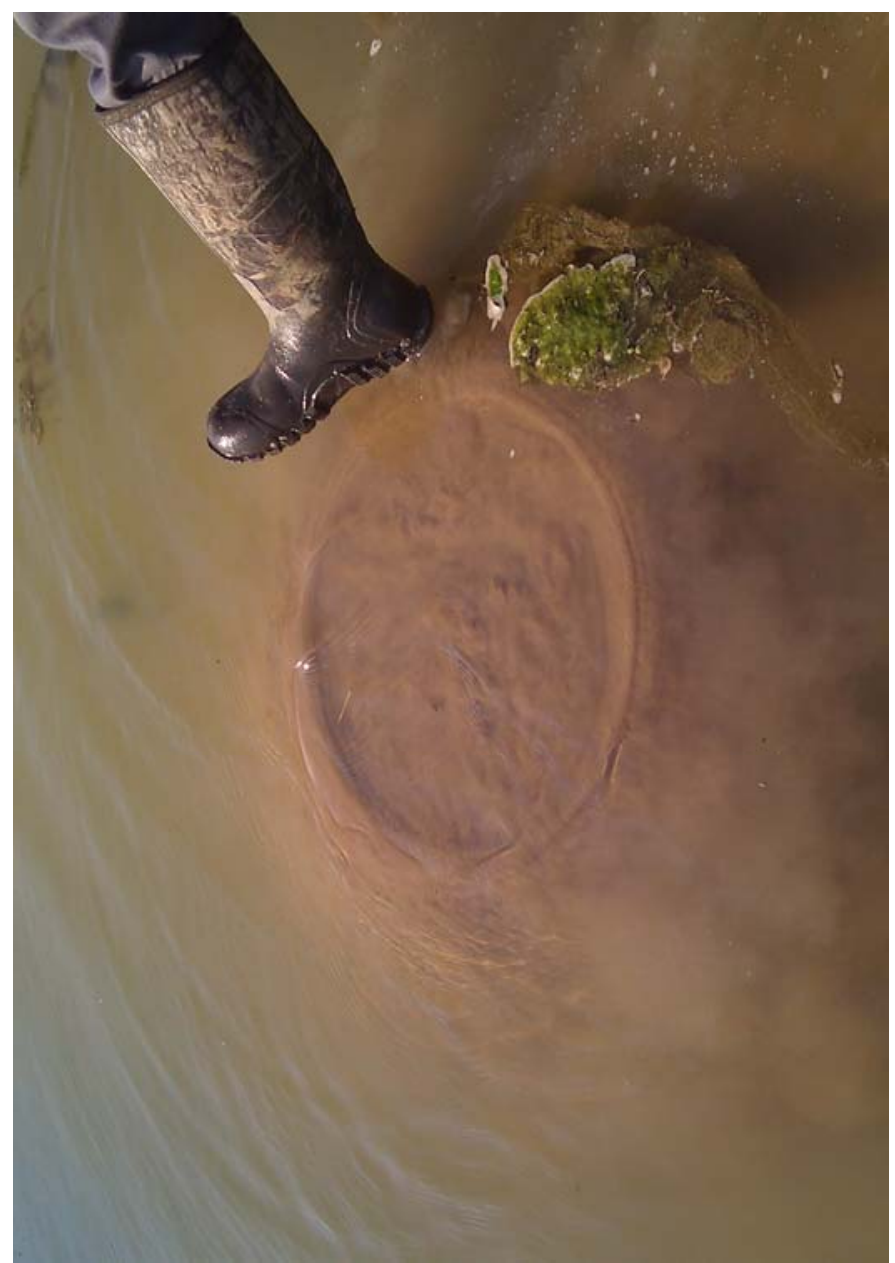

38

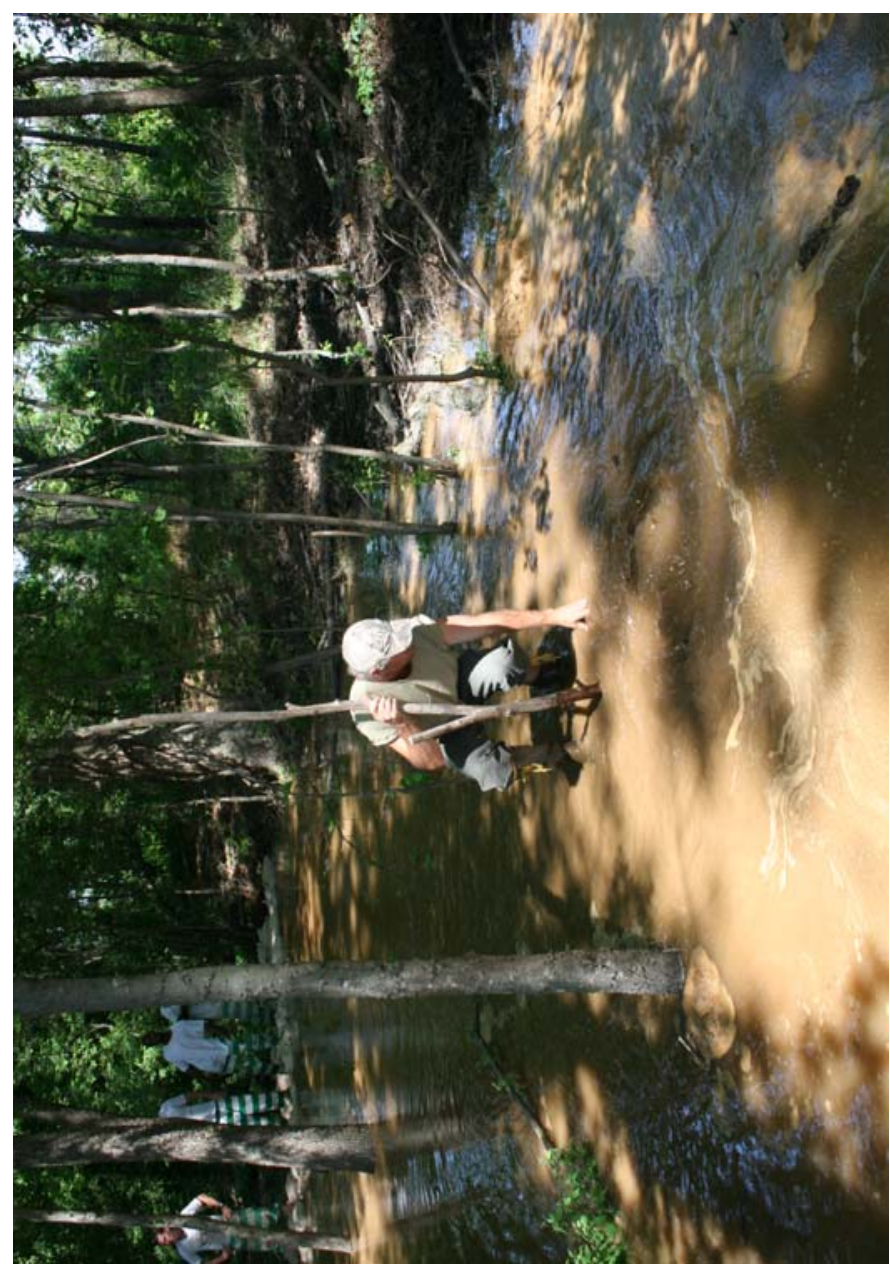




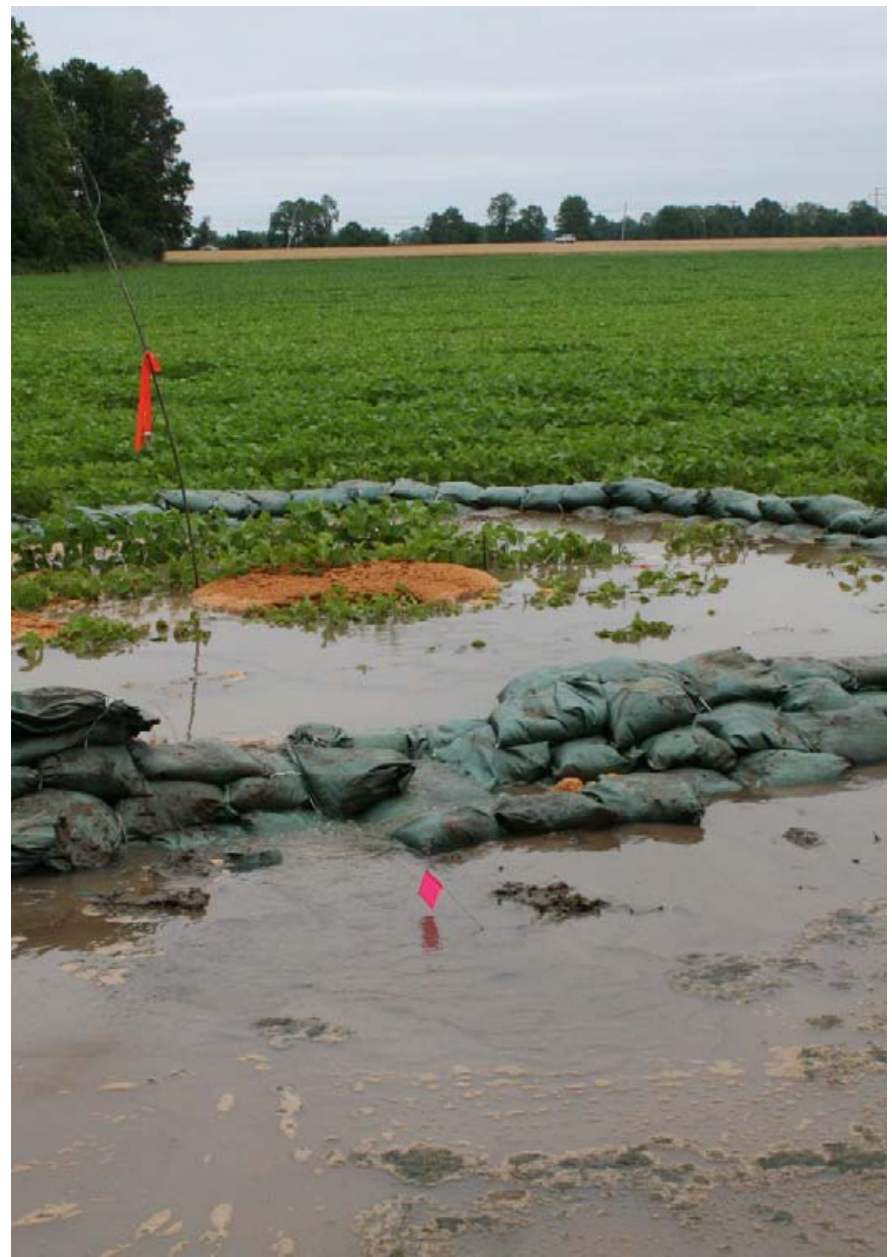

41

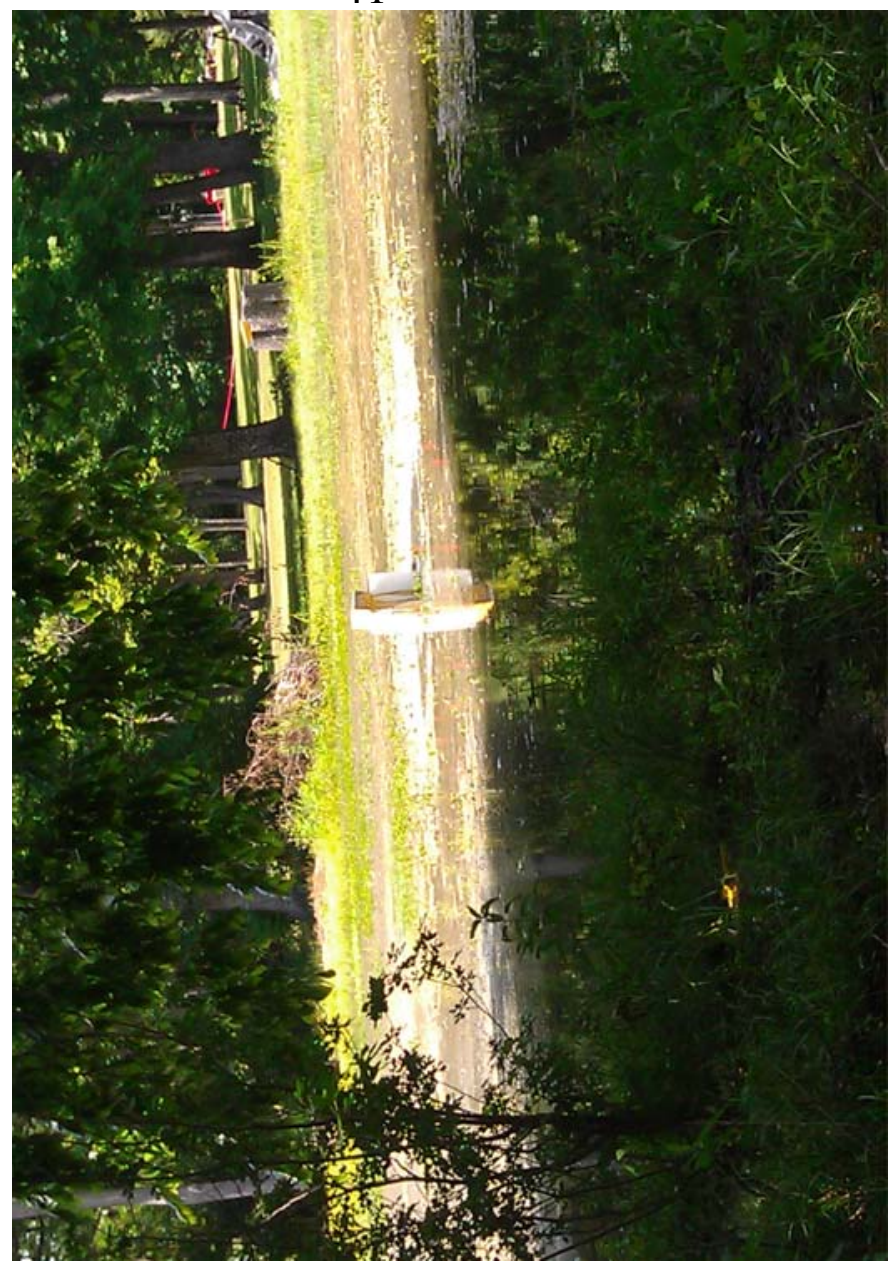

43

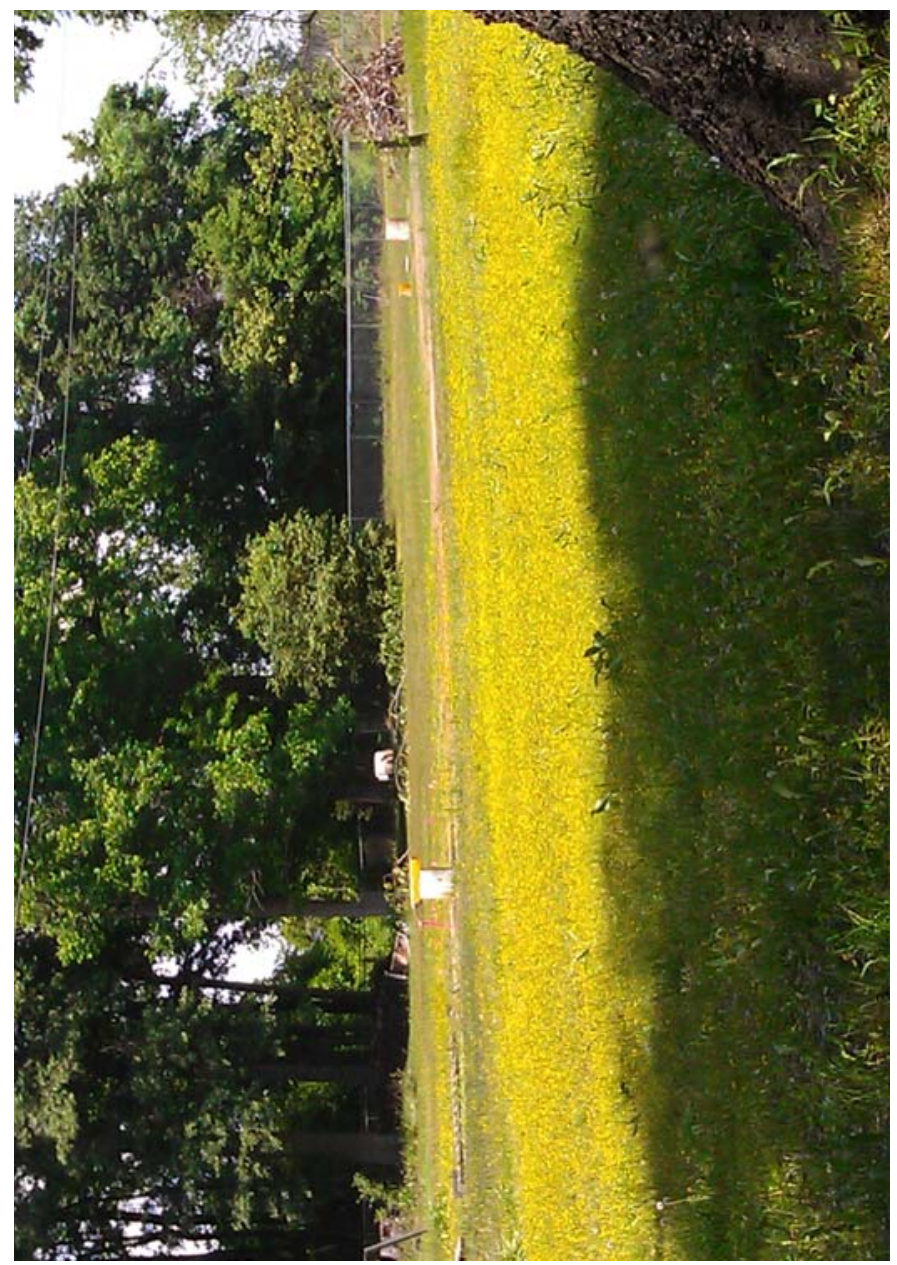

42

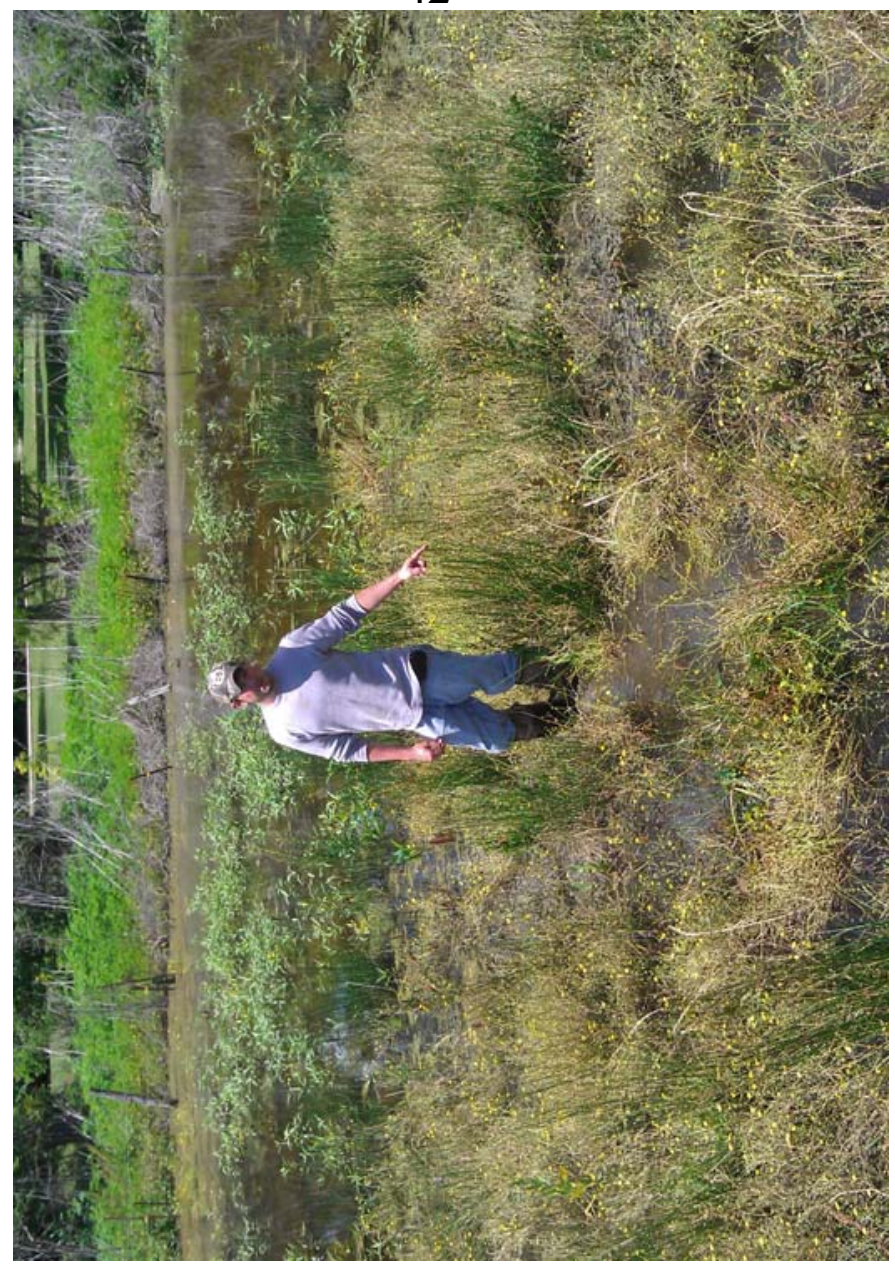



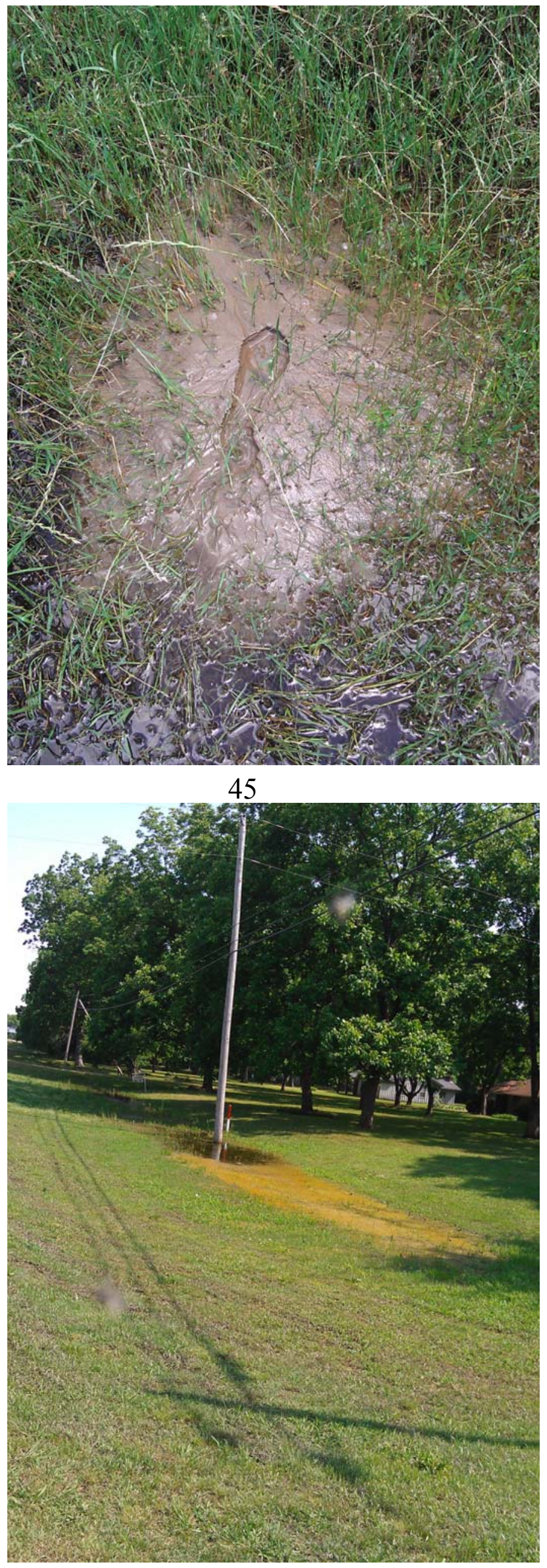
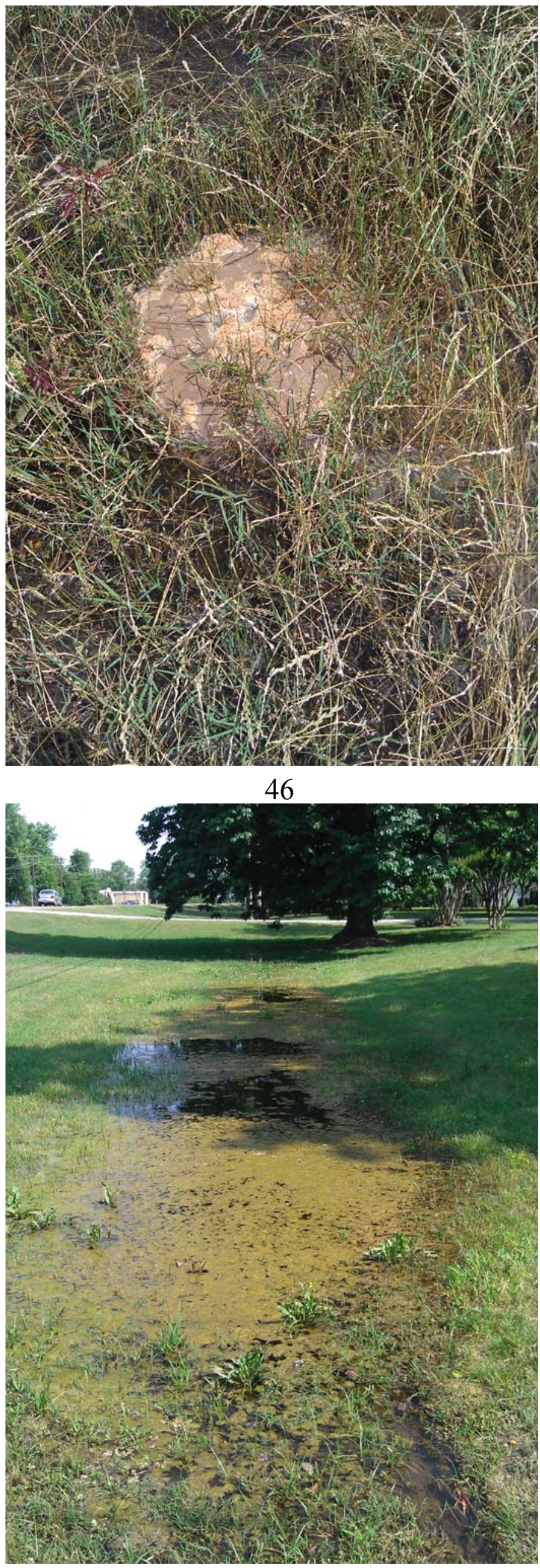


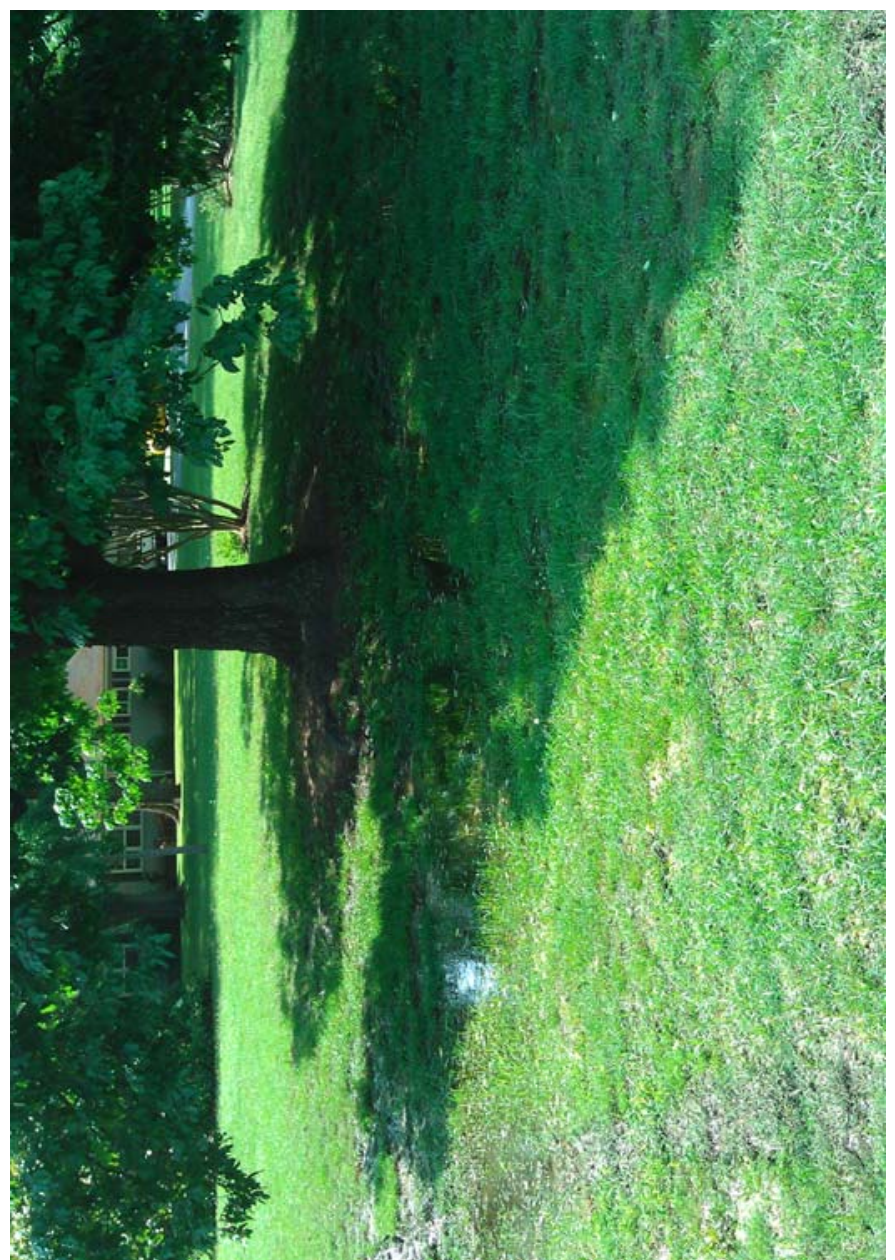

49

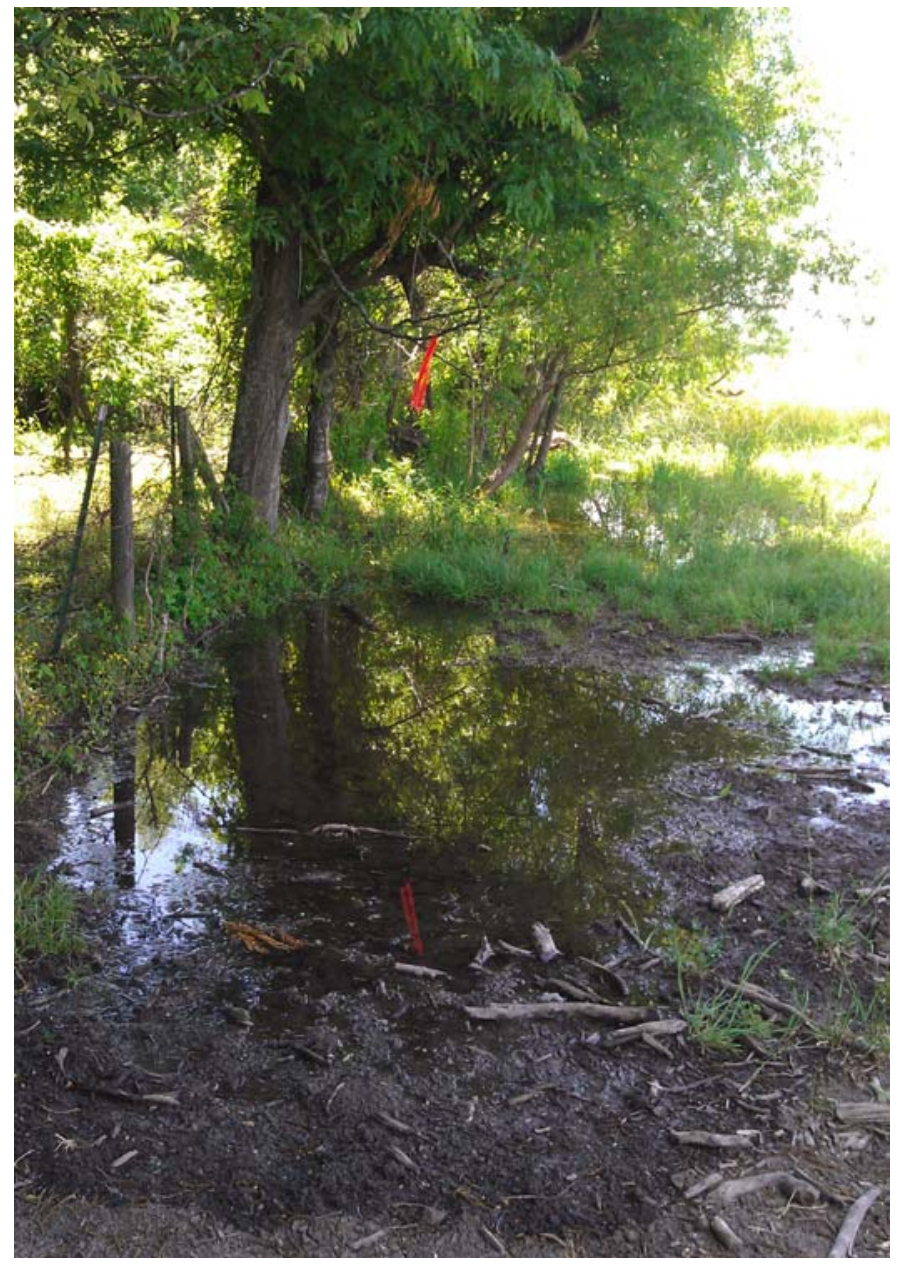

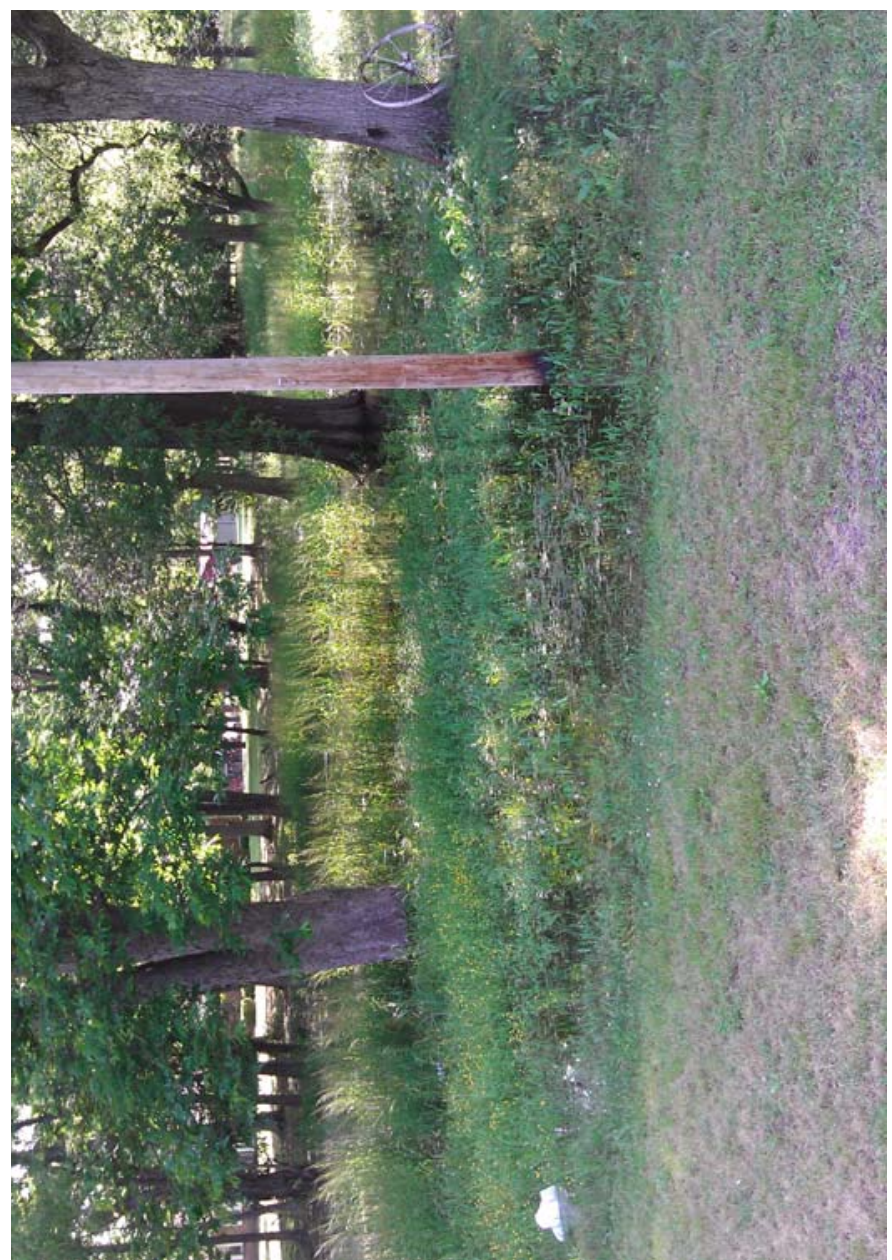

50

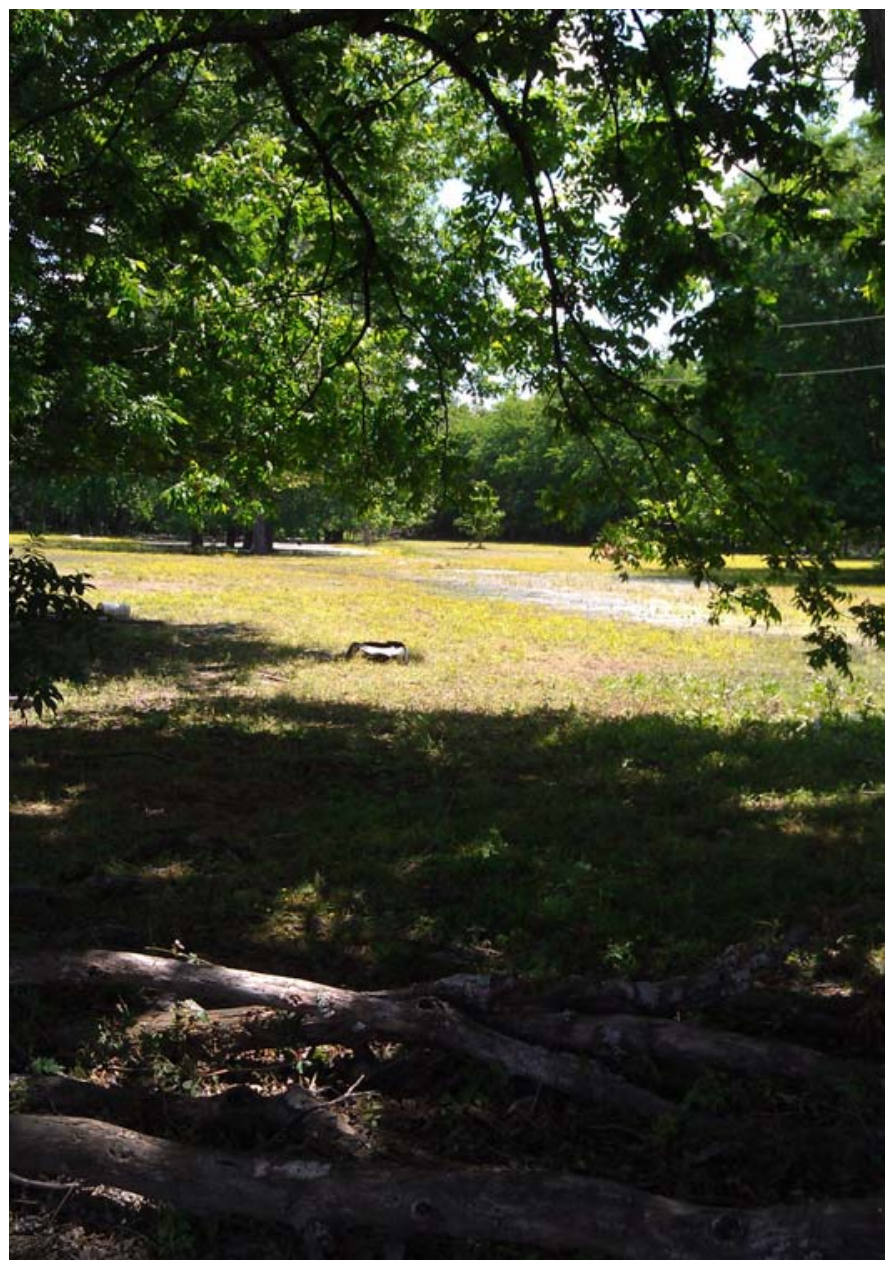




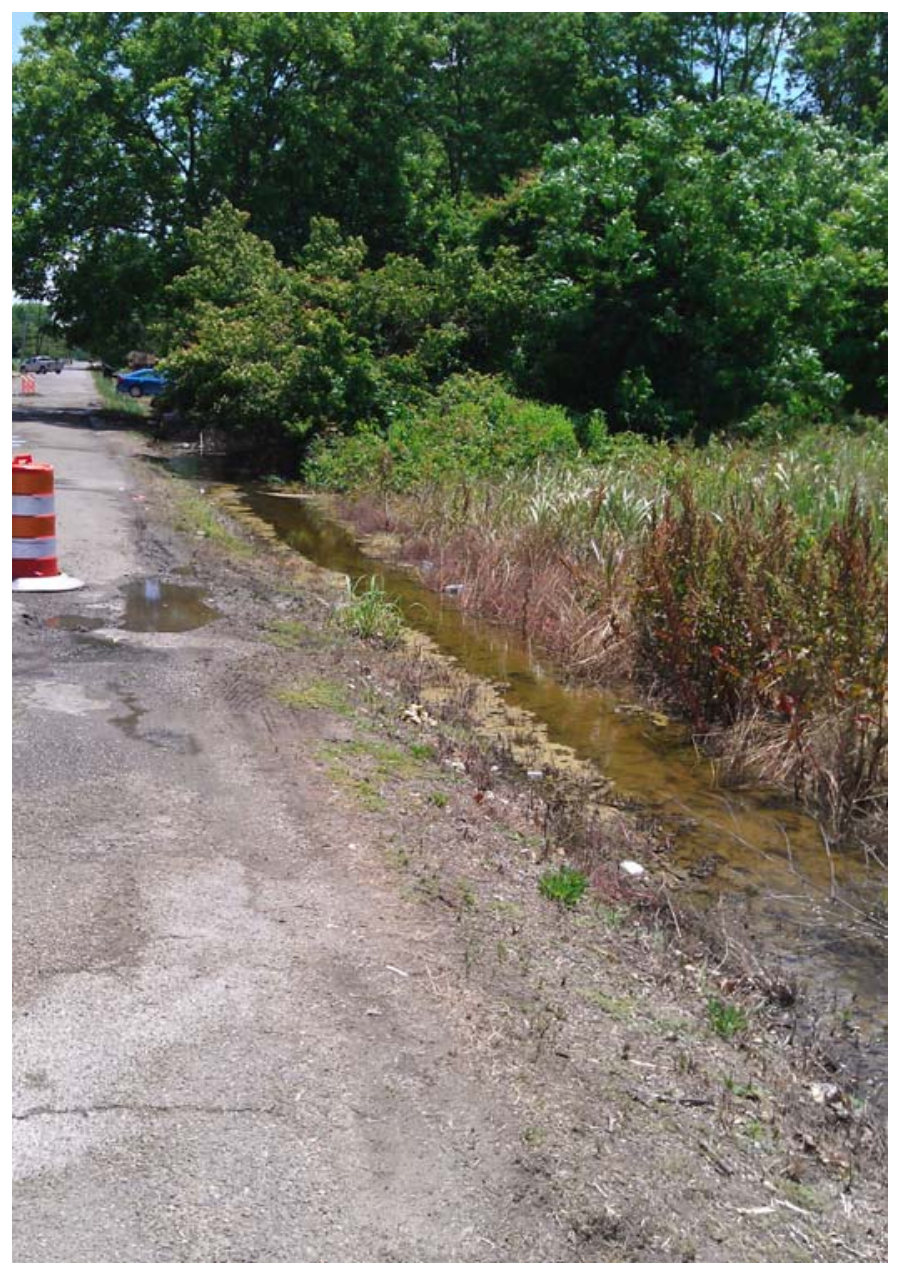

53

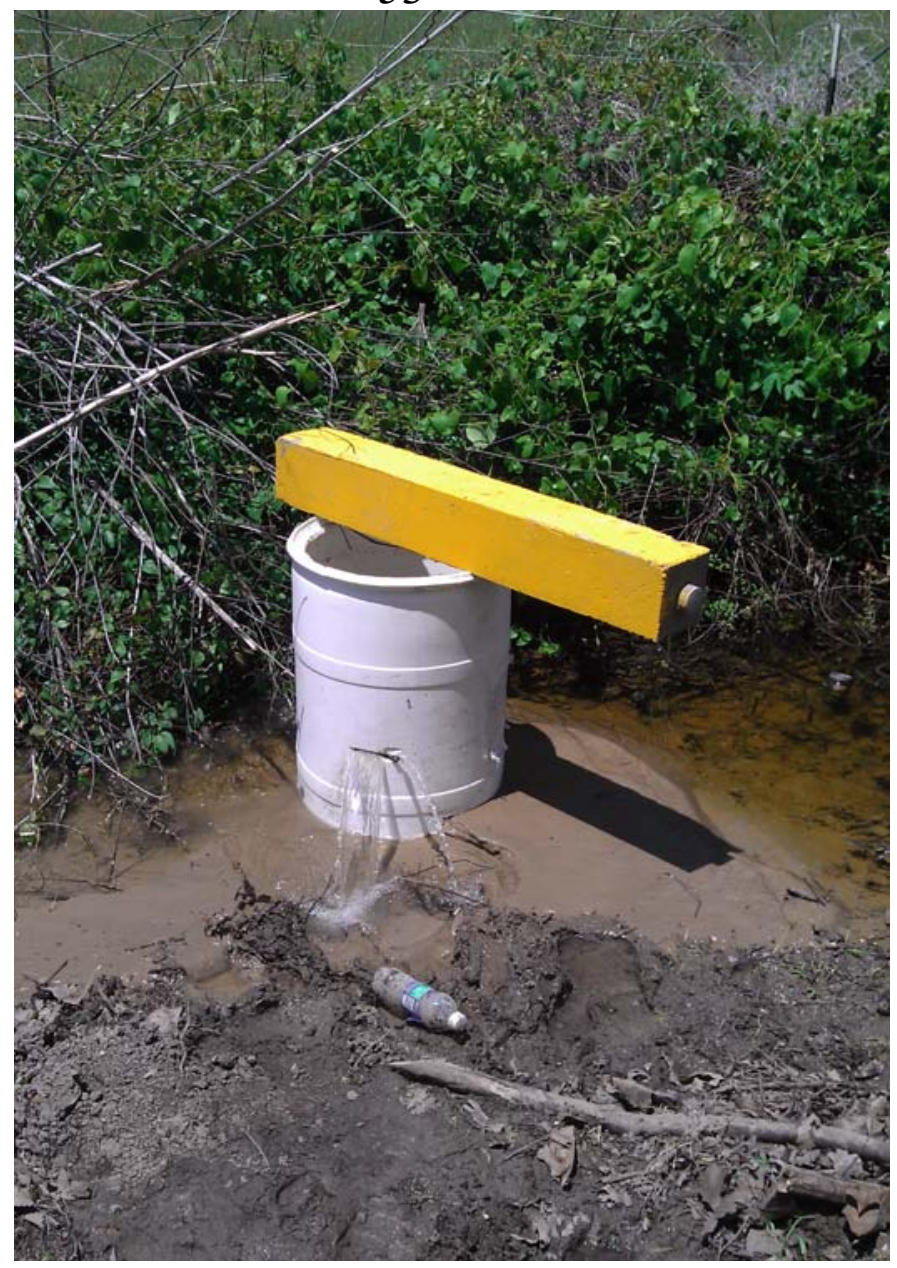

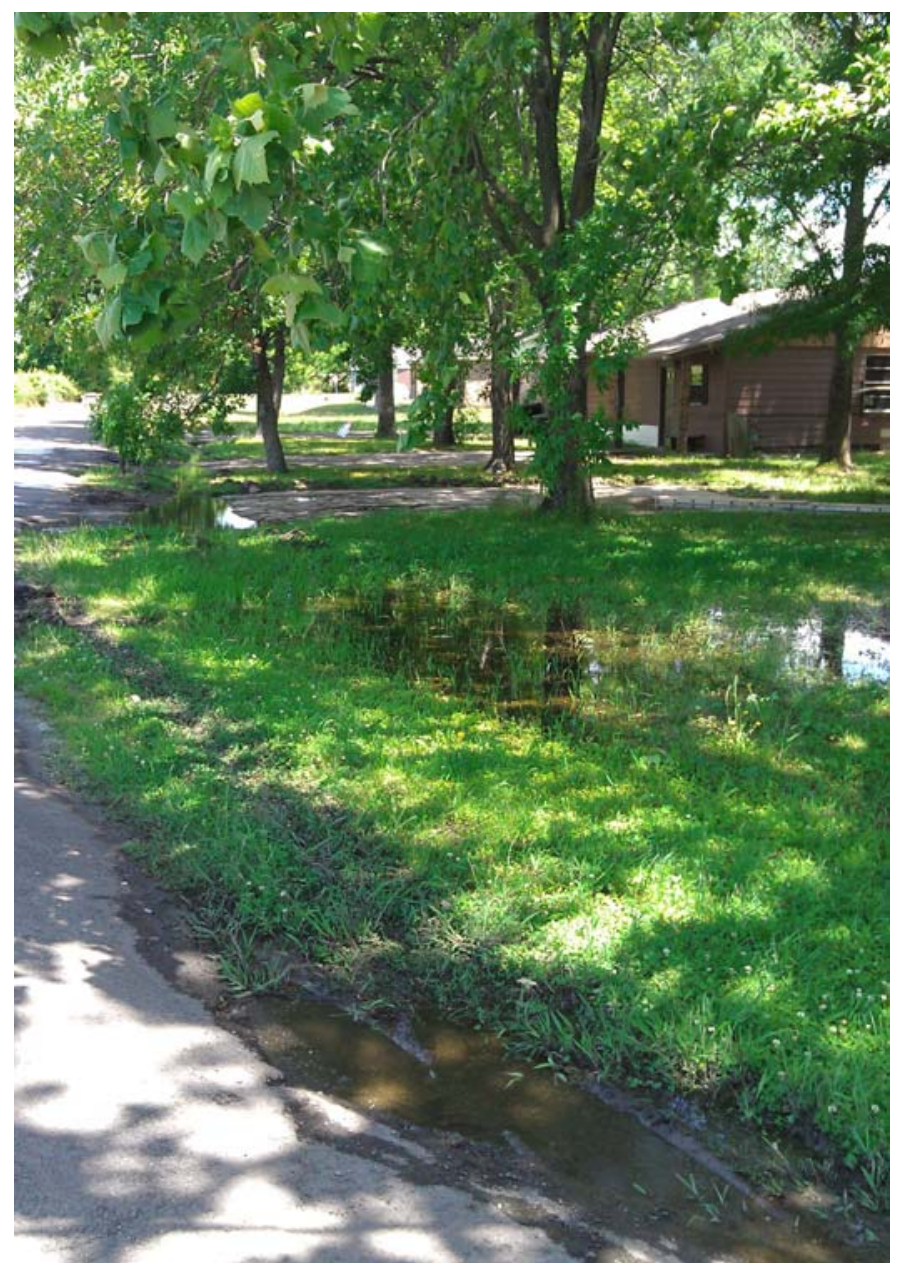

\section{4}

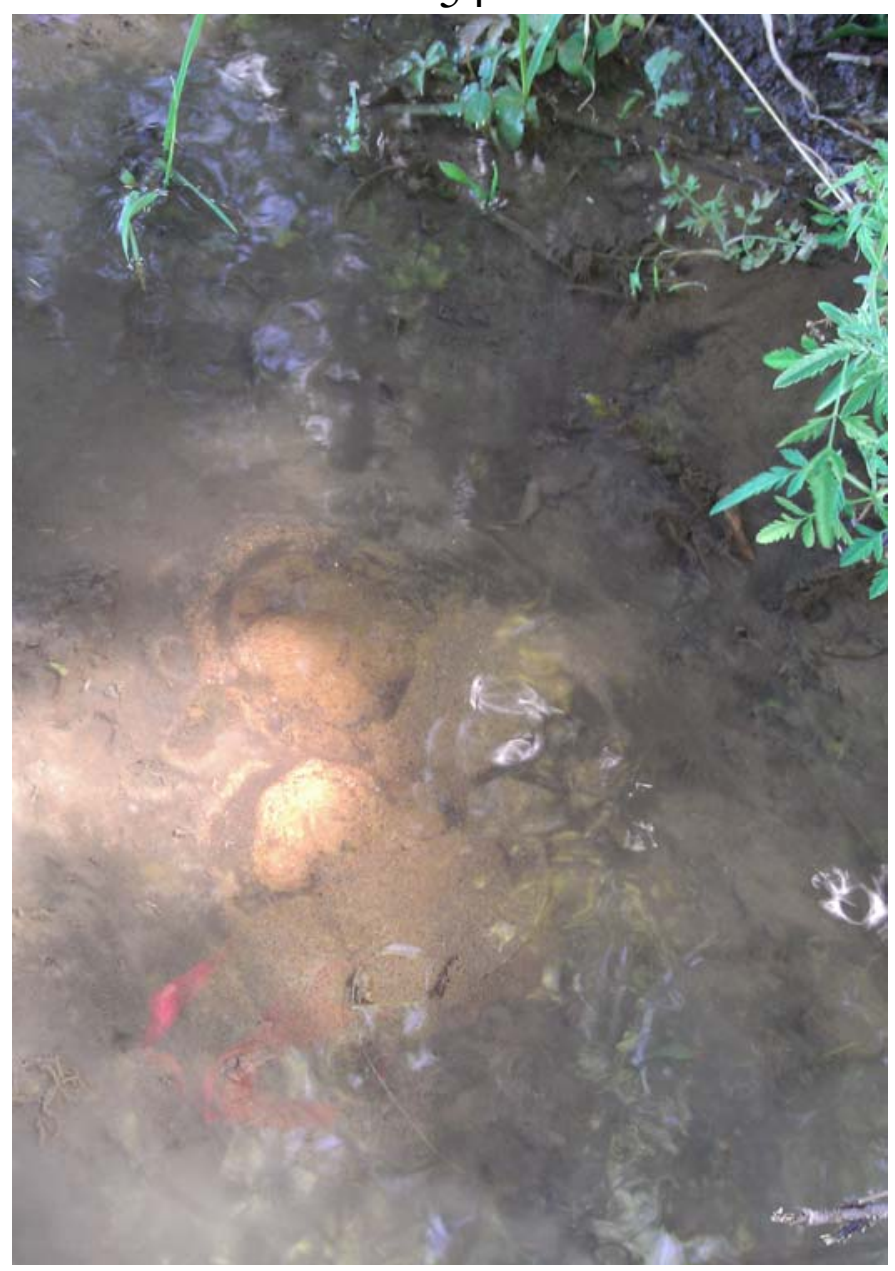




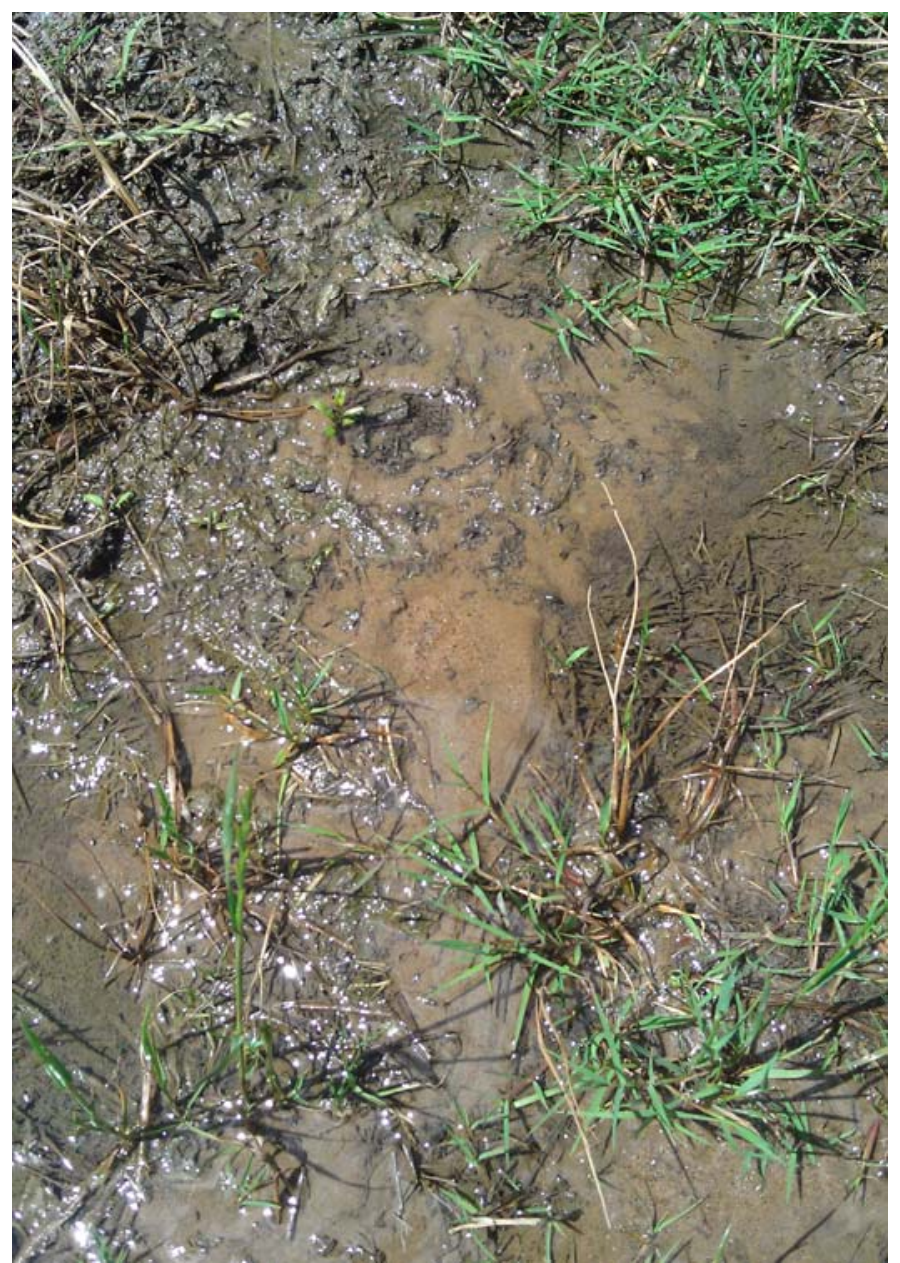

57

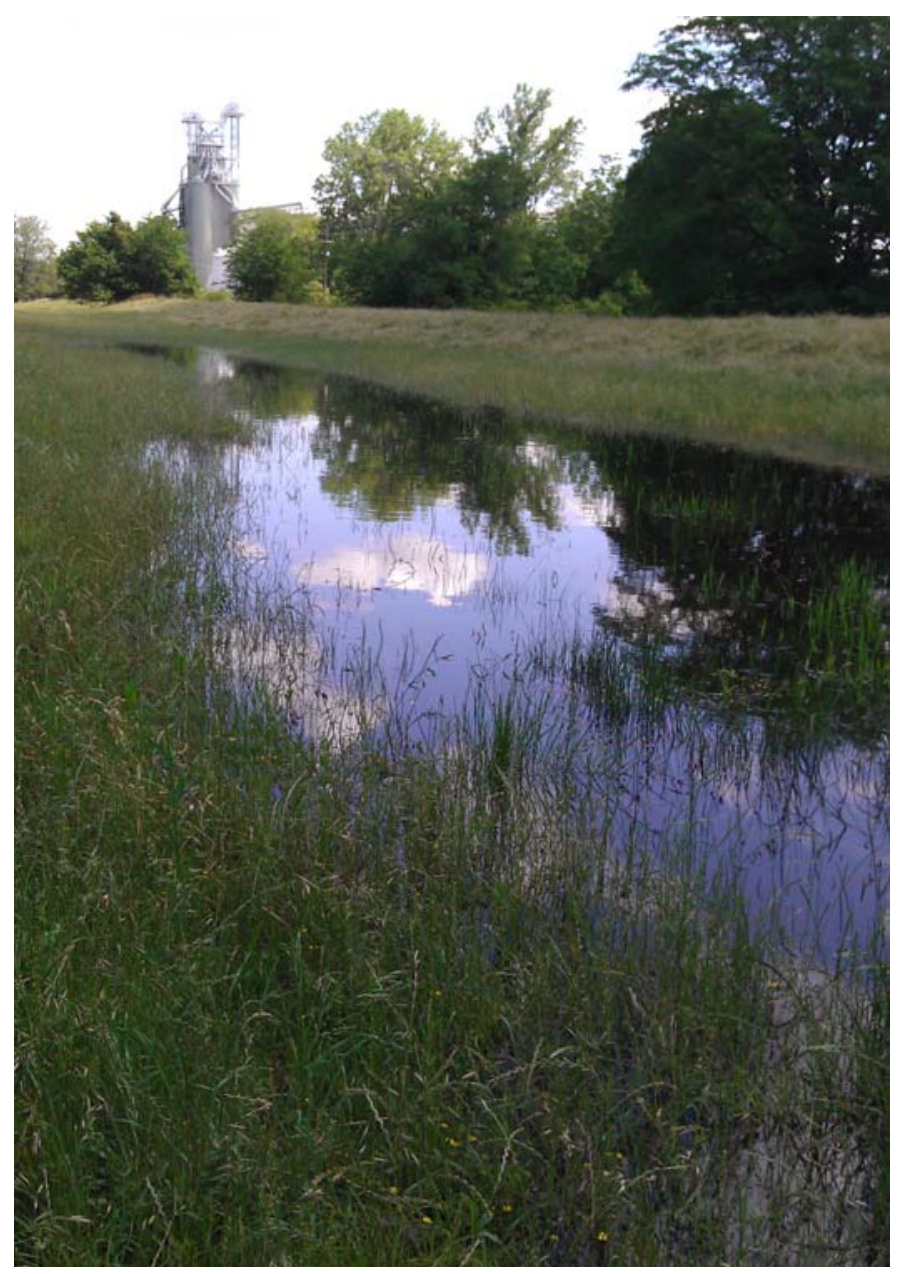




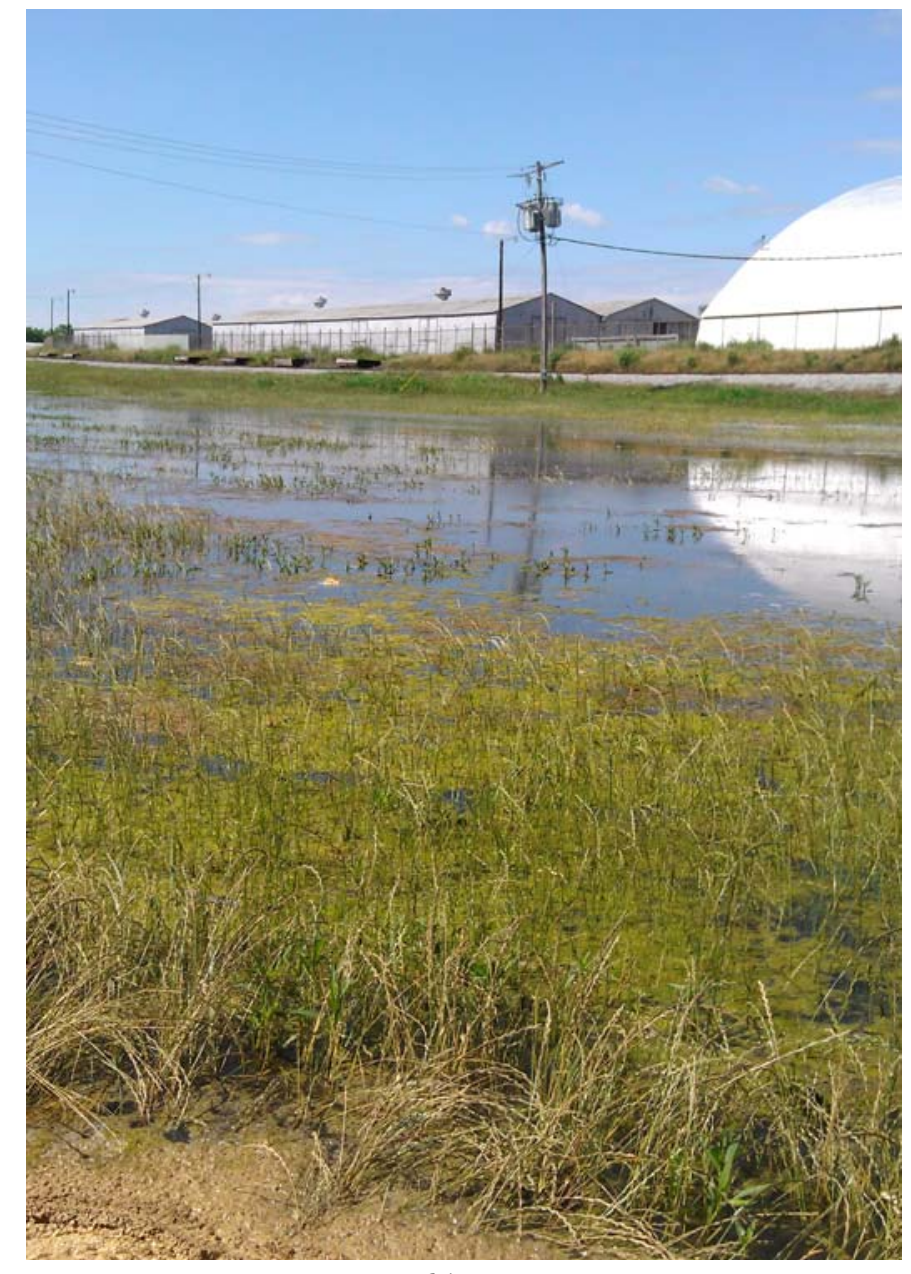

61

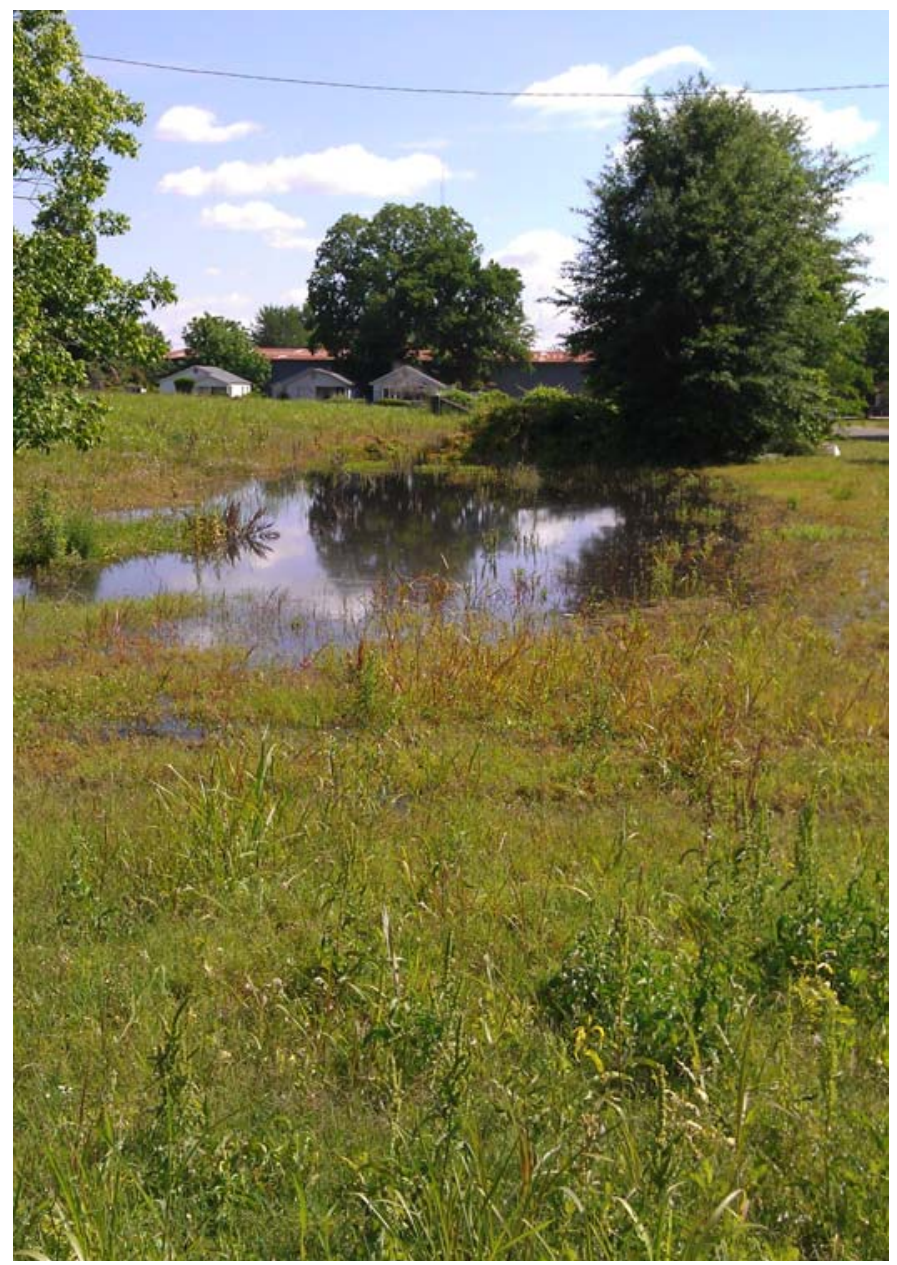

62
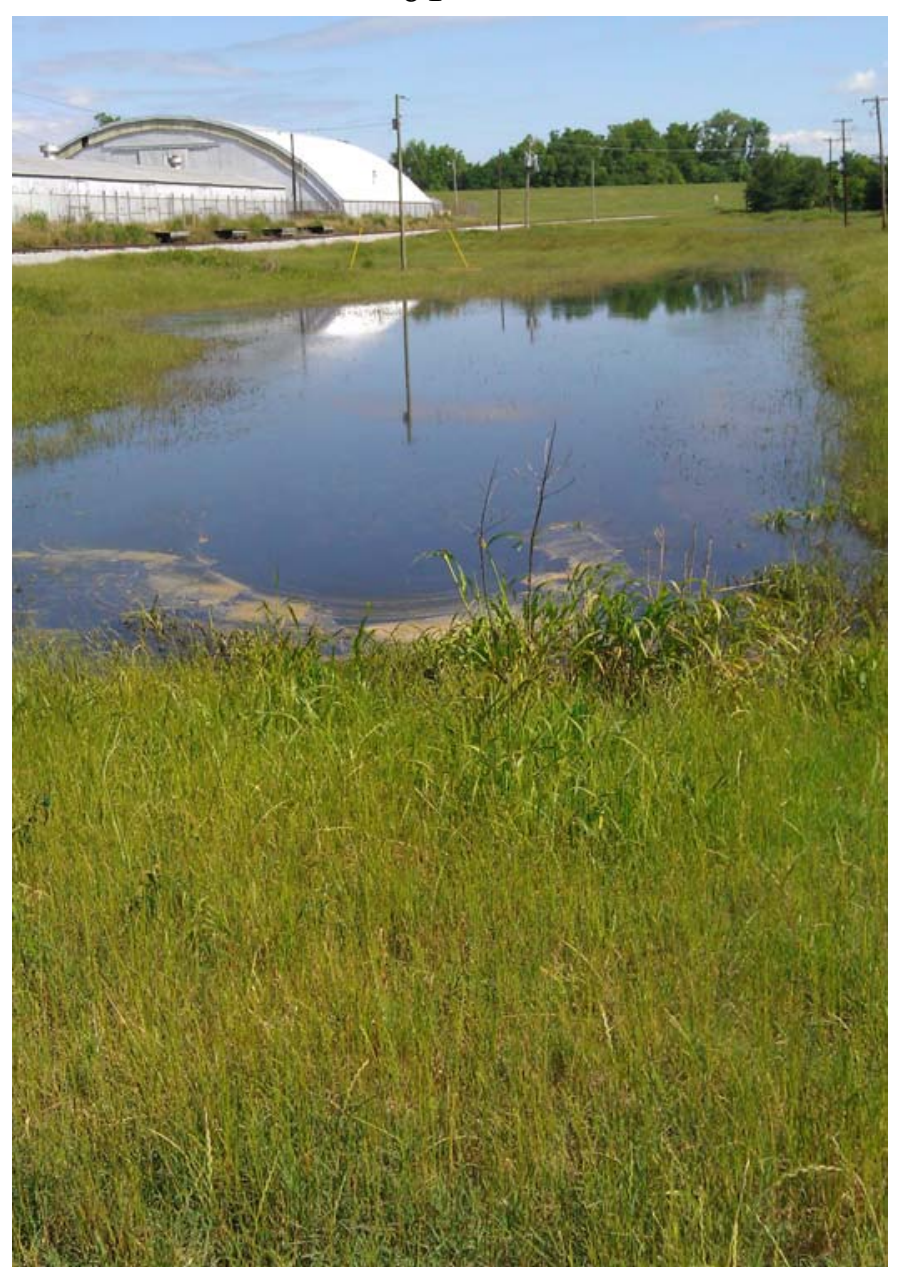

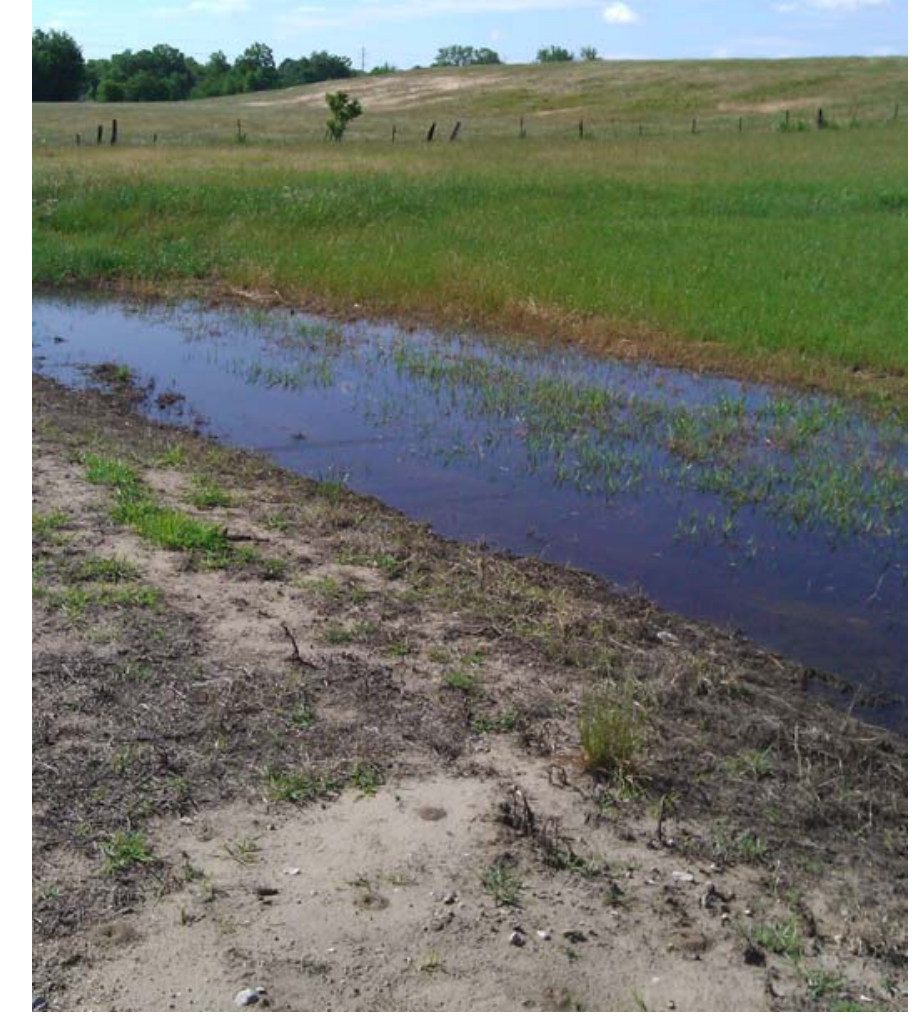

64 


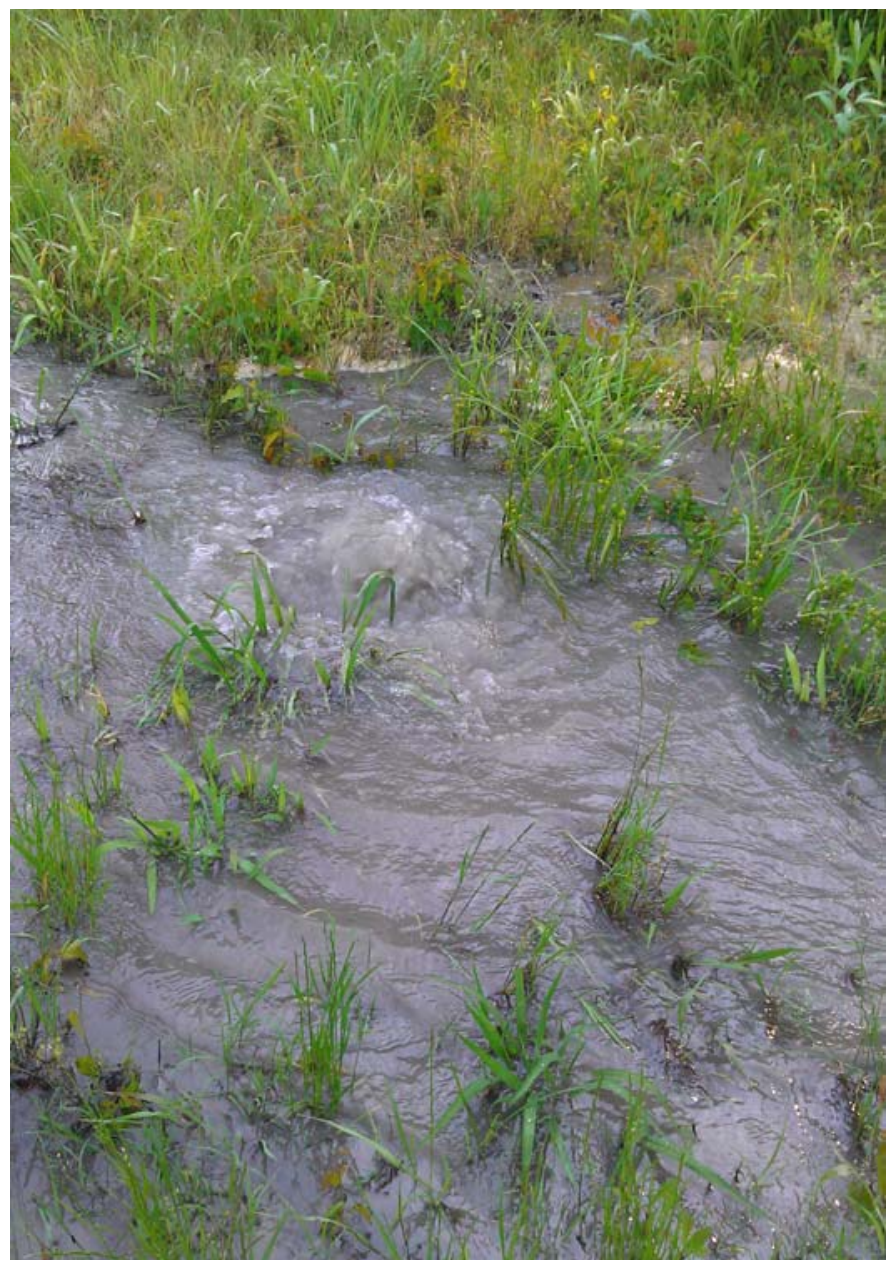

65

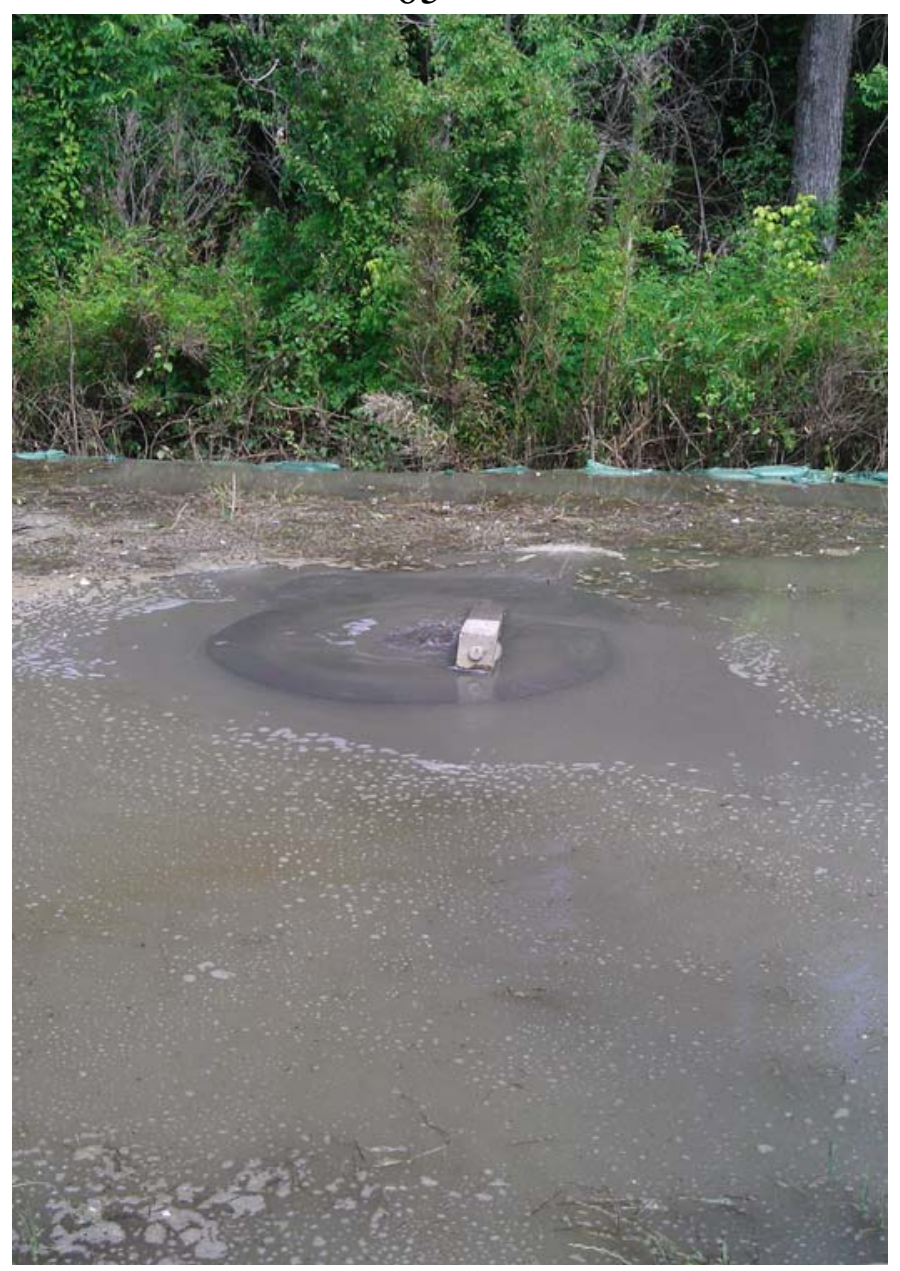

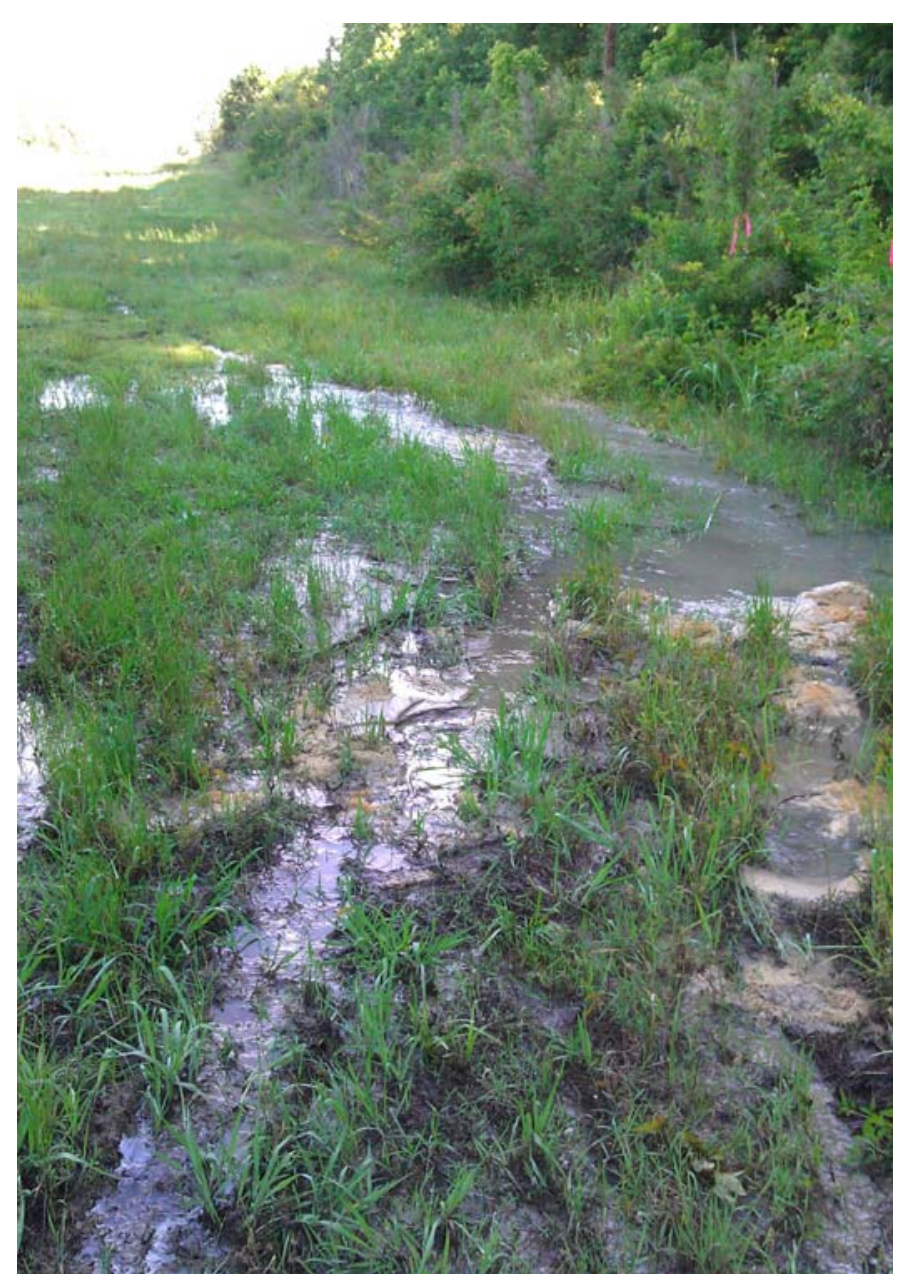

66

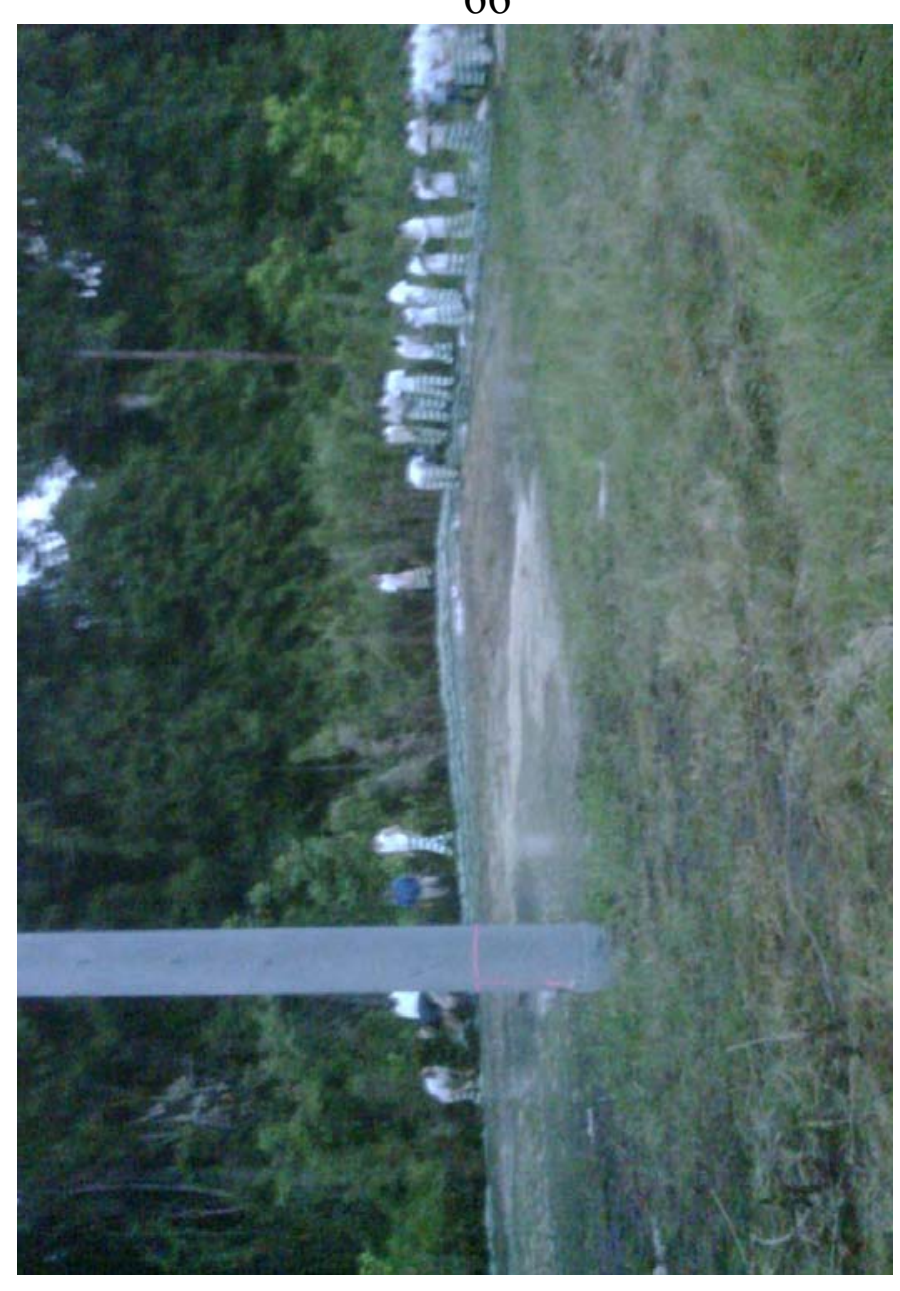

68 


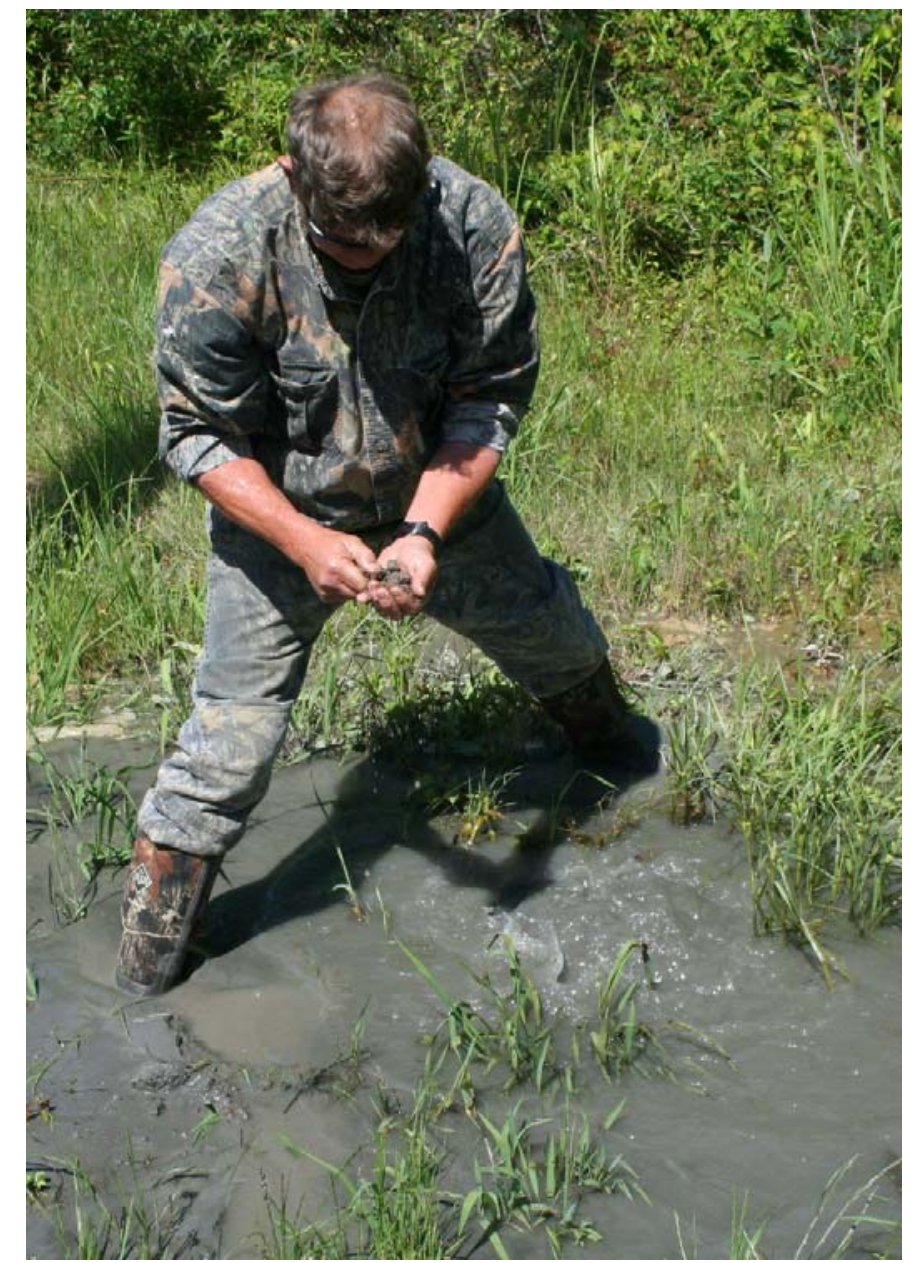

69

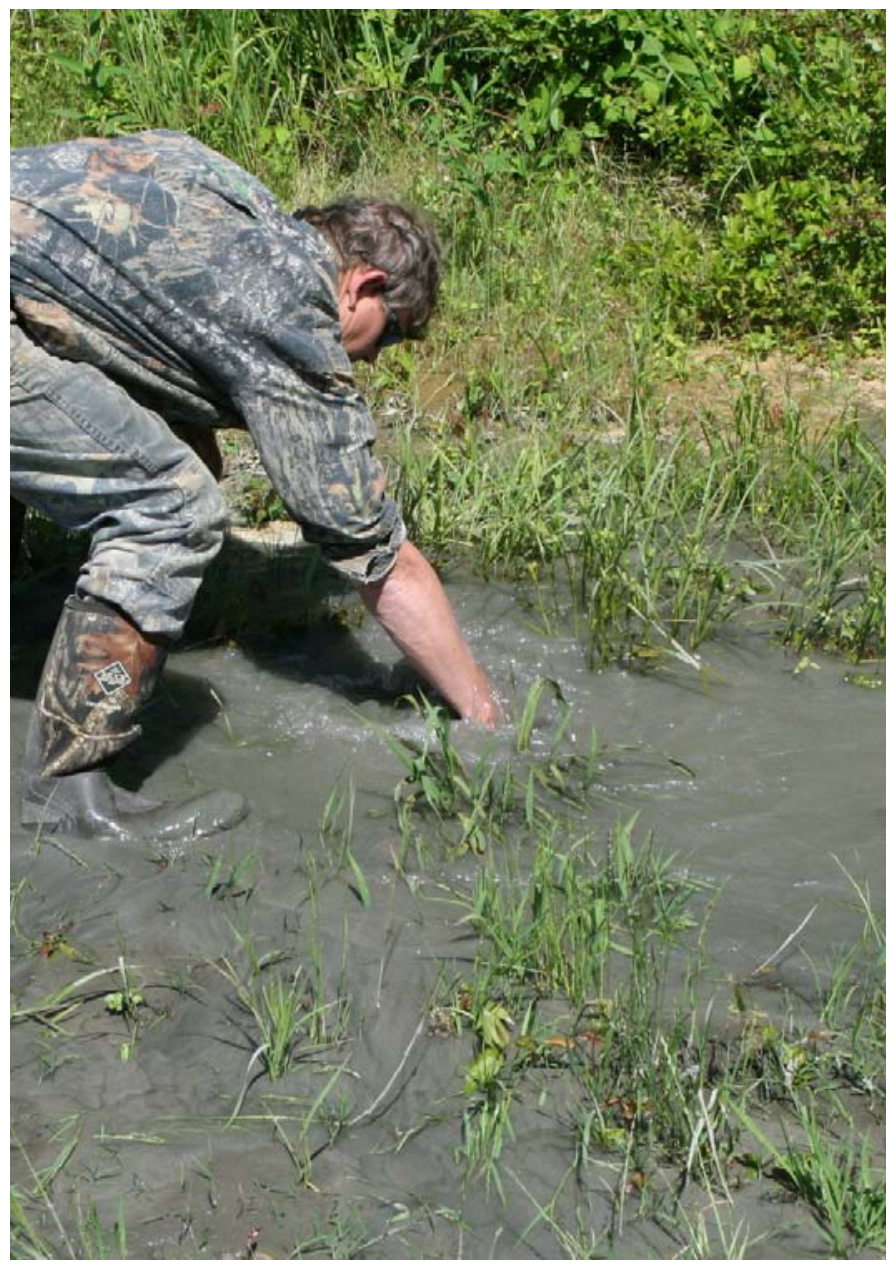

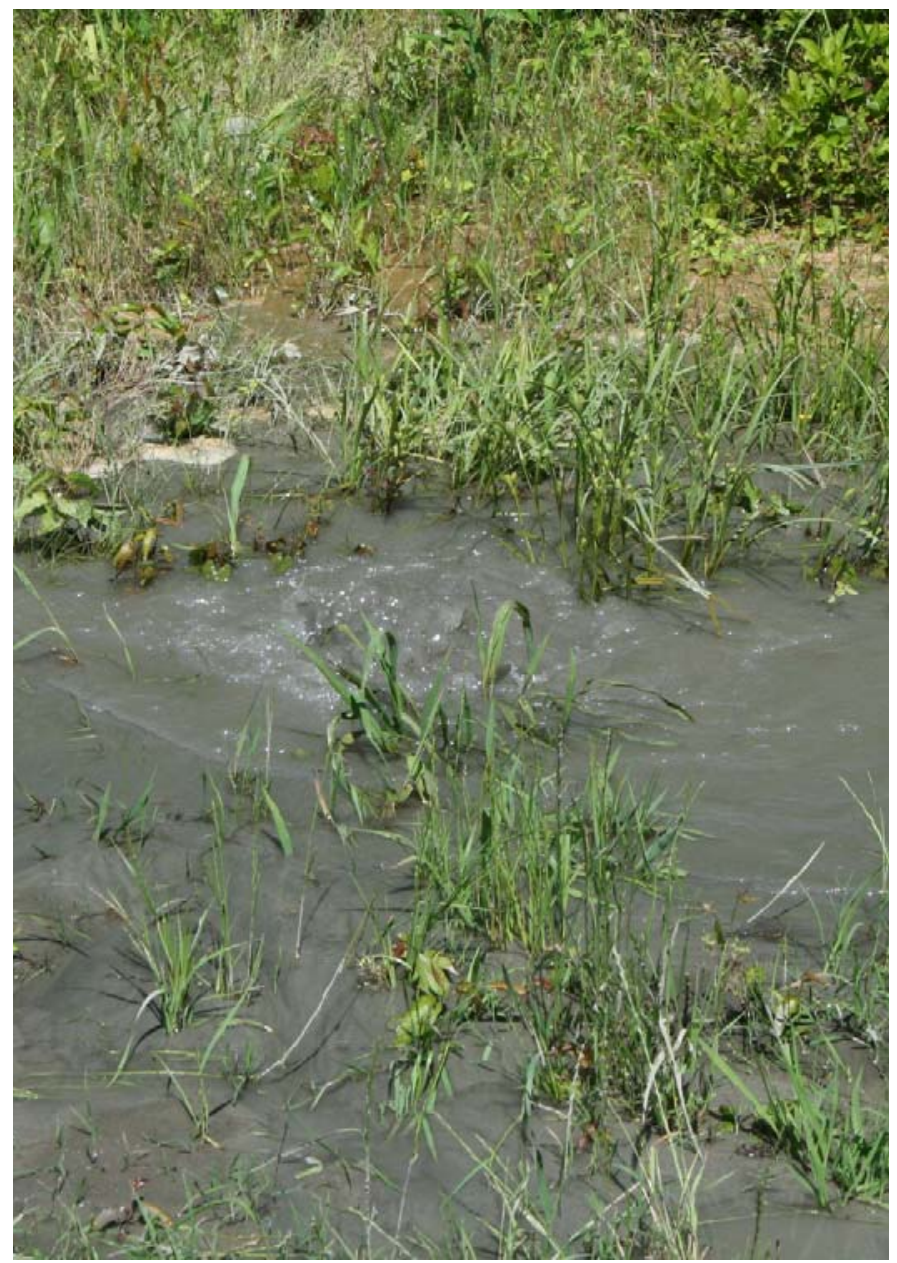

70

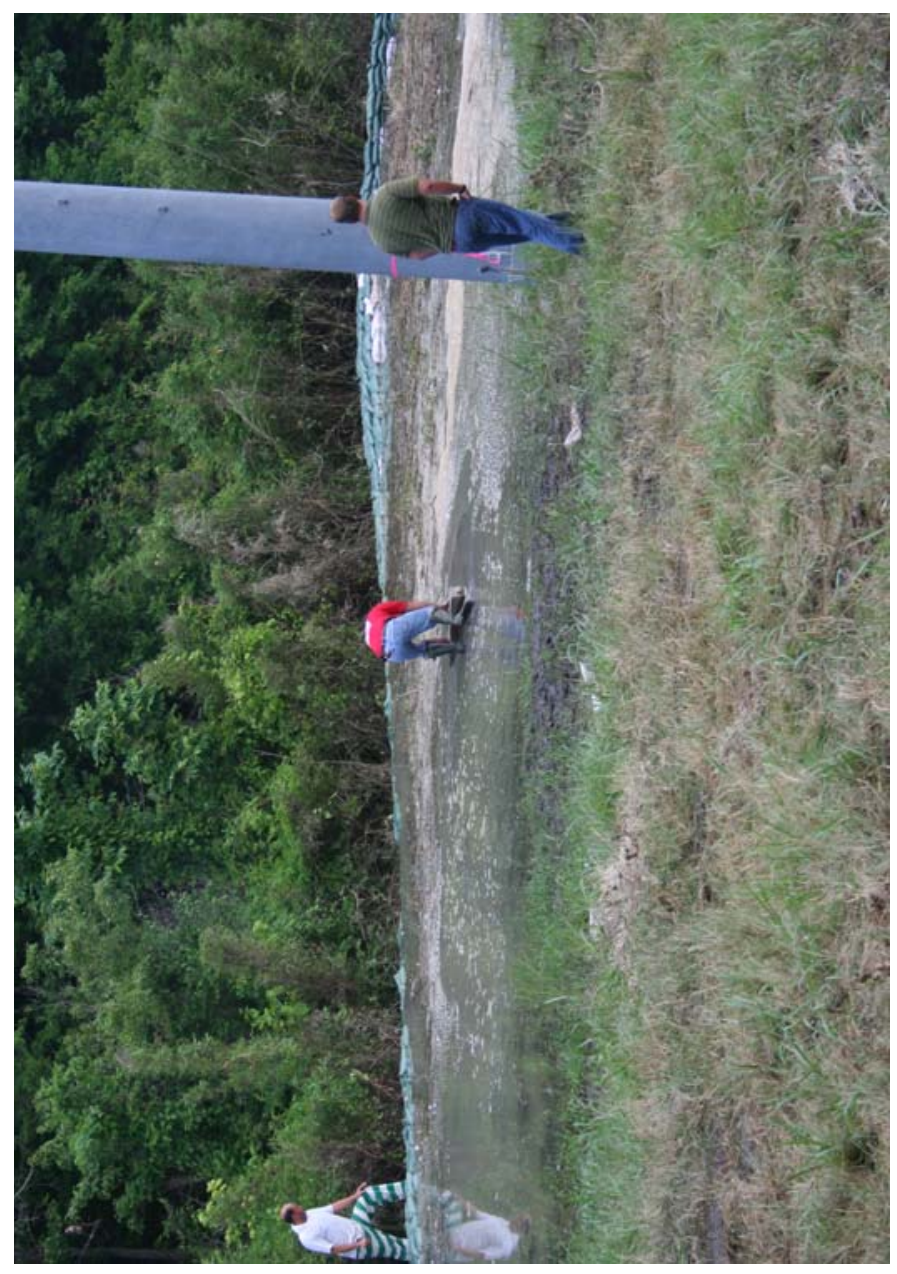




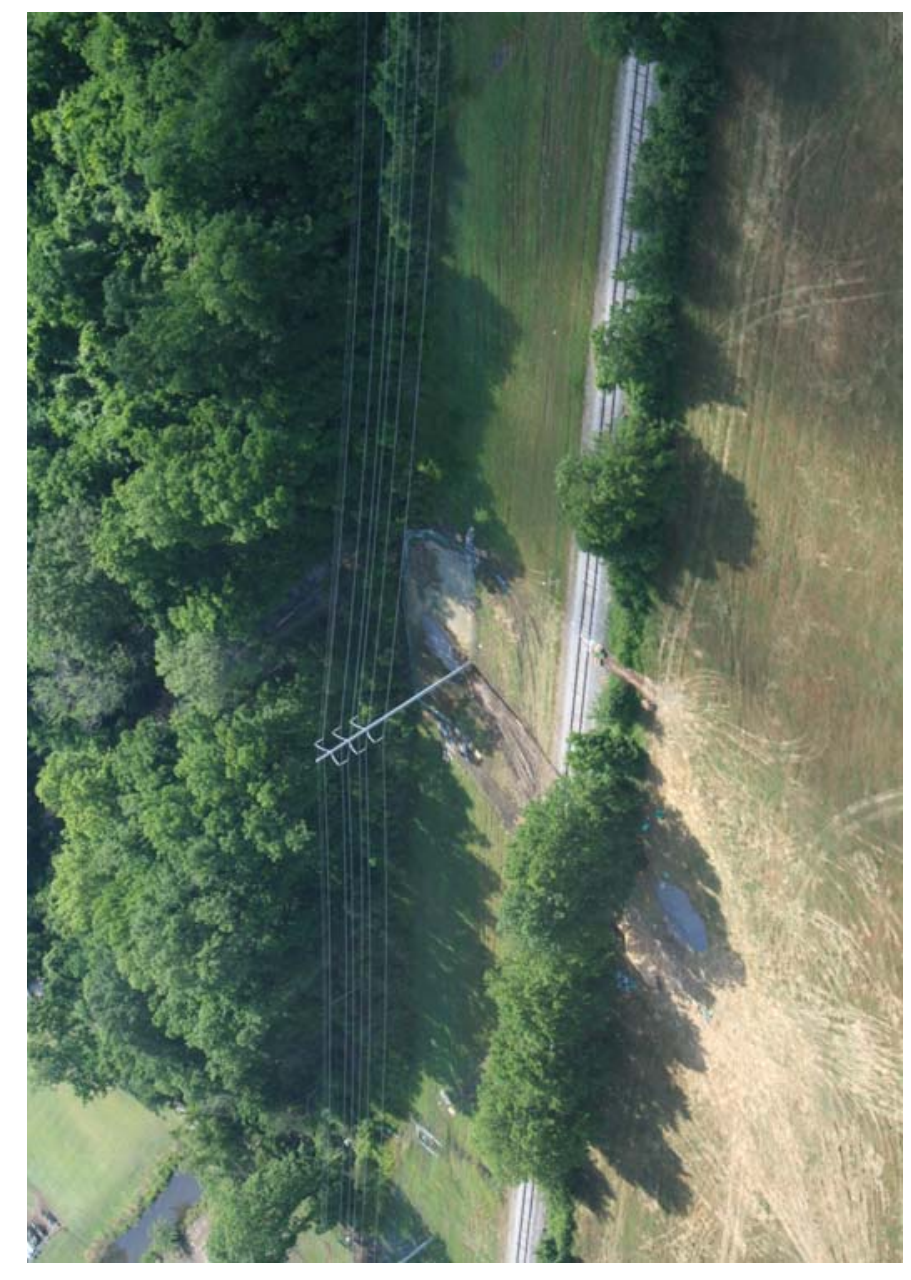

73

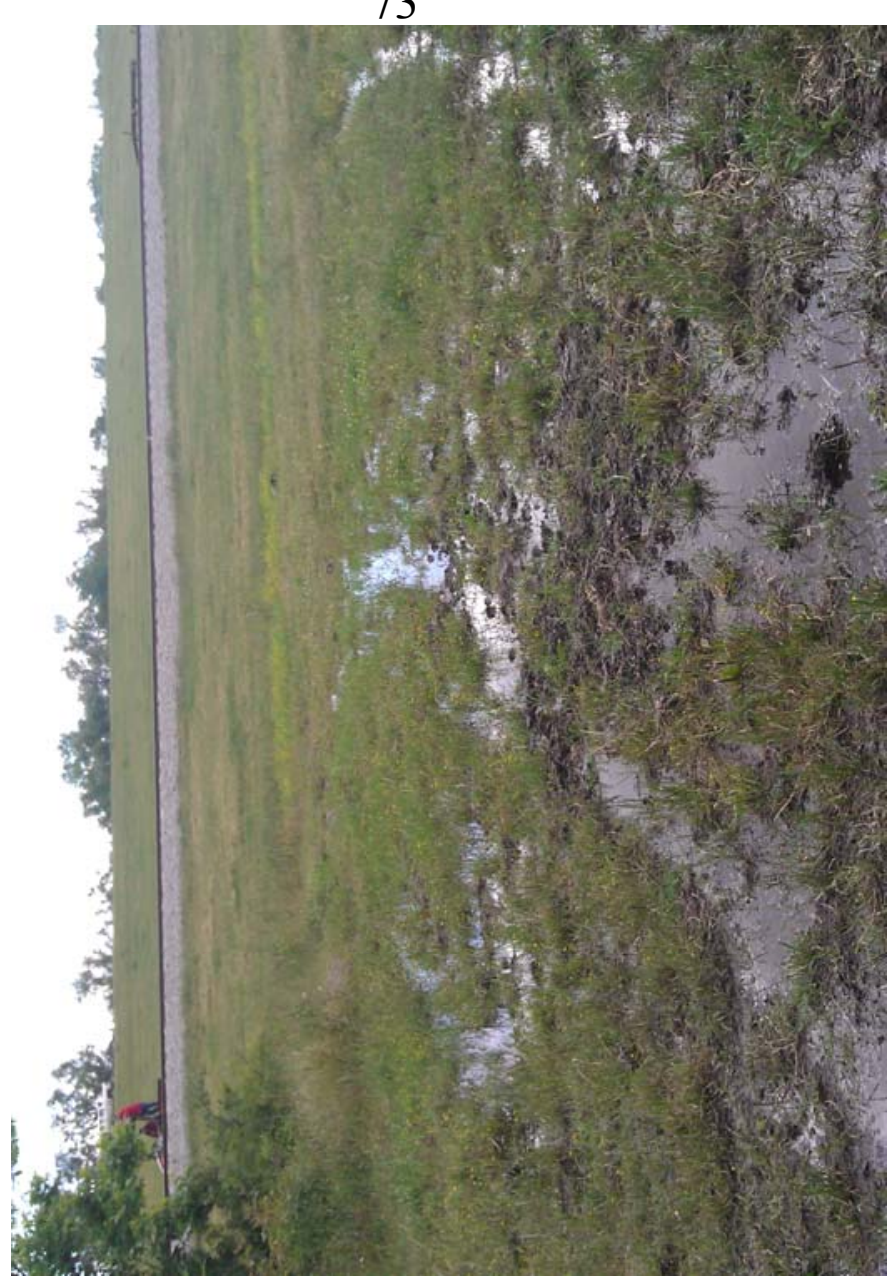

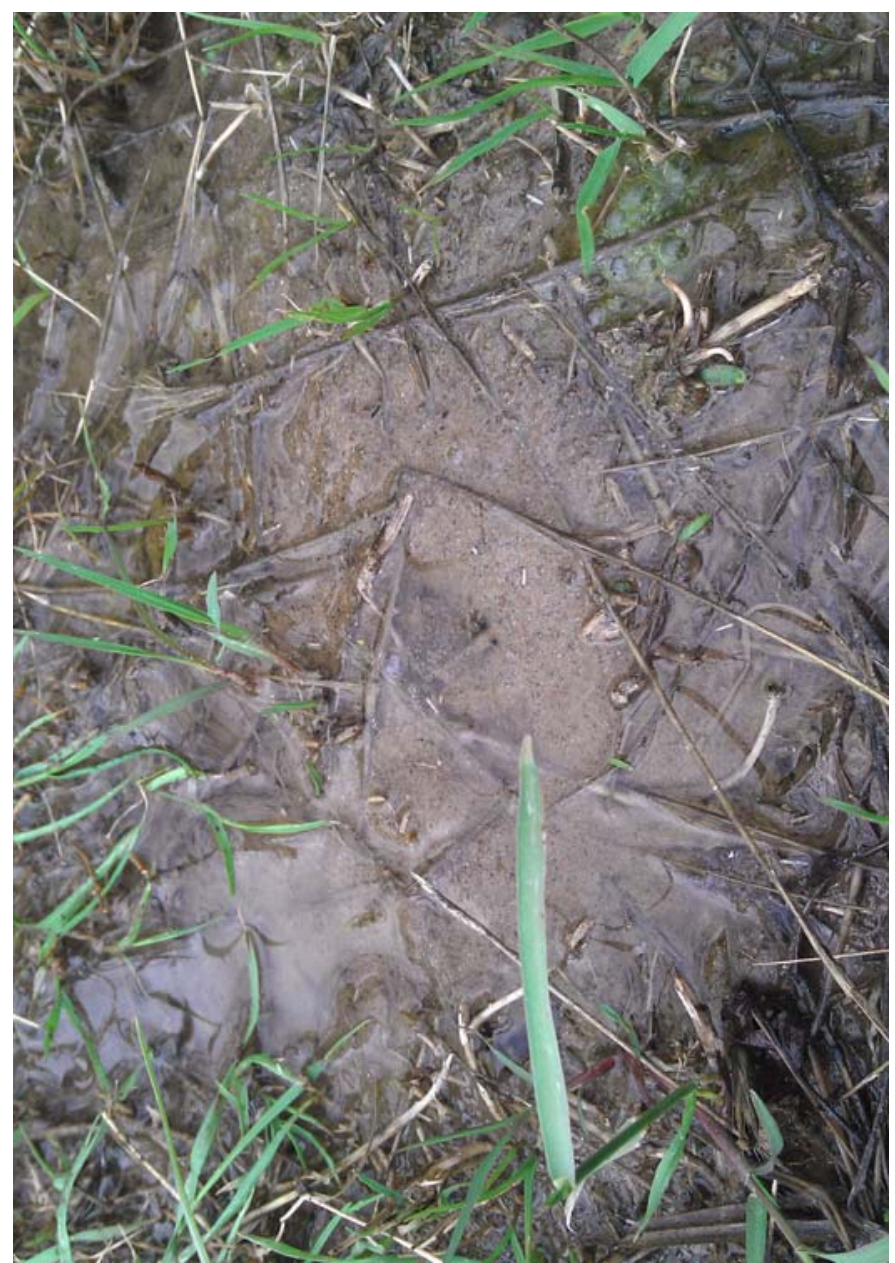

74

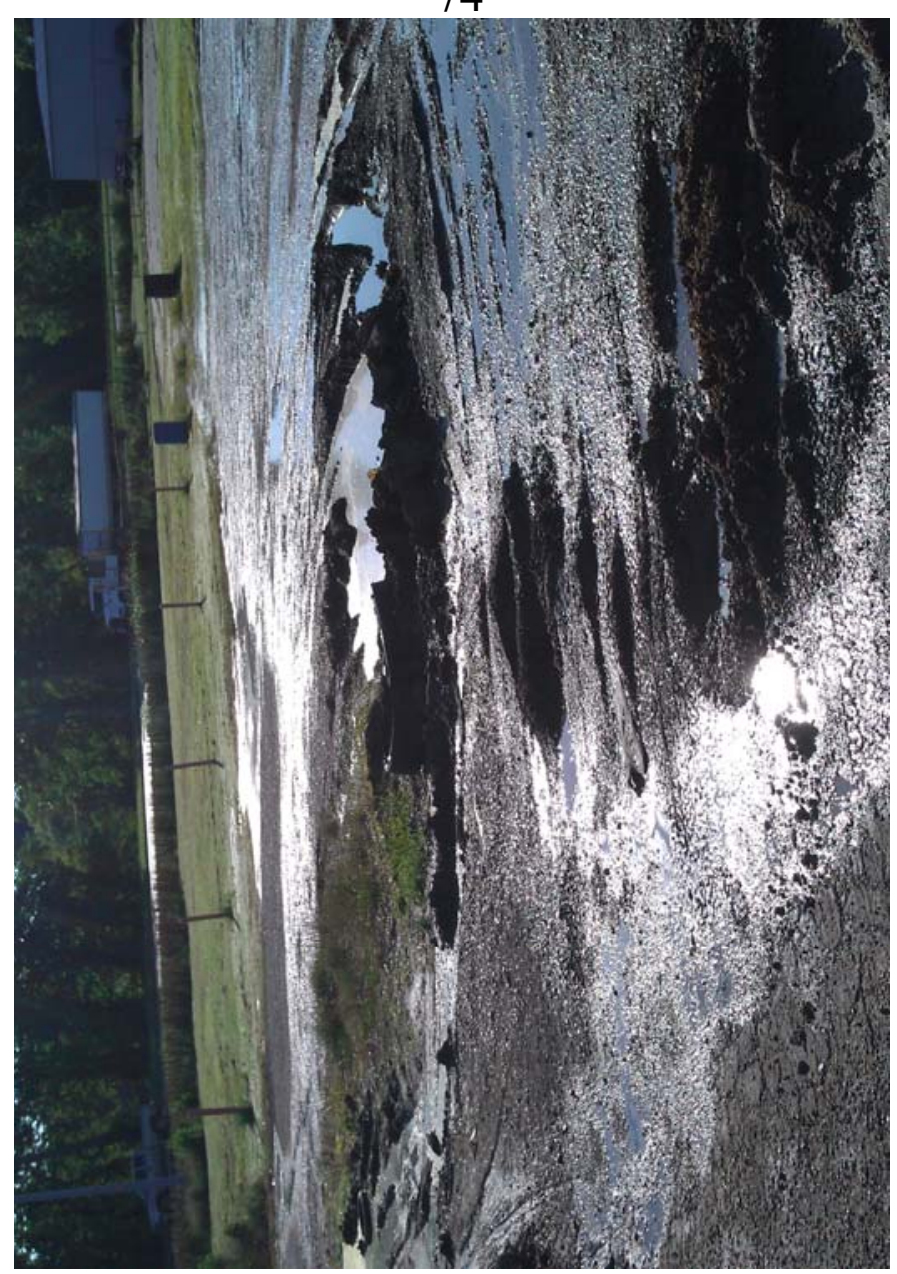




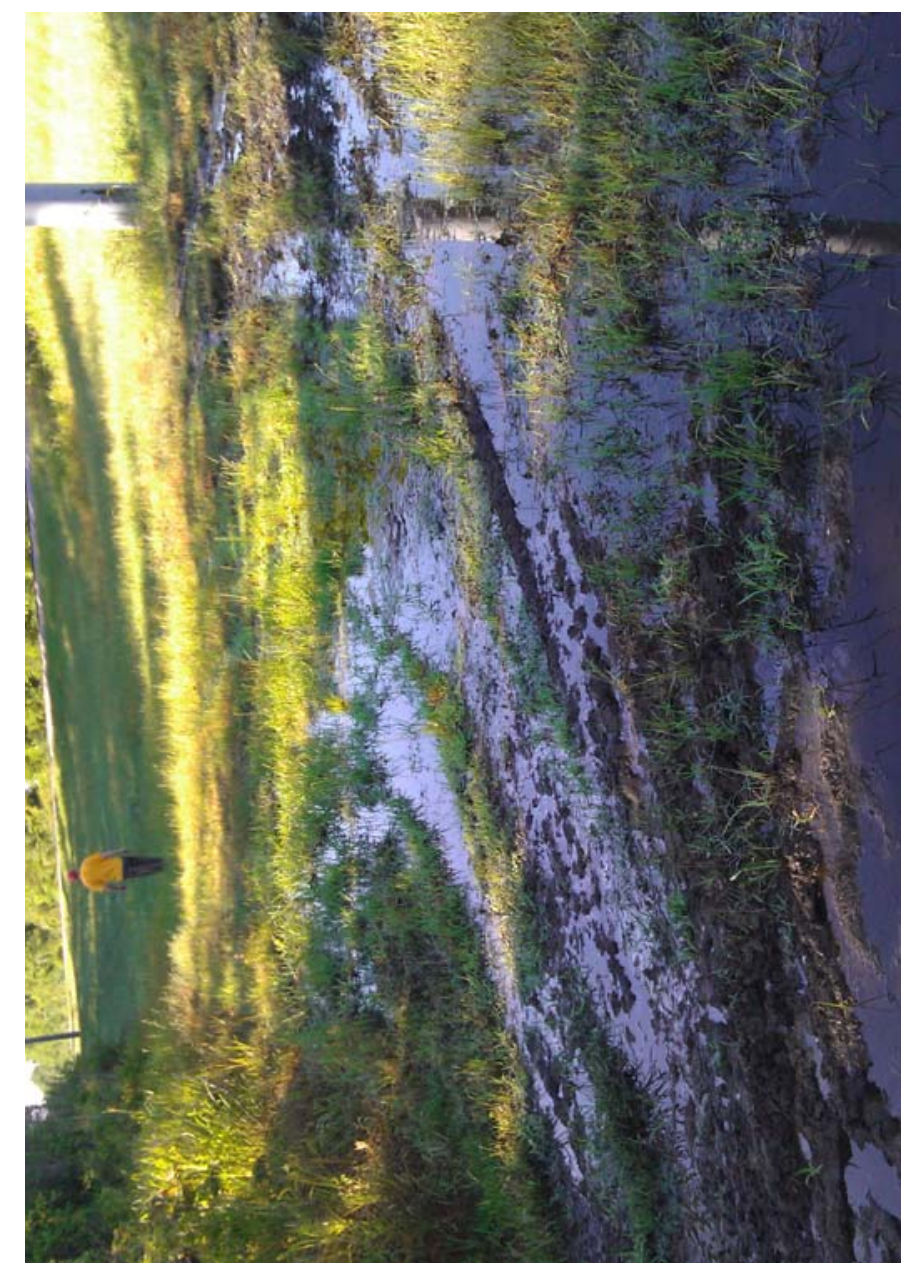

77

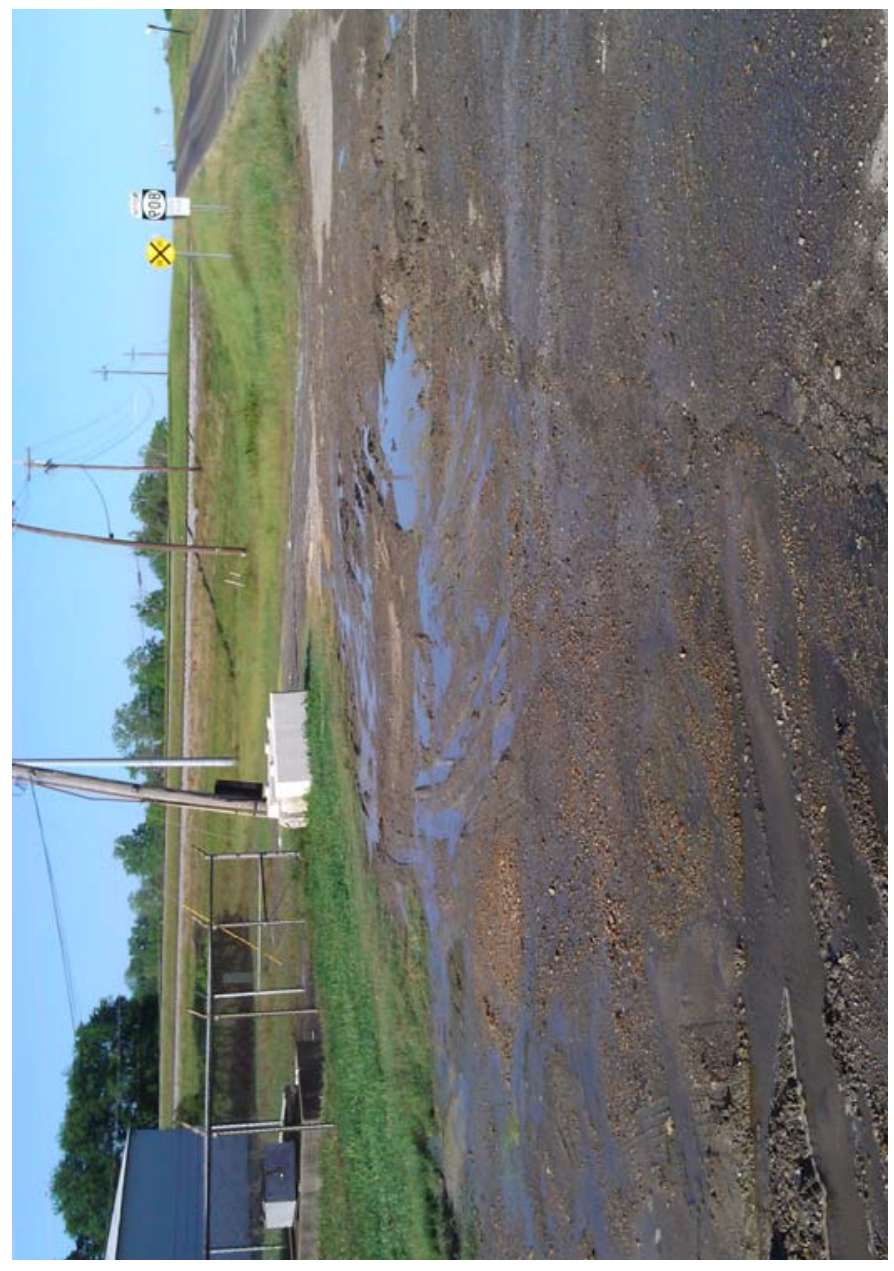

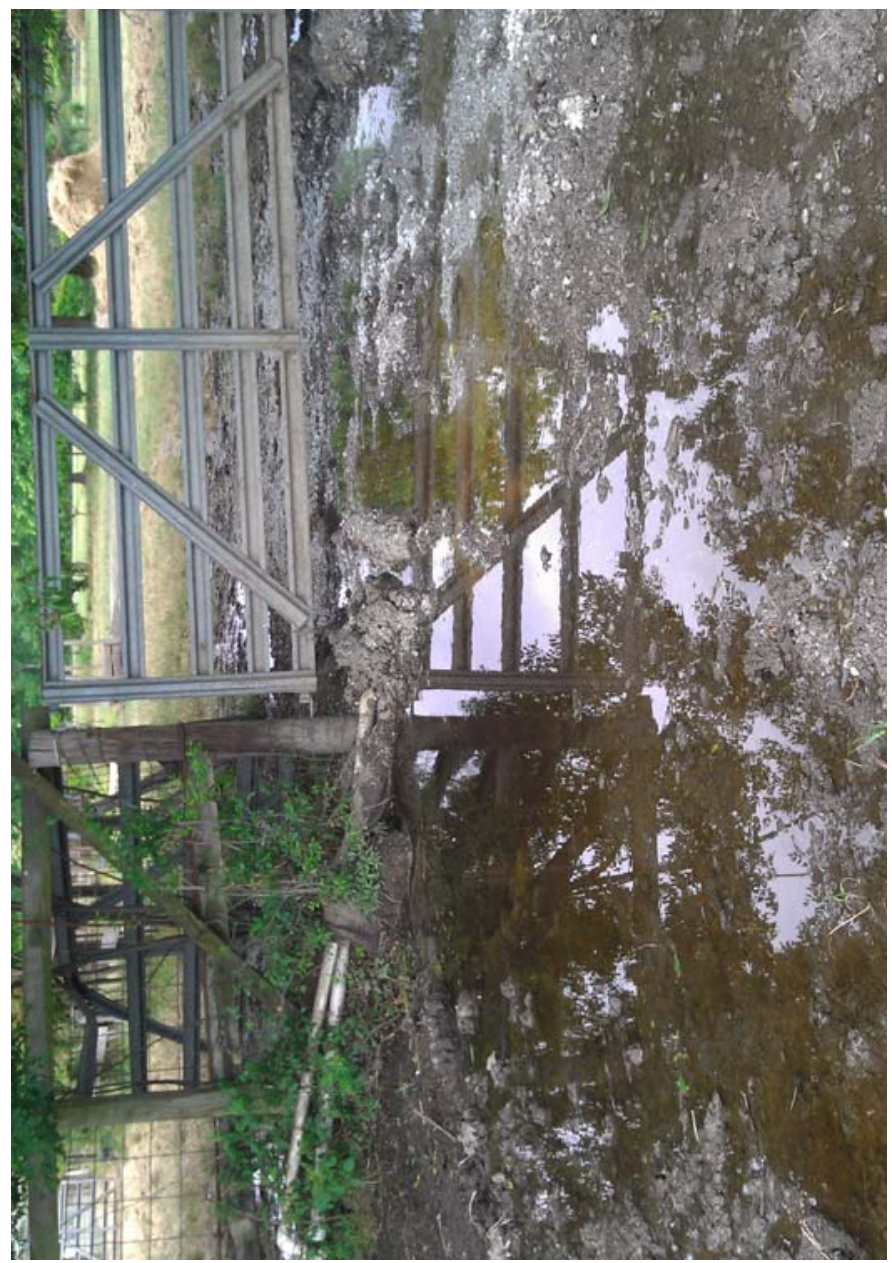

78

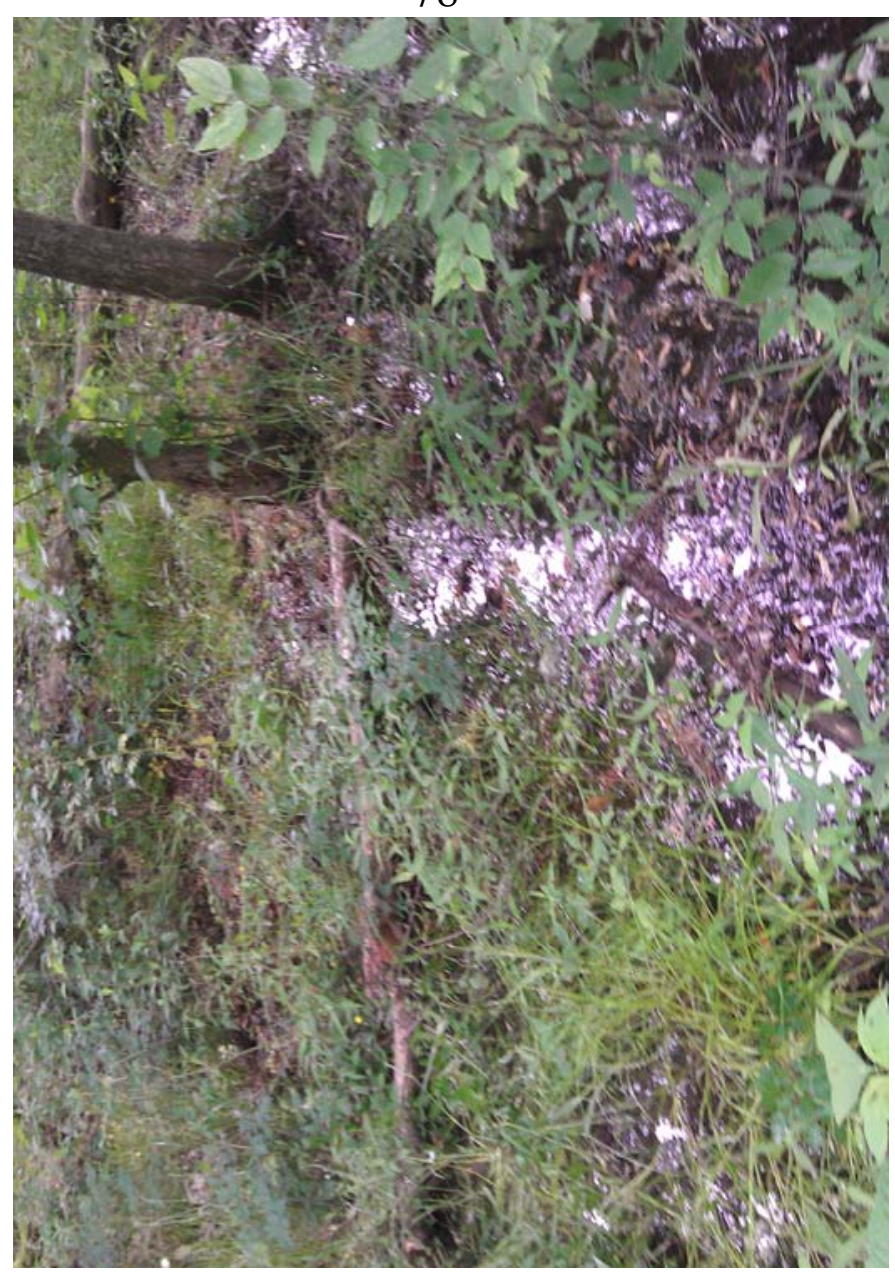




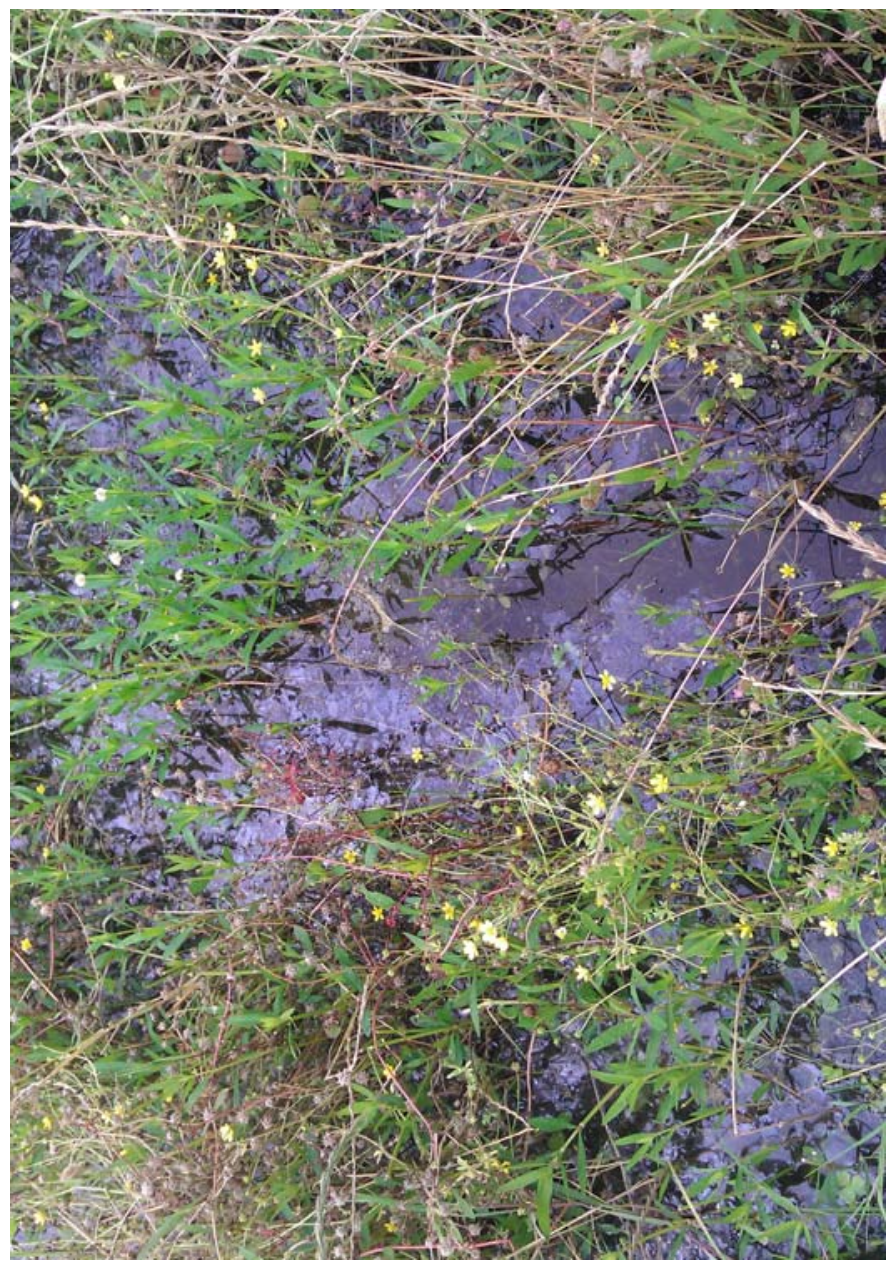

81

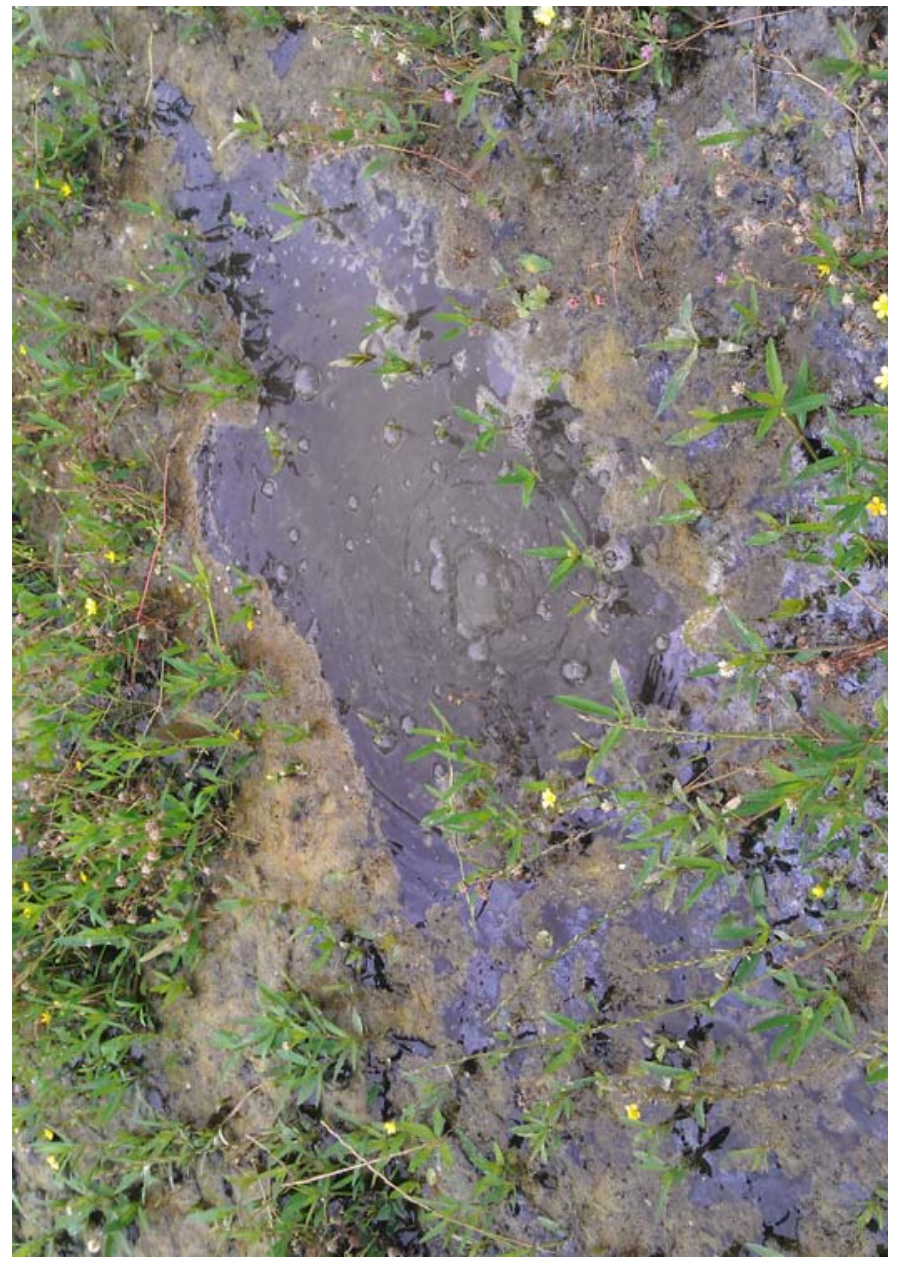

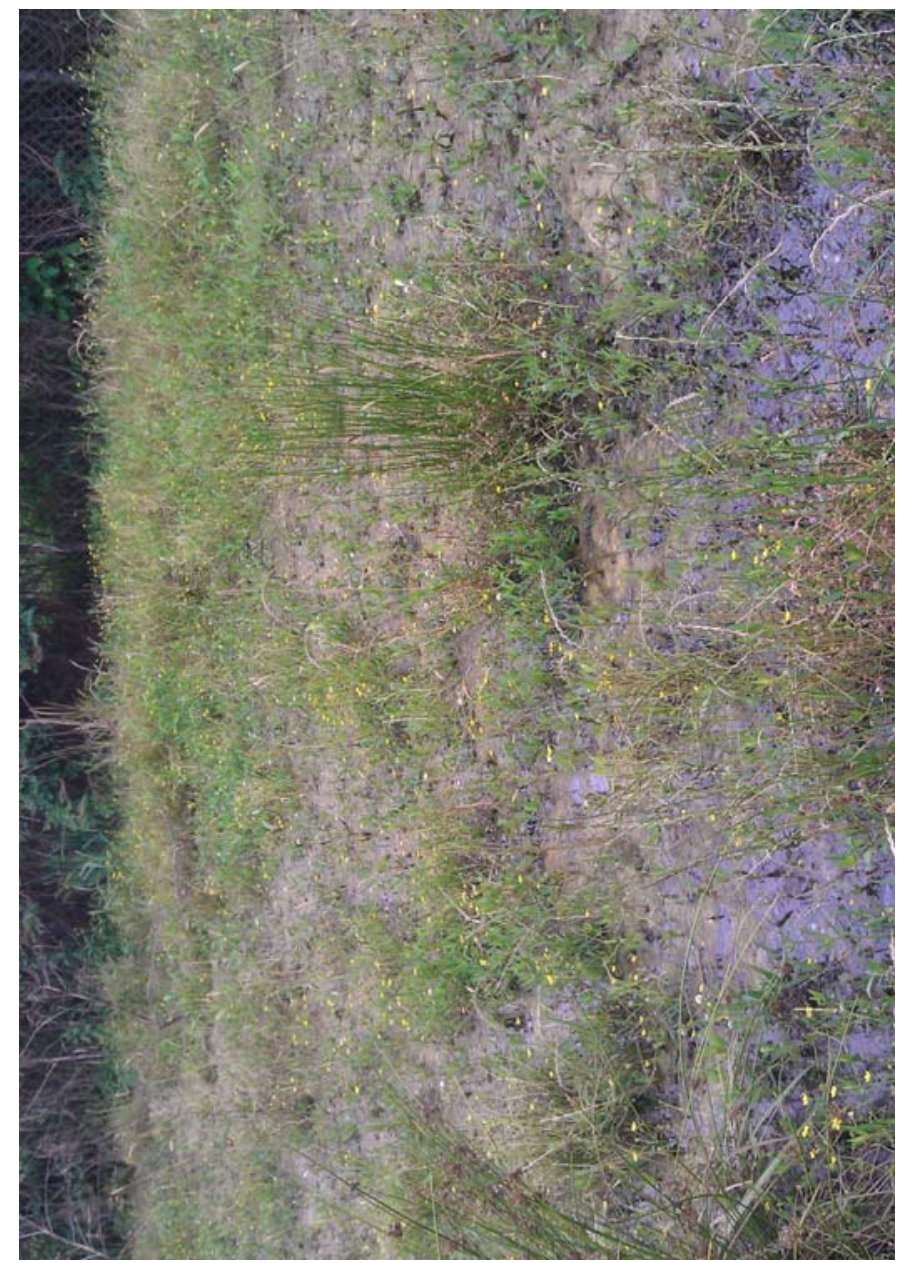

82

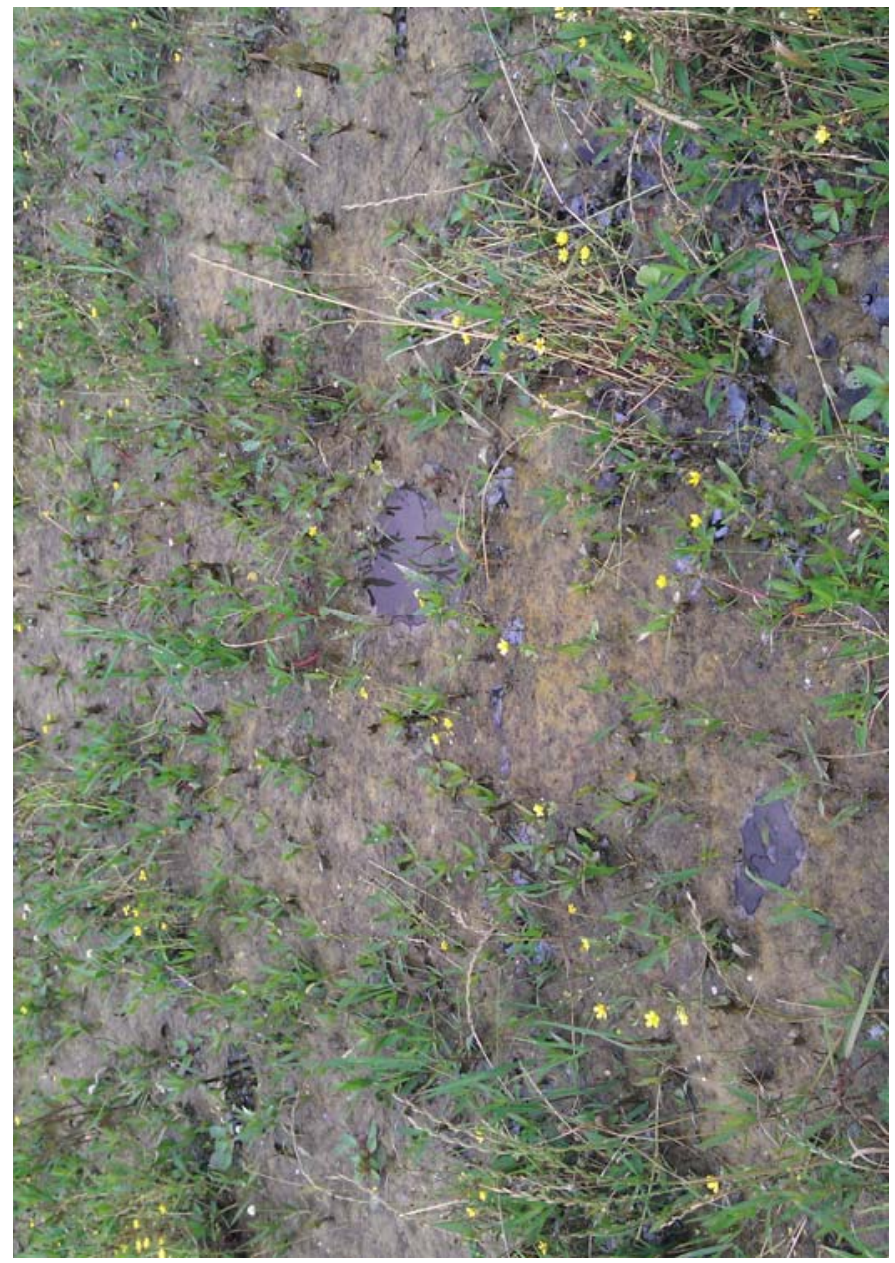



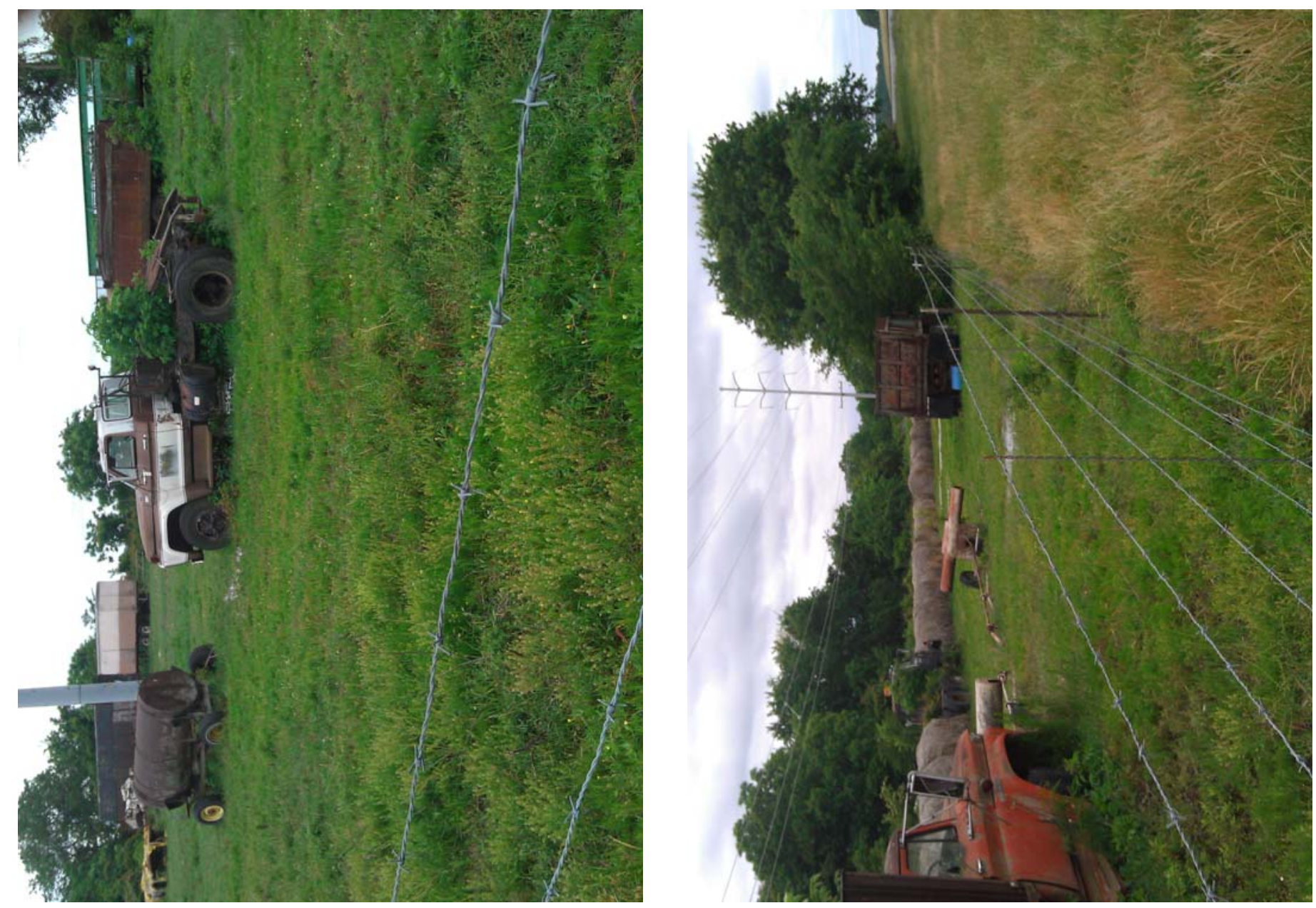

\section{5}

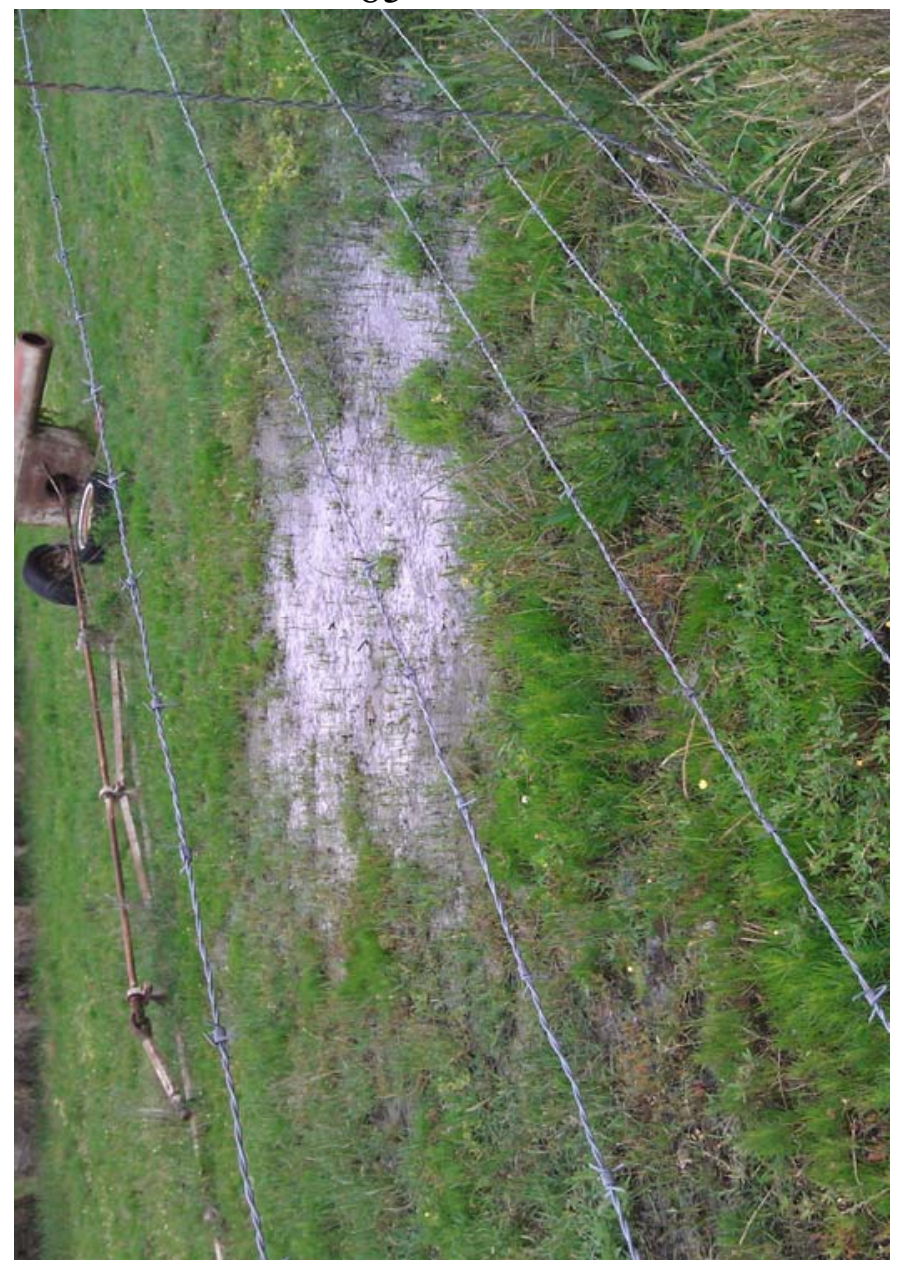




\section{STATION 4500+00 TO 5930+00}


LEVEE SECTOR: Highway 82 to Lake Washington

DATE: May 18-20, 2011

TEAM MEMBERS: Heather Sibley, Lance Gullett and Justin Jones

\begin{tabular}{|c|c|c|c|c|c|c|c|c|c|}
\hline \multicolumn{2}{|c|}{ START } & \multicolumn{2}{|c|}{ END } & \multirow{2}{*}{$\begin{array}{l}\text { STATION } \\
\text { NLD }\end{array}$} & \multirow{2}{*}{$\begin{array}{c}\text { STATION } \\
\text { FIELD MARKER }\end{array}$} & \multirow[t]{2}{*}{ TYPE } & \multirow[t]{2}{*}{ EXTENT } & \multirow[t]{2}{*}{ REMARKS } & \multirow[t]{2}{*}{ PHOTO } \\
\hline Latitude & Longitude & Latitude & Longitude & & & & & & \\
\hline 33.29276142 & 91.1276563 & 33.28505496 & 91.11360415 & $\begin{array}{l}4508+00 \text { to } \\
4559+00\end{array}$ & $\begin{array}{l}4475+00 \text { to } \\
4526+00\end{array}$ & $\begin{array}{l}\text { Under } \\
\text { Seepage }\end{array}$ & Light & $\begin{array}{l}\text { Begins at toe and extends } 200 \mathrm{ft} \text { into corn field. Foamy water, but no pin } \\
\text { boils were seen and the water was standing still. }\end{array}$ & $1-4$ \\
\hline 33.28505496 & 91.11360415 & 33.28272458 & 91.11273423 & $\mid \begin{array}{l}4559+00 \text { to } \\
4568+00\end{array}$ & $\begin{array}{l}4526+00 \text { to } \\
4535+00\end{array}$ & $\begin{array}{l}\text { Under } \\
\text { Seepage }\end{array}$ & Light & $\begin{array}{l}\text { No longer near the toe of the berm. From the crown of the levee it appears } \\
\text { to begin approximately } 150 \mathrm{ft} \text { from the toe of the berm in corn field. }\end{array}$ & \\
\hline 33.28358996 & 91.11158287 & 33.28017218 & 91.09954723 & $\begin{array}{l}4568+00 \text { to } \\
4621+00\end{array}$ & $\begin{array}{l}4535+00 \text { to } \\
4588+00\end{array}$ & $\begin{array}{l}\text { Under } \\
\text { Seepage }\end{array}$ & \begin{tabular}{|l} 
Light to \\
Moderate
\end{tabular} & $\begin{array}{l}\text { Light to moderate seepage in corn field. Starts near the toe. Extends a } \\
\text { couple hundred feet into corn field. }\end{array}$ & $5-9$ \\
\hline & & & & $\begin{array}{l}4576+00 \text { to } \\
4608+00\end{array}$ & $\begin{array}{l}4543+00 \text { to } \\
4575+50\end{array}$ & $\begin{array}{l}\text { Under } \\
\text { Seepage }\end{array}$ & Light & $\begin{array}{l}\text { Note: if berm there is seepage coming through up to } 30 \mathrm{ft} \text { away from the toe } \\
\text { of the levee. }\end{array}$ & 12 \\
\hline 33.28627115 & 91.09395386 & 33.29472924 & 91.07019393 & $\begin{array}{l}4650+00 \text { to } \\
4727+00\end{array}$ & $\begin{array}{l}4617+50 \text { to } \\
4694+50\end{array}$ & $\begin{array}{l}\text { Under } \\
\text { Seepage }\end{array}$ & $\begin{array}{l}\text { Light to } \\
\text { Moderate }\end{array}$ & $\begin{array}{l}\text { Full drainage ditch seems to be above normal with clear water. Drains to a } \\
\text { pond (at } 33.2889274691 .08988867 .) \text { that is also above normal. No seepage } \\
\text { along the banks of the pond, off the berm toe, or } 500 \mathrm{ft} \text { off the levee. At } \\
\text { ending coordinates, the ditch turns awav from the levee. }\end{array}$ & $13-14$ \\
\hline 33.29470325 & 91.06877801 & -- & -- & $\begin{array}{l}4734+00 \text { to } \\
4734+30\end{array}$ & $\begin{array}{l}4701+50 \text { to } \\
4701+80\end{array}$ & $\begin{array}{l}\text { Under } \\
\text { Seepage }\end{array}$ & |Light & $\begin{array}{l}\text { Light seepage in small ditch into soybean field. } 100 \mathrm{ft} \text { from levee toe. The } \\
\text { ditch is only } 30 \mathrm{ft} \text { long. }\end{array}$ & 15 \\
\hline 33.29107669 & 91.0503393 & 33.28948491 & 91.04665348 & $\mid \begin{array}{l}4790+00 \text { to } \\
4801+00\end{array}$ & $\begin{array}{l}4757+50 \text { to } \\
4768+50\end{array}$ & $\begin{array}{l}\text { Under } \\
\text { Seepage }\end{array}$ & |Light & $\begin{array}{l}\text { Light seepage in low area could be more due to drainage than seepage. The } \\
\text { corn field behind is dry. The low area is } 85 \mathrm{ft} \text { from toe and extends } 15 \text { to } 20 \\
\text { ft. At } 33.2901101491 .04770259 \text { the ditch goes away from the levee and } \\
\text { through corn field. For approximately } 100 \mathrm{ft} \text { along a high spot, it is not wet, } \\
\text { but at } 33.2900666491 .04757029 \text { low area is back in same area and wet. }\end{array}$ & $17-19$ \\
\hline 33.28937148 & 91.04665043 & 33.28796512 & 91.04533043 & $\begin{array}{l}4801+00 \text { to } \\
4808+00\end{array}$ & $\begin{array}{l}4768+50 \text { to } \\
4775+50\end{array}$ & & & $\begin{array}{l}\text { Ponding in low area. Not flowing. Located approximately } 80 \mathrm{ft} \text { from the toe } \\
\text { and extends out } 30 \mathrm{ft} \text {. }\end{array}$ & \\
\hline 33.27911873 & 91.03890873 & 33.27704257 & 91.03826811 & $\begin{array}{l}4843+00 \text { to } \\
4853+00\end{array}$ & $\begin{array}{l}4811+00 \text { to } \\
4821+00\end{array}$ & $\begin{array}{l}\text { Under } \\
\text { Seepage }\end{array}$ & $\begin{array}{l}\text { Light to } \\
\text { Moderate }\end{array}$ & $\begin{array}{l}\text { Begins a little past the berm toe and extends into bean field. No boils were } \\
\text { noted, but there is a lot of standing water in field that is slowly flowing } \\
\text { through the bean rows. }\end{array}$ & $20-22$ \\
\hline 33.27159041 & 91.03724613 & 33.27125879 & 91.0372749 & $\begin{array}{l}4873+00 \text { to } \\
4876+50\end{array}$ & $\begin{array}{l}4840+50 \text { to } \\
4844+00\end{array}$ & $\begin{array}{l}\text { Under } \\
\text { Seepage }\end{array}$ & \begin{tabular}{|l} 
Light to \\
Moderate
\end{tabular} & $\begin{array}{l}\text { Starts at the levee toe and runs approximately } 100 \mathrm{ft} \text { away from the toe. Has } \\
\text { very low flow in the cow trail. At the start water is seeping out } 6 \mathrm{ft} \text { up the } \\
\text { levee slope but only for very small reach. }\end{array}$ & 23 \\
\hline 33.27034334 & 91.03711502 & -- & -- & $\begin{array}{l}4878+00 \text { to } \\
4878+30\end{array}$ & $\begin{array}{l}4845+50 \text { to } \\
4845+80\end{array}$ & $\begin{array}{l}\text { Under } \\
\text { Seepage }\end{array}$ & |Light & Light seepage starting at the levee toe. Is only $30 \mathrm{ft}$ long by $30 \mathrm{ft}$ wide. & 24 \\
\hline 33.25367821 & 91.03988996 & 33.2505236 & 91.04084686 & $\begin{array}{l}4939+00 \text { to } \\
4950+00\end{array}$ & $\begin{array}{l}4906+00 \text { to } \\
4917+00\end{array}$ & $\begin{array}{l}\text { Under } \\
\text { Seepage }\end{array}$ & $\begin{array}{l}\text { Light to } \\
\text { Moderate }\end{array}$ & $\begin{array}{l}\text { Starts light coming out about } 6 \mathrm{ft} \text { up slope for hundred feet or so. Goes to } \\
\text { moderate seepage } 150 \mathrm{ft} \text { downstream. }\end{array}$ & $25-27$ \\
\hline
\end{tabular}




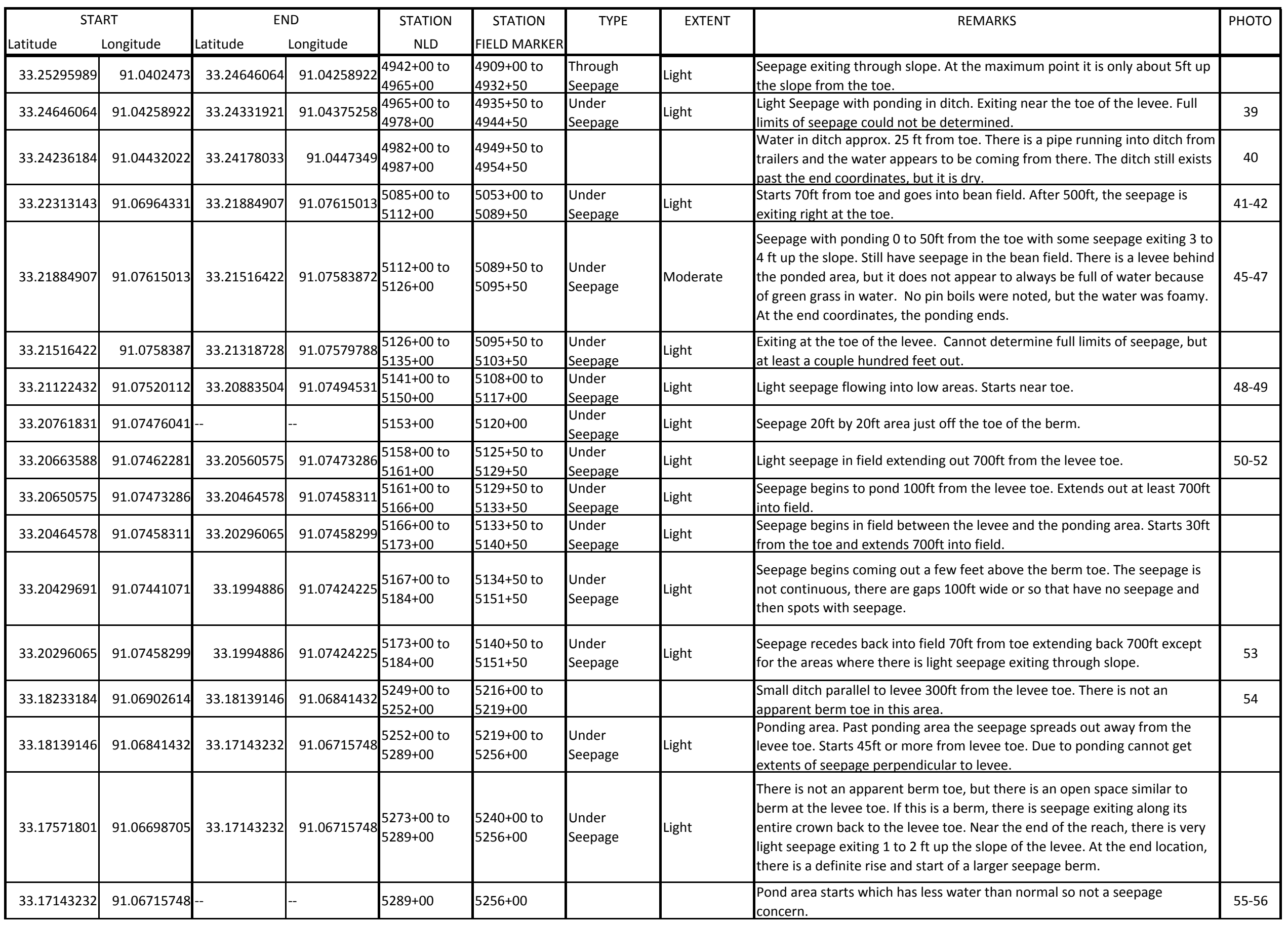




\begin{tabular}{|c|c|c|c|c|c|c|c|c|c|}
\hline \multicolumn{2}{|c|}{ START } & \multicolumn{2}{|c|}{ END } & \multirow{2}{*}{$\begin{array}{l}\text { STATION } \\
\text { NLD }\end{array}$} & \multirow{2}{*}{$\begin{array}{c}\text { STATION } \\
\text { FIELD MARKER }\end{array}$} & \multirow[t]{2}{*}{ TYPE } & \multirow[t]{2}{*}{ EXTENT } & \multirow[t]{2}{*}{ REMARKS } & \multirow[t]{2}{*}{ РHOTO } \\
\hline Latitude & Longitude & Latitude & Longitude & & & & & & \\
\hline 33.16806147 & 91.06444262 & 33.14979227 & 91.06871217 & $\begin{array}{l}5305+00 \text { to } \\
5370+00\end{array}$ & $\begin{array}{l}5272+50 \text { to } \\
5337+50\end{array}$ & $\begin{array}{l}\text { Under } \\
\text { Seepage }\end{array}$ & $\begin{array}{l}\text { Light to } \\
\text { Moderate }\end{array}$ & $\begin{array}{l}\text { Just downstream of pond area, there is a swampy wet area that may have } \\
\text { seepage. Starts just off the toe of the berm and extends into wheat field } \\
\text { approximately } 95 \mathrm{ft} \text { wide. Looks like it is always wet, but water is higher than } \\
\text { usual. Transitions into a small ditch with flowing water then back to larger } \\
\text { swampy area. No seepage outside of the low spot with standing water, but } \\
\text { there is green grass underwater. Walked back into field approximately } 500 \mathrm{ft} \\
\text { and there was flowing water coming out of low area. }\end{array}$ & $57-58$ \\
\hline 33.14979227 & 91.06871217 & 33.1341943 & 91.07510589 & $\left\{\begin{array}{l}5370+00 \text { to } \\
5440+00\end{array}\right.$ & $\begin{array}{l}5337+50 \text { to } \\
5408+00\end{array}$ & $\begin{array}{l}\text { Under } \\
\text { Seepage }\end{array}$ & Light & $\begin{array}{l}\text { In this area, it does not appear there is normally water. Water is flowing out } \\
\text { of culvert under a ramp off of the levee. Seep water is coming out of the } \\
\text { ramp road. Water is about } 200 \mathrm{ft} \text { from the levee toe, there is no apparent } \\
\text { berm. }\end{array}$ & $59-62$ \\
\hline 33.14388 & 91.0719 & -- & -- & $5400+00$ & $5368+00$ & Sand Boil & & $\begin{array}{l}\text { On July } 7,2011 \text {, landowner called and reported a "hole" out in his field. } \\
\text { Levee board took photos and measured hole to be } 2 \mathrm{ft} \text { deep with } 4 \mathrm{ft} \\
\text { diameter. There was evidence of very fine sand material in the buckshot } \\
\text { bean field. The boil was located } 780 \mathrm{ft} \text { from the centerline of the levee at } \\
\text { Station } 5368 \text {. }\end{array}$ & $63-64$ \\
\hline 33.11757493 & 91.09103912 & 33.11564025 & 91.09427613 & $\begin{array}{l}5513+00 \text { to } \\
5527+00\end{array}$ & $\mid \begin{array}{l}5481+00 \text { to } \\
5495+00\end{array}$ & $\begin{array}{l}\text { Under } \\
\text { Seepage }\end{array}$ & |Light & $\begin{array}{l}\text { Starts with light seepage at the toe of the berm. Transitions to a full } \\
\text { drainage ditch, but there is no seepage in the field behind ditch. The } \\
\text { seepage berm ends just past the end of this reach. }\end{array}$ & \\
\hline 33.11750733 & 91.09135419 & 33.11637338 & 91.09342461 & $\begin{array}{l}5514+00 \text { to } \\
5523+00\end{array}$ & $\begin{array}{l}5482+00 \text { to } \\
5491+00\end{array}$ & $\begin{array}{l}\text { Under } \\
\text { Seepage }\end{array}$ & |Light & $\begin{array}{l}\text { Extends from the toe of the berm to within } 25 \mathrm{ft} \text { of the levee toe. On average } \\
\text { extends } 100 \mathrm{ft} \text { from the levee toe. Seep water is in puddles all along the } \\
\text { berm crown. }\end{array}$ & $67-68$ \\
\hline 33.1149811 & 91.09654962 & 33.11048589 & 91.10378433 & $\mid \begin{array}{l}5530+00 \text { to } \\
5559+00\end{array}$ & $\begin{array}{l}5499+00 \text { to } \\
5527+00\end{array}$ & $\begin{array}{l}\text { Under } \\
\text { Seepage }\end{array}$ & $\begin{array}{l}\text { Light to } \\
\text { Moderate }\end{array}$ & $\begin{array}{l}\text { Light seepage starts at toe and extends approximately } 150 \mathrm{ft} \text { into ditch. } \\
\text { Couple hundred feet south a wheat field is behind ditch with moderate } \\
\text { seepage which extends } 500 \mathrm{ft} \text { from the berm toe. When walking in the wheat } \\
\text { field bubbles come up, but there are no flowing pin boils. }\end{array}$ & 69 \\
\hline 33.11454654 & 91.09719702 & -- & -- & $\begin{array}{l}5536+00 \text { to } \\
5537+00\end{array}$ & $\begin{array}{l}5505+00 \text { to } \\
5506+00\end{array}$ & $\begin{array}{l}\text { Under } \\
\text { Seepage }\end{array}$ & |Light & $\begin{array}{l}\text { Seepage exiting berm crown } 25 \mathrm{ft} \text { from end of berm. This berm is thinner } \\
\text { than one near it, but still has an apparent toe cleared so is believed to be a } \\
\text { seepage berm. Very localized area that only extends } 100 \mathrm{ft} \text { parallel to the } \\
\text { levee. }\end{array}$ & $70-71$ \\
\hline 33.10983286 & 91.10501551 & 33.10588712 & 91.1132699 & $\left\{\begin{array}{l}5565+00 \text { to } \\
5593+00\end{array}\right.$ & $\begin{array}{l}5533+00 \text { to } \\
5561+00\end{array}$ & $\begin{array}{l}\text { Under } \\
\text { Seepage }\end{array}$ & $\begin{array}{l}\text { Light to } \\
\text { Moderate }\end{array}$ & $\begin{array}{l}\text { Seepage beginning at berm toe and extends at least } 200 \mathrm{ft} \text { into bean field. } \\
\text { Water in drainage ditch is running from south to north. Downstream, the } \\
\text { bean field gets drier. At } 33.1076769591 .109823 \text { seepage begins } 300 \mathrm{ft} \text { from } \\
\text { the toe in bean field. At } 33.1072792691 .11059336 \text { seepage transitions to } \\
50 \mathrm{ft} \text { from the toe and extends out at least } 300 \mathrm{ft} \text { into bean field. at } \\
33.1066355691 .11142917 \text { seepage starts at the berm toe and extends over } \\
30 \mathrm{nft} \text { into hean field }\end{array}$ & $72-74$ \\
\hline 33.10866818 & 91.10778806 & 33.1082871 & 91.10862132 & $\begin{array}{l}5574+00 \text { to } \\
5578+00\end{array}$ & $\begin{array}{l}5542+00 \text { to } \\
5546+00\end{array}$ & $\begin{array}{l}\text { Under } \\
\text { Seepage }\end{array}$ & |Light & $\begin{array}{l}\text { Seepage begins upstream } 20 \mathrm{ft} \text { from the toe of the berm and downstream } \\
\text { transitions to } 100 \mathrm{ft} \text { from the toe of the berm. }\end{array}$ & \\
\hline 33.10475549 & 91.11450724 & 33.10520954 & 91.12214459 & $\begin{array}{l}5596+00 \text { to } \\
5618+00\end{array}$ & $\begin{array}{l}5564+00 \text { to } \\
5586+00\end{array}$ & & & $\begin{array}{l}\text { Ponding. Low swampy area. No evidence that water is seepage in immediate } \\
\text { area. Appears to be fed by a drainage ditch that is be fed by a corn field that } \\
\text { is being irrigated. }\end{array}$ & $75-76$ \\
\hline 33.10535625 & 91.1270479 & 33.1054538 & 91.12784906 & $\begin{array}{l}5635+00 \text { to } \\
5637+00\end{array}$ & $\begin{array}{l}5603+00 \text { to } \\
5605+00\end{array}$ & $\begin{array}{l}\text { Under } \\
\text { Seepage }\end{array}$ & $\begin{array}{l}\text { Light to } \\
\text { Moderate }\end{array}$ & Starts at the toe and extends out $400 \mathrm{ft}$. & \\
\hline 33.1054538 & 91.12784906 & 33.10507781 & 91.13136746 & $\begin{array}{l}5637+00 \text { to } \\
5651+00\end{array}$ & $\begin{array}{l}5605+00 \text { to } \\
5619+00\end{array}$ & $\begin{array}{l}\text { Under } \\
\text { Seepage/Pin } \\
\text { Boils }\end{array}$ & Heavy & $\begin{array}{l}\text { Seepage transitions to heavy seepage with numerous pin boils. Begins at toe } \\
\text { and extends into corn field. }\end{array}$ & 77 \\
\hline
\end{tabular}




\begin{tabular}{|c|c|c|c|c|c|c|c|c|c|}
\hline \multicolumn{2}{|c|}{ START } & \multicolumn{2}{|c|}{ END } & \multirow{2}{*}{$\begin{array}{l}\text { STATION } \\
\text { NLD }\end{array}$} & \multirow{2}{*}{$\begin{array}{c}\text { STATION } \\
\text { FIELD MARKER }\end{array}$} & \multirow[t]{2}{*}{ TYPE } & \multirow[t]{2}{*}{ EXTENT } & \multirow[t]{2}{*}{ REMARKS } & \multirow[t]{2}{*}{ РНОTO } \\
\hline Latitude & Longitude & Latitude & Longitude & & & & & & \\
\hline 33.10548515 & 91.12947266 & 33.10514556 & 91.13138678 & $\mid \begin{array}{l}5640+00 \text { to } \\
5651+00\end{array}$ & $\begin{array}{l}5608+00 \text { to } \\
5619+00\end{array}$ & Sand Boil & & $\begin{array}{l}\text { Multiple large sand boils in this area. There are multiple boils in drainage } \\
\text { ditch just off toe of berm. Also, there are multiple boils on both sides of the } \\
\text { drainage ditch. } 3 \text { of the boils occur right at the toe of the berm. Most of } \\
\text { these were bagged and were no longer moving material. Throat sizes range } \\
\text { from a couple inches to greater than } 6 \text { inches. Sandbag ring constructed } \\
\text { around a } 30^{\prime} \text { by } 10^{\prime} \text { sinkhole that formed in field. Plywood wall constructed } \\
\text { around boil also. Seepage is also exiting in the berm crown. }\end{array}$ & 78-87 \\
\hline 33.10507781 & 91.13136746 & 33.10431909 & 91.1322489 & $\begin{array}{l}5651+00 \text { to } \\
5656+00\end{array}$ & $\begin{array}{l}5619+00 \text { to } \\
5624+00\end{array}$ & $\begin{array}{l}\text { Under } \\
\text { Seepage }\end{array}$ & Light & Seepage transitions back to light seepage at the toe and into corn field. & 88 \\
\hline 33.10292555 & 91.13399277 & 33.09600423 & 91.14040961 & $\begin{array}{l}5662+00 \text { to } \\
5699+00\end{array}$ & $\begin{array}{l}5630+00 \text { to } \\
5667+00\end{array}$ & $\begin{array}{l}\text { Under } \\
\text { Seepage/Pin } \\
\text { Boils }\end{array}$ & $\begin{array}{l}\text { Moderate to } \\
\text { Heavy }\end{array}$ & $\begin{array}{l}\text { Starts at the toe and extends out over } 500 \mathrm{ft} \text {. Moderate to heavy seepage } \\
\text { with a few pin boils. The number of pin boils increase downstream. }\end{array}$ & $89-90$ \\
\hline 33.09410192 & 91.14123254 & 33.0884052 & 91.13749626 & $\begin{array}{l}5705+00 \text { to } \\
5743+00\end{array}$ & $\begin{array}{l}5673+00 \text { to } \\
5710+00\end{array}$ & $\begin{array}{l}\text { Under } \\
\text { Seepage }\end{array}$ & Light & Seepwater is in drainage ditch and is exiting the toe. & 91 \\
\hline 33.09276903 & 91.14174425 & -- & -- & $5711+00$ & $5688+00$ & Sand Boil & & $\begin{array}{l}\text { Sand boil which has been bagged. Is running clear water. Approximate Sta } \\
5688 \text {. Other small boils developed after sand bags were placed for first boil. } \\
\text { Throat sizes were less than } 3 \text { inches. }\end{array}$ & $92-94$ \\
\hline 33.0884052 & 91.13749626 & 33.07116851 & 91.12504744 & $\begin{array}{l}5743+00 \text { to } \\
5817+00\end{array}$ & $\begin{array}{l}5710+00 \text { to } \\
5794+50\end{array}$ & $\begin{array}{l}\text { Under } \\
\text { Seepage }\end{array}$ & Light & $\begin{array}{l}\text { Light seepage continues in corn field. However, the corn is not discolored } \\
\text { and the ground is only damp, no standing water. At } 33.08078375 \\
91.13263148 \text { drop off of higher ground and seepage starts } 60 \mathrm{ft} \text { from the } \\
\text { toe. In the areas where there was a berm, seepage was beginning at the } \\
\text { berm toe. }\end{array}$ & $95-97$ \\
\hline 33.06960906 & 91.12272822 & 33.05878805 & 91.11495691 & $\begin{array}{l}5827+00 \text { to } \\
5870+00\end{array}$ & $\begin{array}{l}5804+50 \text { to } \\
5848+00\end{array}$ & $\begin{array}{l}\text { Under } \\
\text { Seepage }\end{array}$ & Light & $\begin{array}{l}\text { Light seepage at toe. The corn field behind is wet, but could be more to do } \\
\text { with irrigation because none of the corn is yellow. }\end{array}$ & 98 \\
\hline 33.05878805 & 91.11495691 & 33.0535489 & 91.11527146 & $\begin{array}{l}5870+00 \text { to } \\
5889+00\end{array}$ & $\begin{array}{l}5848+00 \text { to } \\
5867+00\end{array}$ & $\begin{array}{l}\text { Under } \\
\text { Seepage }\end{array}$ & Heavy & $\begin{array}{l}\text { Heavy seepage with pin boils throughout area extends out } 1000 \mathrm{ft} \text {. Pin boils } \\
\text { start approximately } 25 \mathrm{ft} \text { from the toe of the berm. }\end{array}$ & $99-106$ \\
\hline 33.05904653 & 91.11487726 & 33.05878805 & 91.11495691 & $\begin{array}{l}5870+00 \text { to } \\
5871+00\end{array}$ & $\begin{array}{l}5848+00 \text { to } \\
5849+00\end{array}$ & Sand Boil & & $\begin{array}{l}\text { Multiple boils in ditch between toe of berm and logging road. Ditch and } \\
\text { boils are not seen until get across fence from toe about } 35 \mathrm{ft} \text { from berm toe. } \\
\text { Berm is couple hundred ft wide as well. The logging road pumps when } \\
\text { walked on. Most of the boils are similar in size with throats of approximately } \\
3 \text { inches and have only moved small amounts of sand. Less than a yard each. }\end{array}$ & \\
\hline 33.05527 & 91.11521 & -- & -- & $\begin{array}{l}5878+00 \text { to } \\
5882+00\end{array}$ & $\begin{array}{l}5856+00 \text { to } \\
5860+00\end{array}$ & Sand Boil & & $\begin{array}{l}\text { Multiple boils on the side of the ridge. Largest has a 2in throat. } 100 \mathrm{ft} \text { from } \\
\text { the toe of the berm. }\end{array}$ & \\
\hline 33.0535489 & 91.11527146 & 33.04891662 & 91.11671124 & $\begin{array}{l}5889+00 \text { to } \\
5907+00\end{array}$ & $\begin{array}{l}5867+00 \text { to } \\
5886+50\end{array}$ & $\begin{array}{l}\text { Under } \\
\text { Seepage }\end{array}$ & Moderate & Seepage changed to moderate. Begins near toe and extends out $1000 \mathrm{ft}$. & 107 \\
\hline 33.04328102 & 91.11854965 & - & -- & $5927+00$ & $5950+00$ & $\begin{array}{l}\text { Under } \\
\text { Seepage }\end{array}$ & Light & $\begin{array}{l}\text { Very light seepage in a mostly dry field. There are some damp patches that } \\
\text { are no larger than } 40 \mathrm{ft} \text { by } 40 \mathrm{ft} \text {. Ended at Station } 5910+00 \text {. }\end{array}$ & 110 \\
\hline
\end{tabular}



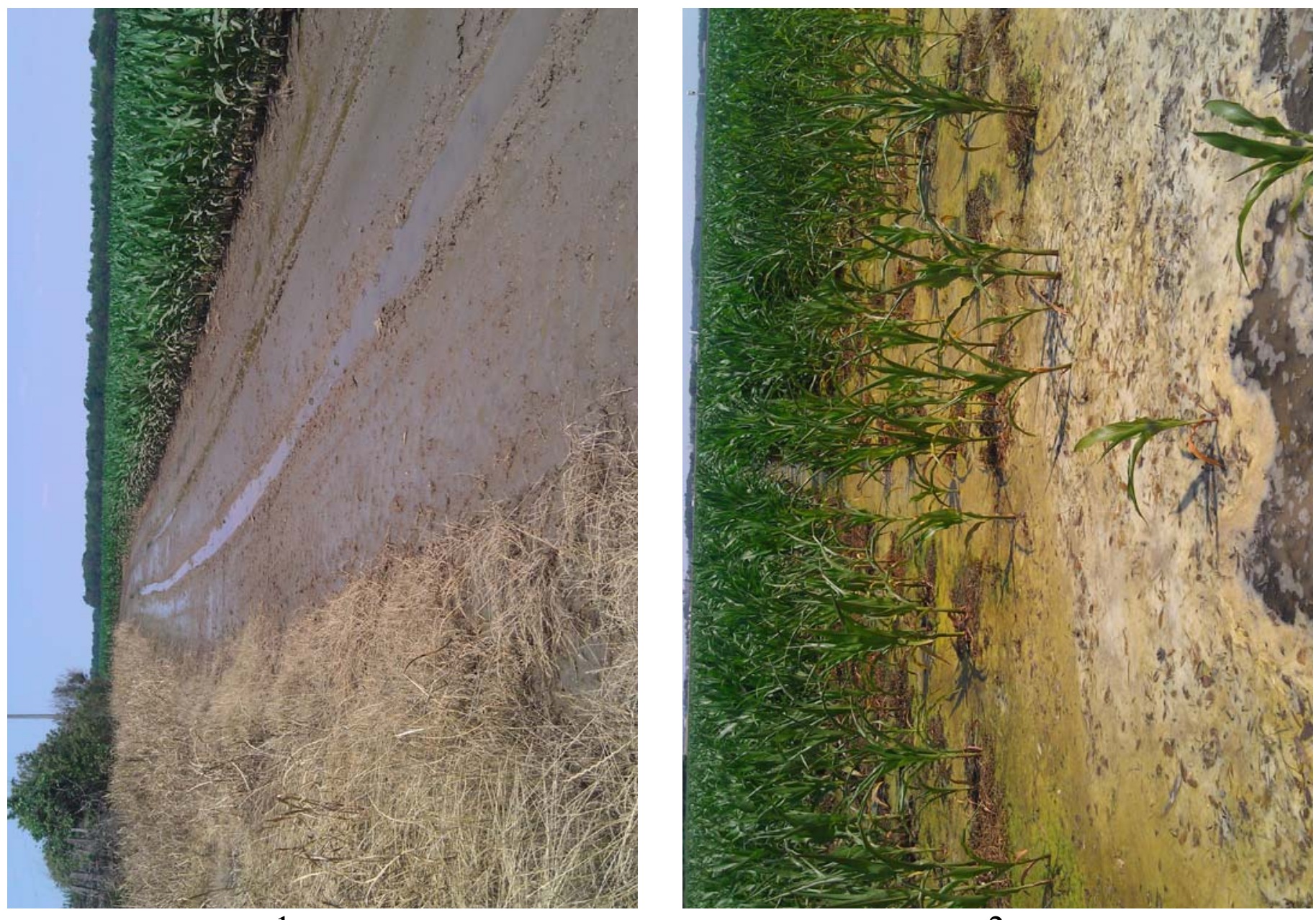

\section{2}
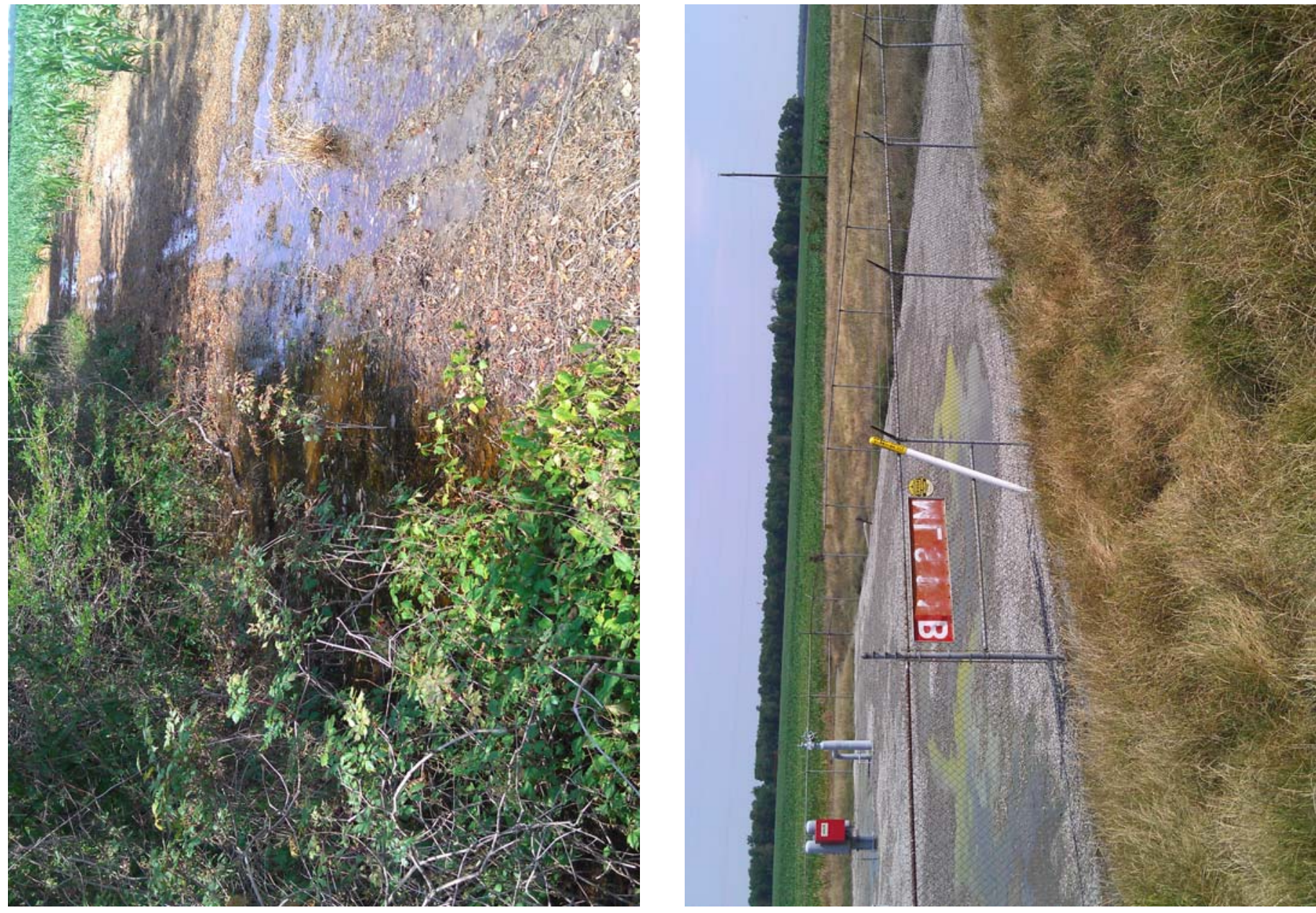


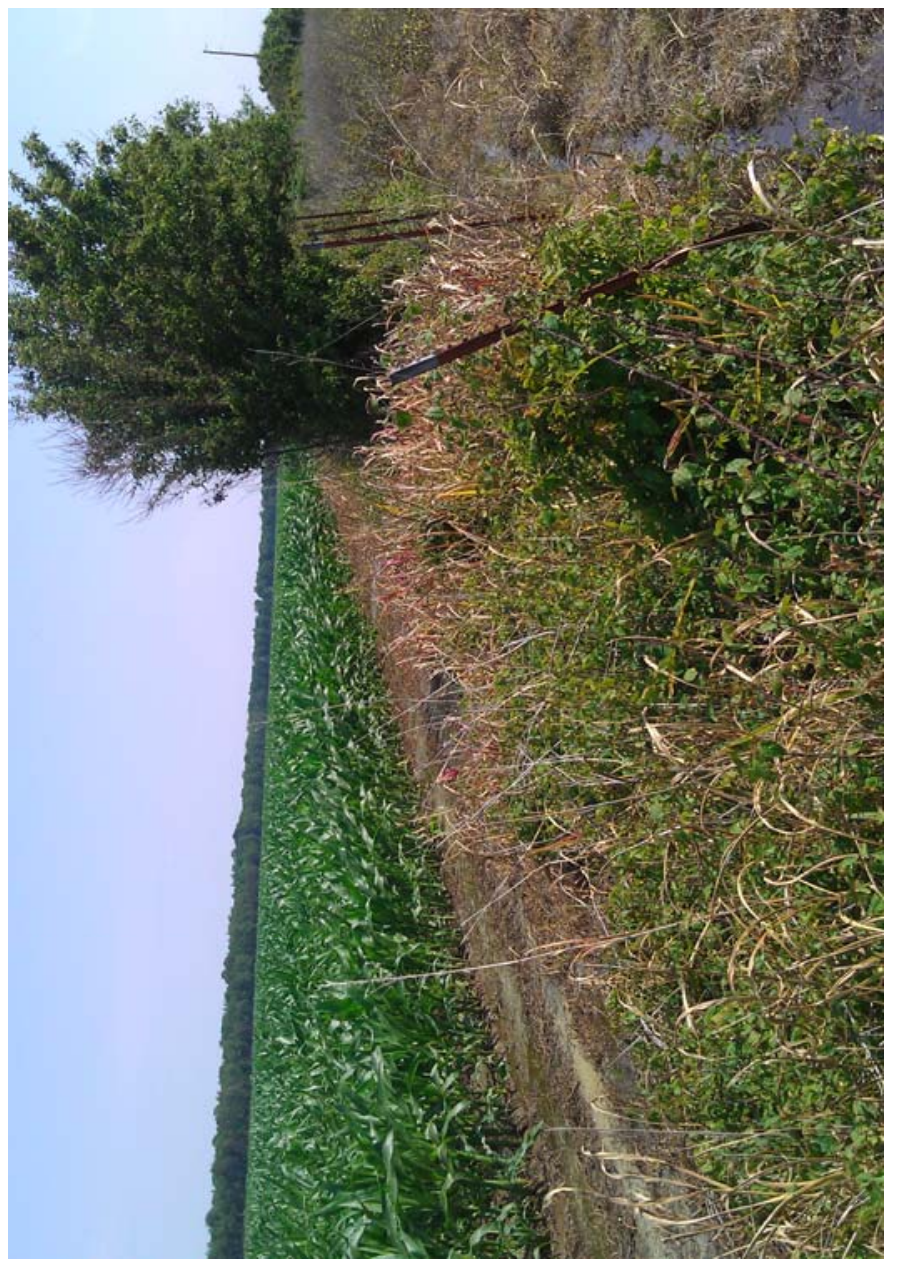

5

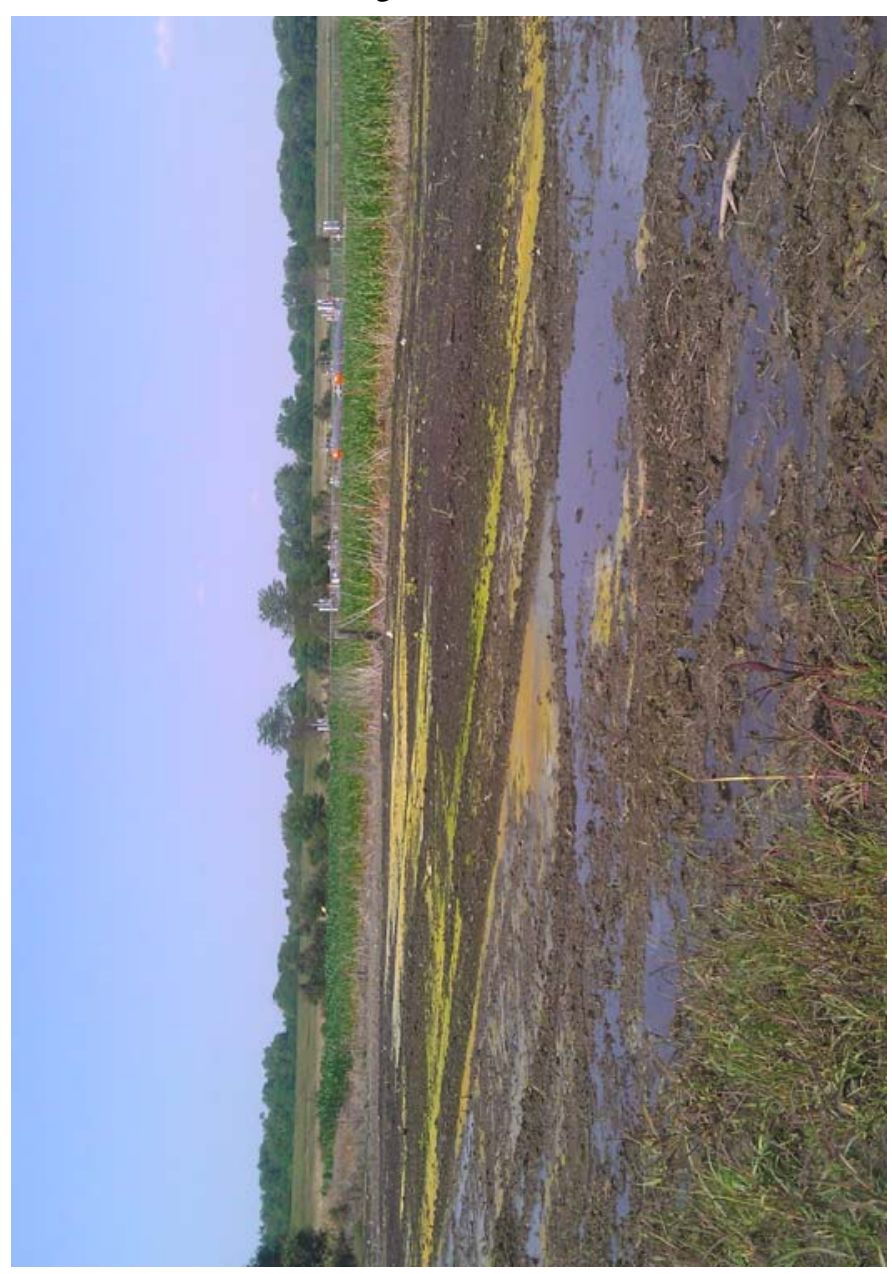

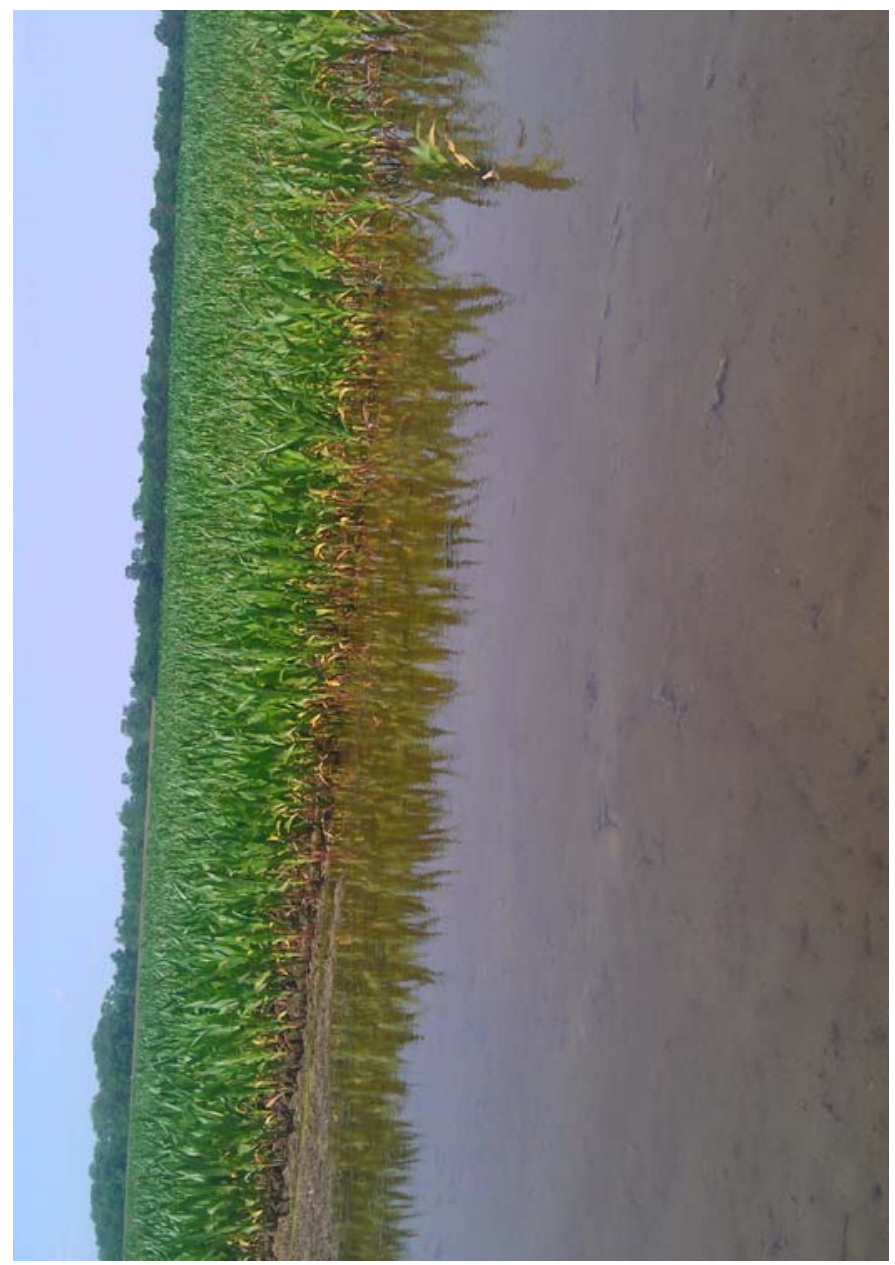

6

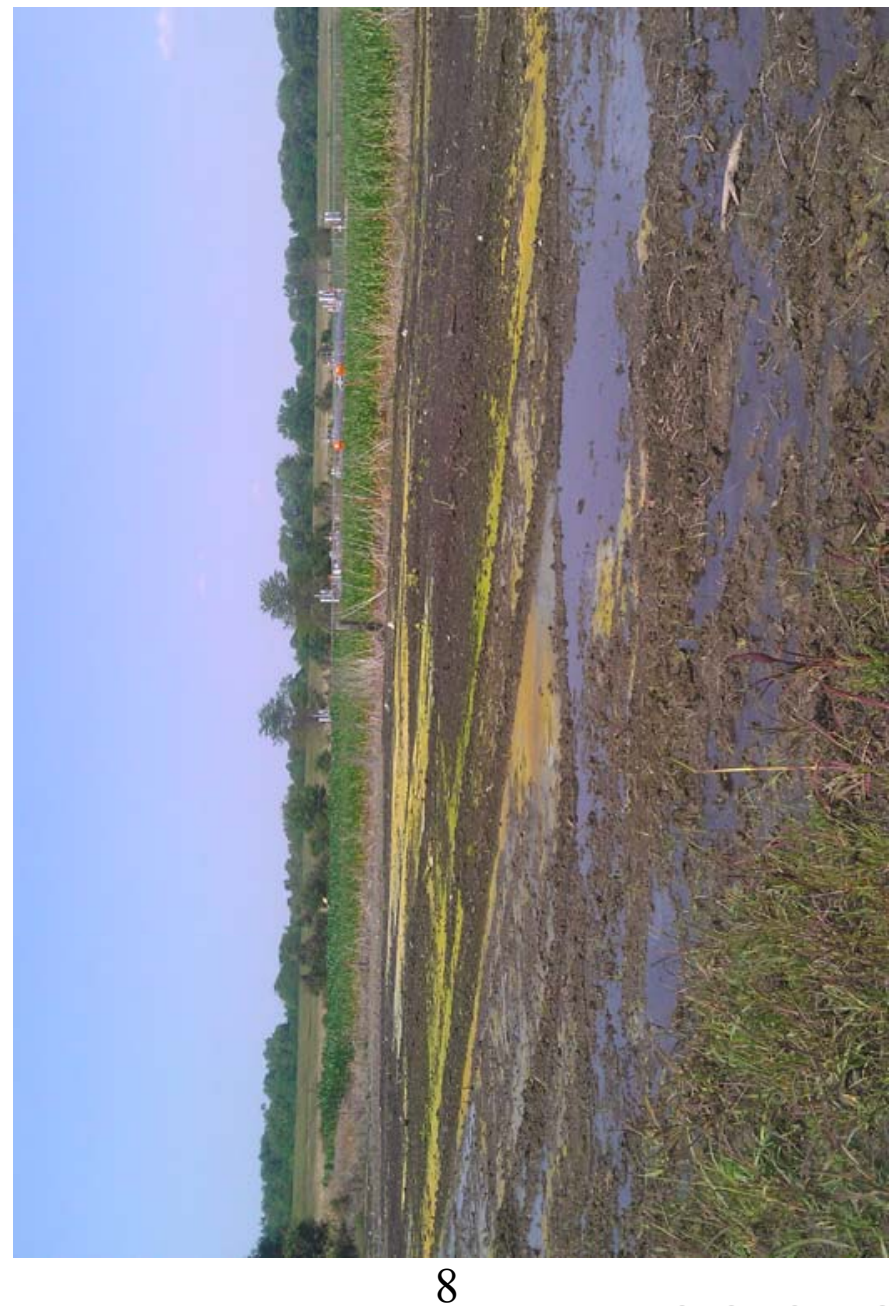

FOR OFFICIAL USE ONLY 

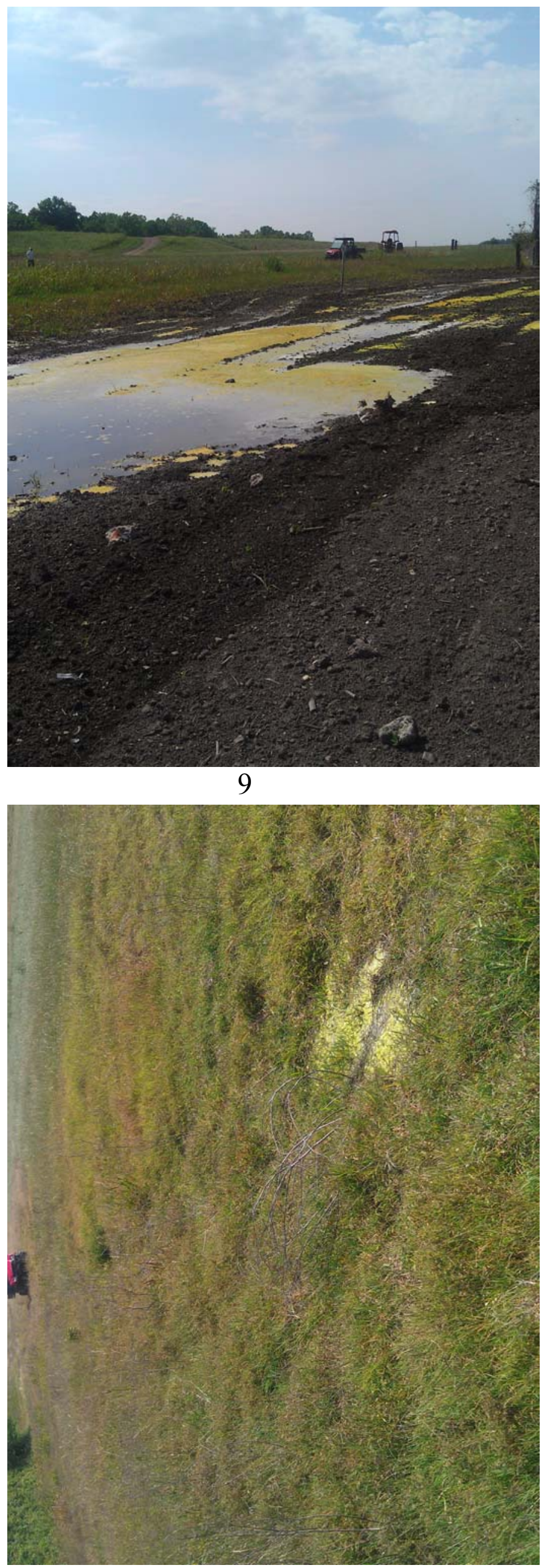


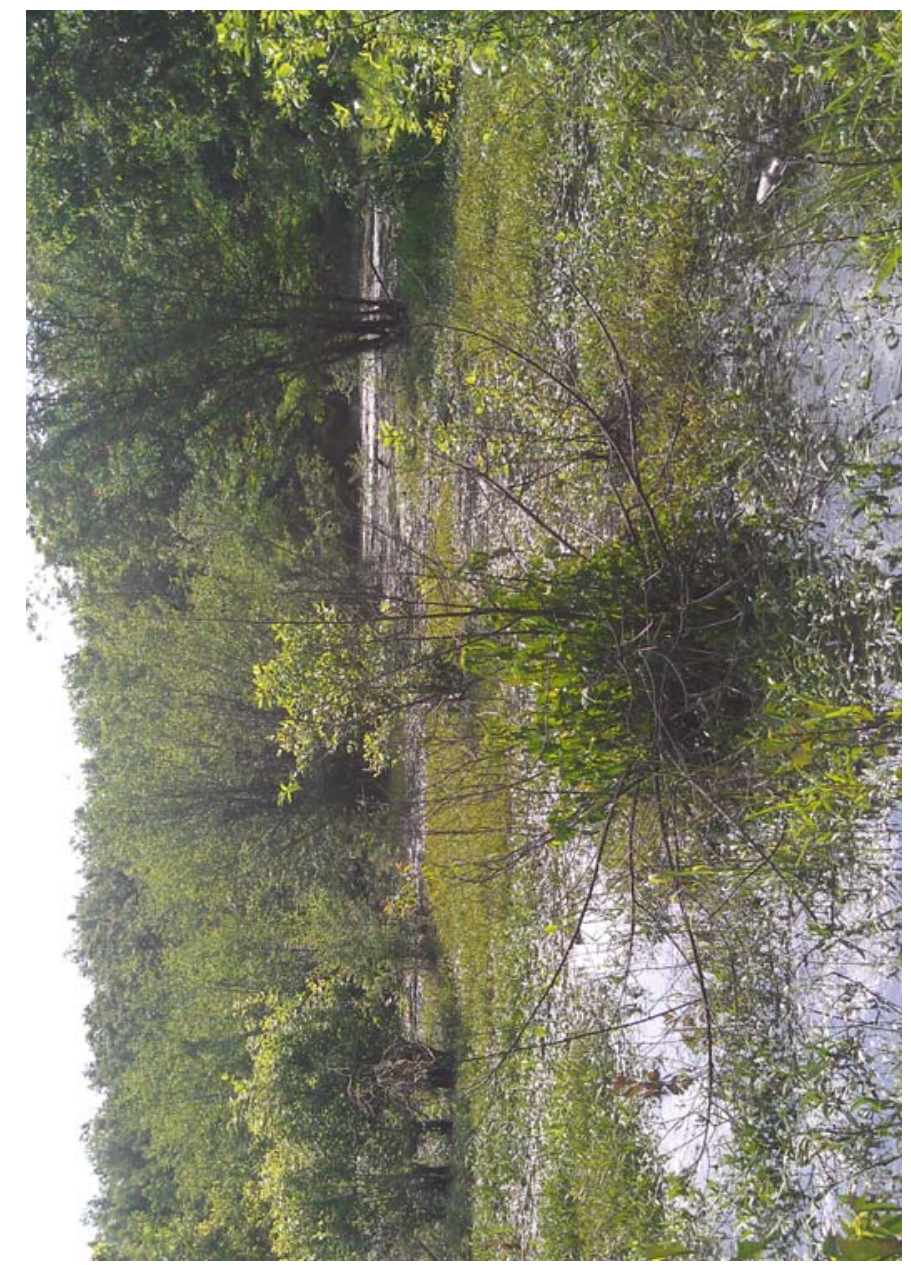

\section{3}

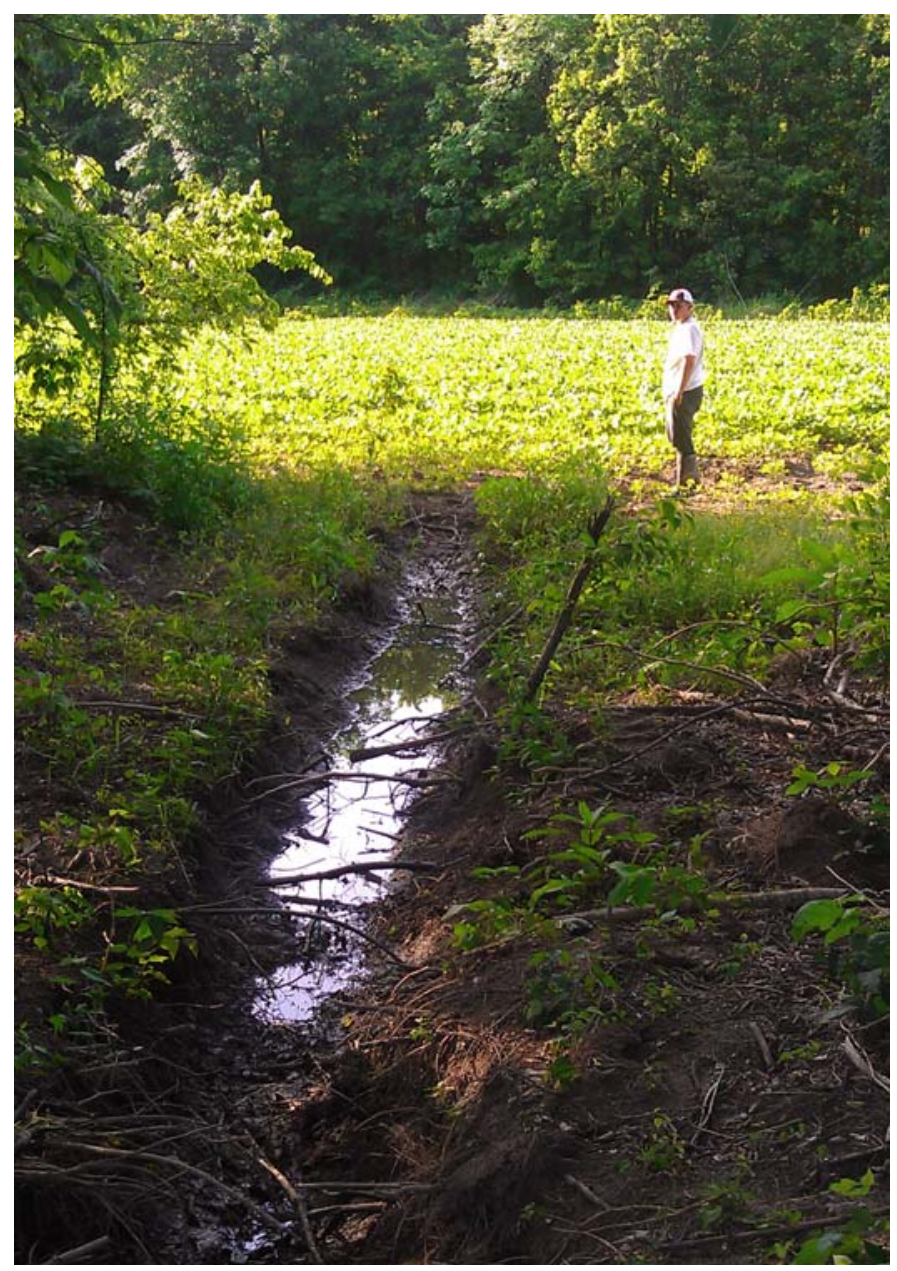

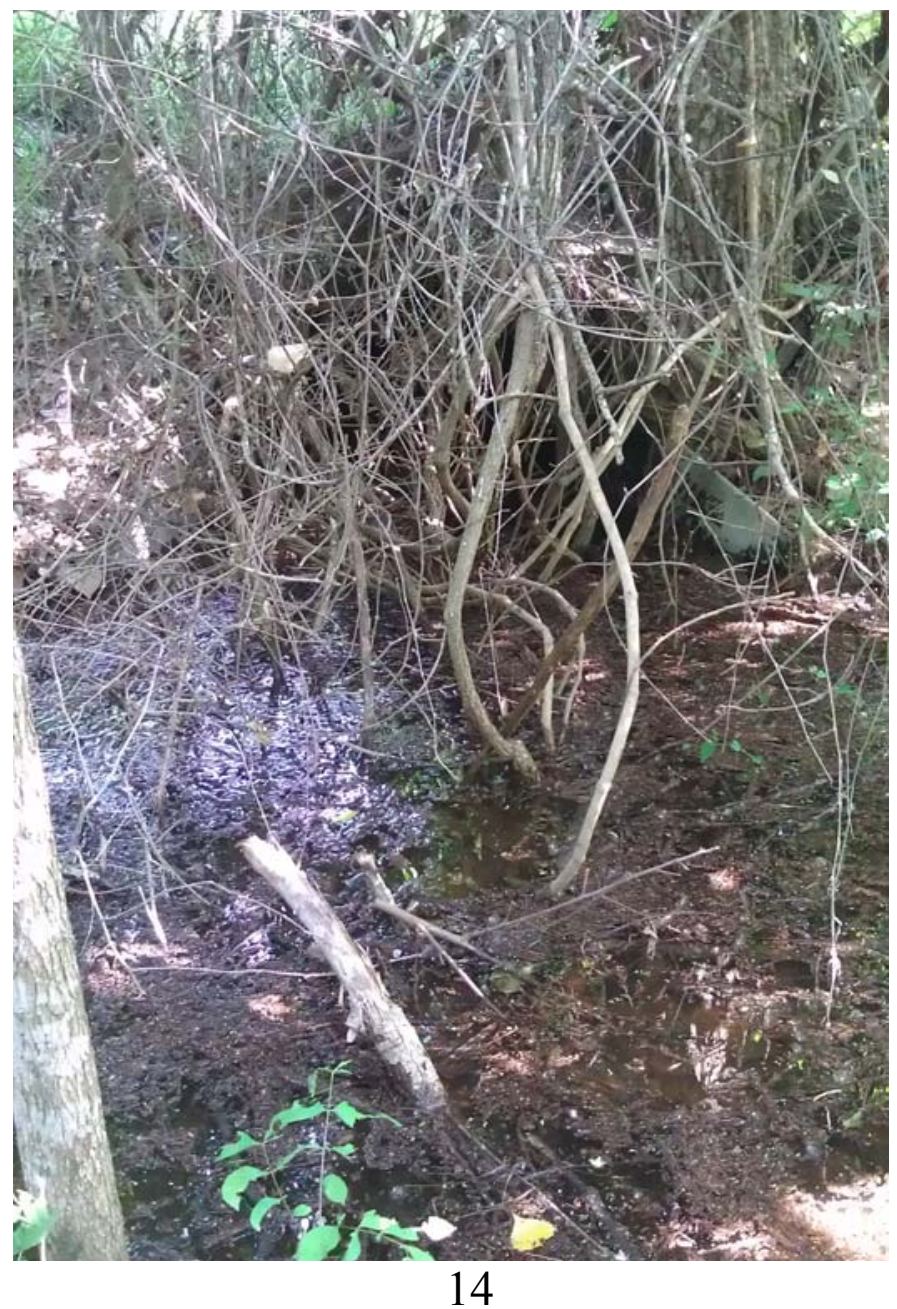

15. 


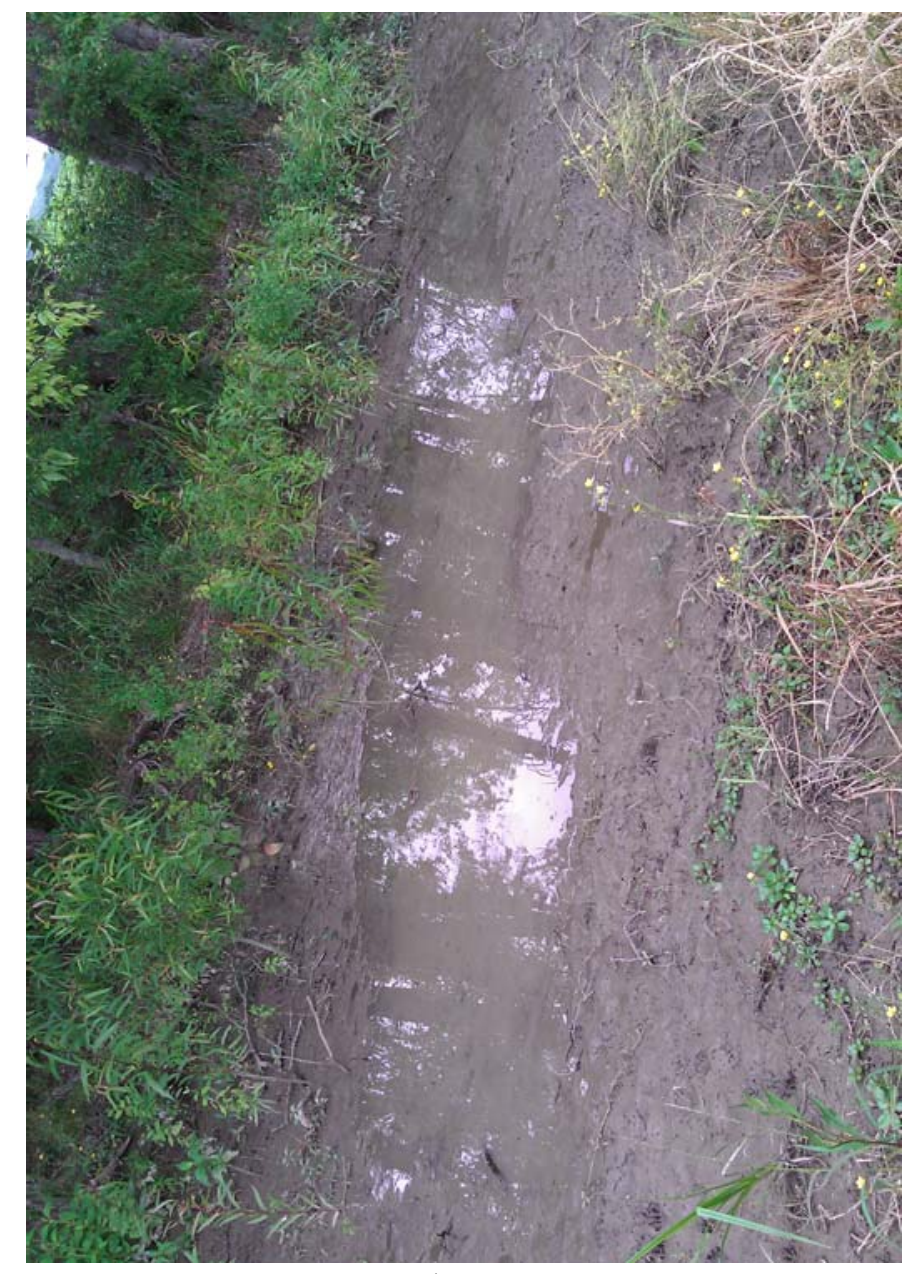

17

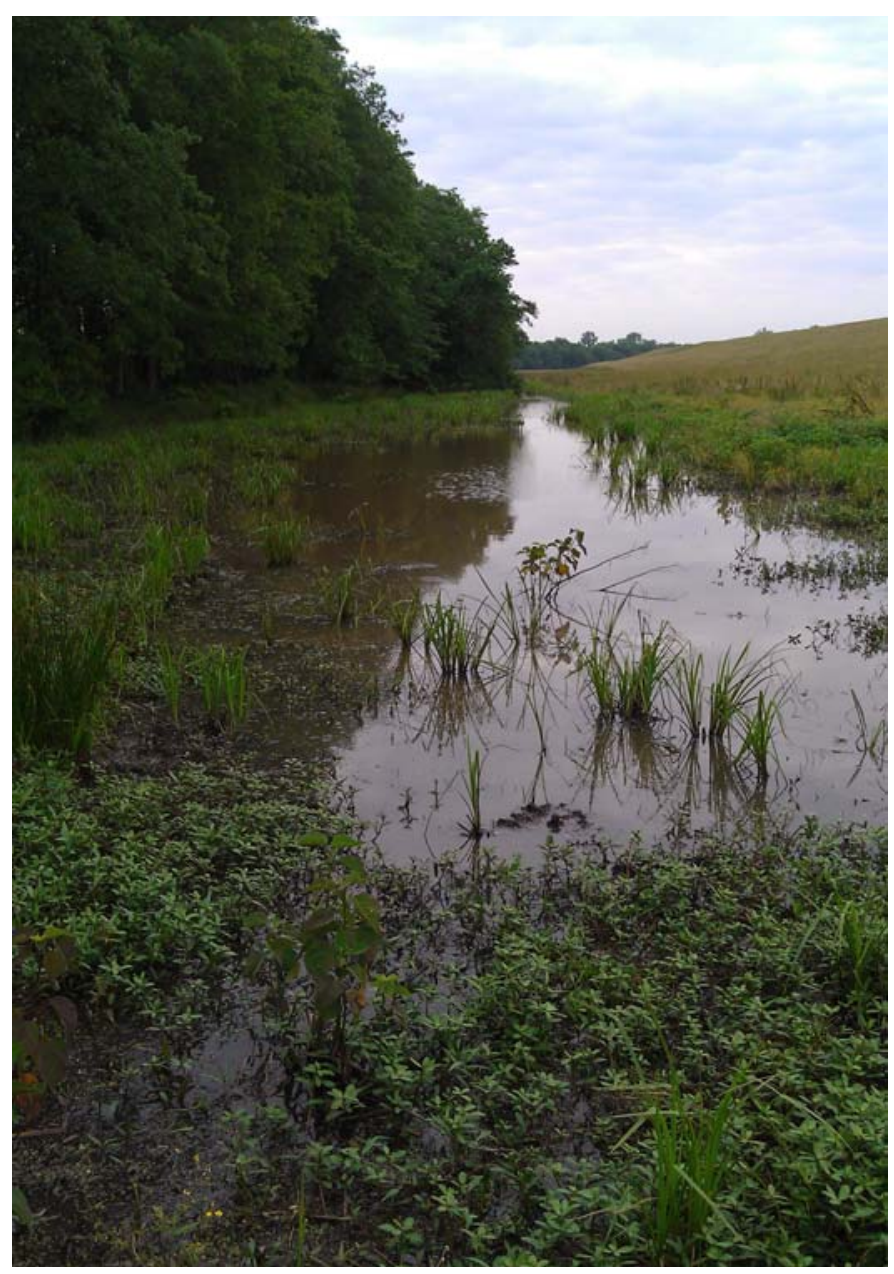

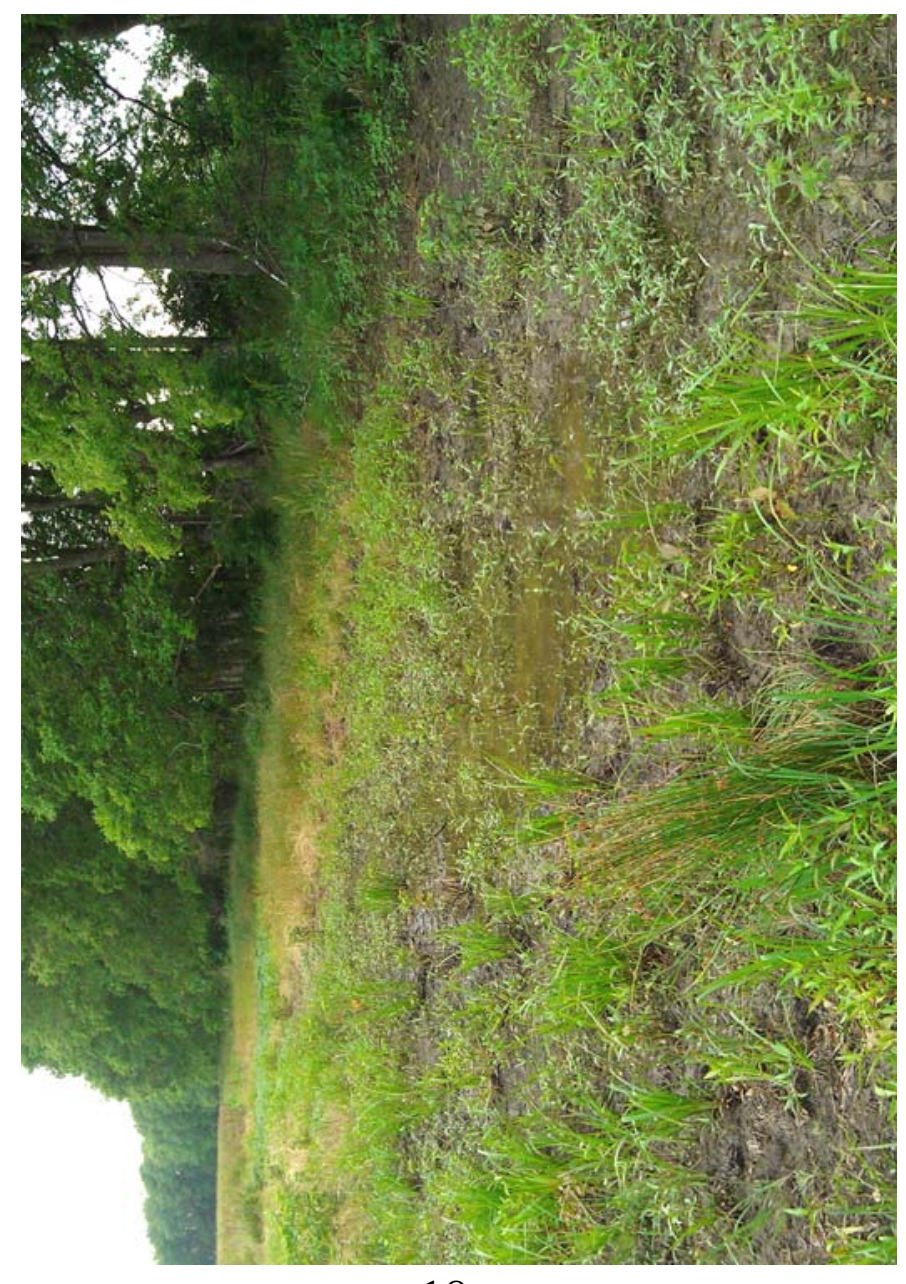

18

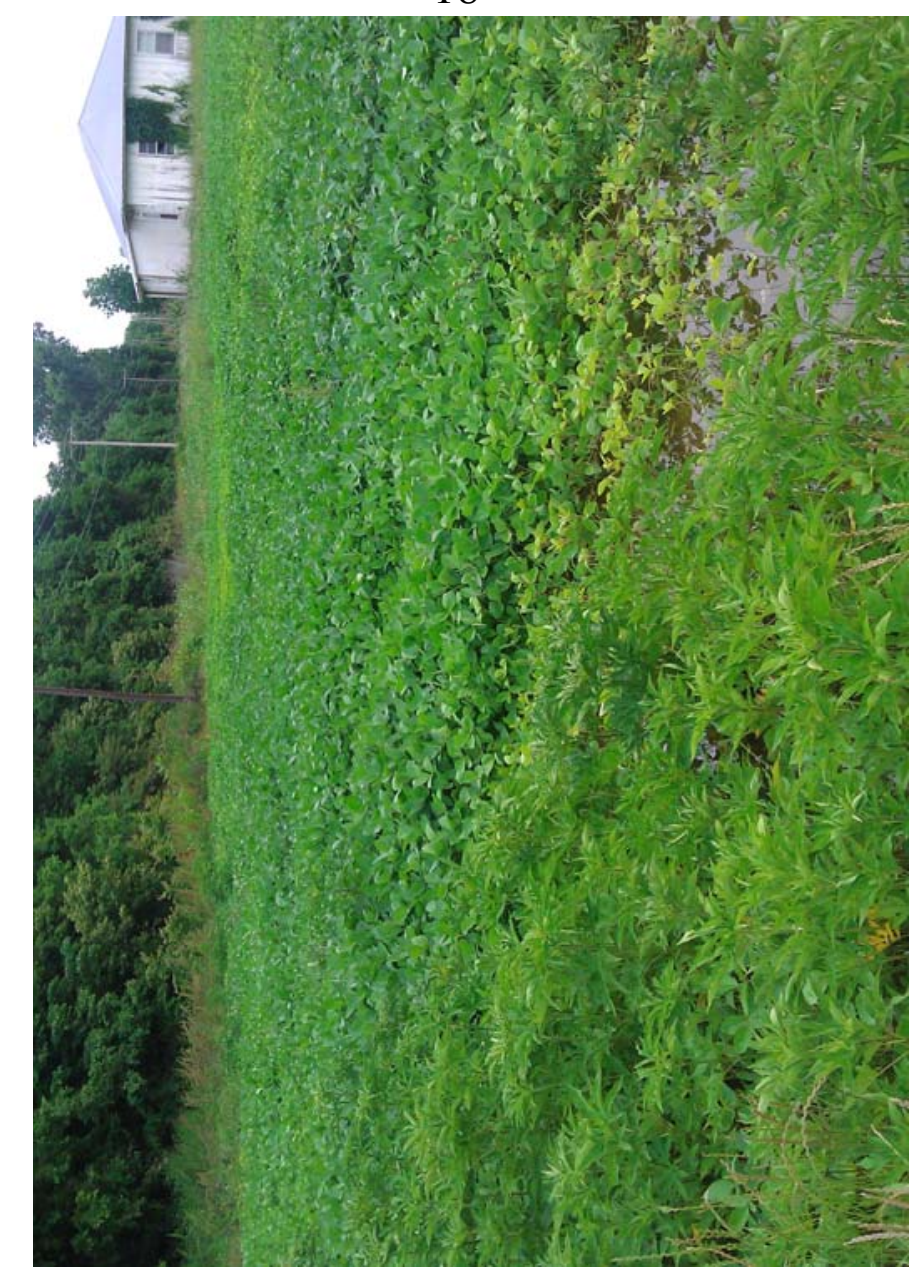




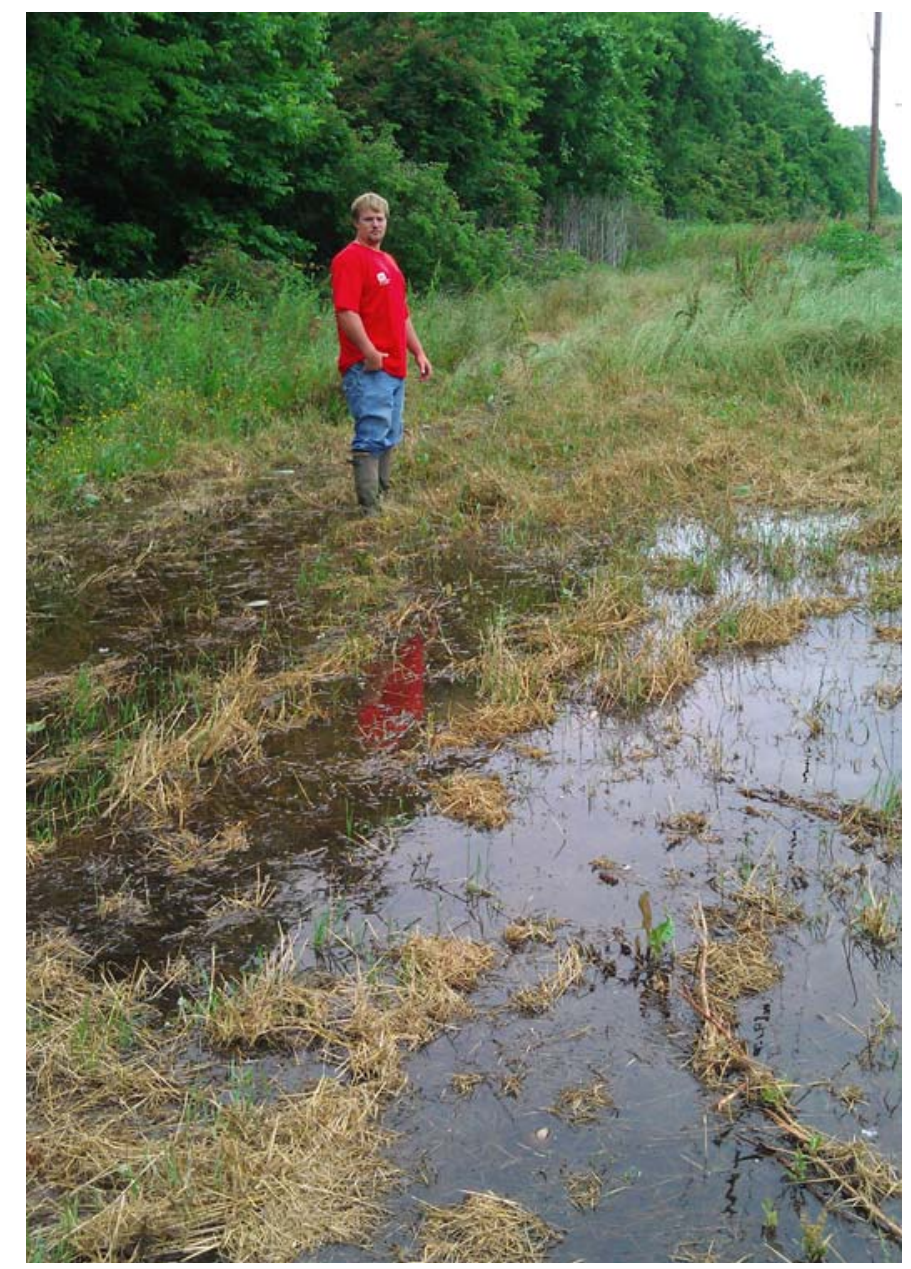

21

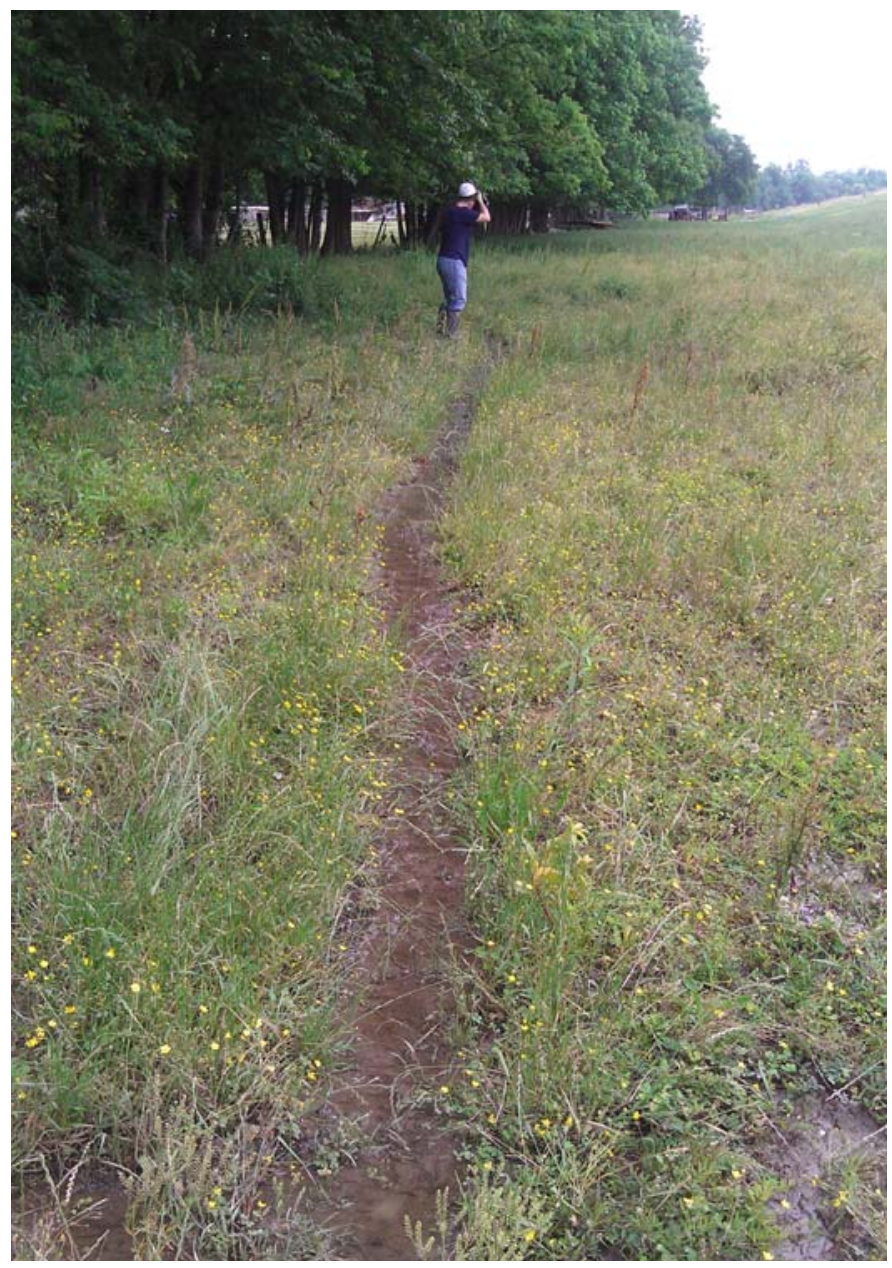

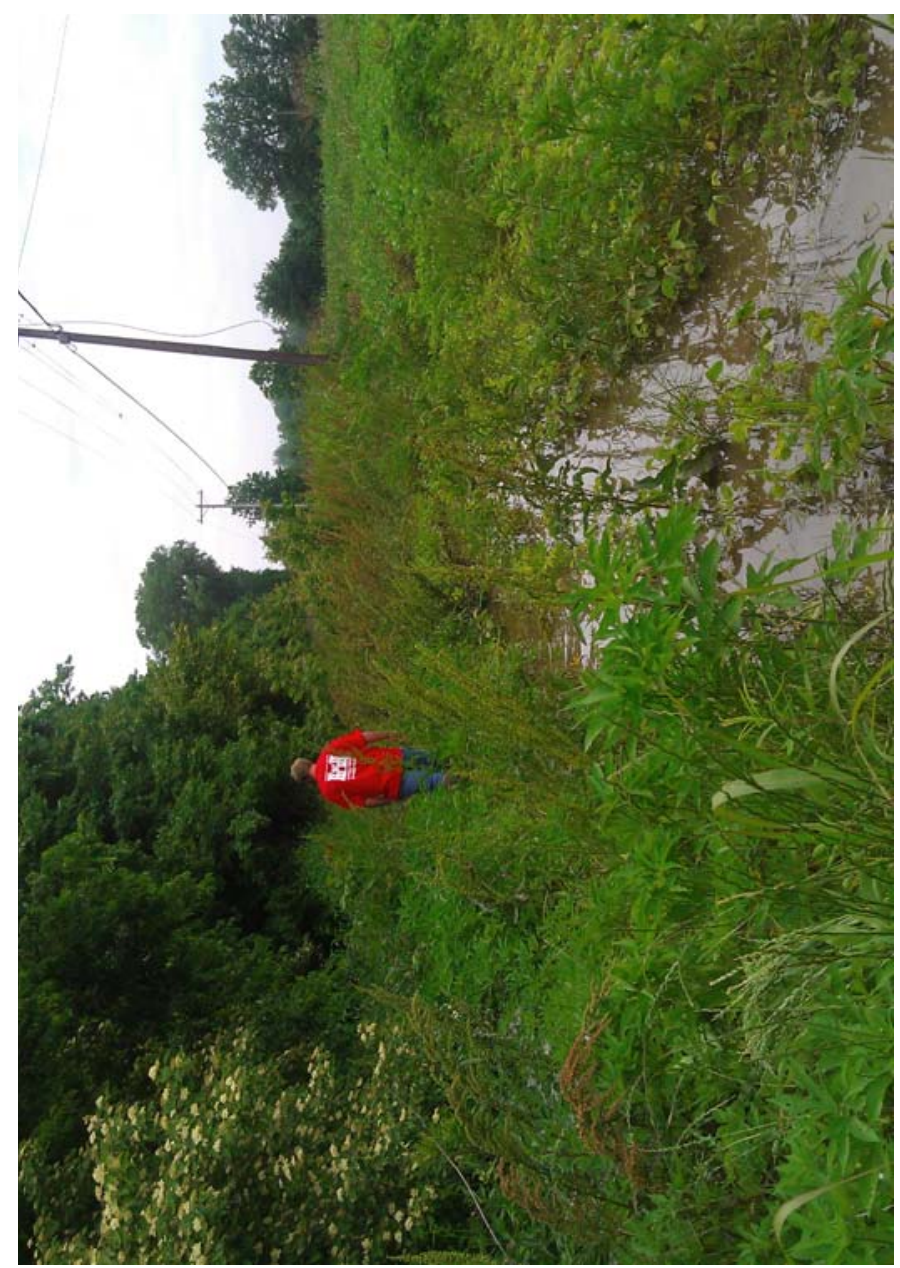

22

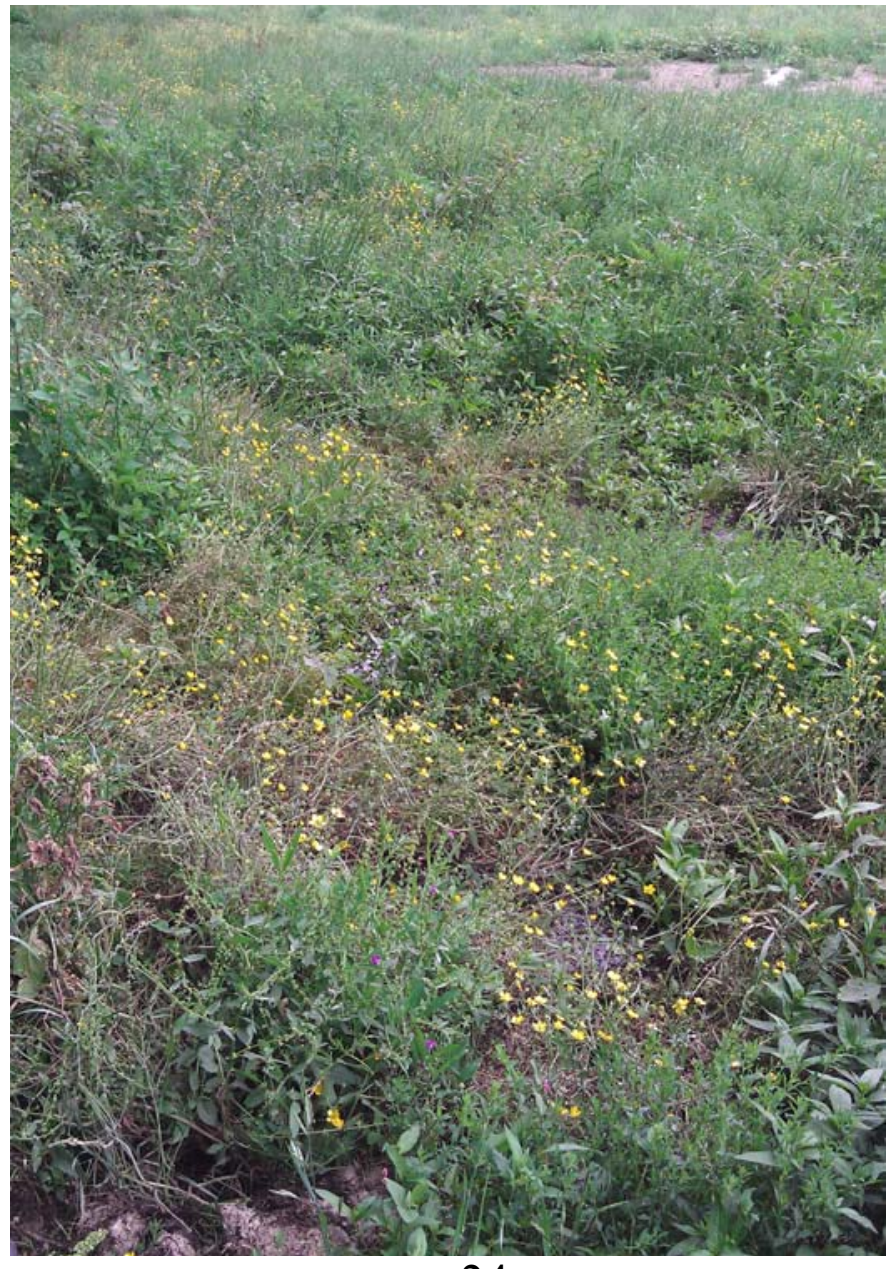




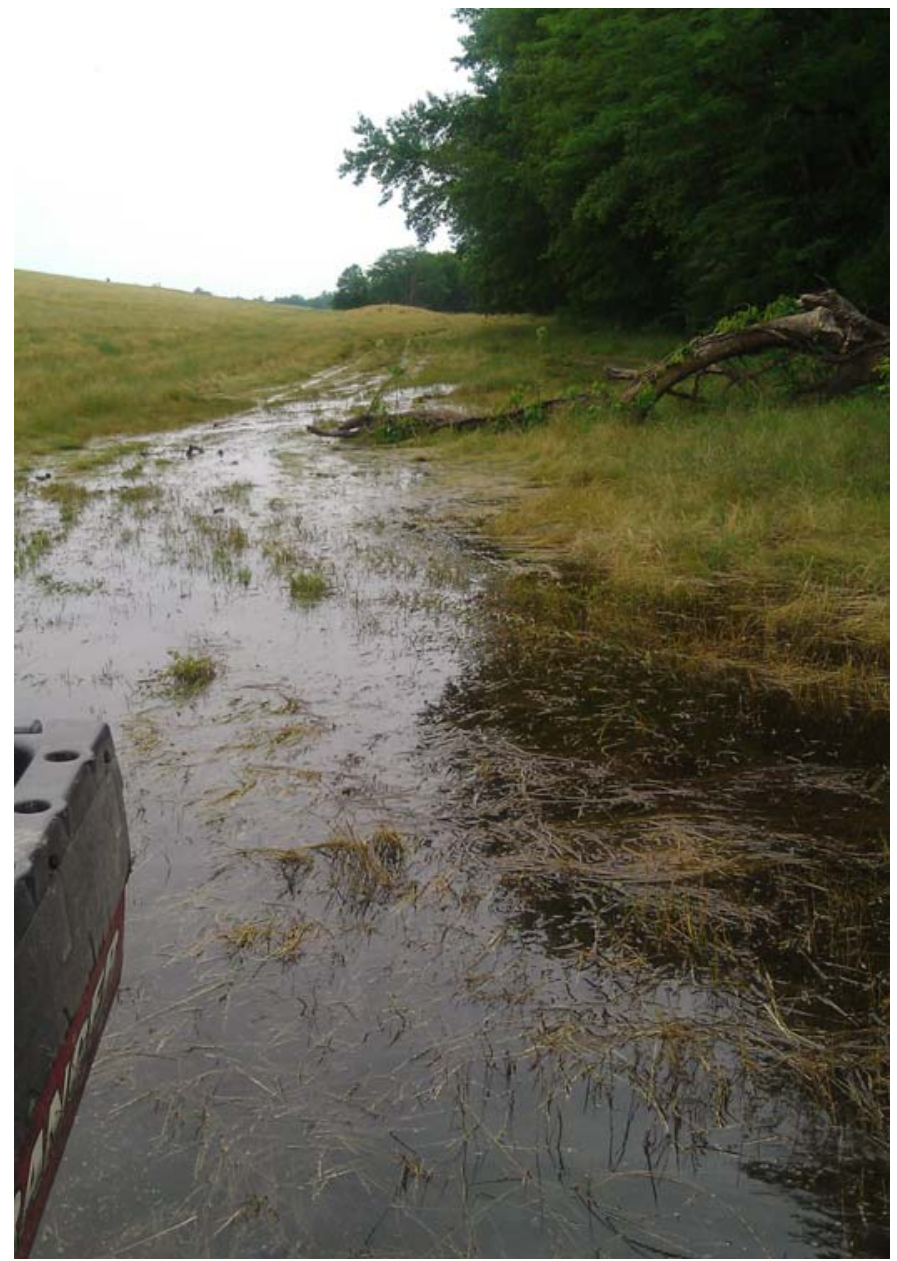

25

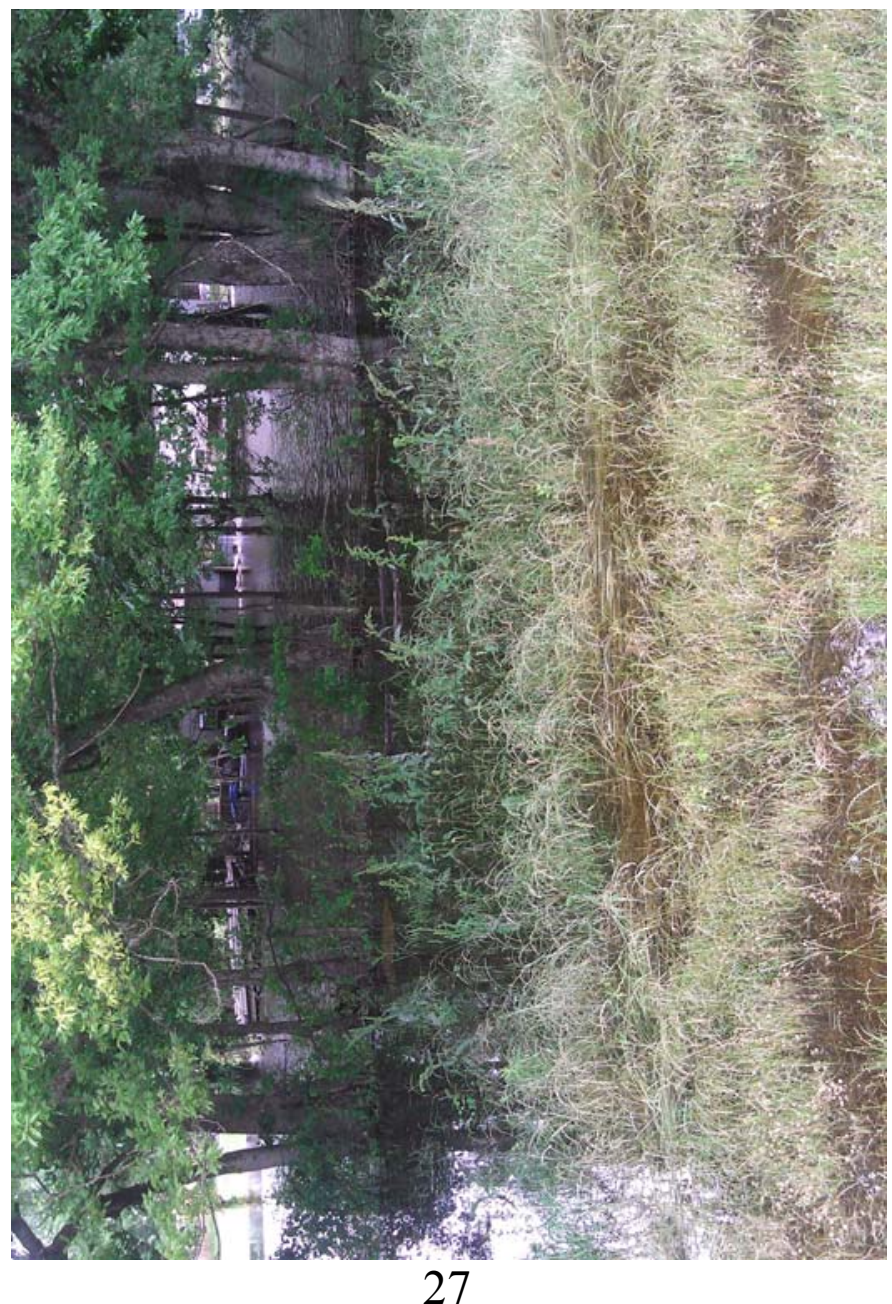

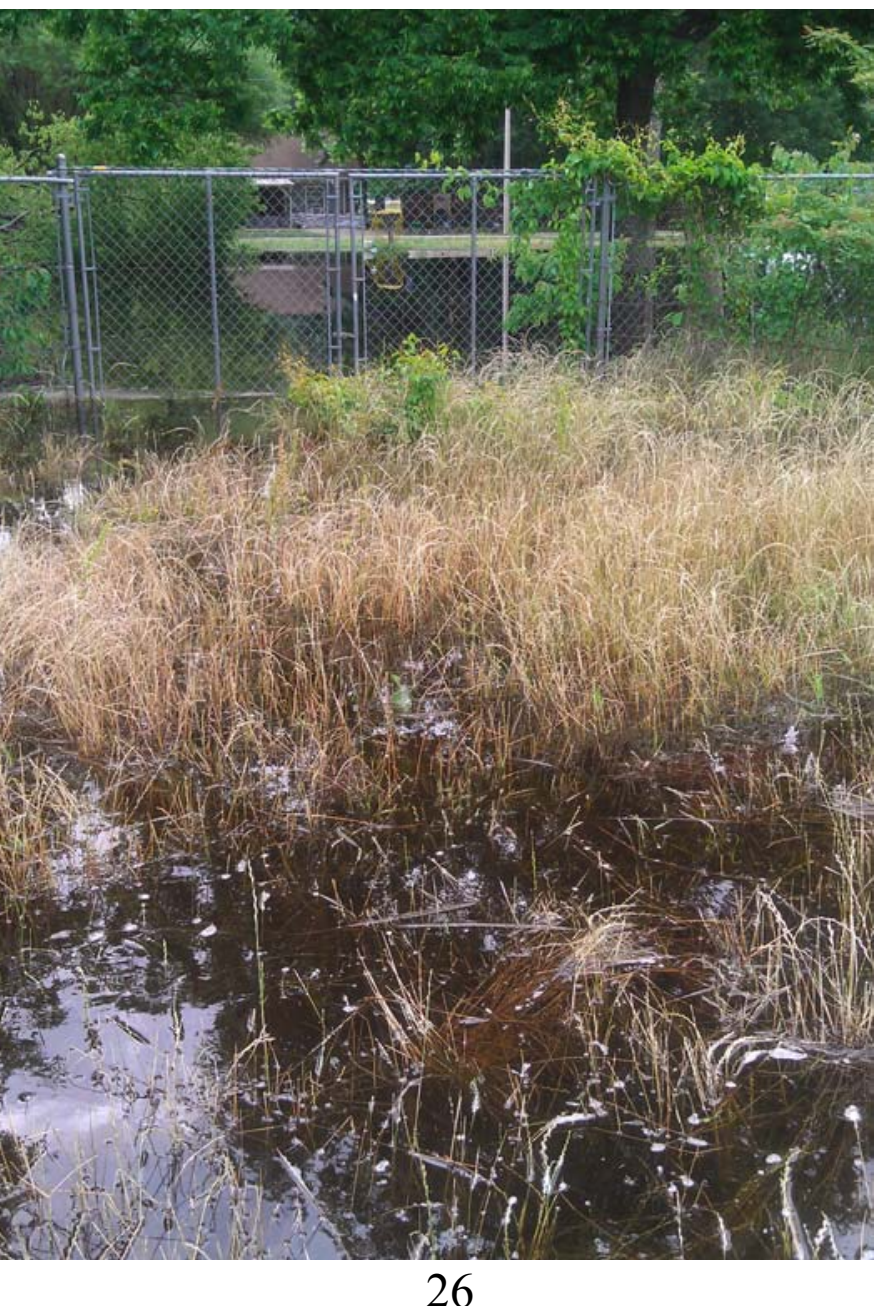

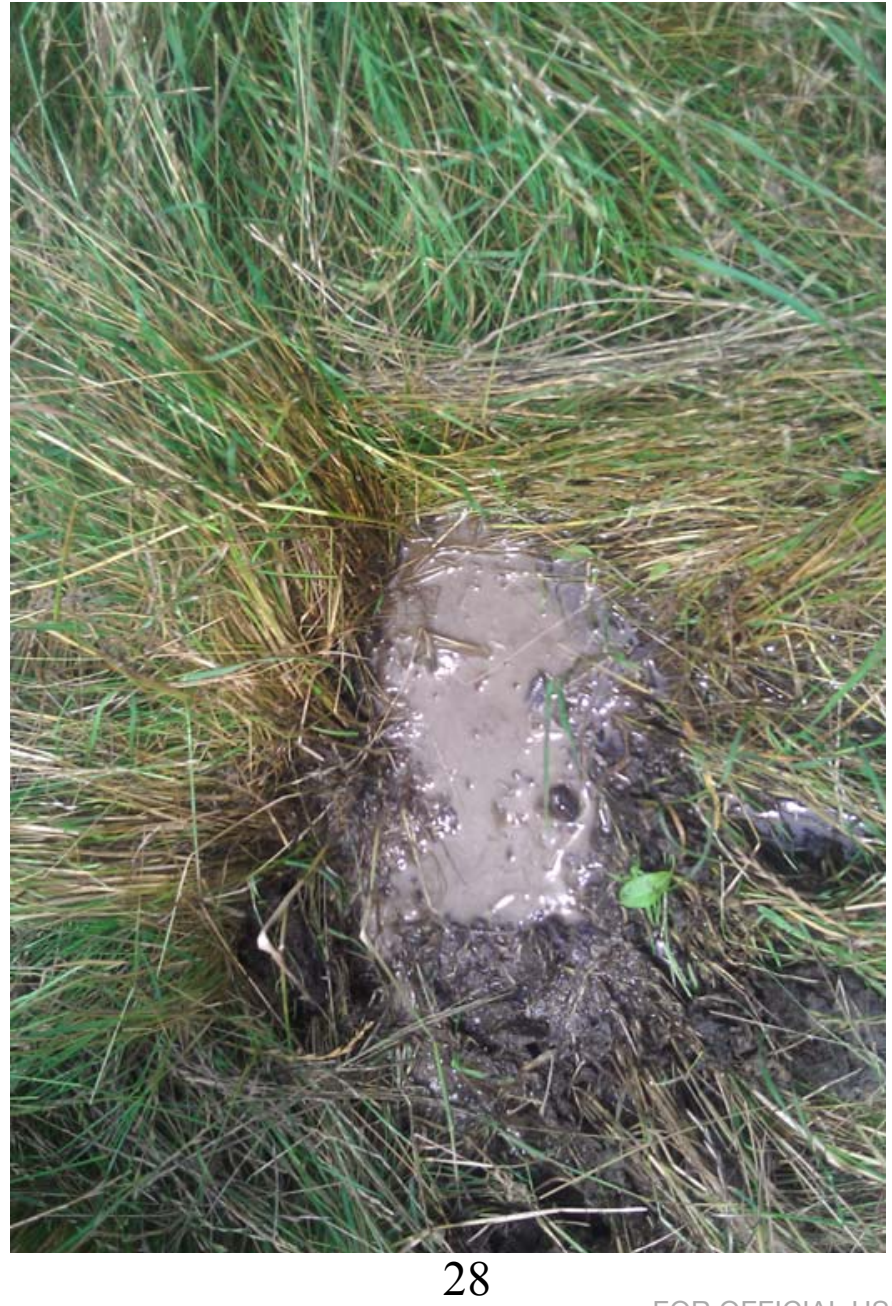




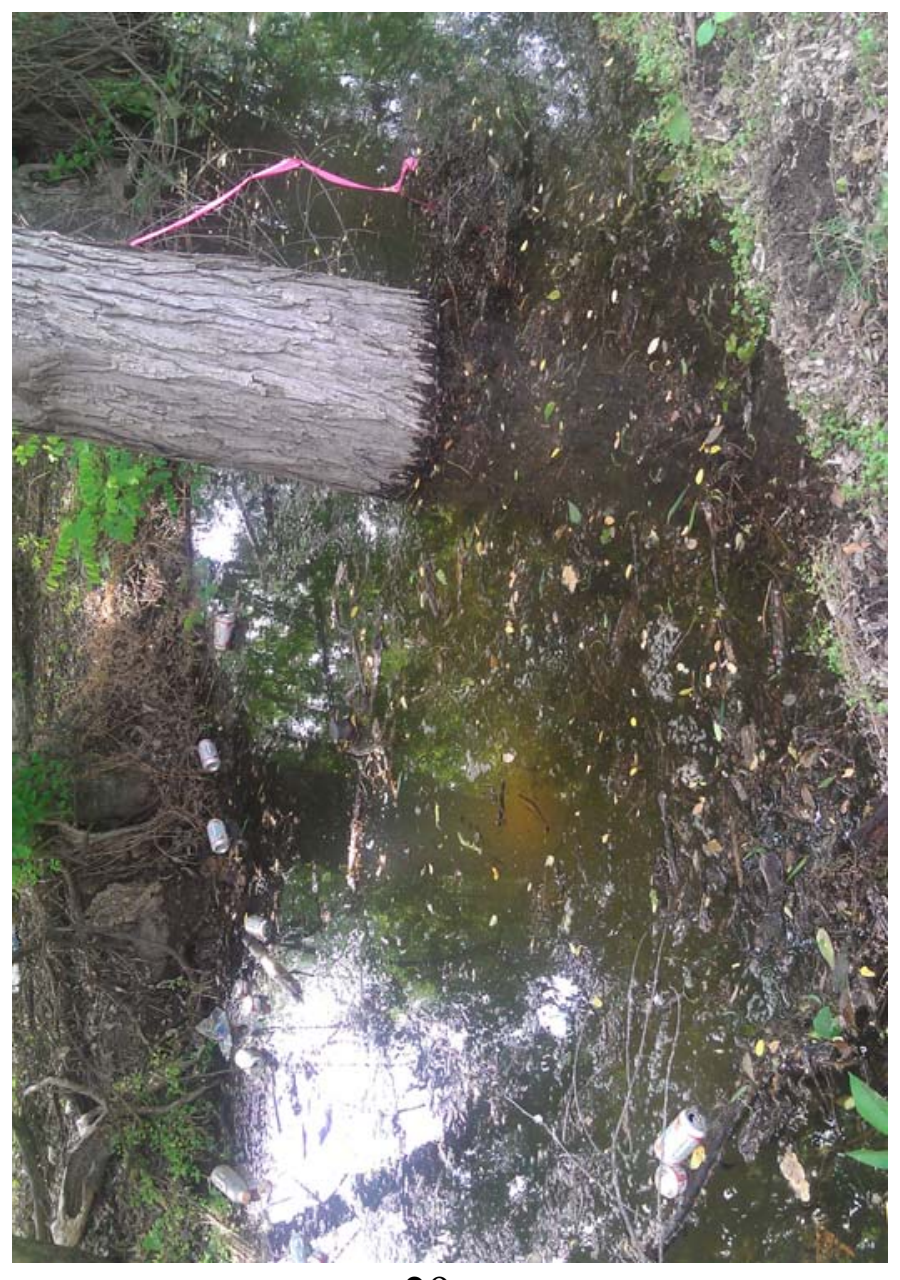

29

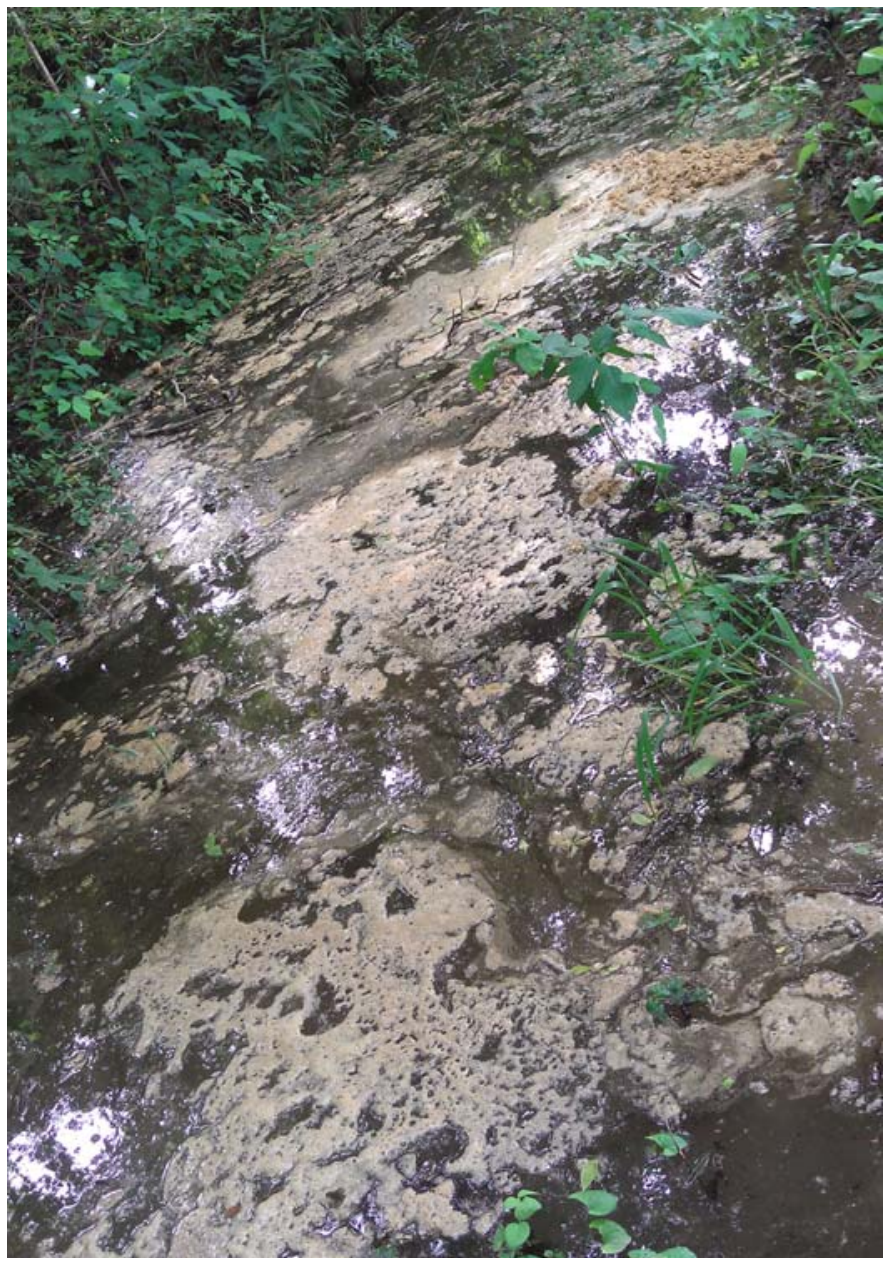

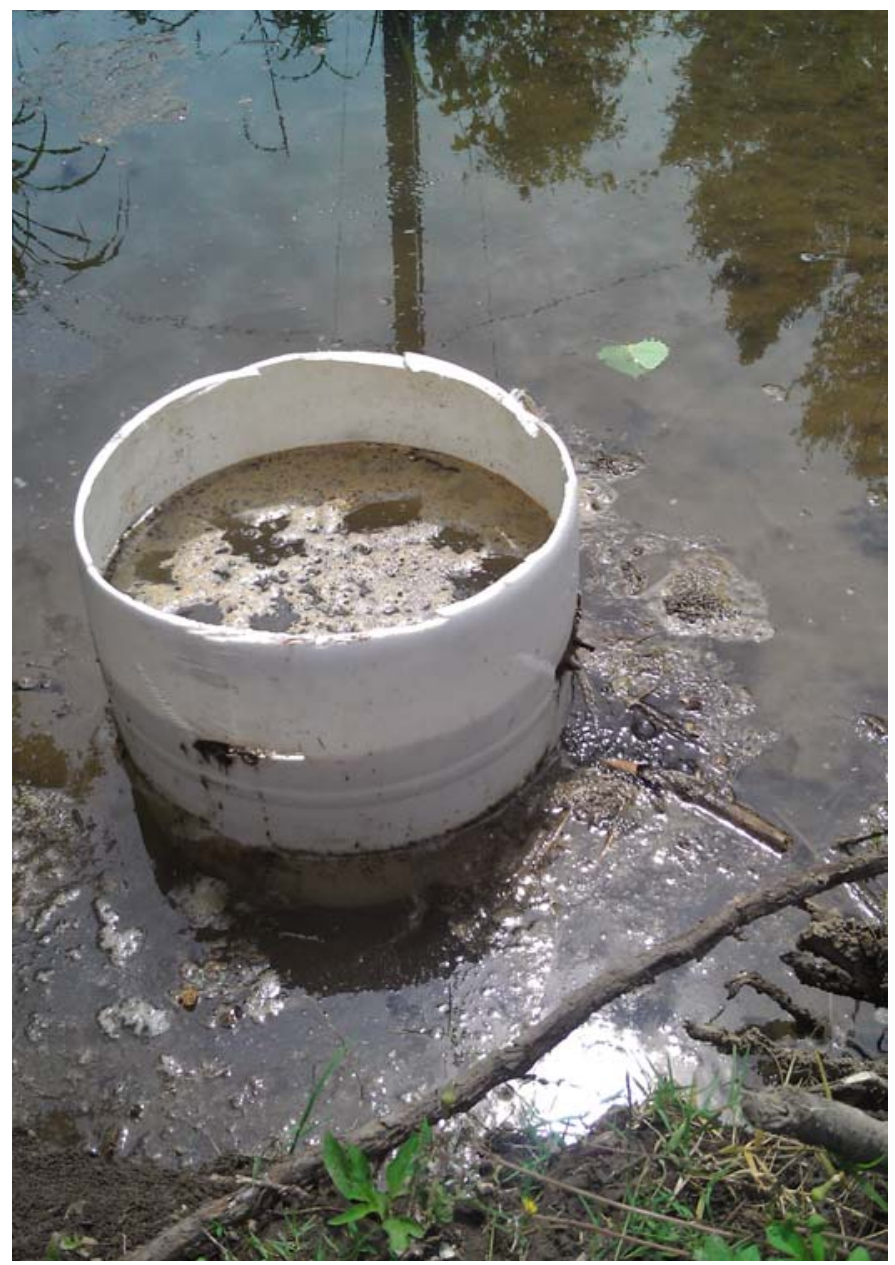

30

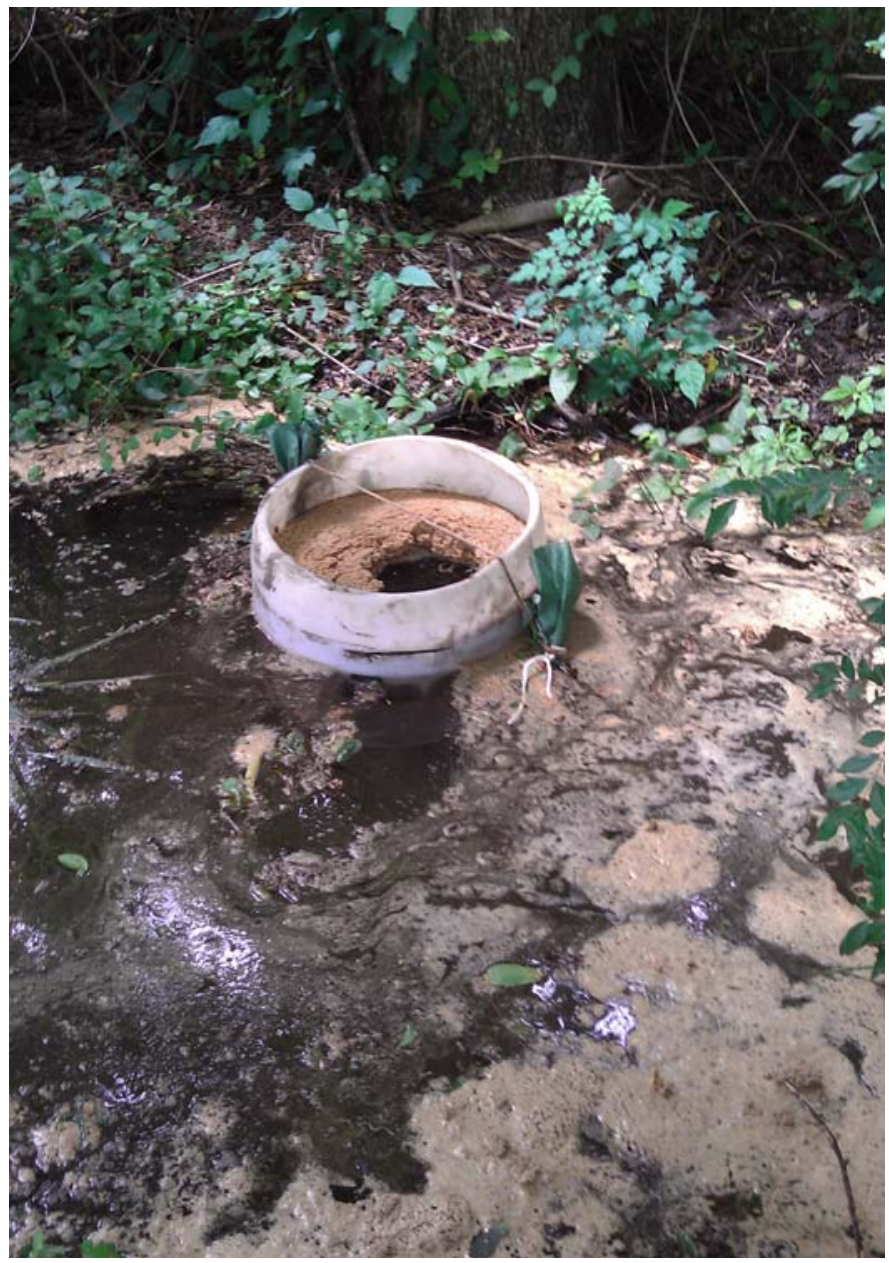




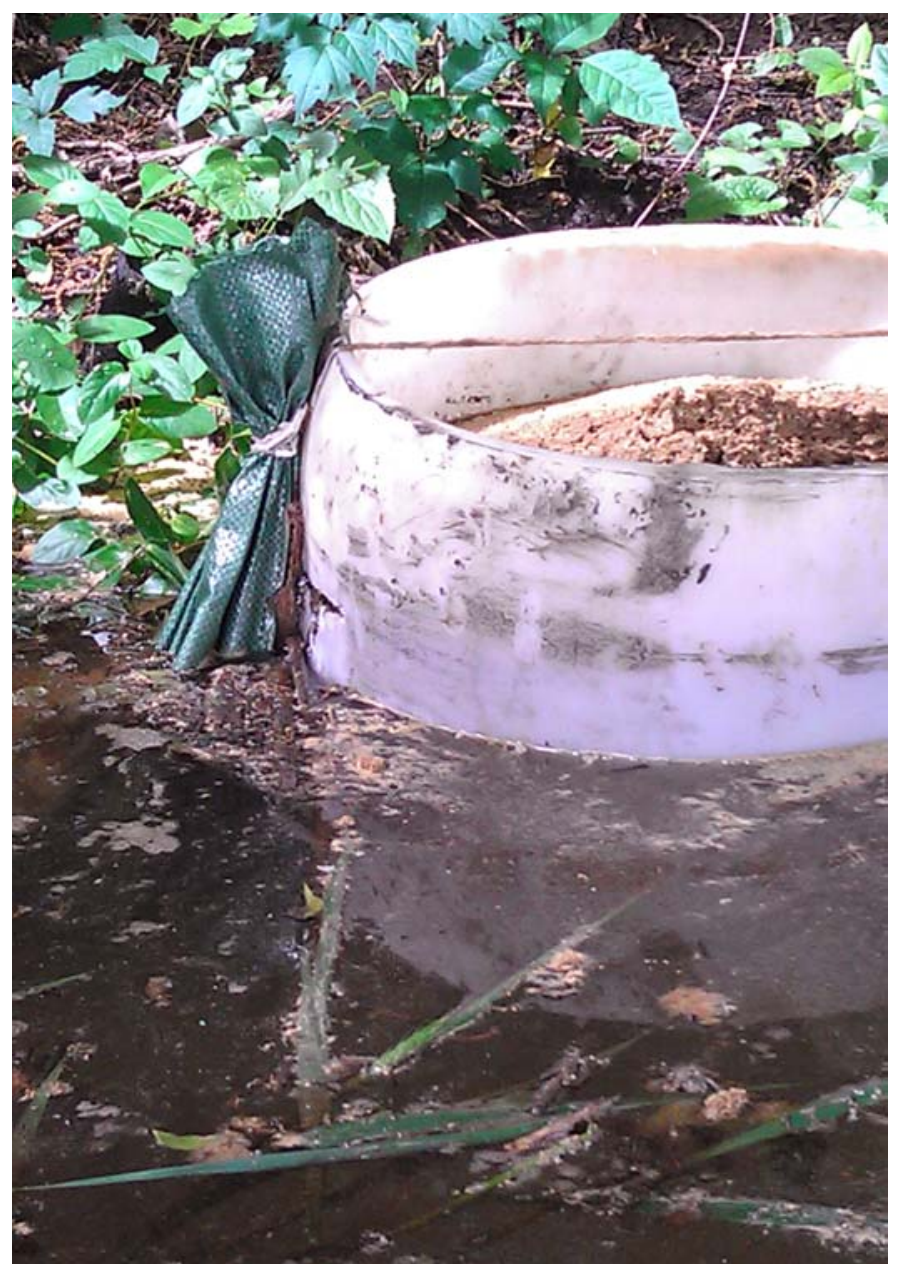

33

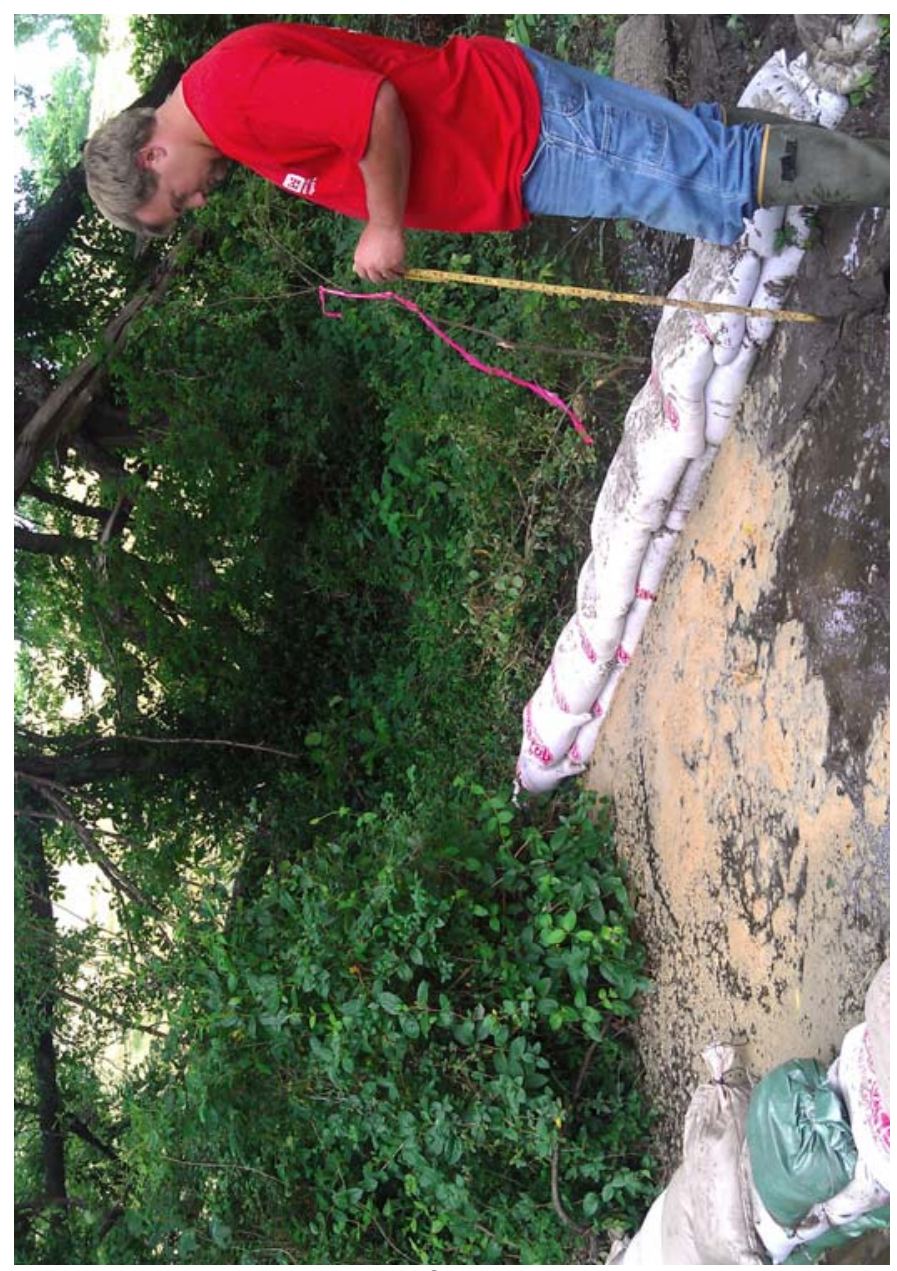

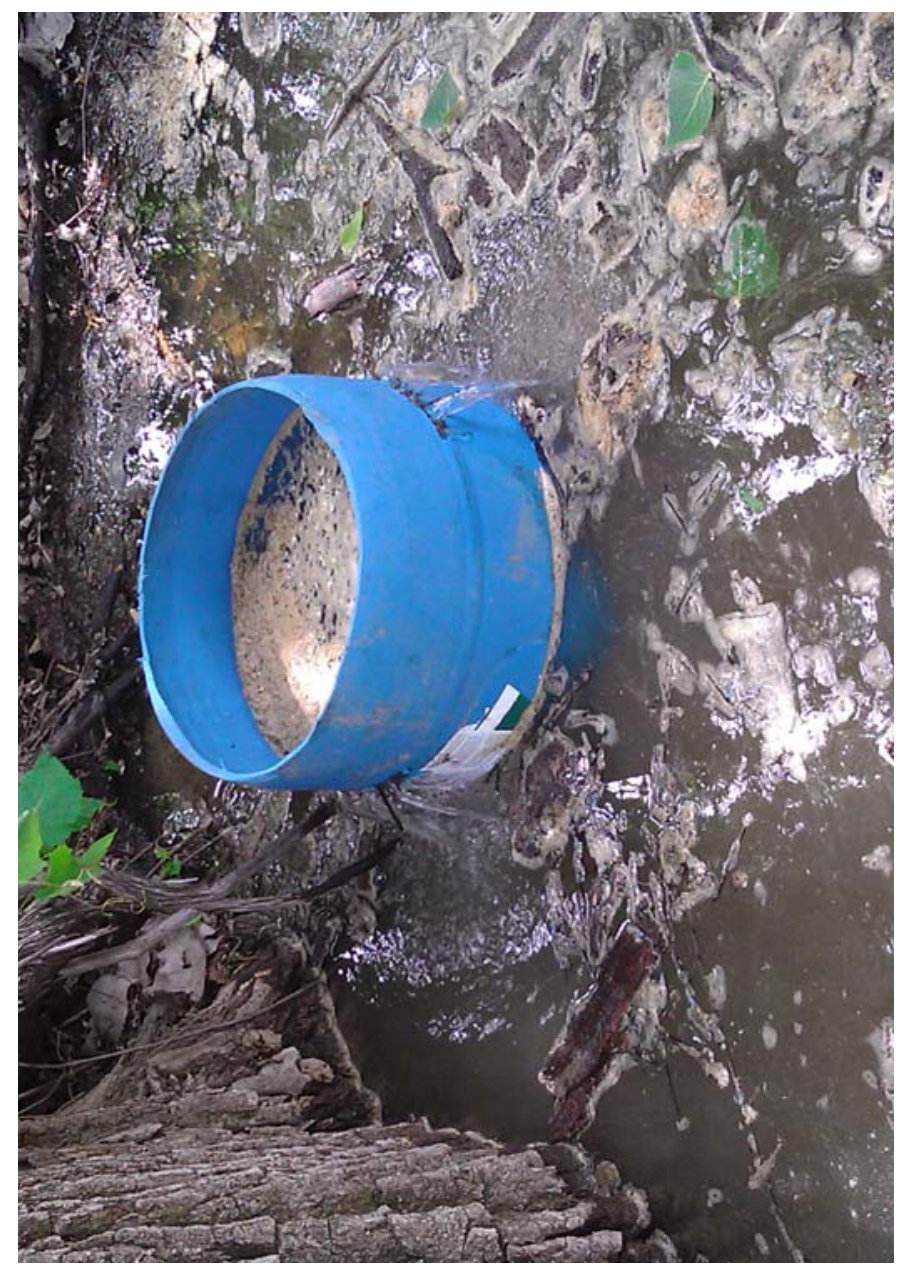

34

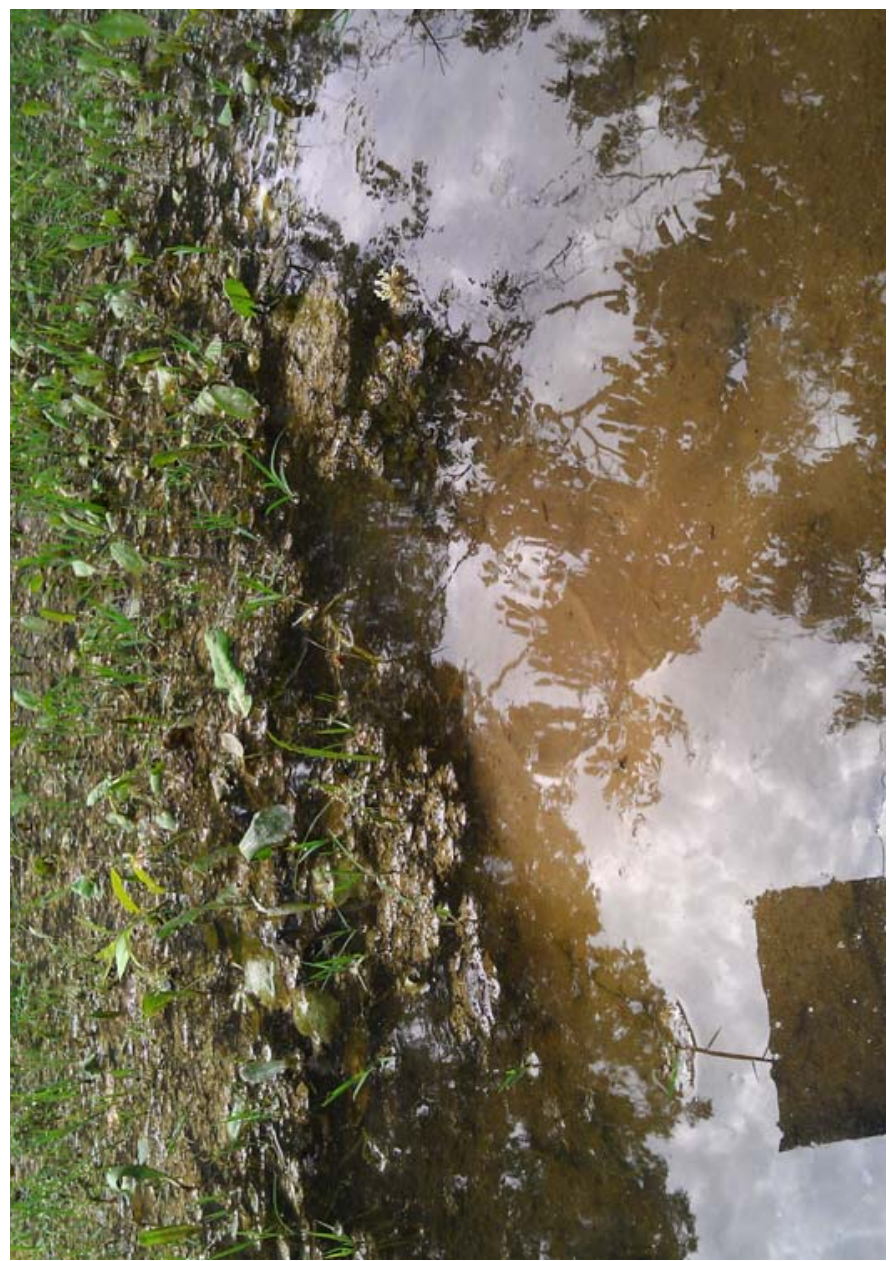




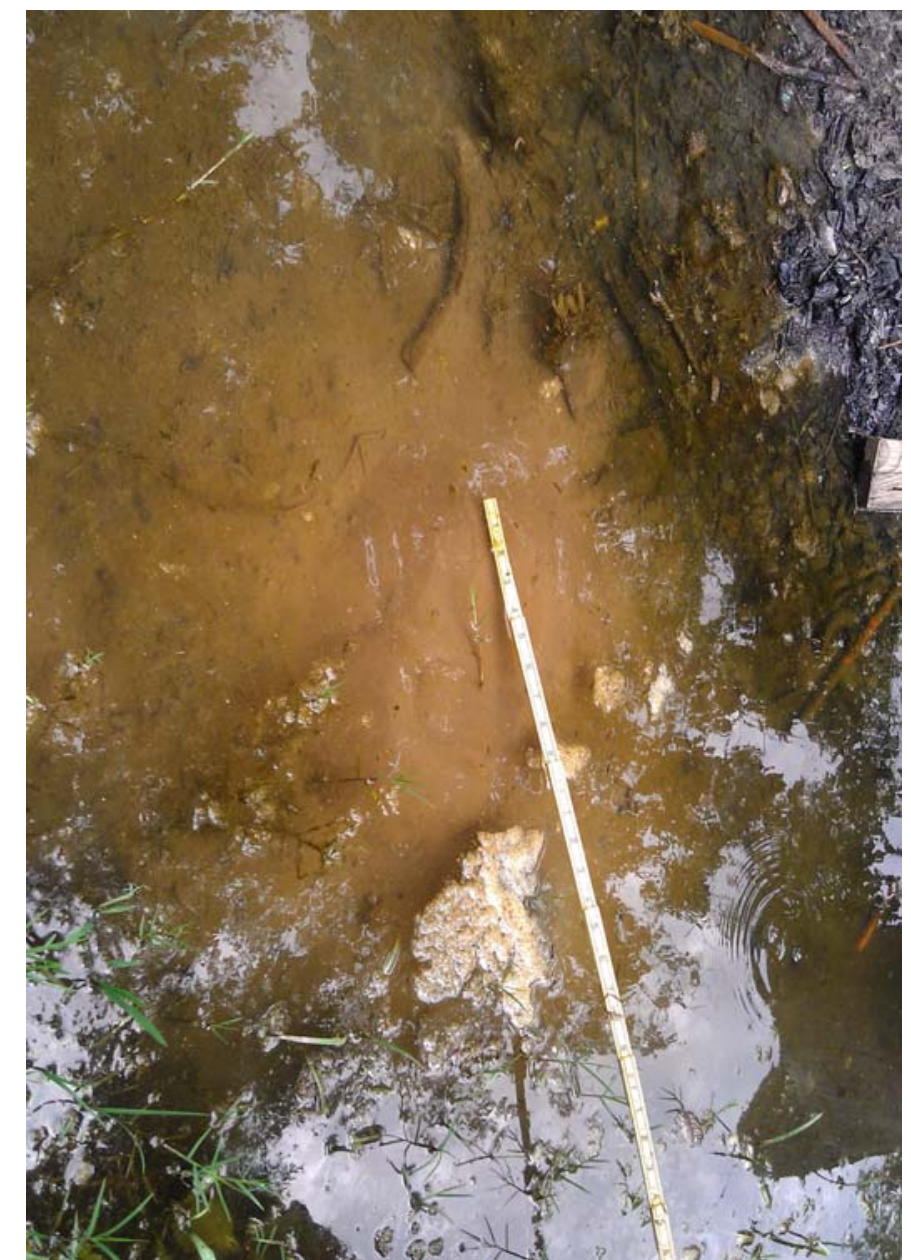

37

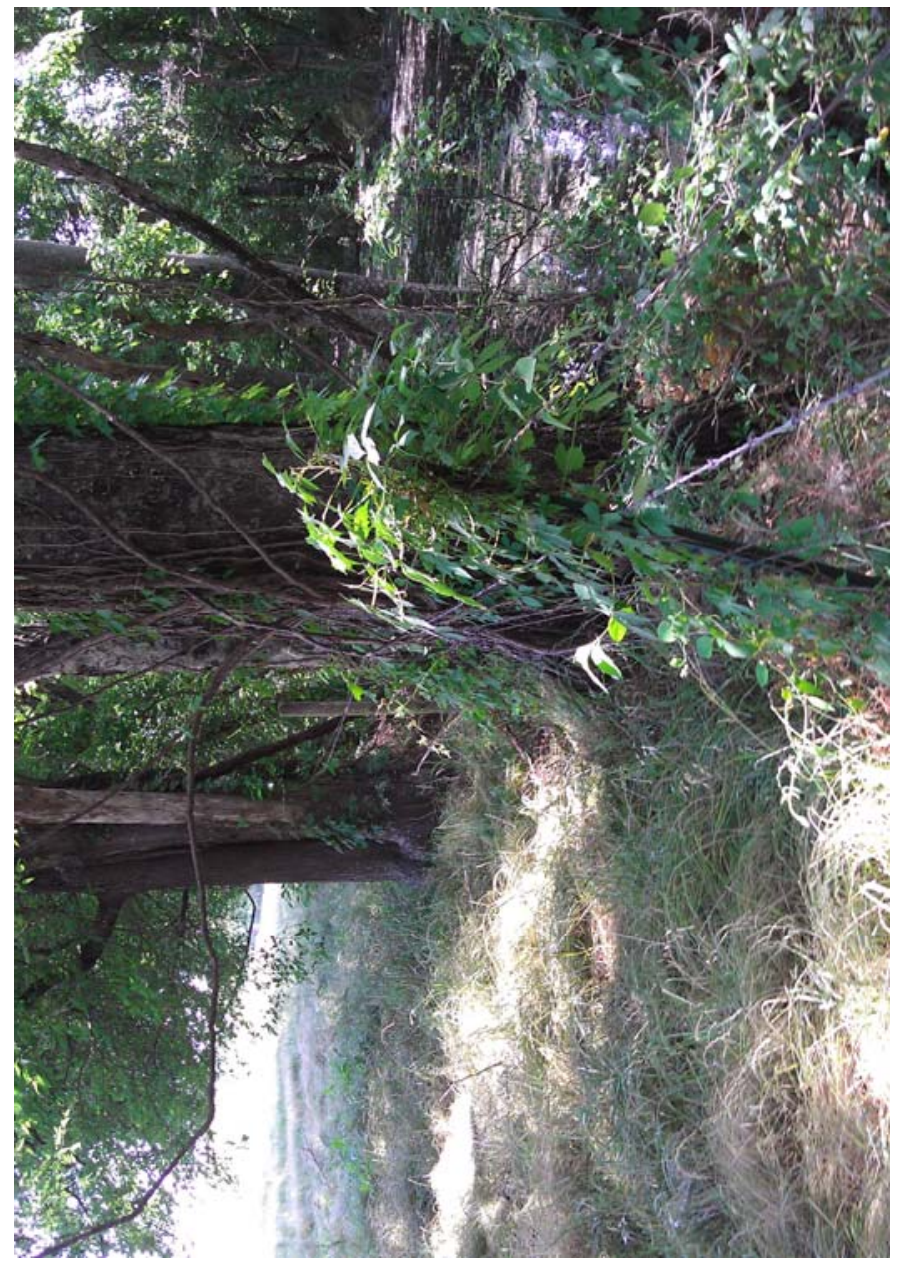

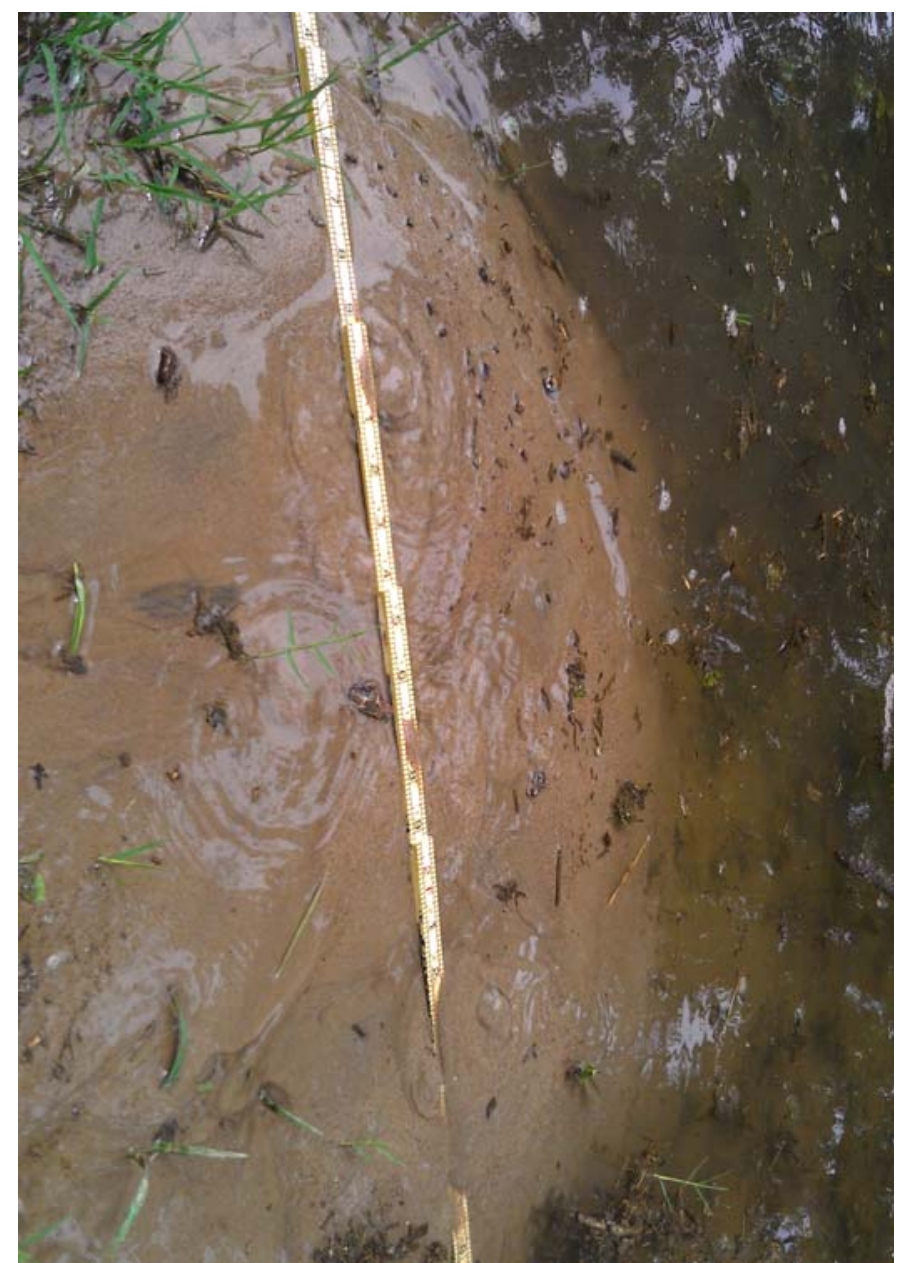

\section{8}

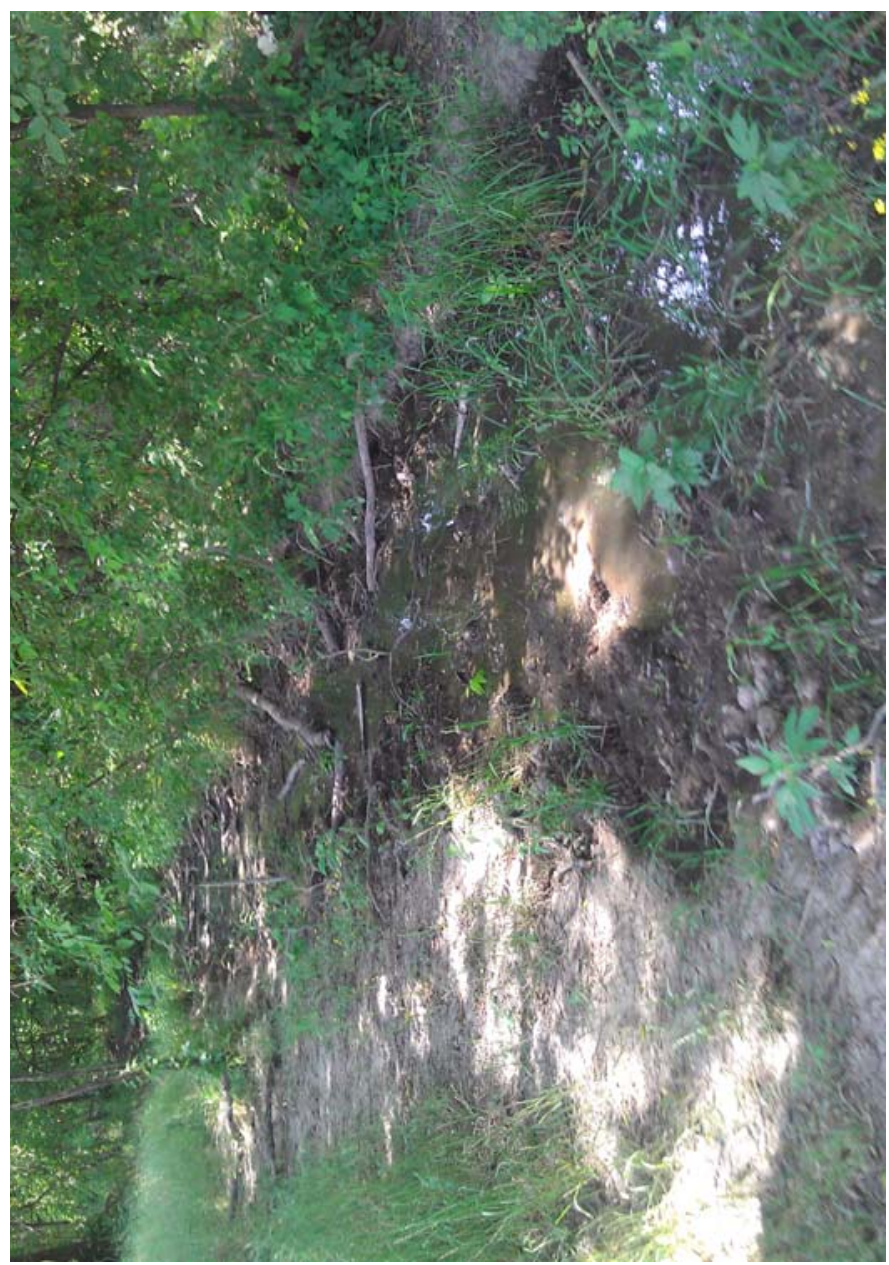




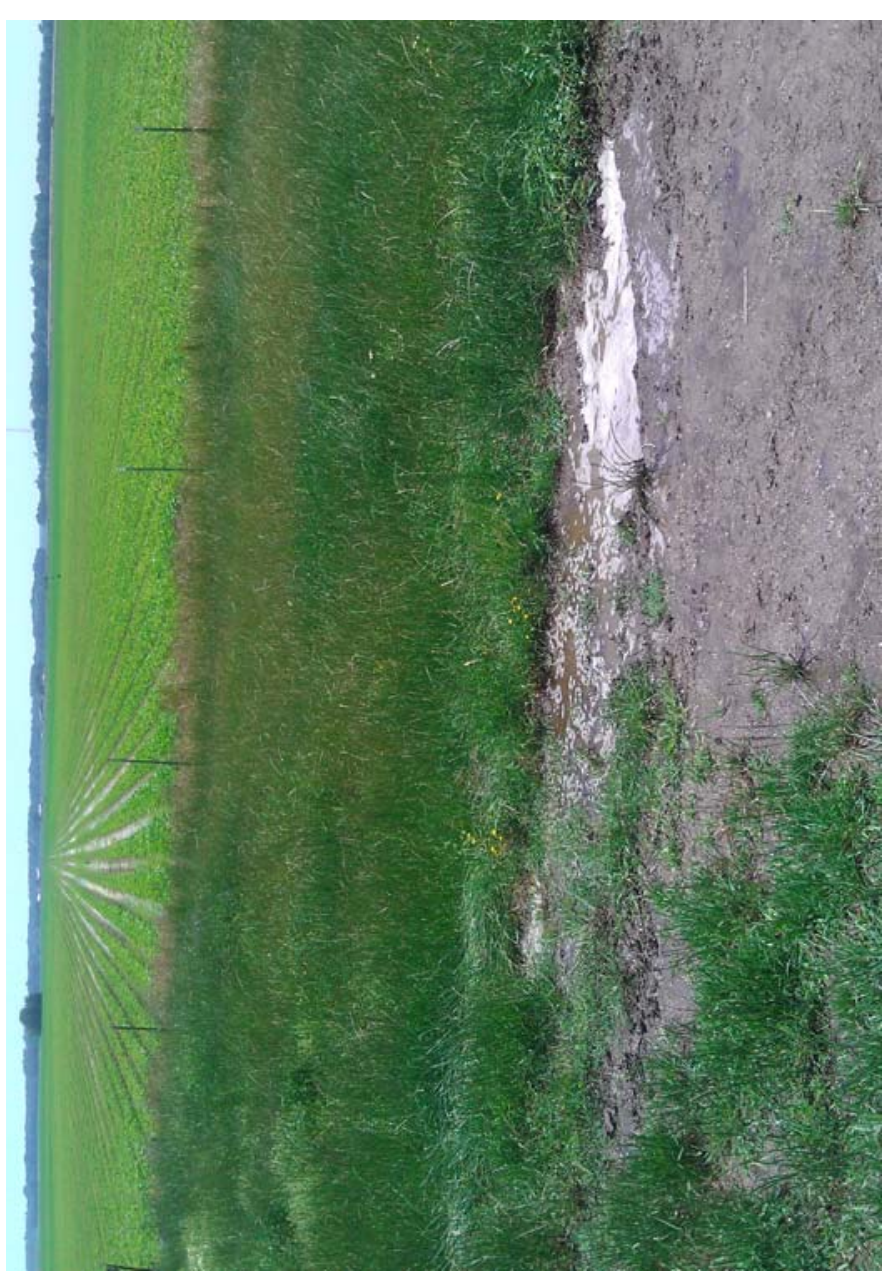

41

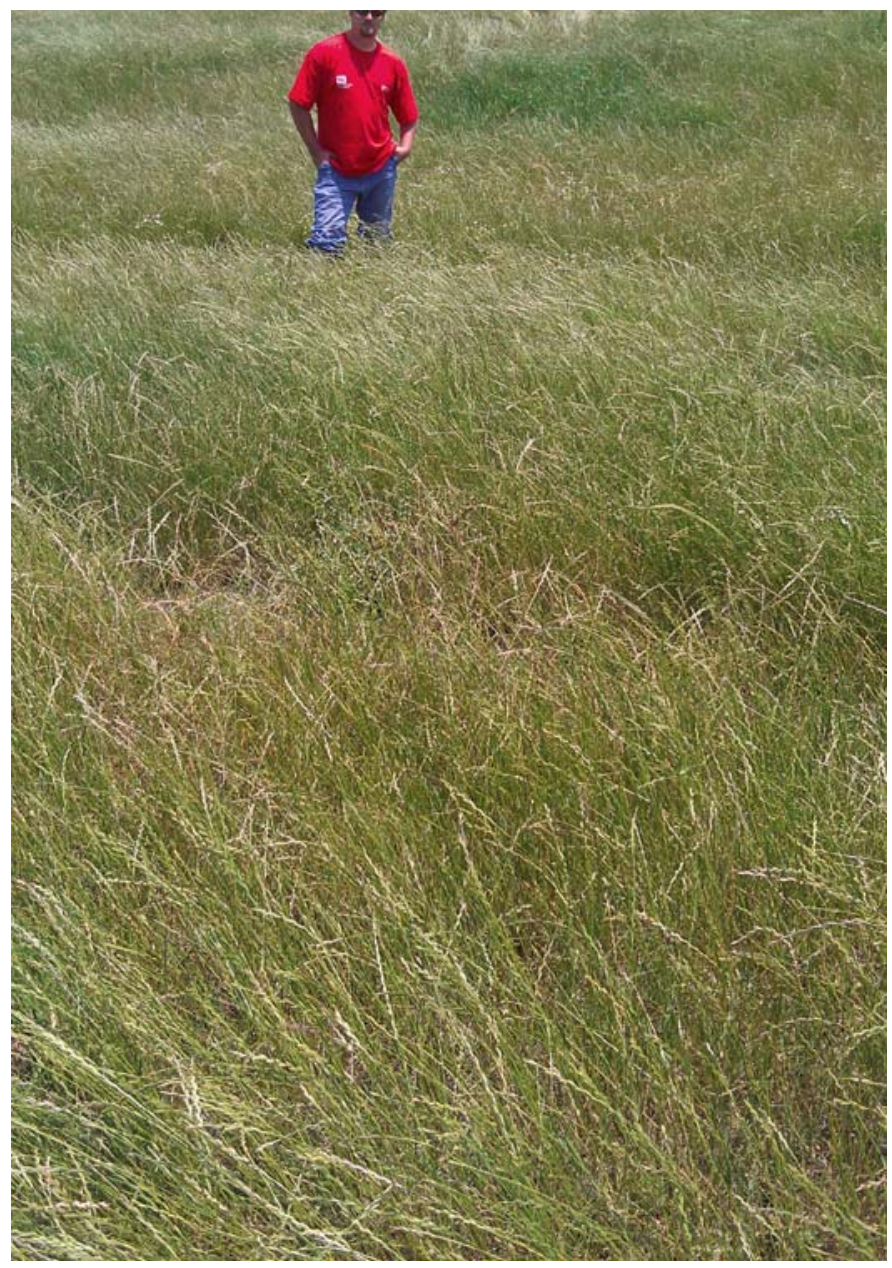

43

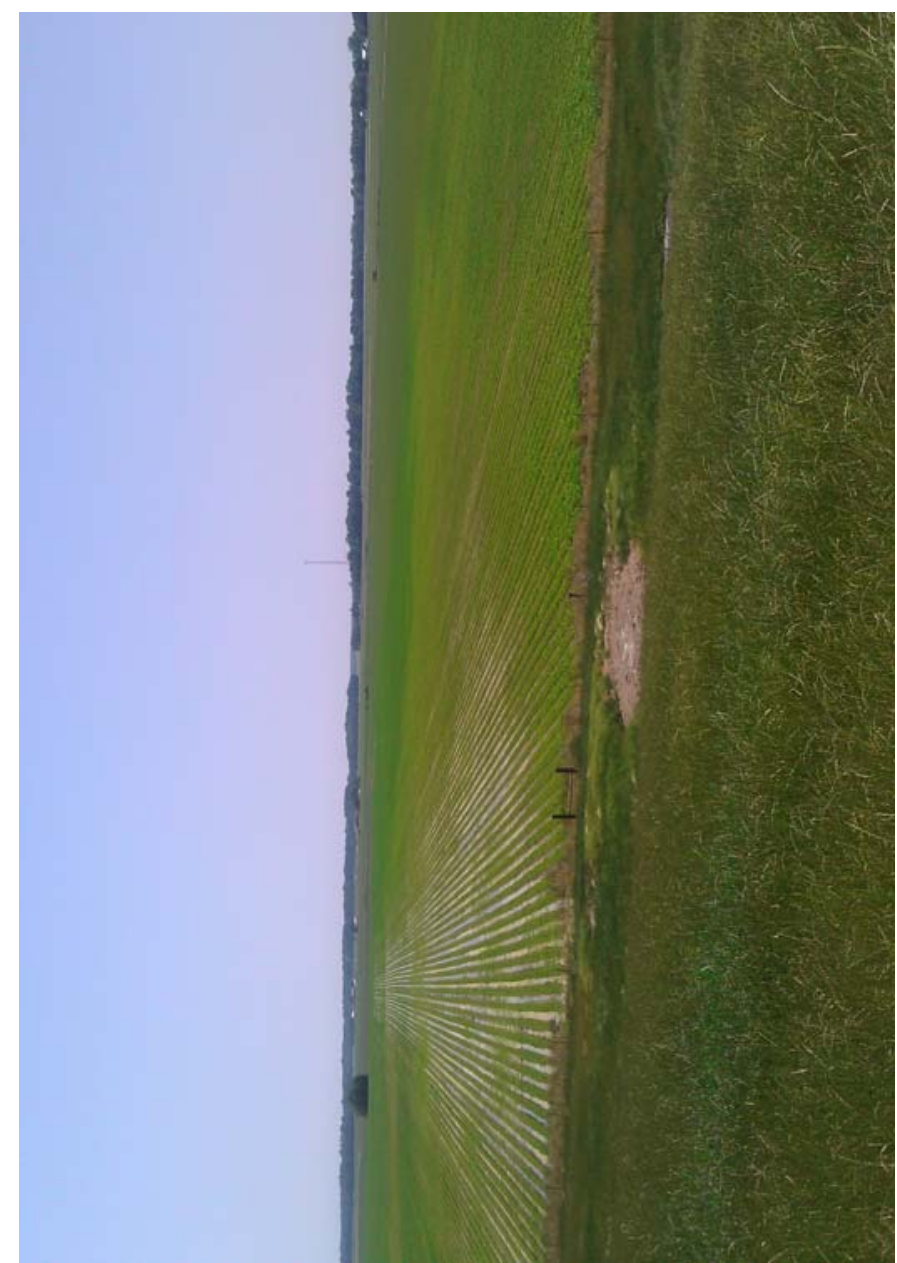

42

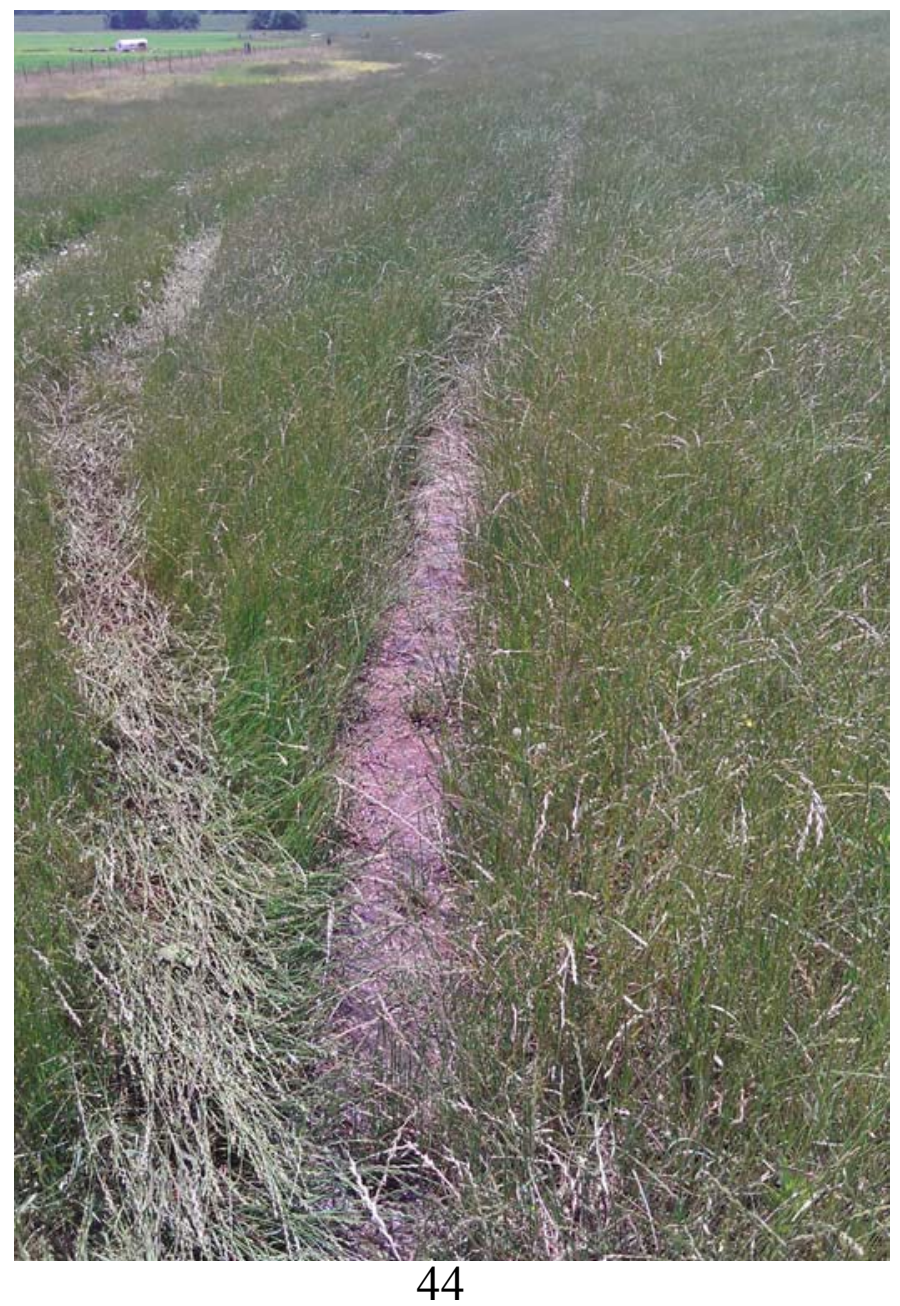

FOR OFFICIAL USE ONLY 


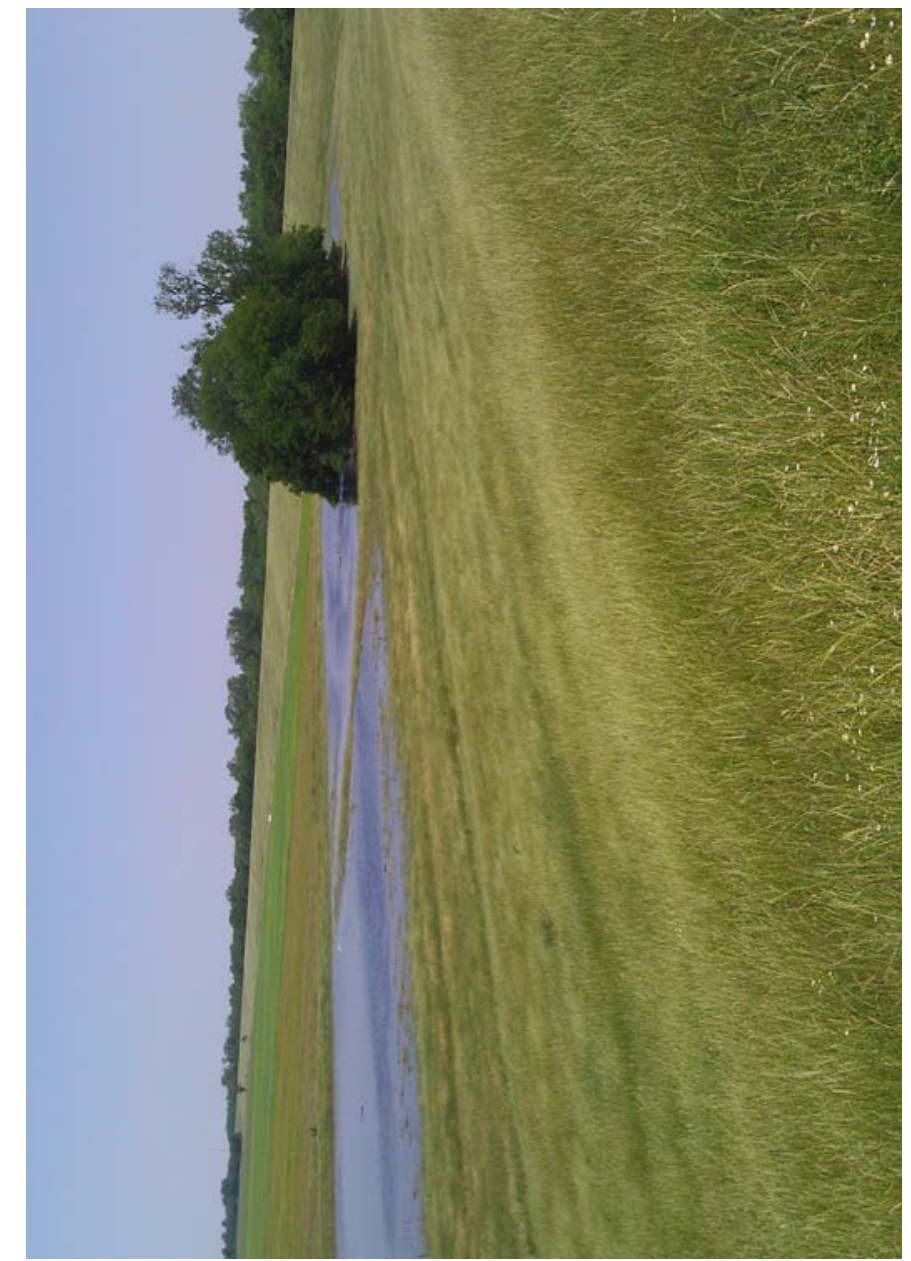

45

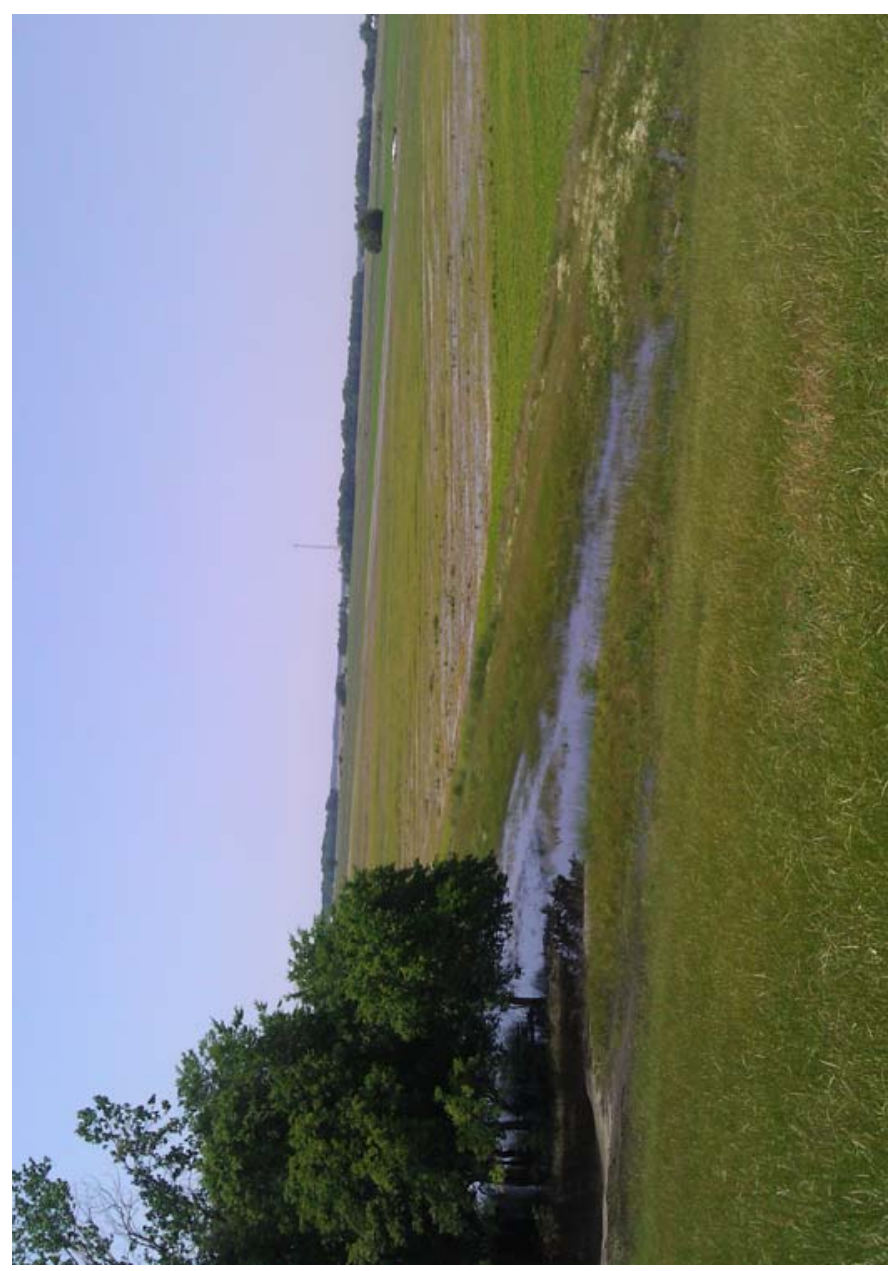

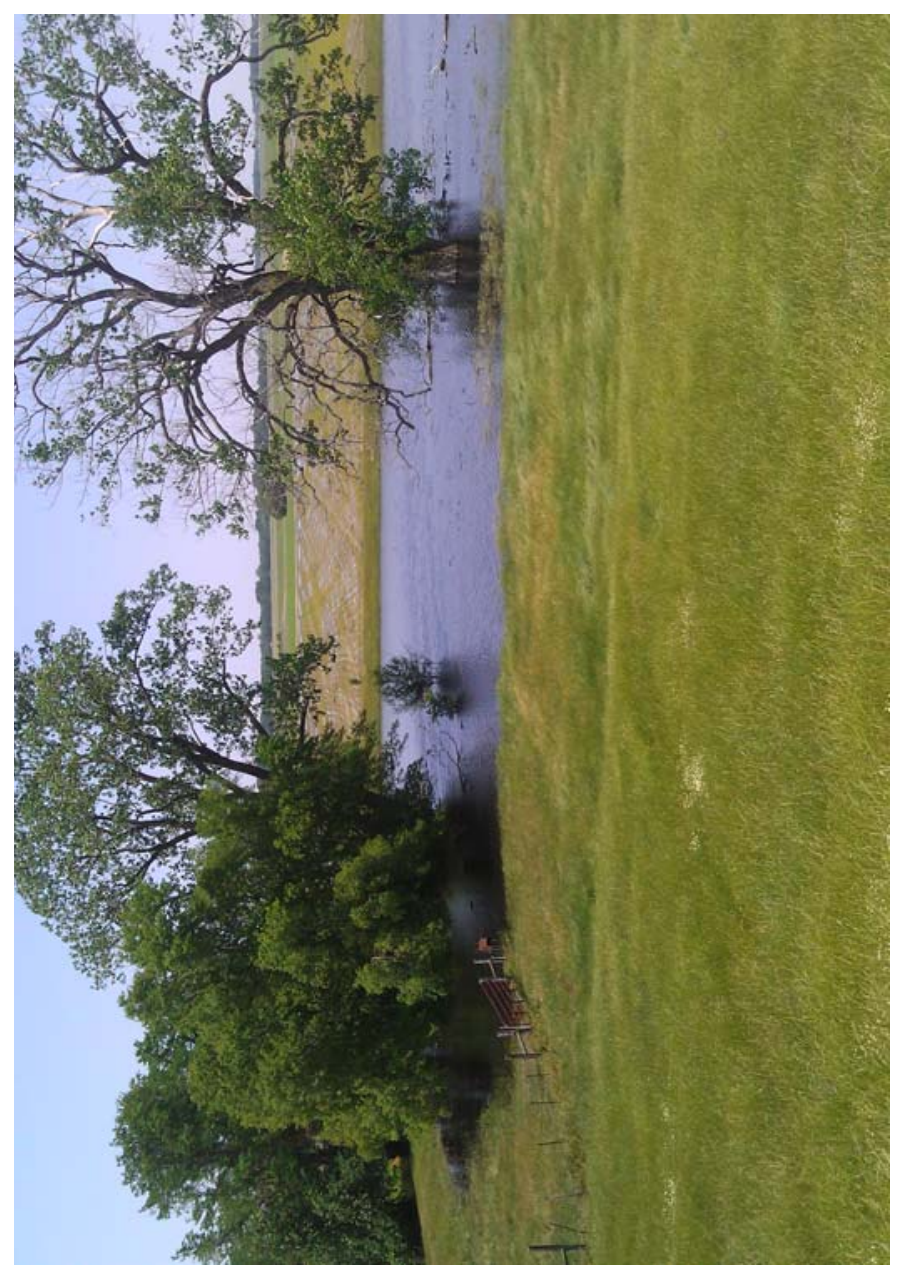

46

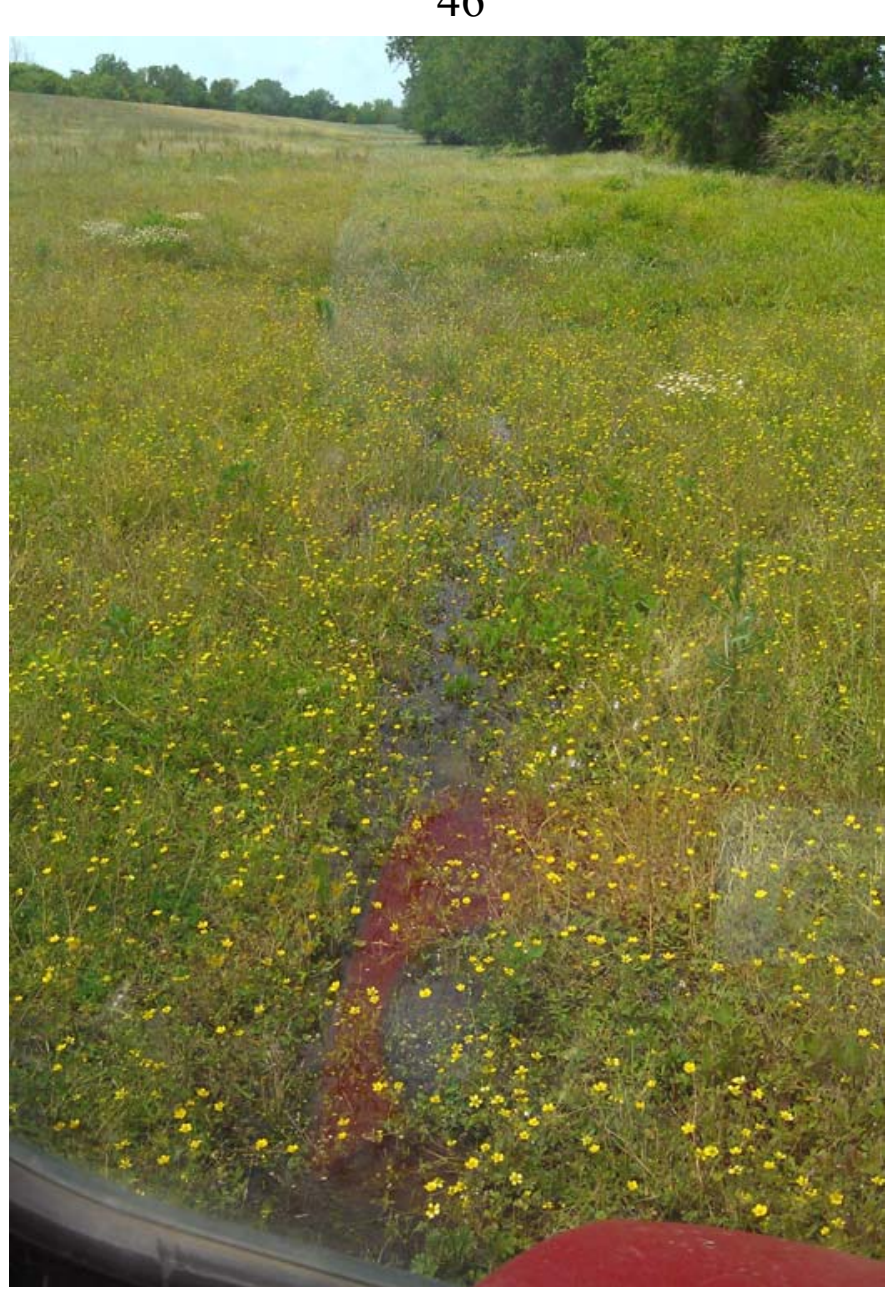




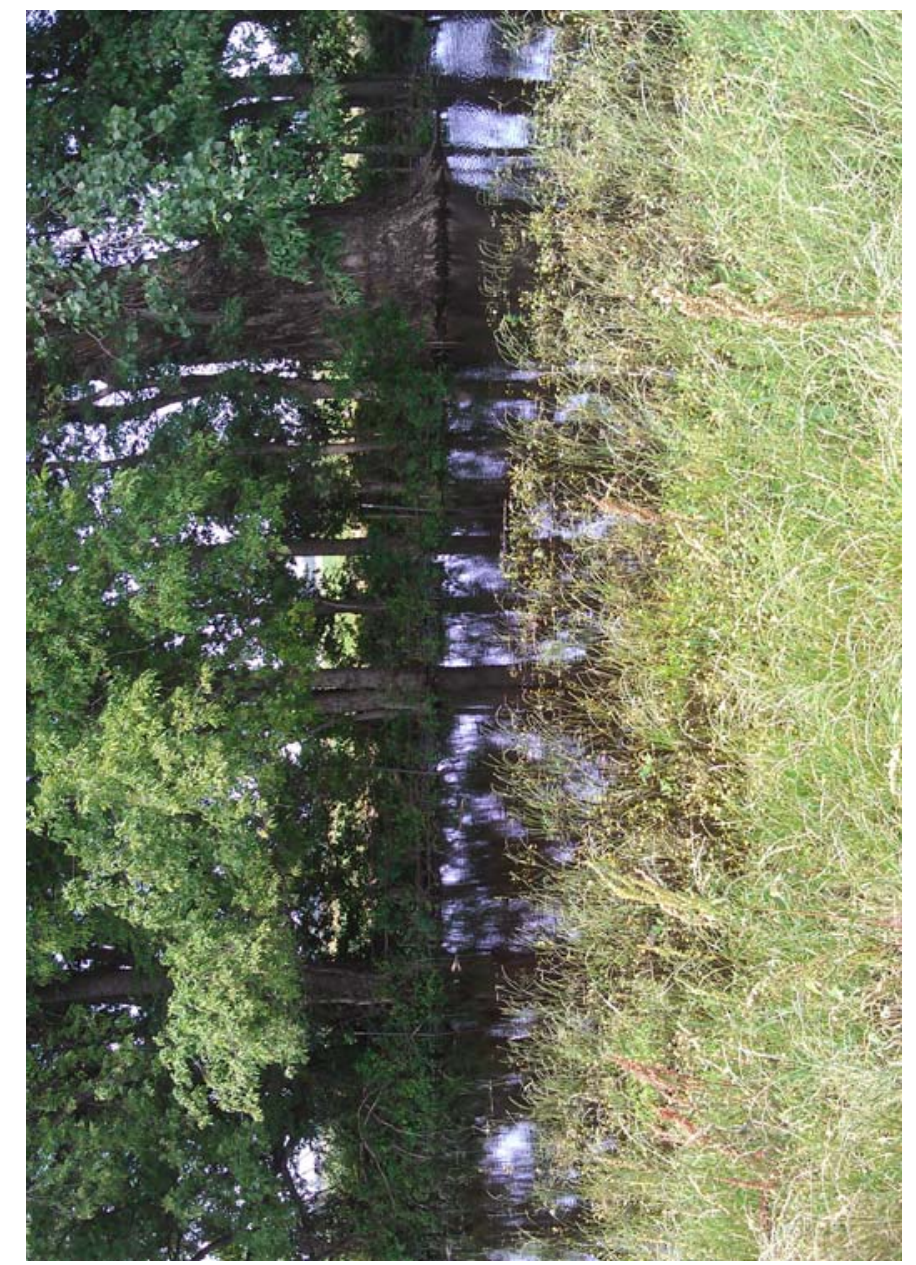

49

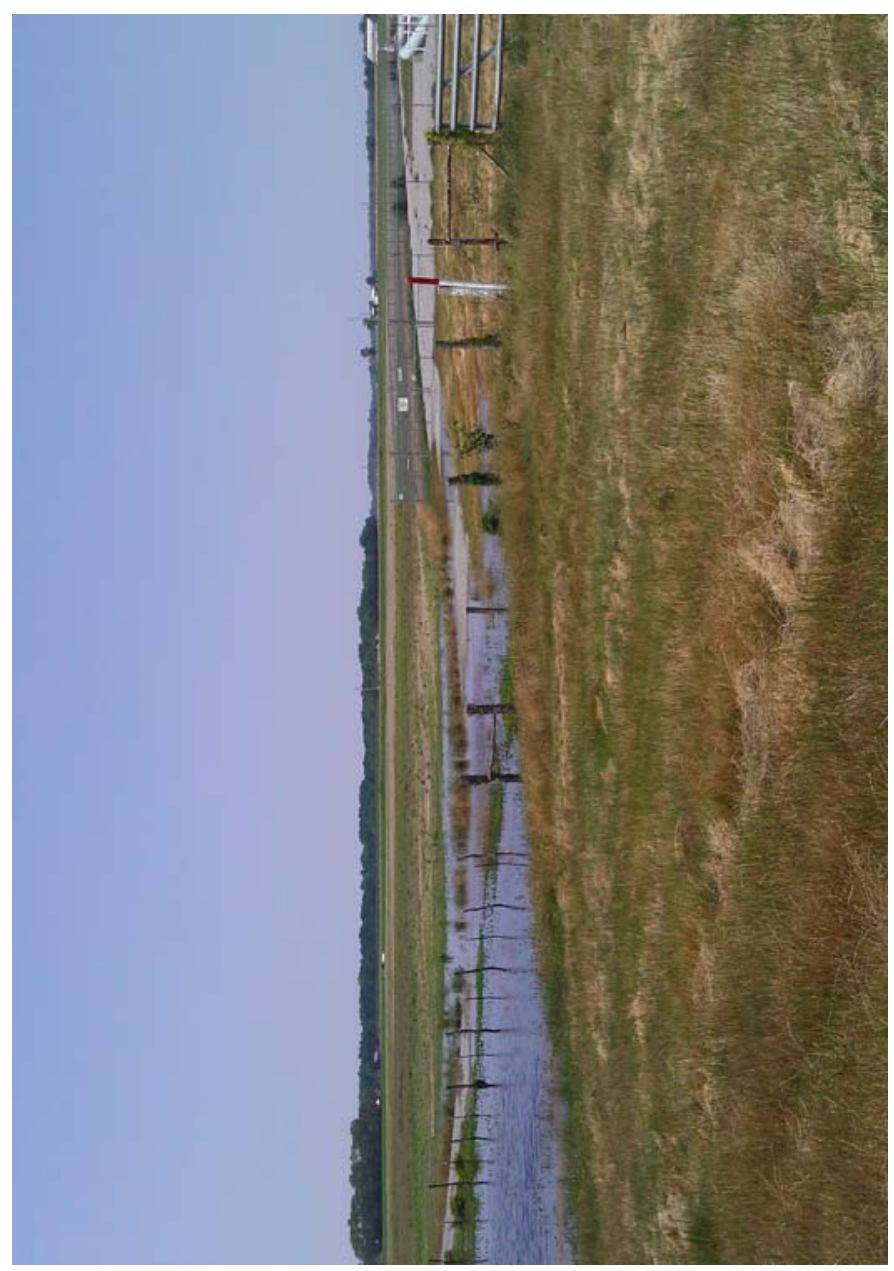

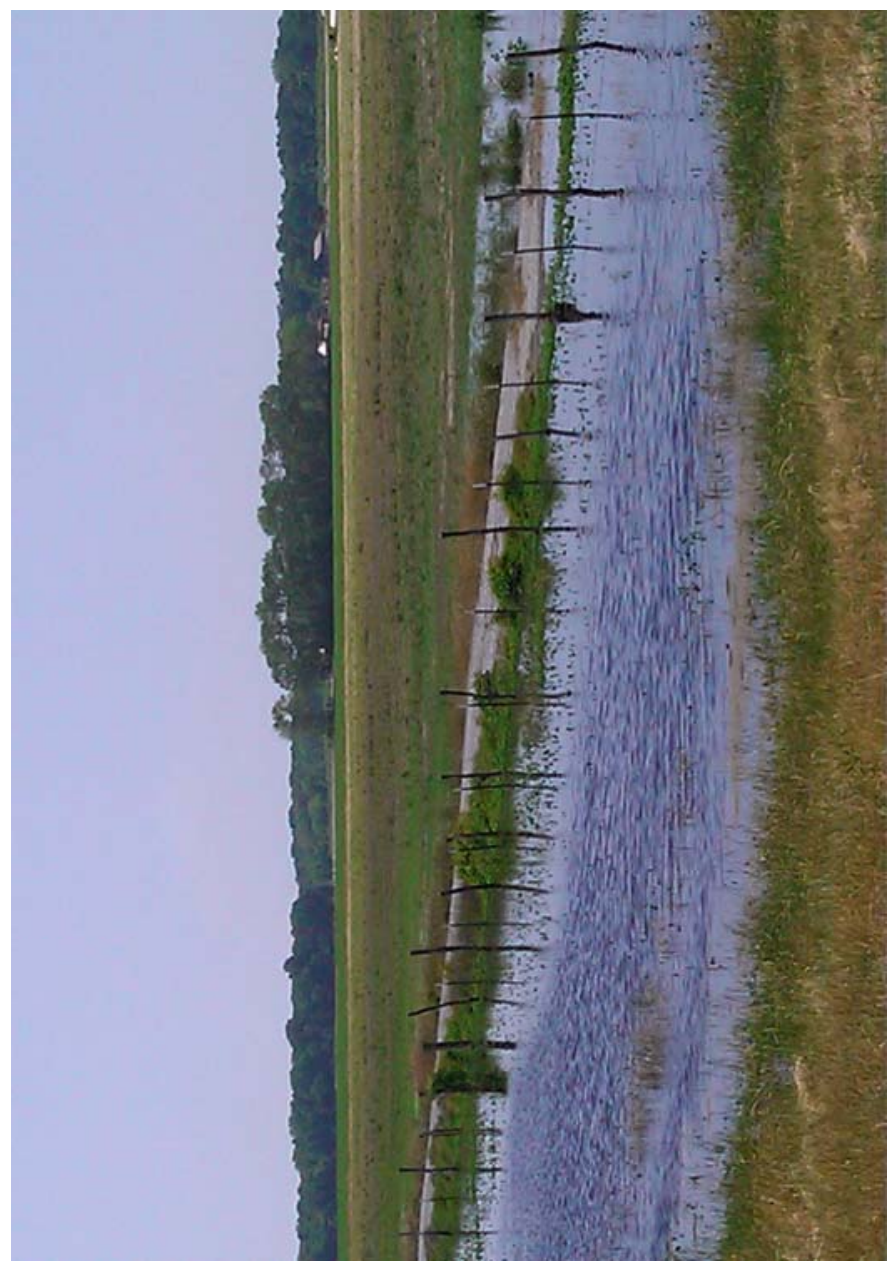

50

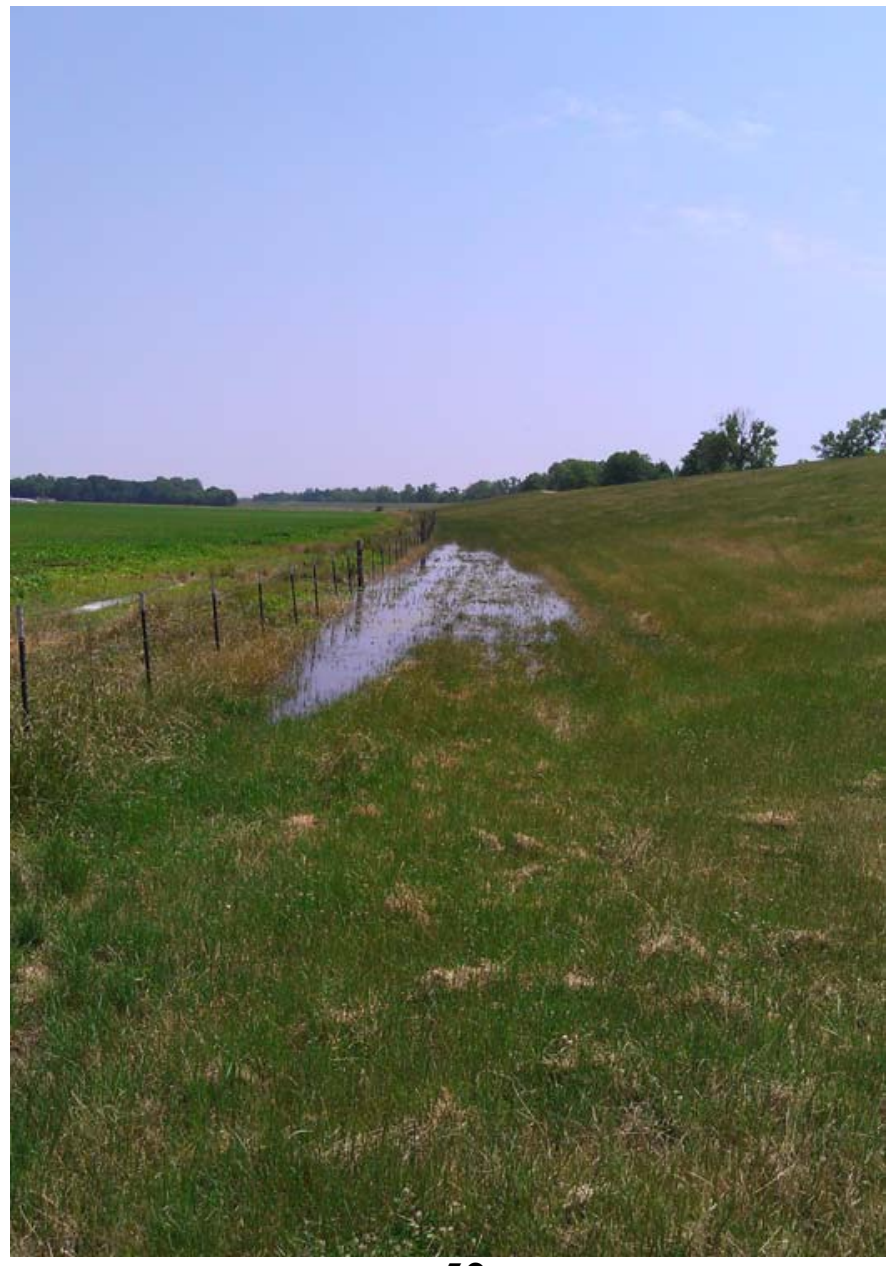




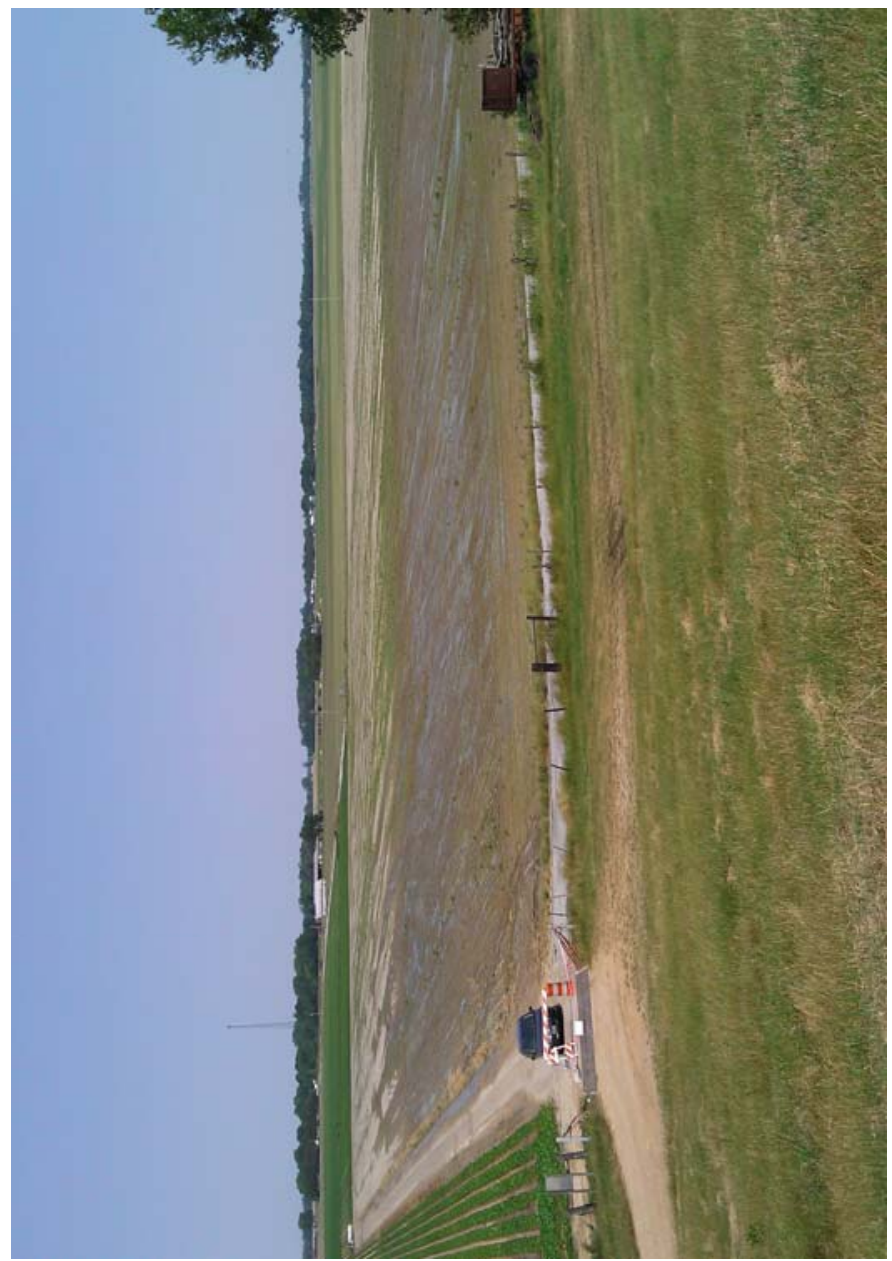

53

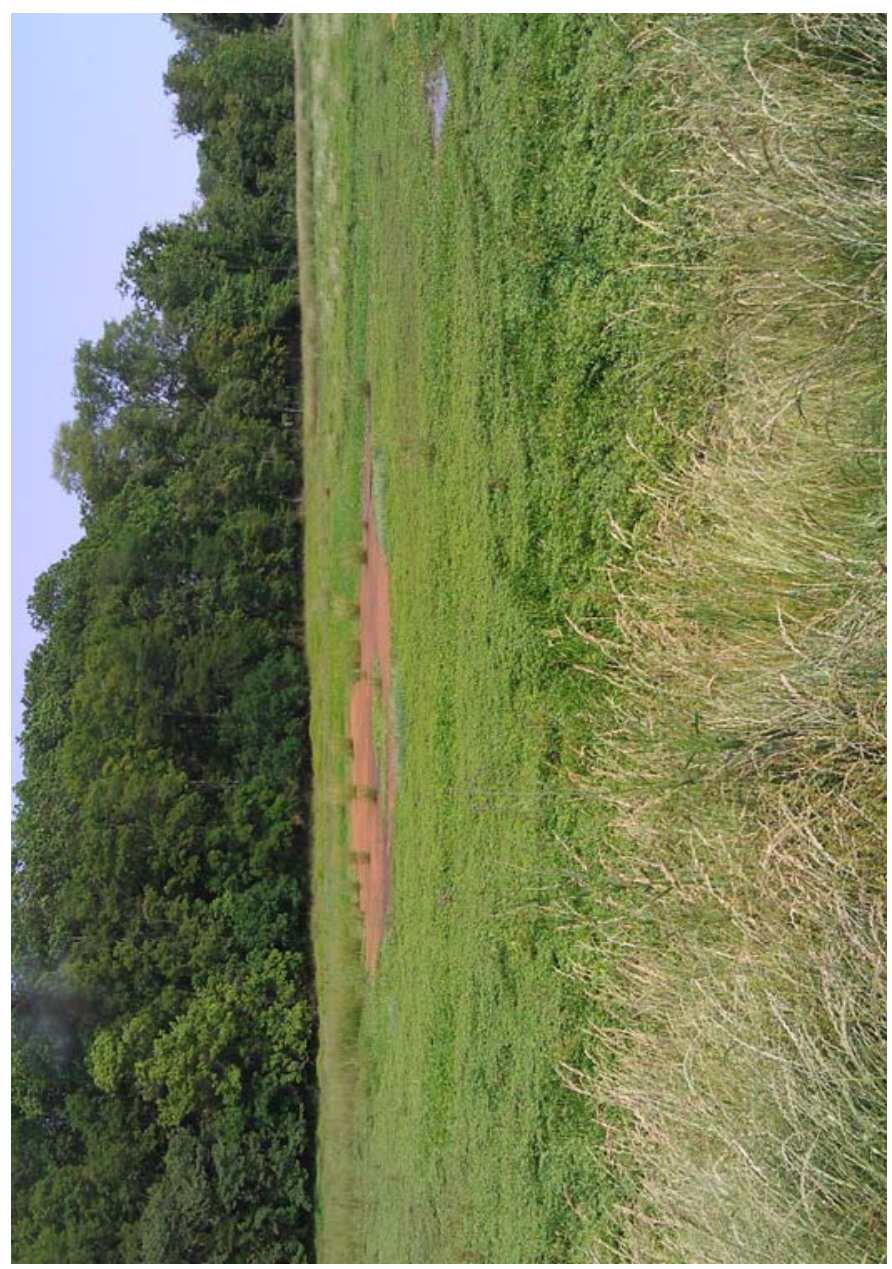

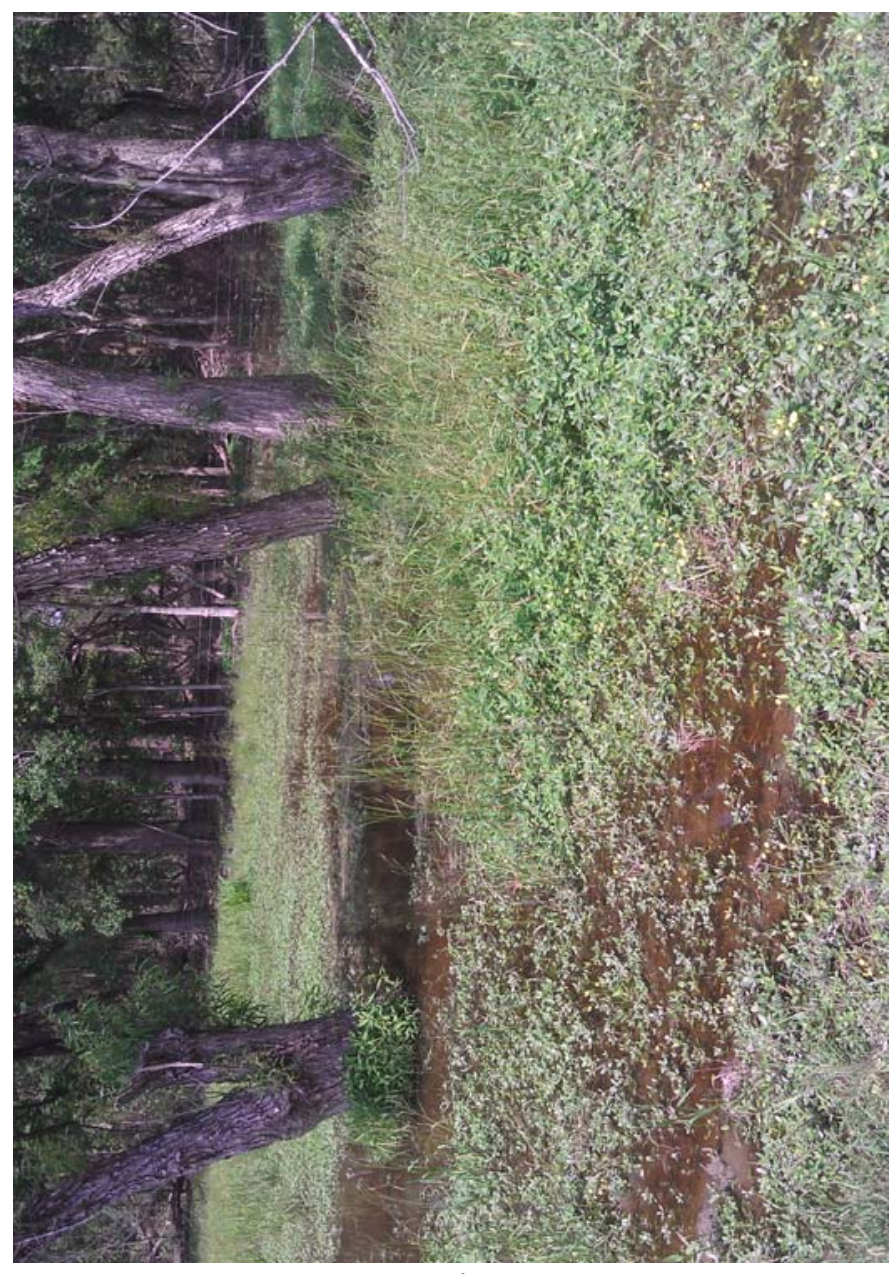

54

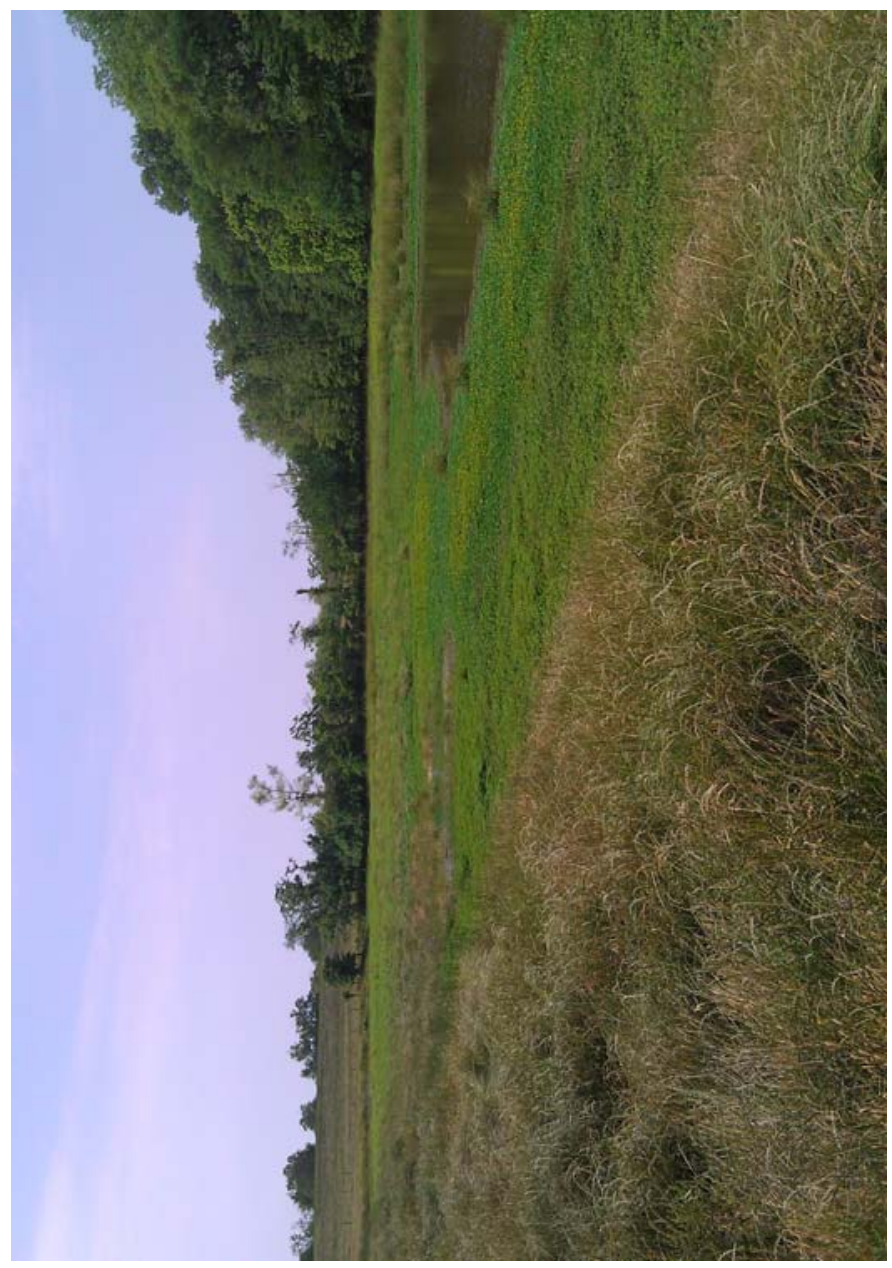




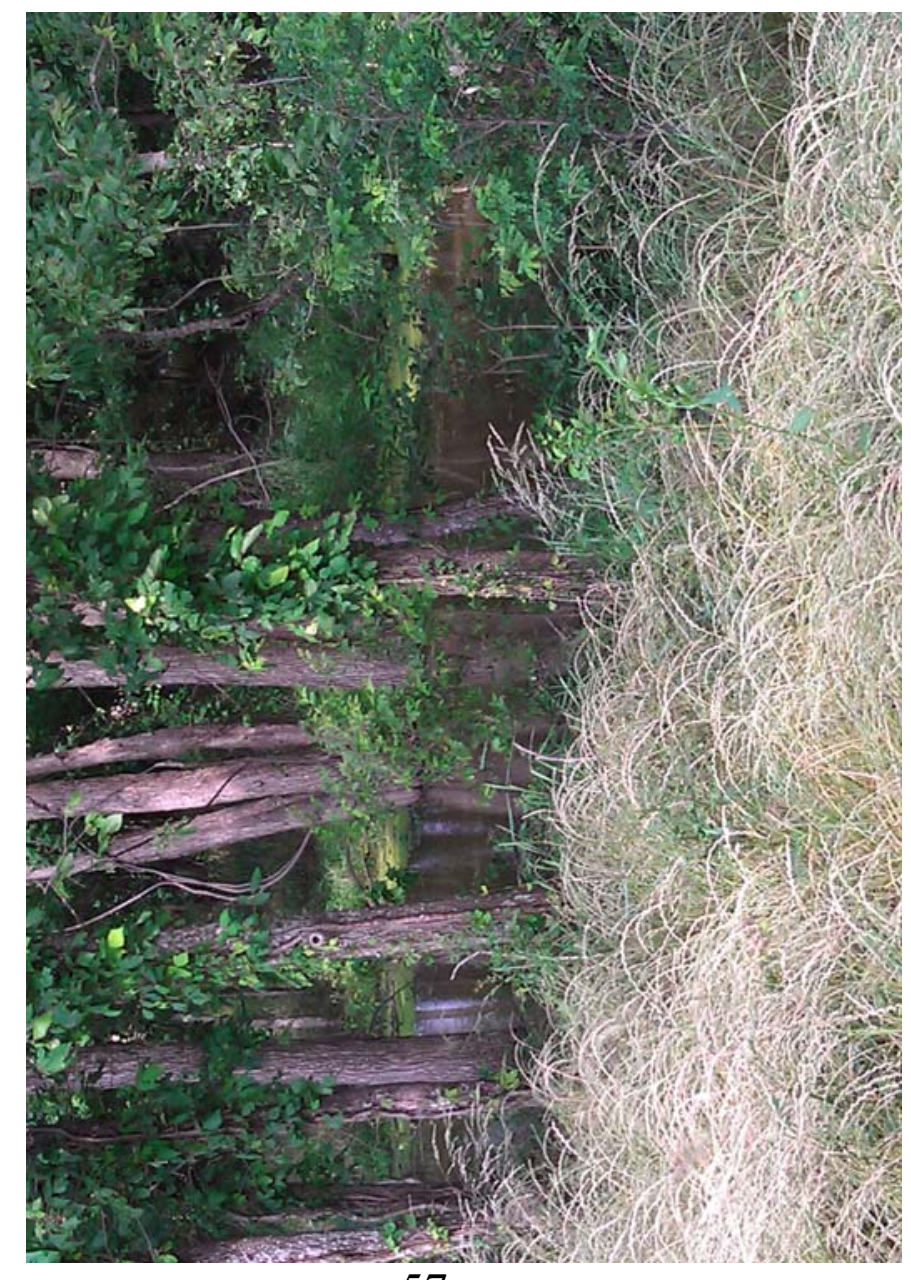
57

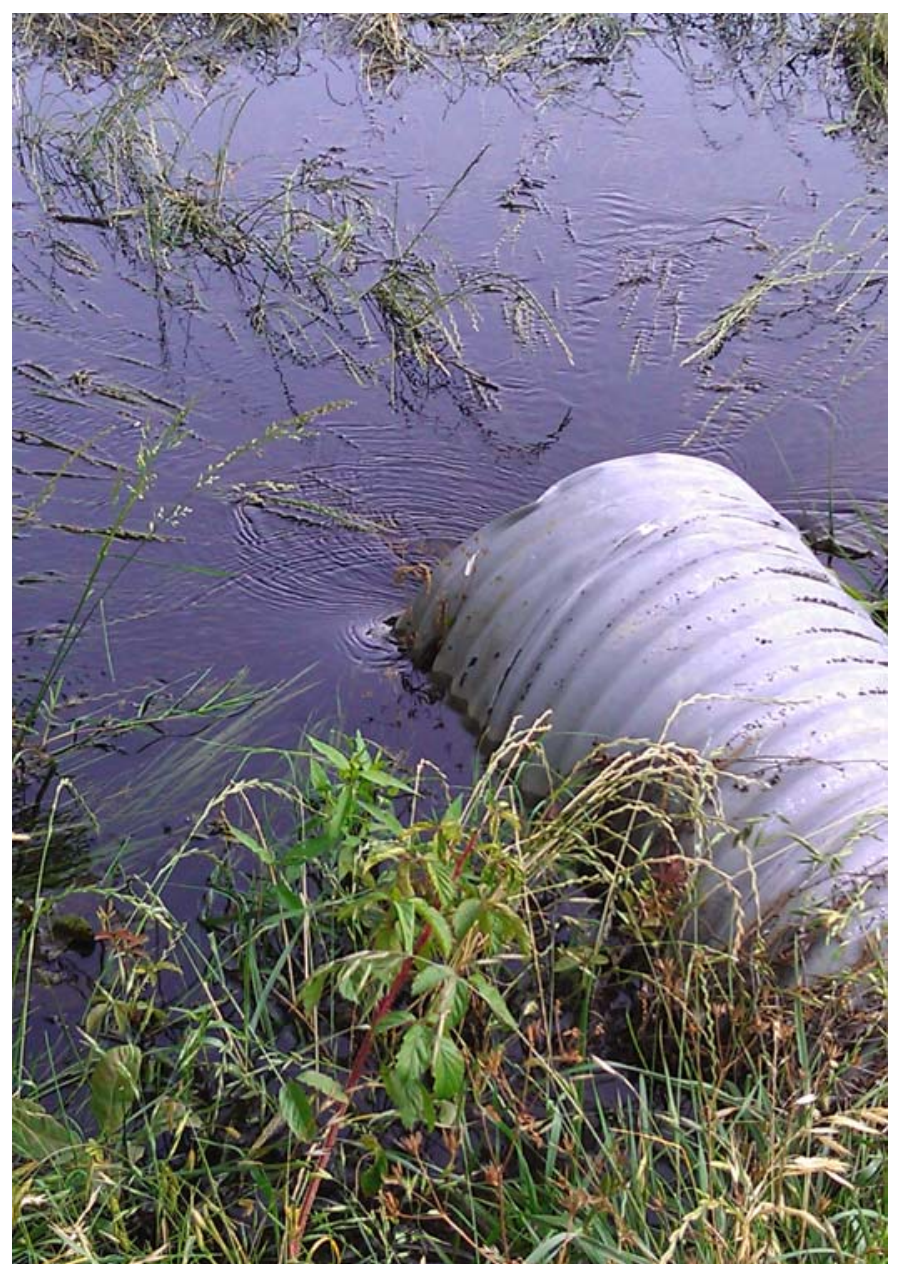

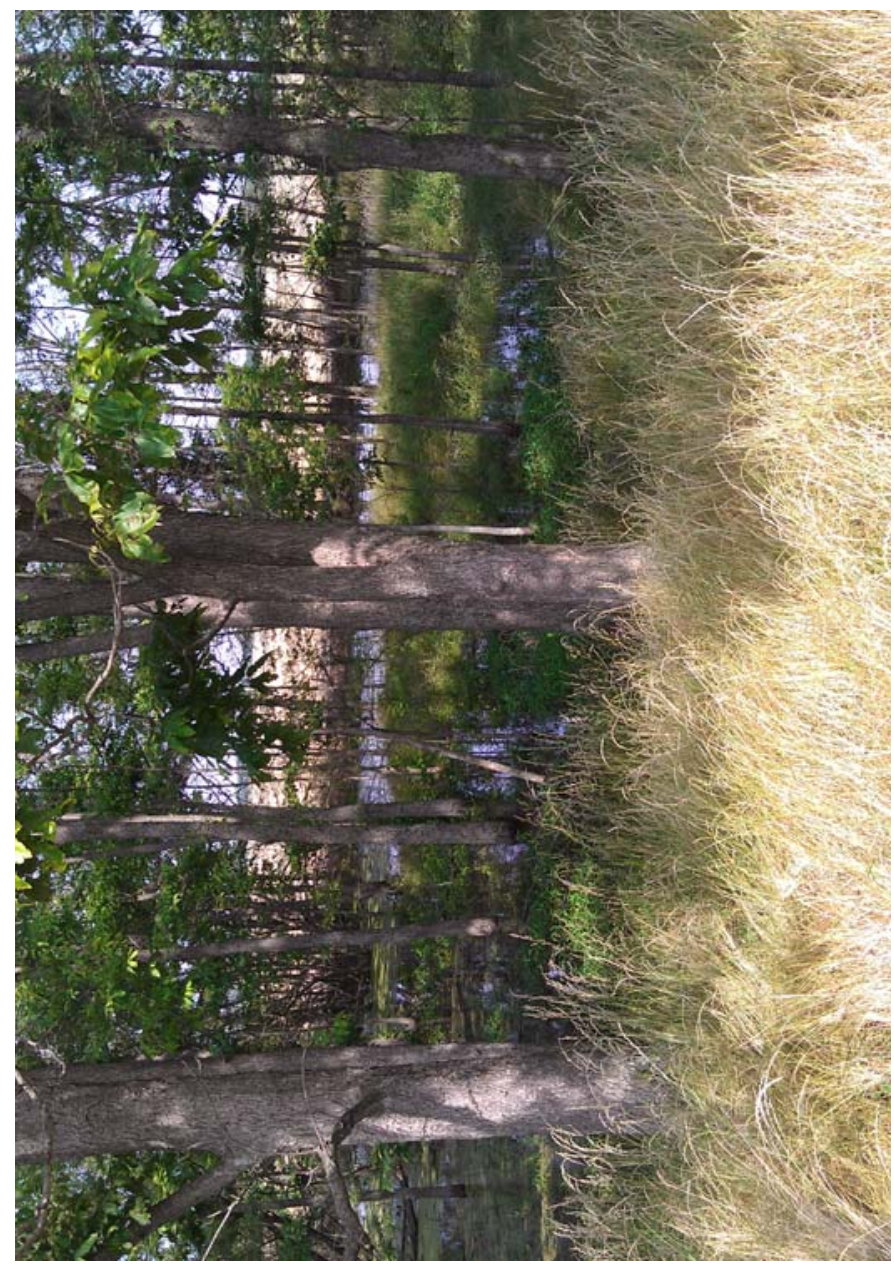

58

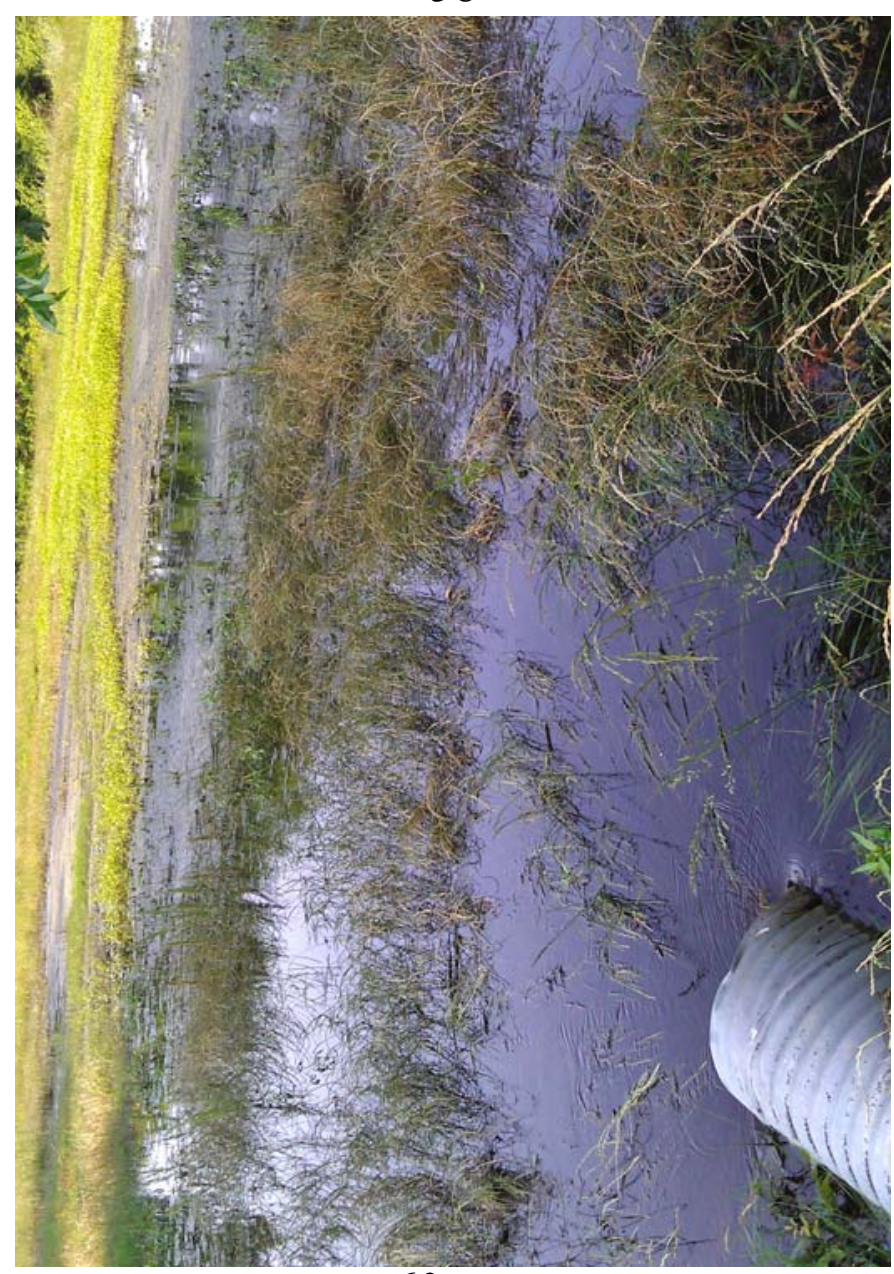

60 


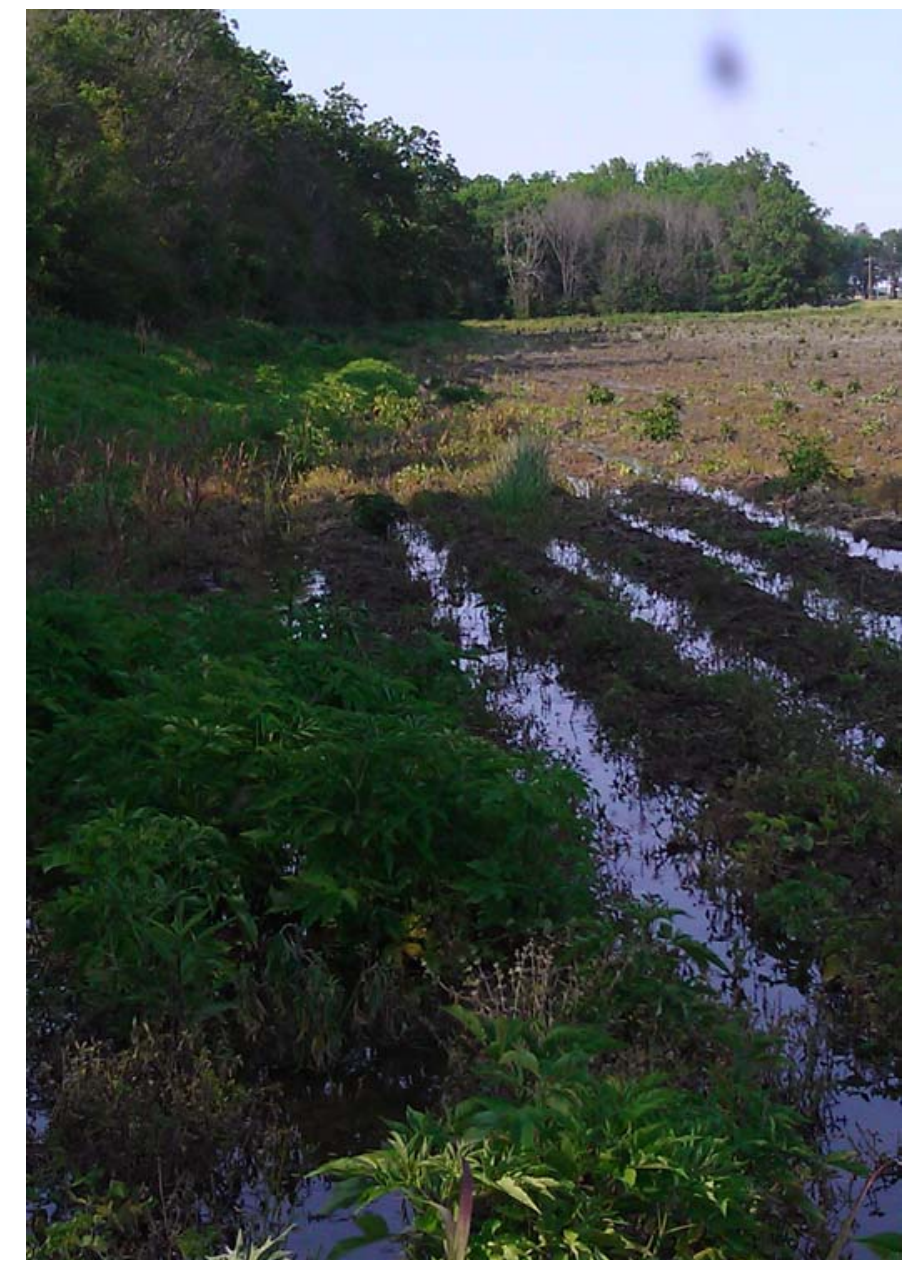

61

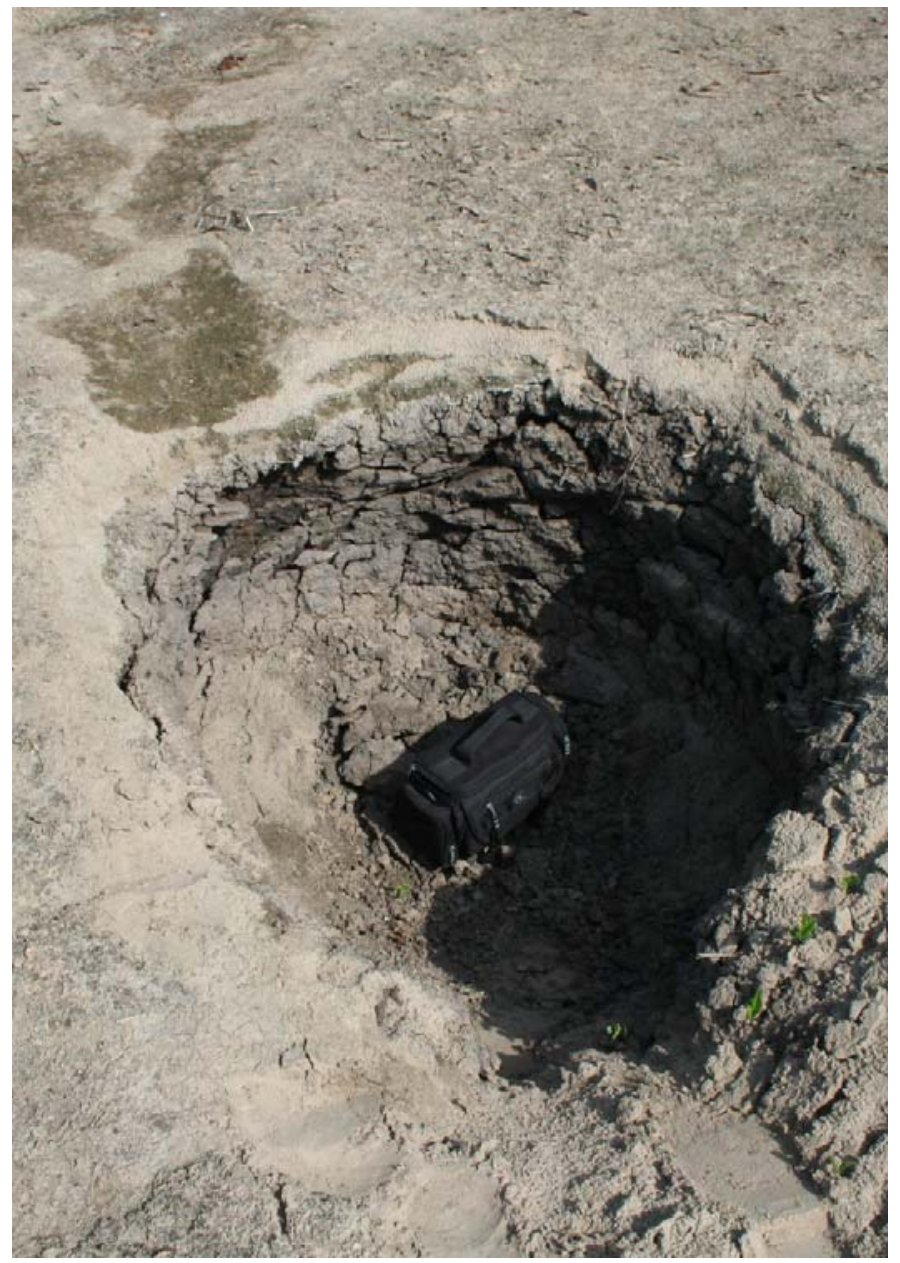

63

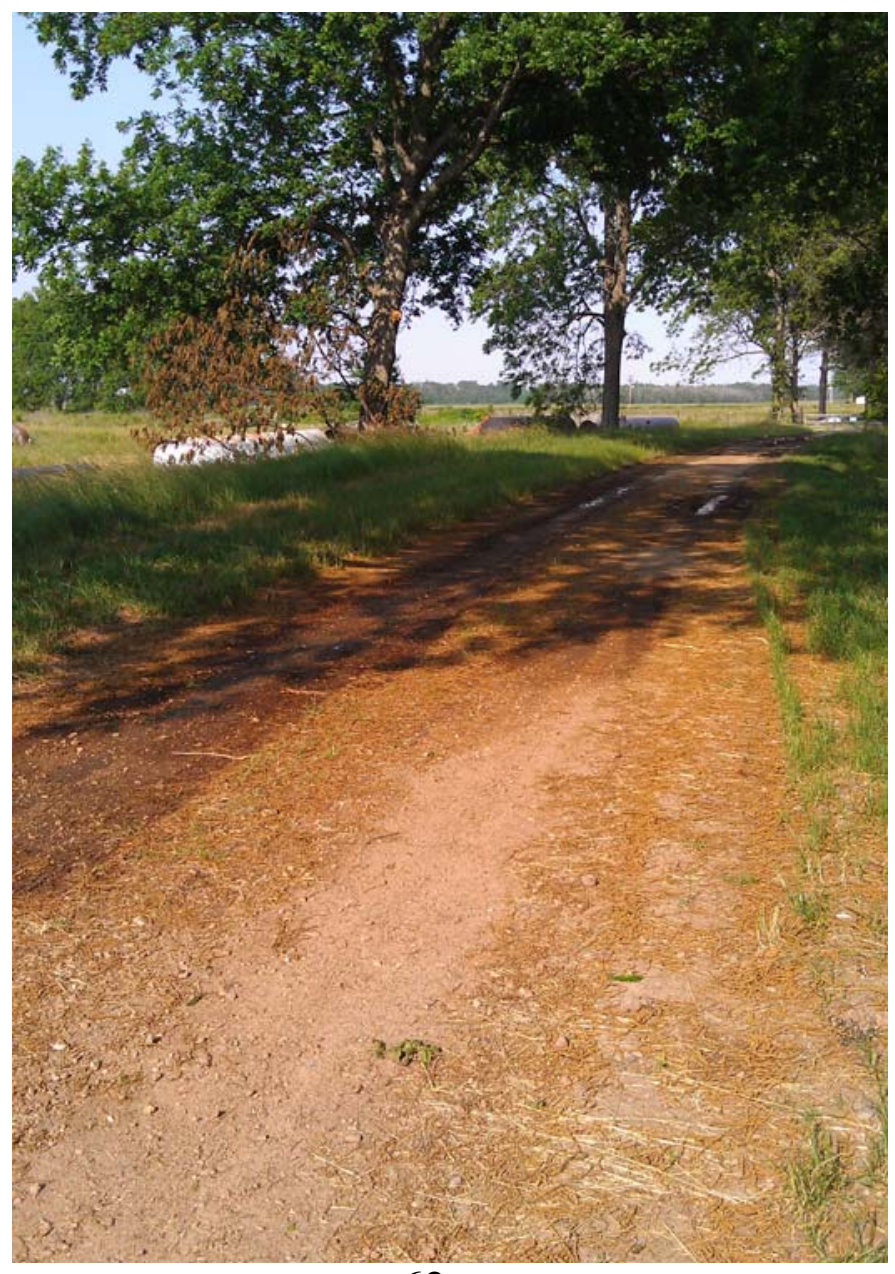

62

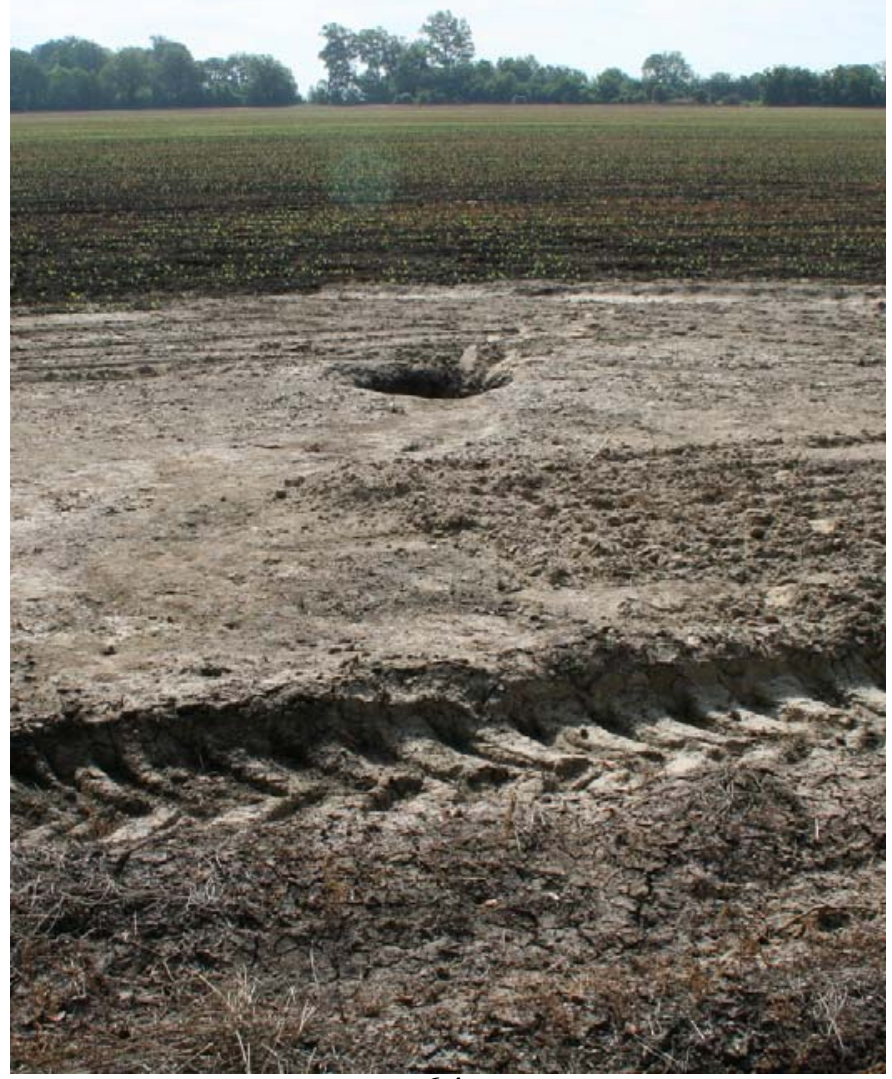

64 


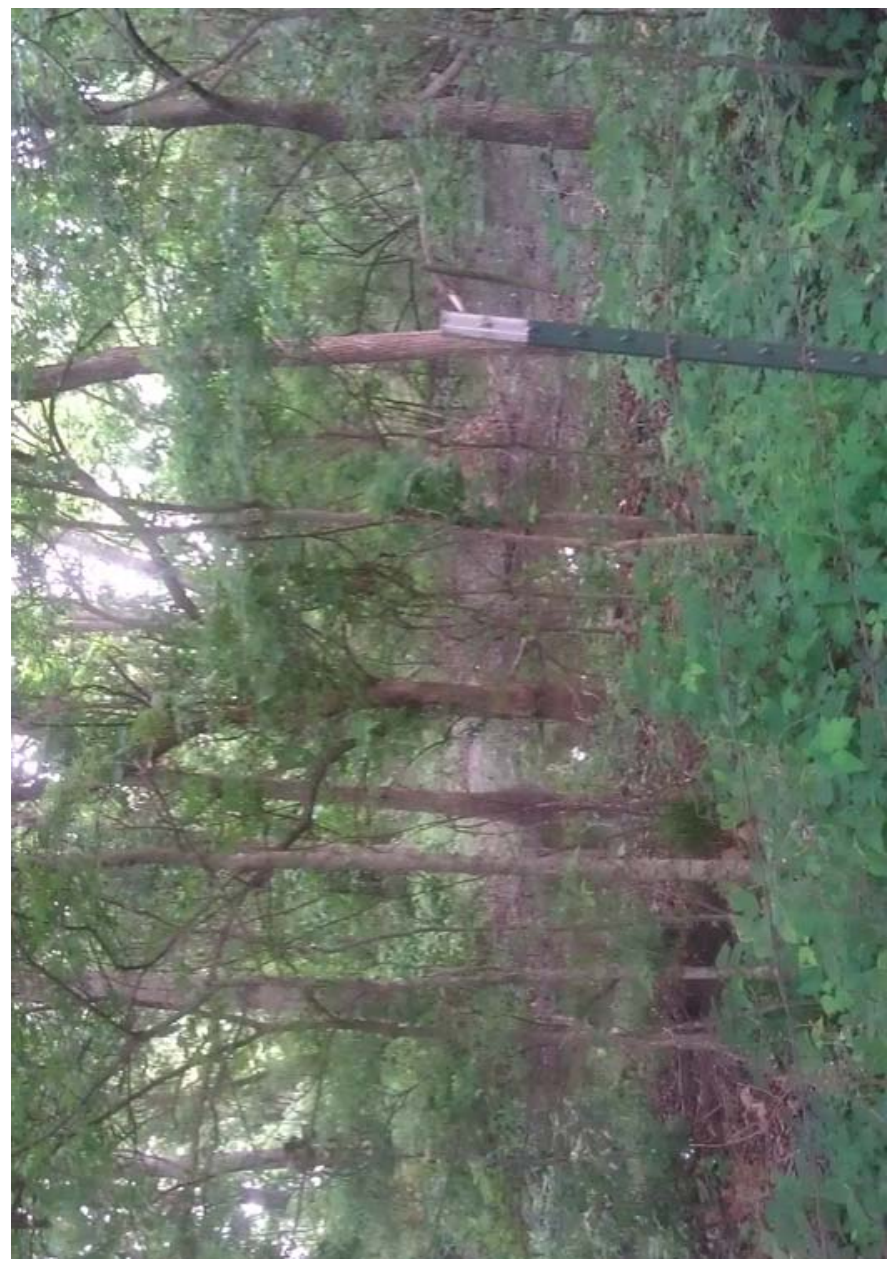

65

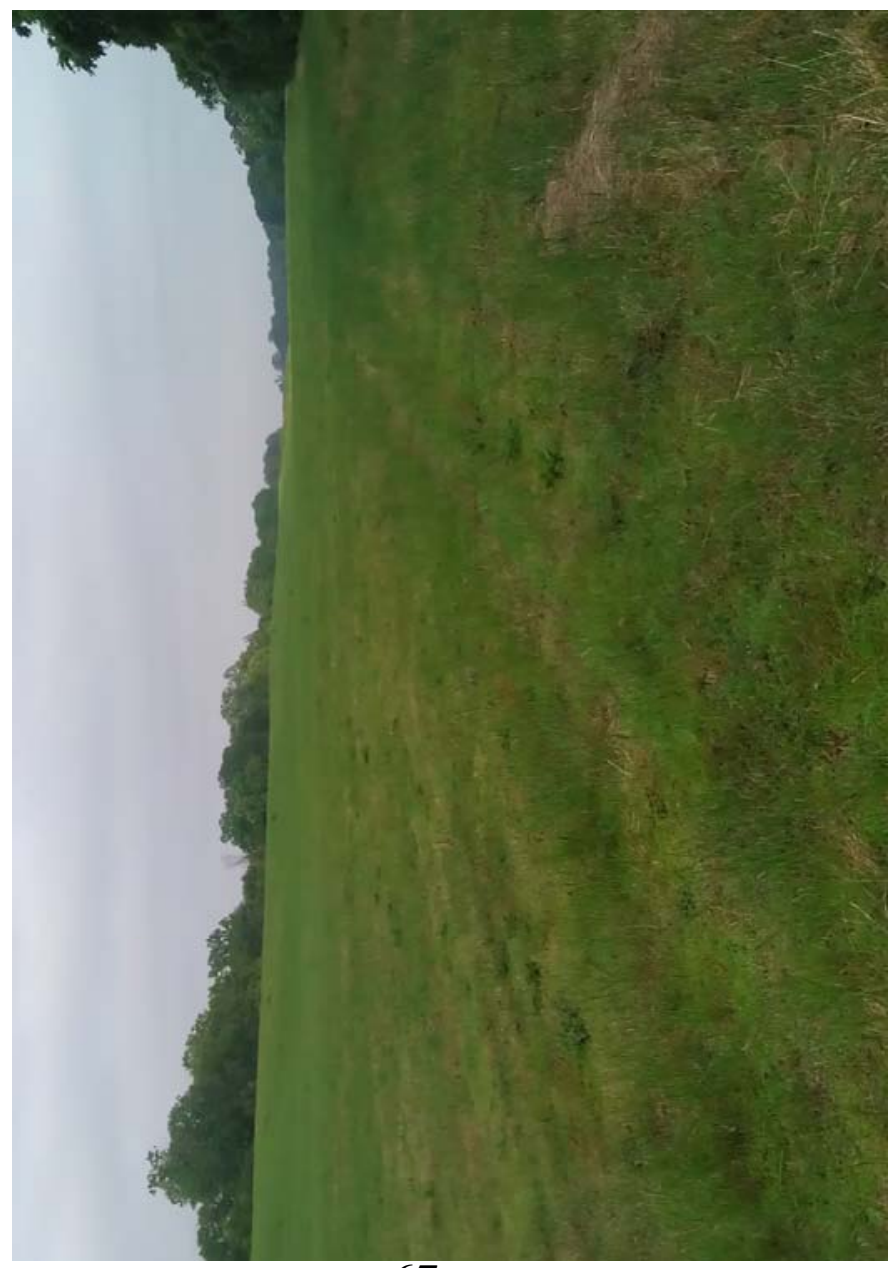

66

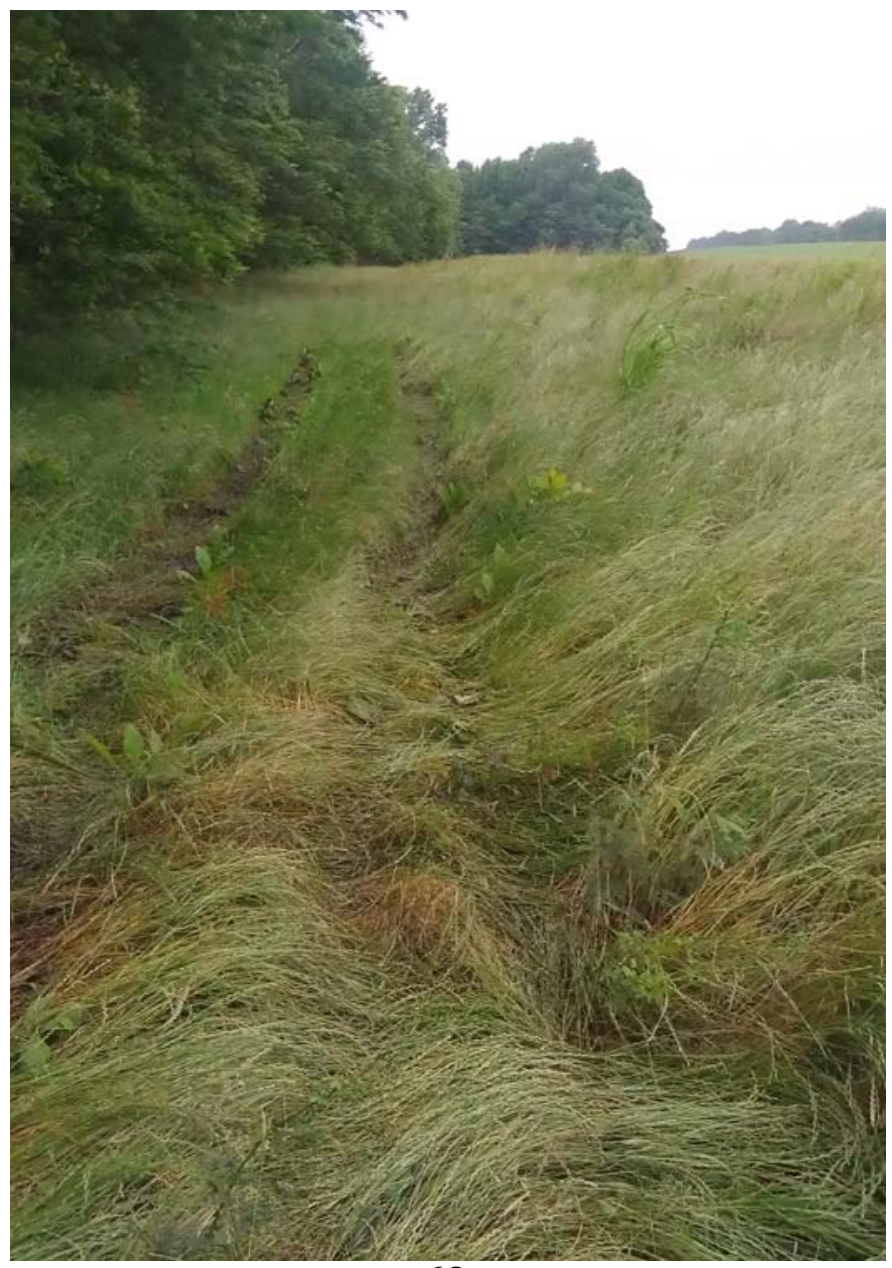




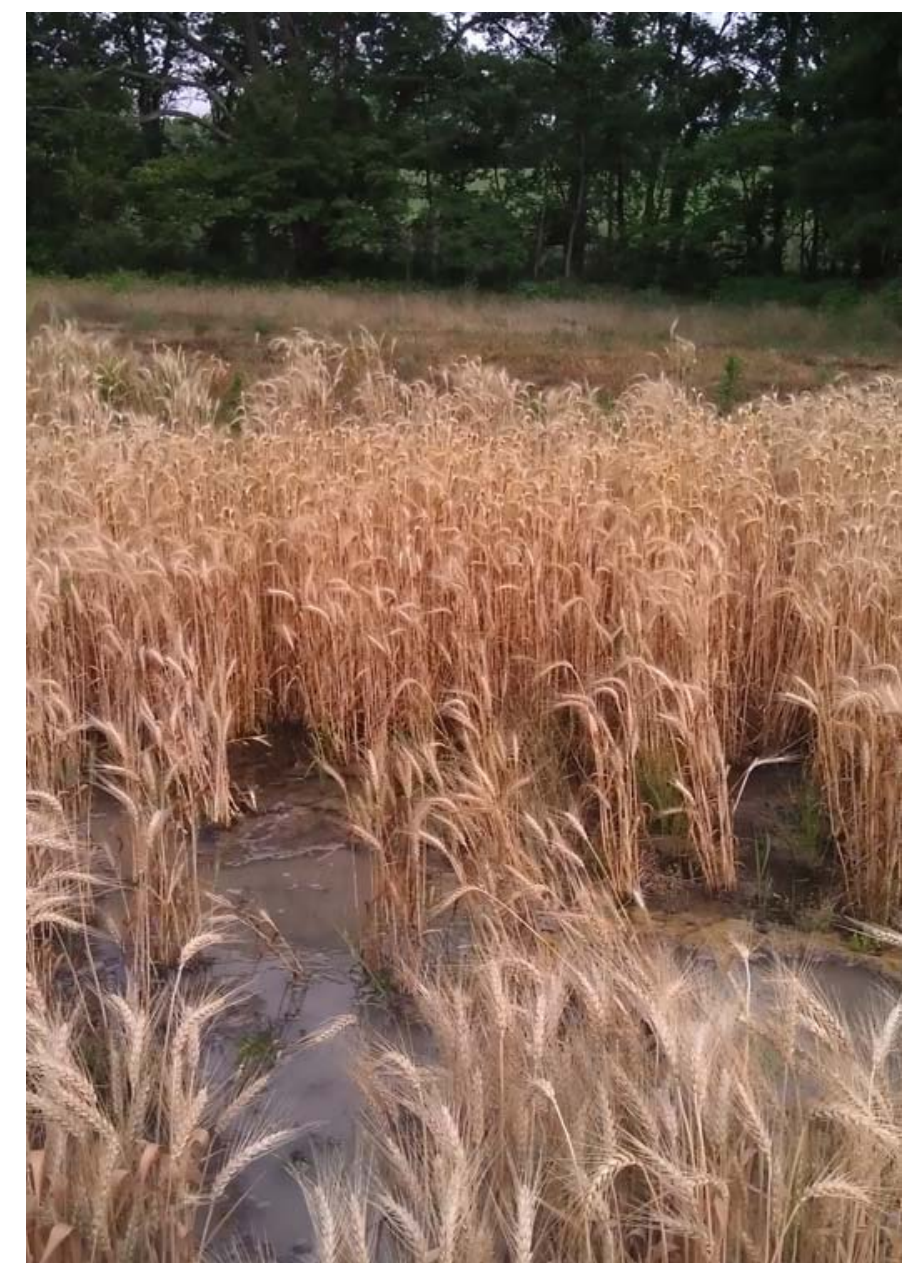

69

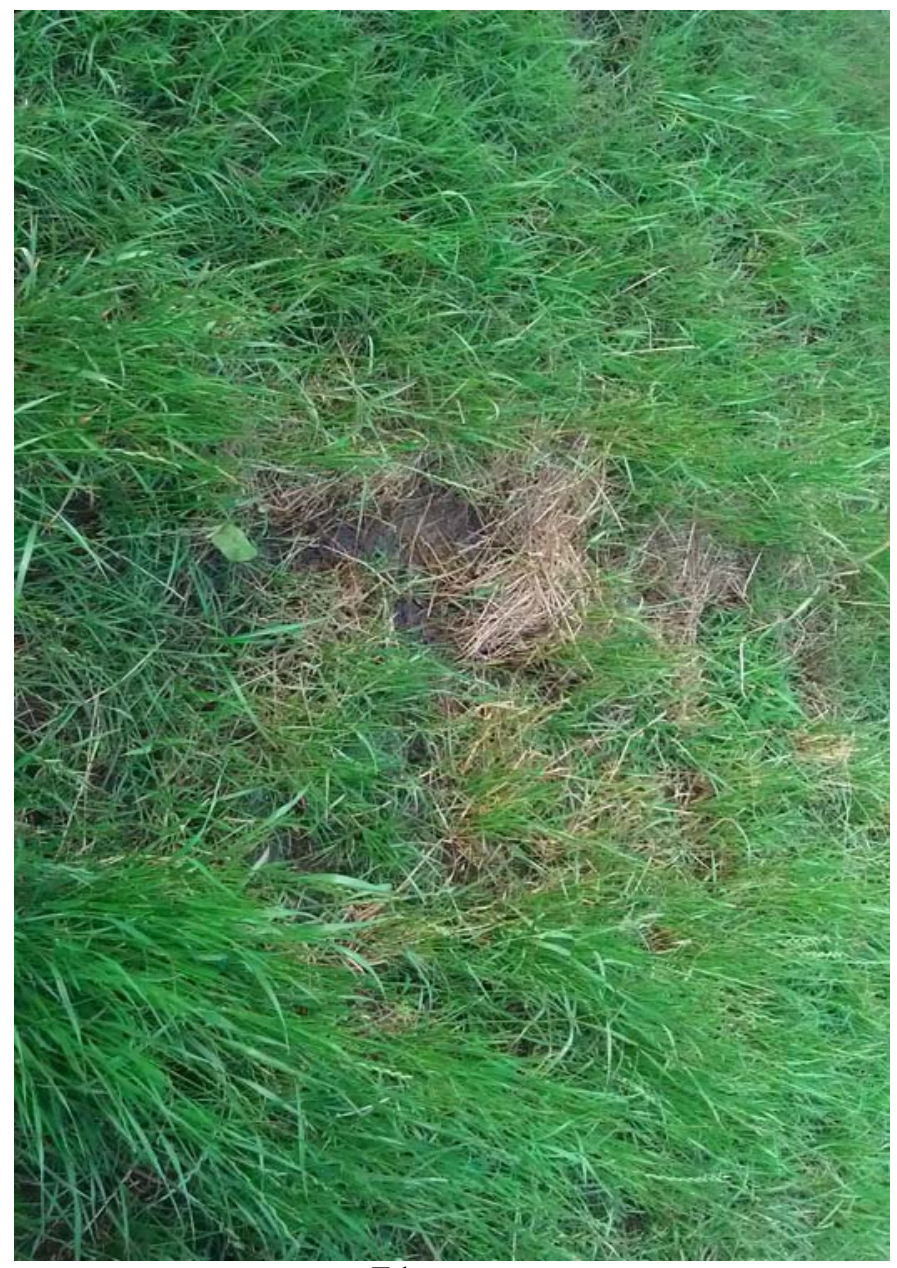

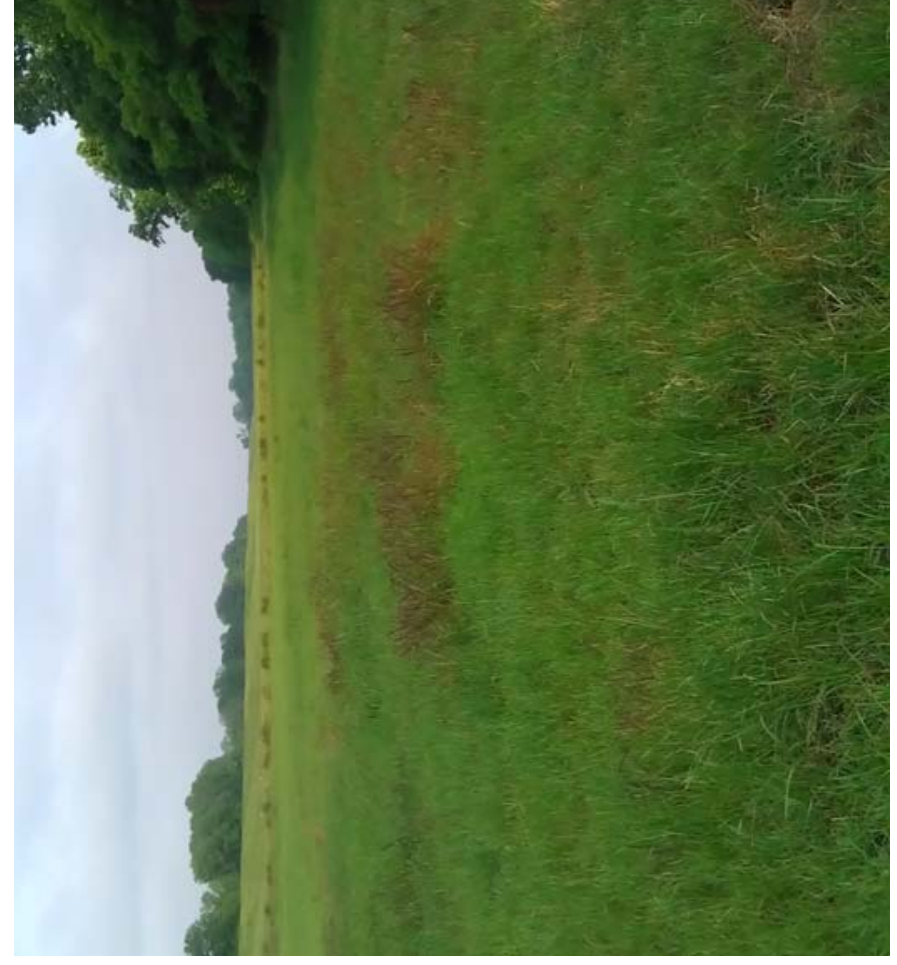

70

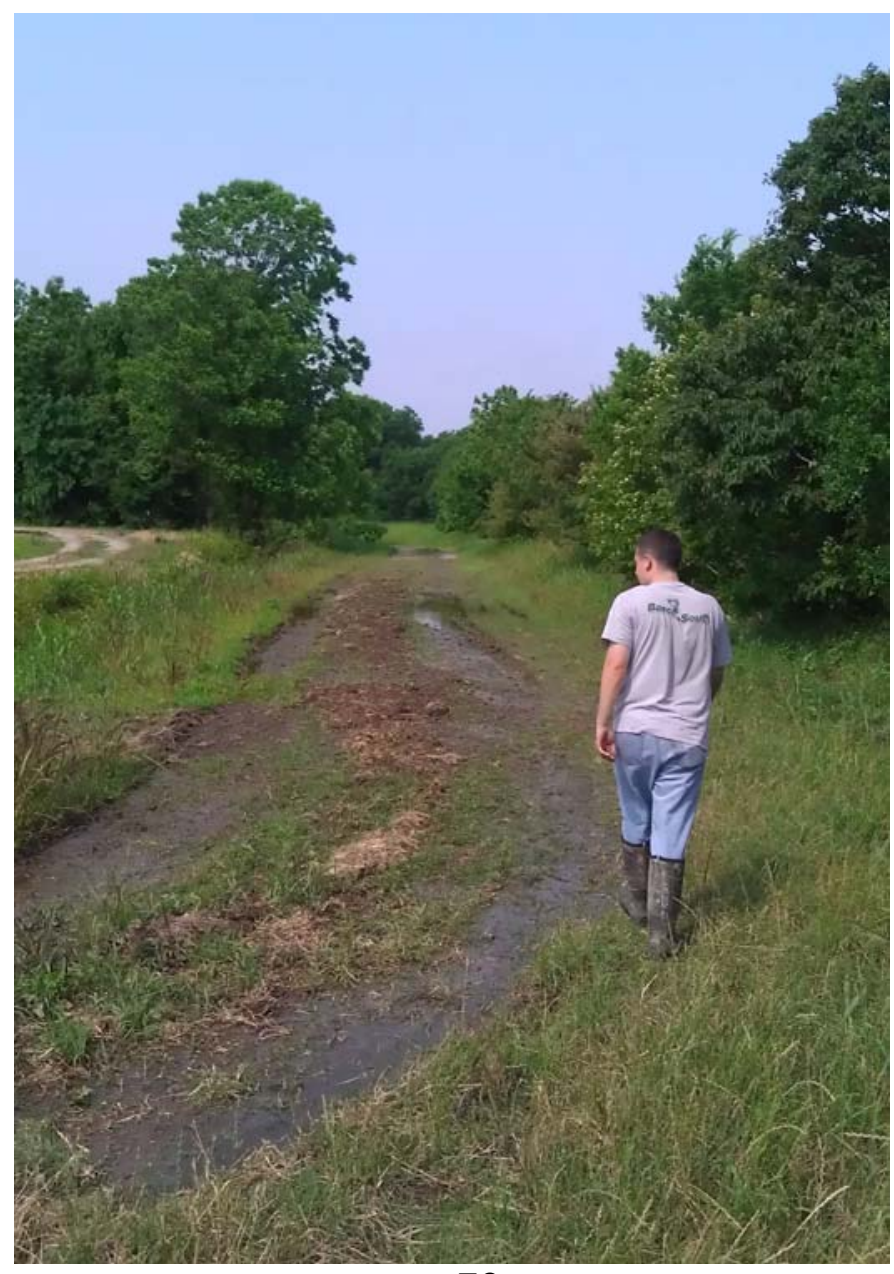

72 


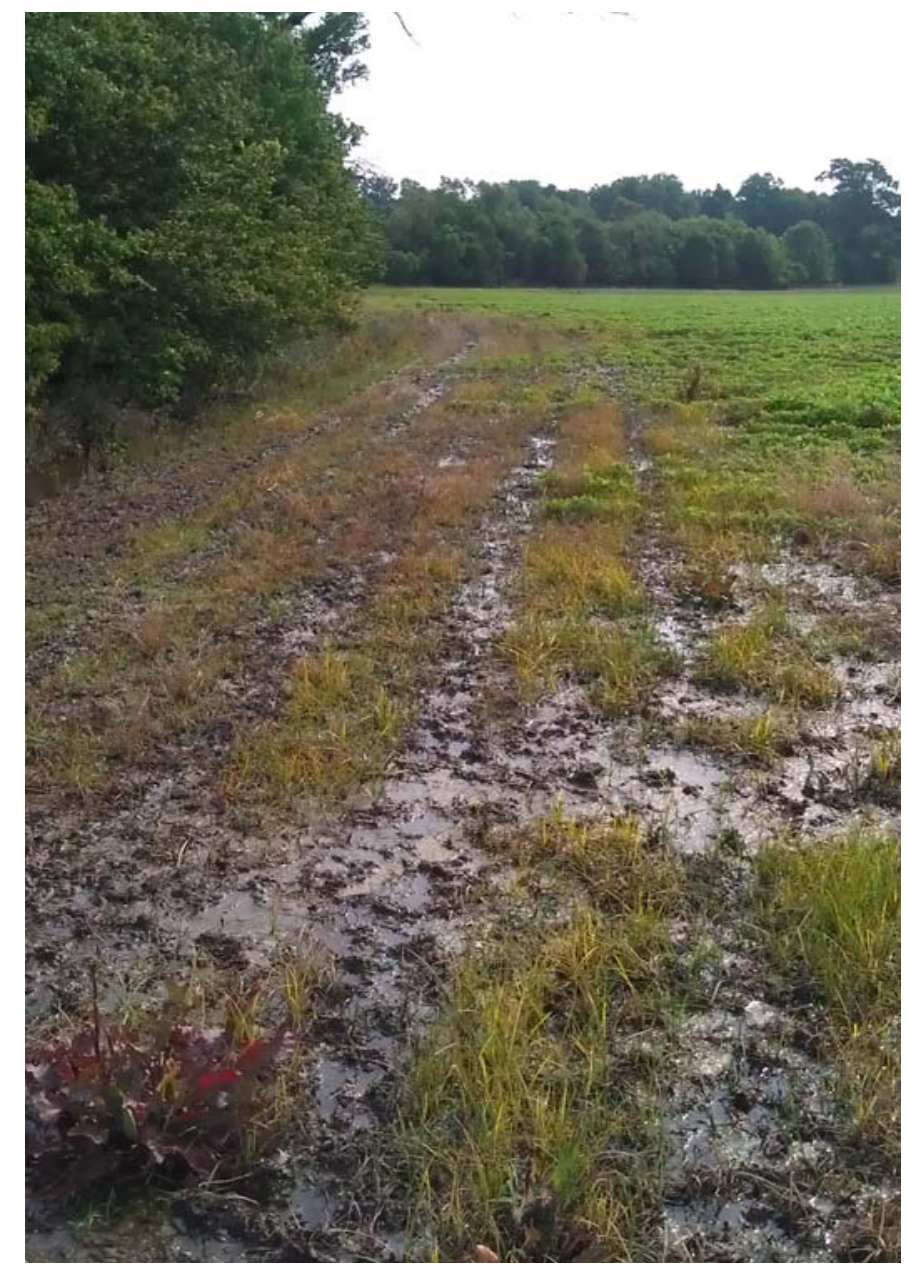

\section{3}
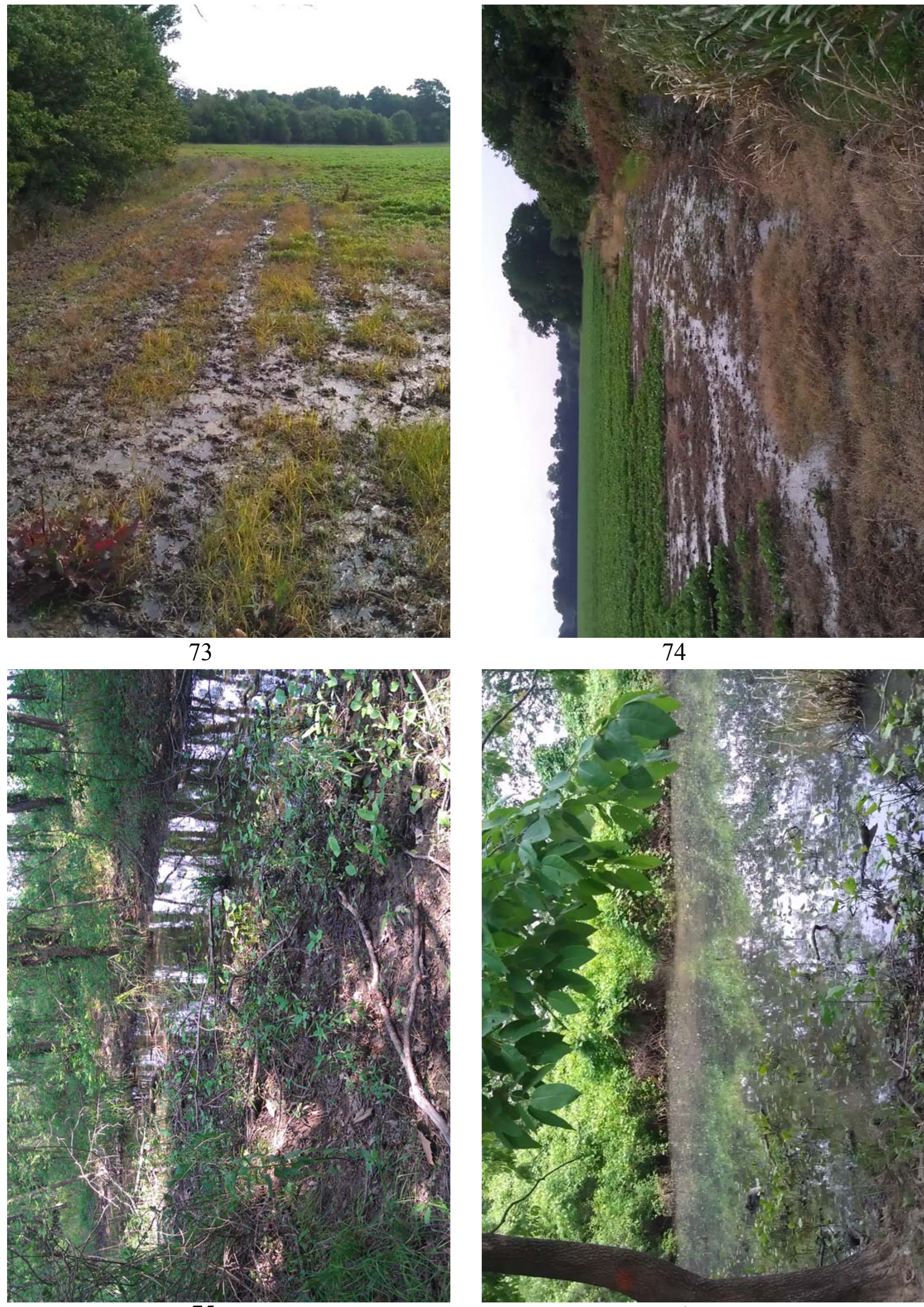

74

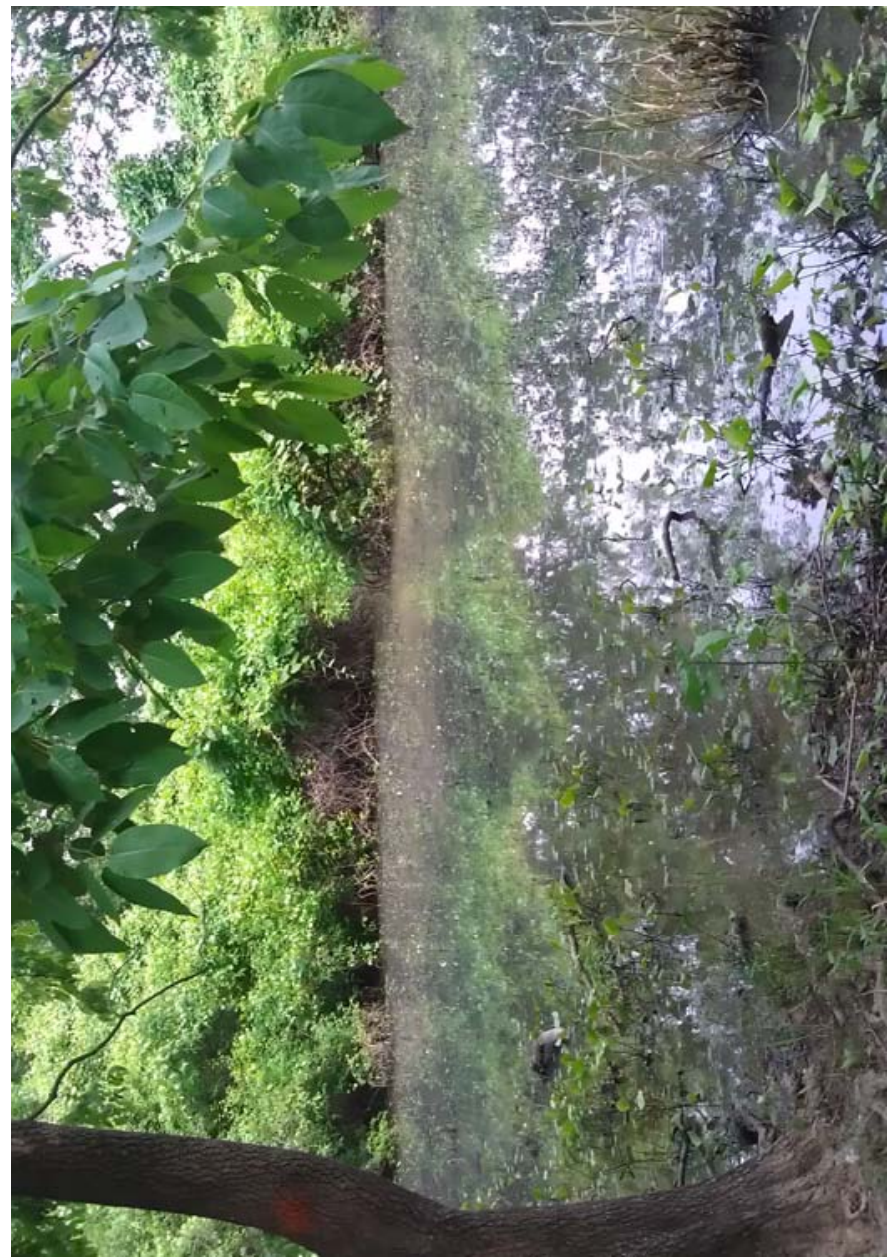




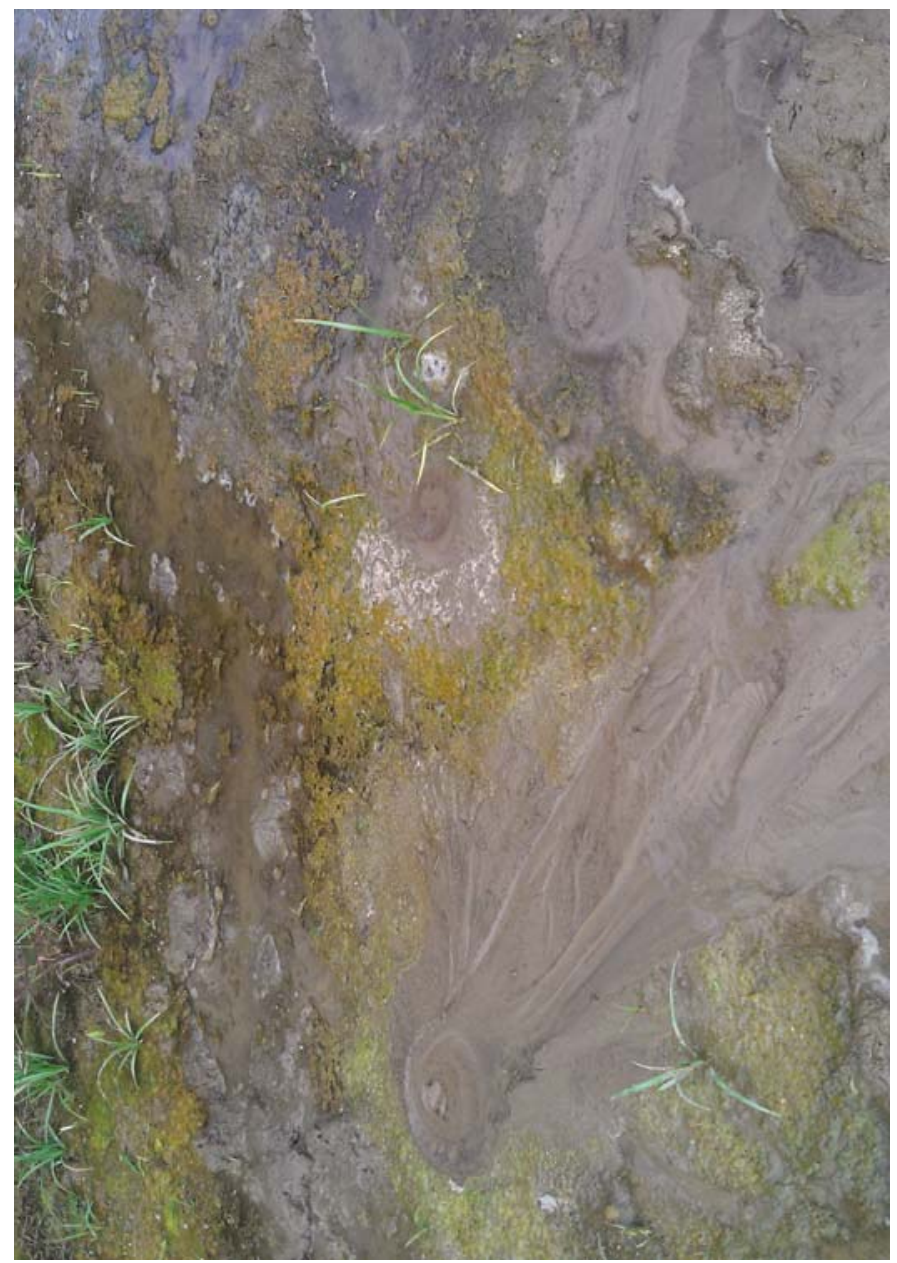

77

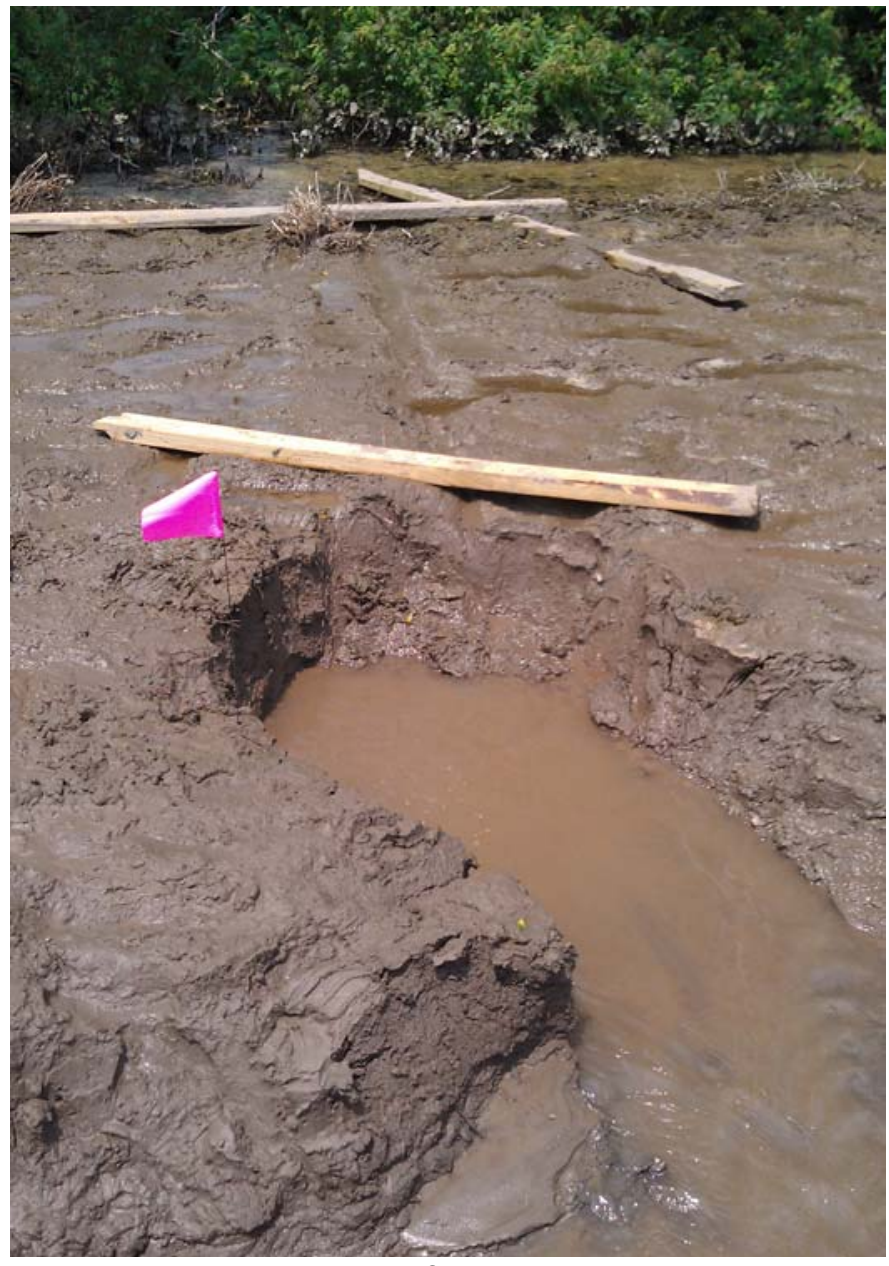

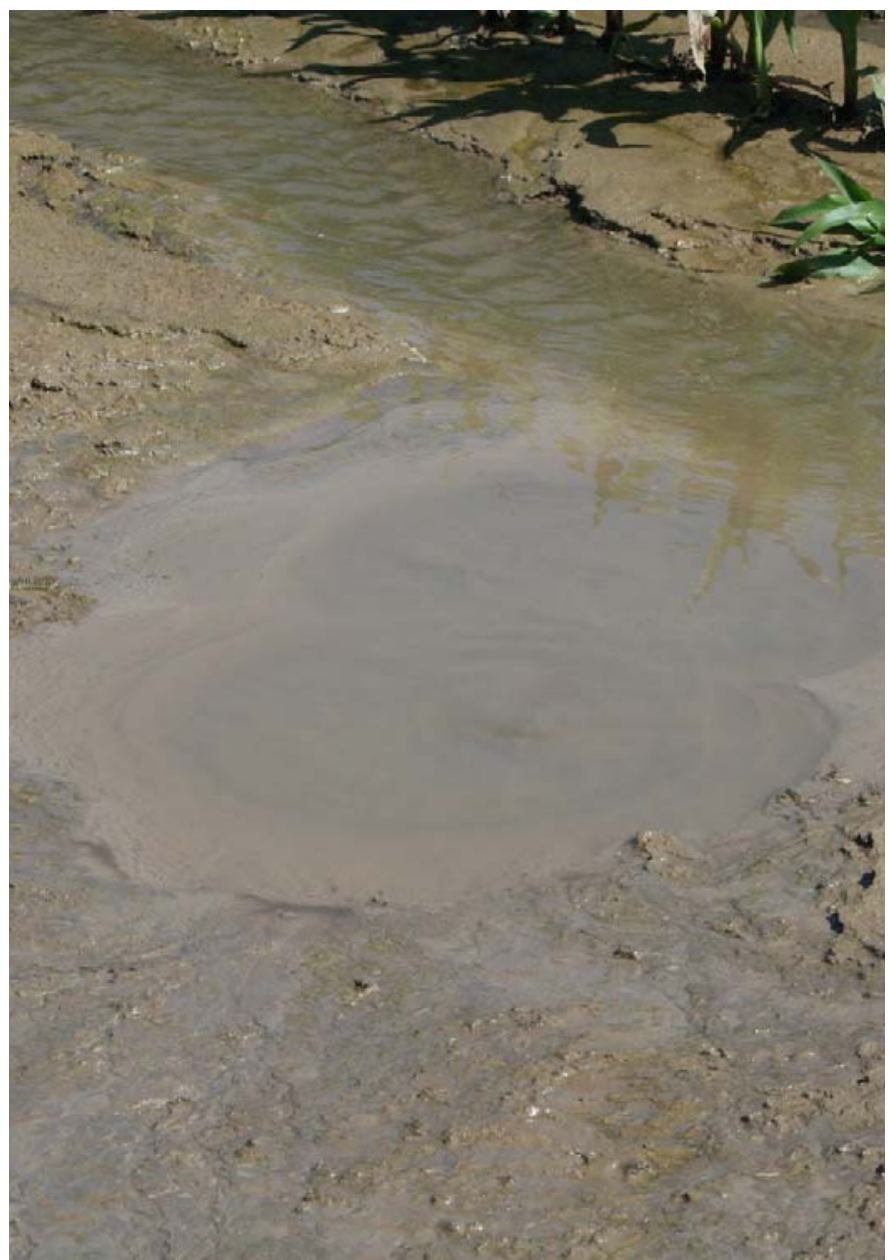

78

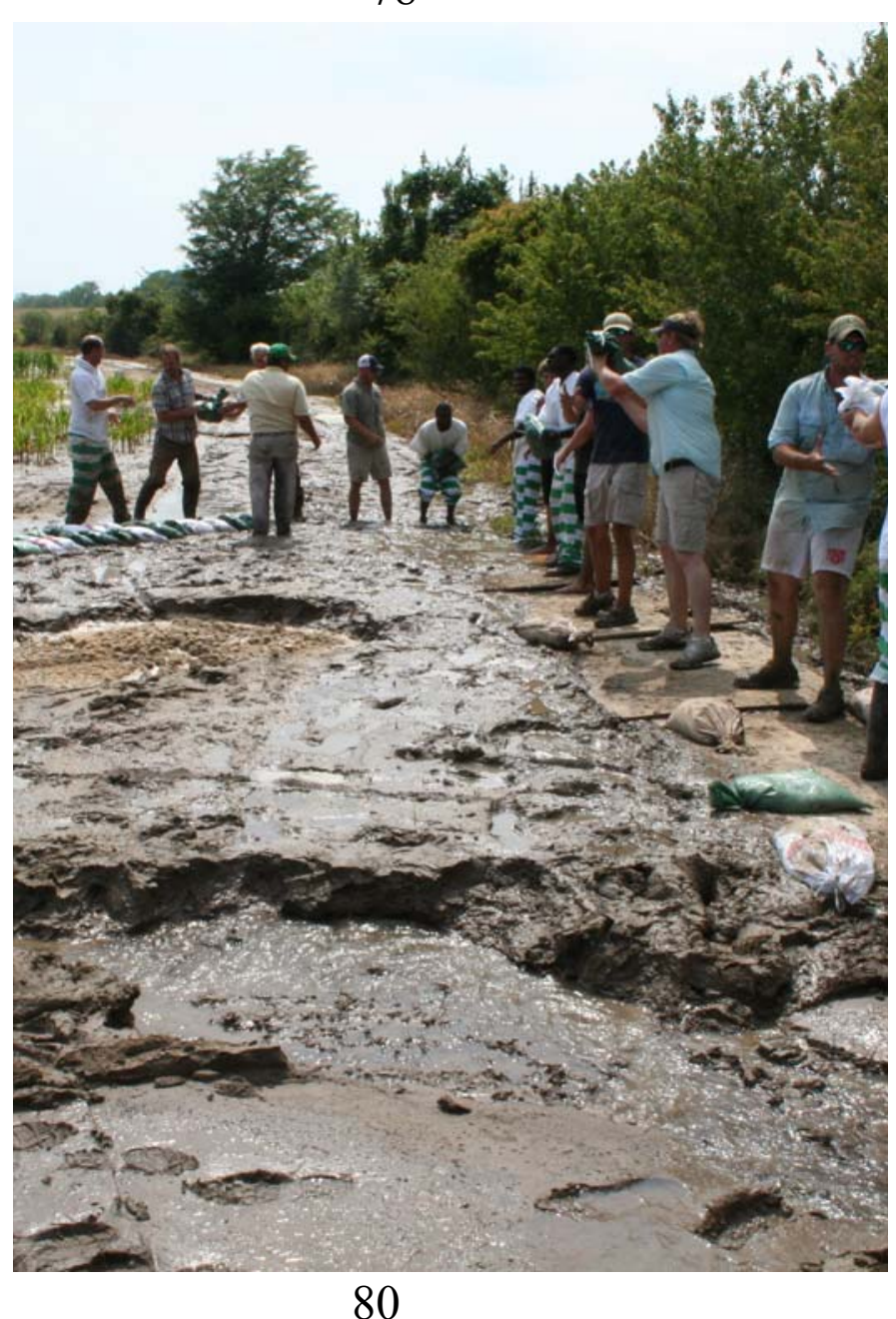




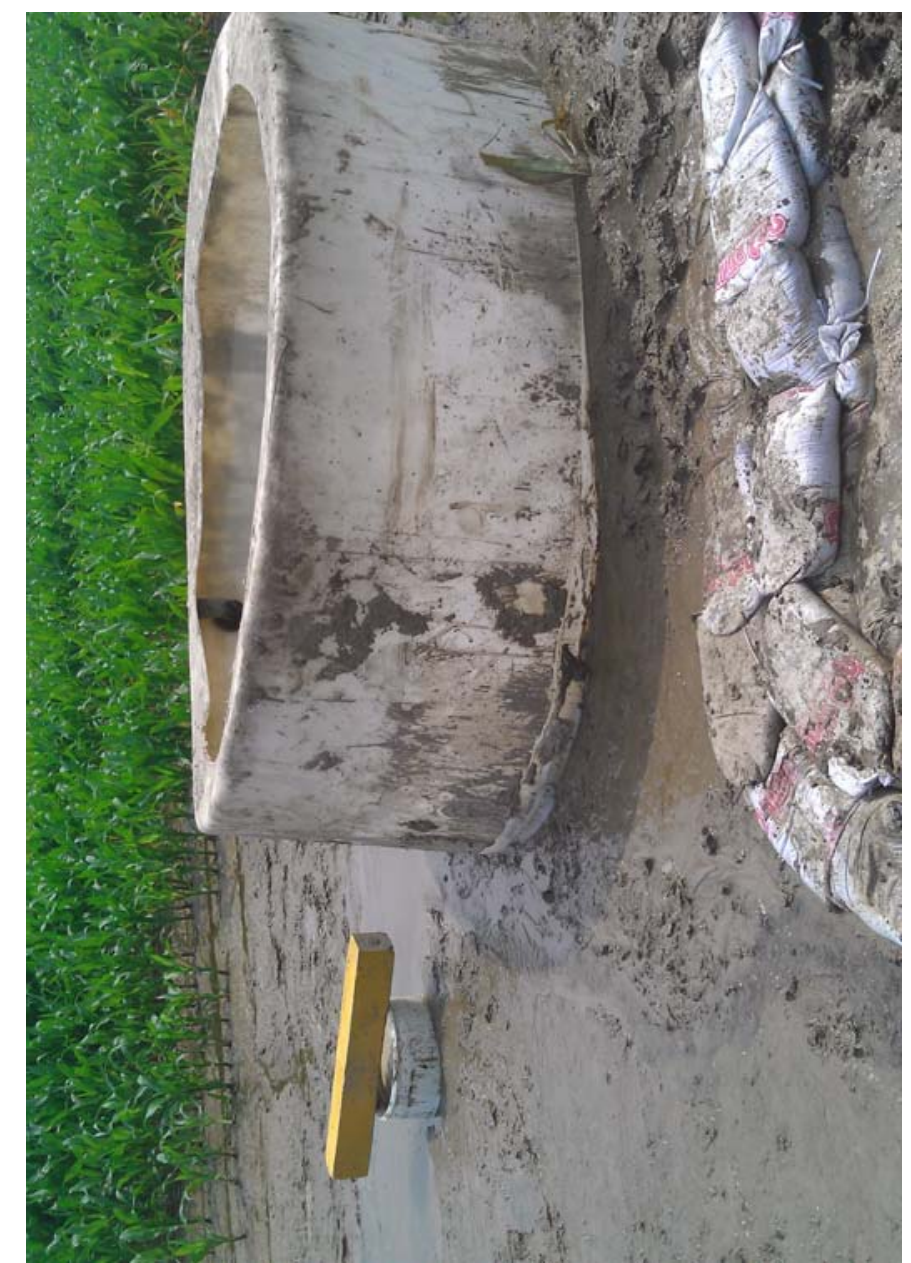

81

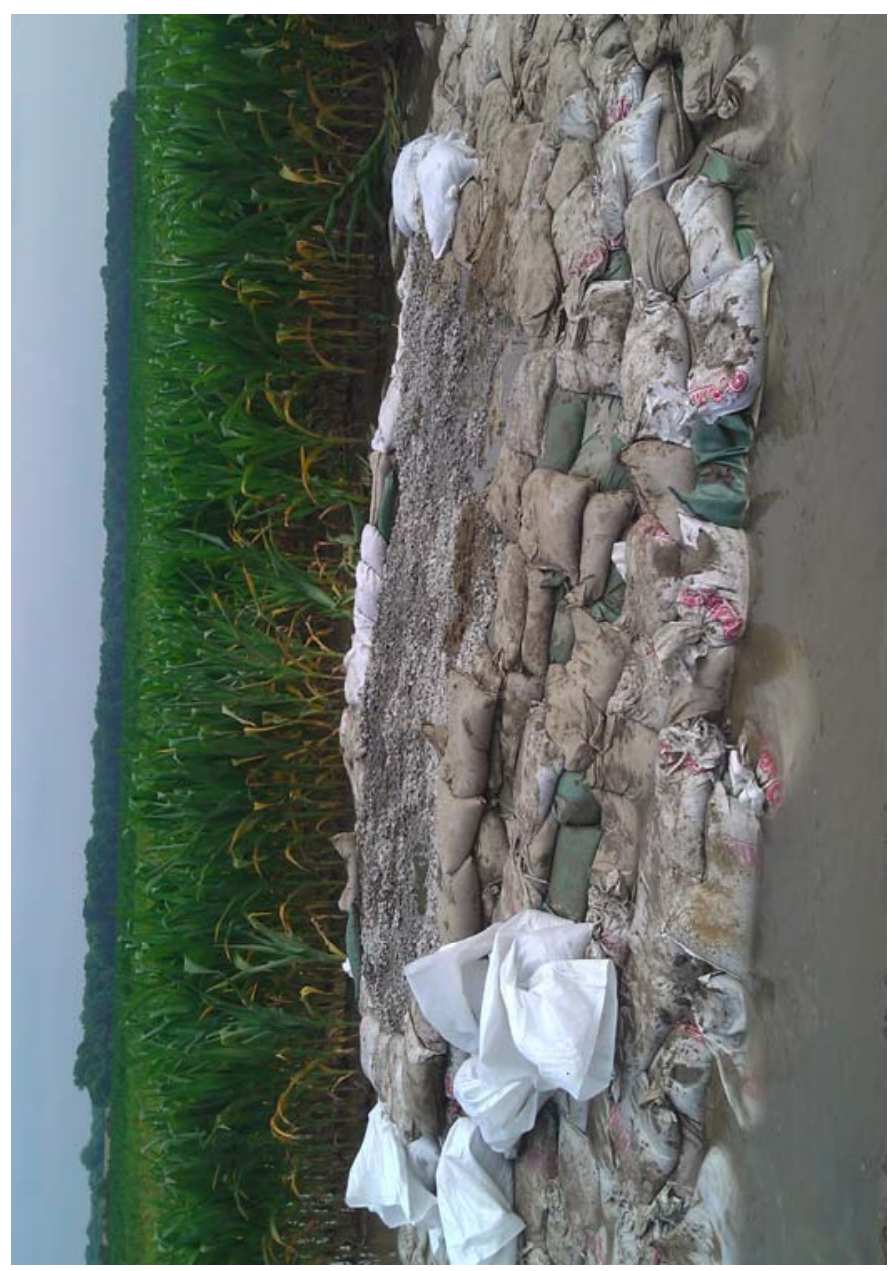

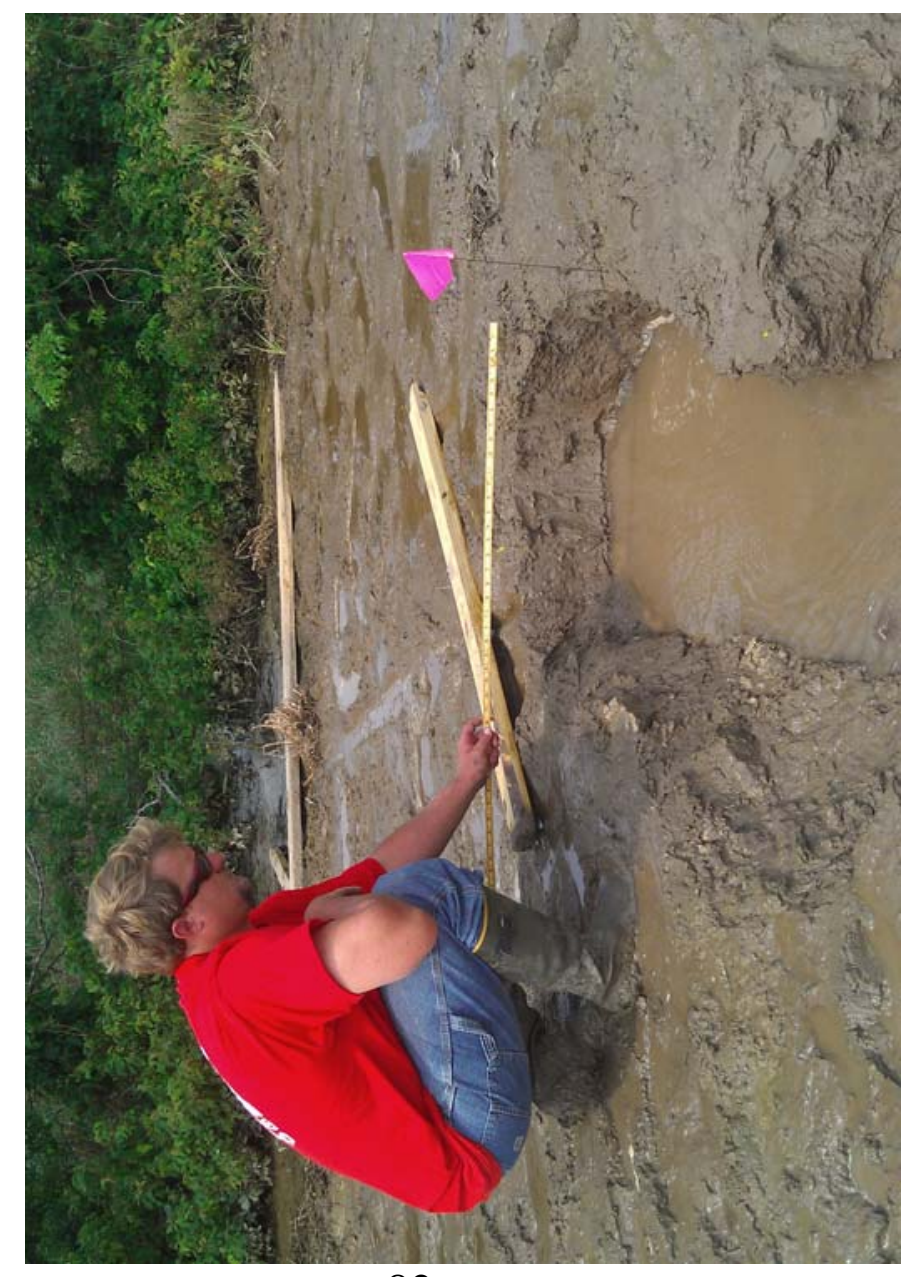

\section{2}

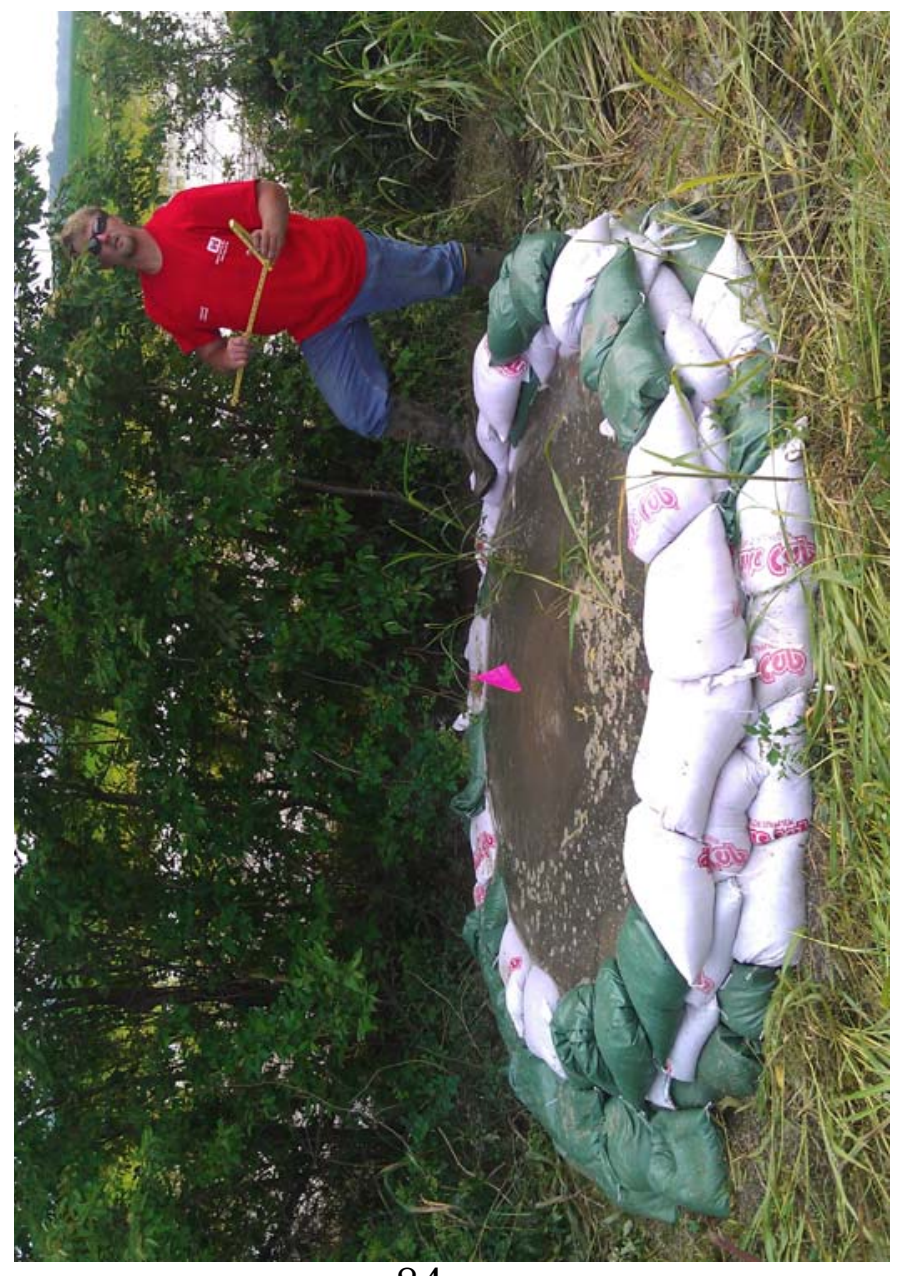




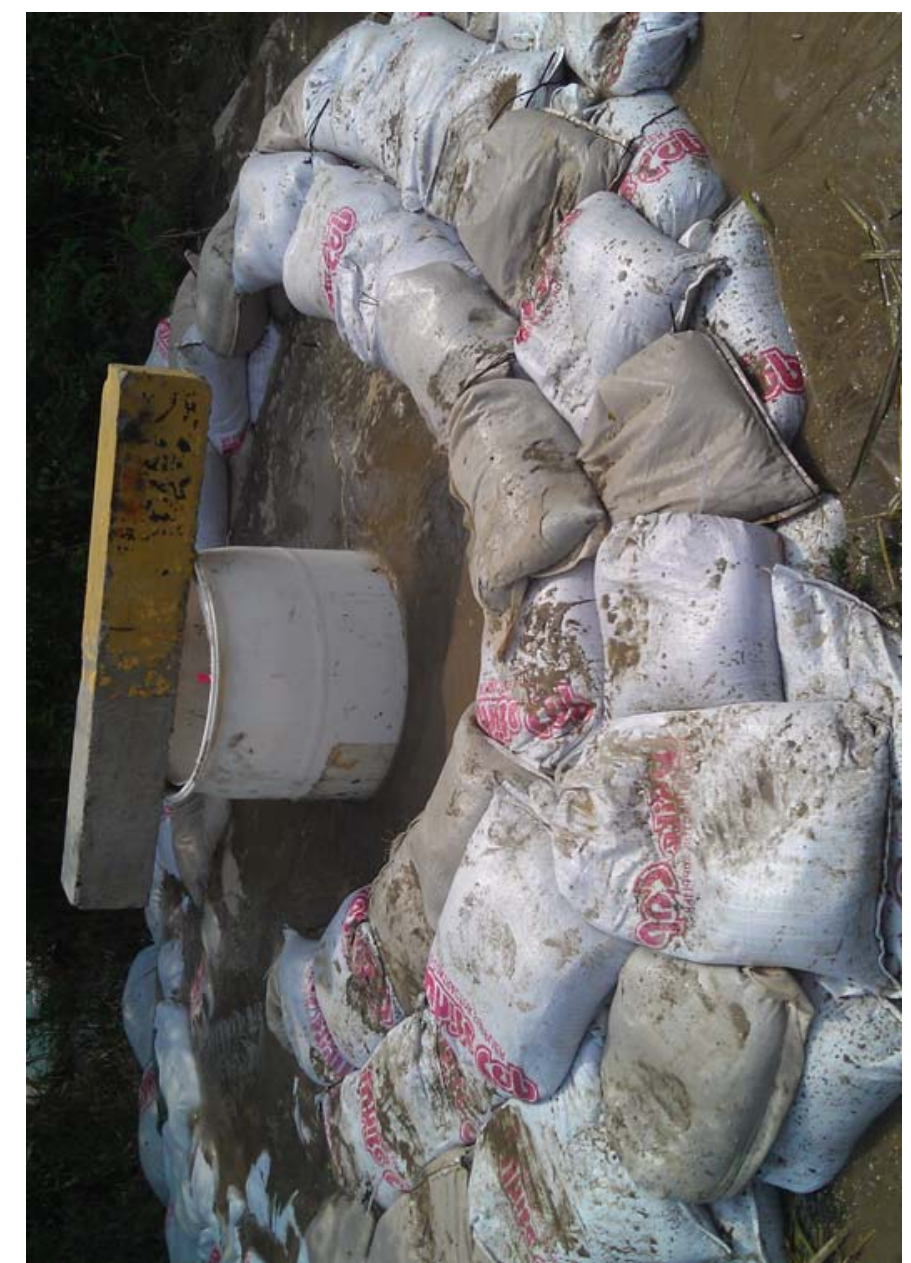

85

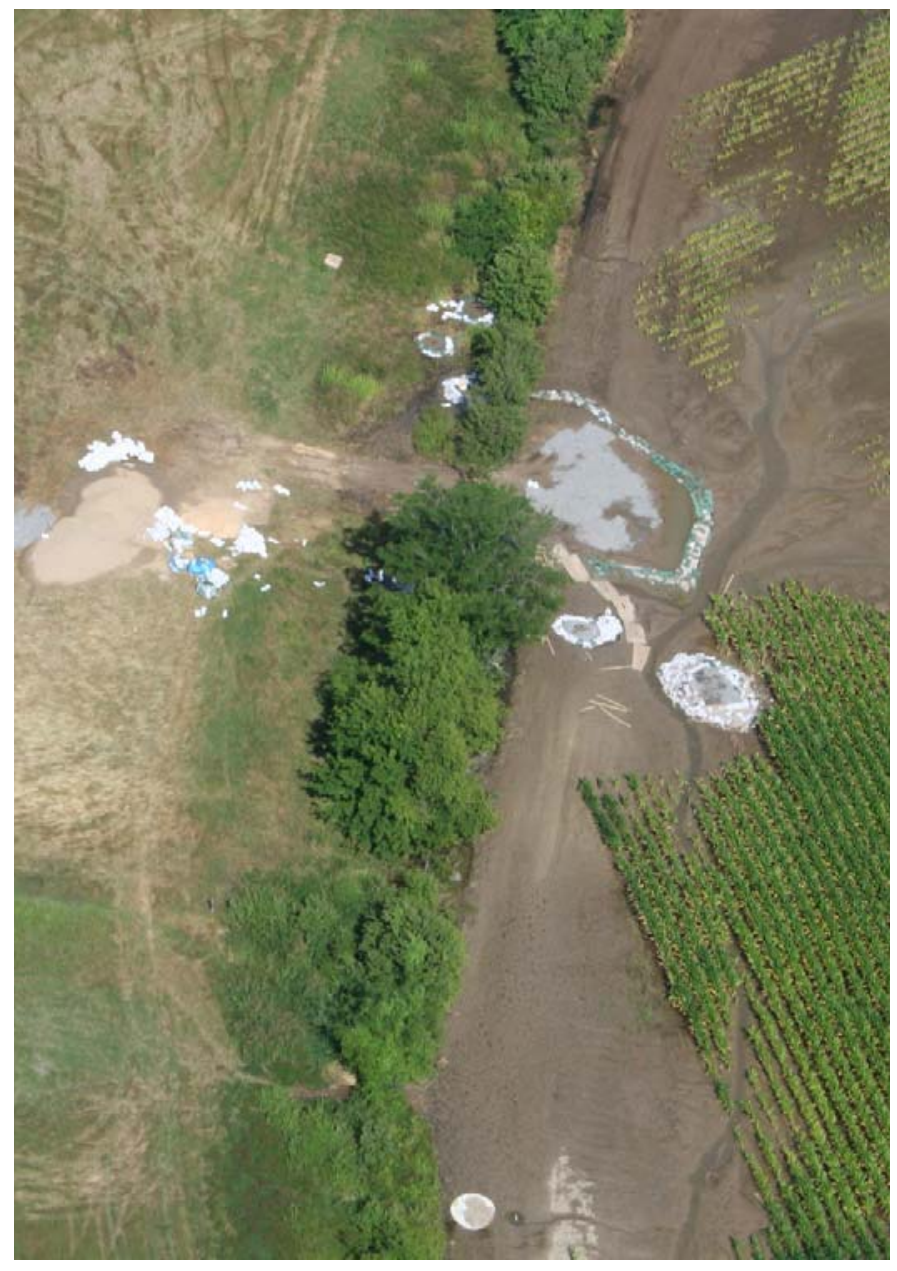

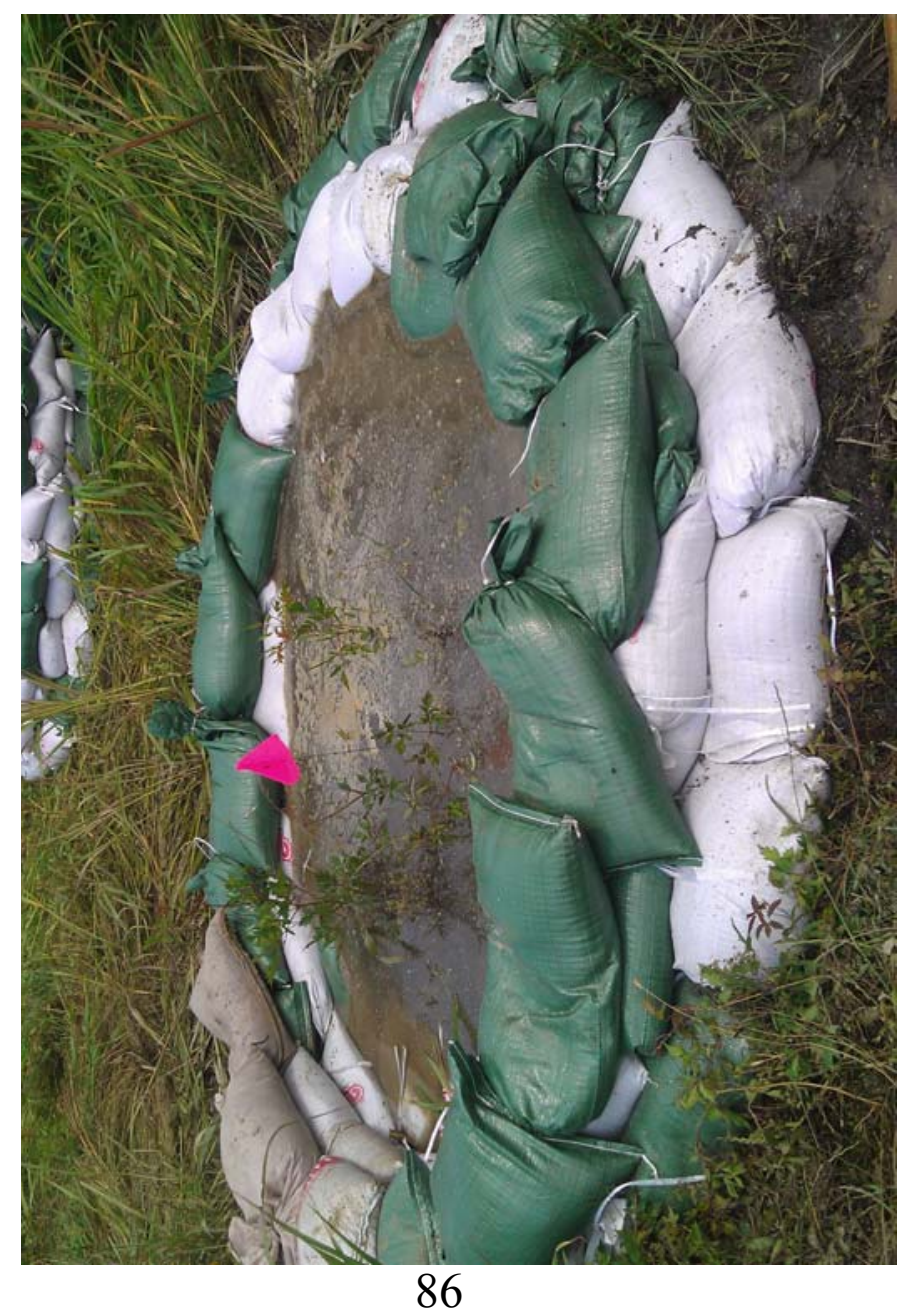

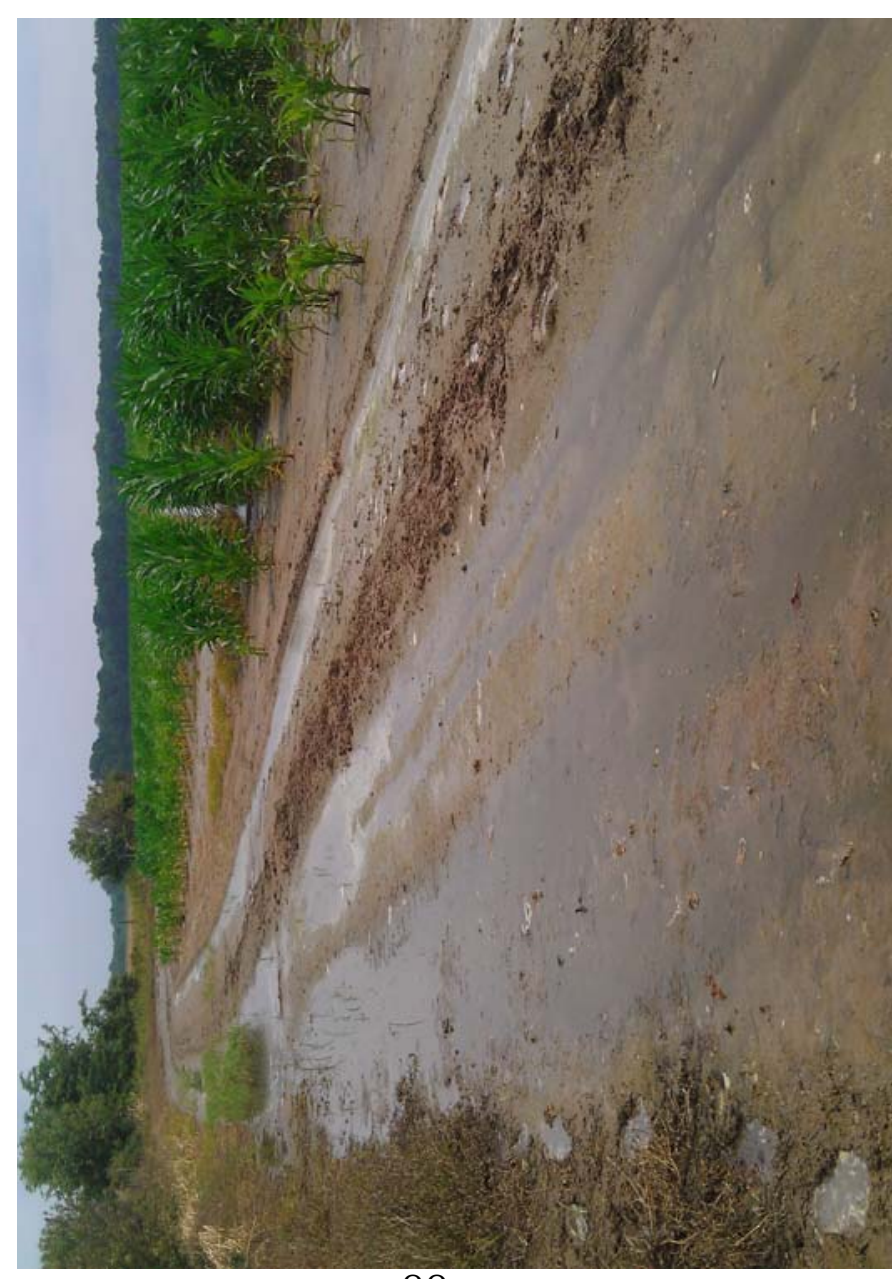




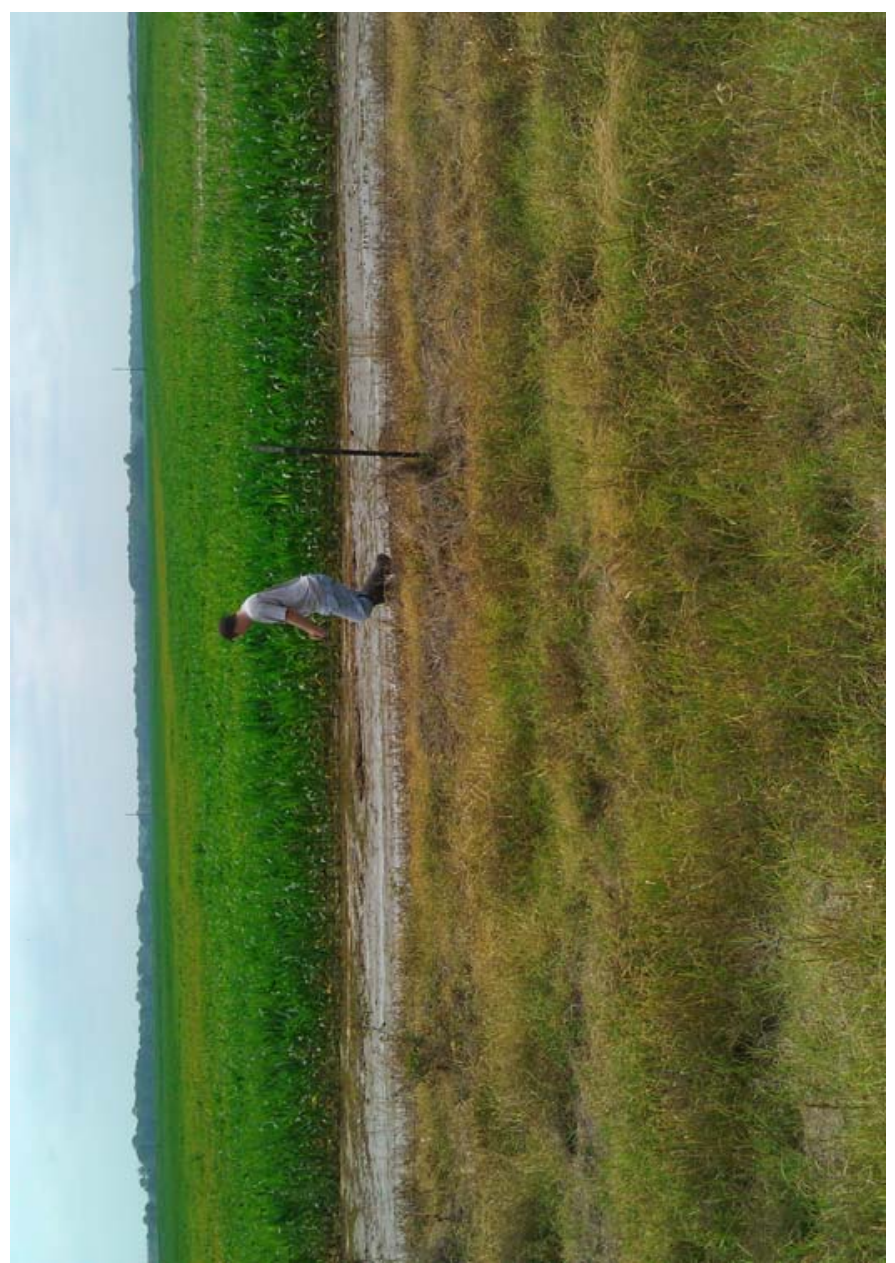

89

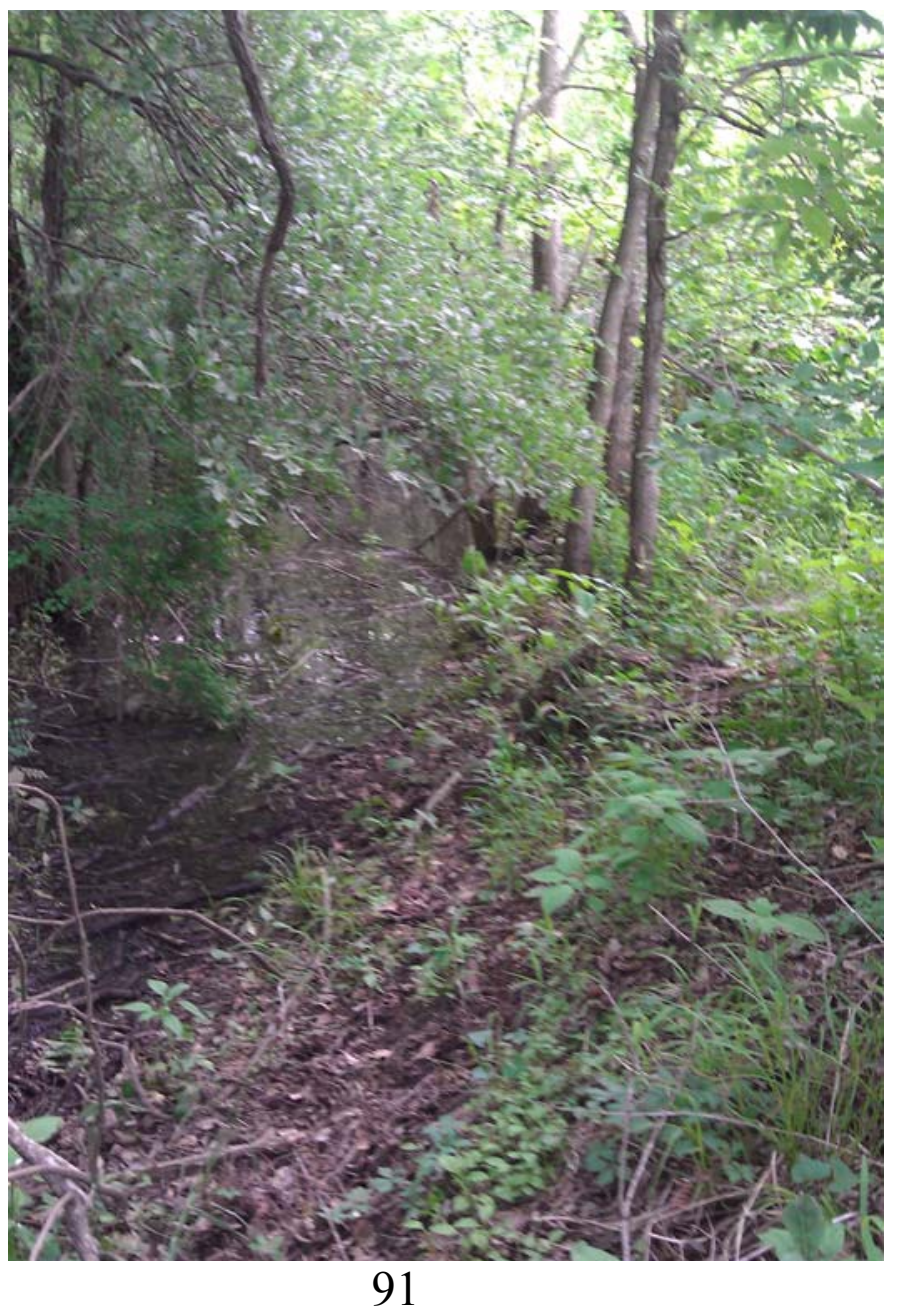

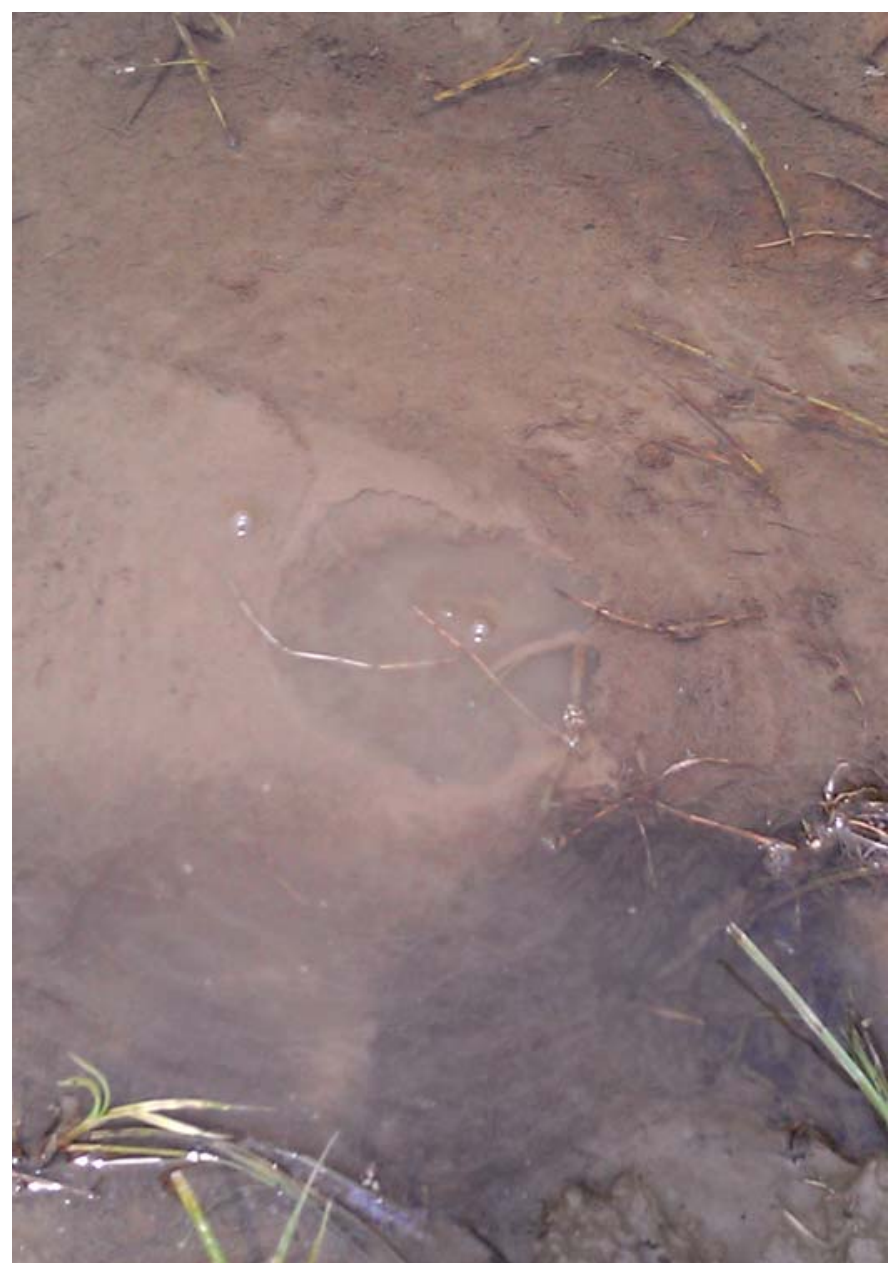

90

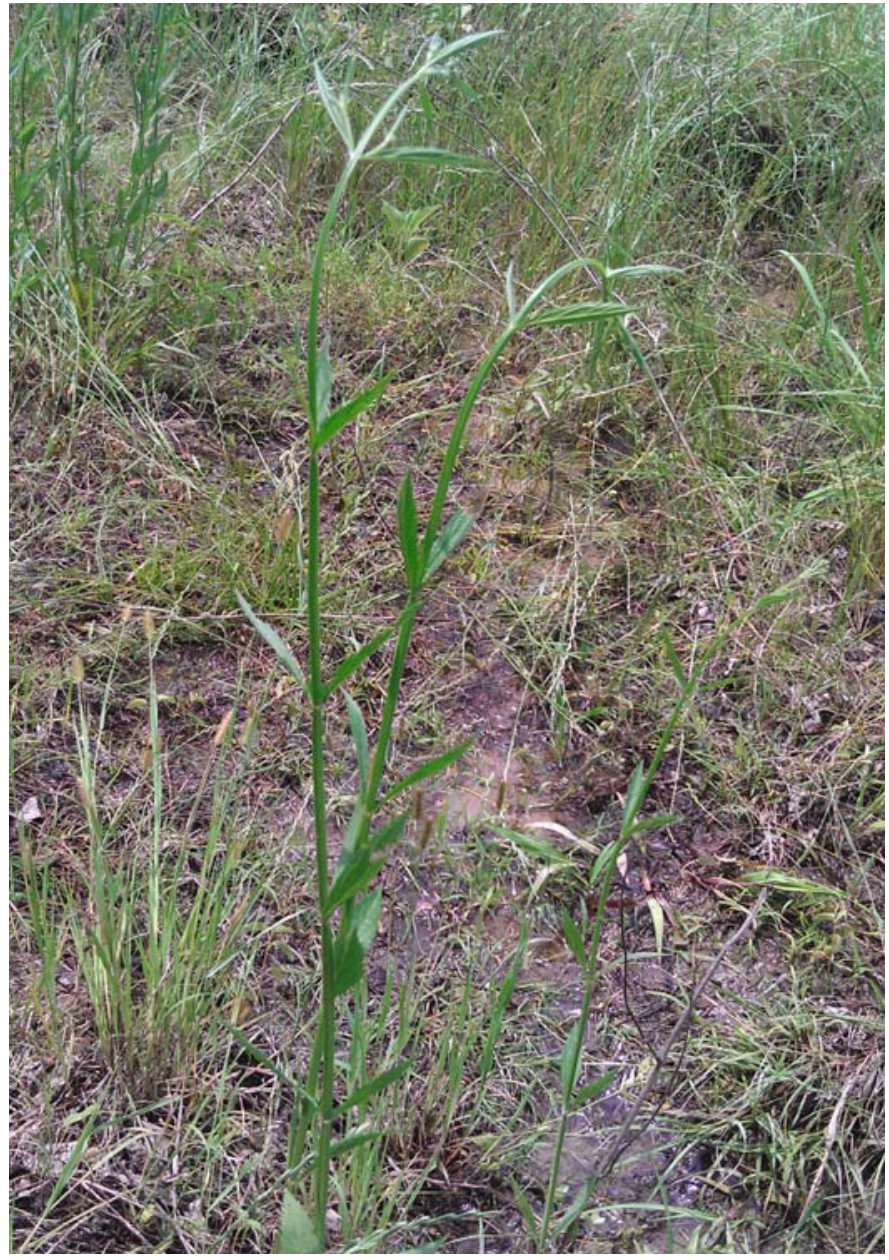




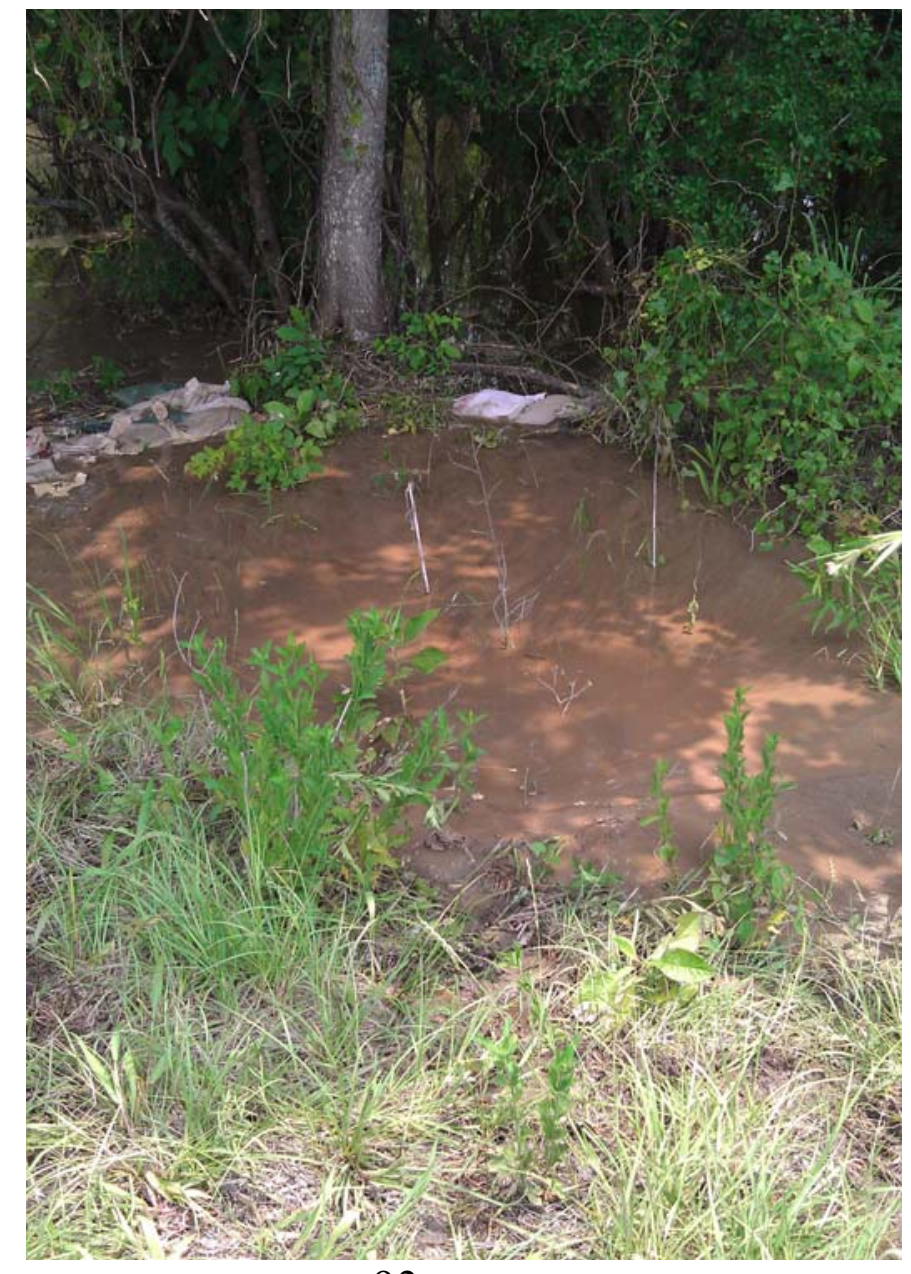

93

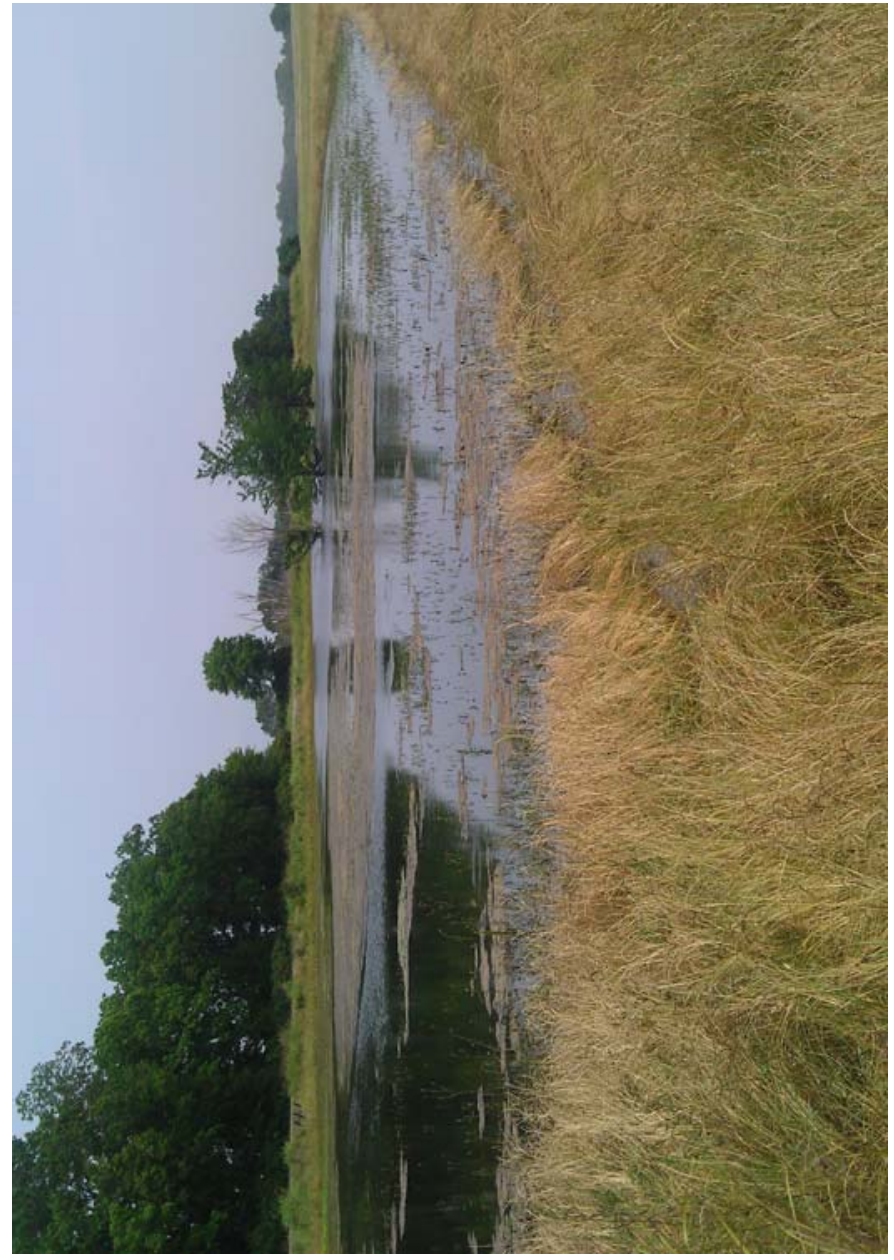

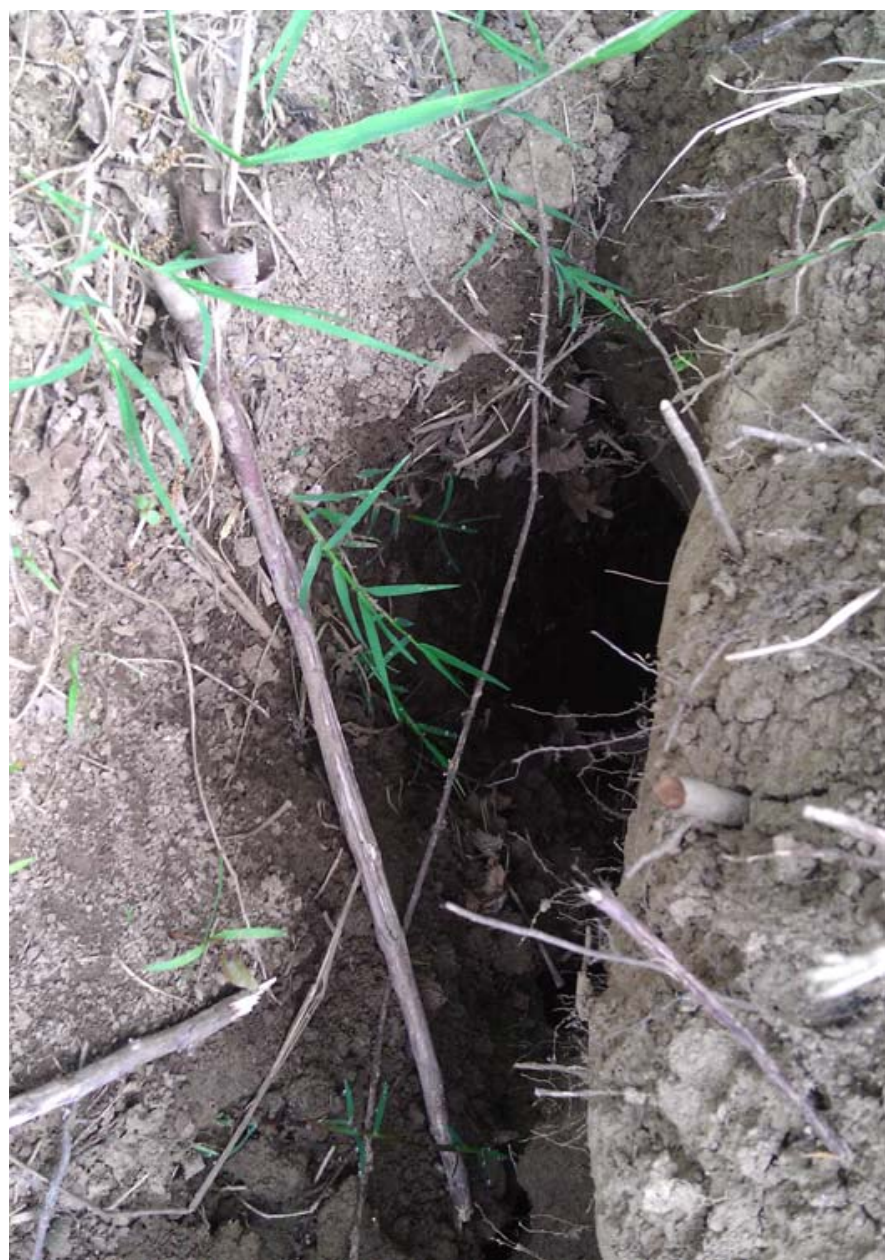

94

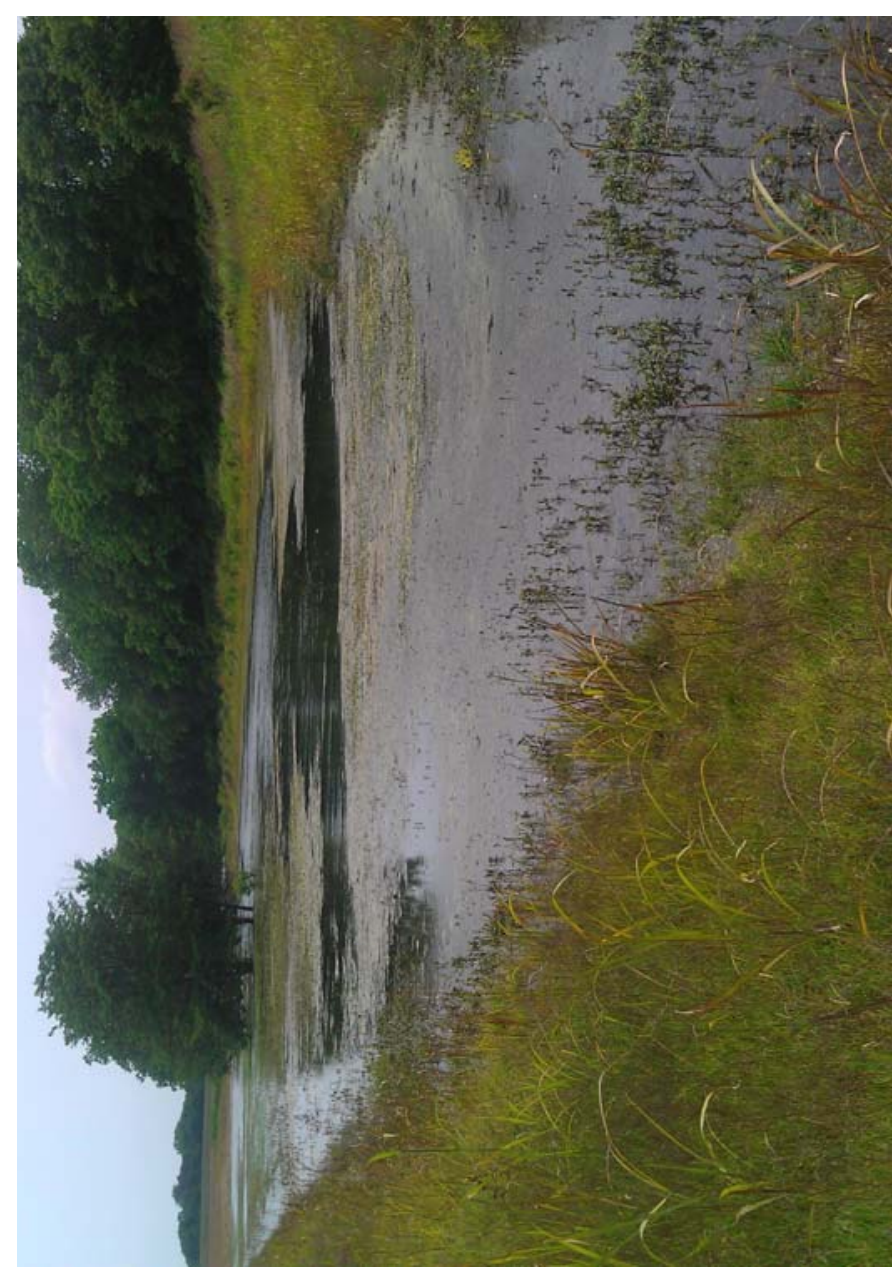




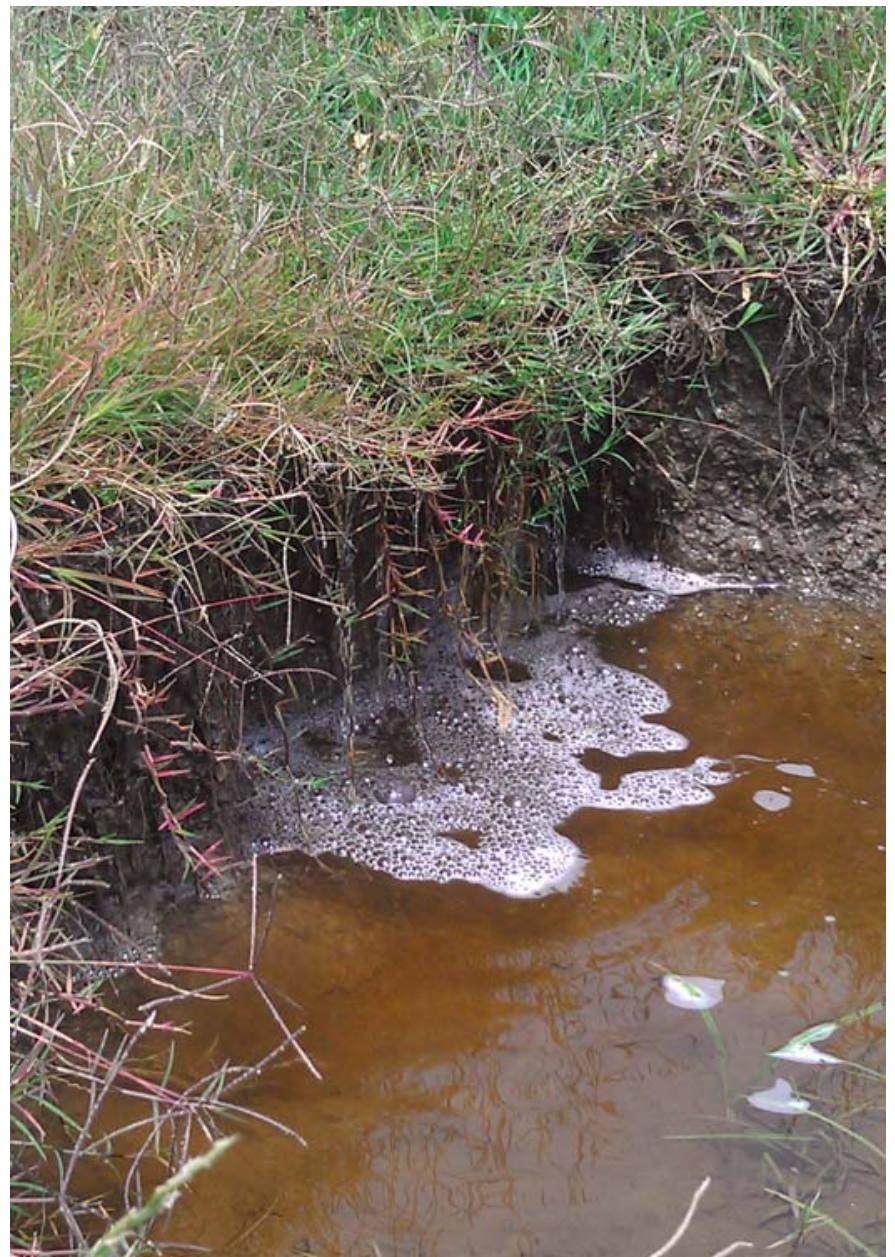

97

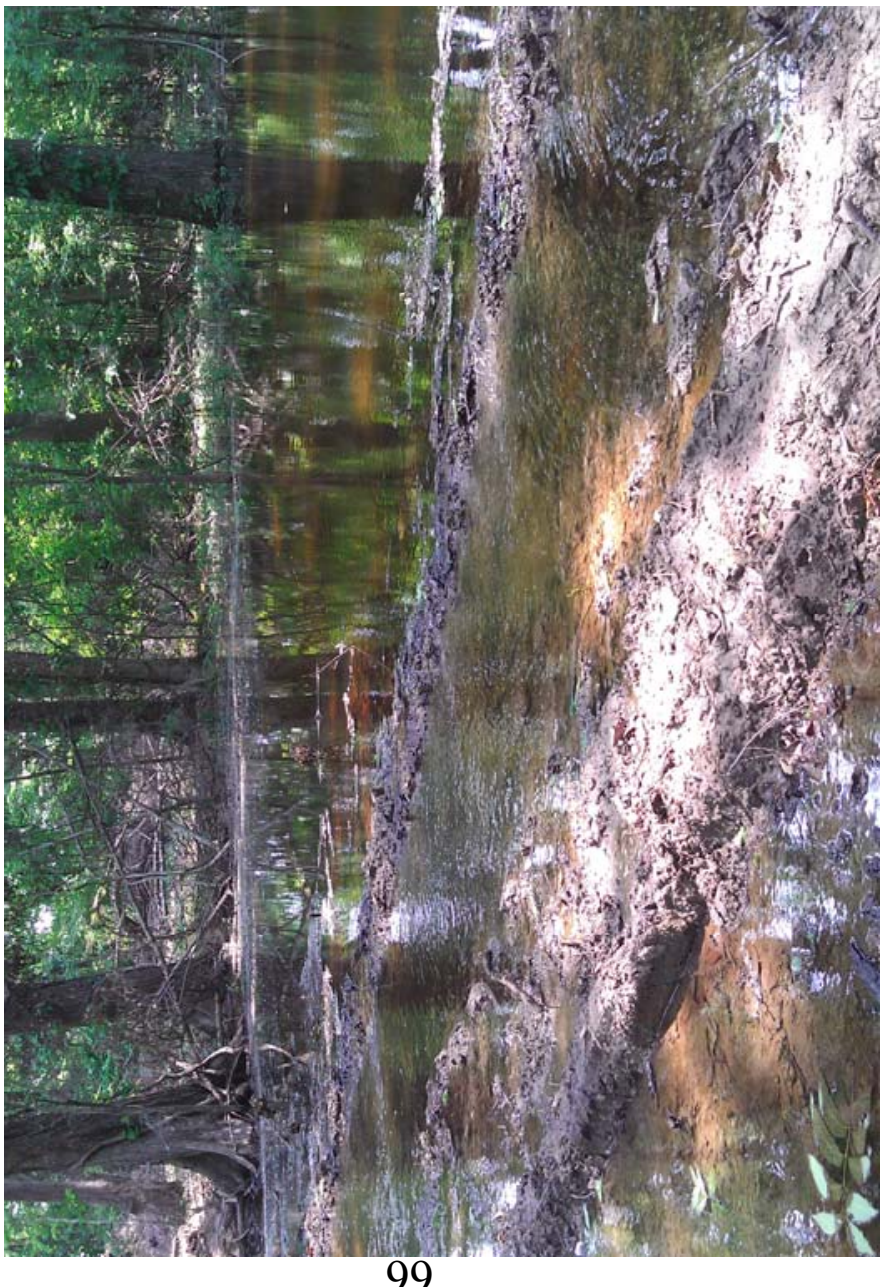

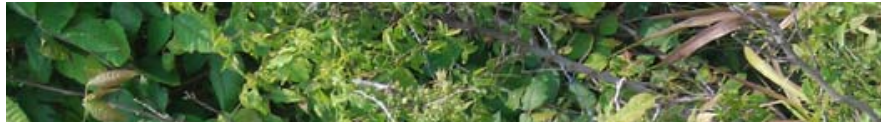

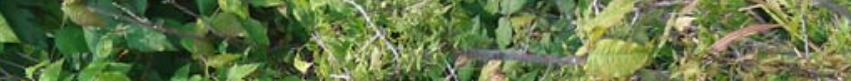

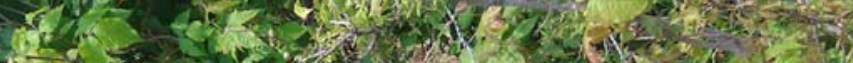

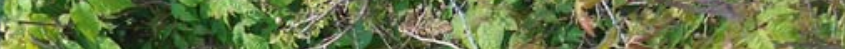

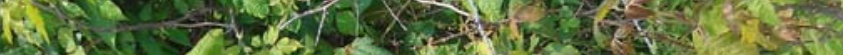

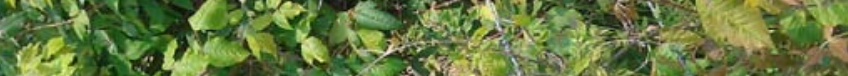

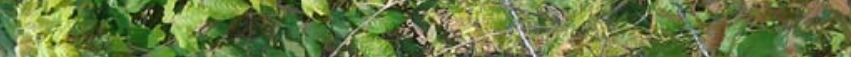

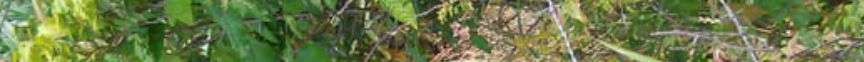

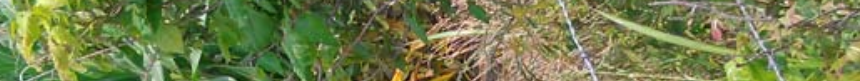

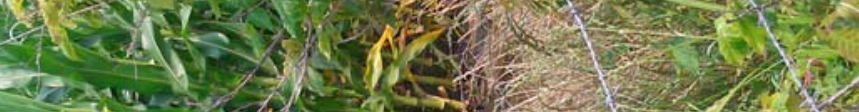
a)

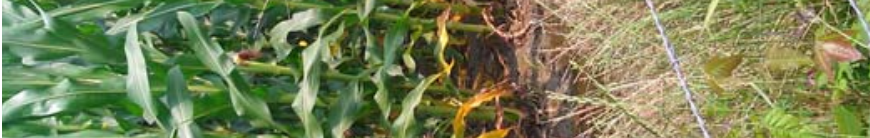

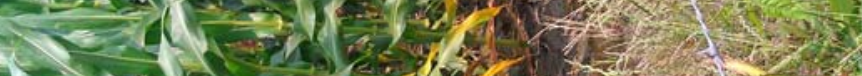
the $\left(\frac{1}{2}\right)=$ 98 


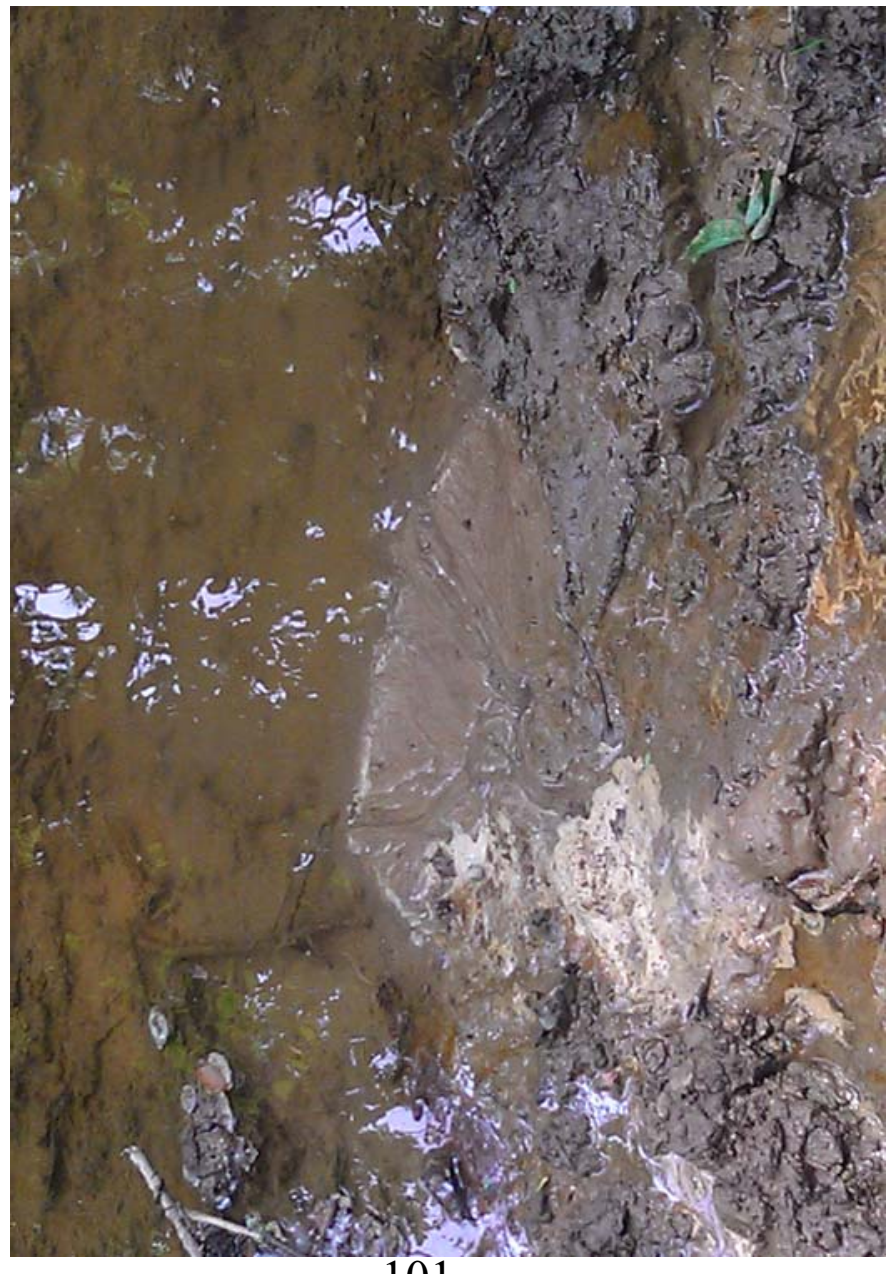

\section{1}

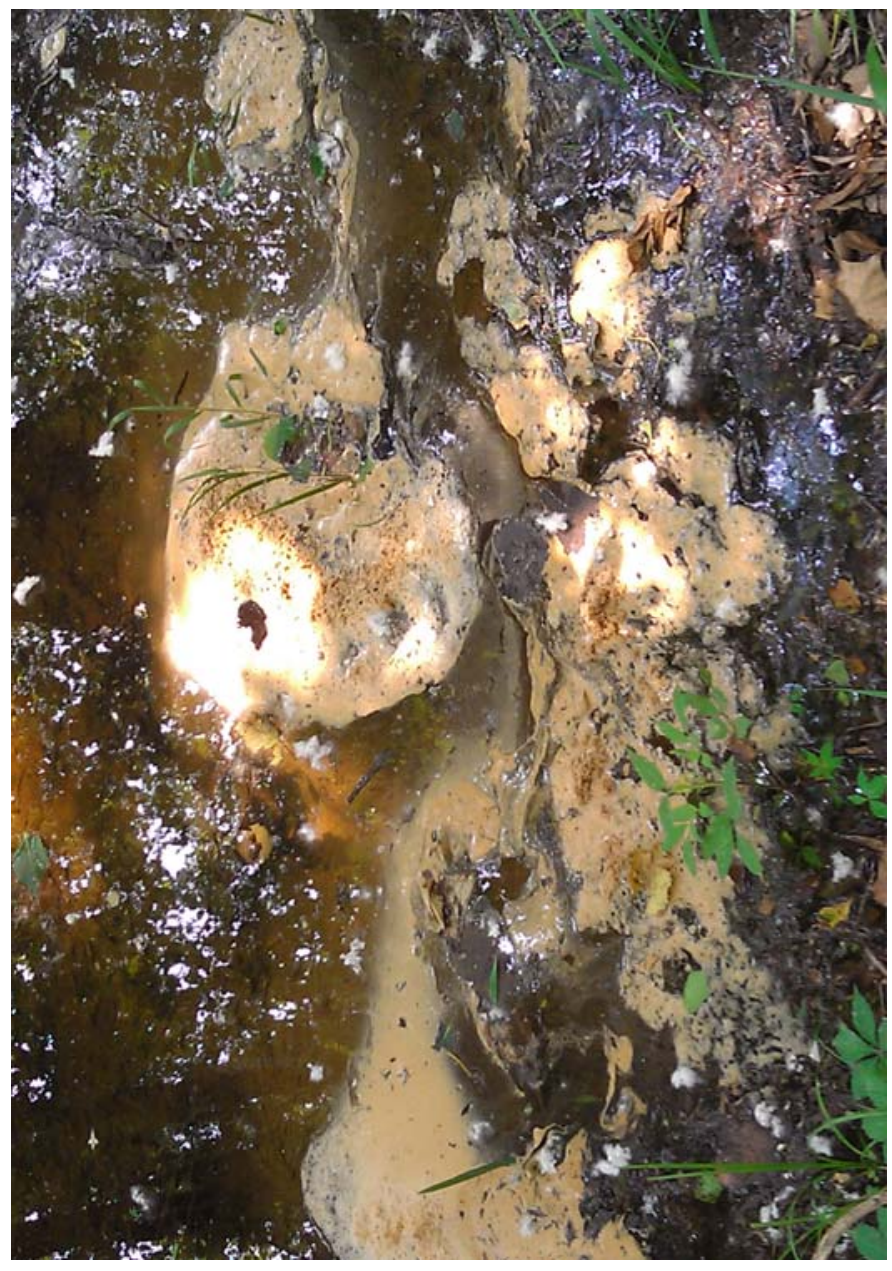

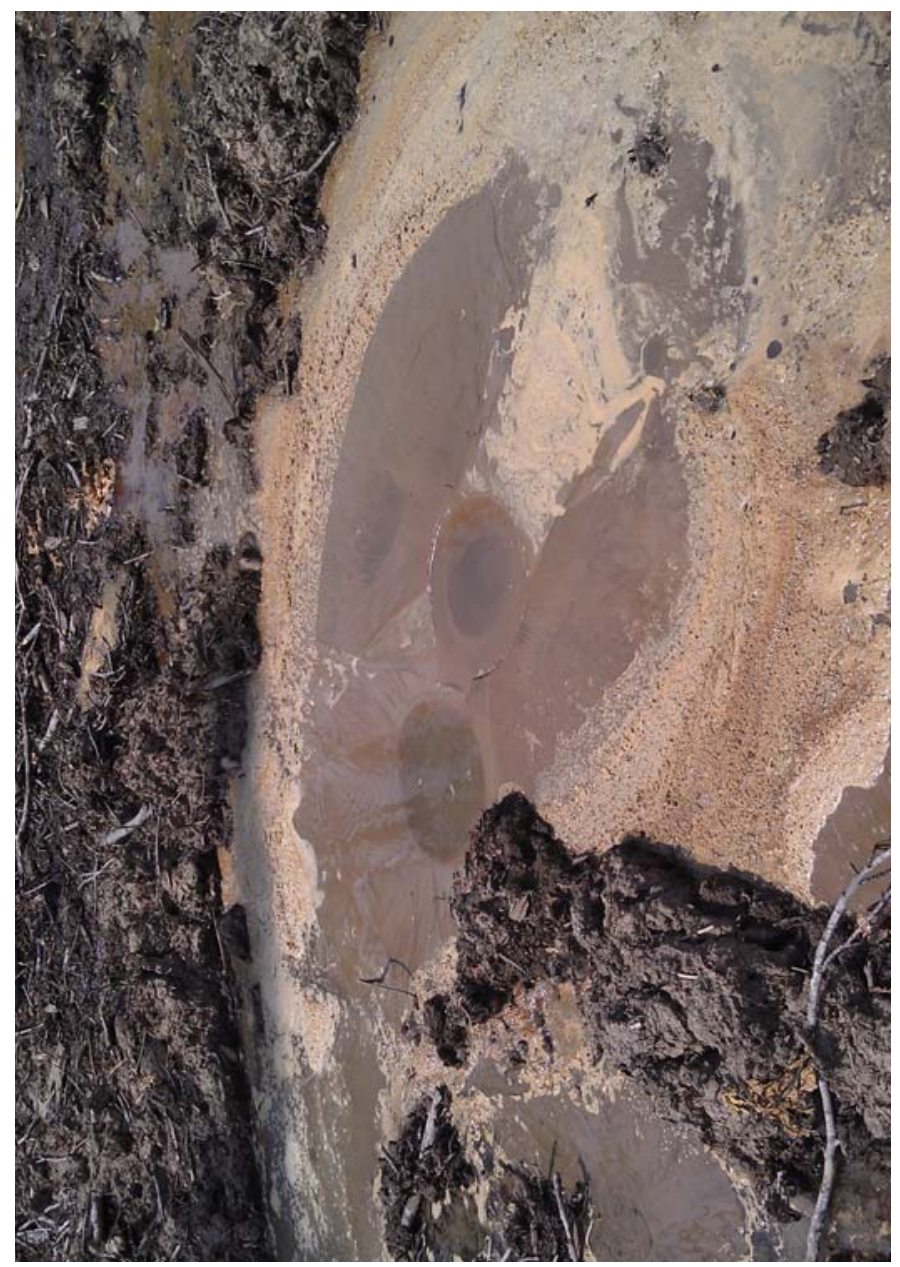

\section{2}

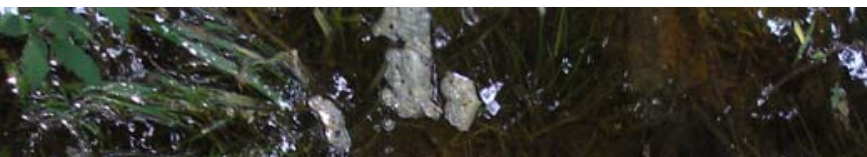

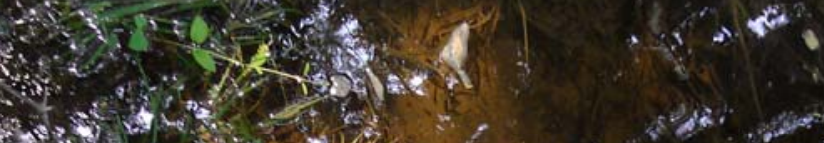

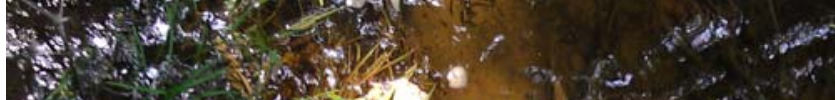

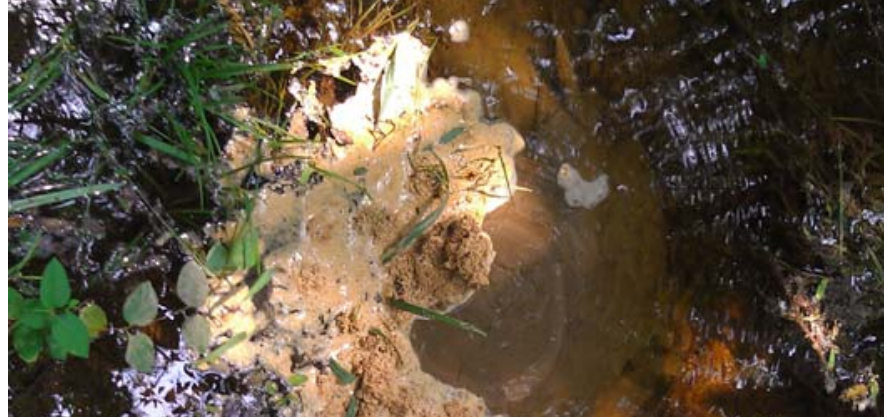

1. (1) ${ }^{3}$ is

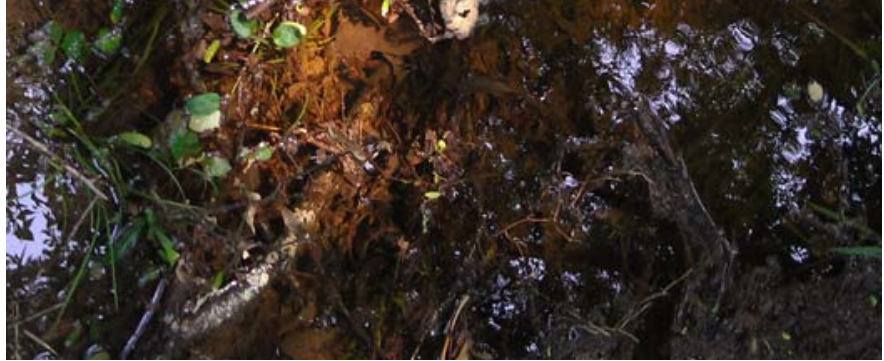




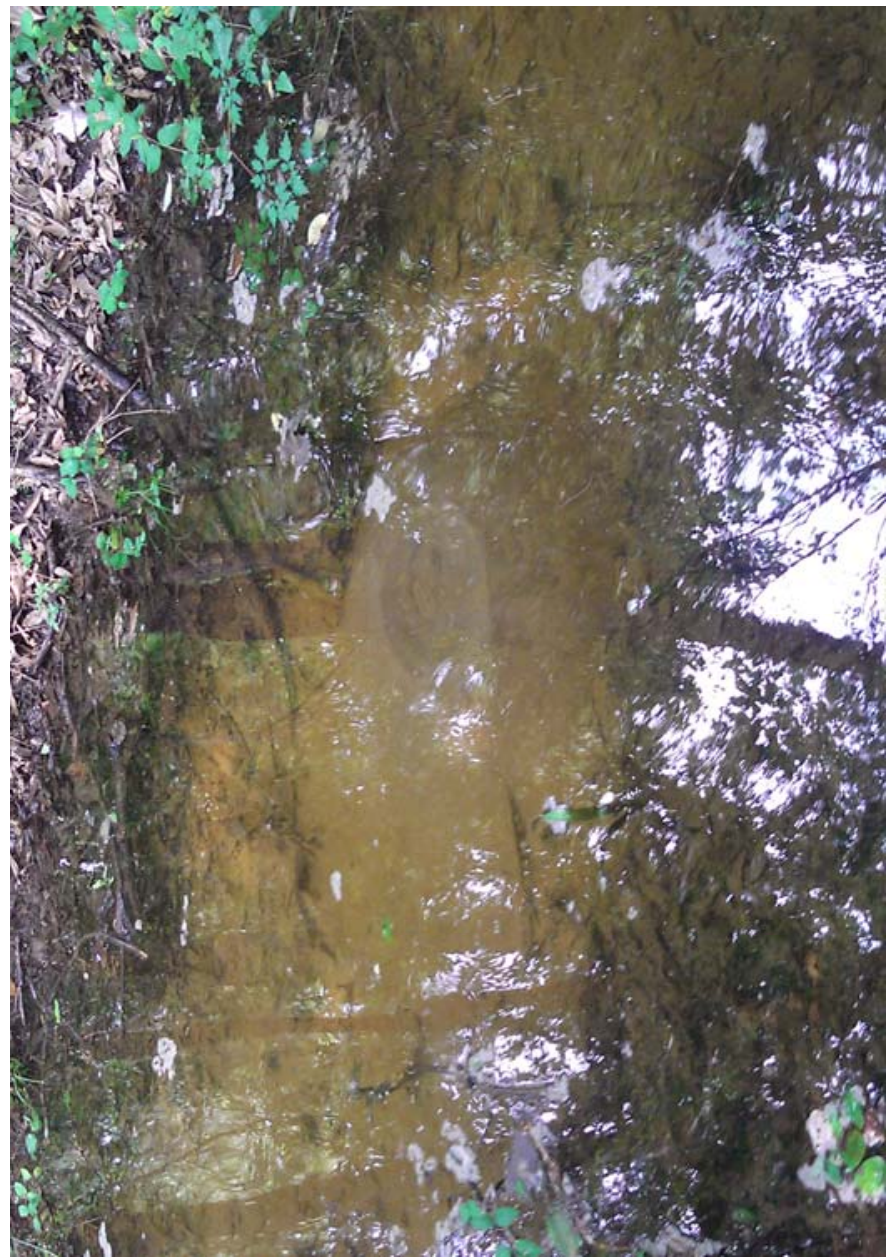

\section{5}

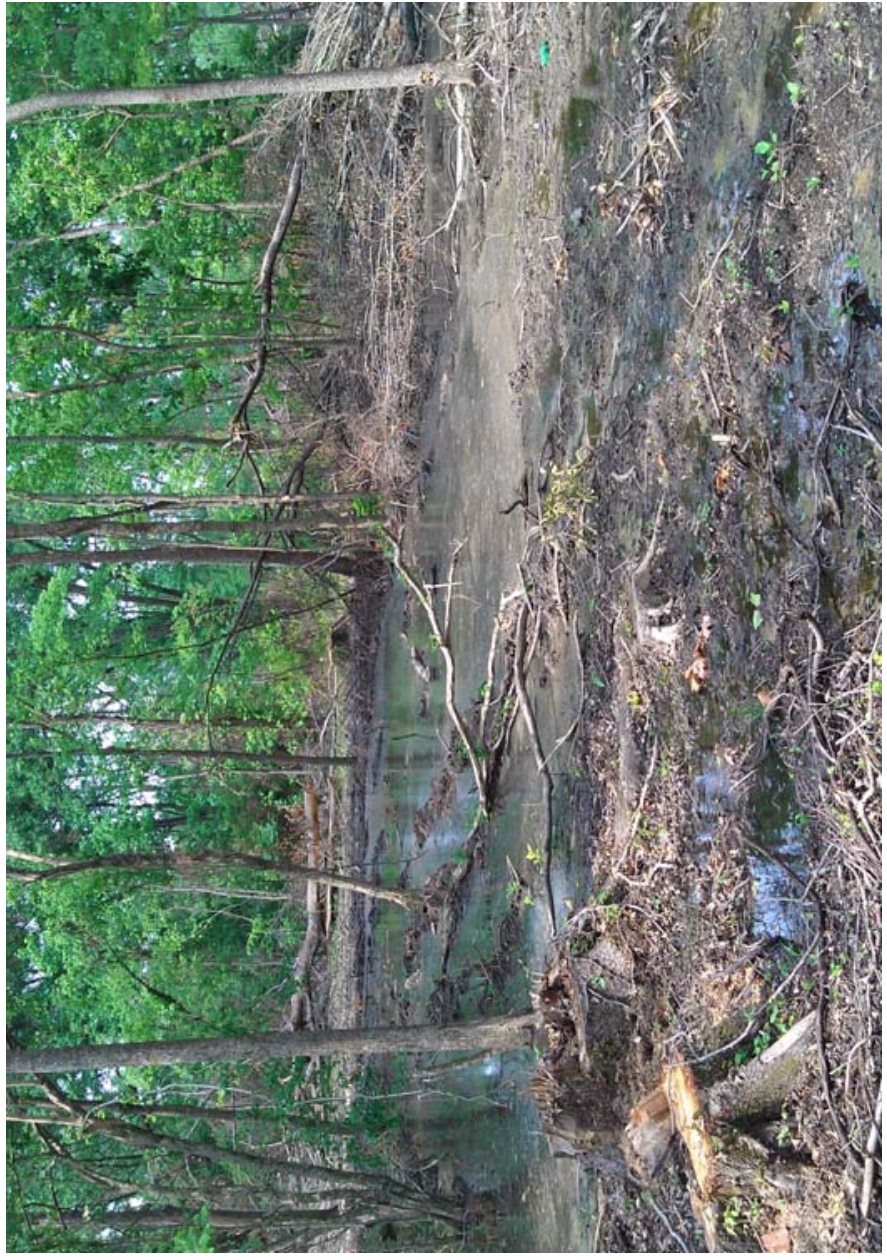

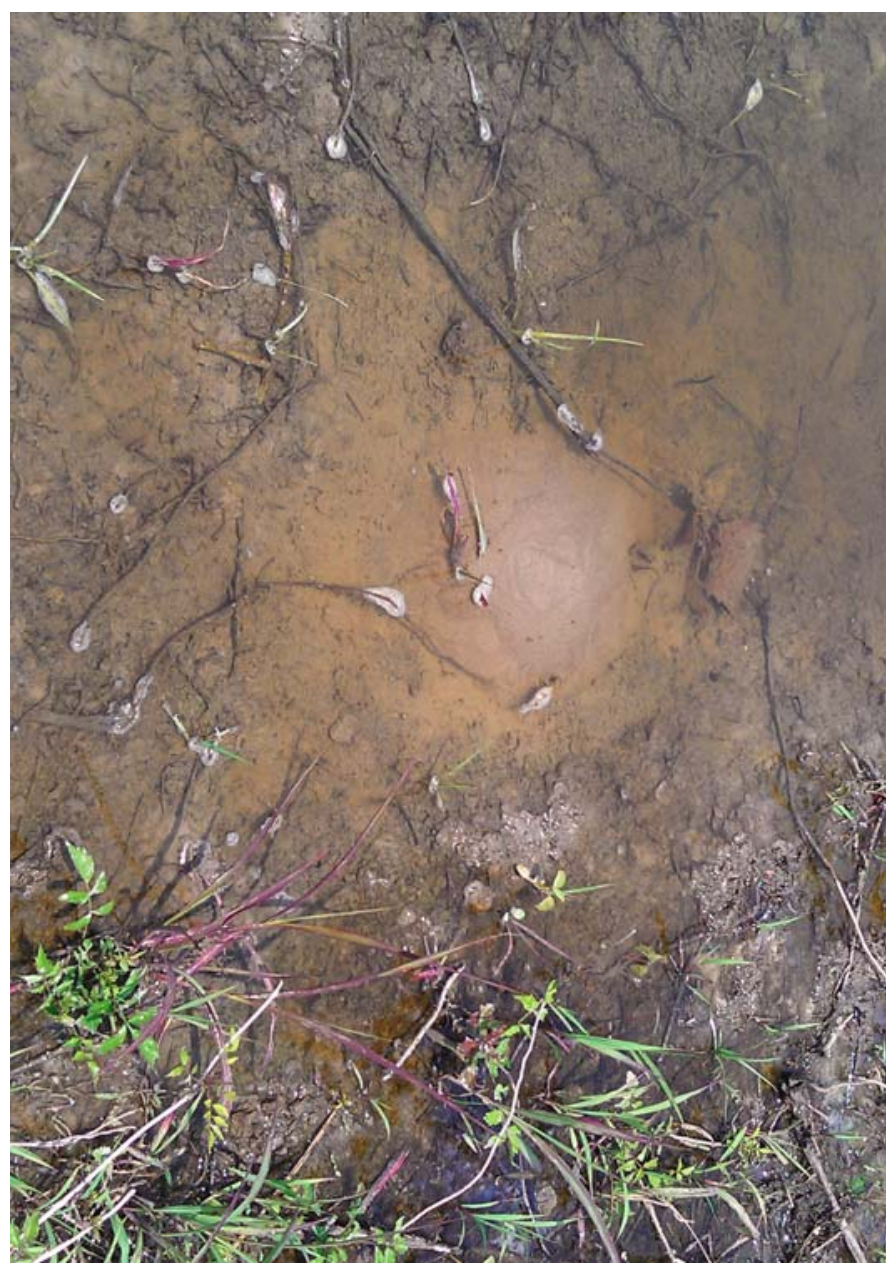

106

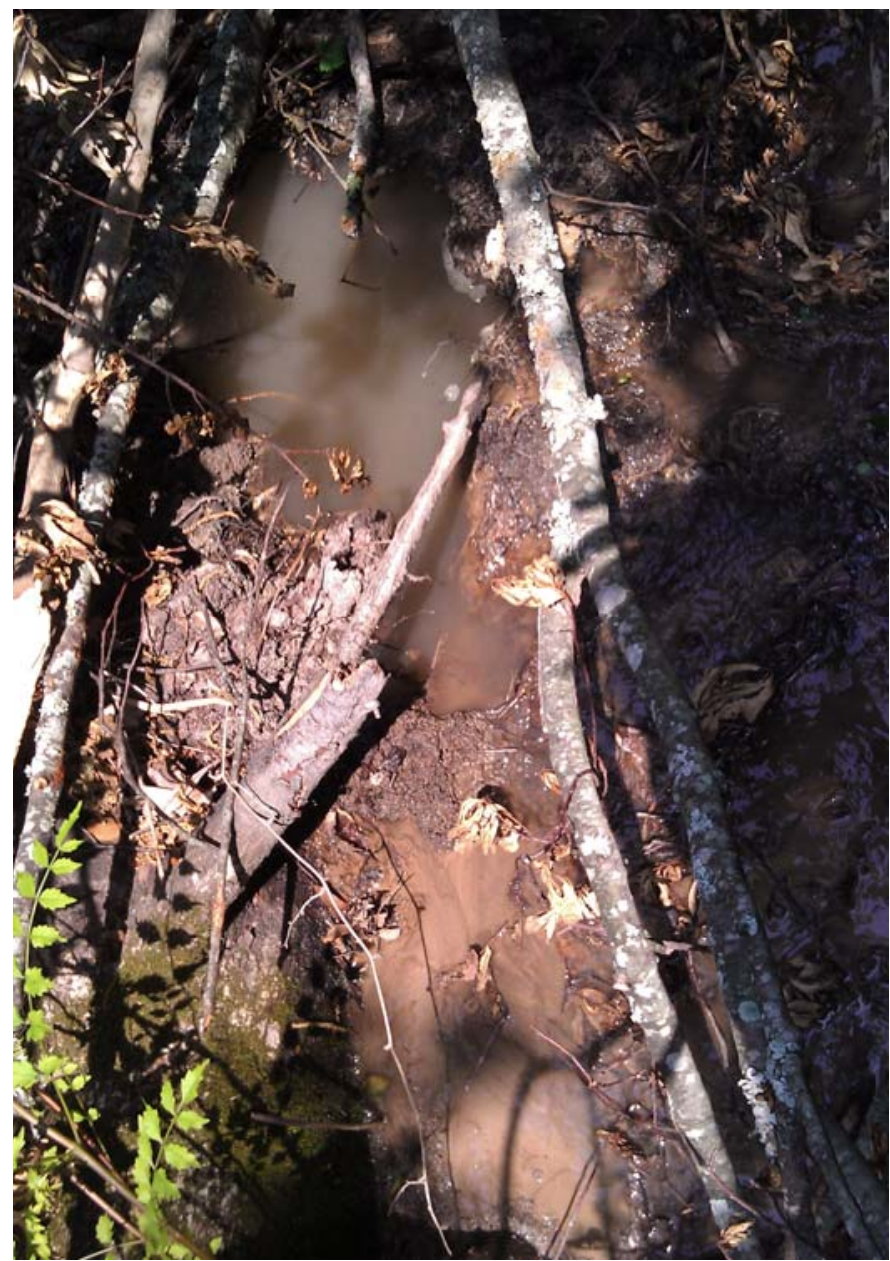



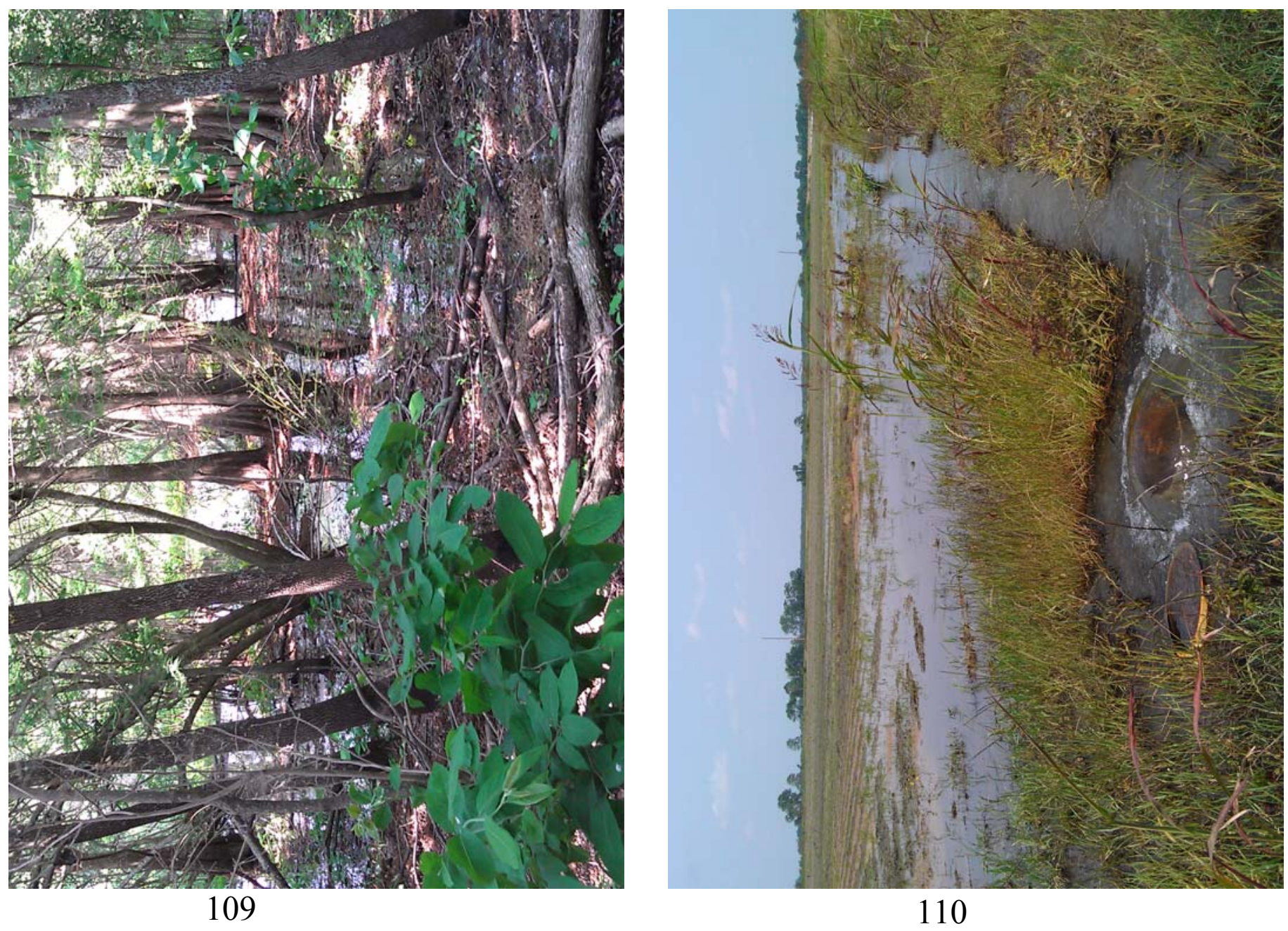
STATION 5930+00 TO 7500+00 
LEVEE SECTOR: Lake Washington to Tallula

DATE: May 20, 2011

TEAM MEMBERS: James Sims, Ryan Reeves, Dustin Herr, Jim Hearn

\begin{tabular}{|c|c|c|c|c|c|c|c|c|c|}
\hline \multicolumn{2}{|c|}{ START } & \multicolumn{2}{|c|}{ END } & \multirow{2}{*}{$\frac{\text { STATION }}{\text { NLD }}$} & \multirow{2}{*}{$\frac{\text { STATION }}{\text { FIELD MARKER }}$} & \multirow[t]{2}{*}{ TYPE } & \multirow[t]{2}{*}{ EXTENT } & \multirow[t]{2}{*}{ REMARKS } & \multirow[t]{2}{*}{ PHOTO } \\
\hline Latitude & Longitude & Latitude & Longitude & & & & & & \\
\hline 33.03621261 & 91.1202294 & 33.03621261 & 91.1202294 & $\begin{array}{l}5953+00 \text { to } \\
5967+00\end{array}$ & $\begin{array}{l}5930+00 \text { to } \\
5945+00\end{array}$ & Under Seepage & Light & $\begin{array}{l}\text { Light seepage from the edge of the seepage berm extending out into } \\
\text { corn field approximately } 500 \text { feet between levee Sta. } 5930 \text { and } 5945 . \\
\text { Seepage ends in a drainage ditch through the corn field near Sta. } 5945 .\end{array}$ & $1-4$ \\
\hline 33.0229638 & 91.12422764 & 33.0229638 & 91.12422764 & $6004+00$ & $5981+00$ & Under Seepage & Light & $\begin{array}{l}\text { Light seepage in the woods aroximately } 400 \text { feet from the toe of the } \\
\text { seepage berm near levee Sta. } 5981 \text {. Seepage is approximately } 75 \text { feet } \\
\text { wide and extends downstream approximately } 500 \text { feet. Seepage water } \\
\text { is generally clear and drains into old slough. }\end{array}$ & $5-6$ \\
\hline 33.02128196 & 91.12472206 & 33.02128196 & 91.12472206 & $\begin{array}{l}6009+00 \text { to } \\
6020+00\end{array}$ & $\begin{array}{l}5989+00 \text { to } \\
6000+00\end{array}$ & Under Seepage & Light & $\begin{array}{l}\text { Light seepage in a small patch of trees approximately } 20 \text { feet from the } \\
\text { seepage berm toe extending along ditch and through field between } \\
\text { levee Sta. } 5989 \text { and } 6000 . \text { Extends out into field at least } 600+\text { feet near } \\
\text { levee Sta. } 5991 .\end{array}$ & 7-9 \\
\hline 33.018994 & 91.12765695 & 33.018994 & 91.12765695 & $6019+00$ & $5999+00$ & Under Seepage/Pin Boild & Moderate & $\begin{array}{l}\text { Moderate seepage with } 5 \text { or } 6 \text { small, active, pin boils approximately } 15 \\
\text { feet from the toe of the seepage berm near levee Sta. } 5999 . \text { Most of the } \\
\text { pin boils have } 1 \text {-inch throats and were flowing generally clear water. }\end{array}$ & $10-12$ \\
\hline & & & & & & & & $\begin{array}{l}\text { Widespread light seepage along the toe of the seeepage berm extending } \\
\text { out into field approximately } 600 \text { feet between levee Sta. } 6005 \text { and } 6025 \text {. }\end{array}$ & $13-15$ \\
\hline 33.01767218 & 91.12961412 & 33.01433551 & 91.1355288 & $\begin{array}{l}6027+00 \text { to } \\
6048+00\end{array}$ & $\begin{array}{l}6005+00 \text { to } \\
6025+00\end{array}$ & Under Seepage/Pin Boils & Light & $\begin{array}{l}\text { Seepage water in the field is clear and a few very small pin boils were } \\
\text { identified in low spots under } 3 \text { to } 6 \text {-inches of water. }\end{array}$ & \\
\hline 33.01433551 & 91.1355288 & 33.01433551 & 91.1355288 & $6048+00$ & $6025+00$ & Sand Boil & Moderate to Heav & $\begin{array}{l}\text { Five or six small, active sand boils with } 4 \text { to } 5 \text {-inch throats were identified } \\
\text { along the toe of the seepage berm near levee Sta. } 6020 \text {. Boils were flowing } \\
\text { approximately } 20 \text { to } 30 \mathrm{gpm} \text { and transporting fine sand producing cones } \\
2 \text { to } 3 \text {-feet in diameter. Area being monitoring by levee board. Some of } \\
\text { the boils are ringed with plastic drums. }\end{array}$ & $16-17$ \\
\hline 33.01215884 & 91.13744505 & 33.01292241 & 91.13667771 & $\begin{array}{l}6051+00 \text { to } \\
6057+00\end{array}$ & $\begin{array}{l}6030+00 \text { to } \\
6035+00\end{array}$ & Sand Boil & Moderate to Heav & $\begin{array}{l}\text { Three to five sand boils and large area of widespread moderate seepage } \\
\text { along the toe of the seepage berm near levee Sta. } 6030 \text {. Seepage } \\
\text { extends approximately } 1 / 4 \text {-mile out into field. Two sand boils were ringed } \\
\text { with } 30 \text {-gallon plastic drums. Two or hree boils were identified near } \\
\text { the drums. Boils were flowing approximately } 10 \text { to } 20 \mathrm{gpm} \text { and } \\
\text { transporting fine sand and clay/silt balls. Numerous small pin boils and } \\
\text { moderate seepage in bean field near levee Sta. } 6035 \text {. Most boils are } \\
\text { transporting a small quantity of material and are under } 2 \text { or 3-inches } \\
\text { of water. }\end{array}$ & $18-22$ \\
\hline 33.01002171 & 91.14228265 & 32.00787 & 91.14659 & $\begin{array}{l}6074+00 \text { to } \\
6050+00\end{array}$ & $\begin{array}{l}6051+00 \text { to } \\
6070+00\end{array}$ & Sand Boil & Heavy & $\begin{array}{l}\text { Numerous, medium to large sand boils ( } 25+\text { ) approximately } 10 \text { to } 30 \text { feet } \\
\text { from the toe of the seepage berm between levee Sta. } 6050 \text { and } 6070 . \\
\text { Levee board was on-site placing drums, galvanized culverts, and sand bags } \\
\text { over and around boils. Entire area is under } 1 \text { to } 3 \text { feet of seepage water } \\
\text { from the boils. Several boils are high energy producing } 50 \text { to } 100 \mathrm{gpm} \text {. } \\
\text { (Clarence Hall Road Site) }\end{array}$ & $23-30$ \\
\hline
\end{tabular}




\begin{tabular}{|c|c|c|c|c|c|c|c|c|c|}
\hline \multicolumn{2}{|c|}{ START } & \multicolumn{2}{|c|}{ END } & \multirow{2}{*}{ STATION } & \multirow{2}{*}{$\begin{array}{c}\text { STATION } \\
\text { FIELD MARKER }\end{array}$} & \multirow[t]{2}{*}{ TYPE } & \multirow[t]{2}{*}{ EXTENT } & \multirow[t]{2}{*}{ REMARKS } & \multirow[t]{2}{*}{ РНОTO } \\
\hline Latitude & Longitude & Latitude & Longitude & & & & & & \\
\hline 33.00545728 & 91.14794463 & 33.00545728 & 91.14794463 & $6102+00$ & $6080+00$ & Under Seepage & Light & $\begin{array}{l}\text { Light seepage approximately } 200 \text { to } 300 \text { feet from the toe of the seepage } \\
\text { berm extending out into field. Seepage is generally clear and no pin boils } \\
\text { were identified. }\end{array}$ & $31-32$ \\
\hline 33.00895 & 91.147 & 33.0042 & 91.14781 & $\begin{array}{l}6088+00 \text { to } \\
6106+00\end{array}$ & $\begin{array}{l}6070+00 \text { to } \\
6085+00\end{array}$ & Heavy Current/Scour & Moderate & $\begin{array}{l}\text { Strong, fast current along the riverside berm of the the levee between } \\
\text { levee Sta. } 6070 \text { and } 6085 .\end{array}$ & \\
\hline 32.99744364 & 91.14408161 & 32.99718 & 91.11069 & $\begin{array}{l}6133+00 \text { to } \\
6272+00\end{array}$ & $\begin{array}{l}6110+00 \text { to } \\
6250+00\end{array}$ & Under Seepage & Light & $\begin{array}{l}\text { Widespread light seepage in a drainage ditch along the toe of the } \\
\text { seepage berm between levee Sta. } 6110 \text { and } 6250 \text {. Seepage runs down- } \\
\text { stream and extends out into a corn field for approximately } 500 \text { to } 600 \text { feet. } \\
\text { A few small pin boils were observed in low areas in the field. Small sand } \\
\text { boils may be present in the bottom of the ditch. }\end{array}$ & $33-40$ \\
\hline 32.99445 & 91.11863 & 32.99445 & 91.11863 & $6144+00$ & $6120+00$ & & Light & $\begin{array}{l}\text { Light to moderate through seepage on top of the seepage berm near } \\
\text { levee Sta. } 6120 . \text { Seepage is approximately } 100 \text { yards long and } 25 \text { yards } \\
\text { wide. }\end{array}$ & $41-42$ \\
\hline 32.996931 & 91.088311 & 32.996931 & 91.088311 & $6339+00$ & $6320+00$ & Sand Boil & Moderate & $\begin{array}{l}\text { Multiple sand boils in Valewood ditch just north of the Addie ramp. Throat } \\
\text { diameter of boils range from } 6 \text { to } 8 \text {-inches. Water in ditch is flowing clear. }\end{array}$ & 43 \\
\hline 32.9980872 & 91.10859187 & 32.9980872 & 91.10859187 & $6280+00$ & $6260+00$ & Under Seepage & Moderate & $\begin{array}{l}\text { Moderate seepage in ditch along Elwood Road and across the road into } \\
\text { field. Several small pin boils and pumping gravel in the road (road closed). } \\
\text { Numerous pin boils in bean field across the road under standing water. } \\
\text { Area is approximately } 250 \text { to } 300 \text { feet from the toe of the seepage berm. }\end{array}$ & $44-50$ \\
\hline 32.99942664 & 91.10728704 & 32.99942664 & 91.10728704 & $6285+00$ & $6265+00$ & Sand Boil & Heavy & $\begin{array}{l}\text { Several (4 to 6) large, high energy sand boils under } 3 \text { to } 4 \text { feet of water in } \\
\text { a drainage ditch in the bean field approximately } 200 \text { feet north of Elwood } \\
\text { Road near levee Sta. } 6265 . \text { Two other boils have cause the banks of the } \\
\text { ditch to cave. Boils are transporting small quantities of silt/fine sand } \\
\text { material. Area was flagged during the inspection. }\end{array}$ & $51-52$ \\
\hline 32.99768333 & 91.09044669 & 32.99387 & 91.08563 & $\begin{array}{l}6333+00 \text { to } \\
6351+00\end{array}$ & $\begin{array}{l}6310+00 \text { to } \\
6328+00\end{array}$ & Under Seepage & Light & $\begin{array}{l}\text { Light, widespread underseepage in field across Elwood and Ross-Winn } \\
\text { Roads approximately } 500 \text { feet from the toe of the levee. }\end{array}$ & $53-55$ \\
\hline 32.99768333 & 91.09044669 & 32.99768333 & 91.09044669 & $6335+00$ & $6311+00$ & & Light & $\begin{array}{l}\text { Light to moderate through seepage on top of the seepage berm near levee } \\
\text { Sta. } 6311 \text {. Area is approximately } 250 \text { feet long and } 100 \text { feet wide. }\end{array}$ & 56 \\
\hline 32.98973 & 91.08112 & 32.98973 & 91.08112 & $6377+00$ & $6356+00$ & & Light & $\begin{array}{l}\text { Light through seepage on top of the seepage berm approximately } 20 \text { from } \\
\text { the toe of the berm near levee Sta. } 6356 . \text { Seepage is approximately } 25 \\
\text { yards wide and } 50 \text { yards long. }\end{array}$ & \\
\hline 32.98167 & 91.07198 & 32.9796684 & 91.07103525 & $\begin{array}{l}6411+00 \text { to } \\
6418+00\end{array}$ & $\begin{array}{l}6389+00 \text { to } \\
6395+00\end{array}$ & Under Seepage/Pin Boils & Moderate & $\begin{array}{l}\text { Moderate seepage with a numerous pin boils in levee entrance road and } \\
\text { residence yard approximately } 100 \text { feet from the toe of the seepage berm } \\
\text { near levee Sta. } 6389 . \text { Moderate seepage extends down stream in the } \\
\text { woods to near levee Sta. } 6395 .\end{array}$ & $57-61$ \\
\hline 32.9796684 & 91.07103525 & 32.9731 & 91.06842 & $\begin{array}{l}6418+00 \text { to } \\
6443+00\end{array}$ & $\begin{array}{l}6395+00 \text { to } \\
6420+00\end{array}$ & Under Seepage & Light & $\begin{array}{l}\text { Light seepage from the toe of the seepage berm extending out } \\
\text { approximately } 200 \text { to } 300 \text { feet into a cleared timber area and continuing } \\
\text { downstream to near levee Sta. } 6420 \text {. Seepage is generally clear and } \\
\text { no pin boils were identified. }\end{array}$ & $62-68$ \\
\hline 32.97548 & 91.06928 & 32.96489 & 91.06773 & $6452+00$ & $\begin{array}{l}6430+00 \text { to } \\
6470+00\end{array}$ & & Moderate & $\begin{array}{l}\text { Moderately fast current flowing against riverside levee toe from near } \\
\text { levee Sta. } 6430 \text { to } 6470 \text {. Light to moderate seepage in field. }\end{array}$ & \\
\hline
\end{tabular}




\begin{tabular}{|c|c|c|c|c|c|c|c|c|c|}
\hline \multicolumn{2}{|c|}{ START } & \multicolumn{2}{|c|}{ END } & \multirow{2}{*}{$\begin{array}{c}\text { STATION } \\
\text { NLD } \\
\end{array}$} & \multirow{2}{*}{\begin{tabular}{|c|} 
STATION \\
FIELD MARKER \\
\end{tabular}} & \multirow{2}{*}{ TYPE } & \multirow{2}{*}{ EXTENT } & \multirow{2}{*}{ REMARKS } & \multirow{2}{*}{ PHOTO } \\
\hline Latitude & Longitude & Latitude & Longitude & & & & & & \\
\hline 32.93982762 & 91.05941308 & 32.93982762 & 91.05941308 & $6670+00$ & $6650+00$ & Under Seepage/Pin Boill & Moderate & $\begin{array}{l}\text { Moderate seepage begins along the toe of the seepage berm along levee } \\
\text { access road to Mayersville Grain Bin near levee Sta. } 6650 \text { and continues } \\
\text { downstream. At levee Sta. } 6650, \text { seepage extends out from the toe of } \\
\text { the seepage berm approximately } 300 \text { to } 500 \text { feet. Two or three small } \\
\text { pin boils were identified along the fence just north of the access road. Pin } \\
\text { boils were low flow. }\end{array}$ & $69-78$ \\
\hline 32.91025 & 91.05331 & 32.91025 & 91.05331 & $6692+00$ & $6690+00$ & & Light & $\begin{array}{l}\text { Light seepage on top of the seepage berm approximately } 10 \text { to } 15 \text { feet } \\
\text { from the toe of the berm just north of Mayersville near levee Sta. } 6690 . \\
\text { Seepage is approximately } 100 \text { feet wide and } 300 \text { feet long. Light } \\
\text { seepage in field across paved road approximately } 150 \text { feet from the toe } \\
\text { of the seepage berm. }\end{array}$ & \\
\hline 32.89250015 & 91.05297813 & 32.84606 & 91.07297 & $\begin{array}{l}6760+00 \text { to } \\
6850+00 \\
\end{array}$ & \begin{tabular}{|l}
$6710+00$ to \\
$6800+00$ \\
\end{tabular} & Under Seepage/Pin Boils & Moderate & $\begin{array}{l}\text { Moderate underseepage with pin boils approximately } 10 \text { to } 20 \text { feet from } \\
\text { the seepage berm toe extending out approximately } 300 \text { feet near levee } \\
\text { Sta. } 6710 \text {. Area extends downstream approximately } 300 \text { to } 500 \text { feet. } \\
\text { Three to five, high energy sand boils in a ditch along the toe of the } \\
\text { seepage berm in the woods near levee Sta. } 6750 \text {. Boils have } 3 \text { to } 5 \text {-inch } \\
\text { throats and are flowing } 20 \text { to } 30 \mathrm{gpm} \text { each. Boils are covered with } \\
\text { approximately } 6 \text { inches of water and have transported approximately } \\
3 \text { to } 5 \text {-cubic yards of silt/fine sand. Area was flagged during the } \\
\text { inspection. Moderate seepage with a few pin boils along the fence } \\
\text { approximately } 250 \text { feet from the toe of the levee (seepage berm not } \\
\text { identified) near levee Sta. } 6800 \text {. }\end{array}$ & $79-83$ \\
\hline 32.87071578 & 91.0749221 & 32.86784 & 91.07434 & \begin{tabular}{|l}
$6874+00$ to \\
$6888+00$
\end{tabular} & \begin{tabular}{|l}
$6830+00$ to \\
$6860+00$
\end{tabular} & Under Seepage/Pin Boils & Moderate & $\begin{array}{l}\text { Light seepage near the toe of the seepage berm extending out into field } \\
\text { approximately } 300+\text { feet between levee Sta. } 6830 \text { and } 6860 . \\
\text { Moderate seepage and five or six small pin boils in a ditch approximately } \\
10 \text { feet from the toe of the seepage berm near levee Sta. } 6860 \text {. }\end{array}$ & $84-87$ \\
\hline 32.85256267 & 91.07582051 & 32.85256267 & 91.07582051 & $6946+00$ & $7020+00$ & Under Seepage/Pin Boils & Moderate & $\begin{array}{l}\text { Light to moderate underseepage along toe of the seepage berm and } \\
\text { extending out and filling low area approximately } 150 \text { feet from berm toe. } \\
\text { Area is very soft/spongy with a few small pin boils that were identified. } \\
\text { Light seepage extended downstream to an old slough near levee Sta. } 7020 .\end{array}$ & $88-94$ \\
\hline 32.83171263 & 91.10317817 & 32.83171263 & 91.10317817 & $7067+00$ & $7100+00$ & Sand Boil & Heavy & $\begin{array}{l}\text { Multiple, high energy, sand boils approximately } 10 \text { to } 50 \text { feet from the } \\
\text { seepage berm toe near levee Sta. } 7100 \text {. Boils were flowing } 20 \text { to } 50 \mathrm{gpm} \\
\text { and transporting moderate quantities of fine sand ( } 2 \text { to } 5 \text { cubic yards each). } \\
\text { Throat diameters for the boils generally ranged from } 2 \text { to } 10 \text {-inches. Some } \\
\text { of the boils were ringed with culverts. }\end{array}$ & $95-99$ \\
\hline
\end{tabular}




\begin{tabular}{|c|c|c|c|c|c|c|c|c|c|}
\hline \multicolumn{2}{|c|}{ START } & \multicolumn{2}{|c|}{ END } & \multirow{2}{*}{$\begin{array}{c}\text { STATION } \\
\text { NLD } \\
\end{array}$} & \multirow{2}{*}{$\begin{array}{c}\text { STATION } \\
\text { FIELD MARKER }\end{array}$} & \multirow[t]{2}{*}{ TYPE } & \multirow[t]{2}{*}{ EXTENT } & \multirow[t]{2}{*}{ REMARKS } & \multirow[t]{2}{*}{ PHOTO } \\
\hline Latitude & Longitude & Latitude & Longitude & & & & & & \\
\hline 32.80137359 & 91.12194688 & 32.80137359 & 91.12194688 & $\begin{array}{l}7195+00 \text { to } \\
7210+00\end{array}$ & $7120+00$ & Sand Boil & Heavy & $\begin{array}{l}\text { Ben Lomand Road Site - Several medium to large sand boils were } \\
\text { identified moving moderate quantities of fine sand and silt in a drainage } \\
\text { ditch along the toe of the seepage berm and in an open area east of the } \\
\text { ditch. All of the sand boils were within } 10 \text { to } 20 \text { feet of the seepage } \\
\text { seepage berm toe. A water berm was created over most of the sand boils } \\
\text { in the ditch by the levee board by constructing dikes on the upstream } \\
\text { and downstream sides of the sand boils. Also, at least three of the } \\
\text { sand boils in the ditch were ringed with galvanized culverts. As a result } \\
\text { of the dikes and culverts, most of the boils in the ditch were covered with } \\
\text { at least three to four feet of water. Also, there were several medium } \\
\text { boils identified in the edge of a field on the east side of the ditch } \\
\text { that were ringed with culverts by the levee board and eventually two sand } \\
\text { bag rings were constructed around the area to increase the head and } \\
\text { slow the movement of material. Most of the boils were flowing } \\
\text { approximately } 50 \text { to } 100 \text { gallons per minute each, and continued to } \\
\text { transport a significant quantity of material until the area was stabilized } \\
\text { by remedial action by the levee board. }\end{array}$ & 100-118 \\
\hline 32.78372228 & 91.12866498 & 32.7652499 & 91.11011642 & $\begin{array}{l}7261+00 \text { to } \\
7368+00\end{array}$ & $\begin{array}{l}7210+00 \text { to } \\
7220+00\end{array}$ & Under Seepage & Light & $\begin{array}{l}\text { Light to moderate seepage in a field approximately } 50 \text { feet from the } \\
\text { seepage berm toe near levee Sta. } 7210 \text {. Seepage extends out } \\
\text { approximately } 200 \text { to } 300 \text { feet and extends downstream to near levee } \\
\text { Sta. } 7420 \text { where new relief wells begin. }\end{array}$ & $119-128$ \\
\hline 32.763281 & 91.092714 & 32.763281 & 91.092714 & $7415+00$ & $7368+00$ & Sand Boil & Moderate & $\begin{array}{l}\text { Sand boil identified approximately } 900 \text { feet from the toe of the seepage } \\
\text { berm near levee Sta. } 7368 . \text { Boils has a throat diameter of } \\
\text { approximately 12-inches and is under water. }\end{array}$ & \\
\hline
\end{tabular}



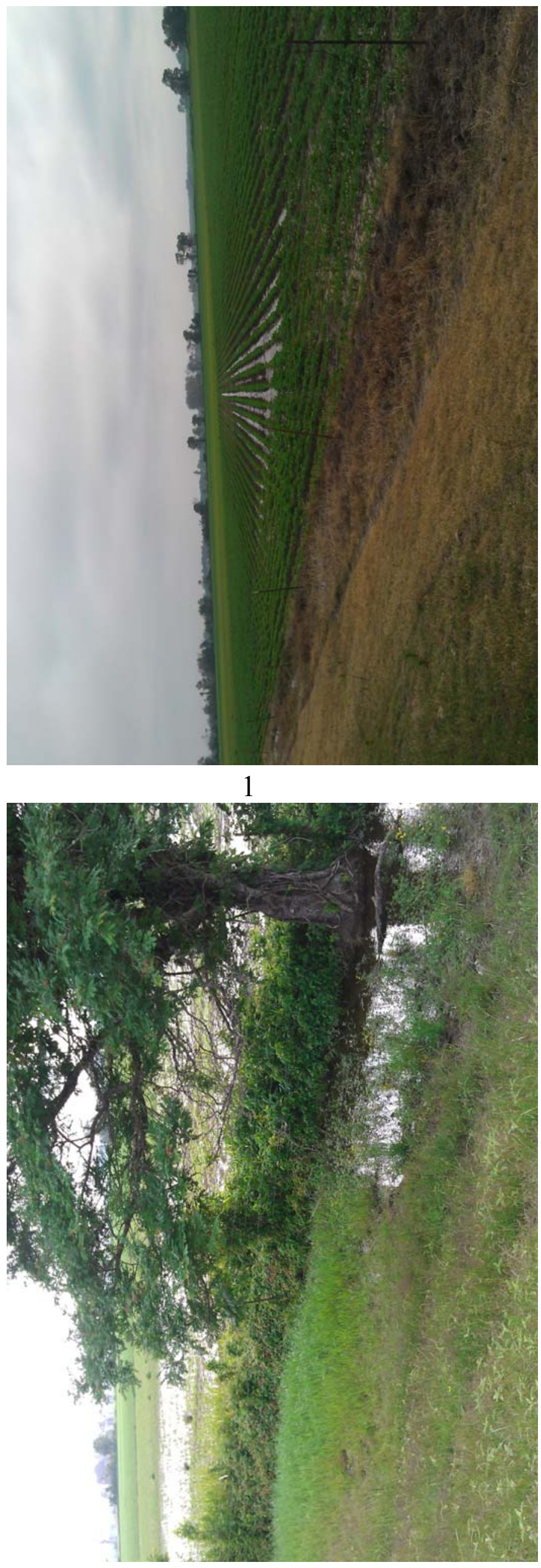

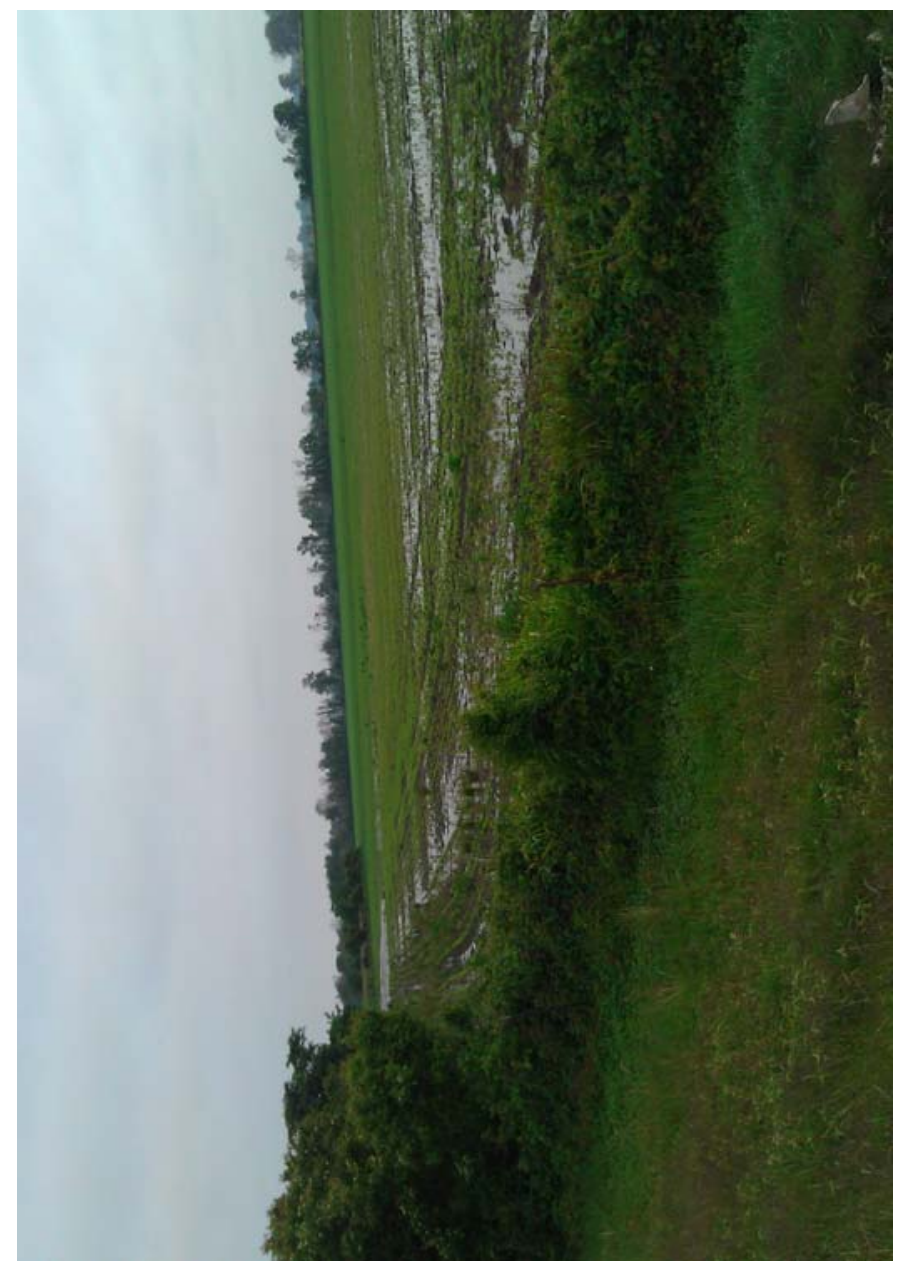

2

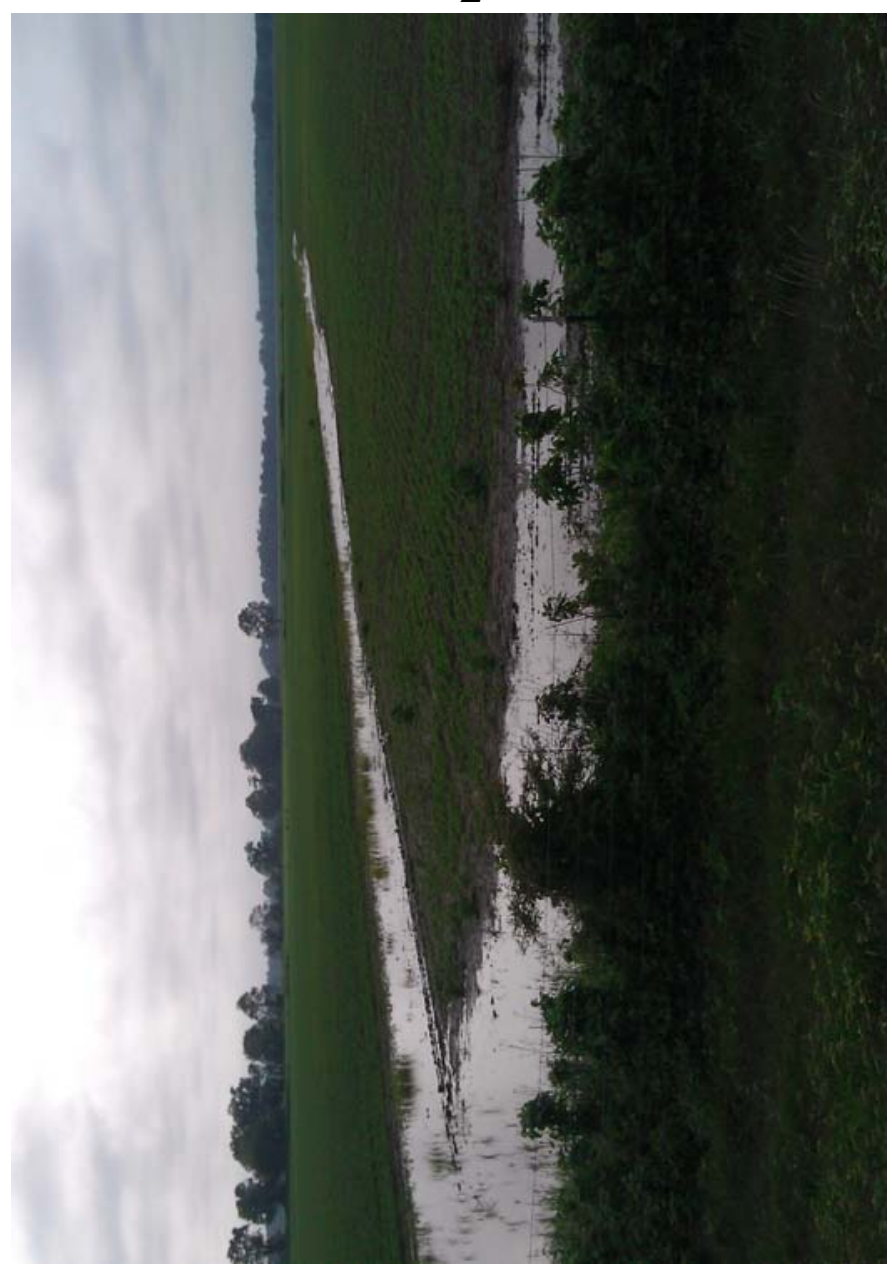




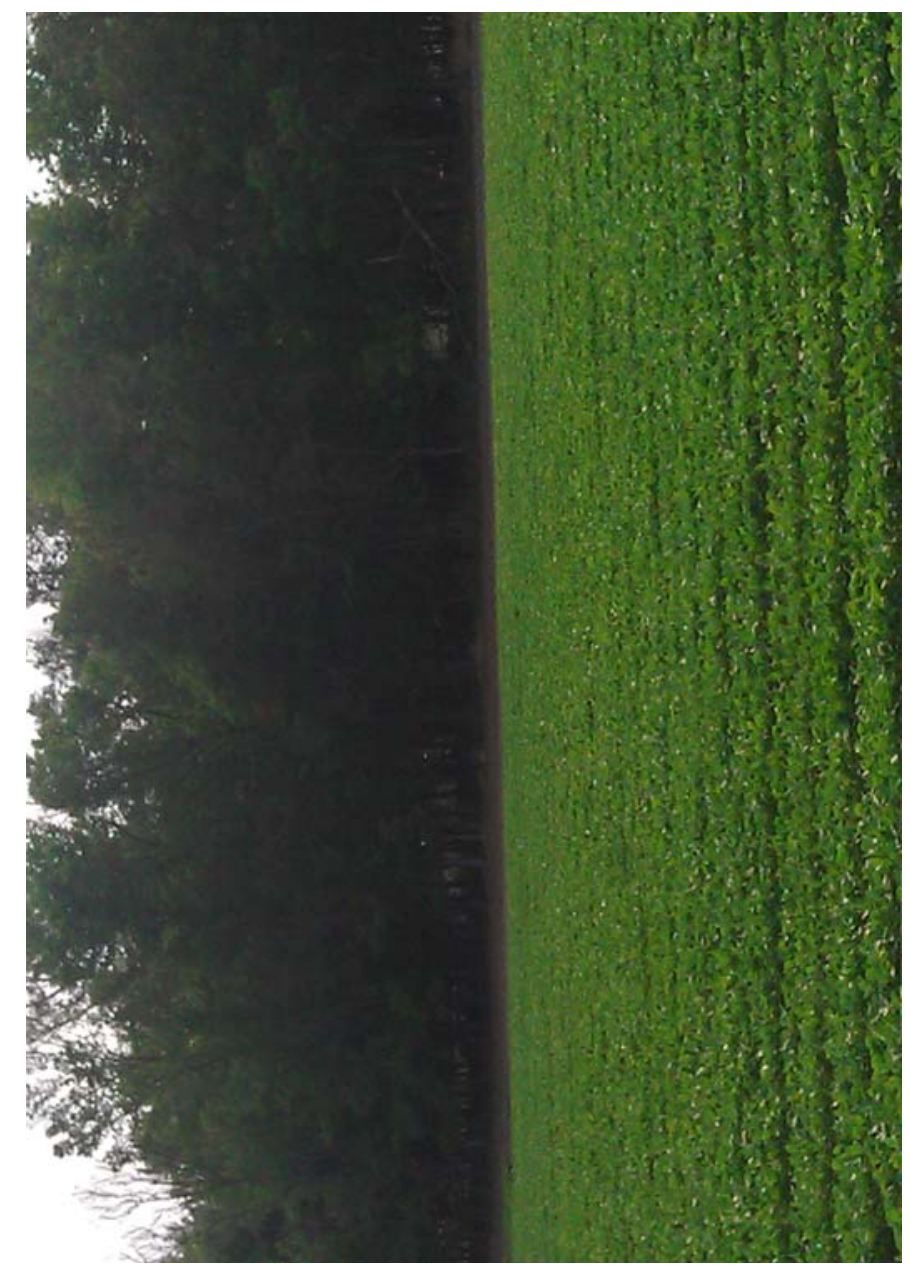

5

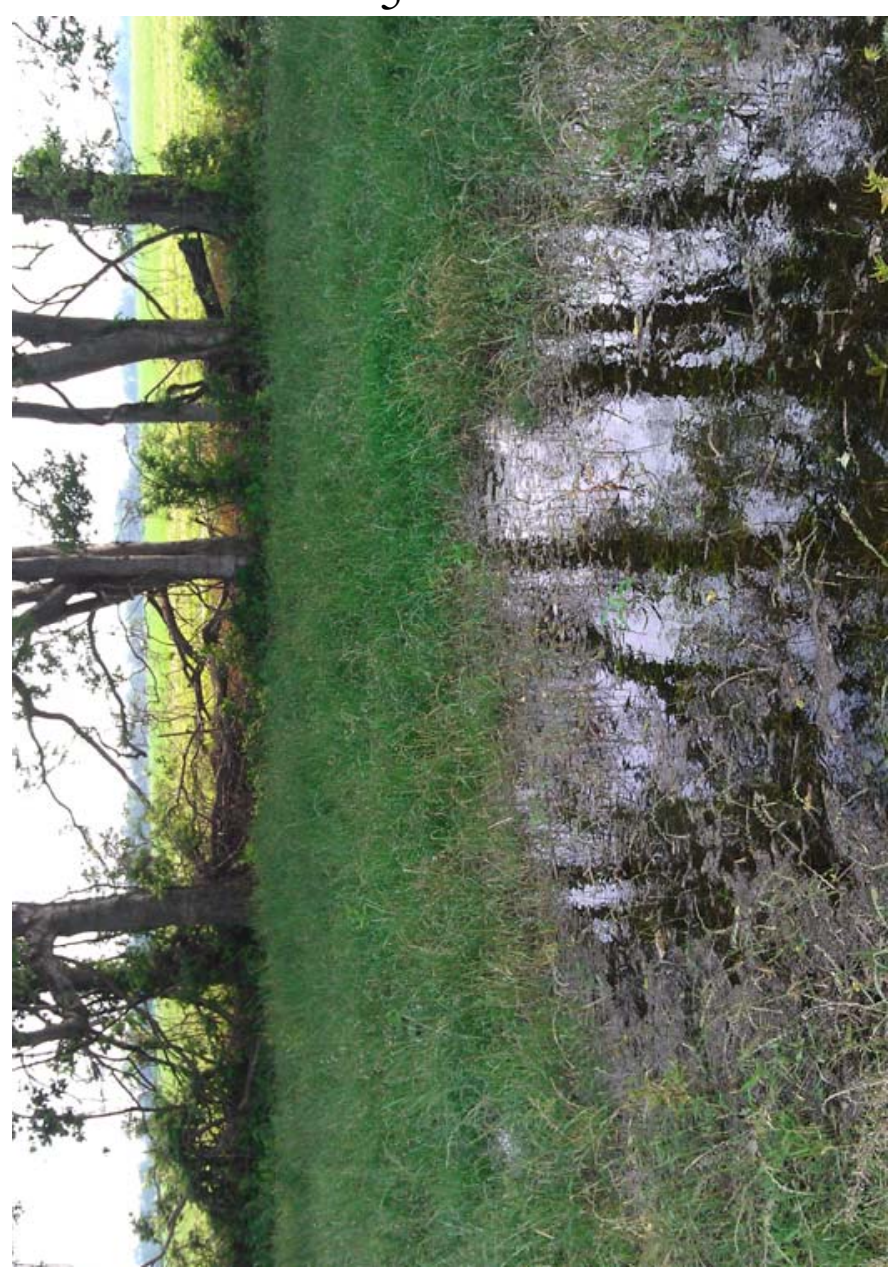

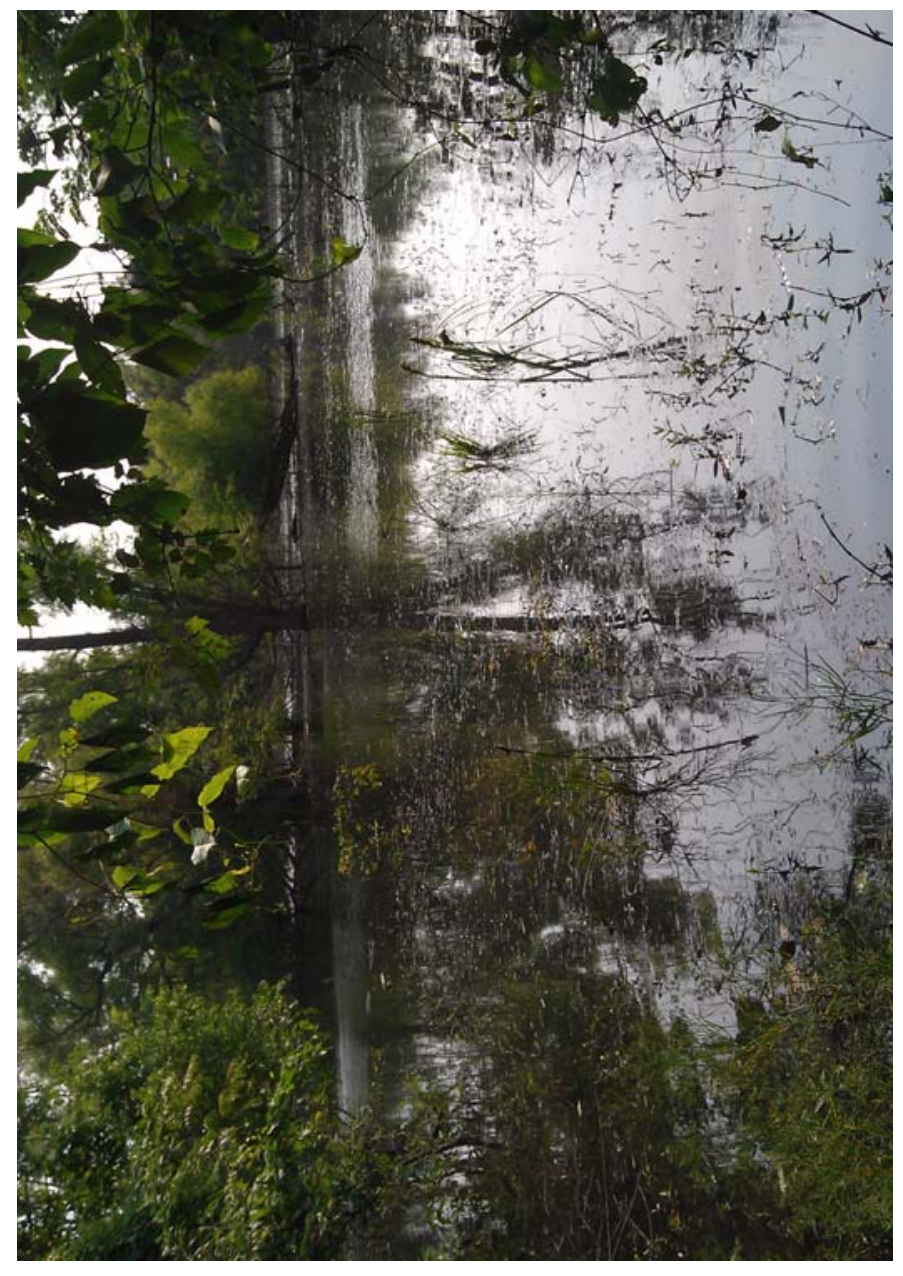

\section{6}

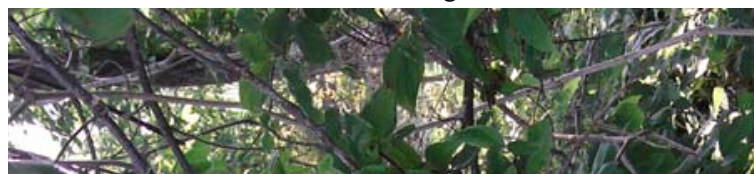

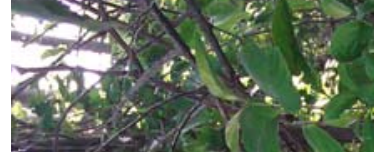

(5)

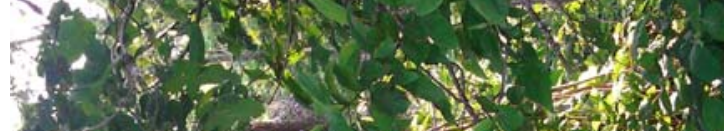

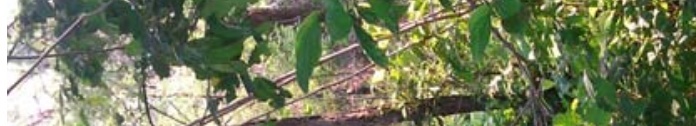

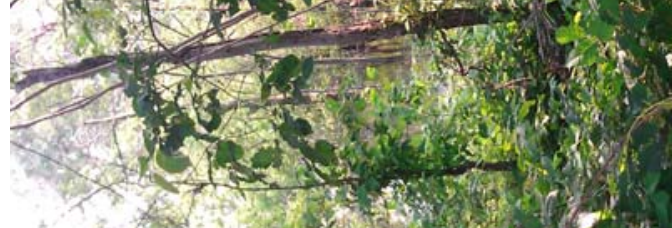

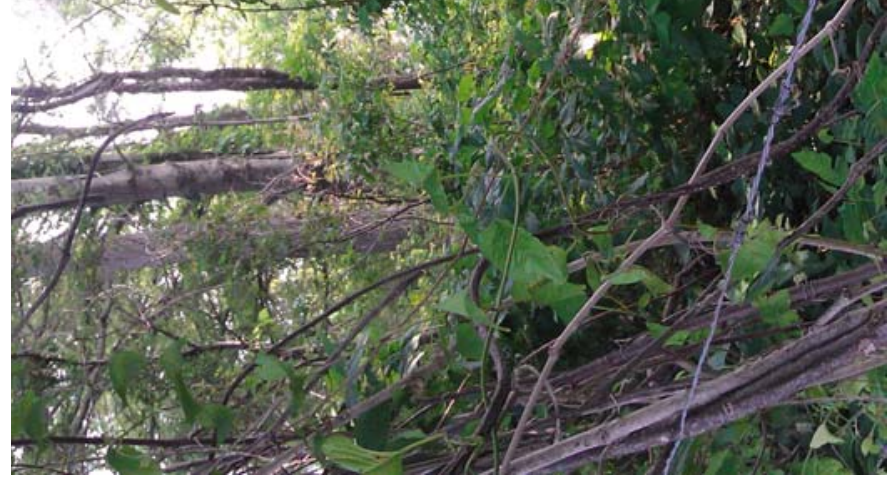




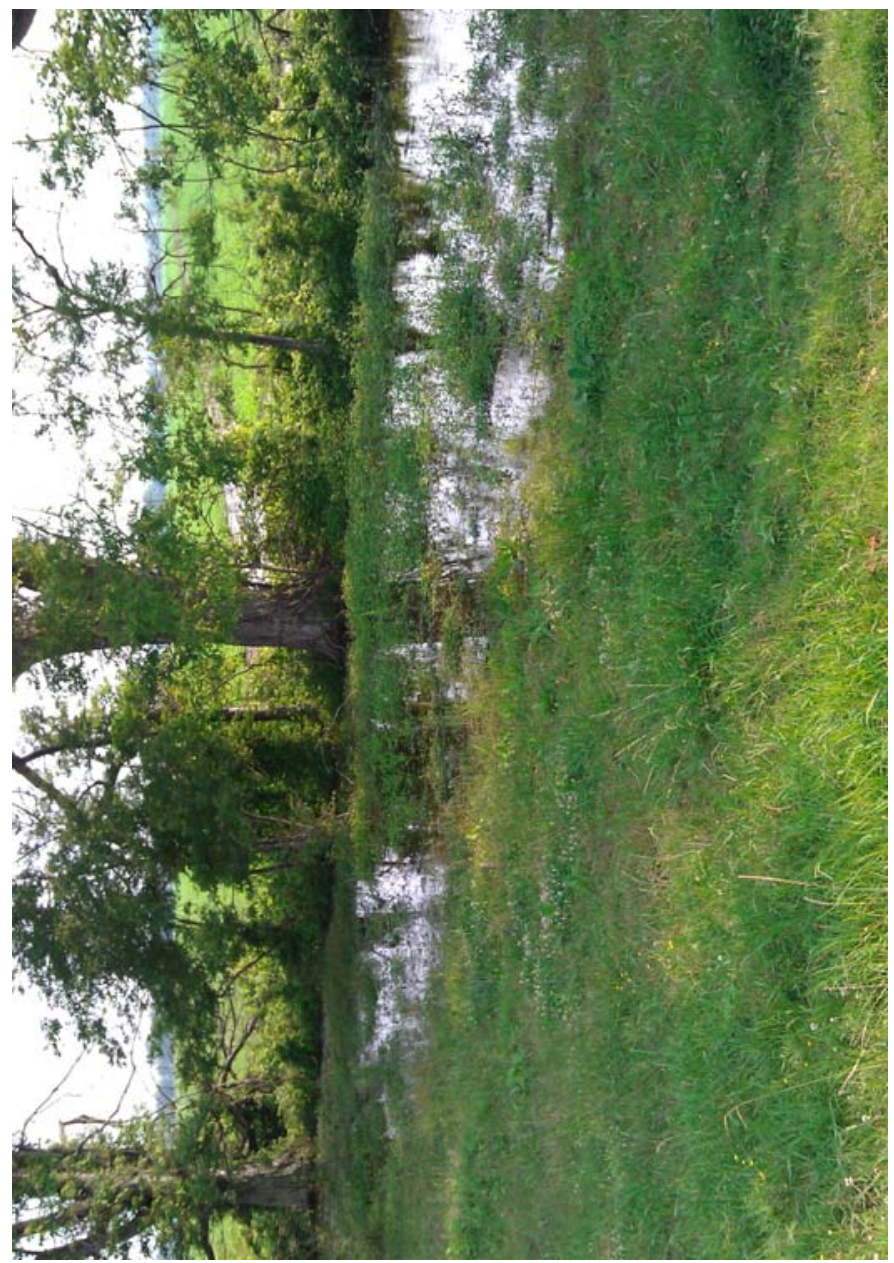

9

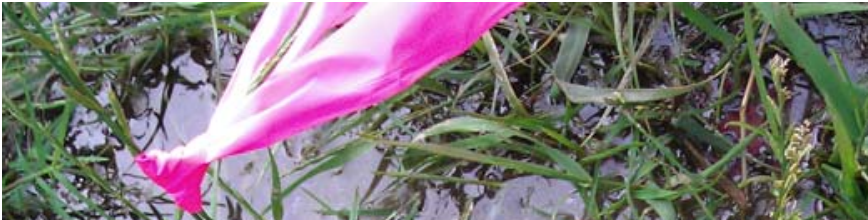

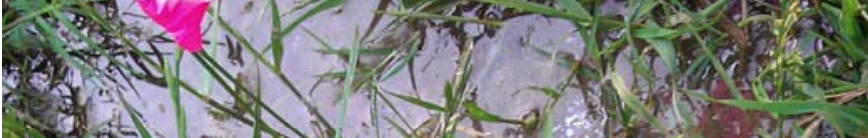
$1+x^{2} \cdot 4$ $\rightarrow+20 \times 2 x^{3}$ ?

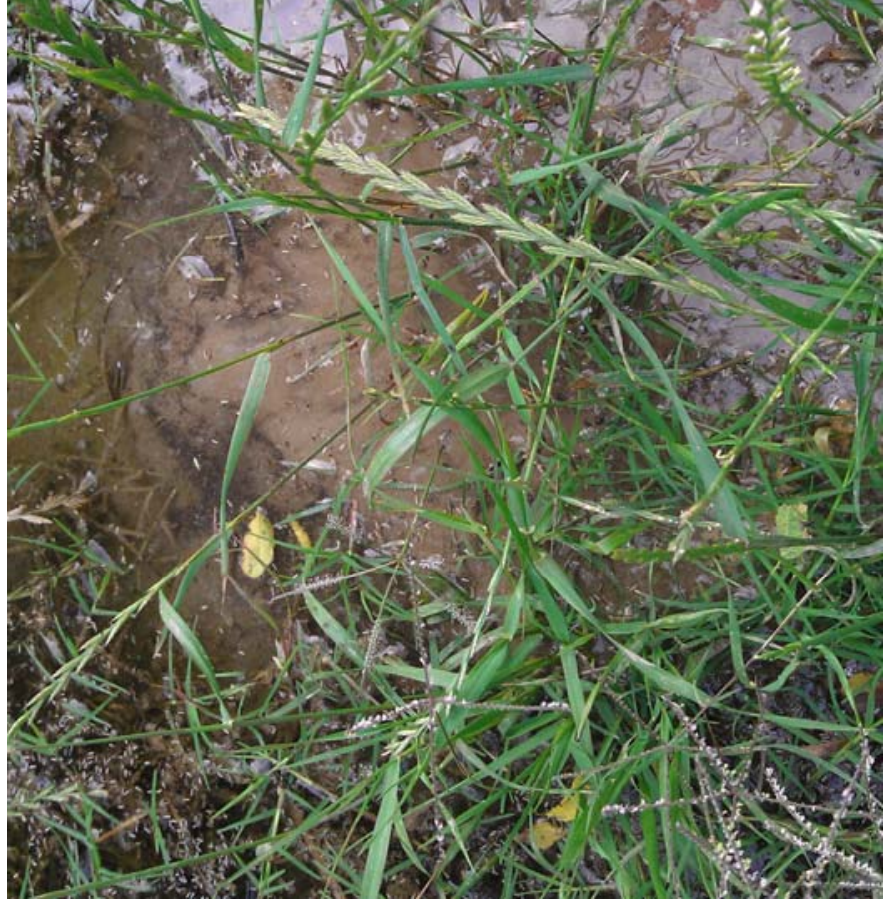

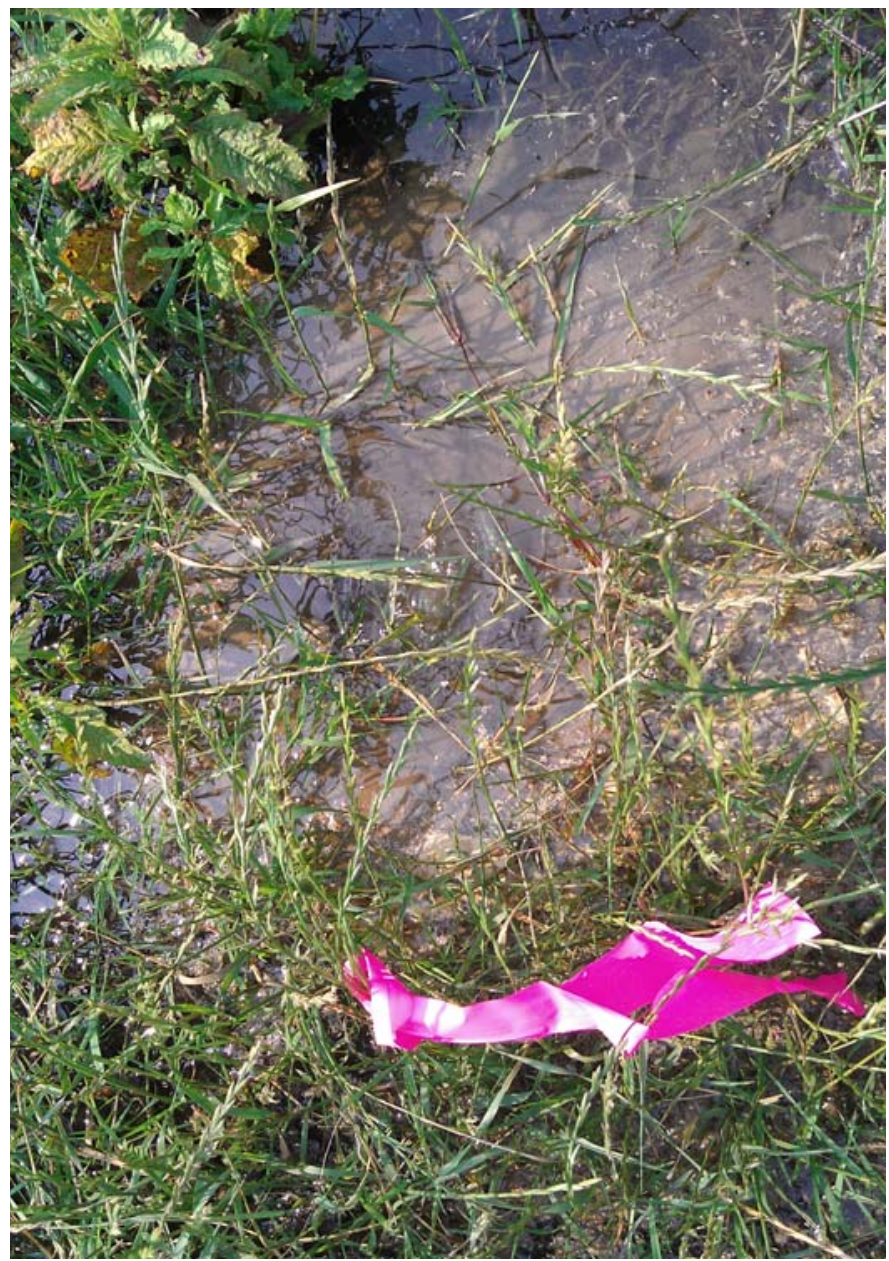

10

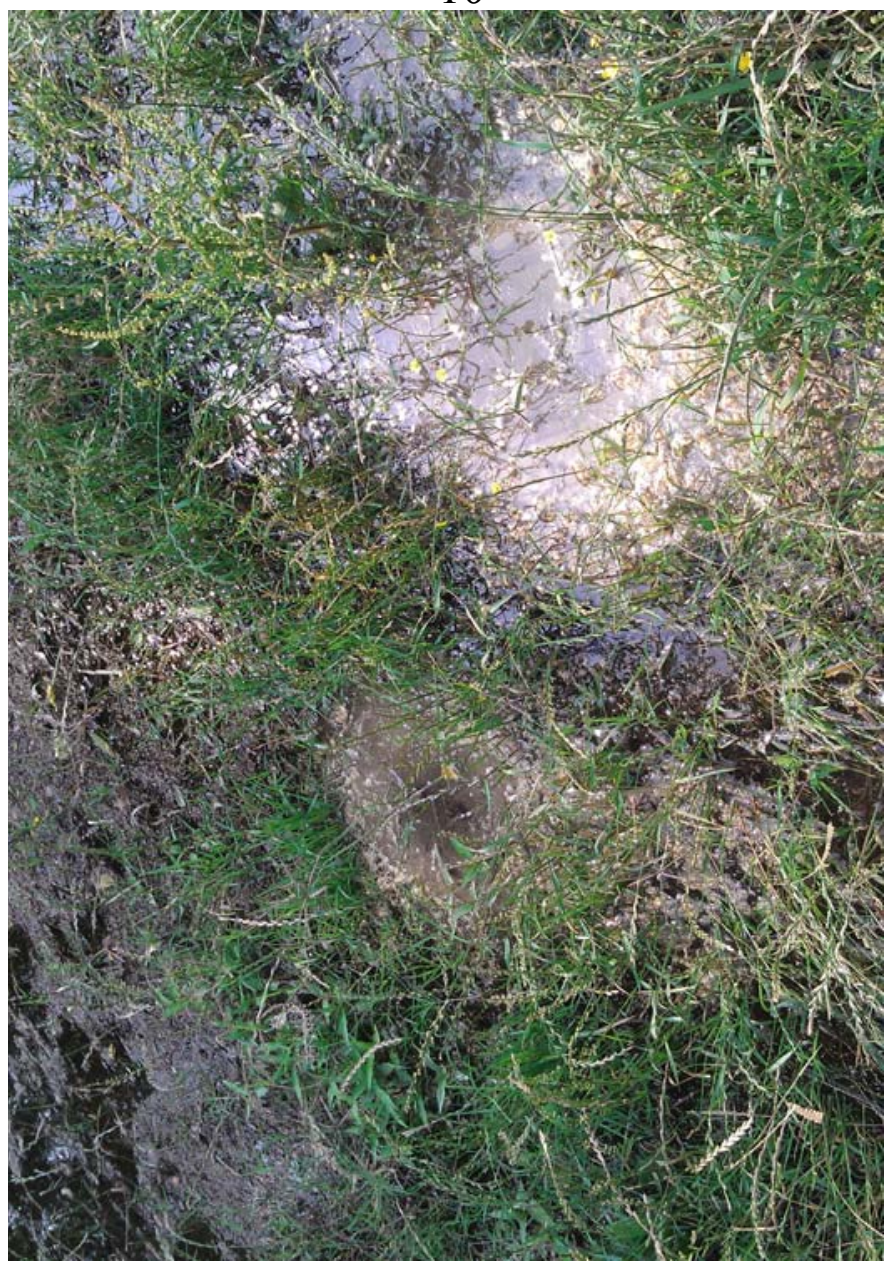




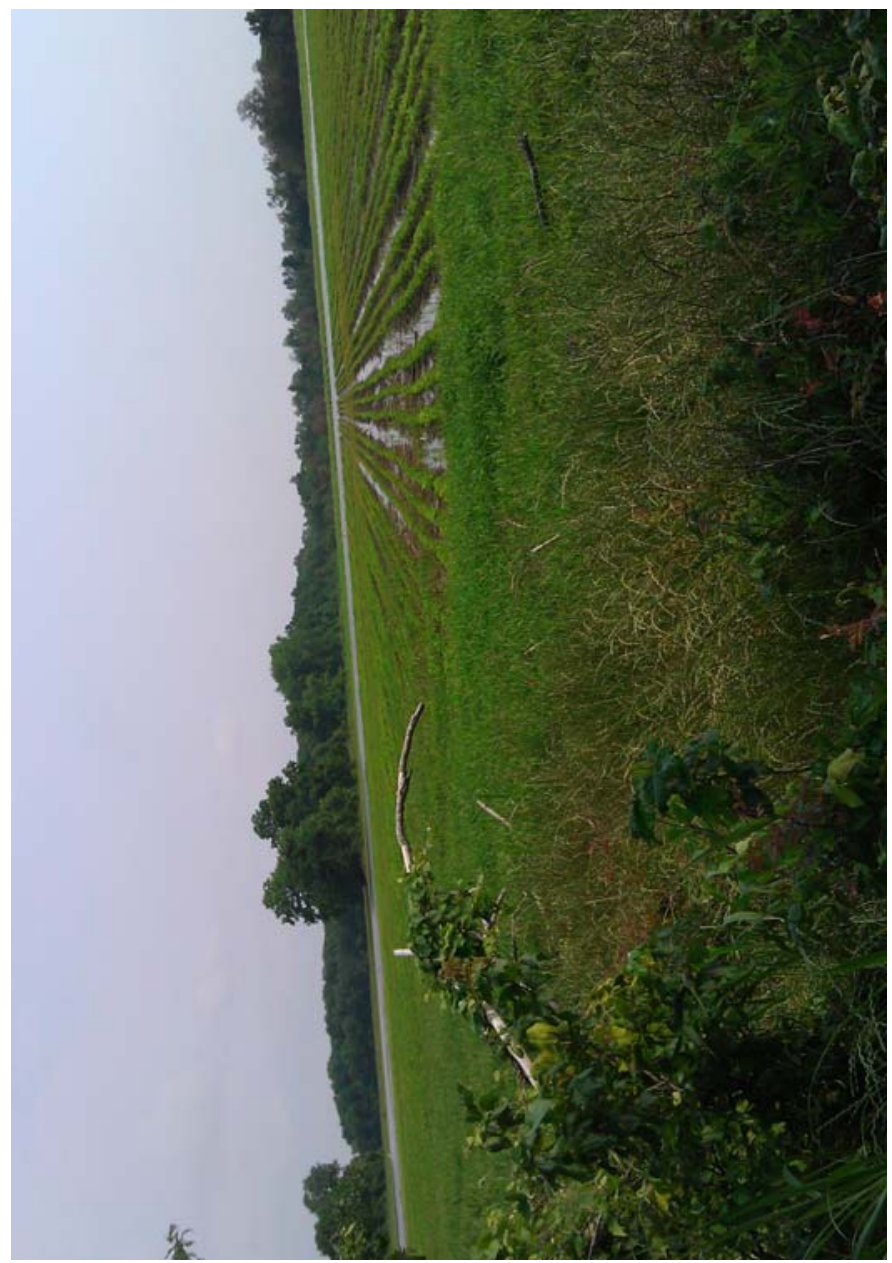

13

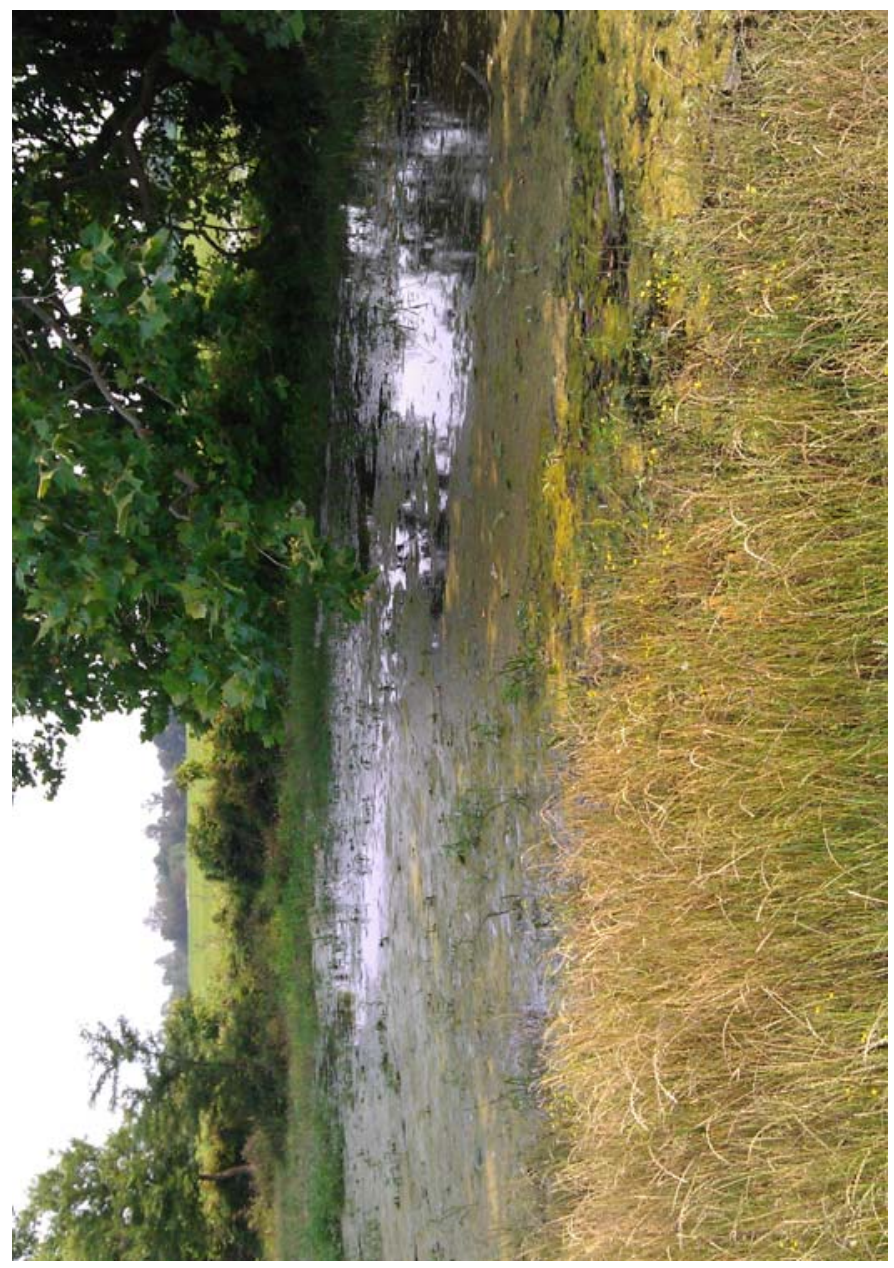




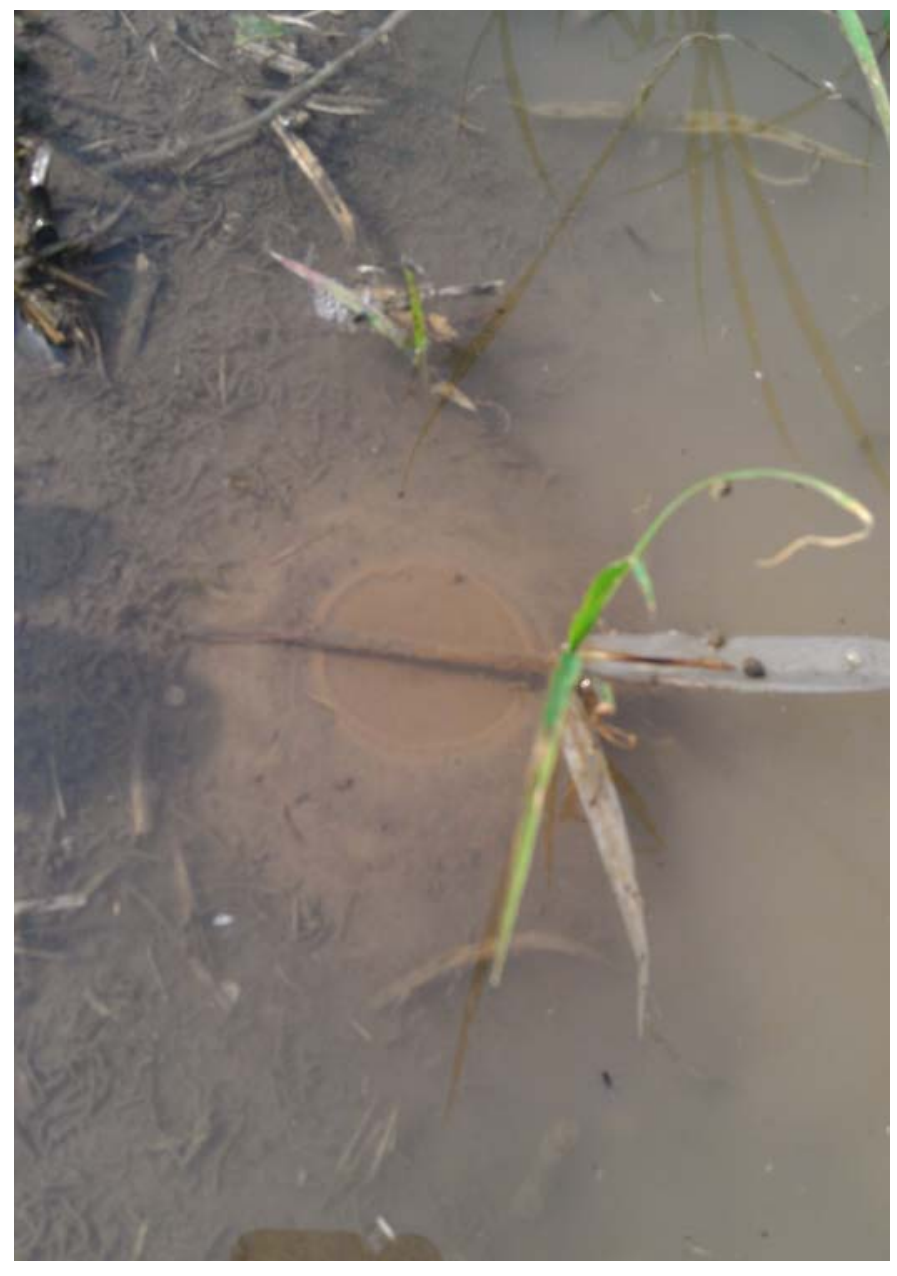

17

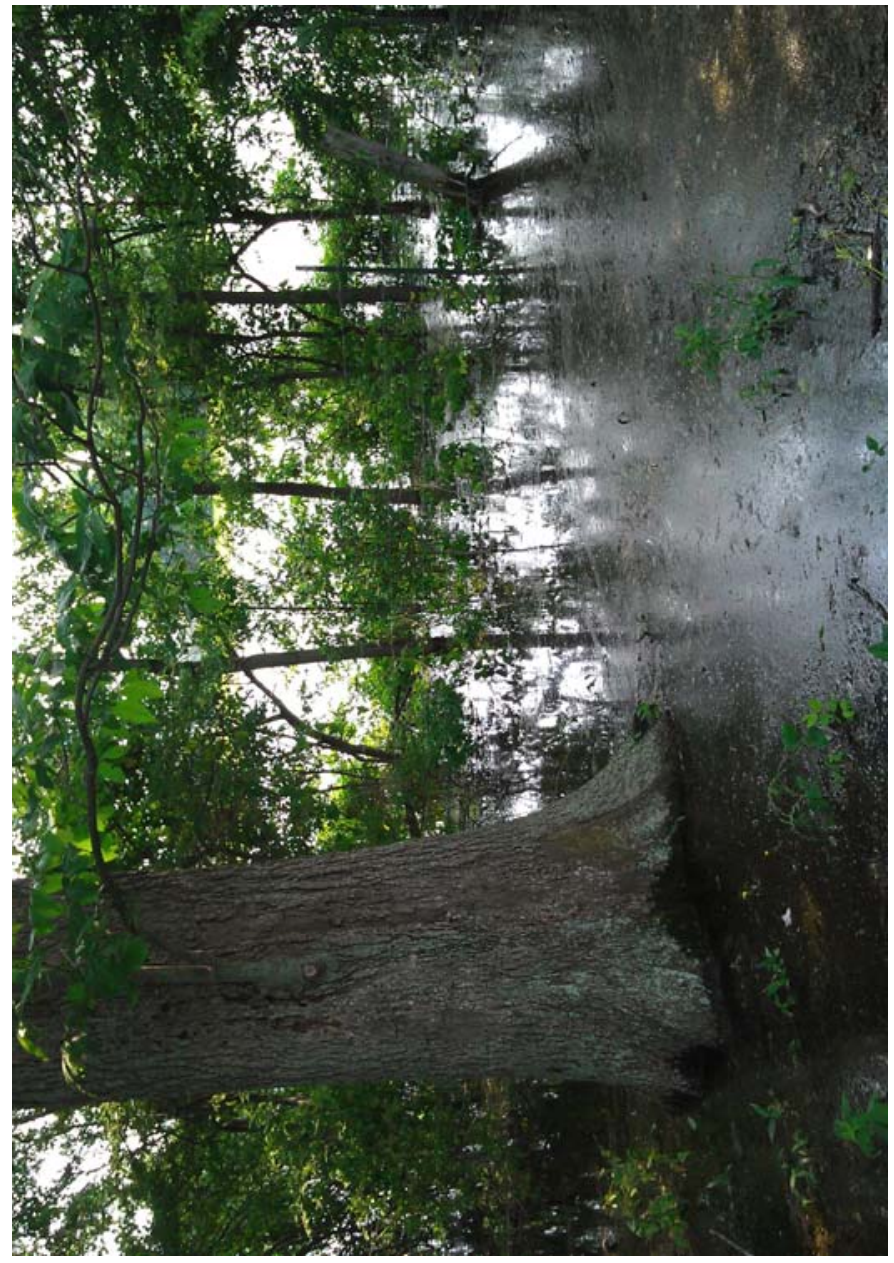

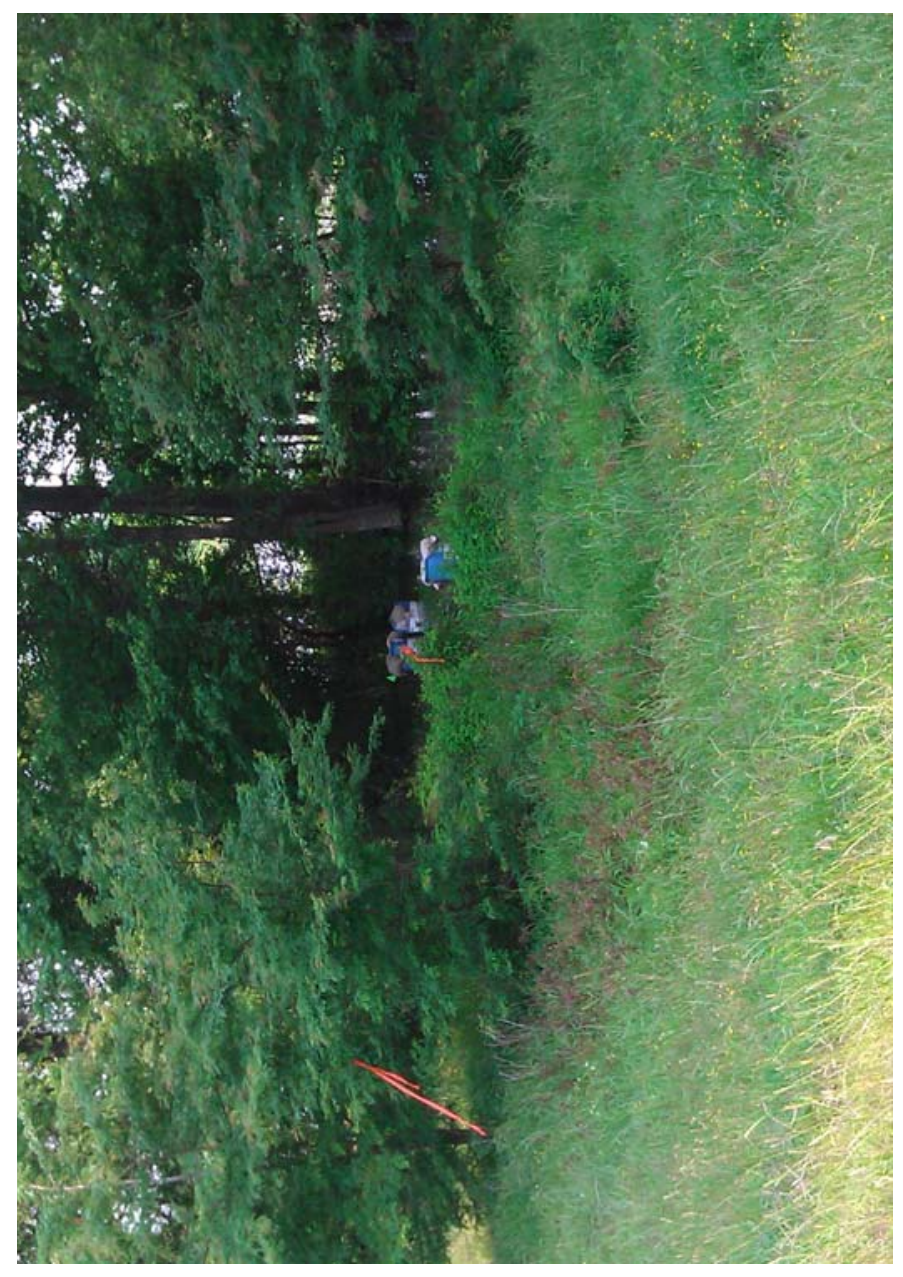

18

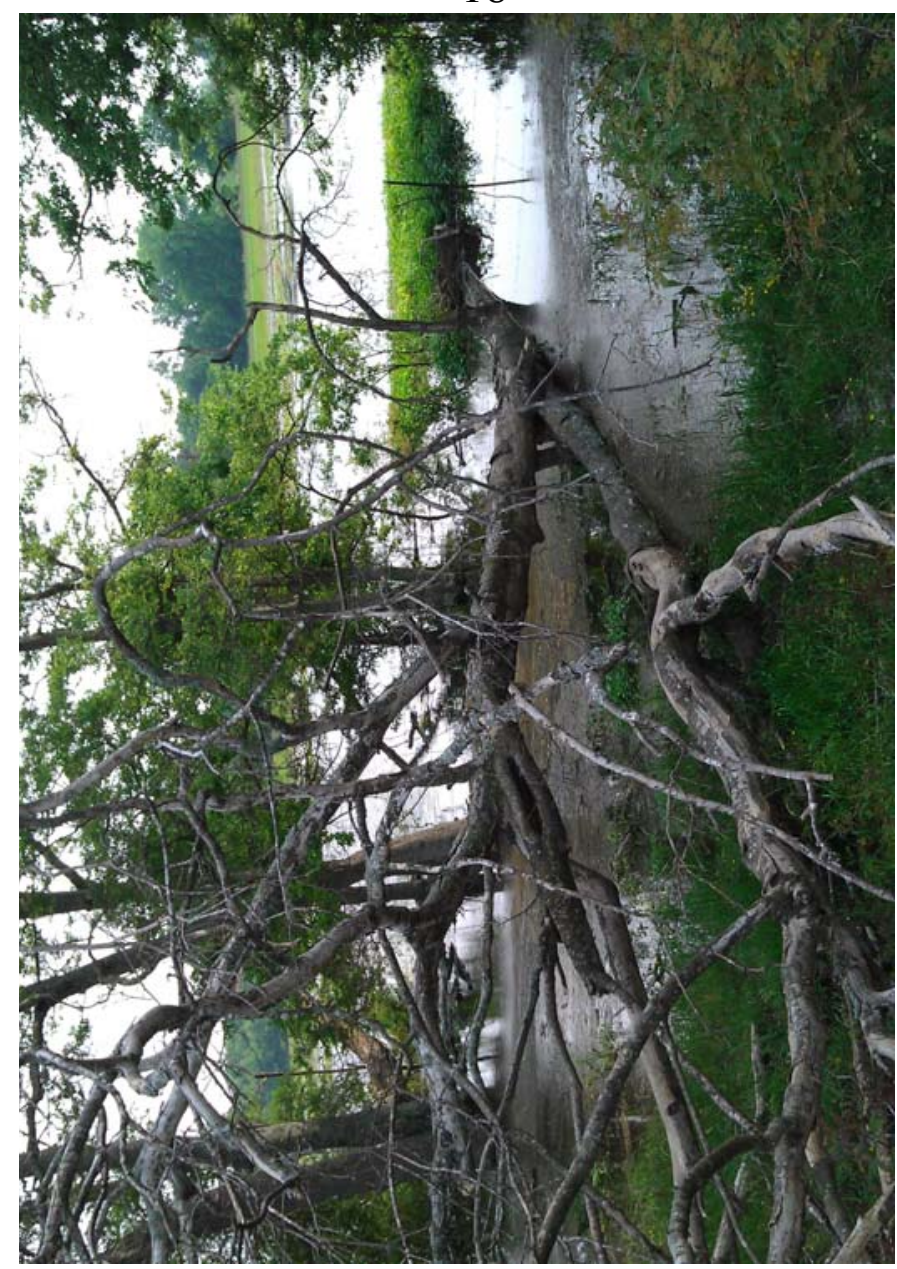




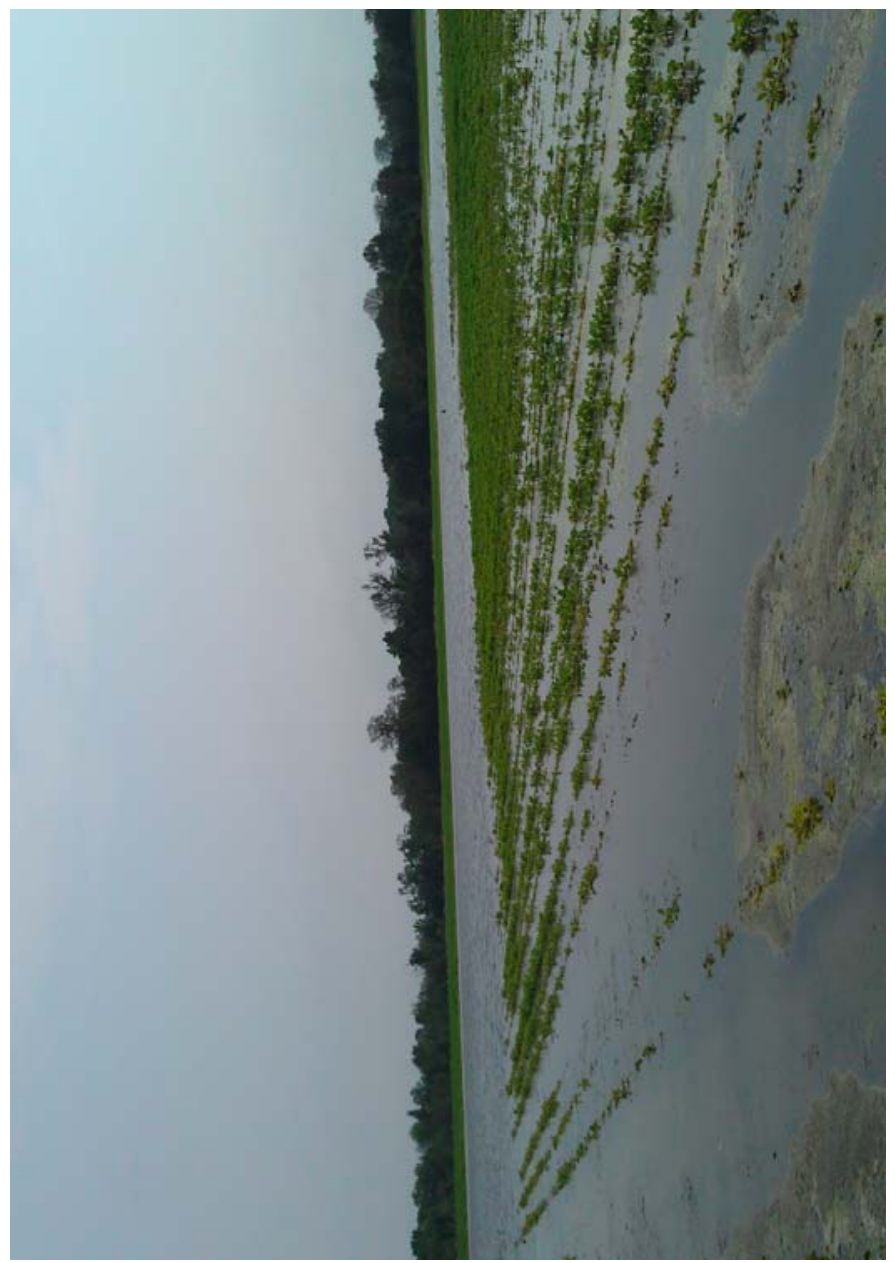

21

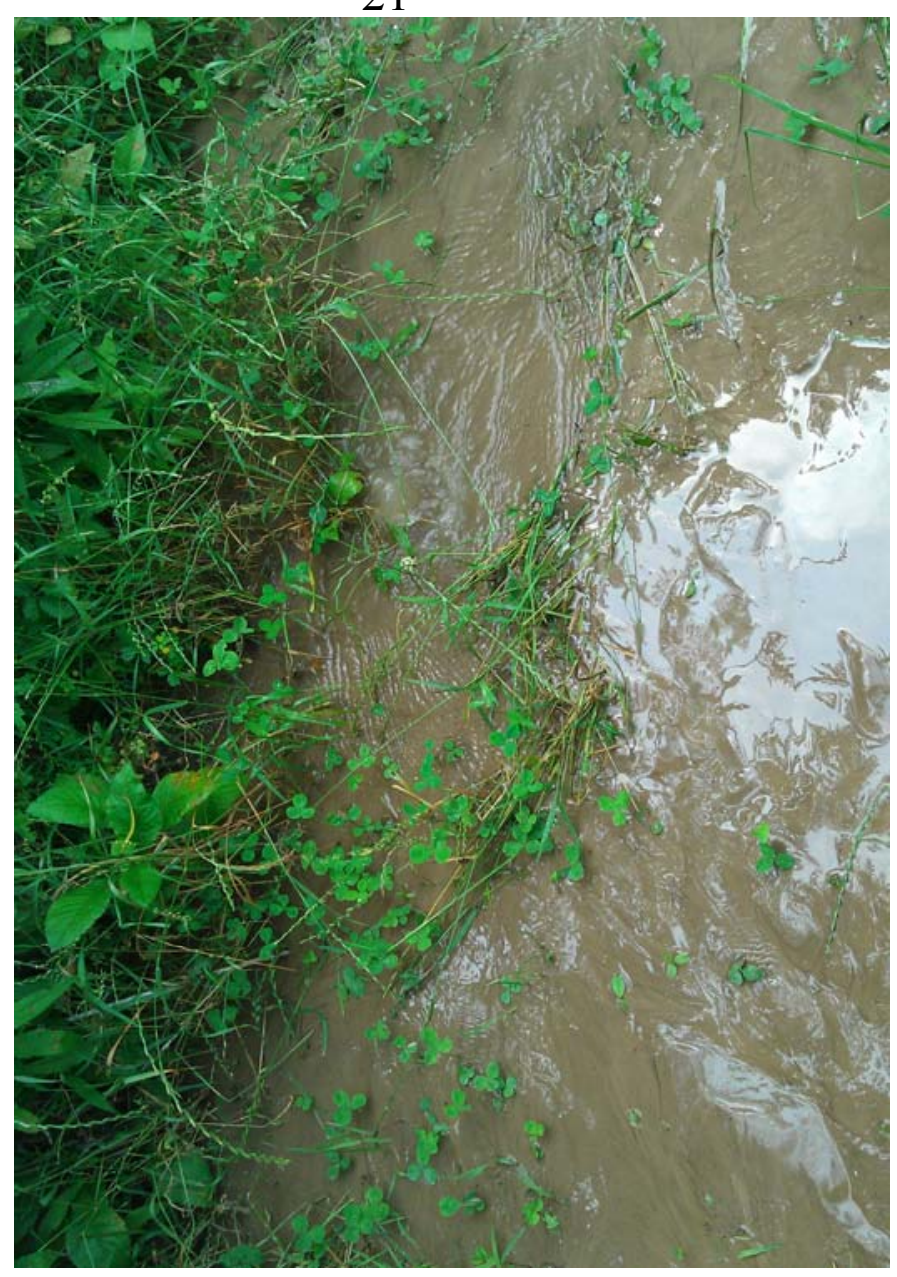




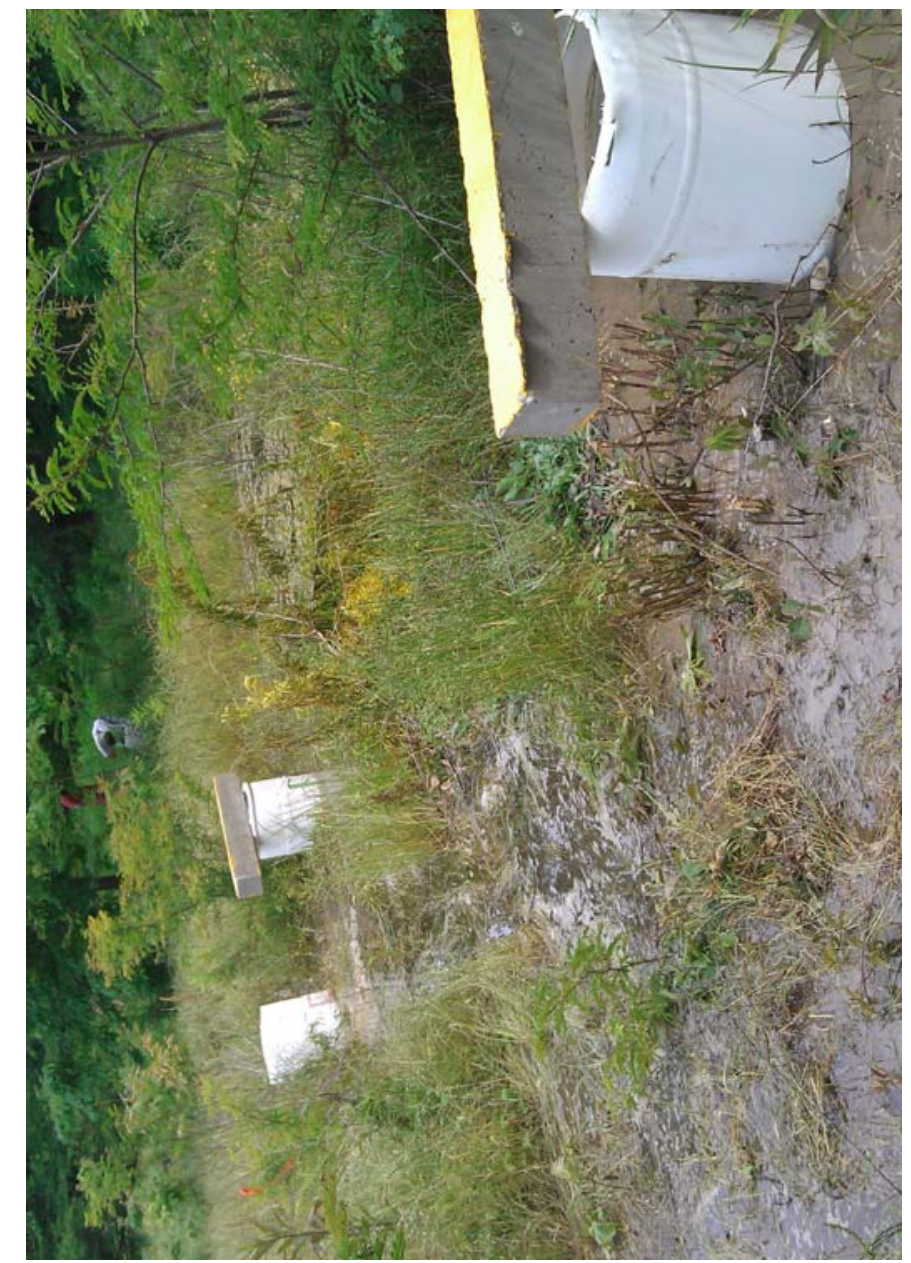

\section{5}

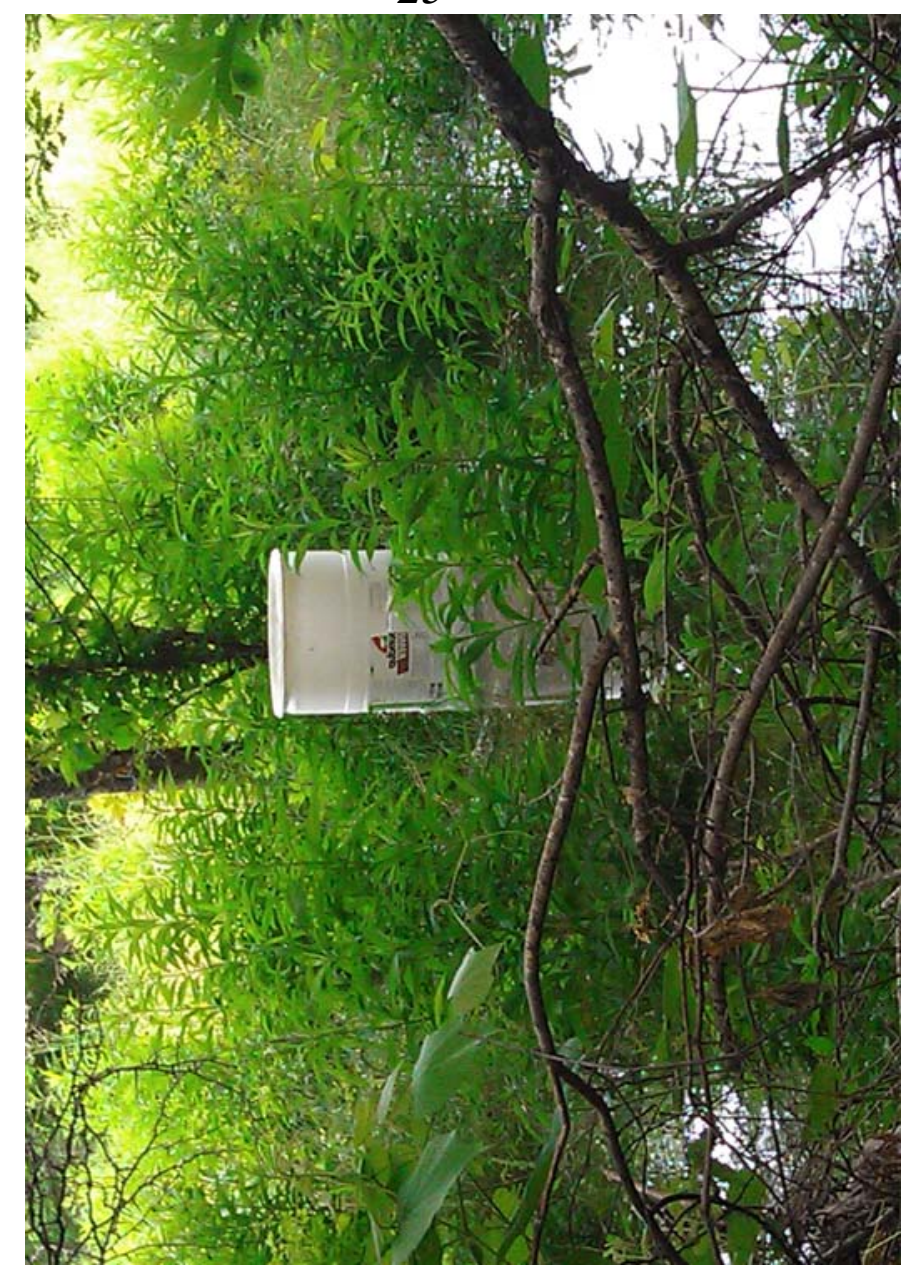

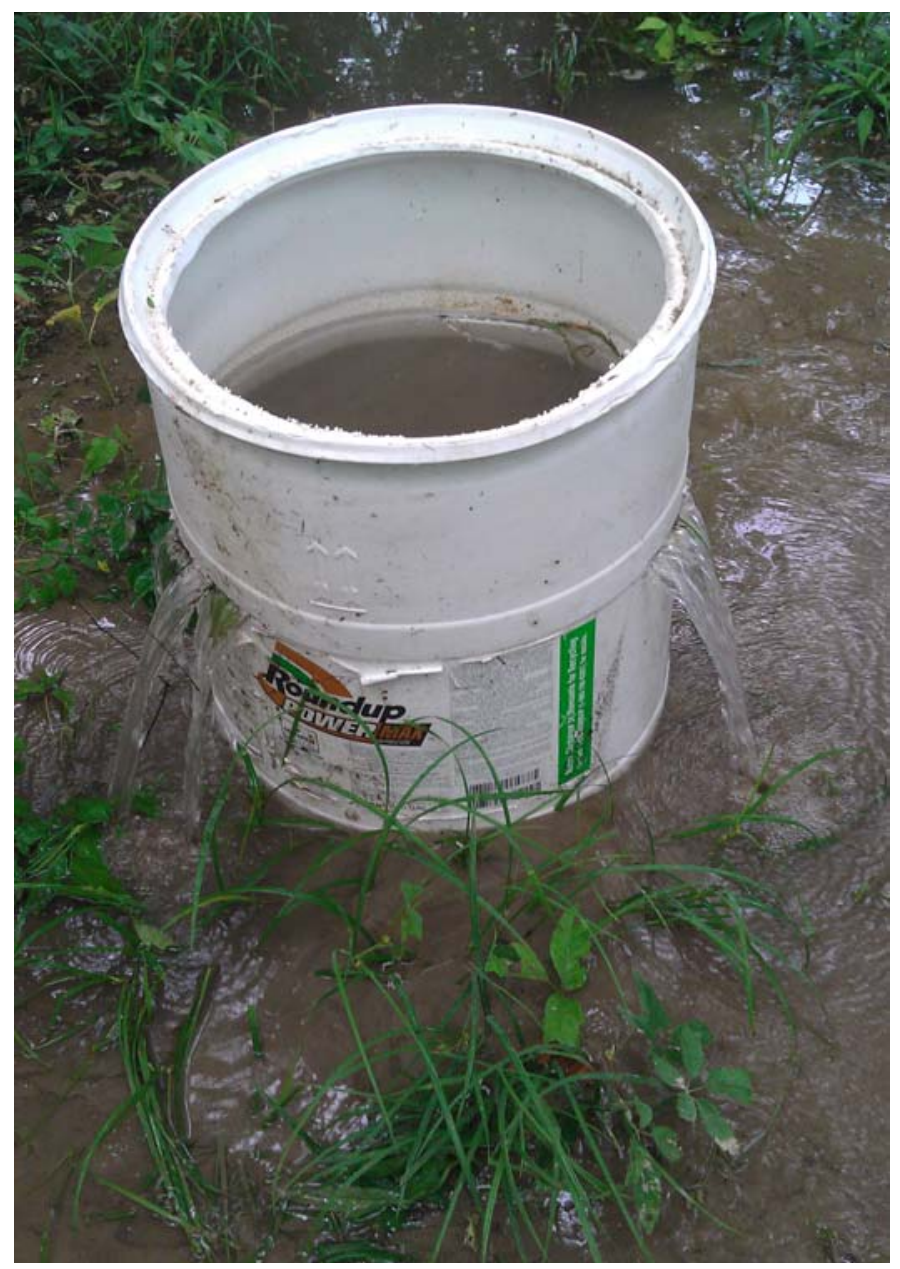

26

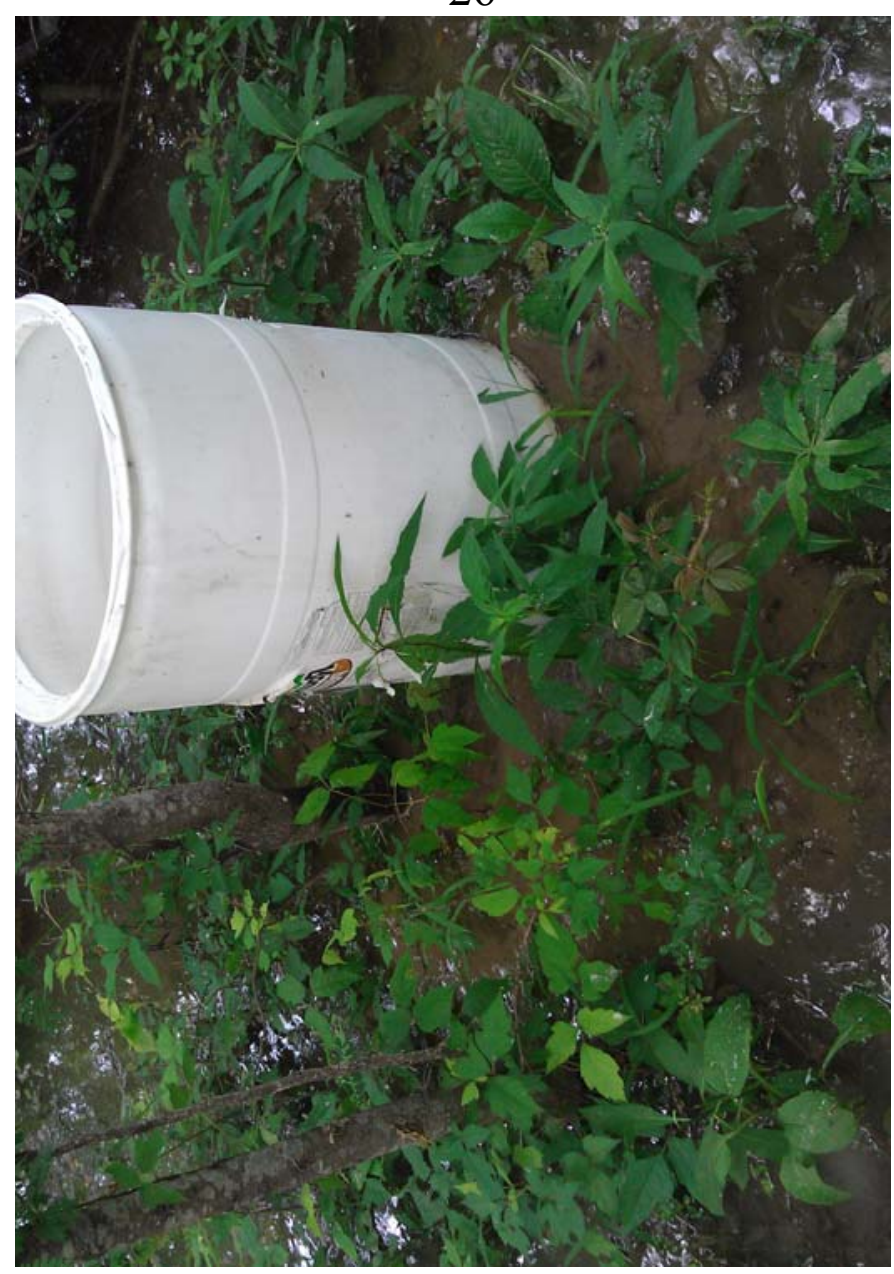




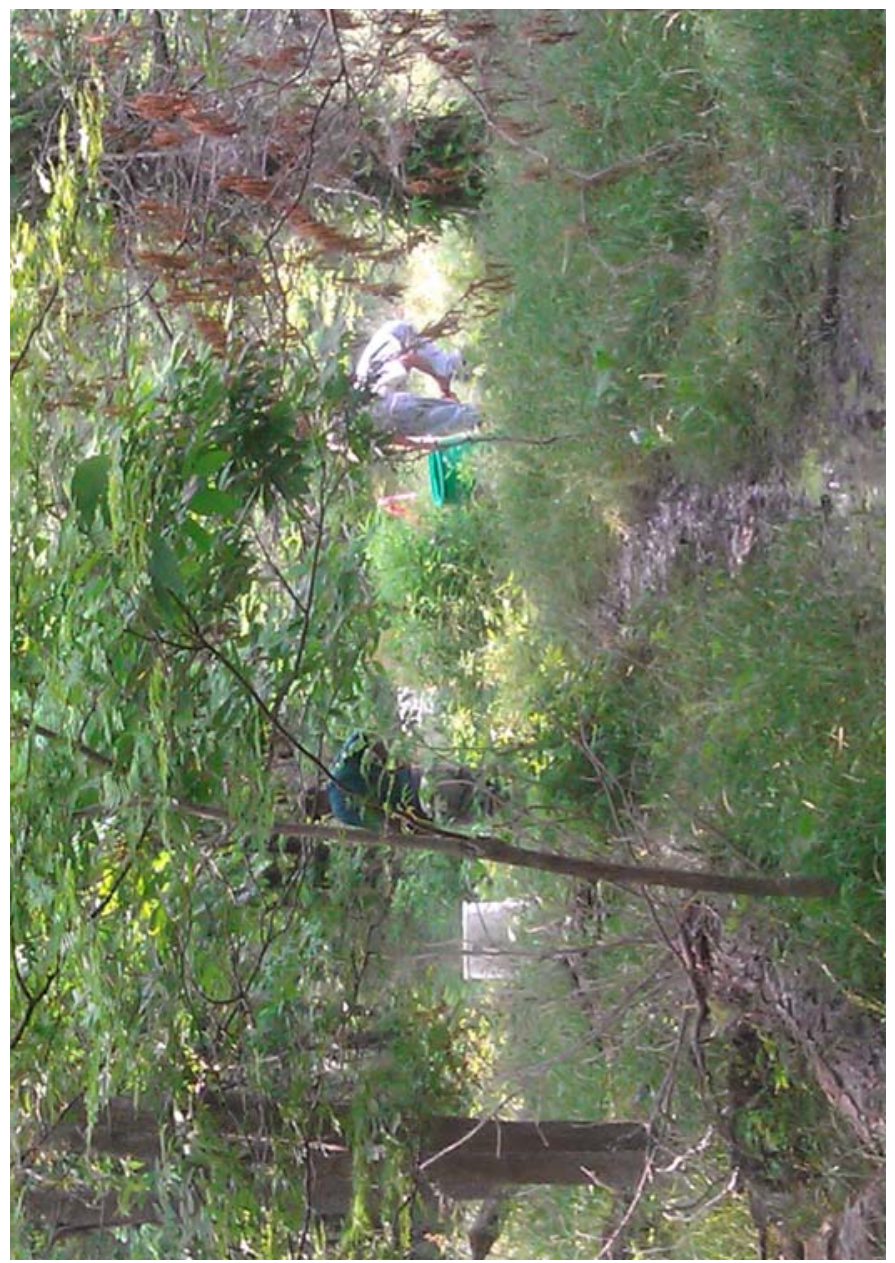

29

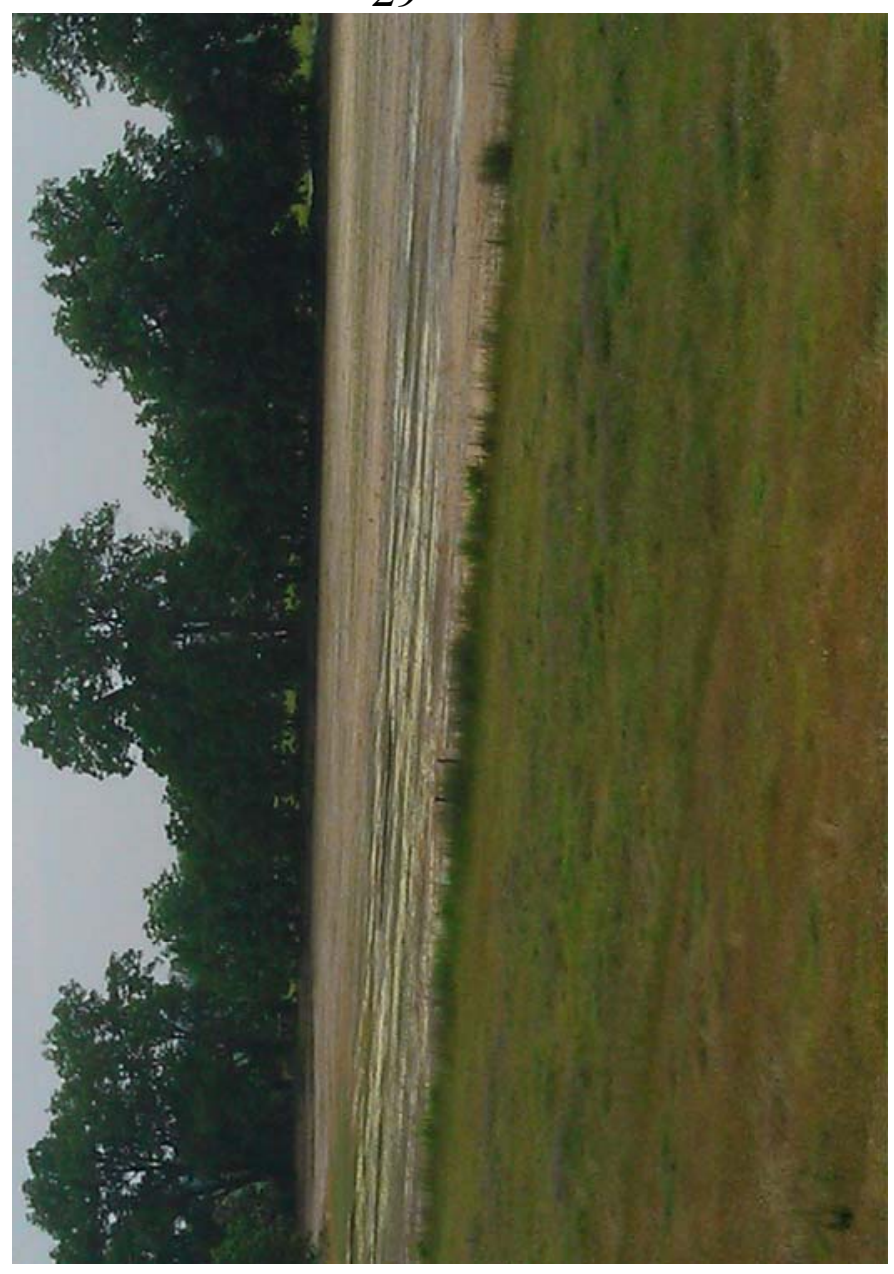

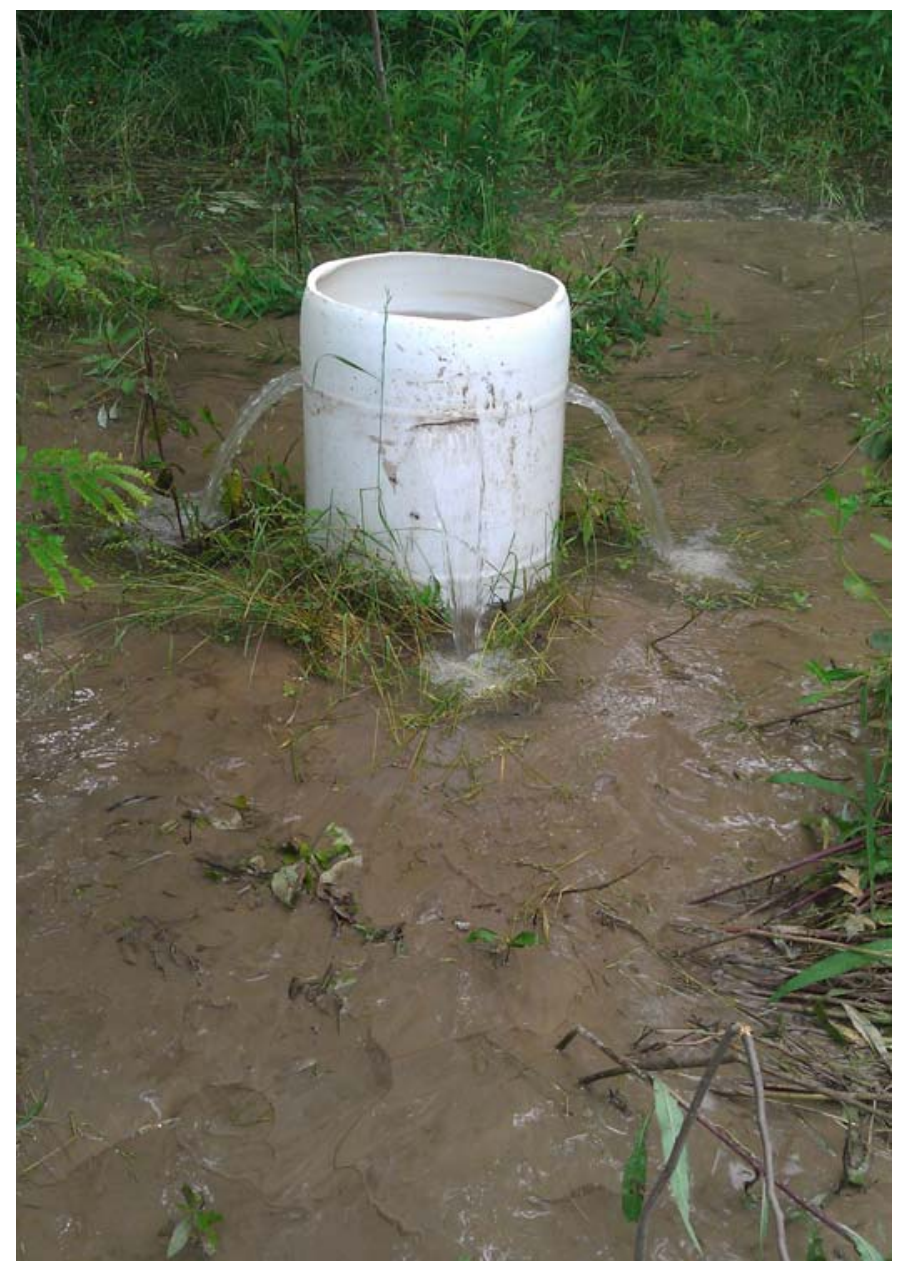

30

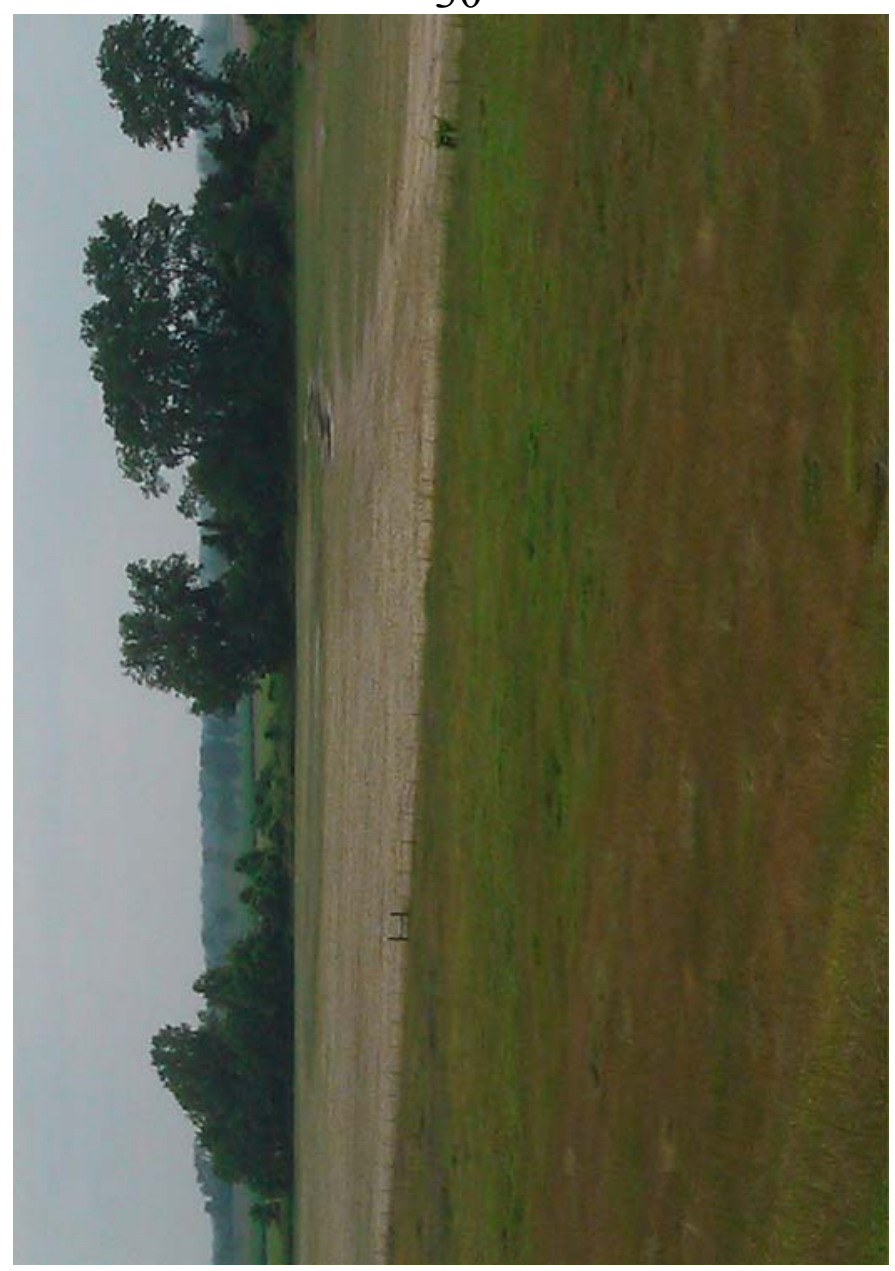




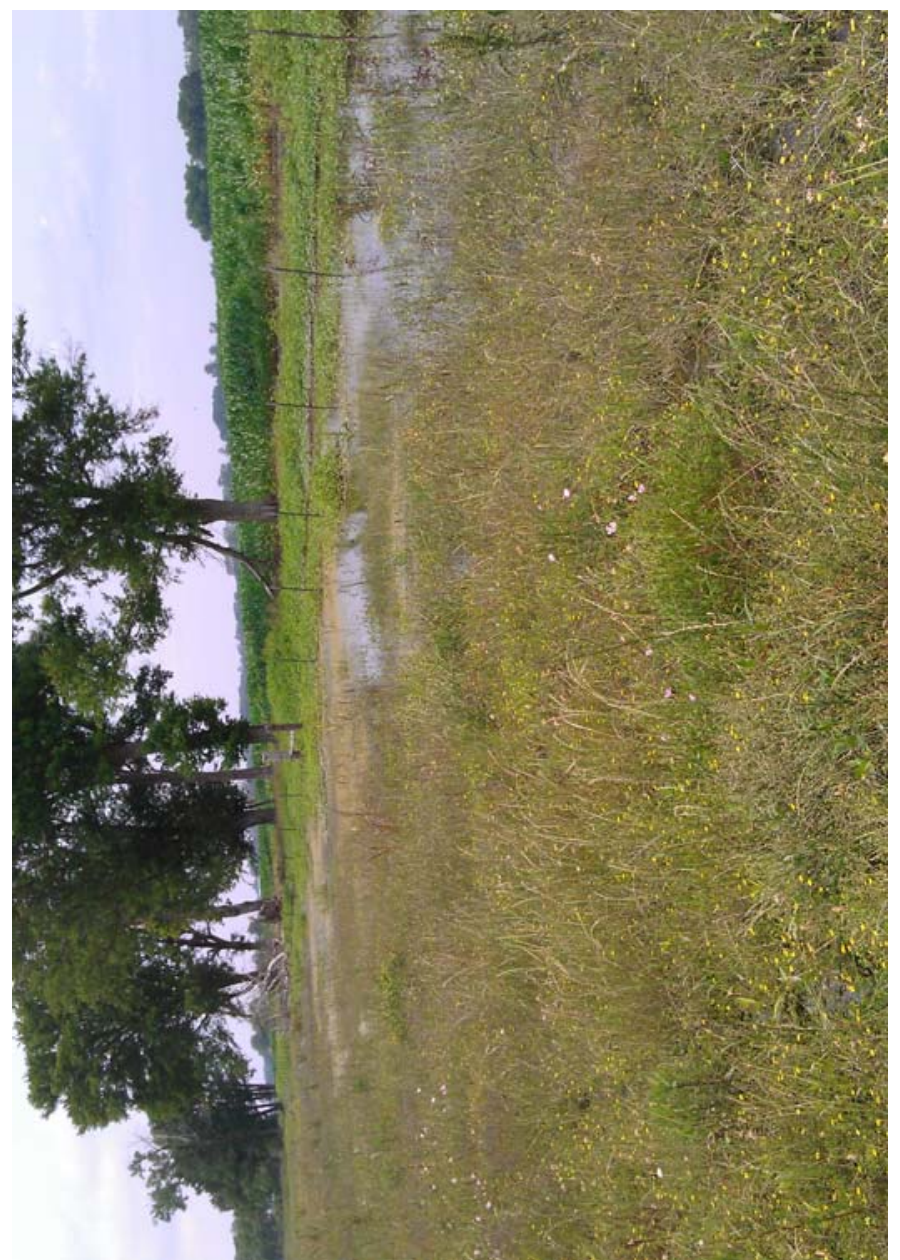

33

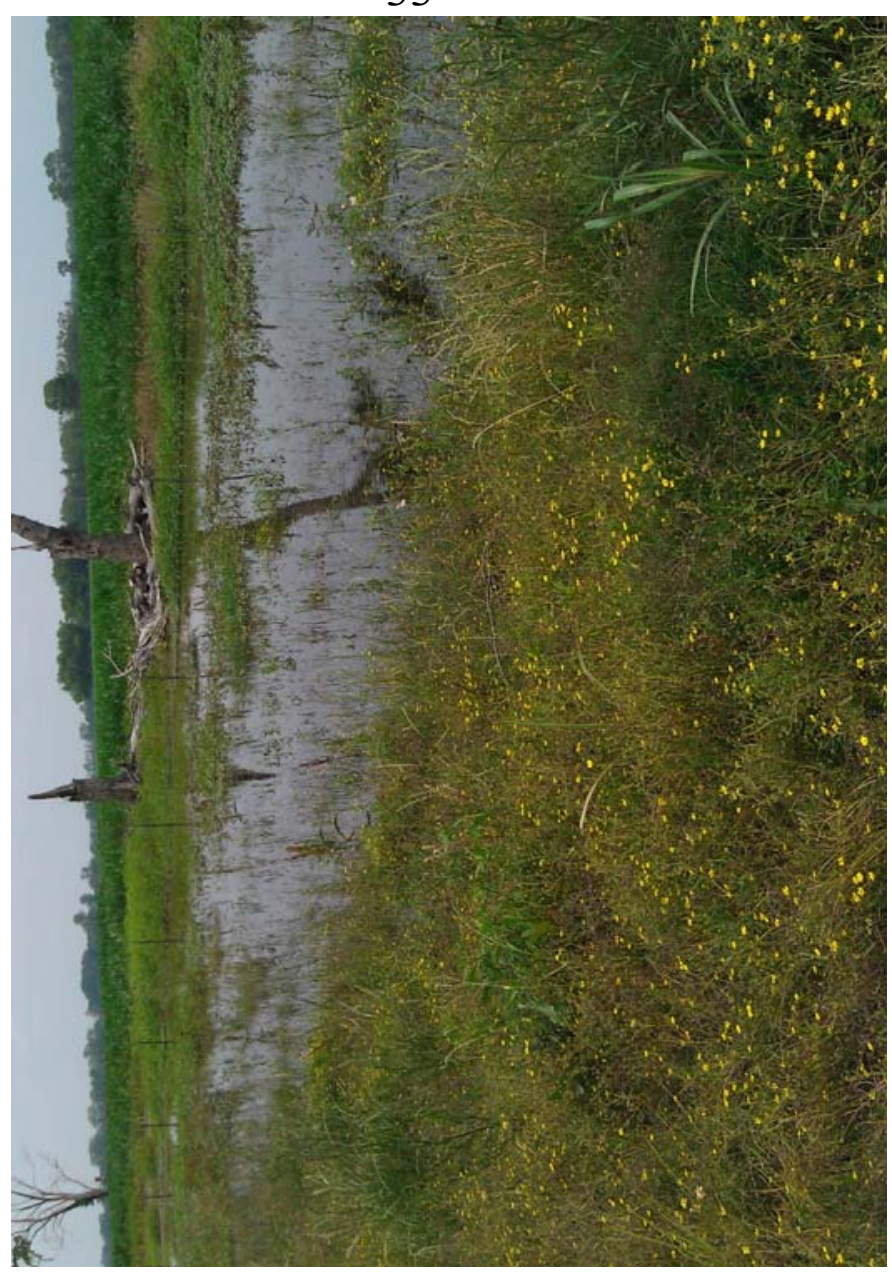

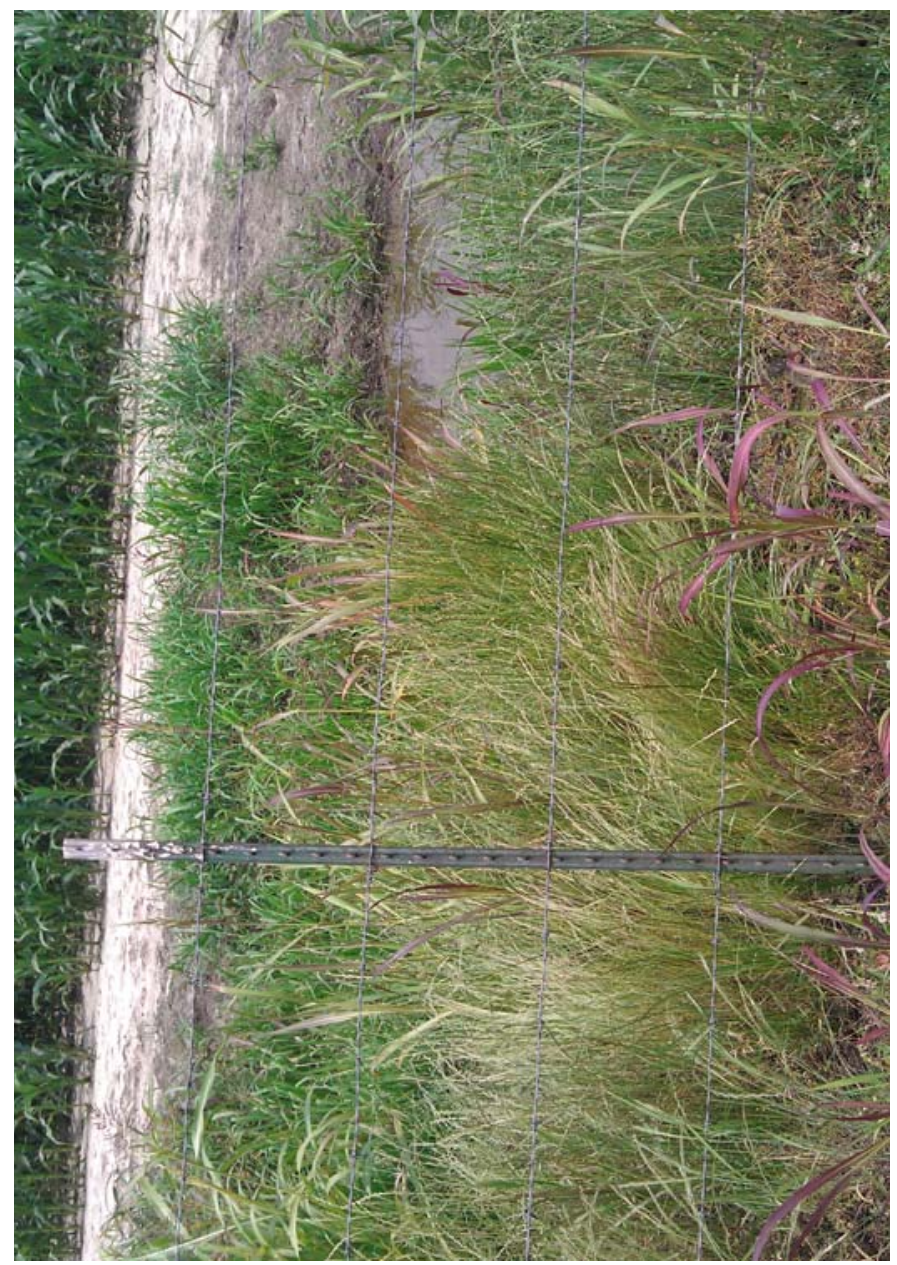

34

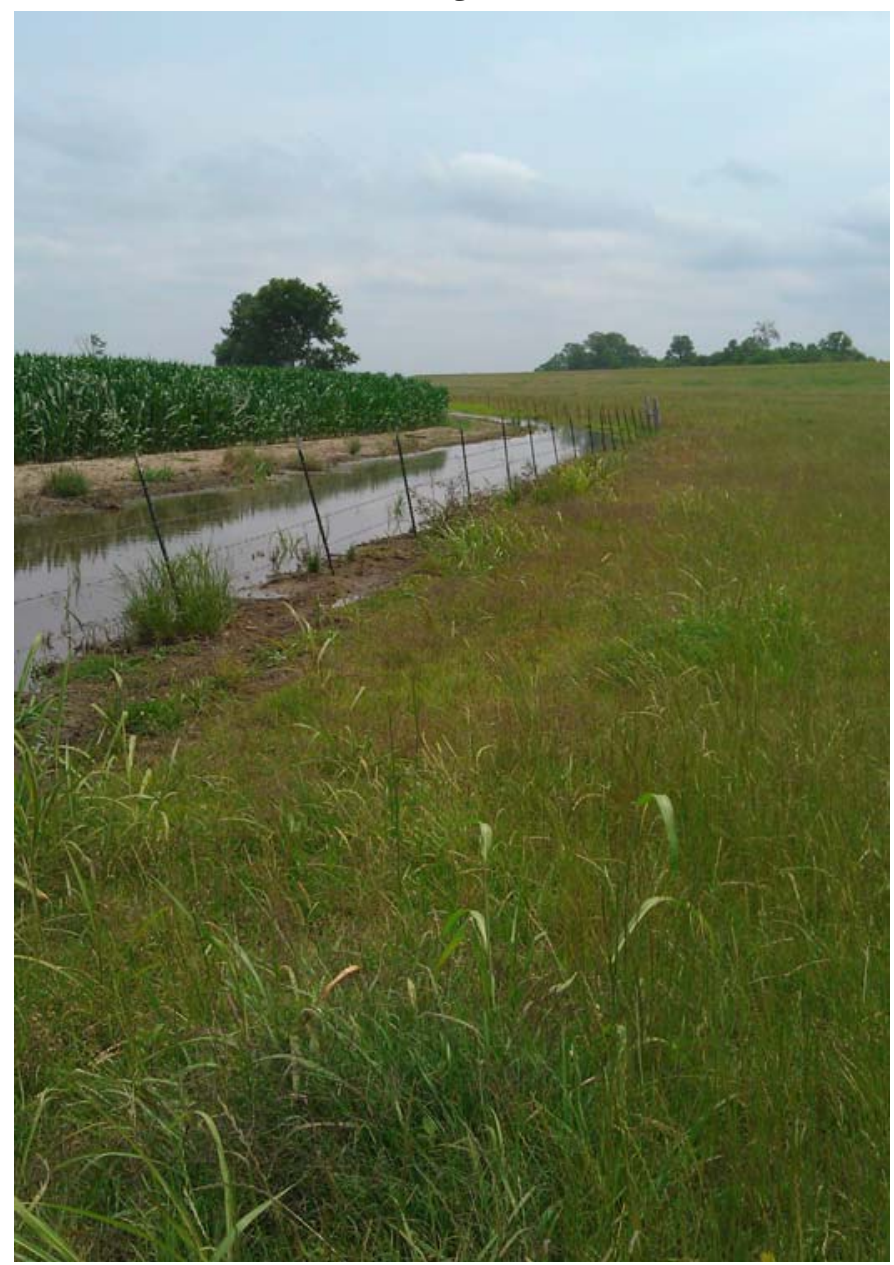




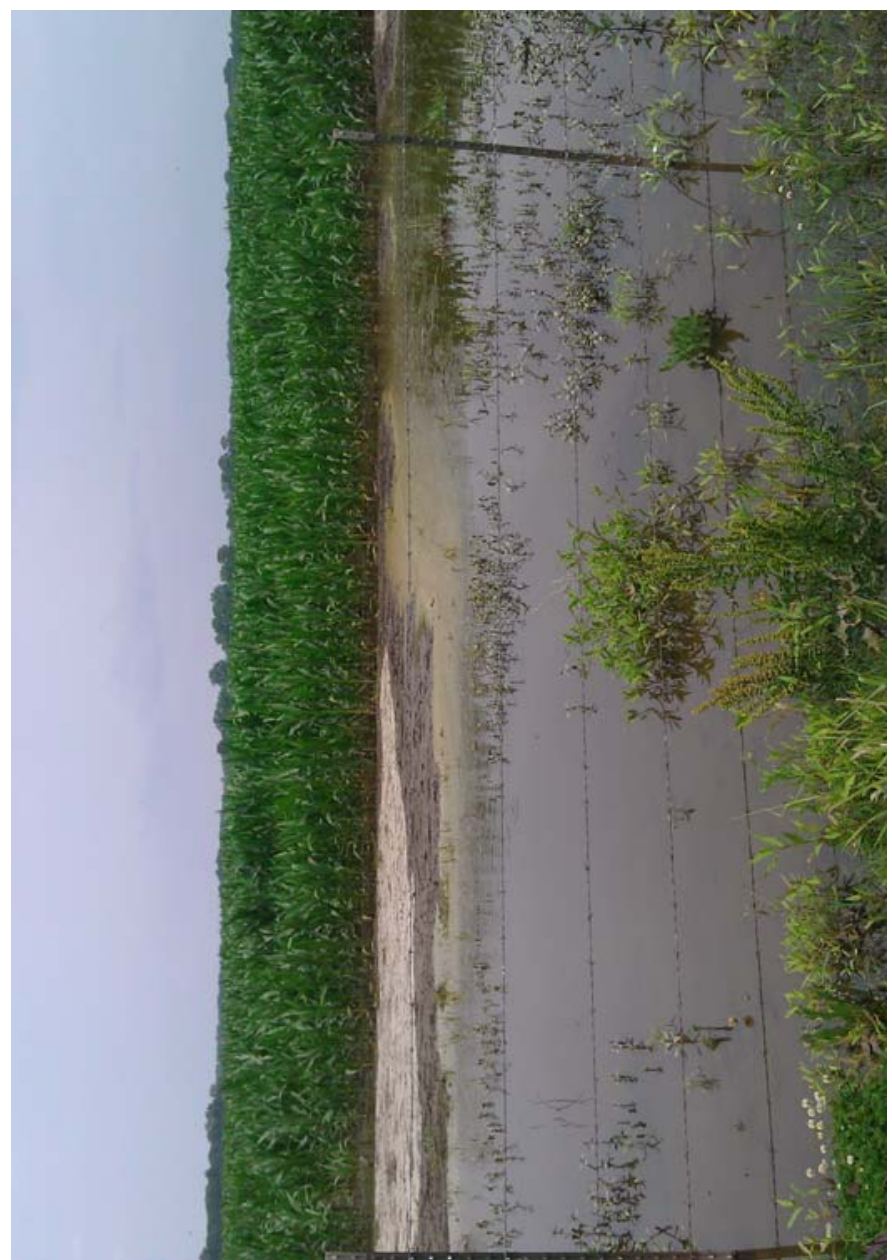

37

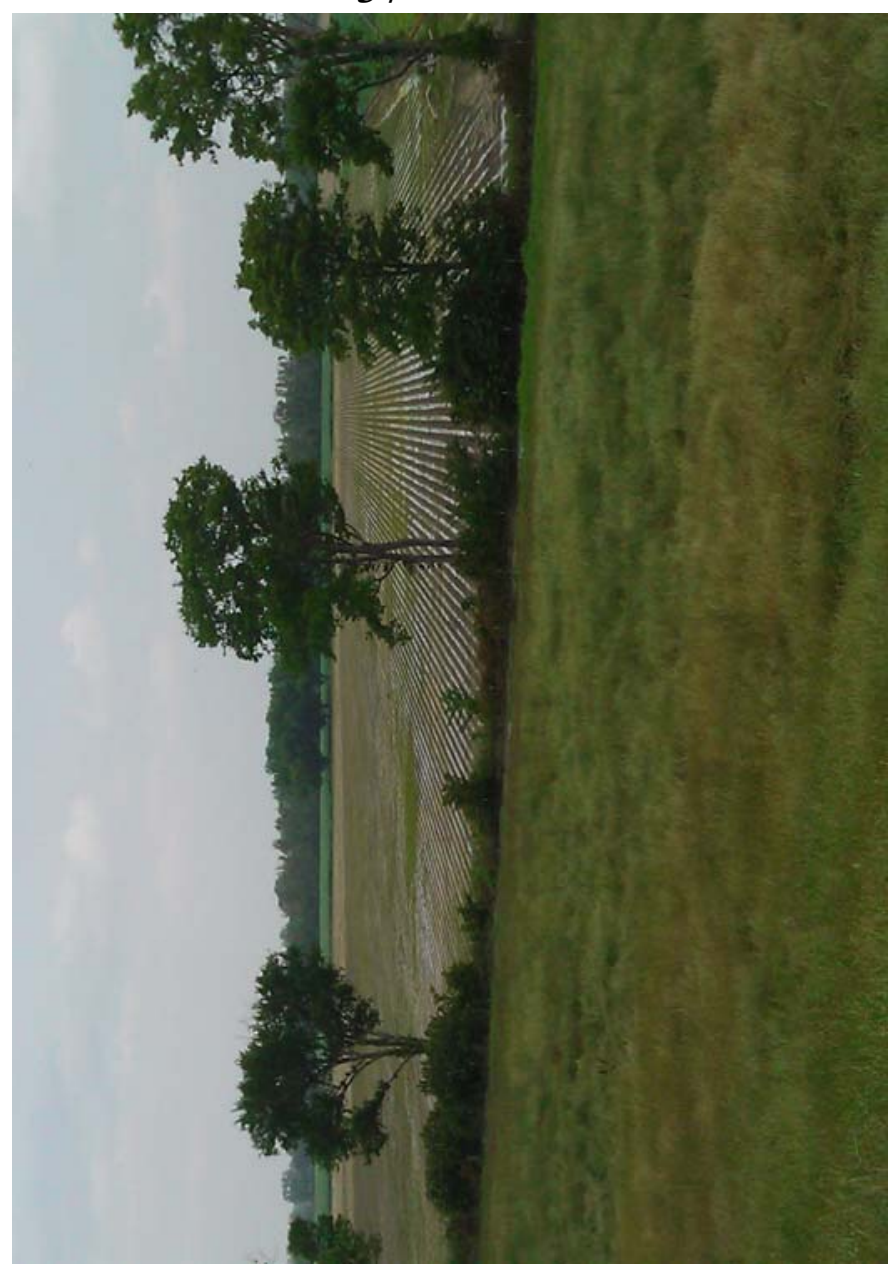

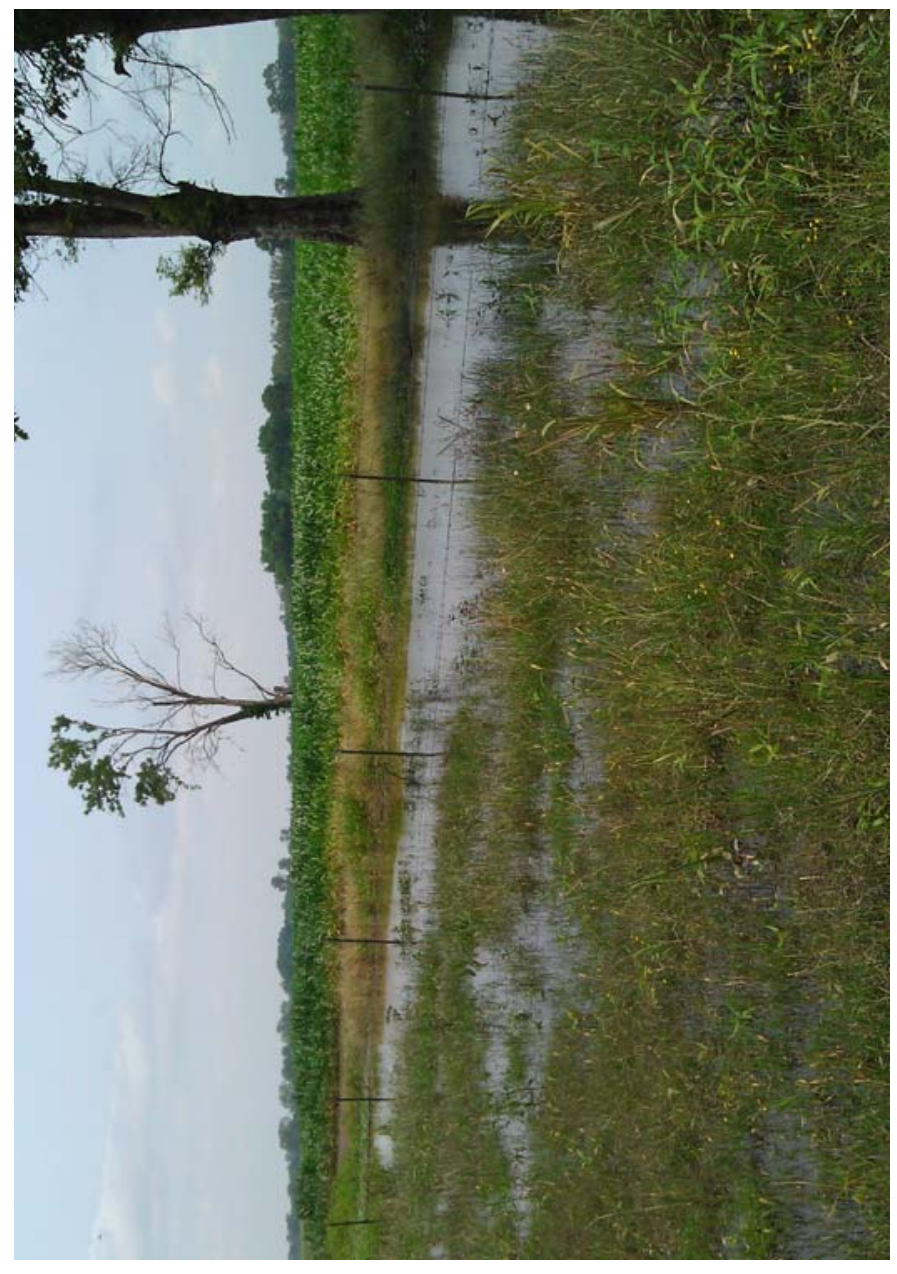

38

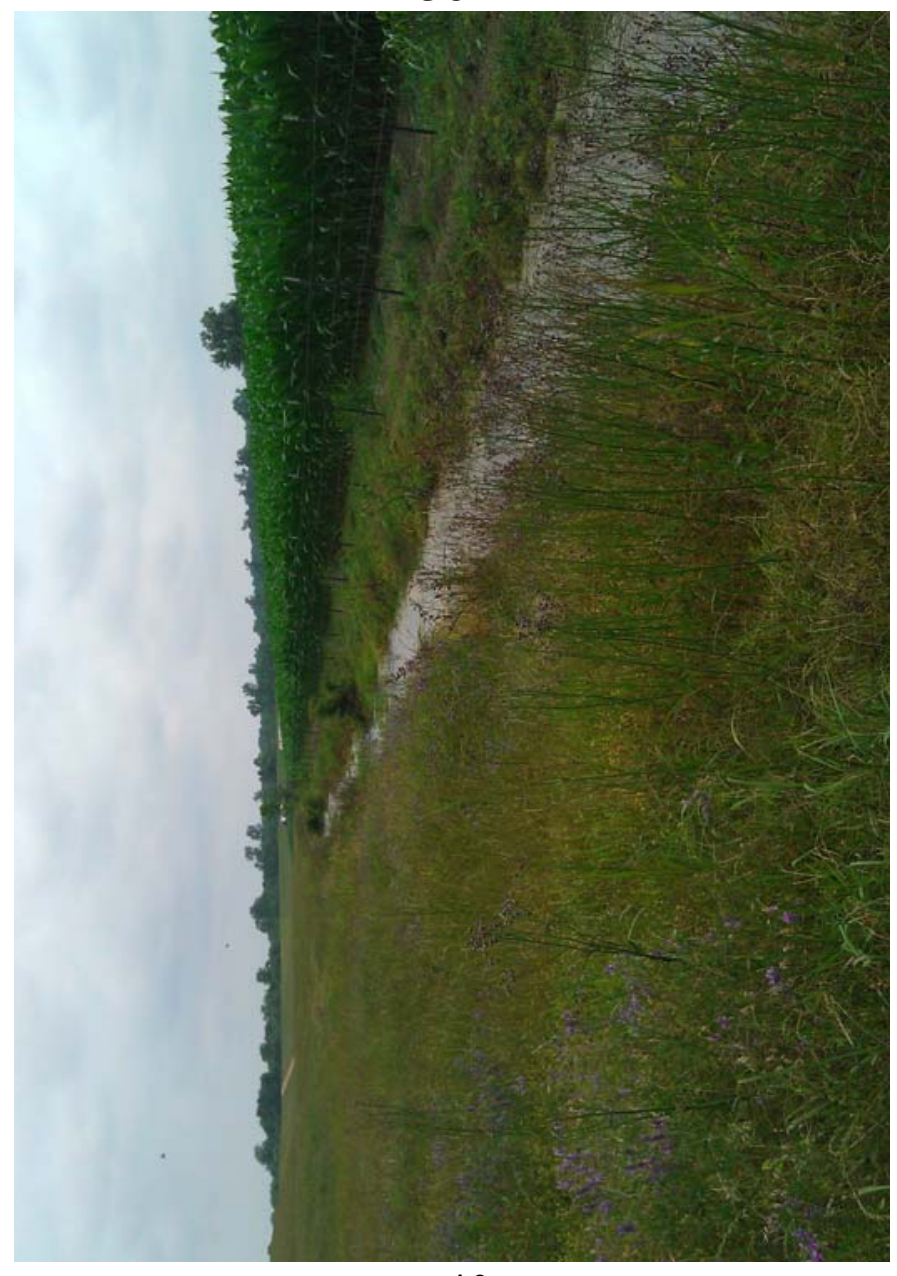



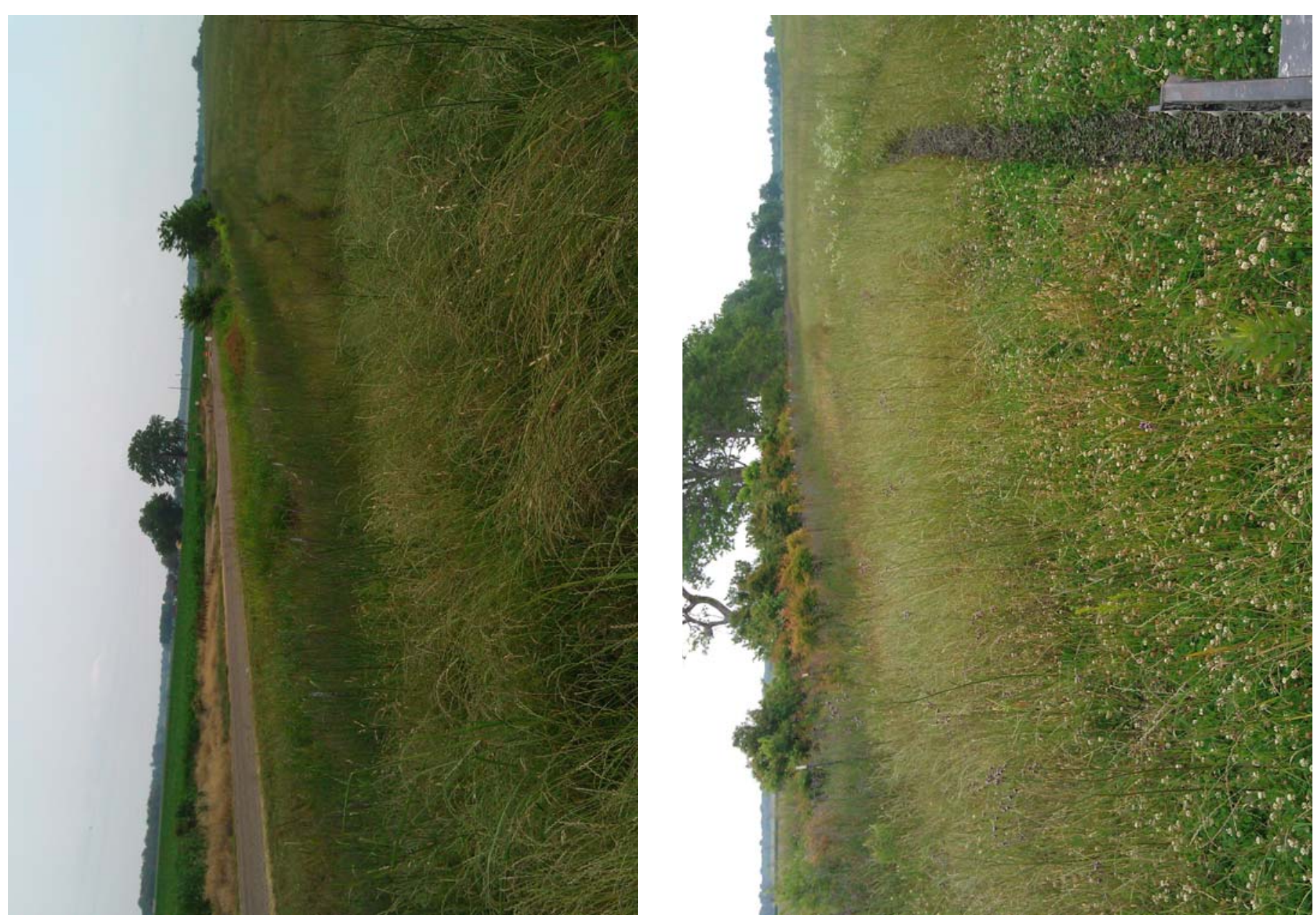

41

42
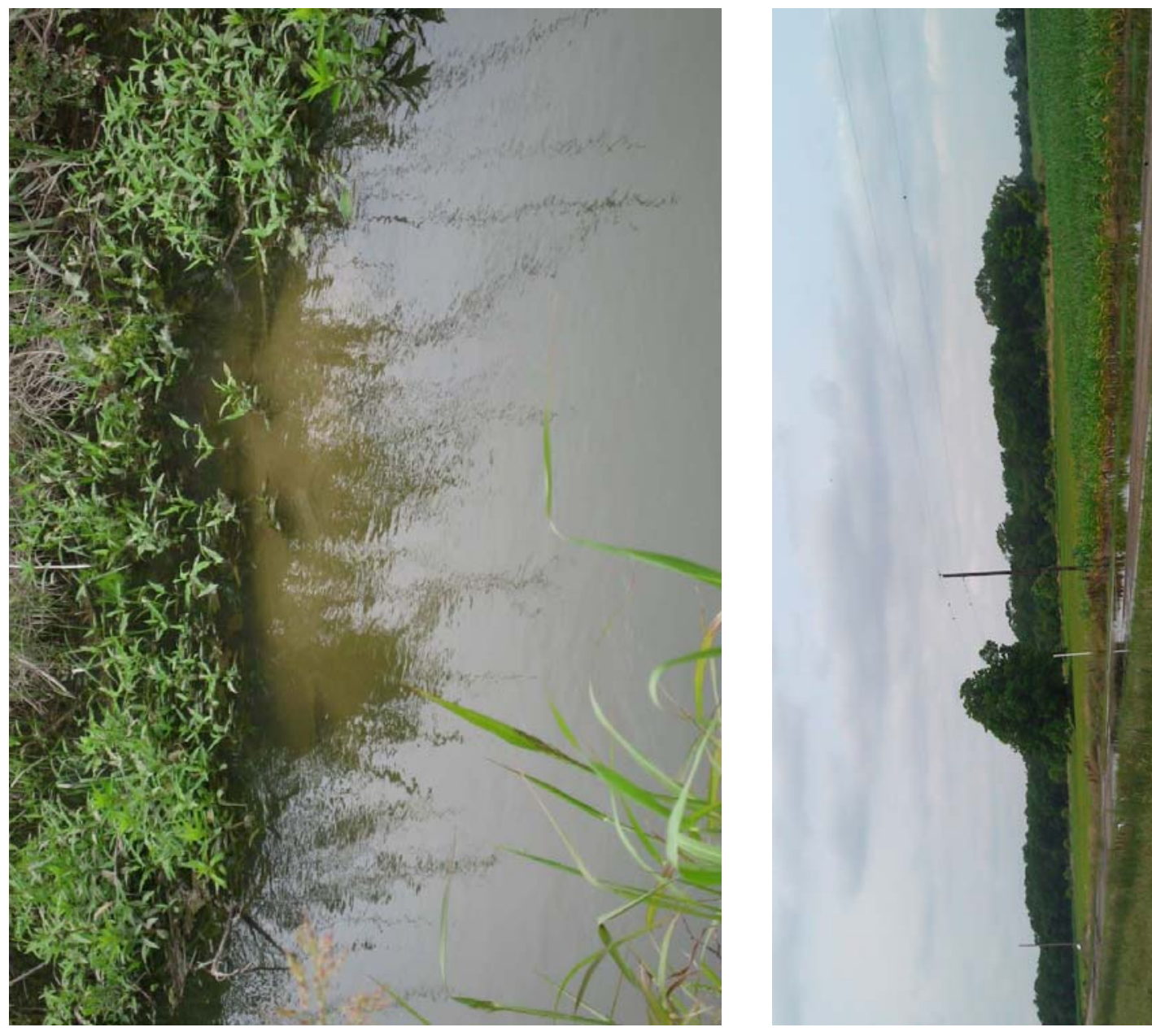


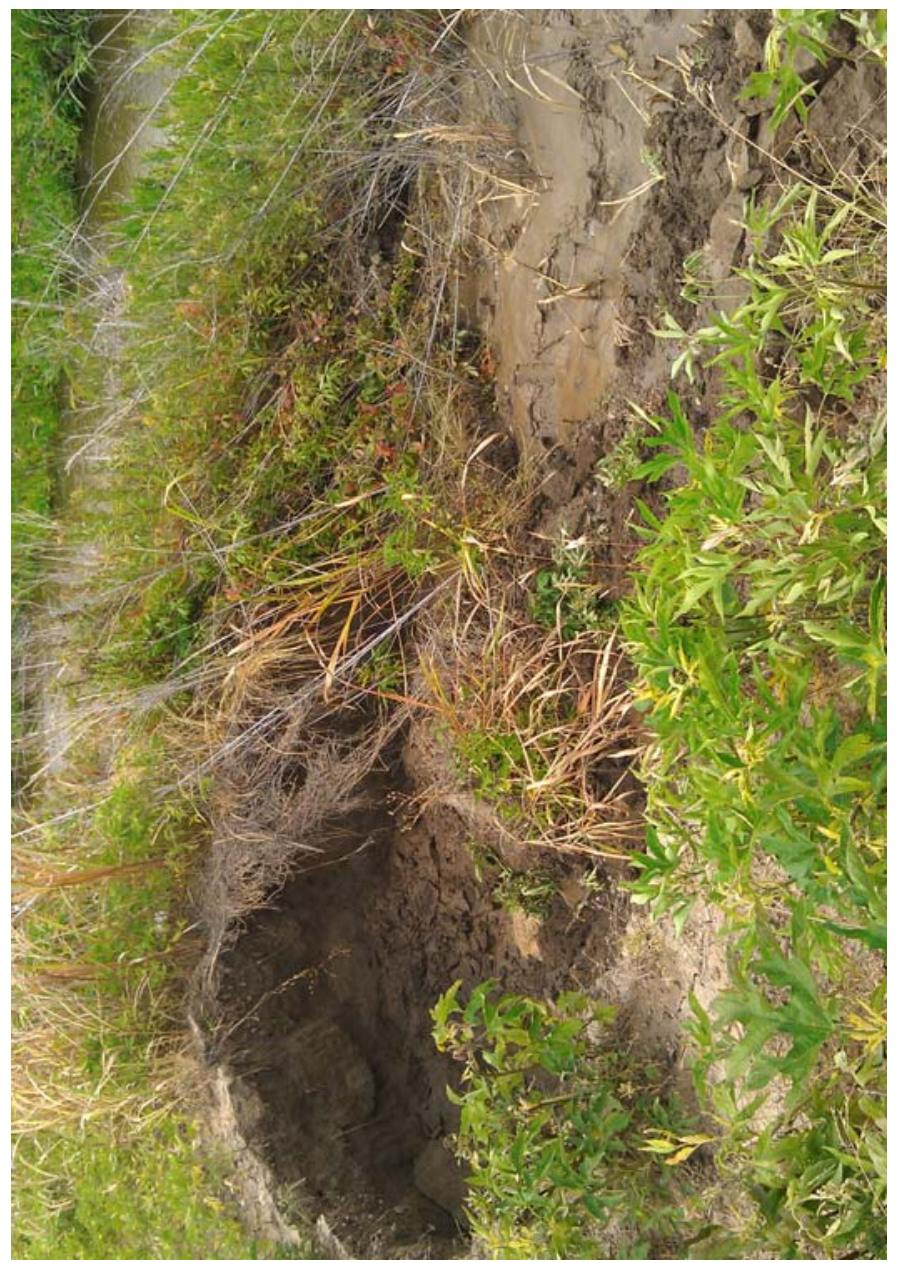

45

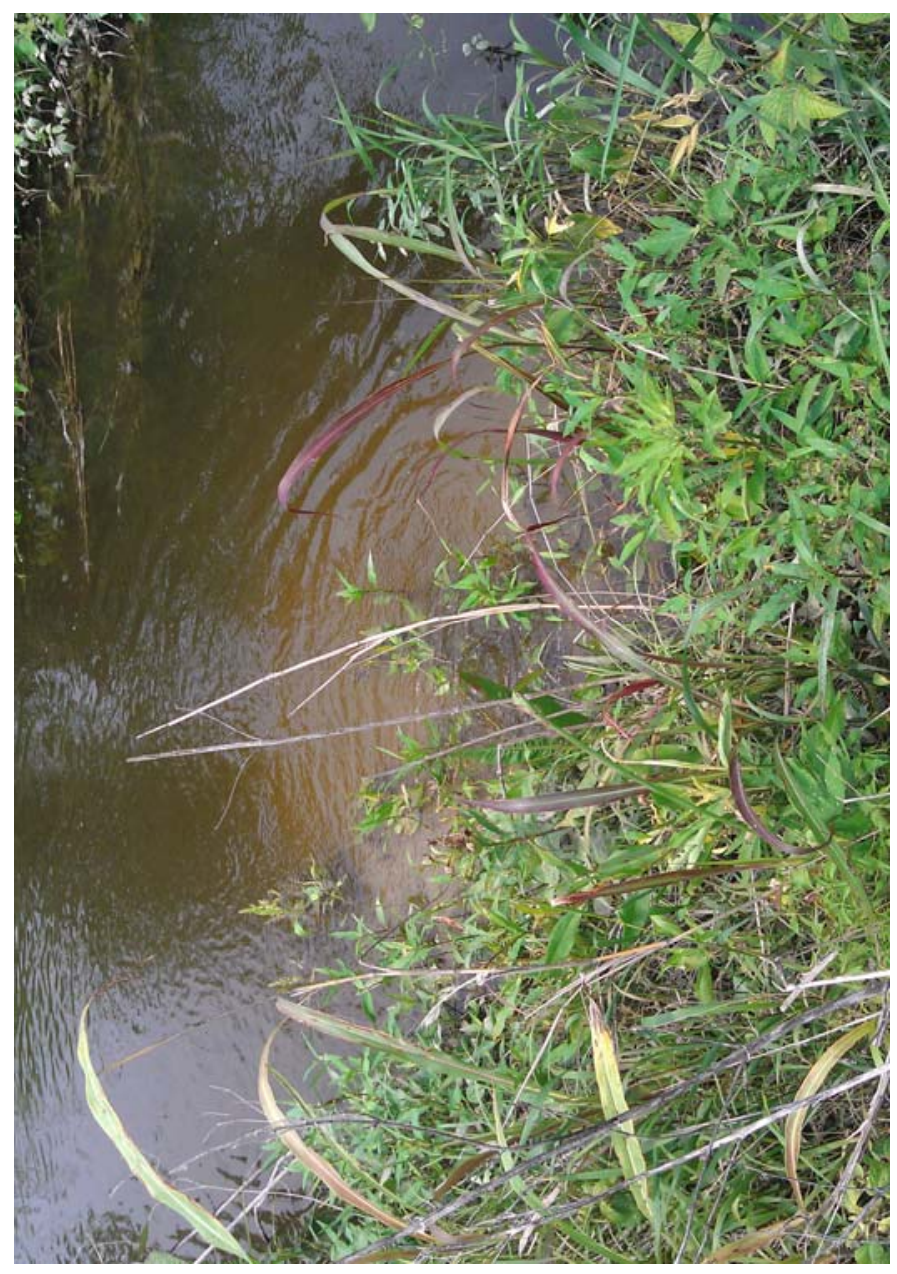

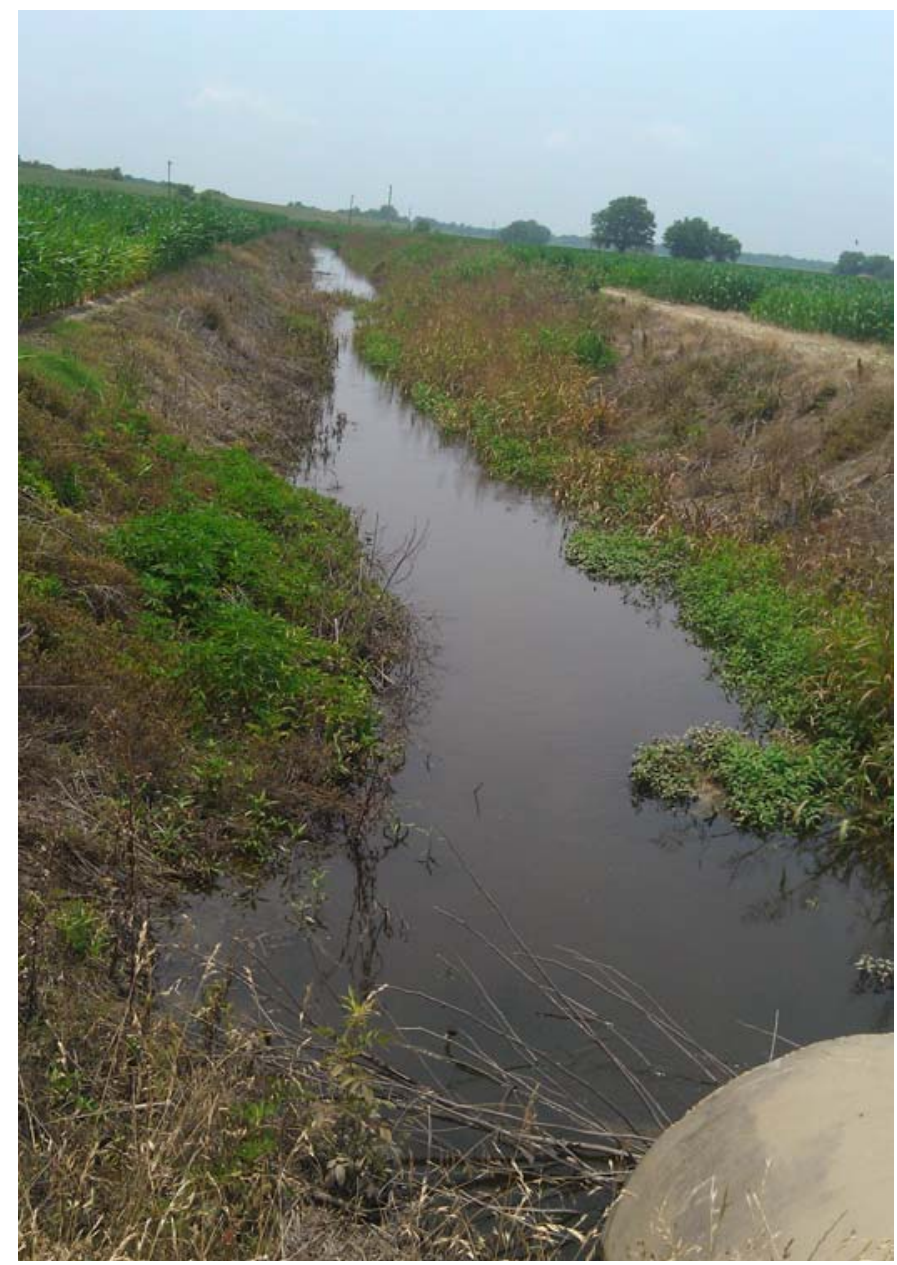

46

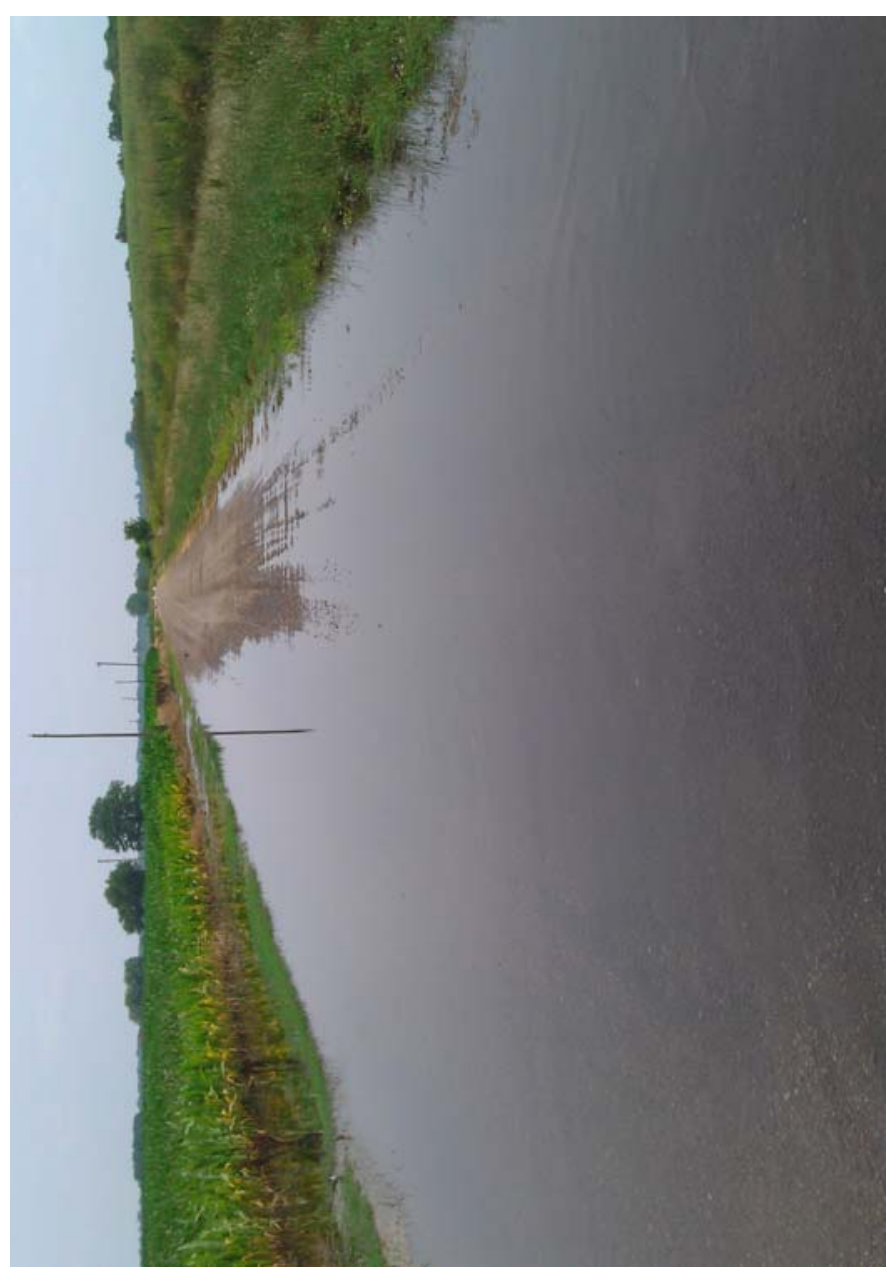




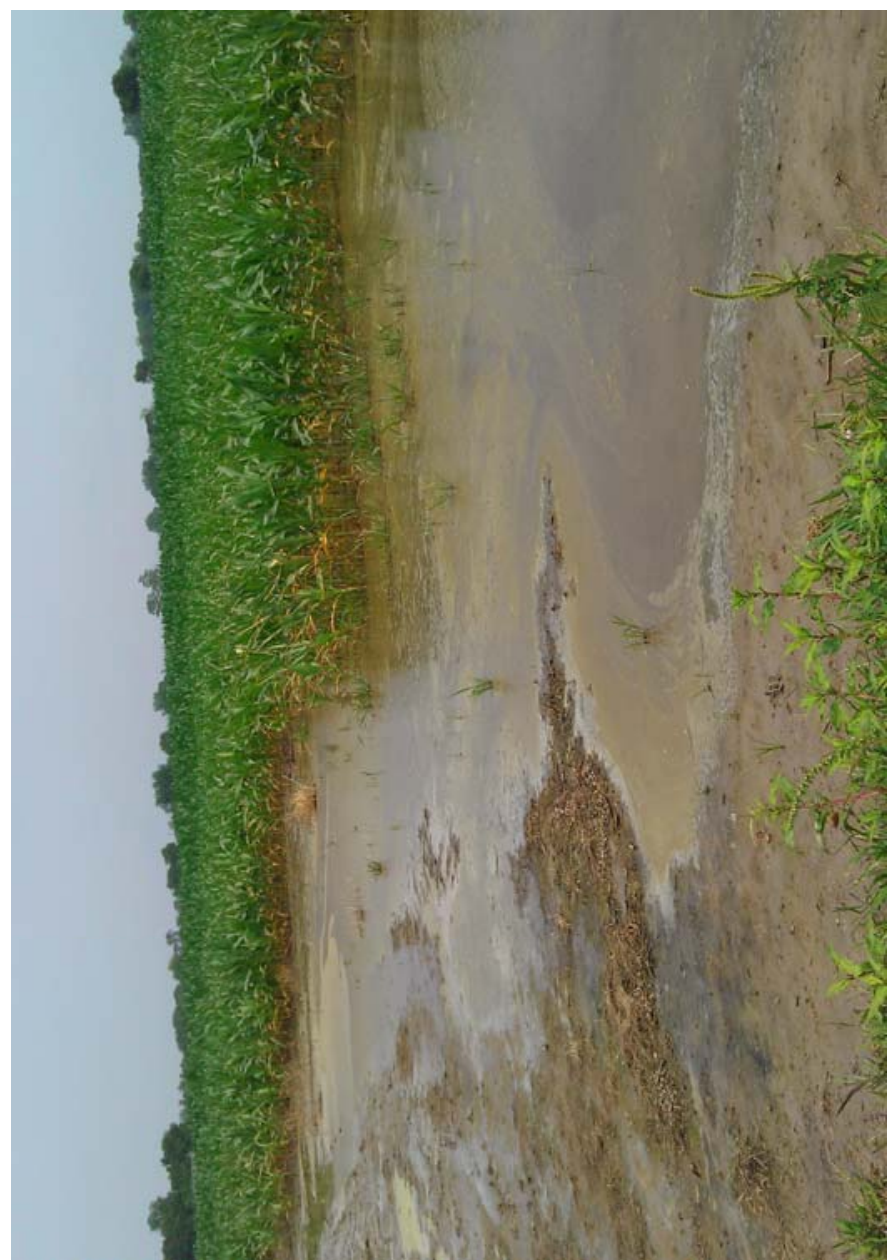

49

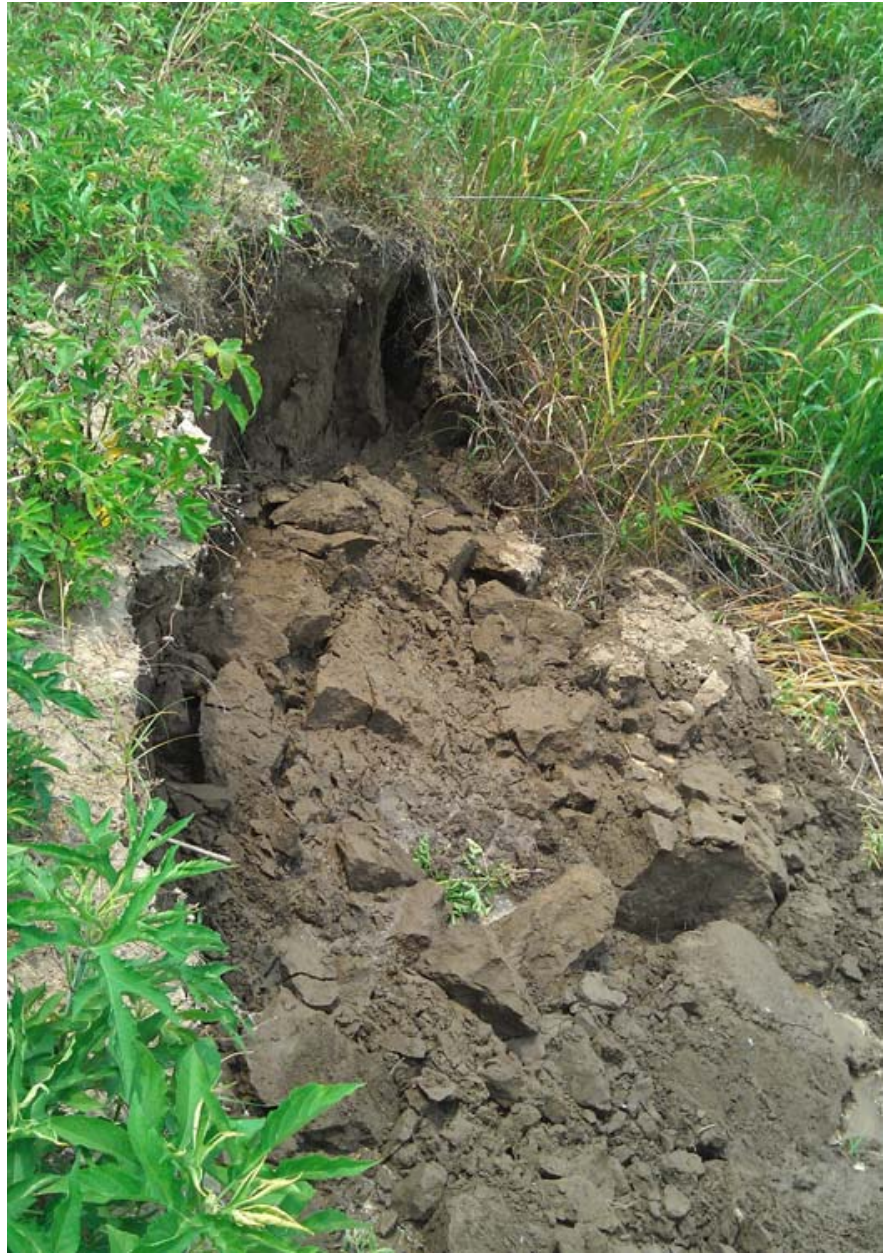

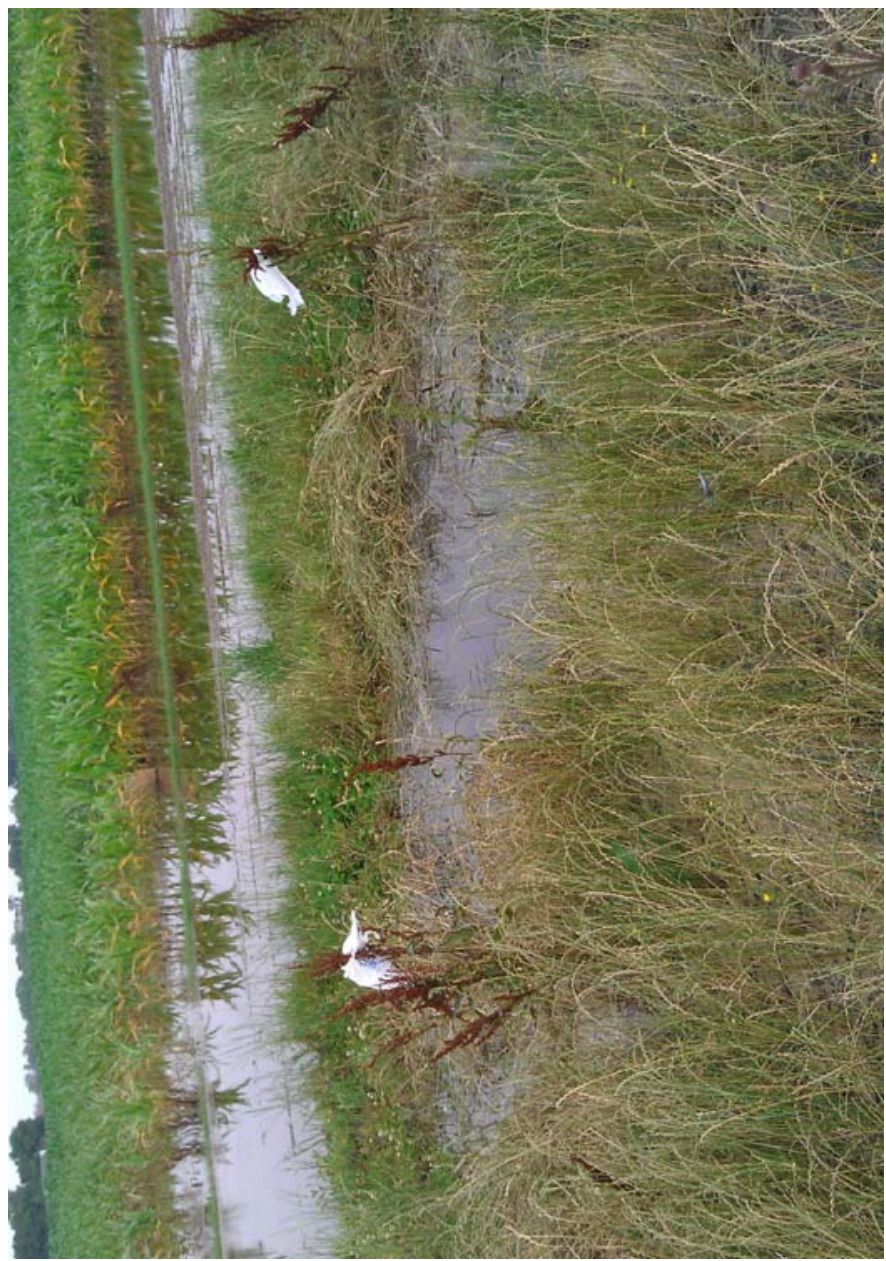

50

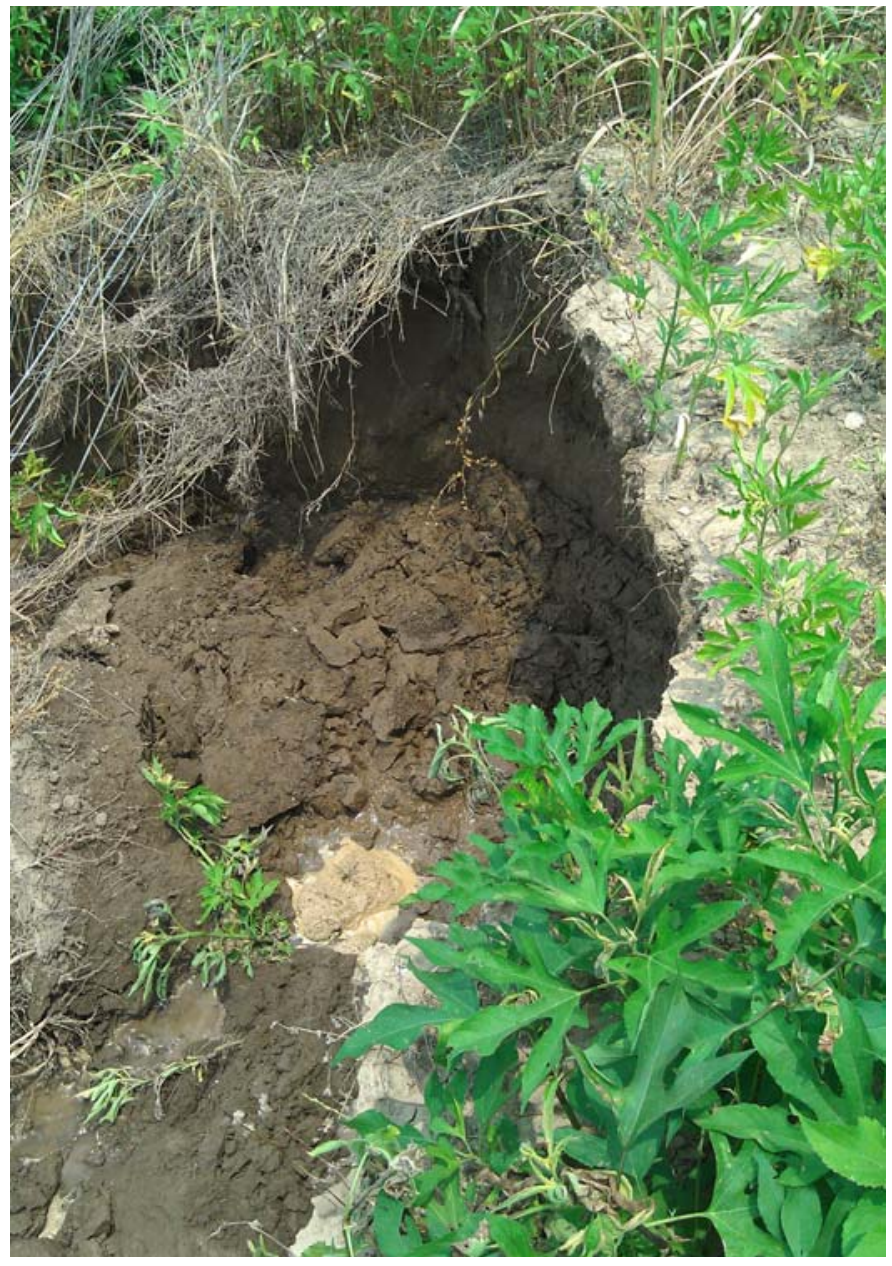




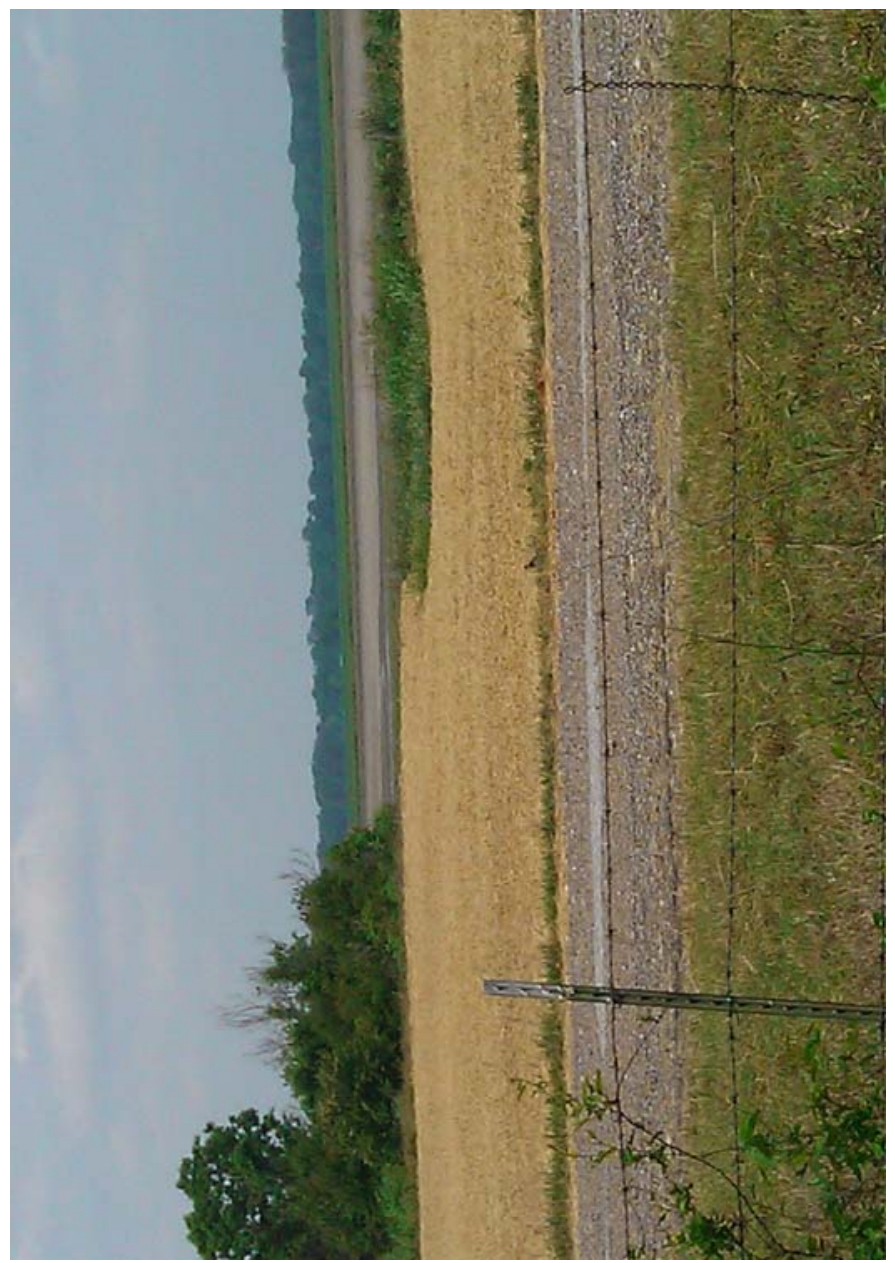

53

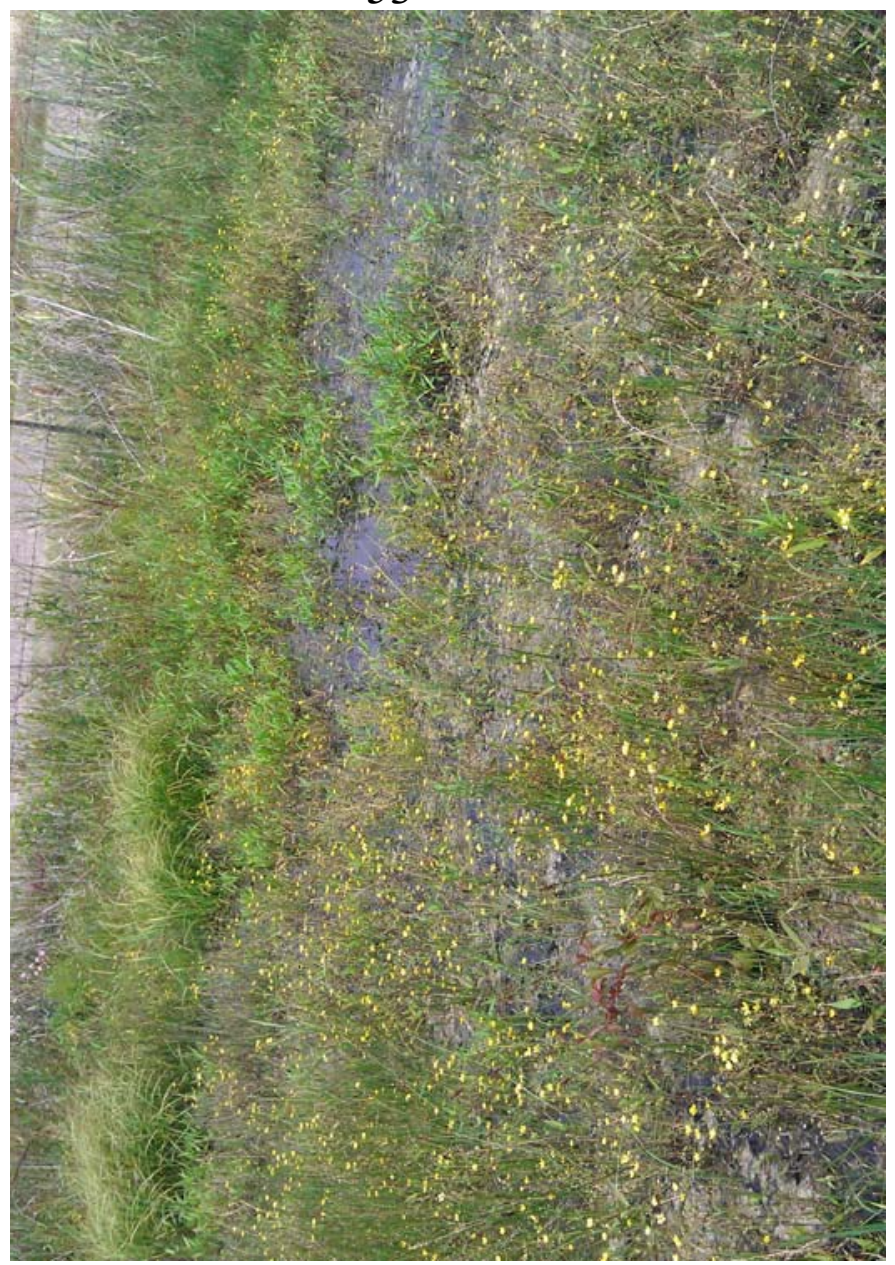

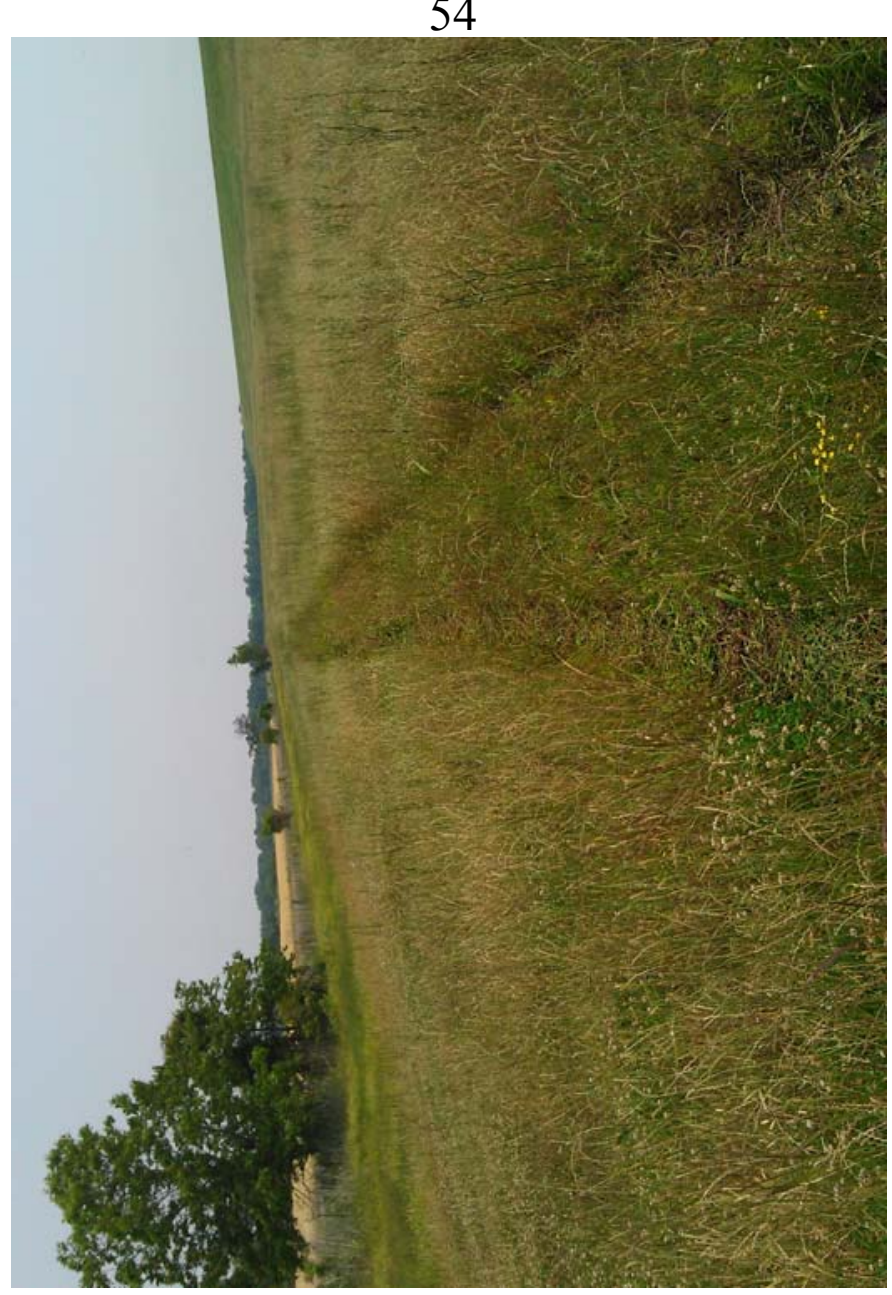




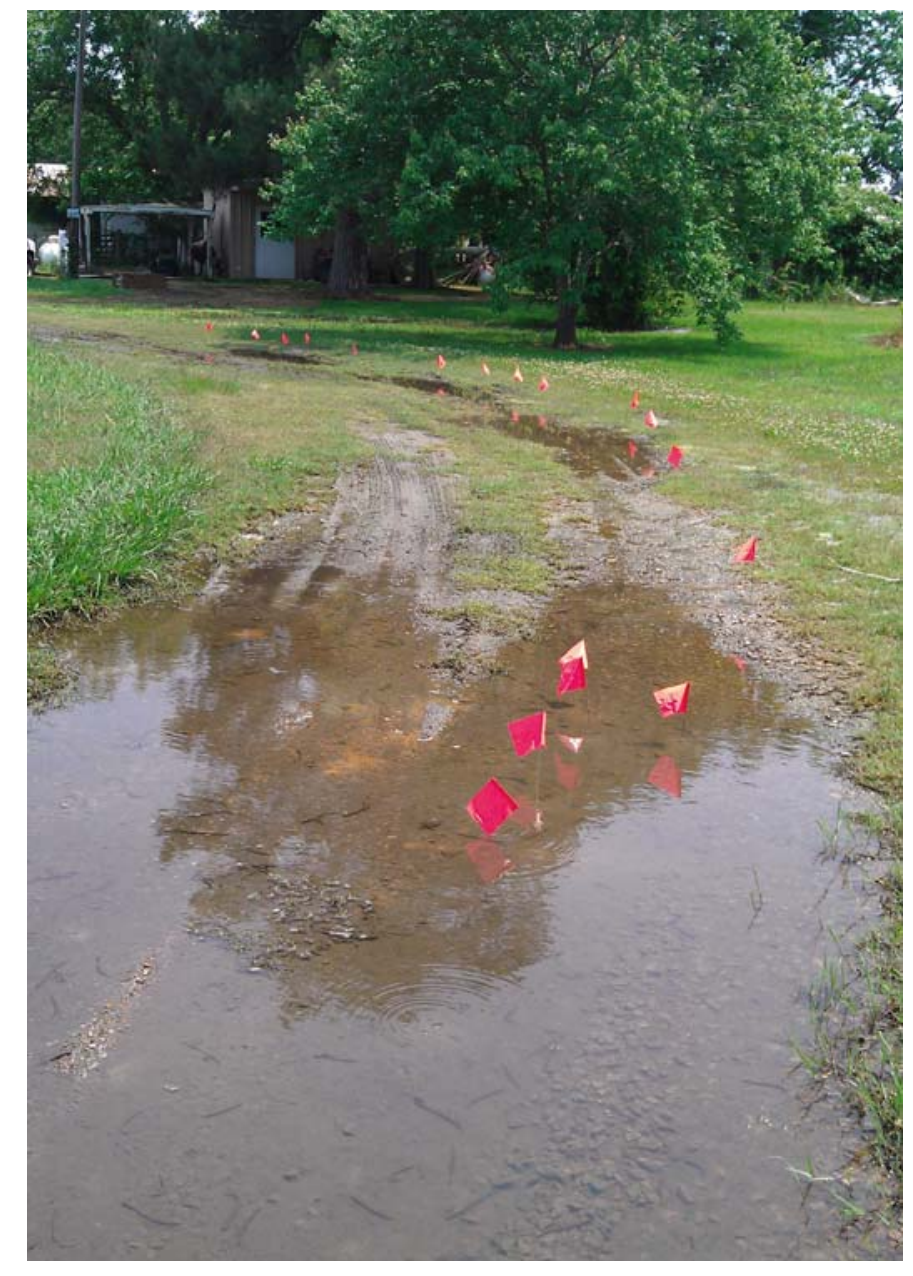

57

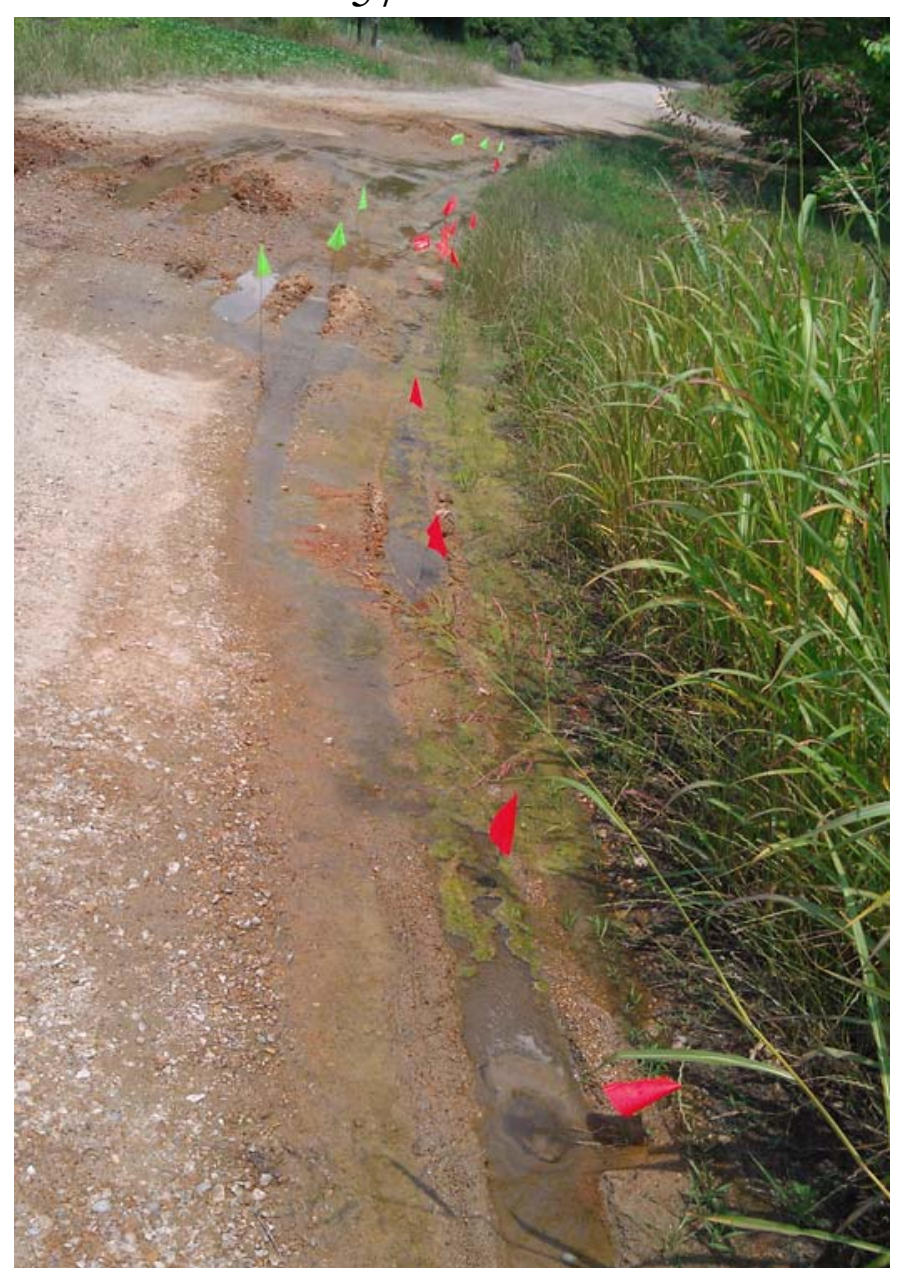

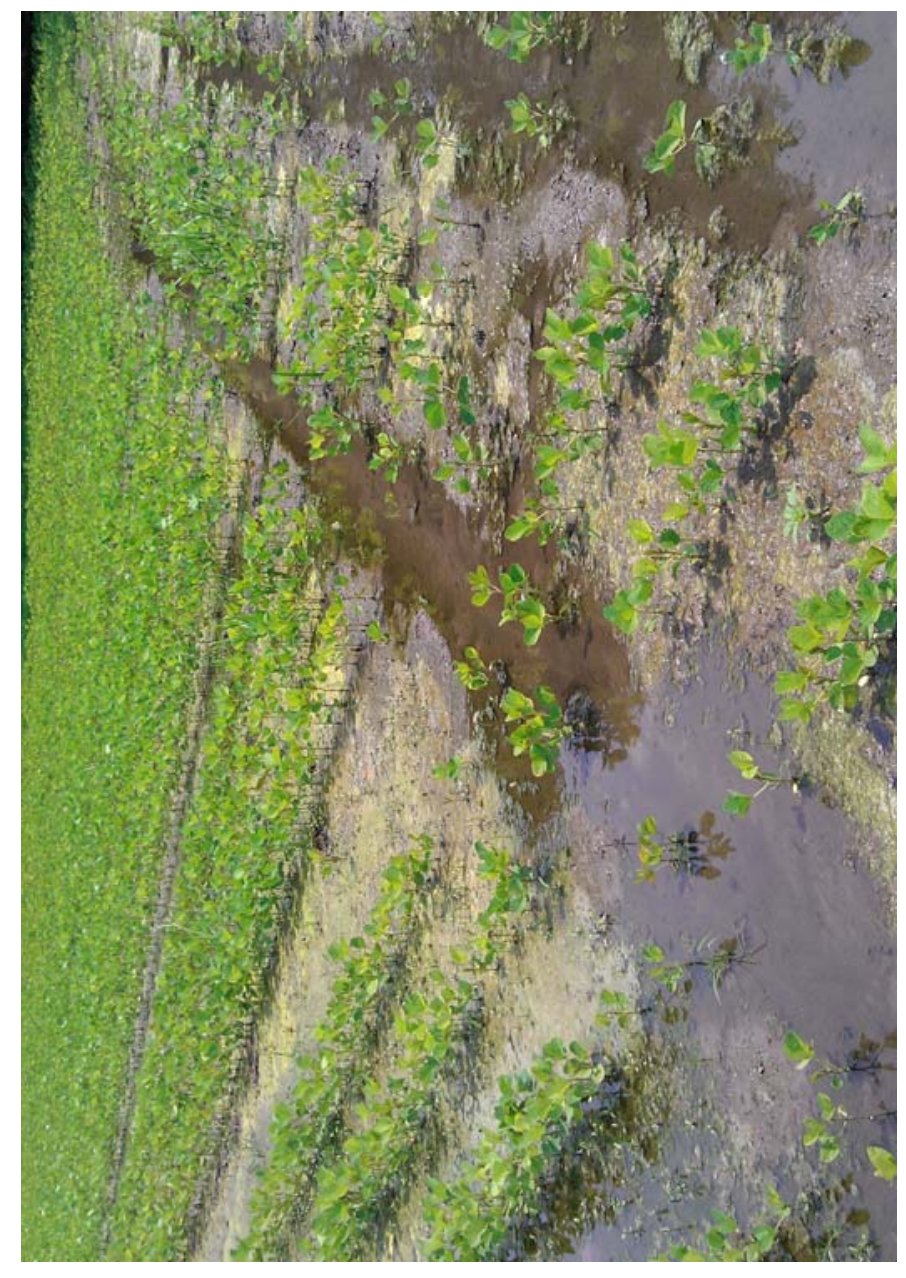

\section{8}

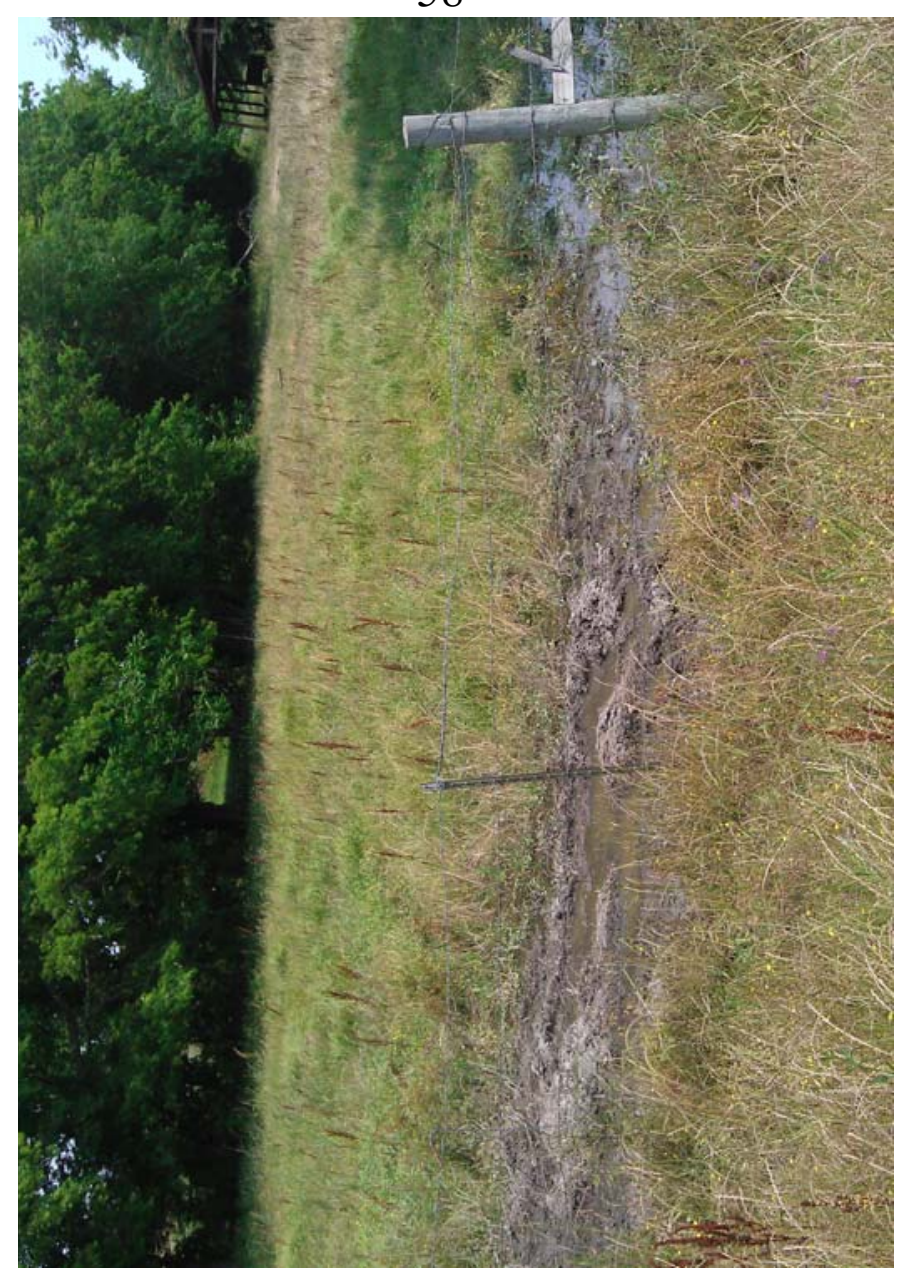




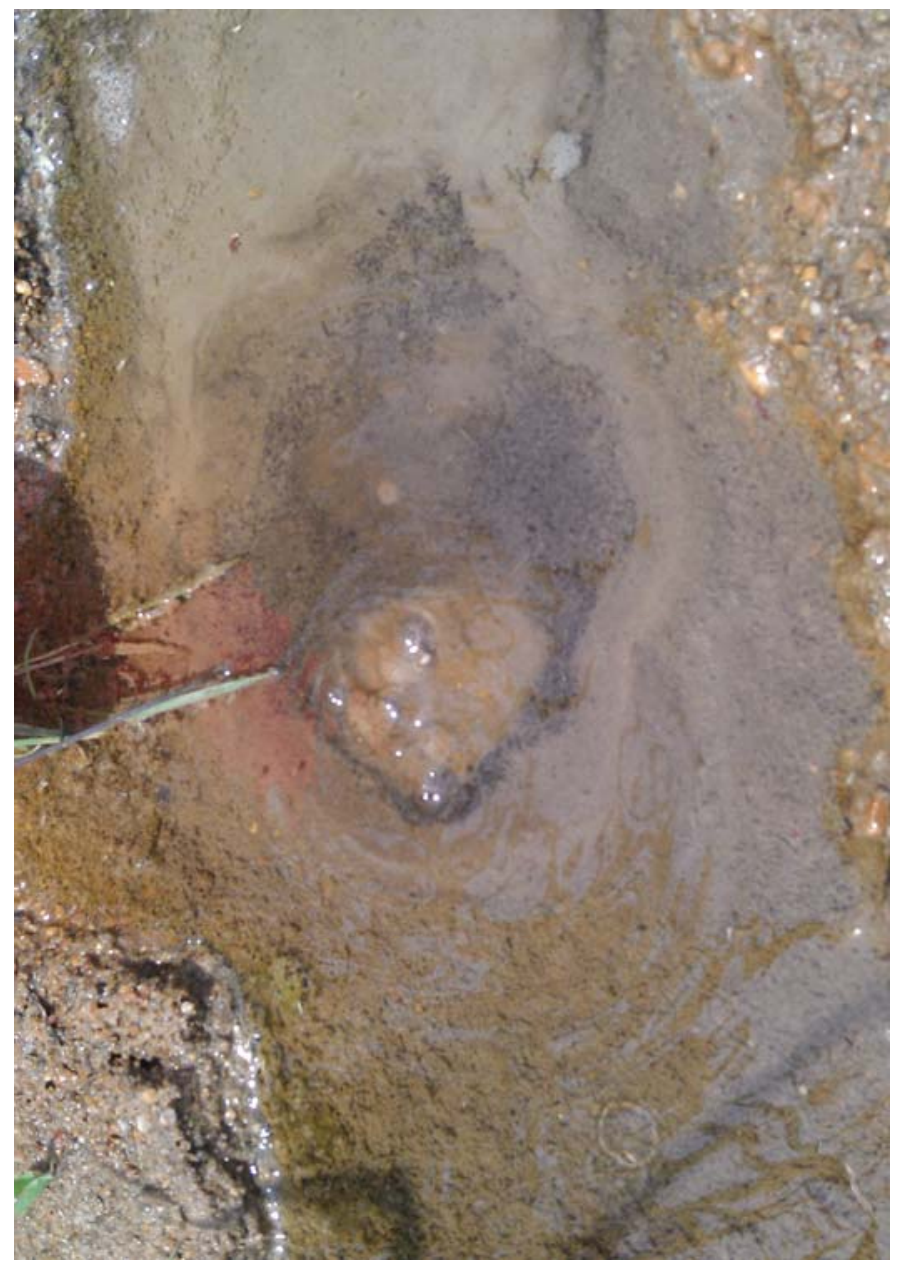

61

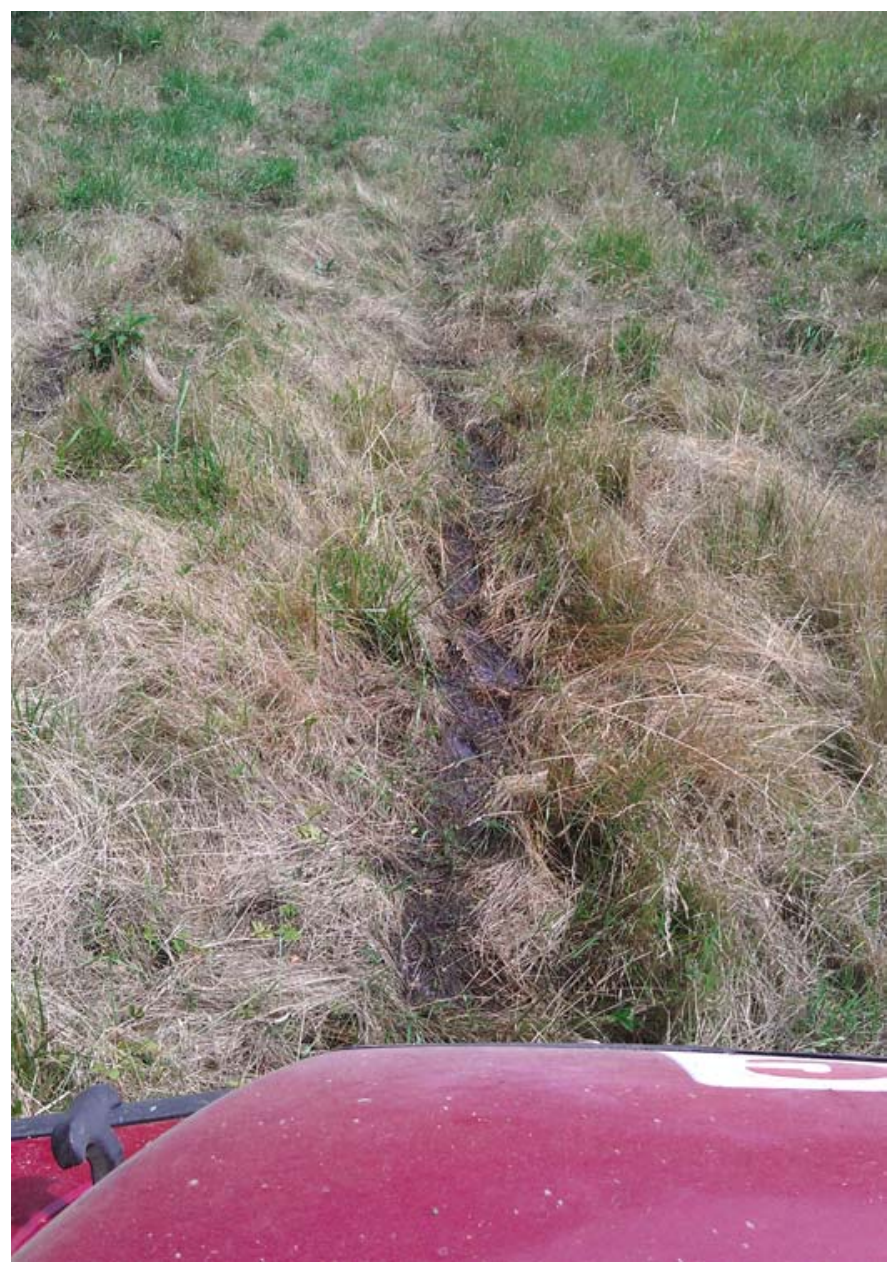

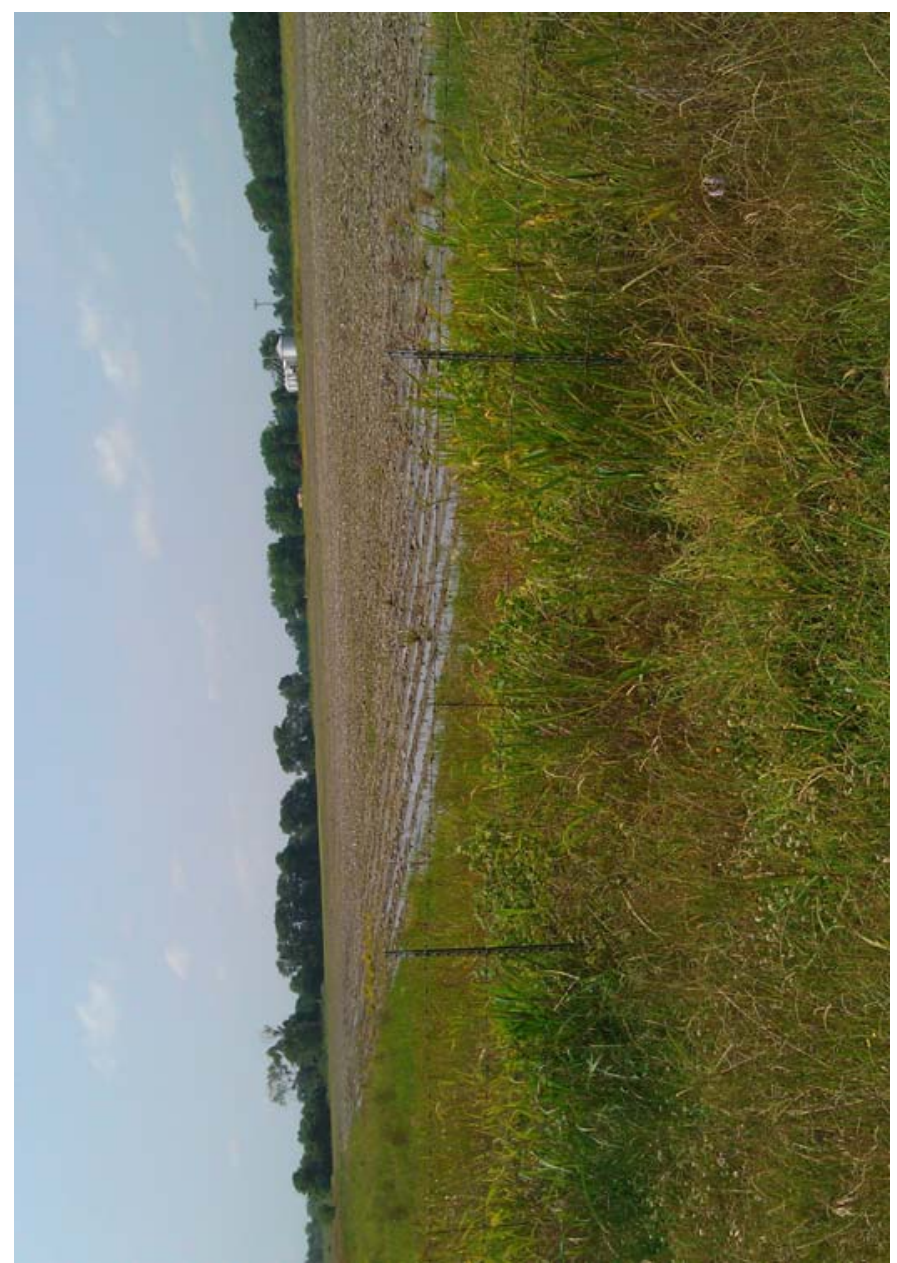

62

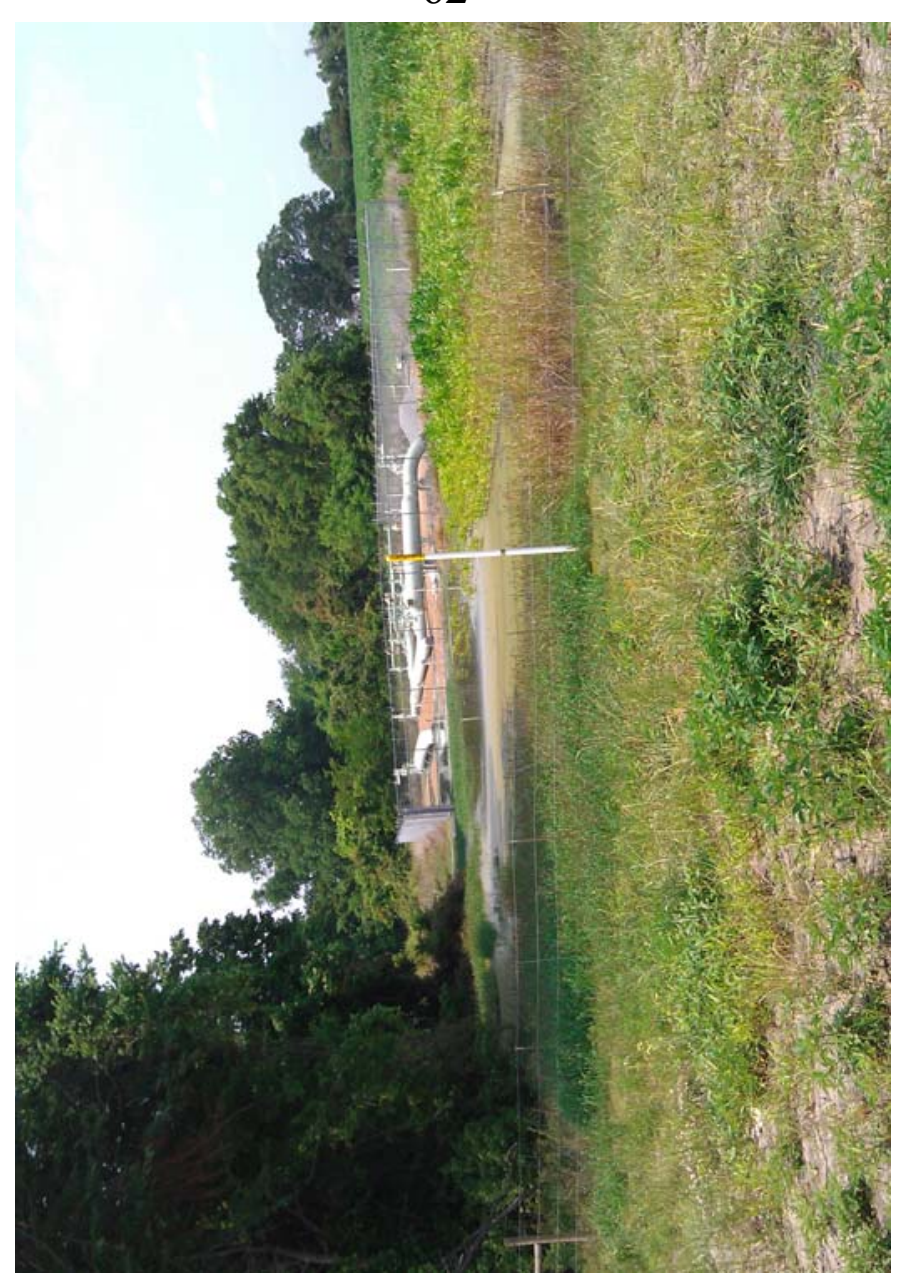




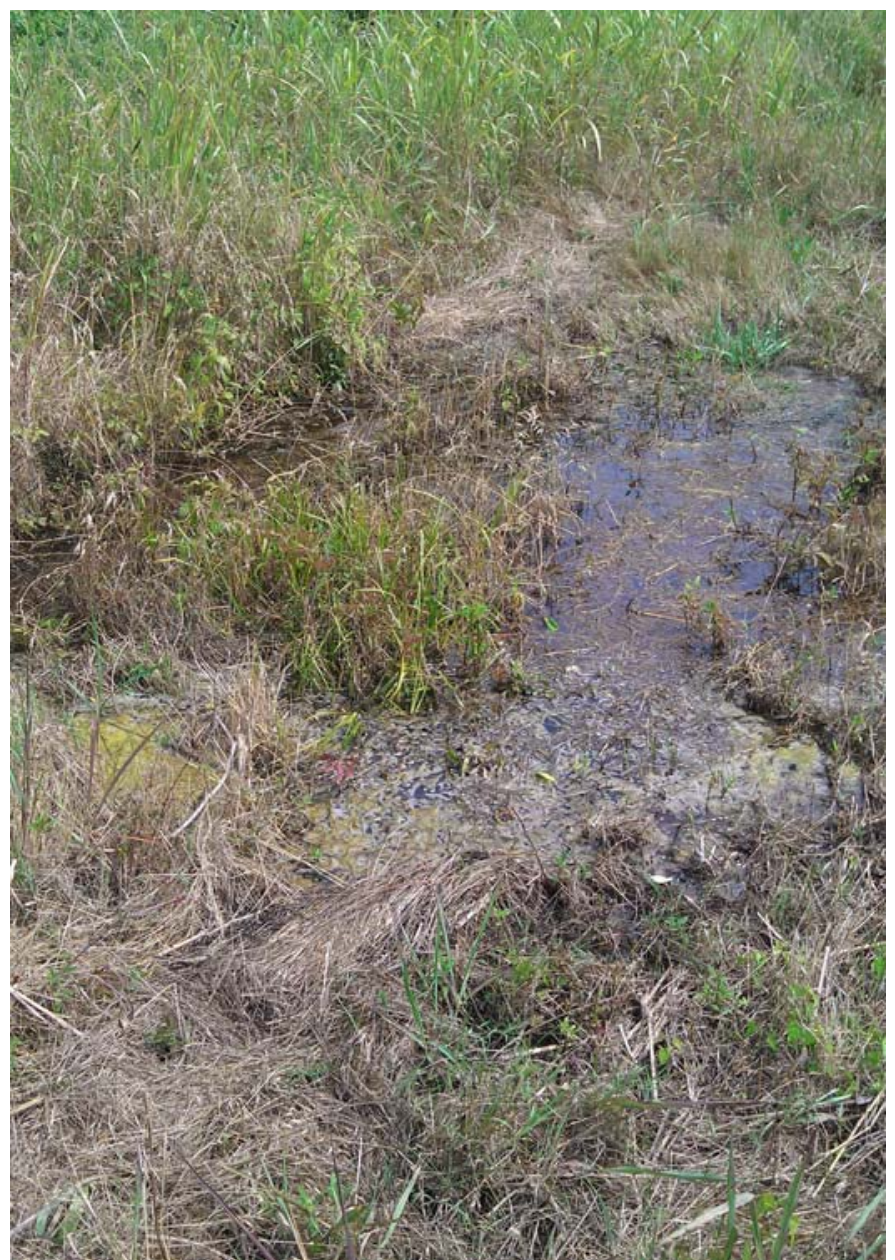

65

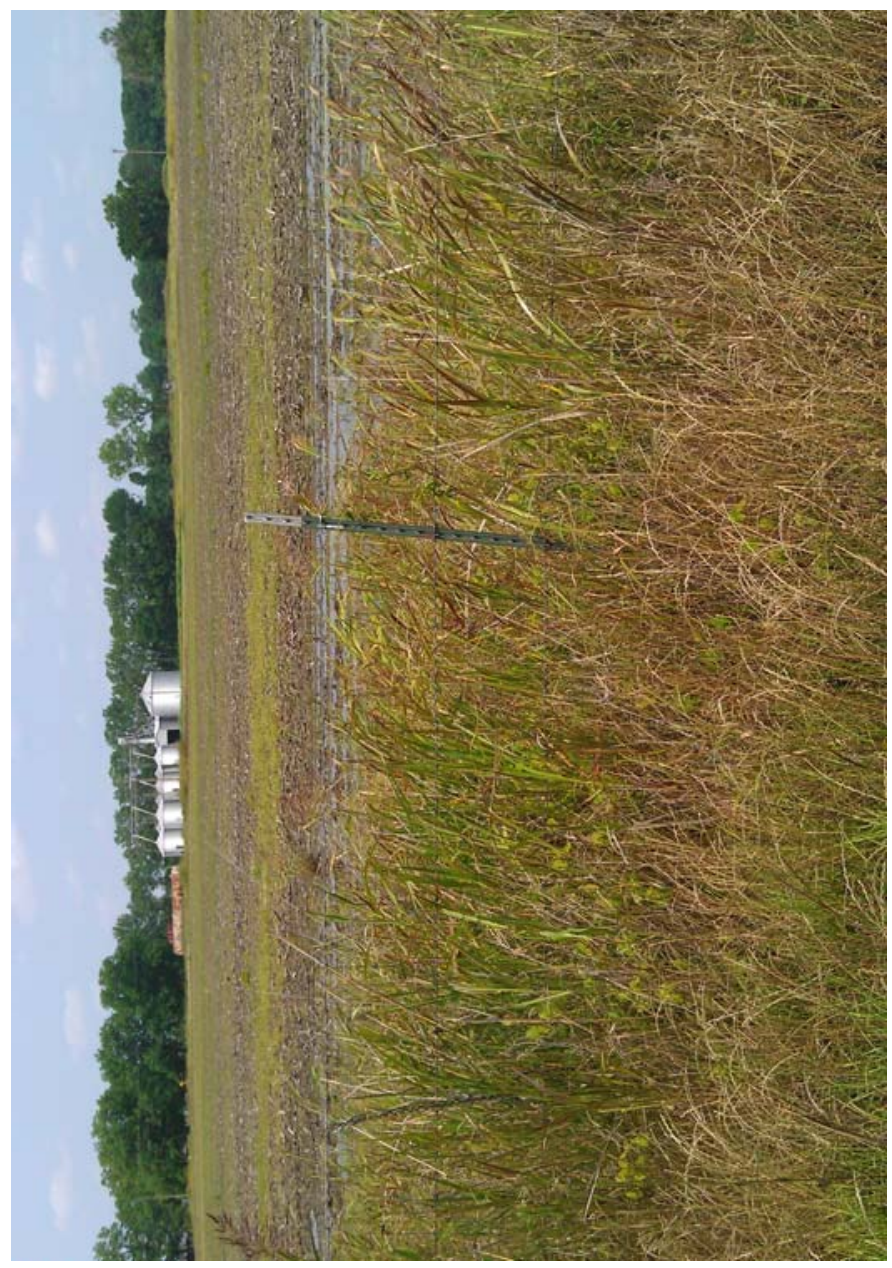

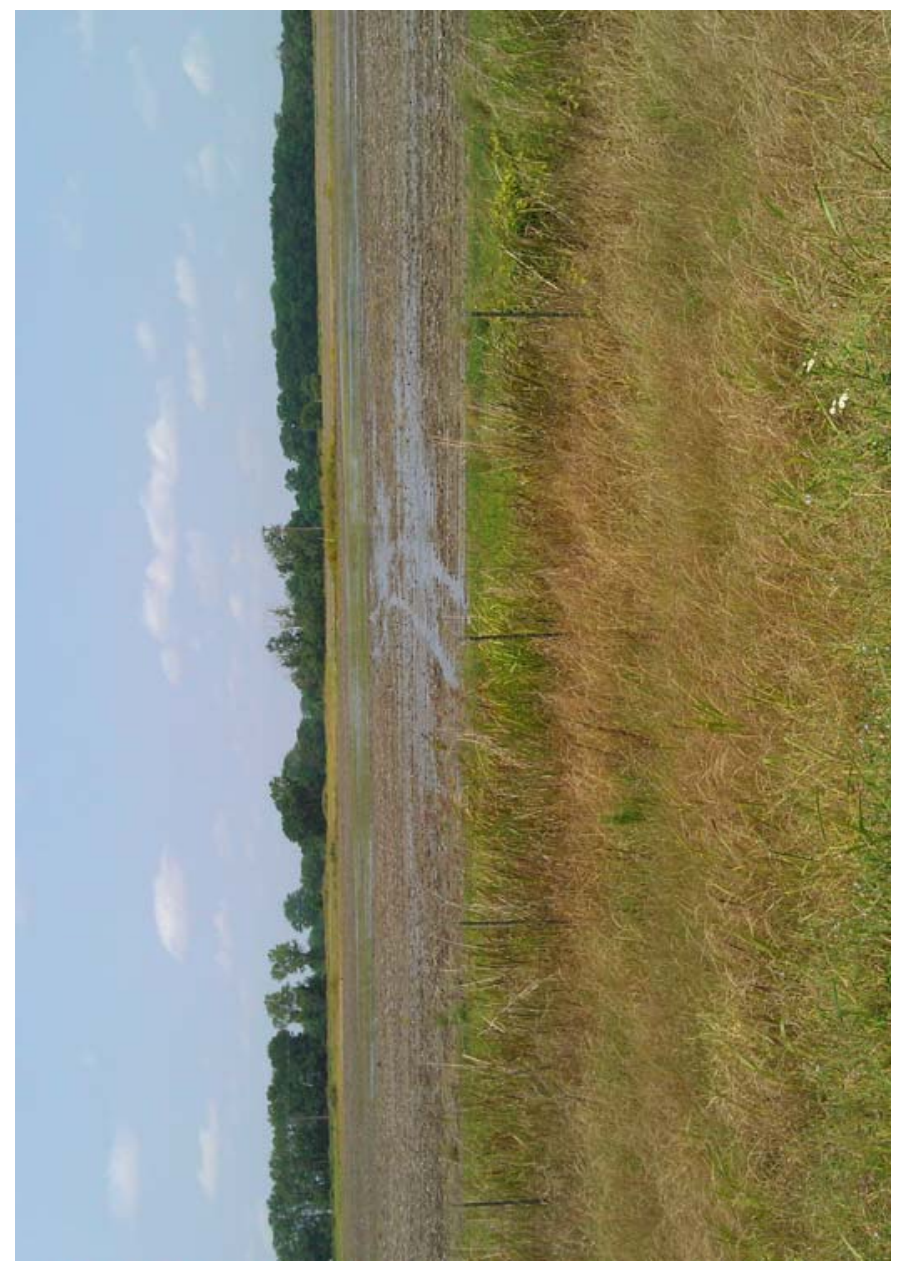

66

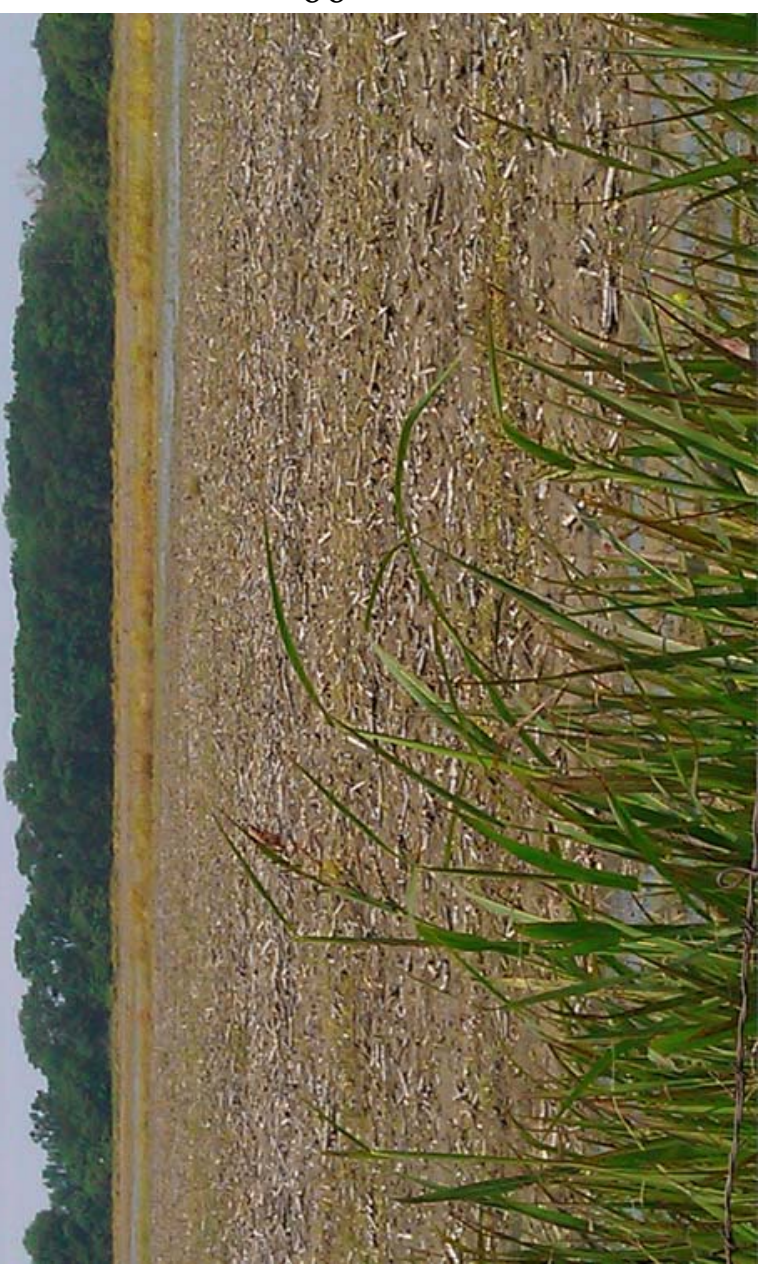

68 


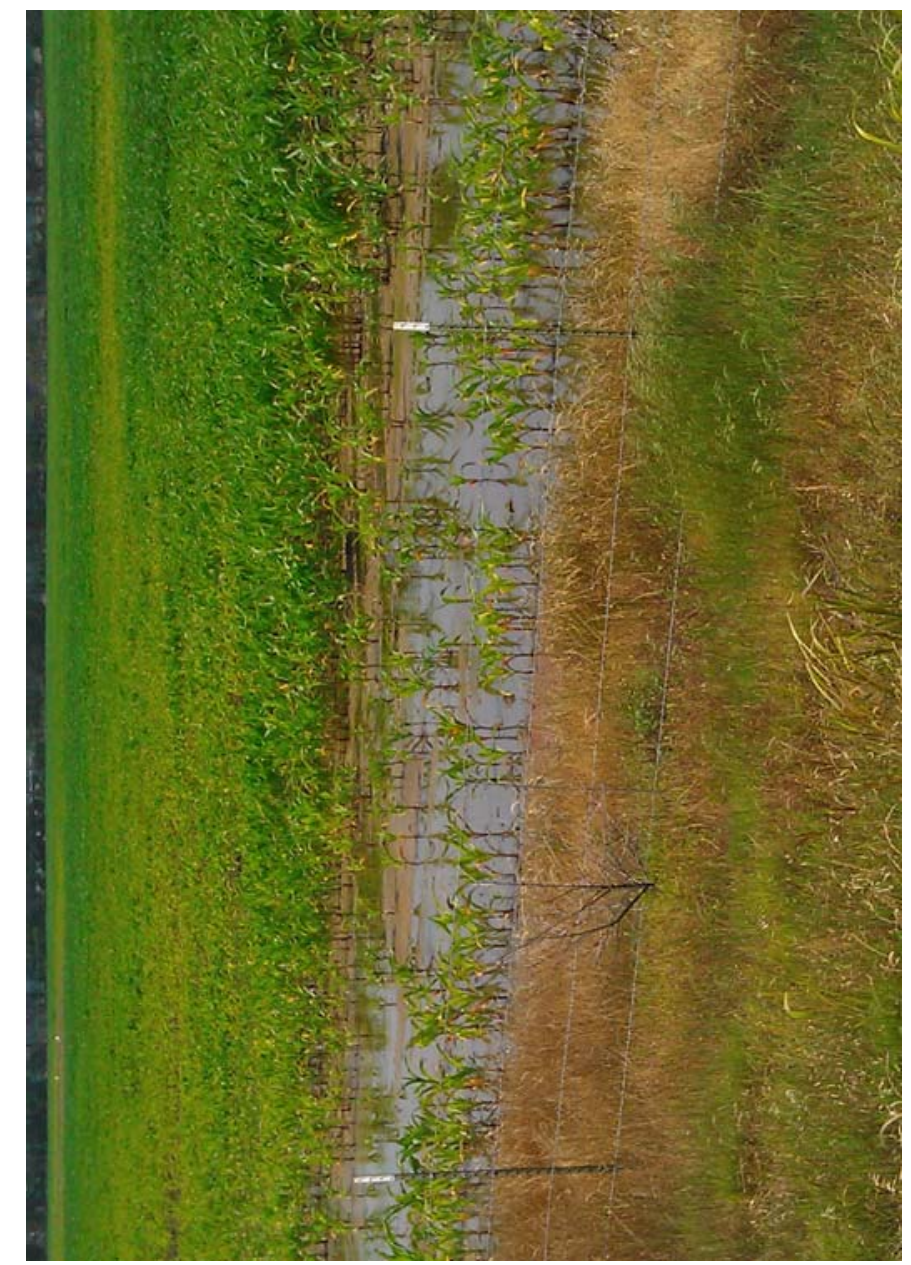

69

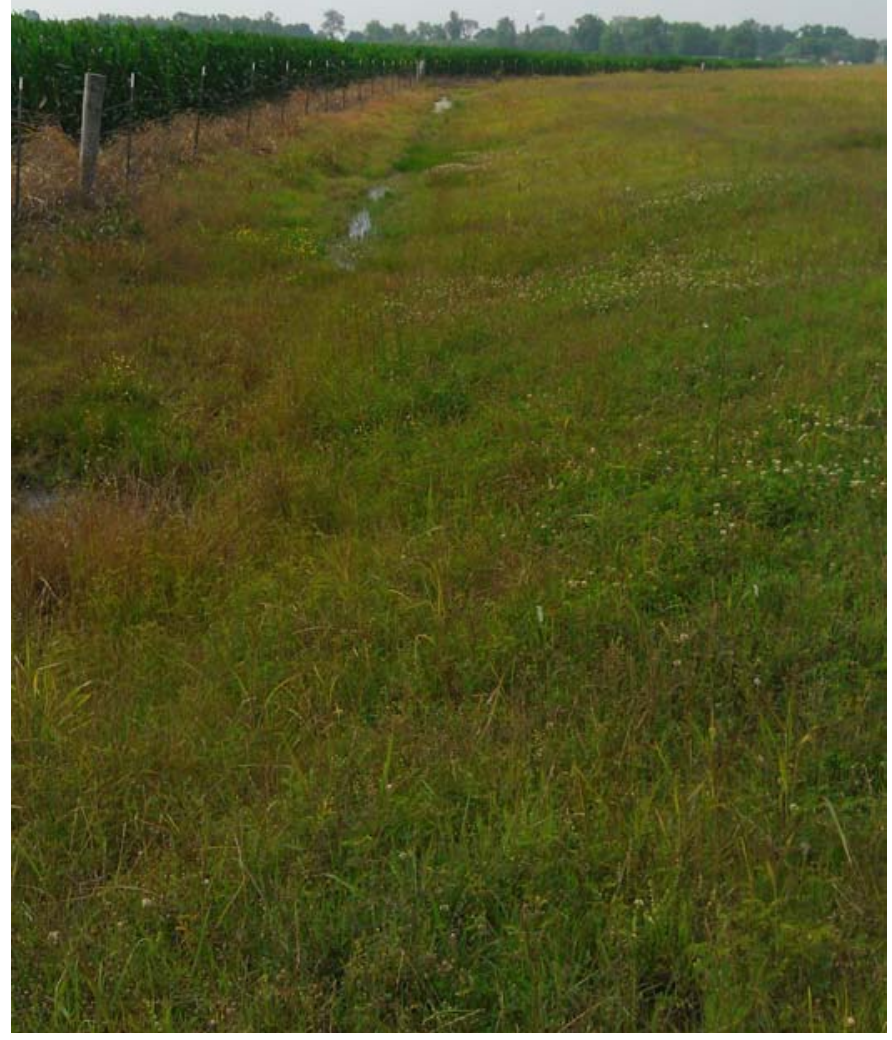



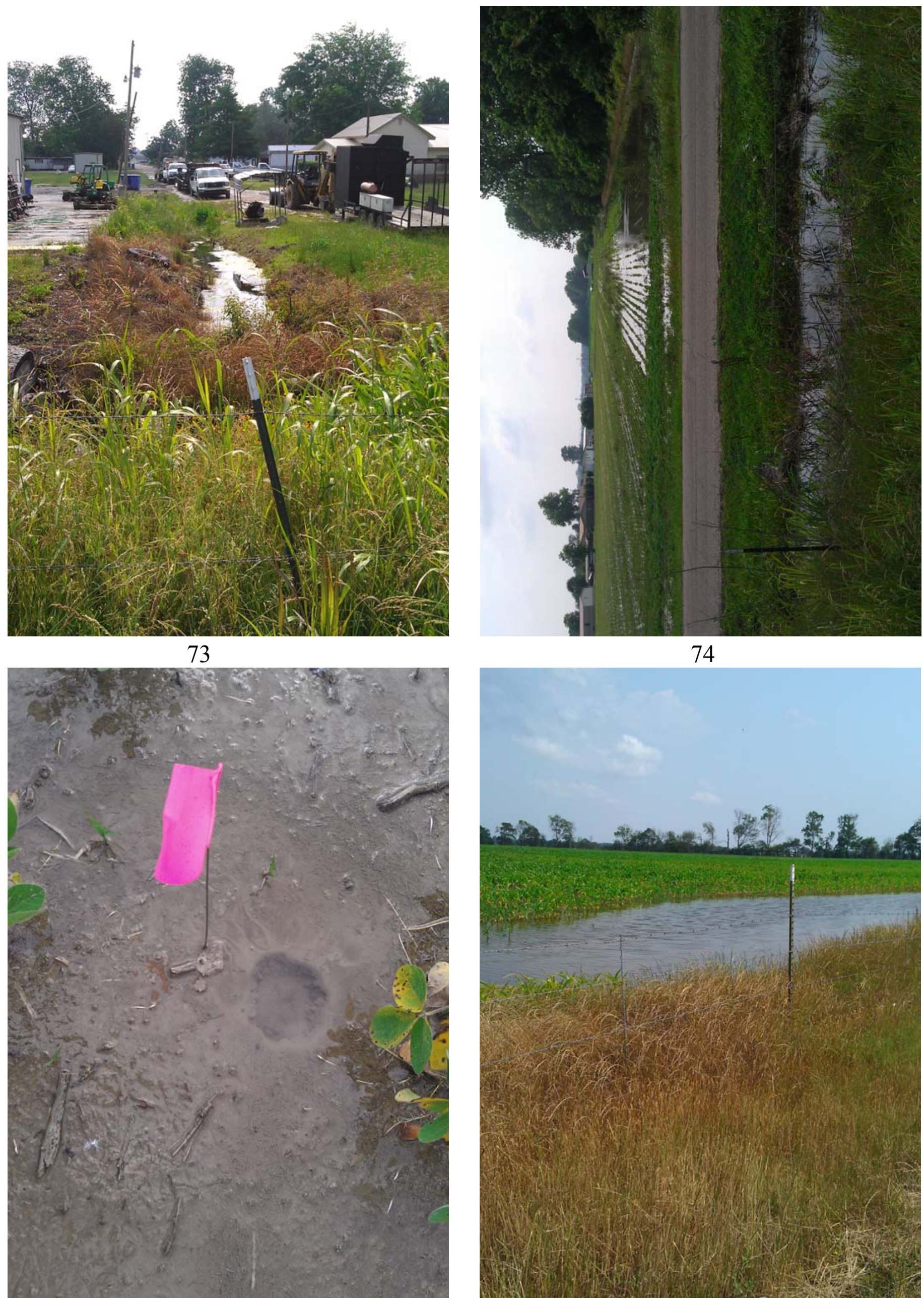

74

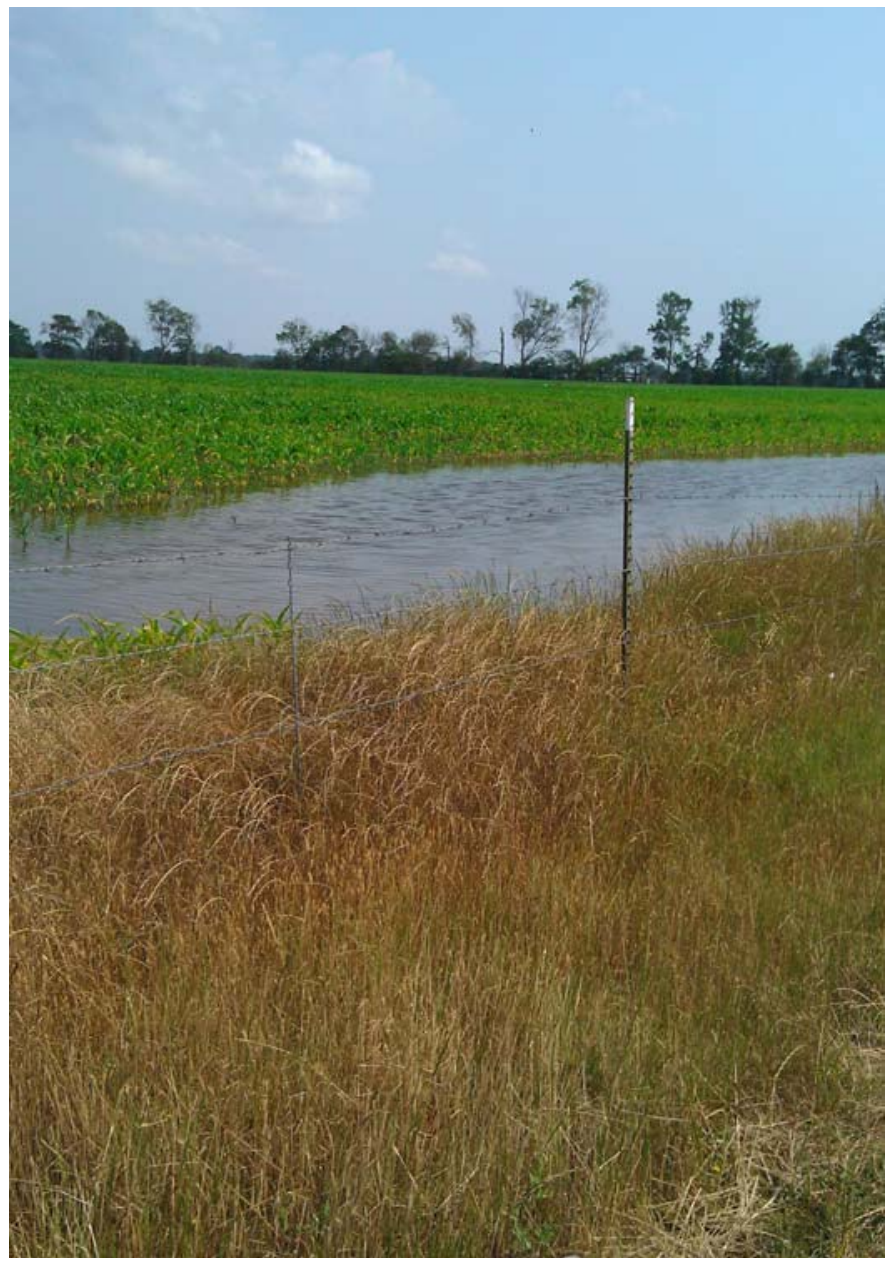




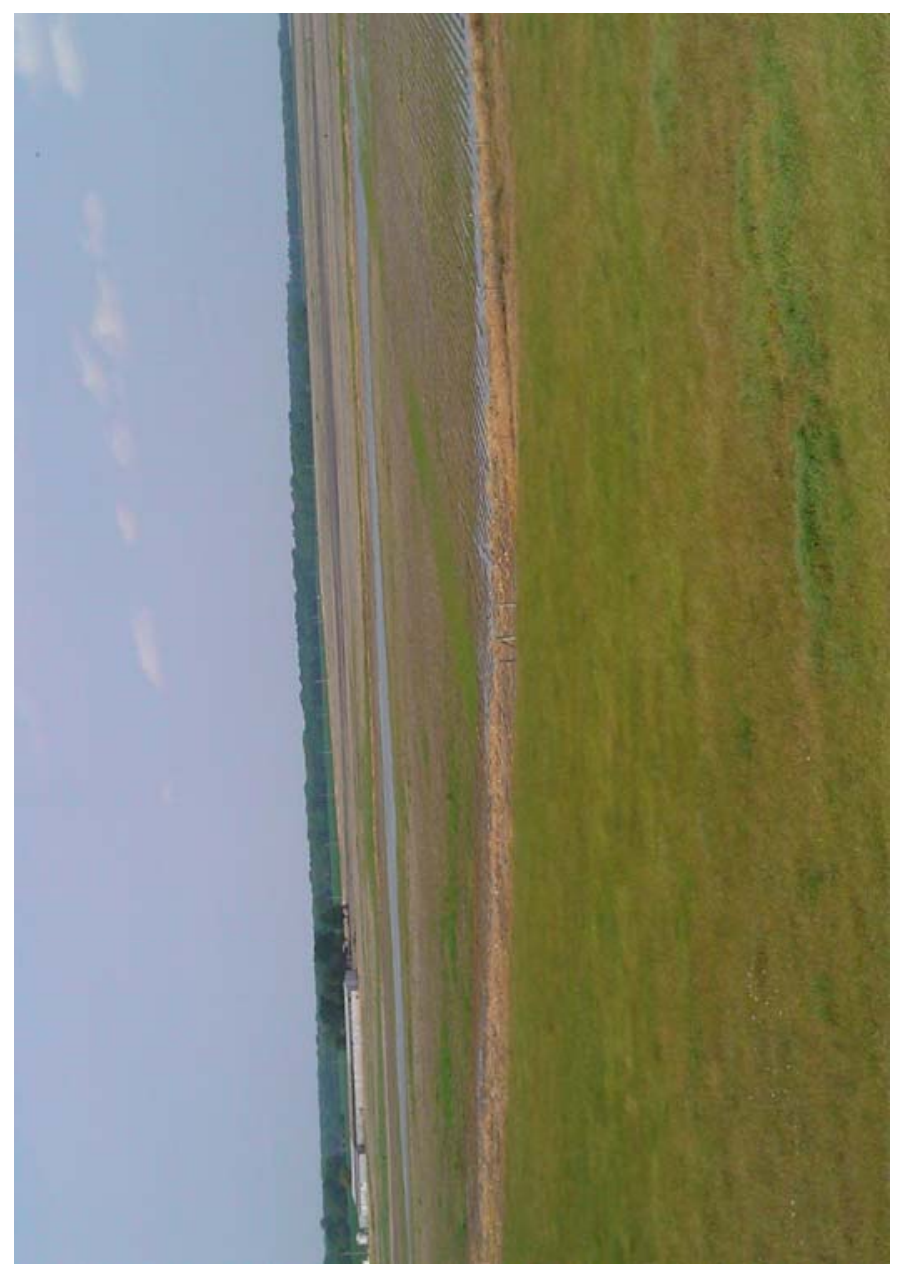

77

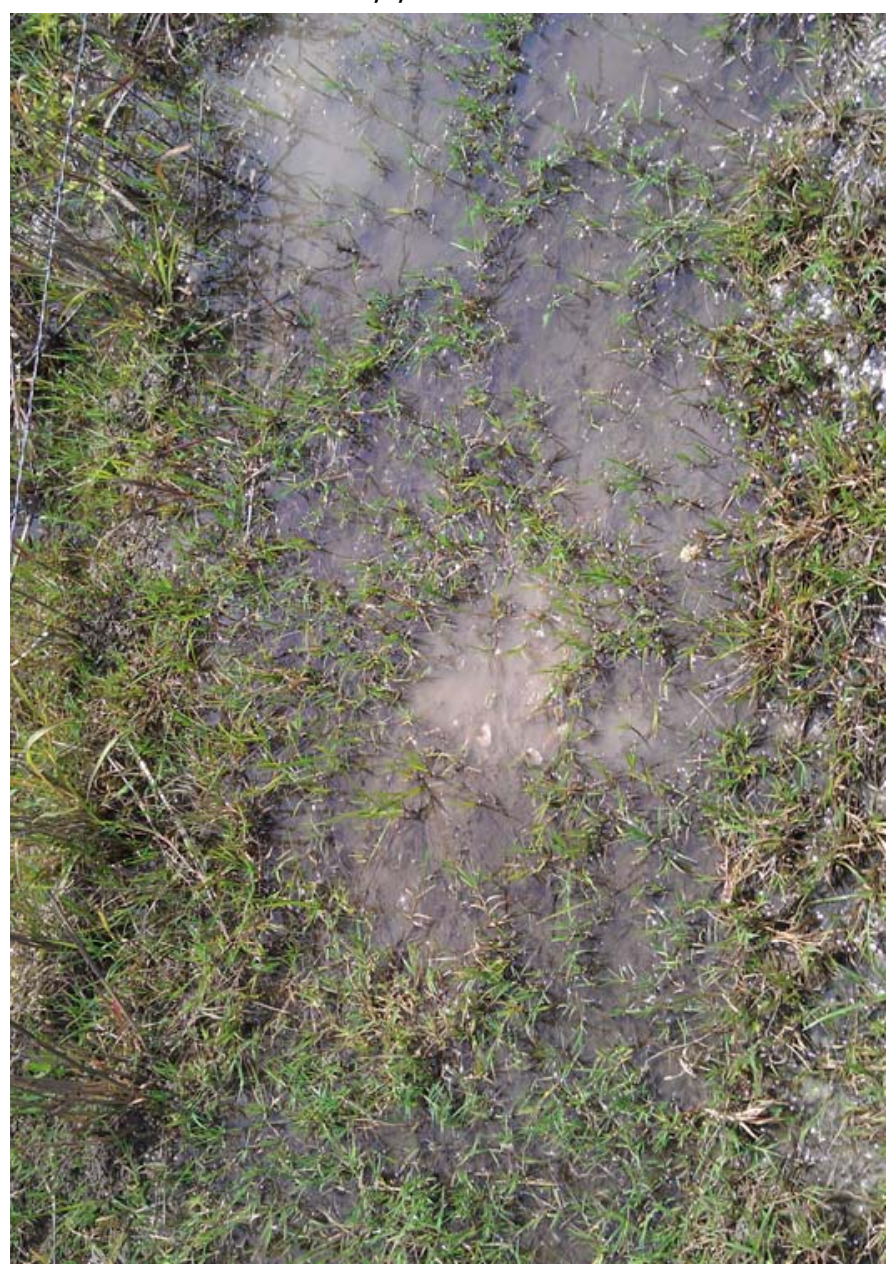

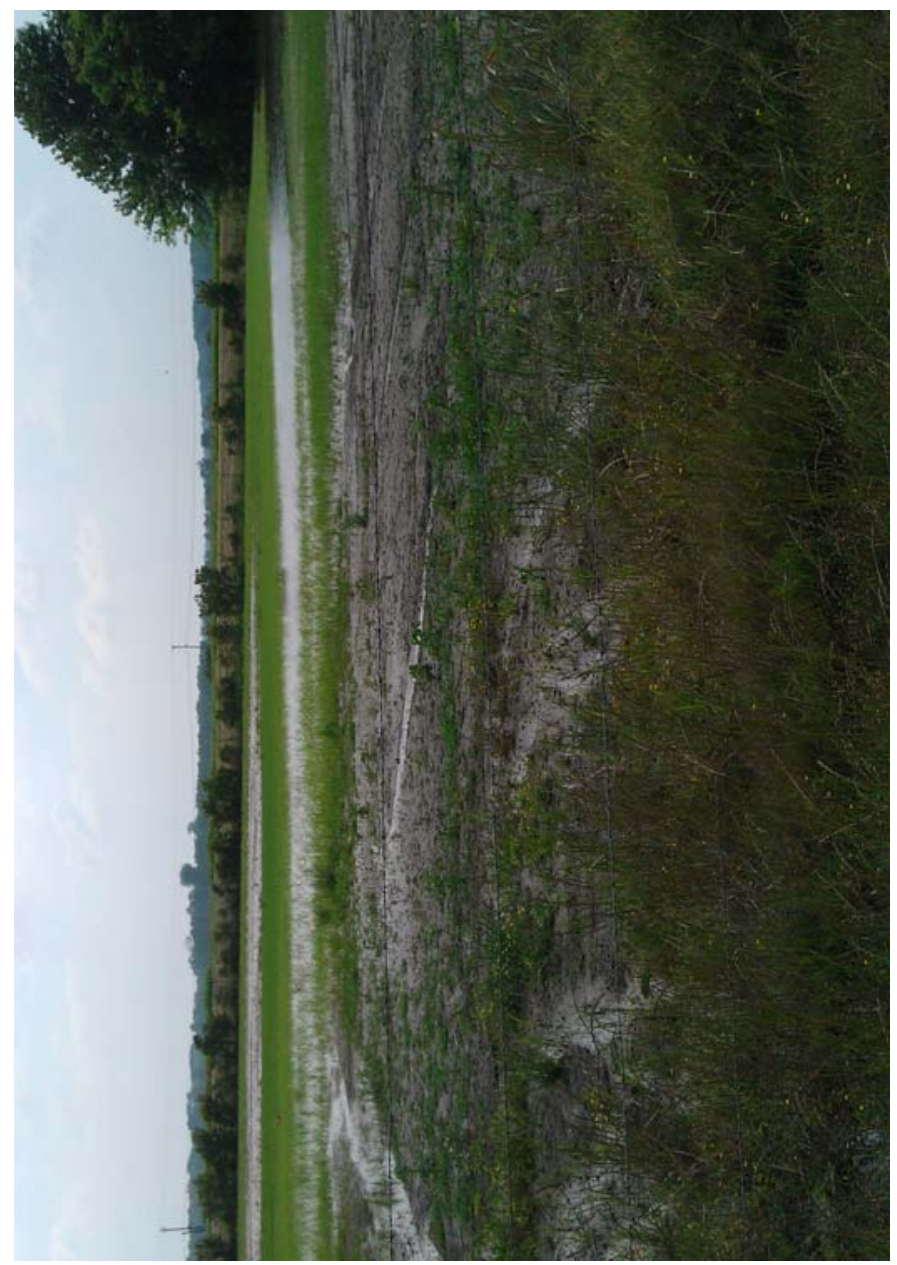

78

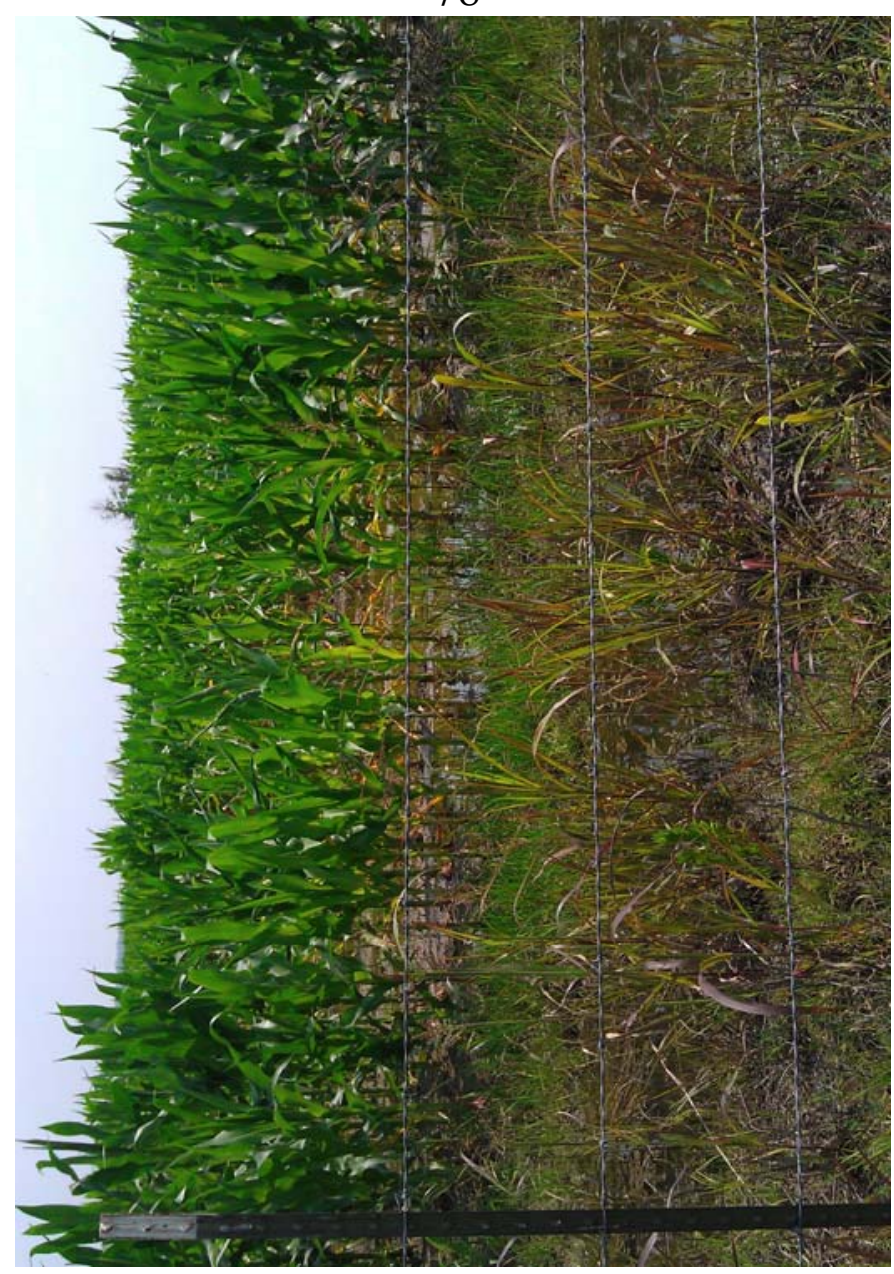




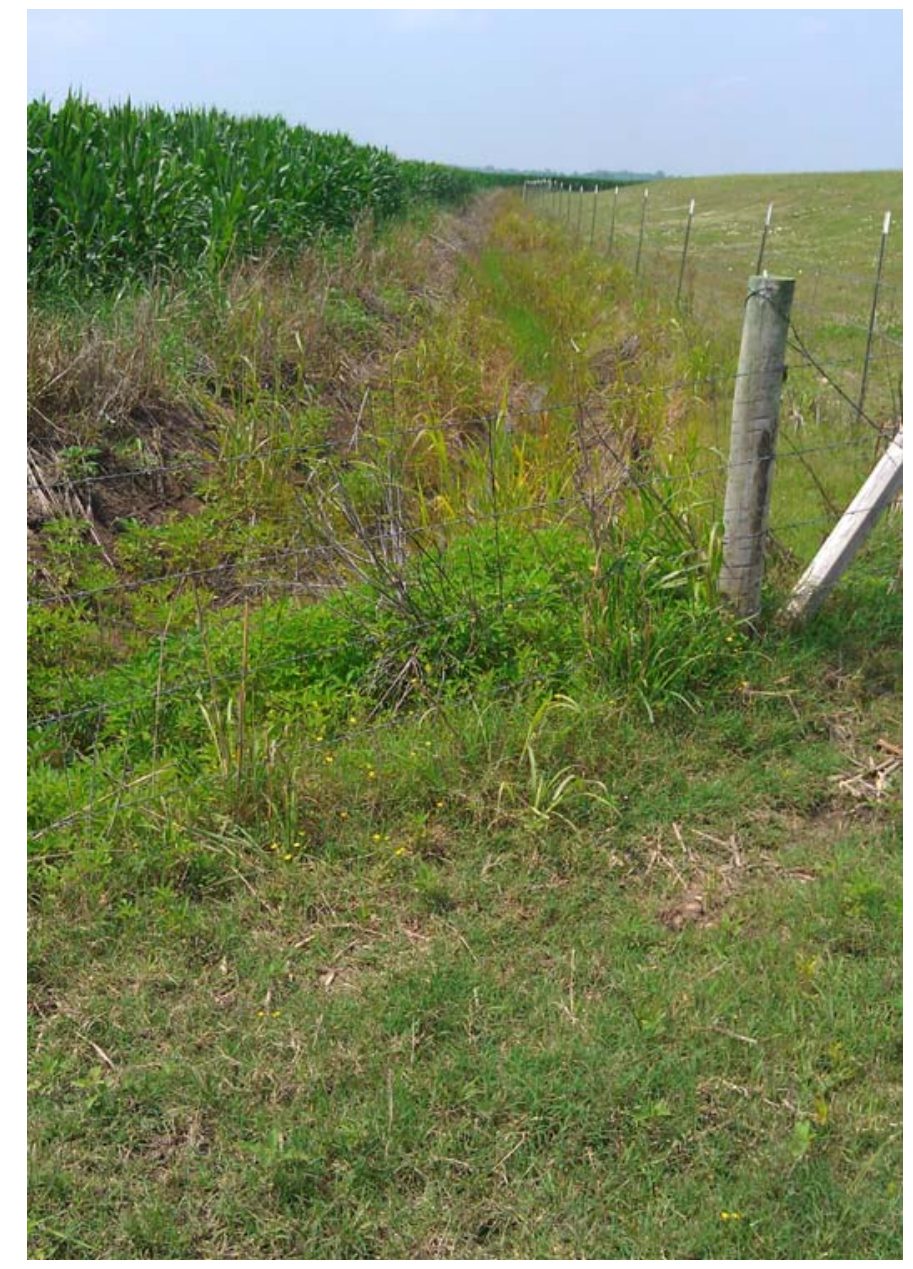

81

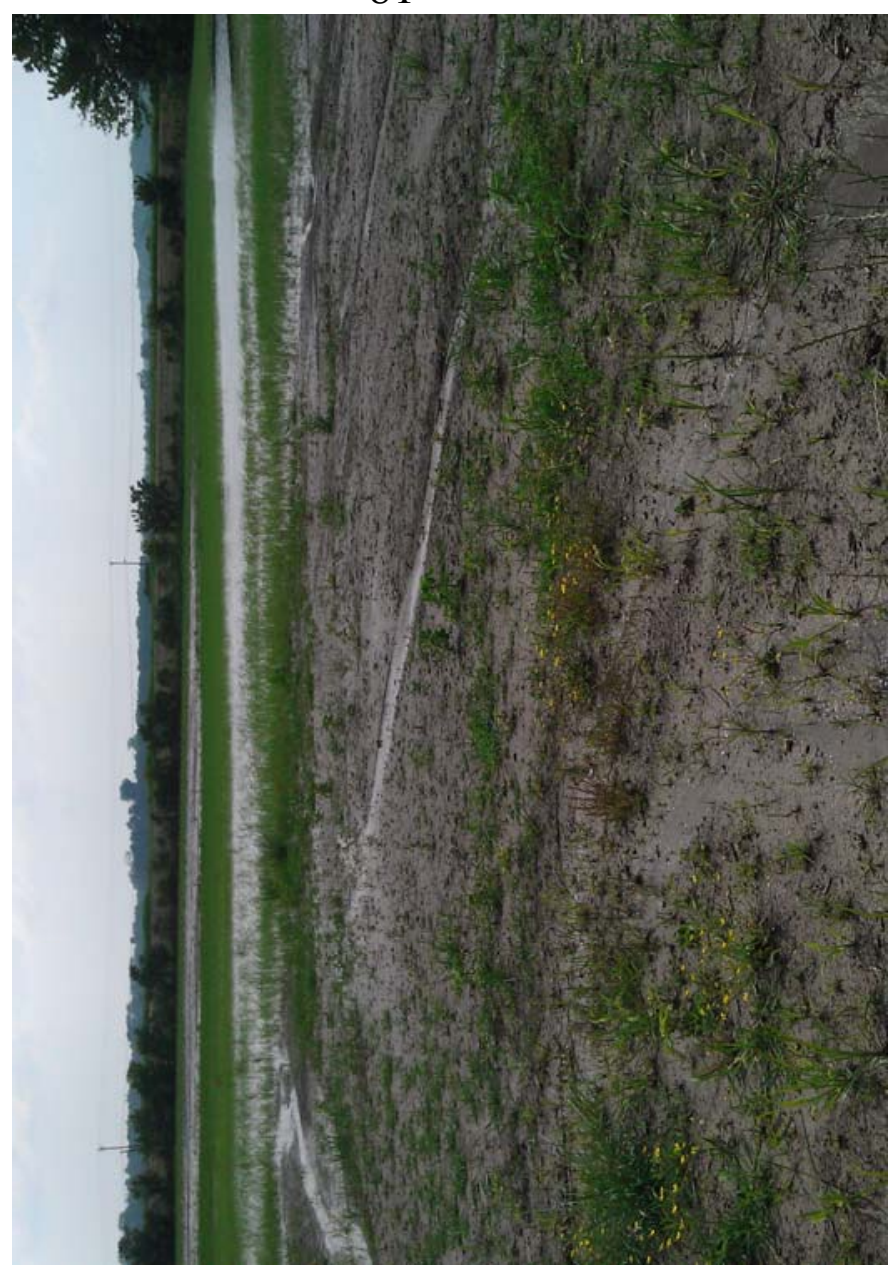

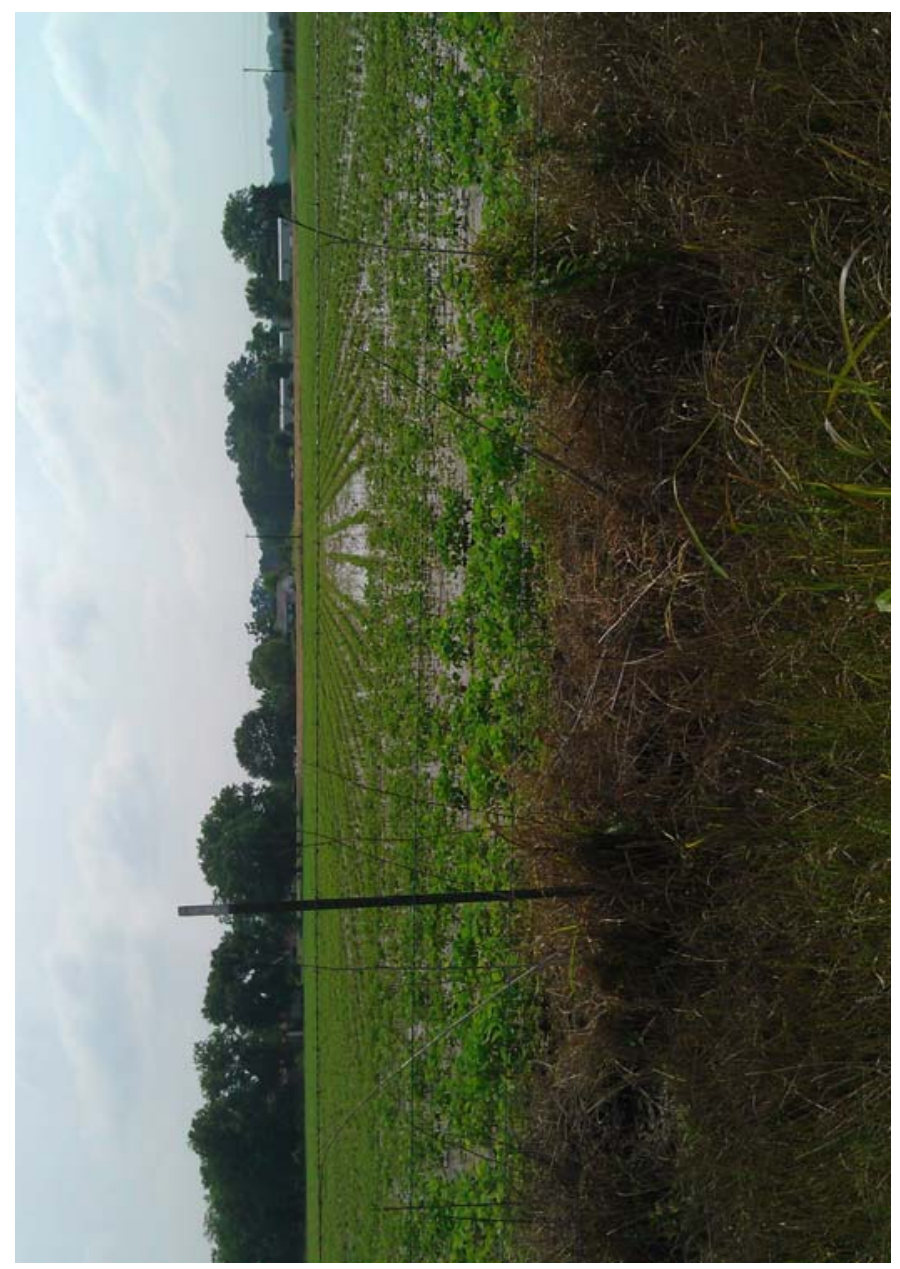

82

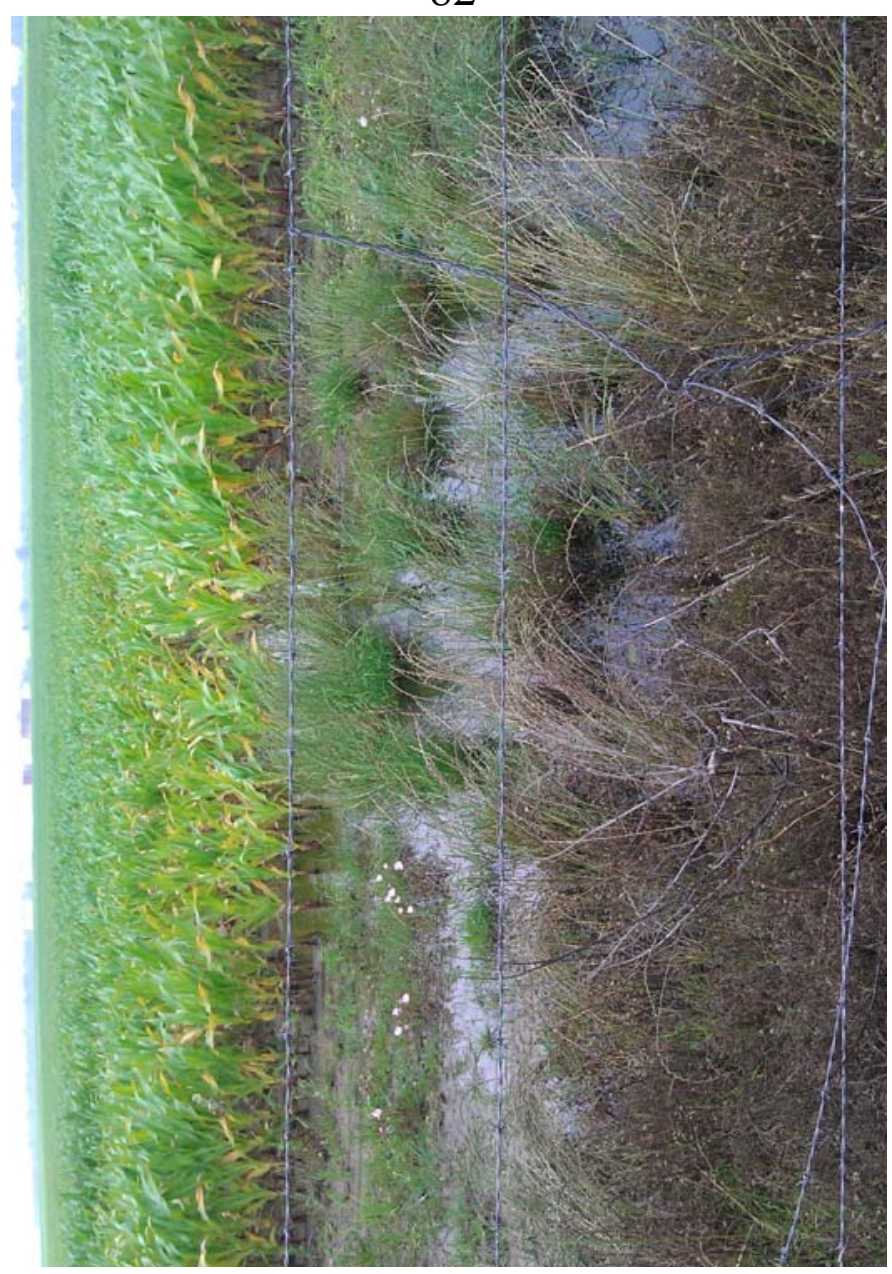




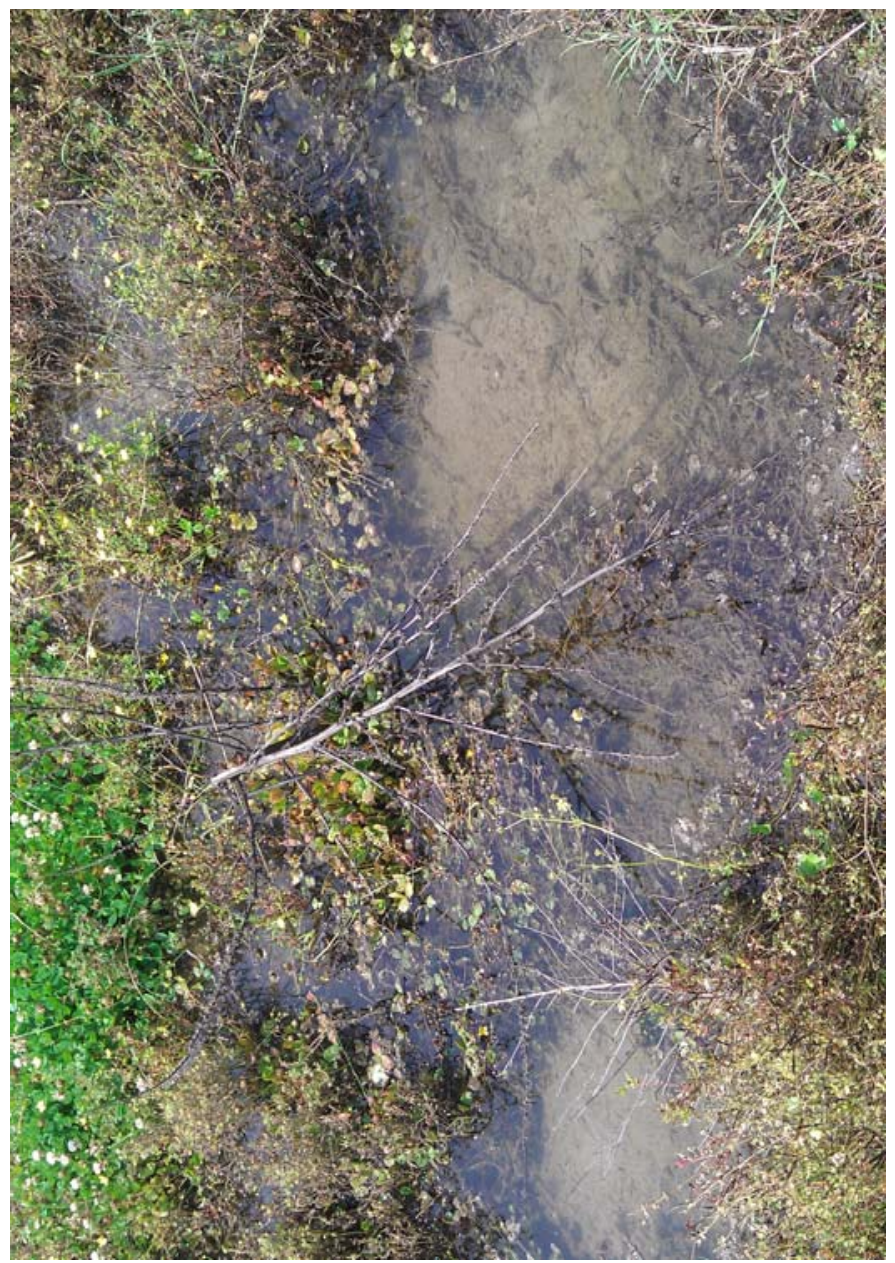

85

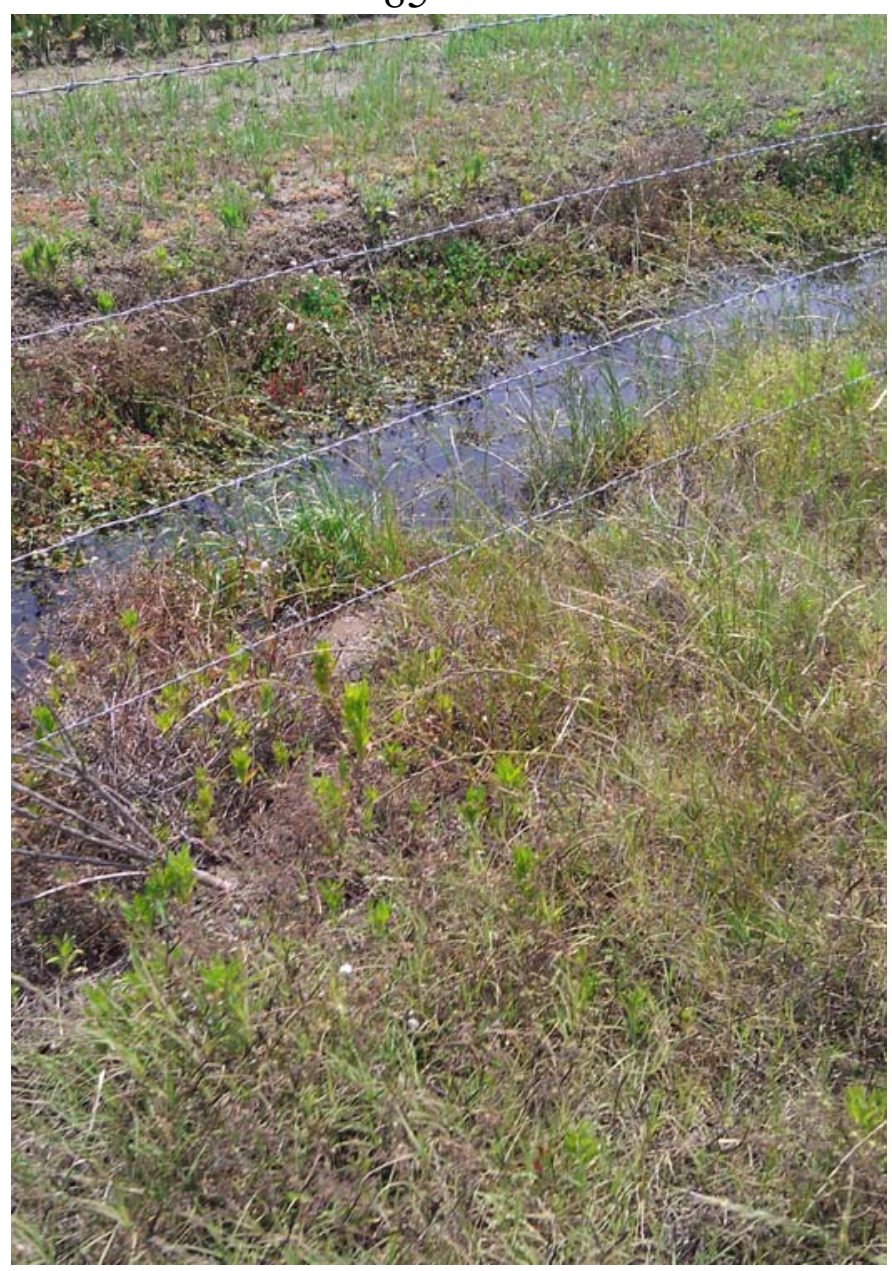

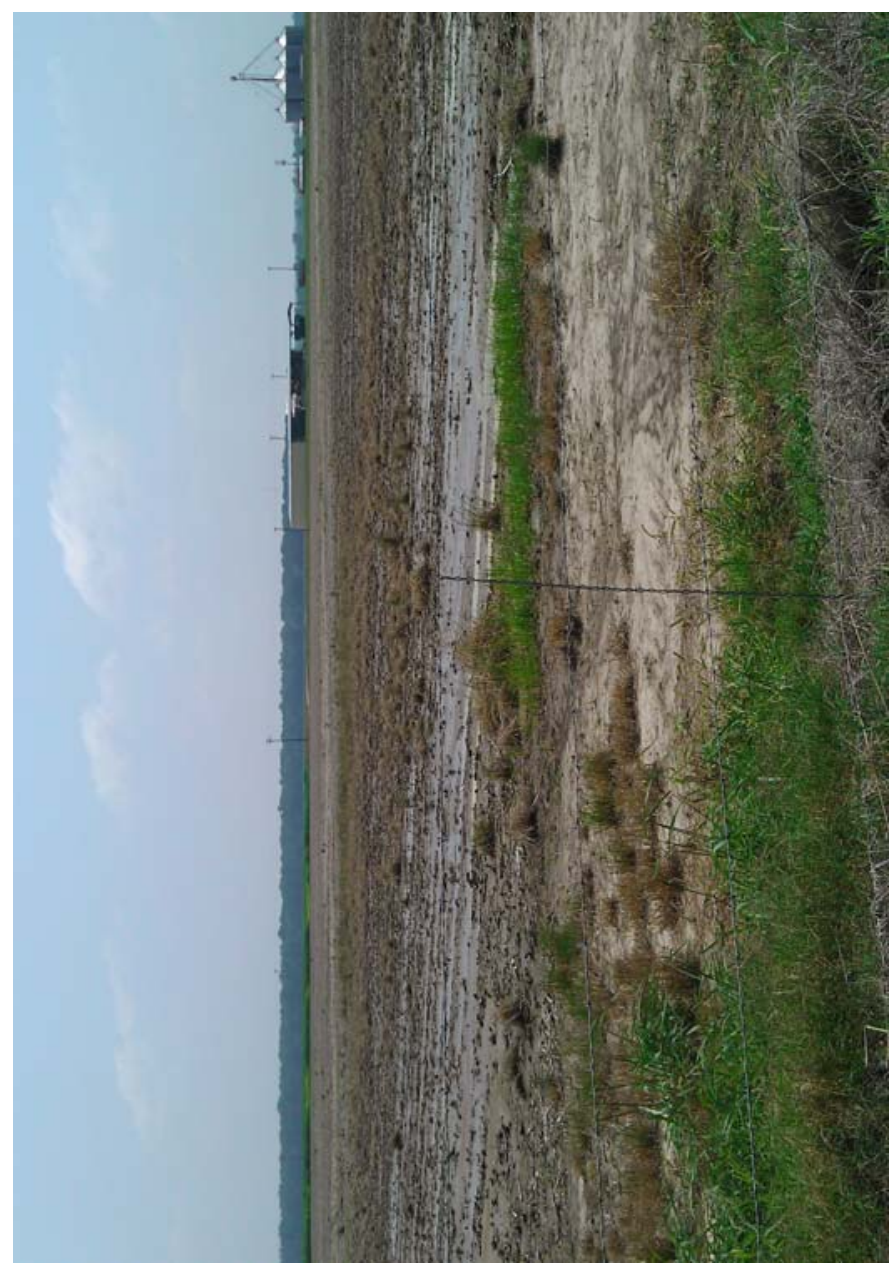

86

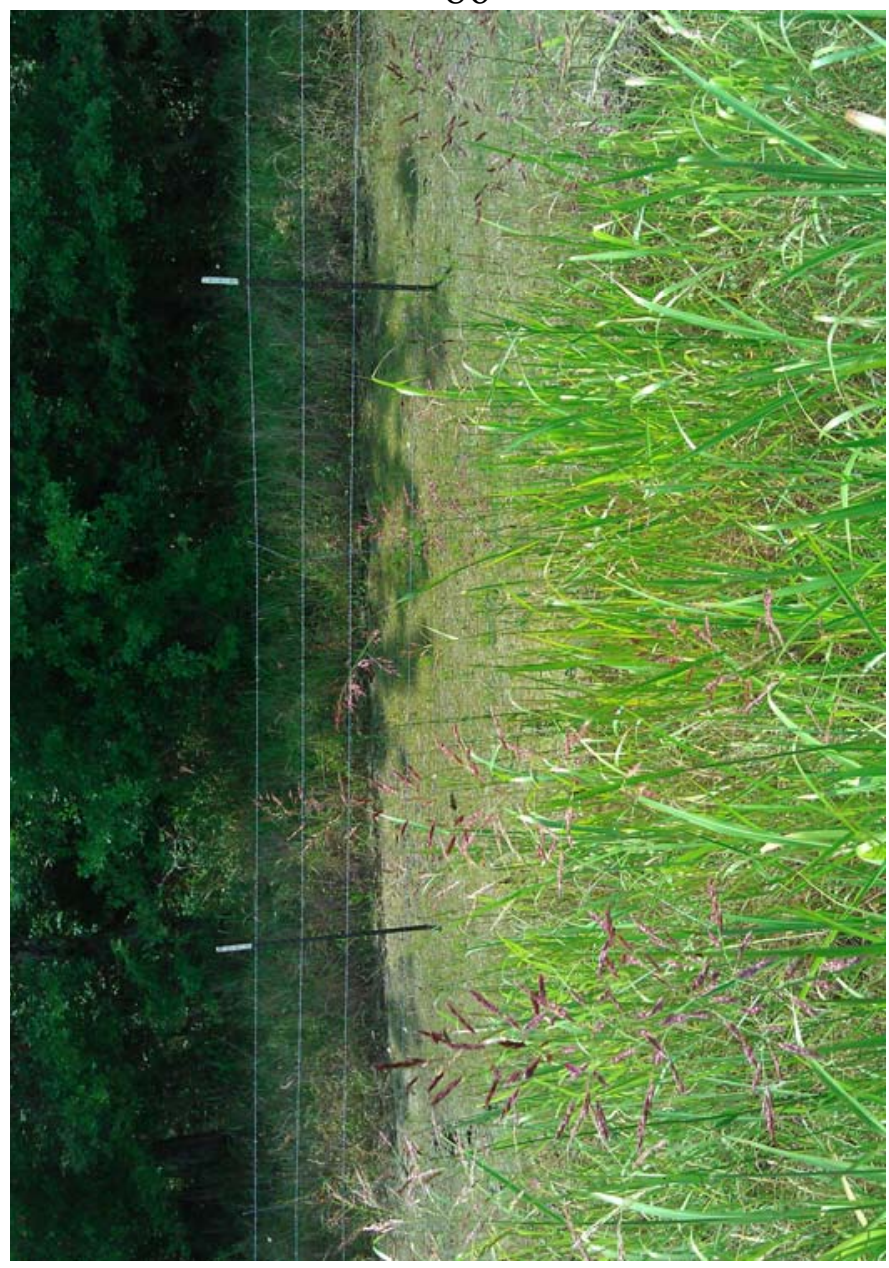




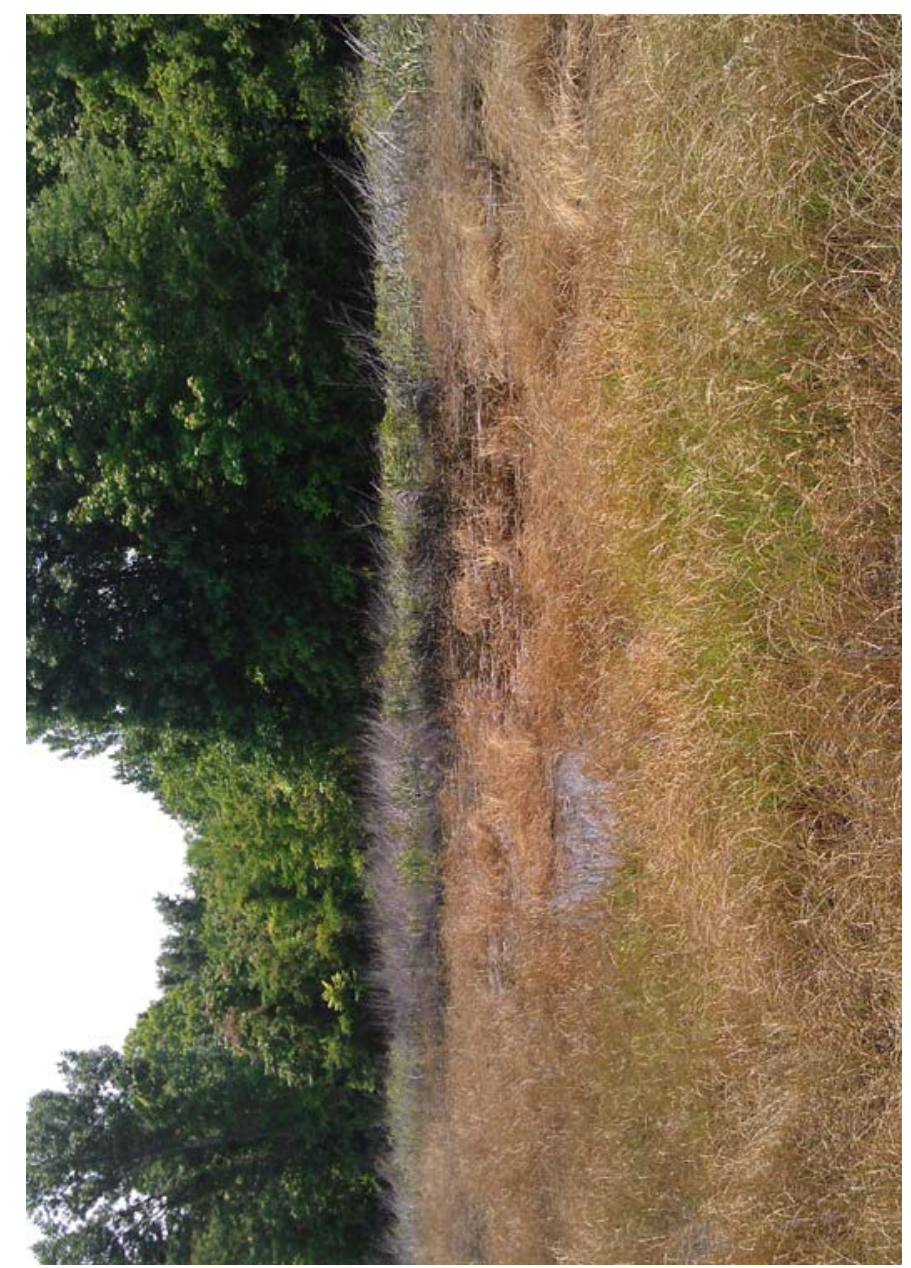

\section{9}

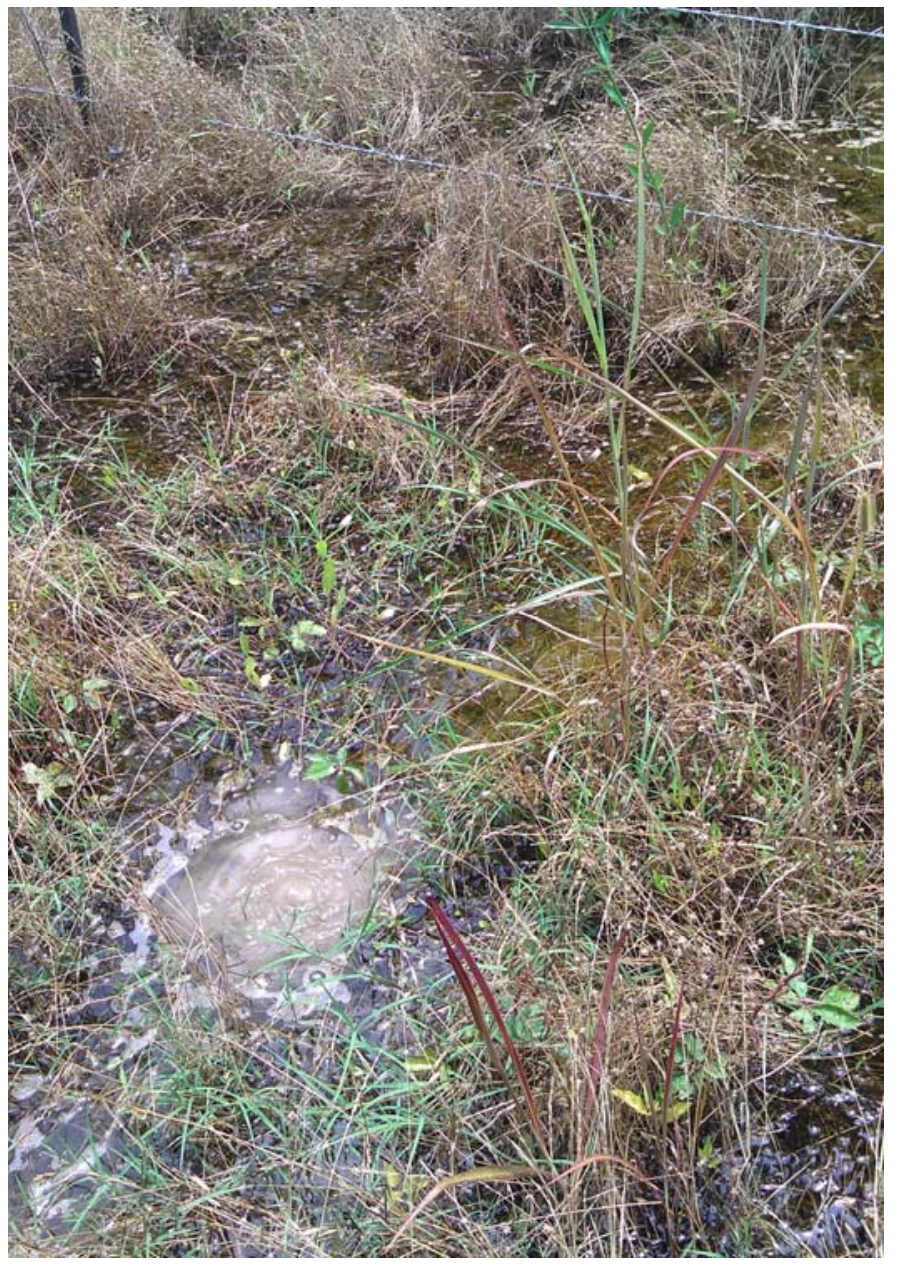

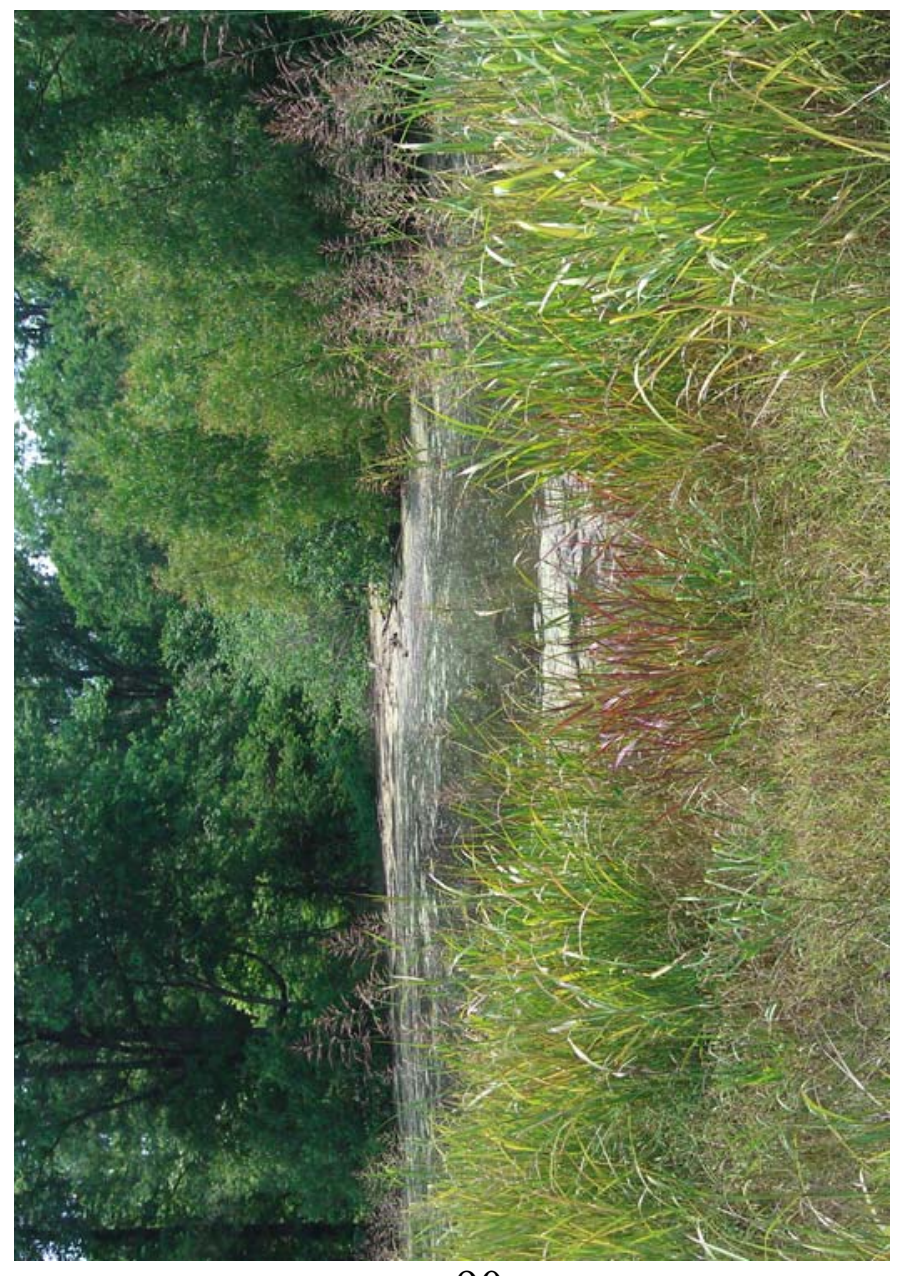

90

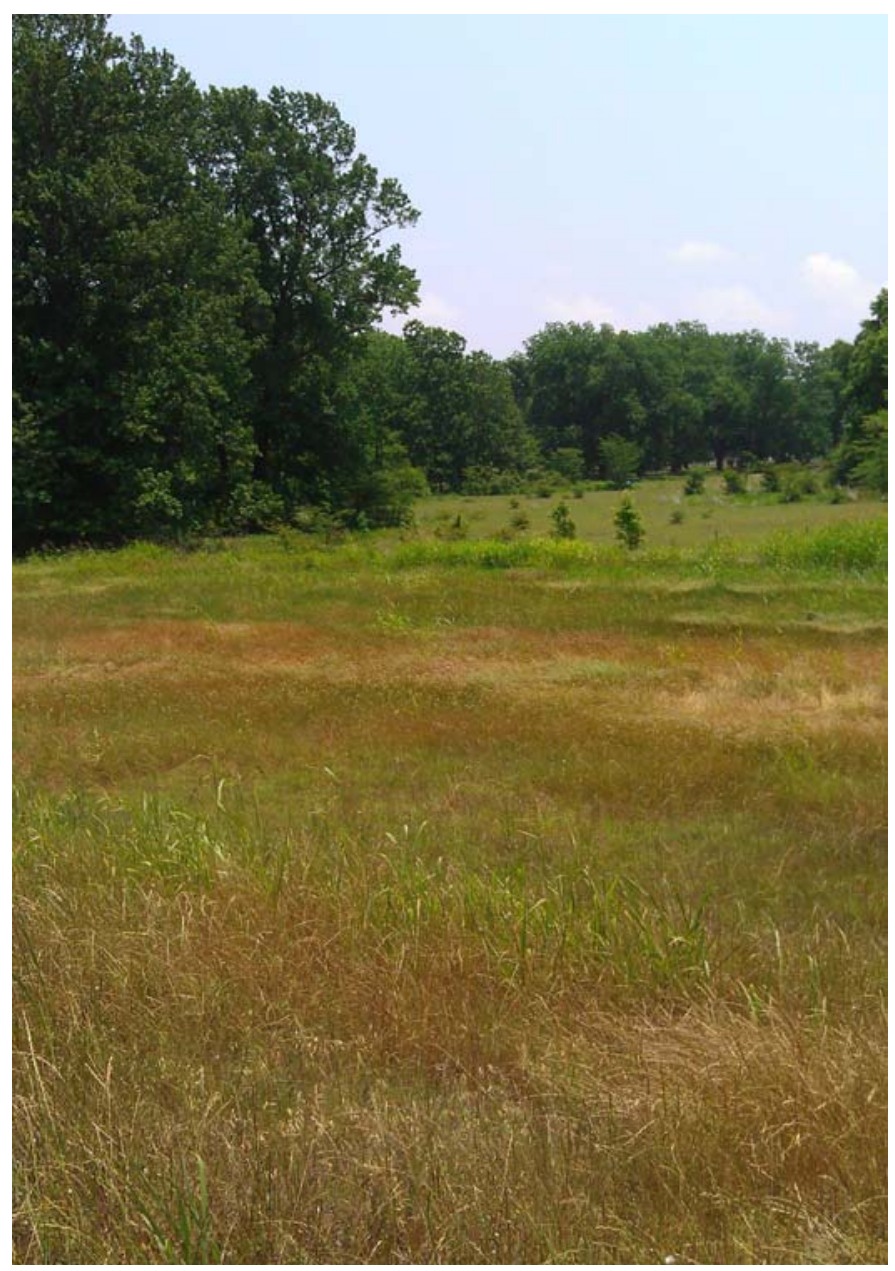




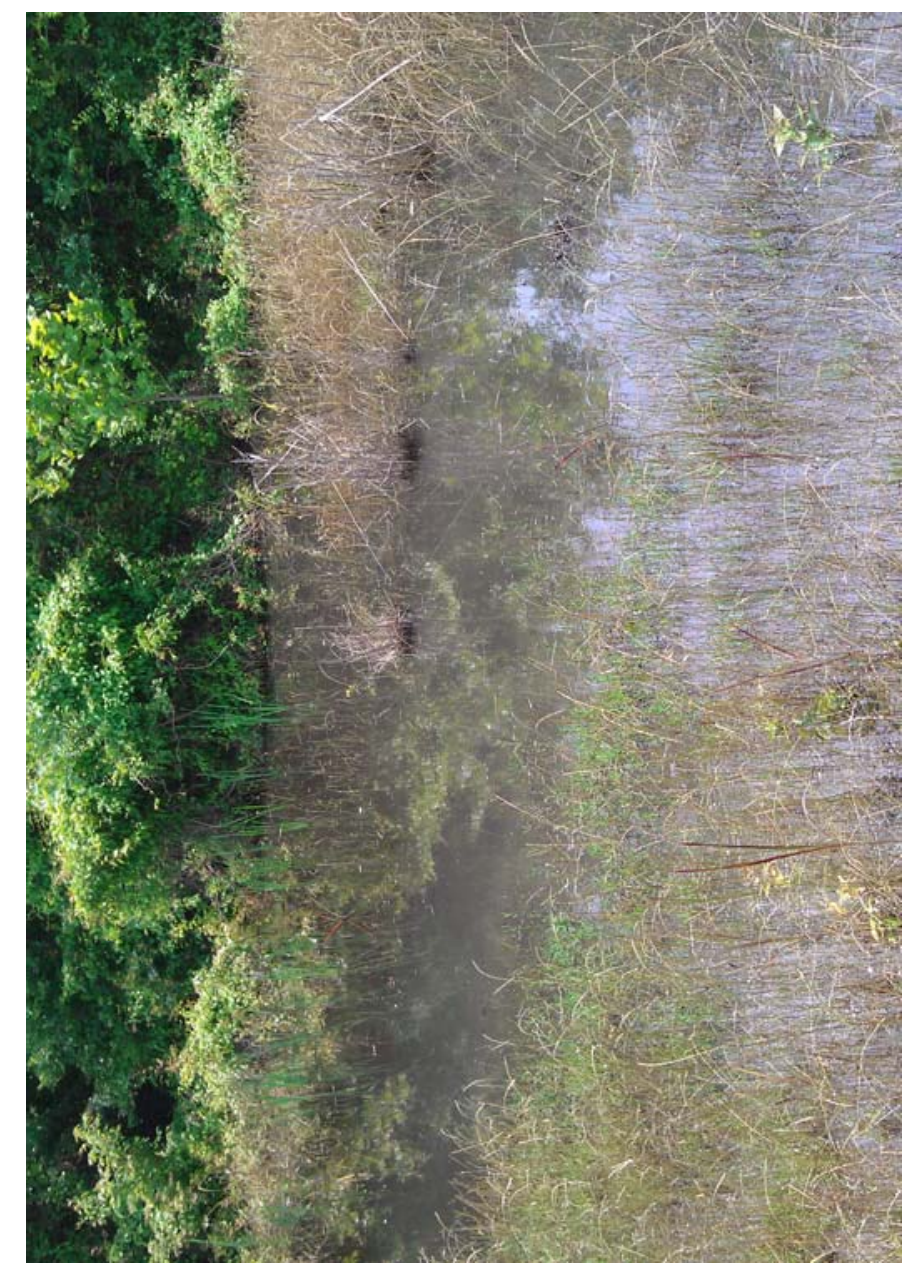

93

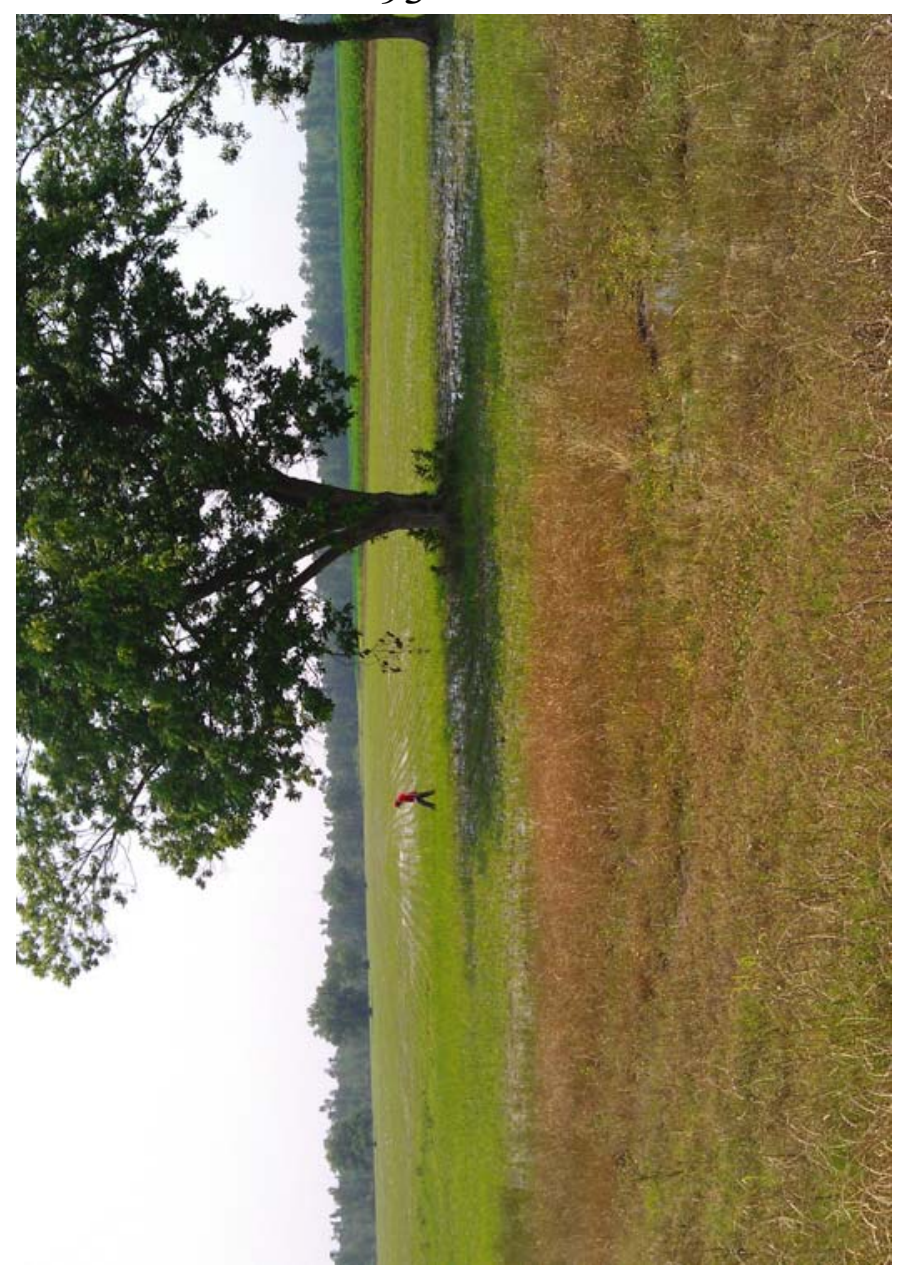

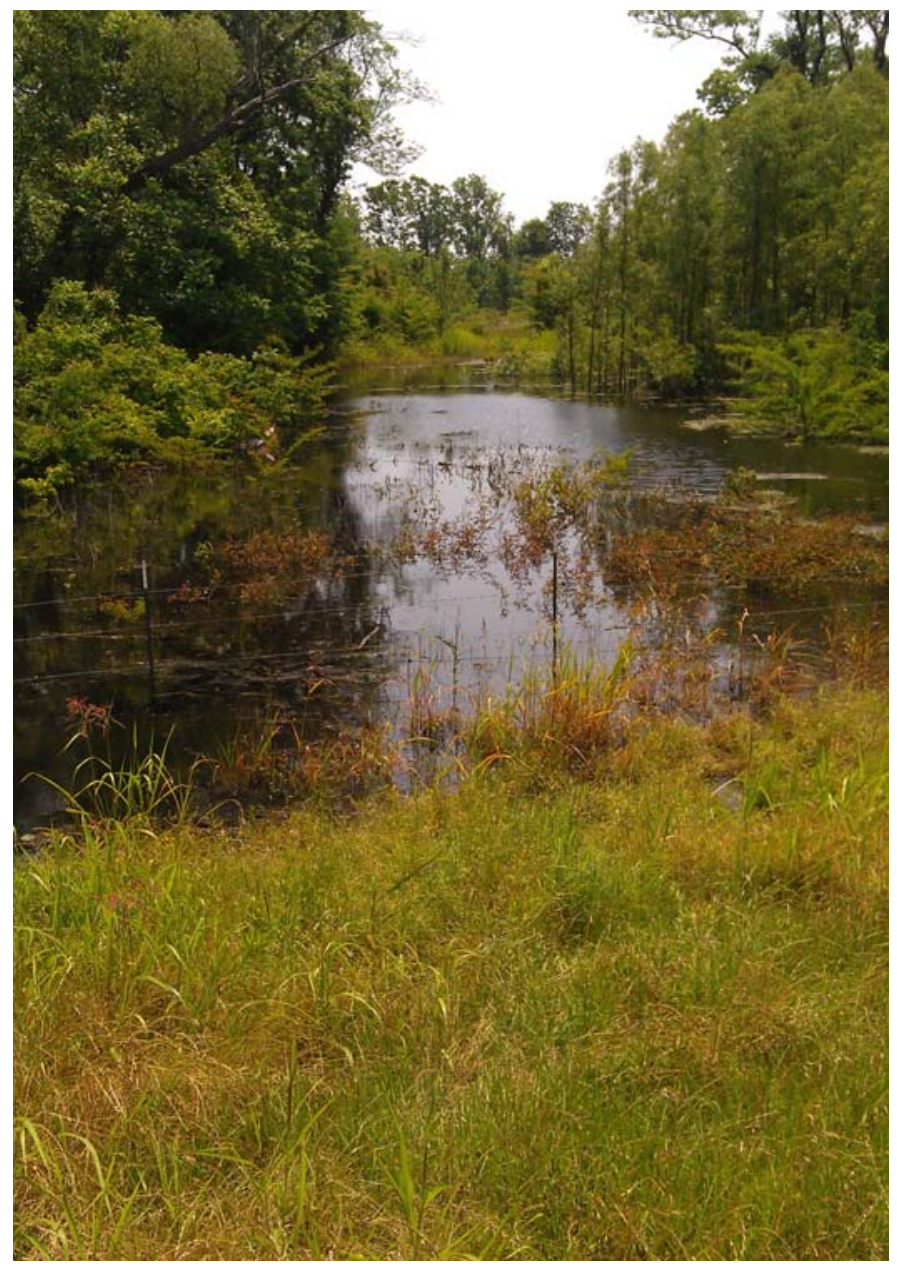

94

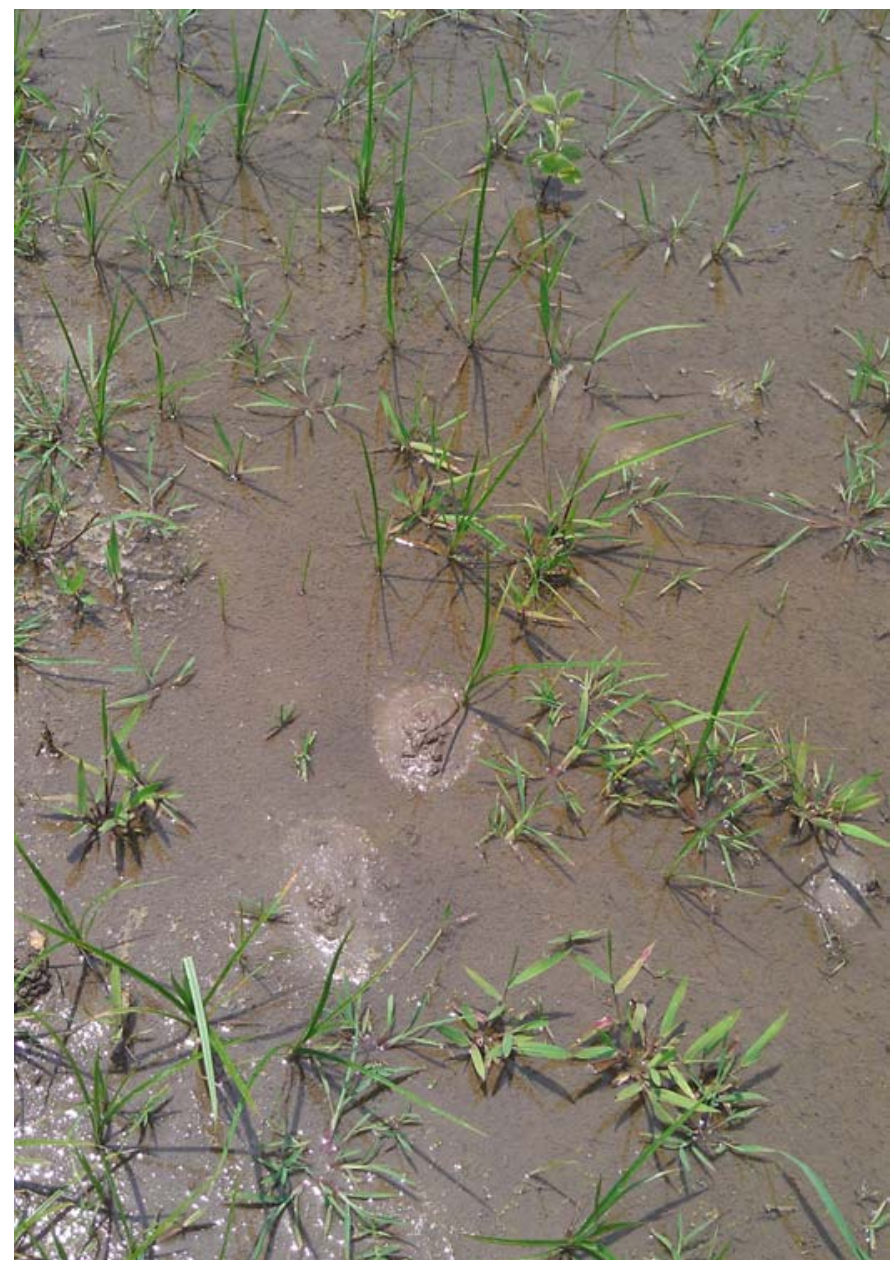

96 


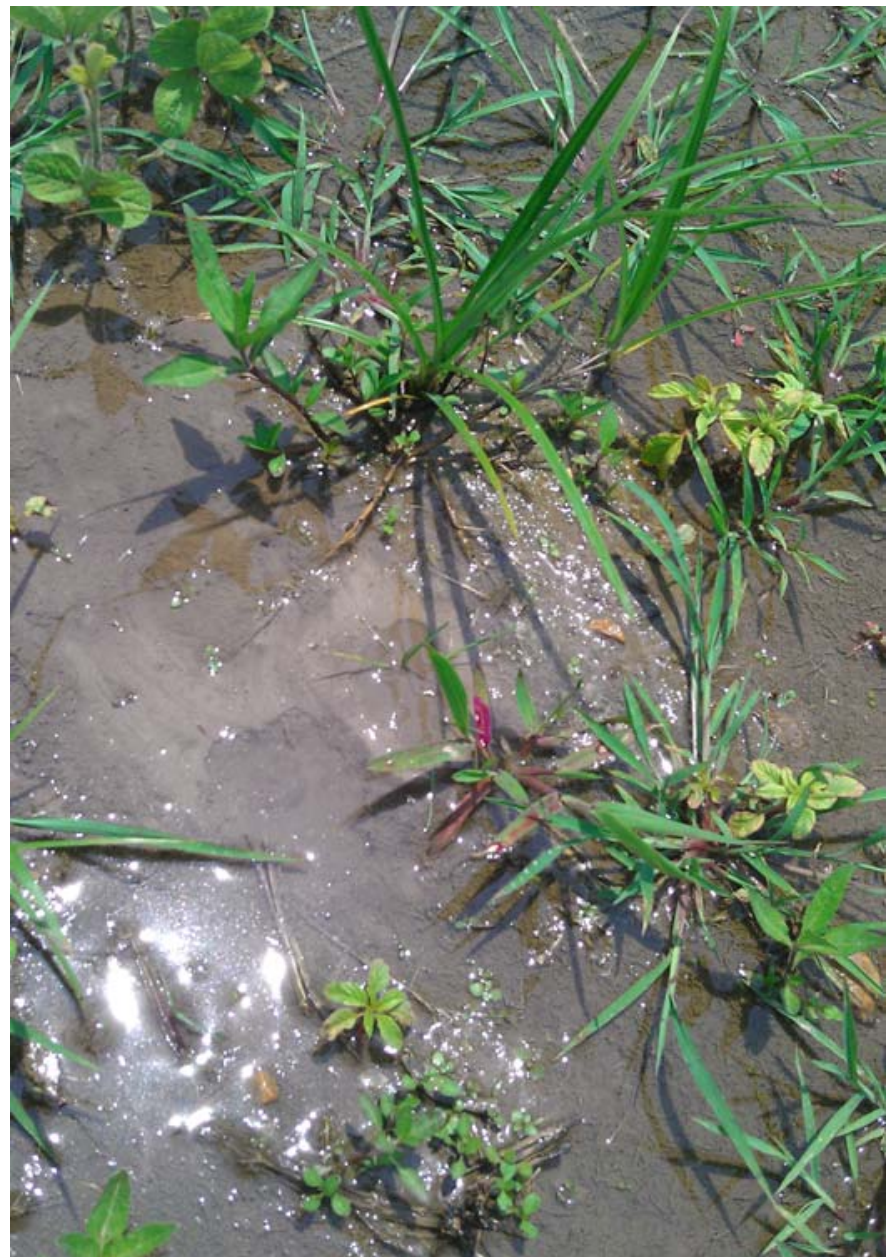

97

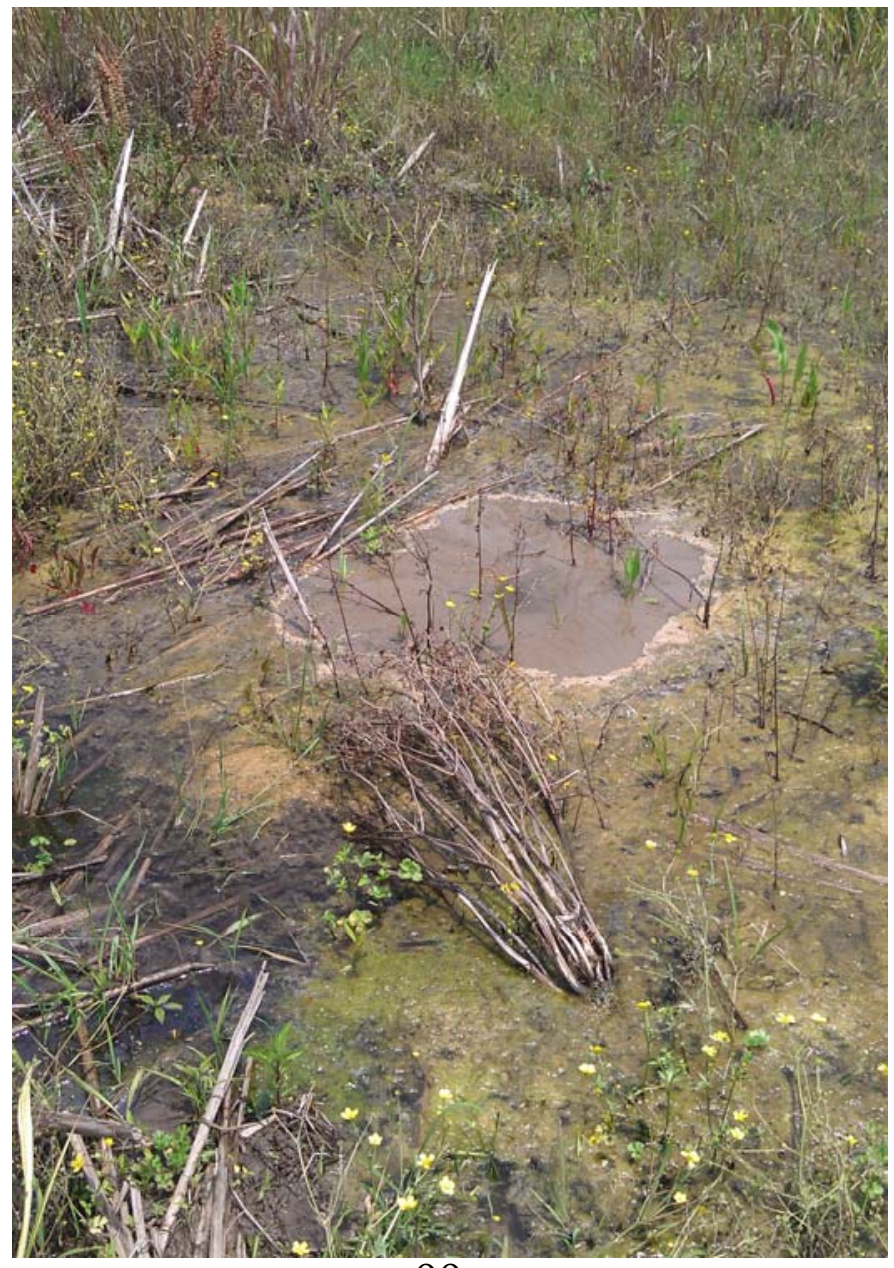

99

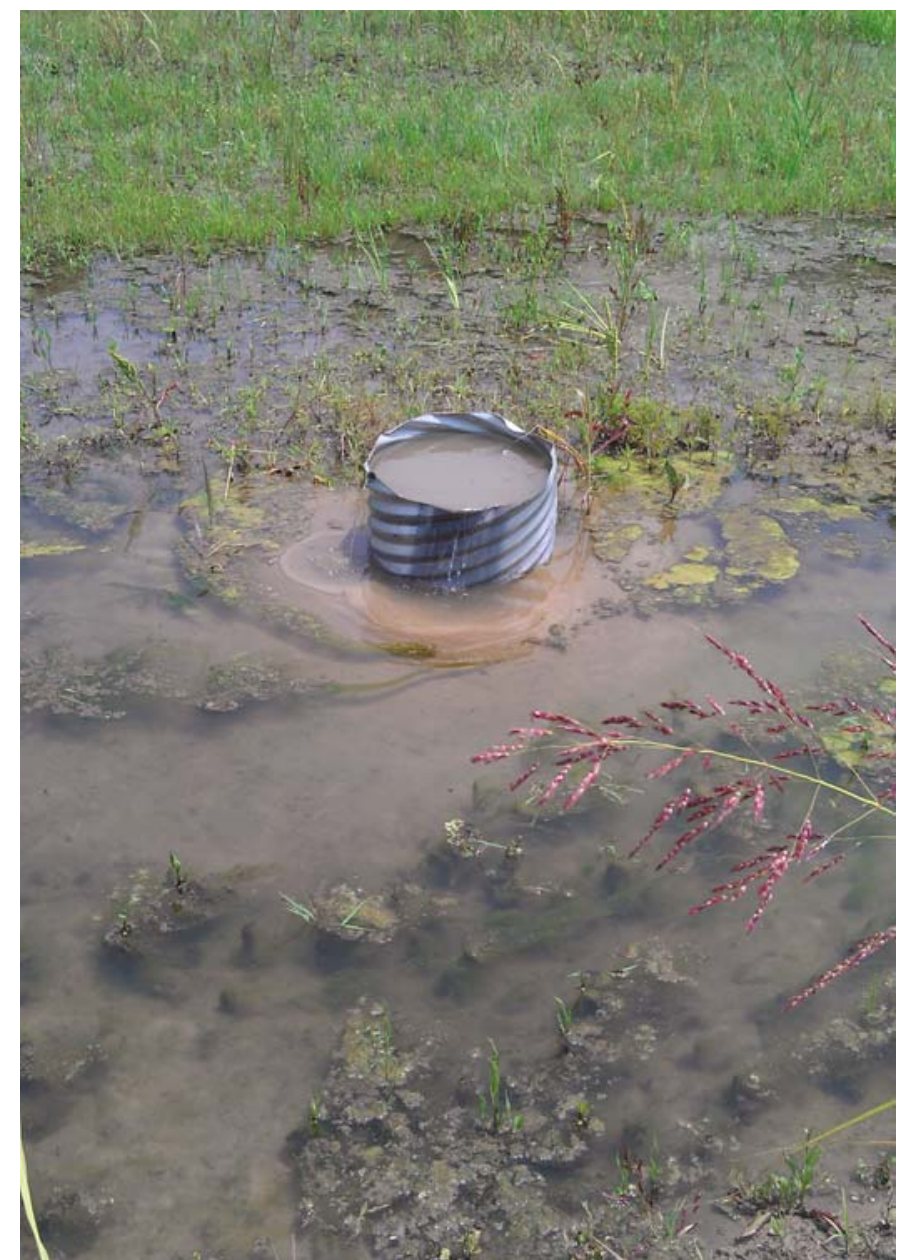

\section{8}

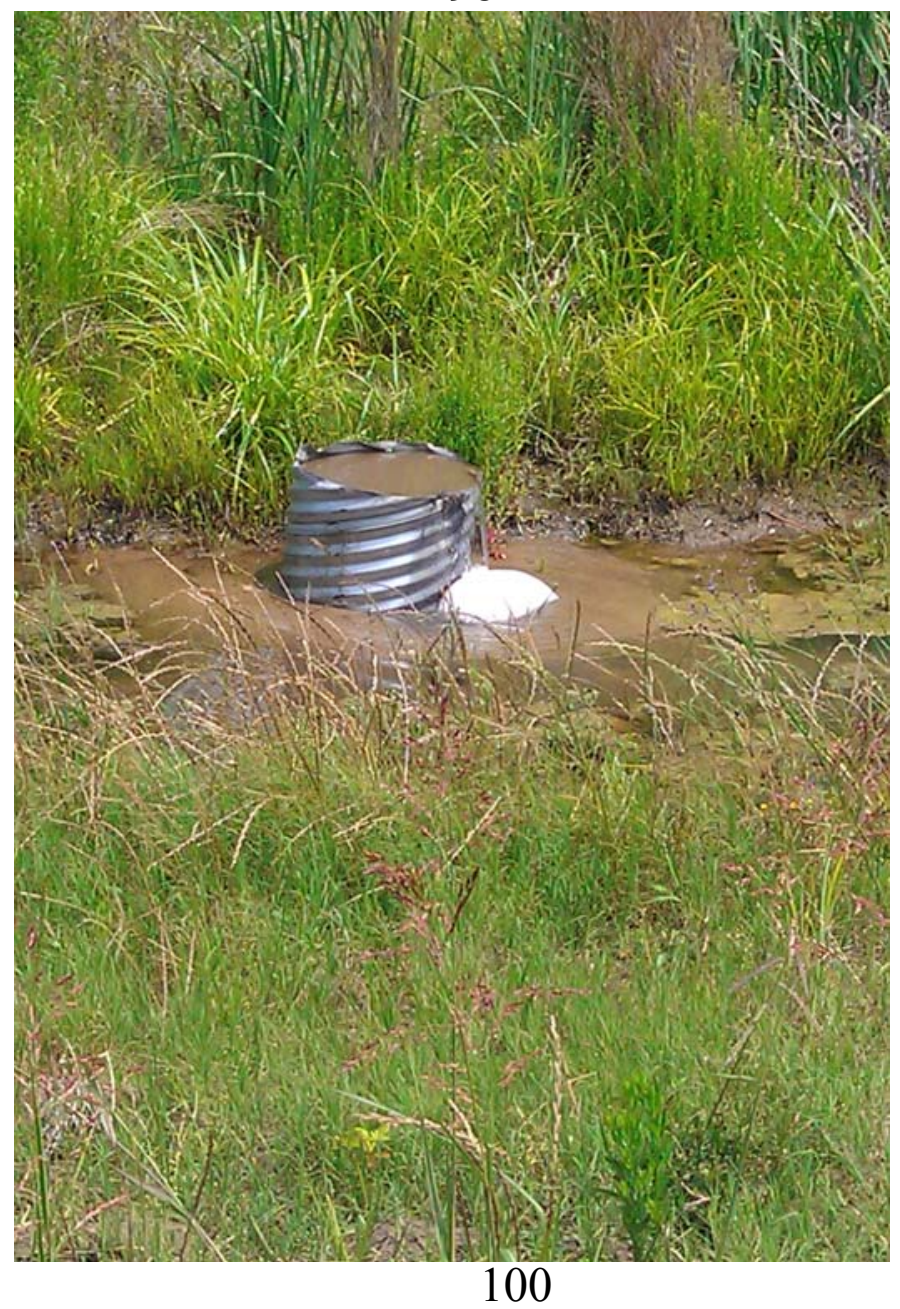

FOR OFFICIAL USE ONLY 


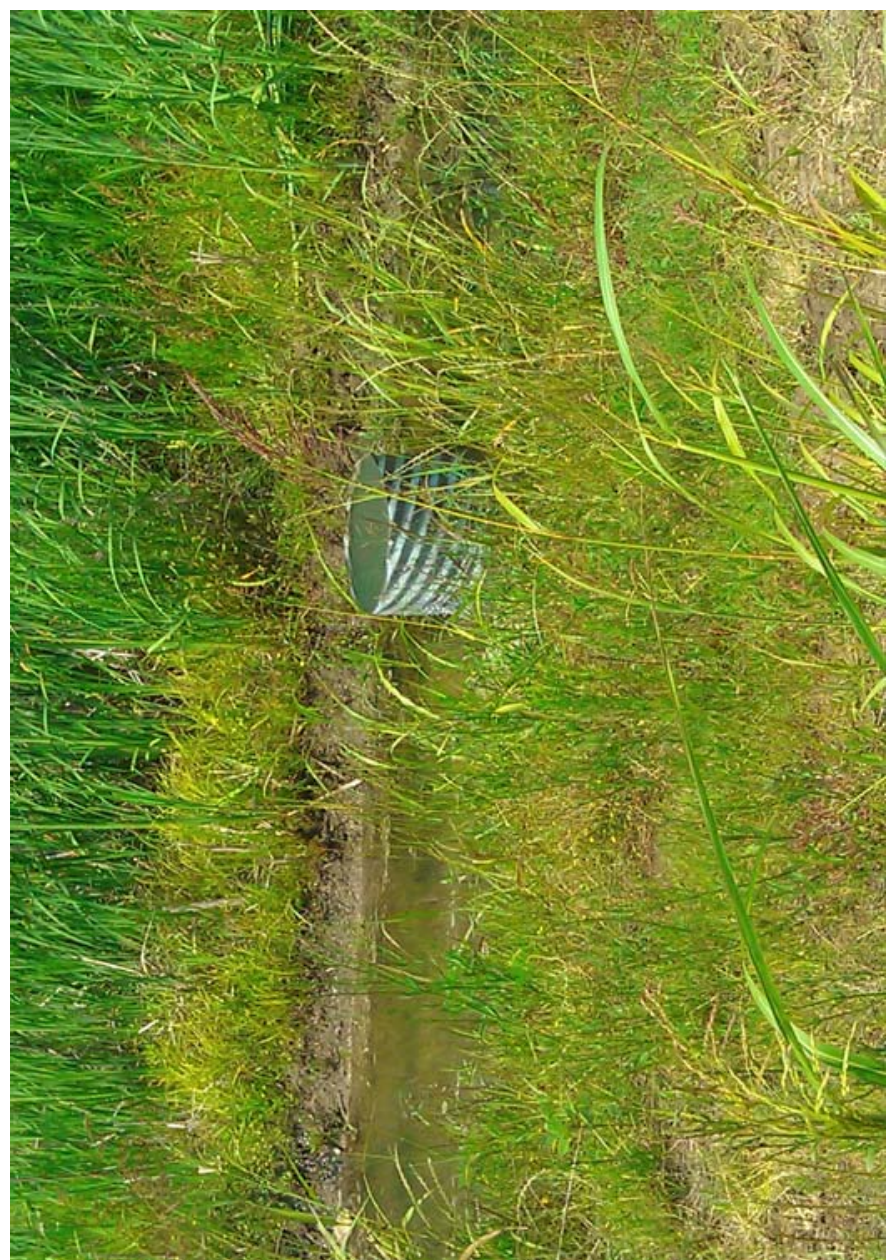

\section{1}

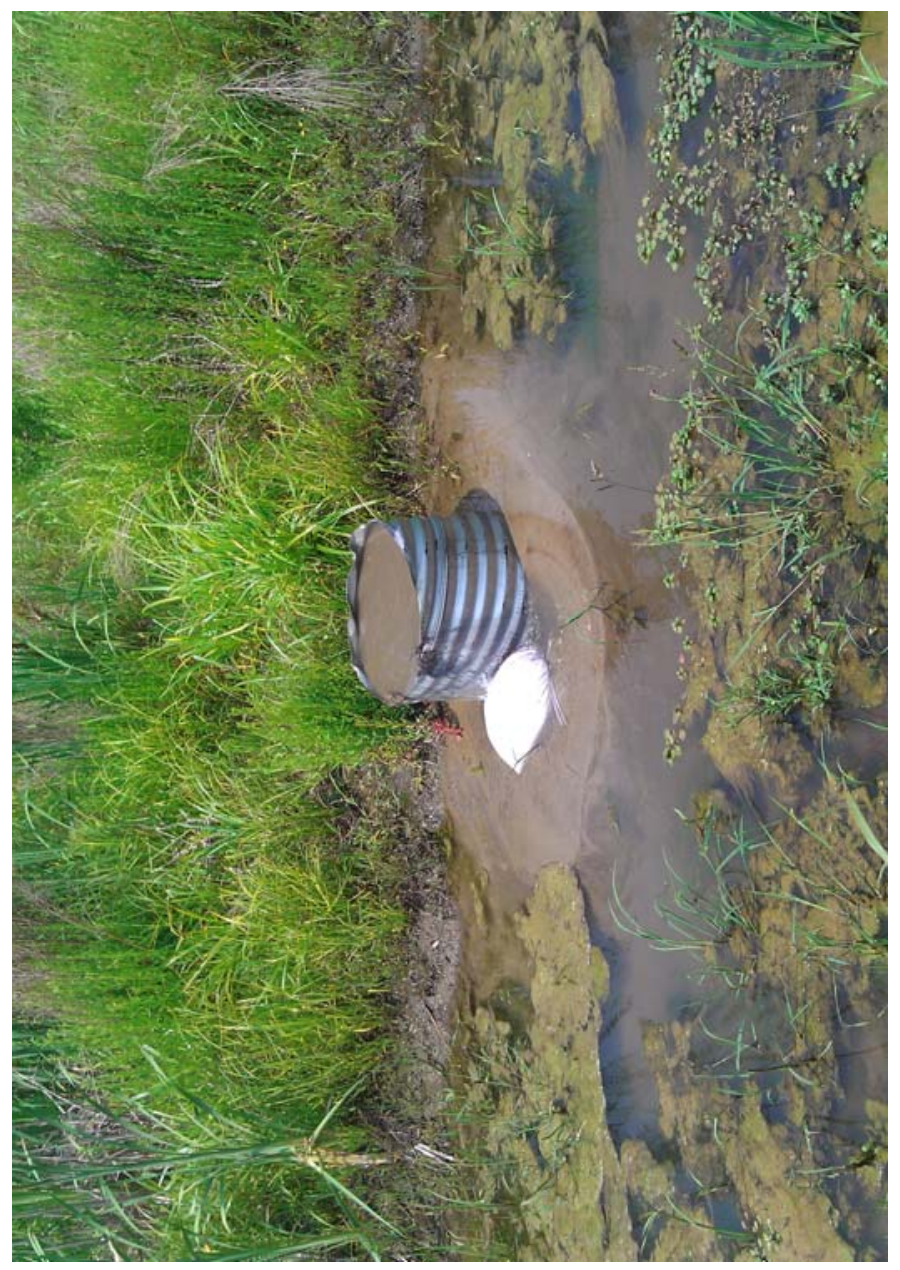

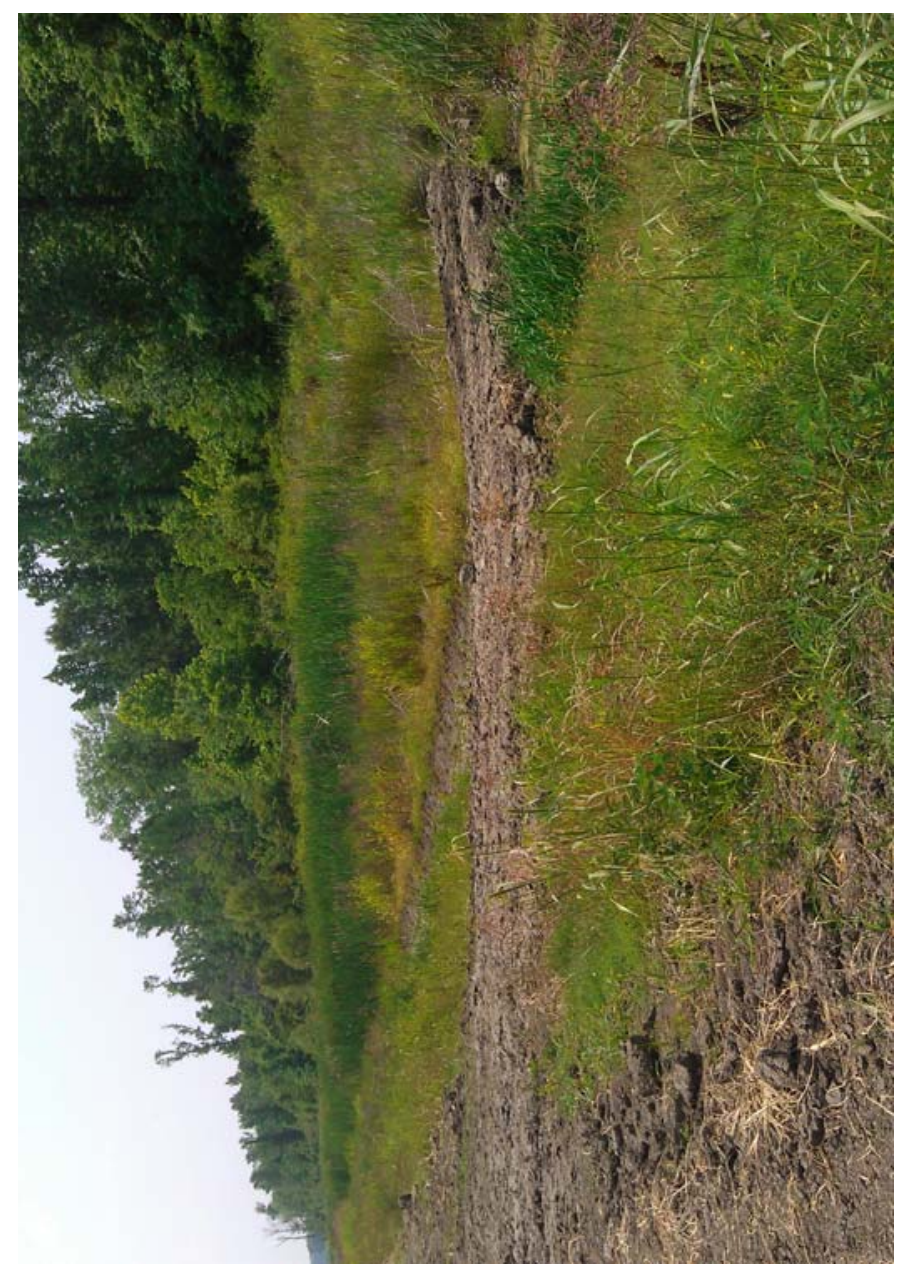

102

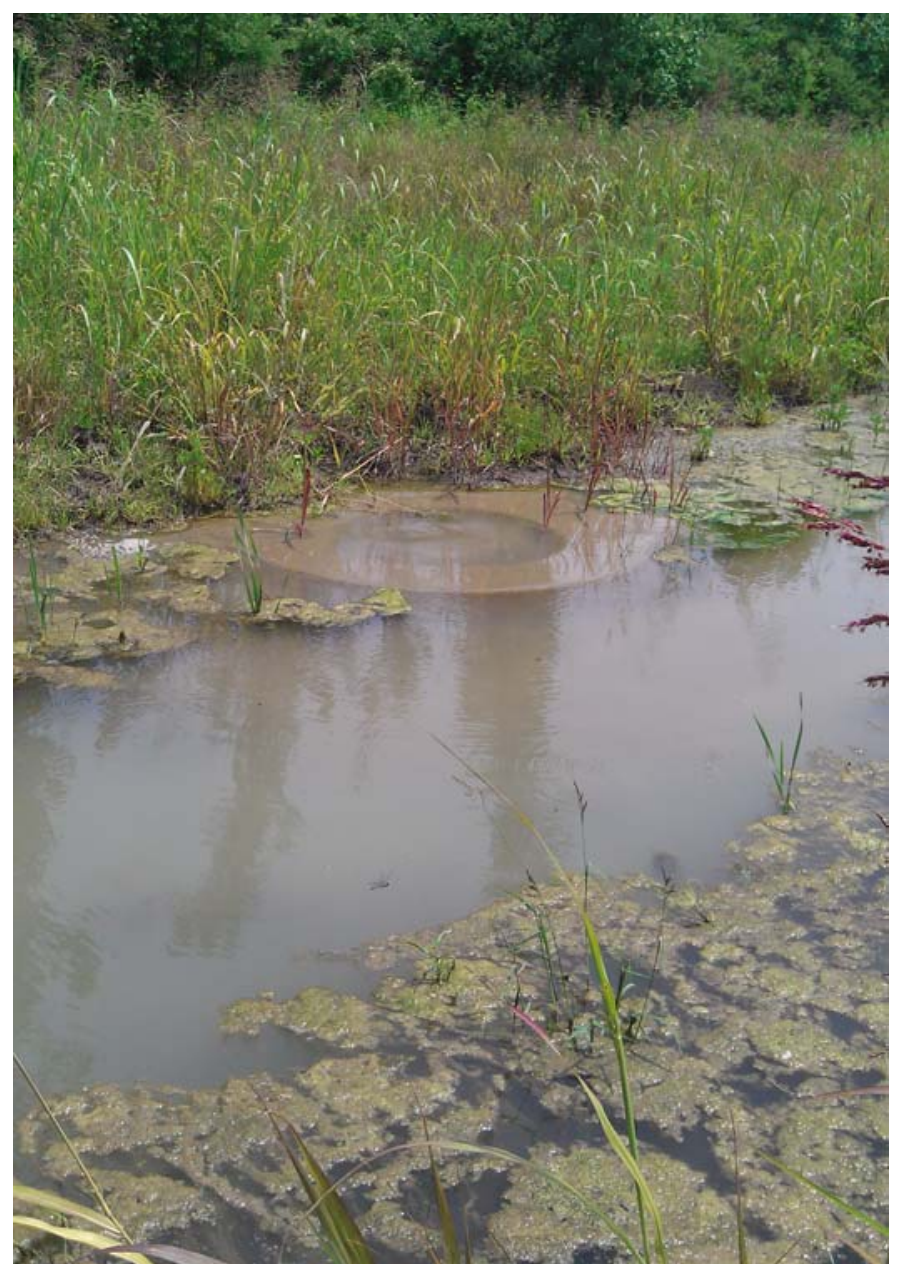




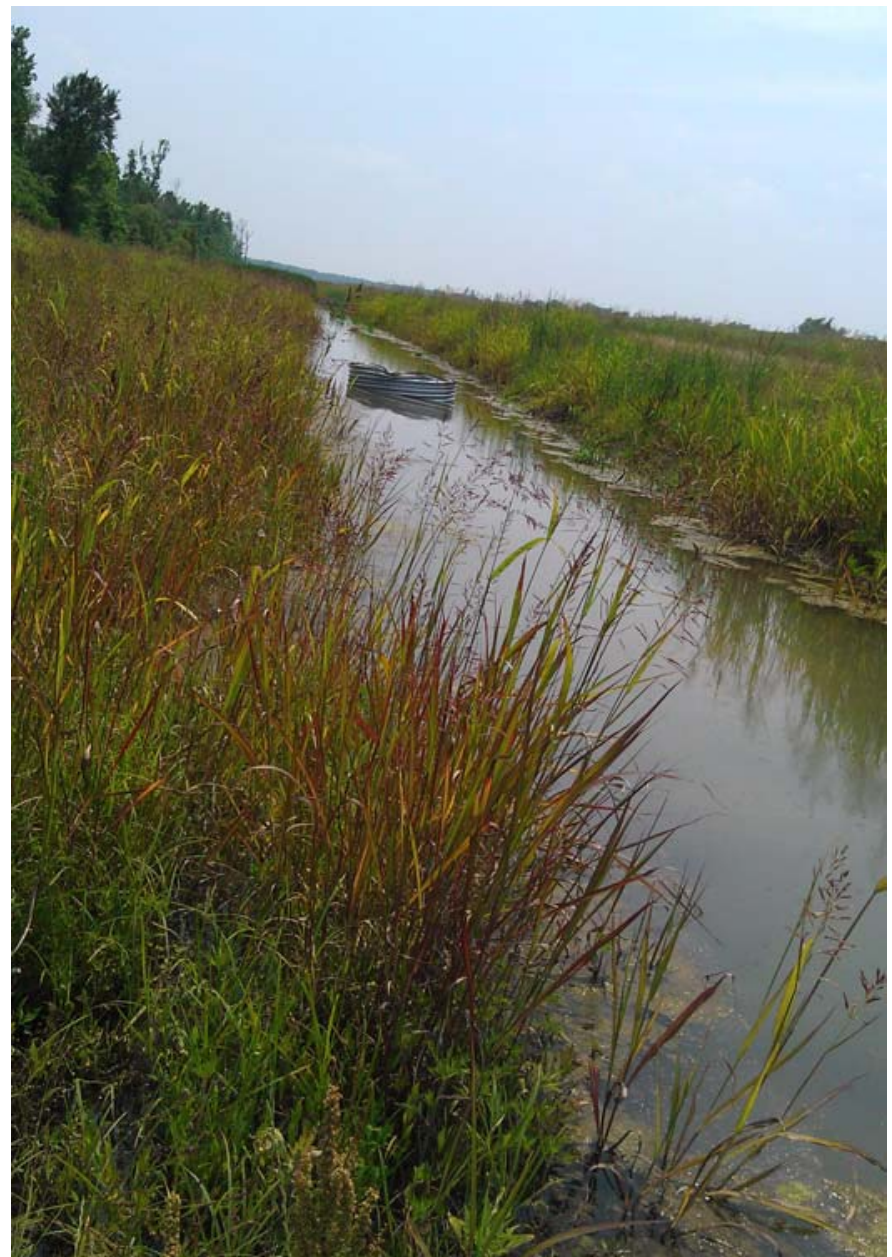

105

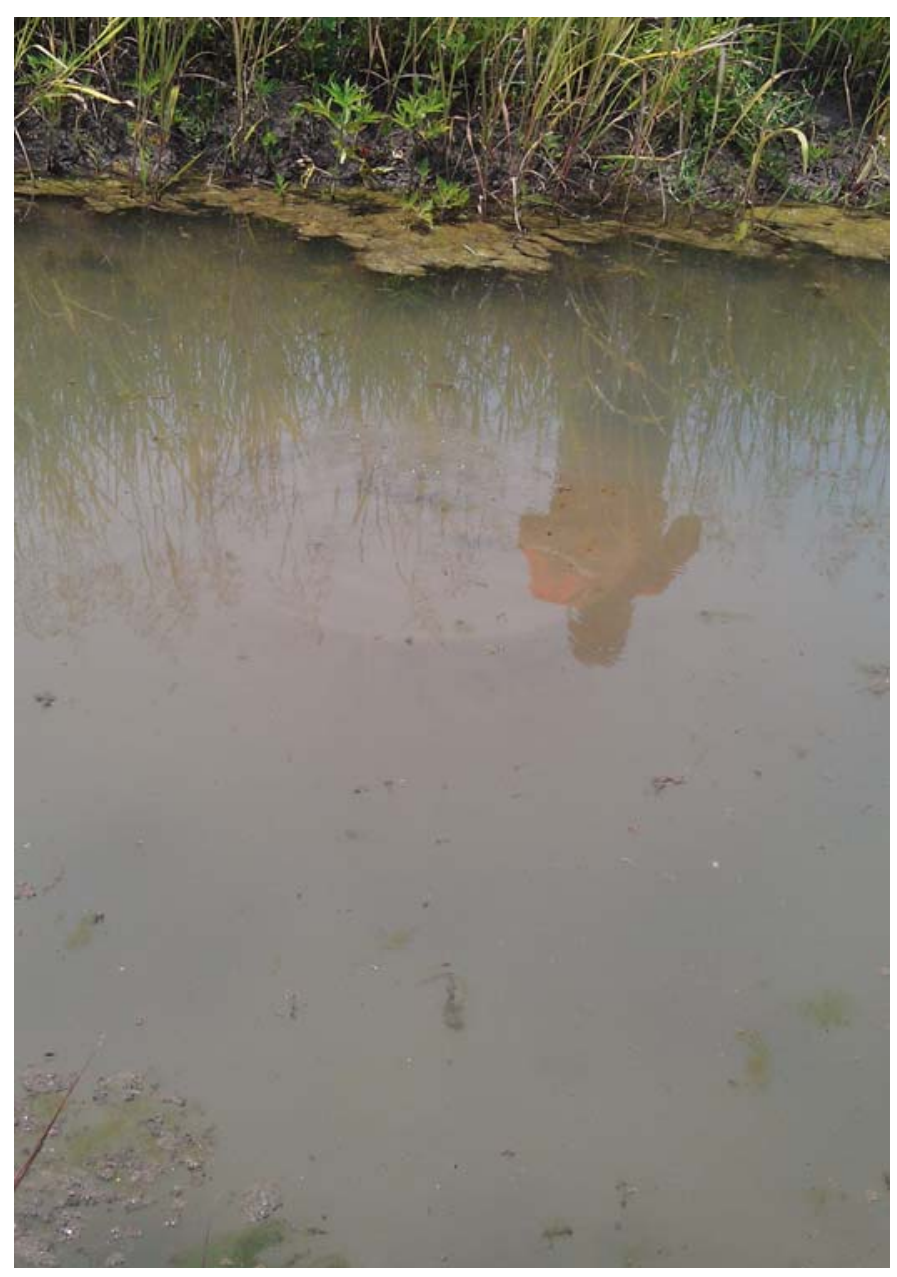

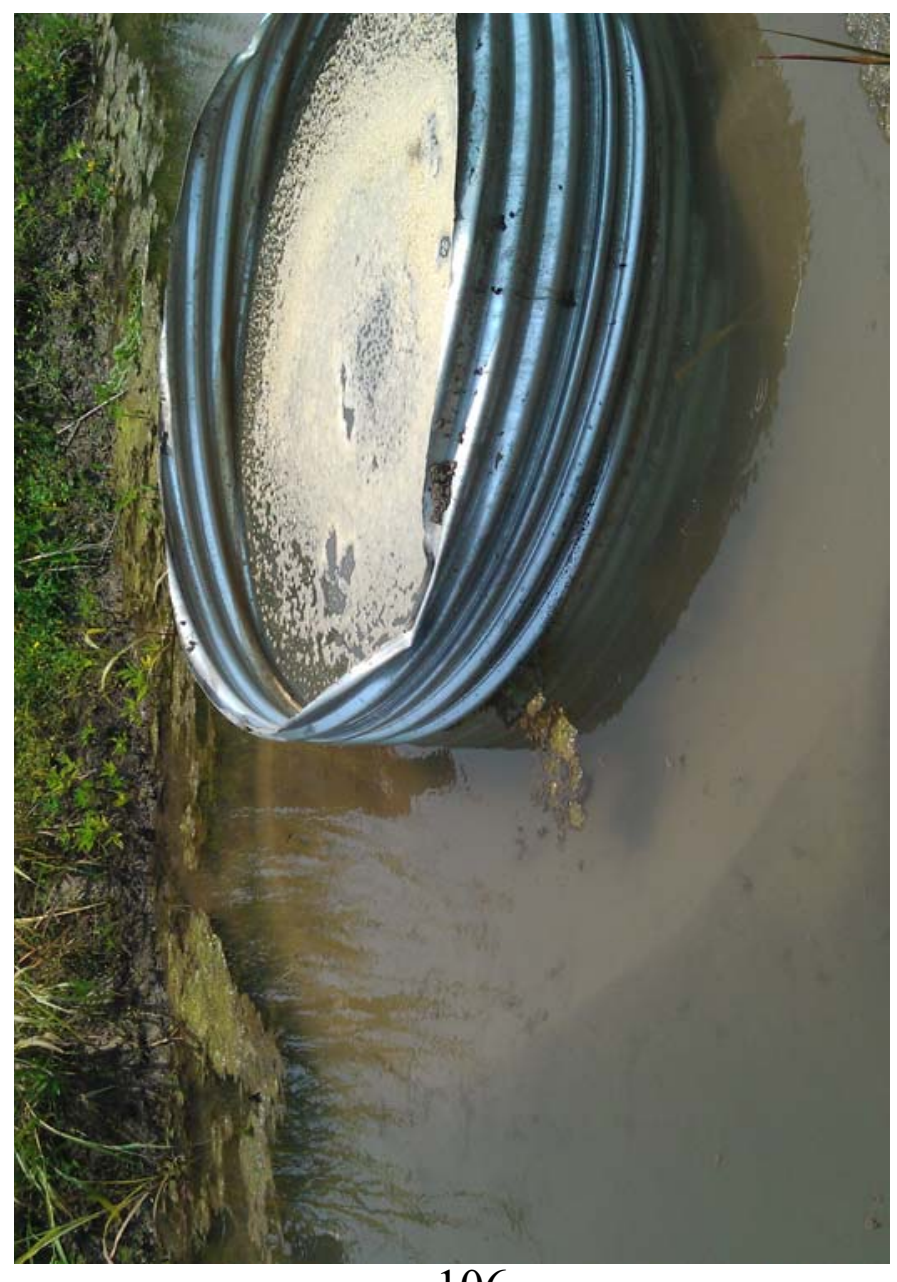

106

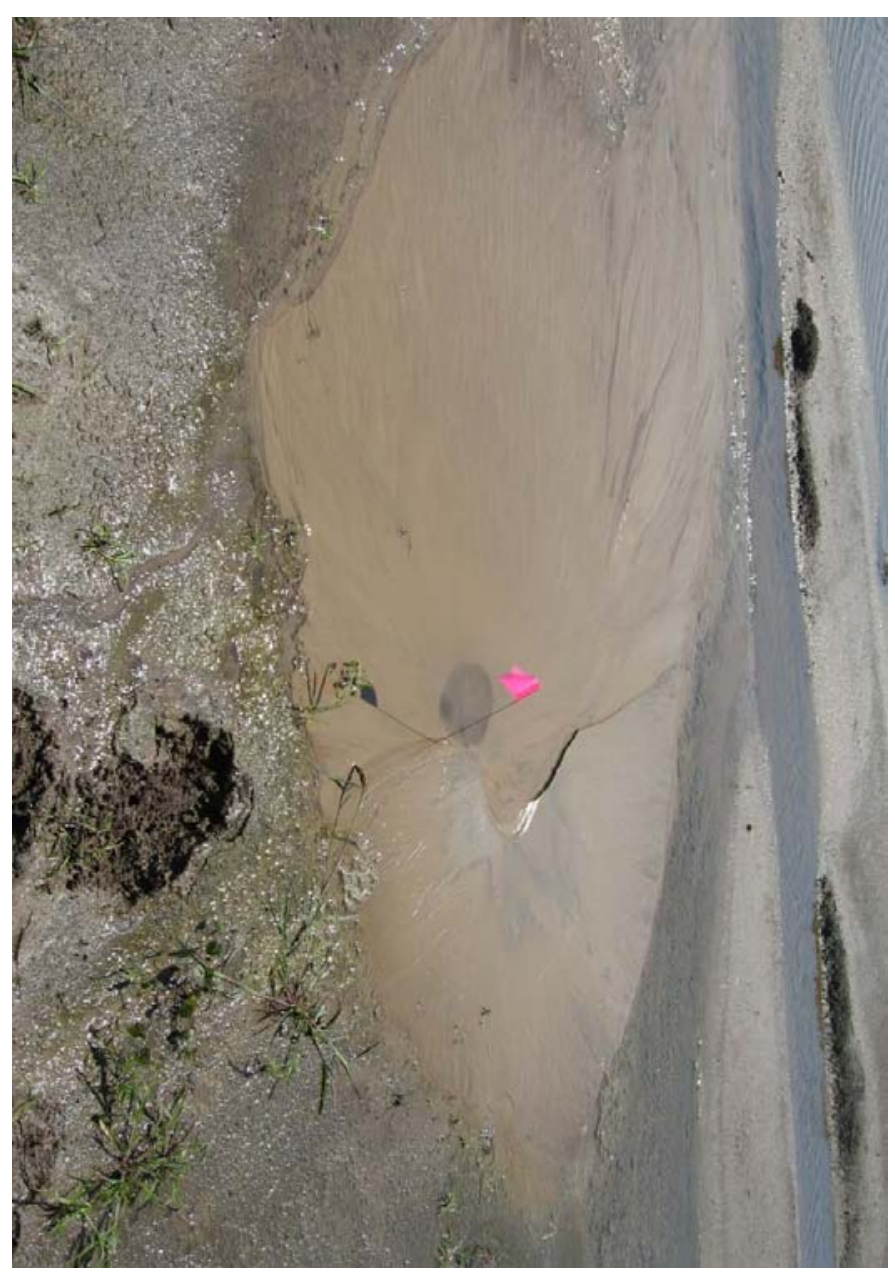




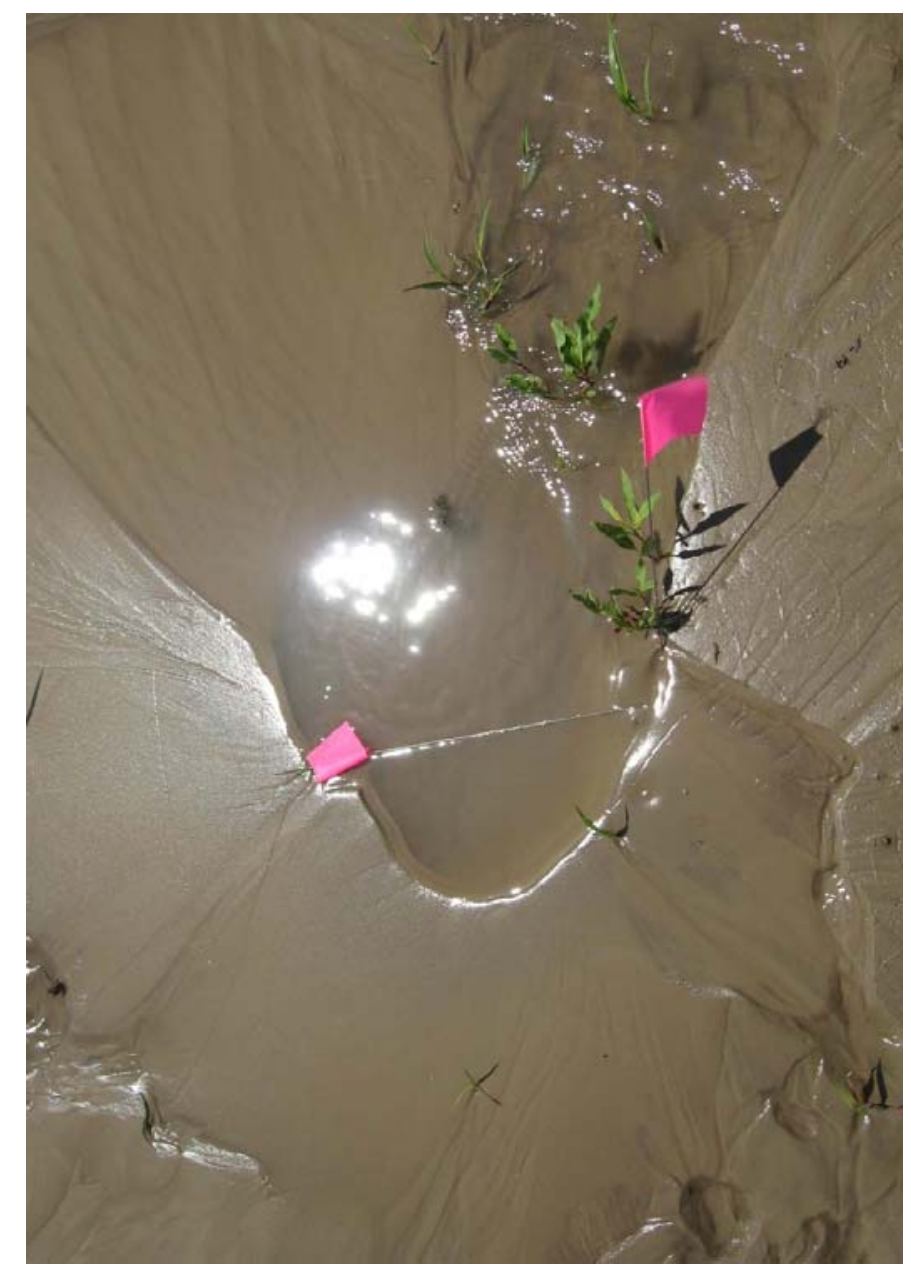

109

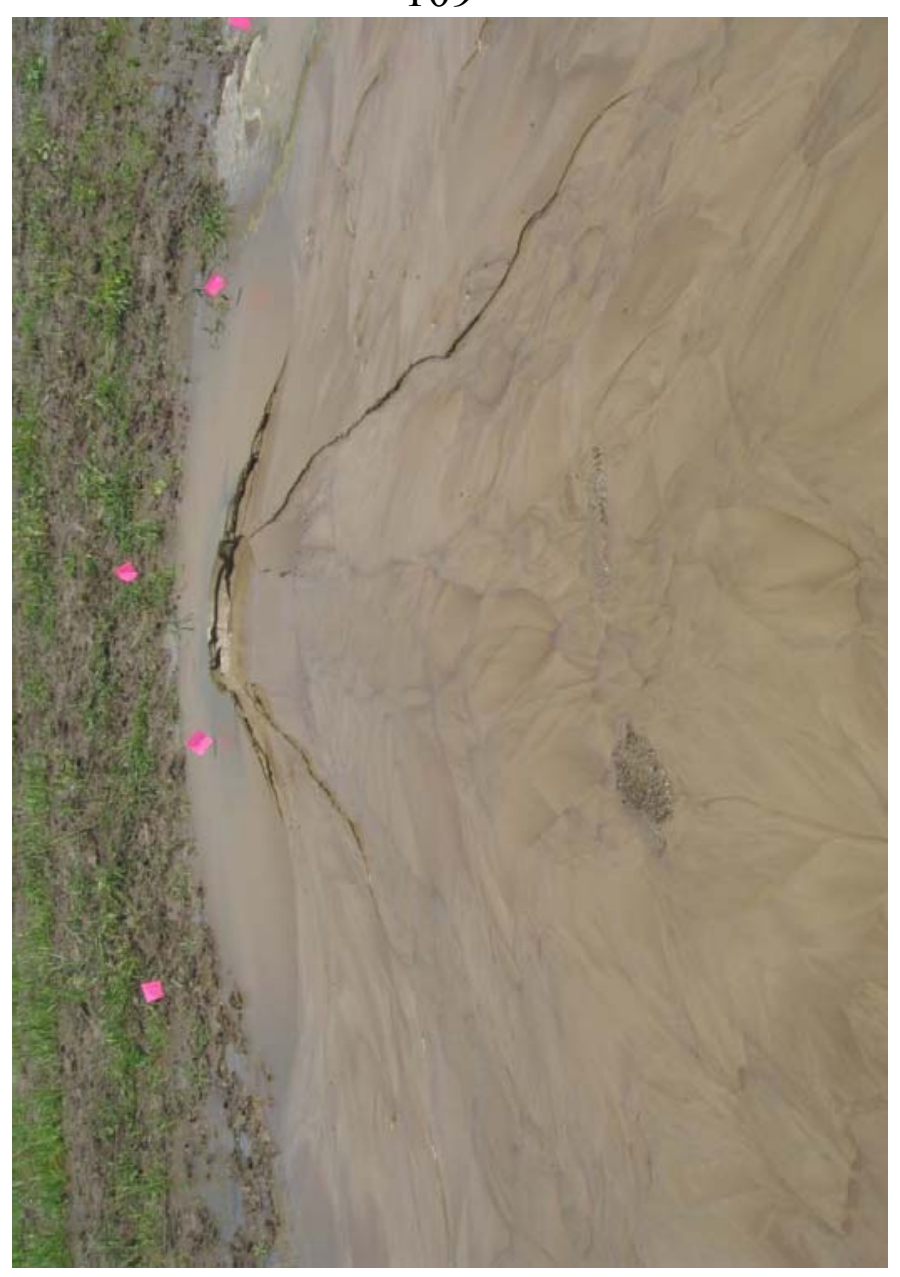




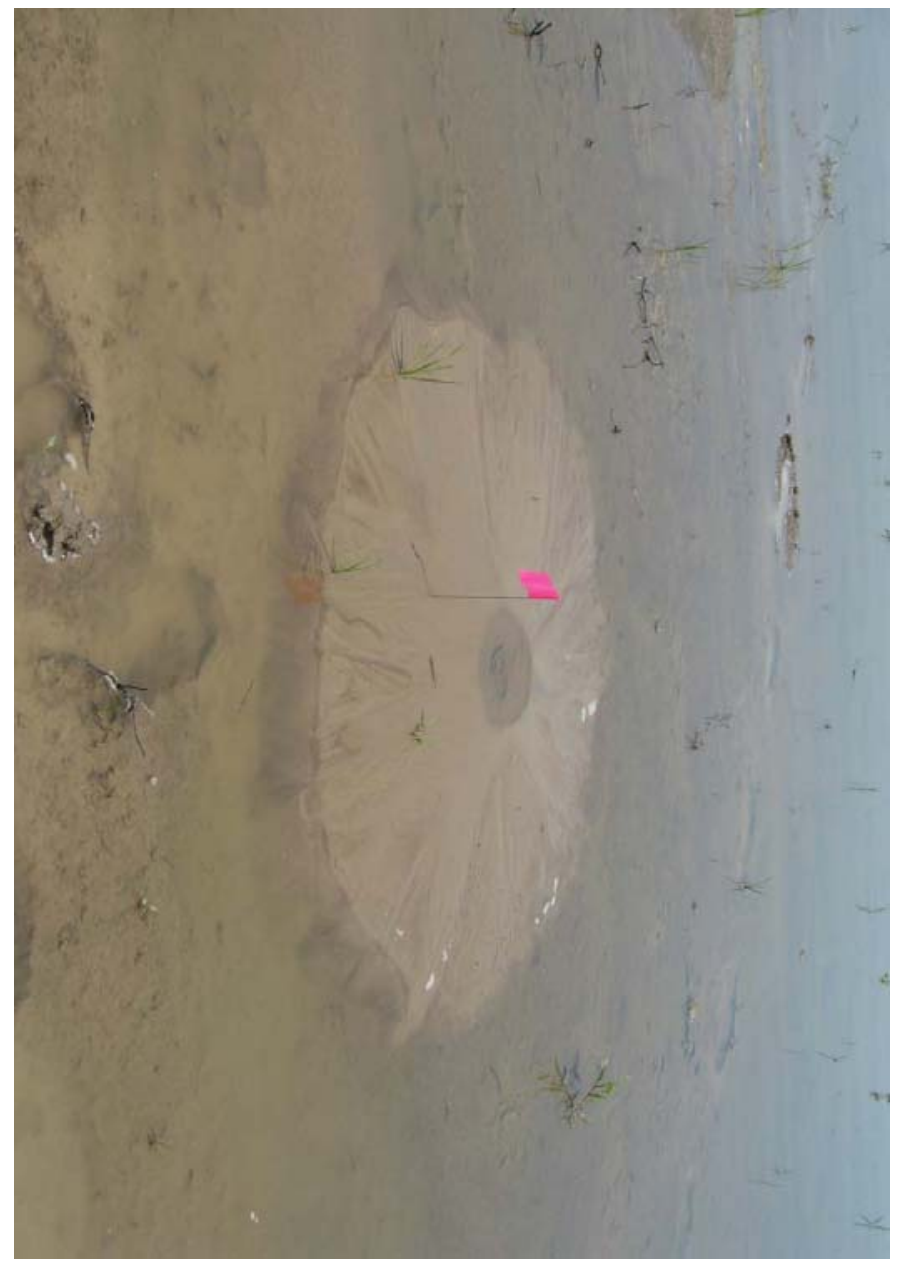

113

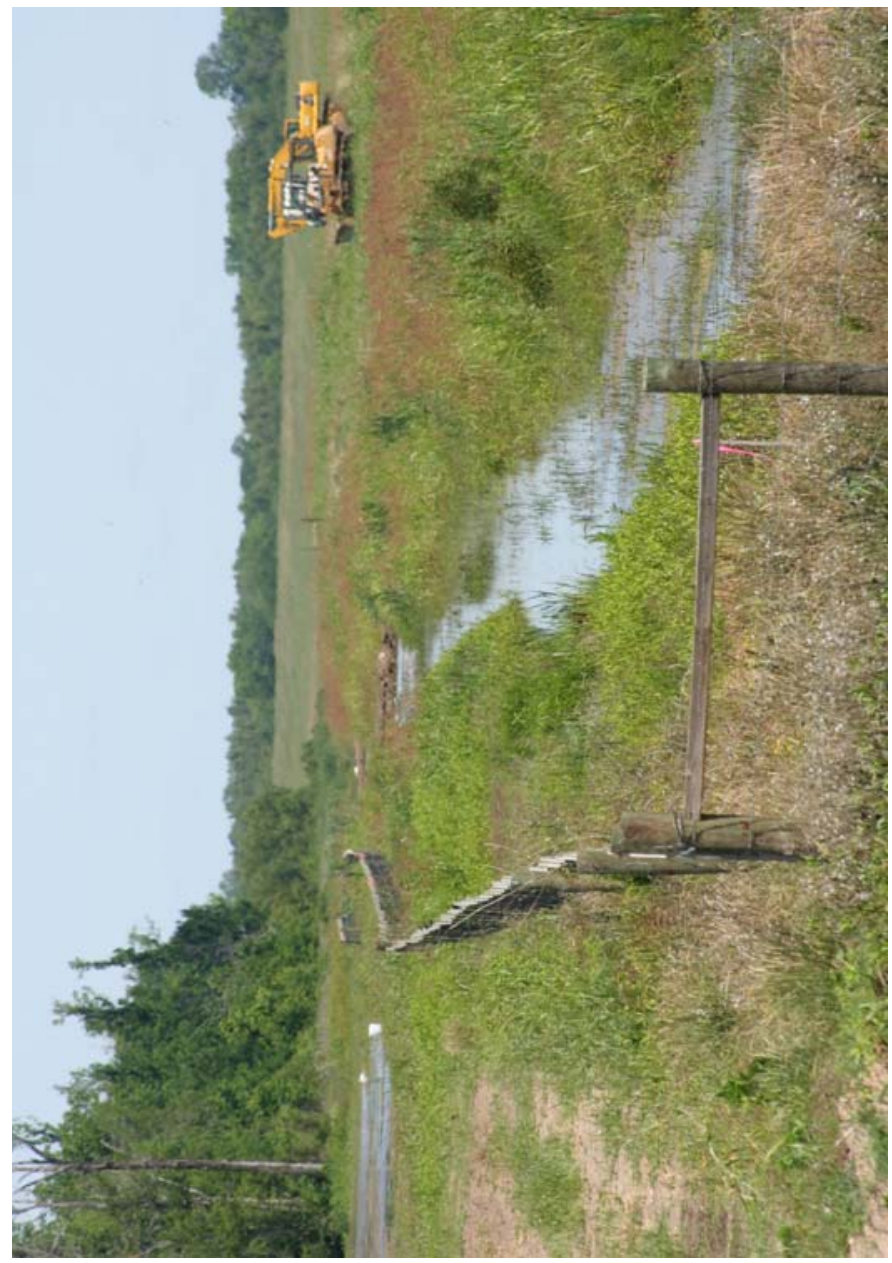

115

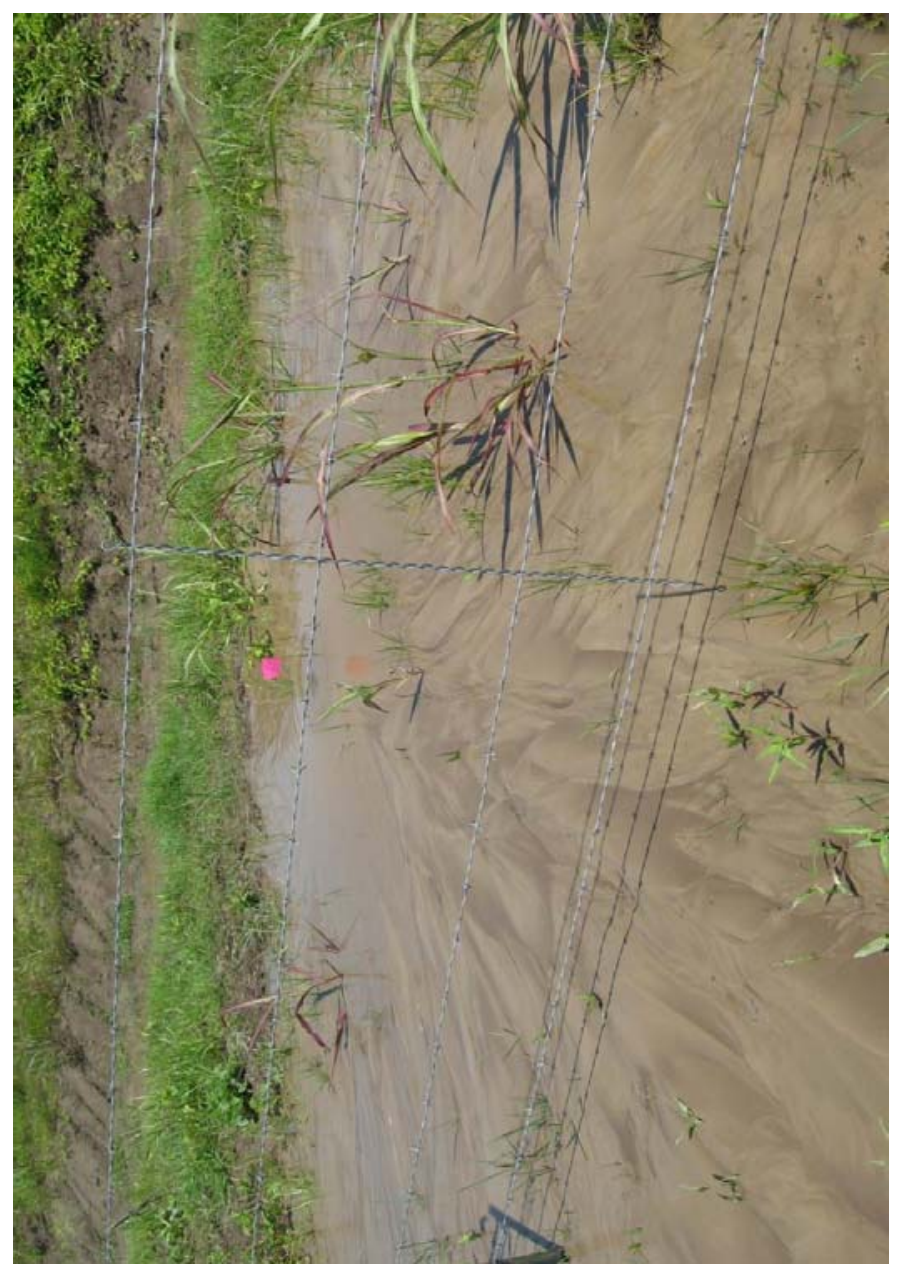

114

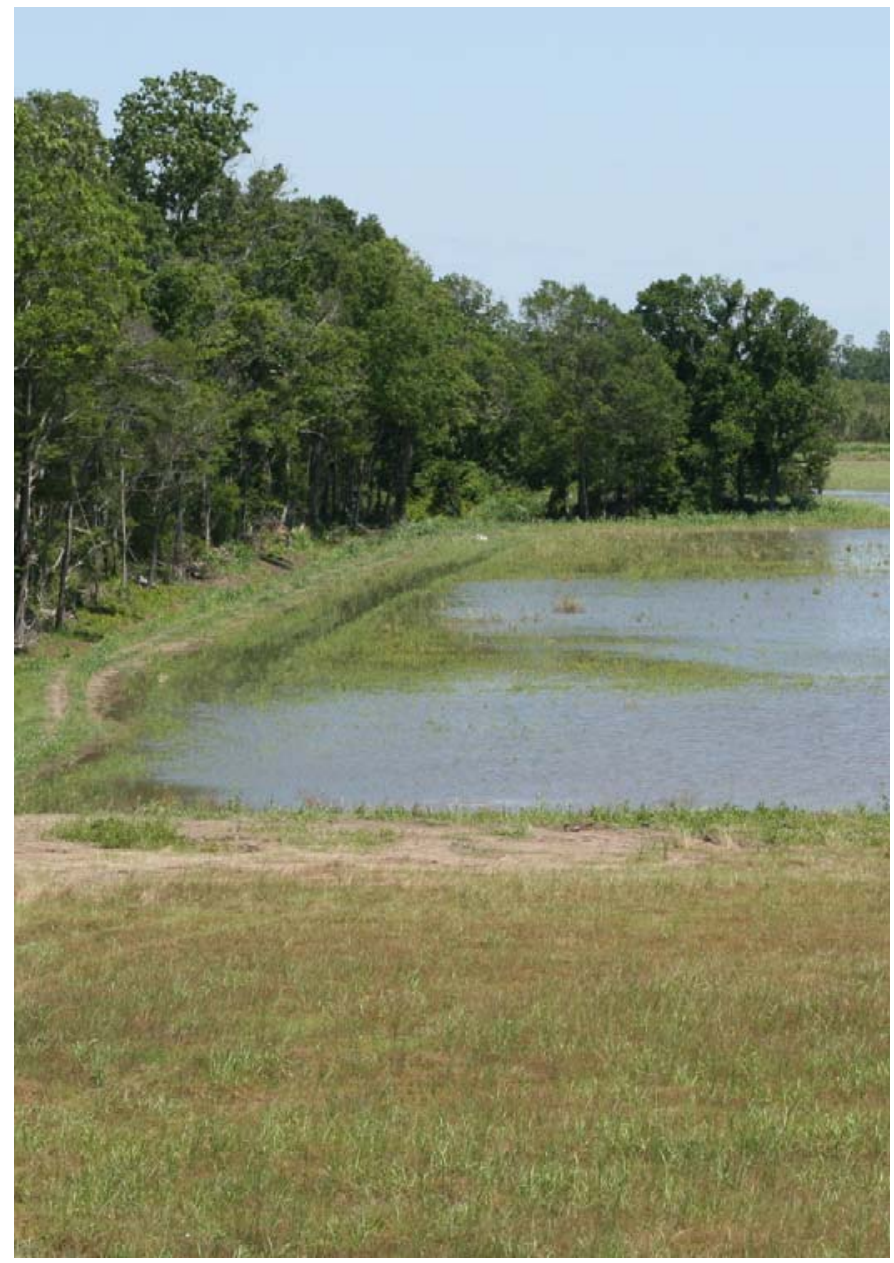




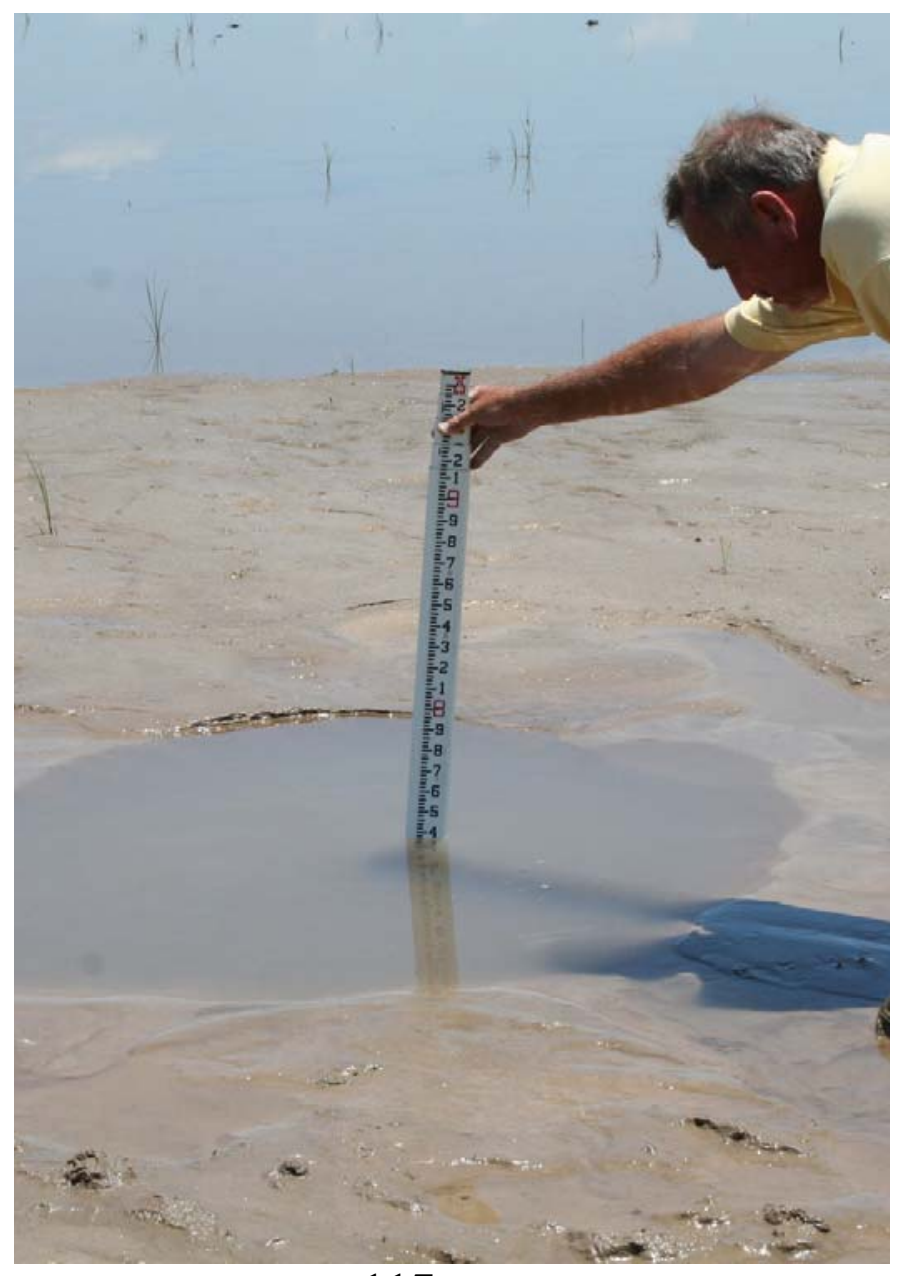

117

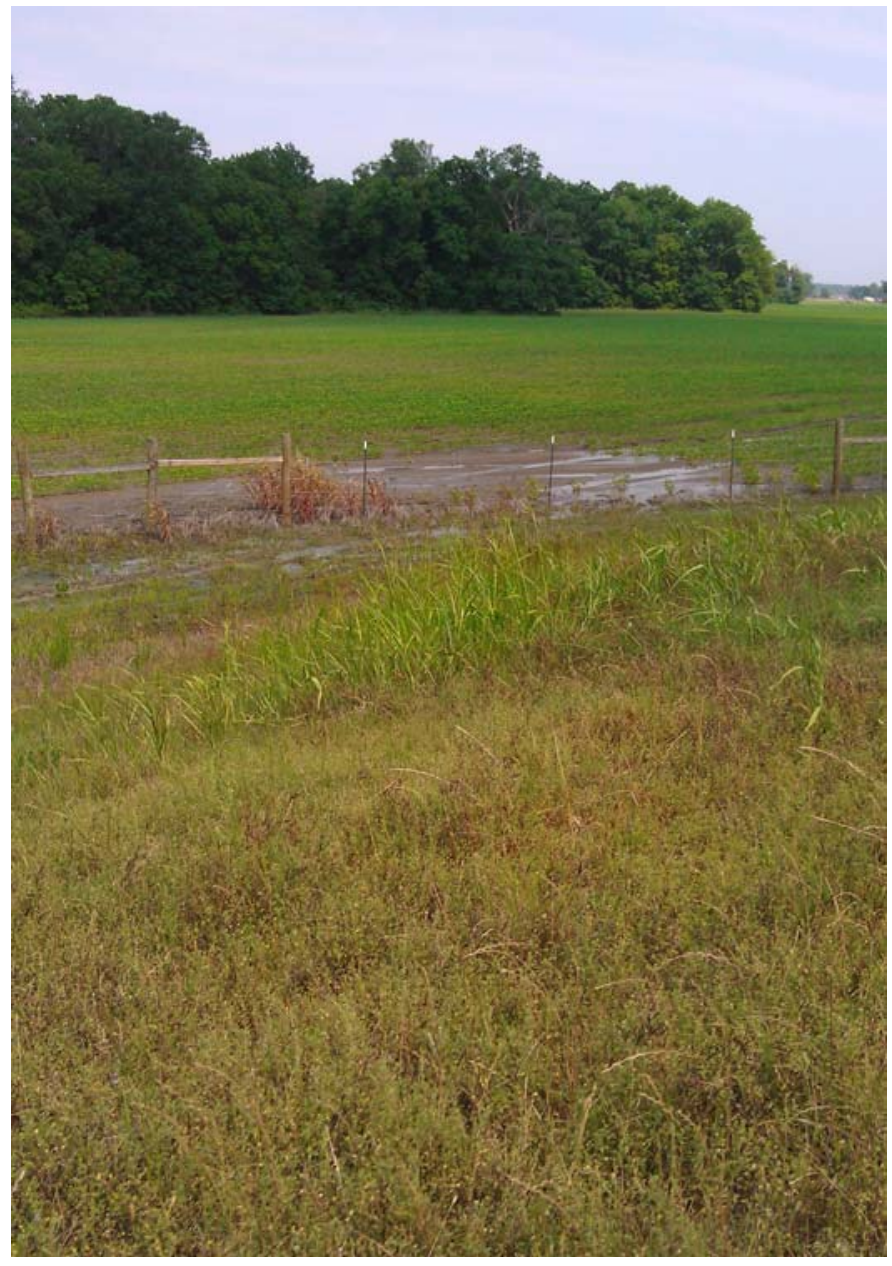

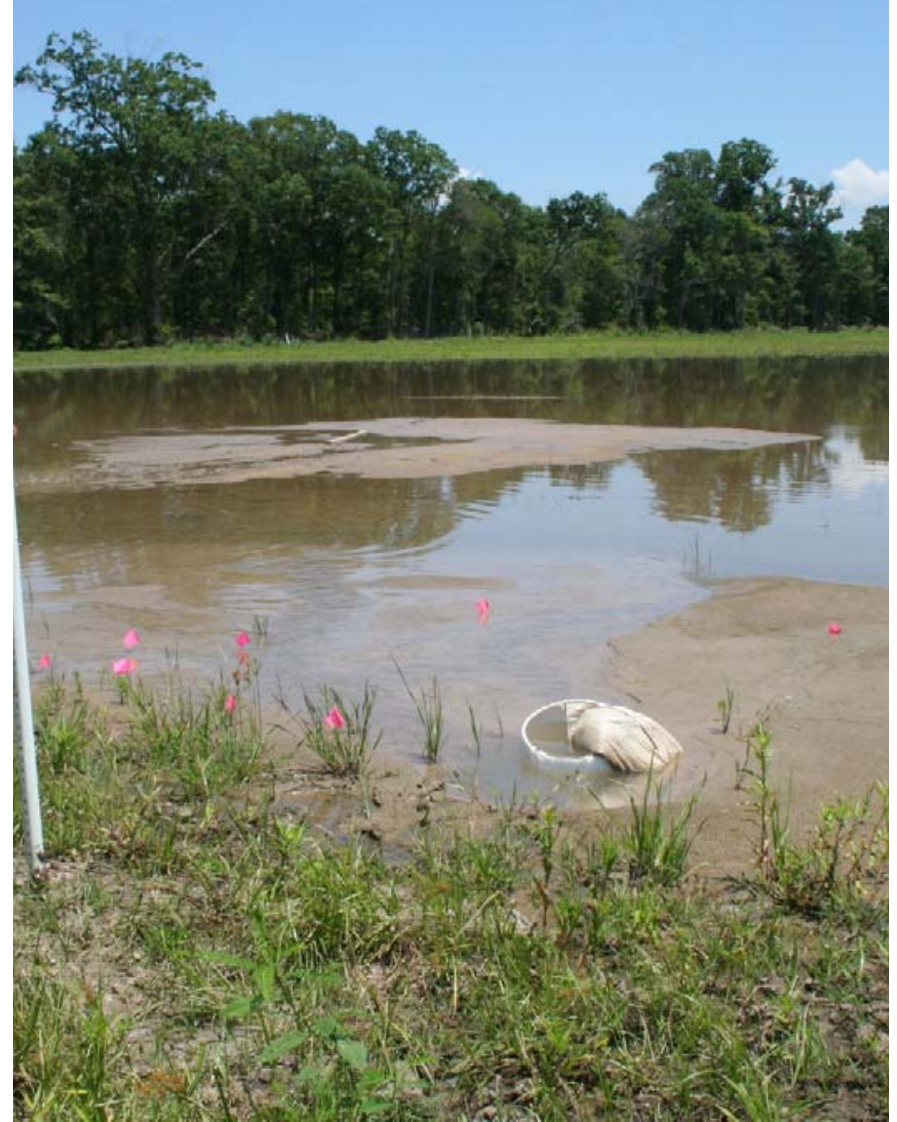

118

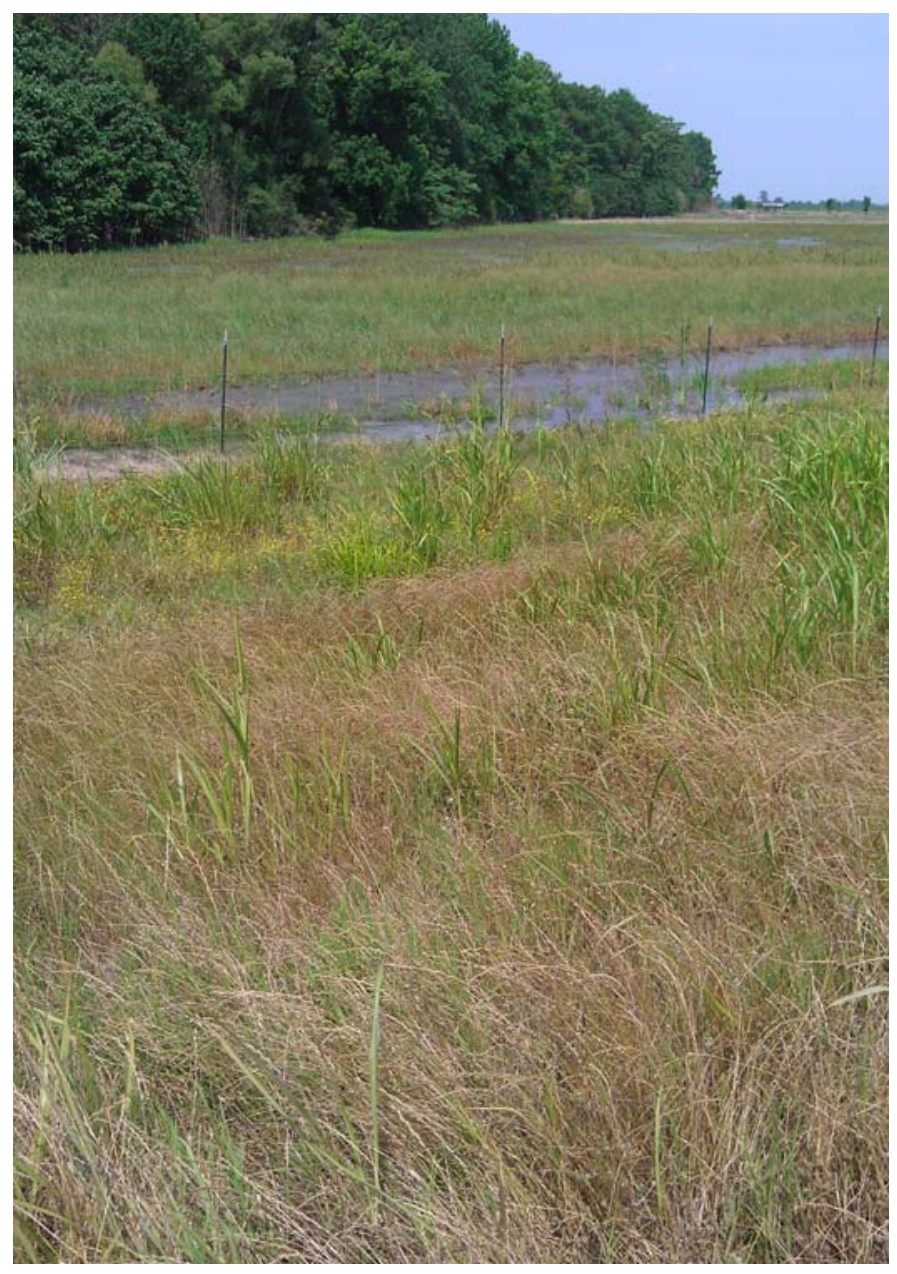




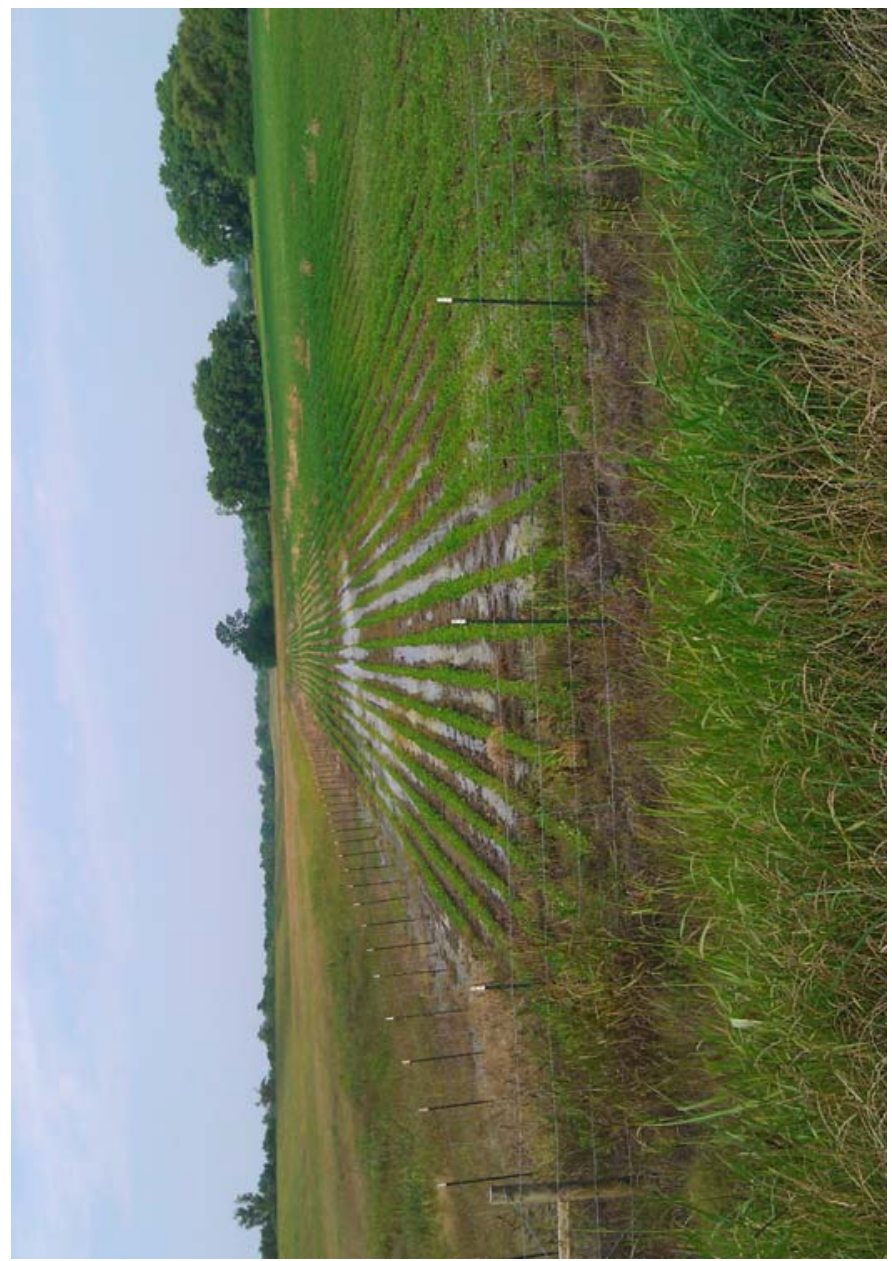

121

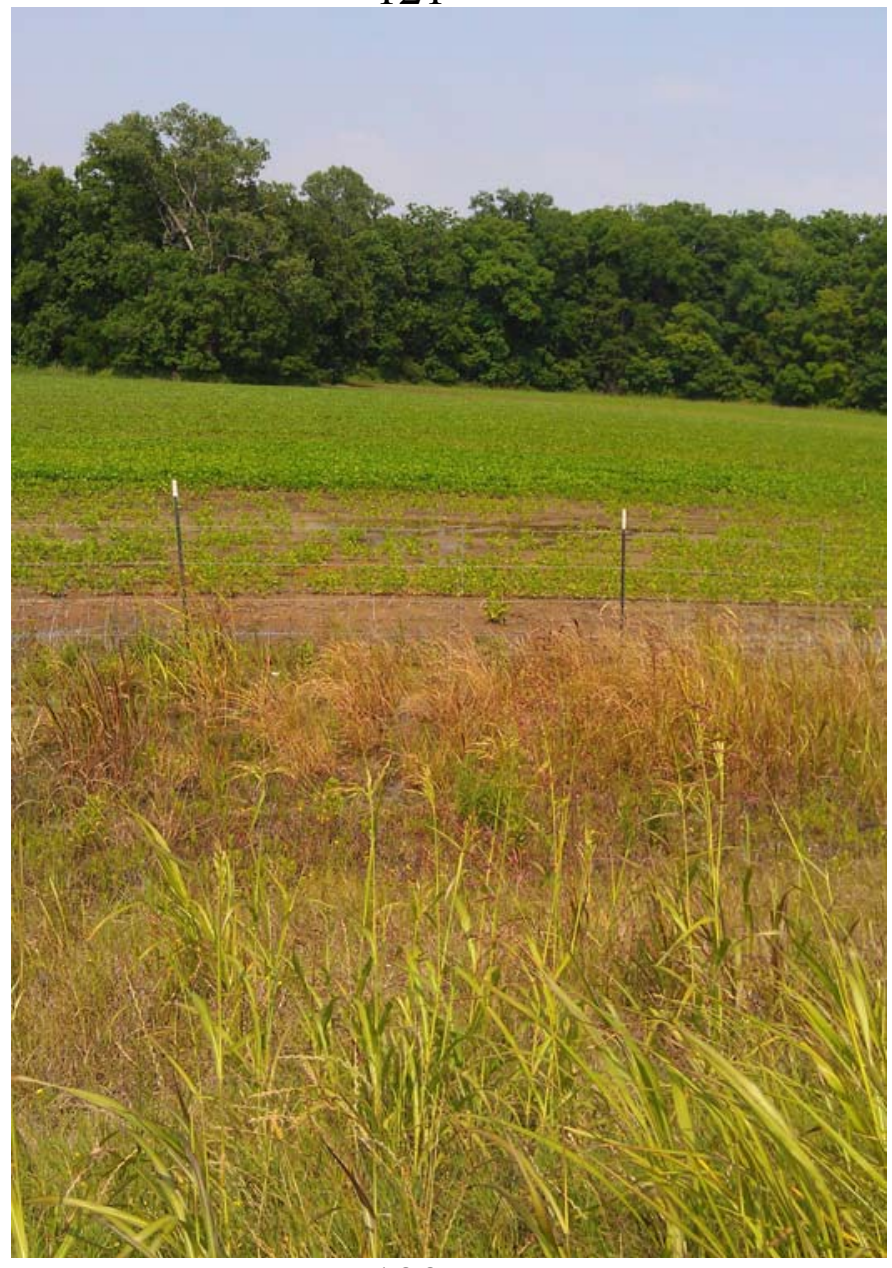

123

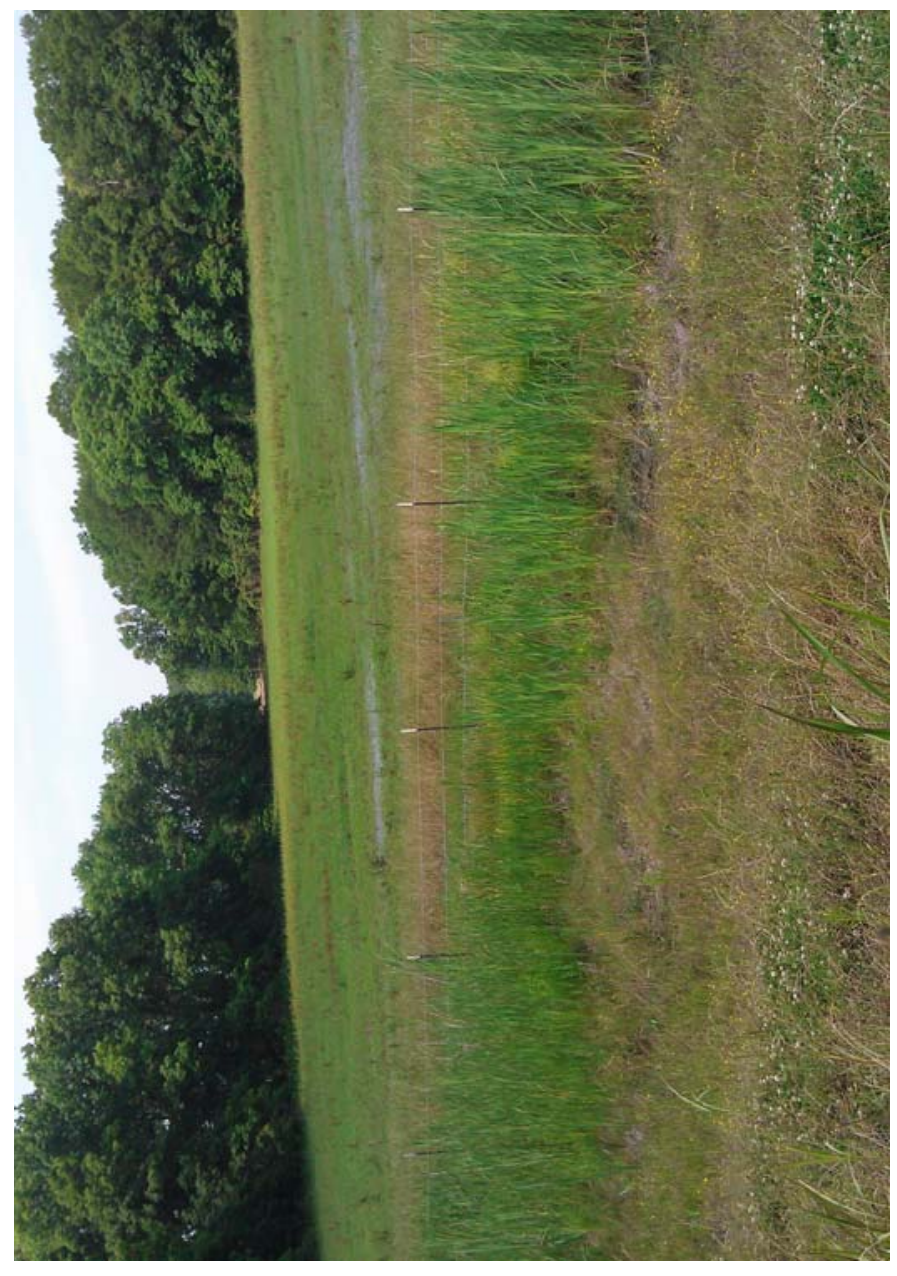

122

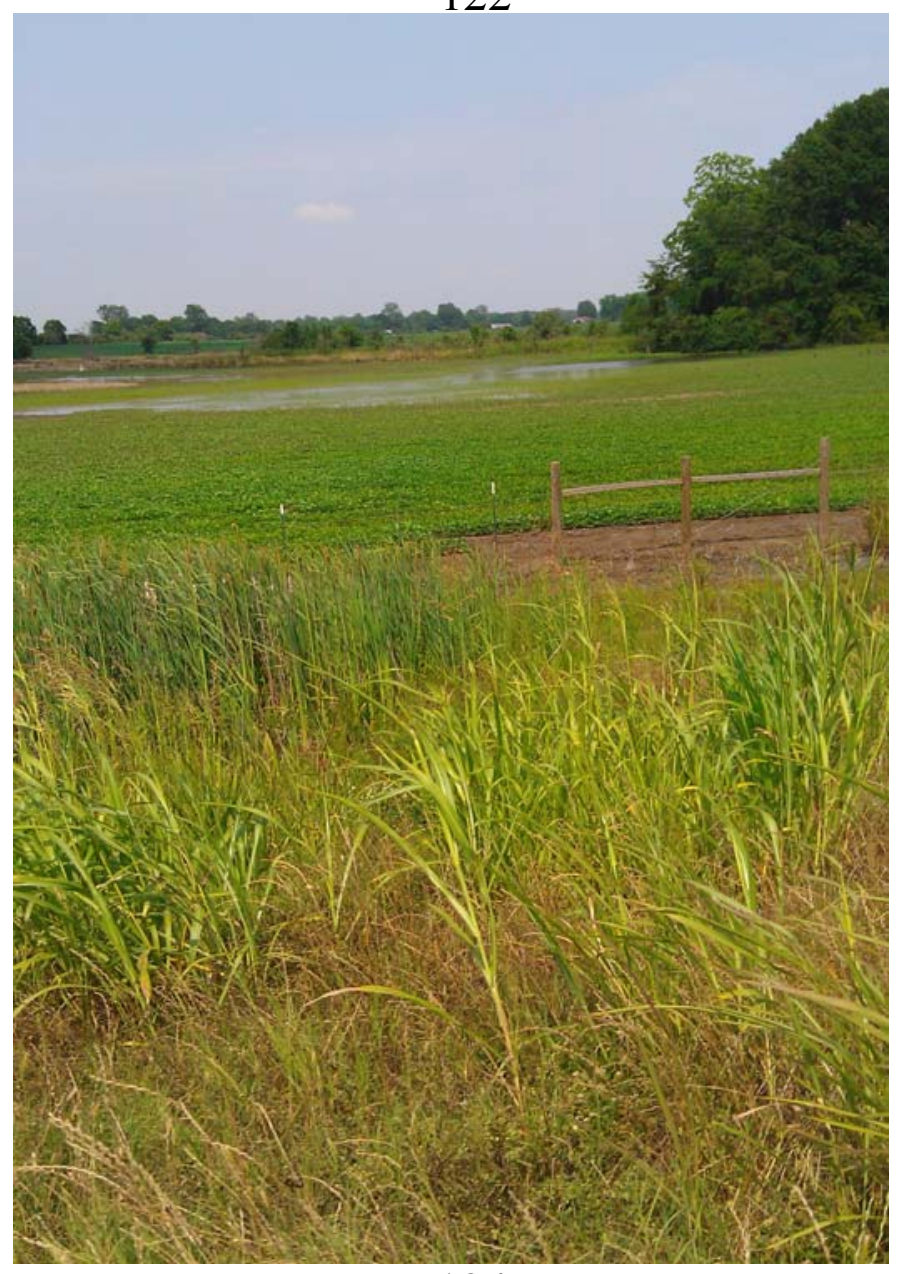



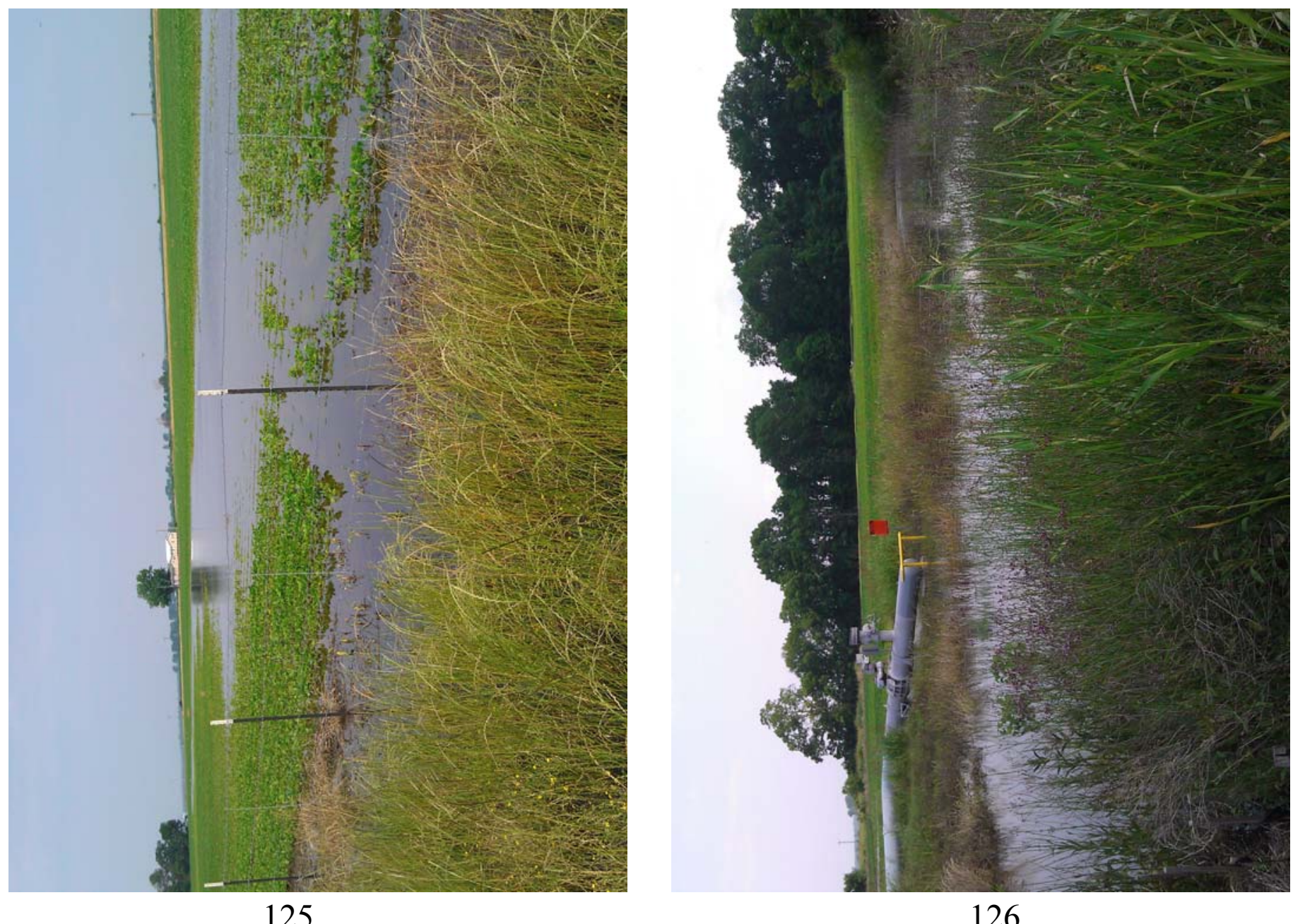

\section{6}
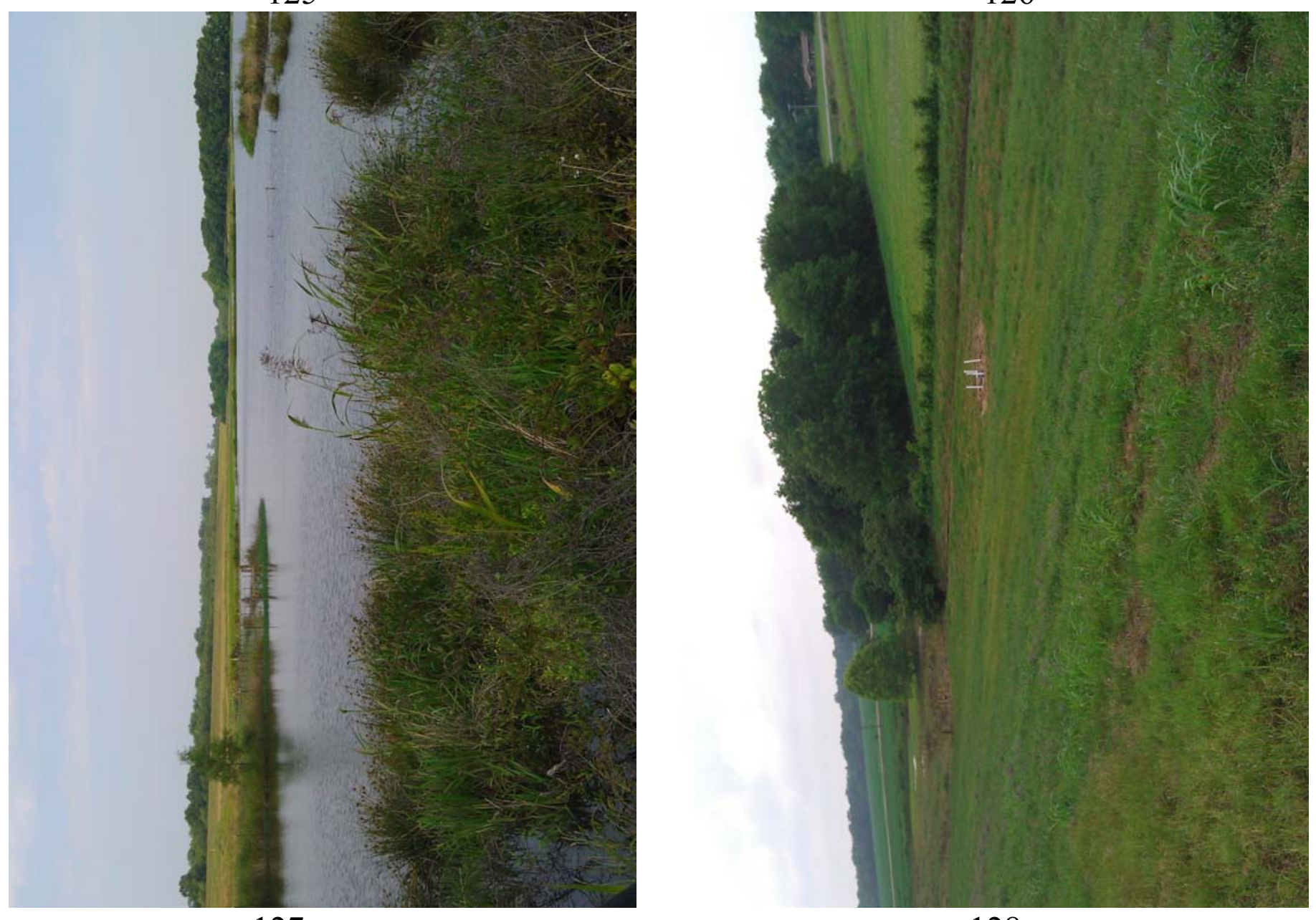
STATION 7500+00 TO END 
LEVEE SECTOR: Tallula to the end of the Mainline

DATE: May 22, 2012

TEAM MEMBERS: James Sims, Ryan Reeves, Dustin Herr, Jim Hearn

\begin{tabular}{|c|c|c|c|c|c|c|c|c|c|}
\hline \multicolumn{2}{|c|}{ START } & \multicolumn{2}{|c|}{ END } & \multirow{2}{*}{$\begin{array}{l}\text { STATION } \\
\text { NLD } \\
\end{array}$} & \multirow{2}{*}{$\begin{array}{c}\text { STATION } \\
\text { FIELD MARKER }\end{array}$} & \multirow[t]{2}{*}{ TYPE } & \multirow[t]{2}{*}{ EXTENT } & \multirow[t]{2}{*}{ REMARKS } & \multirow[t]{2}{*}{ РнОтО } \\
\hline Latitude & Longitude & Latitude & Longitude & & & & & & \\
\hline 32.75107208 & 91.04533914 & 32.75107208 & 91.04533914 & $7592+00$ & $7540+00$ & Under Seepage & Light & $\begin{array}{l}\text { Light seepage in the woods off the toe of the seepage berm near levee } \\
\text { Sta. } 7540 \text {. Seepage is approximately } 50 \text { feet wide. }\end{array}$ & $1-2$ \\
\hline 32.715981 & 91.04105 & 32.715981 & 91.04105 & $7728+00$ & $7680+00$ & Sand Boil & & $\begin{array}{l}\text { Numerous sand boils identified in field/pond area near Fitler downgradient } \\
\text { from relief well 107. Most boils were found in SE corner of an open } \\
\text { pasture around an area of standing water. Some of the boils were under } \\
\text { water. All of the boils are small and were transporting small quantities } \\
\text { of silt/fine sand. }\end{array}$ & \\
\hline 37.70960136 & 91.0460203 & 37.70960136 & 91.0460203 & $7753+00$ & $7705+00$ & Under Seepage/Pin Boi & Moderate & $\begin{array}{l}\text { Light to moderate seepage along the pipeline near levee Sta. } 7705 \\
\text { between relief wells } 104 \text { and } 105 \text {. Seepage extends out } 250 \text { to } 300 \text { feet into } \\
\text { and old slough. A possible sand boil was identified inside a fenced area } \\
\text { that impounds the gas line. Boil is under water and was not accessible. }\end{array}$ & 3-5 \\
\hline 32.70103 & 91.05349 & 32.69494 & 91.05768 & $\begin{array}{l}7791+00 \text { to } \\
7817+00\end{array}$ & $\begin{array}{l}7740+00 \text { to } \\
7770+00\end{array}$ & Heavy Current/Scour & Moderate & $\begin{array}{l}\text { Light to moderate current against the riverside toe of the levee from } \\
\text { near levee Sta. } 7740 \text { to } 7770 .\end{array}$ & \\
\hline 32.69841061 & 91.0545223 & 32.69841061 & 91.0545223 & $7800+00$ & $7751+00$ & Under Seepage & Light & $\begin{array}{l}\text { Light seepage approximately } 100 \text { feet from the toe of the levee extending } \\
\text { out into the woods between relief wells } 89 \text { and } 90 \text {. Seepage is clear and } \\
\text { is approximately } 500 \text { feet long. }\end{array}$ & \\
\hline 32.64874299 & 91.04435171 & 32.64874299 & 91.04435171 & $8030+00$ & $7980+00$ & Under Seepage & Light & $\begin{array}{l}\text { Light seepage approximately } 100 \text { feet from the toe of the levee near } \\
\text { levee Sta. } 7980 . \text { Seepage is clear and drains into an old slough. }\end{array}$ & 6 \\
\hline 32.64868269 & 91.04664869 & 32.64868269 & 91.04664869 & $8039+00$ & $7990+00$ & Under Seepage & Light & $\begin{array}{l}\text { Light seepage from a water well behind hunting camp house near levee } \\
\text { Sta. } 7990 . \text { Well is located appoximately } 100 \text { yards from the toe of the } \\
\text { levee. }\end{array}$ & 7-8 \\
\hline 32.65110227 & 91.02281972 & 32.65110227 & 91.02281972 & $8102+00$ & $8055+00$ & Under Seepage & Light & $\begin{array}{l}\text { Light seepage approximately } 10 \text { feet from the toe of the seepage berm } \\
\text { and on top of the seepage berm between Relief Wells C-5 and C- } 6 \text { near } \\
\text { levee Sta. } 8055 \text {. Relief wells C-5 though C- } 8 \text { were not flowing. Seepage } \\
\text { was identified around the concrete pads of wells C-5 and C-6. } \\
\text { Water level in each well was less than } 1 \text { foot below top of riser. } \\
\text { A possible sand boil was identified approximately } 50 \text { feet south of relief } \\
\text { well C-9. Area was not accessible. Possible boils were under water and } \\
\text { area appeared to be stable. }\end{array}$ & $9-14$ \\
\hline 32.63357532 & 91.00052779 & 32.63357532 & 91.00052779 & $8098+00$ & $8050+00$ & Under Seepage & Light & $\begin{array}{l}\text { Light seepage in the woods approximately } 100 \text { feet from the toe of the } \\
\text { levee near levee Sta. } 8150 \text {. Area is south of the highway } 465 \text { levee access } \\
\text { ramp. Seepage flows into a ditch/creek. }\end{array}$ & 15 \\
\hline
\end{tabular}




\begin{tabular}{|c|c|c|c|c|c|c|c|c|c|}
\hline \multicolumn{2}{|c|}{ START } & \multicolumn{2}{|c|}{ END } & \multirow{2}{*}{$\begin{array}{l}\text { STATION } \\
\text { NLD } \\
\end{array}$} & \multirow{2}{*}{$\begin{array}{c}\text { STATION } \\
\text { FIELD MARKER } \\
\end{array}$} & \multirow[t]{2}{*}{ TYPE } & \multirow[t]{2}{*}{ EXTENT } & \multirow[t]{2}{*}{ REMARKS } & \multirow[t]{2}{*}{ PHOTO } \\
\hline Latitude & Longitude & Latitude & Longitude & & & & & & \\
\hline 32.62829741 & 90.99904092 & 32.62795987 & 90.99906234 & $8218+00$ & $8170+00$ & $\begin{array}{l}\text { Sand Boil } \\
\text { Through Seepage } \\
\text { Slide }\end{array}$ & Heavy & $\begin{array}{l}\text { Five medium-sized, high energy sand boils along the toe of the levee near } \\
\text { levee Sta. } 8170 \text { (no berm). A large, landside, slide developed immediately } \\
\text { downstream from the boils. A stone ring was placed around the sand boils } \\
\text { and a filter of sand was placed over the throats of the boils. The levee board } \\
\text { worked throughout the night to stabilize the boil. The stabilization of the } \\
\text { slide began the following day with Corps hired labor forces. An additional } \\
\text { slide developed during the second night immediately upstream from the } \\
\text { sand boils. Both slides were accompanied with and possibly the result of } \\
\text { heavy seepage exiting at the slide face and on the slope below. Hired labor } \\
\text { continued daytime stabilization of the slide by placing crushed limestone } \\
\text { at the toe and sand on the lower end of the slide to provide additional } \\
\text { weight and drainage. The slides were present in the lower } 1 / 3 \text { of the levee } \\
\text { embankment and were relatively shallow in depth. A small slide near } \\
\text { the levee toe formed immediately above the sand boils on the third day that } \\
\text { connected the two larger slides. The hired labor forces maintained daytime } \\
\text { activities on the site for approximately } 14 \text { days to stabilize both the slides } \\
\text { and the boils. There were approximately } 6,000 \text { tons of limestone (\#57 stone) } \\
\text { and } 11,000 \text { tons of sands placed on the site to stabilize the slope. The boils } \\
\text { at the levee toe and the embankment instability could have progressed to } \\
\text { loss of levee foundation material and/or significant loss of the net levee } \\
\text { section. (Albemarle Slide site). }\end{array}$ & $16-37$ \\
\hline 32.62566294 & 90.99686835 & 32.62566294 & 90.99686835 & $8234+00$ & $8185+00$ & Under Seepage & Light & $\begin{array}{l}\text { Light seepage along the toe of the levee extending out into the woods } \\
\text { approximately } 300 \text { feet near levee Sta. } 8185 \text {. Seepage area is } \\
\text { approximately } 150 \text { feet wide. }\end{array}$ & $38-40$ \\
\hline 32.61603481 & 90.99292562 & 32.61603481 & 90.99292562 & $8269+00$ & $8220+00$ & Under Seepage & Light & $\begin{array}{l}\text { Light seepage from along the toe of the levee extending approximately } \\
200 \text { feet out into the woods near levee Sta. } 8220 .\end{array}$ & $41-42$ \\
\hline 32.60990058 & 90.99396942 & 32.5986 & 91.00508 & $8295+00$ & $8249+00$ & Under Seepage & Moderate & $\begin{array}{l}\text { Moderate seepage with numerous sand boils in a drainage ditch along } \\
\text { a gravel road the parallels the toe of the seepage berm near levee Sta. } \\
8249 . \text { Sand boils have 2-inch to } 8 \text {-inch throats and were moving small } \\
\text { quantities of silt/fine sand. Most of the boils were under water and were } \\
\text { being monitored by the levee board. }\end{array}$ & $43-46$ \\
\hline 32.604097 & 90.999414 & 32.604097 & 90.999414 & $8317+00$ & $8270+00$ & Under Seepage & Moderate & $\begin{array}{l}\text { Moderate seepage along the toe of the levee and over Collins road near } \\
\text { levee Sta. } 8270 .\end{array}$ & \\
\hline 32.60334381 & 91.00052154 & 32.59848 & 91.00639 & $\begin{array}{l}8321+00 \text { to } \\
8347+00\end{array}$ & $\begin{array}{l}8275+00 \text { to } \\
8300+00\end{array}$ & Under Seepage & Moderate & $\begin{array}{l}\text { Moderate seepage with numerous pin boils from the toe of the levee } \\
\text { and extending through the wooded area and into a ditch along a gravel } \\
\text { road that parallels the levee. Seepage area extends from levee Sta. } 8275 \\
\text { to Sta. } 8300 \text {. }\end{array}$ & $47-50$ \\
\hline 32.60110424 & 91.00190834 & 32.60110424 & 91.00190834 & $8335+00$ & $8288+00$ & Sand Boil & Moderate & $\begin{array}{l}\text { Small sand boil with a 4-inch throat near drainage ditch along a gravel } \\
\text { road that parallels the levee near levee Sta. } 8285 \text {. Boil has been flagged } \\
\text { and area is being monitored by levee board. }\end{array}$ & 51 \\
\hline 32.59448316 & \begin{tabular}{|l}
91.01077152 \\
\end{tabular} & 32.59448316 & \begin{tabular}{|l}
91.01077152 \\
\end{tabular} & $8368+00$ & $8320+00$ & Under Seepage & Light & \begin{tabular}{|l} 
Light underseepage from the toe of the seepage berm extending out \\
approximately 30 yards into the woods near levee Sta. 8320.
\end{tabular} & $52-55$ \\
\hline 32.57712271 & 91.02844784 & 32.57712271 & 91.02844784 & $8455+00$ & $8409+00$ & Under Seepage & Light & $\begin{array}{l}\text { Light underseepage in wooded area approximately } 100 \text { feet from the toe } \\
\text { of the seepage berm. Area is approximately } 150 \text { to } 200 \text { feet wide and is } \\
\text { located approximately } 350 \text { feet north of the Warren County line. }\end{array}$ & 56 \\
\hline
\end{tabular}




\begin{tabular}{|c|c|c|c|c|c|c|c|c|c|}
\hline \multicolumn{2}{|c|}{ START } & \multicolumn{2}{|c|}{ END } & STATION & STATION & \multirow[t]{2}{*}{ TYPE } & \multirow[t]{2}{*}{ EXTENT } & \multirow[t]{2}{*}{ REMARKS } & \multirow[t]{2}{*}{ PHOTO } \\
\hline Latitude & Longitude & Latitude & Longitude & $\overline{N L D}$ & FIELD MARKER & & & & \\
\hline 32.56992867 & 91.03724233 & 32.56992867 & 91.03724233 & $8493+00$ & $8445+00$ & Slide & Light & $\begin{array}{l}\text { Small crack noted in seepage berm near levee Sta. } 8445 \text {. Crack width } \\
\text { varies from } 0.5 \text { to } 1 \text { inch and extends approximately } 100 \text { feet in length. }\end{array}$ & 57 \\
\hline 32.56723143 & 91.0416534 & 32.56465365 & 91.05326993 & $\begin{array}{l}8509+00 \text { to } \\
8550+00\end{array}$ & $\begin{array}{l}8460+00 \text { to } \\
8500+00\end{array}$ & Under Seepage & Light & $\begin{array}{l}\text { Light underseepage from the toe of the seepage berm extending into the } \\
\text { woods and open field approximately } 100 \text { to } 150 \text { feet between levee Sta. } \\
8465 \text { and Sta. } 8500 \text {. Seepage water is generally clear. }\end{array}$ & $58-63$ \\
\hline 32.564031 & 91.054686 & 32.5589 & 91.06687 & $\begin{array}{l}8553+00 \text { to } \\
8597+00\end{array}$ & \begin{tabular}{|l}
$8510+00$ to \\
$8550+00$
\end{tabular} & Under Seepage & Moderate & $\begin{array}{l}\text { Moderate to heavy seepage along levee toe between levee Sta. } 8510 \\
\text { and } 8550 .\end{array}$ & \\
\hline 32.56127261 & 91.06164039 & 32.56127261 & 91.06164039 & $8577+00$ & $8530+00$ & Sand Boil & Moderate & $\begin{array}{l}\text { Moderate seepage and sand boils approximately } 30 \text { to } 50 \text { feet from the } \\
\text { toe of the seepage berm near levee Sta. } 8530 \text {. One large sand boil has } \\
\text { been ringed by the levee board with a } 30 \text {-gallon drum. Numerous pin } \\
\text { boils were identified in a field approximately } 300 \text { feet downstream from } \\
\text { the boil that was ringed with the drum. Some boils in the field were } \\
\text { transporting small quantities of silt/fine sand and a few had } 3 \text { to } 4 \text {-inch } \\
\text { throats. Boils near the southern entrance of Highway } 465 .\end{array}$ & \begin{tabular}{|c|}
$64-69$ \\
\end{tabular} \\
\hline 32.55124403 & 91.06668772 & 32.55124403 & 91.06668772 & $8634+00$ & $8586+00$ & Under Seepage & Light & $\begin{array}{l}\text { Light underseepage approximately } 30 \text { feet from the toe of the seepage } \\
\text { berm near levee Sta. } 8590 \text {. Seepage is approximately } 150 \text { feet wide and } \\
\text { extends approximately } 100 \text { feet out into the wooded area. }\end{array}$ & 70 \\
\hline 32.54863775 & 91.06814146 & 32.54863775 & 91.06814146 & $8645+00$ & $8+00$ (BEL) & Under Seepage & Light & $\begin{array}{l}\text { Light underseepage from approximately } 50 \text { feet from the toe of the } \\
\text { levee (no seepage berm) extending out approximately } 300 \text { feet and into } \\
\text { a wooded area near levee Sta. } 8+00 \text { - Brunswick Extension Levee (BEL). } \\
\end{array}$ & $71-73$ \\
\hline 32.53482086 & 91.07807727 & 32.52138 & 91.07268 & 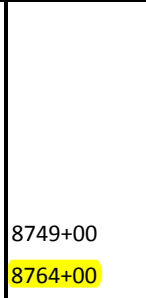 & $\begin{array}{l}110+00 \text { to } \\
131+00 \text { (BEL) }\end{array}$ & Sand Boil & Heavy & $\begin{array}{l}\text { Buck Chute - A stabilization berm was constructed at Buck Chute, which was } \\
\text { completed in early May, 2011, to control seepage and sand boils. Also, a } \\
\text { deviation to the water control plan for Eagle Lake was enacted to minimize } \\
\text { seepage pressures through the Levee. The water level in Eagle Lake was } \\
\text { raised to } 89.8 \text { feet. There were no significant issues with seepage at } \\
\text { buck chute during the flood. However, a significant sand boil developed } \\
\text { approximately } 5 \text { feet west of relief well BC-2-98. }\end{array}$ & \begin{tabular}{|l|}
$74-91$ \\
\end{tabular} \\
\hline 32.52820892 & 91.07615484 & 32.52820892 & 91.07615484 & $8735+00$ & $90+00$ (BEL) & Heavy Current/Scour & Light & $\begin{array}{l}\text { Heavy current and small whirlpools noted along riverside of levee } \\
\text { upstream from Buck Chute near levee Sta. BEL. } 90 .\end{array}$ & \\
\hline 32.51769 & 91.07168 & 32.5154602 & 91.07181245 & $\begin{array}{l}8777+00 \text { to } \\
8786+00\end{array}$ & $\mid \begin{array}{l}140+00 \text { to } \\
150+00 \text { (BEL) }\end{array}$ & Under Seepage & Light & $\begin{array}{l}\text { Light underseepage along the toe of the levee extending out approximately } \\
200 \text { feet from levee Sta. } 140 \text { to } 150 \text {. Seepage is mostly clear water. }\end{array}$ & $92-94$ \\
\hline
\end{tabular}




\begin{tabular}{|c|c|c|c|c|c|c|c|c|c|}
\hline \multicolumn{2}{|c|}{ START } & \multicolumn{2}{|c|}{ END } & \multirow{2}{*}{$\begin{array}{l}\text { STATION } \\
\text { NLD } \\
\end{array}$} & \multirow{2}{*}{\begin{tabular}{|c|} 
STATION \\
FIELD MARKER \\
\end{tabular}} & \multirow[t]{2}{*}{ TYPE } & \multirow[t]{2}{*}{ EXTENT } & \multirow[t]{2}{*}{ REMARKS } & \multirow[t]{2}{*}{ РнОТО } \\
\hline Latitude & Longitude & Latitude & Longitude & & & & & & \\
\hline 32.49862535 & 91.0754191 & 32.47617 & 91.06052 & $\begin{array}{l}8847+00 \text { to } \\
8964+00\end{array}$ & $\begin{array}{l}210+00 \text { to } \\
327+00 \text { (BEL) }\end{array}$ & Sand Boil & Heavy & $\begin{array}{l}\text { Moderate to heavy under seepage, numerous active, medium sized sand } \\
\text { boils and pin boils were observed within } 50 \text { feet of the levee toe between } \\
\text { Brunswick Extension Levee (BEL) Sta. } 210+00 \text { and } 327+00 \text { near and } \\
\text { around Tara Hunting Camp. Two to three, large, high energy sand } \\
\text { boils with } 12 \text { to } 16 \text { inch throats were identified between Sta. } 210 \\
\text { and } 220 \text { that flowed } 100+\text { gallons per minute and transported } 5+\text { cubic yards } \\
\text { of fine sand/silt before and during remedial action. These boils were } \\
\text { located between } 10 \text { and } 20 \text { feet from the toe of the levee. One boil, located } \\
\text { near Sta. } 212+00 \text { BEL was ringed with sand bags by the levee board. The } \\
\text { other boils were eventually stabilized with drums placed over the throats } \\
\text { of the boils. A large water berm, several feet in depth, was created by the } \\
\text { under seepage in this area and the bermed area was investigated by boat } \\
\text { on } 5 / 23 / 11 \text {. During this investigation, over } 30 \text { sand boils were identified } \\
\text { under the surface of the water berm in the general area of levee Sta.260 } \\
\text { BEL. }\end{array}$ & 95-109 \\
\hline 32.47460845 & 91.05658291 & 32.46939 & 91.04095 & \begin{tabular}{|l}
$8967+00$ to \\
$9027+00$ \\
\end{tabular} & $\begin{array}{l}330+00 \text { to } \\
390+00 \text { (BEL) }\end{array}$ & Under Seepage/Pin Boi & i Heavy & $\begin{array}{l}\text { Moderate to heavy seepage and several small, low energy, sand boils along } \\
\text { the levee toe between levee Sta. } 330 \text { (BEL) and Sta. } 390 \text { (BEL). Several } \\
\text { boils were ringed with } 30 \text {-gallon plastic drums by the levee board. Some } \\
\text { of the boils were pin flagged and were being monitored. Numerous } \\
\text { smaller boils are possible under water in this area. }\end{array}$ & \\
\hline 32.46707963 & 91.03314342 & 32.46648 & 91.02852 & \begin{tabular}{|l}
$9052+00$ to \\
$9067+00$
\end{tabular} & $\begin{array}{l}415+00 \text { to } \\
430+00 \text { (BEL) }\end{array}$ & Under Seepage & Light to Moderate & $\begin{array}{l}\text { Light to moderate seepage along and under the seepage berm extending } \\
\text { approximately } 150 \text { feet out into the field between levee Sta. } 415 \text { (BEL) } \\
\text { and Sta. } 430 \text { (BEL). Seepage berm starts near Sta. } 410 \text { (BEL). } \\
\end{array}$ & 110-111 \\
\hline 32.46749665 & \begin{tabular}{|l|}
91.01755564 \\
\end{tabular} & 32.46749665 & 91.01755564 & $9113+00$ & $475+00$ (BEL) & Under Seepage & Light & $\begin{array}{l}\text { Light seepage along the toe of the seepage berm extending approximately } \\
300 \text { feet out into a corn field near levee Sta. } 475 \text { (BEL). Seepage appears } \\
\text { clear with low energy. Area is monitored by levee board. }\end{array}$ & $112-113$ \\
\hline 32.46508251 & 90.99750392 & 32.46508251 & 90.99750392 & $9162+00$ & $525+00$ (BEL) & Through Seepage & Light & $\begin{array}{l}\text { Minor, light, through seepage noted on top of the seepage berm } \\
\text { approximately } 100 \text { feet from the berm toe near levee Sta. } 520 . \\
\text { Seepage also noted along the toe of the berm extending out approximately } \\
250 \text { feet. }\end{array}$ & $114-116$ \\
\hline 32.46288702 & 90.99240566 & \begin{tabular}{|l}
32.46288702 \\
\end{tabular} & 90.99240566 & $9180+00$ & $542+00$ (BEL) & Sand Boil & Heavy & $\begin{array}{l}\text { Moderately high energy sand boil with a 12-inch throat along the toe of } \\
\text { the seepage berm near levee Sta. } 542 \text { (BEL). Boil has transported about } \\
\text { three cubic yards of silt/fine sand and is flowing approximately } 75-100 \\
\text { gpm. Boil was flagged for the levee board. }\end{array}$ & 117 \\
\hline 32.46196046 & 90.99095339 & 32.46196046 & 90.99095339 & $9186+00$ & $550+00$ (BEL) & Through Seepage & Light & $\begin{array}{l}\text { Light seepage through the seepage berm near levee Sta. } 550 \text { (BEL). } \\
\text { Seepage area is approximately } 100 \text { feet wide and approximately } 300 \text { feet } \\
\text { Iong. Some minor seepage was observed approximately } 50 \text { feet from the } \\
\text { berm toe in the same area. }\end{array}$ & $118-120$ \\
\hline
\end{tabular}



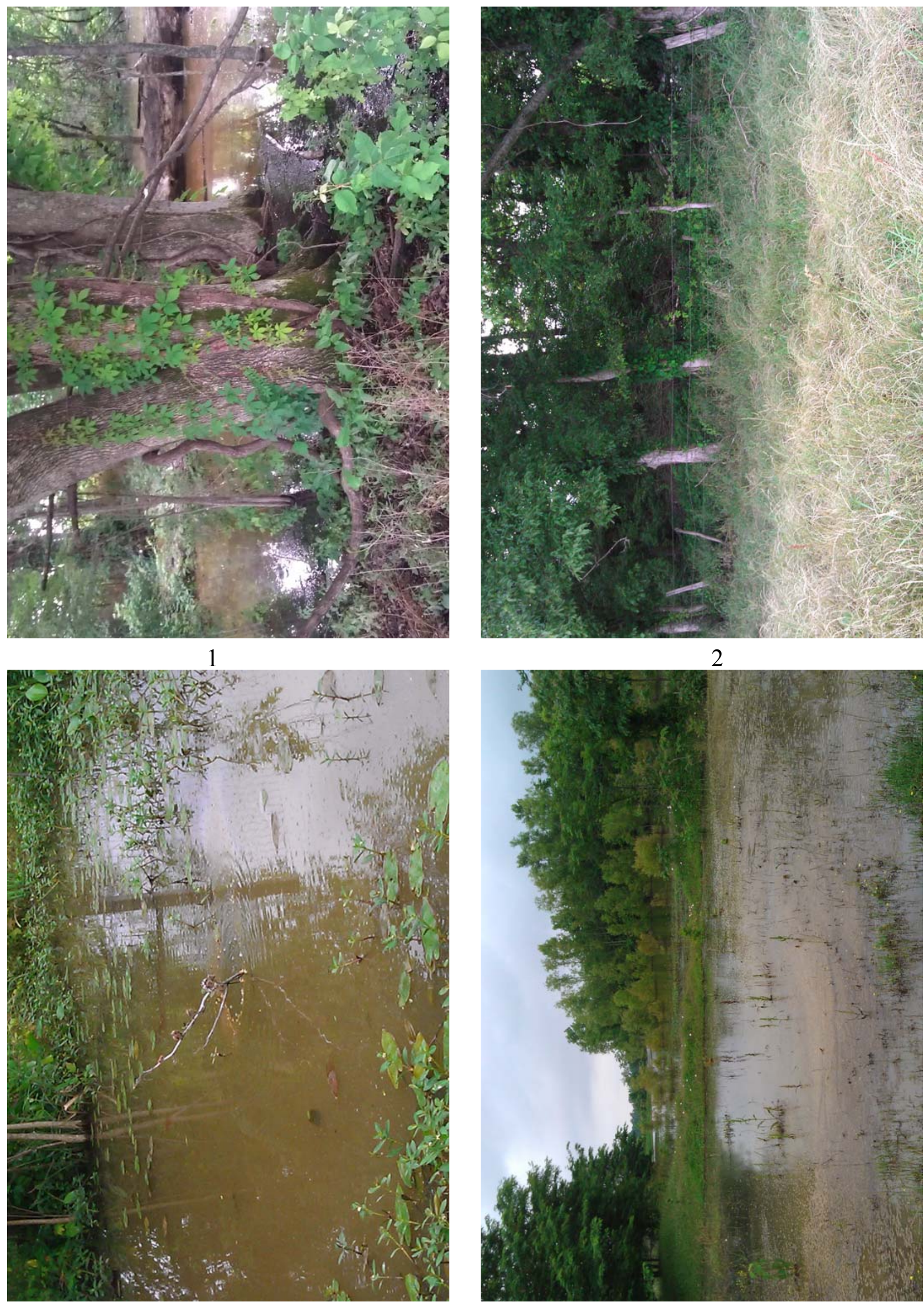

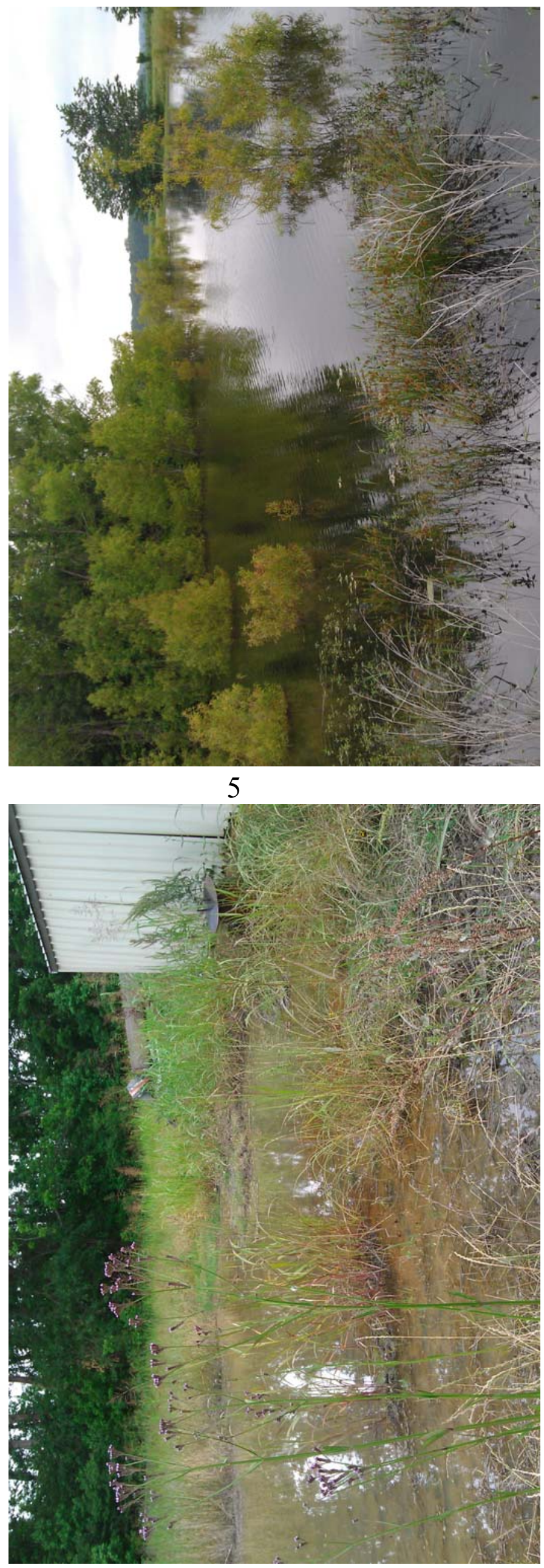


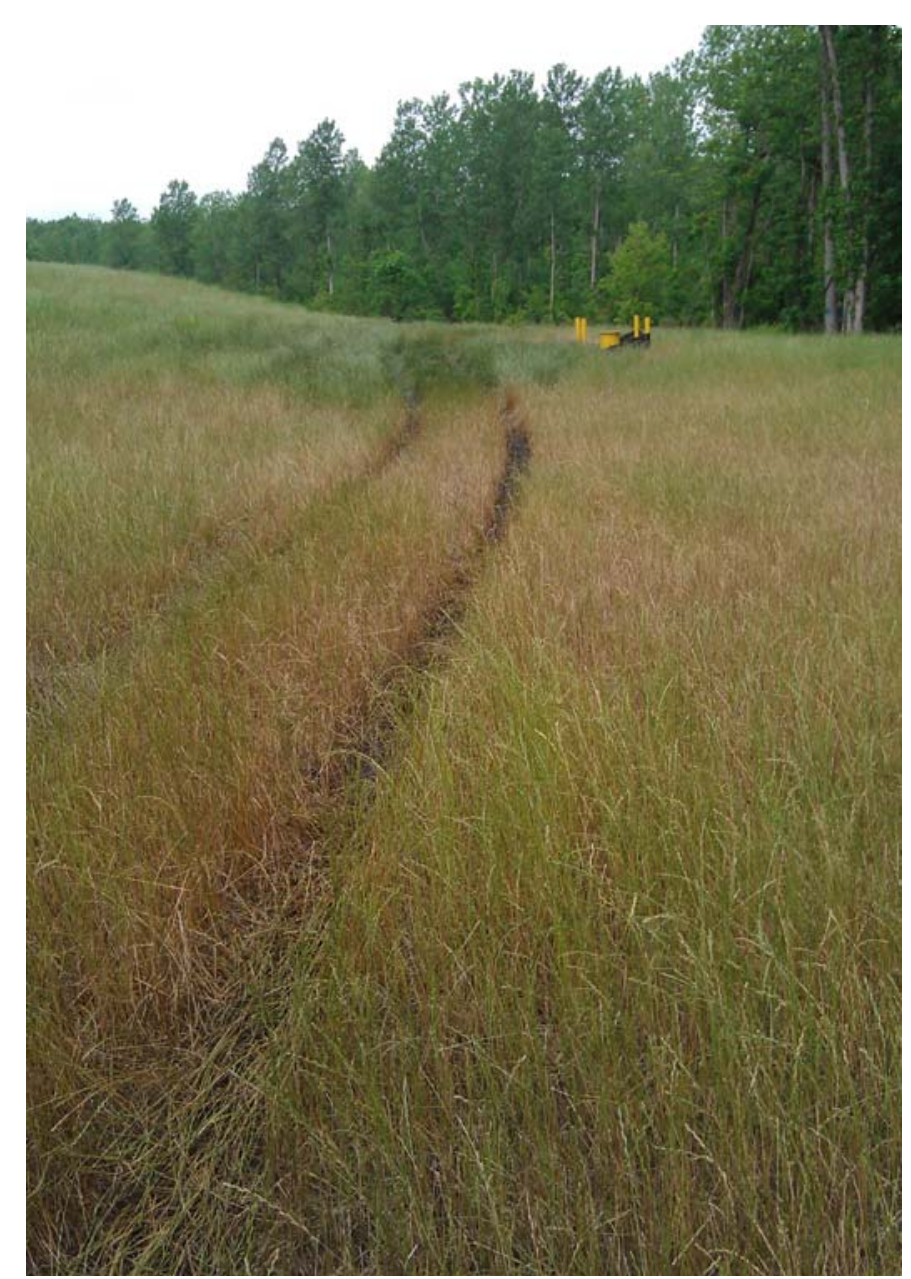

9

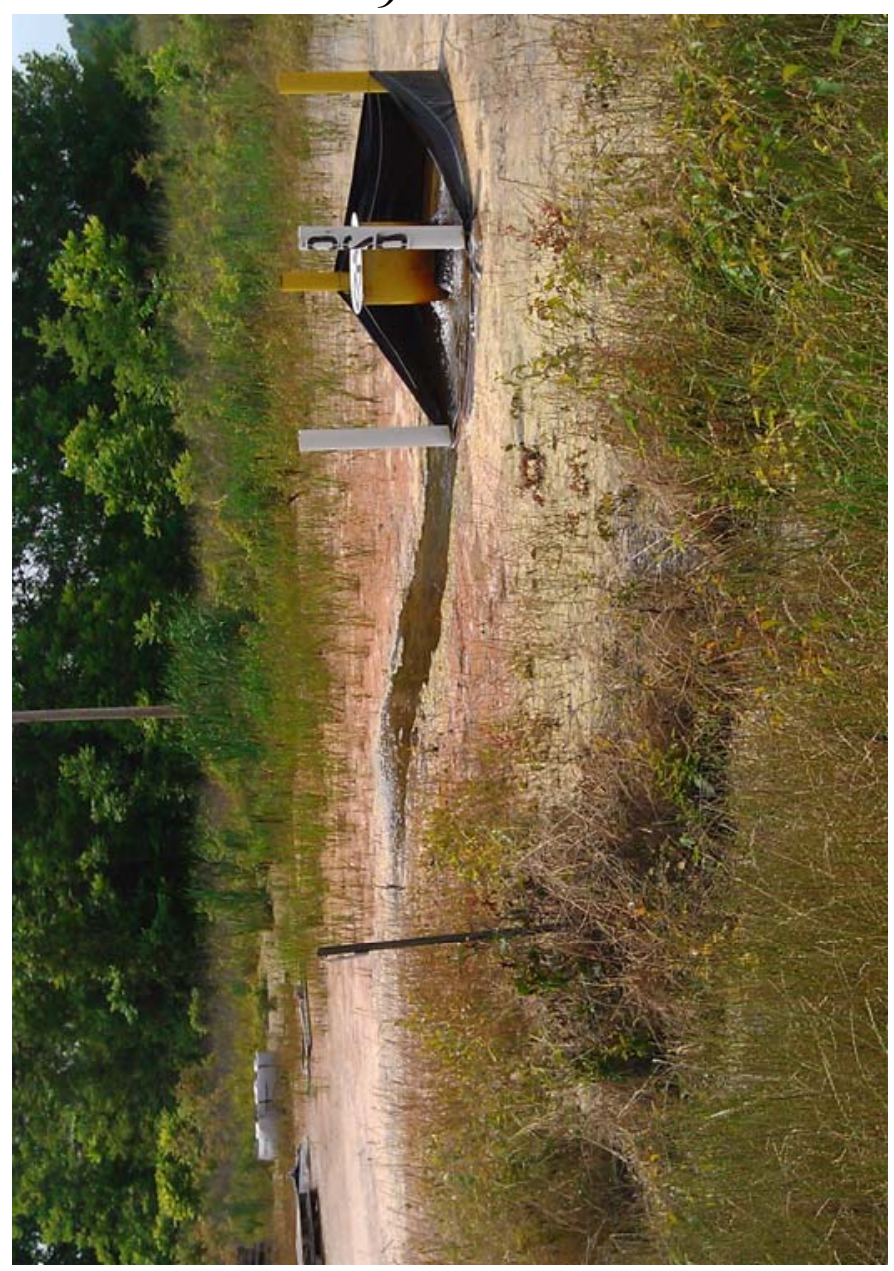

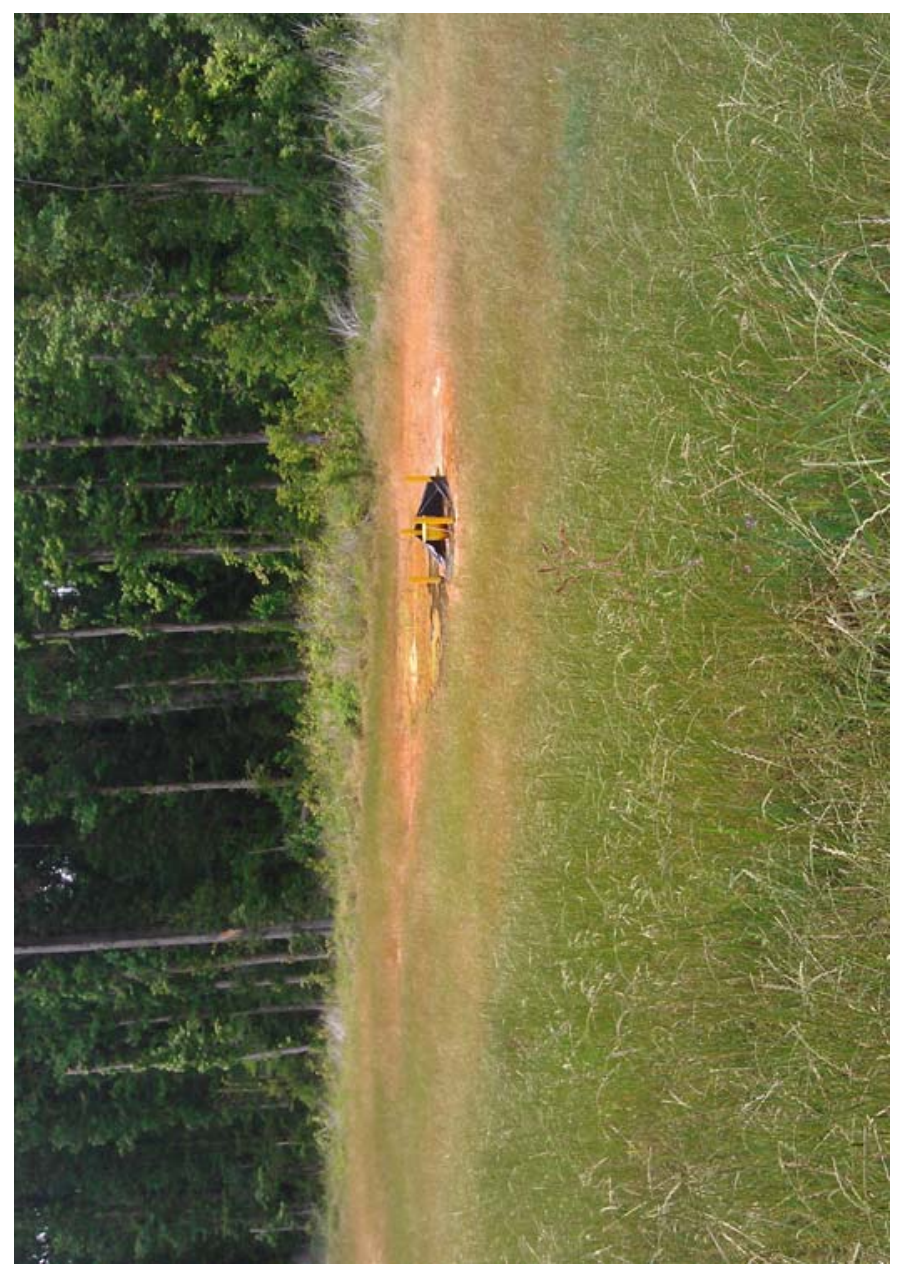

10

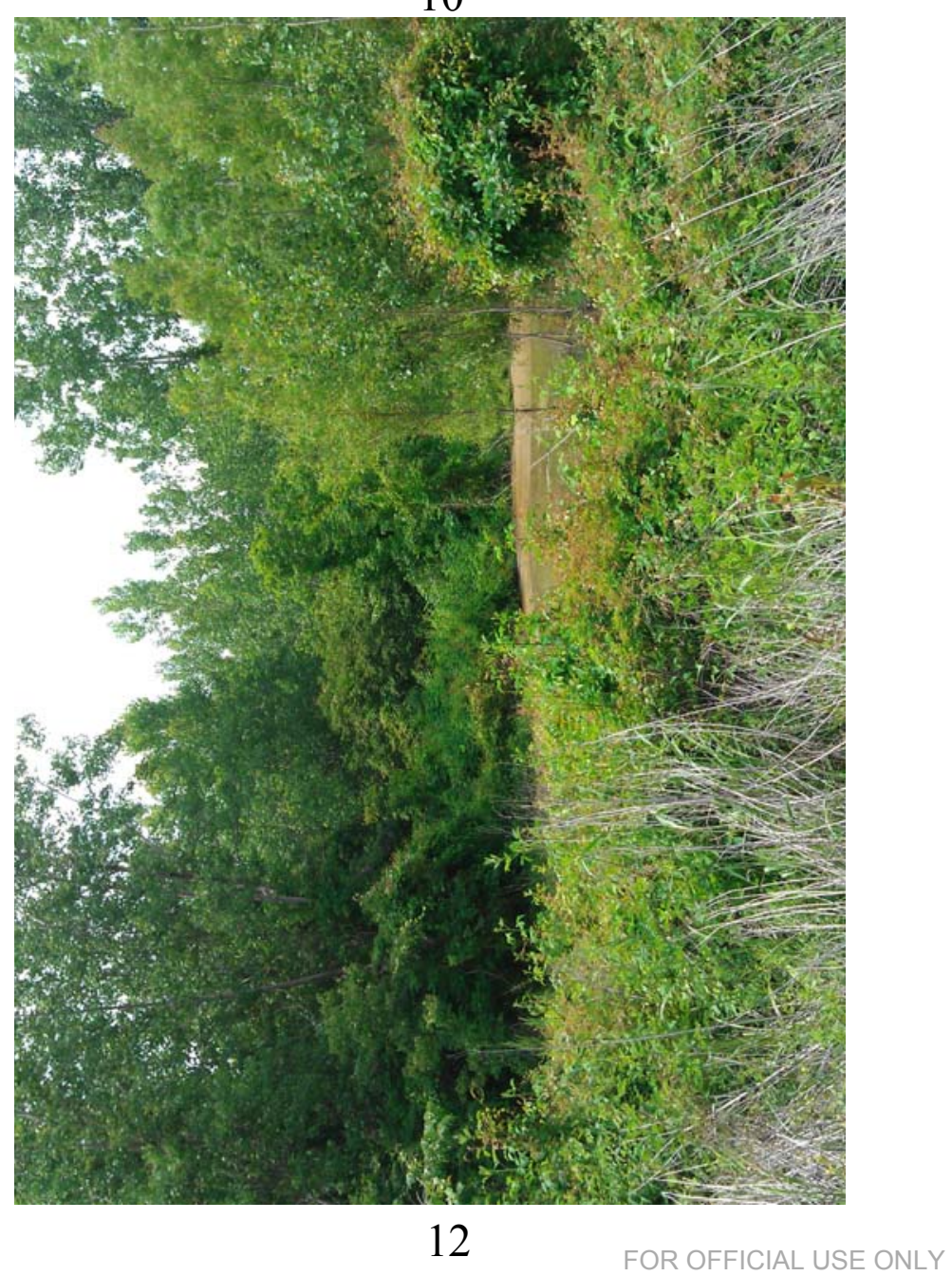




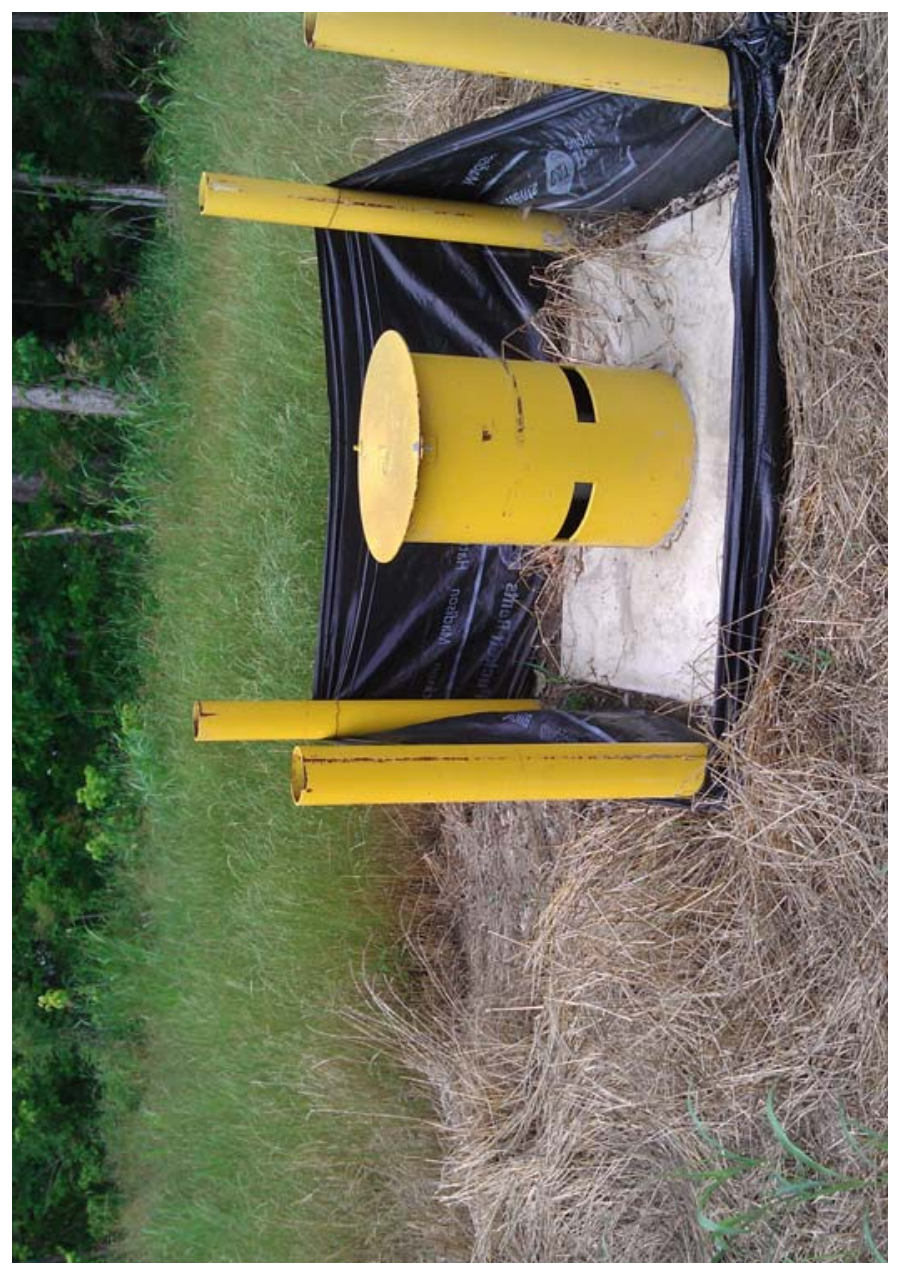

13

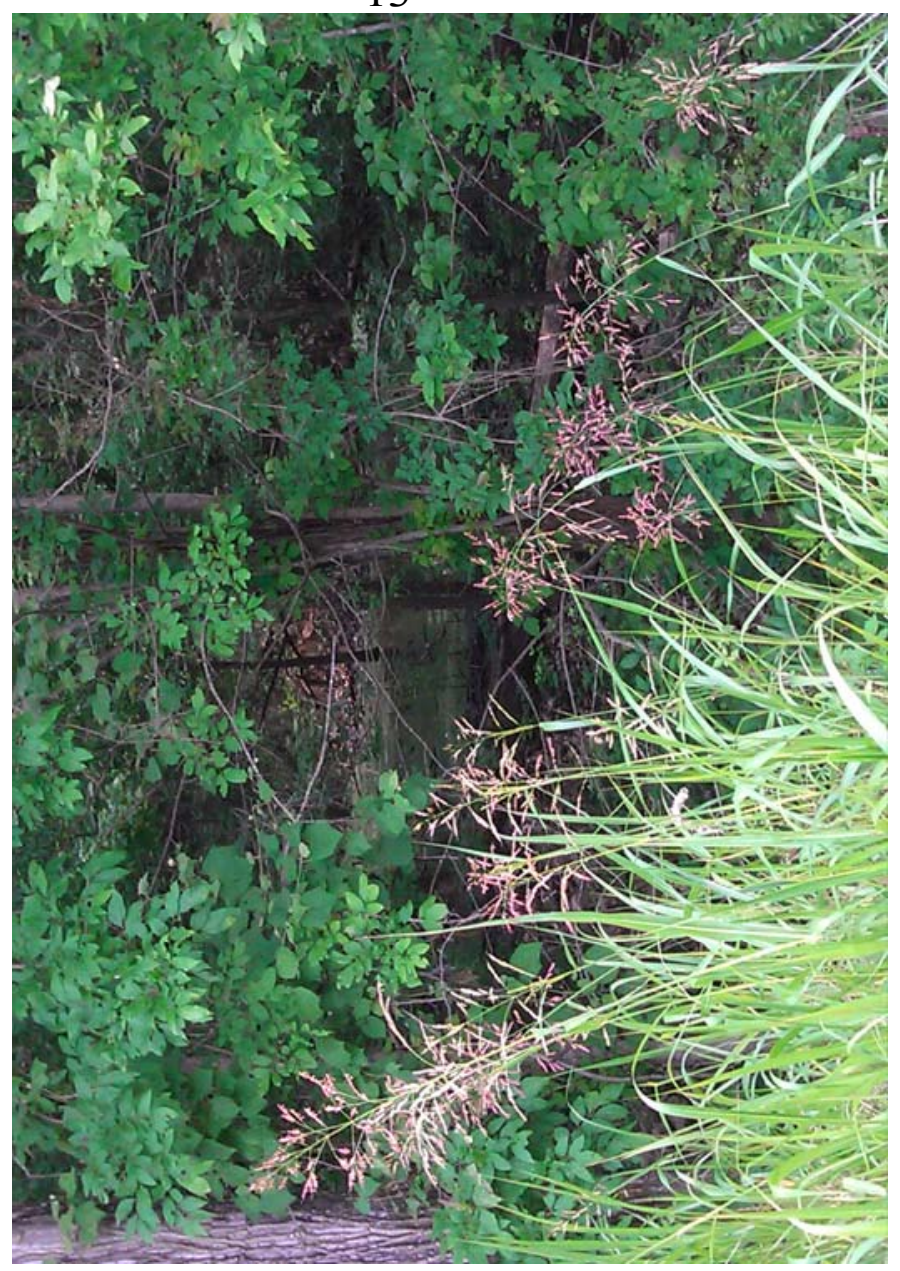

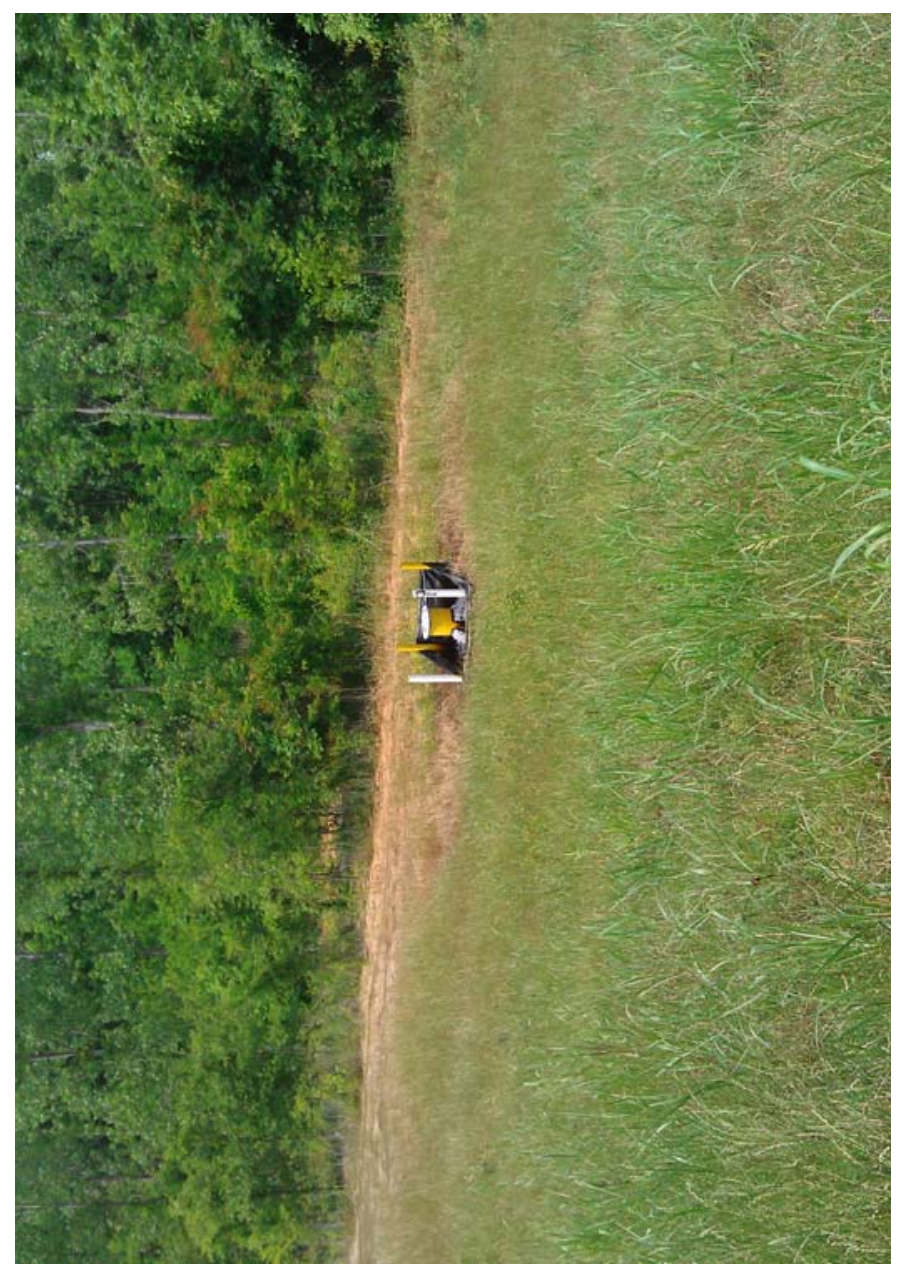

14

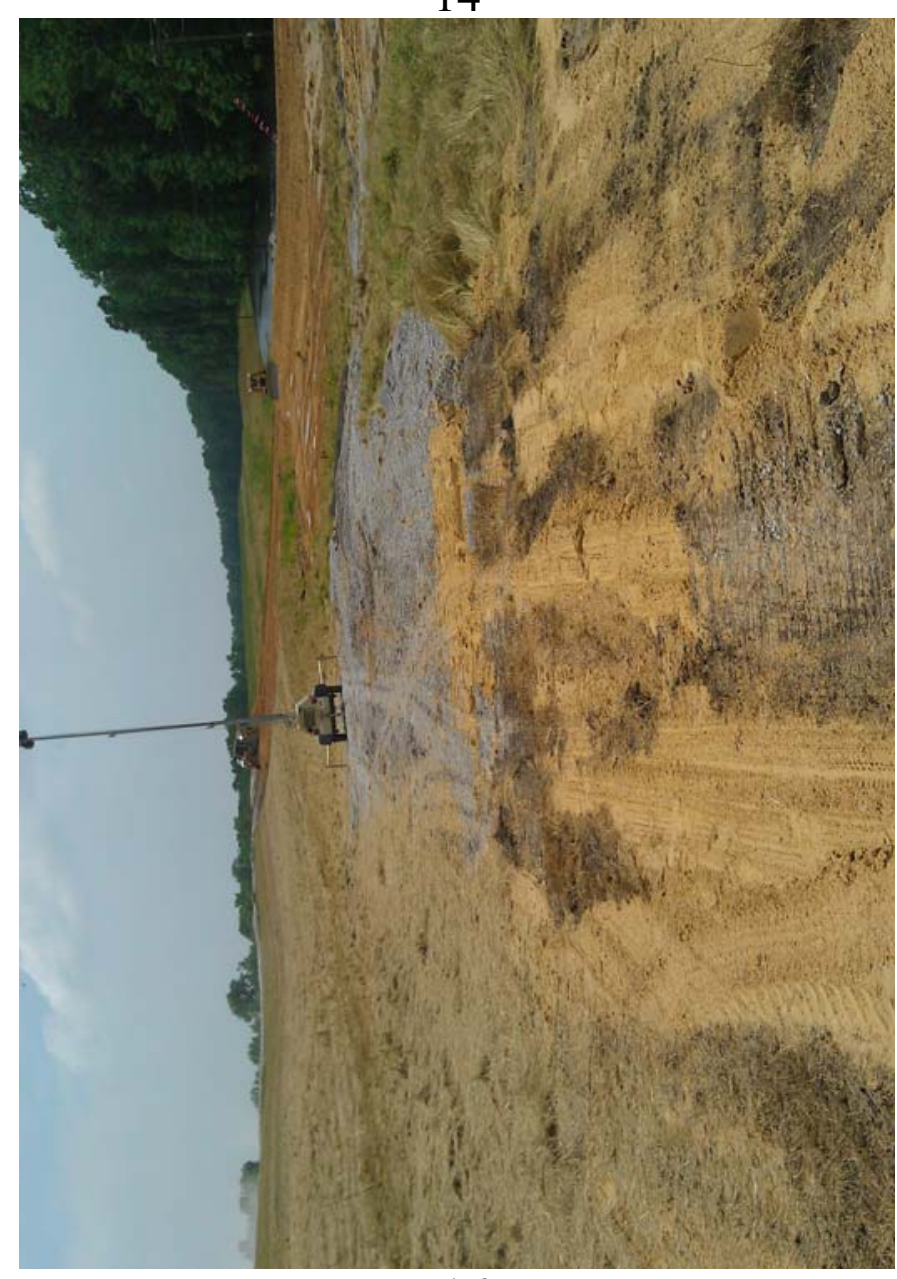




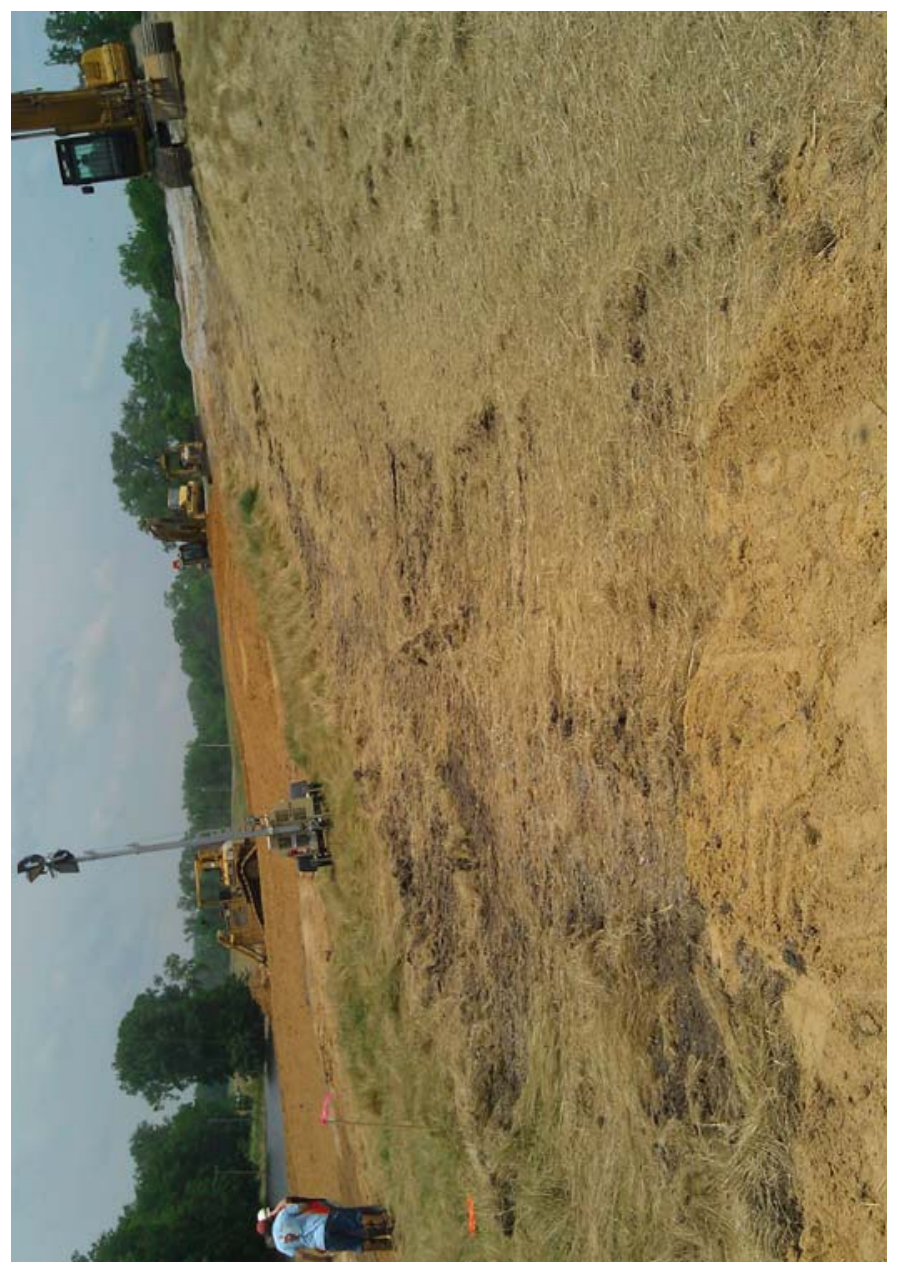

17

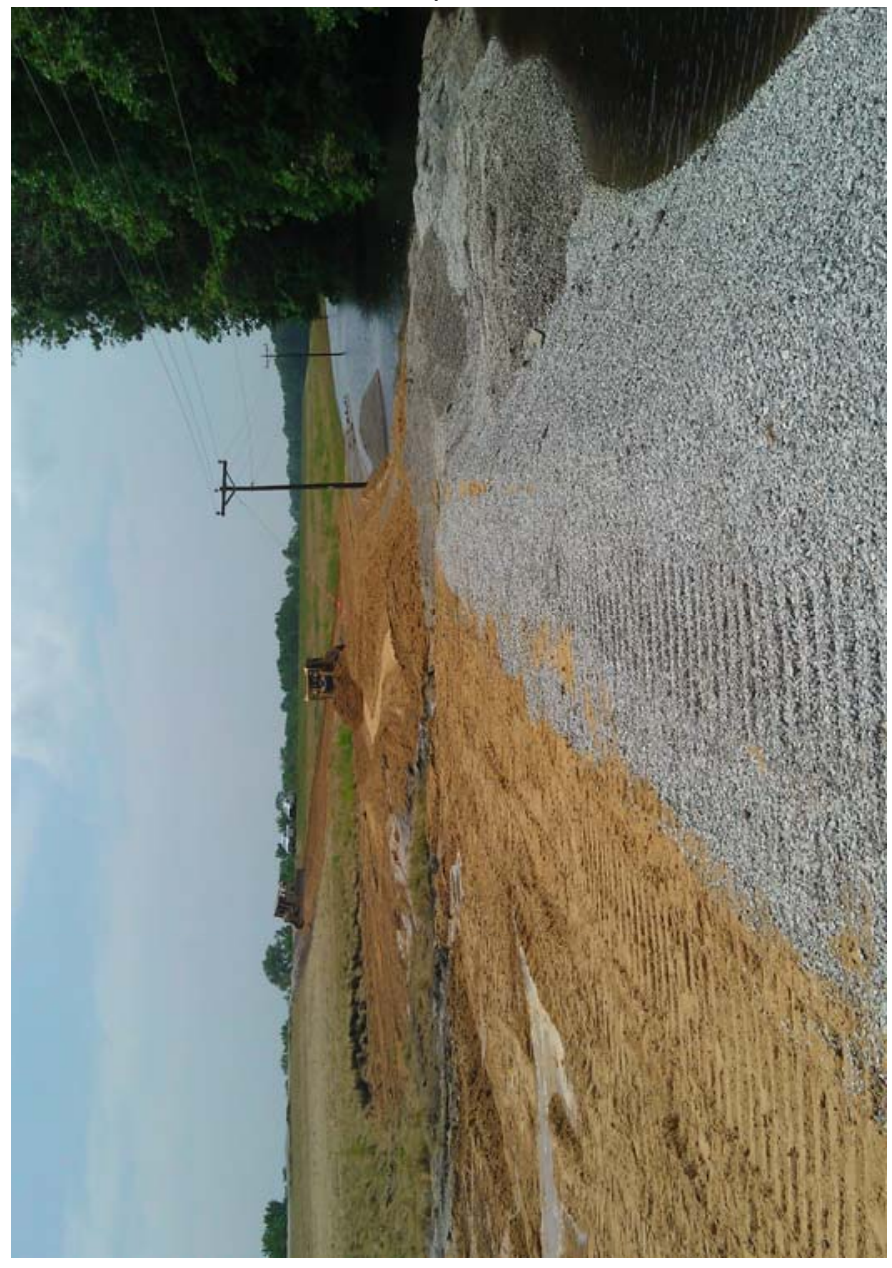

19

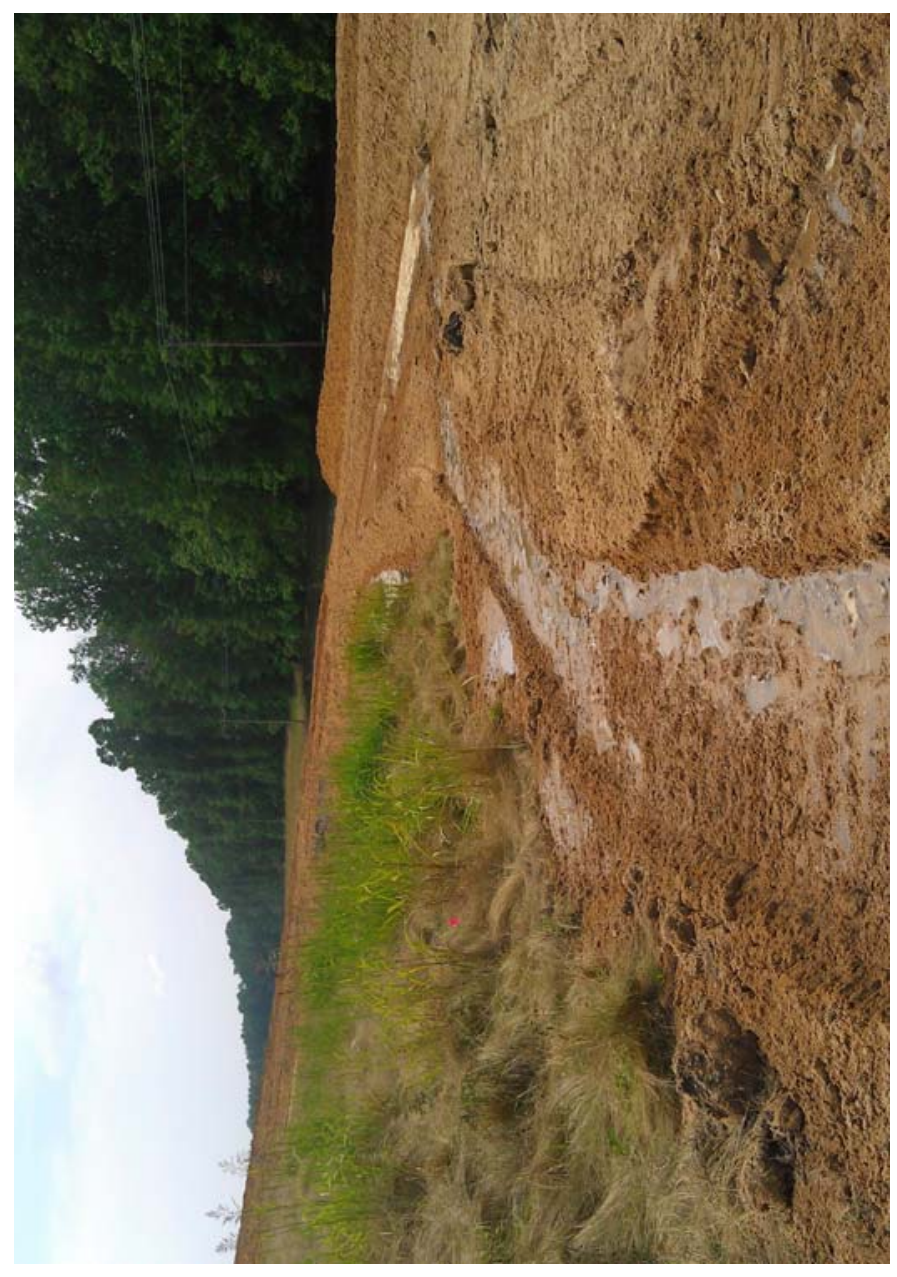

18

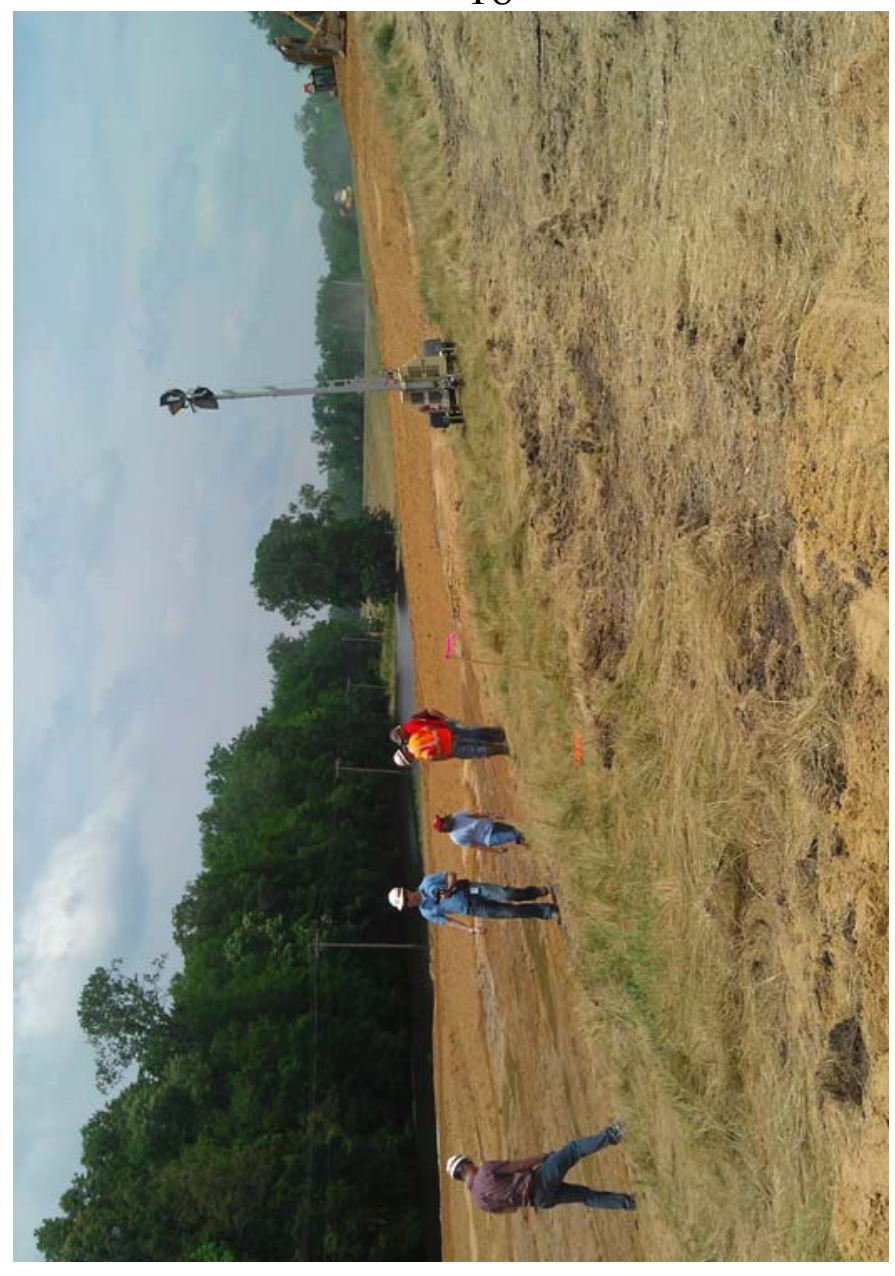




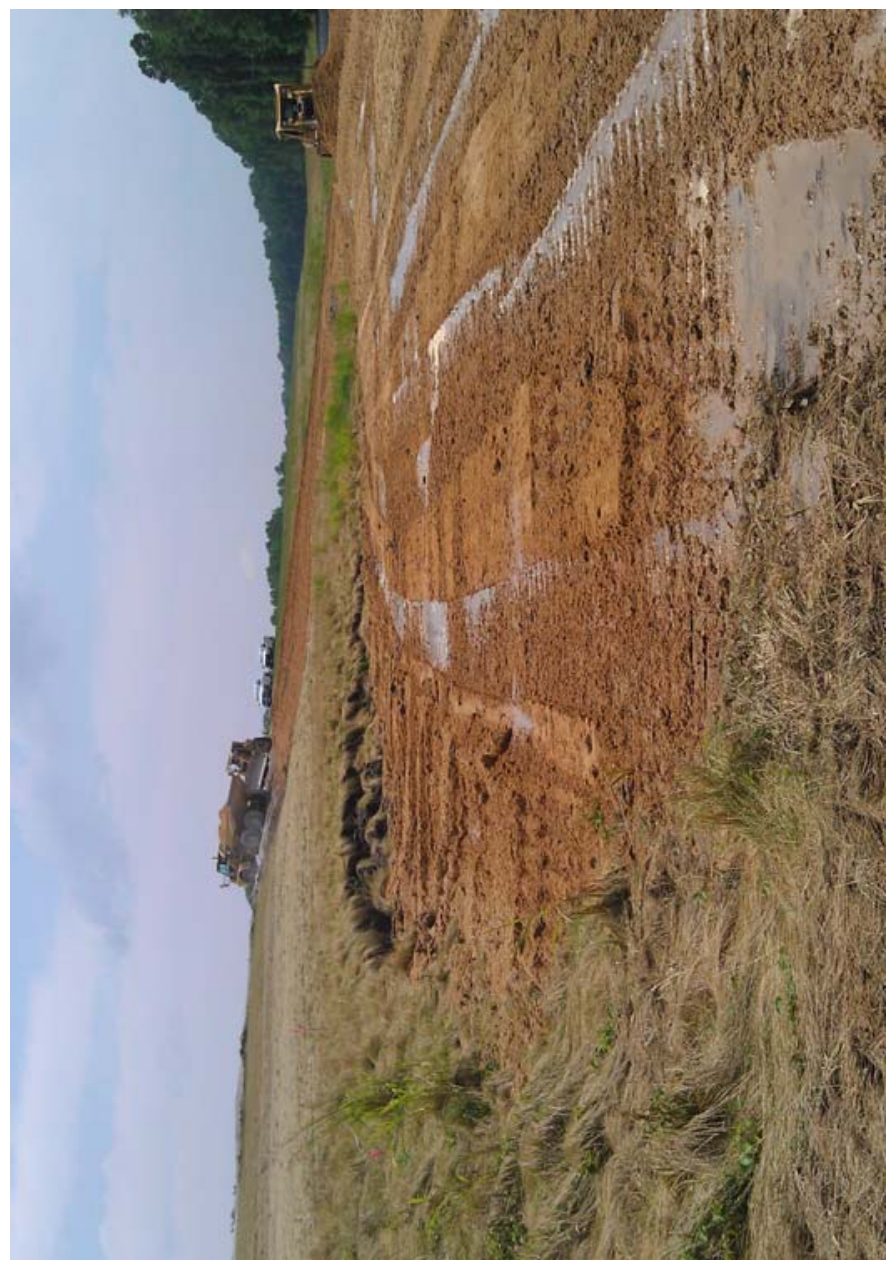

21

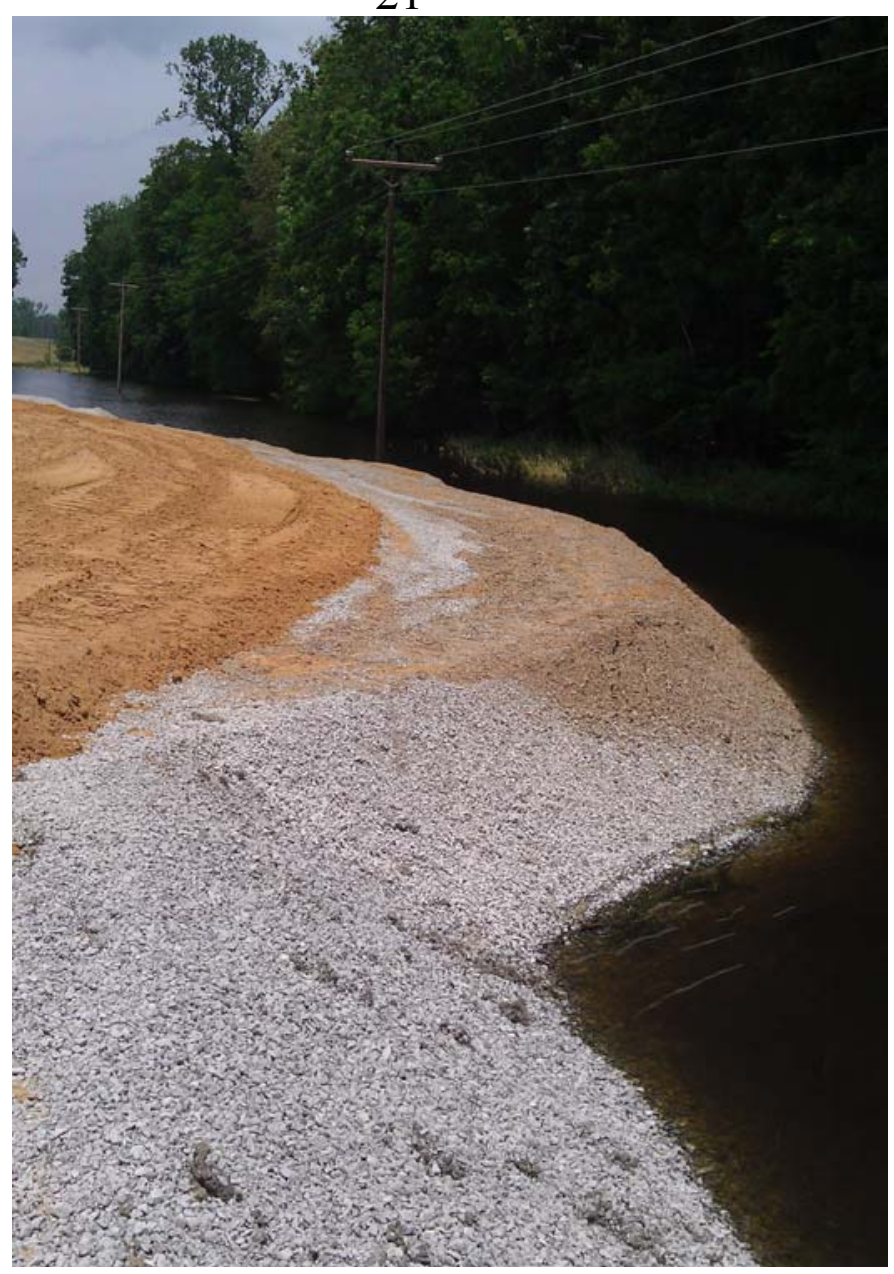

23

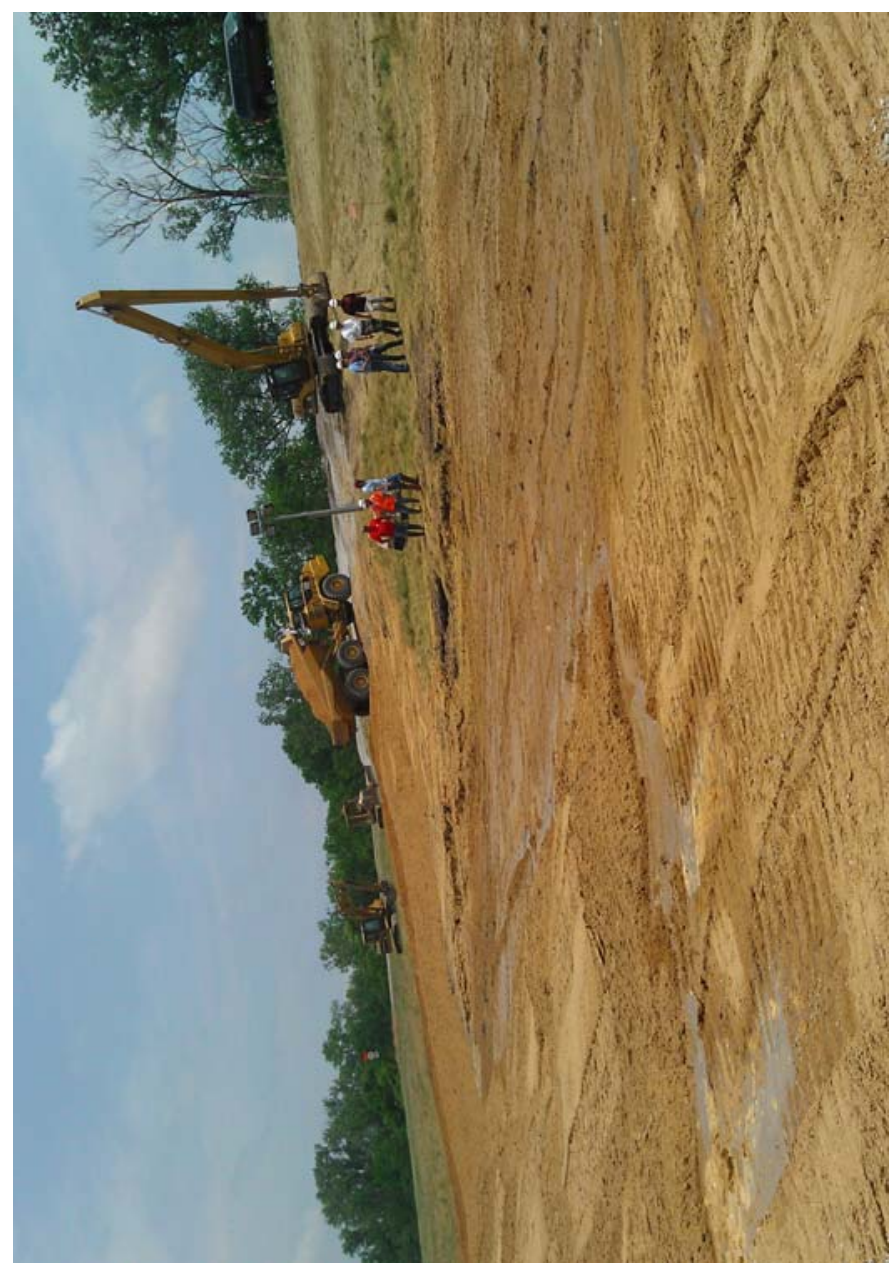

22

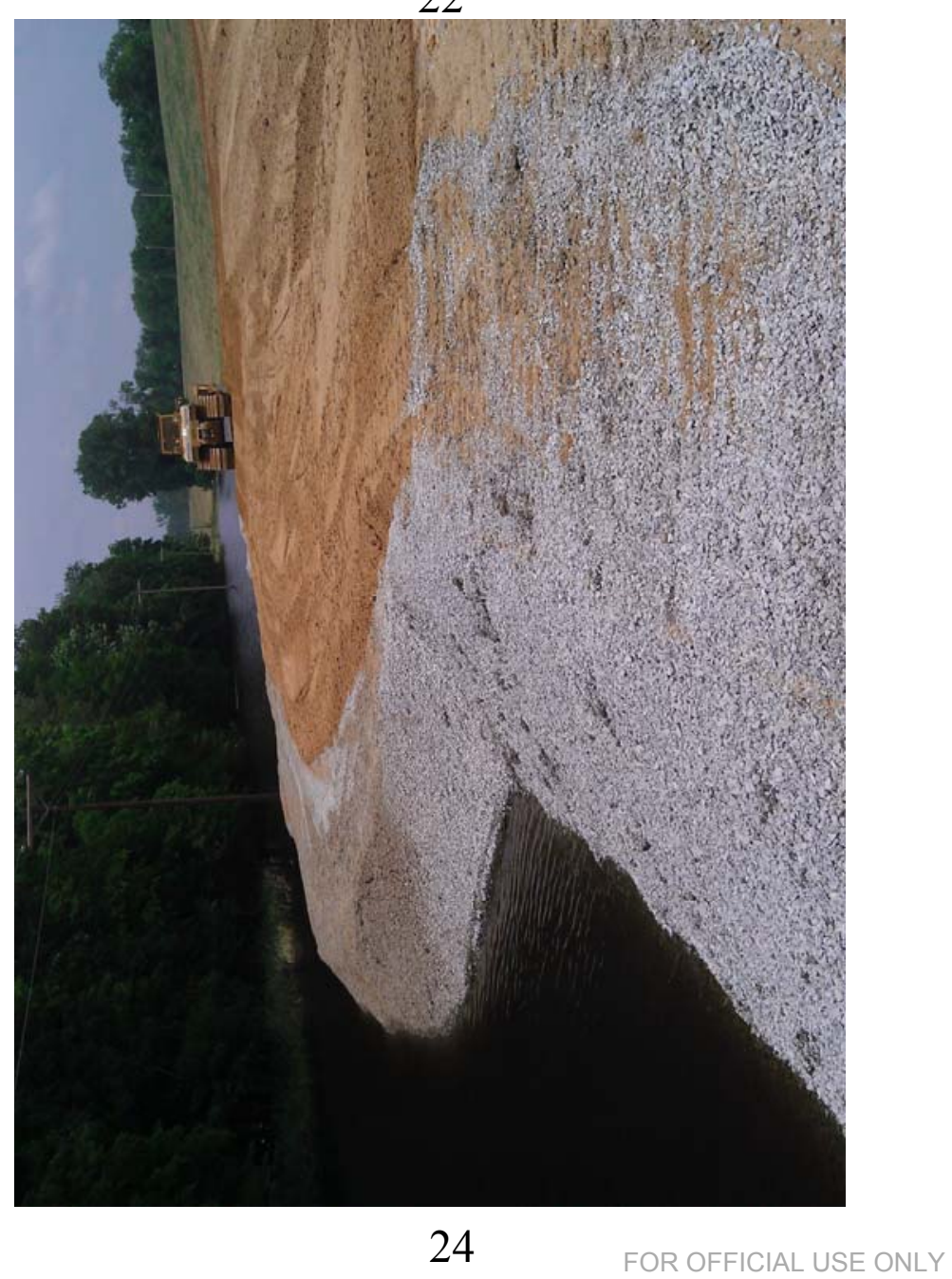




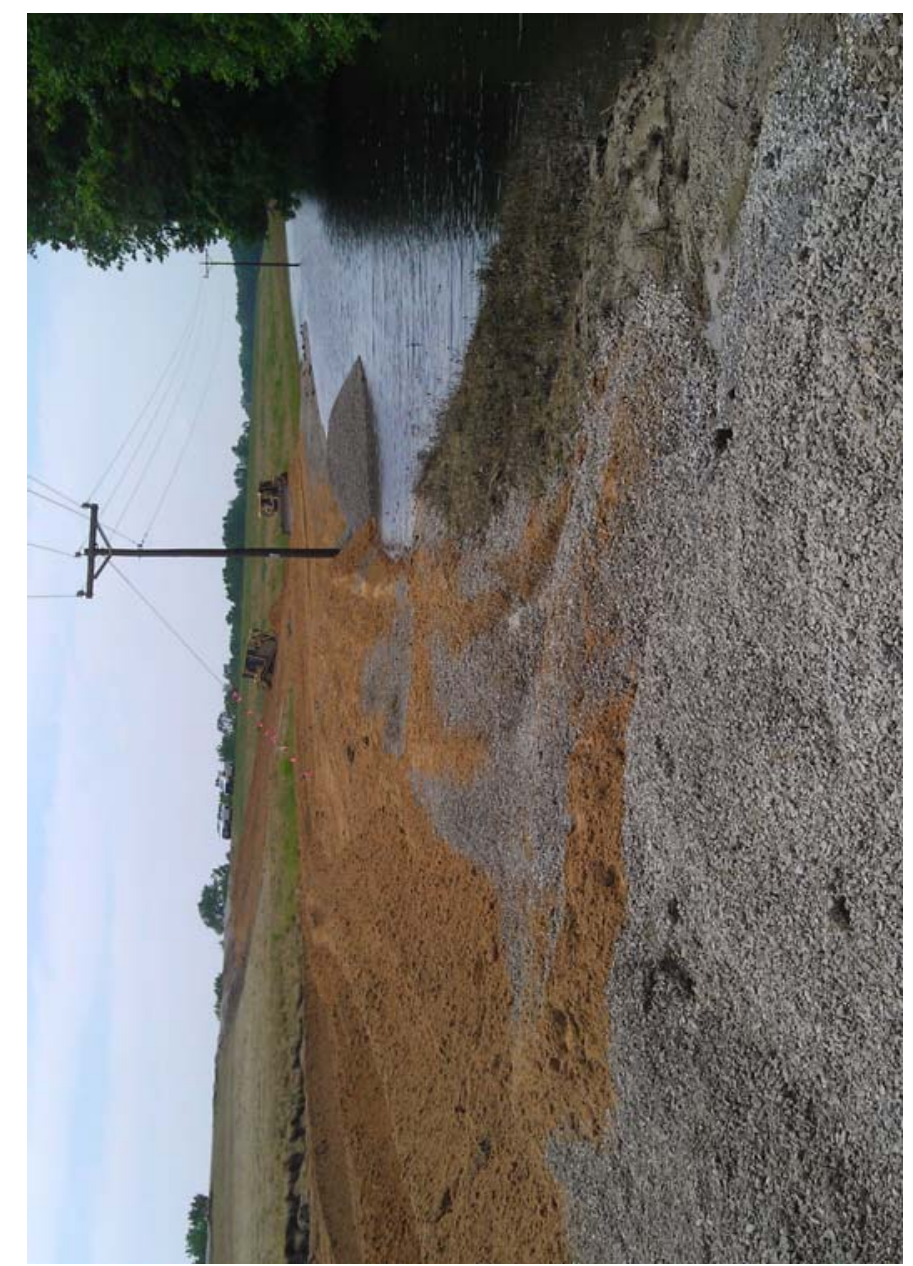

\section{5}
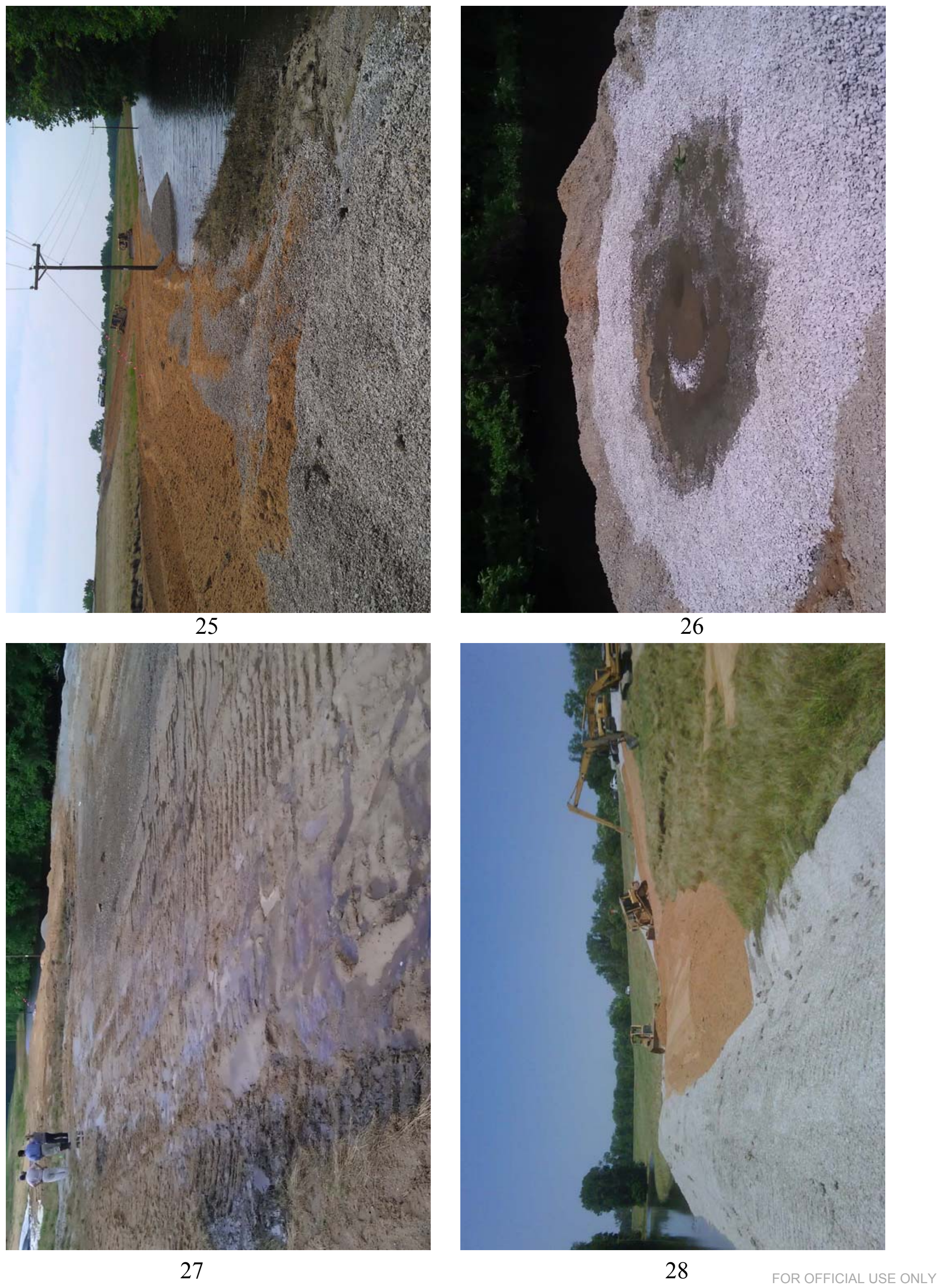


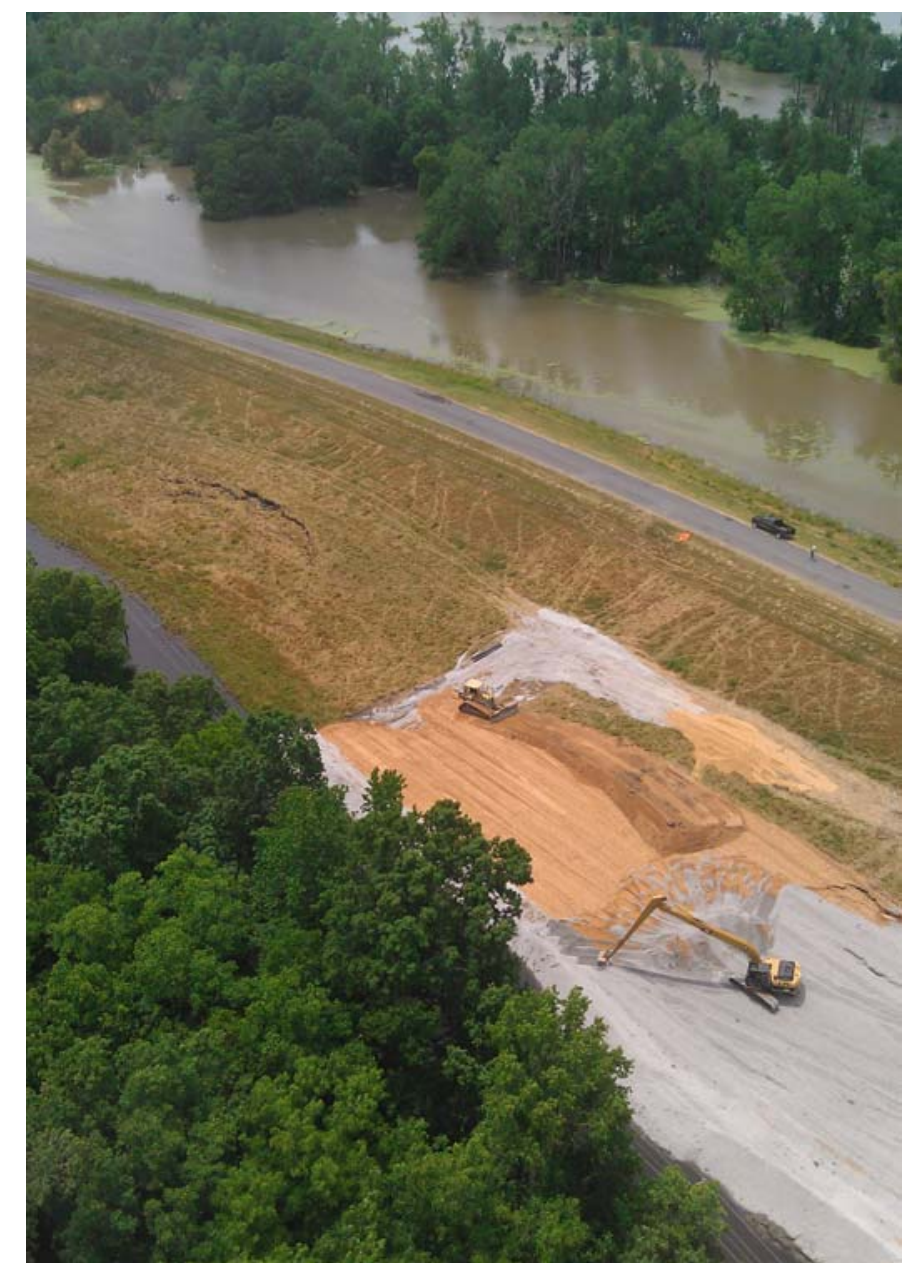

29

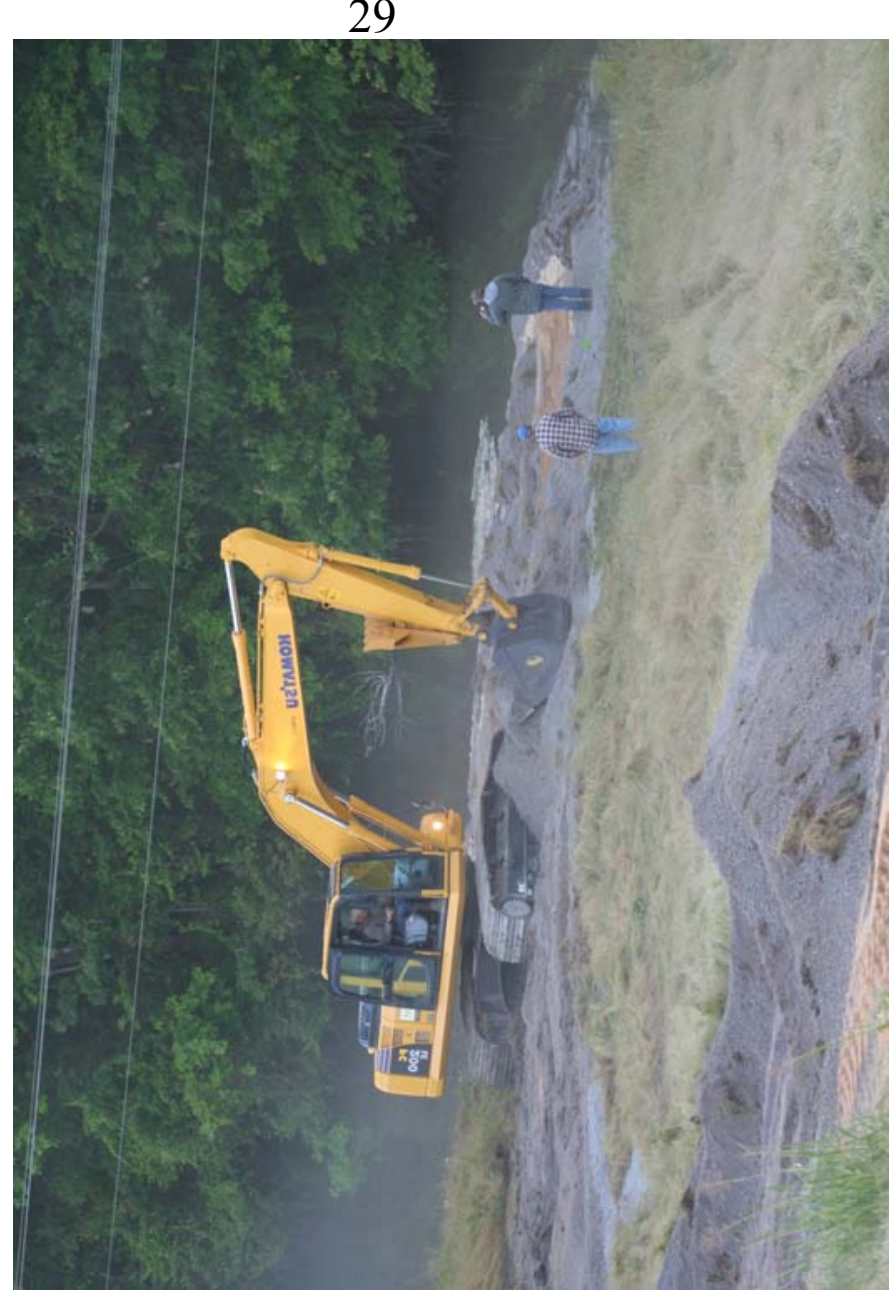

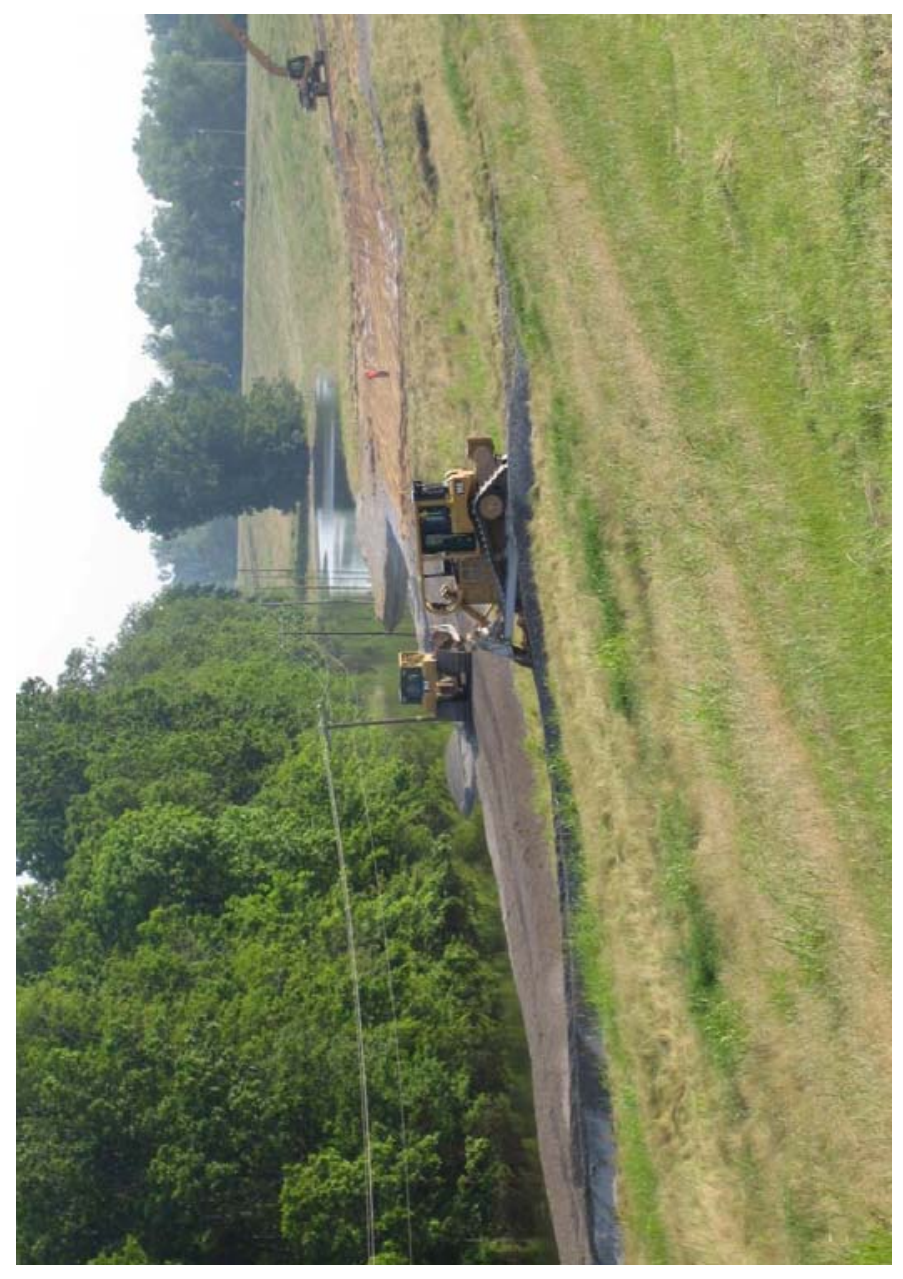

30

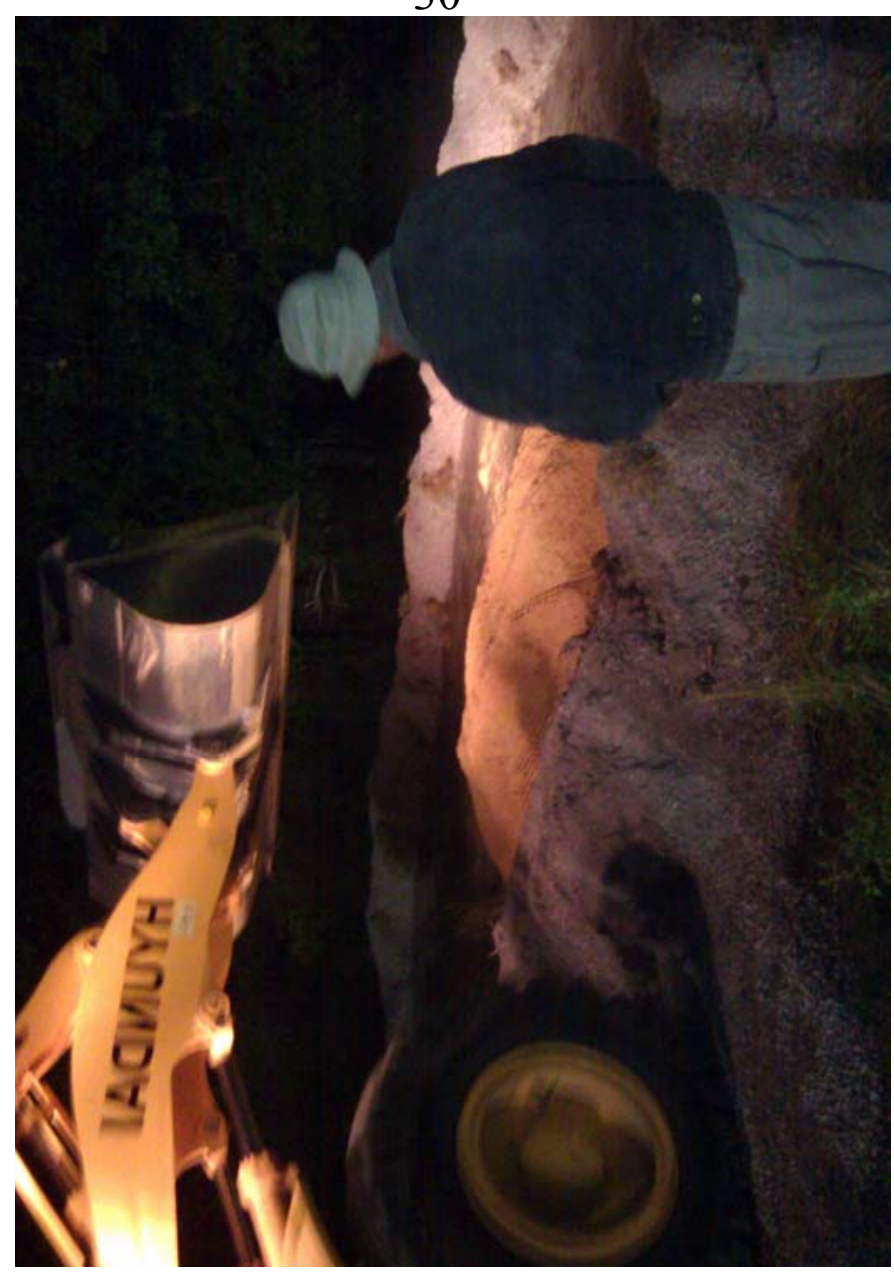

32 


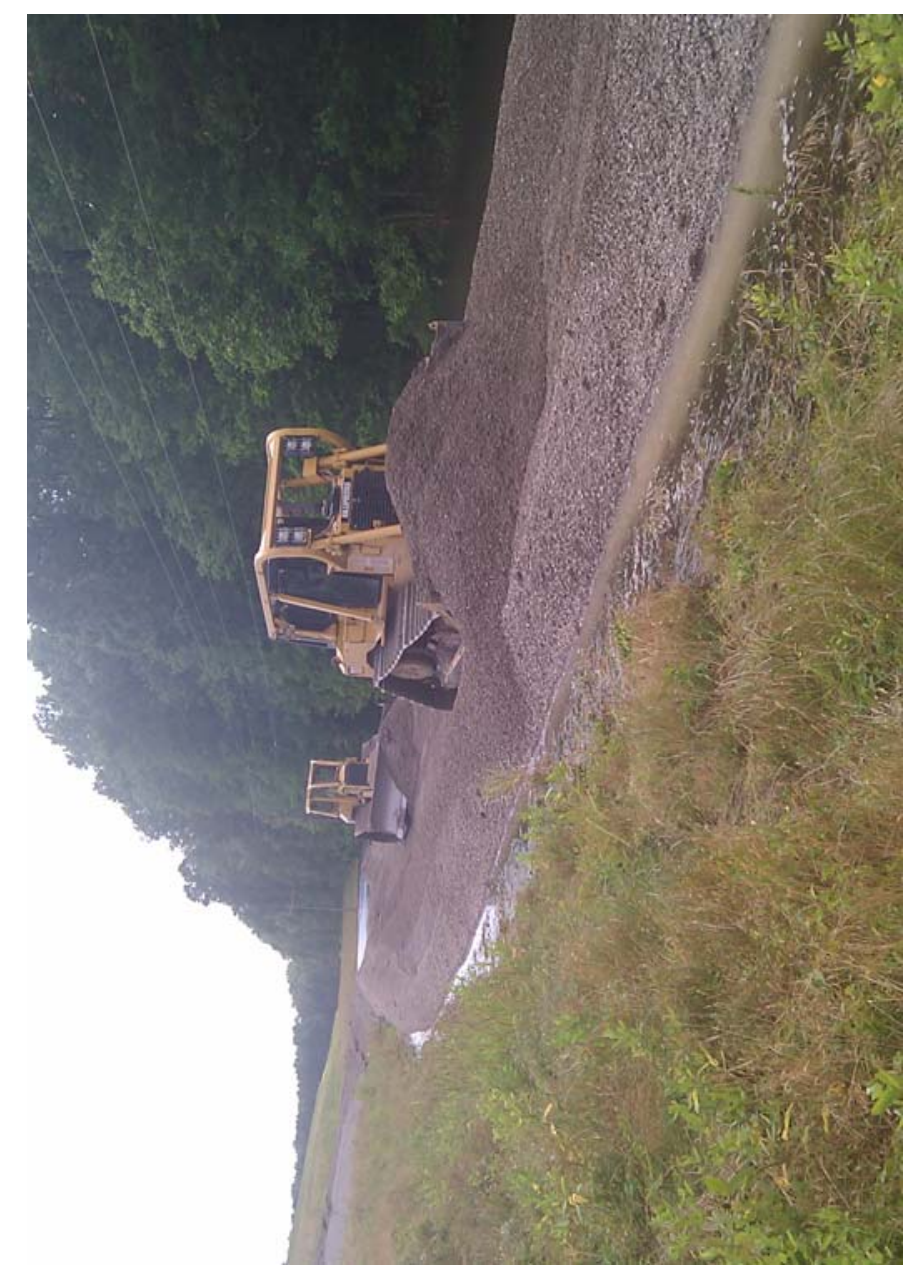

33

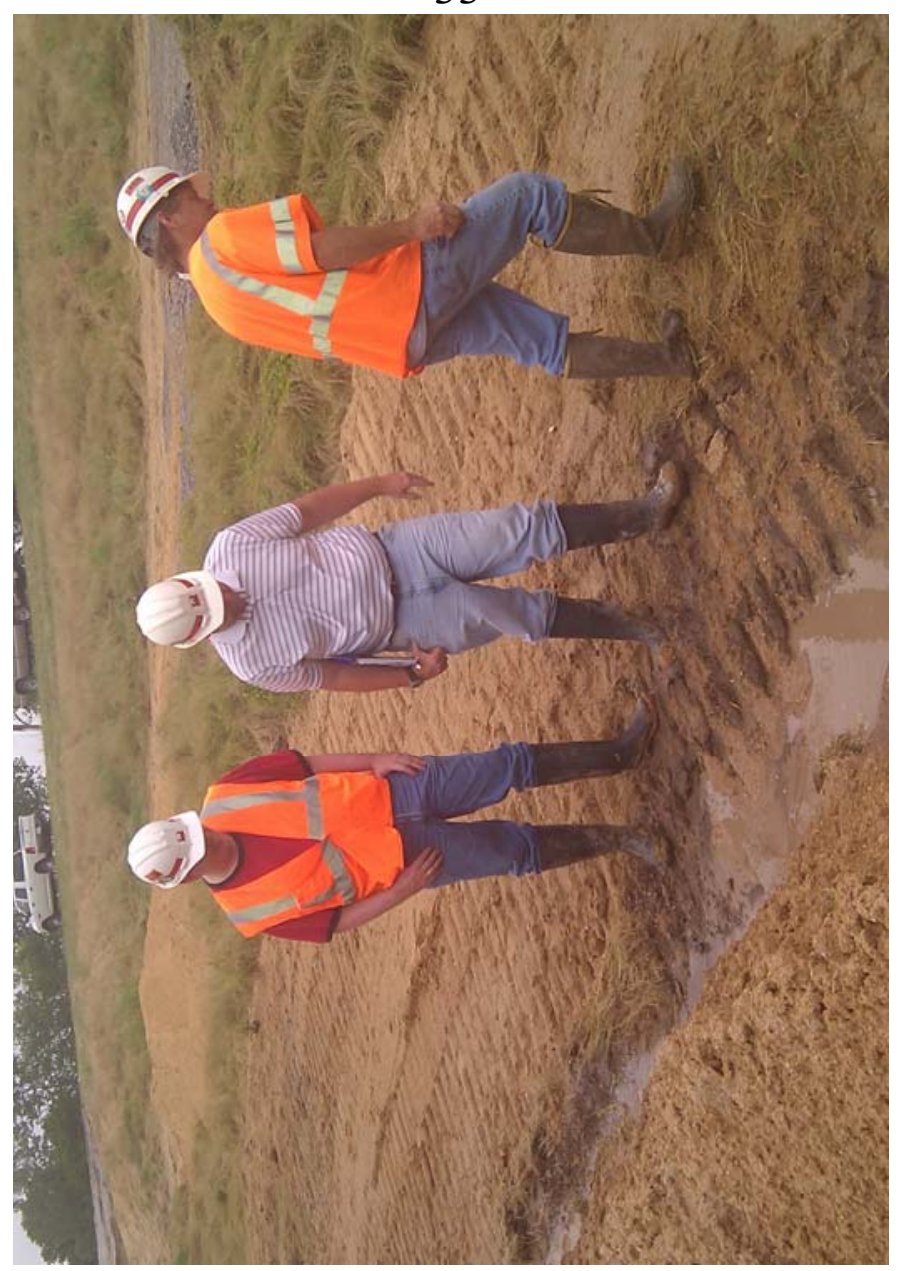

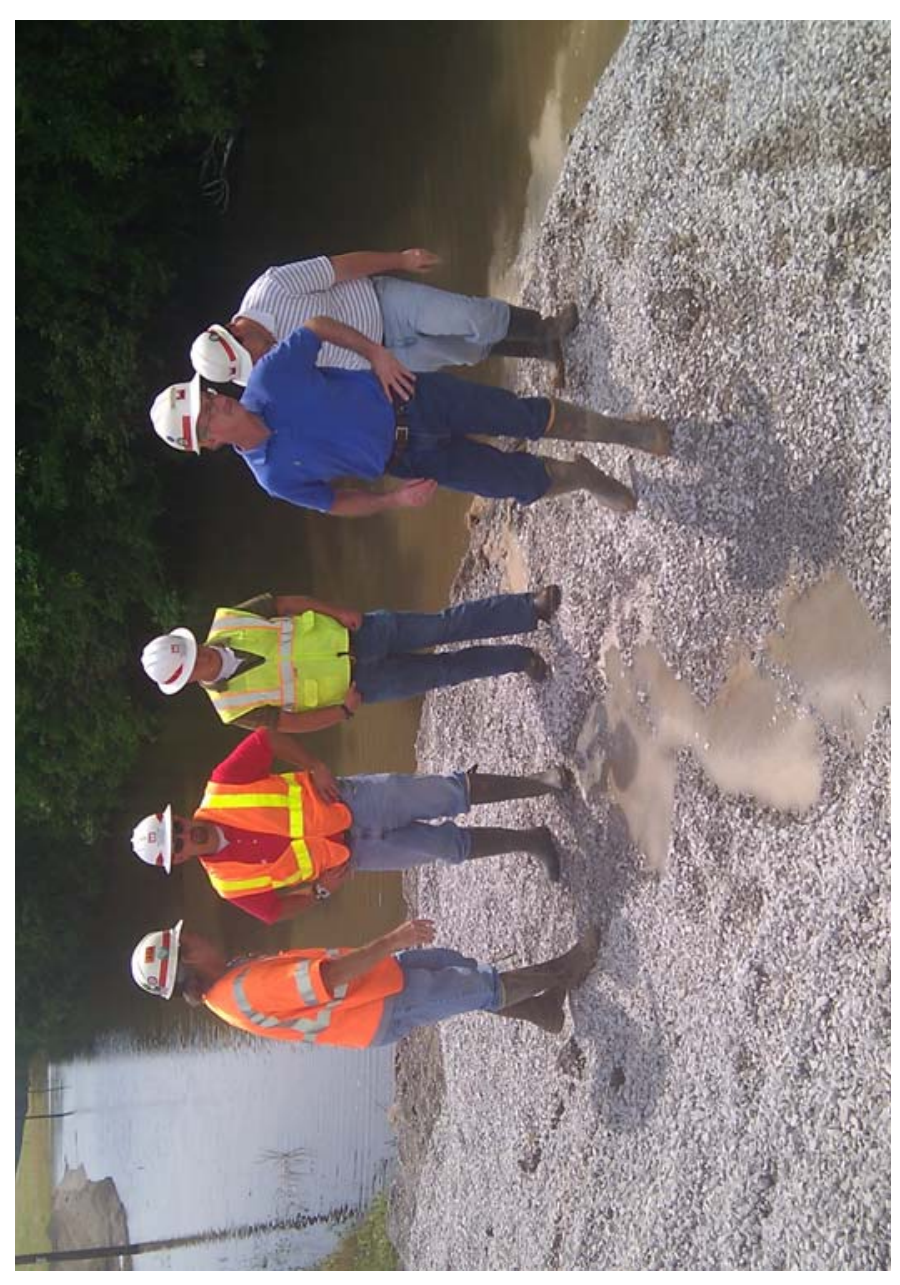

34

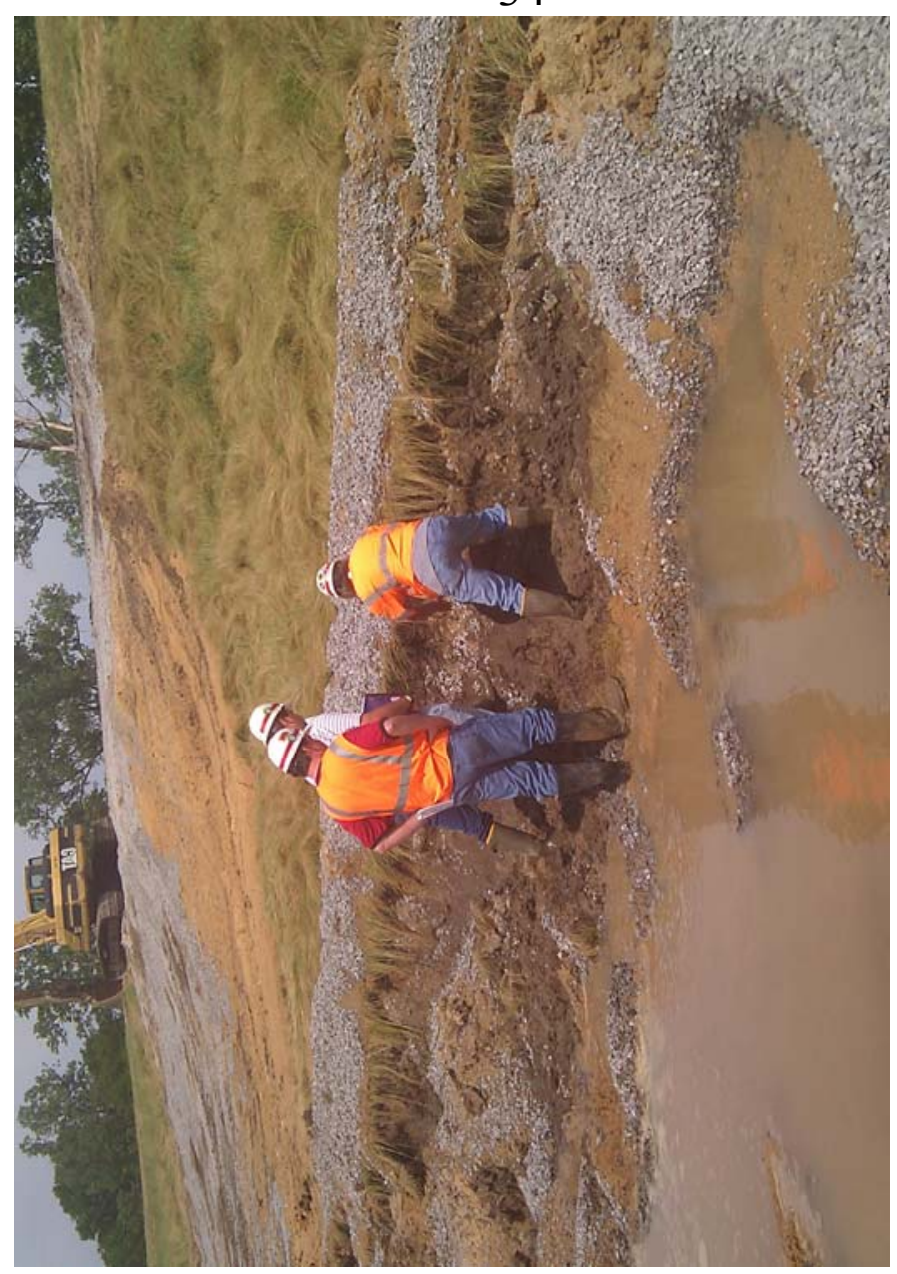




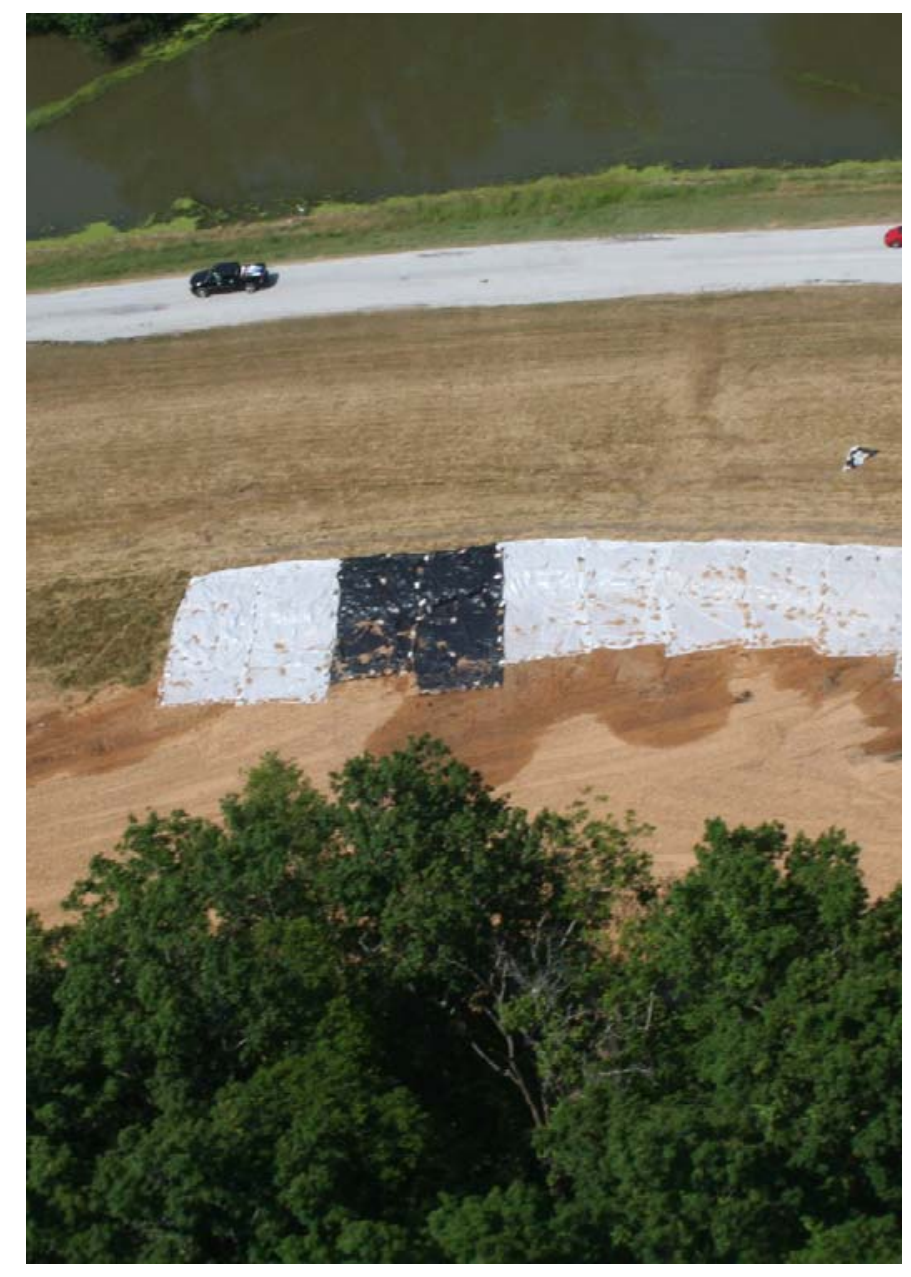

37

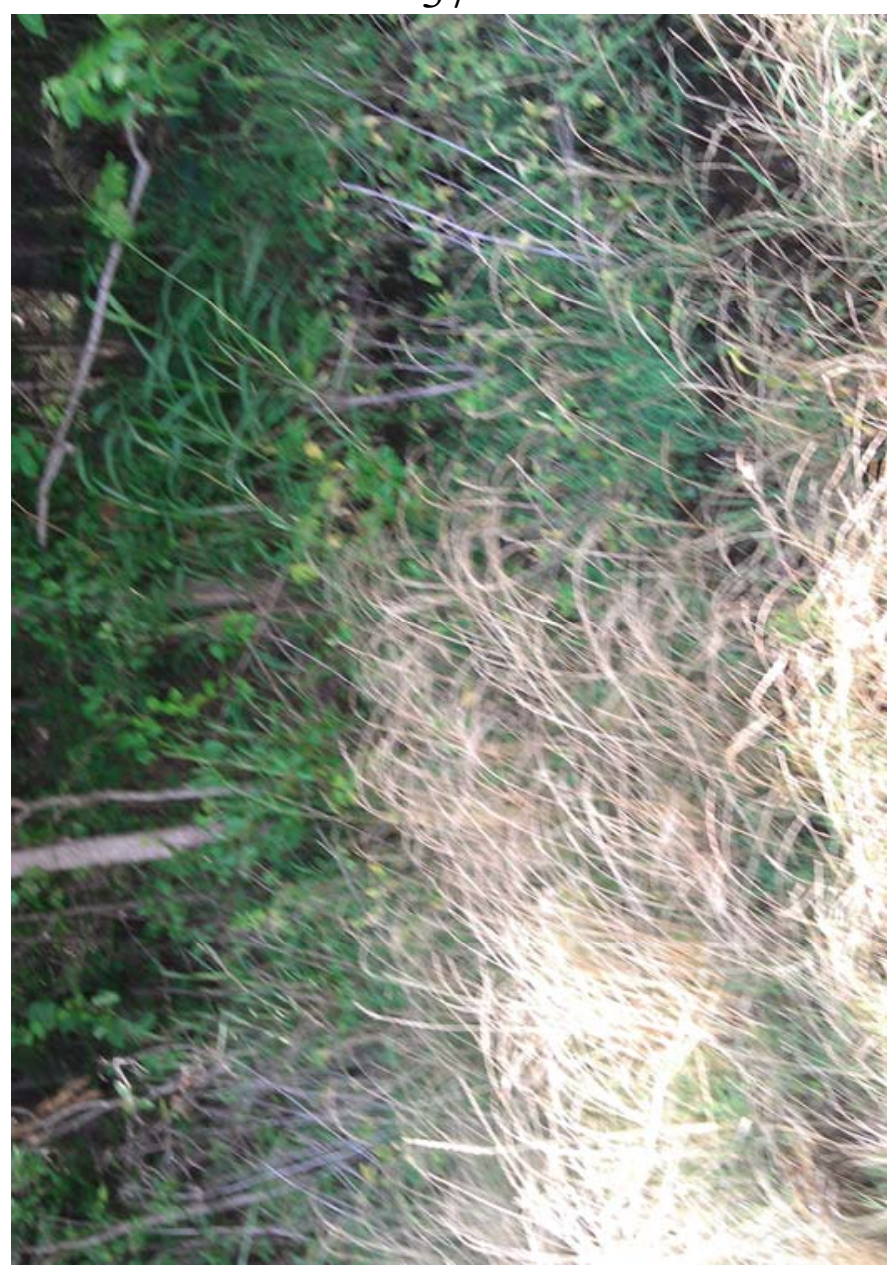

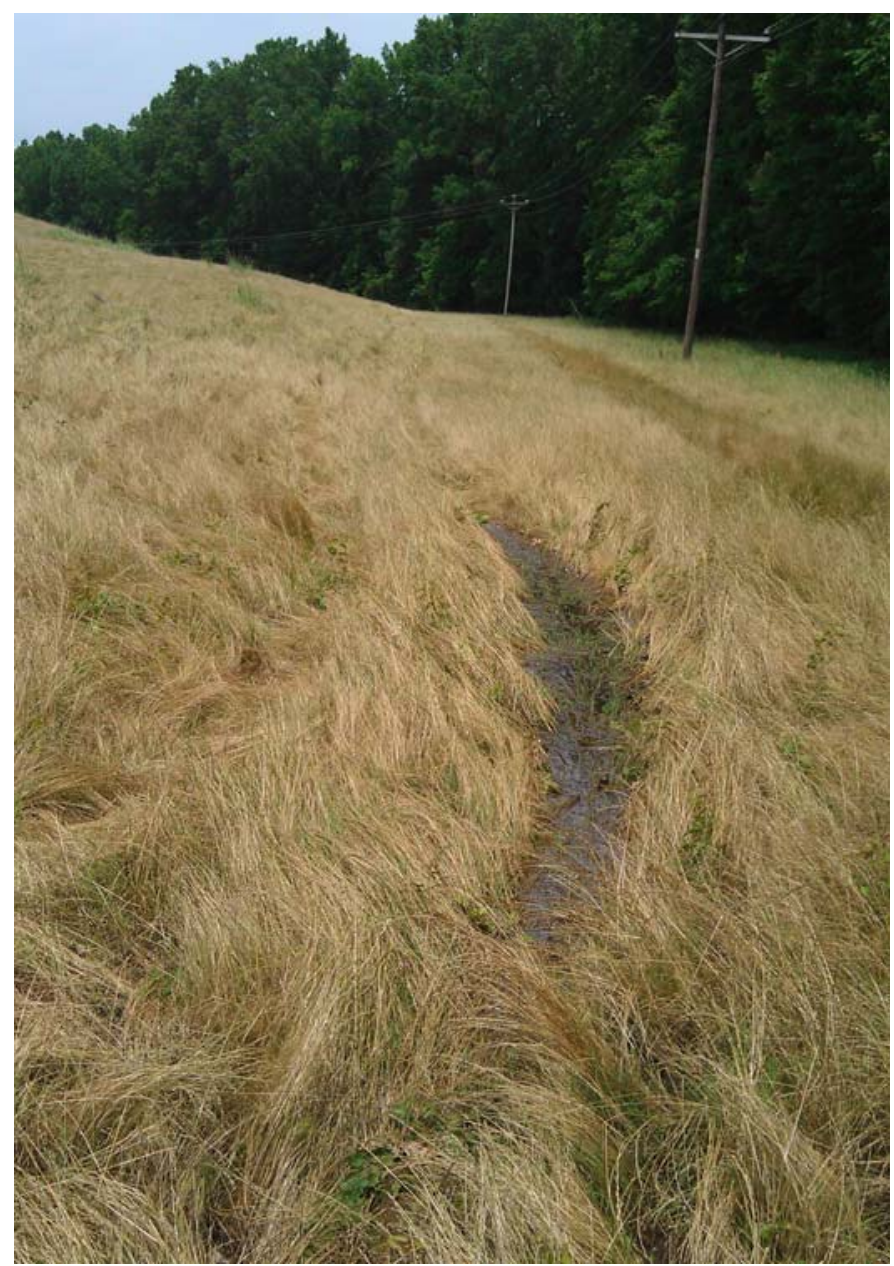

38

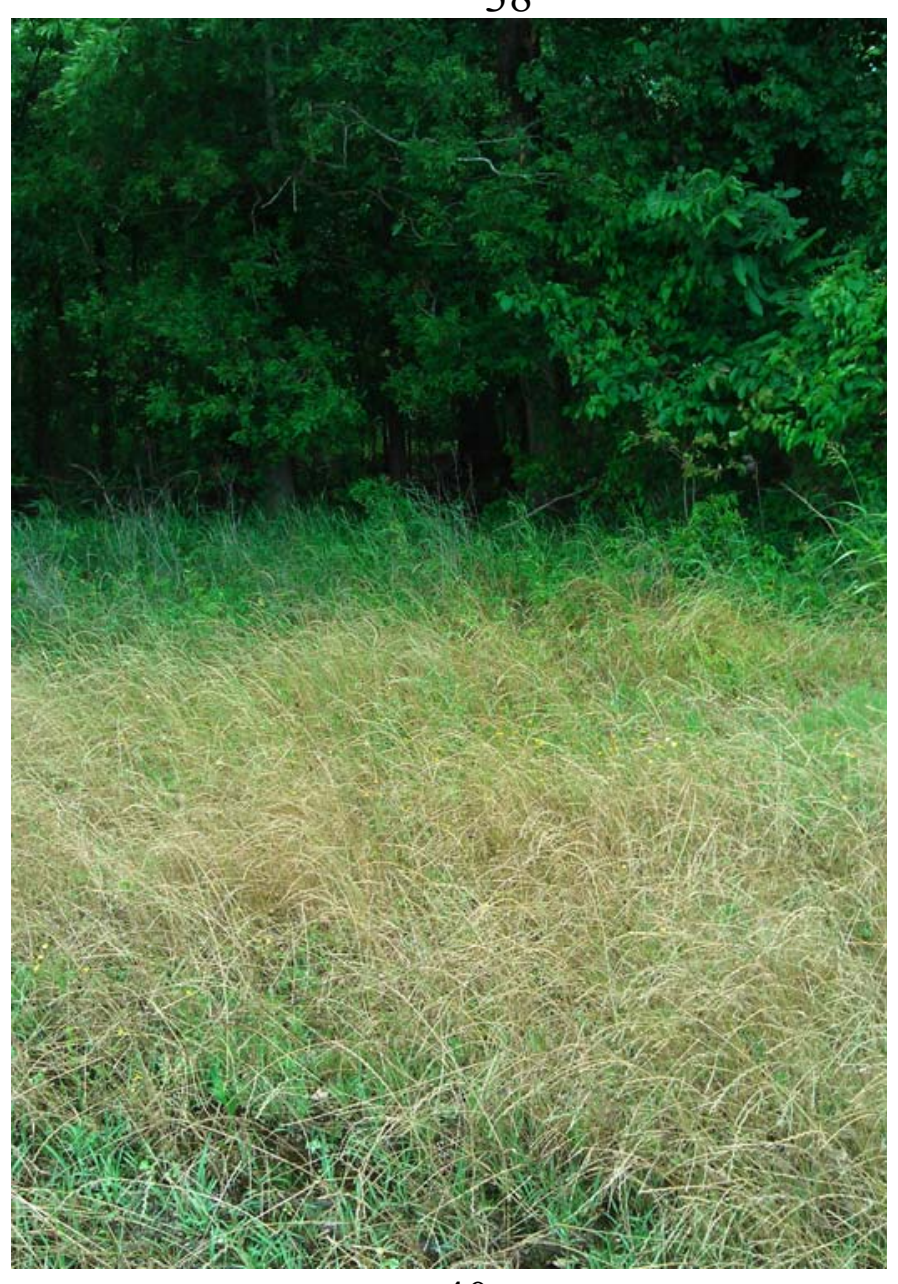




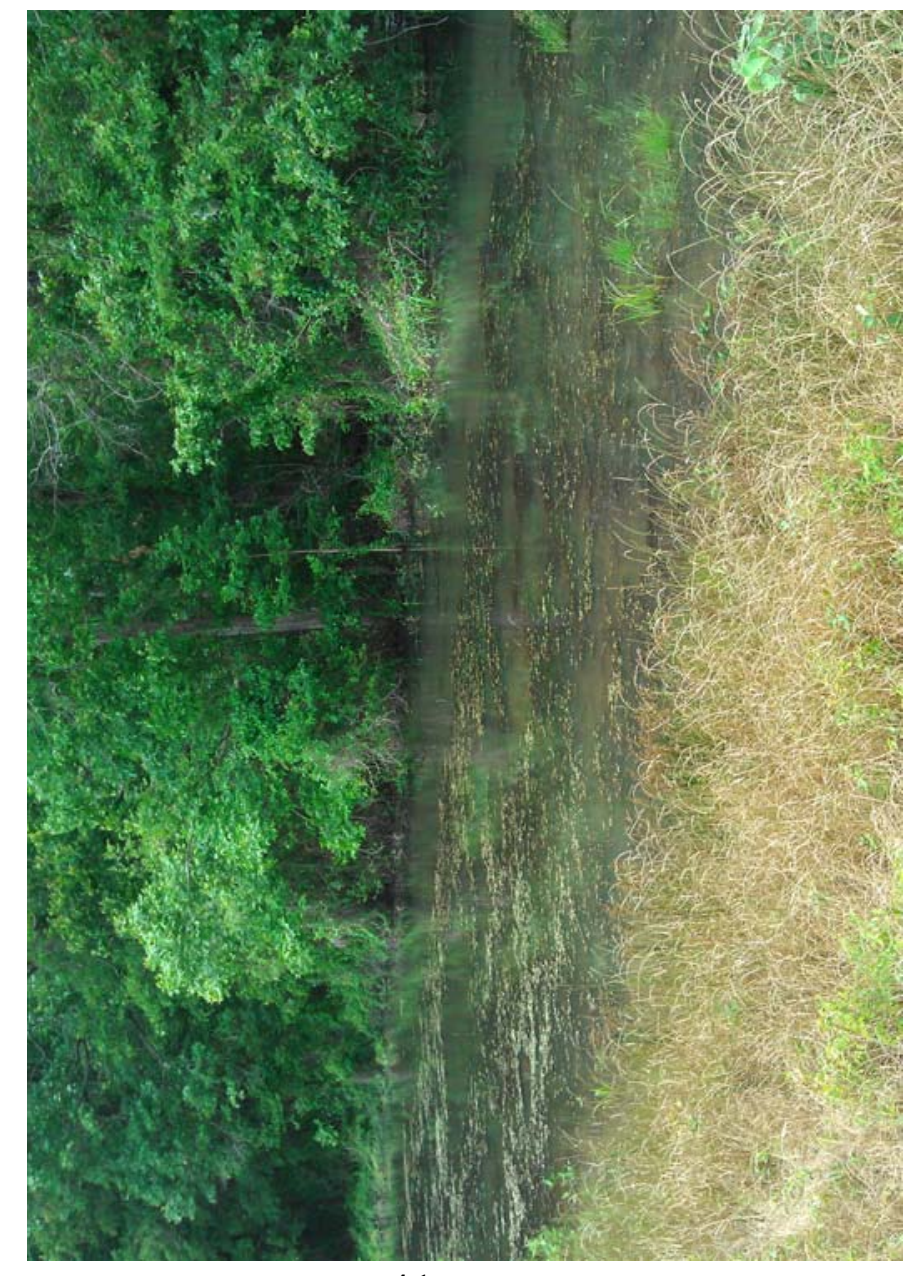

41

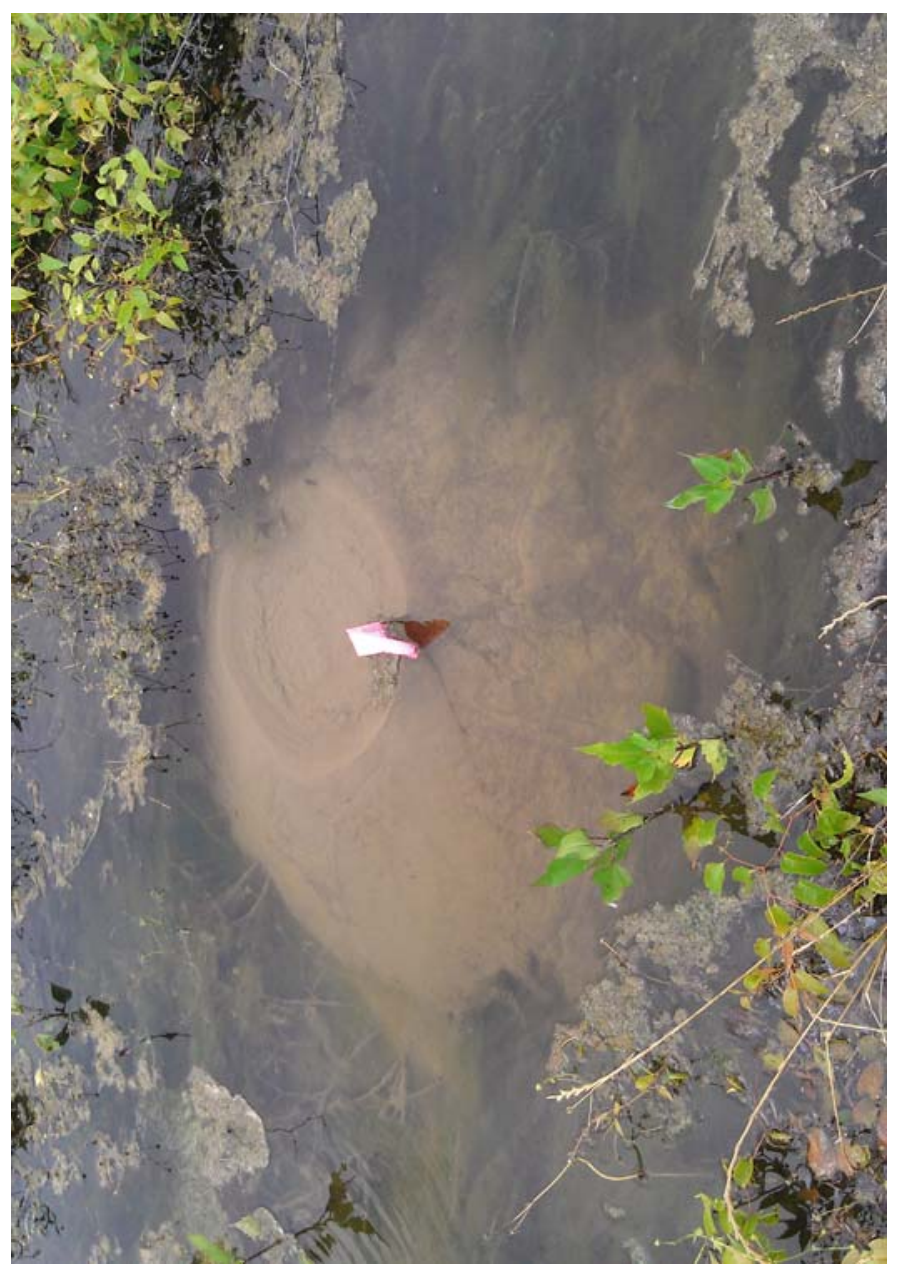

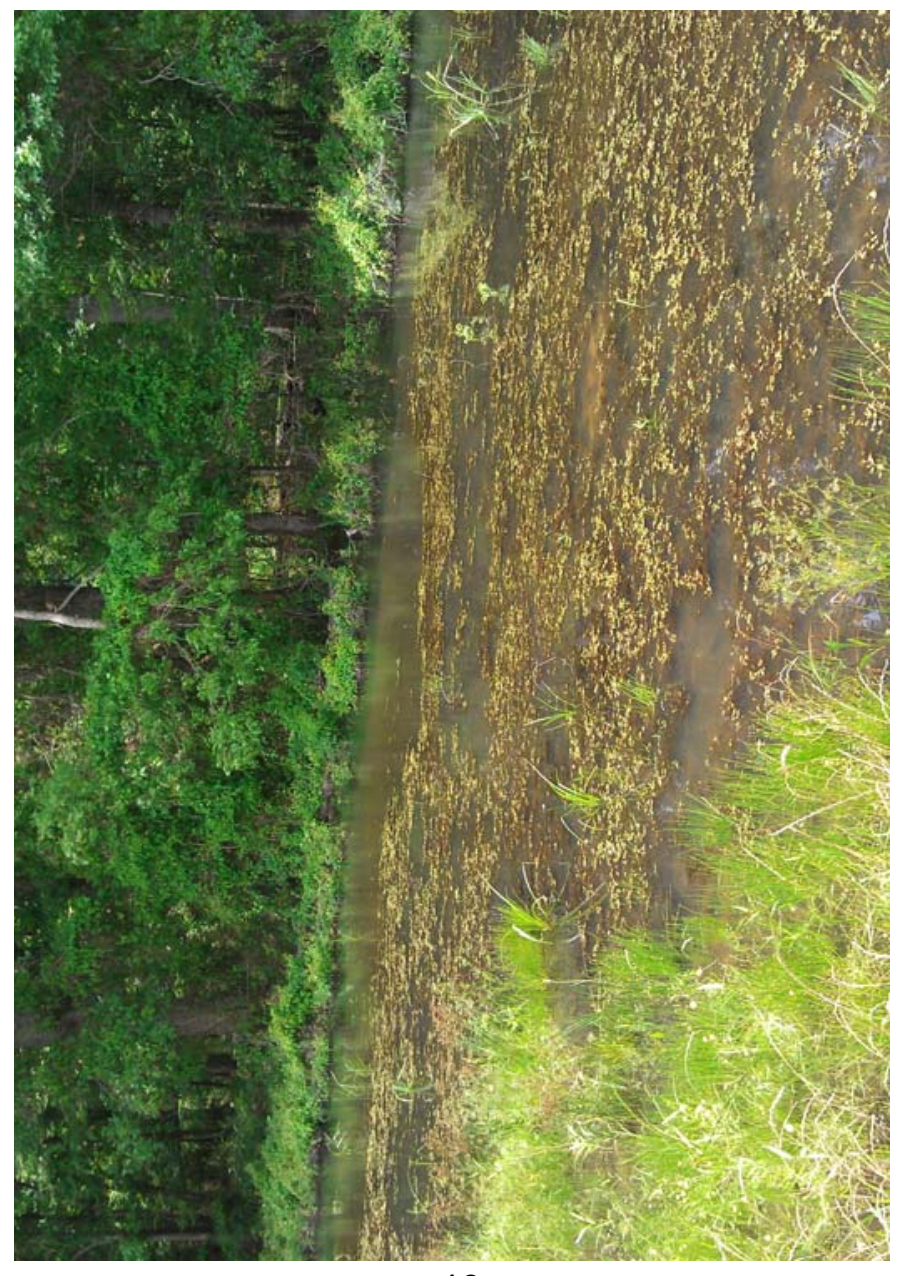

42

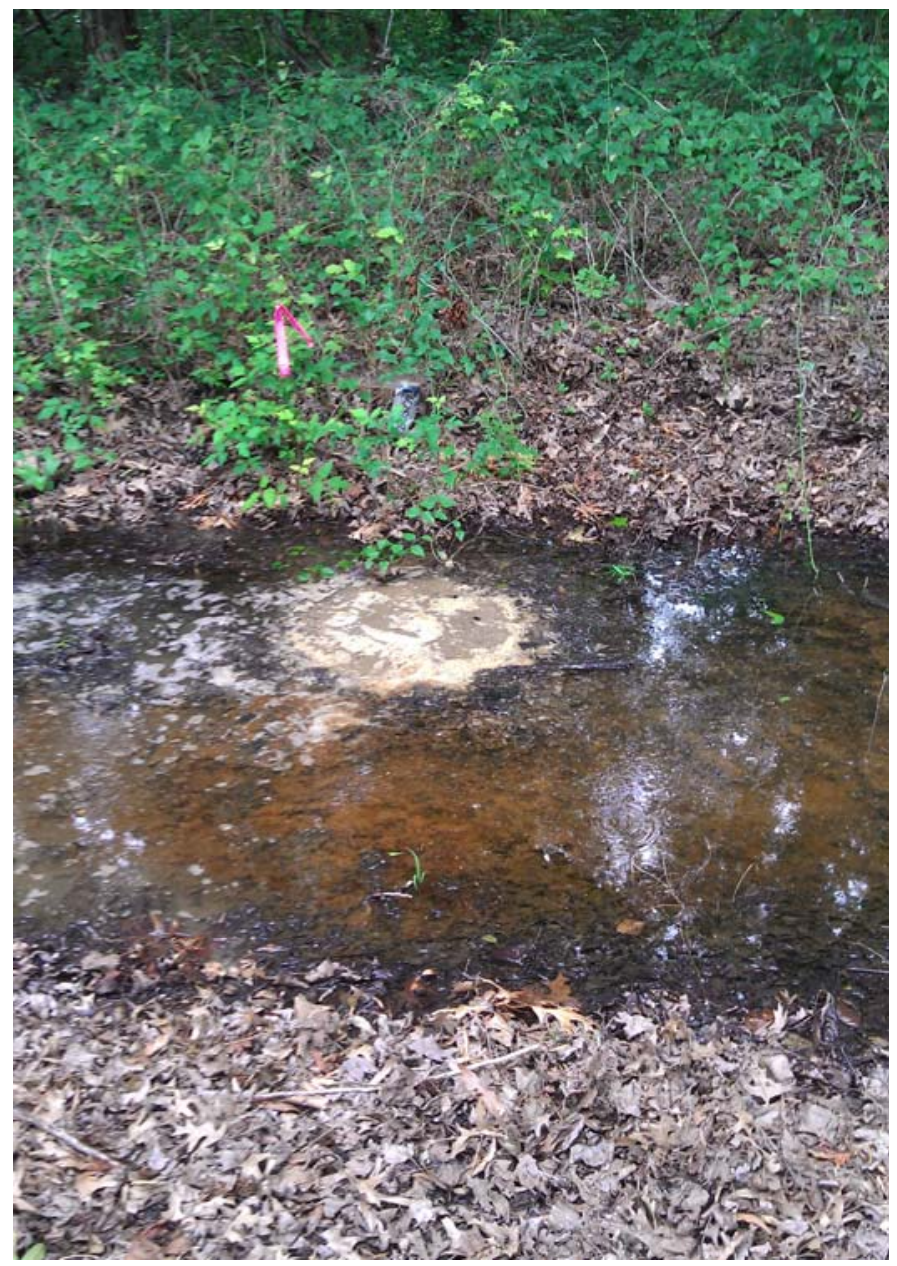

44 


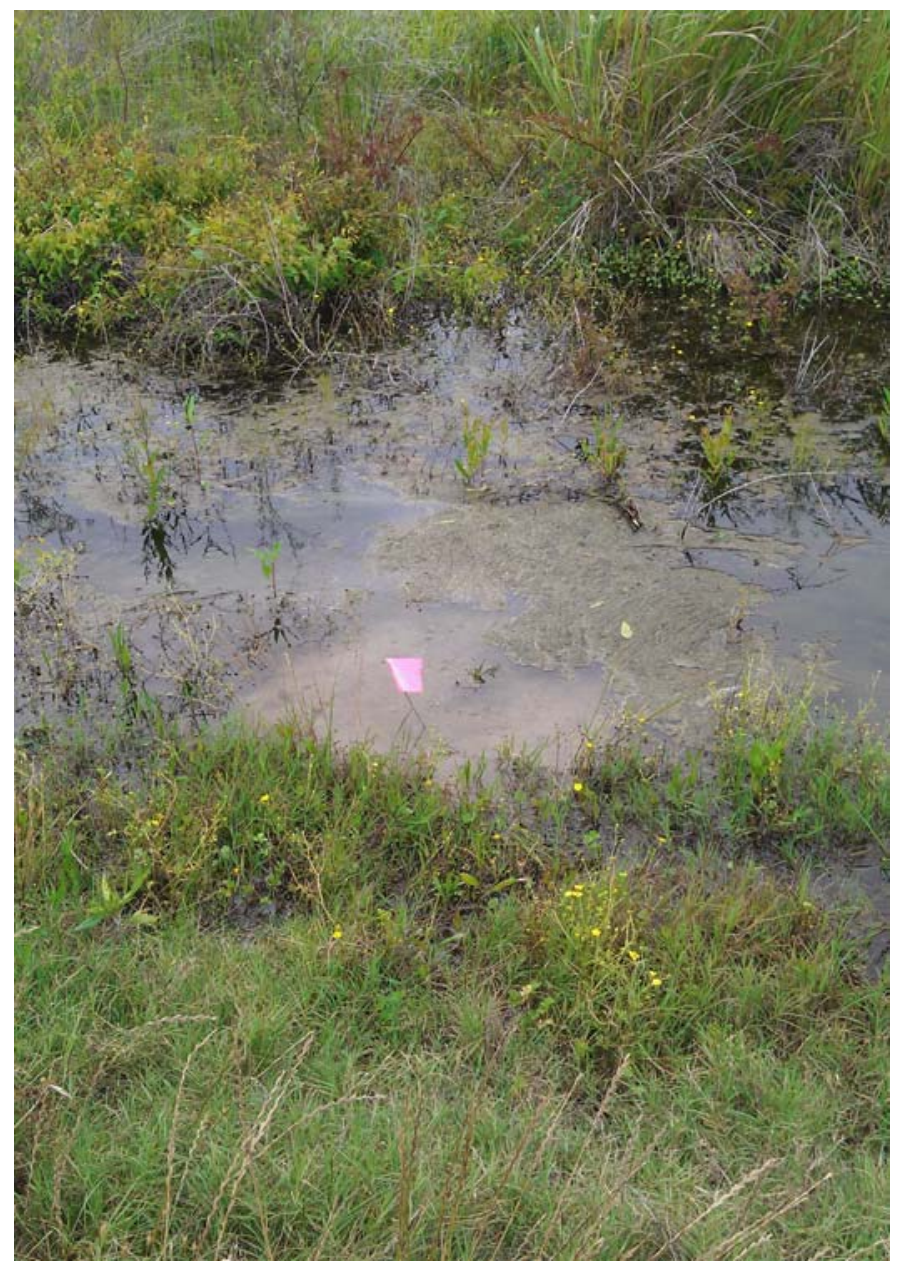

\section{5}

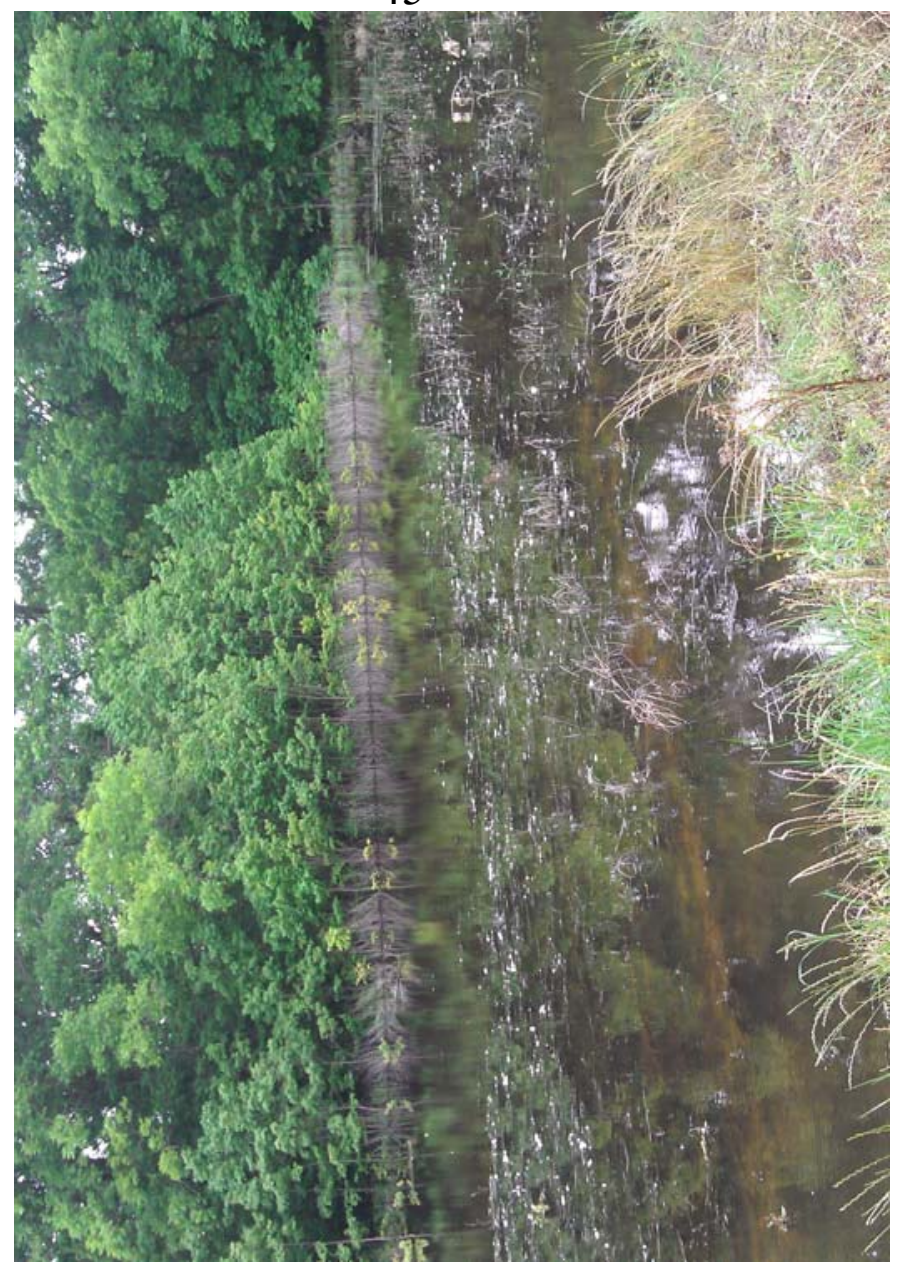

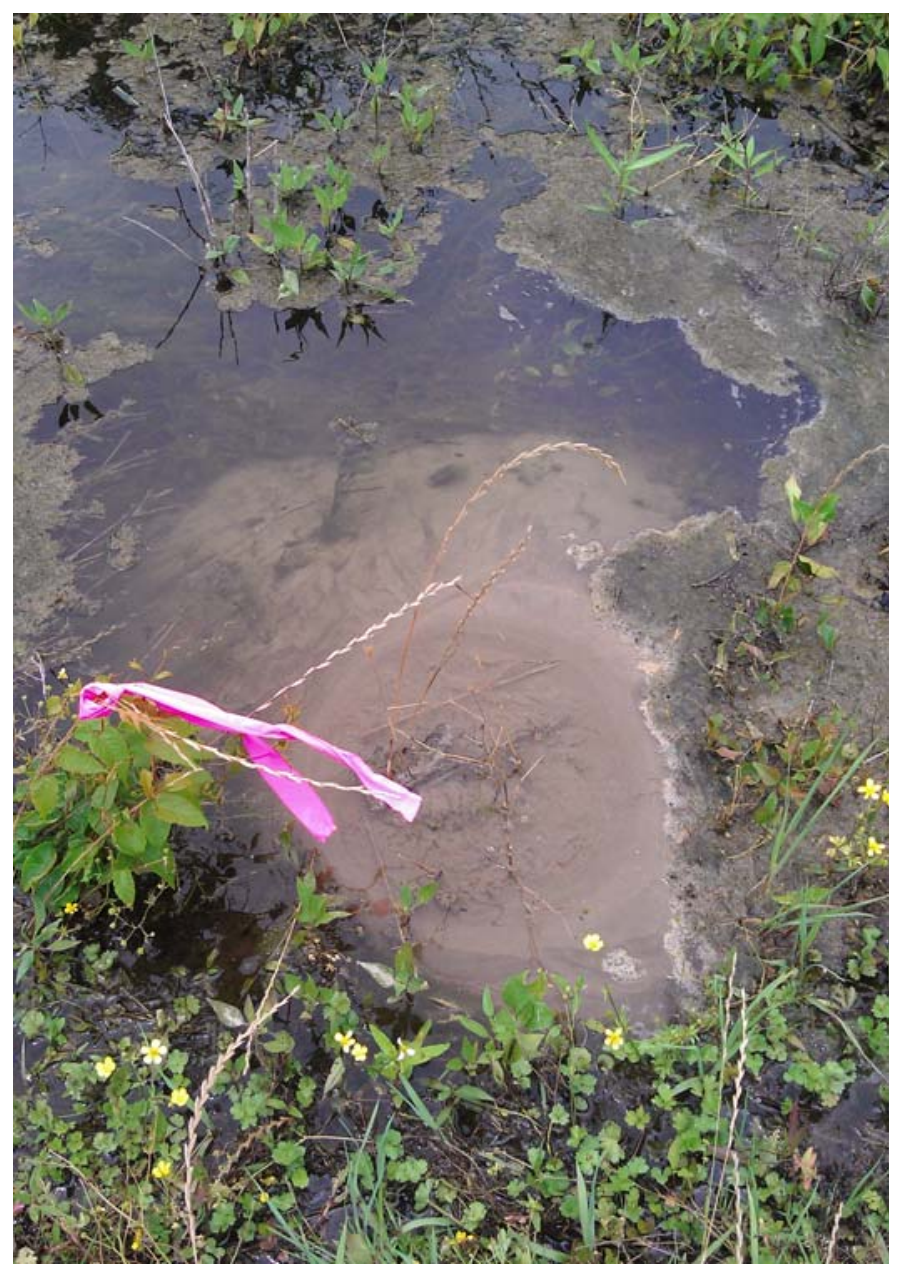

46

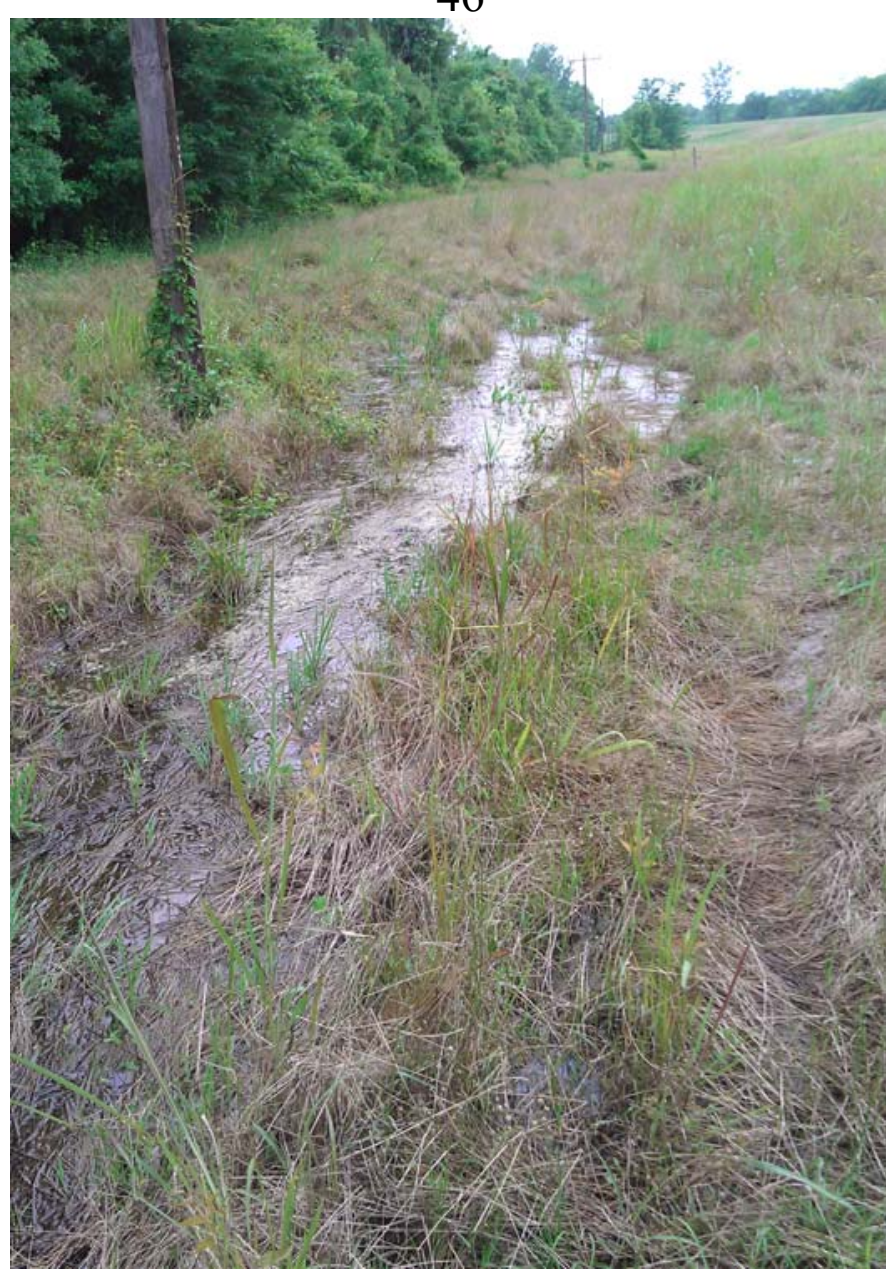




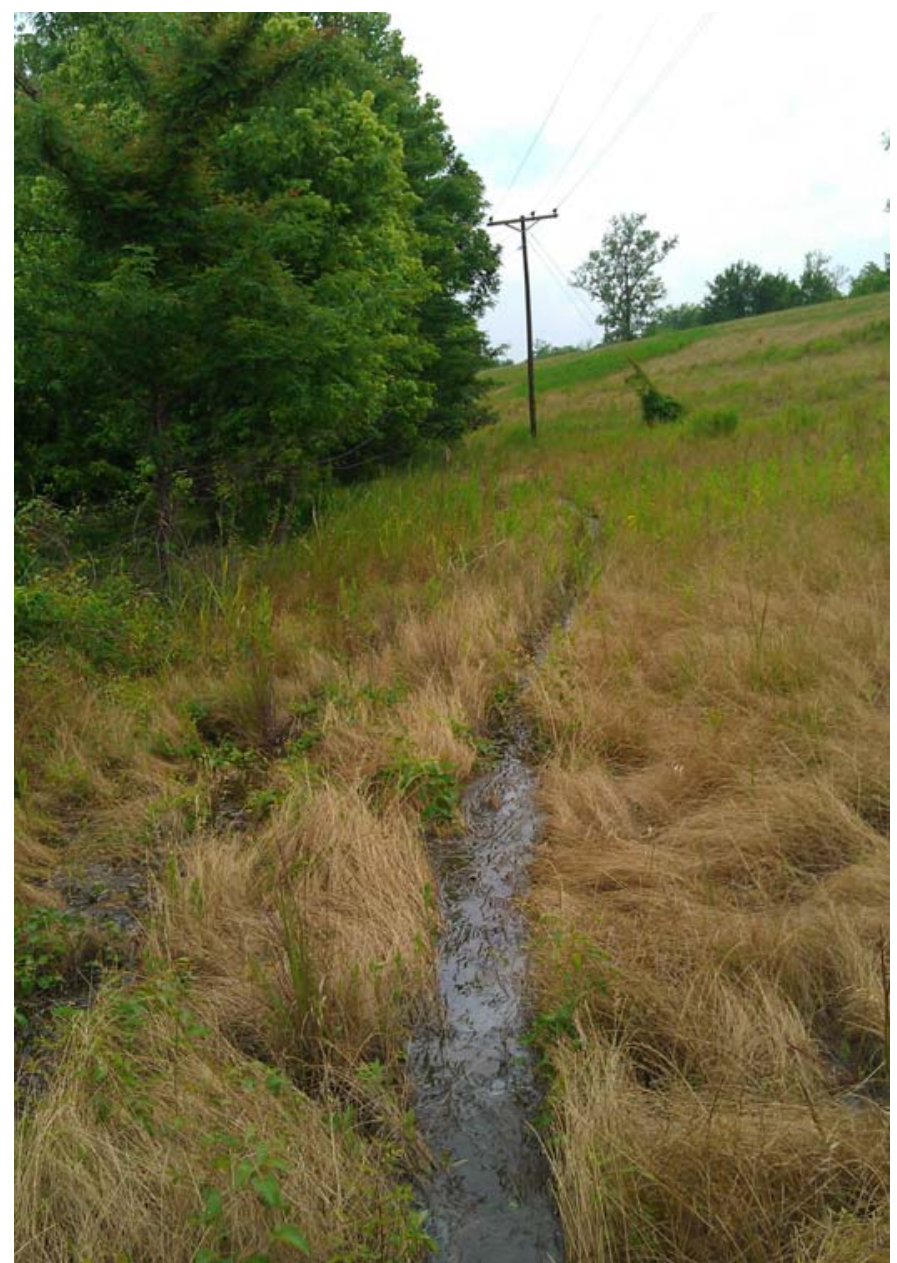

\section{9}

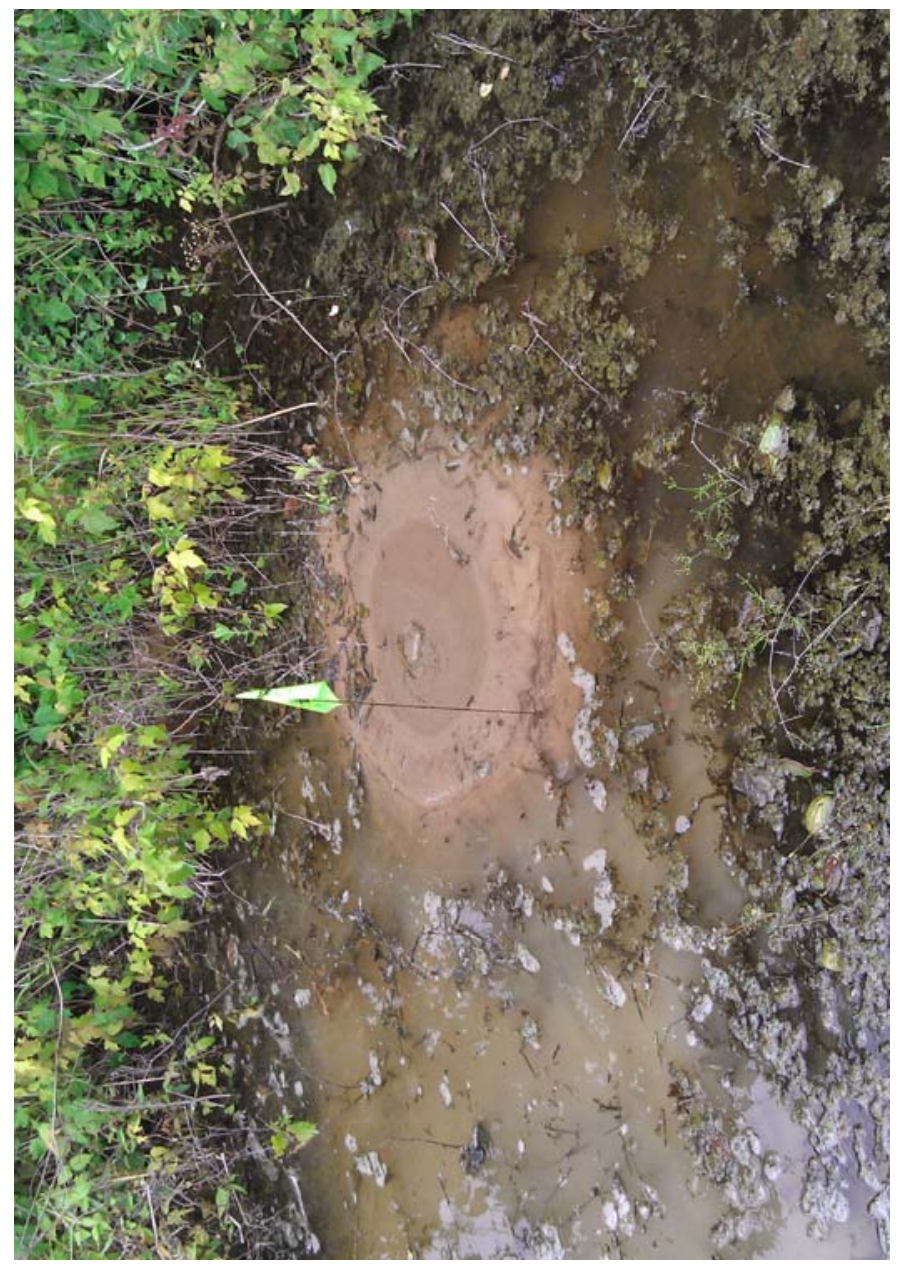

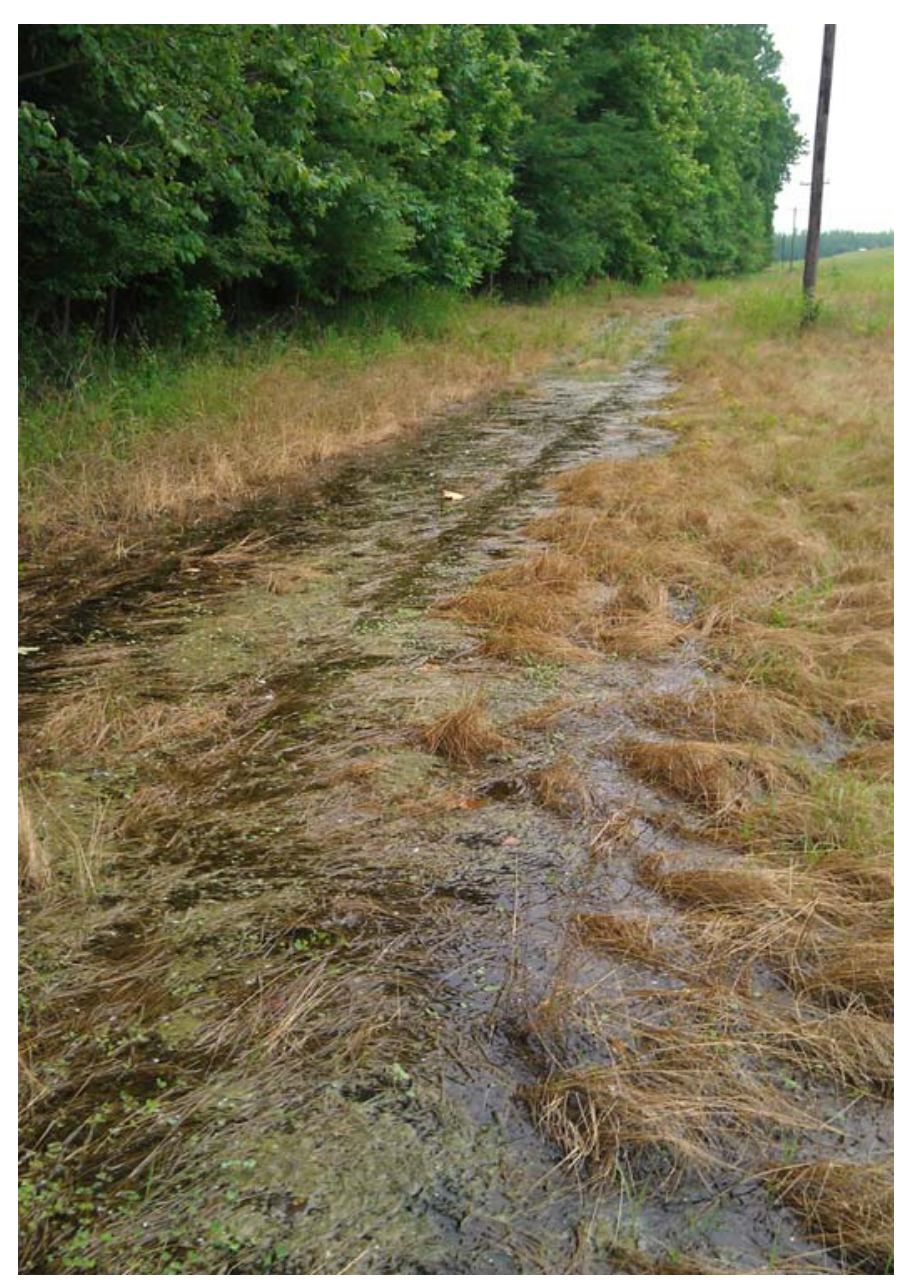

50
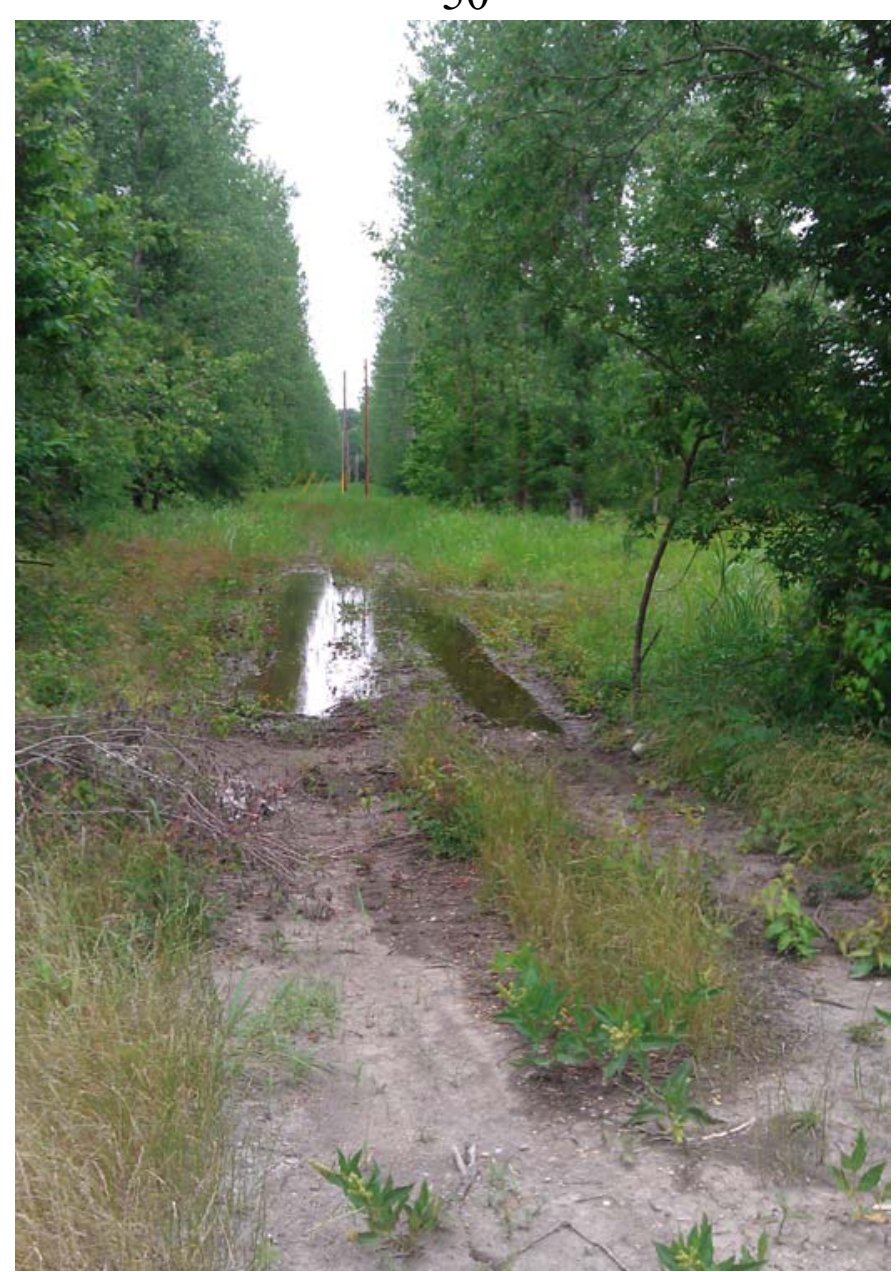


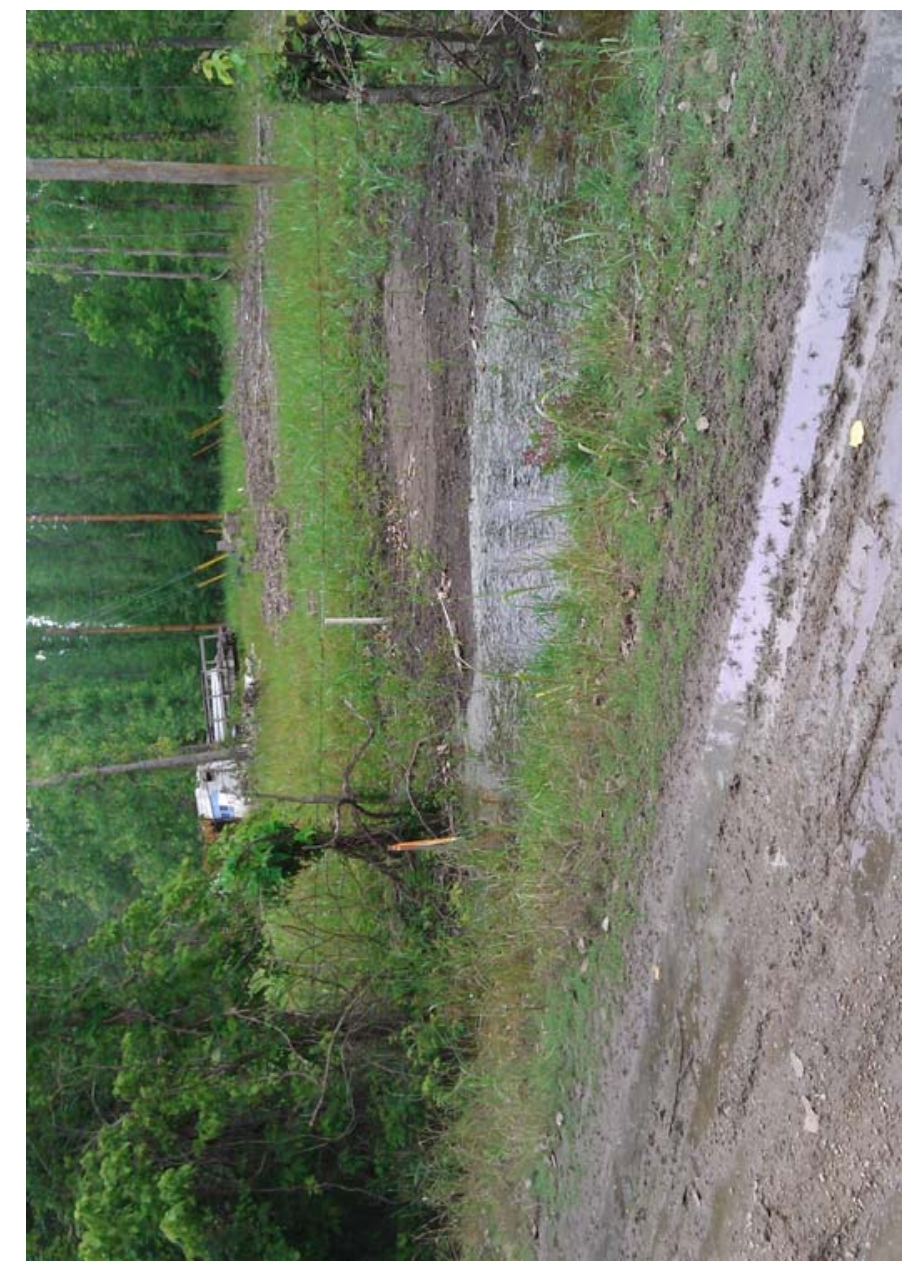

53

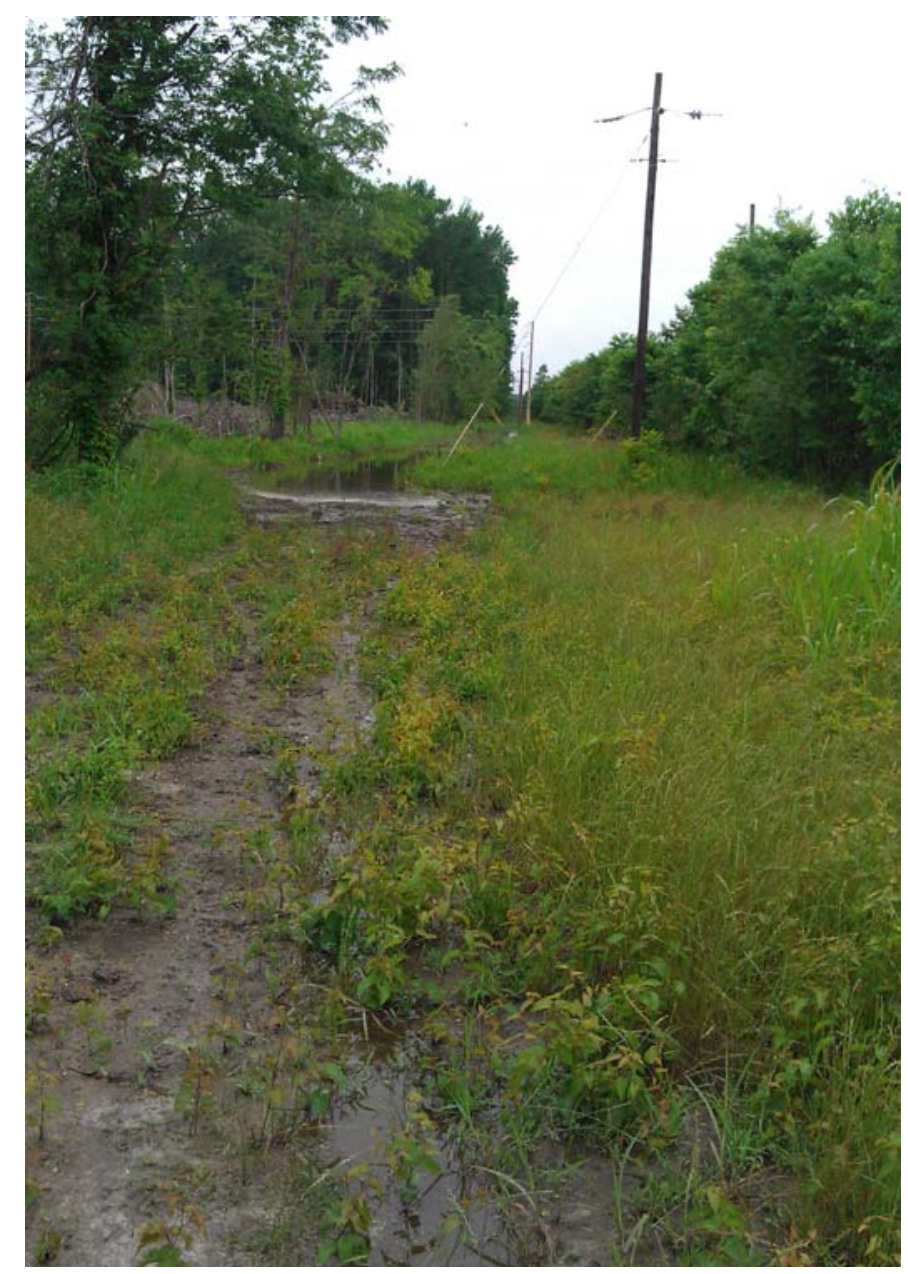

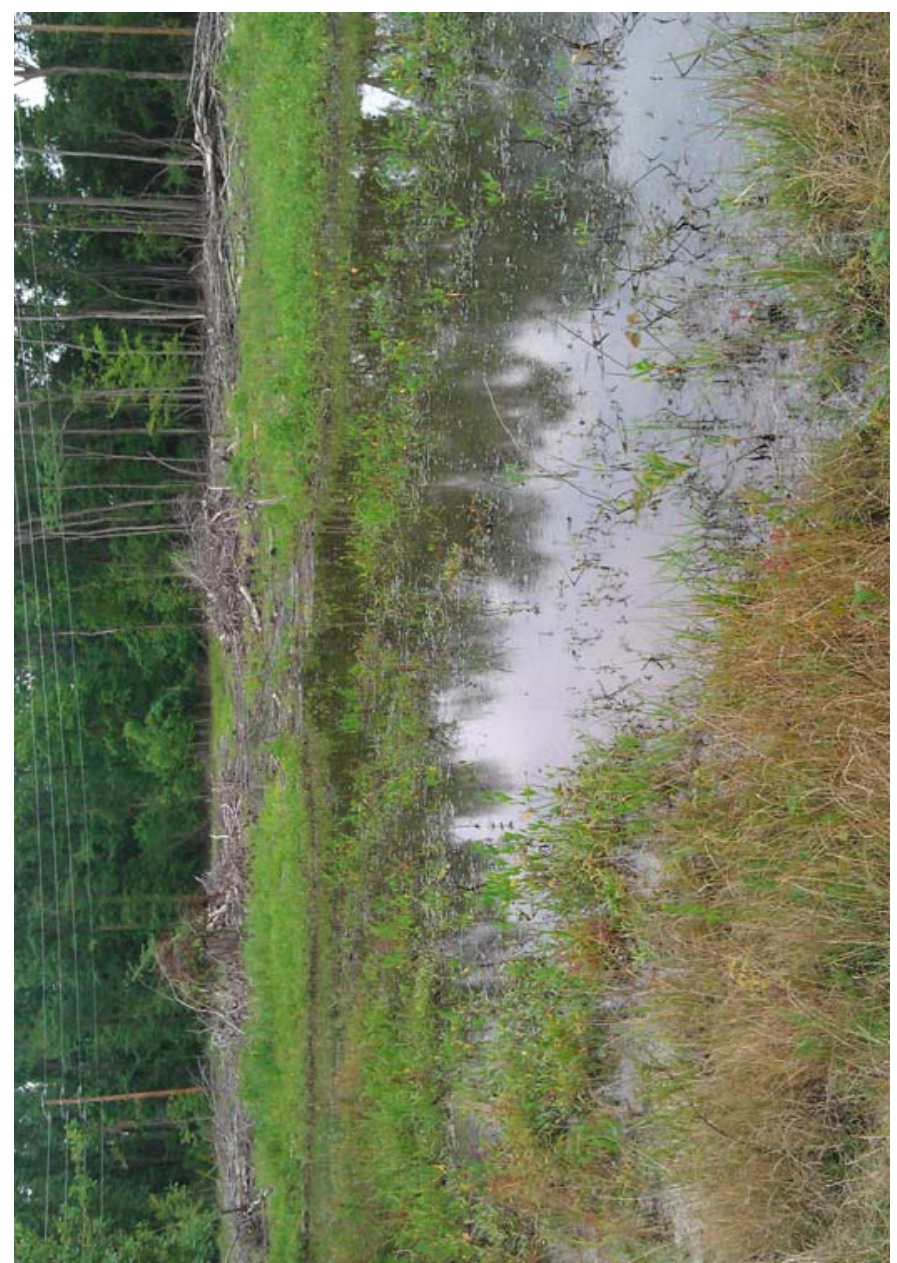

54

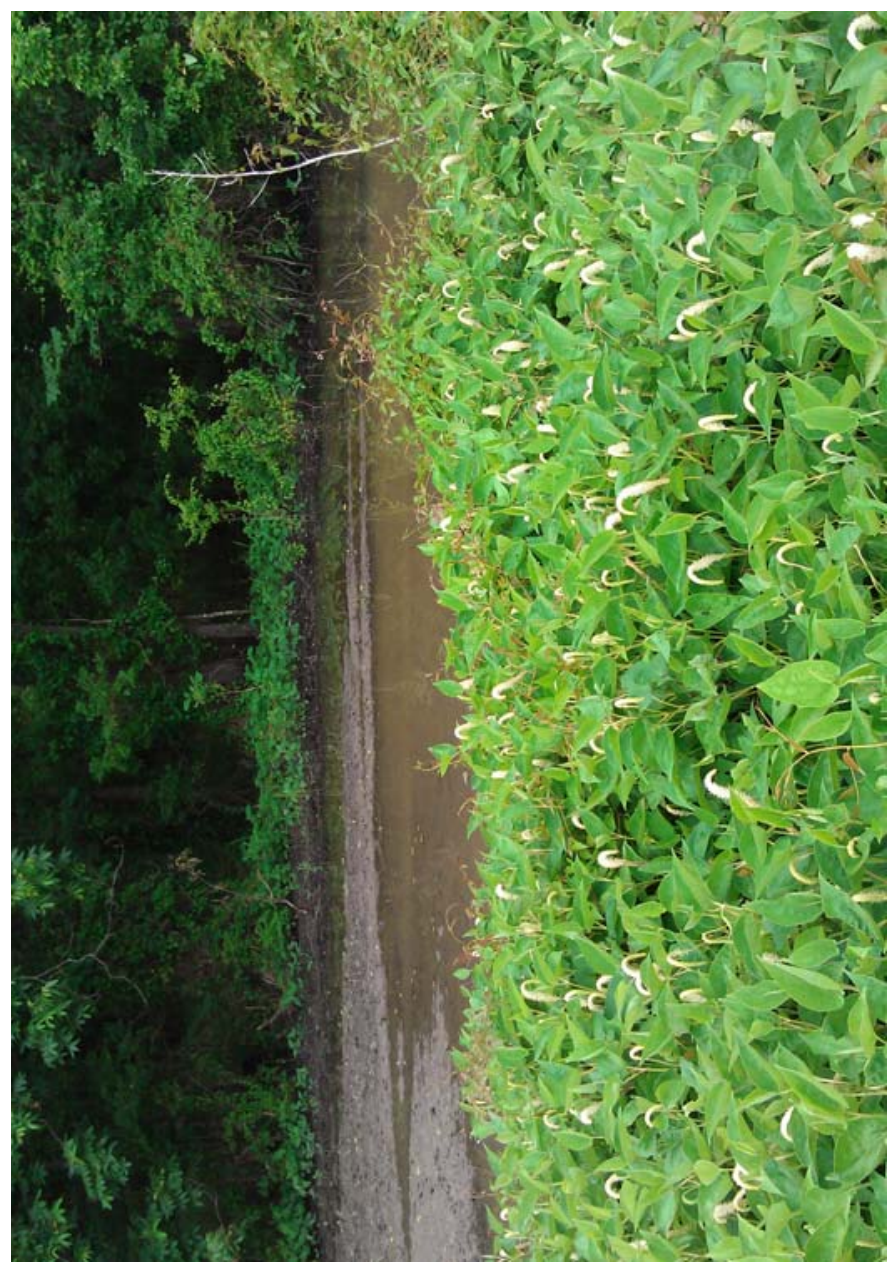




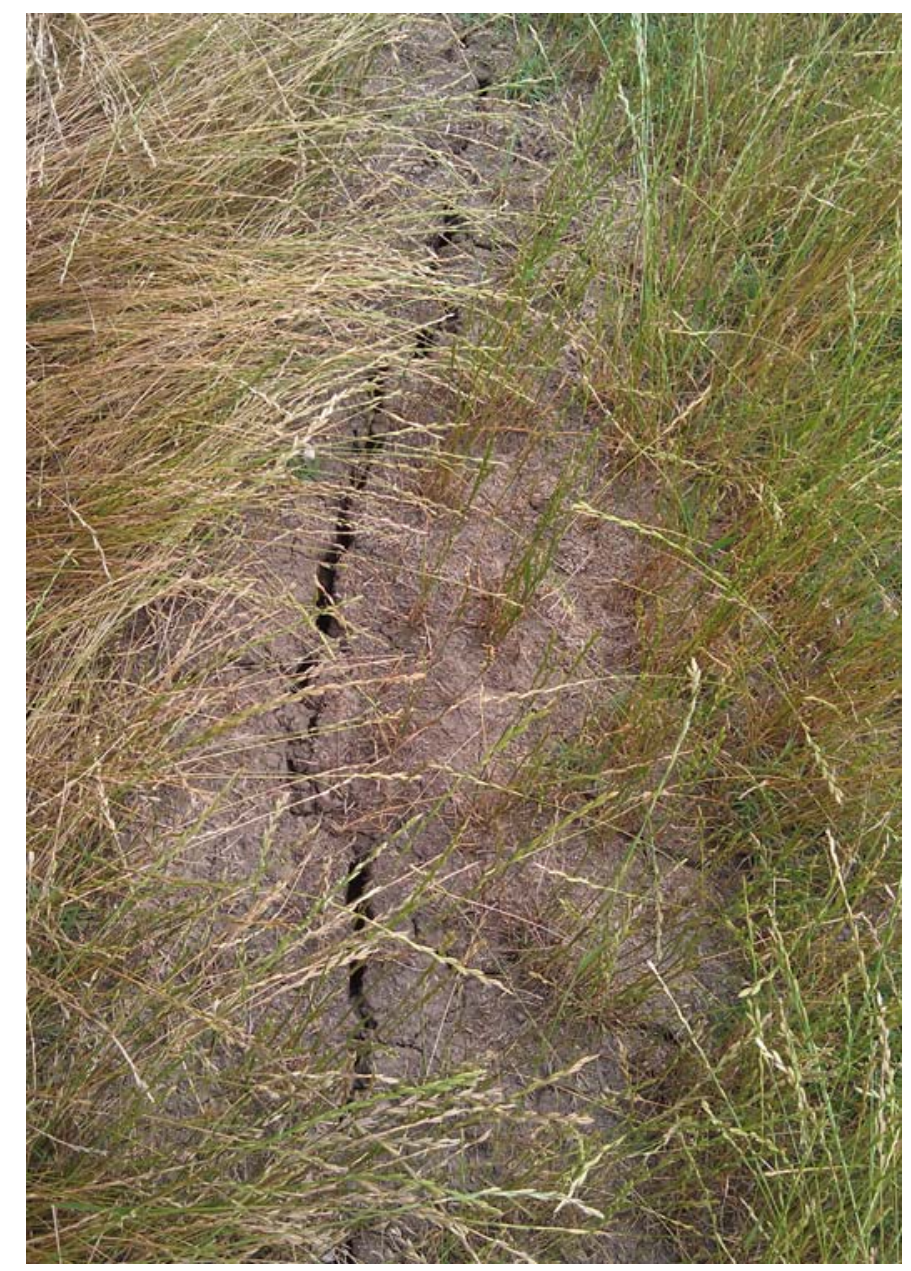

57

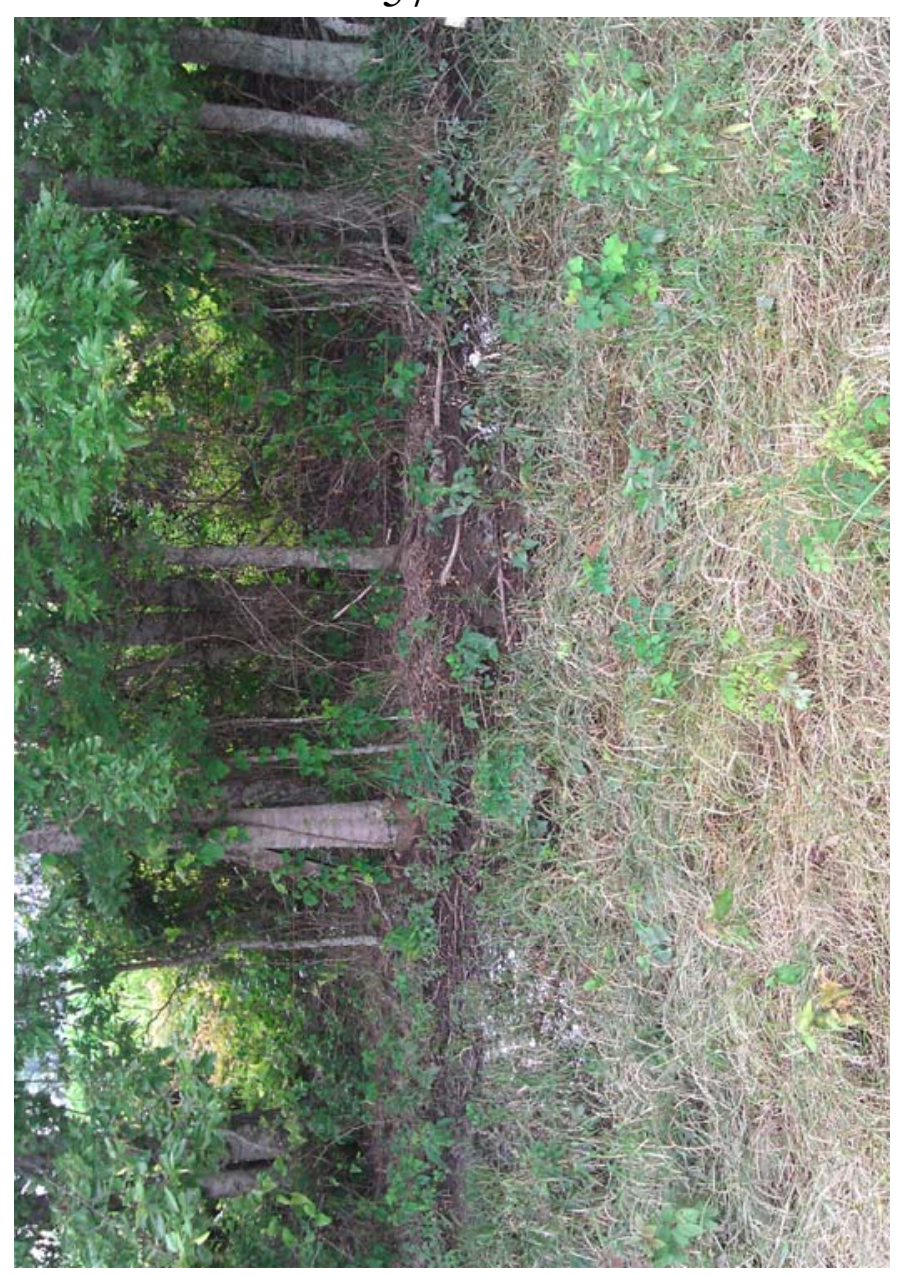

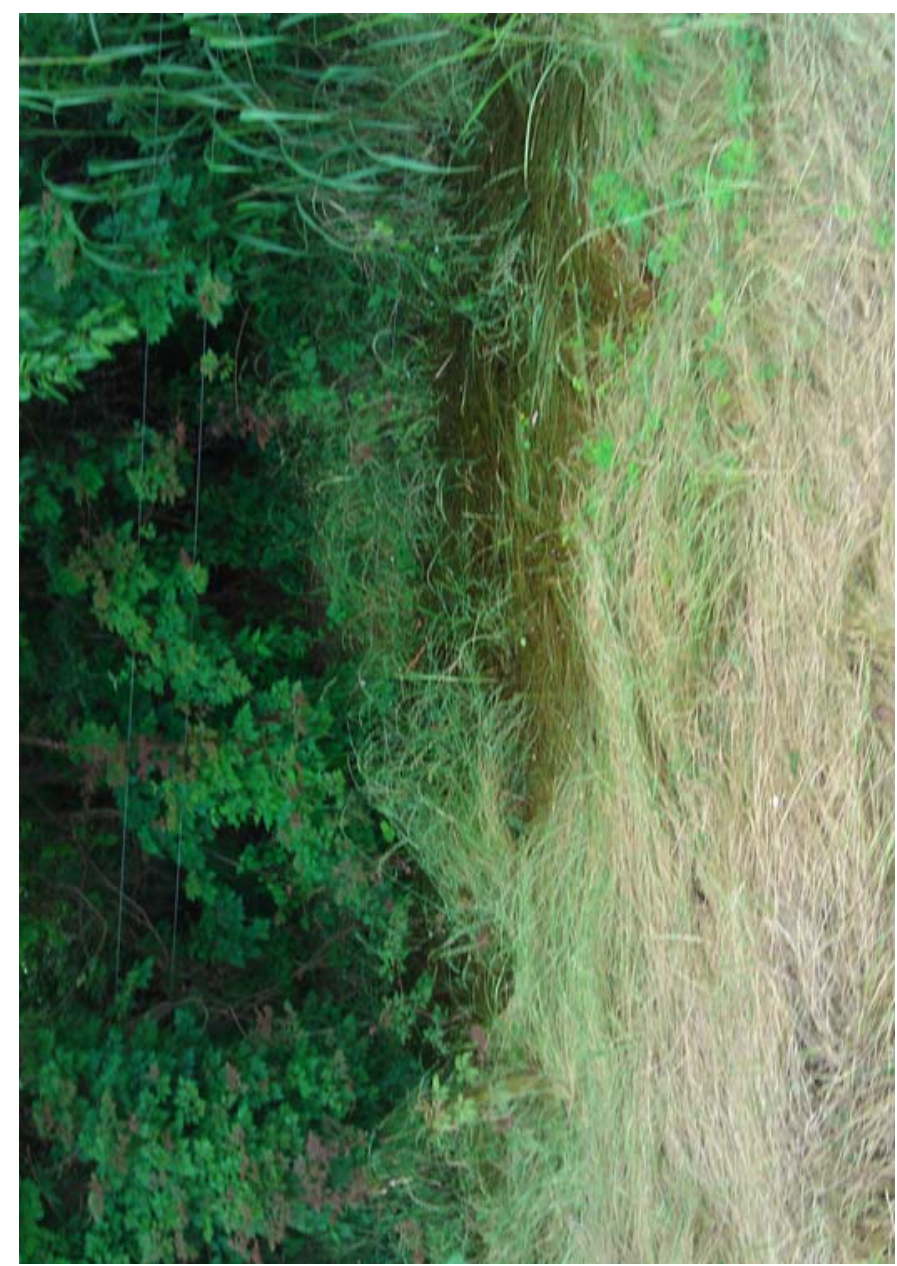

58

308

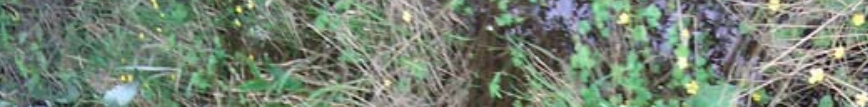

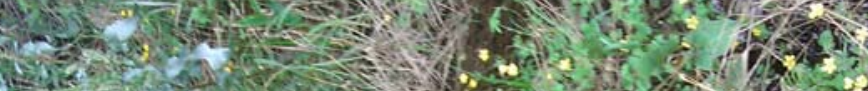

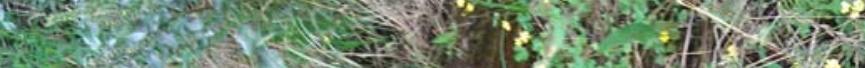

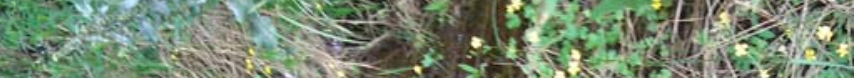
S.1

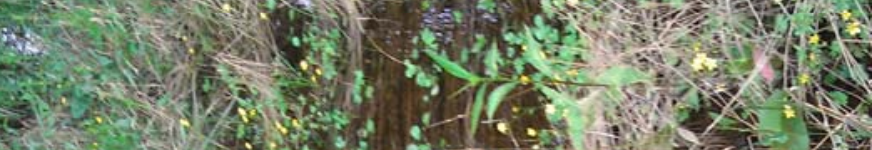

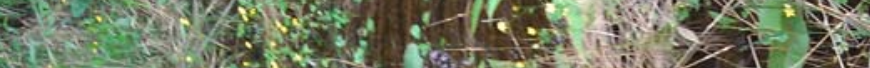

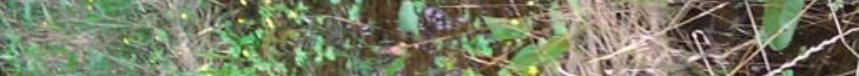
4 (n)

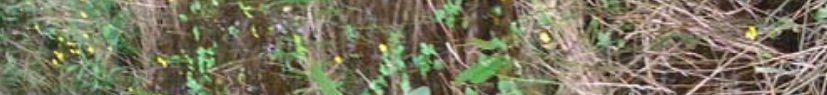

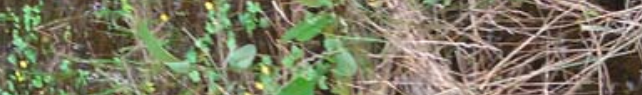

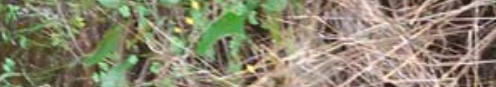
तn

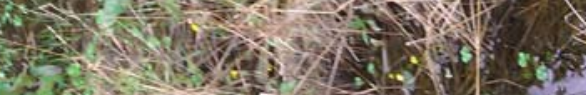

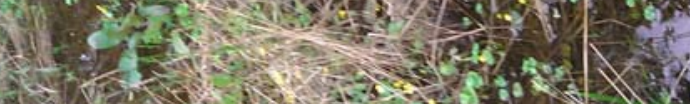

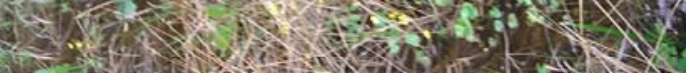
(5)

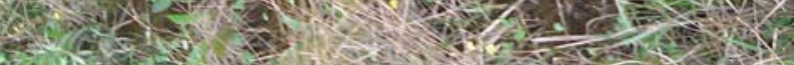

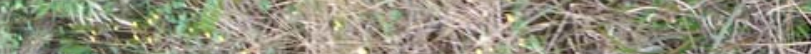

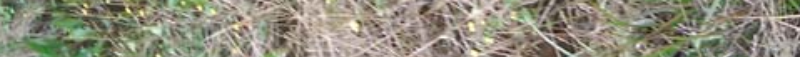

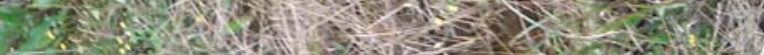

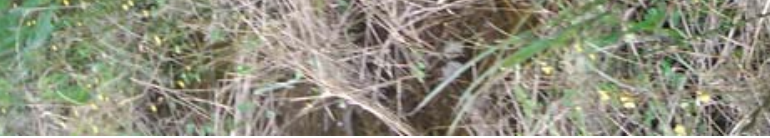
60 


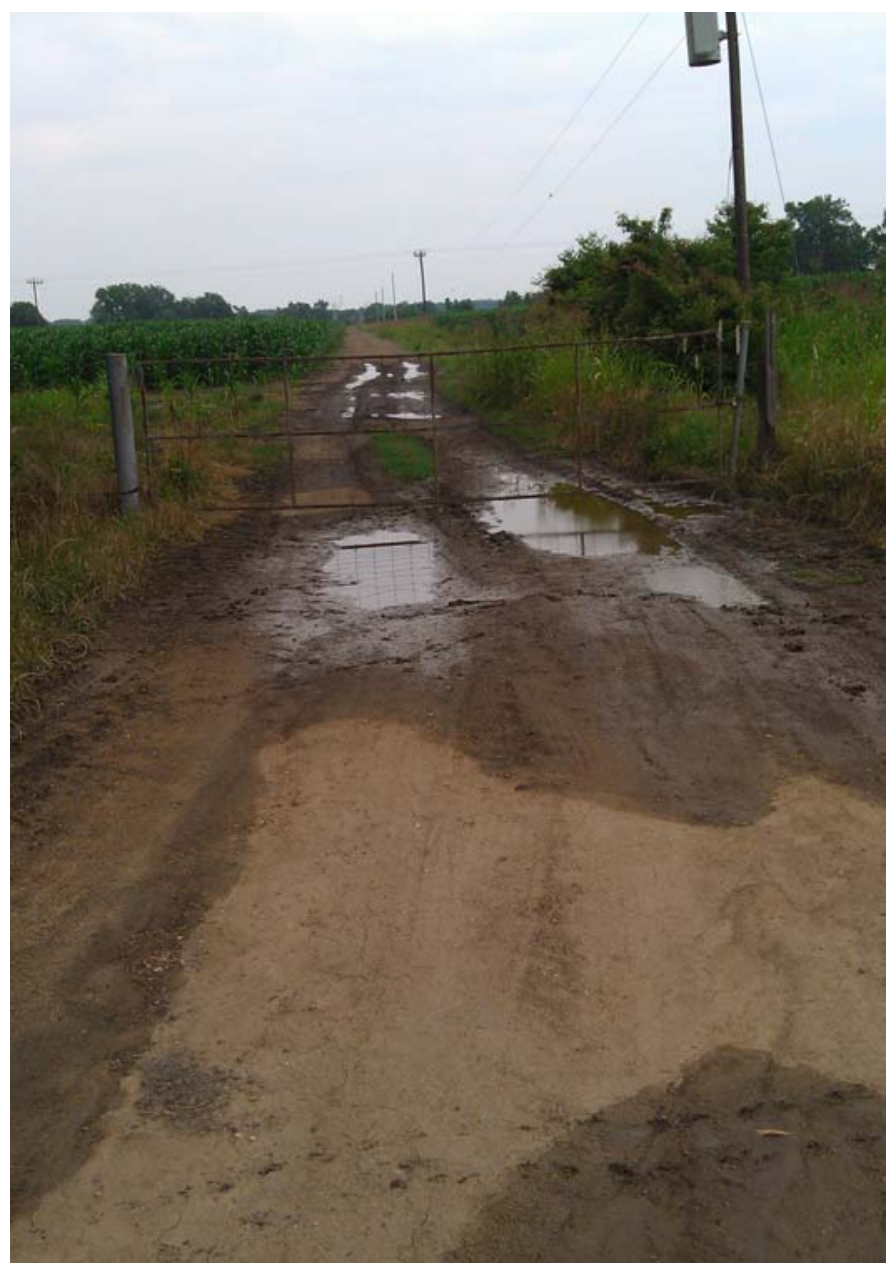

61

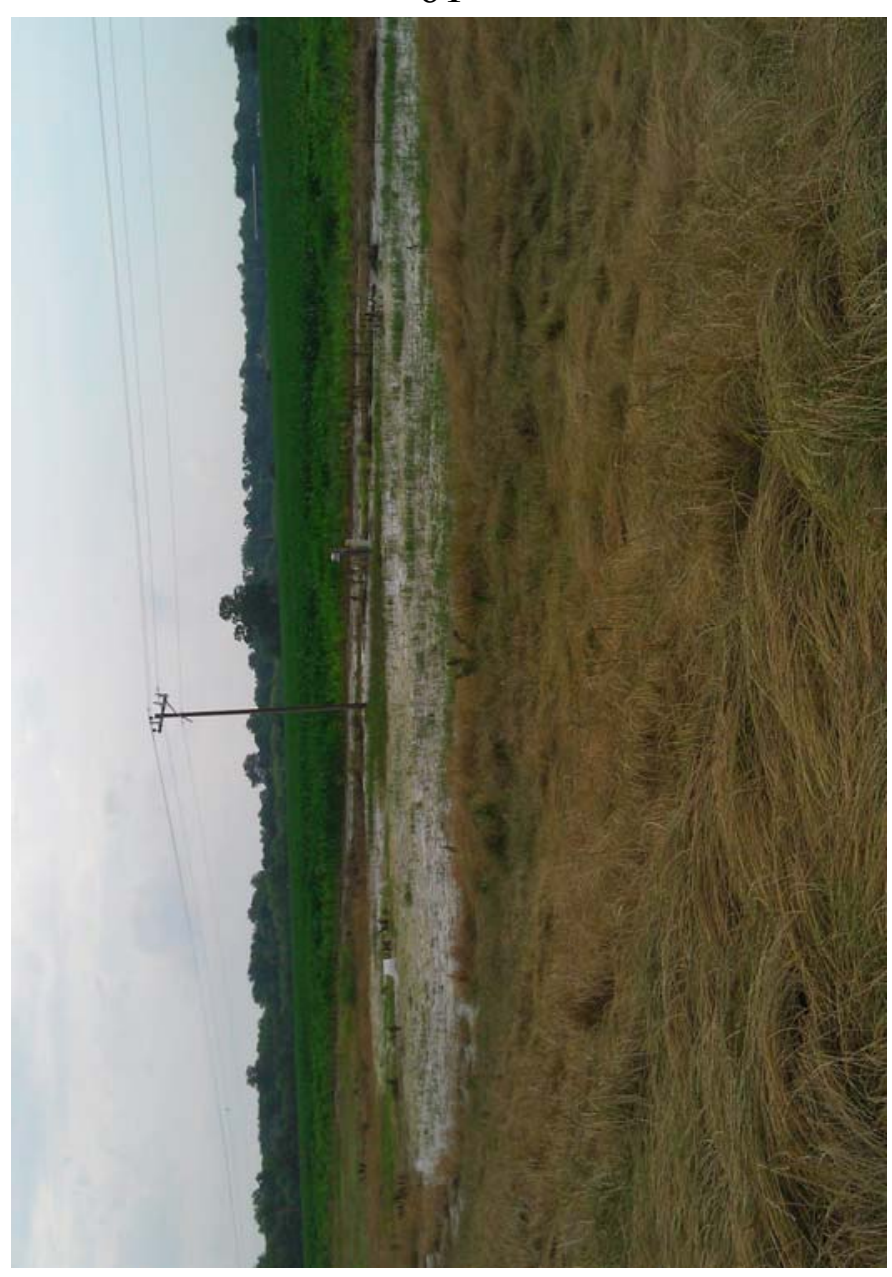

63

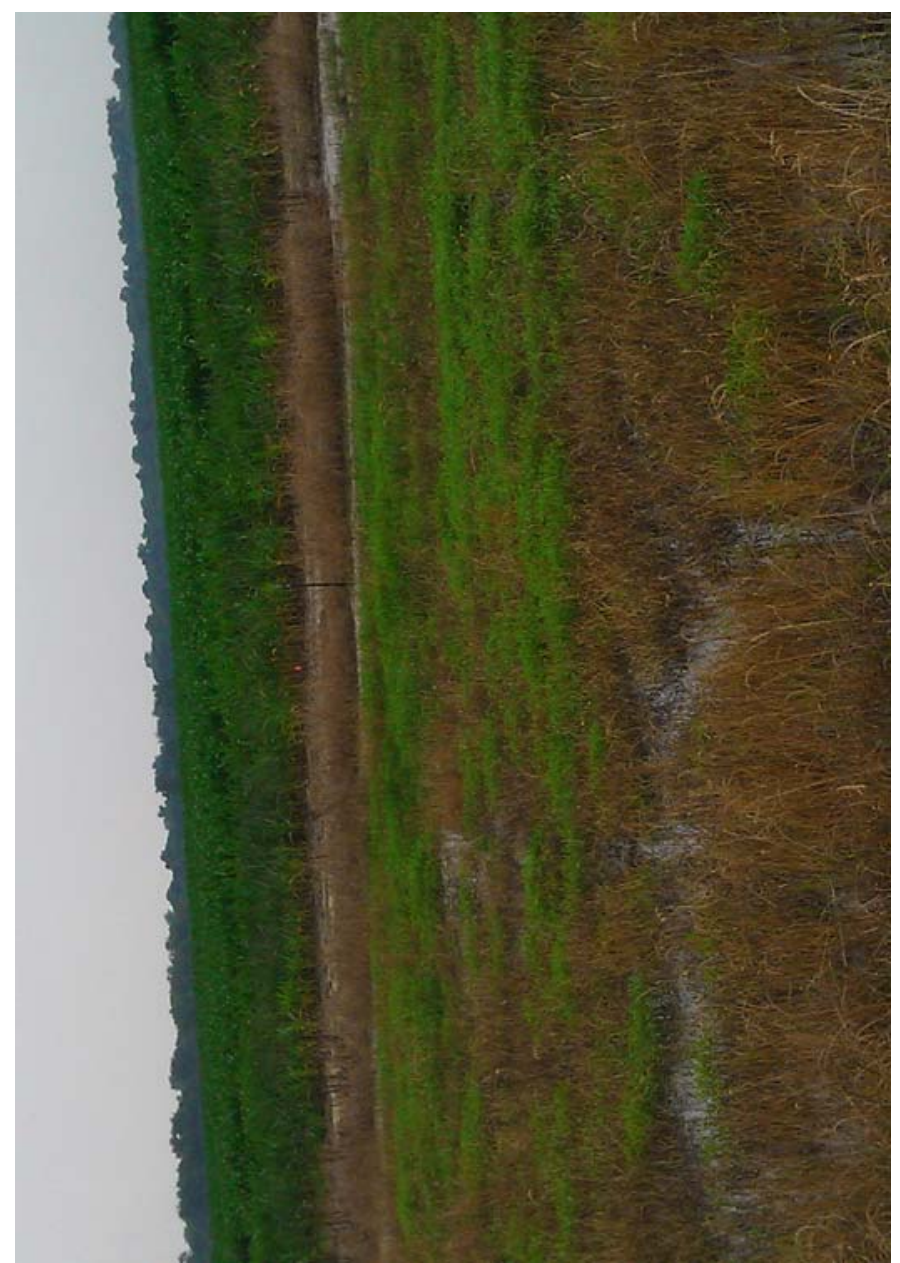

62

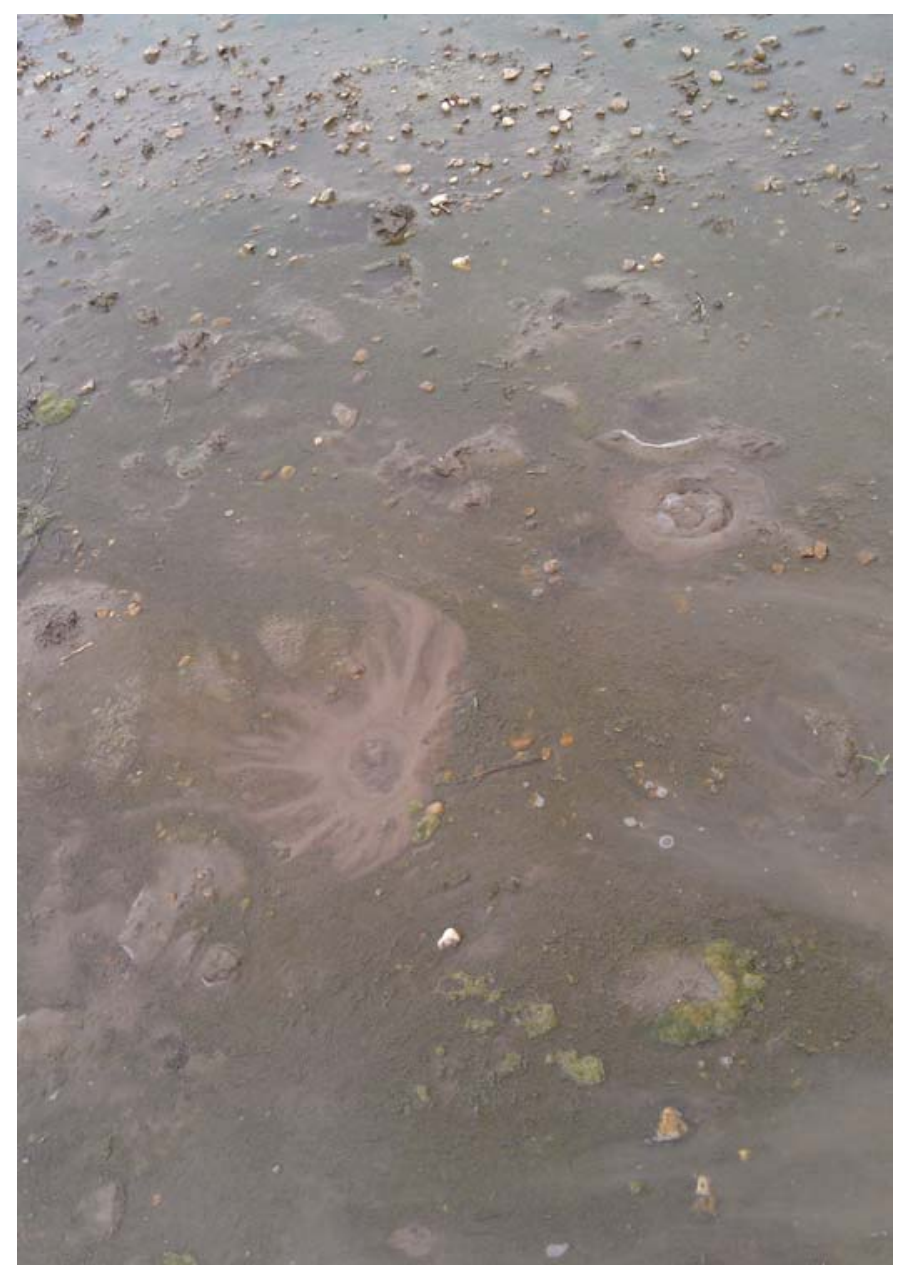




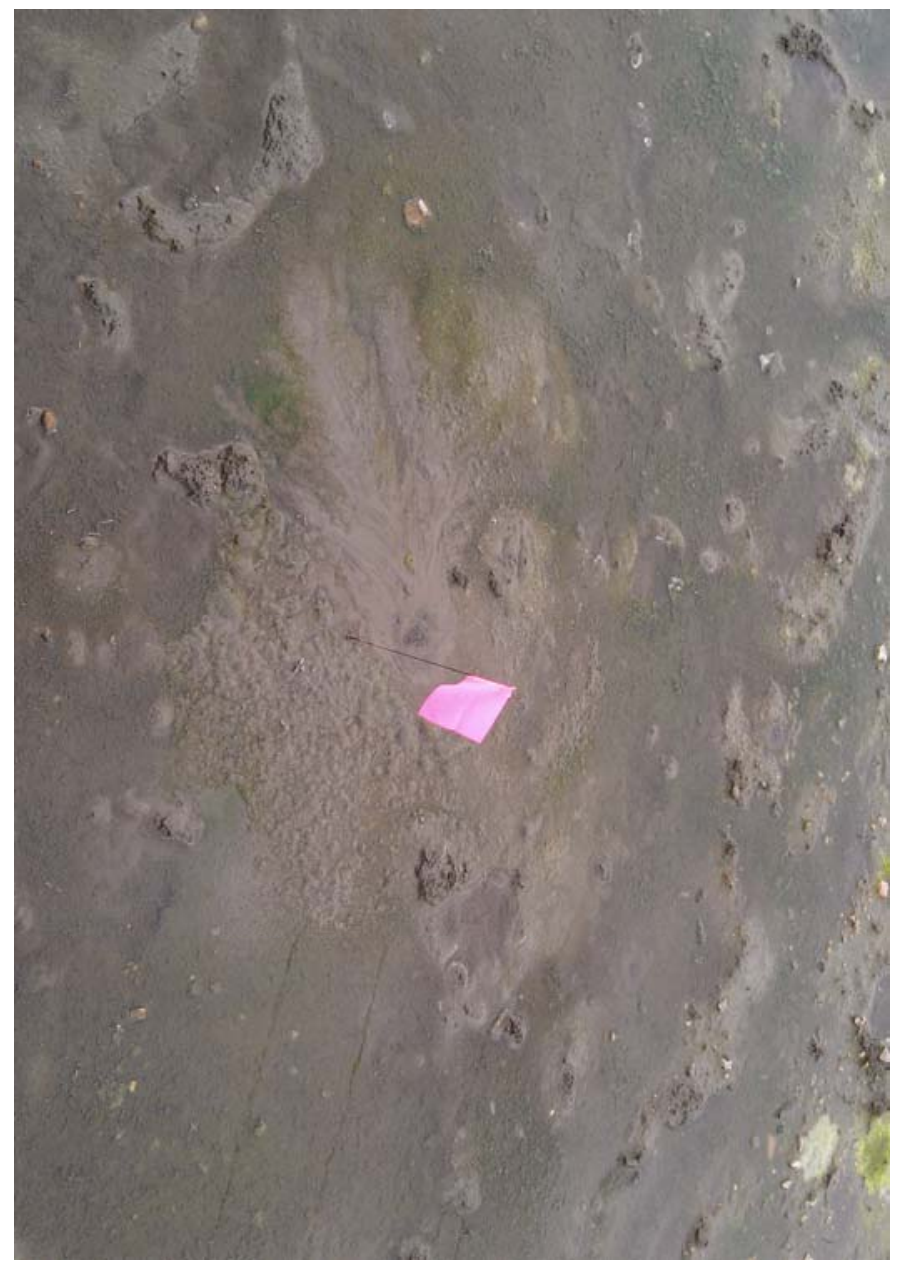

65

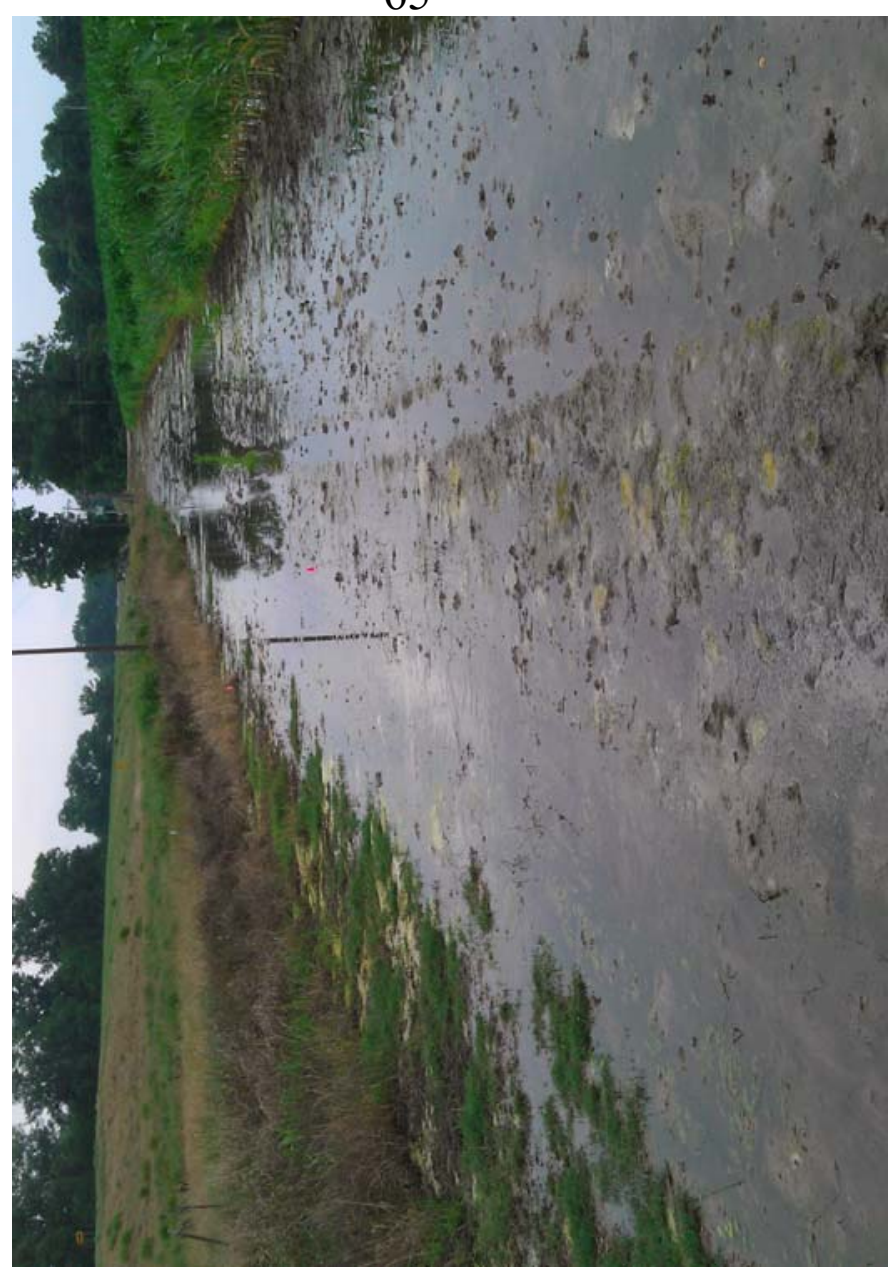

67

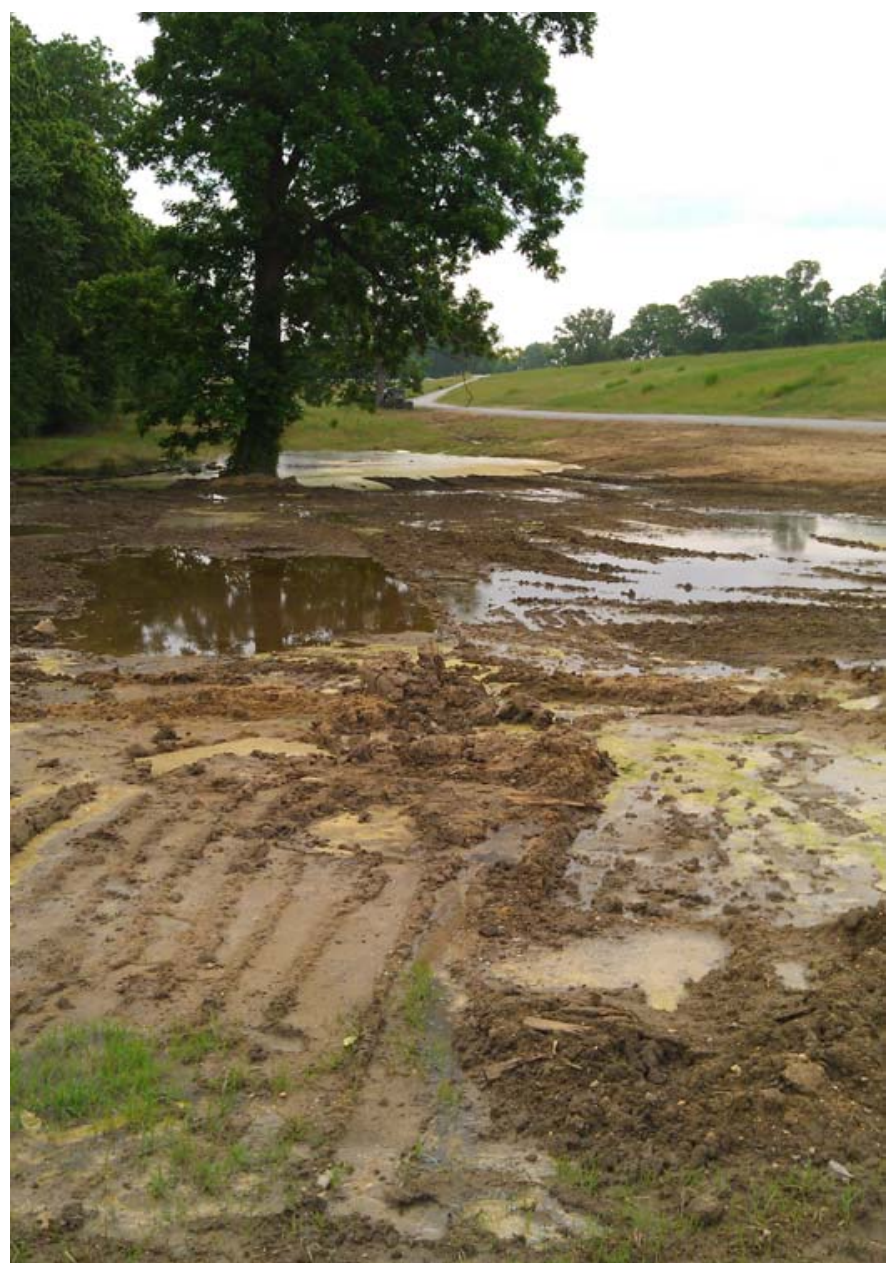

66

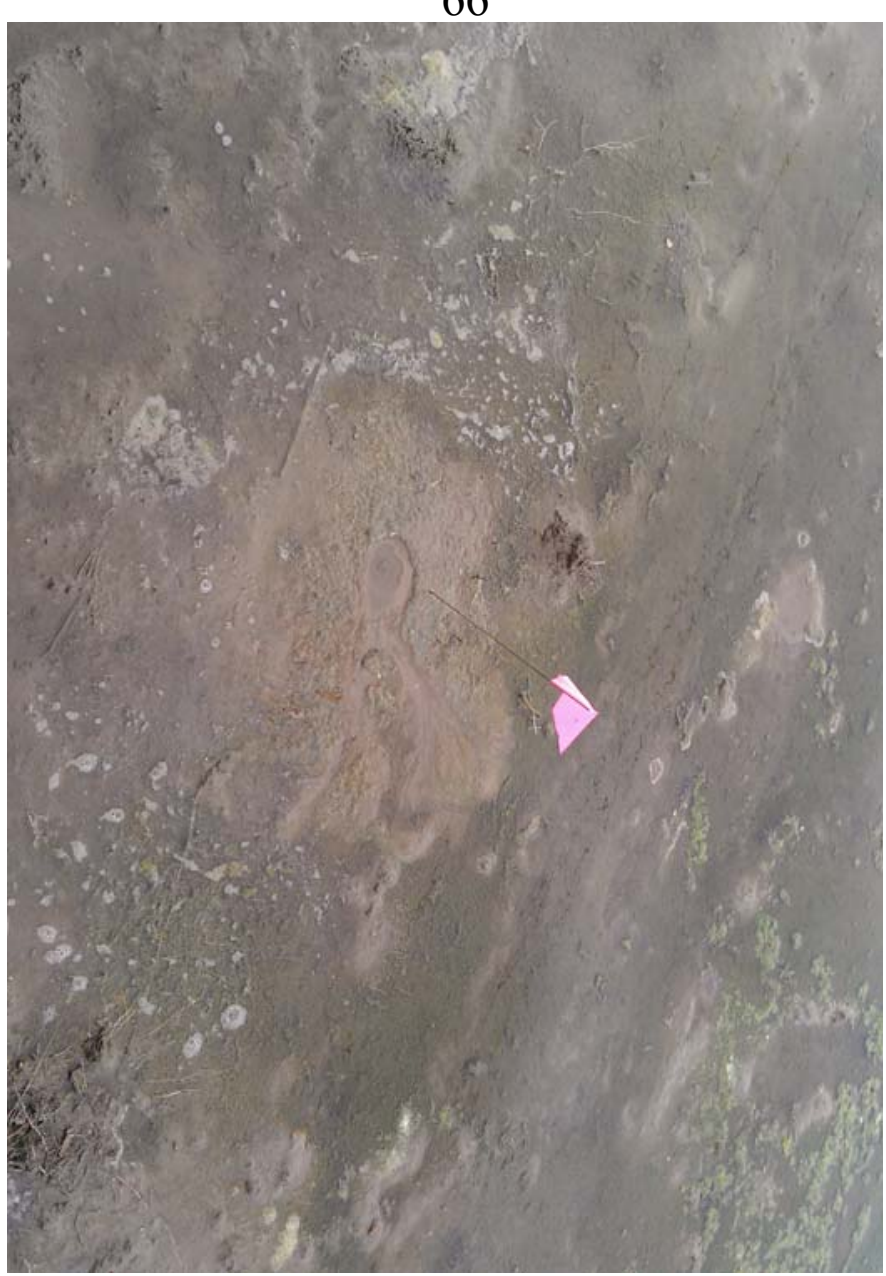

68 


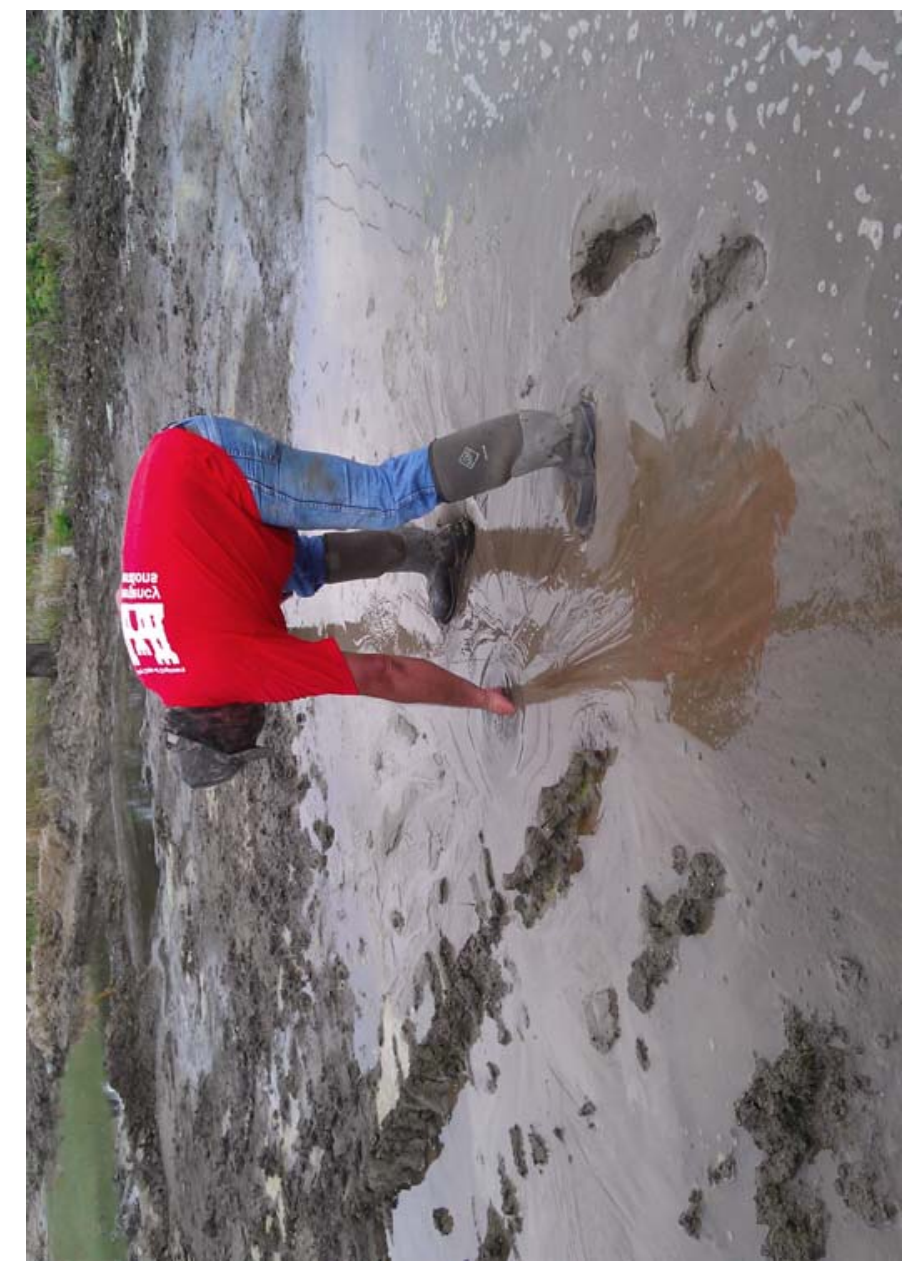

69

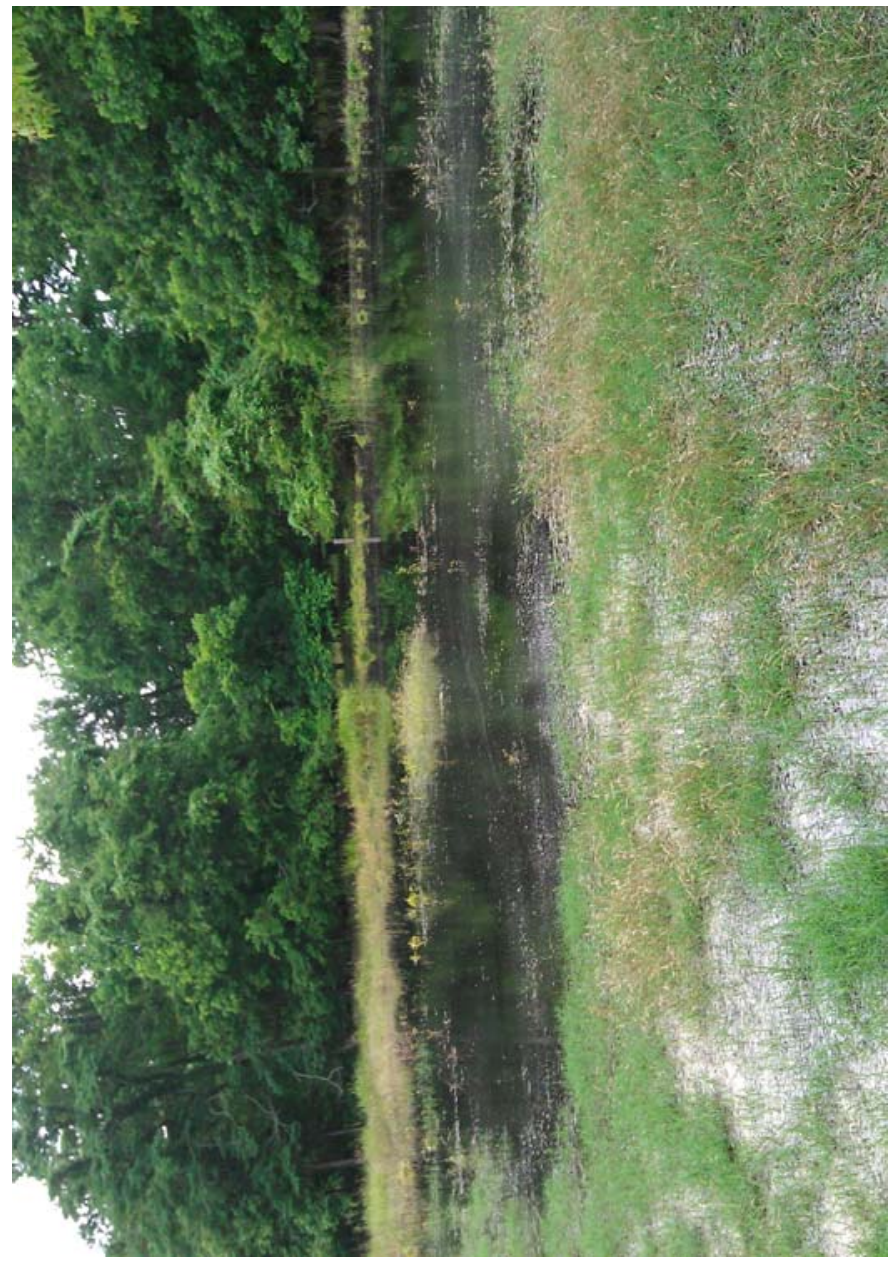

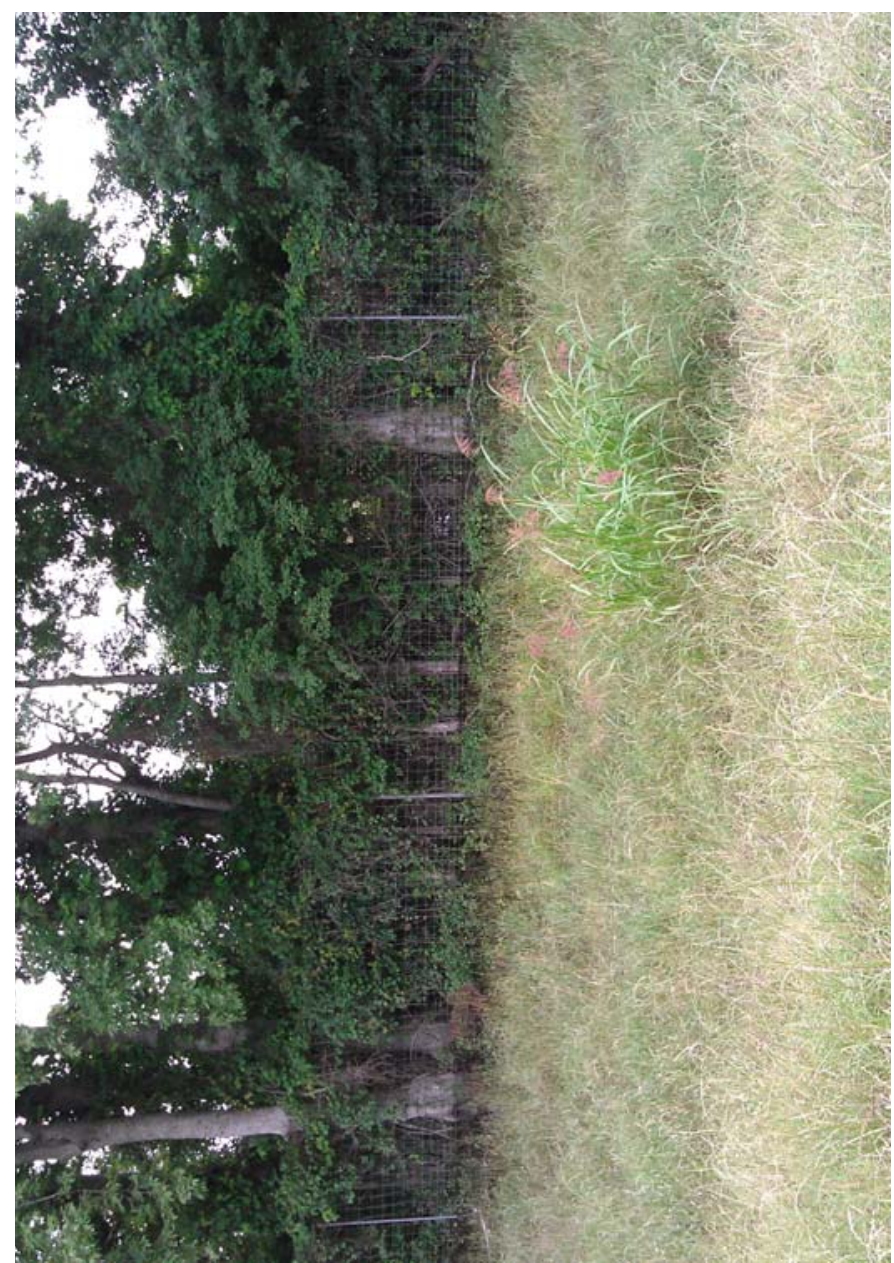

70

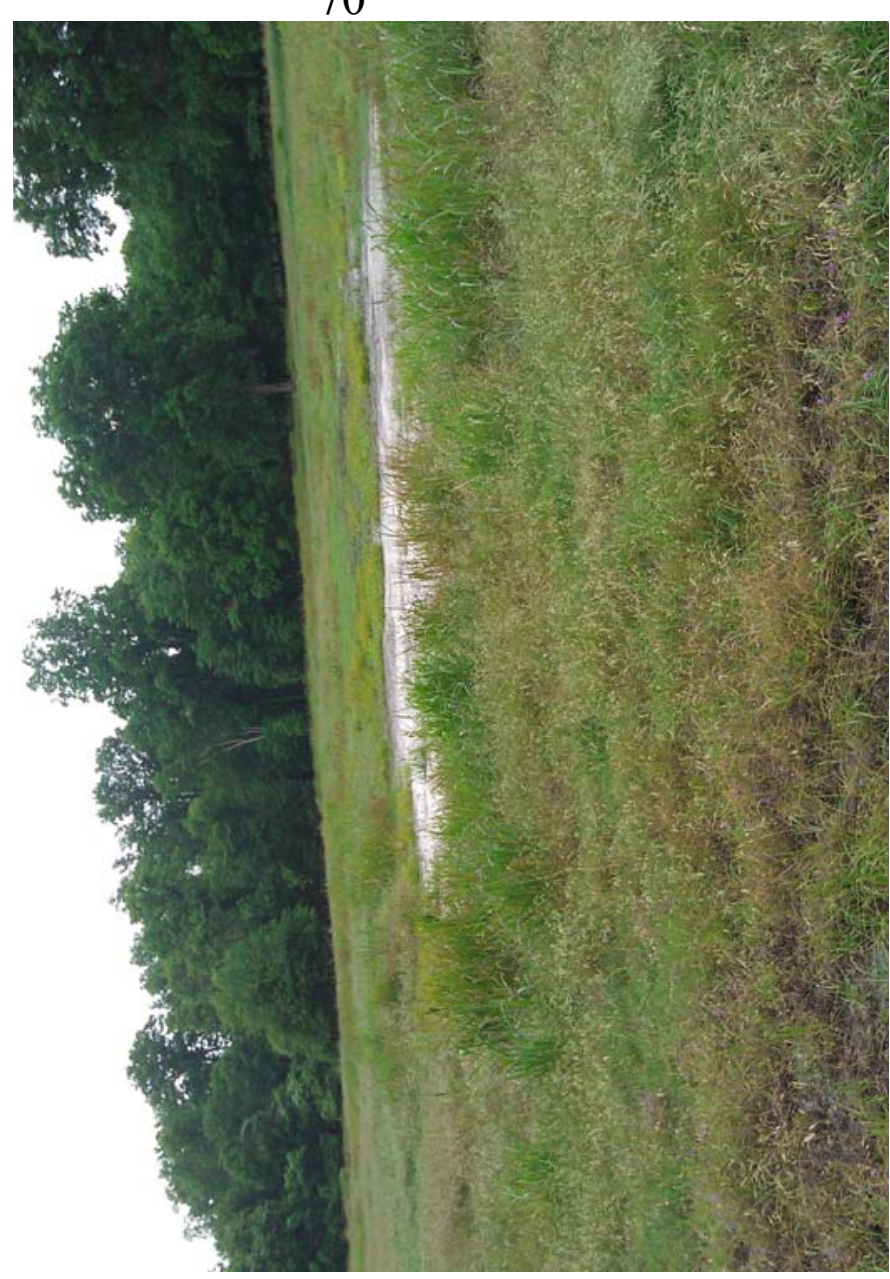




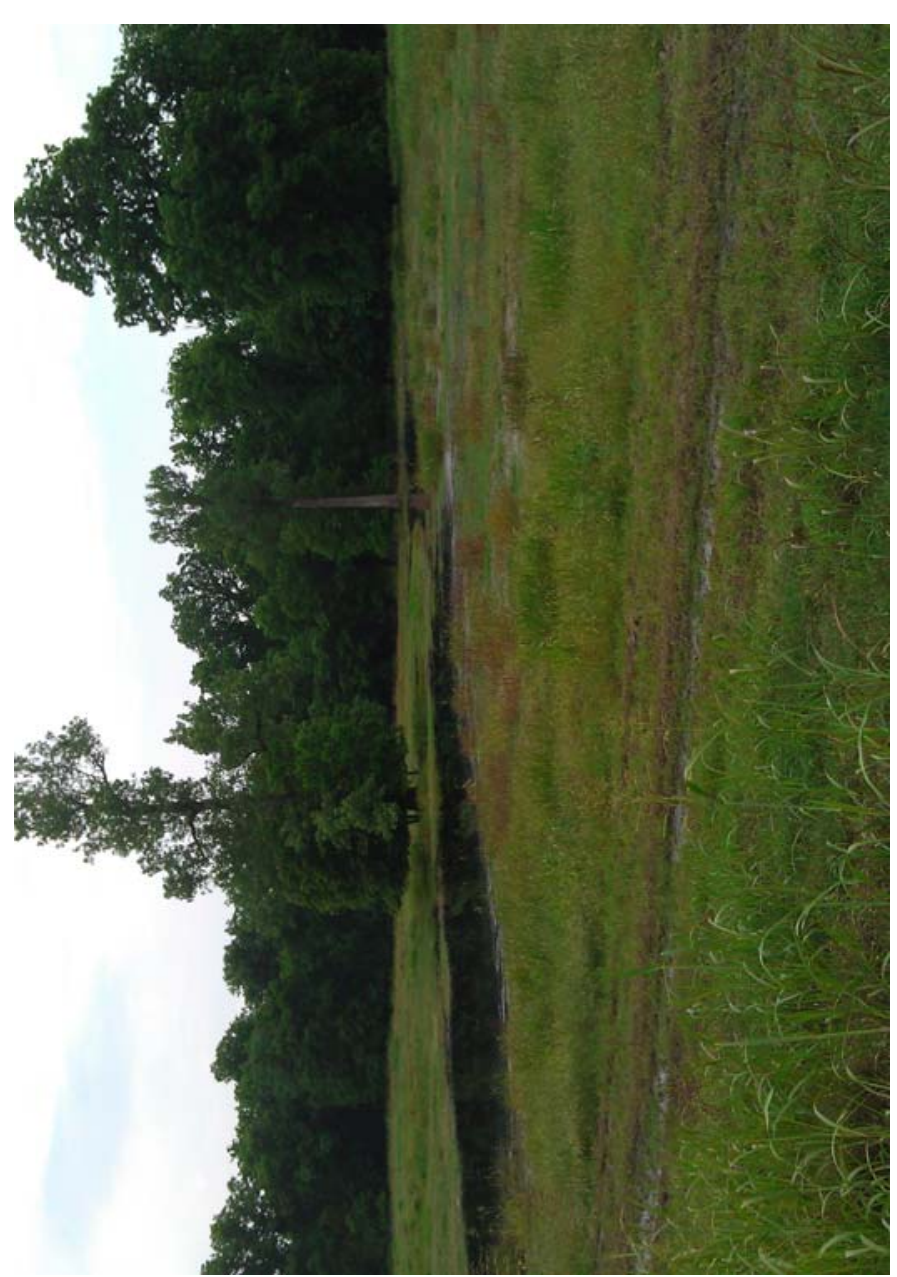

73

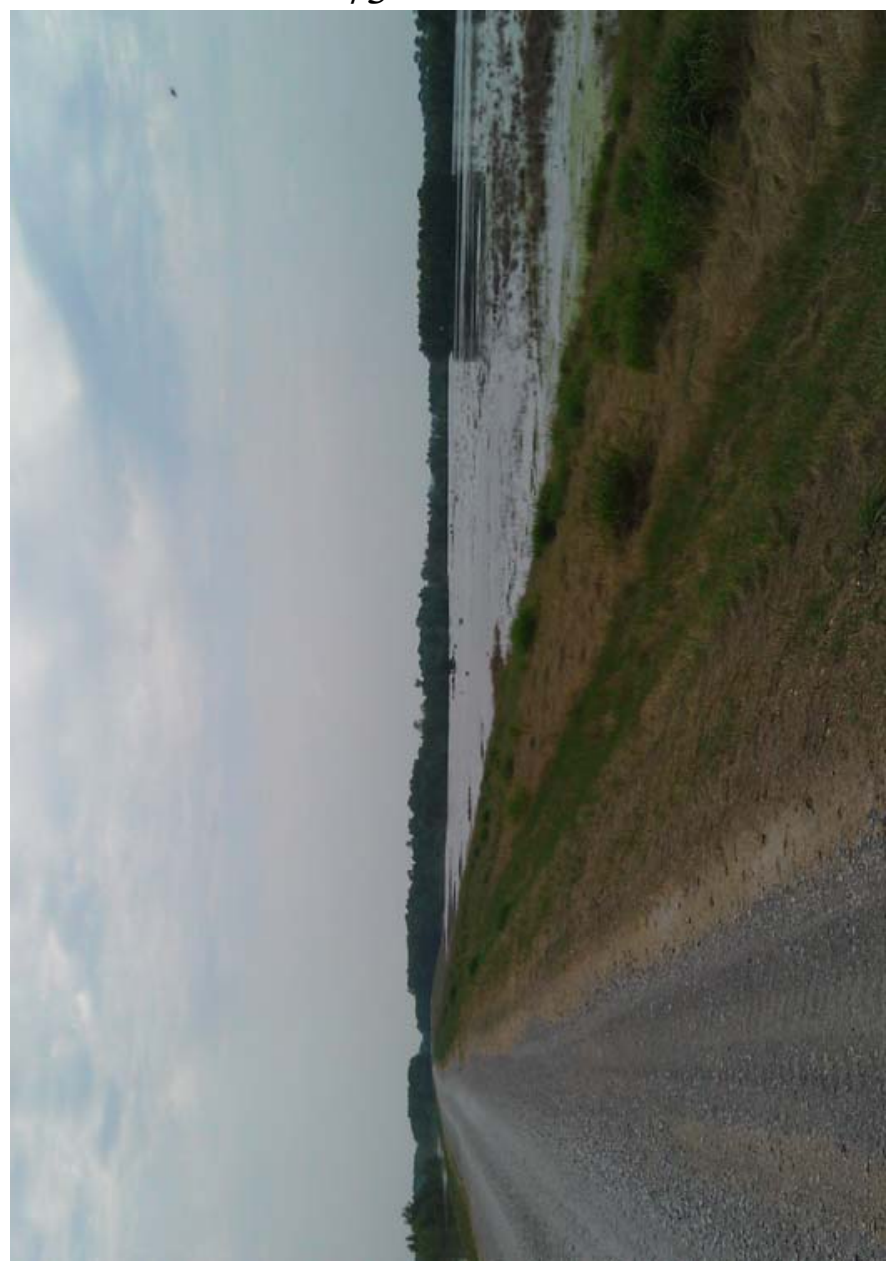

75

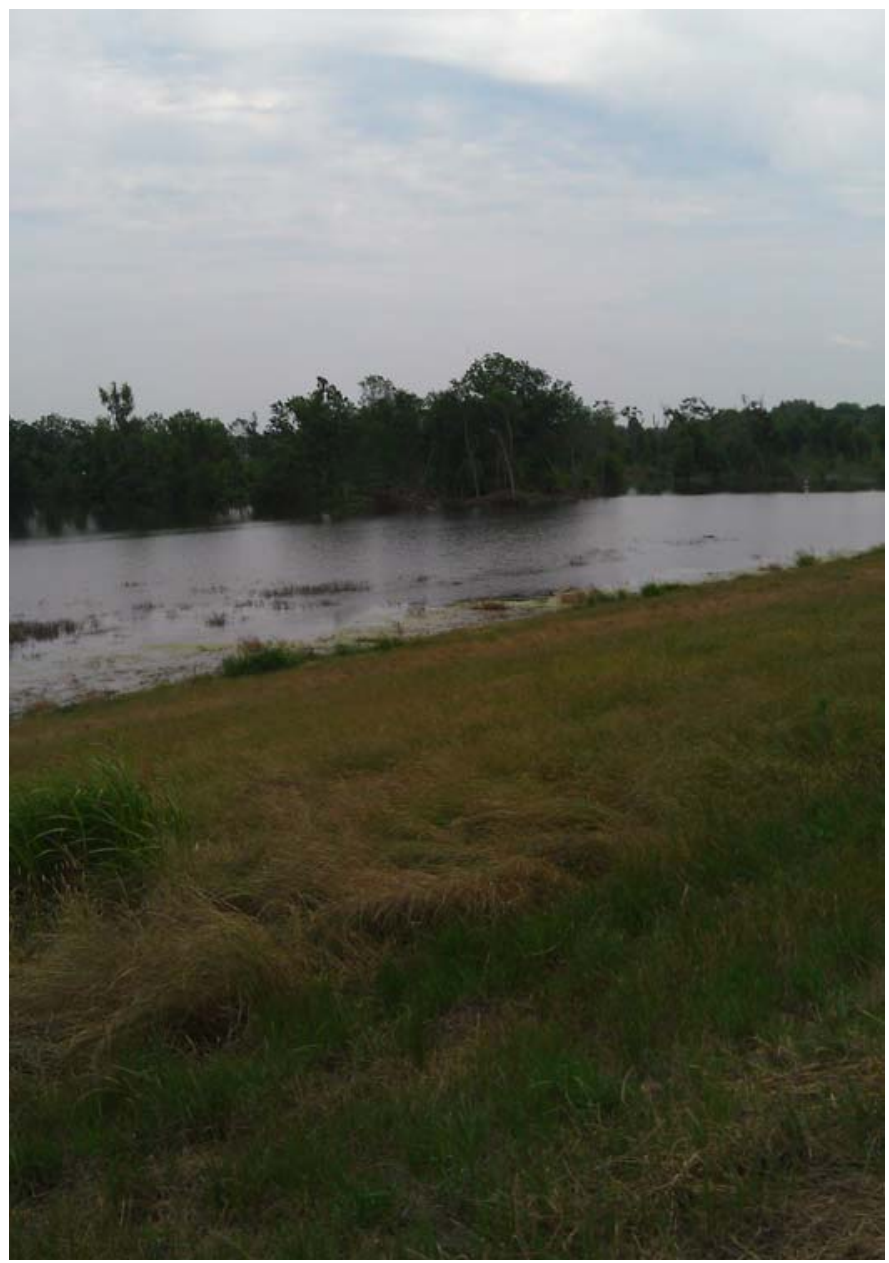

74

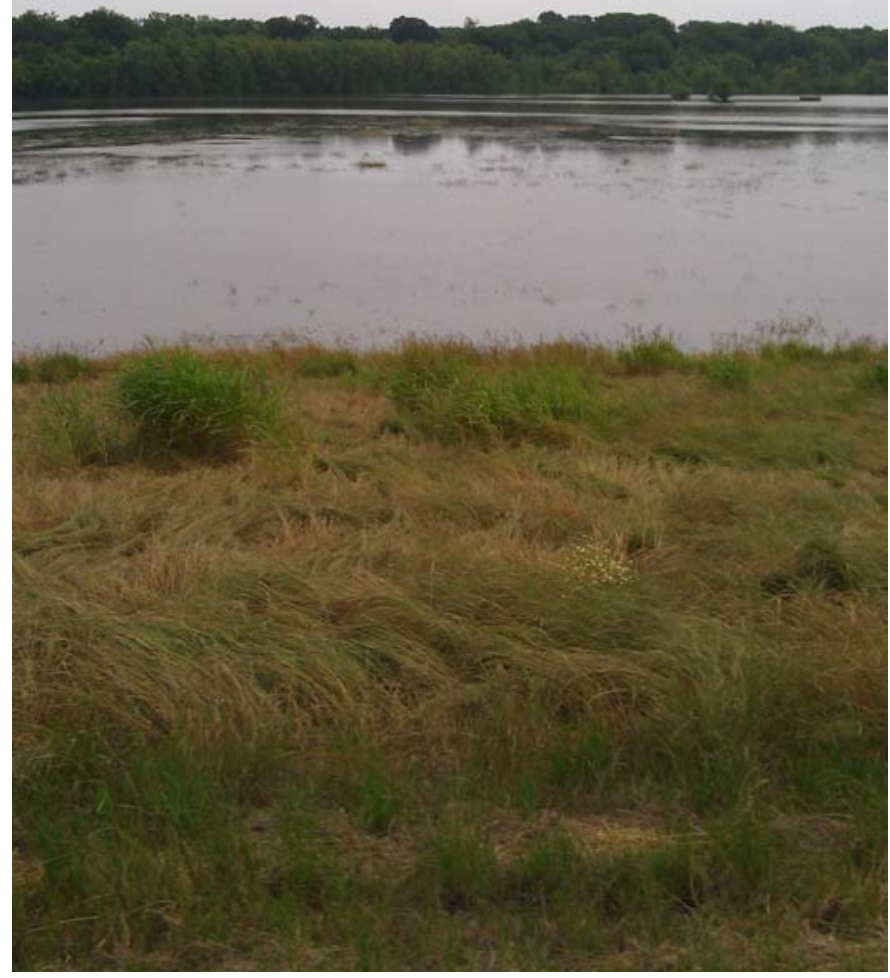




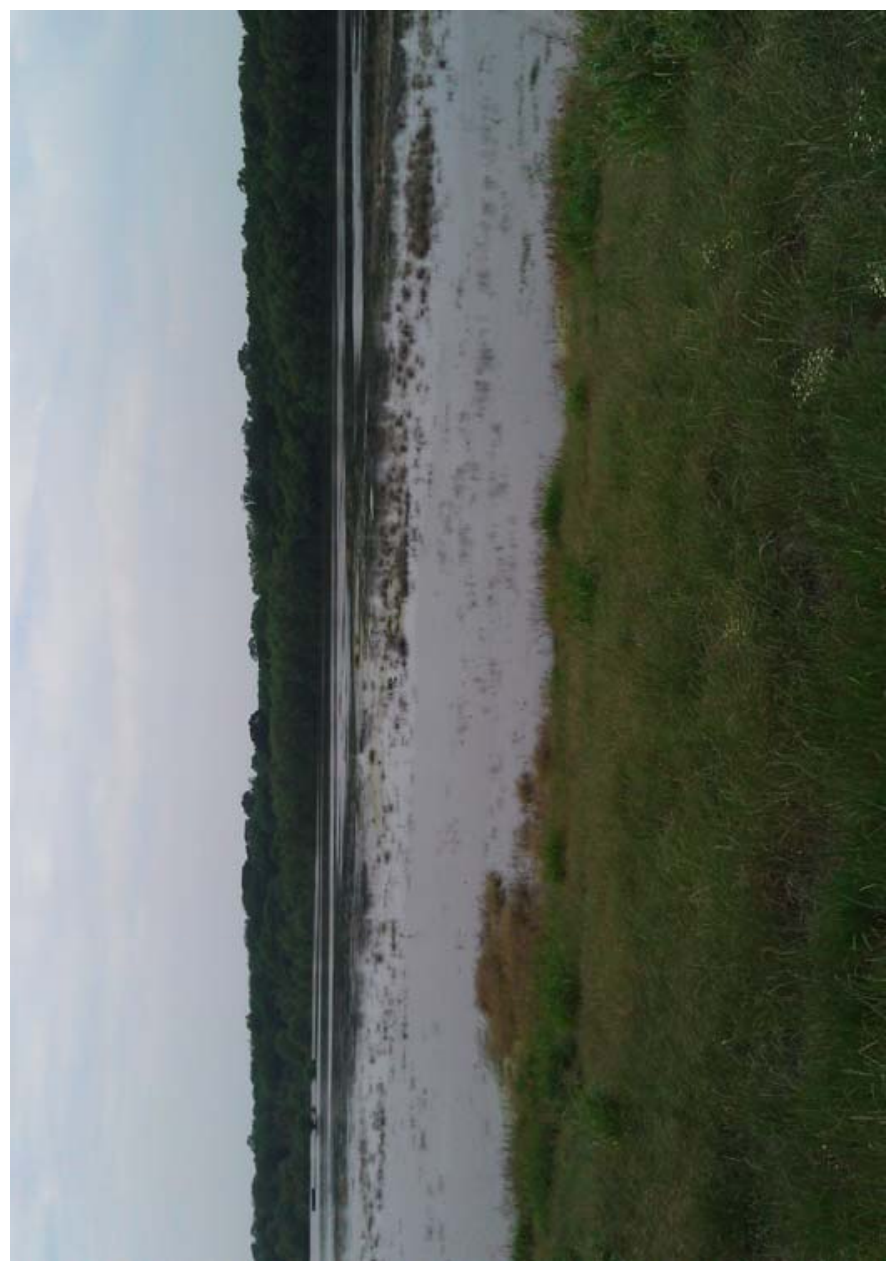

77

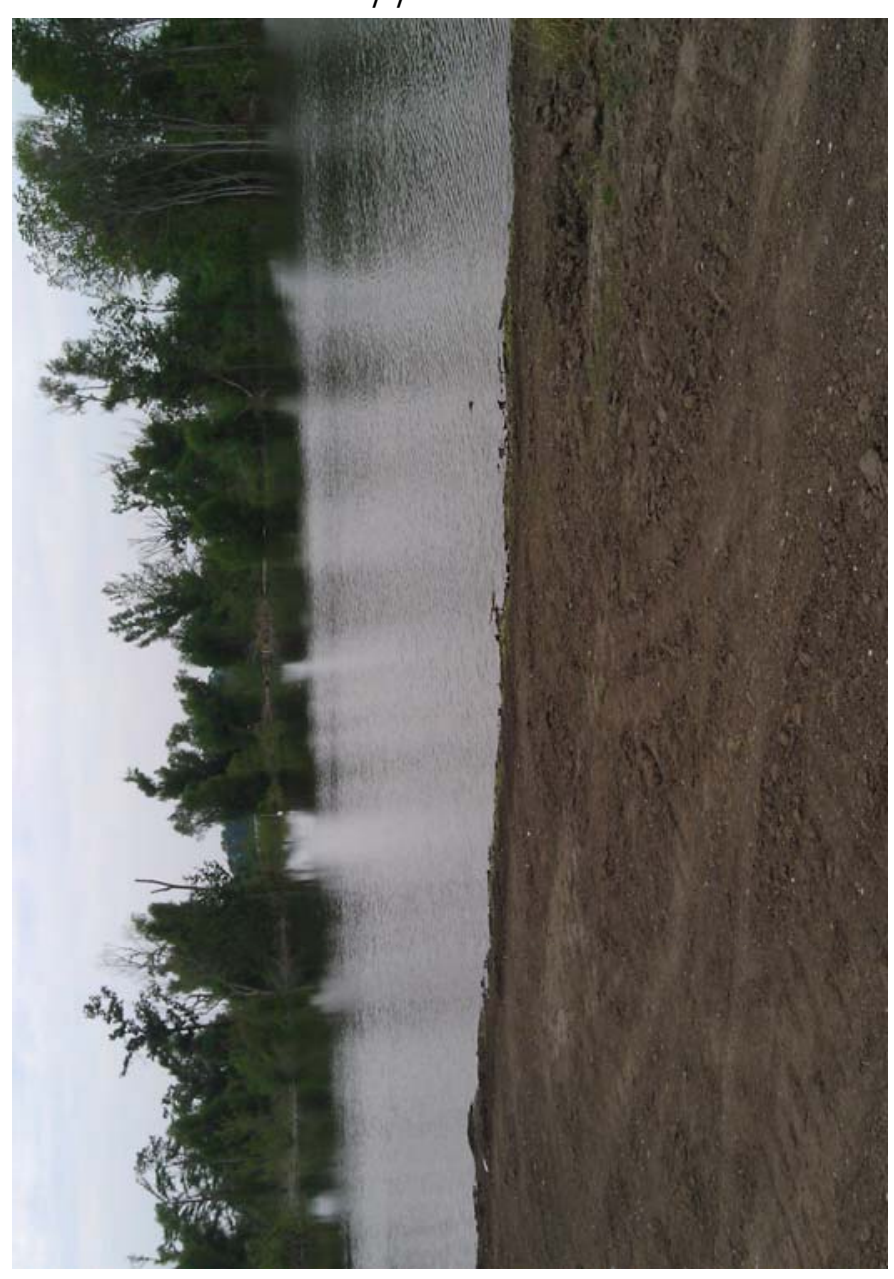

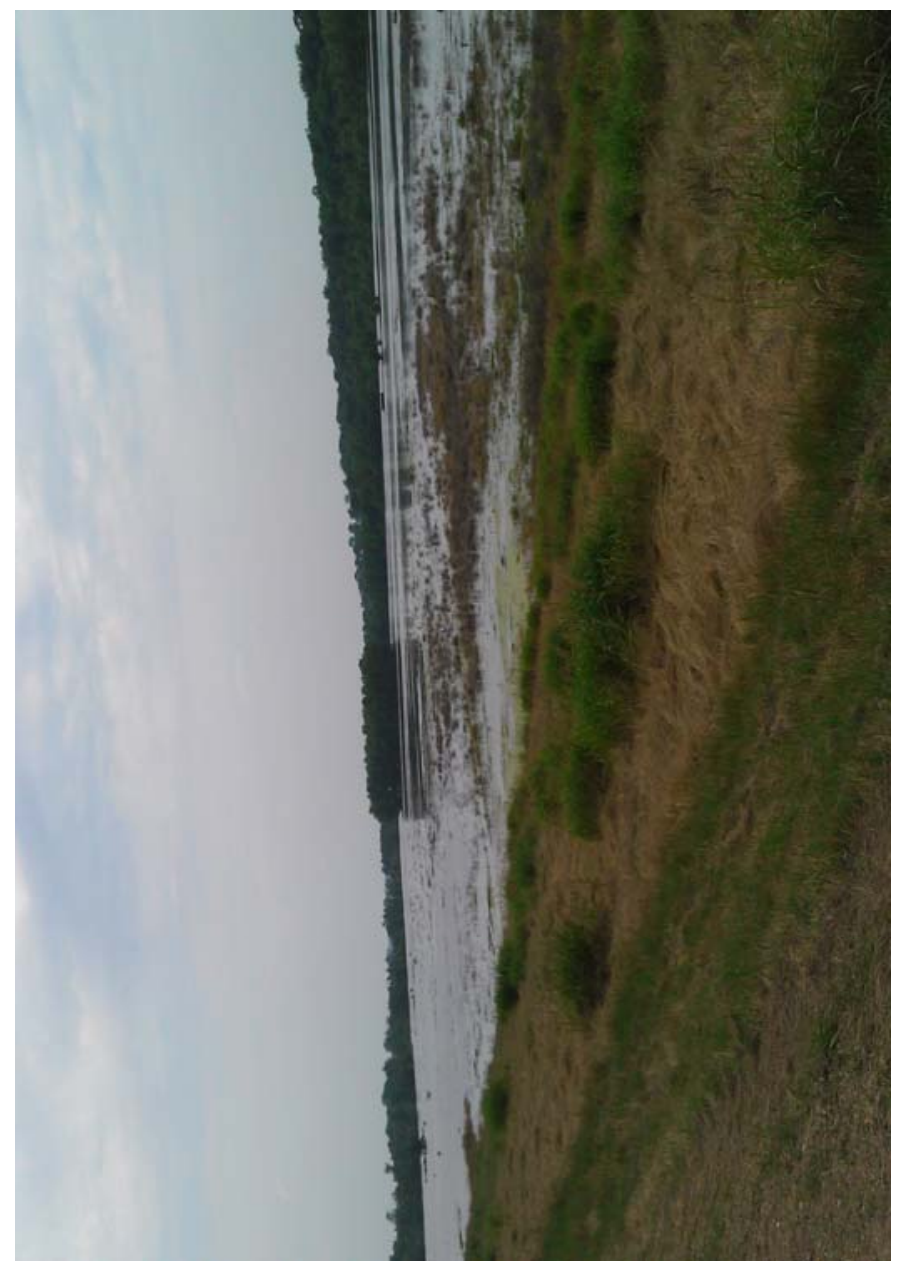

78

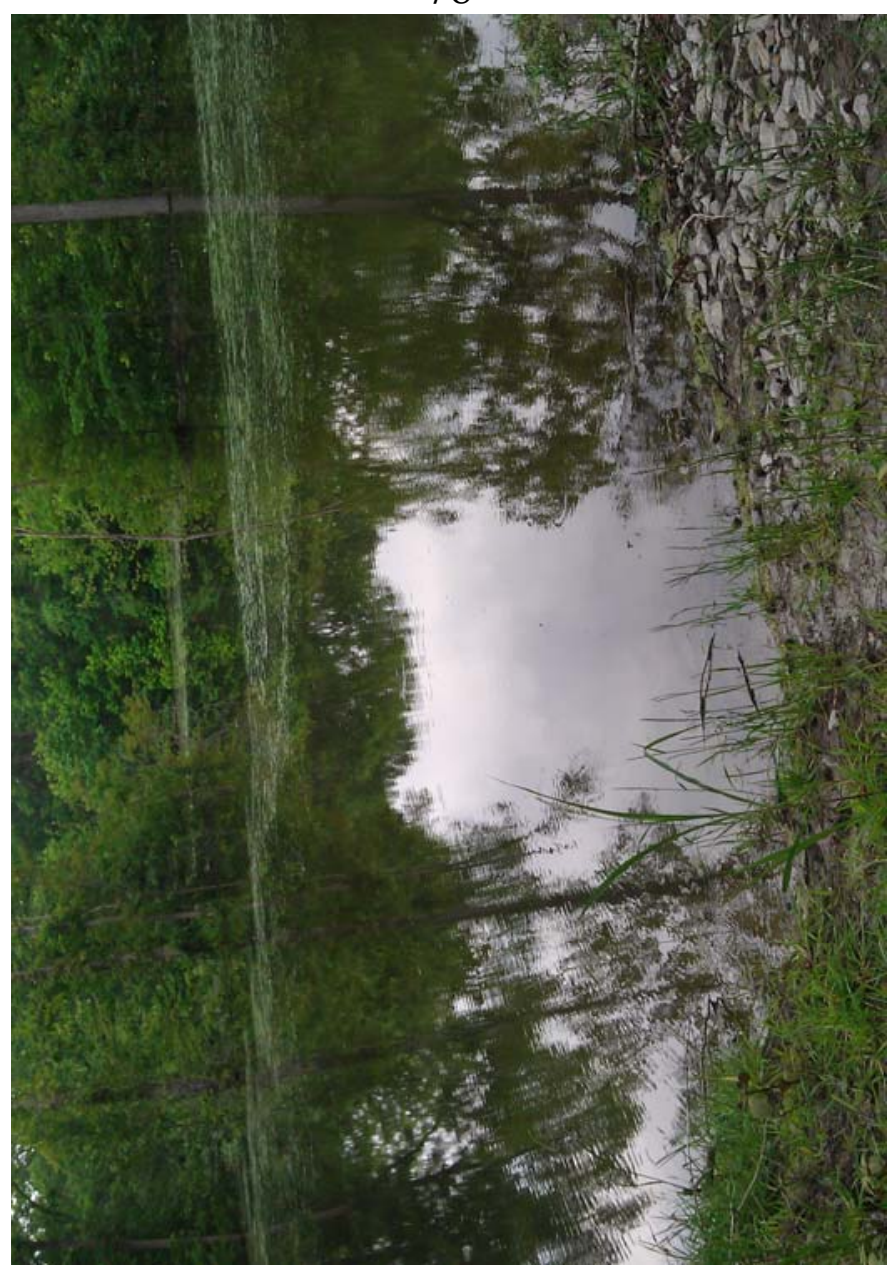

80 


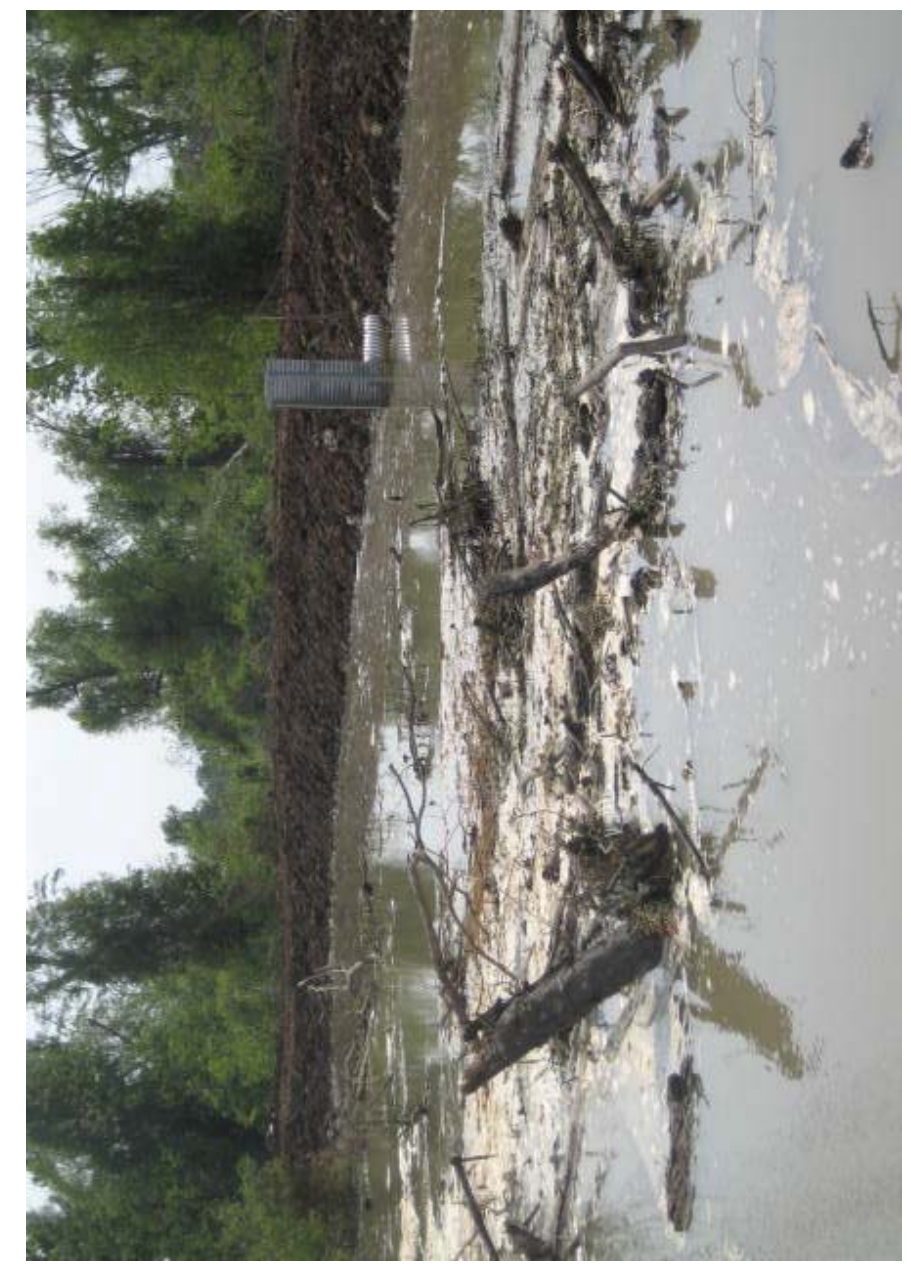

81

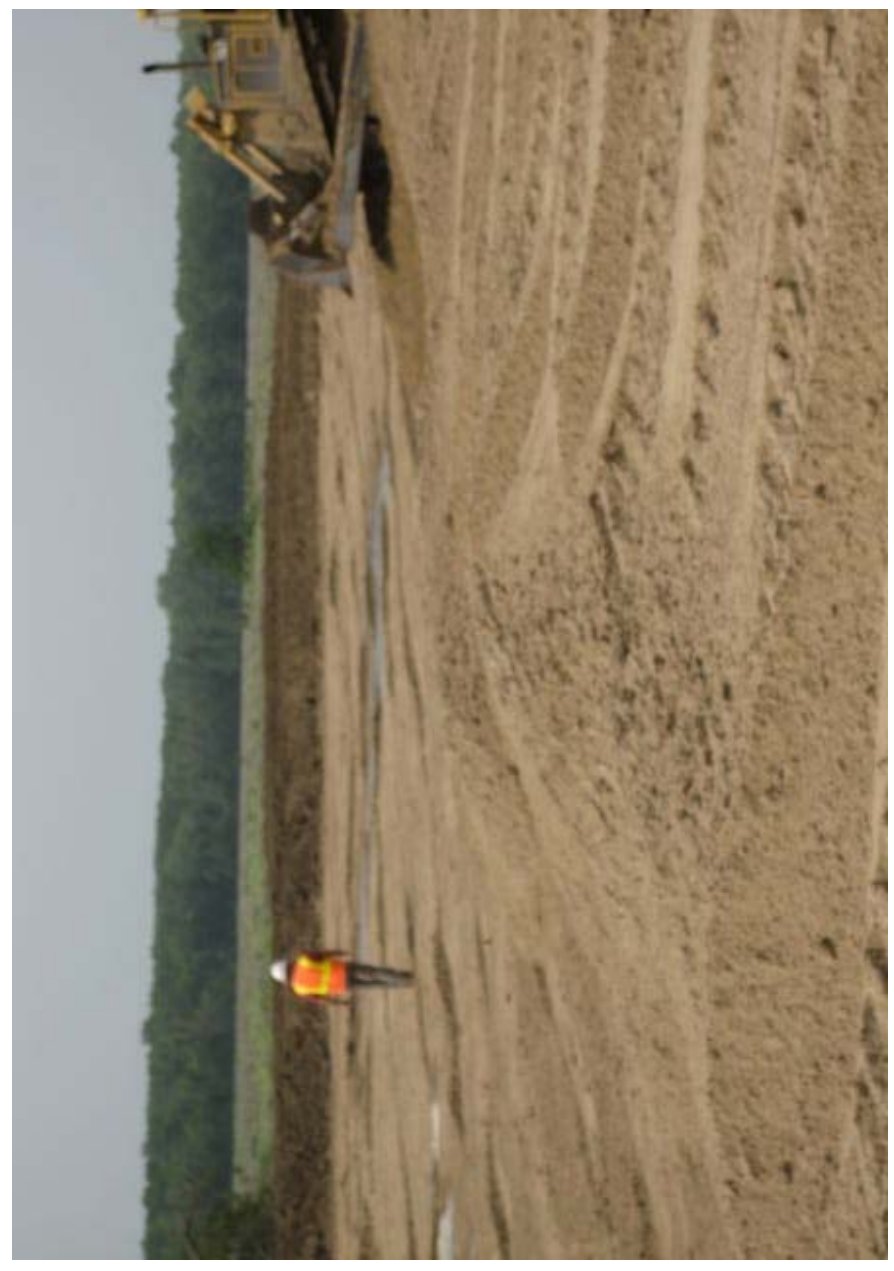

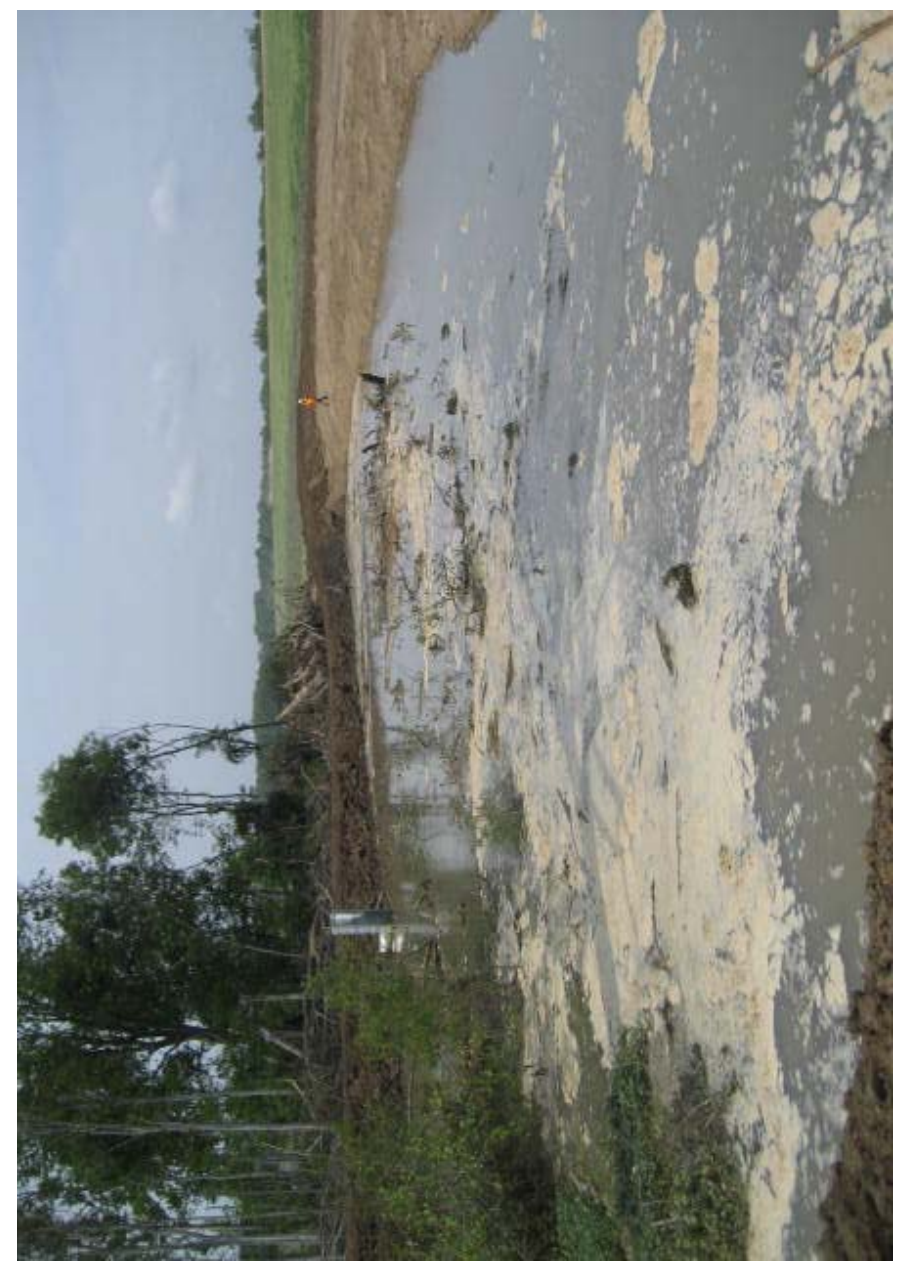

82

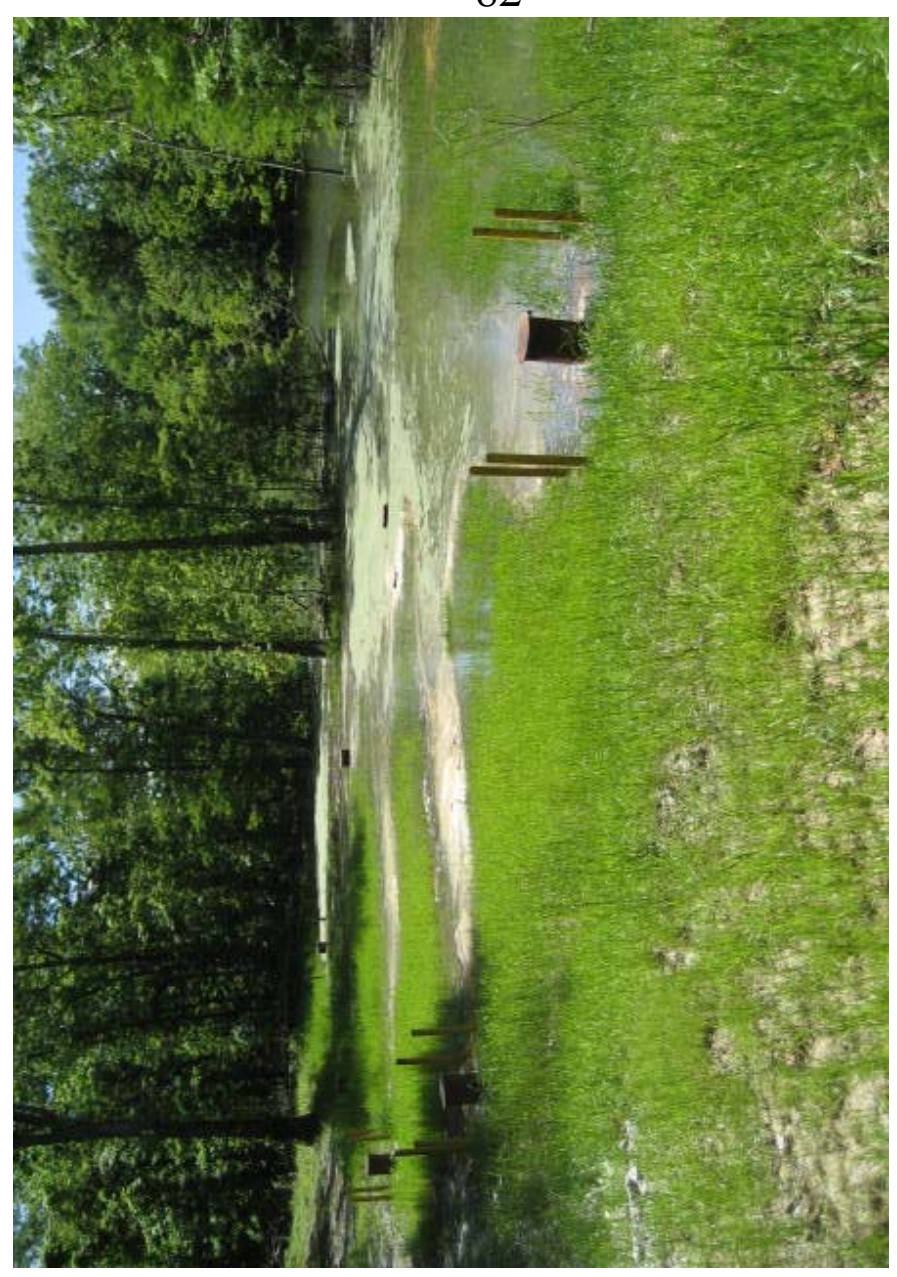




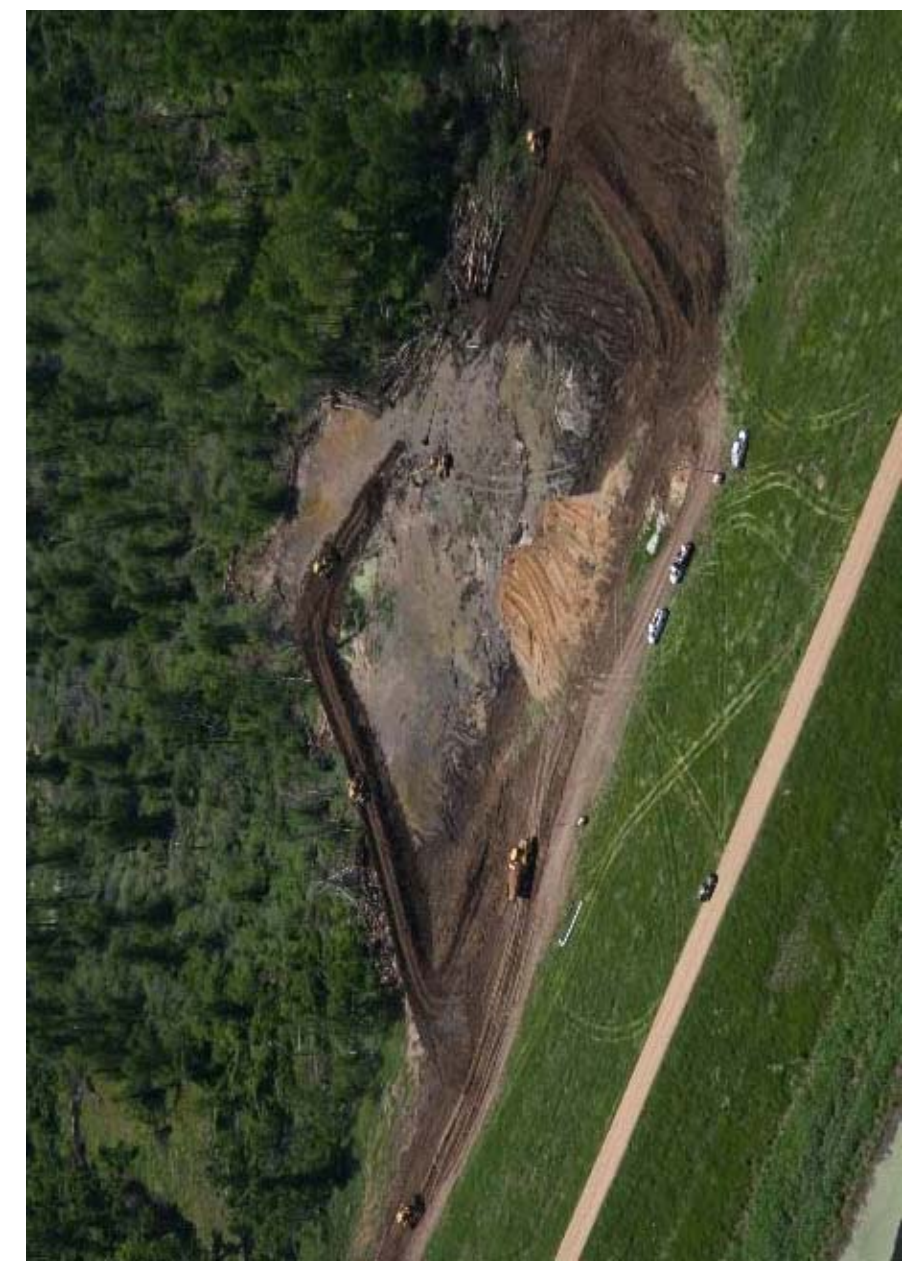

85

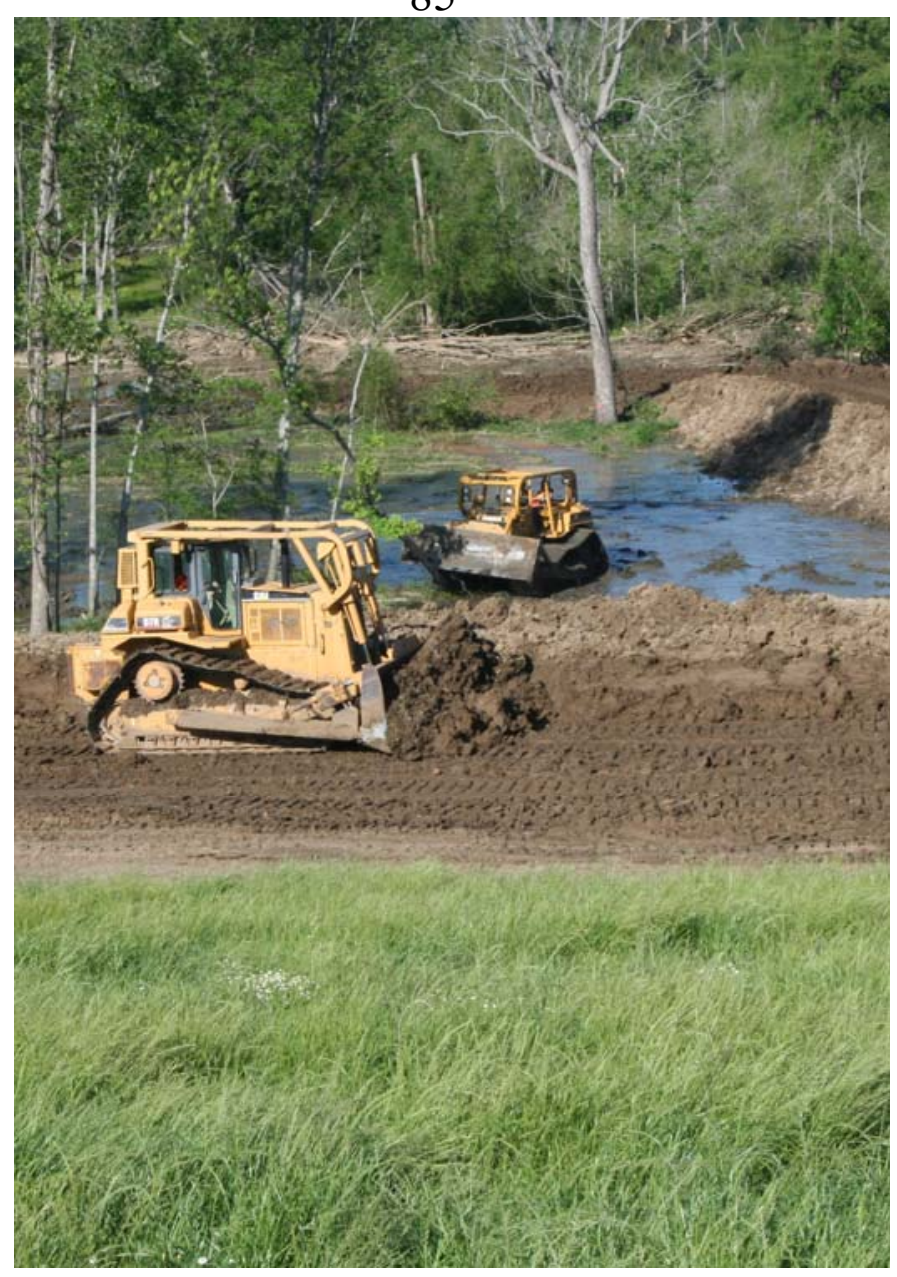

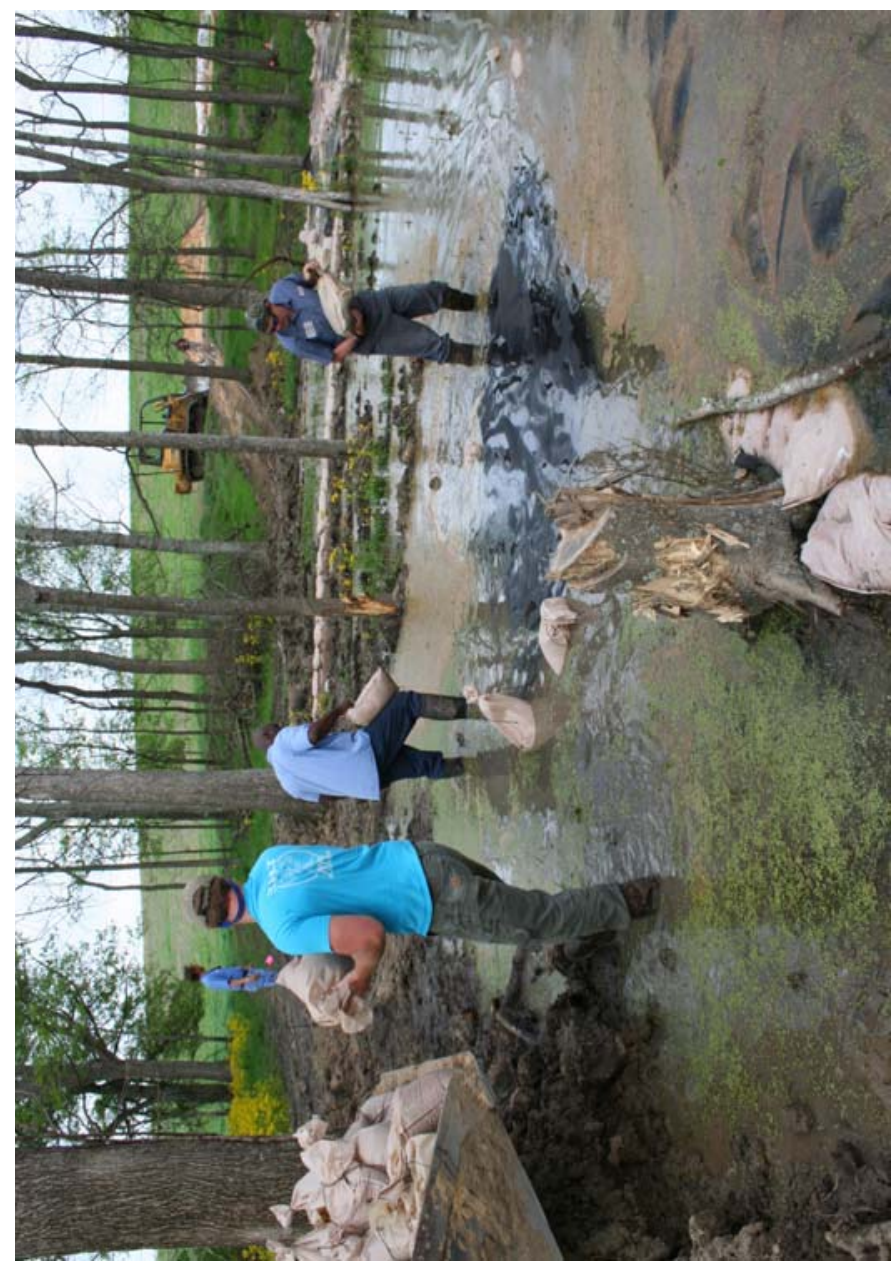

86

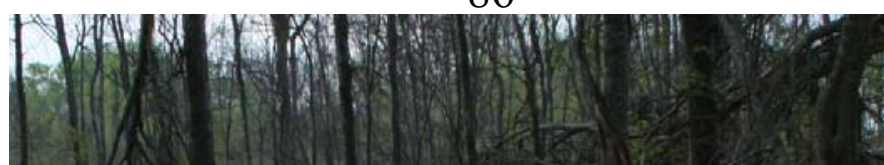

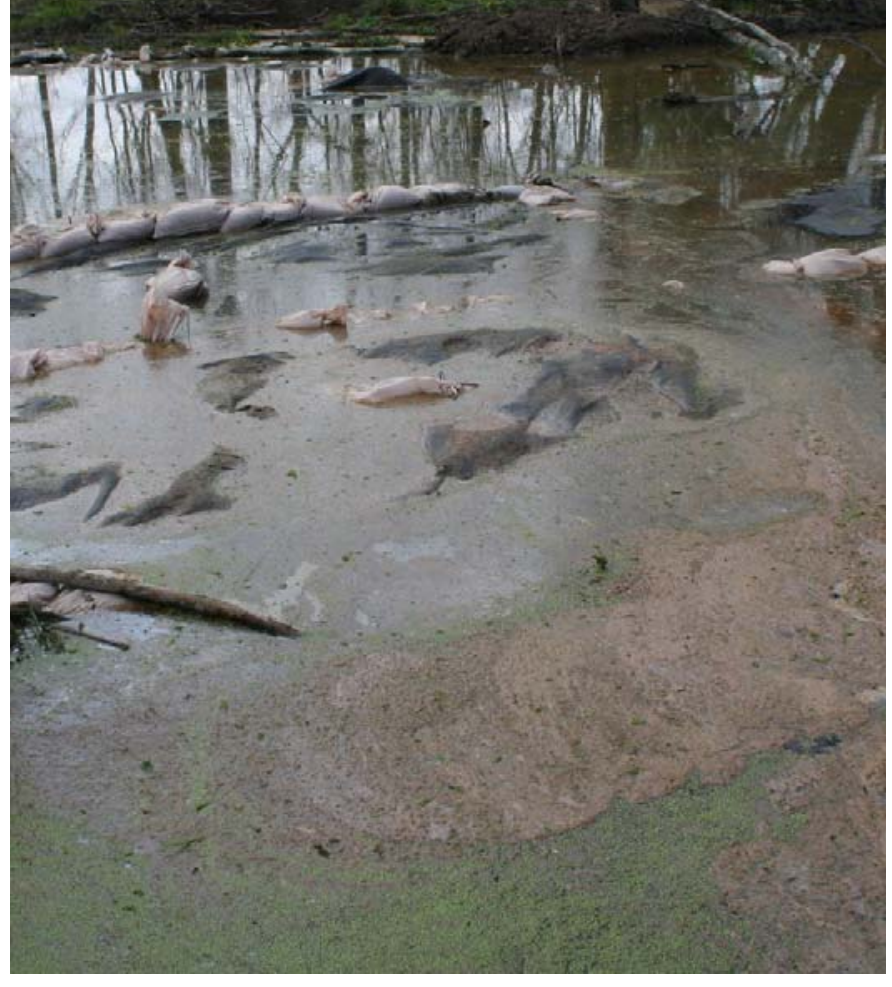




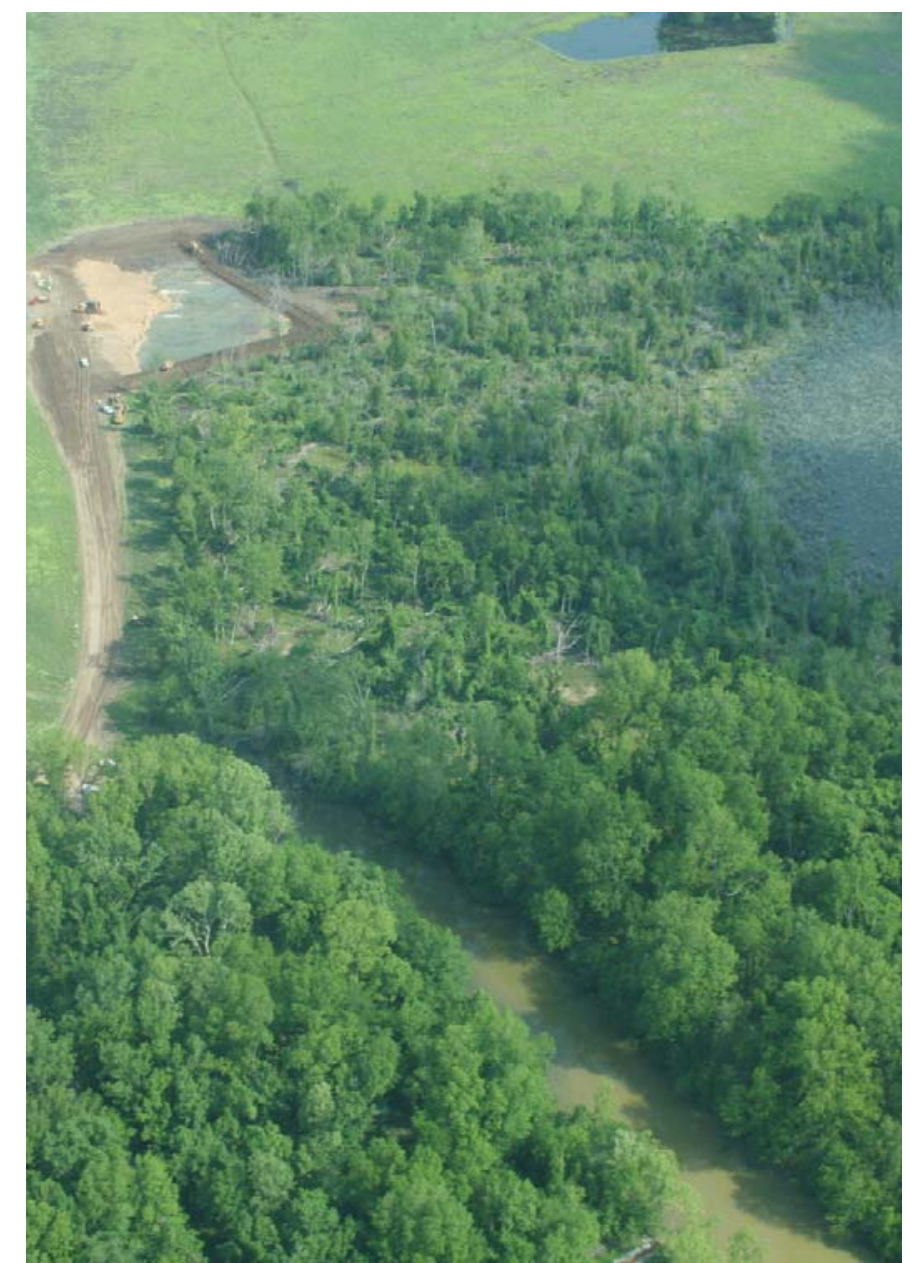

89

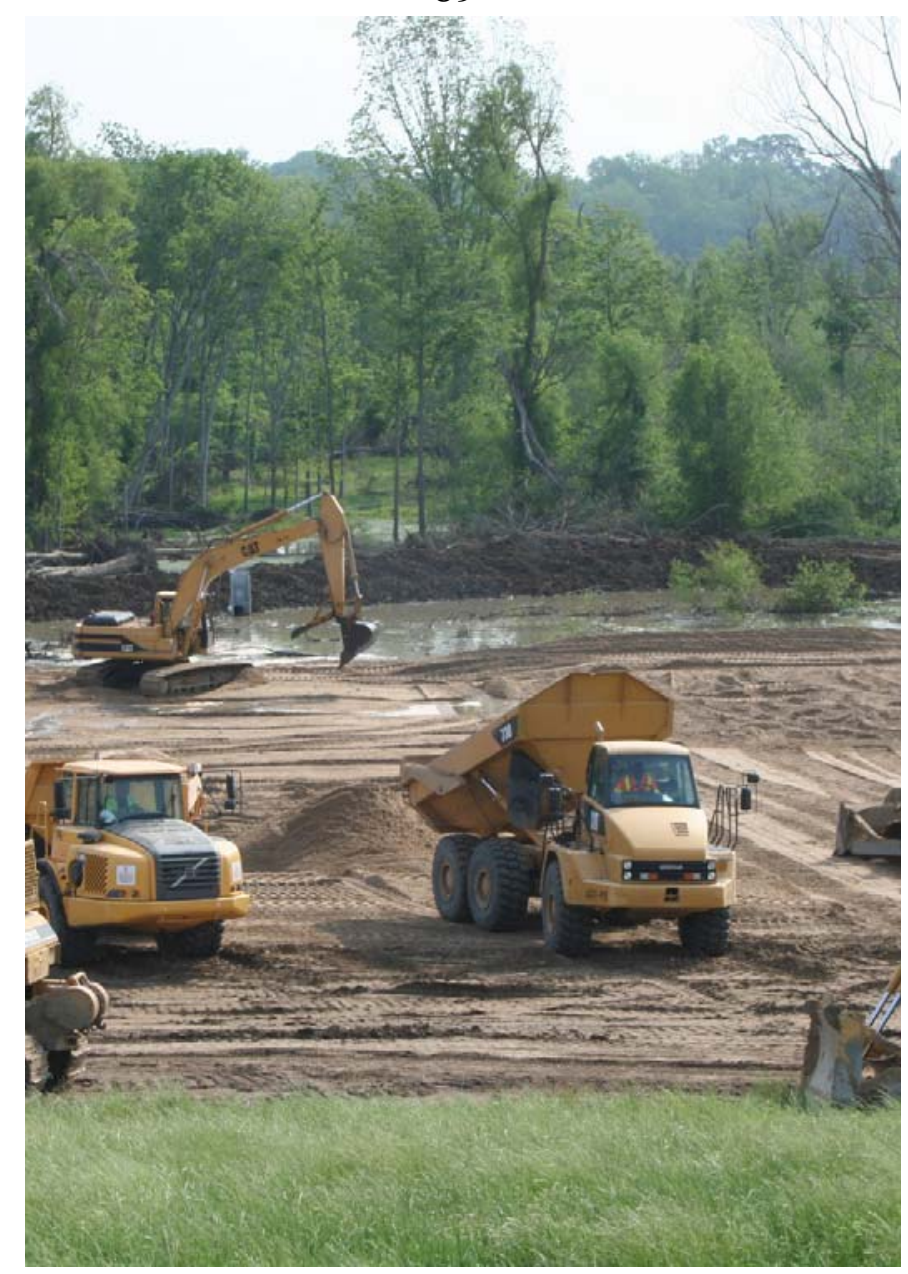

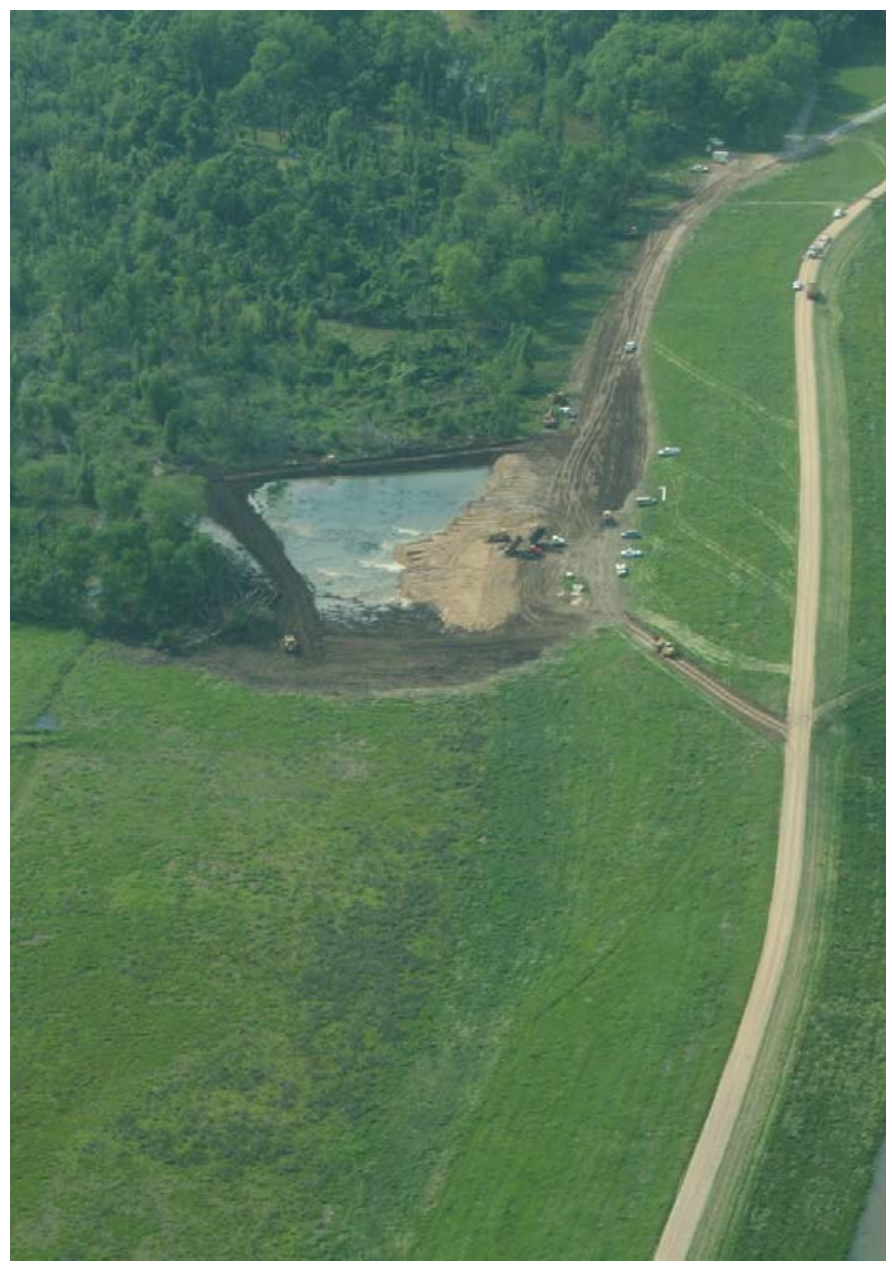

90

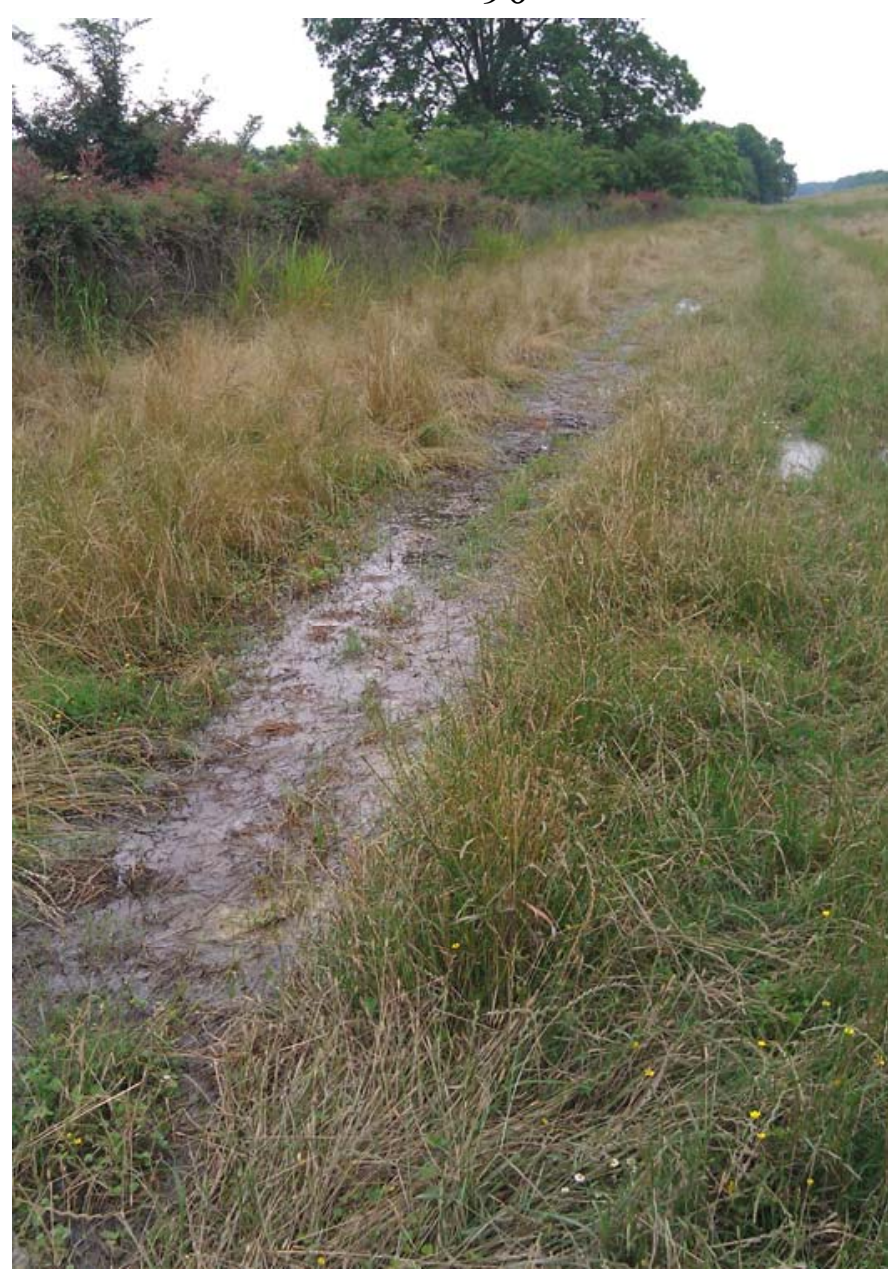




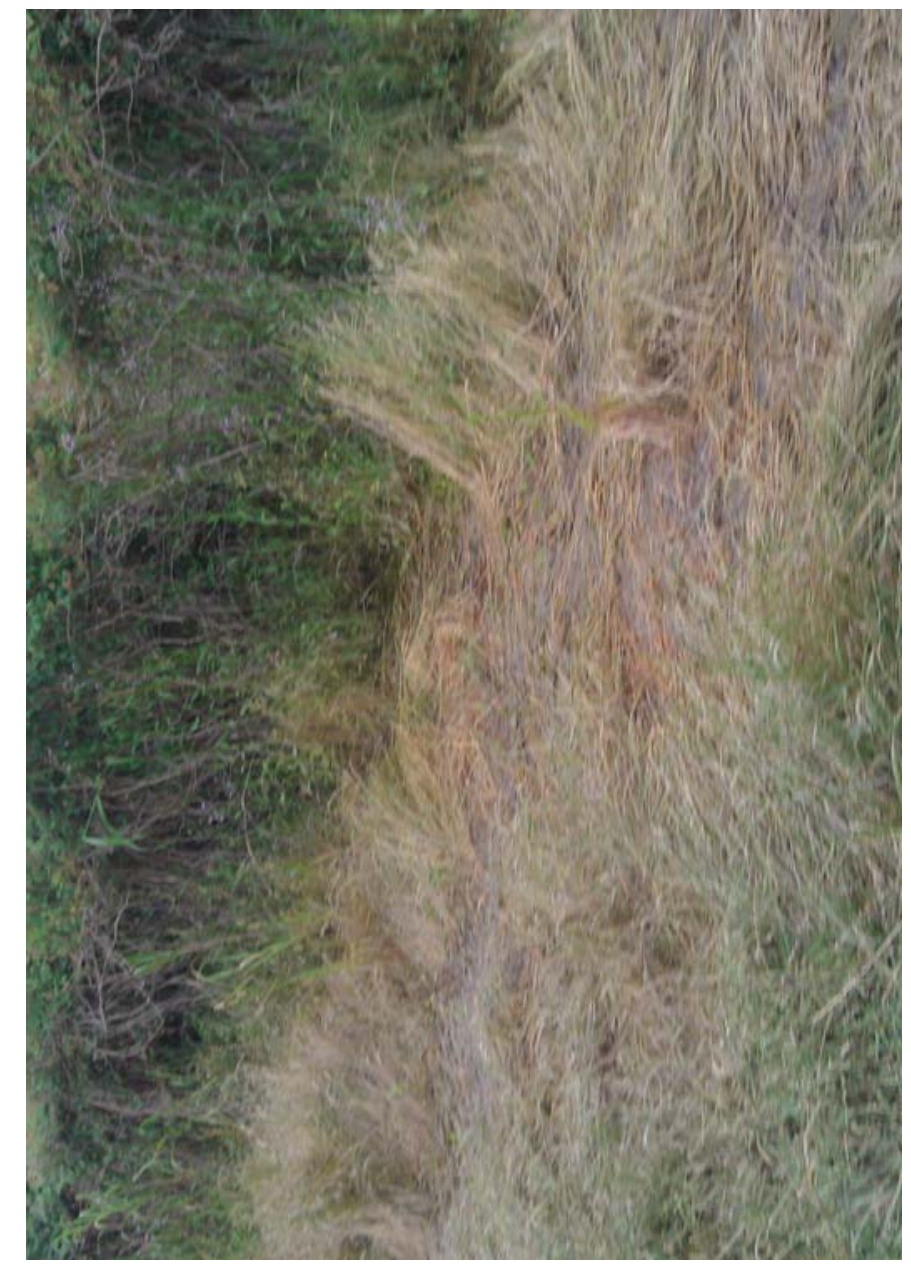

93

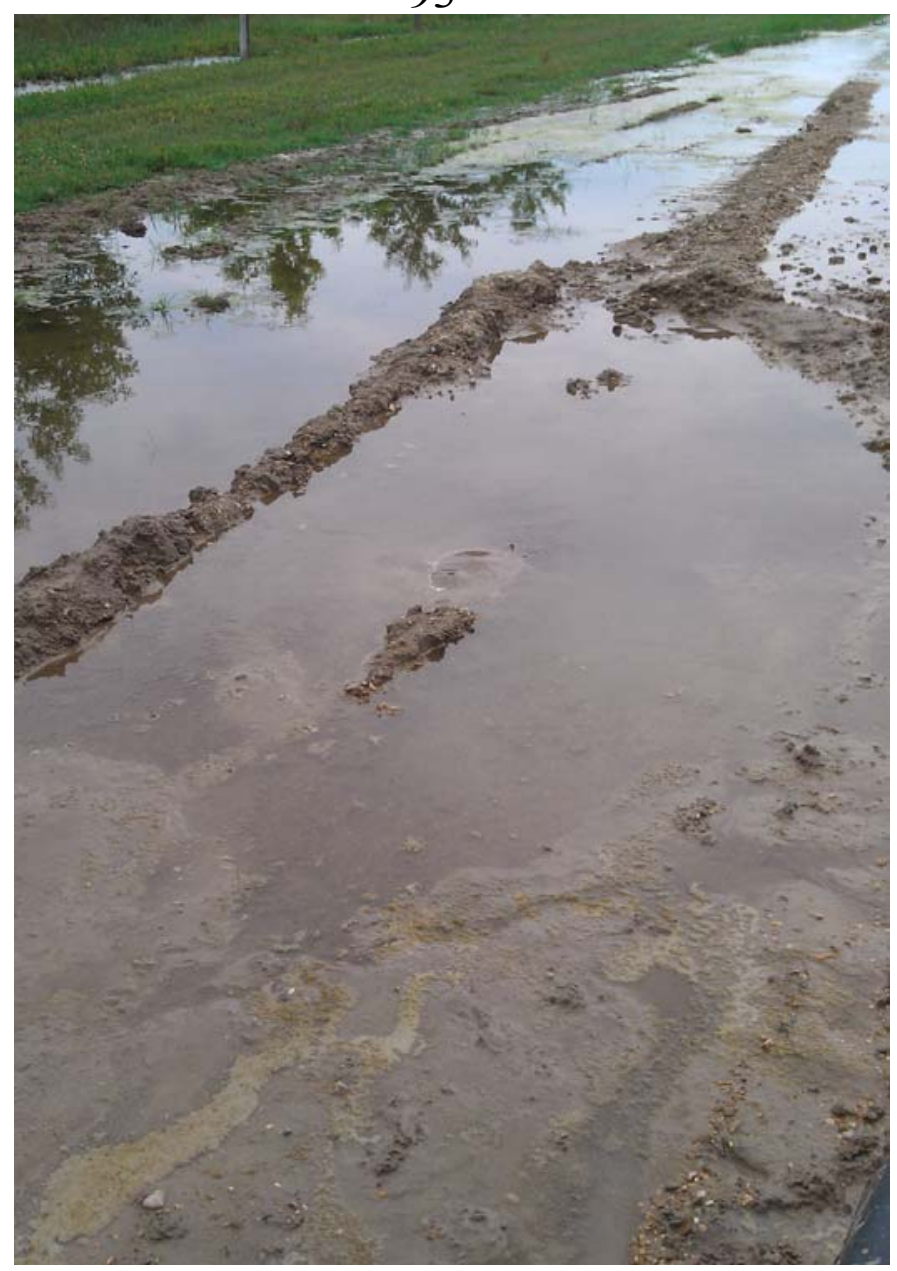




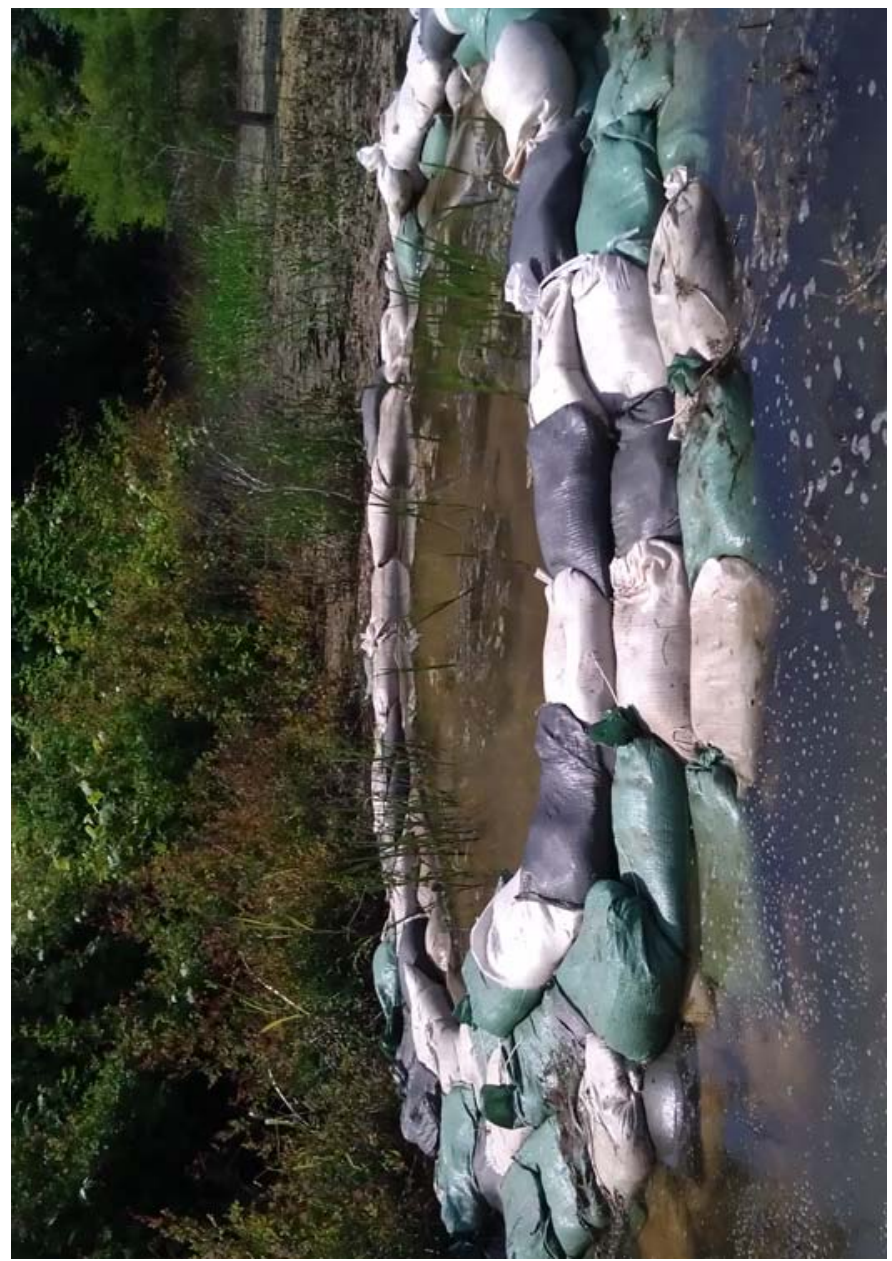

97

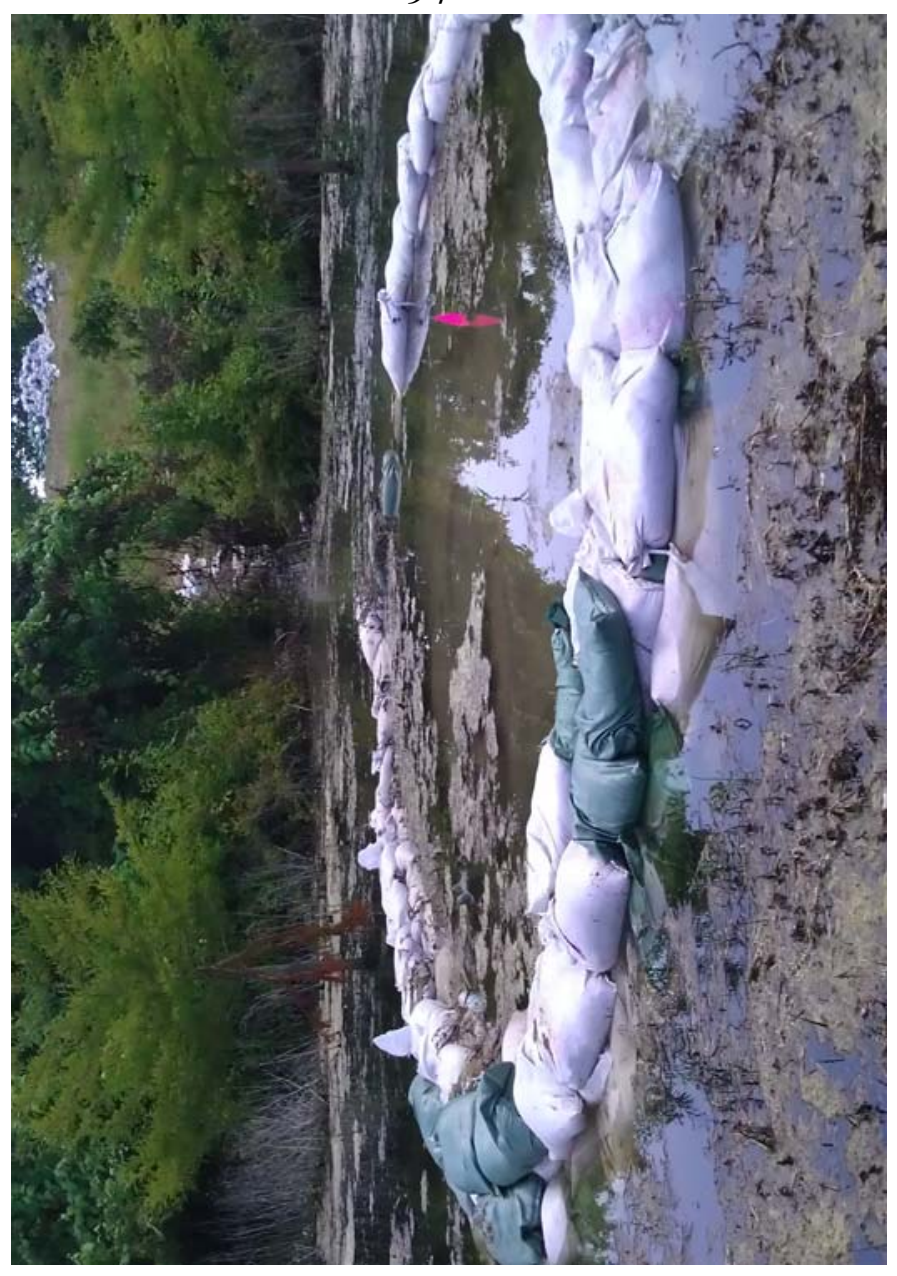

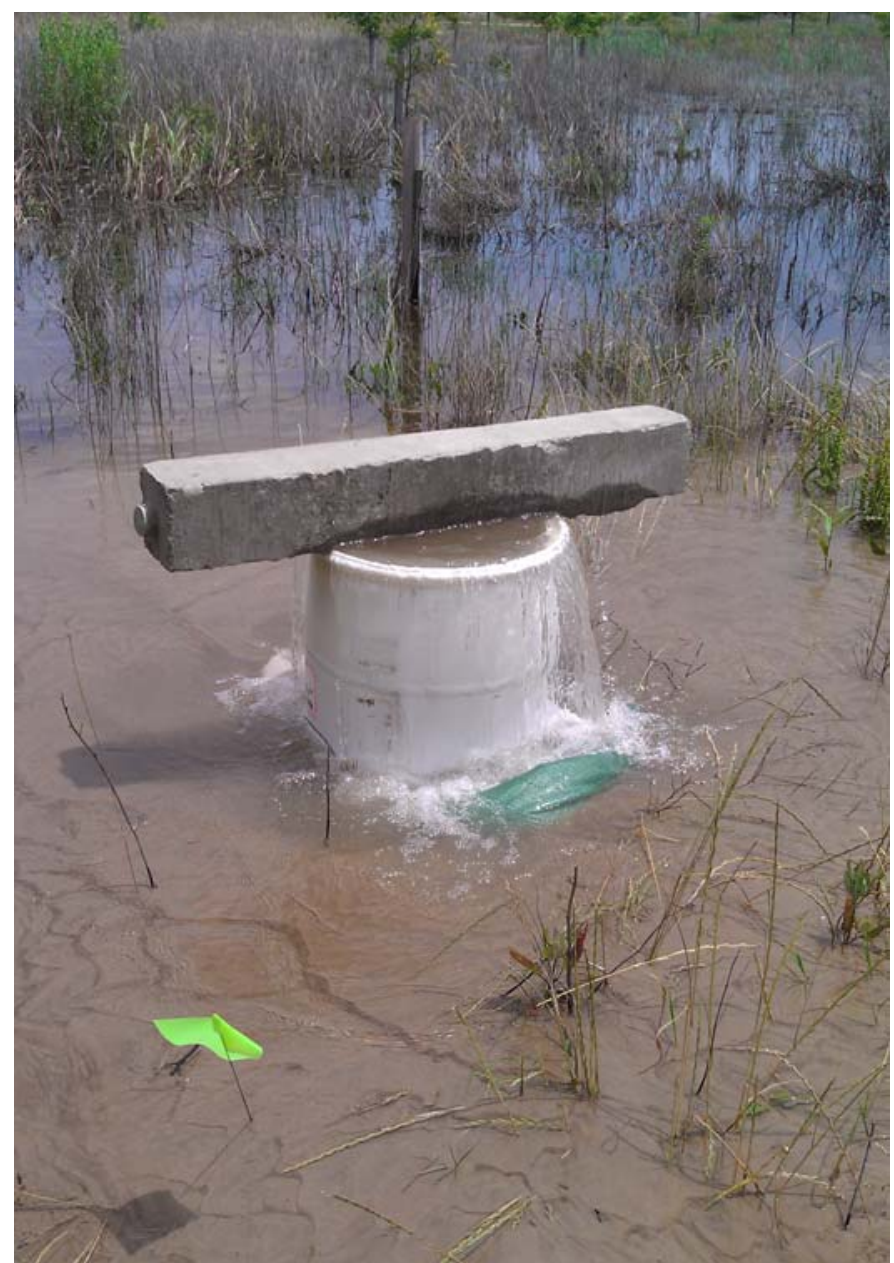

98

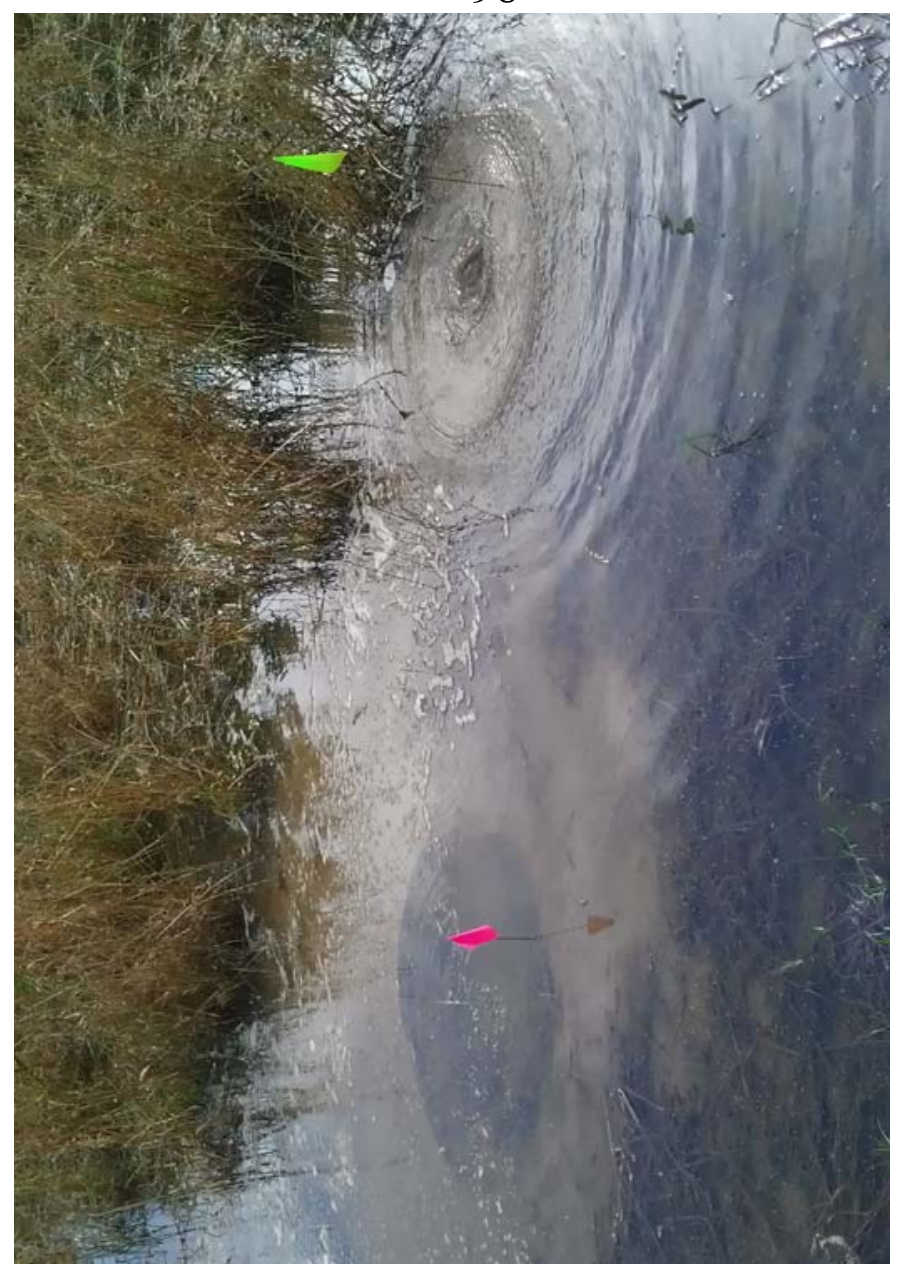




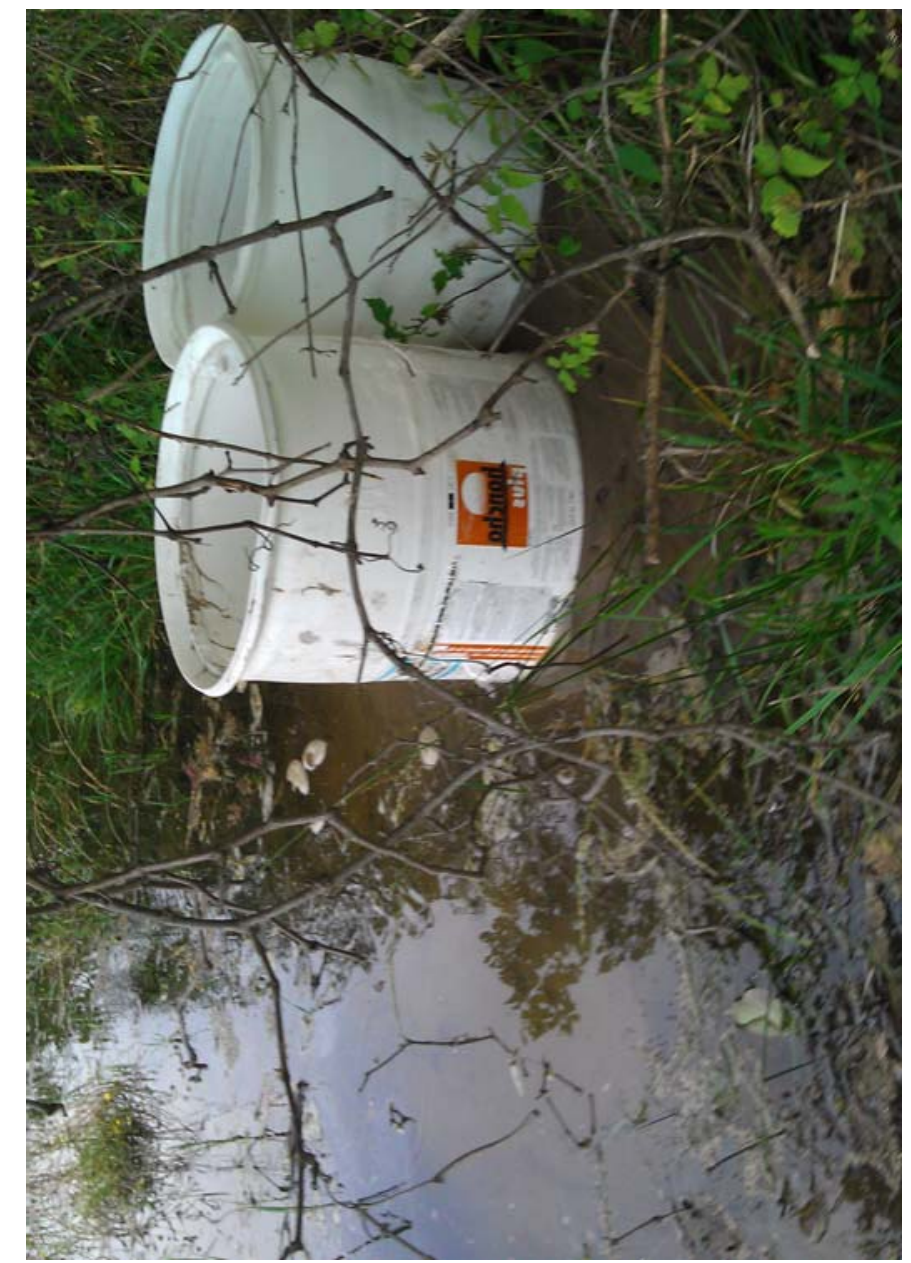

101

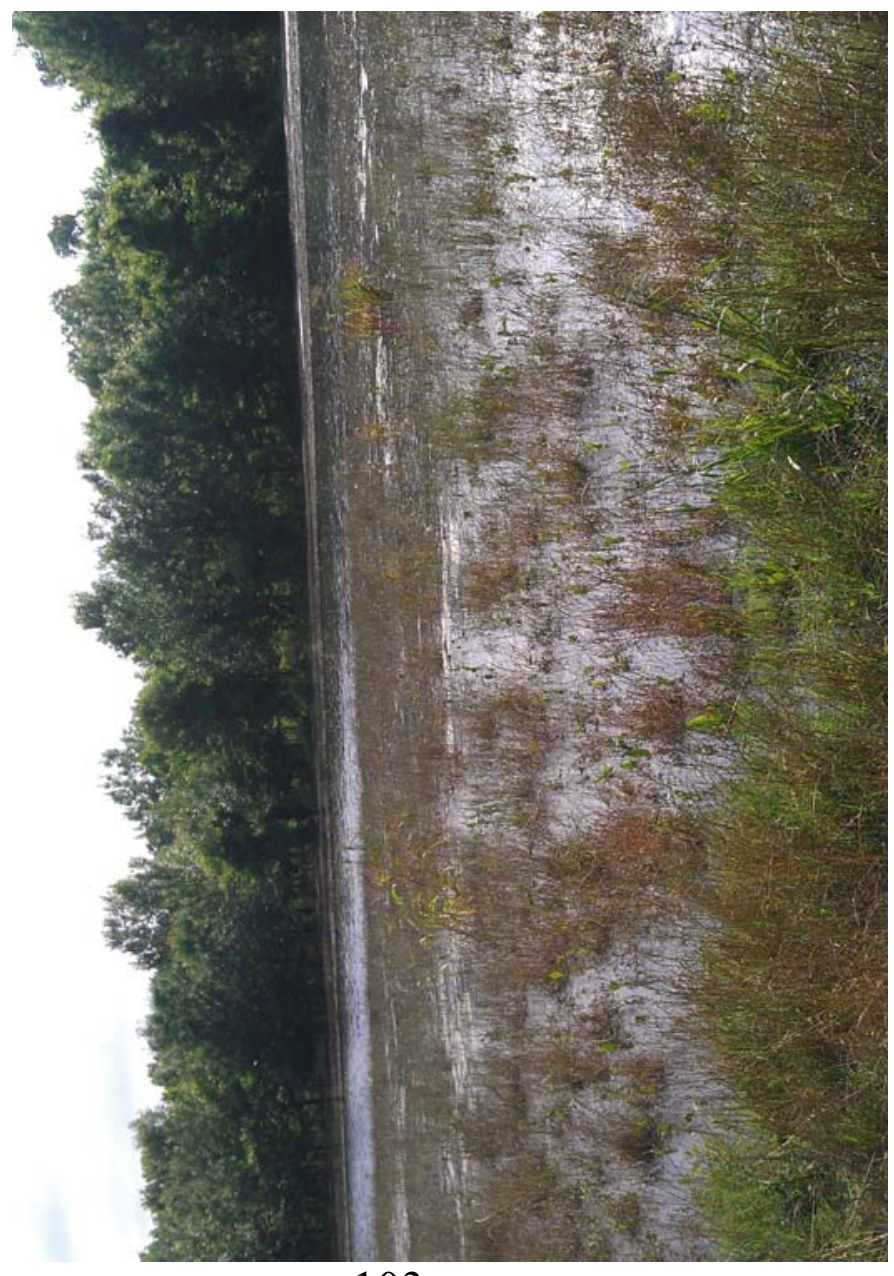

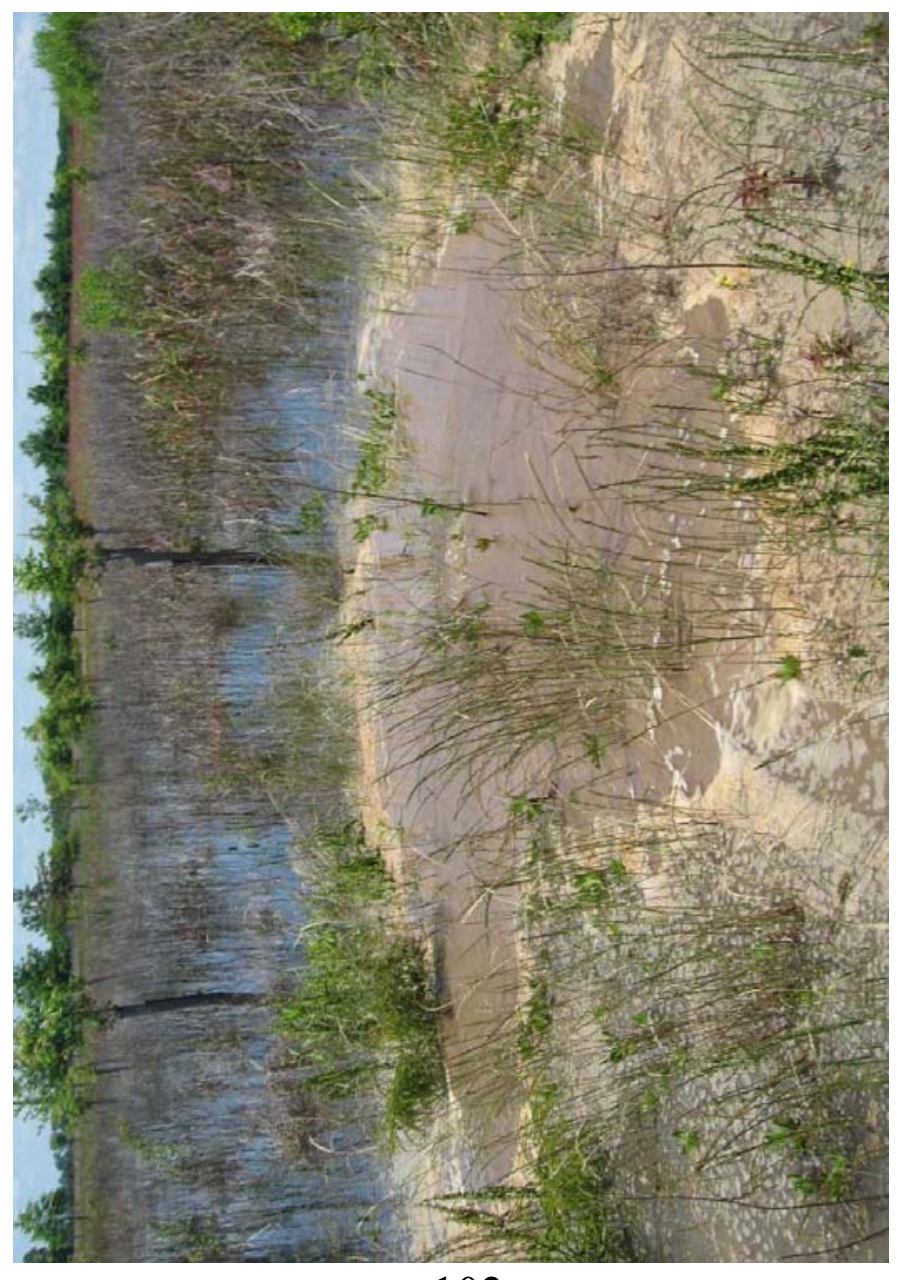

102

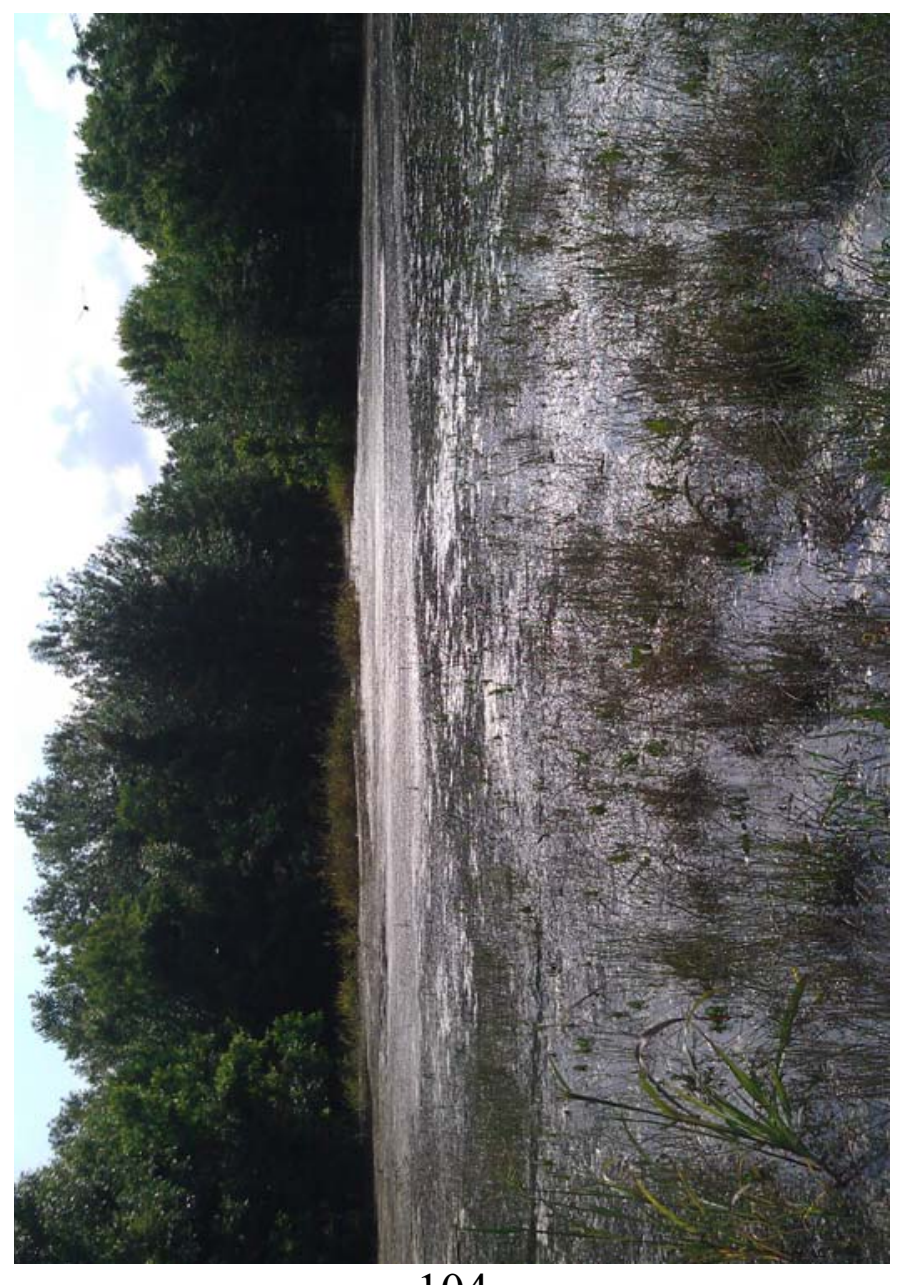



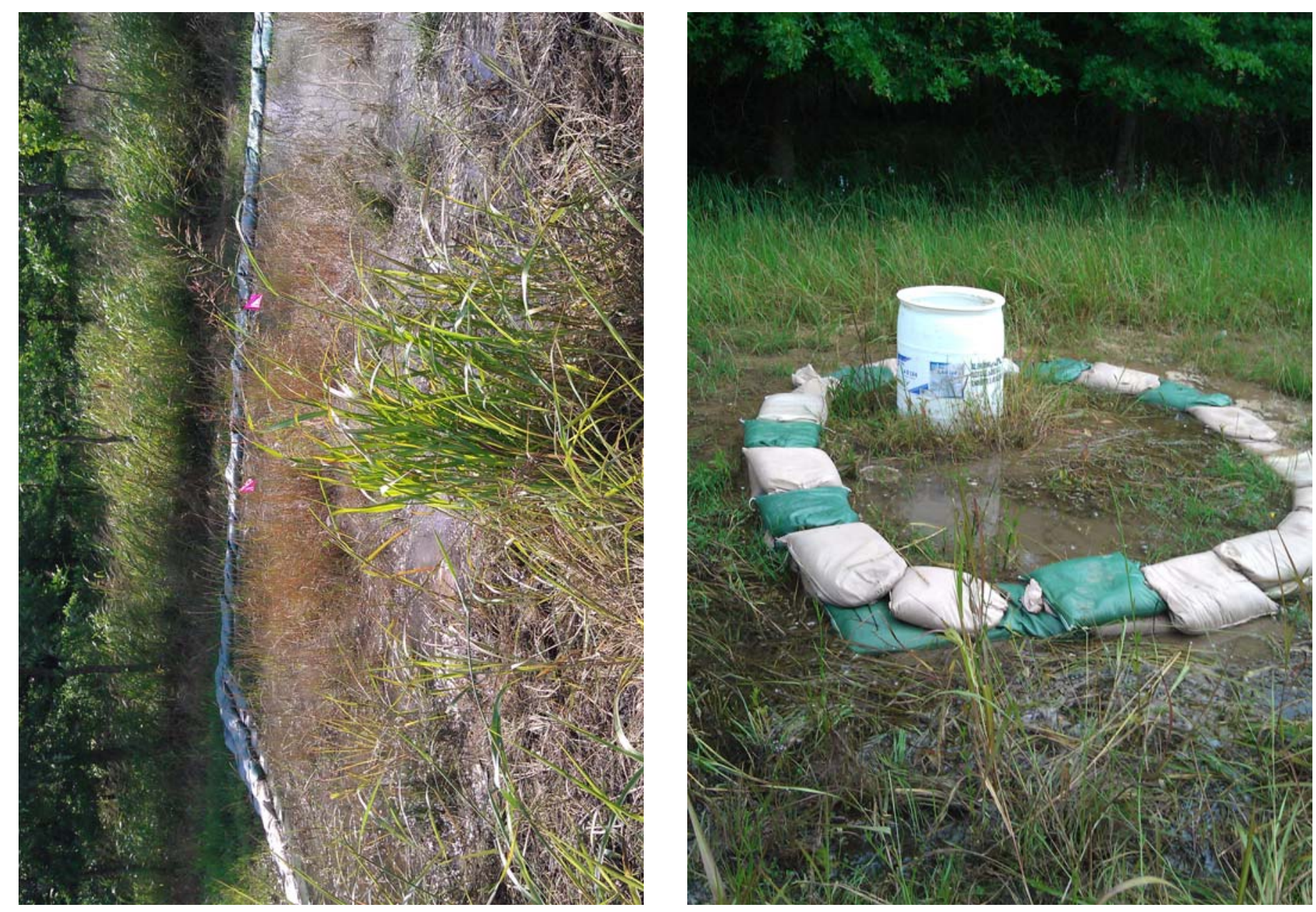

105
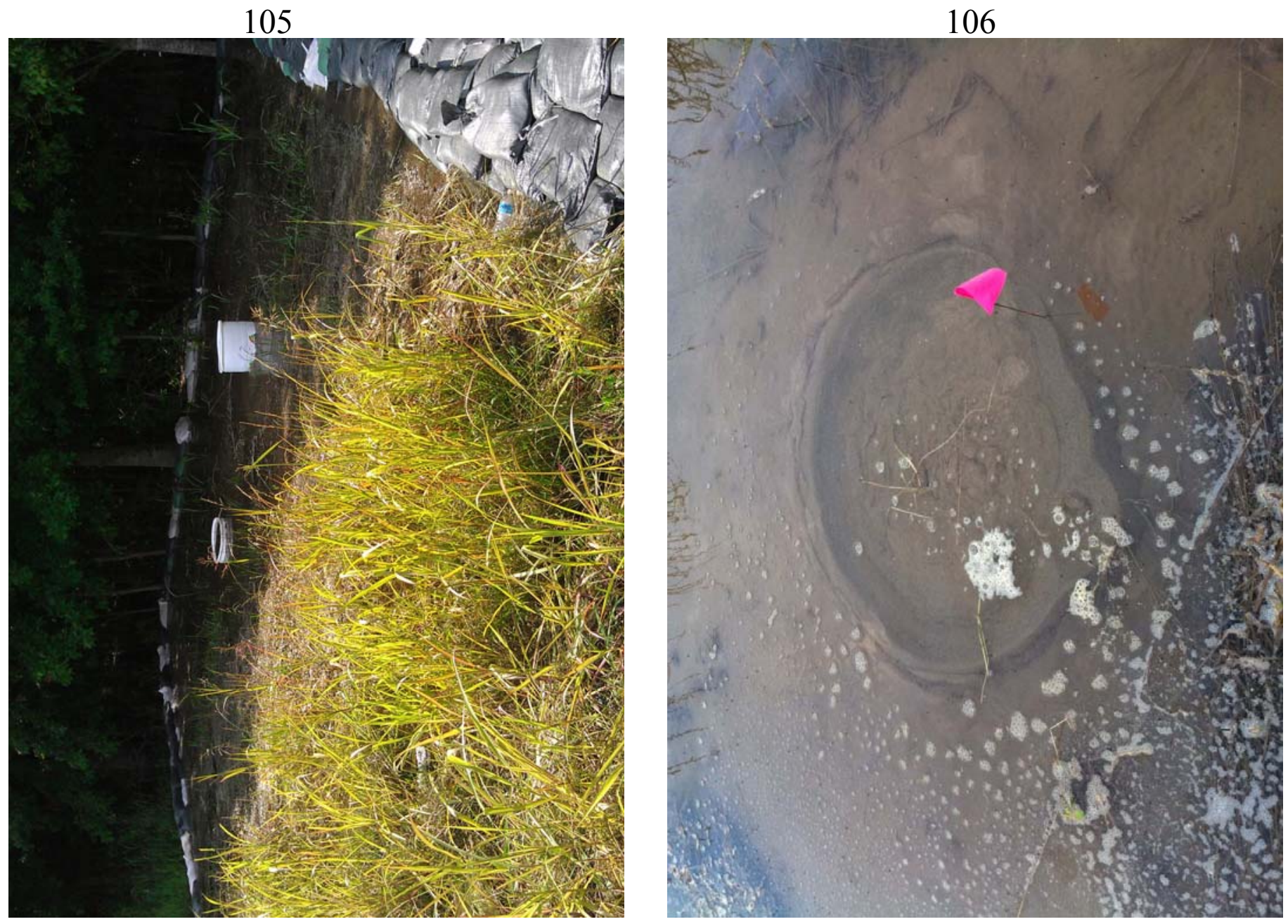


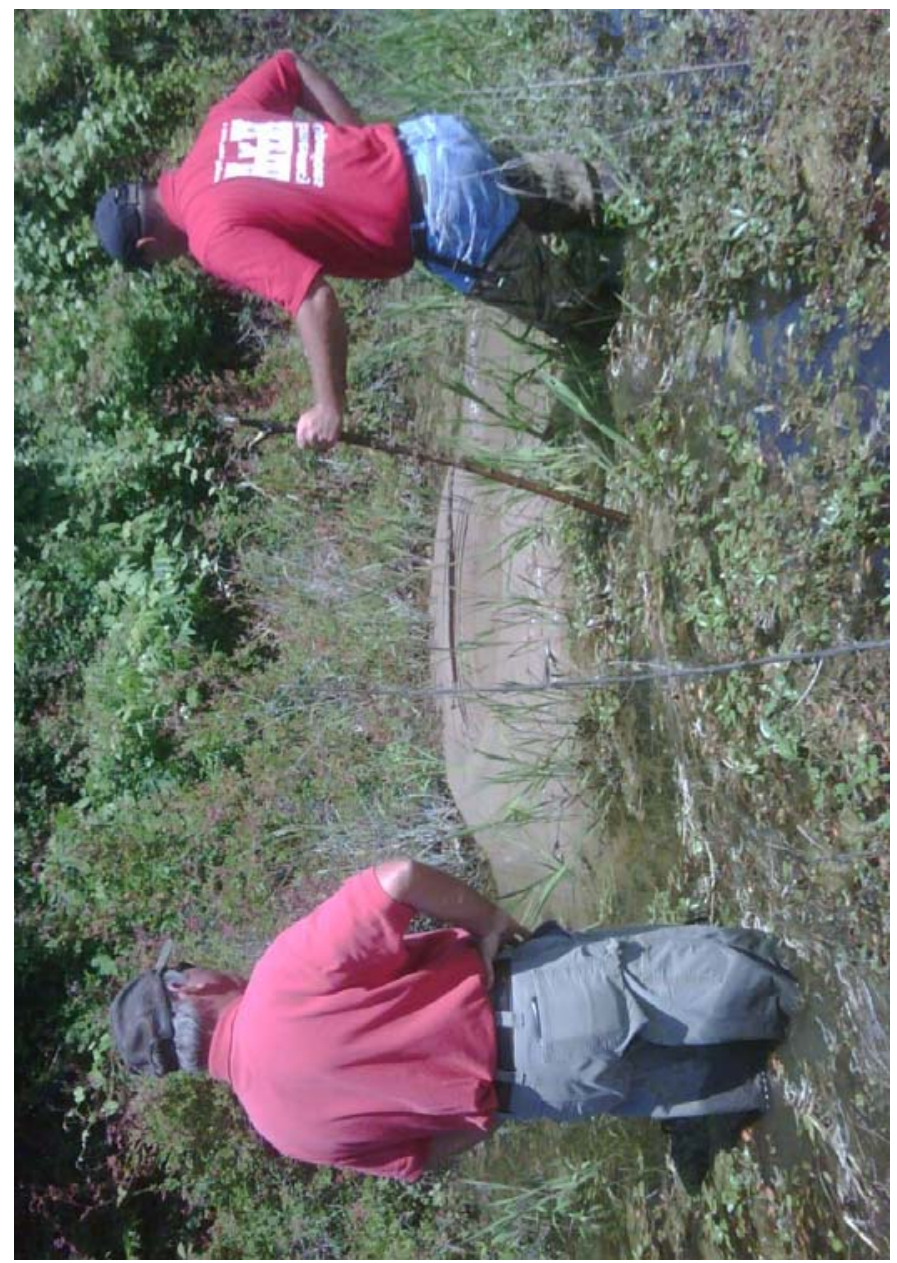

109

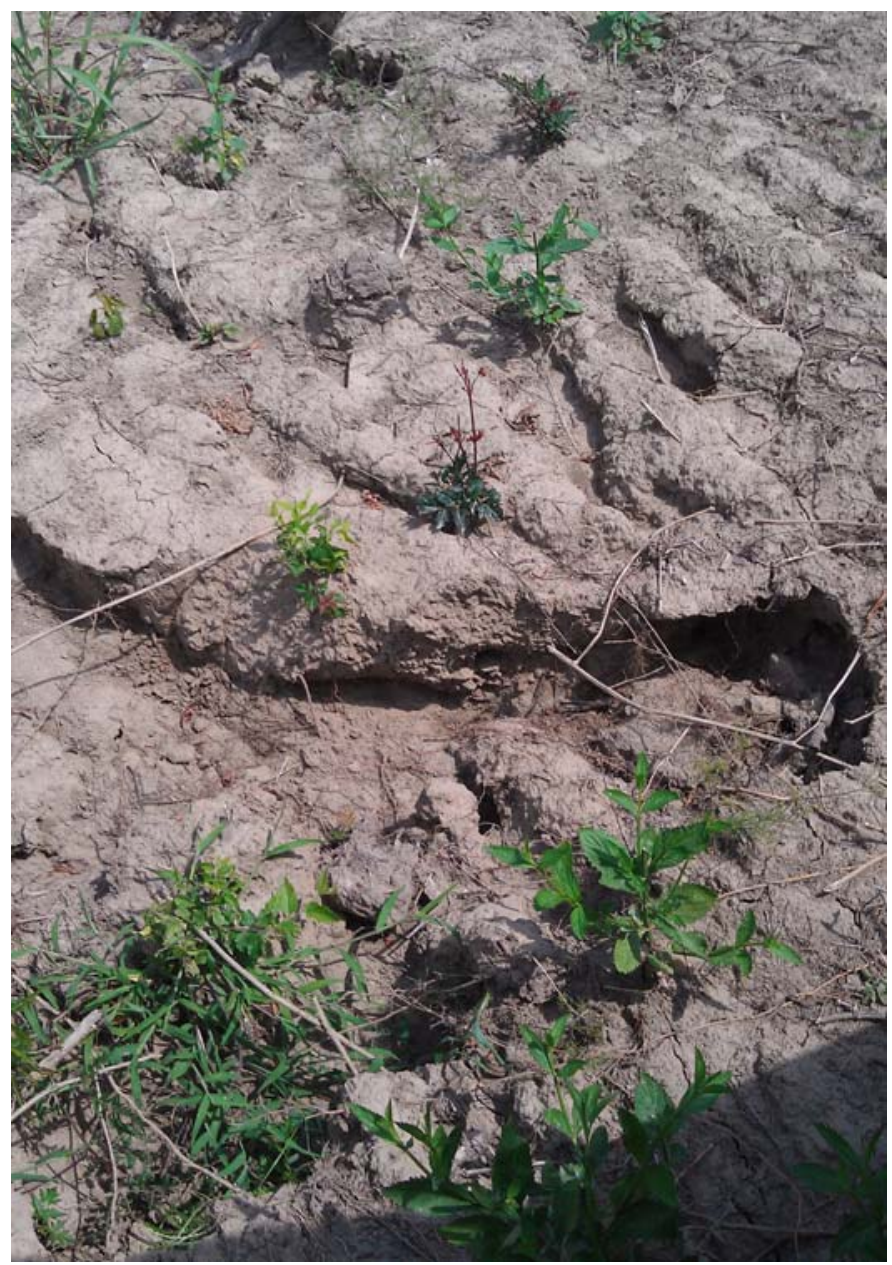

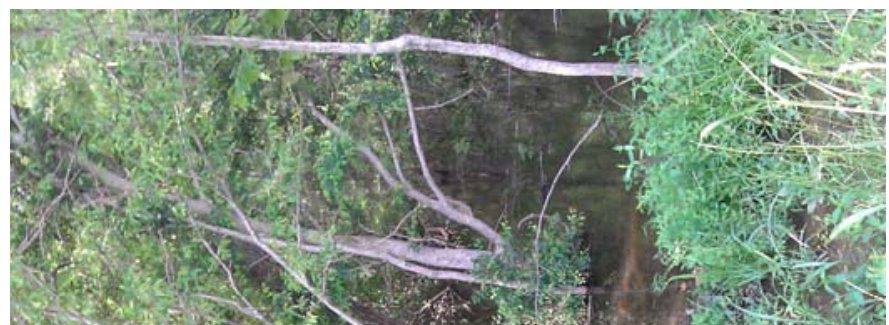

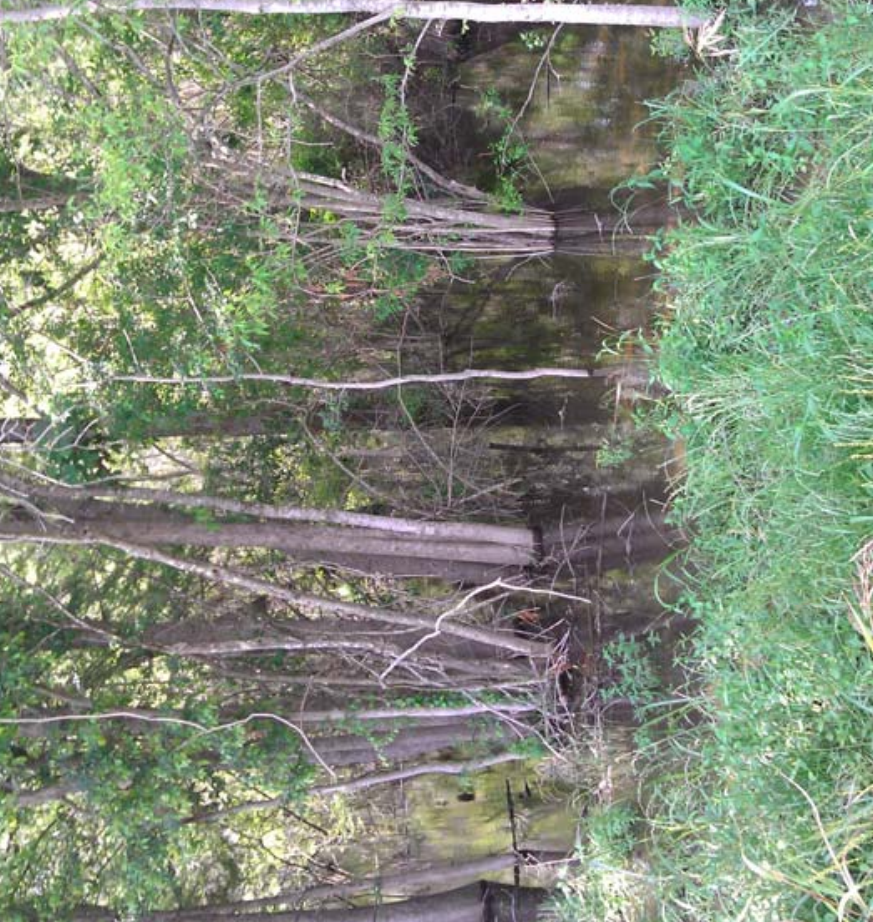
110

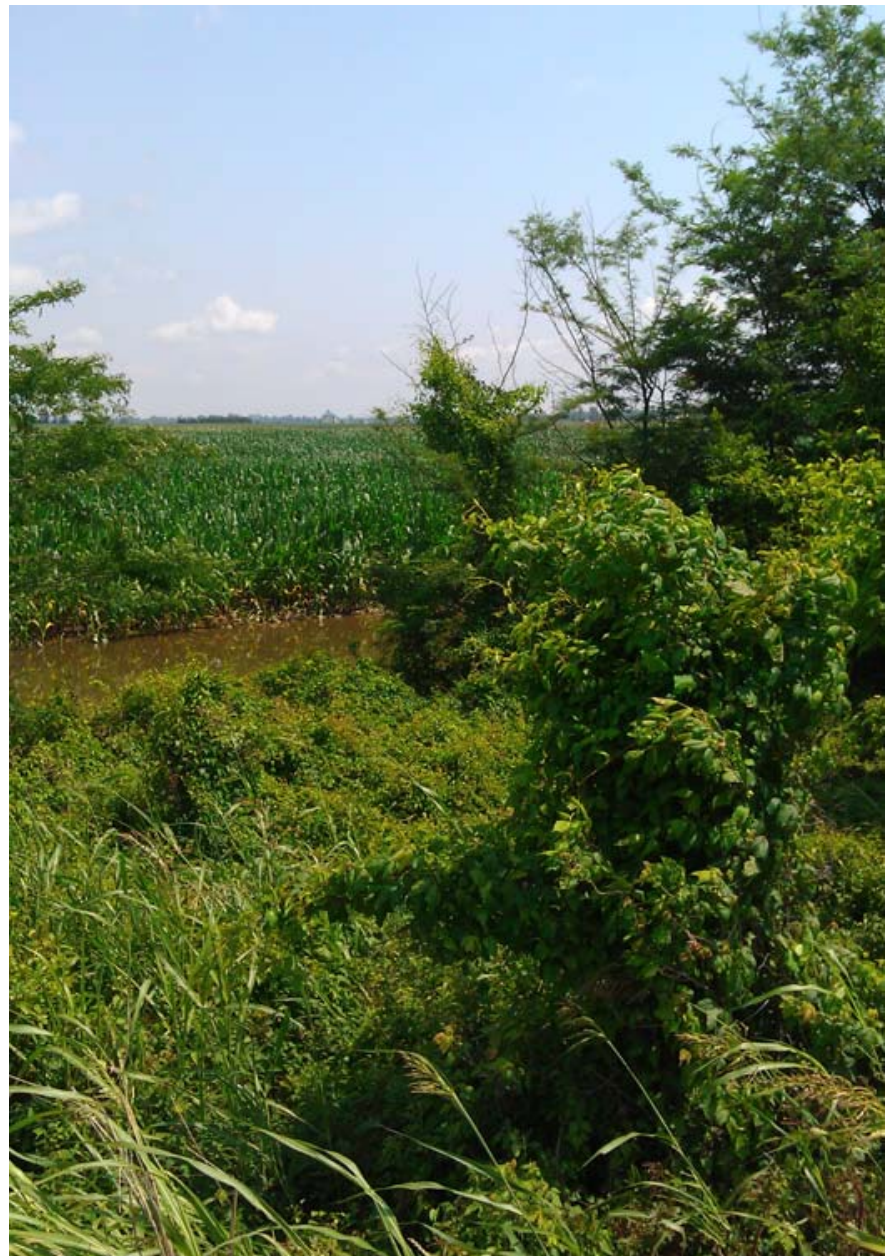



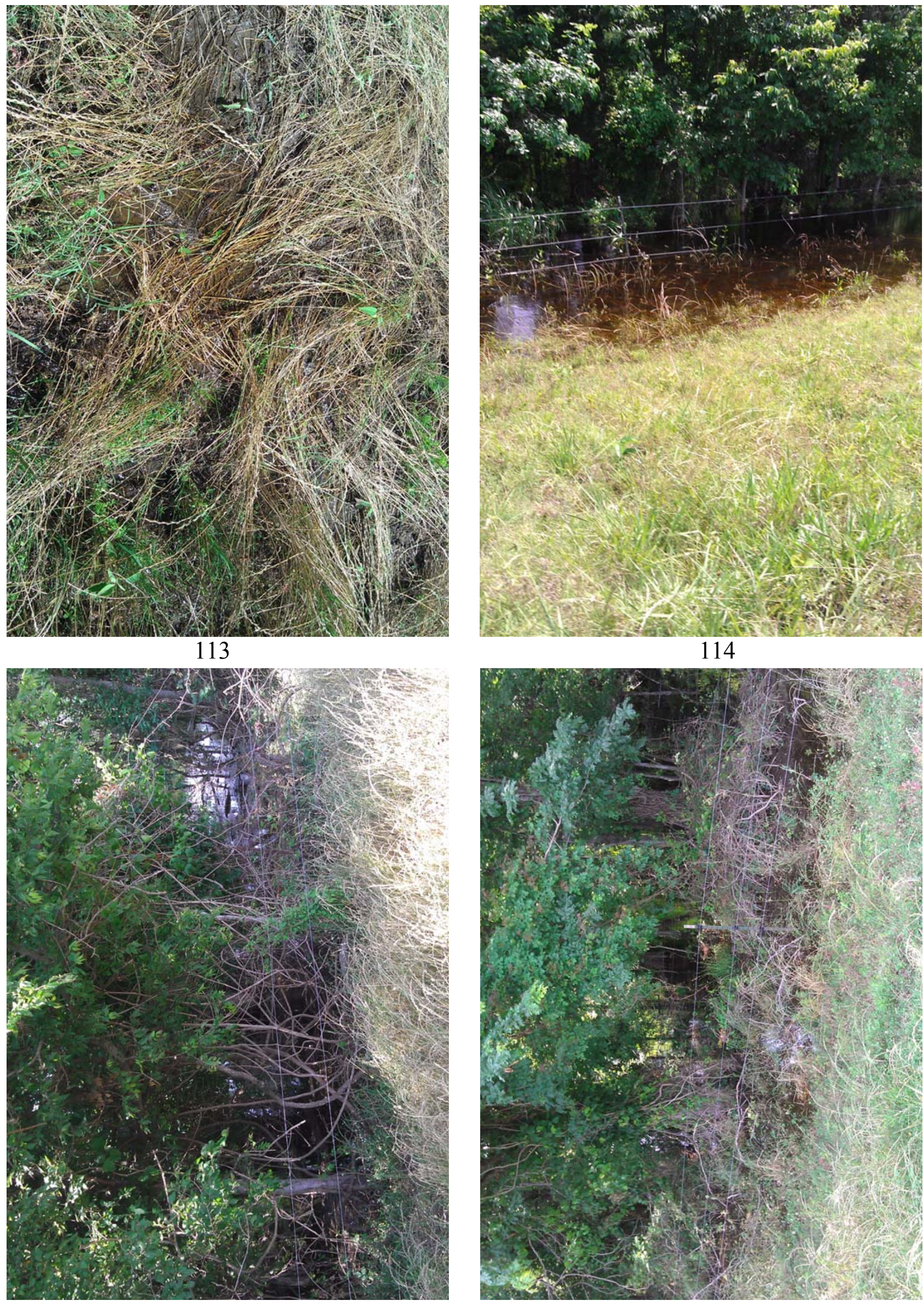


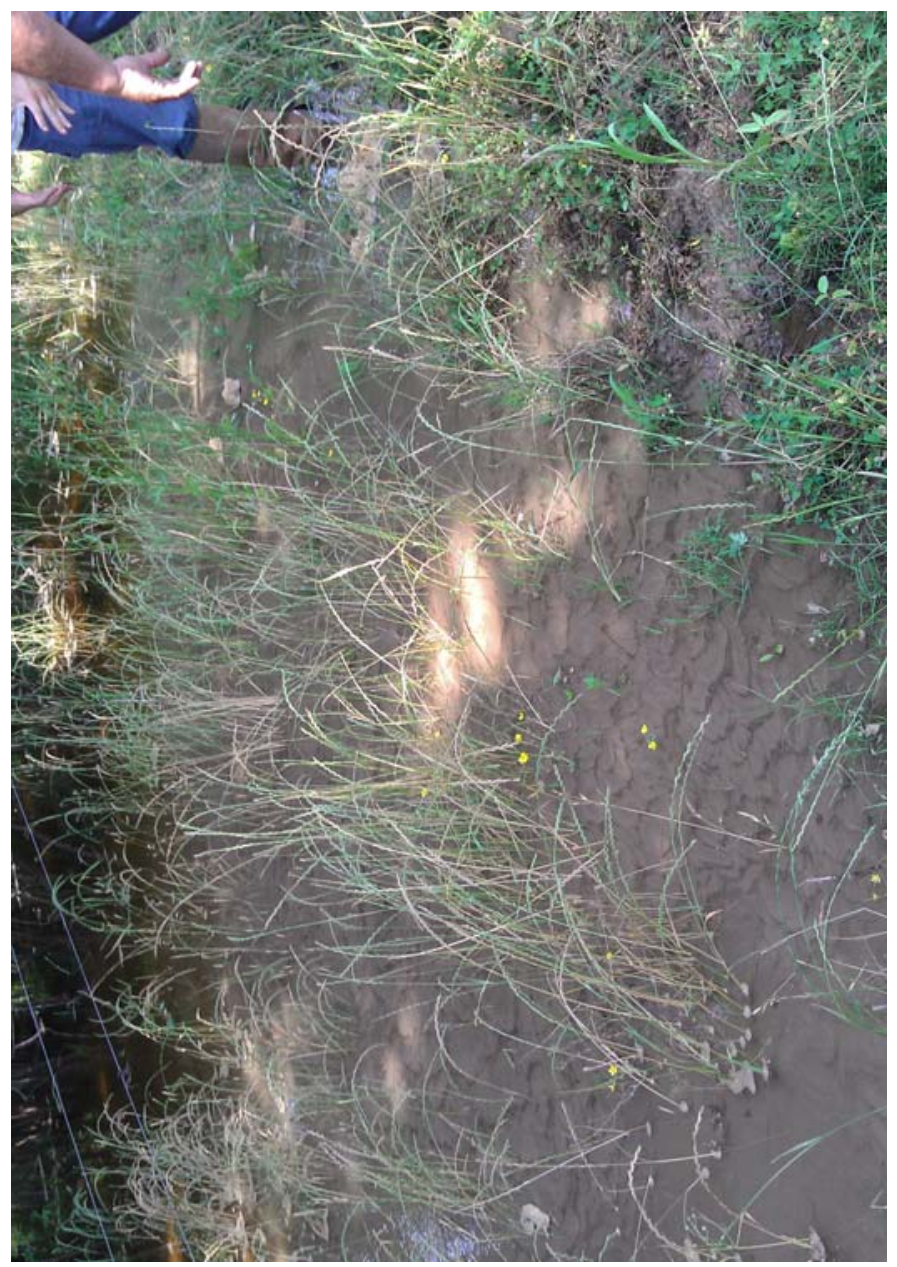

117

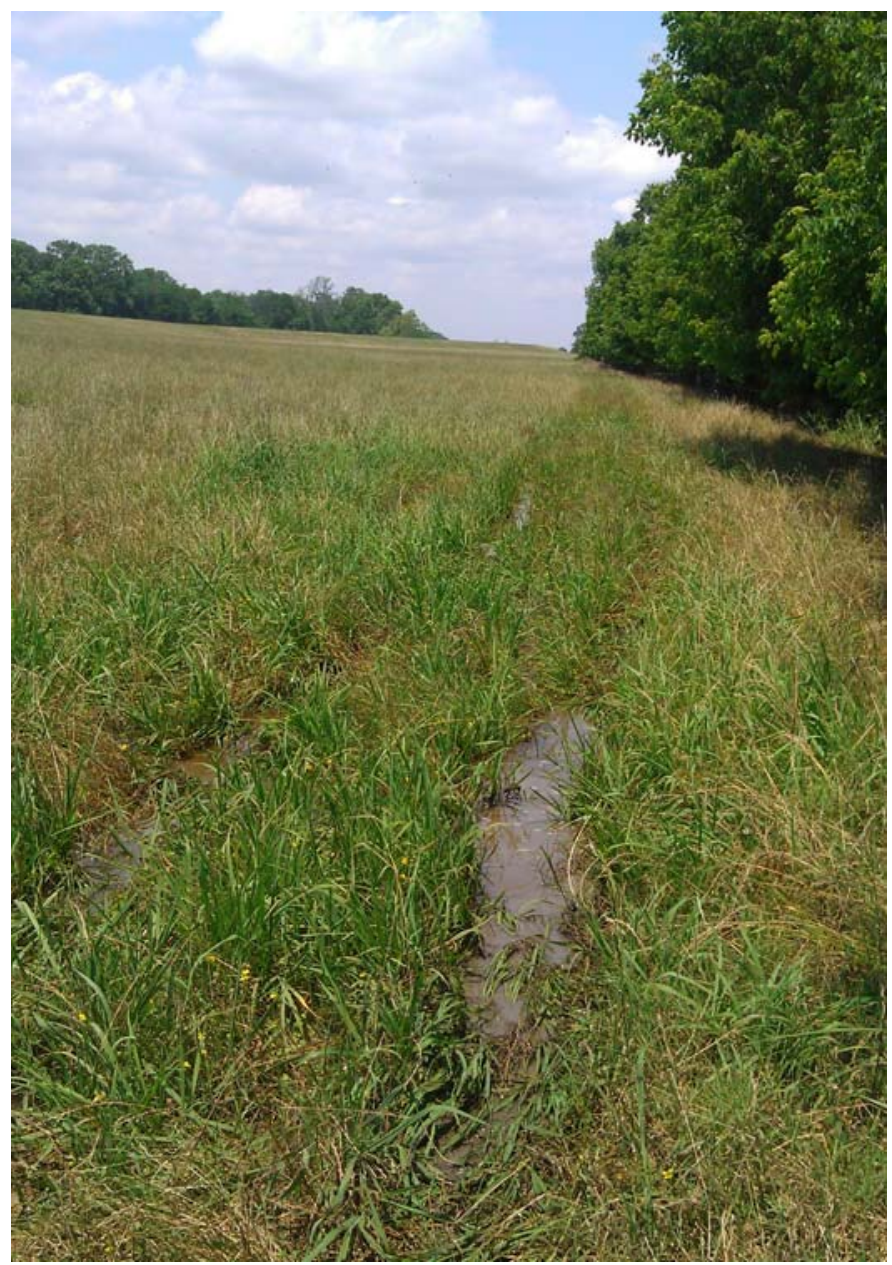

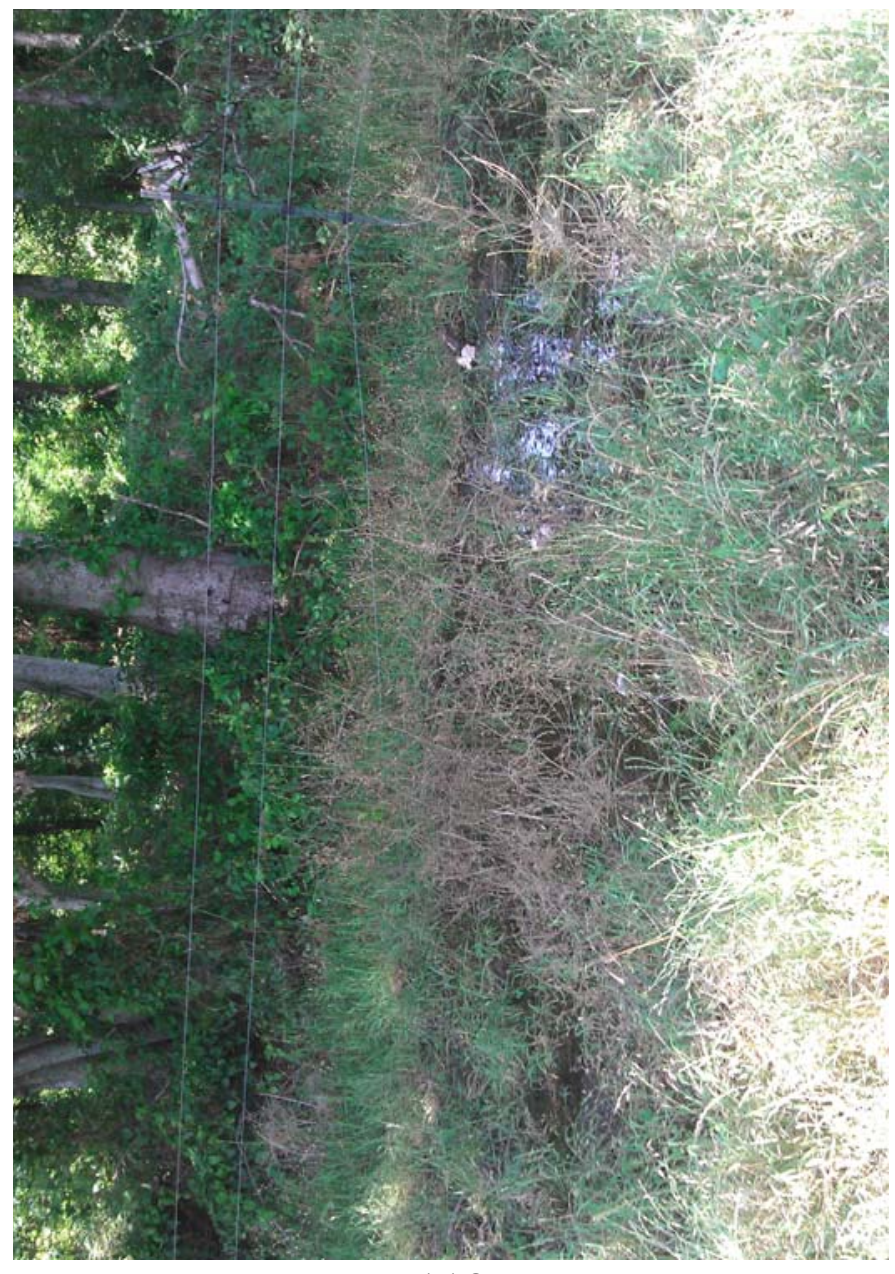

118

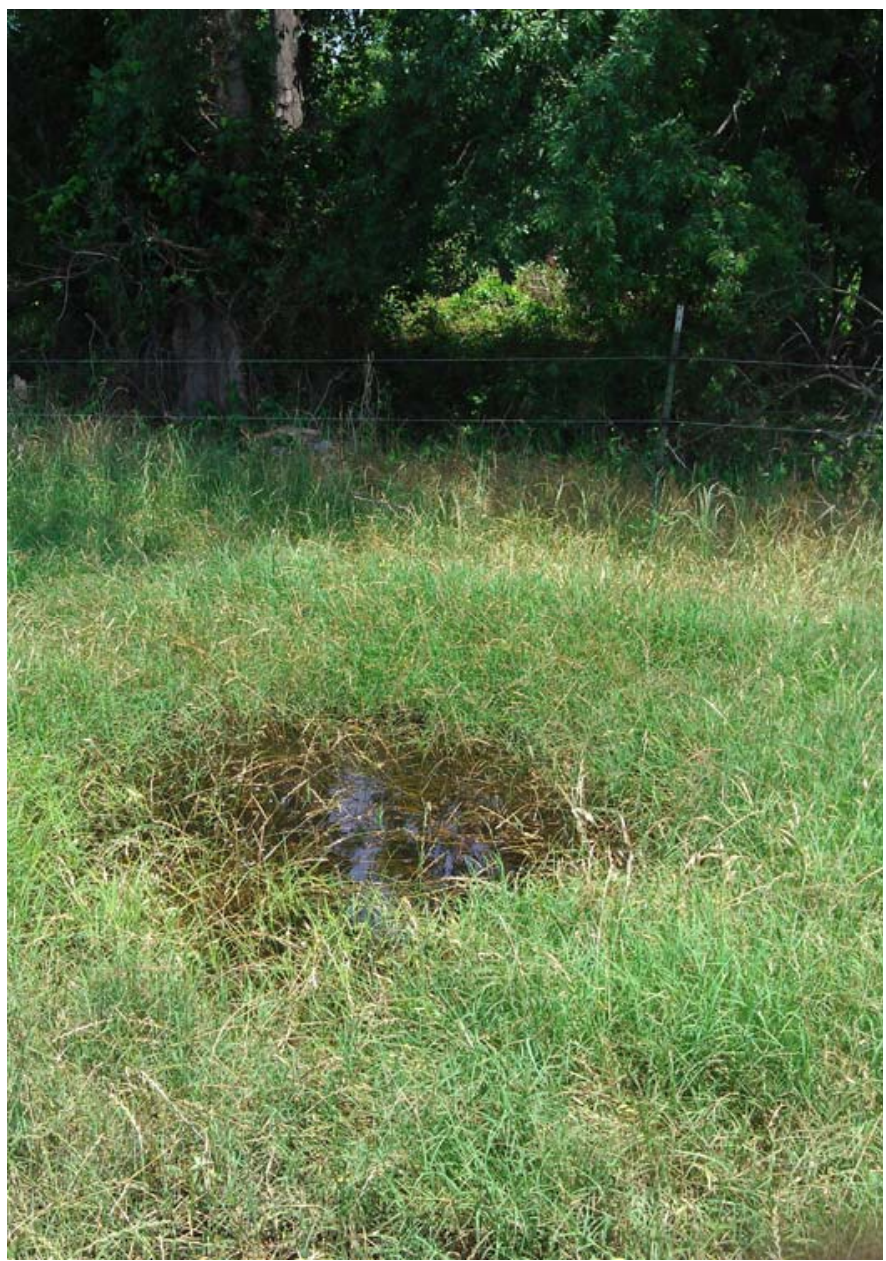

120 


\section{WEST BANK MISSISSIPPI RIVER LEVEE IN ARKANSAS STATION 0+00 TO 3990+77}


LEVEE SECTOR: West Bank MRL - Station 0+00 - Station 3990+77 (Upper end near Rohwer to LA Line)

DATE:

5/16/2011 - 5/18/2011

TEAM MEMBERS: Andy Hardy, Lane Vargas, and Ben Emery

\begin{tabular}{|c|c|c|c|c|c|c|c|c|c|}
\hline \multicolumn{2}{|c|}{ START } & \multicolumn{2}{|c|}{ END } & \multirow{2}{*}{$\begin{array}{l}\text { STATION } \\
\text { NLD } \\
\end{array}$} & \multirow{2}{*}{$\begin{array}{l}\text { STATION } \\
\text { LEVEE }\end{array}$} & \multirow[t]{2}{*}{ TYPE } & \multirow[t]{2}{*}{ EXTENT } & \multirow[t]{2}{*}{ REMARKS } & \multirow{2}{*}{$\begin{array}{l}\text { PHOTO } \\
\text { LINKS }\end{array}$} \\
\hline Latitude & Longitude & Latitude & Longitude & & & & & & \\
\hline 33.74760 & -91.25460 & 33.74540 & -91.25230 & $122+00-132+20$ & $122+00-132+20$ & Under Seepage & Moderate & Seepage at toe of berm and 25 beyond toe of berm. & $1-3$ \\
\hline 33.74630 & -91.25350 & -- & -- & $127+50$ & $127+50$ & & & $\begin{array}{l}\text { Moderate flow visible near toe of berm and into adjacent field but no source } \\
\text { found. }\end{array}$ & $1-3$ \\
\hline 33.74540 & -91.25230 & 33.74440 & -91.25020 & $132+20-142+80$ & $132+80-143+20$ & Under Seepage & Light & Standing water at berm toe and 25 ' into fields. & \\
\hline 33.74440 & -91.25020 & 33.73290 & -91.24200 & $142+80-192+00$ & $143+20-192+70$ & Under Seepage & Light to Moderate & Standing water at berm toe and $1500^{\prime}$ into field. & 4-5 \\
\hline 33.73180 & -91.23940 & 33.72950 & -91.23480 & $200+70-216+90$ & $201+20-217+60$ & Under Seepage & Light & At levee toe and $300^{\prime}$ into field & \\
\hline 33.72390 & -91.22418 & -- & -- & $263+00$ & $263+80$ & Sand Boil & Moderate & $\begin{array}{l}\text { Sand boil with 6" diameter and 1' depth. Clear flow at trickle pace. Located } \\
300 \text { ' from toe of levee. }\end{array}$ & 6 \\
\hline 33.69941 & -91.23174 & 33.69923 & -91.23245 & $371+30-373+00$ & $372+30-374+00$ & Under Seepage & Light & At berm toe and immediate area. & \\
\hline 33.68880 & -91.24030 & 33.68240 & -91.24040 & $422+90-445+90$ & $424+00-447+00$ & Under Seepage & Light & At berm toe and immediate area. & \\
\hline 33.68120 & -91.24050 & 33.67900 & -91.24090 & $456+10-458+40$ & $457+50-459+80$ & Under Seepage & Light & At berm toe and immediate area. & \\
\hline 33.64414 & -91.21746 & -- & -- & $610+00$ & $611+20$ & Under Seepage & Moderate & Leaking well head $20^{\prime}$ from berm toe is the likely source of collected water. & 7 \\
\hline & & & & $615+00$ & $616+20$ & Under Seepage & Light & $\begin{array}{l}\text { Seepage at fence near berm toe and around possible cattle pond near berm } \\
\text { toe. }\end{array}$ & 8 \\
\hline 33.61906 & -91.19824 & 33.61810 & -91.19730 & $722+50-727+00$ & $723+80-728+20$ & Under Seepage & Light to Moderate & In levee toe ditch and $150^{\prime}$ into field. & \\
\hline 33.46592 & -91.24902 & 33.46200 & -91.25090 & $\begin{array}{l}1390+00- \\
1405+50\end{array}$ & $\begin{array}{l}1391+20- \\
1406+70\end{array}$ & Under Seepage & Light & $\begin{array}{l}\text { At levee toe and 300' into fields and around the edge of a small patch of } \\
\text { woods at the toe of the levee near the upstream end of the reach. }\end{array}$ & \\
\hline 33.46200 & -91.25090 & 33.45750 & -91.26200 & $\begin{array}{l}1405+50- \\
1448+00 \\
\end{array}$ & $\begin{array}{l}1406+70- \\
1450+90 \\
\end{array}$ & Under Seepage & Moderate & Seepage on berm, at berm toe, and 300 ' into fields. & 9 \\
\hline 33.46070 & -91.25230 & -- & -- & $1410+30$ & $1411+10$ & $\begin{array}{c}\text { Under Seepage/Pin } \\
\text { Boils }\end{array}$ & Moderate & $\begin{array}{l}\text { Group of pin boils in corner of field adjacent to berm toe. Boils were } \\
\text { numerous, but area was inundated with seep water, providing adequate head } \\
\text { to prevent moving any material. }\end{array}$ & \\
\hline 33.45800 & -91.26010 & -- & -- & $1442+20$ & $1443+00$ & Under Seepage/Pin & Moderate & Group of pin boils in field near berm toe. Minimal material moved. & \\
\hline 33.45750 & -91.26200 & 33.44530 & -91.25980 & $\begin{array}{l}1448+00- \\
1493+80\end{array}$ & $\begin{array}{c}1450+90- \\
1497+00\end{array}$ & Under Seepage & Light & $\begin{array}{l}\text { Seepage on berm, at berm toe, and into adjacent fields and wooded area } 400^{\prime} \\
\text { from berm toe. }\end{array}$ & \\
\hline 33.44370 & -91.25920 & 33.44240 & -91.25900 & $\begin{array}{l}1499+50- \\
1501+70\end{array}$ & $\begin{array}{l}1502+70- \\
1504+90\end{array}$ & $\begin{array}{c}\text { Under Seepage/Pin } \\
\text { Boils }\end{array}$ & Light to Moderate & $\begin{array}{l}\text { Group of pin boils near toe of berm at the edge of the wood line, seepage on } \\
\text { seepage berm, at the toe, and } 50 \text { ' into fields. }\end{array}$ & \\
\hline-- & -- & 33.44340 & -91.25980 & $1500+50$ & $1503+70$ & Sand Boil & Moderate & $\begin{array}{l}\text { Boil at toe of seepage berm in edge of wood line with an 8" cone no longer } \\
\text { moving material and low flow. }\end{array}$ & \\
\hline 33.44240 & -91.25900 & 33.43830 & -91.24330 & $\begin{array}{l}1501+70- \\
1556+50\end{array}$ & $\begin{array}{l}1504+90- \\
1561+20 \\
\end{array}$ & Under Seepage & Light to Moderate & $\begin{array}{l}\text { On seepage berm, at the toe, and into fields. Animal burrow approx. 1' } \\
\text { diameter at toe of berm. }\end{array}$ & 10 \\
\hline 33.43830 & -91.24330 & 33.43420 & -91.24340 & $\begin{array}{l}1556+50- \\
1575+00\end{array}$ & $\begin{array}{l}1561+20- \\
1579+80\end{array}$ & Under Seepage & $\begin{array}{l}\text { Moderate to } \\
\text { Heavy }\end{array}$ & $\begin{array}{l}\text { In ditch at the toe of the berm and into fields. Three sand boils with a trickle } \\
\text { flow and } 10 \text { pin holes within a 200' area located } 300^{\prime} \text { from toe at Sta. } \\
1575+00 \text {. }\end{array}$ & $11-12$ \\
\hline 33.43198 & -91.24282 & -- & -- & $1585+00$ & $1590+20$ & Under Seepage & $\begin{array}{l}\text { Moderate to } \\
\text { Heavy }\end{array}$ & $\begin{array}{l}\text { Sandbag weir structure constructed in ditch located near Lake Chicot Pumping } \\
\text { Plant. Ditch extend upstream beyond Station } 156+00 \text { near berm toe. } \\
\text { Eventually flowed } 20 \text { feet wide and clear. }\end{array}$ & $13-15$ \\
\hline 33.41890 & -91.21040 & 33.41300 & -91.21380 & $\begin{array}{l}1697+10- \\
1723+00\end{array}$ & $\begin{array}{l}1691+40- \\
1717+50\end{array}$ & Under Seepage & Light to Moderate & Seepage on berm, at berm toe and $300^{\prime}$ into fields & $16-18$ \\
\hline 33.41300 & -91.21380 & 33.41160 & -91.21140 & $\begin{array}{l}1723+00- \\
1728+10\end{array}$ & $\begin{array}{l}1717+50- \\
1734+60\end{array}$ & Under Seepage & Light & On seepage berm & \\
\hline 33.37400 & -91.14630 & 33.37150 & -91.13990 & $\begin{array}{r}2018+00- \\
2056+30\end{array}$ & $\begin{array}{r}2013+00- \\
2051+80\end{array}$ & Under Seepage & Light to Moderate & At berm toe and $500^{\prime}$ into adjacent fields & $20-25$ \\
\hline
\end{tabular}


LEVEE SECTOR: West Bank MRL - Station 0+00 - Station 3990+77 (Upper end near Rohwer to LA Line)

DATE:

$5 / 16 / 2011-5 / 18 / 2011$

TEAM MEMBERS: Andy Hardy, Lane Vargas, and Ben Emery

\begin{tabular}{|c|c|c|c|c|c|c|c|c|c|}
\hline \multicolumn{2}{|c|}{ START } & \multicolumn{2}{|c|}{ END } & \multirow{2}{*}{$\begin{array}{l}\text { STATION } \\
\text { NLD }\end{array}$} & \multirow{2}{*}{$\begin{array}{l}\text { STATION } \\
\text { LEVEE }\end{array}$} & \multirow[t]{2}{*}{ TYPE } & \multirow[t]{2}{*}{ EXTENT } & \multirow[t]{2}{*}{ REMARKS } & \multirow{2}{*}{$\begin{array}{l}\text { PHOTO } \\
\text { LINKS }\end{array}$} \\
\hline Latitude & Longitude & Latitude & Longitude & & & & & & \\
\hline 33.36870 & -91.14570 & 33.36670 & -91.14880 & $\begin{array}{r}2077+80- \\
2089+70\end{array}$ & $\begin{array}{c}2072+30- \\
2084+20\end{array}$ & Under Seepage & Light & In adjacent fields near levee toe & 26 \\
\hline 33.36450 & -91.15290 & 33.36370 & -91.15460 & $\begin{array}{r}2105+20- \\
2109+30 \\
\end{array}$ & $\begin{array}{l}2100+50- \\
2105+60\end{array}$ & Under Seepage & Light & In adjacent fields near levee toe & 27 \\
\hline 33.36150 & -91.15810 & 33.35557 & -91.16834 & $\begin{array}{l}2124+60- \\
2161+00\end{array}$ & $\begin{array}{l}2121+20- \\
2156+50\end{array}$ & Under Seepage & Heavy & $\begin{array}{l}\text { Leland Chute - Moderate seepage exiting at the toe of the levee and beyond } \\
\text { as well as numerous small to medium sized boils located in a ditch located } \\
\text { approximately } 100 \text { feet beyond the toe of the levee were identified in a } \\
\text { approximately } 1 \text { mile long reach. There is no berm in this area. A series of } \\
\text { dikes were constructed across the ditch to impound water over a number of } \\
\text { the boils. Other boils were stabilized by sandbag rings. Each boil moved silt } \\
\text { and fine sand; however none of the boils moved a significant quantity of } \\
\text { material. }\end{array}$ & \\
\hline 33.36210 & -91.15900 & -- & -- & $2126+40$ & $2121+20$ & Under Seepage/Pin & Heavy & Pin boils in ditch 100 ' from levee toe, area sandbagged & 28-32 \\
\hline 33.36120 & -91.16100 & -- & -- & $2132+10$ & $2126+50$ & Under Seepage & Heavy & $\begin{array}{l}\text { At levee toe and } 80 \text { ' beyond. Area is low and traps water between levee and } \\
\text { ditch. }\end{array}$ & \\
\hline 33.36010 & -91.16320 & -- & -- & $2139+95$ & $2135+35$ & Sand Boil & Heavy & Bagged boil in ditch & $33-37$ \\
\hline 33.35940 & -91.16370 & -- & -- & $2142+80$ & $2138+20$ & Sand Boil & Heavy & Bagged boil in ditch & $38-43$ \\
\hline 33.35310 & -91.17170 & 33.35310 & -91.17390 & $\begin{array}{r}2176+00- \\
2187+30\end{array}$ & $\begin{array}{c}2171+50- \\
2182+80\end{array}$ & Through Seepage & Light & $\begin{array}{l}\text { Approximately 6' up levee and a few pin boils at toe. No material moved, and } \\
\text { flow is a trickle at most. }\end{array}$ & \\
\hline 33.35571 & -91.18293 & -- & -- & $2215+00$ & $2210+50$ & Slide & & $\begin{array}{l}\text { Crack in the levee is on the riverside crown. The width of the crack varies } \\
\text { from } 1 / 4 \text { " to } 1 " \text { ". The length of the crack is approx } 100^{\prime} \text { long }\end{array}$ & \\
\hline 33.35573 & -91.18975 & 33.34326 & -91.18448 & $\begin{array}{l}2239+00- \\
2294+00\end{array}$ & $\begin{array}{l}2234+00- \\
2290+10\end{array}$ & Sand Boil & Moderate & $\begin{array}{l}\text { Numerous sand boils and pin boils on the upstream end of Lake Chicot. All } \\
\text { boils were } 500^{\prime} \text { to } 1000 \text { ' from levee toe and located on the edge of the lake } \\
\text { water line or in adjacent slough area. Most sand boils moved fine material } \\
\text { and looked 2" to } 4 \text { " in diameter. Boils eventually stopped moving material } \\
\text { and were never bagged. }\end{array}$ & 49-72 \\
\hline 33.35573 & -91.18975 & 33.35017 & -91.18617 & $\begin{array}{r}2239+00- \\
2261+00 \\
\end{array}$ & $\begin{array}{r}2234+00- \\
2257+00 \\
\end{array}$ & Sand Boil & Moderate & $\begin{array}{l}\text { Numerous boils in lake and slough area } 500 \text { ' from berm toe. Boils moved } \\
\text { some material, but eventually moved only clear water. }\end{array}$ & 49-65 \\
\hline 33.34479 & -91.18625 & & & $\begin{array}{r}2274+00- \\
2294+00 \\
\end{array}$ & $\begin{array}{l}2270+00- \\
2290+10\end{array}$ & Sand Boil & Moderate & $\begin{array}{l}\text { Numerous boils in slough area } 500 \text { ' from berm toe. Boils moved some } \\
\text { material, but eventually moved only clear water. }\end{array}$ & $66-71$ \\
\hline 33.34600 & -91.18320 & 33.34470 & -91.18360 & $\begin{array}{r}2280+00- \\
2287+00\end{array}$ & $\begin{array}{l}2276+10- \\
2283+10\end{array}$ & Under Seepage & Light & At berm toe and 100' into adjacent field & $72-79$ \\
\hline 33.34010 & -91.18560 & 33.33890 & -91.18620 & $\begin{array}{r}2304+00- \\
2309+50\end{array}$ & $\begin{array}{l}2300+10- \\
2305+60\end{array}$ & Under Seepage & Light & On berm and at berm toe & \\
\hline 33.29050 & -91.10037 & 33.28790 & -91.16910 & $\begin{array}{l}2309+50- \\
2544+90\end{array}$ & $\begin{array}{l}2305+60- \\
2541+20\end{array}$ & Under Seepage & $\begin{array}{l}\text { Moderate to } \\
\text { Heavy }\end{array}$ & $\begin{array}{l}\text { Lake Chicot - The site is historically an area with large boils. A large, high } \\
\text { energy sand boil was located on the edge of a dredged channel at the south } \\
\text { end of Lake Chicot. There were multiple sandbag rings placed around the boil. } \\
\text { The throat would move and bypass the sandbag rings. A dike was eventually } \\
\text { constructed across the channel. Moderate seepage was exiting the lake bank } \\
30 \text { feet above the water surface. Several other medium to large, moderate } \\
\text { energy boils were located along the lake bank. These boils were also ringed } \\
\text { with sandbags. The boil closest to the levee was approximately } 400 \text { feet from } \\
\text { the toe of a } 300 \mathrm{ft} \text { seepage berm. This boil has repeatedly moved significant } \\
\text { quantities of material during previous high water events and exhibits some } \\
\text { potential to develop pipes that may migrate towards the berm/levee. Boils } \\
\text { were identified up to } 2,000 \text { feet from the levee toe. }\end{array}$ & \\
\hline 33.28813 & -91.17136 & -- & -- & $2544+20$ & $2540+90$ & Sand Boil & Heavy & $\begin{array}{l}\text { Area know as Fish Bayou located approx 500' from berm toe at the } \\
\text { downstream end of Lake Chicot. }\end{array}$ & $80-88$ \\
\hline 33.28838 & -91.16947 & -- & -- & $2544+20$ & $2540+90$ & Under Seepage & Moderate & $\begin{array}{l}\text { In low, wooded area between berm toe and County Rd } 71 \text {. Numerous pin } \\
\text { boils moving clear water. }\end{array}$ & 93 \\
\hline
\end{tabular}


LEVEE SECTOR: $\quad$ West Bank MRL - Station 0+00 - Station 3990+77 (Upper end near Rohwer to LA Line)

DATE:

5/16/2011 - 5/18/2011

TEAM MEMBERS: Andy Hardy, Lane Vargas, and Ben Emery

\begin{tabular}{|c|c|c|c|c|c|c|c|c|c|}
\hline \multicolumn{2}{|c|}{ START } & \multicolumn{2}{|c|}{ END } & \multirow{2}{*}{$\begin{array}{c}\text { STATION } \\
\text { NLD }\end{array}$} & \multirow{2}{*}{$\begin{array}{c}\text { STATION } \\
\text { LEVEE }\end{array}$} & \multirow[t]{2}{*}{ TYPE } & \multirow[t]{2}{*}{ EXTENT } & \multirow[t]{2}{*}{ REMARKS } & \multirow{2}{*}{$\begin{array}{l}\text { PHOTO } \\
\text { LINKS }\end{array}$} \\
\hline Latitude & Longitude & Latitude & Longitude & & & & & & \\
\hline 33.28397 & -91.16861 & -- & -- & $2558+00$ & $2254+30$ & Under Seepage & Light & Light seepage in low area. & \\
\hline 33.22350 & -91.12260 & 33.22230 & -91.12030 & $\begin{array}{r}2833+90- \\
2841+10\end{array}$ & $\begin{array}{l}2829+20- \\
2837+40\end{array}$ & Under Seepage & Light & At levee toe and $600^{\prime}$ into adjacent fields. & $94-95$ \\
\hline 33.21390 & -91.11790 & 33.20400 & -91.10850 & $\begin{array}{l}2873+70- \\
2920+00 \\
\end{array}$ & $\begin{array}{l}2870+70- \\
2917+00 \\
\end{array}$ & Under Seepage & Light to Moderate & On seepage berm and 1500 ' into fields and adjacent woods. & $96-99$ \\
\hline 33.20571 & -91.11270 & & & $2905+00$ & $2902+00$ & Under Seepage/Pin & Light to Moderate & Small group of pin boils 50 from berm toe. & \\
\hline 33.20330 & -91.10640 & 33.19990 & -91.10680 & $\begin{array}{l}2925+90- \\
2940+50 \\
\end{array}$ & $\begin{array}{l}2923+90- \\
2937+50 \\
\end{array}$ & Under Seepage & Light to Moderate & At levee toe and 1500 ' into adjacent fields. & \\
\hline 33.19720 & -91.10540 & 33.19610 & -91.10470 & $\begin{array}{r}2951+00- \\
2956+30 \\
\end{array}$ & $\begin{array}{c}2946+40- \\
2951+70 \\
\end{array}$ & Under Seepage & Light & At berm toe and into the narrow wood line and adjacent fields for $100^{\prime}$. & \\
\hline 33.19330 & -91.10320 & 33.19140 & -91.10360 & $\begin{array}{l}2968+10- \\
2975+60 \\
\end{array}$ & $\begin{array}{c}2963+50- \\
2971+00\end{array}$ & Under Seepage & Light & At levee toe and $300^{\prime}$ into adjacent fields and woods. & \\
\hline 33.18590 & -91.10520 & 33.18460 & -91.10550 & $\begin{array}{l}2996+00- \\
3001+50 \\
\end{array}$ & $\begin{array}{l}2993+00- \\
2997+50 \\
\end{array}$ & Under Seepage & Light & On seepage berm. & 100 \\
\hline 33.18460 & -91.10550 & 33.18210 & -91.10760 & $\begin{array}{r}3001+50- \\
3013+20 \\
\end{array}$ & $\begin{array}{c}2997+50- \\
3010+20 \\
\end{array}$ & Under Seepage & Light & At berm toe and $300^{\prime}$ into adjacent fields. & \\
\hline 33.17880 & -91.11080 & 33.17270 & -91.11450 & $\begin{array}{l}3028+40- \\
3053+00 \\
\end{array}$ & $\begin{array}{c}3025+40- \\
3051+50 \\
\end{array}$ & Under Seepage & Light & At levee toe and 100 ' into adjacent fields & \\
\hline-- & -- & 33.16760 & -91.12110 & $3081+50$ & $3080+00$ & Under Seepage & Light & Small patch of seepage 150 ' from levee toe into field & \\
\hline 33.16500 & -91.12410 & 33.16410 & -91.12590 & $\begin{array}{r}3094+50- \\
3101+10\end{array}$ & $\begin{array}{c}3091+50- \\
3098+10\end{array}$ & Under Seepage & Light & At toe of berm and 600 ' into adjacent fields & \\
\hline 33.16240 & -91.12900 & 33.16210 & -91.13070 & $\begin{array}{l}3112+70- \\
3118+20 \\
\end{array}$ & $\begin{array}{l}3109+70- \\
3115+20\end{array}$ & Under Seepage & Light & At toe of levee and 150' into adjacent fields and woods & \\
\hline-- & -- & 33.15770 & -91.14810 & $3175+20$ & $3172+40$ & Under Seepage & Light & At toe of levee and 75 into fields & \\
\hline 33.16150 & -91.15810 & 33.15960 & -91.17170 & $\begin{array}{r}3210+30- \\
3250+00 \\
\end{array}$ & $\begin{array}{c}3207+60- \\
3247+60 \\
\end{array}$ & Under Seepage & Light & At berm toe and 500 ' into adjacent fields & 101 \\
\hline 33.15960 & -91.17170 & 33.15750 & -91.17850 & $\begin{array}{l}3250+00- \\
3272+20 \\
\end{array}$ & $\begin{array}{l}3247+60- \\
3269+80\end{array}$ & Under Seepage & Light to Moderate & At berm toe and 2000 ' into adjacent fields & 102 \\
\hline 33.15750 & -91.17850 & 33.15650 & -91.18150 & $\begin{array}{l}3272+20- \\
3281+00 \\
\end{array}$ & $\begin{array}{c}3269+80- \\
3278+60\end{array}$ & Under Seepage & $\begin{array}{c}\text { Moderate to } \\
\text { Heavy }\end{array}$ & At berm toe and 600 ' into adjacent fields & 103 \\
\hline 33.15820 & -91.17950 & -- & -- & $3276+40$ & $3273+00$ & Sand Boil & Heavy & $\begin{array}{l}\text { Sand boil in ditch } 200 \text { ' from berm toe with 6" pipe. Moved about } 2 \text { yards of } \\
\text { material. Additional pin boils in ditch with clear flow }\end{array}$ & 104 \\
\hline 33.15390 & -91.18030 & -- & -- & $3278+30$ & $3274+90$ & \begin{tabular}{c|}
$\begin{array}{l}\text { Under Seepage/Pin } \\
\text { Boils }\end{array}$ \\
\end{tabular} & Light to Moderate & Few pin boils in ditch at berm toe with trickle flow. Moving clear material. & \\
\hline 33.15650 & -91.18150 & 33.14910 & -91.19140 & $3281+00-$ & $3278+60$ & Under Seepage & Light & On berm near toe and $1500^{\prime}$ into adjacent fields. & 105,107 \\
\hline 33.15660 & -91.18168 & -- & -- & $3282+00$ & $3279+60$ & Sand Boil & Light & Two small sand boils in ditch at berm toe with clear flow. & \\
\hline 33.14950 & -91.19292 & -- & -- & $3322+00$ & $3319+00$ & Sand Boil & Light & $\begin{array}{l}\text { Sand Boil located Behind a well house near a satellite dish. Three foot } \\
\text { diameter ring levee approx. } 1500 \text { ' from levee toe. }\end{array}$ & 106 \\
\hline 33.14370 & -91.19430 & 33.14090 & -91.19660 & $3342+00-$ & $3339+00$ & Under Seepage & Light & At berm toe and 1500 ' into adjacent fields & \\
\hline 33.14010 & -91.19810 & -- & -- & $3360+50$ & $3357+50$ & Under Seepage & Light & Extending 3 ' feet up berm toe and at the berm toe & \\
\hline 33.13410 & -91.20330 & 33.13060 & -91.20540 & $3387+00-$ & $3384+00$ & Under Seepage & Light & At toe of berm and into adjacent fields & 108 \\
\hline 33.09580 & -91.20760 & 33.09510 & -91.20660 & $\begin{array}{r}3533+30- \\
3537+20\end{array}$ & $\begin{array}{l}3530+30- \\
3534+20\end{array}$ & Under Seepage & Light & $\begin{array}{l}\text { Light at levee toe and into adjacent fields about 150'. Short stretch about } 300 \\
\text { in length where no seepage berm exists. }\end{array}$ & $109-111$ \\
\hline
\end{tabular}


LEVEE SECTOR: West Bank MRL - Station 0+00 - Station 3990+77 (Upper end near Rohwer to LA Line)

DATE:

5/16/2011 - 5/18/2011

TEAM MEMBERS: Andy Hardy, Lane Vargas, and Ben Emery

\begin{tabular}{|c|c|c|c|c|c|c|c|c|c|}
\hline \multicolumn{2}{|c|}{ START } & \multicolumn{2}{|c|}{ END } & \multirow{2}{*}{$\begin{array}{c}\text { STATION } \\
\text { NLD }\end{array}$} & \multirow{2}{*}{$\begin{array}{c}\text { STATION } \\
\text { LEVEE }\end{array}$} & \multirow[t]{2}{*}{ TYPE } & \multirow[t]{2}{*}{ EXTENT } & \multirow[t]{2}{*}{ REMARKS } & \multirow{2}{*}{$\begin{array}{c}\text { PHOTO } \\
\text { LINKS } \\
\end{array}$} \\
\hline Latitude & Longitude & Latitude & Longitude & & & & & & \\
\hline 33.09510 & -91.20660 & 33.09020 & -91.19980 & $\begin{array}{l}3537+20- \\
3564+00\end{array}$ & $\begin{array}{r}3534+20- \\
3561+00\end{array}$ & $\begin{array}{c}\text { Under Seepage/Pin } \\
\text { Boils }\end{array}$ & Heavy & \begin{tabular}{|l|} 
Grand Lake -Two medium sized, moderate energy boils were located \\
approximately 50 feet beyond the $400 \mathrm{ft}$ seepage berm toe. Sandbag rings \\
were constructed around both boils but the rings did not stop the transport of \\
silt and fine sand. Heavy seepage, numerous pin boils and large water blisters \\
were also located in the immediate area. A large earthen berm was \\
constructed around the area to increase the head over the boils. The berm \\
impounded approximately 5.5 acres of water. This effort did minimize \\
material transport.
\end{tabular} & $112-119$ \\
\hline 33.09020 & -91.19980 & 33.08850 & -91.19770 & $\begin{array}{c}3564+00- \\
3573+80 \\
\end{array}$ & $\begin{array}{r}3561+00- \\
3570+80 \\
\end{array}$ & Under Seepage & Moderate & At toe of berm and $600^{\prime}$ into adjacent fields & 120 \\
\hline 33.08850 & -91.19770 & 33.08620 & -91.19420 & $\begin{array}{r}3573+80- \\
3587+10\end{array}$ & $\begin{array}{r}3570+80- \\
3584+00 \\
\end{array}$ & $\begin{array}{c}\text { Under Seepage/Pin } \\
\text { Boils }\end{array}$ & Heavy & $\begin{array}{l}\text { At toe of berm and pin boils with heavy flow. Several water bulges were } \\
\text { bagged. }\end{array}$ & $121-122$ \\
\hline 33.08956 & -91.18778 & -- & -- & $3595+00$ & $3591+90$ & Under Seepage/Pin & Light & Light seepage at toe of berm with several pin boils. & $123-124$ \\
\hline 33.08190 & -91.18740 & 33.07890 & -91.18210 & $\begin{array}{c}3613+10- \\
3633+00 \\
\end{array}$ & $\begin{array}{r}3610+00- \\
3629+90 \\
\end{array}$ & Under Seepage & Moderate & At toe of berm and $800^{\prime}$ into adjacent fields & 125 \\
\hline 33.07770 & -91.18060 & 33.07620 & -91.17960 & $\begin{array}{c}3640+00- \\
3646+00\end{array}$ & $\begin{array}{r}3636+90- \\
3643+90 \\
\end{array}$ & Under Seepage & Light & At toe of berm and 300' into adjacent woods & \\
\hline 33.07600 & -91.17980 & 33.07420 & -91.17820 & $\begin{array}{l}3646+00- \\
3654+50\end{array}$ & $\begin{array}{l}3643+90- \\
3653+10 \\
\end{array}$ & Under Seepage & Light & At toe of berm & \\
\hline 33.07000 & -91.17580 & 33.06940 & -91.17520 & $\begin{array}{c}3671+00- \\
3673+60 \\
\end{array}$ & $\begin{array}{r}3669+40- \\
3672+20 \\
\end{array}$ & Under Seepage & Light & At toe of berm and 150 into adjacent field & \\
\hline 33.06810 & -91.17400 & 33.05080 & -91.16940 & $\begin{array}{c}3680+10- \\
3749+60 \\
\end{array}$ & $\begin{array}{r}3678+50- \\
3746+70 \\
\end{array}$ & Under Seepage & Light to Moderate & On last 25 feet of berm and $1200^{\prime}$ into adjacent fields & $126-129$ \\
\hline 33.05080 & -91.16940 & 33.04170 & -91.17190 & $\begin{array}{c}3749+60- \\
3785+00\end{array}$ & $\begin{array}{r}3746+70- \\
3782+10\end{array}$ & $\begin{array}{c}\text { Under Seepage/Pin } \\
\text { Boils }\end{array}$ & Heavy & \begin{tabular}{|l|} 
Willow Lake - The site is historically an area with numerous small to medium \\
sized boils. There were numerous medium sized boils and one large boil \\
identified. A sandbag ring was constructed around the large boil. The bagged \\
boil was located approximately 100 feet beyond the toe of a $350-$ foot seepage \\
berm. The bagging effort controlled the material transport from the boil. \\
Heavy seepage and pin boils were prevalent throughout the area.
\end{tabular} & $130-133$ \\
\hline 33.03188 & -91.17647 & 33.02788 & -91.17584 & $\begin{array}{c}3820+00- \\
3850+00\end{array}$ & $\begin{array}{l}3815+50- \\
3850+50 \\
\end{array}$ & Under Seepage & Light & At berm toe and 200 ' into adjacent field & \\
\hline 33.00660 & -91.21240 & 33.00490 & -91.21350 & $\begin{array}{l}3986+50- \\
3993+00\end{array}$ & $\begin{array}{r}3986+00- \\
3992+50 \\
\end{array}$ & Under Seepage & Light & At toe of seepage berm and edge of adjacent field. & \\
\hline
\end{tabular}




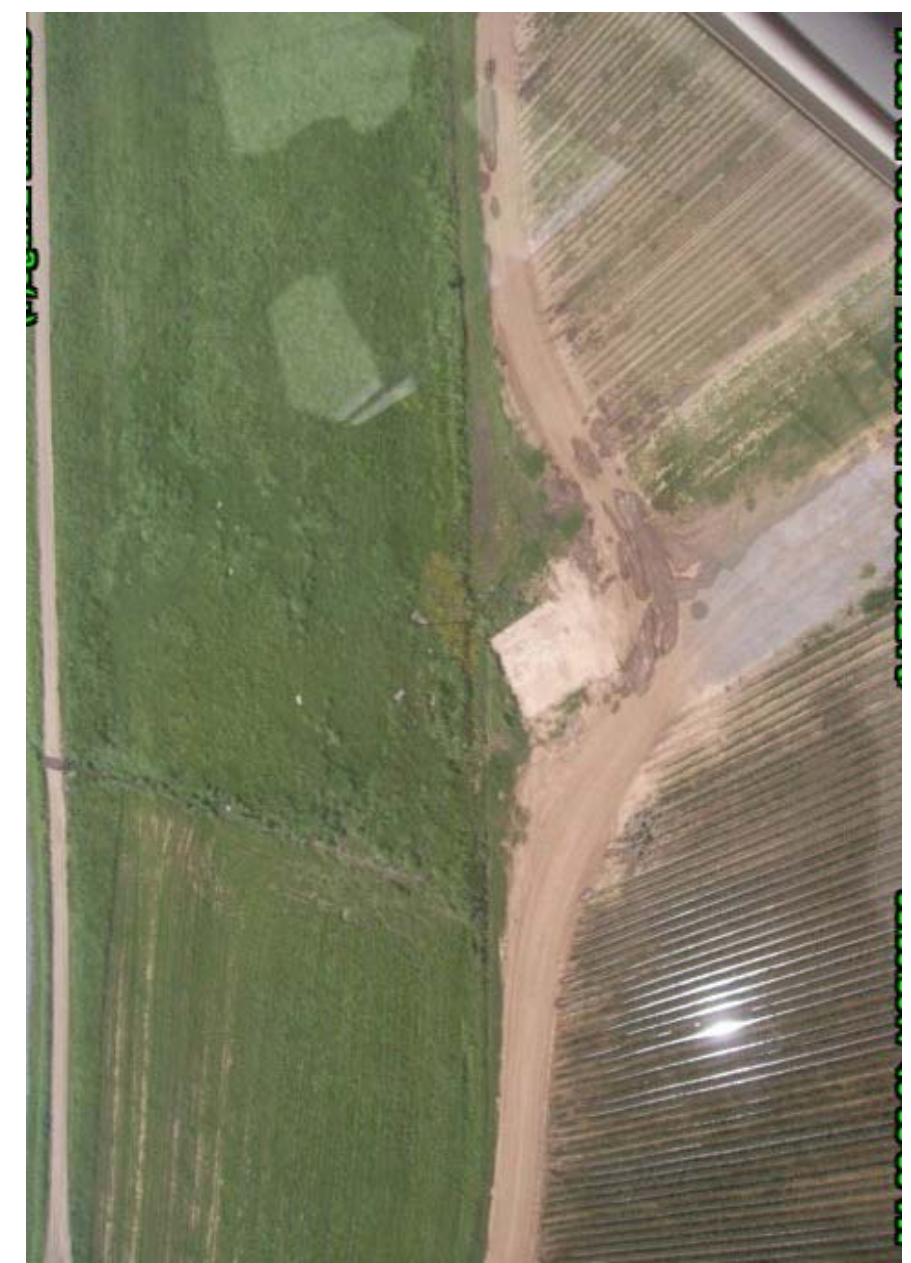

1
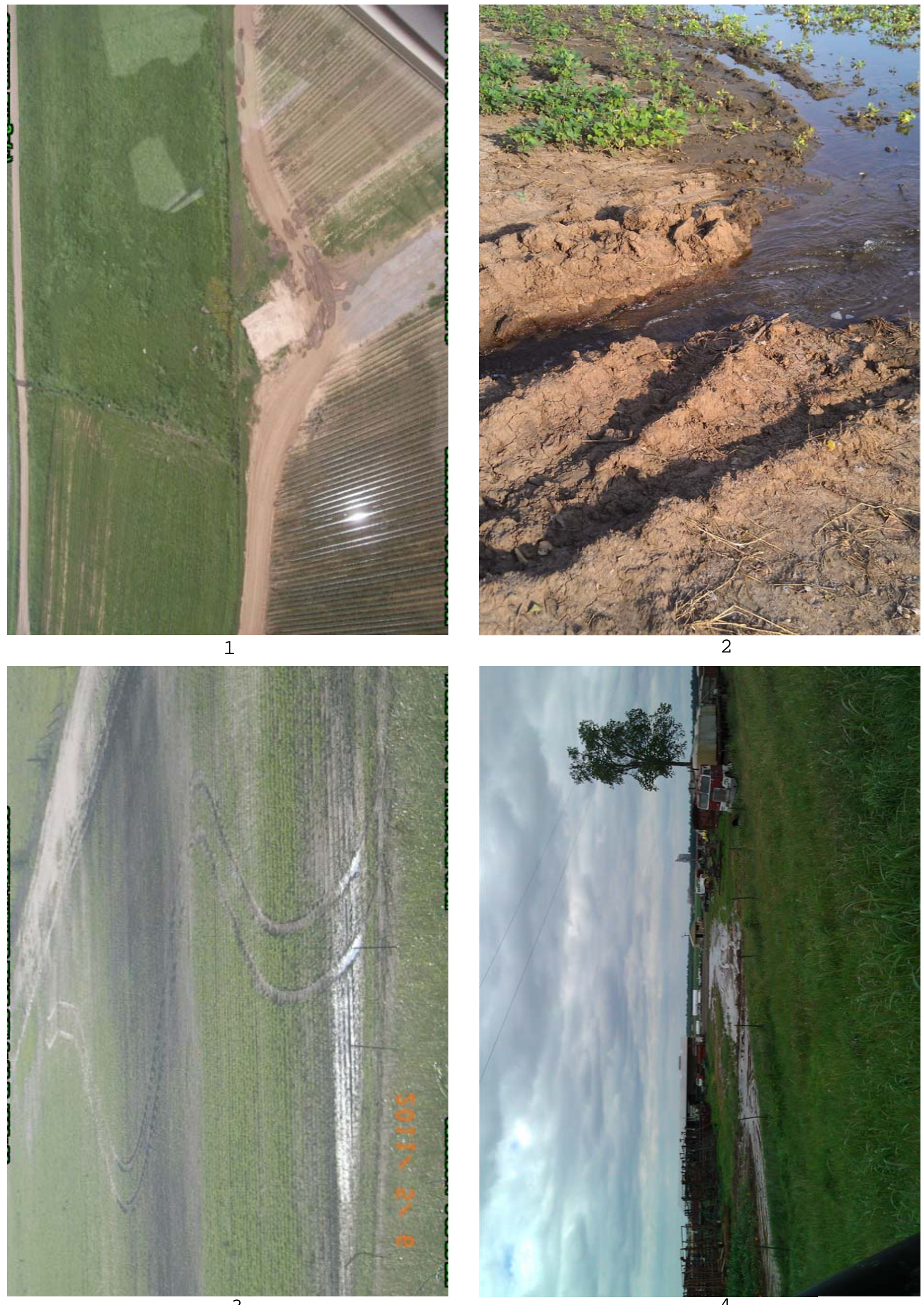


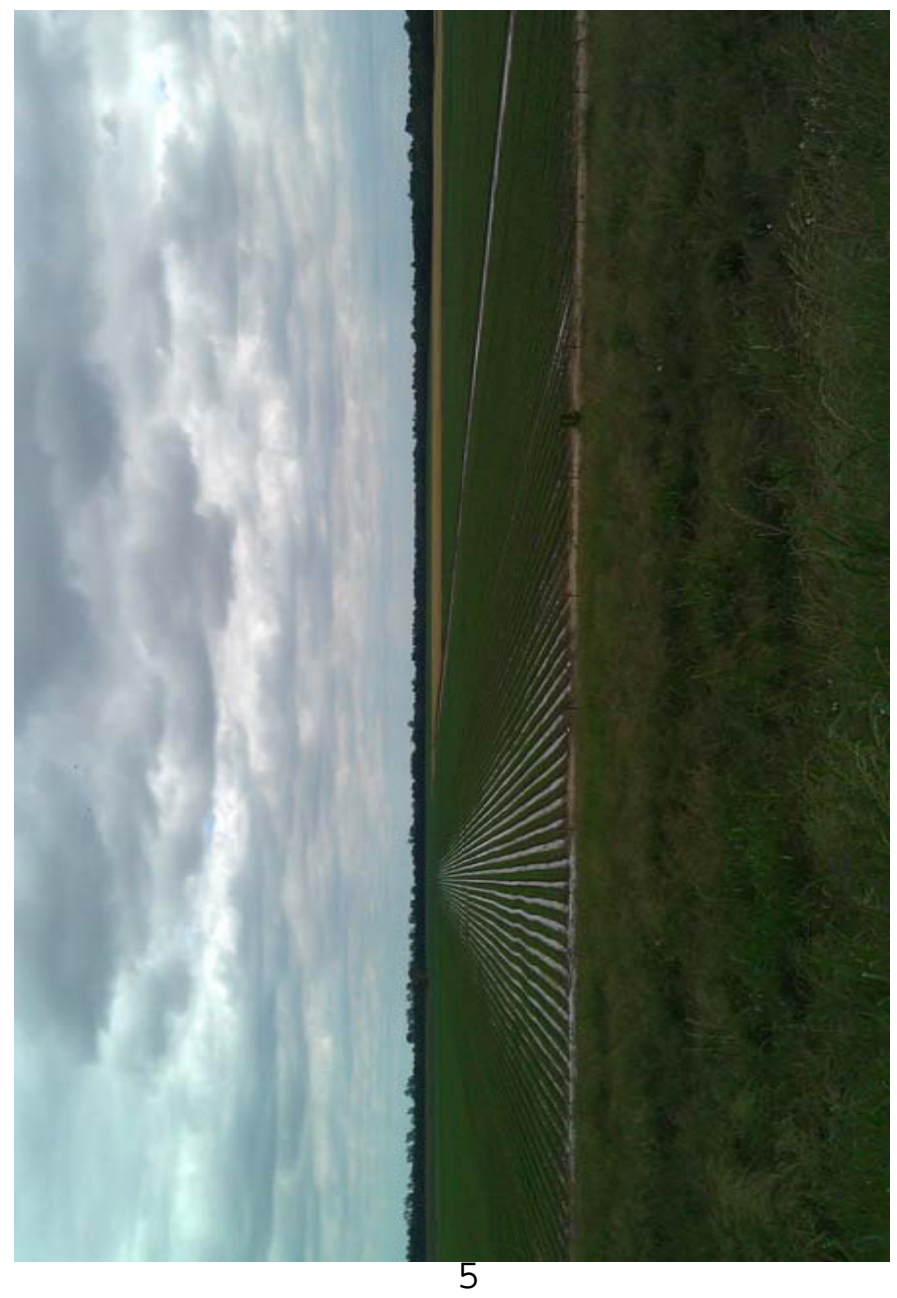

5

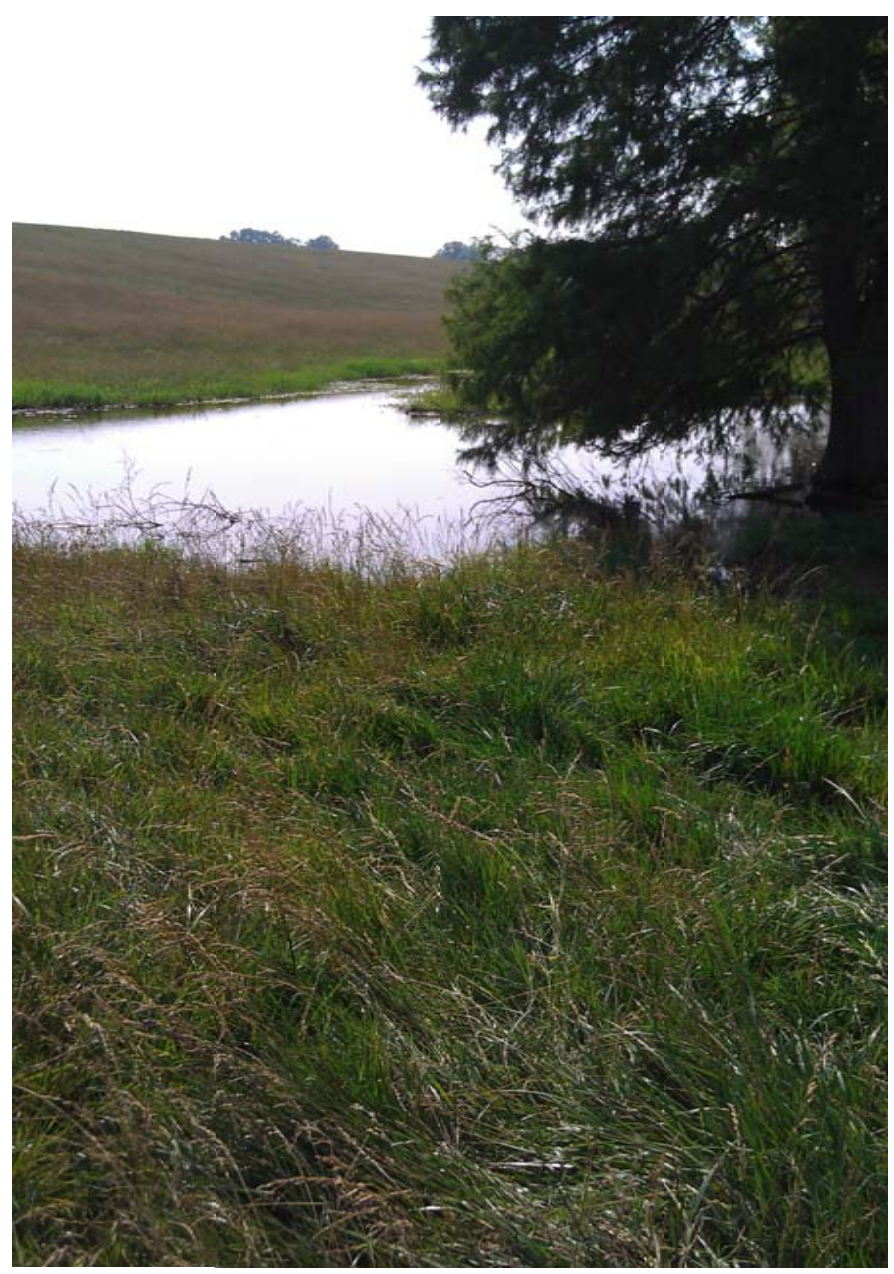

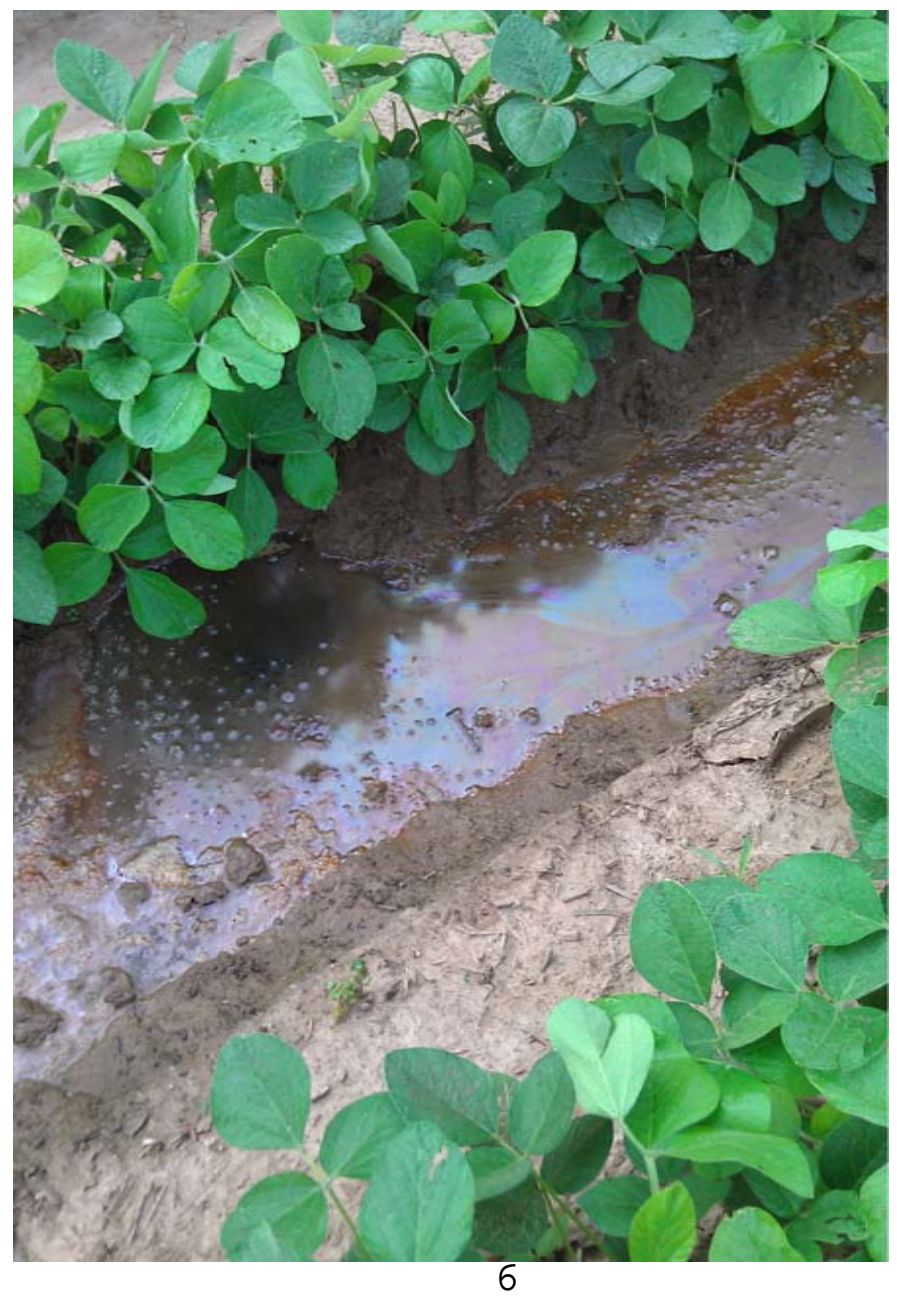

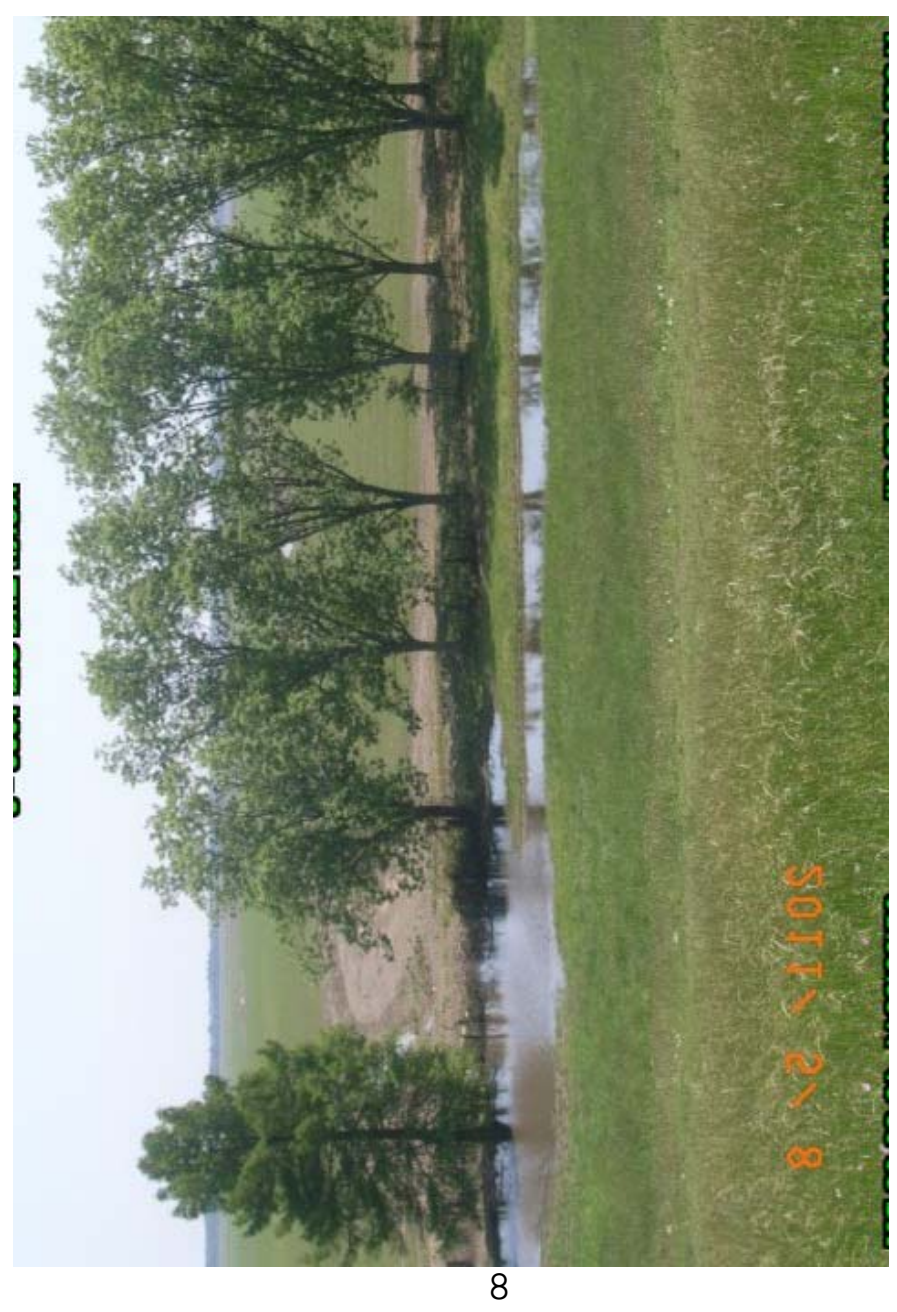




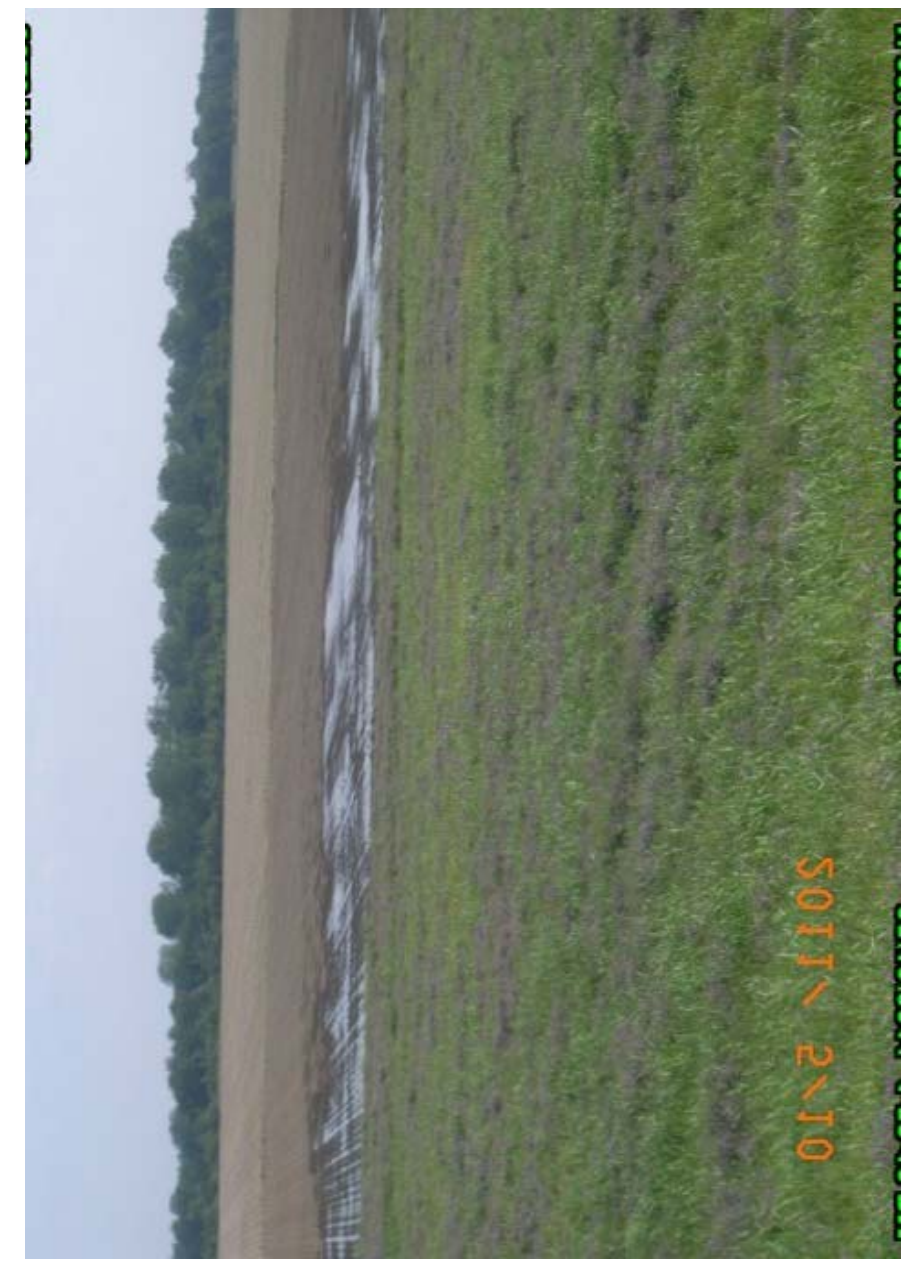

9

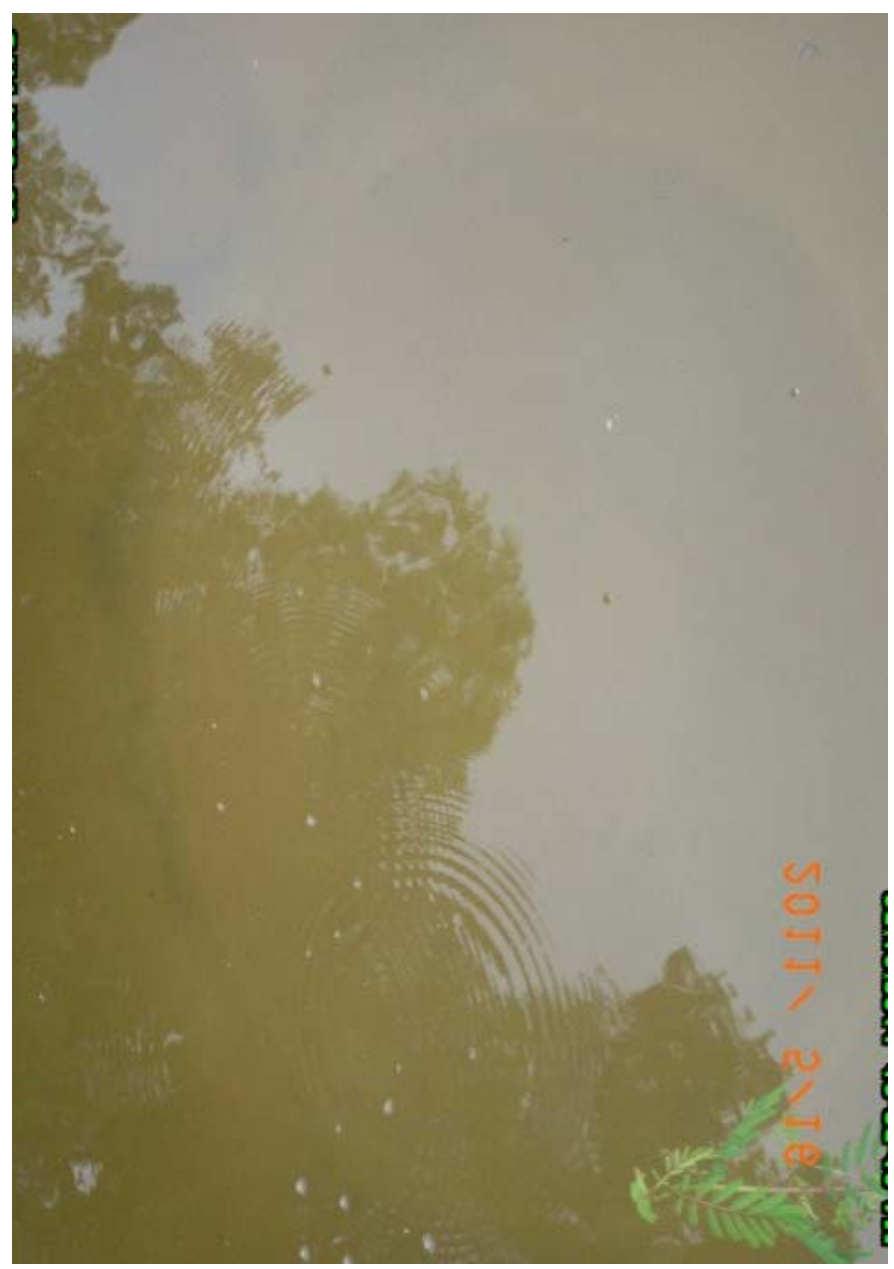

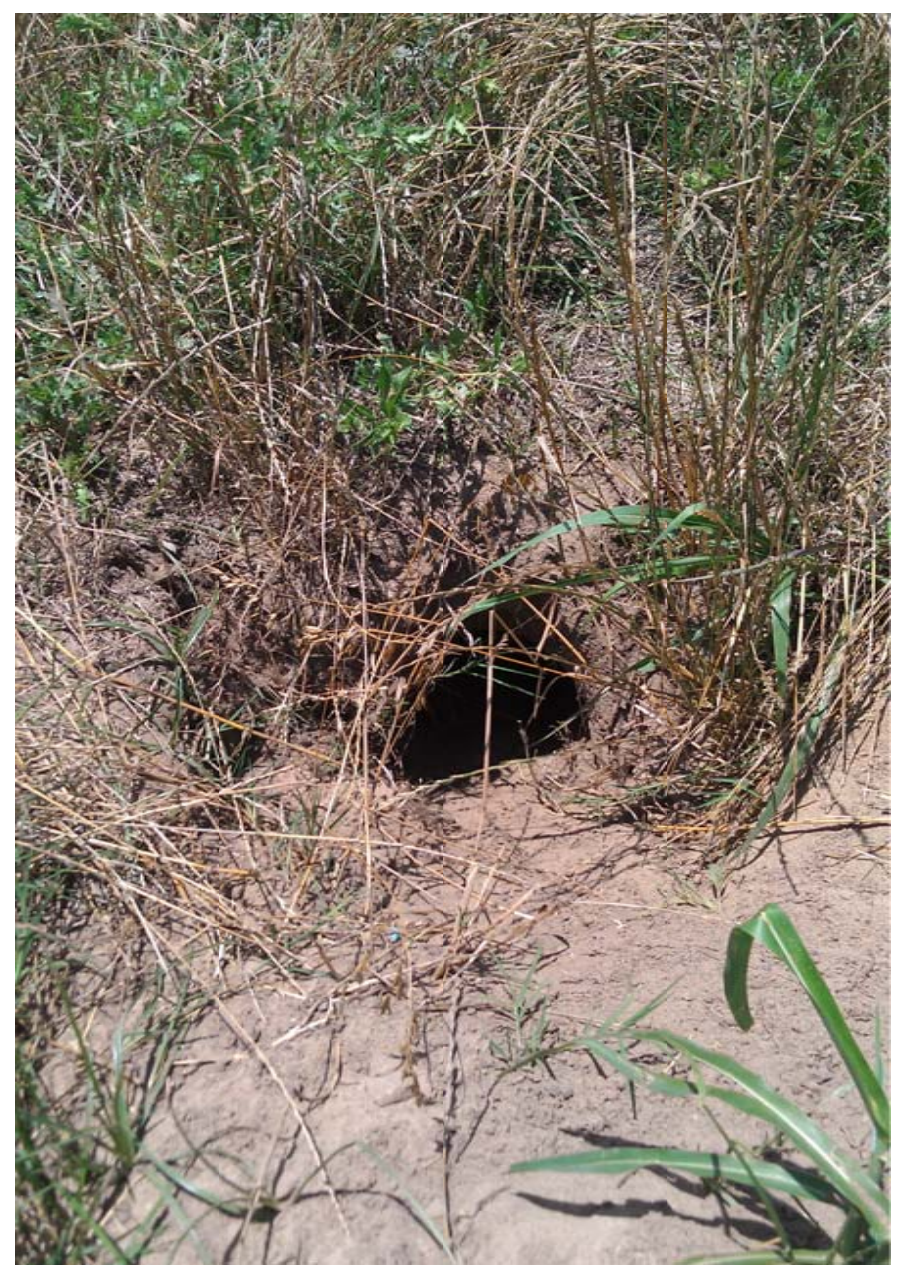

10

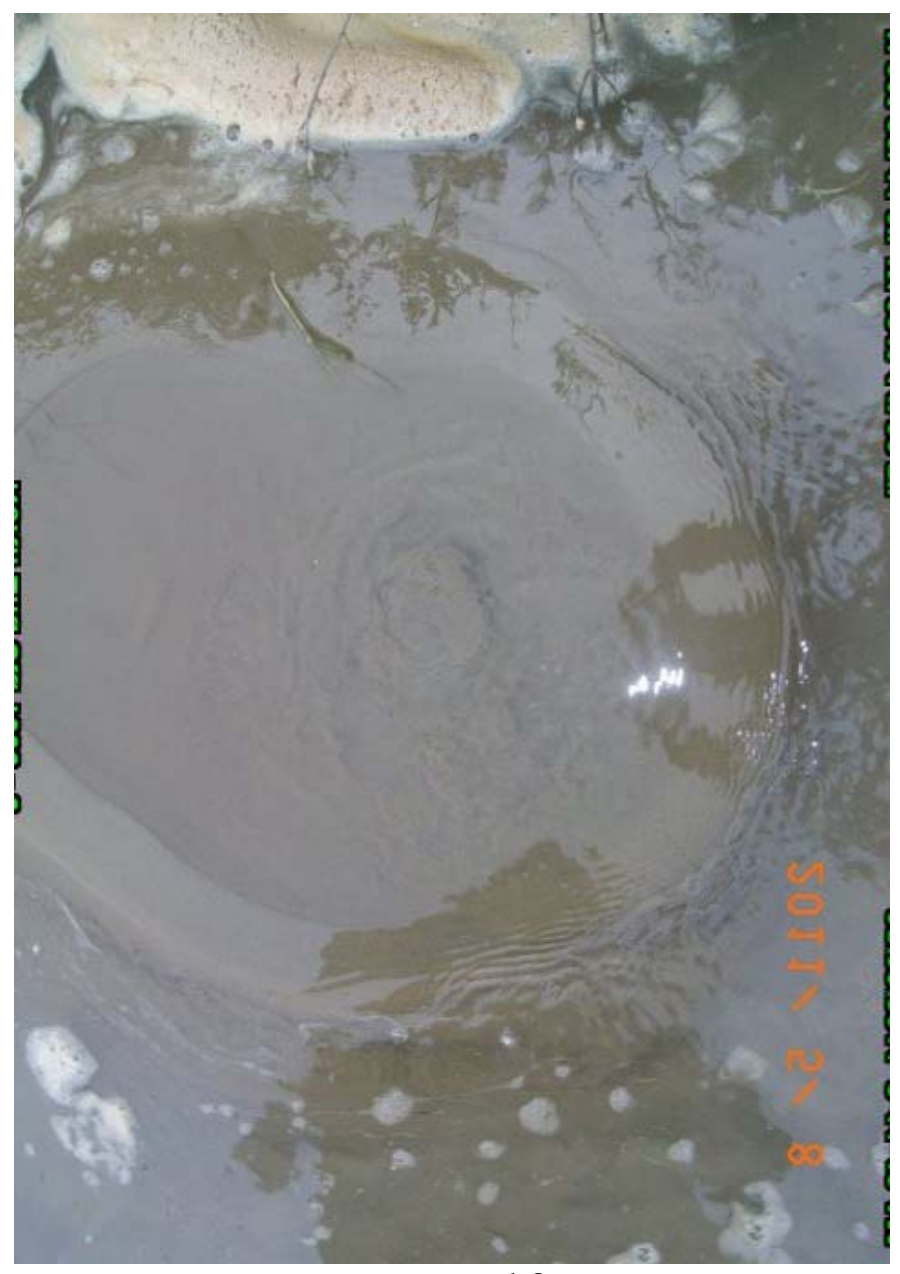




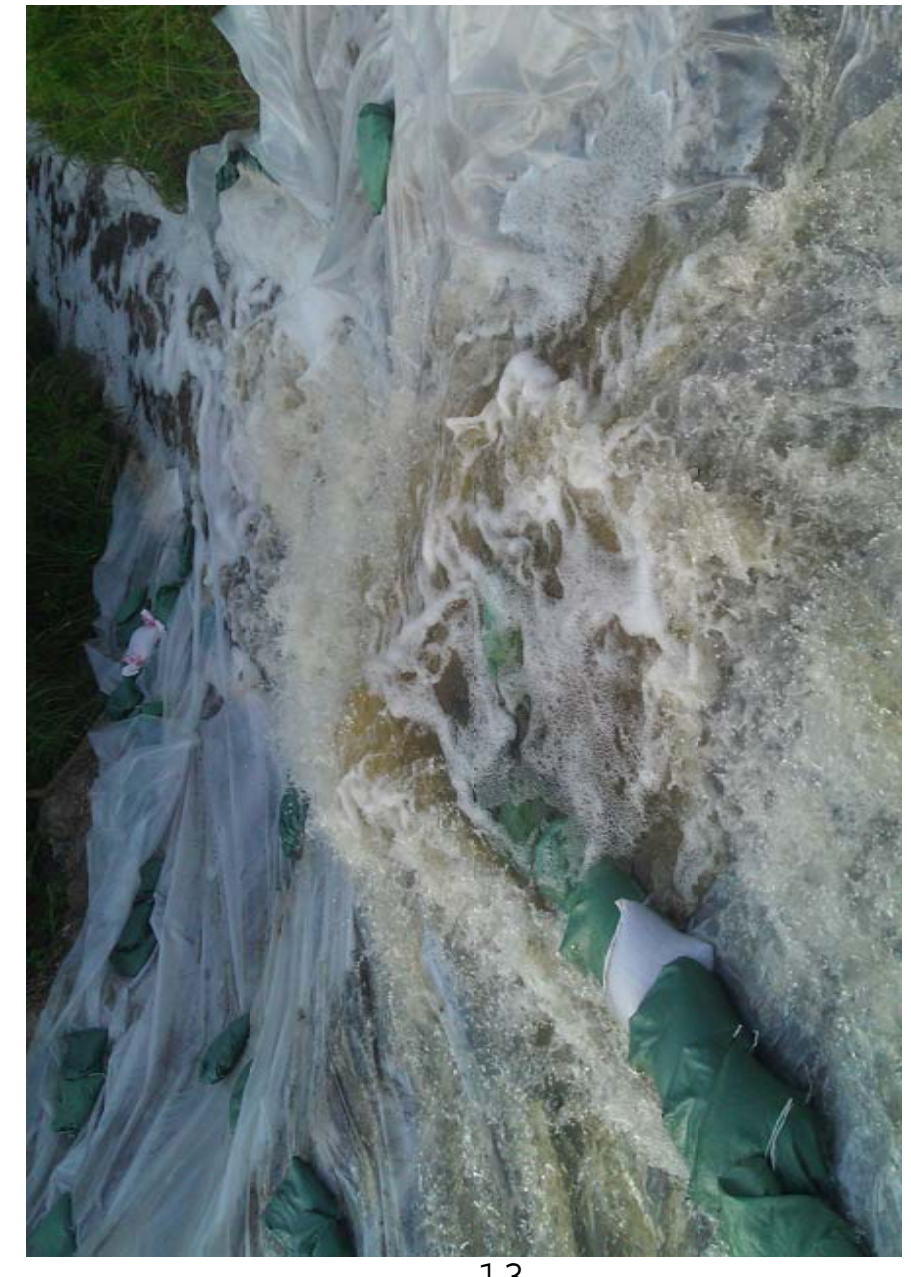

13

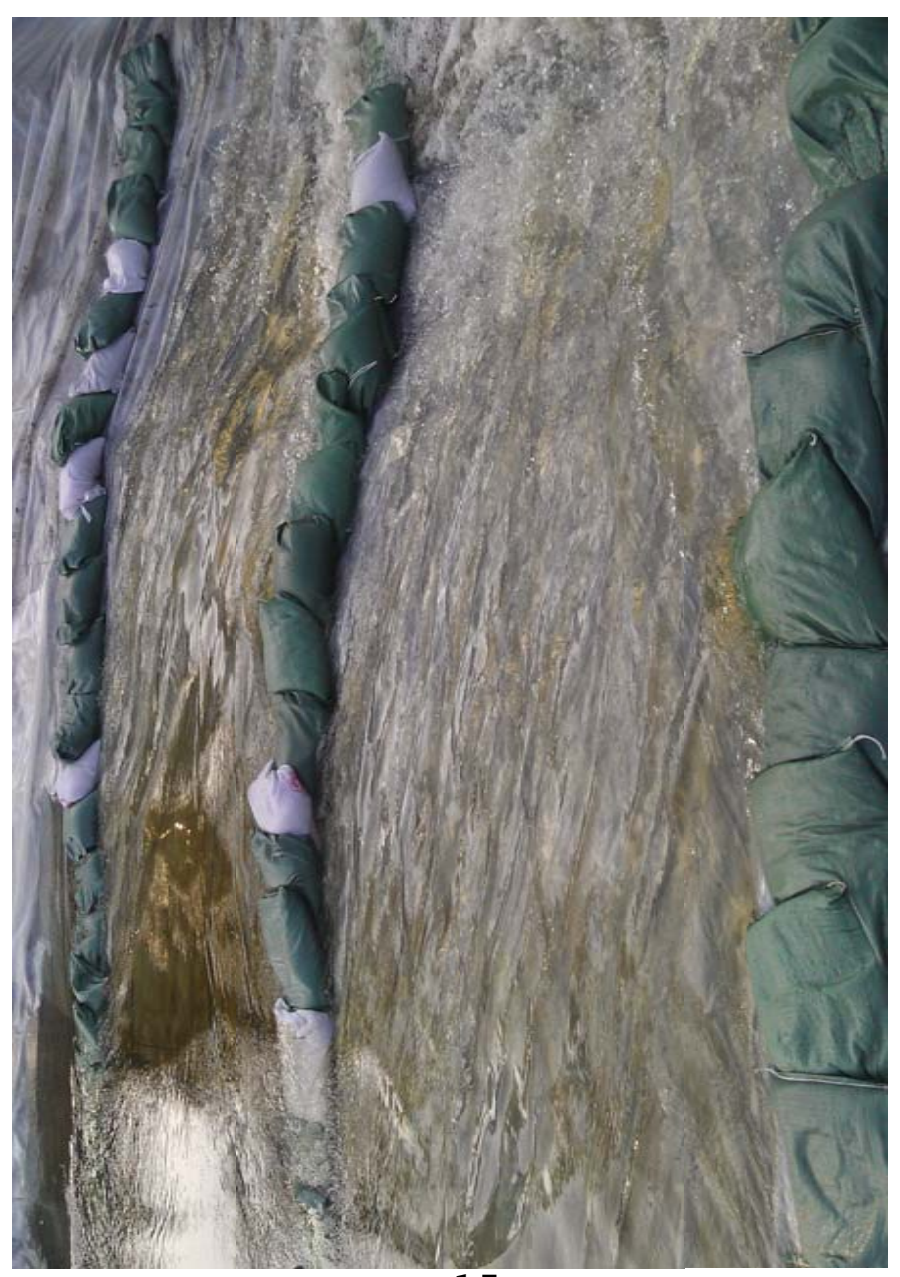

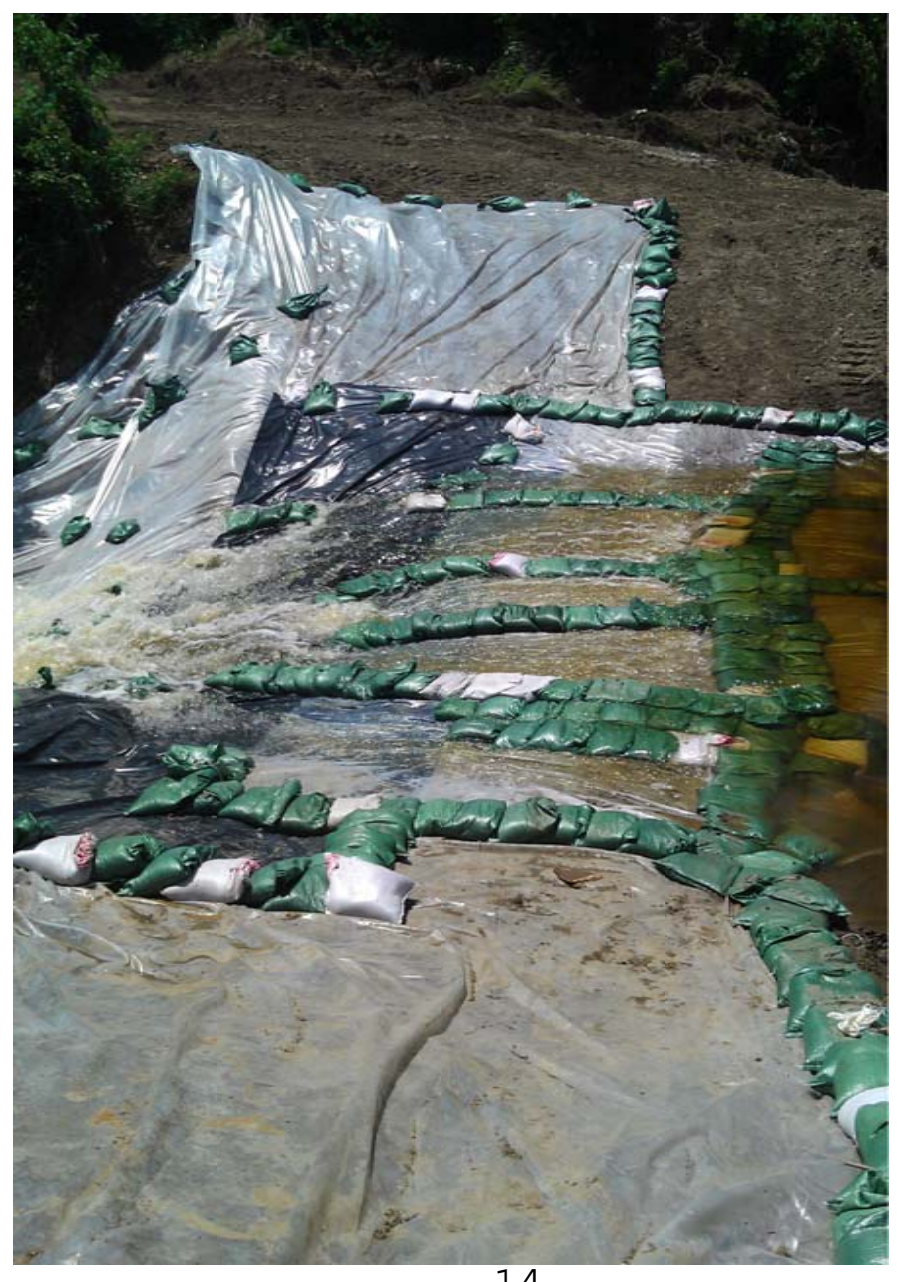

14

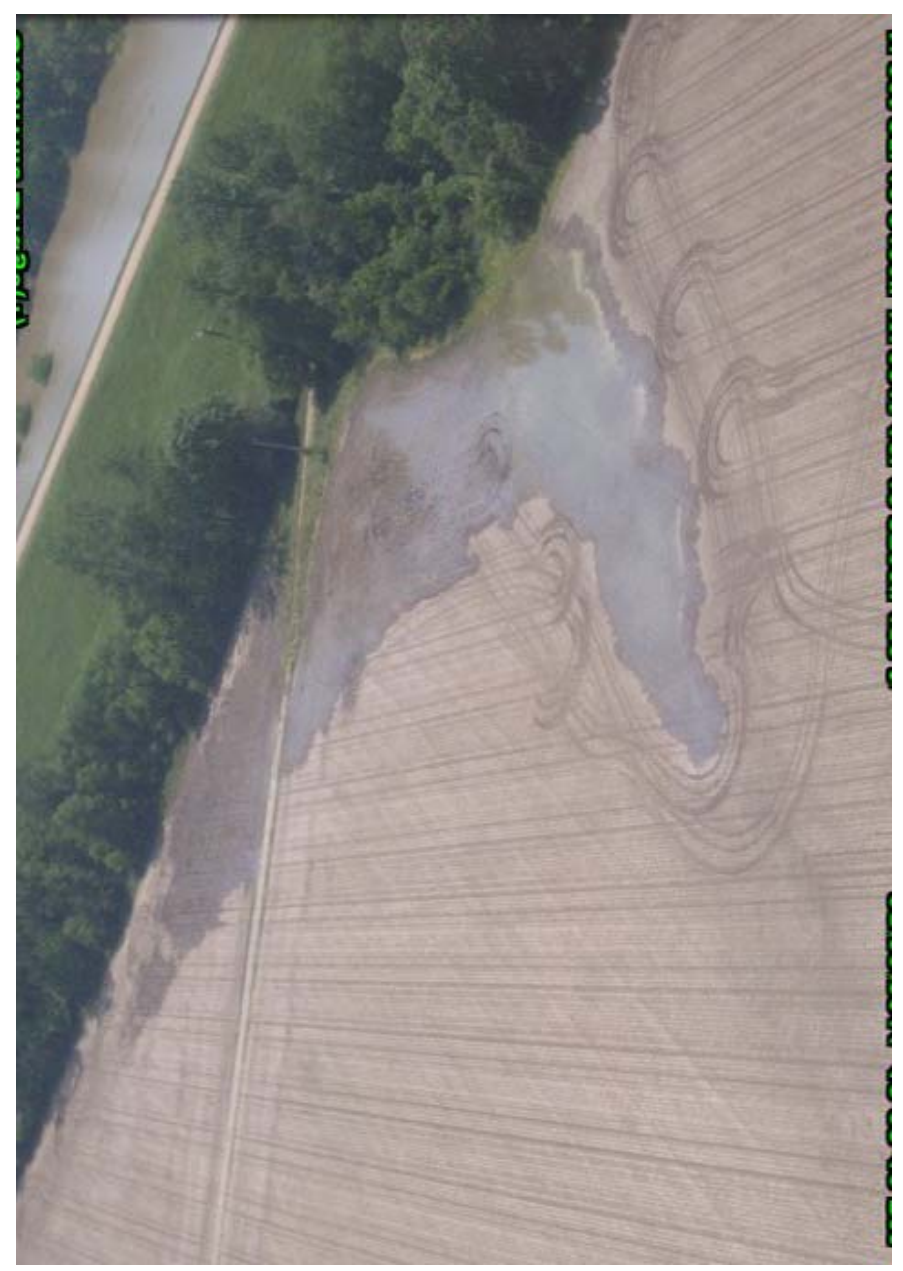

16 

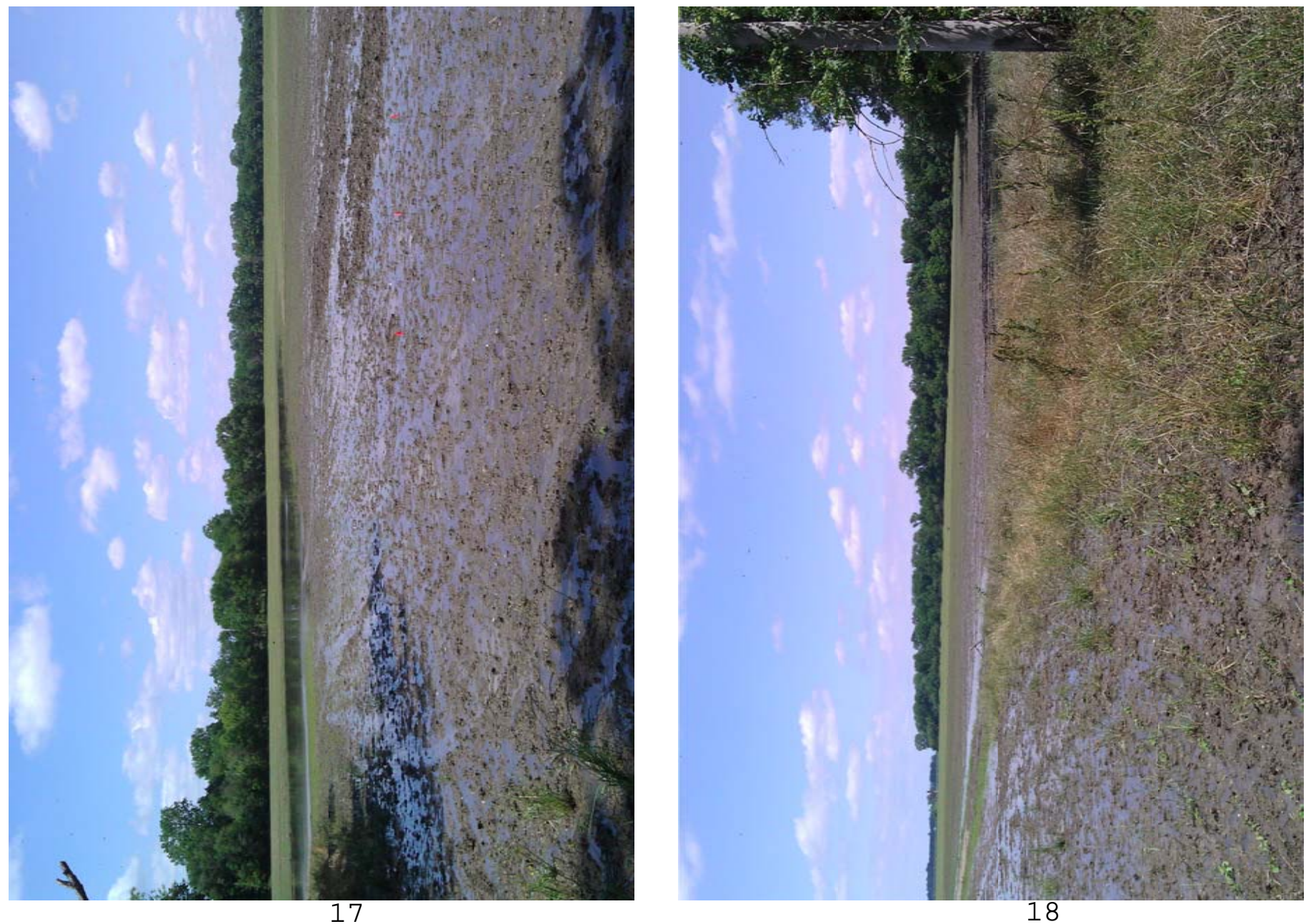

18
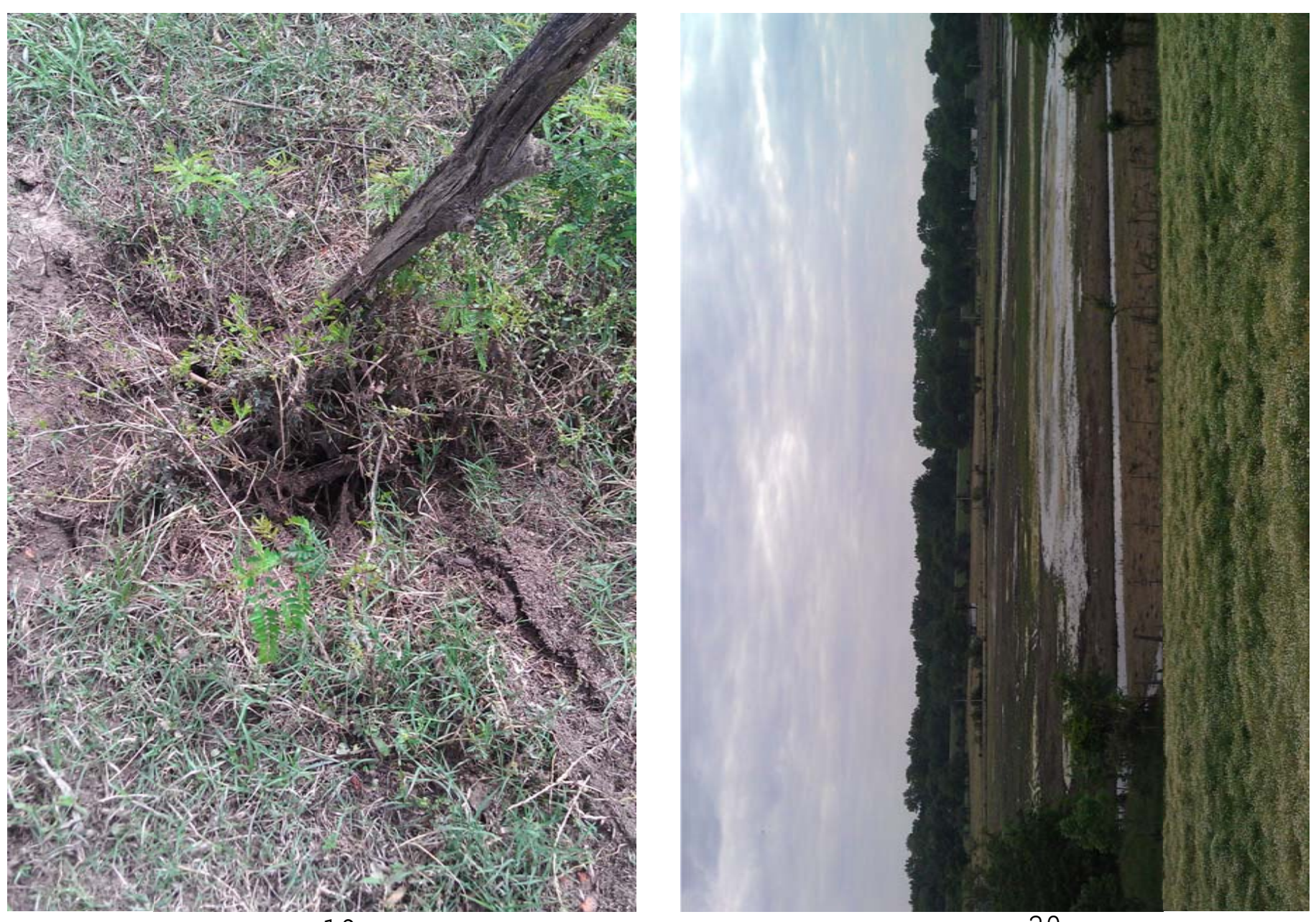

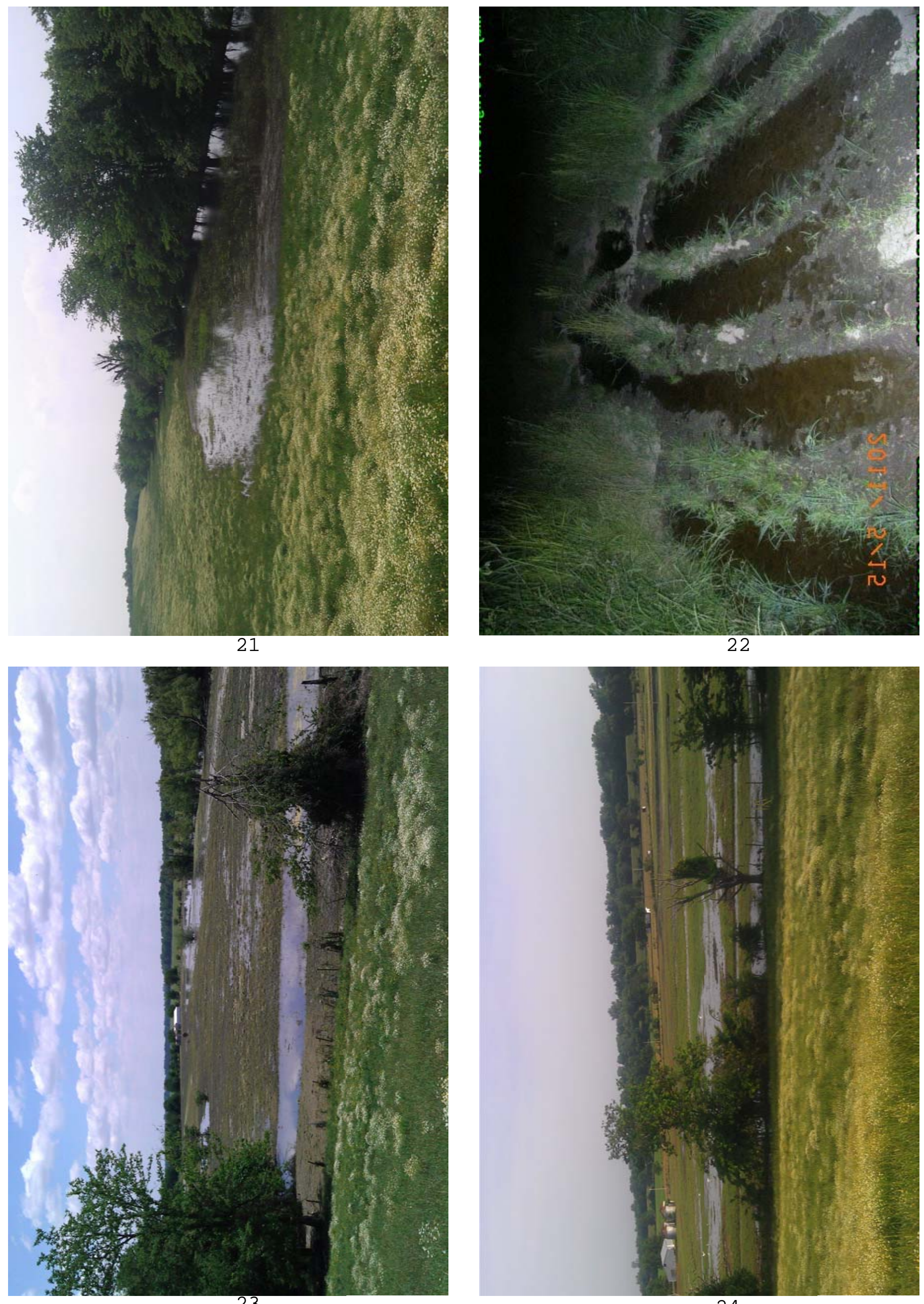

24 


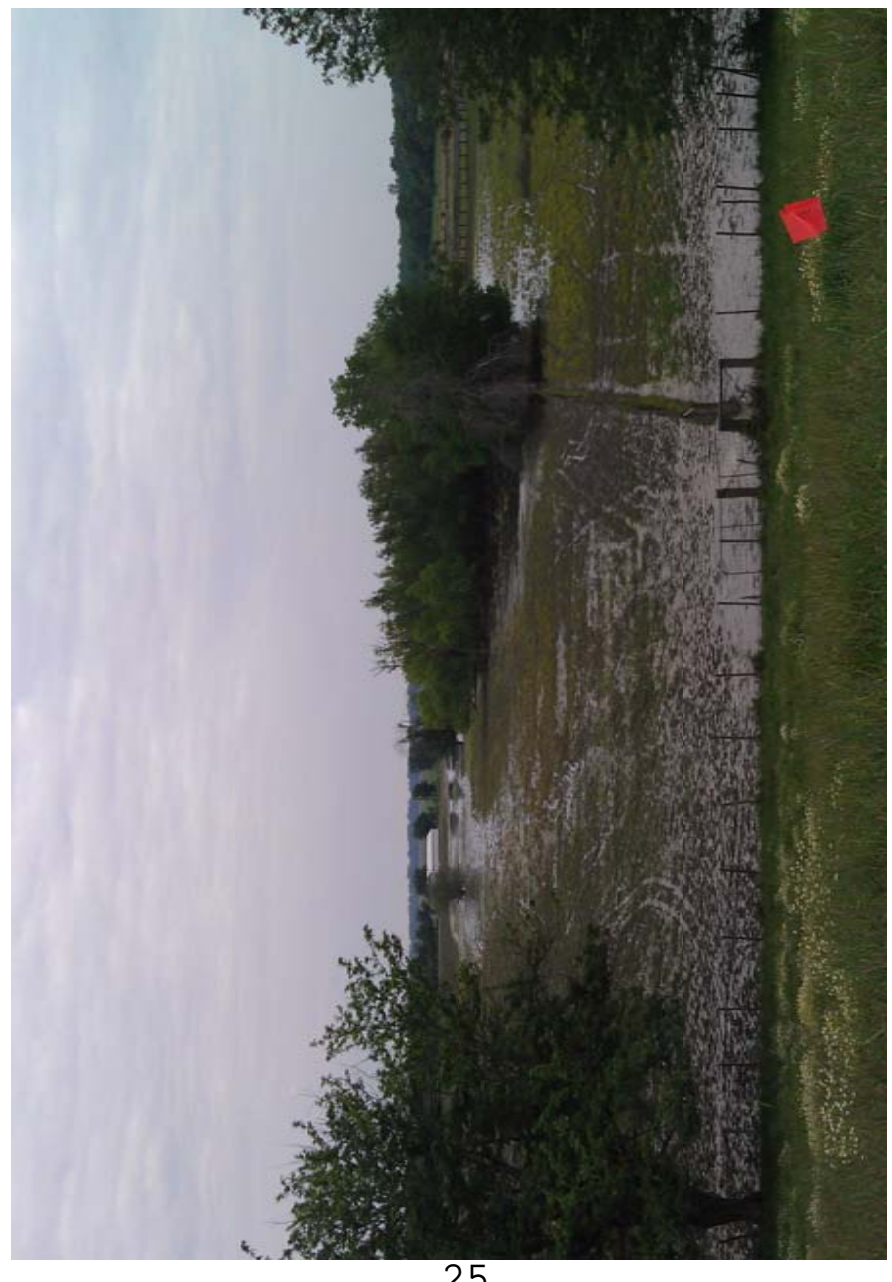

25

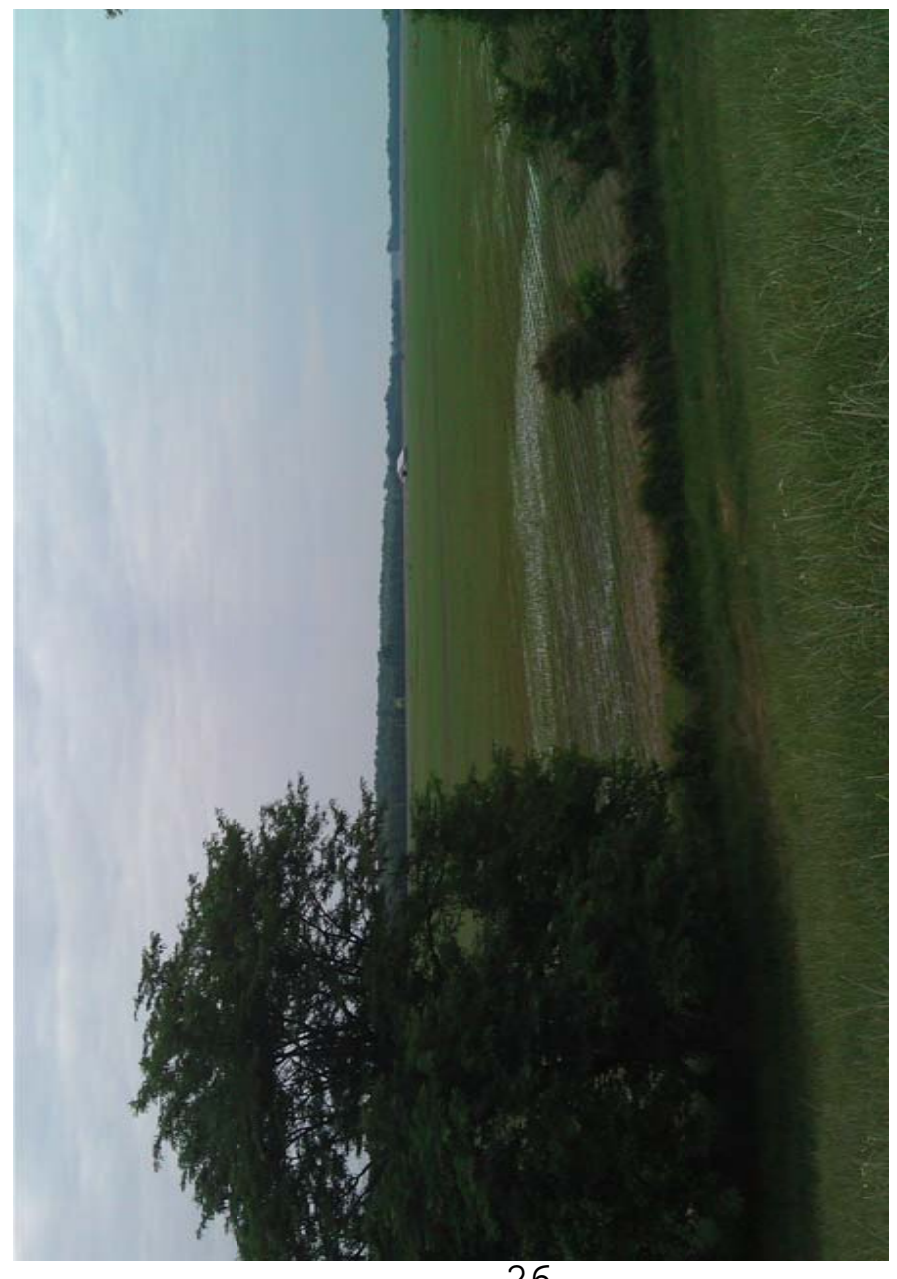

26

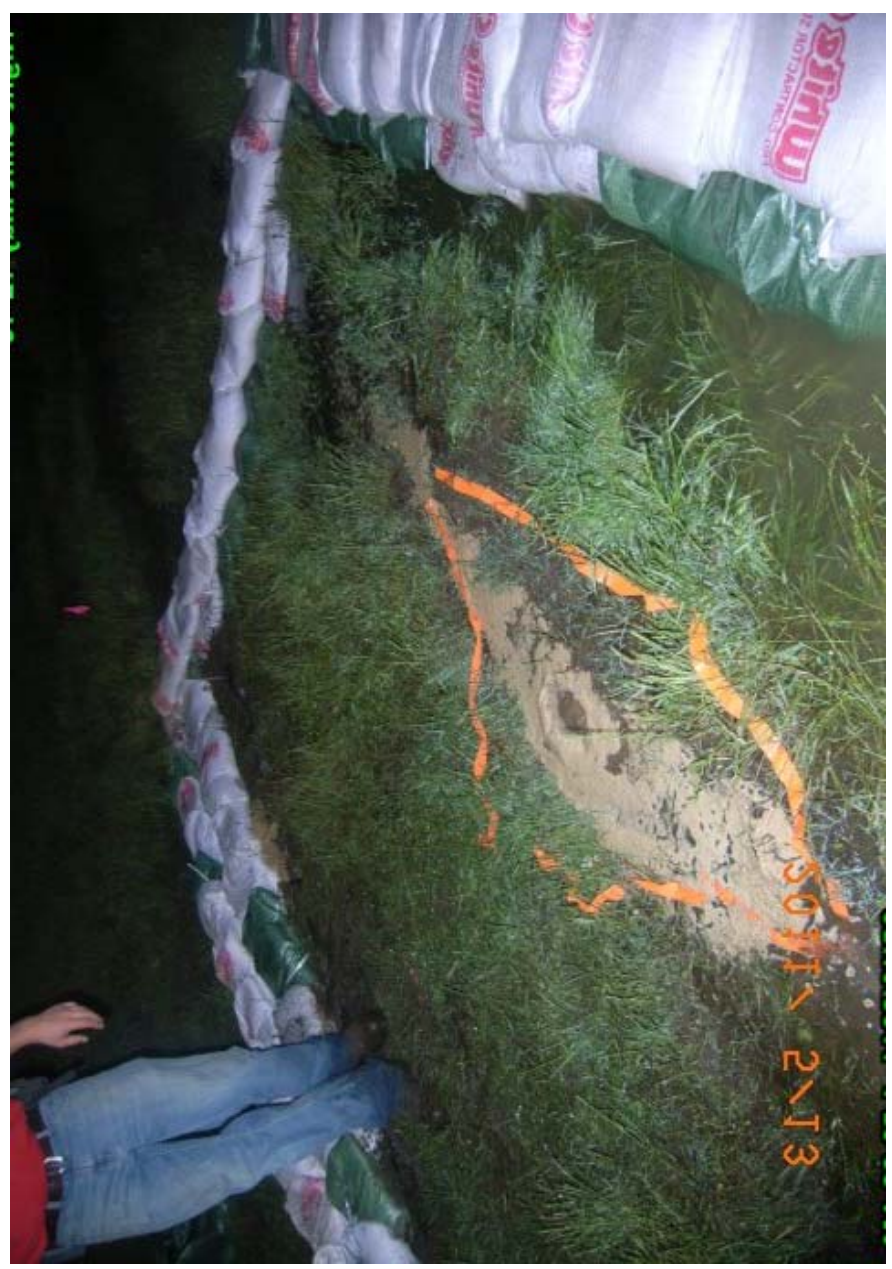

28 


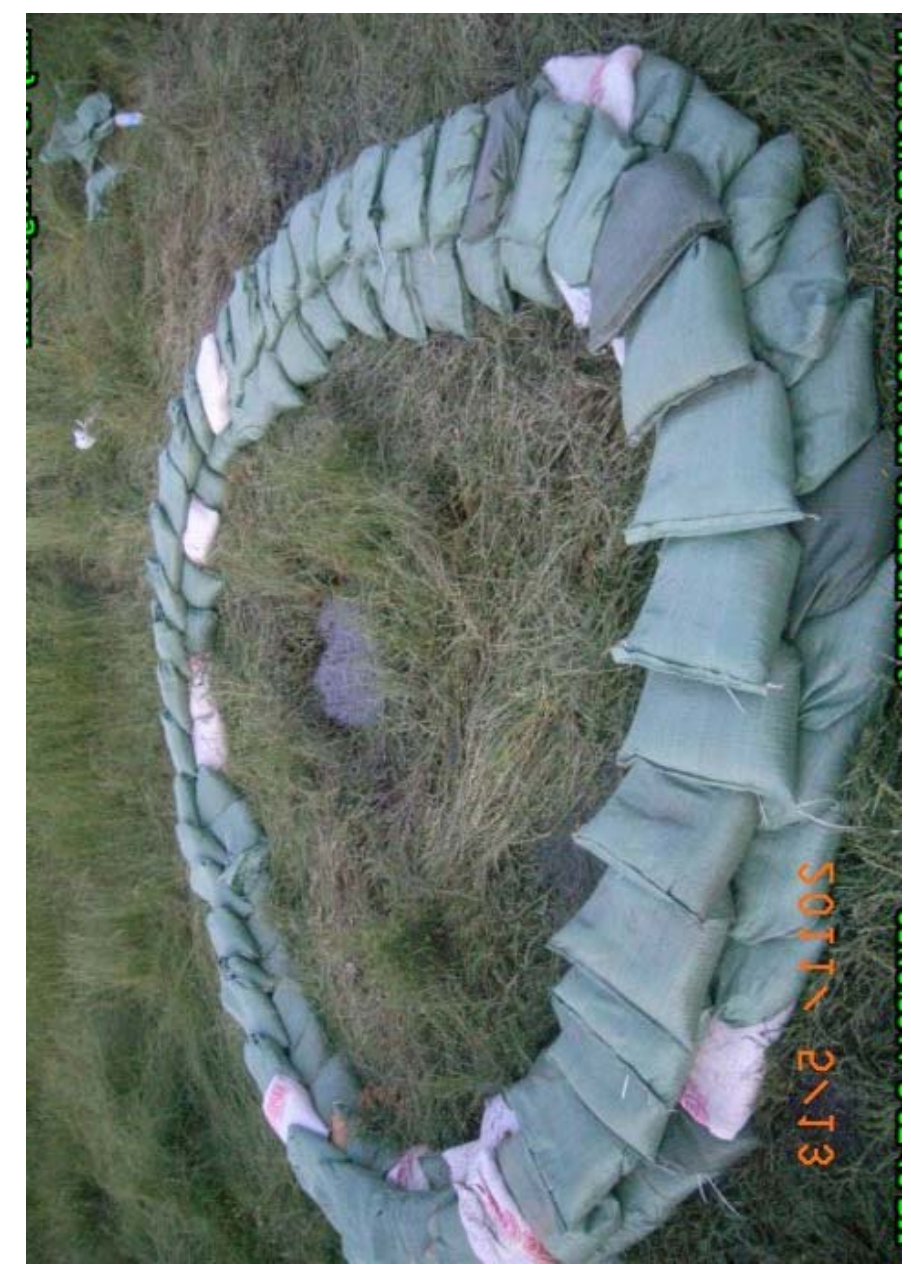

$$
29
$$

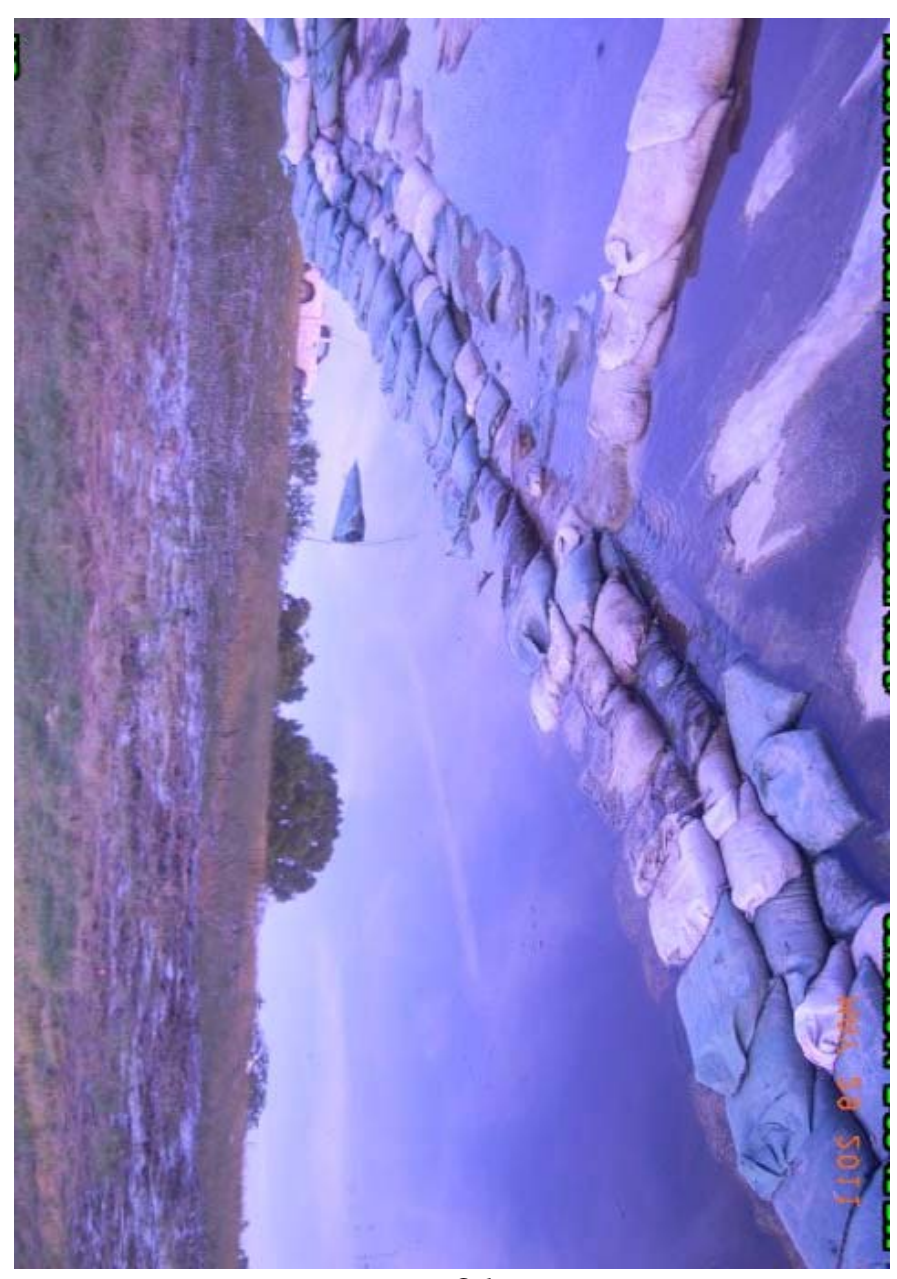

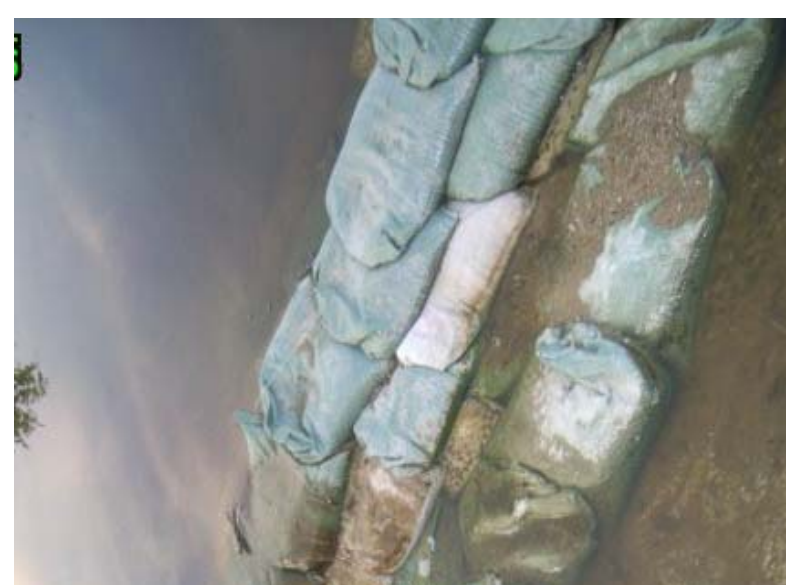

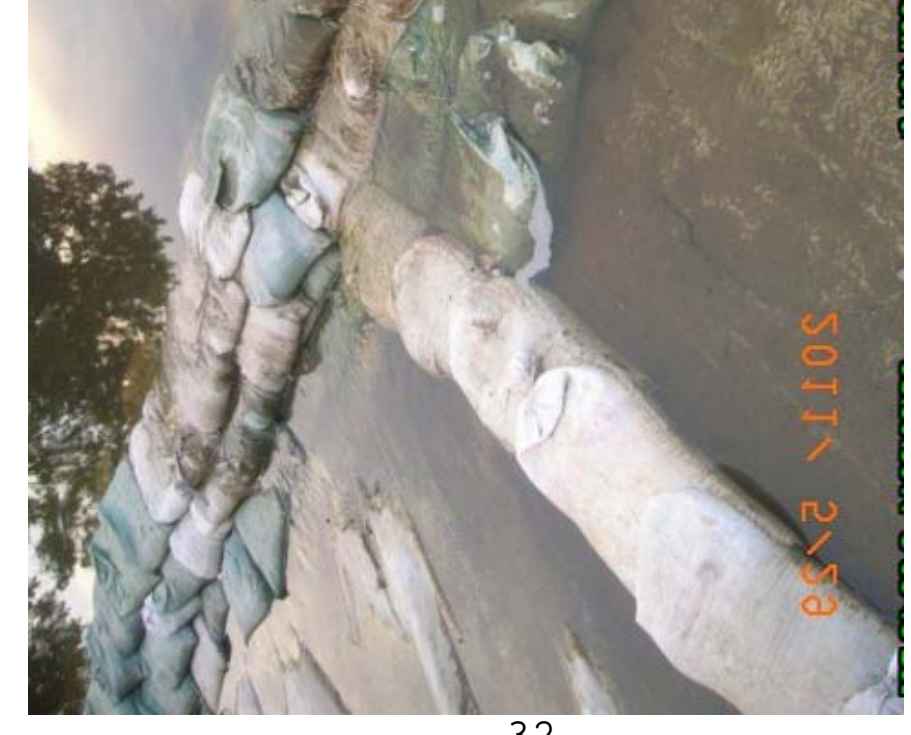




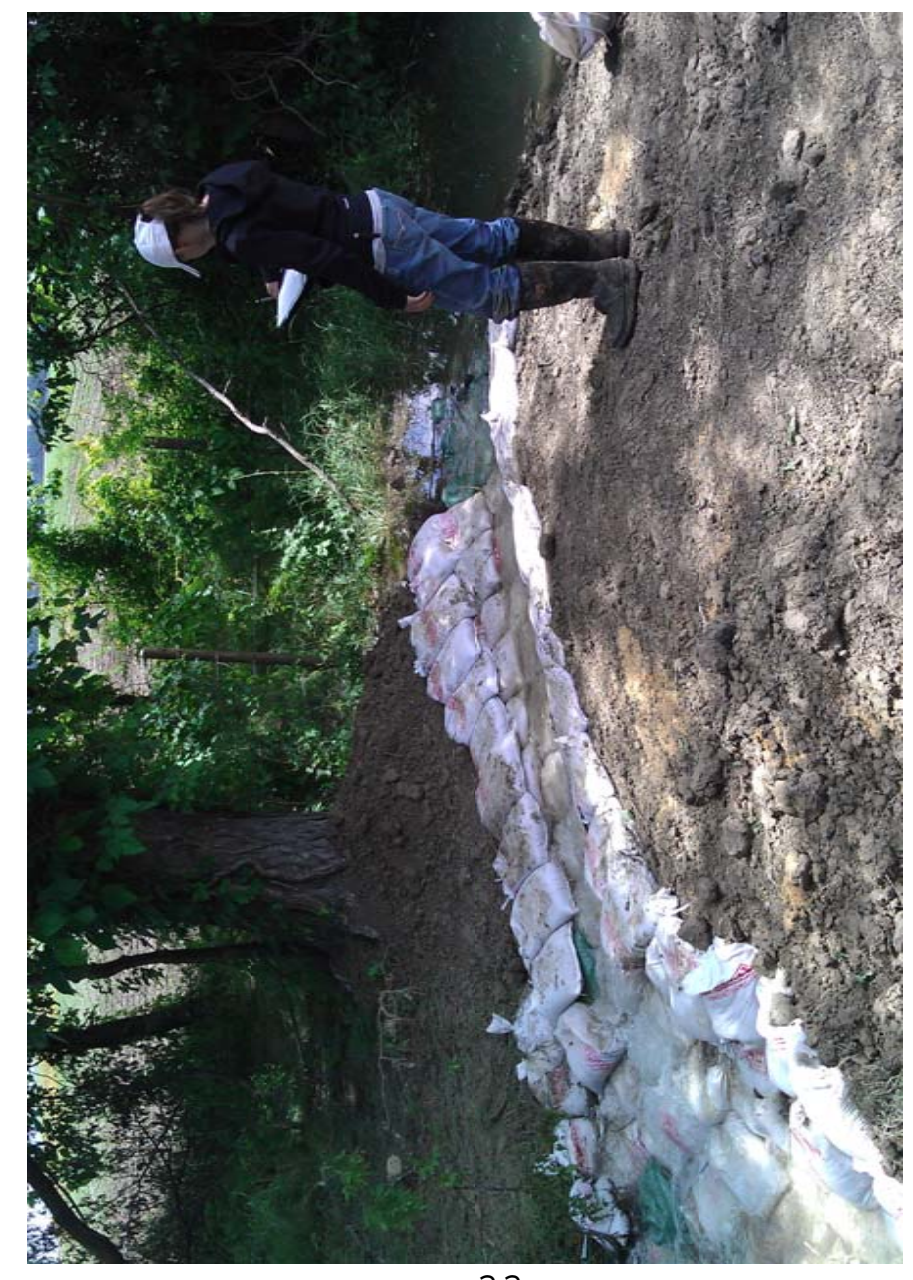

33

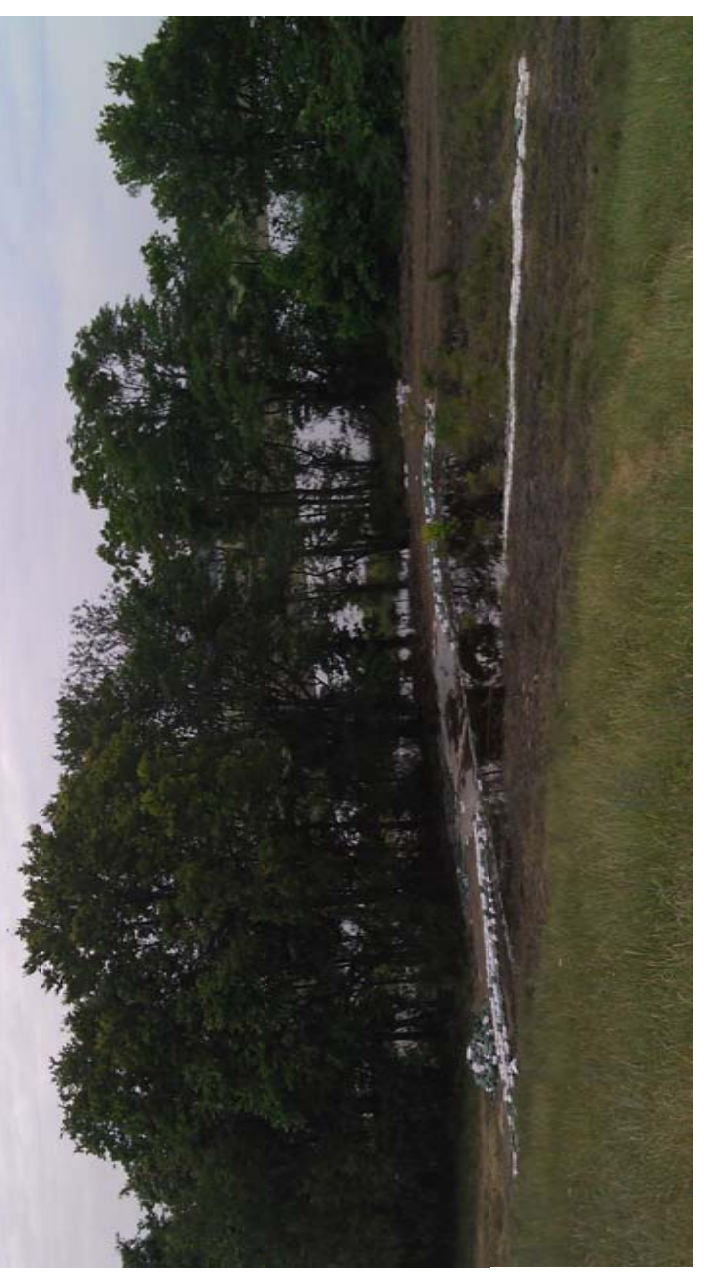

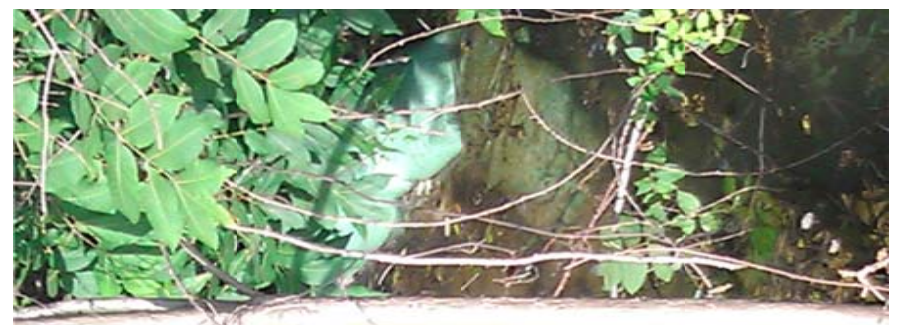

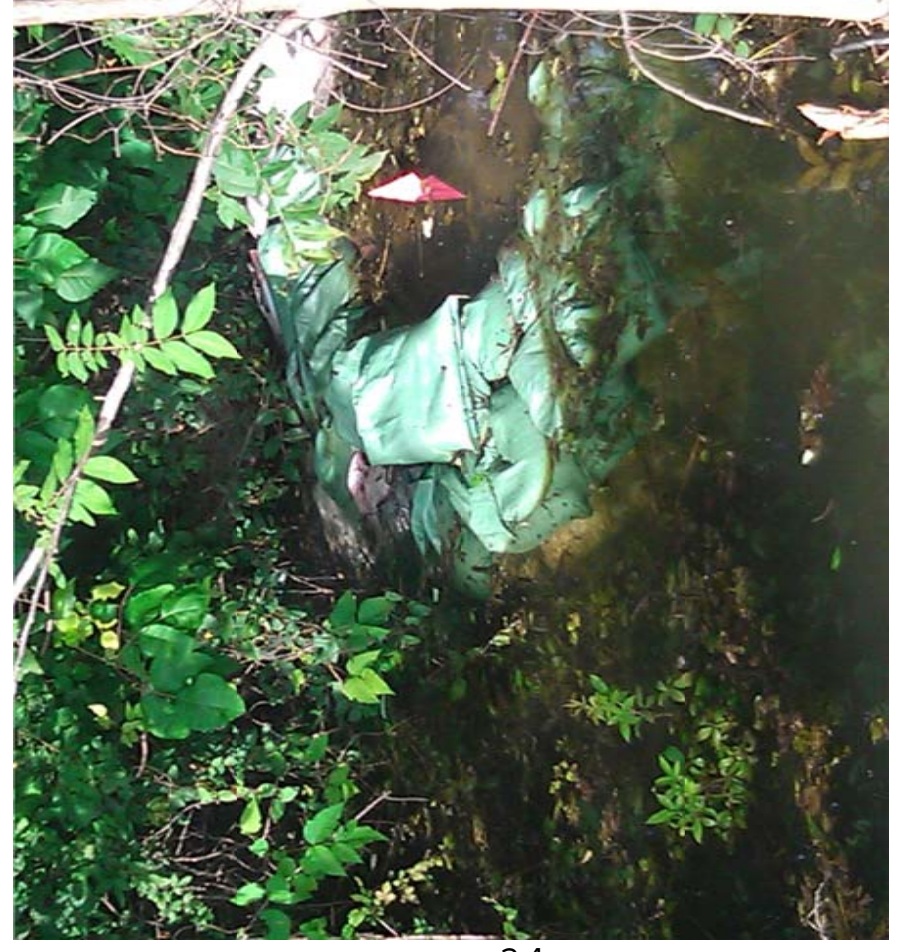

34

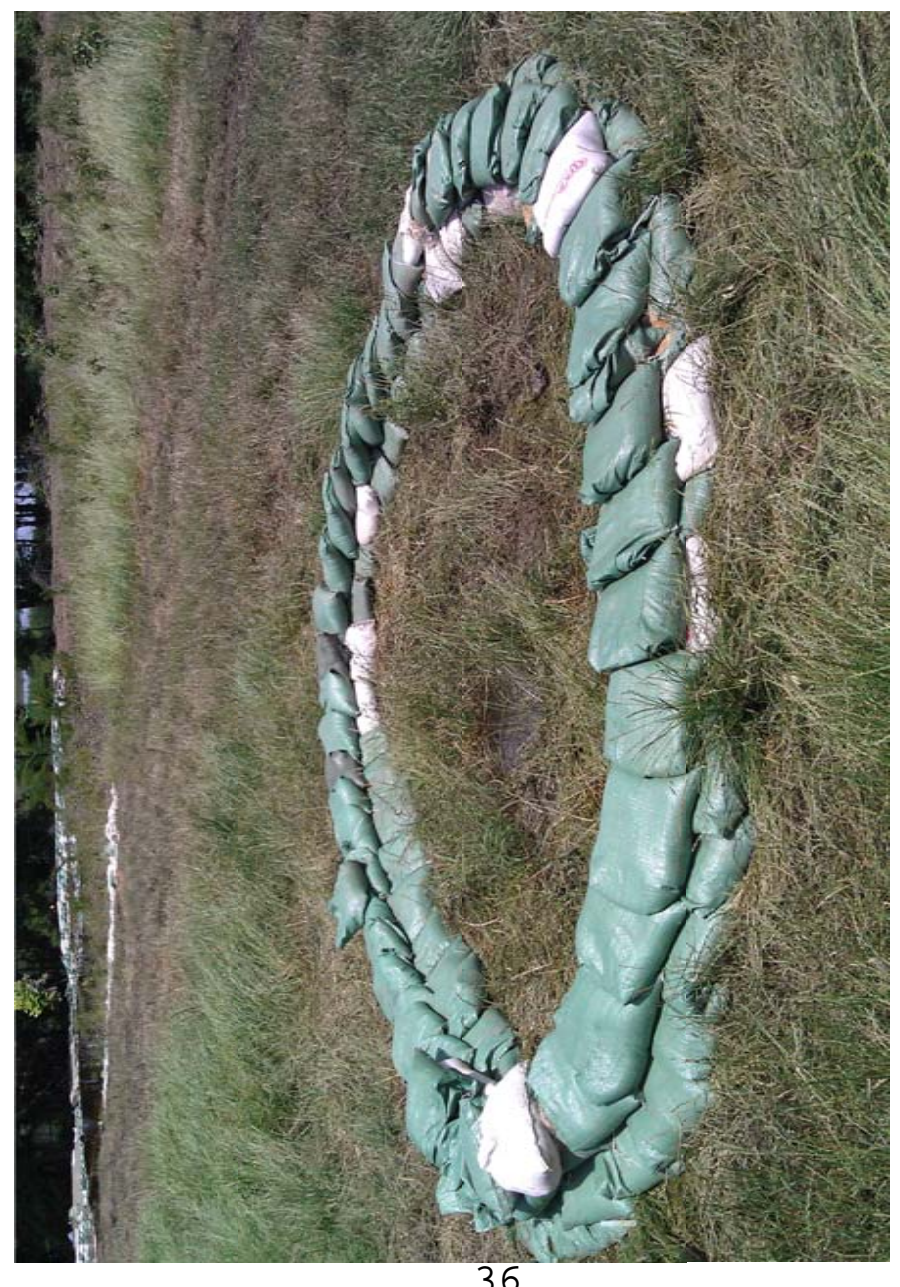

FOR OFFICIAL USE ONLY 


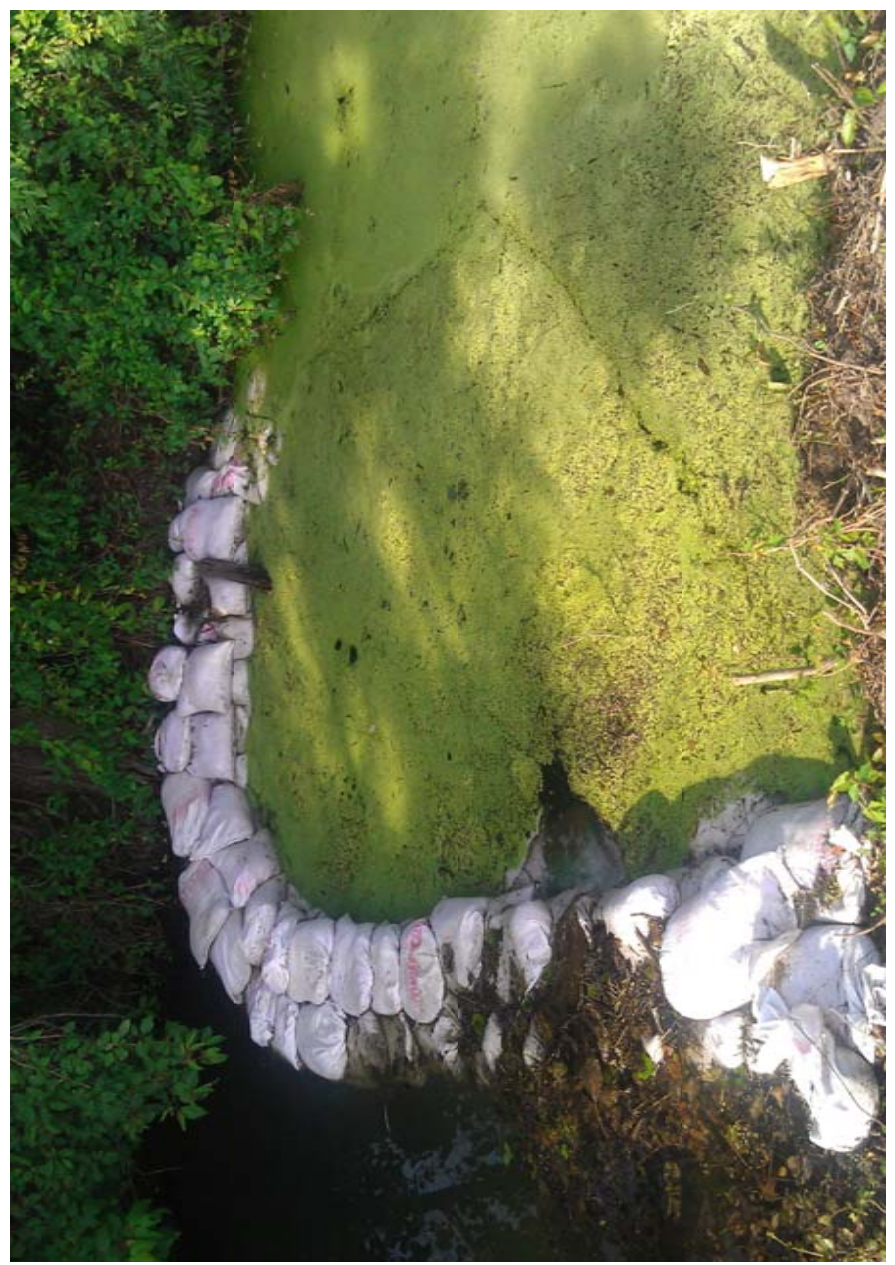

37

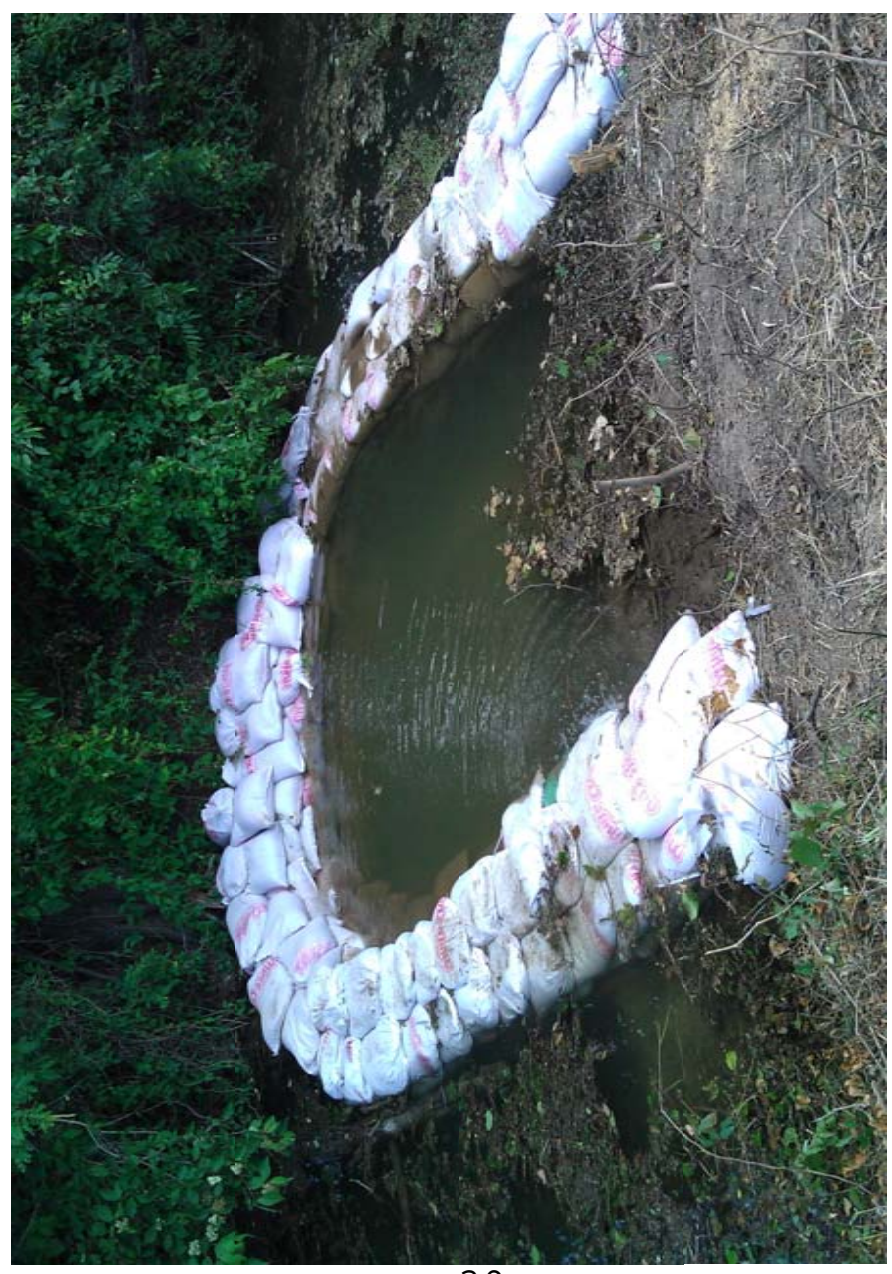

39

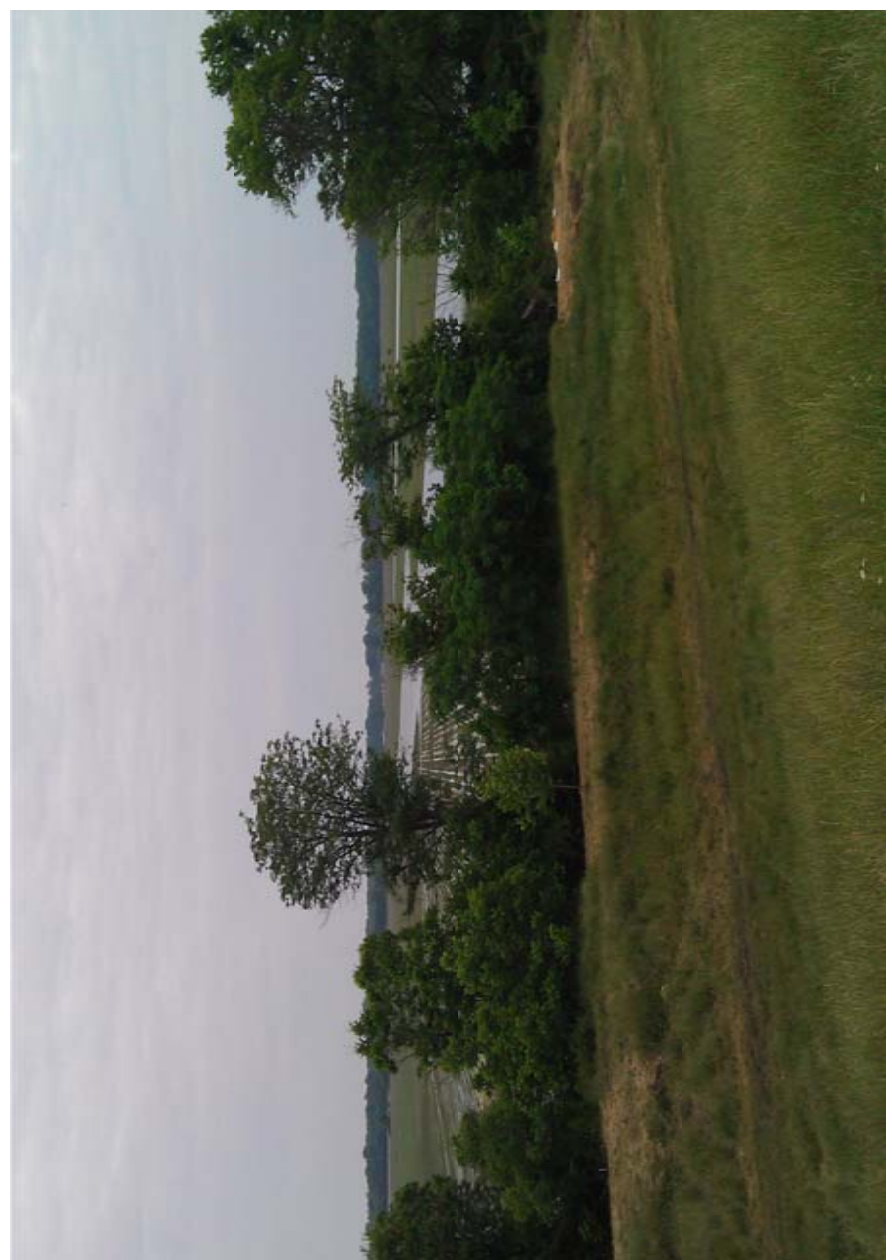

38

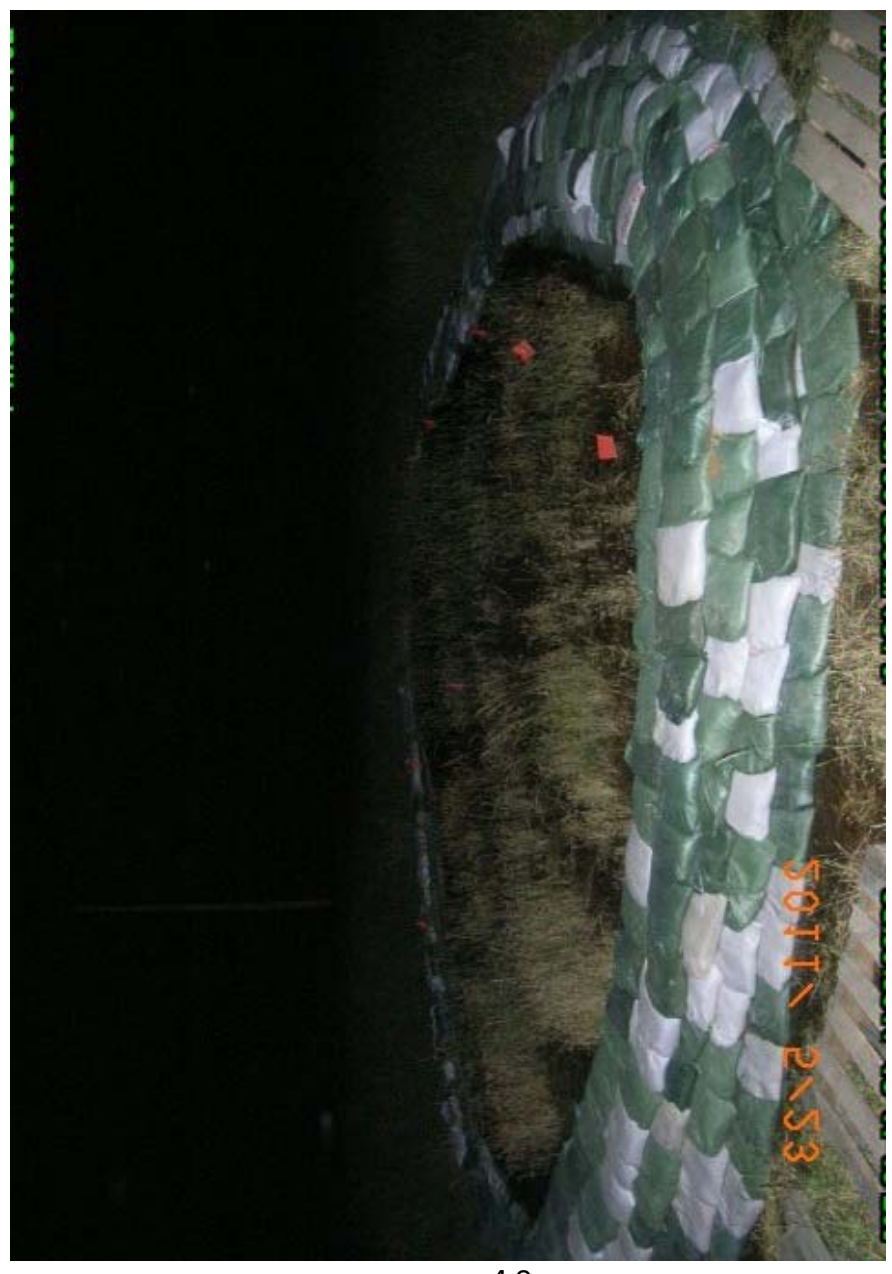



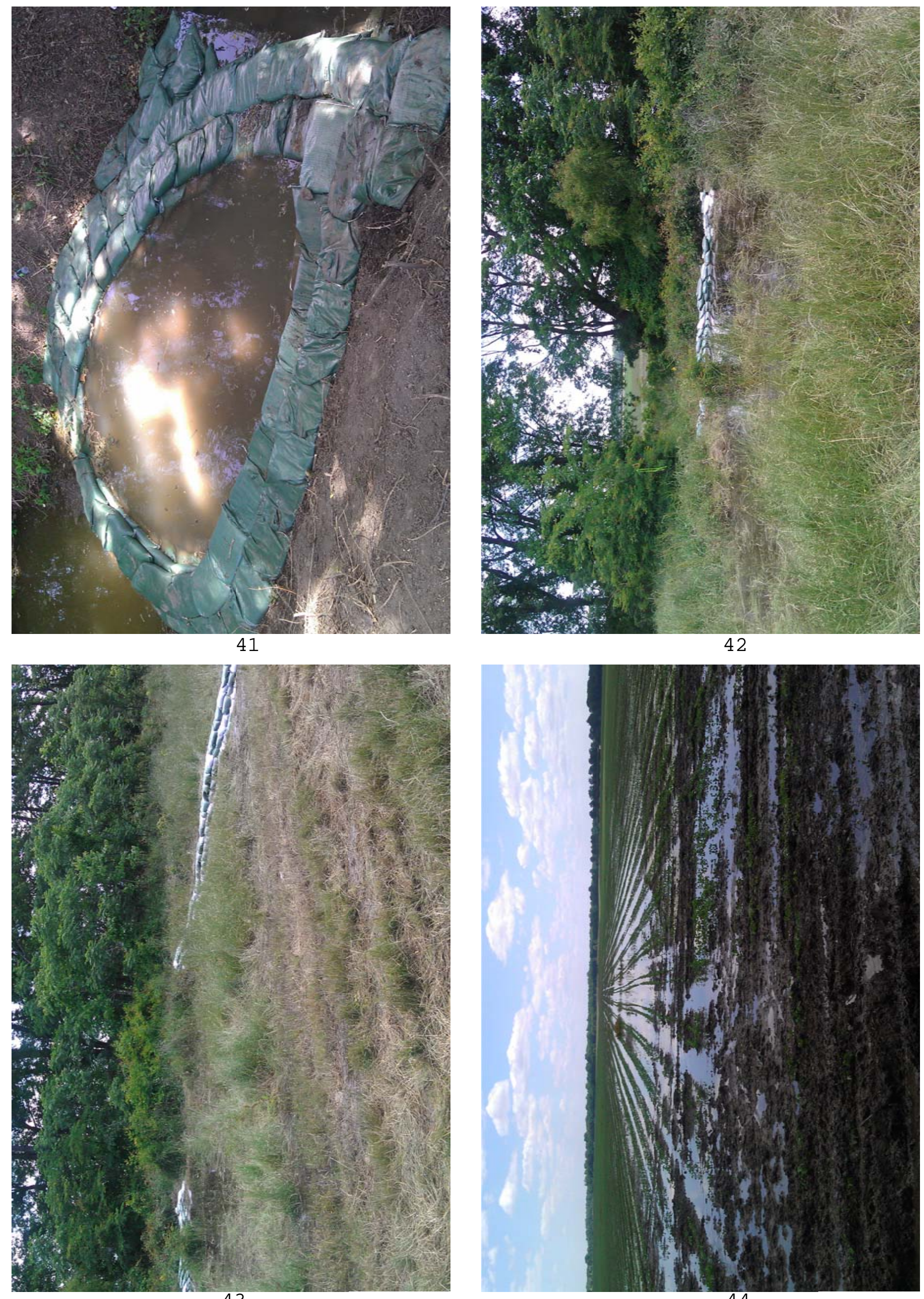


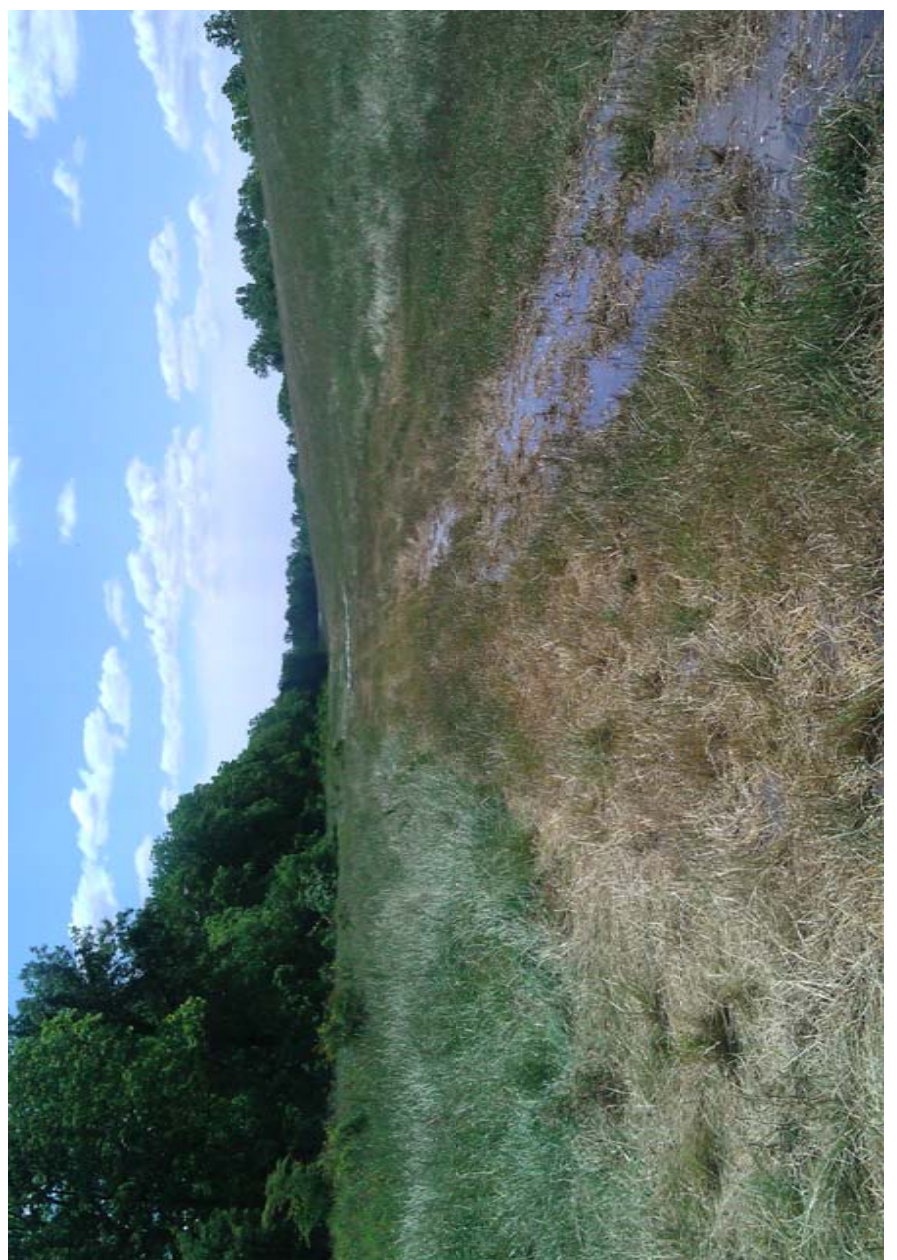

45

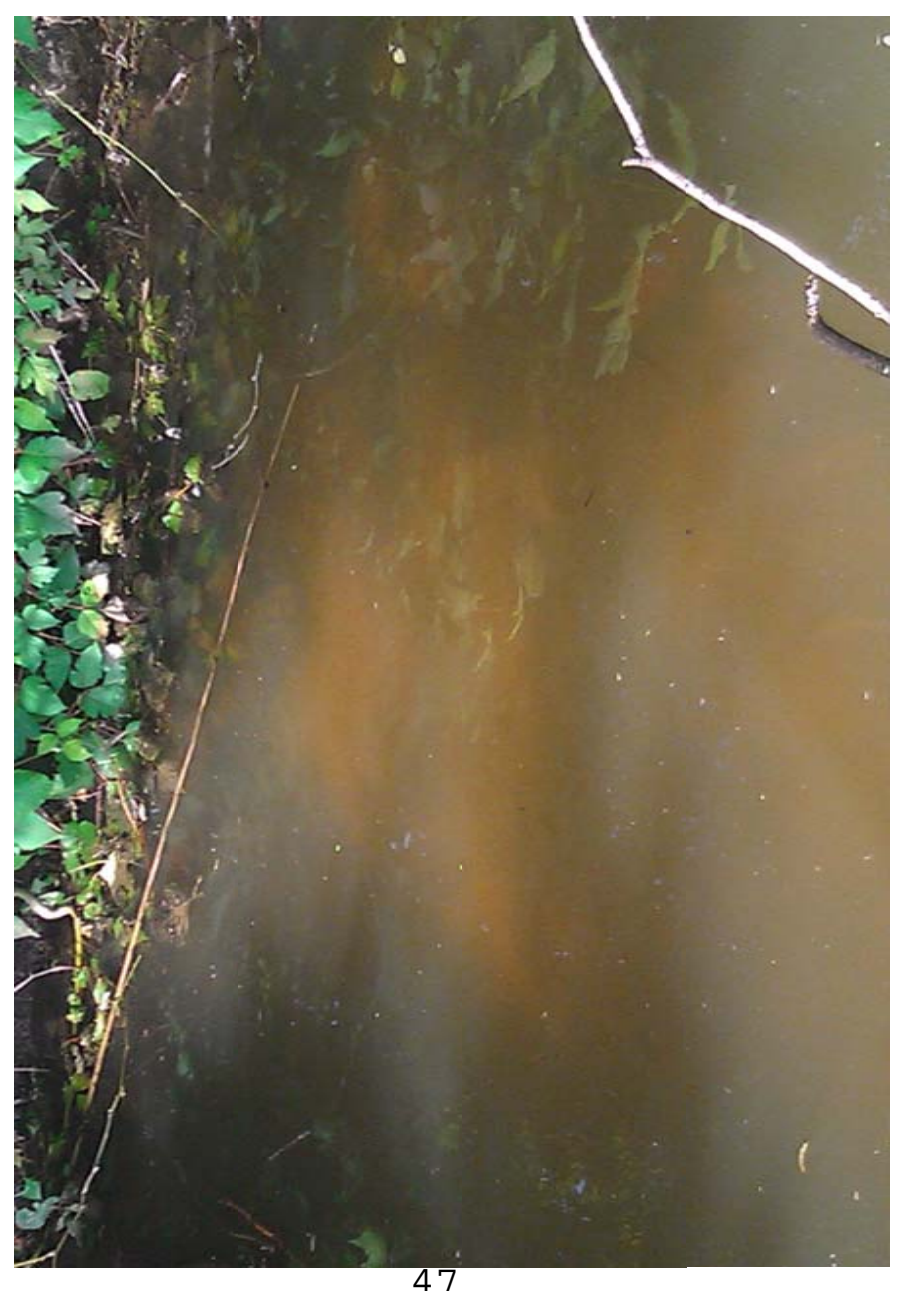

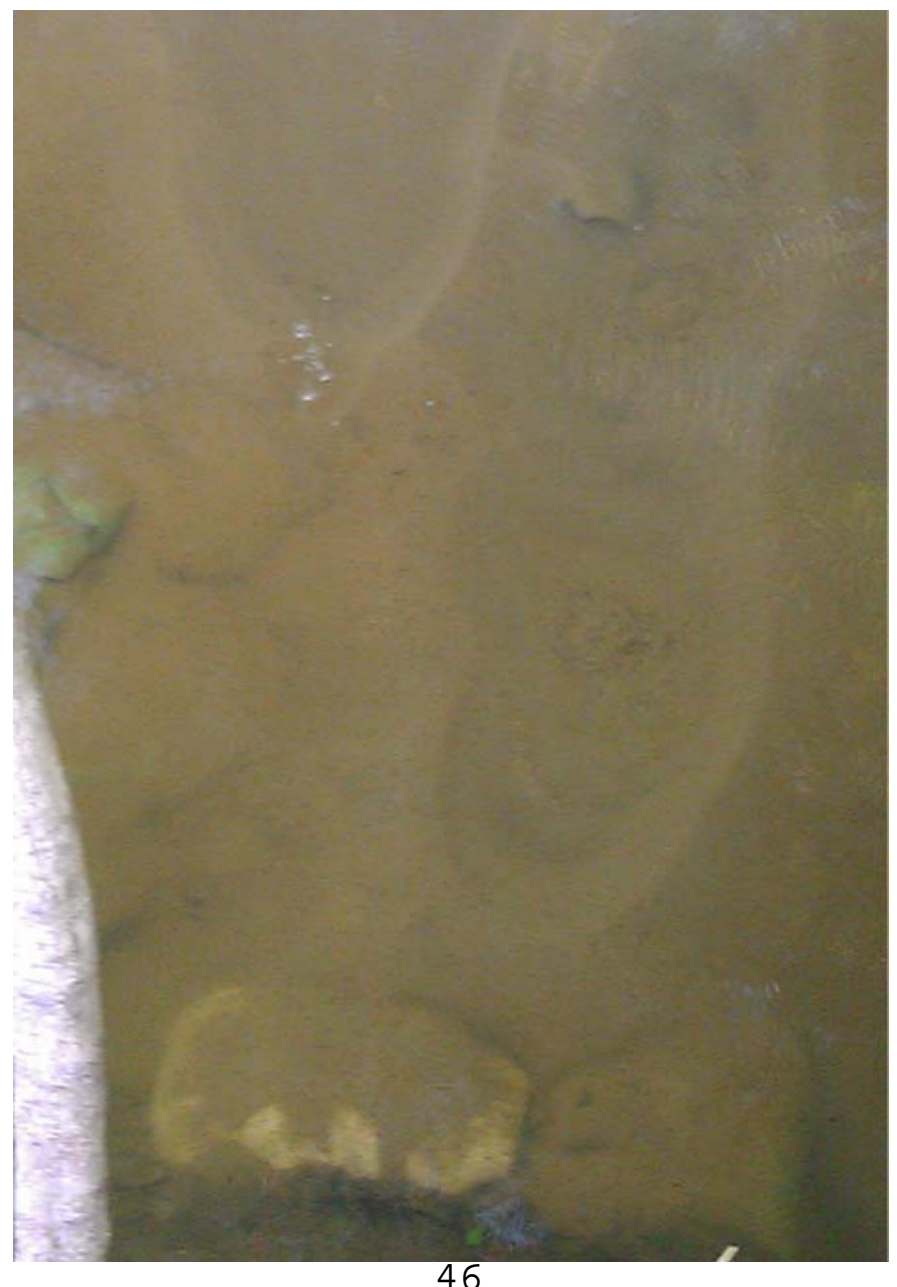

46

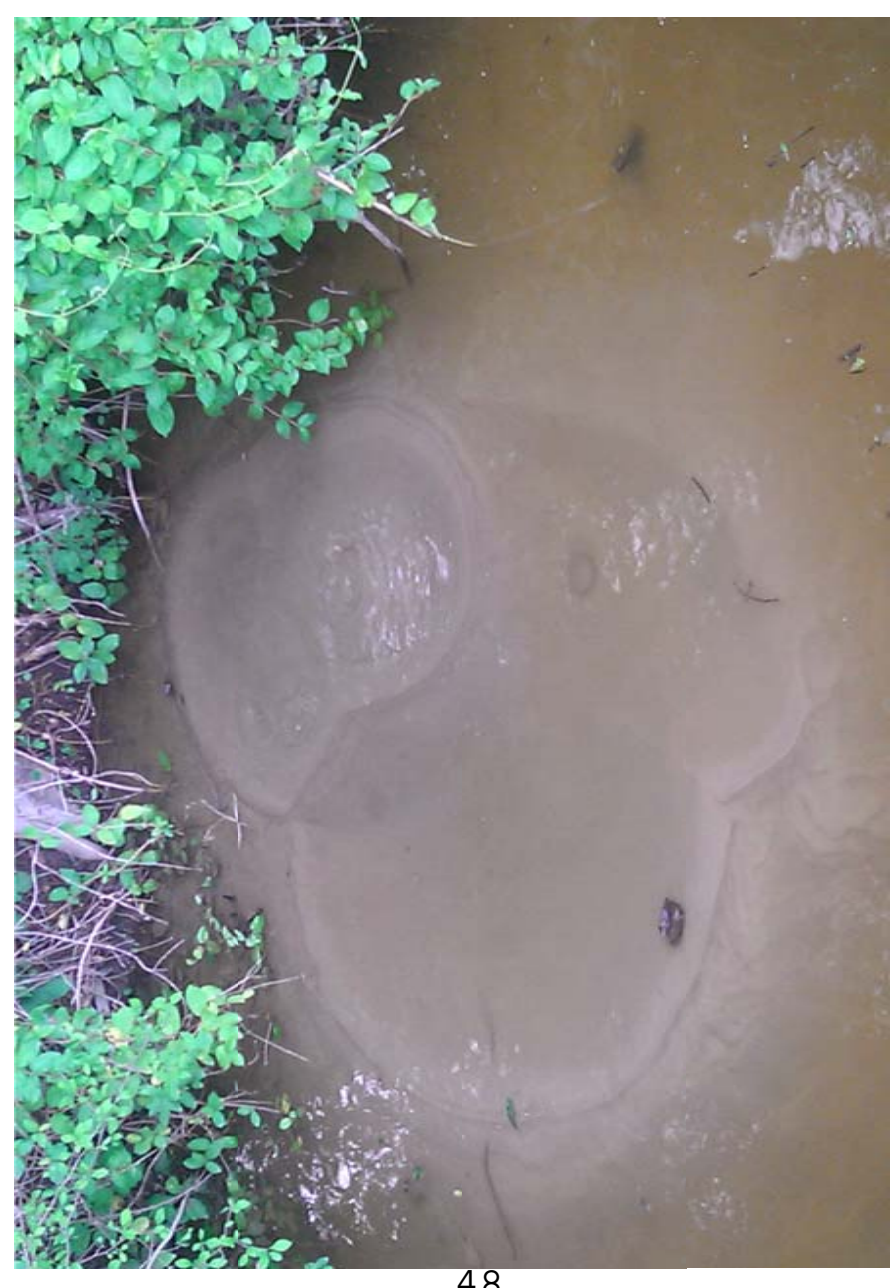

48 

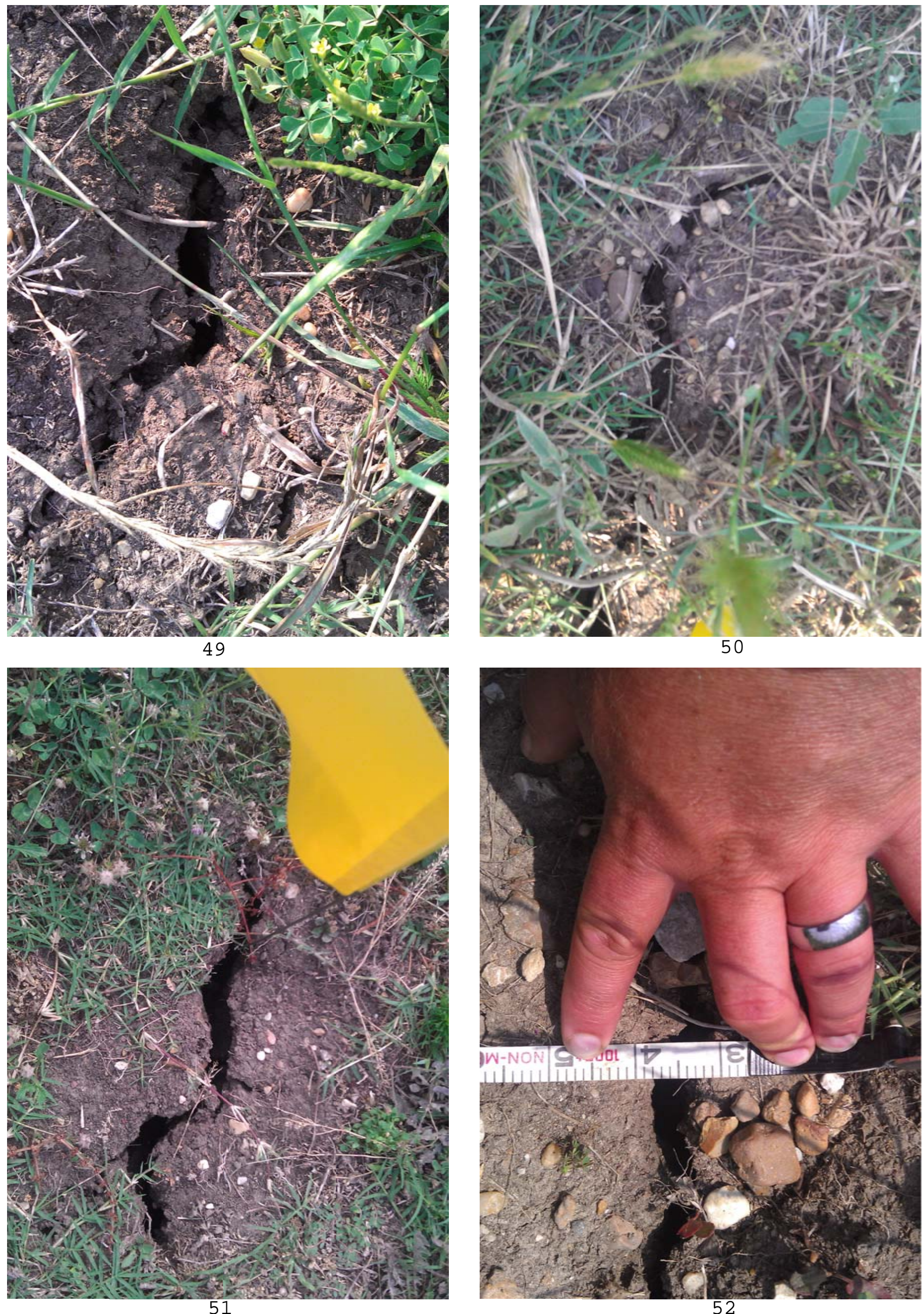


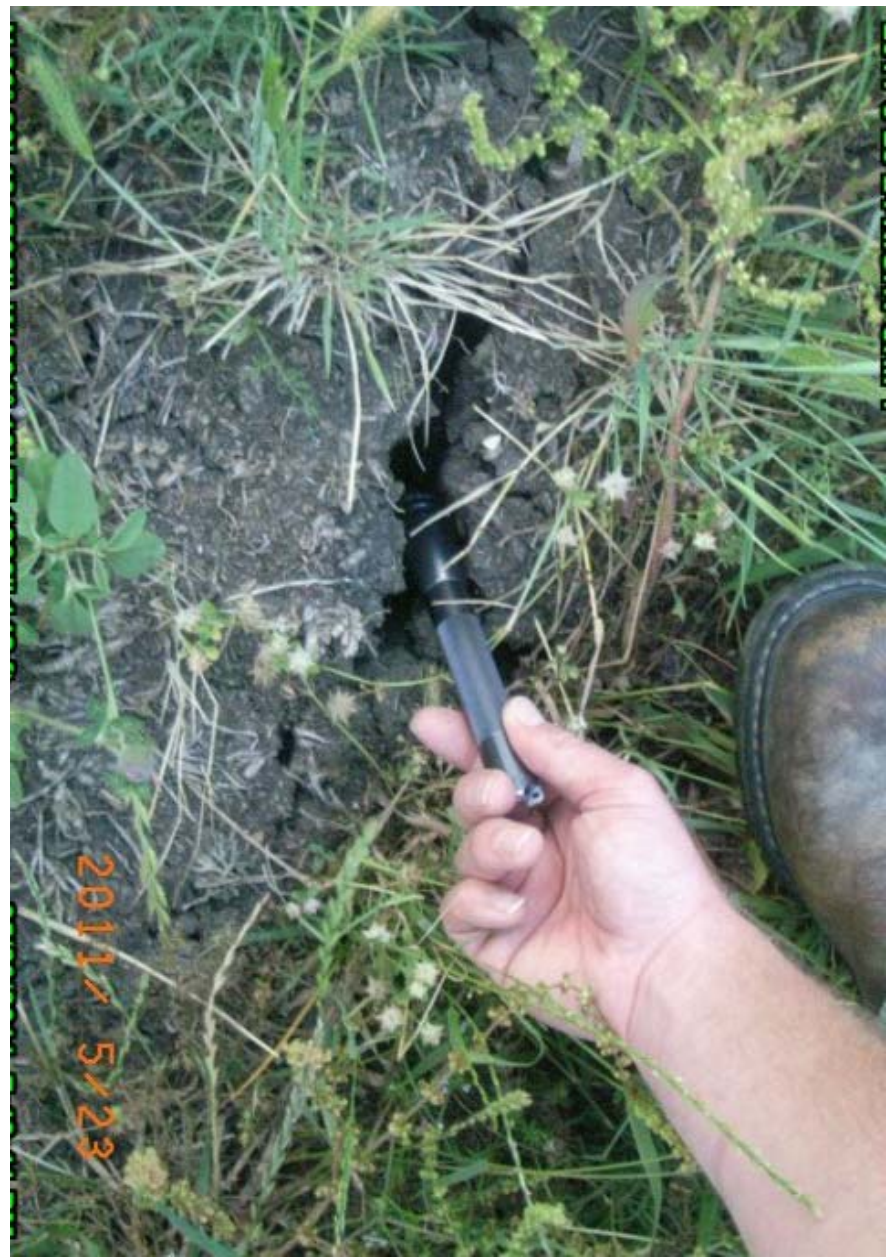

53

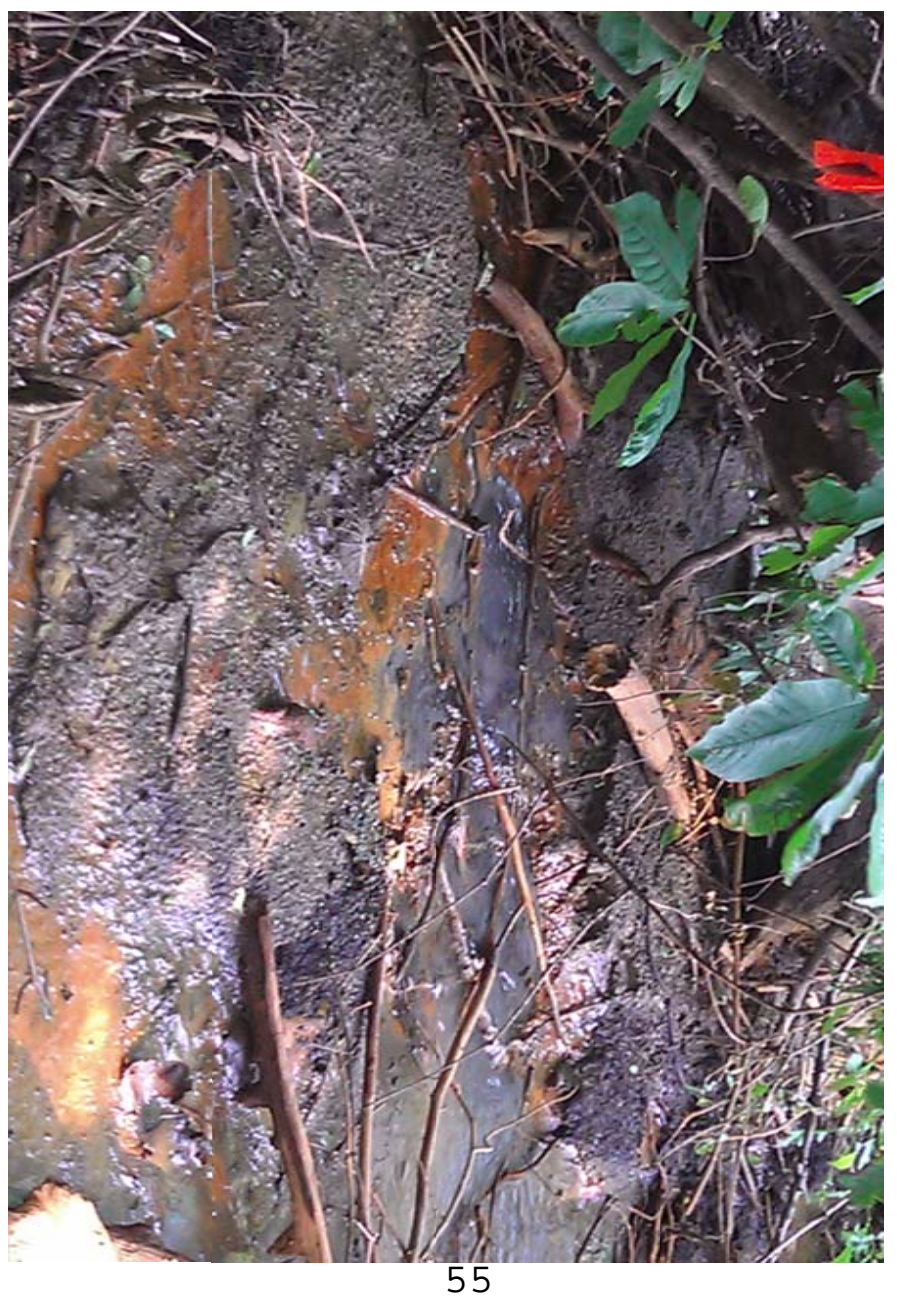

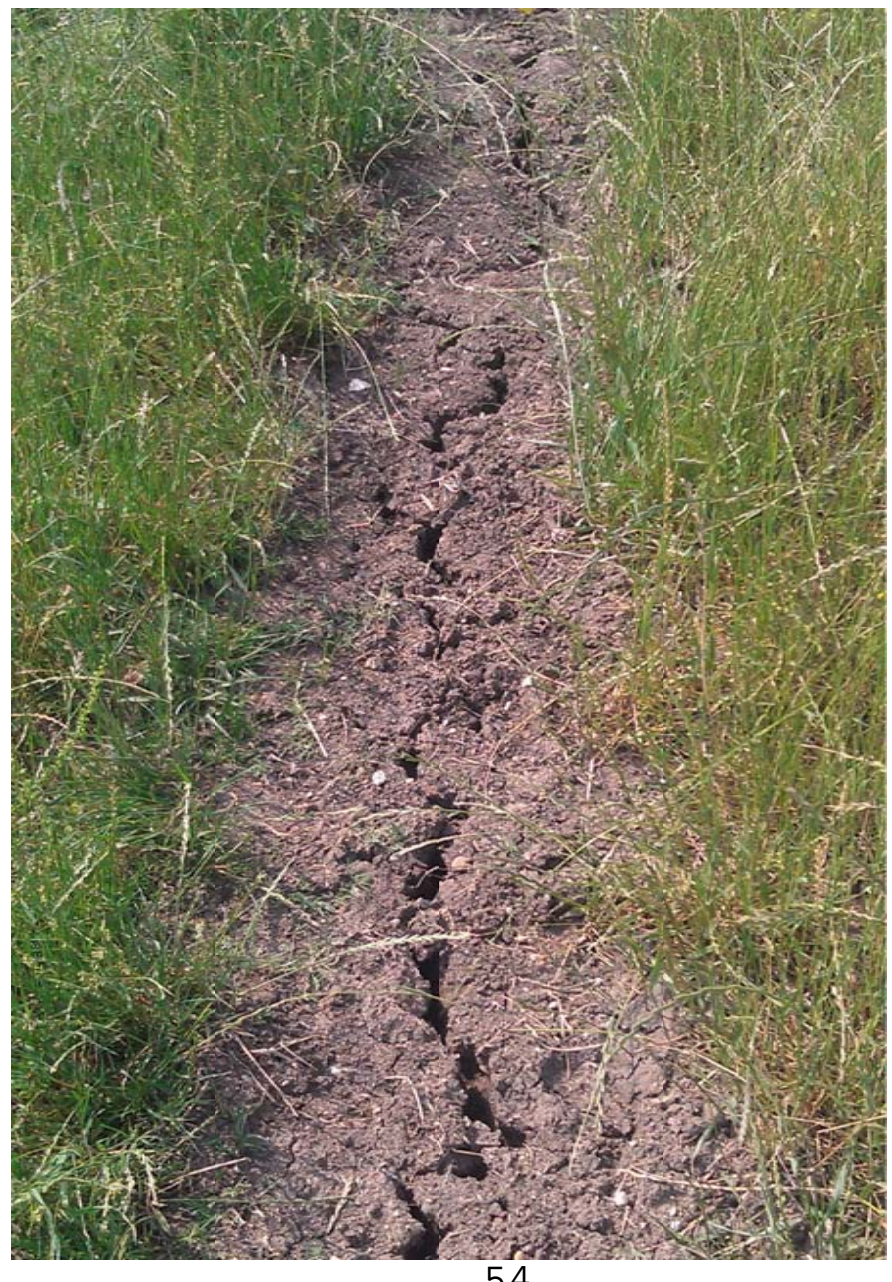

54

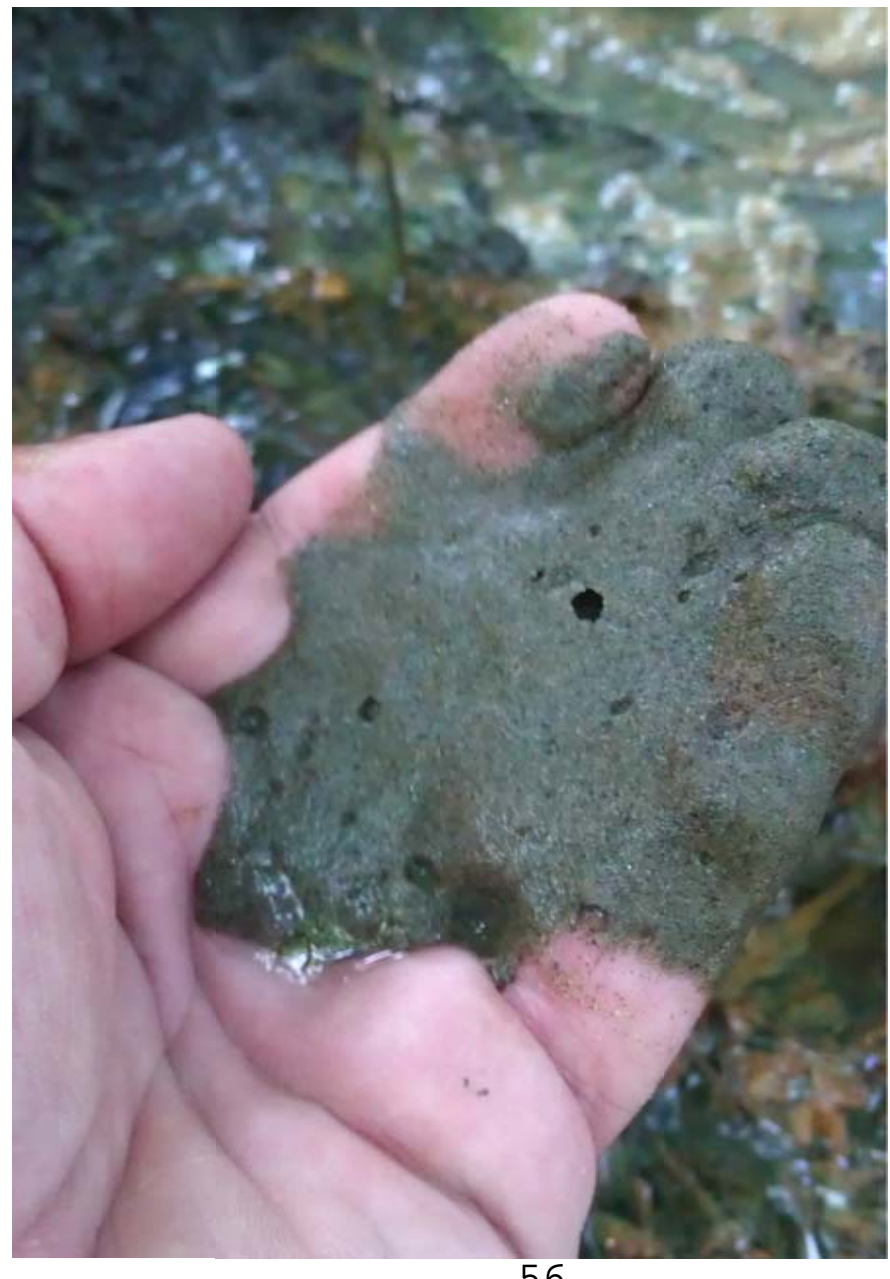

FOR OFFICIAL USE ONLY 


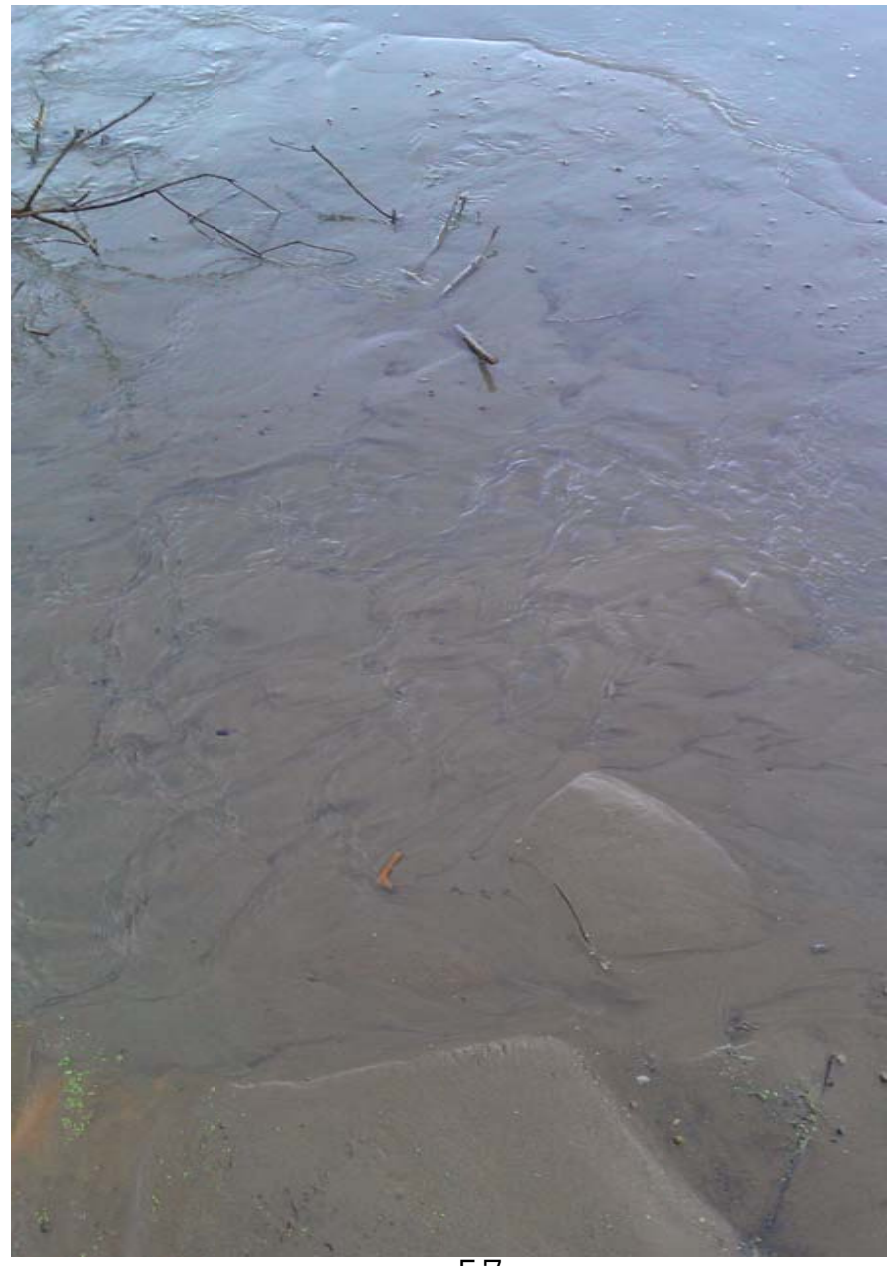

57

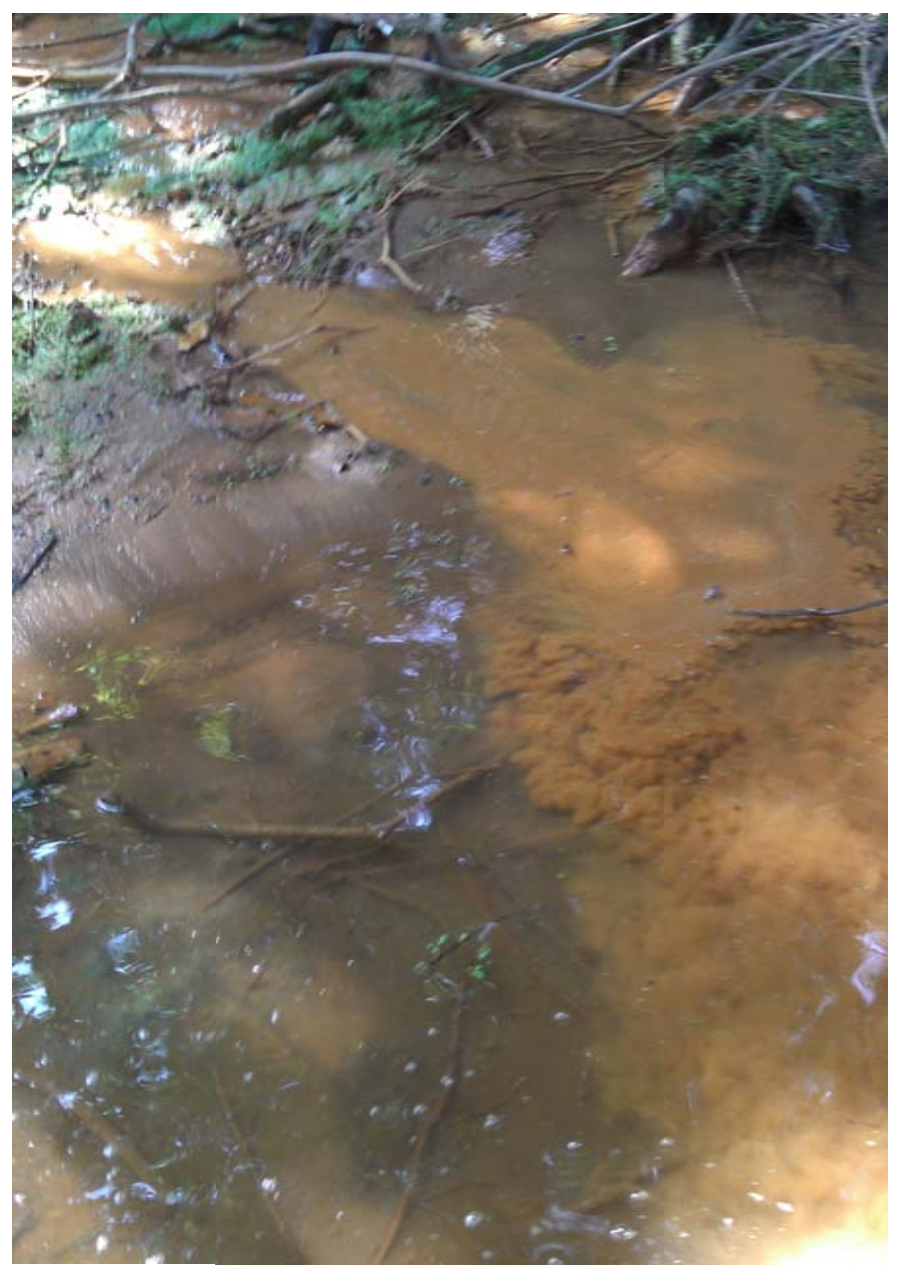

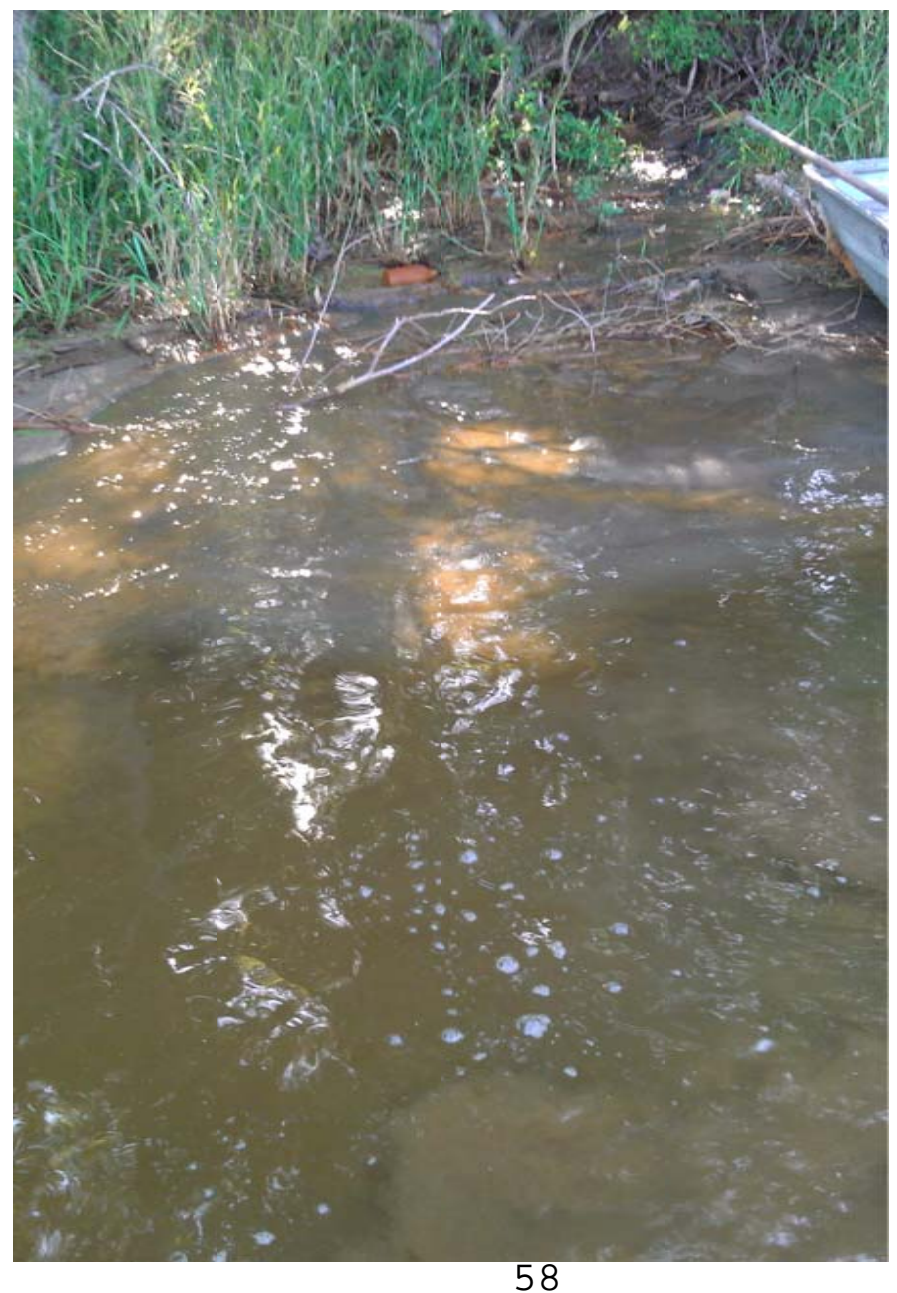

58

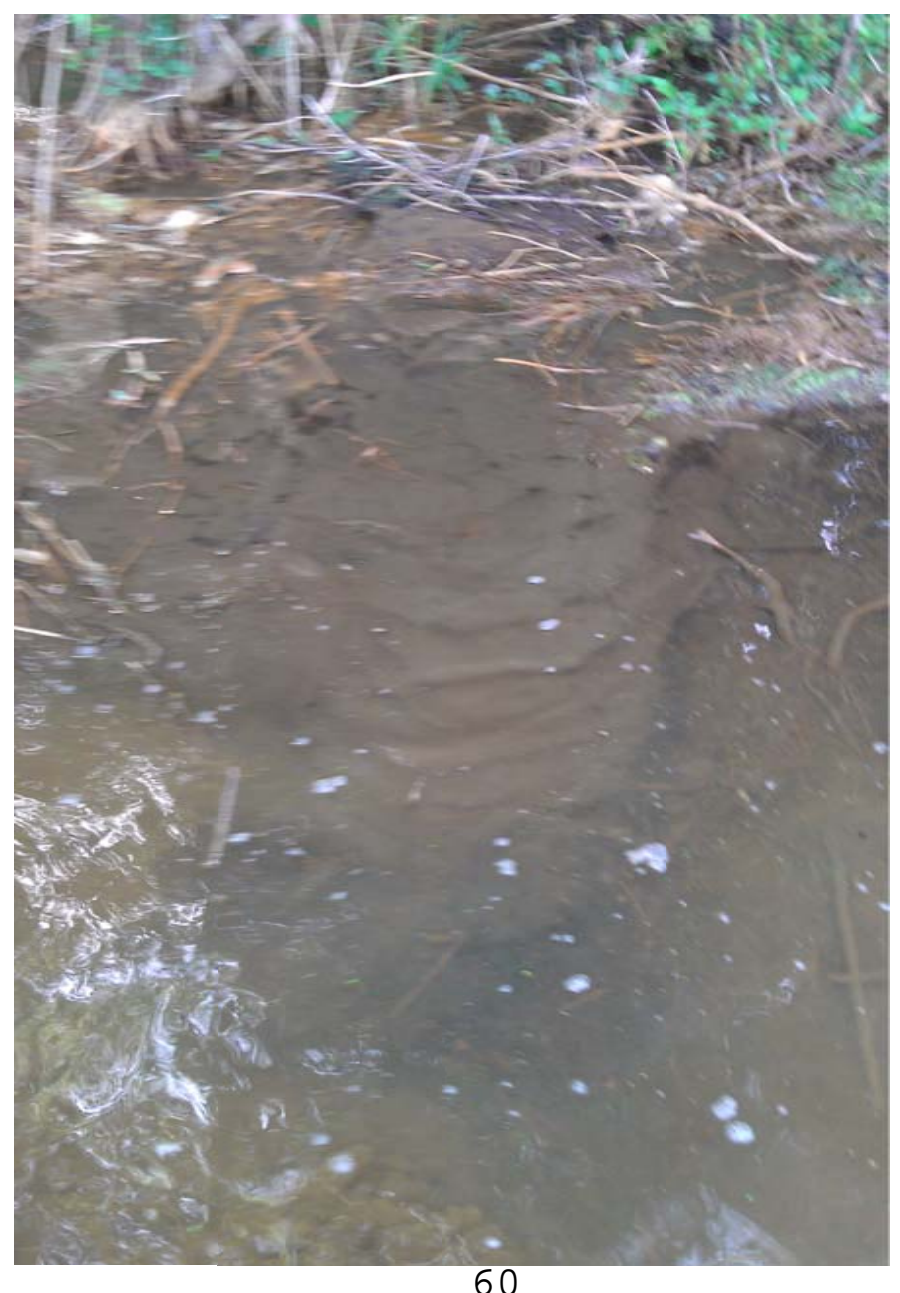

FOR OFFICIAL USE ONLY 


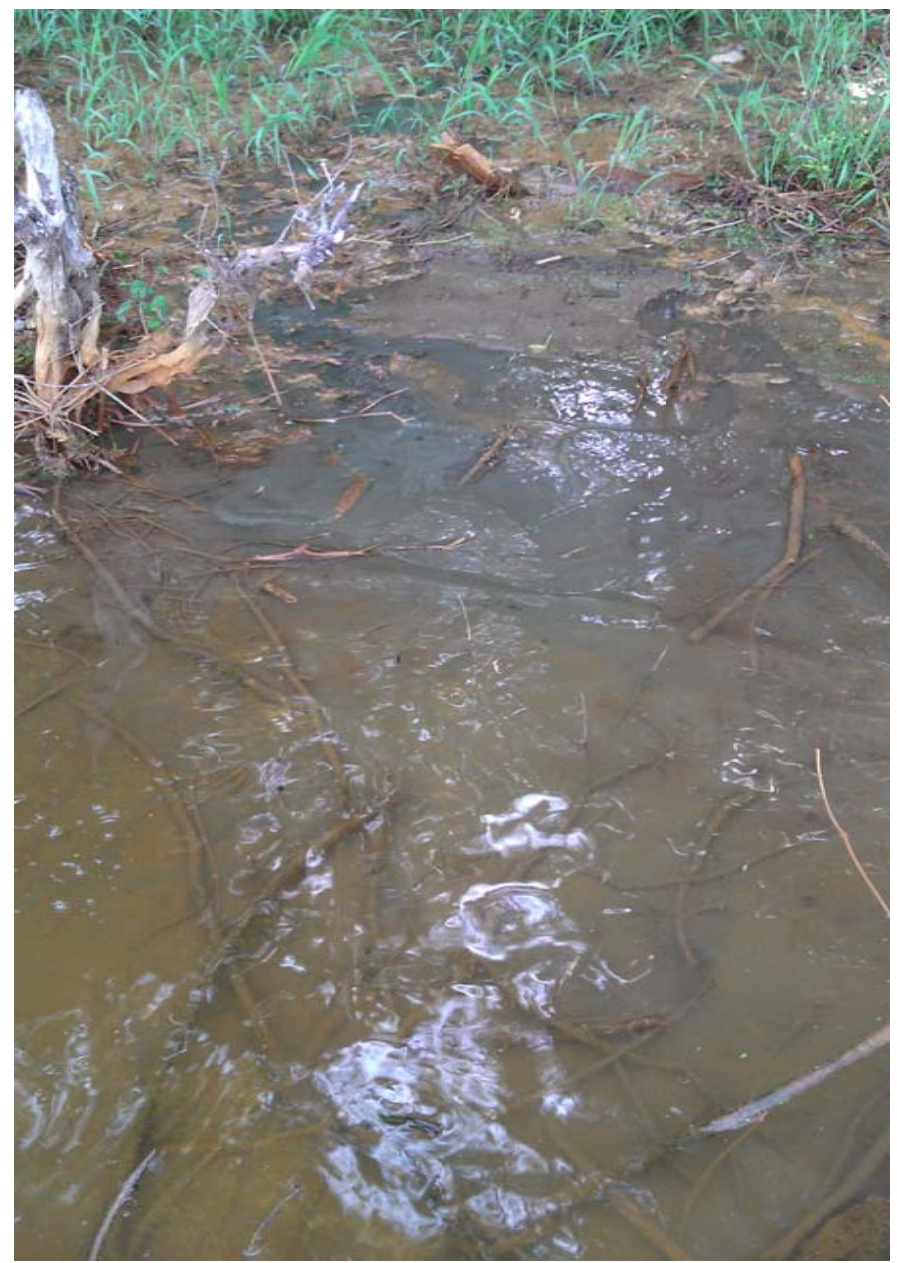

61

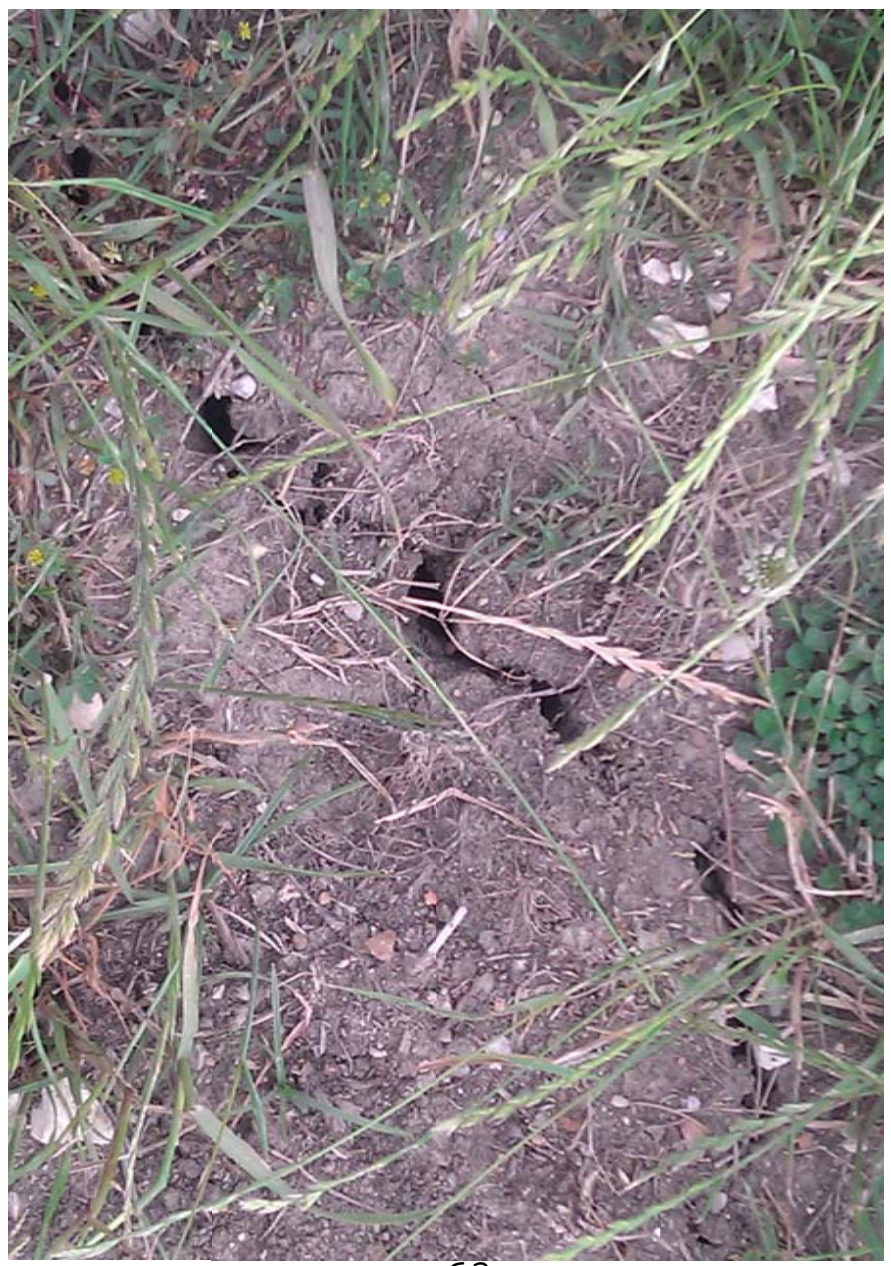

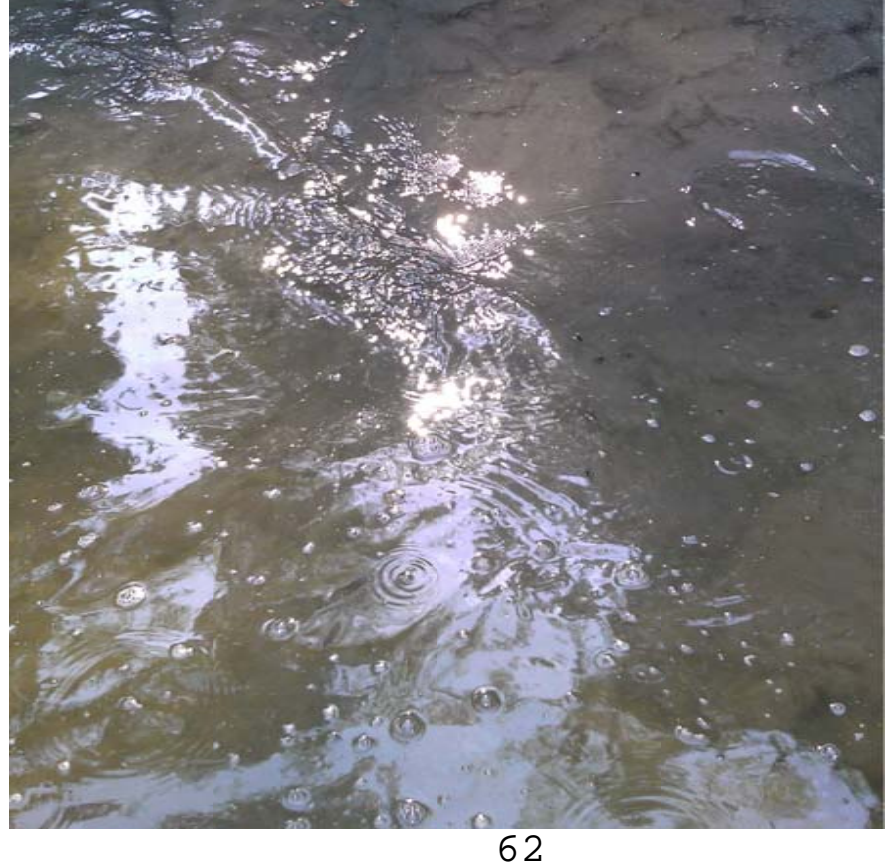

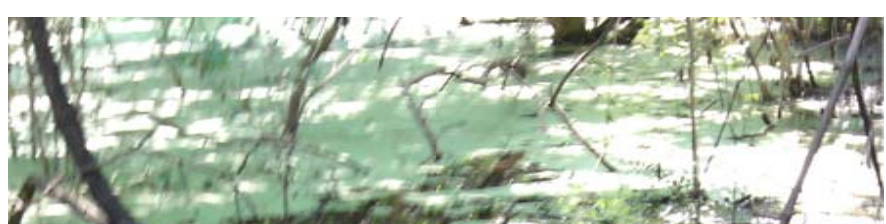

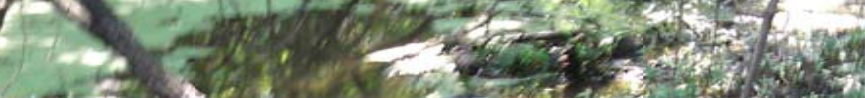

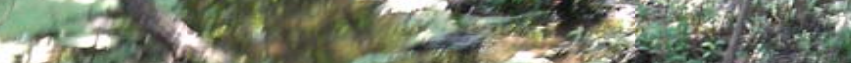
1)

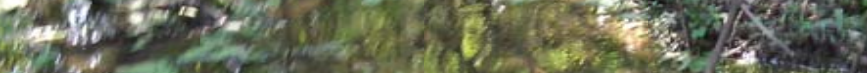
(5)

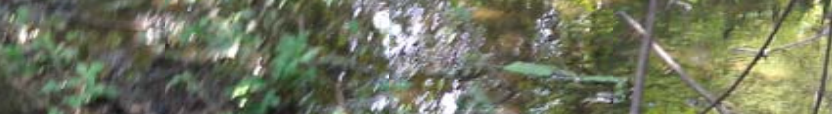

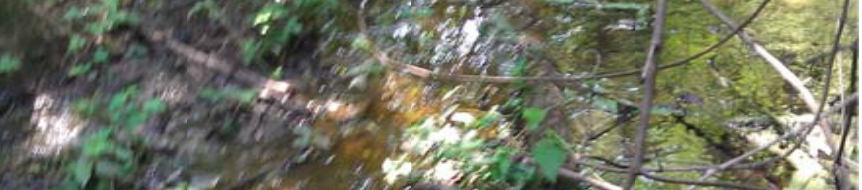

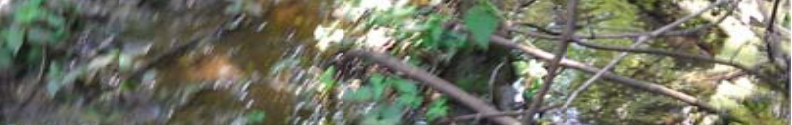

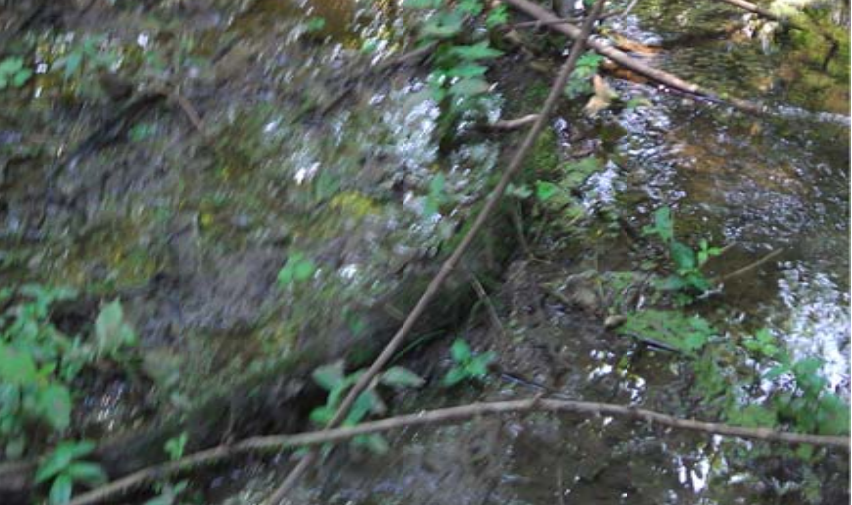



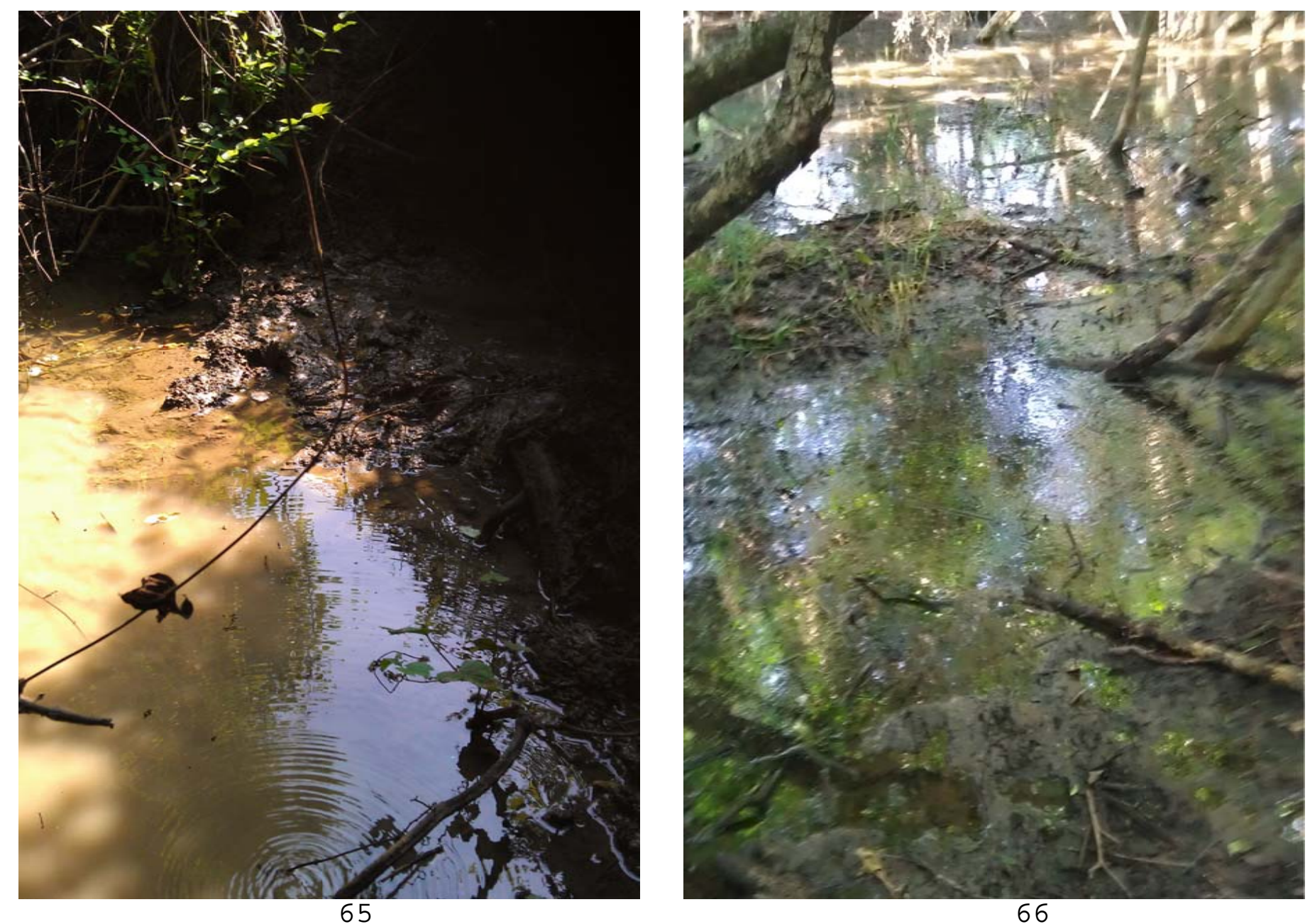

\section{6}
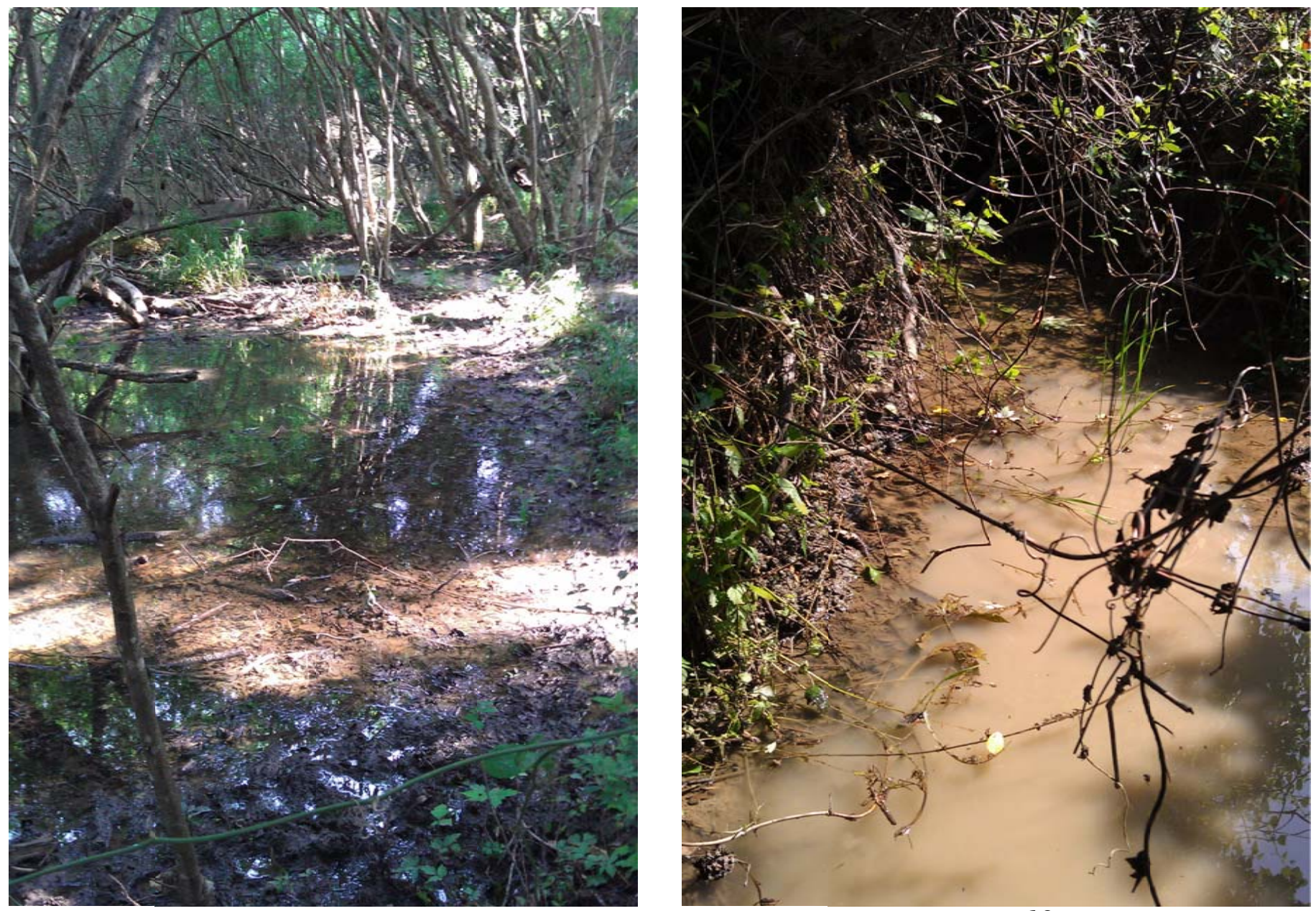


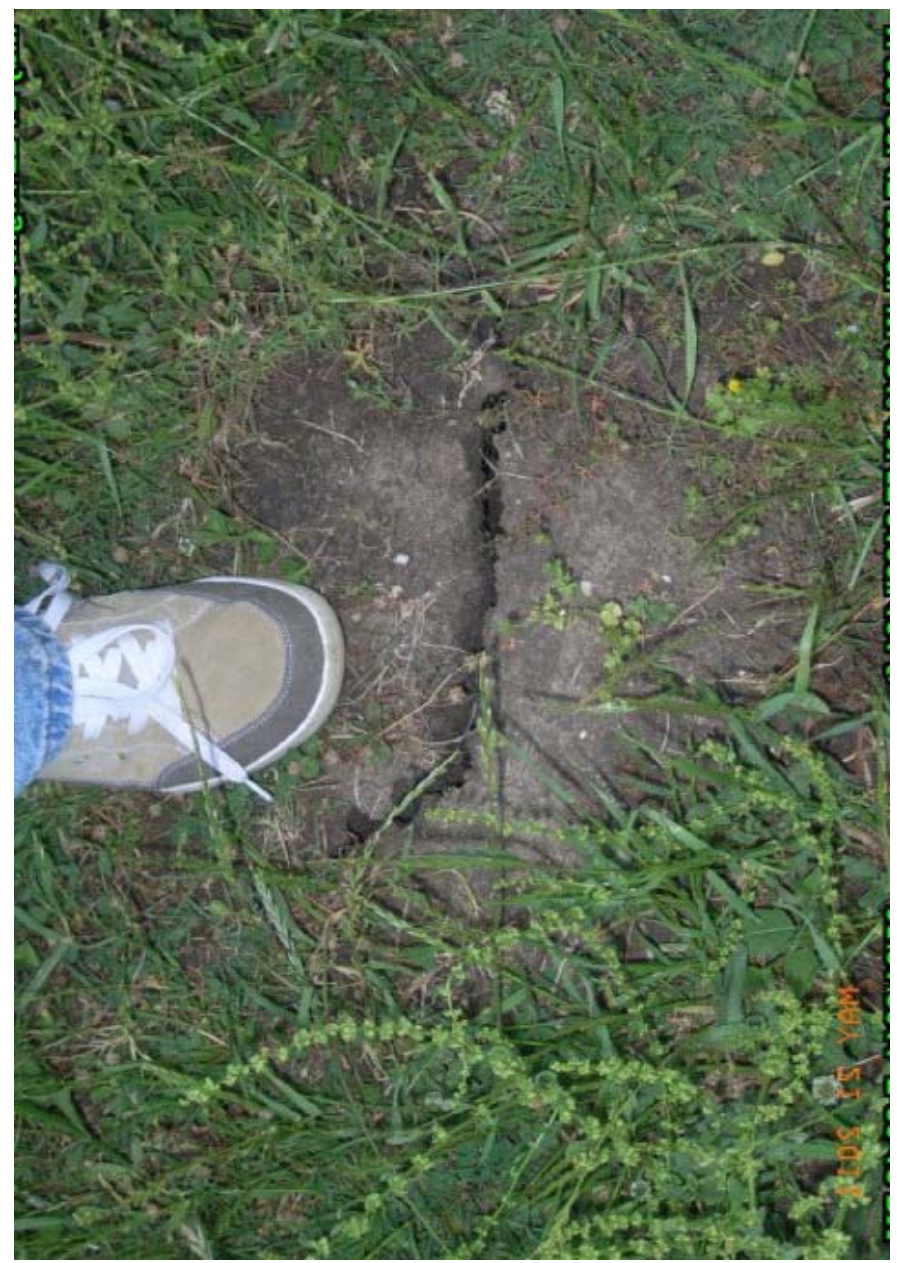

69

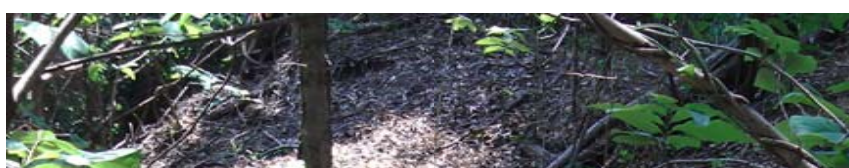

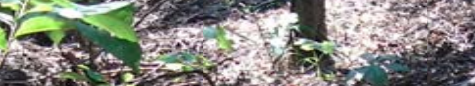

Hind

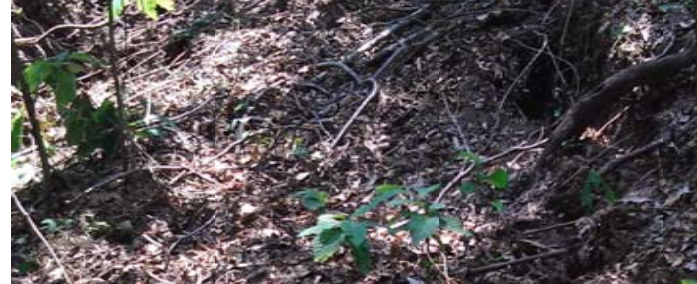

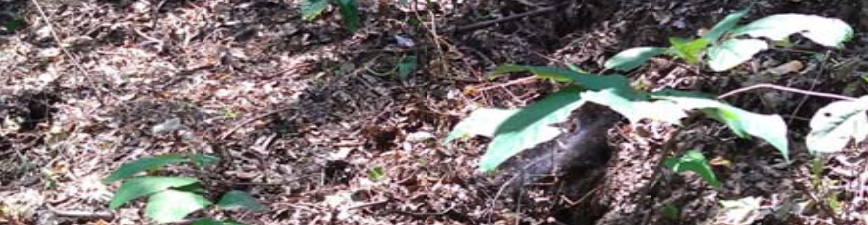

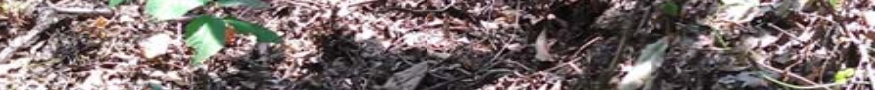
1.4.

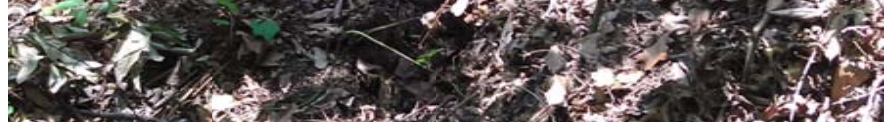

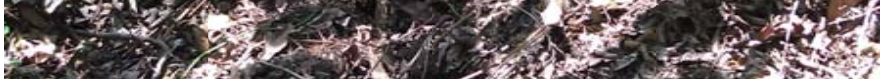

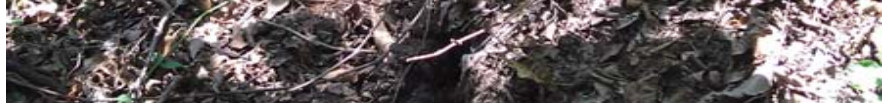
(1)

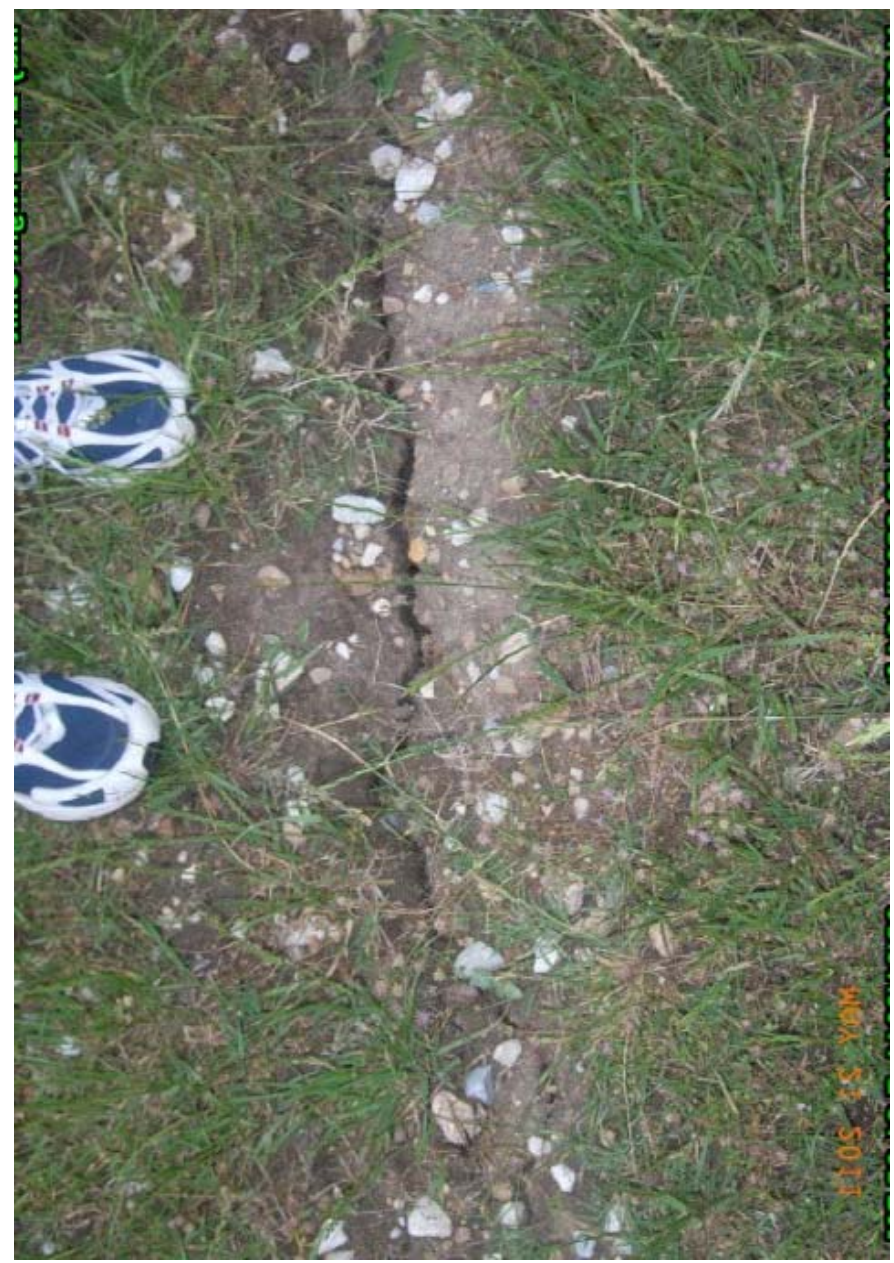

70

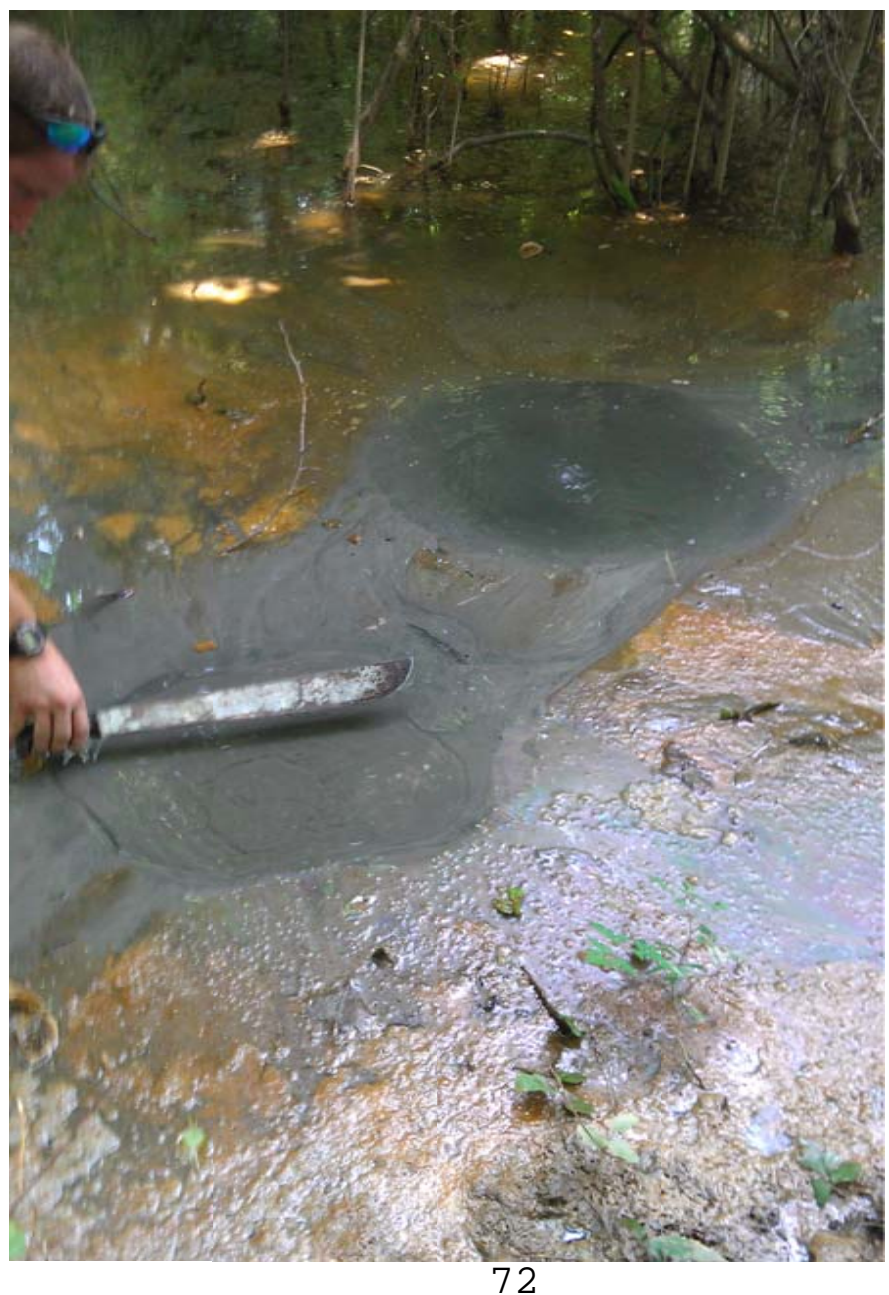

FOR OFFICIAL USE ONLY 


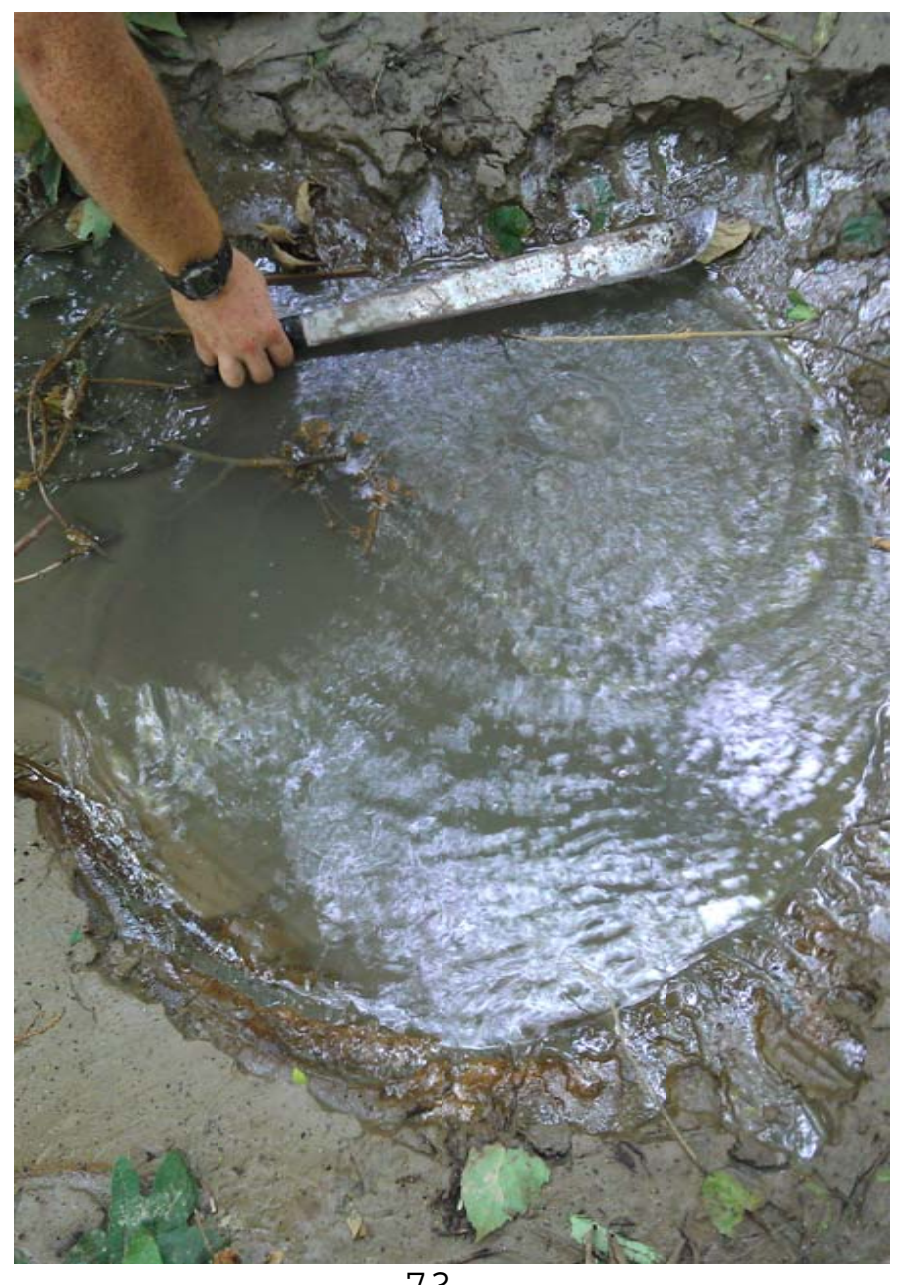

\section{3}

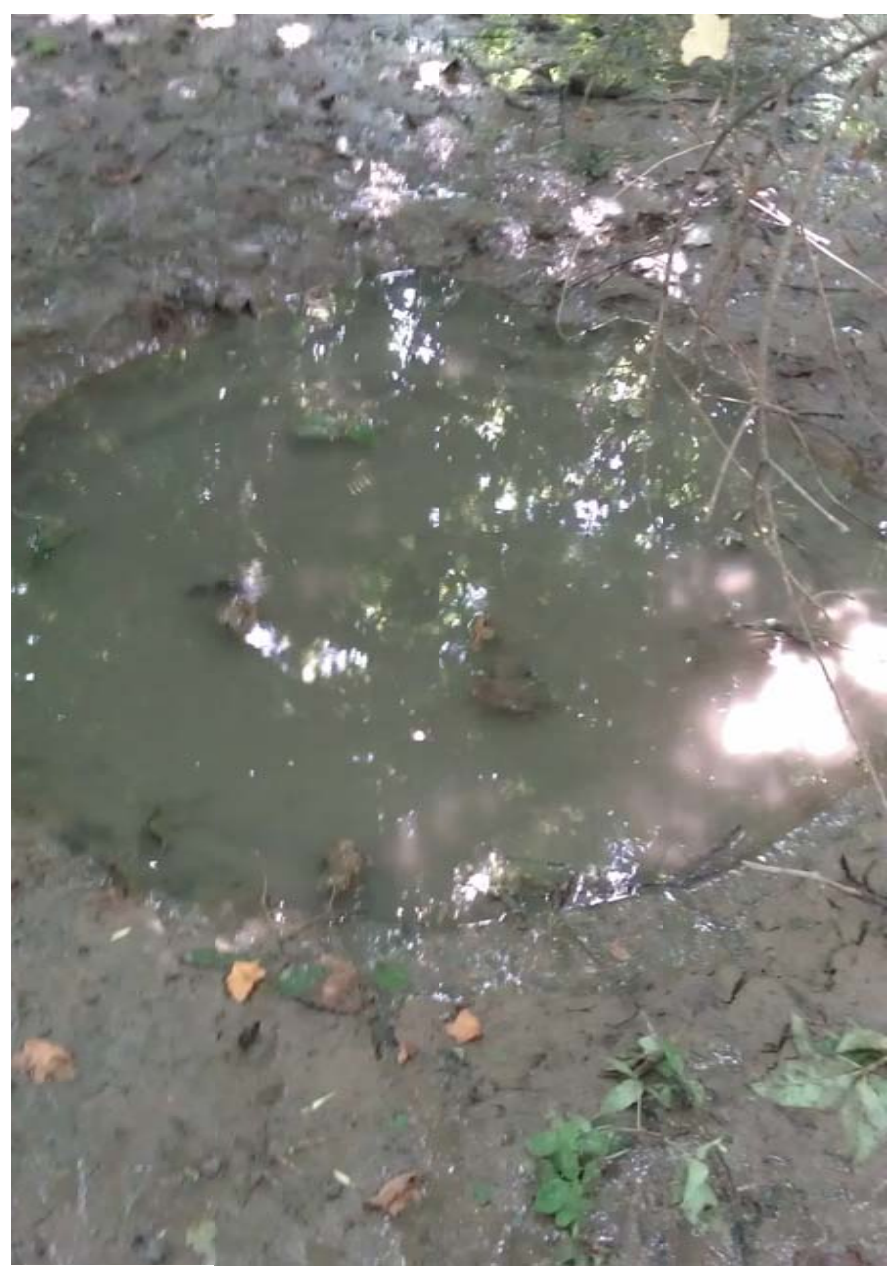




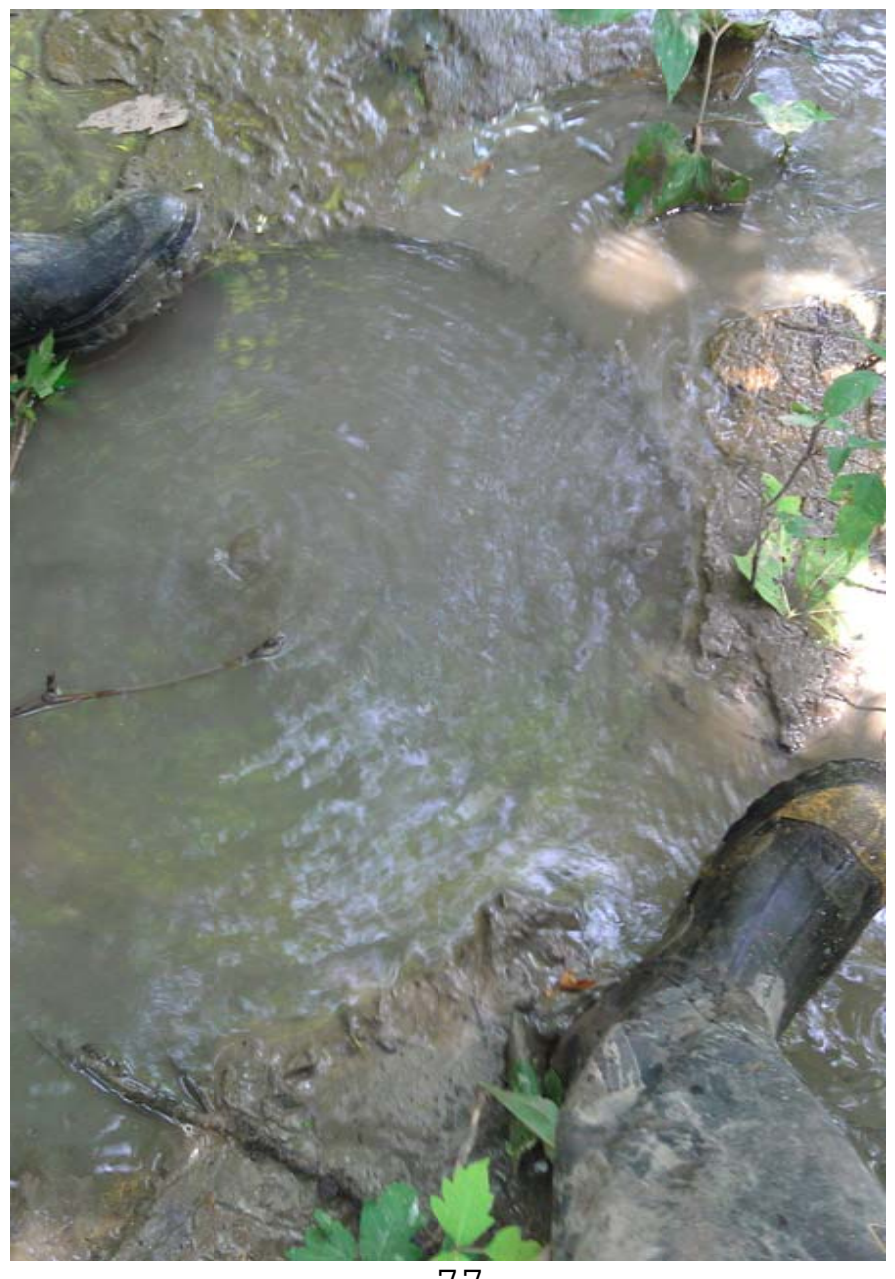

77

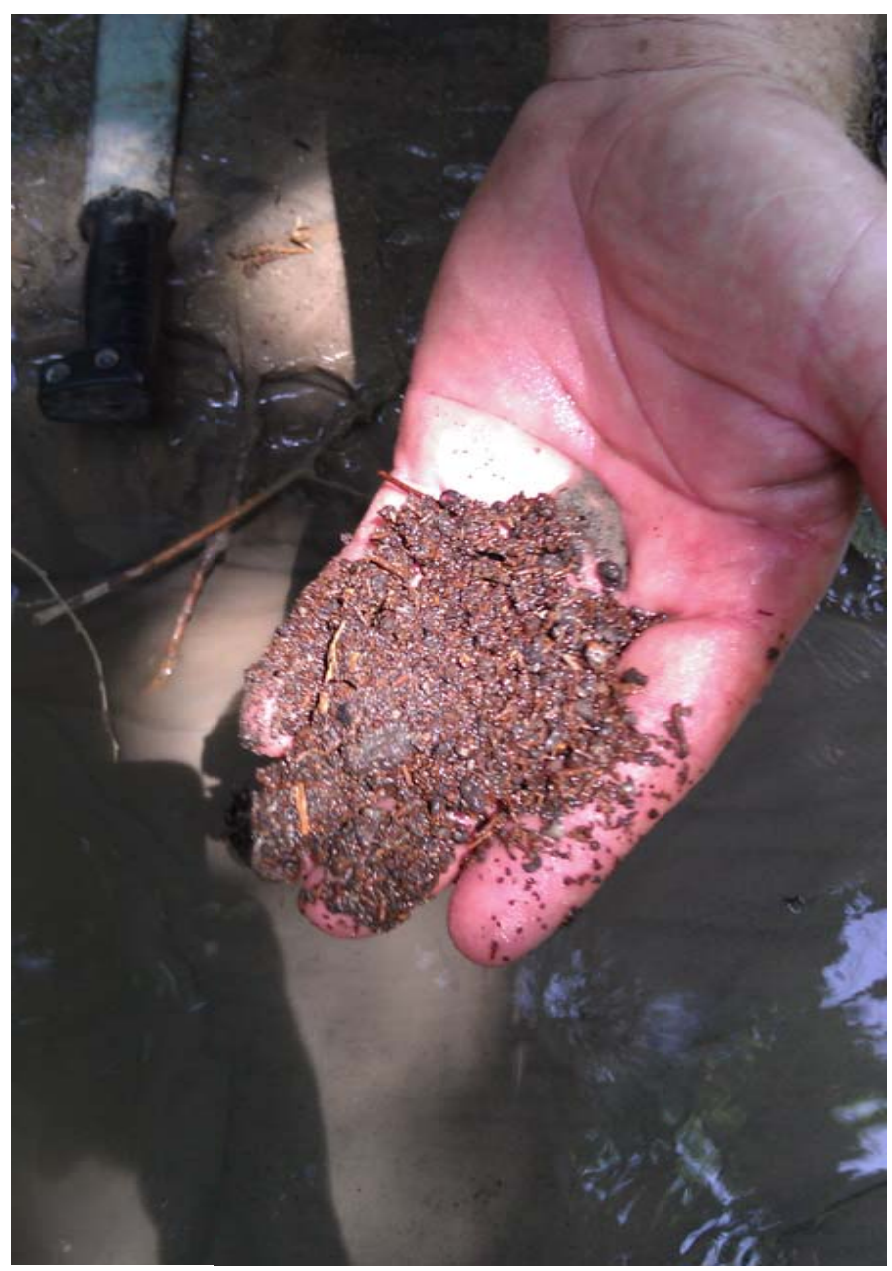

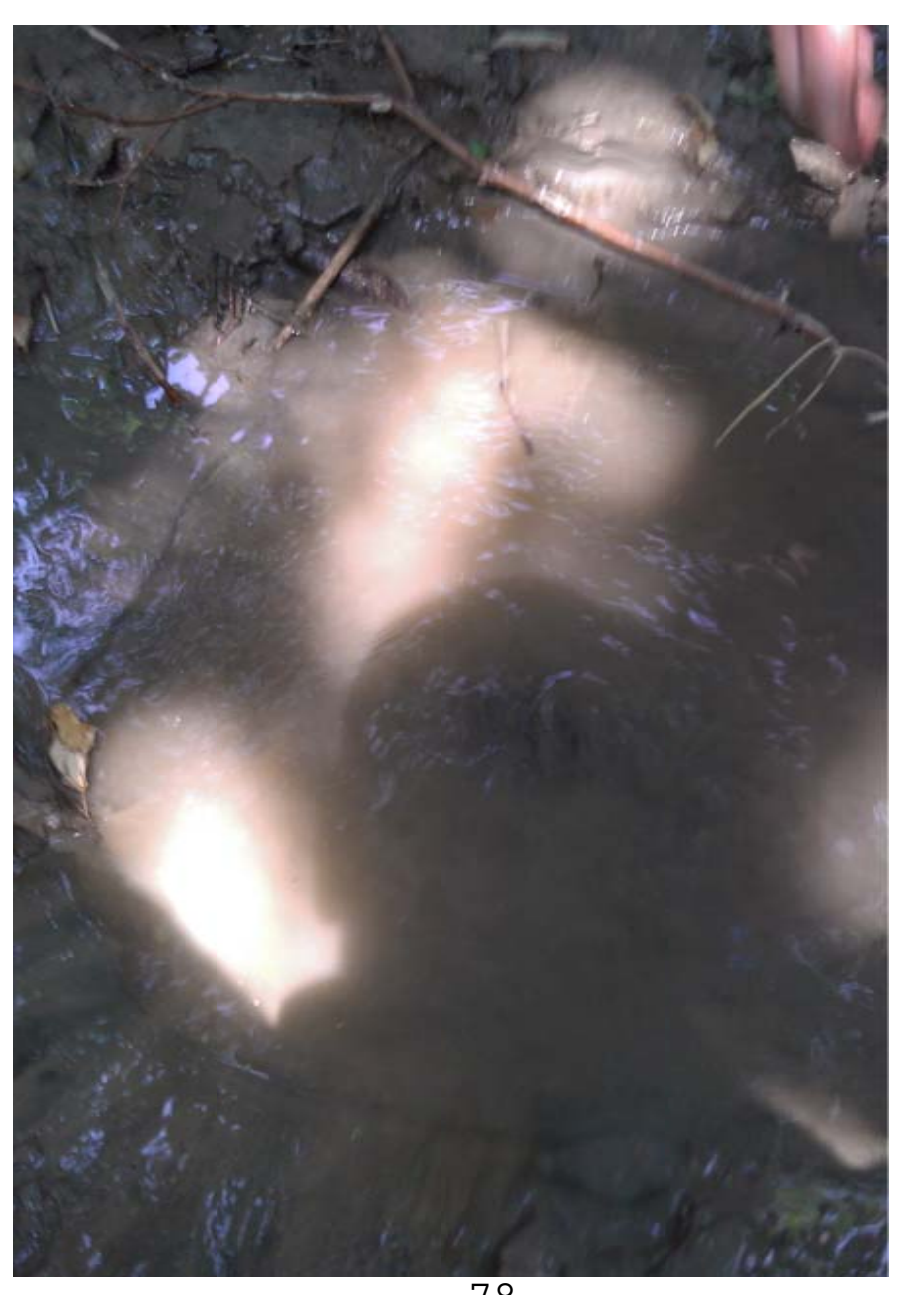

78

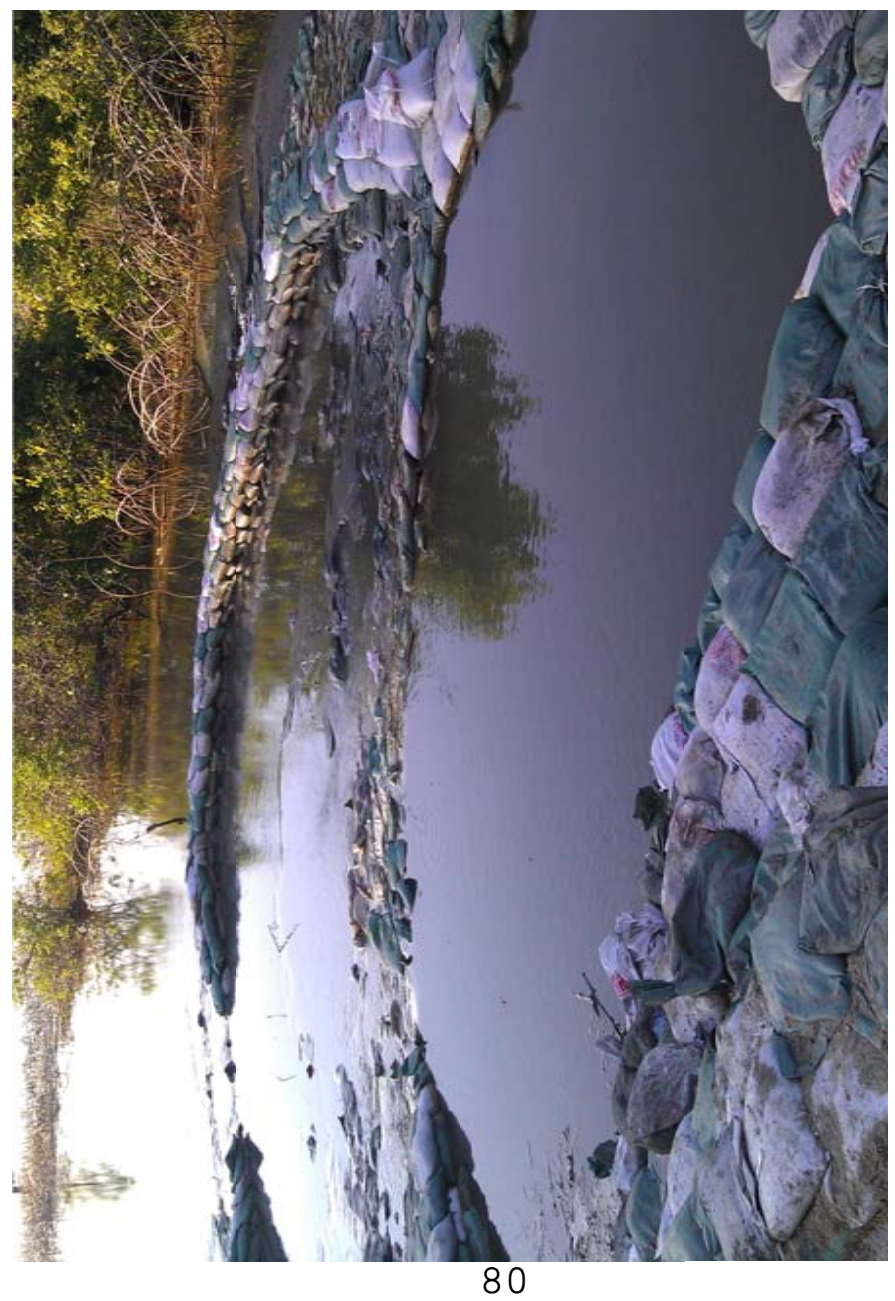

FOR OFFICIAL USE ONLY 

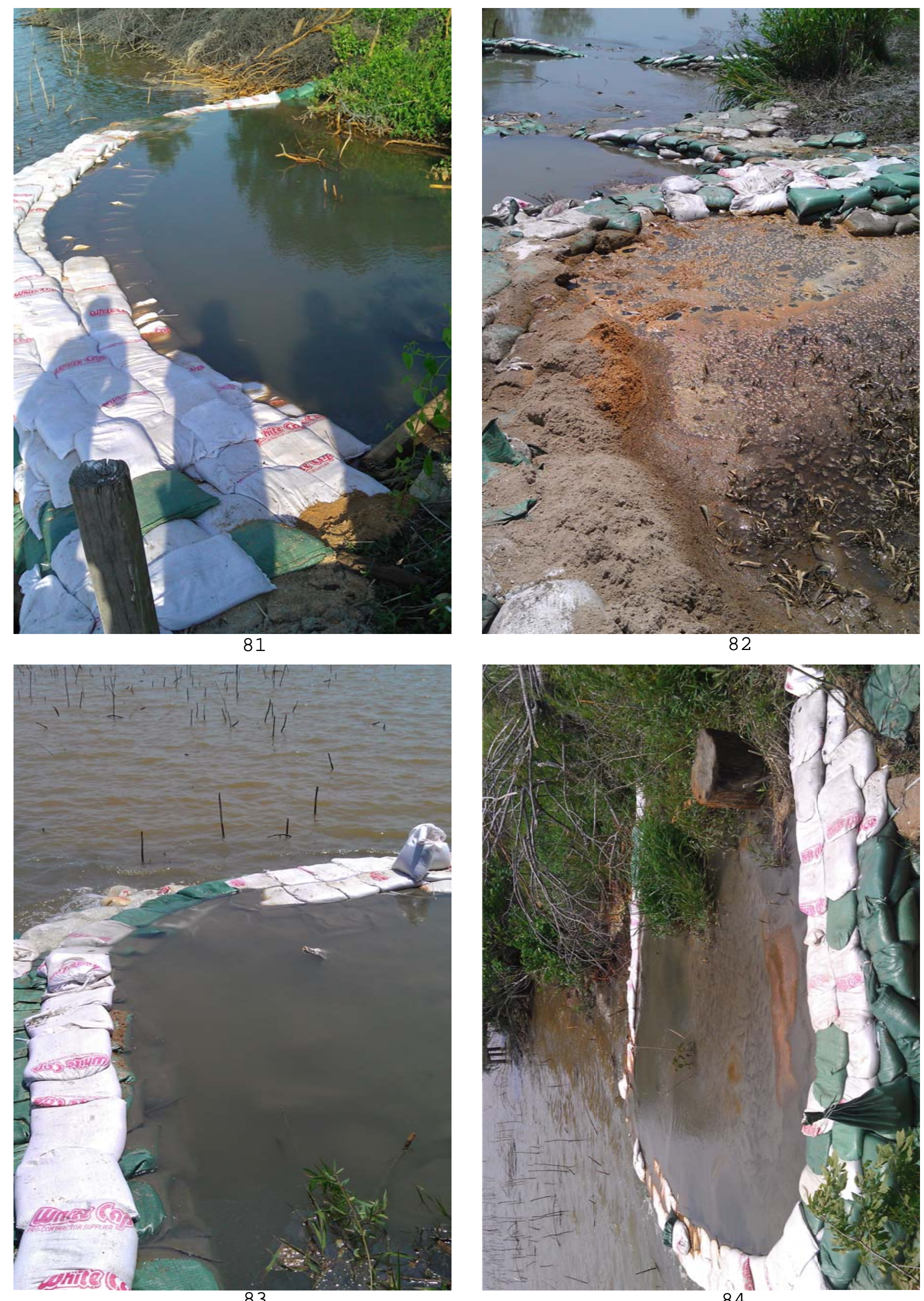

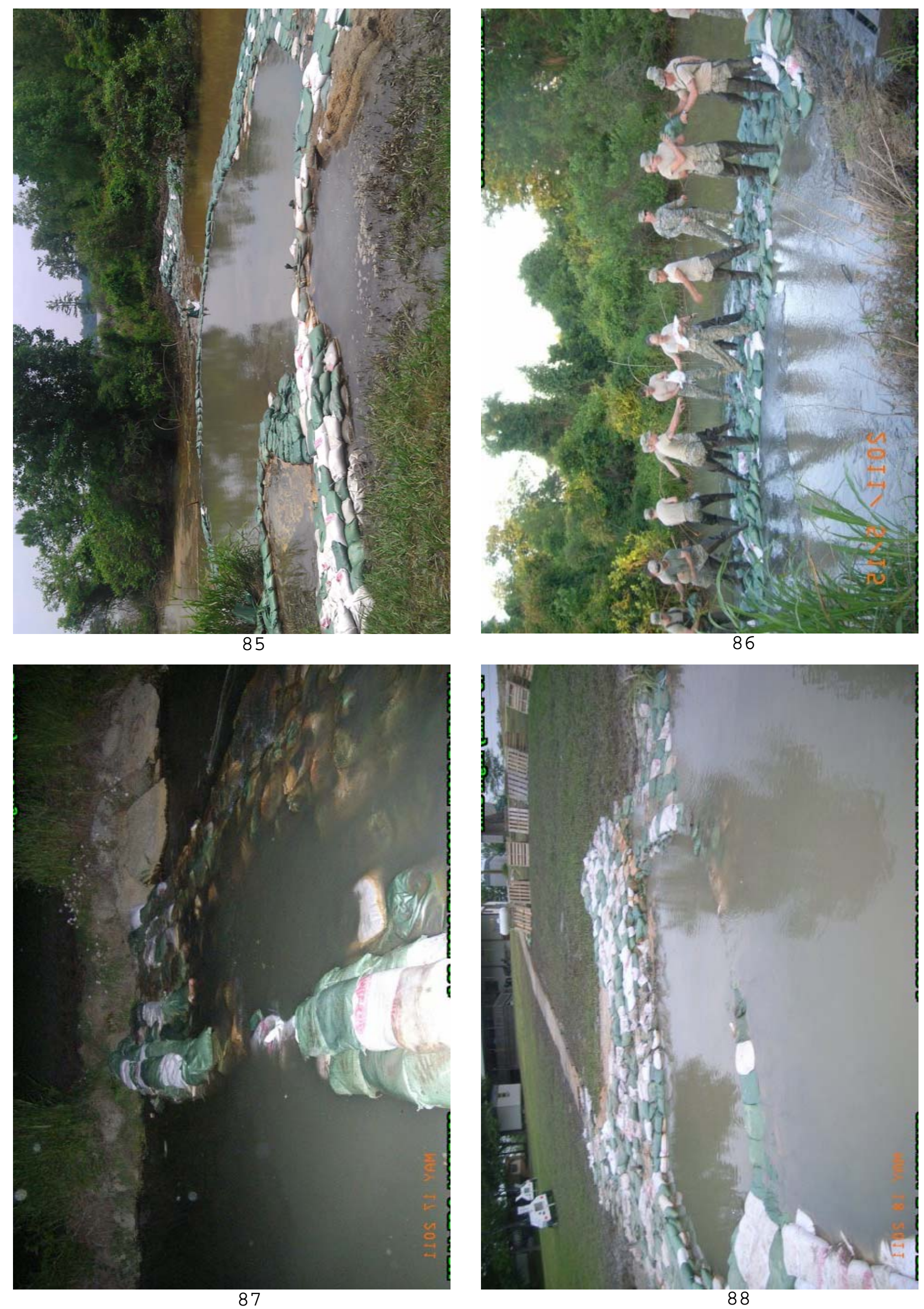

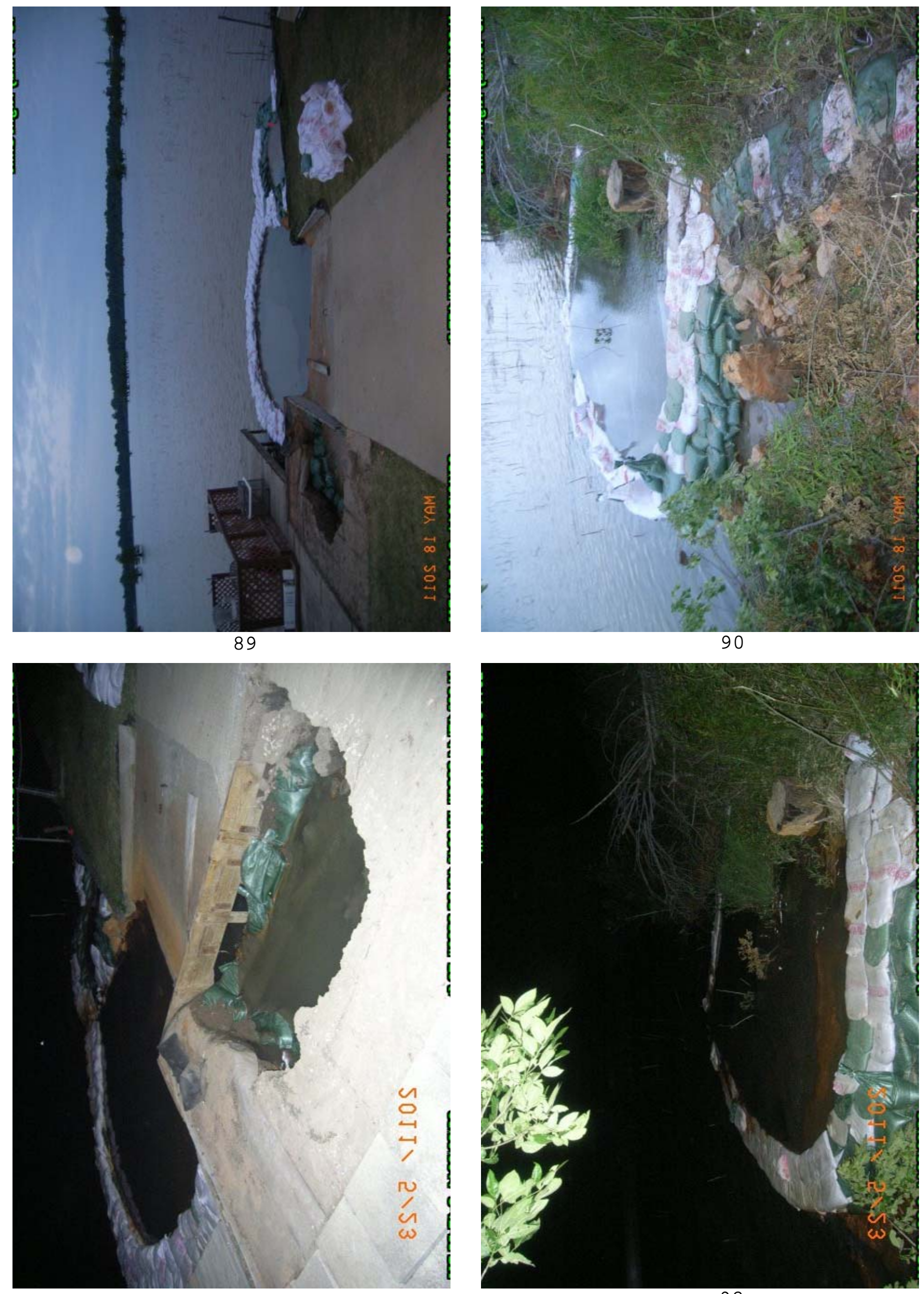


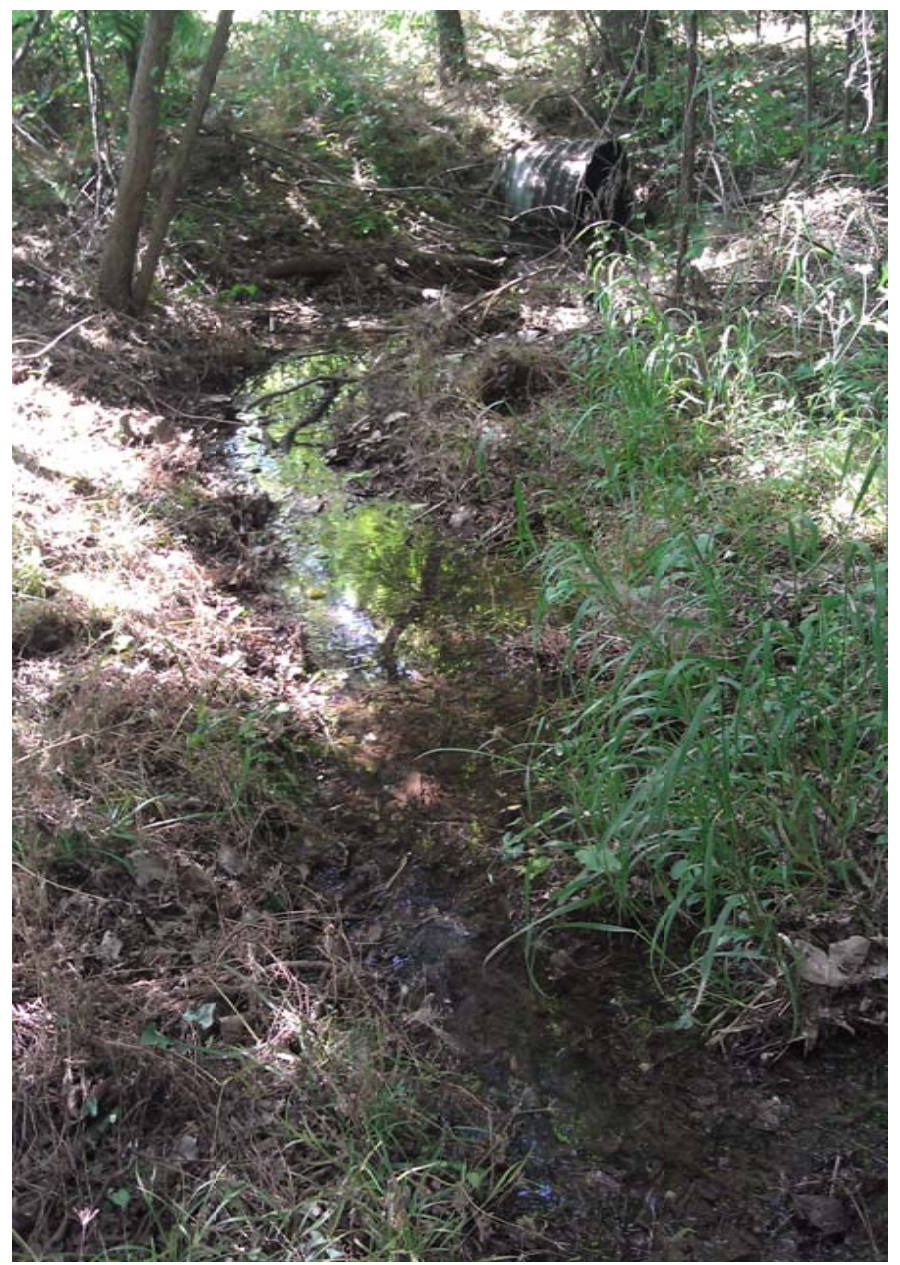

93

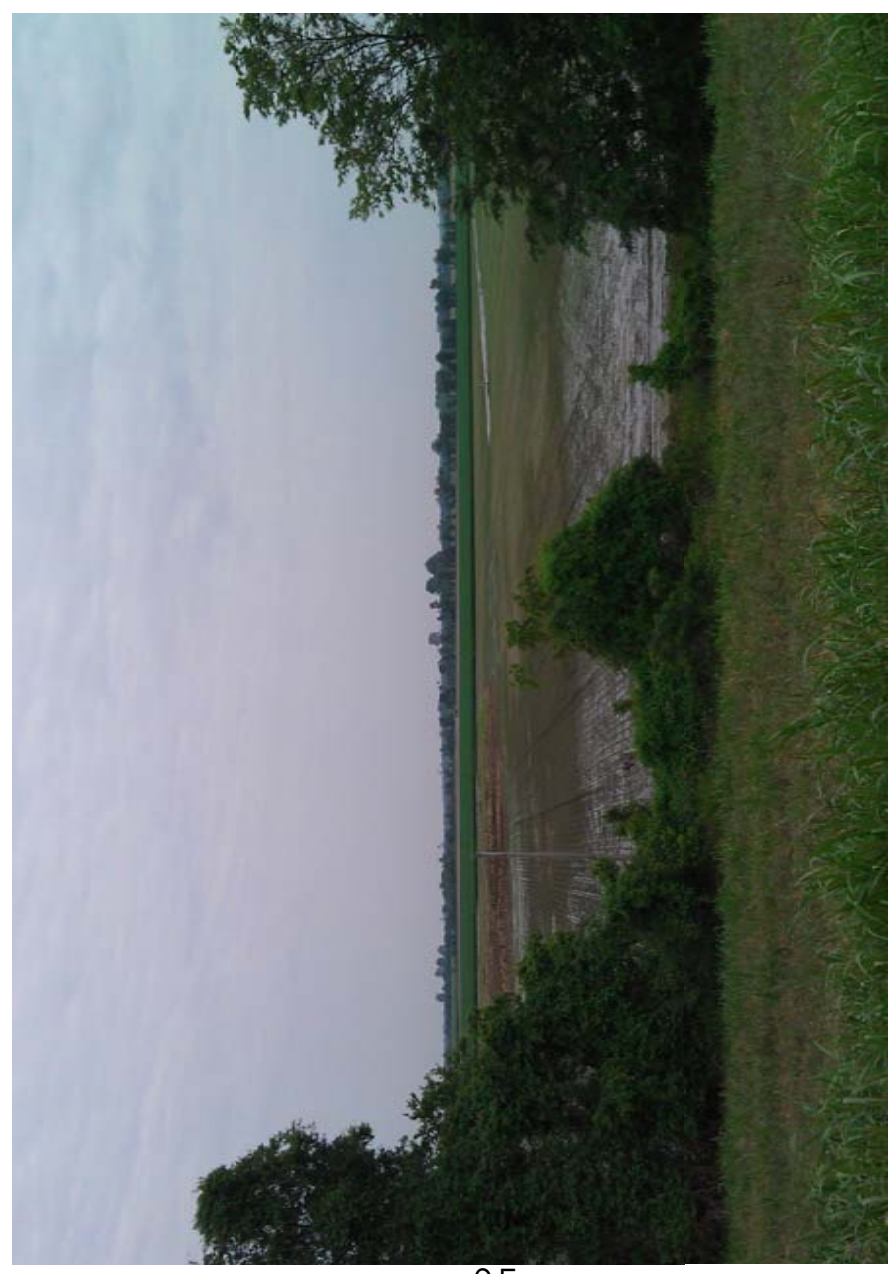

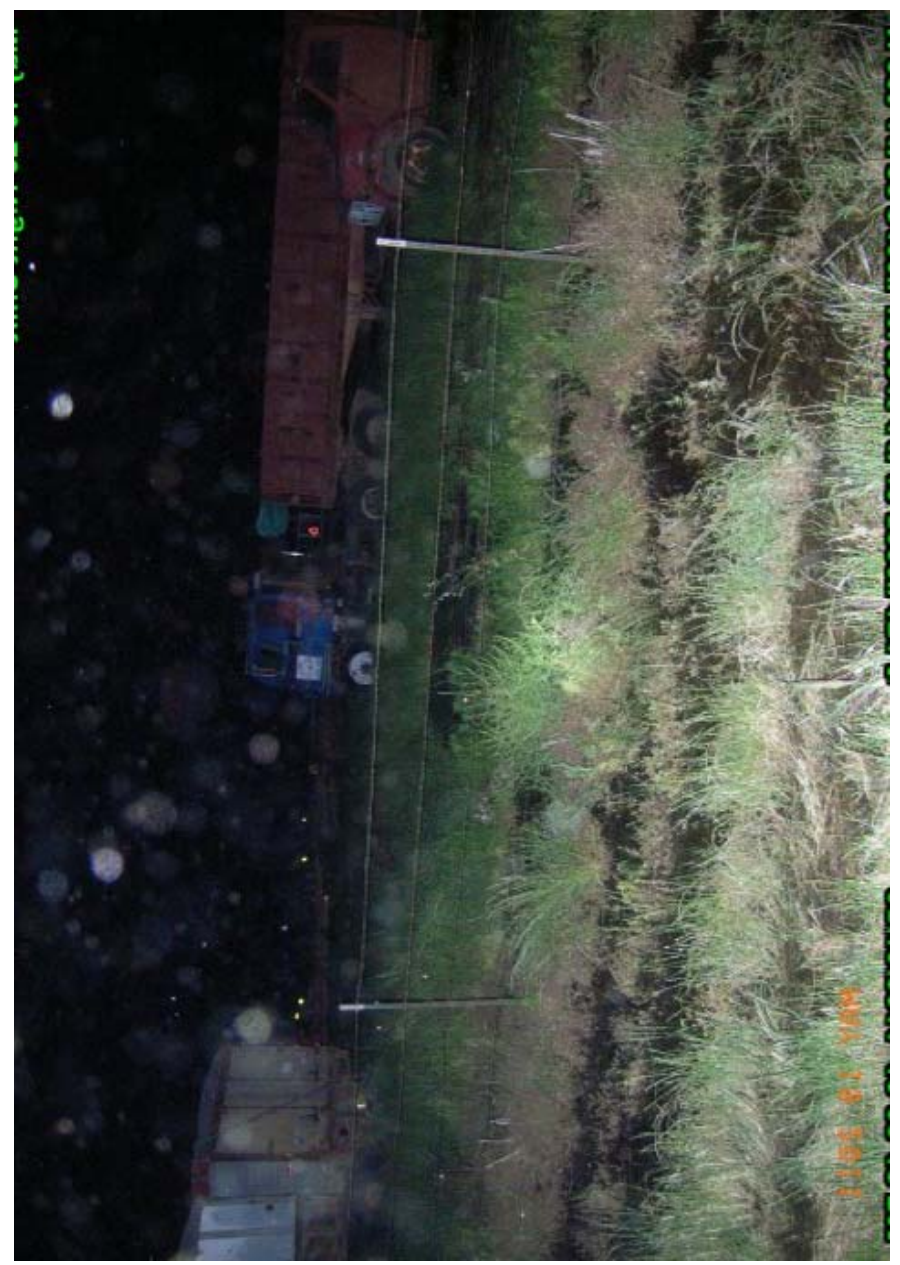

94

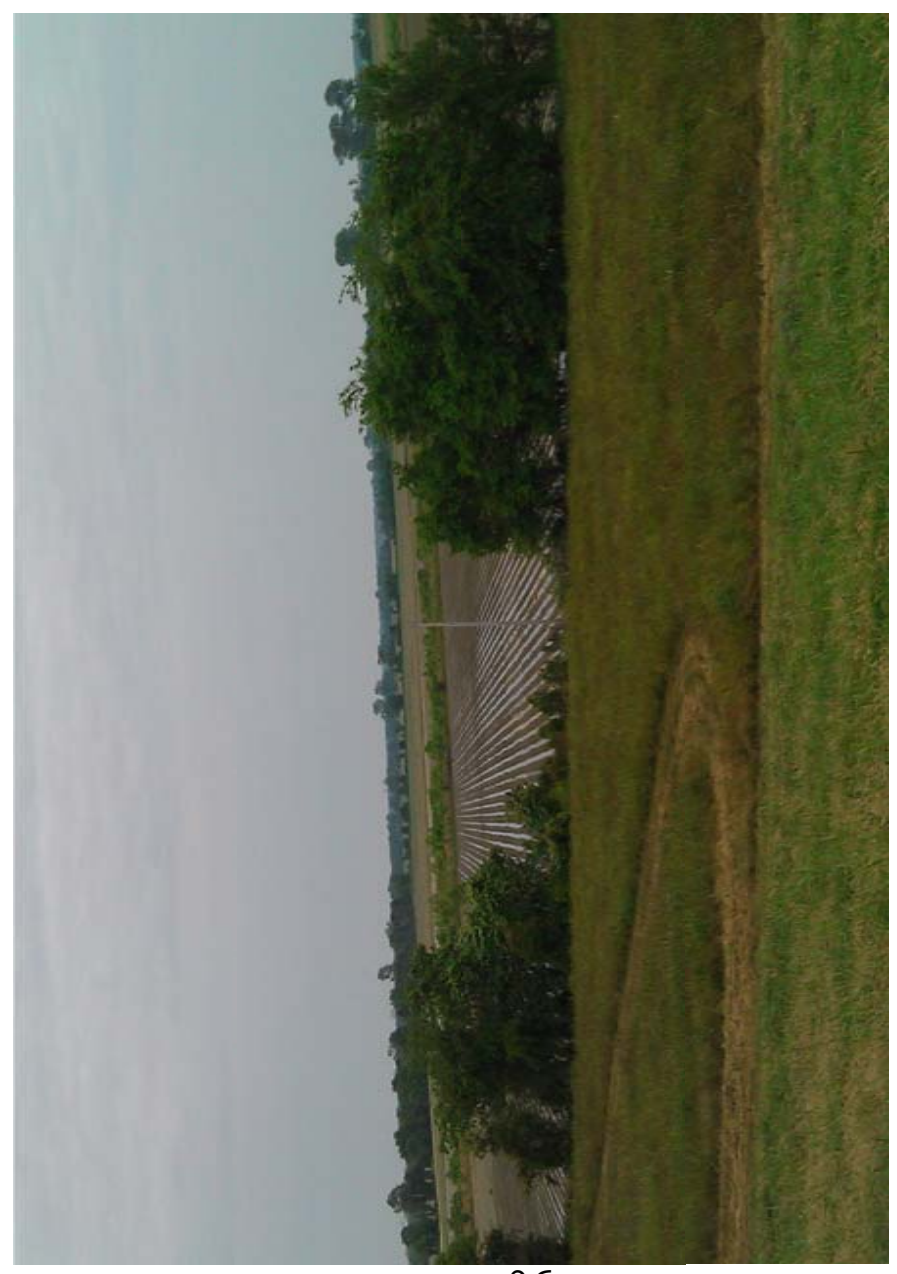

96 


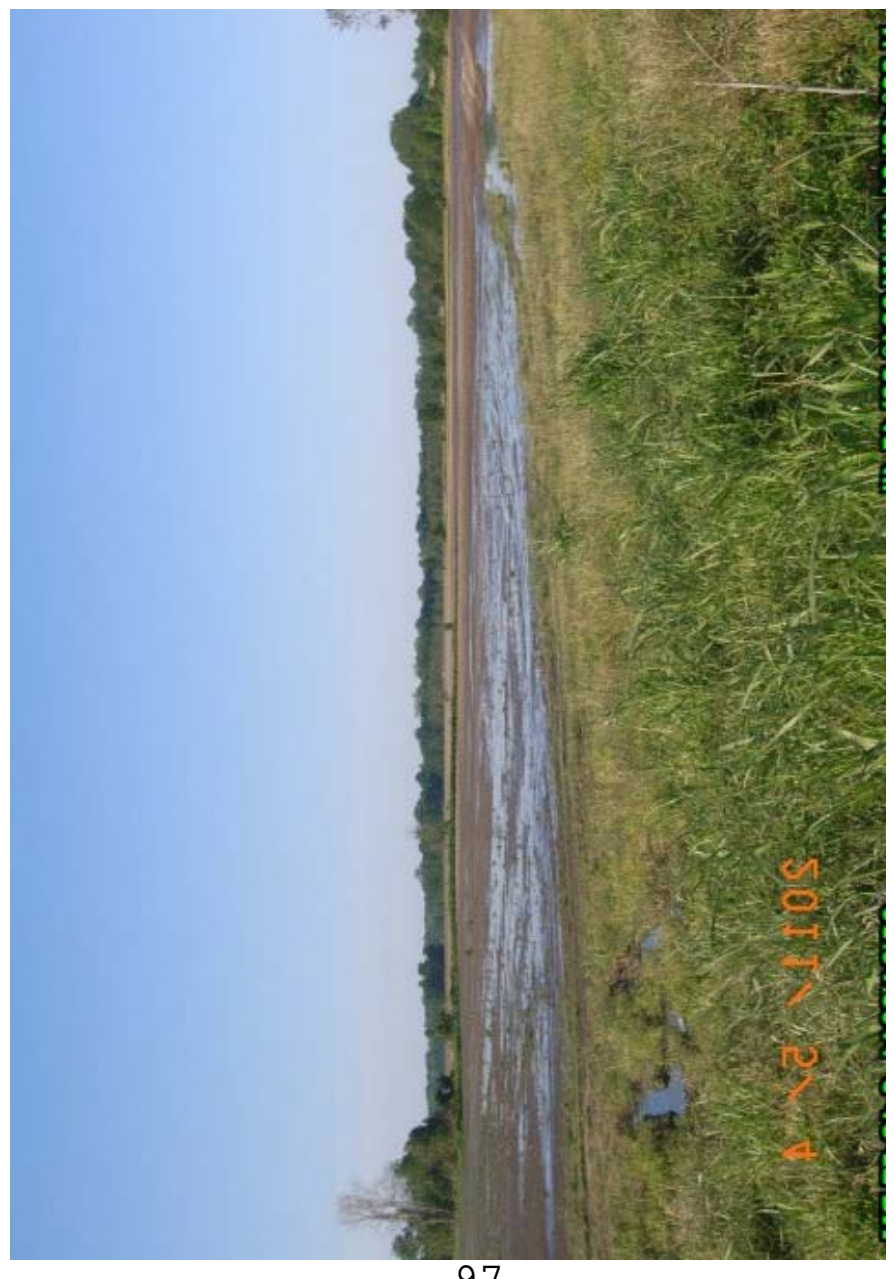

97

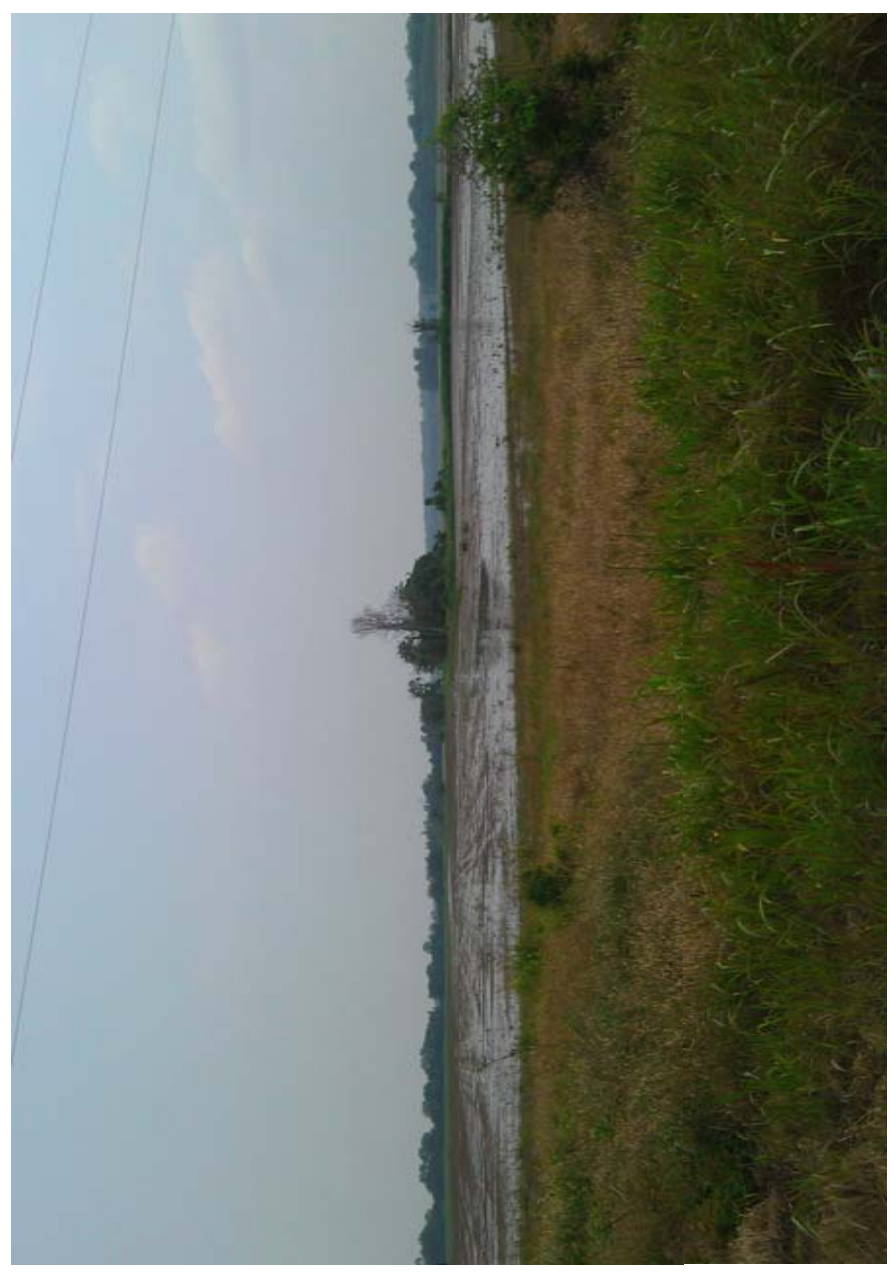

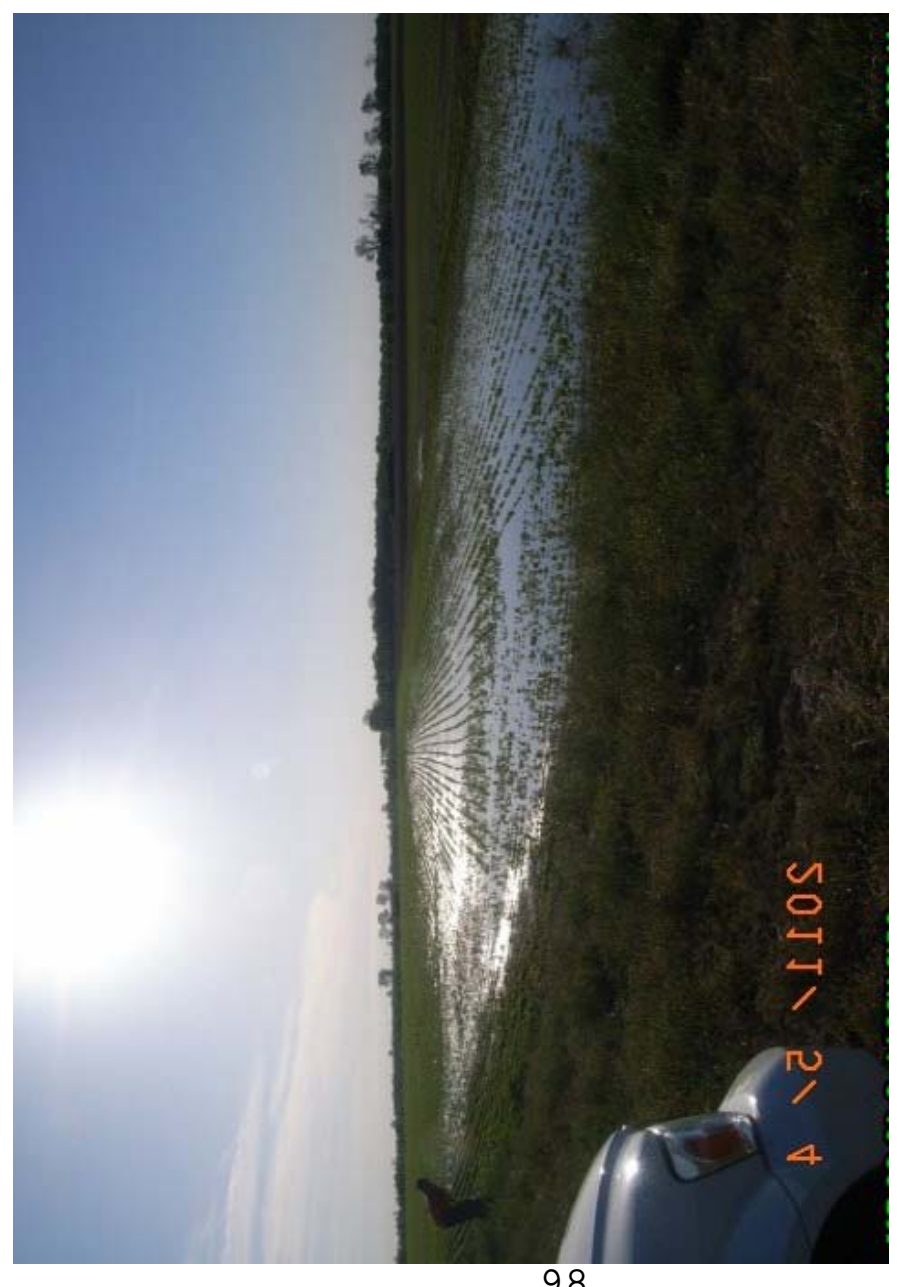

98

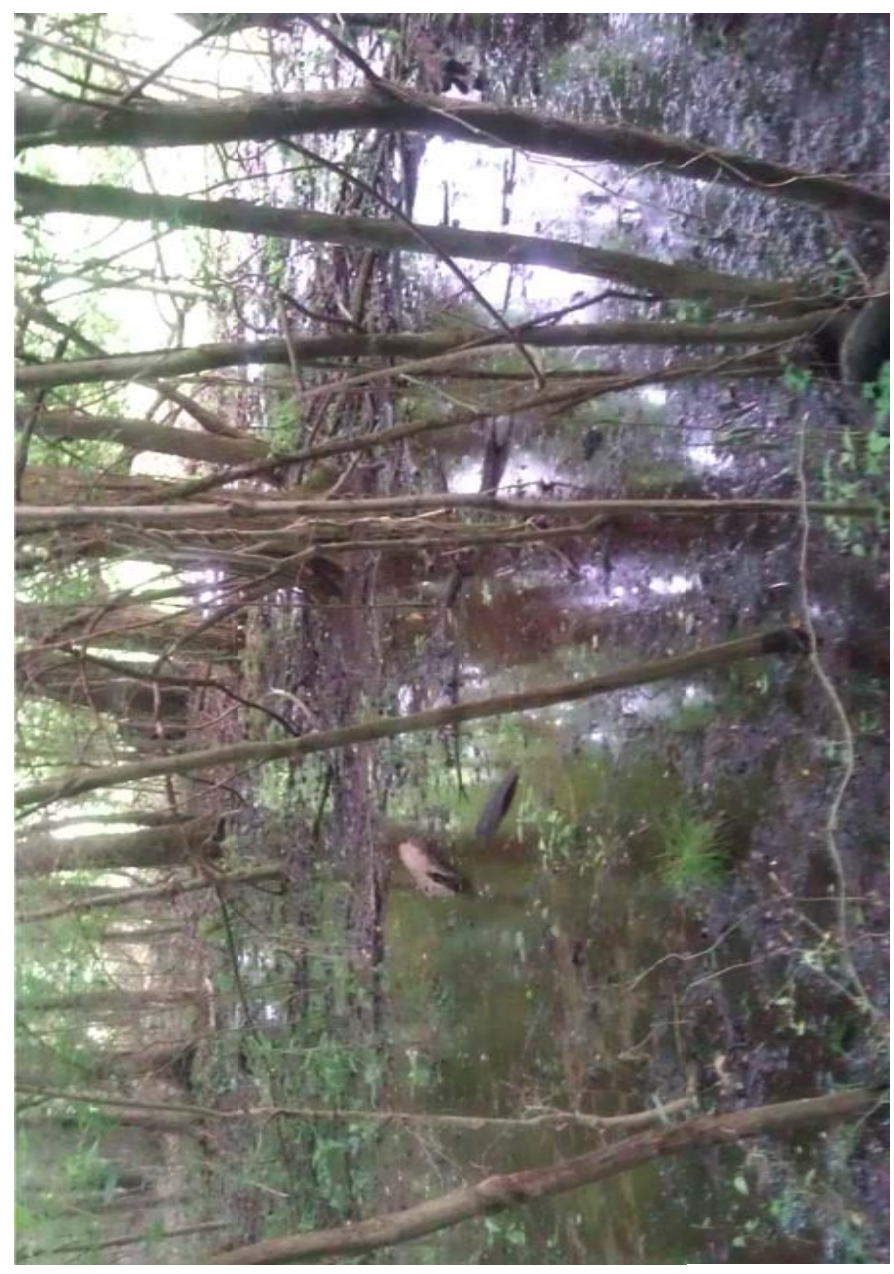

100 


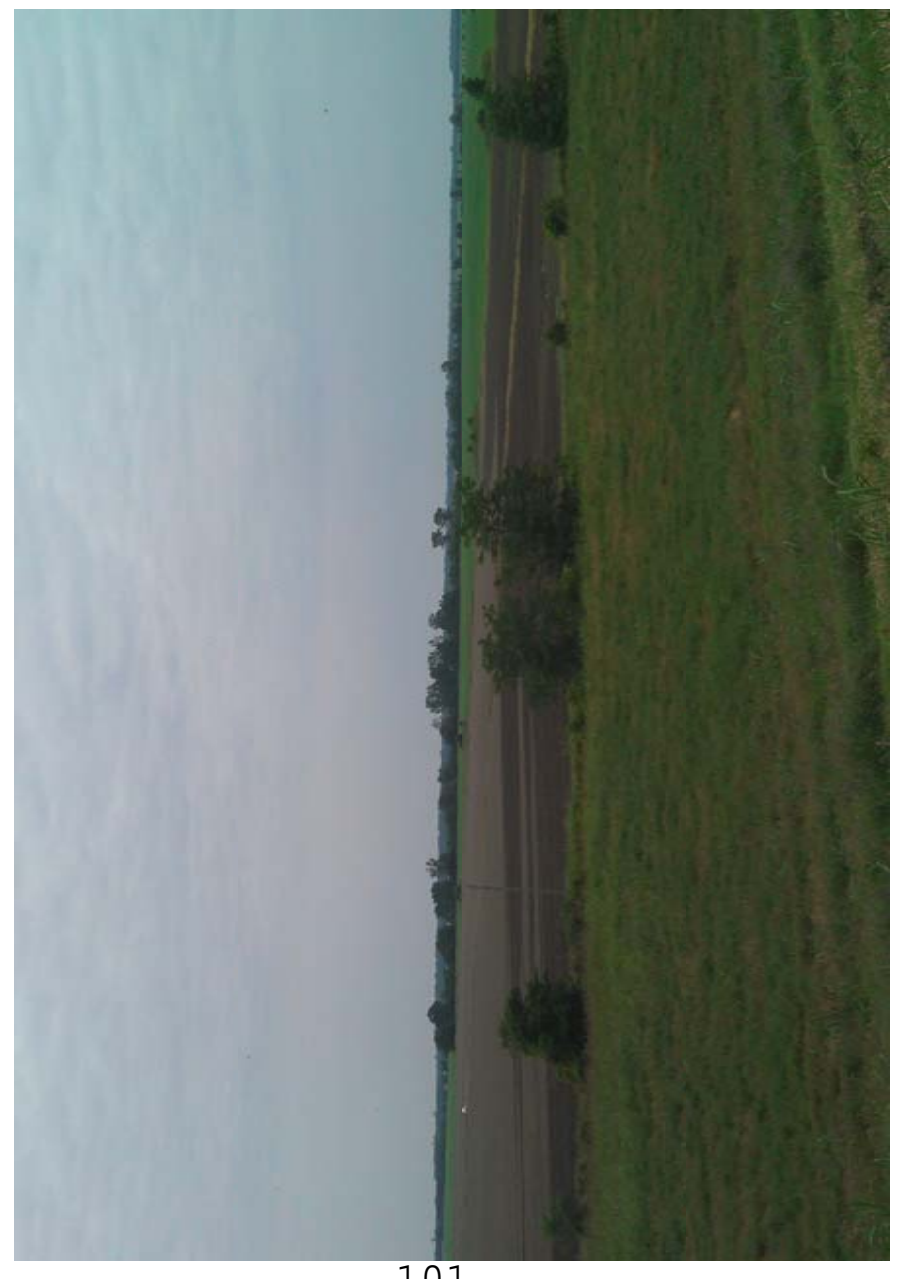

101

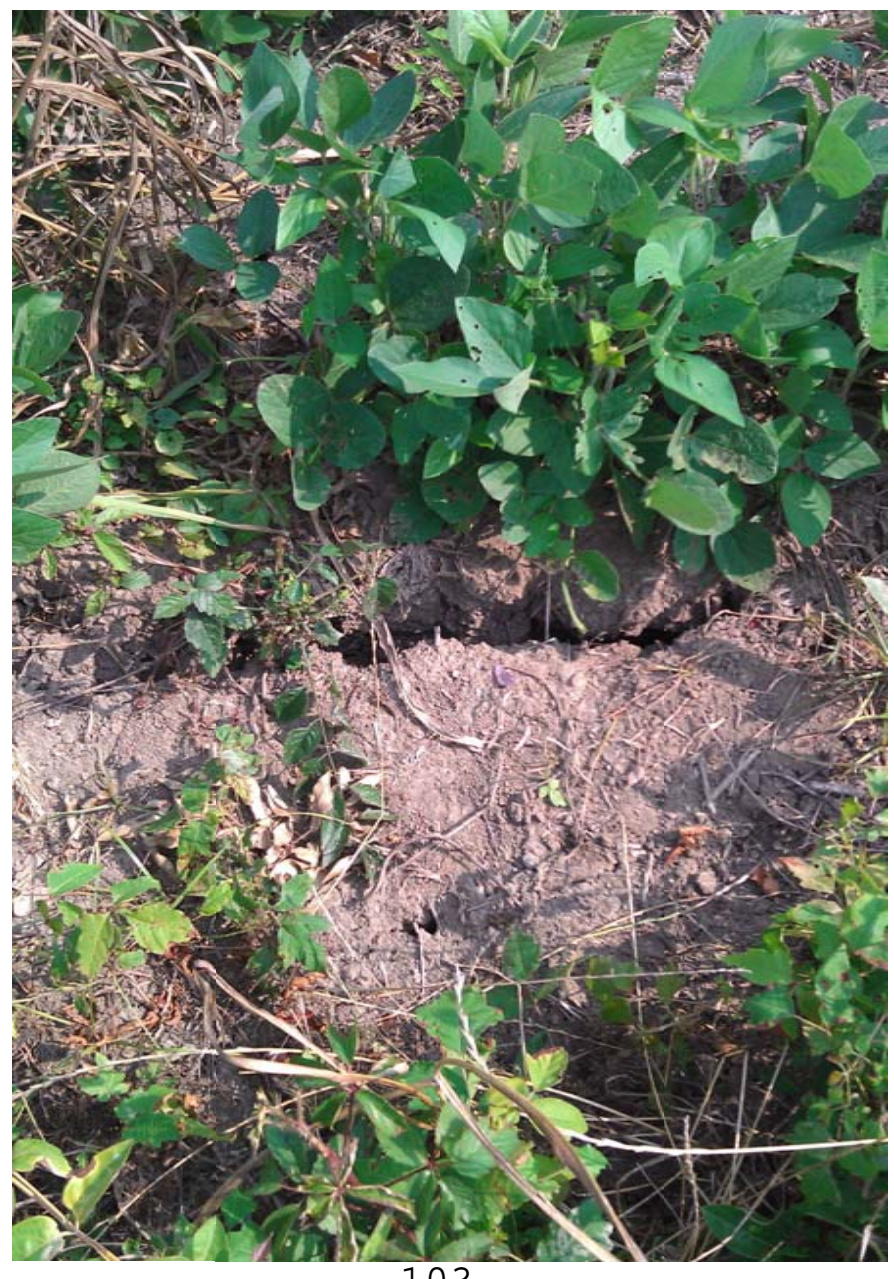
103

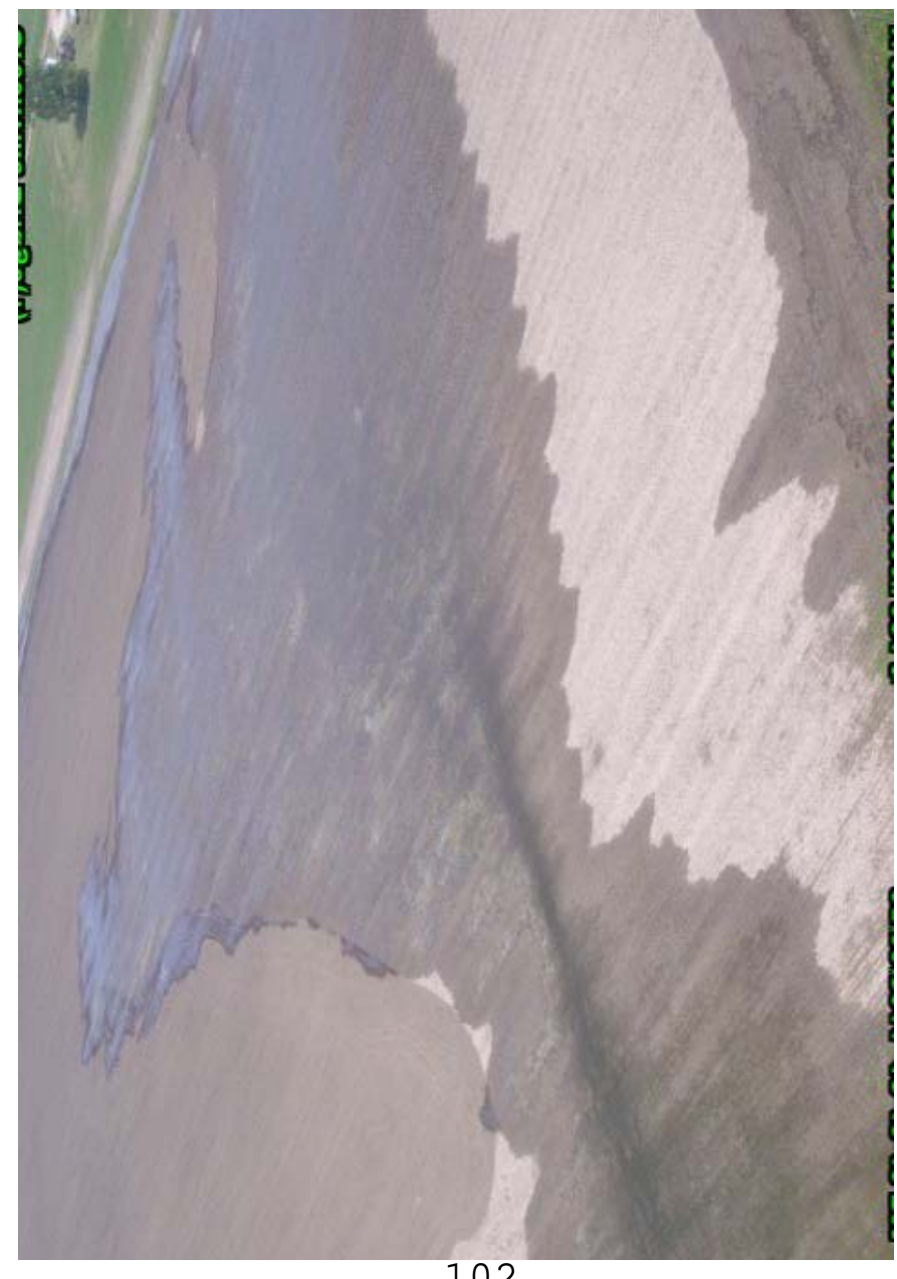

102

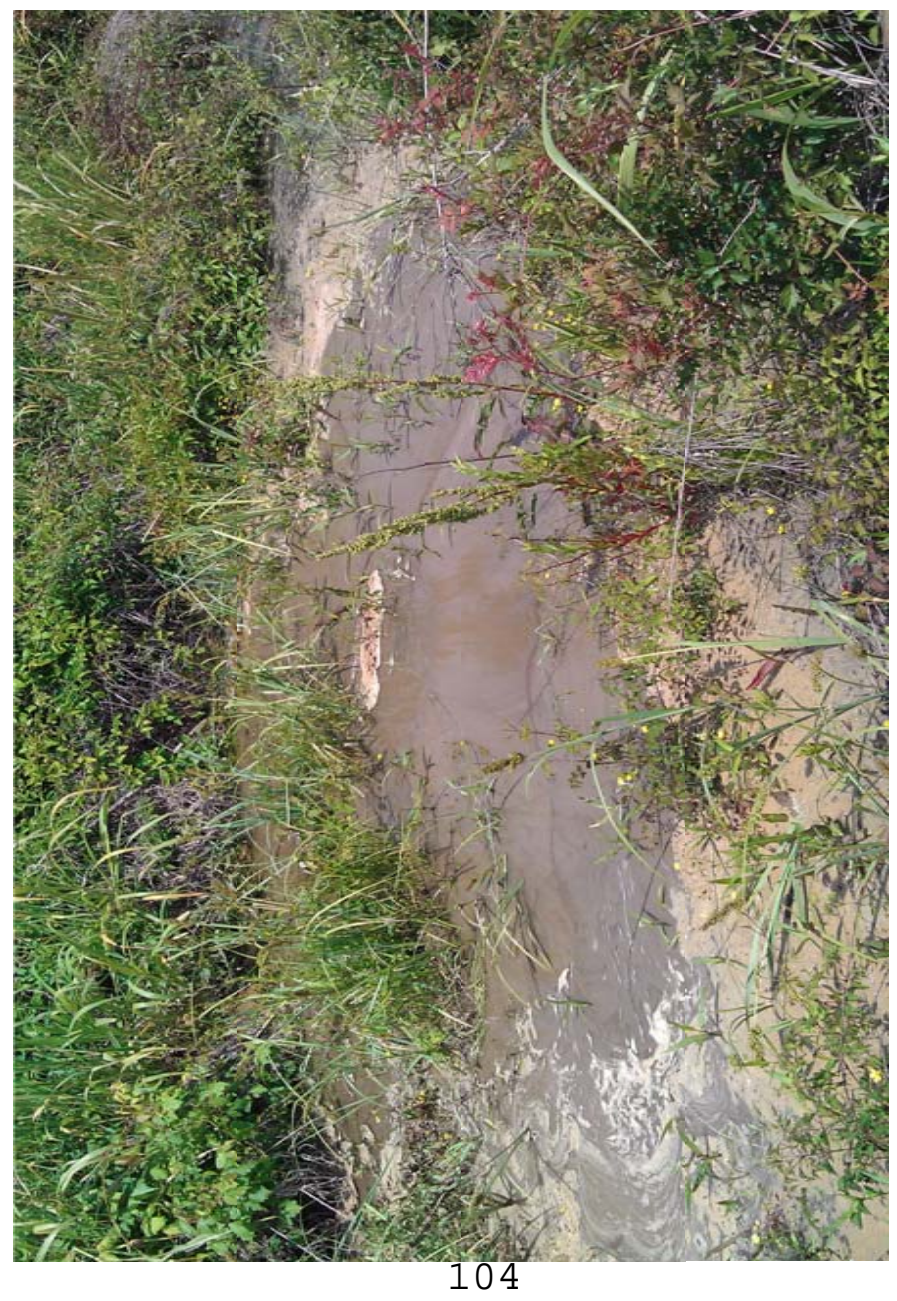



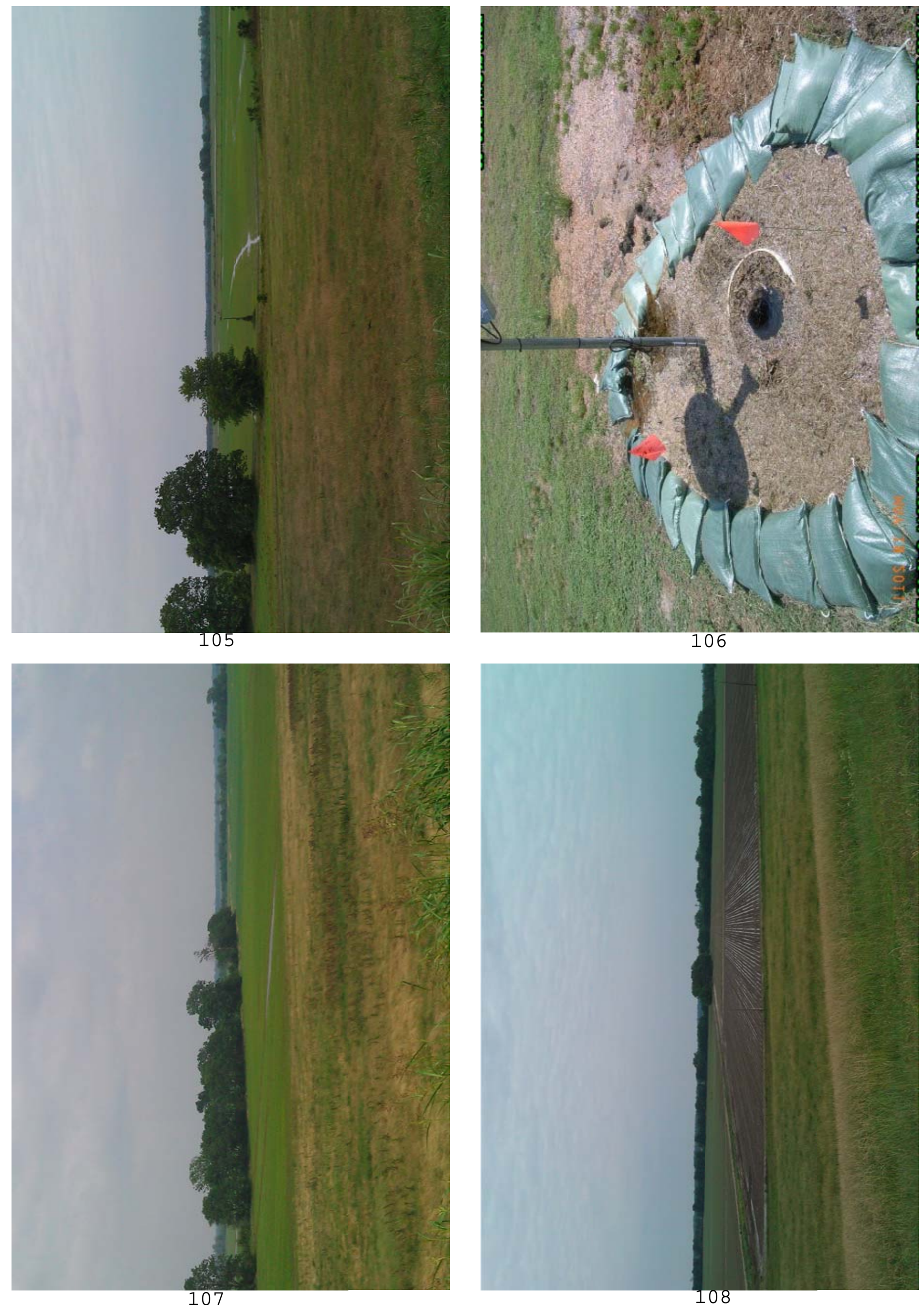


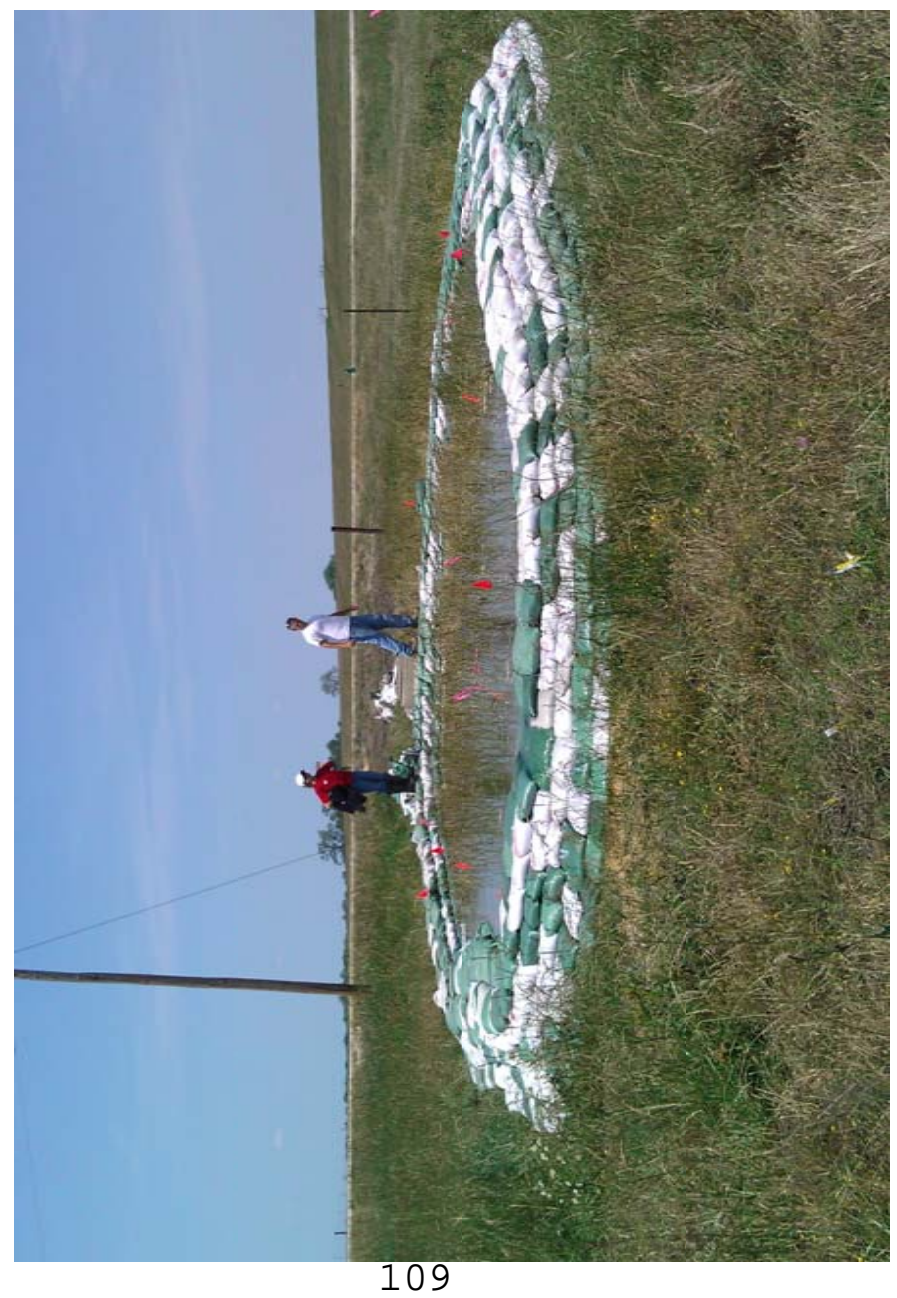

109

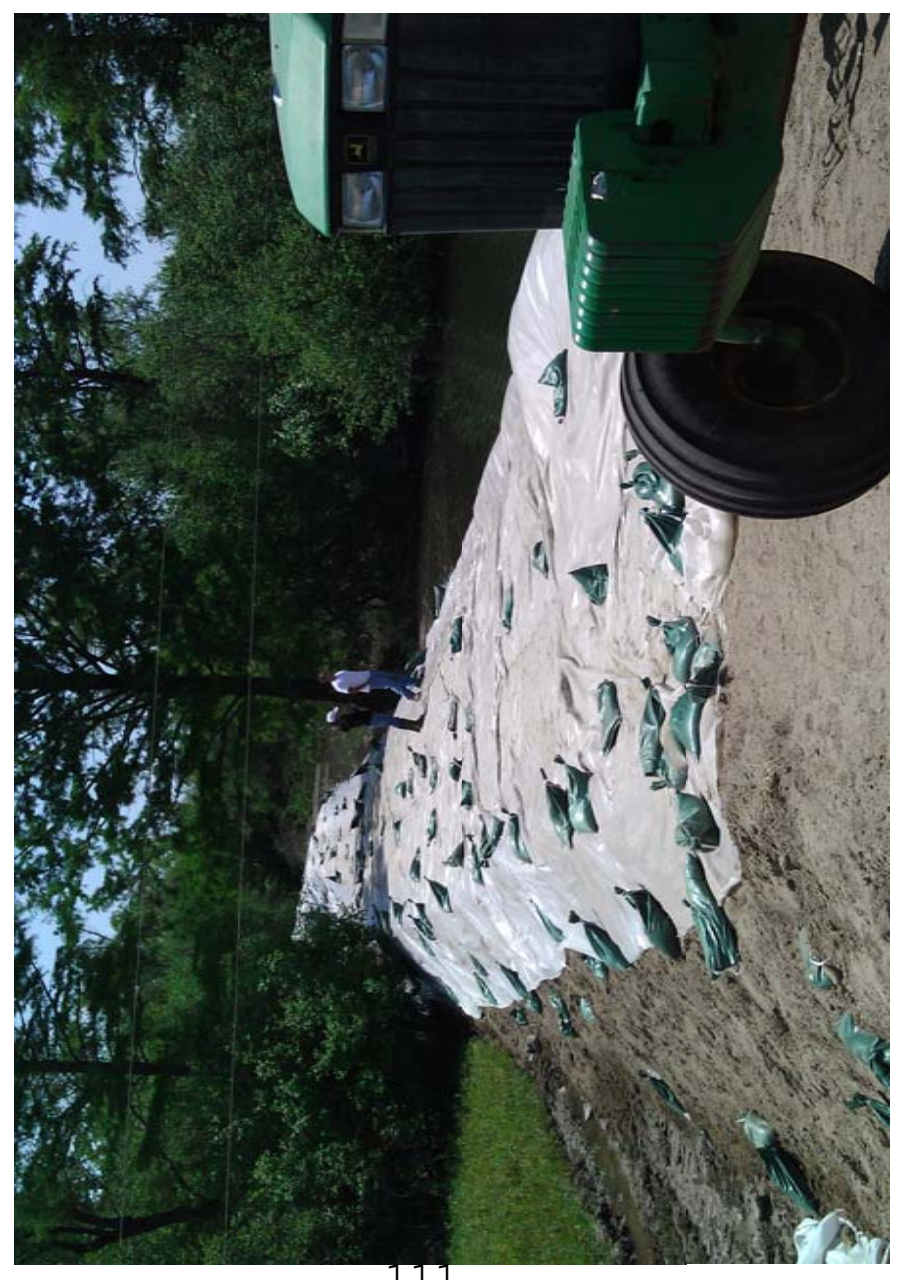

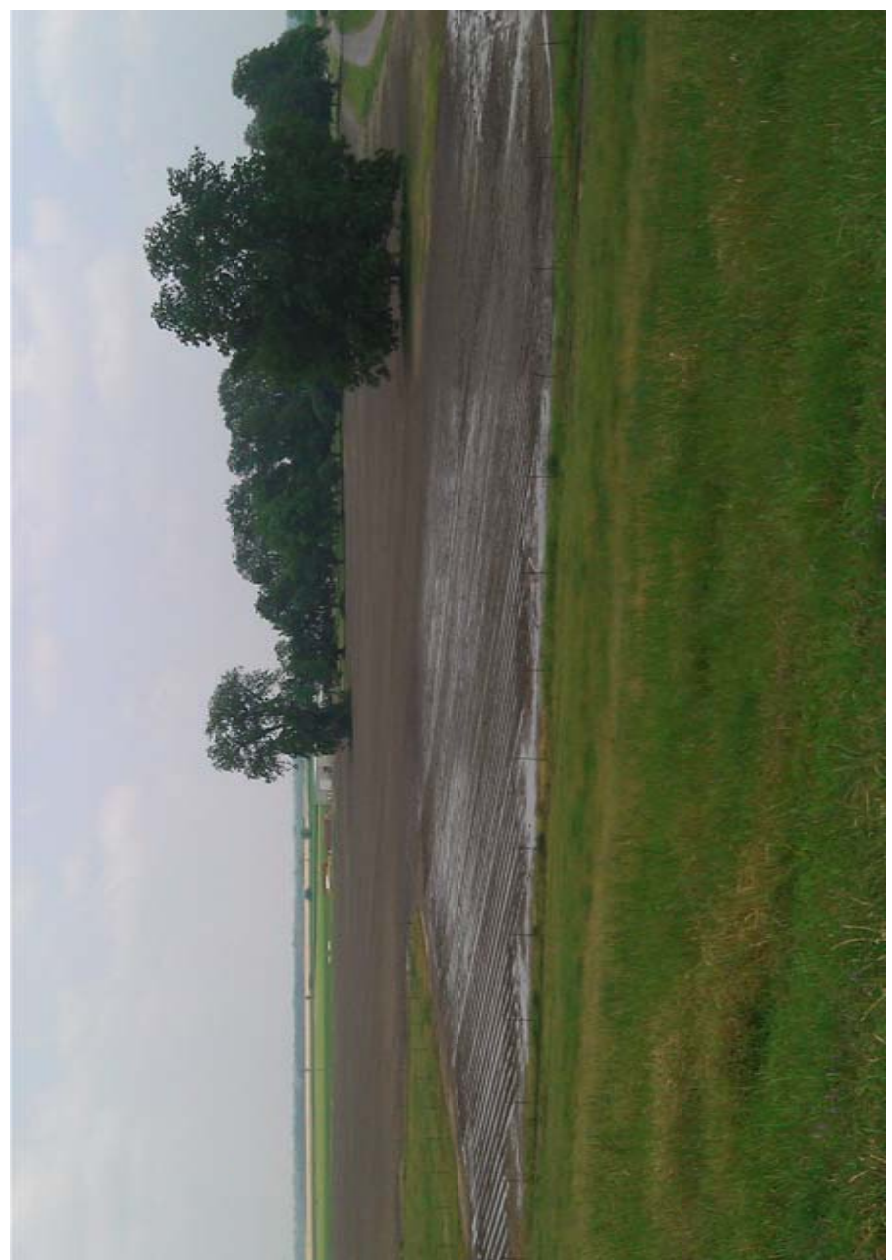

110

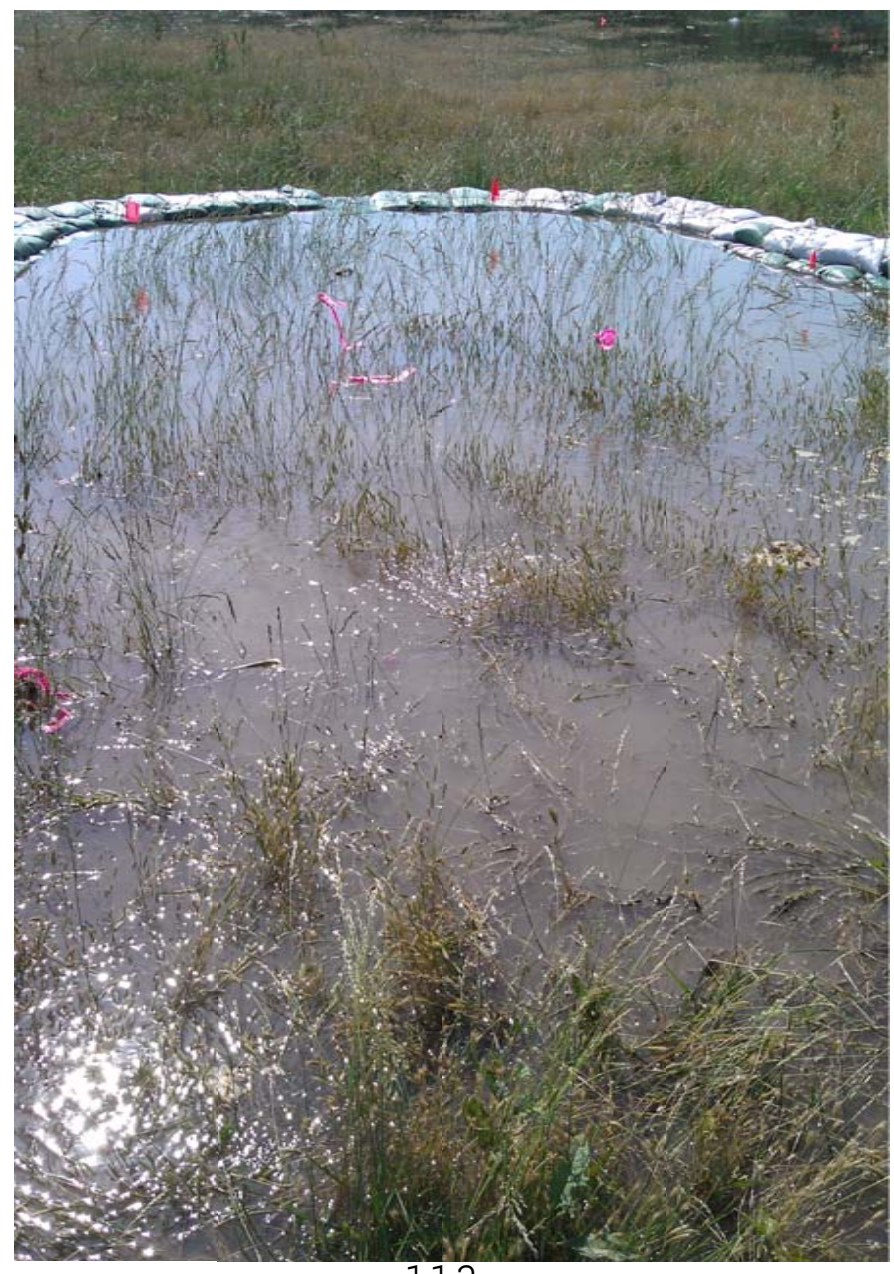




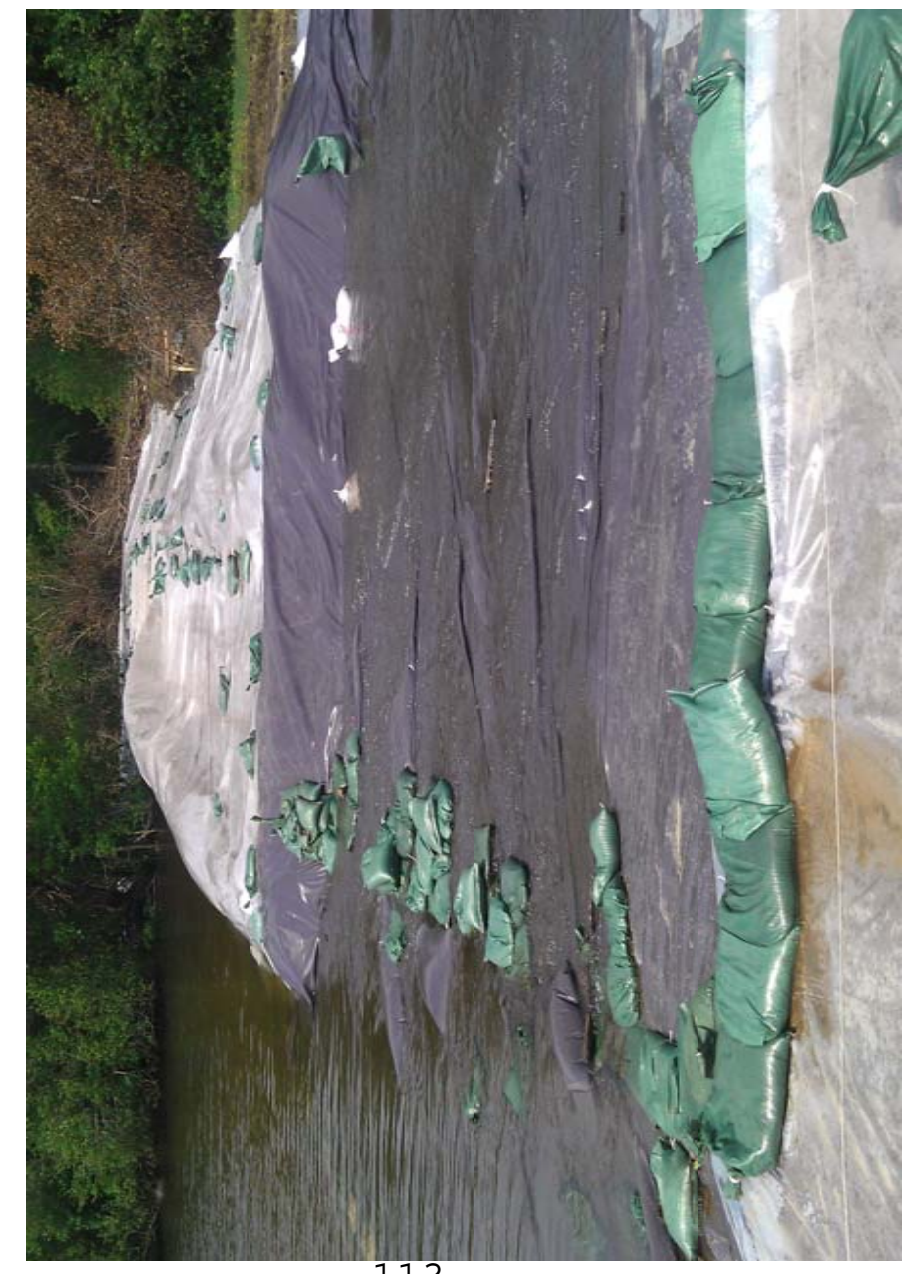

113
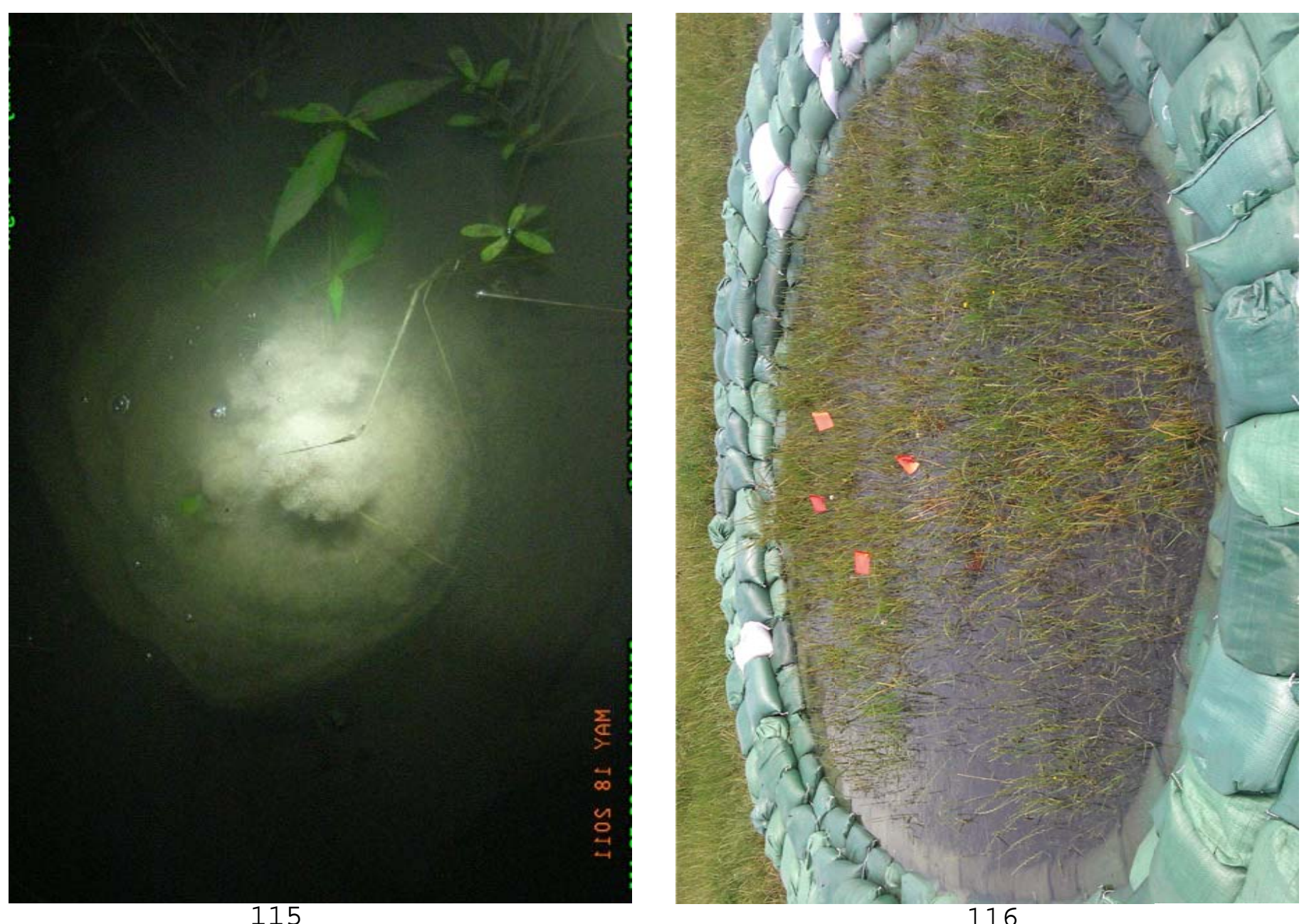

FOR OFFICIAL USE ONLY 


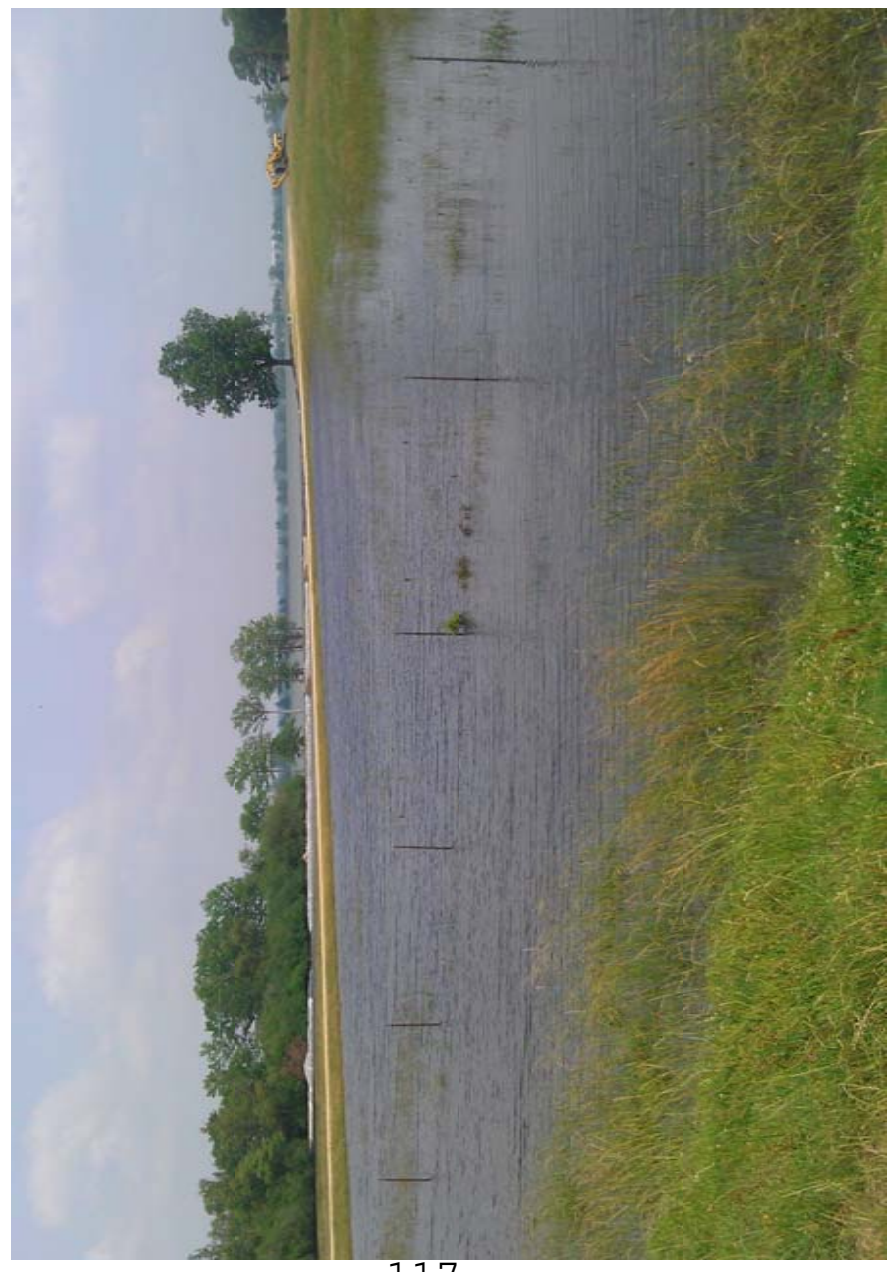

117

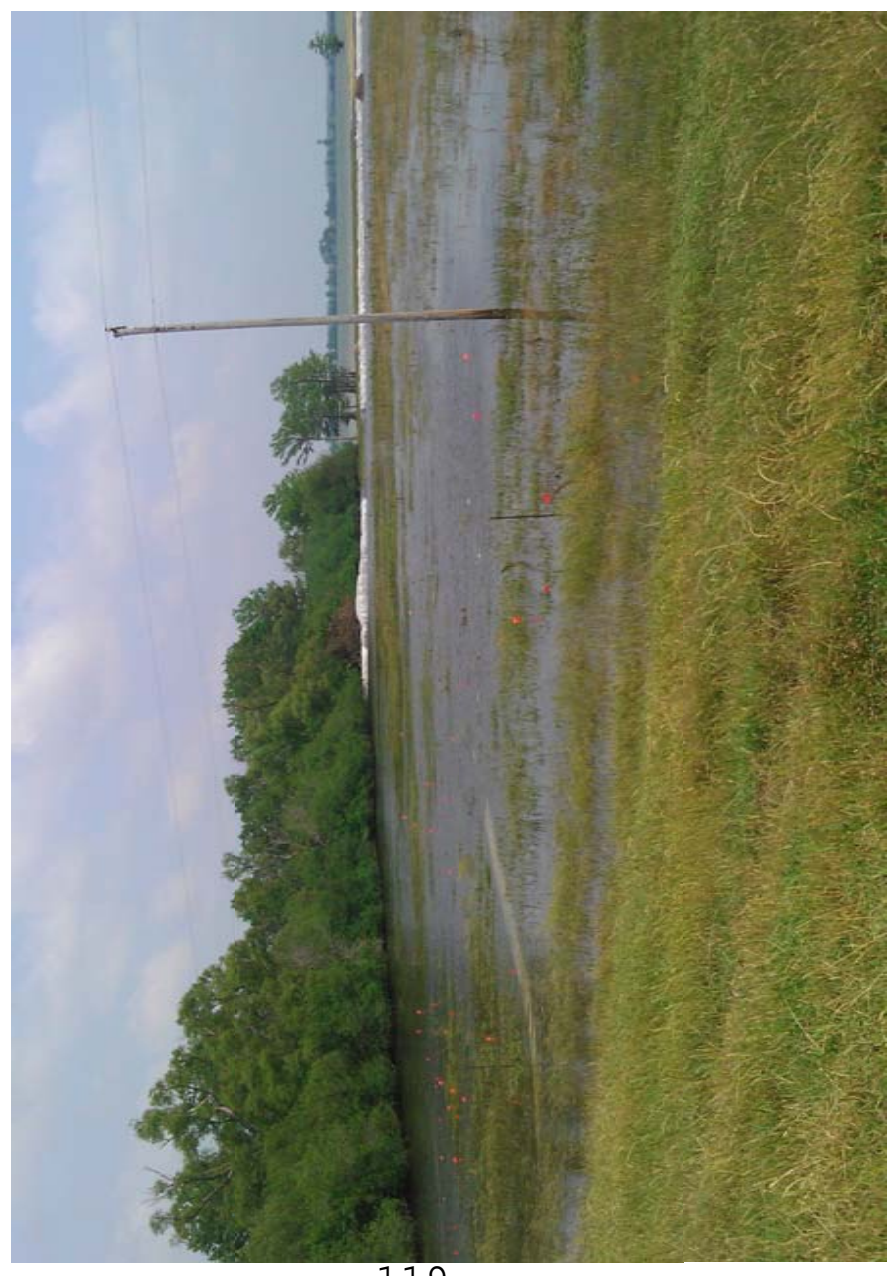

119

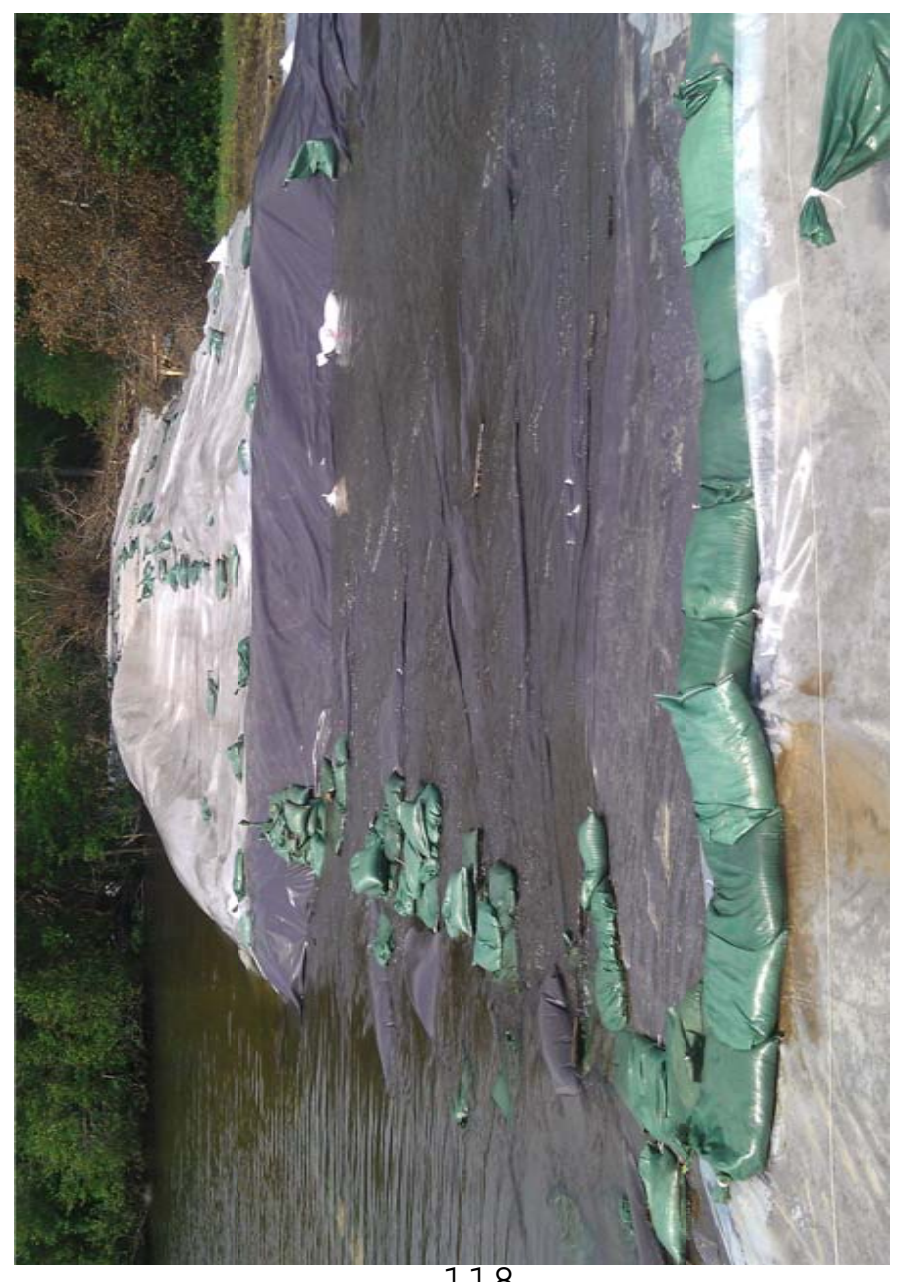

118

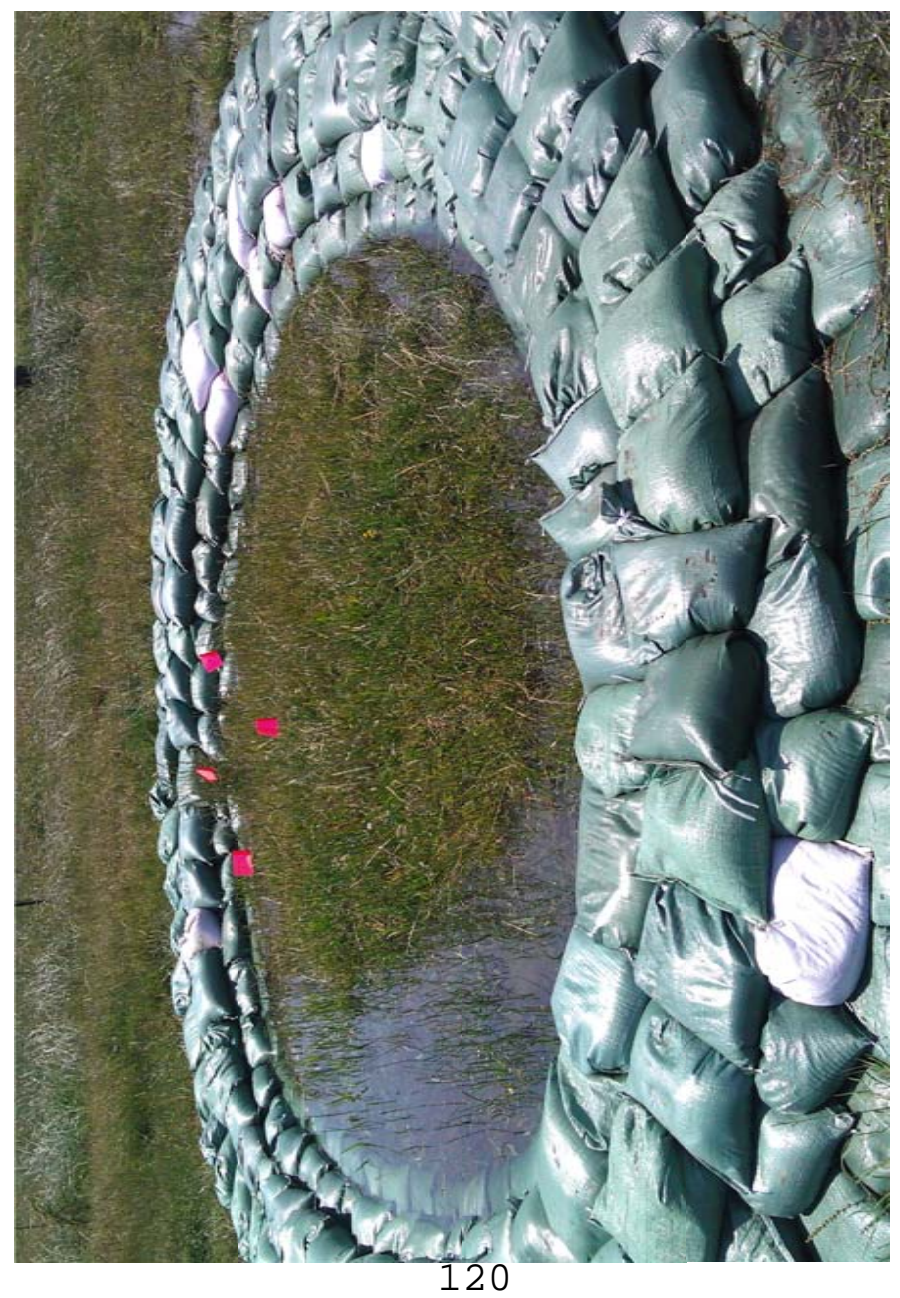

FOR OFFICIAL USE ONLY 

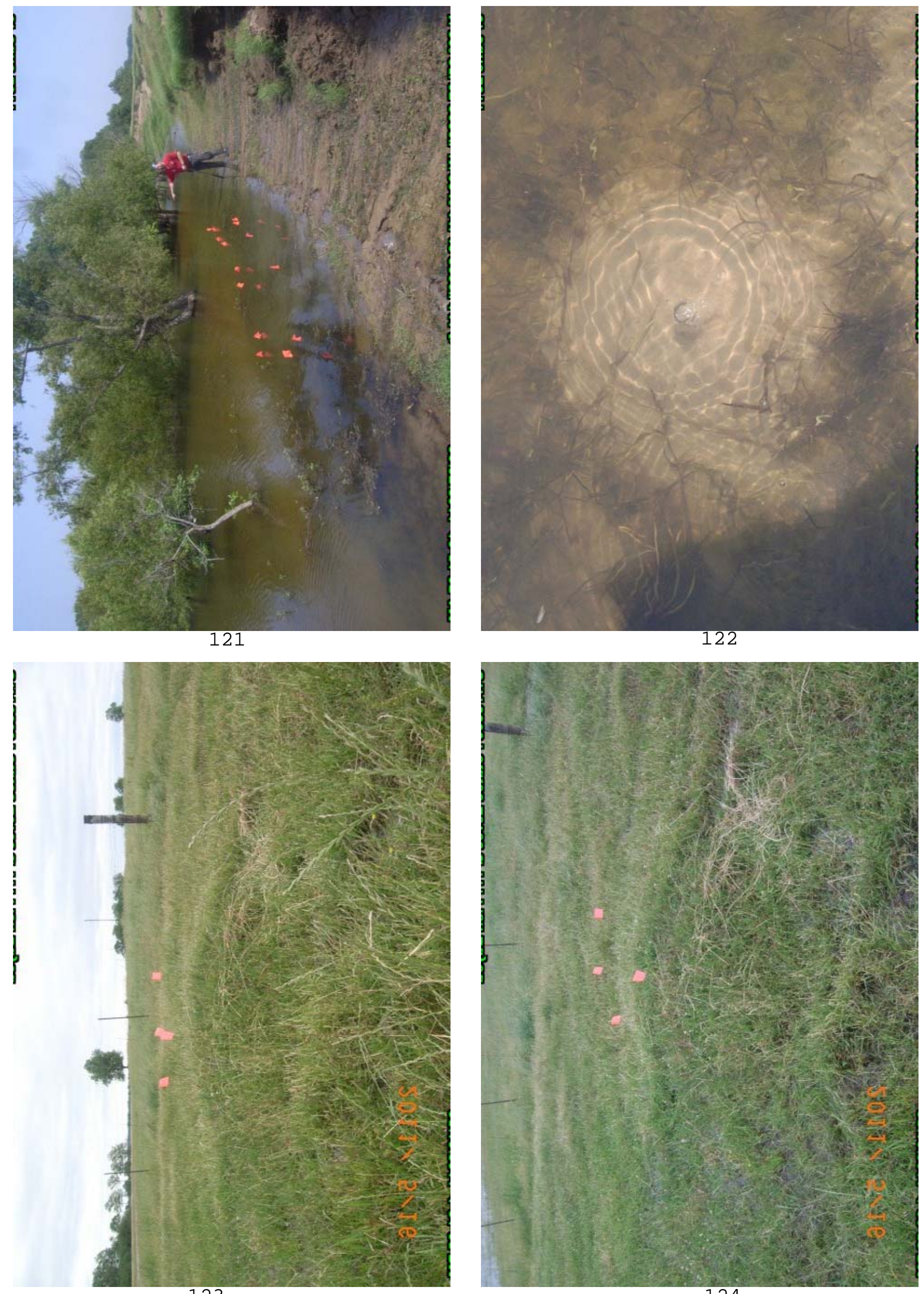


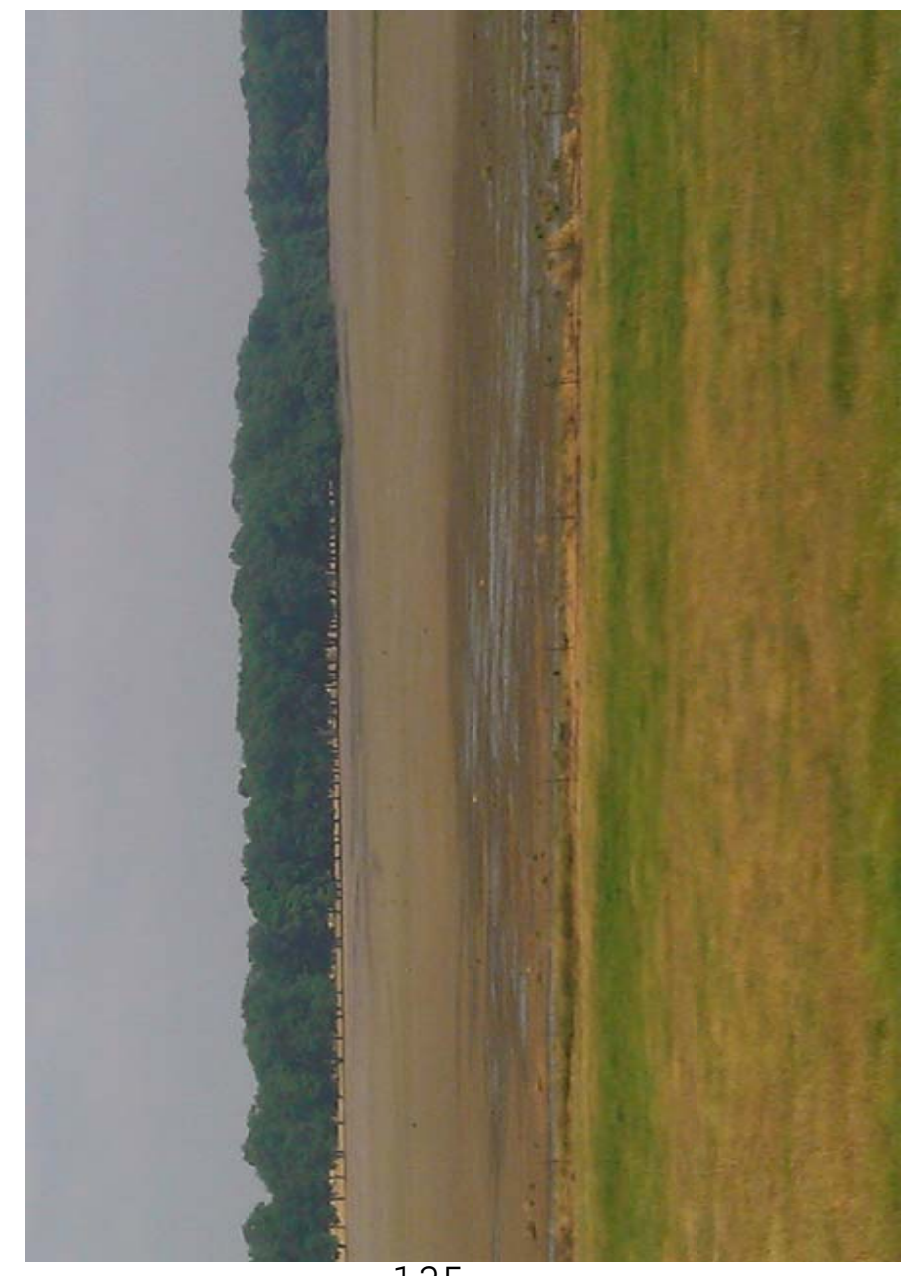

125

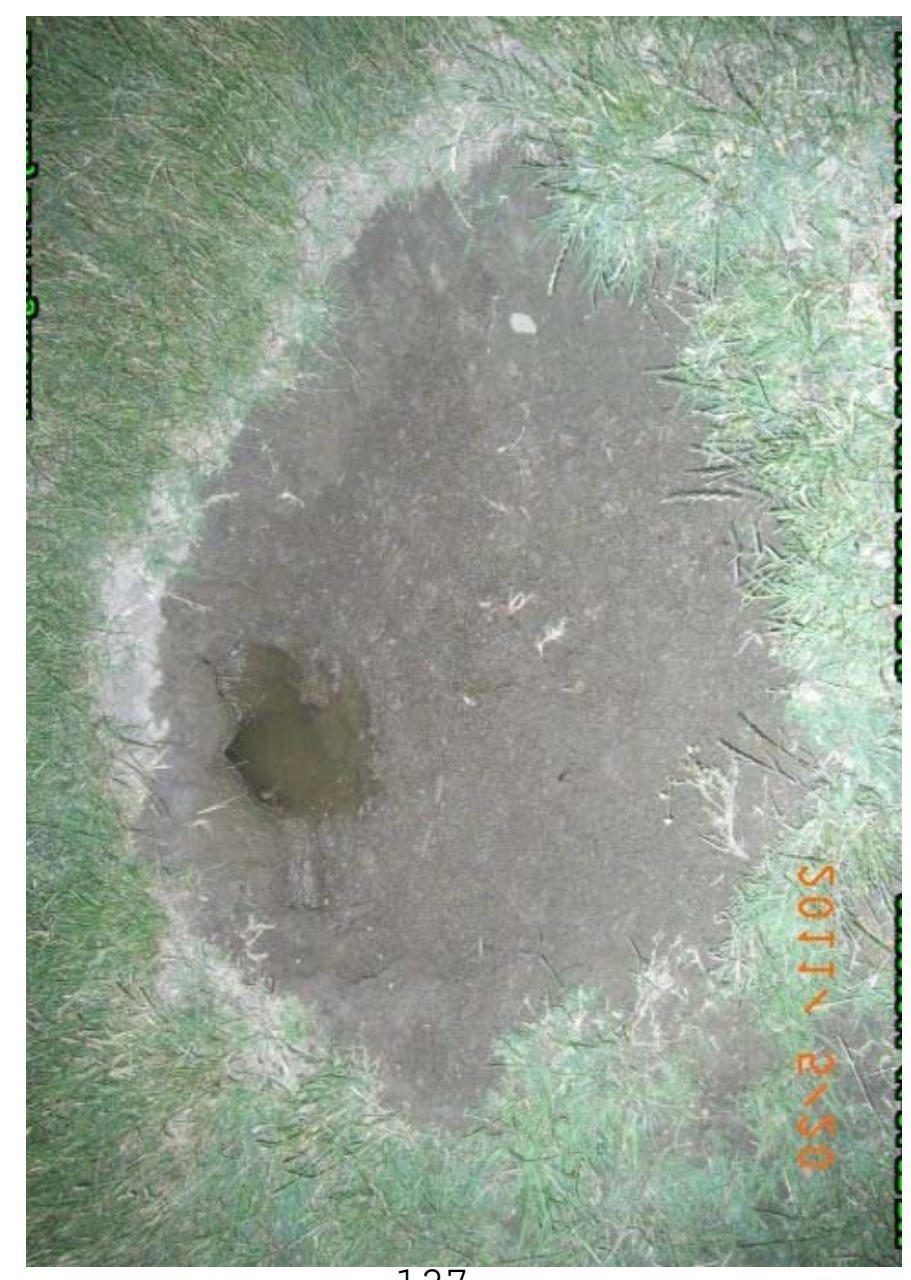

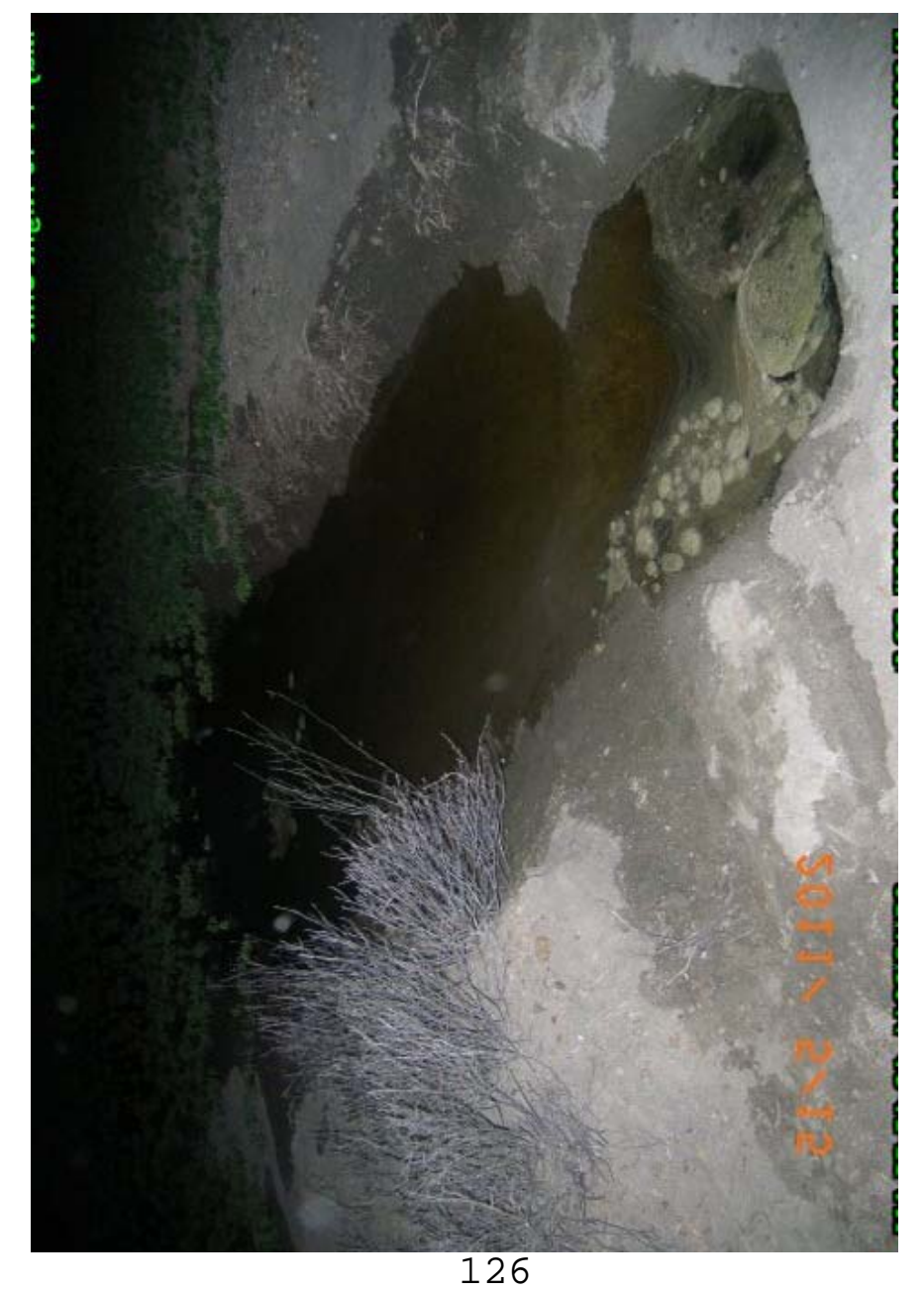

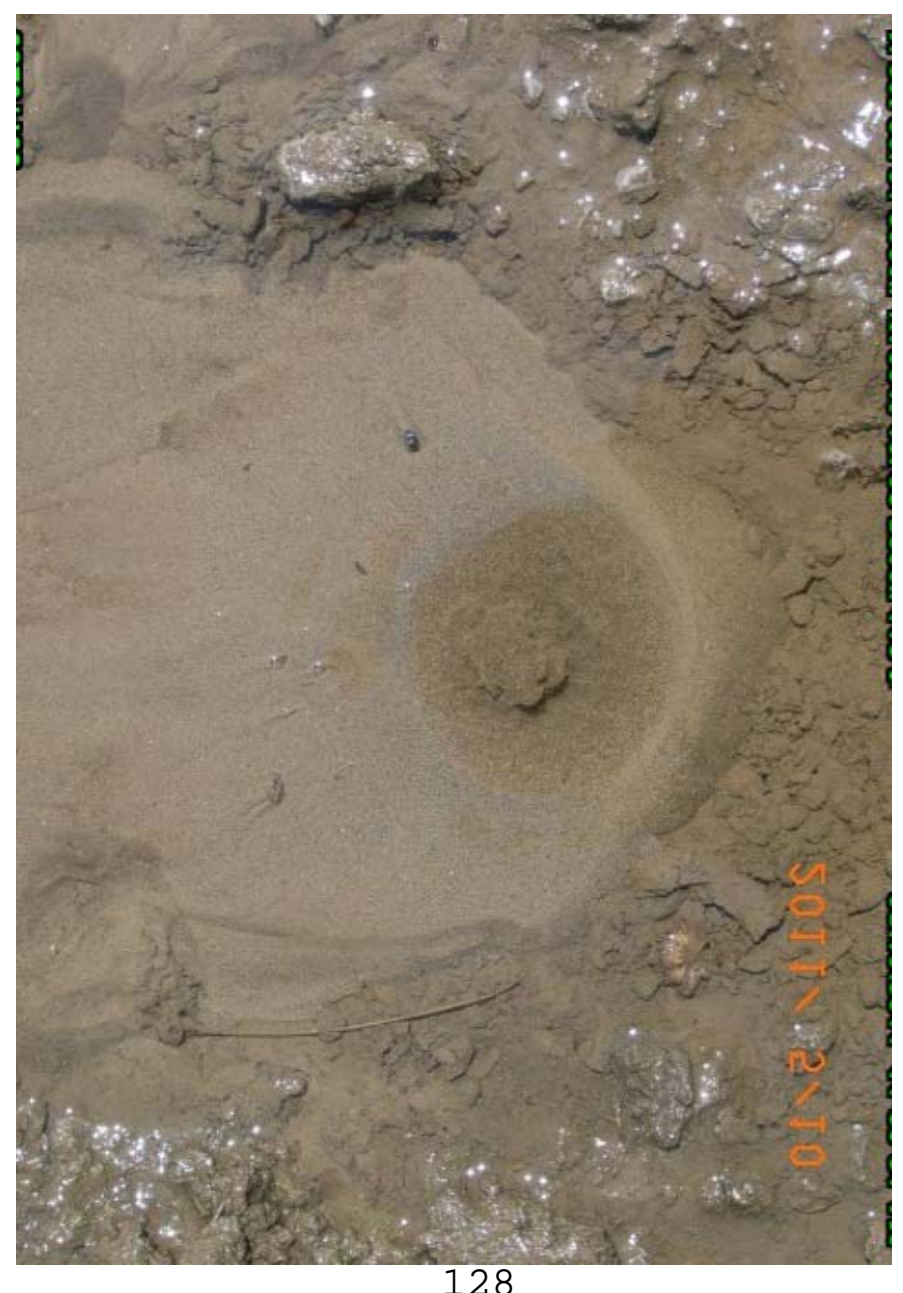

128 

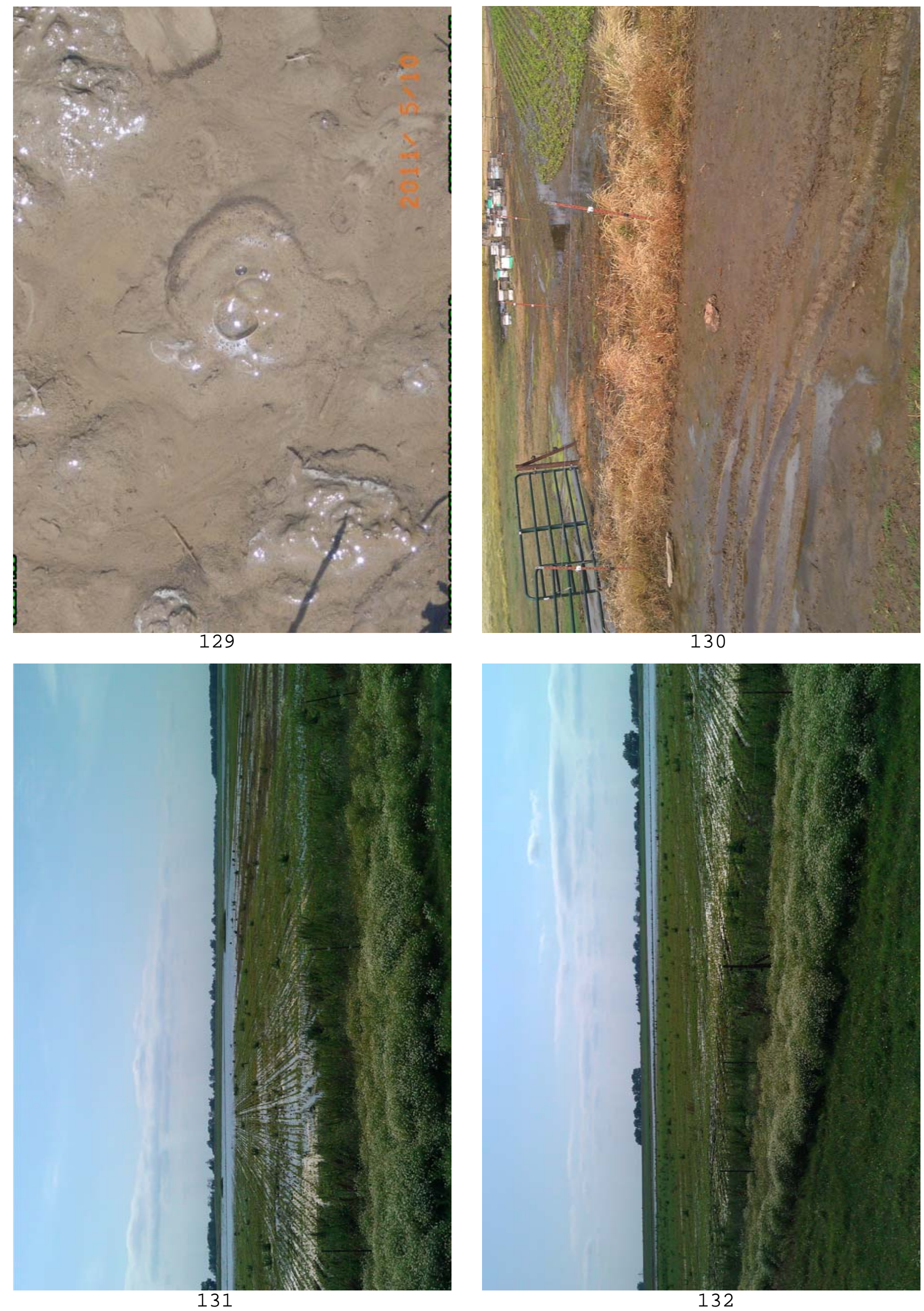


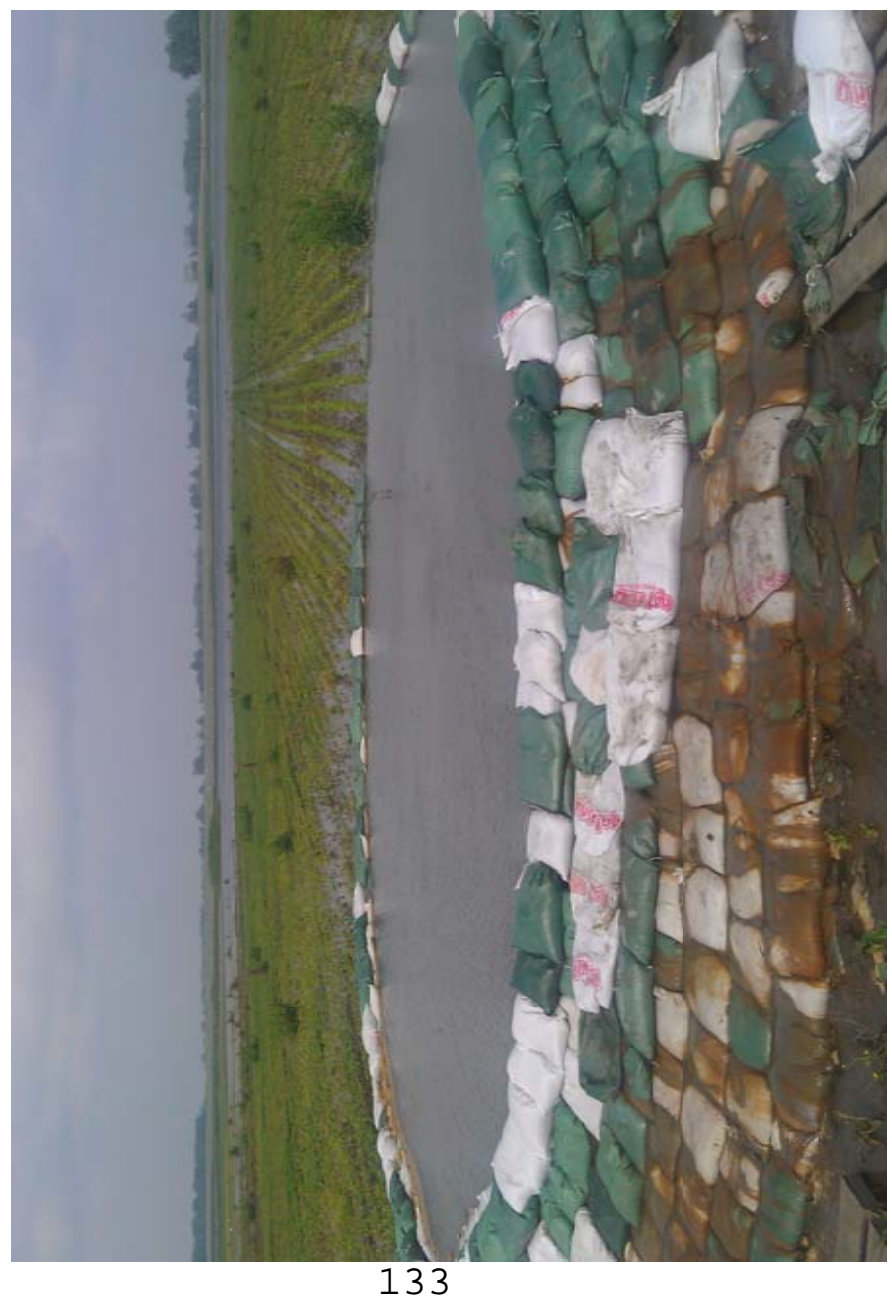




\section{WEST BANK MISSISSIPPI RIVER LEVEE IN LOUISIANA STATION 0+00 TO 3450+00}


LEVEE SECTOR: LA State Line to I-20

DATE: May 22-25, 2011

TEAM MEMBERS: Heather Sibley, Lance Gullett and Justin Jones

\begin{tabular}{|c|c|c|c|c|c|c|c|c|c|}
\hline STA & ART & EN & ND & STATION & STATION & TYPE & EXTENT & REMARKS & РНОTO \\
\hline Latitude & Longitude & Latitude & Longitude & NLD & FIELD MARKER & & & & LINKS \\
\hline 32.9981806 & 91.21704682 & 32.99646549 & 91.21829574 & $\begin{array}{l}28+00 \text { to } \\
35+00\end{array}$ & $\begin{array}{l}28+00 \text { to } \\
35+00\end{array}$ & $\begin{array}{l}\text { Under } \\
\text { Seepage }\end{array}$ & Light & $\begin{array}{l}\text { Seepage begins } 15 \mathrm{ft} \text { from the toe and extends out and undetermined } \\
\text { distance. There is a wet field with standing water around the edge, but } \\
\text { could be due to rain that occurred May } 21,2011 \text {. When the berm ends, } \\
\text { there is standing water inside fence near the toe for about } 25 \mathrm{ft} \text { then the } \\
\text { ground is just damp. Starting at } 32.9970088791 .21775042 \text { the seepage } \\
\text { starts at the toe and extends out } 200 \mathrm{ft} \text {. The field is wet with standing water } \\
\text { at the toe and in the field. }\end{array}$ & $1-3$ \\
\hline 32.99567626 & 91.2187172 & 32.99482473 & 91.21936404 & $\begin{array}{l}39+00 \text { to } \\
43+00\end{array}$ & $\begin{array}{l}39+00 \text { to } \\
43+00\end{array}$ & $\begin{array}{l}\text { Under } \\
\text { Seepage }\end{array}$ & Light & $\begin{array}{l}\text { Light seepage beginning at the toe and extends about } 80 \mathrm{ft} \text { into field. The } \\
\text { rest of the field is only slightly damp. }\end{array}$ & 4 \\
\hline 32.9934623 & 91.22041536 & 32.99171252 & 91.22136013 & $\begin{array}{l}49+00 \text { to } \\
55+00\end{array}$ & $\begin{array}{l}49+00 \text { to } \\
55+00\end{array}$ & $\begin{array}{l}\text { Under } \\
\text { Seepage }\end{array}$ & Light & $\begin{array}{l}\text { Starts at the toe and extends } 60 \mathrm{ft} \text {. Standing water near the toe and edges } \\
\text { of the field. }\end{array}$ & 5 \\
\hline 32.97252901 & 91.22496306 & 32.97187977 & 91.22499448 & $\begin{array}{l}127+00 \text { to } \\
130+00\end{array}$ & $\begin{array}{l}127+00 \text { to } \\
130+00\end{array}$ & $\begin{array}{l}\text { Under } \\
\text { Seepage }\end{array}$ & Light & Very light starts at toe and extends out $100 \mathrm{ft}$. & $6-7$ \\
\hline 32.9663171 & 91.22242151 & 32.96430718 & 91.2213433 & $\begin{array}{l}151+00 \text { to } \\
158+00\end{array}$ & $\begin{array}{l}151+00 \text { to } \\
158+00\end{array}$ & $\begin{array}{l}\text { Under } \\
\text { Seepage }\end{array}$ & Light & $\begin{array}{l}\text { Very light near the toe out } 15 \mathrm{ft} \text {. Looks like it may have more to do with } \\
\text { drainage than seepage because the area around is dry. }\end{array}$ & $8-9$ \\
\hline 32.96306519 & 91.22106288 & 32.96058866 & 91.2200586 & $\begin{array}{l}165+00 \text { to } \\
174+00\end{array}$ & $\begin{array}{l}165+00 \text { to } \\
174+00\end{array}$ & $\begin{array}{l}\text { Under } \\
\text { Seepage/Pin } \\
\text { Boils }\end{array}$ & Heavy & $\begin{array}{l}\text { Starts at the toe of berm and extends down bean rows } 50 \mathrm{ft} \text {. About } 400 \mathrm{ft} \\
\text { downstream it transitions to moderate seepage extending a couple } \\
\text { thousand feet into corn field. Multiple small boils. The slope of the berm is } \\
\text { wet just up to the crown. }\end{array}$ & $10-12$ \\
\hline 32.96060326 & 91.22003495 & 32.95796753 & 91.21855246 & $\begin{array}{l}174+00 \text { to } \\
185+00\end{array}$ & $\begin{array}{l}174+00 \text { to } \\
185+00\end{array}$ & $\begin{array}{l}\text { Under } \\
\text { Seepage }\end{array}$ & Light & $\begin{array}{l}\text { Wet spot at the toe of the berm which is about } 100 \mathrm{ft} \text { wide. Seepage is } \\
\text { behind wet spot in corn field. When the seepage berm ends, there is } \\
\text { seepage all the way up to the toe of the levee for about } 200 \mathrm{ft} \text { then } \\
\text { transitions to } 115 \mathrm{ft} \text { from the toe. }\end{array}$ & 13 \\
\hline 32.95796753 & 91.21855246 & 32.95331457 & 91.21891404 & $\begin{array}{l}185+00 \text { to } \\
202+00\end{array}$ & $\begin{array}{l}185+00 \text { to } \\
202+00\end{array}$ & $\begin{array}{l}\text { Under } \\
\text { Seepage/Pin } \\
\text { Boils }\end{array}$ & $\begin{array}{l}\text { Moderate to } \\
\text { Heavy }\end{array}$ & $\begin{array}{l}\text { At start coordinate, the wet spot ends, but there is still seepage. Some small } \\
\text { pin boils are in the field. }\end{array}$ & 14 \\
\hline 32.95331457 & 91.21891404 & 32.95147644 & 91.21720647 & $\begin{array}{l}202+00 \text { to } \\
211+00\end{array}$ & $\begin{array}{l}202+00 \text { to } \\
211+00\end{array}$ & $\begin{array}{l}\text { Under } \\
\text { Seepage }\end{array}$ & Light & Very light seepage in corn field. & 15 \\
\hline 32.95016613 & 91.21633334 & 32.94804805 & 91.21437165 & $\begin{array}{l}217+00 \text { to } \\
224+00\end{array}$ & $\begin{array}{l}217+00 \text { to } \\
224+00\end{array}$ & $\begin{array}{l}\text { Under } \\
\text { Seepage }\end{array}$ & Light & Exiting near the berm toe and extending a few thousand feet into field. & 16 \\
\hline 32.94804805 & 91.21437165 & 32.91461011 & 91.21046248 & $\begin{array}{l}224+00 \text { to } \\
362+00\end{array}$ & $\begin{array}{l}224+00 \text { to } \\
362+00\end{array}$ & & & $\begin{array}{l}\text { *Note: there was a bean field that was consistently wet and appeared to be } \\
\text { due to rain, not seepage. No standing water was noted, and entire field } \\
\text { appeared to have the same dampness. }\end{array}$ & \\
\hline 32.91461011 & 91.21046248 & -- & -- & $362+00$ & $362+00$ & $\begin{array}{l}\text { Under } \\
\text { Seepage }\end{array}$ & Light & $\begin{array}{l}\text { Extends out } 150 \mathrm{ft} \text { from the toe. There was some standing water, but very } \\
\text { localized area only } 30 \mathrm{ft} \text { parallel to levee so could be drainage problem more } \\
\text { than seepage. }\end{array}$ & 17 \\
\hline 32.90358801 & 91.19321507 & -- & -- & $340+00$ & $340+00$ & & & $\begin{array}{l}45 \mathrm{ft} \text { from the toe there is an old pipe that is broken off at the ground which } \\
\text { is flowing water. No material is being moved, but the area has been } \\
\text { sandbagged. No seepage or boils located near here. }\end{array}$ & $18-19$ \\
\hline 32.877689 & 91.1645389 & -- & - & $591+00$ & $591+00$ & Sand Boil & & $\begin{array}{l}\text { Boil approximately } 1500 \mathrm{ft} \text { from the berm toe in ditch that runs through } \\
\text { field. Has moved small amount of material, but is now running clear. } \\
\text { (WP0007) }\end{array}$ & \\
\hline
\end{tabular}




\begin{tabular}{|c|c|c|c|c|c|c|c|c|c|}
\hline STA & ART & EN & & STATION & STATION & TYPE & EXTENT & REMARKS & PHOTO \\
\hline Latitude & Longitude & Latitude & Longitude & NLD & FIELD MARKER & & & & LINKS \\
\hline 32.87738249 & 91.15966032 & 32.87667818 & 91.15960239 & $\begin{array}{l}595+00 \text { to } \\
597+00\end{array}$ & $\begin{array}{l}595+00 \text { to } \\
597+00\end{array}$ & $\begin{array}{l}\text { Under } \\
\text { Seepage }\end{array}$ & \begin{tabular}{|l|l|} 
Light to \\
Moderate
\end{tabular} & Seepage is exiting near the toe. & 20 \\
\hline 32.87734027 & 91.15957756 & 32.87667818 & 91.15960239 & $\begin{array}{l}595+00 \text { to } \\
597+00\end{array}$ & \begin{tabular}{|l}
$595+00$ to \\
$597+00$
\end{tabular} & \begin{tabular}{|l} 
Under \\
Seepage
\end{tabular} & Light & Berm begins and has seepage exiting the slope. & 21 \\
\hline 32.87667818 & 91.15960239 & 32.86290525 & 91.16136013 & \begin{tabular}{|l}
$597+00$ to \\
$650+00$
\end{tabular} & $\begin{array}{l}597+00 \text { to } \\
650+00\end{array}$ & $\begin{array}{l}\text { Under } \\
\text { Seepage/Pin } \\
\text { Boils } \\
\end{array}$ & Heavy & $\begin{array}{l}\text { Seepage exiting at toe and extending back more than } 1000 \mathrm{ft} \text {. Heavy } \\
\text { seepage. Hundreds of pin boils, some larger boils that have been bagged. } \\
\text { This is part of the Wilson Point area that had never had water on it until the } \\
\text { old levee failed which caused the boils to develop. The end coordinates } \\
\text { mark the beginning of the relief wells. There is still heavy seepage up until } \\
\text { the start of the relief wells. Because of the wells, it is hard to determine the } \\
\text { amount of seepage once the wells start since they are flowing. There are } \\
\text { some boils located behind the wells so there is still some heavy seepage } \\
\text { occuring past the end coordinates. See below for Sand boil information. }\end{array}$ & $22-32$ \\
\hline 32.87389214 & 91.16186656 & -- & -- & $608+00$ & $608+00$ & Sand Boil & & $\begin{array}{l}\text { There is a sand boil in ditch approximately } 850 \mathrm{ft} \text { from the berm toe that has } \\
\text { moved some material, but is now running clear water. WP008 }\end{array}$ & \\
\hline 32.87519453 & 91.15960391 & - & -- & $603+00$ & $603+00$ & Sand Boil & & $\begin{array}{l}\text { WP006 - Sand boil that at time of our inspection had been bagged and filled } \\
\text { with rock. Was located at the levee toe and has moved several yds of } \\
\text { material. Sit rep does not specify size of throat and could not estimate it } \\
\text { due to rock and sand operation. }\end{array}$ & \\
\hline 32.87388065 & 91.15958888 & 1 & -- & $609+00$ & $609+00$ & Sand Boil & & $\begin{array}{l}\text { WP } 005 \text { - still moving some material. Sand cone was } 1.5 \mathrm{ft} \text { tall and } 6 \mathrm{ft} \text { wide a } \\
\text { ruler can be stuck in throat } 3 \mathrm{ft} \text {. Located at the levee toe. Sit rep notes } \\
\text { several boils at the toe of the LS berm that have moved small amounts of } \\
\text { material STA 609. }\end{array}$ & \\
\hline 32.87032312 & 91.16067773 & -- & - & $622+50$ & $622+50$ & Sand Boil & & WP 003 - smaller boil located at the levee toe. & \\
\hline 32.87051104 & 91.16097032 & - & -- & $622+00$ & $622+00$ & Sand Boil & & $\begin{array}{l}\text { WP } 001 \text { - small boil } 25 \mathrm{ft} \text { from the levee toe. Ground is pumping and gurgling } \\
\text { when walked on. Noted in sit rep May } 14 \text {, between levee STA } 600 \text { to } 650 \text { at } \\
\text { toe of LS berm, there are several boils running clear water and several } \\
\text { bulges approximately } 6 \text { in in height. These bulges are at the toe of the berm. } \\
\text { On the date of the inspection for this report, the bulges were not noted, but } \\
\text { there was pumping. }\end{array}$ & \\
\hline 32.87355 & 91.15968056 & -- & -- & $610+00$ & $610+00$ & Sand Boil & & $\begin{array}{l}\text { WP } 004 \text { - several small boils located off toe of berm all have moved small } \\
\text { amount of material Sta } 610 \text {. }\end{array}$ & \\
\hline 32.87504237 & 91.15937619 & 32.87372235 & 91.15958414 & $\begin{array}{l}604+00 \text { to } \\
609+50\end{array}$ & $\begin{array}{l}604+00 \text { to } \\
609+50\end{array}$ & $\begin{array}{l}\text { Under } \\
\text { Seepage }\end{array}$ & Light & Seepage is exiting the berm $25 \mathrm{ft}$ from the toe. & \\
\hline 32.86689 & 91.1706 & & -- & $637+50$ & $637+50$ & Sand Boil & & $\begin{array}{l}\text { There are } 9 \text { boils at this location in ditch along highway 596. Boils are } 2500 \mathrm{ft} \\
\text { to } 3000 \mathrm{ft} \text { from levee. All are moving material. Levee Board built sand bag } \\
\text { dams in ditch and contained boils. }\end{array}$ & \\
\hline 32.86290525 & 91.16136013 & 32.81974277 & 91.16998203 & $\begin{array}{l}650+00 \text { to } \\
824+00\end{array}$ & $\begin{array}{l}650+00 \text { to } \\
824+00\end{array}$ & & & $\begin{array}{l}\text { Relief wells begin. The levee slope at the relief wells is damp 10ft up the } \\
\text { slope. Wells 1-10, 20-22, 25-30, and 73-89 are all flowing above the water } \\
\text { level in ditch. Wells 11-19, 23-24, and 31-72 are all flowing, but they are } \\
\text { underwater. Note: starting at well number } 31 \text {, the bean field behind the } \\
\text { wells is wet and yellow } 1000 \text { ft or more. At the end of the wells, there is a } \\
\text { wet swampy area just past the toe that may have some seep water, but also } \\
\text { has water from the wells running into it. }\end{array}$ & $33-34$ \\
\hline 32.82191023 & 91.16968807 & -- & |-- & $815+00$ & $815+00$ & Sand Boil & & $\begin{array}{l}\text { Boil behind wells looks to be flowing clear water. Small boil located } \\
\text { approximately } 50 \text { ft from berm toe between wells \#81 and \#82. }\end{array}$ & 35 \\
\hline
\end{tabular}




\begin{tabular}{|c|c|c|c|c|c|c|c|c|c|}
\hline STA & ART & EN & VD & STATION & STATION & TYPE & EXTENT & REMARKS & РНОTO \\
\hline Latitude & Longitude & Latitude & Longitude & NLD & FIELD MARKER & & & & LINKS \\
\hline 32.81974277 & 91.16998203 & 32.81665591 & 91.17106614 & $\begin{array}{l}824+00 \text { to } \\
834+00\end{array}$ & $\begin{array}{l}824+00 \text { to } \\
834+00\end{array}$ & $\begin{array}{l}\text { Under } \\
\text { Seepage }\end{array}$ & Light & $\begin{array}{l}\text { End of wells looks like there is some light seepage exiting right at the toe. } \\
\text { Swampy area makes it hard to tell if it extends further back. At the end of } \\
\text { the reach, the swampy area gets further from the toe. }\end{array}$ & 36 \\
\hline 32.811611 & 91.18001944 & 32.80764934 & 91.1758967 & $885+00$ & $885+00$ & Sand Boil & & $\begin{array}{l}\text { Many sand boils. Most are small boils located near the edge of the water at } \\
\text { Lake Providence. There are a few boils out in the water that are flowing and } \\
\text { it is hard to determine their size. Most are only moving trace amounts of } \\
\text { sand. Boils are numbered LP001 through LP025. }\end{array}$ & $37-43$ \\
\hline 32.79987301 & 91.17034029 & 32.79513116 & 91.17081383 & $\begin{array}{l}906+00 \text { to } \\
923+00\end{array}$ & $\begin{array}{l}906+00 \text { to } \\
923+00\end{array}$ & $\begin{array}{l}\text { Under } \\
\text { Seepage }\end{array}$ & Light & $\begin{array}{l}\text { Seepage starts in ditch } 200 \mathrm{ft} \text { away from the toe of the levee and is light to } \\
\text { very light. Fairly localized area and does not extend across road. There is } \\
\text { only a small amount of water in the ditch and it is not flowing. There is a } \\
\text { ditch on the other side of road as well that has a small amount of water in } \\
\text { it, but also not flowing and a field starts downstream is dry. }\end{array}$ & \\
\hline 32.78106847 & 91.17863934 & 32.78067807 & 91.17860221 & $\begin{array}{l}981+00 \text { to } \\
982+00\end{array}$ & $\begin{array}{l}981+00 \text { to } \\
982+00\end{array}$ & Sand Boil & & $\begin{array}{l}\text { Two small sand boils located across Highway } 465 \text { in drainage ditch. } \\
\text { Numbered DD001 and DD002. Couple hundred feet from levee toe. }\end{array}$ & $44-45$ \\
\hline 32.78793371 & 91.17420866 & 32.77578783 & 91.17786367 & $\begin{array}{l}953+00 \text { to } \\
1001+00\end{array}$ & $\begin{array}{l}953+00 \text { to } \\
1001+00\end{array}$ & & & $\begin{array}{l}\text { Relief wells start. Wells } 17 \text { and } 36 \text { are barely flowing and wells } 24,25,34 \text {, } \\
\text { and } 35 \text { are not flowing at all. }\end{array}$ & 46 \\
\hline 32.74790606 & 91.17856086 & 32.73934598 & 91.17483848 & $\begin{array}{l}1101+00 \text { to } \\
1137+00\end{array}$ & $\begin{array}{l}1101+00 \text { to } \\
1137+00\end{array}$ & & & $\begin{array}{l}\text { Relief wells start back with \#37. The corn field is wet a couple hundred } \\
\text { yards before the start of the wells, but looks to be from the well flow, not } \\
\text { seepage. Wells 59-61 are underwater, but flowing. }\end{array}$ & $47-49$ \\
\hline 32.74064739 & 91.17736177 & 32.74004344 & 91.17651382 & $\begin{array}{l}1128+00 \text { to } \\
1132+00\end{array}$ & $\begin{array}{l}1128+00 \text { to } \\
1132+00\end{array}$ & $\begin{array}{l}\text { Under } \\
\text { Seepage }\end{array}$ & Light & $\begin{array}{l}\text { Seepage is coming off of toe of levee above the wells. Less than } 10 \mathrm{ft} \text { up the } \\
\text { slope. }\end{array}$ & 50 \\
\hline 32.73740961 & 91.17286527 & 32.73585151 & 91.16808811 & $\begin{array}{l}1147+00 \text { to } \\
1159+00\end{array}$ & $\begin{array}{l}1147+00 \text { to } \\
1159+00\end{array}$ & $\begin{array}{l}\text { Under } \\
\text { Seepage }\end{array}$ & Light & $\begin{array}{l}\text { Very light seepage on bank of full drainage ditch. Begins } 20 \mathrm{ft} \text { from the berm } \\
\text { toe and extends } 300 \mathrm{ft} \text { out. }\end{array}$ & 51 \\
\hline 32.73585151 & 91.16808811 & 32.73048634 & 91.15934263 & $\begin{array}{l}1159+00 \text { to } \\
1195+00\end{array}$ & $\begin{array}{l}1159+00 \text { to } \\
1195+00\end{array}$ & $\begin{array}{l}\text { Under } \\
\text { Seepage }\end{array}$ & Light & $\begin{array}{l}\text { Light seepage now begins on the ditch bank } 50 \mathrm{ft} \text { from the berm toe and } \\
\text { extends } 400 \mathrm{ft} \text { into field. The berm ends at } 32.7331128891 .16449814 \text {, but } \\
\text { the seepage continues. Once berm ends, seepage is at the levee toe and } \\
\text { extends } 700 \mathrm{ft} \text { into field. }\end{array}$ & 52 \\
\hline 32.73048634 & 91.15934263 & 32.72883297 & 91.15934263 & $\begin{array}{l}1195+00 \text { to } \\
1203+00\end{array}$ & $\begin{array}{l}1195+00 \text { to } \\
1203+00\end{array}$ & $\begin{array}{l}\text { Under } \\
\text { Seepage/Pin } \\
\text { Boils }\end{array}$ & Heavy & $\begin{array}{l}\text { Heavy seepage begins near the levee toe and extends out } 1000 \mathrm{ft} \text {. There are } \\
\text { small, bagged sand boils in reach. This is the reach where earlier there were } \\
\text { blisters that came up on the berm. When popped the blisters ran water out. } \\
\text { There were no more blisters noted at the time of this inspection, but there } \\
\text { were multiple clear boils in the reach. }\end{array}$ & $53-55$ \\
\hline 32.72883297 & 91.15934263 & 32.72802037 & 91.1592073 & $\begin{array}{l}1203+00 \text { to } \\
1207+50\end{array}$ & $\begin{array}{l}1203+00 \text { to } \\
1207+50\end{array}$ & $\begin{array}{l}\text { Under } \\
\text { Seepage }\end{array}$ & \begin{tabular}{|l|} 
Light to \\
Moderate
\end{tabular} & Light seepage $50 \mathrm{ft}$ from levee toe and extends out $400 \mathrm{ft}$ to ditch. & 56 \\
\hline 32.72654862 & 91.15903098 & 32.72467125 & 91.15847617 & $\begin{array}{l}1213+00 \text { to } \\
1219+00\end{array}$ & $\begin{array}{l}1213+00 \text { to } \\
1219+00\end{array}$ & $\begin{array}{l}\text { Under } \\
\text { Seepage }\end{array}$ & Light & $\begin{array}{l}\text { With the exception of the small area at beginning with seepage exiting } 20 \mathrm{ft} \\
\text { on berm, light seepage begins at the berm toe and extends out over } 2000 \mathrm{ft} \text {. }\end{array}$ & $57-58$ \\
\hline 32.72467125 & 91.15847617 & 32.72422624 & 91.15821942 & $\begin{array}{l}1219+00 \text { to } \\
1222+00\end{array}$ & $\begin{array}{l}1219+00 \text { to } \\
1222+00\end{array}$ & $\begin{array}{l}\text { Under } \\
\text { Seepage }\end{array}$ & Light & $\begin{array}{l}\text { Light seepage is exiting at the berm toe and in ditch } 20 \mathrm{ft} \text { away. However, } \\
\text { there is no longer any seepage further out in the field. At the end } \\
\text { coordinates, there is no longer any seepage at the toe, but there is still } \\
\text { approximately } 2 \mathrm{ft} \text { of water in the drainage ditch. }\end{array}$ & \\
\hline 32.72055533 & 91.14955554 & & -- & $\begin{array}{l}1246+00 \text { to } \\
1247+00\end{array}$ & $\begin{array}{l}1246+00 \text { to } \\
1247+00\end{array}$ & $\begin{array}{l}\text { Under } \\
\text { Seepage }\end{array}$ & Light & $\begin{array}{l}\text { Some light seepage is visible } 50 \mathrm{ft} \text { from berm in field across from drainage } \\
\text { ditch. Appears to be a small isolated low area that extends } 100 \mathrm{ft} \text { parallel to } \\
\text { levee. }\end{array}$ & \\
\hline
\end{tabular}




\begin{tabular}{|c|c|c|c|c|c|c|c|c|c|}
\hline \multicolumn{2}{|c|}{ START } & \multicolumn{2}{|c|}{ END } & $\begin{array}{l}\text { STATION } \\
\text { NLD }\end{array}$ & $\begin{array}{c}\text { STATION } \\
\text { FIELD MARKER } \\
\end{array}$ & TYPE & EXTENT & REMARKS & $\begin{array}{l}\text { PHOTO } \\
\text { LINKS }\end{array}$ \\
\hline 32.71957209 & 91.14760893 & -- & -- & $\begin{array}{l}1250+00 \text { to } \\
1251+00\end{array}$ & $\begin{array}{l}1250+00 \text { to } \\
1251+00\end{array}$ & $\begin{array}{l}\text { Under } \\
\text { Seepage }\end{array}$ & \begin{tabular}{|l} 
Light to \\
Moderate
\end{tabular} & $\begin{array}{l}\text { Light to moderate seepage in field across ditch from berm. Starts } 50 \mathrm{ft} \text { from } \\
\text { berm and extends } 600 \mathrm{ft} \text { into field. The water is flowing into the ditch near } \\
\text { the berm. Isolated area that is approximately } 100 \mathrm{ft} \text { parallel to levee. }\end{array}$ & 59 \\
\hline 32.72218295 & 91.14633092 & -- & -- & $\begin{array}{l}1256+00 \text { to } \\
1258+00\end{array}$ & $\begin{array}{l}1256+00 \text { to } \\
1258+00\end{array}$ & $\begin{array}{l}\text { Under } \\
\text { Seepage }\end{array}$ & Light & $\begin{array}{l}\text { Isolated light seepage visible on the south edge of field } 1000 \mathrm{ft} \text { from berm } \\
\text { toe. Less than } 200 \mathrm{ft} \text { wide. }\end{array}$ & \\
\hline 32.72179573 & 91.14397424 & 32.72178269 & 91.14339358 & $\begin{array}{l}1261+00 \text { to } \\
1263+00\end{array}$ & $\begin{array}{l}1261+00 \text { to } \\
1263+00\end{array}$ & $\begin{array}{l}\text { Under } \\
\text { Seepage }\end{array}$ & Light & $\begin{array}{l}\text { Light seepage begins } 200 \mathrm{ft} \text { from levee toe extends into ditch which is } 120 \mathrm{ft} \\
\text { from start of seepage. }\end{array}$ & 60 \\
\hline 32.72070605 & 91.13818384 & 32.72119478 & 91.13318452 & $\begin{array}{l}1284+00 \text { to } \\
1297+00\end{array}$ & $\begin{array}{l}1284+00 \text { to } \\
1297+00\end{array}$ & $\begin{array}{l}\text { Under } \\
\text { Seepage }\end{array}$ & Light & $\begin{array}{l}\text { Light seepage out in field } 200 \mathrm{ft} \text { from levee toe. Extends } 100 \mathrm{ft} \text { at the } \\
\text { beginning, but near the end area drains into ditch and extends } 20 \mathrm{ft} \text { behind } \\
\text { ditch into plowed field. }\end{array}$ & 61 \\
\hline 32.72170783 & 91.13111299 & 32.72205458 & 91.12958076 & $\begin{array}{l}1303+00 \text { to } \\
1312+00\end{array}$ & $\begin{array}{l}1303+00 \text { to } \\
1312+00\end{array}$ & $\begin{array}{l}\text { Under } \\
\text { Seepage }\end{array}$ & Light & $\begin{array}{l}\text { Very light seepage } 100 \mathrm{ft} \text { from levee toe at drainage ditch and extends out } \\
20 \mathrm{ft} \text { perpendicular to ditch. }\end{array}$ & 62 \\
\hline 32.71991937 & 91.1266103 & 32.71863842 & 91.12637569 & $\begin{array}{l}1324+00 \text { to } \\
1327+00\end{array}$ & $\begin{array}{l}1324+00 \text { to } \\
1327+00\end{array}$ & $\begin{array}{l}\text { Under } \\
\text { Seepage }\end{array}$ & \begin{tabular}{|l|} 
Light to \\
Moderate \\
\end{tabular} & $\begin{array}{l}\text { Seepwater in ditch at levee toe. Seepage extends } 500 \mathrm{ft} \text { into woods and } \\
\text { field. }\end{array}$ & 63 \\
\hline 32.71563056 & 91.12073056 & -- & -- & $1345+00$ & $1345+00$ & Sand Boil & & $\begin{array}{l}3 \text { boils located at Homestead. HSO02 located } 15 \mathrm{ft} \text { from toe of berm and has } \\
\text { moved small amount of material (photo } 64 \text { ). HSO03 at } 32.715691 .120815 \mathrm{ft} \\
\text { from berm toe in rowed up field with } 2 \text { to } 3 \text { in throat and has moved } \\
\text { approximately } 1 / 2 \text { yds materia (photo } 65 \text { )I. HSO01 at } 32.71536991 .120769 \\
\text { was discovered from helicopter and is located } 75 \mathrm{ft} \text { from toe of berm and } \\
\text { has moved } 1 / 2 \mathrm{vd} \text { material (photo } 66 \text { ). }\end{array}$ & $64-66$ \\
\hline 32.71863842 & 91.12637569 & 32.71597724 & 91.11507855 & $\begin{array}{l}1327+00 \text { to } \\
1360+00\end{array}$ & $\begin{array}{l}1327+00 \text { to } \\
1360+00\end{array}$ & $\begin{array}{l}\text { Under } \\
\text { Seepage }\end{array}$ & $\begin{array}{l}\text { Moderate to } \\
\text { Heavy }\end{array}$ & $\begin{array}{l}\text { Berm begins and seepage at toe and extends } 300 \mathrm{ft} \text { into woods and field. } \\
\text { Comes up to the pipeline area at Sta. } 1350+00 \text { where the berm is not } \\
\text { constructed and there is standing water all in area where berm should be. } \\
\text { No boils were noted. One the south side of the pipeline when berm starts } \\
\text { back, the seepage is very light at the berm toe and ends about } 100 \mathrm{ft} \text { after } \\
\text { start of berm. }\end{array}$ & $67-69$ \\
\hline & & & & $1340+00$ & $1340+00$ & Current & $\begin{array}{l}\text { Moderate to } \\
\text { Heavy }\end{array}$ & $\begin{array}{l}\text { Current is moderate to heavy } 150 \mathrm{ft} \text { from the water's edge. Light current } \\
\text { right at the water's edge. }\end{array}$ & \\
\hline 32.71392742 & 91.11627539 & 32.70396211 & 91.11692627 & $\begin{array}{l}1366+00 \text { to } \\
1415+00\end{array}$ & $\begin{array}{l}1366+00 \text { to } \\
1415+00\end{array}$ & $\begin{array}{l}\text { Under } \\
\text { Seepage }\end{array}$ & \begin{tabular}{|l} 
Light to \\
Moderate \\
\end{tabular} & $\begin{array}{l}\text { Light seepage exiting at the toe of the berm and extending out } 300 \mathrm{ft} \text {. Water } \\
\text { slowly flowing in low areas of field. No pin boils were found. When berm } \\
\text { ends the seepage is } 100 \mathrm{ft} \text { from the toe. }\end{array}$ & 70 \\
\hline 32.69767148 & 91.13454037 & 32.69947438 & 91.14493777 & $\begin{array}{l}1474+00 \text { to } \\
1511+00\end{array}$ & \begin{tabular}{|l|l}
$1474+00$ to \\
$1511+00$
\end{tabular} & $\begin{array}{l}\text { Under } \\
\text { Seepage }\end{array}$ & \begin{tabular}{|l} 
Light to \\
Moderate
\end{tabular} & $\begin{array}{l}\text { Starts at the toe and extends out } 500 f t \text { into corn field. Water is barely } \\
\text { flowing in corn rows. No boils were seen. At } 32.6981848791 .13849771 \text { a } \\
\text { berm begins and there is light seepage at the berm toe. Judging by the } \\
\text { extents of the yellowed corn, the seepage only extends a couple hundred } \\
\text { feet into corn field once berm begins. }\end{array}$ & $71-72$ \\
\hline 32.6882109 & 91.17382925 & 32.66250311 & 91.17276506 & $\begin{array}{l}1609+00 \text { to } \\
1715+00\end{array}$ & \begin{tabular}{|l}
$1609+00$ to \\
$1715+00$
\end{tabular} & $\begin{array}{l}\text { Under } \\
\text { Seepage/Pin } \\
\text { Boils } \\
\end{array}$ & $\begin{array}{l}\text { Moderate to } \\
\text { Heavy }\end{array}$ & $\begin{array}{l}\text { Light seepage begins at start across road and in corn field just north of the } \\
\text { Transylvania water tower. Begins approximately } 150 \mathrm{ft} \text { from the toe of levee } \\
\text { and extends into corn field. If there is a berm in this area the seepage is } \\
\text { exiting right at its toe. A bean field starts and judging by the yellow beans } \\
\text { the seepage extends } 300 \mathrm{ft} \text { into beans. There are several small pin boils } \\
\text { noted, but most were barely flowing and the water is nearly standing still. } \\
\text { There is a farmers well flowing into field also few hundred feet from levee. } \\
\text { Near well a corn field starts and small pin boils were noted in corn. }\end{array}$ & $73-77$ \\
\hline 32.66551786 & 91.17585728 & & -- & $1699+00$ & $1699+00$ & Sand Boil & & $\begin{array}{l}\text { Located } 10 \mathrm{ft} \text { from the toe of berm in corn field (berm is } 200 \mathrm{ft} \text { wide). } \\
\text { Material moved is in a } 5.5 \mathrm{ft} \text { diameter circle } 9 \text { in thick. Throat is } \\
\text { approximately } 5 \text { inches. Had not been bagged and was moving small } \\
\text { amount of material. }\end{array}$ & $78-79$ \\
\hline
\end{tabular}




\begin{tabular}{|c|c|c|c|c|c|c|c|c|c|}
\hline \multicolumn{2}{|c|}{ START } & \multicolumn{2}{|c|}{ END } & $\begin{array}{l}\text { STATION } \\
\text { NLD }\end{array}$ & $\begin{array}{c}\text { STATION } \\
\text { FIELD MARKER } \\
\end{array}$ & TYPE & EXTENT & REMARKS & $\begin{array}{l}\text { PHOTO } \\
\text { LINKS }\end{array}$ \\
\hline 32.6563094 & 91.17416831 & 32.65136468 & 91.17574285 & $\begin{array}{l}1740+00 \text { to } \\
1761+00\end{array}$ & $\begin{array}{l}1740+00 \text { to } \\
1761+00\end{array}$ & $\begin{array}{l}\text { Under } \\
\text { Seepage }\end{array}$ & Light & $\begin{array}{l}\text { Starts at toe and extends out } 75 \mathrm{ft} \text {. Seepage is light exiting the toe. At } \\
32.6555281391 .17473541 \text { a seepage berm begins and the seepage starts at } \\
\text { the berm toe and extends } 200 \mathrm{ft} \text { into field. At } 32.652998491 .17722243 \\
\text { seepage moves out } 200 \mathrm{ft} \text { from the toe and extends further back in field. } \\
\text { There is a well located there, but it is too far away to see if it is flowing and } \\
\text { the seepage appears to end on the downstream side of the well. }\end{array}$ & $80-82$ \\
\hline 32.64196456 & 91.17330628 & -- & -- & $1796+00$ & $1796+00$ & $\begin{array}{l}\text { Under } \\
\text { Seepage }\end{array}$ & Light & $\begin{array}{l}\text { Light very localized area starting at the toe only wet on either side of ramp } \\
\text { off levee about } 100 \mathrm{ft} \text { and extends out } 80 \mathrm{ft} \text {. }\end{array}$ & 83 \\
\hline 32.62288426 & 91.16251596 & 32.6015931 & 91.15698392 & $\begin{array}{l}1875+00 \text { to } \\
1957+00\end{array}$ & $\begin{array}{l}1875+00 \text { to } \\
1957+00\end{array}$ & $\begin{array}{l}\text { Under } \\
\text { Seepage }\end{array}$ & $\begin{array}{l}\text { Moderate to } \\
\text { Heavy }\end{array}$ & $\begin{array}{l}\text { Swampy area with water higher than usual. Starts at the berm toe with } \\
\text { some seepage exiting along the slope of the berm just up from the toe. This } \\
\text { area is referred to as "Ice Box Hole". No active boils seen at start. Multiple } \\
\text { boils were located in area. Large boils are listed and discussed below, but } \\
\text { there were additional small boils in the area. }\end{array}$ & 84 \\
\hline 32.61420741 & 91.15876504 & 32.611761 & 91.1589 & $\begin{array}{l}1910+00 \text { to } \\
1919+00\end{array}$ & $\begin{array}{l}1910+00 \text { to } \\
1919+00\end{array}$ & Sand Boil & & $\begin{array}{l}\text { Multiple boils in area known as Ice Box Hole. Boils range in size from throats } \\
\text { less than } 1 \text { in to } 6 \text { in throat. Most have not moved more than } 1 / 2 \mathrm{yd} \text { of } \\
\text { material. Located } 100 \text { to } 200 \mathrm{ft} \text { from the toe of the berm. }\end{array}$ & $85-92$ \\
\hline 32.60263781 & 91.15710544 & -- & -- & $1952+00$ & $1952+00$ & Sand Boil & & $\begin{array}{l}\text { New boil at approximate Sta. } 1952 \text { a the toe of the berm. Is about } 1 \text { mile } \\
\text { south of Ice Box Hole. Has moved } 1 / 2 \text { yd material. }\end{array}$ & 93 \\
\hline 32.6015931 & 91.15698392 & 32.59292666 & 91.14931728 & $\begin{array}{l}1957+00 \text { to } \\
1997+00\end{array}$ & $\begin{array}{l}1957+00 \text { to } \\
1997+00\end{array}$ & $\begin{array}{l}\text { Under } \\
\text { Seepage }\end{array}$ & \begin{tabular}{|l} 
Light to \\
Moderate
\end{tabular} & $\begin{array}{l}\text { Heavy seepage transitions to light to moderate seepage beginning at toe } \\
\text { and extending into woods. At the ending coordinates, there is still some } \\
\text { water in drainage ditch, but seepage seems to end. }\end{array}$ & 94 \\
\hline 32.59730922 & 91.15109972 & 32.59292666 & 91.14931728 & $\begin{array}{l}1979+00 \text { to } \\
1997+00\end{array}$ & $\begin{array}{l}1979+00 \text { to } \\
1997+00\end{array}$ & $\begin{array}{l}\text { Under } \\
\text { Seepage }\end{array}$ & Light & Seepage on berm exiting up to $150 \mathrm{ft}$ from berm toe (50ft from levee toe). & \\
\hline 32.5824478 & 91.14047869 & 32.57116579 & 91.12812061 & $\begin{array}{l}2044+00 \text { to } \\
2100+00\end{array}$ & $\begin{array}{l}2044+00 \text { to } \\
2106+00\end{array}$ & $\begin{array}{l}\text { Under } \\
\text { Seepage/Pin } \\
\text { Boils } \\
\end{array}$ & $\begin{array}{l}\text { Moderate to } \\
\text { Heavy }\end{array}$ & $\begin{array}{l}\text { Begin ditch full of water with boils in ditch. This area is refered to as } \\
\text { Henderson. The ditch is located } 150 \text { ft from toe of levee (this is possibly a } \\
\text { berm, but toe not apparent). Levee board had performed a good bit of } \\
\text { dozer work in area and placed sand bag weirs to help raise the level of the } \\
\text { water over some of the boils. Below are the coordinates and description of } \\
\text { located boils. }\end{array}$ & 95 \\
\hline 32.57881394 & 91.13617654 & 32.572011 & 91.1295694 & $\begin{array}{l}2062+00 \text { to } \\
2095+00\end{array}$ & \begin{tabular}{|l}
$2068+00$ to \\
$2101+00$
\end{tabular} & Sand Boil & & $\begin{array}{l}\text { Numerous boils in ditch near toe of berm. Most of which have moved less } \\
\text { than } 1 \text { yd of material. The maximum amount of material moved is } 3 \text { boils } \\
\text { grouped together which have moved about } 6 \text { yds of material and } \\
\text { correspond to HNO01. Sand bag dams were built in the ditch to get water } \\
\text { over all boils. Most of the boils were still moving small amounts of material } \\
\text { May } 24 \text { when they were inspected for this report. Some of the dams were } \\
\text { raised on May } 28 \text { to get more water over boils. These boils are referred to } \\
\text { as Henderson and some are in and around the borrow area that was used } \\
\text { to raise levee item 464-R. The boils are labeled HNO01 to HNO18. }\end{array}$ & $96-103$ \\
\hline 32.57116579 & 91.12812061 & 32.56415977 & 91.125081 & $\begin{array}{l}2100+00 \text { to } \\
2132+00\end{array}$ & \begin{tabular}{|l}
$2106+00$ to \\
$2138+00$
\end{tabular} & $\begin{array}{l}\text { Under } \\
\text { Seepage }\end{array}$ & \begin{tabular}{|l} 
Light to \\
Moderate
\end{tabular} & $\begin{array}{l}\text { Seepage transitions from heavy/moderate to moderate/light. At end } \\
\text { coordinates, there is still water in ditch, but does not appear to be entering } \\
\text { ditch so looks like it is backup from boils and seepage to north. }\end{array}$ & $104-105$ \\
\hline
\end{tabular}




\begin{tabular}{|c|c|c|c|c|c|c|c|c|c|}
\hline STA & $\begin{array}{l}\text { ART } \\
\text { Longitude }\end{array}$ & Latitude & $\begin{array}{l}\text { ND } \\
\text { Longitude }\end{array}$ & $\begin{array}{l}\text { STATION } \\
\text { NLD }\end{array}$ & $\begin{array}{c}\text { STATION } \\
\text { FIELD MARKER }\end{array}$ & TYPE & EXTENT & REMARKS & $\begin{array}{c}\text { PHOTO } \\
\text { LINKS }\end{array}$ \\
\hline 32.56876328 & 91.12542414 & 32.5657694 & 91.1252 & $2115+00$ to & $\begin{array}{l}2121+00 \text { to } \\
2132+00\end{array}$ & Sand Boil & & $\begin{array}{l}\text { At the beginning coordinates, there is a large boil that has moved a few } \\
\text { yards of material. There is a sand bag spillway constructed } 300 \mathrm{ft} \text { down the } \\
\text { ditch from the boil that could be raised to get more head over boil. } \\
\text { Numerous boils in ditch. Boils are located about } 30 \mathrm{ft} \text { from the berm toe. } \\
\text { Most of these boils have moved less than 1yd of material. Sand bag dams } \\
\text { have been constructed in ditch to get water over boils. }\end{array}$ & $106-108$ \\
\hline 32.56236026 & 91.12448006 & 32.55991924 & 91.12628775 & $\begin{array}{l}2139+00 \text { to } \\
2148+00\end{array}$ & $\begin{array}{l}2145+00 \text { to } \\
2154+00\end{array}$ & $\begin{array}{l}\text { Under } \\
\text { Seepage }\end{array}$ & Light & $\begin{array}{l}\text { Starts about } 200 \mathrm{ft} \text { from toe and extends out a couple hundred feet into } \\
\text { corn field. Seepage ends at the end of the corn field. }\end{array}$ & $109-110$ \\
\hline 32.55047241 & 91.12917484 & 32.54785476 & 91.12970785 & $\begin{array}{l}2183+00 \text { to } \\
2194+00\end{array}$ & $\begin{array}{l}2189+00 \text { to } \\
2200+00\end{array}$ & $\begin{array}{l}\text { Under } \\
\text { Seepage }\end{array}$ & Moderate & $\begin{array}{l}\text { Moderate seepage at toe of berm and extends into field on opposite side of } \\
\text { ditch. There is water flowing out of the field into the ditch. The end } \\
\text { coordinates mark where the seepage ends on the levee side of the ditch, } \\
\text { the opposite side of the ditch could not be gotten to due to thick brush and } \\
\text { water. }\end{array}$ & 111 \\
\hline 32.54221734 & 91.13177965 & 32.54166911 & 91.13200435 & $\begin{array}{l}2214+00 \text { to } \\
2217+00\end{array}$ & $\begin{array}{l}2220+00 \text { to } \\
2223+00\end{array}$ & Sand Boil & & $\begin{array}{l}\text { Multiple sand boils in this reach. Labeled } 461-\mathrm{R}-001 \text { thru } 461-\mathrm{R}-004 \text { and } 461- \\
\mathrm{R}-015 \text { all are fairly small with } 1 \mathrm{yd} \text { of material or less moved. At the time of } \\
\text { the inspection for this report, the water level in the ditch had been } \\
\text { increased by sand bag dams enough that all boils were flowing nearly clear } \\
\text { water. Boils are in ditch at toe of landside berm. }\end{array}$ & $112-115$ \\
\hline 32.54221734 & 91.13177965 & 32.52048873 & 91.13263084 & $\begin{array}{l}2214+00 \text { to } \\
2296+00\end{array}$ & $\begin{array}{l}2220+00 \text { to } \\
2304+00\end{array}$ & $\begin{array}{l}\text { Under } \\
\text { Seepage/Pin } \\
\text { Boils } \\
\end{array}$ & $\begin{array}{l}\text { Moderate to } \\
\text { Heavy }\end{array}$ & $\begin{array}{l}\text { From 461-R } 004 \text { boil the field across from the ditch is damp and has been } \\
\text { for } 200 y d s \text {. Ditch has been bagged where the boils are. There are multiple } \\
\text { boils in ditch and moderate to heavy seepage in field behind ditch as you go } \\
\text { south. The seep water in field is draining into the ditch. }\end{array}$ & \\
\hline 32.53683056 & 91.1316 & 32.53204027 & 91.13121395 & $\begin{array}{l}2233+50 \text { to } \\
2251+00\end{array}$ & $\begin{array}{l}2239+00 \text { to } \\
2257+00\end{array}$ & Sand Boil & & $\begin{array}{l}\text { Numerous sand boils in this area. Are referred to as } 461-\mathrm{R} \text { boils. There is a } \\
\text { gap between other } 461-\mathrm{R} \text { boils and these. The boils here are located in ditch } \\
\text { near landside toe } 30 \text { to } 40 \mathrm{ft} \text { from the toe of the berm. Most of them have } \\
\text { moved less than } 1 \mathrm{yd} \text { of material. }\end{array}$ & $\mid 116-121$ \\
\hline 32.5026427 & 91.12946686 & 32.50170596 & 91.12936597 & $\begin{array}{l}2360+00 \text { to } \\
2364+00\end{array}$ & $\begin{array}{l}2366+00 \text { to } \\
2370+00\end{array}$ & $\begin{array}{l}\text { Under } \\
\text { Seepage }\end{array}$ & Light & Seepage begins at toe and extends out. & 122 \\
\hline 32.48153915 & 91.12422098 & 32.47523481 & 91.12069106 & $\begin{array}{l}2440+00 \text { to } \\
2465+00\end{array}$ & $\begin{array}{l}2445+00 \text { to } \\
2470+00\end{array}$ & $\begin{array}{l}\text { Under } \\
\text { Seepage }\end{array}$ & Light & Light seepage confined to ditch at berm toe. & 123 \\
\hline 32.47523481 & 91.12069162 & -- & -- & $2465+00$ & $2470+00$ & Sand Boil & & $\begin{array}{l}\text { 457R-001 - small boil in ditch between toe and stone road that runs along } \\
\text { end of field just below the Madison Port Road. }\end{array}$ & 124 \\
\hline 32.47523481 & 91.12069106 & 32.4654505 & 91.1131995 & $\begin{array}{l}2465+00 \text { to } \\
2507+00\end{array}$ & $\begin{array}{l}2470+00 \text { to } \\
2512+00\end{array}$ & $\begin{array}{l}\text { Under } \\
\text { Seepage }\end{array}$ & \begin{tabular}{|l} 
Light to \\
Moderate
\end{tabular} & $\begin{array}{l}\text { Seepage starts at toe, } 10 \mathrm{ft} \text { goes into full ditch and light wet area in soybean } \\
\text { field } 100 \mathrm{ft} \text { from the berm toe. Seepage is light to moderate with the } \\
\text { exception of boil in ditch. }\end{array}$ & 125 \\
\hline 32.4654505 & 91.1131995 & 32.45725747 & 91.10619601 & $\begin{array}{l}2507+00 \text { to } \\
2545+00\end{array}$ & $\begin{array}{l}2512+00 \text { to } \\
2550+00\end{array}$ & $\begin{array}{l}\text { Under } \\
\text { Seepage }\end{array}$ & \begin{tabular}{|l} 
Light to \\
Moderate
\end{tabular} & Seepage is visible in plowed field $2000 \mathrm{ft}$ from toe. Seepage begins at toe. & 126 \\
\hline 32.45725747 & 91.10619601 & 32.45082803 & 91.1021291 & $\begin{array}{l}2545+00 \text { to } \\
2570+00\end{array}$ & $\begin{array}{l}2550+00 \text { to } \\
2575+00\end{array}$ & $\begin{array}{l}\text { Under } \\
\text { Seepage/Pin } \\
\text { Boils }\end{array}$ & Heavy & Multiple pin boils are located $20 \mathrm{ft}$ from the berm toe. & 127 \\
\hline 32.45082803 & 91.1021291 & 32.4386704 & 91.08098587 & $\begin{array}{l}2570+00 \text { to } \\
2648+00\end{array}$ & $\begin{array}{l}2575+00 \text { to } \\
2653+00\end{array}$ & $\begin{array}{l}\text { Under } \\
\text { Seepage }\end{array}$ & \begin{tabular}{|l} 
Light to \\
Moderate
\end{tabular} & $\begin{array}{l}\text { Light to moderate seepage continues in field beginning at the toe of the } \\
\text { berm. With the exception of the few large boils noted below, no pin boils } \\
\text { are noted in this reach. }\end{array}$ & 128 \\
\hline 32.44968056 & 91.1035611 & -- & -- & $2570+00$ & $2575+00$ & Sand Boil & & $\begin{array}{l}\text { TK001 site. } 8 \text { Boils have been found in ditch approximately } 400 \mathrm{ft} \text { from the } \\
\text { landside berm toe. Each have moved } 0.5 \text { to } 1 \mathrm{yd} \text { of material. Sand bag dams } \\
\text { were constructed to get water over the top of the boils. Sand cone } \\
\text { diameters are } 5 \mathrm{ft} \text { or less. }\end{array}$ & $129-132$ \\
\hline
\end{tabular}




\begin{tabular}{|c|c|c|c|c|c|c|c|c|c|}
\hline STA & ART & EN & ND & STATION & STATION & TYPE & EXTENT & REMARKS & РНOTO \\
\hline Latitude & Longitude & Latitude & Longitude & NLD & FIELD MARKER & & & & LINKS \\
\hline 32.449189 & 91.099711 & - & -- & $2579+00$ & $2584+00$ & Sand Boil & & $\begin{array}{l}\text { TK002 Site. New boil was found May } 25 \text {. Located approximately } 50 \mathrm{ft} \text { from } \\
\text { toe of landside berm in bean field. } 1.25 y d \text { of material has been moved. Boil } \\
\text { has an approximate } 5 \text { inch throat and the sand material is } 20 \mathrm{ft} \text { diameter but } \\
\text { not deep. }\end{array}$ & 133 \\
\hline 32.4386704 & 91.08098587 & 32.43624216 & 91.07560167 & $\begin{array}{l}2648+00 \text { to } \\
2673+00\end{array}$ & $\begin{array}{l}2653+00 \text { to } \\
2678+00\end{array}$ & $\begin{array}{l}\text { Under } \\
\text { Seepage }\end{array}$ & Light & $\begin{array}{l}\text { Lake begins. Light seepage had continued extending far into field. Seepage } \\
\text { was light to moderate. Light seepage continues along the lake. }\end{array}$ & \\
\hline 32.43460846 & 91.07472202 & 32.4241 & 91.03518056 & $\begin{array}{l}2676+00 \text { to } \\
2810+00\end{array}$ & $\begin{array}{l}2681+00 \text { to } \\
2815+00\end{array}$ & $\begin{array}{l}\text { Under } \\
\text { Seepage }\end{array}$ & $\begin{array}{l}\text { Moderate to } \\
\text { Heavy }\end{array}$ & $\begin{array}{l}\text { Light seepage beginning at berm toe and extending into woods at start. } \\
\text { Transitions to moderate to heavy seepage with sand boils and ends just } \\
\text { past the last boil. }\end{array}$ & 134 \\
\hline 32.4243611 & 91.0352389 & 32.4241 & 91.03518056 & $\begin{array}{l}2807+00 \text { to } \\
2810+00\end{array}$ & $\begin{array}{l}2812+00 \text { to } \\
2815+00\end{array}$ & Sand Boil & & $\begin{array}{l}\text { Boils located at each coordinate. Labeled } 450 \mathrm{R}-001 \text { and } 450 \mathrm{R}-002 . \text { These } \\
\text { boils are in ditch that goes away from the levee. Closest one is } 300+\mathrm{ft} \text { from } \\
\text { toe of levee. They have moved some small amount of clay but looks like } \\
\text { they are mostly clear or just moving sand/silt now. }\end{array}$ & $\mid 135-137$ \\
\hline 32.42970688 & 91.06092847 & 32.42585977 & 91.05025334 & $\begin{array}{l}2723+00 \text { to } \\
2758+00\end{array}$ & $\begin{array}{l}2728+00 \text { to } \\
2763+00\end{array}$ & $\begin{array}{l}\text { Under } \\
\text { Seepage }\end{array}$ & Light & $\begin{array}{l}\text { Seepage exiting berm crown all the way back to the levee tie-in. Standing } \\
\text { water is present along most of the berm. Note: for the most part, there are } \\
\text { many small areas } 100 f t \text { long or less that has seepage exiting on the crown of } \\
\text { an apparent berm. }\end{array}$ & 138 \\
\hline 32.42067479 & 91.0296141 & 32.41959217 & 91.02806991 & $\begin{array}{l}2829+00 \text { to } \\
2836+00\end{array}$ & $\begin{array}{l}2834+00 \text { to } \\
2841+00\end{array}$ & $\begin{array}{l}\text { Under } \\
\text { Seepage }\end{array}$ & Light & $\begin{array}{l}\text { If there is a berm here, there is seepage on the crown } 75 \mathrm{ft} \text { from the levee } \\
\text { tie-in. }\end{array}$ & 139 \\
\hline 32.42067479 & 91.0296141 & 32.41641899 & 91.02300178 & $\begin{array}{l}2829+00 \text { to } \\
2854+00\end{array}$ & $\begin{array}{l}2834+00 \text { to } \\
2859+00\end{array}$ & $\begin{array}{l}\text { Under } \\
\text { Seepage }\end{array}$ & \begin{tabular}{|l|l|} 
Light to \\
Moderate
\end{tabular} & $\begin{array}{l}\text { Seepage is located across ditch from toe. Light to moderate amount. Ditch } \\
\text { is just off of levee toe. }\end{array}$ & $\mid 140-141$ \\
\hline 32.41309121 & 91.01989135 & 32.41123311 & 91.01945368 & $\begin{array}{l}2872+50 \text { to } \\
2878+50\end{array}$ & $\begin{array}{l}2877+00 \text { to } \\
2883+00\end{array}$ & $\begin{array}{l}\text { Under } \\
\text { Seepage }\end{array}$ & Light & $\begin{array}{l}\text { Light seepage in corn field off berm toe. Does not appear to extend into } \\
\text { corn field very far as corn is not yellow only first couple of rows nearest toe } \\
\text { are yellow. Also, the actual toe is very dry, could be irrigation. }\end{array}$ & 142 \\
\hline 32.40736478 & 91.01983327 & -- & -- & $\begin{array}{l}2897+00 \text { to } \\
2900+00\end{array}$ & $\begin{array}{l}2902+00 \text { to } \\
2905+00\end{array}$ & $\begin{array}{l}\text { Under } \\
\text { Seepage }\end{array}$ & Light & $\begin{array}{l}\text { Very localized area of seepage extends out approximately } 100 \mathrm{ft} \text { beginning } \\
\text { at toe. Goes approximately } 300 \mathrm{ft} \text { parallel to levee. }\end{array}$ & $\mid 143-144$ \\
\hline 32.40269424 & 91.02545613 & - & -- & $2920+00$ & $2924+00$ & & & $\begin{array}{l}\text { There is some water in the ditch on either side of road, but the field and toe } \\
\text { are both dry. After a couple hundred yards, both of the ditches are dry. } \\
\text { Road is located just off of the toe. }\end{array}$ & 145 \\
\hline 32.39499856 & 91.030726 & 32.39303714 & 91.03140463 & $\begin{array}{l}2953+00 \text { to } \\
2960+00\end{array}$ & $\begin{array}{l}2957+00 \text { to } \\
2964+00\end{array}$ & $\begin{array}{l}\text { Under } \\
\text { Seepage }\end{array}$ & Light & $\begin{array}{l}\text { Starts in the ditch at the toe and there are a few sporadic wet spots in the } \\
\text { bean field across the road. }\end{array}$ & 146 \\
\hline 32.39303714 & 91.03140463 & 32.38445859 & 91.03290175 & $\begin{array}{l}2960+00 \text { to } \\
2992+00\end{array}$ & $\begin{array}{l}2964+00 \text { to } \\
2996+00\end{array}$ & $\begin{array}{l}\text { Under } \\
\text { Seepage }\end{array}$ & \begin{tabular}{|l} 
Light to \\
Moderate
\end{tabular} & $\begin{array}{l}\text { Transitions to light to moderate seepage. Seepage starts across the road in } \\
\text { bean field } 100 \mathrm{ft} \text { from a small berm toe. About } 600 \mathrm{ft} \text { downstream the } \\
\text { seepage begins entering right at the toe of the berm. The road veers away } \\
\text { from the toe and there is a bean field on both sides of the road. }\end{array}$ & 147 \\
\hline 32.37798249 & 91.02962556 & 32.35362296 & 91.01399214 & $\begin{array}{l}3016+00 \text { to } \\
3115+00\end{array}$ & $\begin{array}{l}3020+00 \text { to } \\
3119+00\end{array}$ & $\begin{array}{l}\text { Under } \\
\text { Seepage }\end{array}$ & Light & $\begin{array}{l}\text { Begins at the toe and extends out } 250 \mathrm{ft} \text {. Standing water in field rows. There } \\
\text { does not appear to be any seepage withing } 300 \mathrm{ft} \text { of the levee just past the } \\
\text { boils at the Mound Airport. }\end{array}$ & 148 \\
\hline 32.35173056 & 91.018461 & -- & -- & $3110+00$ & $3114+00$ & Sand Boil & & $\begin{array}{l}\text { Multiple boils located in ditch near bridge leading to airport. Boils are } \\
\text { labeled AR001 - AR005. Boils are a couple hundred ft from toe and are all in } \\
\text { canal/ditch near bridge. 1yd or less of material moved by each boil. }\end{array}$ & $149-151$ \\
\hline 32.32868765 & 90.9535482 & 32.33022931 & 90.9269582 & $\begin{array}{l}3328+00 \text { to } \\
3409+00\end{array}$ & $\begin{array}{l}3332+00 \text { to } \\
3413+00\end{array}$ & $\begin{array}{l}\text { Under } \\
\text { Seepage }\end{array}$ & \begin{tabular}{|l|} 
Light to \\
Moderate
\end{tabular} & Begins at the toe of the berm and extends into the corn field. & \\
\hline
\end{tabular}



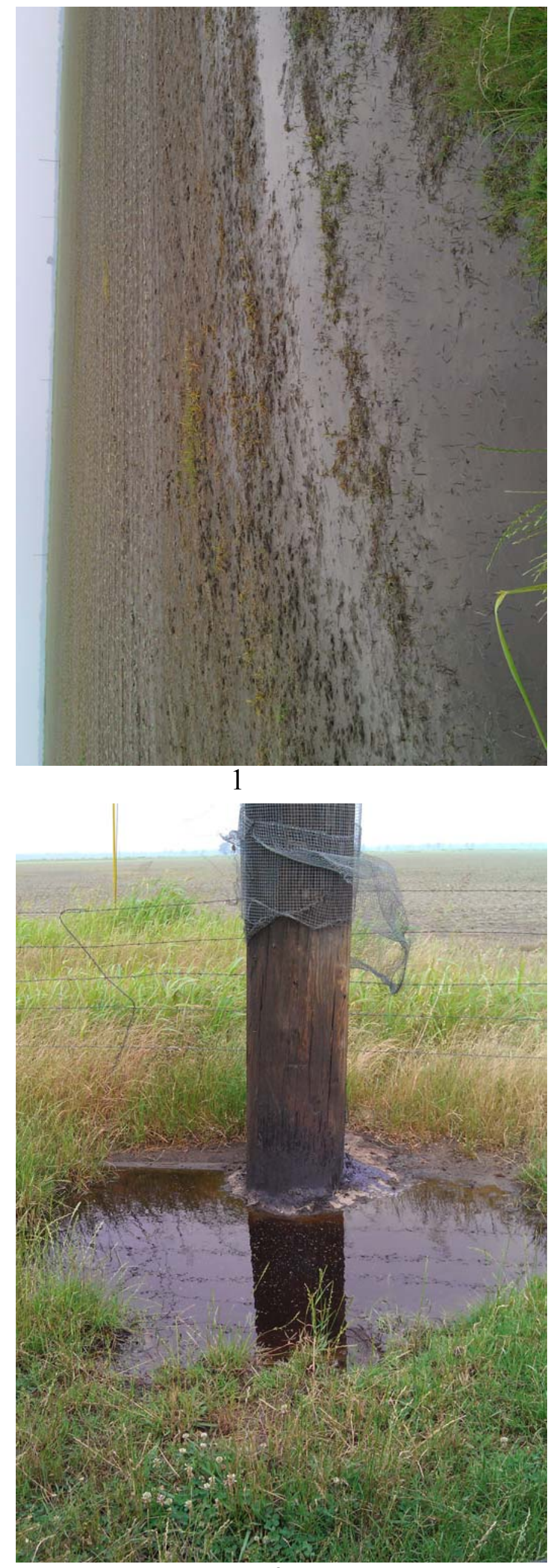

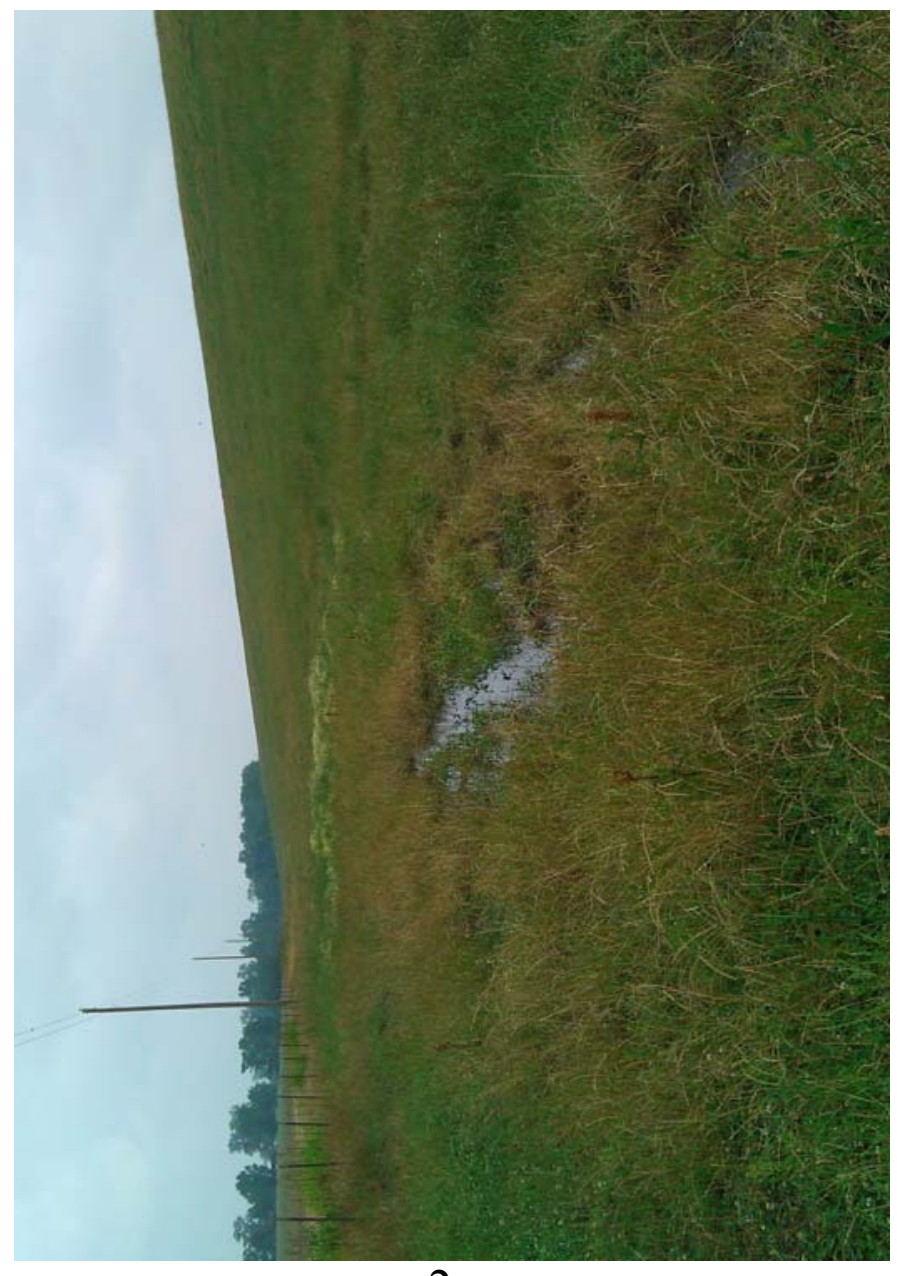

2

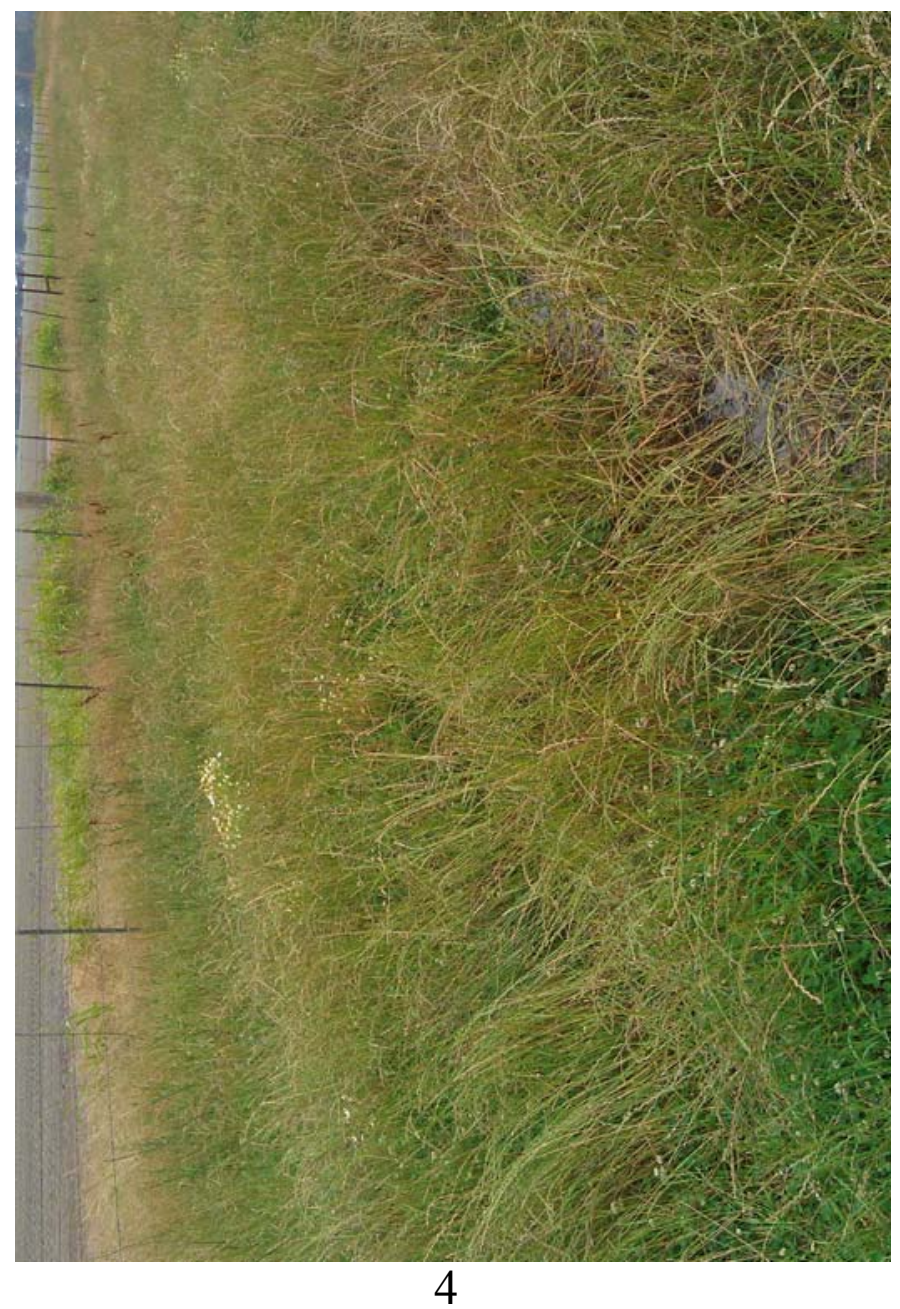

FOR OFFICIAL USE ONLY 


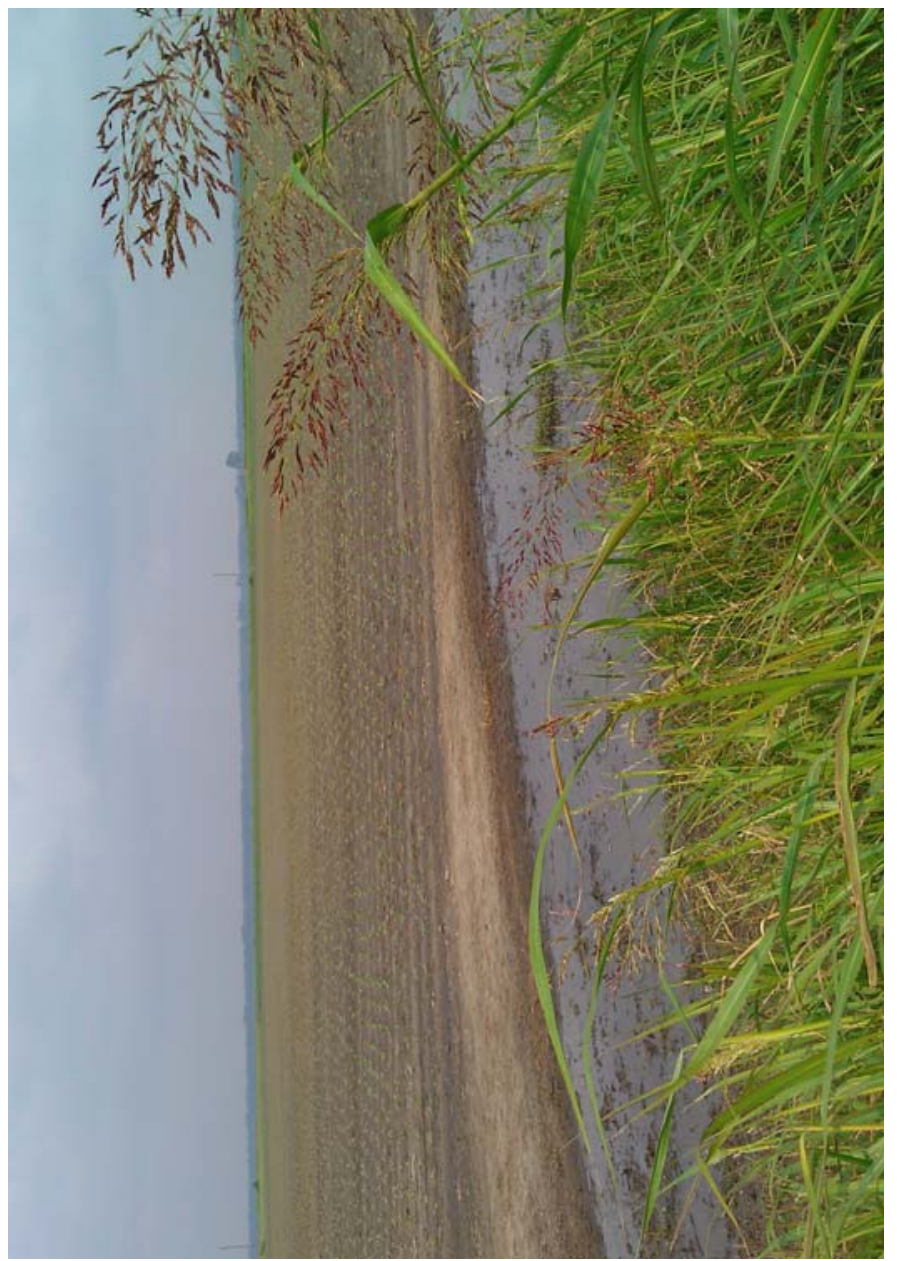

5

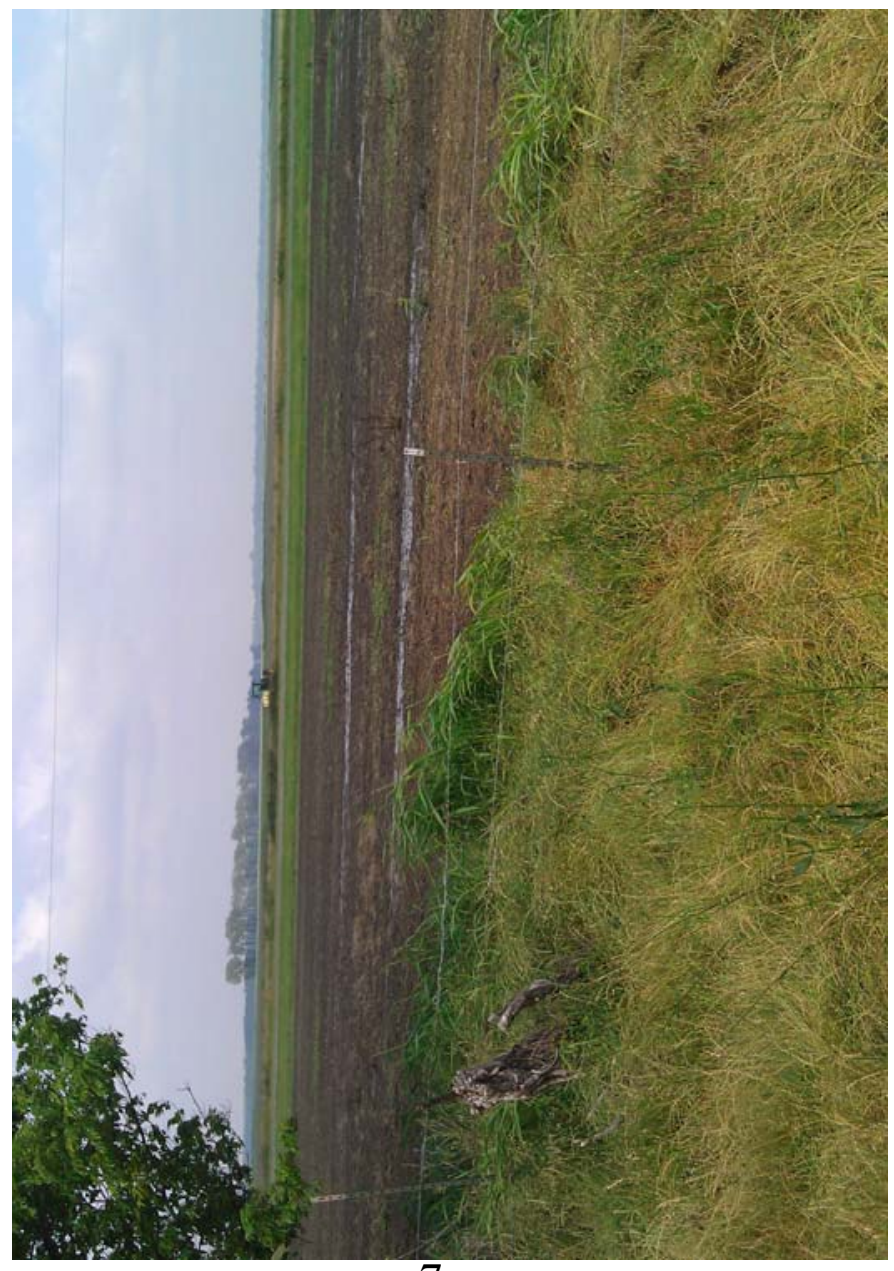

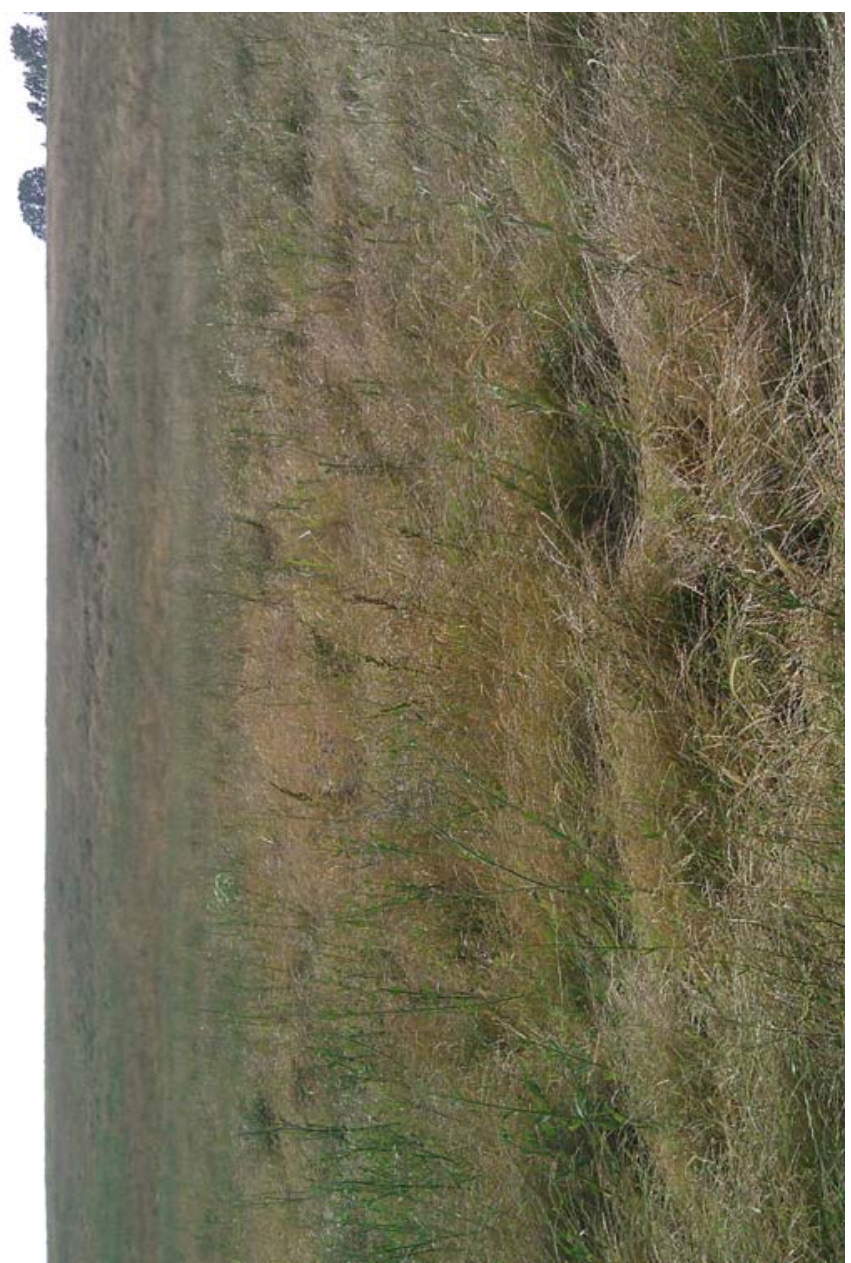

6

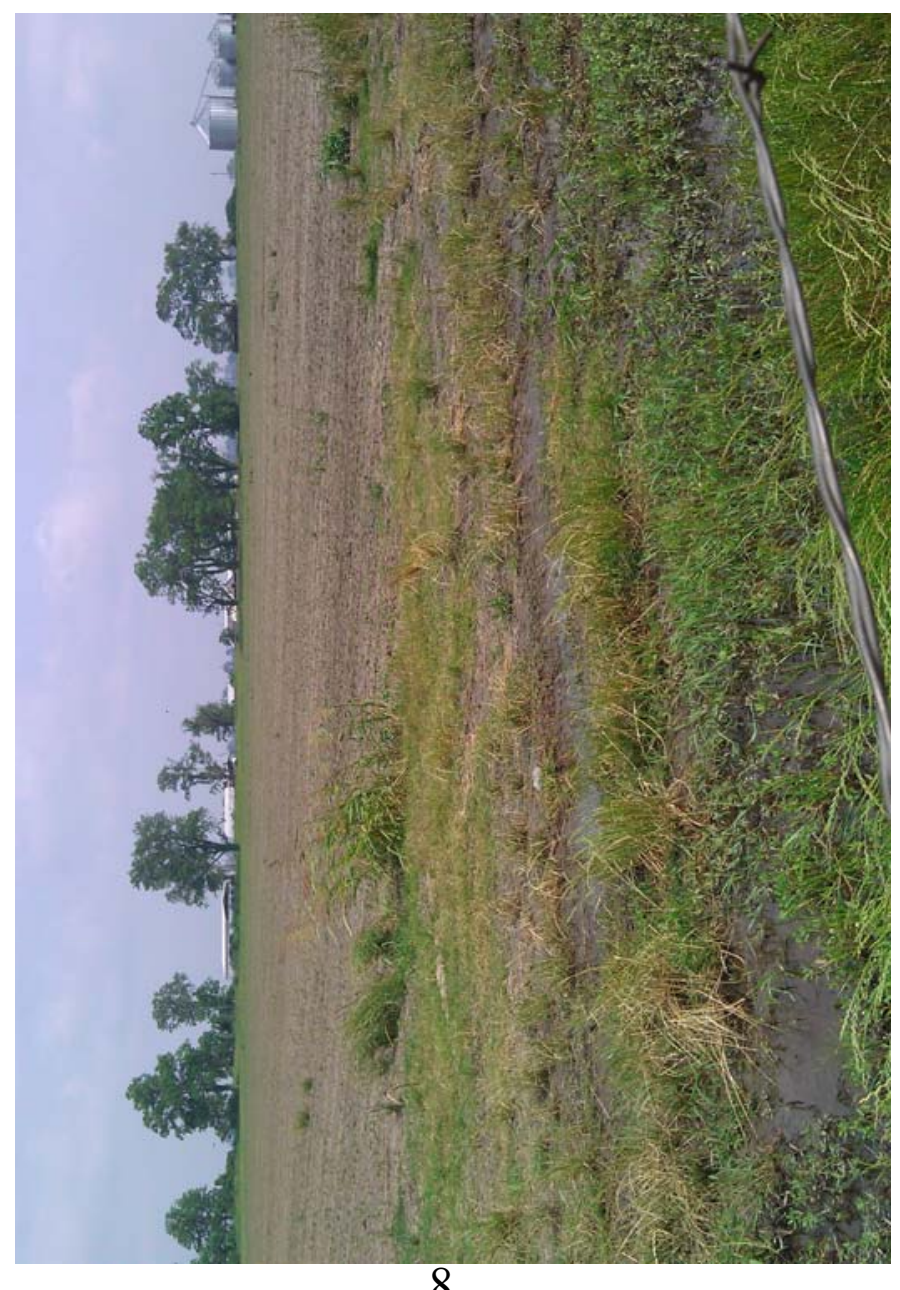

FOR OFFICIAL USE ONLY 


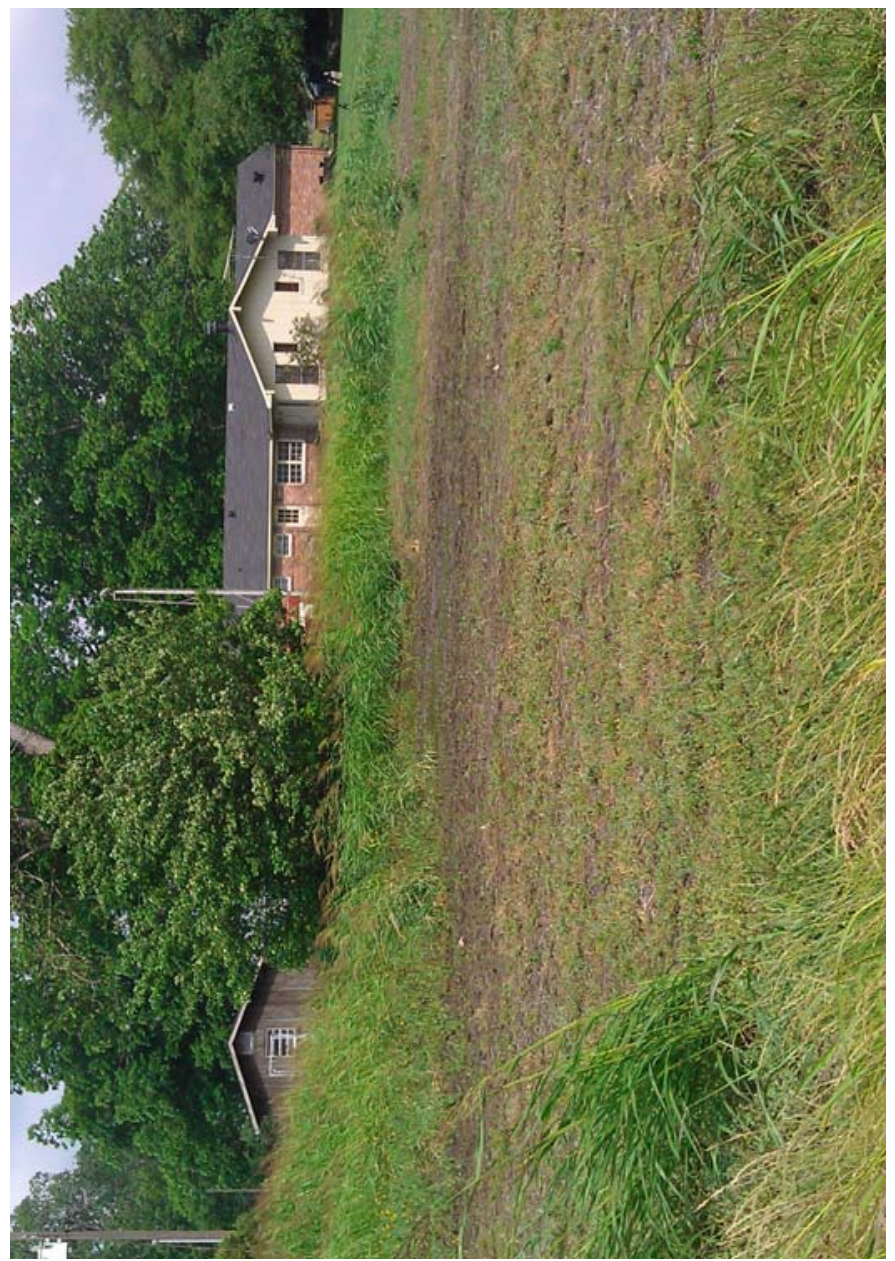

9

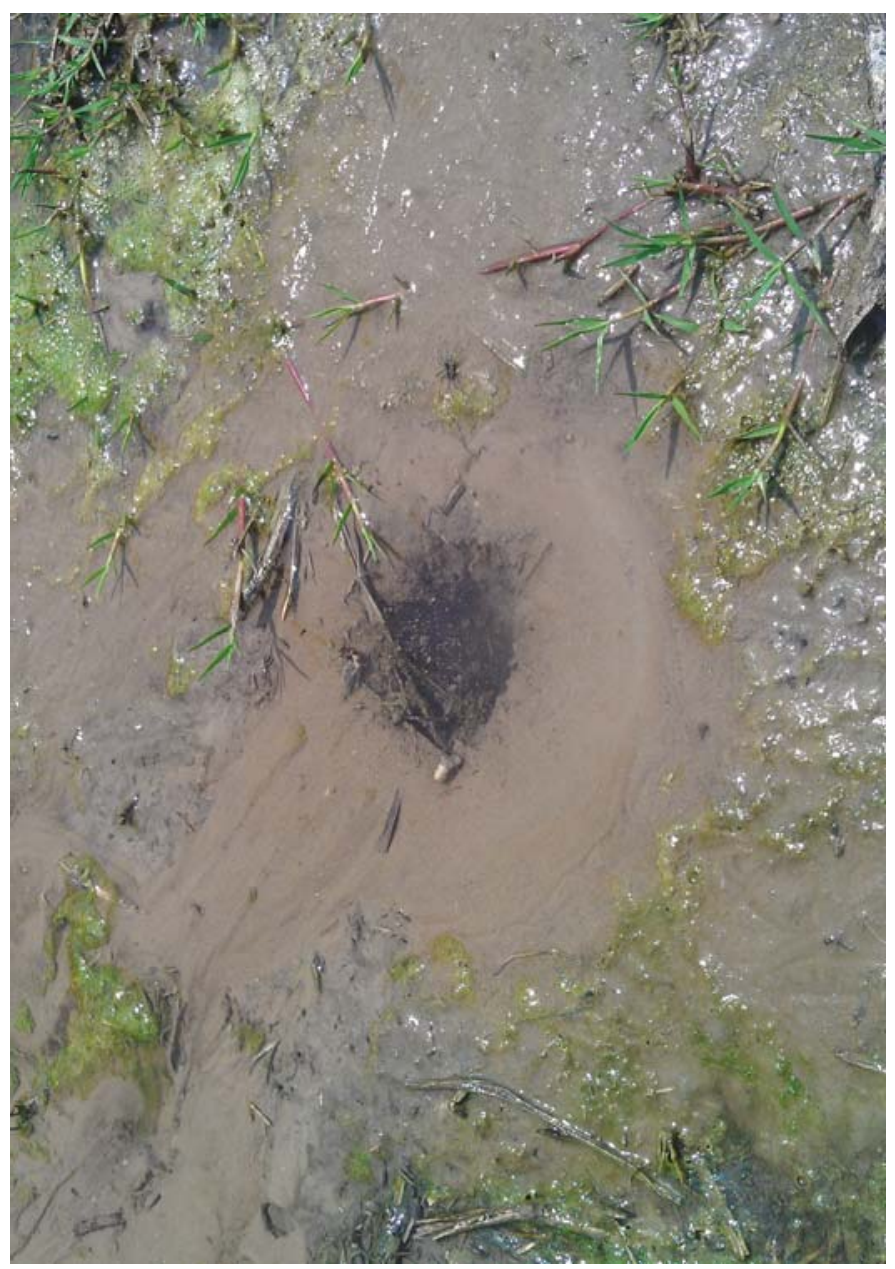

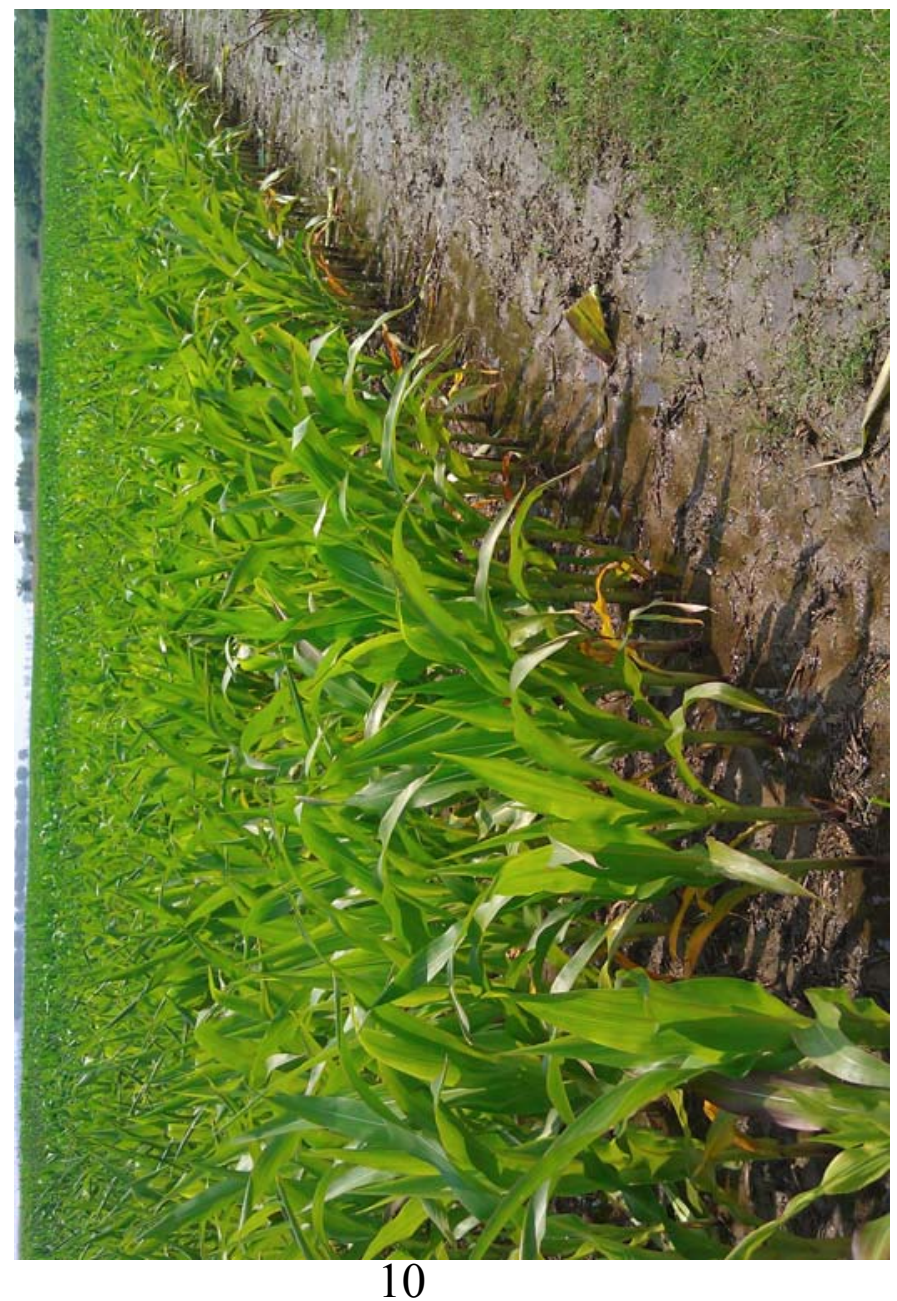

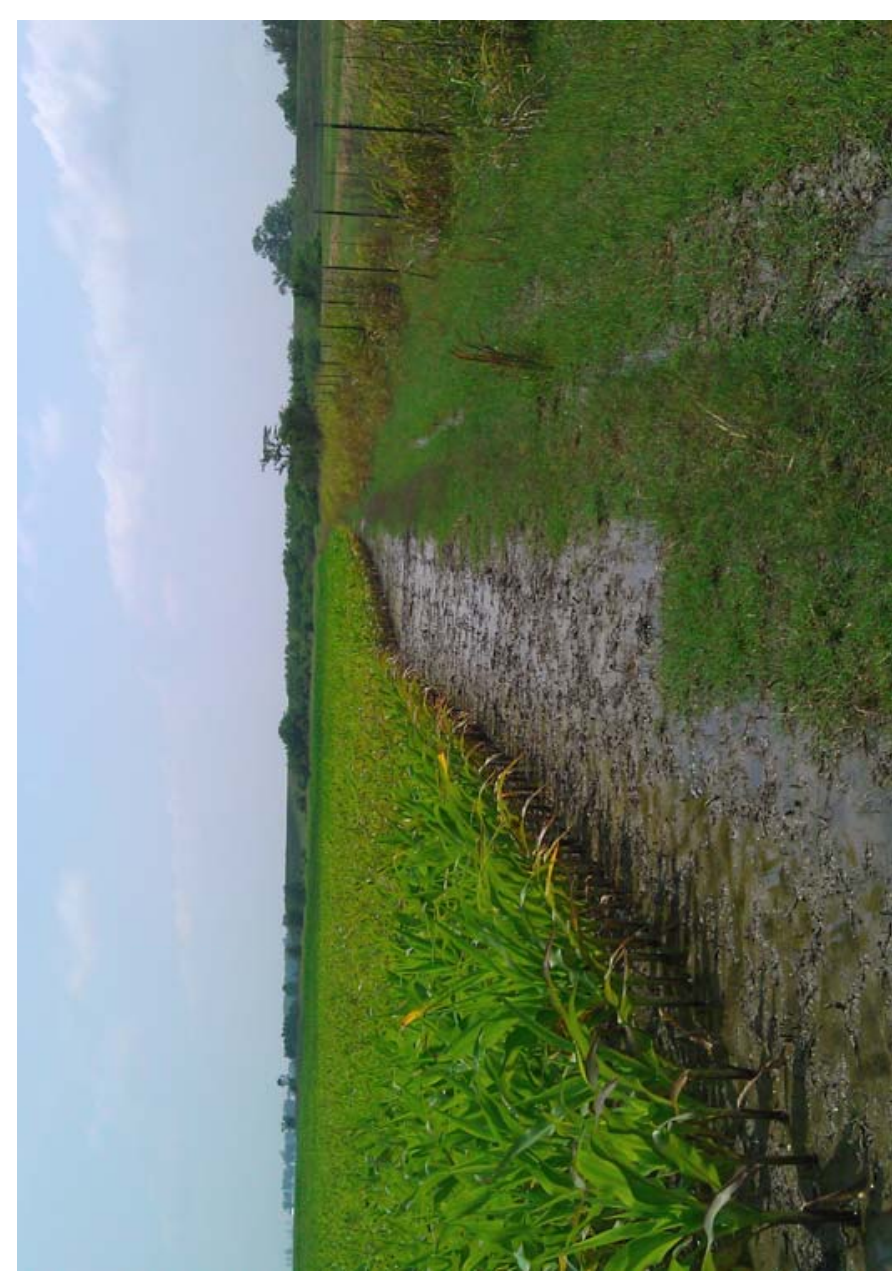




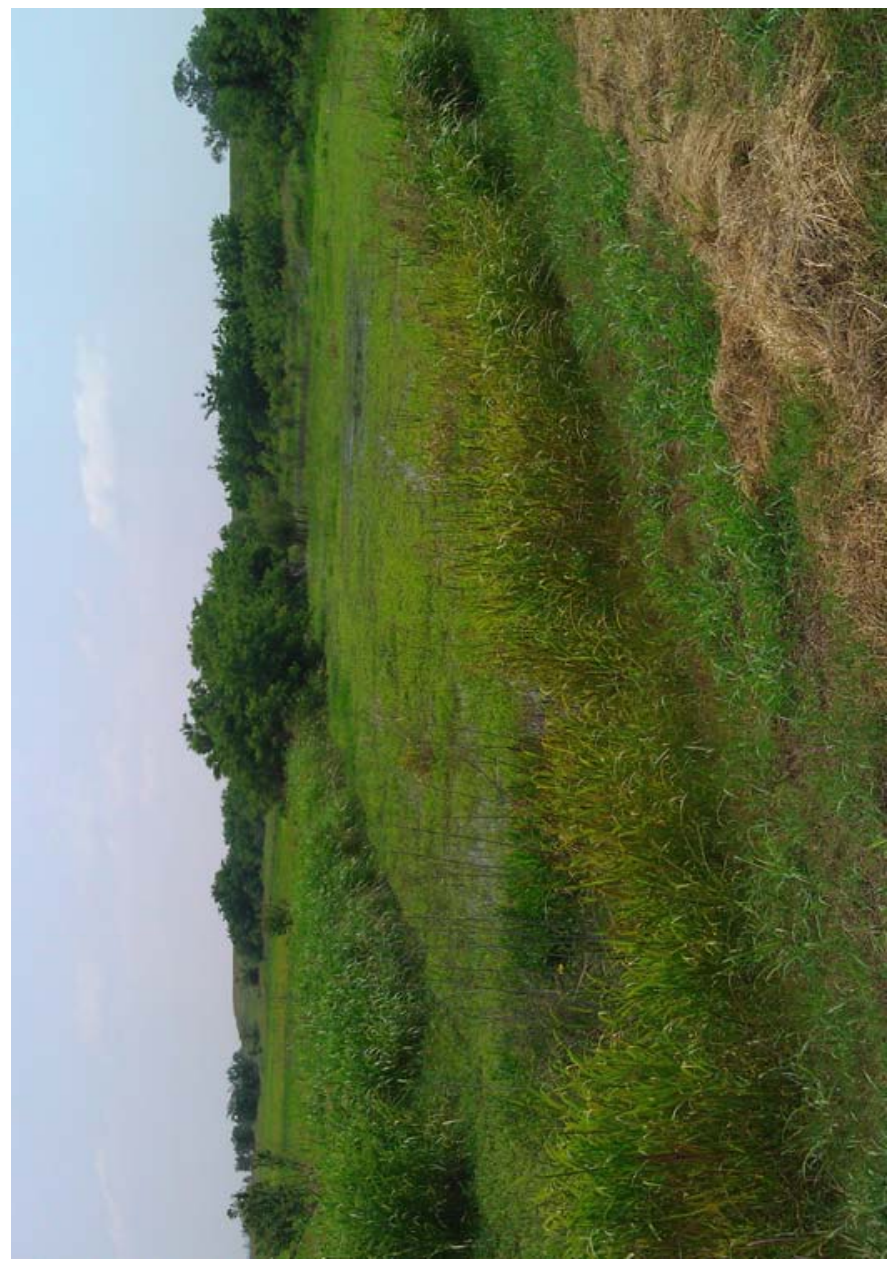

13

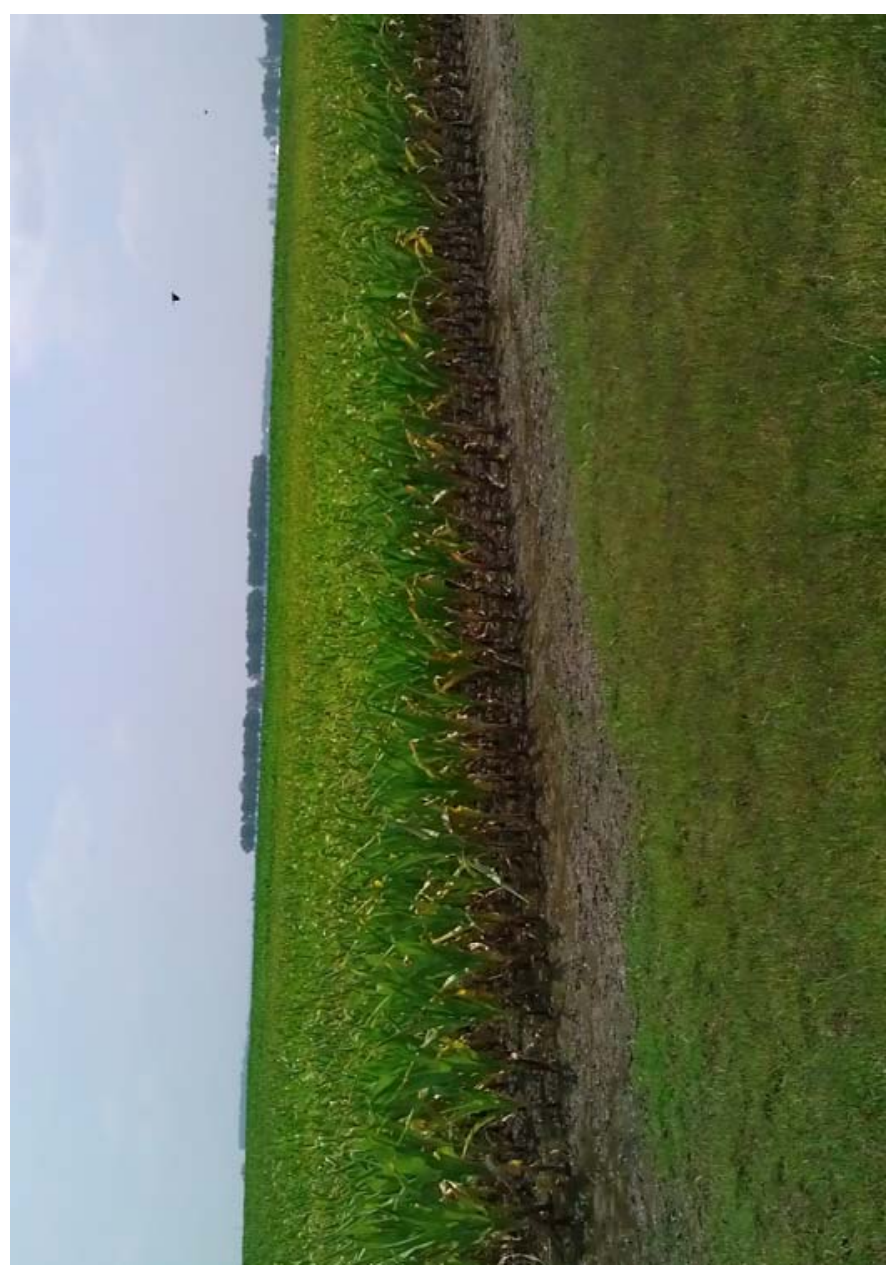

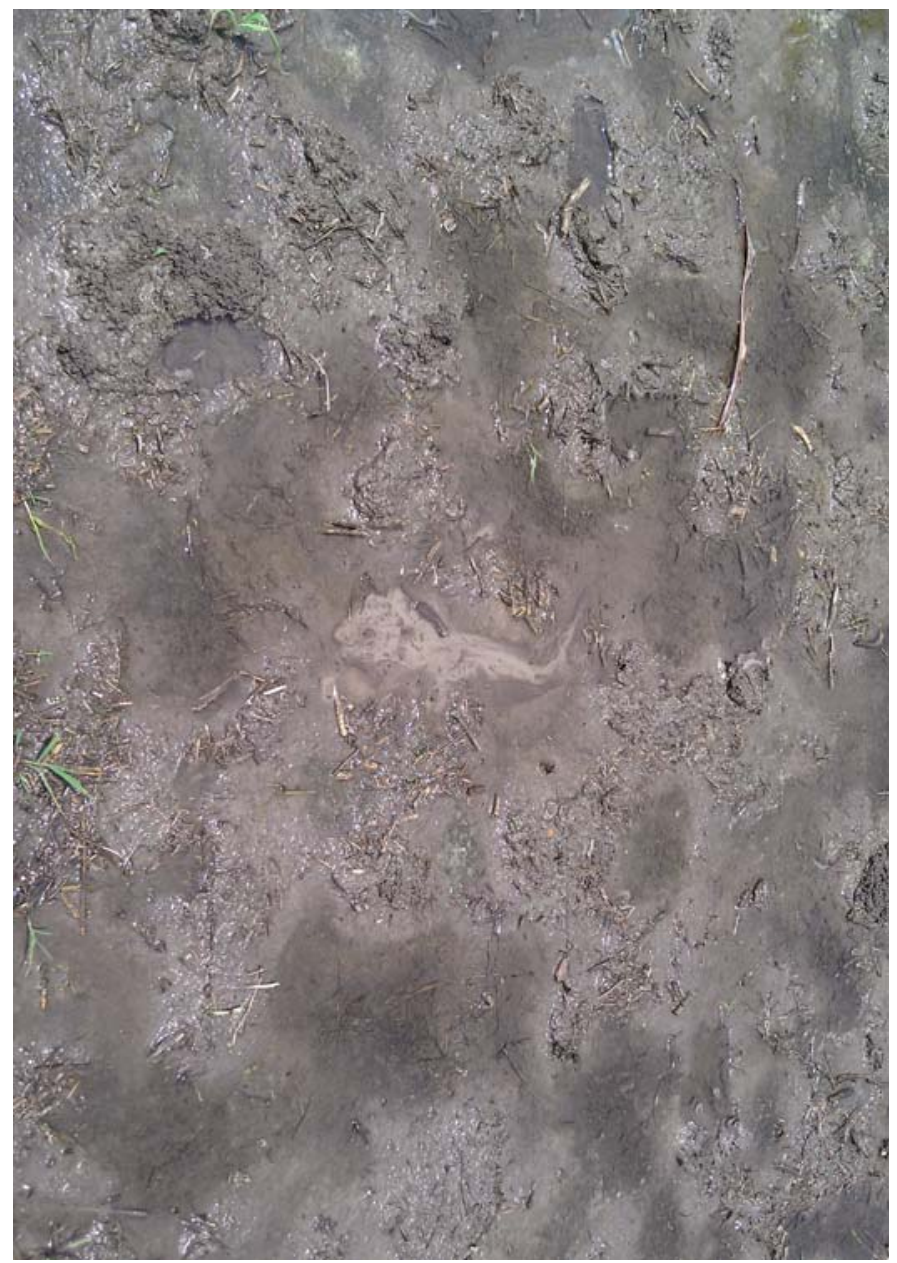

14

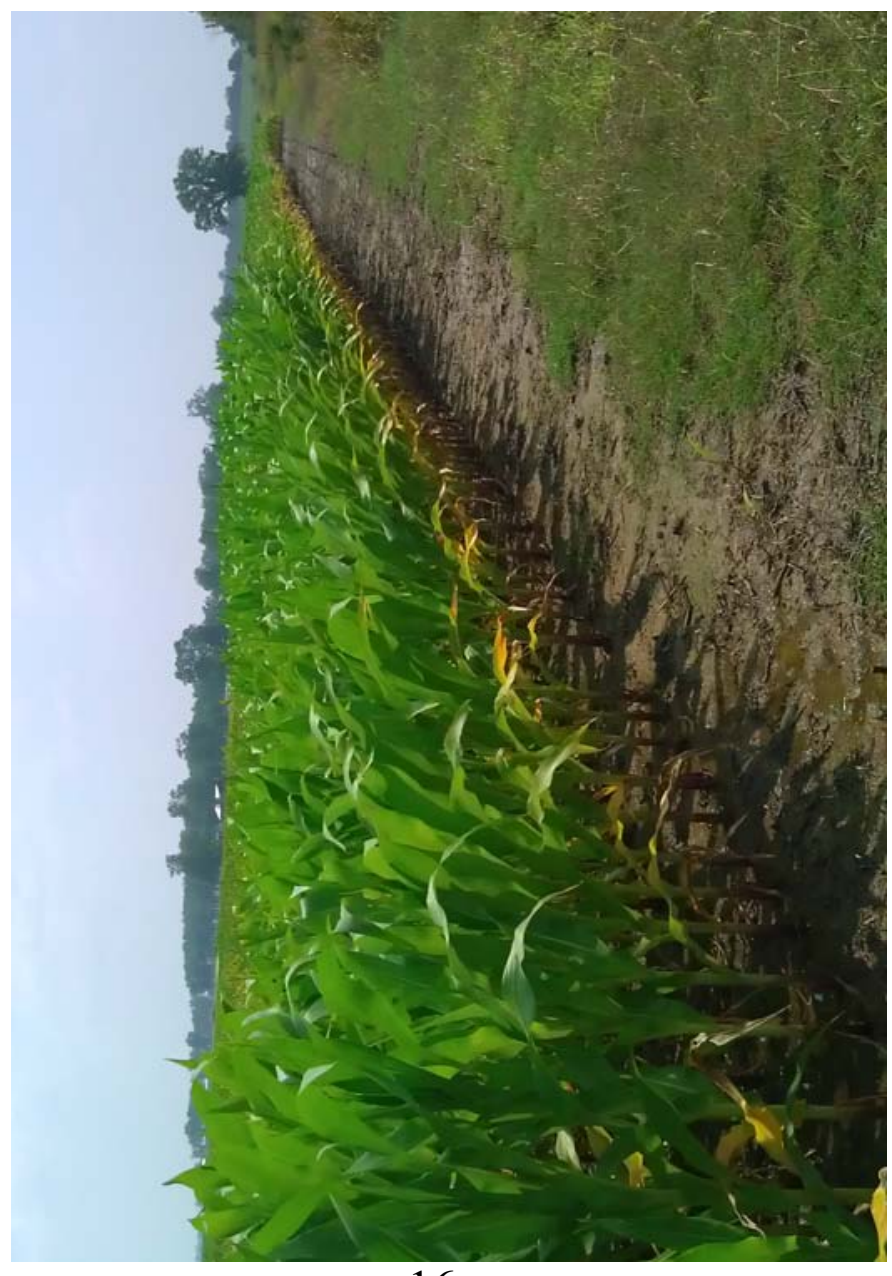

16 


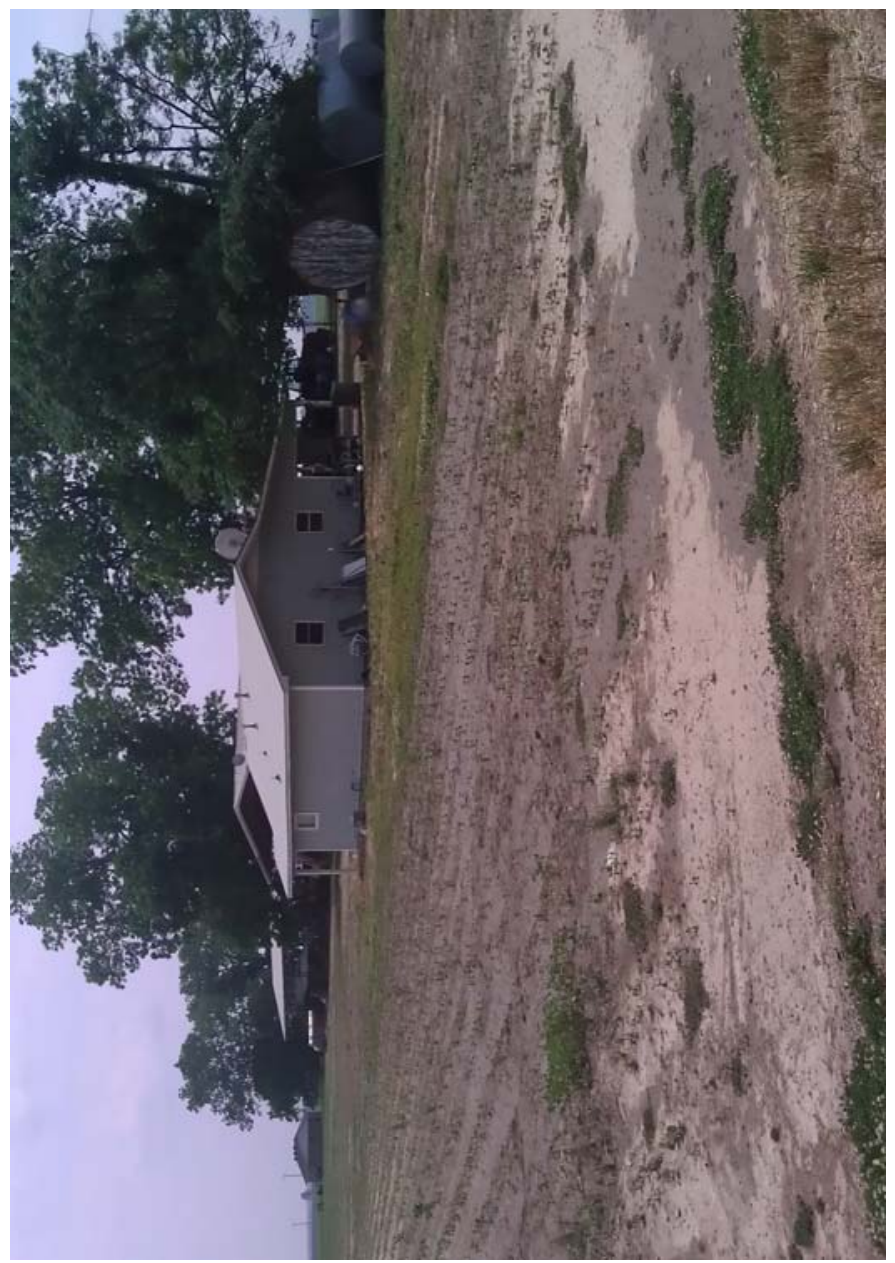

17

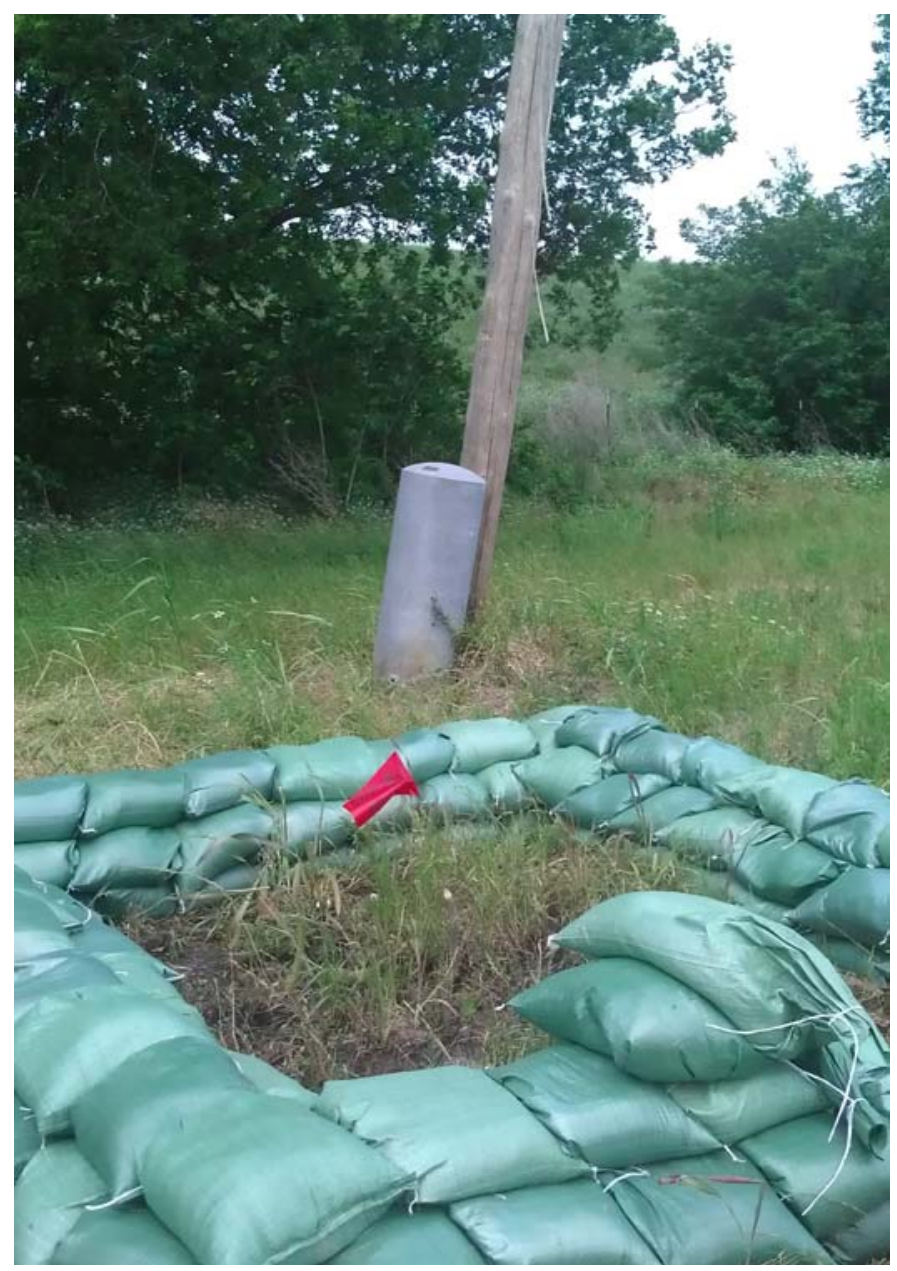

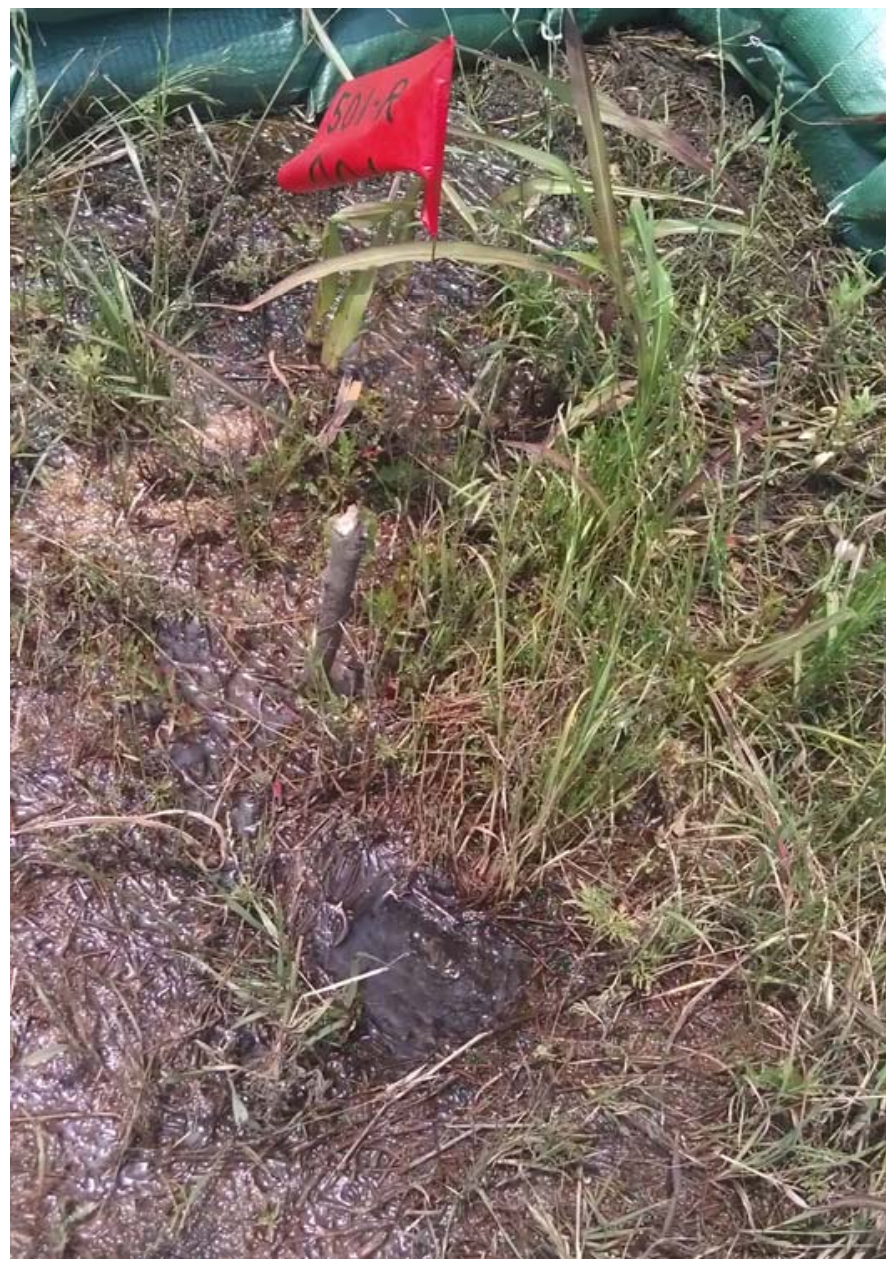

18

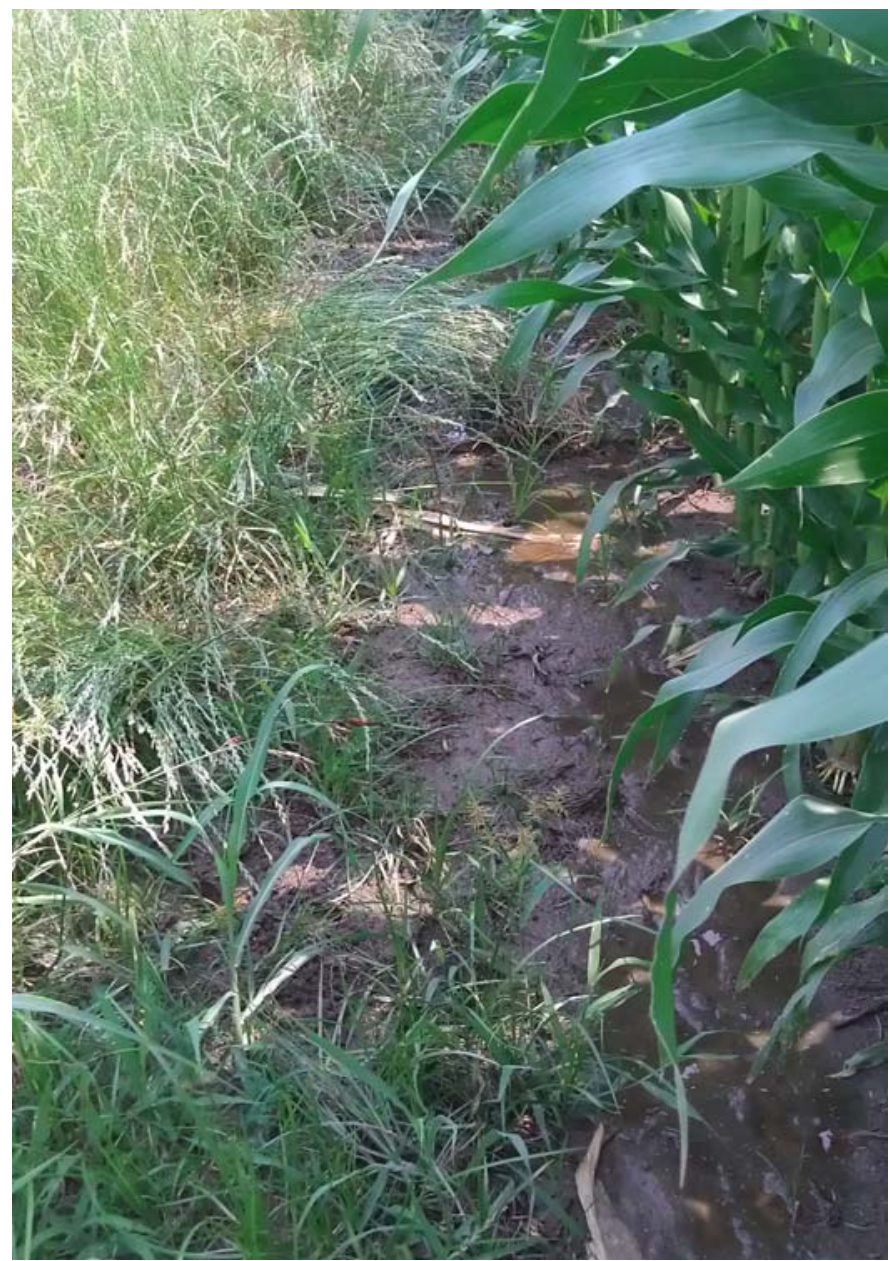




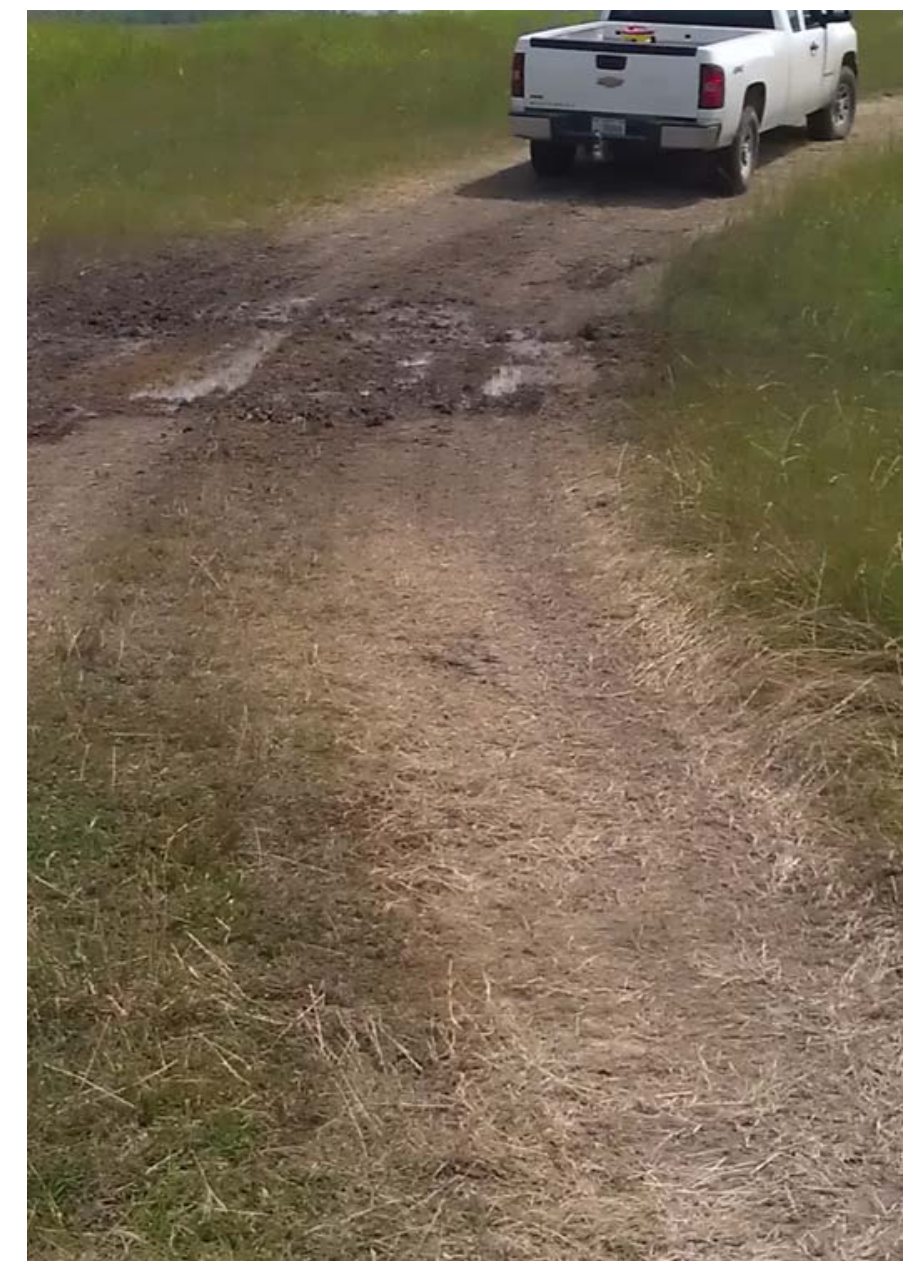

21

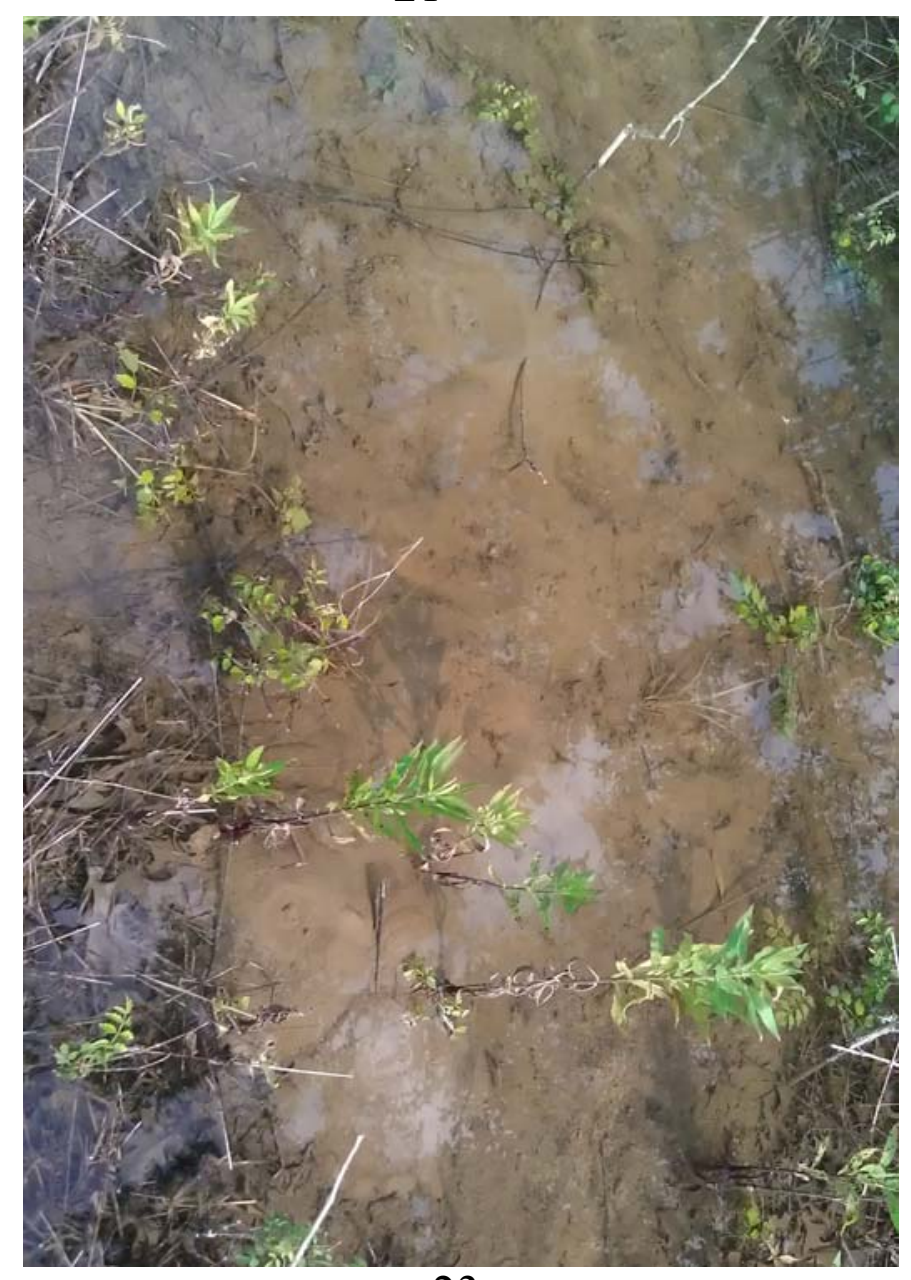

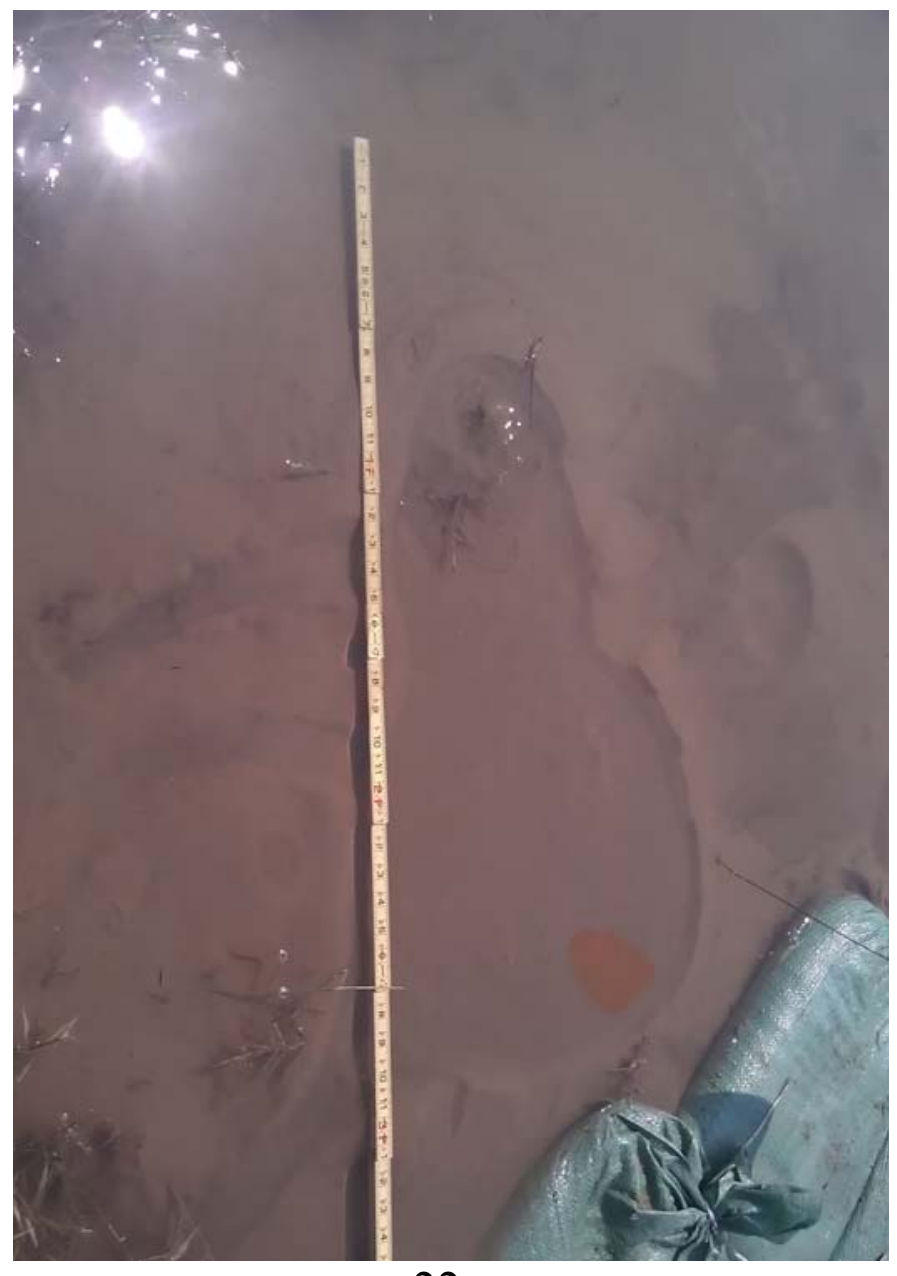

22

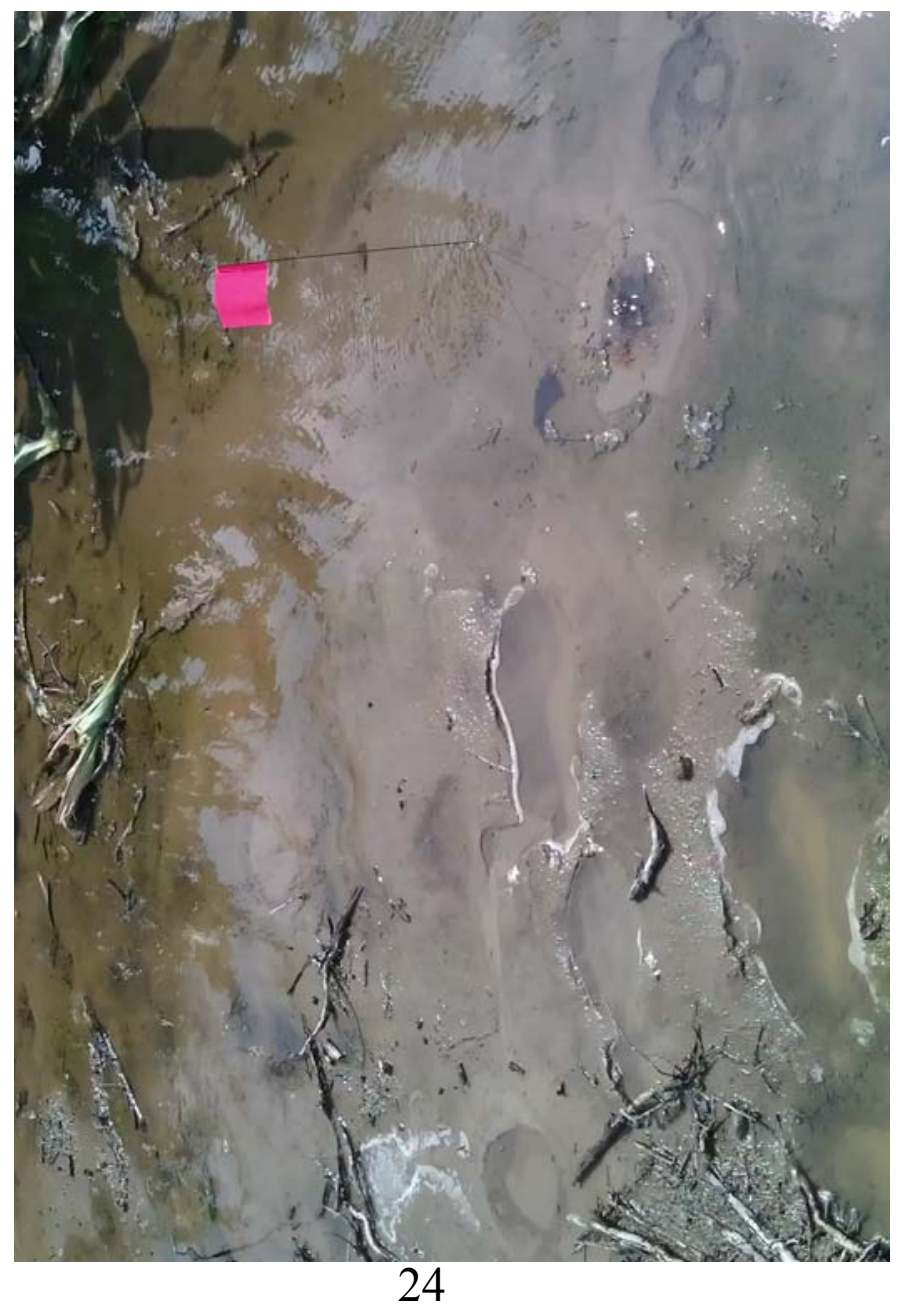

FOR OFFICIAL USE ONLY 


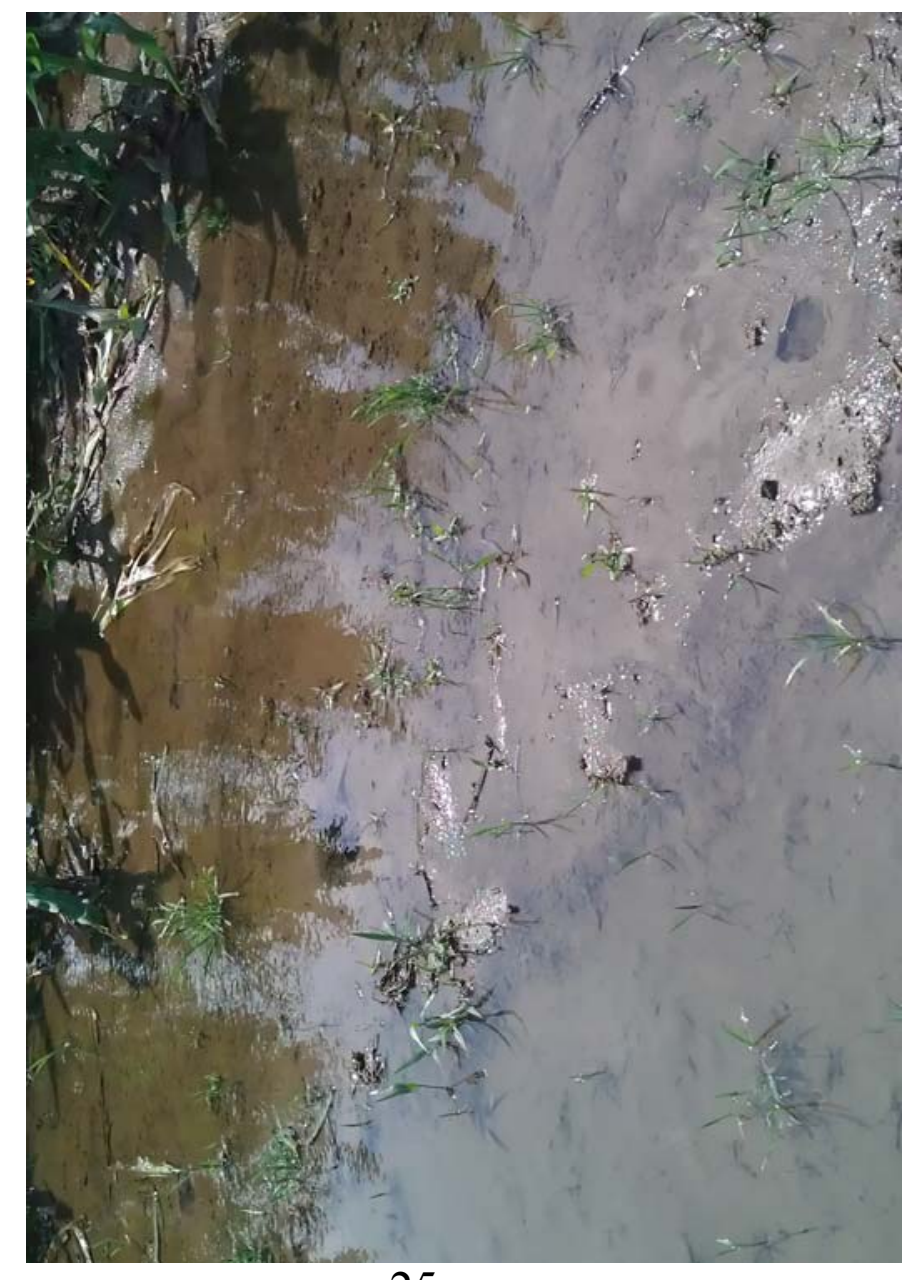

\section{5}
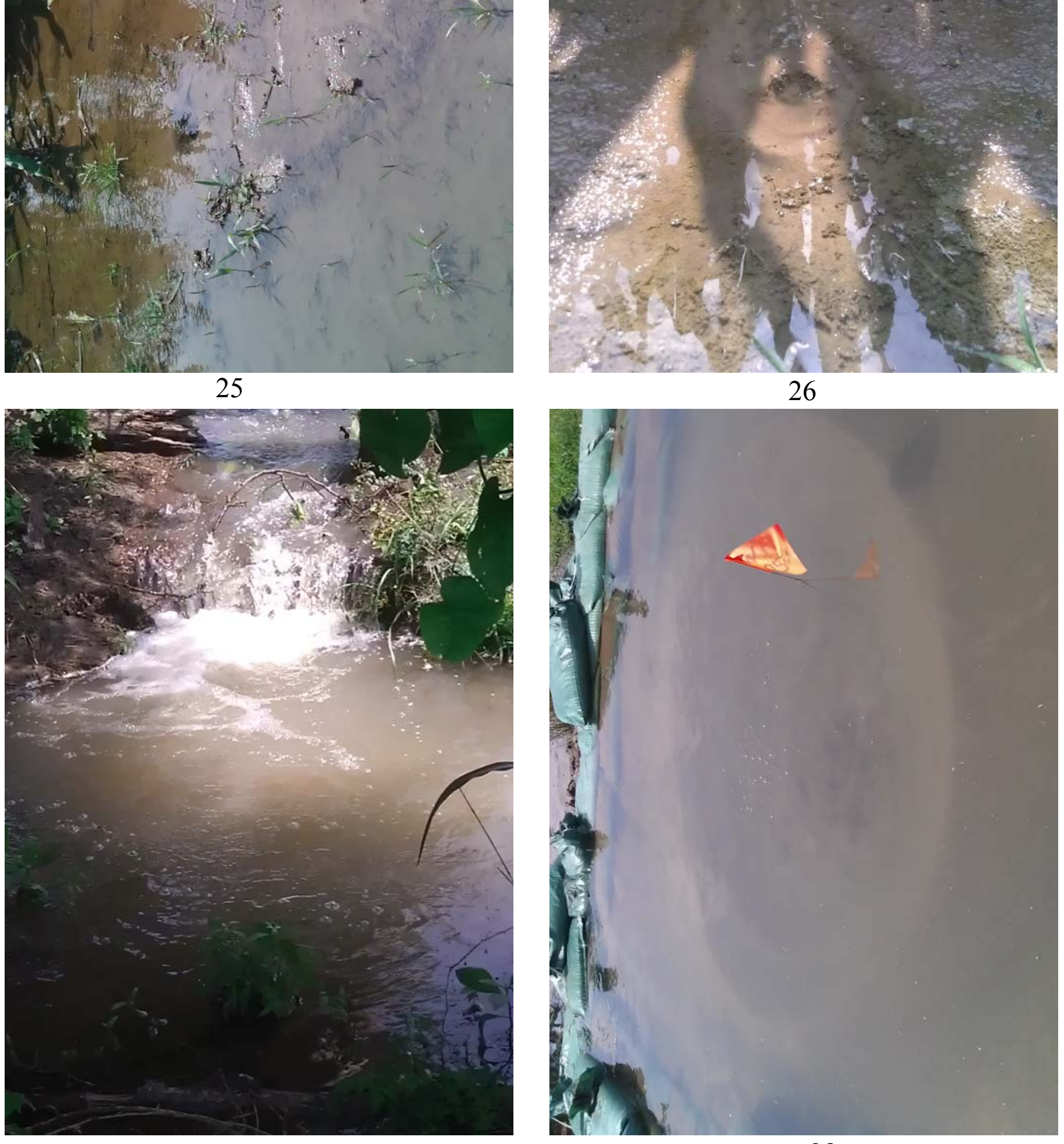


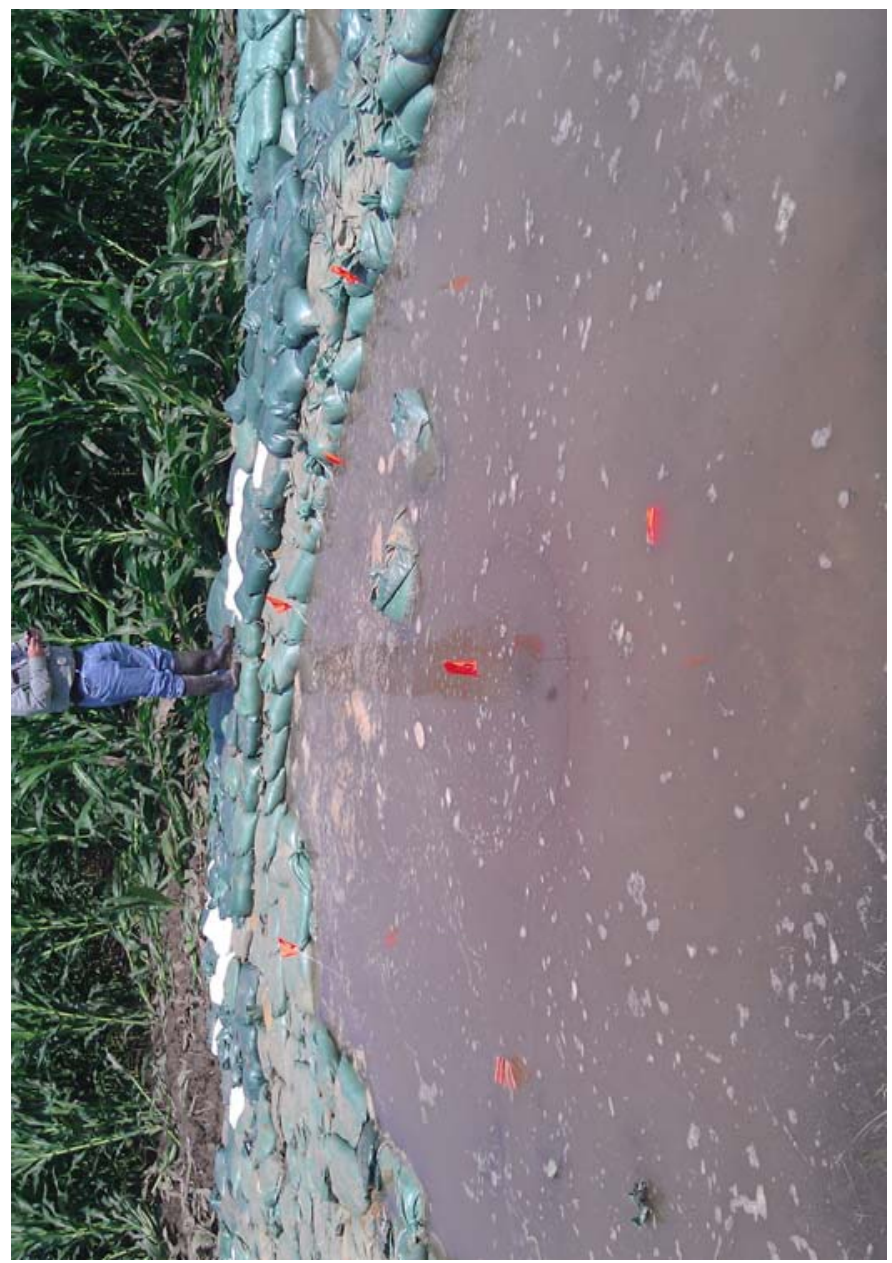

29

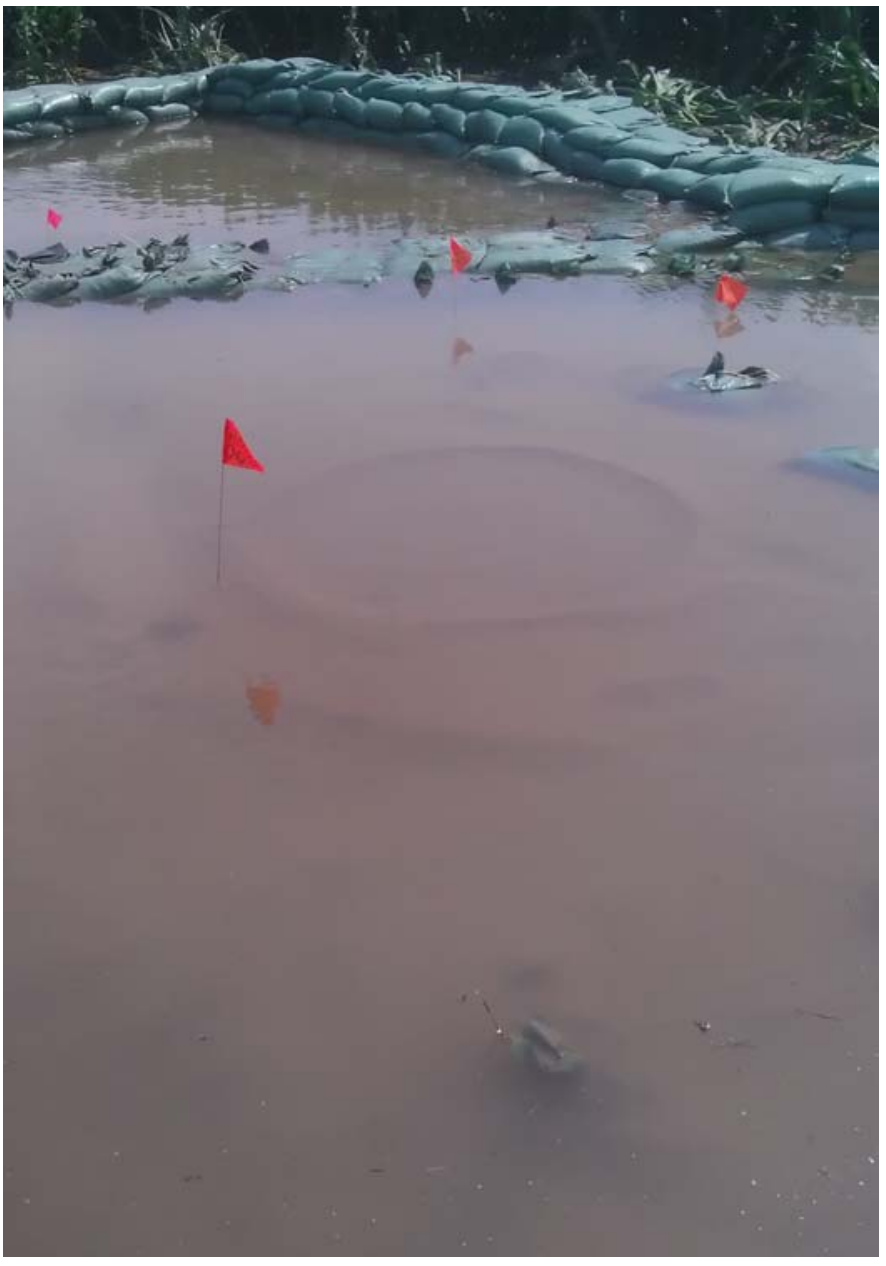




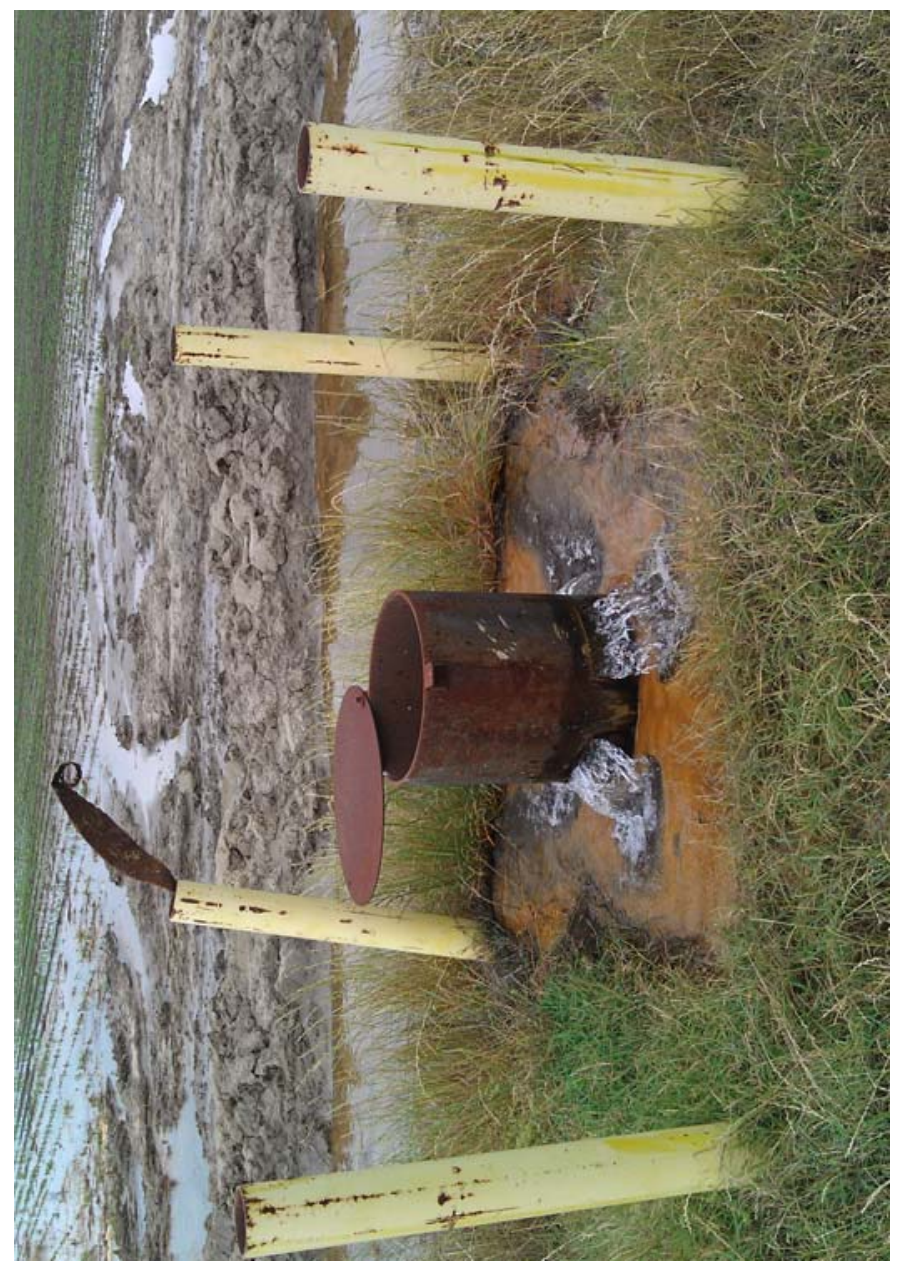

33

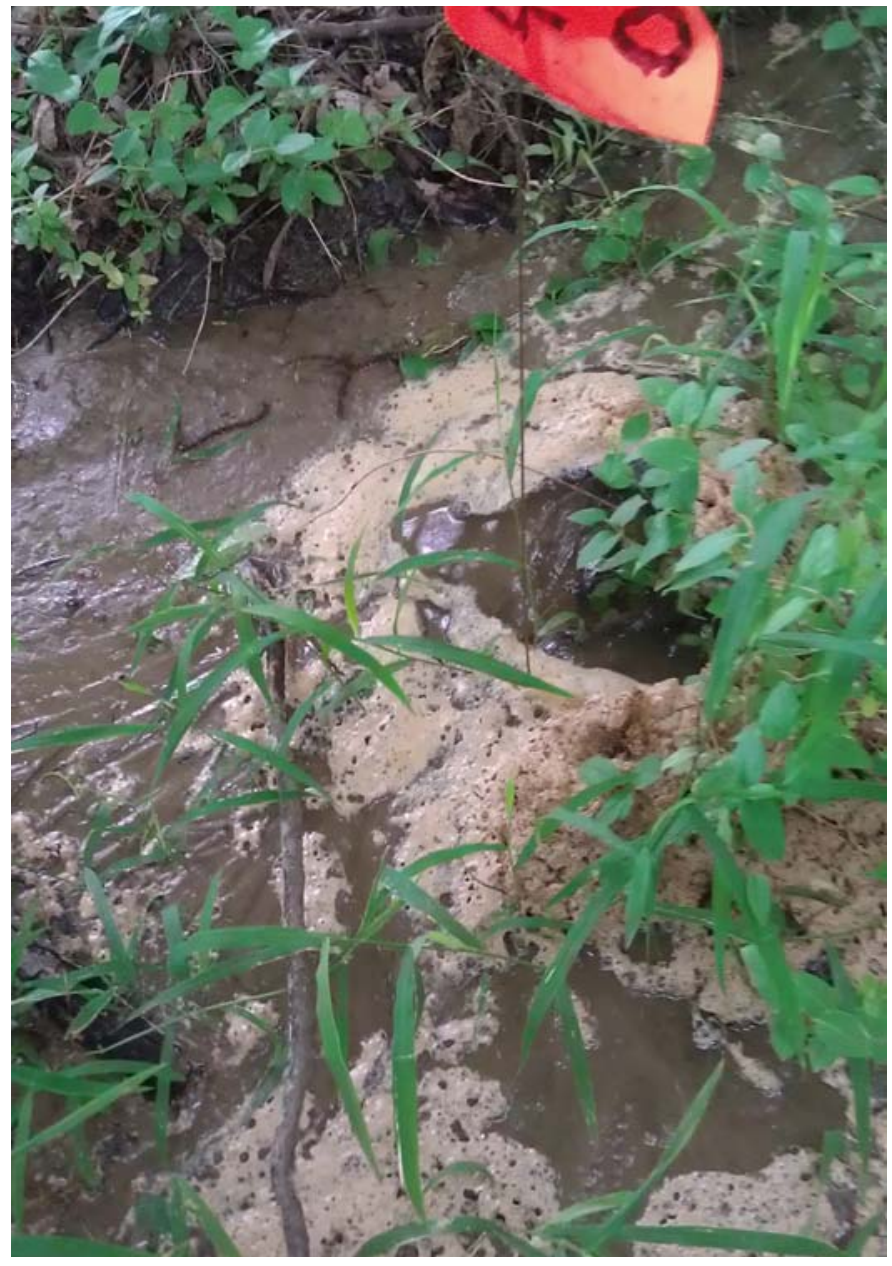

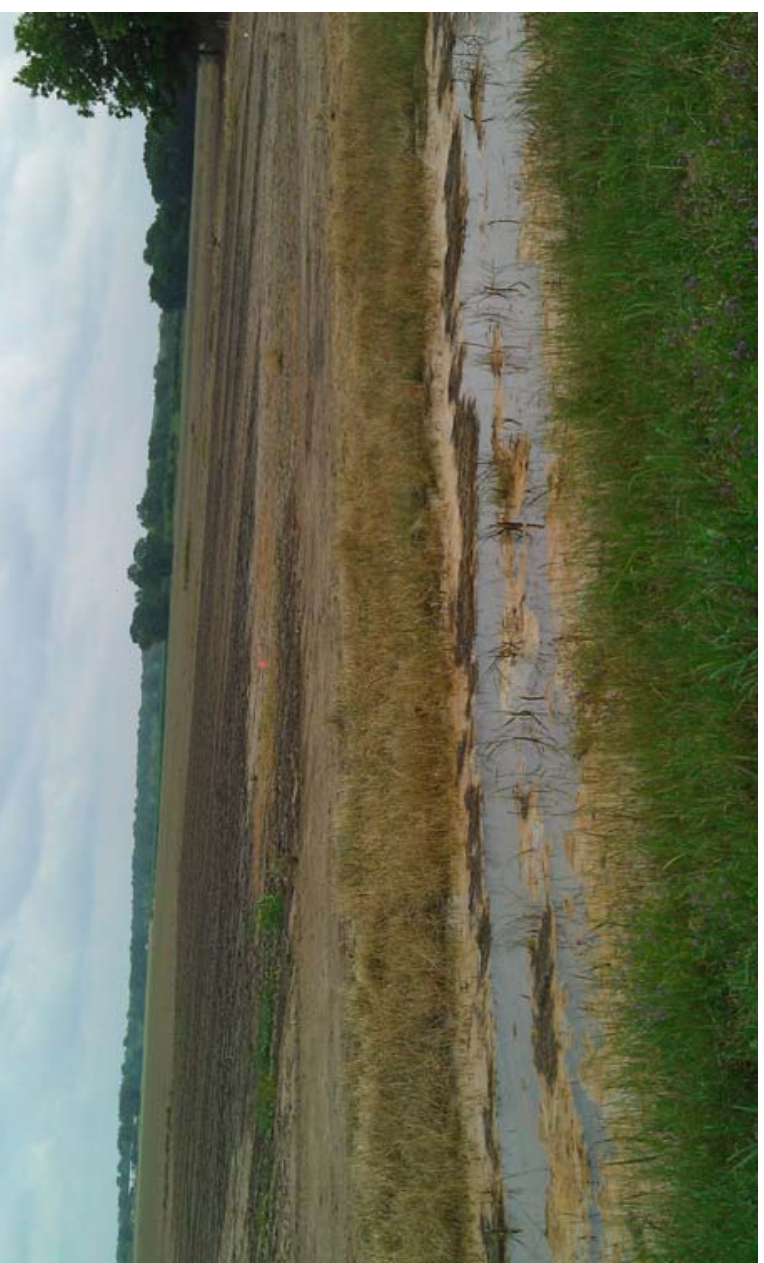

34

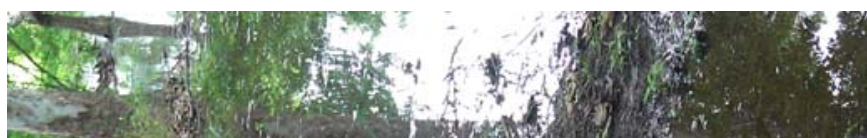

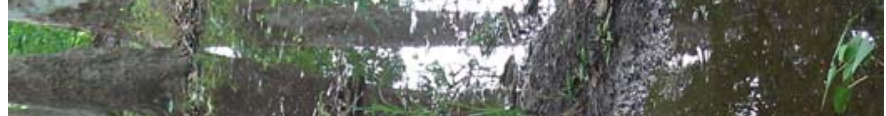

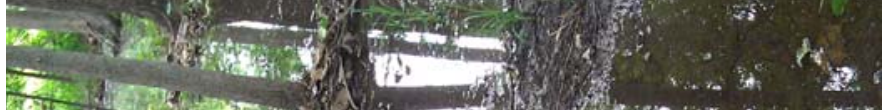

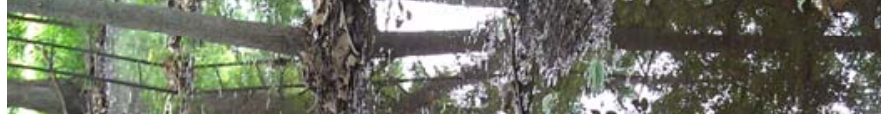

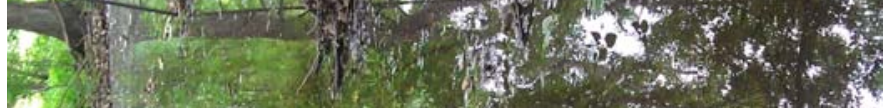

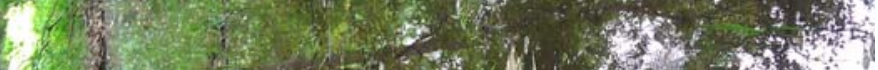

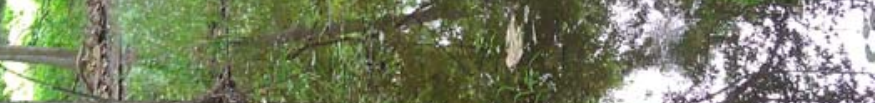

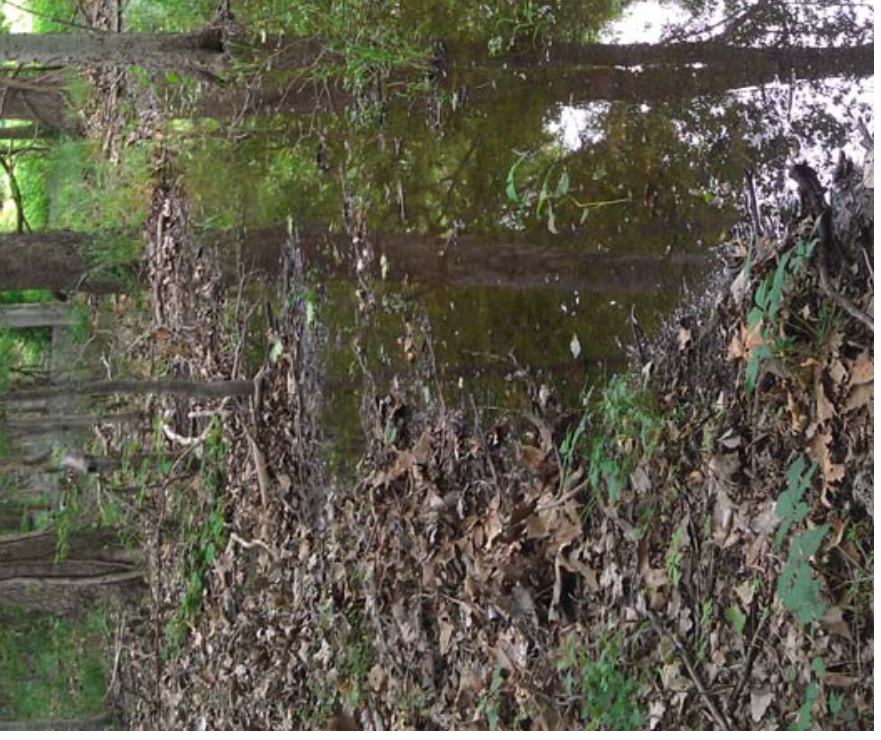




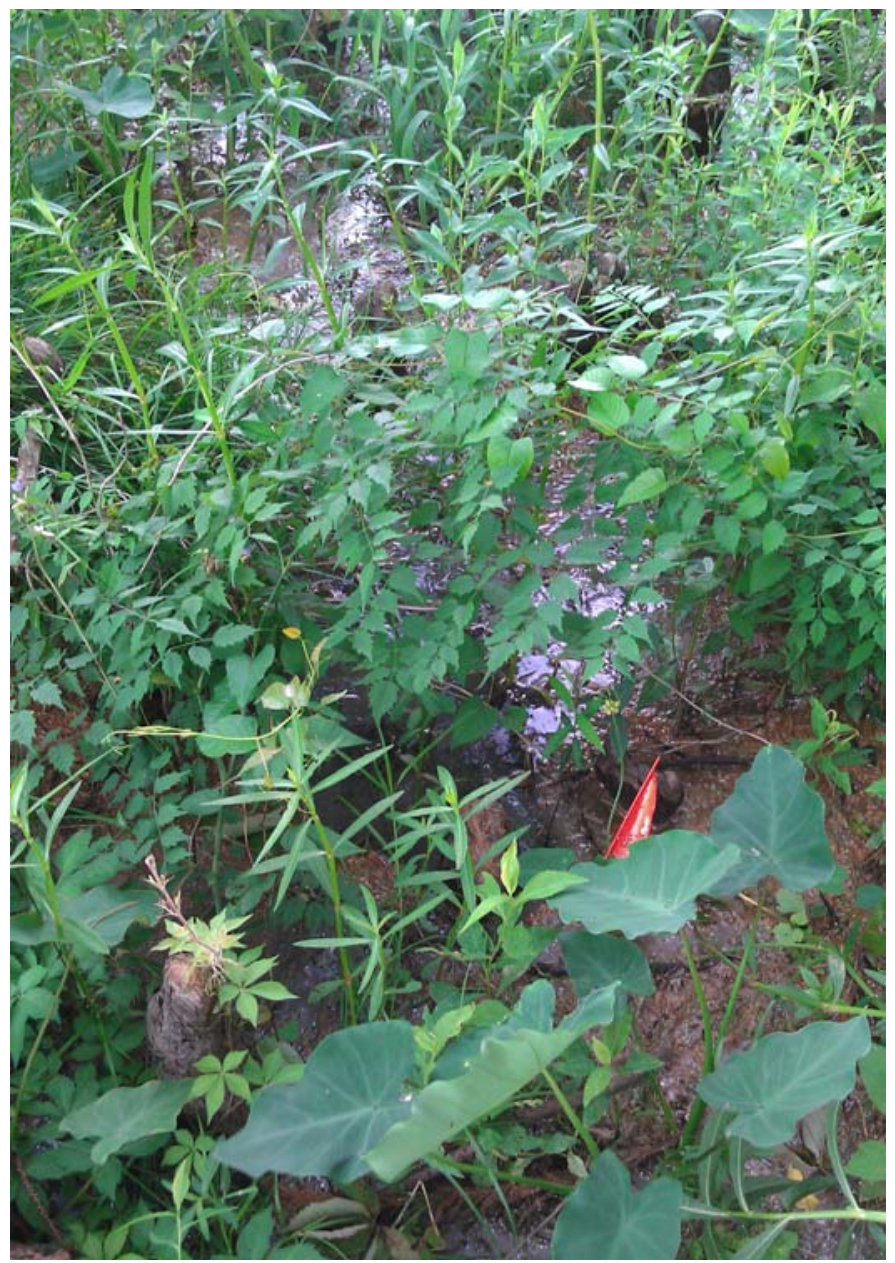

37

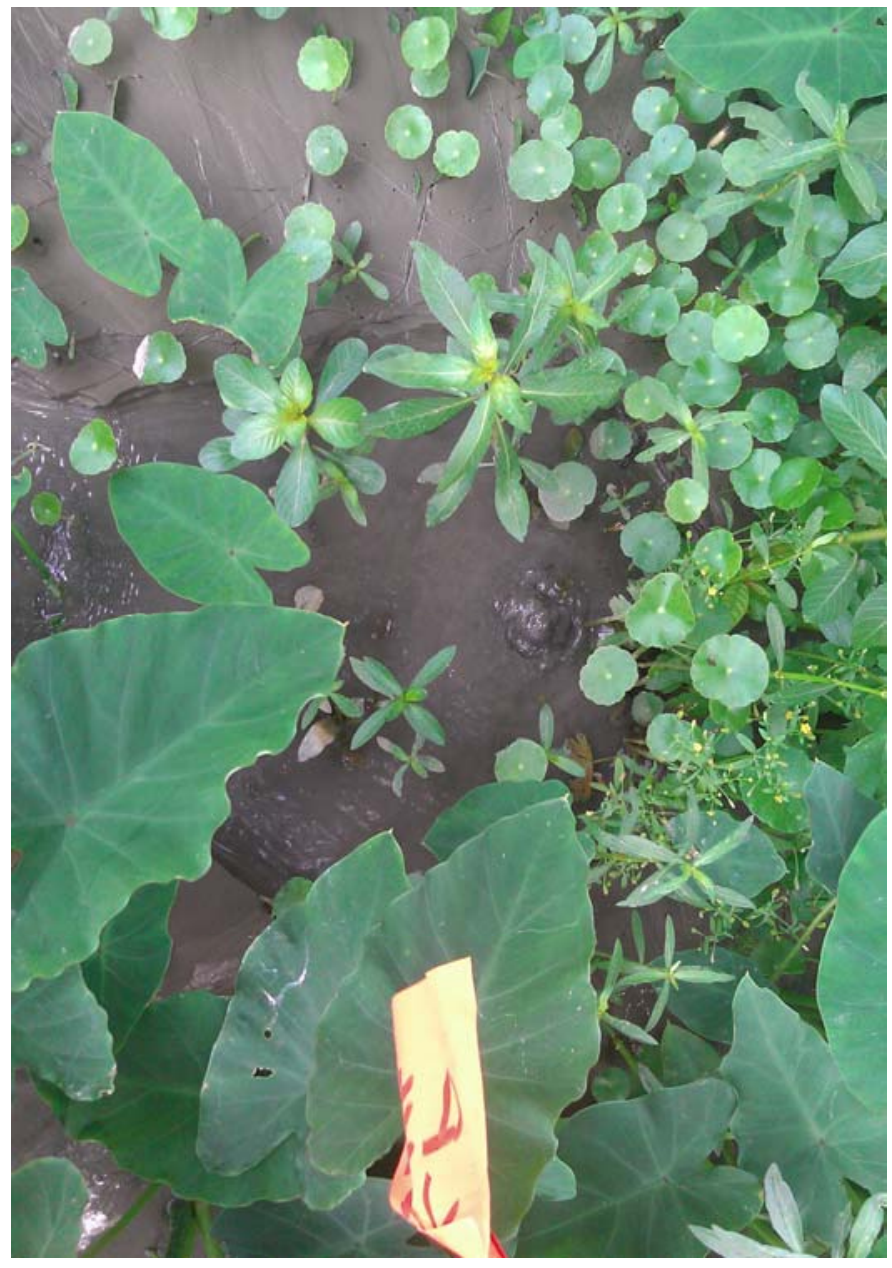

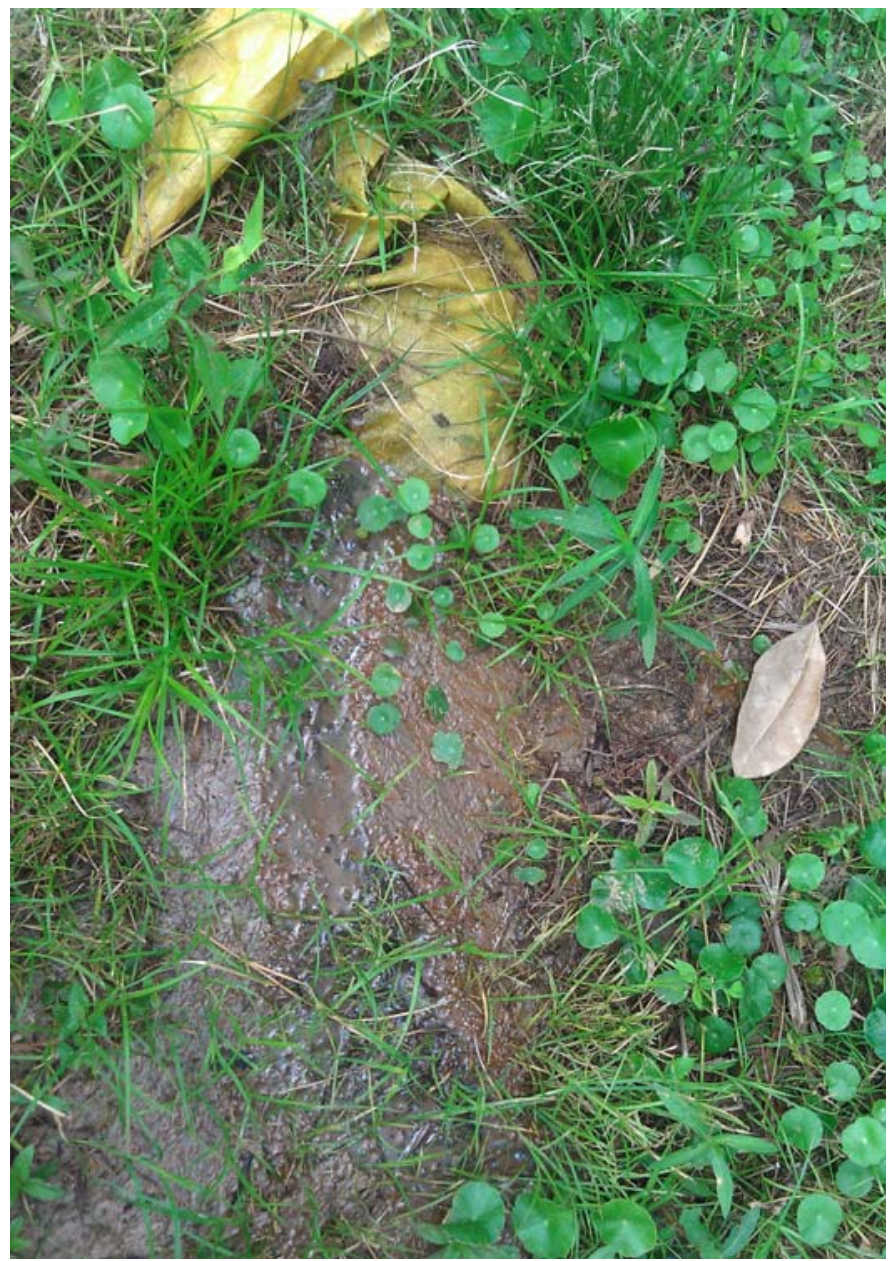

\section{8}

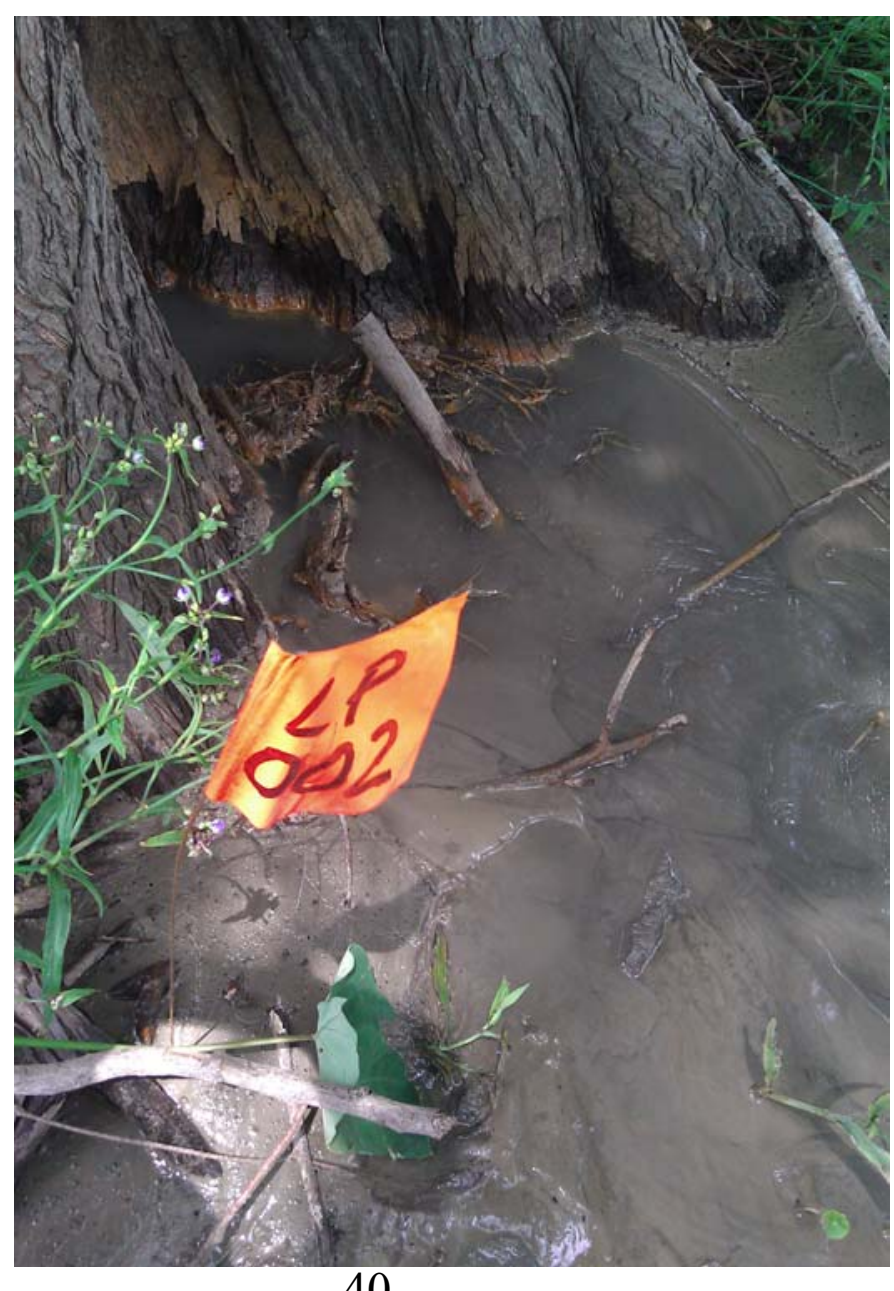




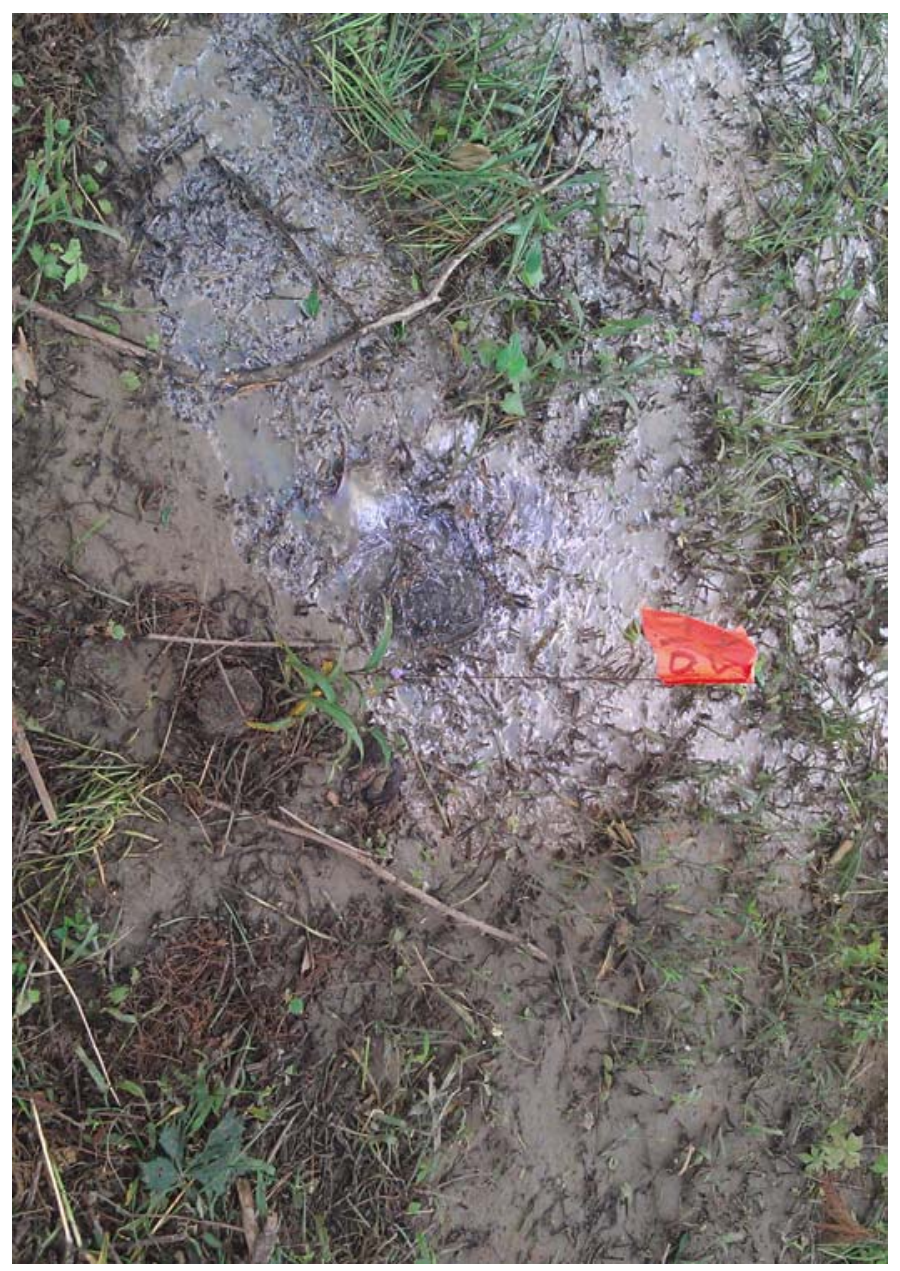

41

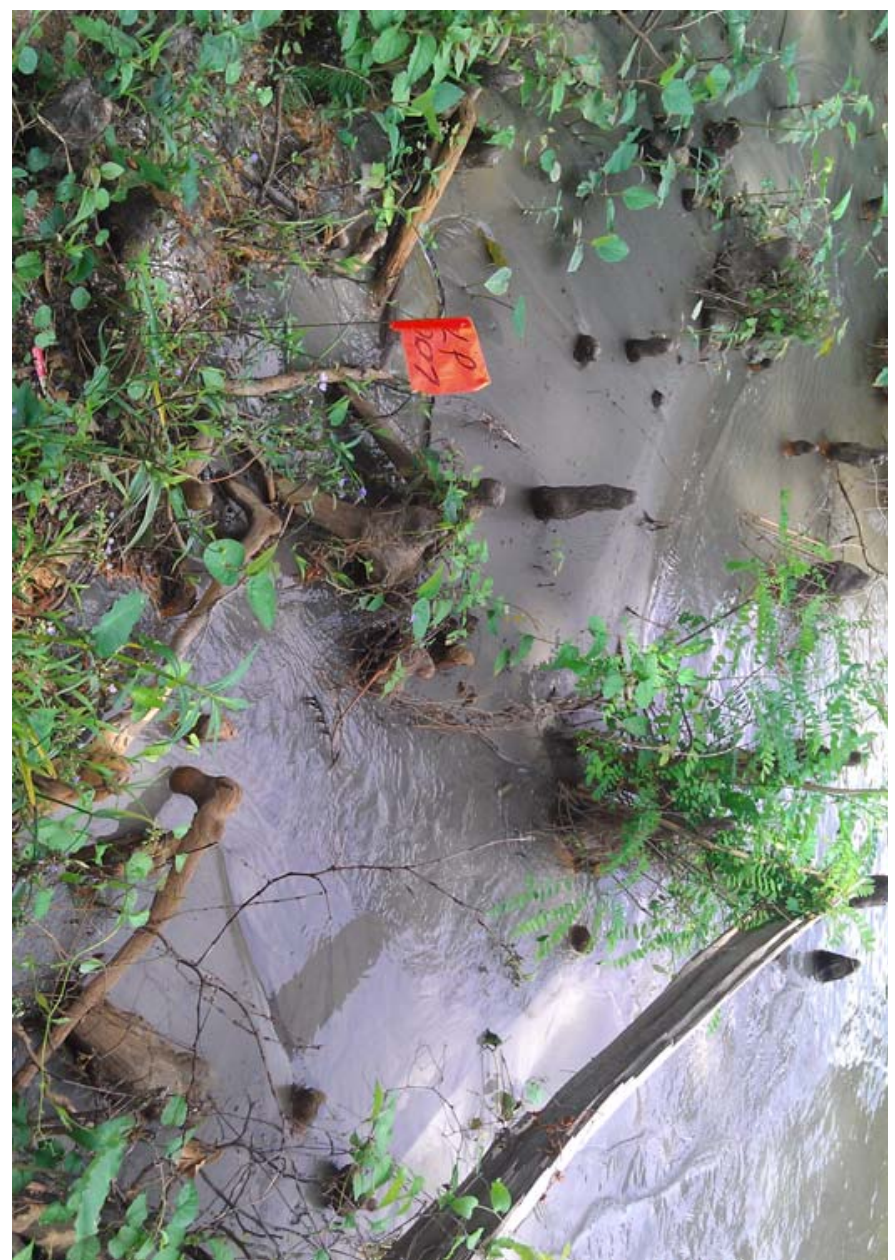
42

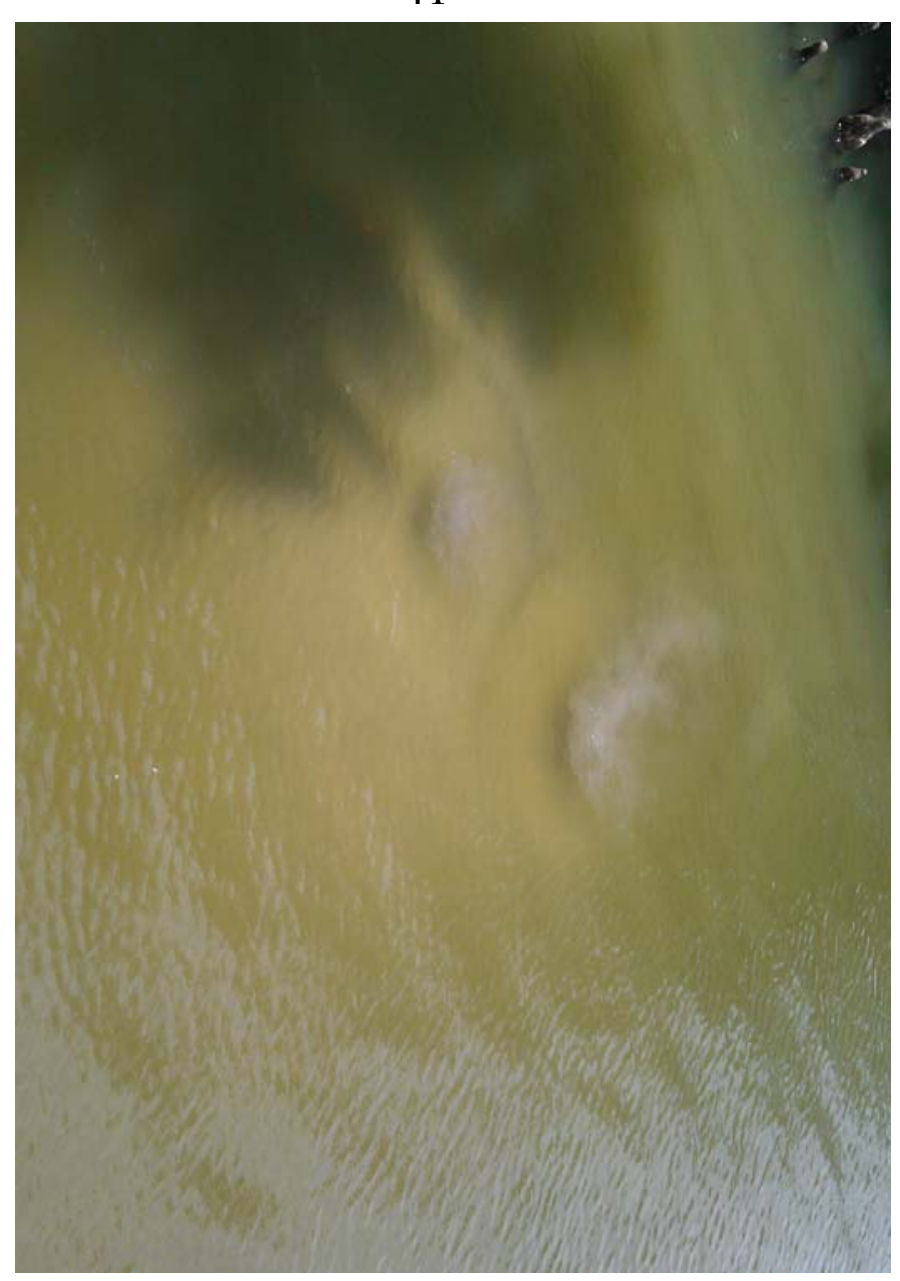

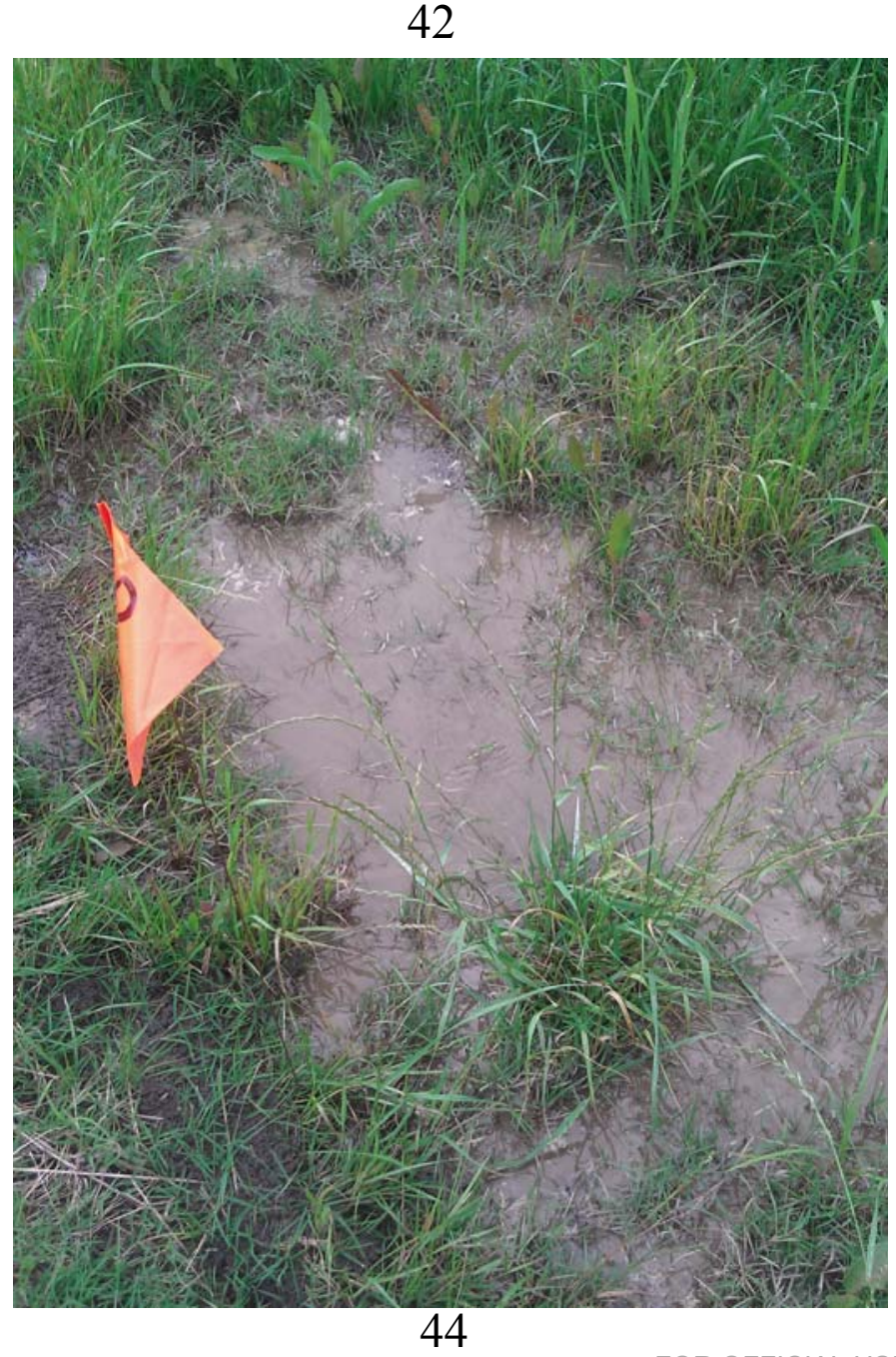




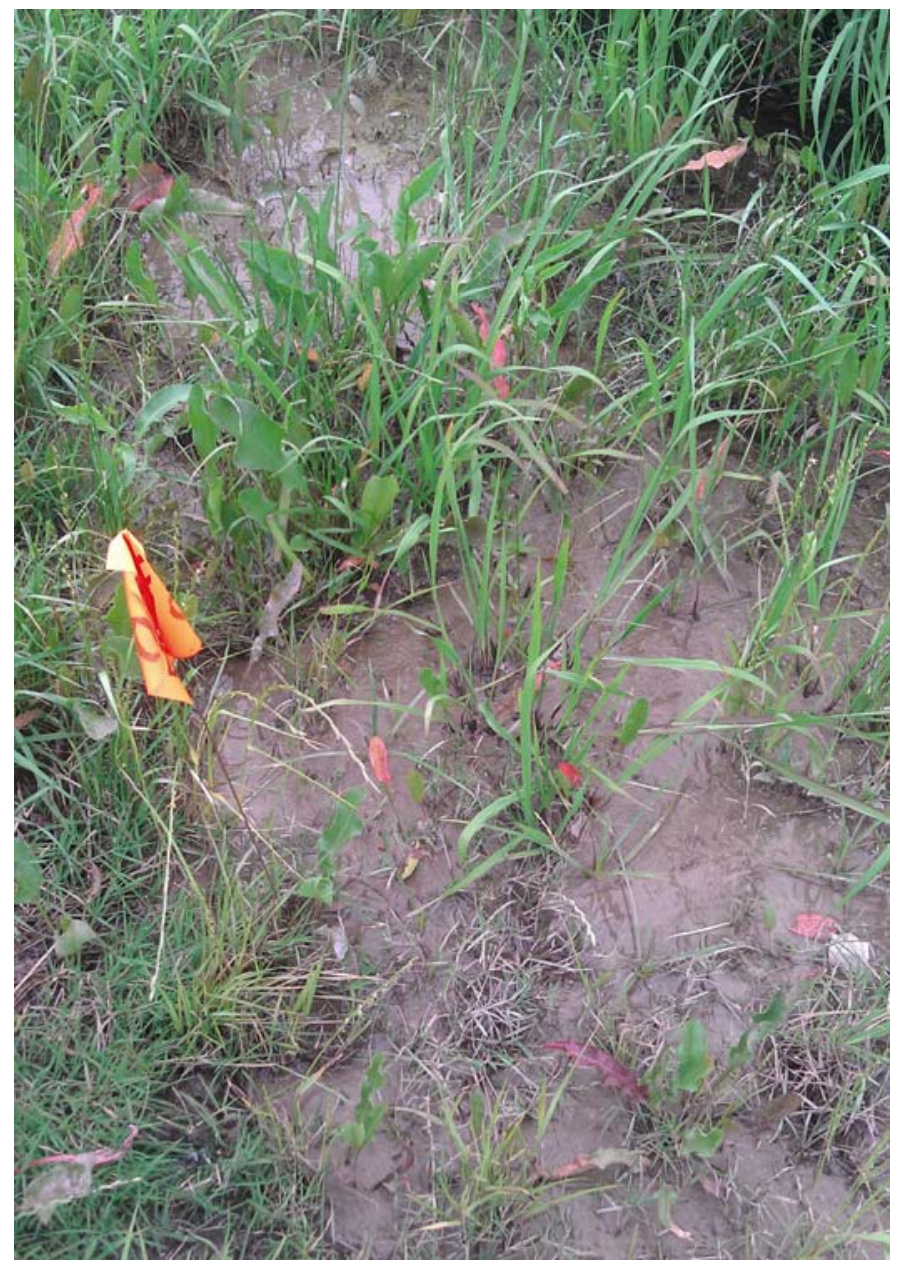

45

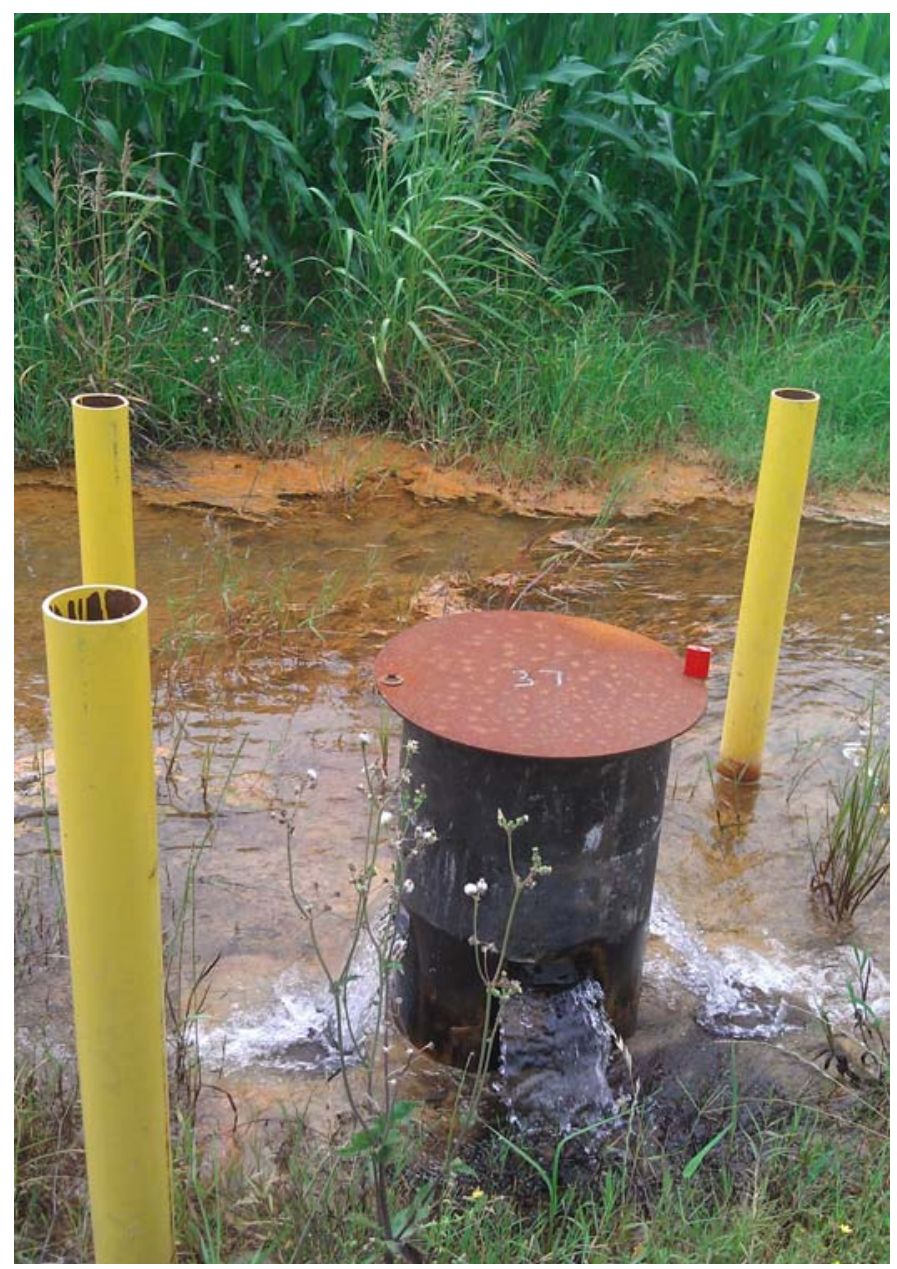

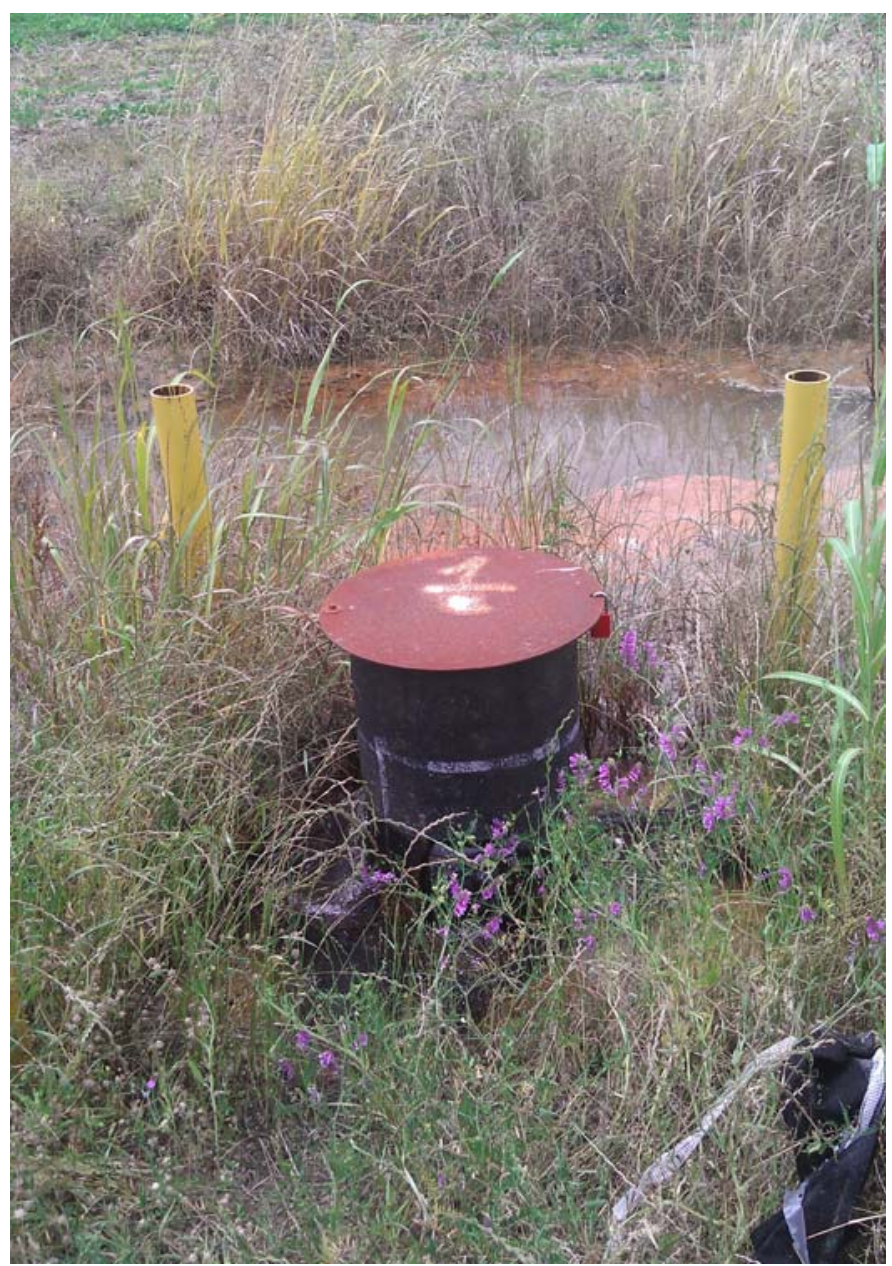

46 


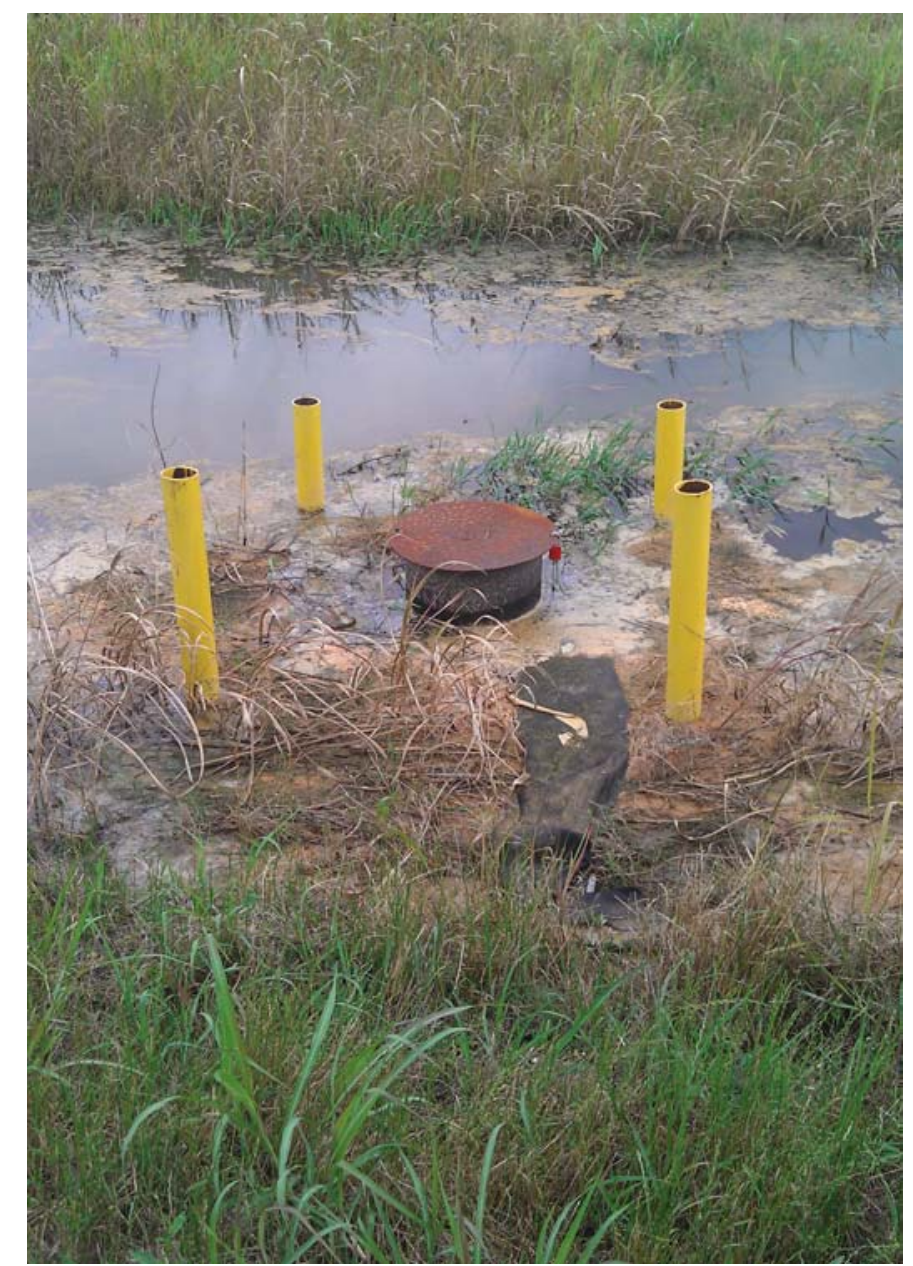

49

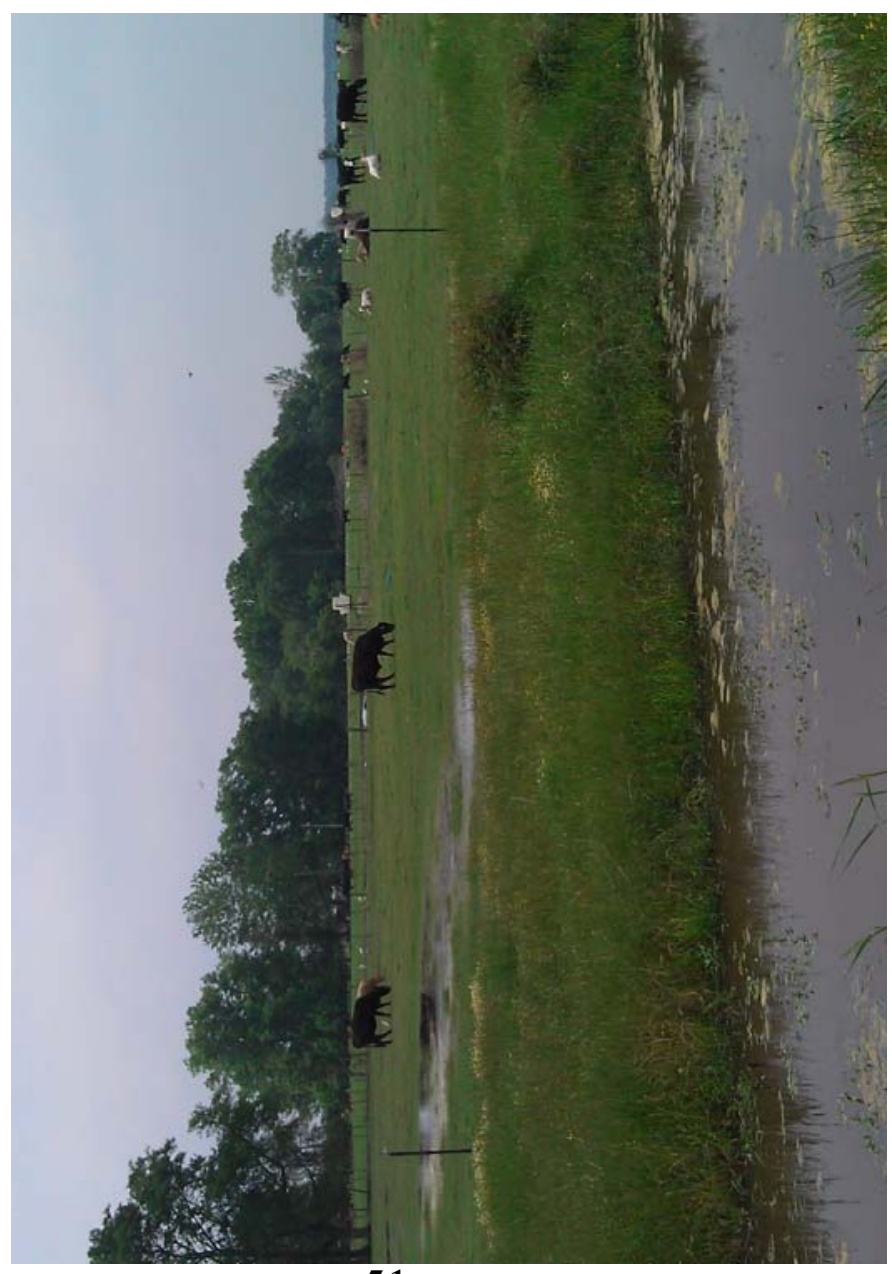

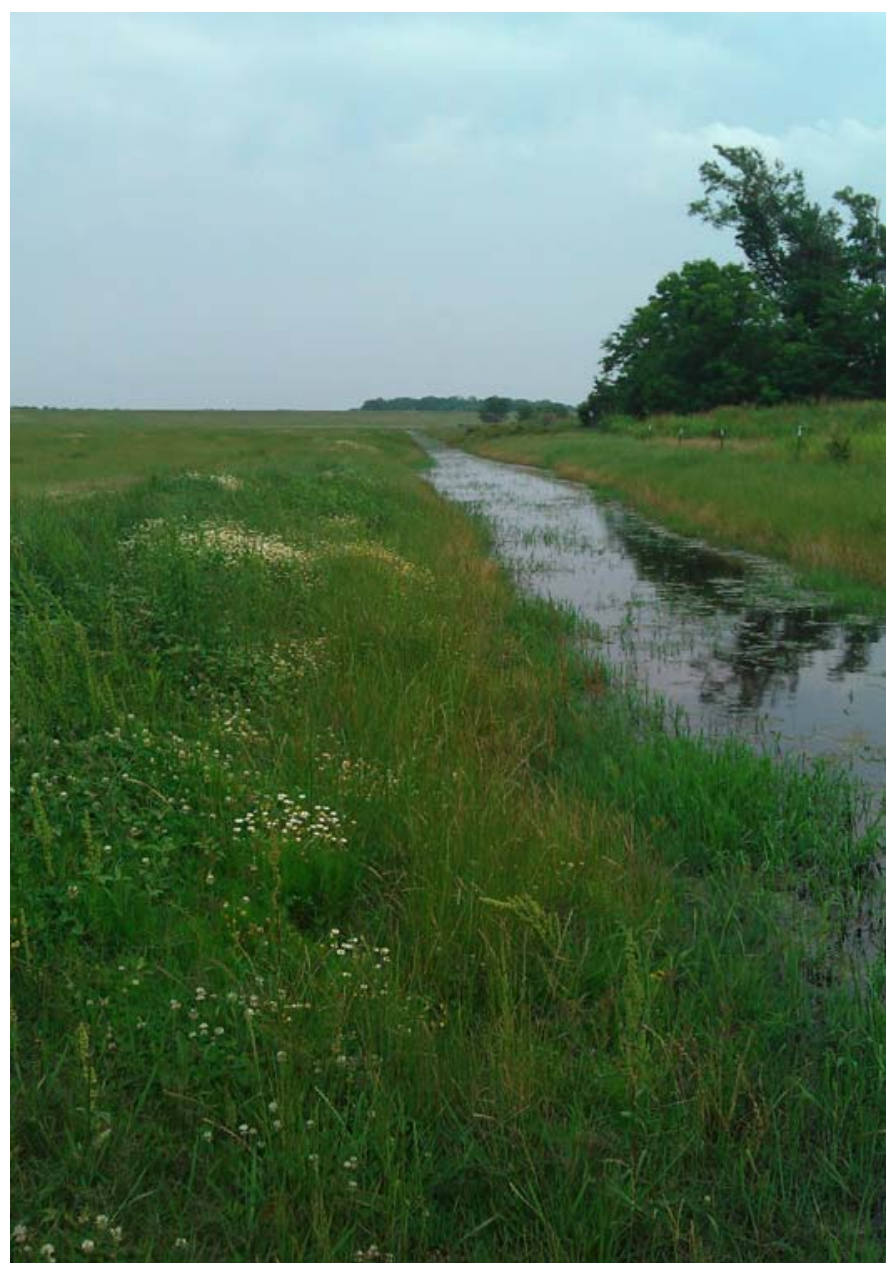

50

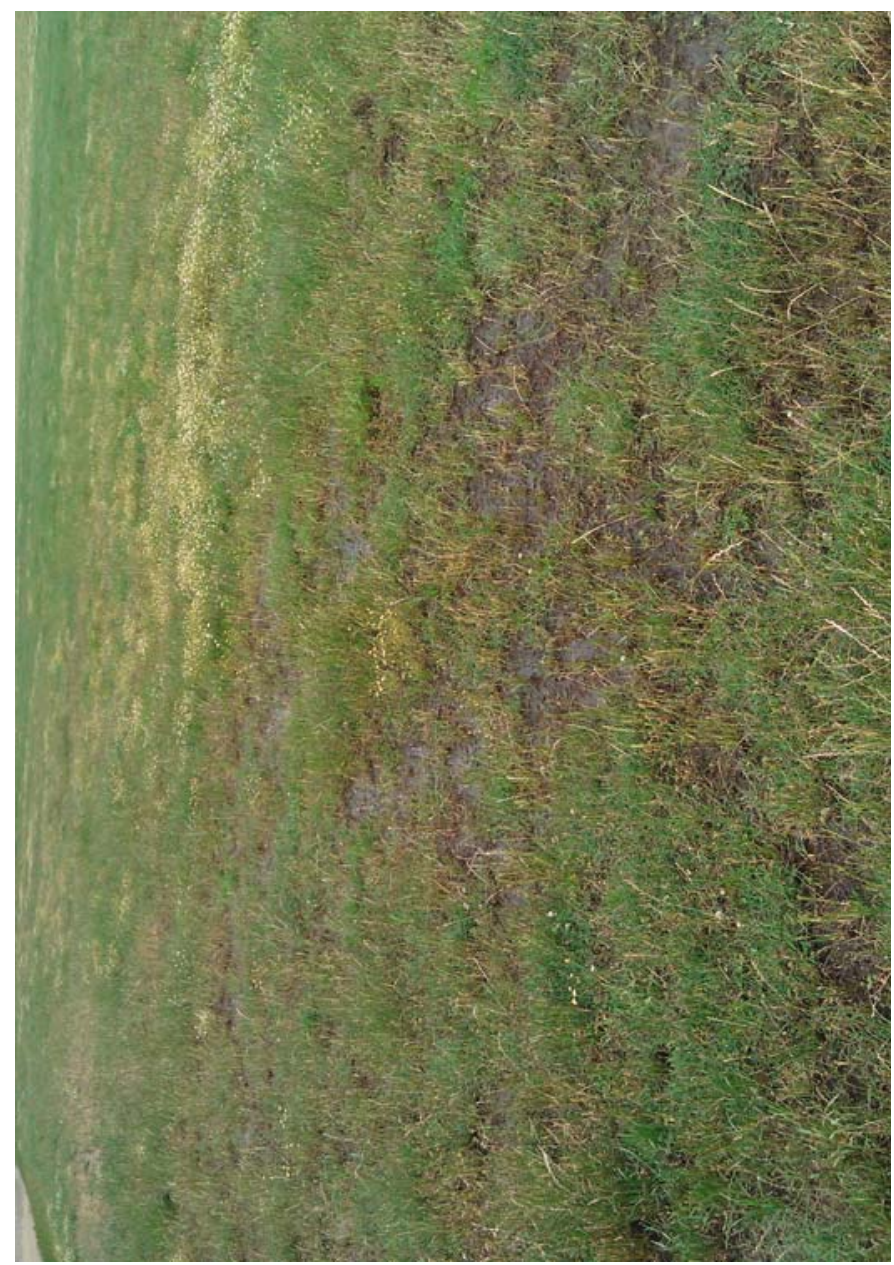




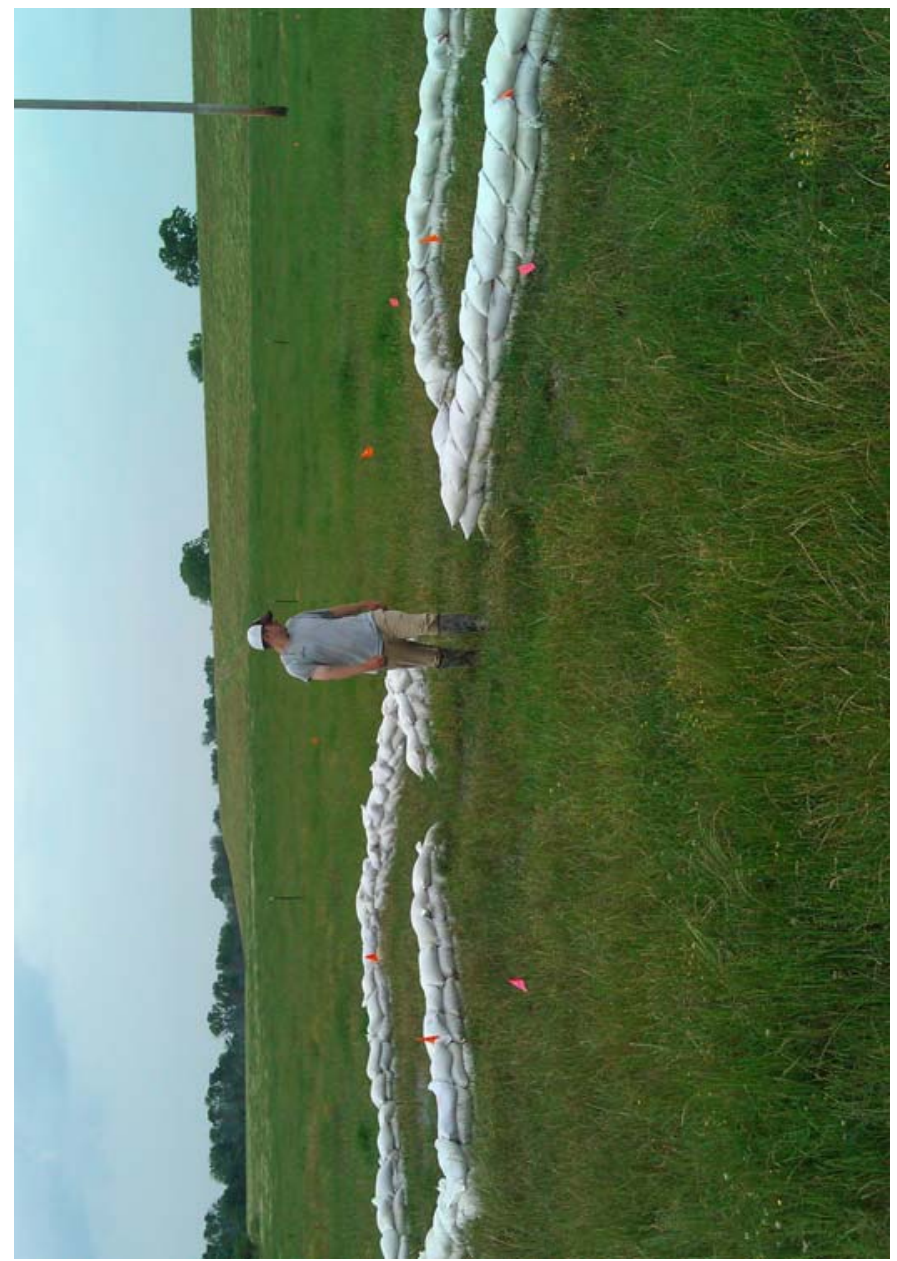

53

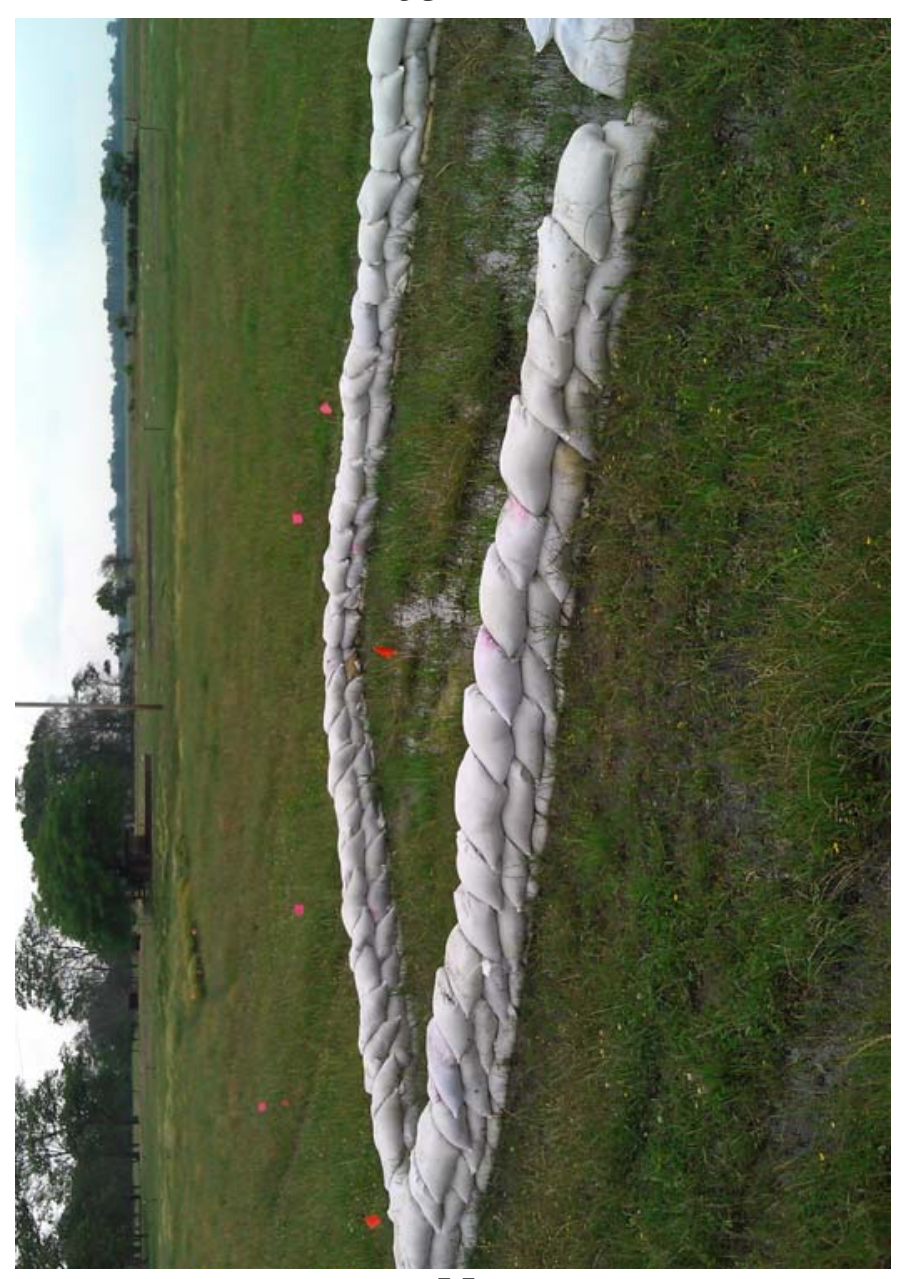

55

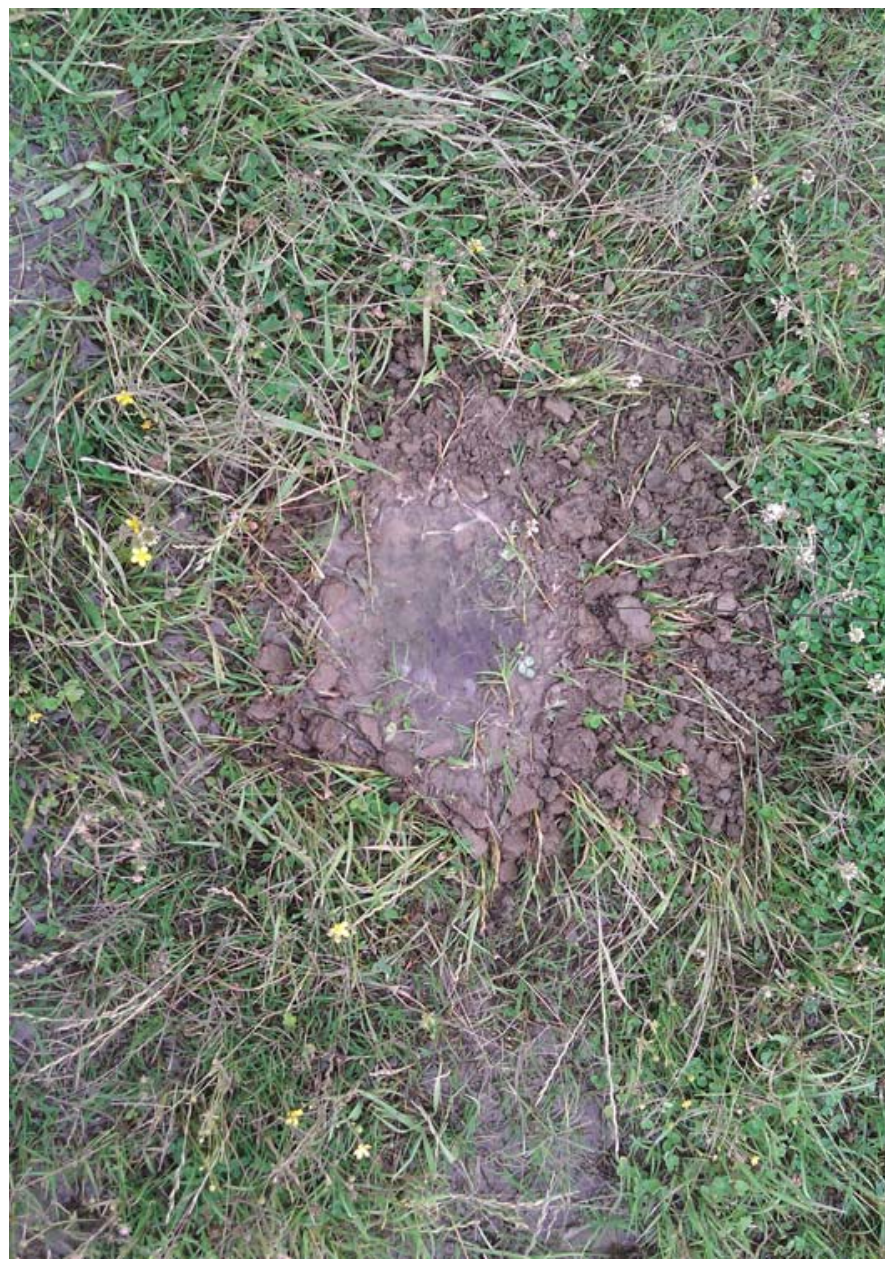

54

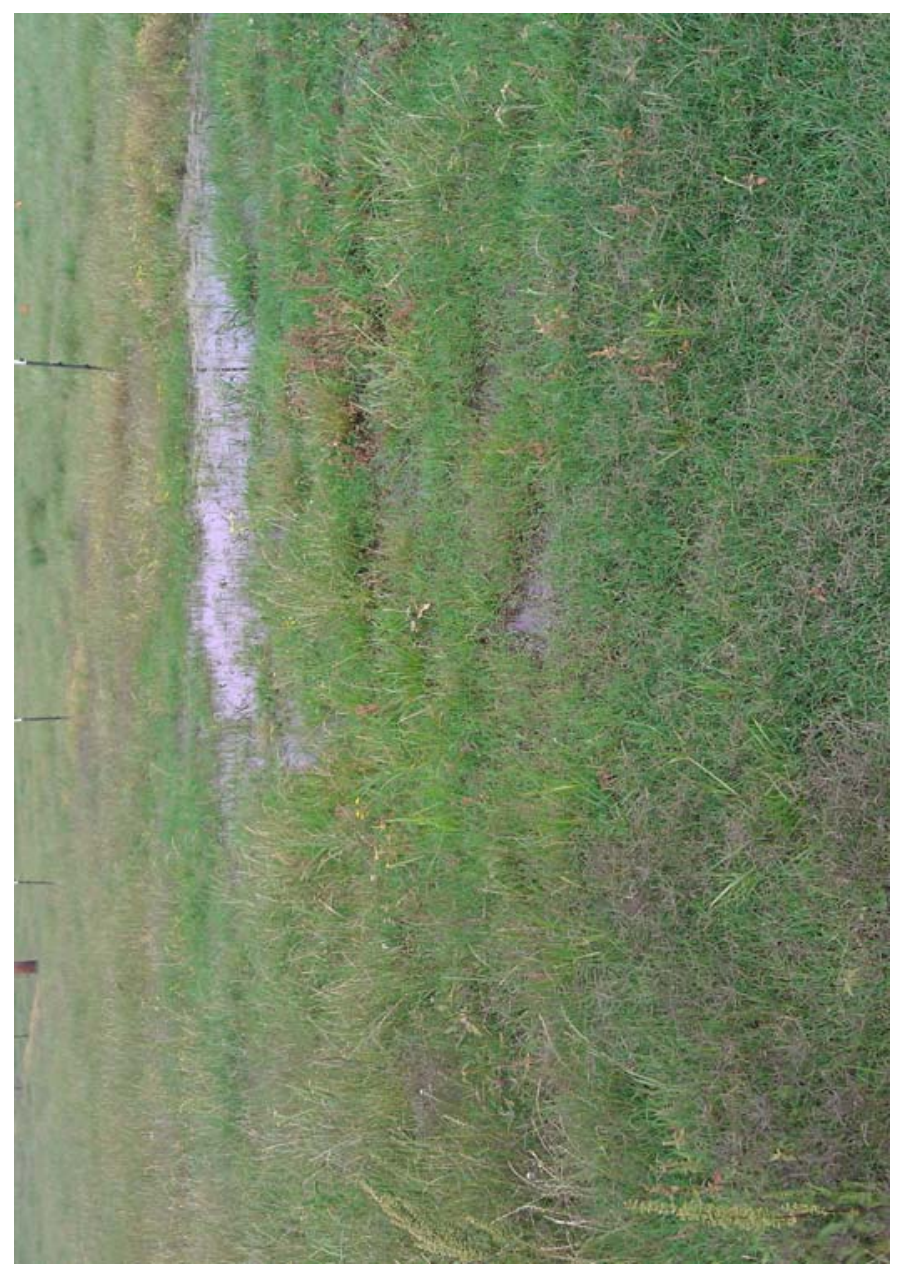




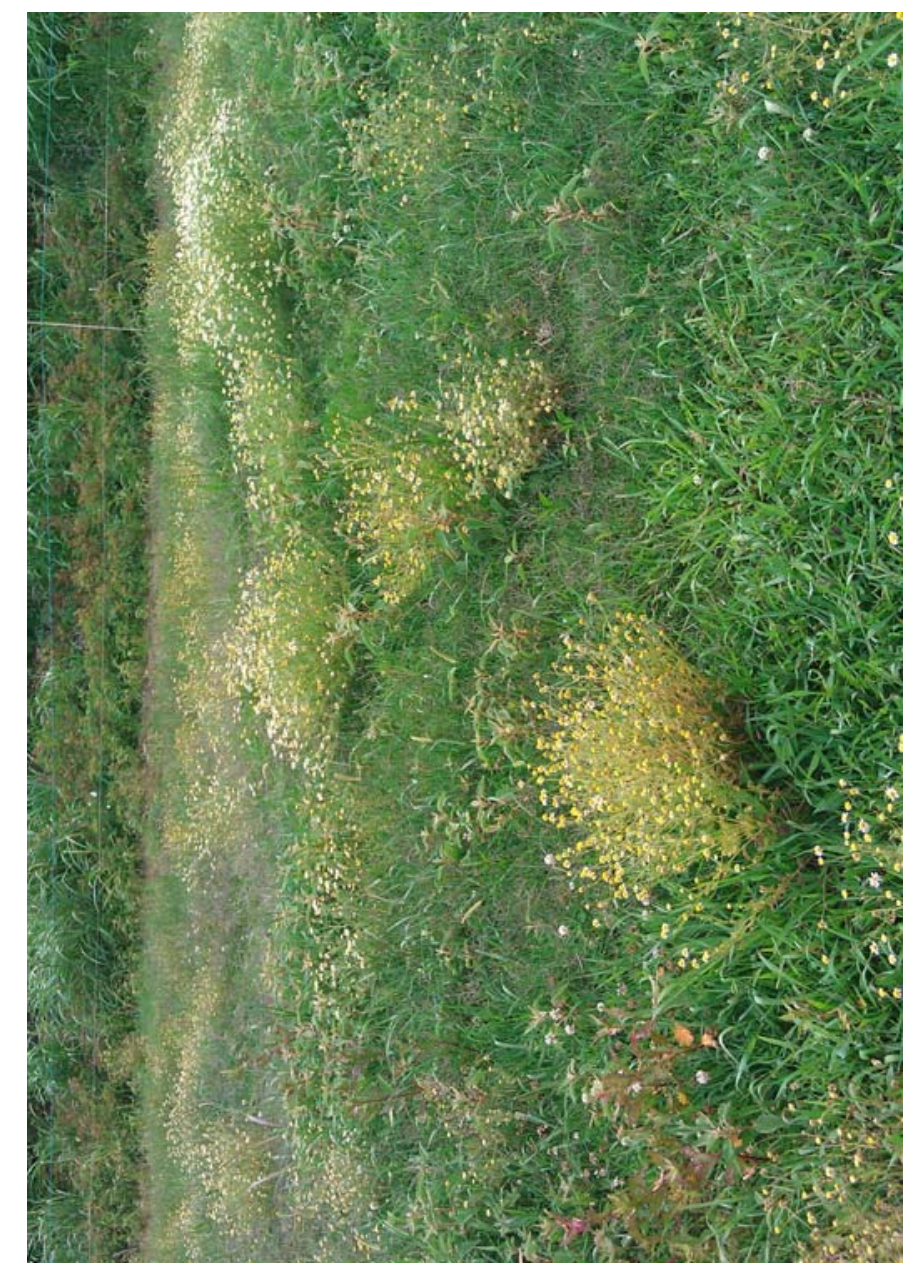

57

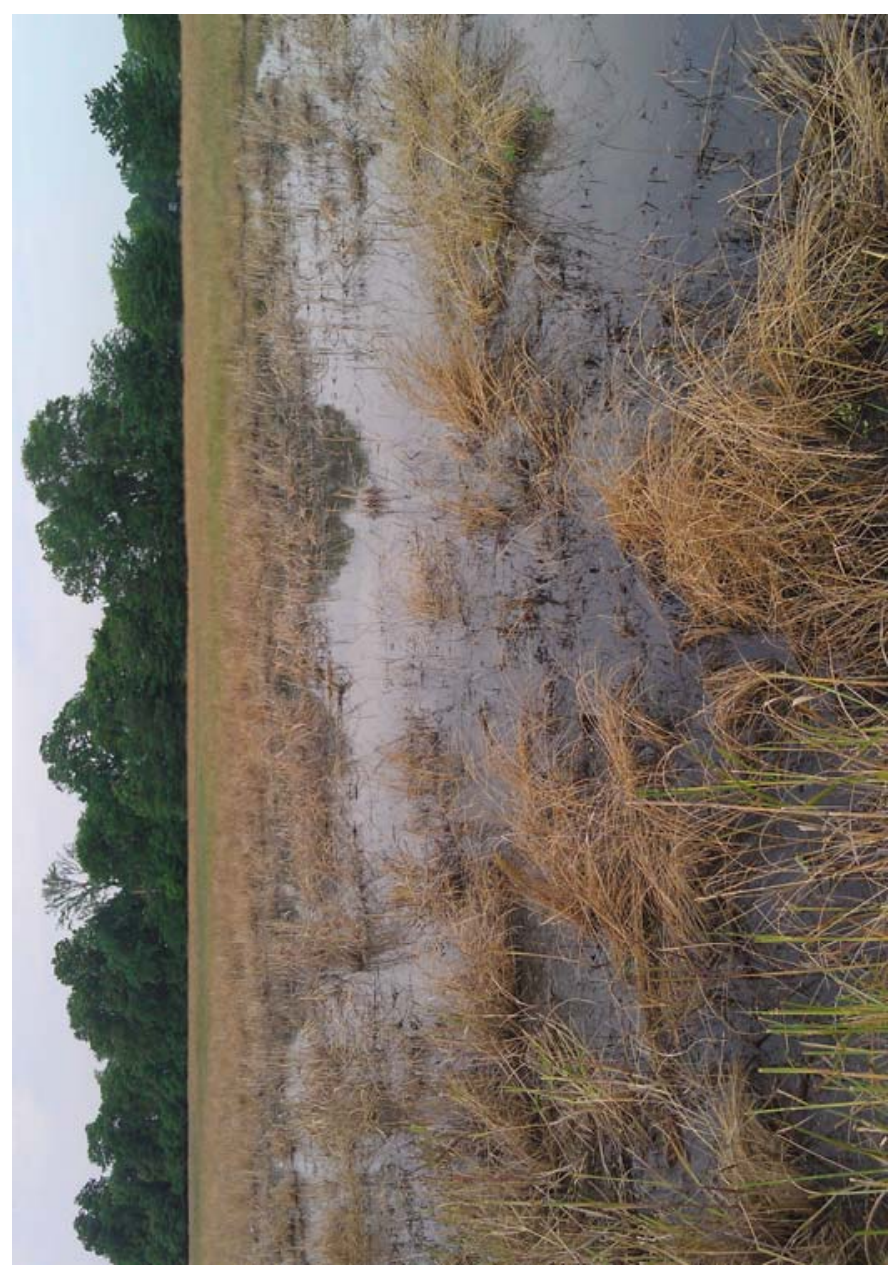

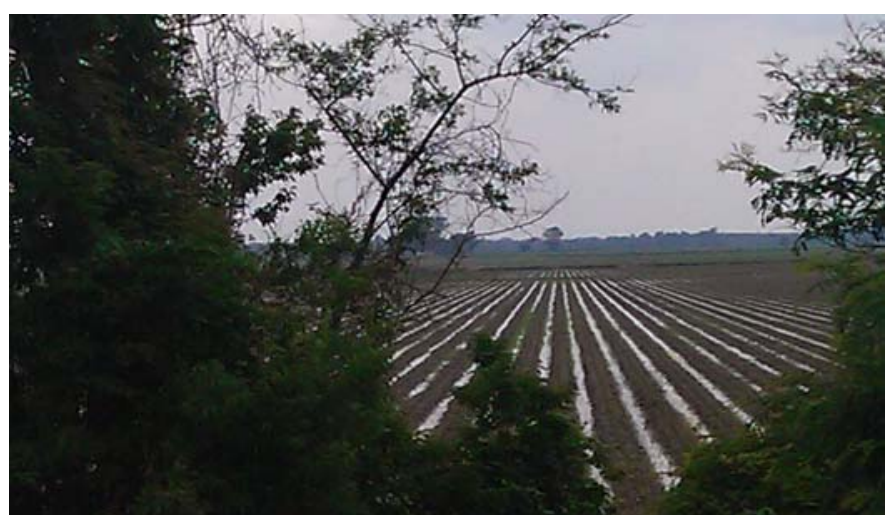

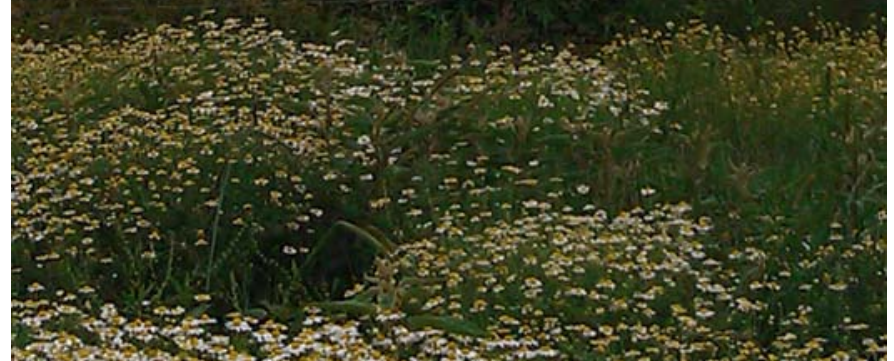

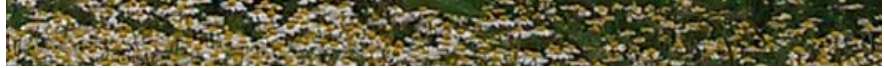

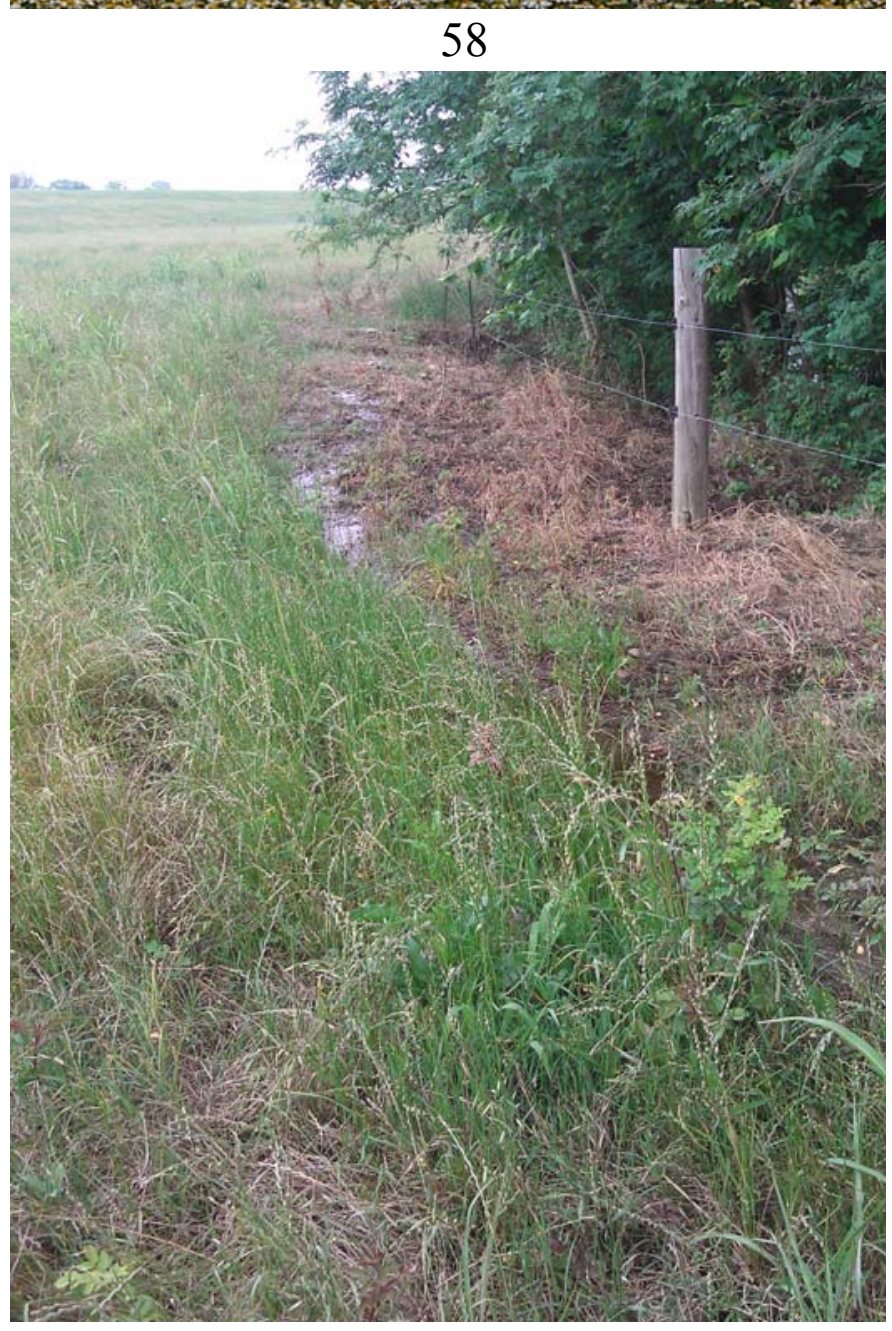




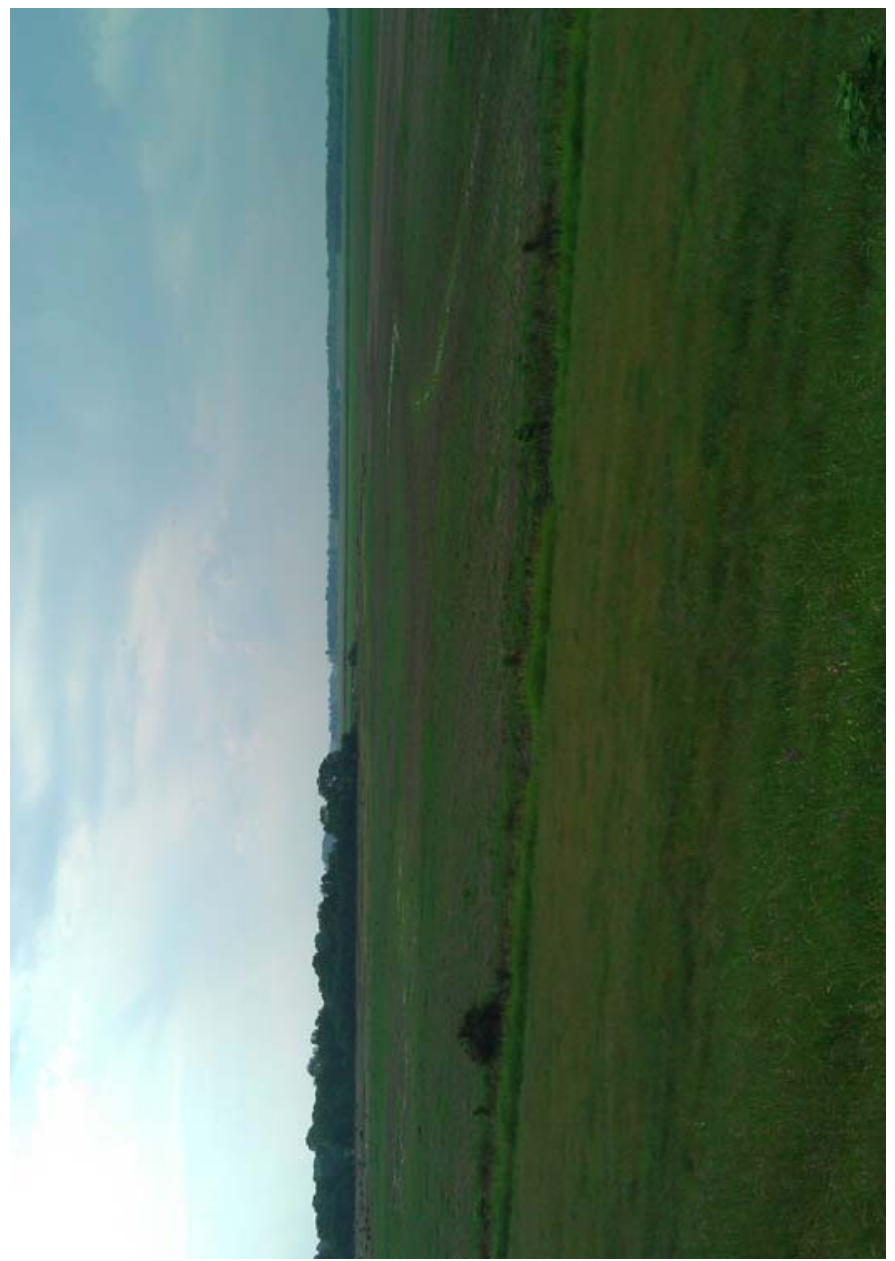

61

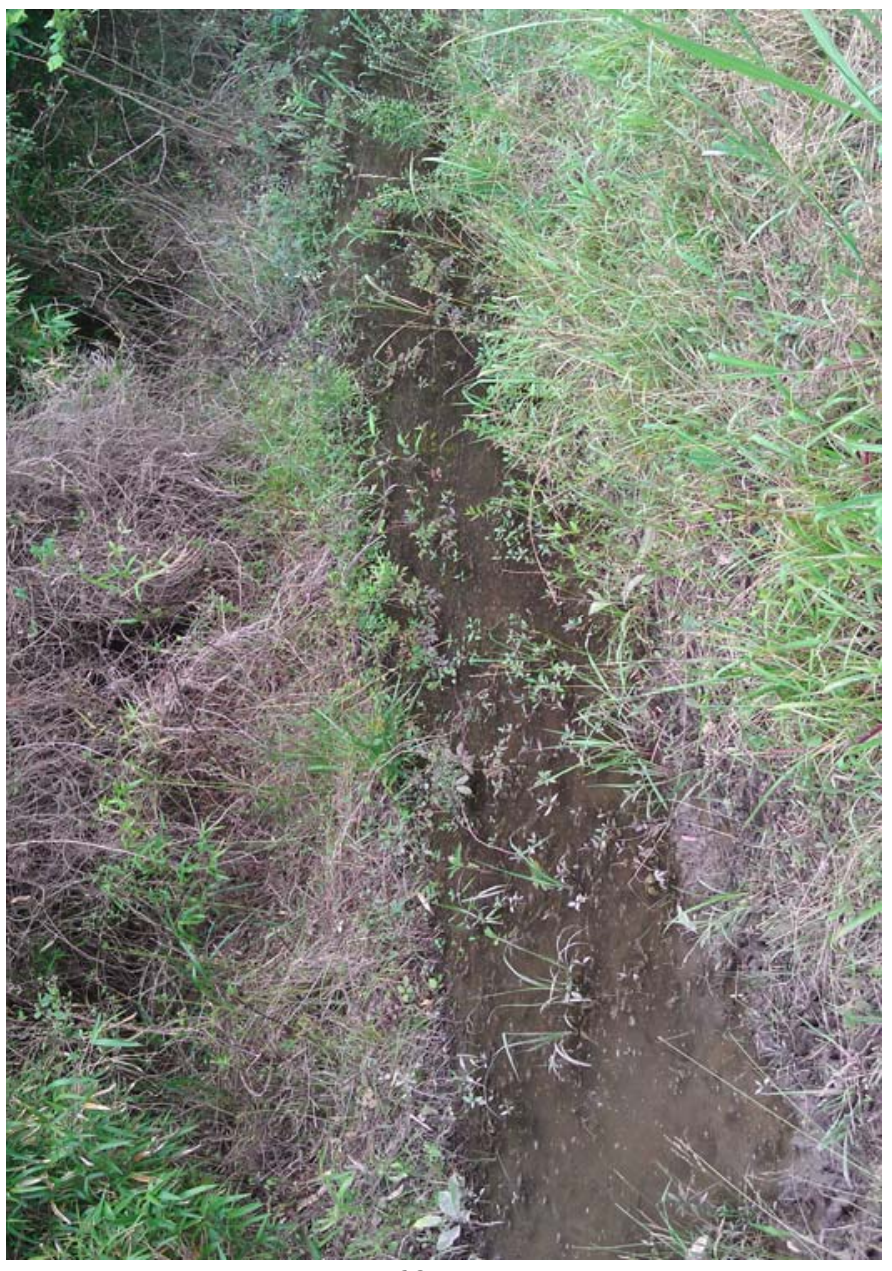

63

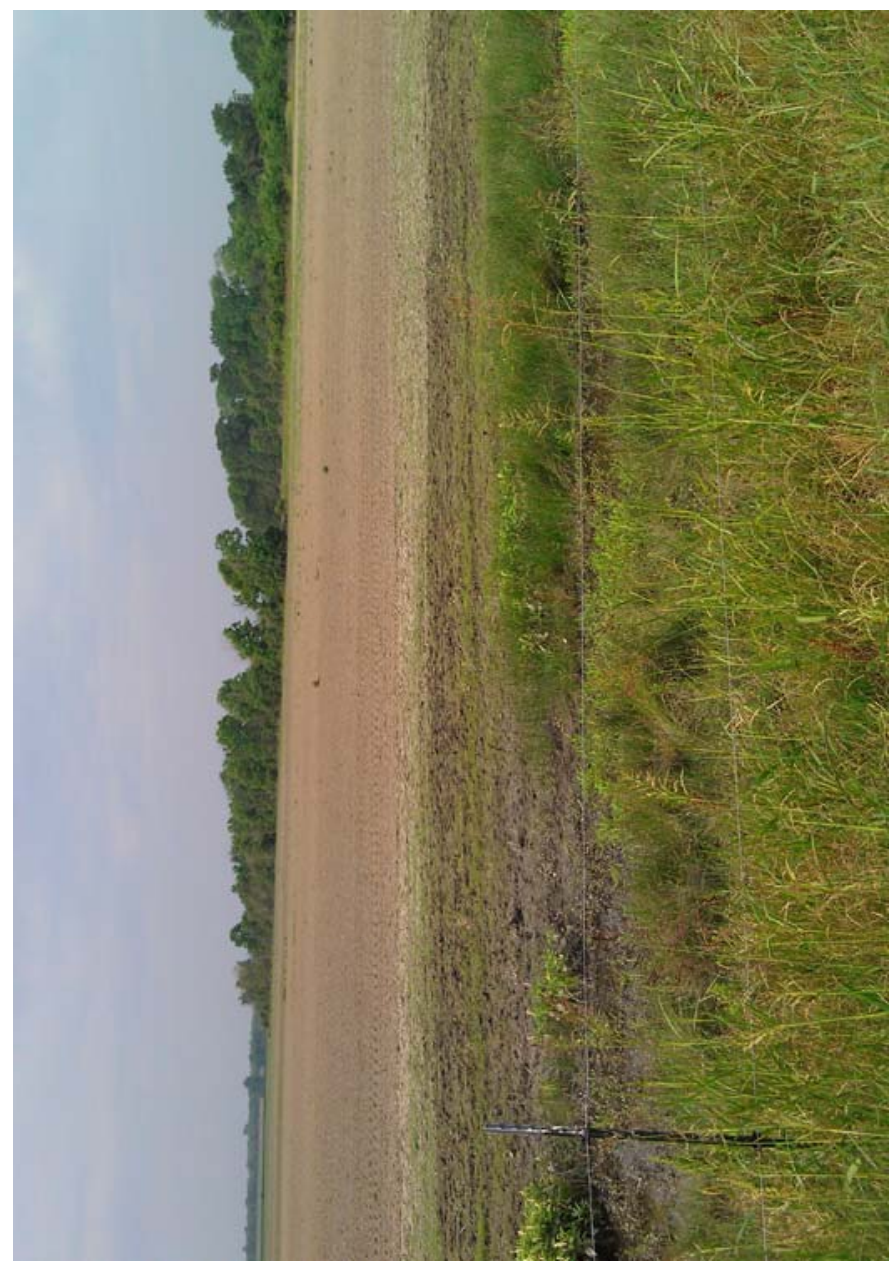

62

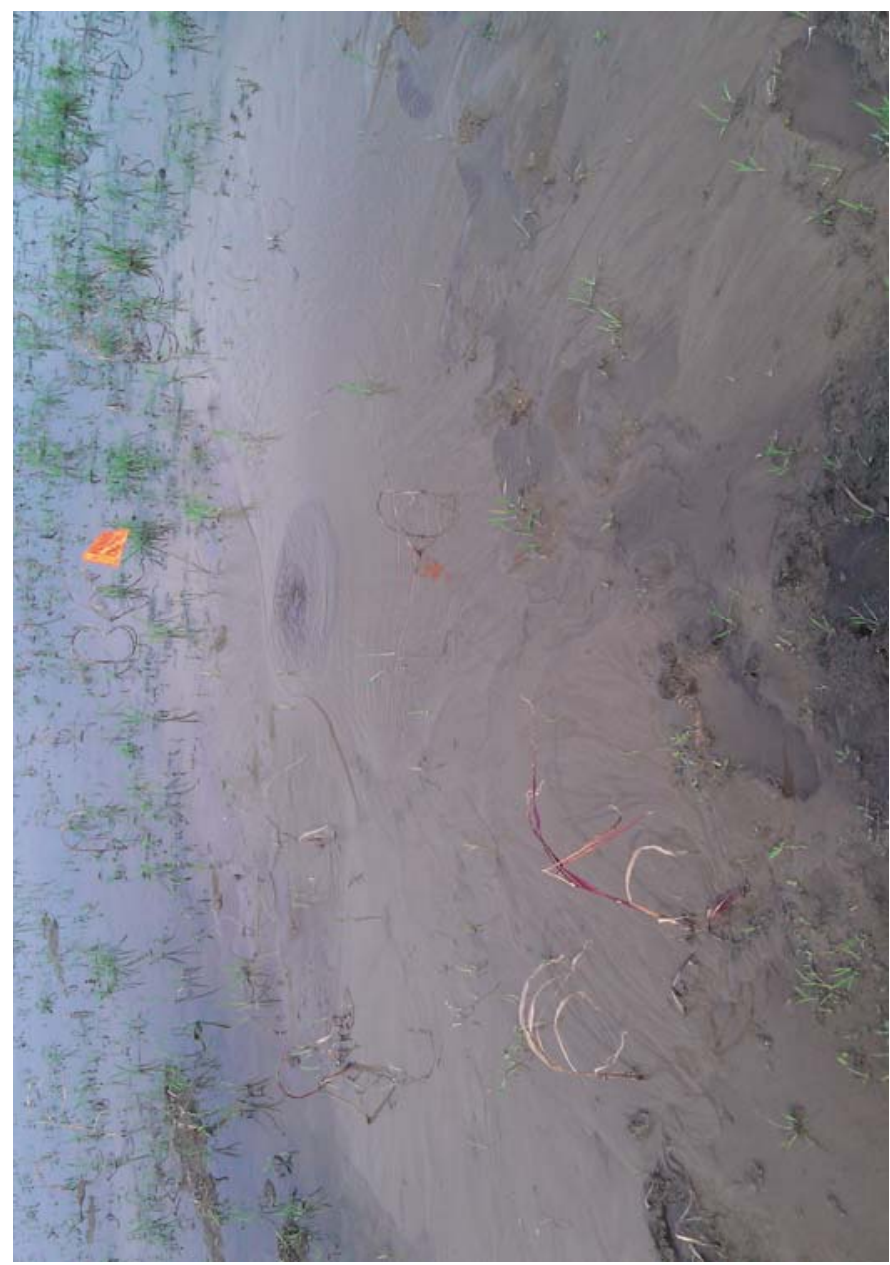

64 


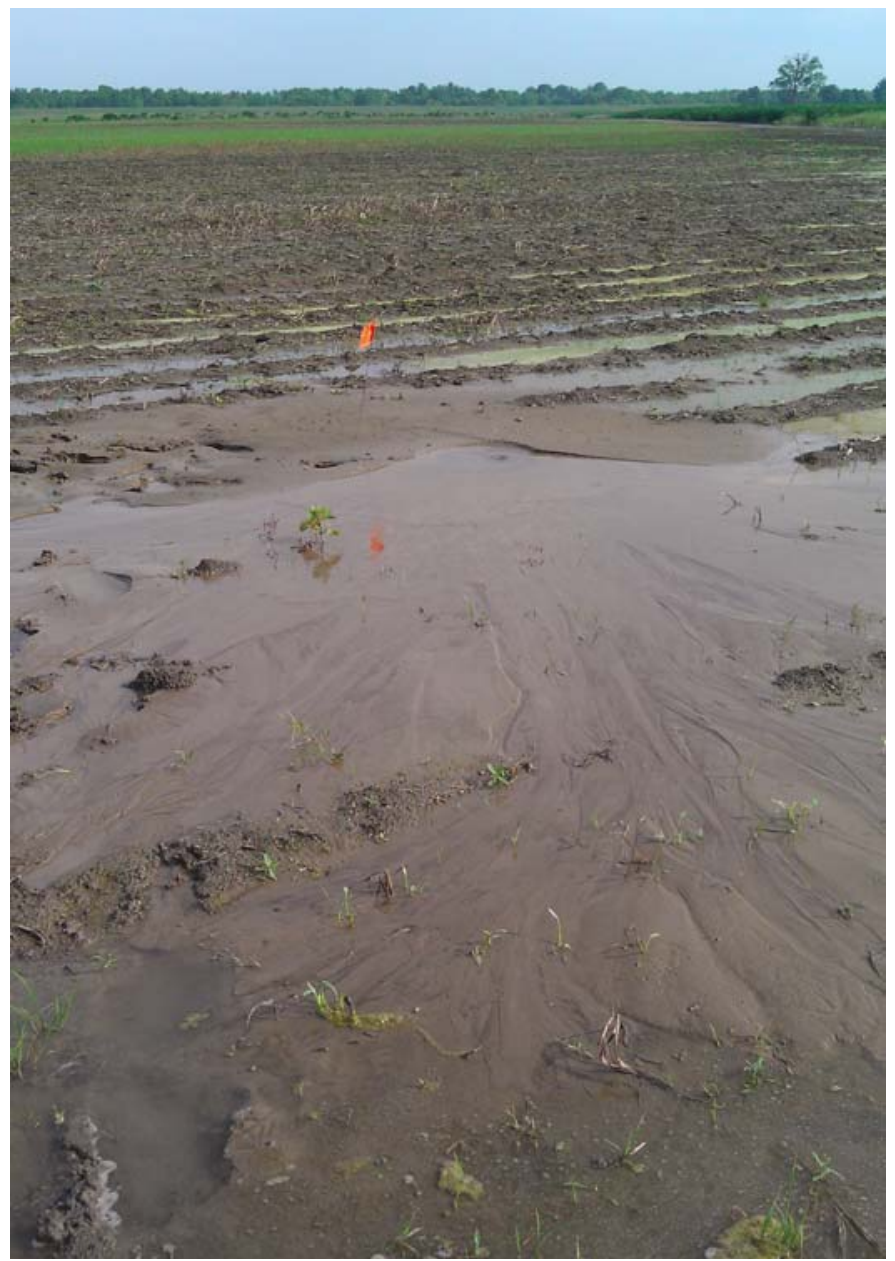

65

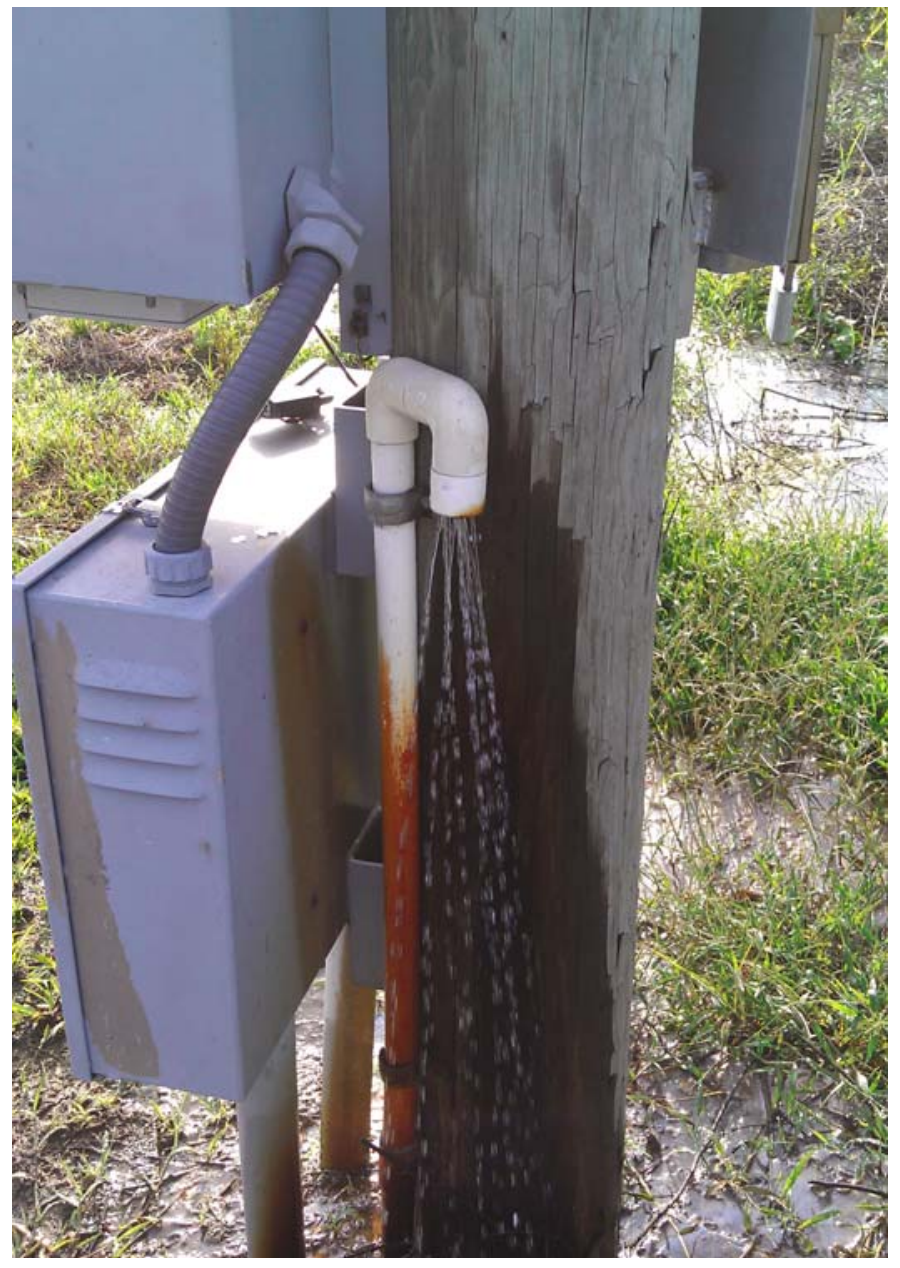

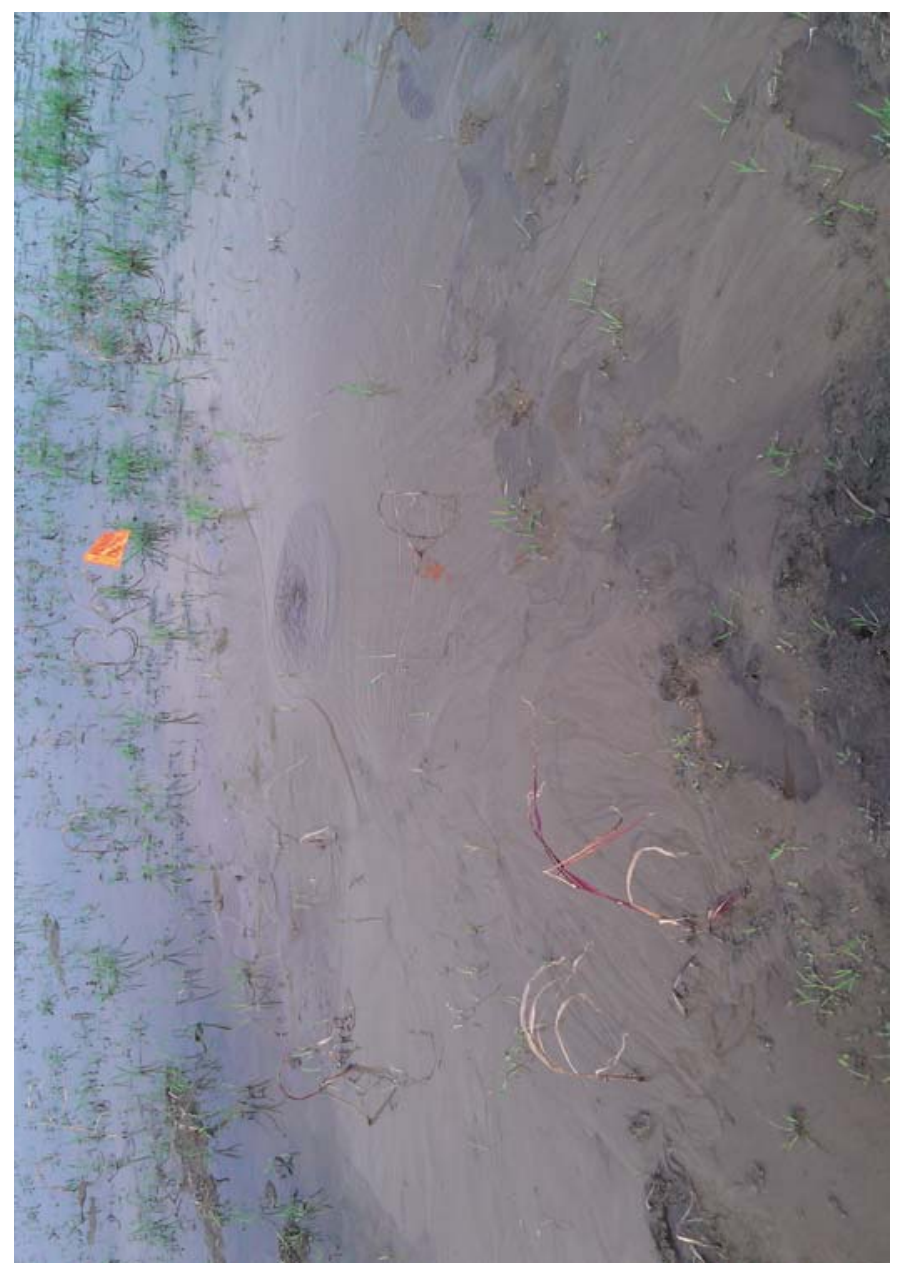

66

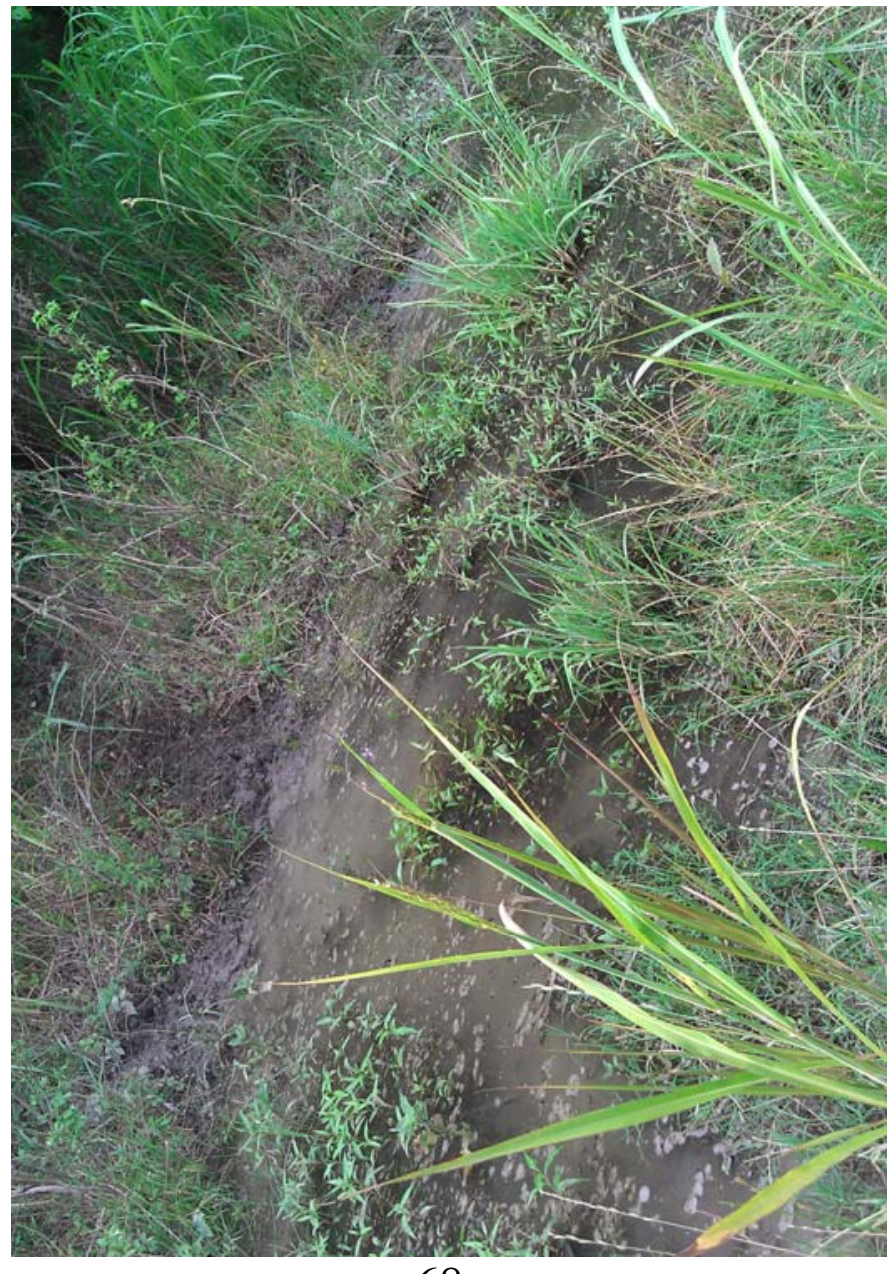




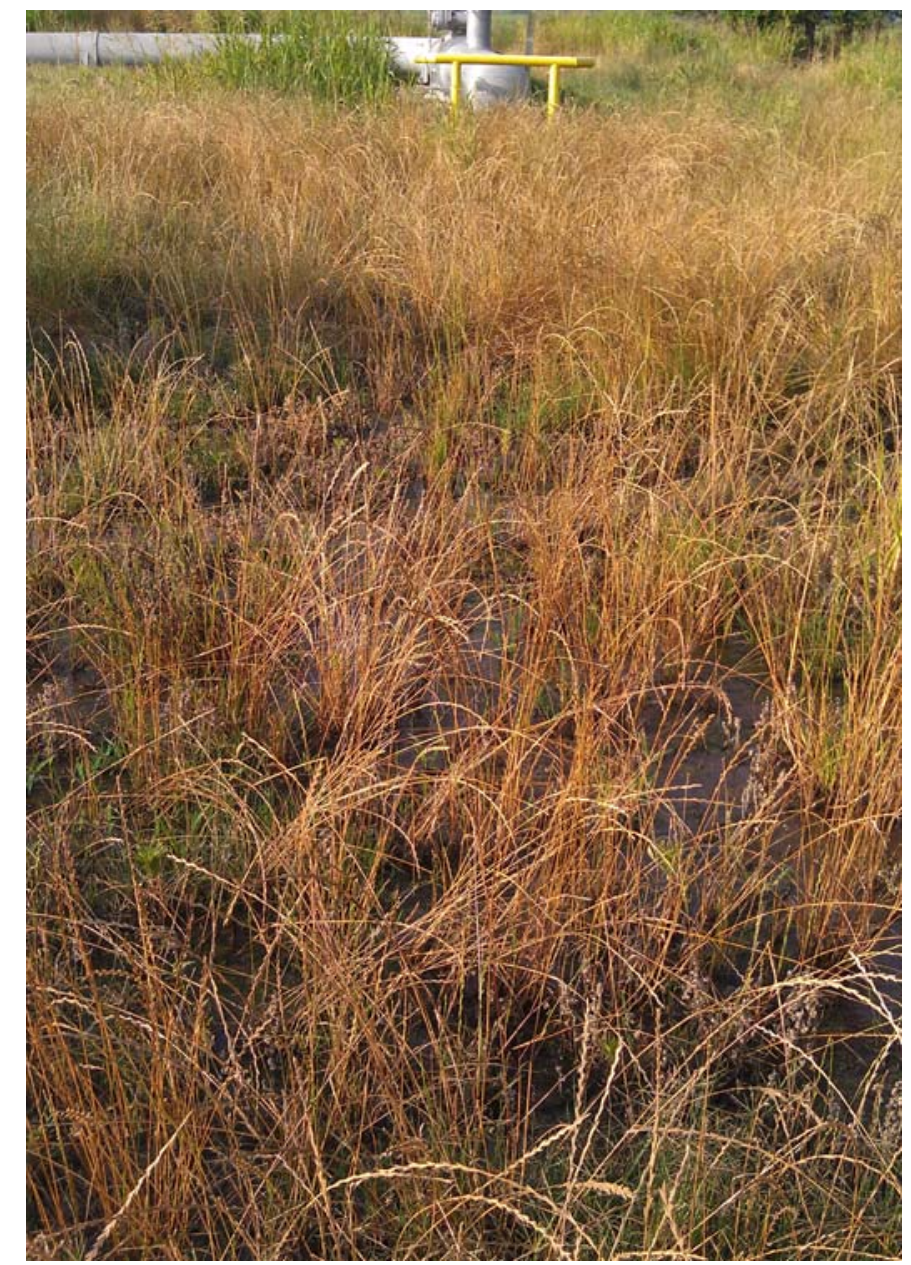

69

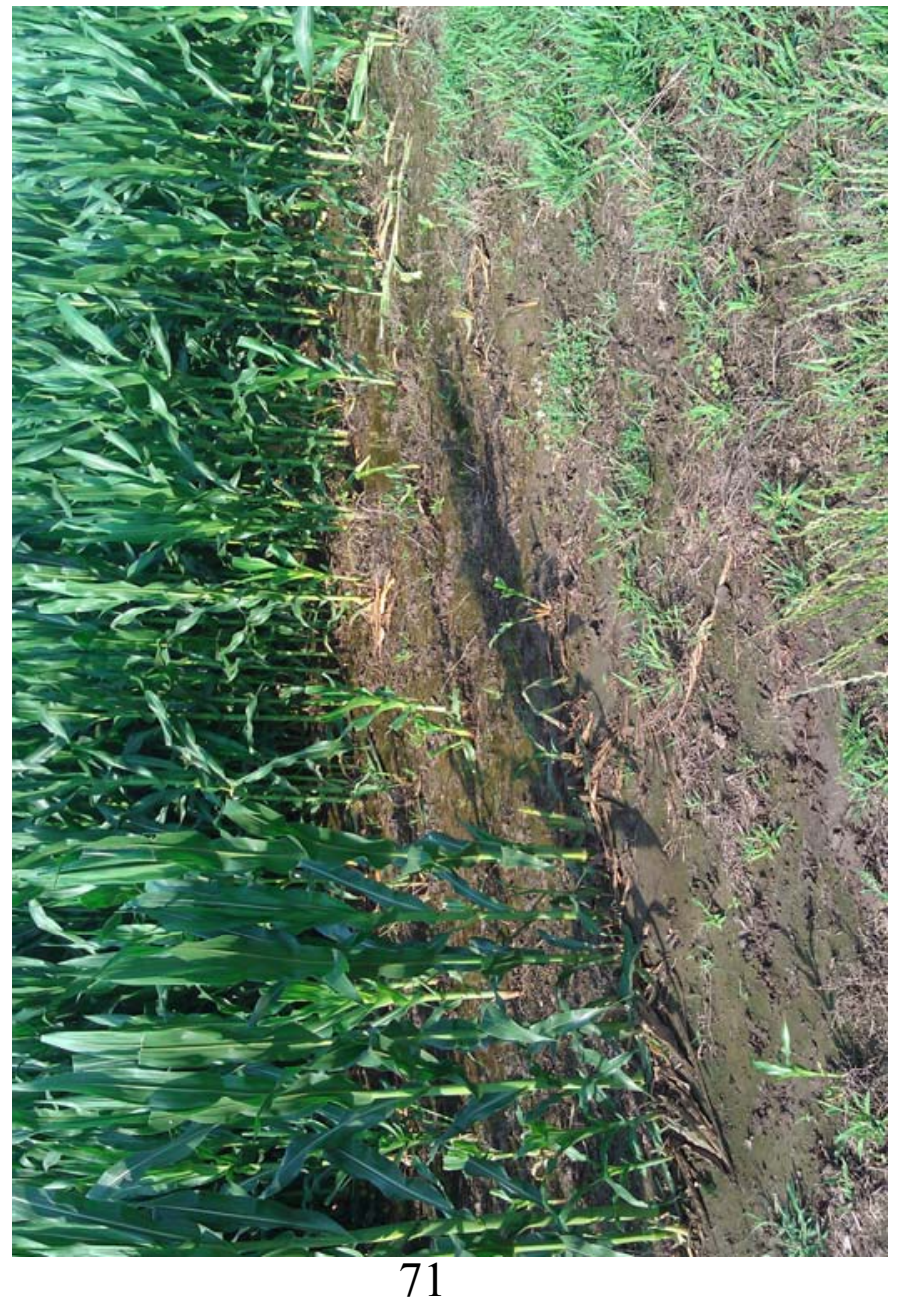

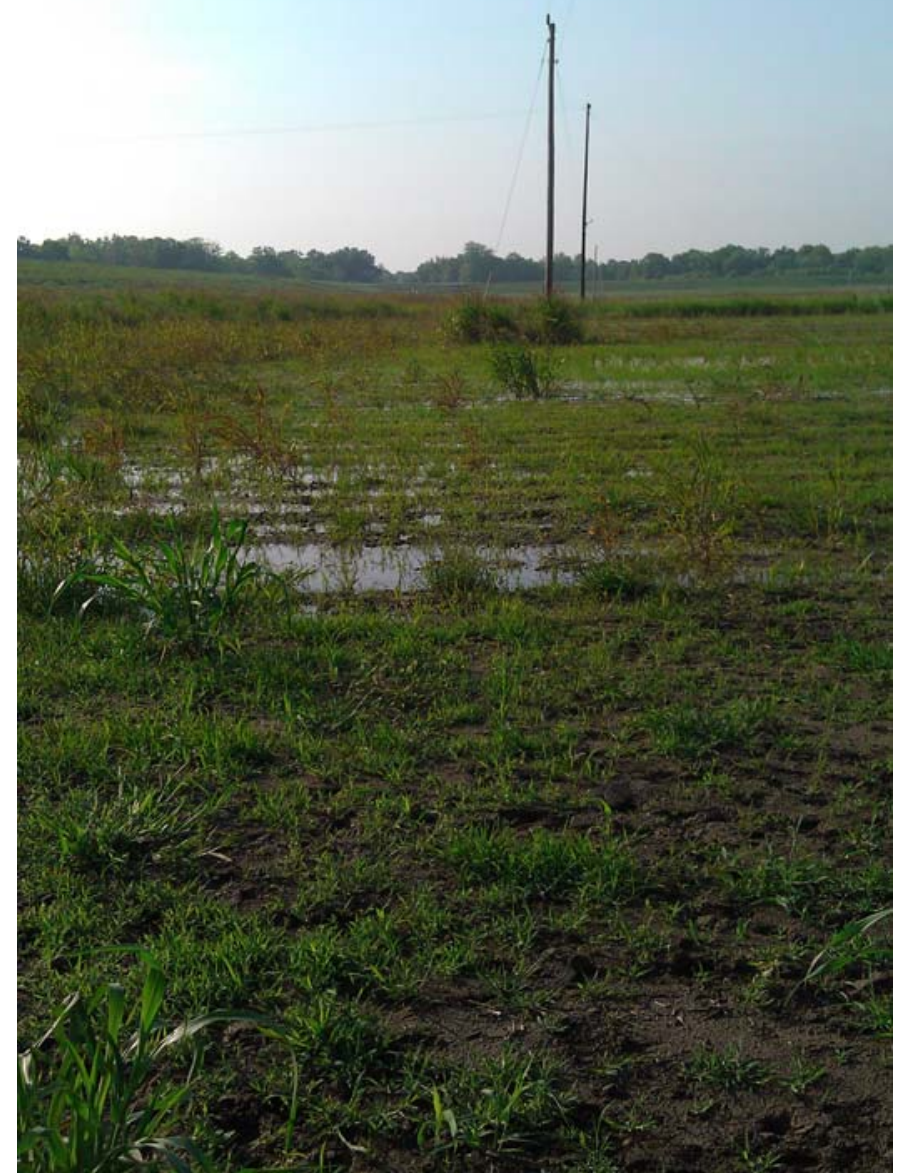

70

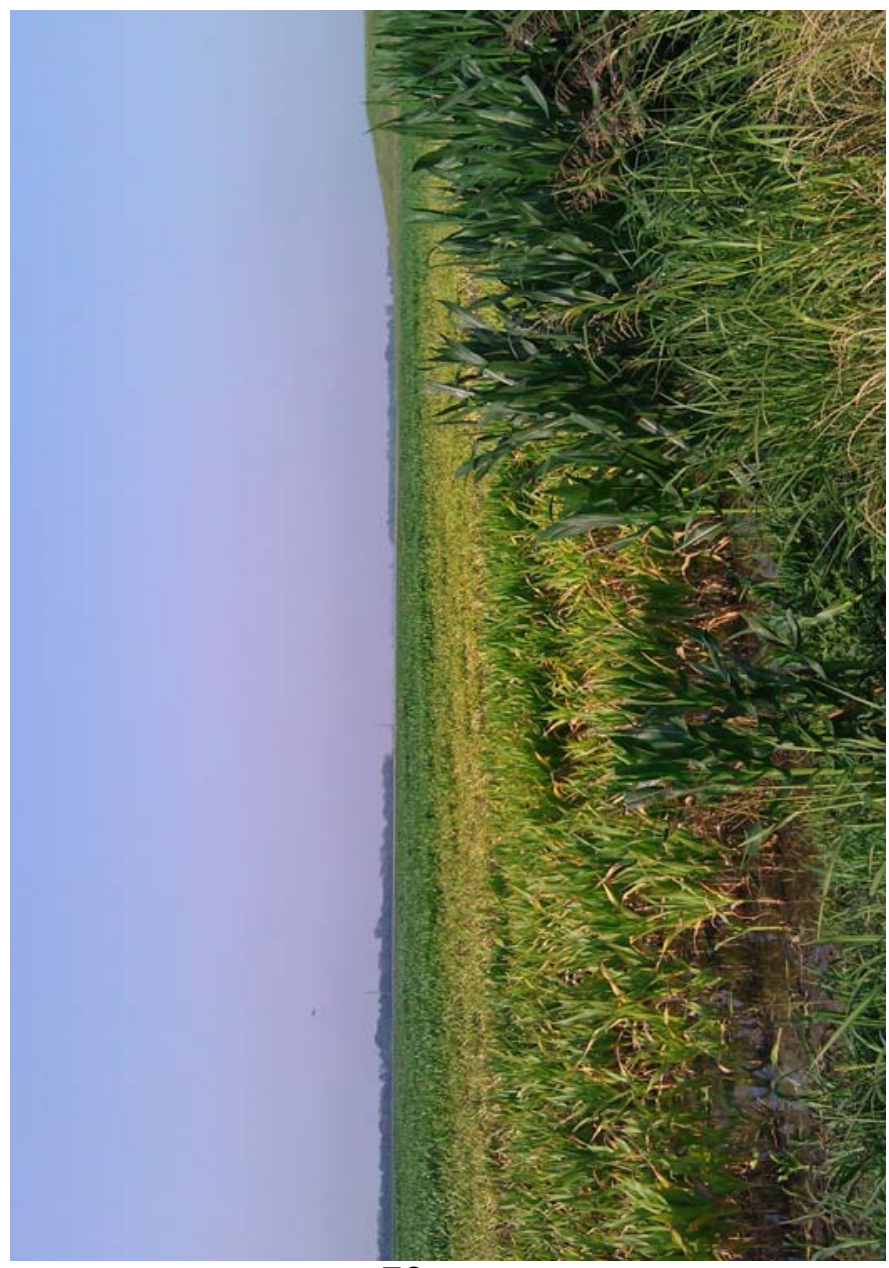




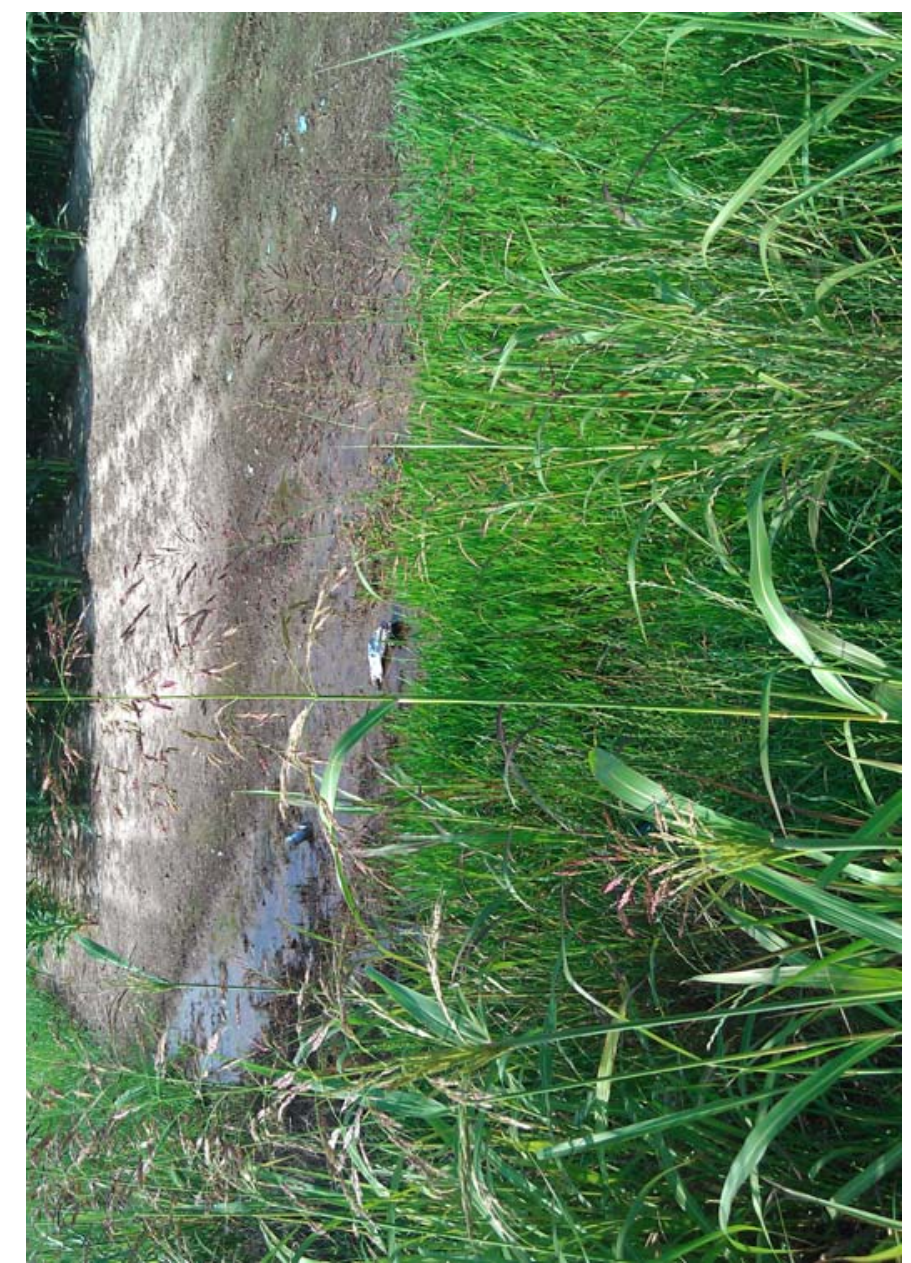

73

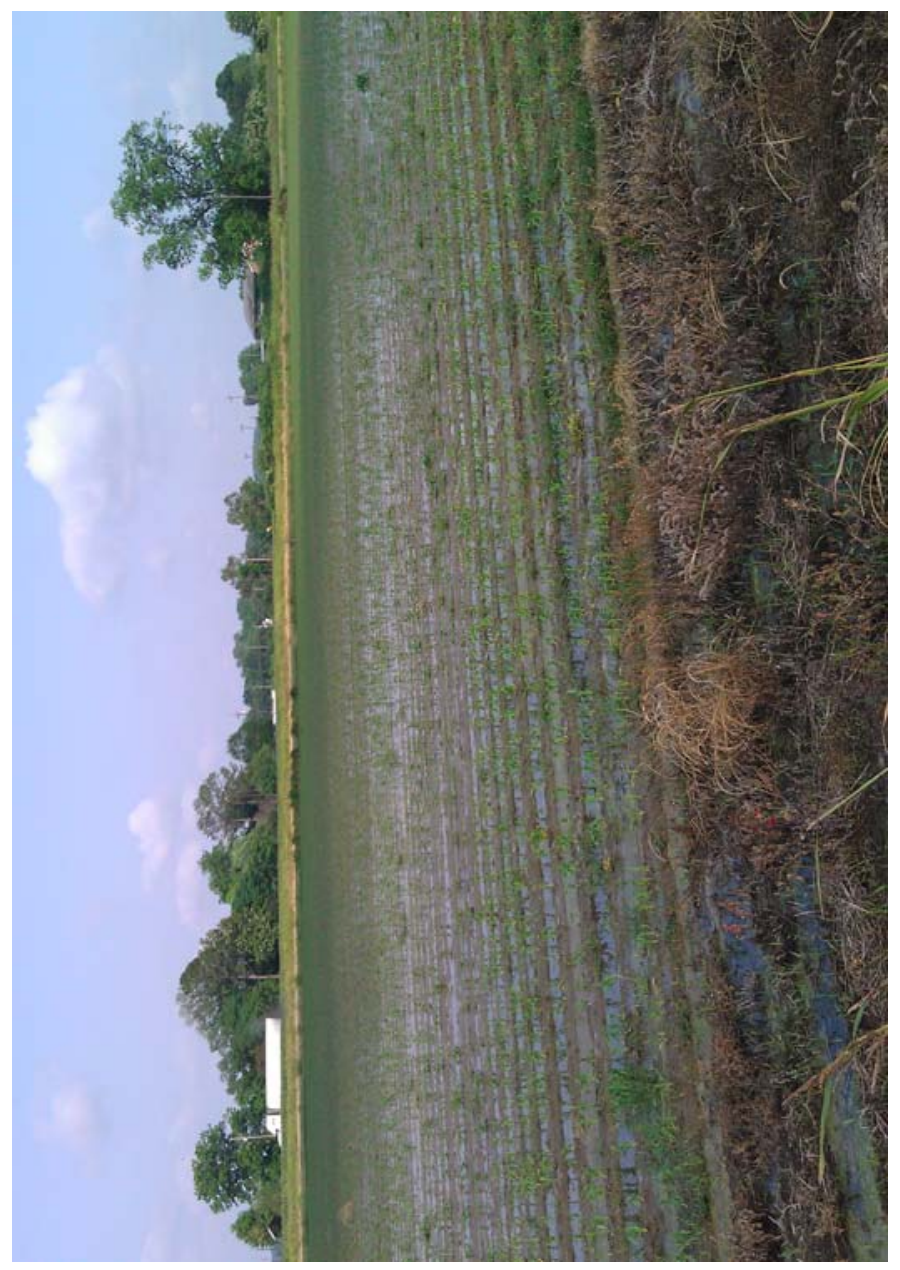

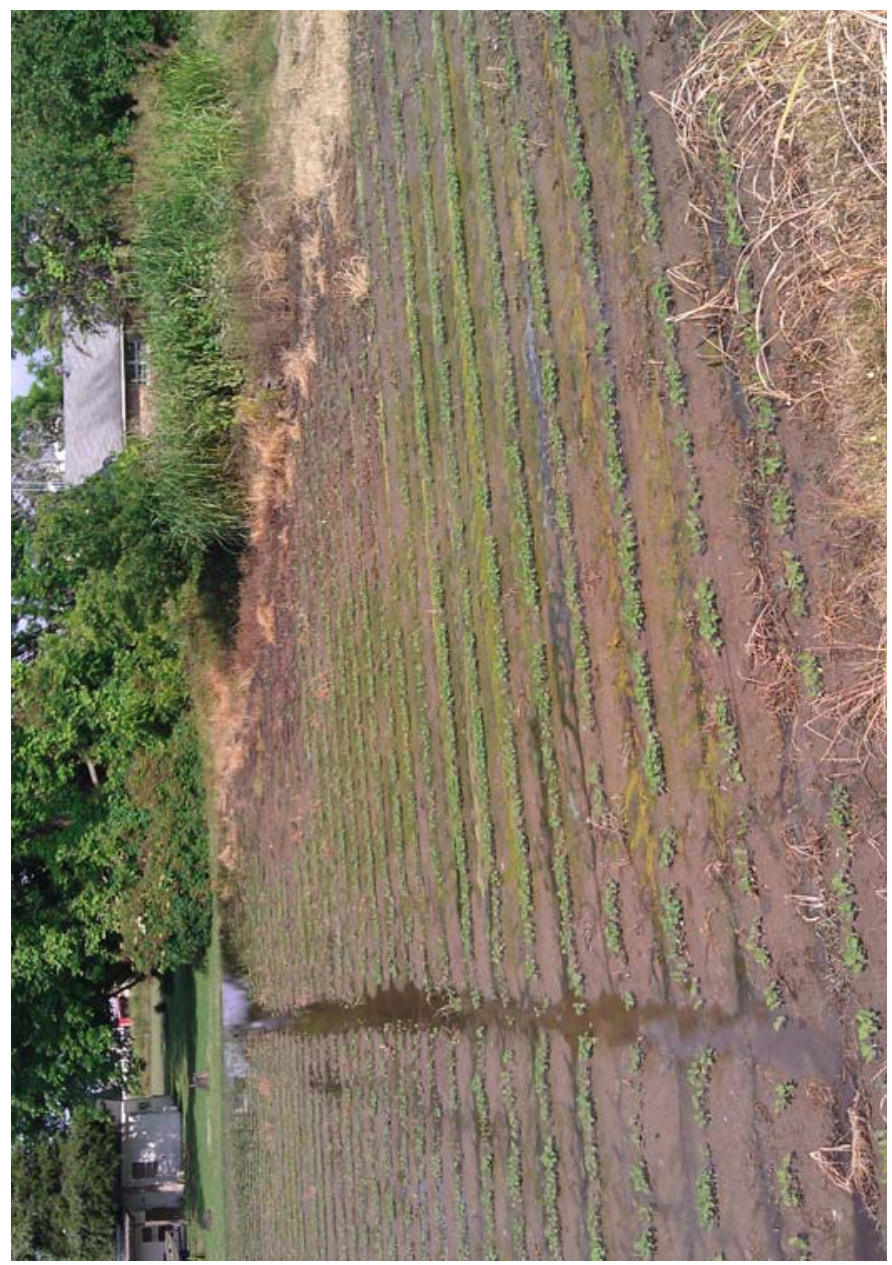

74

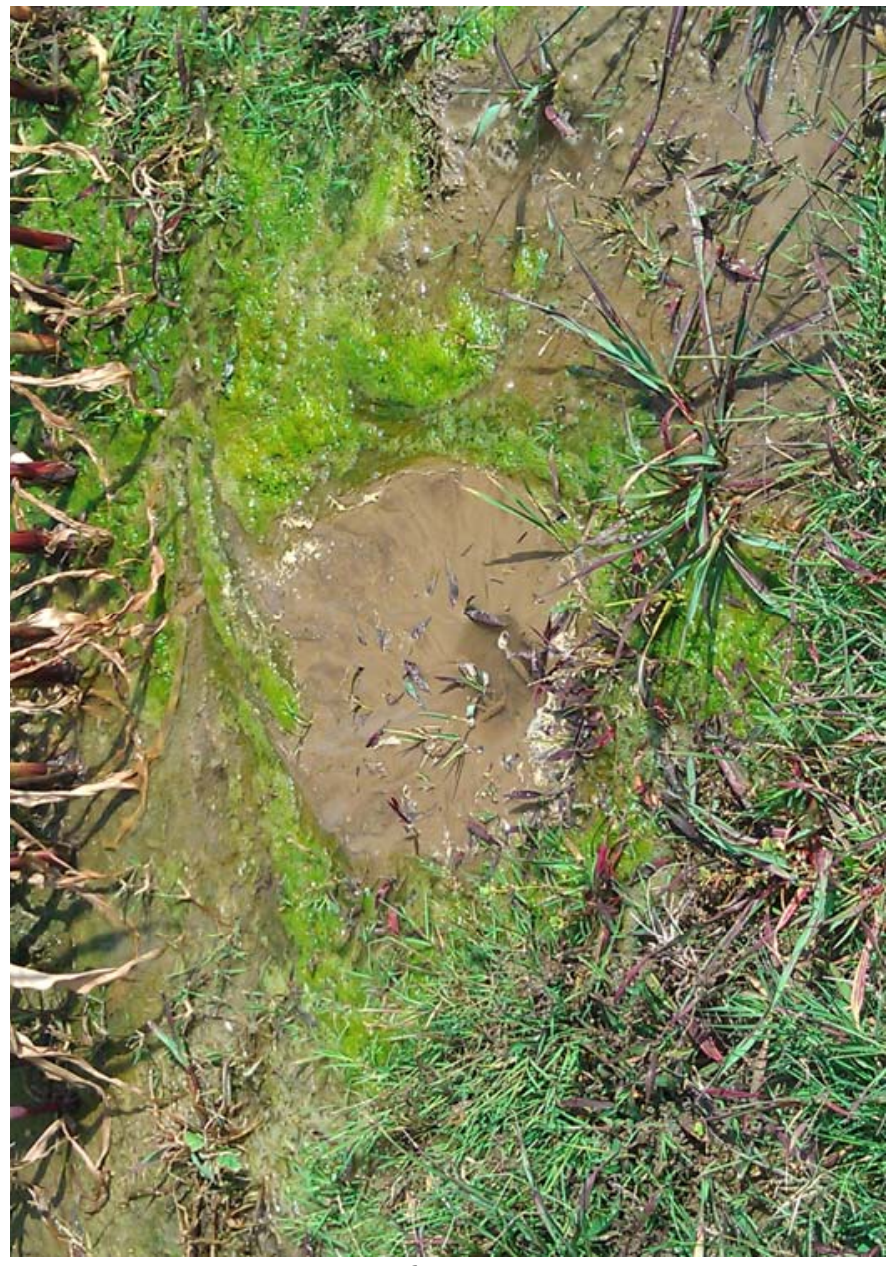



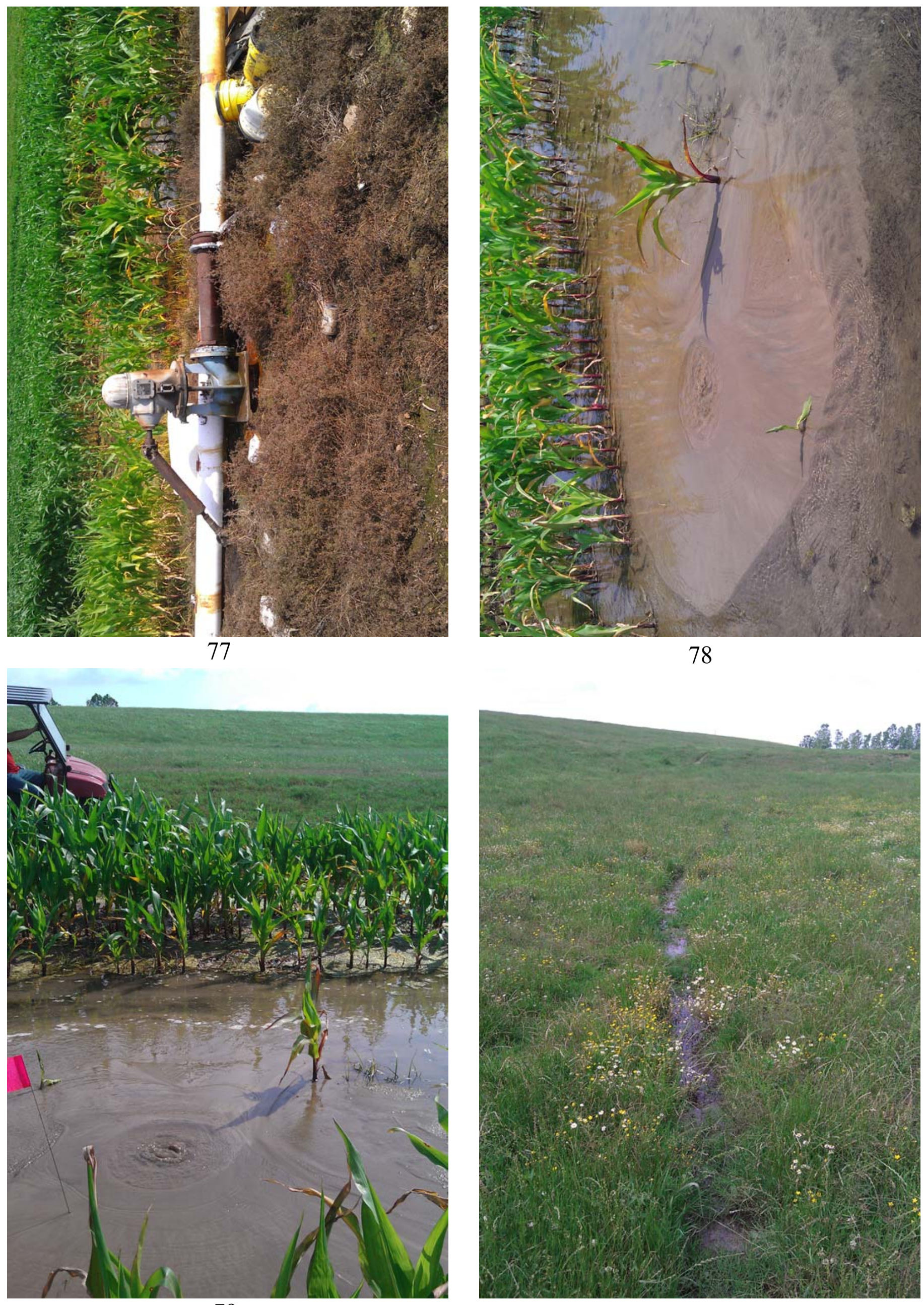


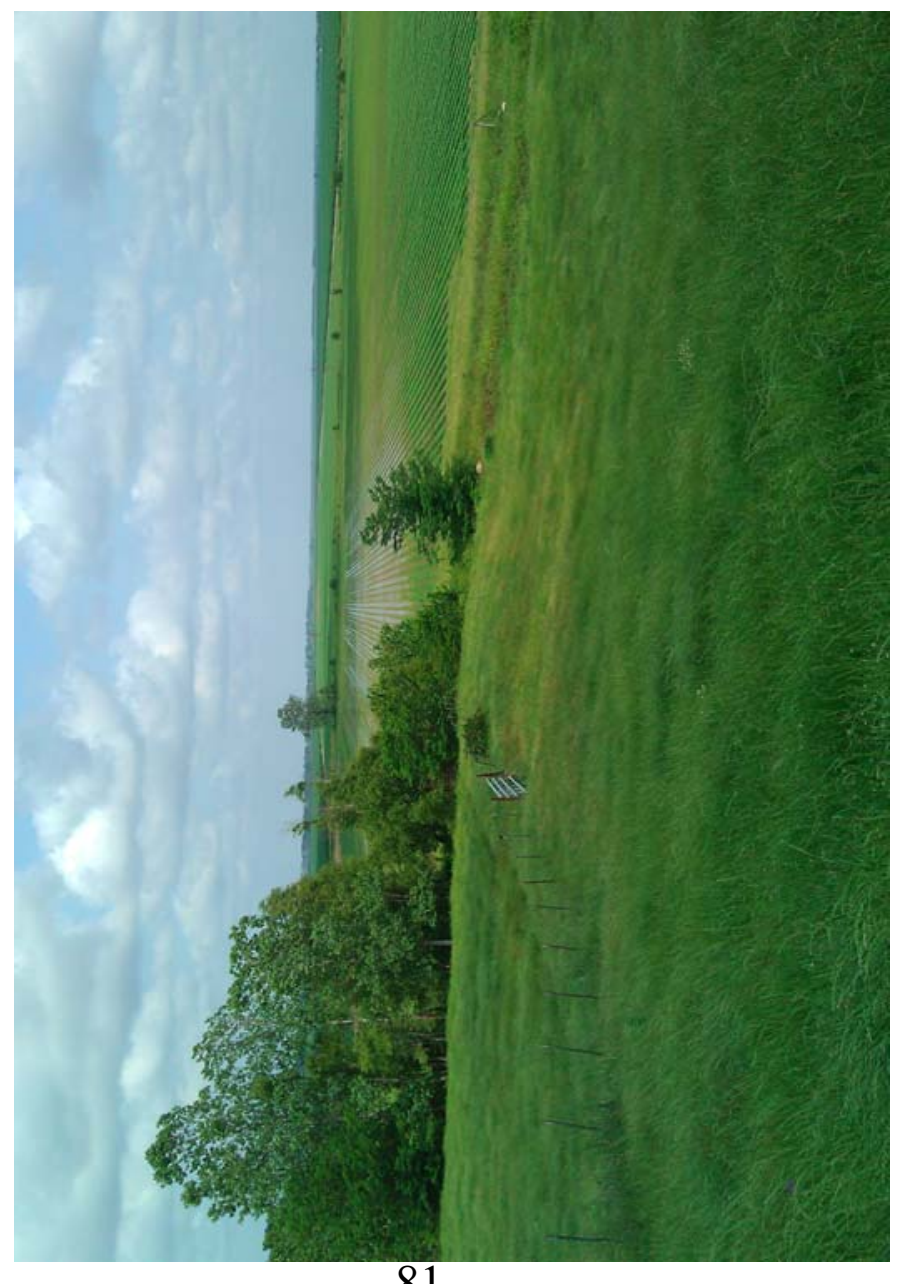

81

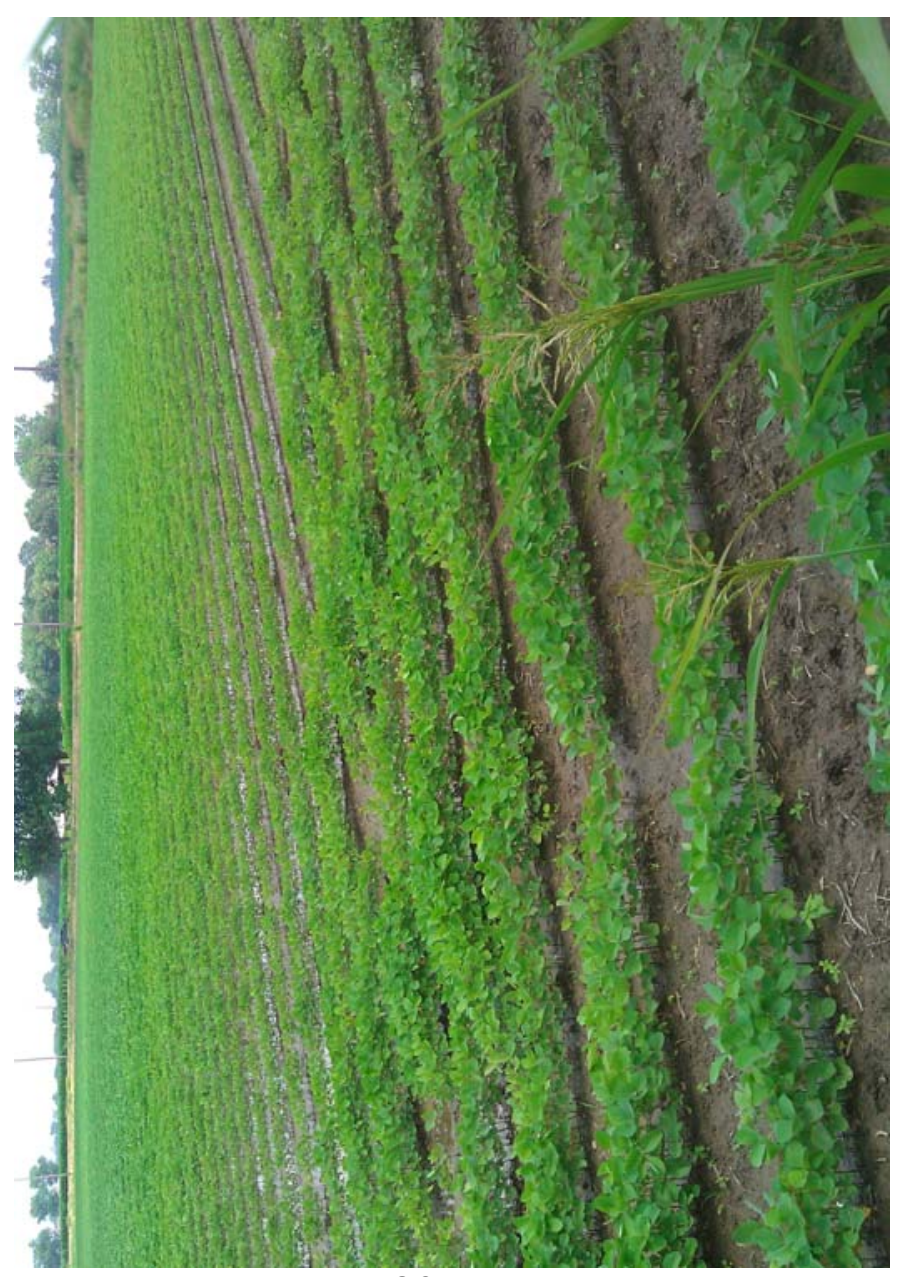

83

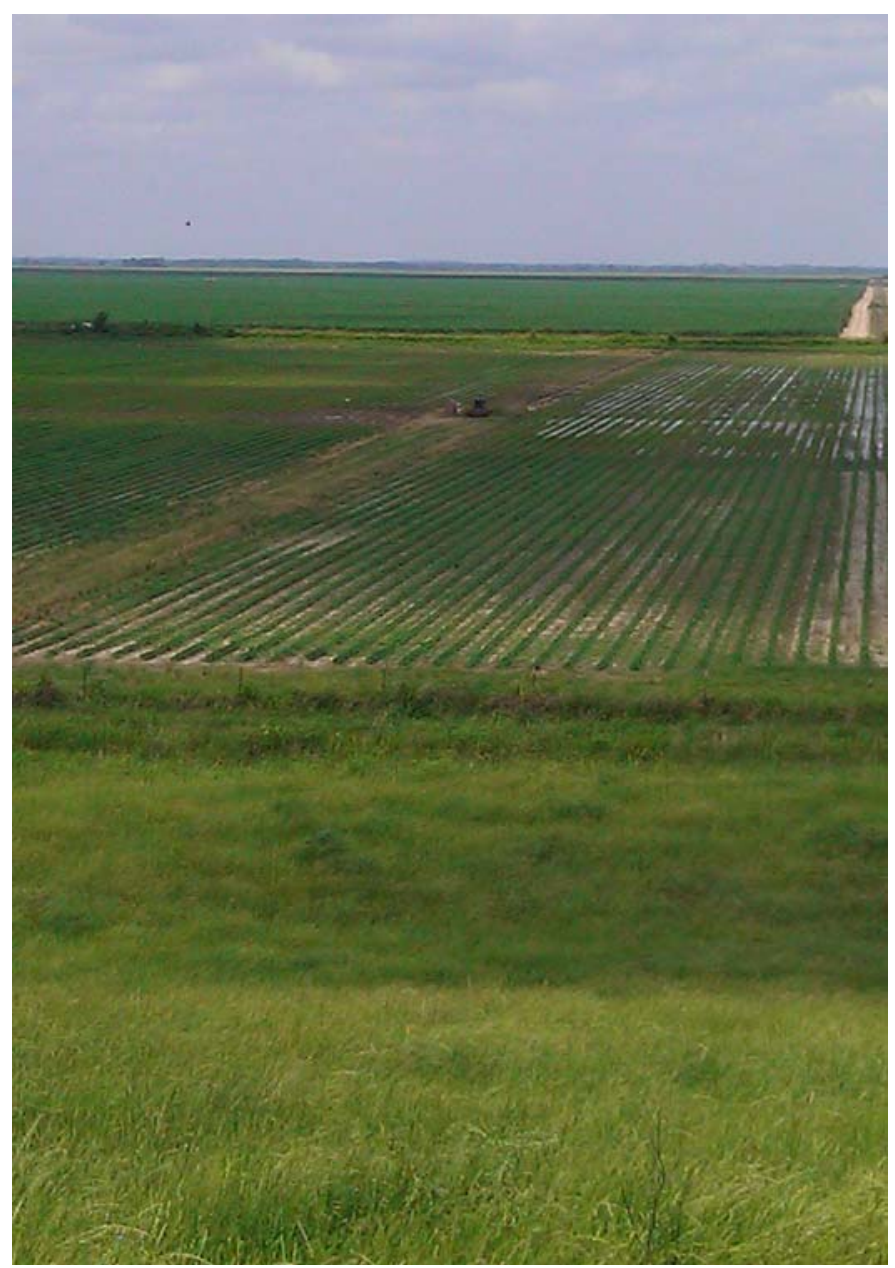

82

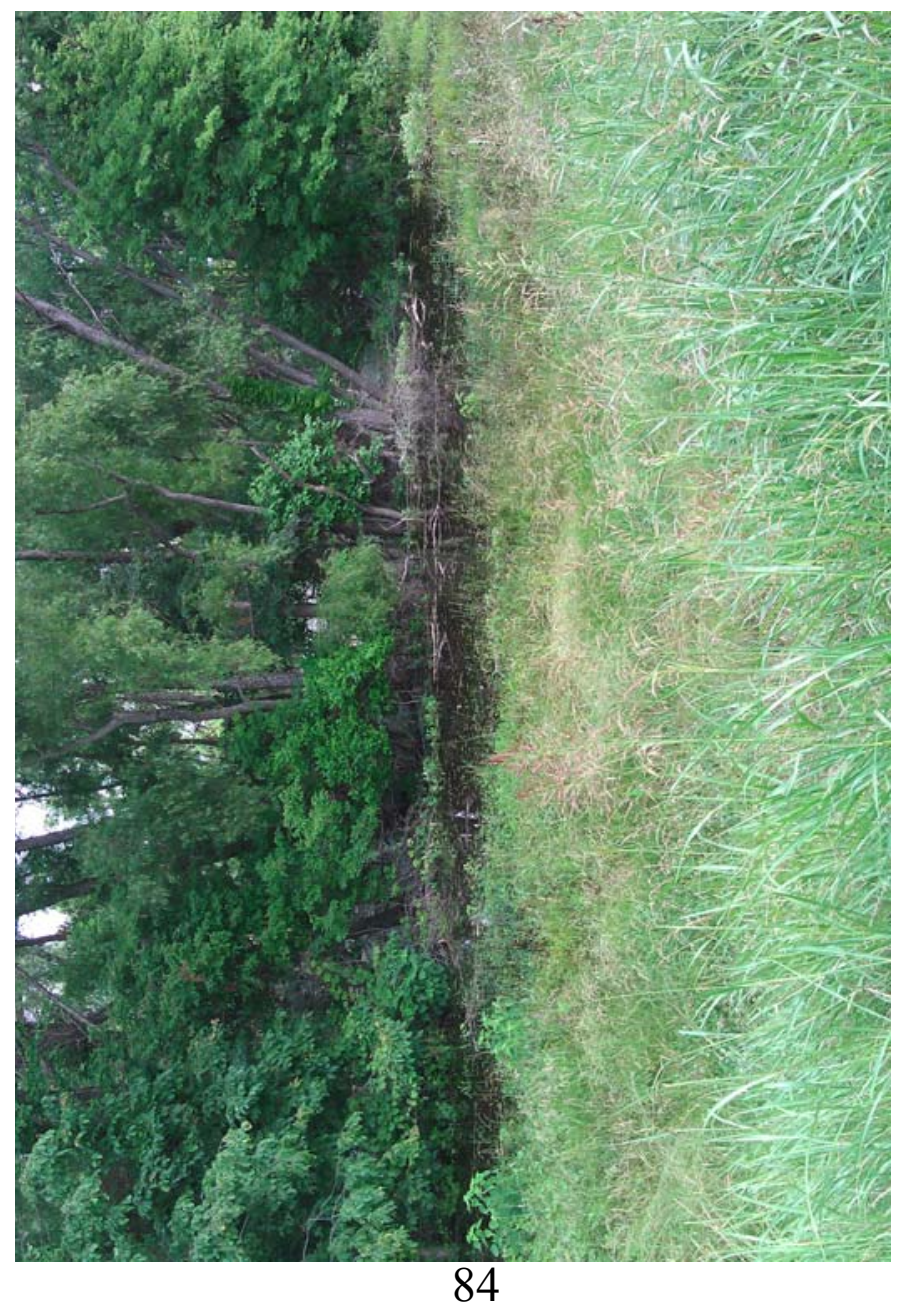

FOR OFFICIAL USE ONLY 

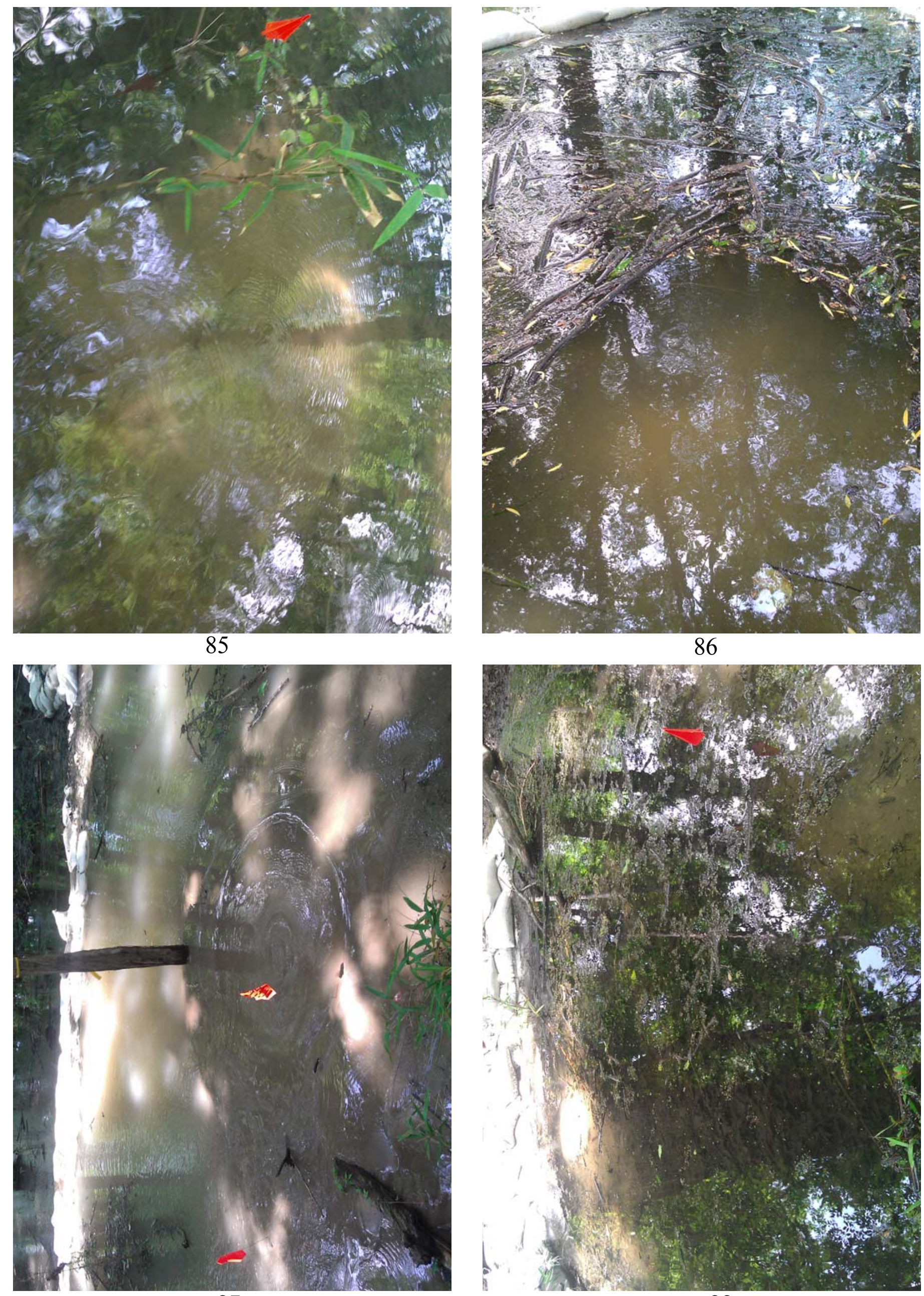

\section{6}
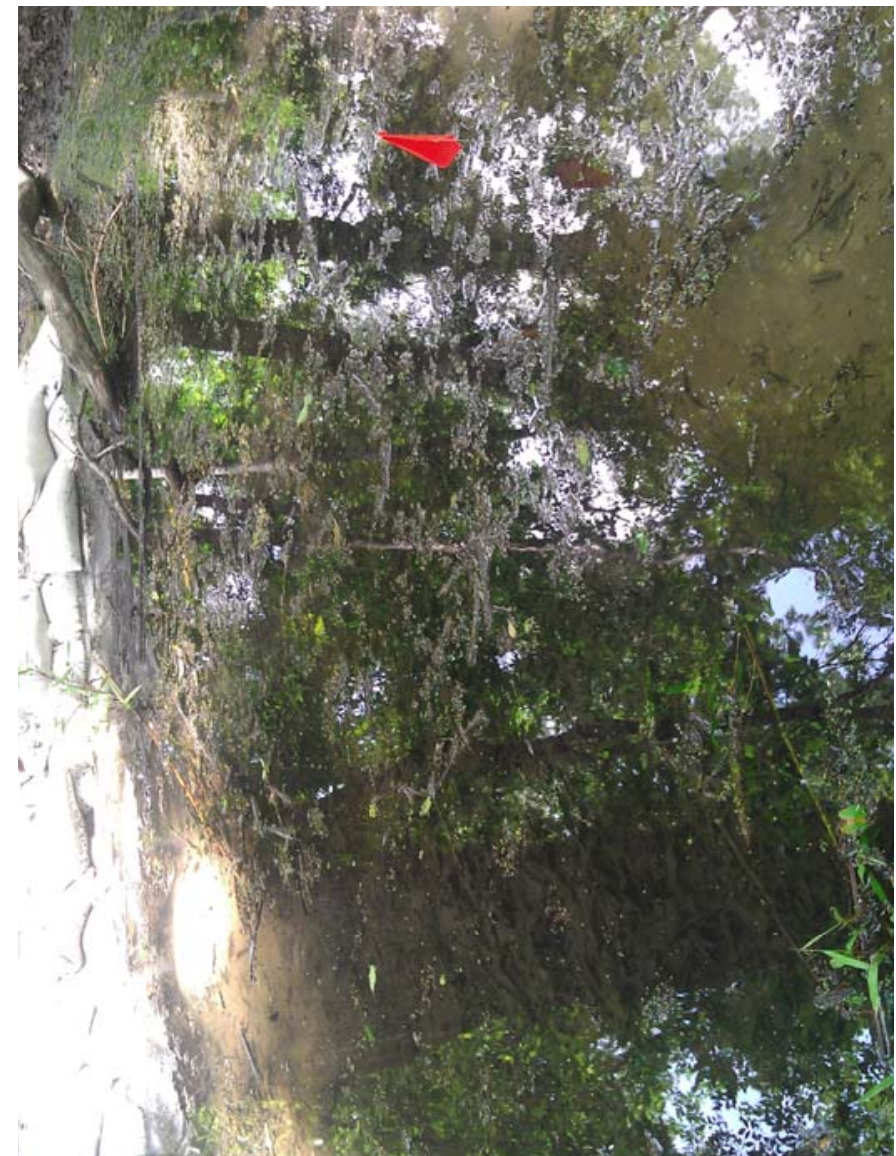

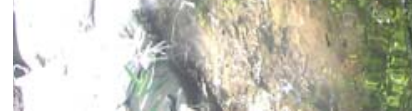
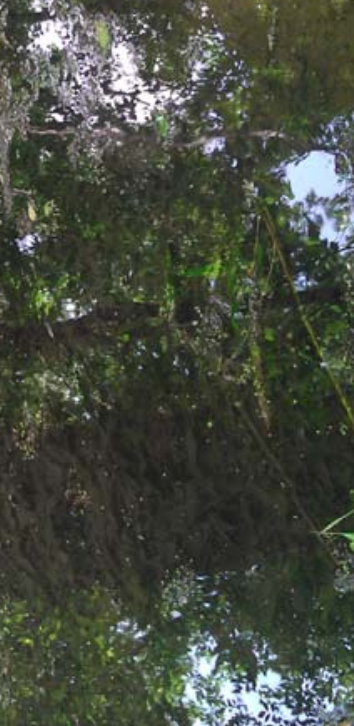

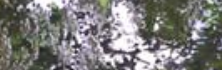

Actist;

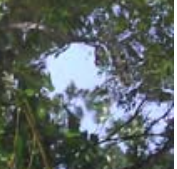

20050 ? an $3 x$. $4=2$. 


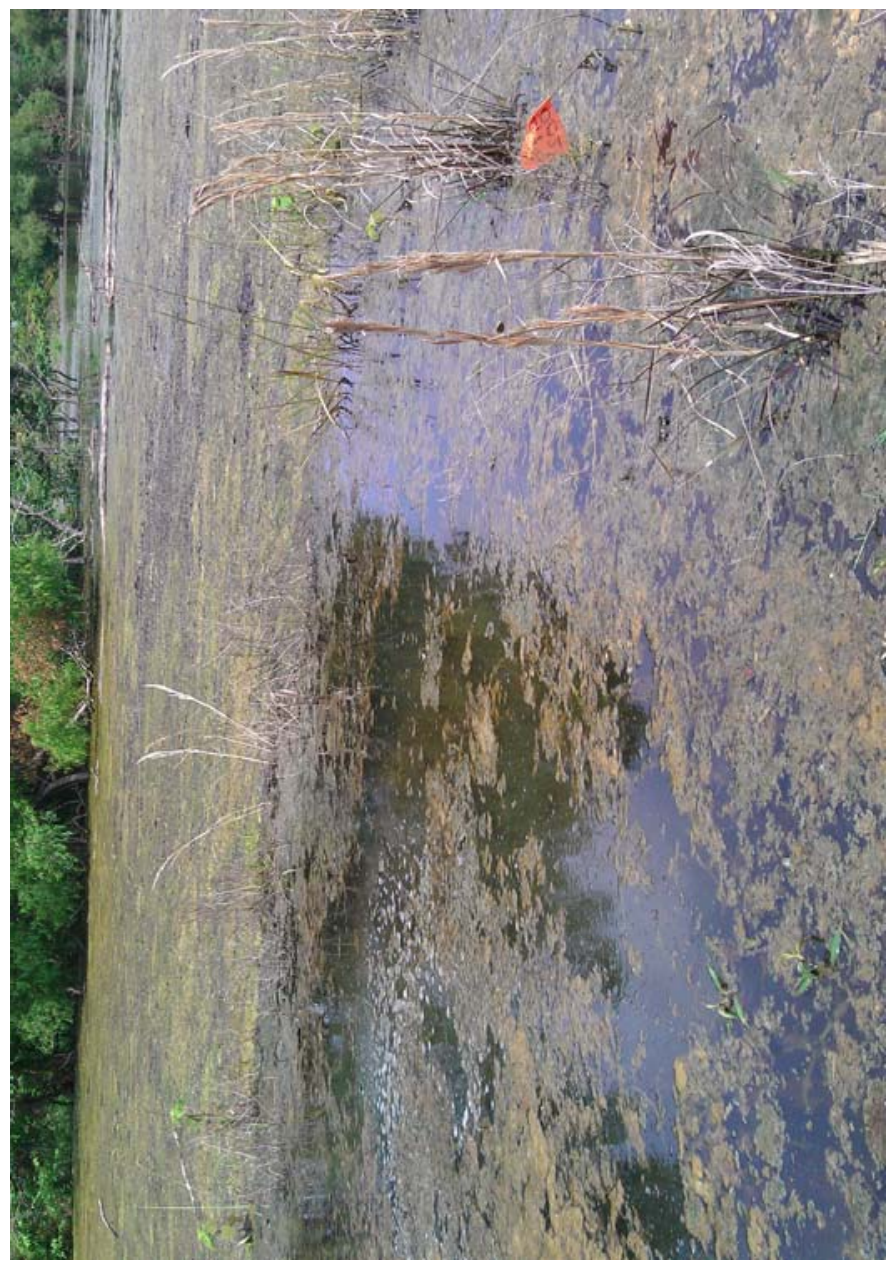

\section{9}

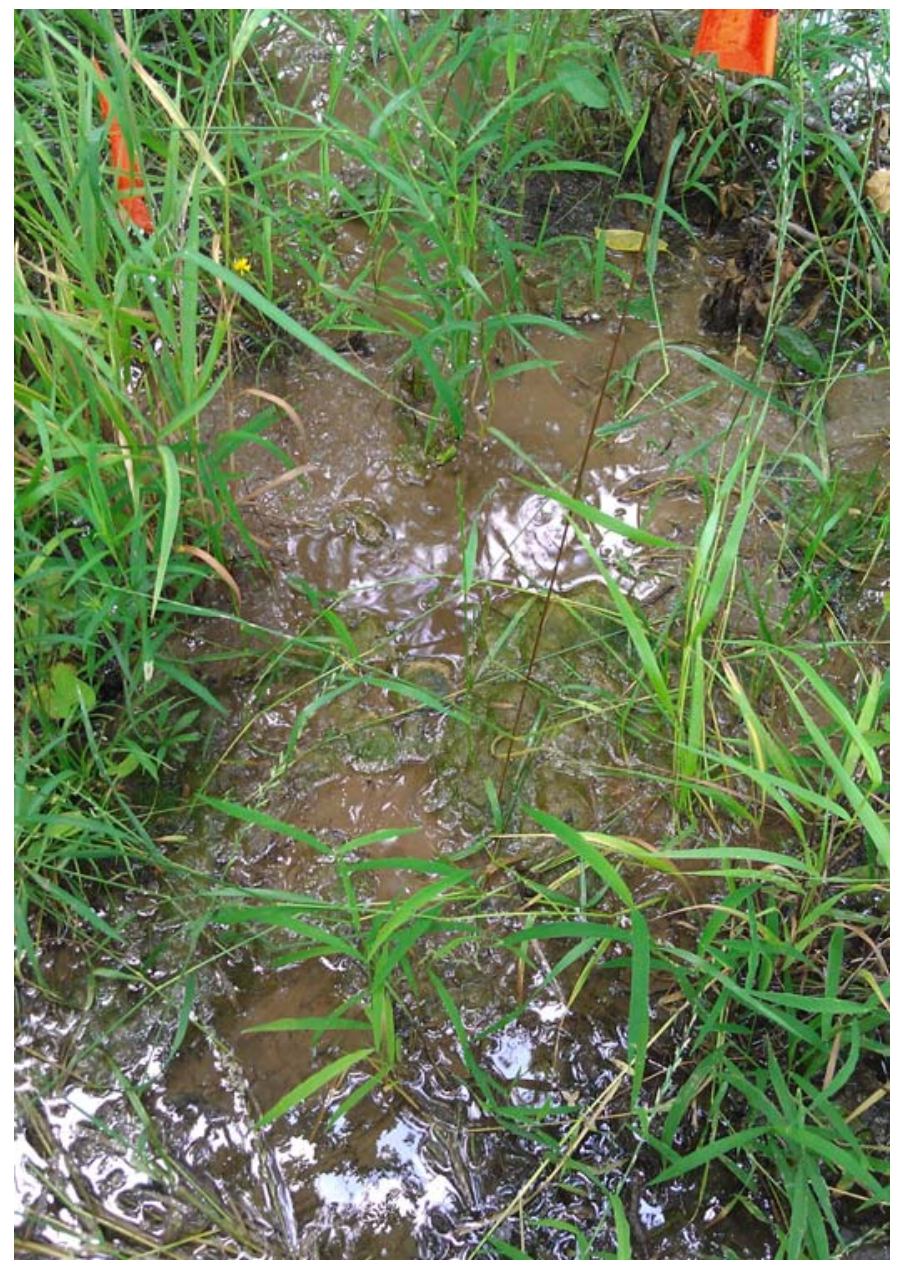

91

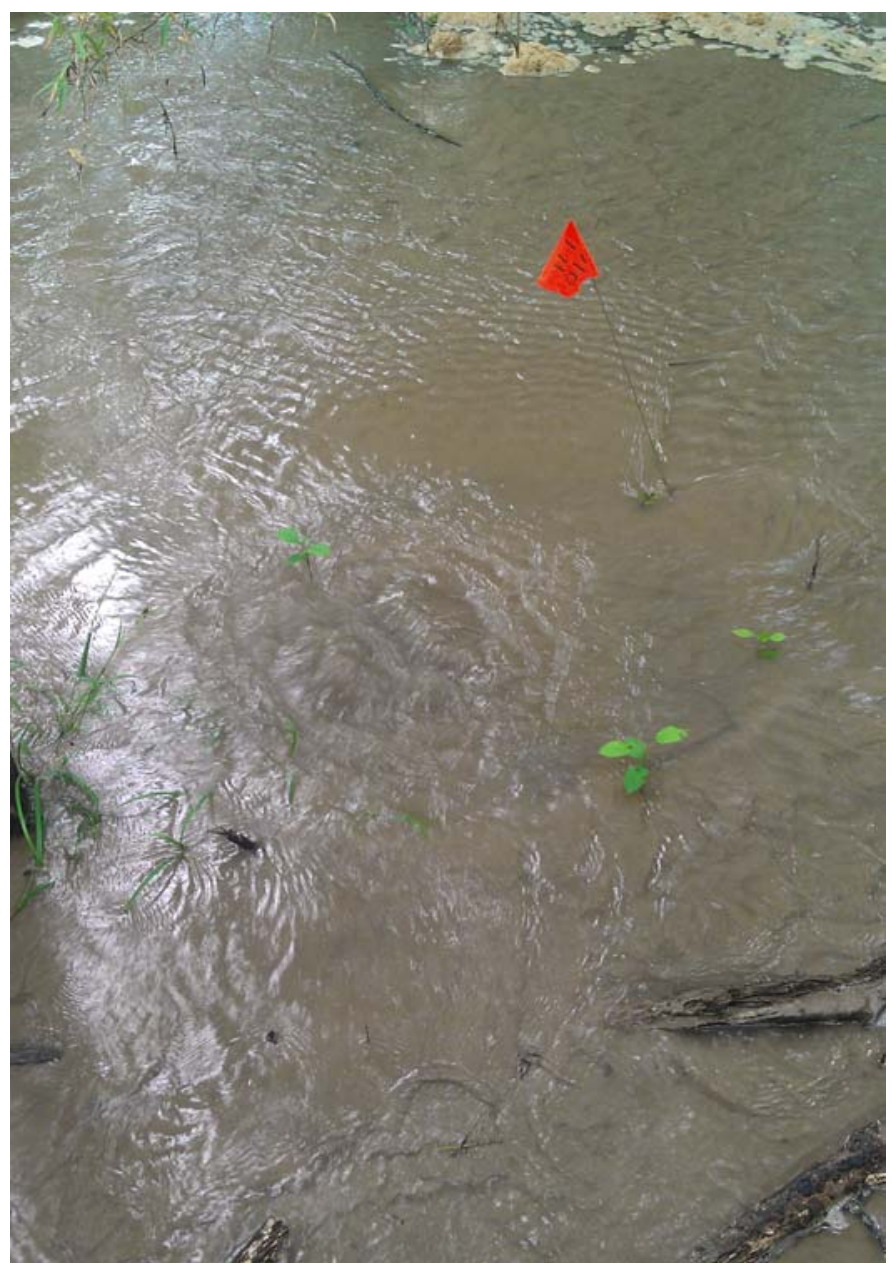

90

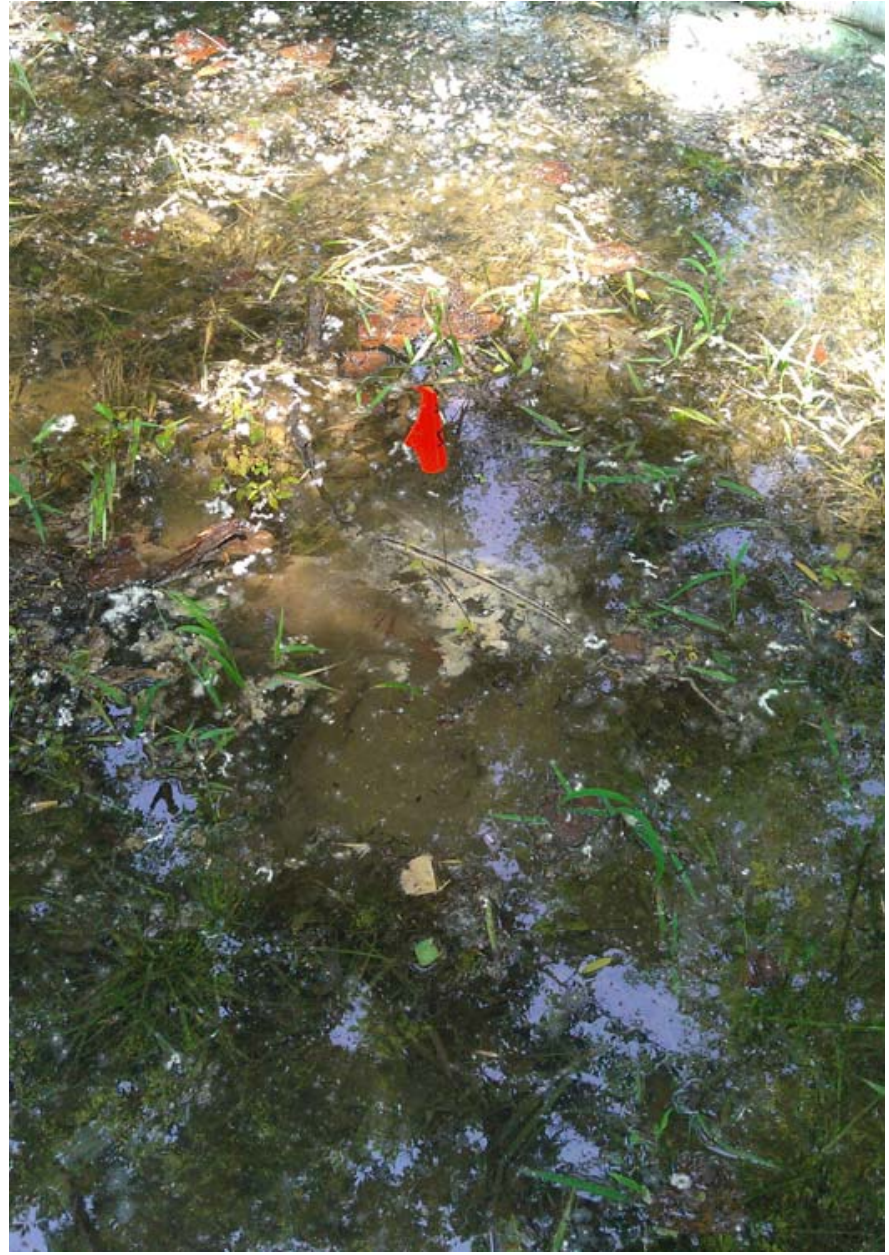

92 


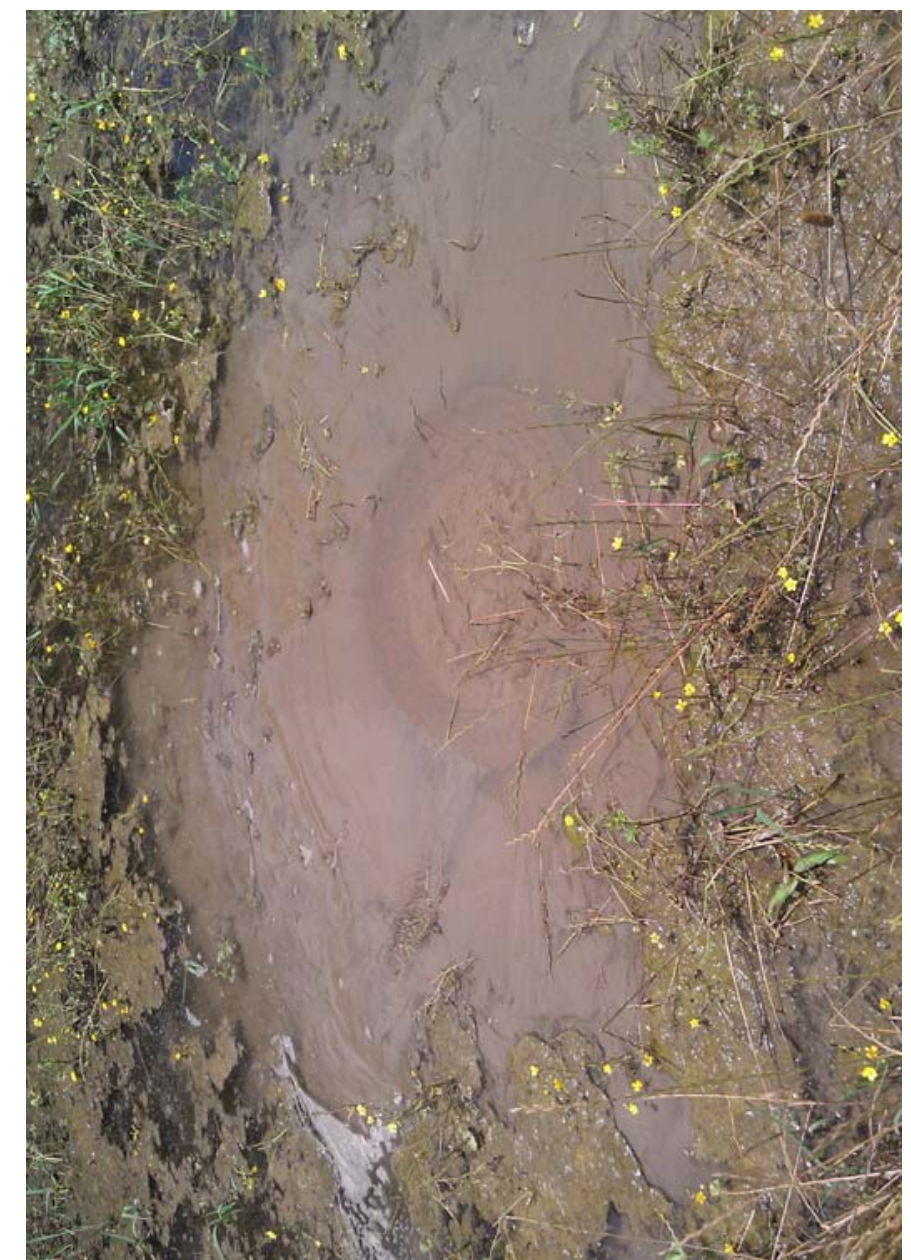

93

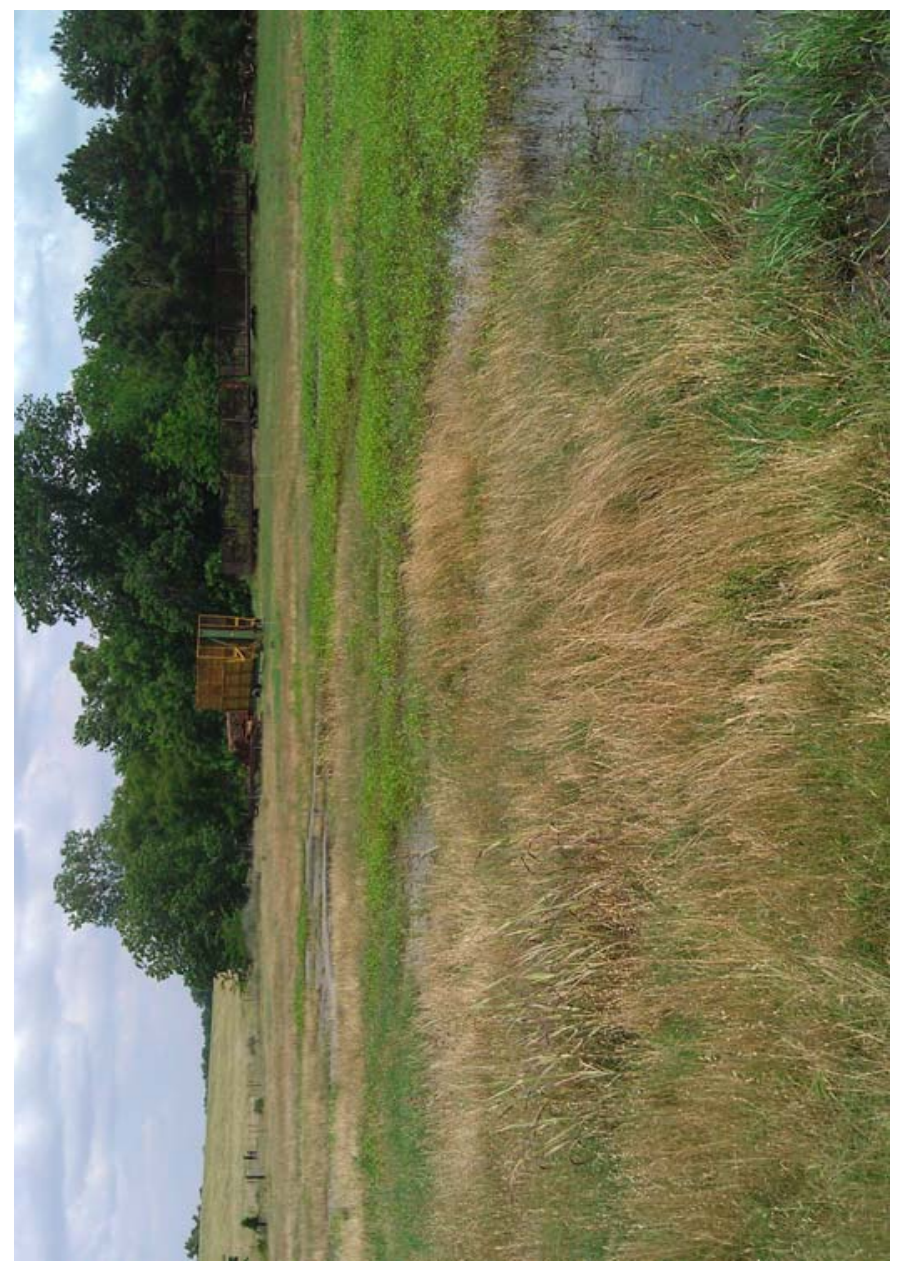

94

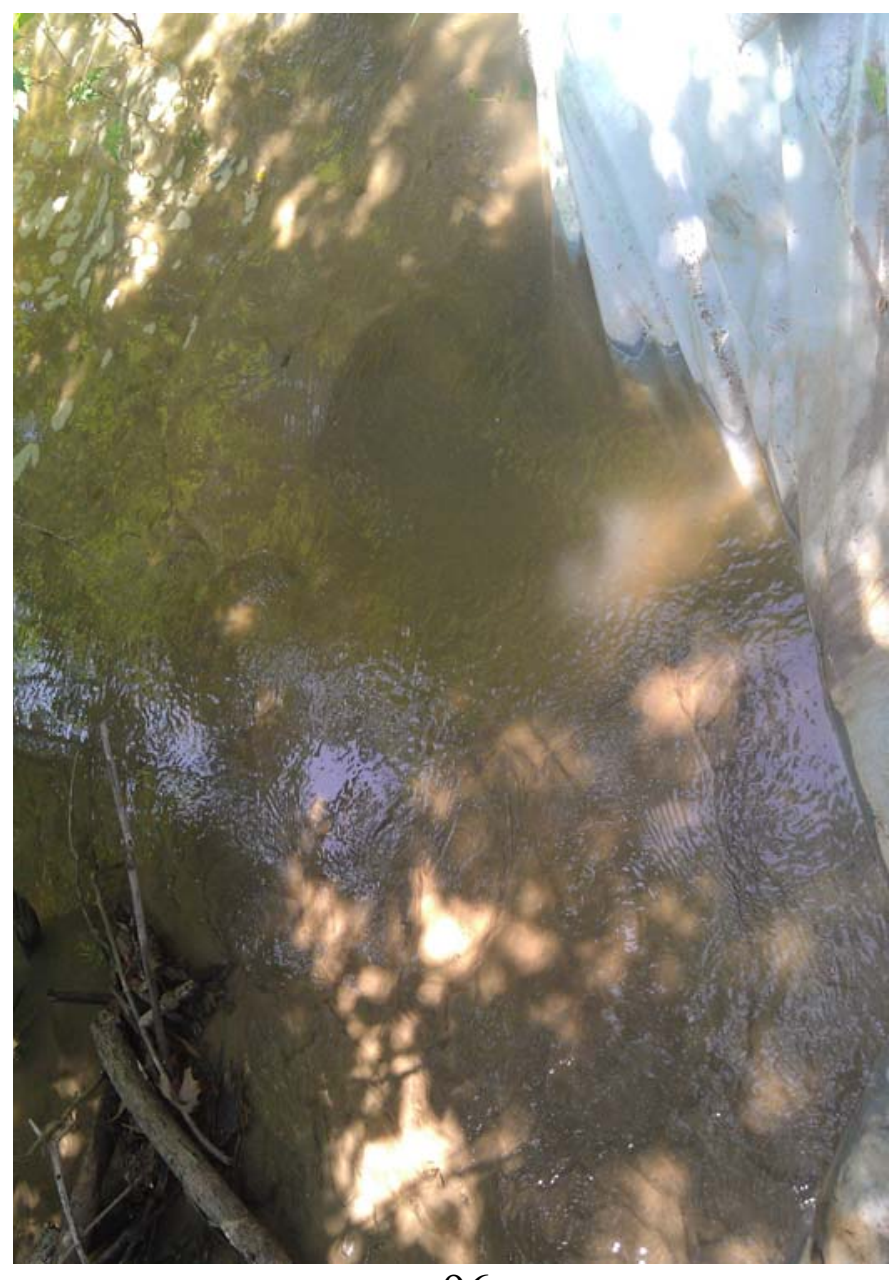




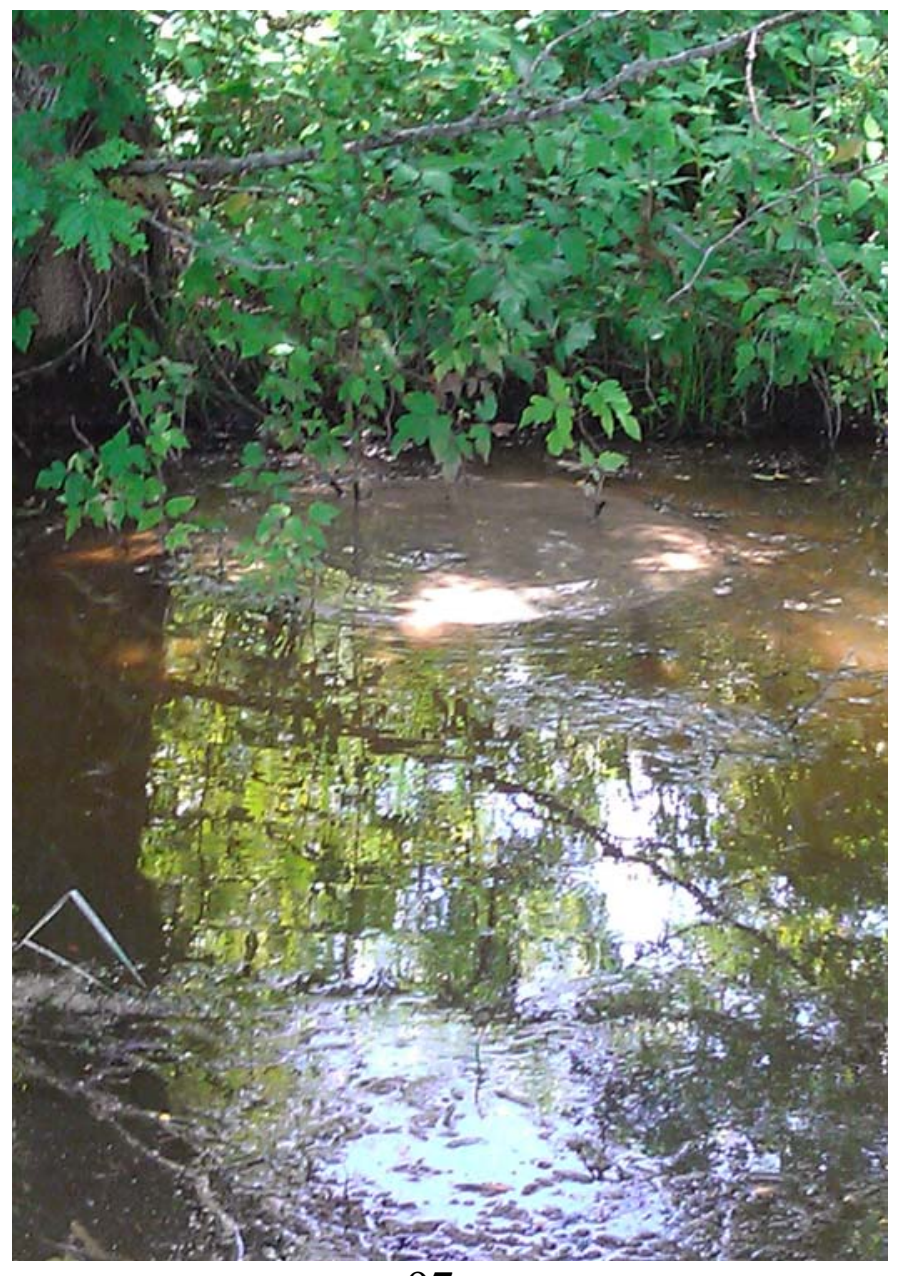

97
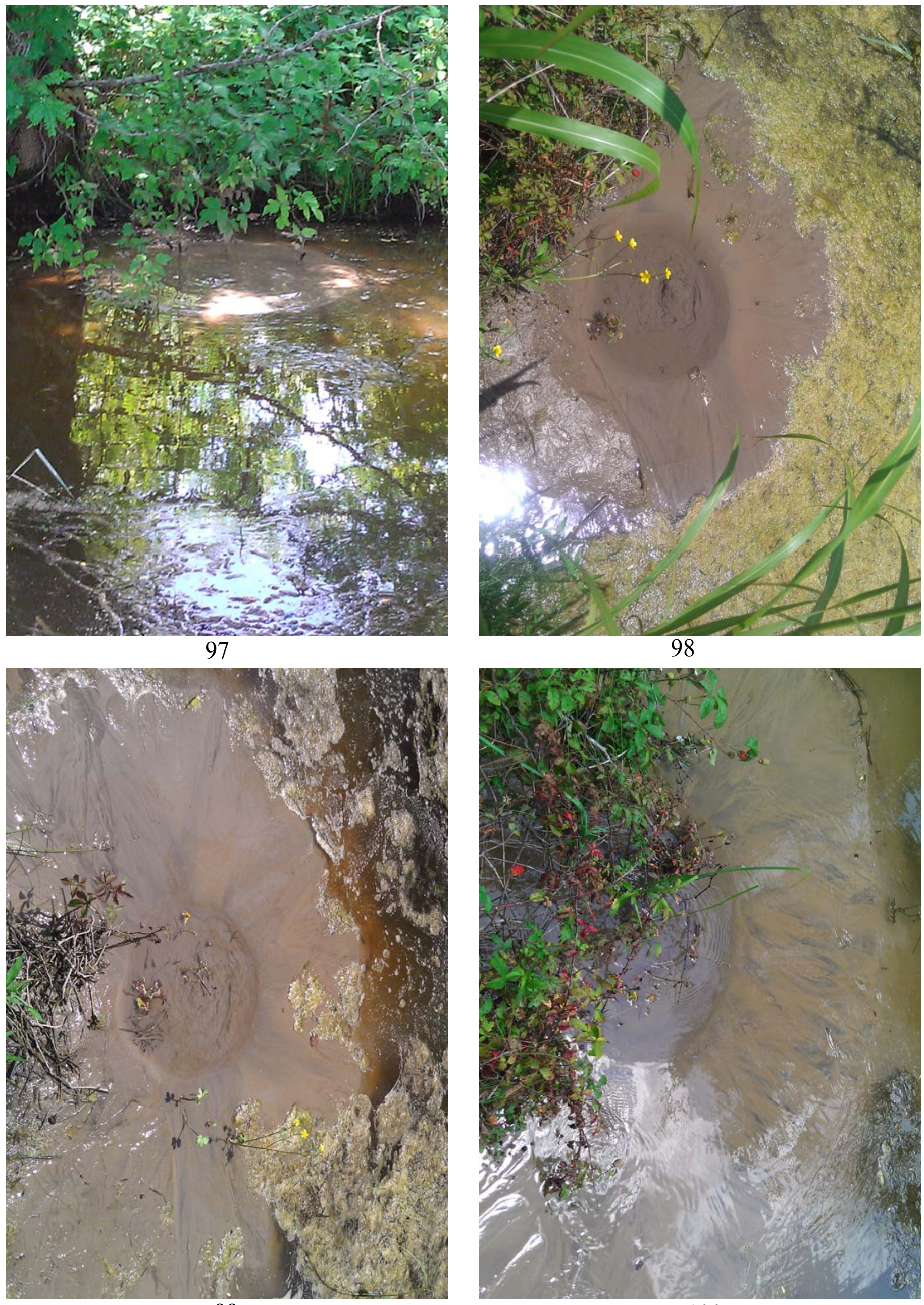


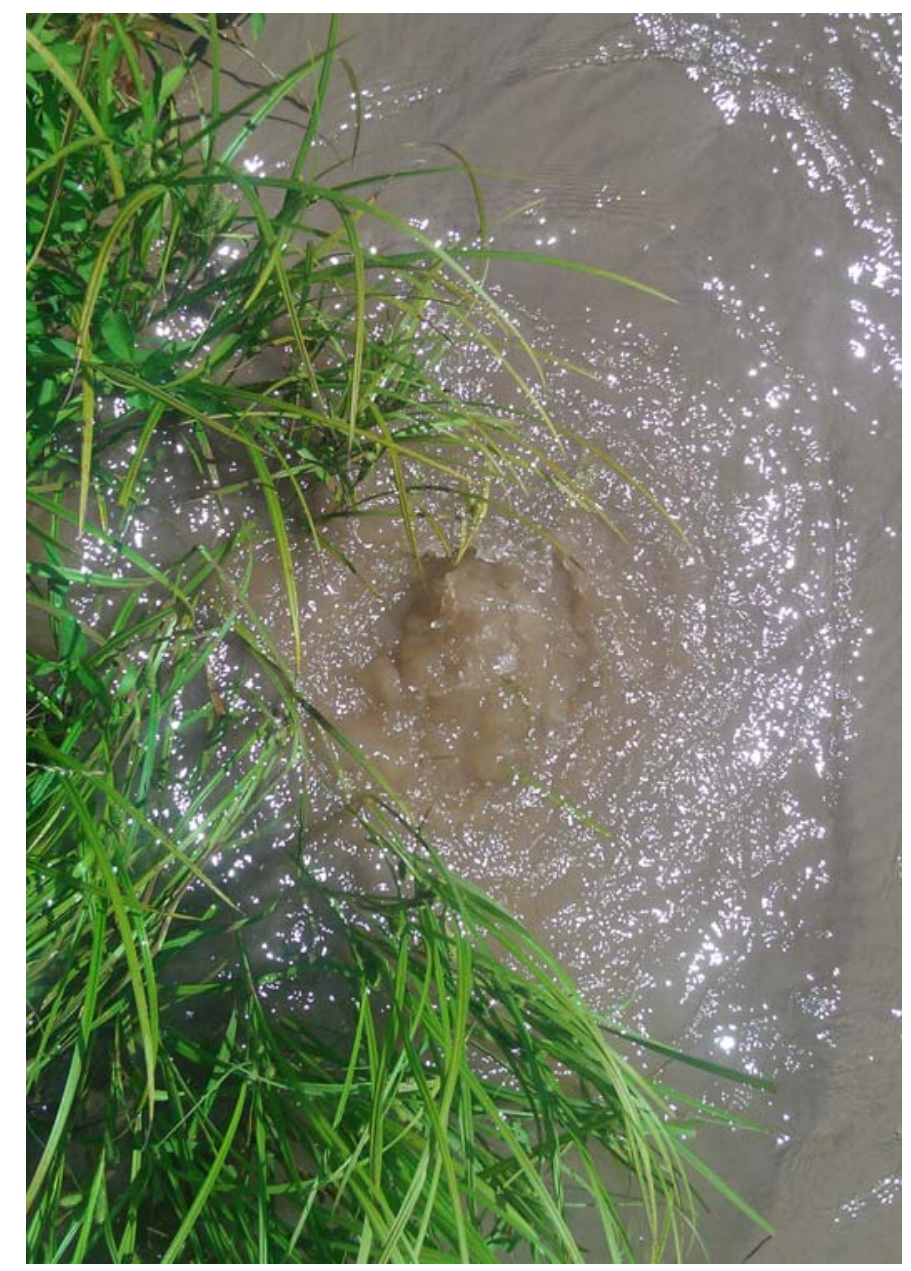

101

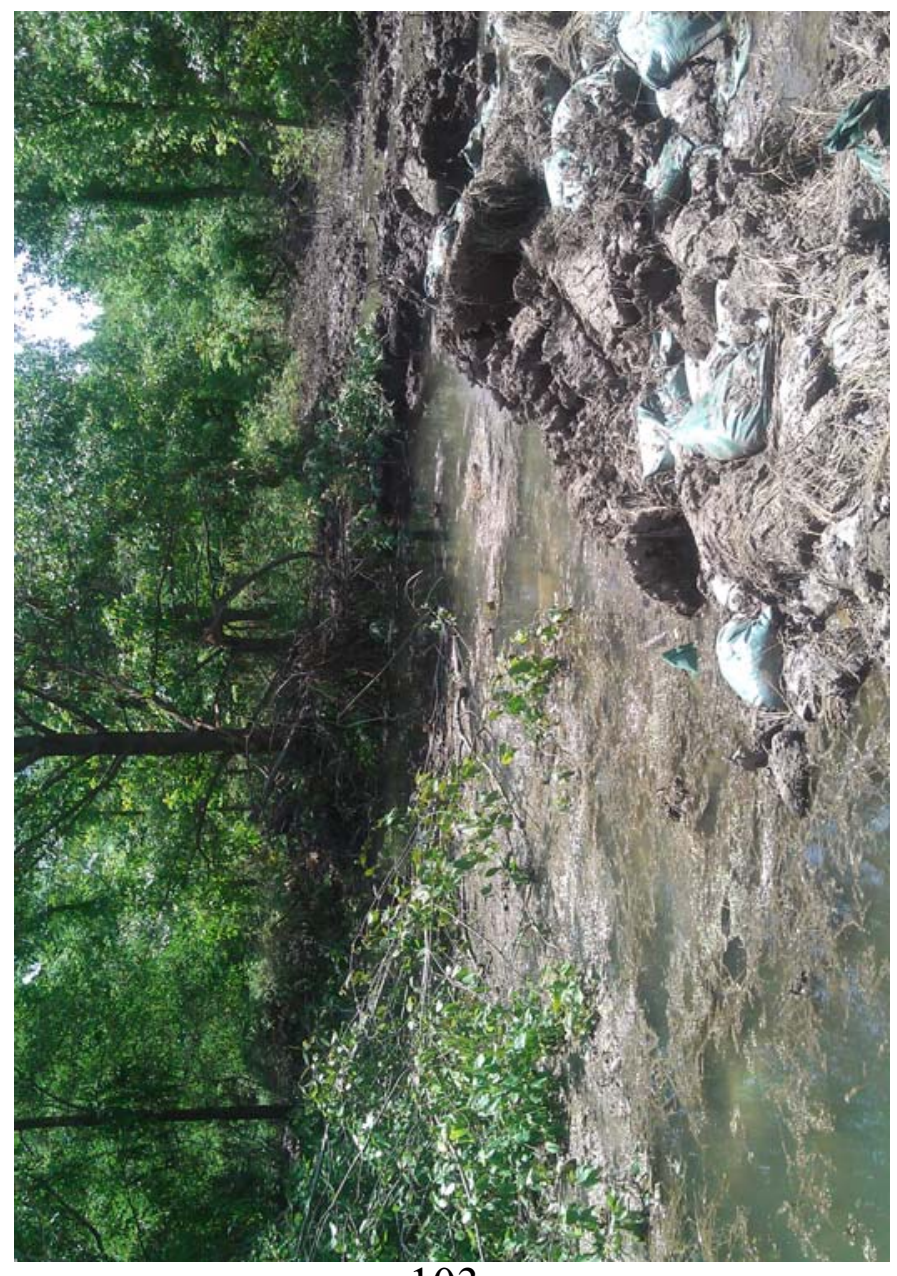

103

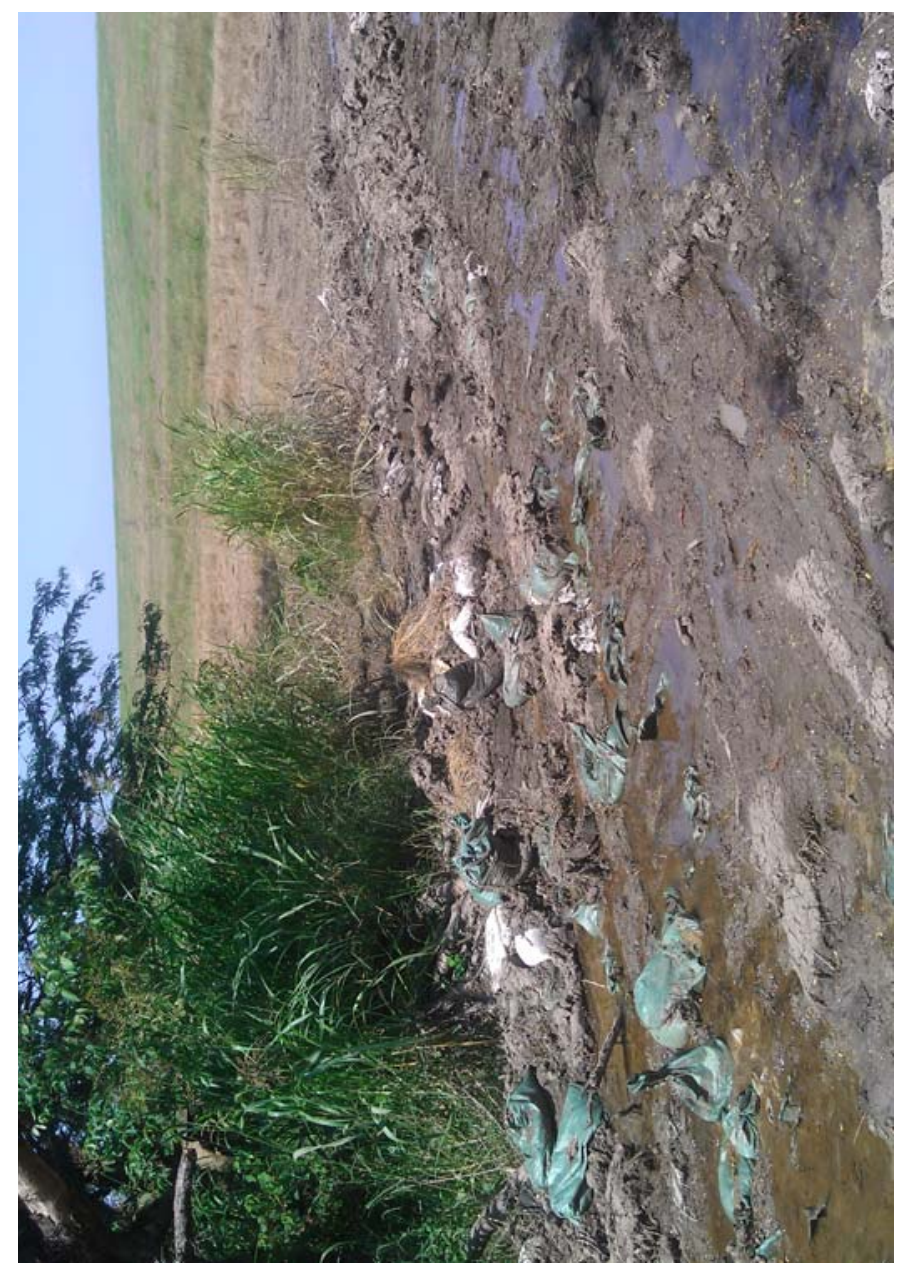

102

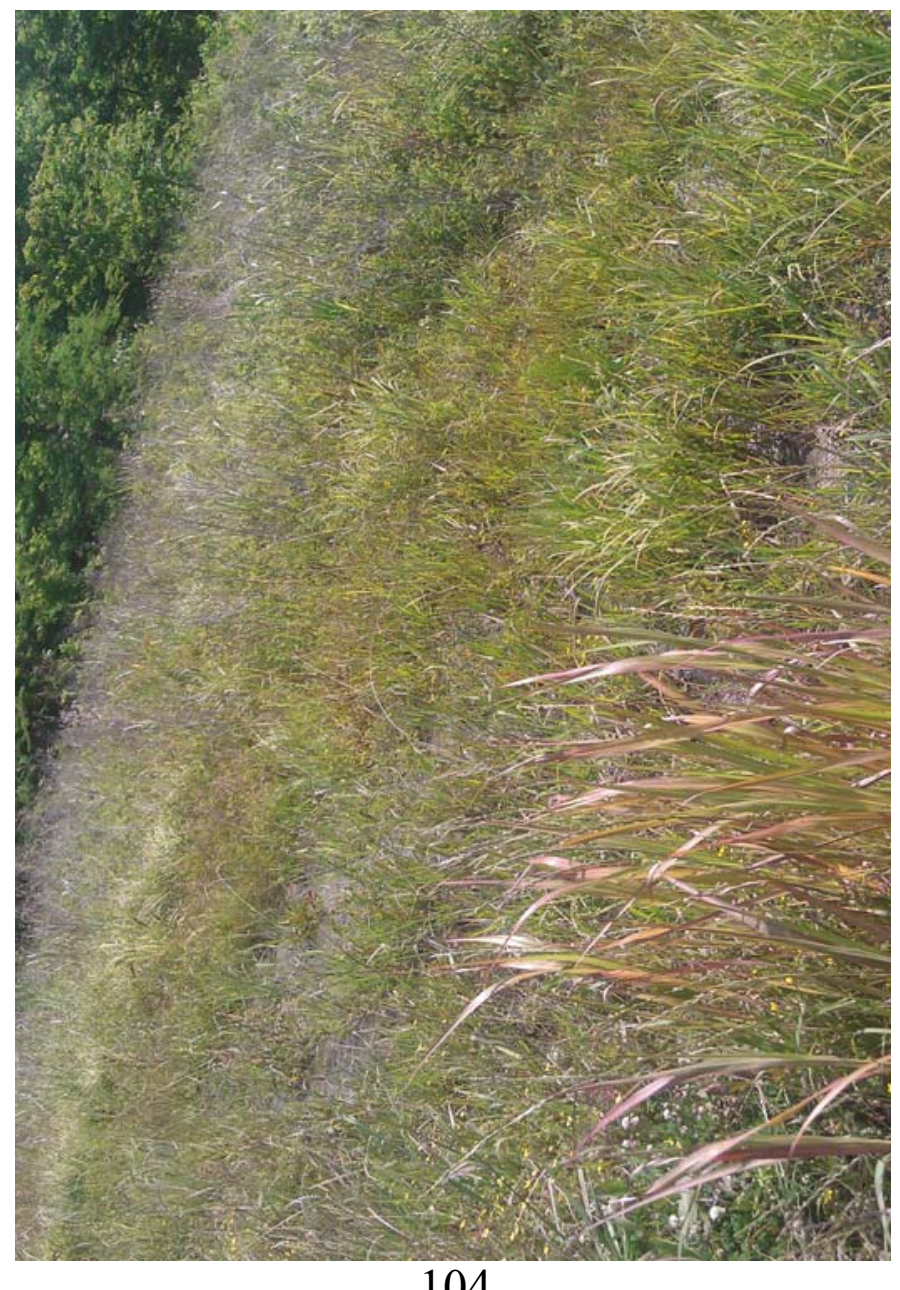




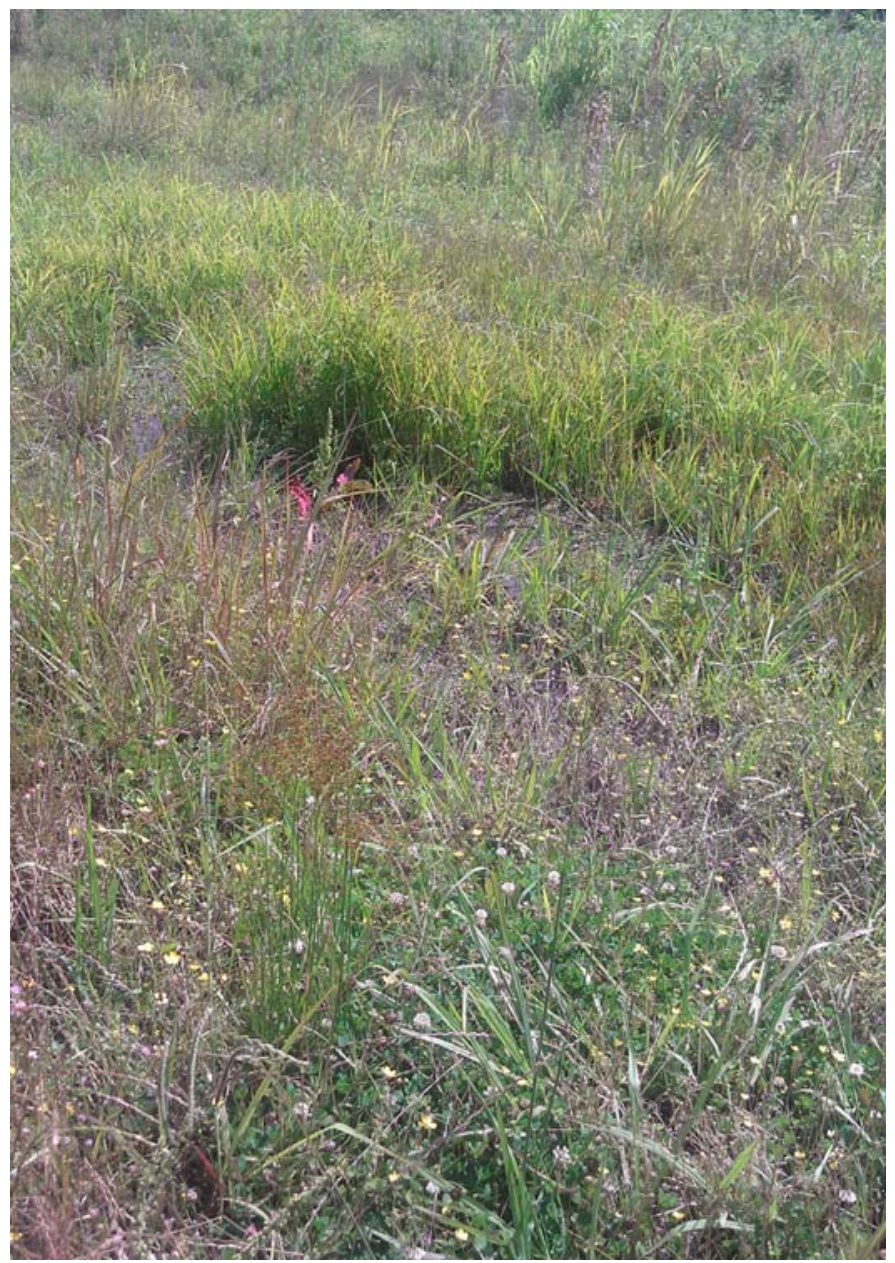

105
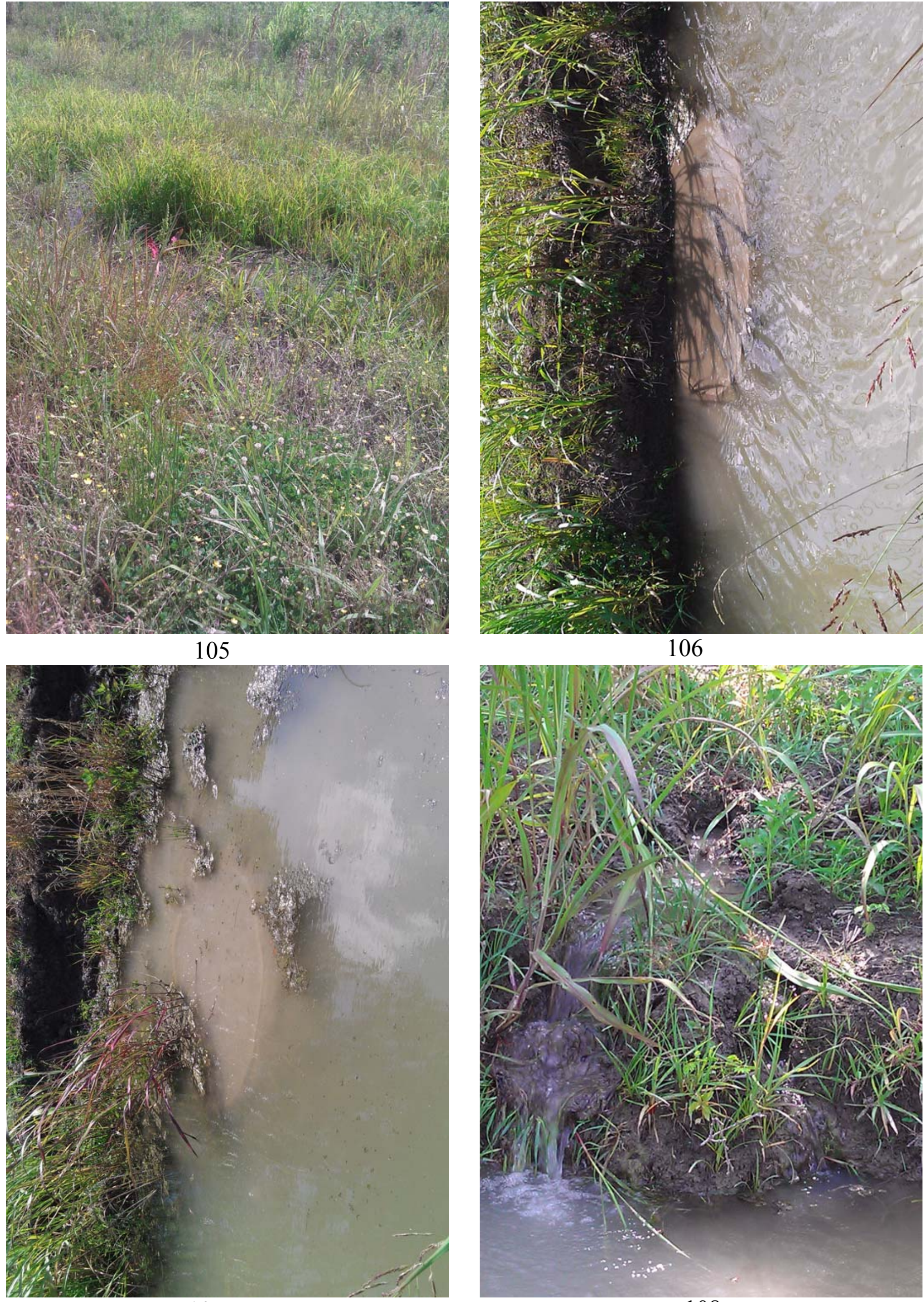

\section{6}

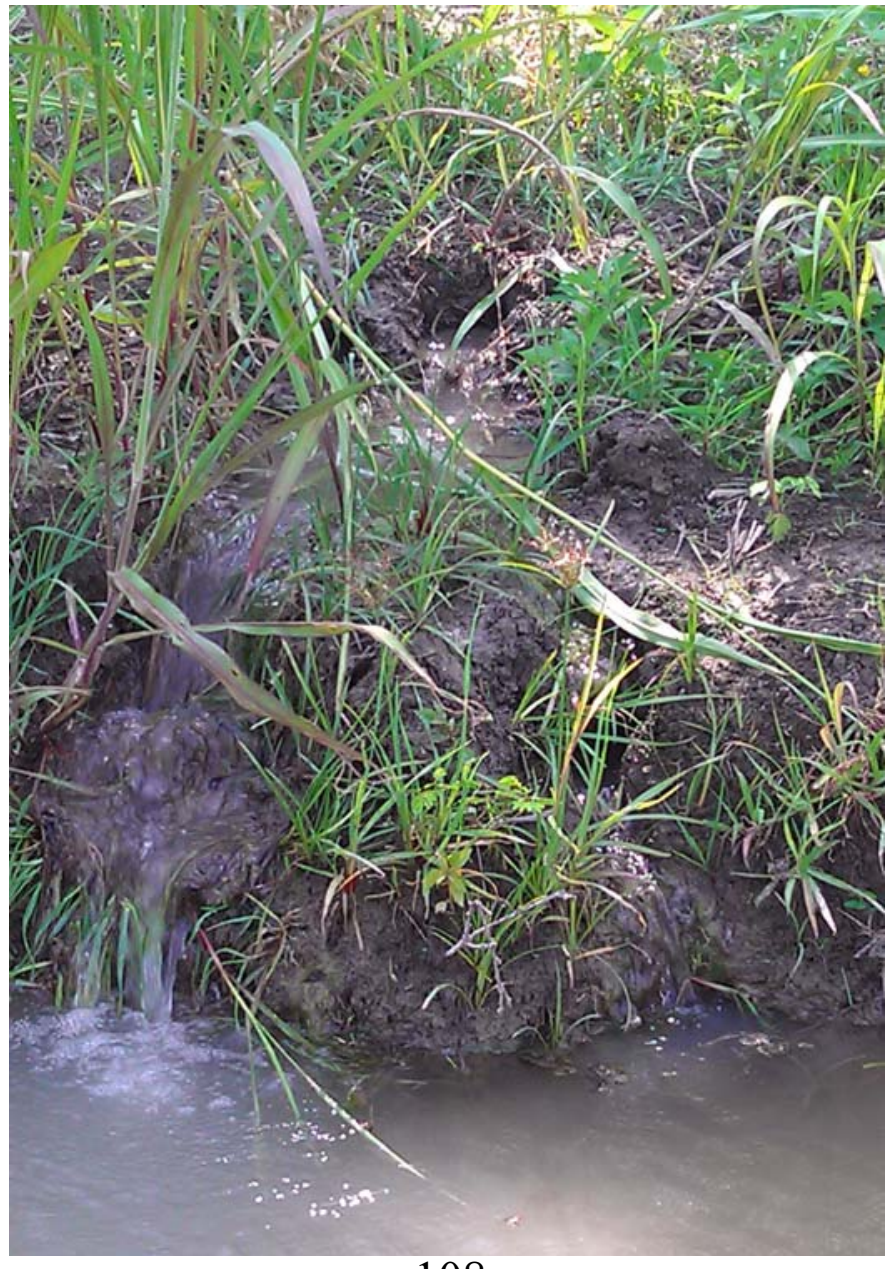




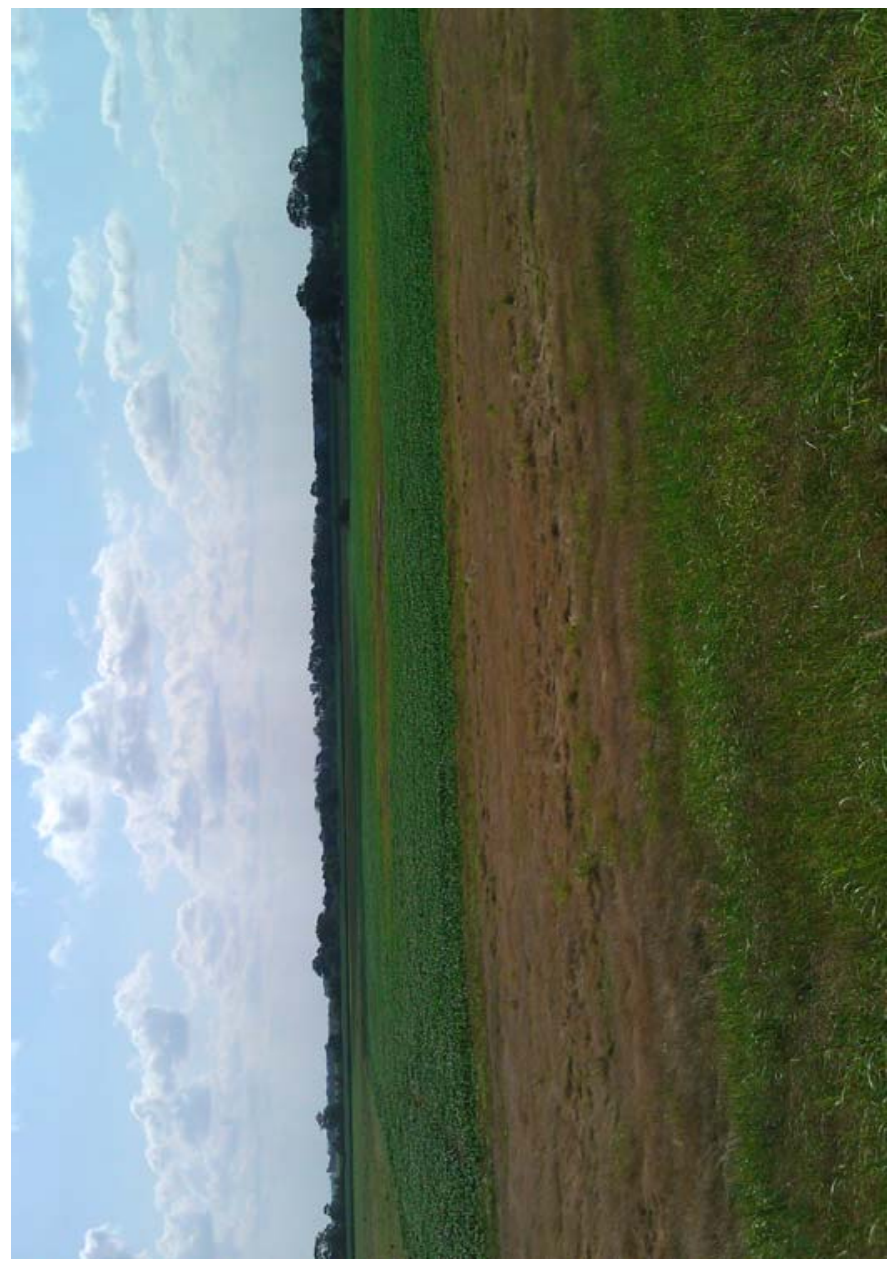

109

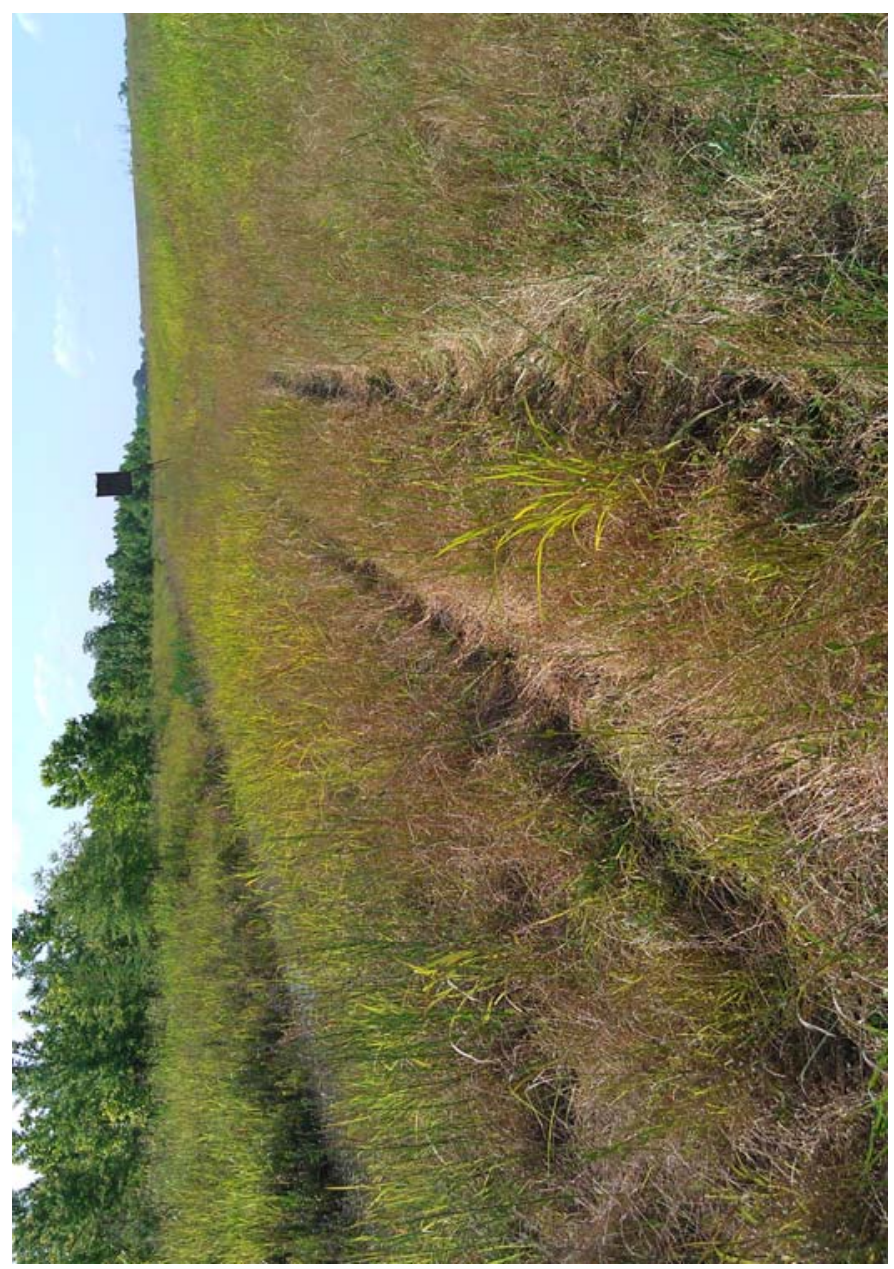

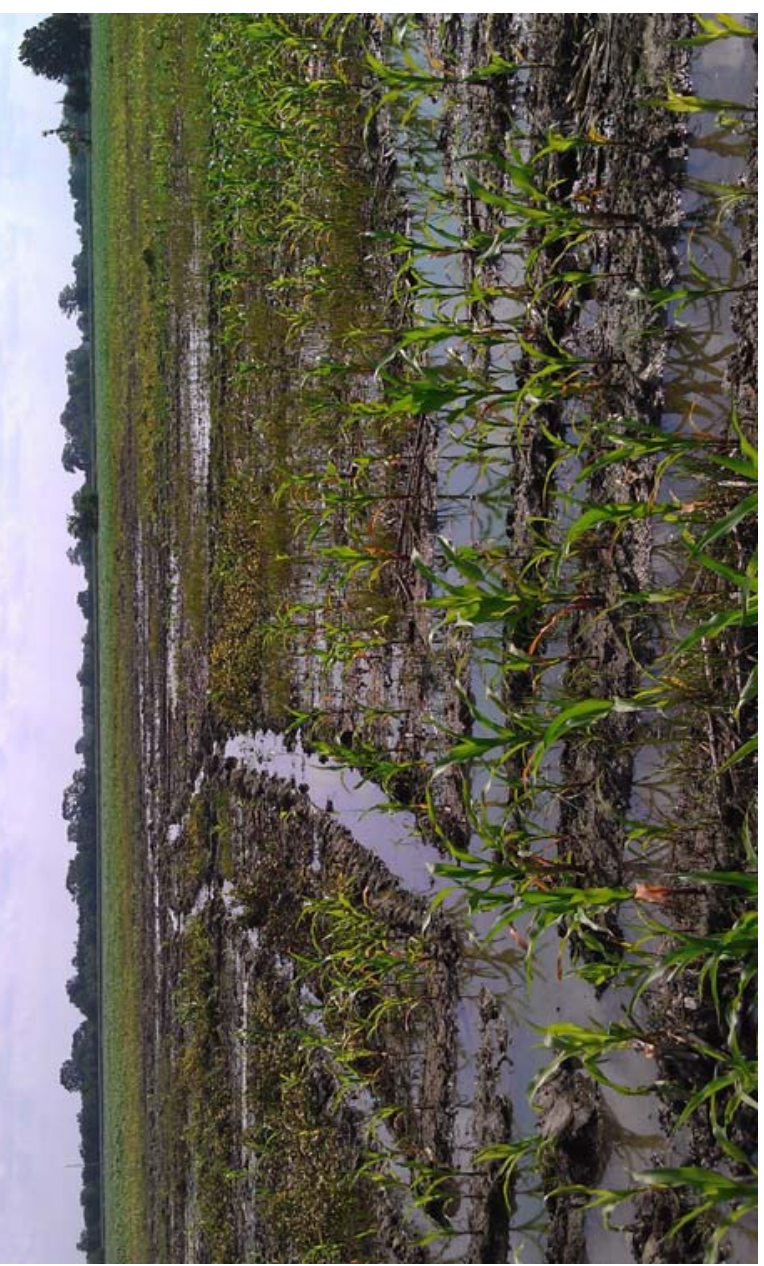

\section{0}

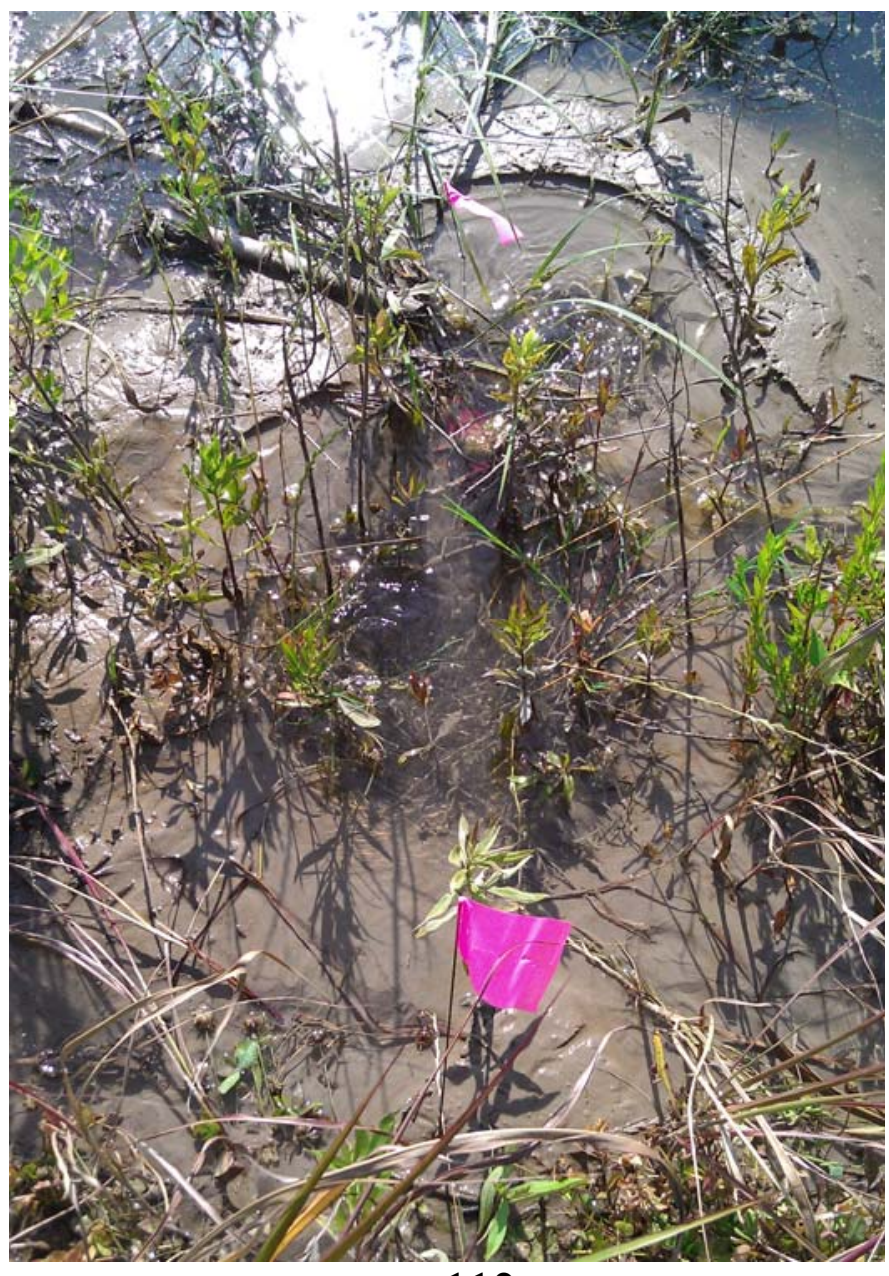

112 

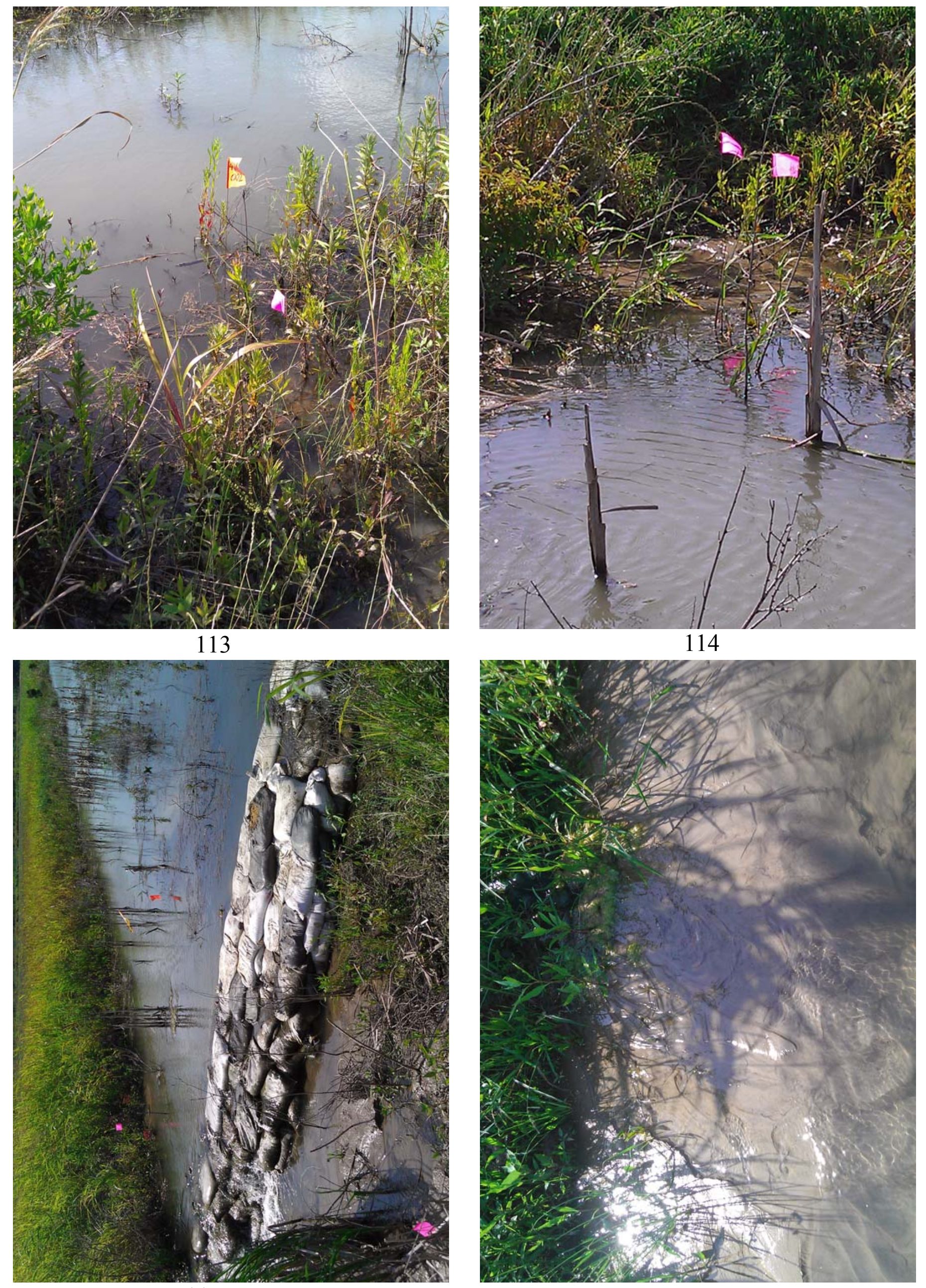


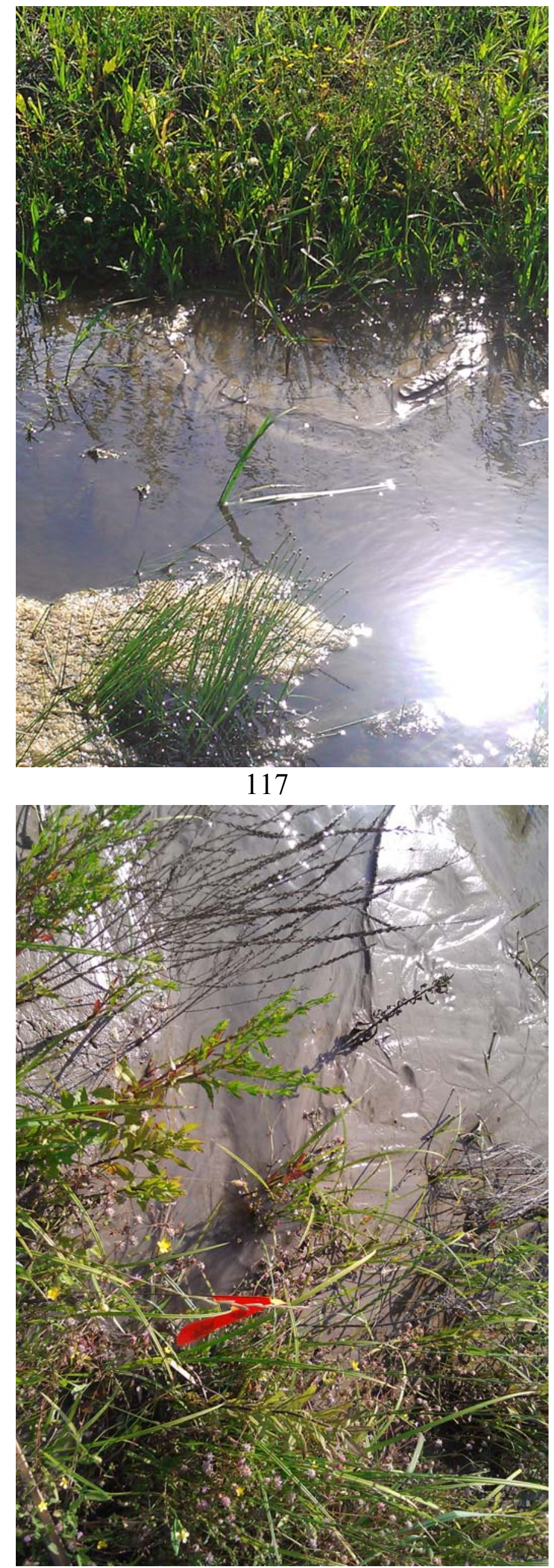

119

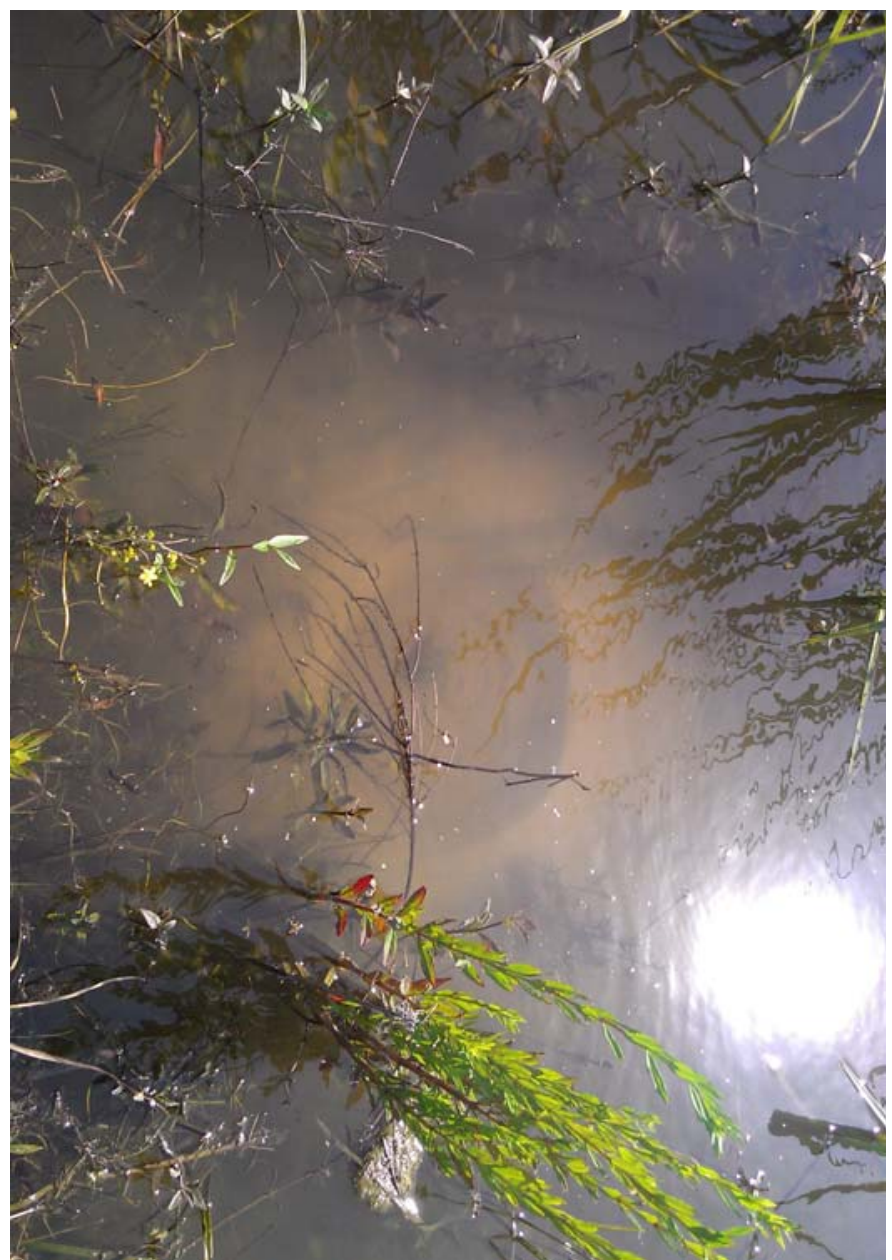

\section{8}

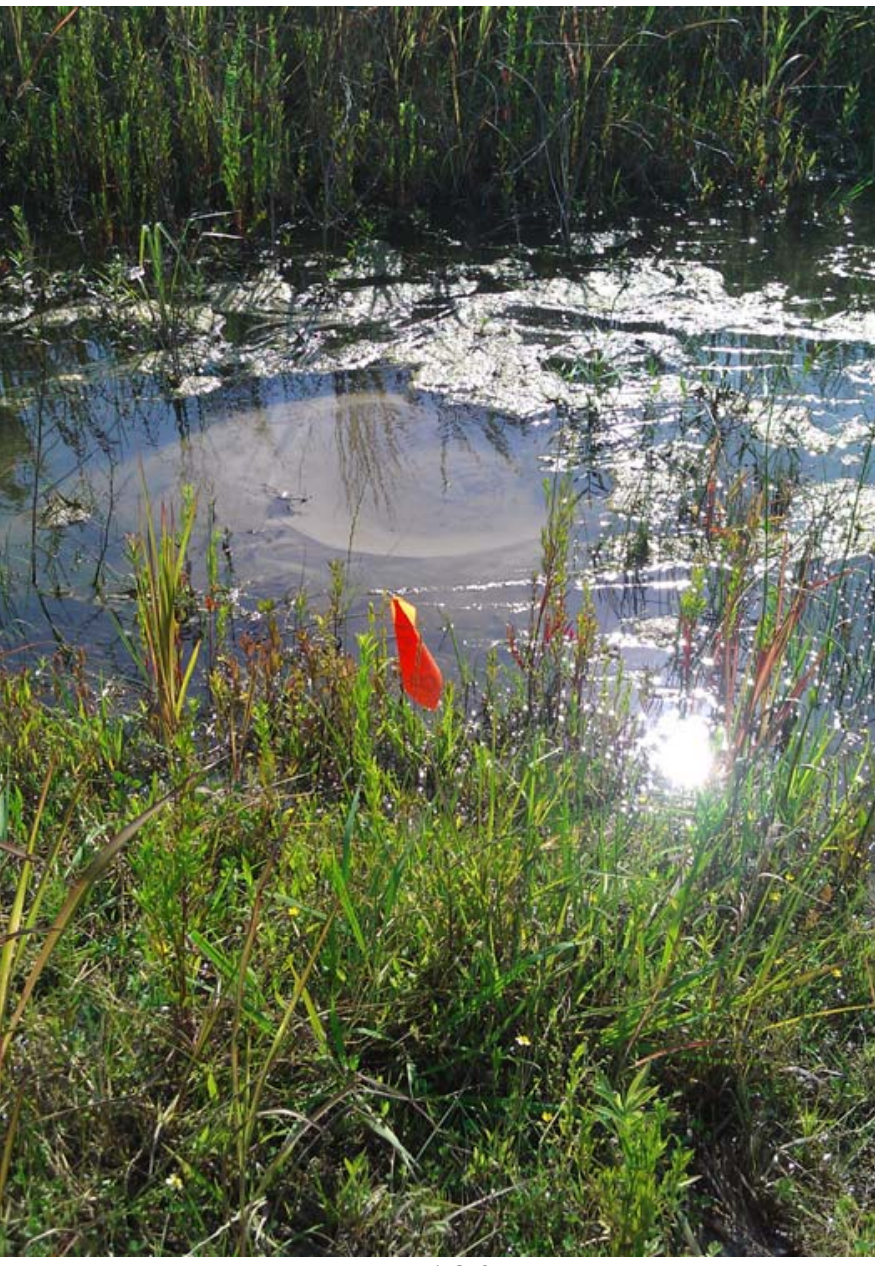




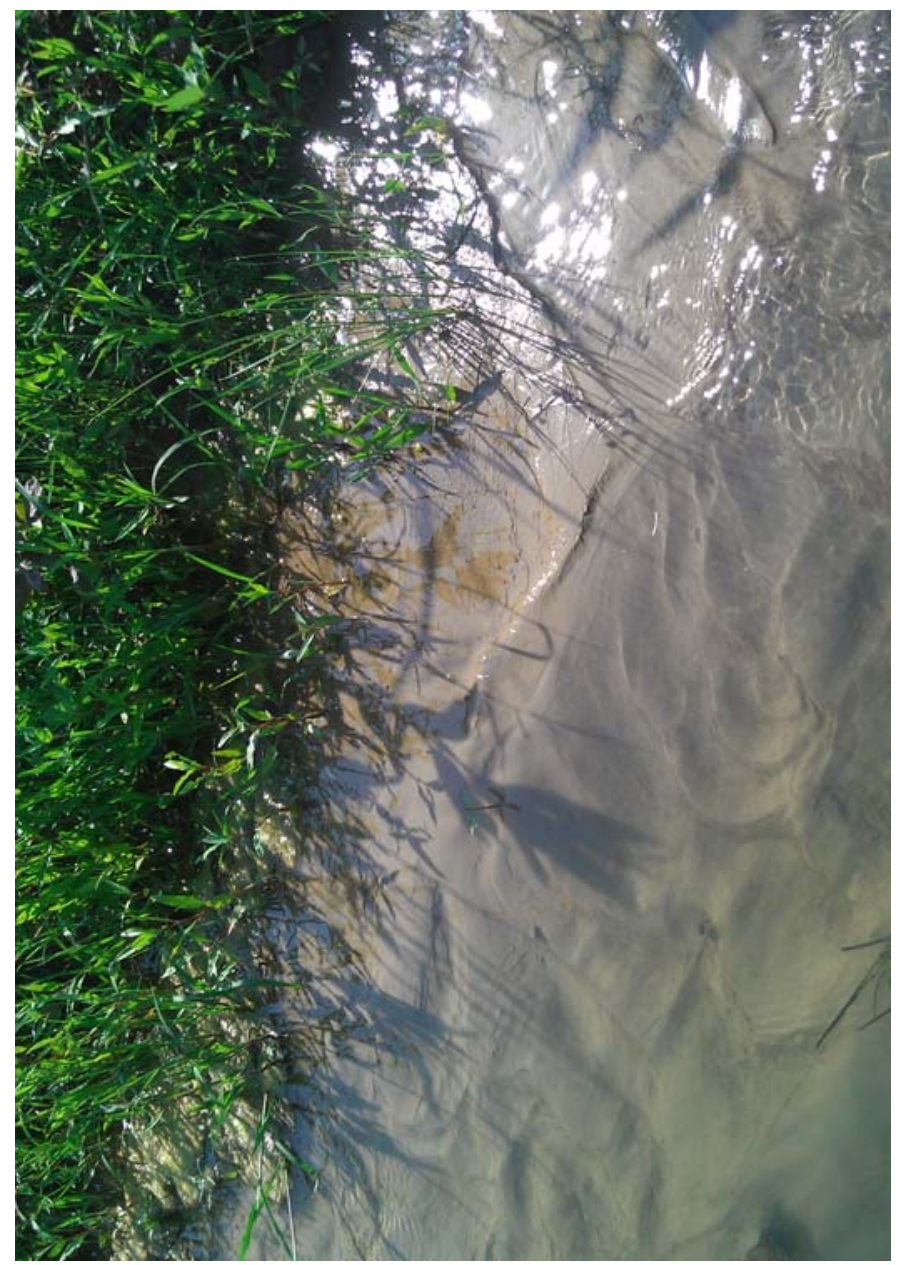

121

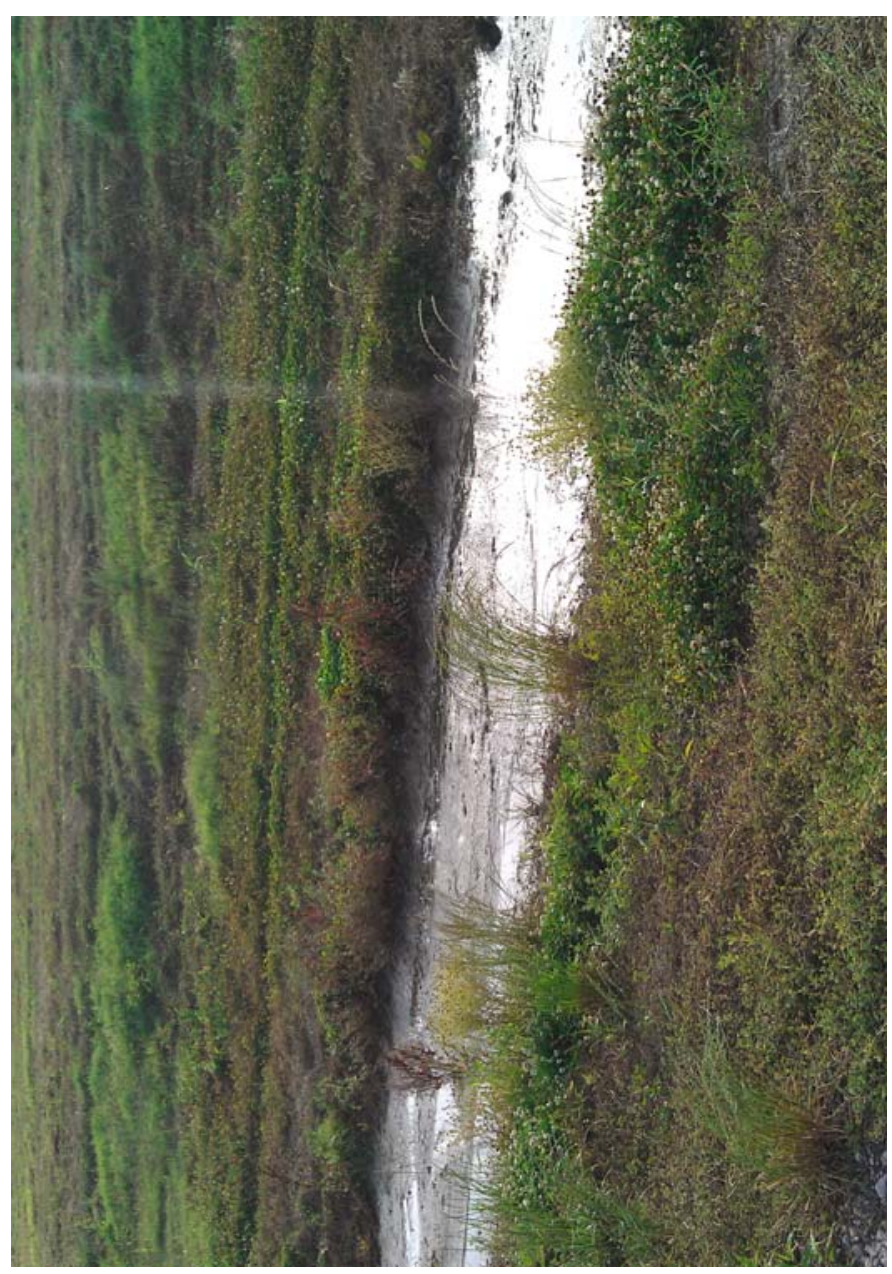

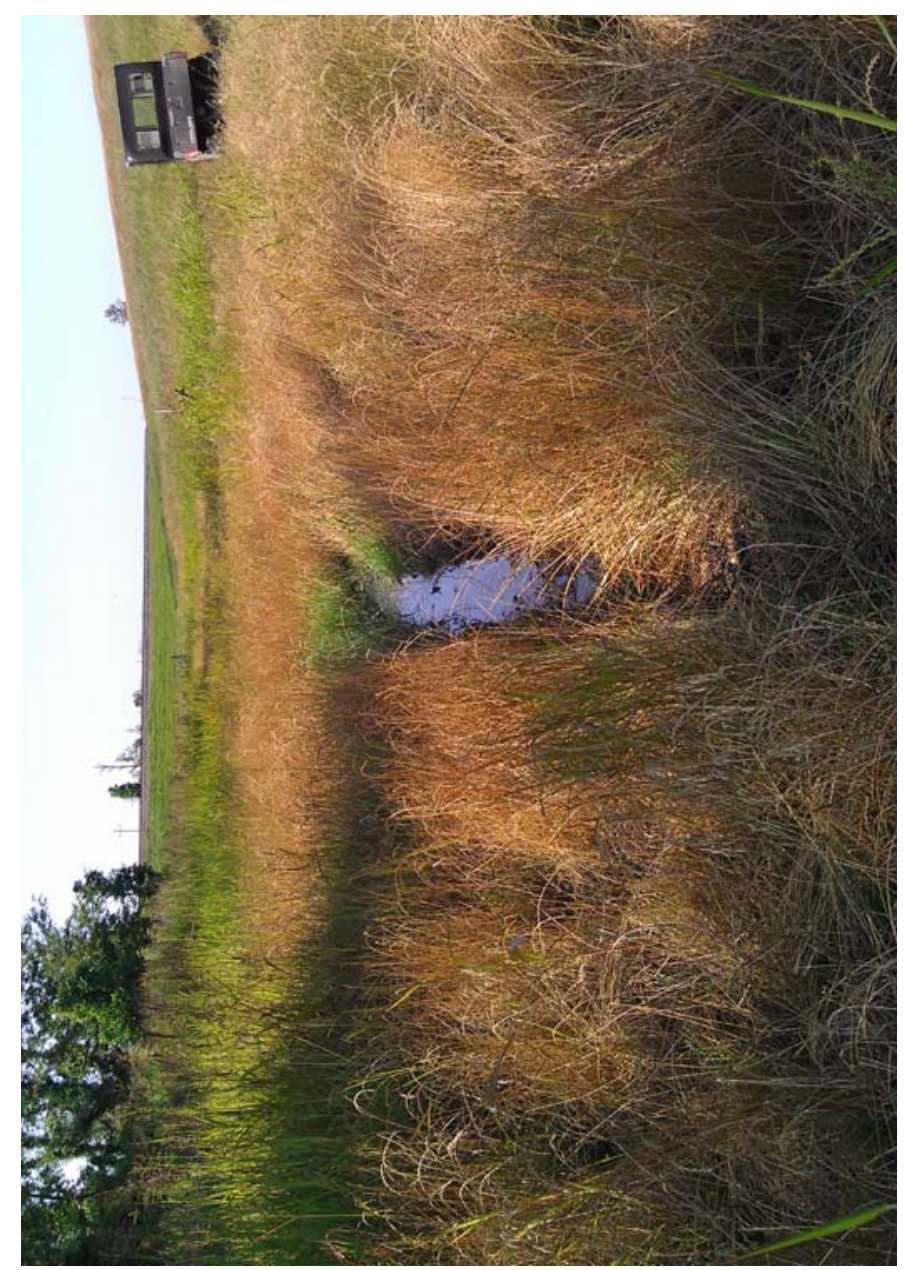

122

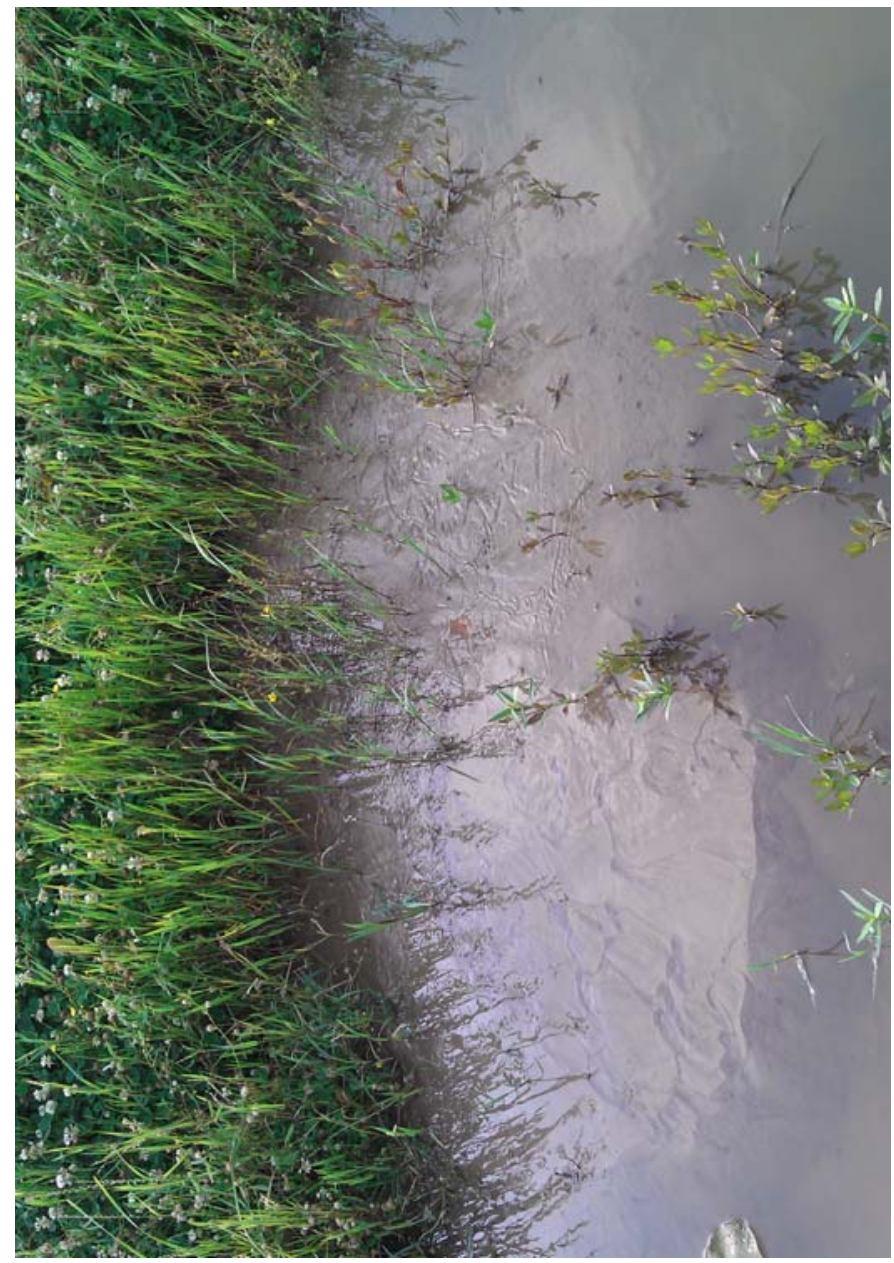




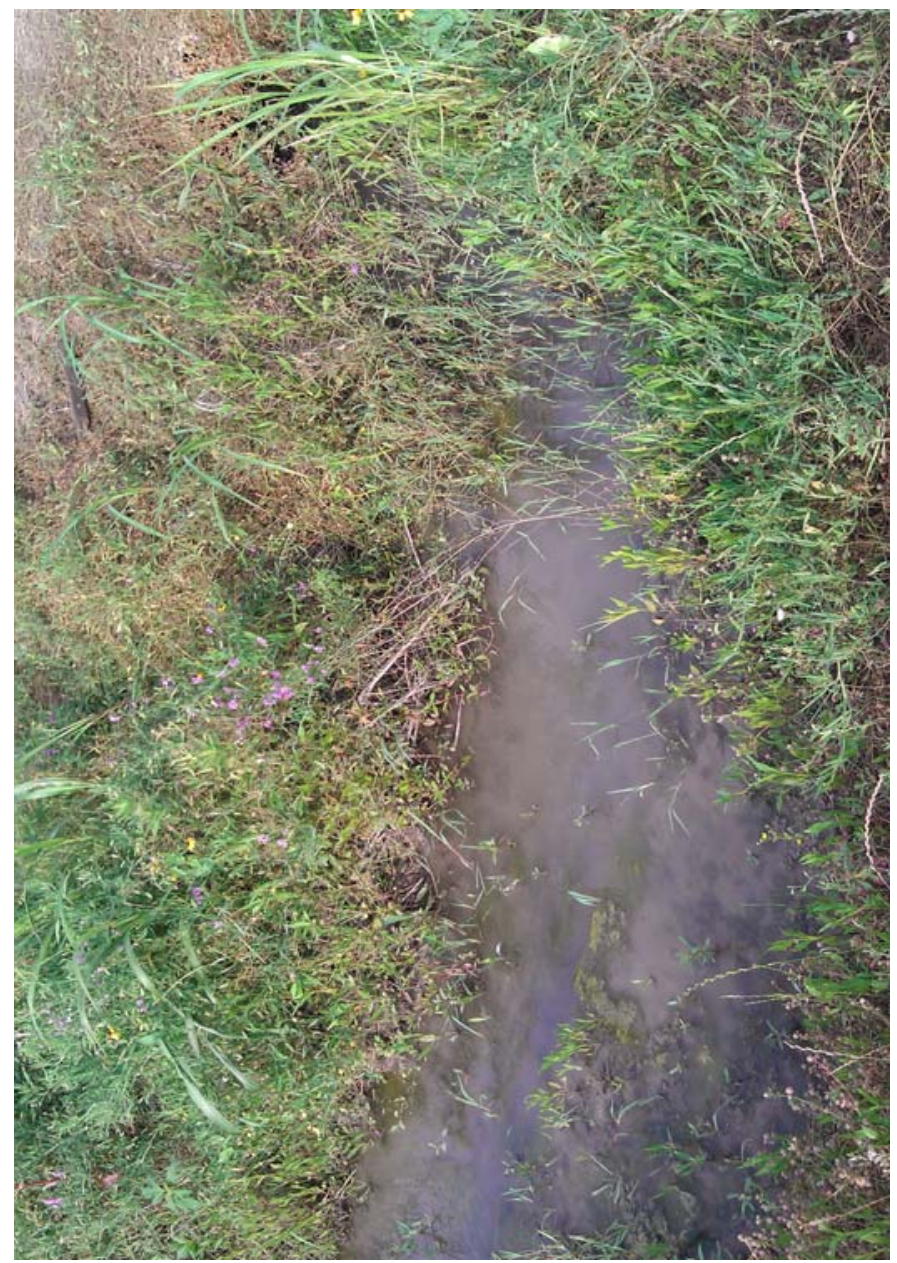

125

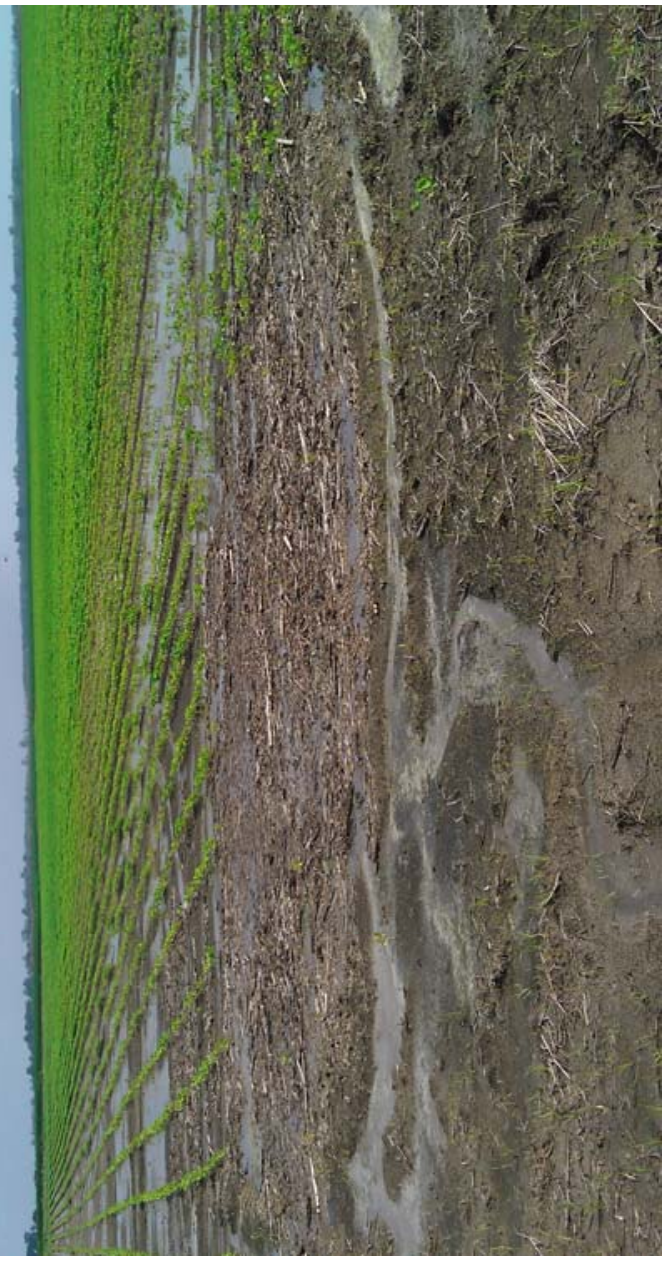

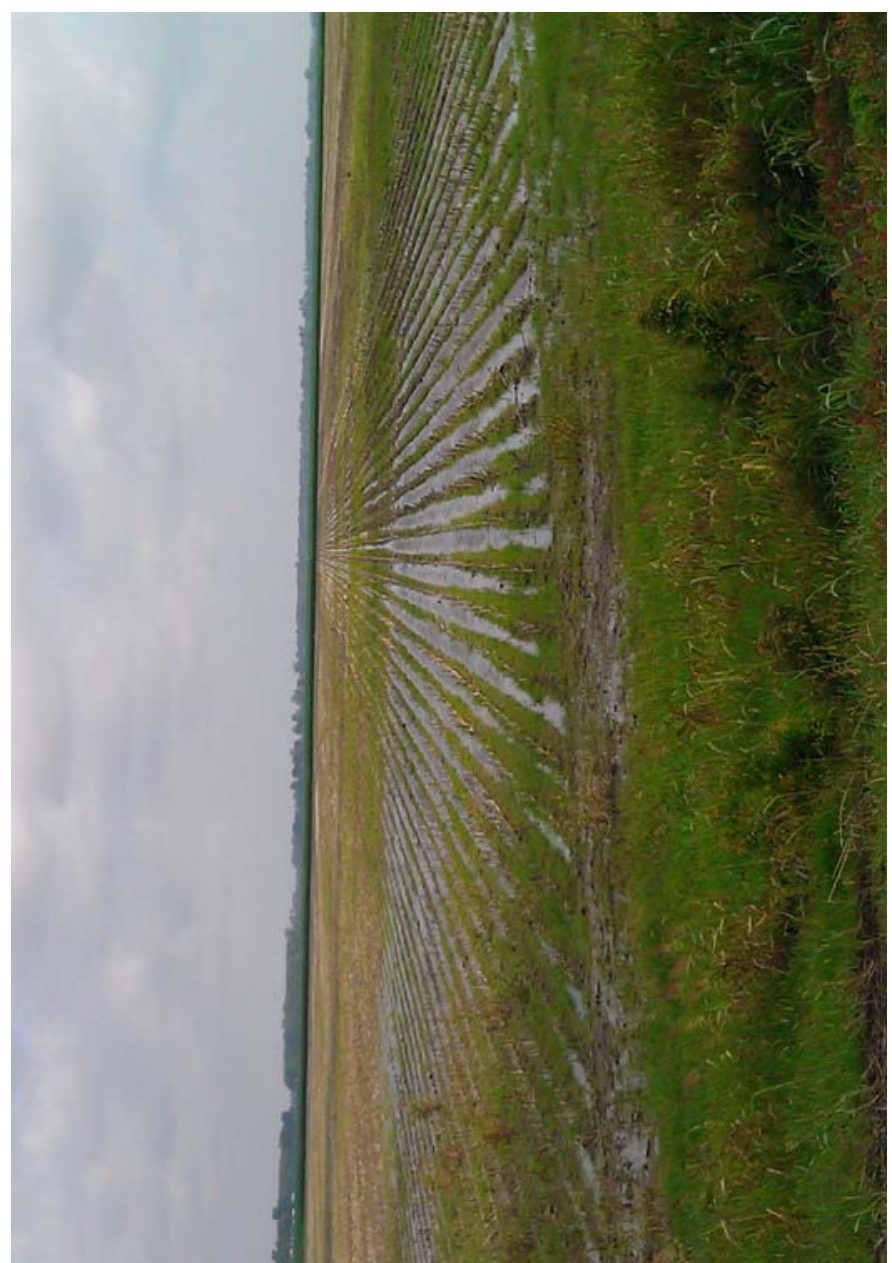

126

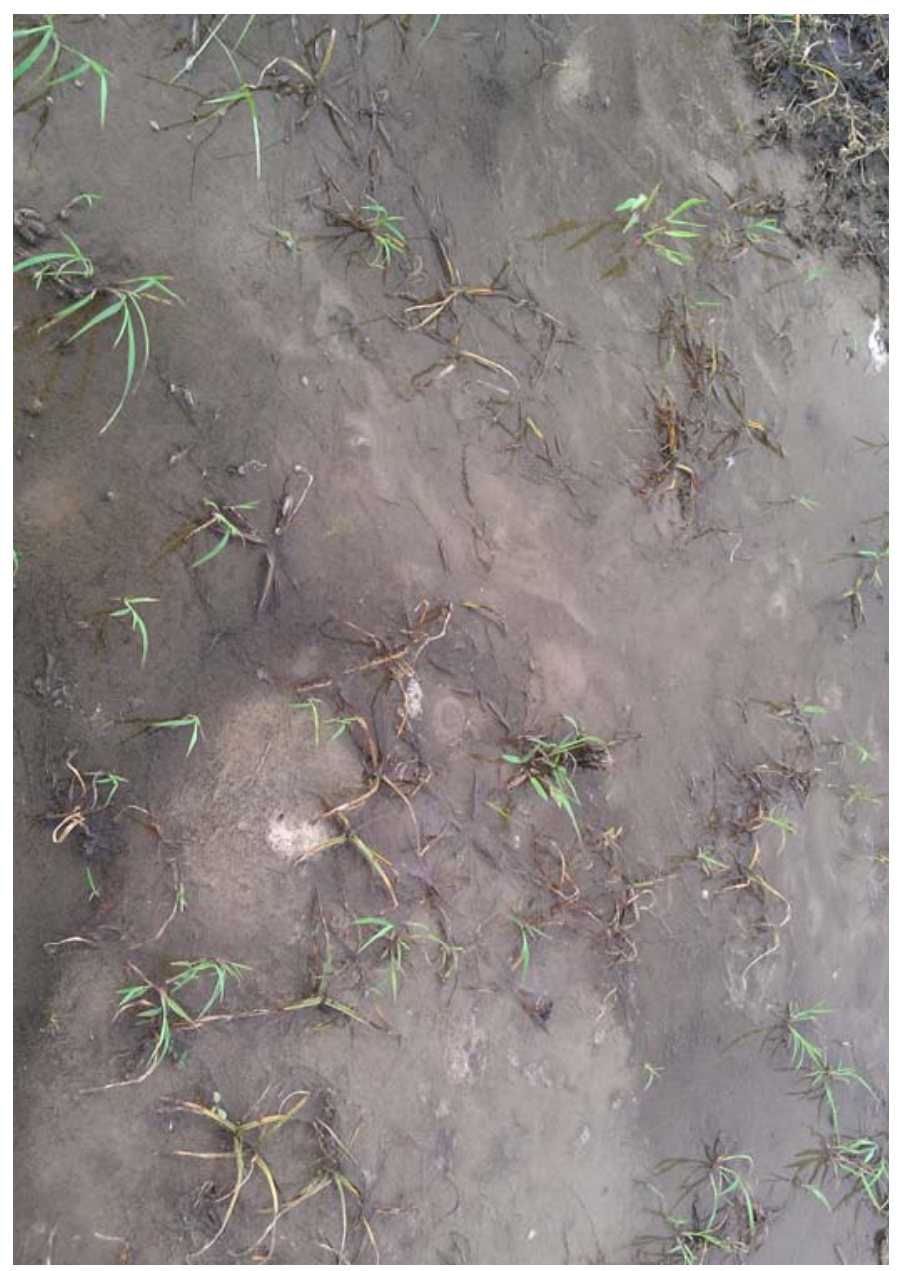

128 


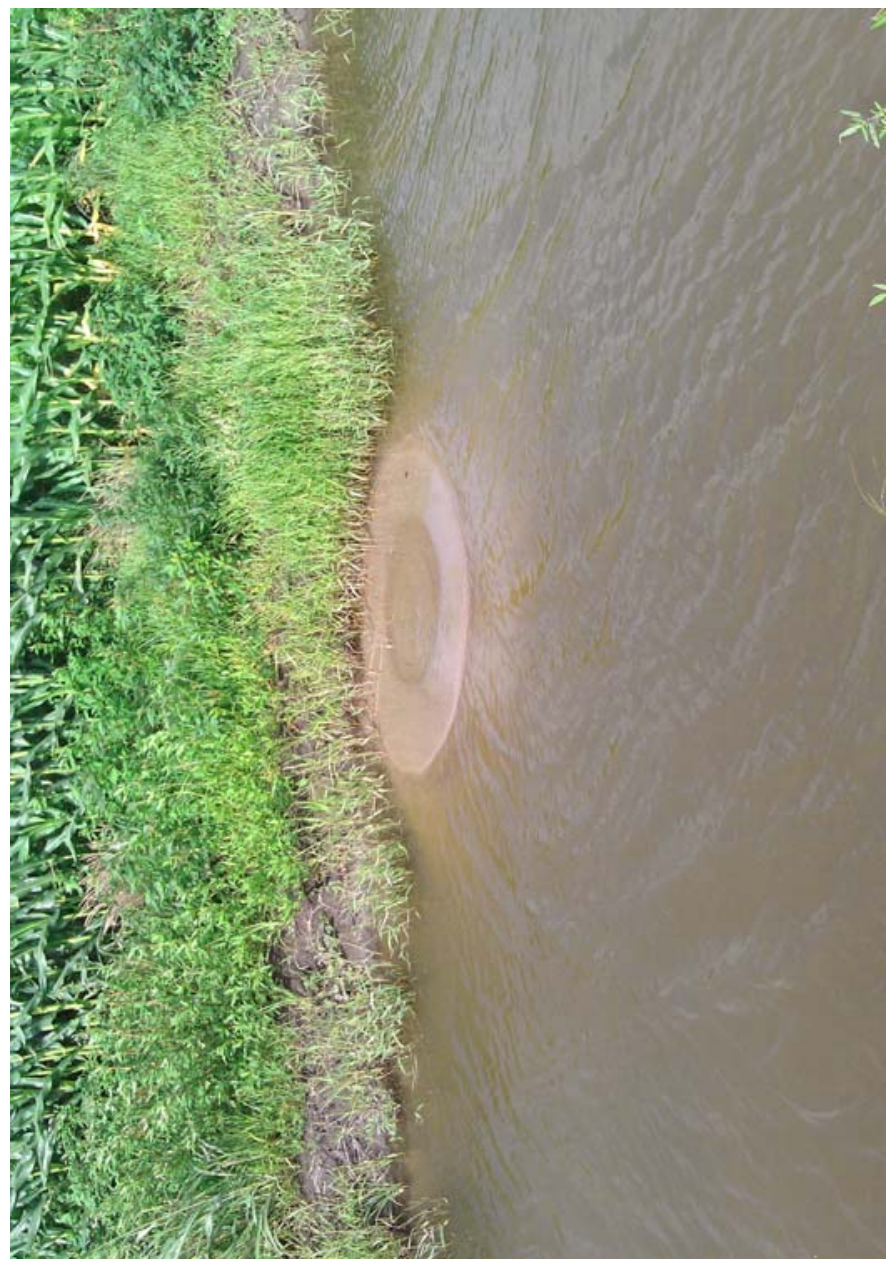

129

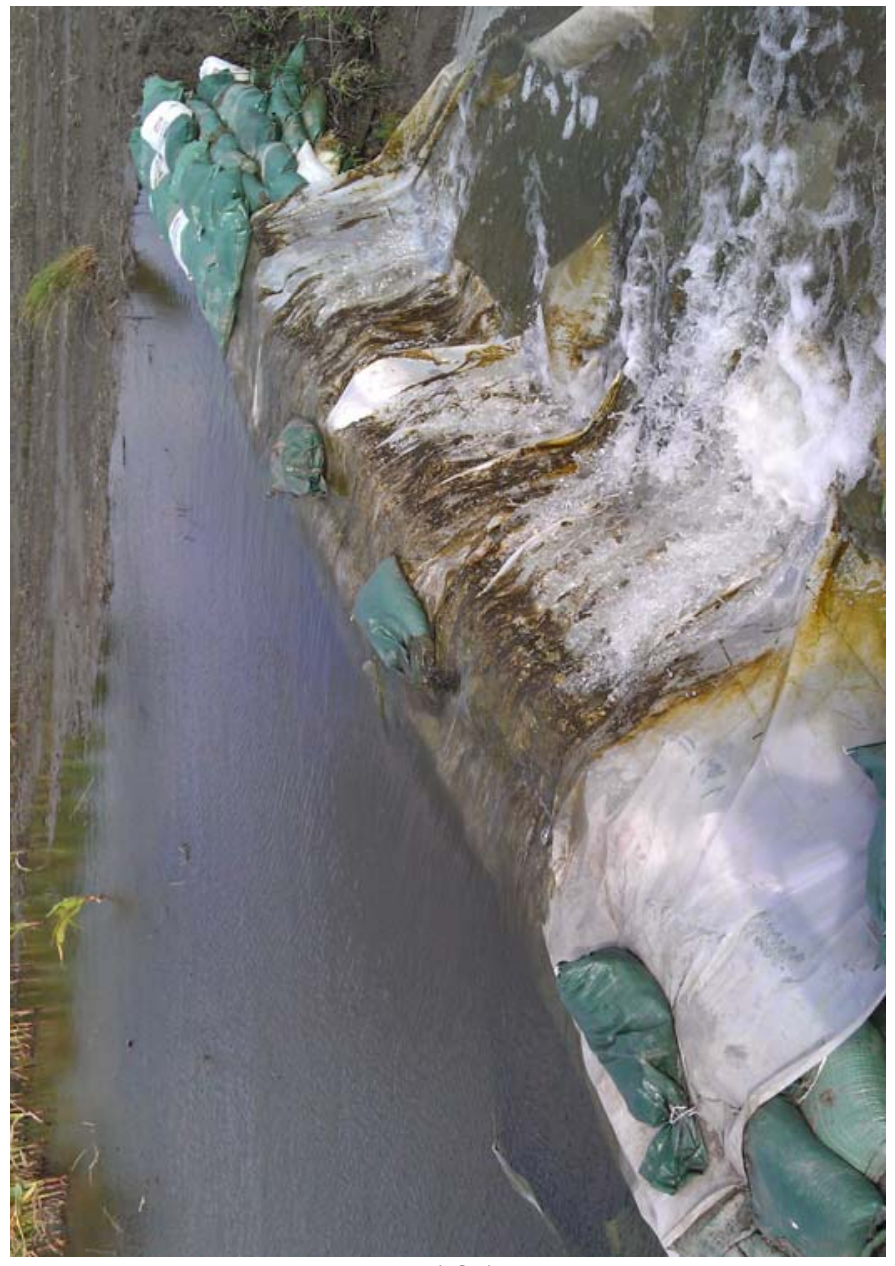

131

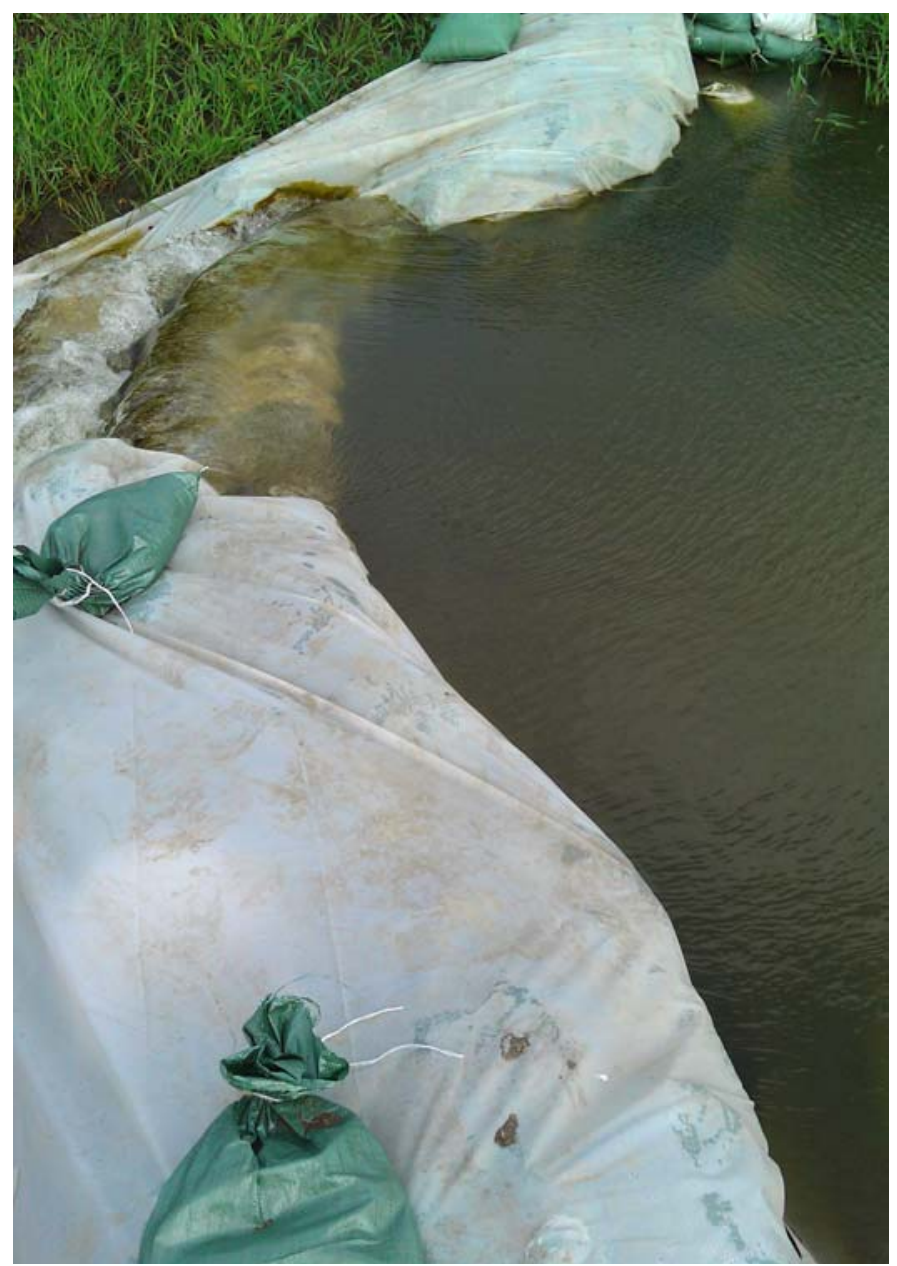

130

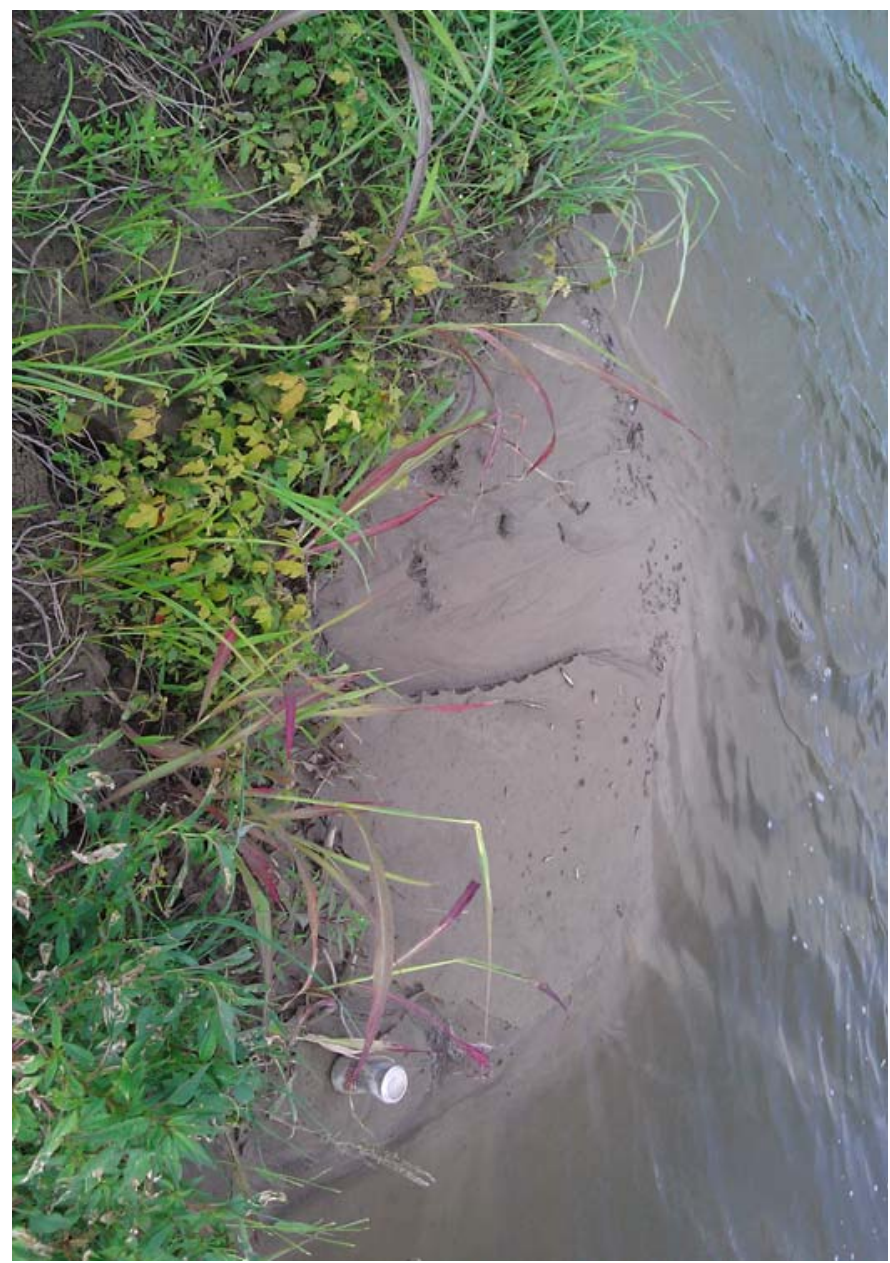

132 


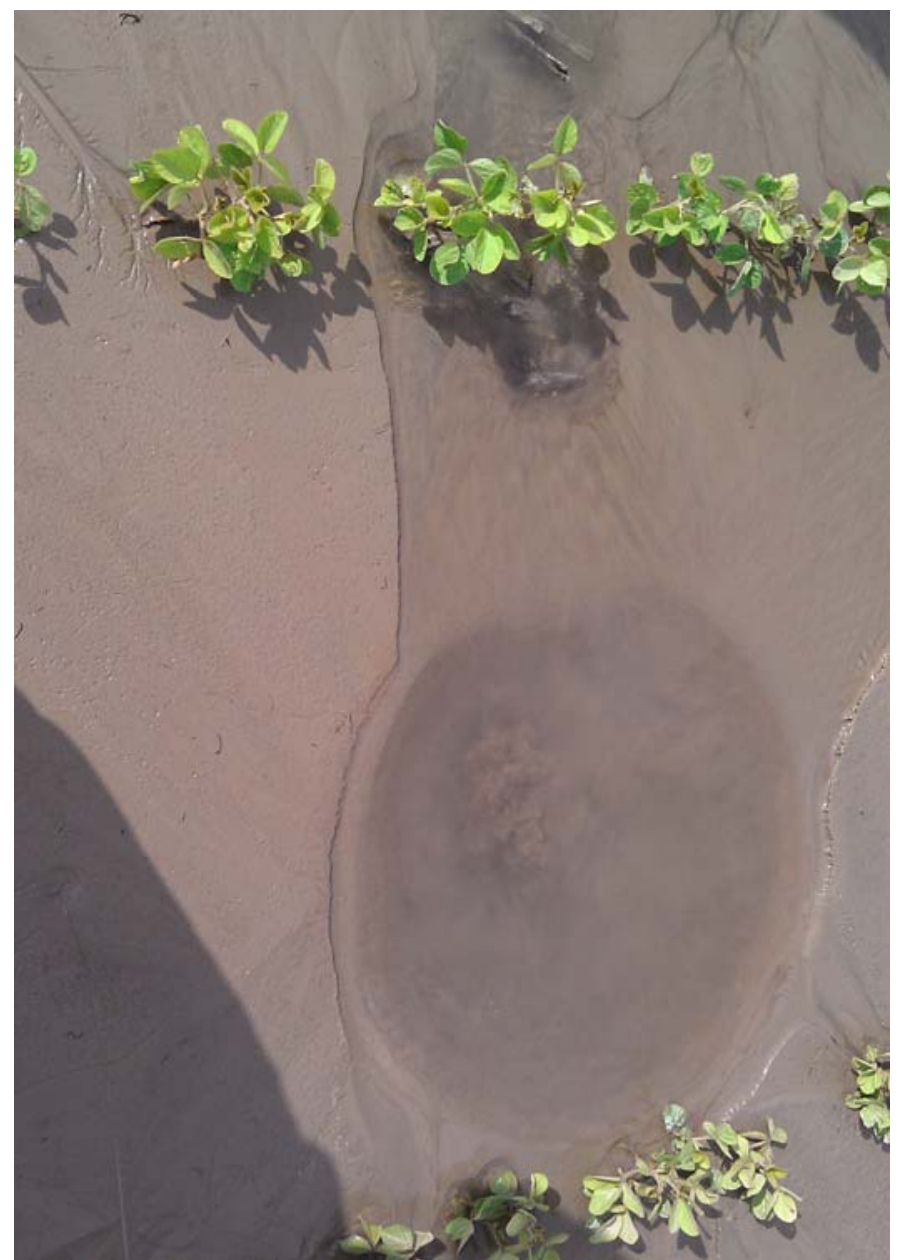

133

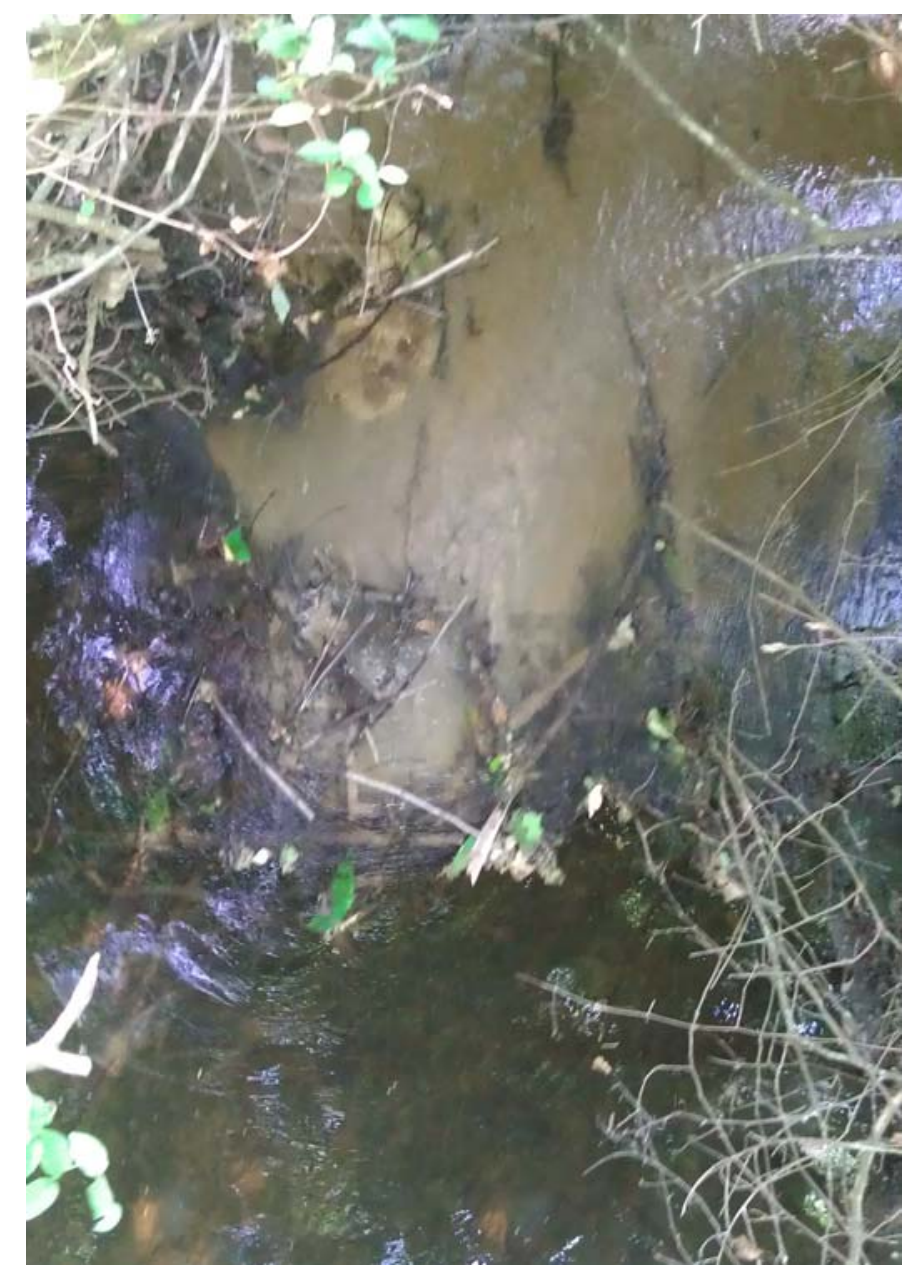

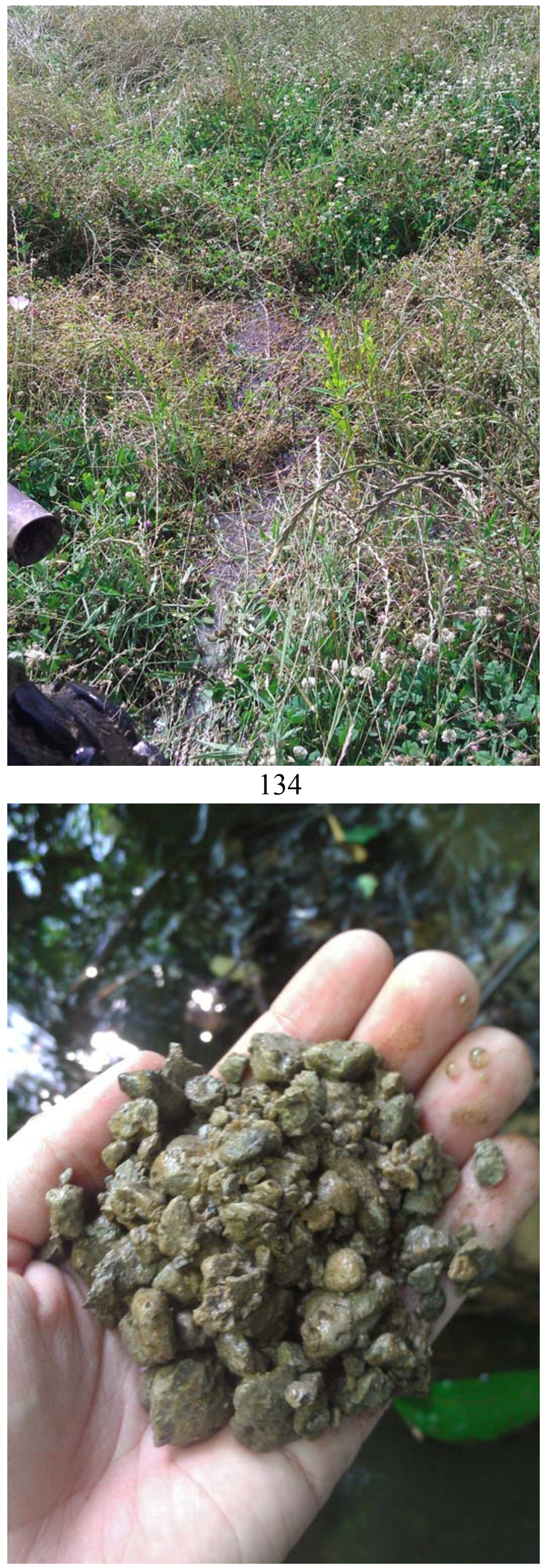




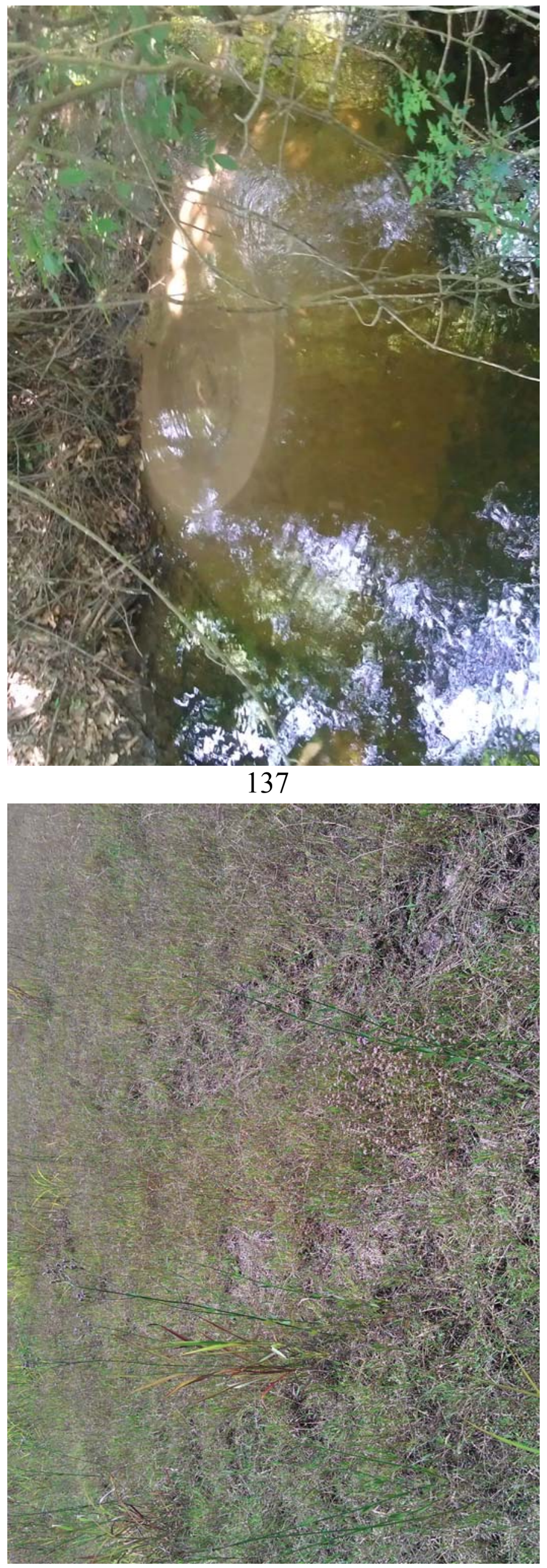

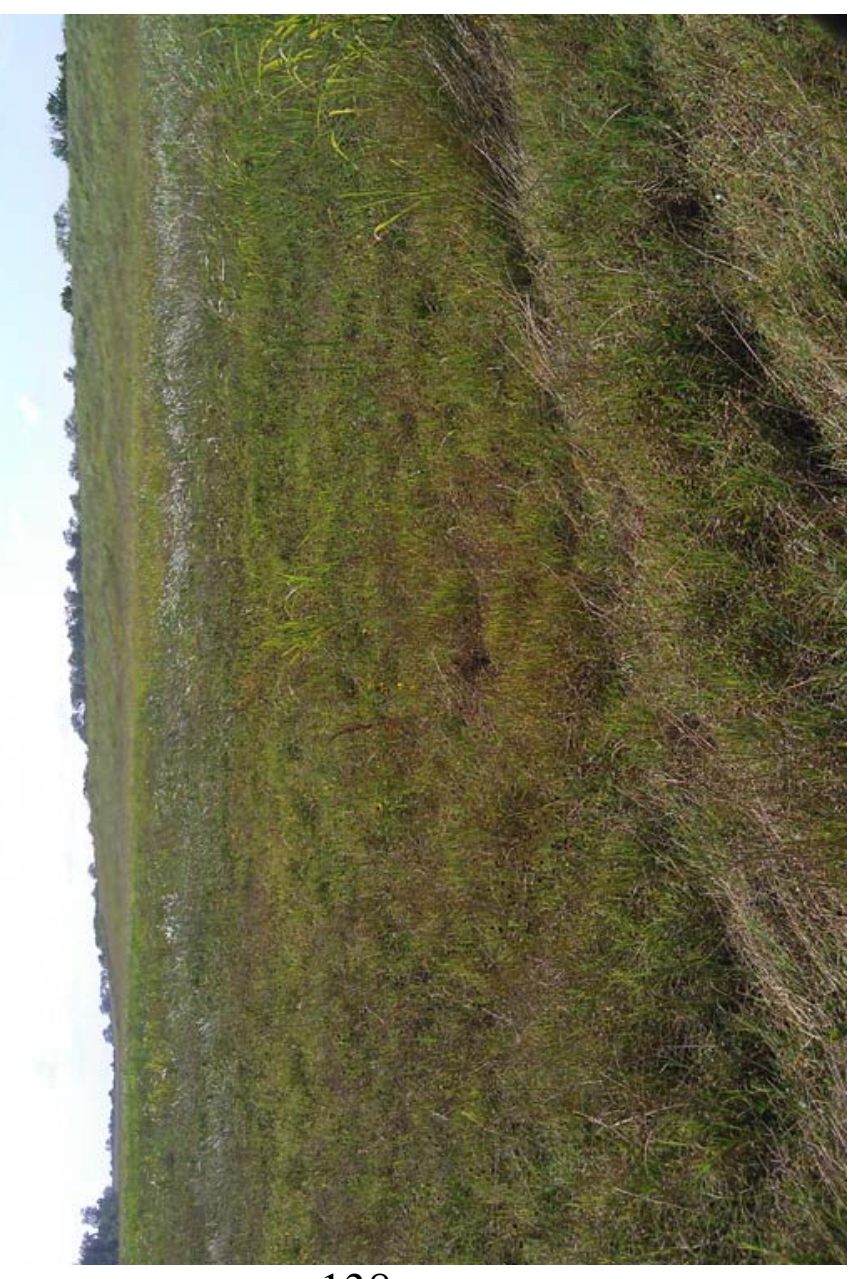

138

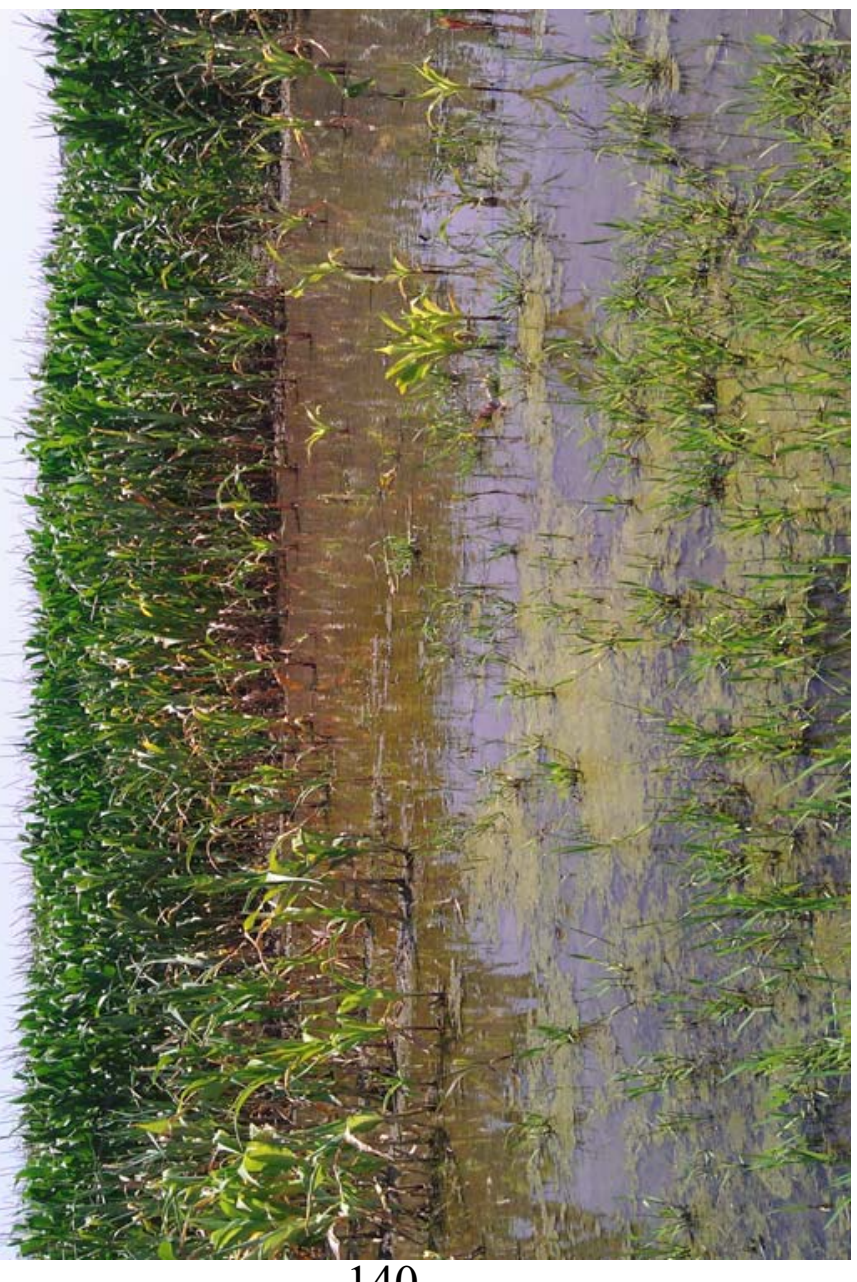



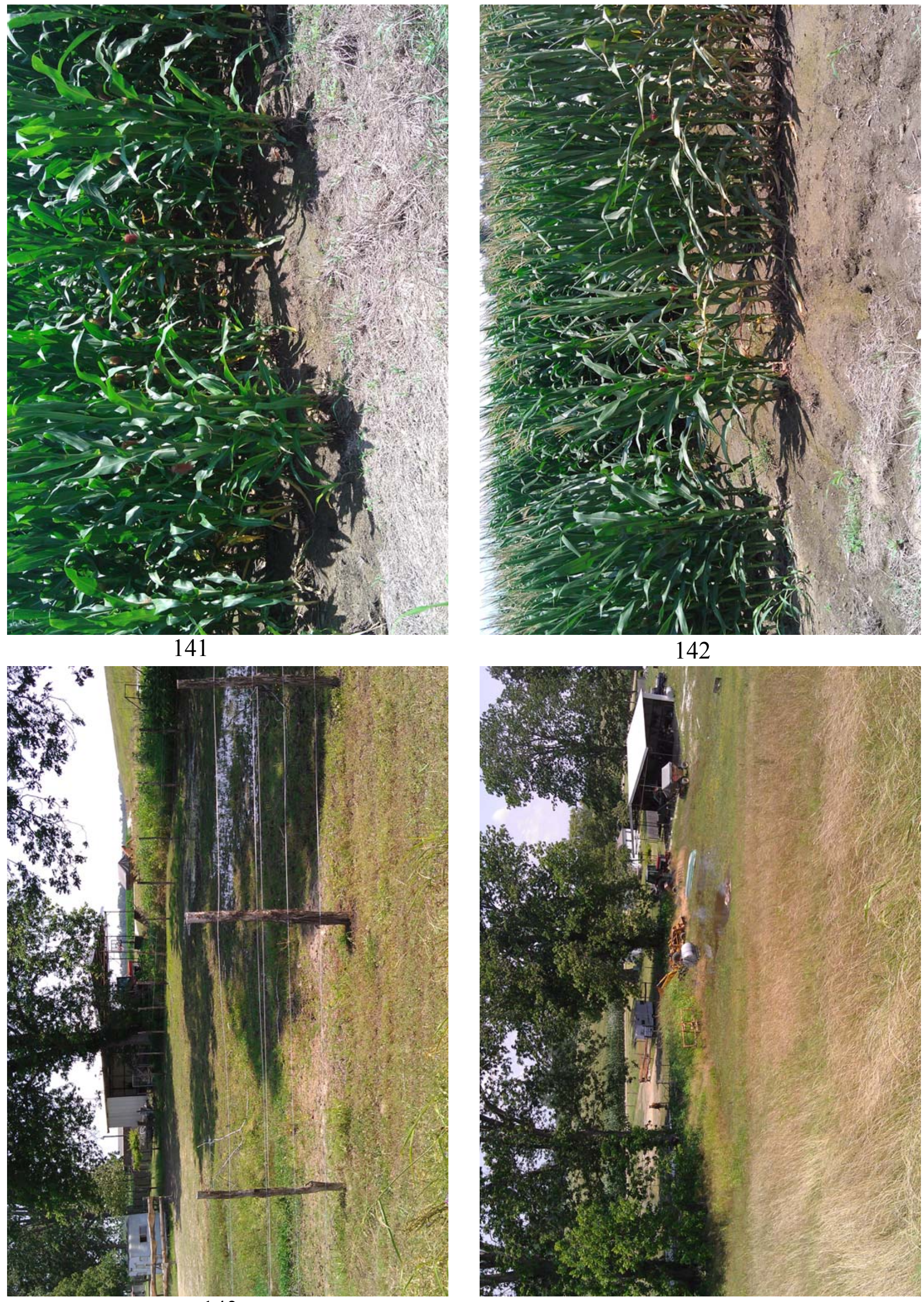


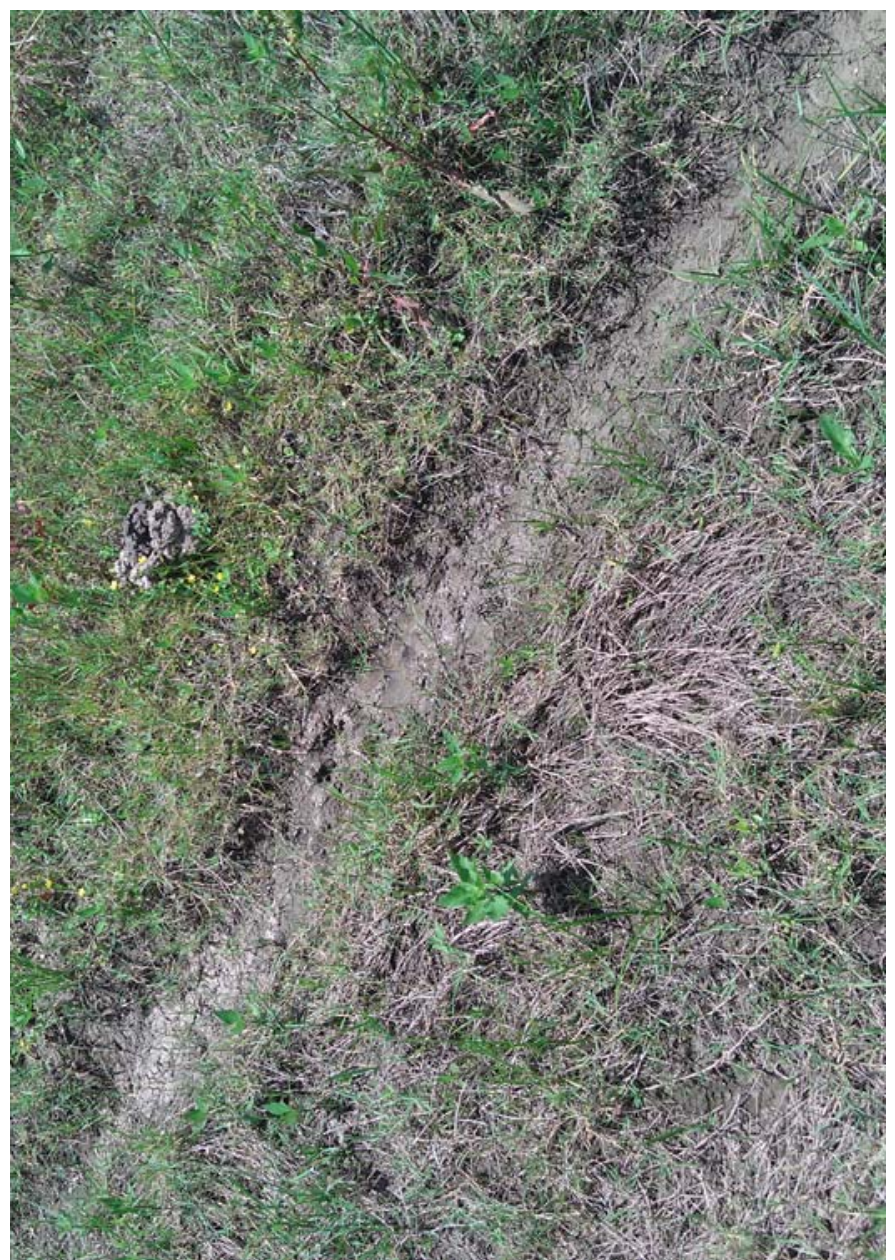

\section{5}

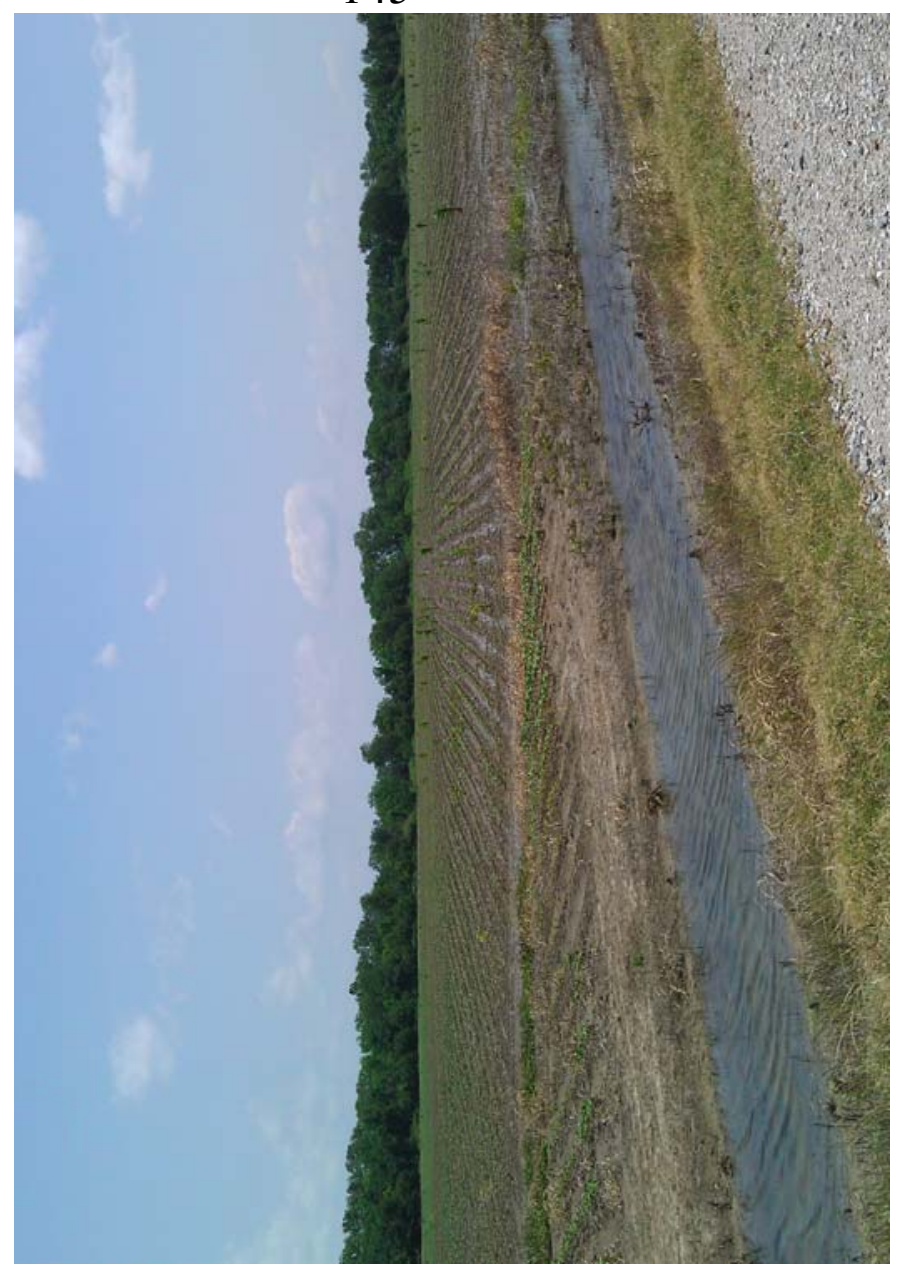

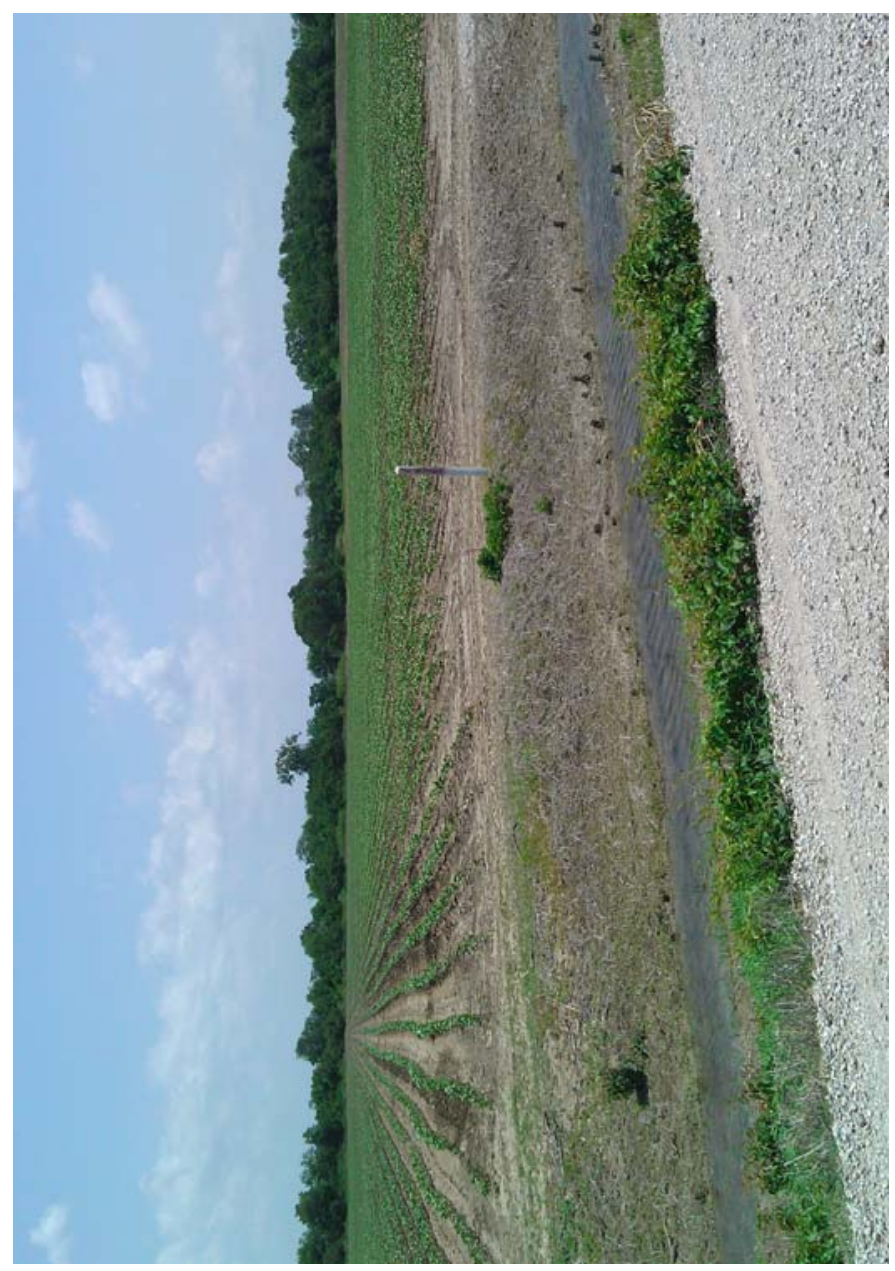

146

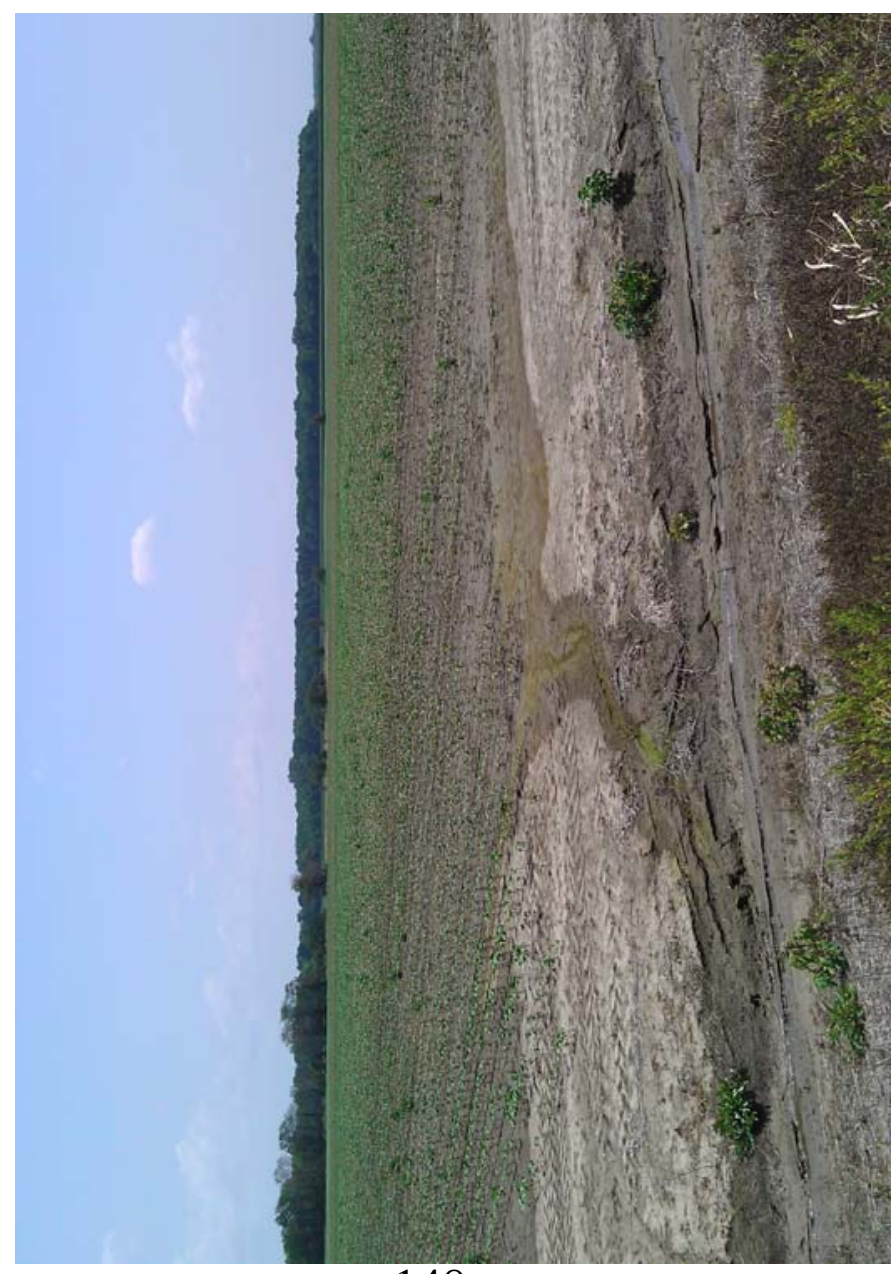




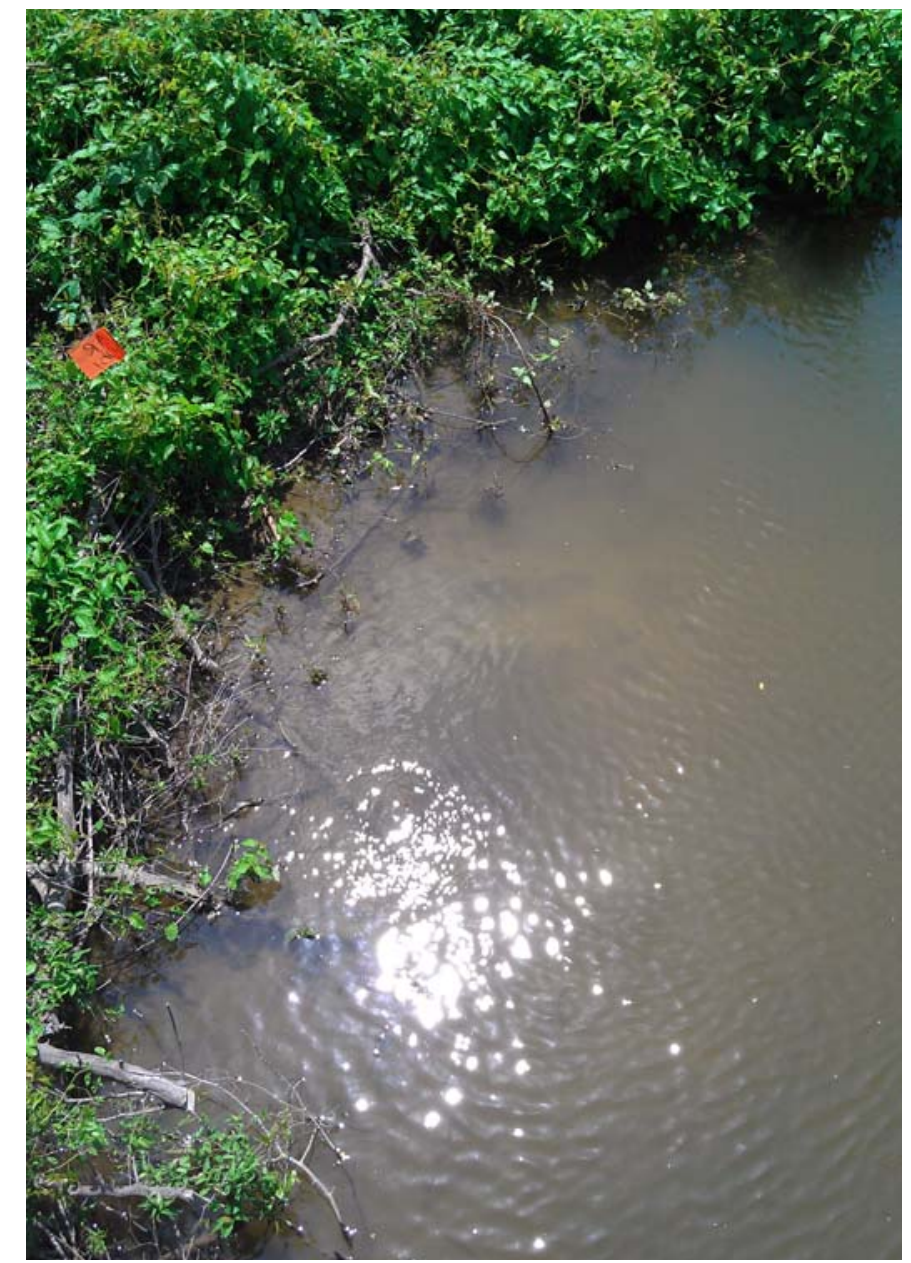

149

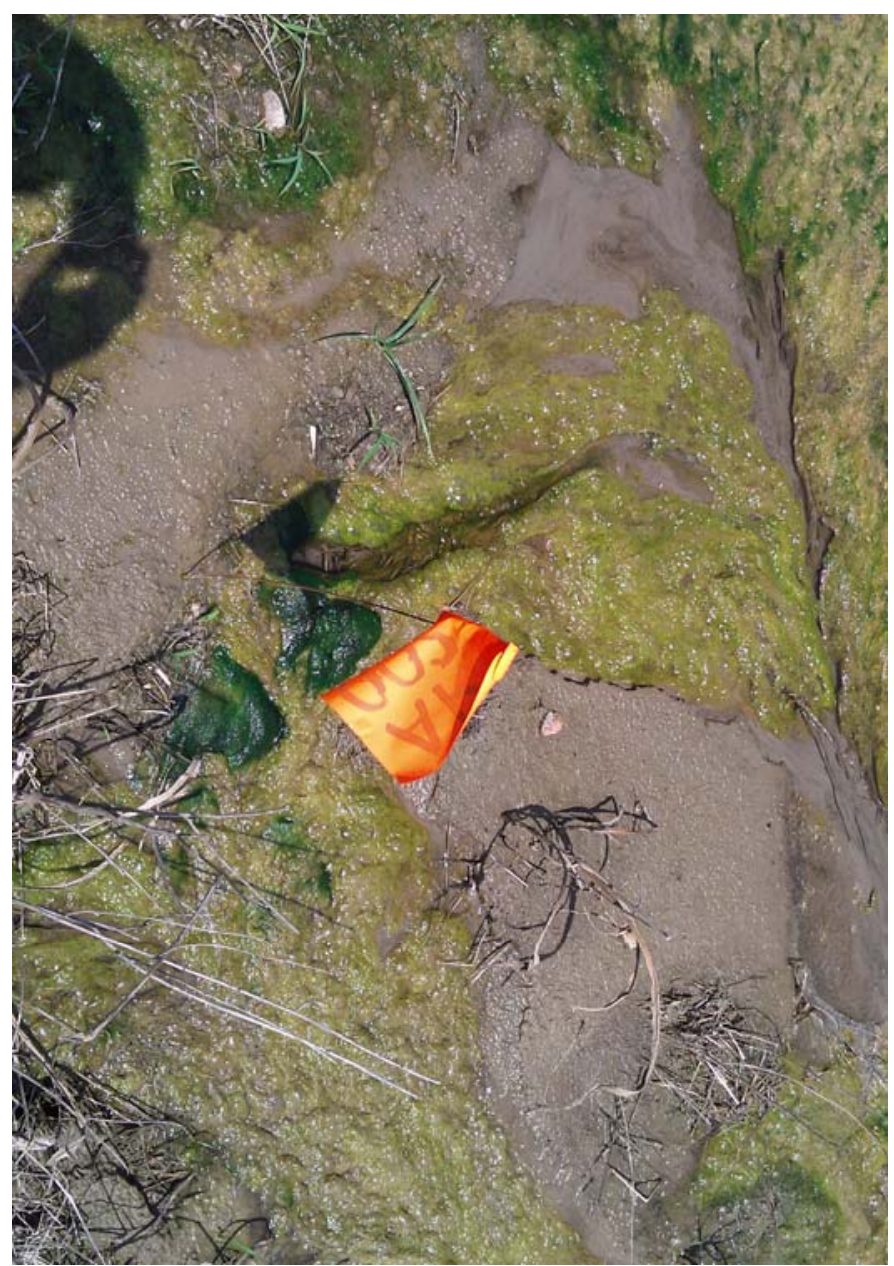

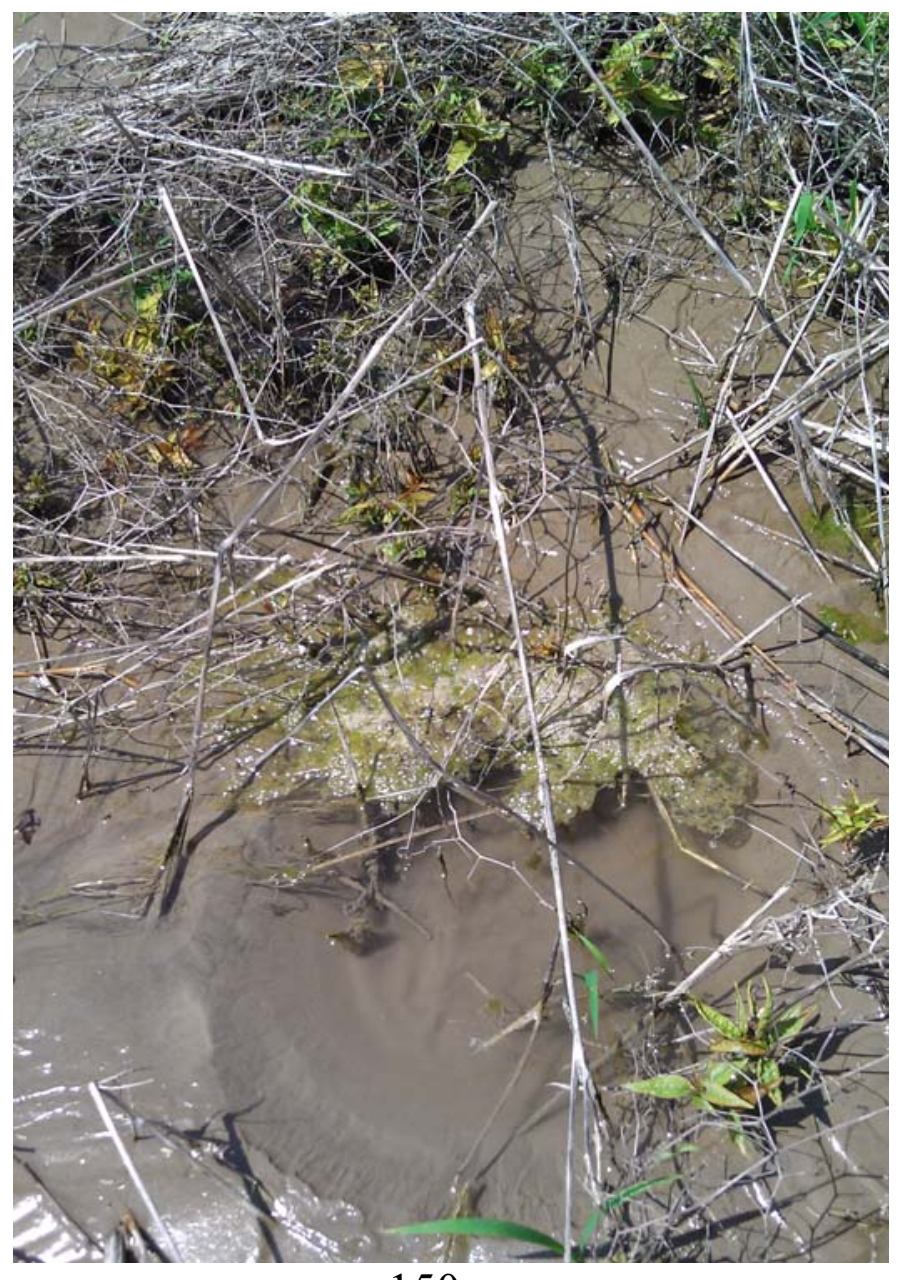

150 
STATION 3450+00 TO 5600+00 
LEVEE SECTOR: West Bank MRL - Station 3450+00 - Station 5600+00 (1-20 to Lake Bruin)

DATE: $\quad$ 5/19/2011 - 5/21/2011

TEAM MEMBERS: Andy Hardy, Lane Vargas, and Ben Emery

\begin{tabular}{|c|c|c|c|c|c|c|c|c|c|}
\hline \multicolumn{2}{|c|}{ START } & \multicolumn{2}{|c|}{ END } & \multirow{2}{*}{$\begin{array}{c}\text { STATION } \\
\text { NLD }\end{array}$} & \multirow{2}{*}{$\begin{array}{l}\text { STATION } \\
\text { LEVEE }\end{array}$} & \multirow[t]{2}{*}{ TYPE } & \multirow[t]{2}{*}{ EXTENT } & \multirow[t]{2}{*}{ REMARKS } & \multirow{2}{*}{$\begin{array}{l}\text { PHOTO } \\
\text { LINKS }\end{array}$} \\
\hline Latitude & Longitude & Latitude & Longitude & & & & & & \\
\hline 32.29780 & -90.98280 & 32.29750 & -90.98300 & $\begin{array}{l}3653+50- \\
3655+50 \\
\end{array}$ & $\begin{array}{c}3657+30- \\
3659+30 \\
\end{array}$ & Under Seepage & Light & At levee toe & 1 \\
\hline 32.28183 & -90.99055 & -- & -- & $3717+00$ & $3713+60$ & Heavy Current/Scour & Light & Wash area on riverside of levee & 2 \\
\hline 32.26610 & -90.98970 & 32.24910 & -90.98860 & $\begin{array}{r}3776+40- \\
3841+70\end{array}$ & $\begin{array}{l}3773+90- \\
3837+00\end{array}$ & Under Seepage & Light & 20 yards from berm toe and 800 ' into adjacent field & $3-4$ \\
\hline 32.25696 & -90.98673 & -- & -- & $3810+00$ & $3807+30$ & Under Seepage & Light & At berm toe and 100 ' into field. & \\
\hline 32.25354 & -90.98905 & 32.25108 & -90.98755 & $\begin{array}{r}3825+00- \\
3835+00\end{array}$ & $\begin{array}{l}3822+30- \\
3832+30\end{array}$ & Under Seepage & Light & $\begin{array}{l}\text { At berm toe and 300' feet into field. Water collected in low area of adjacent } \\
\text { field. }\end{array}$ & $5-7$ \\
\hline 32.24590 & -90.99090 & 32.24510 & -90.99200 & $\begin{array}{r}3857+20- \\
3861+70 \\
\end{array}$ & $\begin{array}{c}3854+50- \\
3858+00\end{array}$ & Under Seepage & Light & 20 yards from levee toe and $300^{\prime}$ into adjacent field & 8 \\
\hline 32.24260 & -90.99570 & 32.24090 & -90.99820 & $\begin{array}{r}3876+30- \\
3886+40 \\
\end{array}$ & $\begin{array}{c}3873+60- \\
3883+70 \\
\end{array}$ & Under Seepage & Light & 20 yards from levee toe and $300^{\prime}$ into adjacent field & $9-10$ \\
\hline 32.24020 & -91.00520 & 32.24060 & -91.01160 & $\begin{array}{r}3910+00- \\
3935+00 \\
\end{array}$ & $\begin{array}{c}3906+50- \\
3931+50 \\
\end{array}$ & Under Seepage & Light & At levee toe and $1500^{\prime}$ into adjacent field & $11-12$ \\
\hline 32.24273 & -91.02016 & -- & -- & $3958+00$ & $3961+00$ & Slide & & $\begin{array}{l}\text { Old slough slide on riverside of levee approx. } 100^{\prime} \text { long and } 10^{\prime} \text { from levee } \\
\text { crown. }\end{array}$ & $13-15$ \\
\hline 32.24520 & -91.03380 & -- & -- & $4000+90$ & $3997+40$ & Under Seepage & Light & At berm toe and $300^{\prime}$ into adjacent field & \\
\hline 32.24570 & -91.04210 & 32.24550 & -91.04400 & $\begin{array}{r}4025+60- \\
4032+10 \\
\end{array}$ & $\begin{array}{c}4021+20- \\
4028+70\end{array}$ & Under Seepage & Light & At berm toe and 600 into adjacent field & $16-17$ \\
\hline 32.24560 & -91.04690 & 32.24620 & -91.05480 & $\begin{array}{l}4041+00- \\
4065+50\end{array}$ & $\begin{array}{l}4037+60- \\
4061+10\end{array}$ & Under Seepage & Moderate & On berm and $1500^{\prime}$ into adjacent field & $18-19$ \\
\hline 32.24620 & -91.05480 & 32.24620 & -91.05710 & $\begin{array}{l}4065+50- \\
4072+60\end{array}$ & $\begin{array}{c}4068+20- \\
4079+10\end{array}$ & Under Seepage & Light to Moderate & On berm and 1500' into adjacent field & \\
\hline 32.24620 & -91.05710 & 32.24640 & -91.06060 & $\begin{array}{r}4072+60- \\
4083+50 \\
\end{array}$ & $\begin{array}{r}4079+10- \\
4134+40 \\
\end{array}$ & Under Seepage & Light & On berm and $1500^{\prime}$ into adjacent field & \\
\hline 32.24640 & -91.06060 & 32.24680 & -91.07850 & $\begin{array}{r}4083+50- \\
4138+80 \\
\end{array}$ & $\begin{array}{r}4079+10- \\
4134+40 \\
\end{array}$ & Under Seepage & Light & At toe of berm and $150^{\prime}$ into adjacent woods & \\
\hline 32.24610 & -91.08150 & 32.24610 & -91.08590 & $\begin{aligned} 4148+00- \\
4161+60\end{aligned}$ & $\begin{array}{r}4152+90- \\
4165+50\end{array}$ & Under Seepage & Light & At levee to and $150^{\prime}$ into adjacent field & 20 \\
\hline 32.23625 & -91.12508 & -- & -- & $4295+00$ & $4299+80$ & Under Seepage & Light & On road at levee toe & 21 \\
\hline 32.22460 & -91.12650 & 32.21730 & -91.13610 & $\begin{array}{r}4341+50- \\
4386+90 \\
\end{array}$ & $\begin{array}{r}4346+30- \\
4391+70 \\
\end{array}$ & Under Seepage & Light to Moderate & At levee toe and $300^{\prime}$ into adjacent field & $22-31$ \\
\hline 32.20624 & -91.15794 & - & -- & $4465+00$ & $4470+80$ & Under Seepage & Light & At levee toe and $20^{\prime}$ into adjacent field. & 32 \\
\hline 32.18840 & -91.17210 & 32.18200 & -91.17450 & $\begin{array}{l}4546+40- \\
4570+50\end{array}$ & $\begin{array}{r}4551+20- \\
4575+30\end{array}$ & Under Seepage & Light & At levee toe and $40^{\prime}$ into adjacent woods. & \\
\hline 32.17690 & -91.17560 & 32.17500 & -91.17610 & $\begin{array}{r}4589+10- \\
4600+90\end{array}$ & $\begin{array}{c}4591+20- \\
4602+00\end{array}$ & Under Seepage & Light & At levee toe and $20^{\prime}$ into adjacent woods. & \\
\hline 32.17280 & -91.17710 & 32.15580 & -91.17940 & $\begin{array}{r}4605+00- \\
4668+00\end{array}$ & $\begin{array}{c}4607+20- \\
4672+90\end{array}$ & Under Seepage & Light & At levee toe and $40^{\prime}$ into adjacent woods. & \\
\hline 32.15350 & -91.17970 & 32.14920 & -91.17840 & $\begin{array}{r}4676+50- \\
4692+10\end{array}$ & $\begin{array}{c}4681+40- \\
4697+10\end{array}$ & Under Seepage & Light & At levee toe and 600' into adjacent field. & \\
\hline 32.14920 & -91.17840 & 32.14190 & -91.17610 & $\begin{array}{r}4692+10- \\
4720+20\end{array}$ & $\begin{array}{c}4697+10- \\
4725+20\end{array}$ & Under Seepage & Light & At berm toe and 500 ' into adjacent field. & 33-34 \\
\hline
\end{tabular}


LEVEE SECTOR: West Bank MRL - Station 3450+00 - Station 5600+00 (1-20 to Lake Bruin)

DATE: $\quad 5 / 19 / 2011-5 / 21 / 2011$

TEAM MEMBERS: Andy Hardy, Lane Vargas, and Ben Emery

\begin{tabular}{|c|c|c|c|c|c|c|c|c|c|}
\hline \multicolumn{2}{|c|}{ START } & \multicolumn{2}{|c|}{ END } & \multirow{2}{*}{$\begin{array}{c}\text { STATION } \\
\text { NLD }\end{array}$} & \multirow{2}{*}{$\begin{array}{c}\text { STATION } \\
\text { LEVEE } \\
\end{array}$} & \multirow[t]{2}{*}{ TYPE } & \multirow[t]{2}{*}{ EXTENT } & \multirow[t]{2}{*}{ REMARKS } & \multirow{2}{*}{$\begin{array}{l}\text { PHOTO } \\
\text { LINKS }\end{array}$} \\
\hline Latitude & Longitude & Latitude & Longitude & & & & & & \\
\hline 32.14190 & -91.17610 & 32.13360 & -91.17650 & $\begin{array}{r}4720+20- \\
4753+00 \\
\end{array}$ & $\begin{array}{r}4725+20- \\
4755+90 \\
\end{array}$ & Under Seepage & Light & At toe of levee and $100^{\prime}$ into adjacent field. & \\
\hline 32.13360 & -91.17650 & 32.12930 & -91.17580 & $\begin{array}{r}4753+00- \\
4767+90 \\
\end{array}$ & $\begin{array}{r}4755+90- \\
4770+80 \\
\end{array}$ & Under Seepage & Light & In the fields $150^{\prime}$ from levee toe and $600^{\prime}$ into adjacent field. & \\
\hline 32.11540 & -91.17270 & 32.11370 & -91.17200 & $\begin{array}{l}4828+00- \\
4834+50\end{array}$ & $\begin{array}{r}4833+80- \\
4840+30\end{array}$ & Under Seepage & Light & At levee toe and 300' into adjacent fields & \\
\hline 32.11370 & -91.17200 & 32.11080 & -91.17070 & $\begin{array}{r}4834+50- \\
4846+80\end{array}$ & $\begin{array}{r}4840+30- \\
4852+60 \\
\end{array}$ & Under Seepage & Light & At levee toe and $800^{\prime}$ into adjacent fields & \\
\hline 32.10850 & -91.16980 & 32.10110 & -91.16710 & $\begin{array}{r}4854+00- \\
4856+30\end{array}$ & $\begin{array}{r}4859+80- \\
4862+20\end{array}$ & $\begin{array}{c}\text { Under Seepage/Pin } \\
\text { Boils }\end{array}$ & Light to Moderate & $\begin{array}{l}\text { At toe of small berm and } 300^{\prime} \text { into fields with a few pin boils scattered near } \\
\text { berm toe and } 30^{\prime} \text { feet into fields and moving only clear water from station } \\
4854+00 \text { to } 4856+00 \text {. }\end{array}$ & $35-36$ \\
\hline 32.10110 & -91.16710 & 32.09964 & -91.16945 & $\begin{array}{r}4886+30- \\
4895+00\end{array}$ & $\begin{array}{r}4892+20- \\
4960+20\end{array}$ & $\begin{array}{c}\text { Under Seepage/Pin } \\
\text { Boils }\end{array}$ & Moderate & $\begin{array}{l}\text { Few pin boils grouped together at Station } 4887+00 \text { at toe of levee in a stretch } \\
\text { where there an } 800^{\prime} \text { gap in the seepage berm. Seepage } 300^{\prime} \text { into fields from } \\
\text { levee toe }\end{array}$ & $37-42$ \\
\hline 32.09964 & -91.16945 & 32.08450 & -91.17740 & $\begin{array}{l}4886+30- \\
4954+30\end{array}$ & $\begin{array}{r}4892+20- \\
4960+20\end{array}$ & Under Seepage & Moderate & At berm toe and 200' into fields. & \\
\hline 32.09802 & -91.17092 & -- & -- & $4901+00$ & $4907+20$ & Sand Boil & Moderate & $\begin{array}{l}\text { Boil located on landside of ditch at north end of corn field, } 2 \text { " diameter hole } \\
\text { with small amount of material. Seepage and pin boils increasing on landside } \\
\text { and levee side of ditch. }\end{array}$ & \\
\hline 32.08396 & -91.17785 & -- & -- & $4952+00$ & $4957+90$ & & Light & $\begin{array}{l}\text { Four bulges found at north end of berm pumping a very small amount of } \\
\text { cloudy water. }\end{array}$ & \\
\hline 32.08450 & -91.17740 & 32.07700 & -91.18150 & $\begin{array}{r}4954+30- \\
4991+90\end{array}$ & $\begin{array}{r}4960+20- \\
4997+90\end{array}$ & $\begin{array}{c}\text { Under Seepage/Pin } \\
\text { Boils }\end{array}$ & $\begin{array}{l}\text { Moderate to } \\
\text { Heavy }\end{array}$ & $\begin{array}{l}\text { Numerous pin boils in field adjacent to berm toe for } 400^{\prime} \text { and seepage } 600^{\prime} \\
\text { into fields. Seep water flowed briskly from corn fields and into a ditch } 400^{\prime} \\
\text { from berm toe. Several small boils in ditch were controlled by constructing } \\
\text { sandbag dams along ditch. }\end{array}$ & 43 \\
\hline 32.07700 & -91.18150 & 32.06940 & -91.18310 & $\begin{aligned} 4991+90- \\
5017+00\end{aligned}$ & $\begin{aligned} 4997+90- \\
5023+00\end{aligned}$ & Under Seepage & Moderate & At berm toe and 600 ' into fields & \\
\hline 32.06940 & -91.18310 & 32.06020 & -91.18220 & $\begin{array}{r}5017+00- \\
5050+50\end{array}$ & $\begin{array}{l}5023+00- \\
5056+50\end{array}$ & Under Seepage & Light & At berm toe and 300' into fields. & \\
\hline 32.06020 & -91.18220 & 32.05620 & -91.18130 & $\begin{array}{r}5050+50- \\
5066+00 \\
\end{array}$ & $\begin{array}{r}5056+50- \\
5072+00 \\
\end{array}$ & Under Seepage & Light & At berm toe and $20^{\prime}$ into adjacent field. & \\
\hline 32.05210 & -91.17950 & 32.05150 & -91.17930 & $\begin{aligned} 5081+50- \\
5084+00\end{aligned}$ & $\begin{array}{r}5087+50- \\
5090+01\end{array}$ & Under Seepage & Light & At berm toe and $20^{\prime}$ into adjacent field. & \\
\hline 32.05150 & -91.17930 & 32.04350 & -91.17760 & $\begin{array}{r}5084+00- \\
5113+10 \\
\end{array}$ & $\begin{array}{r}5090+00- \\
5119+10 \\
\end{array}$ & Under Seepage & Light & Spotty seepage $1000^{\prime}$ - $1200^{\prime}$ into fields from berm toe. & \\
\hline 32.04080 & -91.17550 & 32.03810 & -91.17390 & $\begin{array}{r}5125+00- \\
5136+00 \\
\end{array}$ & $\begin{array}{r}5131+00- \\
5142+00 \\
\end{array}$ & Under Seepage & Light & At berm toe and $40^{\prime}$ into adjacent field. & \\
\hline 32.03410 & -91.15810 & 32.03230 & -91.15450 & $\begin{array}{r}5193+50- \\
5205+40 \\
\end{array}$ & $\begin{array}{r}5199+50- \\
5211+40 \\
\end{array}$ & Under Seepage & Light & at seepage berm toe and 20 yards into fields & \\
\hline 32.02868 & -91.14656 & & & $\begin{array}{r}5215+00- \\
5220+00 \\
\end{array}$ & $\begin{array}{r}5221+00- \\
5226+00 \\
\end{array}$ & $\begin{array}{c}\text { Under Seepage/Pin } \\
\text { Boils }\end{array}$ & Moderate & Moderate seepage and pin boils at toe of berm and into field for $200^{\prime}$. & $45-50$ \\
\hline 32.03370 & -91.13930 & -- & -- & $\begin{array}{r}5250+80- \\
5275+00\end{array}$ & $\begin{array}{r}5257+00- \\
5281+20\end{array}$ & Sand Boil & Heavy & $\begin{array}{l}\text { Davis Landing - The site is historically an area with numerous small to } \\
\text { medium sized boils with heavy seepage. There were several medium sized } \\
\text { boils that were bagged. Some boils that had been previously bagged in the } \\
2008 \text { High Water event reappeared and did not require further sandbagging } \\
\text { efforts. The majority of the boils were located in or near a slough that runs } \\
\text { essentially parallel with the levee, and all boils were at least } 500 \mathrm{ft} \text { from the } \\
\text { levee toe. }\end{array}$ & \\
\hline
\end{tabular}


LEVEE SECTOR: West Bank MRL - Station 3450+00 - Station 5600+00 (I-20 to Lake Bruin)

DATE: 5/19/2011 - 5/21/2011

TEAM MEMBERS: Andy Hardy, Lane Vargas, and Ben Emery

\begin{tabular}{|c|c|c|c|c|c|c|c|c|c|}
\hline \multicolumn{2}{|c|}{ START } & \multicolumn{2}{|c|}{ END } & \multirow{2}{*}{$\begin{array}{c}\text { STATION } \\
\text { NLD }\end{array}$} & \multirow{2}{*}{$\begin{array}{c}\text { STATION } \\
\text { LEVEE }\end{array}$} & \multirow[t]{2}{*}{ TYPE } & \multirow[t]{2}{*}{ EXTENT } & \multirow[t]{2}{*}{ REMARKS } & \multirow{2}{*}{$\begin{array}{l}\text { PHOTO } \\
\text { LINKS } \\
\end{array}$} \\
\hline Latitude & Longitude & Latitude & Longitude & & & & & & \\
\hline 32.02860 & -91.12280 & 32.01680 & -91.13400 & $\begin{array}{r}5338+50- \\
5393+40\end{array}$ & $\begin{array}{l}5344+50- \\
5400+00\end{array}$ & $\begin{array}{c}\text { Under Seepage/Pin } \\
\text { Boils }\end{array}$ & $\begin{array}{l}\text { Moderate to } \\
\text { Heavy }\end{array}$ & $\begin{array}{l}\text { Winter Quarters - Seepage at toe of berm and light } 500^{\prime} \text { into adjacent fields. } \\
\text { Numerous pin boils in ditch near toe of small berm. Several sandbag dams } \\
\text { were constructed along the ditch to create head on the boils and control } \\
\text { movement of material. }\end{array}$ & $64-71$ \\
\hline 32.00600 & -91.16130 & 32.00410 & -91.16890 & $\begin{array}{r}5490+50- \\
5516+00 \\
\end{array}$ & $\begin{array}{r}5511+00- \\
5527+50 \\
\end{array}$ & Under Seepage & Light & At toe of levee and $150^{\prime}$ into adjacent fields. & 72 \\
\hline
\end{tabular}



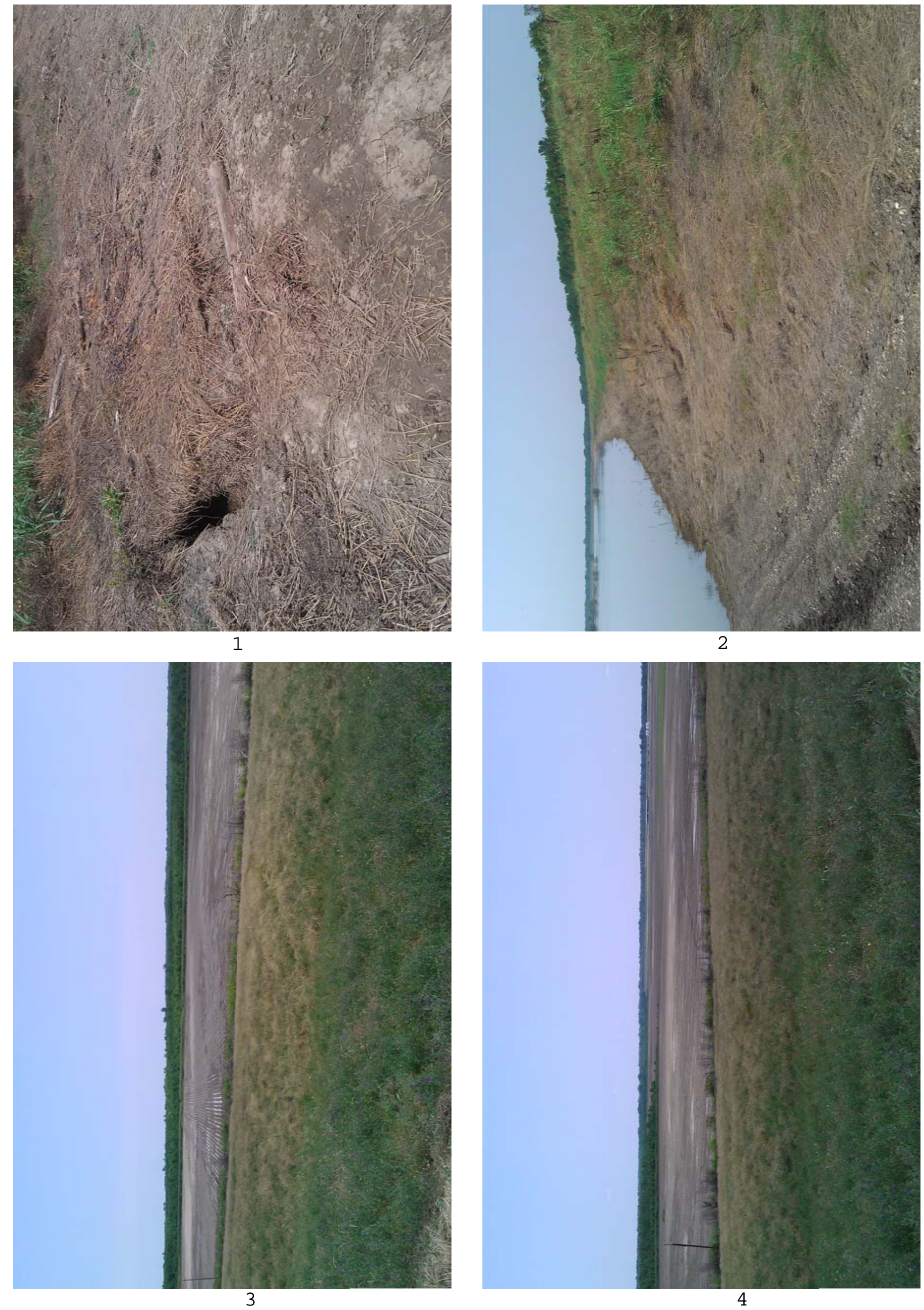


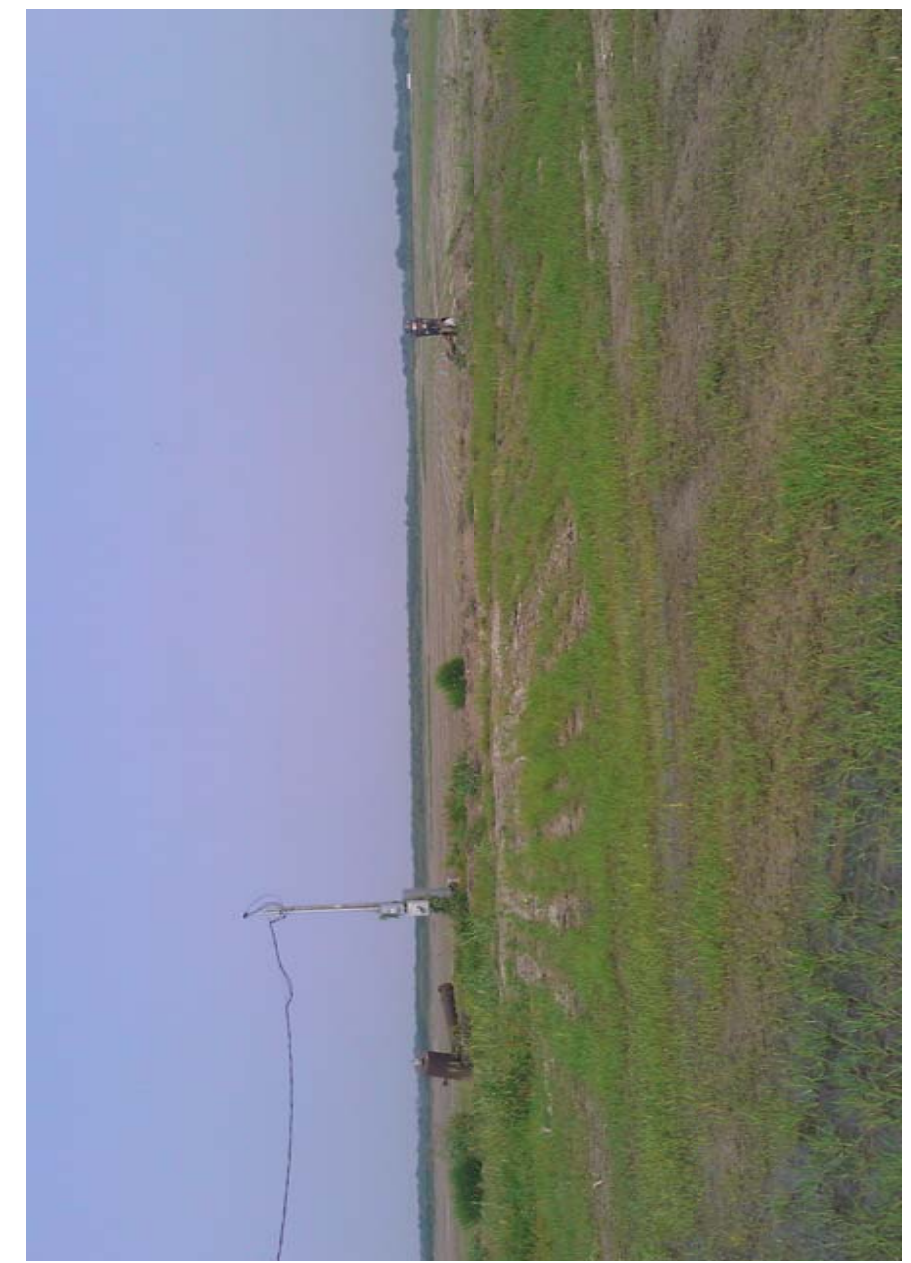

5

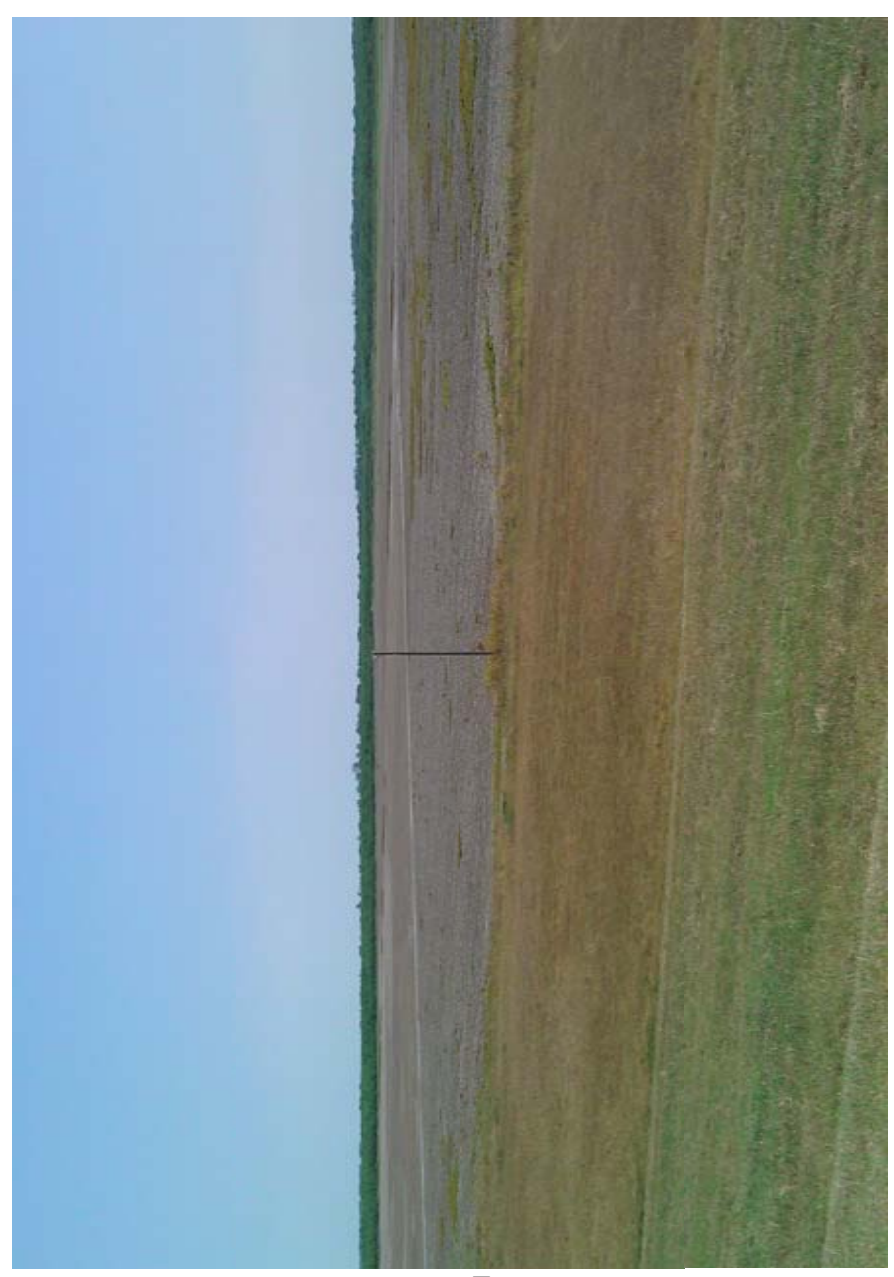

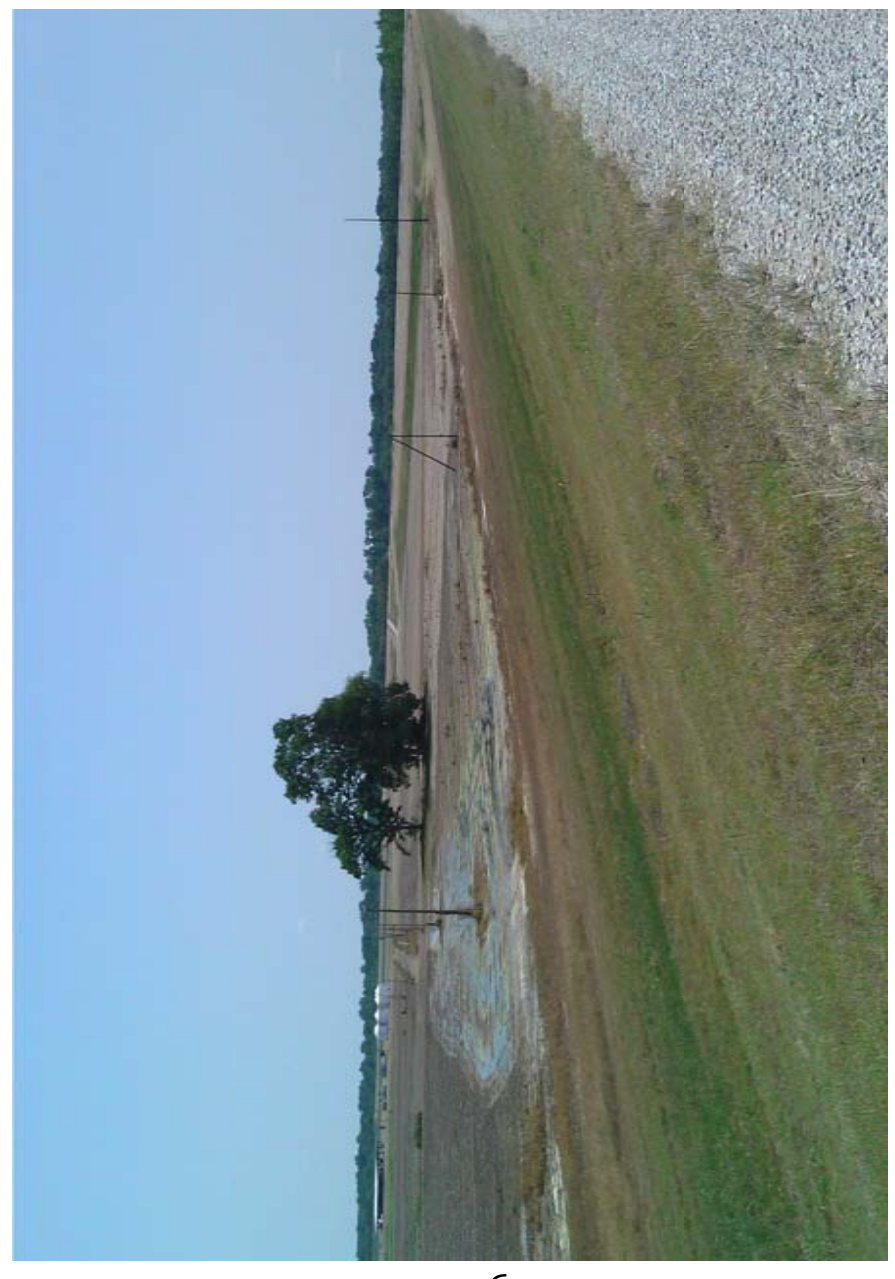

6

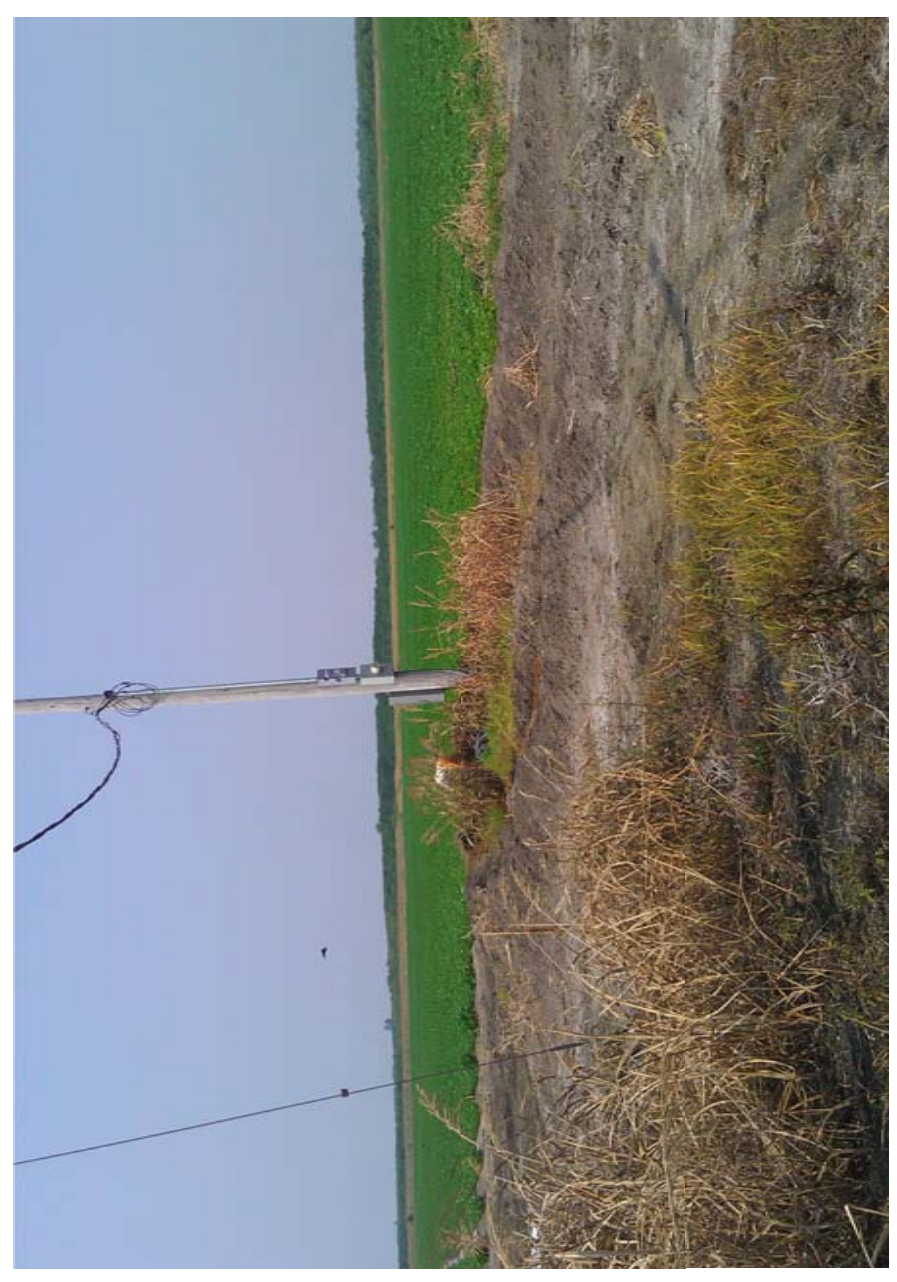

8 

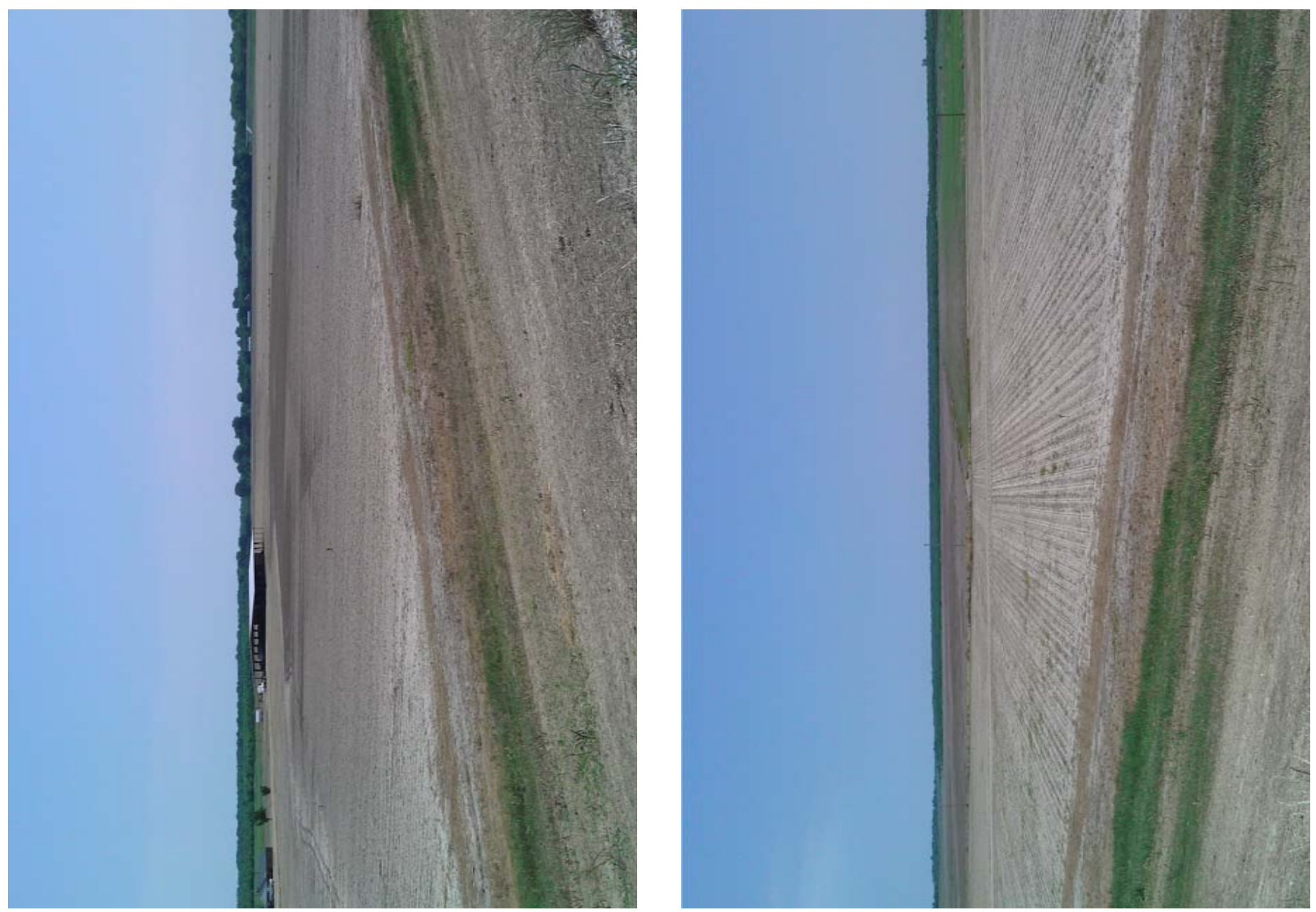

9

\section{0}
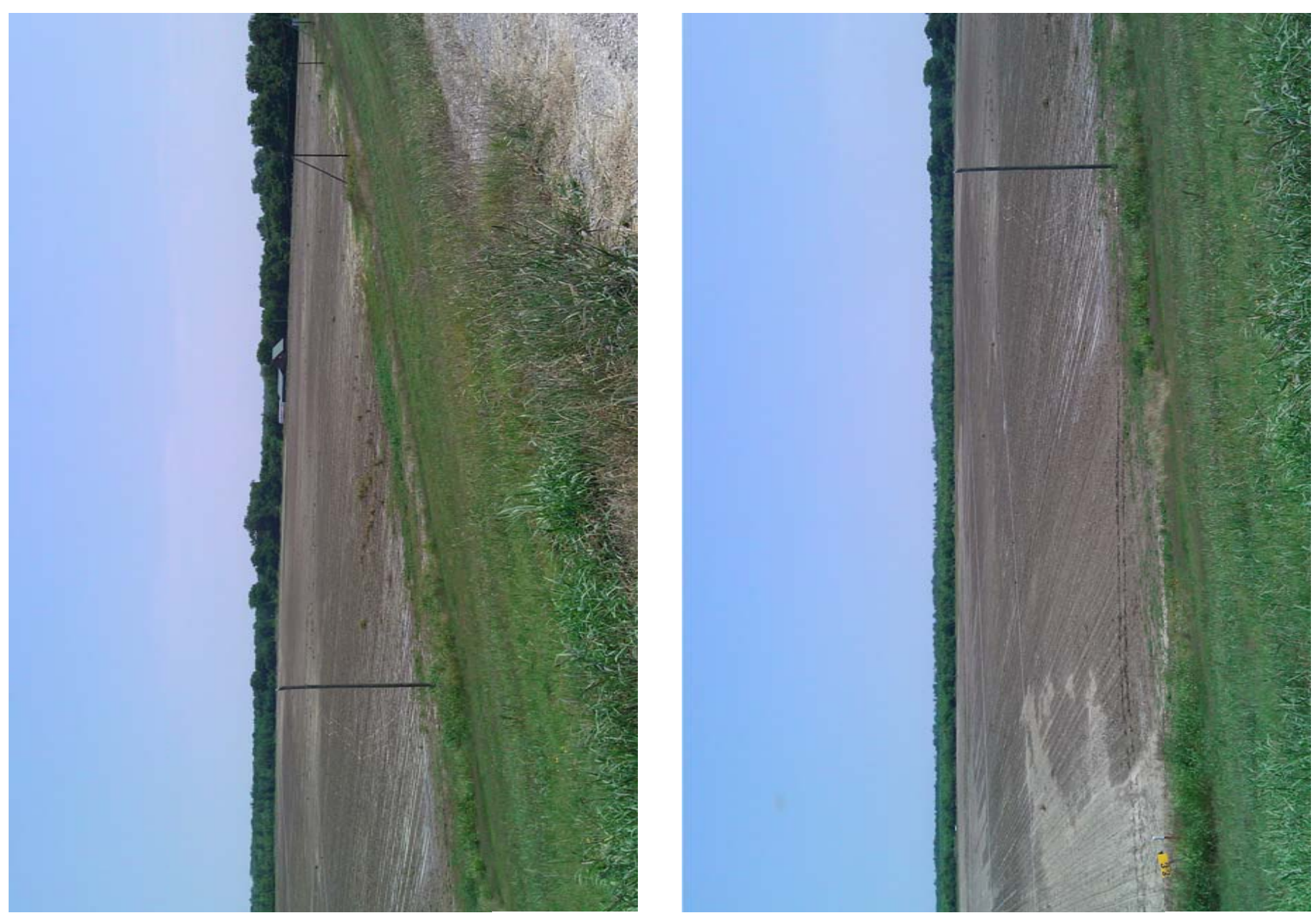


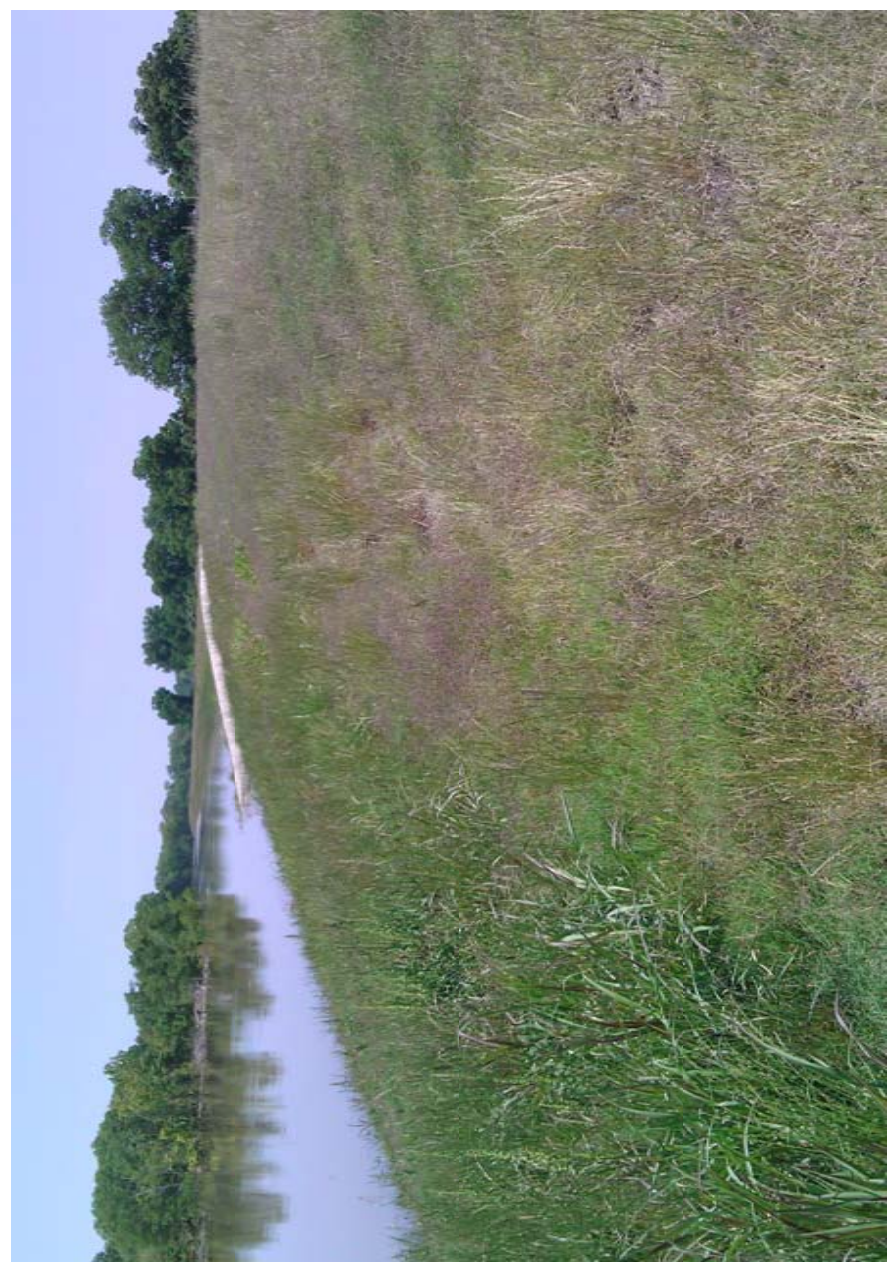

13

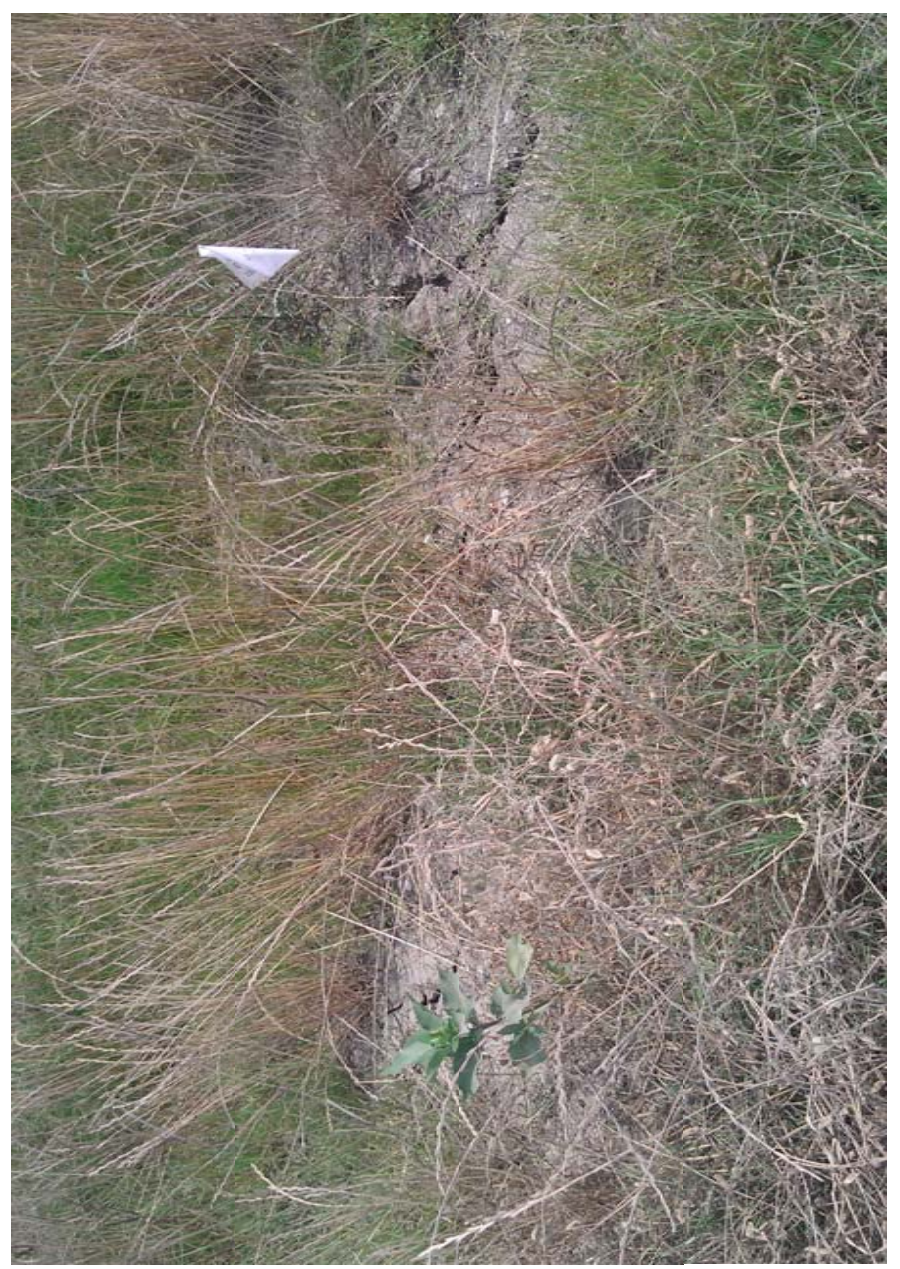

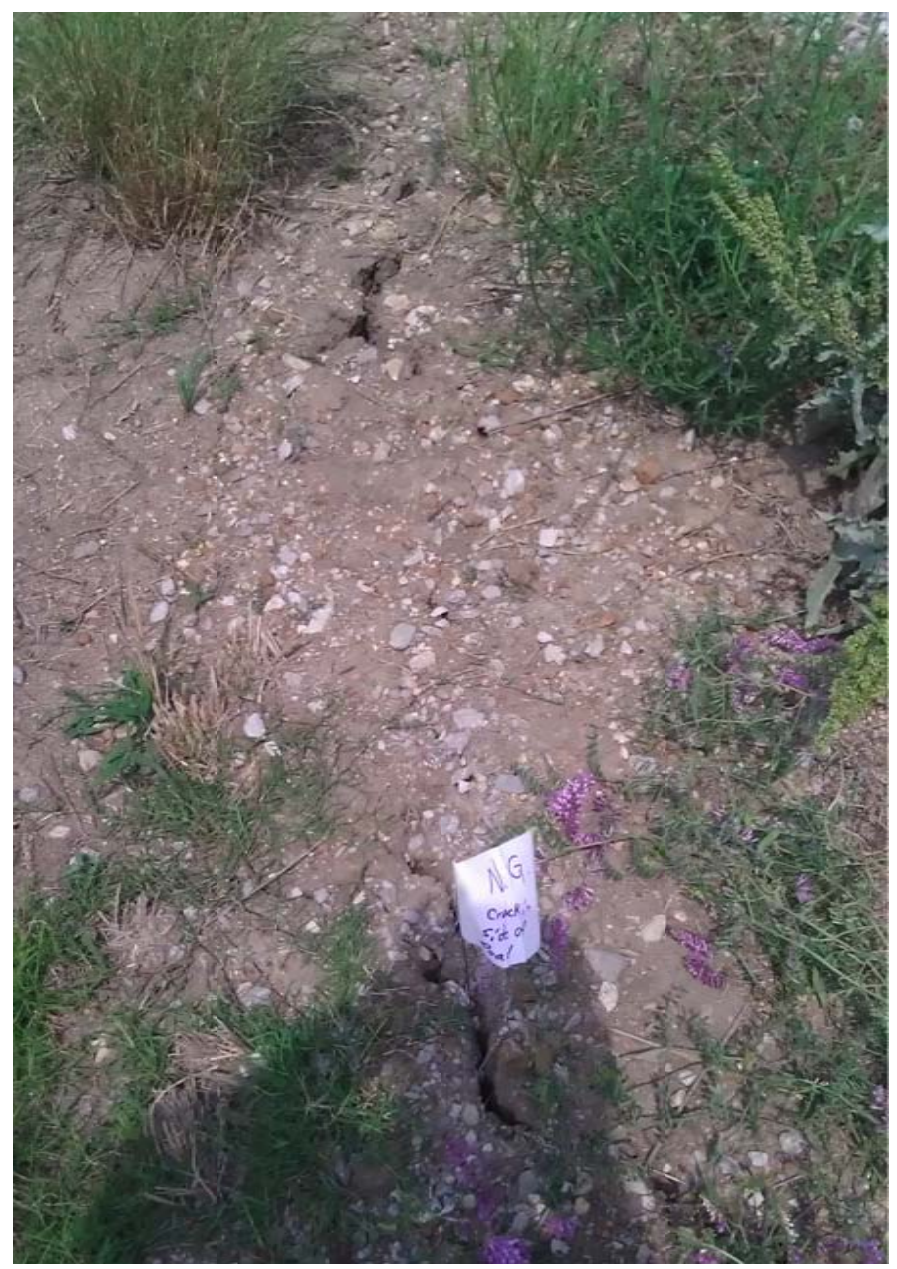

14

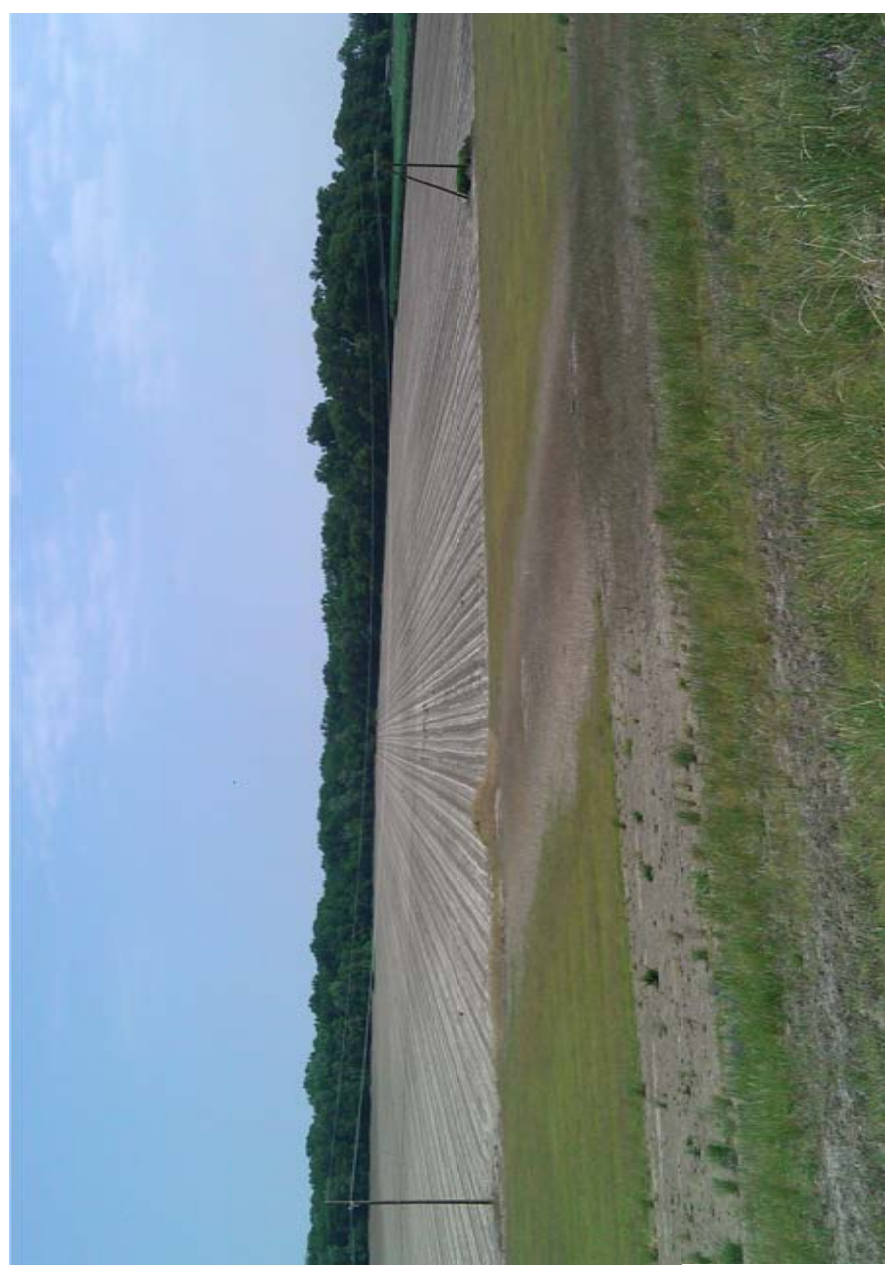

16 


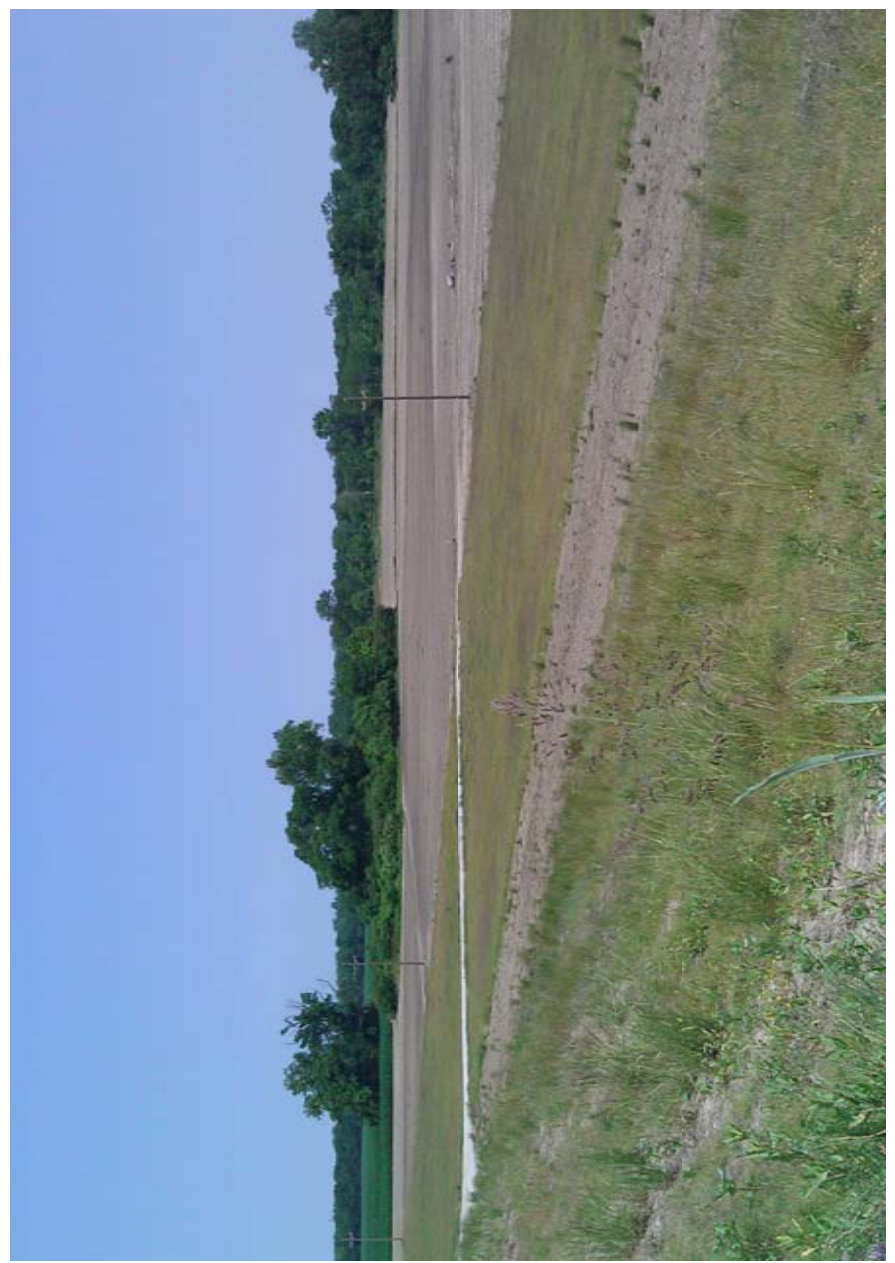

17

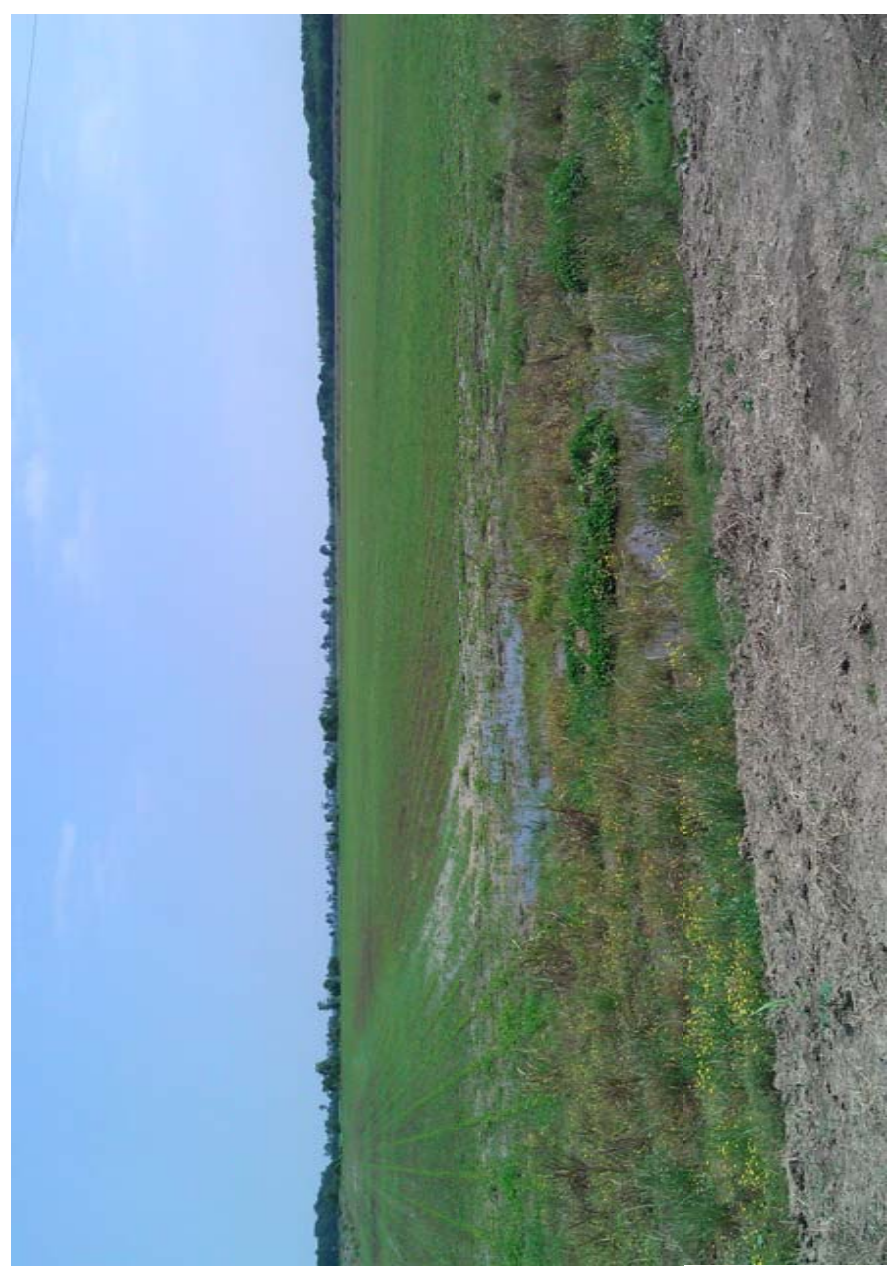

19

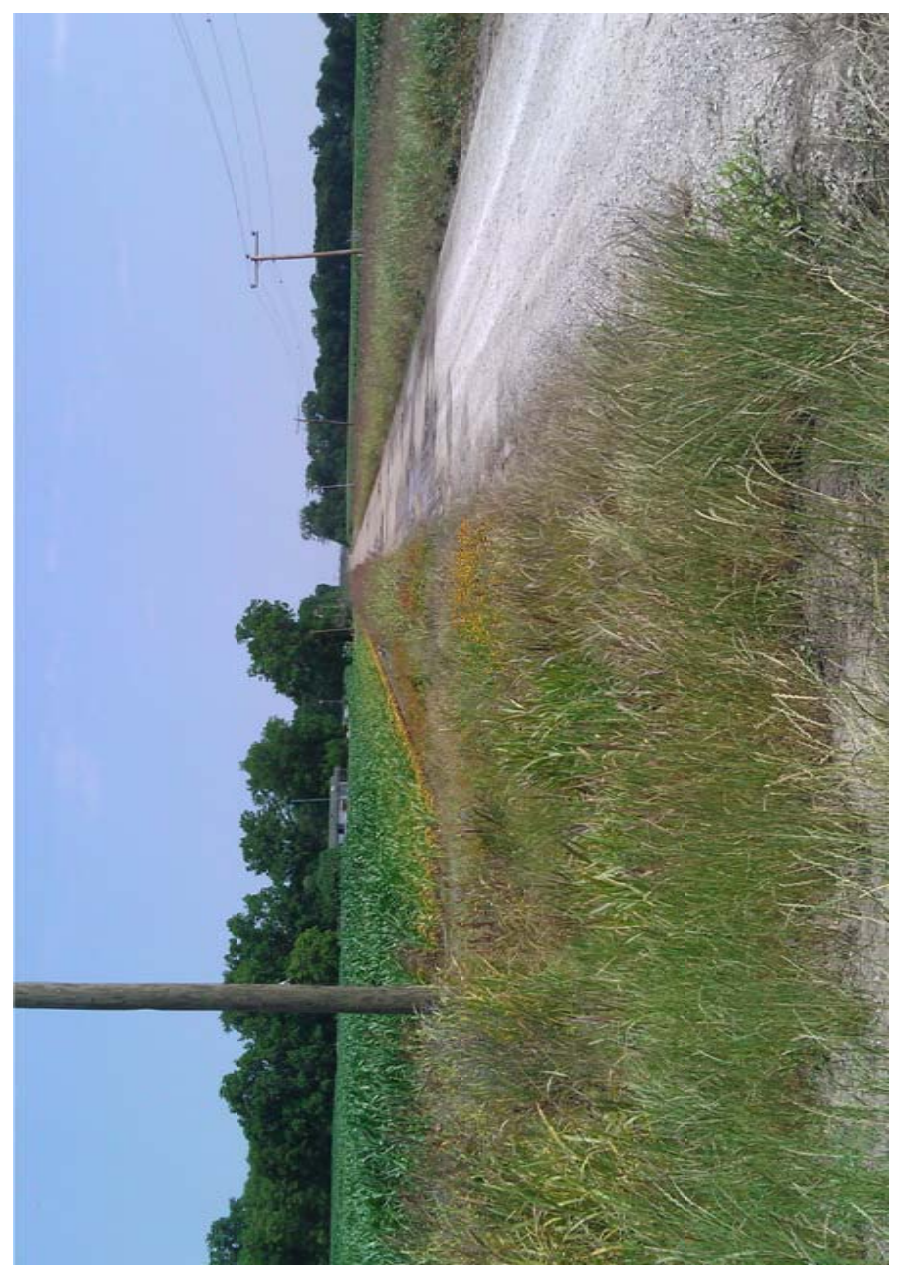

18

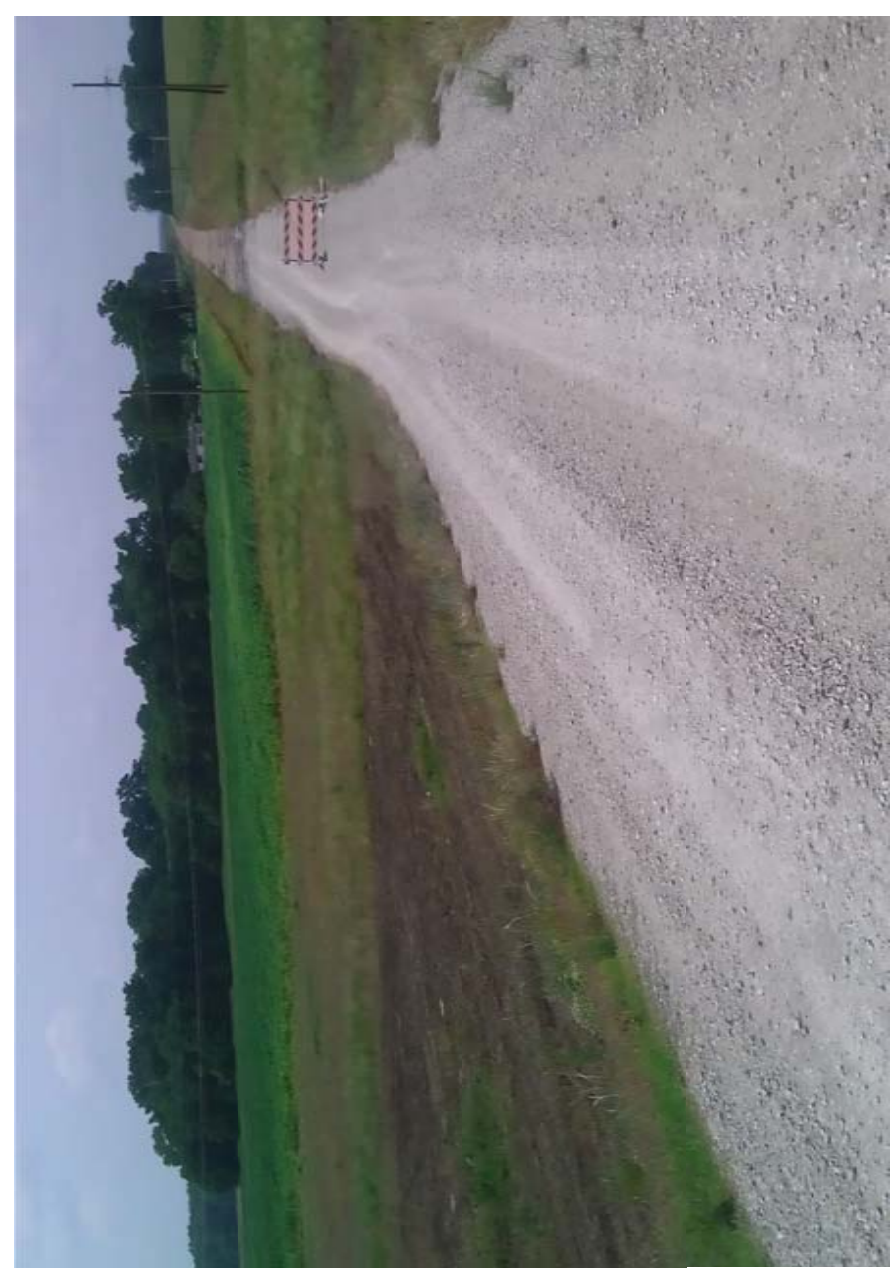

20 


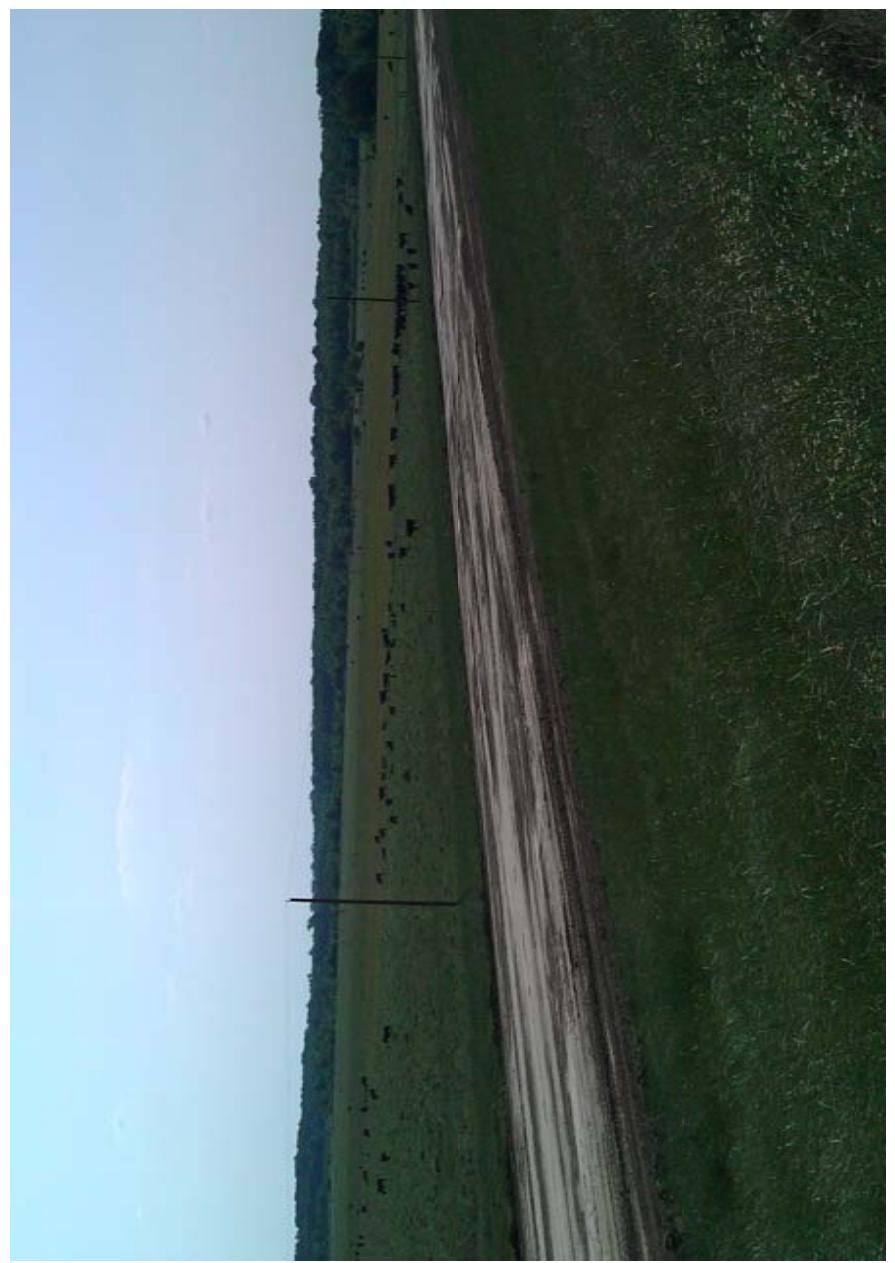

21

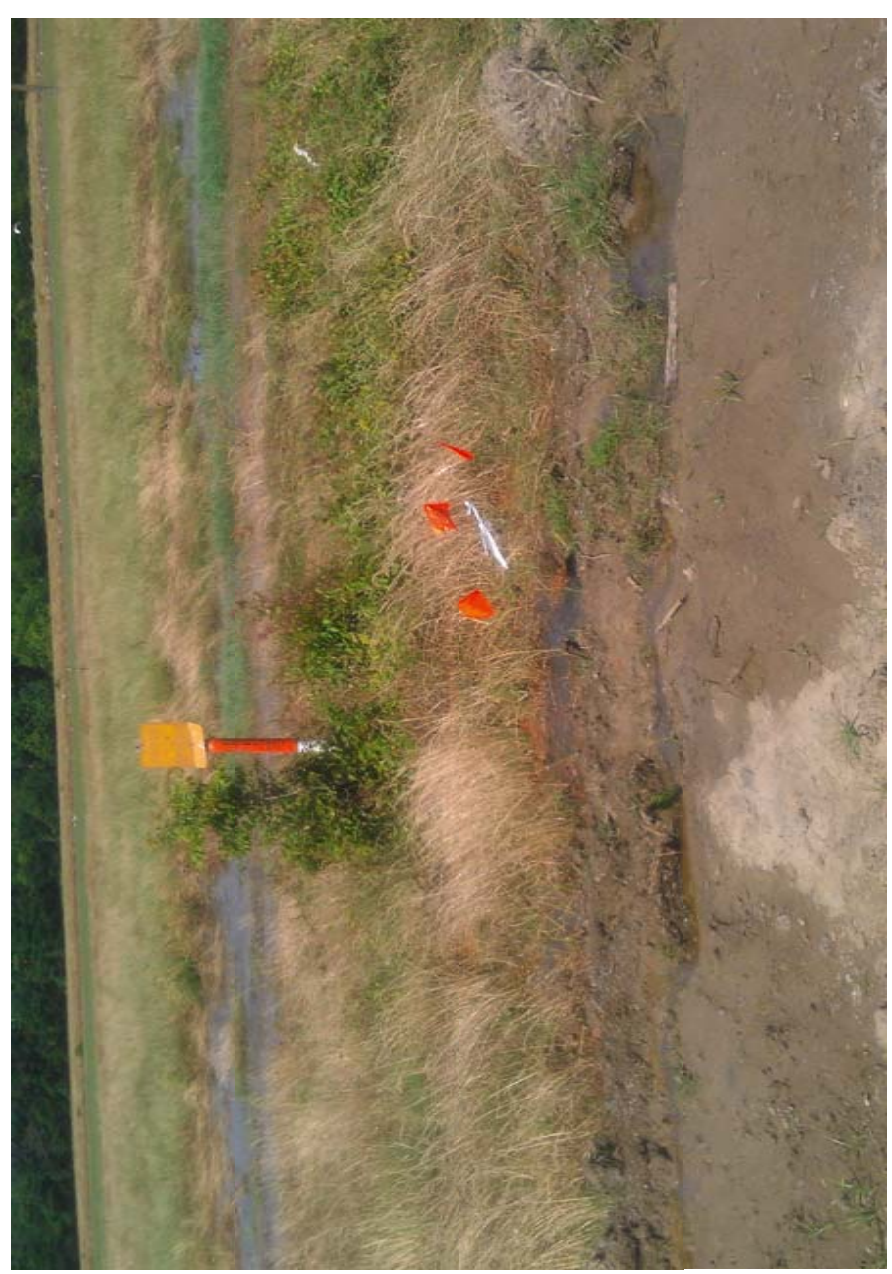

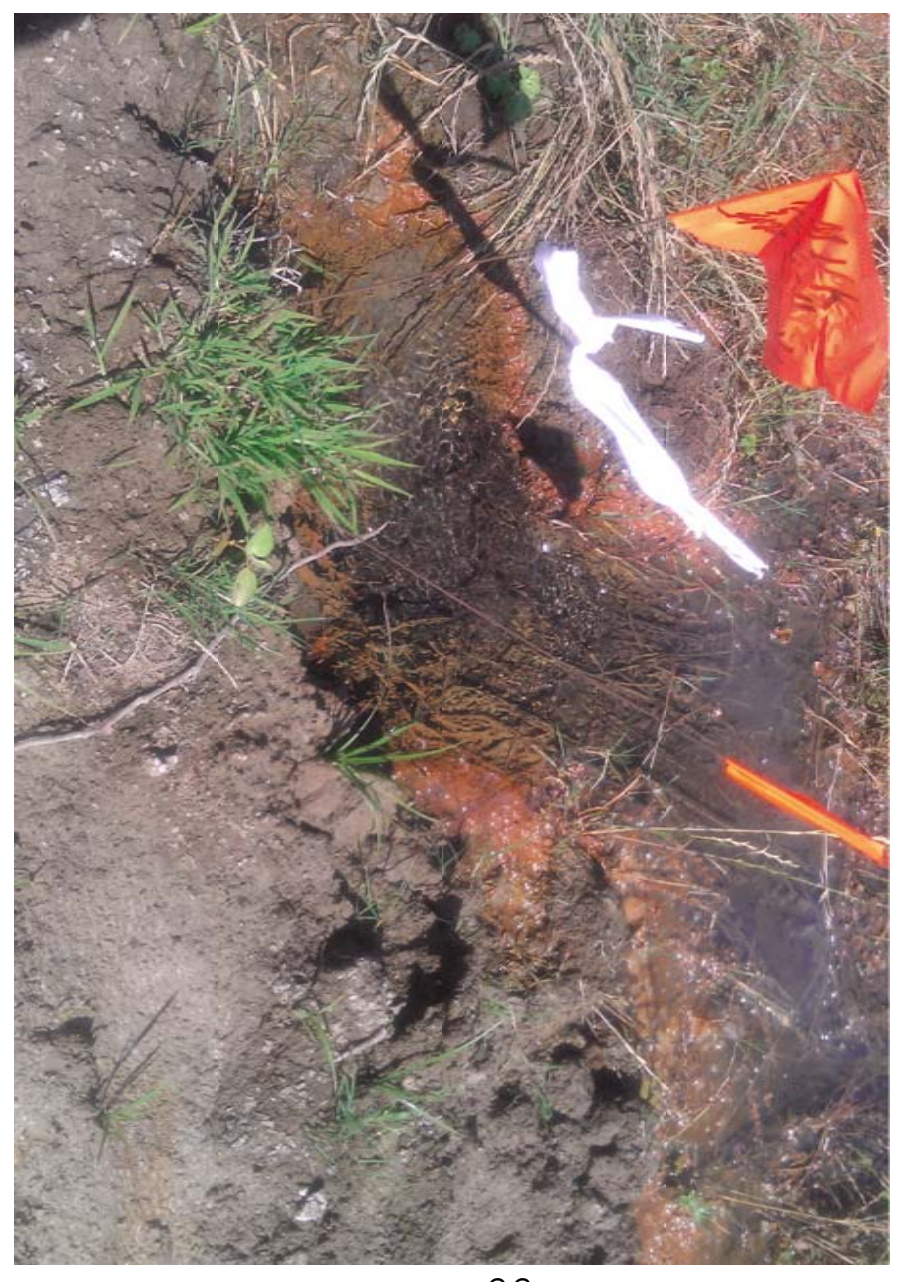

22

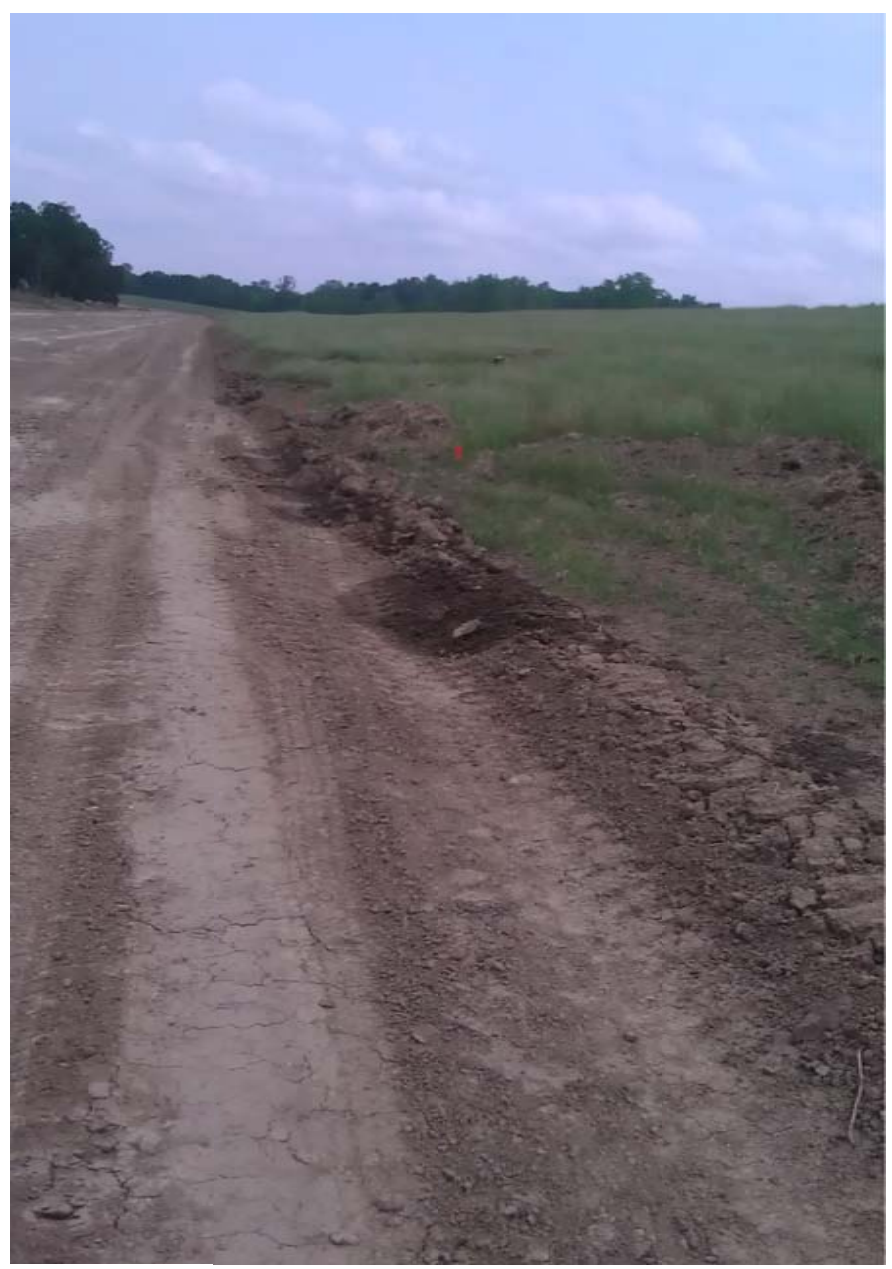




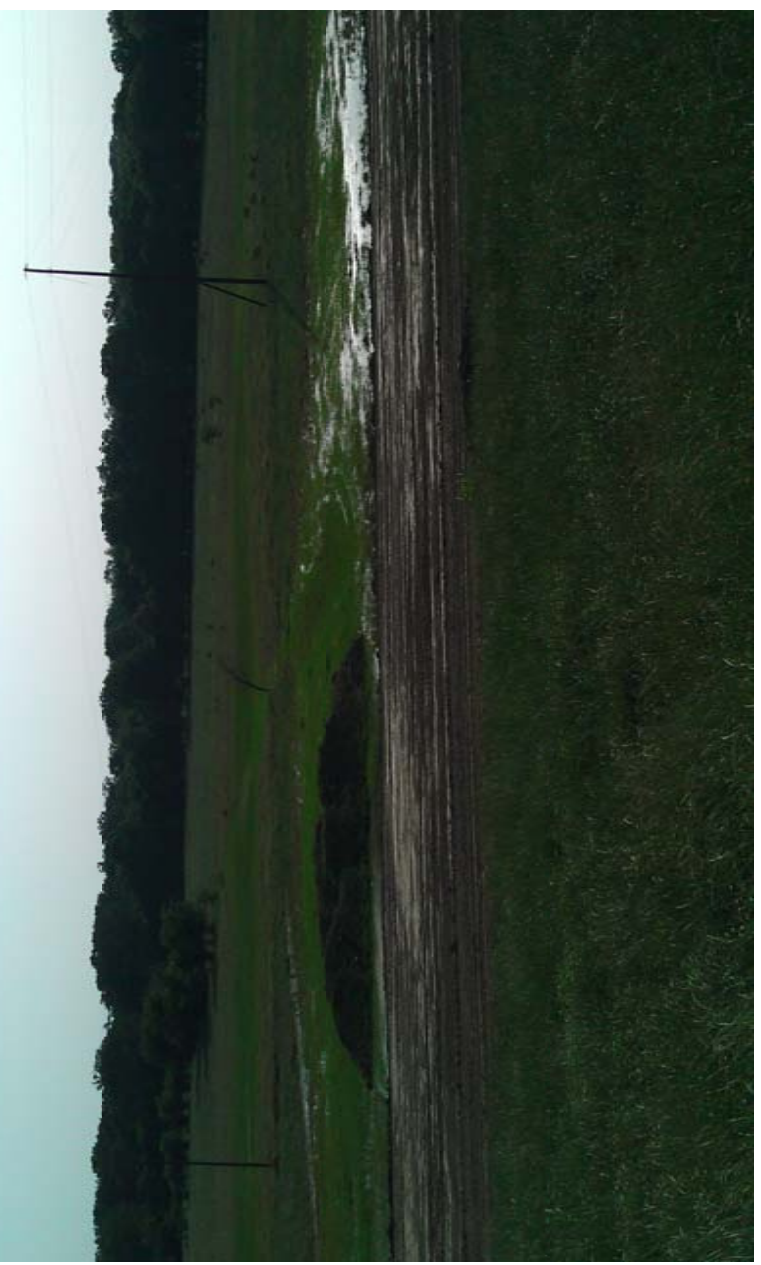

25

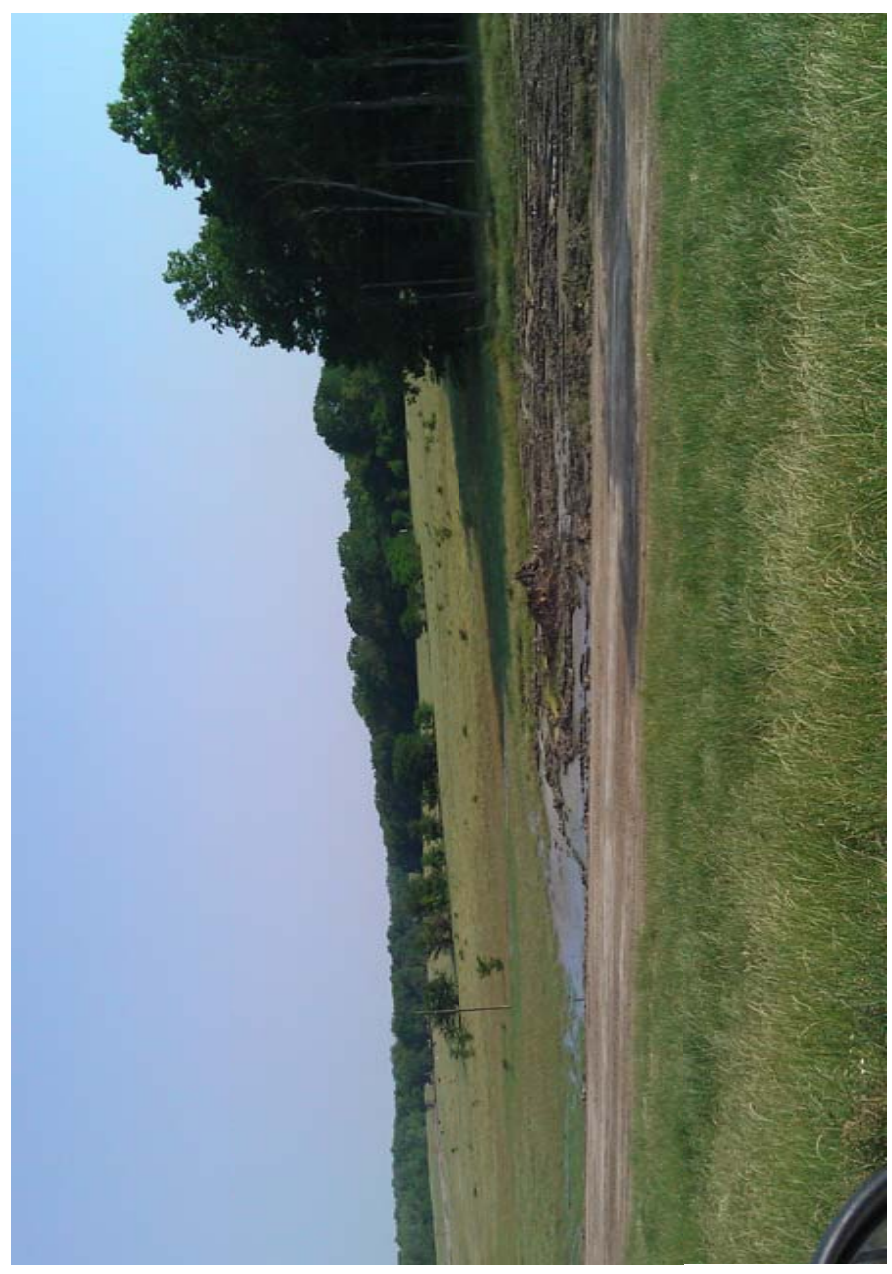

27

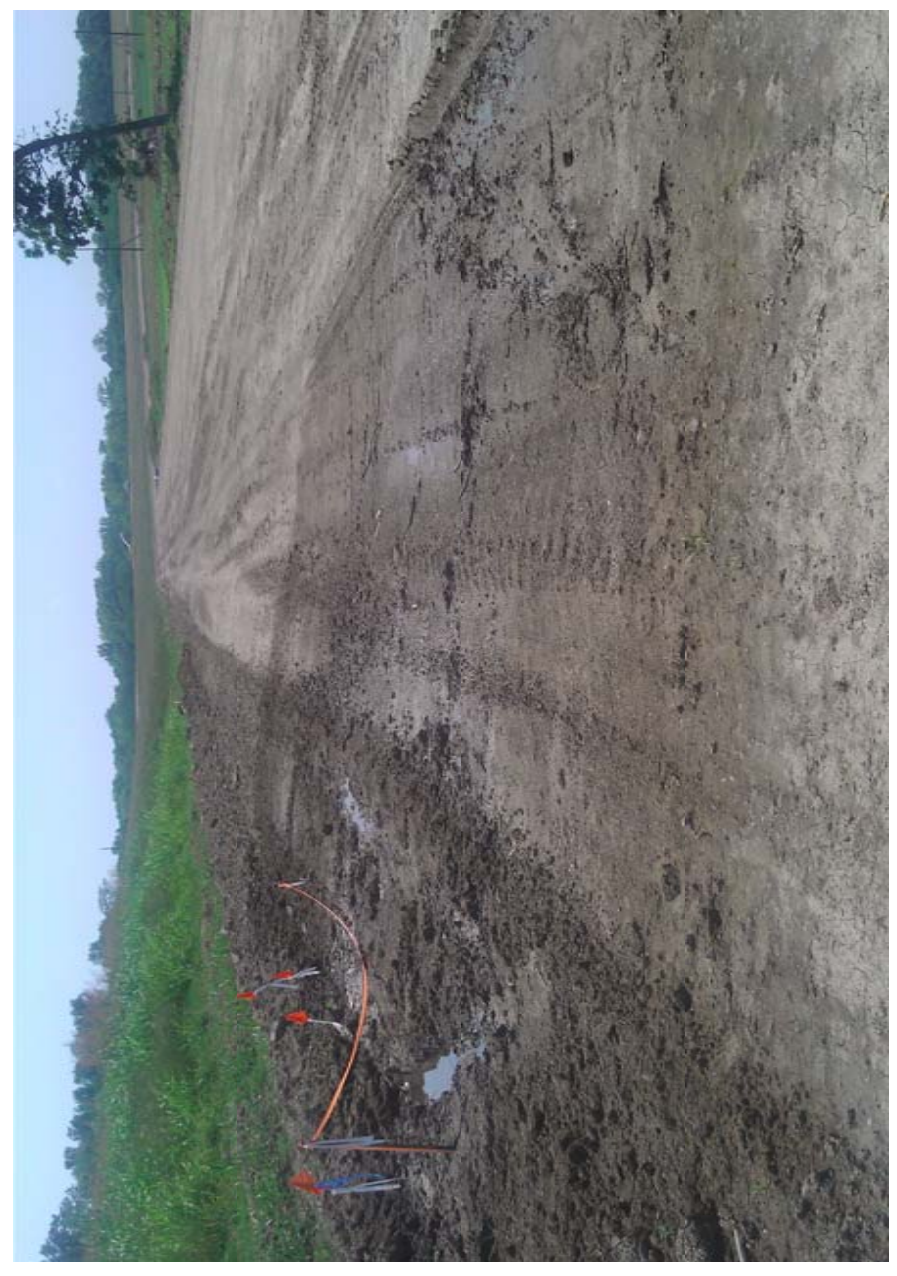

26

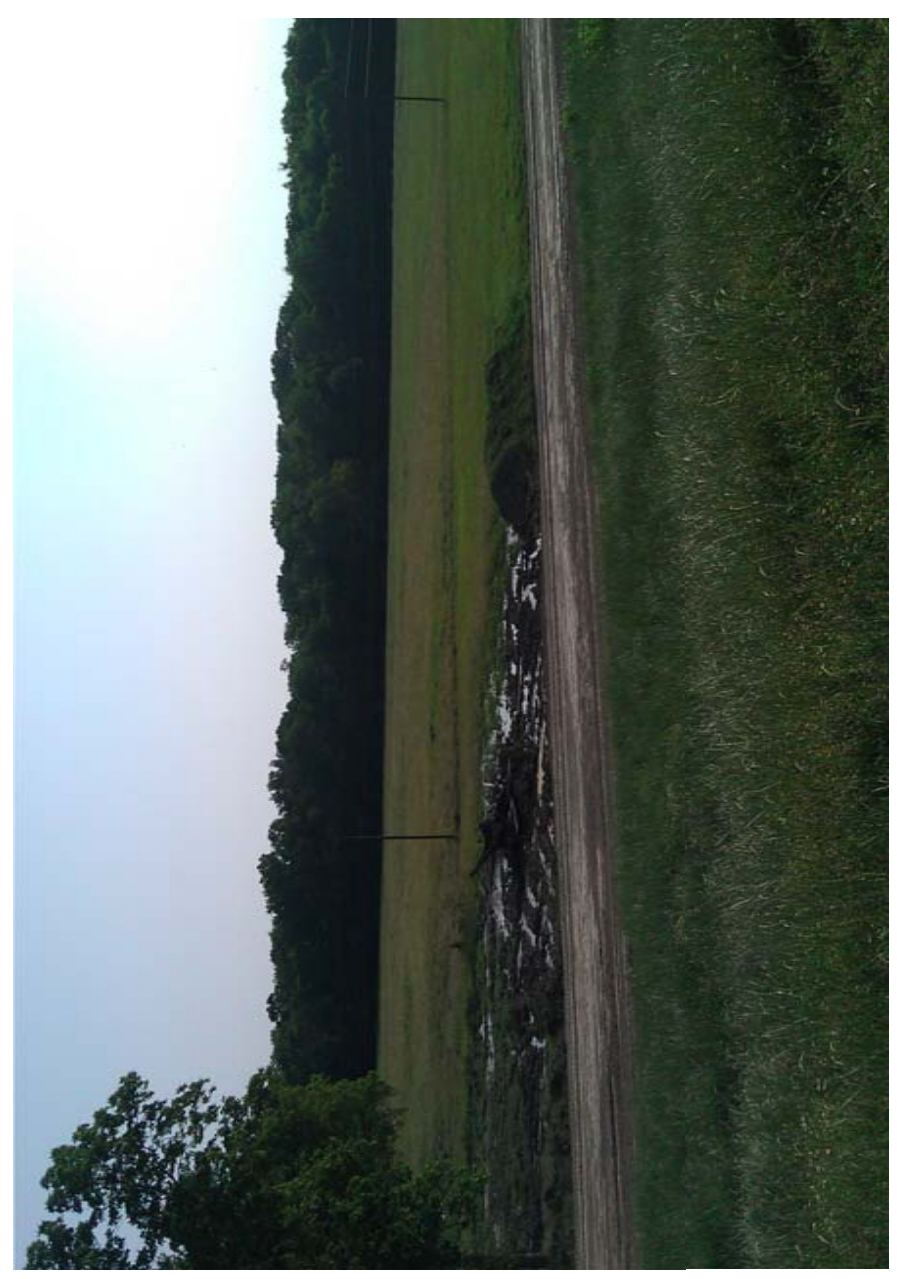

28 

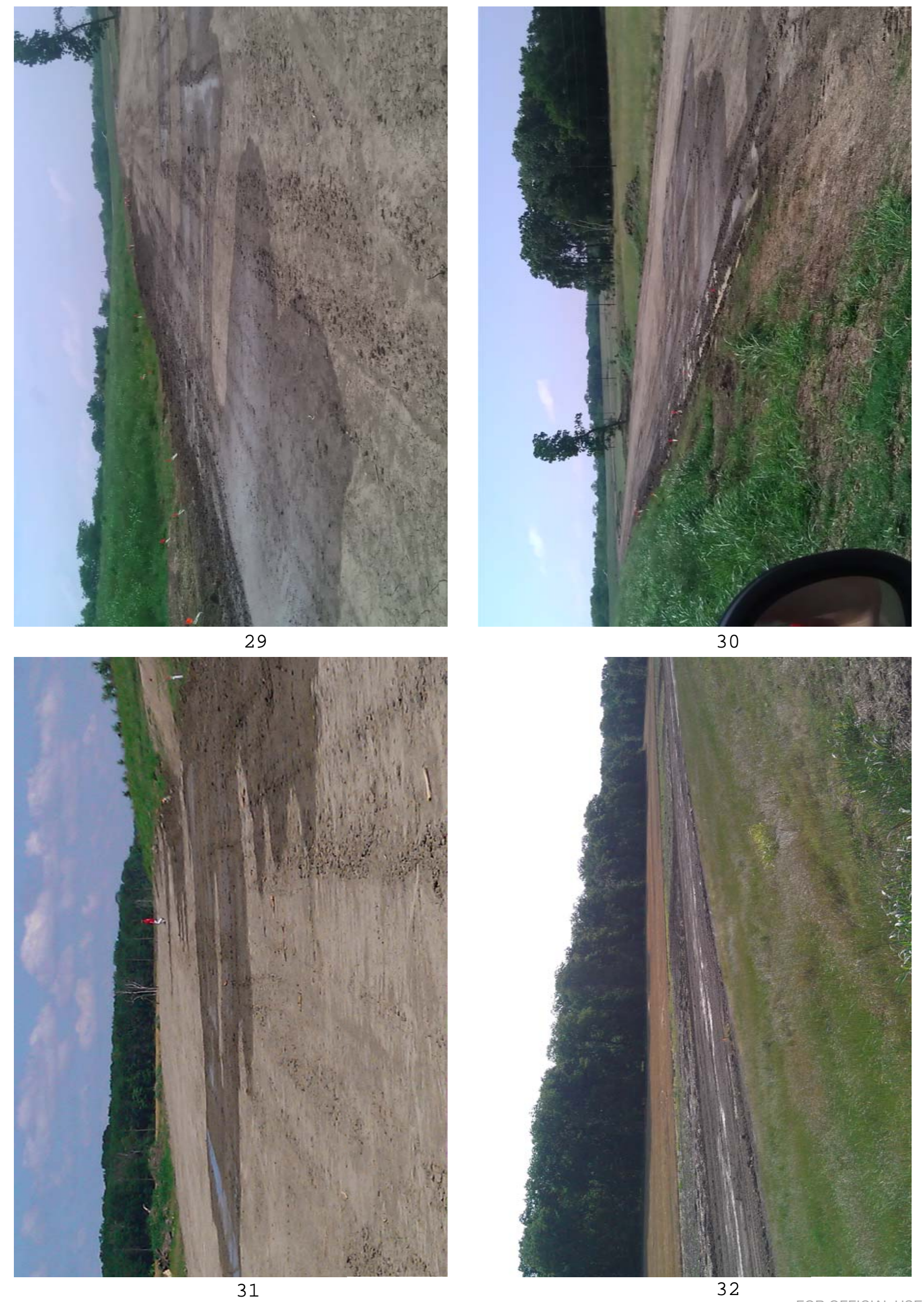


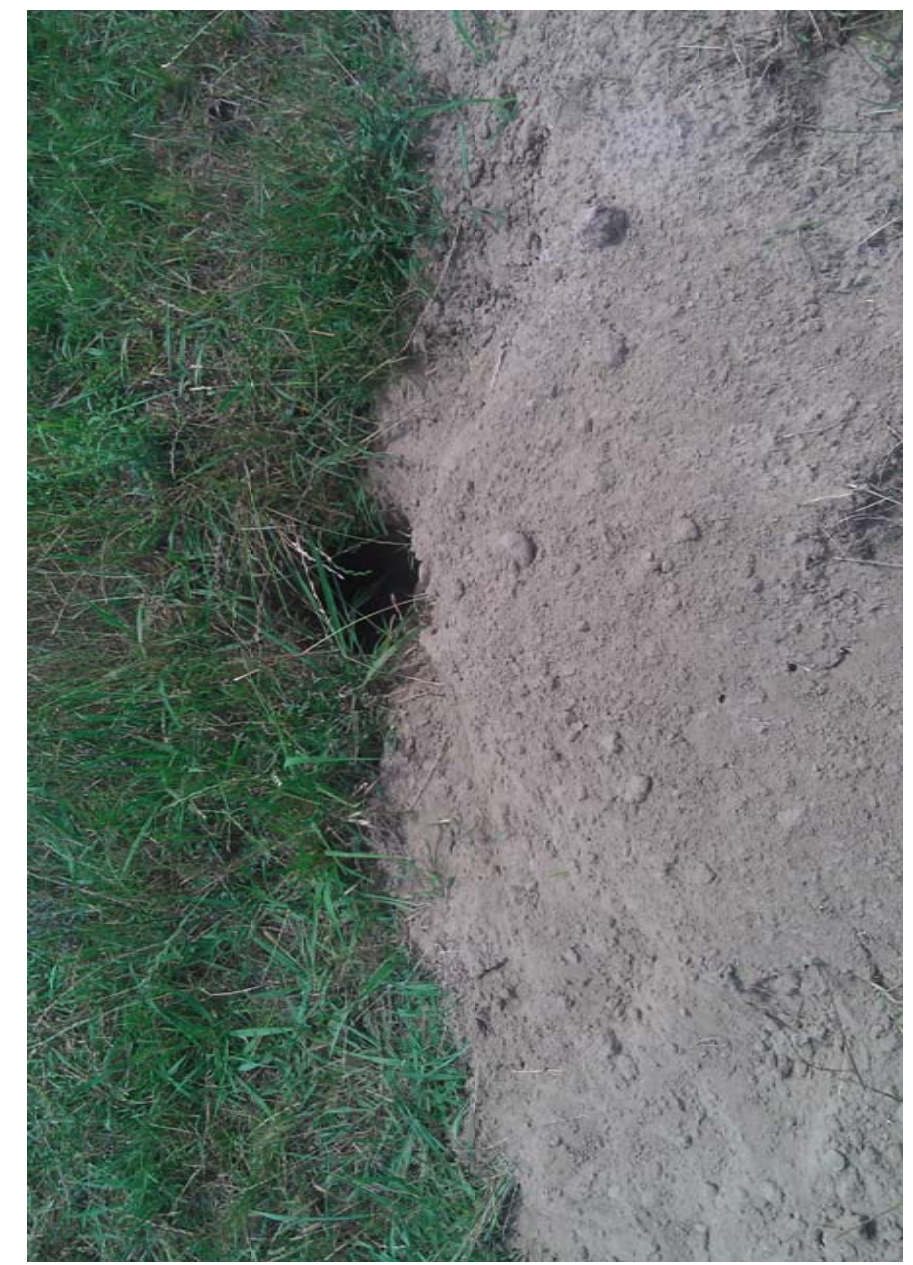

33

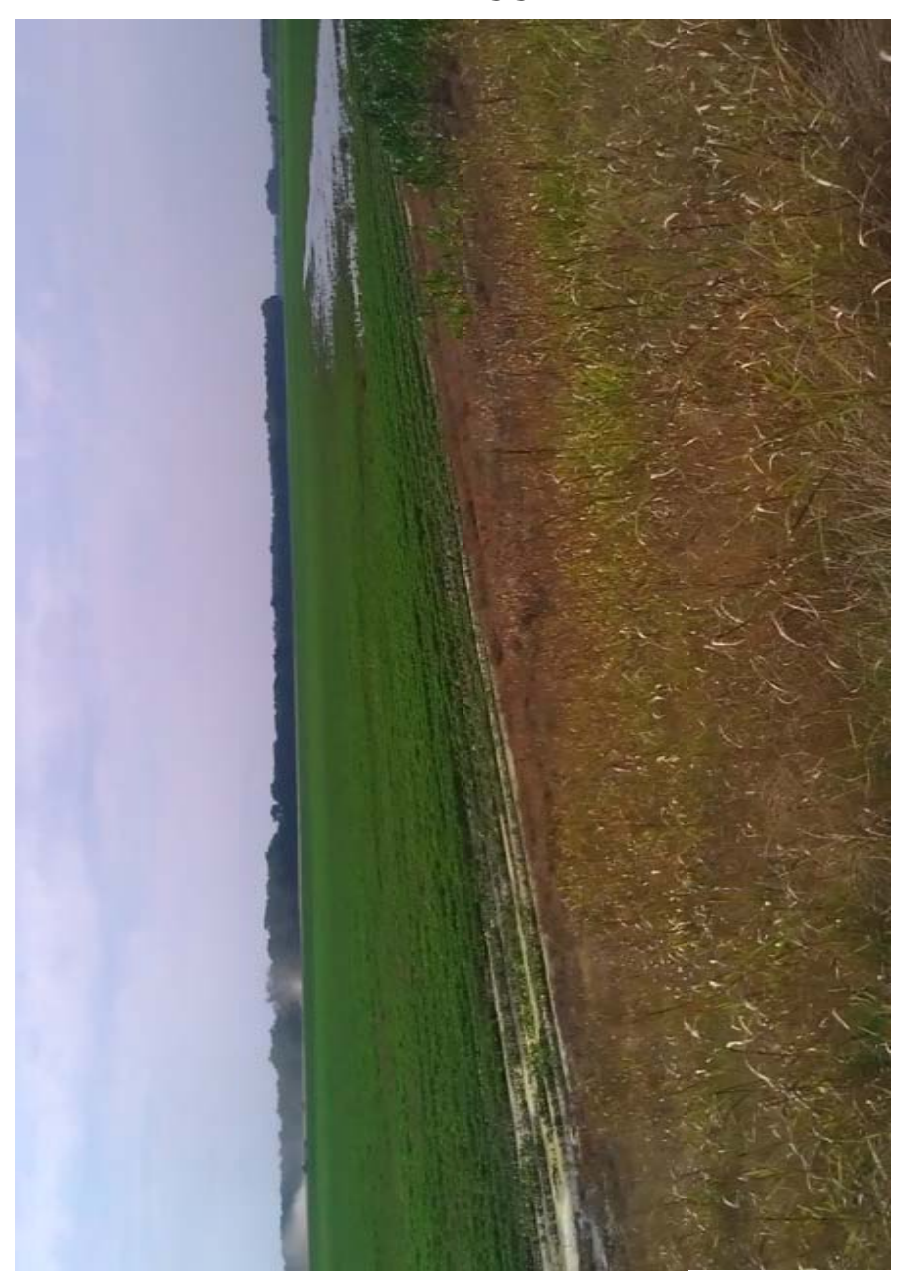

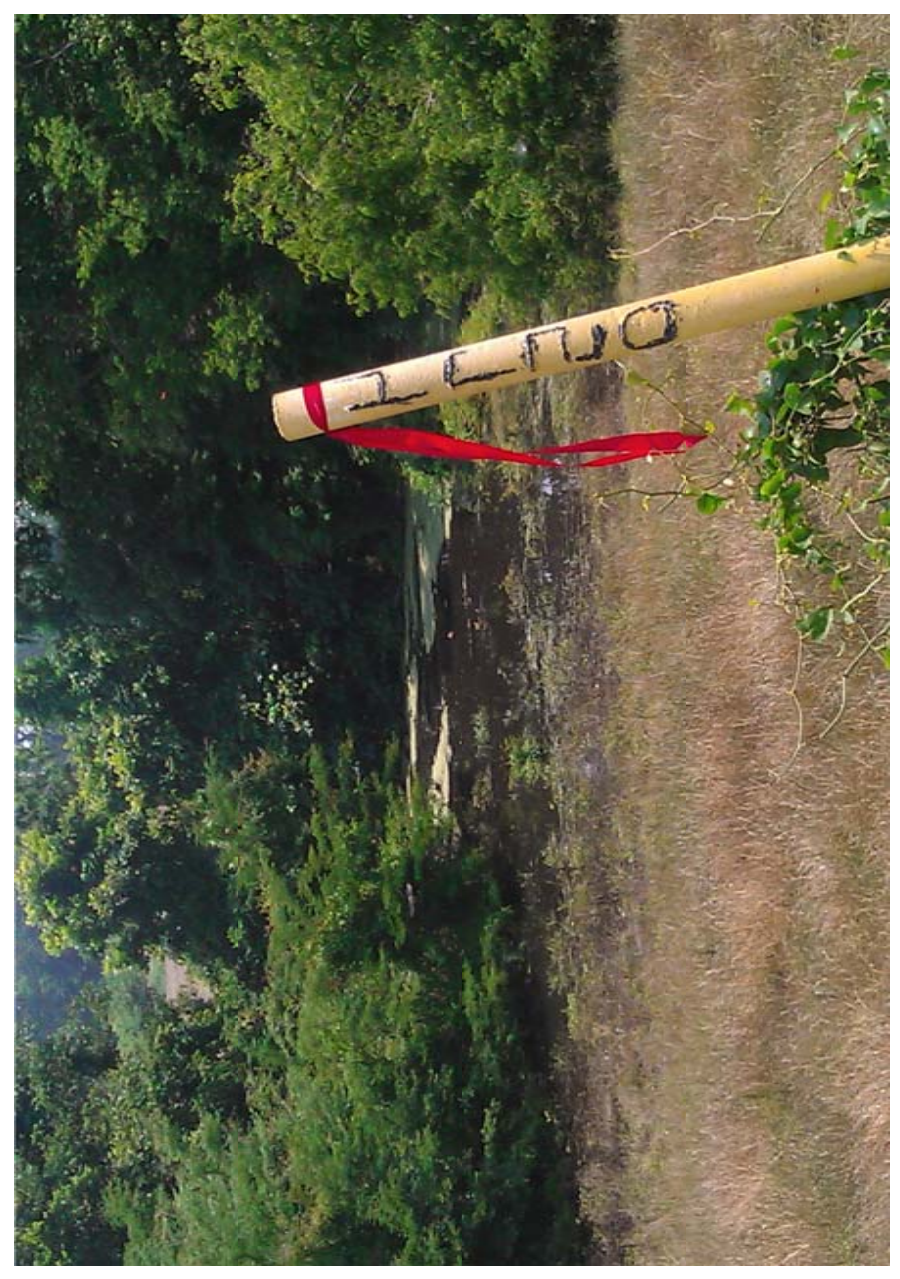

34

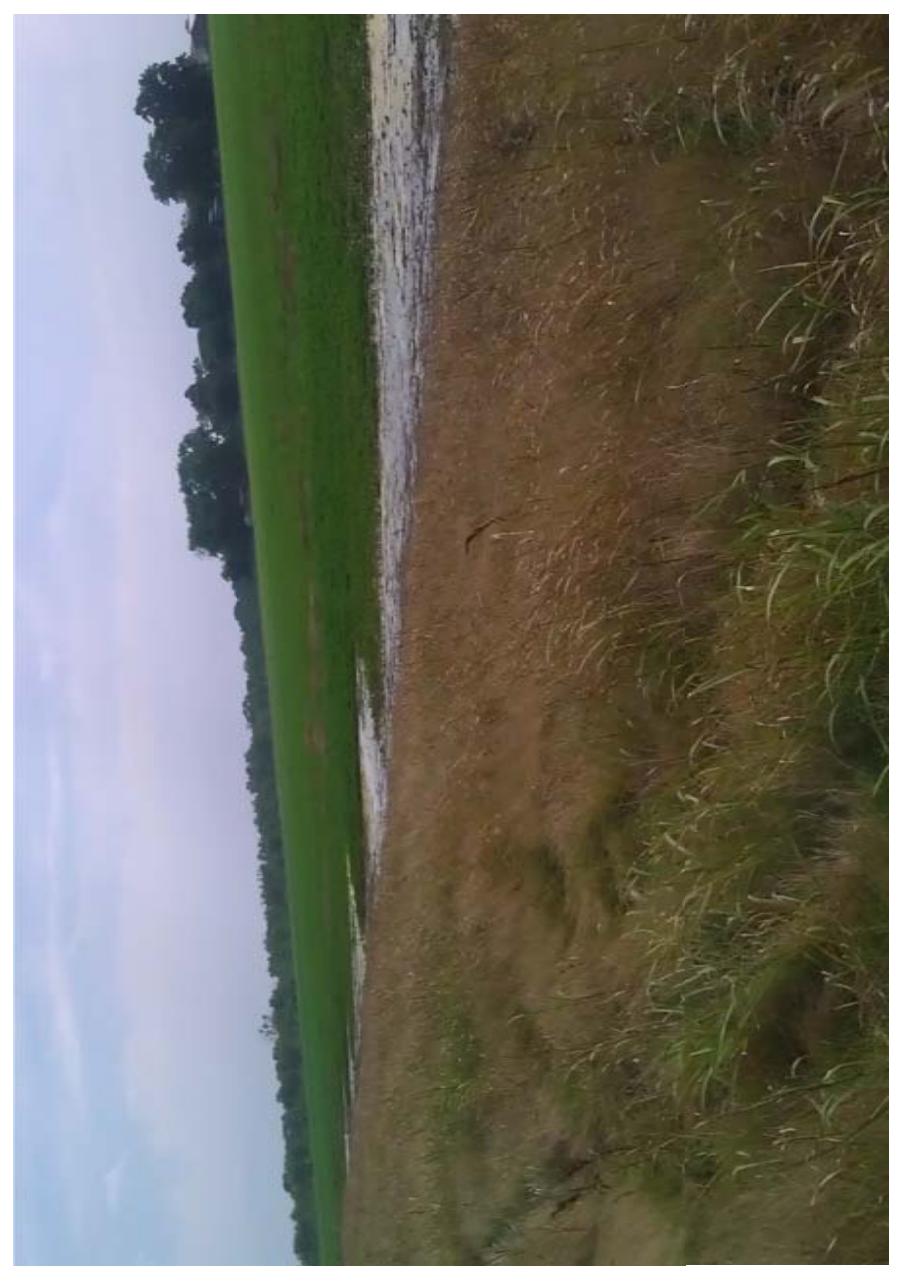



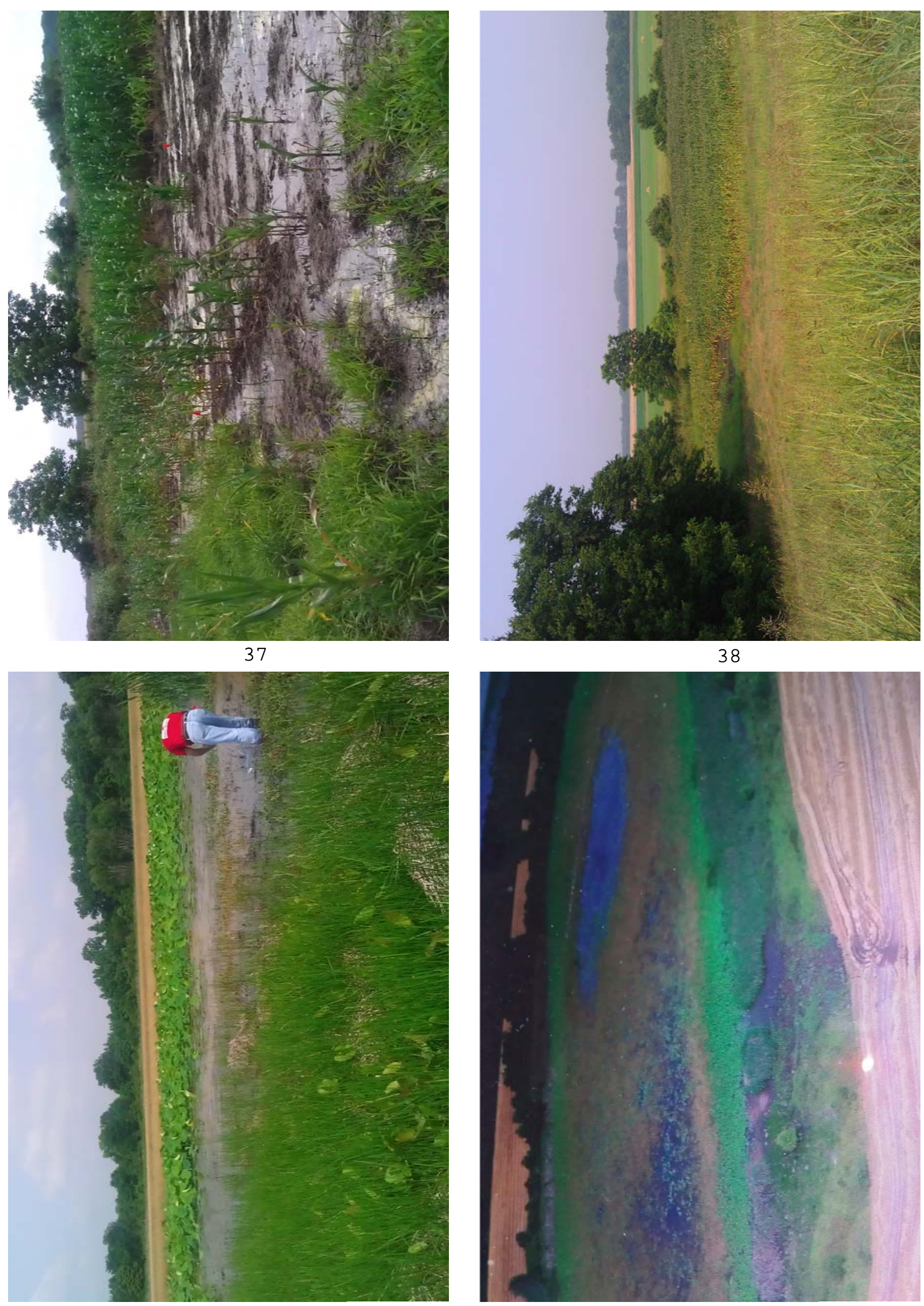


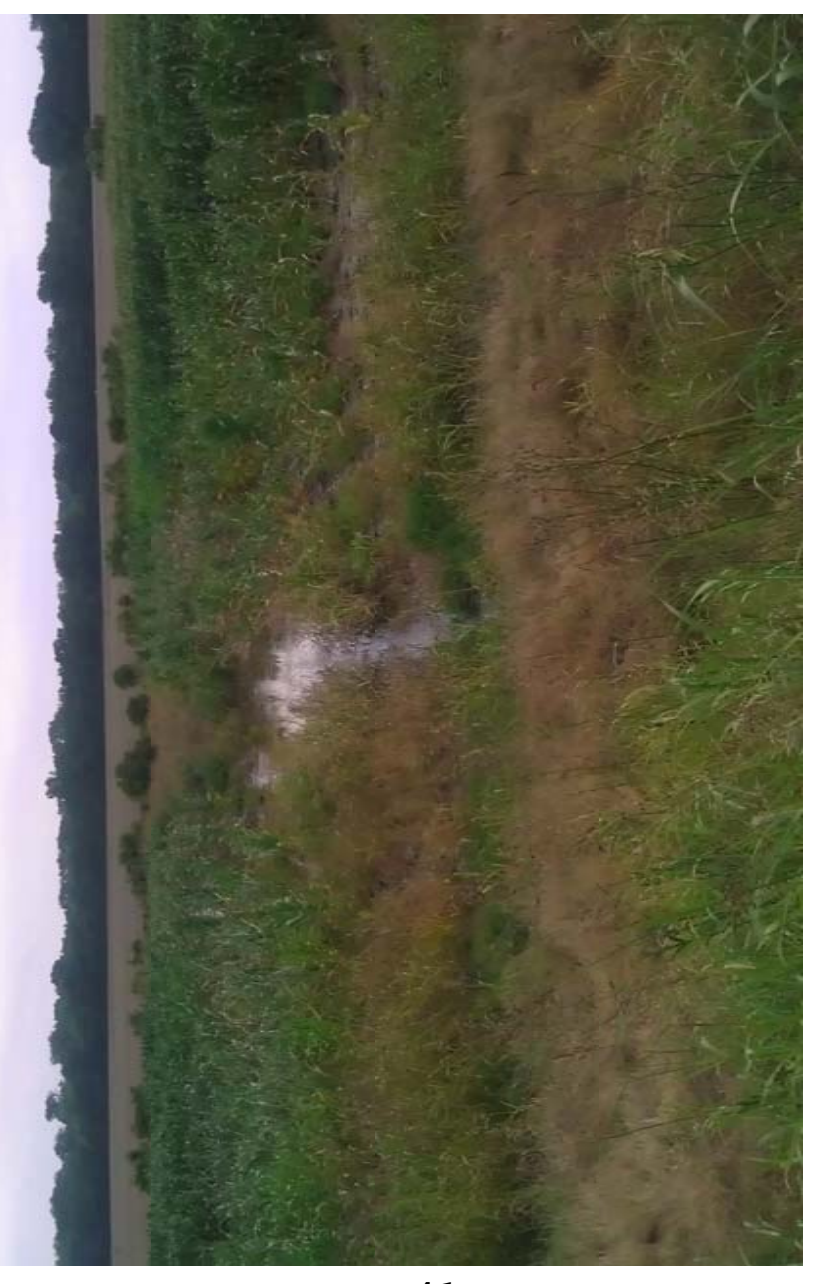

41

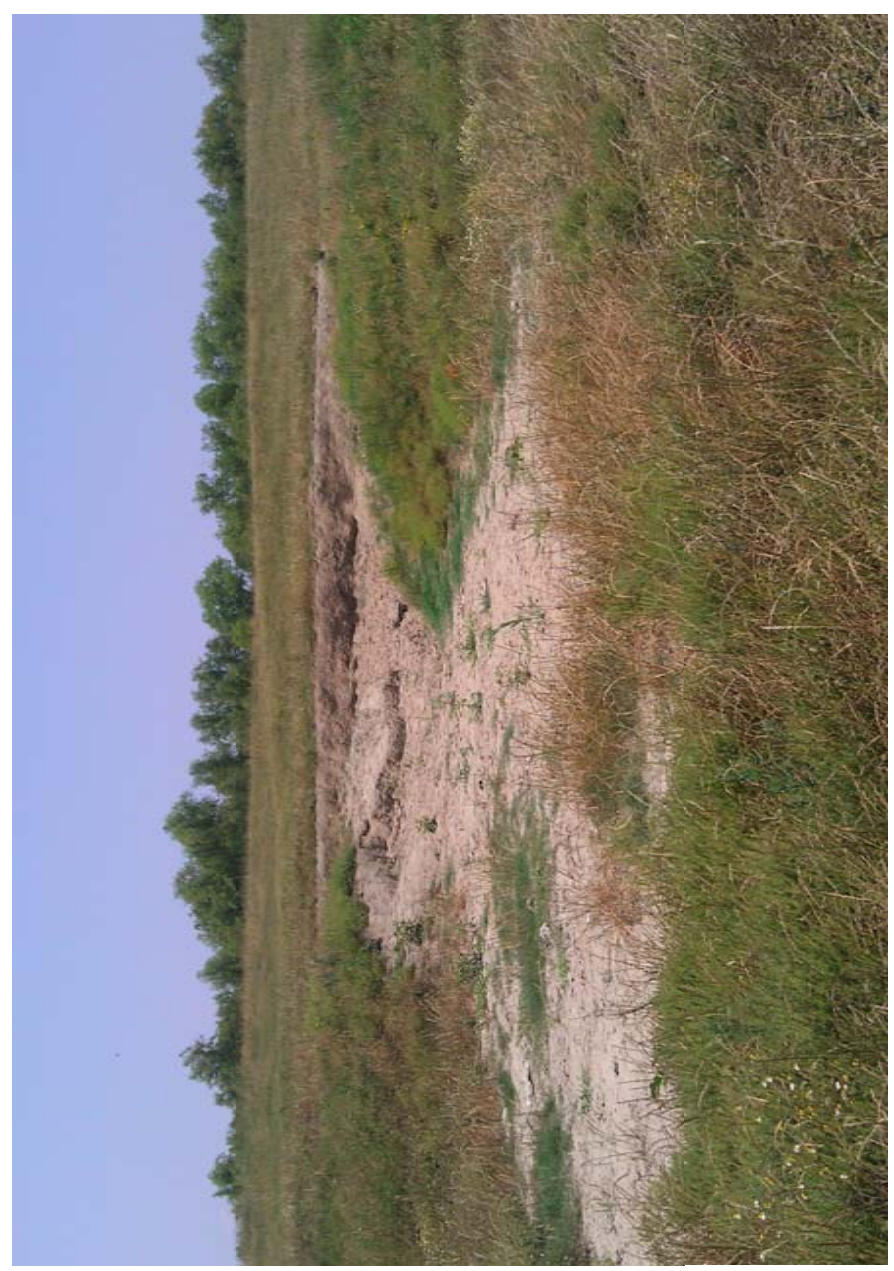

43

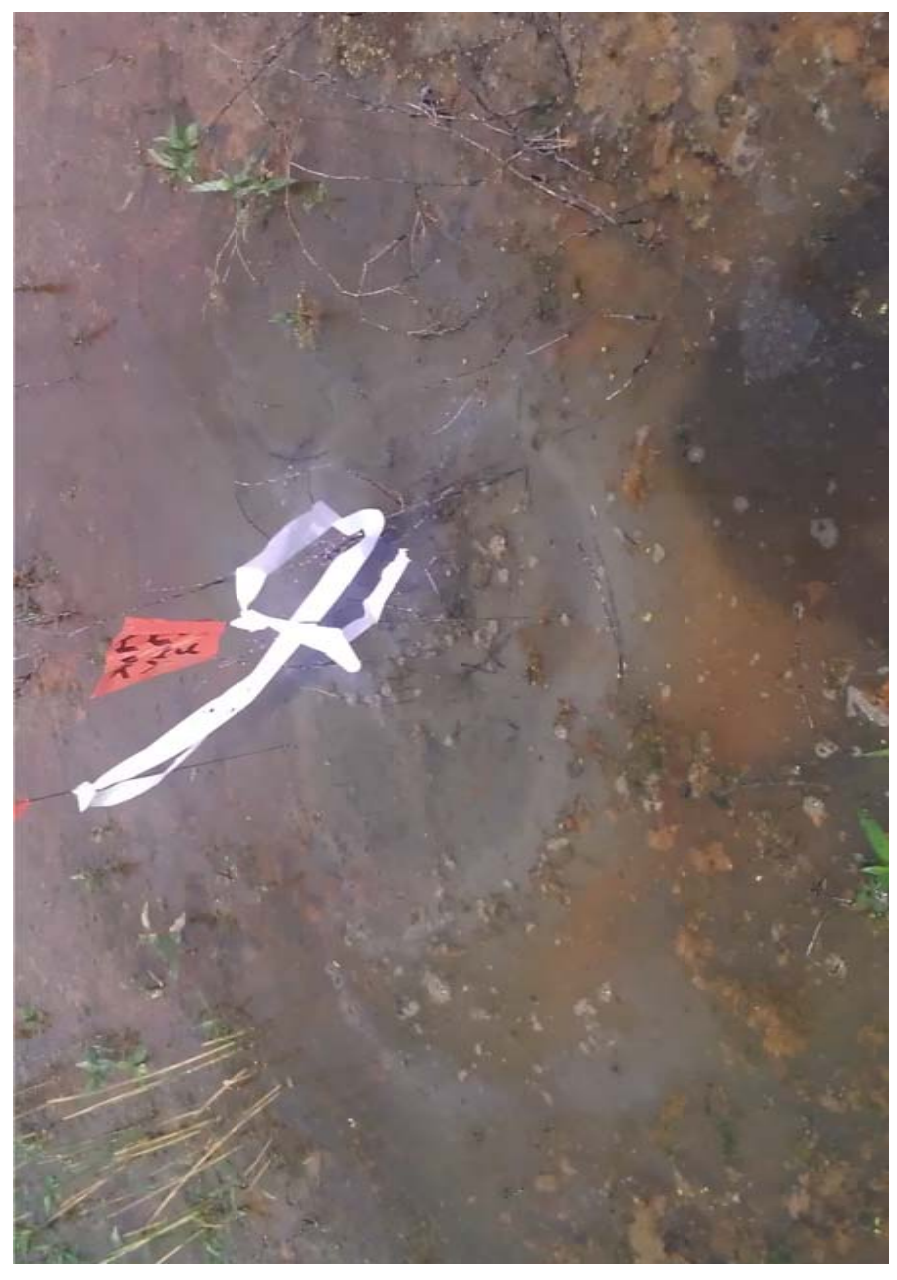

42

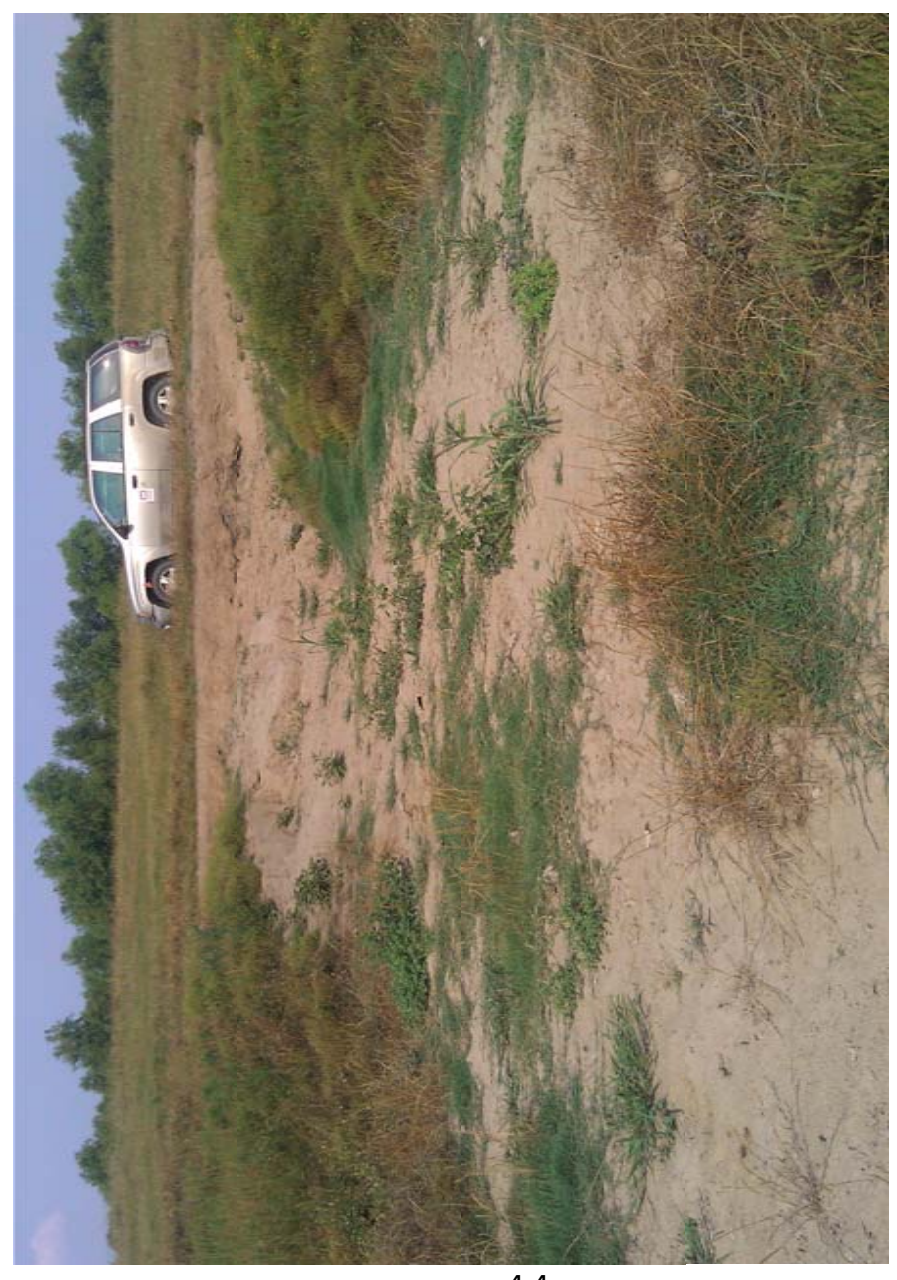




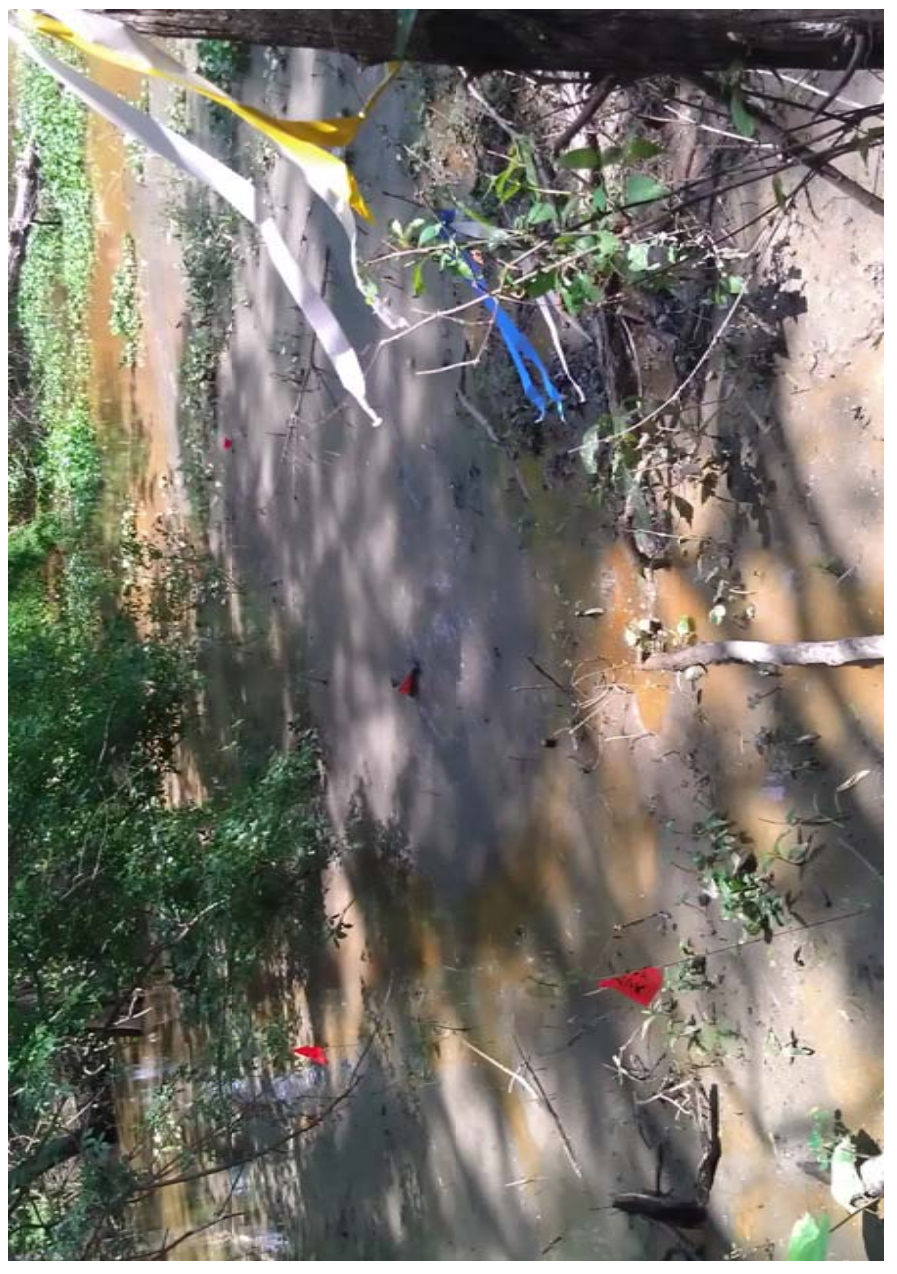

45

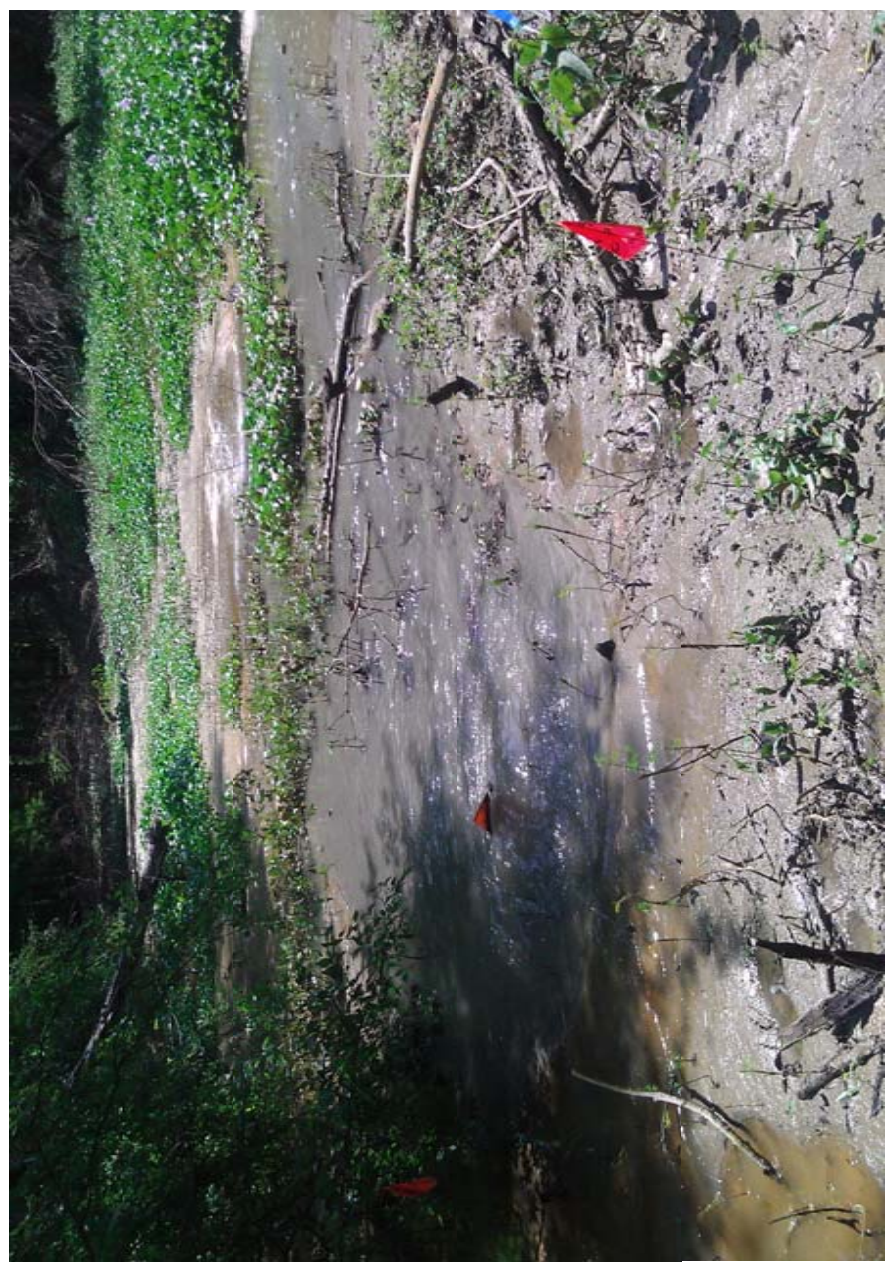

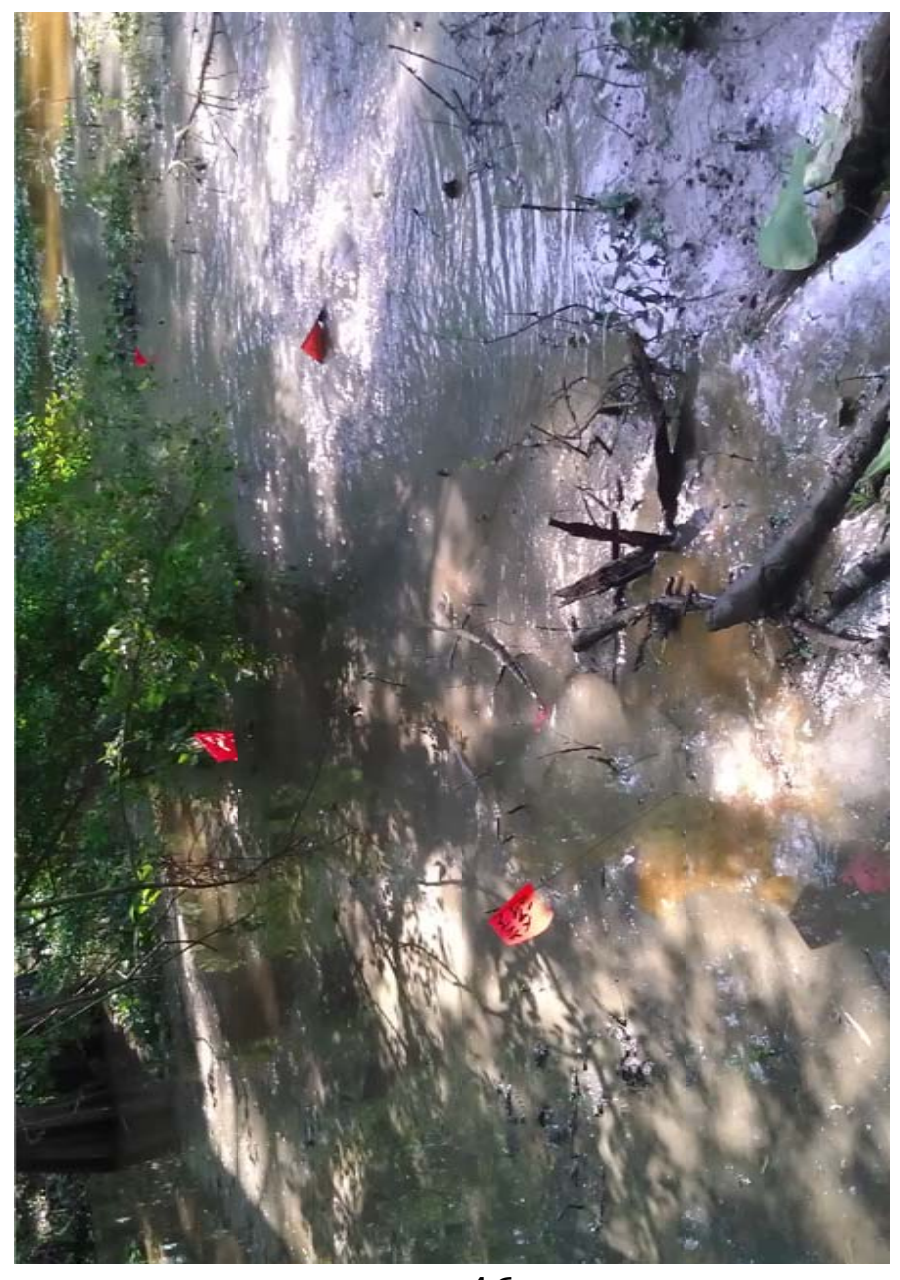

46

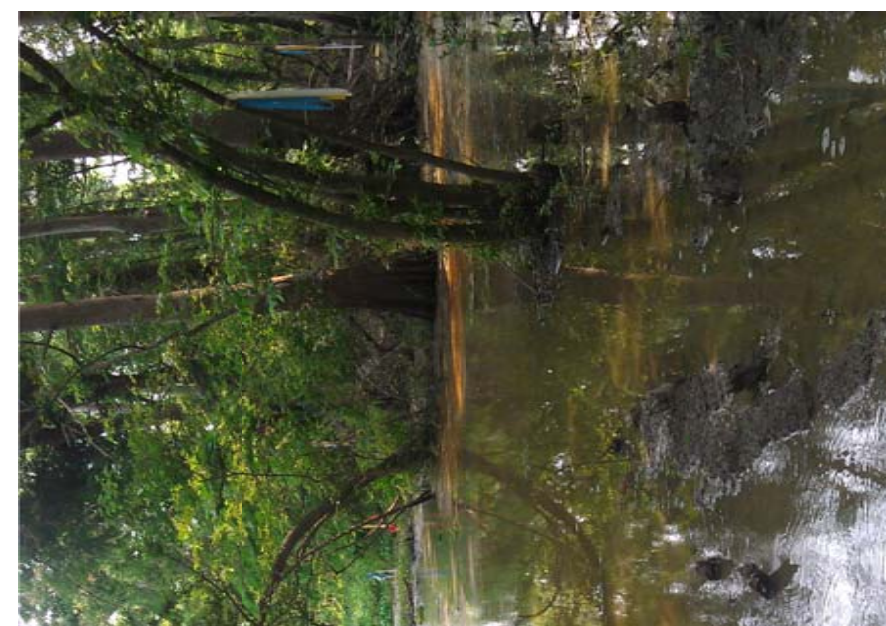

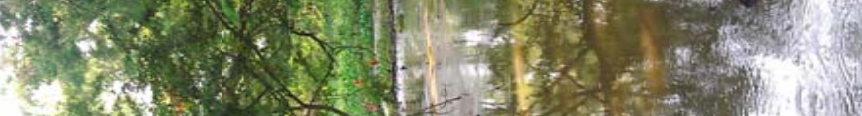

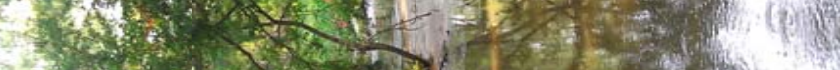

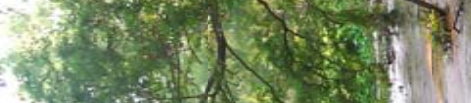

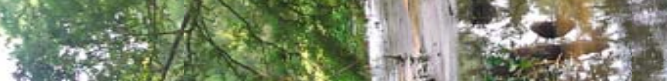

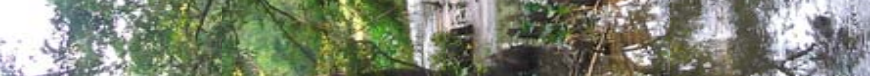
(x)

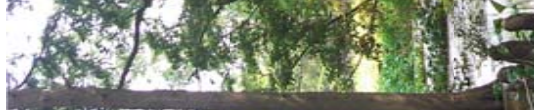

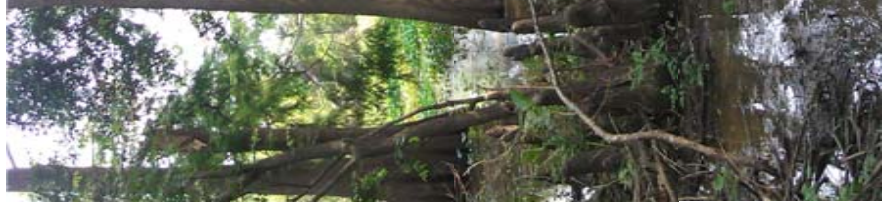
A set. 


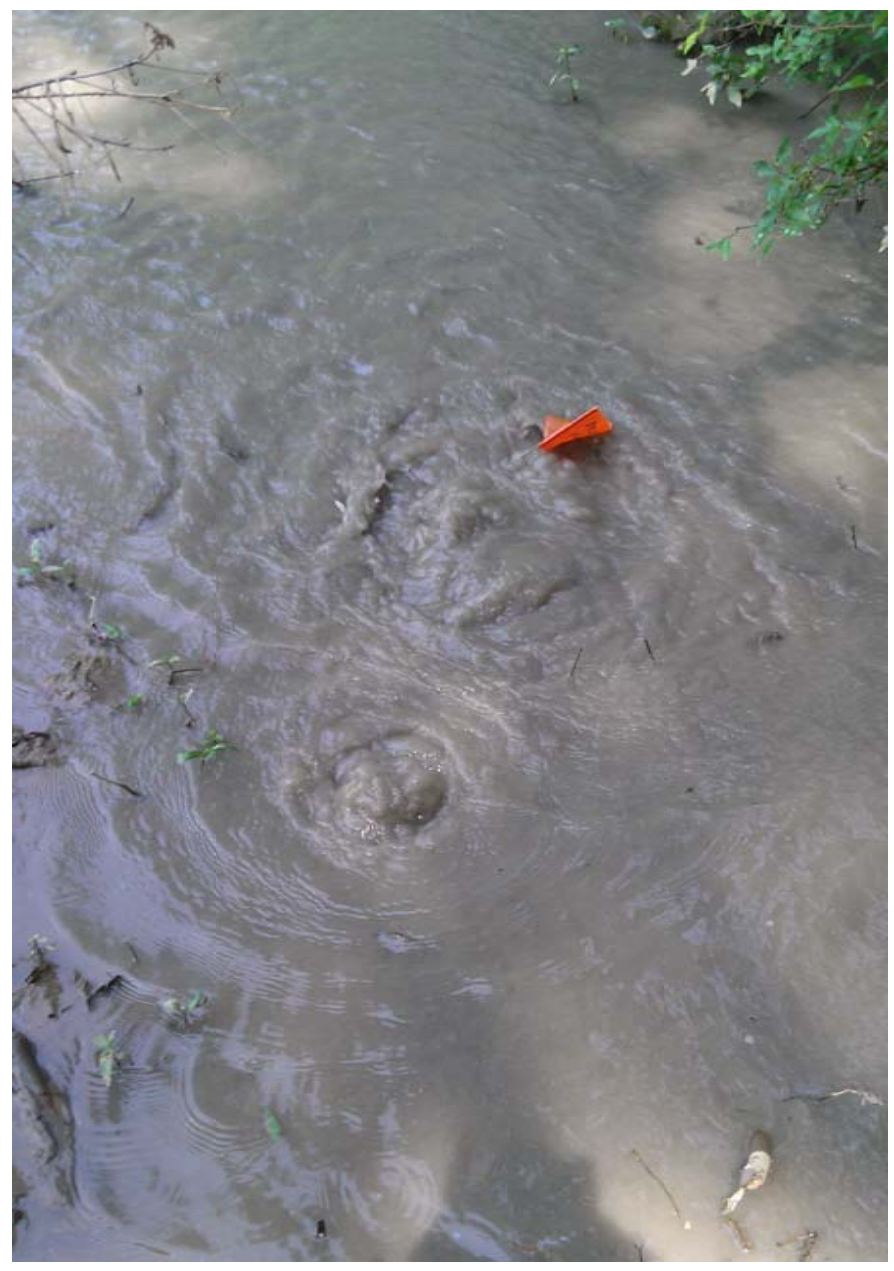

49

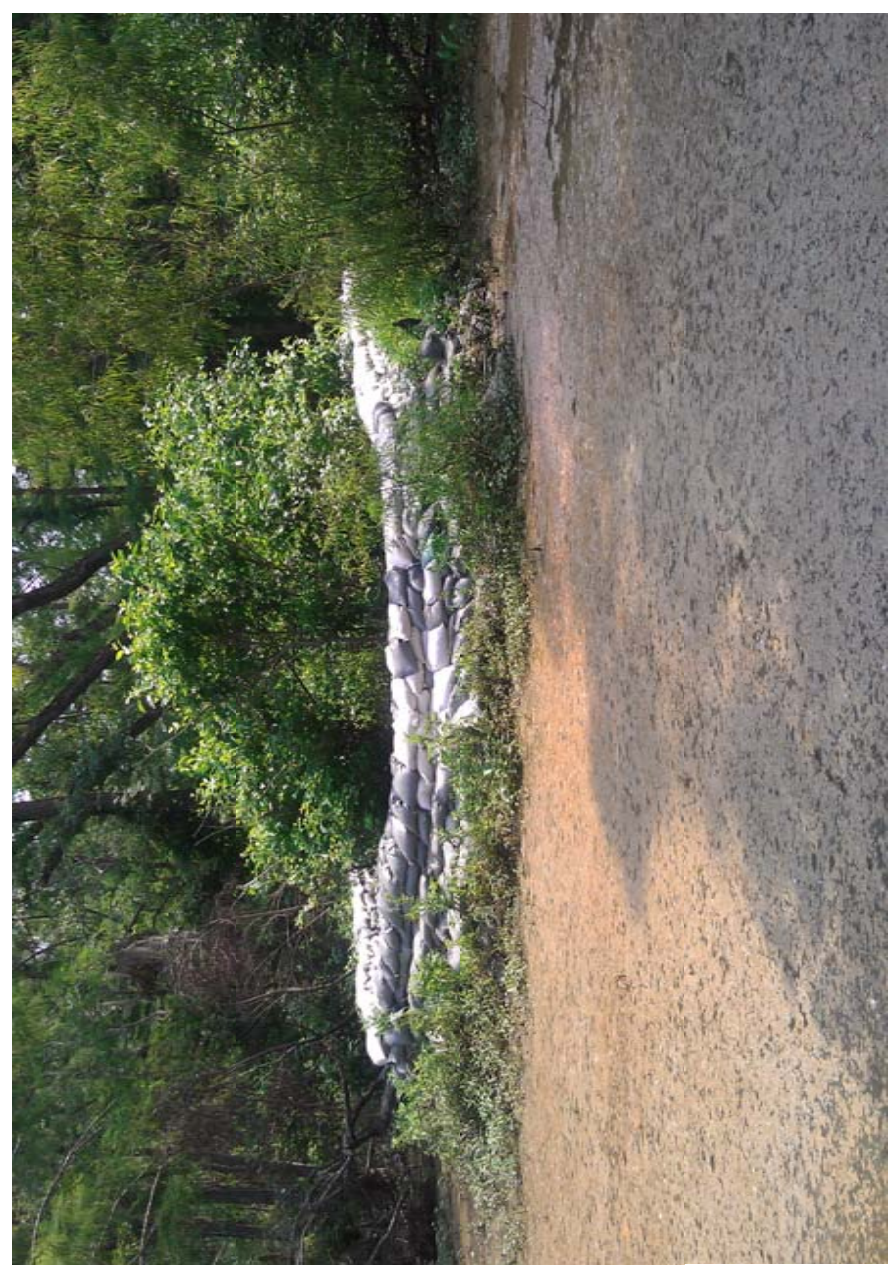

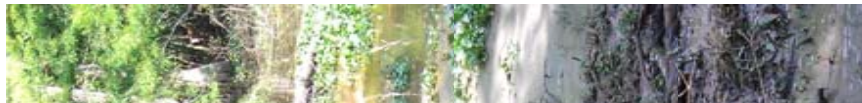
3. 20.

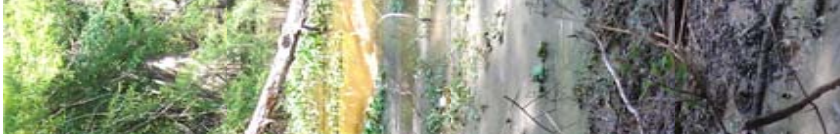

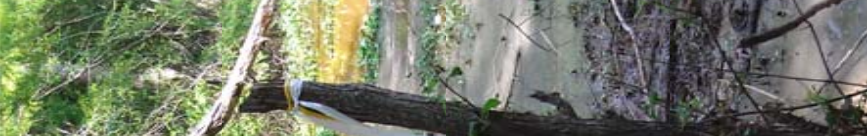

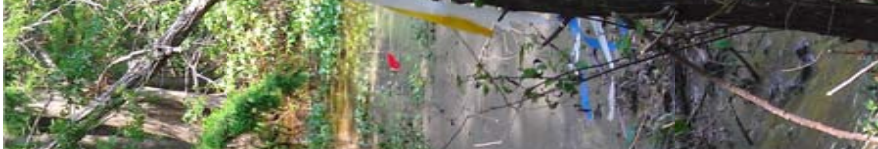
$m=-50.951$ ?
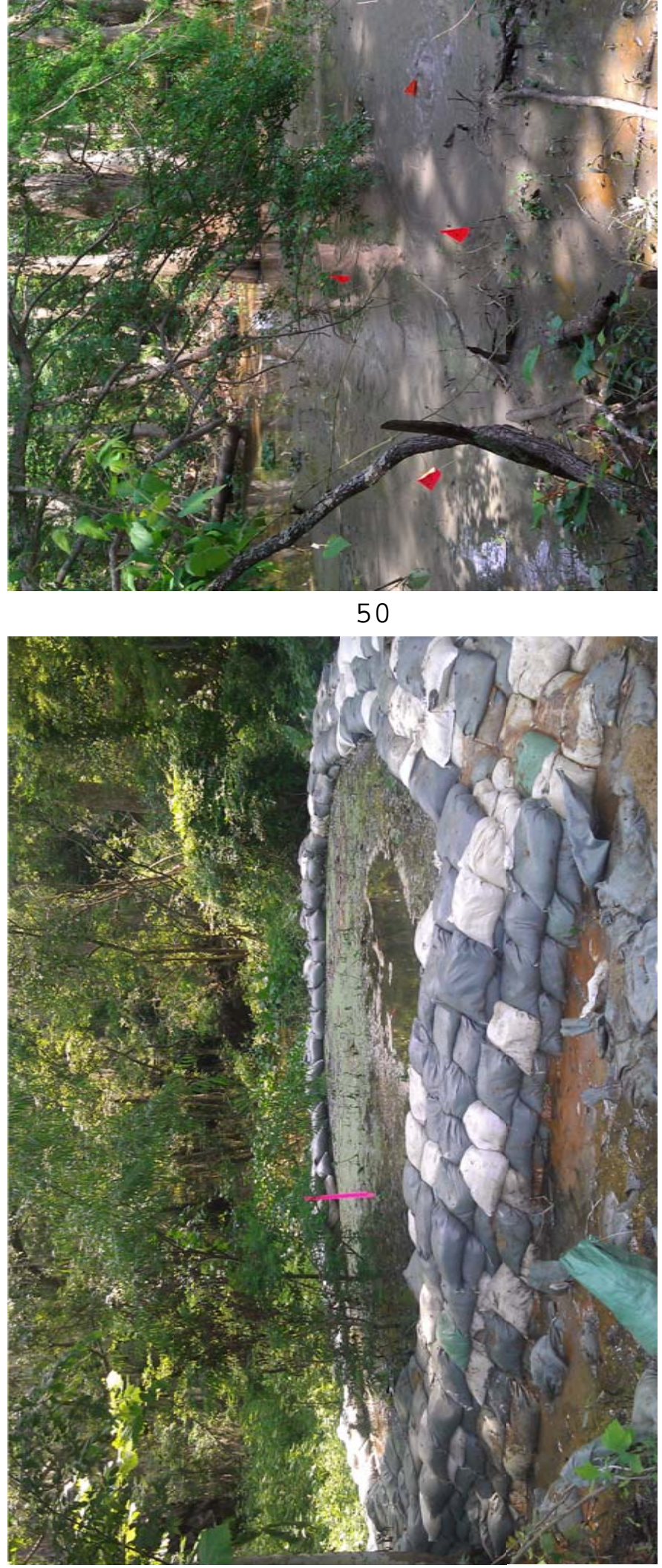


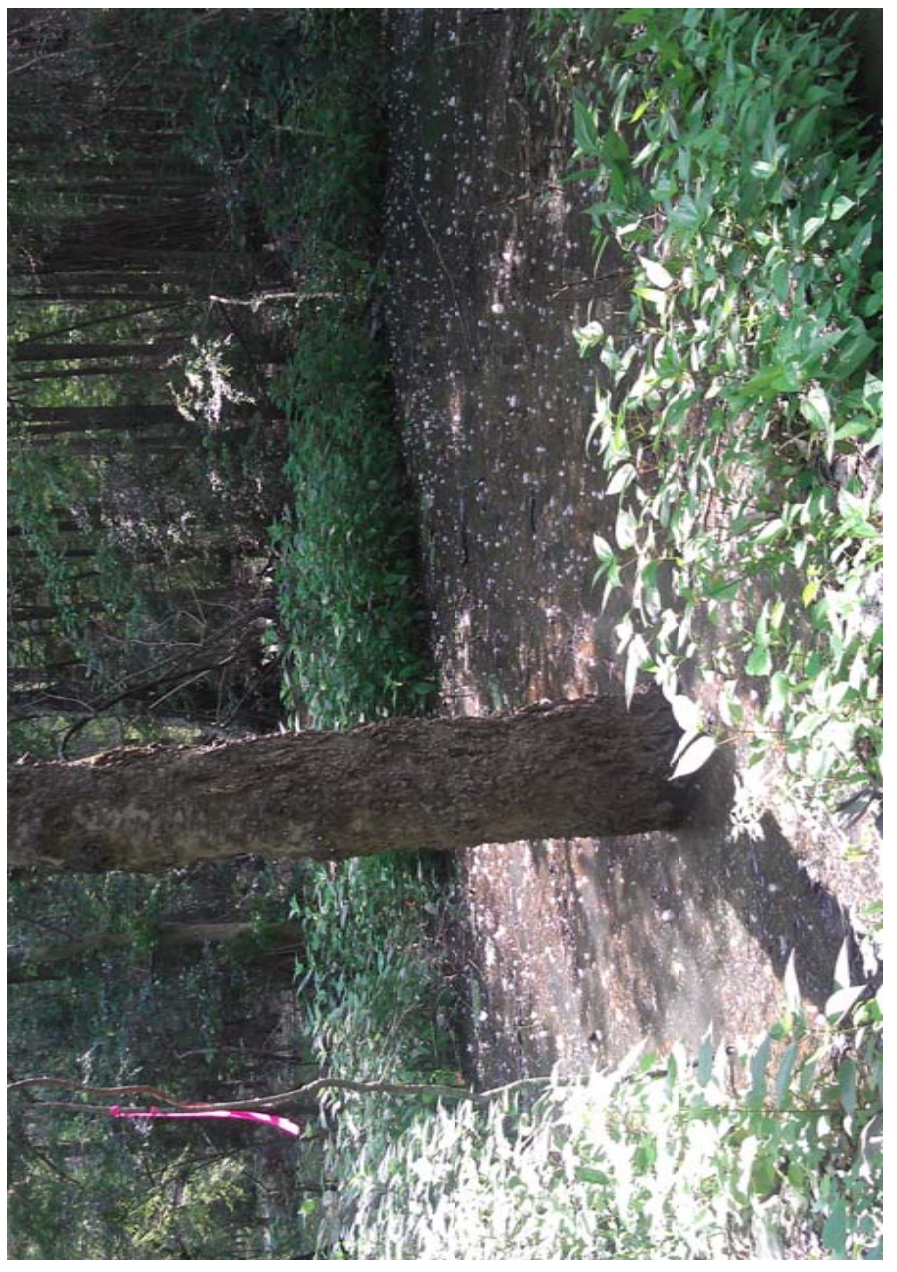

53

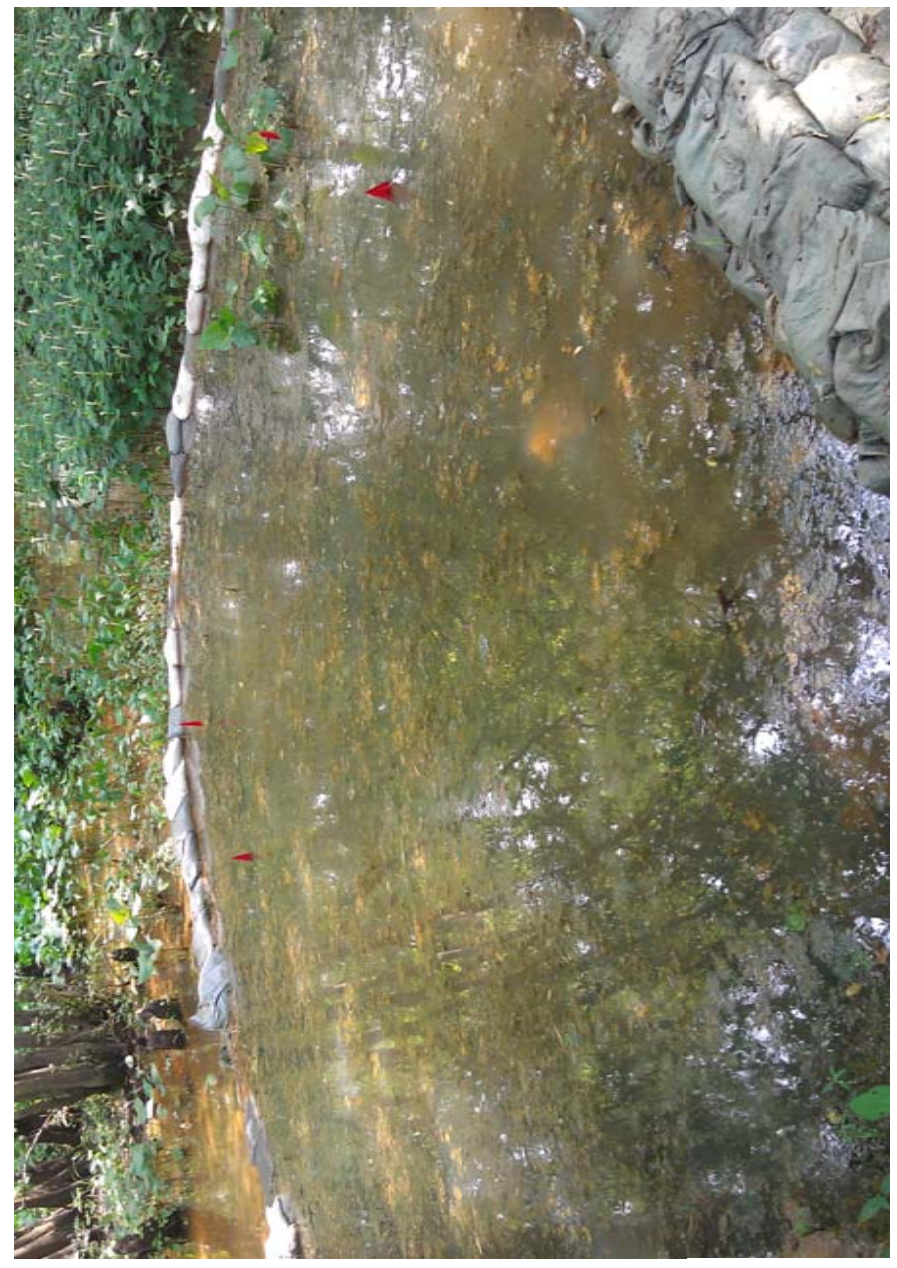

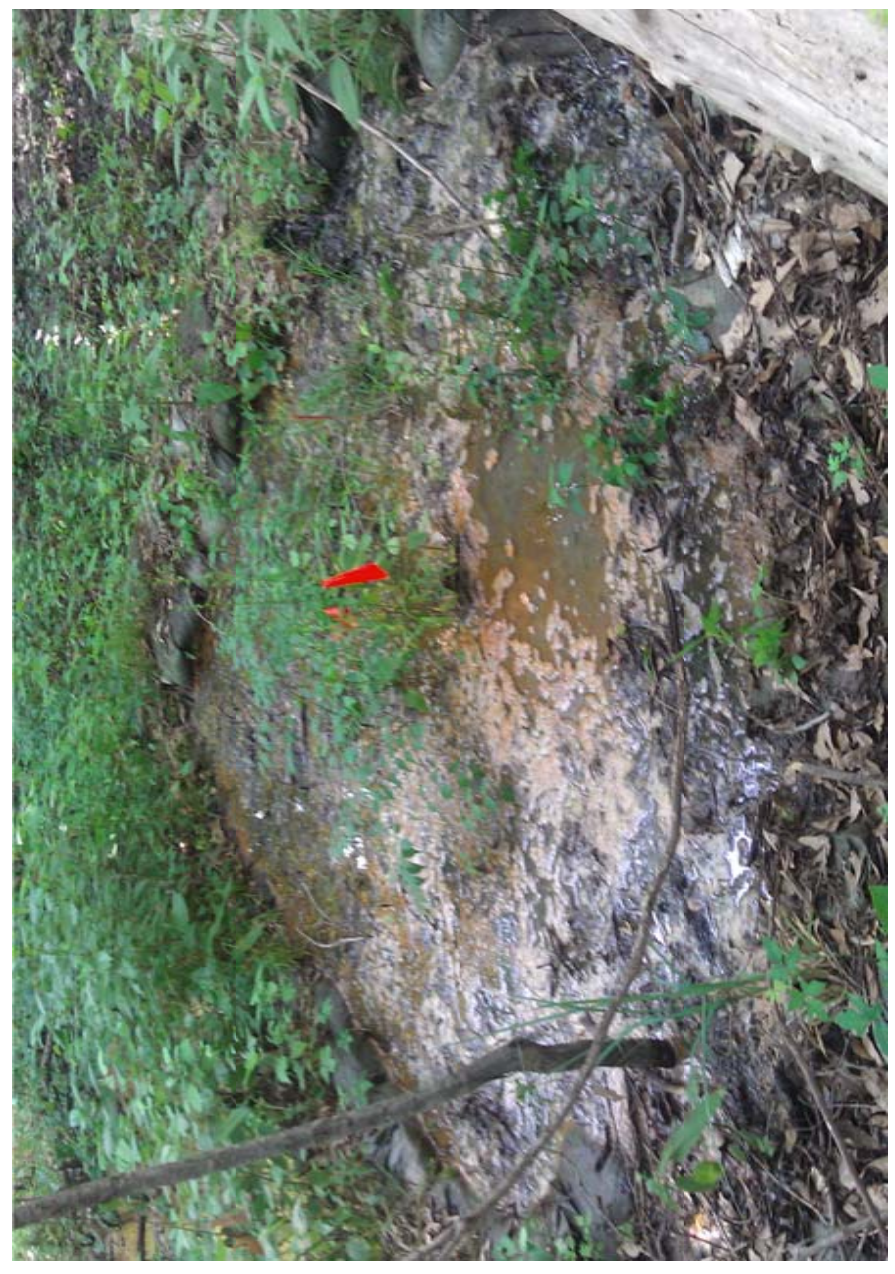

54

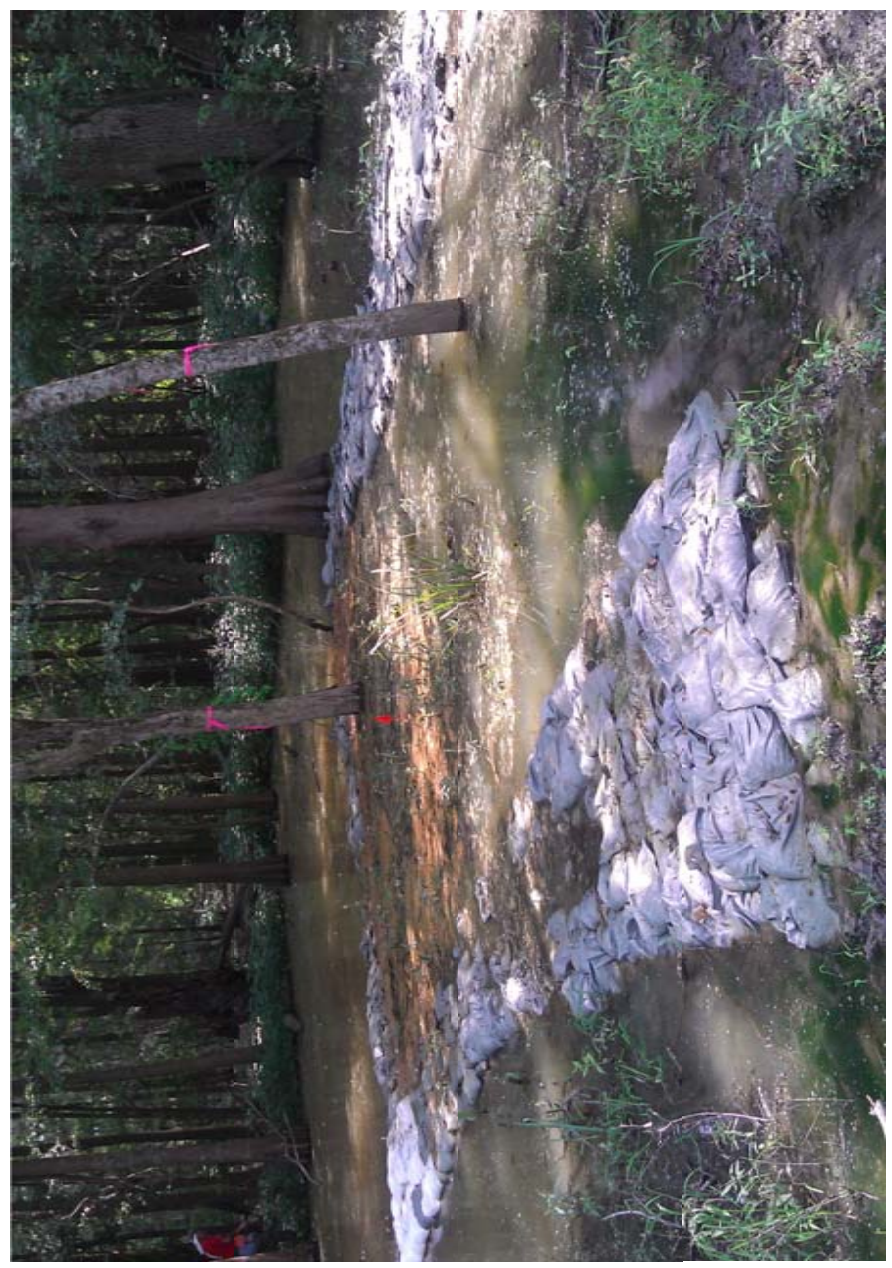




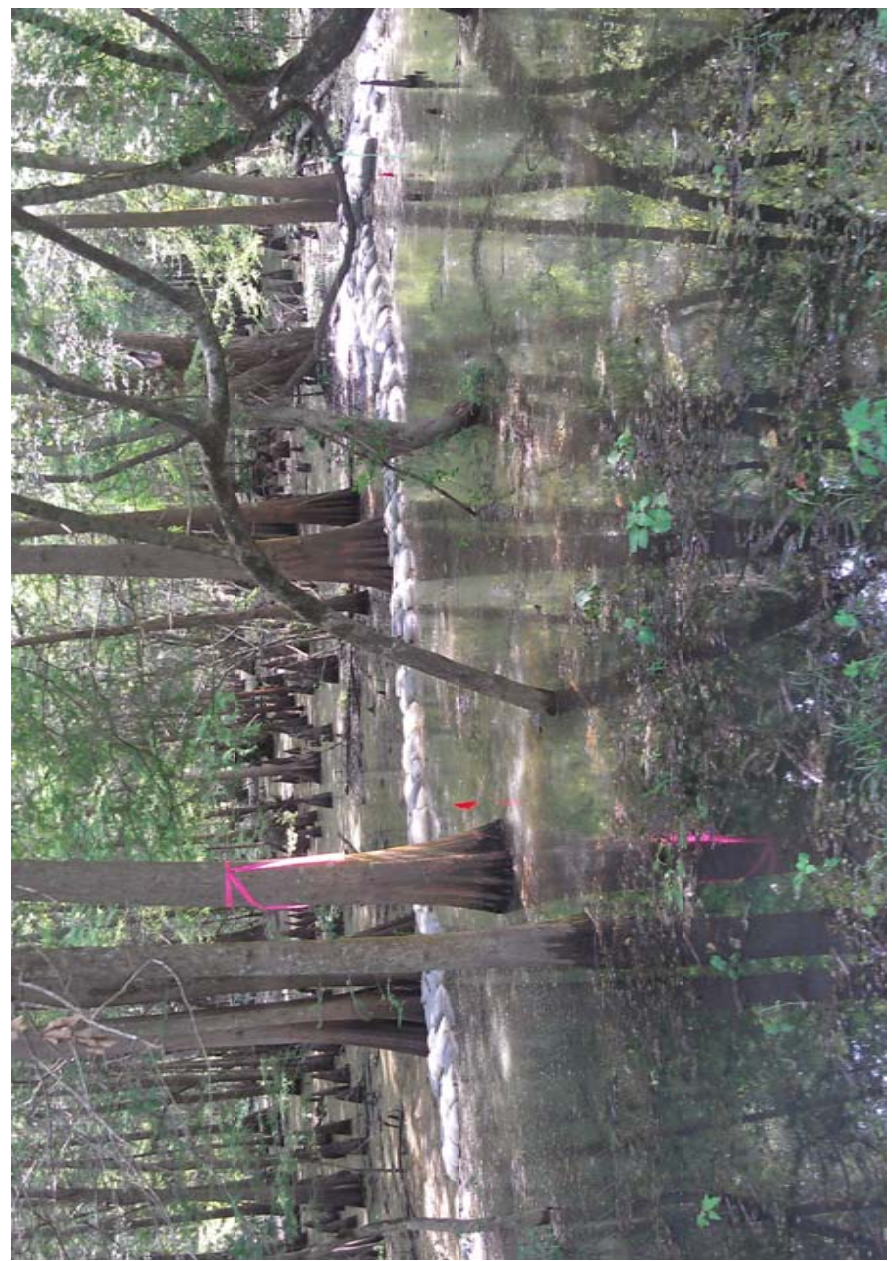

57

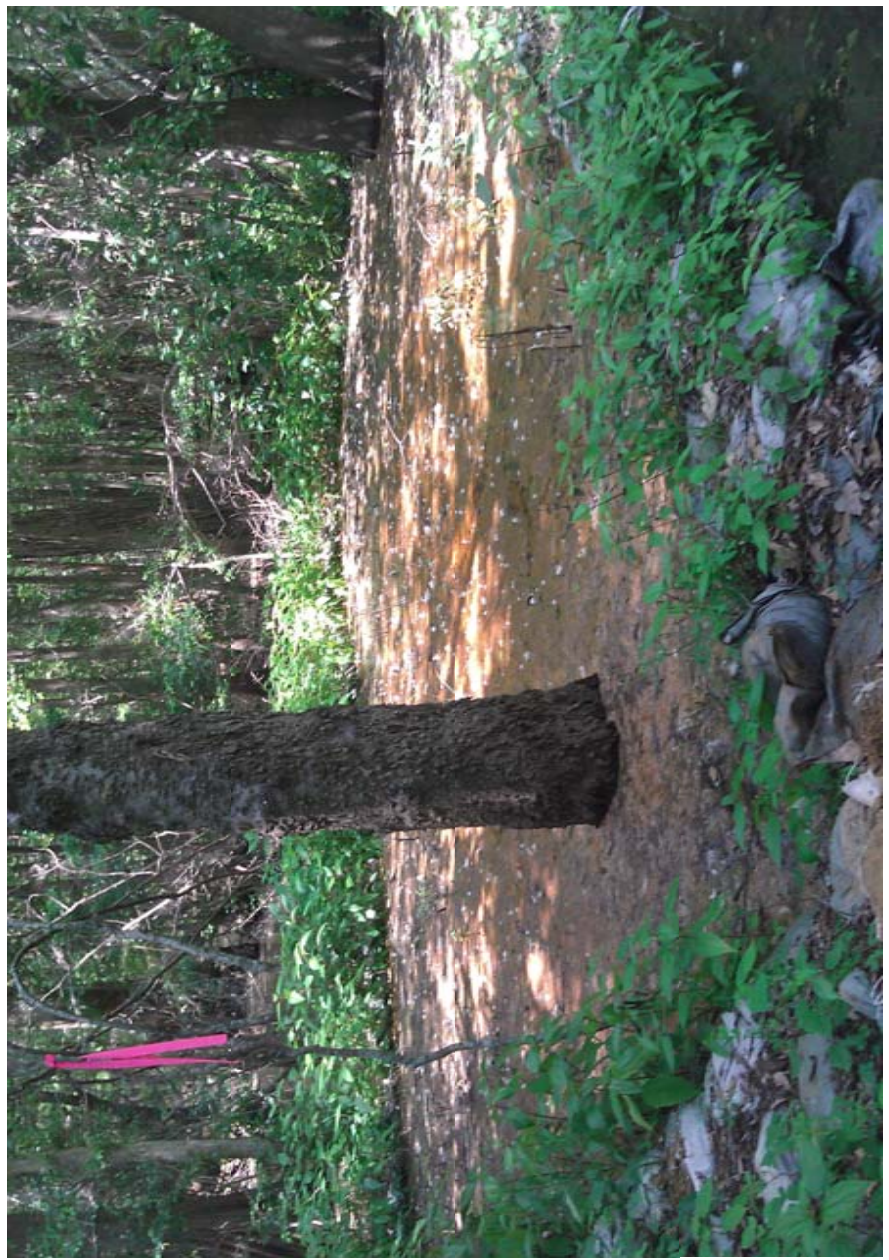

58

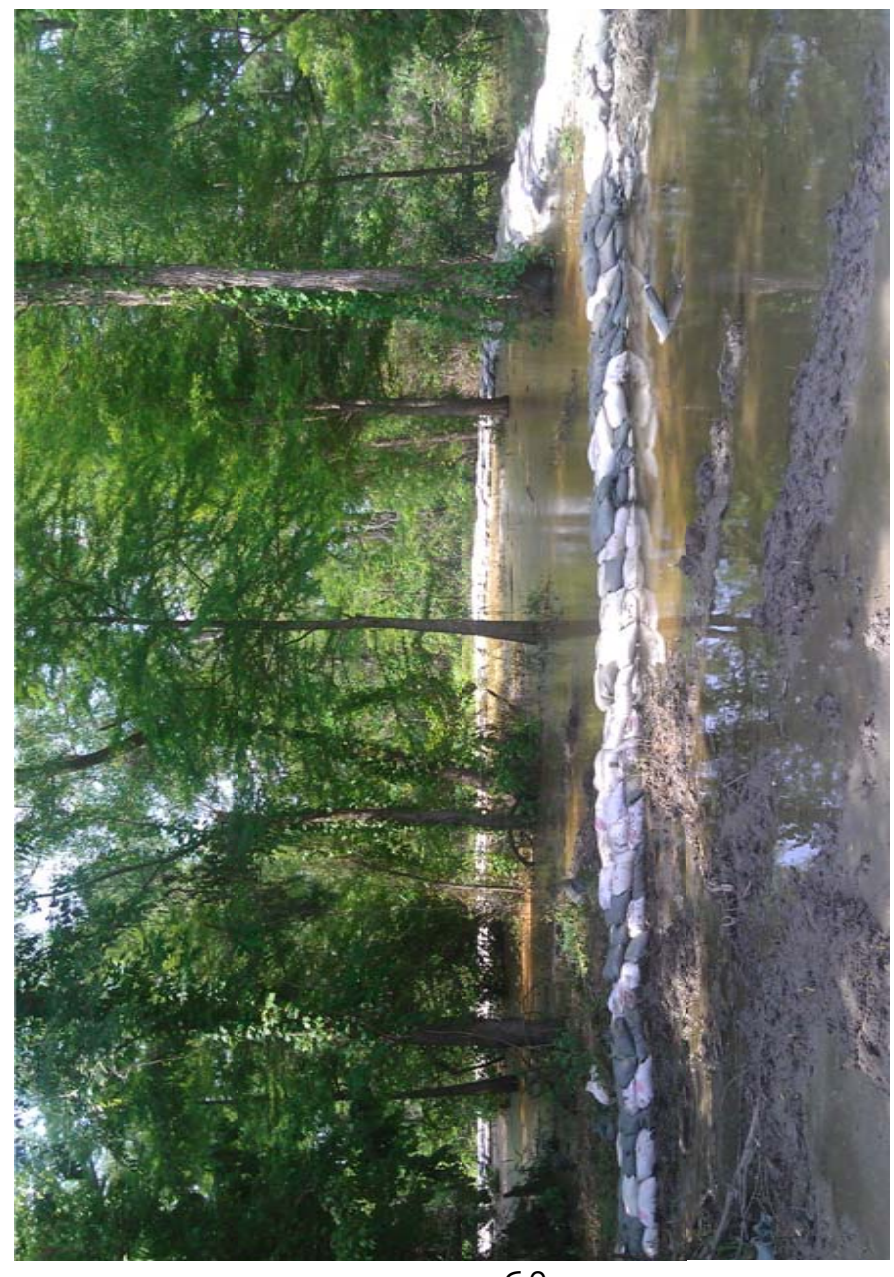




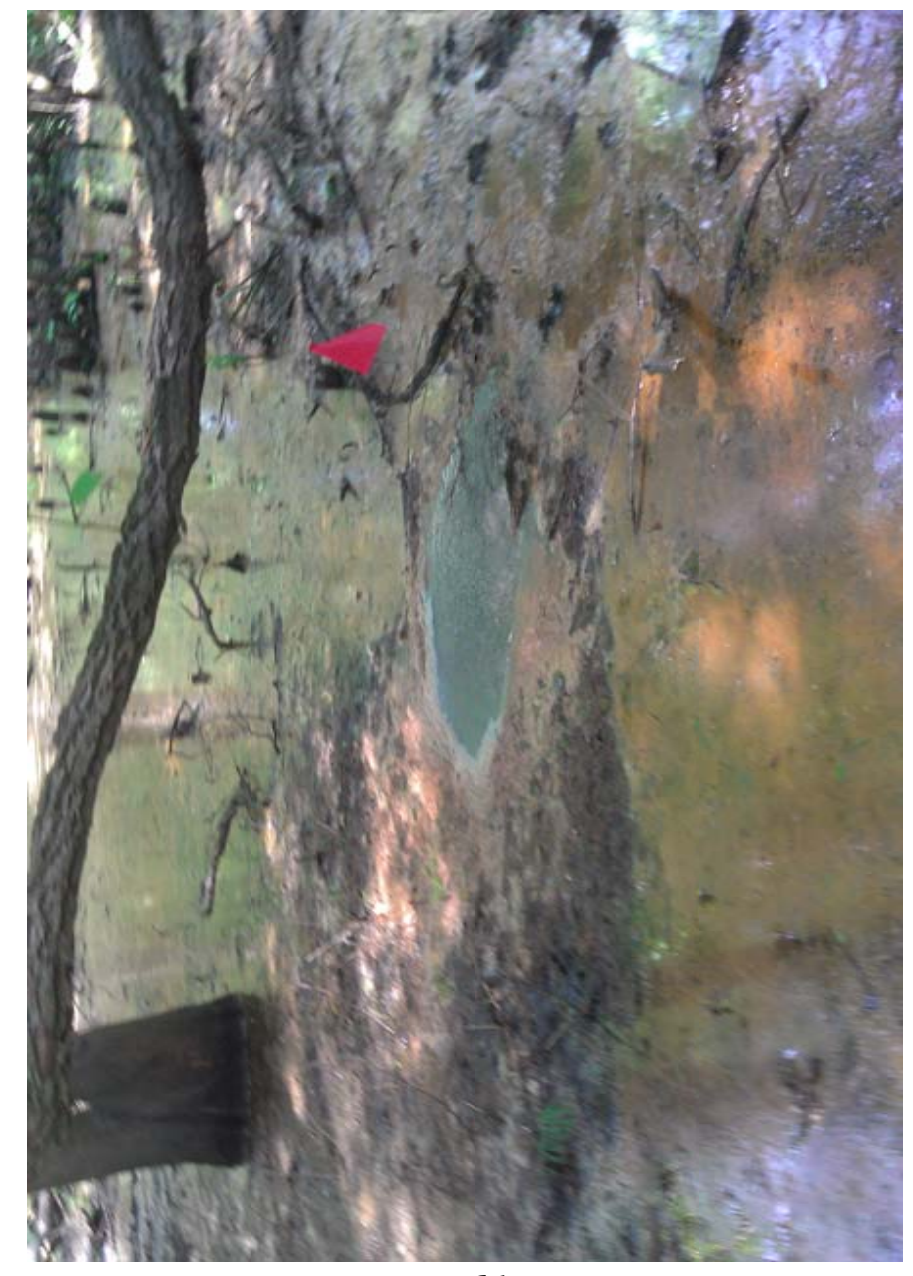

61

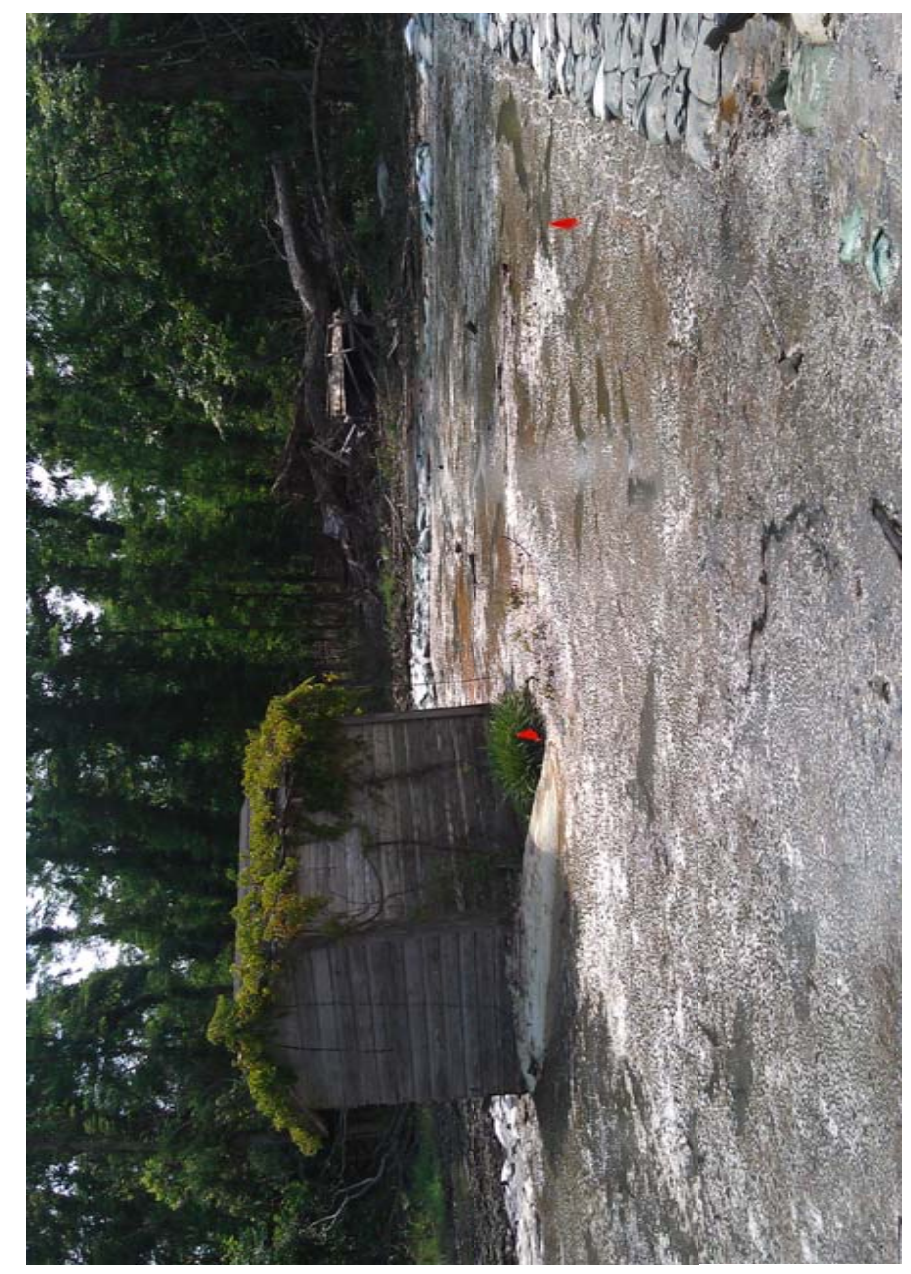

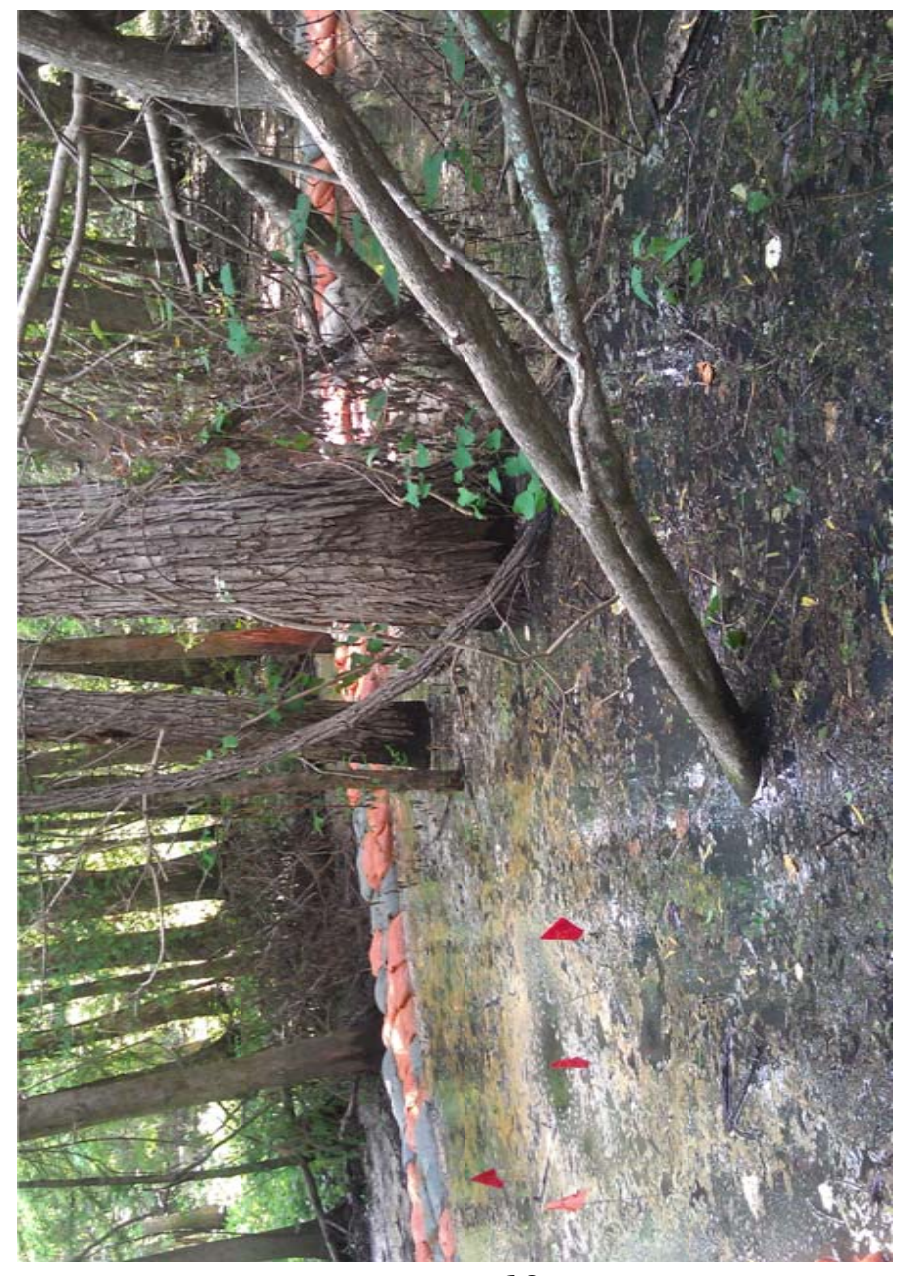

62

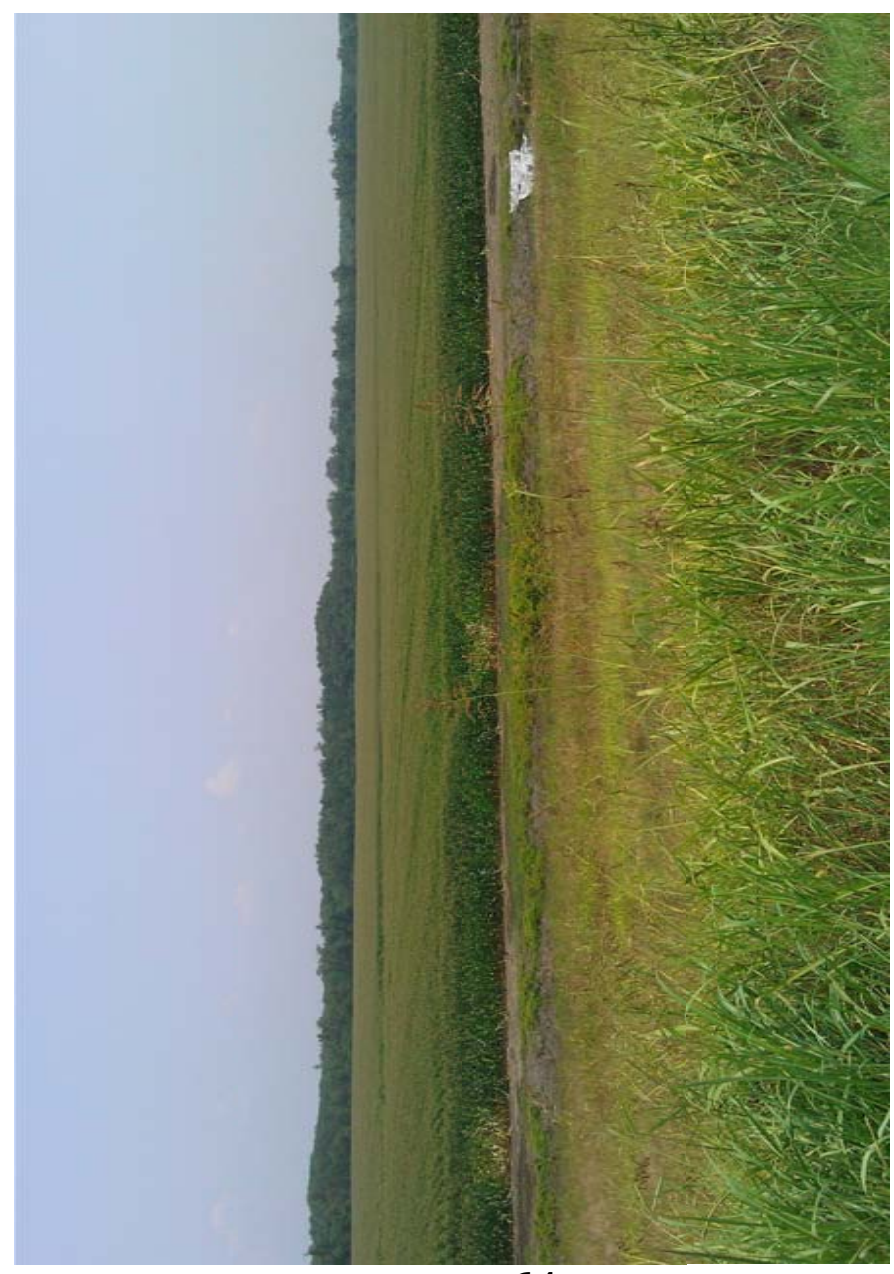




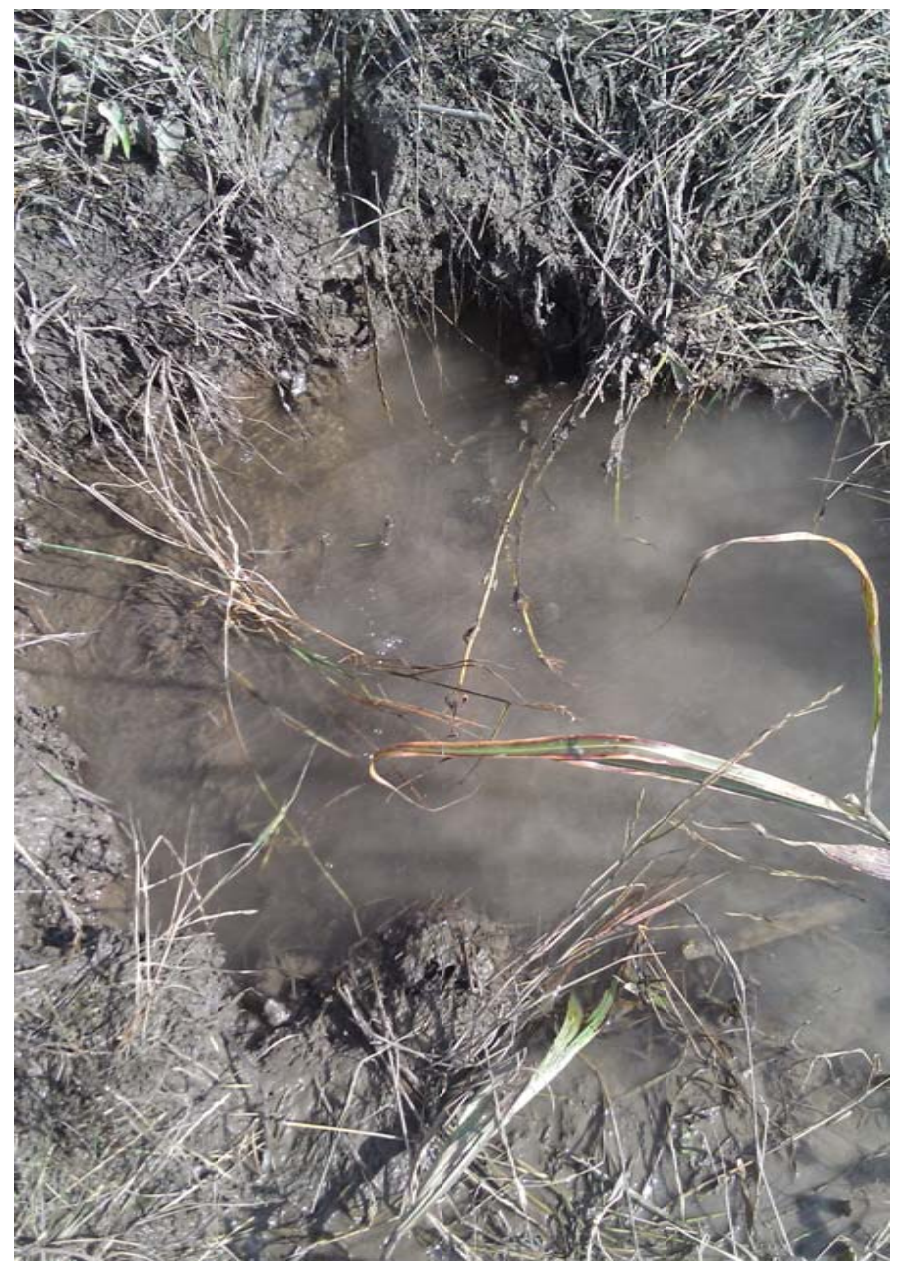

65

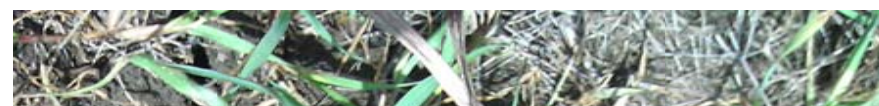

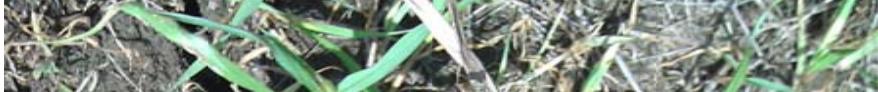

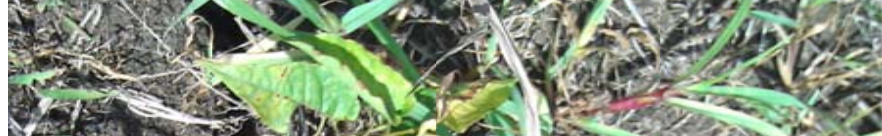

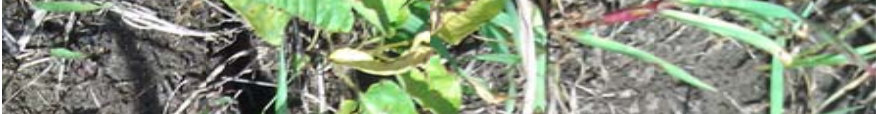
- 5 .

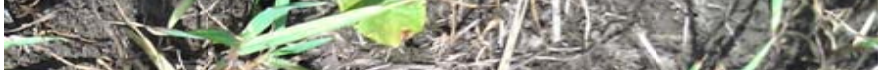

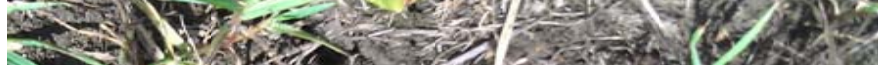

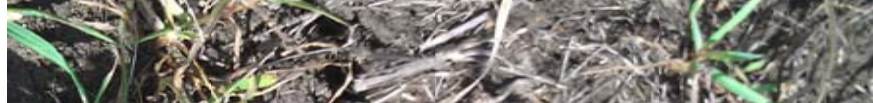

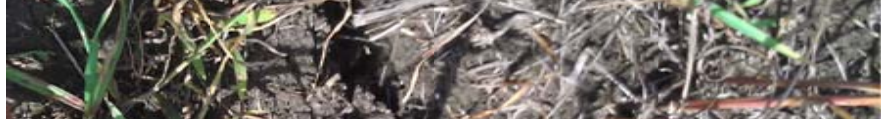

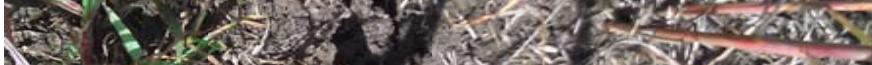

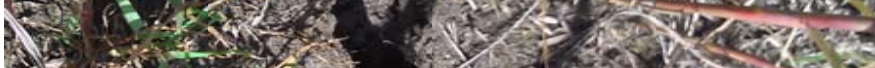

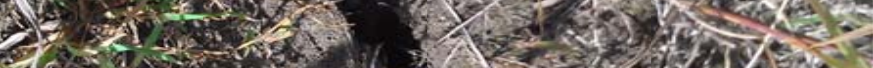
mon $x=2$,

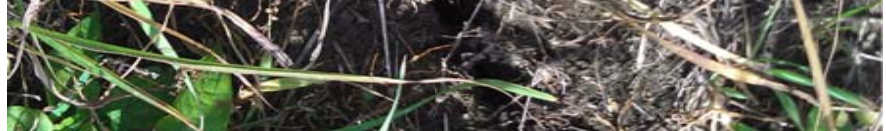

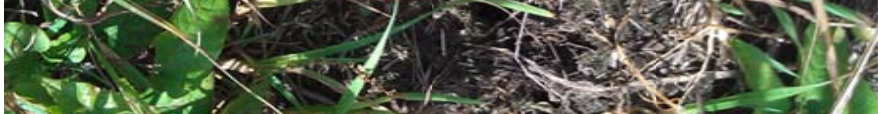
1.

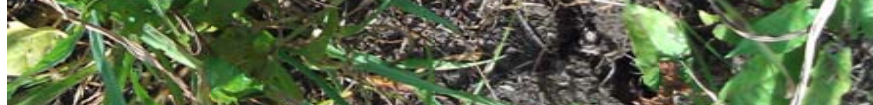

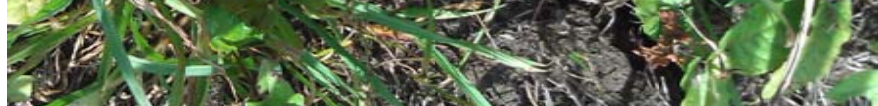

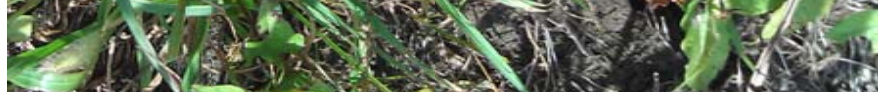

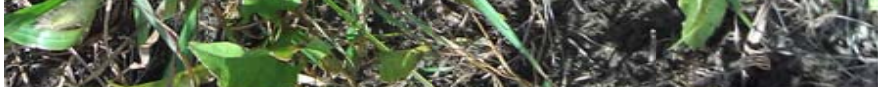

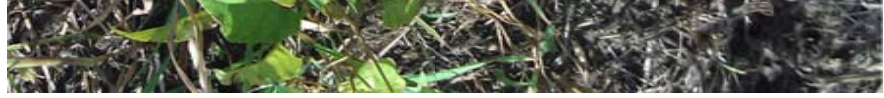
66

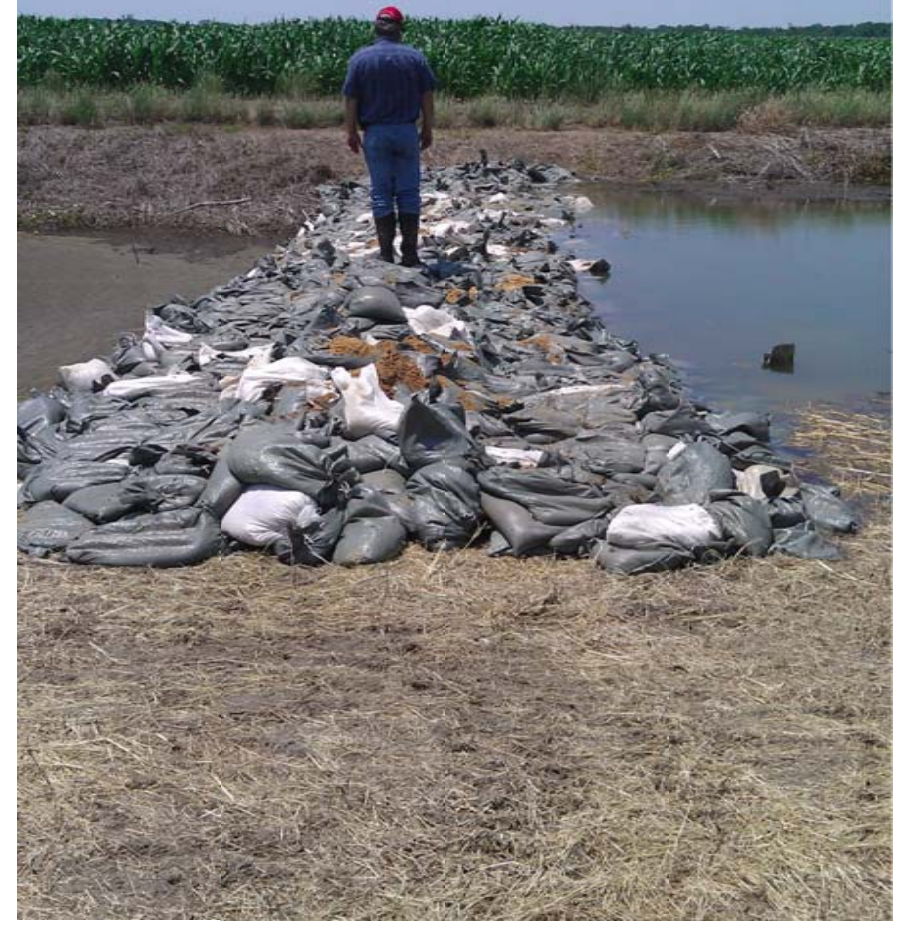




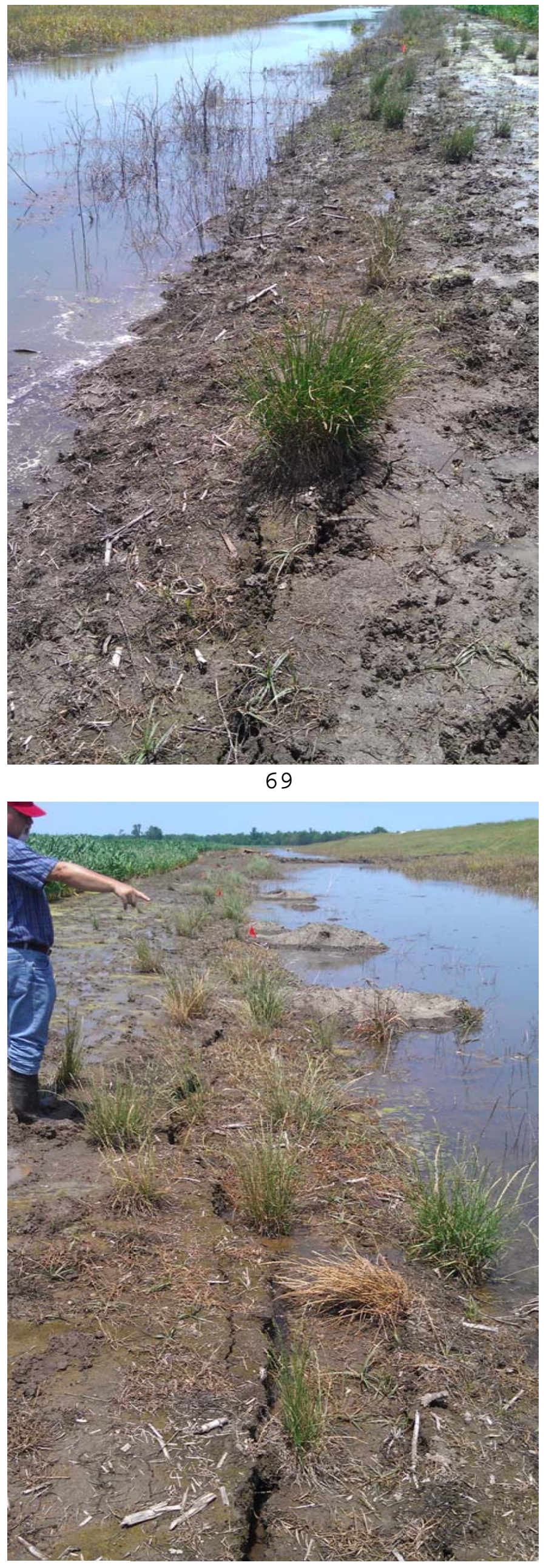

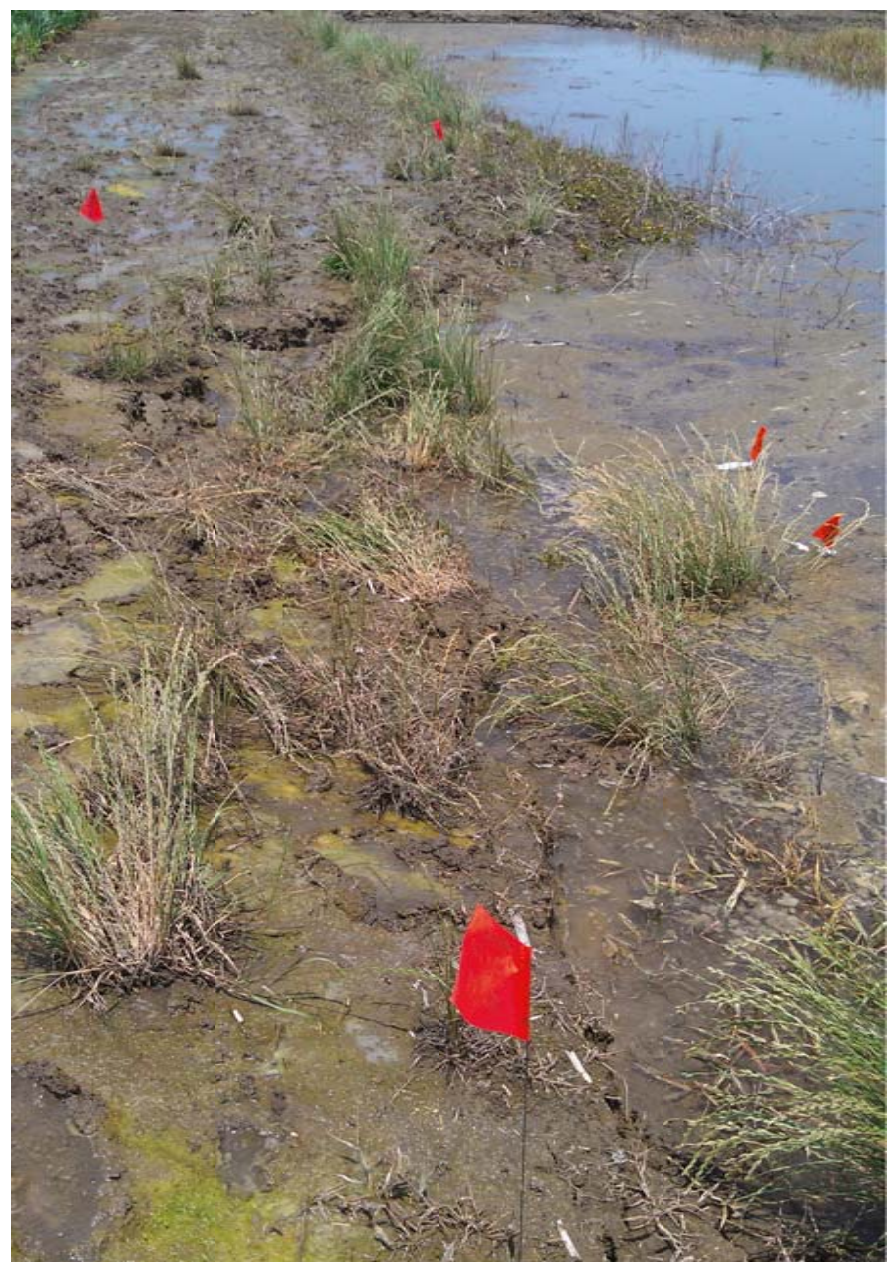

70

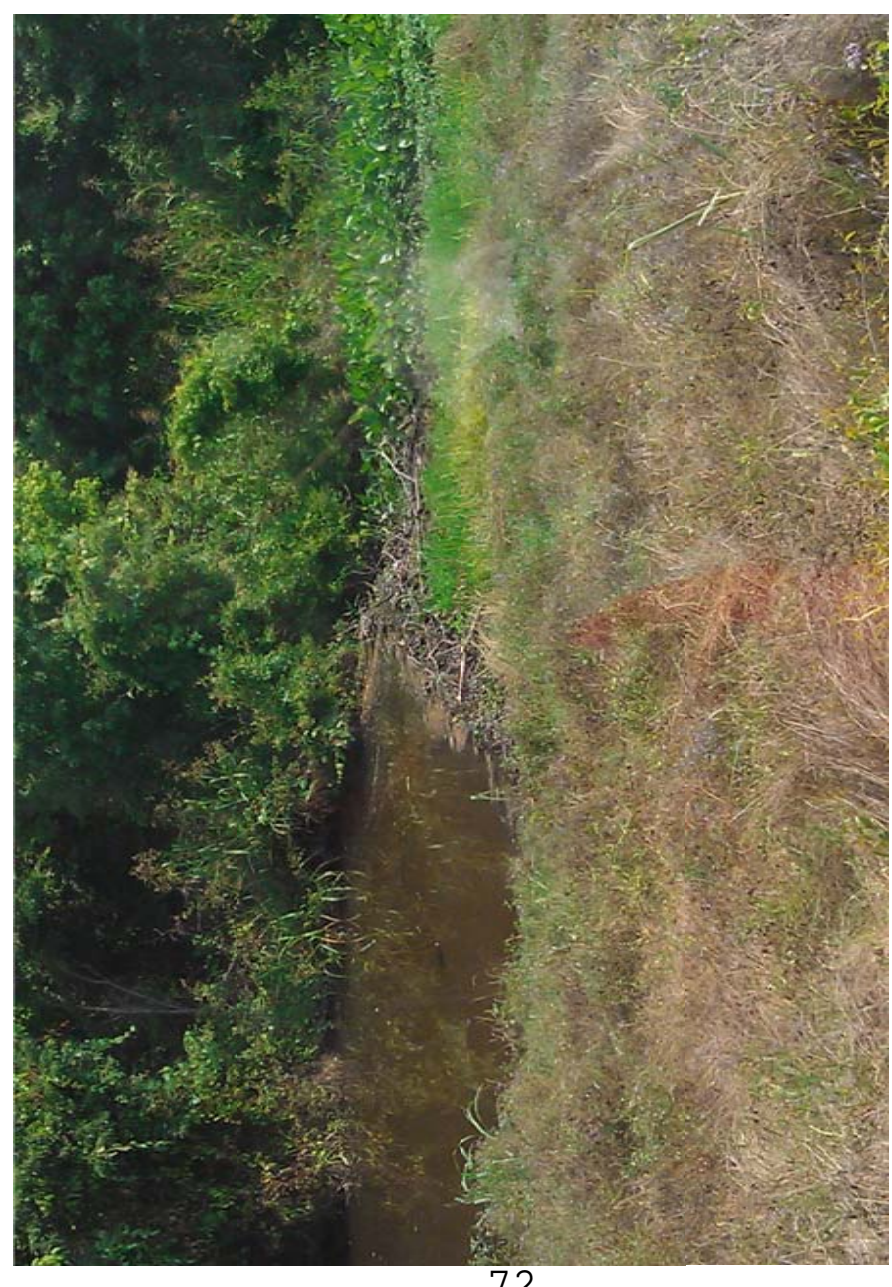


STATION 5600+00 TO 7200+00 
LEVEE SECTOR: Lake Bruin to Lake St. John

DATE: May 26, 2011

TEAM MEMBERS: Heather Sibley, Lance Gullett and Justin Jones

\begin{tabular}{|c|c|c|c|c|c|c|c|c|c|}
\hline STA & ART & EN & ND & STATION & STATION & TYPE & EXTENT & REMARKS & РНОТО \\
\hline Latitude & Longitude & Latitude & Longitude & NLD & FIELD MARKER & & & & \\
\hline & & & & $\begin{array}{l}5600+00 \\
5716+00\end{array}$ & $\begin{array}{l}5604+00 \text { to } \\
5800+00\end{array}$ & & & $\begin{array}{l}\text { Note: From Station } 5600+00 \text { to } 5716+00 \text { there is no seepage near the toe of } \\
\text { the levee, but there are multiple sand boils in the Botany Bay ditch and near } \\
\text { the bank of the lake. See below for details on boils. }\end{array}$ & \\
\hline 31.98802986 & 91.18636091 & -- & -- & $5659+00$ & $5663+00$ & Sand Boil & & $\begin{array}{l}\text { Large boils at Melancon Camp. They have moved material from behind } \\
\text { seawall. Most are located in the lake and cannot be measured. Some small } \\
\text { ones along the bank. } 7 \text { boils in Lake Bruin which have produced } 10 \mathrm{yds} \text { of } \\
\text { silty sand range in size from } 2 \mathrm{ft} \text { to } 5 \mathrm{ft} \text { diameter. Erosion landside of walkway } \\
\text { has increased and does not appear to have any material underneath. }\end{array}$ & $1-6$ \\
\hline 31.97625211 & 91.18912606 & 31.97627105 & 91.18913094 & $5706+00$ & $5710+00$ & Sand Boil & & $\begin{array}{l}\text { Large boils in Botany Bay Ditch. Boils have been sandbagged and ditch has } \\
\text { been bagged to allow higher head over boils. Both have moved large } \\
\text { amount of material. Approximately } 450 \mathrm{ft} \text { from the levee toe. }\end{array}$ & $7-10$ \\
\hline 31.97427198 & 91.19008269 & 31.95778666 & 91.19687706 & $\begin{array}{l}5716+00 \text { to } \\
5782+00\end{array}$ & $\begin{array}{l}5720+00 \text { to } \\
5786+00\end{array}$ & $\begin{array}{l}\text { Under } \\
\text { Seepage }\end{array}$ & \begin{tabular}{|l} 
Light to \\
Moderate
\end{tabular} & $\begin{array}{l}\text { Seepage begins near the toe. There are a couple stretches about } 100 y d s \\
\text { where there is no seepage near toe, but then it starts right back up. There is } \\
\text { also one stretch about } 200 \mathrm{ft} \text { where the seeapge is exiting } 3 \mathrm{ft} \text { up the slope } \\
\text { from the toe. Full extents were unable to be seen, but there are seepage } \\
\text { and boils at lake. }\end{array}$ & 11 \\
\hline 31.97440753 & 91.19457165 & 31.97423744 & 91.19439809 & $\begin{array}{l}5724+00 \text { to } \\
5727+00\end{array}$ & $\begin{array}{l}5730+00 \text { to } \\
5731+00\end{array}$ & Sand Boil & & $\begin{array}{l}\text { Approximately } 5 \text { boils were found } 10 \text { to } 15 \mathrm{ft} \text { from Lake Bruin bank. Ranged } \\
\text { from } 1 \text { to } 4 \text { inch throats. These boils are located over } 500 \mathrm{ft} \text { from the toe of } \\
\text { the levee. }\end{array}$ & $12-13$ \\
\hline 31.96721 & 91.1952305 & -- & -- & $5747+50$ & $5755+00$ & Sand Boil & & $\begin{array}{l}\text { Sand boil moving small amounts of material approximately } 300 \mathrm{ft} \text { from } \\
\text { landside toe of levee. }\end{array}$ & 14 \\
\hline 31.96157886 & 91.19995377 & 31.95764166 & 91.19981029 & $\begin{array}{l}5769+00 \text { to } \\
5787+00\end{array}$ & $\begin{array}{l}5781+00 \text { to } \\
5799+00\end{array}$ & Sand Boil & & $\begin{array}{l}\text { Many boils in Lake Bruin State Park. At the time of this inspection most of } \\
\text { the boils had been bagged and controlled. Only sand bags and pin flags } \\
\text { could really be seen due to water. }\end{array}$ & $15-19$ \\
\hline 31.93843421 & 91.20679698 & 31.93503209 & 91.21155905 & $\left\{\begin{array}{l}5861+00 \text { to } \\
5880+00\end{array}\right.$ & $\begin{array}{l}5869+00 \text { to } \\
5888+00\end{array}$ & $\begin{array}{l}\text { Under } \\
\text { Seepage }\end{array}$ & Light & $\begin{array}{l}\text { At Sta. } 5868 \text { Seepage begins where the old front levee ends. Seepage is } \\
\text { exiting at the toe and extending couple hundred feet into bean field. Further } \\
\text { out in the field, no seepage can be seen from the top of the levee. }\end{array}$ & 20 \\
\hline 31.93001051 & 91.21990788 & - & -- & $5912+00$ & $5920+00$ & Sand Boil & & $\begin{array}{l}\text { Small boil - Panola (Lake Bruin) was noted by other geotech personnel on } \\
\text { May 19. Was not seen at the time of the inspection for this report. }\end{array}$ & 21 \\
\hline
\end{tabular}




\begin{tabular}{|c|c|c|c|c|c|c|c|c|c|}
\hline STA & & EN & ND & STATION & STATION & TYPE & EXTENT & REMARKS & РНОTO \\
\hline Latitude & Longitude & Latitude & Longitude & NLD & FIELD MARKER & & & & \\
\hline 31.88316111 & 91.2736138 & & |-- & $6178+00$ & $6183+00$ & Sand Boil & & $\begin{array}{l}\text { Inspected May } 28,2011 \text {. Reported by night crew approximately } 4 \text { miles } \\
\text { south of St Joe, LA. Boil is located } 950 \mathrm{ft} \text { landside for top of levee at station } \\
6185+75 \text { downstream of culvert in ditch. This large, high energy boil has } \\
\text { produced possibly over } 100 y d s \text { of material. The ditch in this location is about } \\
10 \mathrm{ft} \text { deep and there is material above water level. Within } 2 \mathrm{hr} \text { period the boil } \\
\text { increased from } 4 \mathrm{ft} \text { - } 6 \mathrm{ft} \text { diameter throat with approximately } 8 \mathrm{ft} \text { diameter } \\
\text { sand cone to a } 10 \mathrm{ft} \text { throat with a } 13 \mathrm{ft} \text { diameter sand cone. The outside } \\
\text { perimeter of sand is approximately } 60 \mathrm{ft} \text { in diameter with some material } \\
\text { flowing downstream. This area also has a } 100 \mathrm{ft} \text { diameter sunken (cracked) } \\
\text { area along the upstream and east-west side of ditch. The boil throat is at } \\
\text { least } 18 \mathrm{ft} \text { in depth. The majority of material appears to be a silty sand with } \\
\text { some clay particles inside hole. The clay does not appear to be foundation } \\
\text { material. On May } 29 \text {, the levee board placed two sand bag dams across } \\
\text { ditch one on each side. There was about } 4 \mathrm{ft} \text { of water over the boil. }\end{array}$ & $22-24$ \\
\hline 31.883344 & 91.273727 & -- & -- & $6178+50$ & $6183+50$ & Sand Boil & & Large high energy boil inspected on June $1,2011.75 \mathrm{ft}$ NNW of above boil. & \\
\hline 31.8694779 & 91.34384408 & 31.86861268 & 91.34517923 & $\begin{array}{l}6414+00 \text { to } \\
6419+00\end{array}$ & $\begin{array}{l}6422+00 \text { to } \\
6427+00\end{array}$ & \begin{tabular}{|l|l|} 
Under \\
Seepage
\end{tabular} & Light & $\begin{array}{l}\text { Light seepage right at the toe of the levee. Appears to be only extending } \\
20 \mathrm{ft} \text { perpendicular to the levee. }\end{array}$ & $25-26$ \\
\hline 31.86503046 & 91.35100959 & -- & -- & $6436+00$ & $6444+00$ & Sand Boil & & Kemp Bend \#4 underwater. Noted on May 24 by other geotech personnel. & 27 \\
\hline 31.86438557 & 91.35068807 & -- & -- & $6437+00$ & $6445+00$ & Sand Boil & & $\begin{array}{l}\text { Kemp Bend \#3 Low energy boil 10+ yards of material moved. Noted on May } \\
24 \text { by other geotech personnel. }\end{array}$ & 28 \\
\hline 31.86476999 & 91.35032573 & -- & -- & $6436+00$ & $6444+00$ & Sand Boil & & Kemp Bend \#2 Nearly dormant. Noted May 24 other geotech personnel. & 29 \\
\hline 31.86417696 & 91.34948948 & - & -- & $6436+50$ & $6444+50$ & Sand Boil & & clear flow with low energy Kemp Bend \#1 noted May 24 by others. & 30 \\
\hline 31.85712376 & 91.35006651 & 31.85043195 & 91.35204438 & $\begin{array}{l}6462+00 \text { to } \\
6487+00\end{array}$ & $\begin{array}{l}6470+00 \text { to } \\
6495+00\end{array}$ & \begin{tabular}{|l} 
Under \\
Seepage
\end{tabular} & Light & $\begin{array}{l}\text { Seep water built up in low area } 20 \mathrm{ft} \text { from the toe of the berm. } 500 \mathrm{ft} \\
\text { downstream begins seeping right at the toe. At the end coordinates, the } \\
\text { relief wells begin. Between the two well sections, light seepage exists. }\end{array}$ & 31 \\
\hline 31.85241944 & 91.35528056 & & -- & $6482+00$ & $6490+00$ & Sand Boil & & $\begin{array}{l}\text { Kemp Bend West Ditch (KBWD0001 thru 0007) Station } 6500 \text { to } 6505 \text { no } \\
\text { significant change in slide or seepage at this location was reported May } 27, \\
2011.7 \text { boils were found in ditch approximately } 1500 f \text { from the levee. Boils } \\
\text { range from 2in to } 6 \text { in diameter throats with } 1 \text { cu.ft to } 0.25 \text { yd of sandy } \\
\text { material. Several of the boils are flowing clear. }\end{array}$ & \\
\hline 31.82742728 & 91.35854571 & 31.82259167 & 91.35949946 & $\begin{array}{l}6573+00 \text { to } \\
6591+00\end{array}$ & $\begin{array}{l}6577+00 \text { to } \\
6595+00\end{array}$ & \begin{tabular}{|l|l|} 
Under \\
Seepage
\end{tabular} & Light & $\begin{array}{l}\text { Light seepage at the levee toe and into corn field. Once the wells and berm } \\
\text { ends, the seepage stops. }\end{array}$ & 32 \\
\hline 31.81391133 & 91.36739689 & 31.81300268 & 91.368077 & $\begin{array}{l}6632+50 \text { to } \\
6637+00\end{array}$ & $\begin{array}{l}6640+50 \text { to } \\
6645+00\end{array}$ & \begin{tabular}{|l} 
Under \\
Seepage
\end{tabular} & Light & Light seepage in ditch at levee toe. & 33 \\
\hline 31.76129968 & 91.39675149 & 31.75451889 & 91.40127288 & $86897+00$ & $6905+00$ & Seepage & Light & Light seepage exiting $30 \mathrm{ft}$ from the toe. & 34 \\
\hline 31.7550833 & 91.39995833 & & & $6893+70$ & $6901+70$ & Slide & & $\begin{array}{l}\text { Slide located on riverside } 20 \mathrm{ft} \text { from crown and } 22 \mathrm{ft} \text { long. Slide was found on } \\
\text { May } 7 \text { according to pin flag at location. }\end{array}$ & $35-37$ \\
\hline 31.74867289 & 91.40374754 & 31.70970023 & 91.4125142 & $226919+00$ to & $\begin{array}{l}6927+00 \text { to } \\
7072+00\end{array}$ & $\begin{array}{l}\text { Under } \\
\text { Seepage/Pin } \\
\text { Boils }\end{array}$ & Heavy & $\begin{array}{l}\text { There is seepage and ponding } 15 \mathrm{ft} \text { from the berm toe. The water in pond is } \\
\text { higher than usual and there were several pin boils. Once the relief wells } \\
\text { begin, there are pin boils and larger behind wells } 80 \mathrm{ft} \text { from toe. At the end, } \\
\text { the ditch still has some water in it, but appears to be drainage because field } \\
\text { is drv. }\end{array}$ & $38-39$ \\
\hline
\end{tabular}




\begin{tabular}{|c|c|c|c|c|c|c|c|c|c|}
\hline STA & ART & EN & ND & STATION & STATION & TYPE & EXTENT & REMARKS & PHOTO \\
\hline 31.74516846 & 91.40857498 & -- & -- & $6932+00$ & $6940+00$ & Sand Boil & & $\begin{array}{l}\text { St John \#002 noted on May } 24 \text { by others. Moderate energy with clear flow. } \\
12 \text { inches of head. Also seen by group for this inspection and it was noted } \\
\text { that there has been another boil that has popped up outside of the } \\
\text { constructed sand bag ring that is moving a small amount of material and has } \\
\text { approximately } 5 \text { inch throat. These boils are located a few hundred yards or } \\
\text { more from the levee. From sit rep, the boil outside of ring is a medium } \\
\text { energy sand boil with a 4inch throat and } 7 \mathrm{ft} \text { fone which has moved 1yd of } \\
\text { sand. Approximately } 1050 \mathrm{ft} \text { from the levee crown. The site is historically an } \\
\text { area with numerous small to medium sized boils. There were six medium } \\
\text { sized, moderate energy boils sand bagged during this event. Several of } \\
\text { these were boils that reappeared in existing sandbag rings from the } 2008 \\
\text { High Water event. The boils typically moved } 1-2 \text { cubic yards of silt and fine } \\
\text { sand. The boils are located in an area of the levee with an existing } 300-\text { foot } \\
\text { seepage berm. The boils are located in a large slough and vary from 1,000 } \\
\text { to } 1,500 \text { feet from the toe of the levee. }\end{array}$ & $40-42$ \\
\hline 31.74513957 & 91.40857582 & -- & -- & $6932+00$ & $6940+00$ & Sand Boil & & $\begin{array}{l}\text { St John \#001 noted by others on May } 24 \text {. Moderate energy with clear flow } \\
\text { and } 18 \text { inches of head. Also noted by inspection group and by that time, the } \\
\text { boil was under water and no longer moving material. }\end{array}$ & \\
\hline 31.7457388 & 91.40606944 & 31.7451611 & 91.4072388 & $\begin{array}{l}6928+00 \text { to } \\
6933+00\end{array}$ & $\begin{array}{l}6936+00 \text { to } \\
6941+00\end{array}$ & Sand Boil & & $\begin{array}{l}\text { Multiple boils in area. Most have moved less than } 1 y d \text { of material. All are } \\
\text { located } 800 f \text { or more from toe of levee. These are in same area as St John } \\
001 \text { and } 002 \text {, but are smaller. }\end{array}$ & \\
\hline 31.74364563 & 91.40531459 & & -- & $\begin{array}{l}6937+50 \text { to } \\
6939+50\end{array}$ & $\begin{array}{l}6945+50 \text { to } \\
6947+50\end{array}$ & $\begin{array}{l}\text { Through } \\
\text { Seepage }\end{array}$ & Light & $\begin{array}{l}\text { If a berm, there is seepage on the crown } 60 \mathrm{ft} \text { from the toe. Extends } 200 \mathrm{ft} \\
\text { downstream parallel to levee. }\end{array}$ & 43 \\
\hline 31.73467747 & 91.40771417 & 31.7252404 & 91.40974569 & $\begin{array}{l}6972+00 \text { to } \\
7007+00\end{array}$ & $\begin{array}{l}6980+00 \text { to } \\
7015+00\end{array}$ & & & $\begin{array}{l}\text { Wells begin with \#32. There are some small boils behind the wells. See } \\
\text { below for details and coordinates. All of the wells were flowing. There was } \\
\text { seepage all the way to start of wells and since there are boils there is still } \\
\text { seepage behind wells. }\end{array}$ & \\
\hline & & & & & & & & Seepage and boils behind well pictures & $44-48$ \\
\hline 31.7348166 & 91.4101 & -- & -- & $6973+00$ & $6981+00$ & Sand Boil & & $\begin{array}{l}\text { Medium energy sand boil with a 3inch throat and } 5 \mathrm{ft} \text { sand cone that has } \\
\text { moved } 4 \mathrm{cu} \text {. Ft. of sand. The boil is } 1040 \mathrm{ft} \text { from the levee crown. }\end{array}$ & \\
\hline 31.73366534 & 91.40860752 & 31.7334868 & 91.4088339 & $\begin{array}{l}6976+00 \text { to } \\
6978+00\end{array}$ & $\begin{array}{l}6980+00 \text { to } \\
6982+00\end{array}$ & Sand Boil & & $\begin{array}{l}2 \text { sand boils were noted (one at each coordinate) in this location behind the } \\
\text { relief wells. Both were similar in size with approximately a } 6 \mathrm{ft} \text { diameter } \\
4 \text { inch thick sand/silt mix being moved. Neither are moving much material } \\
\text { now and they both had a throat of } 1.5 \text { inches. Sit Rep note multiple small, } \\
\text { low energy boils in the area. Most of which have moved less than 1yd of } \\
\text { material. All except for the two with presented coordinates are } 600 \mathrm{ft} \text { or } \\
\text { more from the levee. }\end{array}$ & \\
\hline 31.731522 & 91.410188 & -- & -- & $6985+00$ & $6993+00$ & Sand Boil & & $\begin{array}{l}6 \text { small low energy sand boils. The largest has moved less than } 2 \text { cu. Ft. of } \\
\text { sand with a } 4 \mathrm{ft} \text { cone. }\end{array}$ & \\
\hline 31.72605851 & 91.41052715 & -- & -- & $7004+00$ & $7012+00$ & Sand Boil & & $\begin{array}{l}\text { More small boils were noted behind the relief wells. These were even } \\
\text { smaller than the previous ones. }\end{array}$ & \\
\hline 31.7230950 & 91.4106445 & & - & $7015+00$ & $7023+00$ & Sand Boil & & $\begin{array}{l}\text { Several small pin boils and slightly larger boils were noted near the end of } \\
\text { the relief wells. These started a couple hundred feet from the levee toe. }\end{array}$ & 49 \\
\hline
\end{tabular}




\begin{tabular}{|c|c|c|c|c|c|c|c|c|c|}
\hline \multicolumn{2}{|c|}{ START } & \multicolumn{2}{|c|}{ END } & \multirow{2}{*}{$\begin{array}{c}\text { STATION } \\
\text { NLD }\end{array}$} & \multirow{2}{*}{$\begin{array}{c}\text { STATION } \\
\text { FIELD MARKER }\end{array}$} & \multirow[t]{2}{*}{ TYPE } & \multirow{2}{*}{ EXTENT } & \multirow{2}{*}{ REMARKS } & \multirow[t]{2}{*}{ PHOTO } \\
\hline Latitude & Longitude & Latitude & Longitude & & & & & & \\
\hline 31.70662057 & 91.41252234 & - & -- & $\begin{array}{l}7075+00 \text { to } \\
7076+00\end{array}$ & $\begin{array}{l}7083+00 \text { to } \\
7084+00\end{array}$ & $\begin{array}{l}\text { Under } \\
\text { Seepage }\end{array}$ & Light & $\begin{array}{l}\text { May be irrigation water and not seeapge. Corn is not yellow. Extends } 100 \mathrm{ft} \\
\text { south parallel to levee. }\end{array}$ & 50 \\
\hline 31.6829694 & 91.41136389 & -- & -- & $7165+00$ & $7173+00$ & & & $\begin{array}{l}\text { Cow depression on riverside levee slope. } 20 \mathrm{ft} \text { wide with } 3 \mathrm{ft} \text { face. Was } \\
\text { originally noted as a slide. }\end{array}$ & 51 \\
\hline 31.69256691 & 91.41066884 & 31.68682868 & \begin{tabular}{|l|l|} 
& 91.41128218 \\
\end{tabular} & $\begin{array}{l}7127+00 \text { to } \\
7148+00\end{array}$ & $\begin{array}{l}7135+00 \text { to } \\
7156+00\end{array}$ & \begin{tabular}{|l} 
Under \\
Seepage
\end{tabular} & Light & $\begin{array}{l}\text { Light seepage } 200 \mathrm{ft} \text { from the toe in bean field. Downstream the seepage } \\
\text { gets closer to toe. Right near the end of the seepage, it is exiting } 25 \mathrm{ft} \text { away } \\
\text { from the toe. }\end{array}$ & 52 \\
\hline $31.678 \mathrm{~s}$ & 91.41565516 & 31.67634374 & 91.4137144 & $\begin{array}{l}7188+00 \text { to } \\
7200+00\end{array}$ & $\begin{array}{l}7191+00 \text { to } \\
7200+00\end{array}$ & $\begin{array}{l}\text { Under } \\
\text { Seepage }\end{array}$ & Light & $\begin{array}{l}\text { There is light seepage exiting in the corn field } 25 \mathrm{ft} \text { from the toe. This is not } \\
\text { the end of the seepage, but the end of the reach. The seepage extends at } \\
\text { least an additional } 1500 \mathrm{ft} \text { downstream of the end of the reach. }\end{array}$ & 53 \\
\hline
\end{tabular}



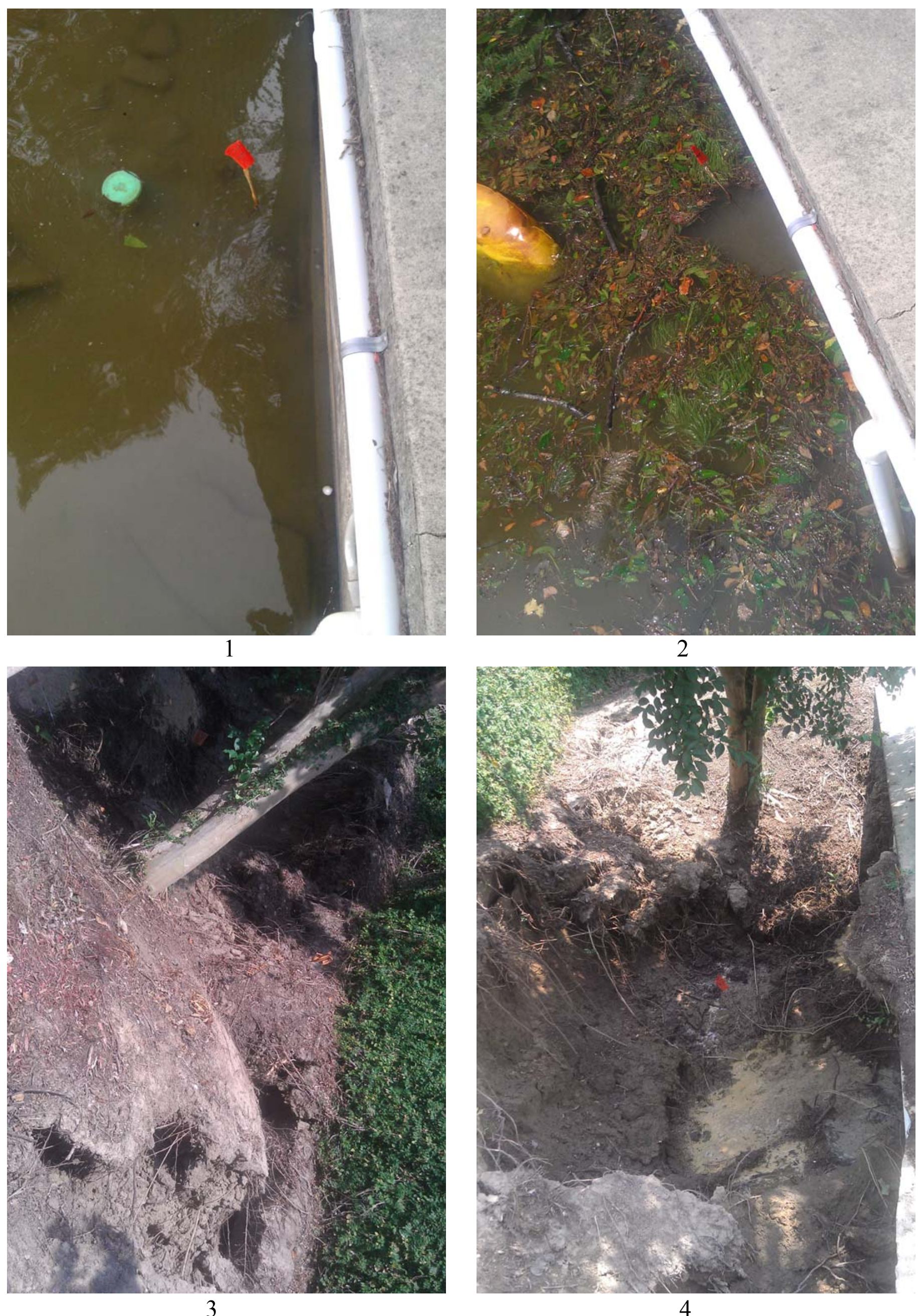


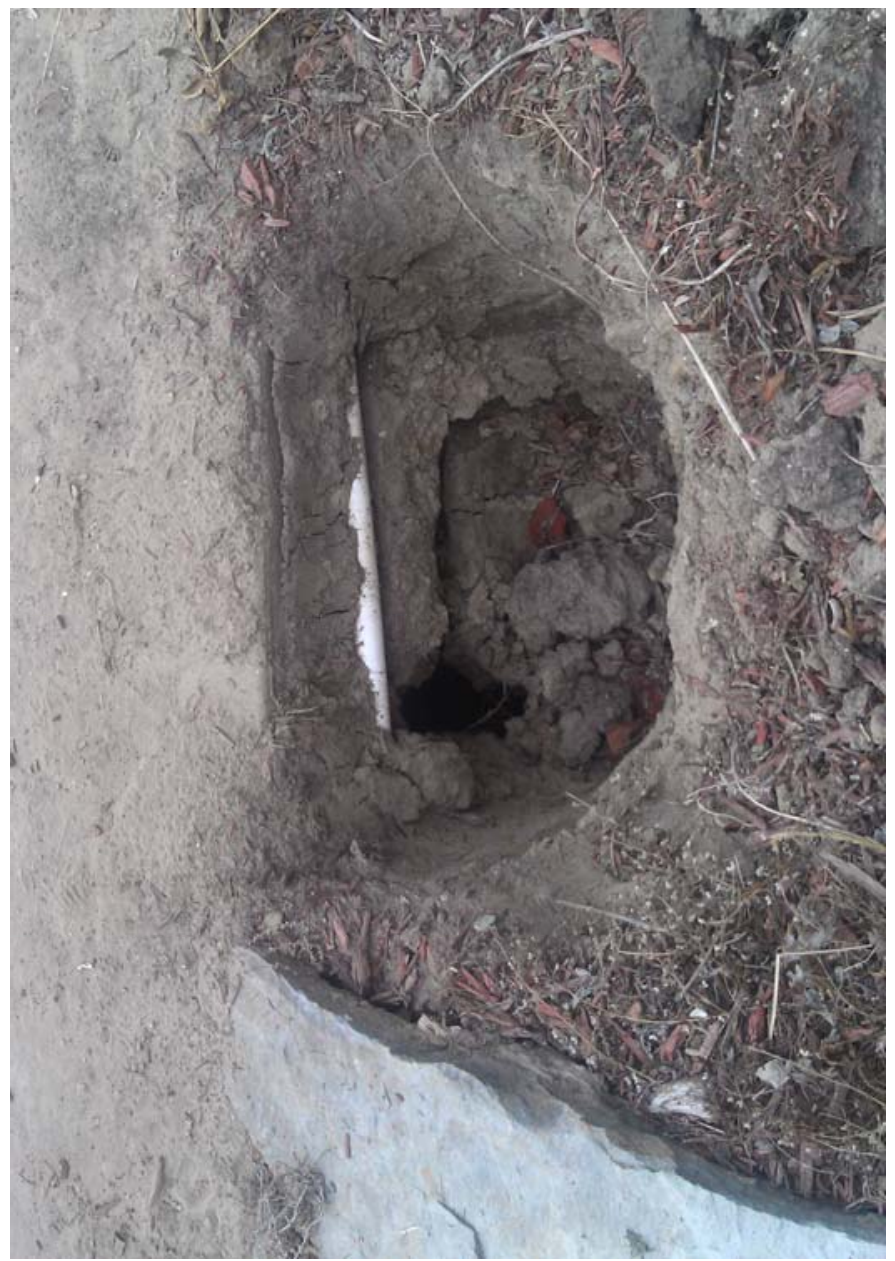

5

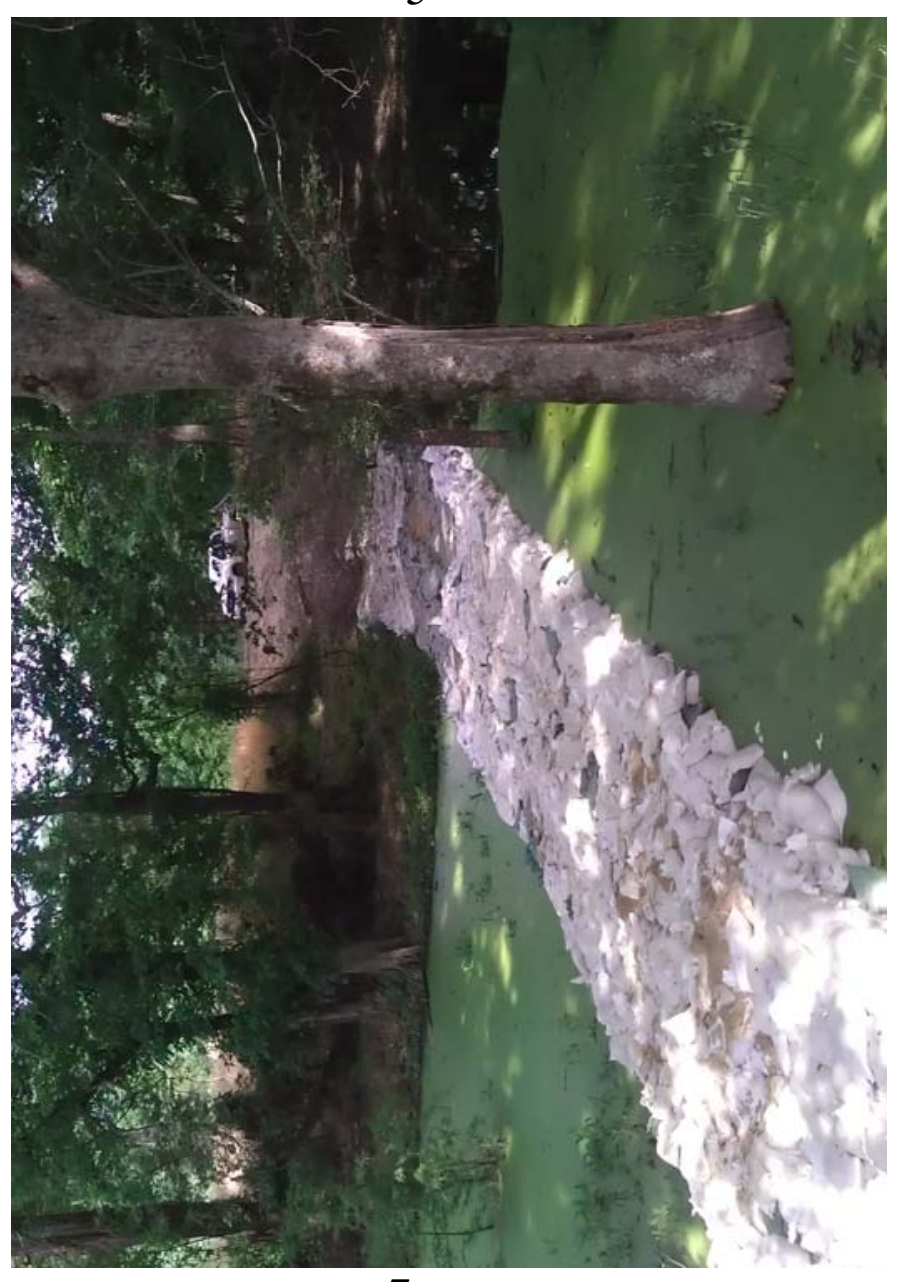

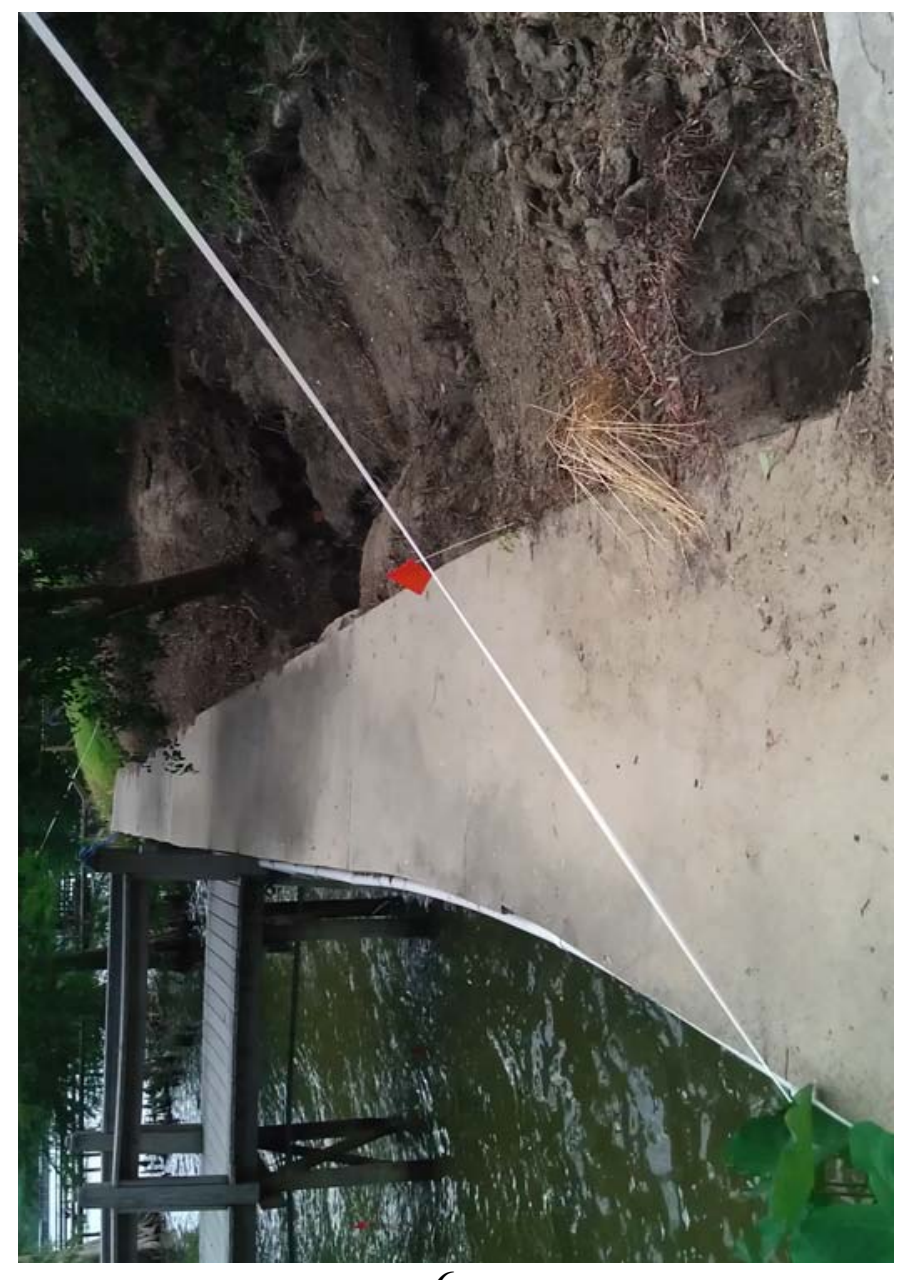

6

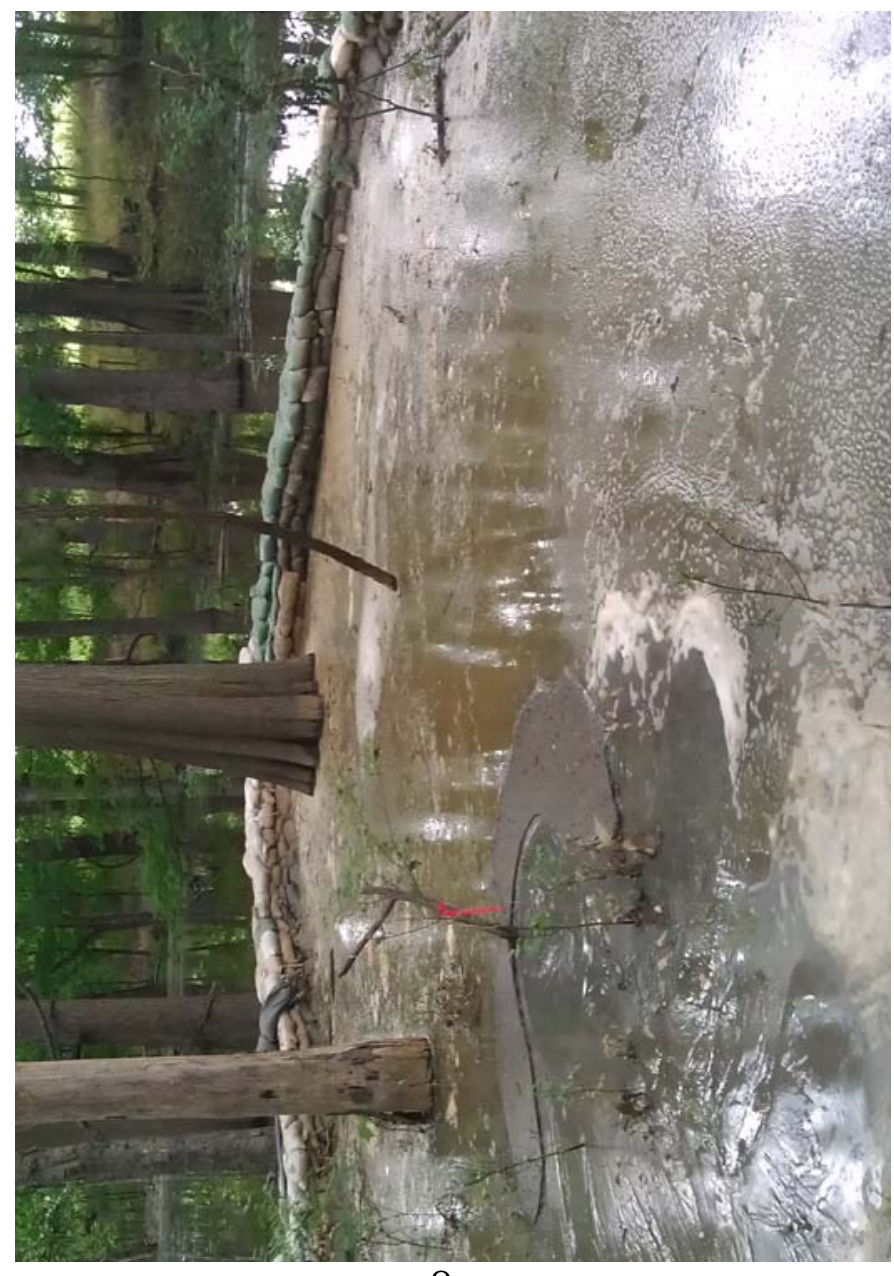




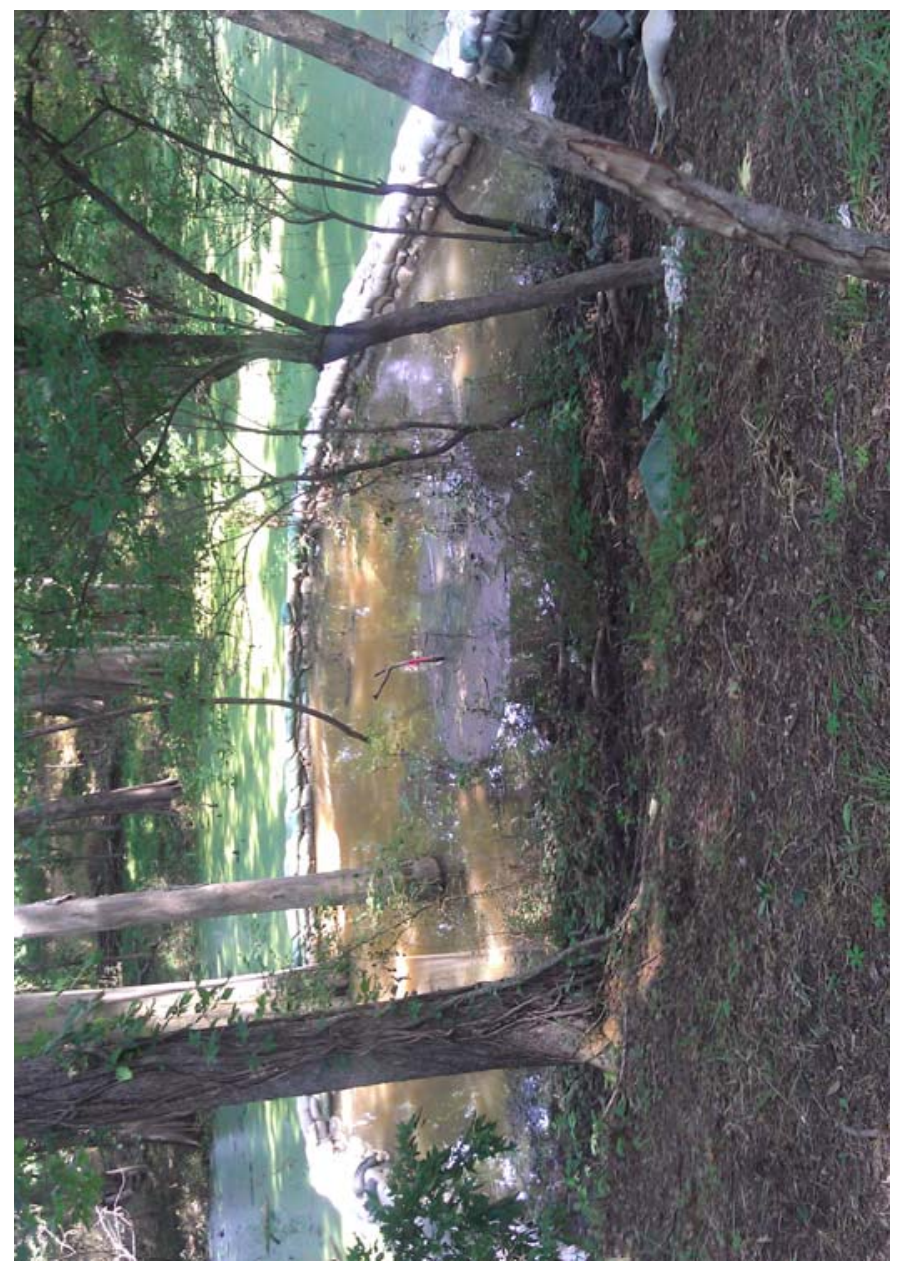

9

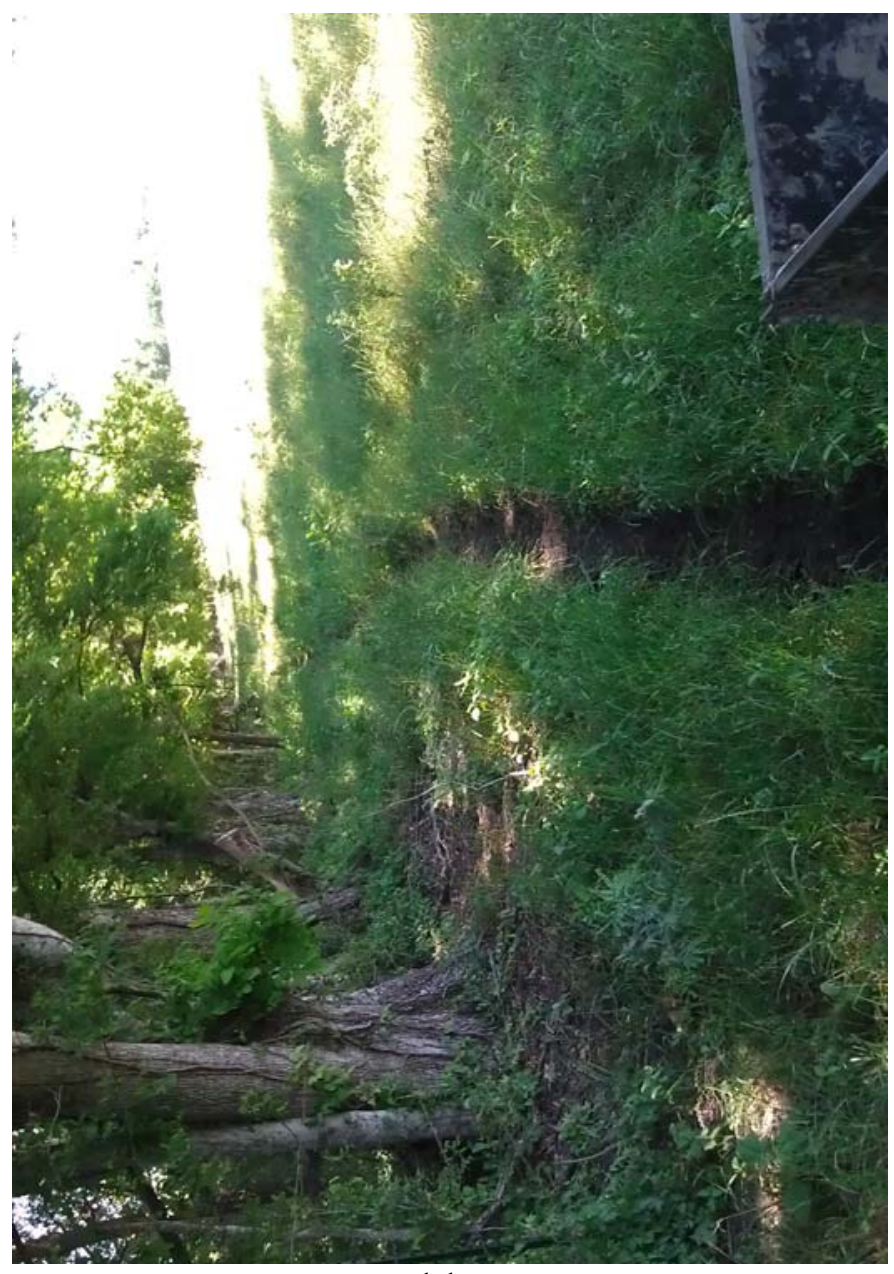

11

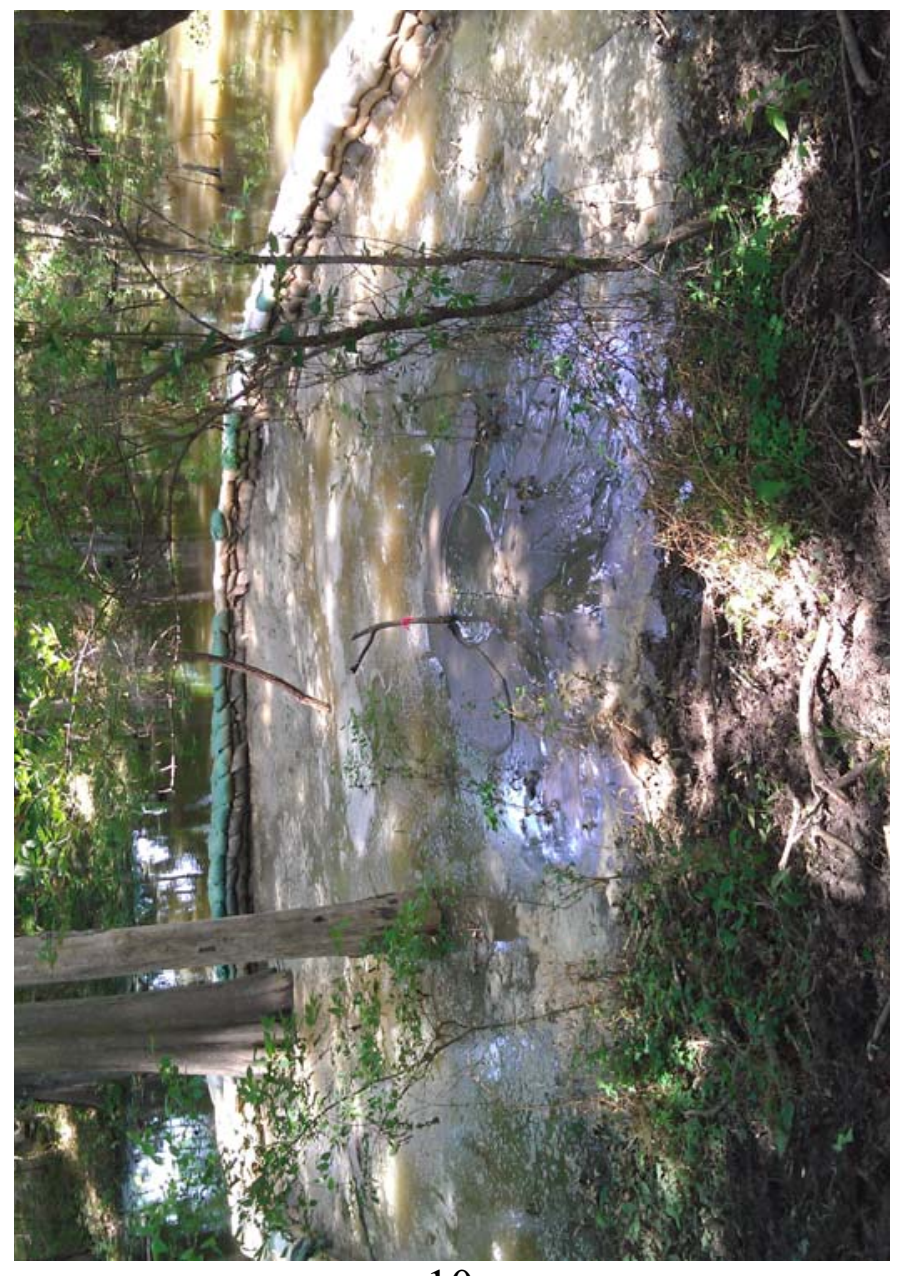

10

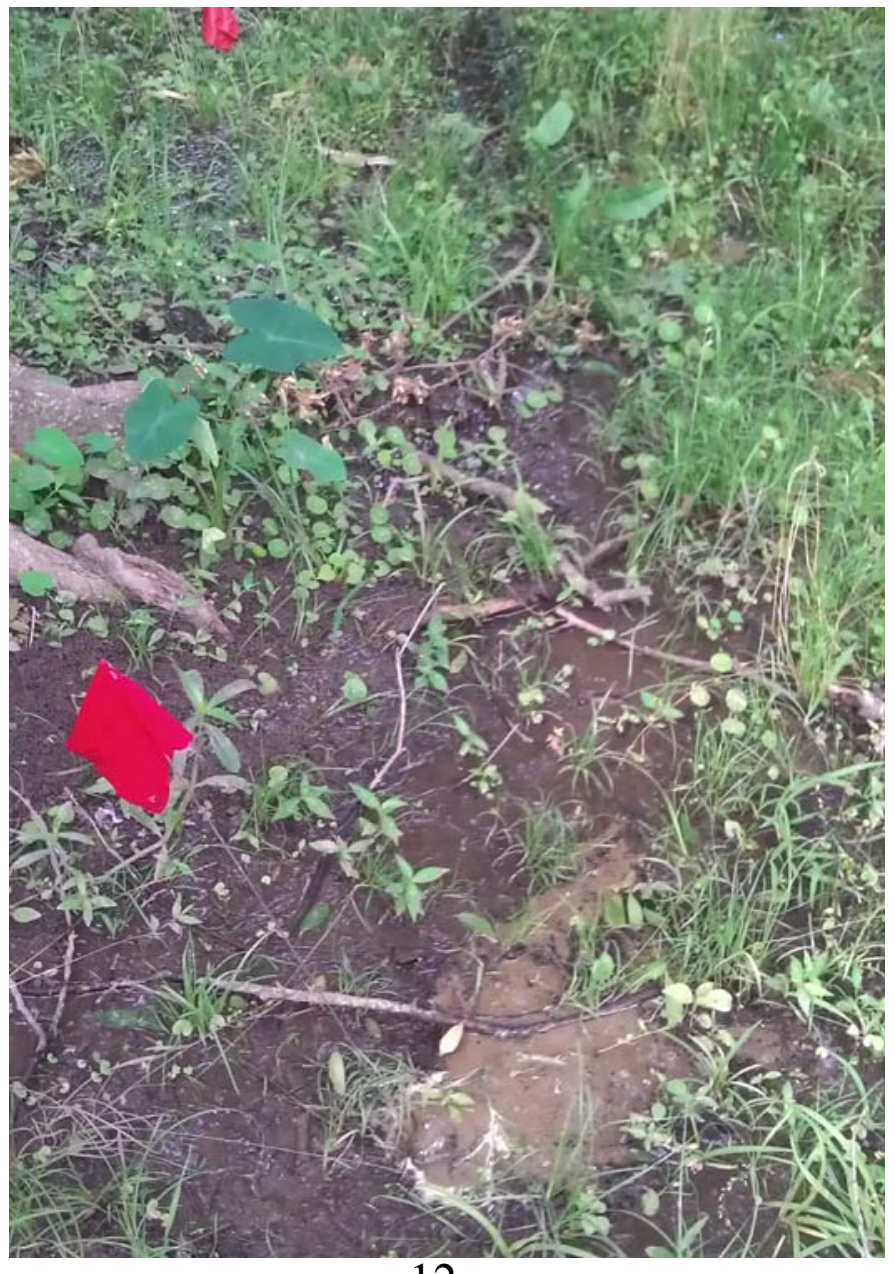




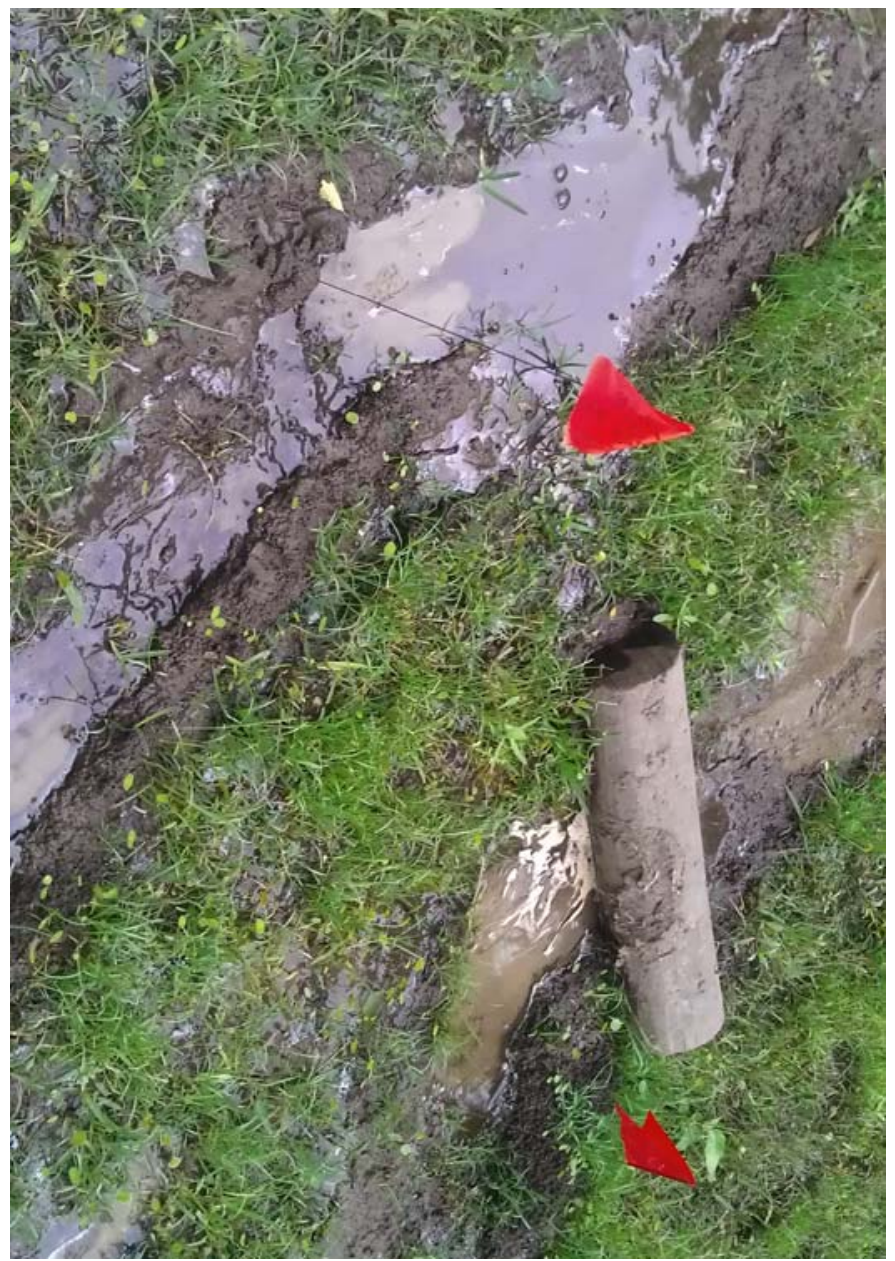

13

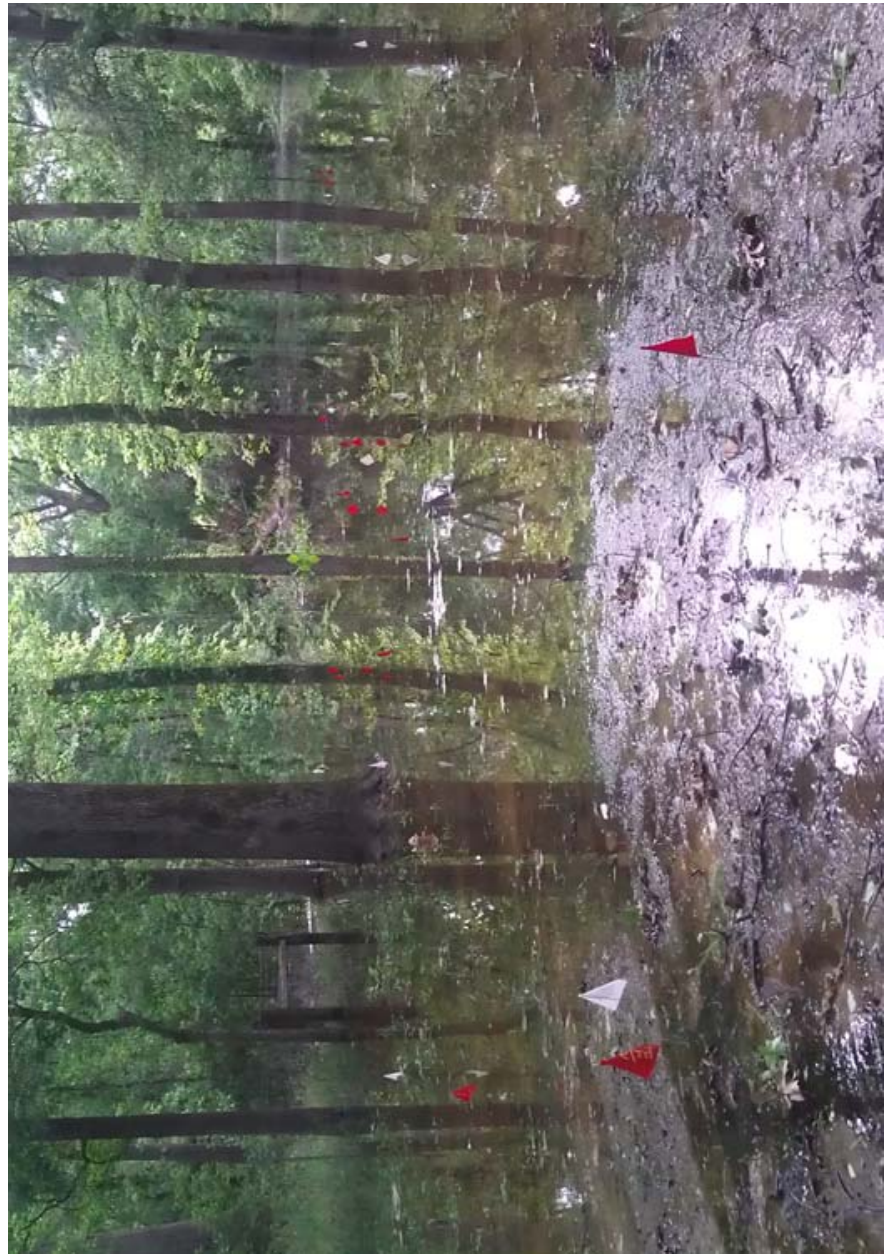




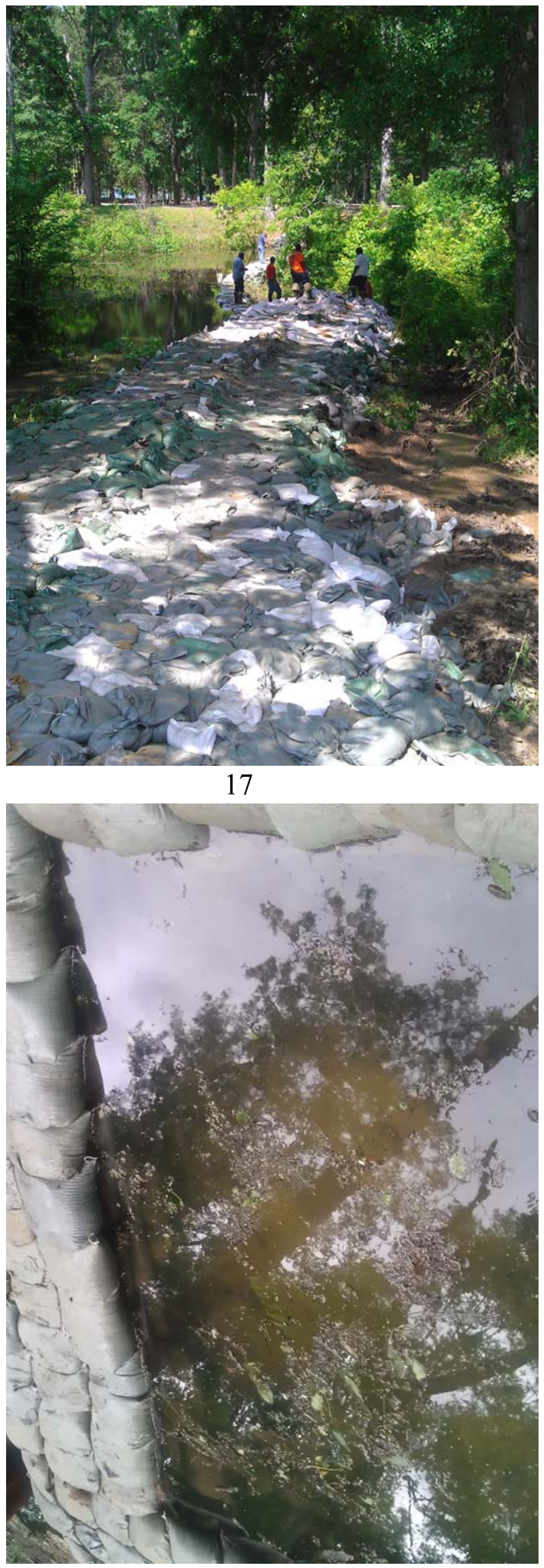

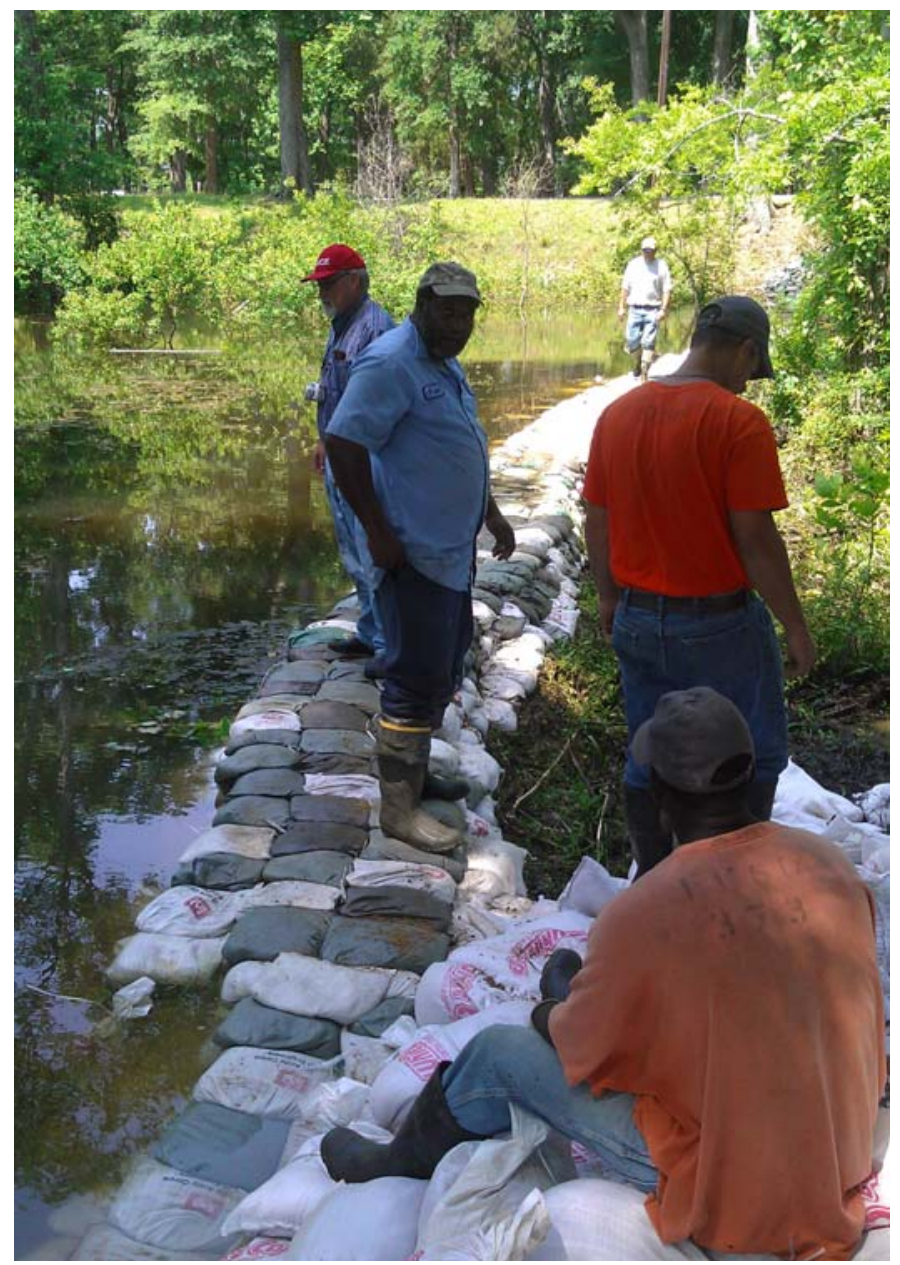

18

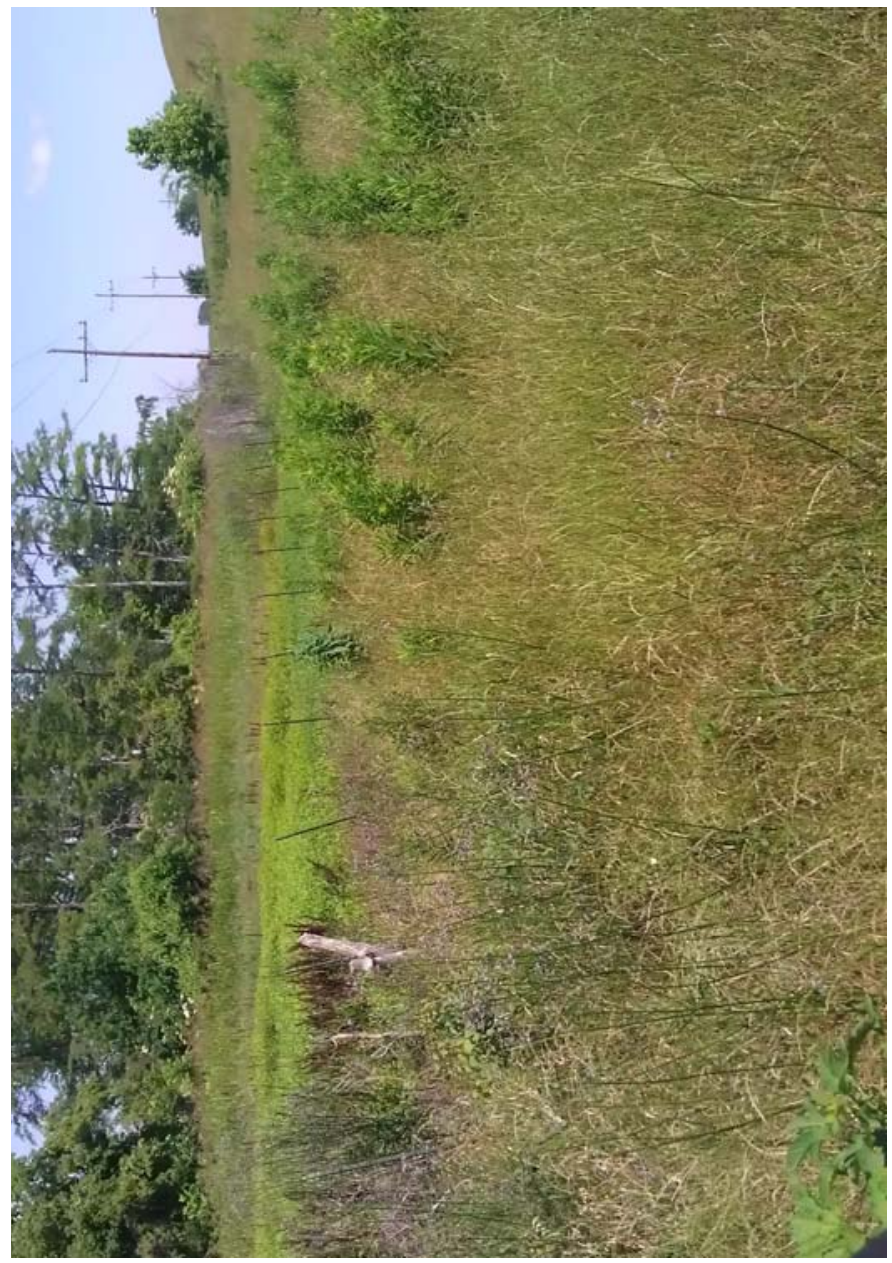




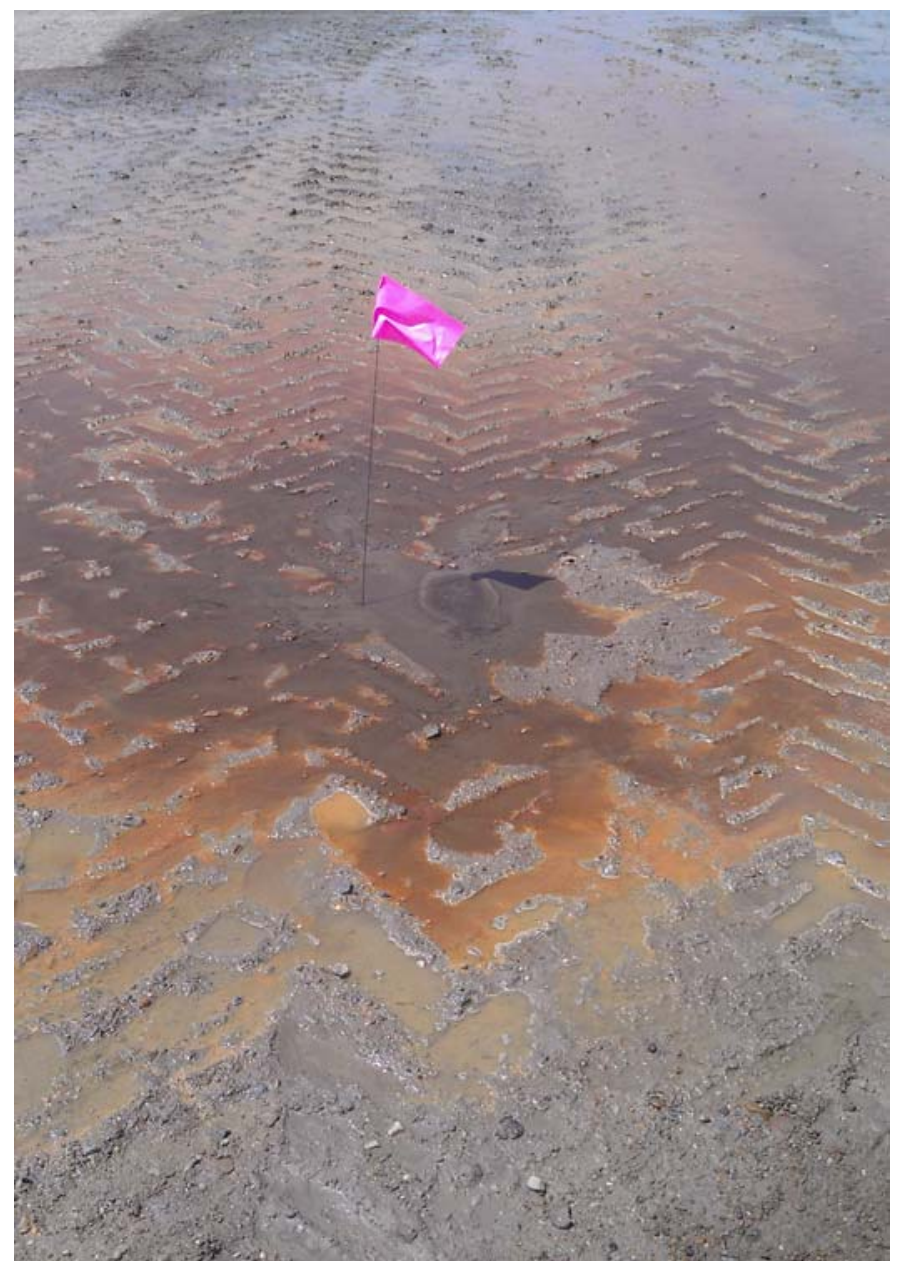

21

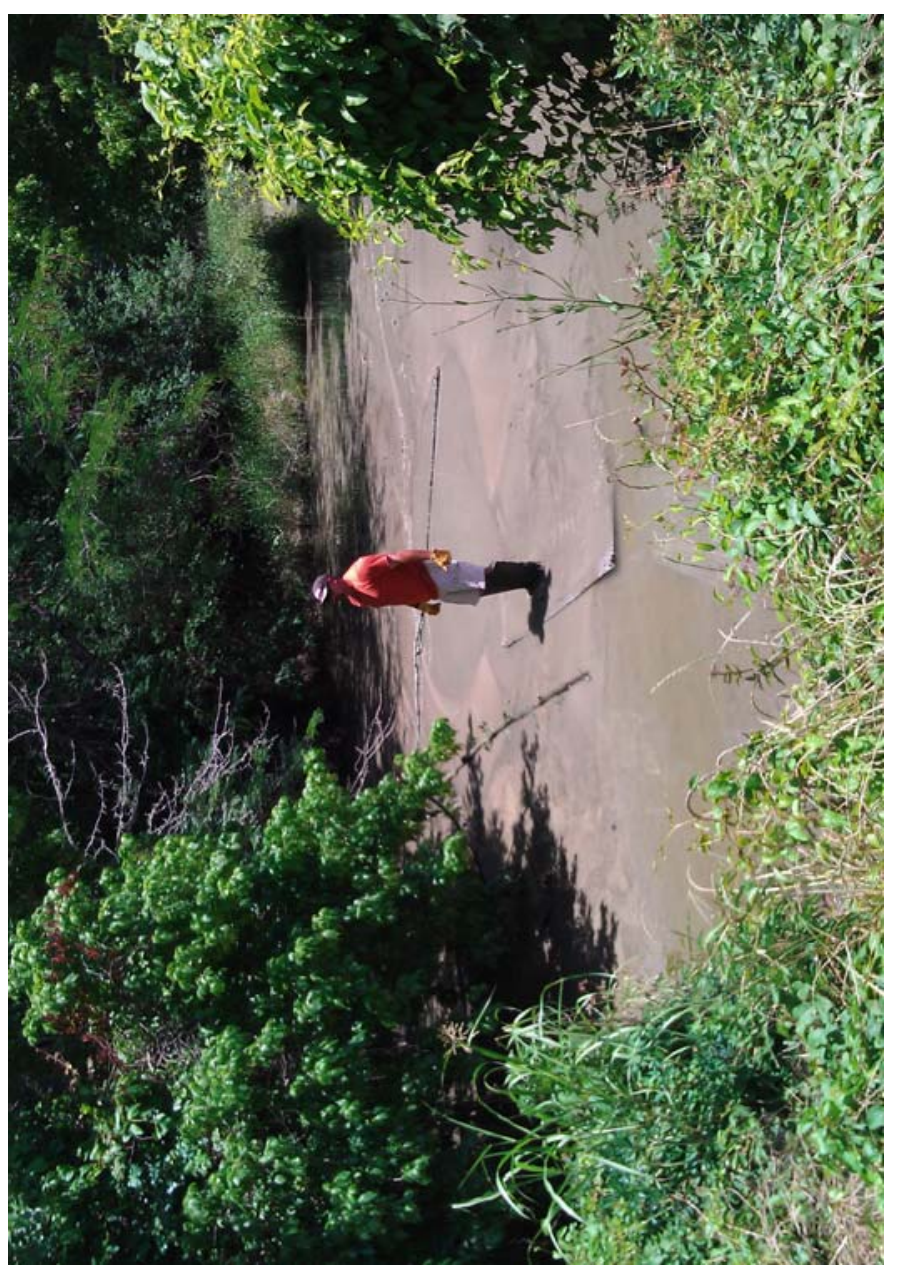

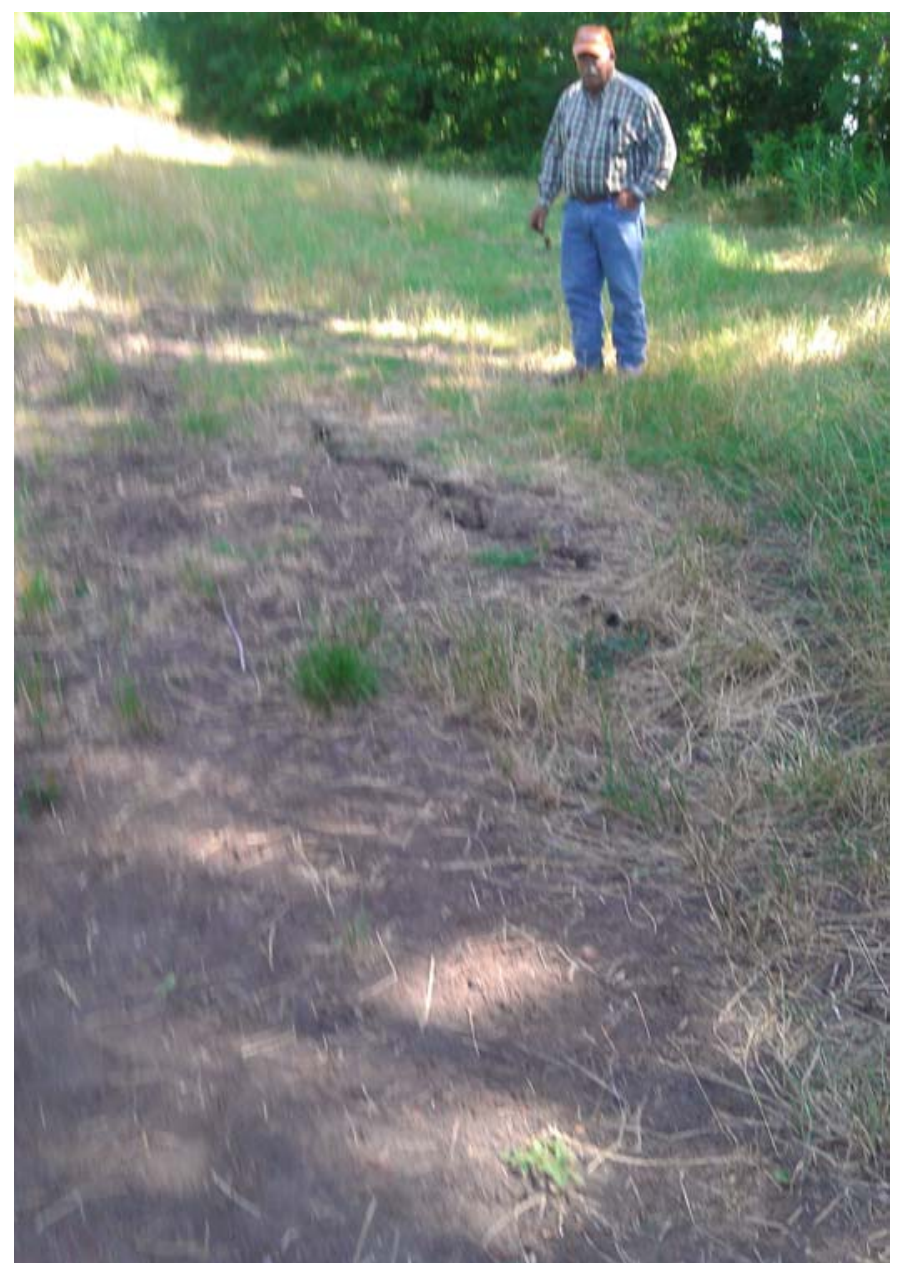

\section{2}
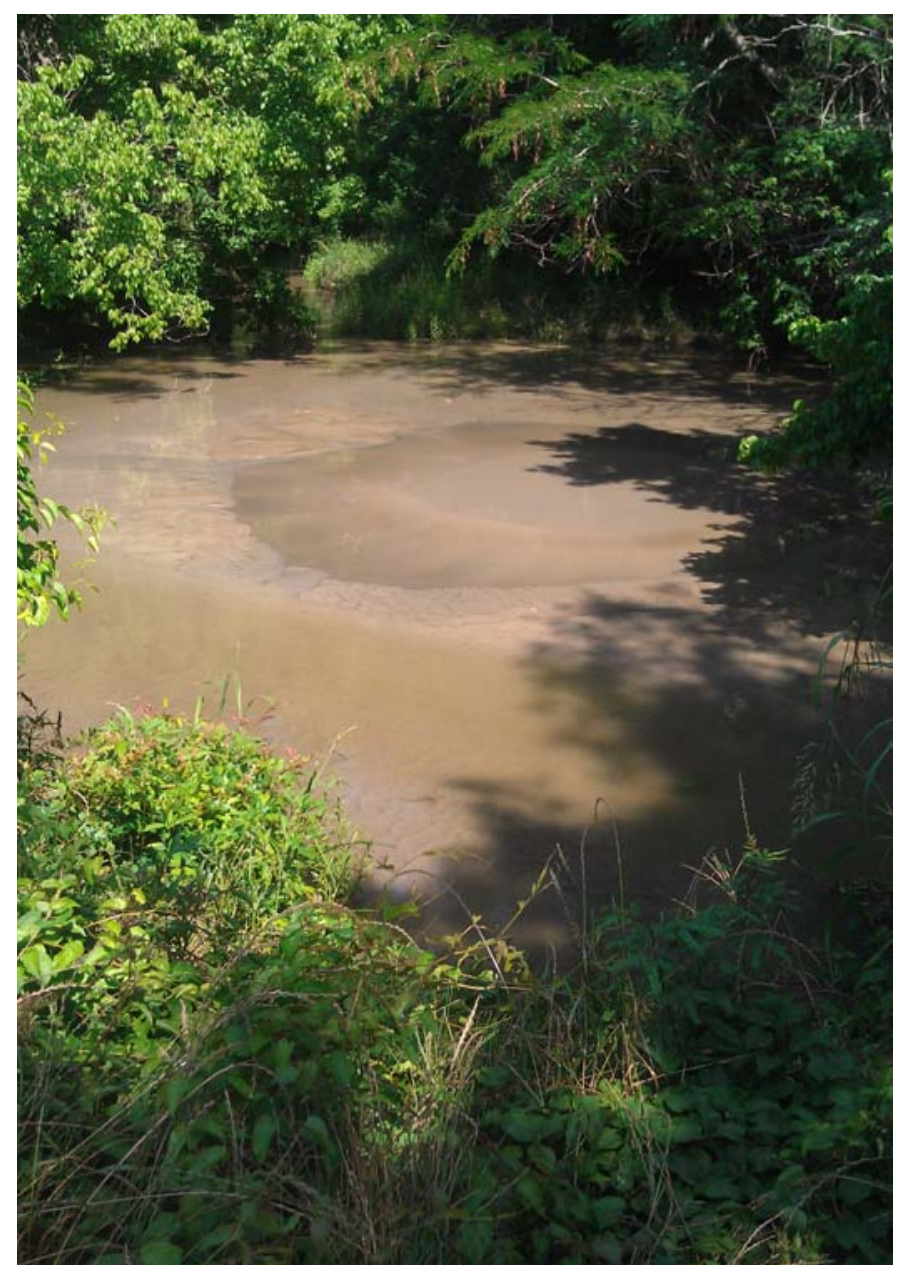


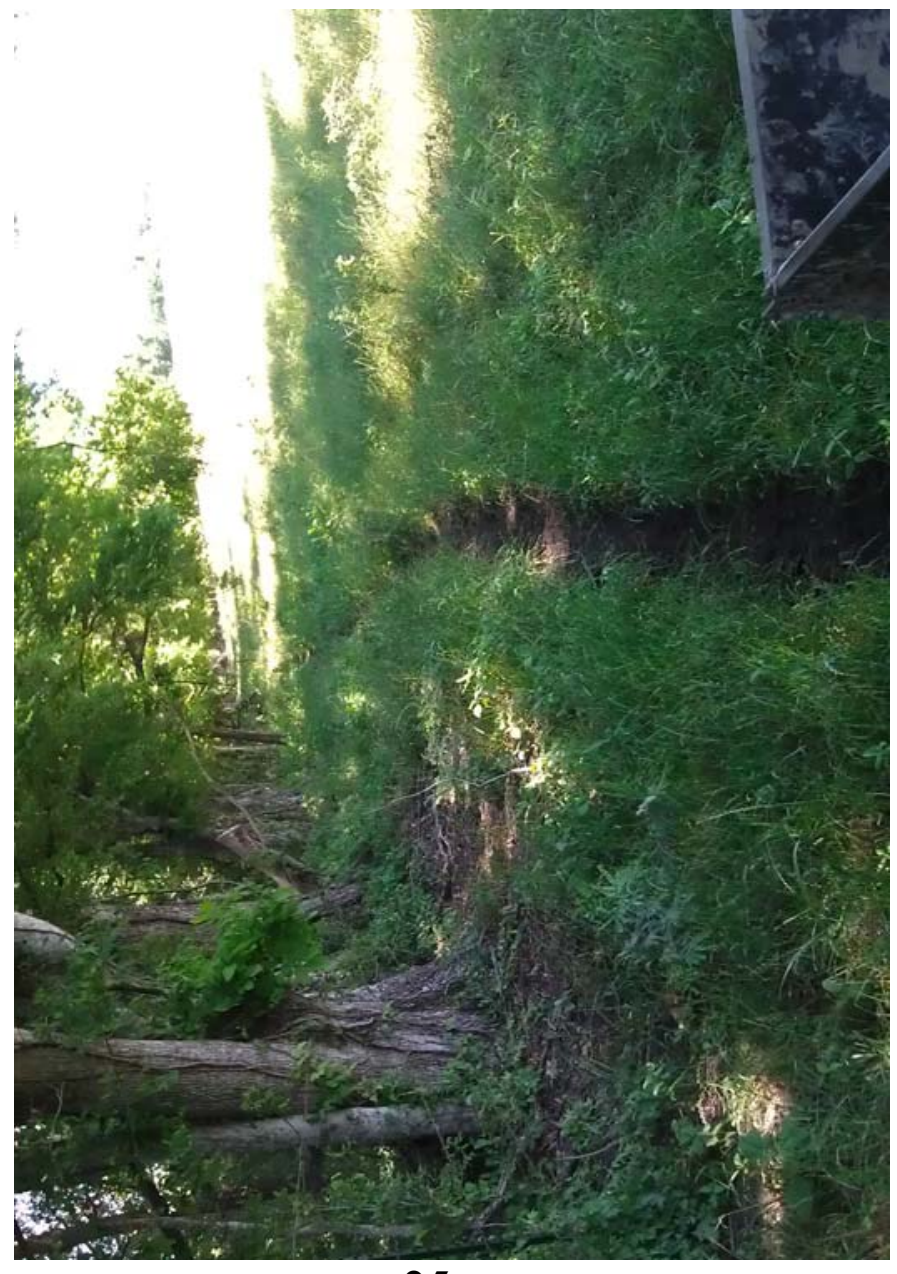

25

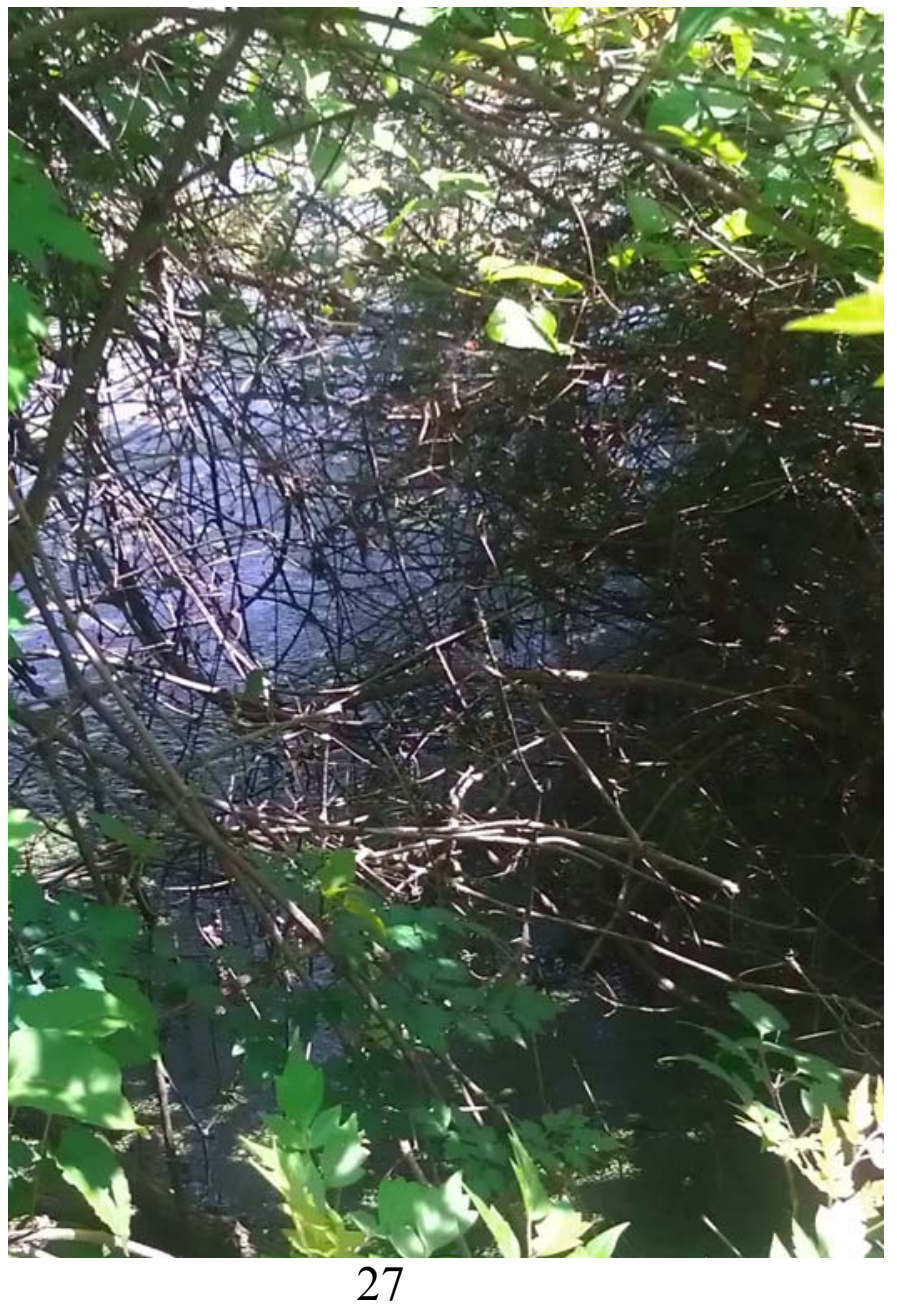

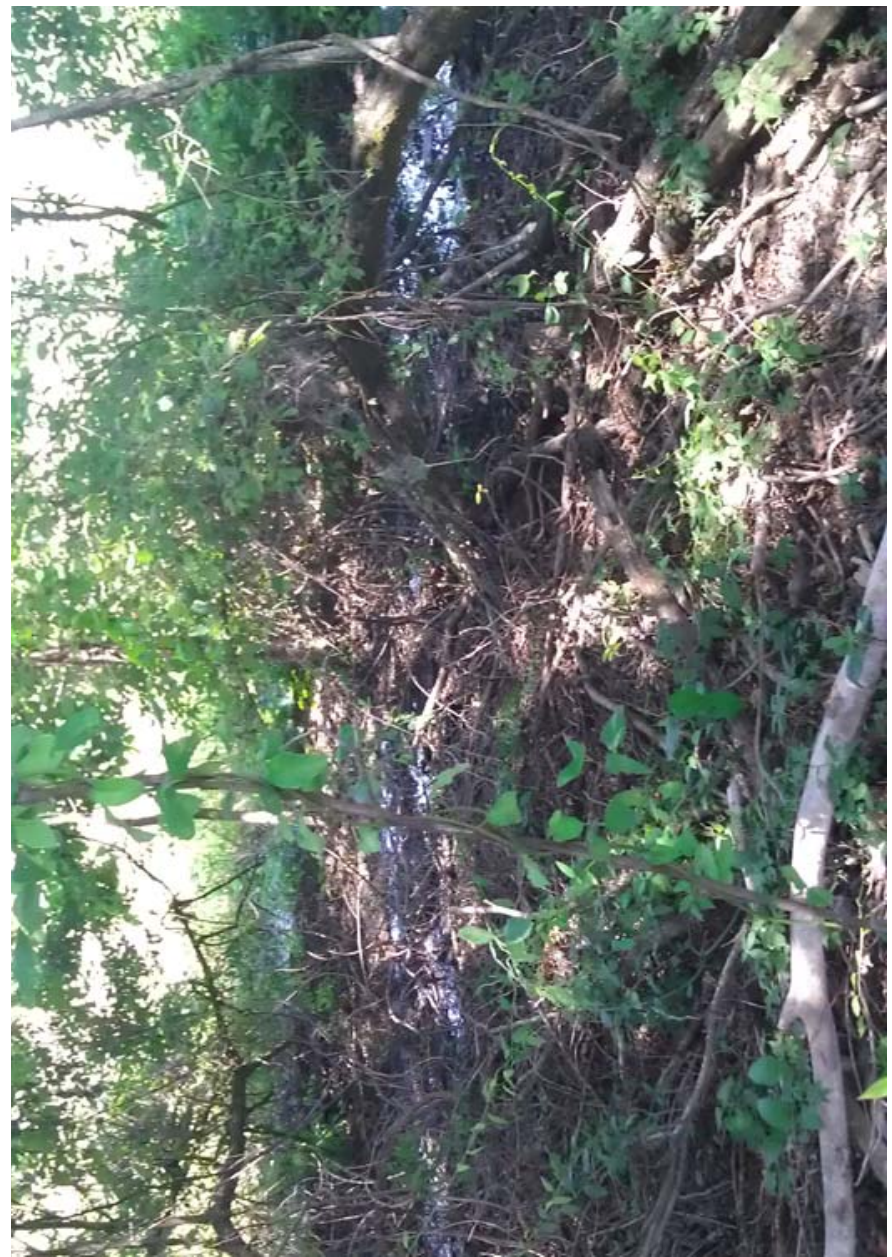

\section{6}

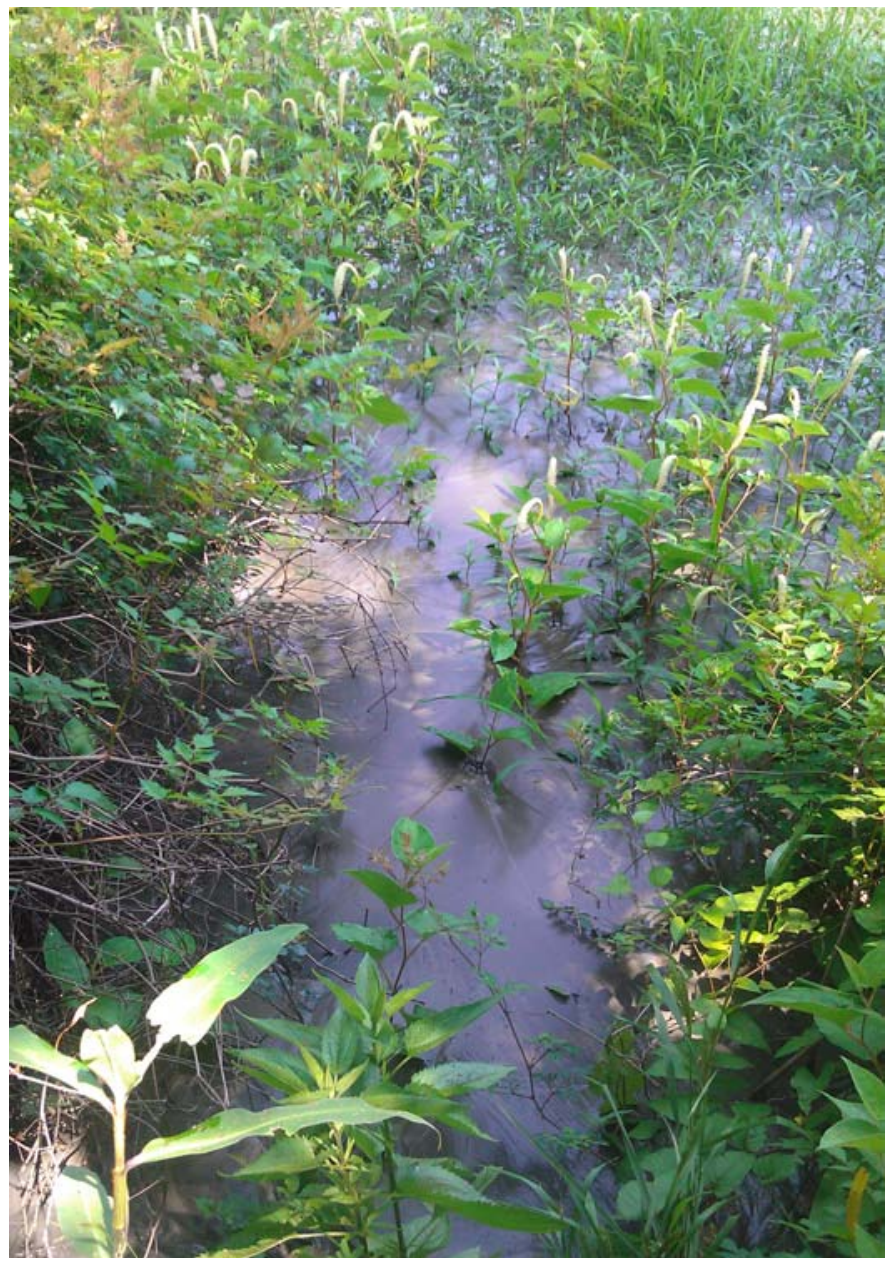




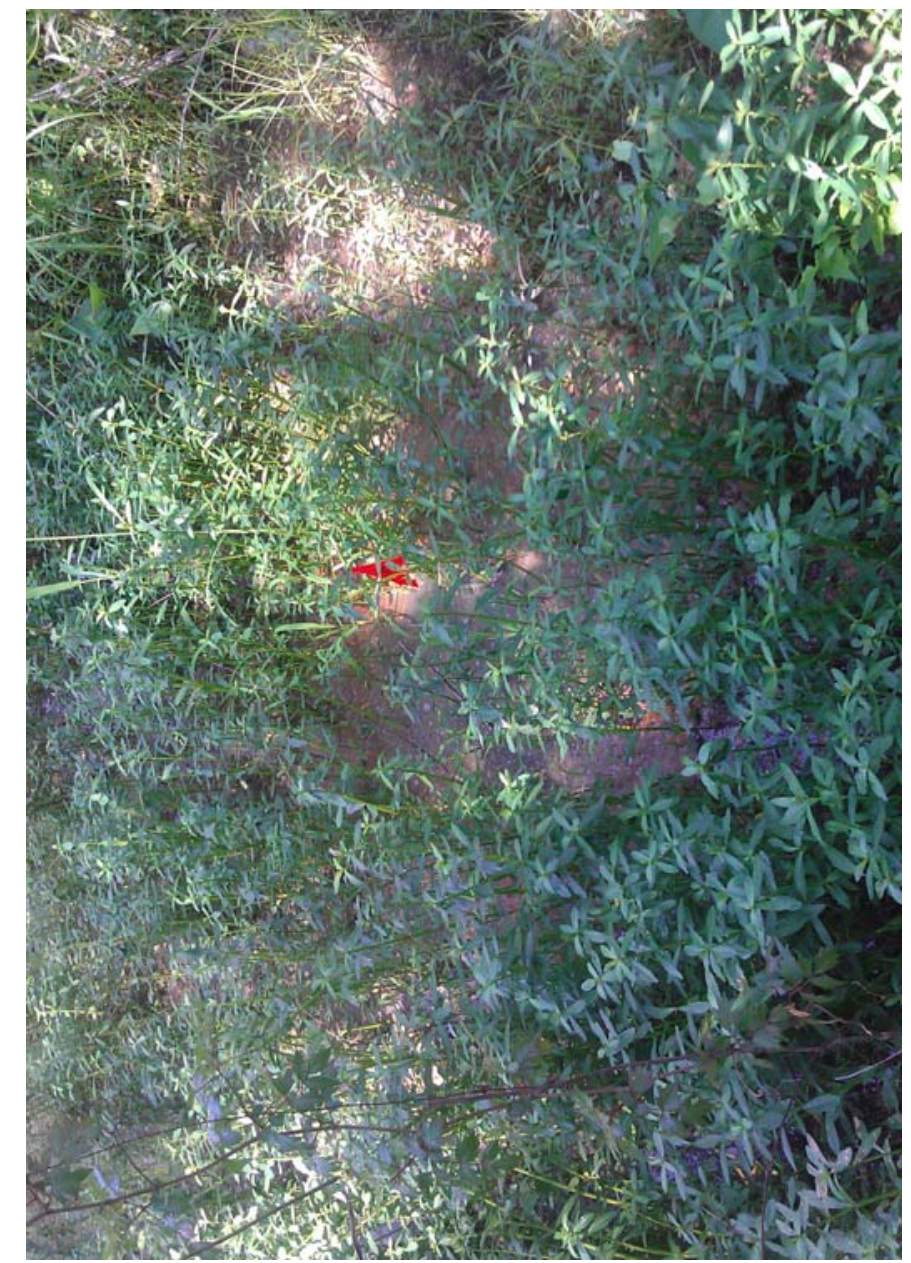

29

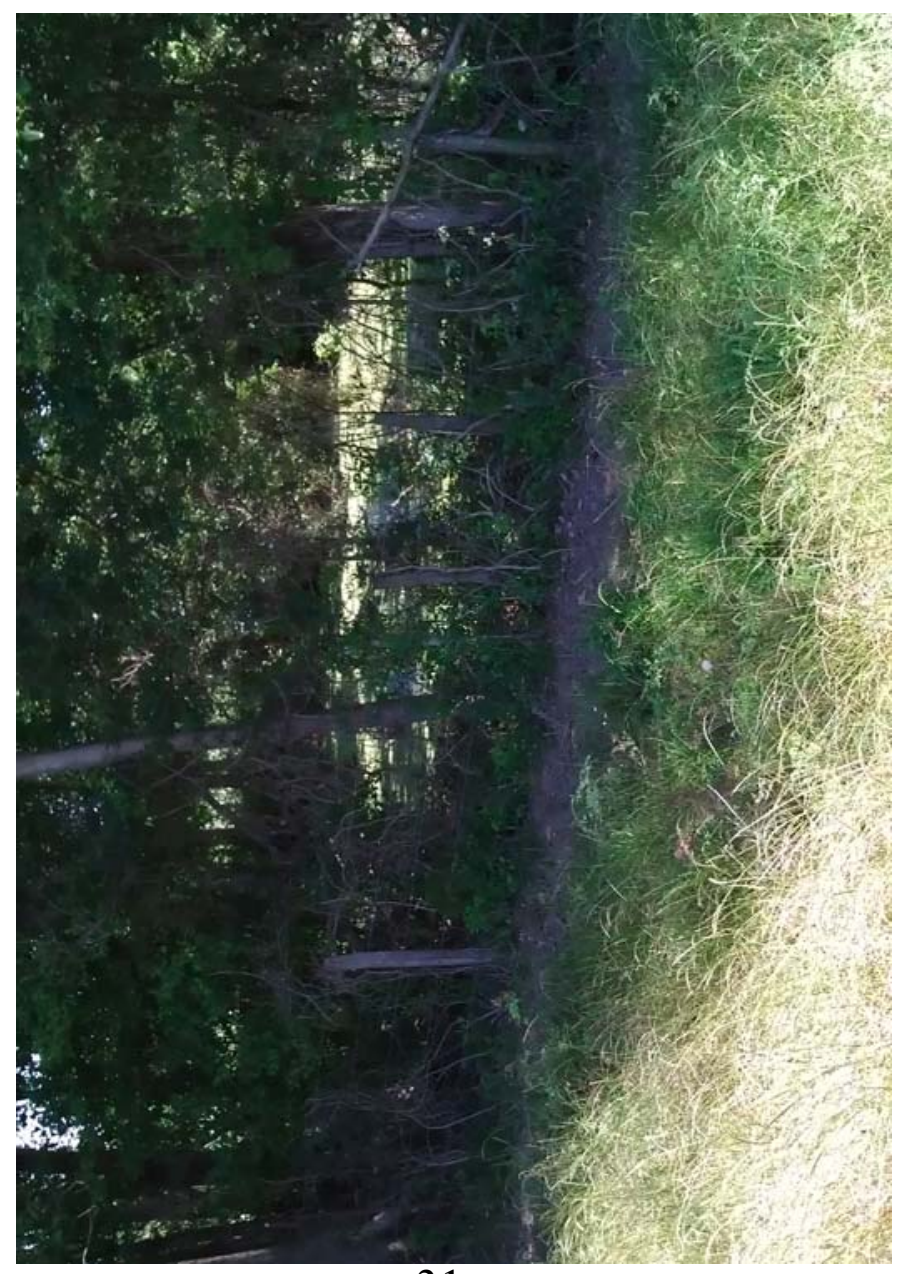

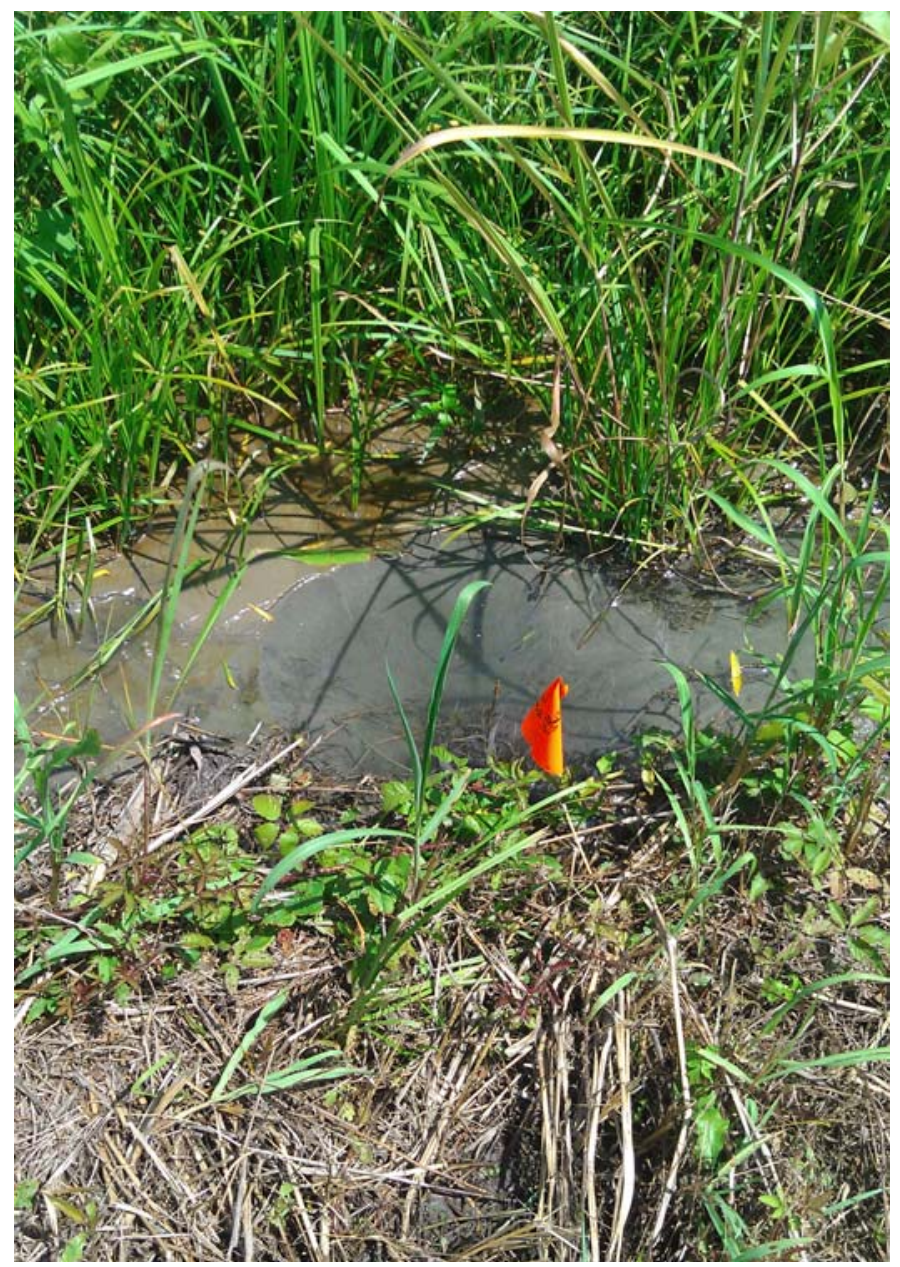

\section{0}

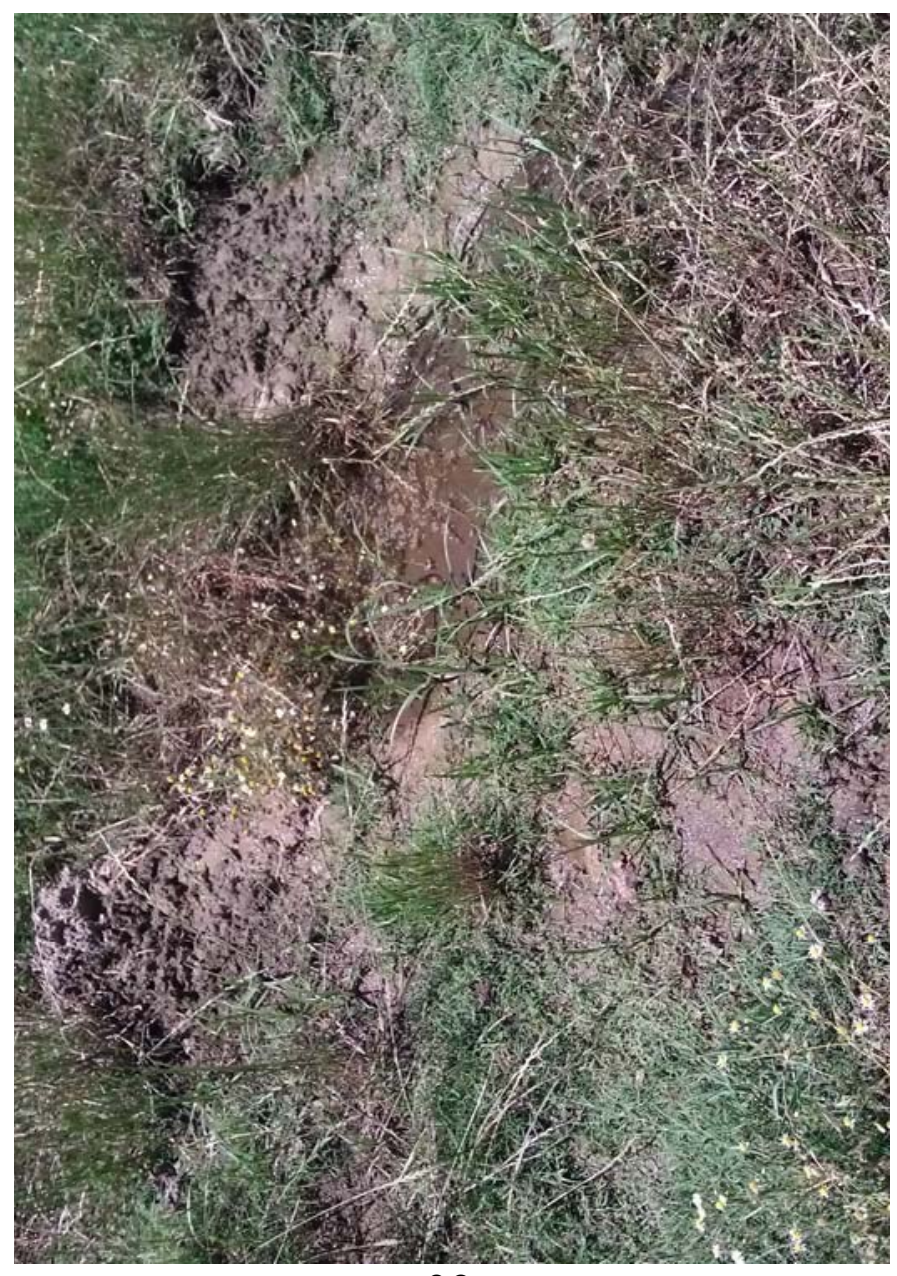




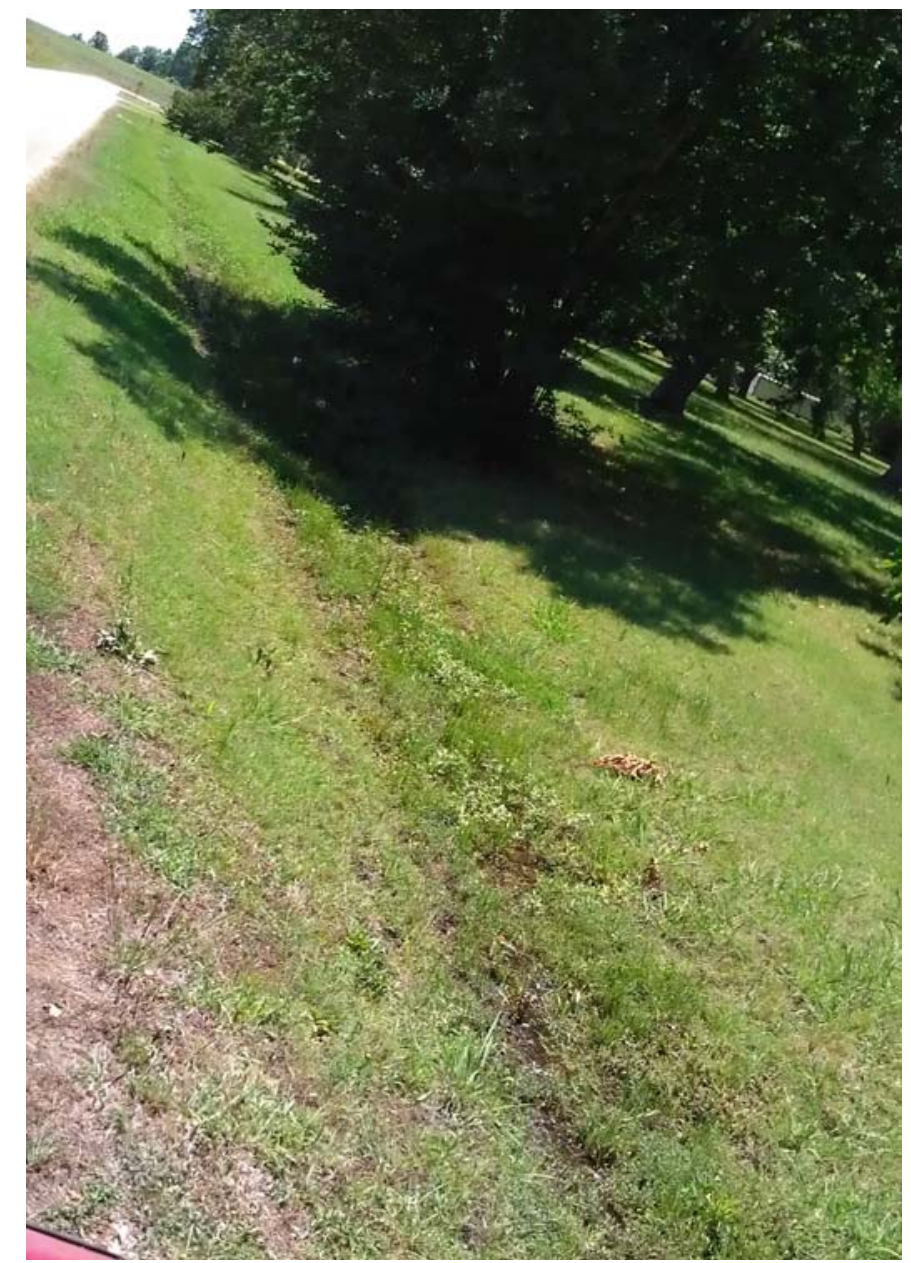

33

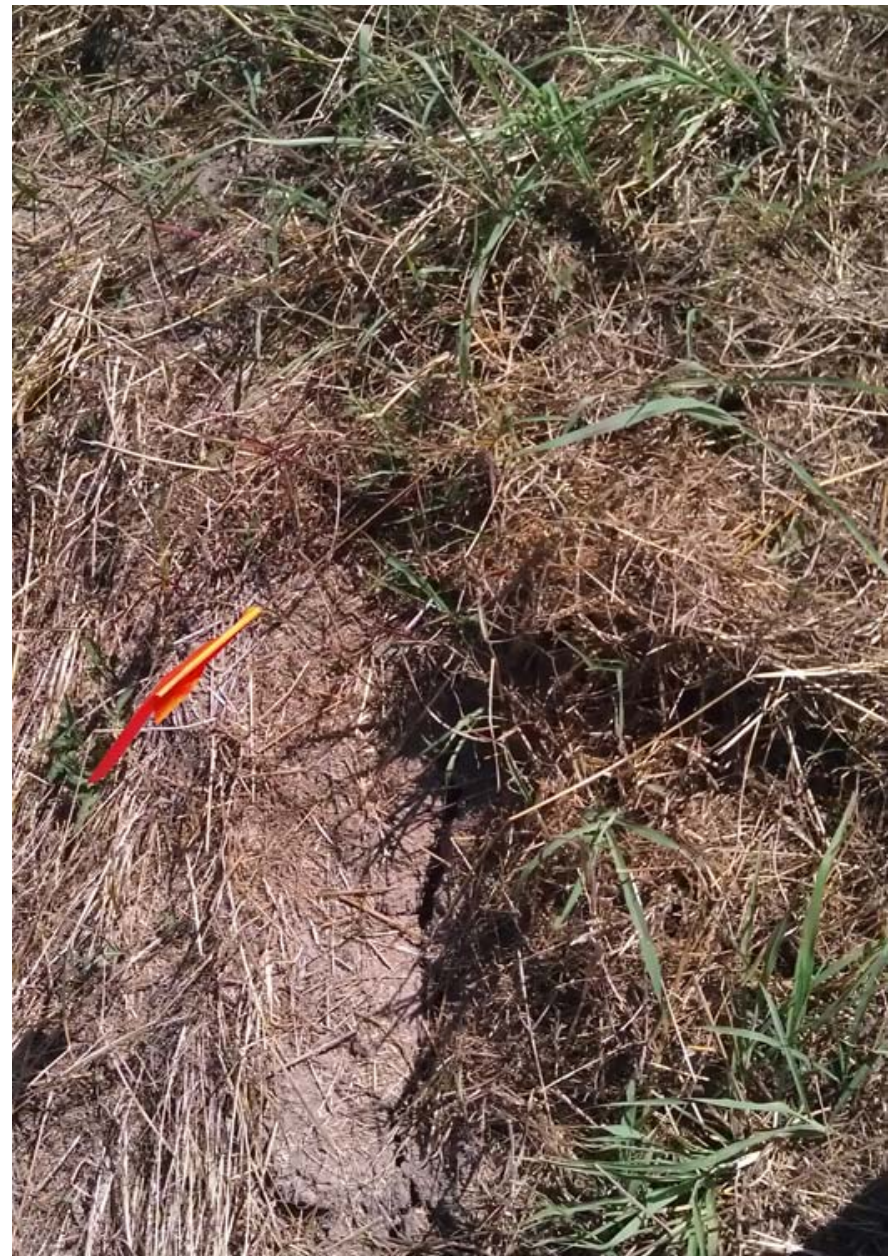

19x

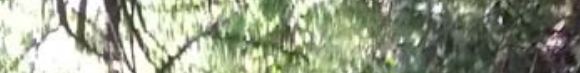

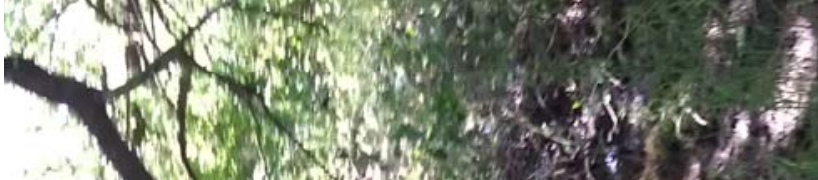

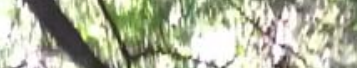

ant-3 Mhen (nit) $40=$

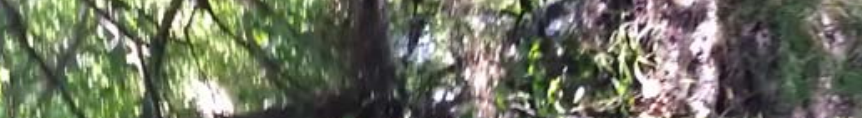

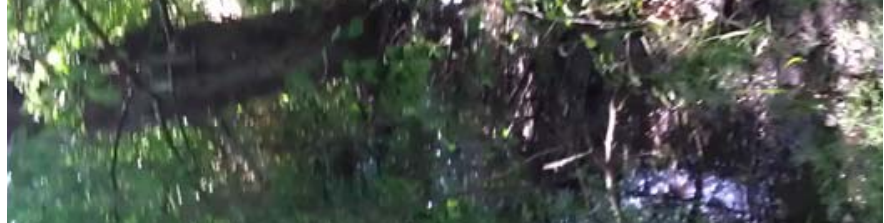

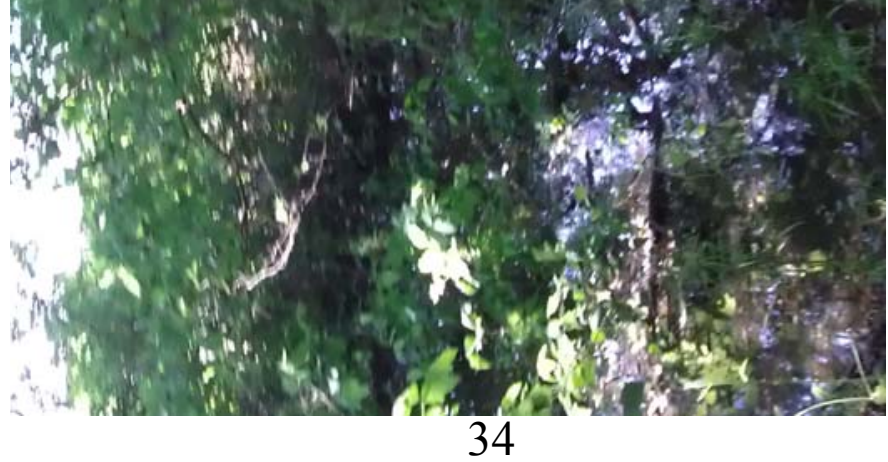

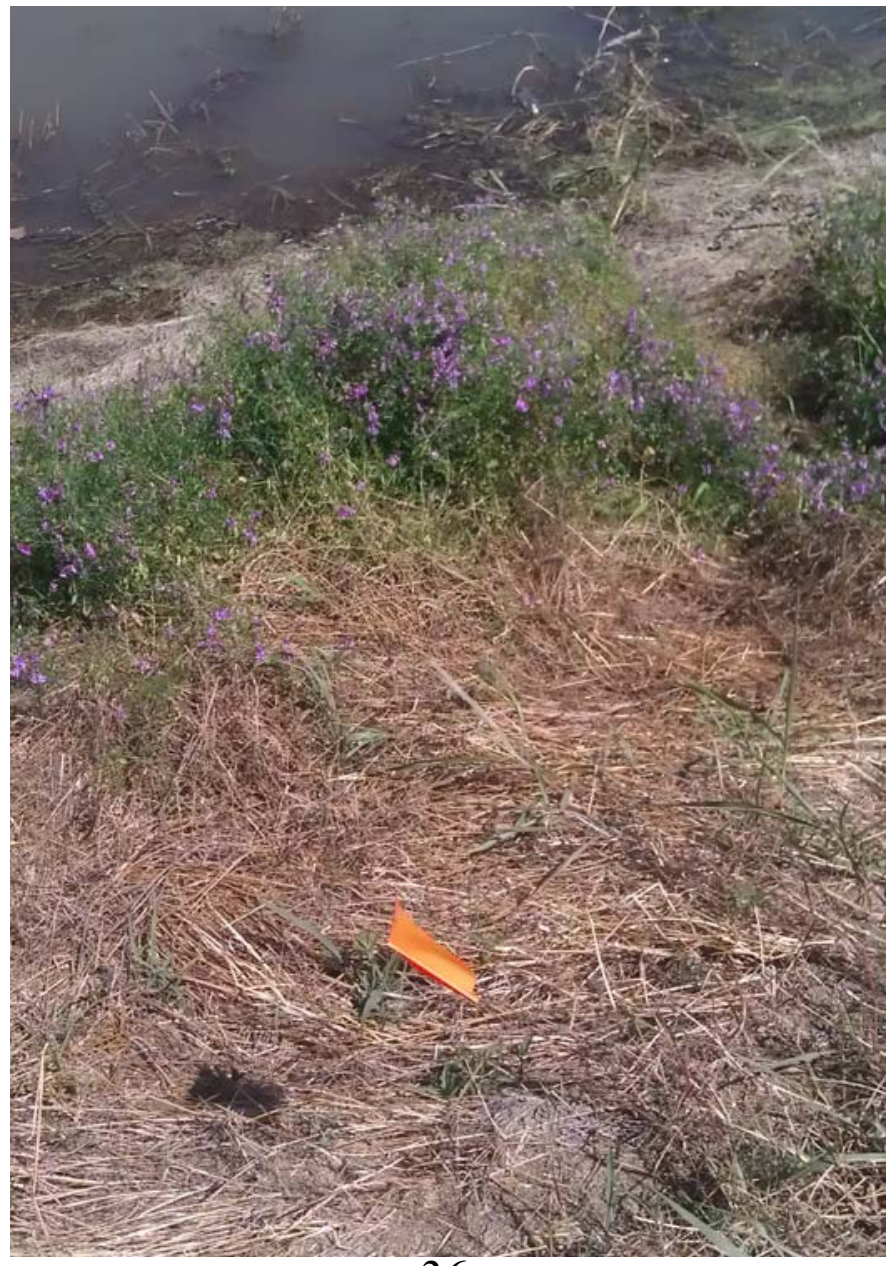




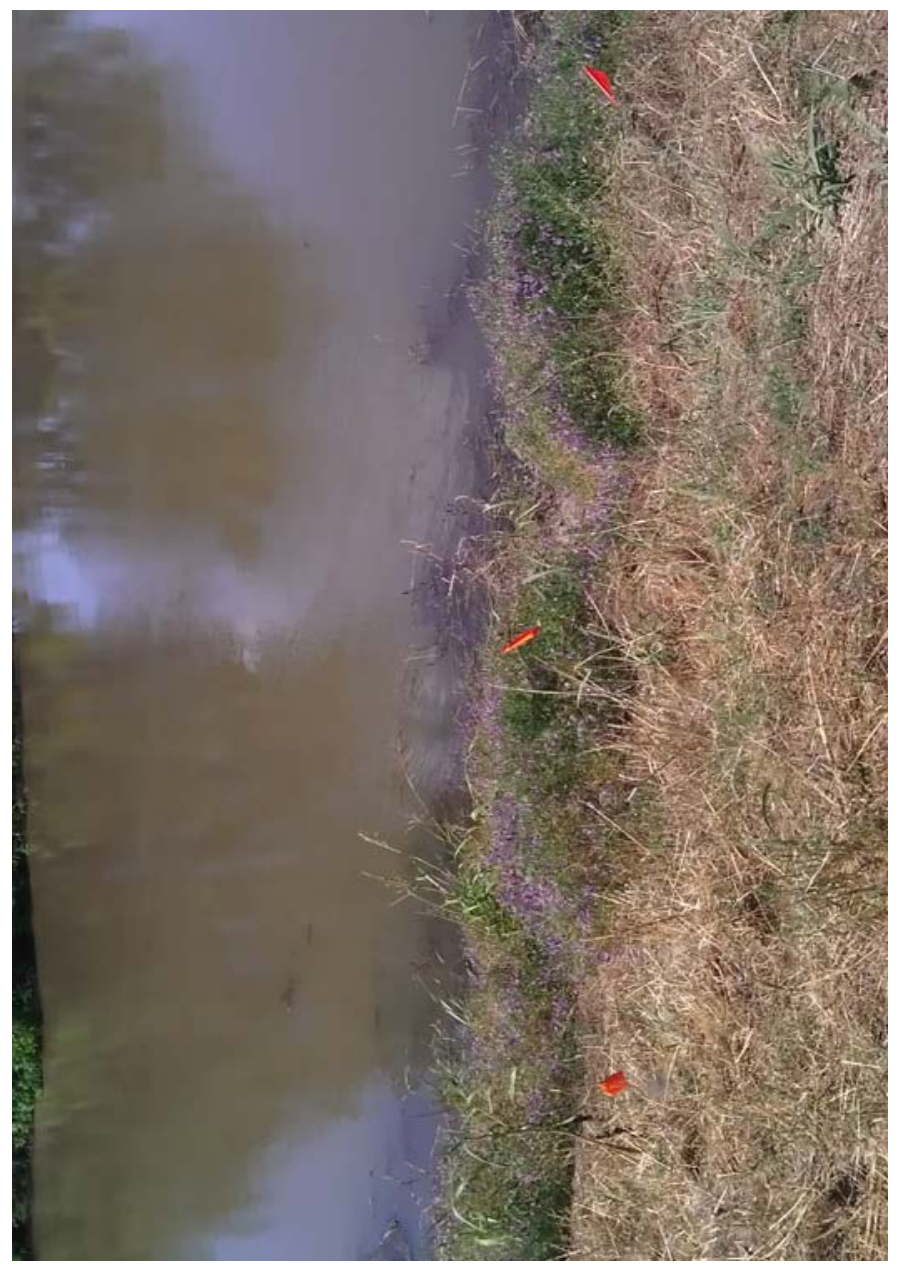

37

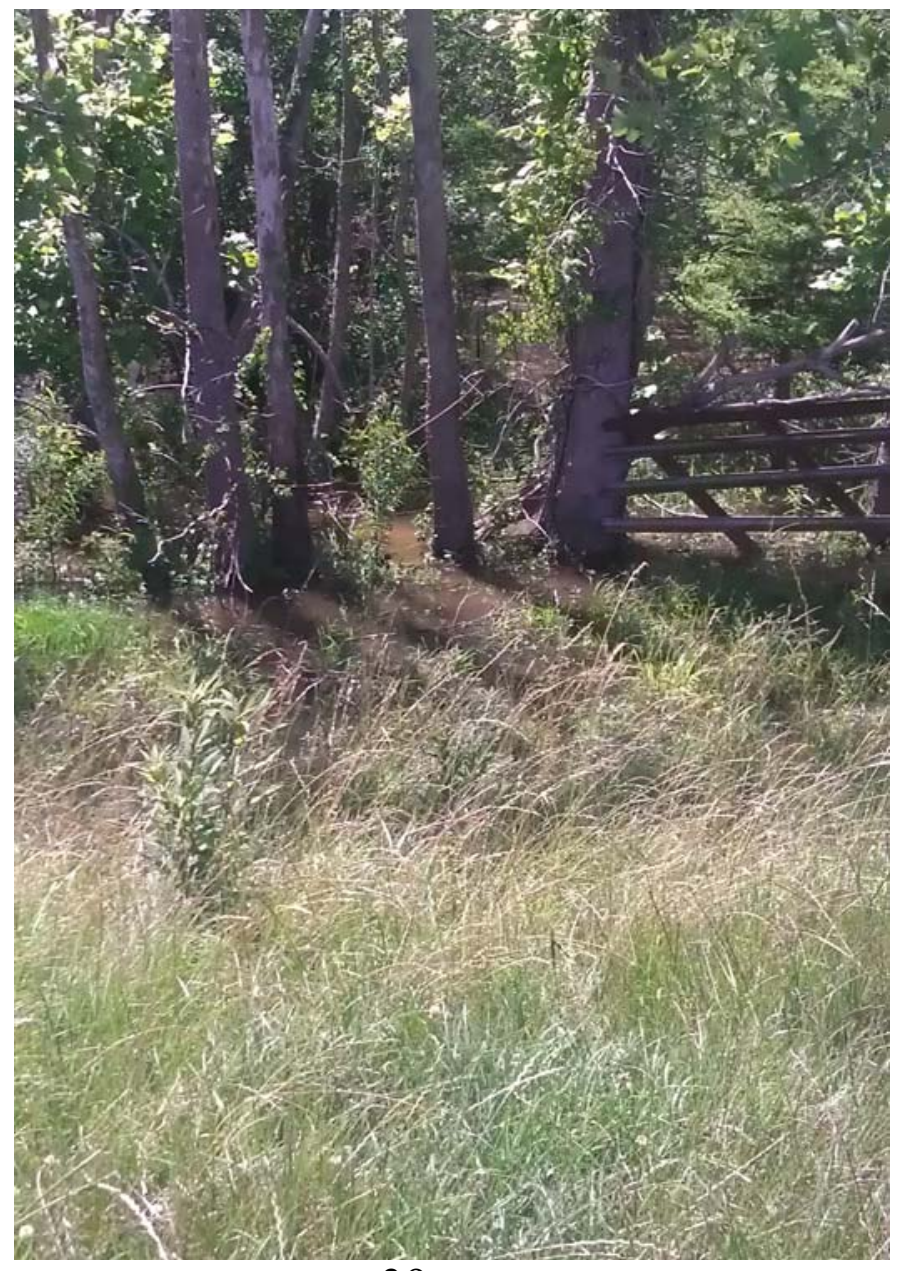

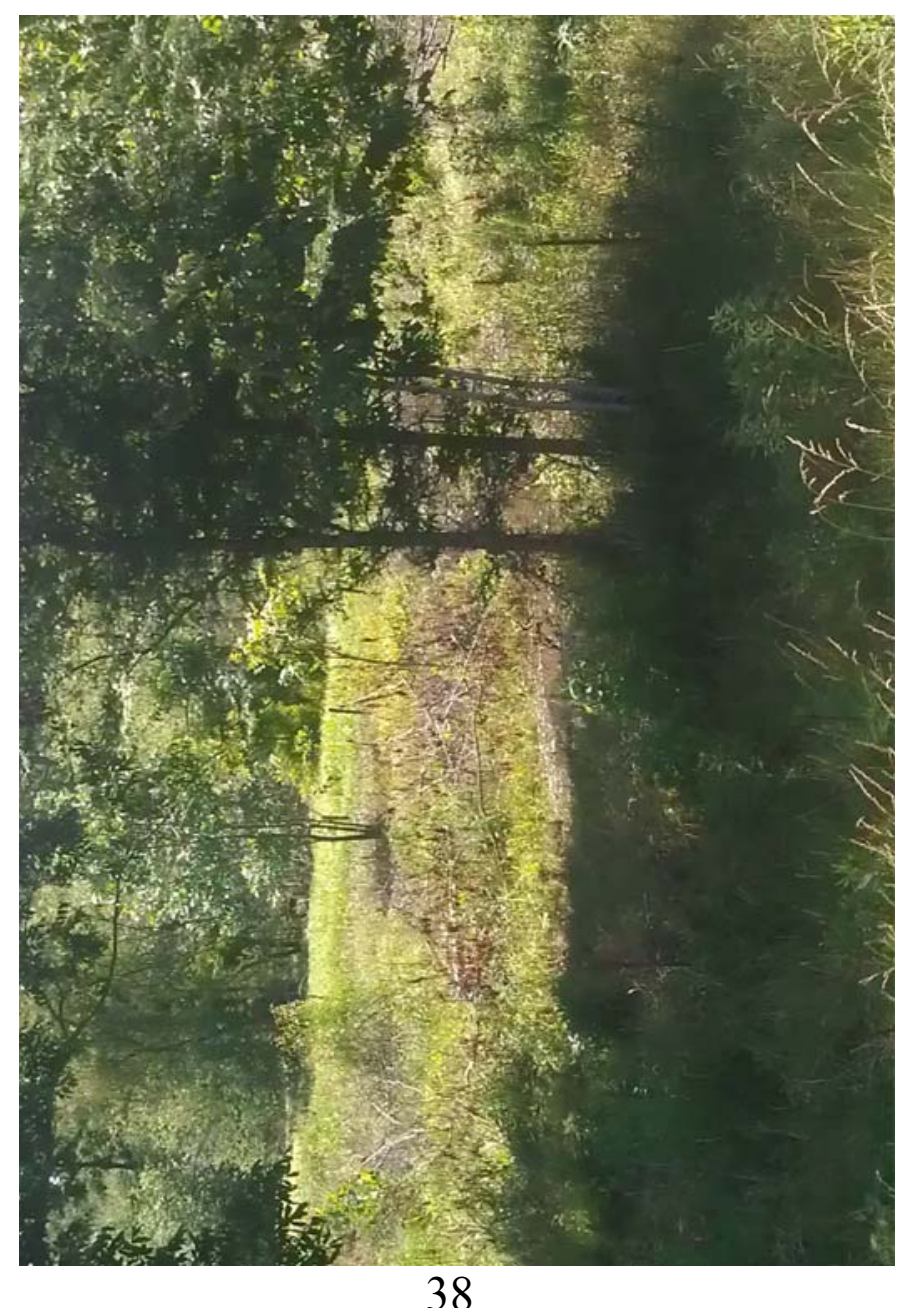

38

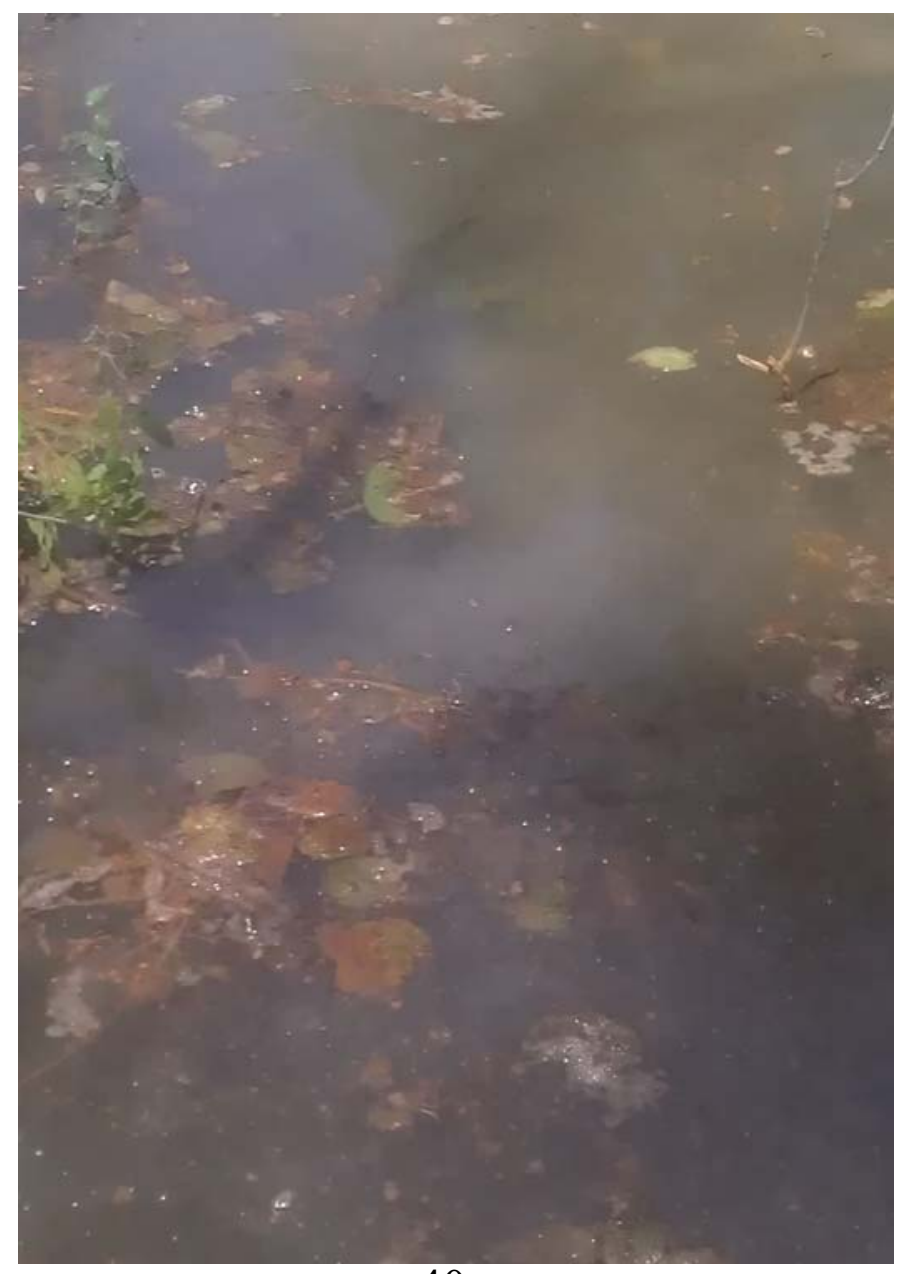




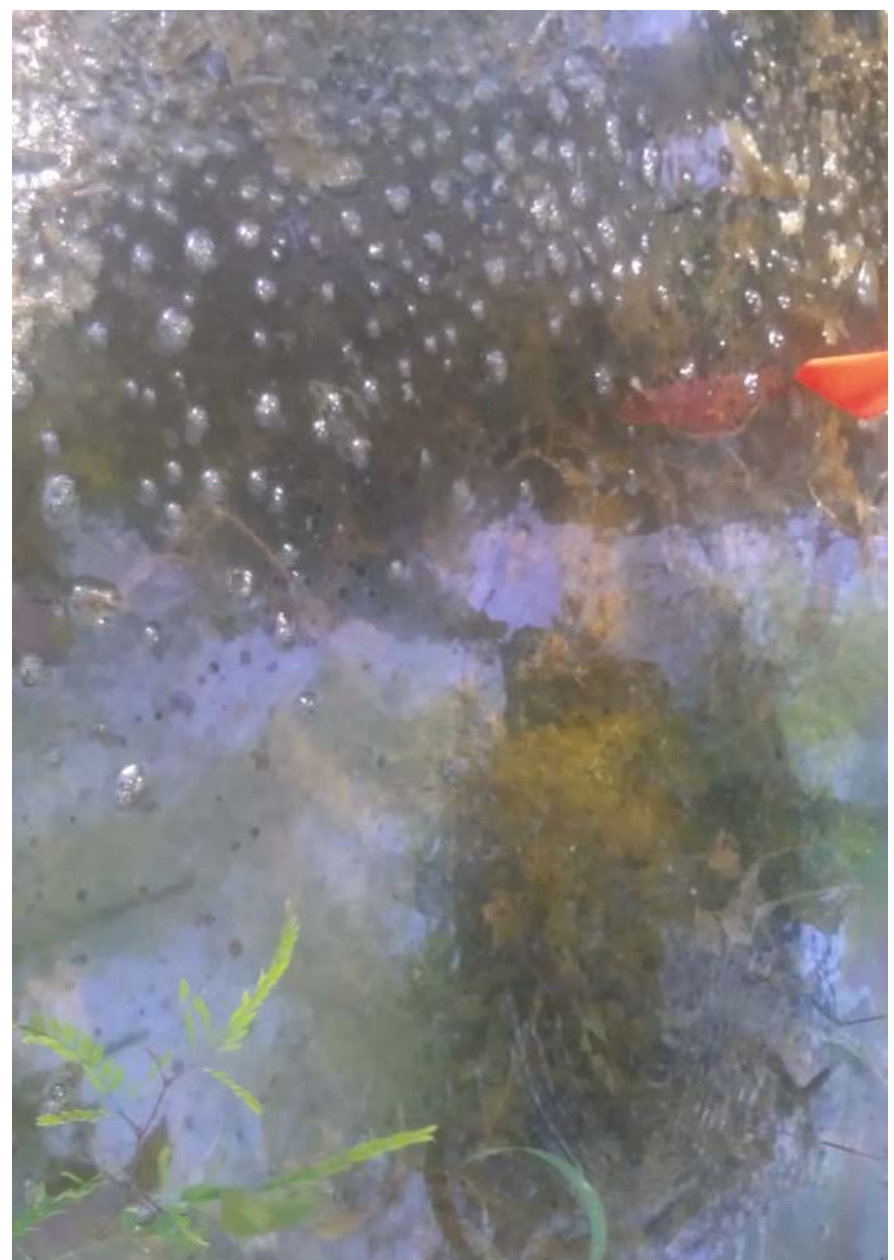

41

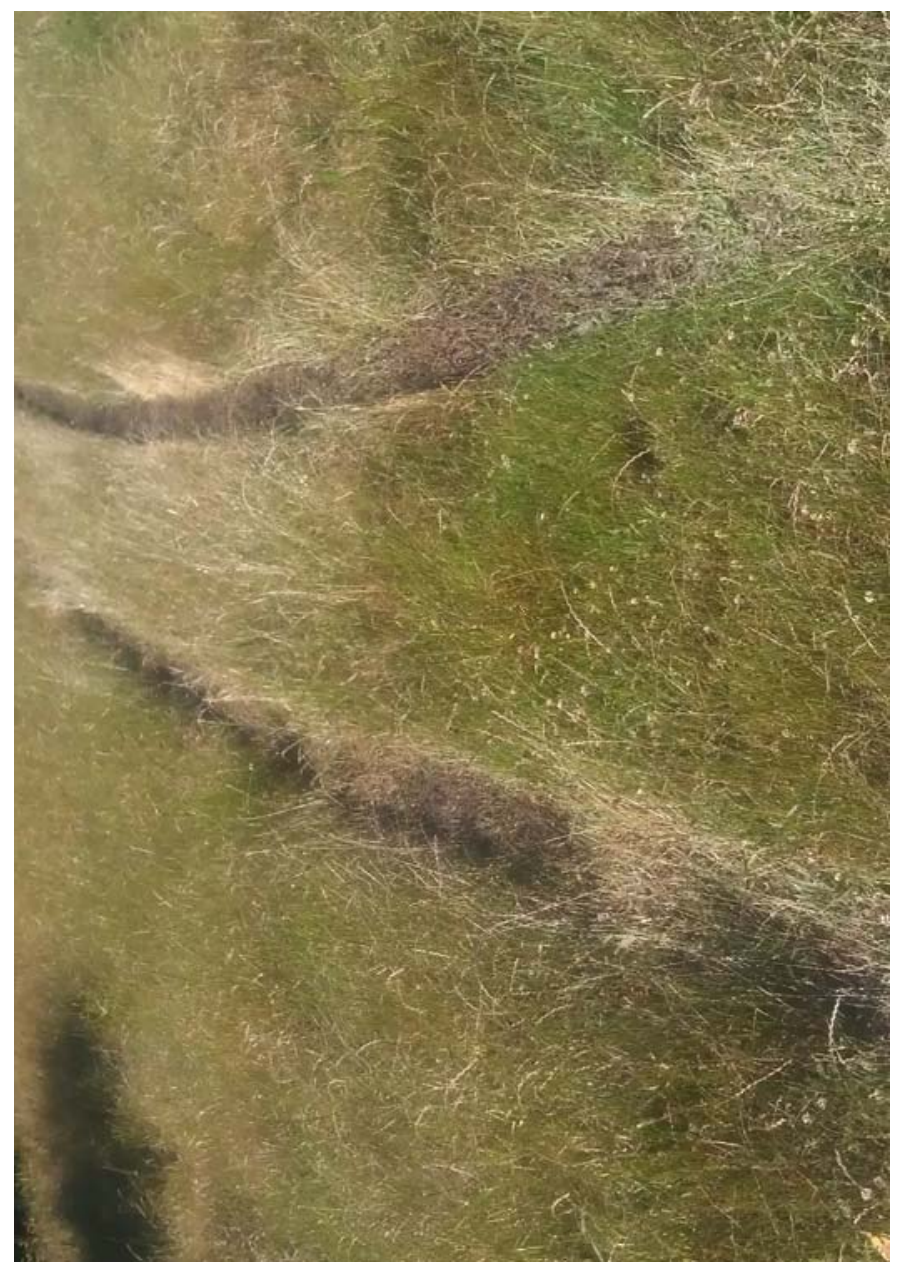

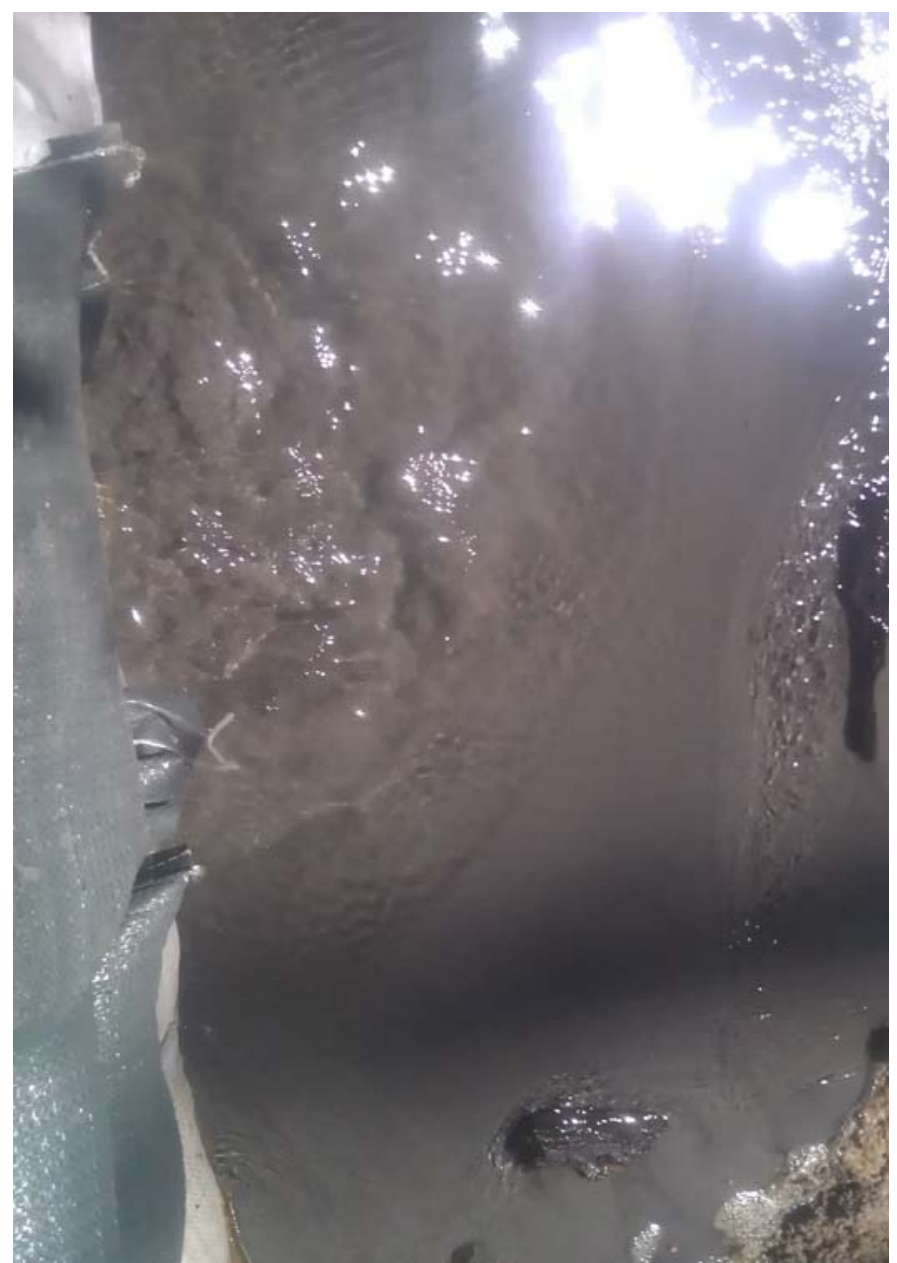

42

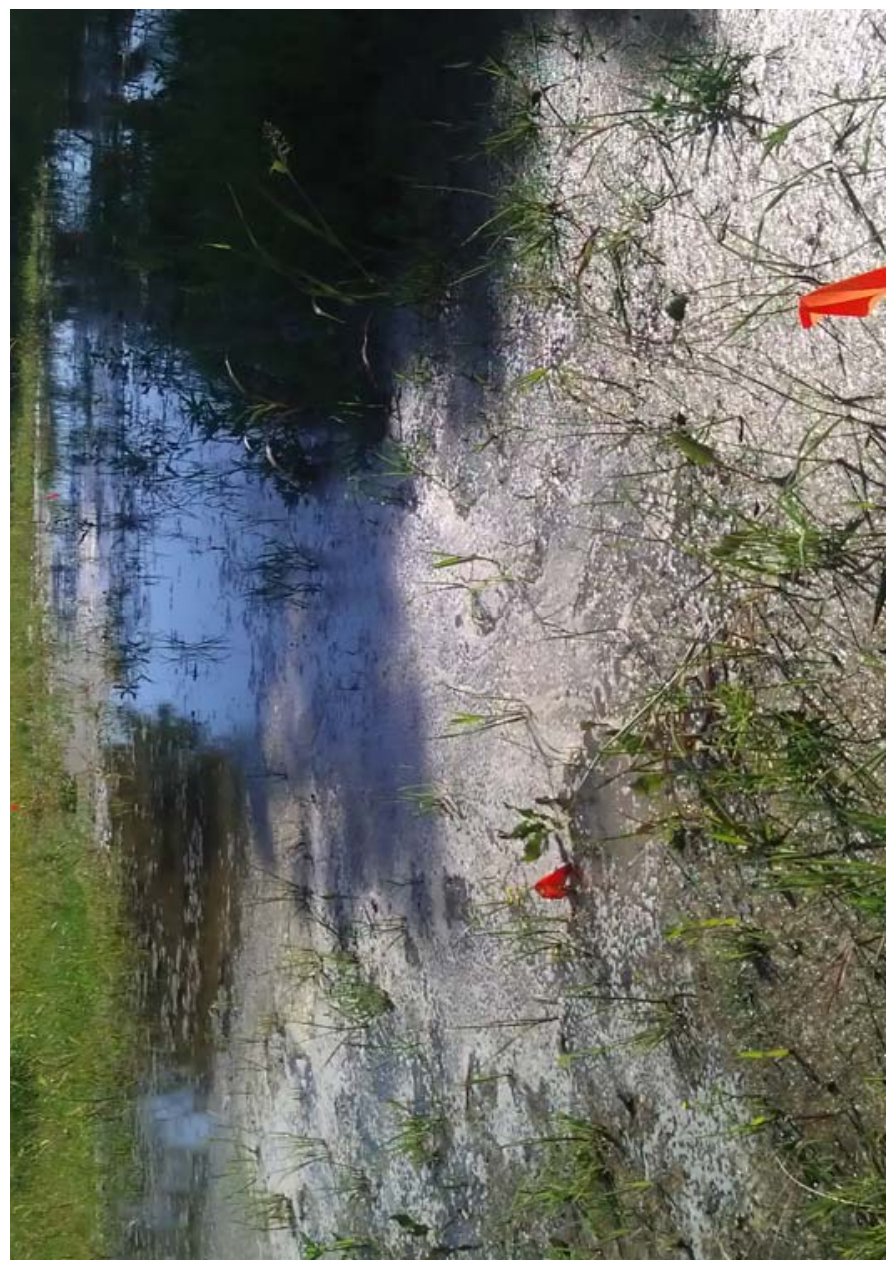




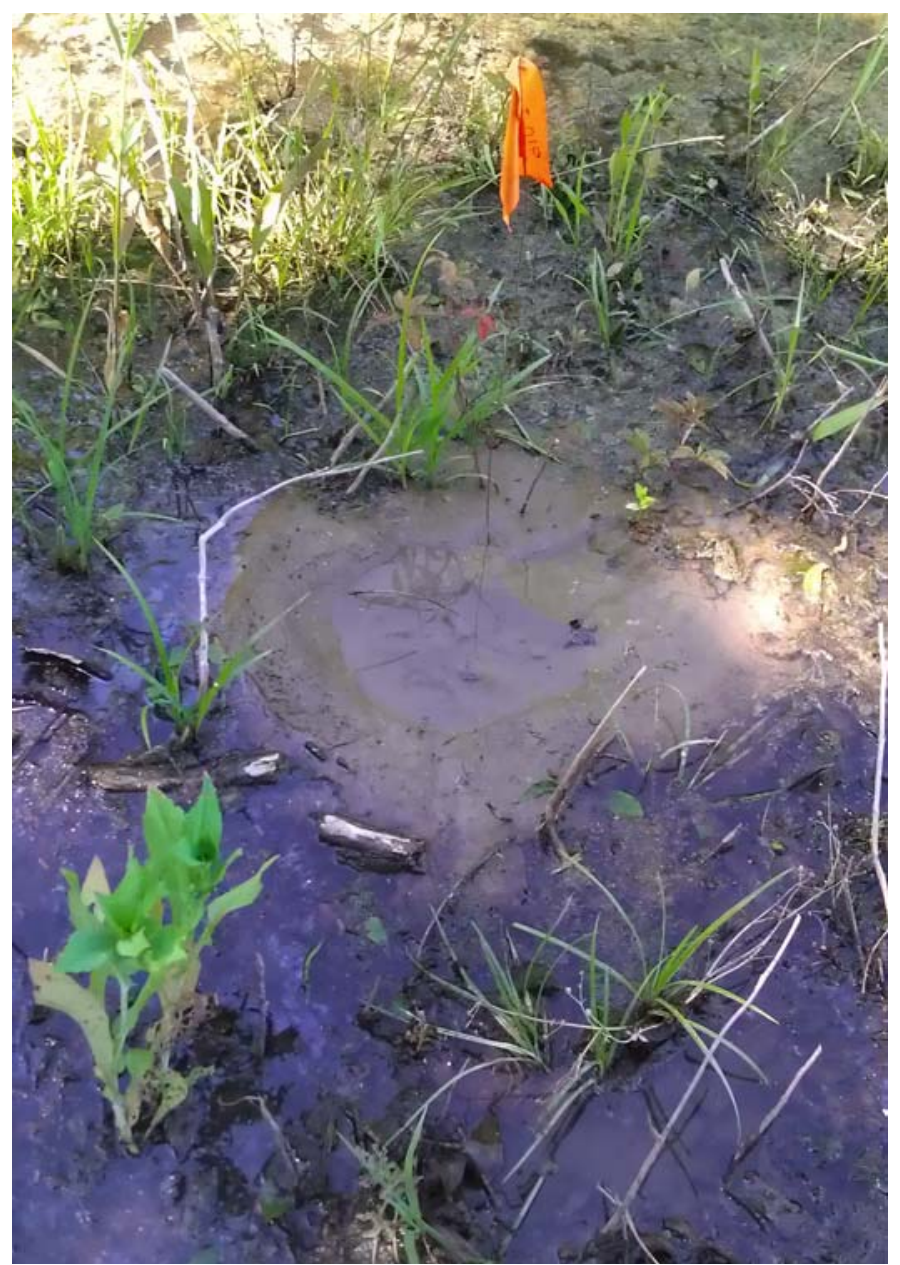

45

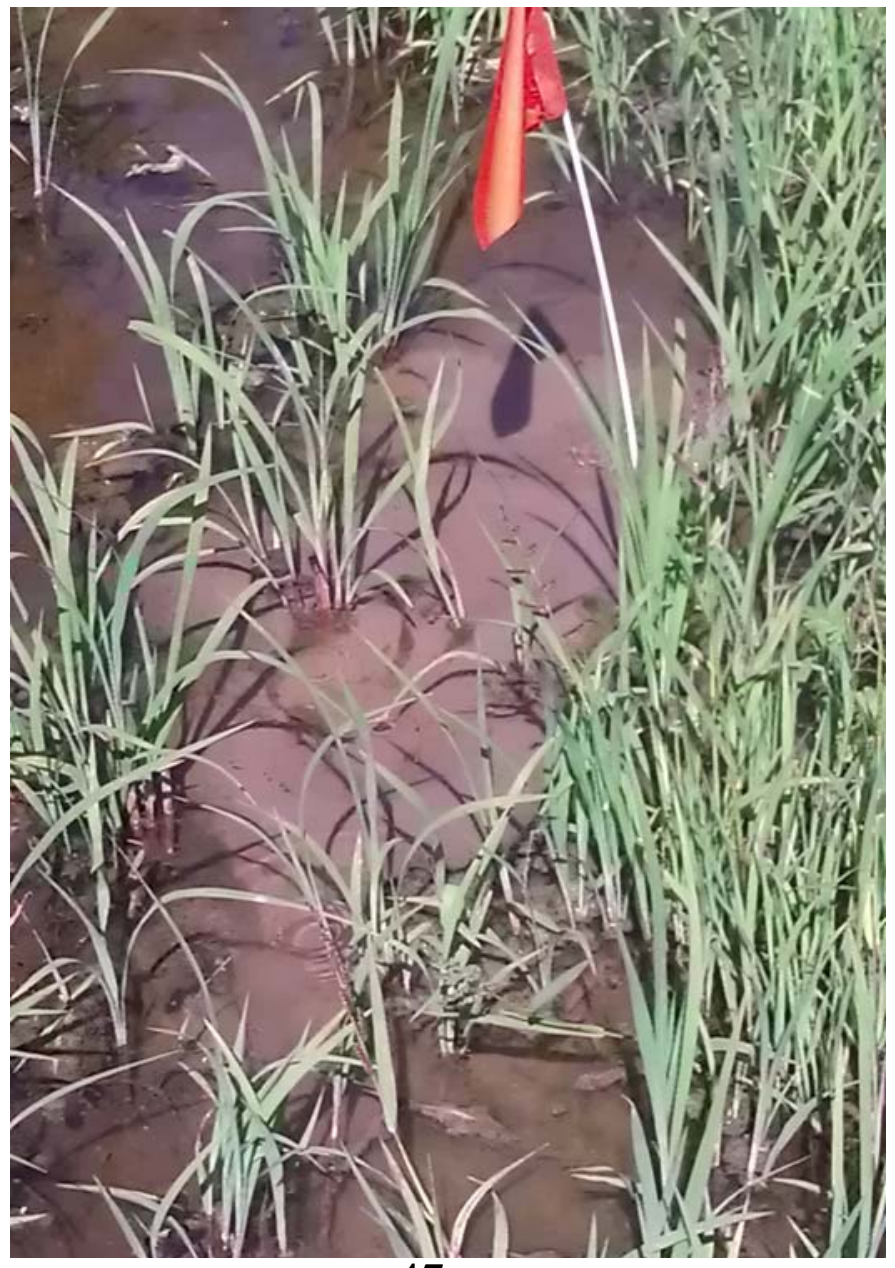

47
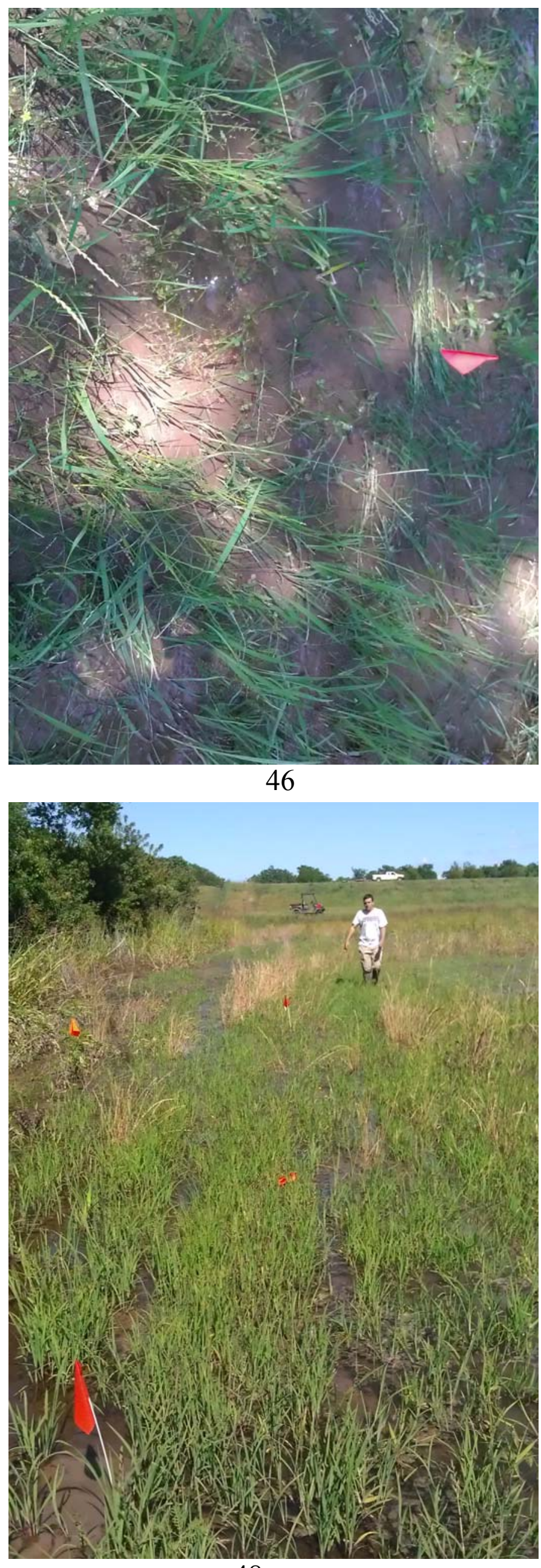


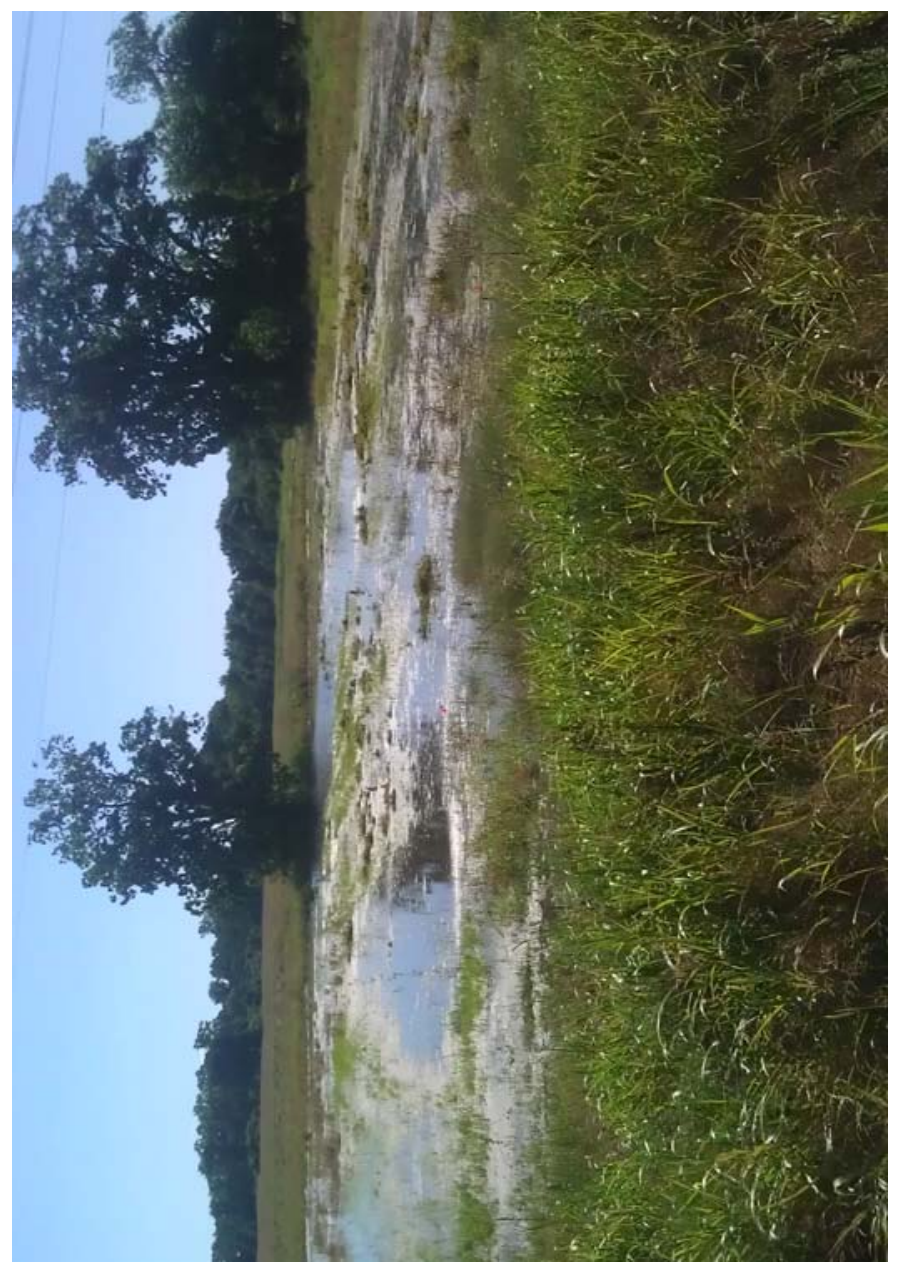

49

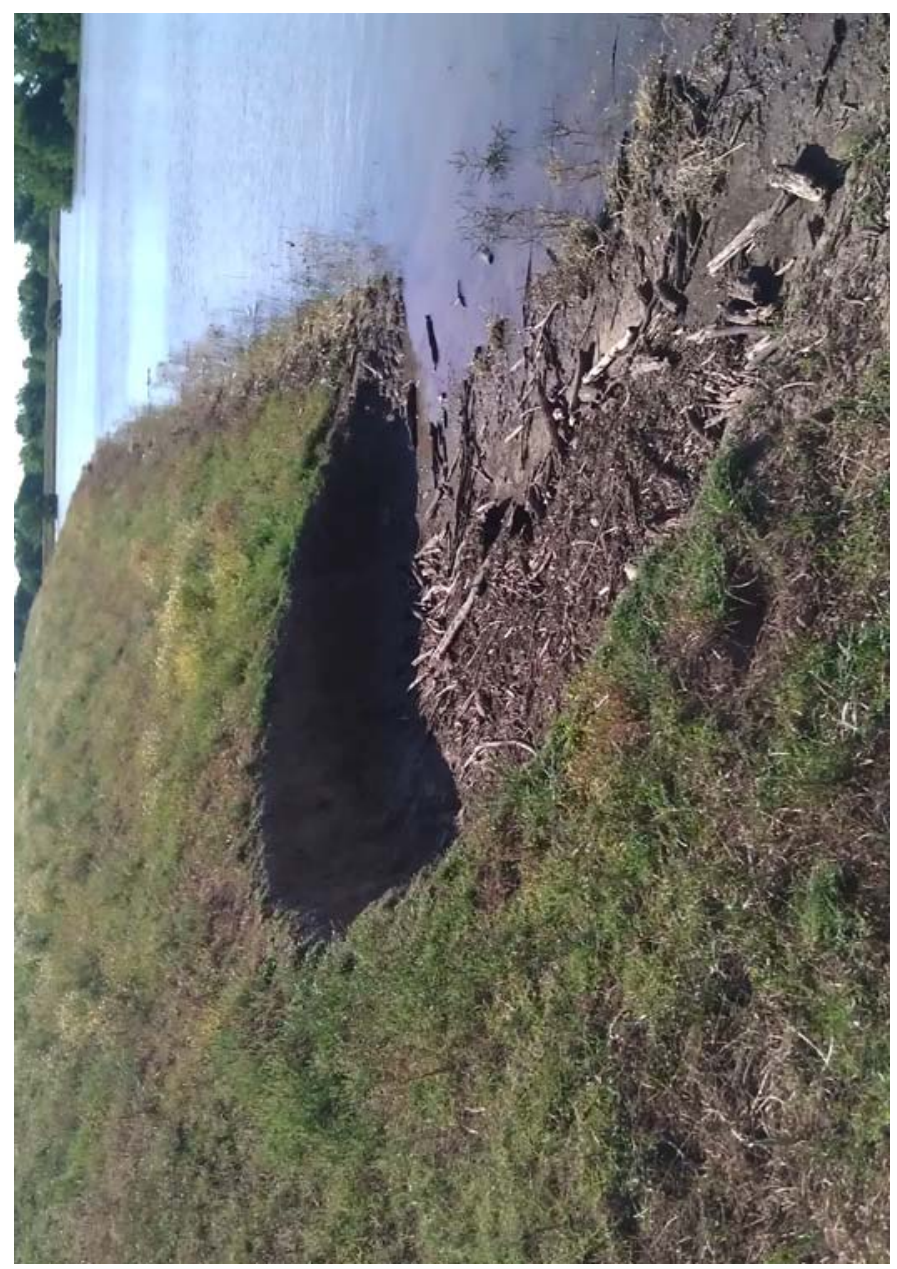

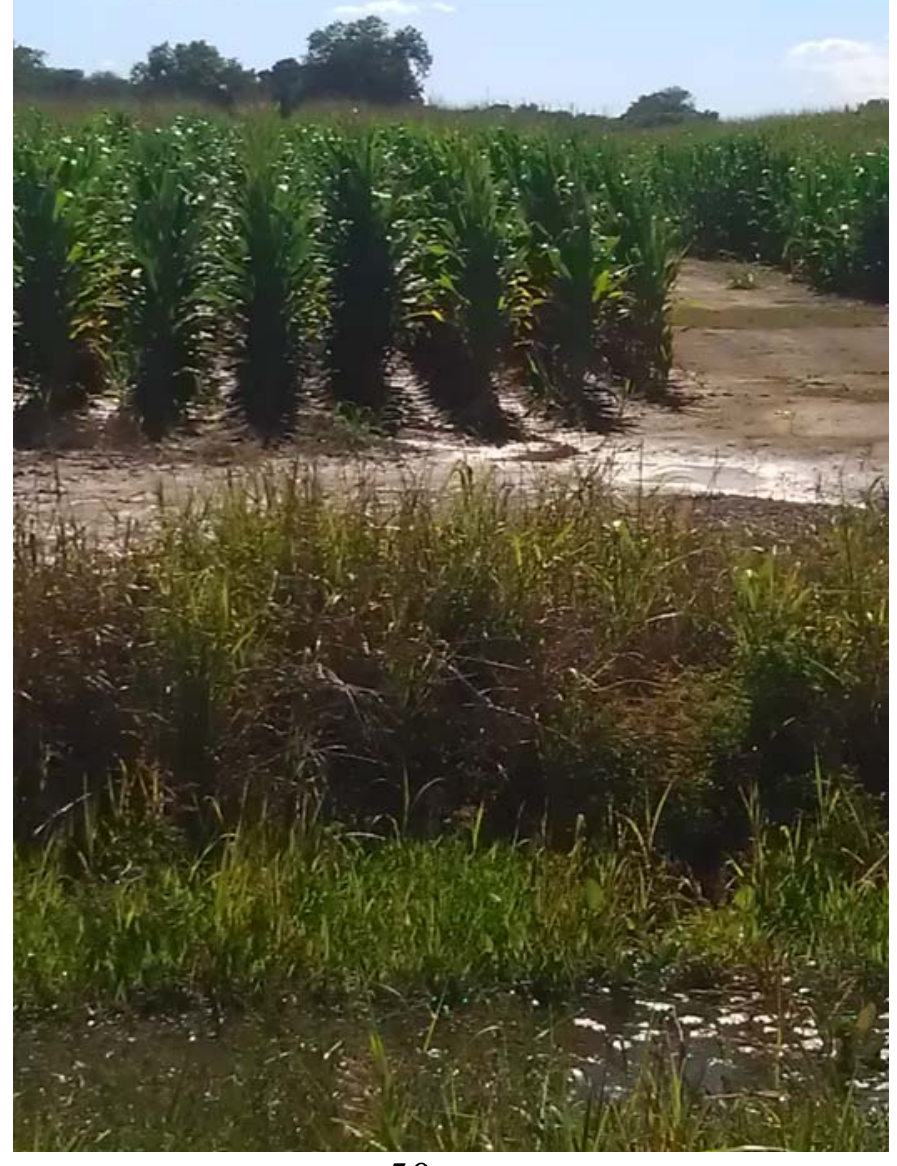

50

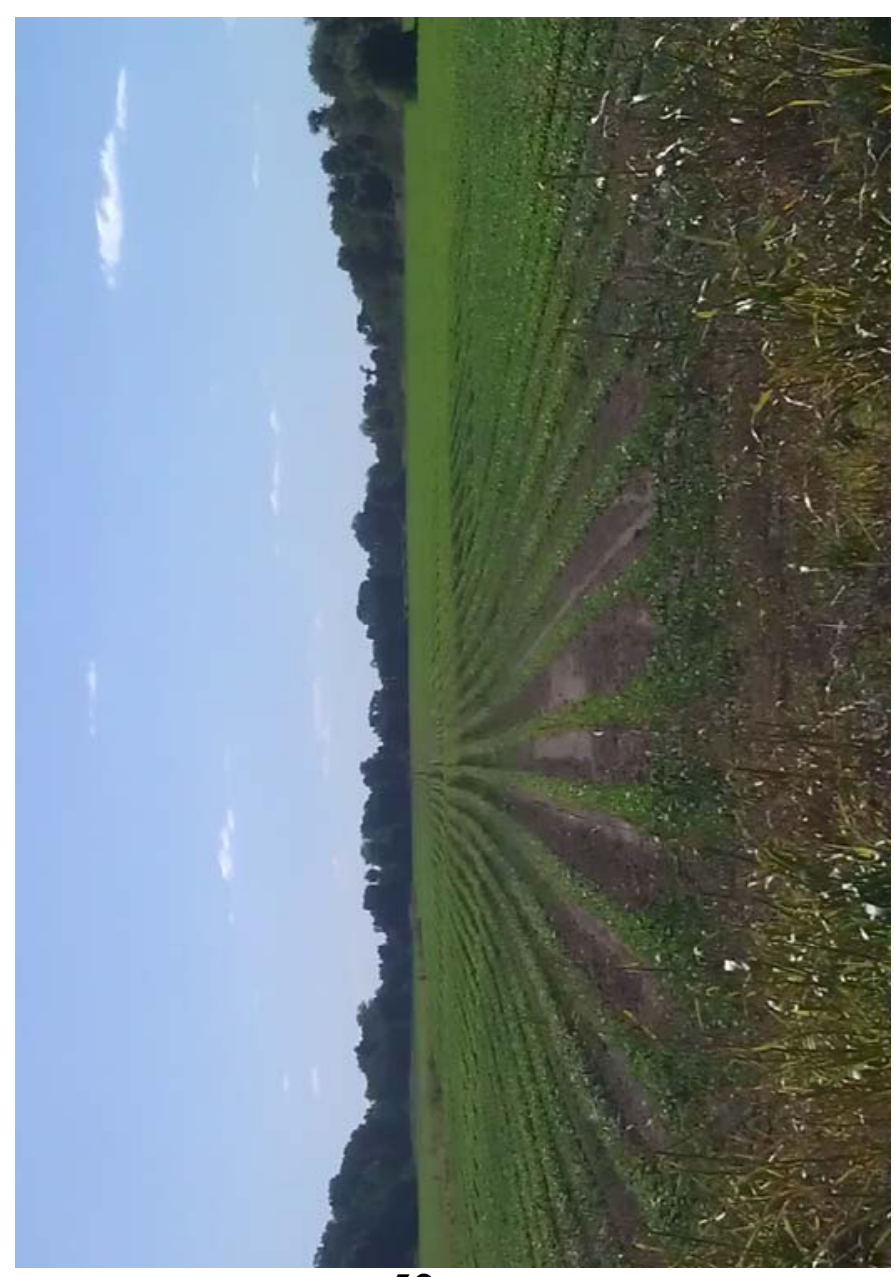

52 


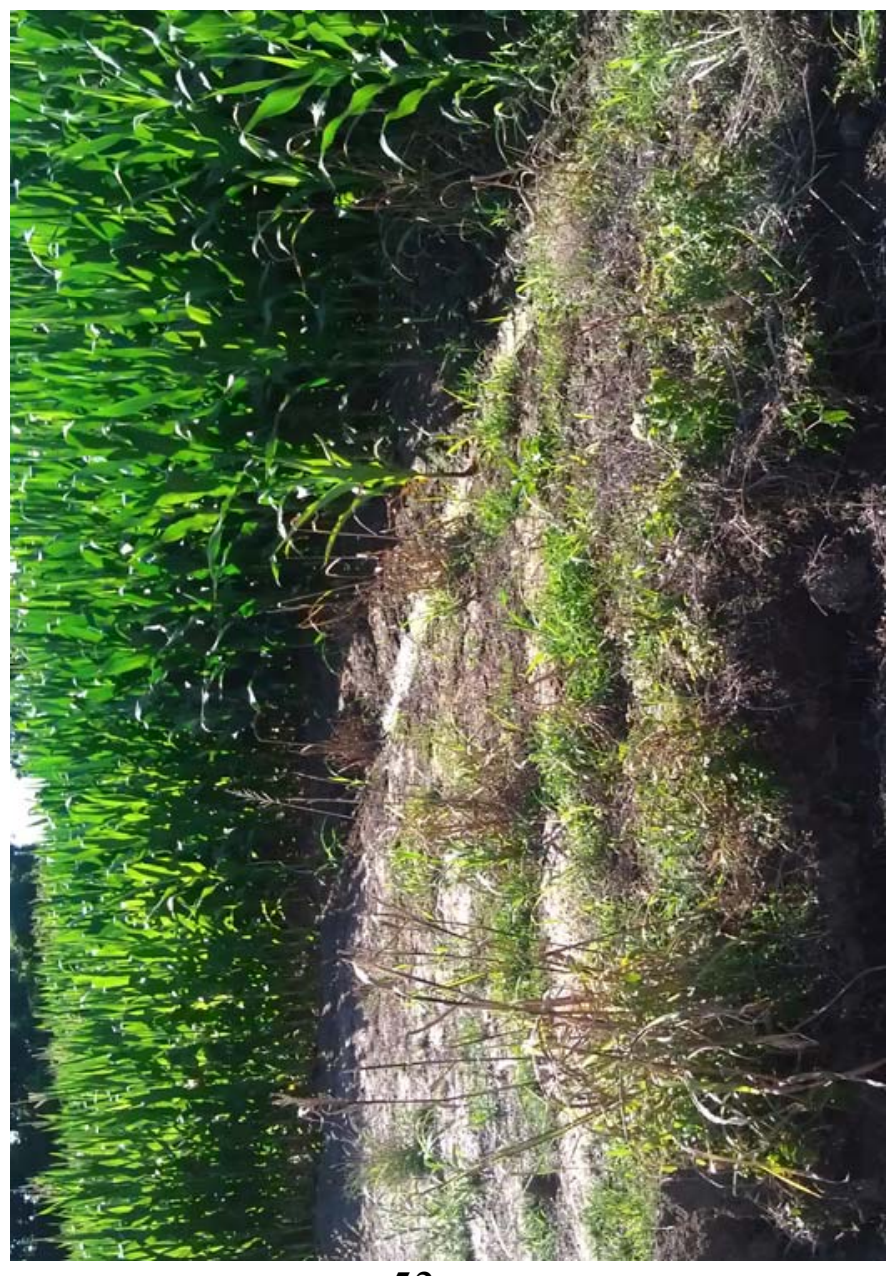

53 


\section{STATION 7200+00 TO 8700+00}


LEVEE SECTOR: West Bank MRL - Station 7200+00 - Station 9050+00 (Lake St. John to below Vidalia)

DATE: $\quad 5 / 22 / 2011-5 / 23 / 2011$

TEAM MEMBERS: Andy Hardy, Lane Vargas, and Ben Emery

\begin{tabular}{|c|c|c|c|c|c|c|c|c|c|}
\hline \multicolumn{2}{|c|}{ START } & \multicolumn{2}{|c|}{ END } & \multirow{2}{*}{$\begin{array}{l}\text { STATION } \\
\text { NLD }\end{array}$} & \multirow{2}{*}{$\begin{array}{l}\text { STATION } \\
\text { LEVEE }\end{array}$} & \multirow[t]{2}{*}{ TYPE } & \multirow[t]{2}{*}{ EXTENT } & \multirow[t]{2}{*}{ REMARKS } & \multirow{2}{*}{$\begin{array}{l}\text { PHOTO } \\
\text { LINKS }\end{array}$} \\
\hline Latitude & Longitude & Latitude & Longitude & & & & & & \\
\hline 31.67630 & -91.41370 & 31.66420 & -91.41500 & $\begin{array}{c}7199+00- \\
7221+50\end{array}$ & $\begin{array}{c}7200+00- \\
7222+50\end{array}$ & Under Seepage & Light & At berm toe and $600^{\prime}$ into adjacent fields & \\
\hline 31.65600 & -91.42170 & 31.65380 & -91.42670 & $\begin{array}{l}7288+40- \\
7307+10 \\
\end{array}$ & $\begin{array}{l}7296+00- \\
7315+20\end{array}$ & Under Seepage & Light & $80^{\prime}$ from levee toe and $600^{\prime}$ into adjacent fields & \\
\hline 31.65010 & -91.43050 & 31.64900 & -91.43300 & $\begin{array}{c}7325+50- \\
7333+70\end{array}$ & $\begin{array}{c}7333+70- \\
7341+90 \\
\end{array}$ & Under Seepage & Light & At levee toe and 300' into adjacent fields & \\
\hline 31.64840 & -91.43600 & 31.64810 & -91.48300 & $\begin{array}{l}7344+60- \\
7351+30\end{array}$ & $\begin{array}{l}7353+10- \\
7359+80\end{array}$ & Under Seepage & Light & At levee toe and $120^{\prime}$ into adjacent fields. & \\
\hline 31.64740 & -91.44290 & -- & -- & $7367+00$ & $7375+50$ & Under Seepage & Light & 100 ' off levee toe in the corner of the field and wooded area. & \\
\hline 31.64760 & -91.44960 & 31.64540 & -91.46060 & $\begin{array}{c}7387+20- \\
7423+50\end{array}$ & $\begin{array}{c}7395+30- \\
7430+50\end{array}$ & Under Seepage & Light & $120^{\prime}$ off levee toe and $600^{\prime}$ into adjacent field. & \\
\hline 31.65130 & -91.47360 & 31.65190 & -91.47410 & $\begin{array}{l}7474+00- \\
7475+00\end{array}$ & $\begin{array}{c}7481+50- \\
7482+50\end{array}$ & Under Seepage & Light & 150 ' off levee toe and extending into adjacent woods. & \\
\hline 31.65270 & -91.47440 & 31.65470 & -91.48820 & $\begin{array}{c}7478+80- \\
7518+70\end{array}$ & $\begin{array}{c}7485+30- \\
7524+60\end{array}$ & Under Seepage & Light & At toe of berm and 300 ' into fields & \\
\hline 31.65470 & -91.48820 & 31.65430 & -91.49120 & $\begin{array}{c}7518+70- \\
7529+00\end{array}$ & $\begin{array}{c}7524+60- \\
7534+90\end{array}$ & Under Seepage & Light & On berm and $600^{\prime}$ into adjacent fields & \\
\hline 31.65430 & -91.49120 & 31.65370 & -91.49570 & $\begin{array}{l}7529+00- \\
7542+80\end{array}$ & $\begin{array}{c}7534+90- \\
7551+20 \\
\end{array}$ & Under Seepage & Light & At berm toe and 600 ' into adjacent fields & \\
\hline 31.65240 & -91.49860 & 31.64110 & -91.51480 & $\begin{array}{l}7550+30- \\
7615+00\end{array}$ & $\begin{array}{c}7558+50- \\
7623+00 \\
\end{array}$ & Under Seepage & Light & At berm toe and 600 ' into adjacent fields & \\
\hline 31.58090 & -91.44450 & 31.58140 & -91.43890 & $\begin{array}{l}8017+00- \\
8034+50\end{array}$ & $\begin{array}{c}8024+20- \\
8041+70 \\
\end{array}$ & Under Seepage & Light & At berm toe and 800 ' into adjacent fields & \\
\hline 31.58420 & -91.42920 & 31.58430 & -91.42780 & $\begin{array}{l}8068+60- \\
8072+60\end{array}$ & $\begin{array}{c}8077+60- \\
8081+60\end{array}$ & Under Seepage & Light & At levee toe and 300' into adjacent fields & \\
\hline 31.58430 & -91.42780 & 31.58250 & -91.41910 & $\begin{array}{l}8072+60- \\
8103+50\end{array}$ & $\begin{array}{c}8081+60- \\
8111+50\end{array}$ & Under Seepage & Light & At berm toe and $150^{\prime}$ into adjacent fields & \\
\hline 31.58170 & -91.41810 & 31.57900 & -91.41680 & $\begin{array}{l}8107+90- \\
8121+00\end{array}$ & $\begin{array}{l}8118+90- \\
8132+00\end{array}$ & Under Seepage & Light & On berm. & \\
\hline 31.57900 & -91.41680 & 31.57480 & -91.41720 & $\begin{array}{l}8121+00- \\
8137+00 \\
\end{array}$ & $\begin{array}{l}8132+00- \\
8145+00 \\
\end{array}$ & Under Seepage & Light & At berm toe and 150 ' into adjacent fields & \\
\hline 31.57480 & -91.41720 & 31.56540 & -91.42170 & $\begin{array}{l}8137+00- \\
8176+00\end{array}$ & $\begin{array}{l}8145+00- \\
8187+00\end{array}$ & Under Seepage & Light to Moderate & $\begin{array}{l}\text { At levee toe and } 300 \text { ' into residential area of north Vidalia. Low lying areas in } \\
\text { yards had standing water, and water seeped though faults in driveways and } \\
\text { roads. Only a minimal flow was observed in outlet ditches. }\end{array}$ & \\
\hline 31.57299 & -91.42372 & -- & -- & $8160+00$ & $8172+00$ & Sand Boil & Light to Moderate & $\begin{array}{l}\text { Sand Boils in and around ditch 2000' from levee toe near baseball park on the } \\
\text { north side of Vidalia. }\end{array}$ & $1-5$ \\
\hline 31.56010 & -91.42970 & 31.55890 & -91.43180 & $\begin{array}{l}8208+10- \\
8216+10\end{array}$ & $\begin{array}{c}8185+00- \\
8193+00\end{array}$ & Under Seepage & Light & $\begin{array}{l}\text { At berm toe and } 150 \text { ' into residential area of Vidalia. Low lying areas in yards } \\
\text { had standing water, and water seeped though faults in driveways and roads. } \\
\text { Only a minimal flow was observed in outlet ditches. }\end{array}$ & \\
\hline 31.55660 & -91.43610 & 31.55160 & -91.44310 & $\begin{array}{l}8231+50- \\
8260+00\end{array}$ & $\begin{array}{l}8208+40- \\
8265+20\end{array}$ & Under Seepage & Light & At berm toe and 100 ' into residential area on south Vidalia. & \\
\hline
\end{tabular}


2011 MISSISSIPPI RIVER HIGH WATER REPORT

LEVEE SECTOR: West Bank MRL - Station 7200+00 - Station 9050+00 (Lake St. John to below Vidalia)

DATE: $\quad 5 / 22 / 2011-5 / 23 / 2011$

TEAM MEMBERS: Andy Hardy, Lane Vargas, and Ben Emery

\begin{tabular}{|c|c|c|c|c|c|c|c|c|c|}
\hline \multicolumn{2}{|c|}{ START } & \multicolumn{2}{|c|}{ END } & \multirow{2}{*}{$\begin{array}{c}\text { STATION } \\
\text { NLD }\end{array}$} & \multirow{2}{*}{$\begin{array}{c}\text { STATION } \\
\text { LEVEE }\end{array}$} & \multirow[t]{2}{*}{ TYPE } & \multirow[t]{2}{*}{ EXTENT } & \multirow[t]{2}{*}{ REMARKS } & \multirow{2}{*}{$\begin{array}{c}\text { PHOTO } \\
\text { LINKS }\end{array}$} \\
\hline Latitude & Longitude & Latitude & Longitude & & & & & & \\
\hline 31.55660 & -91.43610 & -- & -- & $8321+50$ & $8330+20$ & Sand Boil & Light & In ditch along the old railway line 2000 ' from levee toe & 6-7 \\
\hline 31.54400 & -91.46690 & -- & -- & $8340+00$ & $8348+70$ & & & Relief Wells flowing & \\
\hline 31.54400 & -91.46690 & 31.54260 & -91.47050 & $\begin{array}{l}8340+00- \\
8352+10 \\
\end{array}$ & $\begin{array}{l}8348+70- \\
8360+80\end{array}$ & Under Seepage & Light & Between berm toe and adjacent lake (borrow pit) & \\
\hline 31.54260 & -91.47050 & 31.54140 & -91.47980 & $\begin{array}{l}8352+10- \\
8384+50\end{array}$ & $\begin{array}{l}8360+80- \\
8394+40\end{array}$ & Under Seepage & Light & At berm toe and $300^{\prime}$ into adjacent fields. & \\
\hline 31.53900 & -91.49110 & 31.53970 & -91.50360 & $\begin{array}{c}8421+00- \\
8461+50\end{array}$ & $\begin{array}{c}8432+30- \\
8473+20\end{array}$ & Under Seepage & Light & In ditch at berm toe. & \\
\hline 31.50390 & -91.52560 & 31.49920 & -91.52580 & $\begin{array}{l}8631+00- \\
8648+40\end{array}$ & $\begin{array}{l}8639+30- \\
8657+10\end{array}$ & Under Seepage & Light & At levee toe and 150 ' into adjacent field. & \\
\hline 31.49920 & -91.52580 & 31.48460 & -91.52740 & $\begin{array}{l}8648+40- \\
8703+90\end{array}$ & $\begin{array}{l}8657+10- \\
8711+90\end{array}$ & Under Seepage & Light & At berm toe and $150^{\prime}$ into adjacent fields & \\
\hline
\end{tabular}




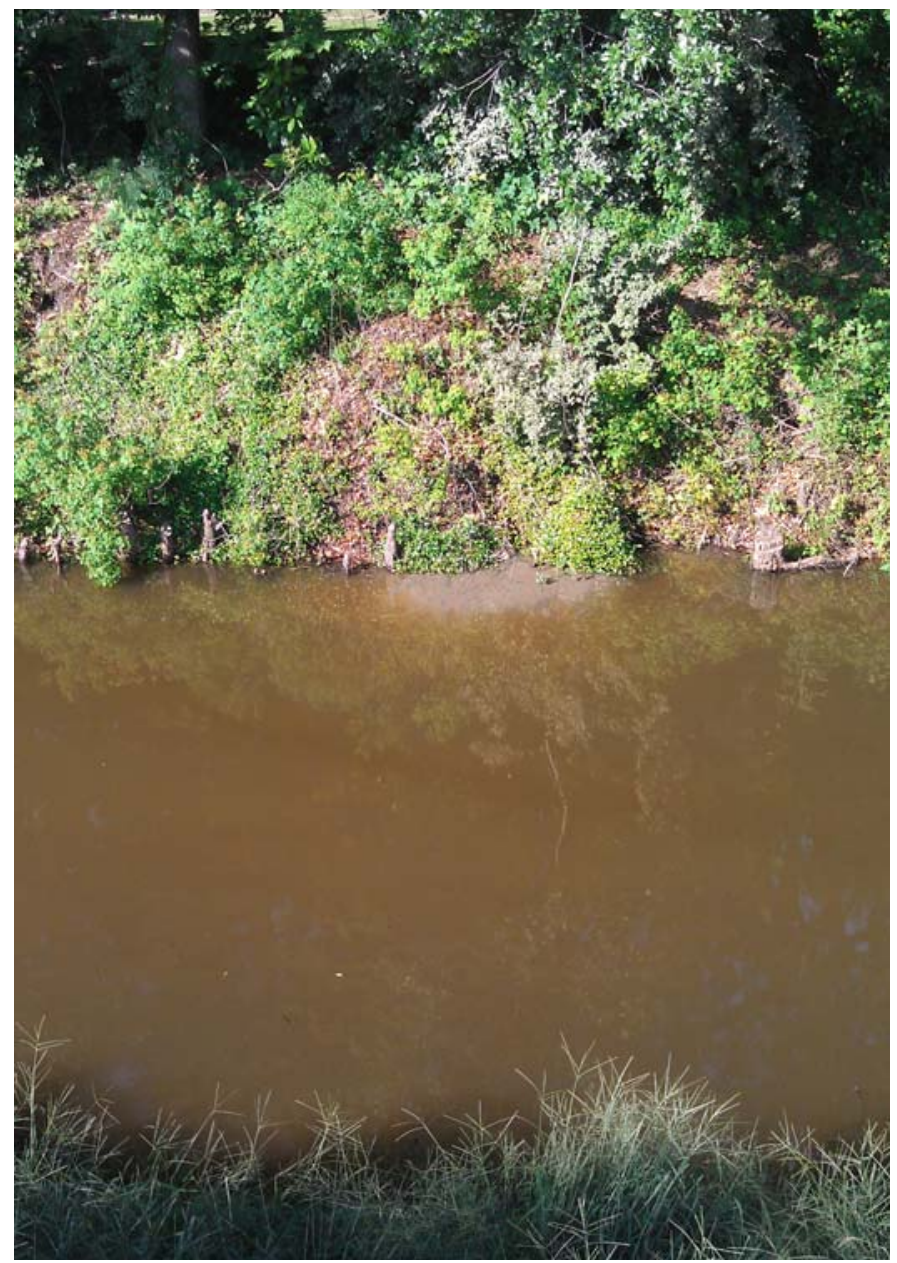

1

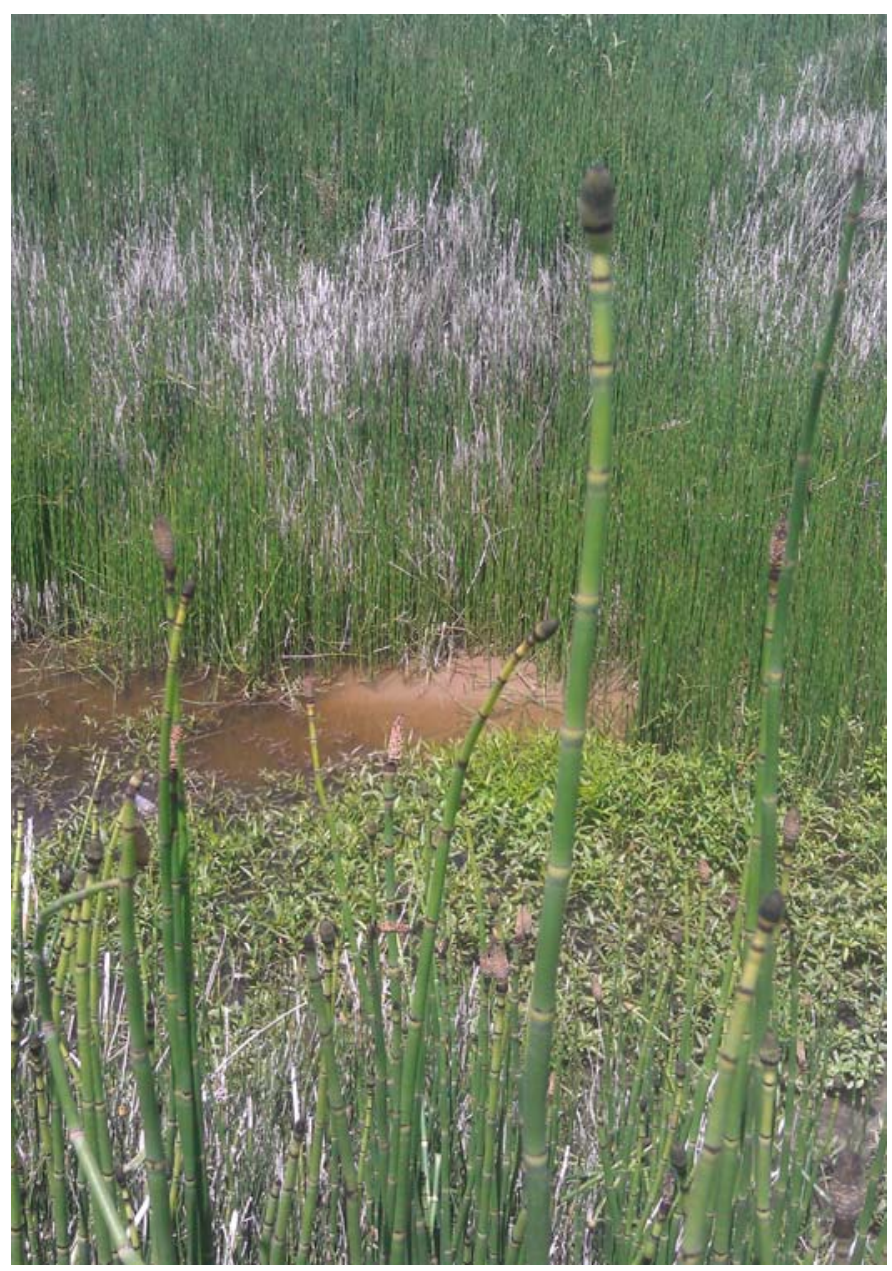

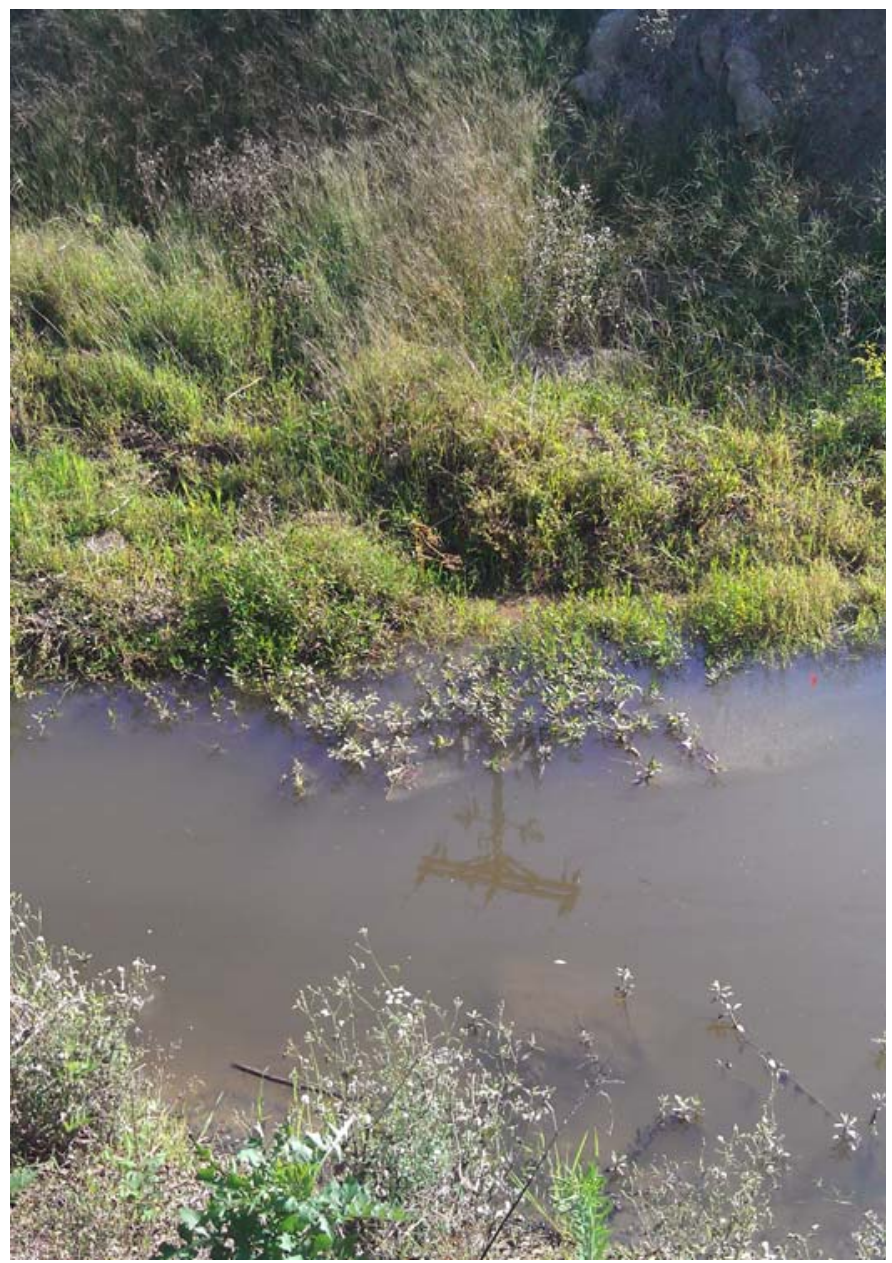
2

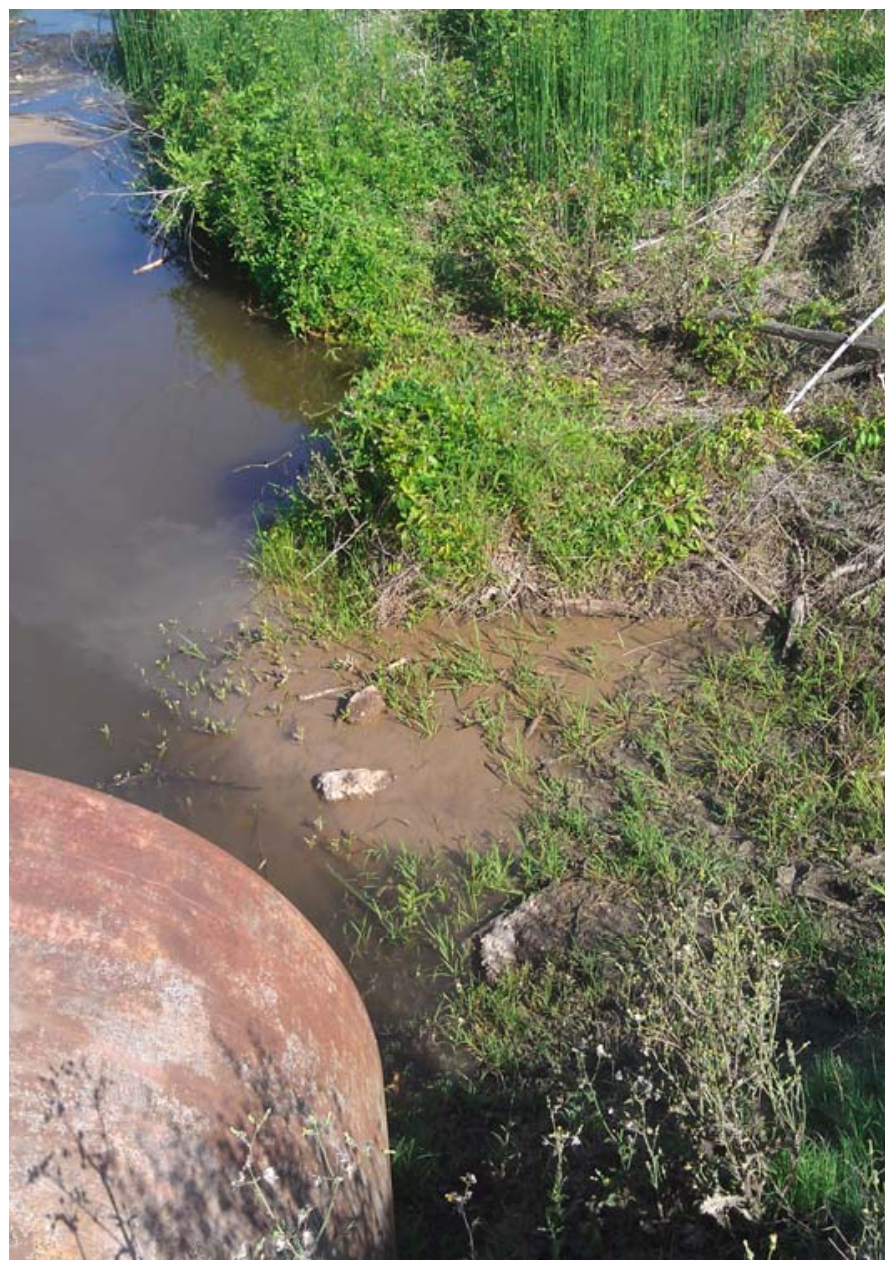




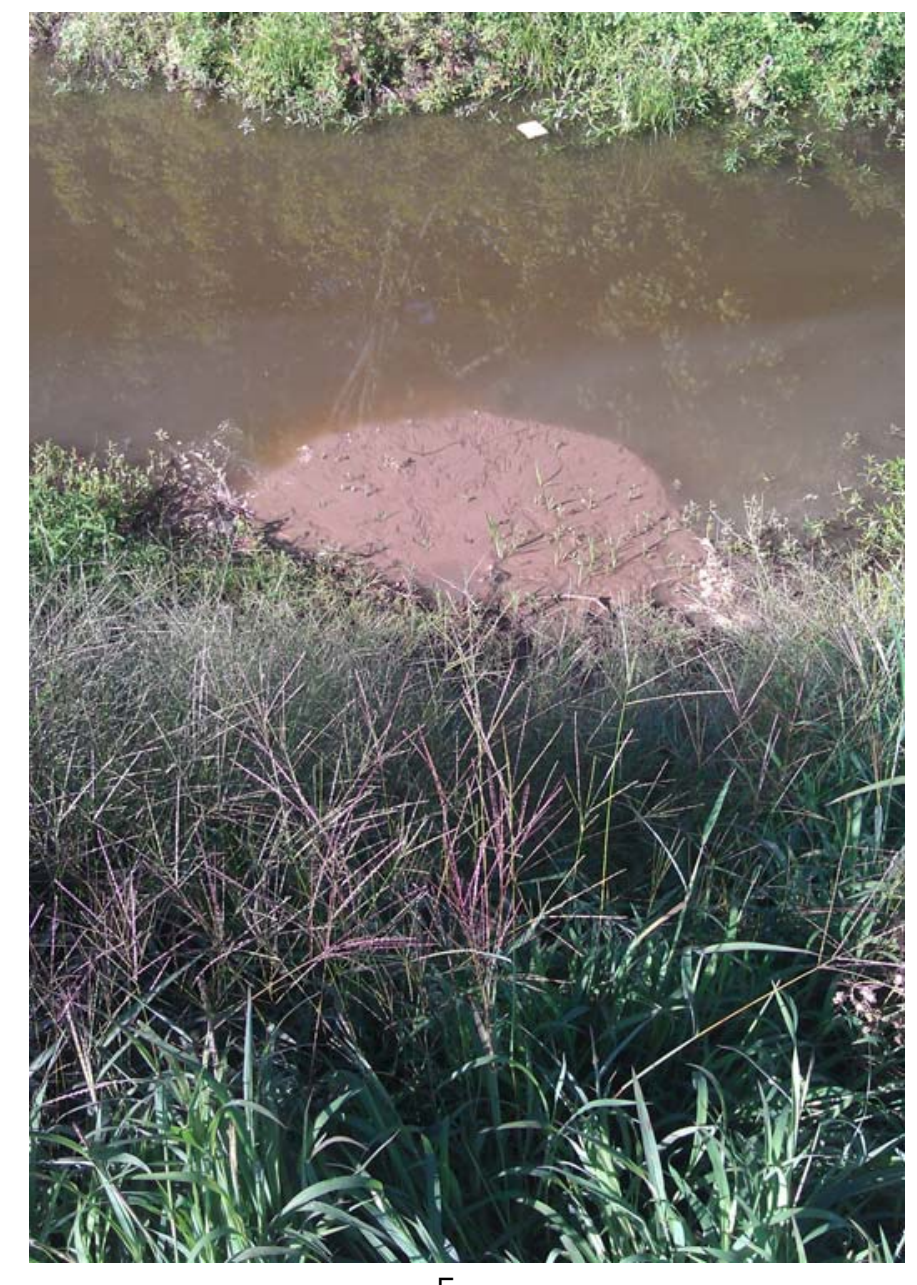

5

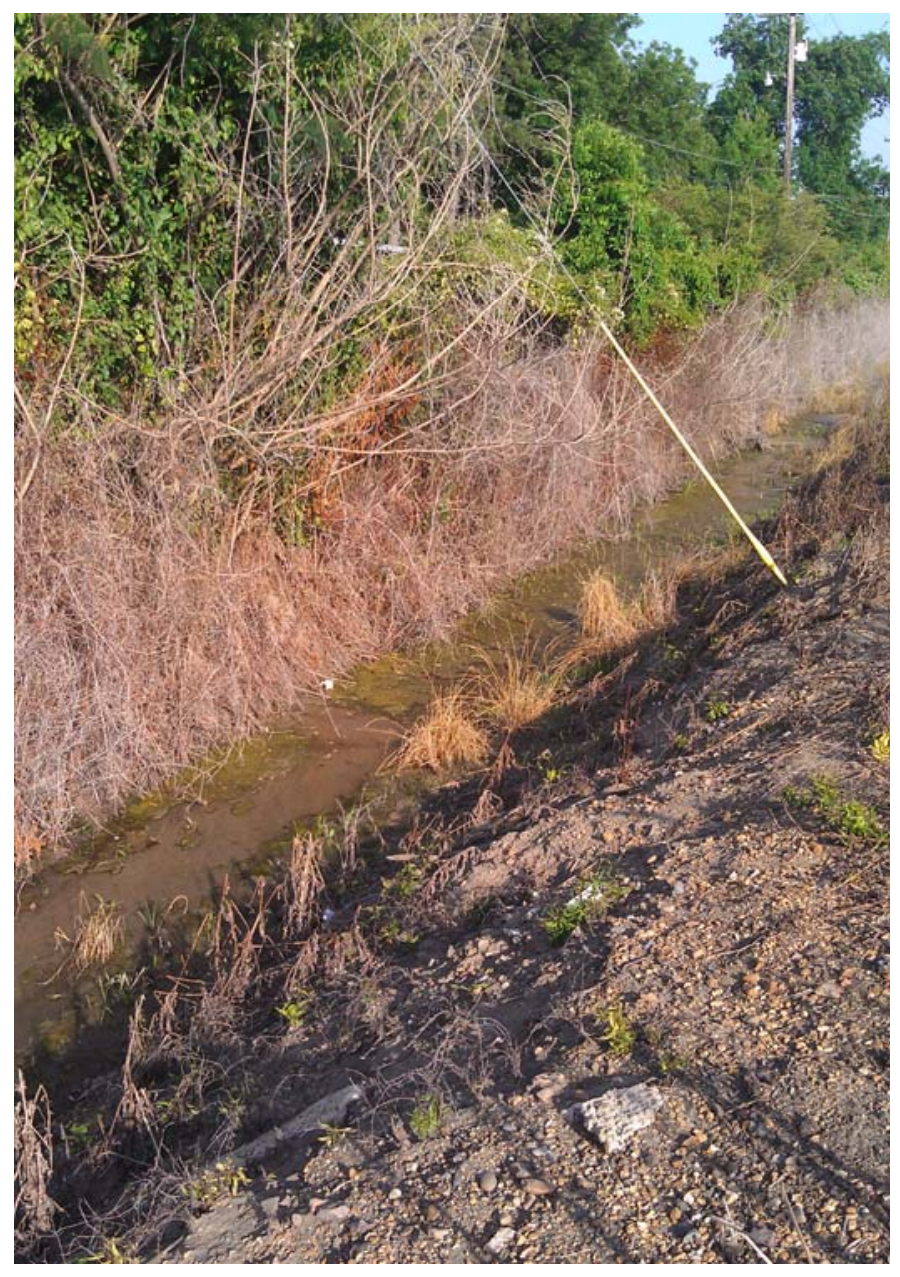

6

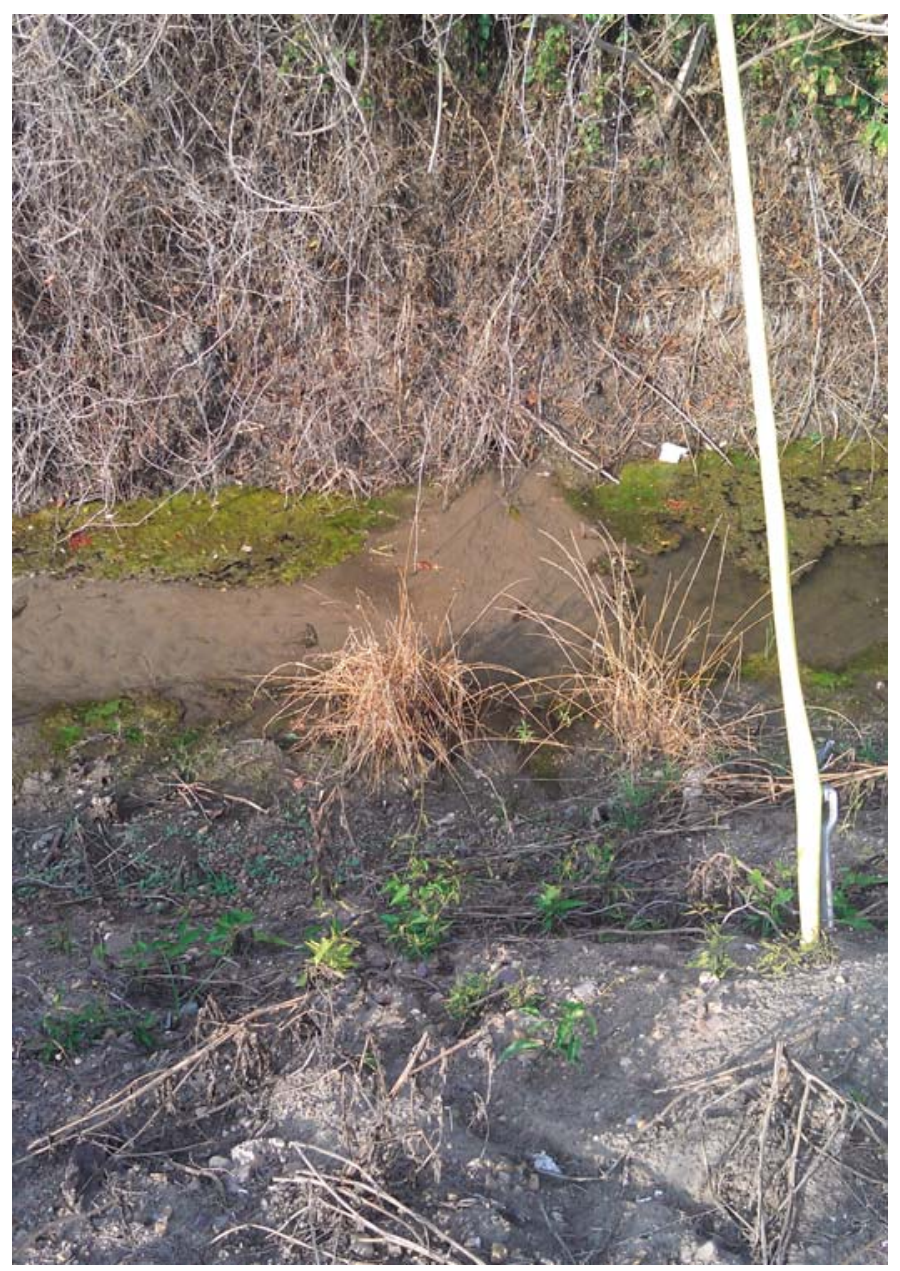




\section{STATION 8700+00 TO 10487+58}


LEVEE SECTOR: Deer Park to the end of the Vicksburg District Line DATE: May 25, 2012

TEAM MEMBERS: James Sims, Ryan Reeves, Dustin Herr, Jim Hearn

\begin{tabular}{|c|c|c|c|c|c|c|c|c|c|}
\hline \multicolumn{2}{|c|}{ START } & \multicolumn{2}{|c|}{ END } & \multirow{2}{*}{\begin{tabular}{|c|} 
STATION \\
NLD \\
\end{tabular}} & \multirow{2}{*}{$\begin{array}{c}\text { STATION } \\
\text { FIELD MARKER }\end{array}$} & \multirow[t]{2}{*}{ TYPE } & \multirow[t]{2}{*}{ EXTENT } & \multirow[t]{2}{*}{ REMARKS } & \multirow[t]{2}{*}{ РНОTO } \\
\hline Latitude & Longitude & Latitude & Longitude & & & & & & \\
\hline 31.36252121 & 91.57804882 & 31.36252121 & 91.57804882 & $9231+00$ & $9245+00$ & Under Seepage & Light & $\begin{array}{l}\text { Light seepage flowing into a possible natural slough approximately } 200 \\
\text { feet from the toe of the seepage berm between levee Sta. } 9240 \text { and } \\
\text { 9250. Light, clear, seepage observed between berm toe and slough area. }\end{array}$ & $1-2$ \\
\hline 31.35345131 & 91.57491101 & 31.35345131 & 91.57491101 & $9256+00$ & $9270+00$ & Under Seepage & Light & $\begin{array}{l}\text { More light seepage flowing into a pond/lake area approximately } 75 \text { feet } \\
\text { from the toe of the seepage berm near levee Sta. } 9270 . \text { Light, clear } \\
\text { seepage flows into north end of lake/slough. }\end{array}$ & 3-5 \\
\hline 31.33965 & 91.5568 & 31.33965 & 91.5568 & $9326+00$ & $9338+00$ & Through Seepage & Light & $\begin{array}{l}\text { Seepage coming through the levee approximately } 2 \text { feet above the toe } \\
\text { near levee Sta. } 9338 .\end{array}$ & \\
\hline 31.33314389 & 91.55507518 & 31.33314389 & 91.55507518 & $9361+00$ & $9369+00$ & Under Seepage & Light & $\begin{array}{l}\text { Light seepage in drainage ditch approximately } 200 \text { feet from toe of the } \\
\text { seepage berm. Clear water noted flowing in the ditch. Area has been } \\
\text { flagged and monitored. }\end{array}$ & 6-7 \\
\hline 31.3318758 & 91.54745181 & 31.3318758 & 91.54745181 & $9385+00$ & $9400+00$ & Under Seepage & Light & $\begin{array}{l}\text { Light seepage along the toe of the berm extending out approximately } \\
100 \text { feet between levee Sta. } 9400 \text { and } 9410 \text {. }\end{array}$ & $8-10$ \\
\hline 31.32611 & 91.53251 & 31.32611 & 91.53251 & $9442+00$ & $9450+00$ & Through Seepage & Light & $\begin{array}{l}\text { Light seepage noted on top of the seepage berm near levee Sta. } 9450 . \\
\text { Seepage is located approximately } 20 \text { feet from the toe of the seepage } \\
\text { berm and is approximately } 20 \text { feet wide and extends downstream } \\
\text { approximately } 100 \text { feet. }\end{array}$ & $11-12$ \\
\hline 31.32321 & 91.52894 & 31.32321 & 91.52894 & $9460+00$ & $9470+00$ & Under Seepage & Light & $\begin{array}{l}\text { Flowing irrigation well approximately } 200 \text { feet from the toe of the } \\
\text { seepage berm near levee Sta. } 9470 \text {. Well was flowing less that } 20 \mathrm{gpm} \text {. }\end{array}$ & 13 \\
\hline 31.31894274 & 91.52878847 & 31.31894274 & 91.52878847 & $9475+00$ & $9480+00$ & Through Seepage & Light & $\begin{array}{l}\text { Light seepage on top of the seepage berm near levee Sta. } 9480 \text {. Seepage } \\
\text { is approximately } 15 \text { feet from the toe of the seepage berm. Seepage also } \\
\text { observed along the toe of the berm extending out approximateley } 100 \\
\text { feet. }\end{array}$ & 14 \\
\hline 31.31485 & 91.52886 & 31.31485 & 91.52886 & $9490+00$ & $9500+00$ & Sand Boil & Moderate & $\begin{array}{l}\text { Several small sand boils observed in a drainage ditch along toe of seepage } \\
\text { berm near levee Sta. } 9500 . \text { Each boil has transported less than one } \\
\text { cubic yard of silt/very fine sand and are flowing approximately } 3 \text { to } 5 \\
\text { gpm. Most of the throats of the boils are 3-inches in diameter or less. } \\
\text { More sand boils were identified approximately } 1000 \text { feet from the levee } \\
\text { toe. These are small, low energy boils. }\end{array}$ & $15-18$ \\
\hline 31.32489 & 91.52936 & 31.0058 & 91.53234 & $\begin{array}{l}9453+00 \text { to } \\
9545+00\end{array}$ & $\begin{array}{l}9450+00 \text { to } \\
9550+00\end{array}$ & Heavy Current/Scour & Moderate & $\begin{array}{l}\text { Rapid current noted along riverside of the levee between levee Sta. } 9450 \\
\text { and } 9550 .\end{array}$ & \\
\hline 31.31192 & 91.52959 & 31.31192 & 91.52959 & $9508+00$ & $9520+00$ & Sand Boil & Light to Moderate & $\begin{array}{l}\text { Numerous pin boils observed approximately } 100 \text { feet from the toe of the } \\
\text { seepage berm extending out approximately } 300 \text { feet or more in a field on } \\
\text { the north end of Sharps relief well. }\end{array}$ & $19-20$ \\
\hline 31.30913134 & 91.52956731 & 31.30913134 & 91.52956731 & $9515+00$ & $9550+00$ & Through Seepage & Light & $\begin{array}{l}\text { Light seepage on top of the seepage berm approximately } 75 \text { feet from the } \\
\text { berm toe above relief wells near levee Sta. } 9540 \text {. Seepage is approximately } \\
30 \text { feet wide and } 200 \text { to } 250 \text { feet long. }\end{array}$ & $21-23$ \\
\hline 31.286356 & 91.571678 & 31.286356 & 91.571678 & $9713+00$ & $9720+00$ & Sand Boil & Light & $\begin{array}{l}\text { Small sand boil under approximately } 10 \text {-inches of water approximately } \\
2000 \text { feet from the landside toe of the levee. }\end{array}$ & \\
\hline
\end{tabular}




\begin{tabular}{|c|c|c|c|c|c|c|c|c|c|}
\hline \multicolumn{2}{|c|}{ START } & \multicolumn{2}{|c|}{ END } & STATION & STATION & TYPE & EXTENT & REMARKS & PHOTO \\
\hline Latitude & Longitude & Latitude & Longitude & NLD & FIELD MARKER & & & & \\
\hline 31.27998407 & 91.55512001 & 31.27998407 & 91.55512001 & $9718+00$ & $9722+00$ & Under Seepage/Pin Boi & Moderate & $\begin{array}{l}\text { Moderate seepage and numerous pin boils in a field just south of the } \\
\text { Sharps relief wells. Seepage extends out } 300+\text { feet from the toe of the } \\
\text { seepage berm and ends in the field near levee Sta. } 9722 \text {. }\end{array}$ & $24-25$ \\
\hline 31.28216928 & 91.57592711 & 31.28216928 & 91.57592711 & $9725+00$ & $9730+00$ & Under Seepage & Light & $\begin{array}{l}\text { Light seepage in a drainage ditch along the toe of the seepage berm near } \\
\text { levee Sta. } 9700 \text {. Ditch is connected to a pond. }\end{array}$ & $26-27$ \\
\hline 31.2830422 & 91.59769039 & 31.2830422 & 91.59769039 & $9796+00$ & $9800+00$ & Under Seepage & Light & $\begin{array}{l}\text { Light seepage around farm buildings on north side of Slocum Levee Road } \\
\text { off the toe of the levee near levee Sta. } 9830 \text {. Seepage area is approximately } \\
300 \text { feet long and } 200 \text { feet wide. Possible flowing residential well inside } \\
\text { small shed. }\end{array}$ & $28-29$ \\
\hline 31.20524799 & 91.62972272 & 31.20524799 & 91.62972272 & $10285+00$ & $10300+00$ & Under Seepage & Light & $\begin{array}{l}\text { Light seepage approximately } 100 \text { feet from the toe of the levee in a field } \\
\text { near levee Sta. 10300. Seepage area is approximately } 10 \text { feet wide and } \\
30 \text { feet long. }\end{array}$ & 30 \\
\hline
\end{tabular}



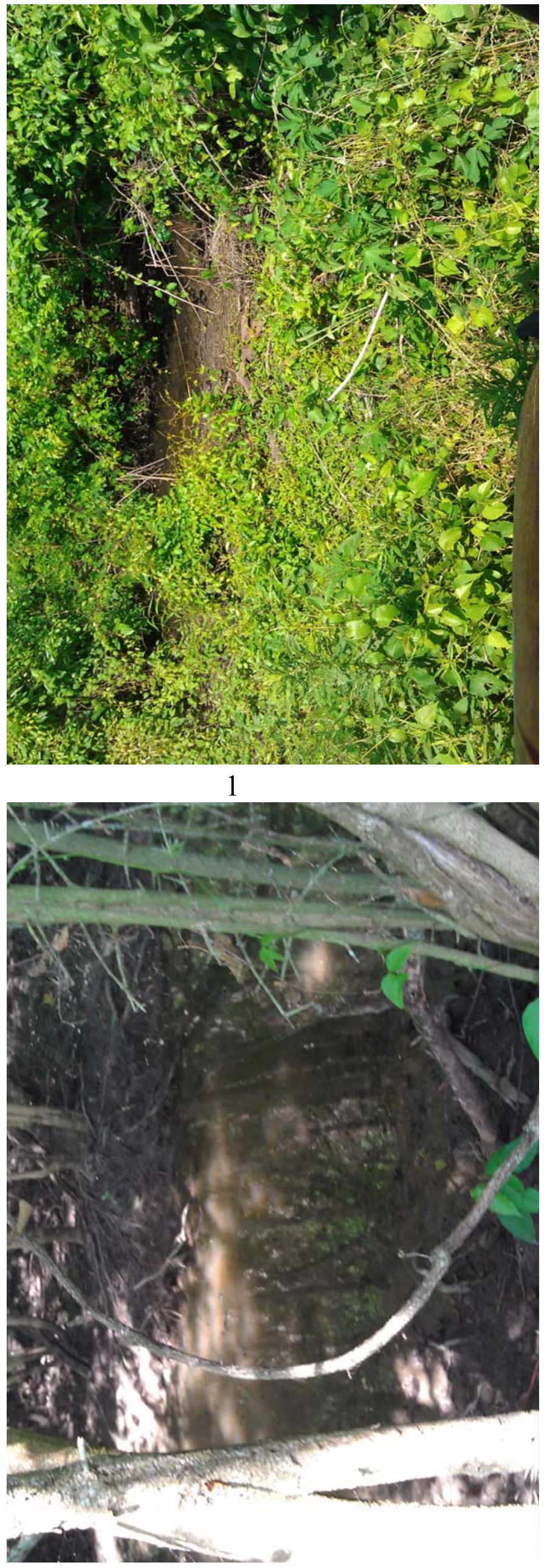

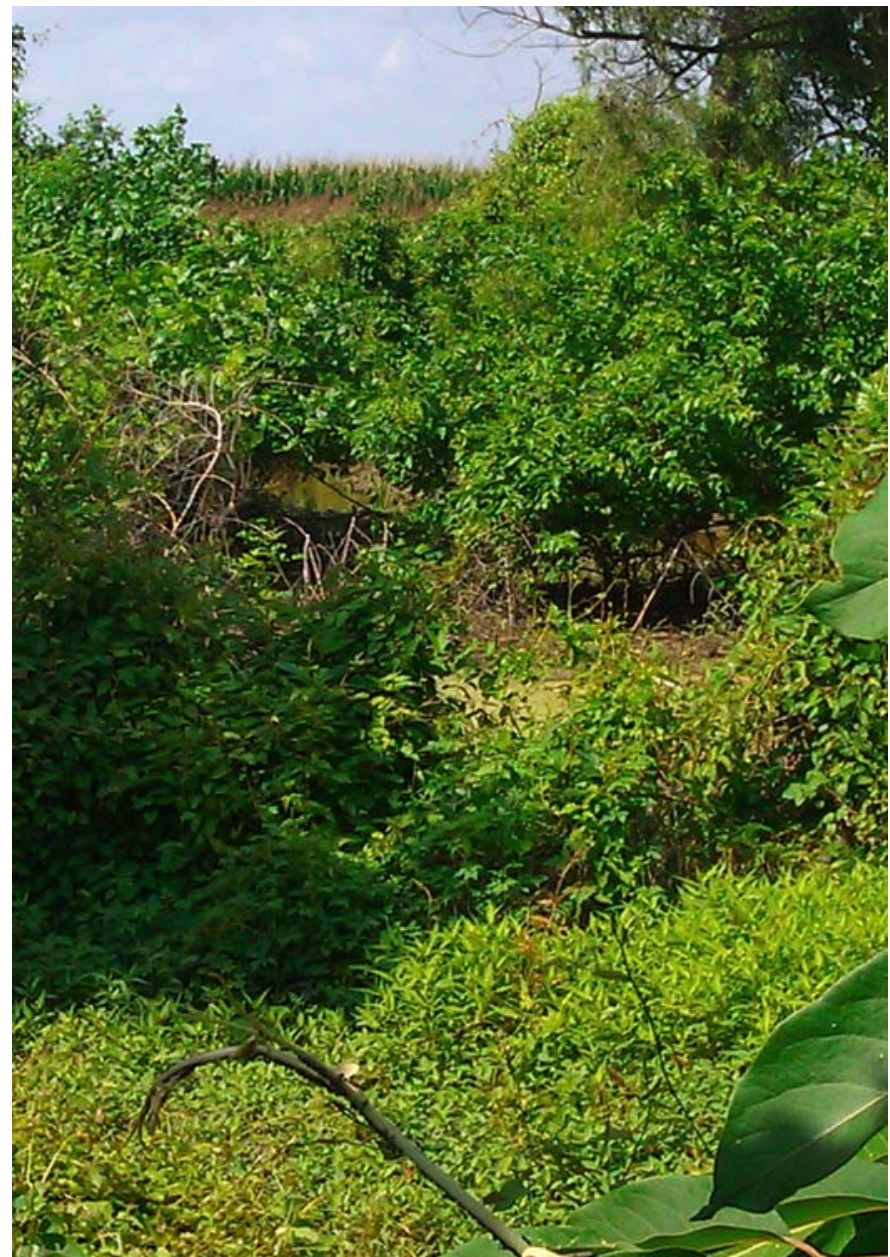

\section{2}

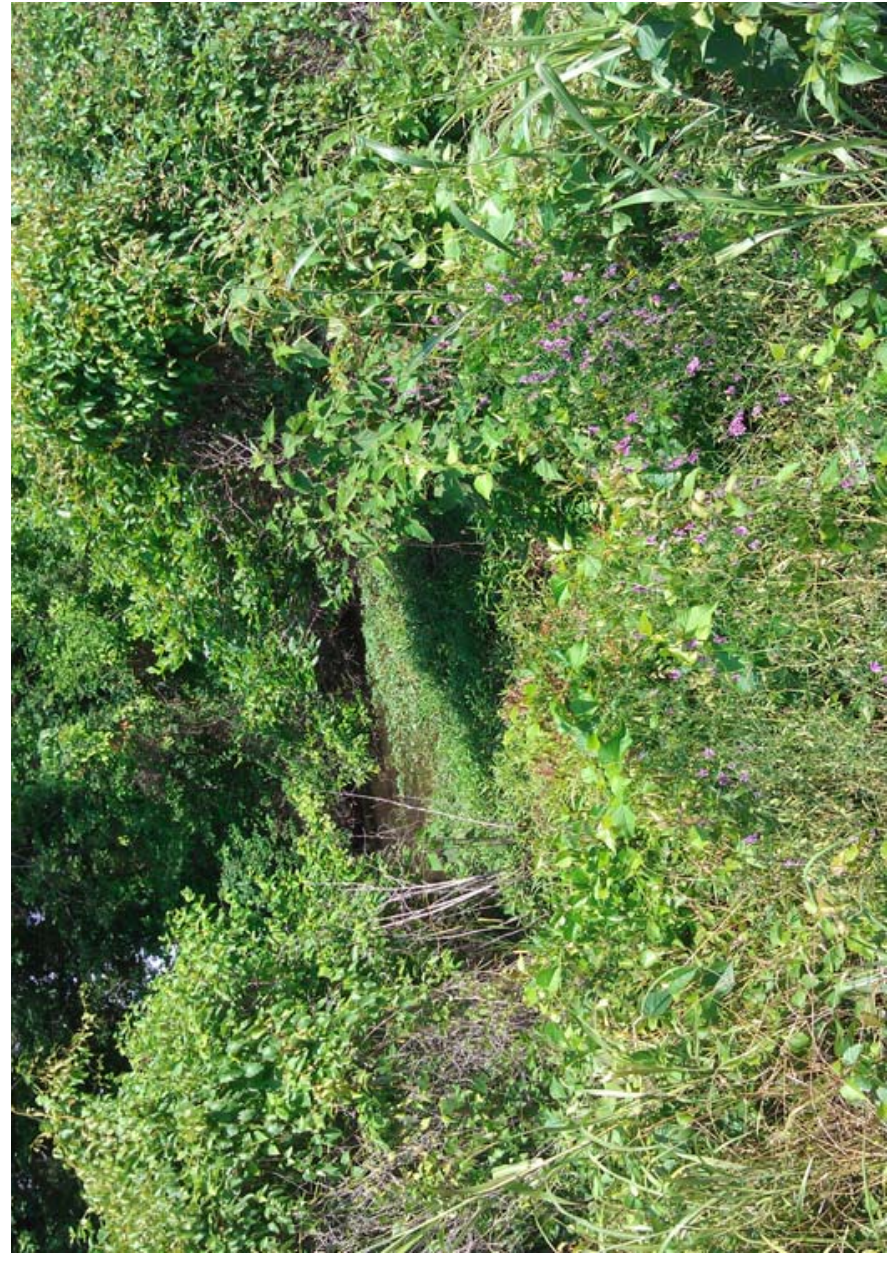




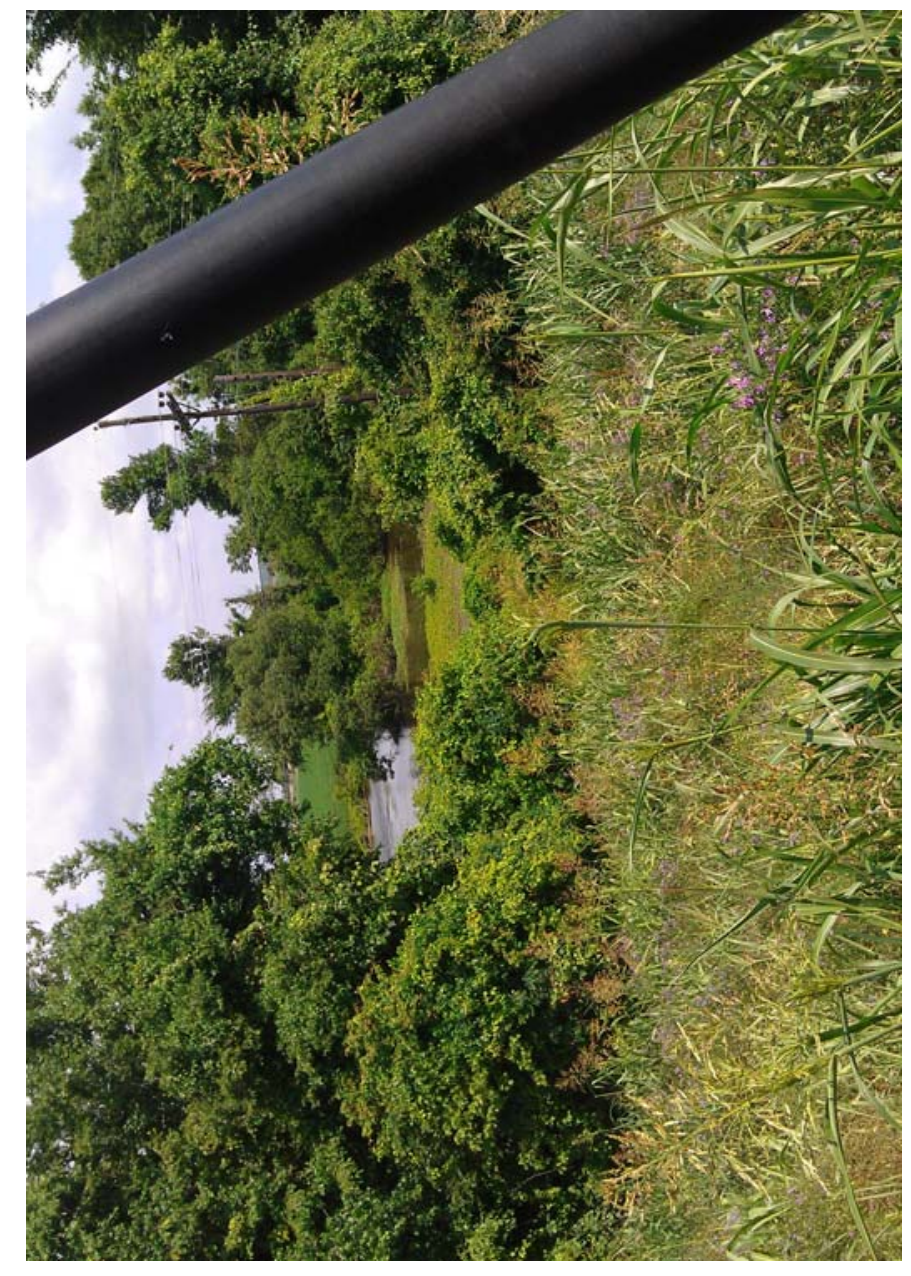

5

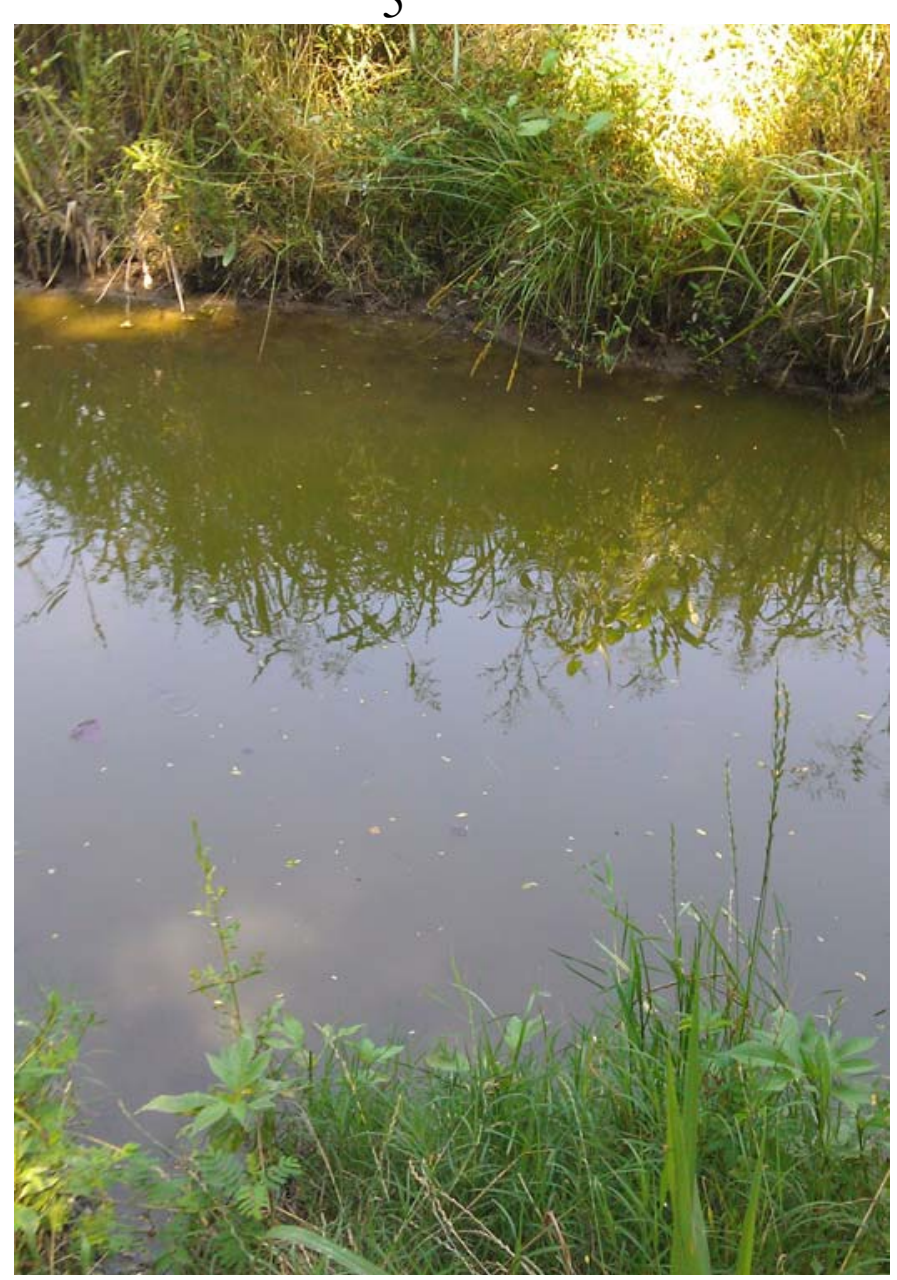

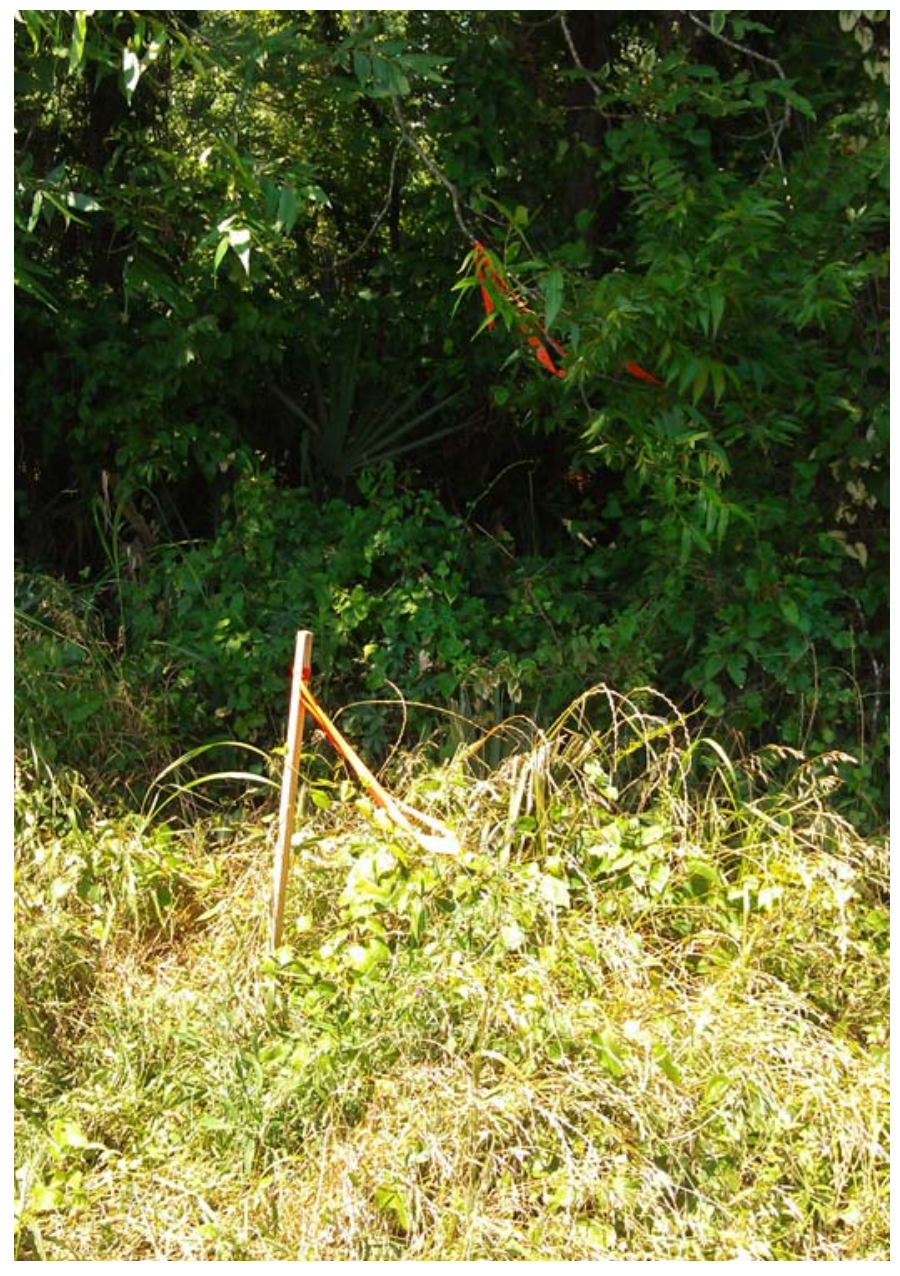

6

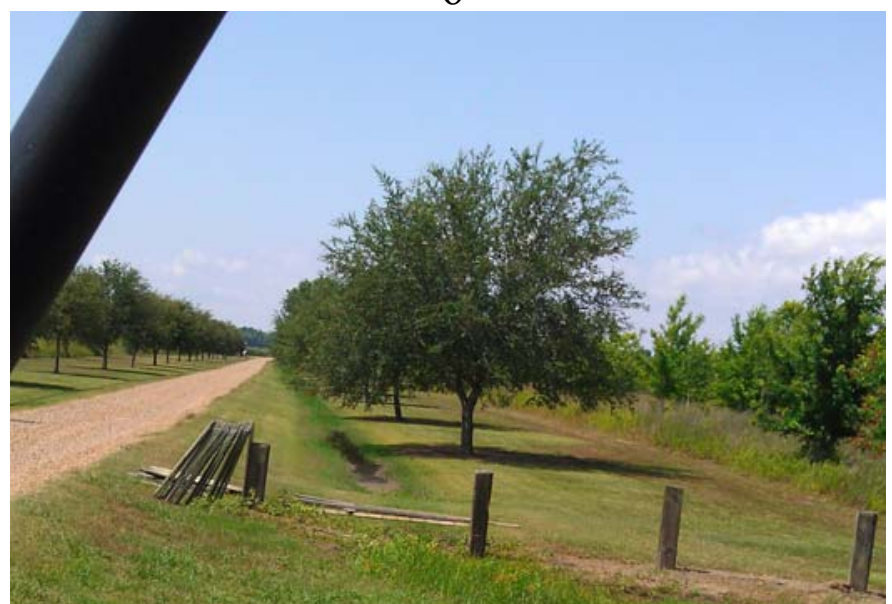




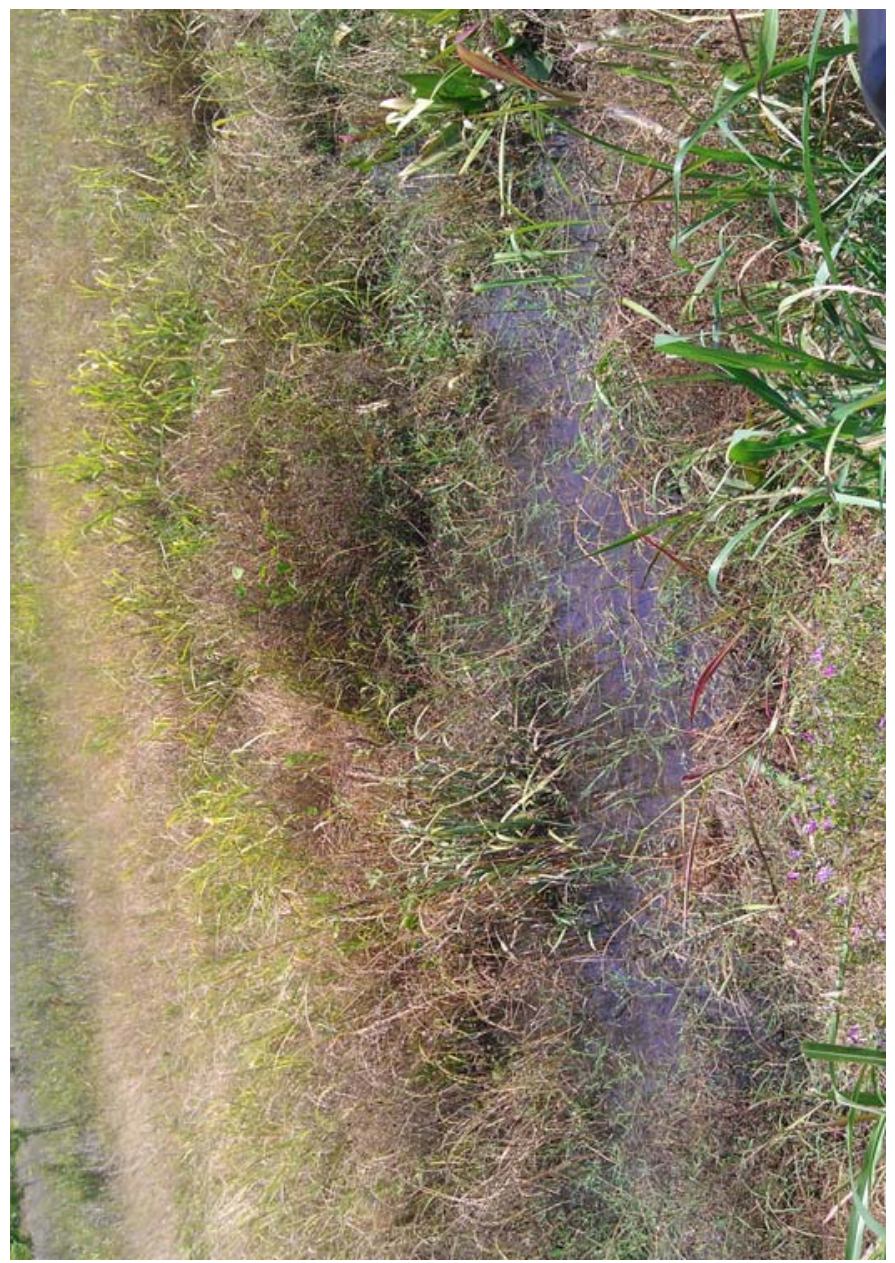

9

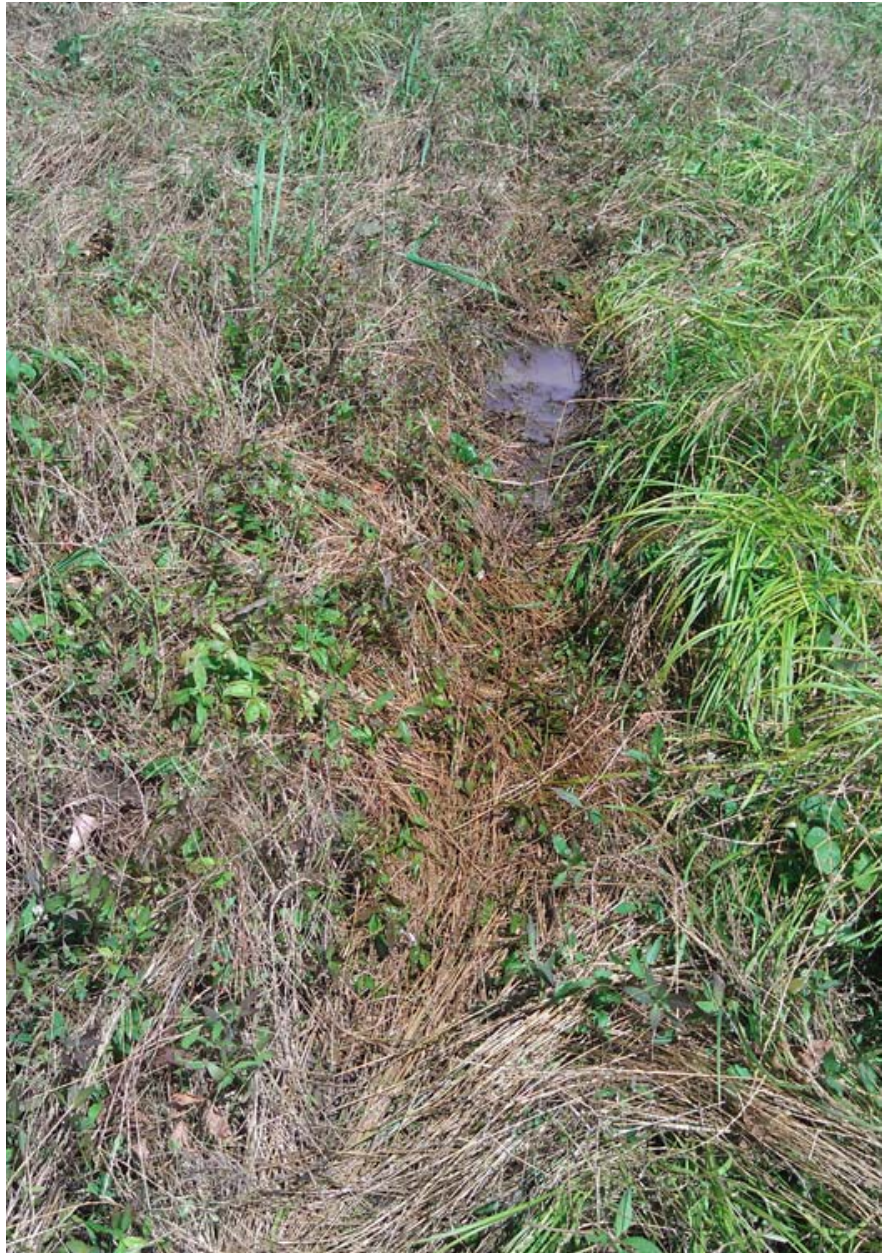

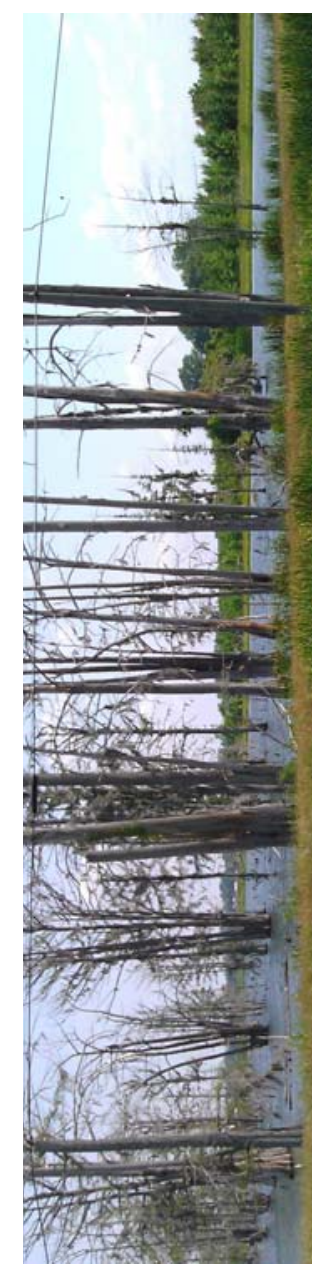

10

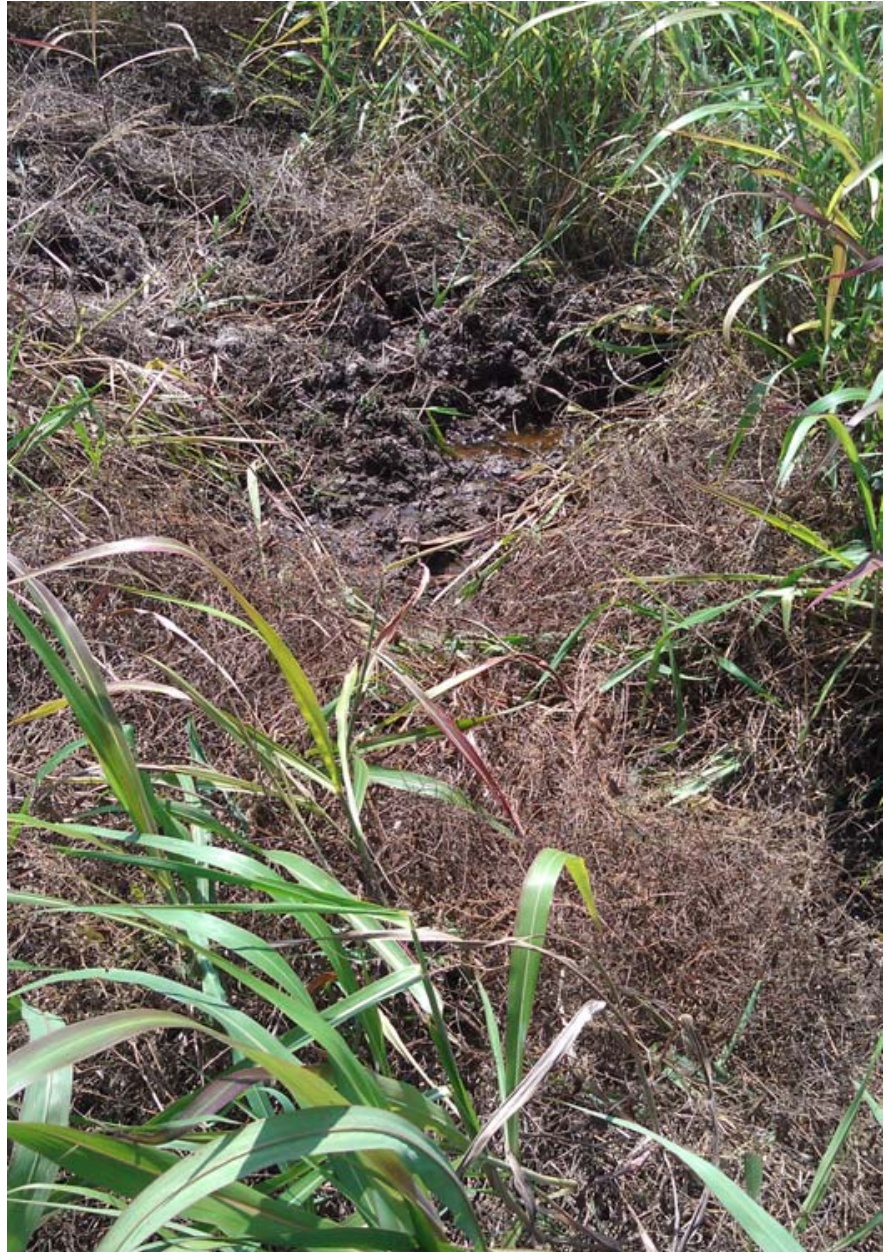

12 


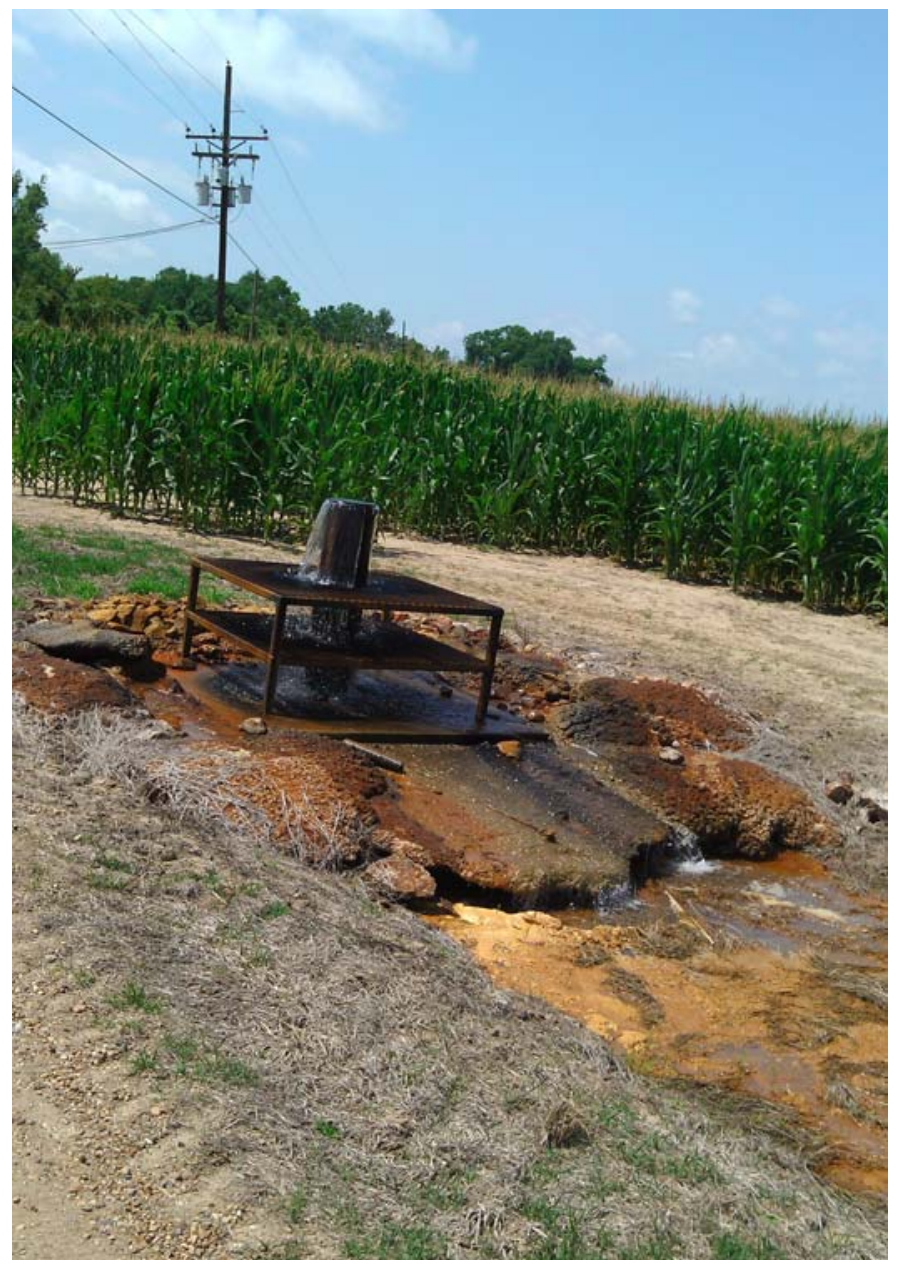

13

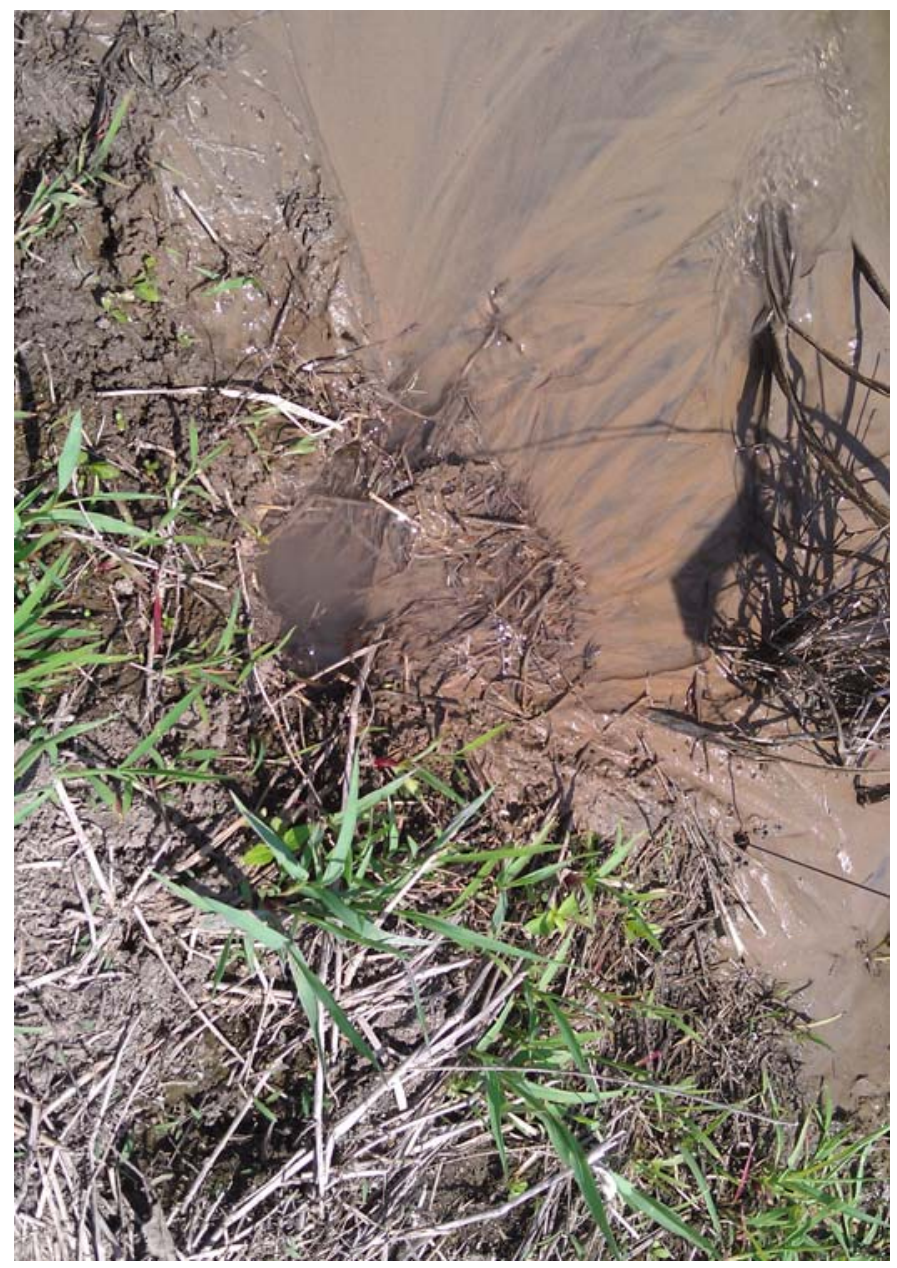

15

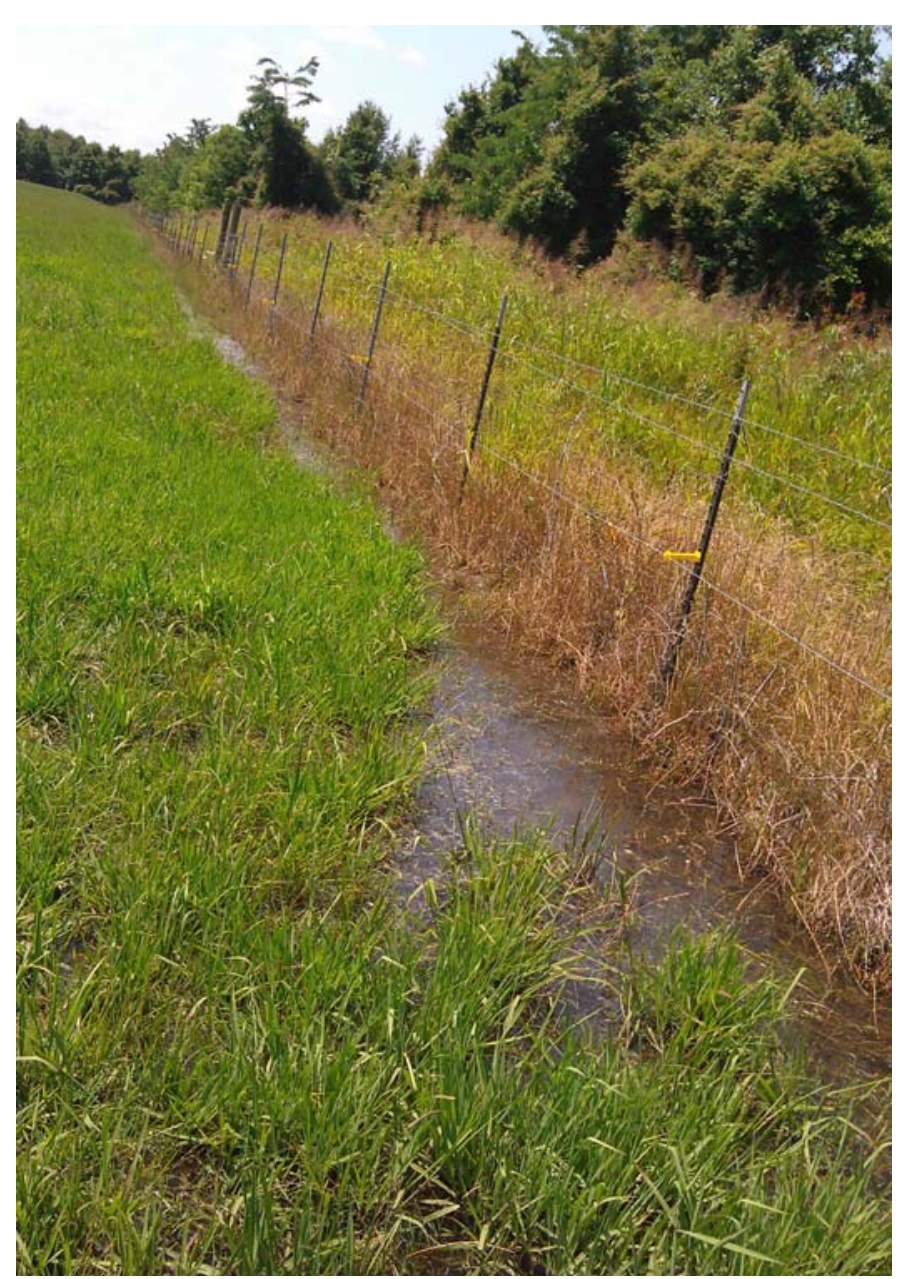

14

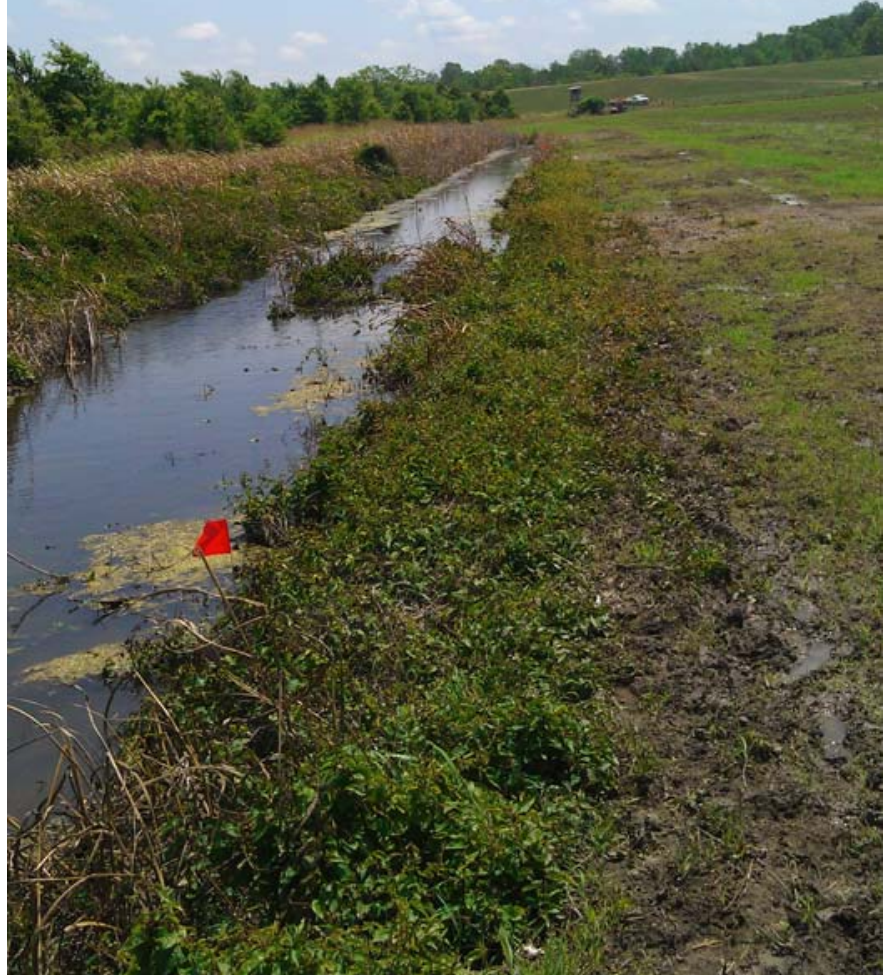




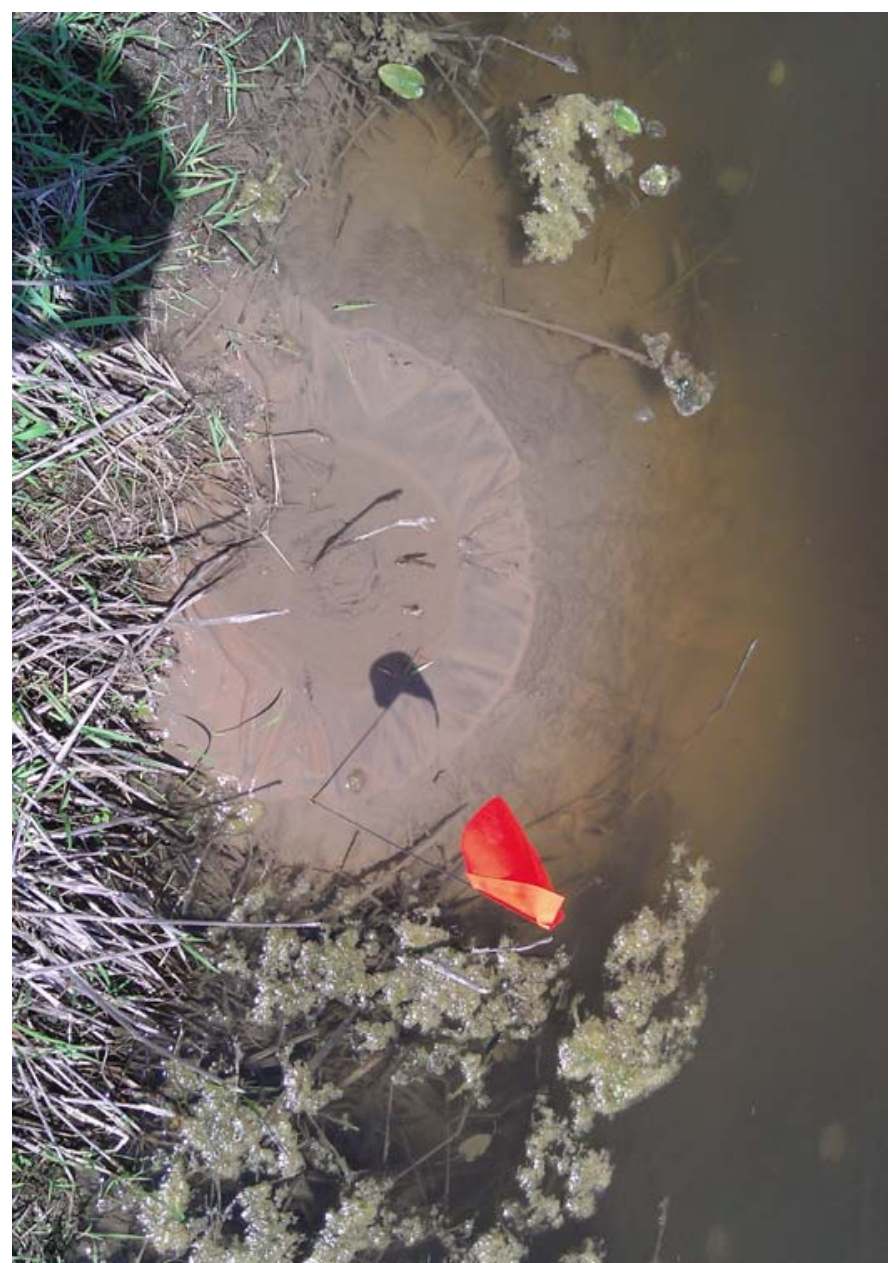

17

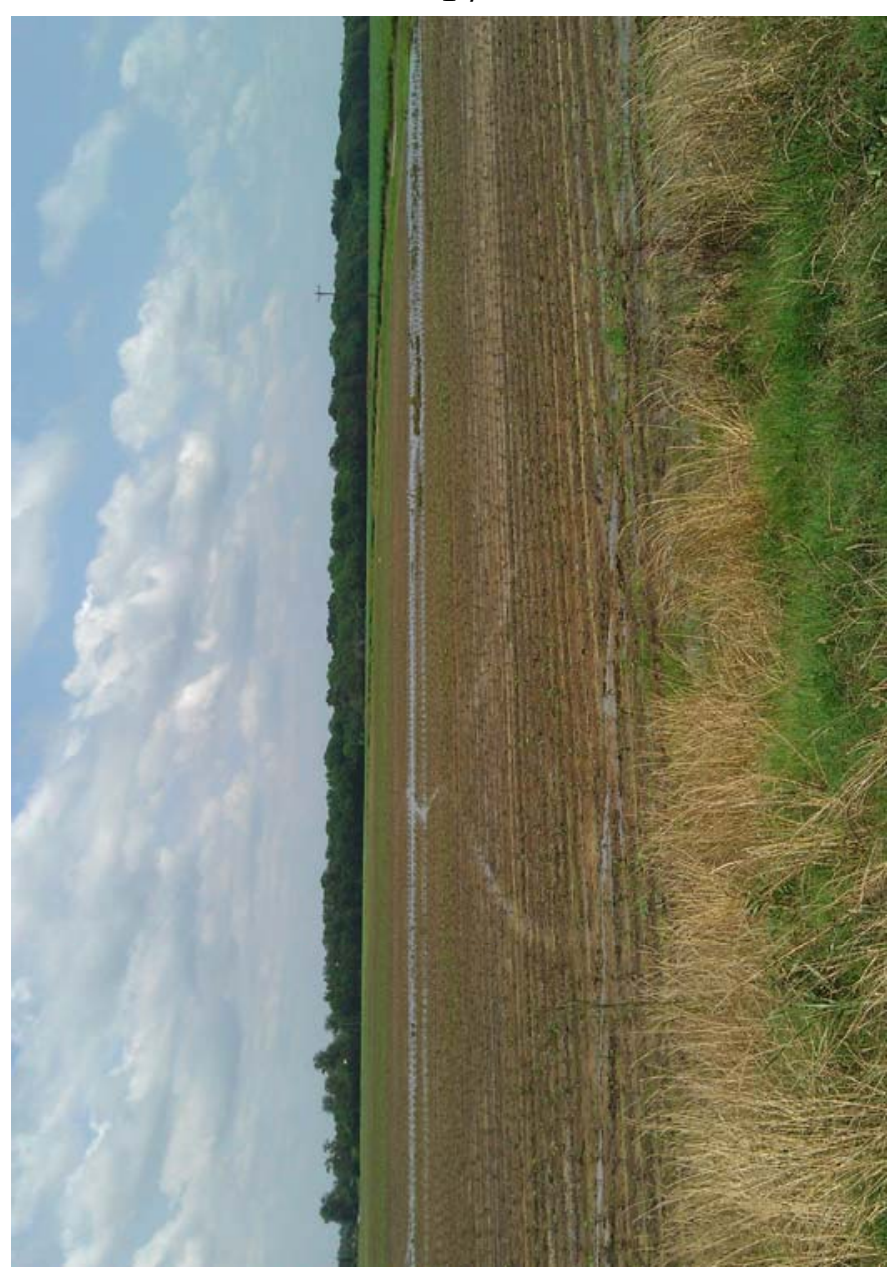

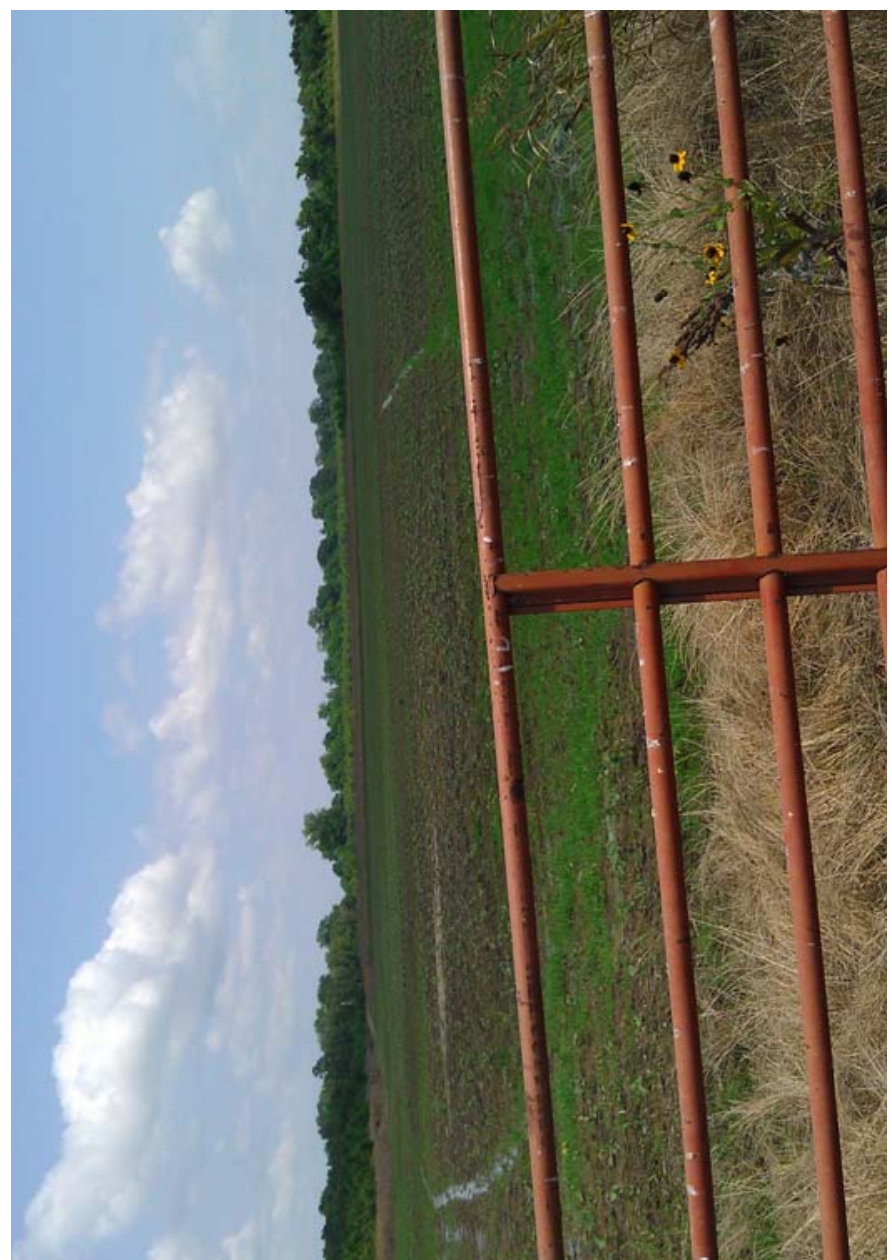

18

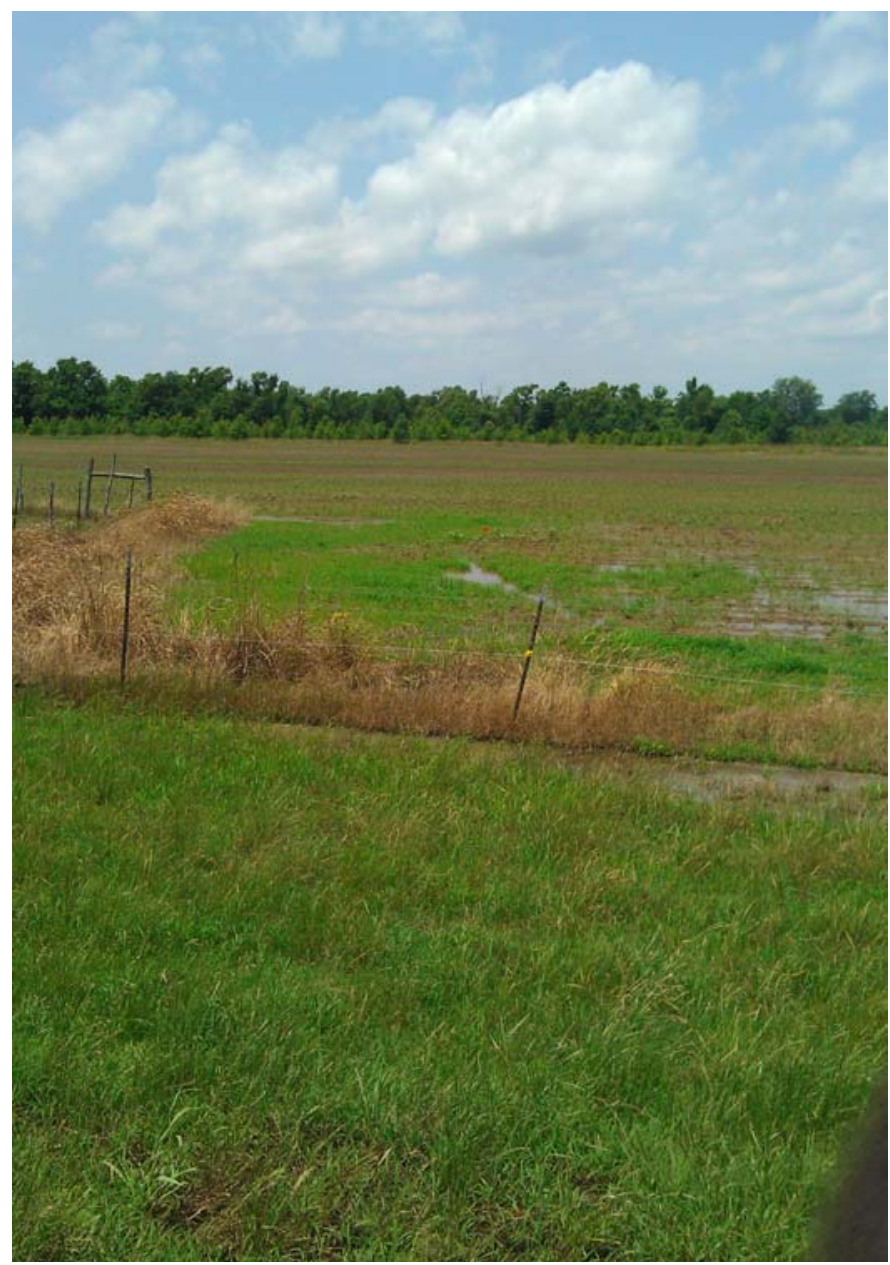




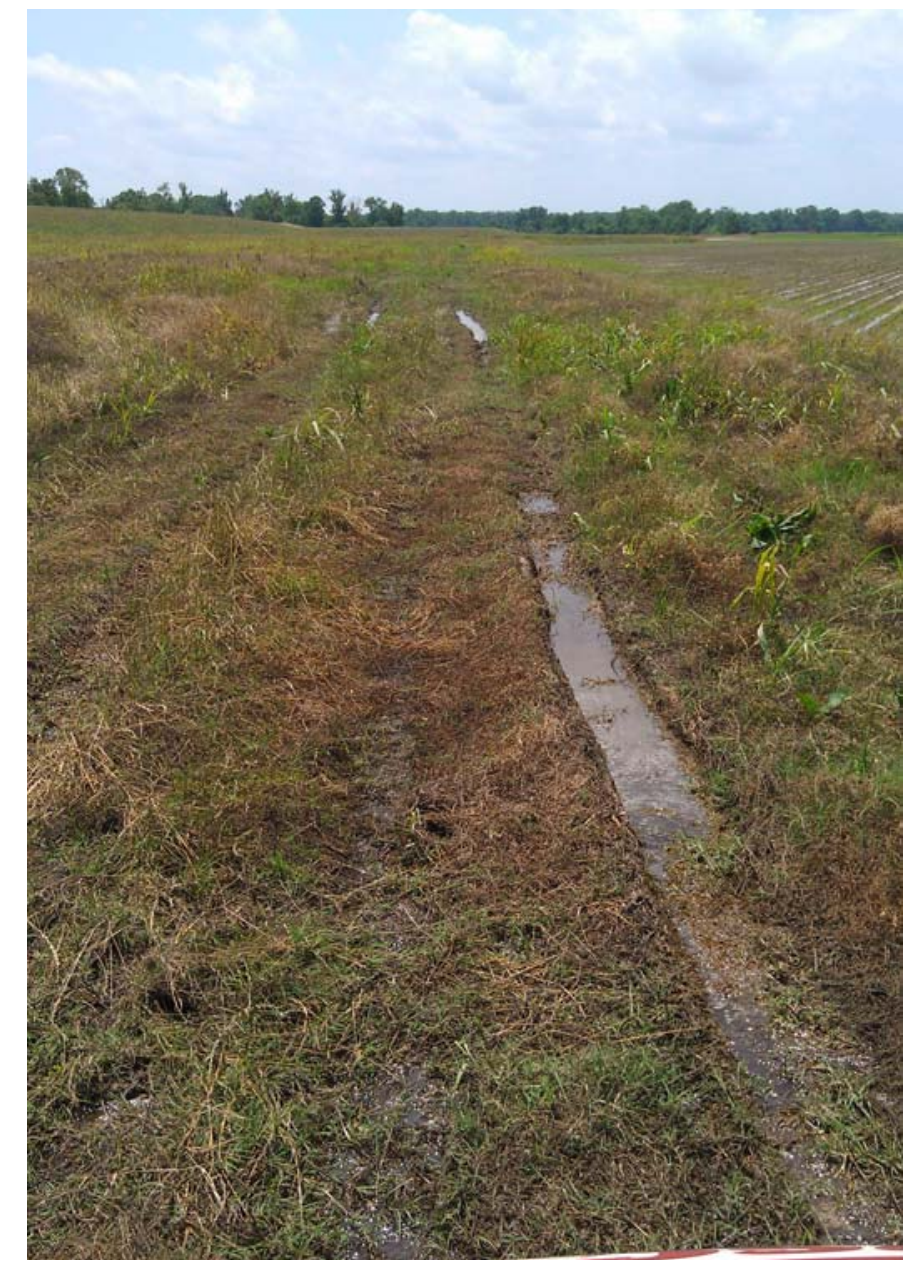

21

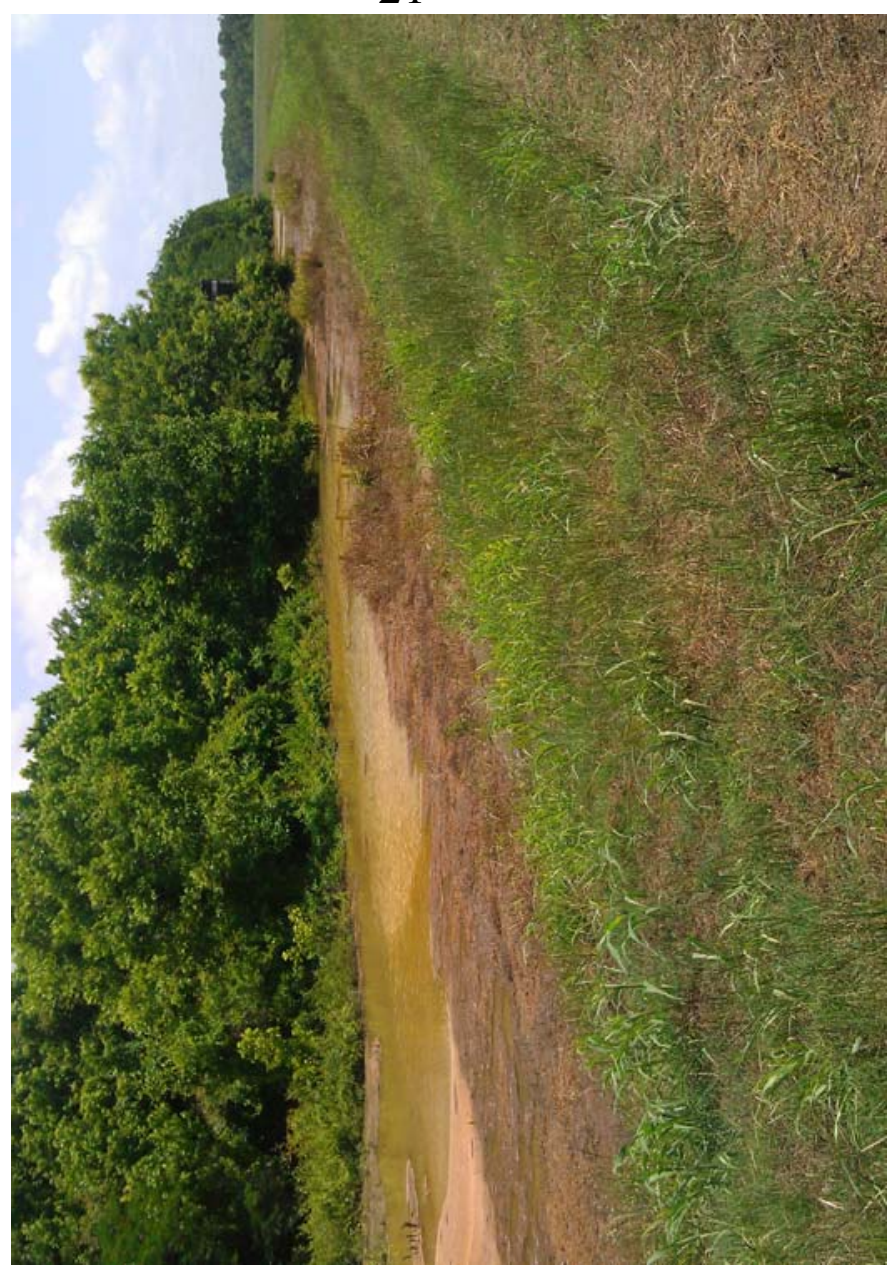

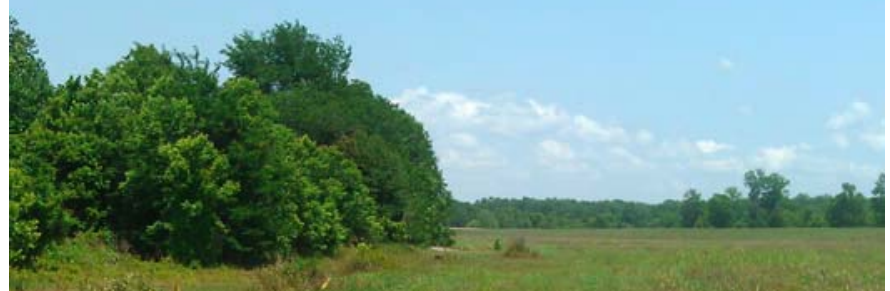

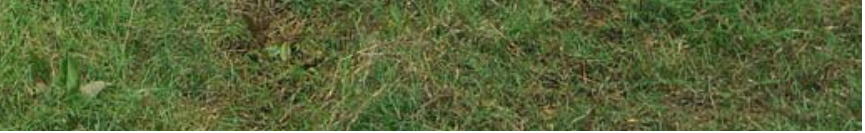

22

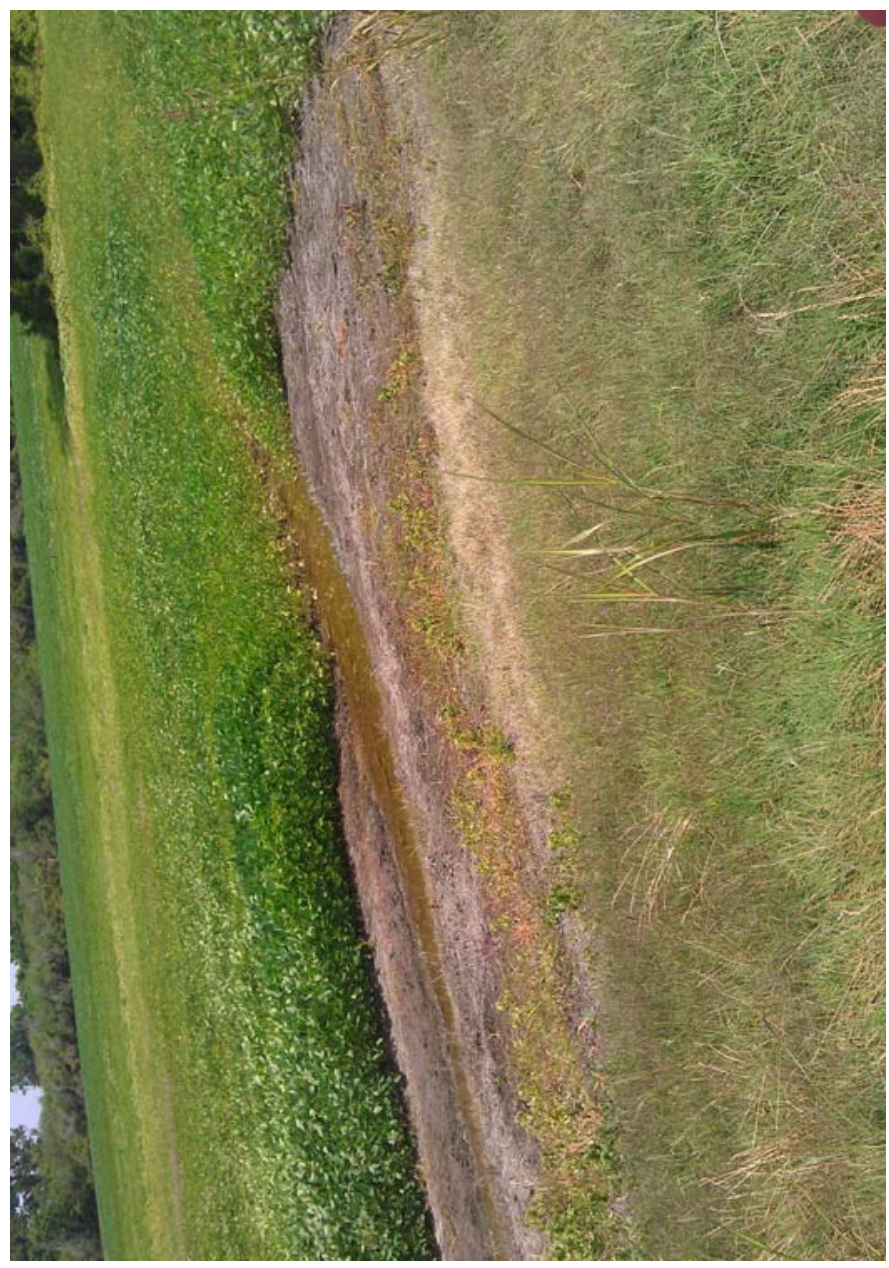




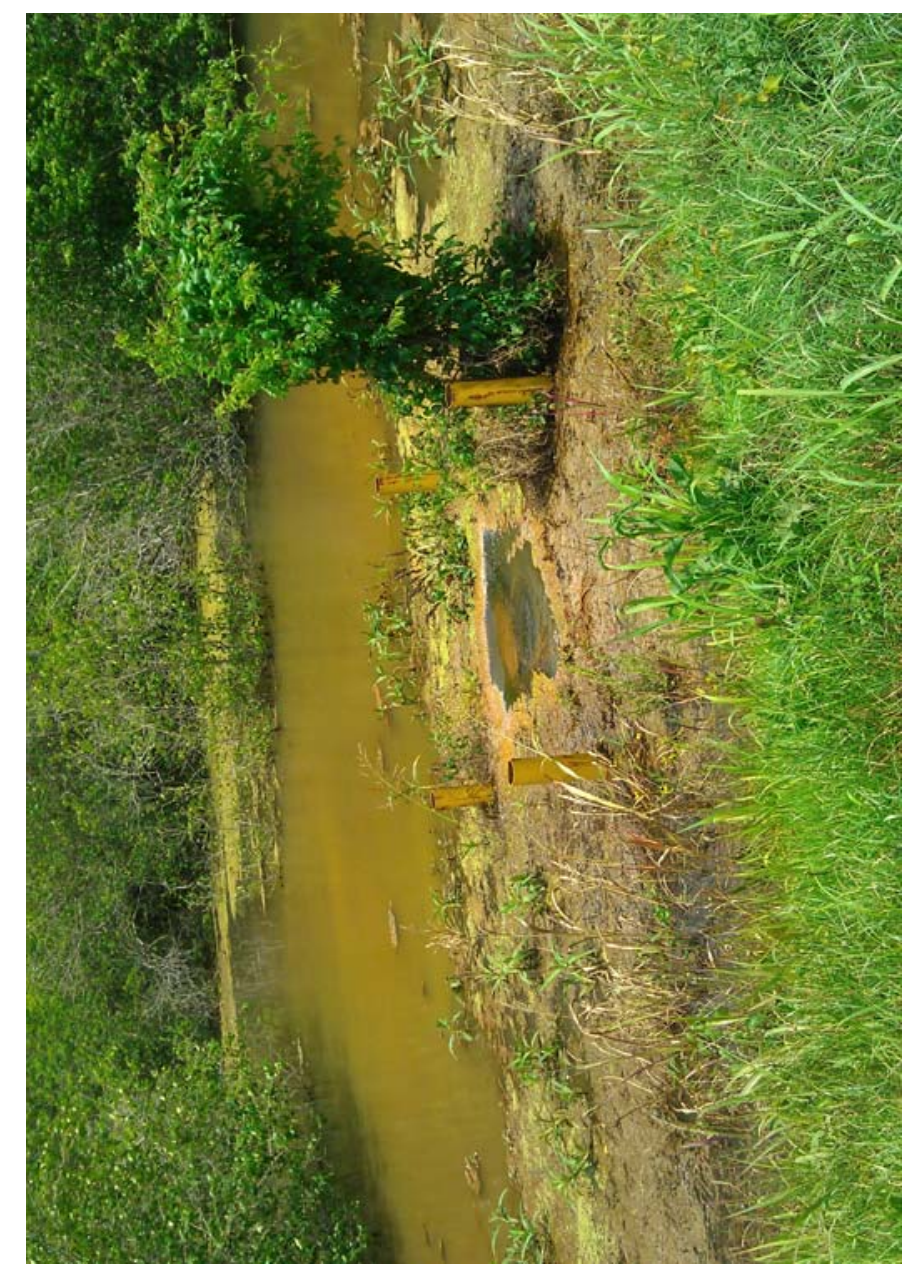

25

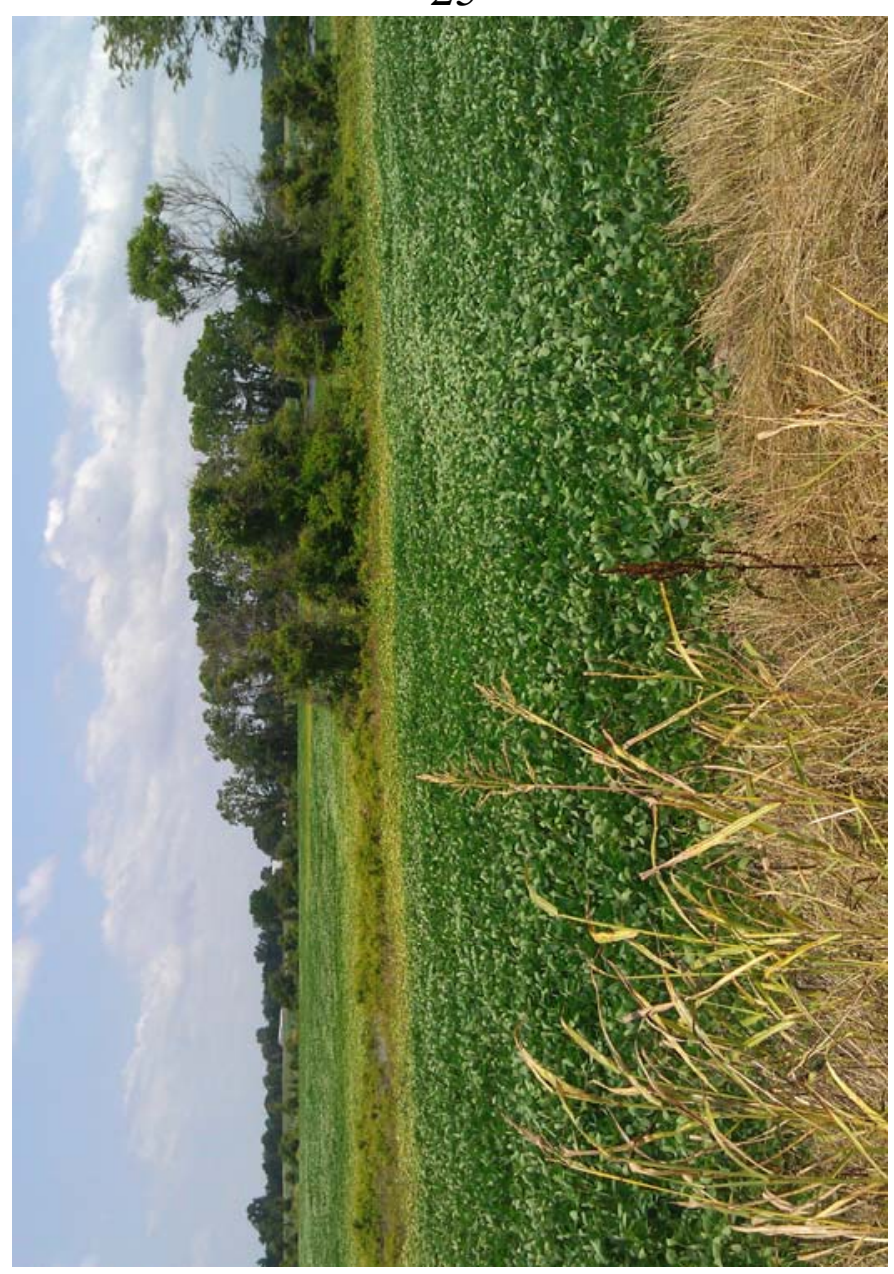

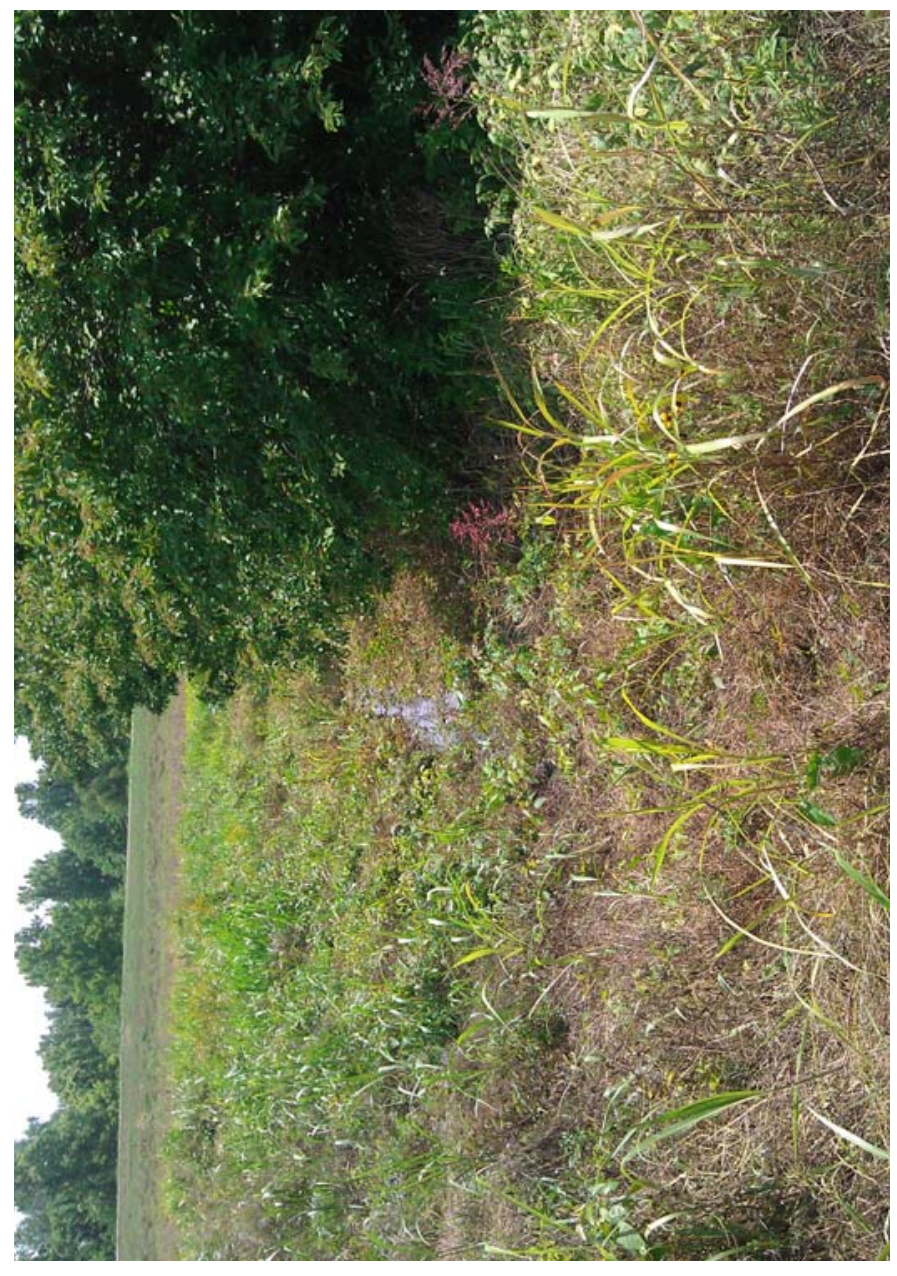

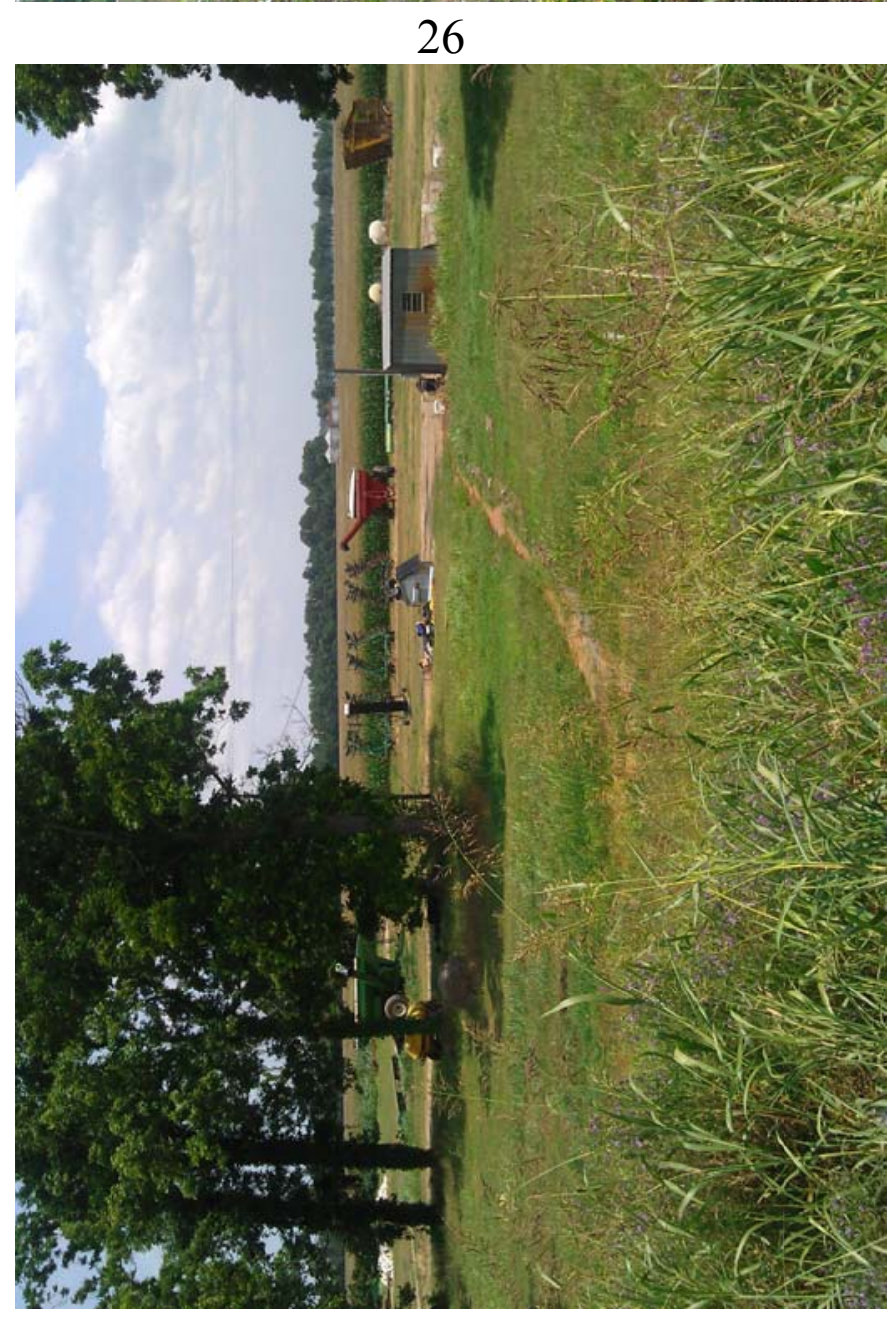




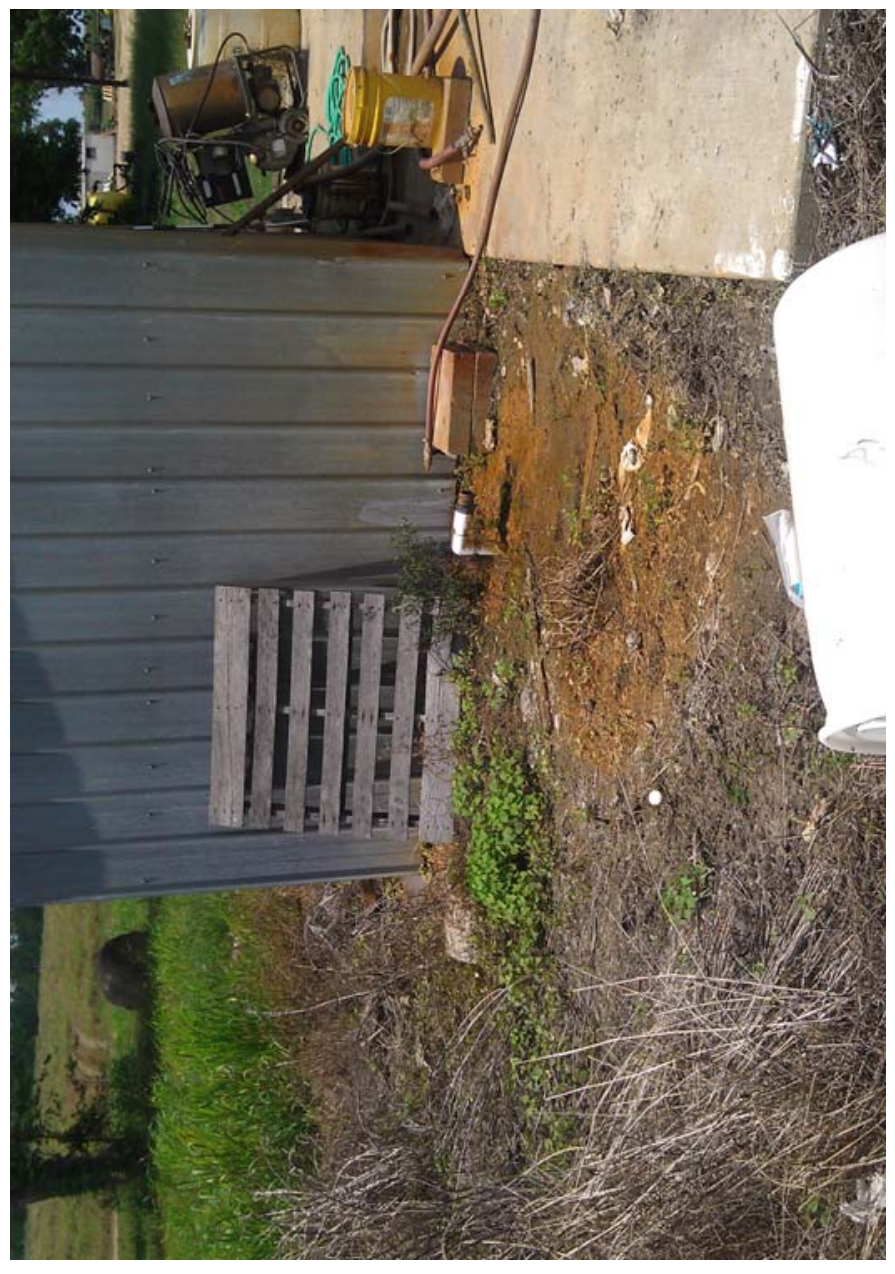

29

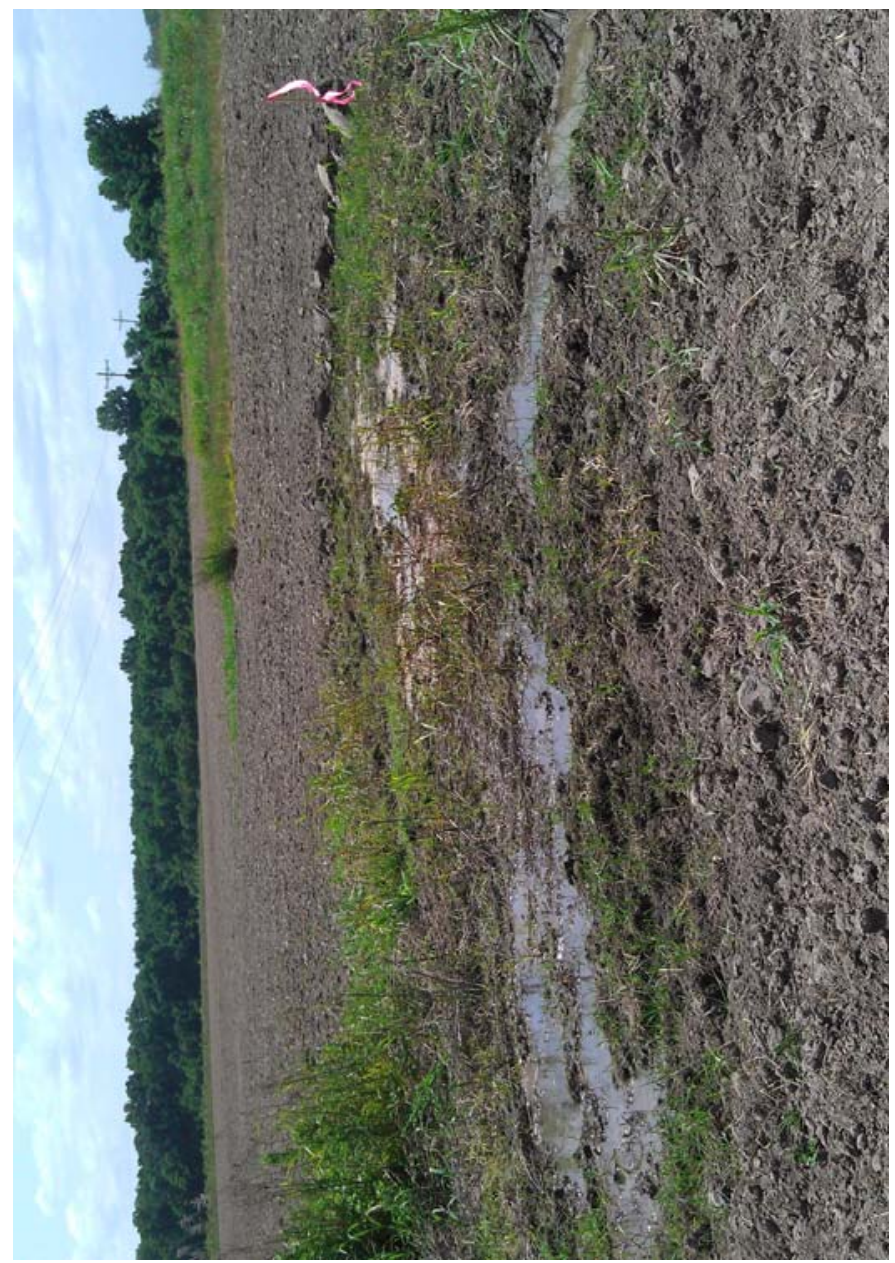

30 


\title{
Appendix B: Lecture IV: Underseepage (Fisk 1946)
}

\author{
(Note accompanying illustrations by R. J. LeBlanc, Assistant \\ Geologist to H. N. Fisk)
}

\section{LECTURE IV}

\section{Historic Background}

The following lecture on underseepage is reproduced here in its entirety from Fisk (1946). This lecture series was presented at the request of the MRC to engineers at the MRC, WES, and LMV districts between 1944 and 1946 for purposes of training basic geologic principals in relationship to levee underseepage. The basic concepts contained in this short narrative and accompanying illustrations forms the fundamental geologic concepts that will be described by Mansur et al. (1956) ten years later. The geologic site characterization described by Mansur et al. (1956) was primarily performed by Fisk and his team of geologists at LSU. Members of this team would later be transferred to Vicksburg in 1947 at the request of the MRC, and this team was established as the Geology Branch, in the Soils Laboratory, USAE Waterways Experiment Station. Dr. R. J. Leblanc would serve as the first Chief of the newly formed Geology Branch in Vicksburg, before accepting a position at Shell Oil in Houston, TX, in 1948. The last co-author in Mansur et al. (1956), Dr. J. R. Schultz, was the second Chief of the Geology Branch at WES during the conduct of this study. It is serendipity from a historical perspective that the following report on the 2011 Mississippi River Flood would occur by a member of the legacy Geology Branch that was formed at WES nearly 75 years earlier. The senior author of this report has great admiration of the 20-year-long research program that was sponsored by the MRC to effectively control underseepage in the LMV, and the successful performance of this amazing engineering accomplishment. 


\section{Introduction}

This lecture is intended to give a brief summary of the main factors which control underseepage and to discuss the secondary factors under which general and localized seepage has occurred at several sites.

\section{UNDERSEEPAGE}

The term underseepage, or underseepage process, is commonly used to denote water transmitted landward from the river under a levee rather than through a levee (through seepage). Seepage which results from such subterranean flow may be general, i.e., occurs along the levee and for considerable distance landside, or it may be localized to areas close to the landside toe of the levee. A sand boil is a special type of localized seepage, where the flow of water is concentrated at a point.

Underseepage is a high-water phenomenon which is controlled by two principal factors; the layering of the alluvial deposits in a relatively impermeable top stratum underlain by a permeable substratum, and excessive substratum pressures developed when the column of river water rises high above the natural ground surface between artificial levees.

Inasmuch as the principal factors controlling underseepage are everywhere present along the levee during high-water stages, the occurrence of seepage at a given locality must of necessity result from conditions peculiar to that seepage site. These local conditions, secondary factors, result from top stratum weakness, and from irregularities in distribution of the alluvial deposits. Most local weaknesses in the top stratum deposits have been formed artificially although some are the result of natural processes or are related to properties of the deposits.

\section{$\underline{\text { Relation of underseepage to the distribution of alluvial deposits }}$}

Studies were made of a large number of sites where underseepage occurred in 1937. Almost without exception, seepage occurred in those areas where the previous substratum approached the surface. Most of the high substratum areas were the narrow ridges which alternate with swales in point bars. Underseepage does not occur in the swales nor has it been recorded in areas where the top stratum is abnormally thick. The distribution of alluvial deposits in areas where underseepage has not been 
recorded are shown on the cross sections of Figure 1. The general nature of the distribution of deposits in areas where seepage was widespread is shown on Figure 2, and the distribution in areas where seepage was confined to the toe of the levee is shown on Figures 3 and 4. An example of possible seepage through the levee is shown on Figure 5.

Movement of subsurface water during change in river stage

In a geological examination made of an underseepage site in the vicinity of Louisiana State University at Baton Rouge, seepage was found to be localized to ridges of a typical "Ridge and Swale" topography of an old point bar. Piezometer wells are installed, some wells being approximately a mile from the landside toe of the levee. Daily readings were made of water level in the wells and correlations were made with river stages. It was found that there was only a short lag between the rise of river stage and the rise of water level in the wells. Plotting of the pressure readings showed conclusively that pressures were translated more rapidly in the substratum underlying the ridges than in the substratum underlying the swales. This was true not only during rising stages but in falling stages when the pressure transfer was riverward. Irregularities in pressure transfer, however, were more pronounced at a distance from the river during rising stages and more pronounced near the river during falling stages. No satisfactory explanation can be presented for this condition except for a possibly higher permeability of the substratum ridge sediments.

The pressures were transferred landward with an irregular steep front. This steep frontal zone was first developed close to the artificial levee and was gradually forced landward by the rise in pressure associated with the rise in river level. Riverward transfer of pressure lagged behind the drop in river stage so that the steep "frontal" area remained as a low pressure ridge during falling stages. 
Figure 1.

\section{DISTRIBUTION OF SEDIMENTS IN AREA WHERE UNDERSEEPAGE HAS NOT BEEN RECORDED}

A. LEVEE CONSTRUCTED ACCROSS WIDESPREAD RELATIVELY IMPERVIOUS SEDIMENTS OF UNIFORM THICKNESS SUCH AS BACK SWAMP CLAY DEPOSITS.

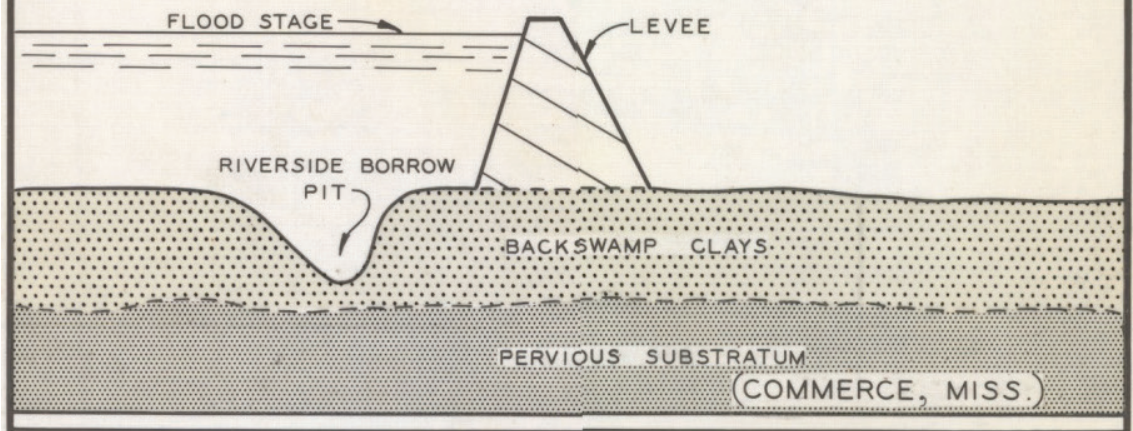

B. LEVEE CONSTRUCTED ACROSS THICK RELATIVELY IMPERVIOUS SEDIMENTS FILLING AND OLD ABANDONED CHANNEL.

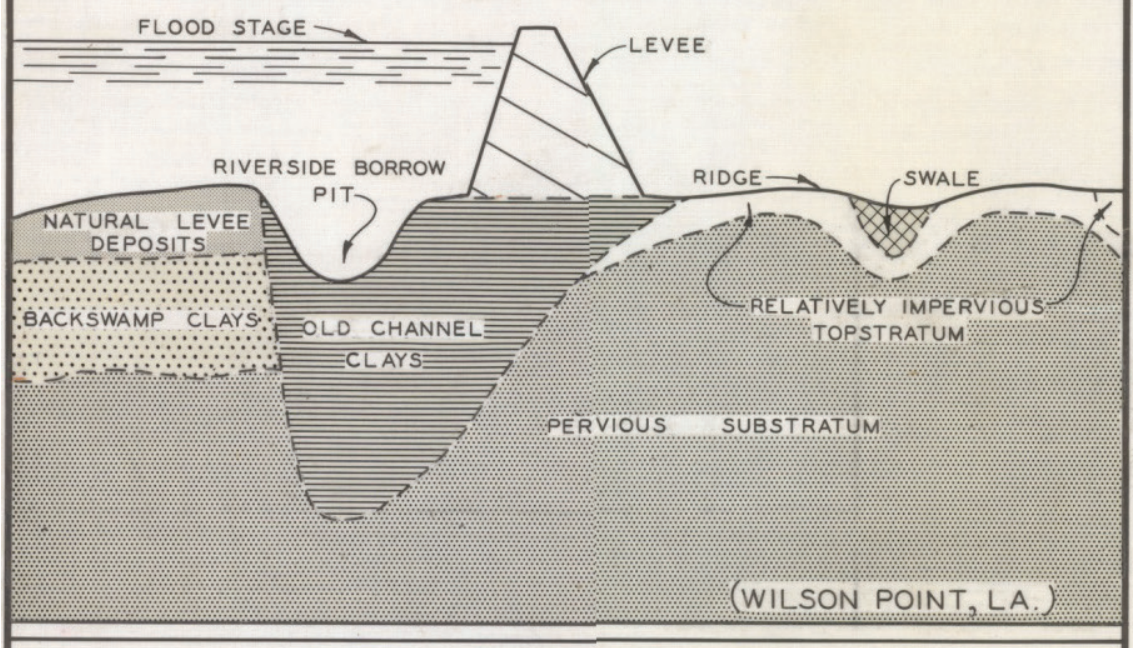

C. LEVEE CONSTRUCTED LANDWARD OF AND PARALLEL TO A THICK CHANNEL FILLED WITH CLAYS

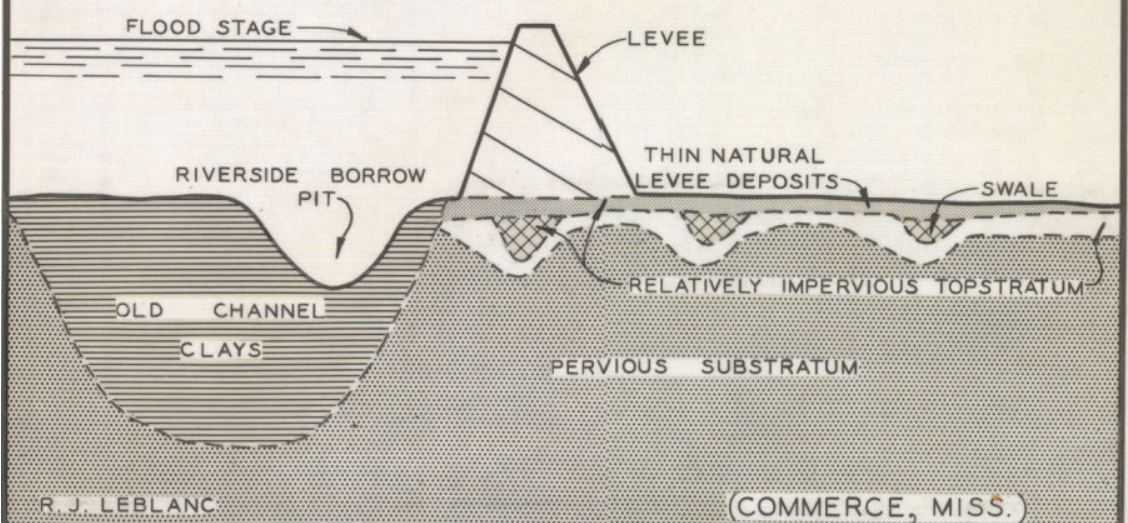


Figure 2. (Note the cover photo of this report).

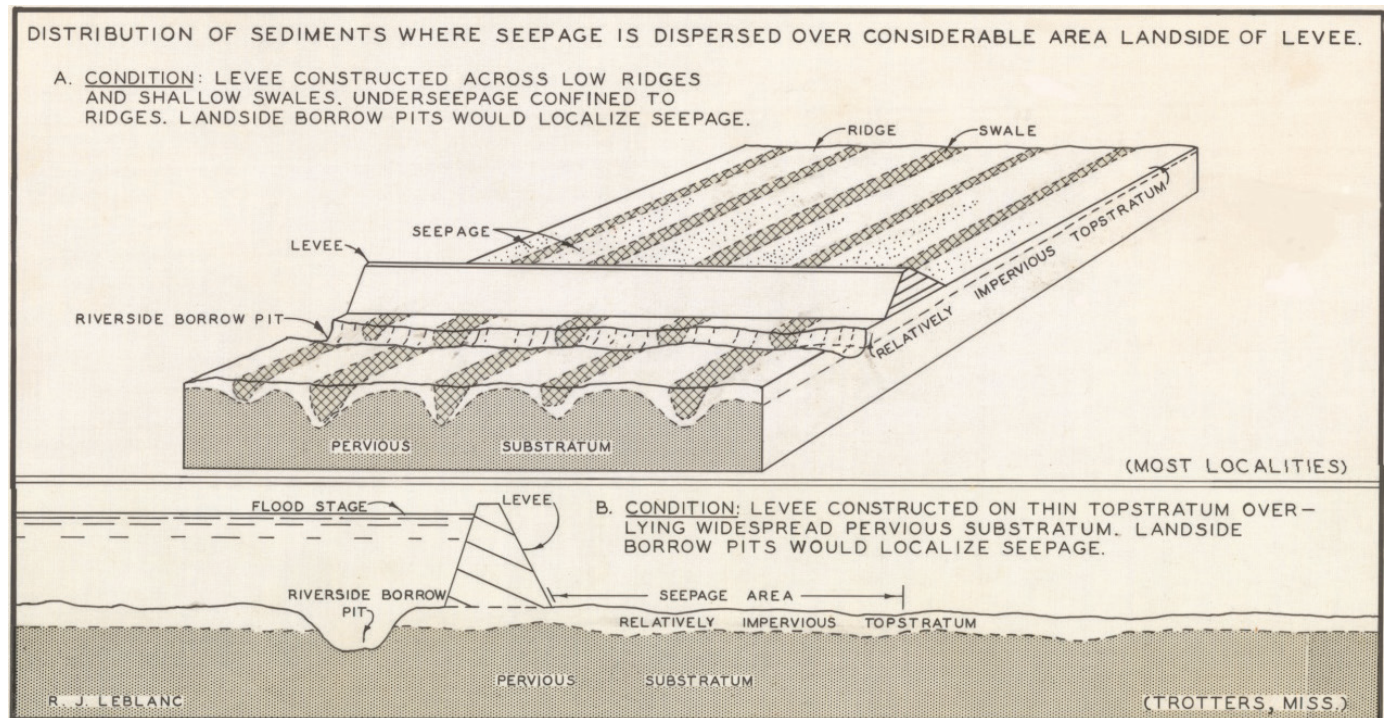

Figure 3.

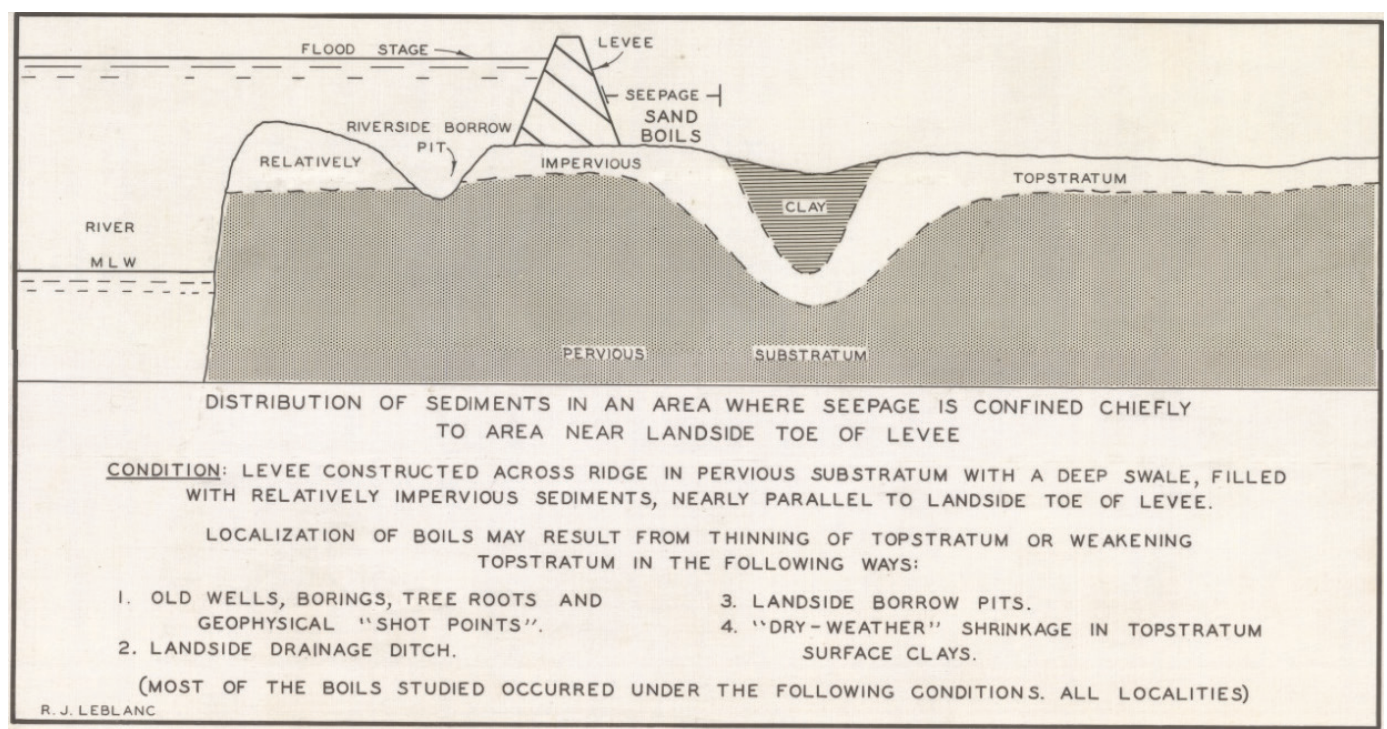


Figure 4.

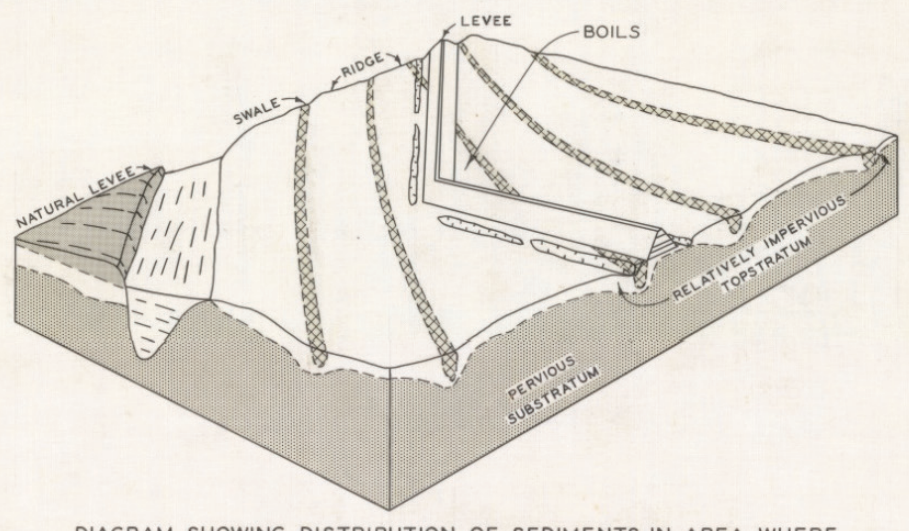

DIAGRAM SHOWING DISTRIBUTION OF SEDIMENTS IN AREA WHERE SAND BOILS OCCURRED WITHIN AN ANGLE IN THE LEVEE

CONDITIONS: ANGLE IN LEVEE CONSTRUCTED ACROSS THIN TOPSTRATUM DEPOSITS WITH THICK TOPSTRATUM FILLING SWALE WHICH CROSSES ANGLE. LANDSIDE BORROW PITS INTENSIFY SEEPAGE.

Figure 5.

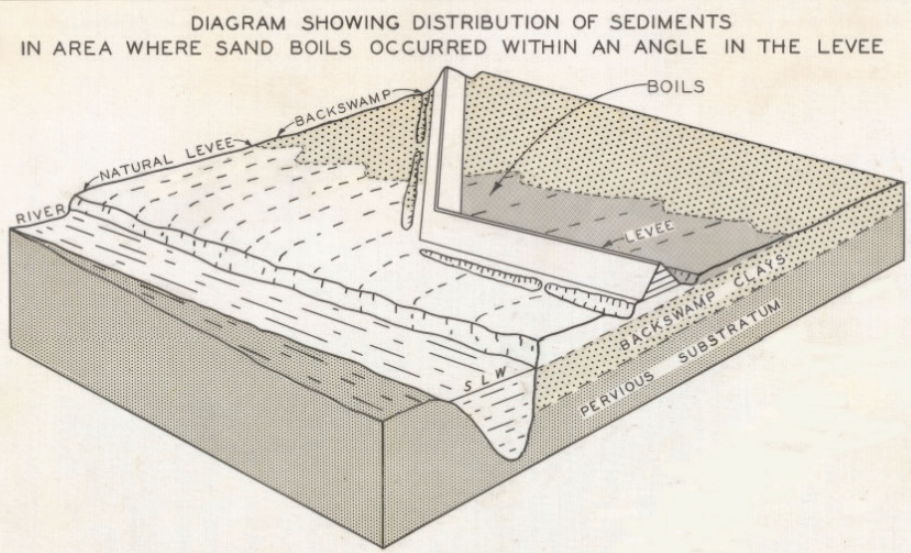

TRANSFER OF WATER THROUGH RELATIVELY IMPERVIOUS TOPSTRATUM

CONDITIONS: ANGLE IN LEVEE CONSTRUCTED ACROSS NATURAL LEVEE SILTS AND SILTY SANDS. BOTH LANDSIDE AND RIVERSIDE BORROW PITS PRESENT. ANGLE IN LEVEE WHICH PERMITS CONCENTRATION OF FLOW OF GROUNDWATER WITHIN THE ANGLE.

(ONLY STUDIED OCCURRENCE OF BOILS WHERE WATER WAS TRANSFERRED THROUGH TOPSTRATUM. WILSON POINT,LA.) 


\section{Appendix C: 47 Levee Code}




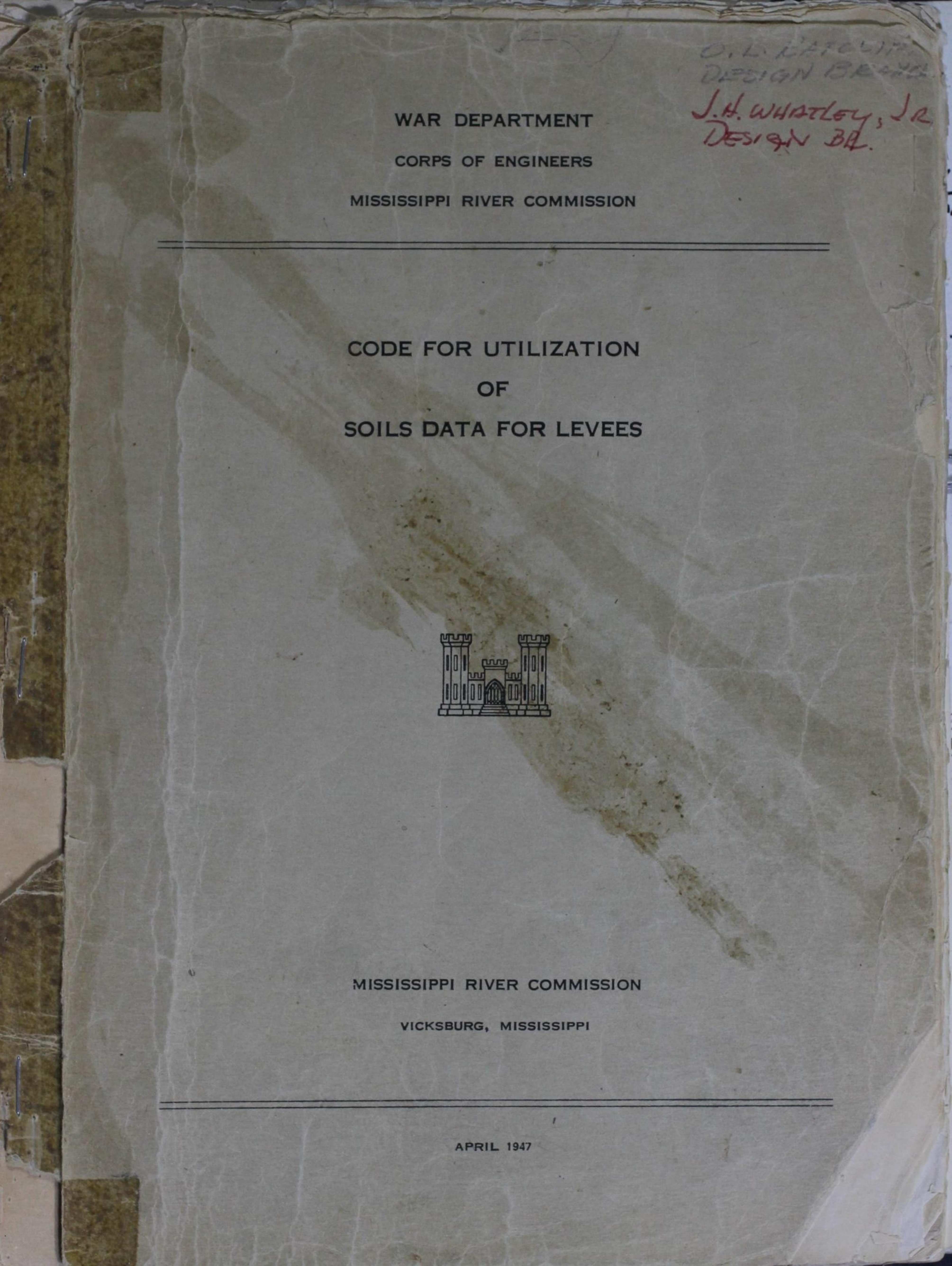




\author{
CORPS OF ENGINESRB, U. S. ARMX \\ office of the President \\ MISSISAIPPI RIVBR COAMISSION \\ Vieksburg, Miseissippi
}

\title{
$15 \max 1956$
}

\section{LuvvY}

\section{SUBJECT: Design Section for Levees}

To:
District Engineer, Meriphis Distriet, Cs, Meraphis, Tenn. Distriet Ingineer, Vicksburg Distriot, CE, Vicksburg, Miss. District Engineer, New Orleans Distriet, CE, New Orieans, La. (COPY TO BACE)

1. Reference: War Department Pamphlet, Corps of Bngineers, Mistisipp1 RIver Comnission, entitled: "Code for Utilization of Solls Date for Levees," dated April 1947.

2. In order to establiah a more uniform procedure for the planning and construction of levees, the following eriteria will be applied to all maln stem levee construction on the Mississippi aiver between Cape Girerdeau and Beton Rouge:

a. All new levees, plus those not yet constructed to authorized grade, w11l be designed to fit the 1947 code section.

b. Existing levees which are up to authorized grade, but defleient In "B" Section, w111 be designed to fit the 1947 Code Section.

c. Existing levees which are up to authorized grade and contain the "B" Section, but require berms and/or impervious blanikets to correct a serious seepage condition, will be designed to fit the 1947 Code Section.

d. Bxisting levees which are up to authorized grace, contain the "B" Section and have no seepage or foundation problem, but require a vider roadway, will be altered only to the extent necessary to widen the roadvay in accordence $w i t h$ the standard levee speeifleations.

e. For existing levees which are up to authorized grade, contain the "B" Section, but whose slopes are less than 1 on $3-1 / 2$ to a degree that seriously hampers performance of satisfactory maintenance, consideration will be given to effecting slope adjustments to conform to the 1947 Code Section.

1. In all cases of recuests for levee enlargement due to serlous seepage and/or foundation conditions, fleld data on soll classification 
and general conditions will be submitted in sufficient detall to permit a reasoneble appraisal of conditions to support the request.

3. Levee cross sections wilu be applied to the project flow line as base of reference when checking existing levee embankments for adequacy to meet the "B" Section or 1947 Code Section as referred to herein.

4. The "2947 Code" Section and the "B" Section as mentioned herein are defined as follows:

\section{a. 1947 Code Section.}

1.

2.

New levee; moderate degree of compaction at natural molsture content; uncorgacted P111s of materials which are too wet for compaction.

Hew levee; compacted to maximum density at optinum molsture content. Couparable to earth dan construetion.

iverside slope, 1 on 3-1/2. Crown, horizontel, $10 \mathrm{ft}$. wide. Iandside slope, 1 on $4-1 / 2$.

Levees less than $25 \mathrm{ft}$. In Helght Riverside slope, 1 on 4. Crown, hor1zontal, $10 \mathrm{ft}$. wide.

Landside slope, 1 on $5-1 / 2$. Levees, 25 ft. or higher Riverside slope, 1 on 4. Crown, horizontal, 10 ft. vide.

Lendiside slope, 1 on 6.

Riverside slope, 1 on $4-1 / 2$. Crown, horizontal, $10 \mathrm{ft}$. vide. Landside slope, 1 on $6-1 / 2$. sufficiently dry for a moderste degree of corgaction

4. Enlargement
For enlargement work the existing levee shall be considered as a semicorapacted f111. Crown width and slopes shall be as preacibed above for the type of construction Involved. 


\section{LitVr:}

SWisucr: Desiga Bection for Levees

b. 1928 "B" Cross Section - net dimensions.

Crown widh $10.0 \mathrm{ft}$.

Riverside slope 1 on $3-1 / 2$

Landside slope to contain seepage line on 1 on $6-1 / 2$.

elevation of the assumed maximuri flow line. The landside slope shall

extend in a straight line from the landside edge of the erown to the point

where the seepage line intersects the ground eurfece.

\section{/8/ John R. Harafn}

JOHN R. HARDIN

Major General, USA

President, Misissippi River Conmission 
Vielsoburg, Missiseigpi

wense

$6 \mathrm{atc} 2955$

struscr: Code for vtiliation of Solls Date for Levees

To:

DIstrict Ingineer, Merphis Distriet, CE, Menphis, Tenn. Dietriet Ingineer, Vieiseburg Distriet, CE, Vieksburg, Ulise. Distriet Engineer, Hew Oxleens Distriet, CB, New Orlesas, La. (COPY mo EACH)

1. Meference is mede to 2etters of this office, subject "Review of Code for Design end Construction of Levees" dated 7 and 30 Juse 1955 convening a cound ttee meeting on 7 July 1955 to alseuss the need for revising the foundation settlement and shrinktuge provlaions of the subject code.

2. The code provisione for levee enlargements, ss puislished, are subject to variable interpretations. The code consittee, therefore, suggested gertaln modirigations which, I belleve, establith a sound besls for design and will lesd to a wore untforin treatment throudhout the Aivialon. Aecorlingly, the rollowing wodsfications are approved and ahoula be wide effective in all future cesign and conetruation of levee works

a. Par 41, Speciel Segtions, Page 21, ade the following sentenge at the end of the paregraph, Jitnor topping and correction of alope deficiencles will be guided by praetieal conslderations with the general objective of restoring the originel design". and substitute the following!

b. $\operatorname{Par} 46$, Page 12 , delete this geragraph in 1ts antirety

"The need for foundation settlexent allowances for levee enisrgonents shall be deteruined on the besis of best methods, dats, and information avallable, and shrinkage allowances sholl be the sawe as those whown in paragraph 45. The construetion gross grade sheul not exeeed the theoretioal gross grede, based upon settlement and alnrinirege saleulatione, by more than $0.5 \mathrm{rt}$. 
c. Par 72, Mreoboaxd, Page 29, add the following sentenee

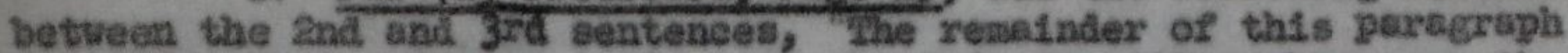
indichtes the expressed cesires of the Code Conmlttee; however, thelx etatements eannot be held to violate offielelly preseribed froeboerds".

3. In eddition to the sbove nodlfications, the Weterways wamerimast Station has ande up a table on solls classirieation to soplece ilgures 1 end 2. This table conteins essential ates shom

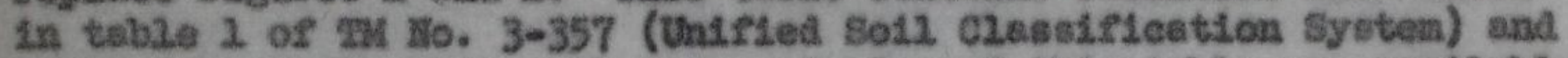
tuble A-1 of Appendix A thereto. Coples of this table sxe avaliable and wi3. be fumatshed ror the eoples in your distriet. This orstee should be advioed as to the number of coples reculred.

4. The code is in need of other minor modifleations to bring the text wi to tate, however, 14 is not proposed to make these edaltions chenges unt12 a new 1 soue of the code is warrasted.

2 Inel: Table 2

\section{/s/ Jolan R. Hartin}

JOM R. HANDIM

BrIgadier Generel, USA

Prestdent, Hastestppi River Coneal sation 


\section{THEATER OF OPERATIONS AIRFIELD SPECIFICATIONS}

\begin{tabular}{|c|c|c|c|}
\hline \multirow{2}{*}{ Features } & \multicolumn{3}{|c|}{ Categories } \\
\hline & 1 & 2 & 3 \\
\hline $\begin{array}{l}\text { RUNWAY GRADES: } \\
\text { Longitudinal max } \\
\text { Transverse required }\end{array}$ & $\begin{array}{l}1.5 \% \\
1.5 \%\end{array}$ & $\begin{array}{l}1.5 \% \\
1.5 \%\end{array}$ & $\begin{array}{l}1.0 \% \\
1.5 \%\end{array}$ \\
\hline $\begin{array}{l}\text { SHOULDER GRADES: } \\
\text { Minimum } \\
\text { Maximum }\end{array}$ & $\begin{array}{l}2.0 \% \\
3.0 \%\end{array}$ & $\begin{array}{l}2.0 \% \\
3.0 \%\end{array}$ & $\begin{array}{l}2.0 \% \\
3.0 \%\end{array}$ \\
\hline $\begin{array}{l}\text { TAXIWAY GRADES: } \\
\text { Longitudinal } \max ^{1} \\
\text { Transverse required }\end{array}$ & $\begin{array}{l}3.0 \% \\
1.5 \%\end{array}$ & $\begin{array}{l}3.0 \% \\
1.5 \%\end{array}$ & $\begin{array}{l}3.0 \% \\
1.5 \%\end{array}$ \\
\hline $\begin{array}{l}\text { RUNWAY: } \\
\text { Length }{ }^{2} \\
\text { Width } \\
\text { Shoulder }\end{array}$ & $\begin{array}{r}4,500^{\prime} \\
120^{\prime} \\
50^{\prime}\end{array}$ & $\begin{array}{r}6,000^{\prime} \\
150^{\prime} \\
50^{\prime}\end{array}$ & $\begin{array}{l}8,000^{\prime 3} \\
200^{\prime}-300^{\prime} \\
50^{\prime}\end{array}$ \\
\hline $\begin{array}{l}\text { CLEARANCE: } \\
\text { Center line runway to obstacle } \\
\text { Center line runway to center line taxiway } \\
\text { Center to center of parallel runways } \\
10^{\prime} \text { elevation sight distance }\end{array}$ & $\begin{array}{r}210^{\prime} \\
485^{\prime} \\
500^{\prime} \\
3,500^{\prime}\end{array}$ & $\begin{array}{l}275^{\prime} \\
512.5^{\prime} \\
750^{\prime} \\
5,000^{\prime}\end{array}$ & $\begin{array}{l}350^{\prime}-500^{\prime} \\
637.5^{\prime}-700^{\prime} \\
1,000^{\prime} \\
6,000^{\prime}\end{array}$ \\
\hline $\begin{array}{l}\text { CLEAR ZONE: } \\
\text { Length } \\
\text { Width }\end{array}$ & $\begin{array}{l}500^{\prime} \\
420^{\prime}\end{array}$ & $\begin{array}{r}1,000^{\prime} \\
550^{\prime}\end{array}$ & $\begin{array}{l}1,000^{\prime} \\
700^{\prime}-1000^{\prime}\end{array}$ \\
\hline $\begin{array}{l}\text { OVERRUN: } \\
\text { Length } \\
\text { Width }\end{array}$ & $\begin{array}{l}500^{\prime} \\
220^{\prime}\end{array}$ & $\begin{array}{r}1,000^{\prime} \\
250^{\prime}\end{array}$ & $\begin{array}{l}1,000^{\prime} \\
300^{\prime}-400^{\prime}\end{array}$ \\
\hline $\begin{array}{l}\text { TAXIWAY: } \\
\text { Width } \\
\text { Shoulders } \\
\text { Clearance from center line of taxiway }\end{array}$ & $\begin{array}{l}50^{\prime} \\
12.5^{\prime} \\
85^{\prime}\end{array}$ & $\begin{array}{l}75^{\prime} \\
12.5^{\prime} \\
97.5^{\prime}\end{array}$ & $\begin{array}{l}75^{\prime}-100^{\prime} \\
12.5^{\prime} \\
137.5^{\prime}-200^{\prime}\end{array}$ \\
\hline $\begin{array}{l}\text { APPROACH ZONE: } \\
\text { Glide angle } \\
\text { Length } \\
\text { Width at opening }\end{array}$ & $\begin{array}{r}1: 40 \\
2 \mathrm{mi} \\
3,000^{\prime}\end{array}$ & $\begin{array}{r}1: 50 \\
2 \mathrm{mi} \\
4,000^{\prime}\end{array}$ & $\begin{array}{l}1: 50 \\
5 \mathrm{mi}-10 \mathrm{mi} \\
4,000^{\prime}\end{array}$ \\
\hline $\begin{array}{l}\text { HARDSTANDS: } \\
\text { Diameter } \\
\text { Center to center spacing } \\
\text { Clearance from taxiway center line } \\
\text { Clearance from runway center line }\end{array}$ & $\begin{array}{l}70^{\prime}-100^{\prime} \\
300^{\prime} \\
85^{\prime}-125^{\prime} \\
210^{\prime}\end{array}$ & $\begin{array}{l}100^{\prime} \\
400^{\prime} \\
137.5^{\prime} \\
275^{\prime}\end{array}$ & $\begin{array}{l}120^{\prime}-160^{\prime} \\
400^{\prime}-500^{\prime} \\
137.5^{\prime}-250^{\prime} \\
400^{\prime}-450^{\prime}\end{array}$ \\
\hline $\begin{array}{l}\text { DESIGN WHEEL LOADING: } \\
\text { Runway } \\
\text { Taxiway } \\
\text { Hardstand } \\
\text { Apron }\end{array}$ & $\begin{array}{l}16,000 \# \\
20,000 \# \\
20,000 \# \\
20,000 \#\end{array}$ & $\begin{array}{l}40,000 \# \\
50,000 \# \\
50,000 \# \\
50,000 \#\end{array}$ & $\begin{array}{l}70,000 \#-150,000 \# \\
87,500 \#-187,500 \# \\
87,500 \#-187,500 \# \\
87,500 \#-187,500 \#\end{array}$ \\
\hline
\end{tabular}

NOTES:

1 - May be increased to $5 \%$ for a length not in excess of $400^{\prime}$.

2 - $5 \%$ increase for each $1000^{\prime}$ above sea level.

3 - Capable of development to 10,000 ' where possible.

\section{AIRFIELD CATEGORIES:}

1 - Light transport and interceptor fighters.

2 - Medium transports, jet fighters, long range fighters and light bombers.

3 - Heavy transports and heavy bombers. 
ANNEX, ORG III A3 SOIL CLASSIFICATION FOR AIRFIELD PROJECTS

REPRODUCED AT THE ENGINEER SCHOOL FOR THE CHIEF OF ENGINEERS

\begin{tabular}{|c|c|c|c|c|c|c|c|c|c|c|c|c|c|c|c|c|}
\hline & 1 & 2 & 3 & & 4 & 5 & 6 & 7 & 8 & 9 & 10 & 11 & 12 & 13 & 14 & 15 \\
\hline & & & & General & identiffcation & & & $\begin{array}{c}\text { Value as } \\
\text { foundation }\end{array}$ & $\begin{array}{l}\text { Value as } \\
\text { base }\end{array}$ & & & & & $\begin{array}{c}\text { Solids at } \\
\text { opt. com- } \\
\text { paction }\end{array}$ & $\begin{array}{c}\text { California } \\
\text { bearing } \\
\text { ratio }\end{array}$ & $\begin{array}{c}\text { Com- } \\
\text { parable } \\
\text { groups }\end{array}$ \\
\hline & $\begin{array}{l}\text { Major } \\
\text { divisions }\end{array}$ & $\begin{array}{l}\text { typical names } \\
\text { tyons }\end{array}$ & $\begin{array}{l}\text { group } \\
\text { symbols }\end{array}$ & $\begin{array}{c}\text { Dry } \\
\text { strength }\end{array}$ & $\begin{array}{c}\begin{array}{c}\text { Other } \\
\text { pertinent } \\
\text { examination }\end{array} \\
\end{array}$ & $\begin{array}{l}\text { tests relating to } \\
\text { material in place }\end{array}$ & \begin{tabular}{|c|} 
classification tests \\
(on disturbed samples)
\end{tabular} \mid & $\begin{array}{l}\text { subject to } \\
\text { frost action }\end{array}$ & $\begin{array}{c}\text { under } \\
\text { wearing } \\
\text { surface } \\
\end{array}$ & $\begin{array}{l}\text { frost } \\
\text { action }\end{array}$ & $\begin{array}{l}\text { expansion, } \\
\text { elasticity }\end{array}$ & $\begin{array}{l}\text { character- } \\
\text { istics }\end{array}$ & $\begin{array}{l}\text { characteristics } \\
\text { and equipment }\end{array}$ & 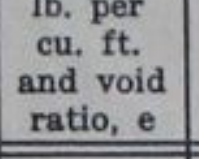 & $\begin{array}{c}\text { por comed } \\
\text { and soaked } \\
\text { specimen }\end{array}$ & $\begin{array}{l}\text { in pouds } \\
\text { roassif- } \\
\text { classif- } \\
\text { cation } \\
\end{array}$ \\
\hline & Gravel & $\begin{array}{l}\text { Well graded gravel and } \\
\text { gravel-sand mixtures, } \\
\text { little or no fines. . . } \\
\end{array}$ & GW & None & $\begin{array}{l}\text { Gradation, } \\
\text { grain shape }\end{array}$ & $\begin{array}{l}\text { Dry unit weight } \\
\text { or void ratio, }\end{array}$ & Mechanical analysis & Excellent & $\begin{array}{l}\text { Good to } \\
\text { excellent }\end{array}$ & $\begin{array}{c}\text { None to } \\
\text { very } \\
\text { slight }\end{array}$ & $\begin{array}{c}\text { Almost } \\
\text { none }\end{array}$ & Excellent & $\begin{array}{l}\text { Excellent, } \\
\text { tractor }\end{array}$ & $\begin{array}{l}>125 \\
e<0.35\end{array}$ & $>50$ & A-3 \\
\hline & and & $\begin{array}{l}\text { Well graded gravel-sand- } \\
\text { clay mixtures, excellent } \\
\text { binder. . . . . . . . } \\
\end{array}$ & GC & $\begin{array}{l}\text { Medium } \\
\text { to high } \\
\end{array}$ & $\begin{array}{l}\text { Gradation, } \\
\text { grain shape } \\
\text { binder exam. } \\
\text { wet and dry } \\
\end{array}$ & Degree of compaction, & $\begin{array}{l}\text { Mechanical analysis, } \\
\text { liquid and plastic } \\
\text { limits on binder } \\
\end{array}$ & Excellent & $\begin{array}{c}\text { Fair to } \\
\text { excellent }\end{array}$ & Medium & $\begin{array}{l}\text { Very } \\
\text { slight }\end{array}$ & $\begin{array}{l}\text { Practically } \\
\text { impervious }\end{array}$ & $\begin{array}{l}\text { Excellent } \\
\text { tamping roller }\end{array}$ & $\begin{array}{l}>130 \\
\mathrm{e}<0.30\end{array}$ & $>40$ & A-1 \\
\hline & gravelly & $\begin{array}{c}\text { Poorly graded gravel and } \\
\text { gravel-sand mixtures, } \\
\text { little or no đnes. . . } \\
\end{array}$ & GP & None & $\begin{array}{c}\text { Gradation, } \\
\text { grain shape }\end{array}$ & $\begin{array}{l}\text { durability } \\
\text { of grains, }\end{array}$ & Mechanical analysis & $\begin{array}{l}\text { Good to } \\
\text { excellent }\end{array}$ & Poor to good & $\begin{array}{c}\text { None to } \\
\text { very } \\
\text { slight }\end{array}$ & $\begin{array}{c}\text { Almost } \\
\text { none }\end{array}$ & Excellent & $\begin{array}{l}\text { Good } \\
\text { tractor }\end{array}$ & $\begin{array}{l}>115 \\
e<0.45\end{array}$ & $25-60$ & A-3 \\
\hline 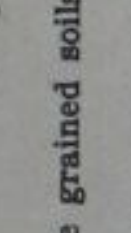 & soils & $\begin{array}{l}\text { Gravel with fines, very } \\
\text { silty gravel, clayey } \\
\text { gravel, poorly graded } \\
\text { gravel s sand - clay } \\
\text { mixtures, ........ } \\
\end{array}$ & GF & $\begin{array}{l}\text { Very slight } \\
\text { to high. }\end{array}$ & $\begin{array}{l}\text { Gradation, } \\
\text { grain shape } \\
\text { binder exam. } \\
\text { wet and dry }\end{array}$ & $\begin{array}{l}\text { Stratification } \\
\text { and drainage } \\
\text { characteristics, }\end{array}$ & $\begin{array}{l}\text { Mechanical analysis, } \\
\text { liquid and plastic } \\
\text { limits on binder } \\
\text { if applicable }\end{array}$ & $\begin{array}{l}\text { Good to } \\
\text { excellent }\end{array}$ & Poor to good & $\begin{array}{l}\text { Slight to } \\
\text { medium }\end{array}$ & $\begin{array}{l}\text { Almost } \\
\text { none } \\
\text { to slight }\end{array}$ & $\begin{array}{c}\text { Fair to } \\
\text { practically } \\
\text { impervious }\end{array}$ & $\begin{array}{c}\text { Good, close } \\
\text { control } \\
\text { essential, } \\
\text { rubber tired } \\
\text { roller, tractor } \\
\end{array}$ & $\begin{array}{l}>120 \\
\mathrm{e}<0.40\end{array}$ & $>20$ & A-2 \\
\hline ठั & Sands & $\begin{array}{l}\text { Well graded sands and } \\
\text { gravelly sands, little or } \\
\text { no fines. }\end{array}$ & sw & None & $\begin{array}{l}\text { Gradation, } \\
\text { grain shape }\end{array}$ & $\begin{array}{l}\text { Ground water } \\
\text { conditions, }\end{array}$ & Mechanical analysis & \begin{tabular}{c|c} 
Good to \\
excellent
\end{tabular} & Poor to good & $\begin{array}{l}\text { None to } \\
\text { very } \\
\text { slight }\end{array}$ & $\begin{array}{c}\text { Almost } \\
\text { none }\end{array}$ & Excellent & $\begin{array}{l}\text { Excellent, } \\
\text { tractor }\end{array}$ & $\begin{array}{l}>120 \\
\mathrm{e}<0.40\end{array}$ & $20-60$ & A-3 \\
\hline & and & $\begin{array}{l}\text { Well graded sand - clay } \\
\text { mixtures, excellent } \\
\text { binder. . . . . . }\end{array}$ & sc & $\begin{array}{l}\text { Medium } \\
\text { to high }\end{array}$ & $\begin{array}{l}\text { Gradation, } \\
\text { grain shape } \\
\text { binder exam. } \\
\text { wet and dry } \\
\end{array}$ & $\begin{array}{l}\text { Traffic tests, } \\
\text { Large scale } \\
\text { load tests or }\end{array}$ & $\begin{array}{l}\text { Mechanical analysis, } \\
\text { liquid and plastic } \\
\text { limits on binder }\end{array}$ & $\begin{array}{l}\text { Good to } \\
\text { excellent }\end{array}$ & Poor to good & Medium & $\begin{array}{l}\text { Very } \\
\text { slight }\end{array}$ & $\begin{array}{l}\text { Practically } \\
\text { impervious }\end{array}$ & $\begin{array}{l}\text { Excellent, } \\
\text { tamping roller }\end{array}$ & $\begin{array}{l}>125 \\
e<0.35\end{array}$ & $20-60$ & A-1 \\
\hline & sandy & $\begin{array}{l}\text { Poorly graded sands, little } \\
\text { or no fines. . . . . }\end{array}$ & SP & None & $\begin{array}{c}\text { Gradation, } \\
\text { grain shape }\end{array}$ & & Mechanical analysis & Fair to good & Not suitable & $\begin{array}{c}\text { None to } \\
\text { very slight }\end{array}$ & $\begin{array}{c}\text { Almost } \\
\text { none }\end{array}$ & Excellent & $\begin{array}{l}\text { Good, } \\
\text { tractor }\end{array}$ & $\begin{array}{l}>100 \\
e<0.70\end{array}$ & $10-30$ & A-3 \\
\hline & soils & $\begin{array}{c}\text { Sands with fines, very silty } \\
\text { sands, clayey sands } \\
\text { poorly graded sand-clay } \\
\text { mixtures. . . . . . . } \\
\end{array}$ & $\mathrm{SF}$ & $\begin{array}{l}\text { Very slight } \\
\text { to high }\end{array}$ & $\begin{array}{l}\text { Gradation, } \\
\text { Binder exam. } \\
\text { wet and dry } \\
\end{array}$ & $\begin{array}{l}\text { California } \\
\text { Bearing tests }\end{array}$ & $\begin{array}{c}\text { Mechanical analysis, } \\
\text { liquid and plastic } \\
\text { limits on binder } \\
\text { if applicable } \\
\end{array}$ & Fair to good & Not suitable & $\begin{array}{l}\text { Slight } \\
\text { to high }\end{array}$ & $\begin{array}{l}\text { Almost } \\
\text { none to } \\
\text { medium }\end{array}$ & $\begin{array}{c}\text { Fair to } \\
\text { practically } \\
\text { impervious }\end{array}$ & $\begin{array}{c}\text { Good, close } \\
\text { control } \\
\text { essential, } \\
\text { rubber tired } \\
\text { roller } \\
\end{array}$ & $\begin{array}{l}>105 \\
e<0.60\end{array}$ & $8-30$ & A-2 \\
\hline 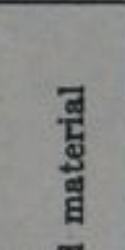 & $\begin{array}{l}\text { Fine grained } \\
\text { soils having }\end{array}$ & $\begin{array}{l}\text { Silts (Inorganic) and very } \\
\text { fine sands, Mo, rock } \\
\text { flour, silty or clagey fine } \\
\text { sands with slight plasti- } \\
\text { city. ................ }\end{array}$ & ML & $\begin{array}{l}\text { Very slight } \\
\text { to medium }\end{array}$ & $\begin{array}{l}\text { Examination wet } \\
\text { (shaking teat } \\
\text { and plasticity) }\end{array}$ & $\begin{array}{l}\text { Dry unit weight, } \\
\text { water content } \\
\text { and void ratio, }\end{array}$ & $\begin{array}{l}\text { Mechanical analysis, } \\
\text { liquid and plastic } \\
\text { limits if applicable }\end{array}$ & Fair to poor & Not suitable & $\begin{array}{l}\text { Medium } \\
\text { to very } \\
\text { high }\end{array}$ & $\begin{array}{c}\text { Slight } \\
\text { to } \\
\text { medium }\end{array}$ & $\begin{array}{l}\text { Fair to } \\
\text { poor }\end{array}$ & \begin{tabular}{|c|}
$\begin{array}{c}\text { Good to poor, } \\
\text { close control } \\
\text { essential, } \\
\text { rubber tired } \\
\text { roller }\end{array}$ \\
\end{tabular} & $\begin{array}{l}>100 \\
e<0.70\end{array}$ & $6-25$ & $\begin{array}{l}\mathbf{A}-\mathbf{A} \\
\mathbf{A}-6 \\
\mathbf{A}-7\end{array}$ \\
\hline 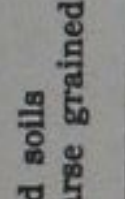 & $\begin{array}{l}\text { low to medium } \\
\text { compressi- }\end{array}$ & $\begin{array}{c}\text { Clays (Inorganic) of low } \\
\text { to medium plasticity, } \\
\text { sandy clays, silty clays, } \\
\text { lean clays. . . . . . . }\end{array}$ & CL & $\begin{array}{l}\text { Medium } \\
\text { to high }\end{array}$ & $\begin{array}{c}\text { Examination in } \\
\text { plastic range }\end{array}$ & $\begin{array}{l}\text { Conasistency - } \\
\text { undisturbed and } \\
\text { remolded, }\end{array}$ & $\begin{array}{l}\text { Liquid and plastic } \\
\text { limits }\end{array}$ & Fair to poor & Not suitable & $\begin{array}{l}\text { Medium } \\
\text { to high }\end{array}$ & Medium & $\begin{array}{l}\text { Practically } \\
\text { impervious }\end{array}$ & \begin{tabular}{|l|} 
Fair to good, \\
tamping roller
\end{tabular} & $\begin{array}{l}>100 \\
e<0.70\end{array}$ & 4-15 & $\begin{array}{l}A-4 \\
A-6 \\
A-7\end{array}$ \\
\hline 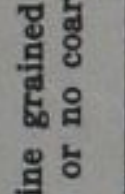 & bility & $\begin{array}{l}\text { Organic silts and Organic } \\
\text { silt-clays of low plasti- } \\
\text { city ............. }\end{array}$ & OL & $\begin{array}{c}\text { Slight to } \\
\text { medium } \\
\end{array}$ & $\begin{array}{l}\text { Examination in } \\
\text { plastic range, } \\
\text { odor }\end{array}$ & \begin{tabular}{|} 
Stratification, root \\
holes, fissures, etc. \\
Drainage and ground
\end{tabular} & $\begin{array}{c}\text { Liquid and plastic } \\
\text { limits from natural } \\
\text { condition and } \\
\text { after oven drying } \\
\end{array}$ & Poor & Not suitable & \begin{tabular}{l|} 
Medium \\
to high
\end{tabular} & $\begin{array}{l}\text { Medium } \\
\text { to high }\end{array}$ & Poor & \begin{tabular}{|l} 
Fair to poor, \\
tamping roller
\end{tabular} & $\begin{array}{l}>>90 \\
e<0.90\end{array}$ & 3-8 & $\begin{array}{l}A-4 \\
A-7\end{array}$ \\
\hline 焉 & $\begin{array}{l}\text { Fine grained } \\
\text { soils having }\end{array}$ & $\begin{array}{l}\text { Micaceous or Diatomace- } \\
\text { ous fine, sandy and silty } \\
\text { soils, elastic silts..... } \\
\end{array}$ & MH & $\begin{array}{l}\text { Very slight } \\
\text { to medium }\end{array}$ & $\begin{array}{l}\text { Examination wet } \\
\text { (shaking test } \\
\text { and plasticity) } \\
\end{array}$ & $\begin{array}{l}\text { water conditions, } \\
\text { Traffic tests, } \\
\text { Torgests }\end{array}$ & $\begin{array}{l}\text { Mechanical analysis, } \\
\text { liquid and plastic } \\
\text { limits if applicable } \\
\end{array}$ & Poor & Not suitable & $\begin{array}{l}\text { Medium } \\
\text { to very } \\
\text { high } \\
\end{array}$ & High & $\begin{array}{l}\text { Fair to } \\
\text { poor }\end{array}$ & $\begin{array}{l}\text { Poor to } \\
\text { very poor }\end{array}$ & $\begin{array}{l}<100 \\
e>0.70\end{array}$ & $<7$ & A-5 \\
\hline 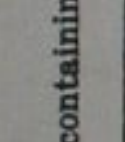 & & $\begin{array}{r}\text { Clays (Inorganic) of high } \\
\text { plasticity, fat clays. . . }\end{array}$ & CH & High & $\begin{array}{c}\text { Examination in } \\
\text { plastic range }\end{array}$ & 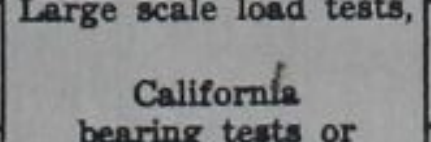 & $\begin{array}{l}\text { Liquid and plastic } \\
\text { limits }\end{array}$ & $\begin{array}{l}\text { Poor to } \\
\text { very poor }\end{array}$ & Not suitable & Medium & High & $\begin{array}{l}\text { Practically } \\
\text { impervious }\end{array}$ & $\begin{array}{l}\text { Fair to poor } \\
\text { tamping roller }\end{array}$ & $\begin{array}{l}>90 \\
e<0.90\end{array}$ & $<6$ & $\begin{array}{l}A-6 \\
A-7\end{array}$ \\
\hline & $\begin{array}{c}\text { compressi- } \\
\text { bility }\end{array}$ & $\begin{array}{r}\text { Organic clays of medium } \\
\text { to high plasticity.... }\end{array}$ & OH & High & $\begin{array}{c}\text { Examination in } \\
\text { plastic range, } \\
\text { odor }\end{array}$ & & $\begin{array}{l}\text { Liquid and plastic } \\
\text { limits from natural } \\
\text { condition and } \\
\text { after oven drying } \\
\end{array}$ & Very poor & Not suitable & Medium & High & $\begin{array}{l}\text { Practically } \\
\text { impervious }\end{array}$ & $\begin{array}{l}\text { Poor to } \\
\text { very poor }\end{array}$ & $\begin{array}{l}>100 \\
e<0.70\end{array}$ & $<4$ & $\begin{array}{l}\mathrm{A}-7 \\
\mathrm{~A}-\mathrm{-}\end{array}$ \\
\hline $\begin{array}{r}\text { Fibrou } \\
\text { witl } \\
\text { com }\end{array}$ & \begin{tabular}{l|} 
o organic soils \\
a very high \\
pressibility
\end{tabular} & $\begin{array}{l}\text { Peat and other highly or- } \\
\text { ganic swamp soils. ... }\end{array}$ & Pt & $\begin{array}{l}\text { Readily } \\
\text { identifled }\end{array}$ & & $\begin{array}{c}\text { Consistency, textur } \\
\text { con }\end{array}$ & $\begin{array}{l}\text { e and natural water } \\
\text { attent }\end{array}$ & $\begin{array}{l}\text { Extremely } \\
\text { poor }\end{array}$ & Not suitable & Slight & Very high & $\begin{array}{l}\text { Fair to } \\
\text { poor }\end{array}$ & $\begin{array}{l}\text { Compaction } \\
\text { not practical }\end{array}$ & & & A-8 \\
\hline & 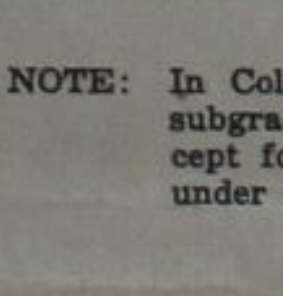 & $\begin{array}{l}\text { umn 7, values are for } \\
\text { de and base courses, ex- } \\
\text { Ir base courses directly } \\
\text { wearing surface. }\end{array}$ & & $\begin{array}{ll}\text { NOTE: } & \begin{array}{l}\text { Valt } \\
\text { for } \\
\text { shol } \\
\text { in a }\end{array}\end{array}$ & $\begin{array}{l}8 \text { in Columns } 7 \text { and } \\
\text { zuidance only. } \\
\text { lb based on test } r \\
\text { ordance with text. }\end{array}$ & $\begin{array}{l}8 \text { are } \\
\text { essign } \\
\text { esults }\end{array}$ & $\begin{array}{l}\text { Unit weights in } \mathrm{Cc} \\
\text { apply only to soils, wit } \\
\text { gravities ranging bet } \\
\text { and 2.75. }\end{array}$ & $\begin{array}{l}\text { lumn } 13 \\
\text { th specific } \\
\text { ween } 2.65\end{array}$ & $\begin{array}{l}\mathrm{G}= \\
\mathrm{s}= \\
\mathrm{M}= \\
\mathrm{c}= \\
\mathrm{Pt}=\end{array}$ & $\begin{array}{l}\text { GRAVEL } \\
\text { SAND } \\
\text { MO. VERY FD } \\
\text { ROCK FDOUR } \\
\text { CAY F F } \\
\text { PEAT }\end{array}$ & NE SAND, & & 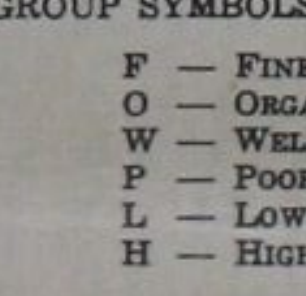 & $\begin{array}{l}\text { TO MER } \\
\text { H COMPR }\end{array}$ & $\begin{array}{l}<0.1 \mathrm{MM} \\
\text { COMPRESSIF } \\
\text { ILITY }\end{array}$ & \\
\hline
\end{tabular}


IxnLI.

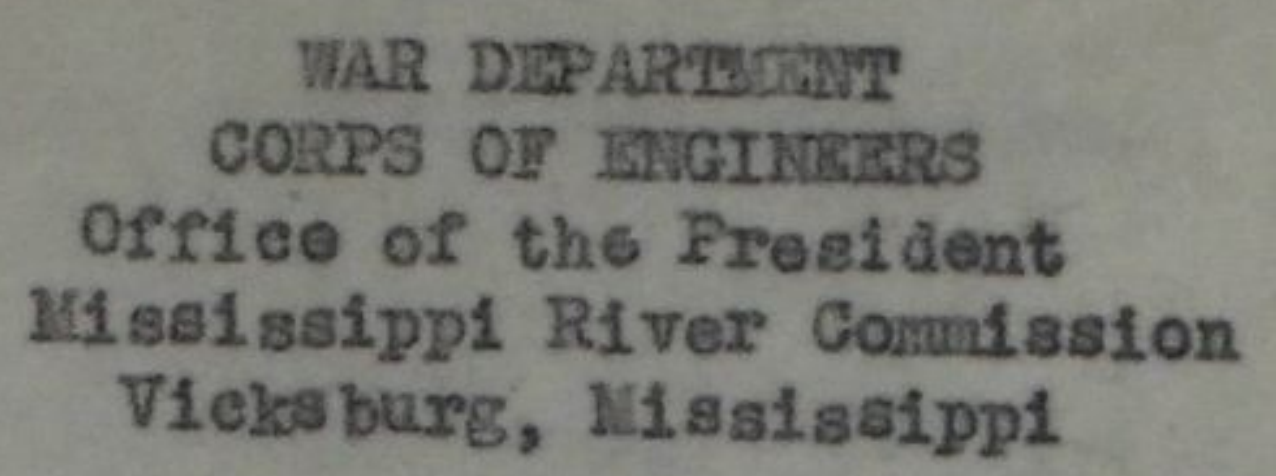

\section{SWBIICR: Lodification or Levee Specifications}

20:

The D1striet Engineer, Vtemphis D1strict, CF, Nemph1s, Tenn.; Vieksburg Di striet, CE, Viekaburg, iliss.; and New Orleans District, CE, Hew Orleans, La. (COPY TO BACH)

1. The Missiasipp1 Valley Flood Control Braneh of the Associated Ceneral Contractors requested a conference for the purpose of discussing certain provisions of tho currently standard spocification for levee construetion. The conference was held on 15 December 1947 and 1 t was tontatively agreed to try out the following changes for the period of one yoar in the interest of redueing bid prices by removing penalties and what appear to be unecessery restrietions:

Pax. 7. As now vritten this paragraph pernits payment of only $67 \frac{1}{3}$ of the value of the yardage in a station of levee fully comploted excopt for dresaling and sodding. The contractors aver that they sometines are delayed in sodding by labor shortases due to cotton plaking, and other causes not their fault, and foel that inasuch as the $10 \%$ retained percentage witheld unt11 inel acceptance is nore than ample to cover the cost of sodaling, the restrietion of payment to $67 \% \%$ (75\% less $10 \%)$ instead of to $90 \%$ for levee fully completed othexvi se often imposes unreasonable finaneing diffeulties.

Par. 14. As now witton paragraph 14 requires the entractor to rumish inspection forees with lodging at fifty cents a night and moals at thirty cents asch. Since the servioes obviousiy can not be furnishod for such prices it is proposed to raise the rates to those now applicable to transients on Government boats and quarterboats, namely \$1.00 for lodghg, seventy-five cents for each moal. The contractor never knows juat how much he will lose on the present rates sinee he does not know hor many men will be guartered on him, so he probably puts a liberal contingeney allowanee in his bid.

Par. 18. The present wording of paragraph 18 requirea the contract or to clear and exub the levee foundation but makes no allowance for paying for ref111 of sturp holes. Former issues of specifications did provide for payment of rofill yardage at contract unit prica. The onission in the current issue sers based upon the videspread use of bull- 
dozers for clearing and exubbing and the diffioulty under such sonditions, of aecurately measuring the holes.

The contractors allege that a great deal of thel $x$ clearing and grubbing still requires hand operation, and that where bulldazes grubbing is used, an arbitrary yardage allowance based upon di anoter of tree will be satisfactory.

This they apparently foel w111 largely remove the uneertainty as to how much to increase the unit price bid for embanknent yardace in order to make thenselves whole in the nattor of foundation preparetion.

Par. 20. The contractors ask that when the coupaction methods ealled for by Par. 20(b) are preseribed, separate payment be made for adding watex to the naterial proparatory to rolling when guch addition is required by the contracting officer. Paragraph $20(\mathrm{~b})$ ralates to rolled flil construction camarable to that of a rolled fill dam. It is applicable only to solls whose nolsturo content approaches optinum and becau se of the high molsture eontents of the natural solls in the lower valley we have not yet preacribed such construetion and are not $11 \mathrm{kely}$ to prescribe it very oftan. Thus the chanse dealrod by the eantractors may be sonewhat acadenic in nature but no objection is soon to incorporating it in the intersst of avoldsns uneertainty in bids. It seons preforable to state a price in paregraph 34 mather than to have the bidalar name a price for the addition of vater. The emount to be added is altogether inaeterminate and is quite 11 kely to be $n i l$, and the making of award should not be further compli oisted by having to consider $1 t$.

Pax. 35. Paragraph 35 forbids any roduction in the espacity of the plant employad on the work except by written permission of tho contracting offlcor. This paragraph hes becone a source of irritation and expense to the contractors, and in sone respects apparentiy milftates against the rederal interest. The contractors hesitate to throw in added equipment which becomes aveilable for a period between other conmtinents, because once they get It on the job they have no assurance whatever that they w111 ever be able to remove it until. the job 1, eompleted. They had even been refused perrission upon oceesion to return apecial plent borrowed from the county for a specific tem and funetion. On the basts of the representations nade I agreed to see hov we got along without the provision for one year.

2. The attached copy of speciflcations has been modified in red to incorporate the changes discussed abovo. These modifications have been approved by the Chief of Ingineers, and it is requested that these modifleations be incorporated in a.11 future levee specifieations. Until such 
IrveL

SUBJECP: Modifleation of Levee Specifleations

t1me as these paragrapha ean be modifled and new pages reprinted, these modifications may be covered in paragraph 34 . On work that has been advertised, nodification of the specifications should be accomplished by the issuanoe of an addendus.

3. It is further requested that your forees check and report upon the effects of these nodifications during the pexiod sgreed upon for their trial, at the end of which tine the situation w111 be resurveyed and such actiox recomended as study indicates to be desirable.

4. This ofrice should be notified iramediately of the quantity of rodifiod pages needed to supersede copios now on hana.

\author{
R. W. CRATEORD \\ Ha jor Canoral, U. S. Axmy \\ President, Hissiasippi. River Conndasion
}

1 Ine1:

Oy Spees as modiriod 


\section{WAR DEPARTMENT}

CORPS OF ENGINEERS

MISSISSIPPI RIVER COMMISSION

CODE FOR UTILIZATION

OF

SOILS DATA FOR LEVEES

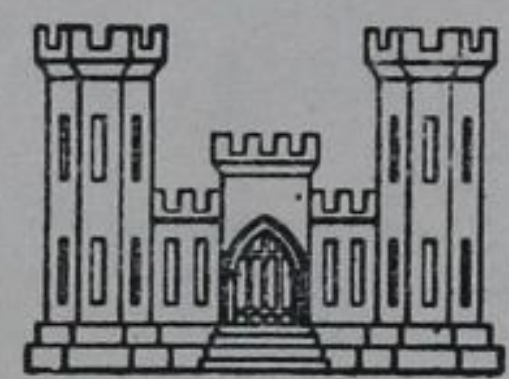

MISSISSIPPI RIVER COMMISSION

VICKSBURG, MISSISSIPPI 


\section{CODE FOR UTILIZATION OF SOILS DATA FOR LEVEES}

\section{Introduction}

1. The Board for Utilization of Soils Data for Levees was established by Special Orders No. 79-1/2, dated 26 September 1945, issued by M. C. Tyler, Brigadier General, Corps of Engineers, President, Nississippi River Commission. The mission of this Board was to make a complete review of current practices and technique in order to bring up to date the Mississippi River Commission soils mechanics and levee code which was developed by a similar Board in October 1941. The Board convened on 8 November 1945 and three subcommittees, namely, Planning, Design and Construction, and Exploration and Testing, were appointed to make a study of practices from 1941 to the present, in order that the 1941 code could be brought up to date. The three committees have convened in numerous meetings since 8 November 1945 and after consideration of the numerous problems involved since adoption of the 1941 code recummend certain general policies with respect to planning, exploration, testing, design, and construction of main line Mississippi River levees, and the application of the same general principles to other levees, insofar as may appear practicable and recessary.

\section{Purpose}

2. The primary purpose and objective of this Board was to revise the 1941 Levee and Soils Code to take advantage of the following specifically listed items in the planning, irvestigation, testing, design, and construction of levees.

a. Utilize all the geological data which have been obtained to date in the development of more intelligent and economical plans, specifications, and design for levees. The geological data will assist materially in the delineation of areas which are obviously safe for levee construction from those areas which are definitely critical as far as safety is concerned. In the safe areas a minimum of field investigation coupled with a standard levee design for simplification and economy will be the goal of the new code. In the critical areas, more detailed investigations and special design procedures than those now followed will prove to be desirable.

b. Eliminate obsolete methods and procedures in design and construction and take advantage of new and improve methods and procedures.

c. By means of a. \& b. above, develop a new code for planning, investigation, design, and construction, which is practicable in application, yet furnishes the necessary safety and economy for levees. 


\section{$\underline{\text { Planning }}$}

\section{Location Planning}

3. General. Planning for levee improvements must of necessity treat with many and varied problems. The type of levee improvements as between enlargement and new levee is determined primarily by an estimation of the anticipated life of the existing levee. There are several controlling factors which are taken into consideration in planning levee improvements. Availability of funds is the first factor which determines the amount of work which can be performed. The nature and location of the improvement must recognize the following additional factors: urgency; availability of rights-of-way; land and crop values; effect of current scour; foundation conditions and availability of suitable borrow materials; changes in alignment of rivers as affected by existing andnatural causes, or as influenced by revetments, dikes, channel dredging, improvement dredging, cutoffs; and by improvements, such as highway and railroad bridges, pipe lines, and population centers.

4. Recognition must also be given to the possibility of affording economical protection by revetments, dikes, or channel improvements in lieu of setting a levee back from a caving bank. Future planning should also be coordinated with the Channel Stabilization Program now authorized; a program which is planned to eliminate to a large extent the necessity for future levee relocation.

5. Levee planning should be separated into two major parts; the Annual and Iong Range Programs. The Annual Program should deal with levee improvements of immediate need. The Long Range Program should procure all pertinent geological data needed in preparation of the Annual Program and should be closely coordinated with the Bank Stabilization Program (which may indicate the need for future levee relocation).

6. Geological studies recently completed by the Mississippi River Commission have demonstrated that geological data can be utilized profitably in both the Annual and Long Range Programs. The Commission staff should include a sufficient number of competent alluvial geologists. As an aid in arriving at better solutions to the problems concerned with the location and construction of levees, geological studies should be used as follows.

7. Annual program. In areas where levee improvements are to be undertaken by the District Engineer, a geological examination should constitute the preliminary step in the Engineering Studies.

8. The function of the geologist is to advise the engineers in charge of investigation, design, construction, and maintenance of levees as to the general nature and distribution of alluvial deposits and faults in the vicinity of proposed levee works. These initial studies should permit the isolation of critical areas in which foundation weaknesses 
and/or seepage problems would be likely to occur. The soil mechanics engineer should review the geological data and advise the design engineer where critical areas are located and what additional exploration or studies are required.

9. Preliminary geological studies would also present information as to the source areas for construction materials.

10. Long range program. Competent alluvial geologists should integrate the several types of data pertinent to levee planning, construction and maintenance, together with data for dredging and channel stabilization. Interpretations should be made of aerial photographs, mapped alluvial valley deposits and all subsurface data, such as logs of borings and seismic records. The geologists should coordinate these basic data for the engineers in charge of the various phases of river control.

11. Predictions of river behavior based upon the systematic geological studies should permit judicious opinions concerning; (a) maximum extent of local channel migration; (b) rate or rates of migration, and (c) areas which will be destroyed by channel migration. The engineer should utilize the above-mentioned data in determining the necessity of and the most advantageous method for treatment.

12. Accumulated geological data should be utilized by the engineer in hydraulic model studies, which should supplement engineering studies and form a new guide for predicting the pattern of future river changes.

13. Upon completion of each geological study, data should be forwarded to the district concerned in the form of a detailed report containing all pertinent information.

Construction planning

14. General. The technique of levee construction has progressed tremendously since its inception. Development of new methods and equipment has resulted in an enormous increase in ability to do work, in greatly reduced costs, and in construction of better levees. Tower excavators, large draglines, and efficient hauling units are examples of developments in equipment. The increase in soil mechanics knowledge has resulted in construction of better levees. Plans for work should be so drawn as to encourage the development of improved methods and equipment which would produce better and more economical levees.

15. Time for construction. In cases where it is neither necessary nor advantageous to complete the work in one season, the specifications should provide for construction in two or more working seasons. Every effort should be made to plan the investigation, design and advertisement of the work that full advantage is taken of the favorable construction season. 
16. Drainage. In heavily wooded areas, or where the existing drainage is poor, consideration should be given to clearing and draining the site of the work well in advance of construction. The drainage of borrow pits is not essential, except where located near population centers and adjacent to caving or revetted banks. All borrow pits within approximately 1,000 feet of caving or revetted banks should be drained to avoid increasing the water pressure behind these banks when the water in the river recedes, and to reduce sloughing. Borrow pits in the vicinity of population centers should be drained for mosquito control. Any necessary drainage of borrow pits, should, if feasible, be included in the plans for levee construction. Iocal interests should be urged to provide landside drainage ditches for the purpose of removing excess water from the levee toe. These ditches should be excavated only to depths sufficient to provide adequate drainage.)

17. Access roads, roadways, etc. For purposes of inspection and flood fighting, access roads should be provided in cooperation with state and local authorities so that all levees can be reached at reasonably close intervals by all-weather roads. A levee roadway 15 feet in width should be added to all main Mississippi River levees, except in urban areas. On tributary and backwater levees, a total crown width of at least 14 feet should be provided. As time and funds permit, the crowns of the more inaccessible levees should be surfaced for all-weather traffic. Road crossings of suitable dimensions should be provided at convenient locations and intervals. Except when set up for use on future enlargement work, the exact location for traverses or road crossings should not be specified, but should be left to the judgment and decision of the contracting officer's field representative, as he is more familiar with the local conditions and can shift them where they would be better located, thus obtaining closer harmony with the local interests. In general, no large amount of road surfacing should be undertaken until the more essential job of strengthening the levees is completed.

18. Wave wash protection. All levees that are exposed to excessive wave action during high-water periods should be protected. The. protective structures should be sufficiently strong to resist not only wave action but also the pounding of drift and floating debris. Concrete and asphalt pavements of good quality on a well-prepared foundation are considered to be the preferable forms of protection for reasonably permanent levees.

Exploration and Testing

General

19. A field exploration manual should be prepared by the Mississippi River Commission to properly coordinate and standardize the 
exploration work of the three Districts.

Location, number and

depth of borings

20. Preliminary borings for the delineation of pertinent geological features should be located by a competent geologist in cooperation with the soil mechanics engineer. The borings should be so located that the nature of the materials will be determined in sufficient detail to fully verify the geological picture of the foundation conditions. Additional borings for determining the general suitability of the levee foundations with respect to soil mechanics should be located. After a thorough review of all borings by the soil mechanics engineer, it may be desirable to further explore certain critical areas. In accretion areas, foundation borings should be sufficiently deep to assure penetration into clean sand. In thick backswamp deposits where unstable foundation materials are encountered, such materials should, in general, be completely penetrated by the borings, but the latter need not necessarily be carried to clean sand. In both cases the minimum depth of the borings should not be less than the height of the levee. At intervals of about one mile borings should be extended completely through the pervious sands and gravels into the tertiary materials to furnish data on the general underseepage problem. For new levees, foundation borings should be located along the proposed center line, and for enlargements along the riverside toe of the existing levee. Full use should be made of all existing reliable data.

21. Borrow pit borings should be located on the recommendations of a qualified geologist in cooperation with the soil mechanics engineer at locations such that the occurrence of the different types of deposits representative of the borrow pits will be developed. As drilling operations progress, additional borings required for the determination of the extent of occurrence of naterials with excessive water content, or for other considerations of an engineering nature, should be located by the soil mechanics engineer. The depth of exploration should be limited to the estimated practical depth of excavation, or as other controlling factors may dictate.

\section{Methods of subsurface exploration}

22. Boring equipment used should be capable of making borings suitable for obtaining the desired information. Wash borings, or borings which do not yield a complete log from top to bottom of hole should be avoided, except for special studies for which they may be suitable. Disturbed samples should be placed in suitable airtight containers, which should be filled as nearly as practicable with the material being sampled and carefully sealed to prevent loss of moisture from the sample during shipment to the laboratory. Undisturbed samples for shear or consolidation tests should be approximately 5 inches in diameter and should be taken in sufficient number to properly evaluate the shear strength of the foundation being studied. Undisturbed samples 
should rarely, if ever, be taken from borrow pit borings, unless other drilling methods will not yield accurate water contents. In all cases, care should be exercised to obtain samples with water contents as nearly as possible equal to those in the natural materials, by removing excess water from the surface of clay cuttings, or by any other method required. Great care should be exercised in taking disturbed samples of sands and gravels to insure that true representation as to gradation is obtained. Such samples are necessary to gain information on the permeability characteristics of the materials and probable severity of underseepage. In locations where underseepage is definitely known to be a very critical problem, it may be necessary to take undisturbed samples of the granular material by the freezing method for a more accurate determination of the permeability characteristics. (Test pits, trenches, probings, and geophysical methods should, in general, not be used for subsurface explorations on routine levee investigations.)

\section{Record keeping}

23. Detailed field and laboratory $\log$ files and location maps of all borings taken should be maintained, and a copy of all field or laboratory logs with location maps should be furnished the geologist and soil mechanics engineer for their use.

Standard laboratory

methods of testing

24. A laboratory testing manual should be prepared by the Mississippi River Commission to properly coordinate the testing procedures of the three districts.

Extent of laboratory

testing required

25. The absolute minimum of laboratory testing required for routine levee design should consist of the following: (I) visual classification of all samples; (2) sufficient mechanical analyses to check and assure accurate visual classification; (3) water content determinations on cohesive materials as indicated from the visual classification, (4) Atterberg limits of a representative number of all materials with high water contents, and (5) effective size of pervious material to appraise underseepage potentiality. If, at this point in the laboratory investigation, it is seen that nowhere on the levees under consideration, either embankment or foundation, are there any materials with water contents which appear too high for safety for the materials as vi sually classified, it is not absolutely essential that further tests or a special design be made. Such conditions normally exist over the major portions of the levee, but over some portions of most items of work it is usually indicated that further tests are needed, to assure safety and to design special berms to protect the standard cross sections. The indications of where a special design for stability is required should be based on comparisons of Atterberg limits with natural water content and soil type. Usually, if the 
plasticity index of a soil is more than 25, and if its natural water content minus the plastic limit is less than 25 per cent of the plasticity index, no difficulties with weak foundation material or wet borrow material are indicated. However, when slightly plastic borrow materials with plasticity indices less than 6 and water contents greater than the plastic limit are encountered, handling difficulties may be experienced, but probably no foundation trouble will be encountered. Decision as to further testing for stability should be made by the soil mechanics engineer from the data obtained from visual classification, water content and Atterberg limit determinations, as explained above, but should also be based on experience with the shear characteristics of the material in the vicinity. If there is indication of water contents in excess of those outlined above for the materials encountered in the foundation, undisturbed samples should be taken for shear testing. For information on the probable severity of underseepage the uniformity coefficient should be determined from the mechanical analysis of the granular materials.

26. Tests other than those given above may be required for special cases where the stability on underseepage problems are critical, but should be held to a minimum. These tests may consist of one or more of the following; compaction, consolidation, solubility, specific gravity (other than those made in connection with shear or compaction data), and permeability. As a general rule, shear data on actual undisturbed foundation materials should be used for design.

\section{Field testing}

27. Field testing should generally be limited to visual classification and, in some cases, water content and density determinations. Simple field in-place permeability tests may be run in bore holes where the underseepage problem appears to be critical. Data from this test may be used to assist in designing the most economical and effective treatment for underseepage. Field tests of large scope are considered to be special items and are, therefore, not covered by the provisions of this Code.

Soil classification

and legend

28. Soils should be classified in accordance with the IMVD classification on the basis of mechanical analysis. A classification triangle for this classification is shown on figure 1. The legend shown on figure 2 should be used in plotting borings for use on contract drawings. (See Geological Section about color legend.)

Definition of

impervious soil

29. The present limitation on permeability of $1 \times 10-5 \mathrm{~cm} / \mathrm{sec}$. is too restrictive and often results in unduly expensive work, consequently this factor should be increased to $1 \times 10-4 \mathrm{~cm} / \mathrm{sec}$. 


\section{Record keeping}

30. Records of tests made should be kept in laboratory files in permanent form. Files should consist of summarized data in graphical or tabular form, and not necessarily of laboratory data sheets. A shear-test record, similar to that shown on figure 3 and containing stress-strain curves and shear diagram is a satisfactory type of sheet for record purposes. Similar sheets should be devised for other tests to show the data.

\section{Design}

\section{General}

31. During the past few years two standard levee sections have been used; i.e., "Compacted" and "Uncompacted." Interviews with the Districts and data obtained from investigations during construction make it appear both desirable and practicable to use three standard cross sections rather than two. The three types of cross sections recommended are as follows:

a. Type 1. Slightly smaller than the present compacted cross section. Compacted to maximum density at optimum moisture content. Comparable to earth dam construction.

b. Type 2. Intermediate in size between compacted and uncompacted fill. Embankments having a moderate degree of compaction at natural moisture content. Uncompacted fills of material which is toowet for compaction.

c. Type 3. Moderately larger than the present uncompacted cross section. Uncompacted emergency construction of relative dry material, that is, material sufficiently dry for a moderate degree of compaction. The reasons for adopting the three cross sections as standards and more detailed description of their characteristics are given in the following paragraphs.

32. The advantages of levees constructed of compacted material are fully recognized. However, one of the fundamental factors which controls compaction is the moisture content of the soil. Moisture control in levee construction has been and will be impractical. This view is generally entertained by all offices interested in levee construction in the Lower Mississippi Valley. There are many jobs on which the water content of the soil is too high to permit 100 per cent standard Proctor compaction being obtained, but yet the soil can be compacted to a worthwhile degree. One of the primary reasons for type 2 construction is to obtain, at a minimum cost, the maximum practicable compaction on soils containing excess moisture. On such work, the compaction obtained under the present "compaction" specifications has been, in general, no more than can be 
obtained under the specifications for type 2 fill, proposed in this Code. This statement is verified by the graph of figure 4, which shows the relationship between per cent compaction and moisture content for both the present compacted and uncompacted fill specifications using hauling equipment. Insertion of the type 2 section will allow more flexibility in construction procedures, and should lead to improved procedures and equipment which will result in greater speed and economy of construction.

33. The rainfall throughout the Lower Mississippi Valley is heavy and fairly well distributed throughout the year. The ground-water table is ordinarily near the surface, so that ground water is usually encountered in borrow pits of any appreciable depth. Prolonged bankfull stages or higher stages of the Mississippi River saturate the surrounding country. These conditions stop levee construction entirely for a considerable portion of the year and reduce the efficiency of construction operations during much of the remaining portion. All types of construction equipment are affected, but hauling equipment is more severely handicapped than long-boom draglines or tower machines. Figure 5 attached shows the relationship between hauled ard cast-in-place fills (data averaged for the Vicksburg and New Orleans districts) with respect to lost time due to weather. This figure shows that draglines are considerably better adapted to perform work in the winter and spring months, while there appears to be only a slight advantage to the dragline during the summer and fall months. Because of its dependency upon favorable weather and working conditions, hauling equipment cannot be relied upon for emergency work (setback levees). In order to be able to meet emergencies, when the soil is too wet for compaction, it is highly desirable to have available the equipment best suited to cope with adverse conditions; namely, draglines and tower machines. Such equipment will not be available if contractors cannot be assured of a reasonable and continual volume of work. A method of construction utilizing draglines, supplemented by some other type of equipment, such as bulldozers, should be developed for type 2 construction so as to provide work for large draglines in sufficient volume to insure their remaining available.

34. Past experience has proven that satisfactory levees can be constructed of uncompacted material. However, in some instances compacted impervious facings should be added, and a larger cross section provided to achieve parity in strength with compacted levees. Therefore, the uncompacted section is retained for use where any form of compaction is obviously impracticable, or as an emergency measure, when the soil is too wet for compaction.

Cross section

35. General. The Board has arbitrarily assumed that the unit shearing strength of the type 1 section is 100 per cent; of the type 2 section, 90 per cent, and of the type 3 section, 80 per cent. These strength figures were used in arriving at approximately uniform stability for the types 1,2 and 3 levee sections. An exception to this assumption is the inclusion of the wet loose fill construction in the type 2 section. The 
justification for this is, first, from a practical viewpoint the change from a semi-compacted method of construction to a loose fill method can be made more feacible as far as contractural and rights-of-way matters are concerned, second, the most severe field problem is encountering wet weather after a job has started, and third, the type 2 section has been proven to have sufficient stability if it is possible to construct the section. In arriving at the size of the section, the material type was given less significance than degree of compaction.

36. The three types of levee sections have been predicated on a stable foundation. In cases where unstable foundations exist, or detrimental underseepage conditions prevail, adequate ccrrective measures will be designed as a secondary consideration, to take care of the special critical conditions which exist.

37. New levees. The recommended net dimensions of the three types of sections for main line levees are as follows:

Type

Designation

1

2) less than 251 in height

2251 and higher

3

Riverside Slope Crown Width Landside Slope.

For tributary levees above the head of Mississippi backwater, the following net cross sections will control:

Height

15 feet or less

Over 15 feet
Riverside Slope Crown Width Landside Slope

$$
1: 3.0-10 \mathrm{ft} *
$$

$1: 4.0=10 \mathrm{ft} \quad 1: 5.5$

$1: 4.0=10 \mathrm{ft}$

$10 \mathrm{ft}$
$1: 6.0$

$1: 6.5$

*Note: Where deemed necessary for roadway purposes, the crown width may be increased to 14 feet.

38. When specifications are submitted to the Commission for review they will be accompanied by a report setting forth the reasons for selection of the type of construction proposed. Except where special conditions require otherwise, the selection of the section to be used should be governed by the following conditions.

a. Type 1. (1) For plastic soils, when the water content as estimated for the time of construction is equal to or less than the plastic 
limit plus 20 per cent of the plasticity index. water content.

(2) For all non-plastic soils except silts, regardless of the

(3) For silty materials of low plasticity when the water content as estimated for the time of construction is equal to or less than the plastic limit.

b. Type 2. When the moisture content of the soil is greater than specified above, except as noted under type 3.

c. Type 3. On uncompacted emergency construction of relative dry material, that is, material sufficiently dry for a moderate degree of compaction, and also uncompacted very stiff wet clays.

39. Enlargements. For enlargements, the existing levee should in all cases be considered as semi-compacted fill. Where the existing landside slope of the levee is flatter than 1:5.5 for levees less than 251 in height and 1:6 for levees greater than $25 \mathrm{r}$, the landside slope of a riverside enlargement should commence at the landside edge of the crown of the existing levee. Where the existing landside slope of the levee is.steeper than 1:5.5 for levees less than 251 in height and 1:6.0 for levees greater than 251, the landside slope of the enlargement should commence at a point, where a $1: 5.5$ or $1: 6.0$ slope (whichever is applicable commencing)at the landside toe intersects the surface of the levee. From either of these commencement points). the net landside slope of the enlargement should be that applicable to the type of construction; i.e., 1:4.5 for type 1; 17 $1: 5.5$ or $1: 6.0$, whichever is applicable) for type 2 , and $1: 6.5$ for type 3 . Crown widths and riverside slopes should be the same as for new levees. Where control of through seepage is required, the minimum thickness of enlargement should be 5 feet, measured normal to the riverside slope of the existing levees.

40. Every effort should be made to obtain the best compaction possible. Often this can be done by requiring the contractor to excavate a vertical or sloping pit face to full depth rather than excavating in thin horizontal layers.

41. Special sections. Variations from the proposed standard levee sections will be necessary at certain locations to fit conditions peculiar thereto. The design for a hydraulic fill section should be special for the location and conditions under consideration. IMserc 7

Gradation of material in cross section

42. Material should be placed in the levee section so that a gradation more permeable to the landward exists. Experience and data have shown that very few cases of through seepage have been recorded on levees constructed to the 1928 section. Most cases of wet and sloughing landside 
limit plus 20 per cent of the plasticity index.

water content.

(2) For all nor-plastic soils except silts, regardless of the

(3) For silty materials of low plasticity when the water content as estimated for the time of construction is equal to or less than the plastic limit.

b. Type 2. When the moisture content of the soil is greater than specified above, except as noted under type 3.

c. Type 3. On uncompacted emergency construction of relative dry material, that is, material sufficiently dry for a moderate degree of compaction, and also uncompacted very stiff wet clays.

39. Enlargements. For enlargements, the existing levee should in all cases be considered as semi-compacted fill. Where the existing landside slope of the levee is flatter than 1:5.5 for levees less than 251 in height and 1:6 for levees greater than 25r/4 the landside slope of a riverside enlargement should commence at the landside edge of the crown of the existing levee. 1 Where the existing landside slope of the levee is.steeper than 1:5.5 for levees less than 251 in height and 1:6.0 for levees greater than 251, the landside slope of the enlargement should commence at a point, where a $1: 5.5$ or $1: 6.0$ slope (whichever is applicable commencing/at the. landside toe intersects the surface of the levee. From either of these commencement points). the net landside slope of the enlargement should be that applicable to the type of construction; i.e., 1:4.5 for type 1; 7 $1: 5.5$ or $1: 6.0$, whichever is applicable) for type 2 , and $1: 6.5$ for type 3 . Crown widths and riverside slopes should be the same as for new levees. Where control of through seepage is required, the minimum thickness of enlargement should be 5 feet, measured normal to the riverside slope of the existing levees.

40. Every effort should be made to obtain the best compaction possible. Often this can be done by requiring the contractor to excavate a vertical or sloping pit face to full depth rather than excavating in thin horizontal layers.

41. Special sections. Variations from the proposed standard levee sections will be necessary at certain locations to fit conditions peculiar thereto. The design for a hydraulic fill section should be special for the location and conditions under consideration. Iysaray

\section{Minor topping and correction of slope defleleneies will be gutded by practical considerations with the generel objective of restoring the orlginal design.}

tion more permeable to the landward exists. Experience anu uata neve shown that very few cases of through seepage have been recorded on levees constructed to the 1928 section. Most cases of wet and sloughing landside 
toes are due to underseepage.

43. All levee sections, except riverside enlargements, may allow placement of sand on the landside, keeping in mind that the levee section must grade more permeable to the landward. The amount of sand should not exceed approximately two-thirds of the cross-sectional area of the levee. Levees constructed entirely of sand must have a watertight riverside blanket facing or an impervious central core.

44. From the viewpoint of ultimate stability, it is satisfactory to use all available borrow materials in new levee construction, with the exception of highly organic materials. Highly plastic clays and very wet materials should not be used, if possible to avoid them. Every effort should be expended during the borrow excavation and placement procedures to secure adequate segregation of materials in the fill, especially when the least permeable material is readily penetrated by water in a short period of time.

\section{Shrinkage and foundation settlement}

45. The foundation settlement in each specific case should be estimated and the same allowance made, regardless of levee type. The shrinkage factors to be allowed for consolidation within the levee section itself are as follows:

Dry fill construction, Type 1 , Dry fill construction, Type 2, $10 \%$ Dry fill construction, Type 3, $15 \%$ Hydraulic fill construction, $10 \%$

46. On enlargements, the total allowances for shrinkage and foundation settlement should be made as above exeept that they should be not ? less than 1 foot for type 1 and 2 feet for types 2 and 3 .

\section{Compaction}

47. Type 1. The specification on compacted fill should be modified to include the mandatory use of the sheepsfoot roller. Although adequate compaction can be secured by the controlled use of hauling equipment, controlling such movement so as to insure satisfactory coverage of the entire area of the fill is generally impracticable, and consequently compaction should be secured by the use of a sheepsfoot roller of adequate weight operated continuously over the entire area of the fill during construction. The amount of rolling equipment should be balanced with the number and size of hauling units. No change should be made in the requirements as to lifts or moisture control.

48. Type 2. One of the primary reasons for the type 2 section is to provide a means of obtaining the maximum practicable compaction of wet soils with the least cost and reduction in output. Alternate methods will be specified for achieving compaction, as outlined below. 
toes are due to underseepage.

43. All levee sections, except riverside enlargements, may allow placement of sand on the landside, keeping in mind that the levee section must grade more permeable to the landward. The amount of sand should not exceed approximately two-thirds of the cross-sectional area of the levee. Levees constructed entirely of sand must have a watertight riverside blanket facing or an impervious central core.

44. From the viewpoint of ultimate stability, it is satisfactory to use all available borrow materials in new levee construction, with the exception of highly organic materials. Highly plastic clays and very wet materials should not be used, if possible to avoid them. Every effort should be expended during the borrow excavation and placement procedures to secure adequate segregation of materials in the fill, especially when the least permeable material is readily penetrated by water in a short period of time.

Shrinkage and foundation settlement

45. The foundation settlement in each specific case should be estimated and the same allowance made, regardless of levee type. The shrinkage factors to be allowed for consolidation within the levee section itself are as follows:

Dry fill construction, Type 1 , Dry fill construction, Type 2, $10 \%$ Dry fill construction, Type 3, $15 \%$ Hydraulic fill construction, $10 \%$

\section{The need for foundation settlenent allowances for levee enlargements sha11. be determined on the basis of best methods, dsta, and information aviliable, and shrinkage allowances shall be the sane 2s those shown in paragraph 45. The construction gross grade shall not exceed the theoretical gross grade, based upon settlement and shrinkage calculations, by more than $0.5 \mathrm{ft}$.}

area of the fill is generally impracticable, and consequently compaction should be secured by the use of a sheepsfoot roller of adequate weight operated continuously over the entire area of the fill during construction. The amount of rolling equipment should be balanced with the number and size of hauling units. No change should be made in the requirements as to lifts or moisture control.

48. Type 2. One of the primary reasons for the type 2 section is to provide a means of obtaining the maximum practicable compaction of wet soils with the least cost and reduction in output. Alternate methods will be specified for achieving compaction, as outlined below. 
a. Each load shall be spread by bulldozer as it is placed in the section or, as an alternate, material may be spotted so as to be spread into layers and compacted by three passes of a tractor or similar equipment weighing at least ten tons and exerting a unit pressure of not less than 6 lbs. per square inch. The thickness of layers will be 12 inches for clay soils and 18 inches for silty or sandy soils. Where casting equipment is used, the material placed in the lower two-thirds of the embankment should be dropped a minimum distance of 10 feet. The bulldozer should continue to operate on the upper one-third of the levee, but dropping of the material 10 feet need not be required.

b. The specifications should be written so as to require the contractor to construct by the above method when the material is dry encugh for such construction and allow uncompacted fill when the material is too wet for this type of construction. If, after the contract has been entered into, the material is found to be too wet for construction by the method described in paragraph a. above, the contractor will be permitted to construct an uncompacted fill to the type 2 cross section and to a gross grade determined by increasing the shrinkage allowance to $15 \%$. In this event the contract unit price will be reduced by $10 \%$. The requirements of this paragraph will not be incorporated in the Standard Levee Specifications, but will be included in the special provisions and will be optional with the contractor on jobs where completion is not urgent.

In all instances, the completed levee shall be finished by rolling the entire surface with three passes of a bulldozer or similar equipment.

49. Type 3. For the uncompacted section and where the moisture content will permit, a worthwhile amount of compaction can be obtained by requiring that on dragline construction the material placed in the lower two-thirds of the height of the levee be dropped a minimum of 10 feet. The dropping of the soil through 10 feet should not be required on tower machine construction. An attempt should be made to improve the tower machine construction procedures.

\section{$\underline{\text { Seepage }}$}

50. General. In the location and design of levees, seepage conditions are considered to be one of the paramount features of design. Seepage correction at critical points on presently built levees is now of primary importance in the work of the three Districts.

51. Through seepage. Through seepage in the present main line levee system seldom offers a serious problem. For those cases where it is a problem, an impervious core placed through the center of the levee section should be more effective against through seepage than a thin riverside blanket of impervious material. The experiment with the trenching machine now being conducted in the Memphis District should be continued with the hope of perfecting a machine capable of excavating a trench through the center of the levee. It may be entirely feasible to build an impervious core in stages of from 5 to 10 feet as the levee is constructed. Such a procedure would involve the general leveling of the 
levee section at the given stage heights and the placement of an impervious core in a trench excavated by dragline or trenching machine. Consideration should be given to the placement of the impervious central core by either means mentioned above, on future construction of new levees where the material is of such a pervious nature as to require protection against through seepage. As soon as the deep trenching machine is perfected, consideration should be given to placing a central impervious core rather than the riverside impervious blanket. The present blanketing practice is unnecessary from the standpoint of through seepage in a large percentage of cases. In many places where impervious blankets have been constructed, the landside toes and the lower portion of the landside slopes become wet when subjected to high river stages. Such a condition probably results from underseepage and not from through seepage.

52. Unquestionably, failures which take place as a result of through seepage develop into either a condition of piping before failure, or a general softening of the fill due to saturation, with resultant loss of shear strength and the inducement of liquid (pore pressure) flow slides. Piping may occur along a line or plane of loose material which is bridged across by a relatively stable layer of material. Holes made by burrowing animals are often the source of piping in small levees. Compacting and flattening of the slopes are the best preventive against liquid flow slides and close maintenance and inspection are the best preventives against burrowing animals.

\section{Underseepage}

53. Where a relatively thin (with respect to levee height) impervious top stratum exists above a highly pervious substratum of sand, conditions favorable to dangerous underseepage are present. Where river stages result in a hydraulic gradient or ratio of head to thickness of top stratum approaching unit, dangerous boils are likely to be encountered. A hydraulic gradient as low as 0.7 approaches the critical gradient for silts and fine sands. Moreover, seep water in the fields is detrimental to farming. Therefore, it is desirable to design corrective measures for underseepage. To do this, certain data are necessary. Principal among these data are: (1) Information on the permeability and thickness of impervious top stratum; (2) Information on accessibility of water to the pervious stratum on the riverside; (3) Information on the thickness and perviousness of the sand strata; and (4) Information on the actual pressures which may be experienced under record river stages. The first three items can be fairly reasonably estimated from field studies and investigations; however, very little is known about the last item. In order to gain information on pressures, which is considered absolutely necessary for the intelligent design of any corrective measures for underseepage and for adequate and proper future planning, a sufficient number of piezometer systems should be installed at strategic locations along the levees. A standing committee should be appointed to determine the proper location and an adequate number of piezometer systems. A study of geological information will materially assist in the selection of these locations. The areas to be studied for piezometer installations should not be restricted to those where free seepage or sand boils have 
been prevalent, but should include areas which have evidenced little or no trouble. Duplicate sites in each District should be selected where the top impervious stratum is 5, 10, and 15 feet in thickness, and sufficient piezometers should be installed to establish adequate piezometric profiles. Any areas which may be suspected as possible locations of serious trouble in case of a record flood should be checked with piezometer systems. Readings on these piezometers should be made at various stage heights of water. Curves should be drawn and extrapolations made to estimate the probable pressures which would exist under the impervious top stratum at the landside toe of the levee under record river stages.

54. There are numerous corrective measures against underseepage. Principal among these are: (1) Landside berms, (2) riverside berms and borrow pit refill, (3) borrow pit restrictions, (4) impervious cutoffs in foundation, (5) landside drainage, which may be obtained by means of dre age wells or drainage trenches, (6) sublevees, and (7) taking advi ge of geological features. These items are briefly discussed in the order named.

55. Landside berms are in most cases a partial safeguard in reducing hydrostatic pressures beneath the top stratum immediately landward of the levee structure by increasing the path of flow. Random fill material may be used, but, wherever possible, pervious sand should be used in berm construction. The design of berms to date has been a cut-and-try problem, based on previous observations and experience. The quantitative effect of landside berms in reducing pressures is generally unknown, in that piezometric information on actual berm installations is lacking. Landside berms have the following advantages: (1) they move boils and seepage farther from the levee proper, and (2) they provide additional working area and facilitate flood fighting.

56. Riverside berms may be utilized when riverside borrow pits have been excavated through an impervious top stratum exposing the pervious sand. The refilling of these pits with impervious material aids in sealing off close entry of seepage on the riverside, and the resultant longer path of flow from the river to the levee will cause a reduction of head.

57. Whenever underseepage conditions are likely to exist, if possible and feasible, riverside borrow pit depth should be restricted so as not to expose the pervious material. Where an impervious top stratum exists to a considerable distance riverward of the levee, the use of landside pits located at a sufficient distance from the levee in lieu of riverside pits will decrease the danger from underseepage and facilitate the control of interior drainage.

58. Development of a trenching machine indicates the practicability of excavating cutoff trenches in natural ground below the water table. Serious study should be given to the possibilities of constructing impervious cutoff walls, extending to depths which will materially decrease underseepage pressures. 
59. Landside drainage by use of drainage wells or trenches may at certain locations be made quite effective in reducing dangerous substratum pressures, by proper and adequate design. In certain specific locations, the use of drainage trenches or wells might be feasible, from the standpoint of both economy and adequate protection to the levee, especially in urban or highly developed areas, where it would be impracticable to use other structures for the control of underseepage.

60. The use of sublevees in relieving dangerous boil areas at the landside toe is feasible, from the standpoint of both economy and reduction of pressures. A sublevee system may have little effect on the total amount of underseepage. The use of adequately designed sublevee systems should be encouraged. Practically the only hazard existing in sublevees can be alleviated by proper compaction and the installation of adequate spillways and cross-drainage culverts in the sublevee systems.

61. The strategic location of levees with respect to the soil profile as indicated by geological and soil investigations is quite important. The proper location of a levee with respect to channel fillings should always be given consideration; also, weak foundations should be avoided, or, if not possible, the shortest path across should be chosen. If feasible, the location of levees on crevasse sands should be avoided, but where it is necessary, adequate cutoffs should be provided. Cognizance should always be given to the favorable location of levees with respect to surface topographic conditions.

62. Study should be given to the engineering feasibility of all the above features, and, in general, selection should be made on the basis of economic considerations.

63. Where obviously critical areas exist on a new levee location, the most effective and economical method of underseepage control should be included in the design and piezometers installed as a check.

\section{Stability}

64. Certain minimum stability requirements, previously stated, imply certain shear strength values. These values can be approximated by field moisture contents and Atterberg limits. If certain conditions are met, as stated in paragraph 25 , it is not necessary to calculate the stability of the embankment and/or foundation of the levee. The stability of the embankment and foundation should be such that on sudden drawdown (where applicable) the factor of safety should be at least 1 . In other cases where drawdown does not apply, the minimum factor should be 1.3, except that where extremely weai materials make this impracticable, a lower safety factor may be used.

65. Where feasibly and necessary, the procedure for constructing levees over very weak foundations in two or more stages is warranted and should be continued. On occasion it may be necessary to use two or more stage construction, due to very wet levee material. No change in 
construction procedure is necessary or contemplated over that for a levee constructed in one stage. Due cognizance should be taken of shrinkage factors. In general, the use of berms for increasing stability has proven satisfactory.

66. On weak foundations, in rehandling materials at the levee toes or within the levee base, the height of stock piles or embankment should be carefully controlled so as to avoid failures, which can be induced by comparatively small loads.

\section{Inspection ditches}

67. Inspection ditches have been provided in all prior levee construction. Future new levees on the main stem of the river will be limited to setbacks made necessary by caving banks. Inspection ditches should be provided as they have in the past.

\section{Plans and Specifications}

Standard project drawings

68. The size of project drawings should conform to the dimensions prescribed in Orders and Regulations. If all pertinent data cannot be clearly shown on one sheet, additional sheets should be used. Scales should be in tenths of a foot and not in inches. Scales of 1:10,000; $1: 5,000$; or 1:2,000 are desired and may be used, as best suited to the particular job in hand. A graphic scale should be shown on each map. A standard title block should be adopted for use in all three Districts.

Information required by contractor

69. In general, the plans and specifications prepared by the three Districts give sufficient information to enable contractors to make intelligent bids. However, for the sake of uniformity, and to avoid possible controversies, the following procedures are considered worthy of adoption:

a. In most cases where selected material is to be used, right-of-way limits should be shown on drawings. If the material is to be procured from side borrow without selection, right-of-way limits need not be shown, unless it is definitely known that the necessary amount of material can be obtained from within those limits.

b. Where the water content of the material available for borrow is known to remain nearly constant, it is satisfactory to indicate on the plans the water content determined f rom soil samples. However, where the water content may change materially, it should not be shown. Where water content is shown, the date of borings, method of taking, and a statement that the data are not guaranteed should also be indicated. 
c. In cases where selection of material is required, the specifications should state that the location of materials as shown by borings is not guaranteed and the contractor may have to drift material, due to variations from those shown, but pits should be so laid out that the contractor will know the maximum limits of drifting to be required.

d. All three Districts should adopt the same abbreviations and symbols for showing soil types.

e. When practicable, the permissible depth of borrow should be shown on logs of borings taken in the borrow areas.

Applicability of

present specifications

70. The present standard levee specifications, developed from experience gained during many years of levee construction, are generally applicable and should be retained in their present form. Adoption of certain changes discussed in other parts of this report would necessarily involve changes in the specifications. Also, there are a few modifications which appear justifiable in order to clarify questionable points or better suit modern construction practices. The more important of these are:

a. Preparation of foundation. Specifications for this phase of the construction, as now written, were applicable years ago when it was contemplated that the base would first be cleared and grubbing operations would follow later. Now, practically all clearing and grubbing are done with bulldozers or similar equipment, and a satisfactory job can be done in this manner. However, when clearing, grubbing and refill of stump holes are practically simultaneous operations it is impossible to make a reasonably accurate estimate of yardage required for refill of the stump holes. The specifications should be revised to provide that where clearing and grubbing are performed by bulldozers or similar equipment, no separate payment will be made for refill of stump holes.

b. Dressing and sodding. Frequently, trouble is experienced in getting contractors to maintain the rate of progress in dressing and sodding required by the specifications. To avoid this difficulty the specifications should be made more stringent. The following sentence should be added to the specifications: "Sod shall not be obtained from the existing levees for sodding the new work, unless such procurement has been approved by the contracting officer."

c. Removal of debris. The specifications provide that all clearing or grubbing debris shall be destroyed or disposed of within the right-of-way limits, but there is no clause which precludes the disposition of material outside these limits. Very frequently the debris is disposed of landward of the 5-foot limit. Not only is it an eyesore, but it may cover an area which could be troublesome during high-water periods. If trouble should develop, it would be difficult to detect and correct, 
due to the presence of debris. On work where it is objectionable, provisions should be incorporated in paragraph 34 of the specifications to prohibit disposal of clearing and grubbing debris landward of the levee in areas where it would hinder maintenance during high water.

71. The above changes are in addition to those made necessary by the adoption of the new Code.

\section{Freeboard}

72. Project authorizations (provide for freeboard. Levees have freeboards ranging from 1 to 5 feet. $x$ All main river levees below New Orleans and the levees below Morgan City should have a freeboard of 5 feet, to provide protection against high waves and tides during tropical storms. On tributary levees, where the project grades are based on experienced floods, the freeboard should not be less than 3 feet. Whenever it is predicted that a flood crest will reduce the freeboard of the main line levees to less than 3 feet, steps should immediately be taken to top out the levee to provide a 3-foot freeboard. In view of the apparent need for a minimum freeboard of 3 feet, serious consideration should be given to raising all main river levee freeboards to at least 3 feet by topping out levees now constructed to project grades. Where levees are not now up to the project grade and cross section, consideration should be given to enlarging the base to obtain that freeboard.

\section{Future Activities of the Board}

Standing committee

73. A standing committee should be appointed, with its general function that of keeping the Code current. This should consist of one member each from the Office, Chief of Engineers, Mississippi River Commission, Waterways Experiment Station and the three Districts. Specifically, this committee should have the following authority: (1) To study and coordinate all phases of planning, investigations and testing, design and construction; (2) wherever problems of considerable magnitude are encountered, the standing committee should be empowered to appoint temporary committees by proper representation to adequately study and report on the particular problem in question; (3) power to initiate, subject to the approval of the President, Mississippi River Commission, the necessary studies and tests to obtain factual information concerning specific problems, and (4) to travel as necessary to prosecute the abovelisted functional duties.

Preparation of Commission manuals

74. The Exploration and Testing Committee should be allowed to function to prepare the Field Exploration Manual and Laboratory Testing 
due to the presence of debris. On work where it is objectionable, provisions should be incorporated in paragraph 34 of the specifications to prohibit disposal of clearing and grubbing debris landward of the levee in areas where it would hinder maintenance during high water.

71. The above changes are in addition to those made necessary by the adoption of the new Code.

Freeboard

\section{The remainder of this paragraph indicates the expressed desires of the Code Comittee; however, their statements cannot be held to violate officially prescribed freeboards.}

line levees to less than 3 feet, steps should immediately be taken to top out the levee to provide a 3-foot freeboard. In view of the apparent need for a minimum freeboard of 3 feet, serious consideration should be given to raising all main river levee freeboards to at least 3 feet by topping out levees now constructed to project grades. Where levees are not now up to the project grade and cross section, consideration should be given to enlarging the base to obtain that freeboard.

\section{Future Activities of the Board}

Standing committee

73. A standing committee should be appointed, with its general function that of keeping the Code current. This should consist of one member each from the Office, Chief of Engineers, Mississippi River Commission, Waterways Experiment Station and the three Districts. Specifically, this committee should have the following authority: To study and coordinate all phases of planning, investigations and testing, design and construction; (2) wherever problems of considerable magnitude are encountered, the standing committee should be empowered to appoint temporary committees by proper representation to adequately study and report on the particular problem in question; (3) power to initiate, subject to the approval of the President, Mississippi River Commission, the necessary studies and tests to obtain factual information concerning specific problems, and (4) to travel as necessary to prosecute the abovelisted functional duties.

Preparation of Commission manuals

74. The Exploration and Testing Committee should be allowed to function to prepare the Field Exploration Manual and Laboratory Testing 
Manual. This committee would cease to function upon completion and acceptance of the manuals. Travel for members of this committee should be authorized any time necessary in connection with the preparation of the manuals. 
Table 1

INIFIED SOIL CLASSIFICATION

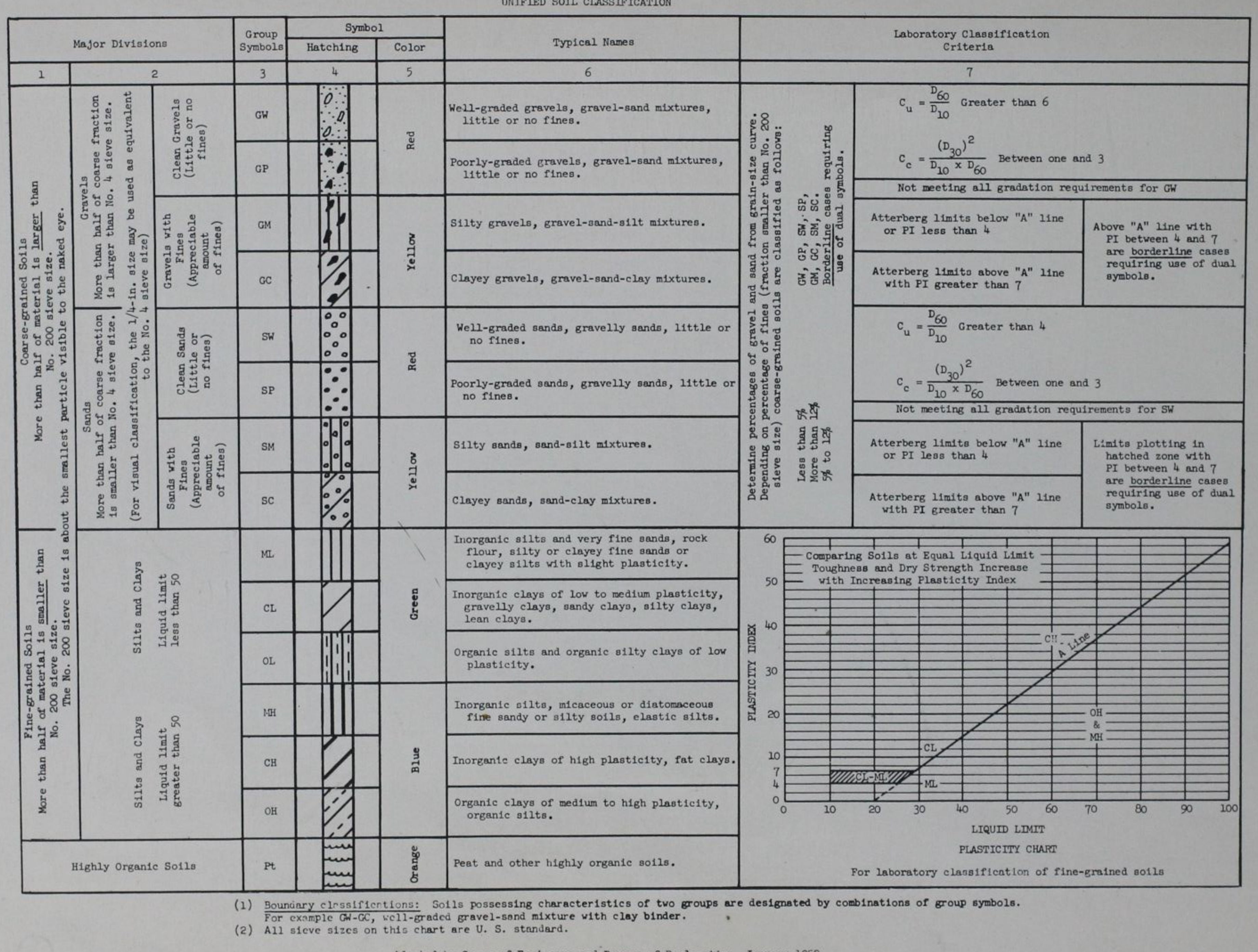

Adopted by Corps of Eng1neers and Bureau of Reclamation, January 195 ? 


\section{May 1946}

Shearing Stress in Tons per Square Foot

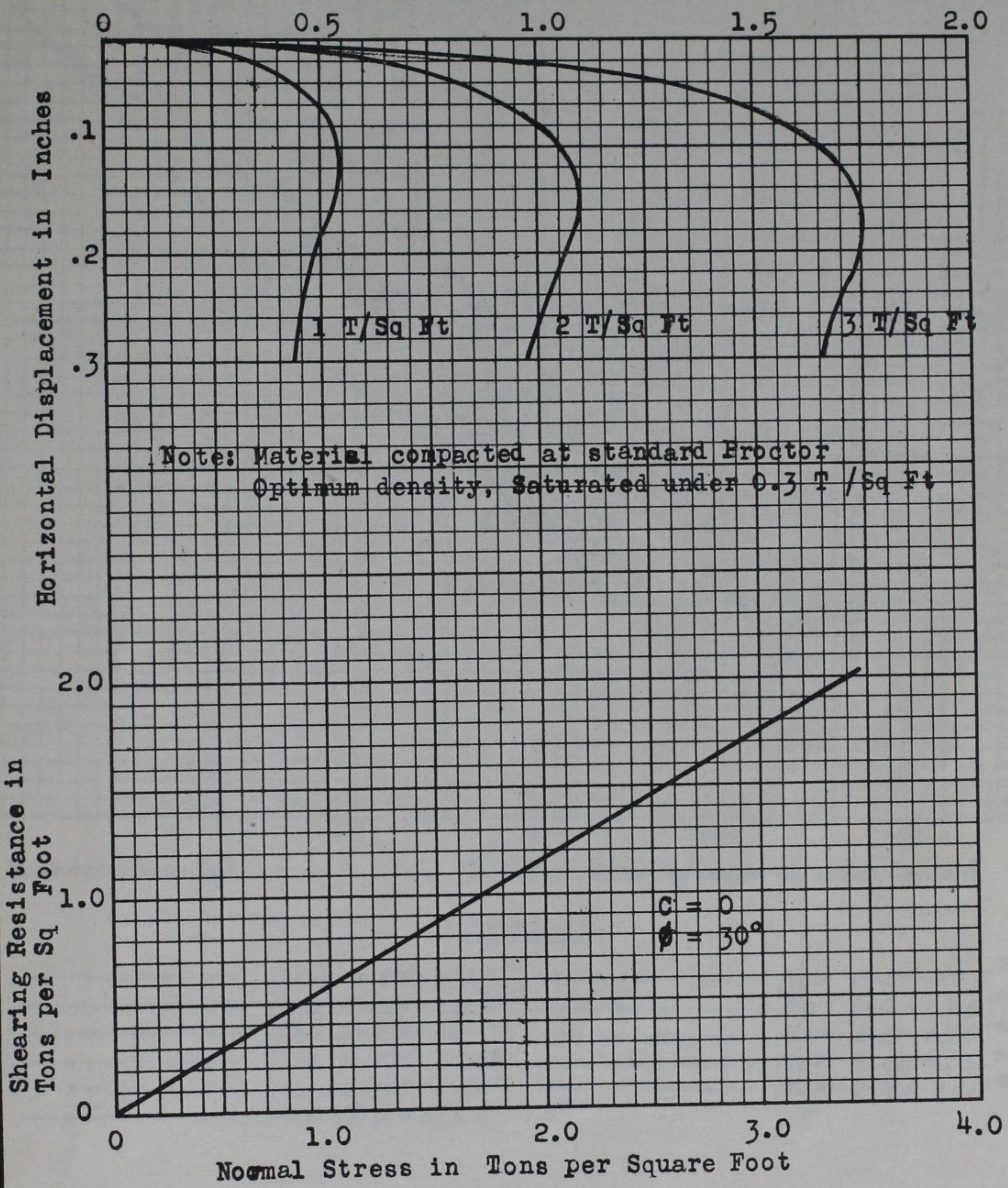

Qc DIRECT SHEAR TESTS

Borrow Area "A"

Boring A- 100 - $\mathbb{\text { Hev. }} 200.9$ to 195.9

Sample 1. - Silty Sand 


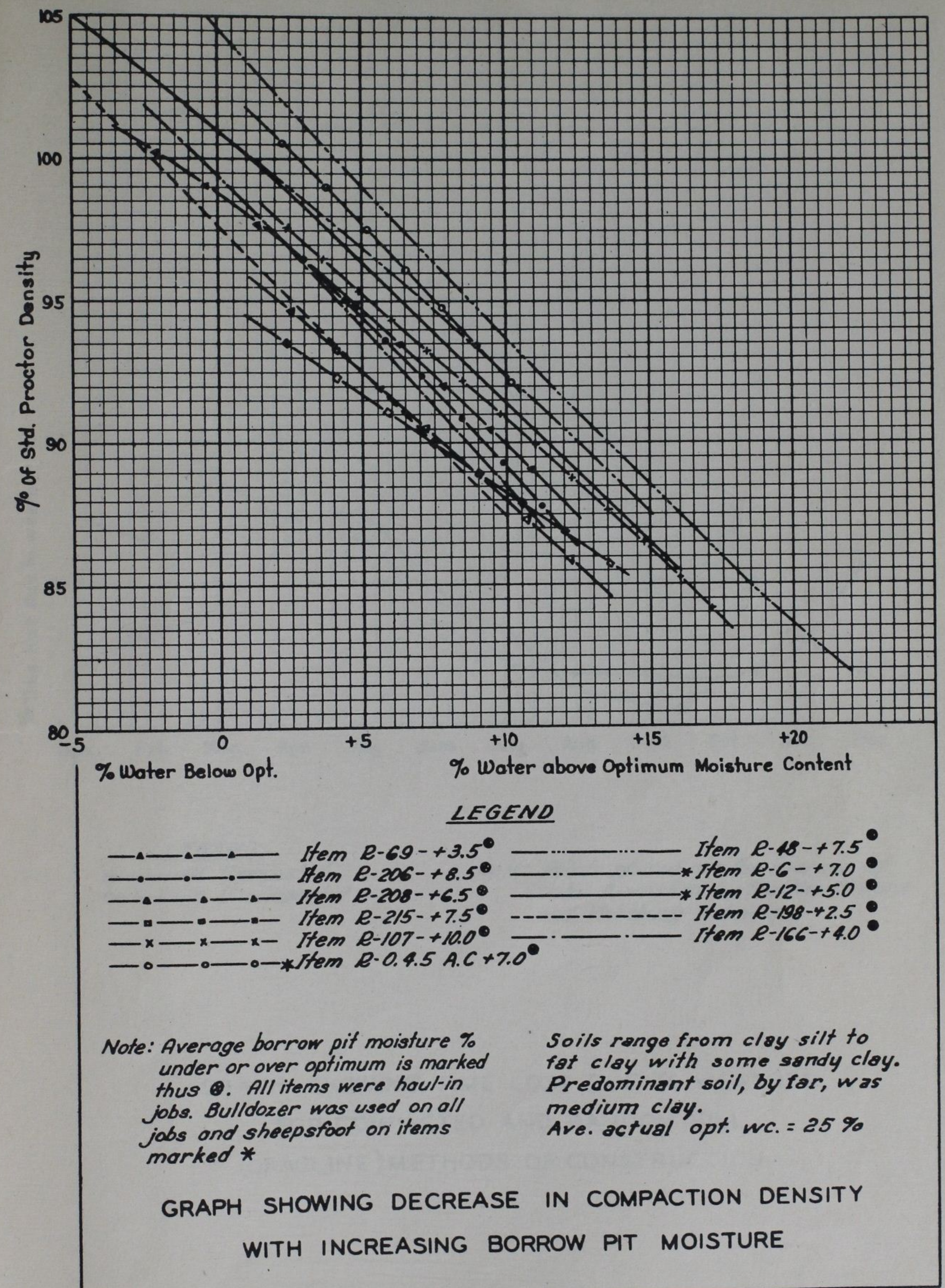




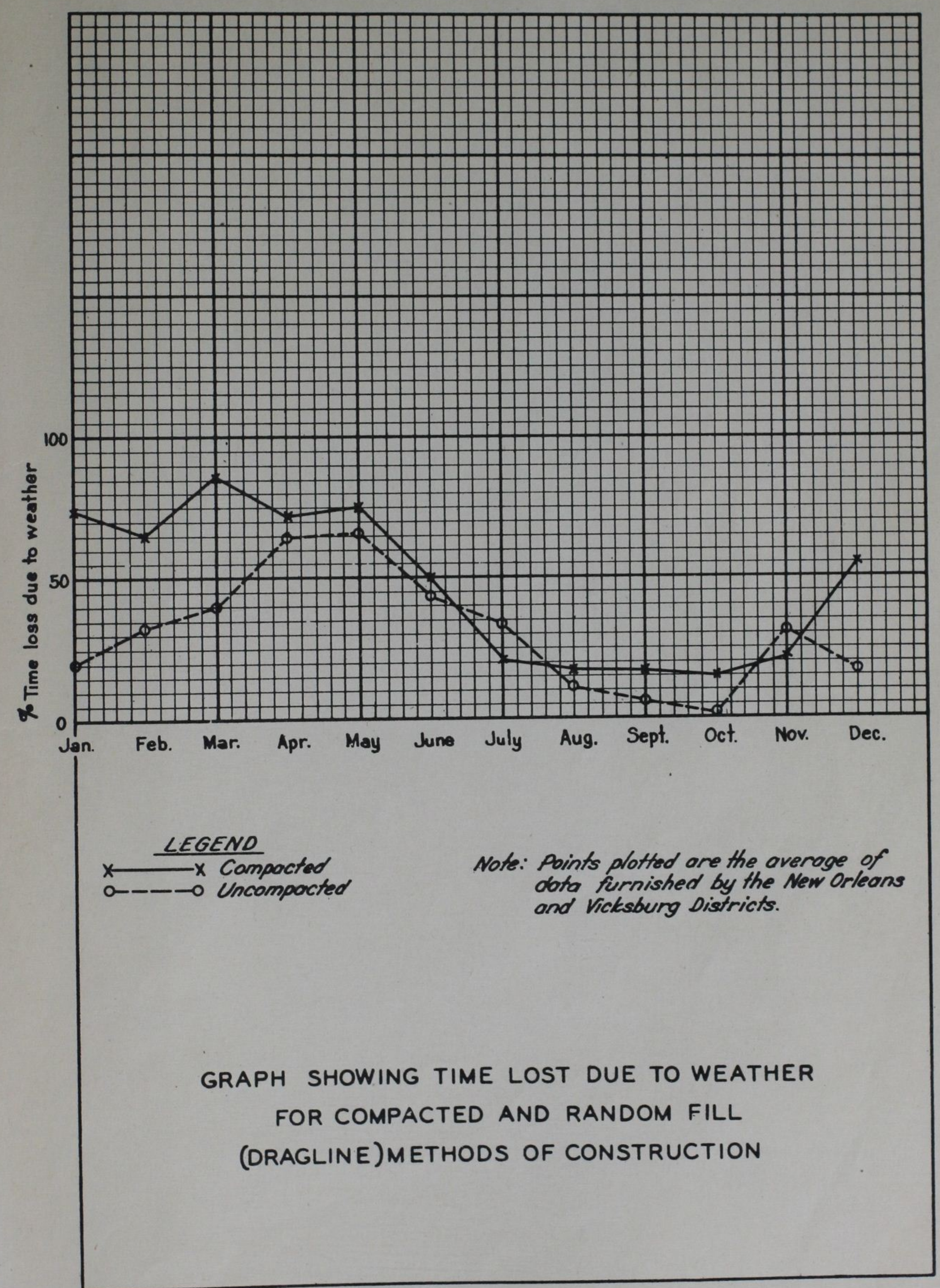

Fig. 5 
ISAYCE

SUBJECT: SO11 and Rock Boxing Logends

1. In a recent discussion whth Mx. Prescott. OCE, we were acisised that cha poxtion of the noto on arr boring legends portaining to tha reprosontativenass of borings should bo revisod to road as \&o130:5:

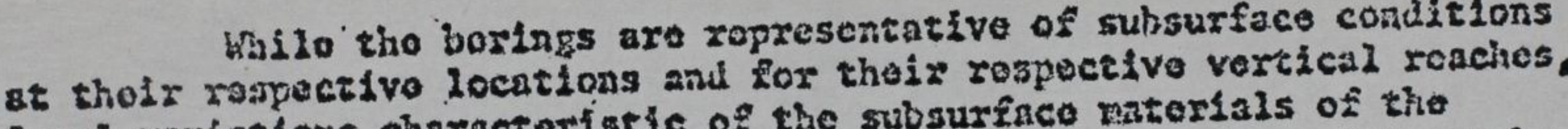
locai vañatlons eharacteristic of the subsurface materials of the rogion aro ontlchetad and, If ancomeored, such varintlons will not bo consldored as differing matarialiy within the purview of clesso 4 of the contract.

2. Plense xovite your soli ard rock borlag legends eccordingly. POR TEL DXVISTON DSEXNEER: 


\section{Appendix D: 1929 Vicksburg District Levee Handbook}




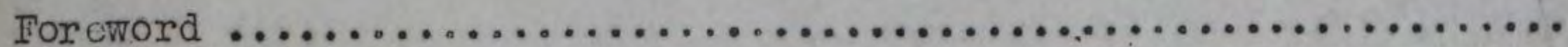

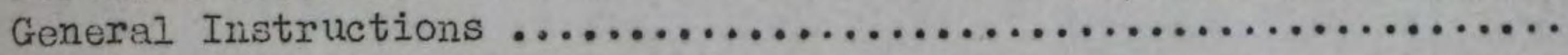

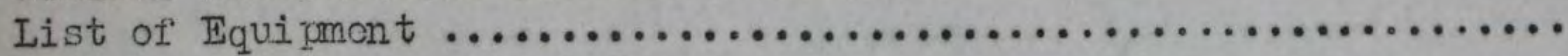
Method of cross sectioning

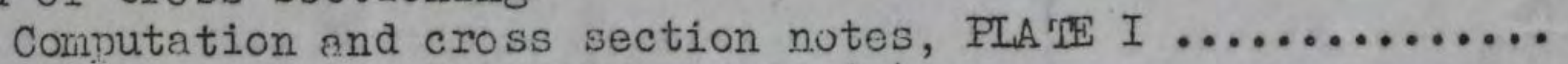

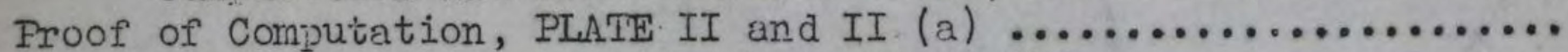

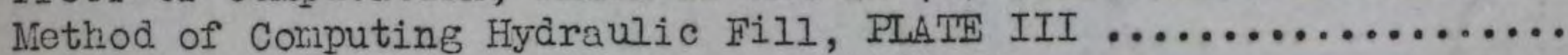

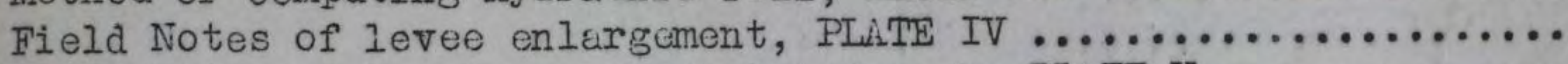
Field Notes of levels over completed work, PLATE $V$............. Field Notes of Curve run by Deflection Angles, PLATE VI ......... Method oi muning curvo by offsets, PIAIE VII ................ Right of Way Chart, $8^{\prime}$ crown, 1 on 3 and 1 on 4 slopes, Types of Sections "A", "B" and "C" Dr. No. 100/40, PLATH XII .... YARDAGE TABLES

1914 Standara section and 1 on 50 borrow pit $\ldots \ldots \ldots \ldots \ldots \ldots \ldots \ldots$

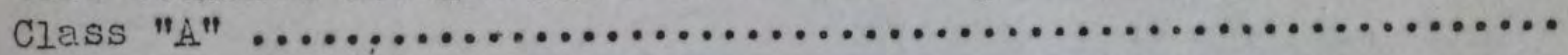

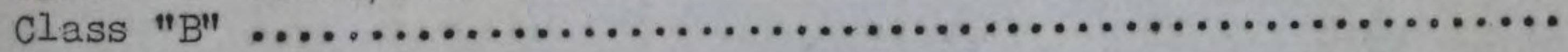

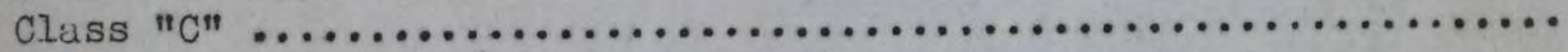

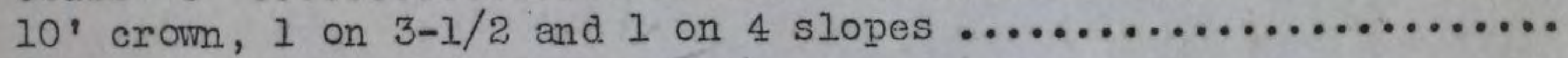

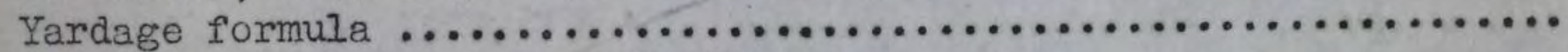

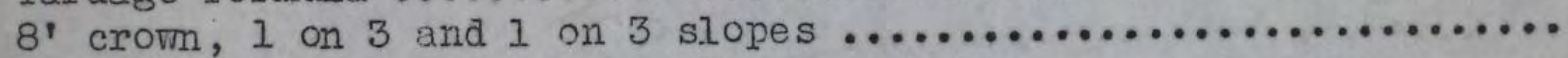

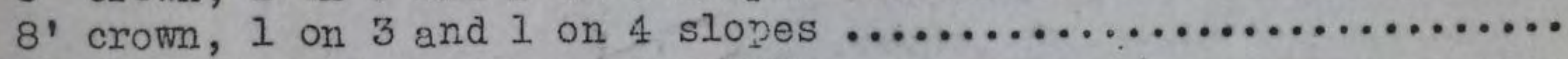

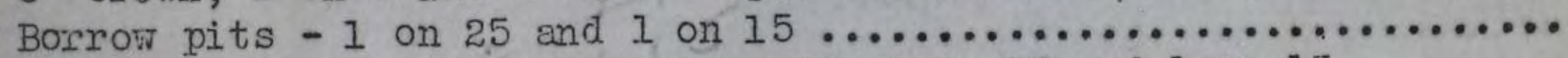
Typical borrow pit sections 1 on 50,1 on 25 and 1 on 15 ,

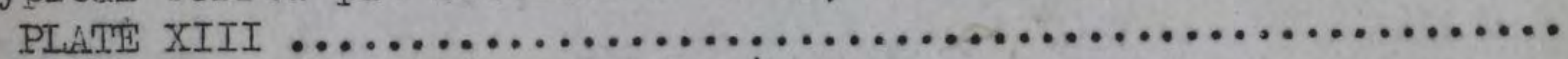

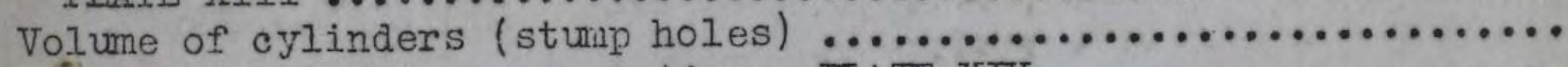
Tyjical completed cross sections, PLATE XIV ................. Progress profile for enlargement PLATE XV $\ldots \ldots \ldots \ldots \ldots \ldots \ldots \ldots \ldots$ Progress profile for new levee PLkTE XVI $\ldots \ldots \ldots \ldots \ldots \ldots \ldots \ldots \ldots$ GRADES

E. Bank Miss. R. in Miss. ..........................

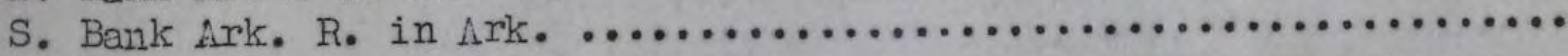

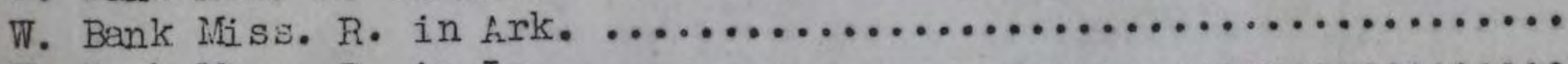

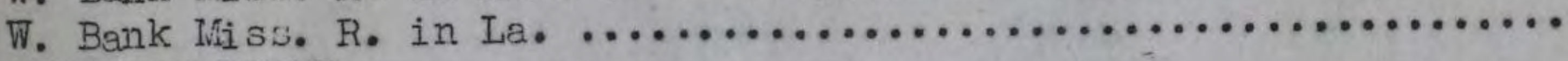
STANDARD FORNS

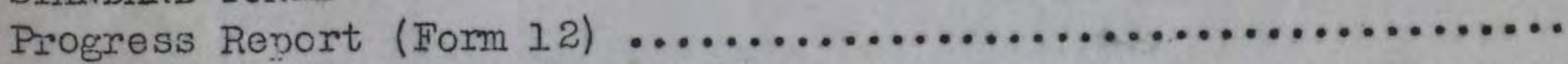

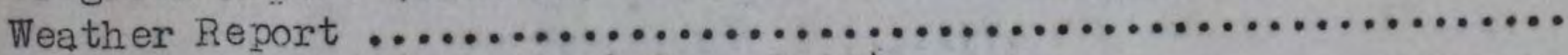

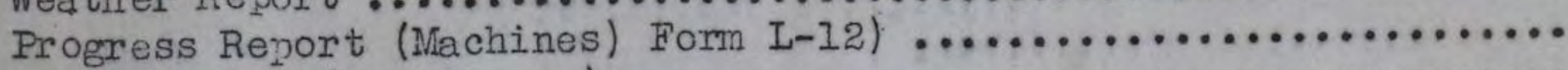

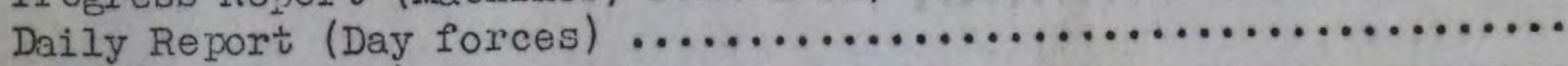

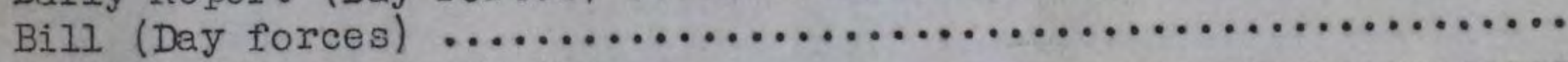

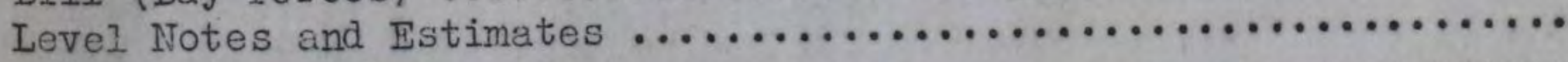

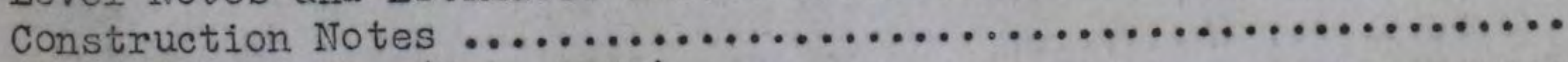

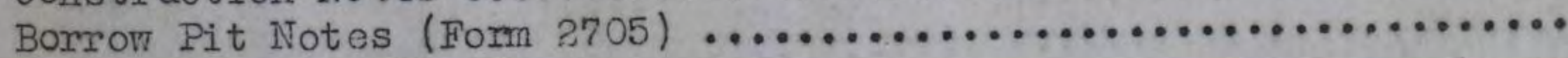

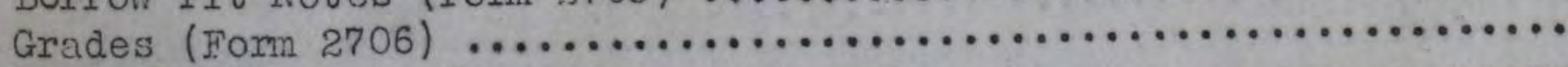

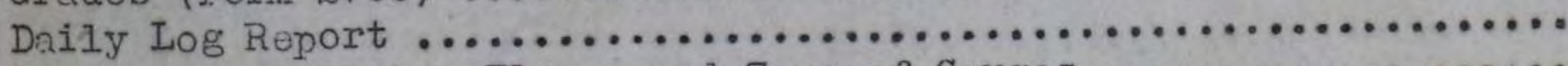
Comparison of Datum Plancs and Zero of Gauges $\ldots \ldots \ldots \ldots \ldots \ldots \ldots$ 


\section{FORE:TORD}

It has been the intention in preparing this set of instructions to foresee the problems with which the field inspectors will be confronted. There are, no doubt, many problems which will arise from time to time in the prosecution of the work which could not be treated in a general manner, but it is expected that the inspector vill consult his immediate superior, when thore is any doubt as to the procedure to be followed.

John C. H. Leo, Major, Corps of Engineers, District Ingineer. 
INUTRRUCTIONS TO FIELD INSFECTORS OF IEVEE SURVEYS, CONSIRUCTIONS, AND PSTPORIS.

In order to guarantee a thoroligh'y efricient inspection system, the inspector will see thet the follorine instructions are carried out in detail. To permit the use of a general term, the levee contractor or machine foreman, as the case may be, shall be hereinafter known as "the represuntutive in charge." Any other derigation shall be made in accordance with the rork being done, as "the clearing contractor."

\section{DUTIISS}

3. The inspector is first duty is to inow tie snecifications, and allied data which is on filo at the Aroa Engineor Offico. As the work progresses the inspoctor must know whether or not it is being performed in accordanco with the specifications and, ir not, to notify immediately the rorrosentative in charge, and if doficioncies are not fully corrected, to notify tho Area Inginoor. The inspoctor must also know from day to day tho porcontago or complotion as against time romaining and funds available. An inspoctor must be present during construction work and his reports must be faithiully, fairly and accurately submitted. Survey notes are regarded as important in all respects as financial eccounts or legal affidavits. An inspector's work must be entirely trustworthy, if his cervices are of any value whatever. When the inspector is assigned to his station, he will see that he has the required equipment (List of equipment given on page 12), and he vill maintain it in servicoable conditions at all times.

2. On arrival at assigned station, the inspector will locate hubs every 100 feet, for enlargoment, along the top of the exi sting levee over which ho will run a line of lovels and estabiish T. B. Ms. on trees to the land- 
side of the lovec at each 1,000 fect. For now leveo, he will rolocate, chain und chock tho proposed contor line, along which ho will set hubs evory 100 fout and reicrence P. Cs. and sll changos indicativo. ( Sao paragraph 12 ). He will thon run a line of lovels over these hubs and cstablish T. B. Bas. on troes to the landsi de of the nroposod now lovee at each l,000 feot. In botil cases, this line of lovuls will be tied into some lnown U. S. P. B. M. This work is to bo kopt rell. in advanec of all construction work and will be complotod for tho scason's proposed vork as carly as possible, consistont with the othor work of tho inspector.

3. Whon tho lovec construction is to bo dono uy hirod labor with governmont equjpment and the clcaring is to bo dono undor a soparate contract, the inspoctor, on rocoipt of a clearing contract, vill show the clcaring contractor, or his ropresentative, over tho area to be cleared, indicating the starting and finishing points. He will then issue to the clearing contractor, or his representative, notes by stations showing the distances from the toe of the existing levee (for enlargement), or from center of levee (new levee) of the area to bo cleared. Check moasurements will be made of the right of way clcarod before tho levee construction work is begun, and before Form 13 is submitted.

4. The representative in charge will koen the clearing 1,000 feet in advance of construction, and the inspector will take cross section notes for the proposed new lovec, or onlargoment, and across pits to the back of the right of way as carly as possible thorcafter (sce paragraph 11, 13 and 14). Whon tho notos aro taken thoy are to be plottod on "Porfoct" cross scction papor using a scale, 20 foot equals onc inch, and plotting nine sections on cach shoet. (Scu typical soctions pago 36). Thoso soctions will show (for enlargumont) tho existing loveo, the proposod onlargomont, 
the old pits and the proposed new pits, or (New levee) the ground surface, the proposed new levee and new pits. When each sheet is plotted and inlied, it will be promptly mailed to the Aree. Engineer.

5. Construction Notes. As the work progresses, the inspector will issue to the representative in charge a set of notes showing the landside and river side toe distances and the net and gross fill at the center (see Plate I, page 13, and page 61). The gross fill equals net fill plus the allowance for shrinkage which varies according to the method of handling. For levee machines, $25 \%$ is added; dump wagons, 20\%; wheelers and fresnos, 15\%. Borrow pit notes show tho distance out and the cut allowed at that point. All distances are measured from conter of levoe. Thoso notos are to be issued on standard approved forms Nos. 2704 and 2705 , the inspector retaining a copy for file. The roprosontative in charge shall sot all slope and grado stakos and set all crow's foot, and they shall bo checked by the inspector.

6. On completion of each 100 feet of levee, the inspector will run grades and tost slopes (sec page 61) and submit same on standard approved form No. 2706 to the roprosentative in charge, a copy to the Area Engincor, and a copy to be kopt on file by the inspoctor.

7. A line of lovels will be run at the ond of each month over all comploted lovees constructed, notes to bo mailod to the Area Engineor.

8. Inspectors are required to keep full notes of borrow pit material classification, wetness, and movements of the embankment, if any, and cross sections will be taken immediately, plotted and mailed to the Area office. (See paragraph 2l).

9. Especial care will be taken that the clearing of the levee base five feet beyond the toe of the enlargoment, or new levee, as well as the grubbing, 
and breaking of the ground or old levee surface will be performed according to specifications.

10. All reports shall be submitted as shown under REPORTS.

\section{METHODS}

11. Method of keeping; notebook. To expedite the work of those who have to interpret and plot maps from the field notes it is necessary that all notes be kept in a standard form (See Plates III and IV) pages 17 and 18. Whenever a notebook is first started the general location and the return ad-dress of the inspector must be intered on the flyleaf; i. e., "Levee notes, Panther Forest new 1oop 1929. Returm to Inspector Joln Jones, Camp C-2, Luna, Ark." First and very essential is the heading of each day's work, the names of the instrumentman, tapeman, rodman, and axcman; the place, kind of work, weathor conditions and the date. At the ond of each day's work, the inspector will sign his notes giving the name of the contractor's superintendent on the job that day. Notos for onlargoment include original loveo and ground elovations of right of way (Plate III, page 17). Notes on the completed work show olevations from the landside toe to the riverside too to the back of the now borrow pits. (Plate IV, page 18). Notebook will show M. R. C. grade on cach page, all clcvations to tie in cross sections to known elevations. All T. B. Ms. and P. B. Ms. will bo correctly describod. Original notobook will bo turmed in to tho Arca Office at the end of the scason, indexed and with proper title on the cover.

NOTE: - All olovations must be referred to Mean Gulf Lovol.

12. Mothod of running curves for alignment. In order to el iminato sharp anglos in the lovee systom, tangents will bo joinod with simplo curves. Reforence is mado to Plates VI and VII, pages 19 and 20, which show the mothod of running curves by defloction anglos and offsets. Since tho mothod 
of runnine curves by deflection anglus canrot bo coverud in detail in this mannor the clomentary furctions are as follors:

\section{The Simple Curve}

The elements of a simple curve which ure usuful it luvee location and construction are the forlowing: (1) the ancle $\widehat{\Delta}$, known as tre intersection angle, centrul ung $g_{\perp}$, or the deflection eng?e $\cap f$ the two tangonts.

Since the formulue for the computation of curve dati are expressed in terms of trigonometric functions of $\widehat{A}$, thuse which will be used morc commonly are:
(a) The "tangent distance"
$T=R \tan \pi / 2 \Delta$
(b) The "Ione chord"
$C=2 R \sin 1 / 2 \Delta$
(c) The "external distance"
$E=R$ ex-act $1 / 2$

in which $\mathrm{R}$ is the radius of the curve. (Exturnin secint $=$ socont minus 1 ).

(2) Curves are lnom by their "dogroes." The dorrec of a curve is the ang Io subtondod at tho contcr by o chord of 100 fout. Thus, in a four dogrce curvo a chord of 100 foot subtonds four dogrocs at the contor of the curvo.

(3) From the dofinition in paragraph (2), if $D$ be tic dogrec of any curve,

$$
R=\frac{50}{\sin 1 / 2 D}
$$

Honec, whon $D$ is known $R$ may bo found.

Tho dogroc of tho curvo is dotormined by juagment or by topography. This is gonorally dotominod from tho oxtomal distanco which can bo used in ejthor case. In this district the allowablo maximum dogree of curvaturo shall be 10 dogroos.

Curves are usuaj.ly laid out on the ground by "deflection angles." The three points on the two tangents which ero used aro:

P. I. Point of intersection of the tro tangents.

P. C. Point of curve (tho borinning of the curvo). 
P. T. Point of tangency (the end of the curve).

Curves do not usual. Iy begin or end with a whole station. To deterinine the P. C., the tanent distance is computed and measured from the P. I. along the tangent. Thus, if the station of the P. I. is $647 / 18.8$ and $\mathrm{T}$, the tangent uistance, from the formula, $T=R$ tan $1 / 2\langle$, is 371.8 feet, the station of the P. C. is 643447 . A stake may also be set on the forword tangent 371.8 feet from the P. I. which point is the P. T., but its station is determined from the P.C. along tho curve and not from the P. I. From the definition in paragraph (2) it is assumed that any chord less than 100 foet will subtend an angle at the center proportional to its length; a fifty foot chord will subtend an angle of $1 / 2 D$, a trenty-fivo foot chord will subtend an angle of $1 / 4 \mathrm{D}$, etc. From this proportion the longth in stations of a curvo of $D$ degrees is

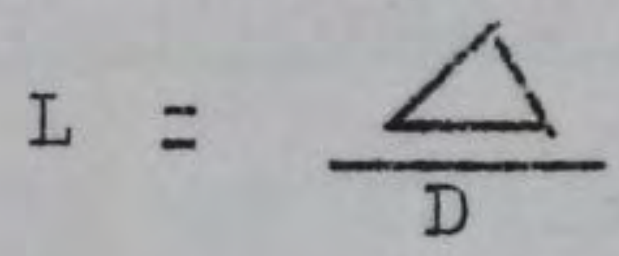

The length of the curvo thus found added to. the station of the P. C. givos the station of the P. T.

As

$$
\begin{aligned}
& \Delta=32^{\circ} 33^{\prime}=32.55^{\circ} \\
& D=4^{\circ} 30^{\prime}=4.50^{\circ} \\
& L=\frac{32.55}{4.50}=7 . \quad+23.3 \text { stations } \\
& \text { P. C. }=643 t 4.7 \\
& \text { I. }=\frac{7 t 23.3}{650+70.3}
\end{aligned}
$$

With the instrument set up at the P. C. With a forosight along tho tangont, doflections for tho location of stations aro taken in tho following mannor - tho deflection for a 100 foot chord $=1 / 2 \mathrm{D}$; the first chord to station 644 will be 53 foot and the doflection an gle will be $53 \times 2^{\circ} 15^{\prime}=$ $\overline{100}$ 
$1.1925^{\circ}=1^{\circ} 11^{\prime} 35^{\prime \prime}$. Deflections for the succeding stations will be:

$\begin{array}{ll}\text { Station } & \text { Deflectio } \\ 644 & 1^{\circ} 11^{\prime} 33^{\prime \prime} \\ 645 & 3^{\circ} 26^{\prime} 33^{\prime \prime} \\ 646 & 5^{\circ} 41^{\prime} 33^{\prime \prime} \\ 647 & 7^{\prime} 56^{\prime} 33^{\prime \prime} \\ 643 & 10^{\circ} 11^{\prime} 33^{\prime \prime} \\ 649 & 12^{\circ} 26^{\prime} 33^{\prime \prime} \\ 650: & 14^{\circ} 41^{\prime} 33^{\prime \prime} \\ 650470.3 \text { (P.T.) } & 16^{\circ} 16^{\prime} 30^{\prime \prime}\end{array}$

As a check on the computation, the total deflection angle equals $1 / 2$ which is $16^{\circ} 16^{\prime} 30^{\prime \prime}$. The last sub-chord should close in both distance and direction on the stake previously set from the P. I.

13. Method of taking cross sections notes. Due to the fact that the procedure varies for new levee and enlargement, they will be treated separately. To avoid confusion, the nerr Class "B" section, which will be used for the most part throughout this district, is used for illustration. The same general principles will be followed where specifications require the use of Classes "A" and "C" (See Dr. No. 100/40, page 25). Class "B" has a 10 foot crom with a 1 on $3-1 / 2$ riverside slope and a landside slope to contain a seepage line of 1 op $6-1 / 2$. The seepage line springs from the riverside slope, at the clevation of the assumed maximum flow line. The lanasiae slope of the levee shall extend in a straight line from the crown elevation to a point where the seepage line intersects the original surface of the ground.

NEW LEVEE. The proposed center lino having previously been determined (par. 2), the inspector will take cross sections, all distances being 
measured from the center of the crown, which shall be known as, or designutoù as, center (seo Plate I, prge 13). Starting at the center with a known constant (difforence betwocn ir.R.C. grade and H. I.), roadings will bo taken at all broaks in the ground surface to that point there tho proposod nct levco will intersoct the natural ground surfaco. Thoso roadings are callod fills (rod roading plus or minus the constant), and for oach reading the distance is takun froin the contor, the distance boing rocorad ovor fill in the notobook. To detormino the rivorsido toe, tost roadings mill bo tekon until such a roading is found that tho fill multipliod by $3-1 / 2$ (1 on $3-1 / 2$ slopo) plus $5^{\prime}$ (half crom) cquels tho tapo reading. Similarly, to dotomino the landside too, tost roadings will be taken until such a roading is found that the fill minus 1 ' multipliod by $6-1 / 2$ ( 1 on $6-1 / 2$ scopago slopo) minus $8-1 / 2$ ( $1 / 2$ iidth of crom plus distanco to point whoro soopage lino springs from rivorsido slopo ono foot bolow crom clevation) oquals the tape reading. For borron pits, tho inspoctor will rofor to paragraph 14.

ENIARGEMENT. To determine the center of the proposed enlargement, the inspector will plot the existing levee, (as shown in par. 4), and superimpose the proposed enlargenent so that the cut and fill on the landside slope vill balance $25 \%$ allowed for shrinkage in the fill. This will have to be done by trial as the landside slope is variable for various heights. The conter having been determined by this method (being for riverside onlarganent at some point on the riverside slope of the existing levee), the inspector will take cross section notes; starting at the center of the now crown with a known constant (difference between M.R.C. grade and H. I.) and measuring all distances from that point. Readings vill be taken at all breaks in the surface of the existing luvec and to that point whero the 
proposud unlargement intersocts the netural ground surface. The method of determining the landside and rivorside toes is the same as shown under NEW LEVEE.

The inspoctor will then take cross section notes from the riversido too to the back of the right of way across the old pits. Readings will bo taken at oach broak in the ground surface, the roadings to be recorded as distances (from center) ovor actual elovations.

14. Borrow Pits. "No matcrial shall be obtainod within 40 feet of tho baso of loveo on the rivurside nor within 100 foet on tho landsido" Par. 25, Standard Specifications. As no material is obtained from landside pits oxcopt under excoptional circumstances and approved by the Chiof of Engineers, riverside pits only will be considorod.

Now Lovec. Cross sections will be taken over tho ground surface to the back of the right of way, and will bo recorded in the note book as distance (from contor) over actual clevation. These notes will be plotted (par. 4), and the proposed pit superimposed thereon. Starting at a point 40 feet from the riverside toe, the side slope of the pit shall be 1 on 2 to a depth of 3 feet below the natural ground surface; from that point outward the pit may be deepened on a slope of 1 on 25 to such distance as to procure the required yardage of the new levee plus $25 \%$.

Inlargement. The inspector will first plot the notes showing the existing levee, the proposed enlargement and the ground surface to the back of: the right of way (see Plate I, page 13). The next step is to plot the proposed pit; starting at a point 40 feet from the riverside toe, the side slope of the pit shall be 1 on 2 to a depth of 3 feet below the natural ground surface; from that point outward the pit may be decpened on a slope of 1 on 25 to such distance as to procure the required material for the 
enlargement plus 25\%. Care should bo exercisod wheje the material is to be taken from old pits that the pits are not deepened more than is allowed.

15. Rutio of Gross and Net Ievne rection to borrow pits. Wherever designated, tests wi.l1 be conducted and detailed instructions will be given by tho Area Engincer.

16. Computation of cross section notes. The standara method of computing cross section notes in this district is the double triangular formula, with the average ond area method for computing yardage (See P.ates I, II and II (a), pages 13, 14 and 15). All cross section notes will be computed and submittea to the Area office as early as possible, consistent with the other work of the inspector, in order that they may be checkec and rechecked $\nabla e 11$ in edvance of peymont on estimates.

\section{REPORTS AND GENERAL .}

17. Progress reports (pago 53) and weather reports (page 54), and progress profiles Plate XV and XVI (pages 37 and 38) will be mailed to the Arca office on tho first of each month.

18. Daily repoxts for day forces (page 56) shall be mailed to the Area offico. The name of the contractor's superintondent on the job for each day will be given and the report shall be signed by the inspector.

19. At the end of each month and on the complotion of contract, the inspector will make up a bill (page 57) which he will sign with the representative in charge, and in case of cluaring, the cloaring cortrcetor will also sign (page 59).

20. In ceso of disputos or whon important instructions aro issued in the fielo. thoso shal. bo givon in writing; a carbon copy boing rotainod for reforenco and filo and a copy to the Area Enginocr. 
21. A daily log (page 63) will be kopt by the field inspector showing important hapnenings in connection with his work (See par. 8). This log is to be turned in at the end of the season, and it is to be subject to inspection at any time.

22. It is essential that all forms, reports, and cross section notes be mailed to the Area office promptly to facilitate the work of the office inspector.

\author{
John C. H. Lee, \\ Wajor, Corps of Engineers, \\ District Engineer.
}

Vicksburg Engineer District, Vicksburg, Mississippi.

July $16,1929$. 


\section{EQUIPMENT \\ for \\ U. S, LEVEE INSPECTORS}

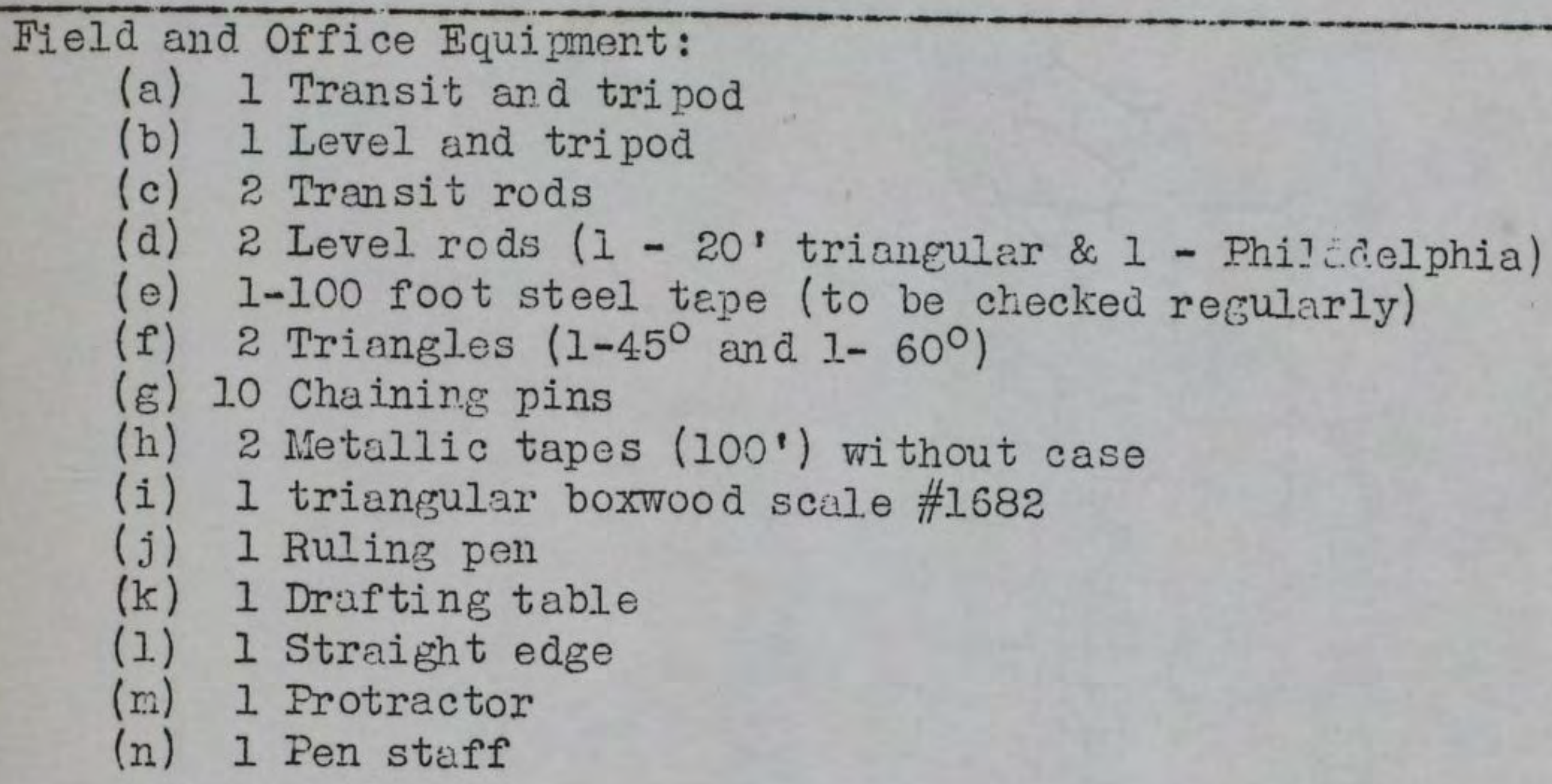

The above list is chargeable as Property, with the exception of (h) Metallic tapes.

The following list of supplies is not chargeable as Property.

(a) I Roll oi "Perfect" cross-section paper

(b) 4 Field sheets

(c) 2 Bottles of India ink

(d) I Box of lumber crayon (blue)

(e) 6 Pencils (assorted)

(f) 3 Erasers

(g) Penpoints

The inspector will be supplied with the following books:

(a) I Instruction book

(b) 1 Transit book

(c) 2 Levee Books

(d) 2 Progress books

(e) Daily Report for Day Forces (when requirod)

(f) 1 Log book

The inspector will be supplied with the following forms:

(a) Lovel lotes and Estimates ( I Pad).

(b) Progress reports (Form 12)

(c) " " (Form L-12) " (when required)

(d) Weather reports (24)

(e) Construction notes (Form 2704)

(f) Borrow pit notes (Form 2705)

(g) Grades (Form 2706)

(h) Daily roport for day forcos (when requirea)

(i) Set of specifications and Blue prints 


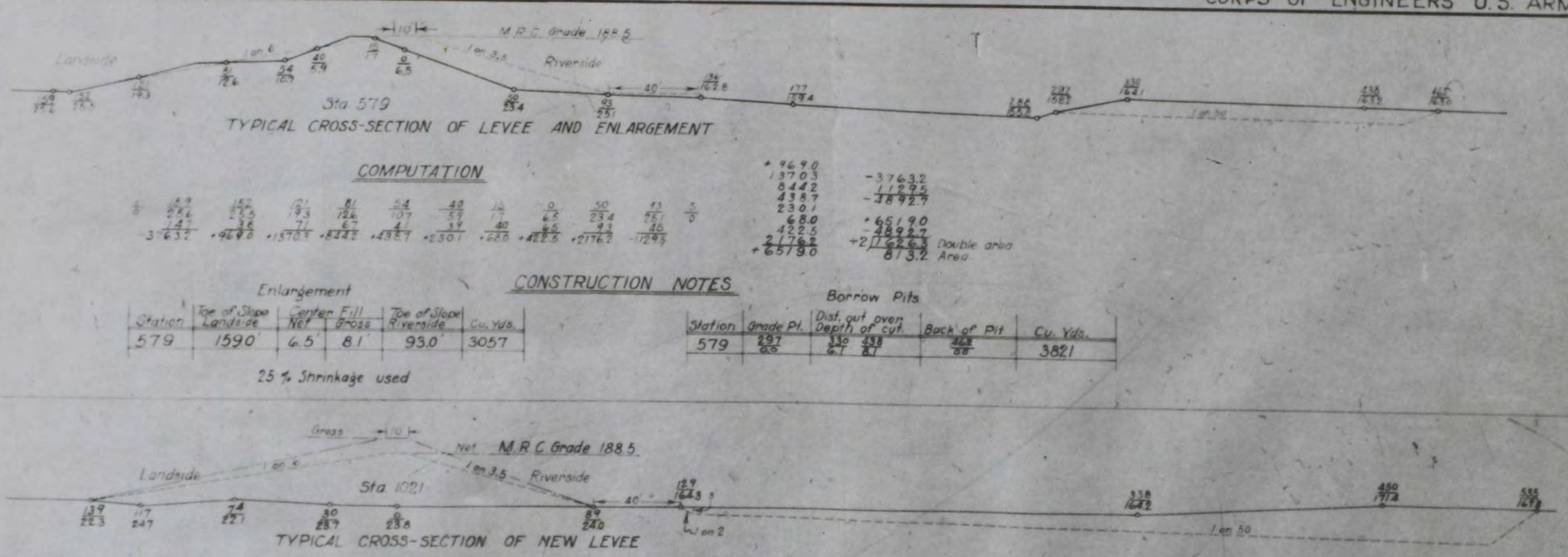

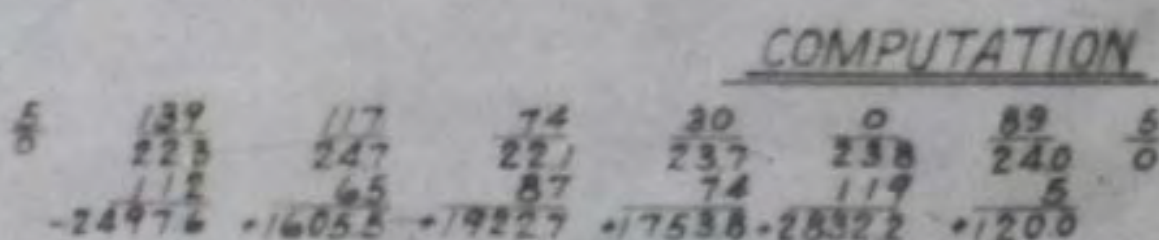

- New Levee CONSTRUCTION NOTES:

Borrow Pits

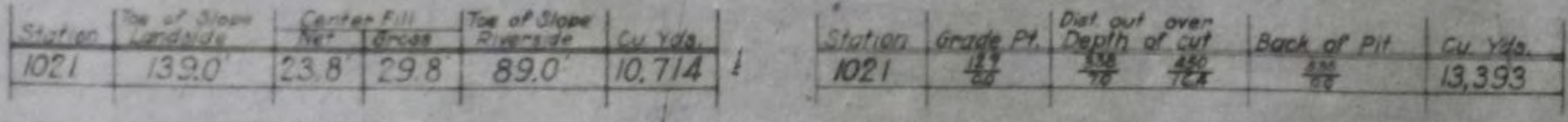
$25 \%$ Shminkage used

METHOD FOR CROSS-SECTIONING. COMPUTATION AND CONSTRUCTION NOTES, VICKSBURG ENGINEER DISTRICT VICKSBURG, MISSISSIPPI.

Feb. 1929. 

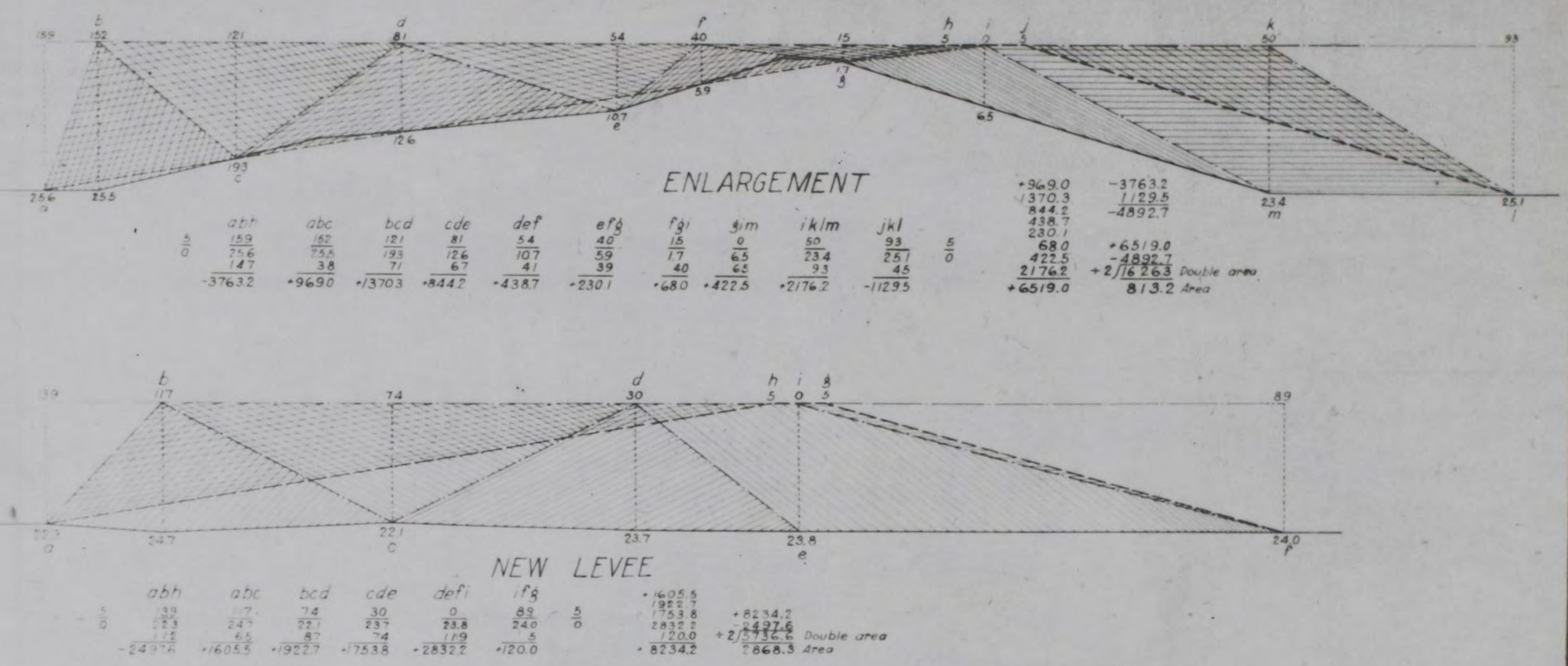

PROOF OF COMPUTATION

OF LEVEE CROSS-SECTIONS BY DOUBLE TRIANGULAR FORMULA VICKSBURG ENGINEER DISTRICT. VICKSBURG, MISSISSIPPI

Feb. 1929 


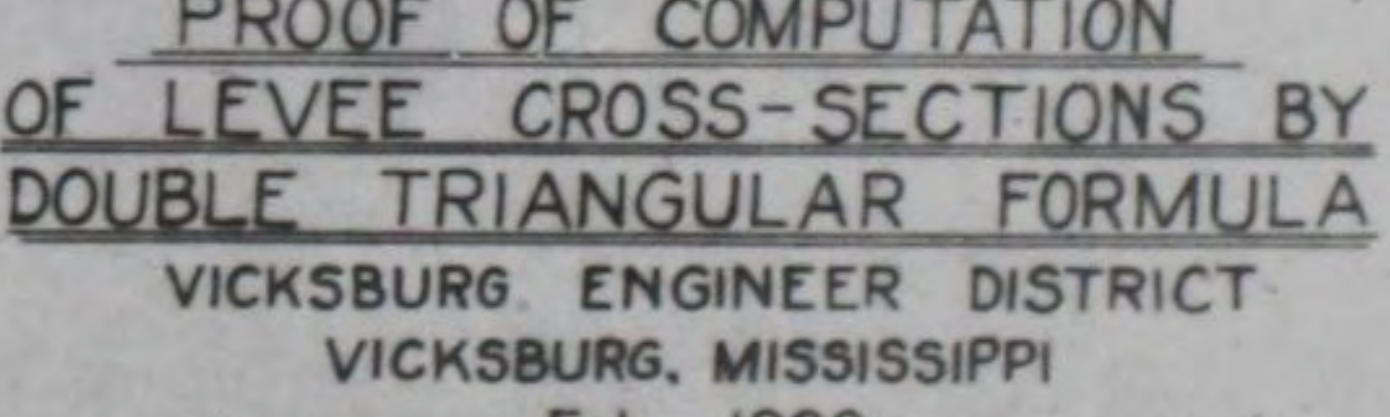

$\bar{v}$ 

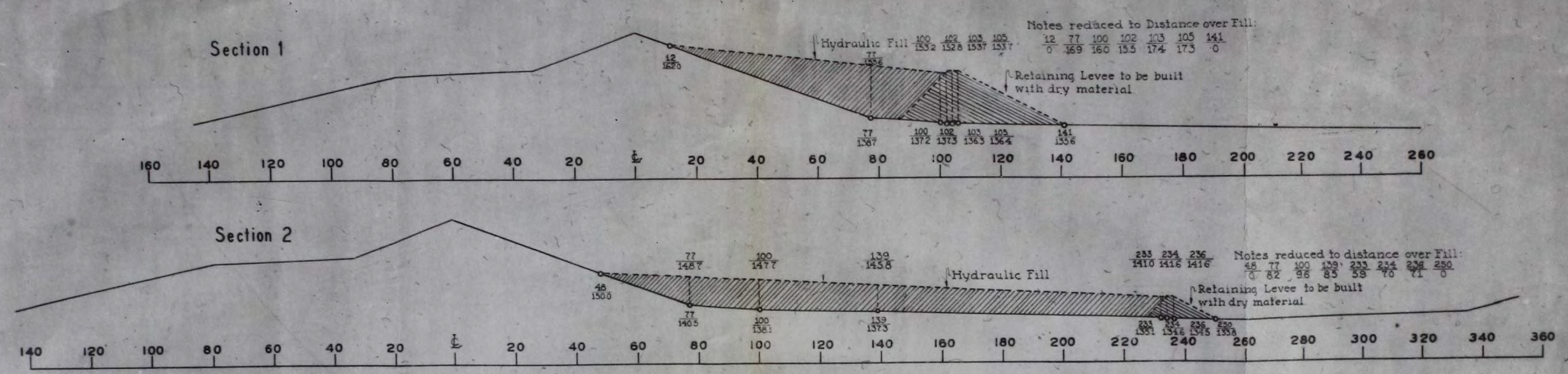

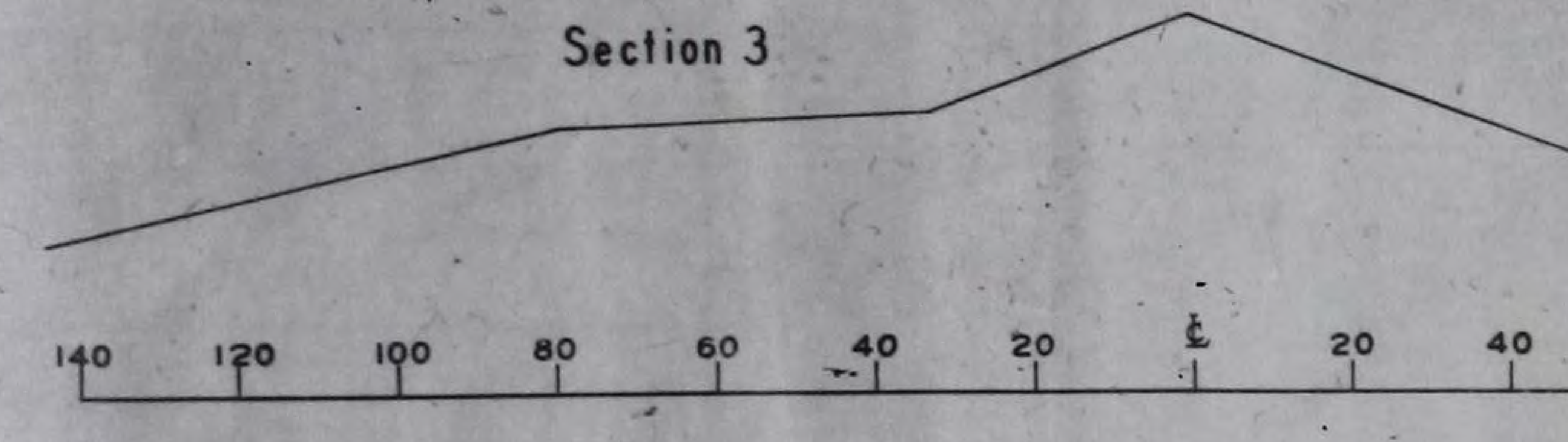

SUPPLEMENTARY REMARKS

Standard Instructions for Levee Inspectors. - The Inspector will locate hubs every 100 feet for enlargement along the top of the existing levee over which he will run a line of Ievels and establish T. B. M's on trees to the landside of the levee
of each 1000 feet." (For hydraulic work this line shall be referenced $\ddagger 0$ points $¥ 0$ the landside of the levee.) "He will take cross-section notes for the proposed enlarge

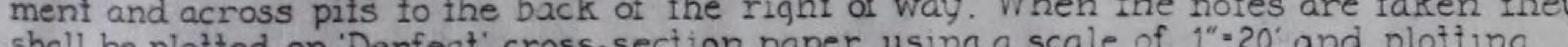
nine sections on each sheet" (Paragraph 13 gives the method of computing the enlargements

When the required yardage is determined, the Inspector will compute the
area of the hydraulic fill and sef grade stakes to conform with the approved plan of placing the material.

the above the inital readings beln at all breaks in the surface of the hydraulic fill These readings will be taken as distance over actual elevation. (Standard Borrow section sheets, and the areas computed by the double triangular formula. Upon completion of the work the Inspector will submit notes as compuled
on this plate, and the nole book will show distance over actual elevation and
fill
COMPUTATION OF NOTES OVER COMPLETED FILL Section $1-\frac{12}{0} \frac{77}{16.9} \frac{100}{16.0} \frac{102}{15.5} \frac{103}{174} \frac{105}{173} \frac{141}{0}$ $\frac{88}{1487.2} \frac{25}{4000.0} \frac{3}{465} \quad \frac{3}{522} \quad \frac{38}{6574}$

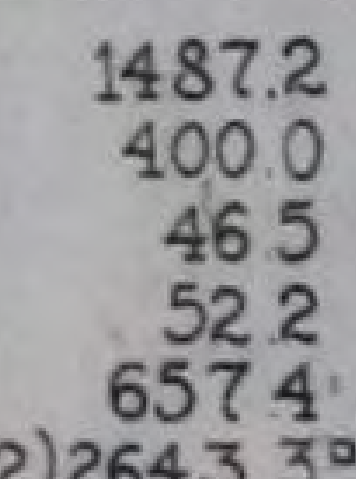
2) $2643^{\circ} 3^{\circ}$. Double Area Section $2 \cdot \frac{48}{0} \frac{77}{82} \frac{100}{96} \frac{139}{85} \frac{233}{59} \frac{234}{70} \frac{236}{71} \frac{250}{0}$ $\frac{52}{4264} \frac{62}{5952} \frac{133}{11305} \frac{95}{5605} \frac{3}{210} \frac{16}{1136}$<smiles></smiles>

2) $28572^{\circ} 0^{\circ}$ Double Area

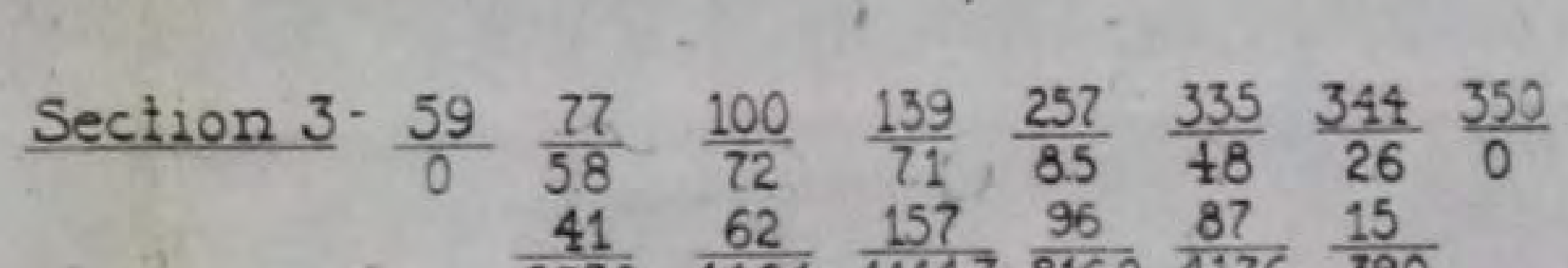
$\frac{44}{2378} \frac{62}{4464} \frac{157}{11147} \frac{96}{8160} \cdot \frac{87}{4176} \frac{15}{390}$
237.8
4464
1114.7
8160
417.6
39.0
30.0

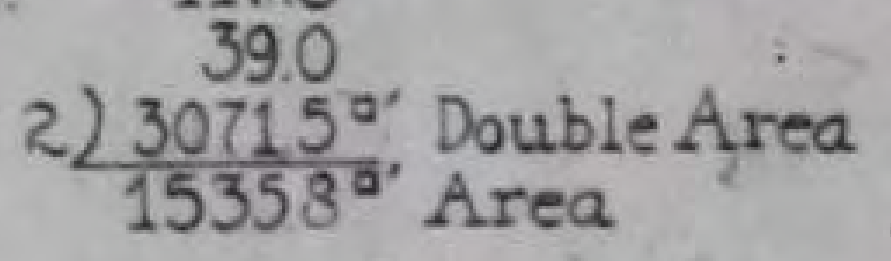

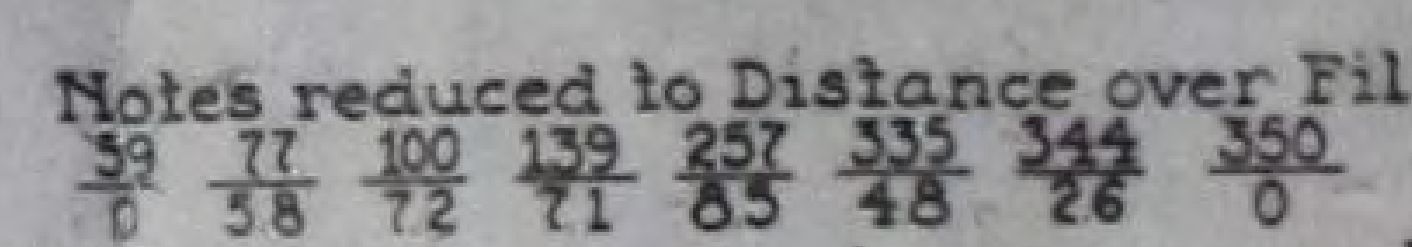
$\frac{257}{1394}$

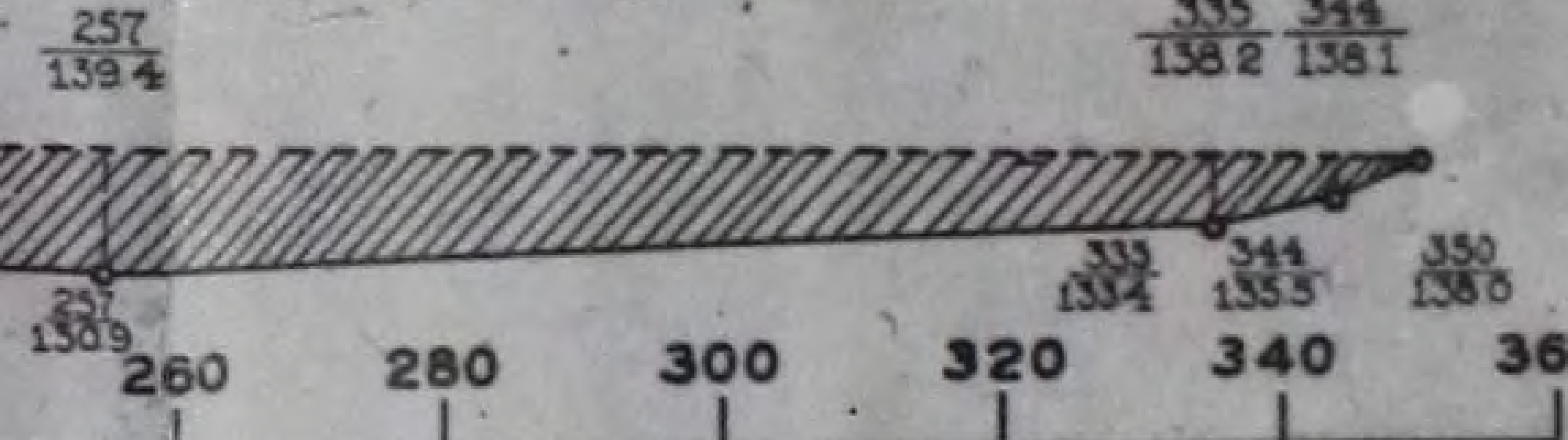

VICKSBURG ENGINEER DISTRICT MISSISSIPPI RIVER \& TRIBUTARRIES FLOOO CONTROL. Method. Computing Hydraulic Fill WITH SUPPLEMENTARY REMARKS SCALE: In $=20^{\prime}$ 


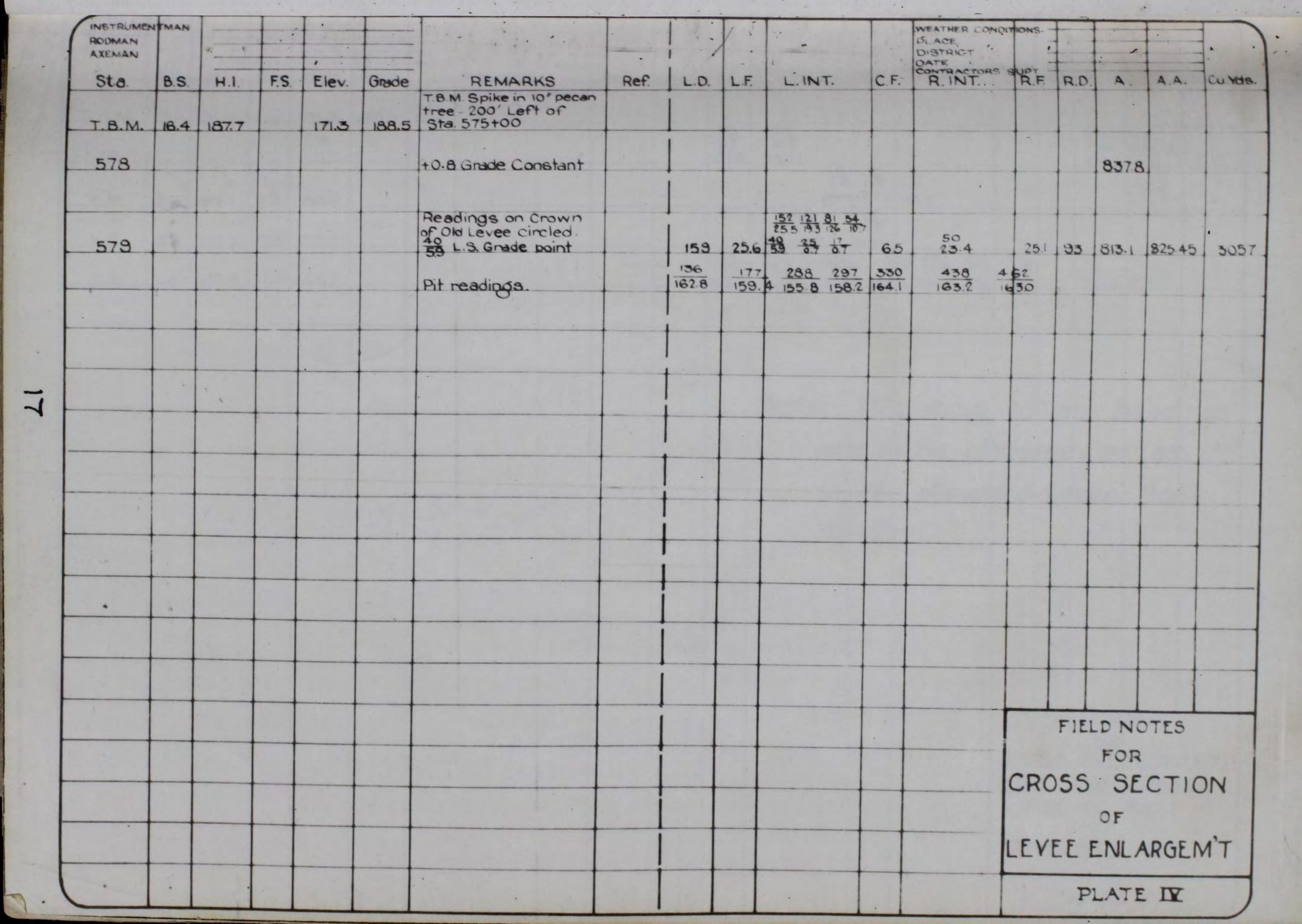



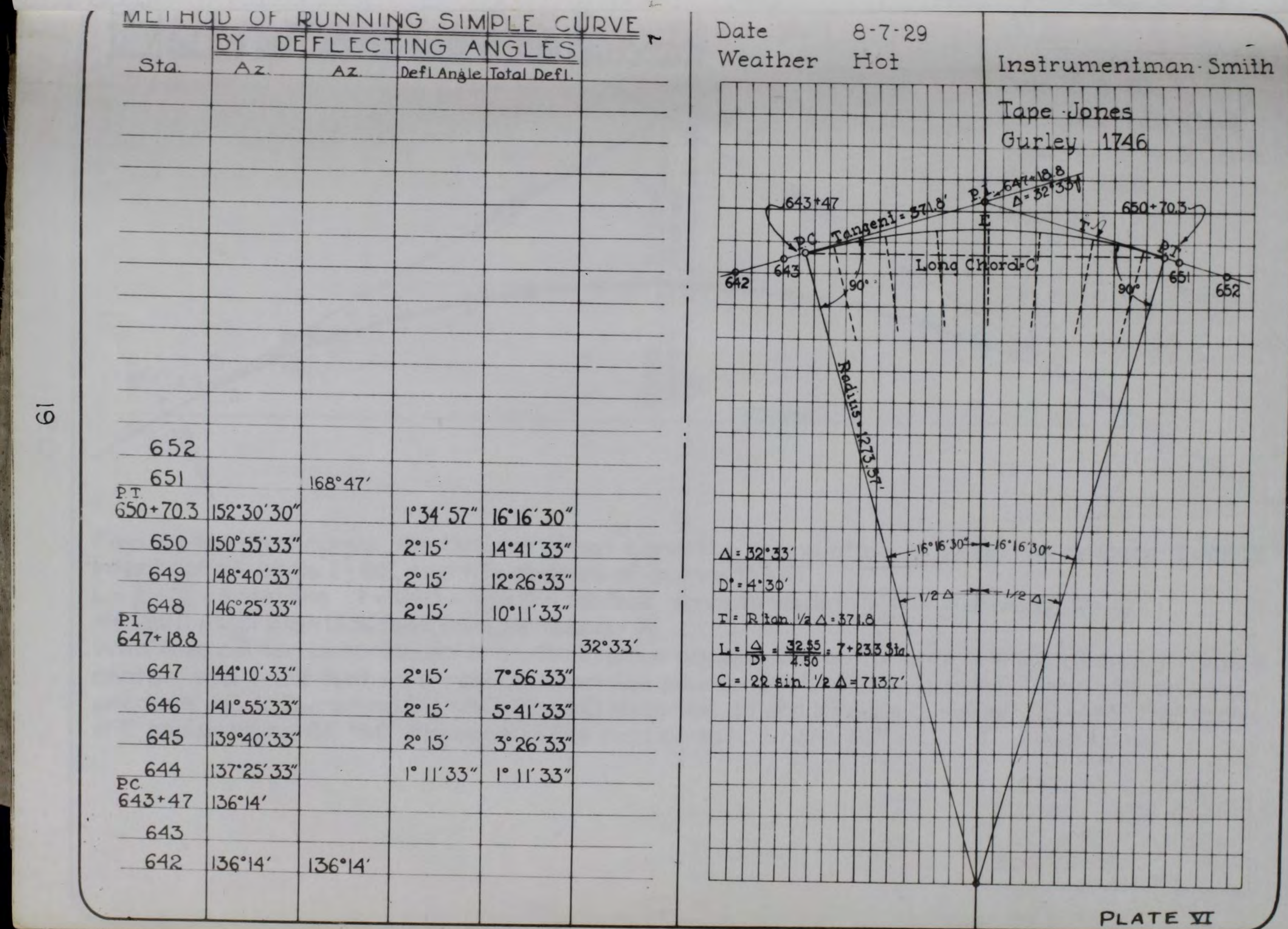


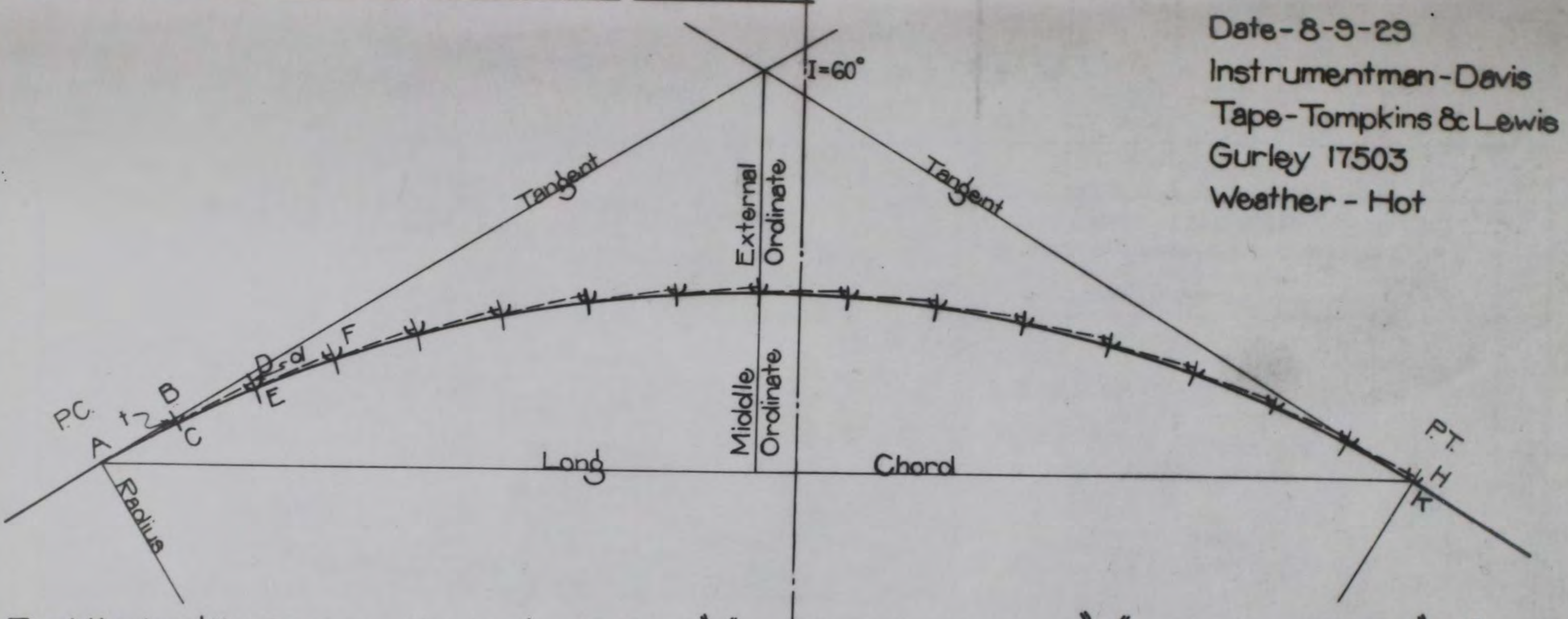

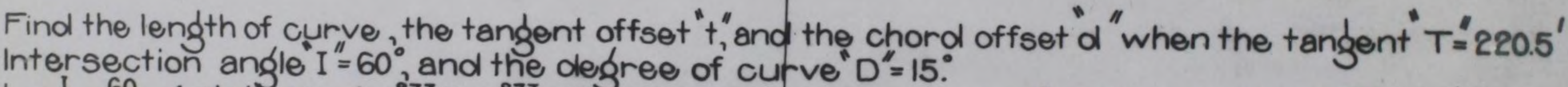
$L=\frac{1}{D}=\frac{60}{15}=4$ stations $t=\frac{873}{16} D=\frac{.873}{16} \times 15=.818$ feet $t$ from formula $t=\frac{C^{2}}{2 R} ; C=1$ gt. of chord, $R=\frac{5730}{D}$
$d=\frac{1.745}{16} D=\frac{1.745}{16} \times 15=1.636$ feet, from formula $d=\frac{C^{2}}{2 R}$

With ${ }^{16} \mathrm{~A}$ as center describe an arc with a radius фqual to 25 feet, or chord lendth, then with $B$ as a center and $t=.818$ feet as a radius describe an intersecting arc through C. Set stake at $C$ and produce $A C$ to $D$ making $C D=A C$. From $D$ describe an arc through $E$ making $D E=1.636$. Set stake at $E$ and produce $C E$ to $F$. Proceed in like manner to $K$ where $H R=t$. 


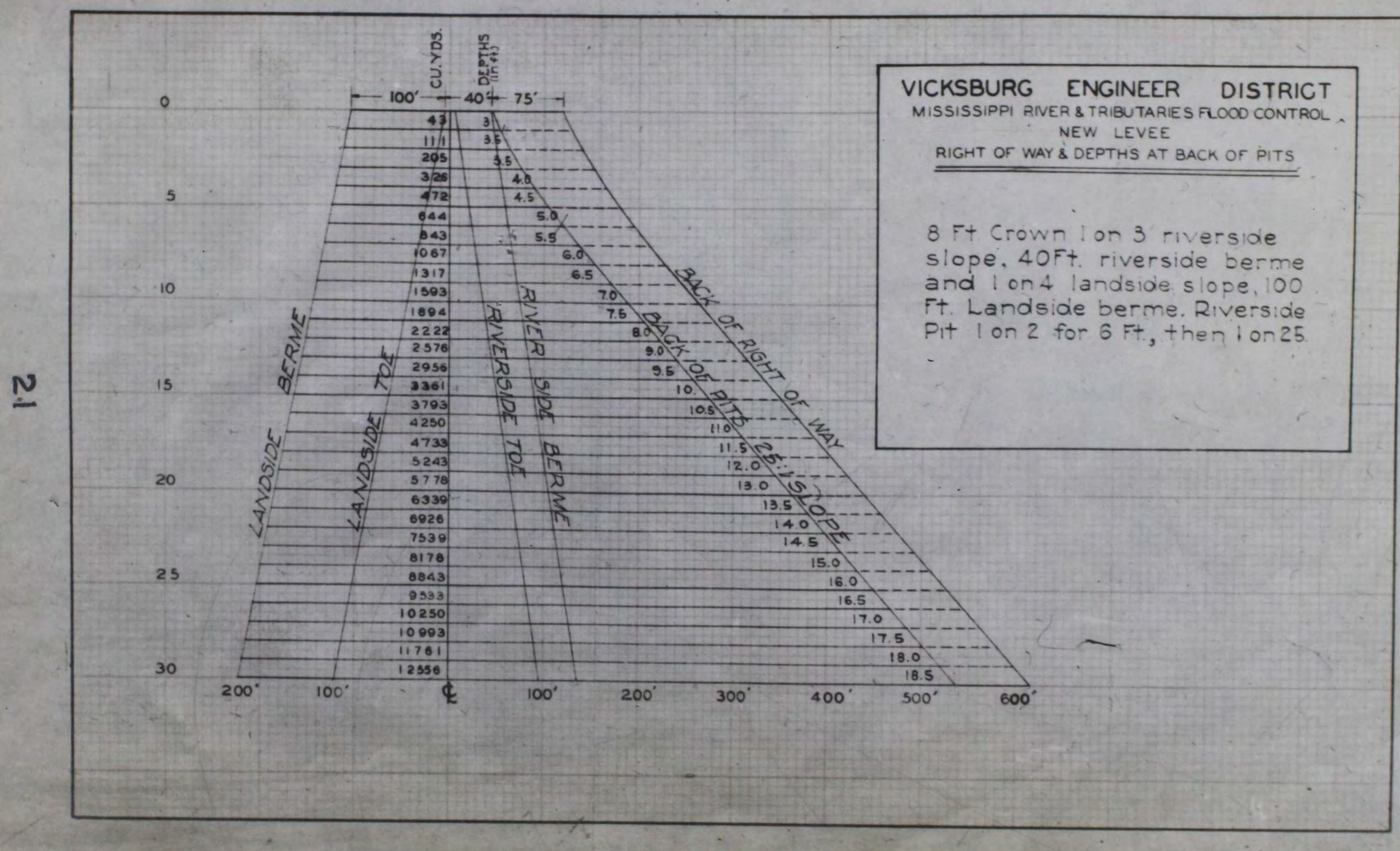

PLATE VIII 


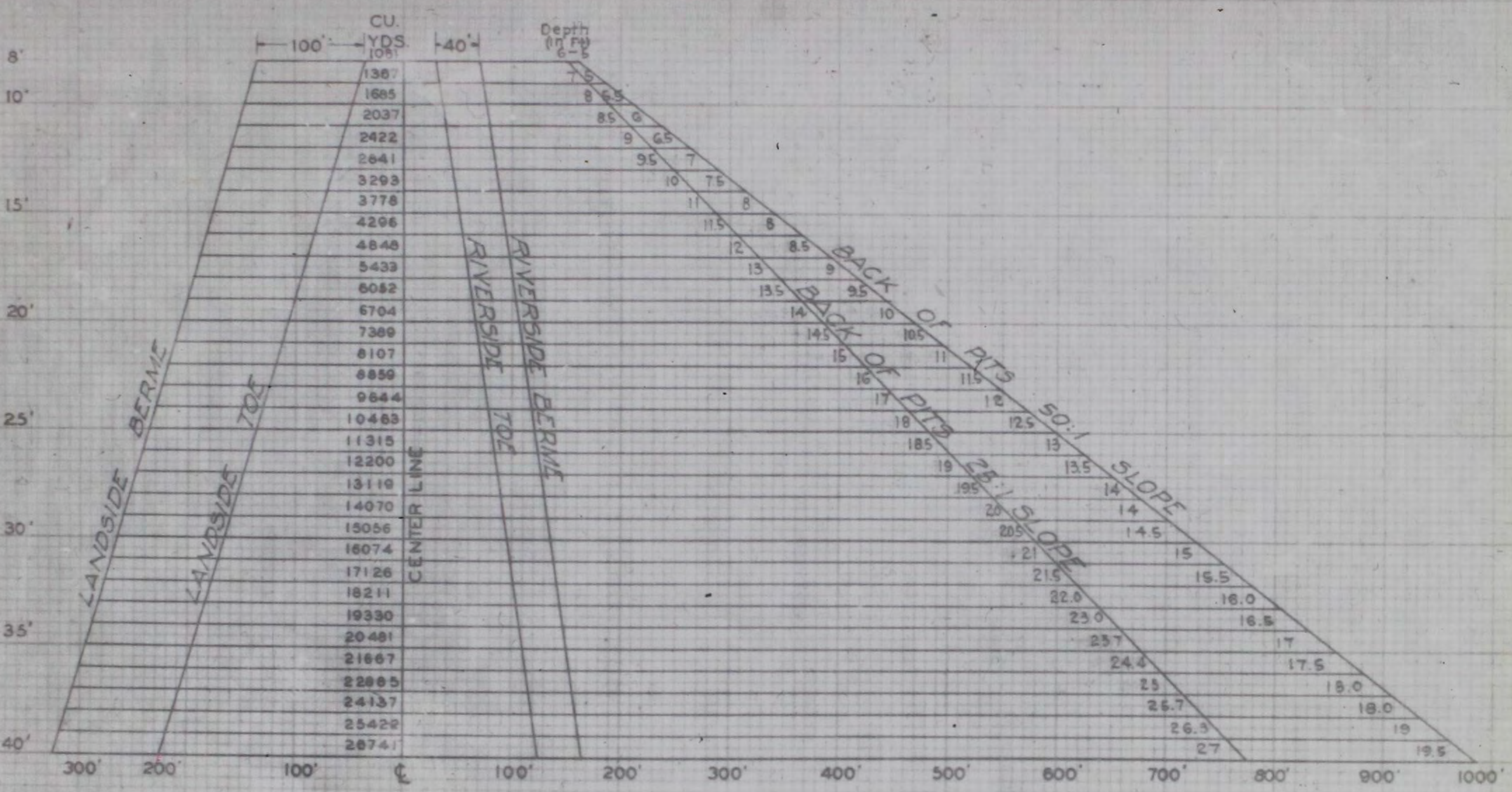




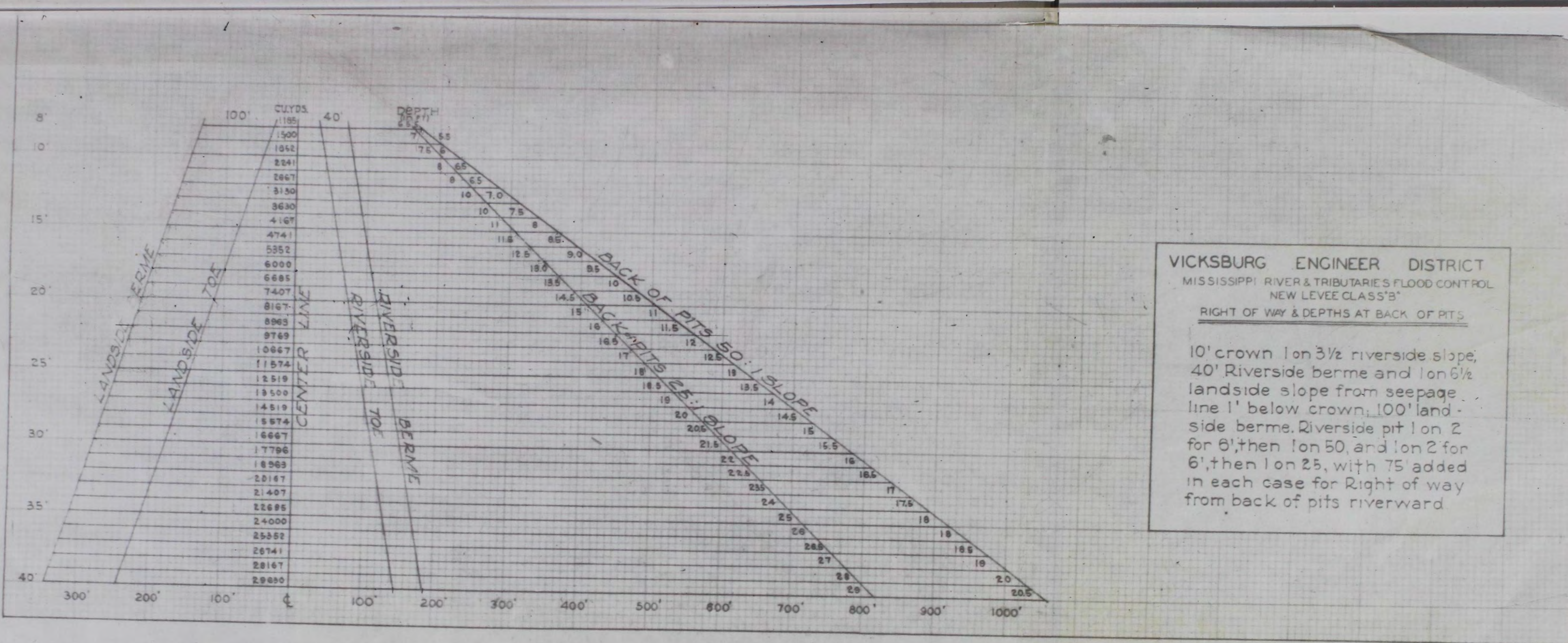

PLATE $X$ 


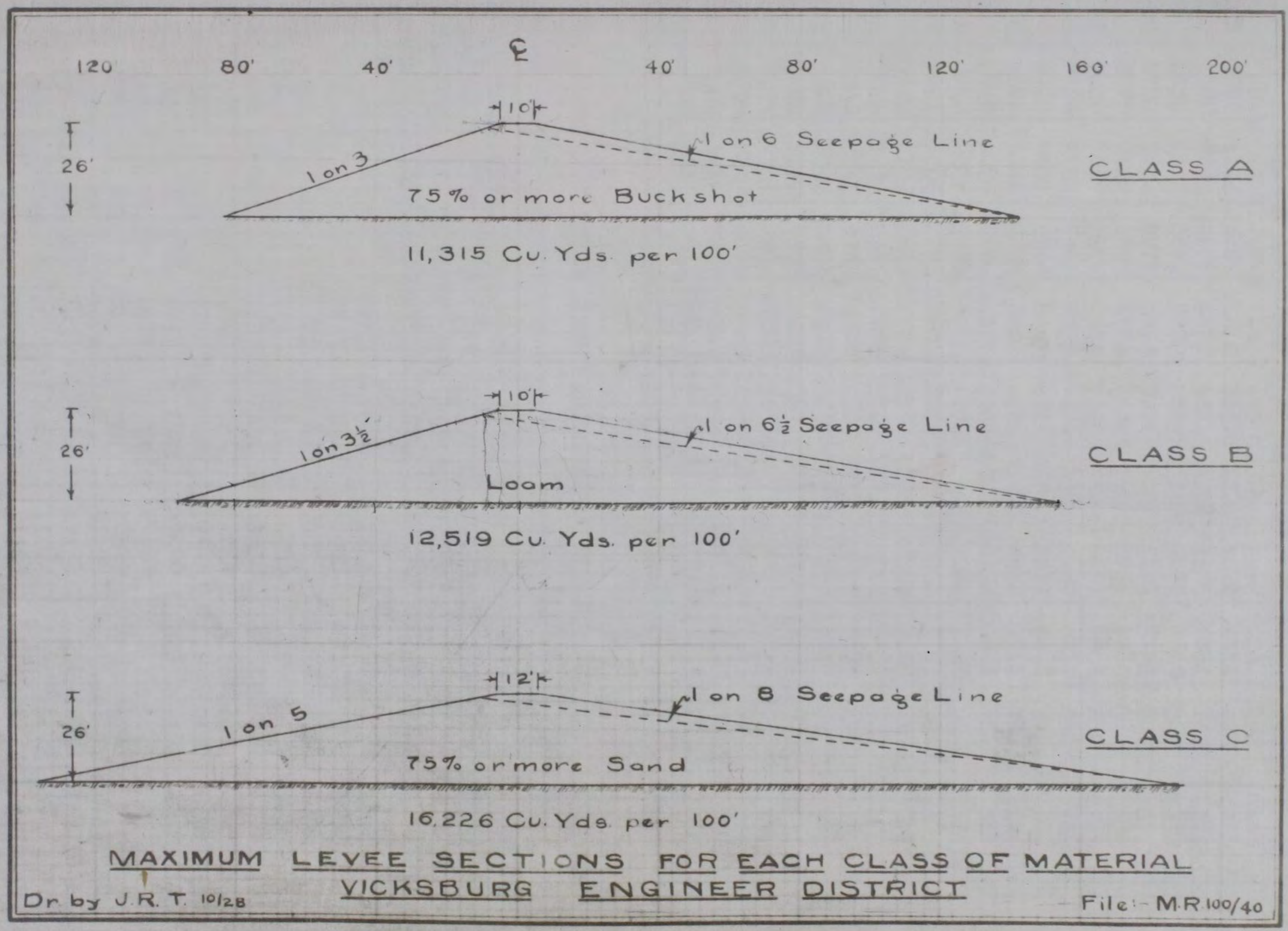


Cubic yards per station. Crown 89 . Slopes $3: 1$ \& $3: 1,10: 1$ \& $5: 1$. Banquette $8^{\prime}$ below grade

\begin{tabular}{|c|c|c|c|c|c|c|c|c|c|c|c|}
\hline $\begin{array}{c}\text { Feet } \\
16\end{array}$ & $\begin{array}{c}0 \\
4000\end{array}$ & $\frac{1}{4052}$ & $4 \dot{1}^{2} 04$ & $\begin{array}{c}.3 \\
4157\end{array}$ & $4: 4$ & $\begin{array}{c}.5 \\
4: 263\end{array}$ & $\begin{array}{c}.6 \\
4316\end{array}$ & $\begin{array}{c}.7 \\
4370\end{array}$ & $\begin{array}{c}\cdot 8 \\
4424\end{array}$ & $\begin{array}{c}\cdot 9 \\
4479\end{array}$ & $\begin{array}{c}\text { Feet } \\
16\end{array}$ \\
\hline 17 & 4533 & 4588 & 4.644 & 4699 & 4755 & 4811 & 4868 & 4924 & 4981 & 5039 & 17 \\
\hline 18 & 5096 & 5154 & 5213 & 5271 & 5330 & 5389 & 5448 & 5508 & 5568 & 5628 & 18 \\
\hline 19 & 5689 & 5750 & 5811 & 5872 & 5934 & 5996 & 6059 & 6121 & 6184 & 6248 & 19 \\
\hline 20 & 6311. & 6375 & 6439 & 6504 & 6568 & 6633 & 6699 & 6764 & 6830 & 6896 & 20 \\
\hline 21 & 6963 & 7030 & 7097 & 7164 & 7232 & 7300 & 7368 & 7437 & 7506 & 7575 & 21 \\
\hline 22 & 7644 & 7714 & 7784 & 7855 & 7925 & 7996 & 3068 & 81139 & 8211 & 8283 & 22 \\
\hline 23 & 8356 & 8428 & 8501 & 8575 & 8648 & 8722 & 8796 & 8871 & 8946 & 9021 & 23 \\
\hline 24 & 9096 & 9172 & 9248 & 9324 & 9401 & 9478 & 9555 & 9632 & 9710 & 9788 & 24 \\
\hline 25 & 9867 & 9945 & 10024 & 10104 & 10183 & 10263 & 10343 & 10424 & 10504 & 10585 & 25 \\
\hline 26 & 10667 & 10748 & 10830 & 10912 & 10995 & 11078 & 11.161 & 11244 & 11328 & 11412 & 26 \\
\hline 27 & 11496 & 1.1581 & 11666 & 11751 & 11836 & 11922 & 12008 & 12095 & 12181 & 12268 & 27 \\
\hline 28 & 12356 & 12443 & 12531 & 12619 & 12703 & 12796 & 12885 & 12975 & 13064 & 13154 & 28 \\
\hline 29 & 13244 & 13335 & 13426 & $1351 \%$ & 13608 & 13700 & 13792 & 13884 & 13997 & 14070 & 29 \\
\hline 30 & 14163 & 14256 & 14350 & 14414 & 14539 & 14633 & 14728 & 14824 & 14919 & 15015 & $\cdot 30$ \\
\hline 31 & 15111 & $15208 \mid$ & 15304 & $15401 \mid$ & 15499 & 15596 & 15694 & 15792 & 15891 & 1.5990 & 31 \\
\hline 32 & 16089 & 16188 & 16288 & 16388 & 16488 & 16589 & 16690 & 16791 & 16892 & 16994 & 32 \\
\hline 33 & 17096 & 17199 & 17301 & 17404 & 17508 & 17611 & 17715 & 17819 & 17924 & 18028 & 33 \\
\hline 34 & 18133 & 1.8239 & 18344 & 18450 & 18556 & 18663 & 18770 & 18877 & 18984 & 19092 & 34 \\
\hline 35 & 19200 & 19308 & 19417 & 19526 & 19635 & 19744 & 19854 & 19964 & 20075 & 20185 & 35 \\
\hline $\begin{array}{l}36 \\
37\end{array}$ & $\begin{array}{l}20296 \\
21422\end{array}$ & 20408 & 20519 & 20631 & 20743 & 20856 & 20968 & 2108.1 & 21195 & 21308 & 36 \\
\hline
\end{tabular}

IEVEY BORROW PIT YARDAGE TABLE

\begin{tabular}{|c|c|c|c|c|c|c|c|}
\hline $\begin{array}{l}\text { Dist. } \\
\text { from } \\
\text { berme } \\
\text { feet. }\end{array}$ & $\begin{array}{l}\text { Cu. yds. } \\
\text { per } 100 \\
\text { station } \\
\text { in nit. }\end{array}$ & $\begin{array}{l}\text { Dist. } \\
\text { from } \\
\text { berme } \\
\text { feet }\end{array}$ & $\begin{array}{l}\text { Cu. yds. } \\
\text { per } 100 \\
\text { station } \\
\text { in nit }\end{array}$ & $\begin{array}{l}\text { Dist. } \\
\text { from } \\
\text { berme } \\
\text { feet }\end{array}$ & $\begin{array}{l}\text { Cu. yds. } \\
\text { per } 100 \\
\text { station } \\
\text { in pit. }\end{array}$ & $\begin{array}{l}\text { Dist. } \\
\text { from } \\
\text { berme } \\
\text { feet }\end{array}$ & $\begin{array}{l}\text { Cu. yds. } \\
\text { per } 100 \\
\text { station } \\
\text { in pit. }\end{array}$ \\
\hline 6 & 33 & 166 & 2759 & 326 & 7381 & 486 & 13900 \\
\hline 16 & 148 & 176 & 2993 & 336 & 7733 & 496 & 14370 \\
\hline 26 & 270 & 186 & 3233 & 346 & 8093 & 506 & 14848 \\
\hline 36 & 400 & 196 & 3431 & 356 & 8459 & 516 & 15333 \\
\hline 46 & 537 & 206 & 3737 & 366 & 8833 & 526 & 15826 \\
\hline 56 & 681 & 216 & 4000 & 376 & 9215 & 536 & 16326 \\
\hline 66 & 333 & 226 & 4270 & 386 & 9493 & 546 & 16833 \\
\hline 76 & 995 & 236 & 4548 & 396 & 10000 & 556 & 17348 \\
\hline 86 & 1159 & 24.6 & 4333 & 406 & 10403 & \multirow{8}{*}{\multicolumn{2}{|c|}{$\begin{array}{l}\text { Table showing available } \\
\text { material from edge of } \\
\text { riverside, which is } 40^{\prime} \\
\text { from toe of levee. } \\
\text { Distances measured } \\
\text { from edge of berme. } \\
\text { Slopes } 2: 1 \text { for } 6^{\prime} \text {, then } \\
1 \text { to } 50^{\prime} \text {. }\end{array}$}} \\
\hline 96 & 1.333 & 256 & 5125 & 416 & 10815 & & \\
\hline 106 & 1515 & 266 & 5426 & 426 & 11233 & & \\
\hline 116 & 1707 & 276 & 5733 & 436 & 11659 & & \\
\hline 126 & 1900 & 286 & 6048 & $4 \div 6$ & 12093 & & \\
\hline 136 & 210 & 296 & 6370 & 456 & 12533 & & \\
\hline 146 & 2315 & 305 & 6700 & 466 & 12981 & & \\
\hline 156 & 2533 & 316 & 7037 & 476 & 13437 & & \\
\hline
\end{tabular}


CUBIC YARDS PER STATION CLASS "A" SECTION

\begin{tabular}{|c|c|c|c|c|c|c|c|c|c|c|c|c|}
\hline Fil1 & .0 & .1 & .2 & .3 & .4 & Fill & .5 & .6 & .7 & .8 & .9 & Fill \\
\hline 8 & 1.081 & 1109 & 1136 & 1164 & 1192 & 8 & 1220 & 1249 & 1278 & 1307 & 1337 & 8 \\
\hline 9 & 1367 & 1397 & 1428 & 1459 & 1490 & 9 & 1522 & 1554 & 1586 & 1619 & 1652 & .9 \\
\hline 10 & 1685 & 1719 & 1753 & 1787 & 1822 & 10 & .857 & 1892 & 1928 & 1964 & 2000 & 10 \\
\hline$\overline{11}$ & 2037 & 2074 & 21.11 & 2149 & 2187 & 11 & 2225 & 2264 & 2303 & 2343 & 2382 & 11 \\
\hline 12 & 3422 & 2463 & 2503 & 2544 & 2586 & 12 & 2627 & 2669 & 2712 & 2754 & 2797 & 12 \\
\hline 13 & 2847. & 2884 & 2928 & 2973 & 3017 & 13 & 3063 & 3108 & 3154 & 3200 & 3246 & 13 \\
\hline 14 & 3293 & 3340 & 3387 & 3435 & 3483 & 14. & 3531 & 3580 & 3629 & 3678 & 3728 & 14 \\
\hline 15 & 3778 & 3828 & 3879 & 3930 & 3981 & 15 & 4033 & 4085 & 4137 & 4190 & 4243 & 15 \\
\hline 16 & 429.6 & 4350 & 4404 & 4458 & 4513 & 16 & 4568 & 4623 & 4679 & 4735 & 4791 & 16 \\
\hline 17 & 4848 & 4905 & 1963 & 5020 & 5078 & 17 & 5137 & 5195 & 5254 & 5314 & 5373 & 17 \\
\hline 18 & 5433 & 5494 & 5554 & 5615 & 5677 & 18 & 5738 & 5800 & 5863 & 5925 & 5989 & 18 \\
\hline 19 & 6052 & 6116 & 6180 & 6244 & 6309 & 1.9 & 6374 & 6439 & 6505 & 6571 & 6637 & 19 \\
\hline 20. & 6704 & 6771 & 6838 & 6906 & 6974 & 20 & 7042 & 7111 & 7180 & 7249 & 7319 & 20 \\
\hline 21 & 7389 & 7459 & 7530 & 7601 & 7672 & 21 & 7744 & 7816 & 7888 & 7961 & 8034 & 21 \\
\hline 22 & 8107 & 8181 & 8255 & 8329 & 8404 & 22 & 8479 & 8555 & 8630 & 8706 & 8783 & 22 \\
\hline 23 & 8859 & 8936 & 9014 & 9091 & 9169 & 23 & 9248 & 9326 & 9405 & 9485 & 9564 & 23 \\
\hline 24 & 9644 & 9725 & 9805 & 9886 & 9968 & 24 & 10050 & 10132 & 10214 & 10297 & 10380 & 24 \\
\hline 25 & 10463 & 10547 & 10631 & 10715 & 10800 & 25 & 10885 & 10970 & 11056 & 11142 & 11228 & 25 \\
\hline 26 & 11315 & 11402 & 11489 & 11577 & 11665 & 26 & 11753 & 11842 & 11931 & 12020 & 12110 & 26 \\
\hline 27 & 12200 & 12290 & 1238.1 & 12472 & 12563 & 27 & 12655 & 12747 & 12839 & 12932 & 13025 & 27 \\
\hline 28 & 13119 & 13212 & 13306 & 13401 & 13495 & 28 & 13590 & 13686 & 13781 & 13877 & 13974 & 28 \\
\hline 29 & 14070 & 14167 & 14265 & 14362 & 14460 & 29 & 14559 & 14657 & 14757 & 14856 & 14956 & 29 \\
\hline 30. & 15056 & 15156 & 15257 & 15358 & 15459 & 30 & 15561 & 15663 & 15765 & 15868 & 15971. & 30 \\
\hline 31 & 15074 & 16178 & 16282 & $1 6 \longdiv { 6 3 8 6 }$ & 16491 & 31 & 16596 & 16701 & 16807 & 16913 & 17019 & 31 \\
\hline 32 & 17126 & 17233 & 17340 & 17448 & 17556 & 32 & 17664 & 17773 & 17882 & 17991 & 18101 & 32 \\
\hline 33 & 18211 & 18321 & 18432 & 18543 & 18655 & 33 & 18766 & 18878 & 18991 & 19103 & 19216 & 33 \\
\hline 34 & 19330 & 19443 & 19557 & 19672 & 19736 & 34 & 19901 & 20017 & 20132 & 20248 & 20365 & 34 \\
\hline 35 & 20481 & 20599 & 20716 & 20834 & 20952 & 35 & 21070 & 2.1189 & 21308 & 21427 & 21547 & 35 \\
\hline$\overline{36}$ & 21667 & 21787 & 21908 & 22029 & 22150 & 36 & 22272 & 22394 & 22516 & 22639 & 22762 & 36 \\
\hline 37 & 22885 & 23009 & 23133 & 23257 & 23382 & 37 & 23507 & 23632 & 23758 & 23884 & 24010 & 37 \\
\hline 38 & 24137 & 24264 & 24391 & 24519 & 24647 & 38 & 24775 & 24904 & 25033 & 25163 & 25292 & 38 \\
\hline 39 & 25422 & $25553 \mid$ & 25683 & 25814 & 25946 & 39 & 26077 & 26209 & 26342 & 26474 & 26607 & 39 \\
\hline 40 & 26741 & 26874 & 27008 & 27143 & 27277 & 40 & 274.13 & 27548 & 27684 & 27820 & 27956 & 40 \\
\hline
\end{tabular}


CUBIC YARDS PHR STATION

CLASS "B" SECTION

\begin{tabular}{|c|c|c|c|c|c|c|c|c|c|c|c|c|}
\hline Fi1] & .0 & .1 & .2 & .3 & .4 & 11 & .5 & .6 & .7 & .8 & .9 & $\overline{F i} \overline{1 I}$ \\
\hline 8 & 1185 & 1215 & 1245 & 1276 & 1307 & 8 & 1338 & 1370 & 1402 & 1434 & 1467 & 8 \\
\hline 9 & 1500 & 1534 & 1567 & 1602 & 1636 & 9 & 1671 & 1707 & 1742 & 1779 & 1815 & 9 \\
\hline 10 & 1352 & 1889 & 1927 & 1965 & 2003 & 10 & 2042 & 2081 & 2120 & 2160 & 2200 & 10 \\
\hline 11 & 2241 & 2282 & 2323 & 2365 & 2407 & 1.1 & 2449 & 2492 & 2535 & 2578 & 2622 & $\overline{11}$ \\
\hline 12 & 2667 & 271.1 & 2756 & 2802 & 2847 & 12 & 2894 & 2940 & 2987 & 3034 & 3082 & 12 \\
\hline 13 & 31.30 & 31,78 & 3237 & 3276 & 3325 & 13 & 3374 & 3425 & 3475 & 3526 & 3578 & 13 \\
\hline 14 & 3630 & 3602 & 3734 & 3787 & 3840 & 14 & 3893 & 3947 & 3991 & 4056 & 4111 & 14 \\
\hline 15 & 4767 & 4223 & 4279 & 4335 & 4392 & 15 & 4449 & 4507 & 4565 & 4623 & 4682 & 15 \\
\hline 16 & 4741 & 4800 & 4860 & 4920 & 4981 & 16 & 5042 & 5103 & 5165 & 5227 & 5289 & 16 \\
\hline 17 & 5352 & 5415 & 5479 & 5542 & 5607 & 17 & 5671 & 5736 & 5802 & 5867 & 5934 & 17 \\
\hline 18 & 6000 & 6067 & 6134 & 6102 & 6269 & 18 & 6337 & 6406 & 6475 & 6544 & 6615 & 18 \\
\hline 19 & 6685 & 6756 & 682 : & 6898 & 6970 & 19 & 7042 & 7114 & 7187 & 7260 & 7334 & 19 \\
\hline 20. & 74.07 & 7482 & 7556 & 7631 & 7707 & 20 & 7782 & 7859 & 7935 & 8012 & 8089 & 20 \\
\hline 21 & 8167 & 8245 & 8323 & 8402 & 8481 & 21 & 8560 & 8640 & 8720 & 8801 & 8882 & 21 \\
\hline 22 & 8963 & 9045 & 9127 & 9209 & 9292 & 22 & 9375 & 9459 & 9542 & 9627 & 9711 & 22 \\
\hline 23 & 9796 & 9882 & 9967 & 10054 & 10140 & 23 & 10227 & 10314 & 10402 & 10490 & 10578 & 23 \\
\hline 24 & 10667 & 10756 & 10845 & 10935 & 11025 & 24 & 11116 & 11207 & 11298 & 11390 & 11482 & 24 \\
\hline 25 & 11574 & 11667 & 11760 & 11854 & 11947 & 25 & 12042 & 12136 & 12231 & 12327 & 12422 & 25 \\
\hline 36 & 12519 & 12615 & 12712 & 12809 & 12907 & 26 & 13005 & 13103 & 13202 & 13301 & 13400 & 26 \\
\hline 27 & 13500 & 13600 & 13701 & 3.3802 & 13903 & 27 & 14005 & 14107 & 14209 & 14312 & 14415 & 27 \\
\hline 28 & 14519 & 14622 & 14727 & 14831 & 14936 & 28 & 1.5042 & 15147 & 15254 & 15360 & 15467 & 28 \\
\hline 29 & 15574 & 15682 & 15790 & 15898 & $1600 ?$ & 29 & .16116 & 16225 & 16335 & 16445 & 16556 & 29 \\
\hline 30 & 16667 & 16778 & 16890 & 17002 & 17114 & 30 & 17287 & 17340 & 17454 & 17567 & 17682 & 30 \\
\hline 31 & 17796 & 17911 & 18027 & 18142 & 18259 & 31 & 18375 & 18492 & 18609 & 18727 & 18845 & $\overline{31}$ \\
\hline 32 & 18963 & 19082 & 19201 & 19320 & 19410 & 32 & 19560 & 19681 & 19802 & 19923 & 20045 & 32 \\
\hline 33 & 20167 & 20289 & 20412 & 20535 & 20659 & 33 & 20783 & 20907 & 21031 & 21156 & 21282 & 33 \\
\hline 34 & 21407 & 21534 & 21660 & 21787 & 21914 & $3 t_{4}$ & 22042 & 22170 & 22298 & 22427 & 22556 & 34 \\
\hline 35 & 22685 & 22815 & 22945 & 23076 & 23207 & 35 & 23338 & $234_{-} 70$ & 23602 & 23734 & 23867 & 35 \\
\hline 36 & 24000 & 24.134 & 24267 & 24102 & 24536 & 36 & 24671 & 24307 & 24942 & 25079 & 25215 & $\overline{36}$ \\
\hline 37 & 25352 & 25489 & 25627 & 25765 & 25903 & 37 & 26042 & 26181 & 26320 & 26460 & 26600 & 37 \\
\hline 38 & 26741 & 26882 & 27023 & 27165 & 27307 & 38 & 27449 & 27592 & 27735 & 27879 & 28022 & 38 \\
\hline 39 & 28167 & 283.11 & 28456 & 28602 & 28747 & 39 & 28894 & 29040 & 29.187 & 29334 & 29482 & 39 \\
\hline 40 & 29630 & 29778 & 29927 & 30076 & 30225 & 40 & 30375 & 30525 & 30676 & 30827 & 30978 & 40 \\
\hline 4.7 & 31130 & 1282 & 31434 & 31587 & 31740 & 41 & 31893 & 32048 & 32203 & 32357 & 32412 & 41 \\
\hline $4: 2$ & 32667 & 32822 & 32979 & 33135 & 33292 & 42 & 33559 & 33607 & 33765 & 33923 & 34082 & 42 \\
\hline 43 & 34241 & 34400 & 34560 & 34720 & 34881 & 43 & 35042 & 35203 & 35365 & 35527 & 35689 & 43 \\
\hline 44 & 35852 & 36015 & 36179 & 36342 & 36507 & 44 & 36671 & 36836 & 37002 & 37167 & 37334 & 44 \\
\hline 45 & 37500 & 37667 & 37834 & 38002 & 38170 & 45 & 33338 & 38507 & 38676 & 38845 & 39015 & 45 \\
\hline 46 & 39185 & 39356 & 39527 & 39698 & 39870 & 46 & 40042 & 40214 & 40387 & 40560 & $407 \overline{33}$ & 46 \\
\hline 47 & 40907 & 41082 & 41256 & 41451 & 41607 & 47 & 41782 & 41959 & 42135 & 42312 & 42489 & 47 \\
\hline 48 & 42667 & 42845 & 43023 & 43202 & 43381 & 48 & 43560 & 43740 & 43920 & 44101 & $4 / 282$ & 48 \\
\hline 49 & 44463 & 4.4645 & 44827 & 45009 & 45192 & 49 & 45375 & 45559 & 45742 & 45927 & 46111 & 49 \\
\hline
\end{tabular}




\section{CUBIC YARDS PER STATION}

CLASS "C" SECTION

\begin{tabular}{|c|c|c|c|c|c|c|c|c|c|c|c|c|}
\hline Fi11 & .0 & .1 & .2 & .3 & & 111 & .5 & .6 & .7 &.$\overline{8}$ & .9 & BiII \\
\hline 8 & 1526 & 1565 & 1604 & 1643 & 1633 & 8 & 1724 & 1765 & 1806 & 1848 & 1890 & $\overline{8}$ \\
\hline 9 & 1933 & 1977 & 2021 & 2065 & 2.110 & 9 & 2155 & 2201 & 2247 & 2294 & 2341 & 9 \\
\hline 10 & 2389 & 2437 & 2486 & 2535 & 2585 & 10 & 2635 & 2685 & 2736 & 2788 & 2840 & 10 \\
\hline 11 & 2393 & 2946 & 2999 & 3053 & $\overline{3108}$ & 11 & $316 ?$ & 3218 & 3274 & 3330 & 3387 & $\overline{11}$ \\
\hline 12 & 3444 & 3502 & 3561 & 3619 & 3679 & 12 & 3738 & 3799 & 3859 & 3921 & 3982 & 12 \\
\hline 13 & 4044 & 4107 & 4170 & 4234 & 4298 & 13 & 4362 & 4428 & 44.93 & 4559 & 4626 & 13 \\
\hline 14 & 4693 & 4760 & 4828 & 4896 & 4965 & 14 & 5035 & 5106 & 5175 & $5240^{\circ}$ & 5317 & 14 \\
\hline 15 & 5389 & 5161 & 5534 & 5607 & 5681 & 15 & 5755 & 5830 & 5905 & 5981 & 6057 & 15 \\
\hline 16 & 6133 & 6210 & 6288 & $\overline{6366}$ & $64 \leq 5$ & 16 & 6524 & 6603 & 6683 & 6763 & 6844 & 16 \\
\hline 17 & 6926 & 7008 & 7090 & 7173 & 7256 & 17 & 7340 & 7424 & 7509 & 7595 & 7680 & 17 \\
\hline 18 & 7767 & 7853 & 794.1 & 8028 & 8116 & 18 & 8205 & 8294 & 3384 & 8474 & 3564 & 18 \\
\hline $19 \mid$ & 8656 & 8747 & 8839 & 8932 & 9025 & 19 & 9118 & 92.12 & 9307 & 9402 & 9497 & 19 \\
\hline 20 & 9593 & 9689 & 9786 & 9883 & 9981 & 20 & 10079 & 10173 & 10277 & 10377 & 10177 & 20 \\
\hline 21 & 10578 & 10679 & 10781 & 10883 & 10985 & 21 & 11089 & 11192 & 11296 & 11401 & 11506 & 21 \\
\hline 22 & 11611 & 11717 & 11324 & 1.1931 & 12038 & 22 & 12146 & 12254 & 12363 & 12473 & 12582 & 22 \\
\hline 23 & 12693 & 12803 & 12915 & 13026 & 13139 & 23 & 13251 & 13365 & 13478 & 13592 & 13707 & 23 \\
\hline 24 & 13822 & 139.38 & 14054 & 14.171 & 14288 & 24 & 14405 & 14523 & 14642 & 14761 & 14880 & 24 \\
\hline 25 & 15000 & 151.20 & 15241 & 15363 & 15485 & 25 & 15607 & 15730 & 15853 & 15977 & 16101 & 25 \\
\hline 26 & 16226 & 16351 & 16477 & 16603 & 16730 & 26 & 16857 & 16985 & 17113 & 17241 & 17371 & 26 \\
\hline 27 & 17500 & 17630 & 17761 & 27892 & 18023 & 27 & 18155 & 18288 & 18421 & 18554 & 18683 & 27 \\
\hline 28 & 18822 & 18957 & 19092 & 19278 & 19365 & 28 & 19502 & 19639 & 19777 & 19915 & 20054 & 28 \\
\hline 29 & 20193 & 20332 & 20472 & 20613 & 20754 & 29 & 20896 & 21038 & 21181 & 21324 & 21467 & 29 \\
\hline 30. & 21611 & 21756 & 21901 & 22046 & 22192 & 30 & 22338 & 22485 & 22633 & 22781 & 22929 & 30 \\
\hline 31 & 23078 & 23227 & 23377 & $235 \approx 7$ & 23678 & 31 & 23829 & 23981 & 24133 & 24286 & 24439 & 31 \\
\hline 3.2 & $2: 593$ & $247 \leq 7$ & 24901 & 25056 & 25212 & 32 & 25368 & 25525 & 25681 & 25839 & 25997 & 32 \\
\hline 33 & 26156 & 26315 & 2,6474 & 26634 & 26794 & 33 & 26955 & 27117 & 27278 & 27441 & 27604 & 33 \\
\hline 34 & 27767 & 27930 & 28095 & 28259 & 28425 & 34 & 23590 & 23757 & 28923 & 29090 & 29258 & 34 \\
\hline 35 & 29426 & 29594 & 29763 & 29933 & 30103 & 35 & 30274 & $30 \leq 4 \leq$ & 30616 & 30788 & 30960 & 35 \\
\hline 36 & 31133 & 31307 & 31481 & 31655 & 31830 & 36 & 32005 & 32181 & 32357 & 32534 & 32711 & 36 \\
\hline 37 & 32889 & 33067 & 33246 & 33425 & 33605 & 37 & 33785 & 33965 & 34146 & 34328 & 34510 & 37 \\
\hline 38 & 4693 & 34876 & 35059 & 35243 & 35427 & 38 & 35612 & 35798 & 35984 & 36170 & $3635 ?$ & 38 \\
\hline 39 & 654.4 & 36732 & 36921 & 37109 & 37299 & 39 & 37489 & 37679 & 37870 & 38061 & 38252 & 39 \\
\hline 40 & 38444 & 38637 & 38830 & 39024 & 3921.8 & 40 & 39413 & 39608 & 39803 & 39999 & 40196 & 40 \\
\hline 41 & 40393 & 40590 & 40788 & 40986 & 41185 & $4 \overline{11}$ & 41385 & 41585 & 41785 & 41986 & 42137 & $\overline{41}$ \\
\hline 42 & 42389 & 42591 & 42794 & 42997 & 43201 & 42 & 13406 & $\angle 5610$ & 43816 & 44021 & 44228 & 42 \\
\hline 43 & 44433 & 4.4641 & 44548 & 45056 & $\angle 5265$ & 43 & $15<74$ & 45683 & 45893 & 46104 & 46315 & 43 \\
\hline 44 & 46526 & 46738 & 6950 & 47163 & 47376 & 44 & 47590 & $4780 \AA$ & 48019 & 48235 & $48 \div 50$ & 44 \\
\hline 45 & 48667 & 48883 & 49101 & 4931.8 & 49536 & 45 & 49755 & 49974 & 50194 & 50414 & 50634 & 45 \\
\hline 46 & 50856 & 51077 & 51299 & 51522 & 51745 & 46 & 51968 & 52192 & 52416 & 52641 & 52867 & 46 \\
\hline 47 & 53093 & 53319 & 53546 & 53773 & 54.001 & 47 & 54229 & 54458 & 54687 & 54917 & 55147 & 47 \\
\hline 48 & 55378 & 55609 & 55841 & 56073 & 568 & 48 & 56538 & 56772 & 57006 & 57241 & 57476 & 48 \\
\hline 49 & 57711 & 57947 & 58184 & $58 \leq 21$ & 58658 & 49 & 58896 & 59134 & 59373 & 59612 & 59852 & 49 \\
\hline
\end{tabular}




\begin{tabular}{|c|c|c|c|c|c|c|c|c|c|c|c|}
\hline Feet & $\overline{0}$ &.$\overline{.1}$ &.$\overline{.2}$ & $-\overline{3}$ & -.4 & .5 & .6 & .7 & .8 & .9 & $\mathrm{Fer}_{\mathrm{s}}$ \\
\hline 0 & 0 & 4 & 8 & 12 & 17 & 221 & 27 & 331 & & & \\
\hline 1 & 51. & 58 & 61 & 72 & 79 & 87 & $\begin{array}{l}27 \\
95\end{array}$ & $\begin{array}{r}5 \\
103\end{array}$ & $\begin{array}{r}39 \\
119\end{array}$ & $\begin{array}{r}45 \\
121\end{array}$ & 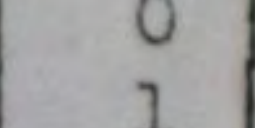 \\
\hline 2 & 130 & 139 & 149 & 159 & 169 & 180 & 190 & 201 & $\begin{array}{l}11 \\
213\end{array}$ & 224 & $\frac{1}{2}$ \\
\hline 3 & 236 & 246 & 260 & 274 & 287 & 300 & 315 & 327 & 341 & 356 & 3 \\
\hline 4 & 370 & 385 & 400 & 4.16 & 432 & 448 & 464 & 481. & 493 & 515 & 4 \\
\hline 5 & 532 & 550 & 568 & 587 & 605 & 624: & 643 & 662 & 682 & 702 & 5 \\
\hline 6 & 722 & 743 & 764 & 785 & 806 & 328 & 849 & 872 & 894 & 917 & 6 \\
\hline 7 & 940 & 963 & 987 & 101.1 & 1035 & 1059 & 1,084 & 1109 & 1134 & 1159 & 7 \\
\hline 0 & 1185 & 12,15 & 1245 & 1276 & 1307 & 1338 & 1370 & 1402 & 1434 & 1467 & 8 \\
\hline
\end{tabular}

(NOTE: - This table is to be used in conjunction with the tables for New Tentative Section, Class "B", for lovees less than $8^{\prime}$ in height.)

CUBIC YARDS FER STATION FON NEW TEENTA-

$$
\begin{aligned}
& \text { TIVE SECTION }= \\
& \text { H }\left[(H-1) \frac{S}{2}+\frac{C}{2}\right] \frac{100}{27} \\
& H=\text { Height of levee } 26 \\
& S=\text { Sum of riverside slope and seenage line slope } \\
& C=\text { Width of crown } \\
& 100=\text { Length of one station in feet. } \\
& 27=\text { Number of cubic feet in one cubic yard }
\end{aligned}
$$


Cubic Yards per Stetion. Slopes 3:1 \& $3:$.

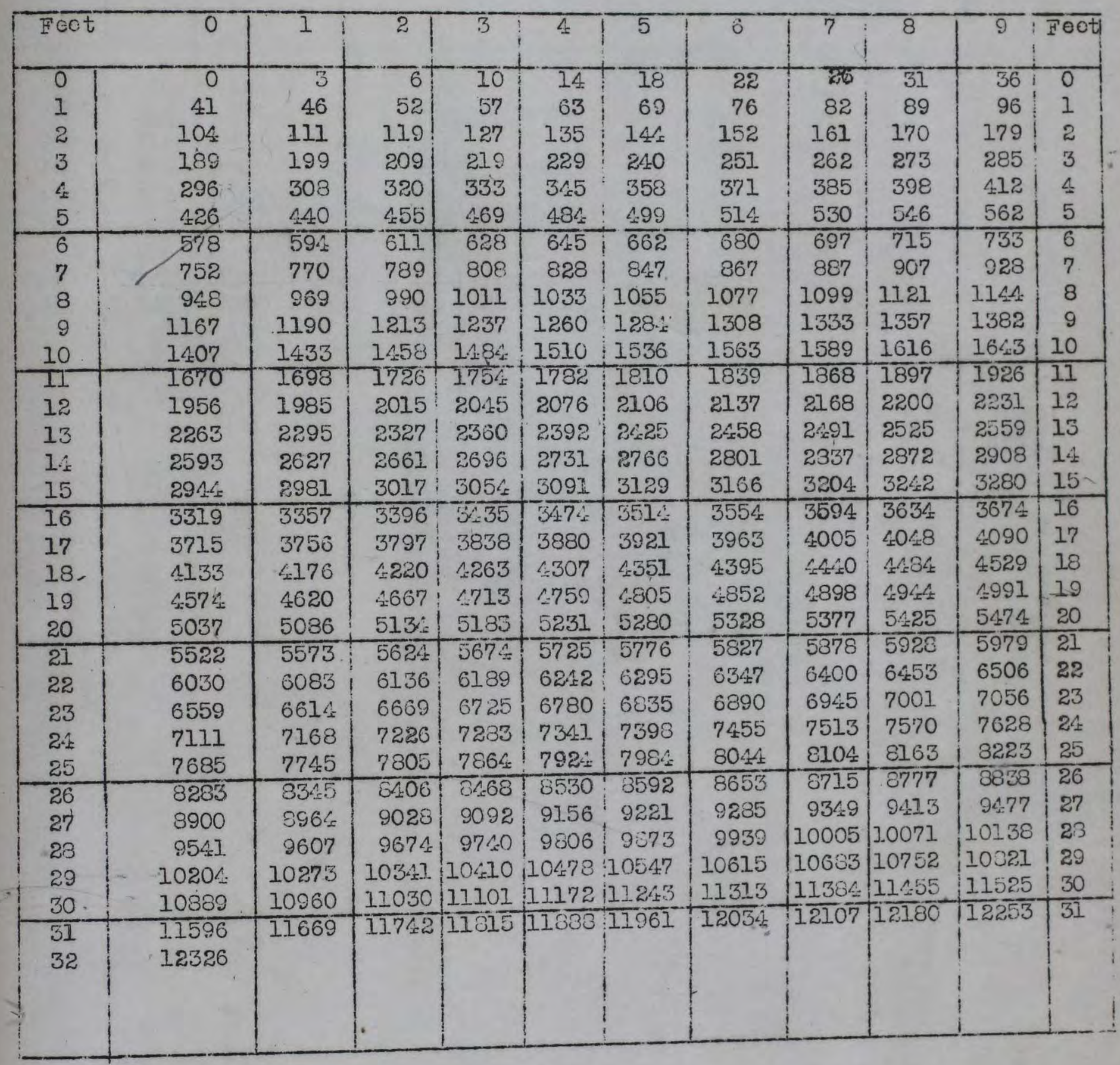




\section{LEVES WITH 3 ' CROMN}

CUBIC YARIS PER STITTON

SLOPES $3: 1$ \& $4: 1$

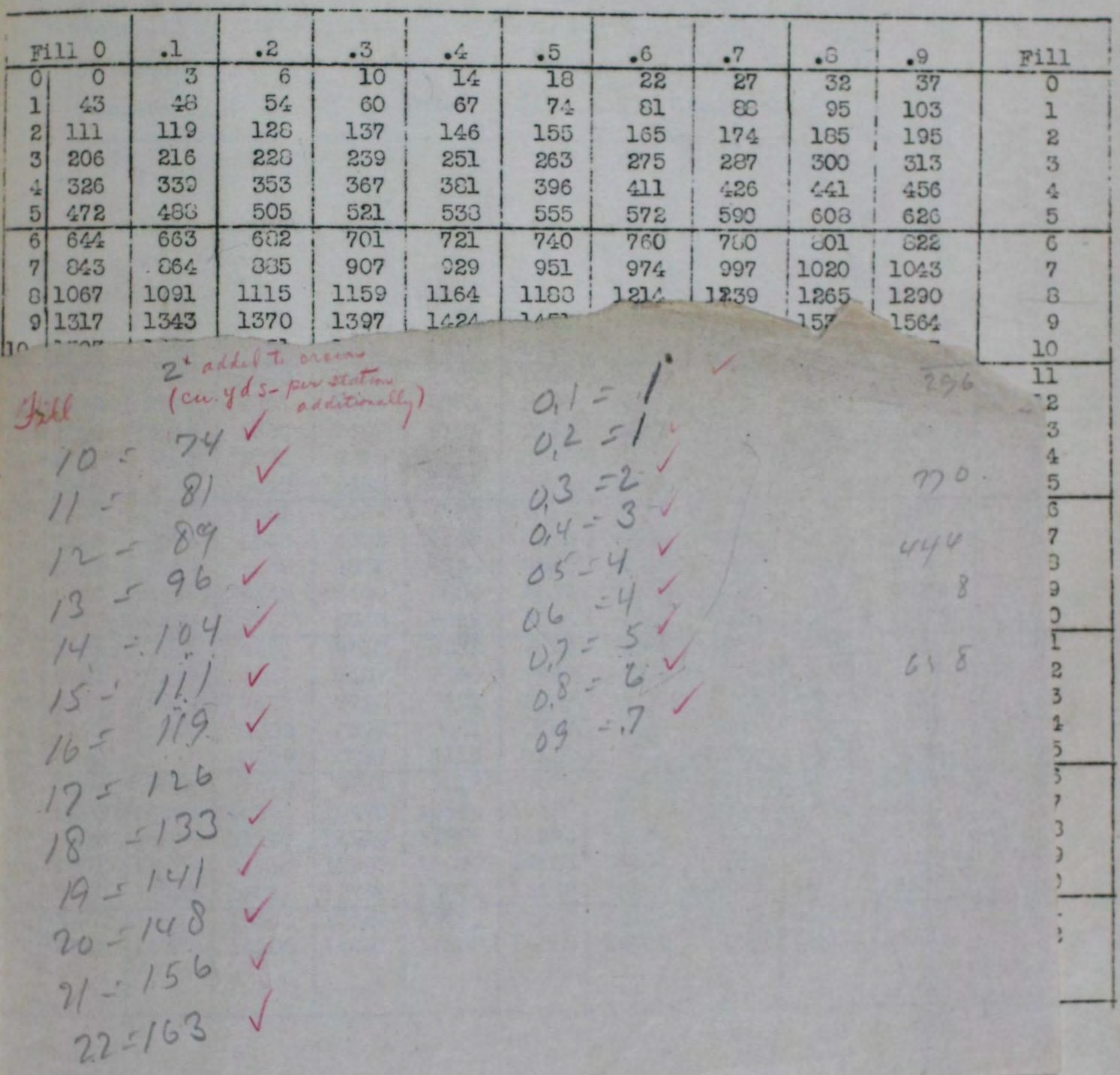




\begin{tabular}{|c|c|c|c|c|c|c|c|c|c|c|c|}
\hline & 1.110 & .1 & .2 & .3 & .2 & .5 & .6 & .7 & .3 & .9 & Fill \\
\hline 0 & $\overline{0}$ & $\overline{3}$ & 6 & 10 & $\overline{I 4}$ & 18 & 22 & 27 & 32 & 37 & $=\frac{1}{0}$ \\
\hline 1 & 43 & 48 & $5 / x$ & 60 & 67 & $7:$ & 81 & 80 & 95 & 103 & 1 \\
\hline 2 & 111 & 119 & 128 & 137 & 14.6 & 155 & 165 & 174 & 185 & 195 & 2 \\
\hline 3 & 206 & 216 & 228 & 239 & 251 & 263 & 275 & 287 & 300 & 313 & 3 \\
\hline 4 & 326 & 332 & 353 & 367 & 3El & 396 & 411 & 426 & L.4I & 456 & 4 \\
\hline 5 & 472 & 485 & 505 & 521 & 533 & 555 & 572 & 590 & 603 & 626 & 5 \\
\hline 6 & 641 & $\overline{663}$ & 632 & 701 & 721 & 740 & 760 & 760 & 01 & $\overline{62 \%}$ & 6 \\
\hline 7 & 84.3 & $864_{t}$ & 335 & 907 & 229 & 951 & 974 & 997 & 1020 & $10 \leq 3$ & 7 \\
\hline 8 & 1067 & 1091 & 1115 & 1.159 & 1164 & 1183 & 1214 & 1239 & 1265 & 1290 & 8 \\
\hline 9 & 1317 & 1343 & 1370 & 1397 & 1424 & 1451 & 1479 & 1507 & 1535 & 1564 & 9 \\
\hline 10 & 1593 & 1622 & 1651 & 1600 & 1710 & 1740 & 1771 & 1301 & 1032 & 1363 & 10 \\
\hline 11 & 1094 & $1 \overline{1926}$ & 1.953 & 1990 & 2022 & 2055 & 2030 & 2121 & 2155 & 2136 & 11 \\
\hline 12 & 2222 & 2256 & 2291 & 2326 & 2361 & 2396 & 2431 & 2167 & 2503 & 2530 & 12 \\
\hline 13 & 2576 & 2615 & 2650 & 2607 & 2725 & 2763 & 2001 & 2339 & 2370 & 2016 & 13 \\
\hline $1: 4$ & 2056 & $2995^{\circ}$ & 30,33 & 3075 & 3115 & 3155 & 3196 & 3237 & 3270 & 3510 & 14 \\
\hline 15 & 3361 & 3403 & $3<\leq 5$ & 34838 & 3531 & 3574 & 3617 & 3660 & 3704 & 3740 & 15 \\
\hline 16 & 3793 & 3837 & 3032 & 3927 & 3972 & 4010 & 4064 & 4110 & 4156 & 4203 & 16 \\
\hline 17 & 4250 & 4297 & 4345 & 4392 & $4 \leqslant 40$ & $4 \div 33$ & $\angle 537$ & 4536 & 4635 & $\angle 634$ & 17 \\
\hline 16 & 4733 & 1783 & 4033 & 4833 & $\therefore 234$ & 3055 & $5: 313$ & 5037 & 5139 & 5130 & 10 \\
\hline 19 & 5243 & 5295 & 5340 & 5400 & 5454 & 5507 & 5561 & 5615 & 5669 & 5723 & 19 \\
\hline 20 & 5778 & 5333 & 5880 & 5943 & 5999 & 6055 & 6111 & 6168 & 6225 & 6232 & 20 \\
\hline 21 & 6339 & 6396 & $64 \overline{454}$ & 6512 & $55 \overline{1}$ & 6629 & $\overline{6630}$ & 6749 & 6000 & 6366 & $\overline{21}$ \\
\hline 22 & 6926 & 6986 & 7040 & 7107 & 7163 & 7229 & 7291 & 7352 & 7414 & 7476 & 22 \\
\hline 23 & 7530 & 7002 & 7665 & 7723 & 7791 & 7855 & 7019 & 7933 & 8048 & 3113 & 23 \\
\hline 24 & 3170 & 0243 & 3309 & 3375 & 3441 & 3507 & 3574 & 8640 & 3703 & 3775 & 24 \\
\hline 25 & 0043 & 3910 & 8079 & 2047 & 9116 & 9135 & $925 \cong$ & 9323 & 9393 & 9463 & 25 \\
\hline$\overline{26}$ & 3533 & 9604 & $9 \overline{675}$ & 9746 & 9017 & 9380 & 2960 & 10032 & 10104 & 10177 & $\overline{26}$ \\
\hline 27 & 10250 & 10323 & 10396 & 10470 & 10544 & 10610 & 10692 & 10767 & 10342 & 10917 & 27 \\
\hline $2 B$ & 10993 & 11063 & 11144 & 11220 & 11297 & 11374 & 11451 & 11520 & 1.1605 & 11633 & 23 \\
\hline 29! & 11761 & 11039 & 11910 & 11997 & 12076 & 12155 & 12235 & 12314 & 12325 & 124.75 & 29 \\
\hline 301 & 12556 & 12636 & 12716 & 12799 & 12001 & 12962 & 130.45 & 13127 & 13210 & 13293 & 30 \\
\hline 31 & 13376 & 13453 & 13543 & 13627 & $\overline{13711}$ & 13796 & 13001 & 13966 & 14051 & $1 / 136$ & 31 \\
\hline 32 & 14222 & 14303 & 14325 & 14481 & 14560 & 14655 & 14741 & 14030 & 14910 & 15006 & 32 \\
\hline
\end{tabular}


BORROI: PIT YARDACE TABTE FOR LEVEES 1 ON 25 SLOPAS

WAR DEPARTMENT

MISSISSIPPI RIVER COMMISSION AND LOWER MISSISSIPPI VALLEY DIVISION VICKSBURG, MISSISSIPPI

Project

Pltolondaqe Fa-ple

Computation 1 on 10 slep

Computed by

Date

Checked by

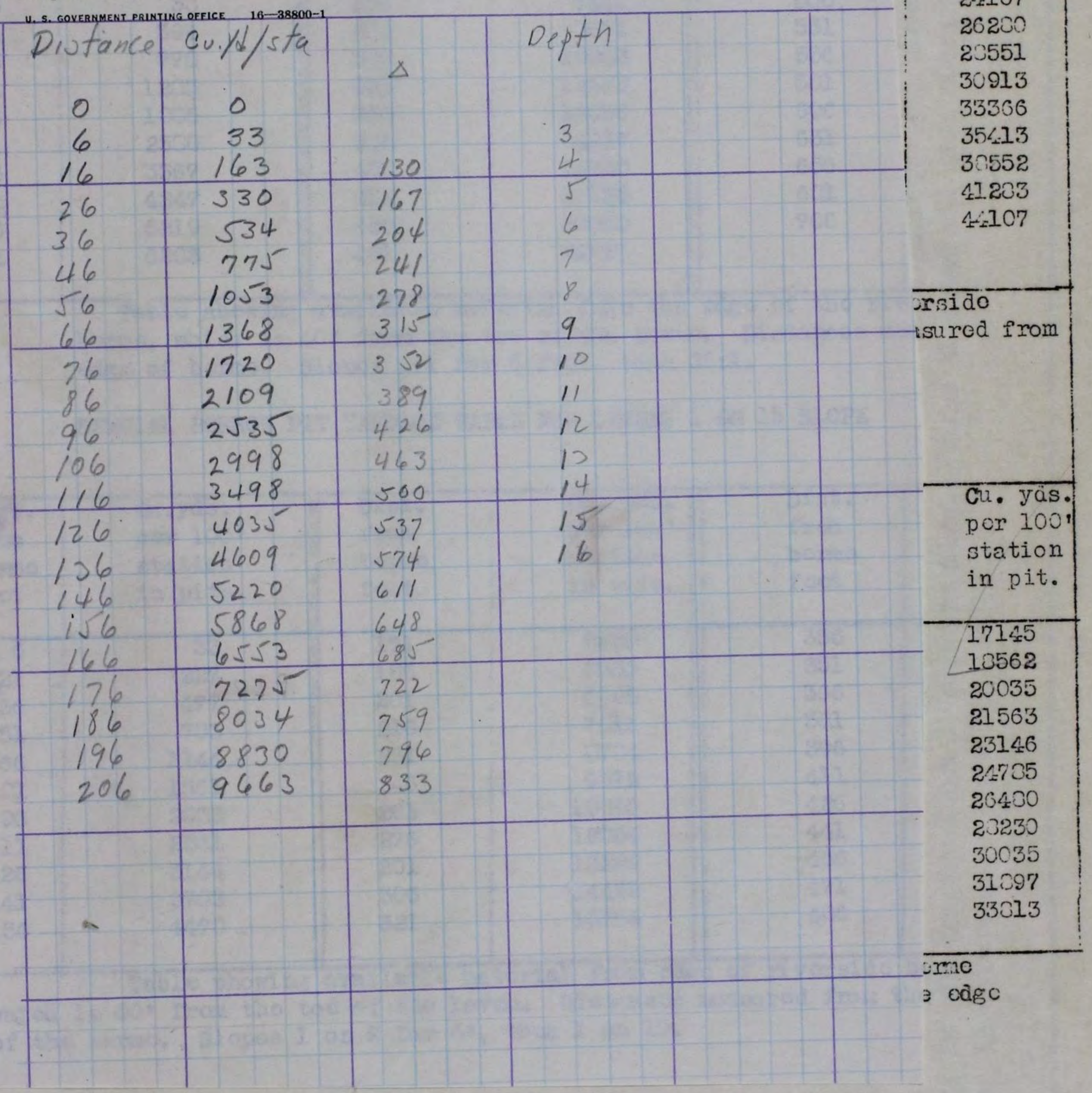


40 foot

Berme ion 2

Slope

$606^{\prime}$
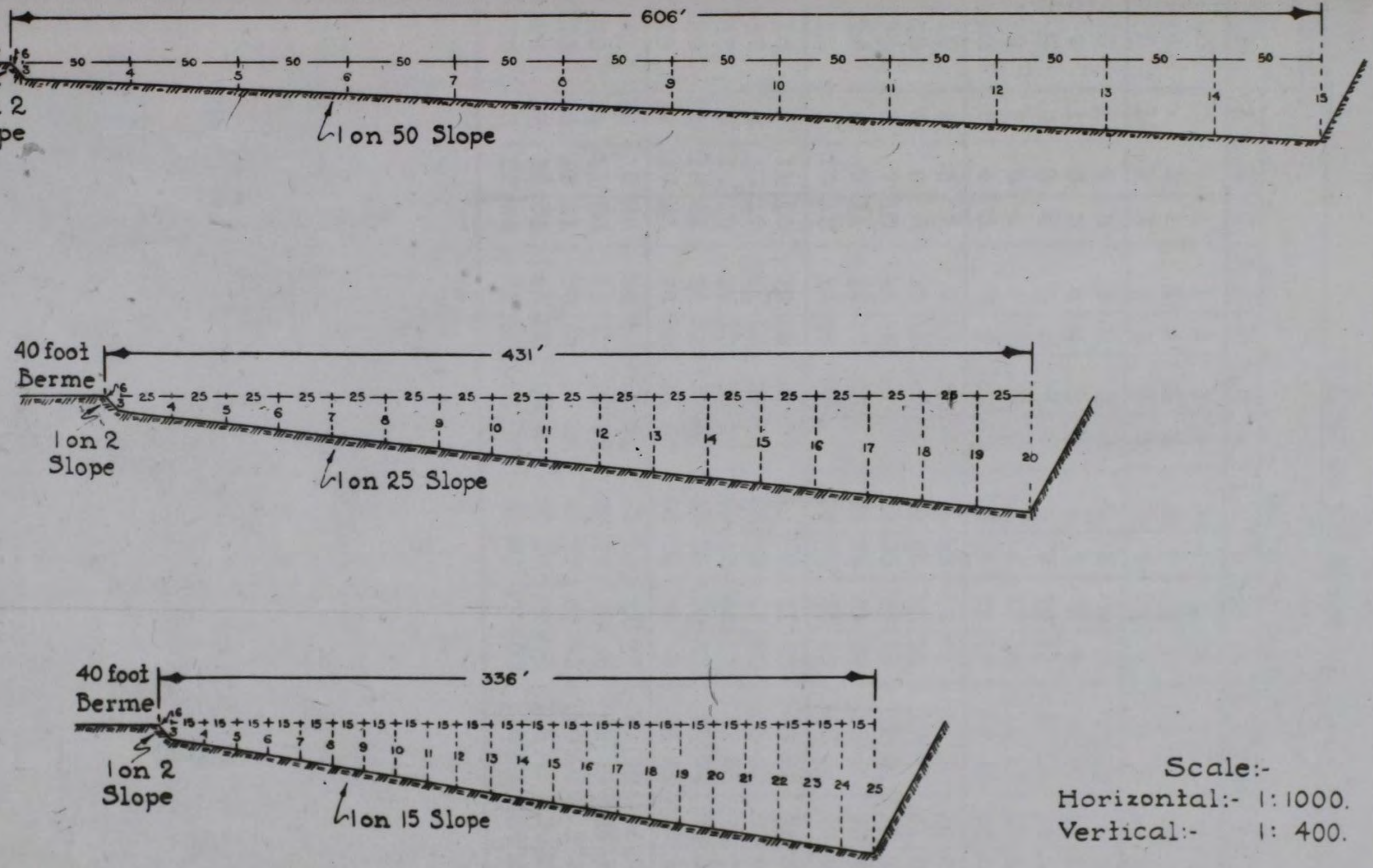

Scale:-

Horizontal:- 1:1000.

Vertical:- 1: 400 .

Typical Borrow Pit Sections of the Standard Pit deepened on ion 50 slope and on 1 on 25 slope and a special pit deepened $n$ 1 on 15 slope. 
VOLUME OF CYLINDERS IN CUBIC YARDS

\begin{tabular}{|c|c|c|c|c|c|c|c|c|c|c|c|c|c|c|c|c|c|c|c|}
\hline \multicolumn{20}{|c|}{$\mathrm{iam}$} \\
\hline ft. & 1 & 9.5 & 2 & 2.5 & 31 & 5 & 4 & 4.5 & $5 !$ & 15.5 & 6 & $6.5 !$ & 7 & 7.5 & 8 & 8.5 & 9 & 9.5 & 110 \\
\hline 3 & & & 1 & 1 & 1 & 1 & 1 & - & 1 & $\overline{11}$ & 2 & 2 & 2 & 2 & 21 & 2 & 2 & 2 & 3 \\
\hline 4 & & 1 & 1 & $=$ & 1 & & 2 & & 2 & & & 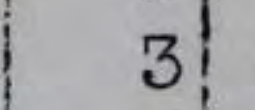 & 3 & & & & & & \\
\hline 5 & $I$ & $I$ & 1 & 2 & 2 & $3 !$ & 3 & 3 & 4 & & 4 & 5 & 5 & $5 !$ & 6 & 6 & 7 & 71 & \\
\hline 6 & 1 & 2 & 2 & 3 & 3 & $I$ & 4 & 5 & 5 & 6 & 6 & 7 & 7 & 8 & 8 & 9 & 9 & 10 & 10 \\
\hline 7 & & 2 & 3 & 4 & 4 & 5 & 6 & 6 & 7 & 8 & 9 & $9 \mid]$ & 10 & 11 & 11 & 12 & 13 & 14 & \\
\hline 8 & 2 & 3 & 4 & 5 & 6 & 7 & 7 & 8 & 9 & $10 !$ & 11 & 12]$, & 13 & 14 & 15 & 16 & 17 & 8 & 19 \\
\hline 9 & 2 & 4 & 5 & 6 & 7 & 8 & 9 & 11 & 12 & $13 !$ & 14 & $15]$ & 16 & 18 & 19 & 20 & 21 & 2 & 24 \\
\hline 10 & 3 & 4 & 6 & 7 & 9 & 10 & 12 & 13 & 15 & 16 & 17 & $19:$ & 20 & 22 & 23 & 25 & $|26|$ & 28 & 29 \\
\hline 11 & 4 & 5 & 7 & 9 & 11 & 7 & 14 & 16 & 18 & 19 & 2 & $23:$ & 25 & 26 & 28 & 0 & $\sqrt{3}$ & 31 & 35 \\
\hline I: & 4 & 6 & 8 & 0 & 13 & 15 & 17 & 19 & 21 & 3 & 2 & $7 !:$ & 29 & 31 & $34 \mid$ & 36 & 3 & 0 & \\
\hline 13 & 5 & 7 & 10 & & 15 & 7 & 20 & $2 !$ & 25 & 7 & $2 !$ & $2: 5$ & 34 & 37 & 39 & 42 & 4 & 71 & \\
\hline 14 & 6 & 9 & 11 & $I 4_{4}$ & $17 !$ & 20 & 23 & 26 & 29 & 31 & 34 & $37:$ & 40 & 43 & 46 & 48 & 5 & 44 & อ? \\
\hline 15 & 7 & 10 & 13 & 16 & 20 & 23 & 26 & 29 & 33 & 36 & 39 & 43 & 46 & 49 & 52 & 56 & 59 & 62 & 65 \\
\hline 16 & 7 & 1 & 15 & 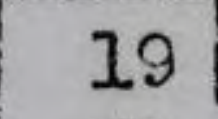 & $2 i$ & 3 & 30 & 4 & 37 & 41 & 1 & $48:$ & 5 & $\overline{56}$ & 10 & 63 & 67 & 71 & 74 \\
\hline 1 & 8 & 13 & 17 & 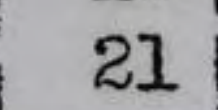 & 25 & 29 & 34 & 8 & 42 & 46 & 5 & $55:$ & 59 & 63 & 67 & 71 & 7 & 80 & \\
\hline $1 \varepsilon$ & 0 & 14 & 119 & & 28 & 33 & 38 & 2 & 47 & 52 & $5^{\prime}$ & $61 ! 6$ & 66 & 71 & 75 & 80 & 85 & 90 & 94 \\
\hline 19 & 11 & 16 & 21 & 26 & 32 & 37 & 42 & 47 & 53 & 58 & 63 & 68 & 74 & 79 & 84 & 39 & 95 & $|100|$ & 105 \\
\hline 20 & 12 & 17 & 23 & 29 & 35 & 41 & 47 & 52 & 58 & 64 & 70 & $76 \varepsilon$ & 81 & 87 & 93 & 99 & 105 & 111 & 116 \\
\hline 27 & 13 & 19 & 26 & 32 & 38 & 45 & & 58 & 64 & 71 & 77 & $\overline{83 i}$ & 90 & & 103 & 109 & 175 & 122 & $\overline{128}$ \\
\hline $2:$ & 1 & 2] & 2 & & $I_{1}$ & & 5 & & 170 & 78 & 85 & 92 & 99 & 106 & 173 & & & & \\
\hline $2:$ & 15 & 23 & 3 & 8 & 46 & 4 & $6:$ & 69; & 77 & 85 & 92 & 1003 & & 115 & 123 & 131 & 138 & 146 & 154 \\
\hline 24 & 17 & 25 & 34 & 42 & 50 & 59 & 67 & 75 & 84 & & & 1091 & 177 & 126 & 134 & 142 & 151 & 159 & 168 \\
\hline 25 & 18 & 27 & 36 & 45 & 55 & 64 & 73 & 82 & 91 & 1001 & & 1187 & & 736 & 145 & 155 & 164 & 173 & $1 \varepsilon$ \\
\hline
\end{tabular}




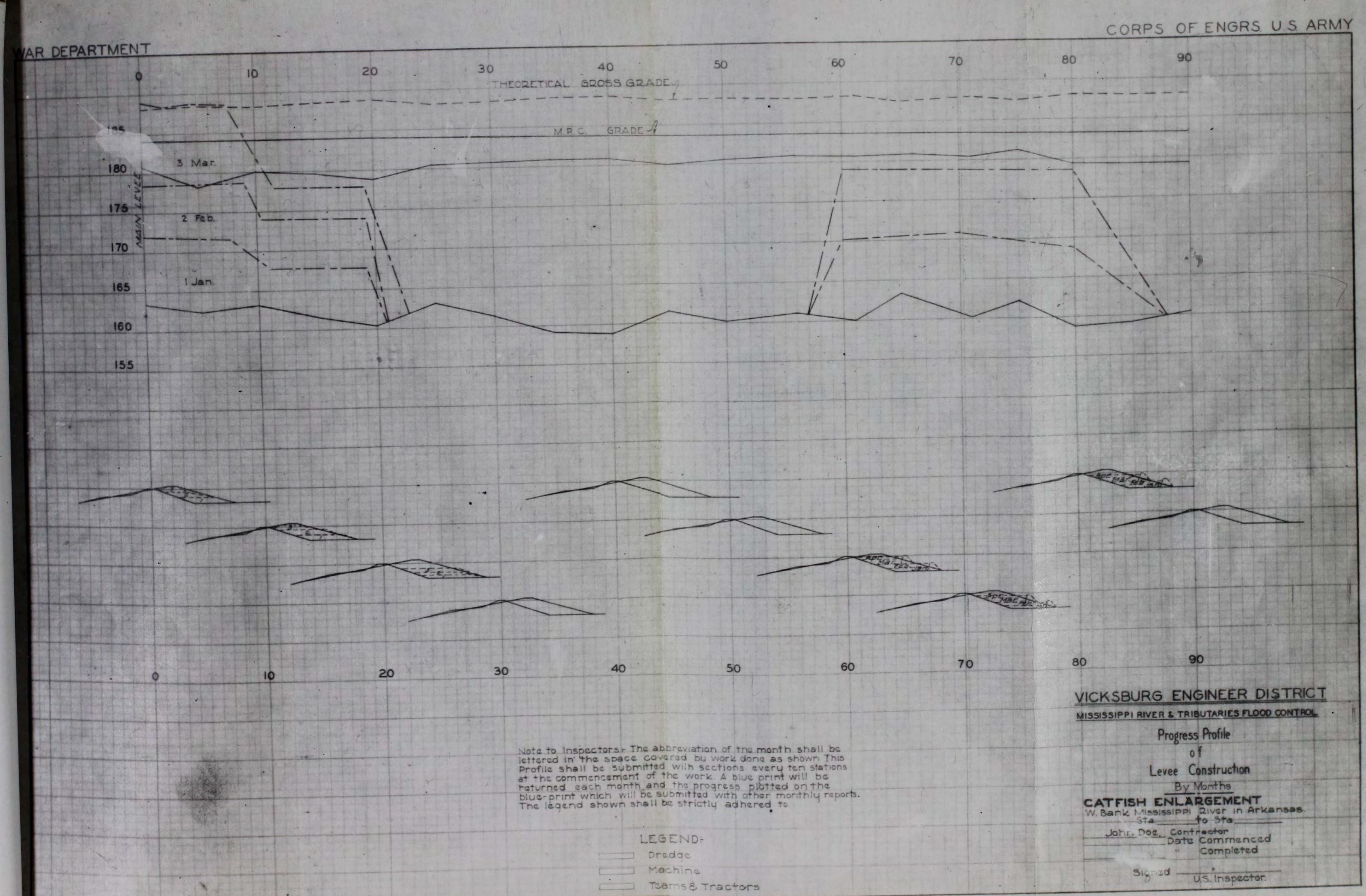



EAST BANK OF THE MISSISSIPPI RIVER IN MISSISSIPPI

Station

Old Grade

New Grade

20

30

40

50

60

70

179.3

179.2

179.1

179.0

178.9

178.8

80

178.7

90

178.6

100

178.5

178.4

178.4

120

178.4

180

200

220

250

280

320

350

370

178.3

178.2

178.1

178.0

177.9

177.8

177.7

177.6

390

177.5

420

450

470

490

$561 f 80 \quad 580$

.177 .5

177.5

177.4

177.4

177.3

177.1

176.9

620

176.7

176.5

176.3

176.2

176.0

175.9

175.7

175.5

175.1

174.8

174.6

175.1

174.2

174.1

174.0

173.9

173.8

173.7

171.7

171.6

171.5

170.1

I71.1

184.0

183.9

183.8

183.7

183.6

183.5

183.4

183.2

183.1

183.0

183.0

183.0

182.9

182.8

182.6

182.5

182.3

182.2

182.1

182.0

181.8

181.8

181.8

181.7

181.6

181.4

181.1

180.9

180.7

180.5

180.3

180.1

179.9

179.8

179.6

179.4

179.0

178.6

178.4

178.8

177.8

177.7

177.5

177.4

177.3

177.1

175.1

175.0

174.6

173.2

174.2

173.2 
FAST BANK OF THE MISSISSIPPI RIVER IIN NISSISSIPPI

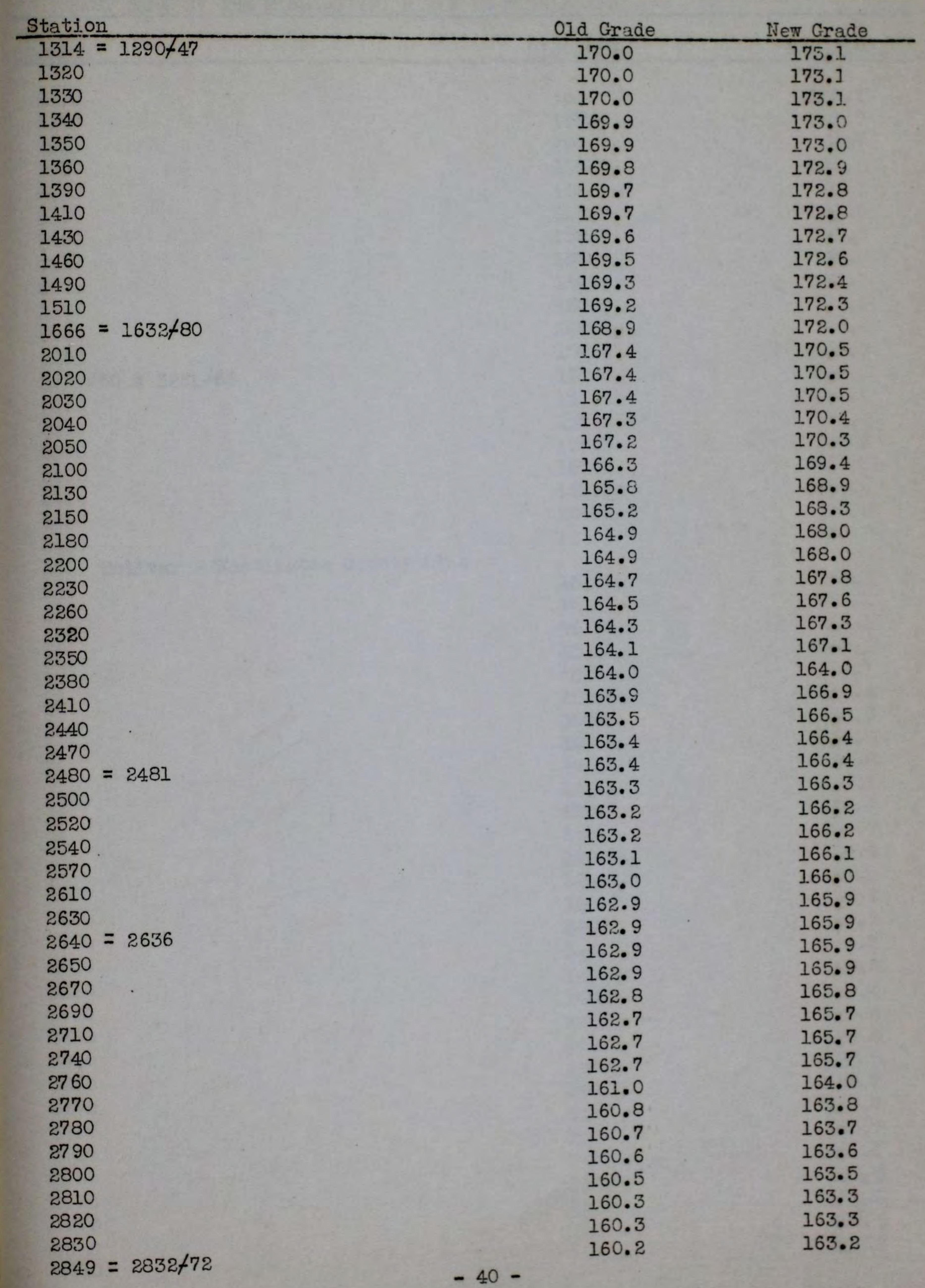


Station

\section{0}

2890

2920

2980

3050

3190

3200

3210

3220

3230

3240

3250

$3258+50=3261+65$

3300

3330

3390

3400

34.14

3430

3450

3452 Bolivar - Washington County Line

3460

3480

3500

3510

3540

3560

3580

3620

3640

3660

3680

3710

3750

3760

3780

3790

3800

3810

3820

3830

3840

3860

3870

3880

3920

3930

3960

2070

4000
Old Grade

New Grade

160.1
159.9
159.7
159.3
159.1
158.7
158.7
157.6
157.6
157.6
157.6
157.6
157.6
157.6
157.6
1.57 .3
157.3
151.3
151.2
151.1

151.1

151.1

151.1

151.1

151.1

150.9

150.8

150.8

150.8

150.7

150.7

150.7

150.6

150.1

148.7

148.0

147.3

146.8

146.8

146.8

146.8

146.8

146.7

146.7

146.7

146.6

146.6

146.5

146.3

146.2
163.1

162.9

162.7

16. 3

162. 1

161.0

161.0

.160 .9

161.0

161.0

161.0

161.0

161.0

161.2

161.4

161.2

161.2

155.2

155.2

155.2

155.1

155.1

155.1

155.1

155.1

154.9

154.8

154.8

154.8

154.7

154.7

154.?

154.6

154.1

152.7

152.0

151.3

150.8

150.8

150.8

150.8

150.8

150.7

150.7

150.7

150.6

150.0

150.5

150.3

150.2 
EAST BANK OF THE MISSISSIPPI RIVER IN MISSISSIPPI

\section{Station}

4020

4030

4040

4050

4060

4070

4080

4090

4100

4.110

4120

4130

4143

4150

4160

4180

4340

4390

4400

4110

4430

$4449+40=4441+80$

4510

4520

4530

4540

4560

4570

4590

4600

4620

4630

4660

4670

4690

4900

4940

5230

5320

5330

5340

5350

5360

5370

5390

$5 s_{5} 00$

$5 / x 10$

5430

$5 \vdots 50$

5470

$5 \div 80$
Old Grade

New Grade

\subsection{6 .1}

146.0

145.9

145.9

145.8

145.7

145.4

145.3

145.2

14.5 .1

145.0

144.9

144.3

144.3

14.4 .3

144.3

143.2

14.2 .9

142.8

142.7

142.5

$1<2.3$

141.7

141.6

141.5

14.1 .4

14.1 .2

141.1

140.9

140.8

140.6

140.5

1.40 .2

140.1

139.9

139.5

139.4

138.7

133.1

157.9

137.6

137.4

137.3

137.2

137.2

137.1

137.1

137.1

137.0

137.0

137.0
150.1

150.0

149.9

14.9 .9

149.8

149.7

149.4

149.3

149.2

14.9 .1

$1 \leqslant 9.0$

148.9

148.3

14.8 .3

148.3

148.3

$1 \div 7.2$

146.9

146.8

146.7

146.5

$1 \leqslant 6.3$

145.7

145.6

14.5 .5

115.4

145.2

145.1

144.9

144.8

14.4 .6

144.5

144.2

144.1

143.9

143.5

143.5

142.7

$1 \div 2.1$

$1 \leq 1.9$

141.6

141.4

141.3

14.1.?

141.2

141.1

$1<1.1$

141.1

141.0

141.0

141.1 .0 


\section{Station}

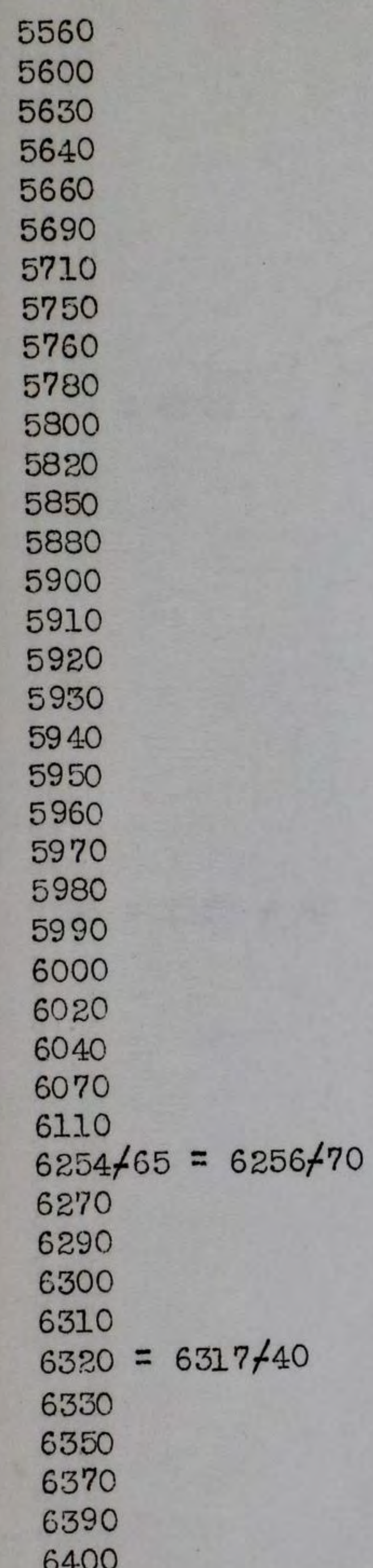

6400 $6405+50$ Nashington - Issaquena County Line 6410

6430

6450

6470

6490

6510

6530

6550

6570

6590
Old Grade

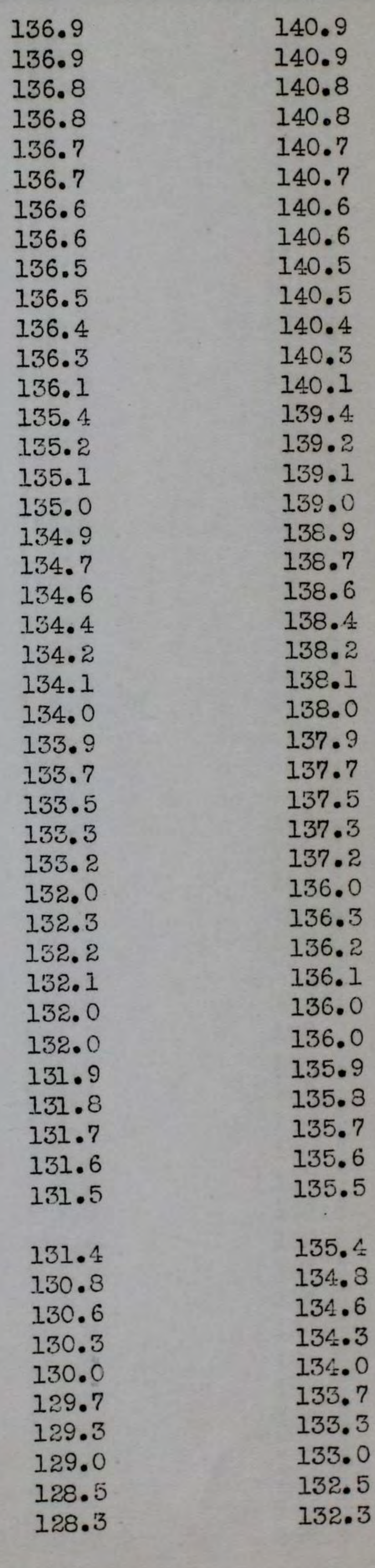

New Grade 
New Grade

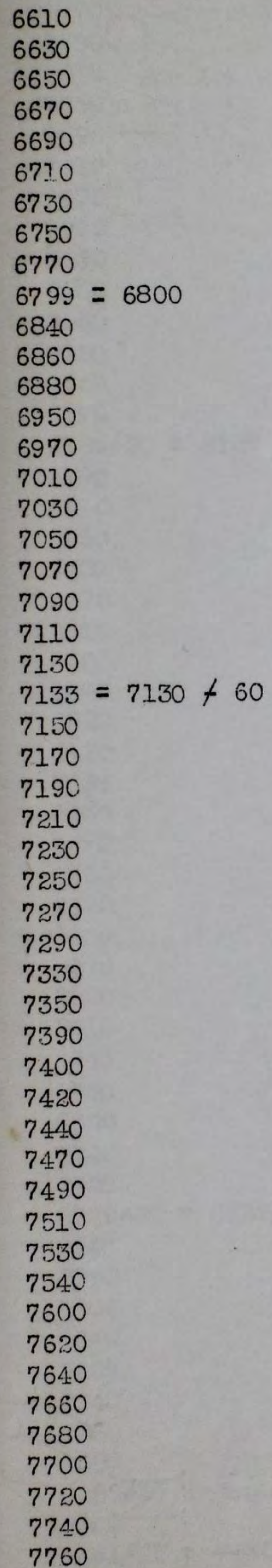

$\begin{array}{ll}128.3 & 132.3 \\ 128.2 & 132.2 \\ 128.2 & 132.2 \\ 128.1 & 132.1 \\ 128.0 & 132.0 \\ 127.9 & 131.8 \\ 127.7 & 131.7 \\ 127.3 & 131.3 \\ 127.0 & 131.0 \\ 126.9 & 130.9 \\ 126.8 & 130.8 \\ 126.8 & 130.8 \\ 126.7 & 130.7 \\ 126.7 & 130.7 \\ 126.5 & 130.5 \\ 126.6 & 130.6 \\ 126.5 & 130.5 \\ 126.5 & 130.5 \\ 126.4 & 130.4 \\ 126.4 & 130.4 \\ 126.3 & 130.3 \\ 126.2 & 130.2 \\ 126.2 & 130.2 \\ 126.1 & 130.1 \\ 126.0 & 130.0 \\ 125.9 & 129.9 \\ 125.8 & 129.8 \\ 125.7 & 129.7 \\ 125.7 & 129.7 \\ 125.6 & 129.6 \\ 125.5 & 129.5 \\ 125.4 & 129.4 \\ 125.3 & 129.3 \\ 125.2 & 129.2 \\ 124.9 & 128.9 \\ 124.6 & 128.6 \\ 124.4 & 128.4 \\ 124.2 & 123.2 \\ 124.0 & 128.0 \\ 123.8 & 127.8 \\ 123.6 & 127.6 \\ 123.4 & 127.4 \\ 123.0 & 127.0 \\ 122.8 & 126.8 \\ 122.7 & 126.7 \\ 122.6 & 126.6 \\ 122.4 & 126.4 \\ 122.3 & 126.3 \\ 122.1 & 126.1 \\ 122.0 & 126.0 \\ 121.9 & 125.9 \\ & \end{array}$


EAST BANKK OF THE MISSISSIPPI RIVER IN MISSISSIPPI

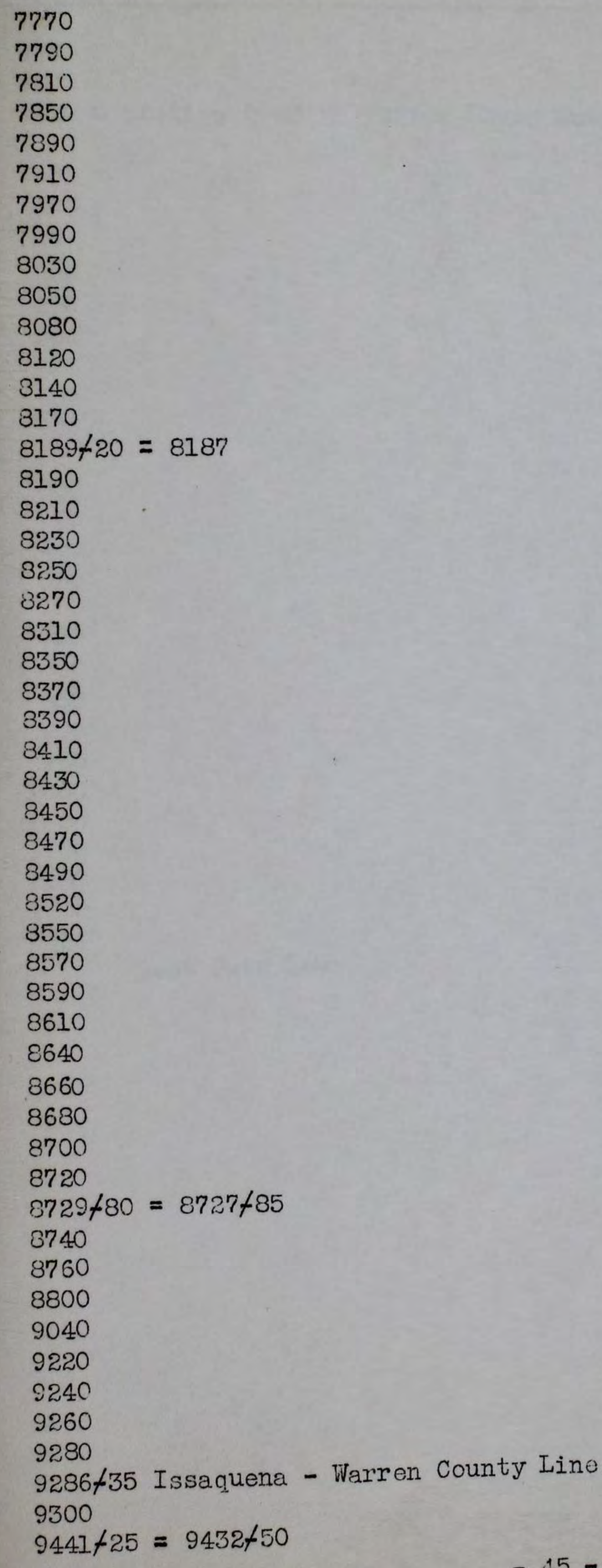

121.7

121.5

121.3

121.2

121.2

121.1

121.0

120.9

120.8

120.8

120.6

120.5

120.4

120.3

120.2

120.1

120.0

119.8

119.5

119.3

119.1

118.9

118.7

118.5

1.18 .3

118.1

117.9

117.8

117.6

117.5

116.7

115.8

115.2

115.0

114.8

114.6

114.5

114.4

114.3

114.3

114.2

114.1

114.0

113.9

113.8

113.7

113.6

113.5

3.13 .4

113.4
125.7

125.5

1.25 .3

125.2

125.1

125.0

124.9

124.8

124.7

124.7

124.5

124.4

124.3

124.2

124.0

123.9

123.8

1.23 .6

123.3

123.1

122.9

122.7

122.5

122.3

122.1

$12] .9$

121.7

121.6

121.3

121.2

120.4

119.5

118.9

118.7

118.5

118.3

118.2

118.1

118.0

113.0

117.9

117.8

117.6

117.5

117.3

117.2

117.1

117.0

116.9

116.8 
EAST BANK OF THE MISSISSIPPI RIVIR IN MISSISSIPPI

Station

9460
9470
$9470=$ Station 0 of Brunswick Levee Extension

0
50

100

150

200

250

300

350

400

450

500

550

563

600

650

700

750

800

850

900

950

1000

1050

11.00

12.50

1200

1250
O1d Crade New Grade

113.3

113.3

116.7

116.7

114.3

114.0

113.7

113.4

113.1

11.2 .8

1.22 .5

112.2

111.9

111.6

111.3

111.0

111.0

110.7

110.4

110.1

109.8

109.5

109.2

108.9

108.6

108.3

108.0

107.7

107.4

107.1

106.8
117.7

117.4

117.1

116.8

116.5

116.1

115.8

115.5

115.2

114.9

114.6

.114.2

114.2

113.9

113.6

113.3

113.0

112.6

112.3

112.0

11.1 .7

11..: 4

111.1

110.7

110.4

110.1 .

109.8

West Pass Levee 
Station

Pine Bluff

Frenchtown Luvee District

0
50
100
150
204

Linwood-Auburn Levee District

0
50
100
150
200
250
300
350
400
450
500
550
60215 O Arkansas River Levee

Arkansas River Levee

0
50
89
100
150
188
200
250
288
300
350
388
400
450
488
500
530
550
580
600
630
650
680
700
730
750
780

O1d Grade

2.15 .4

21.5 .3

214.5

213.8

213.1

212.2

208.1

207.4

206.6

205.9

205.2

204.3

203.4

202.7

201.8

201.2

200.3

199.5

129.15

199.3

199.1

198.8

198.7

198.5

198.3

198.2

198.0

197.8

197.8

197.7

197.6

197.6

197.5

197.4

197.2

196.4

195.7

195.3

195.1

194.9

194.7

194.5

124.4

194.2

194.0

193.8
New Grade

218.4

218.3

217.5

216.8

21.6. 1

215.2

211.1

210.4

209.6

208.9

208.2

207.3

206.4

205.7

204.8

204.2

203.3

202.6

200.'3

202.3

202.1

201.8

201.7

201.5

201.3

201.2

201.0

200.8

200.8

200.7

200.6

200.6

200.5

200.4

200.2

199.4

198.7

198.3

198.1.

197.9

197.7

197.5

197.4

197.2

197.0

196.8 


\section{SOUTH BANK OF THE ARKANSAS RIVER IN ARKANSAS}

Station

OId Grade

New Grades

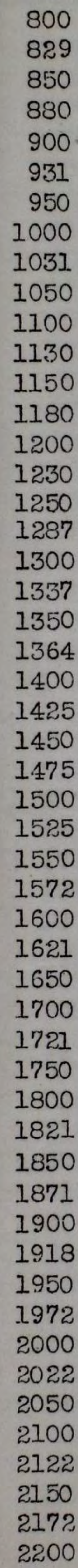

193.6

193.4

192.7

191.6

191.5

191.3

191.2

190.9

190.7

190.6

190.2

190.0

189.8

189.6

189.5

189.3

1.88 .8

188.5

188.4

188.0

187.7

187.4

187.2

$18 \% .1$

186.4

185.7

185.0

184.3

133.5

182.7

182.4

182.0

181.7

181.1

180.9

180.5

179.9

179.6

179.1

178.8

178.3

177.9

177.3

176.9

176.3

175.9

175.6

175.1

174.9

174.6

174.4

174.2

196.6

196.4

195.7

194.6

194.5

194.3

194.2

193.9

193.7

193.6

193.2

193.0

192.8

192.6

192.5

192.3

191.8

191.5

191.4

191.0

190.7

190.4

190.2

190.1

189.4

188.7

188.0

187.3

186.5

185.7

185.4

185.0

184. ?

184.1

183.9

1.83 .5

182.9

182.6

182.1

181.8

181.3

180.9

180.3

179.9

179.3

178.9

178.6

178.1

177.9

177.6

177.4

177.2 


\section{Station}

2222
2250
2300
2322
2350
2400
2422
2450
2471
2500
2521
2550
2571
2600
2621
2650
2671
2700
2726
2750
2776
2800
2826
2850
2876
2900
2930
2950
2980
3000
3030
3050
3080
3100
3130
3150
3180
3200
3220
3240
3250
3290
3300
3350
3380
3400
3450
3500

351716

Old Grade

173.9

173.8

173.6

173.5

173.4

173.0

172.8

172.9

173.0

173.1

173.1

173.2

173.3

173.3

173.2

173.1

173.1

173.0

173.0

172.9

172.9

172.7

172.6

172.1

171.6

171.2

170.7

170.7

170.6

170.5

170.3

170.0

169.5

169.2

168.8

168.6

168.2

167.6

167.0

166.5

166.4

166.2

166.1

165.7

165.5

165.4

165.3

165.2

165.1
New Grade

176.9

176.8

176.6

176.5

176.1

176.0

175.8

175.9

176.0

176.1

176.1

176.2

176.3

176.3

176.2

176.1

176.1

176.0

176.0

175.9

175.9

175.7

175.6

175.1

174.6

174.2

173.7

173.7

173.6

173.5

173.3

173.0

172.5

172.2

171.8

171.6

171.2

170.6

170.0

169.5

169.4

169.2

169.1

168.7

168.5

168.4

168.3

168.2

168.1 
1914 PROVISIONI \& 1928 TERTATIVE GRADES

\section{WEST BANK OF THE MISSISSIPPI RIVER IN AITKAIVSAS}

\section{Old Station _ L New Station}

O1d Grade

New Grade

\begin{tabular}{|c|c|}
\hline 0 & \\
\hline 50 & \\
\hline 100 & \\
\hline 150 & \\
\hline 200 & \\
\hline 250 & \\
\hline $\begin{array}{l}300 \\
350\end{array}$ & \\
\hline $\begin{array}{l}350 \\
400\end{array}$ & \\
\hline $\begin{array}{l}400 \\
450\end{array}$ & \\
\hline 500 & \\
\hline 550 & \\
\hline 600 & \\
\hline 650 & \\
\hline $\begin{array}{l}700 \\
750\end{array}$ & \\
\hline 750 & \\
\hline $\begin{array}{l}800 \\
850\end{array}$ & \\
\hline $\begin{array}{l}850 \\
900\end{array}$ & \\
\hline $\begin{array}{l}900 \\
950\end{array}$ & \\
\hline $\begin{array}{r}950 \\
1000\end{array}$ & \\
\hline 1050 & \\
\hline 1100 & \\
\hline 1150 & \\
\hline $1173+15$ & $1] 73+15$ \\
\hline 1303 & \\
\hline $\begin{array}{l}1329+85 \\
1380+85\end{array}$ & $\begin{array}{l}1200 \\
1250\end{array}$ \\
\hline $\begin{array}{l}1380+85 \\
1430+35\end{array}$ & 1300 \\
\hline $1461+35$ & 1350 \\
\hline $1511 / 35$ & 1380 \\
\hline $1531+65$ & 1400 \\
\hline $1582+35$ & .2450 \\
\hline $1632+35$ & 1500 \\
\hline $1688+50$ & 1550 \\
\hline $1738+50$ & 1600 \\
\hline $1788+50$ & 1650 \\
\hline 1828 & 1700 \\
\hline 1878 & $175 n$ \\
\hline 1928 & 1800 \\
\hline 1989 & .1850 \\
\hline 2040 & 1900 \\
\hline 2091 & 1850 \\
\hline 2142 & 2000 \\
\hline 2175 & 2033 \\
\hline 2276 & 2050 \\
\hline 2326 & 2100 \\
\hline $23^{7} 6$ & 2150 \\
\hline 2426 & 2200 \\
\hline 2476 & $? 250$ \\
\hline 2526 & 3500 \\
\hline 2576 & 2550 \\
\hline
\end{tabular}

$\begin{array}{ll}165.1 & 168.1 \\ 164.7 & 167.7 \\ 164.6 & 167.6 \\ 164.6 & 167.6\end{array}$

164.3

164.2

164.1

164.0

163.1.

162.2

161.7

1.61 .5

160.5

160.0

159.3

158.8

1.58 .6

158.5

157.9

157.2

156.8

1.56 .7

156.6

156.5

156.4

Fuse

Plug

Levee

156.3

155.9

155.3

154.9

154.8

154.7

154.1

154.1

153.8

153.6

153.6

150.3

154.3

149.2

153.2

148.6

152.6

148.5

152.5

148.3

148.1

152.3

148.1

152.1

148.1

152.1

142.8

152.1

146.8

142.3

146.3

141.9

145.9

141.8

145.8

141.7

145.7

1.41 .4

141.1

145.4

145.1 
WEST BANTK OF THE MISSISSIPPI RIVER IN ARKANSAS

\section{1d Station Nev: Station}

Old Grade

New Grade

\section{6}

2676

2727

2777

2827

2877

$2927+70$

3028

3078

312,8

3178

3228

3273

3328

3378

3429

3479

3529

3579

3630

3681

3732

3742

3834

3886

$3937+25$

3988

$4039+72$

$1088+72$

$4138+72$

4187

4208
2400

2450

2500

2550

2600

2650

2700

2800

2850

2900

2950

3000

3050

3100

3150

3200

3250

3300

3350

3400

3450

3500

3550

3600

3650

3700

3750

3800

3850

3900

3950

3973

140.8
140.5
140.2
139.9
139.6
139.3
139.0
138.7
138.4
138.1
137.8
137.5
137.2
136.9
136.3
135.4
134.7
134.7
134.7
134.5
134.3
133.9
133.9
133.1
132.5
132.1
131.6
130.8
130.7
130.5
130.4
130.3

144.8

144.5

144.2

143.9

143.6

143.3

143.0

142.7

142.4

142.1

141.8

1.41 .5

141.2

140.9

140.3

139.4

138.7

138.7

138.7

138.5

138.3

137.9

137.9

137.1

136.5

136.1

135.6

134.8

134.7

134.5

134.4

134.3 


\section{Old Stations \\ New Stations}

\section{1d Grade}

New Grade

$\begin{array}{r}0 \\ 50 \\ 100 \\ 150 \\ 200 \\ 250 \\ 300 \\ 350 \\ 400 \\ 450 \\ 500 \\ 550 \\ 600 \\ 650 \\ 700 \\ 750 \\ 800 \\ 850 \\ 900 \\ 950 \\ 1000 \\ 1050 \\ 1100 \\ 1150 \\ 1200 \\ 1250 \\ 1300 \\ 1350 \\ 1400 \\ 1450 \\ 1500 \\ 1550 \\ 1600 \\ 1650 \\ 1700 \\ 1750 \\ 1800 \\ 1850 \\ 1900 \\ 1950 \\ 2000 \\ 2050 \\ 2100 \\ 2150 \\ 2200 \\ 2250 \\ 2300 \\ 2309=2260 \\ 130 \\ \hline\end{array}$

130.3

130.3

130.1

130.1

129.9

129.9

129.8

129.6

129.1

129.1

129.0

128.8

123.8

128.6

134.3

134.3

134. 1

134.1

133.9

133.9

133.8

133.6

133.1

133.1

133.0

132.8

132.3

132.6

128.6

132.6

128.4

132.4

123.2

132.2

127.1

131.1

126.6

130.6

126.1

130.1

125.4

129.4

125.4

129.4

125.2

125.1

129.2

129.1

125.1

129.1

128.7

128.5

124.5

128.3

128.0

127.9

127.4

127.4

127.3

127.3

127.0

127.0

126.7

126.3

125.5

124.1

123.7

123.1

122.6

122.5

$121 . ?$

121.

121.2

121.0

2309

1.17 .4

117.2 
WEST BANK OF THE MISSISSIPPI RIVER IN LOUISIAINA

Old Station Nev Station

Old Grade

New Grade

2301

2352

2402

2452

2502

2552

2578

2628

2678

2728

2739

2789

2839

2889

2936

2988

3037

3087

3137

31.87

3237

3287

333 ?

3388

34.38

3478

3528

3578

3628

3678

3728

3778

3828

3878

3928

3978

4028

4.078

4129

4180

4230

4231

4332

1.383

4.434

4485

4536

4587

4638
2350

2400

2450

2500

2550

27

2600

2650

2) 100

2750

2800

2850

2900

2.950

3000

3050

3100

3150

3200

3250

3300

3350

3400

3450

3500

3550

3600

3650

3700

3750

3800

3850

3900

3950

4000

4050

4100

4.150

4200

4250

4.300

4350

4.400

4.450

4500

4550

4600

4655 .

4700

4750
117.1

116.9 .

116.9

116.4

1.16 .3

116.3

115.2

115.2

115.2

114.1

1.1 .4 .1

1.13 .1

113.1

112.6

112.6

112.3

112.0

1.11 .3

111.7

111.3

110.8

110.7

110.1

110.3

109.9

109.9

109.2

108.2

108.1

107.8

106.8

106.6

106.6

106.3

105.9

105.9

105.8

$105 . ?$

105.1

105.1

104.6

102.8

102.7

102.3

101.9

101.5

101.1

100.8

100.8
120.9

120.7

120.6

120.1

120.0

120.0

118.9

118.9

118.8

117.7

117.7

116.7

116.7

116.2

116.1

115.8

115.5

115.4

115.2

11.4 .8

114.2

114.1

113.8

113.7

113.3

113.3

.112 .5

111.5

111.4

131.1.

110.0

109.9

109.8

109.5

109.1

109.1

109.0

108.9

108.5

108.2

107.6

105.9

105.8

105.4

104.9

104.5

104.1

103.8

1.03 .8 


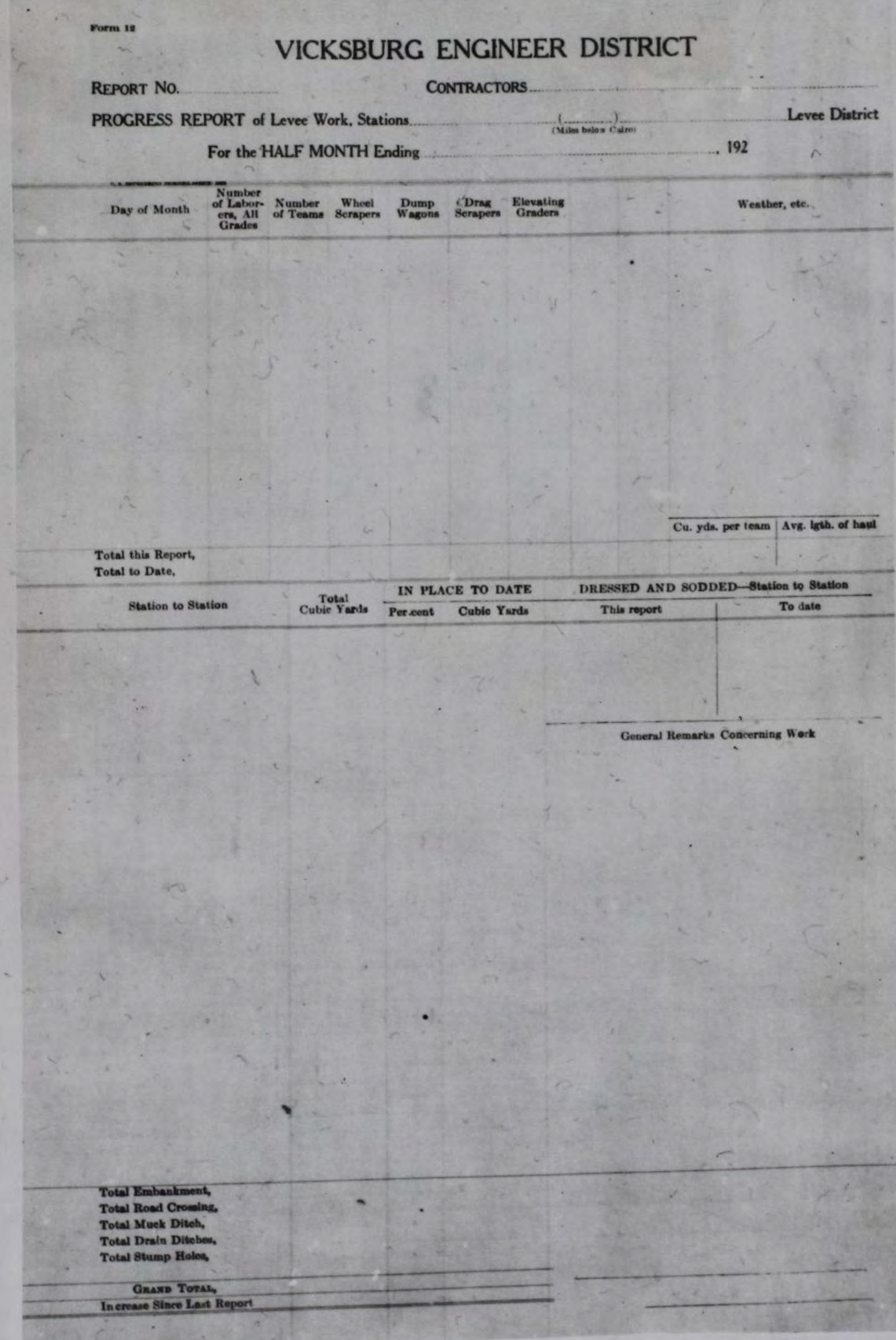


Report No...........

Levee Machine............

\section{Area}

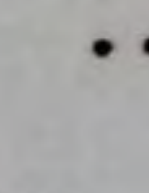

Levee District,

(iniles below cairo).

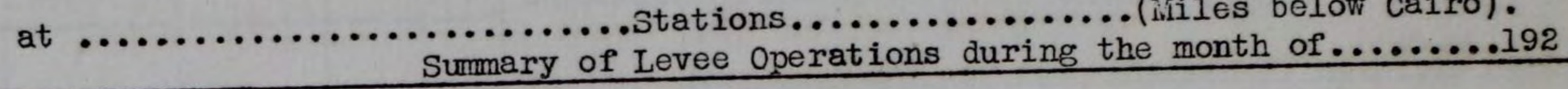

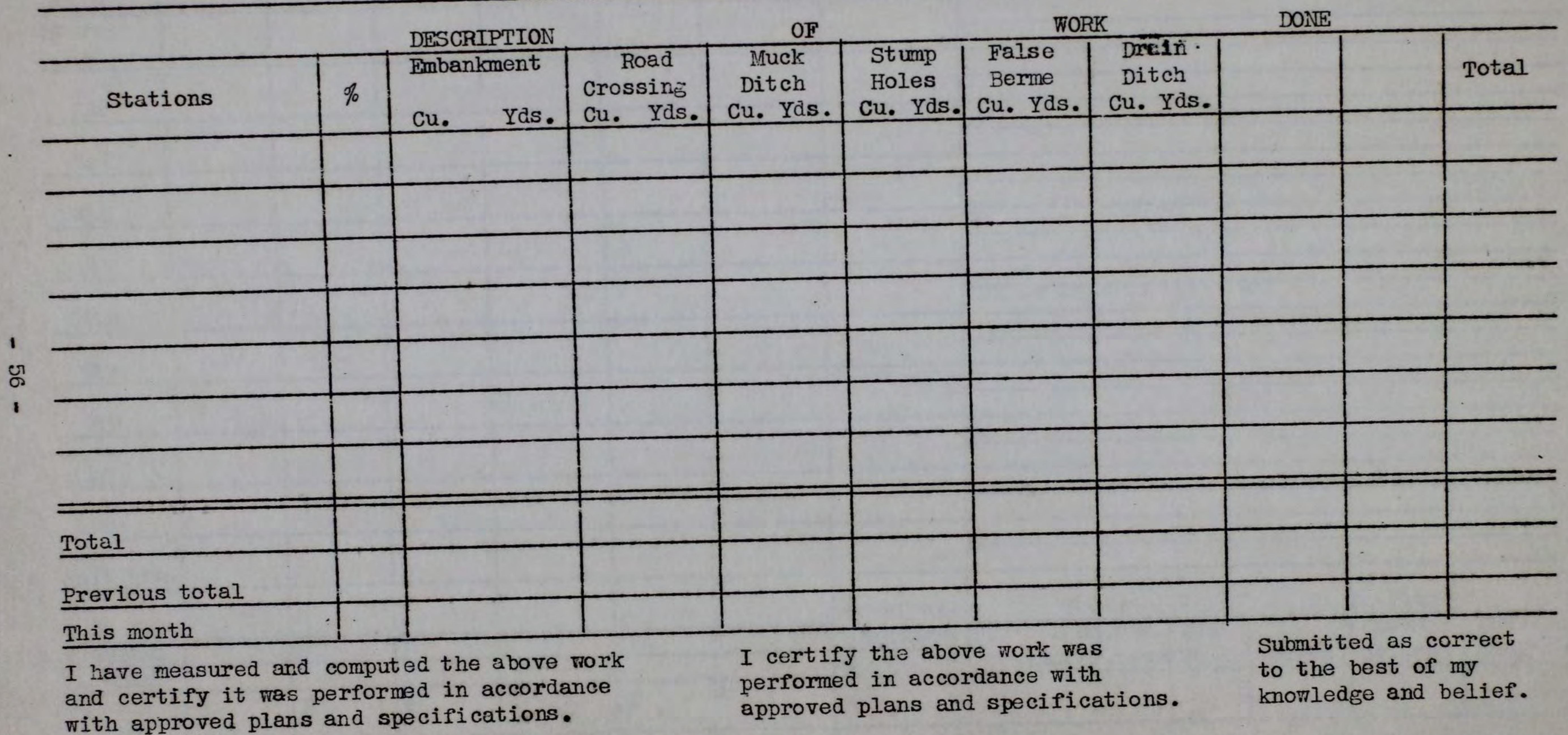




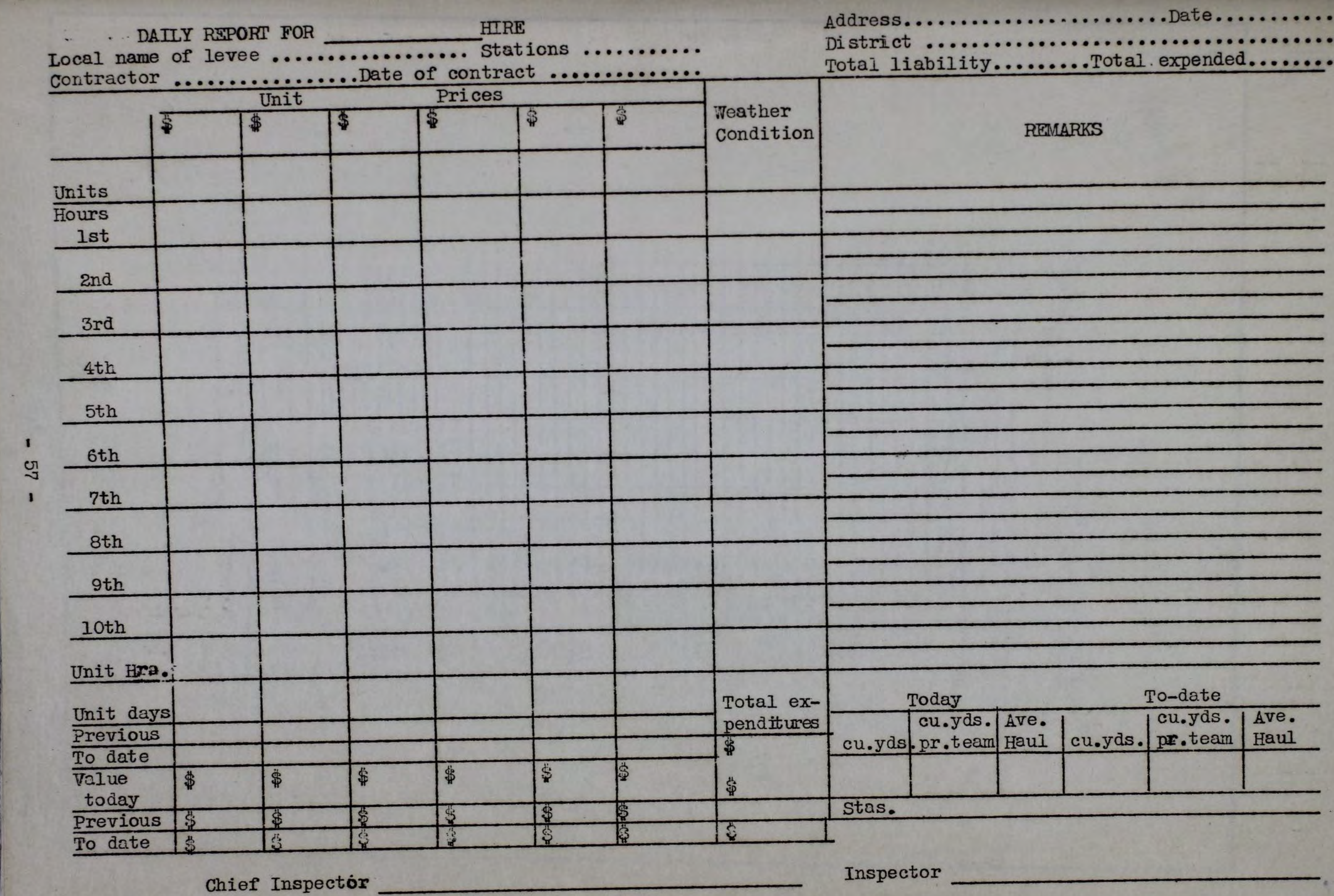


I UNITED STATES,

(Viokeburig Engineer District.)

For hire of teams and extra labor repairing

(t) 19 - 19 as follows

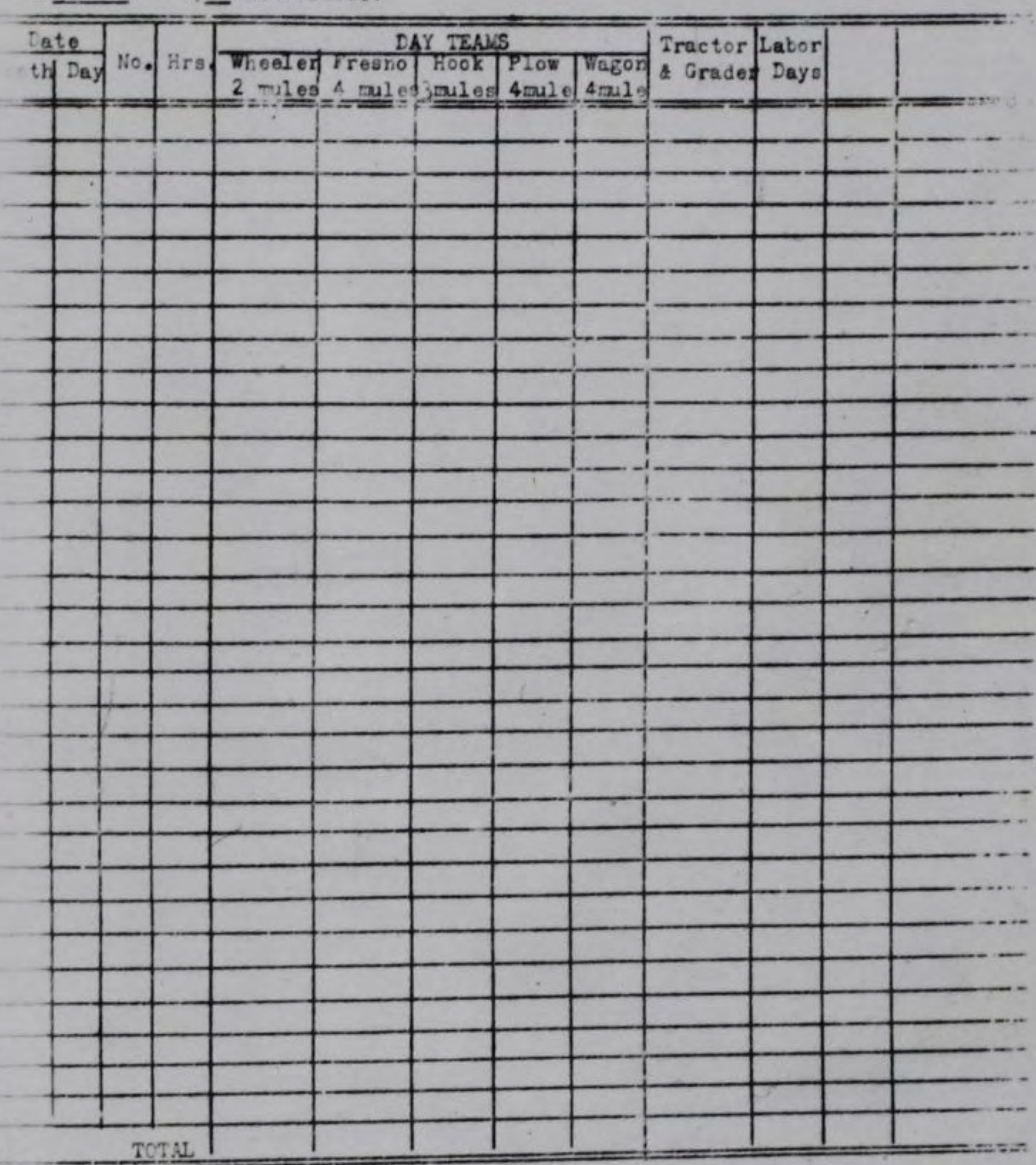

$\underline{\mathbf{3}} \underline{\mathrm{N}} \underline{\mathrm{U}} \underline{\underline{\mathrm{A}}} \mathrm{R} \underline{\mathrm{Y}}$

Wheoler tean dayo os frosino teari days of

hook tean days $\theta$

low tecim deys of

per wheeler tean day of $10 \mathrm{hrs} .$.

per plow toas day of $10 \mathrm{hr} \ldots \ldots \ldots \ldots .$.

wagon teca days o per wagon team day or lo

traetor \& grader dayg per tractor a grader day of lo.....

labor days

$$
6 \$
$$

is
Wail chock to

Date 


\section{LEVEL NOTES AND ESTIMATES}

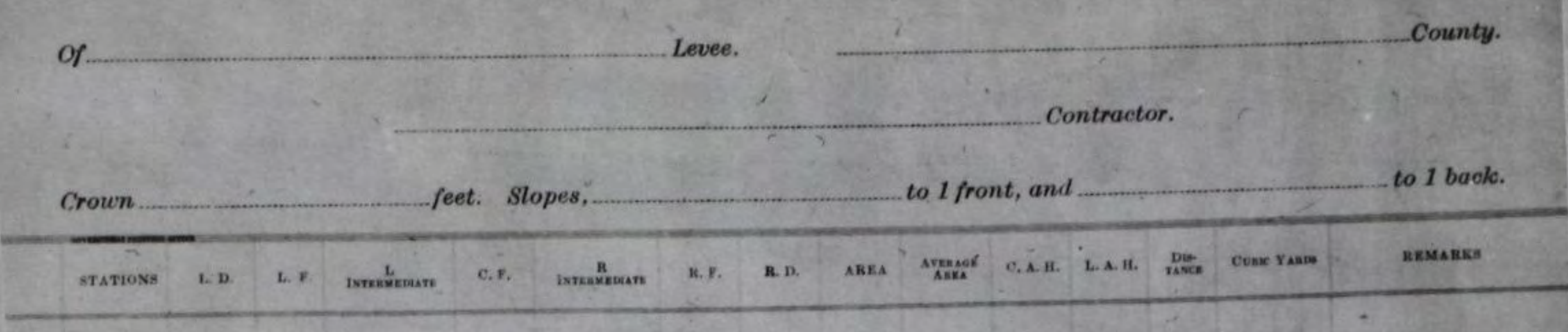

\section{9}




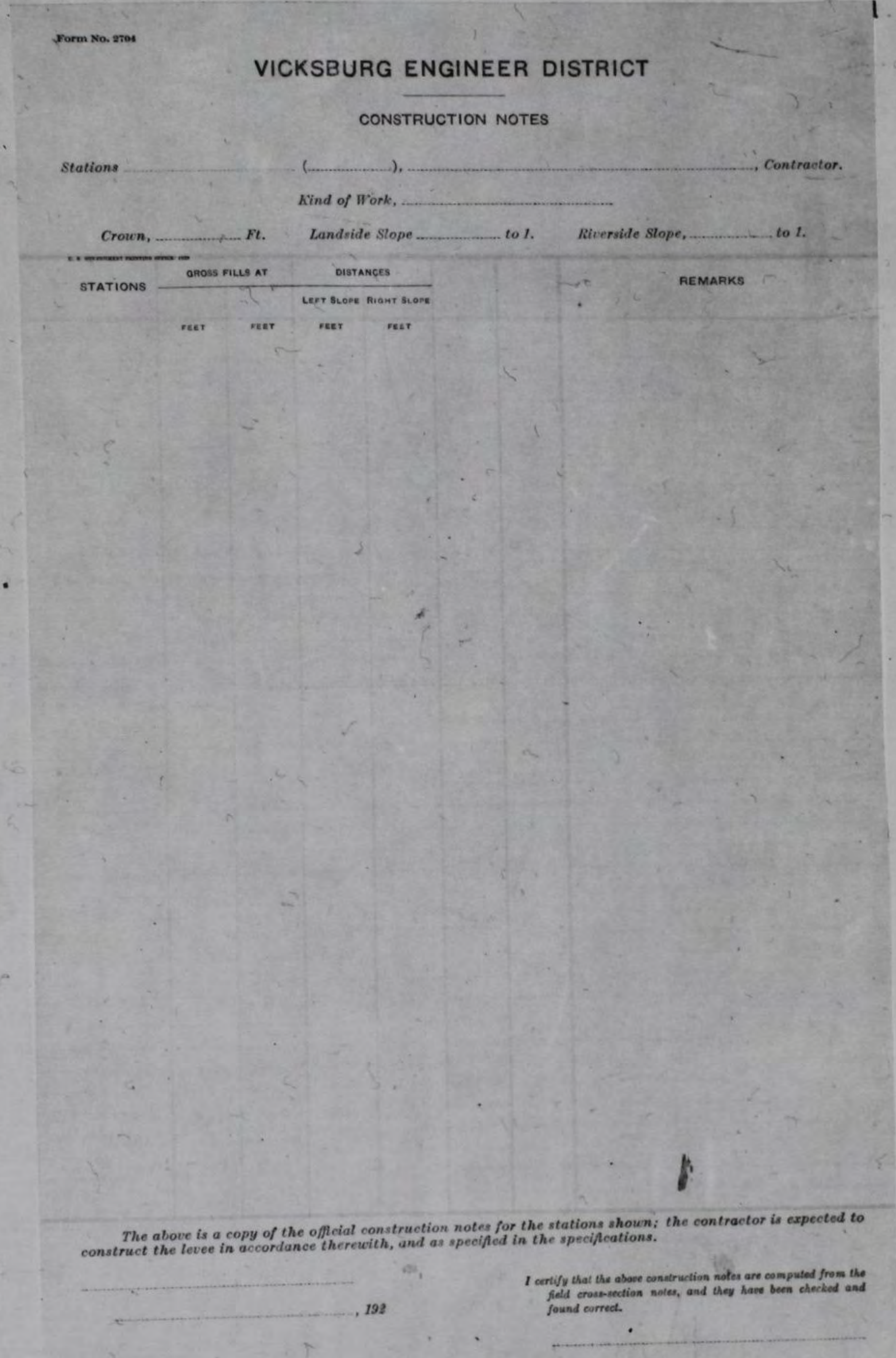


I have run grades over stations belom on dates indicated and found the following: Contractor

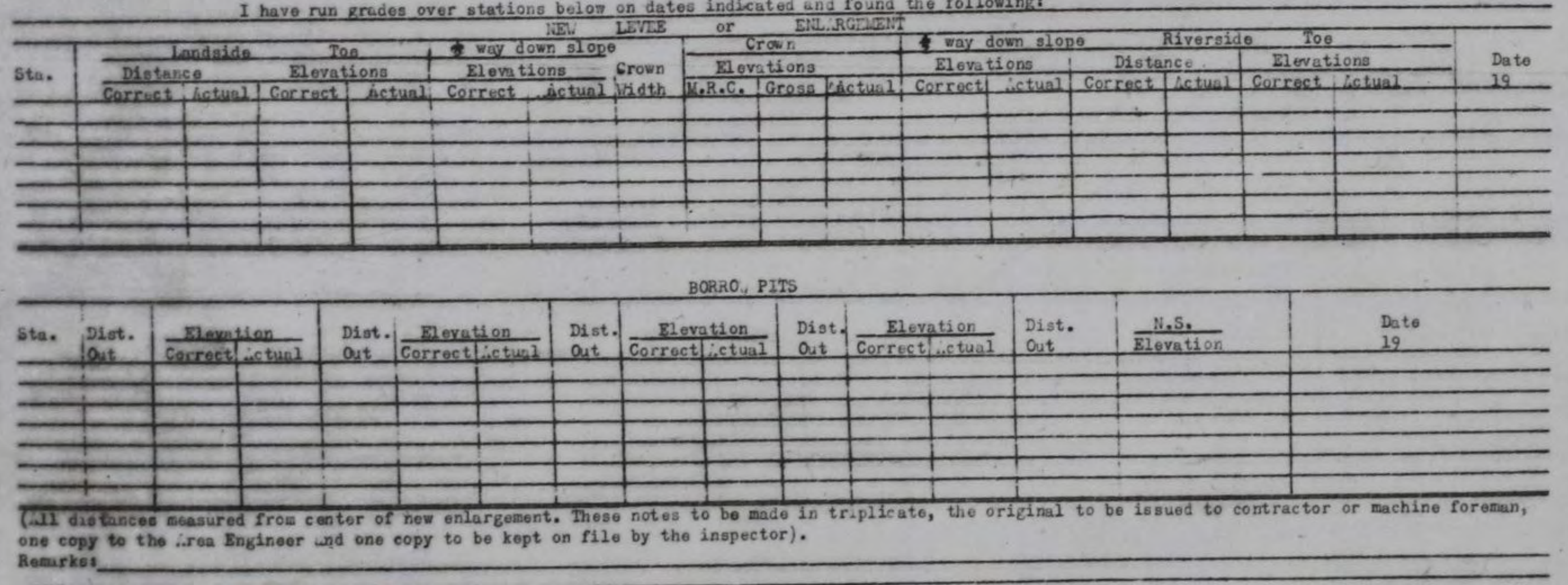

one copy to the i.rea Engineer und one copy to be kept on file by the inspector).

aenork

Deto.

19

U. S. Inspector. 
D A I L Y I O G R P P O T

, (To be mailed to the Area office at close of each day.)

Date

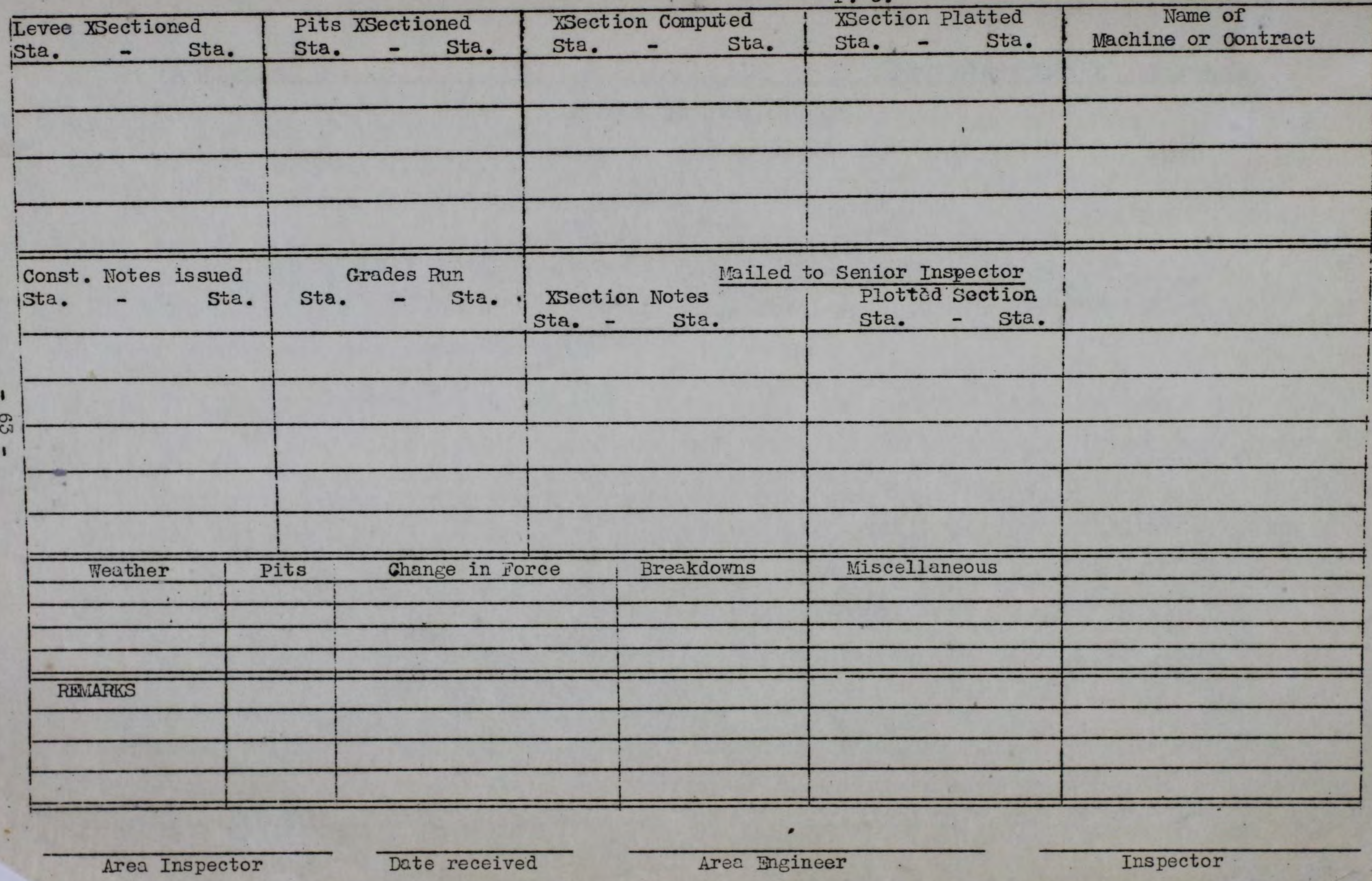




\section{VICKSBURG ENG INEER DISTRICT}

COUPARISON OF UEMPHIS AND CAIRO DATUMS VITH MEAN GULF LEVEL

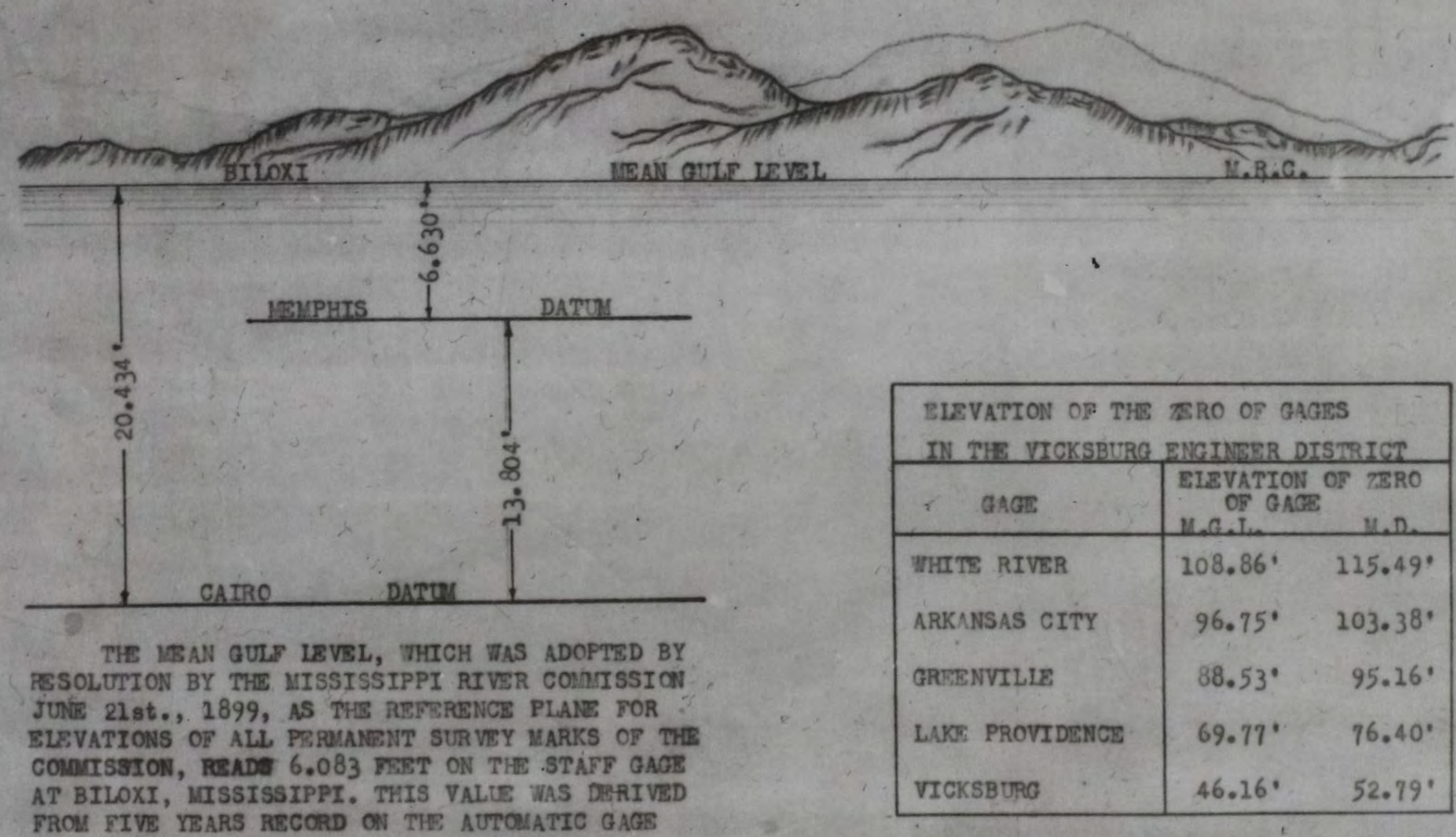

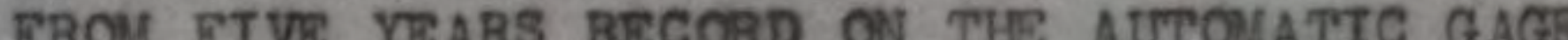
AT THIS STATION. 


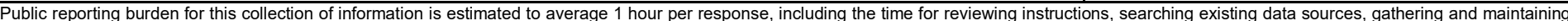

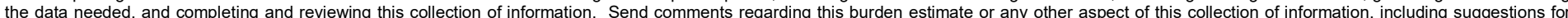

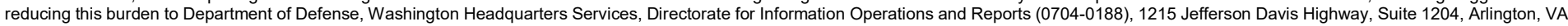

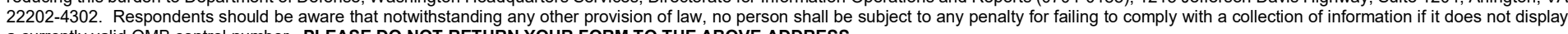
a currently valid OMB control number. PLEASE DO NOT RETURN YOUR FORM TO THE ABOVE ADDRESS.
1. REPORT DATE (DD-MM-YYYY)
2. REPORT TYPE
. DATES COVERED (From - To)

August 2018

Volume 1

\section{TITLE AND SUBTITLE}

Analysis and Comparison of Documented Seepage and Sand Boil Events on the Lower

Mississippi River from 1937 to 2011

5a. CONTRACT NUMBER

5b. GRANT NUMBER

5c. PROGRAM ELEMENT NUMBER

\section{AUTHOR(S)}

Joseph B. Dunbar, Amber L. Ensign, Nalini Torres, and Maureen K. Corcoran

5d. PROJECT NUMBER

J8D2HJ

5e. TASK NUMBER

5f. WORK UNIT NUMBER

\section{PERFORMING ORGANIZATION NAME(S) AND ADDRESS(ES)}

8. PERFORMING ORGANIZATION REPORT NUMBER

U.S. Army Engineer Research and Development Center

Geotechnical and Structures Laboratory

ERDC/GSL TR-18-23

3909 Halls Ferry Road

ERDC/GSL TR-18-23

Vicksburg, MS 39180-6199

9. SPONSORING / MONITORING AGENCY NAME(S) AND ADDRESS(ES)

10. SPONSOR/MONITOR'S ACRONYM(S)

U.S. Army Corps of Engineers

Washington, DC 20314-1000

\section{SPONSOR/MONITOR'S REPORT} NUMBER(S)

\section{DISTRIBUTION / AVAILABILITY STATEMENT}

Approved for public release; distribution is unlimited.

\section{SUPPLEMENTARY NOTES}

\section{ABSTRACT}

The following study examines the occurrence of seepage incidents and sand boils observed and documented during the 2011 Mississippi River Flood in the lower Mississippi River valley within the boundaries of the U.S. Army Corps of Engineers (USACE), Mississippi Valley Division (MVD), Vicksburg District (MVK). This study examines the occurrence of sand boils in relationship to the underlying floodplain geology and identifies locations where large sand boils occurred. Large sand boil areas will be the focus for additional detailed study to better understand the mechanics of underseepage and internal erosion in USACE flood control levees. Seepage and sand boil incidents documented during the 2011 Flood are presented in this report on geologic base maps and pre-flood imagery to compile a record of their occurrence and identify geologic relationships, as well as spatial patterns associated with the underlying fluvial landforms. A review of levee evolution within the lower Mississippi River valley is summarized here along with past research studies of seepage involving major historic floods and their control.

\begin{tabular}{|ll}
\hline 15. SUBJECT TERMS & Flood control \\
Levees - Mississippi River & Sand boils \\
Seepage & Geology - Mississippi River Valley
\end{tabular}

16. SECURITY CLASSIFICATION OF:

\begin{tabular}{|l|l|l|}
\hline $\begin{array}{l}\text { a. REPORT } \\
\text { UNCLASSIFIED }\end{array}$ & $\begin{array}{l}\text { b. ABSTRACT } \\
\text { UNCLASSIFIED }\end{array}$ & $\begin{array}{c}\text { c. THIS PAGE } \\
\text { UNCLASSIFIED }\end{array}$ \\
\hline
\end{tabular}

17. LIMITATION OF ABSTRACT
18. NUMBER
OF PAGES

521 19a. NAME OF RESPONSIBLE PERSON

19b. TELEPHONE NUMBER (include area code) 